\title{
LA CREACION
}

\section{HISTORIA NATURAL}

DIVISION DE LA OBRA:

ZOOLOGÍA Ó REINO ANIMAL

THAIVCIOA Y ARREGLADA DE LA LLTMMA EDICION A.FMANA UE LA ORRA DEL. CFLFRRE.

\section{DR. A. E. BREHM}

ANTROPOLOGIA, BOTANICA, MINERAIOGIA, GEOI.OGIA Y PALBONTOLOGIA

\section{escritas por cruditos untores espanoles}

con presencin de los mas completos y recienles datos de estas diférentes samas de la ciencia

TOMO V

\section{R耳PTIIHS Y PFOHS}
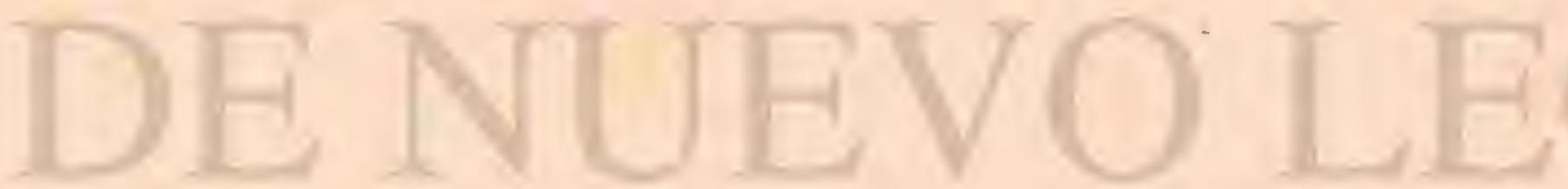

BARCELONA

MONTANER Y SIMON, EDITORES

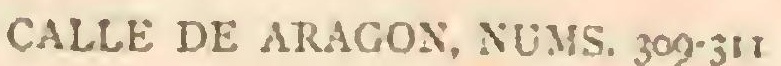




\section{INTRODUCCION}

Anfibios, ó de doble vida, llamó Linneo, el creador de la istoria natural cientifica del reino animal, à una serie de ertebrados que anteriormente habian figurado en parte $\mathrm{en}$. re los cuadrúpedos y los agusanos." Oken quiso sustituir sta denominacion poco acertada con una palabra alemana, - escogió para designar á estos séres los calificativos Ḱroté, Lork ó mejor Lurch, que corresponde á nuestro sapo; mienras Cuvier los llanó reptiles (animales que se arrastran). Recientes observadores dieron mas importancia de la que asta entonces habia tenido á la diversidad de formas, de es. ructura, y sobre todo de desarrollo, que se observa en esta eccion; dividiéronla en dos clases, $y$ las designaron con los tombres de restiles y anfilios.

Apenas hace diez años que algunos zoólogos no aprobaan aun esta separacion, introducida por Blainville; hoy lia se la reconoce en general, $y$ hasta teniendo en cuenta la exactitud, terminase con los reptiles la serie de los vertebralos superiores, considerando á los sapos y peces como tipos nferiores de la primera y mas importante division del reino inimal.

Los reptiles (replilia) son vertebrados de sangre fria, $\delta$ semacrimas, que respiran durante toda su vida por pulmo. nes, y que de consiguiente no sufren trasformacion. Casi to. los ellos tienen un corazon con aurículas completas $y$ un entriculo imperfectamente separado, estando además cubiertas aquellas de placas escamosas; su sangre puede lla. narse fria, puesto que su temperatura sube y baja con el calor ambiente, $y$ le excede en muy poco. La forma exterior es bastante variada; muchos repiles tienen el cuerpo largo y sermiforme, en otros es redondo $\delta$ aplanado, a manera de iisco; unos están provistos de piés, y los hay que carecen de ellos; el cuello es tan pronto corto y sin movimiento, como argo y articulado. Ios reptiles que tienen extremidades ueien llevar generalmente cuatro; pero colocadas tan late. almente, segun dice Vogi, que no parece puedan sostener. el cuerpo; diriase que están solo destinadas á obrar como oalancas, que dirigidas hácia afuera, sirven para la progreion, facilitando el movimiento que le es propio. La cubierta del cuerpo es variable: sobre este punto dice Cárlos Vogt en sus «Cartas zoológicas, que kalgunos saurios ó lagartos presentan verdaderas escamas semejantes á las de los peces, es decir, plaquitas finas, huesosas, que cubren una capa córnea, que se sobreponen entre si, adhiriéndose á la piel por medio de prolongaciones adelgazadas de esta última, $\mathrm{y}$ for. mando además alvéolos. Las escamas de otros lagartos y de las serpientes, no son tales en el sentido indicado, y solo reciben este nombre en el lenguaje vulgar: separándose de la piel marcadamente, forman dos capas, una fibrosa, coriácea, y' otra exterior, semejante á un barniz endurecido: los reptiles que tienen esta última la mudan en ciertas épocas. El dermis presenta en algunas especies verrugosidades, $y$ en otras pro. tuberancias granujientas ó escamosas, åsperas por un lado, sobre las cuales se adapta perfectamente la epidermis. Los crocodilos tienen placas huesosas engastadas en el mismo dermis, cuyas fibras se continuan dentro de los numerosos intersticios de aquellas. Obsérvase que en las tortugas co. mienzan so soldarse ya en la primera edad estos productos óseos de la piel con los del esqueieto, en peto y espaldar; mientras que la piel superior va siendo cada vez mas gruesa, y se endurece hasta formar lo que llamamos conchs,s

Segun Carus, la piel ofrece además un carácter distintivo, y es que à causa de la existencia mas general de sus protube. rancias, tanto las verrugosidades como las glándulas parecen atrofiadas. Las mismas furmaciones duras se designan con los nombres de escamas y escudos: estos úlimos, segun el citado naturalista, son por lo regular formaciones grandes, mas 6 menos angulosas, adheridas á la piel en toda su extension $y$ que no se sobreponen unas á otras; las escamas cuya disposicion y forma pueden variar mucho, segun las especies, se distinguen con los nombres de escamas lisas, aquilladas, etc. Entre las formaciones córneas de la epidermis se cuentan además las unas y otros apéndices en figura de cuerno, de espina ó cucurucho.

En cuanto a la belleza de colores de las formaciones de la epidermis, los reptiles no son apenas inferiores á otra clase. En la mayor parte de las especies el color corresponde al de la residencia preferida por el animal, sobre todo al del suelo, de las hojas, etc.; $y$ hasta hay algunas en que la facultad de apropiarse el color de los contornos es mas ó menos voluntaria, pudiendo los individuos cambiar el suyo probablemente á su antojo. Este cambio de colores se basa sobre todo en la diversa disposicion de ciertas celdillas colorantes; retráctiles y extensibles, adheridas tanto a la piel glandulosa como á la coriácea, y las cuales pueden ser mas ó menos trasparentes. Con la mayor actividad vital parece aumentarse tambien la viveza de color de las escamas y escudos.

Espuereato. - El de los reptiles se osifica casi por completo; pero varía de tal modo en cuanto fa la combinacion de sus partes, que es muy dificil establecer reglas fijas aplicables á toda la clase. La cabeza es inas ó menos achatada; las mandibulas $y$ toda la parte anterior de aquella ofrecen un gran desarrollo; el occipital puede decirse que forna una vértebra, que se divide en los cuerpos impares; la apófisis espinosa y las laterales son generalmente muy anchas, no tienen nunca rnas de un cóndilo, muy saliente y esférico, que se ajusta en el hueco dé la primera vértebra, diferenciándose por este mismo carácter, asi como tambien por el extraordi. nario desarrollo de la apófisis escamosa, del occipital de los anfibios, que en todos ellos está provisto de dos cóndilos. En la parte anterior se cormpleta por el esfenoides con prolonga. ciones muy atrofiadas, las cuales se desarrollan mucho, por el contrario, en los lagartos y serpientes para recibir las late. 
rales. Los parietales suelen soldarse en una placa única, \& menudo con cresta osca, presentando siempre las fosas tem. porales muy profundas. El parietal de las serpientes se extiende hácia la parte posterior de la cabeza á manera de faja; por delante se une con el frontal, que tan pronto es par como impar, sirviendo para cubrir y cerrar las órbitas; el vó. mer, hueso medio de la nariz, que casi nunca falta, forma el extremo de la cubierta óséa del cráneo, y encierra casi siem. pre repliegues especiales, que nacen de los cartilagos nasales. Los lados de la cabeza se completan con huesos frontales anteriores y posteriores, juntamente con el lagrimal; $y$ las $6 r$. bitas por el arco cigonastico y una porcion cscamosa de los temporales. Las demás partes de los huesos son movibles y están unidas por suturas, ó bien adheridas por articulaciones mas ó menos flojas, que permiten abrir la boca considerablemente.

El aparato maxilar, muy variado tambien, es movible en las serpientes, y está unido en todas sus partes cón el cráneo, que es sólidon, por medio de articulaciones poco fijas; en los crocodilós y en las tortugas es inmóvil, exceptuándose la articulacion de la mandibula inferior. El intermaxilar, sencillo $\sigma$ doble, se une por articulaciones suetas con el vómer y el hioides; en algunos casos es fijo. En las serpientes, por ejem. plo, son movibles hasta los palatinos, placas óseas que com. pletan el fondo de las órbitas y la bóveda del paladar. En estos animales aparecen igualmente unidas por tendones $y$ músculos ambas ramas de la mandíbula inferior; de modo que pueden acercarse y separarse á voluntad del individuo; en los lagarros lo están por un cartilago fibroso, y por una sutura en los crocodilos. Cada una de dichas ramas se com. pone por lo menos de cuatro piezas, y en muchos reptiles de scis.

Ia columna vertebral, que en la mayoria de los reptiles puede desunirse en la partc del cuello, en la del dorso, en la del sacro y en la de la cola, está del todo osificada y dividida marcadamente en vírtebras, cuyo número varía, sin embargo, de un modo extraordinario segun la longitud del cucrpo; de tal modo, que en las tortugas apenas excede de treinta, mientras que en las serpientes puede passar de cuatrocientas; las costillas, que tambien varian mucho por el número, están siempre muy desarrolladas, y en las serpientes mas que en los demás animales, por cierto estilo, puesto que en aquellas son movibles, mientras que en las tortugas están soldadas y forman en gran parte el escudo dorsal huesoso. El esternon falta del todo en muchas especies, 6 está muy atrofiado en oiras; lo mismo puede decirse hasta cierto punto de los coracoideos y de las piernas, por ejemplo en las serpientes, porque los huesos atrofiados que tienen algu. nas pocas especies en la region del ano, apenas pueden compararse con los huesos iliacos. En los demás reptiles, las picrnas y los piés se hallan no obstante desarrollados en to. dos los grados de la formacion.

Difontes. - En cuanto a la estructura de la boca, no po. demos decir nada en general: las tortugas carecen de dien. tes, y en su lugar solo tienen unas láminas córneas, que cu. bren los bordes de las mandibulas á manera de pico. Ios demás animales de esta clase están provistos de dientes, además de los huesos de aqquellas, $y$ á reces tambien de todos los palatinos $y$ del hioides. Por lo regular predornina la for. ma ganchuda, aunque tambien se observa que los dientes son aplanados lateralmente, y con coronas dentadas $\delta$ surcos. Jos mas de ellos encajan en un ligero surco del hueso correspondiente, por medio de fuertes encias; en otros reptiles se sucldan en una sola pieza con la mandibula; constituyendo una especie de cresta; especies hay, por último, en que aparecen sólidamente enclavados en alvéolos.
Apakaro picistivo. - Tambien se observa una gran di. versidad en el aparato digestivo: en algunos reptiles, como por ejemplo en los crocodilos, no merece la lengua el nom. bre de tal, pues consiste tan solo en una protuberancia saliente, plana, fija \& inmóvil sobre el fondo de la cavidad bucal; en las tortugas es carnosa, gruesa y corta; en los lagartos afecta la forma de un huevo aplanado, que se bifurca, lo mismo que en las serpientes, presentando dos puntas largas, que parecen hilos. El csófago es ancho, y en algunos reptiles susceptible de una enorme dilatacion, pasando insen. siblemente al estómago, que es ancho tambien y cerrado por el lado del intestino por un repliegue ó tabique. El intestino, bastante voluminoso, apenas forma circunvoluciones; el recto suele distinguirse por tener muy dilatados el ciego y la cloaca.

En todos los reptiles existe el higado, la vejiga de la hiel y el bazo; las verdaderas glándulas salivales falıan casi siempre, mas por lo regular se halla una en el vientre. Ias tortu. gas sc distinguen de otros reptiles pur tener una glandula debajo de la lengua; muchos lagartos y serpientes por la exis. tencia de glándulas en los labios; y no pocas de las segundas por hallarse provistas de una muy grande, situada en la region de las sienes: en todas las especies de un sub-órden, esta glándula segrega un veneno y se comunica con los dien. tes ponzoñosos perforacios.

Los rinones son por lo regular muy grandes, y tienen á menudo muchos lóbulos; los canales que parten de ellos desembocan por detrás del tabique de la cloaca, frente la cual se halla en lós lagartos y tortugas, la rejiga de la orina. Los testiculos están siempre en el interior de la cavidad ab. dominal; sus conductos de salida suelen reunirse en un epi didimo, y de este parten despues los cordones espermáticos. Todos los reptiles tienen los órganos genitales bien desarro llados; las serpientes y lagartos están provistos de dos penes dobles cubiertos de aguijones y ganchos peludos, los cuales se remangan de tal modo en el apareamiento, que la superficie intcrior se convierte en exterior. Ins tortugas y croco. dilos, por el contrario, solo poseen un pene sencillo que se inserta en el tabique interior de la cloaca y no está perforado, hallándose en la superficie exterior un surco longitudinal para conducir el licor esperrmático. Ios ovarios, separados siempre de los conductos, forman placas ó bolsas.

ApARato respikatorio - Segun he dicho antes, el apa. rato respiratorio no ofrece ningun cambio ó trasformacion, pues consta invariablemente de pulmones. I.a faringe existe siempre como organo separado; la traquearteria se divide por lo regular en ramas, aunque es á menudo muy dificil determinar el limite entre aquella y los bronquirios, porque los anillos fibro-cartilaginosos que la forman penetran mu. chas veces muy profundamente en los pulmones; sin contar, además de esto, que sobre una gran parte de los bronquios se extienden células pulmonarés.

Los pulmones son bolsas membranosas, sencillas en la mayor parte de las serpientes, ó provistas de otras laterales, como en algunos lagartos, $\delta$ bien caracierizadas por unas prolongaciones puntiagudas en su extremidad. En las serpientes, cujo lóbulo derecho suele ser mas largo y ancho que el izquierdo, este último cstá á veces atroriado del todo, mientras que el primero se trasforma en varias especies en un-receptáculo aéreo, sin ninguna importancia, al parccer, para la respiracion misma. Por lo regular existen dos lóbu. los del pulmon en forma de bolsa, que se extienden por toda la cavidad abdominal, presentando en la superficie interior unas prominencias celulares de la mucosa, que llegan a formar un iejido esponjoso cuando se desarrollan por completo. 
APARATD CIRCLIATORIO. - El corazon presenta cuatro Ca. vidades, como ya he dicho, saber: dos auriculas y dos ven. triculos, cuyo tabique solo está bien desarrollado en los crocodilos, al paso que en todos los demás reptiles ofrece soluciones de continuidad mas ó menos considerables; de modo que la sangre pasa directamente del ventriculo derecho al irquierdo.

- En las tortugas, en las serpientes, y en la mayor parte de los lagartos, que carcen de tabique completo, dice Vogt, los vasos pulmonares y tambien los capilares arrancan del ventriculo derecho, mientras que en los crocodilos parten de este las arterias pulmonares y una aorta izquierda, al paso que la mayor nace en el ventriculo izquierdo.

Aunque la sangre que afluye del cuespo hácia el pulmon se dirija imperfectamente of la arteria pulmonar por medio de unas válvulas especiales, $y$ ia que proviene del pulmon pase a la aorta, se verifica no obstante la mezcla de ambas, tanto en los animales de tabique incompleto como en los crocodilos, por medio de ramificaciones muy extendidas en. tre el gran tronco vascular, que tienen su origen en los arcos branquióstegos primitivos del embrion. I a aorta presenta casi siempre dos ó tres curvaturas que se unen debajo de la columna vertebral despues de haber formado los vasos de la cabeza. En la circulacion venosa existe siempre además del sistema de la vena porta para el higado, otra que correspon de á los riñones. El sistema linfático está desarrollado de una manera extraordinaria, presentando además grandes depósi. tos situados conunmente cerca del estómago, corazones linfáticos especiales con pulsaciones ritmicas, dos de los cuales se hallan siempre en la region lumbar, inmediatamente de bajo de la piel, 6 bien mas hácia el coxis vertiendose su con tenido en las venas mas próximas.

La comunicacion particular de los grandes vasos de la sangre explica la poca necesidad de respirar, observada en los reptiles. Merced śla lentitud con que se efectúa el cam bio de la sustancia, segun la explicacion de Bruecke, pueden subsistir con cierta cantidad de oxigeno mucho mas ticmpo que los mamiferos y las aves, á pesar del mayor desarrollo de estos, siendoles dado vivir aun en el caso de que se les impida forzosamente la respiracion, porque la superabun. dancia de sangre que por falta de oxigeno suele presentarse en los aparatos circulatorios de los pulmones puede pasar a los mas grandes, evitandose asi que la sangre se estanque en los órganos de la respiracion. A consecuencia de la lenta circulacion de la sangre, el calor del cuerpo se eleva poco so bre el del aire ó el de los alrededores en general.

Aparato SENSITHO. - Los reptiles tienen el cerehrn mu. cho mas imperfecto que los mamíferos 5 las aves, pero mas desarrollado que los anfibios: consiste en tres porciones de médula, ó sea el cerebro antcrior, el medio y el posterior. El primero y útimo son muy pérfectos en los crocodilos, y mas 6 menos atrofiados en las serpientes y tortugas. I.a mé dula espinal y los nervios son muy voluminosos relativamen. tc al cerebro, y por lo tanto no ejerce este mucha influencia sobre ellos.

OrCaso DE: LA vista. - Entre los órganos de los sentidos, el de la vista es sin disputa el mas perfecto, aunque en mu chos casos son muy pequeños los ojos, y hasta pueden estar completamenic ocultos debajo de la picl.

En los diversos grupos y familias es característica la for macion de los parpados, «n las serpientes, dice Vogt, esta formacion es la mas sencilla, porque esos animales carecen completamente de párpados, pero estản reemplazados por la misma piel, que en sus diversas capas es trasparente alli donde cubre los ojos, abovedándose y formando una especie de cajita, la cual se inserta como un cristal de reloj en la ra- nura de la piel que la rodea, protegiendo asi al ojo, que es móvil en su parte anterior. El liquido lagrimal llena el espa. cio entre esta cajita y aquel órgano, y por un ancho canal que hay en el ángulo interior de los ojos pasa a las fosas nasales; en casi todos los demás reptiles el párpado superior está po. co desarrollado, y se reduce por lo regular as un repliegue de la piel, semi-cartilaginoso y rigido; mientras que el inferior, mucho mas grande y movible, puede cubrir todo el glo. bo del ojo; á menudo se apoya sobre una plaquita ósea especial, y en otros casos tiene frente a la niña del ojo un punto trasparente que le facilita la vista. La mayor parte de los lagartos, tortugas y crocodilos están provistos además de una membrana nictitante que tambien contiene una pla. quita bsea y puede cubrir desde el angulo interior del ojo una parte mas ó menos grande de este órgano. Los camaleo. nes se distinguen por este concepto, pues no tienen sino un párpado circular que se oprime contra el globo saliente de los ojos y solo deja abierta una estrecha hendidura para re. cibir la luz Las partes internas del ojo se diferencian muy paco de las de los animales superiores.

En muchos reptiles los ojos son muy poco movibles, pero en cambio se observa en otros todo lo conirario; el camaleon se distingue de tal modo por este concepto, que seguramen. te no existe animal que le iguale; la movilidad de sus ojos es tan extraordinaria, que no solo giran en distintas direc. ciones, sino tambien independientemente uno de otro. El iris suele presentar coloraciones muy vivas: la pupila es circular en unos y prolongada en otros, segun se observa en los gatos y en los buhos: tambien es susceptible de dilatacion y parece adecuada para la vida nocturna del individuo.

ÓRINNO DEL OHNO.-Por su imperfeccion difiere en gran manera del de los animales superiores y carece de pabellon, siendo el interno mucho mas sencillo que el de los vertebra. dos de sangre caliente; pero los reptiles poseen además lo que se llarna el caracol, que algunas veces afecta la forma de un canal corto con membrana divisoria, dispuesto en hélice, si bien incompleto y con una bolita por apéndice. Asi pues, exisic el oido interno en sus partes mas esenciales: su mayor perfeccion en las aves y mamíferos no estriba en el número de aquellas, sino en estar mas afimadas. El oido medio y la caja del timpano varian mucho en su disposicion; las ser. pientes carecen de la última, asi como de su membrana, y de la trompa de Eustaquio; en los otros órdenes, sirve esta membrana, mas ó menos libre, para cerrar exteriormente la caja del timpano, que se pone en contacto con la cavidad buca! por nedio de una trompa corta $y$ ancha. Ia comuni. cacion entre la membrana del tímpano y la ventana oval so ierifica por la cadena, á menudo muy larga, a la cual se agregan en algunos animales otros huesecillos.

SR:NTIDO DEL TACTO.-Siguiendo el órden descendente en el desarrollo de los sentidos, figura el del tacto despues del oido, por mas que sea puramente material y se relacione muy poco con la percepcion de sensaciones. las inlluencias exteriores afectan seguramente á los reptiles, lo cual se reco. noce desde luego por su preferencia al calor del sol; pero estus animales manifrestan por otra parte una pasmosa insen. sibilidad.

El sentido del tacto ofrece en muchos reptiles un gran desarrollo, y particularmente en las especies cuya lengua bace las reces de aquel.

SENTIDO DU. GUSTO. - Está igualmente atrofiado: puede suponerse que las tortugas y ciertos lagarios perciben el sabor de los alimentos; pero con dificultad existe este sentido en los crocodilos y serpicntes.

SESTIDO DEL OLFATO-Lo mismo tenemos que decir res. pecto á este sentido: las fosas nasales de los reptiles se apo 
yan sobre las alas cartilaginosas, y comunican con el interior de la boca, pudiendo hasta dilatarse y contracrse en algunas especies. Los nervios olfatorios están bien conformados, y existe tambien una mucosa entrelazada con vasos reticulados. La observacion no nos ha proporcionado dato alguno para saber a punto fijo si los reptiles perciben las sensaciones exteriores por medio de dichos órganos y en tal caso hasta qué punto.

Geveracion. - Todos los reptiles nacen de huevos (1) que se asemejan en lo mas esencial à los de las aves; la yema tiene sin embargo mucho volúmen, es muy grasienta y apa. rece rodeada de una capa albuminosa mas ó menos conside. rable; la cáscara, coriécea y comunmente clástica, es poco caliza El desarrollo de los huevos comienza casi siempre en el oviducto de la madre antes de su expulsion; en algunas especies se desarrolla alli el nuevo sér completanierite; de modo que el hijuclo rompe la cáscara hallándose aun dentro del uviducto, y nace por lo tanto vivo (2). Otras especics que ponen sus huevos con regularidad, mucho antes de nacer el individuo, pueden dar a luz sus hijos con vida si no les ha sido posible depositar los huevos antes. Cuando estos fltimos están fecundados, presentan en la superficic de la yema un espacio circular mal limitado y de color blanco, que corresponde á la vesicula germinativa y se compoñe de células pequeñas, casi incoloras, las cuales son base y centro del desarrollo de aquellas formaciones que dan origen al embrion. Este punto se prolonga tomando la forma de un disco oval, y adquiere mas trasparencia en el centro que hácia la parte cxterior lan pronto como el embrion comienza à desarro llatse.

En la parte central trasparente la cicatricula forma una eminencia ó prołuberancia dorsal, que á medida que se ex. tiende se cierra por la aproximacion de sus bordes, convirtiéndose el disco brillante en una especie de tubo que con el tiempo ha de ser el cerebro y la médula espinal. Inmediata. mente despues aparece la columna vertebral á manera de jequeño cordon por debajo de la depresion dorsal, distin. guiéndose poco a poco las tres porciones del cerebro, apareciendo desde un principio la anterior como la mas voluminosa. El embrion aplanado $y$ de formal de bizcocho de soletilla, preséntase ligeramente encorvado sobre el vientre y en direc. cion trasversal, y'a medida que se levanta, se dibuja mas y mas, limitandose distintamente por ambos lados; fómase con singular rapidez el extremo de la cabeza, que se inclina todo lo posible sobre el pecho, hasta el punto de penetrar un poco en la yema. Esta inclinacion es tan grande, que imposibilita el estudio del lado anterior de la cabeza y el cuello, si no se levanta aquella violentamente. Los vertebrados superiores ofrecen otra particularidad por la membrana alantóides, que comienza à formarse despues de cerrada la protuberancia ver. tebral. La capa celular del embrion, que constituye poco ta poco la piel, se ra extendiendo sobre toda la yema, hasta que acaba por envolverla; en los extremos de aquel queda un repliegue que oculta la cabeza y la cola, cubre por todos lados el gérmen, y cerrándose por último por la espalda, viene ó ser una continuacion de los rudimentos de la piel del em.

(1) Algunos repriles fúsiles, tales como los ichihiosauros del tersctio jurísico, puetle crecrse q̧ue fueron vivijuzros, opinion cmitida jor el célebre paleontólogo Owen, en vista del cjemplar que posec el Dr. Quensled de Tubingn, en el cual se ve un individuo pequeño deniro de la carrioad alulominal ie uno que debia ser hembra. Lis la escalera del ga binele de Historia natural de .ladrid puede verse otro ejemplar del mismo ichthinsauro con el feto, únicos que se conocen en Europt, traido csic por mil de la famosa localidad de Iboll ea el Wurtemberg.

(2) lixic caso curinso de nacimiento se llama ovoviviparidad, y al sér, osoriviparo.

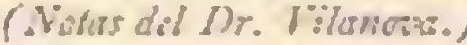

brion. Los demás sistemas de órganos se marcan ya antes de comenzarse à formar la membrana alantóides. Fn la parte opaca del blastodermo, en el airea germinativa, se han ido formando ya los huecos para los primeros vasos, asi como las primeras células sanguíneas; una aglomeracion de estas úliimas en la region del cuello, la cual queda oculta á causa de la excesiva inclinacion de la cabeza, se trasforma lentamente en un corazon tubular. Al principio estś todo el cuerpo, à partir del corazon, completamente aplanado en la superficie de la yema, de tal suerte, que en lugar del intestino hay un canal ó ranura humedecida, que se comunica con la yema. Sin embargo, poco a poco se cicrran los bordes del vientre, y la ranura se encorva mas y mas hasta formar en el interior del cuerpo como un tubo longitudinal, que solo se pone en contacto con la yema en cierto sitio que ha quedado abierto. A medida que se cicran el vientre y el canal intestinal, separándose de la yema, redúcese la comunicacion entre esta y aquellos al ombligo, que se cierra á su vez en el momento de nacer el individuo. La vejiga se forma al cerrarse el canal del intestino. En el sitio donde deben nacer las extremidades posteriores se produce una vesícula, que semejante \& una abeja, no es sino una derivacion lateral y anterior del tabique intestinal, que se desarrolla rípidamente, penetrando à través del anillo anterior del ombligo y extendiéndose por toda la membrana alantóides. Muy diferente de esta, el corion contiene numerosas ramificaciones musculares, que sirven propiamente para que respire el embrion. «Próximo ya el fin del desarrollo, dice Vogt, encuéntrase el gérmen encerrado en su membrana alantóides, con la abertura umbilical en la parte anterior, de la cisal pende el resto de la yema como una ve. jiga piriforme, asi como tambien la bolsa ó envoltura de la membrana de la vejiga de la orina. Bien pronto se cierra la comunicacion con la bolsa de aquella, y lo mismo sucede con la de la yema, quedando solamente los vasos; el gérmen rompe la alantóides y despues la ciscara del huevo, para cuya operacion se válen muchos reptiles de un diente especial cortante é impar, que nace en el intermaxilar, desapareciendo al cabo de cierto tiempo. Una vez nacido el hijuelo se atrolian los vasos de la bolsa de la orina; el animal respira por el pul. mon, y el ombligo se cicatriza sin dejar huella visible.»

DISTRIBUCION GEOGRÁFICA DE LOS REPTILES. - De los reptiles podemos decir que fueron, pues la Palcontologia nos demuestra que en vez de aumentar dismi. nuyen y van desapareciendo lentamente. Los restos fósiles de los reptiles que vivieron en otras épocas, presentan una gran variedad de formas completamente extinguidas, 5 en compa. racion de los cuales parecen enanos los actuales. En el terreno pérmico se encuentran verdaderos lagartos; en cl trias restos de sáurios extraños; en el jurásico otros de varias tortugas, de lagartos grandes y voladores, de crocodilos y sáurios mas modernos; tan numerosos y de formas tan diversas, que bien pudiera llamarse el periodo jurásico « Ëpoca de los rep. tiles. Hasta en la creta se han hallado lagartos gigantescos; pero cen el terreno terciario, donde aparecen por primera vez restos de serpientes verdaderas, predomina en todos el tama. no comun, viéndose que han desaparecido ja los sáurios, que en la creta estaban represeniados tan solo por individuos harto insignificantes. H

Hoy dia existen aun mas de dos mil especies distintas de reptiles; Wallace ha llegadoa contar en su última obra sobre el área de dispersion de los animales unas quinientas mas. Debe advertirse, sin embargo, que la historia de estos animales es poco clara aun por todos conceptos y que no se ha podido determinar todavia la independencia de algunas formas como especies, aunque como tales se han descrito. Supuesto el caso de que todas las noticias de Wallace resultasen 
exactas, habria que apuntar doscientas especies distintas de tortugas, veinticuatro de crocodilos, novecientas șetenta y nueve de serpientes y mil quinientas cincuenta y dos de la. gartos, descubiertas hasta ahora y aun existentes.

Los mas de los reptiles habitan en las llanuras de los pai. ses ecuatoriales, pues mas que todas las demás clases, su nú. mero va disminuyendo á medida que se acercan á los polos, y lo mismo sucede cuando suben á mas altura de las monta. nas. El calor es jara rodos estos animales un clemento vital; cuanto mas cálida es la region, tanto mayor es su número y cuanto mas frio es un país, tanto mas escasean en él. Muy pocas especies pasan del circulo polar; en nuestros Alpes hay algunas especies, por ejemplo la culebra de cruz, que suben a mil ochocientos metros de altura; en los Andes, Castelnau encontró dos serpientes á una elevacion de mas de dos mil metros, y en el Himalaya, Schlagintweit vió varios reptiles á la de cuatro mil seiscientos sesenta. Esta altura parece el último limite á que suben esos animales. A medida que acrece el calor aumenta la actividad vital de los reptiles por todos conceptos. Algunas especies cuya área de disper. sion se extiende á varios grados de latitud son á menudo mucho mas grandes y de colores mas bellos en el sur que en el norte, de tal modo que en ciertos casos es dificil reconocerlas. Además del calor, tambien necesitan humedad: rela. tivamente, pocas especies habitan el Africa; mientras que en el sur de Asia, y mas aun en América, obsérvase la mayor varicdad de formas y tambien el mayor número de indivi. duos de una misma especic. En cuanto al tamaĩo, guarda proporcion hasta cierta punto con el desarrollo de toda la clase, de modo que dentro de los límites de los paises ecua. toriales se ven las especies mas grandes, mientras que en las zonas templadas hállansc casi exclusivamente especies pequeñas.

La residencia de los reptiles ofrece mucha variacion, por mas que sean animales terrestres; solo las tortugas y algunas serpientes viven en el mar; todos los demás están en tierra firme, y con preferencia en las comarcas hímedas. Verdad es que muchas especies habitan las aguas mas dulces; mas todas ellas permanecen largo tiempo en tierra, ya sea para descansar, 6 bien con el objeto de calentarse al sol; muy pocos son los que duermen flotando. La montana es su residencia principal; alli viven mas especies que en el agua y los pantanos: se albergan unos entrc las raices, en matorrales, sobre los troncos y en cl ramaje de los árboles; otros perma. necen debajo de la tierra, cuando no escogen para su domi. cilio arenales 6 rocas peladas; asi es que se encuentran muchas serpientes y lagartos en sitios desiertos, donde casi parece imposible que puedan subsistir.

T'odos los órdenes de una clase habitan, poco mas ó menos, una misma comarca; ningun reptil cmigra ni se traslada de un pais á otro: pues aunque las tortugas diseminadas en una cuenca lidrográfica pueden trasladarse de un punto á otro semejante, solo lo verifican cuando no media entre am. bos un espacio algo considerable de ierreno privacio de agua. Otro tanto sucede exactamente con los órdenes que habitan la tierra firme, pues un pequeño brazo de mar es ya un obs. táculo invencible que les impide extender mas su área de dispersion; y como no hay ejemplo de que reptiles de la fa. milia y órden vivan en comarcas distintas, separadas por obstáculos anślogos, debe suponerse que ciertos paises ac. tualmente separados, no lo estuvieron siempre. Sin embargo, por otra parte, se concibe sin dificultad que el mar facilita hasta cierto punto la diseminacion de estos animales, asi como la de otros, ofreciéndoles en determinados casos la po. sibilidad de viajar.

USOS, COSTUMBRES Y REGIMEN.-El géneTo de vida de los reptiles apenas admite comparacion con el de los mamiferos y de las aves; entre estos y aquellos hay por tal concepto un abismo. Podemos decir que la vida de los repriles es incompleta, á causa de su reducido cerebro y de la imperfecta circulacion de la sangre. Decimos de algunos que son ágiles, flexibles, vivaces, inteligentes; pero entre todas estas cualidades $y$ las análogas de las aves y mamiferos no hay comparacion posible.

Arimexracion:- Si exceptuamos las tortugas y algunos lagartos, debemos clasificar \& todos los representantes de esta clase entre los animales rapaces, y a varios de fllos en. tre los mas terribles, porque igualan á los leones y tigres en fuerza 5 ferocidad. Apenas hay especie animal que no sirva de pasto á los reptiles: los crocodilos se atreven á embestir á los grandes mamíferos, incluso los camellos; apodéranse del hombre con la misma facilidad que si fuese un animal pequeño; peru buscan su alimento sobre todo entre los séres acuáticos, y devoran principalmente los peces. Las tortugas los persiguen tambien y comen además mamíferos peque. ños, aves, reptiles de reducido tamaño, anfibios, caracoles, cangrejos, gusanos, y acaso tambien radiados. Los lagartos se alimentan asimismo de mamíferos, pájaros, animales de su propio órden, anfibios, peces, insectos y multitud de sa. bandijas. Casi todos tragan la presa entera, sin despedazarla en lo mas minimo; solo algunas especies, particularmente las zortugas y crocodilos, destrozan torpemente su alimento, lo mismo que los animales que observan el régimen vegetal; asi es que en el acto de comer 5 tragar se ven obligados con frecuencia á hacer tantos y tales esfuerzos, que repugnan a la vista. Todos los reptiles beben: su voracidad aumenta en $\mathrm{m}$. zon directa de la temperatura; durante la estacion calorosa acumulan sustancia nutritiva para el resto del año, aunque comen mucho menos que los mamíferos $y$ las aves. Tragan de una sez enormes pedazos de su presa, $y$ luego permanecen varios dias en perezosa tranquilidad hasta terminarla di. gestion, pudiendo en caso necesario resistir muchos meses sin tomar alimento alguno. Si encuentran abundante pasto adquierén cierta corpulencia, y hay algunos que llegan á engordar realmente, aunque nunca en la proporcion que lo hacen los mamifetos y las ares.

Las tortugas y crocodilos mudan la piel lo mismo que los mamiferos y las aves, es decir, paulatinamente; pero en los demás reptiles se renueva la epidermis de una sola vez, y en algunos con tanta perfeccion, que se justifica plenamente el nombre vulgar de camisas de culelira con que se designan las pieles enteras abandonadas por las serpientes. Como seme. jante muda supone para estos amimales una verdadera per. dida de vigor, explicase la extraordinaria rnracidad que ma. nifiestan inmediatamente despues, y su afan en la caza. StENo INviRNaL - $A l$ acercarse el inviemo, 6 al princi. piar el tiempo seco, en los trópicos, retiranse los reptiles á sus agujeros debajo de tierra, ó se ocultan en cavidades pro. fundas, donde pasan á un estado de inmovilidad y rigidez semejante al de la muerte ó al sueño iniernal de cjertos ma. miferos. En los limites norte y sur de su área de dispersion, todas las especies alli existentes se preservan de la influencia perniciosa de la estacion desfavorable; pero en la region sur de la zona templada, y en los paises equinocciales, lo hacen solo aquelias que no pueden evitar de otro modo el cambio de temperatura. En los paises húmedos, como el Brasil, se ve i las tortugas terrestres todo el año; mientras que los reptiles que habitan of orillas del Orinoco se refugian, segun observa Humboldt, durante los grandes calores y la sequia, debajo de las piedras 6 agujeros que forman, sin salir ya de su escondrijo hasta que sienten que se humedece la tierra debajo de ellos. Los crocodilos que habitan en rios caudalo- 
sos no están sometidos al súcno invernal, pero pasan toda la estacion desfavorable en sitios donde el agua se agota, cobijåndose entonces en el mismo fango. El citado natura lista refiere que los habitantes de az̧uellos paises le asegura. ron que á veces se ve levantarse lentamente el barro húmedo de los pantanos en grandes masas, $y$ con ruidoso estruendo, cual si alli hubiese un volcan de barro. Si la persona que presencia el hecho sabe ya la causa que lo produce, huye presurosa, porque de alli sale, como resucitada por las pri. meras lluvias, una gigantesca serpiente boa $\delta$ un acorazado crocodilo. No falta quien haya puesto en duda lo que nos dice el célebre geólogo; pero exactamente lo mismo me refirieron á mi los indigenas de Africa, asi como un europeo que presencio un hecho análogo.

Segun parece, no todos los reptiles conservan una inmo. viliảad catalépica, sino que muchos pasan aquel periodo como sonando, pues conservan cierta flexibilidad, ó por lo menos la recobran muy pronto cuando las circunstancias cambian; mientras que otros, no solo permanecen completamente rigidos 6 insensibles, sino que ofrecen dureza al tacto. Algunos cazadores que hallaron serpicntes de cascabel en tal estado, se las llevaron á su casa métidas en un saco, y al acercarlas al fuego, enderczáronse muy pronto; pero volvieron a cacr en el letárgico sucño al dejarlas de nuevo expuestas al frio. Si se repetian estas prucbas muchas veces seguidas, moria con frecuencia el reptil. IL falta del aire e:terior parece ser tambien en estos séres condicion indis. pensable para el sueño invernal, segun observa Schinz. Se comprende fácilmente que unos animales que en su estado normal pasan meses enteros sin probar alimento alguno, puedan hacer lo mismo durante un invierno; pero la verdad es que, asi como los mamíferos sometidos al sueño letárgico, los reptiles consumen en tal estado parte de los jugos del cuerpo, aunque sea en poca cantidad. Esto se prueba por el hecho de morir durante el sueño los individuos que no estaban bien alimentados en el otoño. En unos séres cuyas funciones corporales se pueden interrumpir tan a menudo cuando se hallan en su estado normal, sin perjudicarse en lo mas minimo, no es posible determinar hasta qué punto se paralizan aquellas, $y$ en cuáles se verifica esto del todo. Fs probable, sin embargo, que la circulacion no se interrumpa, aunque se efectúe con suma lentitud, y que Ia respiracion quede suprimida por completo durante este tiempo, lo cuai no seria de extranar, teniendo en cuenta que estos animales necesitan poco el oxígeno. De todos modos, el frio excesivo y continuado los mata tambien cuando no pueden preservarse de él convenientemente; es probable que entonces se hiele la sangre, y en tal caso, siendo ya imposible ni aun la mas lenta circulacion, siguese la muerte como consecuencia inevitable. El consumo de los jugos del cuerpo se reconoce asimismo por la disminucion de peso que se observa en es tos animales al fin de aquel periodo; asl, por ejemplo, una tortuga que pesaba cuatro libras y nueve onzas antes de entregarse al sueño, perdió durante él una libra y cinco drac mas. No debe creerse, sin embargo, que los reptiles se despiertan cxtenuados y sin fuerzas; muy lejos de cllo, al salir de su letargo es cuando se muestran mas activos y vi vaces.

MOVIMIENTO. - Los reptiles reptan, corren, trepan saltan ó andan; de varios podemos hasta decir que vuelan, $\delta$ en otros términos, quue pueden salvar espacios por medio de una membrana que existe entre sus dedos, de la cual se sirven como de un para.caidas; pero nunca les seria dado elevarse como el ave, sino solo descender. Por lo tanto, debe admitirse sin disputa, que las jigantescas especies de los tiempos pasados que cstaban provistas de membranas anaila gas, no se sirvieron de ellas ni pudieron volar, 6 mas bien rezolotear del mismo modo que los murciélagos actuales.

Marcha. - El nombre de reptiles con que se designa estos animales es exacto, porque reptan; su modo de andar y correr consiste en arrastrar el vientre; y esto se observa mejor precisamente en las especies mas ligeras. Verdad es que algunas tortugas pueden andar sin que toque su peto en tierra; pero adelantan tan poco, que su movimiento no merece el nombre de marcha; en cuanto \& las tortugas acuáticas, todas rozan el suelo con la concha; y las marinas son casi mas torpes que los pinipedos para andar. Los la gartos se deslizan con mucha agilidad y rapidez; pero como sus extremidades sobresalen tanto del cuerpo, resulta que sus movimientos, comparados con los de los mamíferos, no dejan de ser fatigosos y torpes. Las serpientes, repilles por excelencia, se valen en cierto modo de sus costillas para la marcha, pues no solo sirven de apoyo al cuerpo, sino tambien de verdaderas painacas unvibles.

Naracios.-Los reptiles nadan de muchos modos; no hay uno solo que na sepa moverse sin dificultad en el agua; y si bien se cuentan varios a los que repugna este elemento, se. guro es que ninguno morira ahogado, pues hasta las mismas tortugas terrestres que caen al fondo del agua como una masa inerte, saben salir á tierra, aunque sea arrastrándose, y llegan al sitio donde habitan. Las tortugas de rio nadan valiéndose de sus anchos piés á manera de remos; las inari. nas se distinguen aun mas en este ejercicio, merced \& sus grandes aletas; los crocodilos se sirven principalmente de la cola, que hace las veces de un remo ó un timon en la papa de una lancha; y las serpientes y los lagartos, por último, nadan describiendo con su cuerpo espirales, ó como suele decirse culebreando, por cuyo medio adelantan con suma rapidez. I.as verdaderas serpientes marinas, cuya cola aplanada adquiere poco á poco la forma de remo, se mueven dentro del agua con sorprendente agilidad, y tambien to hacen con no poca ligereza las que no presentan la misma es. tructura. Como los reptiles no necesitan respirar mucho, pueden permanecer largo tiempo debajo del agua, aun aqué. llos que viven siempre en tierra.

Disposicion BARA TREPAR.-Muchos de estos animales son excelentes trepadores: ciertos lagartos y especies análogas suben por los úrboles, aunque sea muy lisa su corteza, con la misma velocidad que corren por el suelo; las uñas lar. gas y encorvadas á manera de hoz, que tienen muchos de ellos, 6 los dedos asurcados, que se ensanchan en forma de disco, son los órganos mas á propósito para trepar á los árboles 6 correr y sostenerse, con tanta seguridad como las moscas en la superficie inferior de las ramas ó de otros cuer. pos. Las serpientes, por su parte, trepan del mismo modo que nadan, es decit, avanzan culebreando, y se adhieren tan intimamente con sus costillas movibles a las sinuosidades, asperezas 6 grietas exteriores de los árboles, que no pueden caer ni deslizarse por descuido.

MOVIMIENTOS INTERNOS. - Los que hacen los reptiles involuntariamente son mas defectuosos, si cabe, que los que ejecutan por su voluntad.

RESPIRICION Y RESISTR.NCH viTAL-Ia respiracion circulacion de la sangre son por demás irregulares $e^{\prime i m p e r}$. fectas en los reptiles: la segunda estä ciertamente subordina da ála primera; pero mucho mas independientemente que en los vertebrados superiores. En primer lugar, todos ellos respiran perezosa y lentamente, pudiendo sesistir largo tiem. po sin aspirar el aire renovado; por otra parte, la respiracion depende en ellos de la voluntad mucho mas que en los ani males de sangre caliente, pues llenan el pulmon de aire $y$ lo expelen despues con lentitud. Solo una pequeira parte de la 
sangre llega al pulmon para purificarse, segun hemos visto antes; la arterial se mezcla bastante con la venosa, y de aqui resulta que no puede aumentar el calor del cuerpo ni exceder en nucho del ambiente. Añadase á todo esto la independencia relativamente grande de la masa nerviosa del ce. rebro, y por consiguiente la mayor insensibilidad, con 10 cual coincide una resistencia vital extraordinaria. Varias tor. tugas sumergidas en accite vivieron media hora; otras, à las que se habia sujetado con fucrza la boca, lacrándoles las fosas nasales, resistieron un mes; y algunas que solo podian respirar àcido carbónico, vivieron siempre mucho mas tiem. po que los animales de sangre caliente sometidos à la mis. ma prueba. Boyle puso una vibora debajo de la campana de uma ináquina neumática, $y$ habiendo hecho el vacio, observó que todo el cuello y el cuerpo se hinchaban; la glotis subió hasta el mismo borde de la mandibula inferior; vióse salir la lengua, mas á pesar de todo esto, media hora despues de tan horrible tormento, notáronse aun señales de vida en el reptil. Al cabo de veintitres horas, cuando se dió otra vez entrada al aire, la vibora abrió y cerró la boca, y al pellizcar su cola, se movió un poco. Una culebra vivió mas de once horas privada de aire. Resultados análogos se obtuvieron en otras jruebas, como por ejemplo, con tortugas sin cabeza, que à los once dias movieron aun sus miembros; uno de es. tos animales, al que habian quitado el corazon, los intesti. nos y el peto, se volvió al dia siguiente del otro lado y co. menzó á arrastrarse. La cabeza cortada de una serpiente de cascabel, la de una vibora ó la de una tortuga muerden ó co. gen, al dia siguiente de haber sido separadas del tronco, un palo que se les presente.

Todos estos ensayos prueban que el cerebro de los repti. les no infuye en la actividad corporal, como sucede en los animales superiores, $y$ por el contrario, cada micmbro es mas ó menos independiente de los demés, lo cual explica la cualidad que tienen de reproducirse. Si se cortan á los la. gartos los piés y à las serpientes la cola, les vuelven á crecer; las heridas que serian de mucrte en las especies mas perfectas, se curan en los reptiles; y las deformidades no ejercen casi ninguna influencia en ellos.

Ya hemos dicho que la actividad vital de los reptiles au. menta á medida que sube el calor exterior; y he aqui porqute la misma serpiente que vemos en un dia caluroso de verano parece otra en un dia irio. Los órganos respintorios y circulatorios de la sangre no pueden dar calórico interior al reptil, el cual depende por lo tanto mas ó menos de la atmósfera exterior; la recibe en si, vive en ella, y aunque su piej, su escudo, su coraza ó sus escamas se caldeasen de ial modo que al tocarlas nos queurásemos la mano, conserva este calor mucho tiempo, perdiéndolo despues poco á poco hasta que se restablece el equilibrio entre él y el calor pro. pio. I.os reptiles que se han caldeado por el sol exteriot é interiormente se conservan calicntes al tacto aun mucho despues de ocularse el astro; pero su calor baja por la no. che hasta nivelarse con los grados de la atmósfera exterior, y pierde durante el otoino ó en la estacion fria tanto como recibió en rerano. Esto explica tambien el hecho de que las especies que habitan en paises mas frios se rean obligadas a retirarse en los meses de invierno y á dormir durante la estacion fria, pues si no lo hicieran asi, moririan á consecuencia del rigor del clima.

INTELIGENCIA.-De lo que precede resula que las faculiades intelectuales de los reptiles han de ser forzosa. mente muy liminadas, porque es imposible que un animal cuyo cerebro tiene tan poco desarrollo, pueda poseer la capacidad que llamamos inteligencia. Si esta no es exactamente proporcionada al volúmen de aquel, guarda por lo menos cierta relacion, y sabiendo ya que la que existe entre el peso del cercbro $y$ el del cuerpo es en el hombre como de 1 á 40 , $y$ de 1 à 1850 en la tortuga, fácilmente se colegirá lo que pueden ser las facultades intelectuales de este animal. I entiéndase que no es solo la poca cantidad, sino tambien el escaso desarrollo y la imperfeccion del cerebro, lo que co. loca á los reptiles en un grado tan bajo en la escala de los séres. Dado el caso mas favorable, solo presentan vestigios de cualidades superiores, $y$ hasta cierto punto no son mas que máquinas inconscientes. Segun se dijo mas arriba, ape. nas se observa desarrollo intelectual en todos los individuas. de esta clase; solo se reconocen con frecuencia en estos animales alucinaciones, $\delta$ sea la comprension incompleta y defectuosa de las cosas exteriores. En los reptiles no se observan sino los efectos del trabajo mental mas rudimentario, lo cual no merece el nombre de inteligencia propiamente dicha. Cierta facultad para orientarse, un limitado conoci. miento de lo que es ó no comestible, es decir, de lo útil y perjudicial, acaso tambien una comprension de lo que es hos. til, y por último, el instinto de reproducirse, son los únicos indicios de la capacidad intelectual de los reptiles. La gra. duacion de esta última en toda la clase es casi imperceptible, por mucho que se diferencien los individuos en cuanto a sus cualidades exteriores. En algunos, sin embargo, se ha notado cierta disposicion para aprender; en otros alguna 50. licitud con su progenie, por efecto tal vez de una excitacion sexual, en muchos una irritacion que se ha querido compa. rar con la ira; en varios malignidad ó perfidia; pero en muy pocos el conocimiento de su propia fuerza. En ningun reptil llega la capacidad mental hasia la astucia, cualidad que tambien dista mucho de ser una prueba de superioridad intelectual y de su afecto \& otros animales. En cuanto al cariño entre los sexos y á su amor \& la progenie, he dicho mas de lo que el asunto merece, atendidas mis propias observacio. nes. En los reptiles no se reconoce tampoco la menor huella de ese instinto industrial $y$ astistico observado en los animales superiores, a no ser que se quiera considerar como tal el trabajo que ejecutan para practicar los agujeros donde las hembras depositan sus hueros, amontonando alguna hoja. rasca á fin de conservarlos mejor. Saben elegir sitios conve. nientes para albergarse, como son rendijas, hendiduras, hoyos y otros huecos; tambien es verdad que adquieren en cierto modo la costumbre de volver siempre ŝ sus guaridas des. pues de sus excursiones, conservando como un recuerdo de 1. localidad; pero se encarinan con ella como los mamíferos. En cuanto a ese instinto de construccion que tan claramente se manifiesta en las aves cuando hacen sus nidos, es cosa completamente desconocida entre los reppriles; y por lo que hace da prevision que manifiestan para conservar su proge. nie, no puede compararse tampoco con lo que sugiere at los mamíferos $y$ a las aves el instinto de la reproduccion. Los vertebrados superiores eligen sus guaridas con verdadera comprension; pero el reptil sigue en esto el impulso del mo. mento, y dificilmente reconoce diferencia alguna entre las que son buenas y malas. No puede negarse que llegan á ser timidos y miedosos alli donde se les persigue con frecuen. cia; pero tal rez no sepan distinguir los peligros verdadercs de los imaginarios. Dificilmente llama su atencion el hombre que permancce inmóvil en su sitio; hecho que se observa en toda la clase; solo hacen caso de El, ó les parece hostil cuando se mueve 6 produce un rumor.

L.os crocodilos de Egipto han llegado á tener una vaga idea de lo peligroso que el hombre es para ellos; pero no saben distinguir entre el negro y el blanco, ni comprenden que este ultimo es su enemigo mas terrible, puesto que no pierde ocasion de exterminarle á balazos. Los marníferos $y$ 
las aves nos dan en esto precisamente una prueba de su ma. yor perspicacia, lo cual nos demuestra una vez mas que los animales superiores se guian en sus actos por las circunstan. cias, reciben impresiones, se afectau por ellas $y$ obran en consecuencia. Pueden estar alegres $\delta$ tristes, satisfechos $\sigma$ enojados, segun la situacion del momento; pero en los repti. les no se observa nada por el estilo. Ninguno de ellos retoza ni se divierte, ni esta triste ni contento; solo experimentan acaso satisfaccion cuando se hartan de comer, y al recibir la impresion del calor que les vivifica. Dicese que algunas scrpientes oyen con placer la música; y yo mismo he visto que los juglares egipcios consiguen qu: estos reptiles se endere. cen y dancen en cicrto modo al son de un caramillo; pero ignoro hasta que punto serán dabidos los movimientos del reptil a los acordes del instrumento, y qué conexion podrá haber entre unos y otros. En todo caso, dificilmente podria compararse esta pretendida aficion á la música con la influencia que visiblemente ejerce en ciertos mamiferos, por mas que parezca cosa demostrada que obran con bastante fuerza sobre el reducido cerebro de los reptiles las excitaciones de los sentidos. Se la observado, entre otras cosas, que durante el tiempo de la reproduccion no ven ni oyén, ni parece exis. tir para ellos el mundo exterior; en dicho periodo se mues. tran indiferentes \& los peligros que de seguro evitarian en cualquiera otra época; y en una palabra, su modo de condu. cirse difiere en un todo. De esto se podria deducir que una impresion material absorbe temporalmente toda la actividad del su cerebro, suposicion que no deja de justificarse muy bien; podria decirse que su vida es puramente sensual, aun. que no debe negárseles por completo cierta aptitud para aprovechar las lecciones de la experiencia y utilizarlas de la manera que mejor les conviene la serpiente venenosa comprende que tiene un arma mortifera, y espera tranquila à que el tósigo hága su efecto; la cuicbra, la tortuga, el crocodilo y el lagarto sé acercan cautelosamente á su presa, la persiguen o la acechan, precipitanse de pronto sobre clla y tratan de cogerla. Por otra parte, todos los reptiles se domestican hasta cierto punto, es decir, se acostumbran i la persona que les da de comer; pero nunca saben distinguir entre clla y las desconocidas. Yo he visto que algunas -serpientes venenosas se habian amansado hasta el punto de tolerar que les quita. ran su alimento; pero tambien observé que mordian las tenazas de hierro con las cuales se les presentaba la comida, ol. vidando del todo que muchas veces se habian hecho dano con cllas. Estos reptiles, aunque estén amansados, son siem. pre peligrosos si pueden moverse con libertad, porque des. conocen todo sentimiento afectuoso, y solo puede esperarse de ellos perfidia y perversidad. El reptil no se encarina con otros animales, ni aun con los de su misma clase; lo único que de él se consigue es hacerle perder el temor ó que mani. fieste indiferencia. Entre estos séres tan inferiores 130 existe el carácter de verdadera sociabilidad; si á veces se ven cen tenares de tortugas, ó veinte ó treinta crocodilos juntos ca. lentándose al sol, bien se puede asegurar que ninguno de ellos se cuida del otro, á no ser que intervenga la necesidad de aparearse. Tampoco se reunen jamás para la defensa co. mun, ni se dajan guiar por uno de ellos, Se han referido muchas cosas acerca del amor paternal del crocodilo, y de la solicitud de cieitas serpientes con su progénie; pero falta saber si tales cuentos se fundan en hechos positivos. Asegúrase que los crocodilos corren presurosos en auxilio de sus pequenos cuando les amenaza un riesgo, y que algunas serpientes habian salvado á su progenie llevíndusela en la boca; pero yo no me atreveré à emitir parecer acerca del grado de veracidad de semejantes hechos.

GÉNERO DE VIDA.-El género de vida de los rep- tiles es por demás monótono: la mayor parte de ellos son probablemente nocturnos, $\delta$ por lo menos, el número de estos últimos excede á lo que comunmente se cree. En cuanto á las tortugas, son nocturnas con preferencia todas las que no habitan en tierra firme; los crocodilos cazan tambien al acercarse la noche, aunque no dejan de aprovechar toda ocasion de hacer una buena presa durante el dia; los gecos y casi todas las serpicntes venenosas salen á cazar despues de ponerse el sol; solo los lagartos y la mayor parte de las culebras pueden considerarse como animales diurnos propiainente dichos. Como ya se comprenderá, el agua influye en el régimen de vida, en cuanto no permite á los animales que en ella viven reconocer la marcha del tiempo con tanta faci. lidad como los que habitan en tierra; pero sea como fuere, las mas de las especies son nocturnas.

REPRODUCCION.-Con la llegada de la primavera comienza á manifestarse en los reptiles el instinto de repro. ducirse Ios que habitan en los paises septentrionales apa. recen én los primeros dias calurosos de dicha estacion y los que viven en paises templados y cálidos, donde suelen enterrarse durante el invierno, salen de su retiro despues de las primeras lluvias.

Llegado el periodo del celo, trábanse entre algunos reptiles encarnizadas peleas: los crocodilos se persiguen entre si con furor; otro tanto hacen los lagartos; las serpientes $y \mathrm{cu}$. lebrás se reunen en determinados sitios, y entrclazándose confusaniente, forman masas espantosas, que ofrecen á la vista un espectáculo tan repugnante como terrorifico. Mani. fiestan su excitacion con ruidosos silbidos y otras demostraciones, hasta que al fin quedan apareados los scxos. Vemos, pues, que el instinto de la reproduccion produce marcados efectos en los réptiles; la generacion propiamente dicha dura muchos dias, y hasta semanas; pero una vez concluida, la aparente violencia del arnor entre los machos y las hembras se cambia en la mas fria indiferencia, al menos en el mayor número de especies. Pasado cierto tiempo, la hembra busca sitio conveniente para depositar sus huevos, $\delta$ formar lo que pudiera llamarse nido, en el caso de no dar á luz su progenie viva. Los huevos de la mayor parte de los reptiles tienen la císcara como apergaminada; cl número de los de cada hembra varía entre seis y ciento cincuenta, y los depositan en agujeros, abiertos por el mismo animal cuando no en cuentra alguno debajo de tierra. Eligen sitios húmedos y cá lidos, donde haya musgo ú hojarasca, y alli los dejan dispues. tos de modo que puedan incubarse con el calor del sol ó la fermentacion de los vegetales, sin acordarse ya mas de ellos. Dícese, como ya indiqué antes, que los crocodilos y las serpiente's constiluyen una excepcion de esta regla. I.os hijue los se desarrollan rápidamente en pocas semanas, y conser van el mismo género de vida que sus padres desde el dia que salen del huevo.

CRECIMIENTO. - Todos los reptiles sin excepcion, crecen con increible lentitud, de sucrte que tambien por este concepto se reconoce la marcha perezosa de su organi. zacion entera. Esta clase no ofrece ejemplo alguno que pue. da compararse con lo que sc observa entre los mamíferos y aves respecto al desarrollo sápido, porque en ella, hasta las cspecies inferiores necesitan algunos años antes de poder reproducirse; pero en cambio gozan de larga vida. Se han conocido tortugas que vivieron cien años 6 mas en el recinto donde estaban encerradas: los indigenas de Africa han ob. servado en un mismo sitio ciertos crocodilos desde tiempo inmemorial; y asi se explica que has serpientes mas grandes vivan igualmente muchisimo tiempo. En cuanto á las enfermedades, parece que son muy raras entre los reptiles, aunque no han dejado de observarse algunas en individuos en. 
cerrados. A pesar de lo dicho anteriormente, pocos de estos animales llegan a lo que llamamos decrepitud: los mas de ellos mueren violentamente, $y$ de todos modos por causas exteriores.

UTILIDADES Y PERJUICIOS. - En el reino animal nada ofrece tan sorprendente contraste entre lo útil y lo pernicioso como la clase de los peces y de los reptiles. Fn la primera, casi todo es comestible; pueblos enteros se man. tienen de ella; y acaso no exista hombre alguno en e! mundo que no coma, ó por lo menos que no pueda comer pescado. Entre los reptiles nada sirve de alimento, exceptuando las ranas y las tortugas, a no ser que haya algunos salvajes que coman la carne de otros. Si á esto se ainade el beneficio que da la concha de las tortugas, tendremos con corta diferencia, todo lo que en los reptiles pucda servir de alguna utilidad.

s Aquellos que creen que todo lo existente fué creado por amor al hombre, á fin de poner á su disposicion séres que le sirvan de recreo, de alimento, ó para beneficiarse de ellos de diversos modos, cuando.no se complace en martirizarlos, podrian preguntar con qué objeto se crearon los reptiles $y$ los anfibios, que solo cxcitan generalmente repugnancia y repulsion, al paso que la clase de los peces constituye para nosotros un buen alimento. En vano se elogian los bonitos colores de la serpiente, el carácter inofensivo de los lagartos y la cualidad nutritiva de las tortugas; por mas que digan, la vicrdad es que todos los reptiles inspiran una repugnancia universal, que no bastarian a destersar todos los raciocinios del mundo. Seguramente no se puede negar que constituyen la única clase que con su mortífero veneno son una perpetua amenaza para nosotros; todos estos animales acechan su presa para precipitarse sobre ella de improviso; y aunque sean los únicos que en cierto modo se parecen à los mami. feros, difieren en muchos de ellos por su mancra de condu. cirse. Su desnudez, por otra parte, nos inspira la misma repugnancia que sentiriamos al ver animales de otra clase sin su cubierta natural; nos parecen mamiferos contrahechos $y$ asquerosos. Los peces no producen igual impresion en nos. otros, porque sus formas difieren demasiado de las del lrom bre $y$ de los mamiferos superiores, y además porque su aspecto no deja de ser agradable y huyen con rapidos movimientos en vez de acomeiernos. Por lo demás, la relacion entre ambas clases animales y el hombre es puramente sensual: los peces satisiacen para nosotros una necesidad, sirviéndonos de alimento; los reptiles nos inspiran ian solo repugnancia y asco; aquellos recrean la vista, nos acercamos a ellos, y liasta intentamos cogerlos con la mano; pero hui. mos de los segundos para evitar su contacto. No menos cu. riosa es la relacion que existe, bajo el punto de vista moral, entre las aves y los mamíferos por un lado y el hombre por otro. Aquellas nos sirven de recreo y pasatiempo; las conservamos en nuestras habitaciones, no por la utilidad que nos dan, sino por pura diversion, pues ni su carne ni sus huesos podrian reportarnos un beneficio de consideracion. los mamiferos, por su parte, son nuestros auxiliares 5 nos prestan servicios análogos á los del hombre; trabajan para nosotros, labran los campos, etc.; y podemos decir que las cuatro clases superiores nos sirven de alimento, de recreo y de auxiliares. I.os reptiles no producen estas utilidades; mas no por eso debe creerse que son del todo inútiles. $x$

Asf contesta Oken a los que tienen por costumbre pre guntar à cada momento cuál es la utilidad y conveniencia de todo lo creado. Yo miro las cosas bajo otro punto de vista, porque no pierdo el tiempo en hacer deducciones cuando estas son inútiles para llegar al conociniento desea do: y acepto los hechos tal como son. No figuro yo segura mente en el numero de los que manifiestan simpatias por

Towo $\mathrm{V}$ los reptiles y los anfibios; pero esto no me impide sostener que la clase merece nuestra atencion, tenga ó no utilidad para nosotros, aun cuando solo fuese con el objeto de con. tribuir á desterrar toda clase de antiguas preocupaciones, rundadas 6 infundadas. Ya he dicho en otro lugar que no nos gusta ocuparnos de estos séres; pero es preciso dar al olvido el odio heredado de nuestros antecesores, que nos explican ingenua y sencillamente las creencias legendarins; es nécesario reprimir los impulsos de enconada saña que al. gunos tratan de comunicamos, procurando hacer justicia sa los reptiles y anfibios. En vano se ha esforzado la ciencia, durante el trascurso de los siglos, en desterrar de la humanidad el error arraigado, hasta en cabezas privilegiadas, respecto á dichos animales; todo fué siempre inútil, y ni aun hoy se ha podido conseguir que desaparerca el sentimiento de temor que inspira á las almas sensibles hasia la inofensiva rana ó una simple culebra. Lagartos y sabandijas que matín los niños con una caña causan pavor a personas instruidas, y de nada han servido todos los esfuerzos de los naturalistas para tranquilizar á los timidos. No puede darse espectículo mas singular, ó mejor dicho, mas grotesco, para el hombre, que con f́nimo tranquilo y sin preocupaciones considera las cosas como son, que ver los ademanes de las personas que se dicen instruidas, cuando les sale al encuentro un reptil. ni deja tampoco de prestarse este hecho a ciertas considera, ciones. ¿No es muy extraño que nosotros, los hombres poderosos, los que deseamos dominar el mundo y ser conside. rados casi como senıi-dioses; nosotros, que presuminos que todo fú́ creado en beneficio nuestro, y nada para nuestro daño, y que exigimos á todas las demás criaturas reconozcan nuestra omnipotencia, sometiéndose á clla; no es extraño, repiro, que temblemos como niños ante unos séres tan infe. riores á nosotros? ¿No es vergonzoso que al ver reptiles nos conduzcamos casi de la misma manera que lo hacen los mo nos, nuestras caricaturas?

Entiéndase que no digo esto para que se crea que me propongo hacer propaganda en favor de los repliles; que trato de disminuir, aunque solo fuera una gota del venero de la vibora, ni de presentar los dientes del crocodilo menos acerados de lo que son. Harto sé que la utilidad que pueda reportar al hombre loda esta clase se reduce á bien poca co. sa, y que no debe menospreciarse el daño que causaria un solo individuo.

La mayor parte de los reptiles se alimentan de animales que son nocivos para nosotros; y si hay entre ellos algunos herbivoros, no nos perjudican con esto en la menor cosa, aunque ni los unos ni los otros iengan por otra parte im. portancia para nosotros. Casi todos los lagartos, sin excepcion, $y$ las serpientes de nuestro pais, son en cierto modo útiles porque exterminan los ratones y diversos animales daüinos, como insectos, caracoles, gusanos y otros por el estilo; pero el consumo que hacen es tan insignificante que no merece mencionarse la utilidad que producen. Fi aficionado al caldo $y$ á la sopa de tortuga puede felicitarse de que existan tales ś́res, que ademís nos dan la concha, si tiene la dicha de vivir cerca del mar; y aquel que se complace en conservar septiles cautivos, debe agradecer la satisfaccion que le proporciona observar á estos animales; pero si layy en cambio personas que se muestran celosas para matar todos los reptiles, ó por lo menos todas las serpientes que puedan ercontrar, no harán con esto ningun daño, segun he diclio an. tes. 'lenemos derecho de anatematizar sin miramiento cunl. quiera crucldad que el hombre cometa con los animales, ó que les prive de la vida sin necesidad; pero tambien es justo disculpar al que espantado ante una culcbra, le aplaste la cabcza, porque el hombre vale mas que un insignificante rep- 
til por inofensivo que sea Si hay naturalistas que á menudo abogan en favor de la misma vibora amodites, ú olras serpientes venenosas, yo por mi parte declaro que procurar asi la conservacion de todo lo existente es llevar las cosas de. masiado léjos. Todas las viboras amodites del mundo no prestan tantos servicios como la calumniada tribu de los buhos, como los busardos, a los que tanto se desprecia; y como las comadrejas y gardunas, que son miradas con pre. vencion. Un solo busardo hace por si solo mas que centenares de aquellos reptiles peligrosos, cuya inordedura ocasiona por término medio, 12 muerte de dos personas al año ó cuando menos una larga y penosa enfermedad. Nada mas fácil que confundir una vibora amodites con una inofensiva cule. bra, y el error puede producir las mas tristes consecuencias. ¿Por qué, pues, no seria licito evitar tantos peligros de una vez, usando en esto del derecho del mas fuerte? Seguramente valdria mucho mas exterminar todas las serpientes venenosas que exponer ál una sola persona á un percance que puede costarle la vida $\delta$ la salud; y es precisu tambien en este caso, que lo inferior, lo que es vil, ceda ante lo noble y superior. Hé aquí en qué sentido deseó que se me entienda, para que no se diga que yo aconsejaba imatarlo codo. Con coria diferencia, siempre apoyé la misina idea, manifestando mi deseo de que todos los hombres estudiaran y conociesen los reptiles. Creo, si, que el naturalista podrá conseguir arrancar á la vibora su mortífero diente, como lo hizo Moisés con la serpiente de cascabel antes de servirse de ella para recrear \& Faraon; y al expresarme asi quiero decir que el ob. servador científico contribuirá á darnos á conocer los reptiles venenosos, en lo cual consiste todo el auxilio que pudiera prestarnos, porque no hay mejor remedio contra la morde. dura de la vibora que el conocimiento exacto de ella misma.

En remozas épocas, los hombres adoraban aquellos repti. les ique les infundian temor: los antiguos egipcios conserva ban cerca de sus templos crocodilos amansados, y embalsa. maban cuidadosamente sus cadảveres; los habitantes de una parte del Asia, y particularmente los chinos y japoneses, da. ban a sus dioses la forma de serpientes y saurios; los griegos y romanos representaban con una imágen de las primeras sus figuras retóricas, citándolas en sus fábulas y poesias como sćres astutos, inteligentes, proféticos y dotados de otras muchas cualidades preciosas. Tambien se habla de ella en el Génesis, y no como de un sér abominable, sino como seductora de nuestra primera madre Lsa; la mitologia romana, por último, nos muestra al soberano del mundo trasformado en uno de los reptiles para seducir á una mujer; $y$ aun en la epoca actual hay pueblos bárbaros que veneran y adoran á crocodilos y serpientes. Los antiguos egipcios, no obstante, nos han dejado pruebas de que sabian poner limites á su veneracion, pues go mismo he visto en la cseva de los croco. dilos de Maabde, cerca de Monfalut, la cual sirvió de depó. sito âlas momias de los animales sagrados, miles de individuos pequeños de la especie, y tambien de sus huevos. Nadie sostendrá que estos animales fueron embalsamados despues de una muerte natural; y en cambio nos ofrecen una prueba palpable de que los egipcios procuraban ante todo librarse de tan poderosos enemigos. Suponian que hacian lo bastan. te por ellos cuando conservaban su piel en representacion de su espiritu, pues segun sus levendas, este habia sido conde. nado a viajar durante miles de años despues de abandonar su cuerpo. Nosotros no creemos que los espíritus de los cro. codilos ó de otros animales viajen por el firmamento; solo deseamos que algun dia sirva aquel de morada á nuestras almas, y por consiguiente no tenemos necesidad de embalsa. mar reptiles; pero en cuanto á lo demás, procedemos como los antiguos egipcios, y al propio tiempo en armonía con la Sagrada Escritura, es decir, aftastamos la caleea de los rep. tiles qque nós molestan ó que nos mueríen en el fulon.
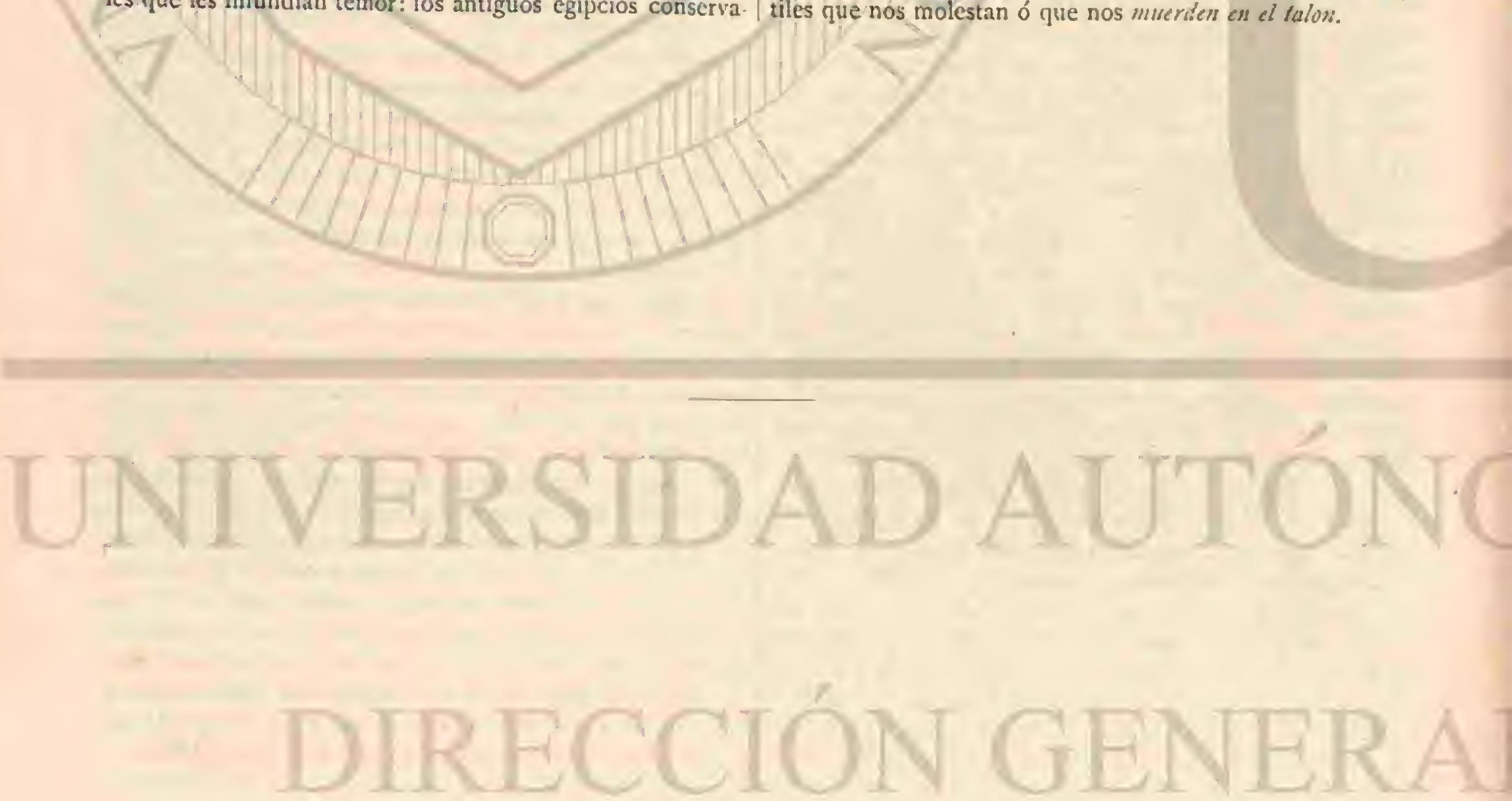


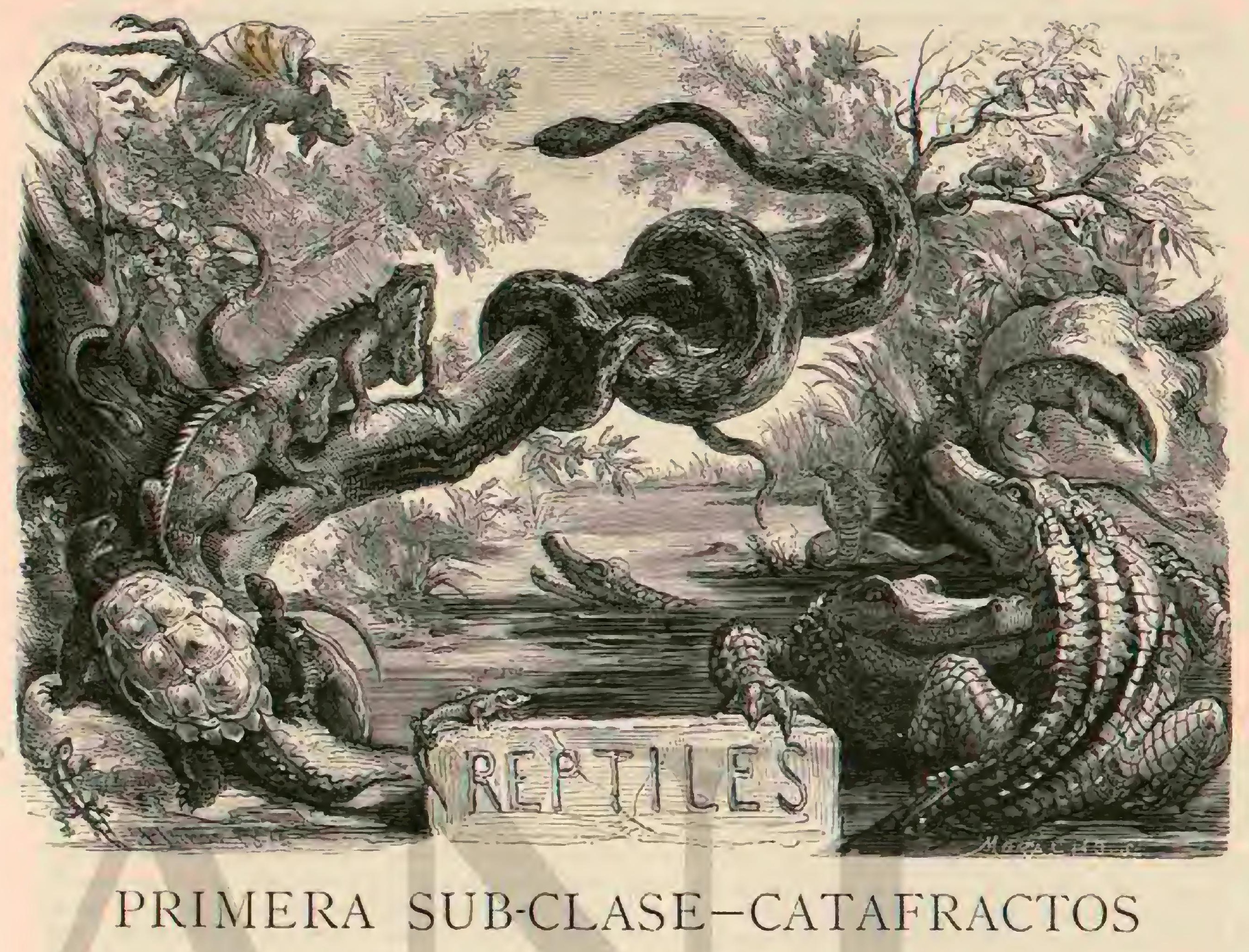

PRIMEK ORDEN

\section{QUELONIOS-CHELONI在}

CONSIDER ACIONES GENERA LES. - Las tortugas, dice el anciano Gessner, son animales de aspecto singular y desagradable, cuyo cuerpo está protegido por una especic de caja dura y tan bien cerrada, que solo se ven la cabcza y las extremidades, las cuales pucde ocultar el animal interior. mentc y volverlins á sacar scgun le convenga: esta cubierta ó concha, es tan resistente, que no se romperia aunque pasa ran sobre ella las ruedas, de un carro cargado. La cabeza y las patas están revestidas de escamas, como las de las serpientes 6 culebras y demás animales de la clase. Algunas tortugas habitan en tierra, otras en las aguas dulces, y varias en el mar.p

El citado autor, imitando \& los antiguos, clasifica todavia á las tortugas entrc los cuacrúpedos, diciendo que son «de la clase de animales que tienen sangre y se reproducen porhuevos; Ios naturalistas actuales las ponen a la cabeza de los reptiles, porque opinan que ofrecen cierta semejanza con las ares en cuanto a la estructura del esternon y del aparato maxilar. Prescindiendo de esta comparacion de poco valor y bastante inexacta, scria dificil encontrar fundamento para asignar el lugar preferente en la clase de los réptiles a unos animales tan mal dotados fisica y moralmente, tan pesados y cstúpidos.

ORGANIZACION.-Ia estructura de las tortugas es tan especial y dificre tanto de la de los demás representantes de la clase, que es imposible confundirlas con ninguno de cllos. Su cuerpo, resguardado por una especie de coraza, su cabeza irregular, cuya mandibula presenta bordes revestidos de materia córnea, semejantes al pico de ciertas aves, son caractéres que no admiten comparacion con los análogos de otros animales. La coraza consiste en dos piczas, la superior y la inferior, ó sea el espaldar y el pelo; la primera es mas ó menos abovedada, larga ó redondeada; la segunda afecta la forma de un escudo ovalado. Ias dos piezas se unen por medio de una masa cartilaginosa, que puede conscrvarse blanda toda la vida, 6 tambien osificarse, en cuyo caso adquiere el aspecto de una sutura. De este modo ambas placas forman una cspecie de caja ó estuche, que solo tiene una abertura por delante para dar paso a la cabeza, y otra por detrás para la cola, sirviendo ambas para las extremidades, de manera que el tronco queda mas $\delta$ menos completamente cerrado. La cabeza, que suele afectar la forma de huevo, aparece trasversalmente cortada por detras; hácia delante es mas ó menos prolongada; el cuello, segun las especies y tribus, es mas ó menos largo, pero siempre muy movible, relativamen. te: los cuatro piés son cortos y en cierto modo mas desarro. Hados, pero muy variables segun las diversas tribus; la cola casi sicnure corta, redondeada y mas 6 menos cónica en la 
punta. La cornza está revestida de placas ó láminas córneas, sustituidas en algunas especies por una cubierta coriácea; las extremidades del cuello se hallan protegidas por una piel verrugosa guarnecida de placas cscamosas mas $\delta$ menos grandes.

ESQUELETO.-Solo despues de haber estudiado el esqueleto (fig. 1) y el desarrollo de estos animales, se llega á comprender su estructura, y principalmente la de su coraza. La cabeza, segun se ha dicho, presenta por detrás como un corte trasversal y tiene un cóndilo simple que se articuia con la primera vértebra; es corta y aplanada; las fosas temporales, tan jronto aplanadas por arriba como abovedadas, tienen una cubierta ósea; el frontal se compone siempre de tres piczas, cubriendo la central las fosas nasales; los huesos maxilares superior y medio se sueldan casi con el críneo y son fijos, mientras que las piezas de la mandibula inferior forman todas por delante una sola pieza sencilla y unida. Las vértebras cervicales, casi siempre en número de ocho, no presen:an apófisis desarrolladas, pcro si articulaciones esféricas muy completas, que permiten la mayor libertad en los movimientos. Se cuentan nueve 6 diez vértebras dorsa les, que se ensanchan hasta formar placas, uniéndose poco a poco con los huesos que, separados de las costillas, correspondian en un principio a la piel. Estas placas se unen entre si por medio de suturas dentadas y acabant por constituir el espaldar, al que cubre la piel exterior, ó epidermis, en forma de placas ó escudos cómeos ó coriáceos. Cúrlos Vogt dice gue las costillas se prolongan las mas de las veces hasta el borde del espaldar; pero hay tambien casos en que solo se desarrollan las placas prósimas al espinazo, de suerte que los extremos de las costillas sobresalen al rededor como los ra dios de una rueda, hallánciose naturalmente ocupados los huecos por escudos resistentes córneos úseos en cl animal vivo. Comunmente se nota en el borde del espaldar una lí nea de placas huesosas especiales, en las que se adaptan los extremos de las costillas, resultando aquel casi completo lasta en los individuos en que estas últimas forman ta. dios salientes. Dos vértebras anchas y aplanadas, y casi tan innóviles como las dorsales, constituyen el sacro; $s$ otras veinticinco pequeñas, aunque movibles, ia cola. El peto se forma de una manera análoga, es decir, merced á un cnsan. chamiento desmesurado del csternón, que por esta causa se subdivide en varios huesos. La porcion basilar del hombro se compone de tres piezas, á saber: la espaldilla, el omoplato y la clavicula. Un brazo de la primera se combina con el disco; el otro extremo de la clavicula con el escudo, formando de este modo ambos huesos por delante un anillo, que da paso a la traquearteria y al csófago; el brazo se halla articulado con los tres huesos del hombro por medio de un cóndilo grande y oviforme; otros tres huesos, cortos y anchos, constituyen la pélvis, la cual está pendiente mas bien que fija en el sacro. El antebrazo y la pierna constan de dos hue sos separados, y el tarso de varios huesecillos pequeños é ir. regulares. El pié tienc cinco huesos con dos $\delta$ tres articula. ciones, provista la última de una uña aguda y roma.

Ni en las vértebras del tronco ni en las costillas se insertan músculos, y los abdominales no existen; micntras que aque llos que sirven para mover el cuello y, la cabeza, las piernas y la cola, se distinguen por su vigor. El aparato cerebral no presenta ningun desarrollo: la caja craneana, aunque muy pequeña, es sin embargo demasiado grande para el cerebro que coniiene, cuya masa no guarda la menor proporcion con la del cuerpo, ni siquiera con la médula espinal, como se ob. serva en los animales vertebrados superiores; tortugas hay de ochenta libras, cuyo cerebro apenas pesa una dracma. 'Todos los nervios son muy gruesos en proporcion al cerebro. Elojo tiene tres párpados, de los cuales el mas movible es el infe. rior, el cual por su estructura ofrece analogias con el de las aves; el anillo que hay al rededor de la córnea tiene lamini. llas óseas; la pupila de las tortugas terrestres es lenticular, pero esférica en las acuáticas. El oido está formado por el oido medio y los canales semicirculares; el espacio que me. dia entre el oido medio y el cráneo permanece parcialmente en estado de membrana; cl huesecillo del martillo tiene una prolongacion delgadita, metida dentro de la masa cartilagi. nosa que constituye las paredes del oido interno, el cual á su vez termina en un canal estrecho que va á parar á la ventana oval en el fondo de la caja, mientras esta en su lado posterior acaba en una celdilla redonda. Una escama gruesa y cartilaginosa cierra la caja del timpano por la parte exterior. Las ventanas de la nariz son pequeñas, prolongadas algunas veces a manera de tubos; la mucosa forma pliegues en el interior. la lengua es carnosa y está cubierta de verrugas gruesas.

De lo que precede resulta que las tortugas ven bastante bien y oyen medianamente; el olfato no es del ludu imperfecto; y probablemente están dotadas del sentido del gusto; pero en cuanto ásu sensibilidad, aventurado seria emitir juicio.

DISTRIBUCION GEOGRAFICA.-Tambien las tortu. gas se cuentan entre los habitantes primitivos de nuestro globio; asi en la oolita como en la caliza hállanse restos pro. cedentes sin duda de tortugas marinas y de agua dulce, ha. biéndose descubierto otros de los grupos citados y de algu. nas tortugas pantanosas en las capas geológicas de la época terciaria; en el mioceno de Europa y en el coceno del norte de Ámérica, en fin, encontráronse los primeros restos de las verdaderas tortugas terrestres.

Strauch nos ha dado los informes mas exactos sobre el área de dispersion de las especies del órden hoy existentes; el citado natumalista enumera en $186 j$ ciento noventa y cuatro especies de torlugas bastante conocidas y suficientemente clasificadas, indicando siete territorios habitados por estos animales. El primero de aquellos corresponde al Mediterra. neo, comprendiendo el sur de Europa, una parte del Asia occidental y toda la costa septentrional del Africa; en él ha. bitan scis especies: treinta y dos son propias del segundo territorio, 6 el africano, al que pertenecen, excepto la costa septentrional, todo el continente de Africa y las islas vecinas: el tercero, ó asiático, con las islas de esta parte del mundo, alberga cincuenta y cuatro: el cuarto, ó sea Australia, ocho; el quinto, que comprende la América del sur con la India occidental, las islas de los Calápagos y de las Tortugas, treinta y cinco; el sexto territorio, que se extiende por el norte $y$ centro de América, contiene cuarenta y cuatro; y el séptimo, ó el mar, cinco. En los dos trópicos habitan sesenta y seis especies: en las regiones cruzadas por el de Cáncer cuéntan. se treinta y cinco; y en los paises del trópico de Capricornio veintiseis; mas al norte del de Cáncer se han reconocido cuarenta y dos, y mas al sur del de Capricornio sicte tortugas de especies distintas. En cl hemisferio oriental se han encontrado noventa y ocho, y en el occidental setenta y ocho, con. tándose trece cuya patria no es conocida. En todos los mares, excepto en el Negro, se han cogido dos especies de tortugas; los otros tipos de la familia tienen el área de dispersion relativamente limitada.

De los datos anteriores resulta que tambien las tortugas están sometidas á la ley generál que rige para el área de dispersion de los reptiles. En las regiones cálidas y donde abunda el agua hállase el mayor número de especies; mientras que á medida que la distancia al ecuador es mayor, su cifra disminuye rápidamente; ninguna especie extiende su área de dispersion hasta el círculo polar: soportan muy bien el calor ardiente y la sequia; pero ro el frio. 
USOS x COSTUMBRES. - Las tortugas habitan los rios, los pantanos, las aguas cenagosas, los bosques húmedos y frondosos; pero tambien se las halla en las estepas, el desier. to y el mar.

En las tortugas se manifiesta la vida por movimientos cuya lentitud no tiene ejemplo; los involuntarios, como la respira. cion y la circulacion de la sangre, no son mas vivaces que los voluntarios. Las tortugas pueden vivir un tiempo increible sin respirar ni mezclar oxígeno con la sangre; se mueven por espacio de varios meses aunque hayan sufrido las mas dolo. rosas mutilaciones, conduciéndose en cierto modo como si estuviesen sanas. Algunos individuos á los que se cortó la cabeza anduvieron todavia durante varias semanas despues de la degollacion, y ocultaban las patas en el interior de la coraza al sentir el contacto de un cuerpo extraño. Redi sacó el cerebro á cierta tortuga, la cual siguió paseándose por la casa despues durante seis meses; en el Jardin de Plantas de Paris vivió una tortuga pantanosa seis años sin tomar ali mento.

En confirmacion de lo anterior véase lo que dice Kersten: «A fin de atormentar lo menos posible á la tortuga que descábamos agregar á nuestra coleccion, destinada por lo tanto á morir, y para evitar al mismo tiempo una lesion de la piel y del escudo, hicimos todos los esfuerzos posibles con objeto de no estropearla; pero su resistencia vital frustró to. do nuestro trabajo. Al fin no hubo mas remedio que aserrar por ambos lados el escudo de los animales vivos, rematándoles despues á fuerza de heridas en las partes sensibles. Mas tarde hice en mayor escala los experimentos para darles muerte. Puse el animal cabeza abajo en un cubo lleno de agua, y oprimi el cuello con un nudo corredizo tan estrechamente como fué posible; pero aun despues de haberle privado muchos dias de la respiracion, vivio luego tan alegremente como antes. Apelando á otro medio, introduje una fuerte aguja entre la cabeza y la primera vértebra cervical, moviéndola por ambos lados á fin de separar el cerebro de la médula de la espina dorsal; pero fué inútil: la tortuga vivió. En tonces quise envenenarla introduciendo por medio de un tubo puntiagudo de vidrio cierta dósis de alcohol en la boca y las fosas nasales del animal, repitiendo la prueba con una solucion del siancalio, que como se sabe es uno de los vene. nos mas fuertes; $y$ hasta la apliqué este terrible liquido en las órbitas y por debajo de la piel: la tortuga resistió con gran desesperacion mia. Aun decapitándola no logré mi fin, pues cortada la cabeza, y al cabo de muchos dias, siguieron agi. tándose las extremidades del tronco. El único medio de matar una tortuga sin abrirla es segun parece colocarla en una mexcla fria, porque estos animales tan resistentes por lo demás son en extremo sensibles al frio.

Fícilmente se comprende que unos séres cuyo cerebro y nervios tienen tan poco desarrollo, no pueden estar dotados de gran inteligencia; mas á pesar de ello, es mayor en las tortugas de lo que podria suponerse á primera vista, al juzgar de sus facultades intelectuales por su pequeño cerebro atrofiado, que en la vida del animal tiene mas importancia de lo que parece. Tambien estos animales obran con premedi. tacion $y$ hasta tienen sueños, si Fischer interpreta bien sus observaciones hechas en algunos individuos. Sin exagerar se les puede conceder una inteligencia que, si bien bastante limitada, ro deja de tener su valor. Saben lo que es la como. didad; reconocen lo que les conviene ó hace daño; distinguen entre los alimentos convenientes y nocivos: entre séres inofensivos 5 enemigos; familiarizanse poco á poco con los hombres benévolos, $y$ aunque no con su guardian, si con la persona que las da el alimento; pierden la timidez que al principio mostraban para con éste, déjanse tratar, excitar $\delta$ apaciguar y el instinto de la reproduccion las despierta tam. bien de su estupidez regular; en una palabra, tambien las tortugas gozan y sufren.

Los movimientos voluntarios se ejecutan igualmente con marcada lentitud $y$ torpe indo!encia; aunque tambien hay tortugas que por este concepto recuerdan á otros reptiles mas ágiles. Todas, sin embargo, son en extremo cachazudas y torpes en la marcha, distinguiéndose scbre todo en este punto las terrestres y marinas, pues en las furviales se obser.

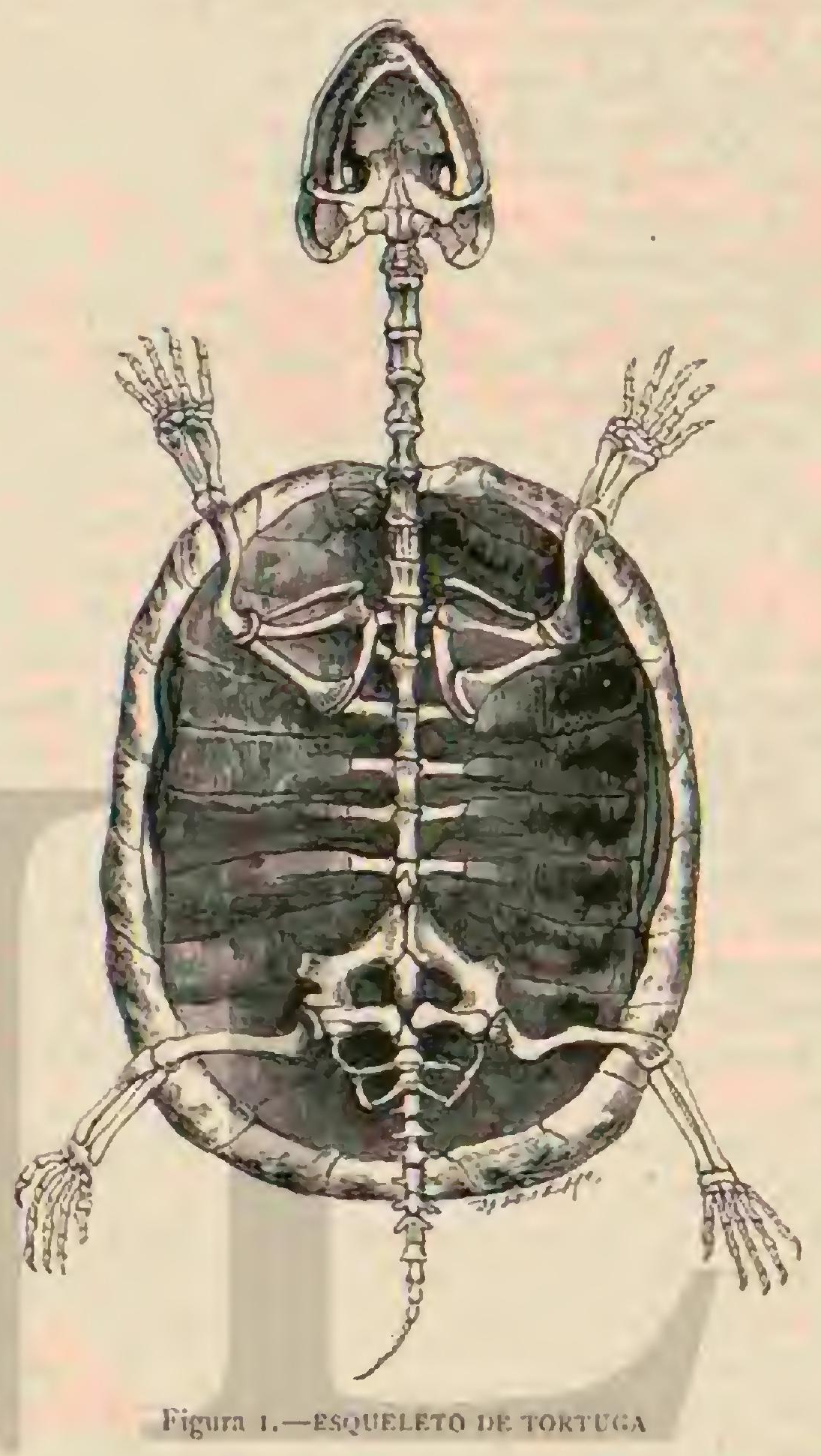

va mayor ligereza. Las tortugas acuáticas manifiestan cuando nadan toda la agilidad de que son capaces; pero dificil. mente aventajarian a ningun otro reptil acuático en tal géne. ro de locomocion.

Una tortuga terrestre de tamaño regular puede llevar un muchacho sentado en su dorso, y una tortiga gigantesca so. porta fácilmente el peso de un hombre. Las tortugas marinas que tan penosamente se arrastran por la arena, buírlanse de los esfuerzos de un hombre que intenta detenerlas; las pe. queñas tortugas de los pantanos que se han agarrado con sus dientes á un palo ó una cuerda quedan colgadas en él muchos dias, sin soltarle aunque se agite con la mayor violen. cia.

REGIMEN.- Las tortugas terrestres se nutren principalmente de vegetales, yerbas, césped, hojas y frutas; tambien comen insectos, caracoles, gusanos y otros animales de esta especie; exceptuando algunas pocas tortugas marinas que se nutren sobre todo de algas, todas las demás son rapaces, y hasta hay algunas que se distinguen en este sentido por su gran destreza, pues cazan, no solo moluscos, sino tambien anćlidos, gusanos, y tal rez radiados. No comen realmente sino en los dias calurosos del verano, $y$ si habitan los paises intertropicales, en la estacion de las lluvias. Engordan rápi- 
damente en el espacio de pocas senzanas; luego van dejando de comer poco ś poco, y llegado el invierno, quedan sumi das en su acostumbrado letargo, dando principio al sueño invernal. Ignórase aun si sucede de distinto modo con las tortugas que pasan toda su vida en montes ó selvas húnedas.

REPRODUCCION. - Poco tiempo despues de haber despertado las tortugas de su letargo, dan principio á la reproduccion, que aun á estos animales de tan obiusa inteli. gencia les ocupa cierto tiempo, prolongánciose á veces varios dias. Llegada la hora de aparearse, los machos de algunas especies se colocan sobre sus hembras, 5 los de otras se co. gen con ellas por el peto. Al cabo de un plazo mas ó menos largo, ocúpase la hembra fecundada en abrir agujeros en el suelo y comunmente en da asena; deposita sus huevos en el interior cuidádosamente y los cubre con una capa de aquelia. La cáscara es calcárea, endeble y apergaminada; su forma redónda, el tamaño reducido, la yema aceitosa; cl color de esta es anaranjado, y la clara, que no se endurece sino á una lemperatura muy elevada, tiene un tinte verdoso. Mu chas tortugas apenas ponen una docena de huevos; pero las especies gtandes suelen dar mas de ciento. La madre no se cuida de su cria, por mas que se haya sostenido con frecuen. cia lo contrario. La incubacion dura varias semanas, y segur la especic hasta meses. Cuando los hijuelos abandonan el cascaron salen de noche fuera de su escondrijo $y$ andan al rededor, ó bien se dirigen a la corriente de agua mas próxima. Mfuchos mamiferos, aves $y$ otros reptiles los cazan entonces y exterminan un número increible de ellos; pero co. mo los que se salvan llegan á vivir muchísimos años, resulta de aqui que no es fácil desaparezca la especie. Los japo. neses, que saben esto muy bien, han clegido la tortuga co. mo símbolo de una vida larga y feliz, y por cierto que no van desencaminados, al menos en cuanto se refiere \& 10 pri.
mero.

La Cépede, naturalista francés que á fines del siglo pasado escribió sobre los reptiles, dice que la coraza de las tortugas es una casa excelente, y para la defensa, un castillo que sirve de refugio al animal contra todos los ataques de sus enemigos. «a mayor parte/de ellos, dice el citado naturalista, pueden ocultar cuando quieren la cabeza, los piés y la cola, bajo la cubierta dura y ósea que les protege por arriba $y$ por debajo; $y$ los agujeros son bastante pequeños para que las garras de las ares de rapiña y los dientes de los carniceros dejen de ser temibles. Cuando se mantienen inmóviles para su defensa, pueden esperar sin miedo ni peligro los ataques de las rapaces; no se las debe considerar entonces como séres vivos, aunque rechacen la fuerza con la fuerza, pues solo oponen al enemigo su fuerte escudo que frustra todos los ataques. Las armas de aquel tocan como una piedra, $y$ las tortu. gas se hallan tan bien resguardadas debajo de su coraza natural como en la caverna mas inaccesible de una roca. Estos párrafos serian muy bonitos si no careciesen de verdad. Bechstein, que tradujo la obra de La Cépede, dice por su parte que las tortugas terrestres tienen un temible enemi. go en el jaguarete, $y$ las marinas en los tiburones, mas peli. grosos que el hombre en ciertos casos. Nosotros sabemos que, no solo el jaguarete, sino tambien el tigre, yquizás otros grandes felinos, atacan á las tortugas grandes; y los adjacs de la Sonda, una especie de perros salvajes, matan hasta tortugas marinas. Ios felinos las tumban boca arriba para poder manejarlas mejor, y extraen con las garras todas las partes carnosas; los cerdos devoran los hijuelos á pesar de su coraza. Además sabemos que las grandes aves de rapina, sobre todo el gipacto barbudo, cogen las pequeiras especies, elé. vanlas á mucha altura y las dejan caer sobre la roca hasta que se rompe el escudo; los buzos y otros halcones, los cuervos y la garza real devoran los hijuelos. No se conocen aun mas enemigos de estus animales acorazados, pero sin duda tienen otros que no se citan, sin contar el hombre, que en todas partes figura en primera linea por tal concepto.

Podemos considerar á las tortugas como los mas útiles de todos los reptiles, no solo porque comemos su carne, sino tambien porque nos gustan los hucros de todas las especies. Verdad es que algunas exhalan un fuerte olor de almizcle, tanto que nosotros los europeos no consideramos esa carne como un bocado exq̧uisito; pero otras, al contrario, nos proporcionan, como se sabe, unos platos verdaderamente suculentos. A pesar de esto, poco habria perdido si no hubiese ninguna tortuga en nuestro globo.

CAUTIVIDAD. - Desde las épocas mas remotas se han tenido tortugas cautivas. Yo he cuidado muchas, pero nunca pude profesarlas gran carino, excepto quizás las tortugas marinas. Me han parecido siempre demasiado indolentes, estúpidas y fastidiosas; pero hay aficionados á quicnes tam. bien estos animales gustan mucho, y que los creen interesantes. Las tortugas exigen mas cuidado de lo que regularmente se supone, pues por grande que sea su vitalidad, sucumben sin embargo fácilmente á toda clase de enfermedades, que en la cautividad reconocen casi siempre por causa el descui. do. El calor es la primera y mas principal condicion de su bienestar; nunca prosperan cuando se las tiene en parajes frios $\delta$ en agua fria. Fischer, á quien debemos informes $y$ noticias préciosas sobre las tortugas cautivas, nos dice: $\$$ Mu. cho se beca contra estos pobres animales suponiendo sin razon que con la gran yitalidad se reune necesariamente una buena salud. Lejos de ello, las tortugas son en extremo set. sibles a las infuencias exteriores, aunque al parecer tengan poca importancía. Sufren con paciencia, y esto nos induce á creer que pueden soportarlo todo. $\$$

CONSIDERACIONES HISTÓRICAS. - LOS escritos de los antiguos nos permiten, no solo formar una idea de los conocimientos que entonces se poseian sobre la tortuga, sino tambien adquirir muchas noticias históricas, dignas hasta cierto punto de nuestra atencion. Como fácilmente se com. prenderá, estos animales eran bien conocidos de los antiguos, mas á pesar de esto, sus relatos contienen noticias que nos. otros consideramos actualmente como fábulas, no sé si siem. pre con razon $\delta$ sin ella. Ciceron se burla del poeta Pacuvio porque este, en vez de scrvirse de la palabra lestudo, corriente para todos, designa al reptil del modo siguiente: «Animal cuadrúpedo, bajo, terrestre, con cabeza corta, cuello de serpiente, ojos maliciosos, sin iripas y sin inteligencia; pero con voz animal. Aristóteles describe la manera de poner los huevos, pero anade \& su informe, exacto por lo general, que la hembra los cubre ó vuelve al cabo de treinta dias al nido para sacarlos de la arena; entonces abre la cáscara y condu. ce á los hijuelos al agua. Dice tambien que las tortugas, des. pues de haber comido parte de una culebra venenosa, devo. ran cierta planta acuática para salvar su vida amenazada. Plinio reune todos los informes de él conocidos, y enumera los remedios médicos que pueden hacerse con las diversas partes de la tortuga, anadiendo que el lujurioso y espléndido Carvilio Polio fué quien primero hizo incrustar varios objetos con concha. Eliano sabe que la cabeza cortada de la tor. tuga marina se mueve $y$ abre y cierra los ojos; tambien ase gura que el fulgor de estos se divisa a mucha distancia y que los globos de los ojos, de un blanco brillante y claro, se montan en oro, utilizándose como collares, que son muy apreciados de las mujeres. Pausanias dice que en el monte Partenon, en Arcadia, hay tortugas con cuya concha se cons. truyen excelentes laudes; pero que no se pueden coger los 
animales, porque los habitantes de aquella region los aprecian como séres consagrados al dios Pan. Julio Capitolino cita el hecho de que en Roma los principes imperiales se bañaban en conchas de tortuga, y Diodoro de Sicilia dice que los comedores de lortugats, habitantes de unas pequenas islas situadas en el Océano, cerca del continente, cogen las tortugas marinas de una manera particular. Estos animales son de un tamano tan enorme, que podrian compararse con las pequeñas barcas pescadoras; de noche van en busca de su alimento, y durante el dia se sitúan á orillas del mar, expo. niéndose a los rayos del sol. Entonces se acercan los cazado. res al lago silenciosamente; algunos levantan el animal por un lado, mientras que otros le bajan por otro, tumbandole asi boca arriba; despues atan una cuerda en la cola y nadan hácia tierra firme, mientras que otros empujan la pesada carga Llegados á la orilla matan la presa, comen toda la carne despiues de haberla asado al sol, y utilizan los cscudos como lanchas ó como techos para las chozas.

CLASIFICACION. - Despues de hacer averiguaciones minuciosas sobre el órden de las tortugas, Strauch las divide en tres familias, comprendiendo en la primera las terrestres y pantanosas 6 las fluviales de la mayor parte de los otros naturalistas y que solo cuando se reune á estos dos grupos parece equivalente con las tortugas blandas y las marinas.

\section{LOS TESTUDINIDOS- TESTUDINIDA}

CARACTERES. - Los testudinidos, ó segun los llamo á pesar de la diferencia del género de vida de las especies, las tortugas terrestres, constituyen la primera familia y se dis. tinguen' por los siguientes caractéres. Fl espaldar cs ovalado, pero de forma abovedada, siempre diversamente; los huesos del escudo del pecho están soldados en todas las especies en forma de placa, que cuando mas deja una abertura en el centro; tanto el espaldar como el peto están cubiertos de unas placas córneas; el timparo es siempre visible; las pier nas tiener una estructura á propósito para andar ó para na. dar; los piés están provistos de garras de formas muy distin tas; en los anieriores no hay nunca menos de cuatro, mas por lo regular se cuentan cinco; los piés posteriores suelen tener cuatro, raras veces cinco, y en un solo caso tres.

\section{LOS QUERSEMIDOS - CHERSEMYDA}

CARACTÉRES. - En los quersemidcs, $\delta$ tortugas terres. tres propiamente dichas, á los que podemos asignar el rango de sub familia, la pélvis es libre, es decir que no está soldada al peto; el número de placas de la garganta no pasá de dos, de las cuales no se ve à menudo sino una, yá veces nin. guna. Casi todas las especies pertenecientes $\mathbf{a}$ este grupo pueden esconder la cabeza y el cuello debajo del espaldar.

DISTRIBUCION GEOGRÁFICA. - Todos los paises cálidos del globo, exceptuando solamente la Nueva Holan. da, albergan quersemidos; en Africa se halla el mayor número de especies, por lo que hasta abora se sabe; mientras que en Europa solo hay tres.

USOS, COSTUMBRES Y REGIMEN.-Aunque estos reptiles habitan las estepas y el desierto, prefieren sin cmbargo los sitios cubiertos de bosques de espesa vegetacion, donde pasan en la soledad la vida mas monótona. Aficionados al calor como todos los reptiles, solo visitan las zonas templadas durante el estio, y llegada la estacion fria entréganse al sueño en los hoyos que ellos mismos abren bajo tierra. Exactamenie lo mismo se observa en los paises ecua- toriales, pero allí es en los meses calurosos que corresponden á nuestro invierno. Durante el gran calor del sol y la sequia, dice Humboldt, estos animales permanecen ocultos sin comer debajo de las piedras 6 en hoyos que ellos mismos han abierto. Solo cuando despues de la primera lluvia conocen que el suelo se humedece, salen de su escondite y comienzan á comer.

Los testudínidos son los séres mas perezosos y apáticos de toda la clase: sus movimientos no tienen comparacion con los de otros animales por lo torpes, pesados y cachazudos. Estos reptiles pueden recorrer considerables distancias sin detenerse, pero con una lentitud pasmosa; primero mue. ven un pié, y cuando este toca en tierra levantan el otro, pa. reciendo que se les resiste adelantar el cuerpo. Diriase que mueven una pesada masa por medio de palancas; pero la fuerza que emplean para cada uno de sus movimientos es considerable. La prueba de ello está en que una tortuga de mediano tamaío podria llevar una persona encima de sil roraza; y observase que esto lo hacen sin la menor dificultad los gigantes de la familia. Cuando caen al agua por casualidad, ó si se les arroja en una corriente, llegan al fondo lo mismo que una piedra; pero una vez alli comienzan á mover sus patas tranquilamente, $y$ al cabo de cierto tiempo, mas o menos largo, vuelven à la orilla ilesas. Los testudinidos no pueden recobrar tan fácimente su equilibrio cuando caen de espalda por haberles acometido un animal ó por otra cir. cunstancia cualquiera: entonces trabajan as menudo muchos dias con la cola á fin de recobrar su posicion natural, puesto que los piés, faltos ya de movimiento, no pueden servirles de nada en semejante apuro. Extraño parece que se mucs. tren comparativamente ligeros para trepar.

En cuanto à su voz, solo producen cuando se les irrita un fuerte resuello, $\delta$ bufido sordo, sin emitir ningun sonido claro. Sus facultades intelectuales guardan proporcion con su escaso cerebro, que solo parece existir para las funciones de los sentidos. Sin embargo, no puede negárseles en absoluto inteligencia, pues dan pruebas de tener bastante desarrollado el instinto de la localidad, recordando su situacion, $y$ hasta manifestando á reces cierto grado de comprension. Si reco. nocen la presencia de un adversario, todos los testudínidos se valen de su facultad de ocultar los miembros en el inte rior de la coraza; y con su resistencia pasiva vencen al mas paciente enemigo, porque una vez espantados esconden sus extremidades bajo su escudo protecior á la menor sospecha. Obsérvase asimismo en estos animales cierto sentimiento afectuoso $\sigma$ de aversion y hasta son susceptibles de experi. mentar la pasion de los celos. En tal caso pelean los machos entre sí muchu tiempo para disputarse una hembra, nostråndose igualmente tenaces; y el rencedor sigue despues á su compaisera durante muchos dias, hasta que llega el momento de aparearse. Esto no sucede sino en la época del celo; al terminar esta todos los individuos se alejan en dis. tintas direcciones, sin cuidarse unos de otros. Al depositar sus huevos las hembras se muestran tan solicitas como todas las de este órden; pero como manifiestan la mayor indiferencia con su progenie, diriase que la aparente solicitud que se observa en ellas al principio es mas bien hija de un ins. tinto inconsciente que previso:

Los testudinidos se alimentan principalmente de materias regetales blandas: las mayores especies devoran toda clase de yerbas, en gran cantidad y con mucha avidez; pero las pequeñas eligen cuidadosamente las partes mas tiernas de las hojas ó de los retoños; las primeras arrancan su alimento de la tierra; las segundas se sirven de los cortes córneos y agudos de sus mandibulas, cual si fueran cuchillos, y para desprender la parte regetal que cogen echan la cabeza hácia 
atrás repetidas veces. En ciertas ocasiones comen tambien caracoles y lombrices. Rara vez beben estos animales, y cuando lo hacen, conténtanse con una pequeĩa cantidad de agua. Obsérvase que no distinguen entre los diversos liqui. dos; toman el que se les presenta sin titubear, bien sea leche, agua, aguardiente 6 cerveza, lo cual inclina ei ánino á supo ner que los sentidos del olfato y del gusto alcanzan tan poco desarrollo, que ni siquicra saben estos animales diferenciar entre sustancias tan distintas.

INCUBACION. - Los huevos que ponen estos reptiles son redondos, y su cáscara blanda, resistente y calcárea; los ocultan en agujeros que abren en tierra con este único objeto, ó ya en montones de hojarasca. Los hijuelos salen ả luz á las pocas semanas, $y$ desde el primer momenio observan el mismo género de vida que sus padres.

UTILIDAD. La que suministran al hombre las tortugas terrestres no tiene la mayor importancia: tan comestibles son estas como las tortugas marinas; pero en muy pocos paises se las caza con el fin dé alimentarse de su carnc. Por lo regular se cogen para conservarlas en un jardin 6 en una habitacion, $y$ en tal concepto son los animales menos exigentes que inaginarse pueda, pues se amoldan $a$ todas las circunstancias, aunque no pueden resistir un frio riguroso. Su calma é indiferencia son invariables, y sorprende verdade. ramente que puedan vivir tanto tiempo sin comer, quedando siempre satisfechos con el alimento mas sencillo.

Segun ciertas noticias, al parecer de buena fuente, algunas tortugas terrestres han vivido setenta, cien y hasta ciento cincuenta años en cautividad.

Los enemigos de estos reptiles son los ya indicados.

\section{LAS TORTUGAS TERRESTRES- TESTUDO}

CAR ACTERES. - Segun Strauch, de cuyos estudios que. lonológicos tomaré tambien datos para describir los diversos géneros, se caracterizan del modo siguiente. El espalúar, casi siempre muy abovedado, se compone de una sola pieza; el peto, que consta sicimpre de doce placas, tiene una ó dos piezas; en este viltimo caso la anterior es inmóvil y la posterior movible; la placa de la cola es sencilla, aunque a veces se divide en la superficie; la de la nuca puedelestar comprendida en la otra ó faltar del todo; las placas de los hom. bros y de las ingles existen. La cabeza está cubierta de placas córneas y la extremidad de la cola provista á reces de una una. Una especie de nudillos escamosos, grandes $y$ dispuestos casi sicmpre en forma de tejas, cubren los antebrazos; en la articulacion de los piés posteriores se ven otros en forma de espuela; tambien los hay á menudo en el lado poste. rior de los muslos. Los dedos son fijos y están soldados hasta la articulacion de la uña; en los piés anteriores se ven cinco garras, raras veces cuatro; y en los posteriores siempre este último número. Todas las especies pertenecientes á este grupo andan apoyándose en los dedos y son animales terrestres en la verdadera acepcion de la palabra.

\section{LA TORTUGA GRIEGA-TESTUDO GR AECA}

CARACTERES. - La tortuga griega se considera regularmente como tipo de las tres especies de esté género propias de Europa. Fl espaldar, de forma ovalada, es muy abo vedado, algo mas ancho en su parte posterior é inclinado mas verticalmente hácia atris que por delante: el peto, plano en la hembra y un poco abovedado en el macho, se corta en su parte anterior y tiene una gran escotadura en la posterior. Las placas son altas; las de las vértebras mas bajas; las tres del centro hexagonales y la anterior y posterior pentagonales; las dos centrales de las costillas tienen casi doble lon. gitud que anchura y forman un pentágono irregular, es decir, que son cuadrangulares con la línca cortada en el lado interior: las dos anteriores son pentagonales y encorvadas en el borde interior; las dos posteriores presentan un cuadro irre. gular. Entre las veinticinco placas del borde, la de la nuca es la mas pequeña; la superior se prolonga en su parte posterior, encorvíndose sobre la cola la mas grande; las demás, dife. rentes entre si, afectan la forma de un pentagono irregular. El centro de todas las placas es granujiento en los individuos jóvenes y liso en los adultos, hallándose rodeado de unas fajas que aumentan en número á medida que se desarrolla el animal. Ia cabeza, bastante pesada, es mucho mas gruesa que el cuello; la punia del hocico obtusa; los ojos de tamaño regular; las orejas casi de igual dimension que los ojos; la parte superior y los lados del hocico están provistos de una gran escama redondeada en la nariz, de otra mas pequeña en la frente 5 de una muy grande y larga en la region de las orejas; el resto de la cabeza presenta pequeñas escamas irregulares. Cada placa del espaldar es negra en el centro, con borde amarillo negro; por el peto se corre una faja longitu. dinal ancha y de color amarillento; los lados son igualmente amarillos; y lo demás negro; la cabeza, el cuello y las extremidades tienen un color amarillo verde sucio. Asi como en la mayor parte de las tortugas en general, la disposicion de los colores es muy variada y aun el número de garras de los piés anteriores puede disminuir en algunos individuos hasta cuatro. Las hembras difieren de los machos por su mayor tamaño y por su cola mas larga y gruesa en la base; los indi. viduos jóvenes se diferencian de los adultos por la forma recogida de su coraza. I.a longitud de este reptil desde el hocico $\$$ la punta de la cola, es cuando mas de $0^{n}, 30 ;$ el peso raras veces excede de dos kilogramos (fig. 2).

DISTRIBUCION GEOGRÁ FICA. - Ia patria primitiva de esta cortuga se limita a los países situados al norte del Mediterráneo, y en rigor solo a las peninsulas griega é italiana con sus islas correspondientes; además se la encuentra en el Asia Menor, y segun Tristram, abunda en Palestina. Tambien existe, sin duda como animal propio del pais, en Grecia, Dalmacia, Turquia, los paises bajos del Danubio, la Italia inferior, incluso las islas de Córcega, Cerdeña y Sicilia, Brussa y Angora, en el Asia Menor. Algunos individuos, importados probablemente y puestos en libertad, han sido hallados en el sur de Francia, Suiza, las Baleares y hasta Suecia. Segun Schreiber, los frailes importaron hace largo tiempo en muchas regiones esta tortuga como animal domés. tico; pero porn á poco volvió al estado salvaje. Habita las regiones cubiertas de bosque y espesuras, algunas de ellas en gran número, y ábunda sobre todo en el sur de Italia, en Grecia y las inmediaciones de Mehadia, al pié del Alion.

USOS, COSTUMBRES Y REGIMEN. - Les gusta mucho el calor, y permanecen horas enteras tomando el sol.

Dumeril las encontró en Sicilia en ambos lados de un ca. mino, y de tal modo se les habia recalentado la coraza, que su mano no pudo resistir el calórico que despedian. Cuando se acerca el invierno practican un hoyo muy profundo en tierra, y alli pasan la estacion mas fria durmiendo, sin que se las vuelva á ver hasta principios de abril.

Esta especie se nutre de varias plantas y frutas; á veces come tarmbien caracoles, gusanos é insectos, por cuya razon se la puede conservar en jardines a fin de exterminar estos animales, nocivos para las plantas. Poco delicada en la eleccion de su alimento, distinguese de sus congéneres de las orillas del mar Negro, las cuales son exclusivamente herbi. voras, segun las observaciones de Erber, quien se expresa 
en los siguientes términos al hablar de estos reptiles: 1.o que mas contribuyó \& quitarme completamente la gana de comer su carne, fué el haber observado que deroran con especial predileccion los excrementos del hombre; con frecuencia vi numerosos individuos reunidos que se cebaban en tan asqueroso alimento. Cuando estos reptiles están cau. tivos, comen hortalizas, salvado, harina y lombrices de tierra, réginen que les sienta perfectamente si se les preserva del frio. Dicese que asi pueden vivir en cautividad hasta sesenta años. White refiere que una tortuga terrestre que habia es. tado cuarenta años en poder de un amigo suyo, quien se la dió despues, se ocultaba todos los años debajo de tierra á mediados de novienbre, y reaparecia á mediados de abril. Entonces tenia poco apetito; pero mas tarde, en los dias ca. lurosos del verano, devoraba mucho alimento con avidez.
Próximo ya el otoño, volvia a disminuir su racion, $y$ algunas semanas antes de cnterrarse dejaba de comer del todo.

Las plantas lactescentes constitusen el alimento favorito de estos reptiles. Cuando llega el otoño, ocupanse en formar sus agujeros para albergarse en ellos durante el invierno; cscarban la tierra lentamente y con precaucion, valiéndose de las patas anteriores, y con las posteriores alejan el material extraido. 'Temen las lluvias y se esconcien durante muchos dias si el tiempo es humedo. Cuando es, por el contrario, bonancible, entréganse al sueño á eso de las cuatro de la tar. de, y no despiertan hasta una hora muy avanzada del dia siguiente. A reces se las re buscar la sombra cuando el sol es muy ardiente; pero esto puede considerarse como una excep. cion, pues por regla general les gusta el calor del sol. Reichenbach observó que los individuos cautivos que él tenia en

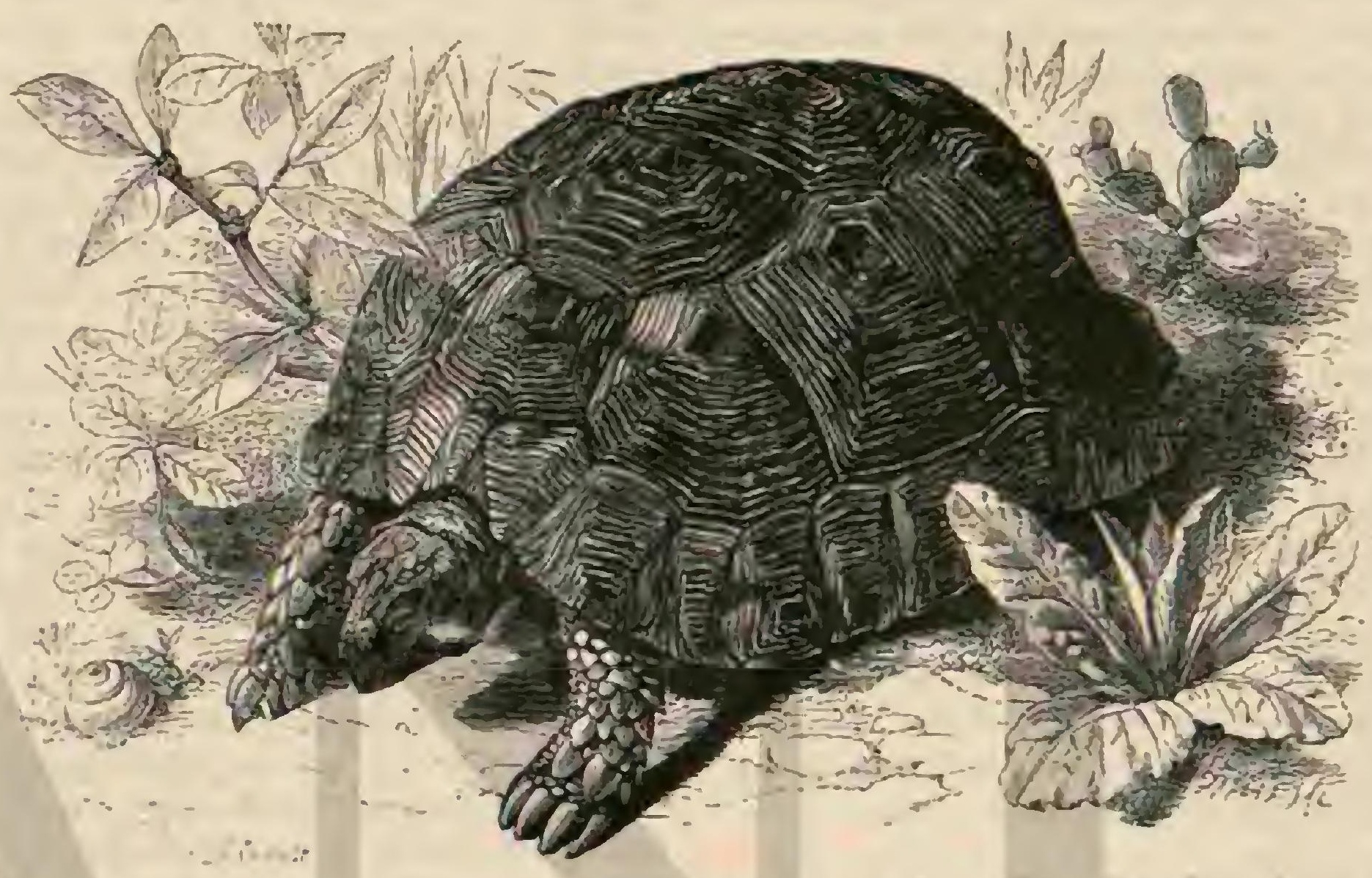

f̈ig. 2.-LA rostugh Gkikes

el Jardin botanico de Dresde, recorrian grandes distancias. sin desviarse de la linea que acostumbraban à seguir; y cuando refrescaba el tiempo ó se oscurccia el sol, introducianse sièmpre debajo de la misma planta. Hácia el otoño se enter. raron, salicndo de su retiro en la primavera, cuando florecian las singenesias, cuyas hojas les sirven de alinento.

En Cerdeña, donde los inviernos, aungue poco rigurosos, son bastante frios para obligar á las tortugas á buscar su re fugio debajo de tierra, estos animales se enticran, segun Certi, en noviembre, y reaparecen en febrero. I legado el mes de junio, la hembra deposita ya sus huevos, en número dé cuatro á cinco: por su dimension se parecen á los de la paloma doméstica, siendo su color blanco. «Para poner los huevos, dice el citado naturalista, eligen el sitio donde mas toque el sol, practican con sus patas exteriores un hoyo, y dejando en el los huevos, confian la incubacion al astro rey. Cuando comienzan las primeras lluvias de setiembre presén. tanse ya las pequeñas tortugas, que tienen el tamano de una media nuez y son los animalitos mas graciosos del mundo. Si se les deja en completa libertad, cundúcense como en su patria aun en los paises muy septentrionales, y tambien se propagan, 6 cuando menos se aparean. Asi, por ejemplo, se gun Sundevall, un trabajador de la region de Kalmar, en el sudestc de Suecia, encontró dos tortugas de esta especie que sin duda habian escapado de la cautividad, en el momento en que se aparcaban. En una habitacion bien caldeada no se entregan al sueño letárgico, pero ampoco viven tanto tiem. Tomo $v$ po, segun las observaciones de Fischer, como cuando todos los inviernos se las deja descansar.

RESISTENCIA VITAL.-LIS tortugas expuestas durante algun tiempo a una temperatura bajo cero, mueren in. faliblemente por insensibles que sean en otros conceptos. Pueden vivir años enteros sin alimento y resistir las mas horribles heridas con una indiferencia inexplicable para ros. otros. Despues de arrancarics el cerebro, cuyo tamano no excede al de una habichuela, se las ve andar aun durante medio año; $y$ cuando se les separa la cabeza del tronco con. tinúa el coraron palpitando por espacio de quince dias; media hora despues de cortada la cabeza muerde la boca todavia.

Lippi demostró la veracidad de estos hechos con varias pruebas de que nos habla Drioli. Habiéndose extraido el ce. rebro á dos tortugas, se cortó la hemorragia de la una por medio de la cauterizacion de los vasos con fuego, y secubrió la herida de la otra con una capa de yeso. Ambas se movian con dificultad despues de la operacion; pero como tenian paralizados los micmbros del costado izquierdo, giraban en circulo de derecha á -izquierda: el ancto parecia haber sufrido alteracion, y el olfato no existia. Habiendo eciado en la nariz. de una yeso amasado con espiritu de vino, comenzó á bufar y dió vucltas circulares, manifestando la mas profunda exci. tacion; pero esto pareció ser la consecuencia de una irritacion del sistema nervioso en general, mas bien que de los nervios olfatcrios. No fué posible infcrir nada con seguridad respecto 
al sentido del gusto, porque los animales mutilados no co mian; pero ambos tragaron terrones de azúcar que les intro dujeron en el ceófago. No parecia causarles impresion las ondulaciones luminosas ni los sonidos, si bien es verdad que conservaban los ojos siempre cerrados.

Se comprende facilmente que un animal cuyo cerebro presenta tan escaso ciesarrollo no pueda distinguirse por su inteligencia; mas á pesar de ello, no es dado negar á este repiil cicrto grado de comprension, pues touos los ificiona dos que han ienido tortugas cautivas, aseguran que estas se acostumbran poco a poco á la persona que las cuida y lie gan à conocerla. Por atra ilarte, resulta de las obscrvaciones de Dumeril que nuestras tortugas se excitan de ve\% en cuando. Este naturalista refiere que mas de una vez vio $\leq$ dos machos lucharpor la posesion dé una liembra, y con una tenacidad incrcible; mordianse en el cuello, procurando mutuaménte volcarse; se acometian de lodas las maneras imaginables; y no ferminó la velea hasta que uno de los dos adversarios quedó fuera de combate. No se sabe cuánto tiempo dura el periodo dul celo; pero es indudable que el aparenmiento entre animales tan cacharudos en sus movi. mientos no se realiza sino despues de muchas tentativas in. hítiles En los primeros dias de julio, la hembra practica en tierra una pequena excavacion en ún stio expuesto á los ra. yos del sol, y con prefereneia pantanosos, segun asegura Eirber. Alli pone de cuatro \& doce liuevos esféricos y blancos, del tamano de una nuca pequeña ; los cubre cuidadosa. mente con tierra, y ya no se cuida mas de ellos ni de sus hijuclos, que salen á luz hícia el otoño.

CAzA.- En toda Italia y espécialmente en Siciila, se vender estos animales en los mercados, porque la carne se come, y se aprecia sobre todo para la sopa. En el Asia Menor se cazan con perros adiestrados al efecto, los cuales se ponen de muestra cuando encuentran una, llamando la aencion del cazador con sus ladridos.

\section{LA TORTUGA POLIFEMO-TESTUDO POLYPHEMOS}

CARACTERES. - La tortuga polifemo, gopher muigofer de los anglo ancricanos, se distingue por tener el espaldar muy convero, de color pardo amirillento, y algunas veces con manclias irregulares mas oscuras; el peto es de un ama. rillo pálido, lo mismo que las escamas tuberculosas de los niembros; el resto de estas partcs, asi como el cuello y la cabeza, y particularmente esta última, presentan un color pardo, 6 mas bien negruzco. Los naturalistas americanos, que han podido observar esta cortuga en los parajes que ha. bita, nos dicen que el individuo adulto suele tener de trece i catorce pulgadas de largo (medida inglesa). (fig. 3).

DISTRIBUCION GKOGRAFICA.-Esta tortuga ha. bita en la América septentrional, en todo cl pais que se cx. tiende desde las Floridas hasta el rio Savannah. Segun Mr. Hoibrook, abunda en Georgia y Alabama; pero no se la encuentra mas allá de la Carolina del sur, en la direccion
norte.

USOS, COSTUMBRES Y-REGIMEN.-LOS pinareS y los terrenos secos y arenosos son los sitios que frecuentan con preferencia estas tortugas; pero los abandonan algunas veces para recorrer los canipos, particularmente los de pata. tas, donde ocasionan grandes daños. Tiambien son temibles por este concepto en las huertas, pues destrozan los melona res, devorando los bulbos y raices. Basta lo dicho para com prender que el régimen de la tortuga polifeno es exclisivamente vegetal. Estos reptiles son nocturnus; durante el dia permarecen escondidos en los profundos agujerns ţue prac- tican al efecto, y luego salen a buscar que comer. Aunque no son grandes, su fuerza es prodigiosa; asegúrase que andan facilmente llevando un hombre sobre el lomo, y que hasta pueden sosteater un peso de seiscientas libras.

UTILIDADES.-Parece que la carne de esta toriuga es excelente como artículo alimenticio: los huevos, que tienen el Lamaño de los de paloma, siendo su forma redonda $y$ la cáscara calcárea, constituyen tambien un bocado exquisito pasa los inteligentes.

\section{LA TORTUGA SALPICADA - TESTUDO TABULATA.}

CARACTERES. - I tortuga salpicada, que llaman sha. busti en cl Brasil, se encuentra en toda la América del sur, y se recibe frecuentementc vira en Europa. Sus formas son toscas; la coraza, en cxiremo abovedada y muy dura, se pro. longaló estrecira en los lados visiblemente; la cabeza es de mediano tamaño; el borde córneo de la mandfbula, collatut: y con dientes muy finos; el cuello algo largo y grueso; la cola corta; los piés norables por su longitud. El espaidar consta como siempre de cinco placas centrales y anchas, á cacia lado otras cuatro, y el borde lo forman veintires mas pe. queinas. I as medias, $\delta$ vertebrales, tienen el centro tan alto, que constituyen, particularmente hácia el lado anterior, un boton regular. Iil peto es mucho mas estrecho que el espal. dar, y está cubierto de doce placas, recortindose en ángulo obutiso y entrante en los dos extremos. El color de todas las placas es amarillento o gris pardusco, algo mas interiso $\mathrm{cn} \mathrm{el}$ borde; el de las partes no cubiertas por la coraza negruzco, con manchas de un tinte anaranjado, gue forman dibujos varios. La region superior de la cabeza es de un amarillo pílido sucio, con manchas y rojas negras, y el resto negruz. co; sobre la nari? se ven dos manchas amarillas y redoncias, otras dos en la membrana del oido, y una en cl extremo posterior de la mandibula inferior. El fondo del color de las extremidades anteriores es negruzco, que hace resaltar vivamente las escamas, cuyo tinte es anaranjado subido; los posieriores solo presentan algunas escamas suelias en la parte superior, y varias manchas amarillentas en el talon. I. longitud total de esta tortuga, con el cuello tendido, es de carorce pulgadas, $y$ de diez el espaldar. Fi macho se distingue de la hembra por tener la cola algun tanto mas larga y el peto un poco mas convexo, siendo la coloracion mas viva en los individuos jóvenes que en los viejos.

Una especie afine, la tortuga carbonera (1estudo carbiona. rin) confundida muy á incrudo con el chahuti, aunque siem. pre se diferencia, habita con este los mismos sitios y observa poco mas ó menos igual género de vida.

Distribucion GEOGRÁFICA.-El ihaliufi está discrninado, segun el principe de Wiéd, por la major parte del Brasil. Al decir de Schomburgk vive en todos los bosques de la Guayana hasta una altura de 600 metros sobre el nivel del mar. Segun Gachet abunda niucho en toda Venezuela $y$ se encuentra tambien en las Indias occidentales.

USOS, COSTUMBRES X REGIMEN. - Estos reptiles hábitan por lo regular los bosques, á reces en gran nu. mero. "Yo vi, dice el principe, varias conchas vacias en lus bosques de Tapebucu, al norte de Cabo Frio, s descie alli encontré individuos vivos en casi todos los grandes bosques del Brasil oriental. En Belmonte las observetambien con fre. cuencia: los botocudos solian llevar en sus alforjas corazas de estas tortugas y de galápagos, que les servian para preparar sus colores $y$ afeites. En nuestro viaje al través de las selvas las vimos igualmente $\{$ menudo a orillas del rio Ilhcos, y hasta en el centro de los besques mas apartados. Dicese qutic 
no habitan sino los parajes secos de estos; $y$ a decir verdad, solo alll las encontre; se paseaban pererosamente apoyindo. se en sus largas 6 informes extremidades, que recogian al punto si se les presentaba algun objeto extrano. Tambien esta especic busca su alimento en el reino vegetal, mante niéndose sobre todo de las frutas maduras que caen de los árboles, tan variadas y abunơntes en aquellos paises.

- En la estacion calurosa fornia la hembra un monton de hojarasca y deposita alli sus huevos. Los pequenos son de color amarillento y tienen la coraza blanda cuando salen \&luz.

ENEMrGos. - Los individuos jóveres, y tambien lus viejos, tienen muchos enemigos. I.os carniccros persiguen á los últimos, y á pesar de su fucrte coraza, los devoran. Los indios que recorten las sclvas, y tgue no se distinguen por es. piritu de observacion alli, ascguran que cuando la onza en. cuentra uno de estos reptiles le pone derecho apojandole en un extremo, y con sus agudas garras extrae poco á poco su carne. A esto se débe, segun dicen, gue se hallen á menudo en los bosques muchas corazas vacias, las cuales encontra. mos abicitás y con señales de mordiscos en sus extremos.

UTILIDAD. - Como estas tortugas no despiden mal olor y son susceptibles de engordar, aliméntanse de su catne los portugueses, los negrus y los indios. Al efecto las guardan en cercados reducidos y circulares, segun se practica en varios puntos a orillas del rio liheos. Puestas en un cajon, se pueden conservar muchos anos: comen toda clase de fruta, hojas y en particular bananas que constituyen su manjar fa. vorito. Al tocar a estas tortugas se ocultan inmediatamente dentro de su coraza y bufan como lo hacen ì veces los gan. sos; yo no las of emirir nunca otro sonido:

CA Z.A. - Aunque no es necesario hacer preparativos para apoderarse de estos animales indefensos, puesto que todo se reduce $a$ ir sa cogerlos en el bosque, cázanlos á menudo con el auxilio de trampas. Listas son de madera y tienen un iravesaño, que cayendo sobre las tortugas, las sujeta sin cau. sárles ningun daño. Los indios aseguran que algunos indivi. duos apresados en irampa vivieron años enteros en tan triste situacion.

CAUTrVIDAD.-Ulimamenie el chabuti llega con fre. cuencia vivo a Europa, conservándose varios años cuando en invierno se le tiene en un sitio preservado del frio. No difiere mucho de las otras tortugas teriestres por su manera de conducirse, pero gracias s. sus largas patas se mueve con un poco mas de ligereza que las otras especies del género. sEa mi casa, dice Fischer, esta tortuga \& su congénere la carbonera corren libremente por las habitaciones; despiértanse al despuntar la aurora y comicnzan á pasearse por la casa rodo el dia cstán en movimiento, olfatean cuantos objetos encuentran en el suelo, beben agua y leche de la rasija puesta al efecio, y aunque á reces comen mucho, hay dias en que apenas prueban el alimento, sobre todo en tiempo nublado y lluvioso. Cuando encueneran una manzana entera en el suelo intentan morderla, pero siempre la hacen rodar, porcque al inclinar la cabeza la eimpujan con el hocico. Fsta maniobra dura á veces mucho tiempo, pero al fin desisten. Mas tarde observé que no hacian caso de manzanas enteras, cual si hubieran reconocido lo inúril de sus esfuctzos.

- A penas comienza á oscurecer ocuiltanse debajo de las camas, sofás, cortinas, etc; pero reaparecen tan lucgo como se coloca cerca de ellas una luz o una lámpara, y vuelven a pansearse. Cuando la estufa de mi habitacion se calienta, salen de sus escondites, permanecen algun tiempo paradas y retiran lentamente sus piés para echarse al rededor de la estufa, donde se complacen con el calor, alargando el cuello y las patas posteriores en toda su longitud.
Su alimento, que toman casi todos los dins, se compone de pan blanco mojado en leche $\delta$ agua, limones, que al parecer les agradan mucho, manzanas, peras, lechuga, col, ca. labazas y carne. Extraño es que los machos coman casi exclusivamente carne, mientras que las hembras solo se alimen. tan de sustancias vegetales.

Al principio mostrábanse muy tímidas, tanto que al acercarme se retiraban en seguida, sibando 6 bufando en su con. cha: pero ahora ni siquiera dejan de comer cuando se las toca la cabeya ligeramente con el dedo; tambien aceptan el alisuento en la mano.

\section{LA TORTUGA ELEGANTE-TESTUDO ELEGANS}

CARACTERES, - Una de las especies mas bonitas del grupo es la tortuga elegante $\delta$ csfrellada, propia de las Indias orientales. L.a coraza, de forma oval prolongada, elévase mu. cho en el centro, inientras que en las dos extremidades se aplana casi por igual, teniendo los lados algo abovedados: toda la coraza en su conjunto es mas bien alta que ancha; el espaldar tienc en su parte anterior una profunda escotadura, y el peto en la posterior, otra casi triangular. El centro de las placas se eleva de tal modo, por lo menos en la mayor par. te de los individuos viejos, que las placas forman altas joro. bas. En las placas vertebrales las proninencias mas altas, para no decir puntas de las jorobas, se hallan en cl centro, en las piacas costillares entre el centro y el borde superior, cn las de los bordes en el ángulo inferior 5 posterior; las tres últi. mas placas de los bordes son las que presentan major pro. tuberancia. La placa de la nuca falıa; las de la garganta son de forma triangular prolongada; las de la parte superior del pecho mas largas que anchas, las de este uiltimo muy estre. chas, las ded vientre tan anchas como largas y las del ano de forma romboidal. Unas pequeiras escamas poligonas cubren la parte superior de la cabeza, distribuidas por igual en ambos lados del hocico; otra mas grande y prolongada cubre como de ordinario la region superior de las orejas; las man. dibulas son ligeramente denticuladas; varias escamas grandes y planas triangulares protegen la parte anterior de las extre. midades anteriores $y$ la posterior de las posteriores, que asi como la cabeza tienen un color amarillento con dibujos irre. gulares análogos á los del mármol; las placas de la coraza son negras, con dibujos verdaderamente magníficos, pues de los campos de color del scritro, que son de un color amaririllo claro muy vivo, parten unas fajas del mismo color en forma de estrellas, que hácia los bordes citeriores se ensan. chan, comunicando al conjunto un aspécto muy agradable en toda la coraza. La longitud del animal desde el hocico.a la punta de la cola es de $U^{\circ}, 30$ y la de esta última de $6^{\prime \prime}, 20$.

DISTRIBUCION GEOGRÁ FICA.-La corluga clegante habita con mucha frecuencia los bosques de regetacion alla, abundantes en gramineas, del Indostan, Birnan y. el Pegú: parece cscasear en los de Ceilan, y no se la coge muy á menudo.

USOS, COSTUMBRES Y.REGIMEN.-Segun Hutton, à quien debemos las siguientes noticias, no es tan fácil de coger esta tortuga porque el color del animal se parece tan exactamente al del suelo de los sitios en que reside, que ape. nas se le puede distinguir de los objetos que le rodean; por otra parte no se deja ver con frecuencia, sino que se oculta en la maleza ó en lo mas espeso de las jerbas, sobre todo cuando hace calor. Los cazadores indigenas expertos buscan sin cmbargo sus huellas en sirios arenosos, y las siguen con una seguridad sorprendente, logrando asi á menudo apoderarse de estas tortugas. En la estacion lluviosa la cortuga 
elegante se muestra mas alegre que de ordinario y corre todo el dia por los alrededores para comer ó aparearse. Cuando el tiempo se fija buscan un escondite, ocultánciose lo mejor posible para preservarse mejor del frio; alli jermanecen como inertes, pero no se aletargan. Llegados los meses de calor vuclven a su vida activa, procurando, no obstante, evitar el calor del medio dia, como en invierno lo hacen para librarse del frio, saliendo solo al oscurecer de sus escondites.

CAUTIVIDAD.-Hutton, que turo varias veces tortugas de esta especie cautivas, llegando á reunir hasta sicte, cuatro machos y tres hembras, las instaló en una espaciosa cerca; mandó poner alli abundante agua, yerba fresca y seca y un gran monton de rámajé $y$ heno, que les servia de es condite, y observoblas con la mayor atencion. Durante el es tio estaban todó el dia ocultas, sin salir hasta pocu antes de ponerse el sol para comer; pero de noche no se retiraban, permaneciendo al parecer dormicas en el mismo sitio, cual si quisieran disfrutar del fresco: solo al rayar el dia dirigianse otra vez á sus escondrijos. En el mismo periodo se baña: ban tambien bastante í menudo, permaneciendo casi siempre medin hora en el agua donde depositaban sus exćremientos: entonces bebian mucha agua.

A principios de la estacion lluviosa eran mas vivaces; se paseaban durante todo el dia en su cerca; comian y descan. saban alternativamente, y al fin hacian los preparativos para el apareamiento. A menudo perseguianse dos machos á cor tos intervalos, aunque sin molestar \& la hembra que mien. tras tanto seguia comiendo tranquilamente en el mismo sitio. Al efectuarse el apareamiento, los machos montaban á las hembras elegidas como lo hacen los mamíferos, agarrándose con las patas anteriores en la concha, mientras que las posteriores se apoyaban en el suelo. Durante el acto, que a menudo se prolongaba por espacio de diez á quince minutos, el macho producia d intervalos un gruñido. Fn toda la estacion lluviosa, es decir, desde últimos de junio hasta mediados de octubre, las hembras aceptaban los machos, pero despues ambos sexos volvian mostrarse indiferentes. Bastante th menudo veiase à dos machos pelear; para esto recogian la cabeza y las patas anteriores y empujaban ambos su coraza una contra otra hasta que uno de los contendientes perdia las fuerzas; espaldas, de cuya posicion no podia librarse sin hacer es. fuerzos verdaderamente desesperados con la cabeza y los piés. Fn estos torneos tomaban parte tambien las hembras, que gracias á su mayor fuerza solian quedar vencedoras en la pclea.

Fi. I I de noviembre una de las hembras empezó á practi. car un hovo para poner sus huevos, procediendo en esta ocasion del modo siguiente: despues de clegir algun sitio apartado cerca de una espesura de yerba, humedecióle primeramente con agua, que expelió del ano; luego escarbó la tierra mojada con las patas posteriores, moviéndolas alterna. tivamente; hizo caer mas agua gota á gota; irasformó poco á poco la tierra en cieno, y solo entonces pudo trabajar á su antojo. Al cabo de unas dos horas habia practicado una cavi. dad de ()$^{m}$, , 0 de diámetro, por $\left(0^{\circ}, 15\right.$ de profundidad, donde depositó cuatro huevos, llenando el hoyo otra vez con la yerba extraida, la cual comprimió con ajuda de sus pies posteriores; despues de haber llenado el hoyo apisonó la superficie, empináncose cuanto podia y dejándose caer súbitamentc. De este modo niveló el suelo tan perfectamente, que Hutton no hubiera encontrado el lugar si no hubiese visto á la tortuga trabajar. El reptil se alejó tan pronto como hubo acabado su obra, pero no tardó en echarse para descansar largo tiempo, cual si estuviera fatigado de su tarea, que habia durado cuatro horas completas.
Llegada la estacion fria, todos los individuos cautivos se manifestaron mas perezosos; raras veces abandonaban sus escondites y permanecicron desde principios de diciembre inmóviles en el mismo sitio, sin tomar alimento, pero ninguno intentó escarbar el suelo, como suelen hacerlo las tortugas griegas. Dos meses completos se las vió en la misma posicion, entregadas á un descanso perezoso, aunque sin aletargarse. A mediados de febrero, cuando empezó á llover, salieron de sus escondrijos, comieron un poco de trébol, bebieron ansio. samente considerables cantidades de agua, y dirigiéronse despues á sus lechos de invierno, para volver al nuismo estado de antes. Solo á mediados de abril, es decir al principio de la estacion lluviosa, presentabanse regularmente en la cerca, casi siempre a la hora del medio dia, y se colocaban cómodamente donde mas tocaban los rayos del sól: por la tarde rolvian á sus escondites acostumbrados.

\section{LAS TORTUGAS GIGANTES -TESTUDO GIGANTEO}

CONSIDERACIONES GENERALES. - En las capas terciarias de la parte inferior del Himalaya se han encontrado entre huesos de mamiferos los fósiles de un monstruoso reptil afine de las tortugas terrestres, cuya coraza media una longi. tud de cuatro metros por tres de altura, y que se designó con el nombre colosseclielis atlas. En América, y uiltimamente en Alemania, se han descubierto tambien unas tortugas fósiles afines, de un tamaño análogo, pertenecientes poco mas ó menos à la misma época. Difícil seria formarnos una idea exacta de estos animales gigantescos, aunque conozcamos las tortugas elefantinas, que todavia existen y que son superiores en tamaño a todas las especies terrestres de su brden. No hace mucho tiempo que las tortugas clefantinas se conside. raron, á pesar de la diferencia de los sitios que habitan, como variedades de una misma especie, á las cuales se llamó tortu. gas indias (testude indica). Guenther, fundándose en una serie de observaciones hechas sobre una infinidad de tortugas ele. fantinas, ha distinguido muchas especies, reuniendo al mismo ticmpo con la mayor claridad los datos antiguos sobre su existencia, el area de dispersion y su utilidad; de modo que de la historia de las respectivas especies podemos formar una idea cxacta.

rCasi todos los viajeros del siglo xvy y xvr, dice Guenther, que nos han dado noticias sobre sus aventuras y descubrimientos en el mar Indico y el Pacifico hacen mencion de un sin número de tortugas gigantes descubiertas en ciertas islas aisladas $\delta$ en archipiélagos. Estas islas, situadas todas entre el Ecuador y el trópico de Capricornio, constituyen dos cen. tros zoológicos; uno de ellos comprende la isla de la Tortuga ó će los Galápagos, y el otro las de Aldabra, Reunion, Mauricio y Rodriguez; ambos centros son de naturaleza muy distinta, pero los dos tenian de comun la circunstancia de que en la época de su descubrimiento no estaban habitados por hom. bres ni grandes mamiferos.

Ningun navegante habla de haber encontrado las citadas toriugas en otra isla ni en el continente indio; y no puede creerse que algun viajero no hiciera mencion de tal encuentro si fuese positivo, pues todos los marinos de aquella época apreciaban en mucho las tortugas gigantes, puesto que constituian una parte esencial de su alimento. Los viajes que ac. tualmente se hacen en pocas semanas exigian entonces meses enteros; todos los buques llevaban una tripulacion tan numerosa como era posible, pero iban provistos de escasas provisiones, y por eso las tortugas, de las que se podian co. ger cuantas se quisicran en pocos dias y con la mayor facilidad, debian ser un hallazgo sicmpre agradable. Colocándolas 
bajo cubierta 6 en otro sitio del buque podian conservarlas muchos meses $\sin$ alimento, para matarlas cuando fuera con. veniente; cada una producia unos cuarenta, $y$ hasta cien kilógramos de carne deliciosa, y no debemos extrañar, por lo tanto, que algunas tripulaciones cogieran en Mauricio ó en las isłas de los Galápagos mas de cuatrocientos individuos para llevárselos. La seguridad completa de que antes disfrutaban estos sẻres en sus islas, y su gran vitalidad, que hacia posible que muchas generaciones pudiesen vivir juntas, explican suficientemente la extremada abundancia de estos ani. males. $\$$

Cuando Leguat visitó en ${ }^{6} 691$ la isla de Rodriguez, estas tortugas abundaban tanto aun, que se reian agrupaciones de dos a tres mil individuos, sobre los cuales se podia recorrer una distancia de mas de cien pasos. En 1740 , los buques que se dirigian á las Indias abordaban, segun Grant, a la isla Mauricio para proveerse de tortugas, y aun veinte años despues varias embarcaciones pequeñas se ocupaban continuamente en trasportar miles de estos reptiles â fin de utilizarlos principalmente en el hospital. Desde aquelia épo. ca parecen haber disminuido rápidamente, pues mientras se cogian los adultos, los cerdos devoraban los pequeños, y tanto unos como otros, rechazados por el culivo en las islas, co. menzaron á desaparecer á principios de nuestro siglo, que. dando exterminadas en varias islas del grupo. Actualmente no se encuentra un solo individuo en la isla Mauricio, ni en la de Rodriguez ni en la de la Reunion; pero aun se ven al. gunos cautivos en las islas Seychelles, de cuyas crias escápase á veces algun individuo para vagar libremente por los con. tomos; pero estas tortugas gigantes son originarias de la pe.

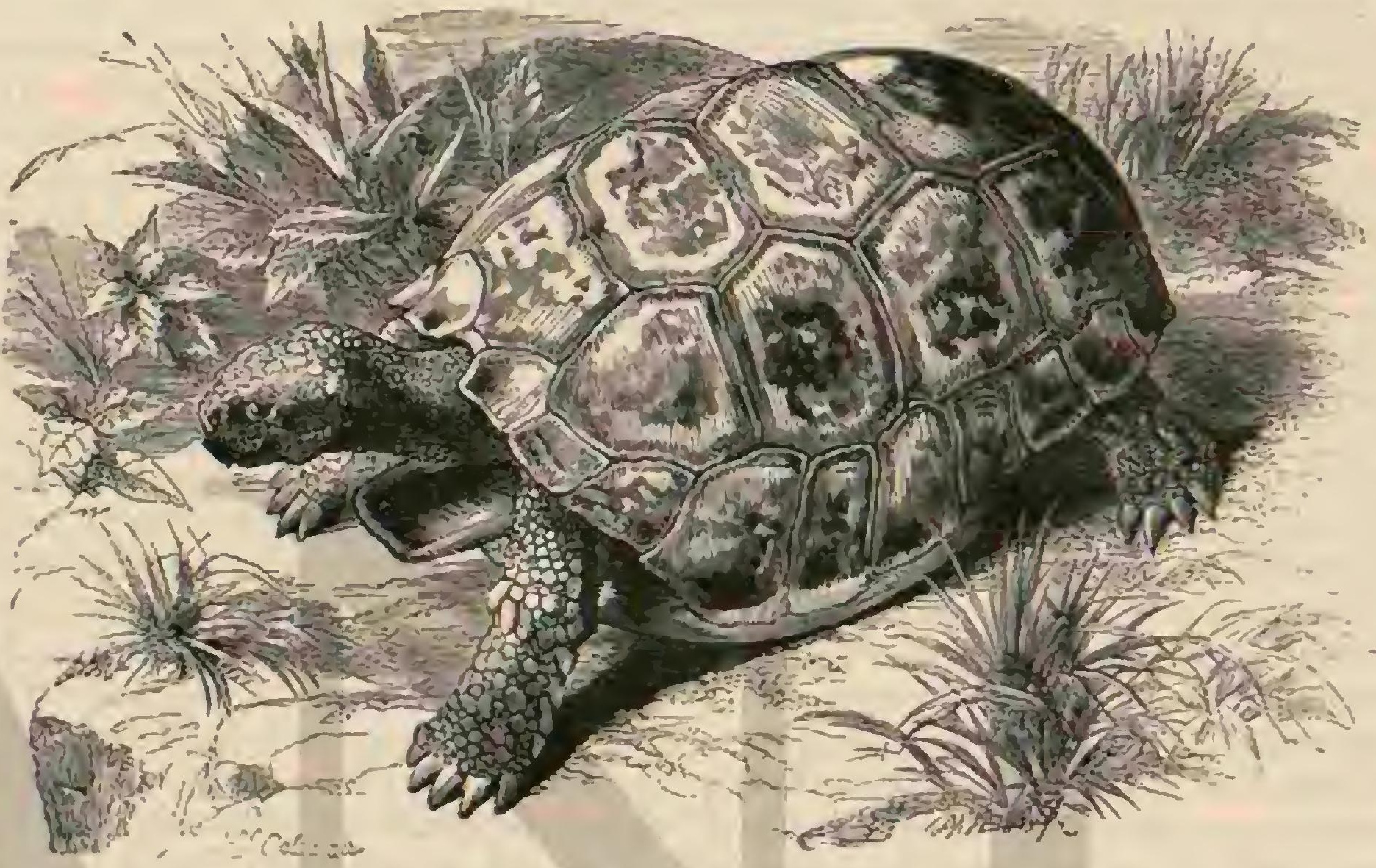

Fig. 3.-LA TOKT:G FOLFEMO

qqueña isla de Aldabra, única del Océano Indico en que aun existen varios indiviouos de la cspecie, aunque tambien aqui disminusen mas y mas por la continua persecucion del hombre.

Los hermanos Rodatz las encontraron alli cn gran número, sobre todo en las espesuras. Los cazadores que todos los años llegaban para coger tortugas habian cercado de muros ciertos sitios á propósito, á fin de poder encerrarlas hasta el dia del embarque para Madagascar ó el continente africano. En una de estas cercas los citados viajeros vieron doscientos individuos y en otra trescientos, los cuales se alimentaban sen. cillamente con jerba y hojas. Un comerciante de Hamburgo dijo $\mathbf{a}$ Kersten que en Aldabra cogieron aun en 1847 , los cien hombres qque componian la tripulacion de dos buques, mil doscientas de estas tortugas, entre las cuales habia colo. sos de cuatrocientos kilógramos de peso. Ahora seria dificil encontrar ni siquiera la décima parte de individuos peque. ños de la especie en la citada isla.

Lo mismo sucederá tambien con el tiempoen las islas de los Galápagos. Cuando los españoles las descubrieron estaban tan pobladas de tortugas, que las dieron el nombre de estos animales. A fines del siglo Xv'11, los navegantes solo visitaban el archipiélago para proveerse de agua y de tortugas. 1 Hay aqui, dice Dampier en sus Viajes, publicados' en 1697 , tal número de tortugas terrestres, que qquinientos ó seiscientos hombres podrian alimentarse de ellas durante meses enteros; son en extremo grandes y gordas, y su carne tan sabrosa como in de un pollo ticrno.s Parece que no han cambiado esencialmente hasta principios de nuestro siglo las condicicnes de las islas de las tortugas. Delano, que en 1800 visitó varias reces las islas, encontró aun numerosas tortugas en Hood, Charles, Sams y Albemarles; describiólas muy bien, y despues de un viaje de sesenta dias volvió con unos trescientos individuos, la mitad de los cuales, poco mas ó menos, embarcó en la isla de Massa-Fuero.

Como los pobres animales no recibieron alimento alguno en el camino y se les deja padecer hambre durante varios meses, muchos de ellos sucumbieron; pero los que llegaron vivos al punto de su destino familiarizaronse con su nueva situacion despues de haber satisfecho su necesidad, y muy pronto parecieron acostumbrarse al clima de Massa-líuero extraño para ellos. Sin duda se hubieran conservado vivos si no se los hubiese muerto para comerlos. Porter encontró en $18 r_{3}$ tortugas en todas las grandes islas del grupo de las de los Galápagos en número mas 6 menos considerable; aun pudo coger gigantes de ciento setenta á doscientos kilógra. mos; de modo qque unos quinientos individuos pesaron mas de catorce toneladas; pero en la isla de Madison dió libertad a un gran número de las tortugas que llevaba. Veintidos años mas tarde que Poter, es decir en $18_{35}$, Darwin visitó las islas de los Galápagos, que habiendo pasadoá poder de la república del Ecuador, se colonizaron con unos trescientos proscritos; estos útimos, como fäcilmente se comprenderá, hicieron mucho mas daño á las tortugas que todos cuantos 
visitaron antes las islas, pues comenzo un verdadero exterminio contra los indefensos animales, cuya carne sirvió de alimento. Los colonos halian llevado cerdos i la isla, y asi aumcató consideramente el número de enemigos de las tortugas. A pesar de esto, Darwin encontró aun individuos en casi todas las islas visitadas por él. Cuando once años mas tarde el buque de guerra Herald, al servicio de la ciencia, abordó a la isła de Cirlos, el naturalista que se hallaba á bordo erscontró en ella numerosas mamadis de animales domésticos, perros y cerdos, que habian vuelto al estado salvaje, pero ninguna tortuga: estas tabian sido exterminadas completamente. Existian sin embargo todavialalgumas en la isla de Chatham: Steindacher dice que en has islas de los Ga. lápagos solo habitaban en 15,2 un blanco y dosnegros, los cuales pasaban su misera existencia en la isha de Corilos; todos los dernás colonos habian muerto 6 emigrado; jutro también en usta viltima isla se habian extinguiòo del codolas torlugas segun dijeron los tres hombres. 1.o que ha sucedido en las islas Mascareinas sucederí tambien en las de los Ga lápagos.

CLASIFICACION Y CARACTERES, - Porter fuc quich primero llamó la atencion sobre las diferencias de las tortugas propias de las diversas islas del grupo do las de los Calápagos. Hin la isla de Porter distingứnse jor su extraor dinario tamaino, pues algunas median mas de ${ }^{\text {t" }}, 50$ de largo por $1 ", 20$ de ancho y casi un metro de altura, sin contar blras mayores, descubiertas, segitn se dice, por varios ma rinos; las tortugas de la isla de James se distinguian por la delgader de sus corazas y la facilidad con que estas se rom pian; la de los individuos de la isla de Cínlos era en cambio mus prolongada y el escudo del dorso cievado en su parte anterior en forma dé silla de montar española, de color par do; los individuos de James eran redondos, pesados y ne gros como el ébano, y los de la isla de Hood pequeños y semejantes a los de la de Cárlos. Guenther toma en conssi deracion estas noticias, pero por su propio cxímen llega al resultado de que lás tortugas de las islas de los Cialajpagos han representado cinco diferentes especics. Me parece que no entra en el plan de la \& Vida de los animalesh tomar en con. sideracion las diferencias citadas, y por to tánto me limitaré decir g̨ue, segun Guenther, todas lás tortugas gigantes 6 ele fantinas de las islas de los Galápagos difieren de las especies de los mascares, muy afines y semejantes en tamano, por no tener en el escudo la placa de la nuca, y por reunirse en é los-bordes posteriores de ambas placas de la garganta, for mando un angulo mas $\delta$ menos obtuso. No pueden confun dirse estos animales con las demás tortugas terrestres, pues no solo difieren por su colosal lamaño, sino tambien por su cuello largo y serpentino, por sus patas prolongadas y el co lor negro de su concha, de ial modo que no es posible desconocerlus.

USOS, COSTUMBRES Y REGIMEN. - I a excelente descripcion de Darwin sobre la vida on libertad de las tor. tugas elefantinas es tan superior 1 los informes de Porter, que debo atenerme à la primera, apelando tan solo à los se. gundos para completar algun detalle.

a En un camino, dice Darwin al comenzar su relato, en contre dos grandes tortugas, cada una de las cuales debia pesar por lo menos cien kilógramos; la una estaba comiendo un pedazo de cactus, miróme al acercarme y continuó despues tranquilamente su paseo; la otra, bufando ruidosa. mente, recogió la cabez.. Estos monstruosos reptiles, rodendos de una espesura sin follaje y de cactus gigantescos, pareciercnme creaciones del mundo antidiluviano.

x Probablemente no se hallarin estos animales en todas las islas del grupo, pero si en las mas; aunque habitan con prefe. rencia en los sitios altos y hímedos, tambien visitan los pra: rajes bajos y secos, y algunos alcanzan un tamano cnorme; L.awson, el gobernador ingicis de la colonia, cuando esturi mos alli, nos habló de varios individuos tan grandes que se necesitaban sictc ú ocho hombres para levantarlos; pues al. gunos producian hasta cien kilógramos de carne. Los ma chos viejos se distinguen de las hembras fácilmente por tener la cola mucho mas larga y ser bastante mas grandes.

Das tortugas que habitan las islas de terrerio seco suelen estar en los parajes bajos y aliméntanse con preferencia del suculento cactus; las que viven en la altura húmeda comen las hojas de varios árboles, una baya agria y śspiera liamada guayabitay una especie de liçuen de color verde pálido que pende del ramaje de los árboles. Les gusta muclıo cl agua, de la cualbeben una gran cantidad, y agrádales tambien re. volcarse en el cieno. Solo cn las grandes hay fuentes, situa das hácia el centro y a una altura considcrable; de modo que cuando las tortugas de la llanura quieren ir á beber, vense obligadis a franquear largas distancias. He aqui porqué se cncuentran sendas abiertas y trilladas por estos animales en todas direcciones, desde los manantiales hasta la costa del mar: estos senderos son los mismos que en.otro tiempo guia. ron a los espaijoles para descubrir los sitios donde abunda el agua. Cuando yo abordé a la isla Chatham no pude ex. plicarme al jorincipio que animal seria el que pasaba por sen. deróstan regulares y bien elegidos, pero en las fuentes vi un espectácuin muy curioso. Muchos de cstos monstruos cstaban alli reunidos; algunos llegaban al parecer sedientos, y otros se alcjaluan despues de laber bubido. Cuando la tortugn esta ya en el manantial introduce su cabeza en el agua linsta mas arriba de los ojos, sin fijar su ater:cion en los es. pectadores; absorbe el liquido can voracidad, y repite esta operacion unas diez veces por minuto. La gente del pais nos aseguró que todos los individuos permanecen tres ó cuatro dias cerca del agua antes de volver á los terrenos bajos; mas no supo decimos si cran muy frecuentes las visitas. El ani. mal se rige probablemente por la naturaleza del alimento que tonia; pero es cosa areriguada que las tortugas viven tambien en islas donde solo beben temporalmente el agua Hovida.

IY Ya está bastante demostrado que la rejiga de la rana sirve de receptáculo a la humedad que necesitan para su existencia, y lo mismo parece suceder tambien en las tortu. gas. Algunos diás despues de visitar el manantial, la rejiga de estos animales se dilata jor efecto dol liquido absorbido; mas tarde disminuye su volúmen y se enturbia la pureza de aquel. Los indigenas se aprovechan de esta circunstancia cuando se hallan en las regiones inferiores $y$ la séd les ator. nenta, pues matan uno de estos animales y beben el conte: nido de la rejiga. Vi matar una tortuga cuyo líquido era del todo claro y solo tenia un sabor ligeramente agrio.

- Cuando las tortugas se dirigen 'á cierto punto andan dia y noche y llegan al término de su viaje mucho antes de lo que podriamos suponer. Los indigenas creen que estos animales, segun obserraciones hechas en individuos señalados, pueden. franquear una distancia de ocho leguas en dos ó tres dias. Una gran tortuga que obscrve andaba con tal rapider, que recorria sesenta metros cada dicz minutos ó trescientos sesen ta por hora; descontando ahora un poco de ticmpo para la comida, tendriase un resultado de cuatro leguas inglesas dia. rias. Sus pasos son lentos 6 irregulares, segun Porter, pero pesados; cuando andan, el tronco se cleva unos l,",30 sobre el suelo.

5urante ol periodo del celo, que reune á lns dos sexns, continúa Daswin, el maclıo jroduce una especic de balido ronco que se oye á la distancia de mas de cien pasos, sobre 
todo durante el apareamicnto; de modo que al oirse la voz se sabe que los sexos se han reunido. Precisamente durante mi estancia, es decir en octubre, las hembras, que no prodiucen ningun sonido, ponian sus huevos. Alli donde el suclo es arenoso abren varios hoyos, depositan aquellos en cualquiera y los tapan en seguida con arena; si el terreno es pedregoso los dejan caer en el primer agujero que encuentran: Bynoe encontró siete en una hendidura. Los huevos son blancos y redondos; uno que yo medi tenia $1 i^{m}, 18$ de circunferencia.

Porter dice, respecto á la reproduccion, que las hembras no bajan probablemente de la montaira sino para depositar sus huevos en la llanura arenosa. Entre las individuos que llevó consigo solo se contaban tres machos, que fueron cogidos muy en el interior, cerca de la montania, pero todas las hem bras llevaban huevos en su completo desarrollo, y en nuime ro de diez a catorce, que sin duda deseaban depositar en la arena.

«Durante el dia, dicc el segundo de los vitados naturalis tas, las tortugas son en extremo astutas y timidas, pues al mas leve movimiento de cualquicr objeto ocultan su cabera y cuello en la concha: mas por la noche parecen del todo ciegas y sordas. Fil ruido mas estrepitoso, aunque sea el de un tiro, no las inquieta lo mas minino ni les causa la menor impresion. 》

Darwin confirma esta última noticia. Los indigenas, dice, creen que las tortugas son del todo sordas; la verdad es que no oyen á la persona que las sigue de cerca. Cuando tomaba la delantera $a$ uno de estos monstruos, que tranqui lamente se pascaban, divertiame ver cómo en el inomento de pasar á su lado ocultaba la cabeza y las piernas, producia un ronco silbido y dejábase caer con gran estrépito, cual si hubiese muerto. A mesudo monté sobre su lomo, y cuandio le daba algunos golpes en la parte posterior de la coraza levantábase el animal para alejarse, pero me pareció dificil conservar el equilibrio.

४Ningun animal, segun Porter, puede producir una carne mas saludable, dulce y sabrosa que la de esias tortugas; y Darwin opina lo mismo sobre el particular. La carne, dicc al terminar su relato, sc puede comer tanto fresca como sa lada, y con la grasa se prepara un aceite bastante bueno y claro. El cazador que encuentra una tortuga le abre la pie cerca de la cola para ver si liene por debajo de la coraza una gruesa capa de grasa; si esta no existe, deja en libertad al reptil, que segun dicen, restablécese pronto de su diolorosa herida: para sujetar \& la tortuga no basta tumbaria boca arriba, pues con facilidad recobra su posicion natural. Los pequeños recicn nacidos son con mucha frecuencia victimas de una especic de buzo; y 110 pocus adulios micren, segun parece, por caer desde alguna altura. Los indigenas me aseguraron, por lo menos, que nunca han encontrado un indi. dividuo muerto por otra calisa.

CAUTIVIDAD. - Varios marinos aseguraron a Poiter haber tenido tortugas de esta especic cautivas bajo cubicrta durante' diez y ocho meses, sin darles alimento alguno, $y$ cuando al cabo de este tiempo las mataron, vieron que no se habian perjudicado en nada, ni ampoco percido su grasa, å pesar de los malos tratamientos. Una de anuellas tortugas habia estado ya cautiva algunos años, $y$ hasta llegó á servir de tajo: aburridos por las continuas tentativas de fuga del animal, los criados del duchoo, of quienes se mandaba ir en busca de la tortuga escapada, acabaron por encerrarla en un estrecho recinto, $y$ despucs utilizaron su escudo para cortar leña. Gracias sa la facilidad con que estos animales gigantes. cos soportaban largos viajes por mar, llevabanlos á menudo á Europa y liace poco mas de un decenio que aun se les reia con bastante frecuencia en jardines zoulógicos y caśas défic. ras ambulanes. Yo mismo he cuidado varios y observado otros. No era nada dificil mantencrlos, ni exigian mayor cui. dado que cualquiera otra tortuga terzestre. En invierno se les tenia en espacios bien abrigados, alimentándolos con sustancias regetales de toda clase; en verano se les conducia $a$ un prado cubierto de césped, donde podian pacer á su antojo, proporcionándoles ademàs una cantidad suficiente de yerbas y patatas. Las tortugas cortan ó arrancan con sus dientes grandes $y$ espesas matas de yerba, forman el bolo alimenticio mascándola, y devóranle al fin con visibles esfuerzos. No he podido reconocer si preferian su guardian á las demás personas; unas veces parecia que si, pero otras, conducianse con el como con cualquier extraño. De todos modos, familianzanse al fin con el hombre, dejan de bufar, pierden su limidez, y hasta permiten que se monte sobre sul lomo, perocon ducen al jinete con indiferencia y cxtremada lentitud.

Hoy dia, solo en los jardines zoológicos mas ricos se encuentra alguna tortuga de csta especie, y de aqui á pocos años ni aun esto scrá posible, cuando los pocos individuos cautivos que se encuentran en Europa sufran, a pesar. de su gran vitalidad, la inevitable suerte de sus congéneres.

\section{LOS CINIXIS-CINIXYS}

CARACTLRES. - Varias tortugas pueden mover la parte anterior ó la posterior del escudo del pecho, abriéndolas bajo la coraza del lomo; pero solamente los cinixis pueden opri. mir el peto contra el espaldar. Lste último, muy aboredado, se compone de dos piezas que solo están unidas por cartilagos fibrosos y que por lo lanto permiten la movilidad de la parte posterior. La linea divisoria de estas dos piezas, encor. vada algunas veces argulosamente, está situnda entre la ter. cera y cuarta placa vertebiales, las dos últimas costilliures y las dos posteriores del borde; la de la nuca puede estar muy desarrollada ó faltar del todo; la de la cola es sencilla; las de los sobacos y de las caderas existen. La cabeza esta cubierta de escudos, y el antebrazo y la parte posterior de las piernas de escamas sobrepuestas. Los piés anteriores tienen circo dedos, soldados basta la articulacion de la uña; los postericres cuatro, un poco mas separados; los primeros tocan en tierra con las puntas de las unas cuando el animal anda; y los segundos con la nedia planta.

DISTRIBUCION GEOGRÁFICA.-Solo se conocen tres especies de este género originarias del Africa.

\section{EL CINIXIS DE HOME-CINIXYS HOMFANA}

CARACTERES. El cinjuis de Home no es la especie mas diseminada, pero si la mas conocida: caracterizase por su coraza oval, prolongada, plana en el dorso, ahorouillada lateralmente y deprimida en la region de la nuca; la j) laca do esta parte no existe; la cola es larga y carece en su punta de la materia córnea. El color predominante de la coraza es un castaño claro; los escudos que cubren la cabeza y las escamas de las piernas, así como las mandibulas, scon de un amarillo claro; algunos de los escudos de la cabeza tienen un viso pardusco. Ell tamaño es bastante considerable: se ven indivi. duos de $0^{\prime 2}, 30$ de longitud.

DISTRIBUCION GEOGRAFICA.- H] área de disner. sion de esta especie comprende el ocste de Africa; se ha encontrado en Guinca, á orillas del Gabon, y en las islas de Cabo Verde. No se sabe aun hasta dónde se prolonga su área de dispersion en el interior del continente. Algunos indivi. duos de nucstras colecciones europeas, adpuiridas en la (iun. yana, lueron importados sin duda del Africa.

USOS, COSTUMBRES Y REGGIMEN.-Hasla úl:imed 
mente no hemos adquirido algunas noticias sobre el géncro de vida de esta especie y de los demás cinixis. Solo sabia. mos, al menos por lo que yo he podido averiguar, que una de estas tortugas fué comprada en el Delta del Niger á un indigena que la llevaba atada con una cuerda; este individuo fué trasportado vivo á Europa, y aunque solo se le dió un poco de galleta dos $\delta$ tres semianas para su alimento, conserváronle algunos años viro. Ultimamente, no solo se recibie ron otros cautiros, sino tambien noticias sobre la vida en libertad de estos animales. Los informes han arrojado una luz. inesperada sobre la clasificacion de los cinixis, dándonos á conocer la ciactitud de la opinion de Strauch cuando dice que las tortugas terrestres y pantanosas, no solo constituyen una sola familia, sino que pertenecen tambien á una sola sub familia.

Monteiro designa una especie del grupo (cinixy's Welliana) como reptil terrestre que solo vive en suelo arenuso if otro terreno nuy seco, el cual solo abandona duranic la calurosa estacion de las lluvias, mientras que en la estacion fria, es decir desde mayo hasta octubre, se oculta, segun aseguran los indigenas, en profundos hoyos; pero los relatos que tenemos sobre las otras dos especies indican precisamente todo lo contrario. Ussher asegura que el cinixis descrito es un animal bastante comun en el país dé los fantis y de los auras; dice que sirve de alimento á los indigenas, por lo cual estos le aprecian mucho. Y raras veces le venden; $y$ añade lo siguiente: $\mathrm{Al}$ parecer vive mucho ticmpo en el agua; uno de los individuos que yo lleve á casa permaneció durante meses enteros en un estanque. Con esto se halla del todo conforme una noticia de Falkenstein. \& Respecto a los cinixis, me escribe el citado viajero, no he podido adquuirir muchos datos, ni por observaciones propias, ni por conducto de los negros. Lo único que yo sé és que li especie que he traido viva (cinixys erosa) no es comun y se encuentra en los rios ó en sus orilias hasta donde llega el agua del mar. Ia hem. bra sale á tierra para depositar sus huevos, pero no sé de cierto en qué periodo del año. Estoy convencido de que a pesar de sus pesados piés es una buena nadadora Mis caltivos, por lo menos, sacaban su alimento de un estanque profundo, sumergiéndose en ell hasta el fondo.

CAUTIVIDAD. - Fischer nos ha dado una breve des. cripcion de la vida en cautividad de los cinixis, segun obser. vaciones hechas en las tres especies del género. No difieren por mada en cuanto s sus usos y costumbres; son animales diurnos muy perezosos y estúpidos que apenas parecen moverse de un mismo sitio; sus movimientos son tan lentos como la marcha del minutero de un reloj; $j$ su torpeza para comer es tal, que Fischer se asombró de que pudieran satis. facer su hambre. Un individuo cuidado por Effeldt solo aceptaba cerezas: $y$ los cautivos de Fischer comian exclusivamente manzanas, pero no mas una ver. cada ocho ó quin cè dias, dándose el caso de que pasasen tres ó cuatro se manas sin comer nada. Cuando el tiempo estaba claro, 6 despues de un bano caliente, parecia abrírseles el apetito; cuando comen se les cae á menudo el bocado de la boca, y entonces muerden un sin nuimero de veces antes de que puedan volver á recogerlo; de modo que para satisfacerse del todo su apetito necesitan dos 6 tres horas. Fiffeldt me dijo poco antes de su muerte que el nodo de andar de los cinixis difiere del de todas las tortugas terrestres que cono. cia; pues caminan de lado, apoyándose en las unias de los piés anteriores.

Cuando se les asusta súbitamente ó se les infunde temor, ocúltanse del todo en su coraza, cicrran la parte móvil pos. terior de la misma y forman como una cápsula, abierta solo por delante.

\section{LOS TERRAPENES - TERRAPENE}

CARACTERES. - El terrapene de la Carolina, que por sus usos y costumbres es una tortuga terrestre, y por sus formas lo es pantanosa, representa otro tipo de tránsito entre las especies que viven en tierra firme y las que habitan en el agua, por lo cual merece nuestra particular atencion. Sus ca. ractéres distintivos consisten en tener el espaldar muy abovedado; placa cervical y doble placa caudal; el peto es oval, componiéndose de doce placas que forman dos piezas movi bles, tan grandes que ambas pueden oprinuirse por delante y detrás estrechamente sobre el espaldar; las placas de los hombros y de los costados están atrofiadas ó faltan del todo; ia cola es corta; los piés bastante largos; los anteriores tienen cinco dedos y los posteriores cuatro, provistos de membranas natatorias. La cabeza está cubierta de una piel lisa, y los piés anteriores de grandes escamas.

\section{EL TERRAPENE DE LA CAROLINA- TERRAPENE CARINATA}

CARACTÉRES. - Esta especie varia mucho: el color de sus partes superiores suele ser un bonito pardo $\delta$ pardo negrurico; los dibujos consisten en manchas y fajas de color amiarillo; las placas de la coraza y del pecho son amarillas, con lineas pardas. La longitud de la coraza es cuando mas de ()$^{m}, 15$ por $0^{m}, 09$ de ancho. La cabeza forma un óralo pro. longado; las mandibulas son cortantes, y no denticuladas; así aquellas como los piés anteriores y posteriores presentan manchns pardas 5 amarillas (fig. 4).

DISTRIBUCION GEOGRAFICA.-El área de dispersion del terrapene de la Carolina se extiende por la major parte de los Estados.Unidos, desce el Maine hasta la Flo. rida y en el oeste hasta Iowa, Missouri y 'T'exas; está repre. sentada por una variedad en el sur de México, pero falta en las islas de la. India occidental.

USOS, COSTUMBRES Y REGIMEN.-Dentro de los limites indicados esta especie se encuentra casi en todas partes y con mucha frecuencia; su género de vida es análogo en un todo al de otras tortugas. Segun Ord, que la observó minuciosamente, se la encuentra mucho mas á menudo en terreno seco que en huimedo, y efectivamente, si se la ob. serva en este, el naturalisia puede estar convencido de que solo un bocado favorito la indujo a visitar los parajes poco convenientes para ella. Asi, por cjemplo, puede buscairsela con seguridad en los pantanos elegidos por el nicticorax para reproducirse, pues sicmpre hay bajo las guaridas de estos ardeidos gran nimero de peces medio podridos, que pare. cen ser verdaderas golosinas para el terrapene de la Carolina. Además de tales restos come insectos, caracoles, gusanos, setas ticrnas y bayas, estas lilimas hasta con gran voracidad. Otros observadores están del todo conformes con estas noti. cias. Tuve á menudo ocasion, dice C. Mueller, de observar terrapenes de la Carolina, tanto en el estado libre como en cautividad, pero nunca los encontré en el agua, notando, por el contrario, que cuando se les llevaba a un estanque mostraban una gran repugnancia, abandonándole tan pronto como era posible. Cicrto que tambien se les encuentra en terreno húmedo ó pantanoso, mas por lo regular viven en bosques ó praderas y parecen preferir á los demás sitios las selvas frondosas. A veces se les ve en lugares muy secos y hasta en colinas arenosas. A menudo, segun Mueller, están medio ocultos en la tierra y en el nusgo, ocupados probable mente en buscar setas, gusanos e insectos. Mueller cogió una vę un individuo en el tronco de un árbol hueco, habialc oido trabajar ya desde léjos, y al acercarse le vió rodeado de 
larvas de insectos que debian servirie de almuerzo. Le gusta mucho la oscuridad; los cautivos observados por Fis. cher ocultábanse, cuando habia sol, detrás de la estufa y de. bajo de los armarios y otros objetos que preservan de la luz; pero al cerrar la noche recobraban su agilidad y cuando habia luna corrian mas por la habitacion. No cabe duda que lo mismo harán en libertad; el terrapene de la Carolina se muestra aqui no menos timido y medroso que otras especies pequeñas de su familia; si otro animal mayor se le acerca, recoge la cabeza y las piernas, cerrando su coraza de tal modo, que nada pueden hacerle las rapaces ordinarias, pero cuando se le irrita, se defiende, muerde y no es fácil hacerle soltar lo que una vez ha cogido. Schil presentó un individuo que halló en las Praderas cogido de una rama del grueso de un dedo. Para saber si soltaria el objeto, y cuándo, atóla en su coche de modo que la tortuga quedó suspendida; el carruaje se puso en movimiento y el reptil estuvo colgado en la rama desde la mañana hasta por la noche, sin soltar ni tampoco cansarse.

Ord describe muy minuciosamente el modo de reproducirse el terrapene de la Carolina. Tuvo algunos años segui. dos varios de cstos animales en su jardin, muy propio para el caso por todos conceptos, y asi pudo hacer observaciones detalladas. A pesar del gran espacio que tenian a su disposi. cion y de su libertad, poccs individuos se reprodujeron, habiéndose malogrado muchos huevos, los mas por causa de las pequeñas hormigas que destruian los nidos. La mancra de abrir el hoyo y de poner los huevos no difiere de lo que ya hemos descrito al hablar de la tortuga elegante; los cinco 6 seis huevos que la hembra deposita, aunque salen siempre con intervalos de cinco minutos por lo menos, no causin dolores de parto. Las hembras medio adultas proceden exacta. mente del mismo modo qque las viejas, rodeando con tierra cada huevo despues de ponerle; una vez lleno el hoyo, apiso.

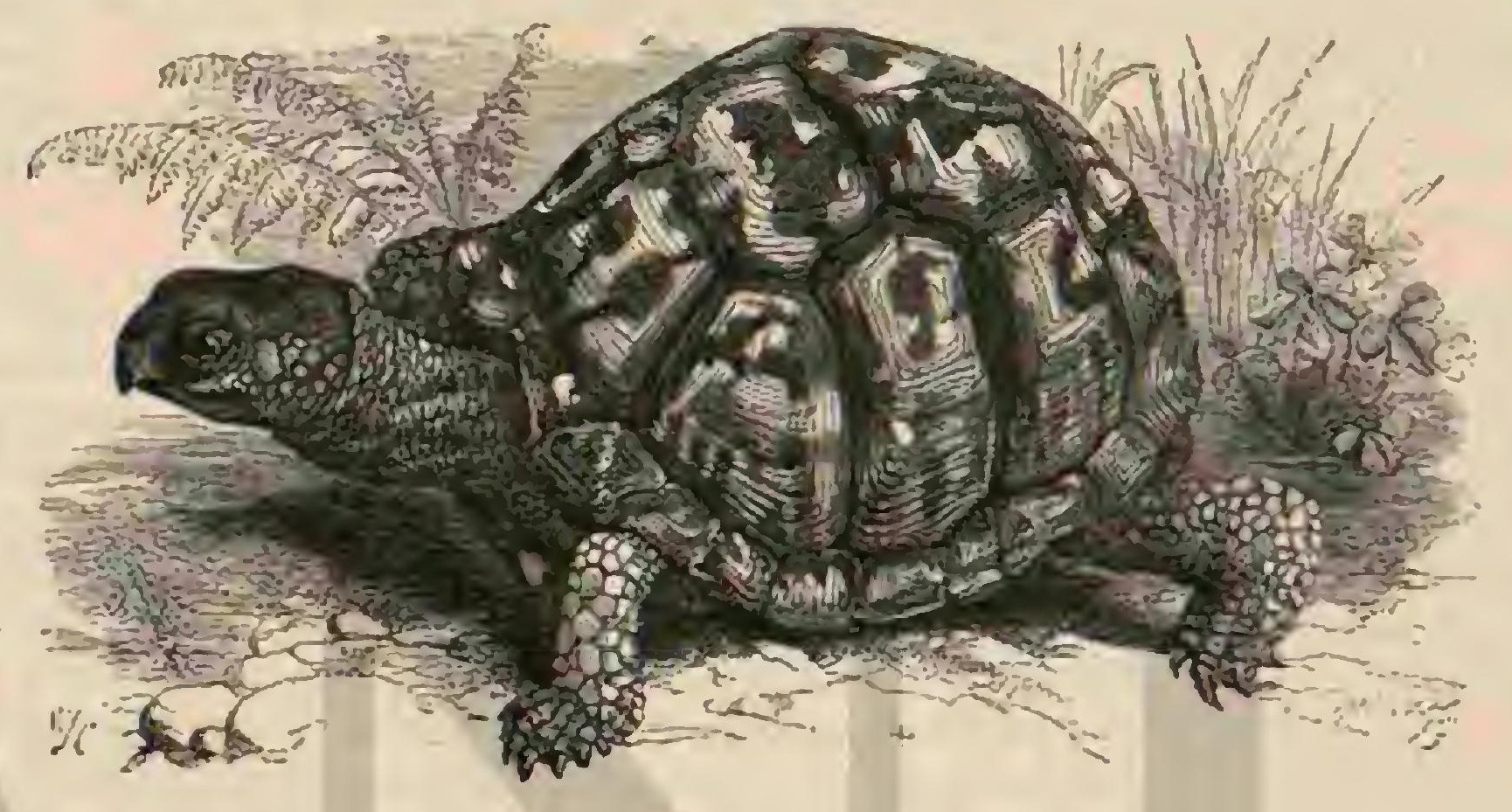

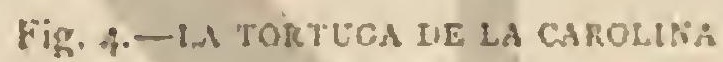

nan el terreno cuidadosamente. Mientras escarba y pone la tortuga no cambia de posicion y ni siquiera vuelve la cara hácia atrás. Cuando se la estorba en la puesta no empieza á escarbar hasta despues de quince dias.

Ord cogió los huevos de una hembra cierto dia despues de la puesta y los colocó en una caja llena de tierra. El pri. mer pequeño salió á los 88 dias, y el último á los 109; los hijuelos cran de diverso tamaño y fuerza, mas por lo regular bien desarrollados y tambien desde el primer momento ágiles y vivaces: sus conchas, sin embargo, eran todavia muy blan. das y cartilaginosas, viéndose aun los restos de la yema en el centro del peto. Sucede sin embargo muy á menudo que, el calor medio del verano de Pensilvania no basta para desarrollarlos; de modo que el invierno les sorprende en el cas. caron.

En tal caso perecen naturalmente con mucha mas facili. dad que los adultos por causa del frio; $y$ á menudo corren gran peligro por el hielo cuando el hoyo no tiene bastante profundidad. Los recien nacidos, por fortuna, se ocultan al mismo tiempo con los adultos á mediados de octubre, y no rcaparecen hasta el 20 de abril: siempre eligen con mucho acierto para sus cuarteles de invierno, un terreno ligero $y \mathrm{en}$ parajes que rio se hallen expuestos al viento del norte.

CAzA. - El terrapene de la Carolina no sufre una perse. cucion sistemática; su carne, por sabrosa que sea, no se co. me, pues se tiene contra ella la misma prevencion que induce à los campesinos á no comer ancas de rana. \&Un marino viejo y retirado, dice Ord, que habiendo llegado á Pensival. nia encargó á todos los muchachos que le llevasen tortugas y ranas para comerlas, pues sabia apreciar un alimento tan sabroso, infundió desconfianza en toda la poblacion.s Con mas frecuencia se comen los lruevos.

CAUTIVIDAD. - Muhlenberg asegura que la tortuga de la Carolina es muy útil porque caza ratas y culebras. Cuando ha cogido una la oprime con fuerza entre el peio y el espaldar hasta que la mata, comiéndosela luego con la major satis. faccion. Semejante aserto demuestra claramente que aquel naturalista ha dado crédito á una fábula referida por algun indigena. Lo quue si puede admitirse como muy probab!e, es que estos animales deroran toda clase de sabandijas y animales nocivos, y que por esta razon se les ziene en las habitaciones. Pronto pierde esta lortuga su natural timidez, y con el tiempo se acostumbra à tomar el alimento de manos de las personas. Come las cosas mas diversas, tales como hon. gos, hortaliza, patatas, frutas, pan, insectos y came. Un individuo cautiro que tenia Reichenbach, manifestó singular aversion á una tortuga griega con la cual vivia: véase lo que refiere dicho naturalista «Cuando yo trabajaba solia oir unos golpes semejantes álos de un martillo pequeño, sin que al principio pudiera explicarme la causa de semejante rumor. Al fín descubri que la tortuga pequeña acometia á la mas grande con cierto furor; colocibase para ello como 1 una pulgada de distancia de su compañera, ocultaba luego la cabeza, y apoyandose sobre sus extremidades anteriores se lanzaba sobre la otra sirviéndose de la parte anterior de su coraza como de una catapulta: repetia esta operacion diez 6 doce veces seguidas. Aquel curioso espectículo se renovaba todos los dias, y muchos de 'mis amigos pudieron presenciarlo, 
hasta que la tortuga pequeña, rabiosa sin duda al ver su impotencia y la inutilidad de sus esfuerzos, pagó su aversion con la vida.

\section{LA TORTUGA PIXIS-PIXIS ARACHNOIDES}

Caracterres. - La pixis no pertenece â las grandes especies: su color es tan variable, que apenas se encuentran dos individuos iguales exactamente; pero en general predominan los tintes negto $y$ amarillo. Las placas del espaldar presentan varias manchias triangulares, $y$ las del borde lineas negras (figs. 5 y 6 ).

DISTRIBUCION GFOGRÁFICA.-Esta tortuga se en. cuentra en varios puntos de la India, y particularmente eo Madagascar.

USOS, COSTUMBRES Y RIGIMEN.-Segun hemos dicho antes, nada se sabe acerca del género de vida de la tortuga pixis.

\section{LOS EMIDIDOS-PAI.UDIVAGI}

CARACTÉRES. - La major parte de los naturalistas, reuniendo las tortugas terrestres que tiener el espaldar lige. ramente abovedado $y$ cortas patas natntorias, forman una sub familia aislada, aunque la separacion de las especies que exclusivamente viven en tierra firme no puede sostenerse. Fn cambio, el género de vida de las llamadas tortugas pan. tanosas ofrece tantas analogías que a los géneros siguicntes puede preceder una descripcion general.

USOS, COSTUMBRES Y RÉGIMEN.-REl que quiera estudiar las tortugas en sus muchas variedades y cn estado de libertad, que vaya á la América del norte, dice Weinland; aquel es el verdadero pais de las tortugas, sicndo mas de dos docenas de especies las que pueblan los estanques, lagos, rios, bosques y valles; alli no debe temer. el sabio que se extingan estos reptiles tan pronto.

¿El naturalista europeo que en los calurosos dias del rerano se pasea por los hermosos campos de Nueva Ingla. terra, país que ofrece tantas analogías con Alemania, se cansaria inútilmente si intentara descubrir alguna lagartija de las que en su pais remueven de repente en el borde de todos los senderos calentados por el sol, las hojas secas esparcidas á sus piés. Pero si dirige sus pasos á cualquier lago ó estan. que, $\delta$ á un arroyo cuya corriente atraviesa tranquila los prados, entonces encontrará alli abundante materia para su estudio. Sobre una hoja de nenúfar ve de pronto un objeto pequeño, de forma redondeada, del tamaño de un duro $y$ de color pardo; acércase presuroso; pero en el mismo ins. tanie salta aquel objeto al agua, con la rapidez del rayo y desaparece de pronto. Entonces el naturalista le sigue con los ojos y descubre por fin que es una tortuguita que avanza con paso decidido por el fondo del arrojo, acabando por ucultarse en el limo $\delta$ en alguna espesura de plantas acuáti. cas. Trascurre lo menos una hora antes que vuelva á salir para respirar; y si el naturalista quiere apoderarse del reptil, debe permanecer inmóvil y silencioso como el cazador en acecho. Pasado este tiempo, ve asomar la cabeza de la tor. luga sobre la limpida superficic del agua; suis negros y bri llantes ojos son por demís expresivos; el animal se acerca remando, casi sin agitar el líquido clemento, al sitio mismo donde está el naturalista inmóvil, porque todo animal infetior no reconoce al hombre ó á cualquier otro sér animado sino por sus movimientos. Asi, pues, una tortuga se colocaria tranquilamente lo mismo sobre la mano que sobre una piedra, siempre que aquella se rnantenga completamente inmó vil. El hombre se apodera por lo tanto del reptil, porque su mordedura no daina; y todo alhorozado, corre con su presa para enseñaria al primer amigo que encuentra; pero este le dice sonriendo: «Si con tan poca cosa sois feliz, podreis coger tantas tortugas como os plazca \#

En efecto, América es el pais de estos reptiles, pues solo ćl, por lo que ahora se sabe, posee tantas especies como las demis partes del mundo reunidas; $y$ eso que el Asia es rica en tortugas, $y$ no es pobre tampoco el Africa por tal con. cepto: donde hay agua en paises cálidos, se encuentran estos reptiles.

Los emididos viven solamente en comarcas bastante húmedas, y los mas en las aguas de los rios de poca corriente, en las lagunas y en los lagos. Aunque en tierra se mueven con torpeza y pesadez, son sin embargo mas ágiles y ligeros que las tortugas terrestres, y sorprenden por su destreza y habilidad en la natacion. Se les ve flotar ó nadar tranquila mente en la superficie del agua, y de pronto, rápidos como el rayo, precipitarse al fondo, para esconderse en el limo ó entre las raices, apenas sospechan la presencia de un ene. migo. Muller dice que no parece sino que estos animales han estudiado el arte de hacerse invisibles; expresándose á propósito de esto en los siguientes términos: Encontré á veces las orillas de las lagunas ó arroyos tan pobladas de tortugas de la especie mas comun, que ocupaban hasta las mas insignificantes eminencias; parecian disfrutar alli de los benéficos rayos del sol; pero al aproximarme yo con cautela, hasta el punto de no faltarme mas que cogerlas, desaparecian como por encanto, y solo me era posible atrapar alguna en el fondo claro y limoso si el agua era trasparente y limpida, pues por lo general, huir y ocultarse dentro del fango era obra de un momento, gracias á la fuerza de sus extremidades y śsu habilidad en manejarlas. Admirable es realmente la destreza con que nadan para cazar, pucs se alimentan sobre todo de mamíferos pequeños, pájaros, insectos, anfibios, peces y moluscos, siendo probable que no coman vegetales mientras no les falten animales. Los individuos cautivos, por lo menos, prefieren decididamente la carne $\alpha$ las patatas $\delta$ al pan, aunque no rechazan del todo este último alimento. Algunas especies son verdaderos animales de mpina, que no contentándose con pajaritos, se atreven con las aves del tamaño de nuestros patos; y aun con el hombre si las irrita.

Las facuitades intelectuales de estas tortugas guardan armonía con su ligereza y rapacidad, como es fácil de com. prender: sus scntidos parecen alcanzar mucho mas desarrollo que en los quersénidos, a los cuales aventajan mucho en cuanto à inteligencia. Reconocen perfectamente cuando ảl. guien las inquicta, 5 las hay que dan pruebas de una astucia y precaucion que no se habria sospechado en ellas; escogen los escondites mejor situados y obran aprovechando muy bien la experiencia adquirida. Tambien se domesticin con mas facilidad que todas las demás tortugas y llegan positivamente a reconocer al que las cuida, aunque solo hasta cierto punto; es decir, que se acostumbran á vivir entre personas, sin aprender por esto á distinguir unas de otras.

Al aproximarse el invierno se entierran à una profundidad muy regular donde pasan la estacion desfavorable cual si estuviesen muertas; lo mismo hacen en los países intertropicales en la época de la sequía cuando se agotan temporal. mente las aguas en que habitan, época que viene á ser para ellas la estacion invernal. Mïller dice que realmente llegan á socavar las orillas de los rios de la América del norte; que ciertas especies no se pueden encontrar sino á cuatro piés de profundidad; $y$ que por la misma razon se reconocen con la mayor facilidad las guaridas de invierno de estos reptiles, pues ofrecen el aspecto de un campo donde hubiera estado hozando una manada de cerdos. Las primeras tortugas aban. 
donan su retiro, en América, á principios de mayo, y aun en abril, cuando la primavera no es tardia; entonces dan prin. cipio a su vida de verano, comenzando ante todo el periodo del celo.

REPRODUCCXON. - El apareamicnto dura varios dias, y mientras las tortugas se ocupan en él, no parecen cuidarse de ninguna otra cosa, deponiendo entonces su timider y precaucion acostumbradas. Müller dice que pudo pescar con red una tortuga pintada en el momento de estarse aparean. do, pero no quiso interrumpir la operacion. Efectúan este acto uniendo los petos, y cogiéndose por las patas con tal fuerza, que se necesita bastante vigor para separarlas. Poco tiempo despues del apareamiento comienza la hembra á practicar agujeros en tierra donde deposita de seis á ocho huevos.

Estos huevos tienen para muchos pueblos una gran im. portancia, de la cual participan todas las tortugas pantanosas y fiuviales. Bates refiere que en Ega, á orillas del Amazonas, se habia alimentado casi todo el año de carne de tortuga, hartándose de tal modo que al fin no pudo soportar el olor, aunņue padecia realmente hambre. Cada propietario tiene alli un pequerio estanque en el que se guardan los cautivos hasta el periodo de escasez, es decir, hasta la esta. cion lluviosa: Los propietarios que tienen algunos indios á su servicio envian á estos á cazar cuando las aguas bajan para proveer de nuevo su estanque, pues á pesar del asombroso número de tortugas, es dificil adquirirlas en los meses húmedos, ni aun por dinero, porque la facilidad de encon. trarlas y cogerlas está en relacion con la mayor ó menor altura del agua. Cuando el rio baja menos que de ordinario estos animales escasean, pero si desciende mucho se les coge en gran nímero, porque entonces todos los charcos y pantanos de los bosques quedan llenos de tortugas. Para cazarlas se emplean redes y flechas, cuya punta al penetrar sepárase del mango, quedando enlazada con este por una larga cuerda; el mango sobrenada en el agua; el cazador se acerca con la lancha, tirando de la cuerda hasta que el animal se aproxima á la superficic, $\mathrm{g}$ entonces se le atraviesa, segun las circunstancias, con una segunda lecha, llevándole despues á la orilla. Las mujeres indigenas saben guisar la carne de tortuga de varios modos, y siempre muy bien; es muy tierna, sabrosa y saludable, pero cansa pronto, y al fin repugna á todo curopeo. Segun asegura el mismo autor, solo una especie, la mayor de las que se encuentran en el Amazonas, puede conservarse mucho ticmpo cautiva; las mas pequenas, mucho mas sabrosas, solo soportan pocos dias la pérdida de su libertad. No sucede lo mismo con las tortugas pantannsas de la América del norte, que se mantienen muy bien en un espacio limitado si se las trata de un modo conveniente. Algunas de ellas han vivido cuarenta 6 mas años cautivas. En Ceilan, segun Tennent, vénse tambien estas tortugas en el interior de las casas, portyue se cree que las purgan de toda clase de parásitos; estos animales se conservan asinismo muchos años, al parecer en mejor salud, cuando se les da agua y un poco de carne.

La mayor parte de los aficionados no saben cuidar de las tortugas pantanosas, relativamente muy insensibles, pues en invierno no las dan el calor necesario. Las que se tienen al aire libre practican ellas mismas agujeros en el cieno formando asi albergues convenientes, mientras que las que están obligadas á vivir en una habitacion solo pueden aco. modarse con una temperatura uniforme. Hace varios años, escribe Effeldt, aficionado muy conocedor, recibi emididos norte-americanos, pero siempre morian en invierno. Los po. $\cos$ que sobrevivian á la estacion rigurosa no comian nada $y$ enflaquecian de tal modo, que en la primavera perccian sin remedio. Al fin se me ocurrió tener el agua tibia en invierno, habiendo observado que mis tortugas, aun en el verano, solo tomaban alimento cuando el agua se tempiaba Entonces mandé poner una estufa sobre la cual pude colocar mis cautivos, y esto me dió por resultado que todas mis tortugas pantanosas, desde la mas pequeĩa á la mas grande, no solamente comieran diariamente sino que hasta se dispu. taban el alimento; de modo que me fué preciso dárselo por separado ślas laspecies mas grandes. Pronto se domesticaron de tal modo qque levantaban la cabeza cuando yo me acercaba, aceptando carne cruda de la mano. $\mathrm{El}$ mismo pro. cedimiento observan últimamente todos los aficionados cuidadosos que quieren conservar sus tortugas vivas. El calor es y será la principal condicion para la prosperidad de estos animales, y apenas se les dará todo el quue necesitan, al paso que fảcilmente se pueden cometer faltas. Los hijuelos, segun Fitcher, se crian con mas seguridad cuando se les coloca en vasijas bien claras, como, por ejemplo, de vidrio; se deben tener tambien en agua tibia, y cuando aun no pueden digerir carne cruda ó peces, se les alimenta con pequeños crustá. ceos, moluscos, gusmos, huevos de rana $\delta$ de peces, larvas de hormigas y otras; mas tarde se les dan cochinillas acuáticas, renacuajos y nececillos, acostumbrándolas á la carne cuando son medio adultas. Segun mis experiencias, tambien los individuos adultos prefieren los peces à la carne de aves y mamíferos.

\section{LOS GALÁPAGOS-EMYS}

CARACTERES. - Entrc los cmididos asignaremos el primer lugar a las especies que se encuentran en nuestros paises. El espaldar de los galípagos, ó tortugas de los charcos, es ligeramente abovedado; la placa de la nuca y una doble placa de la cola existen; el peto, reunido con el espaldar por un ligamento cartilaginoso, es ancho y se compone en su parte anterior de doce placas y dos piezas movibles, pero estas últimas son demasiado pequeñas para poder cerrar la abertura del espaldar. Los piés anteriores tienen cinco dedos y los posteriores cuatro, provistos todos de membra. nas natatorias bien desarrolladas. Una piel lisa cubre la ca. beza, mientras que las piernas, sobre todo las anteriores, están revestidas de grandes escamas; la cola, bastante larga, carece de la pieza córnea que rodea la extremidad de este órgano en estas toriugas.

\section{EL GALÁPAGO DE EUROPA-EMYS EU- ROPEA}

CARACTÉRES. - El galápago de Europa alcanza una longitud total de $0^{\prime \prime}, 35$. de los que $11^{\circ}, 10$ pertenecen á la cola; la coraza puede medir hasta $0^{\circ}, 20$. I as partes no cubiertas tienen un fondo de color negruzco, con varios puntos amarillos; el de las placas del espaldar es verde oscuro, con líneas 5 motas amarillas; el peto es de un amarillo sucio, salpicado irregularmente de algunas manchas pardas $\delta$ raya. do; todos estos colores y dibujos varian mucho.

DISTRIBUCYON GEOGRÁFICA. - La verdadera pa. tria de esta tortuga es el este y sudeste de nuestro continente: abunda en Grecia, Dalmacia, Turquia, Italia, incluso sus islas, la Suiza meridional, los paises bajos del Danubio y Hungria; tambien se encuentra en el sur de Francia, España, Portugal y Argelia, así como en una gran parte del imperio ruso, en el este hasta el Sir-Daria y hasta en Persia. En Alemania habita las aguas corrientes y estancadas de Brandenburgo, Silesia, Posen, Prusia Occidental y Oriental, Mecklenburgo, Sajonia y Baricra, sobre todo el territorio del 
Filba, del Oder 5 del Weichsel, en Baviera el Danubio hasta el Passau. En el Havel y Spree no es rara, aunque solo se la ve en algunos puntos con regularidad; tampoco escasea en las partes meridionales del Oder $y$ del Weichsel; no se acerca sin embargo al Báltico. En el territorio del Rhin se coge algun individuo, pero no se puede asegurar aun si se cuenta aqui entre las especies constantes 6 solo se ha im. portado. Strauch reconoció que habitaba en la region de Kreutznach, y \& mi me dijo el Dr. Leimbach que última. mente se cogió un individuo cerca de Krefeld, pero que ya antes habian encontrado otros: no podemos dar importancia \& casos tan aislados. De todas las tortugas es la que penetra mas hácia el norte y tambico se extiende en una region mucho mas vasta que todos sus congencres, pues fija su residencia entre los $35^{\circ}$ y $56^{\circ}$ de latitud norte, y entre los $9^{\circ} y$ $32^{\prime \prime}$ de longitud este, es decir entre Argelia y Curlandia, entre Portugal y el Sir-Daria.

USOS, COSTUMBRES Y RÉGIMEN. - El galápago de Europa prefiere las aguas estancadas 6 poco profundas $y$ sucias mas bien que los rios rápidos y lagos claros. De dia solo abandona el agua en parajes del todo tranquilos para tomar el sol, permaneciendo mas ó menos en el mismo lugar; poco antes de ponerse el sol se despierta desplegando entonces.su actividad durante toda la noche. Durante los meses de invierno se entierra en el fango, y hácia mediados de abril, por poco que la temperatura le sea favorable, aparece

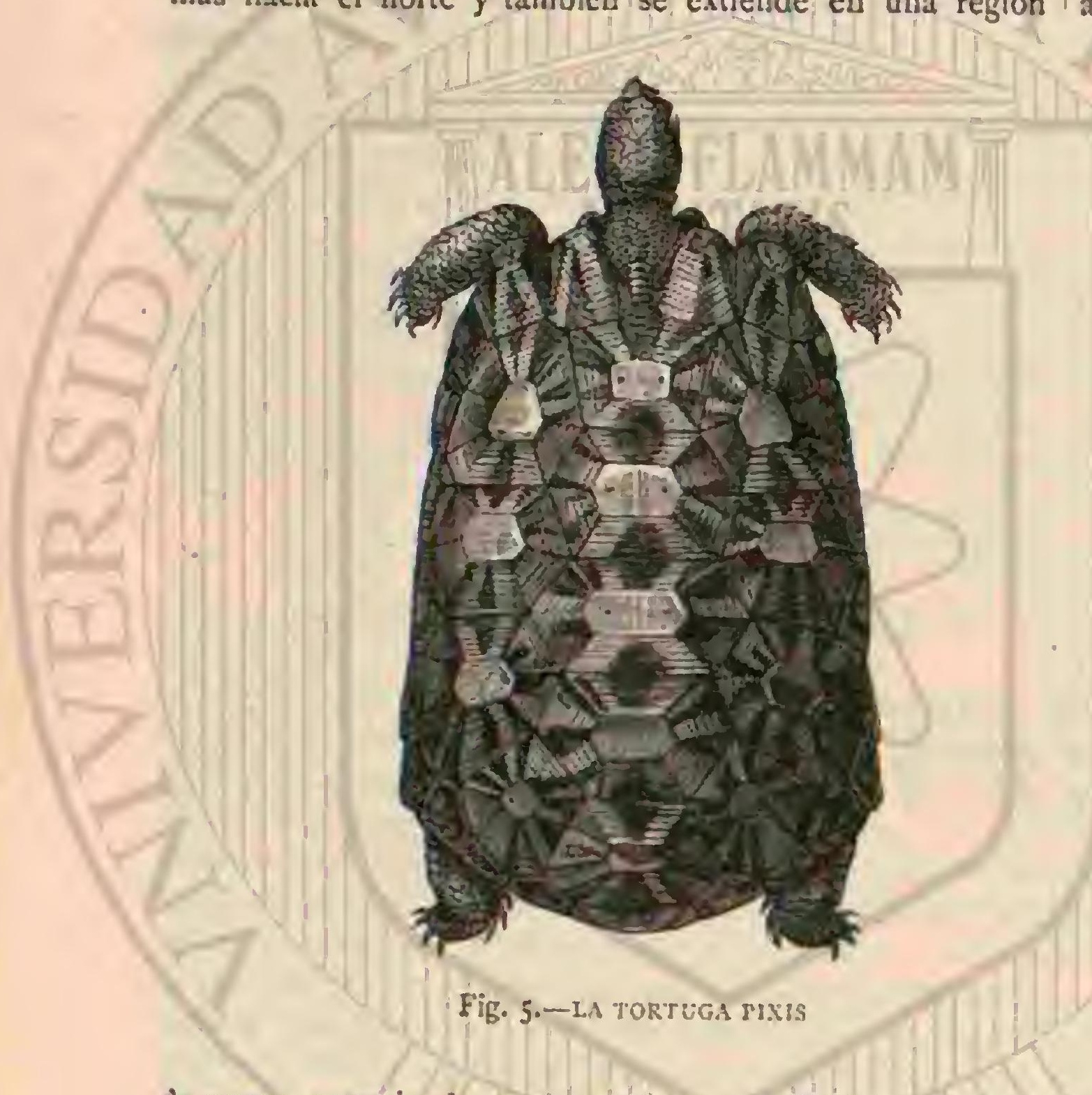

de nuevo, anunciando su presencia con un silbido particular, que algunos suponen ser el reclámo del celo. Es recelosa, y cuando nada, se sumerge al menor ruido. En el agua es ágil, y aunque en tierra no se muestre tampoco torpe, no son, sin embargo, sus movimientos tan rápidos como los de la tortuga terrestre. Su alimento consiste en caracoles y gusanos de toda especie; pero tambien acecha a los peces y hasta se atreve con los de tamano bastante regular, a los que muerde por debajo hasta que la victima pierde las fuerzas, apoderán. dose entonces de clla. Maregraf observú algunos individuos de la especie, que tenia en un estanque, y pudo ver cómo despues de muerto el pez se comen hasta las espinas. Sucede á menudo que, separada la vejiga natatoria del per, sube, como es natural, a la superficie del agua, $y$ por eso cuando se ven muchos es señal de que existen tortugas en las cercanias. Estos reptiles se nutien tambien de plantas acuáticas, si bien algunos pretenden que únicamente lo hacen cuando carecen de otro alimento. A los individuos cautivos se les puede conservar durante muchos años en perfecto estadio, proporcionándoles caracoles y gusanos; se les domestica fá. cilmente, hasta el punto de darles la comida con la mano y acostumbrarles \& un sitio fijo. Evitase así, segun Erber y otros observadores, que se entreguen al suerio invernal; micntras que si se les conserva en jardines se entierran al principiar la estacion fria.

Miram habla minuciosamente sobic la reproduccion del galápago de Europa, y en particular de la puesta de los hue.

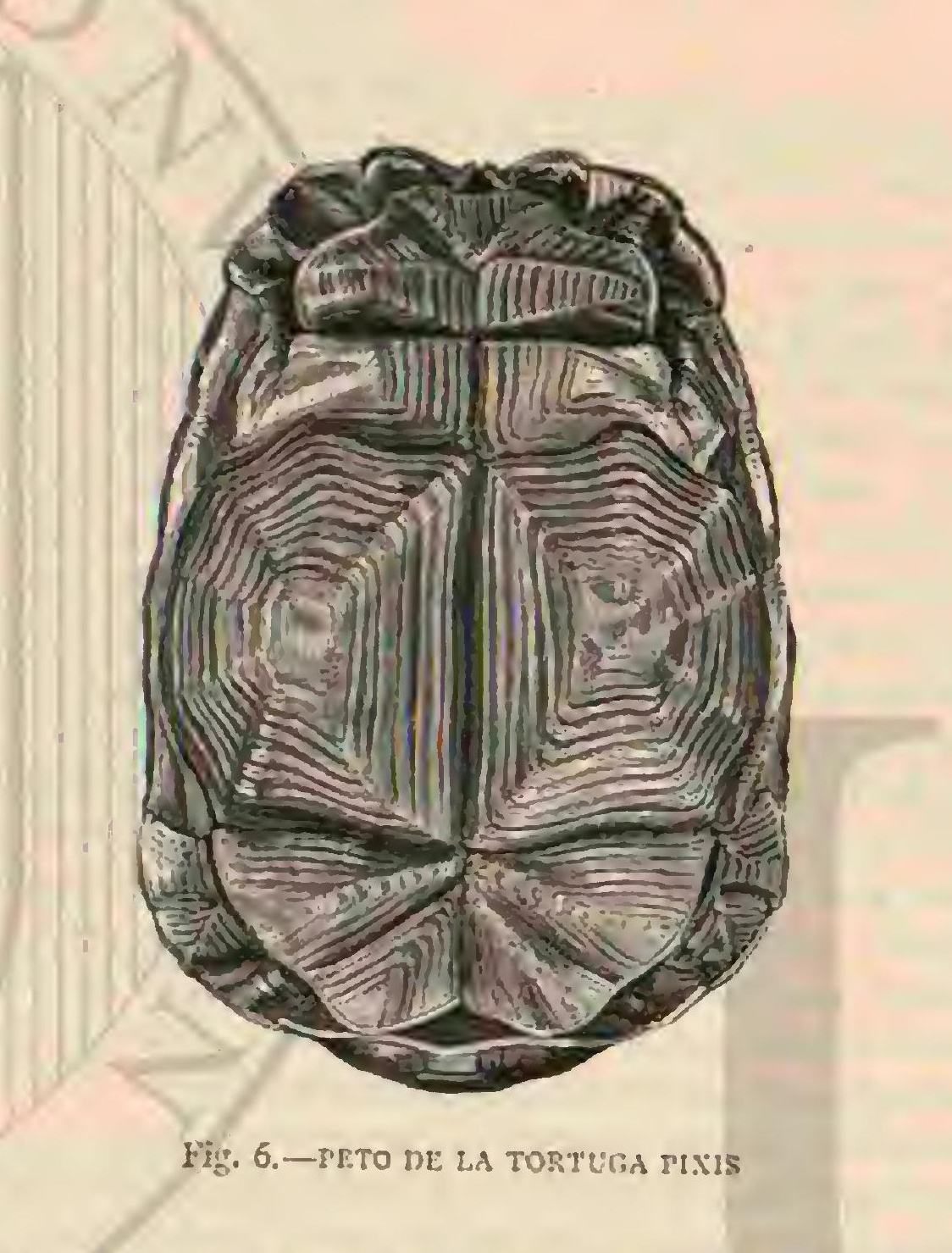

vos. Cierto que los resultados de sus observaciones son esencialmente los mismos que se han hecho en otras tortugas, pero la descripcion de Miram es sin embargo mas detallada que ninguna otra y por eso merece que la copiemos aqui entera. Parn sus averiguaciones científicas el citado naturalista turo mucho tiempo un gran numero de tortugas vivas en su jardin, cercado de un muro y con una hondonada que servia de estanque. los campesinos de los alrededores de Kiew le trajeron de los próximos lagos y estanques tantos galápagos de Europa como deseaba, pero casi siempre indi. viduos adultos, y muy raras veces pequeños, cogidos los mas en abril 6 mayo. Sucedió \&́ menudo que las hembras cautivas dejaron caer huevos en el jardin; Miram las dió por lo tanto cierta libertad, 5 pronto observó que las fecundadas busca. ban el sitio mas alto del jardin, en cuyo suelo habia mezcla de arena y barro, para escarbar sus guaridas.

La puesta se verifica siempre por la tarde antes de ponerse el sol, es decir de las siete a las ocho, pero como estos rep. tiles deben practicar la abertura y cubrir los huevos, la ope. racion dura casi toda la noche. En 28 de mayo de $1 \$ 49$, un dia de verano inuy hermoso y cálido, despues de una se. quia de mucha duracion, cinco tortugas pusieron al mismo tiempo sus huevos, reuniéndose en el citado lugar á las siete de la noche, pero no en un espacio reducido, sino á considerable distancia una de otra. Despues de elegir un sitio có modo, desprovisto de toda vegetacion, orinaron copiosamente para ablandar el suclo un poco, aunque solo superficialmen. 
te; despues, ayudándose con la cola, cuyos músculos se pusieron rigidos, abrieron un agujero en la tierra; la punta de aquel órgano se oprimia con fuerza contra el suelo, mientras que la parte superior de la misma hacia movimientos circulares. De esta manera practicaron una abertura ancha por arriba y estrecha por debajo, que las tortugas bumedecieron de nuevo varias veces con pequeñas cantidades de orina para ablandar el suelo. Despues de haber abierto este agujero á una profundidad que recogió ya toda la longitud de la cola, empezaron á ensanchar el agujero con las patas traseras. A este efecto extrajeron la tierra alternativamente ya con la derecha ya con la izquierda, formando con ella al borde del hoyo una especie de terraplen. En este procedimiento las patas trabajaban del nismo modo que las manos humanas; las tortugas escarbaban con el pié derecho de derecha á izquierda, y con el izquierdo á la inversa, extrayendo cada ver, por decirlo así, una paletada de tierra, la cual co. locaban cuidadosamente en un circulo á corta distancia del borde del hoyo, continuando asi la operacion mientras pudieron alcanzar tierra. El cuerpo permanecia entre tanto inmóvil, solo la cabeza sobresalia un poco del peto y del espaldar. De esta manera cada tortuga practicó un hojo de

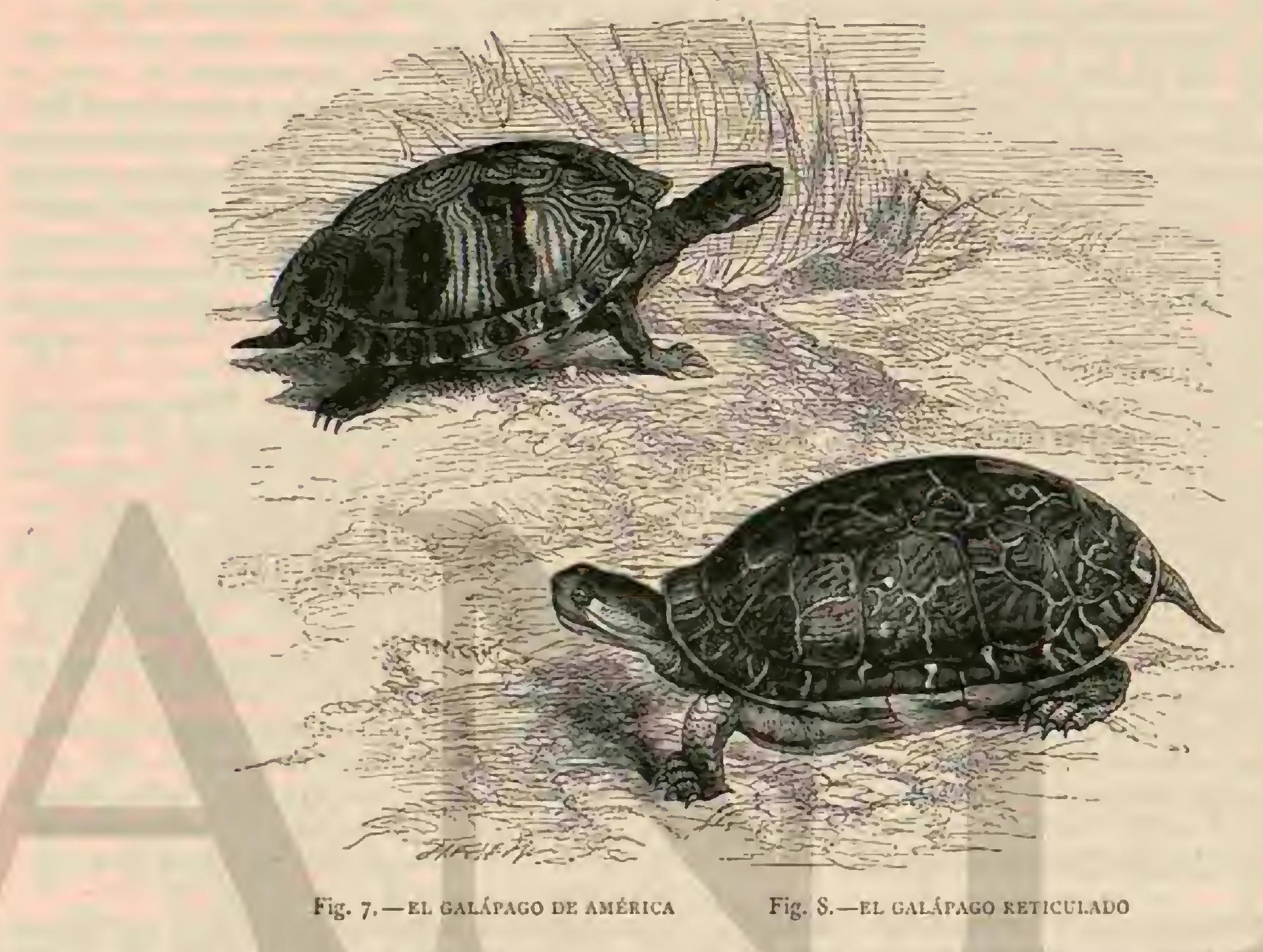

unos $0^{2}, 12$ de diámetro; pero que en el interior se ensanchaba mucho mas, adquiriendo casi la forma de un huevo. 1)espues de algunas tentativas frustradas para sacarmas tierra de la cavidad, la tortuga pareció haberse convencido de que cl nido estaba acabado; todo el trabajo habia durado una hora ó mas.

Sin cambiar de posicion, la tortuga emperó inmediatamente $a$ poner los huevos, de un modo tan particular como to fué el acto anterior. El huevo que salió del orificio del ano era recogido cuidadosamente con la planta de la pata poste. rior; esta se alargaba y le depositaba en el suelo del hoyo. En seguida retiró el pié que acababa de trabajar, el otro reco. gió del mismo modo un segundo huevo salido del orificio, y depositóle en la cavidad, continuando asi la operacion con las dos patas posteriores. La cáscara de los huevos era toda. via blanda al salir, pero endurecióse pronto al aire. Su número regular era de nueve, raras veces menos, y solo una vez Miram vió á una tortuga poner once. Como los huevos se seguian répidamente, á menudo á intervalos de un minu. to, y en raro caso despues de dos 6 tres, la puesta duraba poco mas 6 menos quince minutos, y por excepcion media hora.

Despues de poner la hembra parecia descansar un poco, echada en el suelo, sin ejecutar ningun movimiento; á me. nudo el pié que habia depositado el víltimo huevo quedaba inmóvil y pendiente, lo mismo que la cola, que durante el trabajo y la puesta se habia mantenido ladeada. Asi pasó media hora hasta que la tortuga dió principio á su última, pero al parecer mas penosa operacion, la cual consistió en llenar el hoyo é igualar el suelo.

A este efecto ladeó la cola otra vez, retirando tambien la pata, la otra cogió un poco de tierra y acercíndola al fondo del hoyo, extendióla cuidadosamente sobre los huevos. Despues se repitió lo mismo con el otro pié y asi alternativamente mientras bastó la tierra extraida. Las últimas capas no se extendicron sin embargo con la misma precaucion que las anteriores, pero el animal se esforź cn oprimirlas mas con el borde exterior de la pata. Cuando al cabo de una media hora no quedó ya tierra, la tortuga volvió á descansar otro tanto tiempo; despues se levantó, y alargando la cabeza por en medio de la coraza describió círculos al rededor del nido, cual si quisiern reconocer cómo habia consumado su obra. Enionces apisonó con la parte posterior del peto la especie de colina que habia formado; para esta operacion elevaba la parte posterior del cuerpo dejándola caer con cierta fuerza; la tortuga se movia circularmente y el trabajo fué muy penoso, pues el animal procedia con una rapidez que apenas podria esperarse de una tortuga; mas puso tal cuidado en la 
operacion que logró borrar codas las huellas que pudieran descubrir la presencia del hojo. Tanto es asi, que à no haber señalado Miram el sitio, en vano habria buscado los huevos al dia siguiente.

Los huevos puestos de tal roodo á una profundidad de $4 \mathrm{~m}$, os bajo la superficie del suelo quedaban alli hasta abril del año siguiente, y solo entonces, po: lo regular del 15 al 20 , salian a luz los hijuelos. Estos tienen una longitud de $\left(l^{\operatorname{th}}\right.$, or 5 á $11^{\circ}, 020$; si no se presentan aun con el saco de la yema, se observan cuando menos los vestigios del mismo en el centro del peto en medio de las placas.

Miram hacia grandes esfuenos para criarlos, pero no pudo nunca conservarlos vivos mas de tres meses. Marcgrave fué mas afortunado, pues consiguió criar varios galápagos recien nacidos; uno de ellos alcaná́ álos trés años una longitud de $0^{\circ}, 02$ y pesaba 16 gramos (1). Durante el invicrno comia muy poco, permaneciendo inmóvil en el fondo del agua; solo en dias serenos pascábase un poco. Al principio de la primavera volviá comer y ya al tercer año pudo devorar lombrices enteras y matar pececillos. In junio cra cuando comia con mas voracidad; desde setiembre menos, y en noviembre nada; llego a una edad de cinco años.

No sé si todos los huevos del galápago de Europa deben permanecer mas de nueve meses debajo de tierra antes de salir á lur los hijuelos, 6 si les basta menos tiempo. Las noticias de Miram están conformes con las de Marsigli, pero no con las de Marcgrave; este último trmbien observó en su jardin el apareamiento, la puesta de los huevos y el nacimiento de los penueños. Su relato es sin embargo tan breve como poco detallado y no le podemos considerar por lo tanto como válidb; de modo que las obsetvaciones de Miram respecto al largo tiempo que los hijuelos necesitan para nacer quedarán en pié hasta que se pruebe lo contrario.

La carne de estas tortugas es comestible; siquiera sea fnfi. mo el provecho que de ellas saca el hombre, y el bencficio que le proporcionan exterminando los caracoles y lombrices de tierra, no compensan los perjuicios que causan.

\section{LOS CLEMIS-CLEMMYS}

CARACTERES. - El género de los clemis ó tortugas acuáticas comprende especics mas diversas que cualquier otro. El espaldar, provisto de placa cervical y de doble placa caudal, es ligeramente abovedado en las especies tipos; el peto forma una sola pieza compuesta de doce placas y está unido en el espaldar por un ligamento óseo; las placas delos hombros y las de las caderas existen. Los piés anteriores tie. nen cinco unas y en algunas especies solo hay cuatro; en los membranas cuentan siempre cuatro; el desarrullo de las de punta córnea. La cabeza está cula cola es larga y carece á veces se divide en pequeñastá cubierta de una piel lisa que ma variada y sobrepuestas cubren los antebrazos. escamas de for.

\section{EL CLEMIS Ó GALÁPAGO DE AMÉRICA- CLEMMYS INSCULPTA}

CARACTERES. - El clemis de América, que tambien tiene representantes en Europa, es la especie mas conocida del género. Su longitud es de 10,24 , correspondiendo á la cola $0^{\circ}, 04 ;$ la coraza mide $0^{\circ}, 15$. El espaldar es oval y un poco aquillado, con una escotadura en su parte posterior; el peto tiene el borde anterior entero y el posterior igualmente

(1) Asi dice el iexto aleman; crecmus quue haya algun cror en estas citras.

(A: del T:) escotado; las placas del espaldar" son de un pardo rojizo, con lineas rayadas algo curvas y motas de color amarillo; las del peto son de un color azufrado, $y$ en el borde inferior presen. tan manchas negras. El lado inferior del cuello, de los piés y de la cola es rojo, con puntos negros; una linea que se corre á cada lado del cuello, amarilla; el iris pardo y un ani. llo que le rodea amarillo.

DISTRIBUCION GEOGRAFICA.-En todo el conti. nente atlántico de los Estados. Unidos, desde el Maine hasta la Pensilvania, se encuentran estas tortugas en número con. siderable.

USOS, COSTUMBRES Y REGIMEN.-Fstos reptiles habitan en pantanos y rios; pero abandonan el agua mas á menudo, y durante mayor espacio de tiempo que sus congé. neres, pasando algunas veces meses enteros en terrenos se. cos. Halderman opina que cuando emprenden sus largos viajes por tierra, lo hacen solo por evitar los sufrimientos que les ocasiona en el agua cierta especie de parásitos. Holbrool. ha observado que los individnos cautivos de esta especic se muestran tan vivaces $y$ ágiles en tierra como en el agua, $y$ que pueden conservarse lo mismo en un elemento que en el otro. Esta tortuga, como indica Müller, emprende á menudo largas excursiones de unas aguas a otras, á través de campos y selvas, y de ahile viene el nombre de torluga de bosyur, que vulgarmente se le da en América. En los sitios donde escasea el agua, se entierran estos animales en el musgo, cuando se quieren ocultar, y como allí mismo acechan la presa que les sirve de alimento, es mas fundado suponer que la vida que hace en tierra esta especie, constituye una particularidad suya, mas bien que atribuir sus excursiones a las molestias que les producen los parásitos en el agua, se. gun indica. Halderman. Se muestran muy activas en la caza; siempre están dispuestas á perseguir á los animales que ha. bitan en las mismas aguas.

Por lo que hace á su régimen y propagacion, apenas se diferencian de las denás tortugas palustres.

\section{EL GALÁPAGO RETICULADO-CLEMMYS RETICULATA}

CARACTERES. - El clemis reticulado tiene el espaldar de un color pardo oscuro, presentando el peto una mezcla de amarillo; las placas están cruzadas por lineas de este últi. mo tinte. El cuello es muy prolongado, en proporcion al tamaño del animal; las mandibulas y la garganta son amari. llas; el color de la cabeza pardo oscuro, que es el que predo. mina en las demás partes (fig. 8 ).

DisTRIBUGION GEOGRÁfICA.-Los naturalistas americanos aseguran que esta especie no ha sido obiservada aun, en los Estados-Unidos, mas allá de Fayette-Ville, en la Carolina septentrional.

USOS, COSTUMBRES Y REGIMEN:-El clemis reticulado es muy comun en los estanques y lagos y en los terrenos pantanosos. Aunque muy pesado en sus movimientos, no se le coge fảcilmente, porque es muy desconfiado y desaparece al momento en el agua, donde nada muy bien, aun. que no con mucha rapidez.

CAZA. - Esta tortuga es muy perseguida, porque su carne se aprecia mucho como alimento, y hasta se considera por algunos como un manjat delicioso.

\section{EL GALÁPAGO DE LÍNEAS CONCÉNTRI- CAS-CLEMMYS CONCENTRICA}

CARACTÉRES. - El color de esta tortuga, aunque algo variable, stele ser pardo oscuro negruaco en el espaldar, y 
amarillas las placas que rodean el borde; el peto tiene este último tinte, con manchas irregulares de un gris oscuro en algunos individuos. La parte superior del cráneo parece cu. bierta de una sola placa escamosa sumamente tenue, de for. - ma romboidal prolongada; los dedos están reunidos por membranas muy anchas; las uñas son casi rectas y muy deprimidas; la cola mediana, pero redondeada y gruesa en su nacimiento. La cabeza es rerdosa, con manchas negras; las placas córneas del espaldar, de un tinte aceitunado, presen. tan un conjunto de lincas concéntricas pardas, que forman en cada una de aquellas circulos irregulares, en cuyo centro existe á reces una mancha del mismo color de estos. El iris del ojo es amarillo y la pupila negra (fig. 9).

DISTRIBUCION GEOGRÁFICA. - Esta especie es propia del norte de América.

USOS, COSTUMBRES Y REGIMEN,-La tortuga de lineas concéntricas habita en los pantanos salados, donde abunda mucho, y rara vez se aleja de ellos a gran distancia. Durante los meses mas calurosos del ano se ocupa de conti. nuo en cazar; pero llegada la estacion fria se entierra en las orillas cenagosas; y alli permanece hasta que recobra de nue. vo la vida con el calor. Su régimen no difiere del de las es. pecies anteriores

UTILIDAD. - La carne de esta tortuga es muy buena en todo tiempo; pero mucho mas sabrosa, al decir de los inteli. gentes, cuando se coge el reptil mientras se halla entregado a su letárgico sueño.

\section{LOS CINOSTERNOS - CINOSTERNON}

CARACTERES. - Se designan con este nombre unas doce especies de tortugas palustres propias del norte, centro y sur de América, caracterizadas por tener el espalciar bastante abovedado, casi siempre provisto de la placa cervical y de una doble placa caudal; el peto, ancho, largo y oval, se compone de once placas que constituyen tres piczas, de las cuales la anterior y posterior son movibles. Las del vientre forman la pieza compacta del peto, en la cual las placas de los hombros y de las ingles son notables por su tamaño relativamente grande. Los piés anteriores tienen cinco uñas, los posteriores cuatro; y tanto los primeros como los segundos están provistos de anchas membranas interdigitales de longitud re. gular; la cola tiene en su extremidad una uña, muy larga en los machos y corta en las hembras; una sola placa delgada protege la cabear; algunas grandes escamas en forma de me. dia luna cubren la parte exterior de los antebrazos $\mathrm{y}$ la pos. terior de los tarsos; el resto de las piernas y del cuello está desnudo ó revestido solo de pequeñas verrugas; la region de la barba y de la garganta está provista de cuatro $\delta$ seis bar. billas.

\section{EL CINOSTERNO Ó GALÁPAGO CENAGOSO DE PENSILVANIA-CINOSTERNON PENNSYLVANICUM}

CARACTERES. - Esta especie, pequeña y fen, mide $\left(0^{\pi}\right.$, i 5 de longitud total, por $0^{*}$, i 1 en la coraza. El espaldar es de color pardo aceituna; el peto amarillo ó de un tinte naranja, y negro \& reces en la parte donde toca el espaldar; la cabeza es parda, y tanto esta como parte del cuello presen. tan líneas y manchas irregulares de color mas claro; los piés y la cola son de un pardo opaco, mas claros en su parte infe. rior; el iris de un pardo oscuro (fig. 10. )

DISTRIBUCION GEOGRÁFICA. - Este cinosterno, como su nombre lo indica, abunda en el sur de los Estados
Unidos, si bien se encuentra asimismo en las comarcas del norte, pero mas escasamente.

USOS, COSTUMBRES Y RÉGIMEN.-Su modo de vivir es casi igual al de sus congeneres; sin embargo, Miiller pretende que habita mas en las aguas cenagosar que en las corrientes. Su alimento consiste en pequeños peces, toda clase de animalejos acuáticos y lombrices de tietra. Wood, que ha observado mucho estas iortugas, dice que sus movimientos en el agua son muy pausados; que nadan cautelosamente hácia la orilla á que se dirigen y se entierran en el fango, para salir a la superficie un poco mas léjos. Cierto dia que se dedicaba Wood a cazar salamandras, fué mordido fuertemente por un individuo de esta especie. I Los pescado. res de America profesan con harto motivo la mas profunda aversion á estas tortugas, porque muy á menudo se engañan con ellas, pues figurándose tener cogido un gran pez, encuén. transe con uno de dichos reptiles que suelen tragarse el cebo.

CAUTIVIDAD.-Esta tortuga se domestica muy fácilmente; toma el alimento de manos del hombre, circunstancia por la cual difiere de sus congéneres en cuanto a su voracidad. Un individuo que crió Müller llegó a engordar tanto que ya no podia unir las placas, porque en todas partes so. bresalia la carne. Fischer la llama, à causa de su voracidad, el cerdo de las tortugas. Un olor de almizcle, á veces fuerte y desagradable, inșira repugnancia á muchos aficionados.

\section{LOS PLATISTERNOS- PLATYSTERNON}

CARACTERES. - Los platisternos ó tortugas de cabeza grande se caracterizan sobre todo por su espaldar plano con placa cervical y doble placa caudal; el peto, muy anchos plano, constituye una sola pieza compuesta de cinco placas; el punto en que se toca con el espaldar y las placas de los hombros y de los costados está revestido de tres placas in. tercostales; la cabeza, colosal y cubierta solo de un escudo grande, no puede recogerse en la coraza; la cola, en extremo larga, está del todo cubierta de escamas.

\section{EL PLATISTERNO DE CABEZA GRANDE- PLATYSTERNON MEGALOCEPHALUM}

CARACTERES. - Esta especie, tipo del género, representa una de las especies mas extrañas de la subiamilia. Además de los caracteres del género distinguese por los siguientes: los piés anteriores tienen cinco unas y los posteriores cuatro, hallàndose provistos de membranas interdigitales poco desarrolladas. Ia parte cxterior de los antebrazos está cubierta de grandes escamas córneas muy anchas; otras iguales protegen los tarsos y los talones de los piés posteriores; el resto de la piel de las piernas y la del cuello cstá revestido de escamas granosas. El color de las partes superiores es pardo accituna; el de las inferiores amarillo, con mezcla de pardo claro; las partes inferiores de las piernas y de la cola presentan unas manchas irregulares rojizas, $y$ una faja negra cruza la region del ojo. La longitud total es de $1^{\prime \prime}, 50$, la cabeza mide $4^{\circ}, 8$, la coraza $l^{*}, 20$ y la cola $0^{\circ}, 1 \mathrm{~S}$.

DISTRIBUCION GEOGRÁEICA.-El platisterno de cábeza grande es originario de la China; nada se sabe sobre su área de dispersion, su residencia ni su género de vida.

\section{LOS EMISAUROS-CHELYDRA}

CARACTERES. - Los emisauros ó borlugos crocodilos se distinguen por los caractéres siguientes: el espaldar, ligera. 
mente abovedado, presenta tres series de placas aquilladas de mediana altura, de las qque sin embargo la de las vertebrales no llega a desarrollarse; la placa de la nuca existe; la de la cola es doble; las laterales del borde están dispuestas una junto á otra. El peto, que es angosto, afecta la forma de cruz y se compone de diez placas, rara vez de once, por. que la del ano, que por lo regular falta, puede existir, y bastante desarrollada; el ligamento de ambos cscudos está cubierto de tres placas; trece forman el centro del espaldar; las cinco del medio están dispuestas casi horizontalmente y apenas difieren por el tamaño; su forma es casi cuadrangular, mientras que en las placas laterales, al menos la primera, figura un pentágono mas 6 menos marcado. Hil borde se compone de veinticinco placas, de las cuales la primera es muy estrecha, mientras que las posteriores son tan puntiagudas que forman de seis á ocho escotaduras. La cabeza es grande, plana y triangular; las mandibulas, muy fuertes, cor- tantes, y no denticuladas solo en la punta, forman una especie de gancho; el cuello, que parece corto cuando el animal descansa, puede prolongarse mucho. Las piernas son robustas; los piés anteriores tienen cinco dedos y los pos. teriores cuatro; las membranas interdigitales están bien desarrolladas. La cola, notable por su longitud, ocupa dos terceras partes de la de la coraza; es muy gruesa, y á lo largo de su cara superior se corre una seric de puntas óseas y agudas que poco á poco disminuyen de tamano, formando en los lados unas prominencias comprimidas. Su lado interior está cubierto de dos series longitudinales de escamas cuadrangulares.

\section{EL EMISAURO ALIGATOR-CHELYDRA SERPENTINA}

CARACTERES. - Esta tortuga, monstruosa por sus

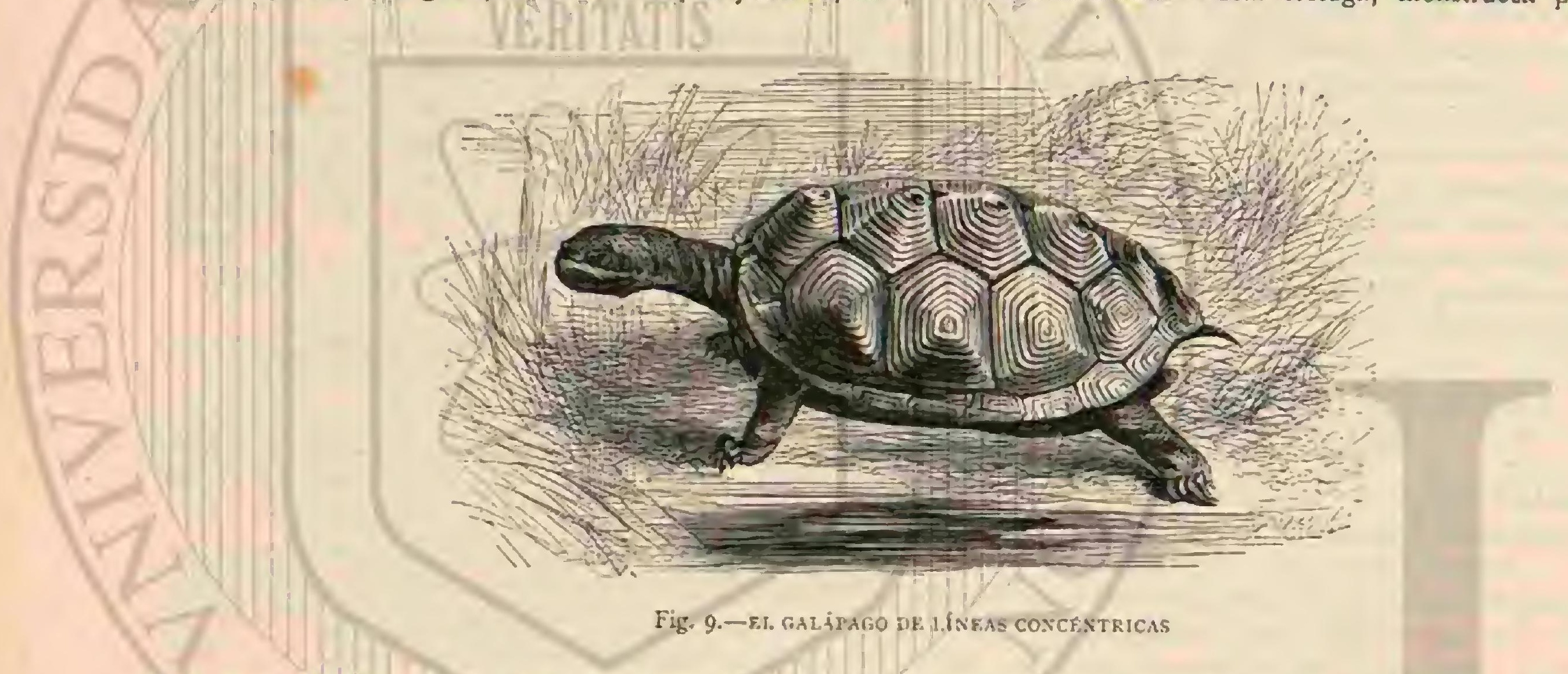

formas y costunbres, es la única especie conocida del grupo. Además de los caractéres del género, distinguese por los si guientes: las partes del cuerpo descubierias de la coraza tienen una piel rerrugosa, ancha en el vientre, śspera, rugosa y cubierta en todas partes de peqqueñas escamas; otras trasversales, bastante grandes, cubren los antebrazos y el lado exterior de las piernas posteriores. De la barba penden dos barbillas. El color de la piel es muy dificil de describir, pues consiste en un verde de aceite muy variado; el espaldar es en su parte superior de un pardo negruzco ó negruzco sucio, en la inferior de un pardo amarillo, y segun costumbre mas claro en los jórenes que en los adultos. Estos últimos pue. den llegar á la longitud de un metro á $1^{n}, 30$ y á un peso de veinte á veinticinco kilogramos (fig. i1).

La foituga buitre (Macrorlemmys Temminckii), especie afine que en el sur de los Estados Unidos vive à manera del emisauro aligator y se distingue entre otros caractéres por tener las escamas laterales del centro doblemente sobrepuestas, es la única especie que se puede confundir con la que acabamos de describir.

USOS, COSTUMBRES Y RÉGIMEN. - Vive esta especie en los rios y grandes pantanos, en bastante número, y con preferencia en las aguas de fondo cenagoso de los Es. tados Unidos; sin despreciar, segun asegura Müller, los mas pestilentes charcos. Holbrcok dice que generalmente perma. nece en el fondo del rio ó pantano, apareciendio solo de vez en cuando a la superficie y dejándose llevar por la corriente; huse sin embargo al menor ruido, sobre todo en las comarcas muy pobladas; en aquellas que frecuenta poco el hombre no parcce tan miedosa. Con mzon son odiadas y temidas; muerden los objetos que se les presentan y no abandonan tan fácilmente la presa. «Apenas pone sus patas en el bote la tortuga acabada de coger, dice Weinland, se apoya furiosa en sus sólidas extremidades posteriores y con impetu terrible se abalanza contra el remo que la presentan, clavando en él sus mandibulas.》 No hay duda que conviene tratarla con bastante cautela, porque es feroz y maligna; el hombre que se introduce en el agua donde habita este reptil corre verdadero peligro, pudiendo causarle graves heridas sus fuertes mordiscos. Wcinland asegura que un remo de media pulgada de grueso quedó agujereado como por una bala de fusil por el hocico agudo, á manera de pico, de este animal; otros varios observadores afirman que rompe con facilidad suma un grueso baston. Mientras el ojo de ias demás tortugas, dice Müller, solo expresa cierta torpeza de buena indole, el de esta parece animado de astucia y maldad, y pocos son los hombres que al verla por priniera vez no se aparten de su camino. Su larga cabeza, su cola escamosa, y en una palabra, toda la figura del animal, es horrible y repugnante. ¿Qué efecto produciria su presencia en aqquellos á quienes tan solo el aspecto de una salamandra ó de un lagarto ins. pira pavor?

Este reptil es mas ágil que la mayor parte de sus congé neres; anda por tierra tan ligero como ellos; nada mejor, y es muy diestro para cazar. Se alimenta de peces, ranas y toda clase de pequeños animales acuáticos, llevando su audacia hasta el punto de acometer á los ánades y gansos. Los labradores se quejan a menudo de los destrozos que ocasiona en 
sus aves domésticas, á las que arrastra al agua a fin de aho. garlas y comérselas despues. Cuenta Müller, que un campesino al oir graznar repetidas veces á uno de sus ánades, echó á correr para indagar lo quue ocurria y se encontró con que el ave se agitaba dentro del agua pareciendo irse á fondo; la cogió, y al sacarla á la superficie se quedó no poco admirado al ver que tras ella seguia una tortuga que no queria soltar su presa.

CAutrvidad.-Fontaine, sacerdote de Texas, comu. nicó á Agassiz lo siguiente acerca de dos de estas tortugas, cuyas costumbres estudiaba hacia mucho tiempo, pues las habia conservado algunos años en su estanque: \& Llegaron á domesticarse bastante, pero observando que se comian mis peces, mate $a$ una y heri a otra con un arpon, mas sin poder cogerla gracias á su astucia. Cuando repartia pan á mis pe. ces, la tortuga lo devoraba tambien con avidez Un din mien. tras me entretenia en esta operacion, el elodita permaneció inmóvil sobre un pedazo de roca que estaba un pié bajo el nivel del agua; multitud de peces se agolpaban para coger las migas que les echaba, sin que aquel diese señal alguna de su presencia: tenia la cabeza y las patas recogidas todo lo posible debajo del caparazon, y cubierto por el musgo, ape. nas se le distinguia. Algunos de los peces mayores nadaban á su alrededor, $y$ tan luego como uno de estos, que tendria tal vez unas catorce pulgadas de largo, se puso al alcance de su hocico, estiró de repente el cuello y lo cogió, hincándole su corvo pico en la parte inferior del cuerpo; se lo acercó y sujetándole sobre las rocas con las patas delanteras, se lo comió tan vorazmente como el halcon su presa. Cogi enton. ces un fuerte anzuelo, en el que puse como cebo un pececillo y' se lo eché, decidido á librarme de una vez jara siempre de tan hábil pescador; el elodita mordió el cebo, quedándo. sele clavado el anzuelo en la mandíbula inferior; pero como me fuese algo dificil izarlo hasta la roca donde me encontra-

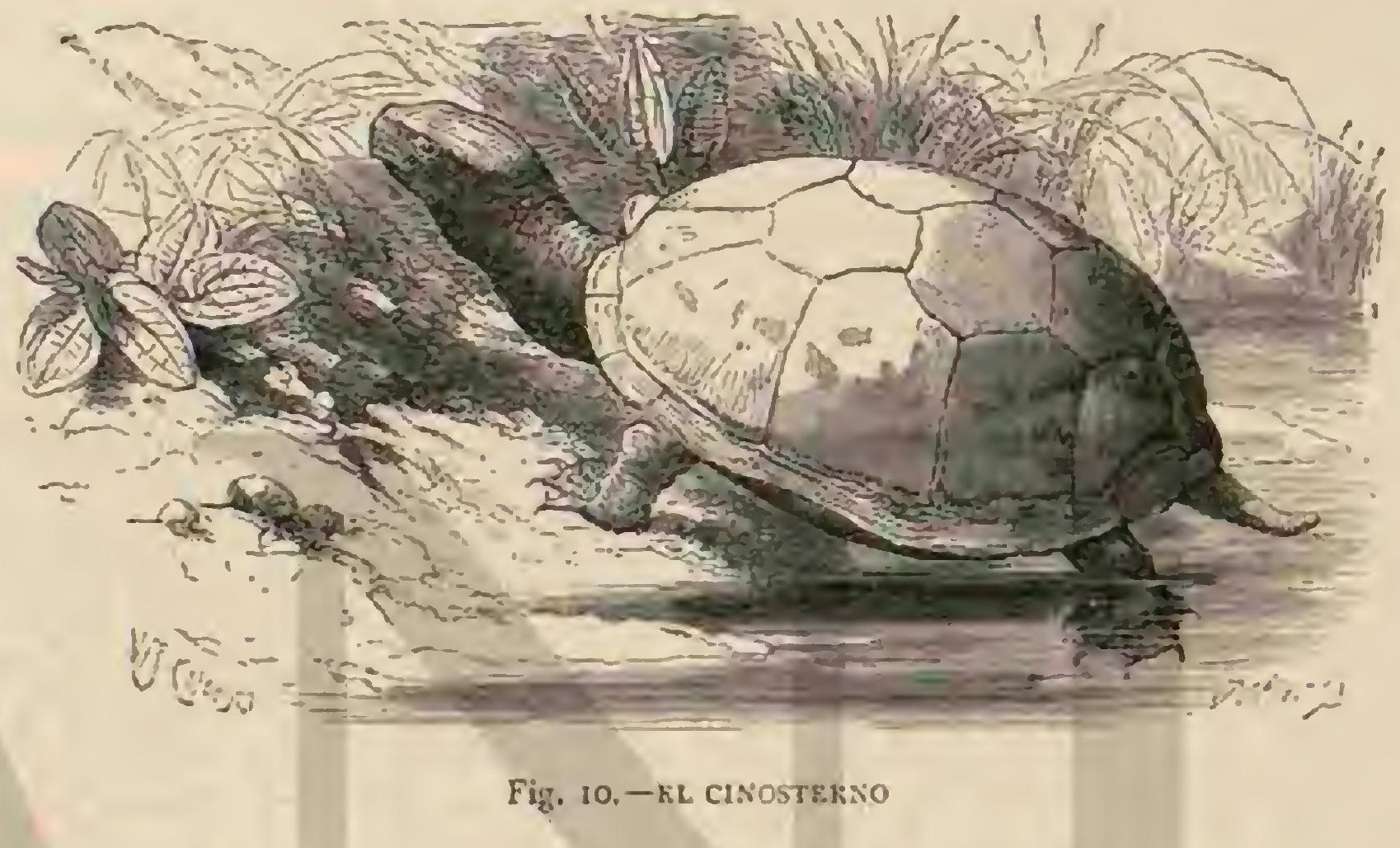

ba, y que sobresalia unos seis piés del nirel del agua, co. mencé à tirar de la cucrda á fin de atraer al reptil á la otra orilla del estanque, que era mas baja y donde el agua tenia muy poca profundidad. Sin embargo, cuando le tuve á unos dos piés de distancia, echó anclas, por decirlo asi, enterrando sus patas delanteras en el fango, y á pesar de todos mis esfuerzos no pude acercármelo. La tortuga daba señales de terrible furor, mordiendo repetidas veces la cuerda, hasta que consiguió cortarla, retirándose entonces al sitio mas profundo del estanq̨ue. Desde entonces no pude lograr que cogiese otra vez el cebo, y se mostró siempre recélosa, pues conoció mi intencion. No volvi a verla mas sobre la roca, pues se mantuvo siempre á gran profundidad; otra vez le lancé un arpon, teniendo la suerte de clavárselo en el cue. 110 , pero haciendo un poderoso esfuerzo con las patas delan. teras puco desprenderse de él, corriendo so ocultarse debajo de la roca. $\mathrm{La}$ vi despues varias veces; pero siempre en el inomento de retirarse hácia su escondite, que era inaccesible para mí. Resuelto á exterminar aquel reptil, proponiame pre. parar una trampa de hierro, poniendo por cebo un pedazo de carne, y colocándola en el fondo del estanque; pero como me fuese de todo punto necesario abandonar la comarca, la tortuga se libró de mis iras, y no me cabe duda que vive hoy todavia alli, pues le dejé el estanque bien provisto.

Esta especie fué la que sirvió de base à Agassiz para sus observaciones acerca de las tortugas, pues abundan bastante en las cercanias de Cambridge y por otra parte sus huevos, snuy parecidos á los de paloma, que entierra cerca del agua cubriéndolos con follaje, se recogen fácilmente. Weinland, que tomaba gran parte en estas observaciones, dice que \&durante algunos meses, salian todos los dias pequenas tortugas de los huevos escondidos entre tierra \& musgo, y, cosa extraordinaria, el primer movimiento que hacian sus cabecitas al asomar fuera del cascaron era para morder y desgarrar. L Lo mismo habia observado antes el principe de Wied.

Los adultos reducidos á cautividad se niegan en general ́́ tomar alimento, cualquiera que sea, mientras que á los jóve. nes se les acosturnbra fácilmente sa que lo tomen. Uno que tenia Müller, se negó ś comer durante todo un ano. «Le ofreci, dice el nismo, toda clase de alimento, pero en vano; al principio se contentaba con morder tan solo lo que le presentaba, pero despues hasta lo hacia en mis manos, pues pa. recia conocer que asi me causaba dolor, vengándose en mi de su cautiverio. Muchas veces le colgaba un pedazo de carne en el hocico y se paseaba con él por la habitacion, y ni aun metiéndoselo en la boca podia conseguir que se lo tragara.y

Otro que pesaba ochenta libras, sometido á la observacion. de Weinland, dejaba intactos los peces que nadaban en torno suyo en el estanque donde se le tenia, sin que al parecer le molestasen tampoco los saltos que á su lado daban las ranas; de un mordisco rompia en dos pedazos los bocados que se le metian entre las mandíbulas sin querer tragárselos. A pesar de las repetidas pruebas que varios observadores han hecho siempre en vano, Effeldt afirma que es posible acostumbrar á los cautivos de esta especie á que coman; $y$ aniade en confirmacion de este aserto, que tenia uno que al principio re. chazaba todo alinento, conduciéndose del mismo modo que el individuo de Müller, consiguiendo por fin dominar su ter. 
quedad, despues de introducirle muchas veces la comida en la boca, haciéndosela engullir por fuerza. Poco á poco se fué acostumbrando á tragar por sí mismo, acabando por comer roluntariamente, sin dar mas señales de su feroz instinto, y quedando en parte domesticado.

Pero cautivos de esta índole son poco agradables. Su aspecto sombrio y maligno, dice Fischer con mucha razon, corresponde a su proceder y manera de vivir. Se oculta timi. damente apenas raya la aurora, y busca los escondites mas oscuros para esperar en ellos la noche, hora en que comienza \& cazar. Fischer ciee que en su patria debe emprender tocias las noches grandes viajes; pues su, cautivo estuvo toda una temporada ausente de su escondite, paseándose sin cesar por todas las habitaciones y arrastrando su larga y puntiaguda cola por el suclo. Al rayar el dia ocultábase debajo de la cama 6 en algun rincon oscuro. Tambien mis cautivos bus caban los rincones en un gran estanque que les estaba desti nado, y siempre los mas oscuros, permaneciendo durante el dia en el fondo corno piedras, sin hacer el menor movinien. to; pasaban muchas horas seguidas sin subir $\hat{i}^{1}$ la superficie, ni siquiera para respirar.

Seria muy fácil aclimatar al emisauro aligator entre nosotros si solo fuera de alguna utilidad, pues $y^{2}$ hemos podido convencernos de que soporta nuestro clima sin molestia al guna, y sabe arregharse en inviemo. Hejer refiere que $\{$ un jardinero se le escapó en $\mathrm{t}_{3} G_{3}$ un emisauro que habia reci. bido de la América del norte, $y$ no fuc posible volver $\$$ en contrarle, á pesar de tocias las pesquisas. Tres años mas tarde, unos trábajadores ocupados en limpiar un canal encontraron con gran asombro el reptil nunca visto, oculto á mucha pro. fundidad en el cieno, y no solo vivo, sino tambien muy alegre y con muchos deseos de morder. No ha podido explicarse cómo se habia alimentado en este sitio; mas sin duda no le faltó que comer, segun lo demostraba su gordura

USOS Y PRODUCTOS. - I a carne de los individuos adultos no puede comerse á causa del fuerte olor de almiz. cle; la de los individuos jósenes, sin embargo, pasa por ser tan sabrosa como saludable. Mas se aprecian aun los huevos; Kay asegura que algunas reces debió agradecer ś este animal una buena comida Para encontrar estos huevos en junio, es decir, en el periono de la puesta, se escarba con un baston en los sitios arenosos donde los emisauros aligatores han dejado sus huellas; por el terreno recien trabajado se reco. noce el tesoro oculto, y abriendo el hojo se encuentran a menudo de sesenta á setenta deliciosos huevos en un solo nido, hecho quizàs por varias hembras.

\section{LOS QUÉLIDOS - CHELYDA}

CARACTÉRES. - La segunda sub-familia, que comprende las tortugas fluviales 6 acuáticas, se distingue sobre todo por los caractéres siguientes: la pélvis de todos los quélidos está soldada siempre al peto, y este se compone de trece placas, uniéndose a las dos de la garganta una tercera en medio. Los mas de los quélidos no pueden recoger su cuello, que por lo regular es en extremo largo; tienen que oprinirle lateralmente bajo cl borde del espaldar que comunmente so. bresale, para ponerle asi en seguridad.

USOS, COSTUMBRES Y REGIMEN. - En cuanto á su género de vida, el de los quélidos no difiere en lo mas esencial del de las demás tortugas terrestres que viven en el agua. No parece necesario decir mas sobre ellos en este lugar, porque uno de los mas célcbres naturalistas de todos los liempos ha descrito el género de vida de una especie de que a continuacion nos ocuparemos, y esta descripcion es tan minuciosa como puede serlo tratándose de una tortuga.

\section{LOS PODOCNEMIS-PODOCNEMIS}

CARACTÉRES.-I Los podocnemis se distinguen porlos siguientes caractéres: el espaldar, algo abovedado, tiene el borde saliente en sentido horizontal y carece de la placa cer. vical; en el peto faltan las del sobaco y de las ingles; la cer. vical es doble; las de los brazos son en extremo pequeñas y apenas llegan á la mitad del tamaño de las placas del peto. Unos escudos grandes y gruesos cubren la cabeza, notable so. bre todo por los anchos y profundos surcos que hay entre los ojos; la barba está provista de una ó dos barbillas; los ante. brazos y las extremidades de los piés posteriores se hallan revestidos de algunas escamas; la piel de las extremidades y Ia de la cola está desnuda; las membranas interdigitales ofrecen gran desarrollo.

\section{EL PODOCNEMIS ANCHO-PODOCNEMIS EXPANSA}

CARACTÉRES. - El podocnemis ancho, tipo del género, es una tortuga grande, que mide $\theta^{m}$, So de longitud total, correspondiendo a la coraza $0^{\mathrm{m}}, 50$ : sus caractéres son los del género.

DISTRIBUCION GEOGRÁFICA.-El podocnemis an. cho, llamado tambien arrau, habita en el Orinoco y en gran número de rios de la Guayana, sobre todo el Tacatu, el rio Branco, el Essequibo, el Amazonas con sus afluentes y otros rios del Brasil; encuéntrase tambien en las provincias sep. tentrionales del Perú, de modo que su área de dispersion es muy extensa.

\$A eso de las once, dice Alejandro de Humboldt, desembarcamos en una isla situada en medio del rio, considerada por lns indios de la mision Uruana como de su propiedad. Esta isla tiene gmn fama á causa de las muchas tortugas que alli se encuentran y de la cosecha de huevos que proporcio. na, segun se dice aqqui. Encontramos mas de trescientos indios acampados en chozas construidas con hojas de pal. mera; además de los guanos y otomacos de Liruana, que tienen fama de salvajes indómitos, habia tambien alli caribes y otros indios del bajo Orinoco. Las tribus, fáciles de distin. guir por el color con que pintan su piel, estaban separadas unas de otras. En medio de aquella ruidosa multitud observamos algunos blancos, especialmente traficantes de Angostura, que habian remontado el rio para comprar à los indigenas el aceite de huevo de tortuga, 5 tambien nos encontramos con el misionero de Uruana, el cual nos dijo que habia venido con los indios a fin de tomar parte en la cosecha de huevos, decir misa por la mañana a! aire libre $y$ recoger aceite. Añadió que su principal mision era conservar el órden entre aquellos indios, pues cada cual solia querer para si lo que Dios ha dado para todos.

En compañia de este misionero y de un fabricante, que se jactaba de haber tomado parte diez años seguidos en la cosecha de huevos, dimos la vucita á la isla, que se visita aqui como en nuestro pais las grandes ferias. Nos hallábamos sobre un arenal, y nos dijeron que en todo el espacio que abarcaba la vista, habia huevos debajo de tierra. El misione. ro llevaba en la mano un palo largo y nos enseñó cómo hacian para descubrir á quéé profundidad estaba la capa de huevos, procediendo en esto como el minero cuando trata de averiguar los limites de una capa de marga, de limonita ó de hulla. Si se clava el palo verticalmente en tierra, se puede reconocer cuándo se ha llegado á la cavidad que forma e! depósito de los huevos, por la resistencia que estos oponen. La capa de huevos se extiende, segun observamos, casi uniformemente s. una misma profundidad; de manera que se 
está seguro de encontrarla con el palo en una circunferencia de mas de diez toesas de radio, a contar desde el punto en que se perfora la tierra. La manera de expresarse aquella gente está conforme con lo que acabamos de decir, pues no se oje hablar sino de palos de huevos, como medida del terreno que $a$ cada uno le corresponde explorar. Sin embar. go, la capa de huevos no se extiende por toda la isla; cesa donde se eleva el terreno algo bruscamente, porq̨ue la tortuga no puede subir. Yo referi a mis compañeros las exageracio. nes que habia leido en la descripcion del padre Gumilla, quien dice que las márgenes del Orinoco no contienen iantos granos de arena como tortugas hay en el rio; que hasta llegarian á impedir el curso de los barcos si los hombres y los animales no destruyesen tantas cada ano. El traficante me dijo en voz baja que esto era un cuento; pero los indios nos aseguraron que remontando desde la embocadura del Orinoco hasta la confiuencia del Apure no se encontraba isla ni playa alguna donde no pudiesen recoger huevos de tortuga en cierta cantidad. Los parajes de la playa en que suelen encontrarse casi todas las tortugas del Orinoco, están situados entre los antientes del mismo rio $y$ del Apure y las cataratas, donde asimismo se encuentran los puntos mas importantes de caza. Una de las especies no pasa de las cataratas, $y$ segun se nos asegura, en el alto Apure y en el alto Maypure no se encuen. ira sino la tortuga terekas.

bl arrau, animal timido y espantadizo, que asoma la cabeza en la superícic del agua y al menor ruido se escondc, huye de las orillas habitadas por el hombre 6 cuyas aguas agitan las embarcaciones, es una tortuga de agua dulce, de gran tamaño, con piés palmeados y cabeza muj aplanada. Debajo de la barba tiene dos apéndices carnosos, muy puntiagudos, cinco dedos en las extremidades anteriores y cuatro en las posteriores, con surcos en la parte inferior. El espaldar cons. ta de cinco placas en el centro, ocho laterales y veinticuatro marginales; es gris oscuro, casi negro en la parte su. perior y anaranjado en la inferior; los piés, que son largos, tienen igual color. Entre los ojos hay un surco profundo; las uñas son muy fuertes y corvas; el ano está situado en el último quinto de la cola. El animal en todo su desarrollo pesa de cuarenta á cincuenta libras. Sus huevos, mucho mayores que los de la paloma, tienen una cáscara calcárea, y son tan duros, que los chicos de los otomacos, muy aficionados al juego de pelota, se sirven de ellos para este objeto. El terekay, mas pequeño que el arrau, no suele medir mas de catorce pulgadas de dismetro; en su espaldar tiene tantas placas como el otro, pero distribuidas de distinto modo. He contado cuatro centrales, cinco cxágonas a cada lado y vein. ticuatro en la circunferencia, de cuatro caras y muy convexas. El color del escudo es negro con viso verdoso; los piés y las uñas no difieren de los del arrau; las partes no cubiertas son de color aceitunado; en la cabera lleva dos manchas con mezcla de rojo y amarillo; el cuello, que tiene una excrecencia en forma de arista, es amarillo. Los terekays no forman tan considerables manadas como los arraus, cuando van id depositar los huevos en la misma orilla. Estos tienen un gusto asaz agradable y son muy buscados por los habitantes de la Guayana española. El arrau no pasa de las cataratas $\delta$ raudales; mientras que el terckay se encuentra lo mismo en el alto Orinoco, que mas abajo de aquellas, asi como en Apure, Uritucu, Guarico y los pequeños rios que cruzan las llanuras de Caracas.

$>$ La Epoca en que el arrau pone sus huevos coincide con el descenso de las aguas, pues como el Orinoco no comienza á crecer en el equinoccio primaveral sino desde los primeros dias de enero hasta el 20 ó 25 de marro, aparecen secas en. tonces las mas profundas márgenes. Antes de febrero ya se reunen los arraus en grandes manadas, salen del agua y se calientan al sol en la arena, pues dicen los indios que necesitan muclio calor para su bienestar y que el sol promieve el desove. Podria decirse que durante todo el mes de febrero los arraus pasan la mayor parte del dia en ticra. A principios de marzo se reunen los varios grupos dispersos y se dirigen a las pocas islas donde acostumbran 1 depositar sus huevos. Pocos dias antes del desove aparecen millares de estos que. lonios en las orillas de las islas Cucuruparu, Uruana y Para. ruma: estiran el cuello y asoman la cabeza por encima del agua, para observar si bay que temer de los tigres ó de los hombres. Los indios, que tienen gran interés en que las ma. nadas permanezcan juntas, colocan vigias en las márgenes á fin de que los reptiles no se dispersen y puedan poner con toda tranquilidad. Fstos vigías hacen señales á las embarcaciones para que se mantengan en el centro de la corriente y no espanten a las tortugas con sus roces.

¿Ll desove se verifica siempre de noche, y empieza tan luego como se pone el sol. El animal practica con sus patas traseras, que son muy prolongadas y tienen fuertes garras corvas, un agujero de tres piés de dí́metro por dos de proiundidad, cuyas paredes humedece con su orina, para consolidar la arena, segun afirman los indigenas. Es tal la impaciencia por poner, que muchas tortugas se meten en los agujeros abjertos por otras, y que todavia no han vuelto a cubrir de tierra, depositando su contingente sobre la capa de huevos recien puesta.

Y Eu medio de tal trastorno y-confusion se rompen tantos hueros, que la pérdida, segun el misionero nos hizo ver en el terreno, asciende muchas veces á la tercera parte de la cosecha total. Asi se explica que halláramos arena de cuarzo y cáscaras de huevo convertidas en una especie de argamasa por la meacla de las yemas de los huevos. Son tantos los individuos que durante la noche practican en la orilla sus agu. jeros, que á muchos les sorprende el dia antes de haber po. dido terminar el desove; activan entonces la operacion y cubren los agujeros abiertos \& fin de que los tigres no los puedan descubrir. Las tortugas reaagadas no reparan en los peligros que les pucdan amenazar, sino que trabajan con ahinco á la vista de los indios, quienes muy de mañana van s. la orilla y se mofan de aquellos animales llamándoles tor. tugas tontas. A pesar de sus movimientos bruscos y violen. tos, se dejan coger fácilmente con las manos.

- Los tres campamentos indios situados en los puntos que dijimos antes, quedan establecidos en los últimos dias de mayo 6 á primeros de abril. In cosecha de huevos de tortuga es cada año la cxacta repeticion de la anterior, llevándose a cabo con aquella regularidad que preside en todo lo que hacen los jesuitas. Antes que los misioneros visitasen el rio, explotaban los indigenas en muy pequeña escala el producto que la naturaleza les ofrece alli en tan rica abundancia. Cada tribu cxploraba los bordes del rio a su antojo, y rompiase inconsideradamente una infinidad de huevos, pues como no se procedia con cuidado, se sacaban mas huevos de los que era posible llevar.

: los jesuitas corresponde el mério de haber reglamentado la explotacion; ellos prohibieron, desde luego, que se socavara toda la orilla, obligando á dejar una parte intacta, pues ternian el completo exterminio de las tortugas, ó por lo menos su gran disminucion. En la actualidad se remuere la tierra en toda la orilla sin cortapisa alguna; pero tambien se empieza á conocer ya que las cosechas son cada aijo mas reducidas.

* Una ver establecido el campamento, se nombra el misionero encargado de la direccion, el cual divide ha zona en que se hallan los huevos en tantos lotes cuantas son las tribus quic 
se deben repartir la cosecha. Da principio el encargado á su cometido investigando con la vara á qué profundidad se halla la capa de huevos, que segun nuestras medidas, se extiende en el espacio de unos ciento veinte piés desde la orilla, teniendo por término medio tres de profundidad; luego se fijan los límites dentro de los cuales debe trabajar cada tribu. Causa no poca cxtrañeza oir evaluar el producto de la cosecha de huevos como el de un campo sembrado: una porcion de terreno llano, de ciento veinte piés die largo por treinta de ancho, produce cien cántaros de àceite, $\sigma$ sea por valor de mil francos. Los indios escarban el suelo con las manos, co. locan los huevos recogidos en pequeños cestos, llamados mapiris, los llevan al campamento y los echan en grandes dornajos de madera llenos de agua. Alli los aplastan con pa. las, y despues de bien revueltos, los exponen al sol hasta que la parte oleaginosa de la yema sobrenada y adquiere cierta consistencia. Se extrae entonces el aceite y se pone á hervir bajo la accion de un fuego muy sostenido, siendo opinion general que cuanto mas hierve, mejor se conserva despues. Bien preparado, este aceite es claro, inodoro y de un color amarillo pálido; los misioneros lo consideran tan bueno como el mejor accite vegetal. Se usa no solo para el alumbrado, sino tambien, y muy especialmente, para guisar, pues no ccmunica á las viandas sabor alguno desagradable. Sin embargo, es difícil procurarse aceite de tortuga completamente limpio: en general tiene un olor nauseabundo, debido á que entre los huevos habria algunos en los cuales ya estaba formado el animal.

- Las orillas del Uruana producen mil cántaros de accite al año: cada uno vale en Angostura, capital de la Guayana,

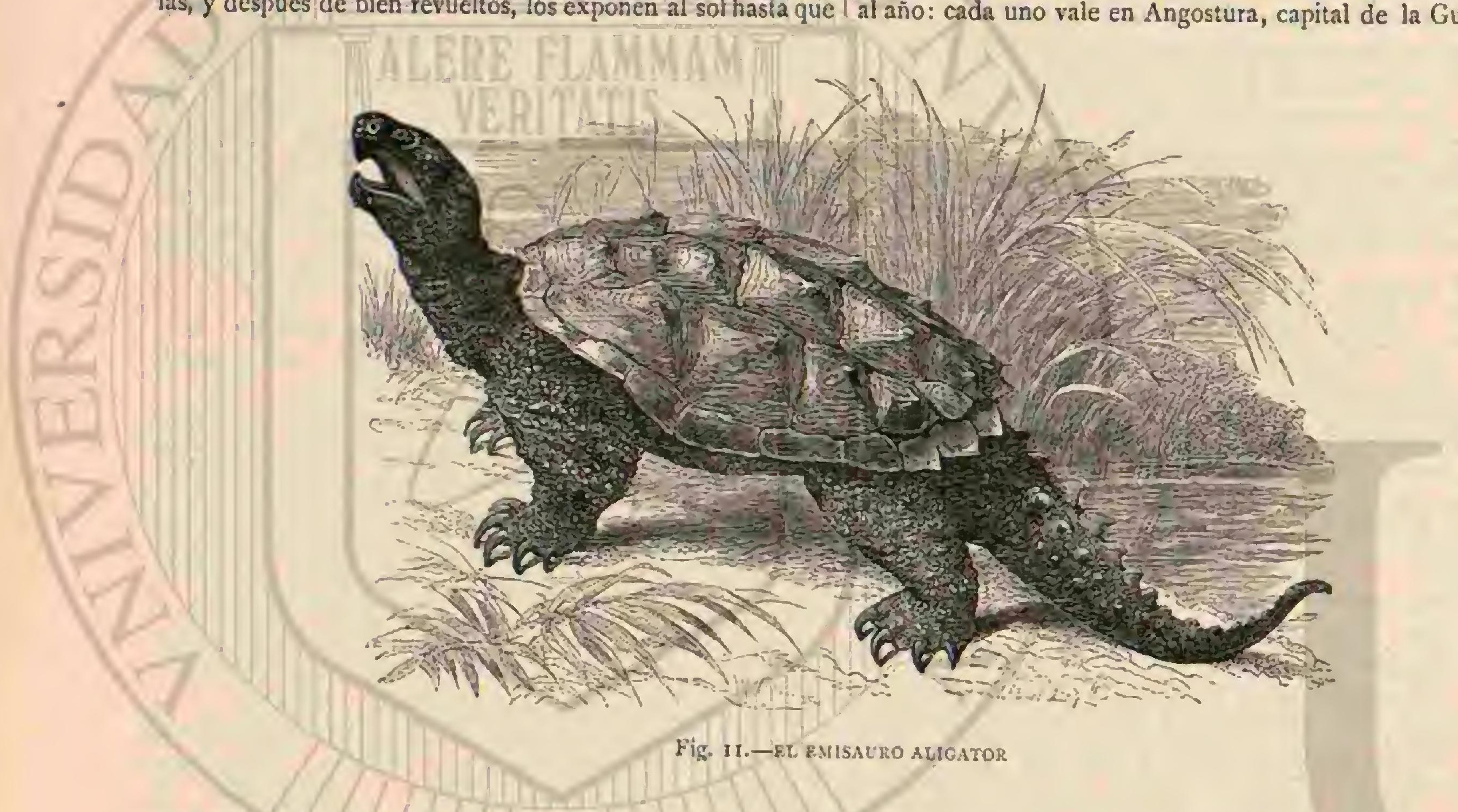

de dos á dos y medio duros. El producto total de las már. genes en las que se hace la recoleccion de huevos todos los años, se calcula que asciende á cinco mil cántaros. Ahora bien, necesitłndose doscientos huevos para obtener una bo tella, $\delta$ sea un litro de aceite, dedúcese que cada cántaro representa cinco mil; si suponemos despues que cada tortuga produzca de ciento á ciento diez y seis huevos y que una tercera parte se rompe durante el desove, gracias á las tortugas \&tontas, resulta que para llenar de aceite los citados cinco mil cántaros, es necesario que trescientos treinta mil arrass, que pesan juntos ciento sesenta y cinco mil quinta. les, entierren en los tres puntos de cosecha treinta y ires millones de huevos todos los años. Este cálculo dista mucho, sin embargo, de la realidad: muchas tortugas producen solo de sesenta á setenta huevos; no pocas son devoradas por los jaguares al salir del agua; los indios se llevan gran número para secarlos al sol y comérselos; y además rompen una infinidad durante la recoleccion, por incuria y poca maña. La cantidad de huevos vacios es ya tan inmensa antes de procederse á la recoleccion, que cerca del campamento de Uruana pude observar cómo pululaban en la orilla del Ori. noco pequeños quelonios de una pulgada de ancho que con dificultad podian librarse de la caza que les daban los mu. chachos indios. Considerando por otra parte, que no todos los arraus desovan en los tres puntos indicados, sino que muchos lo verifican aisladamente, $y$ algunas semanas des. pues en todo el territorio que media entre la embocadura del Orinoco y la afluencia del Apure, debemos deducir que el número total de tortugas que todos los años van á desorar á las orillas del bajo Orinoco, no dista mucho de un millon. Esto es muy considerable tratåndose de un animal de tamaño nada pequeño, que pesa cerca de medio quintal y en cuya familia tan grandes destrozos causa el hombre; pues, comun. mente, la naturaleza propaga en el reino animal las especies mayores con mucha menos profusion que las inferiores.

- Los pequeños arraus rompen la cáscara del huevo de dia; pero solo por la noche se atreven á salir á la superficie del suelo, pues temen el calor del sol, segun pretenden los indios. Estos nos hicieron ver tambien, que cuando se llevan tortugas pequeñas, aunque vayan encerradas en un saco y se vuelvan á dejar en el suelo, colocándolas de espaldas al rio, inmediatamente emprenden el camino mas recto hácia el agua, por mas que se hallen á cierta distancia de la orilla. Confieso que esta prueba, de la que ya hizo mencion el pa. dre Gumilla, no siempre salió bien; pero debo decir que por lo general me pareció, en efecto, que las pequeñas tortugas, aunque estuviesen léjos de la orilla, $y$ hasta en una isla, sabian distinguir de qué lado soplaba el aire mas húmedo. Si se considera la mucha extension qque en la orilla ocupa la capa de huevos y los millares de pequeñas tortugas que tan luego como salen á la superficie se echan al agua, dificilmente puede concebirse que entre tantos reptiles como van al mis. 
mo sitio a construir sus nidos, pueda cada pareja encontrar sus hijuelos y conducirlos, como lo hacen con los suyos los crocodilos, á las charcas del Orinoco. Sin embargo, lo cierto es que estas tortugas pasan los primeros años de su vida en los pantanos, y solamente cuando han adquirido casi todo su desarrollo se deciden á entrar en la corriente del rio. ¿Cómo encuentran los pequeños dichos pantanos y charcos? ¿Serán conducidos alli por las hembras, que cuidan de ellos así, para abandonarlos despues? De seguro que la hembra puede distinguir, lo mismo que el crocodilo, el sitio donde hizo su nido; pero, no atreviéndose á volver á la orilla cuando los indios han establecido su campamento, ¿cómo puede reconocer mas tarde sus hijuelos? Por otra parte, aseguran los otomacos haber visto, cuando ya han subido las aguas, arraus hembras seguidas de gran número de pe- queñas tortugas; $y$ dicen que son aquellas que han desovado en una orilla aislada, á la cual pudieron volver despues. Los machos son muy raros en esta época; apenas se encuentra uno entre centenares de hembras, sin que pueda atribuirse este fenómeno à la misma causa que produce resultados parecidos entre los crocodilos, los cuales pelean encarnizadamente durante el periodo del celo.

$\$$ La recoleccion de los huevos y la preparacion del aceite duran unas tres semanas, y solo entonces comunican las misiones con la costa y con las vecinas comarcas civilizadas. Los franciscanos, que residen al sur de las Cataratas, acuden a la recoleccion, menos para provecrse de aceite, que por el deseo de ver caras blancas. Los tratantes en aceite tienen un beneficio de sesenta á setenta por ciento, pues los indios les venden el cántaro por un duro $y$ los gastos de

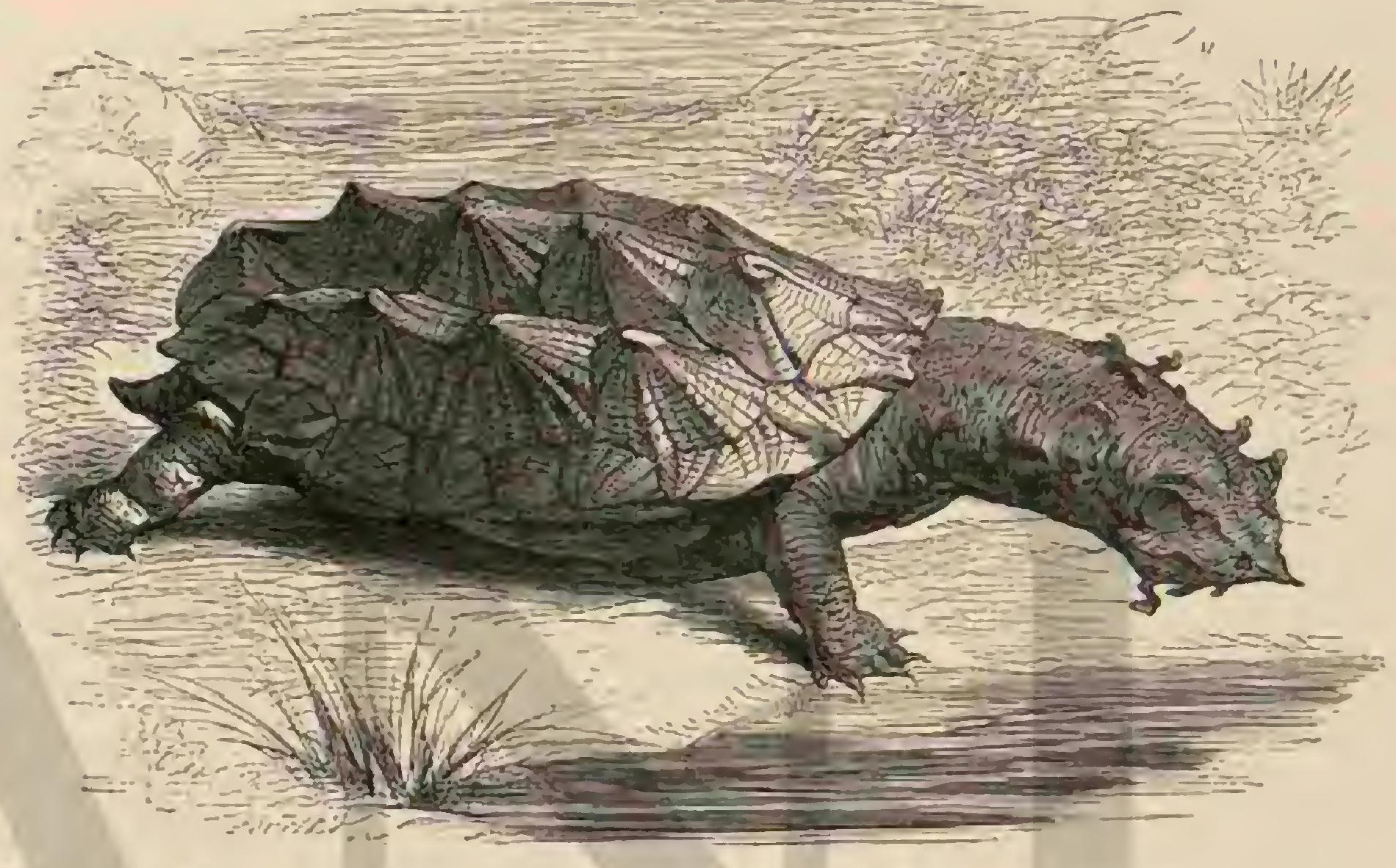

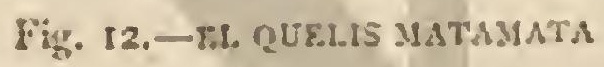

trasporte ascienden tan solo á dos quintos de duro por cántaro. Todos los indios que toman parte en la cosecha se llevan, cuando regresan $\&$ sus hogares, grandes cantidades de huevos secados al sol, ó pasados por agua hirviendo. Nuestros remeros siempre iban provistos de este comestible, del cual llevaban llenos, sus cestos unos, y otros, pequenios sacos de tela de algodon; nosotsos lo probamos varias veces y no nos pareció su sabor desagradable, mientras se pudo conservar en buen estado.

Ia siguiente descripcion de Schomburgk nos demuestra que los huevos del arrau se aprecian tambien por otro concepto. "No puedo explicarme, dice el citado naturalista, el júbilo con quue los barqueros saludaban ciertos bancos de arena del Essequibo hasta que varios indios, antes de que las lanchas tocaran en la orilla, arrojábanse con impaciencia al rio, nadiaban hácia uno de dichos bancos, y empezando á escarbar la arena sacaban una infinidad de huevos. El periodo de la puesta de las tortugas habia comenzado, periodo espe. rado por el indio con el mismo anhelo con que nuestros gastrónomos esperan la caza de la becada ó los envíos de ostras frescas. Ia voracidad de los indios cra tal, ñue yo creo que si se hubiera impuesto pena de muerte á los que sin permiso abandonasen la lancha, no hubieran dejado de ir á los bancos de arena para coger los sabrosos huevos. Cuando conoci esta celebrada golosina pude explicarme la pasion de los indios. ¡Qué son nuestros tan elogiados huevos del avefria en comparacion de los del arrau!
El animal penetra en estos bancos de arena casi siempre \{ la profundidad de ochenta á ciento cuarenta pasos en el interior, abre un hoyo, deposita los huevos, cubrelos de arena y vuelve al agua. Un europeo sin experiencia en la busca de estos huevos trabajaria mucho tiempo en vano; pero el hijo práctico de la selva pocas veces se engaña, y casi nunca extrae la arena de un punto sin hallar en seguida los huevos. Una ligera prominencia ondulada en la superficie del suclo le indica el punto donde se halla el nido; yo no reconoci semejante señal hasta que hube visto algunos bancos de arena en los que toda la superficie presentaba un aspecto ondulado. Si un huevo no se endurece en el agua hirviendo y se conserva liquido, solo se come la sabrosa yema, que es de nuucho alimento. Las yemas crudas meacla. das con azúcar y algunas gotas de ron nos proporcionaban una golosina exquisita, pues tenian un sabor semejante al del mazapan mas fino.

- Martius indica los meses de octubre y novienbre como periodo en que esta tortuga pone sus huevos en el Amazonas; segun Humboldt, en el Orinoco lo hace en marzo; en el Essequibo comienza en enero y termina á principios de febrero. Esta diferencia en el período de la puesta parece estar en relacion exacta con la llegada de la estacion lluviosa en los territorios de los tres rios. Estos animales depositan sus huevos en los dias favorables en que el sol puede aun desarrollarlos antes de comenzar las lluvias abundantes. Para los indios, la presencia de las tortugas pequeñas es la 
señal mas segura del principio de esa estacion. Cuarenta dias despues de la puesta los pequeños salen del cascaron y se dirigem hícia el agua.

Además del ho:nbre, que cugiendo con toda regularidad los huevos perjudica muchisimo la propagacion de los arraus, aunģue son todavia muy numcrosos, tambien los car. niceros persiguen as estos reptiles.

Nos enseñaron, concluye Humboldt, varios caparazones de :ortugas de gran tamano, vaciados por los jaguares; estos siguen de cerca a los arraus por las márgenes donde van á desovar, los sozprendea y los vuelcan sobre el espaldar para poder devorarlos con soda comodidad. Una vez en tal pos iura, estos reptiles no pueden recobrar su equilibrio,y como el tigre vuelca muchos mas de los que puede devorar en una noche, los indios suelen aprovecharse de la astucia y codicia del carnicero.

"El riajero naturalista que sabe lo dificil que es la cutracción del cuerpo de la tortuga, conservando intactos y unidos el espaldar y el peto, no nuede menos que maravillarse de la destreza del tigre, que con sus garras vacia la caja del arrut, separando los músculos con la limpicza y precision del escalpelo mas diestranenta marjado. Fil ligre persigue 'ila tortuga hasta dentro del agua, siempre que esta no tenga mucha profundidad; desentierra sus huevos;y es juntamente con el crocodiloy el gran buitre, el mas temible cnemigo de los indiviciuos jórenes. El año pasado fueron tantos los crocodilos que visitaron la isla Pararuma, durante la recolec. cion de los huevos, que en una sola noche cogieron los indios, por medio de garíos de hicrro con cebo de carne de vaca marina, diea y ocho de estos saurics, de doce \& quince piés de largo. Por otra parte, los indios salvajes causan igual. mente gran perjuicio á la fabricacion del aceite: asi que cesan las primeras lluvias, que ellos Haman Jisions de las tortirizs, se dirigen a las orillas del Órinoco y matan con flechas envenenadas los eloditas que con la cabeza levaniada y las patas estiradas se calientan al soly.

\section{LAS HIDROMEDUSAS- HYDROMEDUSA}

CARACTERES - Con este nombre designamos algunas pocas especies de la segunda sub-familia reunicias por Wagler, con mucha razon, en un género independiente. El espaldar es plano, abovedado, levantado en los bordes late. rales en forma de surco y coinpuesto de catorce placas; el peto es muy plano y solo consta de una pieza; la cabeza, bastante achatada, está cubierta de una piel blanda, cl cuello es muy largo y verrugoso y la cola corta; todos los piés tienen cuatro dedos. Las catorce placas del espaldar, número \& que llega por excepcion, resultan segun Strauch "de la circunstan. cia de que la cervical no está situada como por lo regular en el borde medio de las laterales del cuello, sino derrás de la misma en una escotadura de la primera placa vertebral, formando en cierto modo una sexta placa de esta seric. La placa de la cola es doble, la media de la garganta casi cla. drangular y uuy grande; las del sobaco y de los costados faltan, asi como las barbillas.

\section{LA HIDROMEDUSA DE MAXIMILIANO- HYDROMEDUSA MAXIMILIANI}

CARACTÉrES. - Aunque se sabe poco sobre el género de vida de esta especie, la elijo como tipo del género. Fi espaldar es ancho, oval, redondeado en su parte anterior, $y$ prolongado en ángulo obtuso; todas sus placas presentan en los individuos jóvenes un sin numero de prorninencias irregulares, en las que por lo regular, pero no siempre, puede distinguirse el centro del escudo; en los adultos, por el con. trario, todas las placas son lisas. El color del espaldar es un aceitunado muy oscuro; el del peto amarillo pardusco sucio que resaita tambien en el borde inferior de las placas supe. riores, mientras que en el punto en que se tocan ambos escudos conviértese en pardo negruzco. La cabeza, el cuello, los piés y la cola son de un gris de plomo; una faja que parte del borde superior del hocico por ambos lados de la nariz, continuándose en forma de linea hasta los ojos, y pro. longándose desde aqui en igual anchura á lo largo del cuello, es de color amarillento asi como otra faja que corriéndose ś cada lado de la mandíbula inferior se reune pronto con aquella; los lados trasrersales de los musios son tambien de un blanco amarillento. La longitud total de esta tortuga, segun se dice, es de $1^{\circ}, 20$, la del cuello de $0^{\circ}, 40$, la de la coraza de $10^{\prime \prime}, 72$.

DISTRIBUCION GEOGRAFICA.-El área de dispersion de la hidroimedus: de Maximiliano parece limitarse al extreino sur del Brasil y á las repúblicas vecinas. Natterer la encontró en la capitania de San Pablo; d'Orbigny, mas tarde, en Montevideo y Buenos Aires, y Hensel la recibió igual. inente de la Banda Oriental. D'Orbigny dice que es comun 6 indica comó su residencia los pequeños lagos y rios, pero no dice nadá mas sobre su género de vida. La obra de Mi. kau, en la cual se encuentra la primera descripcion, no ha liegado ómi poder, $y$ en las diversas descripciones de viaje que he examinado no hallé nada sobre esta especie.

USOS, COSTUMBRES Y REGIMEN.-El géneto de vida de la hidromedusa de Maximiliano, aunque análogo al de otras turtugas acuáticas, debe ser extrano por mas de un concepto, segun lo demuestra un individuo de la especie, por el cual trazo esta descripcion. Durante el dia raras veces se ve mas que la coraza; pues la cabeza y las extremidades están del todo recogidas. El largo cucllo parece entonces un grueso bulto colocado trasversalmente $\mathrm{y}$ á bastante profundidad en el espacio del espaldar, mientras el peto llena casi todo el ancho de la abertura interior; la cabeza se oprime de tal modo contra la piel blanda de la region de los hom. bros, que solo por casualidad se ve mas de una parte del occipucio, al paso que la nariz y los ojos quedan del todo invisibles, porque la piel cubre estos órganos por todas partes. I.os piés y la cola se recogen 6 repliegan del modo acos. tumbrado; los pies tienen uñas largas y fuertes y sus plantas quedan visibles; de modo que esta tortuga solo deja descu. biertas dichas extremidades y la coraza cuando es atacada por algun enemigo.

Su largo cuello, sin embargo, puede tendcrsc súbitamente, desplegando una agilidad y movilidad tan sorprendentes que el observador no puede menos de recordar la serpiente. Cuando asi sucede, este reptil, siempre dispuesto ála defen. sa, sabe tambien atacar tan luego como le parece bien; sus acometidas no tienen nada que envidiar en viveza á las del emisauro aligator, y aun son muy superiores por su agilidad. Un ardor maligno parece animar sus ojos amarillos; $\{$ la manera de la serpiente, hace que su cuello forme circunvo. luciones para ganar la longitud necesaria, y con la rapider del rayo, tiéndele hácia adelante cuando cree llegado el momento conveniente. Prescindiendo de la agilidad y rapi: dez con que esta tortuga recoge y estira, vuelve y revuelve el cuello, todos los demás movimientos, si bien no tienen nada que envidiar ál los de otros congéneres, apenas merecen mencion especial, ó al menos no tienen nada de carac. terístico.

Si de un individuo pequeño cautivo nos permitimos formar idea de su vida en liberiad, podremos trazar poco mas ó me. 
nos la siguiente descripcion. La hidromedusa de Maximiliano permanece de dia descansando en el agua ó en un sitio seco sobre aquella, y solo por la noche empieza su caza. Su espaldar, que tiene el mismo color del cieno y que cstá medio cubierto por este, no puede ser visto por los peces que acecha; acércase á ellos sin que nada recelen, y tendiendo brusca mente su largo cuello, con sus mandibulas en forma de pico, apodérnse en un momento de la imprudente victima. Si el acecho no da buen resultado, el largo cuello prestará excelentes servicios para cazar á nado. No cabe duda que la hidromedusa de Maximiliano se defiende con tanto valor y energía como habilidad y éxito contra todos sus enemigos, de modo que estos solo podrán atreverse con los individuos pequeños. Toda la organizacion de esta tortuga es la de una esoberana del aguas como lo dice su nombre thidromedusa, perfectamente aplicado.

\section{LOS QUELIS-CHELYS}

CARAGTÉRES. - Una de las formas mas extrañas del óden está representada por el género de los quelis. El es. paldar, tan poco abovedado que parece plano, provisto de placa cervical y de doble placa caudal, tiene tres series lon. gitudinales de jorobas aquilladas, desunidas entre si por profundios y anchos surcos; el peto, muy largo, estrecho y aq̧uillado en los lados, se compone de una sola pieza y carece de las placas del sobaco y de los costados. La cabeza es muy achatada $y$ trilateral; la boca hendida hasta la region de las orejas; las mandibulas, mas $\delta$ menos recogidas hácia adentro, están revestidas de una piel blanda y gruesa; la nariz, prolongada en forma de trompa, tiene una longitud regular; el cuello es bastante largo, pero muy ancho y aplastado; la cola corta, con punta córnea; los piés anteriores tienen cinco de. dos $y$ los posteriores cuatro, con las membranas interdigitales mus desarrolladas. Unas placas pequeñas y algunos apéndices membranosos cubren la cabera; varias series longitudinales de pequeñas escarnas protegen el cuello; otras muchas, bastante grandes $y$ muy anchas, las piernas; on la cola hay una especie de verruguitas. Los citados apéndices consisten en un lóbulo triangular membranoso, delgado, bastante grande y recto, que en cierto modo representa una oreja exterior sobre cada oido; en la barba se ven dos barbillas, otra en la extremidad de la garganta, y cuattro 6 cinco protuberancias en la piel, dispuestas en fila á cada lado del cuello, y de la misma forma que las barbillas de la garganta.

\section{EL QUELIS MATAMATA-CHELYS} FIMBRIATA

CARACTÉRES. - El quelis matamata alcanza una lon gitud total de $\mathrm{I}^{\circ}, 30$, y segun Dumeril, hasta $2^{\circ}, 20$, en cuyo caso corresponden a la cabeza $0^{\prime m}, 3 \hat{3}$, al cuello $\left(1^{\prime \prime}, i_{2}\right.$ y's la cola $0^{\circ}, 11$; la longitud de la coraza es de $I^{\prime \prime}, 23$. Fl color de la parte superior es un castaño uniforme, el de la inferior amarillo verdoso sucio; las placas están cruzadas por fajas inas oscuras; en la parte inferior del cuello hay seis fajas longitudinales negras (fig. 12).

DISTRIBUCION GEOGRÁFICA.-El área de dispersion del quelis matamata se linita á la Guayana y al norte del Brasil; Sp̣ix le encontró aqqui en las aguas estancadas del Amazonas, Castellnau en este mismo rio, y Schomburgk en el Essequibo, el Rupununi y el Tacutu, asi como en los lagos y pantanos de la sabana.

USOS, COSTUMBRES Y RÉGIMEN. - Este reptil parece abundar en los puntos de su residencia, por lo cual todos los colonos europeos y criollos le conocen muy bien; los últimos le profesan mucha aversion y critan su encuen. tro á causa de su horroroso aspecto y de su abominable olor.

Schomburgk dice de esta tortuga: Es imposible que exista animal mas feo que este, cuya horrible figura, bastante asquerosa de por sí, no necesitaba por cierto el nauseabundo olor que despide para hacerlo todavfa mas repugnante. Aquella cabeza y cuello en forma de trompa, cubiertos de excre. cencias de toda especie: aquellos piés con toda clase de apéndices, susceptibles unos y otros de encogerse debajo del caparazon, me infundias el mas profundo horror cada ve\%. que los contemplaba. Hollenbrenghel, con ioda su fantástica imaginacion, jamis hubiera podido encontrar tan completo ideal de lo feo y asqueroso, como el que la natamleza ofrece en esta especie.... Generalmente se esconde el matamata en la arena ś orillas ciel agua, de manera que esta le cubre unos dos piés, y parece estar alli en acecho de su presa. Cuando se halla en esta posicion no es dificil cogerle; sin embargo, pocas veces nus atreviamos á hacerlo á causa de su hedor insoportable; con todo, los indigenas que teniamos á nuestro servicio, comian con avidez lan repugnante vianda.

Algunos de los obsermadores que nos precedieron preten. den que el matamata se alimenta de las plantas que crecen i orillas de los rios y que solo busca este alimento de no. che sin alejarse nunca mucho del agua No cabe duda que esta opinion es crrónea, pues el hecho de tencr las mandi. bulas revestidas de una piel abultada en forma de labios se opone a ello; por lo mismo es incxacta la noticia de Schomburgk. Mucho mas probable me parece el dato de Poeppig: Aliméntase, dice, de pececillos y ranas acechando su presa entre las plantas acuáticas flotantes; nada tan rápidamente que pucde alcanzar á los peces, y tambien coge avecillas acuáticas inmergićndose en la superficie. Iss posible que los extraños apéndices de su cabeza sirvan de cebo á los pececillos incautos, que atraidos por las fornaciones vermiformes se accrean para encontrar su perdicion. Geusicr asegura haber manteniclo una hembra muy fácilmente con yerba y pan, pero no dice curnto tiempo. I os individuos que vi en cautividad 6 cuidé yo mismo no aceptaban ningun alimento $y$ morian siempre al cabo de algunas semanas; fastidiaban ndems por su temor á la luz y su pereza. No sé si otros han sido mas afortunados.

El matamata se propaga muy poco, segun dicen; pero su modo de reproducirse no difiere en general del de otras especies afines. La hembra cuidada por (ieutier puso antes de morir cinco huevos, de los cuales uno, contra la esperanza de su propietario, se desarrollo en el cajon donde se conservaba.

\section{LOS TRIONIQUIDOS- TRIONICHYDF}

CARACTERES.-LOS trioniquidos, ó forlugras blambirs, forman la segunda familia del órden, naturalmente limitada: el espaldar, siempre oval y en la mayor parte de los casos tan solo ligeramente abovedado, figura una placa central ósea, revestiỏa de una piel blanda con manchas en forma de puntos ú ondulaciones: esta placa tiene un borde cartilaginoso, sostenido muy raras veces por algunos huesos; los que forman el peto se consersan separados toda la vida. Ambos escudos cstán cubiertos de una piel, pero carecen de placas córneas. Ias fosas nasales se hallan en una trompa blanda y movible; el tambor está oculto debajo de la piel, y las mandibulas revestidas de una piel carnosa. La cabeza y el cuello pucden recogerse bajo la concha, asi como los piés, que tienen tres dedos y membranas natatorias muy desarrolladas; la 
corta cola se oculta igualmente, á veces por unas placas mo. vibles separadas.

DISTRIBUCION GEOGRÁFICA.-Conócense actual. mente unas veinticinco diferentes especies de trioniquidos que habitan las grandes corrientes, los rios y los lagos del Asia, Africa y'América. En Asia se encuentran las mas y en América las menos.

USOS, COSTUMBRES Y RÉGIMEN.-Poco se sabe aun sobre el género de vida de estos reptiles: para depositar sus huevos la hembra abandona el agua bastante tiempo, pero fuera de este caso, siempre vive en ella. A pesar de que en ticrra firme no es torpe para andar, y corre, segun Baker, con bastante rapidez, no emprendé nunca, al menos que sepa. mos, grandes viajes í pié, ni aun cn el caso de secarse el agua donde habian; en tal circunstancia se ocultan sencillamente en el cieno y esperan la llegada de la estacion lluviosa Por el contrario, son muy emprendedoras cuando el agua les ofrece caminos y senderos. Algunas especics se han cogido bastante distancia en la desembocadura de un rio en el mar, y puede suponerse que tales expediciones son bastante fre cuentes, pues todos los rios que desembocan en cierta parte del mar y á poca distancia uno de otro albergan por lo regular los mismos trioniquidos, mientras que aquellos que se dirigen d diversos puntos del mar y en-su curso superior no se hallan reunidos por afluentes, solo conilenen de ordinario tortugas blandas de diversas especies.

Poco se ha observido el género de vida de estos reptiles en el agua; lodas las especies parecen nocturnas, pues no ma. nifiestan actividad hasta despues de ponerse el sol. Durantc el dia perinanecen del todo $6 \mathrm{cn}$ parce ocultas en el cieno, descansando perezosamente en el mismo sitio, muy á menudo en tan poco fondo, que fóscilmente penetran los rayos del sol; de noche cazan toda clase de animales acuáticos. Esto no quiere decir que en las horas del dia no cojan tambien la presa que se les ofrezca, pues mientras el sol ilumina, tragan vorazmente los cebos de los anzuelos. Tampoco desprecian las sustancias vegetales, aunque el alimento animal constituse sin duda la base de su régimen nutritivo. Ruppell no encontró en el estómago y en los intestinos del irioniquido propio del Nilo mas que restos de dátiles, pepinos, calabazas y otros vegetales; pero los árabes me dijeron que esta especie perse guia los peces, y tambien Baker asegura que se deja engañar por el cebo. Seria por lo tanto inexacto deducir de las observaciones de Ruppell que estos reptiles prefieren el alimento vegetal, ni tampoco se comprenderia que viviesen en ciertas aguas, como pot cjemp!o las de Mongolia, donde no halla rian frutos.

CAZ A.- Ia malignidad, convertica a menudo en rabia, y el valor que los trioniquidos demuestran cuando se les coge, sobre tocio si están lieridos, revela sus inclinaciones de carnicero y por lo tanto tambien que se alimentan de sustancias animales. No todos, pero si la mayor parte de los observado res que tuvieron ocasion de conocer tortugas blandas vivas, están conformes cn que pertenecen á las especies mas furio sas y mordedoras del órden, $;$ que no solo silban y bufan roncamente, sino que tambien clavan los dientes con fuerza. El considerable tamaño de.cstas toriugas, cujo peso en aigu nas especies puede exceder de cien kilógramos, y además su carne muy sabrosa son causa de que se las persiga con mas ó menos actividad. Se cogen con redes de pescar y anzuelos, matándolas con escopeta 6 lanza, segun parezca conveniente para el mejor éxito; pero es preciso mantenerse siempre á respetable distancia de un trioníquido cogido. \$Para cazar el trioniquido del Ganges, dice Theobald, se emplea una larga horquilla de hierro con puntas afiladas, ó una caña de bam bu puntiaguda, escarbando con estos irstrumentos en varios sitios el cieno blanco ô la hojarasca medio podrida, á lo largo de las orillas de las corrientes. Si el cazador toca un trioni. quido, reconócelo por sus movimientos; entonces se hace cargo cuidadosamente de su situacion, y segun el tamaño del animal, fija uno $\delta$ varios anzuelos en la parte superior del borde cartilaginoso de su coraza; hecho esto, tira vigorosa. mente con todas las cuerdas del anzuelo y saca la tortuga que se resiste furiosa con una rabia increible 6 intenta mor. der cuanto se pone á su alcance. Si el animal es muy grande ó se encuentra a mucha profundidad, introdúcese en el agua con ayuda de un pesado martillo, un grueso palo puntiagudo y hácese salir \& la tortuga á la superficic. Ay del miembro que entonces se ponga al alcance del furioso animal! Yo he visto cómo un trioniquido cortó con sus mandibulas los de. dos de los piés de un hombre. En todas las circunstancias debe aconsejarse atravesar tan pronto como sea posible con una bala el cerebro del furioso reptil, tan ágil como maligno; pero adviértase que el trioníquido tiene una resistencia vital extmordinaria, tanto que su boca muerde furiosamente aun despues de separar la cabeza del tronco. Los mogoles parecen conocer muy bien el carácter malicioso de los trioni. quidos, propios de su país, y revisten su historia natural de fábulas y cuentos. \$Nuestros cosacos, dice Przewalski, renun. ciaron á bañarse con nosotros en el rio Tachylga, pues temierón á los trioniquidos, de los cuales les habian hablado los mogoles, quienes atribuyen á esos séres una fuerza particulat de hechizo, indicando para demosirar la exactitud de su opinion unas letras tibetanas que segun ellos se observan en la parte superior del espaldar. Habian infundido temor s nuestros cosacos asegurándoles que las tortugas penetran en el cuerpo de los hombres a fuerza de chupar, en cuyo caso no es posible cxtraerlas por la vía natural. El único medio consiste en traer un canello y un corzo blancos, obligándo. les á gritar cuando ven á la tortuga, que de este modo aban. dona su víctima. En tiempos anteriores no habia trioni. quidos en el rio Tachylga; pero los terribles animales se presentaron subitamente y los habitantes, tan asombrados como poseidos de espanto, no supieron qué hacer. Al fin dirigiéronse al Higén ó abad del próximo convento y este declaró que la tortuga que tan de repente se habia presentado seria en adelante dueña del rio y que debia contarse entre los animales sagrados. Desde este tiempo se ora todos los meses una vez con devocion en la fuente del Tachylga.

Cautryidad. - Carecemos de informes minuciosos sobre los irioniquidos cautivos. Kelaart dice que meses en. teros tuvo un individuo propio de Ceilan, vivo, en un bar. reño de agua y que comió voluntariamente sustancias vege. tales, pan y arroz cocido; añade que los pescadores suelen ponerla en el espacio agujereado de las lanchas para que coman los restos del alimento. Muy raras veces llegan ános. otros tortugas vivas de esta familia, mas por lo menos vi el pequeño de una especie que aun no podia distinguirse. Era un sér graciosisimo cuyos ojos miraban fijamente y casi con astucia á su alrededor, y que por sus movimientos aventajaba en gracia a todo cuanto conozco de tortugas de agua dulce.

USOS X PRODUCTOS. - I.a carne de los trioníquidos no se come en todas partes, pero cuantos la han probado elógianla mucho. Segun Baker da un caldo excelente; los huevos parecen menos sabrosos. \$De una sola hembra, dice el citado viajero, ture mas de cien huevos, de los que hicimos tortillas, pero tenian un sabor bastante fuerte.

\section{LOS TRIONIX - TRIONYX}

CARACTÉRES. - La familia de los trioniquidos se di. vide en tres géneros, pero solo nos ocuparemos del de los 
trionix. El espaldar es abovedado, muy ligeramente; la placa del centro de un tamaño regular; el borde cartilaginoso que hay al rededor es grande $y$ sin vestigio de formacion ósea; el peto corto, con estrechos lóbulos posteriores y sin placas movibles, de modo que los piés posteriores y la cola no pueden recogerse bajo el mismo. La cabeza estś cubierta de una piel blanda y lisa asi como el cuello; las piernas y la cola; solo en los antebrazos se ven algunos repliegues trasversales que afectan la forma de escamas.

\section{EL TRIONIX FEROZ - TRIONYX FEROX}

CARACTÉRES. - Lintre las especies que pertenecen it este género, el trionix feroz es la que mas cunocemos; puede llegar á tener un peso de treinta \& cinco kilogramos, midiendo una longitud de $\mathrm{I}^{m}, 60$, de los cuales corresponden al cucllo $\|^{\circ}, 33$, á la coraza $\|^{\prime \prime}, S_{4}$ y á la cola $0^{\circ}, 16$. Su coraza es en la parte superior de un gris de pizarra oscuro con nu. merosas y grandes manchas oculares, y en el borde de puntos oscuros; la parte inferior, en cambio, es de un blanco sucio; la cabeza de color de pizarra con manchas oscuras en los lados; en la region de los ojos se observa una faja que llega hasta el cuello; la barba, los piés y la cola tienen dibu. jus blancos y negros semejantes á los del márriol; el iris es amarillo (fig. 13).

DISTRIBUCION GEOGRÁFICA. - El trionix feroz ha.

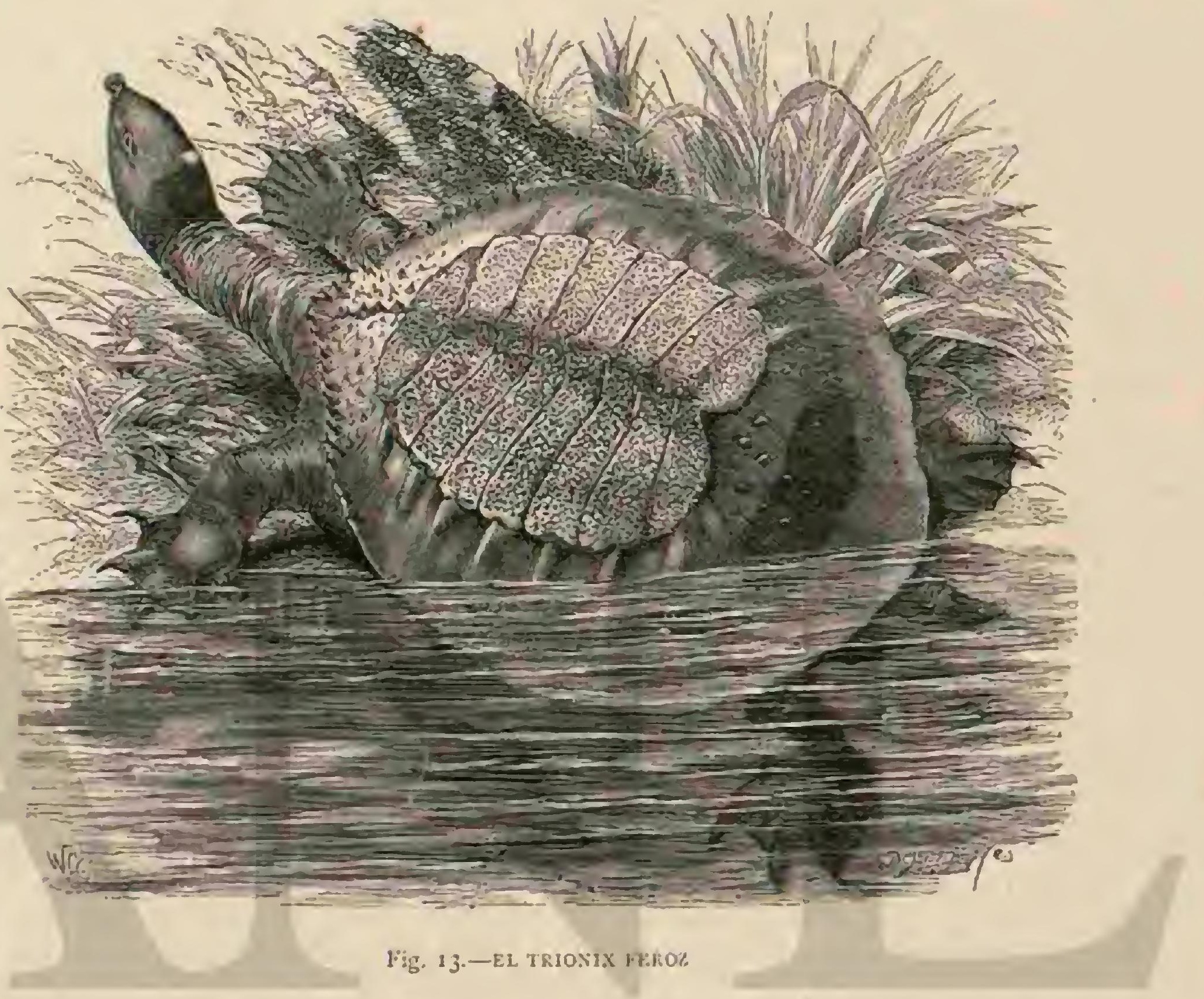

bita, segun Hollbrook, los rios Savannah y Alabama, y todas las corrientes que desembocan en el golfo de México, asi como los lagos septentrionales y el Hudson; falta, sin em. bargo, en todos los rios que entre este último y el Savannah desembocan en el Atlantico. Es probable que llego a los grandes lagos del norte desde los rios del sur, que deben considerarse como su patria primitiva, quizśs durante las inundaciones de la primasera, las cuales ponen en comuni. cacion el Illinois con el lago de Michigan y el Pedro con la parte septentrional del Colorado; a las aguas del Estado de Nueva. York no llegaron sino por medio del canal de NuevaYork antes de cuya terminacion no se les conocia alli. En la mayor parte de estas aguas, sobre todo en las mieridionales, esta especie es muy frecuente.

USOS, COSTUMBRES Y REGIMEN. - En tiempo tranquilo se ve un considerable número de estas tortugas flotar en la superficic de los lagos Ohio y Eric; en los rios se presentan á menudo en grandes agrupaciones cerca de las rocas, para exponerse á los rayos del sol.

A menudo se ocultan tambien entre las raices y plantas acuáticas, acechando su presa. Dan caza \& los peces, aves acuáticas, ranas, caracoles, etc, dirigiéndose con toda preTomo $\mathrm{V}$ caucion a la orilla y estirando con la velocidad del rayo y con grande precision su largo cuello para apoderarse de su victima. En los Estados mas al sur causa este testudo verda. deros destrozos en los aligatores, pero á su vez esta expuesto al las iras de los caimanes. Ocasiona tambien el trionix feroz bastantes perjuicios á los colonos, pues no desperdicia oca. sion de cogeriez algun pato 6 ganso. En los Estados meridionales causa, segun se dice, grandes estragos entre los caimanes pequeños; pero, en cambio, les devoran los aliga. tores adultos.

En mayo busca la hembra un sitio arenoso en la orilla de las aguas que habita, y á pesar de sus torpes movinientos; logra trepar á pequeñas eminencias de algunos piés de aitura. Los huevos son redondos y mucho mas quebradizos que los de las tortugas fluviales que viren en las mismas aguas. Acerca del modo de vivir los pequeñuelos de esta especie, que rompen la cáscara en el mes de junio, pocos ó ningunos detalles han sido publicados hasta ahora.

Entre todas las especies americanas de tortugas, esta es la de carne mas sabrosa, por cuya razon se la persigue con afan, colocando redes al rededor de su retiro 6 bien pescán. dola con anzuelos; mas para apoderarse de las adultas hay 
que ir con suma precaucion, porque se defienden hasta del hombre, $y$ le pucden causar dolorosas heridas con su mordedura, especialmente aquellas que se cogen con anzuclo, las cuales parecen frenćticas, dan repetidos mordiscos al aire si alguno se acerca á ellas, y demuestran por todos los me. dios posibles el furor que las domina.

Bell refierc que uno de estos animales arrancó í un hombre un dedo de un mordisco.

\section{LOS QUELÓNIDOS CHELONIIDA}

CARACTERES. - Los quelónidos, ó tortugas marinas, se distinguen de sus congéneres por tener las piernas lrasfor madas en aietas, siendo las anteriores mucho mas largas que las posteriores Cada uno de sus piés forma una larga aleta aplanada que segun dice Vagler se parece mucho à las de las focas; los dedos están cubiertos de una piel comun y por lo mismo son inmóviles. Tambien pierden la mayor parte de las uñas, pues solo los dos primeros dedos de cada pie, y aun estos no siempre, tienen garras puntiagudas. Los queló. nidos se caracterizan además por el espaldar en forma de co. razon, que en su parte anterior presenta una escotadura re. dondeada; es puntiagudo en la posterior, ligeramente abovedado, y hácia la extremidad de las costillas imperfectamente osifícado, no pudiendo recogerse en $€ \mathrm{l}$ las extremidades; las placas del peto no forman un escudo compacto sino que están unidás por cartilagos; distínguense zèemás por sus esca. mi2s y placas; el cuello, corto, grueso 5 arrugado, se puede recoger por mitad; la cabeza es corta, fuerle y cuadrangu. Lar; las manciibulas, desnudas, con bordes córneos, cortan. tes, y á veces denticulados, se encorvan en la punta en forma de gancho y encajan de tal modo que la superior se adapta del todo en la inferior; los ojos son grandes y saltones; las fosas nasales muy pequeñas; los escudos de la cabeza j de los piés de ena conformacion muy particular; la cola corta; obtusa y cubiertá de escamas, etc.

USOS, COSTUMBRES Y REGIMEN, - Todas las tortugas perterecientes á este grupo viven en el mar, á veces á centenares de leguas marinas de distancia de la costa; na. dan y se sumergen con gran maestría, y solo van a tierra fir. me para depositar sus huevos. Es difícil decir hasta qué punto se disingue el género de vida de las especies, porque solo durante el periodo del celo ó mas bien de la puesta se han podido hacer observaciones minuciosas sobre todos los quelónidos; mientras que de su vida en el mar no se sabe mucho mas de lo que ya sabian los antiguos. Cierto que no faltan nnirias sobre sus usos y costumbres, pero nu se sabe cuáles son los informes debidos á una observacion concienzuda y cuáles á la fantasia ó á una repeticion de noticias fal. sas. Ciegamente podemos fiarnos de autores cono el príncipe de Wied, Audubon, Holbrook y Tennent; pero aun no estamos dispuestos a probar la veracidad $\delta$ falsedad de los rela. tos de otros. Me limitaré á dar, segun las fuentes que conorco, las descripciones de las especies mas importantes, tan bien como puedia hacerlo con los medios que están á mi disposi.
cion.

Esta familia, que sin duda cuenta menos especies de lo que por lo regular se supone, se divide en dos agrupaciones a las que puede concederse el rango de subiamilias.

\section{LOS QUELONINOS - CHELONINA}

CARACrérEs.-En cl primer grupo, el de los queloninos, se reunen las especies cuya coraza estå cubierta de placas regulares dispuestas una junto á otra ó sobrepuestas y cuyas aletas tienen una ó dos caras.

\section{LOS QUELONES - CHELONE}

CARACTÉRES.-La cabeza de los quelones ó tortugas de concha tiene forma de pirámide y se inclina mucho por los lados; las extremidades anteriores son casi doble mas lar. gas, pero mucho mas estrechas que las posteriores. El espal. dar se compone de trece placas planas, entre las cuales las primeras costillares son mucho mas grandes que las posteriores, y de veinticinco á veintisiete en el borde: el peto consta igualmente de trece placas, á cuyo nuimero se agregan á cada lado cuatro ó cinco correspondientes á las costillas del pecho, algunas bastante grandes y otras mas pequeñas; la placa media de la garganta está bien desarrollada. la superficie supe. rior de la cabeza es horizontal y tiene de diezá doce escudos regulares; en las piermas hay escudos poligonos de tamaño muy variado, pero no en la region de los hombros ni en la parte superior de los muslos; iguales escudos cubren el cen. tro, y la extremidad de la corta cola.

Segun las averiguaciones minuciosas de Strauch, este género no cuenta mas que dos especies, con muchas variedades: el quelon verde y el quelon carcy.

\section{EL QUELON VERDE-CHELONE VIRIDIS}

CARACTERES.-El quelon verde es un animal muy grande que alcanza mas de dos metros de longitud, y cuyo peso puede pasar de quinientos kilógramos; caracterizase por las mandibulas obtusas y no ganchudas y prolongadas, pero cortantes y denticuladas; las placas del espaldar están una junto á otra y no sobrepuestas; tiene un solo par de es. cudos en las fosas nasales y el escudo frontal. 'Todos los demás caractéres varian de tal modo que han dado lugar à la formacion de unas dier especies distintas. Tampoco el color es constante; el de la parte superior es por lo regular un verde azulado oscuro, y el de las inferiores de un blanco sucio, con muchas lineas azuladas y rojizas (fig. 1.q).

DISTRIBUCION GEOGRÁFICA.- Excepto el Mediterráneo, donde está representado por otras especies, el quelon verde habita todos los mares de la zona cáliela y templada y parece abundar en todas partes. Se le ha visto desde las Azores hasta el Cabo de Buena Esperanza, á lo largo de toda la costa del Africa y en las islas de este continente. En las costas atlánticas de América encuéntrase desde los $34^{\circ}$ de latitud norte hasta la desembocadura del Rio de la Plata; en el Pacífico desde el Perú hasta California, y en la isla de la Tortuga, y por último, en el Océano Indico con sus bahias y estrechos, desde las islas Mascareñas y el canal de Mozambique hasta el mar Rojo. Tambien se halla en todas las costas de las Indias orientales, en las islas de la Sonda y en las Filipinas, así como en las costas de Australia. Algunos individuos errantes fueron cogidos en el nordeste de América y en las cosias europeas.

USOS, COSTUMBRES Y RÉGIMEN.-Los quelones, lo mismó que todos sus congéneres, son perfectos animales marinos; habitan con preferencia las cercanias de la costa y se presentan bastante á menudo en las desembocaduras de los grandes rios y corrientes, pero muchas veces se les encuentra á larga distancia de estos, y hasta en medio del mar. Aquí nadan cerca de la superficie ó fiotan al parecer dur. miendo sobre las aguas, pero al mas leve tropiezo desaparecen en seguida en la profundidad. "las tortugas ierrestres, dice Lacépede, considerábanse desde los tiempos mas remotos como símbolo de la lentitud; las tortugas marinas 
pueden llamarse el simbolo de la prudencia.s En efecto todas las noticias están conformes en que estos reptiles, mientras estén despiertos ó no dominados por otros ins. tintos mas poderosos evitan tímidamente la presencia del hombre; pero dificilmente se les podria reconocer un grado superior de inteligencia sobre sus congéneres del nismo órden; no es el enemigo conocido lo que le asusta sino cl objeto inusitado, lo cual indica alguna inteligencia, aunque bas. tante poca. Las facultades intelectuales son tan escasas como notables las corporales: asegúrase que en tierra firme pueden andar llevando encima tantos hombres como puedan colocarse sobre su espaldar; los individuos grandes cargarian hasta con catorce; pero solo en el agua desplegan su verda. dera habilidad. Cuando retozan en ella, recuerdan mucho las grandes aves de rapina, como por ejemplo las águilas al volar, pues nadan de un modo admirable con tanto vigor como rapidey, con tan incansable perseverancia como gracia; y esto lo hacen del mismo modo ś diferente profundidad, tomando en el agua todas las posiciones posibles. Alli donde abundan se ven a veces verdaderas manadas de estos animales, que en general parecen muy sociables.

-Como encuentran siempre alimento suficiente en las cos. tas que frecuentan, dice Lacépede, nunca se disputan la co. mida, que es abundante; asi como todos los reptiles, pueden ayunar meses y hasta anos enteros y por lo mismo reina una paz eterna entre esos animales. No se buscan unos á otros, pero se encuentran sin trabajo y quedan reunidos sin verse obligados á ello. No se reunen en manadas para cogér mas fácilmente su presa; el mismo instinto les conduce á un lugar dado, y un géncro de vida igual mantiene el órden en sus manadas. Siempre fieles á sus costumbres, son mas bien pasivos que activos y nunca violentos sus deseos; prudentes pero no valerosos, raras reces se defienden de hecho; prefie. ren buscar siempre lo mas rápidannente posible la seguridad, valiéndose de todas sus fuerzas para lograr este fin. 3 Yo creo que podemos aceptar como buena esta descripcion, ó en otros términos, decir que es exacta en su conjunto. Un ca. rácter-sociable y pacífico es la cualidad dominante de muchas tortugas y sobre todo de los quelónidos.

Difiriendo de su congénere el quelon carey, que es verdaderamente carnicero, el quelon verde se alimenta, cuando menos temporalmente, de plantas marinas, solıre todo de algas; y alli donde abunda reconócese su presencia por los restos cortados de estas plantas, que sobrenadan en la superficie del mar. Asi lo dice Holbrook, de conformidad con casi todos los autores, añadiendo de acuerdo con 10 dicho por Audubon, que prefiere \& todo las partes mas tiernas de cierta planta marina (snstera marira) llamada yerba de las tortugas. Segun dice, tambien los cautivos se alimentan exclusivamente de sustancias vegetales, sobre todo de portulaca. No puedo re. futar estos asertos, pero debo decir que no solamente mis careys cautivos, sino tambien los quelones verdes que con ellos compartian el mismo estanque, comian pescado voraz. mente.

En ciertos periodos las hembras del quelon verde abando. nan la alta mar dirigiéndose á los sitios acostumbrados para depositar sus huevos. Fligen parajes arenosos de islas deshabitadas ó de costas lejanas, y buscan siempre el mismo lugar para la puesta, no durante toda la vida, pero si para cicto ticmpo, aunque debiernn tecorrer centenares de leguas marinas. Segun Dampier, los machos siguen a las hembras en estos viajes, pero no salen à la orilla mientras estas ponen, limitindose a permanecer cerca de clla en el mar. El aparea. miento se verifica ya antes, y segun Catesby dura mas de quince dias. Villemont dice que el macho está sentado durante el apareamiento en el lomo de la hembra, como sifuera una cabalgadura; Lacépede, en cambio, sostiene, fundảndose en los manuscritos de Fougeroux, que machoy hembra oprimen los petos uno contra otro y que el primero se agarra con las unas de los piés anteriores à la ancha piel del cuello de la segunda. Segun se dice, tanto el macho como la hembra pierden su timidez mientras dura el apareamiento, sobre todo el macho. Yo cogi machos durante el coito, dice Darnpier; entonces no son nada timidos y poco cuesta apoderarse de ellos; una hembra quiso huir al ver la lancha, pero el macho la sujetó con las alctas anicriores. Si se quiere coger a las tortugas en el momento de apareatse basta matar à la hembra para tener ya seguro al macho. No se sabe cuánto tiempo pasa despues del apareamiento hasta que los primeros hucros se desarrollan del todo. Llegada cerca de la costa, la tortuga espera la hora oportuna y sale entonces por la noche con gran precaucion á la orilla. Ya de dia, se la ve nadar, segun la observacion del principe de lVied, à poca distancia de la costa, sin mostrar mas que la cabeza, corta y redonda, y tocando apenas con el espaldar la superficie; entonces examina del modo mas minucioso la costa que pocas veces visita el hom. bre. Audubon, que la observó desde un escondite, asegura que antes de salir á tierra firme adonta sus precauciones lan. zando sobre todo un silbido á fin de ahuyentat a cualquier enemigo oculto. El mas leve ruido la obliga á huir al instante á la profundidad del mar y à buscar otro sitio. Segun asegura St. Pjerre, un buque anclado algunas horas cerca de una isla donde haya tortugas las ahuyenta durante dias enteros de las cercanias, y un cañonazo las espanta de tal modo, que solo al cabo de algunas semanas vuelven á presentarse en la costa. Cuando todo está tranquilo, la tortuga se acerca lentamente á la orilla, sale á tierra furme y avanza con la cabeza levanta. da hasta una distancia de treinta $\delta$ cuarenta pasos mas allá de la alta marea; entonces mirn oira vez. \& su rededor y em. pieza a depositar sus huevos.

El principe de Wied, que ha podido observar en este acto á una tortuga verde, nos comunica sobre el particular lo que sigue: Nuestra presencia no la inquictó; pudinzos tocarla y hasta levantarla del suelo, para lo cual fueron necesarios cuatro hombres; solo manifesto su temor con una especie de resuello semejante al que producen los gansos cuando ren algo extraño cerca de su nido, si bien pudo ver y air nuestras demostraciones de sorpresa. Siguió practicando lentamente en el suelo arenoso, con el auxilio de sus nadaderas posteriores, una excaracion cilindrica de 8 á 10 pulgadas de ancho situada precisamente debajo del ano. La tortuga echaha á los lados el material extraido con singular destreza, y hasta acompasadamente, y cuando hubo terminado, comenzó á depositar sus huevos.

- Uno de los dos soldados que nos acompañaban se echó en ticrra colocándose al lado de la tortuga, y sacó los huevos del agujero uno á uno, a medida que clla los dejaba cacr. Por este medio reunimos en el espacio de diez minatos unos cien huevos. Despues comenzamos a discurrir si seria conveniente enriquecer con aquel hermoso animal nuestra colec= cion; pero su peso enorme, que requeria para el trasporte uno de nuestros mulos, junto con la dificultad de cargar aquella mole gigantesca, nos determinó á perdonarle la vida y a contentarnos con su contribucion de huevos. Cuando al cabo de algunas horas volvimos á la playa, se habia ido ya: el agujero estaba cerrado, y la ancha huella que habia dcjado en la arena nos dió a entender que se habia vuelto á su elemento.

En sus apuntes para la Historia Natural del Brasil, añade el principe de Wied lo siguiente: Sế por experiencia que estos animales se aproximan en gran número á las costas durante el verano del Brasil, es decir, en los meses de di- 
cicmbre, enero y febrero, para enterrar alli sus huevos en la arena abrasada por los ardientes rayos del sol. Esta es la costumbre de todas las tortugas marinas, y a todas es aplicable lo que dije sobre la manera de efectuarse la operacion, segun pude ver yo mismo. El espacio desierto comprendido entre las embocaduras de los rins Doce y San Mateo, y el que se extiende entre la de este último y del Mucuri, asi como tambien otras varias comarcas cuyo acceso no se halla obstruido por escarpadas rocas, son los sitios mas farorables para que las tortugas depositen sus huevos. Con frecuencia encuentra el viajero en la estacion de la puesta, varios sitios en la arena de la playa donde esta indicado por medio de dos surcos paralelos el camino que siguen las tortugas al salir á tierra. Estos surcos son los rastros que dejaron sus extremidades; y en medio de ellos se ve otra depresion para-
Icla y ancha formada por el pcto. Siguiendo luego esta huella en un trecho de treinta a cuarenta pasos se podria descubrir al animal inmóvil y casi oculto en un hoyo de poca profun. didad, el cual forma girando en círculo su enorme y pesado cuerpo. Despues de haber puesto los huevos de la manera indicada, reune otra vez la arena por ambos lados, la pisotea, y siguiendo el mismo rastro, se vuelve con igual lentitud á su elemento. Tennent asegura, por el contrario, haberse reconocido en las costas de Ceijan, que al poner sus huevos proceden con cierta astucia. Encaminanse al sitio dando un gran rodeo, vuelven al mar por un camino diferente, con el ubjeto, segun dice, de ocultar mejor su agujero. Por eso se ven obligados los ceilaneses á reconocer lodo el rastro, sondeando siempre con un palo para ver si lo encuentran, pues no hay otro medio de saber dónde se halla.

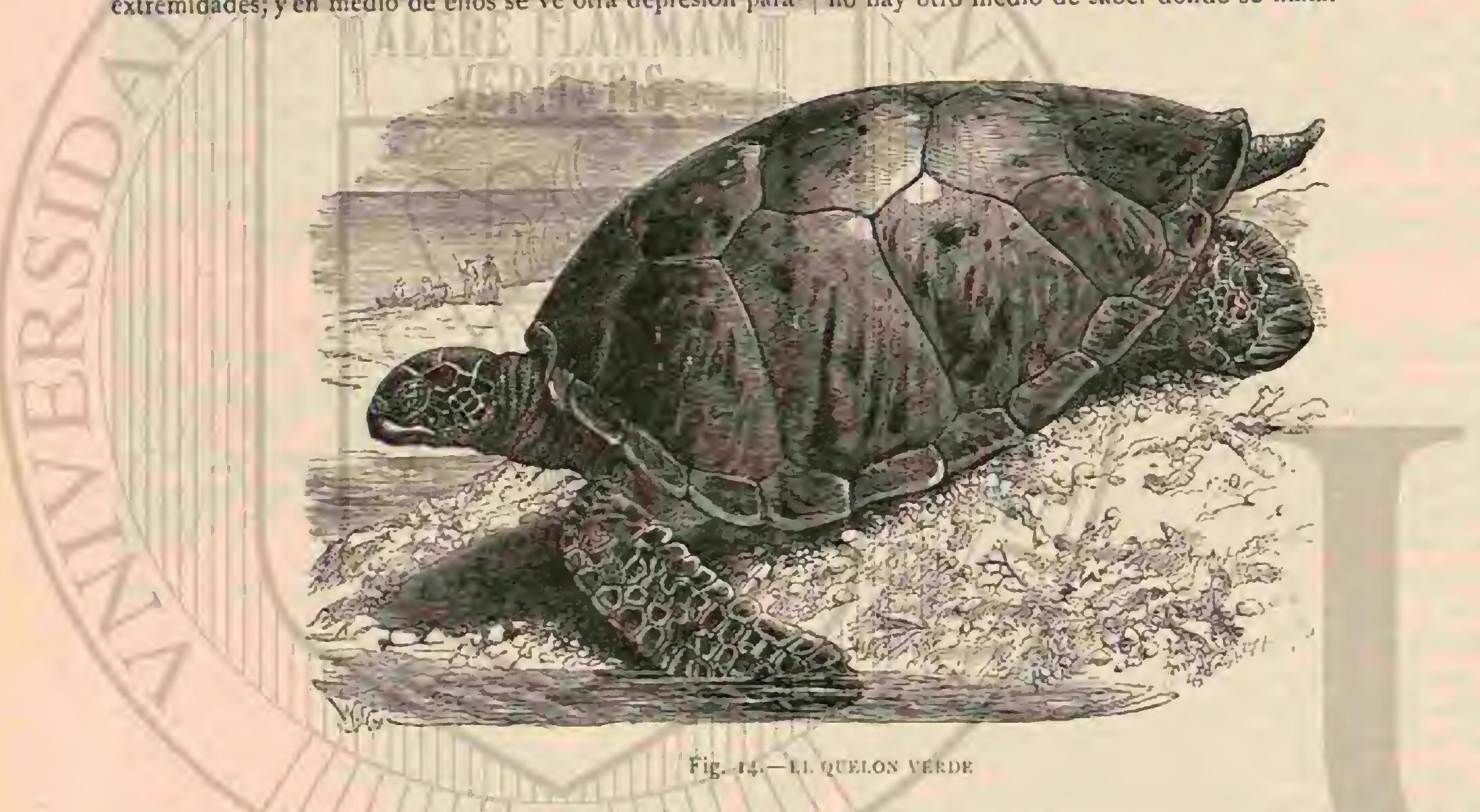

Parce que en la primera puesta no deposita la hembra lodos los huevos fecundados, y que al cabo de mucho tiempo ruclve al mismo sitio para poner otros tantos; de modo que el número total de los de una hembra adulta puede lle. gar \& trescientos, y aun quizás a cuatrocientos. Los autores antiguos y modernos que tuvieron ocasion de observar los quelones verdes en los sitios donde ponen sus hueros, ó de recoger aqui noticias sobre ellos, están conformes en que estos repriles se presentan todos los años mas de una vez en tales parajes para depositar mayor ó menor número de huevos. Se ha podido reconocer la vuelta de algunas hembras a los mismos lugares con dicho objeto; en la isla de la Tortuga, sitio preferido por esos animales en la América central, se cogieron, segun Strobel, vatios quelones verdes que se marcaron para llevarlos despues á Cayo Hueso y encerrarlos en un arca. Una tempestad destruyó esta última, dejando en libertad á los cautivos, y pocos dias despues se volvieron a coger en el mismo sitio, y por lo tanto en làs mismas circuns. tancias que la primera vez.

El perlodo de la puesta var ia segun la region: En el estre cho de Malaca tiene lugar en los mismos meses que en el Brasil; en la isla de la Tortuga desde abril á setiembre; y en la costa de Oro, segun loyer, desde setiembre á enero. No encuentro noticias mas minuciosas. La incubacion dura unas tres semanas, mas ó menos, segun el calor de la region.

En las islas de Cabo Verde aparecen los hijuelos à Ins irece dias de la puesta, segun dicen, y en seguida se dirigen al mar, pero como aun no pueden sumergirse, muchos son victimas de las pollas acuáticas, de las garzas reales y de las rapaces. Su coraza está cubierta al principio de una membrana blanca y trasparente; pero muy pronto se endurece, dividiéndose con placas escamosas de un color mas oscuro.

Ciertos naturalistas opinan que el crecimiento es rápido; pero este aserto no concuerda con las observaciones que se han hecho en tortugas palustres; ni parece digno de crédito lo que refiere Villemont respecto á cierta tortuga verủe, que conservaba cautiva un habitante de Santo Domingo, $y$ la cual creció un pié en un mes, segun dijo su dueño.

Durante la puesta de los huevos, los quelones verdes pue. den correr tambien peligros, aunque por lo regular estén bas. iante seguros, pues el hombre y los carniceros se apoderan entonces de los indefensos animales. Al tratar de los perros salrajes en el tomo primero de esta obra hablé ya de los ata. ques de esios cuadrúpedos; pero no podemos considerar á estos cánidos como los encmigos mas peligrosos de los que. lónidos, â pesar de la matanza que de ellos hacen. El hombre es el que perjudica mas a estos reptiles, tanto el blanco como el negro; y en pocos sitios se da caza á estos preciosos animales de un modo racional. En las costas de Guajana se colocan unas redes de anchas mallas sostenidas en las regiones supe. riores del agua por medio de maderos flotantes, y examinan se de vez, en cuando para coger los quelónidos enredados en 
las mallas; en el Mediterráneo, y sobre todo cerca de las Cicladas, la caza se verifica aun de un modo semejante al usado en los tiempos antiguos. Una lancha que en la mas perfecta calma surca lentamente, remando \& intervalos, el agua azul del mar de las Cicladas, suele encontrar, segun Frhard, a varjas leguas marinas de distancia de la isla mas próxima, un quelónido que, durmiendo, flota en la superficic (por lo re. gular la tortuga kaguana propia del Mediterráneo), parecien do desde léjos una barca volcada Si los pescadores pueden acercarse á ella antes de que despierte, cl mas experto de ellos la coge por una pierna, tumbándola bruscamente de espaldas é impidiéndola de este modo defenderse; mas á pesar de esto, nadie se acerca para no exponerse $\{$ un mordisco del animal, pues solo una dentellada basta para cortar palos de dos centímetros de grueso. Por lo regular, el oido de la tortuga es mas fino que su pesado sucño, y si despicrta á tiempo sumérgese lentamente â la vista de sus engañados enemigos, casi sin movimiento hasta llegar a la yrofundidad, een la cual queda visible aun á los dicz minutos; mas al fin desaparece como una estrella verde que se desyaneciera poco \& poco. Esta noticia, afirmada por Erhard, me parece mas creible que un relato de Anson, tomado de la obra de Lacépede. «Un pescador experto se sumerge (en el Océano del sur) á alguna distancia del sitio donde durante el calor del dia las tortugas flotan durmiendo en la superficie; vuelve á salir muy cerca de uno de estos animales; le coge por la coraza en la region de la cola, y arrójale por la parte posterior al agua. La tortuga se despierta, y trabrjando con sus aletas anteriores, sostiénese á si misma y al hombre sobre el agua, hasta que los compañeros de este llegan y los pescan á los dos. Ni los americanos indigenas ni otros cazan los quclónidos de un modo semejante: los acechan cuando salen i tierra firme para poner sus huevos.

Rara vez sienta el viajero su planta en la arena de las so litarias playas, que en el Brasil son los lugares elegidos por las tortugas para depositar sus huevos; mas apenas llega la estacion de la puesta, aquellos sitios vienen a ser entonces el punto de reunion de todos los indios que moran en aque. llos alrededores. Estos indigenas, dice el principe de Wied, son los enemigos mas crueles de las tortugas, pues diariamente encuentran varias, que acaban de salir del agua para depositar sus huevos, y las matan al momento, tanto mas facilmenic, cuanto que los pobres animales, pesridos y torpes, se mueven en ticra con tanta dificultad, como notable es su ligereza en el agua.

* Los indios matan las tortugas marinas para obtener el aceite que produce su carne por medio de la ebullicion, $y$ recogen en grandes cestos los muchos huevos nue encuen. tran en la arena, los cuales les sirven de alimento. Durante la estacion de la puesta se ven muyá menudo familias enteras de indios cargadas de este producto; mientras que otras construyen en la playa chozas de hojas de palmeras, donde viven varios dias, y aun semanas.

Así son perseguidos estos animales tan útiles en todos los lugares que eligen nara la incubacion, y as pesar de eso, la con siderable reproduccion del quelon verde compensaria las pérdidas causadas si los pescadores quisieran contentarse con las hembras mismas y no saqueasen los sitios de incubacion, robando miles y miles de huevos. Por esta inconsiderada sustraccion se expone al mayor peligro la existencia de la espe. cie; pero el rudo y egoista cazador de tortugas no piensa en eso. Cuando-se accrca el ticmpo de la puesta de estos anima. les reunese toda clase de mala gente para obtener un botin lo mas rico y pinguie posible.

Si son islas deshabitadas, se aproximan los cazadores a las playas cautelosamente en ligeros esquuifes; si en tierra firme, ocultanse en las inmediaciones y están al acecho sin mover. se, hasta que las tortugas se hallán á bastante distancia del agua. Si los cazadores se lanzan antes de tiempo, apresúranse las tortugas a volver al mar; y lo consiguen cuando la playa forma una pendiente algo rápida, pues bástales dar media vnelta y deslizarse para volver al agua. Cuando un cazador llega en momento oportuno, puede contar por seguro sa botin, pues lo único que tiene que hacer se reduce á volver las tortugas boca arriba, en cuya situacion ninguna puede mo. verse, aunque haga los mayores esfuerzos. Algunas lu. chan en rano para recobrar el equilibrio, hasta que sus ojos se injectan de sangre saliéndose de las brbitas Sucede con frecuencia que los hombres vuelcan mas tortugas de las que necesitan, ya sea por ligereza $\delta$ por instinto de crucldad, $y$ abandonan las sobrantes, que sufren luego una muerte lenia y atroz. 
Cuando los animales son de grandes dimensiones empléan. se palancas para volcarlos; muchos se cogen con redes y otros con la lanza arrojadiza. Audubon conoció un cazador de tortugas que en un año habia cogido nada menos que ocho. cientos individuos, número que pone en peligro la existencia de la especie porque se trata casi exclusiramente de hembras adultas. Se caza siempre de noche y al dia siguiente comien. za el trabajo de recoger los cautivos; unas veces los echan en criaderos construidos al efecto ó bien los embarcan. En los criaderos, que como fácimente se comprende estín llenos de agua de mar, se las ve nadar lentamente $y$ a veces colocarse tres ó cuatro unas sobre otras; pero como rara vez prue. ban el alimento, debilitanse y enfaguecen muy pronto. Las tortugas que se venden en los mercadós de Europa proceden las mas de las Indias occidentales, y principaimente de la Jamaica. Durante la travesia las colocan en un sitio conveniente de la cubierta, atadas con cuerdas y tapadas con un paño que se moja de vez en cuando con agua de mar, á fin de te nerle siempre, si no mojado, húmedo al menos; en la boca les introducen un pedazo de pan mojzdo en dicha agua, y lo demás se confia á su gran resistencia vital. Fn las ciudades maritimas de Europa las conservan en grandes cubas llenas de agua del mar que se renueva cada dos ó tres dias. Para matarlas les cortan la cabeza y las cuelgan por espacio de beinticuatro a cunrenta yocho horas, a tin de que escurra toda la sangre; solo entonces se puede reconocer si la carne es propia para obtener aquella sopa que tiene tanta fama.

Merios consideraciones se tienen en la India y particular. mente en la isla de Ceilan, con las tortugas destinadas al consumo: Tennent dice que el aspecto que ofrece su venta al por menor es lo mas repugnante que pueda imaginarse. Alli atormentan 1 las tortugas de una manera increible. Parece que los compradores desean obtener la carne tan fresca como sea pusible, ó tal vez los vendedores son demasiado perezosos para despedazar al animal de una vez; el hecho es que se conientan con separar el peto, y despues van cortando de la iortuga viva los trozos de carne que piden los comprado. res. Como estos reptiles tienen tanta resistencia, Jos órganos tan independientes unos de otros, el europeo ve con horror cómo los pohres animales desolindos inueven los ojos, abren y cierran alternativamente la boca; mientras que el corazon, que suele ser lo último que se pide, sigue latiendo; en una palabra, cómo se conserva la vida en todas las partes que aun no se han vendido.

UTILIDADES $X$ PERJUICIOS.-Segun la estacion del año, se come ó no la carne de la tortuga verde, porque puede llegar á Ser nociva. En el año I $S_{40}$, de 28 personas que habian comido carne de tortuga en el mes de octubre dicz y ocho murieron 1. Jas pocas horas y las otras diez caye. ron gravemente enfermas. Esto sucedio en Pantura, al sur de Culombo: las que se salvaron aseguraron que en apariencia la carne no se diferenciaba- de la usual sino por su mayor cantidad de grasa; pero aun no se sabe á punto fijo porqué puede ser nociva.

\section{EL QUELON CAREY-CHELONE IMBRICATA}

CARACTERES.-El quelon carey, segunda especie del género, es mucho mas pequeño que el quelon verde, pero se le parece mucho par su forma y estructura; distinguiéndose de su congénere, sin embargo, en todas las edades, por tener la mandibula superior mas 6 menos ganchuda, por la cubierta de la cabeza, que entre las fosas nasales y la placa frontal presenta dus pares de escudos colocados uno despues de otro, y en fin, por las placas del espaldar sobrepuestas en parte á manera de tejadillo, $y$ en cuya serie media 6 verte. bral se ve tambien de ordinario una quilla longitudinal. Todas las placas del espaldar son de un color pardo verdoso 6 negruzco oscuro, con dibujos que figuran llamas, pues de una parte, por lo regular desde el ángulo posterior de cada una de las placas, arrancan unas fajas mas claras, trasparentes, de color sonrosado rojizo, rojo pardo, amarillo de cuero ú otro semejante, fajas que á veces pueden ensancharse de tal modo que el color oscuro primitivo de los escudos simila un dibujo; las placas del peto son de un blanco amarillento $y$ tienen algunas manchas 6 dibujos negros; la cabeza, el cue. 110 y las extremidades, por encima ó por debajo de la base del espaldar y del peto, son de igual color, mas oscuro hácia el borde ó la extremidad de las aletas, pero carecen de manchas: Dumeril y Bibron dan para la longitud total del carey I ,90, correspondiendo a la coraza $I^{n}, 45$; Guenter, en cam. bio, dice que en el Océano Índico, por lo menos, nunca al. canza mayores dimensiones que las de otras tortugas y que una coraza de $0^{\circ}, 60$ de longitud se considera extraordinariamente grande (fig. I5).

DIsTRIBUCION GEOGRÁFICA. - Segun parece, el área de dispersion del carey es poco mas ó menos la misma que la del quelon verde Tambien habita los mares de ambos hemisferios situados entre los trópicos, y abunda sobre todo en el mar de los Caribes y en el de Joló. Fuéccogido y observado en muchos puntos de las costas atlanticas de América, desde el sur de los Fstados Unidos hasta Santa Rosa; se halla igual. mente en el Cabo de Buena Esperanza, en el canal de Mo. zambique, en el mar Rojo, en muchos puntos de la costa de las. Indias orientales, de la Malasia, en el mar de la Sonda, en los de la China y del Japon, en el Austral y en las costas del Pacífico de $\Lambda$ mérica.

USOS, COSTUMBRES Y REGIMEN.-El género de vida del carey es el mismo que el del quelon verde, al menos por lo que hasta ahora sabemos; pero esta tortuga es un carnicero en toda la cxtension de la palabra; probable. mente desprecia del todo el alimento vegetal, nutriéndose solo de sustancias animales, pues segun dicen sabe cazar séres bastante grandes. Los pescadores americanos, segun $\mathrm{Ca}_{a}$. tesby, dicen que á menudo se encuentran grandes conchas medio cortadas por estos reptiles; Condreniere asegura que se atreve hasta con los crocodilos jórenes, mutilándolos á menudo; no necesito decir que no creo exacta csta tiltina noticia. Además de los moluscos, los peces constituyen pro. bablemente el alimento principal de este animal cuya habili. dad en nadar nos induce \& creer que tambien puede apode. rarse de especies agiles.

La reproduccion es sin duda análoga por todos conceptos á la de todos los quelónidos. Deposita sus huevos tambien en la arena de la costa y en los mismos meses que el quelon verde; así como este kiltimo, vuelve tambien siempre á los mismos sitios en donde nació, En 1826 , segun Tennent, se halló cerca de Ahampangtotte un carey que en una de sus aletas llevaba un anillo puesto treinta años antes por un of. cial holandés, precisamente en el mismo sitio donde deposi. taba sus huevos.

La querencia, por no decir pertinacia de esos animales al lugar de su nacimiento tiene la deplorable consecuencia de que su numero disminuye de un modo visible, pues el hombre los persigue con ese afan desapiadado é inexorable tan propio de él. Cierto que la carne no la comen sino los indigenas de las costas que visita, pues á los europeos les produce cólicos 5 náuseas, y hasta tumores y úlceras. En oppinion de los indios y americanos es un paliativo contra ciertas enfermedades. Los careys no se cogen sin embargo ni por la carne ni por los huevos, insipidos segun Klunzinger, y nuy sabrosos segun otros autores, sino por la concha, que 
en un individuo adulto pesa de dos $\mathfrak{i}$ ocho kilógramos. Las crucldades que se practican para adquirir este precioso articulo de comercio no ceden en barbaric $a$ las que antes sufrian los quelones verdes.

Debe advertirse que la conclia no se separa del espaldar sino cuando se calienta mucho, $y$ en su consecuencia se cuelga el pobre animal al fuego, tostándole hasta que se logra el resultado apetecido. Despues de hacer sufrir s. la tortuga este tormento, la dejan libre, por si quiere y puede volver al mar; y proceden asi porque creen que la concha se reprodu. ce Los chinos llegaron á observar que esta podia echarse al perder por la aplicacion del calor seco, y por eso emplean ahora el agua hirviendo para obtener la separacion. No hay producto córneo conocido que iguale $\{$ la concha en hermosura ni en otras excelentes cualidades, y además tienc la ven. taja de soldarse. Para esto basta pasar por agua hirviendo las placas ú hojas obtenidas, que suelen ser quebradizas y de un espesor desigual; luego se oprimen entre dos tablas ó plan. chas de metal, y cmplcando una presion conveniente quedan unidas con tal fuerza, que ya es imposible distinguir las hojas sueltas. $\Lambda$ esto debemos añadir que conservan para siempre la forma de cualquier molde en que se las prense despues de reblandecidas. Por esta razon se utiliza tanto la concha para fabricar cajitas, estuches y otros objetos análogos. Hasta las raspaduras se aprovechan: sirven para corregir las desigual. dades que resulten en el espesor de las diferentes hojas, y formar despues por la aplicacion simultánea del calor $y$ de la presion una sola masa 6 placa, intimamente unida $y$ homo génea.

En algunas partes se emplea tambien el espaldar despues de haber extrajdo la concha; asi, por ejemplo, dice Klunzin ger, los pescadores árabes le usan para adornar sus barcas. El aceite obtenido de la grasa de estas tortugas se considcra por algunos europeos como un verdadero remedio milagroso.

CAUTIVIDAD. - Los carevs llegan vivos hasta nosotros con tanta frecuencia como los quelones verdes; se pueden adquirir por lo tanto sin grandes gastos, y conservarse facilmente en cautividad cuando se les cuida bien. Klunzin. ger me escribió que durante su estancia á orillas del mar Rojo tuvo varias veces careys pequeños en un pozo que recibia agua del mar y en el cual parecian alimentarse de conchas; observaba sin embargo que los animales siempre perecian cuando en la jrimavera comenzaba á calentarse el agua del citado pozn. Esta noticia es extraña, pues por otra parte se ha observado que tambien los quelónidos necesitan un agua tibia para mostrarse alegres $\delta$ prosperar; ni siquiera requieren en tal caso agua de mar. Fischer tuvo quelónidos pequeños que se conservaban muy bien hasta en agua dulce, alinentándoles siempre sin dificultad con insectos acuáticos.

Yo cuidé varios individuos y les tomé mucho carinio, aunque al principio me parecian fastidiosos; faltos Iargo tiempo del agua, costóles mucho trabajo bajar á la profundidad del estanque que tenian, y cuando por fin se acostum braron a su alimento permanecian dias enteros en el mismo sitio, hasta que hubieron recobrado sus fuerzas. No he ob. servado que fueran mordedores, como se ha dicho al hablar dè los individuos cautivos de su especie, $y$ eso que gracias á un alimento abundante se habian hecho muy fuertes. Cuando no se les pone en agua demasiado fria, es decir de menos de diez grados $K$. causan poca molestia, aceptan pronto el alimento hasta de la mano de su guardian, y á pesar de que comen pescado con mas voracidad que cualquier otro ali. mento, no atacan á los peces que tienen en el mismo es. tanque; en fin, cautivan á todo observador por sus graciosos movimientos. La comparacion empleada mas arriba por mi con aves de rapiha volando ocurrirá á cualquiera que los vea nadar. Las aletas se inueven con lentitud pero ce continuo, y el cuerpo se desliza tranquila y acompasadamente en todas direcciones por las capas de agua. Ninguna de las especies que yo conozco de otras familias nada como los quelónidos en general: numca se observan movimientos apresurados; surcan el flúido como jugando y á pesar de ello franquean en el mismo tiempo igual distancia que una pequeña tortuga acuática con sus bruscos movimientos: su modo de nadar puede llamarse un vuelo sostenido en el agua.

\section{LOS ESFARGIDINOS-SPHARGIDINA}

La sub-familia de los esfargidinos ó tortugas coriáccas se compone de una sola especie, el laud.

\section{EL LAUD Ó TORTUGA CORIÁCEA- DERMATOCHELYS CORIACEA}

CARACTERES.-El laud es un animal gigantesco, de una longitud de $2^{\prime \prime}, 30$ y de un peso de 500 á 600 kilógramos. La cubierta córnea de la mandíbula superior presenta tres profundas escotaduras triangulares; las extremidades an. teriores son doble mas claras que las posteriores; el espaldar, el peto y los piés se hallan revestidos de una piel coriácea; las placas óseas formadas por el ensanchamiento de las cos. tillas y el esternon existen, pero los escudos faltan. El espaldar, ligeramente abovedado, se redondea bastante en su parte anterior; es puntiagudo en forma de cola en su parte posterior, y esta dividido en placas por siete costillas longi. tudinales salientes que en los individuos adultos son continuas y un poco denticuladas; en los pequeños se componen de jorobas redondeadas. En la parte inferior se distingue un escudo del vientre bicn marcado; esta parte, blanda y elástica, presenta igualmente en los individuos jóvenes cinco fajas longitudinales cartilaginosas, debajo de las cuales se ven vestigios del escudo longitudinal bseo; en los adultos no se observa ningun restigio de tales quillas; la cabeza, el cuello y los piés de los hijuelos cstán cubiertos de escudos que desaparecen poco á poco; de modo que la piel de los adultos queda lisa, 6 cuando mas tiene algunas prominencias bastante planas en la nuca. El color es un pardo oscuro con manchas mas claras amarillas (fig. 16).

DISTRIBUCION GEOGRAFrCA. - Aunque el laud se ha observado tambien en varios puntos del Océano Indico, incluso el iaar Rojo, es sin embargo propio del Atlántico. Aqqui se le ha cogido con mas frecuencia, pero probablemente emprende expediciones que le conducen al Mediter. xáneo. Desviado por las tempestades, $\sigma$ quizás tambien por su inclinacion a viajar, llega algunas veces a las costas atlán. ticas de Europa y del norte de los Estados-Unidos; y tanto aqui como alli se le ha cogido repetidas veces.

USOS, COSTUMBRES Y REGIMEN. - Sabemos mUy poco sobre el género de vida de la tortuga coriácea. Su alj. mento principal, si no exclusivo, consiste en diversos anima. les, sobre todo peces, crustáceos y moluscos. Despues del apareamicnto llegan á menudo ó la isla de la 'lortuga, cerca de la Tlorida, numerosos individuos; $y$ en las costas arenosas del Brasil, segun ha observado el principe de Wied, se ven grupos mas 6 menos considerables, depositando sus hue. vos del mismo modo que los otros congéneres de su familia. El príncipe de llied dice que cada hembra se presenta cua. tro veces al año, con intervalos de unos quince dias, en lus sitios de la puesta, donde deposita cada vez de dicz y ocho á veinte docenas de huevos. Dieckell confirmá, por lo menos en parte, este informe. A primeros de febrero de 1862 
unos pescadores vieron un laud en la costa de Tenasserin, cerca de la desembocadura del rio In, y despues que hubo puesto unos cien huevos, apoderáronse de él, no sin sostener una lucha desesperada. Al abrir el cuerpo del gigantesco animal halláronse en sus ovarios aun mas de mil huevos en todos los estados de desarrollo. No cabe duda, por lo tanto, que la reproduccion de la tortuga coriácea es muy considerable, y debe admirarnos de consiguiente que solo se la vea raras veces. Es posible que la mayor parte pierdan la vida en su primera juventud. Los hijuelos se dirigen al mar tan

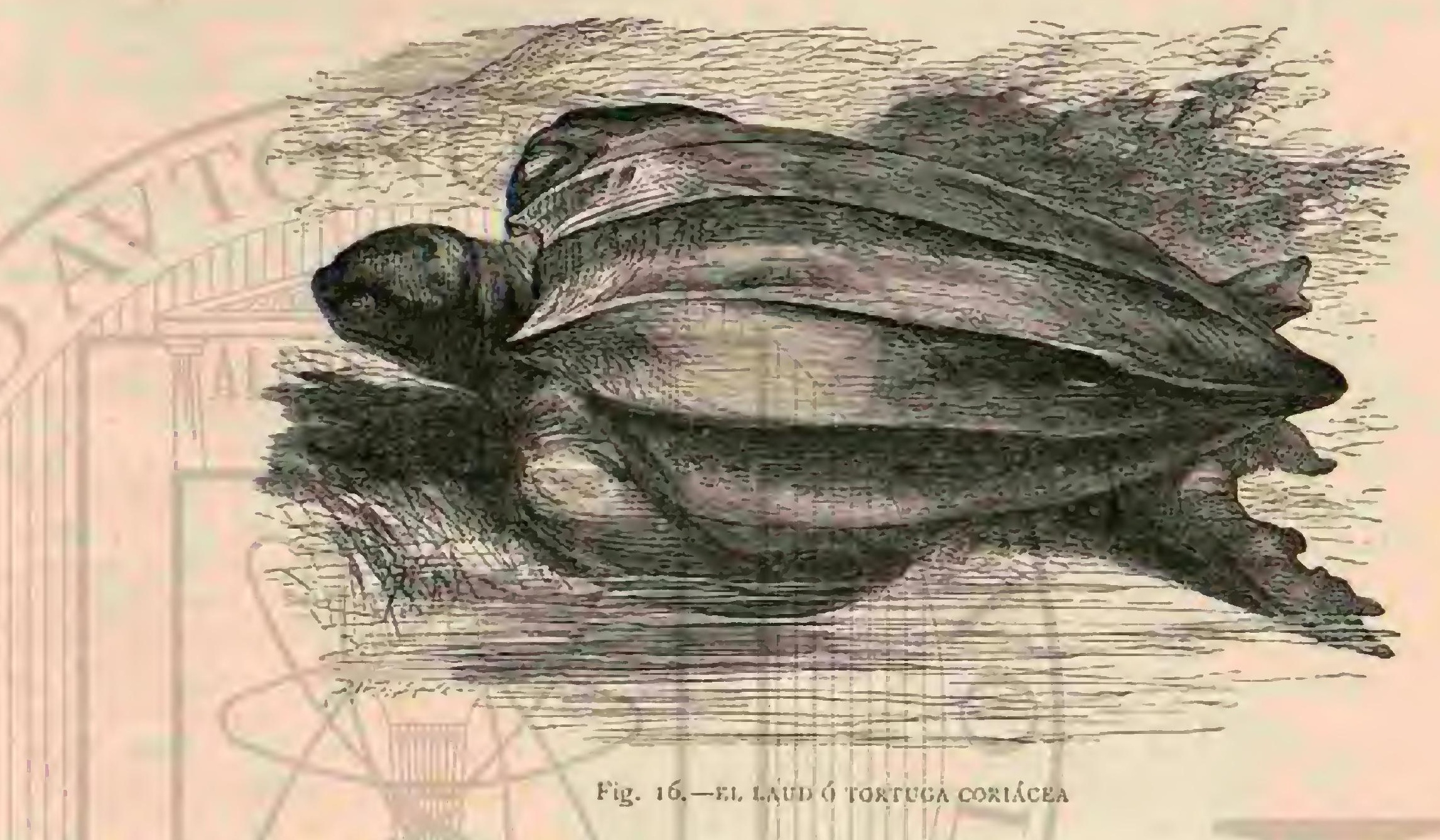

pronto como han salido del cascaron, pero aqui les amenazan, segun parece, mas enemigos que en tierra firme. Varios peces roraces se comen gran parte de la cria; de modo que Ih gran reproduccion de esas tortugas es evidentemente necesaria para conservar la especic.

Del citado informe de Dieckell resulta que no son exage. radas las descripciones de los autores antiguos sobre la fuerza y el valor del laud. En el citado caso se trabó una desespe. rada lucha, pues seis pescadores, al querer apoderarse del animal, fueron arrastrados por este en una pendiente de la orilla y precipitados casi al mar. Solo despues de haber

llegado otros pescadores en su auxilio se logró dominar al gigantesco animal y" atarle å gruesas estacas, necesitándose dicz ó doce hombres para llevar la pesada carga hasta la proxima aldea. De la Font dice que un laud que en 4 de fébrero de 1729 fué cogido cerca de Nantes lanzó unos gri. tos tan horrorosos que se oyeron à un cuarto de legua de distancia, pues le habian clavado un gancho de hierro que le destrozó la cabeza. No se sabe mas sobre el gennero de vida de este animal, tan raro aun en todas las colecciones. La carne no se come porque produce tambien, segun se dice, malas consecuencias.

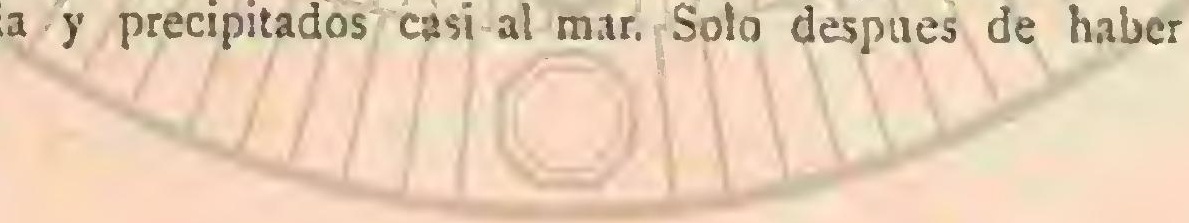

\section{SEGUNNDA SUB-CLASE-HIDROSAURIOS}
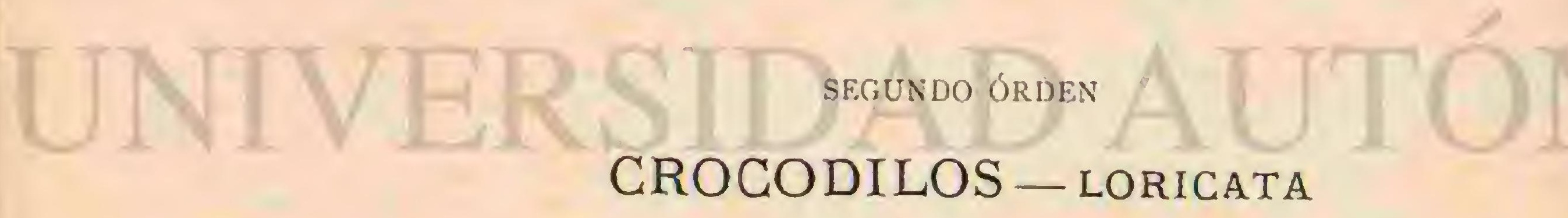

LORICATA

CONSIDERACIONES GENERALES. - En ciertos periodos de la historia terrestre los reptiles ocupaban el primer rango en todo el reino animál: verdaderos monstruos, poblaron primero los mares, y despues los pantanos y rios, pero ya desaparecieron; y excepto unos pocos, cuyos huesos petrificados extraemos de las profundidades de la tierra, todos se han extinguido. Las formas mas singulares observabanse reunidas en estos monstruos; algunos tenian \& la vez algo de la ballena y del ave; otros del crocodilo y de la serpiente; y por eso continúan siendo para la ciencia cnigmáti- cos, á despecho de las inducciones mas ingeniosas. Un lagarto con forma de ballena recibió el nombre de ictiosau. ro; atro que tenia aletas y cuello de scrpiente se le llamó plesiosauro; y por último, sun tercero provisto de membranas interdigitales, como destinadas para el vuelo, se le designó con el calíficativo de pterodáctilo. De alguno de estos animales se han conservado hasta nuestra época esq̨ueletos tan enteros, que podemos reconocer su afinidad con los animales análogos de hoy dia; de otros poseemos tan solo restos insuficientes, por los cuales no podemos inferir sino 
que deben haber sido reptiles pertenecientes al brden que ahora vamos á estudiar.

CARACTERES. - Se han conservado hasta nosotros algunos animales atines á los gigantes de otros tiempos de que antes se hiro mérito. Semejantes á los lagattos en cuanto a su forma general, difieren no obstante de ellos por varios caraciéres importantes; y aventajan en tamaño, ya que no en peso, ¿t todas las demás especies de la clase. Distinguense adeniás por la disposicion de sus dieites, por su coraza formada de escudetes óseos, por la membrana de la caja del timpano oculta debajo de una especie de opérculo á manera de pabellon de oreja, por su lengua corta, soldada á la boca, y por otras particularidades. El tronco es prolongado, mucho mas alto que ancho; la cabeza baja y plana; el hocico muy largo; el cuello cortisimo; la cola mas larga que la cabeza y aplanada lateralmente, formando un poderoso remo: las extremidades son cortas, con piés muy desarrollados; las anteriores tienen cinco dedosy las posteriores cuatro, unidos por membranas interdigitales completas ó incompletas y con unas corvas. Los ojos, pequeños y provistos de tres párpados, están hundidos en el fondo de las órbitas; dirigense un poco hacia arriba y presentan una pupila longitudinal. Los conductos auditivos se hallan cubiertos por un plicgue de la piel â manera de válvula; las fosas nasa!es se hallan situadas una al lado de la otra en el extremo de la mancibula superior; son de forma semicircular y pueden cerrarse. I a parte superior é inferior del cuerpo, y la cola, estín cubier. tas de escamas y placas cundradas, gruesas y duras, con la particularidad de que las del dorso se distinguen por llevar una cresta ó elevacion longitudinal, miemtras que las de la cola forman dos hileras dentadas á inanera de sierra, que se unen hácia cl cxtremo en una sola. los escudetes ó escamas laterales son mas ó menos redondeadas.

En el lomo $y$ hasta en el vientre se osifican aigunos de es. tos escudos, comunicando á la piel el aspecto de coraza. Las placas óseas, cuyo número y disposicion es asaz constante en las especies, tienen gran imporancia para la clasificacion de las mismas, y se distinguen segun su posicion en la picl blan- da; detrás de la cabeza están las pequeñas placas cervicales separadas y dispuestas en una ó dos series; la parte superior del cucilo está cubierta igualmente de escudos.

Varios naturalistas de nota han hecho un cstudio completo de la estructura interna del crocodilo (fig. 17).

In cabeza de este animal, sumamente aplanada, larga y ancha en su parte posterior, va estrechándose hảcia la anterior, que se prolonga hasta el punto de que el críneo propiamente dicho no forma sino la quinta parte de la longitud total de la cabeza. El occipital se compone de cuatro huesos; el esfenoides de siete; cada uno de los temporales de tres; los parietales de uno y el frontal de tres; existe un pequeño et. móides; los palatinos son granđes y prolongados; los hucsos maxilares superiores, q̨ue abrazan el maxilar medio, están muy desarrollados y forman la superficie ancha y plana del paladar. Hácia atrís se unen por medio de una prolongacion con el vómer $\mathrm{y}$ las grandes alas del esfenóides. Las fosas nasales, que se hallan formadas en parte por los mismos hucsos, se ciersan por dos conchas inferiores muy largas. La mandibula inferior, grande y robusta, consta en la parte anterior de dos ramas, unidns por una membrana, y cada una de ellas se compone de seis piezas unidas por suturas. Los dientes están fijos en alvéolos ó cavidades; son cónicos, de acerada punta y encorvados ligeramente hácia atrís; aunque semejantes entre.sí, difieren por su longitud; su corona tiene, asi en la parte anterior como en la posterior, el borde afilado; la raiz es siempre sencilla y hueca, casi-hasta la corona. Los dientes de la mandibula inferior encajan en los huecos que dejan entre si los de la superior. Suelen ser los mas afilados $y$ largos el primero y el cuarto de la mandibula inferior $\mathrm{y}$ el tercero de la superior. Su número varia, segun la especie, de treinta y ocho á sesenta en la segunda, y de treinta á cincuenta y ocho en la primera, siquiera no sea cosà bien averiguada que su número haya de ser siempre igual en ia misma especie. La columna vertebral cuenta siete vértebras cervicales, doce ó trece dorsales, cinco lumbares, dos sacras y de treinta y cuatro a cuarenta $y$ dos caudales. No todas estas vértebras están soldadas en una pieza única, sino que se componen de varias unidas por suturas y masas cartilaginosas; su lado posterior es esférico, el anterior cóncavo. Adénás de las doce 6 trece costillas existen todavia cartilagos especiales $y$ delgados que no llegan à unirse á la columna vertebral, pero quue se en. cuentran entre las diferentes capas de los músculos abdoninales y se enlazan por delante con el cartílago de las últimas costillas y del esternon, y por detrás con el púbis. El esternon se compone de una piezá ósea, larga y estrecha, y de una prolongacion larga iambien, cartilaginosa y en forma de es. pada. Fl esqueleto de las extremidades anteriores consiste en los huesos ciel hombro, el húmero, el antebrazo y el metacarpo formado de cinco huesos; el decio primero tiene dos fa. langes, tres el segundo y quinto, y cinco el del medio y cl cuarto. La porcion basilar consta de lleon, púbis é isquion; viene despues el fémur, la tibia y el peroné; el tarso tiene cinco huesos. Pocos núsculos, pero muy robustos y de calor blanquizco, se insertan en los huesos. En ambos lados de la columna vertebral, y siguiendo las apófísis espinosas. se en. cuentra un músculo largo y robusto, destinado á sostener el ráquis, auxiliado de varios otros músculos, dificiles de separar de él. Los de la cola son numerosos y de una fuerza extraordinaria; los del abdómen, cmpero, son delgados y membranosos, y fuertes y roluminosos los que mueven los miembros. Entre el pulmon y el higado existe un músculo con membrana resistente á mancra de tendon, adherido śla superficie interna del esternon, que recuerda el diafragma de los aninales superiores, el cual debe tener seguramente mu. cha importancia para la respiracion. La cavidad del cráneo, que forma solo la dozava parte de la cabeza, esti ocupada toda por el ccrebro, que presenta, mirado por encima, cinco secciones, dos mayores anteriores, dos menores en el centro, y una posterior pequeĩa, de forma triangular. 
Las semi-esferas que con una delgada capa se abovedan sobre las protuberancias longitudinales no cubren, segun Carus, las cuatro prominencias de la parte posterior $y$ se continuan por delante en las fosas nasales, que son huecas. Ia médula espinal $y$ los nervios en general tienen proporcio. nalmente un gran desarrollo. Ia lengua, corta y plana, está fija en toda su extension en el fondo de la cavidad bucal, distinguiéndose por lo tanto en todo de la de los lagartos.

$\mathrm{El}$ ancho esóngo se va dilatando hasta constituir el estó. mago, dividido en dos partes y situado en el lado izquierdo de la cavidad abdominal: estas dos divisiones no son iguales; la mayor forma una bolsa redondeada, y la menor, que solo comunica con la otra por un agujero redondo, no es mas que un apéndice de este. Fl tuvo intestinal es corto, el recto ancho; la glándula salival grande, y el hígado nucho mas; la rejiga de la hiel es periforme y el bazo reducido. Los rinones, lobulados y de un color rojo oscuro, están junto á las rérte. bras lumbares; los vasos urinarios forman ramificaciones, que se juntan en el uréter, que desemboca en la çioaca, muy cerca de los testiculos, colocados en la cavidad abdominal junto á los riñones. El pene, situado en la parte posterior de la cloa. ca, es cúnico, con un surco profundo, que forma espiral desde la base hista la punta. La faringe termina en una abertura que existe detrás de la raiz de la lengua, la cual se va ensanchando hasta formar la traquearteria, que baja por el cuello 5 penetra en la cavidad del pecho, donde se divide en dos tubos largos y encorvados. Estos desembocan is su vez en grandes depósitos de aire, situados en el centro de ambos pulmones, desde los cuales pasa á numerosas células cl aire aspirado.

El corazon, relativamente pequeño, está encerrado en una fuerte bolsn y dividido del todo en un ventriculo izquierdo y otro derecho; del primero parte la arteria derecha, y del segundo la izquierda del corazon, con el tronco de las arterias del pulmon; ambas se comunican sobré su nacimiento por medio de aberturas que sin embargo solo están libres cuando las válvulas de los ventriculos que afectan la forma de media luna se llenan de sangre venosa.

Conúcense ahora veintiuna especies bien determinadas de crocodilos, que se dividen en tres gtupos, fundados en la estructura de sus dientes. Strauch, de cuya opinion participo, los reune todos en una sola familia, pero otros naturalistas, sobre todo Gray y Huxley, han querido elevar al rango de familias independientes los varios grupos considerados por Straucl como géneros y caracterizados de una manera tan breve como exacta, agregando â cada una de cllas un nú. mero mas ó menos considerable de géneros. Ios caractérés de estos últimos son sin embargo de tan poca importancia y tan inciertos, que esa division mas bien sirve pata cmbrollar que para aclarar nuestra ciencia. Mucho mas difieren aun las opiniones de los naturalistas respecto sa la clasificacion de las especies. Todos los crocodilos varían segun la edad, y en. parte tambien segun su residencia, esto de un modo tan no. table, que fácilmente se explica el hecho de crearse tantas especies nuevas porque segun la opinion de los autores no habian sido descritas aun. Falta mucho todavia para terminar las averiguaciones, no solo sobre estos, sino en general sobre todos los animales; pero el numero de especies, ya citado no aumentará considerablemente.

DISTRIBUCION GEOGRAFICA. - LOS crocodilos cstán diseminados por todos los continentes, excepto Eu. ropa, pues su área de dispersion se limita á la zona cálida y sus partes limitrofes de nuestro globo. En Asia y América es donde mas se extienden húcia el norte; en América y Africa llegan cuando mas hasta el sur: en el hemisferio oriental del norte, el $34^{\circ}$ de latitud, $y$ en el occidental el $35^{\circ}$ representan los limites de su área de dispersion. Fxcepto Australia y algunas islas oceánicas donde solo se encuentran crocodilos pertenecientes al territorio asiático, cada continente alberga especies aisladas; Asia y América poseen tambien cada una su género especial, pues solo los crocodilos propiamente dichos se extienden por todos los continentes.

USOS, COSTUMBRES Y REGIMEN,-Al hablar de las otras condiciones generales del género de vida de estos rệtiles me bastarín pocas palabras, prorque describiré minuciosamente los usos y costumbres de todas las especies mas conocidas é importantes, danco asi una idea casi com. pleta del modo de vivir de toda la familia. Me limito pues en este lugar á lo siguiente.

Todos los crocodilos habitan en el agua, con mas frecuencia los rios de corriente lenta, y casi en igual número los lagos interiores, tanto los de agua dulce como los salados; tambien se encuentran en charcos y pantanos donde el agua abunda y en ciertos casos hasta en la costa del mar. Solo salen á ticrra firme para disfrutar con toda comodidad de los rayos del sol y dormir, 6 para depositar sus huevos, 6 ya en fin para dirigirse a otro rio $\delta$ lago cuando falta el agua en el que ocupan. Si el camino es demasiado largo ó incó. modo, ocúltanse sencillamente en el cieno, permaneciendo en él aletargados hasta que abunda de nuevo ol agua y se despiertan. Lo mismo sucede, segun Catesby, en el norte de América, sobre todo en las Carolinas.

Alli donde hay crocodilos se encuentran por to regular muy susncrosos, pues los adultos y jórenes viren juntos, en bastante buena inteligencia, aunque los hijuelos no están libres de ser victimas de la voracidad de los grandes de su propia especie. Los vertebrados de toda clase, desde el hom. bre hasta los peces, y lo mismo varios invertebrados, sobre todo crustáceos, moluscos é insectos, constituyen el alimento de estos reptiles carniceros; solamente los animales cuyo ta. maño ó fuerza son muy superiores a los de cstos saurios, tan peligrosos como cobardes, no deben temer nada de ellos. Necesitan mucho alimento $y$ devoran considerables cantidades del mismo $x$ la vez; á fin de ayudar la digestion ó acaso tambien para que les sirva de lastre, tragan hasta piedras de mucho peso; pero pueden ayunar meses enteros, pareciendo por lo tanto mas voraces de lo que son en efecto.

Todos los crocodilos se propagan como las tortugas; sus huevos tienen poco mas ó menos el mismo tamaño y forma que los de la oca y están cubiertos de una cáscara caliza, pero flexible. Ia hembra deposita de veinte a ciento en un sencillo hoyo abierto en la arena, $\delta$ en un nido formado con hojarasca. Dícese que algunas veces, pero no siempre, vigila el tesoro confiado á la tierra.

Al cabo de mucho tiempo salen los hijuelos de la cáscara madurada por el sol ó por el calor de sustancias vegetales en fermentacion, y se dirigen en seguida al agua. Al principio de su vida crecen rópidamente, y si tienen alimento abundan. te, aunque estén cautivos, su longitud aumenta todos los años al menos en $0^{\circ}, 30$, pudiendo propagarse ya $\mathbf{a}$ la edad de seis á ocho años. Desde esta edad su crecimiento se efec. tua con mas lentitud; pero en cambio no cesa sin duda hasta ia muerte. No se sabe á qué codad llegan, pero es indudable que viven varias generacioncs humanas.

Fl aspecto amenazador de los crocodilos, que siempre inquieta al hombre, su voracidad y el sensible daño que ocasionan obligan al señor de la tierra á perseguirle en todas partes donde una ciega fe no les hace sagrados, y donde se justifica su exterminio. Cuando se les cuida bien desde la juventud se domestican tambien hasta cierto punto; acostúmbranse al hombre que les da su alimento, conocen su 
voz ó una señal, abren la boca para recibir su pitanza $\delta$ la toman de manos del guardian, y demuestran por lo general inas inteligencia que cualquiera otra especie de su clase.

\section{LOS GAVIALES-GaviaLiS}

CARACTÉRES. - Gaviales ó crocodilos de trompa se llaman las especies cuyo intermaxilar tiene en su parte an. terior dos escotaduras para encajar los dos dientes primeros, y cuşa mandíbula superior presenta en cada lado otra en el cuarto diente. El número de dientes varia, segun las espe. cies, de veinte á veintiocho ó veintinueve en cada maxilar superior, y de diez y nueve á veinticinco ó veintiseis en cada uno de los inferiores. Cada una de las especies mas conocidas se ha elevado por este carácter al rango de género.

\section{EL GAVIAL DEL GANGES-GAVIALIS GRNGETICUS}

CARACTERES. - La especie mas conocida del género es el gavial del Ganges 6 el maldela de los indios; a los ojos de los habitantes de Malabar es un animal santo, consagrado á Wischnu, creador y soberano del agua. Este reptil se encuentra en el Ganges, en el Brahmaputra y otros afluentes del rio santo, $y$ segun Dap, iambien habita en el Indo $y$ en el Djunma La cabeza estrechada junto $\{$ los ojos, el ho. cico largo, angosto, aplanado y muy ancho en la punta, el esfenóides, relativamente corto, pues no liega ni con mucho al hueso intermaxilar, el gran número de dientes en cada uno de ambos maxilares, los escudos cervicales, las órbitas proporcionalmente pequeñas, $y$ por último las piernas poco desarrolladas, son, segun Strauch, los carnctéres distintivos del gavial del Ganges, en toda edad, y de sus congéneres mas afines. Ia mandibula superior es tan extremadamente larga, que Edwards, el primero que describió este reptil, la compara con mucha razon con el pico de un mergo; en cada lađo tiene de veintisiete á veintinueve dientes, y en la inferior se cuentan de veinticinco á veintiscis, delgados y ligeramente corvos; de modo que la dentadura se compone del considerable número de ciento cuatro á ciento diez dientes bastante iguales $y$ bien desarrollados; los mas fuertes son los dos primeros laterales de la mandibula superior, y el pri. mero, segundo s cuarto de la mandibula inferior. Inmedia. tamente detrás de la cabeza y del hueso occipital hay cuatro pequeños escudos 6 cuando mas seis en una serie trastersal; otro par ocupa el cspacio entre ellos y las primeras placas del lomo, que comicnzan en la mitad de la longitud del cuello, formando hasta la base de la cola veintidos serics trasversales; la primera de estas se compone de dos escudos, las dos siguientes de otros tantos mas pequenios laterales, el resto de cuatro centrales y dos pequeños á los lados Fn la cola se cuentan diez, y nueve pares de escamas aquilladas y el mismo número sencillas, que se elevan en forma de crcsta. En los machos adultos, la prominencia anterior del hocico, mas alta que en las hembras, tiene un espacio hueco para la recepcion del aire: de modo que los primeros pueden resistir mas tiempo debajo del agua que las segundas. FI color de la parte superior es un verde pardusco sucio, con numerosas manchas pequeinas y oscuras; el de la inferior puede ser verde amarillo 6 blanco. La longitud de los indi. viduos adultos es, segun dicen, de seis metros $\delta$ mas.

USOS, COSTUMBRES Y REGIMEN.-Eliano conocia ya dos especies de crocodilos del Ganges, que se distinguen en que la una es poco dinnina, mientras que la otra caza hombres y animales con la mayor roracidad. «Estos, dice el naturalista griego, tienen en su hocico una prominencia como un cuerno, y los indigenas se sirven de ellos para ejecutar á los criminales que les entregan.

Yo no aseguraré que esta diferencia se funde en hechos reales y positivos, porque los datos modernos son castialmente muy escasos é insuficientes. Es probable que los viajeros confundan la mudela con el crocodilo listado, y atribuyan al uno lo que observan en el otro; por lo demás, la forma del hocico no justifica en manera alguna las cualidades de manso y domesticable que se han supuesto en el crocodilo del Gan. ges. Sobre este punto tenemos tambien la descripcion que hace Paolino, en la cual asegura que en la antigüedadse sentenciaba á las personas acusadas de algun crimen, af va. dear el rio en presencia de los brahmanes, y se absolvia álas que escapaban ilesas de las mudelas. No cabe duda que aun hoy se consideran estos animales como sagmdos, porque dificilmente habrá viajero que no hable de ellos, ni haga men. cion tambien de esta creencia de los babitantes de aquellos paises. Ortich visitó en el año $\delta_{4} 2$ la laguna søgrada, ccrca de la ciudad de Kurachi, lugar célebre á donde van en pere. grinacion los indigenas. Alli habitan como unos cincuenta crocodilos, y entre ellos algunos de 15 piés de largo. Iil sa. cerdote encargado de cuidar de estos representantes de 1 ij ch. nou, les llamó en presencia del viajcro, para darles de coner, y con gran asombro, vió Orlich que los crocodilos, obedientes á su adomdor, salieron del agua y se colocaronal rededor de ¿́l, formando un semicírculo, con el hocico abierto y dejándose gobernar sin resistencia con una simple caña. Para darles de comer se mató un macho cabrio, $y$ despues de cortarle en pedazos arrojaron á cada reptii su parte. Terminada la comida, el guardian los condujo a su laguna golpeándolos con la caña. "Trump dice ņue por lo menos hay doce fakires destinados al servicio y culto de aquellos crocodilos, cura manutencion, como es justo, corre á cargo del jucblo cre. yente que alli vive.

Schlagintweit habla tambien de crocodilos domesticados y bien cuidados, pero los Ilana aligatores y no los describe mas minuciosamente, siendo por lo tanto imposible detcr. minar la especie. «De la circunstancia, dice, de que los musulmanes han pintado al b́leo algunos grandes dibujos y sen. rencias religiosas en las cabezas de los aligatores del estanque de Nagar, podemos inferir qué mansos deben ser estos rep. tiles. Fs un espectículo admirable verse rodcado por todas partes de aligatores; pero precisamente por su movedad y rareza no causan sa nadic el sentimicnto de temor tan natu. ral en tales circunstancias

Dicen que el dios crococilo causa los mayores destrozos entre los peces con su terrible dentadura, y quue acecha asimismo, como los demás crocodilos, i los animales mayores que se acercan al rio para apagar su sed.

Los autores que yo conozco nada dicen sobre la exactitud de csta noticia: Cicrto que la estructura del hocico del gavial indica que se alimenta con preferencia, si no cxclusivamente, de peces; Day le califica terminantemente de everdadero cro. codilo piscivoro, que coge su presa nadando. 2 No seria, sin cmbargo, crocodilo si despreciase otros buenos bocados di. ferentes. Tal vez. consista su alimento sobre todo en los cadáveres que son arrojados al rio; y quién sabe si na se aprodera de rez en cuando de aigun indio devoto, de aquellos que se hacen trasportar, cuando sienten su in próximo, á las orillas del Ganges para morir á la vista del rio sagrado.

Sobre la reproduccion del gavial nos habla últimamenic Anderson, quien obtuvo, no dice dónde, huevos de este cro. codilo entersados en la arema, de los cuales salieron varios hijuelos con su ayuda, que pudo tener algun tiempo en cautividad. Los huevos, cuyo número era de cuarenta, estaban dispuestos en dos capas de veinte, separadas por la arena $\dot{z}^{2}$ 
la distancia de unos $0^{\circ}, 70$, lo que indica que quizás se pusieron en diferentes dias. Los pequeños, unos séres graciosísimos, tenian al nacer una longitud de $0^{\circ},{ }_{4} 0^{\circ}$, correspondien. do $U^{m}, 04$ al hocico y $\|^{\prime \prime}, 22$ á la cola; su color era un gris pardusco, con cinco fajas trasversales irregulares entre los piés anteriores y los posteriores y nucve en la cola. Inmediatamente despues de nacer se escaparon con una rapidez sorprendente; uno de ellos, al que Anderson ayudó á salir del cascaron, repartió furiosos mordiscos, alcanzando el dedo del viajero antes que el animalito hubiese acabado de salir del cascaron.

En las colecciones curopeas el gavial es mas raro que nin. gun otro crocodilo; nunca le he visto vivo en nuestro continente.

\section{LOS CROCODILOS PROPIAMEN- TE DICHOS-CROCODILUS}

CARACTERES.-Como crocodilos, en el sentido mas estricto de la palabra, designamos todas las éspecies en que el intermaxilar tiene en su parte anterior dos profundos ho. yos para encajar los dos dientes primeros, y cada maxilar superior una escotadura para el cuarto diente de la mandibula inferior. El número de los dientes desiguales varia de diez y ochó á diez y nueve en cada maxilar superior, siendo de quince en cada inferior, de modo que forman un total de sesenta y seis á sesenta y ocho.

\section{EL CROCODILO ACORAZADO-GROCODILUS} CATAFRACTUS

CARACTERES. - Comenzaremos con esta especic la descripcion de los crocodilos que daremos á conocer, pues por la estructura de su delgado hocico nos parece en cierto modo el tránsito enire los gaviales y crocodilos, ó por lo menos es la especie que mas se parece a los primeros. Caracterizase por tener el hocico muy estirado, estrecho y pun; tiagudo, abovedado en su parte superior y liso: la frente es cóncara; tiene muchas placas pequeñas en la nuca, dispuestas en dos ó ires series, y los escudos del cuello forman de tres a cinco trasversales; la viltima toca con lás seis series longi sudinales de la coraza del lon:o. La parte inferior del muslo presenta, como en otros muchos crocodilos, una cresta que remata en fuertes puntas. Is cabeza es de un color aceituna con manchas pardas; cl tronco y la cola de un pardo verdo. $5 \pi$, con grandes manchas trasversales negras; el vientre de un blanco amarillento, con manchas del mismo color, pero un poco mas pequeñas. El individuo adulto puede alcanzar, segun se dice, una longitud de oclıo metros; pero este dato, no obstante, será un poco exagerádo.

DISTRIBUCION GEOGRÁFICA.-Adanson lué el primer viajero que distinguió el crocodilo acorazado, observado-en el Senegal, del crocodilo del Nilo que se encuentra en este rio, habiéndole descrito, aunyue no con la suficiente minuciosidad. Desde entonces se le ha observado en las grandes corrientes de la costa occidental, desde el Senegal hasta el Gabon, sobre todo en el Gambia, en el Galbar, el Niger, el Binué y el Kamerun.

USOS, COSTUMBRES Y RLEGIMEN. - Adanson habla del género de vida del crocodilo que observó, pero lo hace de un modo tan indeterminado, que sus noticias podrian refcrirse lo mismo al crocodilo del Nilo que al acorazado. Savage dice lo siguiente sobre esta especie: EI nombre Cirsinh, aplicado por los negros al crocodilo acorazado, es el mismo que dan a los perros. Las costumbres de este reptil no se distinguen de las de atros crocodilos. Habita los pe. queños rios, y aguas estancadas re las regiones bajas, ali. mentándose de peces y reptiles acúticos. Elige temporal. mente para su resiciencia alguna cavidad en la orilla del rio, desde donde se precipita sobre su presa. La hembra deposita sus huevos en el suelo, cubriéndolos de hojas y oiras ma. terias ligeras, difiriendo por todos corceptos de los demás crocodilos y caimanes. Es timido y poco peligroso, gracias a lo cual los indigenas le cogen muy at menudo para comer su carne, que es su alimento favorito.

A estas noticias se reducia nuestro conocimiento sobre la vida de ese reptil; pero debo a Reichenow otro relato escrito para la EVida de los animales, el cual me permite completar las noticits anteriores. El crocodilo acorazado, me escri. be el citado viajero y naturalista, es muy comun en el Africa occidental, en la Guinea superior, y por lo menos mucho mas numeroso que su congénere de hocico obtuso (Crocodi. lus fromedulius.). Encontré aquella especie tanto en los lagos situados cerca de la costa, sobre todo en los vastos terrenos de las desemibocaduras de los grandes rios, como en el agua dulce de la parte superior de las corrientes. Fin el delta del rio Kanerun, en lós estrechos canales que cruzan el panta. noso terreno aluvial, pobiado de varios árboles, siempre vi á este crocodilo aislado, tomando el sol en un banco de arena desde el cual se precipitaba con gran rapidez al agua apenas oia el ruido de los remos de una lancha. En el afluente del Kamerun, en el Wuri, hállanse, por el contrario, en número verdaderamente asombroso. Muchas veces pude re. conocer que los crocodilos acorazados no atacan en el agua dulce, ó por lo lmenos raras veces, á un enemigo poderoso, cono por ejemplo al hombre ó a los grandes animales, pues tanto estos como aquel pueden oponerle resistencia. En una liguna cerca de Aura, en la costa de Oro, los negros irecuentaban un vado, y nunca oi hablar de una sola desgracia, aunque los crocodilos eran temporalmente muy numerosos. Yo mismo pasé á menudo con agua hasta el pecho esta lagu. na, anies de tener conocimiento de la presencia de los cro. codilos, para matar garzas reales ; otras aves pantanosas; en tales ocasiones observé á menudo que un animal oculto en la profundidad, y molestado por mi, removió bruscamente el agua; yo crel qque serian grandes peces; pero cierto dia paseándome otra ver por el agua sin pensar en mada, vi śla distancia de ocho pasus que un crocodilo enorme levantaba su monstruosa cabeza sobre la superficic. En el primer mo. mento tanto el reptil como yo permanecimos igualmente asombrados, pero no vacilé en apuntarle mi escopeta, dispa. rándole, á falta de otra cosa, una descarga de perdigones de los qque se usan para cazar pajjaros; entonces el saurio sacudió al punto el agua con la cola, y vile desaparecer en la profundidad. Fácilmente se comprenderá que despues de este suceso no volvi á pascarme por la laguna, pues no me fiaba lo bastante de mis observaciones para exponer mi per. sona a tan gran peligro. Sin embargo, tambien los negros na. daban en el Wurien los puntos de poca profundidad sin hacer caso de los numerosos crocodilos. A pesar de todo, cuando en la estacion lluviosa abundó cl agua en el rio, dióse con frecuencia el caso de que los crocodilos arrebataran hombres de las lanchas planas. En este caso, tos reptifes po. dian sumergirse y ahogar en seguida su presa sin que a csta le fuera posible oponer mucha resistencia.

- La cualidad que tiene la coraza de este crocodilo de ser impenetrable á las balas no parece an grande como muchas reces se supone; yo maté pequeños saurios de la longitud de un brazo sa una distancia de veinte á treinta pasos, con perdigones de escaso tamano. Ln los grandes individuos no probé mi carabina, porque al volver al Wuri no quise perder la caza de hipopótamos disparando tiros á los crocodilos. 
$\$$ Parece que tambien esta especie emprende viajes en la estacion seca, ó por lo menos los encontré al principio de dicho periodo mucho mas numerosos que antes en la citada laguna cerca de Aura, $y$ debo suponer que han emigrado de los puntos donde las aguas se han secado.

\$ La carne de esta especie es blanca, tierna y muy sabrosa, por lo cual los negros la prefieren á cualquicra otra.\$

\section{EL CROCODILO DE HOCICO AGUDO-CRO- CODILUS ACUTUS}

CARACTÉRES. - El tipo americano mas conocido del género es el crocodilo de hocico agudo, llamado así por te. ner esta parte muy prolongada, estrecha y puntiaguda, mas ó menos abovedada en la parte superior y ligeramente rugo. sa. Su frente es muy cóncasa; las cuatro placas estain dispuestas en una seric; los escudos del cuello, por lo regular en número de seis, forman dos, pero la cifra saria mucho, de modo que esta puede bajar á dos ó stibir á ocho y hasta diez; en este último caso los escudos están dispuestos en tres ó cuatro series; los del lomo siempie forman solo cuatro longitudinales. La parte posterior de los muslos está provista igualmente de una cresta; el color de las regiones superiores es un pardo sucio con lineas onduladas amarillas; el de las inferiores amarillo claro mas puro. Los individuos adultos llegan a una longitud de seis metros.
DISTRIBUCION GEOGRÁEICA.-- El crocodilo de hocico agudo se extiende sobre una parte considerable del gran cuntinente sud americano, de la América central y de las islas occidentales, sobre todo en las aguas dulces del Ecuador, Nueva Granada y Venezuela, Yueatan, Guatema. la, México meridional, Cuba, Santo Domingo, Jamaica, Martinica y Margarita; encuéntrase por lo tanto en casi todos los paises y grandes islas entre el trópico de Cáncer y el $5^{\circ}$ de latitud sur.

La siguicnte descripcion de su género de vida es un resuimen de las noticias dadas por Alejandro de Humboldt en varios pasajes.

(1)esde Diamante, dice el sabio naturalista, se pasa a un territorio solo habitado por animales, y que en ciertos sitiós puede considerarse como el verdadero reino de jaguaretés y crocodilos. Una orilla del rio está casi siempre seca y es are nosa á causa de las inundaciones; la otra, mas alta s poblada, tiene árboles corpulentos, que en ciertos puntos clévanse en ambas orillas del rio. Los grandes cuadrúpedos del pais, el tapir, el pécari y el jaguareté han abierto senderos en las espesuras de la orilla, por los cuales bajan á la corriente para beber. Como no hacen mucho caso de una lancha que pasa, el viajero puede ver cual se deslizan lentamente 2 lo largo de la orilla hasta que desaparecen por uno de los estrechos claros. Aquí e! naturalista se ve trasladado á un nuevo mun. do, donde se ostenta una naturaleza salvaje y soberbia De pronto se presenta en la orilla el jaguareté; despues el hokko se desliza lentamente por la espesura, y otros individuos de las clases mas diversas del reino animal se dejan ver sucesivamente uno despues de otro. «Estamos como en el paraiso, \$ dijo nucstro timonero, anciano indio de las misioncs. $Y$ en efecto, todo recuerda aqui el estado primitivo del mundo, cuya inocencia y felicidad, cuyas traciciones antiguisimas y respetables venéranse en todos los pueblos; pero al observar el proceder de los animales notamos que se temen y critan unos á otros; la edad de oro ha pasado y en este paraíso de las selvas americanas, asi como en todas partes, una larga y triste experiencia habia enseĩado á todos anquellos séres que rara vez la dulzura y la iuerza pueden armonizar.

- Alli donde el valle tiene una extension considerable las espesuras están mas léjos detrio; en el espacio descubierto Se ven crocodilos que â meaudo en número de ocho á diez descansan en la arena; del todo inmóviles, con las mandibulas abiertas en śugulo recto, están echados uno junto á otro, sin dar ni una de esas ser̃ales de cariño que por lo regular se observan en los animales sociables. Ll grupo se divide tan luego como parte de la orilla, aunque prabablemente se com. pone de un solo macho y muchas hembras, pues los machos son bastante raros, porque en la ćpoca del celo traban en. carnizadas luchas y se matan. Estos colosales reptiles son tan numerosos que en todo el curso del rio pudimos ver casi á cada instante cinco $\delta$ seis, á pesar de que las aguas cie! Apu. re apenas labjan comenzado á subir; de modo que rontenares de crocodilos estaban ucuitos aun en cl cicno.b

Tambien el rio Neberi está poblado de esos monstruos hasta cerea de su desembocadura: estos reptites se atreven á 
salir á la alta mar, soure todo cuando reina calma ó viento. \$No es dificil comprender, continua Humboldt, que un animal cuyo cuerpo está cubierto de una coraza no puede ser muy sensible al agua salada. Estas obserwaciones son de gran importancia para la zoología respecto á la extraña mezcla de animales íósiles de agua dulce y salada.

* A las cuatro de la tarce me detuve para medir un croco. dilo muerto que el rio habia arrojado a la orilla; solo tenia 5 , 24; pero algunos dias mas tarde, Bonpland encontró un macho de $6^{7}, 80$ de largo. En todas las zonas tanto de Amć. rica como de Egipto, esos animales alcanzan las mismas dimensiones; la especie tan comun en el Apure, en el Orinoco $y$ en el rio Magualena no es tampoco un caiman, sino un verdadero crocodilo, con los piés denticulados en los bordes exteriores, muy parecido al crocodilo del vilo: es cl arase de los tamanacos, el ammio de los maypures, el crocodilo puntiagudo de Cuvier.

*B1 crocodilo del Apure se muere con mucha rapidez y agilidad cuando ataca, pero si no está excitadn por la ira y el hambre, se arrastra lentamente como una salamandra; cuando corre se oye un ruido que parece provenir cel roce de las placas de su piel; muchas veces oimos en la orilla el rumor de estas placas en las cercanias. No es verdad que, como lo pretenden los indios, los crocodilos adultos puedan dirigir sus escrimas y toda su cornza como el pangolin; pero cuando corren encorvar el lomo y sus piernas parecen masaltas que mientras descansan. Cierto que casi siempre se mucven en direccion recta 6 mas bien como una fecha que de trecho en trecla carnbiase de direccion; mas á pesar de los peque. ños apéndices de costillas falsas que reunen las vértebras cervi. cales y parecen linitar los movimientos laterales, el reptil los ejecuta muy bien cuando quiere. Yo he visto bastante á me. nudo pequeños que se mordian la cola, y otros observaron lo mismo en crocodilos adultos. El hecho dé parecer que sus movimientos se efectúan casi siempre en linea recta es consecuencia de que, asi como en los lagartos, ejecítanse siempre ántervalos. Nadan muy / bien y vencen sin dificultad la cor. riente mas råpida, pero me pareció que no podian volierse con tanta ligereza cuando nadaban rio abajo. Cierto dia ur perro grande que en nuestro viaje nos acompañó desde Caracas fué jerseguido en el rio por un enorme crocodilo, faltando poco para que este último le alcanzara; y el perro no escapó sino porque se revolvia y nadaba otra vez contra la cortiente. El crocodilo cjecuto al fin el mismo moviniento, pero con mucha mas lentitud que el perro; de modo que cste pudo salvarse en la orilla.s

La índole de los crocodilos es, sin embargo, segun dice Humboldt en varios pasajes, muy diferente segun los sitios que habitan. Fin muchos rios se les teme en extremo, y en otros poco ó nada. "Las costumbres de los animales de la misma especie, dice el naturalista, demuestran diferencias causadas por las influencias cie los sitios, muy dificiles de explicar. En el ro Burituka se nos advirtió que no permitie. ramos á nuestros perros beber en la orilla, porque estí infes. tada de crocodilos en extremo salvajes quue bastante á menu. do salen del agua para perseguir á los perros en tierra firme. Ese atrevimiento es tanto mas extraño cuanto que en el rio 'Tisanao los crocodilos son bastante timidos y poco dañinos. Tambien en el rio Neveri abundan los grandes caimancs del Mississippi, y no son tan maliciosos como en el Orinoco. Segun el estado de la civilizacion de los difercntes paises atendida la poblacion mas 6 menos numerosa á orillas de los rios, tambien varian las costumbres de estos grandes lagartos que en tierm firme son tímidos $y$ hasta huyen del hombre cuando tienen abundante alimento y el ataque ofrece peligro. En Nueva Barcelona se ve á los indios llevar la madera de un modo muy particular al mercado; los grandes leños, arrojados al rio, flotan en la corriente y el propietario, nadando por aqui ó por alli, saca los pedazos que encallan en las curvas del rio. En la mayor parte de las corrientes donde hay crocodilos tal procedimiento no puede practicarse ja por la misma naturnleza del asunto.

\$En el estómago de un crocodilo de $3^{10}, 60$ de largo dise. cado por Jionpland y por mi encontramos peces medio digeridos y trozos redondos de granito de ocho á diez centímetros de diámetro. No puede suponerse que los crocodilos devoran estas picdras casualmente, pues cuando cogen los peces en el fondo del rio su mandíbula no descansa en la arena. Los indios han inventado la absurda especie de que á estos ani. males perezosos les gusta hacerse pesados para poder sumer. girse mas f́cilmente. Yo creo que llenan su estómago de grandes piedras para producir una segregacion abundante del jugo digestivo. I.os experimentos de Magendie hablan en pro de tal opinion. Estos reptiles encuentran abundante alimento en el Apurc, gracias álos cerdos acuáticos, que reunidos en grupos de cincuenta \& sesenta individuos, beben en las orllas del rio. Estos desgraciados animales no tienen ninguna arma defensiva; cierto gue nadan un poco mejor de lo que corren, pero en el agua son presa de los crocodilos, y en tierra firme victimas de los jaguaretés. Apenas se comprende

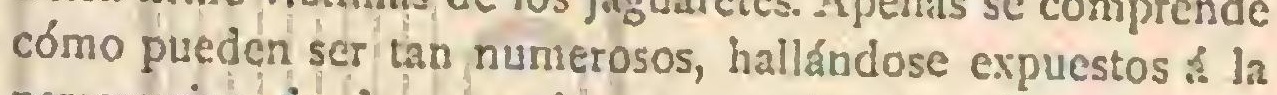
persecucion de dos enemigos tan poderosos. Con sorpresa mia vimios un eriorme crocodilo dormitando en medio de es. tos rocdores; desperíóse cuando nos acercamos con nuestra piragua, dirigiéndose lentamente hácia la orilla sin molestar á los cuadrúpedos. Nuestros indios veian la causa de esta indiferencia en la estupidez de los animales: pero probable. mente los cerdos acuáticos saben por una larga experiencia que el crocodilo del Apure y del Orinoco no ataca en tierra firme, á no ser que el objeto que quicre coger cruce su cami. no en el instante de precipitarse al agua.

p Muchos mas hombres de lo cque se piensa en Europa son tódos los años víctimas de su imprudencia $y$ de la voracidad de los crocodilos, sobre todo en los pueblos cuyos contornos están expuestos á menudo ś inundaciones. Los mismos cro. codilos permanecen mucho tiempo en ciertos parajes, llegan. do á ser cada vez mas atrevidos, segun pretenden los indios, sobre todo cuando una vez han probado la carne humana. Los indigenas nos dijeron que en San Fernando no pasa fácilmente un año sin que sean devoradas dos ó tres perso. nas adultas, sobre todo mujeres, cuando van á buscar agua al rio. Nos contaron la historia de una muchacha de Urituku que, gracias á su intrepider. y presencia de espiritu extraordi. narias, se habia salvado de los dientes de un crocodilo. $\Lambda$ pe. nas se sintió cogida, agarróse a los ojos del animal, empujando los dedos con tal fuerza en las órbitas, que el crocodilo la solto despues de haberla cortacio el antebrazo izquierdo. A pesar de la gran pérdida de sangre, la india, nadando con la mano que le habia quedado, logró salir á la orilla. Un in. dio de la tribu de los Guayqueris de la isla Margarita quiso amarrar su piragua en una ensenada de menos de un inetro de profundidad, pero un crocodilo muy feroz que siempre vagaba por los contornos le cogío por la pierna y alejóse, permaneciendo en la superficie de la orilla Los gritos del indio atrajeron una multitud de espectadores, quienes vieron cómo el infeliz buscó prinzero con una energia inaudita un cuchillo en el bolsillo del pantalon; como no lo encontraba, cogió la cabeza del crocodilo, hundiéndole los dedos en los ojos; pero el indigena no fué tan feliz como la muchachn de Urituku. El crocodilo no abrió la boca para soltar su presa; hostigado por el dolor, sumergióse y ahogó al indio; pero volvió á presentarse en la superficie, dirigiéndose al punto 
con cl cadaver a una isla frente al puerto. Reliúrense casos conmovedores de esclavos africanos que se sacrificaron para salvar a sus amos cogidos por crocodilos. Hace pocos años que en los llanos de Calabozos un negro, al oir los gritos de su scinor, cogió una larga navaja, y salıando al rio, sacó al saurio los ojos, obligindole asi à soltar su presa. El esclayo trajo a su señor moribundo á la orilla, pero todos lus esfuer. zos para hacerle volver à la vida fucron inútiles, pues se habia ahogado. Para los habitantes de las orillas del Orinoco, los peligros à que están expuestos forman un tema de la con. versacion diaria Han observado las costumbres del crocodilo como el torero las del toro; saben calcular de cierto modo anticipadamente los movimientos del monstruo acorazado, sus medios de ataque y el grado de su atrevimiento. Cuando se ven amenazados se sirven con la serenidad y energia pro. pias de los indios y zambos, y en general de los hombres de color, de todos los medios que se les ha enseñado desde su niñez. En los paises donde la naturaleza se presenta tan po. derosa y terrible, el hombie siempre está armado contra el peligro. La muchacha india que supo librarse de los dientes del crocodilo dijo: «Yo sabia que el caiman me soltaria in. troduciéndole los dedos en los ojos. Esta muchacha pertenecia a la clase pobre del pueblo, en la cual la costumbre de ejercitar las fuerzas corporales aumenta las espirituales. Pero lo verdaderamente asombroso es cuando en los paises aso. lados por los terremotos, las mujeres de las clases mas altas de la sociedad denuestran la misma serenidad $y$ energia en los momentos de peligro.

Como el crocodilo puede coger, peto no devorar su presa bajo el agua a causa de la estructura de su laringe, el hueso de la lengua y la disposicion de esta última, raras veces des. aparece un hombre sin que cerca del sitio donde pasó la desgracia se vea volver al reptil á la superficie despues de algunas horas para devorar su victima. A pesar de esto, raras veces se da caza a estos peligrosos carniceros; son muy astutos y por esto no es fácil matarlos. Un balazo solo es mortal cuando toca en la boca ó en el sobaco (?). Los in. dios, que raras veces se sirven del arma de fuego, los ata. can con lanzas, tan luego como los reptiles han quedado cogidos en fuertes y puntiagudos ganchos de hierra, cebados de carne $y$ atados en troncos de árboles con una cadena; pero solo les acosan de cerca cuando han agotado ya sus fuerzas para desprenderse del hierro. No es probable que jamás se logre limpiar el pais de crocodilos, porque en el la. berinto de aquel sinnúmero de rios todos los dias bajan nuevas bandadas desde la pendiente oriental de los Andes por el Meta y el Apure \& las costas de la Guayana española Los progresos de la civilizacion solo producirán el efecto de que los animales se vuelvan mas timidosy huyan mas fa. cilmente.

Parece que en la América del sur se sacan pocas ventajas delos crocodilos-muertos; Humboldt solo dice que la grasa de caiman se considera como un excelente purgante y que cuando menos cn algunas partes se come la carne blanca.

Aparte del hombre, los crocodilos de hocico agudo tienen pocos enemigos que puedan serles peligrosos. Refírense muchos cuentos de luchas entre ellos y las grandes serpientes de agua; estos relatos sin embargo no merecen el menor crédito, segun mi opinion. Por lo regular estos crocodilos tan solo hacen caso de los animales que les sirven de alimento, mientras que tratan con indiferencia a los otros. Humboldt refiere que vió unas pequeñas garzas reales blan. cas como la nieve correr por el lomo de estos reptiles y hasta por la cabeza sin que ellos les hicieran caso, costumbre anśloga a la que existe entre el crocodilo del Nilo y su evigilan. te. In cambio parece que no les gustan los habitantes de sus aguas que causan mucho ruido: Humboldı los vió sumergirse cuando se acercaron a clios los delfines marinos. Los crocodilos adultos se hallan, segun fícilmente se comprende, poco expuestos á los ataques de otros animales; á los pe. queios sin embargo les persiguen varias aves pantanosas, $y$ segun hemos dicho en su lugar, los pernopiercs les dan caza con grande afan y habilidad.

Uilloa nos diú ya noticias sobre la reproduccion de estos crocodilos. Depositan, dice este antiguo naturalista, durante dos dias por lo menos cien huevos en un hoyo que abren en la arena, y que cubren en seguida revolcándose por encima para borrar las huellas. Despues se alejan por espacio de algunos dias, vuclven acompanadas del inacho, escarban la arena y rompen la cáscara de los huevos; la madre se pone los pequenos a la espalda y los lleva al agua. El pernoptéro se apodera de algunos en el camino y tambien el macho come tantos como puede; y hasta la madre devora los que caen 6 no pueden nadar en seguida, de modo que al fin no quedan mas que cinco 6 seis. A los pernopteros les gustan muchísimo los huevos de crocodilo, y por lo tanto se ocul. tan en veramo como centinclas en los árboles; observan con impaciencia \& la hembra cuando pone, $y$ apenas se aleja precipitanse sobre el nido, lo descubren con el pico y las garras y se disputan los huevos. No necesito decir que Lilloa ha merclado la verdad con la fábula; lo que en su relato hay de probable está confirmado por Humboldt. "Los crocodilos, dice, depositan sus huevos en hoyos separados, y la hembra vuelve a prescrntarse hácia el fin de la incuba. cion para llamar a los hijuelos, que contestan al punto, $y \mathfrak{d}$ los que ayuda casi siempre á salir de tierra. . No sé si el gran naturalista habla aqui por propia experiencia 6 si solo reproduce un relato que le hicieron, pues no he podido encontrar un solo pasaje en sus obras que se refiriese a este asunto. Los crocodilos jóvenes prefieren los charcos y ca. nales pequenos \& los rios anchos y profundos y se hallan á veces en fosos bordeados de cañas, en tal número, que bien podria decirse que pululan como los gusanos unos encima de otros.

De las otras noticias de Humboldt resulta que los croco. dilos de hocico agudo se aletargan en invicrno. (Mas abajo de la desembocadura del rio Arauca, dice en la descripcion de sus viajes, veianse mas crocodilos que en utras partes, sobre todo frente ả un gran lago que se comunica con el Orinoco. Los indios nos dijeron que los crocodilos vicnen del país seco donde habian estado oculios en el cieno. Despues de las primeras lluvias abundantes despiertan de su letargo, reúnense en grupos y se dirigen hácia el rio en el cual vucel ven i dispersarse. Aqui, bajo el trúpico, se despicrtan cuando el suelo vuelve á humedecerse, mientras que en el clíma tem. plado de la Georgia y la Kilorida el calor les hace salir de su letargo $\sigma$ de un estado de debilidad de los nervios y músculos, durante el cual se interrumpe ó por lo menos se linita mucho la respiracion. El periodo de la gran sequia, llamado impropiamente verano de la zona cálida, corresponde al invier. no de la zona templada: y es un curioso fenómeno fisiológico que en la América del norte se entreguen al sueno insernal á causa del frio, al propio tiempo que en el Orinoco caen en su sueño en rerano. Si pudiéramos suponer como probable que cstos animales pertenecientes á la misma familia hubie. sen vivido úna ver juntos en el pais septentrional, podríamos creer que, aun trasladados mas cercn del Ecuador, experimentan, despues de haber fatigado seis ó siete meses sus múscu. los, la necesidad de descansar, por lo cual permanceen en el nuevo clima fieles á su géncro de vida, que esencialmente parece depender de la estructura de su cuerpo. Nuestro patron nos enseñó una choza, 6 mas bien un cobertizo, en el 
cual habia presenciado un hecho muy curioso. Dormia con un amigo en un banco cubicrto de cuero, cuando muy tem. prano por la mañana unos golpes violentos, un ruido estrepiloso y unos pedazos de tierra que con estruendo penetraban en la choza despertáronle sobresaliado. Al poco tiemplo, un crocodilo jóven, de un metro de longitud, salió por debajo del banco, precipitóse sobre un perro que estaba echado en el umbral de la puerta, y habiéndosele escapado, en el impetu de su carrera dirigióse hácia ha orilla y se lanzó en el rio. Al examinar el suelo debajo del hanco explicósc al punto la extraña aventura: en el cieno secado y revuclto da mucha pro. fundidad, el crocodilo se habia entregado á su sueño de verano, y el ruido de los hombres y caballos, ó quizás tam hien el olor del perrol habiante despertado. Ta choza estaba situada \& orillas de un estantiue y halläbase una parte del ano sumergida; de modo que el crocodilo entraria sin duda du. rante la estacion de las inundaciones por el mismo agujero por donde don Miguel le vió salir. Vemos por lo tanto que en los'llanos la sequia y ul culor producen en los animalcs y en las plantas los mismos efectos que el frio. Los reptiles, sobre todo los crocodilos y las boas, diffcilmente abandonan los charcos en los que durante las inundaciones hallaron agua, Cuanto mas se secan estas aguás tanto mas penetran los animales en el cieno en busca de la parte húmeda, que conscrval a flexibilidad de su piel y de sus placas. En tal es. tado de descanso viene a dominarles el sueño letárgico; no están separados del todo de la atmósfera exterior, y por poco que el aire lus toque basta para alimentar la respiracion en un lagarto que tiene las bolsas del pulmon sumamente grandes, que no ejecuta ningun movimicnto con los músculos, y en el cual están paralizadas casi todas las funciones vitales.

\section{EL CROCODILO LISTADO-GROCODILUS BIPORCATUS}

CARACTERES. - Entre las especies asiáticas del género el crocodilo listado es la que merece figurar en primer término, porque es la mas propagada de toda la familia. Este crocodilo, segun Strauch, se distingue bastante cie todos sus congéneres por faltarle casi siempre los escudos de la nuca, que cuando existen solo se hallan en núncto de dos; los del lomo están dispuestos en cinco $\delta$ sejs series longitudinales; en el hocico se ven dos listas bseas muy largas, divididas á la manera de un cordon de perlas que casi alcanza a la punta de la mariz. El hocico, tambien largo, mas 6 menos estrecha. do, puntiagudo y cóncavo, estå lleno de repliegues, y tambicn cxiste la cresta denticulada de la parte posterior de los muslos. Iil color es un verde amarillento con manchas mas oscu. ras. El animal puede alcanzar, segun dicen, una longitud de diez metros.

DISTRIBUGION GEOGRÁ FICA.-Fi crocodilo listado habita en gran número todos los rios y aguas del Asia meri. dional, sobre todo los de la India, aquende y ailende el Ganges; no escasea en Siam y en el sur de la China; perocs mas comun en las grandes corricntes y los lagos de las islas de la Sonda y otras del Asia meridional, desde Ceilan hasta la Nueva Irlanda; encuentrase hasta en algunas islas de la Oceania, aunque tal vez scan solo indiriduos extraviados. Tambien rive en Nueva Cuinea, en la costa septentrional de Nueva Holanda, en las islas Seychelles y en la de Mauricio. Sin faltar á la rerdad podemos desiguarle cono crocodilo ce mar, pues le visita con mas frecuencia que ninguna otra especie desde las desembocaduras de los rios, viéndoscle á menudo á varias leguas marinas de distancia de la costa en las bancas de arena, en estrechos de poca extension ó en medio de las islas.
En Ceilan suelen labitar con preferencia, segun afurma T'ennent, los rios, lagos y pantanos de la tierra bajáálo largo de la costa, mientras que otra especie de la misma lamilia, el crocodilo palustre (crocodilus falusfris), solo se encuentra en las aguas dulces y evita la proximidad del mar. En Korneo son tan abundantes, que Salomon Muller asegura que vió una ver. de diez. á doce de estos animales terribles en el esnacio de menos de una hora.

USOS, COSTUMBRES Y RÉGIMEN.-Schlegel, que publicó las observaciones de Muller, dice lo siguiente: El crocodilo listado es sin duda uno de los reptiles mas feroces y peligrosos. Nos inclinamos a creer que en la India no es mayor el número de personas muertas entre las garras de los tigres que el de las devoradas por los crocodilos: lodo cuanto pertenece al reino animal y se halla á su alcance les sirve de pasto, bien esté fresco ó en estado de putrefaccion; su vora. cidad es tal, que se tragan hasta las picdras. Suelen sorpren. der casi siempre á sus victimas desde un sitio resguardacio; apodéranse de ciertos animales, como son el riervo, el cerdn, el perro, la cabra y el mono cuando se accrcan al agua para apägar su sed.

Cuando este voraz repril acecha su presa desde el agua, no suele asonar sino el extremo del hocico, y permanece horas enteras inmóvil en el mismo lugar. La finura de su oido, que parece ser en los saurios el sentido mas perfecto, le permite oir debajo del agua lo que pasa a una distancia bastante regular. Apenas percibe el mas ligero rumor, acér. case cautelósamente á la orilla; si son personas has que se aproximan, espera algun tiempo, oculto debajo de la superfi. cie del agua, hasta que se ofrece una circunstancia favorable para arriésgar el ataque, que rara vez se le frustra, pues no se precipita sobre la presa sino cuando esta se cree del todo segura. En cl acto de morder y arrastrar à su victima, mú. vese el crocodilo con la velocidad del rayo, por manera que a las personas cogidas no se les oye ni un solo grito. El monstruo se lleva al momento su presa al agua, saliendo otra vez con ella á la superficie al poco rato; si es pequeña se la traga nadando, en cuyo caso conserva la cabcza fuera del agua; pero si consiste en un animal grarde ó en un hom. bre, entonces le devora de noche, con calma, ocultíndole entre tanto en algun lugar solitario de la orilla. Parece que quebranta y estruja sus victimas, arrojândolas de una parte á otra 0 contra el suelo $y$ las destroza con sus patas delanteras.

"Tan audaces y fuertes son los crocodilos en el agua, como cobardes fuera de ella. Al divisar una persona que se les acerca, ya por tierra ó en una lancha, huyen presurosos al rio, donde se arrojan produciendo un gran estrépito con sus fuertes coletazos, hasta que desaparecen en el fondo.

¿Su marcha en tierra es por.demás pesacia y penosa, aun: que pueden atravesar trechos cortos con una rapidez increible. No enaprenden mas largas excursiones sino de noche, porque scn mas bien animales necturnos que diurnos, $j$ de consiguiente mas peligrosos cuando reinan las tinieblas, como sucede con las grandes especies felinas. En el agua se mueven con igual facilidad contra la corriente como si. guiendola.

* Jamás se ha observado en estos reptiles el menor indi. cio de alegria ó de afecto mutuo; cada uno vive para sí y solo para sís

Tennent refiere que el crocodilo palustre se atreve fiemprender largos viajes en la estacion de las lluvias. En una de las provincias orientales tuvo aquel naturalista ocasion de examinar el lecho de uno de csos saurios, que presentaba el molde exacto de todas sus formas. Un oficial le contó, que habiendo fijado una vez su tienda sobre el limo endurecido de un lago en seco, vió con espanto cierta noche que la tierra 
comenzaba á moverse đebajo de él, continuando las oscilaciones todo el dia siguiente, hasta que se explicó el misterio por la aparicion de un crocodilo.

No menos que los indigenas temen todos los animales mayores al crocodilo. \&Los perros, continúa Muller, que han visto una vez. de cerca \& uno de esos monstruos, le cogen tal miedo, q̧ue despues solo se acercan al agua muy lentamente y con gran cautela. En la playa de 'Timor observamos mas de una vez, que uno de estos perros huia de su propia sombra, permaneciendo tembloroso y amedrentado, á seis u ocho pasos del agua, fijando sus ojos asustados en el sitio donde se le habia aparccido el espantajo, y prorumpiendodespues en plañideros aullidos. Si en una de las excursiones for el agua que suelen hacer los indigenas en pequeños botes, les sor. prende la noche, procuran siempre conservarse en cl centro del rio, porque alli no se encuentran tan fácilmente los cro. codilos como cerca de la orilla. Sin embargo, á pesar de estas precauciones, ocurre á menudo en la India que son arrebatadios hombres de las embarcaciones, sin que lo noten apenas otras personas que se hallan á su lado. Tambien sucede que los crocodilos vicjos destrozan de un coletazo el pequeño esquife, de cuyas resultas, uno de los tripulantes, f́ lo menos, les ha de servir infaliblemente de pasto. Una des. gracia semejante ocurrió en el mes de octubre del año $18_{3} \mathrm{~S}$ en la isla de Bornco, y hé aqui cómo: UUn malayo, cuya mujer y único hijito habian sido, en el espacio de quince dias, victimas de un crocodilo muy grande en la orilla del rio Duson, quiso al cabo de algunas semanas vengarse del animal, á cuyo fin preparó un anzuelo para cogerlo. Al estar el hombre ocupado en estos preparativos fué cuando nos. otros le hablamos. Para cebo tenia dispuesto el cadáver de un mono jóven; y al dia siguiente se trasladó al sitio en compañia de otros tres indigenas, para dejar alli el anzuelo colgado de un arbusto que se inclinaba sobre el agua. Apenas hubieron llegado en lancha al lugar donde el arbusto exten. dia sus ramas, cuando aquella fué destruida en el mismo instante á consecuencia de un tremendo golpe que recibió por debajo, cayendo los cuatro tripulantes al agua. Sobrecogidos de espanto, cada uno tenia bastante que hacer por su parte para aicanzar nadando lo mas pronto posible la orilla; felizmente lo consiguieron tres de ellos, pero el cuarto, que era el vengador, faltaba: lo mismo que su mujer y su hijo, habia sido pasto del voraz reptil.s Orro caso parecido ocurrió pocos meses antes de nuestra llegada á Borneo, cerca de Carau, en el rio Sungej, muy renombrado por la multitud de crocodilos que alberga. Un malayo de la aldea de Keiab quiso volver á su casa en compañia de su mujer, y mientras remaba, á poca distancia de la enbocadura del rio, fué co. gido por detrás por un crocodilo descomunal, de un mocio tan silencioso é instantáneo, q̨ue la mujer, que estaba senta $\mathrm{da}$, segun costumbre, en la proa, al volverse cuando sintió la sacudida de la lancha, solo pudo ver el brazo de su esposo, cuyo cuerpo habia desaparecido ya debajo del agua. Este malayo era sobrino del jefe indigena Bodien, quien desespe. rado por este suceso ordenb inmediatamente que se prepa. raran anzuelos para coger y matar al reptil, y.si posible fuese, á otros individuos de la misma familia. A esta circunstancia debemos la adquisicion de varias cabezas de crocodilo Segun nos aseguró Bodien, el crocodilo que babia devorado á su sobrino, habia tenido una longitud de tres brazas; antes de apoderarse del monsiruo, hallaron la cabeza de la víctima en una espesura de árboles, y despues de cogido se le encontró en el cstómngo la ropa y casi todos los huesos del infeliz Hemos traido á Europa la cabeza enorme de este crocodilo, la cual, con la boca muy abierta y junto con otras, habia estado expuesta a la orilla del rio.

* Oiro caso merece todavía mencionarse. Cuatro personas se fueron una tarde hácia el lago Jompur para pescar. Una de ellas, ocupada en la proa del barco en cchar las redes, fué cogida de repente y arrastrada al agua por un crccodilo horriblemente grande, que le habia hecho presa en una pierna. Creiasela perdida, cunndo al poco rato volvió á apa. recer el carnivoro animal cerca de la lancha, lievario toda. vía en la boca á la victima aun viva, que pidió auxilio á grandes roces. Inmedietamente, $y$ sin titubear un inștante, salta al água el hermano del desgraciado, dominacio por el horror $y$ la compasion, decidido \& todo para ver si podia libertar a su hermano de los dientes del monstruo; saca el sable, y cogiéndole de un brazo, da con el otro un golpe tan terrible en la nuca del animal, que inmediatamente soltó al hombre; pero este murió á los dos dias de resultas de las graves heridas çue le habia inferido el crocodilo. 
Todos los viajeros que residen algun tiempo en las Indias, en el Asia meridional $y$ sobre todo en las grandes islas del archipiélago indico, cuentan casos análogos. Epp, que vivió diez años en Banca, dice que durante este tiempo fueron devorados treinta hombres por los crocodilos, contándose otros muchos gravemente heridos. Parece que en Ceilan no causan tantas desgracias, ó por lo. menos, Tennent no da noticias de ellas.

Es muy natural que estos voraces saurios sean muy perseguidos en Asia, aunque en algunas localidades los respetan, considerándolos como dioses.

En aquellos países miran como sagrados á estos feroces animales, creyendo que despues de su muerte se trasforman en ángeles. Hé aquí porqué no los persiguen nunca; y mur léjos de ello, quisieran vivir en buena armonia con los terribles saurios.

Anderson dice que en el rio Sumatra vió un enorme crocodilo, al que alimentaban con cabezas de peces, lo cual fué bastante para que se amansase. Aquel animal santo, comóle llamaban los indigenas, se familiarizó de tal modo con los que le mantenian, que se dejaba tocar por ellos; cuando le daban su conjida, nostrábase nuy vivaz; pèro despues permanecia inmóvil.

(Los indigenas de las islas del archipiélago de las Indias orientales, dice Martens, segun me aseguran en mas de una isla, no persiguen al crocodilo, el cual vive junto al hombre $y$ devora algunas veces sus hijos; lejos de ello, considéranle como santo, crejendo que el alma de alguno de sus antepasa. dos vive en ese reptil y tiene, por decirlo asi, el derecho de llevarse al nieto. En algunas partes la gente no es tan crédula; muy por el contrario, persigue á estos peligrosos repti. les, empleando diferentes medios para apoderarse de ellos: por lo regular se valen de anzuelos cebados, $y$ en algunos puntos de grandes redes, 6 ya, en fin, de unos aparatos de madera, de los cuales no puede escapar el crocodilo cuando ha entrado, impidiéndole la retirada la trampa. En las Filipinas, al decir de Sagor, constrúyese una ligera balsa de bam. bú con un armazon, atando en este, á cierta altura, un perro $\delta$ un gato, que tienen á su lado un anzuclo, puesto en comunicacion con la balsa por medio de un hacecillo de fibras de lino de Manila: todo este aparato se abandona ô las olas del rio. Cuando el saurio ha devorado el cebo, y al misino tiempo el gancho, hace inútiles esfuerzos para librarse, pues la ligereza de la balsa le impide destrozarla, $y$ la elasticidad del haz de fibras cortarle á mordiscos; la balsa indica al mismo tiempo el lugar donde se halla el reptil aprisionado. Un crocodilo cazado con anzuelo se conduce como si estuviera rabioso, oponiendo al hombre una tenaz resistencia; pero una vez en tierra firme se abandona casi con resignacion á su suerte. Tennent dice que cuando se trata de sacar con redes un crocodilo de aguas de poco fondo, penetra cuanto puede en el cieno, dejando pasar la red por encima, con to cual demuestra una astucia que aun en la India no se supone en cllos.

Como los grandes crocodilos no sirven alli para nada, les dan muerte en seguida; pero en algunos puntos, sin embargo, como por cjemplo en Siam, utilizan su carne, y tambien los destinan para las luchas de fieras. Koegel cuenta que los ha. bitantes de Java cogieron una vez un crocodilo al que en. cerraron con un tigre con el objeto de ver cómo pelearian. \$El carnicero quiso saltar sobre su enemigo para desgarrar. le; pero sus afilados dientes no pudieron hacer mella en la coraza de su adversario, ni siquiera arrancar el mas pequeño pedazo de carne. El saurio pudo coger al fin al tigre por las piernas, y le destrozó la cabeza. Réprodurcco esta historia li. teralmentc, sin salir garante de su cxactitud. Pero tambien el doctor Schmidtmuller nos habla de otra lucha entre un tigre $y$ un crocodilo: algunos soldados de Java habian logra. do coger un individuo vivo, no sin que les costase la muerte de uno de sus compañeros; $y$ cuando se proponian ininolarle, varios indigenas, de los que veneran á este reptil, intercedieron por su vida; pero como les fuese negada su peticion, envenenaron al crocodilo, robaron despues su cuerpo, y envolviéndole en una especie de piel, diéronle sepultura.

\section{EL GROCODILO DEL NILO-CROCODILUS NILICUS}

GENERALIDADES.-La historia de la especie mas conocida, cual es el crocodilo del Nilo, cuyas proezas refieren antiquisimas tradiciones, y cuya existencia ha dado origen a tantas fábulas y leyendas, que se remontan á los tiempos primitivos, fué trazada ya por Herodoto y el autor del libro de Job; este último describe perfectamente el Ievilatan con escogidas frases y poético cstilo, micntras que aquel sc limita a referir fielmente lo que él mismo vió y ayó cuando estuvo en Egipto, expresándose poco mas ó menos en los términos siguientes:

\& El crocodilo habita en el agua y en tierra; en esta pone é incuba sus huevos, pasando en ella la mayor parte del dia; de noche vuelve al agua, porque entonces encuentra alli mas calor que al aire libre. De todos los animales, este es el que ofrece mas diferencia entre su tamaño al nacer y el que al. canza en la edad adulta. Sus huevos no son mucho mayores que los de la gansa, y están en proporcion con los hijuelos; pero cuando estos adquicren todo el desarrollo de que son capaces, miden unas trece varas.

Este saurio tiene cuatro extremidades, ojos como el cerdo $y$ grandes dientes, que sobresalen mucho; carece de lengua $y$ solo puede mover la mandibula superior, no la inferior al contrario de todos los animales. Sus uñas son sólidas y la piel escamosa. Aunque ciego en el agua, tiene la vista muy perspicaz, al aire libre.

¿Como vive en el agua, se le llena la boca de sanguijuelas. Todos los animales evitan su presencia; pero hay una ave llamada trochilus, que vive con él en buena armonia, porque le es útil. Cuando el crocodilo sale á tierra para des. cansar y abre su enorme boca, deslizase en ella el brochilus á fin de comerse las sanguijuelas; $y$ como este servicio le com. place, no causa ningun daño á la avecilla. Su nombre en Egipto no es crocodilo, sino jansa; pero los jonios le llaman crocodilo a causa de su semejanza con los lagartos que viven en las tapias de sus jardines.

Otros autores de la antiguiedad, sobre todo Aristóteles, Diodoro de Sicilia, Séneca, Estrabon, Plinio, Plutarco, Máximo Tírio, Dion Casio, Eliano, Flavio, Vopisco, y Amiano Marcelino, han descrito tambien el crocodilo del Nilo, dando muchas noticias curiosas; pero no completan sino imperfectamente cl relato bastante veraz de Herodoto, aumentando en cambio su sencilla descripcion con va. rias fábulas. Nuestro antiguo autor Gessner ha recogido muchas de estas noticias en su kibro de los animales y las reproducimos con las palabras de Forer que tradujo dicha obra.

CARACTERES. - Dicese que tambien este crocodilo puede alcanzar una longitud de diez metros, pero me parece que este informe se funda solo en un cálculo superficial y que la largura de siete metros es la mayor á que puede llegar el crocodilo del Nilo ú otro cualquiera. Distinguese esta especie de la de los pantanos propios del sur de Asia, y de la de Siam, ambas muy congenéricas, por la naturaleza de la piel del cuello y de los costados, que está cubierta de plaquitas cór- 
neas lisas, mientras que en estas dos especies se ven protuberancias muy abovedadas que alternan con algunos escudos aquillados. Detrás del cráneo hay dos pares de estos y en la nuca tres; el número de series trasversales de la parte del lomo es variable, pero asciende regularmente á quince ó diez y seis; el de las placas de la cola es de diez y siete á diez y ocho pareadas, y de diezy seis a dier y siete sencillas. El color predominante es un verde bronceado oscuro, con pequeñas manchas negras en el lomo; en los lados del tronco y del cuello hay otras oscuras é irregulares: la cara inferior del cucrpo es de un amarillo sucio, mas parece que el color está sujeto á muchas variaciones.

DISTRIBUCION GEOGRÁFICA.-Todos los crocodi. los que habitan el continente del Africa y la isla de Mfadagascar pertenecen generalmente á esta sola especie; la diferencia citada por algunos naturalistas entre el crocodilo del Nilo superior É inferior, y los del rio Sagrado is otros rios del Africa, no se ha demostrado hasta la evidencia Ahora bien, suponiendo que solo hay una cspecie, debemos considerar como su patria todas las grandes extensiones de agua del Africa: el Nilo con sus afluentes, todas las aguas dulces y es. tancadas del Africa oriental, desde los riachuclos costeros hasta los grandes rios de Mozambique $y$ del Africa meridional, Gabon, Niger, 'T'sadda y Senegal; y todos los lagos del Africa central y los rios grandes de Madagascar. Abunda mucho no solo en el territorio superior del Nilo, sino tambien en el Dschub, Zaire, Niger y Senegal, y no es menos nume. roso en los grandes lagos del interior. Fn los últimos tiempos se le ha visto igualmente en Palestina, sobre todo en los rios Gison y Zerka. Los informes que sobre este particular tenc. mos son sin embargo tan confusos, que se necesitan otros mas exactos antes de que se pueda comprender ś este pais entre las regiones del área de dispersion de dicho saurio. No debemos pasar en silencio que Wetzstein, segun me refirió verbalmente, vió un crocodilo que al decir de su propietario habia sido muerto en un pequeño rio costero de Palestina.

USOS, COSTUMBRES Y REGIMEN.-Este animal, tambien del género de los lagartos, es muy grande, repugnante $\mathrm{y}$ cruel; es acuático, y aunque salga a la tierra firme puede llamarse muy bien crocodilo acuático, si se le com. para con el terrestre, que no entra nunca del todo en el agua; come en tierra; se refresca al aire porque tiene pulmones $y$ no quiere carecer de aquel ni de agua; segun se dice, está de noche en este ultimo elemento, y de dia en tierra, á veces tomando el sol quicto 6 inmóvil, de manera que aquel que no le conociera, creeria que está muerto.

Nestos reptiles se alimentan de todo cuanto pueden coger; de hombres y niños, de toda clase de animales, y hasta de peces; destrozan la presa con sus garras para devorarla des. pues; pero la matan antes con su cola; en cuyo órgano tienen la mayor fuerza.

* Estos animales son muy fecundos, pues las hembras po. nen por espacio de sesenta dias un huevo diario, del tamano de los de la gansa, despues de llevarlos en su cuerpo otro tanto tiempo; para la incubacion y la cria de su progenie necesitan respectivamente el mismo plazo. Depositan sus huevos en parajes secos, arenosos y cálidos. Macho y hembra se ocupan en la incubacion, relevándose por turno, segun describe Soli. nus. No existe animal que siendo tan pequeño al principio, adquiera desde luego tan enormes dimensiones: aunque el tamaño del huevo no excede del de una gansa, llegan á tener los hijuelos veinte varas de largo, si bien suponen algunos que crece mientras vive, aunque pquede llegar á la edad de sesenta años.

- Es un reptil traidor, astuto, feroz y rapaz; es el enemigo mas terribic de todos los demás animales.
Dicen que este saurio posee una cualidad extrana: cuan. do los hijuelos salen del huevo, el macho los vigila, para observar si en el momento de nacer cogen algo con la boca y muerden, aunque no sea mas que una paja, un poco de yerba, una lagartija ú oira cosa cualquiera. Si lo hacen así, demostrando que no desmerecen de su raza, el padre los deja en paz; pero de lo contrario los hace pedazos.

La pequeña ave llamada trochilus y el enorme crocodilo parecen profesarse una amistad y simpatía particulares, cuya causa explican los maturalistas de este modo: cono aninal acuático tiene siempre sanguijuelas en el hocico, y como carnivoro, le quedan restos de carne entre los dientes; esto lo sabe muy bien el avecilla, que introduciéndose en la boca abierta del animal cuando duerme ó se calienta al sol, le saca la carne de los dientes y le limpia picotenndo; el crocodilo, que experimenta en ello la mayor satisfaccion, conserva la boca abierta, y cuando el ave está harta y quiere irse, la deja salir ilesa, moviendo lentamente la mandibula superior.

Segun dicen, no son cstos aniuales tan crueles y ủañinos, cuando tienen suficiente alimento, ya sean peces ú otra cosa cualquiera, y tambien se afirma que alguna que otra ver. lle. gan a domesticarse; pero cuando les aguijonea el hambre se muestran crueles; derriban en tierra à los animales mas fuertes con un solo golpe de su cola, y los devoran al momento ávidamente.

y. I.os machos profesan un gran cariño á sus hembras: cuéntase que cuando los barqueros los encueniran en el acto del apareamiento, y se abalanzan sobre ellos con grandè algazara, salta el macho espantado y se introduce en el agua, dejando á la hembra indefensa, porque sus cortas extremidades no le permiten volverse. Pero si al volver reconoce por la sangre que tiñe el suelo que laan dado muerte à su compañera, enfurécese de tal modo.á veces, que lanzándose en seguimiento de la embarcacion con inusitada furia, clava en ella mandi. bulas y garras, poniendo en grave peligro a los tripulantes.

* Ascgúrase tambien que los cerdos se llemn bien con el crocodilo, pues pacen y viven a orillas del Nilo, sin que el saurio les moleste jam\{s.

El crocodilo aborrece á la rata llamada icneumon, por. que devora sus huevos donde quiera que los halle.

Tambien se da el caso de que este roedor se introduzca en el cuerpo del reptil mientras duerme, y cuando llega roe y devora los intestinos, practicando despues un agujero para salir otra vez. El trochilus no ignora esto, é impulsado por su amor y simpatia al crocodilo, le despierta tan pronto como conoce el riesgo.

- Este saurio profesa igualmente la mayor aversion á los monos llamados cercopitecos, al buey salvaje y al azor; pero mas que á todos estos, aborrece al delfin. Conociendo este cuán poderosa es el arma de que está provisto su lomo, se. mejante a un cuchillo afilado, apenas divisa al crocodilo, se sumerge a la profundidad necesaria, y como sabe que su vientre es blando, le embiste furiosamente por esta parte. Entonces, à pesar de su tamaño y su fucra, el gigantesco saurio sucumbe y llega á ser pasto de los peces. Vemos, pues, por esto que cada animal ticne sus enemigos naturales. - Tambien se habla de la cnemistad que existe entre el crocodilo y el alacran: esto explica porqué los egipcios, cuan. do quicren representar simbólicamente á dos enemigos, pintán al saurio $y$ al insecto.

Yo he llegado á conocer bastante al crocödilo durante mis viajes, habiendole observado en Egipto, en la Nubia y en el Sudan oriental; he visto centenares de individuos, á los que pude apuntar con mi carabina; he dado muerte á varios, con. servando otros en cautividad; y he comido sus huevos y su carne. 
En Egipto han sido casi completamente exterminados estos reptilcs; lo que no pudieron contra ellos las flechas y las piedras arrojadas por las hondas de que nos habla Job, lo han conseguido las balas. Verdad es que este saurio no ha retrocedido, sino que se ha conservado con insistencia en el mismo punto; pero por eso ha muerto a manos del hom. bre de los tiempos modernos. Ios dias de gloria de que gozó en las épocas primitivas no volverán mas; acabó de ser temible desde que las modernas armas de fuego destrozan su coraza, desde que un niño puede vencer \& un gigante. Hoy dia nos burlamos del icneumon, de ese héroe legenda. rio, y dudamos de sus obras; ya no le será dado devorar los hucros del crocodilo, ni-introducirse por su boca pam co merse el corazon, porque es probableque hayan sido victimas de las balas de los viajeros ingleses los pocos saurios acorazados de está especie que ví en Egipto; el icneumon habrá de contentarse, pues, con hueros de gallina, como lo ha becho siempre, en mi concepto.

Cuando recorri por primera vez el interior de Africn, pude reconocer por mis propias observaciones que habian pasado ya los buenos tiempos para el crocodilo. Iba yo en companía de algunos jesuitas que se dirigian a! Sudan para convertir á los indigenas de Rio Blanco: cierto dia les ví de pronto pro rumpir en ruidosas exclamaciones; y con gran algazara, im propia de su graveciad, empunó cadn cual su carabina é hizo fuego. Seis tiros resonaron á un tiempo, mas no el mio, pues á la primera mirada reconoci que el crocodilo que habian visto mis conpaneros estaba ya inuerto. Eicctivamente, luego se supo que unos viajeros habian inmolado en la noche anterior al reptil. A no ser por esta circunstarcia, el animal no hubiera muerto, porque de las scis balas dirigidas a su cora. 2a, ninguna tocó en el blanco; pero este furor por la caza, de que se sienten poseidos hasta los hombres piadosos, me de mostró claramente que cra bastante aflictiva la situacion del saurio antediluviano, continuanente perseguido por el hombre. Debo confesar que yo mismo aproveche cuantas ocasio nes tuve de exterminar algun individuo de la especie. Héaqu explicado por qué no se encuentran hoy dia los crocodilos a miles sino en las cavernas de Maabde.... pero momificados.

No sucede así en el Sudan oriental, $\delta$ en el interior del Africa, ni alli donde las modernas armas de fuego no han recmplazado todavia á las primitivas de los indigenas. En todos aquellos rios cuyas orillas están cubiertas de selras virgenes, se puede estar seguro de encontrar en cada banco de arena un crocodilo grande por lo menos y una media docena cie menor talla y diversa cdad. Tanto en aquellos sitios, como tambien á orillas de los pantanos, lagos 5 terrenos húmedos, pueden verse los ejemplares mas hermosos de estos monstruos, 5 observarlos cómodamente. Aun hoy dia son una veruad en el Sudan las palabras del poeta hebraico, porque alli no existe aldea cuyos habitantes no tengan que contar desgracias; alli no hay persona que no admire la fuerza del Timsaj y le maldiga. $Y$ á fe que les sobra razon a los natura. les, porque son del todo impotentes para combatir al croco dilo y se ven obligados á mirar con paciencia cómo el terrible monstruo arrebata \& sus parientes ó su ganado para devorarlos en las proiundidades del agua: ni le pueden ahujentar ni exterminarle. Yo supongo que hoy dia habitan en el Rio Azul por lo menos unos quinientos crocodilos, y en el Rio Blanco mas de dos mil, de gran tamaño, \&los cuales se debe agregar acaso un número cuatro veces mayor de individuos mas pequeños, pues yo los vi en todas partes. Cierto dia conté en un solo banco de arena diez $y$ ocho, $y$ en Asrakh vi otra ver. mas de treinta, observando entre ellos algunos gigantescos cuya longitud calculé no bajaria de diez y seis piés, es decir, individuos que debian contar algunos siglos de edad.
Debo añadir que tan fảcil es engañarse sobre la longitud de un crocodilo que fuera del agua toma el sol, $\delta$ se muevic dentro de ella, como sobre ia de una serpiente. Un crocodilo de cinco metros de largo es un monstruo gigantesco, pero al observador inexperto le parece mucho nas grande. Yo no creo que entre los centenares de individuos que vi hubiese uno solo de siete metros de largo, y por lo tanto dudo de la exactitud de los informes en que se nos habla de crocodilos de una longitud de nueve metros y mas. Seguramente no se obtuvieron tales medidas por una persona concienzuda. Tampoco es posible determinar la longitud total por la del críneo, porque en los crocodilos adultos es relativamente mucho mas largo que en los jóvenes. Un individuo de cinco metros puede considerarse como adulto, pero aumenta des. pues en tamaño, aunque lentamente, y crece quizis hasta su muerte, que bajo condiciones favorables no ocurre hasta despues de una larguisima serie de años.

Un banco de arena bañado por el sol es el lugar que pre. fiere cl crocodilo para vivir; no le gustan los parajes ruidosos ni las corrientes rápidas de los rios, y rara vez se le encuen. tra alli; pero una vez elegida su residencia, no la abandona jamás. Por esto nos prevenian siempre antes de llegar a un sitio del rio, abundante en crocodilos; 5 los hombres mas ancianos nos aseguraron que conocian algunos de estos rep. tiles desde su infancia por haberlos visto siempre en un mismo banco de arena. In la estacion de las lluvias, cuan. do llueve á torrentes $\delta$ cuando las selvas vírgenes se hallan anegadas, emprenden excursiones al interior de las tierras.

Nos inclinamos á creer que el crocodilo se mueve con pe. sadez; pero esto es un grave error. En el agua da pruebas de agilidad; nada y se sumerge con asombrosa ligereza; y corta las olas con la rapidez de la flecha que cruza el espacio.

Su cola, de extraordinaria fuerza, es un remo excelente, y sus membranas interdigitales le facilitan la natacion en gran manera. Irritado y furioso, ó en la agonia de la muerte, azota las ondas con tal violencia, que no puede tacharse al poeta antiguo de exagerado cuando dice, «que hace hervir las aguas del profundo mar. En tierra se mueve evidentemente con torpeza; pero rara vez le llevan á ella sus instintos. Cuando sale del agua para subir \& los bancos de arena, lo hace con gran lentitud, moviendo un pié despues de otro, con el cuerpo tan caido que lo arrastra; pero se precipita ra. pidamente hácia el agua si se asusta de pronto léjos de la orilla; y con igual velocidad sale de ella cuando trata de apo. derarse de alguna victima.

Mi amigo Penney ahuyentó cierto dia á un crocodilo que estaba escondido en un arrojo seco y lleno de hojarasca. Al oir las pisadas del caballo, echó el animal á correr en línea recta hácia el rio, distante como legua y media, y con tal ve. locidad, que fué.imposible alcanzarlo con los camellos de montar mas veloces. Cualquiera que haya visto salir a un crocodilo del agua y volver á ella, comprenderk que es una fábula aquello de que estos anirisales no pueden correr incli. nándose á uno y otro lado.

Dificil es emitir un juicio sobre las facultades intelectuales del crocodilo. Herodoto incurrió en error respecto \& 10 que dice sobre el sentido de la vista, porque este animal ve con extraordinaria precision debajo del agua, y suficientemente bien en ticrra. Su oido es sorprendente, y de seguro mas fino que el de los demás reptiles; pero en cambio parecen nulos el olfato, el gusto y el tacto, segun se infiere por algu. nos datos que citaré despues. No puede negárseles cierto grado de inteligencia, porque se acuerdan de las persecuciones que sufren y tratan en su consecuencia de evitarlas con precaucion. Todos los crocodilos que aun existen en el Egipto, $\delta$ mas bien, los que vivian alli cuando yo estaba, se 
introducian en el agua al acercarse un barco, $y$ siempre tan á tiempo, que solo por casualidad les alcanzaba alguna bala. Los crocodilos que habitan en los rios ciel Sudan dejan que se aproximen mucho mas las embarcaciones; de modo que se les puede tirar muy bien desde aquellas. Los individuos viejos que se fijan en un mismo banco de arena durante una serie de años, lo abandonan cuando se les molesta en él re petidas veces, $y$ entonces eligen otro; pero siempre uno donde pueden disfrutar del sol y dormir. Se acuerdan de los sitios donde encontraron casi siempre abundante presa, como los senderos que conducen á la orilla y que frecuenta el ganado $\delta$ las mujeres cuando van por agua; alli se ponen al acecho; pero como ya dije antes, no distinguen entre las personas inofensivas para ellos $y$ las que pueden causarles dano; si bien suclen retirarse al agua cuando ven al hombre, prefiriendo los animales, que les parecen alimento mas fácil de coger. Su astucia para acometer no puede compararse ni remotamente con la sagacidad de los mamiferos y aves; en esto, como en todo lo demás, resalta su estupidez, su inferioridad y cscasa inteligencia. Su modo de conducirse es diferente segun las circunstancias; en tierra son los crocodilos mas que cobardes, y en el agua, probablemente, poco bravos; pero distinguense por su osacia y audacia, cual si com. prendiesen cuánta seguridad les ofrece su elemento favorito.

Entre si viven pacificamente los de gran fuerza cuando no intervienc el celo; son de un peligro constante para sus congéneres menores, pues si les atormenta el hambre, no guardan ya ninguna considicracion.

De los otros animales no se cuida el crocodilo sino cuando le interesa cogerlos para devorarlos: aquellos de que no le es posibie apoderarse, pueden vivir cerca de él; y asi se ex. plica su aparente amistad con el avecilla de que antes hablé.

El crocodilo puede lanzar mugidos sordos, aunque solo deja oir su voz cuando está excitado; yo creo posible que pasarán algunos meses sin que el observador aténto percibiese un solo sonido de estos reptiles. Cuando se espantan de pronto $\delta$ se les hiere, grunen ó lanzan mugidos fuertes. En una cacería de garzas reales, á orillas del Nilo Blanco, hube de acercarme cautelosamente á un lugar escarpado de la playa, $y$ en el fondo, debajo de mis piés, vi, en vez del aye deseada, un gran crocodilo, contra el cual disparé la perdigonada. Al momento se lanzó al agua, gruñó con fuerza y desapareció en las olas.

El individuo sorprendido por Penney manifestó tambien su espanto por un rugido. Cuando se le excita bufá 6 pro. duce un silbido ronco. Los pequeños emiten al salir del huevo un extraño rac rac, que recuerda la roz de las ranas.

El animal suele salir del rio al medio dia para tomar el sol y dormir descansadamente; esto ulitimo no lo puede hacer en el agua, porque bajaria \& la profundidad cuando la respiracion no estuviese bien regulada, despertándole en este caso necesariamente la faita de aire; solo pueden dormitar cuando están echados sobre el agua de la manera indicada, $\delta$ por lo menos asi lo he observado en mis cautivos.

Acostumbran á salir del agua à eso del medio dia para tomar el sol y dormir, pues no pueden hacer esto último dentro de aquella, porque cada diez minutos, poco mas 6 menos, deben salir á la superficie para respirar. Cuando quieren entregarse al sueño, se arrastran con lentitud y precaucion sobre un banco de arena poco elevado, dirigen con sus verdes ojos una prudente mirada á su alrededor, y despues de observar un buen rato, prepáranse para dormir, apoyándose sobre el vientre. Casi siempre se enroscan y con frecuencia queda la punta de la cola tocando el agua Una vez culocado á su gusto, levanta las cubiertas que cierran las fosas nasales, bufa, bosteza y abre finalmente todo lo posible su horrible boca, tan guarnecida de dientes. Descie anuel momento queda inmóvil en el mismo sitio, y parece dormido muy pronto; pero su sueño es ligero, pues al menor ruido se espanta y precipirase al agua. Yo mismo pude observar todos estos detalles desde una choza que habia arreglado en el banco de arena, y con el auxilio de mi excelente anteojo de larga vista; de manera que puedo. salir garante de cuanto digo.

Cuando no se le molesta permanece este animal en tierra hasta el anochecer, y segun el caso, en compañia de sus con. géneres. A veces están echados varios individuos, unos enci. ma de otros; pero comunmente, cada uno por si solo y separado de los demis; esto es lo que se observa, sobre todo en los mas jóvenes, que se mantienen siempre á respetuosa distancia de los mayores. Despues de anochecido quedan todas las islas desicrtas, porque entonces dan principio a la caza, que no se interrumpe ya en toda la nocinc, y que tal vez se continúa aun en las primeras horas de la mañana. Persiguen principalmente á los peces; no cabe la menor duda de que estos animales pesados, y al parecer tan torpes, saben atrapar \& los ágiles habitantes del agua, toda rez que estos constituyen, por decirlo asi, el alimento propio y natu. ral de los saurios acorazados. Claro es que despues de los peces se apodera el crocodilo tambien de toda clase de ma. míferos grandes $y$ pequeños, si se acercan descuidados al rio para apagar su sed, y hasta de las aves acuáticas y palustres. En tales casos, acércase con mucha lentitud y suma precau. cion átos sitios donde espera encontrar sus victimas; sumér. gese en el agua, sacando solo las narices para respirar; y luego, veloz como el rayo, salka sobre la superficie y se precipita contra su presa, segun yo mismo he visto. Jamús intenta perseguir por tierra a un animal que se le pueda escapar; asi tuvimos ocasion de presenciar una vez cómo un antilope, que satisfacia su sed al pié de una márgen algo elevada, dando dos enormes saltos, evitaba la acometida de un crocodilo que en el mismo momento saltó hasta la mitad de la orilla.

El saurio engaña \& las aves con su tranquilidad aparente 6 su quietismo; finge no hacer caso de esos séres y se preci. pita despues bruscamente en inedio de ellos, ó se acerca al principio con suma lentitud, paso á paso, sin atacarlos hasta llegar á una distancia que le parece suficiente. Continua. mente soy testigo ocular, dice Baker, de su manera de aco. meter á las numerosas bandadas de aves pequañas que se reunen en las espesuras a orillas del agua; estas aves conocen perfectamente el peligro y evitan el ataque cuanto pueden. El crocodilo permanece inmóvil sobre el agua cual si por casualidad se hallase alli; de csta mancra llama la atencion de las aves, y despues se aleja lentamente, seguido de sus miradas, a una distancia considerable. Engañadas asi por el traidor reptil, las arecillas creen que el peligro ha pasado; ruelven a posarse en el arbusto, y acosadas por la scd sú. mergen sus picos en el agua, sin notar entonces que el enemigo no está ya en la superficie. Un ruido sordo en las ondas, la presencia súbita de dos colosales mandibulas debajo del arbusto, y la desaparicion de algunas docenas de victimas son la señal inesperada de la vuelıa del saurio, que con la major astucia se ha sumergido para volver por debajo del agua. Continuamente he visto á los crocodilos cazar de esta manera; engañan con una falsa retirada y acometen luego por debajo. No dudo en lo mas minimo de la exactitud del informe de Baker, quien dice que tambien las aves del ta. maño de los fringílidos son victimas de un crocodilo adulto. Day encontró en el cstómago del crocodilo de los pantanos, muy afine de la especie que nos ocupa, no solo restos de nutria, de aves y de serpientes venenosas, sino tambien de 
escarabajos acuáticos. Asi como aquella especie, el crocodilo del Nilo no despreciará una presa pequeña, si bien prefiere las grandes.

Este reptil hasta ataca mamiferos de gran tamano, y arrastra al fondo de las aguas, asnos, caballos, bueyes y camellos. En las dos arterias principales del Nilo pierden los pastores todos los años infaliblemente algunos de los animales confia dos á su custodia. A orillas del rio Azul observamos cierio dia un buey con la cabeza cortada, y su propietario nos con. tó, lamentåndose amargamente, que el hijo, nièto y bianie:o del maldecido por Alá habia muerto al inofensivo animal, arrancándole aquella parte. Yo no podia comprender cómo un reptil que tiene los dientes tan quebradizos fuese capaz de separar del tronco ja cabeza de un buey; me es casi imposible explicarme un esfuerzo tan poderoso, a pesar del ter. rible armazon de dientes que presenta la boca de este saurio. Poco tiempo despues de mi llegada al Sudan oriental refirié. ronme el siguiente caso de cuya veracidad nadie dudaba: Un camello se acercb despues de anochecido al rio para beber; esperabale en la orilla, algun tanto escarpada, un leon colo sal, dispuesto \{lanzarse sobre su presa; y un gigantesco cro codilo, oculto en el agua, acechaba tambien al camello sediento. Ambos, el carnicero y cl saurio, cayeron á la vez sobre su victima: clavóle aquel las garras en el lomo, y el crocodilo le sujetó el cuello con su enorme boca; los dos pugnaban por llevarse la presa, y de tal modo redoblaron sus esfuerzos, que el camello se partió al fin por la mitad, lle. vándose una parte el leon y la otra el crocodilo. Ya se com. prenderá que esto no pasa de ser un cuento, una pura invencion; pero reconócese por aqui qué opinion tienen los árabes del terrible saurio. En cuanto á si se atreve con animales tan corpulentos, hasta el punto de sujetarlos, de ello pude convencerme mas tarde, pues á un camello que iba a beber, le arrancó un crocodilo una pierna, hecho que presencié yo cuando me liallaba en Kartoum, en el rio Blanco. En mis excursiones por éste último punto s por el rio Azul, observé tambien que los pastores del Sudan oriental tienen siempre Ia precaucion de llevar toda la manada reunida, produciendo gran algazara al acercarse 2 las margenes, 2 fin de espantar á estos reptiles. Alli donde existen crocodilos peligrosos no van jamàs a beber al rio los animales comparativamente me. nores, como son caballos, buejes, asnos, ovejas y cabras, sino que apagan su sed en depósitos construidos cerca del rio y que los pastores han de llenar de agua con mucho trabajo, $\sigma$ bien en recintos formados en el rio por medio de cercas es pesas de espinos.

Si el crocodilo es temible y peligroso por los destrozos que causa en los rebaños, tambien se le puede considerar como tal para la seguridad de las personas, pues no existe una sola aldea en todo el Sudan donde no haya que lamentar la pér. dida de algunos habitantes, que sirvieron de pasto á los cro. codilos. Estas desgracias se repiten todos los años, y si los viajeros no dieron cuenta del hecho siempre, es porque no toman suficientes informes sobre el particular. Al que pregunta a los indigenas, le refieren casos numerosos de crocodi. los que devoraron á alguno de sus conocidos, amigos ó parientes, despues de arrastrarlo al fondo de las aguas; $y$ asimismo le cucntan que muchos de sus caballos, camellos, mulos, asnos, perros, carneros y cabras, fueron pasto del terrible saurio. Las personas suelen ser su presa cuando entran en el rio para sacar agua, y rara vez escapa la victima, porque las acometidas del animal son tan rápidas, que no dan tiempo para huir. Hasta en los estanques y corrientes de las ciudades populosas se encuentran á veces los feroces cro. codilos: hallándome en Kartoum, uno de ellos arrebató un niño á pocos pasos de la casa de sus padres; llevóle al agua á fin de ahogarle, y arrastrándole despues a un banco de arena situado en medio del rio, le devoró à la vista de mis criados. El terror sin limites que inspira el crocodilo a los su. daneses es por lo mismo muy fundado.

Todos los animales inteligentes conocen el crocodilo y su manera de acometer. Cuando los nómadas de las estepas del Africa llegan con sus rebaños y perros á orillas de los rios, deben tener mucho cuidado, sobre todo con los últimos, pues siempre suelen perder algunos de estos excelentes animales, porque les falta la experiencia indispensable que ticnen los perros de las aldeas del rio. Rara vez son estos presa del peligroso reptil: para beber se acercan con gran sigilo al agua, la observan con atencion, beben un poco y vuelven presu. rosos á un sitio seguro, donde permanecen largo rato parados, mirando fijamente al agua; despues se acercan otra vez para beber con las mismas precauciones, y repiten igual maniobra hasta quedar del todo satisfechos.

El terror que inspira el crocodilo ś estos animales se re. convce cuando se les enseña un individuo grande; entonces retroceden como los monos á la vista de una culebra y ladran con furor.

El crocodilo no se alimenta solo de animales vivos, sino que devora tambien todos los que el rio arrastra muertos. Mas de una vez me arrebataron aves, que estimaba en mucho, al caer heridas al agua, y acordábame entonces del en. cuentro que tuve cierto dia con un individuo de la especie, en circunstancias que pudieron ser fatales para mi, por lo que desde aquel momento les declaré guerra á muerte. Ins. trumentos de mi venganza han sido todas las balas que per. foraron la piel acorazada de esos monstruos y que fueron disparadas por mi mano; jamás dejé escapar ocasion alguna de probarles mi odio. El caso fué el siguiente: habia planta. do una tienda de campaña delante de Kattoum, donde me hallaba cazando hacia algun tiempo; y cierto dia, casi á la hora de anochecer, disparé contra un águila marina, que en aquel entonces tenia gran mérito para mí. Herida el ave cayó revoloteando al rio y comenzó á flotar á lo largo de la orilla, hasta que llegó á un paraje donde la corriente se desvia hácia el centro. Si no me apoderaba pronto del ave, podia dar. la por perdida, y como en aquel momento acertase á pasar un árabe, le rogué que me pescase el águila. \&Libreme el cielo, señor, contestóme al punto; aquí no entraré yo en el agua, porque en este paraje hormiguean los crocodilos. No hace todavia tres semanas que cogieron dos carneros cuando bebian y se los llevaron para devorarlos; á un camello le partieron una pierna, $y$ un caballo escapó á duras penas de sus dientes. $D$

Yo prometi no obstante al hombre una buena recompensa, llaméle cobarde y le excité a que probara su valor; pero me replicó con mucha calma, que aunque le ofreciera todos los tesoros del mundo no entraria en el agua. Entonces me des nudé enojado, lancéme al rio $y$ nadé en direccion al ave, pero de repente exclamó el árabe: Señor! ;por el amor y la misericordia de Alá; vuélvete, un crocodilo! Asustado, vol vime a la playa, y vi en efecto, que por la otra parte del rio llegaba un crocodilo gigantesco, mostrando las crestas de su coraza sobre la superficie del agua. Dirigióse en linea recta al ave, y cuando esturo próximo, sumergiose, abrió la boca, que me pareció lo bastante grande para que cupiese yo con mi águila, y apoderándose del ave, ocultóse con ella en las turbias ondas. Mas tarde nadaba otro crocodilo en direccion ¿ un chorlito del que trataba de apoderarse mi criado; y probablemente hubiera cazado al hombre antes que al ave, si yo no le hubiese impedido para siempre tales desmanes, mer. ced à una certera bala bien dirigida.

A veces cogen hasta objetos inanimados que flotan en el 
rio, sin tomarse siquiera la molestia de tocarlos antes de tra. gárselos. Un pellejo lleno de aire ó de agua, como el que usan los habitantes del Sudan, les puede parecer en ciertos casos, segun Baker, una buena presa, lo cual basta para sal. var la vida del hombre que lo lleva.

I.os negros chiluj, que habitan el pais contiguo al territorio egipcio-turco, no entierran jamás sus muertos, sino que los arrojan al rio, simplemente como lo hacen los indios del Ganges con los suyos. A pesar de esto, muy rara vez se ve Potar el cadáver de un negro, y es que los crocodilos que alli habitan, tan numerosos como gigantescos, no dejan escapar tan buena presa.

La osadia de que da pruebas el crocodilo cuando se halla en su elemento, ofrece el mas singular contraste con la co. bardía que demuestra en tierra. Pocas veces se aleja á mas de cien pasos de la orilla y precipitase al agua en seguida á la menor señal de peligro. Apenas divisa al hombre, huye con la mayor celeridad, sin que le ocurra jamás perseguirle en tierra. Me he divertido infinitas veces en sorprenderles de pronto, y siempre observé que se precipitan al agua con ridiculo apresuramiento, a la manera que lo hacen las ranas. Uno de mis criados quiso acercarse cierto dia al amanecer á un resto de tronco de árbol no léjos del rio, para sorprender algunos ánades silvestres, cuando advirtió con terror que el tal tronco era un crocodilo. Felizmente se condujo el animal como siempre, es decir, que se espantó del criado, y en vez de precipitarse sobre este, emprendió la fuga. Igual es su temor cuando le cortan la retirada; entonces se esfuerza por introducirse en el primer escondrijo que encuentra al paso y permanece alli quicto. Una mañana nos sorprendió un crocodilo de ocho piés de largo, durante una excursion de caza en los bosqques del rio Azul; pero nos admiró sobre. manera rerle huir inmediatamente, refugiándose en la pri. mera espesura que pudo alcanzar, donde permaneció com pletamente inmóvil, de suerte que no nos fué posible conocer el sitio en que se hallaba oculto para enviarle una bala.

Es probable que solo de noche emprenda semejantes excursiones portierra, $y$ entonces tal vez con la intencion de pasar á otras aguas, pues seguramente no dejará el rio para ir á cazar, $\delta$ por lo menos, jamás lo oi decir ni yo lo he observado tampoco. Durante la estacion de las lluvias remonta los torrentes, avanzando tanto por ellos algunas veces, que se le corta la retirada cuando deja de llover, pues las aguas se alejan rápidamente, el lecho quueda en seco, y entonces no tiene mas recurso que ocultarse lo mejor posible hasta que la renida de las aguas le permite volver á su centro. En tales casos, trasládase al principio de un charco a o:ro, pasando semanas enteras alli donde queda un poco de agua, aunque la cantidad no sea proporcional á las dimensiones de su cuerpo, por manera que á veces se ven verdaderos gigantes de esta especic un charcos muy reducidos;y cuando estos llegan a secarse se enticrran en el fango. Cierto dia, durante una expedicion de caza, llegó el doctor Penney con sus hombres á un torrente seco, que iba as desembocar en el rio Azul y se hallaba a tres leguas de este. Habiéndose resuelto abrir un pozo dentro del lecho, para suplir su escasez de agua, dióse principio \& la excavacion, y ya llegaban los trabajadores á la profundidad de ocho piés, cuando saltaron asustados fuera del, hoyo, llamando a grandes roces al médico, y diciendo que dentro del pozo se movia una ecosa parda de un lado á otro.

Practicado el reconocimiento, resulto que lo que se movia cra el extremo de la cola de un crocodilo muy grande: entonces se abrió otro pozo en el sitio que debia ocupar la cabeza, y dióse muerte al reptil alanceándole la nuca ; despues le desenterraron y se vib que era un individuo de quince piés.
El torrente aquel se llama con tal motivo, aun hoy dia, Chor el Timsaj, ó sea, Torrente del crocodilo.

Crocodilos de $3^{m}, 50$ de largo pueden ya reproducirse; pero las hembras de esta edad ponen menos huevos y mas peque. ños que las adultas de diez y seis, diez y ocho, y veinte piés de longitud. El número de huevos que ponen, semejantes en cuanto á forma y tamaño á los de ganso, pero que se distinguen de estos por su cáscara flexible, rugosa y muy calcárea, oscila entre veinte y noventa. De cuarenta á sesenta formarán el término medio de una nidada. Las hembras los ponen en un hoyo profundo sobre un islote formado por la arena que cubren despues con la misma, sirviéndose de su cola. Dicen que borra las huellas de su operacion con tanto cuidado, que solo puede reconocerse el sitio por las muchas moscas que alli se reunen. Por otra parte, sostienen tambien los sudane. ses que la hembra del crocodilo cuida y vigila los huevos y ayuda además á los pequeñuelos cuando nacen á salir del hoyo y á ir al agua; esto se dicc, pero no sé hasta qué punto será verdad. De combates entre machos en celo no oi contar nada, pero si que la cópula se efectúa en los islotes de arena donde el macho empieza por tumbar a la hembra de espaldas, poniéndola despues del acto otra vez vientre abajo. Los pequeñuelos crecen con extrema lentitud; en el primer año medran á lo mas 6 pulgadas, y menos aun en los que siguen, por manera que puede afirmarse con toda seguridad que los gigantes de esta especie, que miden de 5 \& 6 metros deben tener mas de cien años. No puede decirse qué edad alcanzan.

CAUTIVIDAD. - Segun lo que nos comunica Herodoto sobre el Bajo Egipto, se conoce que allí tenian, en remotas épocas, crocodilos en cautividad. Hay egipcios, dice, que consideran estos animales como séres sagrados; pero hay otros que ven en ellos sus peores enemigos. Aquellos habitan las orillas del lago Moeris, y estos al redecior de Elefantina. Los primeros crian un crocodilo y lo domestican hasta tal grado que se deja tocar; se esfucrzan en darle una vida regalada, adoman con anillos de piedras talladas y de oro sus orejas, con brazaletes de oro sus extremidades anteriores y lo mantienen con manjares hechos de harina y con carne de los sacrificios. Despues de muerto lo cmbalsaman y 10 colocan en un sepulcro sagrado, de los cuales hay muchos en los aposentos subterraineos del laberinto situado \& la orilla del lago Moeris, no léjos de la Ciudad de los crocodilos.

Estrabon completa estas noticias. "La ciudad de Arsinoe en Egipto, dice, teria en otros tiempos el nombre de Ciudad de los crocodilos, porque en aquella region eran muy esti. mados estos animales. Alli hay en cierto lago un solo crocodilo, muy manso para con los sacerdotes, y llamado suchos: se le alimenta con carne, pan y vino, que llevan siempre lus forasteros cuando quieren ver el animal. Mi huésped, hom. bre muy considerado y el cual quíso enseñarme las cosas sagradas de aquel sitio, nos acompañó al lago; iba provisto de una pequeña torta, carne asada y una botella de hidromiel. Encontramos el repiil echado en la orilla; los sacerdotes se acercaron á él, abriéronle la boca, y uno de ellos le intro. dujo la torta, despues la carne y por último la bebida. El saurio se precipitó entonces en el lago y madó hasta la orilla opuesta; pero como llegase otro forastero trayendo su pre. sente, los sacerdotes le tomaron, dirigiéronse á la otra parte del lago y diéronselo al reptil del mismo modo. Segun nos refiere Plutarco, los crocodilos conocen, no solo la roz del que suele llamarlos, sino que se dejan tocar, limpiar los dientes y frotar con un pedazo de hilo. Diodoro Siculo, en fin, nos indica porqué se veneraba á este saurio como una divinidad. Dicese que tanto la anchura del rio como la multitud de crocodilos que en él habitan, impiden á los ladrones árabes y libios cruzar la corriente. Otros cuentan que 
uno de los reyes antiguos, Menas, perseguido por sus propios perros, se habia refugiado en el lago de Moeris, donde por milagro un crocodilo le recibió sobre su lomo, llevándole á la orilla opuesta. Para demostrar su agradecimiento á este animal por haberle salvado, el rey edificó cerca del lago una ciudad, á la cual dió el nombre de Ciudad de los crocodilos, imponiendo á los habitantes como ley adorar á los cro codilos cual si fueran dioses. El mismo rey construyó en aquel sitio además una pirámide y el laberinto. No falta sin embargo quien indica muy diferentes causas de la deificacion de estos animales.

Para que se comprenda cuán fervorosa ha sido la veneracion á este reptil, véase lo que dice Máximo Tyrio: ¿En el Egipto cierta mujer crió un crocodilo, 2 lo cual debíó que la venerasen como a una diosa. Su hijo, muchacho aun, vivia y júgaba con el crocodilo, hasta que este, alcanzando mayor tamaño y mas fuerza, deroró ppor fin a su compañero. La desgraciada madre ensalzó desde entonces la dicha de sus hijo, considerando que habia sido devorado por un dios.

Lo que es en el dia nadie se acuerda en el Africa oriental de domesticar crocodilos, lo cual es además un trabajo que parece ofrecer dificultades muy sérias. En Kartoum compré en 20 de julio de $\$ 850$ un crocodilo para observarle, el cual tenia de largo ocho pies y se habia enredado en las redes de unos pescadores, pagando por él como cinco reales escasos de nuestra moneda. Los pescadores le habian agarrotado fuertemente el hocico para impedir que mordiera, pero cuando nos acercamos â êl, nos embistió con tal impetu y dando un brinco tan repentino que retrocedimos espantados á pesar de que sabiamos que no podia morder. nos; cuando lo empujábamos con el pié dejaba oir un grito casi parecido á un silbido ó resuellos penosos; pero por lo demís se mostrỏ en extremo insensible, porque le pincharnos con agujas, le metimos rapé en las narices, le pusimos ascuas sobre la piel, y lo atormentamos de otros modos, sin que mostrase la menor incomodidad; solo el humo de tabaco pareció molestarle, porque cuando mi compañero, el doctor Vierthaler, le acercú $̂$ las narices su pipa encendida, se puso furioso. Por la noche llovió, ló que nos vino muy de molde, porque un hoyo bastante grande y profundo, que estaba delante de nuestra casa, se trasformó en balsa donde pudimos alojar al prisionero $y$ conde parecíb encontrarse bien, aunque se dejo ver muy poco en la superficie, $y$ cuando io hacia solo sacaba la nariz para respirar; y eso que habia respirado aire sin intersupcion todo el tiempo que le habian tenido en tier. ra. Para los habitantes de la capital fué nuestro crocodilo un motivo de verdadera diversion; chicos y grandes sitiaban la balsa que habitaba este sijo de perro.» Para impedir que husera y ganara el rio Azul, que no está demasiado léjos, lo habia hecho atar a una cuerda de la cual tiraban los que pasaban para sacarlo del agua à tierra á fin de inspeccionarlo, 8 despues lo soltaban otra vez con imprecaciones é improperios acompañados á veces de pedradas; hasta los chiquillos querian gozar del placer de poder siquiera maltratar una vez en su vida á un crocodilo. Para ahuyentarles á todos habia yo mandado cortar la cuerda que le agarrotaba el hocico, pero ni esto valió; parque venian con palos y le pe. gaban en el dorso y cuando lo habian irritado bastante le enseñaban el palo para que lo mordiera, lo que hizo en efecto y con tal rabia, gue se dejó arrastrar de una parte á otra con

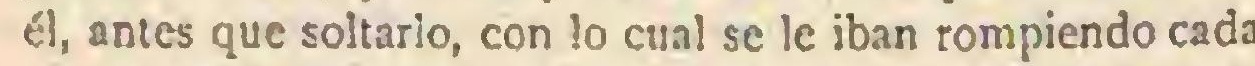
rez algunos dientes, pero sin afiojar por esto el palo. Gracias á estós infinitos esfuerzos de toda la poblacion de Kartoum, exhalo cl cautiro á los pocos dias su «espiritu mal. dito. 9
Los crocodilos que se cogen cuando son pequeños llegan a ser tan mansos como lagartos: déjanse tecar al cabo de algun tiempo, ó coger con la mano, sin bufar; acostúmbranse á cierta voz; toman el alimento que se les da y son entonces muy agradables. Puede suponerse con seguridad que los in dividuos cuidadosamente criados son tan dóciles, aun en la edad adulta, como es posible para un crocodilo; de modo que los relatos de los antiguos no deben considerarse como exagerados.

CAZA.-Segun Herodoto, cazaban los antiguos egipcios el crocodilo de varias maneras. El cazador, oculto en la orilla, echaba al agua un cerdo con un anzuelo en la espalda, mientras hacia gruñir un lechoncillo dándole golpes; al oirle el crocodilo, acudia y se comia el cerdo, siendo despues arrastrado á tierra con auxilio del anzuclo y la cuerda atada al mismo; entonces el cazador le cubria los ojos con limo para precarcrse de sus ataques, y lo mataba despues con toda calma. De los tentiritas refiere Plinio que poseian bastante'valor para seguir al crocodilo á nadu, echarle un lazo al pescuezo y sentarse sobre sus espaldas, y cuando alzaba la cabeza para morder, le metian en la boca un travesaño de madera que les servia de freno para dirigir el animal como un caballo, y conducirle á tierra. $A$ esto añade Plinio que los crocodilos conocian á los tentiritas por el olor, y que el temor que les tenian era tan grande que no se atrevian á subir á la isla que estos habitaban.

Iiste sistema de caza ha caido en desuso, y en su lugar se practica hoy dia otro que no requiere menos valor. Ruppell fue el primero que lo describió, é idénticamente me lo han explicado las gentes en muchas comarcas. \&mpieza la caza cuando baja el nivel de las aguas, y cuando salen fuera de la superficie de los rios los bancos é islotes de arena donde los crocodilos toman el sol y duermen. El cazador toma nota de estos sitios, y se fabrica un agujero á sotavento donde se esconde $y$ está en acecho hasta que el animal sale á tierra y se echa á dormir. Su arma consiste en un renablo, cuya punta de tres cortes con tres púas encorvadas á manera de ganchos, está fija en el palo por medio de un anillo y además por veinte $\delta$ treinta cuerdas recias separadas unas de otras, pero reunidas de trecho en trecho en el asta, que por su parte se halla atada á, un tarugo de madera.

* La gran habilidad del cazador consiste en arrojar el venablo con bastante fuerza para que el hierro atraviese la coraza del animal y penetre hasta unas cuatro pulgadas en las carnes. Una vez disparado aquel, se separa el asta de la punta, que está tan solo encajada en la misma, y cae al suelo. El crocodilo, al sentirse herido, sacude furioso la cola, y hace todos los esfuerzos posibles para cortar la cuerda con sus dientes; pero esta que se compone de iantas piezas en gran parte sueltas, se desliza en los claros que forman los dientes y no sufre deterioro, ó por lo menos muy poco, de las mordeduras del animal, que naturalmente se ha vuelio al agua. Aquí lo persigue el cazador en un pequeño bote sirviéndole de guia y señal de la direccion que toma el ani. mal, el palo que fiota en la superficie, 6 si el animal se mueve á mayor profundidad, el tarugo, hasta que llega á un sitio á propósito para desembarcar. Desde alli tira de la cucrła hasta sacar al animal á la superficie del agua, y le da con una lanza muy afilada el golpe de gracia en la nuca, $\delta$ sin mas lo arrastra á tierra. "Si no lo liubiese presenciado, dice Ruppell, me pareceria increible que dos hombres bastaran para sacar del agua un crocodilo de catorce piés de lárgo; líganle el hocico, agarrótanle despues las extrenidades sobre el lomo, rematandolo, por último, de una cuchillada en la nuca. Solo casualmente se cogen crocodilos con redes, y casi nunca los de mayor tamaño, pues son tan violentas 
sus sacudidas, que con dificultad pueden resistirlas aquellas, por sólida que sea su construccion.

Los europeos, los turcos y los indigenas del F,gipto central cazan el crocodilo con arma de fuego, teniendo la bala de carabina la gran rentaja de atravesar la coraza del animal. Yo he disparado mas de cien balas sobre estos reptiles, sin que jamás rebotase alguna como afirman varios viajeros. Es, sin embargo, muy cierto que pocas son las que ma. tan instantáneamente al crocodilo; su resistencia vital cs en verdad extraordinaria, y herido de muerte consigue las mas de las veces escapar al agua, siendo entonces pieza perdida para el cazador. Muchos de los que logré herir en la cabeza, arotaban como furiosos el agua, se revolvian á poca profundidad de su superficie en todas direcciones, $y$ despues de algunos estremecimientos nerviosos, abrian la enorme boca, $y$ dando un grito indescriptible $y$ sin seme. janza á ningun otro, acababan por desaparecer en las tur. bias ondas. Pasados algunos dias, subian á la superficic sus cadáveres, pero tan descompuestos ya; que no los podia. mos aprovechar. Un dia me hallaba en acecho en una choza cubierta y oculta con esteras y arena en un islote en el Rio Azul para cazar grullas, cuando antes que aparecieran las aves se dejó ver un crocodilo de unos die\% y seis piés, distante de mi apenas quince pasos, arrastrảndose con lentitud, y el cual se tendió a unos veinte pasos en la arena para dor. mir. Reprimi todo sentimiento de venganza con el fin de

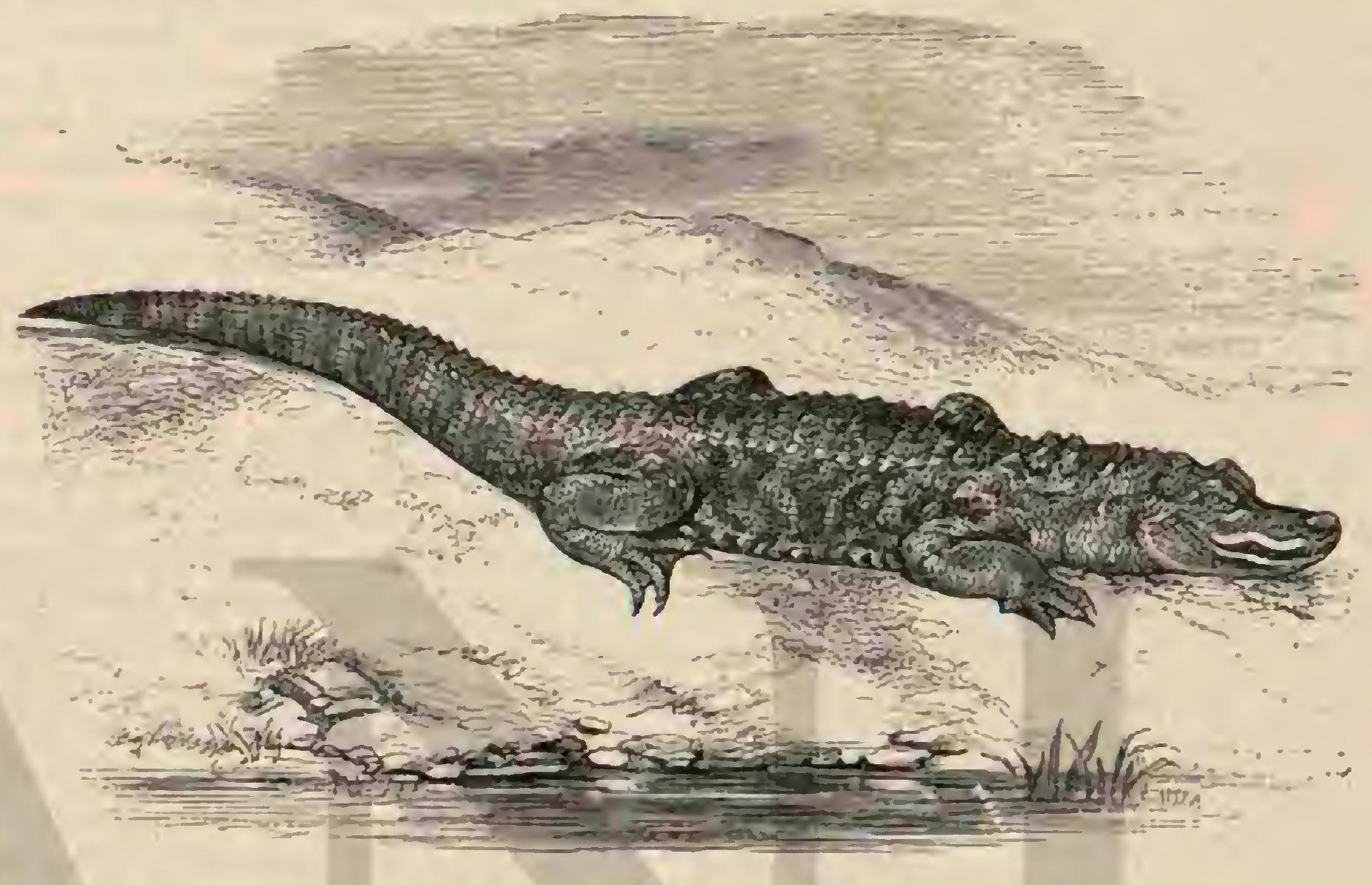

Fig. 20.-TiL CAIMAR DEL MISSISSIPPI

observarlo, pero tambien con la idea de enviarle al cabo de algun tiempo la bien merecida bala; con todo, una grulla que se presentó le salvó la vida por de pronto, porque esta ave tenia para mi mas mérito; la tomé por blanco y disparé. El crocodilo, atolondrado por el estruendo del tiro, se habia echado al agua; pero apenas tuve yo tiempo de ir por la grulla muerta $y$ de volver á cargar, cuando el crocodilo apa. reció otra vez y en el mismo sitio. Entonces le apunté tranquilamente á la nuca y vi con placer que el monstruo, tocado por la bala, dió un tremendo brinco vertical voiviendo á caer pesadamente en el suelo donde quedó inmóvil. En este mismo momento un penetrante olor á almizcle llénó literalmente el aire, y mi criado Tomboldo, que estaba sen. tado en otro hoyo al extremo opuesto del banco de arena, saltó de su escondrijo con demostraciones de júbilo para decirme en tono de súplica: «uen señor, para mi las glándulas, para mi el almizcle, à fin de poder llevar á mi mujer tambien algo de este viaje. Èn esto llegamos al sitio donde se hallaba el animal, cuyo cuerpo se estremecia y temblaba aun. Cuidado con la cola, me avisó Tomboldo, vale mas meterie aun otra bala en el cuerpo á fin de que no se escape.) Esto me pareciú-del todo imposible; sin embargo, satisfice el deseo de mi fiel criado, y aplicando la boca del fusil al mismo oido del aninal, le atravesé la cabeza con otra bala, pero en el mismo instante, encabritándose, por decirlo asi, $y$ arrojándonos con la cola arena y guijarros ála cara, sacudió convulsivamente todos sus miembros y echó á correr, como si no tuviese herida alguna, hácia el rio, desTомо $V$ baratando de esta suerte toda esperanza de provision de almizcle

Para los sudaneses, las cuatro glíndulas de almizcle cons. tituyen el mayor beneficio que saben sacar del cadáver del crocodilo. Durante mi estancia en aquel pais, su precio era de cuatro á seis duros, equivalente á un par de novillos. El hecho es que las hermosas de la Nubia y del Sudan dan con estas glándulas á su cuerpo y cabellera aquel perfume que las hace tan irresistibles á los ojos, 6 mas bien dicho, al olfato del sexo feo; y que las distingue en efecto rentajosa. mente de las mujeres de las comarcas centrales del Nilo, las cuales untan su cabello lanudo con aceite de ricino, con cuyo motivo es imposible, á lo menos para los europeos, acercarse a ellas \& una distancia menor de treinta pasos. Estas glándulas comunican á la carne del crocodilo un olor tan fuerte, que ningun europeo puede comer la de los individuos adultos. He probado varias veces la carne de croco. dilo, pero solo he podido tragar la de individuos pequeños; sin embargo, para los indigenas no hay manjar mas exquisito que la carne y grasa de estos animales. Por los autores antiguos sabemos que los habitantes de Apolonopolis tambien gustaban de dicha carne, no matando á los reptiles sino des. pues de tencrios colgados largo tiempo y haberlos sacudido con palos hasta que daban los mas lastimeros gritos. Ios naturales de la Nubia y del Sudan no necesitan hoy dia tan. tos preparativos: cuecen sencillamente la carne de crocodilo en agua hirviendo, $y$ la condimentan, todo lo mas, con un poco de sal y pimienta 
Al regresar de una caceria encontré mi crocodilo despe. dazado, $y$ tan solo reintiseis huevos de los muchos que lle. vaba en su seno; los marineros no habian podido resistir á la tentacion del apetitoso bocado que tenian á la vista, y ha. bian hecho ya, segun me aseguraron, una excelente comida. Al dia siguiente llevaron al mercado de Wolled.Medineh dos cuartos del animal, que muy pronto fueron vendidos en parte, y el resto cambiado por merisa, una bebida de un sabor parecido al de la cerveza. Por la tarde hubo gran fiesta al rededor de la barca. Animadas por la promesa de un buen guisado de crocodilo, acudieron tantas muchacnas del país como marineros contaba nuestra embarcacion, organizándose asi una fiesta, que solo podia tener el carácter de tal por la concurrencia y los atractivos de las niñas y las mujeres. Alli hervia la singular pitanza en tres ollas redondas y grandes, colocadas sobre otras tantas hogueras, al rededor de las cuales lucian sus negras formas las convidadas, bailando al estilo del pais. Dulcemente resonó la tabaruca, ó tambor de los indigenas, y arquellas encartadoras beldades esparcieron el delicioso perfume, debido à la pomada incomparable que les habian preparado sus adoradores, sácrificando para ello una glándula de almizcle. El tambor se dejó oir hasta muy entrada la noche, y no terminó cl baile antes de la madrugada; todos comieron alegremente la carne del crocodilo, remojando el paladar con merisa; a mi me ofrecieron ambas cosas, f admiráronse no poco de que rehusase la primera.

En la antigüedad se confeccionaban varios meciicamentos con los crocodilos muertos. La sangre tenia fama de ser un remedio eficaz contra el veneno de las serpientes, y para hacer desaparecer las nubes de los ojos; la ceniza, resultante de la combustion de la piel curaba las heridas; la grasa precavia las calenturas, $y$ era un paliativo para $\mathrm{el}$ dolor de muelas y las mordeduras de sabandijas; crelase que un diente llevado en el brazo á manera de amuleto tenia el don de comu. nicar una fuerza particular. De todo esto no se dice ya nada hoy dia; solo se suele atribuir á cictas partes del crocodilo la virtud de comunicar nuevo vigor á los hombres que viren cntregados á la poligamia, quienes buscan con afan un reme. dio tan extraño.

CULTO RELIGIOSO. - No todos los crocodilos fueron enterrados en Egipto con aquellos grandes honores de que dan muestras las momias depositádas en los sepulcros de Te. bas, y en las cuales se ven todavia, segun Geofiroy, los agujeros en que llevaban anillos; pues todas las que nosotros pudimos examinar en la gruta de Maabde, cerca de Monfalut, se hallaban simplemente envueltas en paños de tela, impregnados de pez. Esta gruta está situada en la márgen derecha del Nilo, en la primera'meseta que se encuentra despues de haber ascendido las montañas de la orilla. Forma la entrada un pequeño pozo de 10 á 12 piés de profundidad, cubierto en parte por una roca imponente, cerca de la cual se ven discuinados huesos, músculos y otros restos de crocodilos y de momias. Desde este pozo pasa el viajero á una galería bastante larga, que se debe atravesar arrastrándose â gatas, y la cual le çonduce á una gruta subterránea, ancha y espaciosa, que sirve de morada á miles y miles de nurciélagos. De esta primera cueva, parten en todas direcciones varias galerias de diferente longitud $y$ altura; todas ellas tienen aun hoy din su aspecto primitivo, $y$ sin el menor vestigio de la. bor, pues parece que tos antiguos egipcios no hicieron yุso alguno del cincel en estos panteones de los «animales sagra. dos. \& En una de las grutas mayores observa el viajero una eminencia bastante elevada, y al examinarla de cerca, des. cubre que está formada de cadáveres humanos.

En otra mas apartada y todavia mayor, se encuentran las momias de los crocodilos, amontonados á millares unos sobre otros, y de todos tamaños, desde los mas enormes monstruos hasta los pequeñuelos recien nacidos, no faltando tampoco gran cantidad de huevos secos é impregnados de pez. Todos los cadáveres de gran tamaño están envueltos en tela, cada uno de por si, mientras que los pequerios, si bien se hallan empaquetados no menos cuidadosamente, aparecen reunidos en número de sesenta á ochenta dentro de cestos puntiagudos, fabricados con hojas de palmera; del mismo modo están conservados los huevos. Cuando se contemplan esas monta. nas de cadáveres de los «animales sagrados» ocurre inmediatamente la idea de que mayor debia ser el temor que la veneracion de los egipcios hácia los crocodilos, y que el culto que les profesaban era simplemente su destruccion: á buen seguro que no fenecieron de muerte natural todos los mons. truos qque se ven en aquellas cuevas, sino que mas bien fue. ron muertos por supuestos adoradores, y cmbalsamados despues, como acin de contricion por el (sacrilegin cometi. do. Dificil es explicar la relacion que debe existir entre las momins humanas y las de los crocodilos; tal vez sean los cadáseres de aquellos que se encargaban de cazar los crococoi. los y embalsamarlos despues.

\section{EL CROCODILO DE LOS PANTANOS- CROCODILUS FRONTATUS}

CARACTERES. - Esta especie, que representa el tránsito entre los crocodilos y los caimanes, se distingue por los siguientes caractéres. La parte del cráneo es en extremo alta, con la frente muy deprimida; el hocico ancho, plano y poco puntiagudo, con una protuberancia en su parte anterior. Los párpados superiores están en su mayor parte osificados; las membranas natatorias que unen los dedos se caracterizan por su cortedad, y en rez de la cresta de la parte inferior de los muslos se ve una serie longitudinal de placas grandes y sencillamente aquilladas: todos estos caracteres distintivos establecen ya la semejanza entre el crocodilo de los pantanos y los caimanes. En la cabeza se cuentan seis escudos óseos, dispuestos en una serie, pero divididos en dos grupos separados; en la nuca se ven cuatro, dispuestos en dos pares, uno tras otro; $y$ en el lomo hay seis series longitudinales y diez y ocho trasversales de placas óseas. El cartilago de la nariz está osificado. En la parte superior del tronco predo. mina el color pardo oscuro mate; solo la cabeza, la coraza del lomo y algunos sitios de la cresta de la cola son de un pardo claro sucio, con manchas y puntos negros; la cara inferior es de un negro pardo brillante. I.a longitud del individuo adulto no se conoce aun, pues hasta ahora solo se han medido algunos jóvenes.

DISTRIBUCION GEOGRAFICA. - Dü Chaillu fué quien primcro trajo un crocodilo de los pantanos, proce. dente del rio Ogabei, en América, $y$ por el cual pudimos conocer la especie. Murray recibió otros del rio Kalabar, y otros viajeros posteriores le encontraron en el Gabon. Rei. chenob le vió en el Kamerun. Su área de dispersion se extiende por lo tanto, segun los informes recibidos, desde los $7^{\circ}$ de latitud norte hasta los $4^{\circ}$ de latitud sur, y probable. mente mas aun hácia cl sur.

USOS, COSTUMBRES Y REGIMEN. - No sabenos si este saurio difiere de otros crocodilos por su género de vida 5 por sus usos y costumbres, pues parece que no se han hecho en su patria observaciones que con seguridad puedan referirse al crocodilo de los pantanos. Yo, por lo menos, no sé que se haya dicho nada acerca de esta especie. Ultima. mente recibimos con bastante frecusencia individuos pequeños, que se pueden ver en los jardines zoológicos ó en las colecciones ambulantes de fieras; mas por lo regular en unos 
estanques tan pequeños, que desde luego nos impiden hacer observaciones exactas. Los individuos que yo mismo cuidé se conducian por todos estilos exactamente como sus congéneres mas afines.

\section{LOS CAIMANES-ALLIGATOR}

CARACTERES. - Los caimanes constituyen el último género de la familia, y difieren de sus congéneres hasta ahora descritos por tener en la mandibula superior, en vez de escotaduras, unas cavidades en que encaja el cuarto diente de ambos lados de la inferior. El número de dientes es cuando menos de diez y ocho en cada maxilar, pero puede ascender $\dot{a}$ veintidos en los superiores $y$ á veinte en los infe. riores, siendo asi ochenta y cuatro el número total de dientes.

\section{EL CAIMAN CHACARE-ALLIGATOR LATIROSTRIS}

CARACTÉRES. - Esta especie, diseminada en una gran parte de la América del sur, y descrita por observadores concienzudos, ha sido confundida muy á menudo con el caiman de anteojo (Alligator sclerops), porque es dificil, y hasta imposible \& veces, determinar la especie de que hablan los diferentes viajeros. En ambas se observa que los parrpados superiores estän osificados en parte y son membra. nosos en lo demás, con arrugas y fajas en la superficie; las cubiertas de los ojos están reunidas en la parte anterior por una lista trasversal, carácter á que el reptil debe su nombre de caiman de anteojos; en ambas especies los escudos de la nuca son grandes $y$ se hallan pareados $\sigma$, cuando mas, dispuestos en serics.de tres; en el chacare, sin embargo, los escudos del cuello forman tres 6 cuatro series trasversales, inientras que en el caiman de anteojos su número es siempre de cinco. El chacare mide cuatro metros de largo; el caiman de antcojos no pasa nunca de tres; el color de la cara superior del cuerpo es en las dos especies de un pardo aceituna oscuro, con dibujos de un tinte gris; la inferior es de un blanco amarillento verdoso.

DISTRYBUCION GEOGRÁEICA. - El chacare habita principalmente la parte meridional del este del Brasil, Buénos dires y el nordeste del Perú, pero se encuentra tambien en Surinam; el caiman de anteojos vive en el norte del Bra. sil, el nordeste del Perú, la Guayana y la isla de Guadalupe.

USOS, COSTUMBRES Y RÉGIMEN. - Azara y el principe de Wied han descrito con bastante exactitud el gé. nero de vida del chacare. Tambien á este reptil le agradan mas los brazos muertos de los rius $\delta$ las aguas estancadas, las cuales prefiere a las corrientes rápidas; y por eso se le ve mas á menudo en los grandes pantanos del interior. En las gran. des corrientes el príncipe no ha visto ningun chacare, pero sí muchos en los brazos de agua estancada $\delta$ en los rios pe. queños de corriente lenta, aunque no tanto como en pantanos y charcas. Cuando este peligroso reptil está echado en el agua acechando su presa, solo se puede ver la parte ante. rior de la cabeza levantada sobre la superficie de manera que los ojos y las fosas nasales quedan descubiertas. Así permanece durante el dia en el mismo sitio, ó se dirige hácia la orilla $\delta$ a una roca para tomar el sol ó dormir; mas apenas se acerca un hombre ó un perro vuelve en seguida al agua. \&u. chas veces, dice el príncipe, el viajero pasa junto is estos animales, cuyo color pardo oscuro dificilmente se distingue del color de las rocas de granito en que descansan; mas por lo regular sumérgense entonces ruidosamente en las ondas. En un pequeño rio de corriente lenta, que desemboca en el Parahypa, vénse estos reptiles en gran número. Cuando nos hallábamos en las orillas un poco escarpadas y cubiertas de una espesa vegetacion de tres á cuatro metros de altura, di. visábanse siempre algunos que solo mostraban el hocico y los ojos en la superficie del agua; alli donde las grandes hojas de varias plantas, en particular de las rosas acuáticas, sobresalian de la superficie, era seguro encontrar alguno de los caimanes que alli se ocultaban. Cuando les inquietába. mos se sumergian, para reaparecer en otro sitio.

\$Su alimento consiste en toda clase de séres vivos de que pueden apoderarse. Uno de mis cazadores mató un caiman pequeño, que habia devorado ja un pato. Yo encontré en el estómago prircipalmente restos de peces y de aves acuá. ticas, asi como escamas y espinas; pero tambien piedrecitas y asena, habiendo observado que á veces las tienen tambien grandes. Los pescadores brasileños pretenden que el chacare ataca en ciertos casos à los hombres en el baño, pues no falta quien ha mostrado las señales de la dentadura del rep. til en brazos y picrnas. Aunque este informe es fundado, no se puede decir, sin embargo, que estos reptiles son peligrosos para el hombre. Todos los que yo observé eran en extre. mo timidos y desaparecian apenas se acercaba cualquicra á mas de treinta 6 cuarenta pasos. En cambio se dice que de. voran á menudo los perros cuando cruzan los rios, así como otros animales pequeños. En la laguna de Arara, junto al Mucuri, un chacare habia elegido su residencia cerca de nuestras chozas, y comia siempre los restos de viveres, intes. tinos y otras cosas que nucstros hombres arrojaban al agua. Azara dice que no se les teme mucho, y que el hombre se baña sin cuidado cerca de ellos 6 cruzando los rios, porque solo le atacan cuando se acerca á sus huevos; pero aun en. tonces no le destrozan ni le devoran. Heusel nos da detalles en el mismo sentido. "Preténdese sin embargo que el chacare es peligroso para el hombre: pero los hechos en que se apoya esta opinion son muy poco seguros y deben aun confirmarse. Este caiman se alimenta sobre todo de peces, de los cuales se apodera muy fácilmente en los golfos poco profundos, á pesar de su pesadez; tambien devora animales invertcbrados, segun lo demuestran las numerosas cáscaras del gran caracol acuático (Ampullaria), que siempre se encuentra en su es. tómago.s

* En el periodo del celo, continía el principe, sobre todo al principio del mismo, los chacares exhalan un fuerte $y$ des. agradable olor de almizcle. En los meses de agosto y setiembre, cuando nos hallábamos en las orillas del Belmonte, ála sormbra de los bosques, hemos percibido á menudo este olor, sin poder divisar el reptil mismo, por haber desaparecido este hacia tiempo en el fondo de las olas. Los botocudos que nos acompanaban gritaban entonces al punto aehac, nombre que dan al chacare. $A$ orillas de Ilheos reconoci el mismo olor á primeros de diciembre $\delta$ en enero. $\gg$ Azara nos dice que la hembra deposita en la arena unos sesenta huevos blancos, del tamaño de los de la oca; cúbrelos de yerba seca y abandónalos despues al calor del sol. Segun observó el príncipe, los recien nacidos buscan en seguida el agua, y. tienen por enemigos á los buitres y otras rapaces, asi colno tambien varios cuadrúpedos.

CAzA.- EEl chacare reporta muy poca utilidad, y por eso no se le da caza. Algunos negros y los salvajes comen la carne blanca, sobre todo la de la base de la cola, semejante á la de los peces; pero rara vez pueden estos indigenas apoderarse de uno de esos crocodilos. Dificil es matarlos, pues asi como todos sus congéneres, tienen mucha resistencia vital y se sumergen apenas se les dispara un tiro, lo cual hicimos muy á menudo, hiriéndolos por lo regular mortal. mente con los perdigones, pero entonces nos faltaban casi siempre los instrumentos necesarios para sacar el reptil del 
agua. Mi cazador hirió mortalmente un chacare de una perdigonada en la nuca, y al examinar el cuerpo vimos que el plomo no habia penetrado completamente en la coraza del animal, pero si en la piel blanda de aquella parte. Los per. digones de mayor tamaño penetran mejor, sobre todo cuando se apunta a la cabeza, la nuca, ó los costados. Si se sorpren. de a un chacare en tierra firme, cuando quiere pasar de un rio á otro, ya se puede dar por perdido; pues todo lo que tiene de agil en el agua, tiene de torpe y lento cuando se mueve en tierra. 'Tan luego como en tal ocasion divisa un enemigo, permanece inmóvil y dejase matar sin resistencia; solo muerde cuando se le provoca repetidas reces con un palo. Los pequerios son mucho mas ágiles en tierra firme que los adultos.

Los habitantes del Paraguay persiguen al chacare con mu. cho mas afan que los brasileños; los indios se sirven para ello de una flecha á propósito, y los europeos de las armas de fuego. I a flecha se dirige al costado del caiman y está construida de modo que al penetrar la punta de hierro cae el asta; esta última, atada al extremo de una cuerda, flota entonces en la superficie, indicando á los indios el sitio don. de se ha ocultado el animal herido. Para cogerle los españo. les se sirven de un peciazo de madera puntiagudo en ambos lados, átanle á una cuerda y le envuelven en un pulmon de buey; despues arrojan este cebo al agua, donde cl caiman le devora, siendo fácil entonces atraerle a tierra firme.

Keller. Seuzinger describe una manera particular de coger el chacare y los caimanes en general. Una tribu india, la de los camichanas, prefiere la carne de caiman á toda otra, y raras veces deja pasar la ocasion de apoderarse de su presa favorita Uno de los cazadores ata un fuerte nudo corredizo de piel de buey á la extremidad de un largo palo; introdúcese desnudo en el agua poco profunda, y avanza lentamente há. cia cl reptil, recogiendo el cuerpo cuanto le es posithe, mientras empuja la punta del palo por delante de sí. \&El caiman que hasta entónces ha observado todo esto con indiferencia, sin dar mas señal de vida que algun movimiento perezoso de su poderosa cola, fija por fin su atencion en el indio, al ver que cste se acerca mas y mas, y mirale con los ojos muy abiertos; el peligroso nudo corredizo se halla ya muy cerca de su hocico sin que el animal se aperciba de ello; el caiman contempla con asombro al atrevido cazador, que un momento despues le arroja el nudo sobre la cabeza, estrechándole por un movimiento vigoroso. Los compañeros del indio, que acurrucados en la orilla esperaban entre tanto silenciosamen. te, acuden al punto; cuatro ó cinco de los mas robustos, se. mejantes à estatuas de bronce, atraen al chacare, á pesar de su resistencia, hasta que toca en la orilla, y una vez aqui, algunos hachazos en la cola y el cráneo acaban pronto con su vida. Si el reptil, en vez de tirar hácia atrás atacara a los indios, estos se verian sin duda obligados á dejar el nudo corredizo y el palo en poder del monstruo; pero este no pien. 5a al parecer en tal cosa, por lo cual la lucha acaba casi siempre con su muerte. Mas de diez veces he presenciado esta caceria, pero solo una crei conveniente disparar al reptil un tiro, apuntándole al cráneo; el caiman, extraordinaria. mente vigoroso, media unos cinco metros de largo y descargaba tan furiosos golpes à derecha é izquierda, que temí que uno de los indigenas llegara á conocer á costa de sus huesos cuán poderosa es la cola de este saurio. Antes de que el ani. mal se haya secado del todo, córtanse cuidadosamente las cuatro glándulas de aimizcle para impedir que el fuerte olor se extienda mas por la carne de los muslos. Dichas glándu. las son saquitos de tres á cuatro centímetros de largo, del grueso de un dedo, y cstán llenas de un liquido pardo $y$ su. cio; atanse en su parte superior y se ponen al sol para secar. las. Segun nos dijeron, à las señoras de Bolivia les agrada perfumar sus negros cabellos con esta sustancia, mezclada con agua de rosa, aunque su olor es tan desagradable que causa dolor de cabeza.

Yo he tenido, concluje el principe, varios chacares pe. queños vivos; eran indómitos y violentos, inflamaban el vientre y la garganta cuando se les tocaba, silbando como una oca que defiende su progenie, y abrian su enorme boca; si se les tocaba por detrás revolvianse con suma rapidez; mordian y descargaban fuertes golpes con la cola. Tambien reconoci en ellos el desagradable olor de almizcle.

\section{EL CAIMAN NEGRO-ALLIGATOR NIGER}

Los caimanes que encontramos en la parte superior del Essequibo y por lo tanto en los rios de la sabana, dice Schomburgk, difieren de los de la costa no solo por su tamano sino tambien muchas veces por sus dibujos. Pueden alcanzar una longitud de cuatro á seis metros; son mucho mas negros, y, en algunas partes del cuerpo tienen manchas amarillas; su hocico, es mas corto y recogido, y los pies mas cortos que en sus congéneres. Son completamente iguales al caiman negro encontrado por Martius en el Amazonas. 2 Tambien Bates dice que los indigenas de la parte superior de este rio distinguen las dos especies y además otra mas pequeña.

CARACTERES. - El caiman negro pertenece igualmente al grupo de los caimanes de anteojos, pero difiere de las demás especies por tener una lista trasversal entre los ojos, por su mayor tamaño y por los numerosos escudos de la nuca, que por lo regular forman cuatro series trasversales bastante irregulares; además de esto, dicha lista trasversal suele presentar en su centro un ángulo saliente; y los pár. pados superiores, medio osificados, tienen finas fajas en vez de arrugas. Las placas del cuello forman cinco series tras. versales dispuestas unas tras de otra. La cara superior del cuerpo es de un negro oscuro con manchas amarillas en al. gunas partes del cuerpo; la cara inferior de este es de un blanco amarillénto:

DISTRIBUCION GEOGRAFICA.-La Guayana, el norte del Brasil, Bolivia, el Ecuador y el norte del Perú son la patria del caiman negro, que segun parece habita en todas las grandes extensiones de agua dulce, siendo muy conside. rable el número de individuos.

USOS, COSTUMBRES Y REGIMEN. - No creo que se exagera, dice Bates, cuando se asegura que en la es. tacion seca hay en las aguas que circuyen la parte superior dcl rio Amazonas tantos caimanes como en los estanques de Inglaterra renacuajos. Durante un viaje de cinco dias que en noviembre hice en un vapor, vimos en casi todas partes un gran número de estos saurios y los viajeros se entretenian desde la manana hasta la noche en dispararles tiros. Abun. daban sobre todo en las bahias tranquilas, formando un caos de cuerpos que se dispersaban con gran ruido cuando pasaba el vapor. Asi como las tortugas, los caimanes negros emprenden tambien todos los años viajes regulares, dirigiéndose en el periodo de las inundaciones hácia los pantanos y charcas del interior, desde donde vuelven á los rios á prin. cipios de la estacion seca. En los lagos y lagunas cuyas ramificaciones llegan á secarse durante el estio, los caimanes se ven obligados á practicar agujeros en el cieno, en los cuales viven dormitando hasta que se acerca de nuevo la estacion lluviosa; mientras que en la parte superior del Amazonas, donde la estacion seca es mas corta, observan una vida activa todo el año. Los indigenas temen it esta especie pero no á sus afines mas pequeñas, de las cuales se apoderan 
á veces, segun dice Bates, hasta con las manos. Los caimanes negros, por el contrario, se han hecho respetar en todas par. tes, porque no solo atacan en el agua, sino que molestan de noche en tierra firme, apoderśndose, por ejemplo, de los perros que vagan alrededor de las hogueras del campamento. Un atrevido macho adulto interrumpió varias noches sezui. das el sueño de Bates, visitando la choza en que el naturalista dormia con sus compañeros; y una vez solo se le pudo ahuyentar despues que los indigenas le hubieron arrojado varios leños encendidos en su coraza. Tambien Schomburgk asegura que los caimanes negros son los animales mas feroces que imaginarse pueda. Algunos individuos observados por él mucho tiempo vagaban continuamente por las bahias tranquilas del rio; acechaban á los perros, y cogieron cierta noche una ciguieña gigantesca domesticada, que dormia en la orilla. Los perros, que saben ya cuán temibles son estos reptiles, conocen muy bien el peligro que les amenaza y ladran con furia cuando ven al enemigo en acecho.

«Para observar, dice Schomburgh, cómo cogen su presa, até á menudo aves 6 peces grandes á un madero, abando. nándole despues á las olas. Apenas uno de los caimanes divisaba el cebo, dirigiase lentamente hácia la presa, sin agitar ell lo mas minimo la superficic del agua; despues de haberse acercado lo suficiente á su vícima encorvaba el cuerpo en forma de semicirculo, desviando con la cola, cuya punta puede enroscar hasta la boca, todos los objetos que hallaba al paso; cerraba las fauces y desaparecia con la presa debajo de la superficie del agua, para volver å presentarse pocos minutos despues en la orilla ó en un banco de arena, donde devoraba su victima. Si esta no era demasiado grande, el reptil se elevaba solo hasta los hombros por encima de la superficic, rragándose en esta posicion la presa. Los peces constituyen el alimento regular de los caimanes; los matan de un coletazo, lanzándolos casi siempre por encima del agua, y recógenlos con la boca. El juego de las mandibulas y el golpe de la cola producen un fuerte ruido, que en noches silenciosas se oye á larga distancia.

> Cierta tarde fuimos testigos de una lucha en extremo interesante. El rio extendia ante nosotros su tranquila y tersa superficie, cuando nntamos á corta distancia un movimiento inusitado en el agua: un gigantesco caiman negro habia cogido un knikukthi, $\delta$ caiman pequeño, por el centro del tron. $\mathrm{co}$ de manera que la cabeza y la cola sobresalian por ambos lados de sus terribles fauces. Aquello era una lucha encarnizada, pero todos los esfuerzos del mas débil quedaron para. lizados por la furia y voracidad del mas fuerte: ambos des. aparecieron debajo de la superficie y solo las olas agitadas del rio, cuya superficie estaba por lo regular tan tersa como un espejo, indicaron que en la profundidad se trababa una lucha s muerte. Pasados algunos minutos aparecieron nuevamente removiendo con sus colas el agua que en todas las direcciones se dividió en circulos: pero pronto dejó de ser el resultado dudoso, pues el vigor y los esfuerzos del kuikutchi so debilitaron, precisamente cuando haciamos fuerza de remos para acercarnos. Tan luego como el caiman nos divisó sumergióse, pero como no pudo devorar su victima debajo del agua, volvió á la superficie y se dirigió a un pequeño banco de arena donde al momento empezó su festin.

Muy notable me pareció que las hembras muestren aun mucho tiempo el mayor cariño sus pequeños; los vi. gilan continuamente, $y$ los defienden con la mayor furia, se. gun me convenci por propia experiencia. Acompañado de un niño pasé un dia á lo largo de una laguna del Atkarikuri para cazar peces con flecha. Unos extraños gritos muy parecidos a los del gato pequeño llamaron $\mathrm{mi}$ atencion y ya me creí cerca de la guarida de un jaguarete, cuando mi compa- ñero, indicando el agua, lanzó un grito: «aimanes peque. ños! Los sonidos parecian provenir del tronco de un arbol, cuyas raices socavadas por el agua habian perdido su punto de apoyo de modo que el tronco se habia inclinado hácia la superficie, tocandola con sus ramas. Nos deslizamos cautelo. samente sobre el tronco hasta la copa, donde vídebajo de mi reunidos los hijuelos que median unos cincuenta centimetros de largo. Como solo nos hallábamos un metro por encima de la superficic del agua, fué fácil para el indio atravesar uno

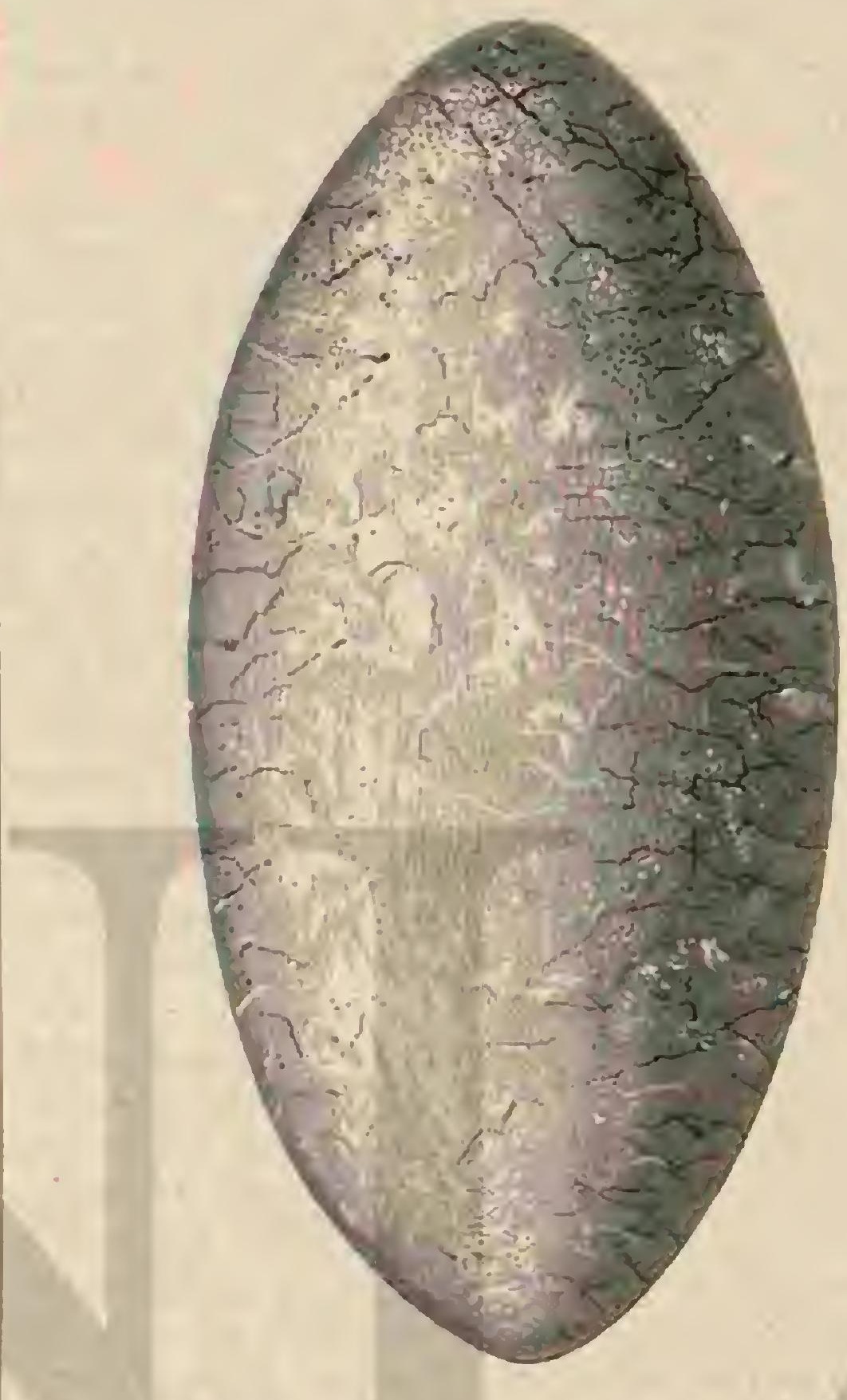

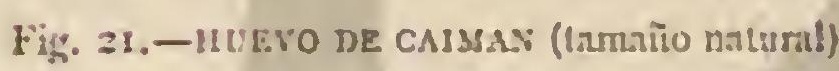

de los pequeños animales con una flecha y recogerle de su elemento á pesar de sus pataleos y de sus gritos. En el mismo momento apareció un caiman adulto, la madre, que sin que nosotros la viéramos nos habia observado ya mucho tiem. po; se presentó por debajo de nuestros piés en medio del ramaje para defender sus pequeũos, lanzando al mismo tiempo un rugido horroroso. No sé por cierto con qué comparar esta terrible roz: no era aquello el mugido del toro 6 el rugido del jaguarete ni tampocio la voz de otro sér que yo conociera, sino mas bien una mezcla del uno y del otro, que a decir verdad me helo la sangre en las venas. El rumor atrajo muy pronto \& otros caimanes, que fielmente ayudaron á la furiosa inadre, mientras que esta clevaba á menudo la mitad del cuerpo sobre el agua para cogernos en nuestro observatorio. Mi compañero, alargando al pequeño que atravesado por la flecha se movia convulsivamente, aumentó aun la furia del terrible animal; cuando le herimos con una de nuestras flechas se retiró un momento por debajo del agua, pero pronto volvió a aparecer, renovando su ataque con redoblado furor. La superficie del rio, tranquila hasta entonces, habiase convertido en un confuso caos de revueltas olas producido por los furiosos golpes de la cola del monstruo; debo confesar que el increible atrevimiento del animal hizo latir mi corazon con doble rapidez. Una sola pisada falsa nos hubiera entrega- 
do inmediatamente a la terrible dentadura del animal. Despues de acabar nuestra provision de Rechas crei lo mas conveniente retiratnos con la mayor cautcla posible; la hem. bra nos persiguió hasta la orilla, pero no mas adelante, por. que en tierra firme el caiman tiene demasiada timidez para ser peligroso; parece conocer él mismo su impotencia cuando se halla en tierra, pues siempre emprende rápidamente la fuga para llegar al elemento donde es el habitante mas peligroso.

- Las cscamas del pequeño eran aun blandas y elásticas; no hacia por consiguiente sino pocos dias que habia salido del huevo, $y$ sin embargo ya dejaba sentir un fuerte olor de almizcle. 1 poca disiancia del sitio vinios en la orilla un ancho sendero que nos condujo al puesio donde estaban los hueros y que se hallaba anos diez metros de distancia del rio. El nido se compenia de una cavidad en el suclo tapizada de maleza, bojas y rerba y habia contenido a jurgar por el número de las cúscaras vaclas unos treinta ó cuarenta hivé. vos que inabian sido sobrepuestos unos encima de los otrós á manera de capas. Cada una de estas estaba separada de la otra por yerba y cieno y la superior tambien habia sido cu. bierta de cieno.

- El periodo en que los caimanes ponen sus huevos corres. ponde con el de las tortugas y los hijuelos salen a luz aun antes de principiar la estacion lluviosa- En su viaje hácia el

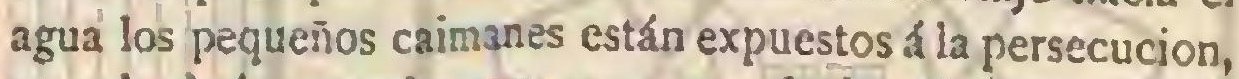
no solo de las grandes ares rapaces y de las ciguieñas gigantescas, sino tambien á la de los caimanes machos. Si no se exterminase asi la mayar parte de la cria, el número de estos animales se aumentaria recesariamente de una manera espan. tosa. Se dice que en los bancos de arena las hembras no ocultan nunca sus hueros.

A la mañana siguiente me dirigf acompañado de varios indios y armado de carabinas y de balas otm vez al sitio de nuestra aventura La madre habia desaparecido con sus pe. queños. A pesar del sin número de cabezas que sobresalian de la superficie y a pesar de todas las tentativas con grandes anzuelos no logramos apoderarnos de uno de los mónstruos; pero al volver al campaminto el mutasor de caimanes, que habia fijado su residencia en la bahia, me rogó le dejase la cambina porque de segaro cazaria un saurio durante el dia. Por la tarde llegó con la noticia de que habia cumplido su palabra. El caiman estaba aun cn el agua atado por el cue. llo con un fuerte bejuco á uno de los árboles, y media cua. tro y medio metros de largo. Una gran herida, ya cicatrizada, era debida probablemenie a lina de las encarnizadas luchas que en la epoca del celo sa traban entre los machos; de los diez y ocho dedos de sus piés le faltaban tres y una de sus extremidades anteriorcs cstaba muy mutilada. Segun pretenden los indios, estas mitulaciones proceden de los voraces pirais (Pygoctulnus nigr) único animal segun parece que molesta á los caimanes ndultos. El cazador de caimanes no habia muerto al mónstreo hasta dispararle la séptima bala, que por el ojo habia persirado en el cerebro.

Otro caiman negro, carado por los compañeros de Schom. burgk, en otra ocasion, massifestó por sus movinuientos convul. sivos, mucho tiempo despees de haber recibido el balazo, que no habia muerto aun. Dapues de haberle sacado a la orilla, los rajos del sol parecian comunicarle nueva vida; cl enemigo que todos habian craido muerto comenzó á moverse y hasta se preparó al atagec. Varios indios se alejaron apresu. radamente y volvieron ca palos; el mas atrevido de ellos se precipitó sobre el animal ņre le esperaba con la boca abierta, y le introdujo la punta écj palo con toda su fuerza en el esófago. «A pesar de gre el caiman cerró sus mandíbulais mordiendo profundamente el palo, no le gustó sin embargo esta manera de atacar á juzgar por sus dolorosos gemidos. Los otros indios valientes se habian acercado mientras tanto por detras descargando fuertes golpes de maza sobre la punta de la cola A cada golpe el animal se enderezó furiosamente abriendo la boca, en la cual cada vez se introdujo rápidamen. te otro palo. Los indios preteriden que la punta de la cola es el sitio donde se concentra la vida del animal; y en efecto, esta parte del cuerpo es una de las mas sensibles del caiman, segun lo demuestra el hecho de que despues de cada golpe el monstruo se endereza con furia, mientras que no hace aprecio de los muchos recibidos en la cabeza y el lomo. Despues de largas y encarnizadas luchas, el repiil sucumbio al fin d manos de sus enemigos.

\section{EL CAIMAN DEL MISSISSIPPÍ-ALLIGATOR MISSISSIPPIENSIS}

CARACTÉRES.-El caiman del Mississippi ó caiman propiamente dicho se caracteriza, segun Strauch, por tener el hocico ancho, plano, parab́lico, casi liso en la superficiey muy semejante al del sollo comun; el cartilago de la nariz está osificado y exteriormente afecta la forma de una lista longitudinal bastante ancha, que separa las dos fosas nasales; en el cuello se observan dos escudos paralelos y en la nuca seis placas pareadas, dispuestas en tres series trasversales seguidas; estos caractéres son tan marcados así en los jóvenes como en los adultos, que no se puede confundir al caiman del Mississippí con las demás especies de su género. Este reptil puede alcanzar una longitud de cinco metros; el color de la cara superior del cuerpo es por lo regular un verde sucio de accite, con algunas manchas mas oscuras; y la cara inferior es de un amarillo claro sucio (fig. 20).

DISTRIBUCION GEOGRÁFICA.-El área de disper. sion del caiman se limita al sur de los Estados Unidos; por el norte llega hasta los $35^{\circ}$ de latitud. Es muy comun en casi todos los rios grandes y pequeños, lagos y pantanos de la Carolina meridional, Georgia, Florida, Alabama, Mississippi y Luisinna; mas hácia el norte su número disminuye gra.

USOS, COSTUMBRES Y REGIMEN. - I a América mala yerba de la mentira; un suelo en extremo fértil para la bles que se refieren al sencillo público los cuentos increimostrándolo en particular el relato de un tal Bartram, quien ascgura estar familiarizado intimamente con los crocodilos ó caimanes de aquel pais. A creer á aquel hombre, deberiamos admirarnos de que los valles de los rios-de Florida hos dia aun pueden ser habitados.

Bartram, hablando de una navegacion por el San Juan, refiere sobre su encuentro con los caimanes poco mas ó menos lo siguiente: una pequeña lancha cesciende por el rio; el sol está á punto de ponerse y una turba de crocodilos la rodea por todas partes. El viajero se apresura á terminar su pesca, y temeroso de que su escopeta pueda caer en el agua, solo se arma de un palo. La primera falange de croco. dilos se divide al accrcarse; los mas fuertes le persiguen; mueve los remos con todas sus fuerzas esperando escapar del peligro; mas apenas llega \& la mitad del camino cuando por todas partes le atacan. Sus enemigos intentan volcar la lancha; dos de los mayores levantan la cabcza y parte del tronco sobre el agua, rugen de una manera terrible y arrojan, si bien no fuego á modo de los dragones, corrientes de agu? sobre el aventurero digno de lástima cuya situacion se hace ahora en extremo peligrosa. Teme á cada momento que sus enemigos le arrebaten de la lancha y le devoren, reparte con su palo golpes sin ver a donde, $y$ tiene al fin la suerte de 
ahuyentar á los terribles saurios: aunque estos forman una nueva linea de ataque, el viajero se salva en la orilla; los caimanes se alejan, y todo se tranquiliza.

Nuestro héroc se acerca entonces apresuradamente s la orilla del agua $\mathrm{f}$ demuestra su valor pescando de nuevo. Despues llega á otro sitio, donde un caiman, viejo como Matusalem, le mira con ojos furiosos; por eso le quiere cas. tigar disparándole un tiro, $y$ al efecto marcha en busca de su escopeta; pero entonces nota, con tanto asombro como des. agrado, que el caiman se ocupa en devorar sus peces. Cuando el monstruo le mira de nuevo furiosamente, dispárale un tiro en la cabeza, con lo cual cree laberle muerto. Entonces quiere preparar sus peces y se dirige a la orilla para linpiarlos, mas por fortuna vuelve la cabera para mirar hácia atrás, y ve en las claras ondas las fauces y los hombros de otro caiman grande, el cual se dirige latemlmente hácia él, de modo que apenas le queda tiempo para retirarse; el mons. truo, haciendo un movimiento en extremo hábil con su cola, arroja los peces al agua, con lo cual prueba al viajero gue tambien hubiera podido devorarle. Sin embargo, consigue escapar, y entonces se propone encender fuego, trepar á los árboles y valerse de otros medios de seguridad, puesto que ahora le amenazan por el agua los caimanes y por tierra los lobos y los osos; pero antes de acabar con sus preparativos le asusta un nuevo ruido que segun le parece se oye cerca del sitio donde tiene la lancha. Cautelosamente se dirige hácia alli, y observa que dicho rumor proviene de una multitud increible de caimanes. Estos cubren toda la anchura del rio, atanto que se hubiera podido pasar por encima de ellos hasta la otra orilla; y reunen los peces de tal manera, que parecen formar un terraplen compacto. A los miles de caimanes agré. ganse otros tantos y devoran millones de peces. Ciracias as su penetrante vista, el viajero observa á pesar de la oscuridad, cómo varios crocodilos lanzan grandes peces al aire, los cogen con la boca y los trituran con los dientes. El castañcteo de las mandibulas causa un ruido espantoso; corrientes de san. gre salen de la boca del monstruo; las fosas nasales de los mismos echan humo como chimeneas y la lucha dura toda la noche.

Con toda intencion he trascrito aqui las anteriores lineas, no para burlarme de las mentiras de Bartram, sino de la credulidad de sus lectores, y respectivamente de los autores de historia natural que ayudan a propagar semcjantes falsedades sin oponer su veto enérgico. Aun hoy dia nuestros escritos sobre ciencias naturales revelan falta de juicio en los respectivos autores, falta que es preciso conbatir con toda la energía posible porque perjudica gravemente la generalizacion de la riencia. Tales fábulas se propagan de libro en libro, de padres à hijos cual si fueran hereditarias; se comentan siempre de nuevo, al parecer con cictta compla. cencia, y se cree haber descubierto algo de particular en el género de vida de un animal que apenas difiere de otros congéneres. Veremos á continuacion que el caiman de la América del norte es un crocodilo, si bien peligroso, sin em. bargo tan cobarde como todos los otros de su familia.

En los rios arriba citados, segun Audubon, cuyo relato tomare ahora por guia, se ve \& los caimanes tomando el sol en las orillas cenagosas ó sobre los grandes troncos de árbo. les flotantes, ó bien nadando por el rio en busca de su ali. mento. En Luisiana todos los pantanos, lagunas, rios, es. tanq̧ues $y$ lagos están llenos de estos animales; se les halla en todas partes donde tienen bastante agua para encontrat su alimento y ocultarse en ella; están discminados hasta la desenbocadura del Arkansas; por el este hasta el norte de la Carolina, y en el oeste por todas partes. Antes de ir los vapores eran tan frecuentes en el rio Colorado, que á cente- nares se les observaba á lo largo de las orillas ó en los enormes maderos flotanies. Los pequeños estaban echados ó posados sobre el lomo de los grandes y a veces producian un rugido semejante al de miles de toros furiosos que quieren trabar una lucha. Asi como se observa generalmente en el norte de Anerica, alli tenian tan poco miedo del hombre, que apenas hacian caso de cuanto pasaba en el rio ó en sus orillas; cuando no se les dirigian tiros ó se les ahuyentaba intencio. nalmente dejaban pasar las lanchas \& pocos metros de dis. tancia sin hacer caso de ellas. Solo en las aguas cenagosas se presentaban y se presentan aun hoy dia raras veces.

En tierra firme el caiman se nueve por lo regular lenta y pesadamente; su andar se reduce a una especie de pa. taleo penoso; adelanta con trabajo una pierna despues de otra; toca casi con al vientre en tierra y arrastra la larga cola por el cieno. De esta manera sale del agua y asi vaga por los campos ó por los bosques en busca de otra residencia que le prometa alimento, $\delta$ de un sitio conveniente para depositar los hucros. Del siguiente informe se desprende cuán cacha. zudos son sus movimientos. Audubon encontró por la mahana un caiman de unos cuatro metros de largo á la distan. cia de unos treinta metros de un estanque con la intencion aparente de dirigirse $\mathbf{a}$ otra agua situada dentro del hori. zonte. Al principiar el crepúsculo respertino el animal ha. bia adelantado unos sciscienios pasos. En tierra firme se muestran, probablemente a causa de su torpeza, en extremo cobardes. Si en sus expediciones para pasar de un rio á otro divisan algun enemigo agdchanse todo lo posible, oprimiendo el hocico contra el suelo, y permanecen inmóviles en esta misma posicion observando al enenigo con la vista fija en é. Al acercarse á ellos no intentan huir, ni tampoco atacan; limitanse á levantarse sobre sus piernas y bufan cual si tu. viesen un fuelle de fragua en el vientre. El que entonces quiere matarlos no corre peligro alguno, mientras se mantenga a bastante distancia de la cola, pues el animal tiene en ella su mayor fuerza y hasta cicrto punto su mejor arma; un solo golpe bastaria para matar á un hombre.

El agua es el verdadero elemento del caiman y en ella el animal es mas vivaz $y$ atrevido. A veces sucede que aquí ataca al hombre; pero por lo regular le evita miedosamente y con seguridad lo hace cuando el hombre le ataca á él. Fn la América del norte los pastores de buejes al llegar á un agua poblada de caimanes entran en ella armados de palos para abrir un camino para el ganado ó para impedir á los voraces reptiles molestar á este al beber; cuando se dirigen en linea recta hácia la cabeza del caiman no corren peligro alguno $y$ hasta pueden sin riesgo darle de palos hasta que retroceda. A reces se ric a los hombres, los mulos y los caimanes oprimiéndose en el agua; el ganado, poscido de es. panto, procura escapar de los crocodilos; los pastores se ocupan en atemorizar a los reptiles con sus palos; y los cai. manes contemplan con ojos de codicia la presa que bien les gustaria, pero de la cual se mantienen â distancia conve niente por temor á los garrotazos.

Las ovejas y las cabras que se acercan al agua para beber, los perros, ciervos 5 caballos que la pasan á nado corren riesgo de que los caimanes les ahoguen para devorarlos des. pues; pero el alimento verdadero de estos crocodilos son los peces. En las inunáaciones anuales de los rios, los grandes lagos y charcos a ambos lados de los mismos se llenan no solo de agua sino tambien de peces, que sirven de pasto a los caimares. Despues de la inundacion sécanse todas las comunicaciones entre estos lagos; los peces se ven obligados á buscar los sitios mas profundos, y tambien alli les persiguen los caimanes, dirigiéndose desde un estanque ả otro, ó segun se dice en América, de un agujero á otro. Despues de po. 
nerse el sol, óyese desde léjos el rumor que los reptiles producen con sus colas, y al llegar al sitio obsérvase cómo agitan con sus movimientos las olas, espantando de tal modo á los peces que saltan á centenares sobre la superficie con la intencion de escaparse de su enemigo mas peligroso; á me. nudo los golpes de cola de los reptiles les lanzan directamente á la boca de estos. Audubon se divittió á veçes en arrojar á los caimanes reunidos en un estançue una vejiga de buey llena de aire: uno de estos saurios se acercó á ella, atrájola con la cola hácia st é intentó cogerla con los dien. tes, pero se le escapó; otros procuraban coger con mas ha bilidad la supuesta presa, sucediendo á reces que jugaban verdaderamente $\{$ la pelota. A menudo se les arroja tambien una botella tapada, la cual pueden coger sin dificultad, y entonces se oye como el vidrio se rompe entre los dientes, y se desea buen provecho al crocodilo mirado en todas partes con malos ojos.

En lá primavera, es decir, en el período del celo, los caimancs son temibles, porque cl instinto de la reproduccion les excita Los machos traban encarnizadas luchas tanto en el agua como en tierra, enfureciéndose de tal modo, que ya no temen al hombre, quizás tambien porgue en esta temporada todas las llanuras están inundadas, siéndoles diricil co ger los peces entonces mas aislados. Mucho tiempo despues la hembra fecundada deposita los huevos, relativamente pequeños, blancos y de cáscara dura y calcinosa, cuyo número excede á veces de ciento. Segun los datos conformes de Au'ubbon, Luetzelberger y Lyell, la hembra los pone en un hoyo que al efecto practica en sitio conveniente, á unos cincuenta 6 sesenta pasos del agua, en un espeso cañaveral ó maleza, á donde lleva hojas, maderos y otros materiales; despues deposita los huevos $y$ los cubre cuidadosamente. Segun se dice, vigila continuamente cerca de la madriguera, y ataca furiosamente á todo sér que se acerca á los huevos. El calor que se desarrolla por la efervescencia de las materias regetales hace salir los pequeños; estos se deslizan con mucha habilidad por las plantas que los cubren, $y$ al abandonar el nido les recibe la madre que los conduce al agua, por lo regular á un pequeño charco separado para asegurarles contra el maclio y las grandes aves pantanosas.

La gran vitalidad del caiman dificulta su caza, pues solo es posible matarle en el acto cuando la bala penetra en el cerebro 6 el corazon. En vez de las armas de fuego $\mathrm{cm}$. pléanse mas á menudo grandes redes, con las cuales se sacan los animales de los charcos, arrastrándolos a la orilla, donde se les mata á hachazos. Algunos negros tienen mucha destreza para coger caimanes por medio de nudos corredizos, los cuales les arrojan sobre la cabeza cuando se acercan á la orilla, sacándolos despues del agua. Los caimanes heridos causan entre los compañeros que con ellos habitan el mismo estanque, tal miedo y excitacion que estos emigran regularmente ó cuando menos se ocultan varios dias, mientras que los que con una bala se matan instantáneamente llaman mu. cho menos la atencion de sus compañeros. En el rio Colorado se mataban en años anteriores miles de estos animales porque los zapatos, botas y sillas de piel de caiman se habian hecho moda. Algunas tribus nómadas de indios se ocuparon algun tiempo exclusivamente en la caza de estos reptiles, y sin duda los habrian exterminado si no se hubiera reconoci. do que las pieles no son bastante fuertes y gruesas para preservar los piés de la humedad. Actualmente se emplea todavía la grasa para untar las máquinas; pero segun parece, nadie ha pensado hasta ahora en hacer servir las glándulas que tienen un olor tan fuerte de almizcle como las de los crocodilos.

Cautividad.-Esta especie de la familia de los cro. codilos es la que se ve en los jardines zoológicos y en las colecciones ambulantes de fieras. Todos los años llegan va. rios centenares de individuos viros al mercado europeo, y todos ellos encuentran compradores; los pequeños que ape. nas han salido de la madriguera suelen ir á poder de algunos aficionados que los incorporan á su acuario, domesticándo. los de tal modo que al fin toman el alimento de la mano; los grandes pasan á ser propiedad de las colecciones ambu. lantes de fieras, en las cuales figuran hasta que el mal trata. miento, el hambre y el frio los matan al fin. Los caimanes cogidos adultos suelen despreciar el alimento, pero los de un metro $y$ medio de longitud comen pronto cuando se les proporciona un espacio grande, por ejemplo un estanque en un jardin. Para acostumbrarlos a comer es preciso darles al principio presa viva, por ejemplo, gorriones, palomos, galli. nas, etc., \& quienes se ha quitado la facultad de volar; mas tarde aceptan tambien carne cruda, puesta en movimiento por un cordon, $y$ al fin ya abren la boca tan luego como se les enseña el alimento. Cuando se les cuida bien se conser. van tambien al descubierto muchos años cautivos; mas para ello es preciso que en invierno puedan preservarse suficientemente de los rigores del frio, guareciéndose si es posible en el cieno para entregarse al sueño invernal; de no sei así, ni siquiera sobreviven al primer invierno. Por lo demśs, no aconsejaria á nadie que se aficionara á tener caimanes cau. tivos. Ios pequeños son bastante graciosos, pero todo lagarto divierte mas á su amo que ellos, y los individuos adultos fastidian pronto aun al mas aficionado.

\title{
UN TERCERA SUb-CLASE-Escamosos 1
}

\author{
TERCER ORDEN
}

\section{1) ID SAURIOS-SAURIA}

CARACTÉRES. - El precioso lagarto, conocido sin duda de todos mis lectores, puede considerarse como proto. tipo de todos los lagartos, si bien esta forma fundamental, por decirlo asi, varía murcho, notándose desproporciones entre las extremidades, espinas y crestas membranosas, ló. bulos y repliegues, así como la atrofin de algunos miem. bros, en cuyo caso los respectivos animales se parecen á las serpientes.

Tienen por lo regular los escamosos. una configuracion análoga a la de los crocodilos, siendo muy pocos los que, careciendo de extremidades, se asemejan á los ofidios: dis. tinguense, empero, tan marcadamente de estos como de los 
acorazados por varios caractéres externos 6 internos, Su cuerpo está casi siempre dividido, de manera muy aparente, en calseza, cuello, tronco y miembros, y si bien á veces hay atrofia y hasta carencia absoluta de estos últimos, afectando entonces la especie cierta semejanza exterior con las serpientes, con todo, la analogia que el profano cree descubrir entre la misma y otras de distinto órden, no es mas que su. perficial y desaparece ante un examen mas detenido. 'Todas las especies que forman este órden tienen el cuerpo cubierto de escamas córneas, la lengua movible, los dientes innatos ó fijos en el vértice de los bordes maxilares, 6 adheridos lateraimente á los mismos, y por lo general doble párpado. Carecen los escamosos de pabellon auricular; el timpano aparece libre á fior de la cabeza, á veces en una pequeña cavidad, y muy excepcionalmente cubierto por la piel del cuerpo.

Los părp̧ados son movibles; las fosas nasales se hallan separadas, y el orificio del ano está hendido trasversalmente, pero no como en las tortugas y crocodilos.

Las escamas, que difieren mucho segun las especies, se han designado con los nombres de tabularins, sobrepuestas y paralelas: las primeras se reducen a unas formaciones cór. neas, pequeñas, redondas ó angulosas, adheridas en toda la superficie a la piel, y que por lo ianto no se cubren; mientras que las sobrepuestas se insertan por su borde anterior en la piel, quedando el posterior libre; cúbrense por los la-

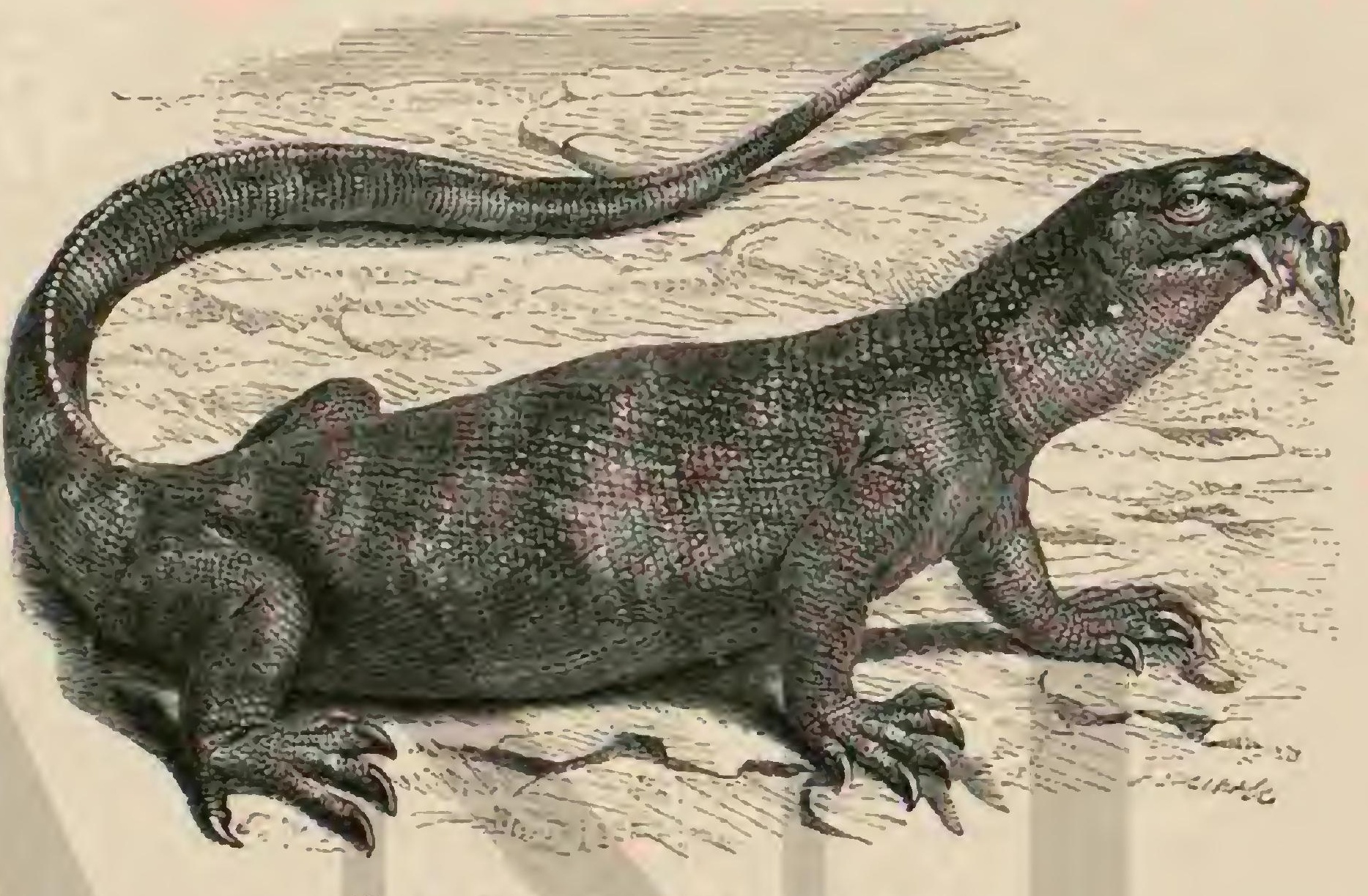

dos, y en parte tambien por las puntas; las escamas parale. las están dispuestas unas junto á otras en linens rectas; las de mayor tamaño, qque están adheridas en toda la superficie de la piel, se denominan placas ó escudos, distinguiéndose tanto por su forma como por sti posicion. A esto deben su nombre de rostrales, nasales, oculares, frontales, labiales, occipitales, ctc., contándose además las placas del hocico, las anteriores $y$ posterioris, las de ojos, de la linea naso-ocular, de las sienes, etc. Todas estas denominaciones no corres. ponden efectivamente á los huesos del mismo nombre de la cabeza, y su uso no es por consiguiente exacto. Asi, por ejemplo, de los llamados escudos occipitales no suele hallarse en el occipucio ninguno, y cuando mas uno solo, estancio los demás 6 todos en la coronilla; el escudo anterior de. csta parte sobre el hueso frontal, etc. Ademís de las escamas y escudos, se observan á menudo espinas, listas, crestas y otras formaciones córneas.

El cráneo se distingue esencialmente del de los crocodilos. El hueso cuadrado en que acaba la mandibula superior se inserta por lo regular movibleniente en el cráneo; la mandibula superior es fija, con una sola excepcion. Por lo regular existe un fuerte cóndilo arqueado hácia afuera que termina en el agujero occipital; el hueso frontal es comunmente sencillo y raras veces aparece dividido por el centro; los parie. tales se hallan separados de los huesos inmediatos, y el esfenoides atrofiado con frecuencia. La columna vertebral contiene un número muy variable de vértebras, huecas en su parte anterior, abovedadas en la posterior, y alguna vez cón.

cavas en ambos lados. Los sacros faltan, ó existen cuando mas en número de dos; las costillas acaban siempre en extremidades sencillamente redondeadas. El esternon, el omoplato y la pélvis pueden presentarse mas ó menos-atrofiados, pero jamís faltan por completo como sucede en las serpientes.

La lengua, que es de gran importancia para la clasificacion de la familia, afecta distintas formas: es hendida en la punta y vermiforme, carnosa, apenas escotada ó redondeada, corta y mas grtuesa en la raiz, adelgazada y mas 6 menos escotada, ctcêtera: sobre estas formas daré luego las explicaciones necesarins. Se dice que los dientes se hallan insertos cuando estain soldados con el borde de los maxilares; sobrepuestos, si se presentan unidos con la cara exterior de la extremidad de su raiz en la interior del maxilar; de inodo que el lado interno de aqquella queda libre y solo está cubierto por la encía. Además de estas dos clases de dientes, los escamosos tienen otros llamados palatinos insertos en los terigoideos; todos ellos difieren mucho por sus formas. Fi limite entre el esó. fago y cl estómago no está marcado; csic último afecta una forma cónica, se ensancha á menudo en su parte antcrior por medio de una protuberancia circular ó de una válvula verdadera de diversa longitud, presentando varios repliegues sinuosos, y sepárase por una válvula especial de la cloaca. Los riñones se hallan en la parte posterior de la cavidad abdominal, son prolongados en forma de cinta y á menudo aparecen unidos en los dos mitades posteriores. El corazon tiene dos auriculas completamente separadas, pero los ren. triculos se comunican entre sí los pulmones no están rete- 
nidos en la cavidad pectoral por medio de un músculo en forma de diafragma, como sucede con los crocodilos, sino que llegan hasta el abdómen.

Lo mas notable, en fin, son los órganos genitales, siempre dobles, y semejantes por este concepto a los de los ofidios, pero no de las tortugas ni de los crocodilos.

El sentido que tienen mas perfecto los escamosos es la vista. Casi todos poseen este aparato bien desarrollado, con la pupila redonda, que no es susceptible de gran contrac. cion; algunos la tienen prolongada, distinguiendose de este modo como animales nocturnos. El oido es el otro sentido que despues de la vista se puede considerar como mas per fecto en la gran mayoría de estos reptiles. El tacto lo ejercen únicaniente con la lengua, como las serpientes, sirviéndoles este apéndice solo de un modo nuy secundario para las funciones del gusto, tanto mas cuanto que no mascan ó trituran sus presas, sino que las engullen enteras. En cuanto al olfato no nos atreveremos a manifestar opinion alguna, pues las observaciones que se han hecho respecto \& este punto son tan incompletas, que no permiten formar un juicio preciso y definitivo.

Por lo que toca á inteligencia, puede decirse que no hay reptil alguno que aventaje á los escamosos. Por lo general, ven estos en todo sér de mayor tamaño y especialmente en el hombre un enemigo temible, pero en los paises meridicnales, viven por el contrario, en relaciones muy familiares con los habitantes de las casas, en las que se introducen á todas horas sin temor alguno, acercándose á las personas y acabando por convertirse en verdaderos animales domésti. cos; sin que por eso dejen de manifestar alli tambien el ter ror que les infunde todo otro enemigo, cuya sola presencia basta para ponerlos en precipitada fuga. Todos los aficionados que han tenido en cautividad individuos de las especies mas agradables para estc objeto, manifiestan la opinion de que sus prisioneros acaban por conocerlos, y si bien no se puede tomar este aserto en su sentido mas literal, de que los reptiles distingan \& su guardian entre otros hombres, con todo, viene á demostrar que á causa de la experiencia adquirida cambian estos animáles su modo de obiar, patentizando de este modo la actividad cerebral que llamamos raciocinio.

DISTRIBUCION GEOGRÁrICA.- Lis el órden de los escamosos el mas abundante en especies de la clase de los reptiles. Extiéndense, con excepción de las zonas frias, por todas las partes de nuestro globo, $\mathrm{s}$ encuéntranse sus indivi. duos desde las orillas del mar hasta los limites de las nieves perpetuas; en las mas distintas localidades, lo mismo en las tierras mas productivas que en los desiertos, en las inmedia. ciones del agua y en los terrenos áridos. En los países mas frios de la zona templada esián representados tan solo por pocas especies, pero van aumentando rápidamente hácia el Ecuador.

USOS, COSTUMBRES Y RÉGIMEN. - Algunas espe cies de los escamosos, viven en el agua, y solo van á la tierra firme, como los crocodilos, para apoderarse de alguna presa, ó para dormir y calentarse al sol; la gran mayoria, sin embargo, son animales terrestres en todo el sentido de la palabra y evitan las localidades húmedas; muchos viven en los árboles, pero los mas en el sucloy en las rocas. Por su con. figuracion exterior se puede ya deducir el modo de vivir de las varias especies: Ias que tienen el cuerpo aplanado, viven por lo general en las llanuras arenosas y fijan su morada debajo de las piedras, en las paredes ó en las cavidades del suelo; las de cuerpo comprimido lateralmente, frecuentan las espesuras de los arbustos y los árboles; y por último, las que le tienen redondeado habitan los escondrijos que les ofrecen el suelo y los árboles añosos. Sin embargo, esta regla que en conjunto es bastante exacta, tienc tambien sus ex. cepciones.

Los escamosos son sin duda alguna los reptiles mejor do. tados; ejecutan los mas variados movimientos con suma agilidad y destreza: andan con bastante velocidad, si bien arrastrando parte del cuerpo y con ondulaciones parecidas á las de las serpientes, y saben servirse de su cola, pegando fuertemente con ella en el suelo y apoyando en la misma el resto del cuerpo, para dar saltos á regular distancia y ele. vacion.

Las pocas especies que viven en el agua, nadan y se su. mergen con toda perfeccion, aunque no tengan los piés pro. vistos de membranas natatorias; y otras, que por lo demás, parecen tener gran repugnancia al elemento liquido, cuando caeu casualmente en él saben salirse del mal paso con mucha agilidad; por último, las que trepan por las paredes y los árboles, lo hacen con maravillosa destreza. Algunos escamosos que moran tambien en los árboles, se sirven de la cola como de instrumento prensil; otros, provistos de dedos de piel áspera y ensanchados en forma de disco, corren en todos sentidos, ya sea con el dorso hacia arriba, ya sea vuelto hácia abajo, y con igual seguridad por la parte superior que por la inferior de las ramas; habiendolos tambien que apo. yados en un repliegue de su piel, dispuesto en forma de alas, pueden dar grandes saltos oblicuos desde una rama mas alta á otra maś baja. Los reptiles de este órden, cuyos piés aparecen atrofiados, ó que carecen por completo de ellos, reptan del mismo modo que los ofidios, si bicn las costillas no les facilitan la locomocion en tan alto grado como á estos.

Pocos escamosos póseen el don de la voz, propiamente dicha, Casi todos, cuando están enfurecidos, hacen oị una especie de silbido; algunas especies, sobre todo las nocturnas, producén ciertos sonidos que se asemejan mas al canto de las ranas que al bramido de los crocodilos.

Algunos escamosos se nutren de materias vegetales, sin que por eso desprecien del todo las animales; todos los de más buscan su alimento en varias clases del reino animal. Las especies de mayor tamaño persiguen á todos los verte. brados; osan atacar á los pequeños mamíferos y aves, siendo á veces hasta peligrosas para los de mayor corpulencia; sa. quean los nidos de las aves; acometen á todos los reptiles, batracios y peces, y devoran tambien cuantos anélidos pueden atrapar. Ias pequeñas especies se alimentan especialmente de estos últimos séres, muchas con preferencia de insectos, otras de gusanos y caracoles. Su digestion es muy viva, sobre todo en tiempo caluroso; comen entonces muchisino, engordan. do hasta cierto grado, pero en otras circunstancias pueden padecer hambre mucho tiempo y sin perjuicio visible. Las partes duras de su presa, ó los vegetales devorados inciden. talmente, son expelidos con los excrementos. T'odas las especies conocidas beben con la lengua, que sumergen y retiran repetidas reces en el agua; las mas se contentan con.el rocio recogido en las hojas y en las piedras, y algunas, segun pare. ce, pueden pasar meses enteros sin agua.

La vida diaria de estos animales, aunque mas variada que la de otros individuos de la misma clase, no deja de ser igual. mente muy monótona. Muéstranse mas activos y desenvueltos en los climas tropicales, especialmente en aquellos paises donde las estaciones varian muy poco, y no se ven obligados por lo tanto à buscar refugio contra la inclemencia de la temperatura. Alli empiczan ya a moverse desde las primeras horas de la mañana, corriendo alegres de un lado $\mathrm{s}$ otro hasta la puesta del sol, hora en que abandonan el campo á las especies nocturnas del mismo órden hasta la mañana si. guiente. 
Dedican las primeras y últimas horas del dia á la caza, permaneciendo reunidos y jugueteando en las restantes, excepto aqueilas mas calurosas que pasan medio adormecidos, pues tanto temen el calor excesivo del sol como el frio. Cada reptil se escoge cierto distrito $\delta$ pedazo de terreno, en el que busca escondrijos adecuados, sabiendo preparárselos él misıno si no los encuentra. De esta localidad no se aleja jamf́s a gran distancia, $y$ en ella se refugia tan pronto como cree que algun peligro le amenaza. Los escamosos que viven en el agua, asi como los que tienen su morada en los árboles no hacen excepcion de esta regla. Puede decirse que cada lagarto se procura con cierto cálculo una localidad que esté en armonía con la coloracion de su cuerpo, y alli acecha sus presas. Todos aquellos que andan como los reptiles espian su victima, y cuando creen llegado el momento oportuno, se precipitan sobre ella, á veces por medio de un gran salto; la cogen entre sus dientes, in aplastan un poco con estos y se la tragan, empezando por la cabeza; los que solo se mueven adelantando primero un pié y luego el otro, se van aproximando muy lentamente á su presa, y de impro. viso proyectan su larga lengua, con la que recogen aquella con maravillosa precision y seguridad. Despues de una abun. dante comida tambien permanecen los escamosos en perezosa inactividad, pero nunca caen en el estado de sopor propio de las serpientes. Con la puesta del sol se retiran los lagartos diurnos á sus escondrijos, que no abandonan á veces durante dias y semanas si la temperatura es desfavorable. Todas las especies del órden, que no viven en los paises de primavera continua, sobre todo las que moran en cl agua y en los árbo. les, pasan la estacion rigurosa en un estado parecido al sueño invernal de los mamíferos. En los paises septentrionales de Europa, los lagartos se esconden ya en el otoño en profundos agujeros en el suelo y no vuelven á salir hasta la prinavera siguiente.

Pero las mismas especies que en Alemania solo duermen cinco meses, cuando habitan mas al norte de Europa ó á mucha altura en lns montañas, pasan de ocho á diez sumidas en el letargo. De las pocas observaciones que hasta ahora tenemos de viajeros prácticos y concienzudos, resulta por unanimidad que en los países tropicales sucede tambien cosa semejante.

Poco despues de haber despertado del sueño invernal en primavera, cualquiera que sea la temperatura con que esta se presente, los escamosos entran en el periodo del celo; ob. sérvase entonces una viva excitacion, viéndose cómo dos machos se persiguen con empeño, 9 traban una lucha encarnizada por la posesion de la hembra. Esta vive solo con el macho durante el perfodo citado; al cabo de algunas semanas preparase á depositar de seis á quince huevos, y sin esfuerzos ni cuidados, arregla un sitio conveniente, practicando un agujero en tierra ligera, en el musgo, en la madera podrida de troncos de árboles, ớ en los montecillos de hormigas y térmites, etc; alli hace su puesta y la cubre ligeramente. Los hueros se diferencian muy poco de los de otros reptiles; tie. nen una câscara dura poco caliza, clástica como cuero; tienen igualmente la yema aceitosa y la clara liquida. Unos dos meses despues salen á luz los pequenos sin ayuda alguna de parte de sus padres y empiezan al punto el mismo modo de vivir de estos.

Esta es la regla general, pero no todas las hembras po. nen huevos, sino que algunas paren vivos sus hijuelos; es decir, que llevan los huevos hasta que, desarrollado por completo el gérmen, se rompe la cáscara poco antes de que salgan de la matriz, naciendo de esta manera los hijuelos vivos del cuerpo de la madre. Se ha observado que las especies ovoviviparas se exponen antes á los rayos del sol, por lo cual se ha supuesto q̨ue este modo de proceder de la hembra será una condicion imprescindible para el desarrollo de los hijuelos. Debe notarse, sin embargo, que la diferencia entre los escanosos oviparos y los ovoviviparos no tiene importancia ninguna para la vida de estos animales en general, ó para la de familia: en los paises del norte, los pequeños nacidos á úl. timos de verano mudan la piel, é inmediatamente buscan los sitios y escondrijos mas á propósito para entregarse al sueño invernal.

Los escamosos son entre todos los reptiles los qque sufren mas por los numrerosos enemigos que tienen. Un verdadero ejército de animales de rapiña los amenazan y persiguen en todas las fases de la vida. Las grandes especies estan bas. tante seguras contra los ataques de otros animales, gracias á su fuerza $y$ á su valor; pero las pequeñas sirven de presa á las martas, vesos, serpientes, buitres, águilas, halcones, buzos, estrígidos, cuervos, gallinas, aves pantanosas y acuáticas y hasta á los individuos mas fuertes del mismo órden; de modo que en rigor deberiamos admirarnos de que puedan escapar de tantas persecuciones. En algunos paises el hombre contribuye tambien al exterminio de tan inofensivos séres, á veces por pura maldad, por la sola inclinacion á matar. A algunas especies se las considera como venenosas, pero sin razon alguna, porque las mas minuciosas observaciones no han podido descubrir en ellas glándulas de veneno; á otras se las confunde con los ofidios, haciéndoles sufrir las consecuencias del odio general que contra estos reptiles existe. Lo uno es tan inexacto como lo otro. No se puede decir que los escamosos nos reportan verdaderos beneficios, pero tampoco nos causan daño; la carne de algunas especies grandes se puede comer, y hasta gusta á los europeos; la graciosa agilidad de otra anima los campos y bosques, y por lo dóciles se pueden conservar, agregándose á esto que la ma. yoria se nutre de animales desagradables para nosotros. Hay algunas que nos molestan por su rapacidad, atacando à nuestras aves de corral $y$ á sus huevos; otras asustan a las personas apocadas por su semejanza con las serpientes y por cl ruido sospechoso que producen al pasar por la hojarasca: esta es toda la utilidad y todo el daño de que se puede ha. blar en cuanto à los escamosos. No tienen en rigor importancia para nosotros, pero tampoco hacen nada que justifique su persecucion por parte del hombre. El numero extraordinario de especies que este órden contiene y la falta de observaciones sobre su género de vida no permiten, en ninguna obra popular, ni tampoco en la Vida de los animales, tratar minuciosamente de la infinidad de formas $y$ especies que en los escamosos se encuentran. Debo limitarme por lo tanto á los tipos mas importantes de la generalidad, pasando jor alto hasta algunas familias, porque no se han recogido hasta ahora ni publicado observaciones sobre los usos y costum. bres de las especies que les pertenecen. Una historia natural de los reptiles correspondiente al estado actual de la ciencia y que describa minuciosamente todas las especies de la clase, no pasa hasta ahora de ser un deseo piadoso de los natura. listas, y sobre todo por lo que hrace al brden de los escamo. sos, convendria en alto grado un trabajo concienzudo, escrito por un autor experto. Para todo aquel que no esté empleado en uno de los primeros museos y que no tiene todos los es. critos sobre ciencias naturales a su disposicion es muy dificil orientarse en el caos que actualmente reina en los nombres y descripciones; asi es que el que intenta conocer la vida de los reptiles y describirla se ve á menudo en la mayor perpleji. dad, sin saber por đónde empezar ni acabar, siéndole por consiguiente del todo preciso hacer una eleccion muy limitada de las especies que deben servir para la descripcion ge. neral de este órden del reino animal. 


\section{LOS HATÉRIDOS-}

\section{HATTERIAD压}

Un escamoso extraño por todos conceptos, que reune en sí los caractéres de varios órdenes y hasta se asemeja en cierto modo á los batracios, ocupa el primer puesto entre las especies elegidas por mi. Guenther, que disecó el notable reptil, juzgóle tan particular que le escogió como tipo de un órden independiente; y aunque mucho podria oponerse á semejante proceder, debemios confesar, sin embargo, que á este animal le pertenece en la clasificacion un lugar que exprese las difcrencias entre él y los verdaderos escamosos, al parecer tan congenéricos.

Nosotros le consideramos como tipo del sub órden de los Rincocéfalos esencialmente distinto de todas las demás divi. siones del mismo rango. El animal de que hablamos es ia hateria punteada.

\section{LA HATERIA PUNTEADA-HATTERIA PUNCTATA}

CARACTÉRES. - La hateria punteada tipó del sub-óden citado y además prototipo de una familia independiente, es un escamoso muy grande y algo pesado. Su cabeza afecta la figura de cuadrilátero; el tronco es recogido; las extremidades robustas; la cola tan larga como el tronco, de forma triangular y comprimida; los piés anteriores y posteriores tienen cinco dedos fuertes, cortos y redondos, unidos entre si por pequeñas membranas, y provistos de cortas garras. Los poros femurales faltan. En la parte posterior del pecho se observa un repliegue trasversal; en la nuca, á lo largo del centro del lomo é igualmente à lo largo del centro de la cola se levanta una cresta formada de espinas comprimidas é interrunipidas en la region de los hombros y en las de las ca. deras. Unas escamas pequeiras cubren la cabeza; otras seme. jantes y mayores el tronco; las de la cara inferior del cuerpo son mas grandes, de forma plana $\delta$ aquillada, $y$ dispuestas en series trasversales; la cola y la parte inferior y superior de los dedos están protegidas por escamas pequeñas; las de toda la cara superior del cuerpo son granujientas, $y$ las que cubren los repliegues irregulares son mas grandes que las otras. El color predominante es un verde aceituna opaco interrum. pido por pequeñas manchas blancas y por otras mas grandes amarillas en los costados y en las extremidades; las espinas de la nuca y del lomo son amarillas, las de la cola de color pardo.

De la diseccion anatómica del animal resultan unos caractéres mucho mas particulares é importantes que los exte. riores. El hueso cuadrado, al contrario del de todos los ani. males, cstá solidamente fijo en el cráneo y la parte anterior de este reunida con la region de las sienes por medio de dos cóndilos óscos que pasan por las fosas temporales. Los dien. tes se insertan como de costumbre por su base en el borde de los maxilares, pero excepto los dos anteriores, se desgastan de tal modo en los individuos viejos, que estos se ven obli. gados á morder con los bordes de las mandíbulas, á la ma. nera de las tortugas; los dos dientes anteriores tambien se mudan, pero no desaparecen del todo. Ambas ramas de la mandibula inferior están reunidas por una faja como en los ofidios. Las vértebras son cóncavas en su cara anterior y posterior como sucede en algunos batracios y en los peces 6 en los reptiles fósiles, los ictiosauros, melagosauros $\$$ teleosau. ros. Las costillas son análogas á las de la mayor parte de los escamosos; algunas, es decir, tres pares se reunen con el es. ternon, contándose despues once de costillas falsas; las $\mathrm{cx}$. tremidades inferiores de estas últimas se reunen sin embargo á su vez con unas listas óseas particulares, llamadas costillas abdominales, que se insertan en el dermis del abdómen y corresponden por su número y disposicion a los escudos $\mathrm{ex}$. teriores del vientre, dispuestos en series trasversales; su nú. mero es sin embargo el doble mayor que el de las vértebras y costillas falsas y se reunen de tal modo con los escudos del vientre que solo con ayuda del bisturi se les puede sepa. rar de ellos: una serie trasversal de escudos del vientre de este animal corresponde por consiguiente á un solo escudo abdominal de un ofidio. A cstos últimos se parece asimismo la hateria punteada, por faltarle el timpano, asi como una caja limitada de este; los huesecillos auditivos están repre. sentados por el yunque. Guenther no pudo encontrar órganos genitales masculinos, carácter que comunica á la hateria punteada nueva analogía con los batracios. Solo se puede asegurar, dice Martens, que este animal es un reptil que por su conjunto pertence á los escamosos, y por algunos carac. téres impurtantes de las fornas a los batracios, habiéndose desarrollado por otros como los crocodilos y los ofidios.

DISTRIBUCION GEOGRÁFICA.-La hateria punterda habita, segun se sabe hasta ahora, en algunas partes de Australia.

USOS, COSTUMBRES Y RÉGIMEN, - Las noticias que hasta ahora tenemos sobre el área de dispersion y el gé. nero de vida de esta especie son muy escasas. Cook fué quien primero hizo mencion de ella «en su tercer viaje. «En la Nueva Zelanda hay, segun se dice, unos lagartos de enorme tamaño, que miden $2^{\circ}, 60$ de largo y son tan gruesos como un hombire, al cual atacan á veces y devoran. Habitan en agujeros subterráneos y se les mata encendiendo fuego debajo de la entrada de su guarida. Polak habla igualmente de este animal: «El lagarto gigantesco 6 suana, dice, habita sobre todo en lá isla Victoria; pero algunos se hallan tambien en las islas de la bahia de Plenty. Los indigenas aseguran que estos animales son antropógafos; yo, por el contrario, creo que son unos séres inofensivos.

Dieffenbach obtuvo noticias mas amplias. 8 Me han hablado, dice, de la existencia de un gran lagarto muy temjdo de los incigenas que le llaman tuatera ó narara; mas á pesar de que examiné todos los sitios donde al decir de los habitantes del pais tenia sus guaridas, y aunque ofreci una considerable recompensa por su captura, solo algunos dias antes de mi salida de Nueva Zelanda logré obtener un individuo, cazado en la pequeña isla pedregosa de Karewa, en la bahia de Plenty, á unas dos leguas de la costa. De todo cuan. to me dijeron parece resultar que la hateria punteada abunda. ba en otros tiempos en todas las islas, donde vivia en madri. guerras subterráneas, y á menudo tambien en las colinas arenosas de la costa; los indigenas le perseguian y mataban para comer su carne. Con motivo de la persecucion que sufria, sin duda tambien á causa de la importacion de los cerdos; el animal ha llegado á escasear tanto, que muchos natura. les ancianos del país no le han vuelto à ver. La hateria pun. teada que trajeron viva \& Dieffenbach llegó mas tarde al Museo británico, ofreciendo ocasion á Gray para dar á cono: cer esta especic al mundo científico. Despues del tiempo de Dieffenbach, hácia $x 8_{4} \mathrm{I}$, se cnviaron algunos individuos muertos ó vivos á Inglaterra, pero siempre tan pocos, que ya en I 867 . Guenther pudo indicar el temor de que la hateria punteada figuraria muy pronto entre las especies extinguidas. Mas tarde, Bennett dijo que hasta el año 185 I existian aun muchos de estos animales en algunos islotes de la citada bahía, sobre todo en Rurima y Montoki. Varios oficiales cogieron aqui en media hora unos cuarenta individuos de $0^{\circ}, 80$ á $0^{\circ}, 60$ de largo, que tomaban el sol. En I869, en fin, llegó otro de estos 
reptiles viro a Inglaterra enviado por Hektor, el cual lo habia cogido en la provincia de Wellington en la Nueva Zalan. da. De este individuo sabemos que comir con roracidad los gusanos de harina y otros insectos y Dieffenbach nos dice que la hateria cautiva es en alto grado perezosa, pero tambien muy dócil, y que se deja tocar sin morder ni resistirse.

No conozco otras noticias sobre su género de vida.

\section{LOS CIONOCRANIOS - CIONOCRANIA}

CARACTERES. - Entre los demás escamosos que tienen el hueso cuadrado unido y fijo en el cráneo, las ramas de la mandibula inferior reunidas por una sutura compacta y úrganos genitales, los lagartos ocupan en cl sentido mas lato de la palabra el primer lugar, constitugendo un grupo especial dentro de su clase, al que se da el rango de subórden de los cionocranios 6 leptoglosos. La mayoría de los es. camosos pertenece á esta division. Sus caracteres comunes consisten en las órbitas $y$ arcos cigomditicos mas 6 menos desarrollados, en el parietal sencillo, en la presencia del yun. que en el interior de los oidos y en las vértebras cóncavas solo en su parte anterior. Además se han reconocido, segun $\mathrm{Ca}$. rus, los siguientes caracteres exteriores. En el tronco prolongado, con cola regularmente larga, se cuentan por lo comun cuatro extremidades, y cuando estas últimas se atrofian ó desaparecen, obsérvanse aun los hombros y la pélvis. Los dientes se ensanchan solo en un género. Las escamas están dispuestas en forma pentagonal 6 en la de dados, 6 en series trasversales poco marcadas. Suelen existir los párpados su. periores é inferiores; la lengua es larga, delgada y capaz de alargarse, 6 gruesa, carnosa y cubierta de verrugas.

\section{LOS VARÁNIDOS- VARANIDE}

Por un extraño error de algunos naturalistas alemanes se ha dado á varios grandes escamosos, que forman la primera familia del sub órden, el nombre de lagartos nailisadores. Las especies mas conocidas de la familia habitan el Egipto donde se les llama auman, palabra que se ha trasformado en zuarner (avisador), conservando la misna significacion en el nombre cientifico de monilor: pero las palabras warran y auarner no tienen ninguna relacion entre si, pues la primera significa sencillamente lagarto.

CARACTÉRES. - Los varanidos, ó lagartos acuáticos, se parecen á los otros cionoctanios por su tronco prolongado, lomo ancho y sin quilla y piés completamente desarrollados, con cinco dedos provistos de fuertes unas; difieren de ellos por la forma de sus escamas y de la lengua, y por la disposicion y figura de los dientes. Su cabeza es relativamente mas larga que la de otros escamosos y se asemeja un pocośla de los ofidios; pero tambien el cuello y el resto del cuerpo in. cluso la cola son mas enjutos que las partes correspondientes de sus congéneres. Cuando la lengua está recogida se oculta por completo en una vaina membranosa, pero puede alargar. se mucho, presentando entonces dos puntas largas y córneas. los dientes, que se oprimen en la cara interior de los surcos maxilares, son bastante claros y de forma cónica, es decir puntiagudos for delante y obtusamente cónicos por detrás: los dientes palatinos no existen. Las pequeñas escamas tabulares, dispuestas en forma pentagonal ó en series trasversales, no forman verdaderos escudos en la cabeza, y las de los lados del abdómen no difieren tampoco mucho de las del lomo.
DISTRIBUCION GEOGRÁFIGA. - LOS varanidos, de los cuales se conocen unas treinta especies, habitan el henxisferio oriental del globo, sobre todo el Africa, sur de Asia y Oceania.

USOS, COSTUMBRES Y RÉGIMEN.-Algunas es. pecies son del todo terrestres $y$ buscan una cavidad conveniente que les sirve de escondrijo; en las inmediaciones cazan las unas de dia y las otras de noche; varias de cilas deben contarse entre los animales acuáticos, pues solo viven en las cercanins de las aguas, en los pantanos y á orillas de los rios, refugíndose en caso de peligro en el agua con toda la ligereza posible. Tanto unos como otros son animales sumamente activos; corren por el suelo ejecutando movimien. tos serpentinos y tan rápidamente que pueden alcanzar álos pequeños mamiferos y aun á las aves; trepan con la niagor destreza a pesar de su tamaño y nadan y se sumergen en el agua con mucha agilidad, sin cansarse, aunque no tengan los piés paimeados. Dos grandes cavidades que llevan en el interior de la parte superior del hocico, las cuales se comunican con las fosas nasales, teniendo la facultad de llenarse de aire, y que pueden cerrarse con los bordes movibles de las fosas nasales, permitenles pasar mucho tiempo en el agua.

Por sus usos y costumbres, y su modo de ser, los varanidos se parecen álos pequeños lagartos, no álos crococillos; pero da proporcion de su tamaño y su fuerza, son mucho mas rora. ces, atrevidos y reñidores que aquellos. Sienujre huyen del hombre $y$ de otros animales grandes cuando pueden; 125 es. pecies terrestres se refugian con la rapidez del rayo en sus guaridas, y las acuáticas vuelven á su elemento; pero cuando se les corta la retirada á su guarida aceptan resueltamente la lucha y dando un gran salto con ayuda de sus piés y su fuerte cola, se precipitan atrevidamente sobre la cara $y$ las manos del agresor.

Compónese su alimento de animales de toda especic. El varano propiamente dicho, que es el género tipico de esta familia, reptil muy famoso entre los antiguos egipcios, cuya imágen han perpetuado en sus monumentos, tenia fama en aquellos tiempos de ser el enemigo mas peligroso del croco. dilo, diciéndose de él que buscaba los huevos de este y los rompia, y que perseguia álos jóvenes individuos de dicha fa. milia y los devoraba. Dificil seria averiguar lo que haya de verdad en esos cuentos, pero no nos parece improbable que un varano se trague $\mathbf{f}$ un jóven crocodilo si puede atraparlo. Lechenault asegura haber presenciado cómo algunos varanos de la India reunidos perseguian un corzo, acabando por atra. parlo en el agua, añadiendo que ha encontrado huesos de oveja en el estómago de otros.

Yo por mi parte dudo que una cspecie de la familin ataque a los animales de mayor tamario con la intencion de devo. rarlos; pero los arabes y africanos en general me han asegu. rado repetidas veces que las aves del tamaño de un are fria, 6 los mamiferos de la dimension de una rata, suelen ser víc. timas de esos reptiles. Los varanidos terrestres cazan ratones, aves pequeñas y sus huevos, peqqueños lagartos, serpientes, ranas $E$ insectos y gusanos; las especies acuáticas de la familia se nutren segun parece principalmente de peces, pero tampoco desprecian los mamiferos débiles que imprudentemente corren por la orilla of una avecilla torpe cuando pueden apoderarse de ellos. Alli donde no se les persigue y tienen sitios para ocultarse se les teme $y$ odia en general á causa de sus fechorias, pues devoran las crias y los huevos de las aves de corral. Sobrada razon hay para aborrecerlos.

En los individuos cautivos se puede observar fácilmente que los varanidos son reptiles muy voraces. Aunque no des. precian animales muertos, prefieren sin embargo la presa viva: parecen trasformarse completamente cuando se les ecba una 
docena de lagartos vivos 6 de ranas en la jaula; sobreponiéndose á su característica pereza, fijan la mayor atencion los animales; sus pequeños ojos brillan, la larga lengua aparece y desaparece alternativamente sin interrupcion; $y$ al fin se ponen en movimiento para apoderarse de alguna de las des. graciadas víctimas. Los lagartos corren, trepan y saltan de. sesperadamente por el espacio; las ranas brincan poseidas de espanto, mientras su enemigo las sigue lentamente; pero los ojos y la lengua indican que solo espera el momento para precipitarse sobre su presa. El varanido alarga bruscamente su prolongada cabeza; con una seguridad casi infalible coge una rana, $\delta$ el lágario mas ágil, y despues de aturdirle de un mordisco le devors. La misma suerte sufre una victima despues de otra hasta que todas han desapareciỏo, aunque sean una docena delagartos ó ranas, Cuando se ponen uno ó varios huevos en su jaula se acerca lentamente, toca uno de ellos con la lengua, lo coge suavemente con las mandibulas, levanta la cabeza, rompe la cáscara y traga cómodamente el contenido, lamiéndo con la lengua que domina todo el hocico y parte de la cabeza, la clara ó la yema que le sale por fuera de la boca. No cabe duda que procede del mismo modo en li. bertad.

Extraño es que aun no tengamos noticias suficientes sobre la reproduccion de los varánidos. Si durante mi estancia en el Africa hubiera sabido que existia este vacio en su historia natural, habrlame consagrado con mas celo á observar csos reptiles, lo cual no quiere decir, sin embargo, que hubiera obtenido noticias exactas, pues los árabes y los naturales del Sudan, que por lo regular dan infornes sobre todo ani. mal sin preguntárseles nada, no me dijeron cosa alguna, si mal no recuerdo, sobre la reproduccion de estos escamosos. Solo Theobald, al menos que yo sepa, da un breve informe sobre una especie de la familia, el varano amarillo (Vara. mus flarescrns). "Los varanos, dice, depositan sus huevos en el suelo, $y / a$ reces se sirven para ello del nido de las hormigas blancas. Ios huevos tienen unos $0^{n}, 05$ de largo; son de forma cilindrica, redondeados en ambas extremidades y de color blanco sucio, pero siempre ofrecen un aspecto des. agradable. \$ Parece que cada hembra pone al misno tiempo un número considerable. Durante el viaje del digno Klaus von der Decken, muerto en el servicio de la ciencia, matóse cierto dia de una perdigonada un varano de un metro de longitud, $y$ al disccarle encontráronse en el útero veinticuatro huevos fecundados.

USOS Y PRODUCTOS. - Los varánidos tienen bastante importancia para el hombre; perjudican por sus robos de animales domésticos y sus crias, pero en cambio son útiles por su excelente carne $y$ por sus huevos, mus sabrosos. En muchos paises de su extensa área de dispersion se desprecia una cosa y otra, pero en otros estímase a estos reptiles en lo que valen y sc les persigue con afan, por lo regular haciendo uso de los perros, que los buscan y paran en el bosque. Se. gun Theobald, un birman, por perezoso que sea en general, no considerará demasiado trabajo cortar el árbol en que se oculta un varano, á fin de apoderarse del animal, cuya carne le parece una golosina. Una vez cogido, átanle los cuatro piés sobre el lomo, y utilizan para ello cruelmente los tendo. nes de los dedos del pobre reptil, rotos de antemano al cfecto. En los mercados de Birmania los huevos de varano se venden mas caros que los de gallina; con mucha razon pasan por un manjar delicado; no despiden ningun mal olor; tienen un gusto verdaderamente exquisito, y solo se distinguen de los huevos de ave por quedar la clara líquida cuando se cuecen. Los indios comen la carne asada, mientras que los europeos, por lo comun, solo la utilizan para hacer caldo. Kelaaert probó este último y considérale excelente, seme. jante en el sabor al caldo de liebre. Tambien se aprovecha la picl escamosa: en algunas partes, por ejemplo en el nordeste del Africa, sirve para cubrir toda clase de herra. mientas y diversos objetos. Alguna especie debe prestar aun sus servicios á los titiriteros, y varias figuran fantásticamente en la preparacion de venenos.

CAUTIVIDAD. - Los varínidos cautivos recrean poco; al principio se mucstran muy furiosos; silban y bufan como las serpientes cuando su guardian se acerca, é intentan morder con rabia cuando creen poder alcanzarle. Poco à poco se amansan algo, pero rara vez $\sigma$ nunca se domestican del todo; muy al contrario, siempre son peligrosos, y no debe menospreciarse la fuerza de sus mandibulas. Solo se les puede tener en grandes espacios, pero tambien aqui molestan tarde 6 temprano, á causa del ruido que hacen corriendo y trepando, y por su voracidad y poco aseo.

CLASIFICAGION. - Tambien con la familia de los varánidos se han formado varias subdivisiones, pero apenas se las puede conceder el rango de género, porque las diferencias alegadas se limitan á particularidades de poca importan. cia No creo menester ocuparme de ellas.

\section{LOS VARANOS PROPIAMENTE DICHOS - POLYDEDALUS}

CARACTERES.- Este subgenero difiere de otros de la familia por ser la cola un poco comprimida, formando en su parte superior una quilla clevada; los dientes anterio. res son cónicos, mientras que los posteriores presentan un vértice obtuso; además se distingue por la disposicion de las fosas nasales.

\section{EL VARANO DEL NILO-POLYDAEALUS NILOTICUS}

CARACTERES. - Esta especie es el tipo del subgénero; el individuo adulto alcanza una longitud de dos metros, de los cuales corresponden á la cola casi la mitad. El color predominante es un verde amarillo opaco, con manchas ne. gras, mezcladas en los hombros $y$ en los carpos con unas motas en forma de herradura y puntos de color amarillo verdoso dispuestos en series; delante de cada hombro hay una faja negruzca semicircular; el primer tercio de la cola presenta anillos negros; los demás son amarillos.

DistribuCION GEOGRÁ FICA. - Parece que el varano del Nilo habita en la mayor parte de los rios de Africa, pues no solo se le ha encontrado en Egipto y en la Nubia, sino tambien en Guinea y la Senegambia y ademís en el sur de Africa. Segun mis observaciones, este reptil es mucho. mas comun en Figipto que en la Nubia, probablemente porque alli su área de dispersion que es el rio, le ofrece mas abundante alimento; en el Sudan oriental se le encuentra en algunas partes en considerable número, si bien aisladamente y nunca en sociedad.

USOS, COSTUMBRES Y REGIMEN.-Por lo regular se ve el varano cuando se pone en movimiento para retirar. se apresuradamente al rio; en el agua misma se oculta casi siempre, $y$ en tierra firme permanece por lo regular inmóvil calentándose al sol. Al contrario del crocodilo, solo en caso de necesidad elige bancos de arena llanos para descansar y dormir; prefiere un punto saliente de la orilla escarpada ó una roca; á veces se le encuentra tambien en las espesuras de la orilla, pero muy pocas veces á gran distancia del agua que le sirve de residencia. Heuglin le vió sin embargo emprender expediciones só mucha distancia, $y$ hasta el desierto. 
En la maleza de las orillas, las raices desnudas de los árboles son su escondite favorito, sobre todo en los rios que temporalmente se secan del todo. Ls probable que no se alctargue en verano, pues aunque le gusta decididamente el agua, no depende de ella tanto como el crocodilo.

Los egipcios y africanos en general conocen muy bien al varano y no le confunden nunca con el crocodilo: Ia noticia de Geoffroy indicando al varano como crocodilo jóven es indudablemente errónea.

Es posible que los antiguos egipcios consideraran $\$$ nucs tro varano como exterminador de su deidad Crocodilo por lo cual le concedieron un lugar preferente en sus monumentos. Hoy dia no necesita perseguir a los crocodilos pequenoos; conténiase, como ya hemos dicho, con mamiferos de escaso tamaño, aves y otros lagartos que se encuentran en gran número en todas partes de Egipto y por consiguiente en las inmediaciones del Nilo; caza las ranas y quizás tambien las tortugas pequeiras, pero principalmente á los peces: saquea los nidos de las aves acuáticas y hasta visita los pa. lomares y corrales para robar huevos y aves domésticas: alguna vez come tambien insectos. Ios varanos cautivos observados por Geoffroy eran muy voraces y acometian a todos los animales pequeños que se ponian en su jaula.

CAZA. - Yo he muerto varios varanos, pero siempre ca. sualmente, cuando en la caza de aves los vi calentándose al sol y pude acercarme á cllos sin ser visto. Los pescadores tienen á reces individuos cautivos que se cogieron en las redes, pero en Egipto no se les persigue con regularidad. No sucede sin embargo asi en el centro y sur de Africa: Livingstone al hablar del leguas, cuya carne recomienda como sabrosa, se refiere probablemente al varano del Nilo. Schweinfurth me dijo que en Galapat se persigue con afan a todos los grandes escamosos y en particular á los varanos: desuéllanse estos últimos, se asan despues $\$$ la brasa y ob. tiénese asi un bocado exquisito. En Zanzibar se cogen a nuenudo segun Kersten, átanlos en un palo y los llevan asi á la ciudad, mas no para la cocina, porque ni los habitantes ma. homctanos de aquella region ni los indigenas de la costa continental comen la carne de estos animales. Los huevos de la hembia preñada de que hablamos antes, muerta por un companiero de Von der.Decken, se cocieron y agradaron mucho álos curopeos: pero en vano ofreció Kersten este manjar á los compañeros indigenas de los viajeros. Hasta los wanikas, que por lo regular no ponen ningun reparo en la eleccion de su alimento, $\dot{y}$ a quienes los mahometanos de la costa, oriental llaman cochinos, porque comen toda clase de animales, encuentran comestible aun el contenido de los intestinos de los bueyes muertos y que ven un bocado exquisito en un ave de rapiña, aunque sea el buitre mas hediondo, se negaron á probar estos huevos, á pesar de que Kersten comió delante de ellos para vencer su preocupacion.

CAUTIVIDAD. - El varano del Nilo, dotado de una gran resistencia vital, como la mayor parte de los cionocranios, es muy propio para conservarle cautivo: vive alternativamente en el agua y en tierra, y constituye un interesante adorno en toda coleccion bien arreglada.

VITALIDAD. - Sparrmann pudo reconocer con gran asombro cuín grande es la resistencia vital del varano. Para matar \& un cautiro de esta especie pinchóle con una aguja bastante gruesa varias veces en el corazon y el cerebro, multiplicando en este último las heridas; ya estaba convencido de haber muerto al reptil, cuando este turo aun fuerza sufi ciente para escapar. Entonces le rompieron las costillas, y como tampoco esto produjo efecto, colgáronle del cuello durante cuarenta y ocho horas, con los piés atados; al cabo de este ticmpo habiase desatado $y$ huia otra vez; pero estaba muy débil y se le volvió á coger. Puesto en espiritu de vino murió al cuarto de hora.

\section{LOS HIDROSAUROS-HYDRO- SAURUS}

CARACTÉRES. - En el continente indico s en las grandes islas vecinas los varánidos están representados por $\mathrm{el}$ subgénero de los hidrosauros, que se distinguen por tener la cola mas comprimida lateralmente, los dedos largos, las fosas nasales situadas en la punta del hocico, y las escamas pe. queñas.

\section{EL HIDROSAURO DE FAJAS-HYDROSAU- RUS SALVATOR}

CARACTERES.-La cara superior del cuerpo es negra con manchas amarillas dispuestas en series; uña faja negra se corre por los costados y otra blanca por el cuello; la cara iu. ferior del cucrpo es blanquizca. Los individuos compleramente adultos pueden tener una longitud de 2 metros.

DISTRIBUCION GEOGRAFICA.-El hidrosauro de fajas, llamado por los cingaleses kabaragoja, habita princi. palmente en las islas de la Malasia, y sobre todo en las de la Sonda, las Filipinas y las Molucas; pero tambien se le en. cuentra en el continente de la India oriental, en Ceilan, Siam y la China. Cantor le conoció en la peninsula de Malaca, donde habita con frecuencia las colinas y llanuras.

USOS, COSTUMBRES Y REGIMEN.-Durante el dia se le ve regularmente en el ramaje de los grandes árboles a orillas de las corrientes, donde acecha las aves y los lagartos pequeños, ó saquea los nidos; pero cuando se le sorprende salta en seguida al agua, a menudo desde una altura consi. derable. Cuando las circunstancias le parecen favorables, fija su residencia tambien en la inmediacion de las viviendas humanas ó en estas mismas, mostrándose entonces tau rapaz como atrevido en los corrales. Un plantador europeo de los contornos de Manila dijo á Eduardo Martens que debajo de su casa habitaba un crocodilo que salia de noche para robar gallinas; pero Martens no dudó que este crocodilo solo podia ser nuestro varano. Por atrevido que sea el hidrosauro de fajas para robar su presa y saquear los corrales cerca de las casas del hombre, procura evitar su encuentro, y sicmpre teme la persecucion del señor de la tierra. Cuando se le sorprende en terreno llano emprende la fuga, segun Cantor, con toda la rapidez posible, dirigiéndose cuando puede al agua; su ligercza no es sin cmbargo tanta que no le pueda alcanzar un hombre agil. ruando se le coge defiendese valerosamente con dientes y garras, dando fuertes colctazos.

Los indigenas suelen apoderarse del hidrosauro excavando su guarida: su carne les gusta mucho. El animal tiene sin embargo, mucha mas importancia por otro concepto à los ojos de los indus, es decir por la preparacion de los venenos mortales que los cingaleses emplean aun hoy dia con harta frecuencia Segun indicaciones hechas á Tennent, se emplea para el katraritel, la mezcia mas venenosa y mas temida de todas, serpientes, sobre todo la colva de capella ( Viaja friph. dians), la tikpolongu ( Piperne elegans) y la Caranilla (Trigo. nocephalus hypralis), haciendo cortes en sus cabezas y colgándolas sobre una vasija en la creencia de que recogerán así el veneno. La sangre obtenida se mezcla con arsénico y otras sustancias, cociéndolo todo en un cráneo humano con los kabaragoyas 6 hidirosauros de fajas. Estos varanidos deben figurar entre los animales de las cocinas de las brujas de Fausto. Se les coloca por tres lados en el fuego con las cabezas dirigidas contra él; se les liga en esta posicion ator- 
mentándoles á palos hasta que silban, sirviendo de este modo, si asi podemos decir, de fuclle para el juego. 'Toda la saliva que entonces dejan caer se recoge cuidadosamente para echarla en el cocimiento, que se retira del fuego apenas se forma en la superficic una materia accitosa. Claro que el arsénico es la única sustancia verdaderamente activa de este veneno; pero la inocente kabaragoya ha llegado á tener tan mala fama por los embustes de los que preparan el reneno, que ahora infunde en todos los puntos citados un temor que raya en ridicule\% Tambicn este reptil, asi como el varano, habita en Ceilan principalmente cerca del agua, donde se refugia apenas se apercibe de algun peligro; pero como las aguas que le sirven de morada se agotan á veces del todo, el hidrosauro se ve obligado á emprender viajes por tierra firme, y entoncés se le puede ver cerca de las viviendas de los cingaleses. Ia vista de este reptil es de mal agüero para aquellos indigenas; su presencia les hace temer enfermedades y otras desgracias, y piden proteccion a los sacerdotes incios para evitar, si es posible, las malas consecuencias. Estos servidores de Dios, despues de hacer que sus buenos fe ligreses se aligeren un poco el bolsillo en favor de ellos, pre. séntanse en la choza próanada por la kabaragoga para practicar el exorcismo, que se reduce á pronunciar las palabras; kabura goyin sun dosey, aria buluyn i dosey, lo cual significa: A Ahora, todo el mal que ha crusado la kabaragoya no puede hacer daño.s

\section{LOS SAMOSAUROS - PSAMOSAURUS}

CARACTERES.- Los de este subgénero consisten prin cipalmente en la cola redonda; no carenada; en sus escamas redondeadins, pero no ovales, y en los dientes incisivos, peque. ilos y anchos.

\section{EL SAMOSAURO GRIS-PSAMOSAURUS GRISEUS}

CARACTERES. - Herodoto nos habla ya de un croco. dilo terrestre que habita el territorio de los nómadas libicos y se parece a los lagartos; Próspero Alpino considera al mismo reptil como el cirruo de los antiguos, que al parecer se alimentaba de plantas aromáticas, sobre todo del vermut; pero nosotros designamos actualmente con este nombre otro escamoso. Fl citado crocodilo terrestre de Herodoto es el simosauro gris, tipo del suh-género de los samosauros ó varanos arenarios; su longitud es de poco mas de - ",50; tiene la cara superior de color pardo claro, con manchas cuadran gulares de un amarillo verdoso; la inferior es de un amarillo de arena, y en la cola tiene varios amillos amarillentos.

DISTRIBUCION GEOGRÁFICA.-El samosauro gris se encuentra solo en las partes mas secas del nordeste del Africa, de la Arabia Peirea y de Palestina.

USOS, COSTUMBRES Y RÉGIMEN. - Esta especie habita sobre todo en los desiertos, y asi como su congénere del sur de Africa, elige los sitios pedregosos, pero à veces extiende sus excursiones \& las llanuras cubiertas de arena, en medio de las colinas pedregosas. Los arabes le temen con razon, porque es superior en audacia y malignidad á todos los demás lagartos del país; cuando se le sorprende en descubierto defiéndese resueltamente; elevándose por medio de su fuerte cola á mas de un metro de altura del suelo, precipítase sobre la cara del hombre ó sobre el pecho, ó bien se agarra al vientre de la cabalgadura con los dientes, con lo cual se espanta en extremo, bien sea camello, caballo ó asno. Su alimento consiste en animales pequeños, de los mas di versos: lYogler eucontró en el estómago de un samosauro gris examinado por él, además de dos piedras del tamaño de una avellana, once ó doce langostas enteras, dos huevos de un ave corredora, $y$ un escorpion casi intacto de la longitud de un dedo.

Los árabes me aseguraron que este reptil caza principal. mente pequeños lagartos y serpientes, pero sabe apoderarse tambien de ratones y ares, amenazando sobre todo los nidos de estas últimas.

CAUTIVIDAD. - En el mercado del Cairo se ven bas. tante á menudo samosauros cautivos en manos de un hawi ó domador de serpientes, quien presenta este reptil desconocido de los habitantes de las ciudades, á los hijos 6 hijas de la capital, haciendo maravillosos relatos y atribuyéndole las cualidades mas increibles, para ganar su pan cuotidiano. IBien se comprende que el astuto impostor ha tenido bucn cuidado de arrancar los dientes al reptil, disminuyendo en una gran parte su fuerza y malignidad por el mal tratamiento, pues el hari no se ocupa en cuidar sus animales. Tanto al varano como á la serpiente de anteojos, 6 la vibora de cuernos, arráncanles desde luego los dientes, conservando á estos animales cautivos mientras lo soportan. Su jaula se reduce á un sencillo saco de cuero ó una caja llena de salvado, de la cual se le saca cuando comienzan los cjercicios. Ios reptiles no reciben comida ni bebida, pues el haui cree mas conveniente coger otros y enseñarlos, a fin de ahorrar gastos de manutencion. Lin cuanto al varano del desierto, es de advertir que cuando está cautivo rara vez toma voluntariamente el alimento; de modo que el guardian se ve obligado á intro. ducirle la comida por fuerza; en tal caso, el reptil le hiere á menudo gravemente.

USOS Y PRODUCTOS. - Tambien el varano del desierto, así como todos los grandes lagartos en general, constituge para los beduinos un bocado exquisito, y por eso le persiguen con afan.

\section{LOS PAQUISAUROS - PACHY- SAURUS}

CARACTÉRES.-Este sub-género se caracteriza por sus formas mas recogidas; hocico corto; cola muy comprimida lateralmente y con doble quilla; dedos cortos, provistos de unas en extremo fuertes; fosas nasales que tienen su orificio entre los ojos y la punta del hocico; y en fin por las grandes escamas redondeadas.

\section{El paQuisauro de garganta blanca -PACHYSAURUS ALBOGULARIS}

CARACTERES. - Este reptil mide cuando mas I",70 de longitud; su color es pardo oscuro, con fajas y manchas blancas; la cara inferior del cuerpo mas clara y la region de la garganta de un blanco amarillento (fig. -22).

DISTRIBUCION GEOGR pio del Africa del sur.

USOS, COSTUMBRES Y REGIMEN.-A. Smith fué quien primero nos dió informes algo exactos sobre el género de vida del paquisauro; Dumeril y Bibron ni siquiera conocian su patria. Smith le encontró en el norte de la colonia del Cabo de Buena Fsperanza, donde se le ve en las paredes de las rocas y en las colinas pedregosas, i cuyas liendiduras se retira en caso de peligro. Cuando ya no pucde escapar se agarra con tal vigor \& las piedras 6 la roca, que solo á costa de grandes esfuerzos se consigue arrancarle. Un hombre solo no puede hacerlo con un individuo adulto, aunque le haya atado antes los piés posteriores con una fuerte cuerda. Yo he visto, dice Smith, que eran necesarios dos hombres para 
obligar á un paquisauro adulto a soltar las piedras a que se habia agarrado; pero despues de lograr su intento fuéles for. zoso emprender la fuga, porque en el mismo instante el ani. mal se precipitó con verdadera furia sobre sus enemigos amenazandoles con sus mordiscos. Despues de haberle nuserto se reconoció qque por sus esfuerzos para cogerse se habia roto las puntas de todas las unias.

El alimento del paquisauro de garganta blanca consiste en insectos, cangrejos, ranas, pequeños cuadrúpedos y otras especies, á los cuales persigue de dia. Bastante á menudo se le ve cerca de los rios, y los indigenas creen por lo mismo deberle considerar como santo, figurándose que su muerte podria causarla la falta de agua. Es extraño que los campesinos holandeses le teman en extremo, no solamente á causa de su irascibilidad $y$ de sus poderosos dientes, sino tambien porque tienen la conviccion de que es venenoso, por lo cual le dieron el nombre de adder.

\section{LOS LACERTIDOS-LA- CERTIDE}

GENERALIDADES. - Los lagartos propiamente dichos que consideramos como el prototipo del órden, son en general de formas esbeltas y graciosas, con miembros com. pletamente desarrollados. Se distinguen exteriormente por sus párpados escamosos y las placas que cubren su cuerpo; las cefálicas tiener varias caras; las de la parte inferior del cuerpo y de la cola, que es siempre redonda, son cuadriláteras y dispuestas en lineas trasversales. Tienen además los dientes huecos en su base y la lengua afilada, terminando en dos puntas y con papjilas escamiformes. En casi todas las especies se observan muy distintamente los poros femo. rales.

DISTRIBUCION GECGRÁFICA.-Todos los lagartos

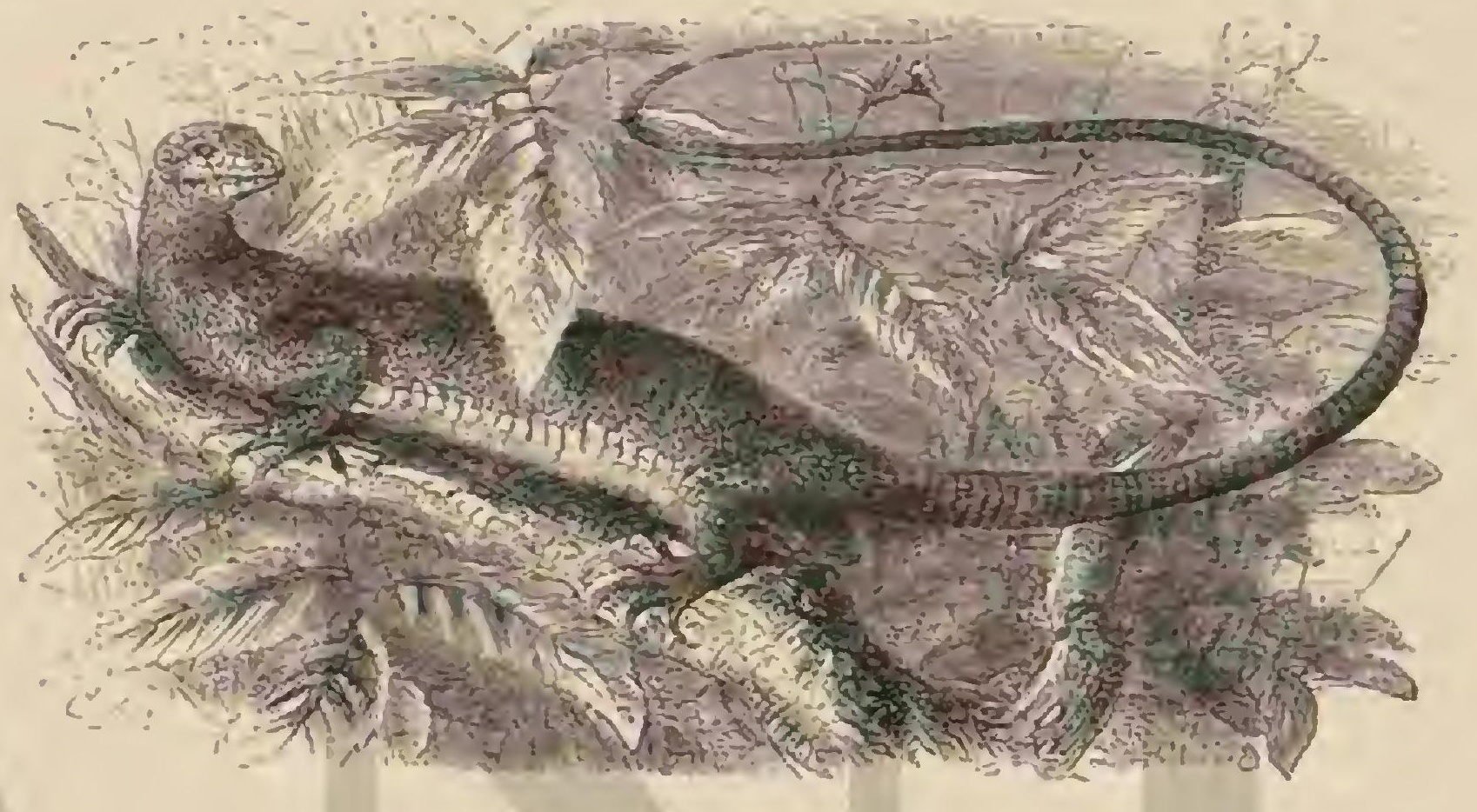

Fig. 23.-8.T BaGsRTO VERDE

son propios del Antiguo continente y en Europa se encuentran muchas especies. Excepto nuestro orveto comun, todos los escamosos de Alemania pertenecen á esta familia; muchas especics habitan el sur de Europa y tambien en Africa y en Asia De las ochenta que se han reconocido, mas de cuarenta se hallan en la zona templada del Antiguo continente; las demás viven en el sur. de $\Lambda$ sia, en el centro y sur de Africa y en Australia.

USOS, COSTUMBRES Y REGIMEN. - Estos reptiles fijan su morada en las pendientes de los montes bañados por el sol, en las paredes y montones de piedras, en las raíces de los grandes árboles, en las cercas, empalizadas y matorrales; en tales sitios abren sus madrigueras, ó se aprovechan de alguna cavidad ya practicada, alejándose muy raras veces á gran distancia del centro de su territorio. Llos lagartos, dice Leydig, quien ba escrito tíltimamente una obra tan minuciosa como excelente sobre las especies alemanas, tienen una costumbre comun 2 otros muchos animales, tanto inferio. res como superiores, y es la querencia al lugar donde nacicron. En muchas regiones que conozco muy bien por mis car. rerias observamos que los lagartos permanecen todo el año en ciertos distritos $\sin$ trasladarse a otros, que al parecer serian igualmente farorables.

La emigracion no se clectúa sino cuando la necesidad obliga, es decir, cuando el punto de residencia es demasiado pequeño para alimentarlos. En tiempo caluroso agrádales á los lagartos estar al aire libre, y sobre todo bajo los rayos del sol acechando con sus brillantes ojos toda clase de presa, en particular insectos voladores. En los dias írescos 6 lluviosos Tus:o $v$ permanecen ocultos en sus guaridas; de modo que dependen del sol, en el verdadero sentido de la palabra; solo se dejan ver cuando este ilumina el firmamento, y desaparecen apenas se pone. Para calentarse al sol buscan siempre los sitios donde este astro concentra mas sus rayos y á fin de conseguirlo trepan hasta los árboles, empalizadas, etc; alli se estiran y dilatan su piel cuanto es posib!e, como si temieran perder un solo rayo del benéfico astro. Cuanto mas calienta el sol tanto major es la vivacidad y atrevimiento del animal; por la mañana temprano $;$ al anochecer se muestran a veces pere. zosos y en extremo apacibles; mientras que a la hora del medio dia no solo se mueren con mucha agilidad, sino que son is menudo audaces y jendencieros. Hacia el otoño pasan mucho tiempo en el interior de su guarida, y en octubre bus. can su madriguera de invierno, donde permanecen hasta principios de la primavera, 6 cuando menos hasta últimos de marzo. Leydig, confirmando el informe anterior, dice: Sin. gular aspecto ofrecen los individuos que en la prinavera se hallan todavia en un estado de inercia, cuando apenas han salido de sus guaridas de invierno. Tambien los cautivos pierden su agilidad apenas baja la temperatura; se mueven pesadamenie y con extrema lentitud, poniendo un pié delan. te del otro; mientras que bajo los rayos del sol sus movimien. tos revelan una fiexibilidad sin igual, como si no pesara nada su cuerpo. Bajo una temperatura de $16^{\circ} \mathrm{R}$ las especies meridionales que se guardan en una habitacion donde no toca el sol, no solo son del todo frias al tacto, sino que tienen tambien un aspecto raquitico; pero si se les expone á los ra. yos del astro del dia aumentan las palpitaciones del corazon, 
Ia respiracion se activa, y precisamente por esta viltima circunstancia, es decir, por la dilatacion de los pulmones, que recogen mas aire, vuelven \& ofrecer un aspecto mas rollizo. El misno autor dice que las horas en que los lagartos toman con preferencia el sol son las de la mañana desde las nueve \& las doce; á las once, los cautivos salen aun en dias huimedos. "Cuando se anuncia el viento del sur, dice Leydig, despiér. tanse ya á las primeras horas de la mañana; y si amenaza lluvia permanecen ocultos, mientras que precisamente esta temperatura hace salir $\mathbf{a}$ los ofidios. El verdadern frio ejerce al parecer una influencia muy perniciosa en ellos: Pallas ob. servó que en el Quersoneso, despues de tres veranos frios consecutivos, el lagarto de Tauria, antes muy numeroso, ha. bia desaparecido casi por completo.n Ja estacion en que se retiran, á la llegada del invierno, difiere no solo segun la region sino tambien segun las especies, y en opinion de Ley: dig hasta segun el seso y la edad: los machos adultos des. anarecen en otono anies que las hembras adultas, y tanto los unos como las otras, antes que los jovienes. Estos últimos son los primeros que en la primavera se presentan; a ellos siguen los machos y despues las hembras. En sis vivienda de invier. no, donde por lo regular se reunen, permanecen sin movimiento, con los ojos cerrados, y la boca abierta, cual si estu. vieran muertos; pero cuando se les calienta vuclven pronto a la vida, comienzan a moverse, respiran, abren los ojosy se despiertan poco \& poco.

Todas las especies cuya area de dispersion se extiende relativamente á larga distancia, revelan mas claramente que los otros reptiles, inclusas las serpientes, cuán poderosa es la in. flucncia que el calor cjerce en ellos. Una misma especie se conduce en el sur de su área de dispersion de un modo muy distinto que en el norte. Con el aumento de calor acrece tambien su actividad vital, y al mismo tiempo la belleza de sus colores; la mayor duracion del verano, 6 mejor dicho, del calor, limita su sueño invernal á pocas semanas, si no lo evita del todo; la alimentacion $y$ la digestion pueden efectuarse con mas regularidad y abundancia, $\delta$ quizás no se interrum pa; $y$ una consecuencia muy natural de esto es el tamaño que alcanzan los individuos habitantes del sur, muclio mas considerable que el de los de la misma especie propios de las re giones septentrionales.

En cuanto al color, debo añadir que todos los lagartos pueden cambiarle hasta cierto punto; cuando están excitados es mas vivo, y en caso contrario mas pálido. No se ha reco. nocido aun la causa ni la manera de efectuarse este cambio.

Todos los lagartos contribuyen esencialmente a prestar animacion al paisaje en los puntos donde habitan. En Alc. mania se nota esto muy poco; pero en el sur de Europa obsérvase marcadarnente, pues en todas partes se deslizan estos reptiles, dando vida a las paredes, a las calles y á los caminos; y su brillo, verdaderamente magnifico, seduce fo la vista cuando las diversas especies, ostentando sus viros y bellos colores, retozan ágilmente en los campos. Semejanteá un collar de piedras preciosas, dice Ehrhard, el cuerpo serpentino del ligarto dorado, con sus brillantes colores de co. bre, bronce y oro, deslizase enire las ramas y el follaje de las higueras $y$ algarrobos de las islas Cícladas, siempre desiertas y monótonas; el esbelto cuerpo escamoso de otras especies del sur fulgura tambien á los rayos del sol, j todo aquel que atemorizado al pronto por el ruido que en la hojarasca producen los pequeios reptiles piense en huir, experimentará nuy luego un sentimiento de benevolencia para esos gracio. sos séres. Todo el mundo les mira con bondad a primera vista, aunque no conozca todaria bien sus usos y costum. bres.

Todos los lagartos son animales ágiles, vivaces y alegres; tienen los sentidos bien desarrollados, y son relativamente astutos. Cuando no están calentándose al sol recorren las innediaciones de su vivienda, al parecer muy ocupados y activos. Hacen gala de su viveza continuamente; todas las especies se parecen por la rapider, con que corren y su destreza para trepar, y hasta nadan sin gran irabajo en caso ne. cesario. El grado de movilidad difiere sin embargo segun la especic Cada movimiento se efectúa por ondulaciones del cuerpo, con ayuda tanto de la cola como de las piernas. Los individuos cuya cola ha sido arrancada pierden el equilibrio, y con ell la viveza y regularidad de todo movimiento, $y$ hasta parece que la carencia de cola les molesta mas que la pérdida de una pierna. Todos los sentidos están muy bien desarrolla. dos, con la sola excepcion quizás del olfato: su vista es pene. trante, como lo indican sus vivos ojos; el oido tan fino, que cl mas leve rumor llama su atencion; demuestran su sensibilidad por lo mucho que les gusta el calor; y el tacto por los movinientos continuos de la lengua; pero esta última parece además un verdadero sentido del gusto, pues se puede observar que distinguen muy bien los jarabes, los dulces y la miel entre ottas sustancias. El desarrollo de sus sentidos esta en armorila con su actividad; son unos séres tan vivaces como inquietos, tan excitables como volubles; demuestran curiosidad 6 interés, se divierten y se aburren, 6 cuando menos bostezan bien marcadamentc; son tímidos $\delta$ audaces, segun las circunstancias, y fácilmente se encolerizan, pero pronto se calınan; todo llama su atencion, incluso la música, que segun parecc les agrada mucho; su inteligencia no es por cierto inferior la de cualquier otro género de la clase; muy por el conirario, son superiores tambien por este concepto á la mayor parte de sus congéneres. En su manera de proceder manifiestan tanta astucia como puede tener un reptil; saben distinguit con exactitud; hacen sus observaciones y varian en su consecuencia de conducta; acostúmbranse al cambio de las condiciones y toman cariño á séres de que antes huian timidamente, como por ejemplo el hombre. Leydig cree que las facultades intelectuales de los lagartos se funcian esen. cialmente en las experiencias que de padre á hijo se trasmi. tieron. Ias situaciones por que ha pasado un individuo, los incidentes que vuelven of presentarse is menudo, las observa. ciones hechas por una familia, producen poco a poco cambios corporales que se manifiestan en la progenie; la pruden. cia, la inclinacion á ciertas cosas, la mayor ó menor destreza, son cosas heredadas como disposiciones naturales. No quiero oponerme śla opinion del excelente naturalista, pero tampoco puedo conformarme del todo con él. Cierto que los lagartos dc una misma especic se conducen esencialmente de igual manera; pero todos los pequeños proceden de distinto modo que los adultos, probando con eso que cada individuo hace sus ob. servaciones por si. La enseñanza y el ejemplo de compañeros viejos y expertos infuira sin duda en la aplicacion de la experiencia adquirida, tanto y quizás mucho mas que la tras. mision hereditaria of las disposiciones naturales, que sin embargo no se pueden negar del todo.

Los lagartos son animales muy rapaces. Persiguen \& los insectos, gusanos y caracoles; atacan á los pequeños verte bradns, saquuean los nidos de los prijaros, y sobre todo devo. ran los huevos de reptiles. Algunas especies desprecian del todo las moscas, segun observó Gluckselig, y hasta parecen temer a los moscardones; otras, por el contrario, no conocen tales escrúpulos, sino que devoran con tanta voracidad las moscas grandes y pequeñas como cualquier otro insecto; cazan con aficion las arañas, consideran como golosina los caracoles desnudos, y no les gustan tanto los gusanos; las langostas y cigarras, las mariposas nocturnas y cscarabajos, con sus larvas, constituyen al parecer su alimento farorito. 
Saben distinguir muy bien entre varias especies, aunque estas se asemejen tanto que un hombre inexperto las confundiria; y cuando pueden, eligen entre la presa que se les ofrece de una manera que honra tanto á su buen gusto como á su inte. ligencia Asi, por ejemplo, en todas las circunstancias prefie ren los escarabajos de escudo blando á los de alas duras, despreciando algunos completanente, al menos en cautividad. Se les puede mimar dándoles alguna golosina, por cjemplo gusanos de harina, pero entonces pasa mucho tiem. po sin que quieran tomar ninguna otra cosa; aceptan ciertos insectos algunas veces sin resistencia, despreciándolos des pues pertinazmente. Todo lo que cogen ha de ser viso; no tocan los insectos muertos á no ser que se les engañe mo viendolos disimuladamente. Se apoderan de su presa con la rapidez del rayo, á menudo dando un gran salto; la quebran tan entre sus dientes y la tragan despues poco á poco. A los insectos grandes sacúdenlos con la boca hasta que los aturden, $s$ á veces tambien los sueltan, los miran y cogen de nuevo. A las pequeñas especies cuéstales al parecer mucho devorar un insecto grande; le vuelven y revuelven en la boca hasta que la cabeza de la victima queda delante, y despues le engullen lentamente, relamiéndose con gran satisfaccion. Demuestran los instintos de verdaderos reptiles en el hecho de perseguir a sus propios hijuelos, y cuando consiguen atraparlos mátanlos y los devoran. En los dias calurosos de verano beben mucho, introduciendo la lengua dentro del agua y retirándola repetidas veces. La micl es uno de sus manjares favoritos y la saborean con verdadero placer; lo mismo hacen con el jugo de las frutas dulces, y es de suponer que en liber. tad tampoco desprecian del todo aqquellas.

REPRODUCCION. - Al despertar de su sueño inver nal, en la primavera, empieza el periodo del celo de estos lagartos. Los machos se mucstran entonces muy pendencieros; el mas fuerte persigue con furia al mas débil: se ende. reza sobre sus patas y se adelanta con las mandibulas abiertas contra su adversario; cste permanece un instante inmóvil, como considerando la fuerza del otro, y una vez convencido de su superioridad, busca su salvacion en una pronta reti. rada; el provocador le persigue con tanto furor que si tro. pieza en su camino con la hembra la muerde tambien, y si llega á atrapar al fugitivo procura cogerle por la cola, siendo este el origen de las mutilaciones que muy a menudo se observan en los lagartos. Despejacio el campo por el rival, se acerca el vencedor, segun las observaciones hechas por Gluckselig, á la hembra, levantando parte del cuerpo con la cola retorcida; si aquella le indica con las ondulaciones de su cuerpo y continuos movimientos que sus nxances son bien recibidos, entonces el macho la coge con sus dientes un poco mas arriba de las patas traseras, la vuelve en parte hácia si y se verifica el aparcamiento. Permanecen unidos y sin mo. vimiento durante unos tres minutos, pasados los cuales el macho suelta a la hembra, alejándose esta inmediatamente. Este acto se repite varias veces en el curso del dia, sin que exista verdadera monogamia, pues lo nismo sucede que un macho tenga relaciones con varias hembras, que una hembra con varios machos. Unas cuatro semanas despues del primer apareamiento, pone-la hembra (segun Tschudi, de noche) de seis a ocho huevos, del grueso de un garbanzo, algo ovalados y de un color blanquizco sucio; el sitio donde acos tumbra ponerlos, varia segun la localidad, encontrándose lo mismo en los puntos expuestos al sol, debajo de la arena, que entre las piedras $y$ cn cl musgo; no pocas veces desoran en montículos fabricados por las grandes hormigas ne gras. La condicion esencial para la incubacion es la hume. dnd, pues al aire libre se secan los hueros muy prontu; algunos observadores pretenden que tienen aquellos la par. ticularidad de despedir cierto brillo durante la noche los hijuelos rompen la cáscara en agosto ó setiembre, y desde el primer dia de su vida son ágiles y desenvucltos como los padres; cambian de piel luego que entra el otono, y nuy pronto se buscan guarida conveniente para pasar el sucno invernal. Los adultos mudan de piel durante el curso del verano varias veces; cuanto mas fuertes mas á menudo ; $\mathrm{cm}$ pieza por desprenderse en parte, y acaba de caer con el continuo roce contra las piedras, raices, etc. En los animales de constitucion mas débil necesita esta operacion unos ocho dias, pero en los robustos y mas fuertes bastan dos dias.

Nuestros inofensivos lagartos padecen, no solo por efecto del frio sino tambien por la persecucion de un gran número de ágiles enemigos. Todos los rapaces arriba citados les amenazan continuamente y esto nos explica su timidez y precaucion. Solo el aspecto de una serpiente peligrosa les causa un espanto que rerdaderamente les aturde: huyen con toda la rapider. posible, y cuando no pueden hacerlo, perma. necen inmóviles con los ojos cerrados, en el mismo sitio, al parecer rigidos de terror. Por lo demás, tienen bastante mo. tivo para temer á sus congéneres, pues algunas especies de ofidios se nutren casi exclusivamente de lagartos, los cuales sucumben al veneno de la vibora tan rápidamente como un animal de sangre caliente. Saben reconocer muy bien los diferentes ofidios: los cautivos de Leydig se comportaron de la manera indicada al ver una coronela, mientras que no hicieron el menor caso de un tropidonoto.

La vitalidad de los lagartos es mucho menor que la de otros reptiles. La cabeza cortada unuere en pocos momentos, 5 el vivo movimiento del tronco despues de separada la cabcza, y el de las extremidades cortadas, no parece fundarse en la in. dependencia del sistema nervioso del cerebro, sino en la naturaleza especial de los mismos nervios. Los venenos animales mas débiles matan pronto é infaliblemente fo los lagartos mas fuertes, y asi sucumben por efecto del liguido lechoso de las glándulas mucosas del sapo. Mejor resisten los vene. nos minerales y vegetales: un gato mucre en menos tiempo que ellos si se le da una dósis de ácido ciánico veinte veces mas pequeña. Ia nicotina es cntre los venenos vegetales el que mas pronto los mata: una dósis de rapé introducida en su boca, $\delta$ algunas golas de jugo de tabaco bastan para matarlos rápidamente.

CAUTIVIDAD.-La conservacion de los lagartos en este estadio ofrece distraccion y atractivos á los aficionados. Sabiendo proceder con el debido cuidado, es fácil procurarse gran númcro de estos animales; pero por el contrario, se pueden perder muchos dias sin coger uno solu, si nu se conocen los medios adecuados para conseguirlo, pues la caza de estos reptiles, tan ágiles y vivaces, no es fácil en manera alguna. El medio mas sencillo y de buenos resultados es valerse de una corta y fina red, provista de mango largo, para que se pueda colocar desde distancia conveniente cerca de la guarida, ó sitios que se sabe que frecuenta el lágarto. Una vez hecha la presa, lo que con un poco de prictica se consigue con bastante facilidad, hay que tener cuidado en hacerla pasar á un saco de cuero, dentro del cual puede ser trasportada sin peligro de estropearla. La jaula que se destine al cautivo debe estar cubierta en parte con musgo, $y$ tener varias cavidades donde pueda guarecerse aquel; pero la circunstancia mas indispensable que hay que tener presente es la de que el calor directo del sol no falte al animal, pues le es tan necesario como el alimento. Mientras el la. garto se muestra vivo y alegre, hay seguridad de que se encuentra bien; pero cuando empieza á pasar gran parte de los dias inmóvil, en el mismo silio, cun lus parrpados cerrados, no hay duda que le falta algo, ya sea alimento suriciente y 
adecuado, ó calor, y si pronto no se pone correctivo no tarda en morir. La persona que cuida diariamente y con cariño á estos pequeños reptiles, acaba muy pronto por conquistar su confianza. Al principio el lagarto huye tan pronto como se acerca el amo y se esconde en la parte mas recóndita de su prision; despues ya empieza á sacar del agujero la cabeza con curiosidad, y por fin, ya no huye y permite hasta que le toquen y le pasen la mano por el lor. $\%$ y no pocos llegan á to. mar la comida de las manos de su guardian. Es verdaderamente divertido, cuando se tienen reunidos varios lagartos en una misma jaula, echarles un gran gusano: procuran entonces robarse la présa los unos a los otros; cada cual tira por un lado, hasta que se rompe, $\delta$ el mas fuerte acaba por llevar sela quirándola de la boca á los démás. Gluckselig asegura que los lagartós liegan á domesticarse hasta el punto de ju-

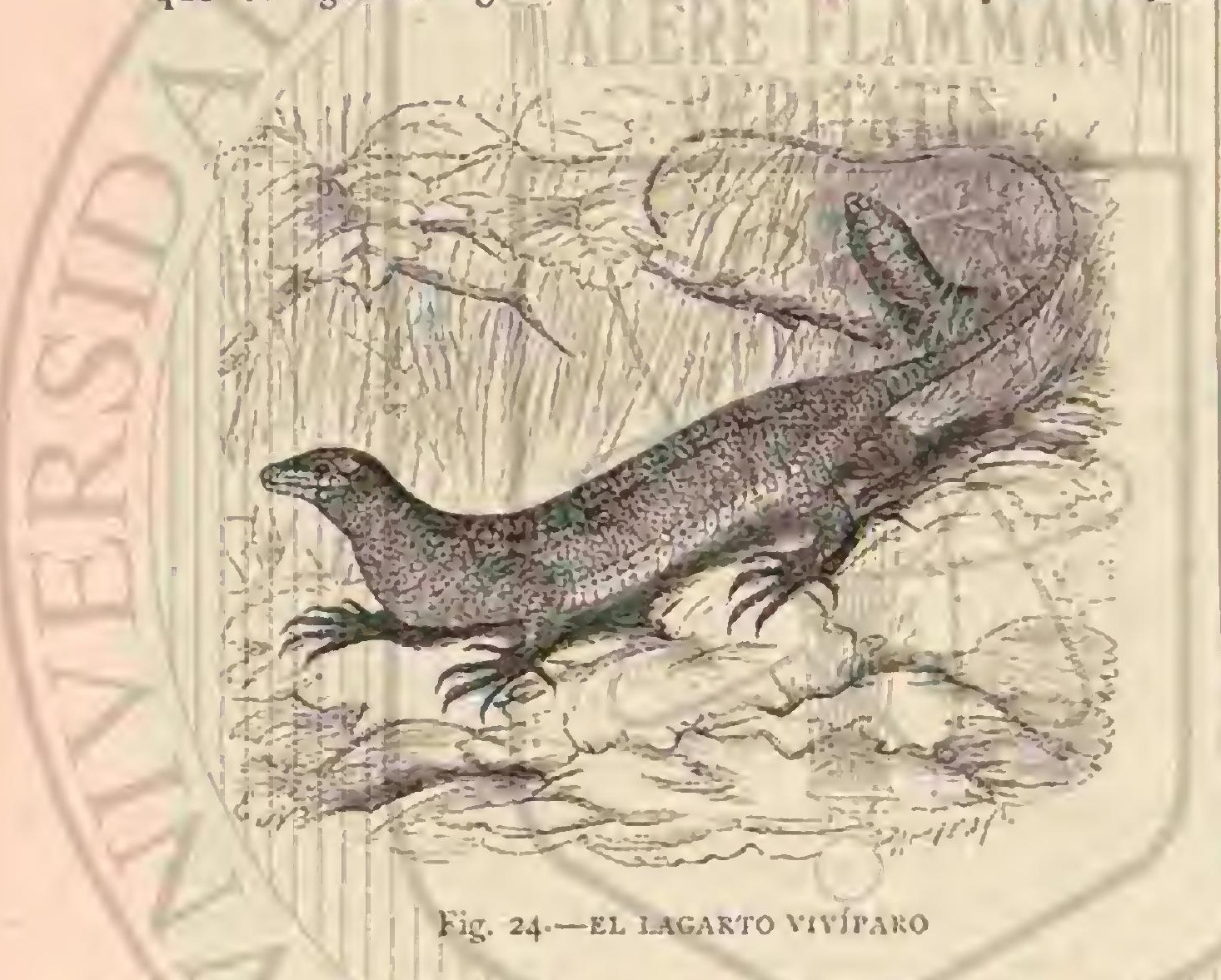

gietear con su amo, refiriendo lo siguiente: «El mayor la garto se enfada fúcilmente á pesar de lo domesticado que se halla, y lo consigo \& menudo dándole pequeños golpes en la cabeza con la punta de los dedos; no se escapa entonces, sino que se prepara resueltamente a la defensa, pega en la mano, de la manera mas graciosa, con sus paras, y procura morder. Por lo comun, despues dé esta excitacion acostum. bra \& correr por la jauia mal humorado y atacando á sus compañeros. Pero aunque esta sea la regla general en los lagartos cautiros, los hay, sin embargo, à los que este estado acaba por sobrexcitarles, mostrándose entonecs pendencieros y siempre dispuestos á morder.

Actualmunte nus contentamos con reconocer la utilidad que los lagartos nos reportan exterminando toda clase de animalejos perniciosos, pero en tiempos anteriores obtenianse aun otras ventajas de estos reptiles. Ita hiel del lagarto verde, dice Gessner, se emplea para untar los troncos de los árboles frutales; con ella se evita que las manzanas se pudran ó que les ataque la oruga Los africanos mezclan la carne de estos animales con la comida, considerándola como remedio eficaz, sobre todo para combatir el dolor de riñones; cortada en pedacitos, cruda ó cocida, y mezclada con el ali. mento del azor $\delta$ del halcon, cambia en poco tiempo el plumaje de estas aves, $\mathrm{y}$ el mismo efecto produce cuando se las frota con esta carne. El tronco solo, sin cabeza ni piés, cocido en vino, del cual se ha de beber cada mañana un vaso, devuelve las fuerzas a los tísicos y á los pobres de san. gre. Si se encierran en una vasija de vidrio algunos anillos de hierro, plata ú oro, por espacio de nueve dias, mezclados con la carne, sangre, ceniza ó el cuerpo entero de estos rep. tiles, los anillos constituyen, segun se asegura, un remedio muy eficar contra las enfermedades de los ojos. Si se echa este lagarto cn una libra de aceite comun, dejándole ahogarse y exponiéndole despues tres dias al sol, el aceite sirve para blanquear y afinar el cutis mas áspero y manchado. Algunos cuecen el animal en el aceite, y sirvense de él como remedio para la conservacion del cabello; el mismo efecto produce la hiel hervida con vino blanco $y$ expuesta al sol hasta que la materia se espesa.

\section{LOS LAGARTOS DE COLLAR -LACERTA}

CARACTERES.-Despues de lo dicho puedo limitarme a la descripcion de algunas pocas especies, entre las cuales corresponde el primer lugar á los lagartos de collar, á cuyo género pertenecen todas las especies alemanas. I.os caractéres de este género, que igualmente se ha subdividido, son los siguientés; el tronco, mas 6 menos enjuto, es cilindrico, $\delta$ algo comprimido de arriba abajo; la cabeza, de forma pira. midal, deprimese en los lados del todo, y por delante mas ó menos en sentido rertical; el cuello tiene la longitud de la cabera y nó está separado de ella marcadamente; la cola, cuya longirud excede siempre sa la del tronco, afecta la forma de cilindro delgado y es á menudo muy larga, raquitica y puntiagudà La cabeza y el vientre están cubiertos de pla. cas; y el resto del cuerpo de escamas, que en el tronco forman anillos, mientras que en la cola cstán sobrepuestas; en el cuello se hacen notables por su gran tamañoy constitujen una especie de collarin. Los dedos, en número de cinco, son de longitud muy diferente $y$ tienen garras falciformes comprimidas lateralmente y provistas de un surco en su cara in. ferior.

\section{EL LAGARTO VERDE-LACERTA VIRIDIS}

CARACTERES. - Entre las especies propias de Alema. nia el lagarto verde ocupa por su tamaño y belleza el primer lugar. En dicho pais mide unos $0^{\mathrm{m}}, 40$, mientras que en el sur alcanza hasta $0^{m}, 65$, de los que solo la tercera parte cor. responde á la cabeza y al tronco; a causa de la larga cola, el animal parece muy enjuto, pero sus formas son realmente muy recogidas. La cabeza ofrece un carácter notable, y es que de las cuatro placas de la línea naso ocular, las dos ante. riores están sobrepuestas en linea recta; la occipital es trian. gular y muy pequeña y la region de las sienes se halla revestida de escudos y escamas irregulares; en el tronco se ve que los del vientre están dispuestos en ocho scries longitudinales y que los del collarin son denticulados. En el intermaxilar hay de nuevea diez dientes, en cada uno de los maxilares superiores diez y nueve ó veinte; en los inferiores de veinti. tres á veinticuatro, $y$ en cada lado del paladar ocho grandes y algunos pequeños.

El macho difiere de la hembra por tener la cabeza mas larga y alta, la base de la cola mas abovedada, las extremidades posteriores mas fucrtes, y en la major parte de los casos tambien por su mayor tamaño. Su color es verde vivo brillanic de varios matices, desde el verde azulado hasta el verde esmeralda, y que en la cara inferior pasa al amarillo verdoso. En las regiones superiores se ven motas blancas y negras; las de la cabera llegan a veces al tamaño de una perla; las regiones inferiores tienen siempre un solo color excepto la garganta y la mandibula inferior, que á menudo son azules. La hembra se parece con frecuencia al macho, solo que le falta el azul de la garganta y sus colores suelen tirar mas 6 menos á pardo con varias series longitudinales de man. clas blanquizcas orilladas de negrn. En los jórenes predo. 
mina un color pardo de cuero. Los dos seros varian esencialmente segun la edad y la patria; los individuos originarios del sur, sobre todo de Dalmacia, tienen siempre unos colores mas boniros que los del norte.

DISTRIBUCION GEOGRÁ FICA.-Los países del este y norte del Mediterráneo son la verdadera patria del lagarto verde. A bunda en Portugal y no escasea en España; en Francia penetra hasta en Paris y se le ve en toda Italia, excepto la isla de Cerdeña; tambien habita en el sur y este de Suiza y el Tirol meridional, figurando en la península del Balkan entre las especies mas comunes, aquí es igualmente donde alcanza su major desarrollo; se le encuentra en los paises del Danubio, en el sur de Rusia, en Crimea, en el Cáucaso, en el Asia Menor, Siria y Palestina; por último se halla aislado en Austria y Alemania; el valle del Danubio, Viena hasta Passau, Moravia, Bohemia, Palatinado renano, valle del Els. ter, cerca de Zeitz, en los alrededores de Oderberg, en las montañas de Ruedorser, en la Marca, en los contomos de Dantzig y en la isla de Ruegen; tambien aparece alguna vec. en otras regiones de Alemania.

USOS, COSTUMBRES Y RÉGIMEN.-El lagarto ver. de habita los sitios mas variados, tanto de las llanuras como de las montañas altas y bajas; solo necesita que la base del terreno se componga de cal ó arenisca. Desde las costas del mar hasta una elevacion de mil metros, y en el valle del F.ggen á mas altura aun, se le ha observado en todas las zonas. Alli donde abunda se le encuentra en todas partes: se. gun Gredler, en el 'Tirol se le ve en rocas 6 en sitios pedrego. sos caldendos por el sol á orilla de los caminos, en jromon. torios y espesuras; pero raras veces en el llano 6 en las viñas. Segun Bedriaga, en Italia preficre las montainas de cal cubiertas en algunas partes de maleza baja; y Erber dice que se le ve en todas las partes de la Dalmacia pedregosa. \& Un grupo de arbustos, segun Bedriaga, sirve de escondite \& una parcja de lagartos verdes; estos reptiles se calientan al sol siempre á cierta distancia de su morada para que la mas leve sombra producida por los arbustos no les moles. te; tiéndense cuan largos son sobre cualquiera piedra y sus viros colores resaltan de un modo extraño en la roca. Tam. bien le agrada al lagarto verde subir á los arbustos para tomar el sol ó trepar ł los árboles a fin de disfrutar mayor seguridad.

Sus movimientos admiran; son tan rápidos como ágiles y graciosos. Veloz como el rayo cruza los caminos, cscribia Dante. Cuando salta, dice Leydig. pasa como una fecha con la cola tendida y muy recta sobre superficies lisas, y tal cs su impulso, que con frecuencia deja detrás á la presa perse. guida. Si se le acosa, refugiase en los árboles, y si aquí tam. bien se le inquicta, huye a menudo dando saltos enormes, para ocultarse debajo de las piedras ó agujeros. aCuando se encuentran casualmente, dice Leydig, individuos con la cola mutilada, podemos explicarnos la gran importancia que esta larga extremidad tiene en los movimientos rápidos en línea recta. Los individuos que se hallan en este caso pueden $\mathrm{cm}$ prender una precipitada fuga, pero careciendo de ligereza en los movimientos, procuran escapar á la carrèra, serpenteando rápidamente con el tronco.

Todas las demás facultades del lagarto verde no son infe riores \& las de sus congéneres: es tan timido como vivaz, tan astuto como ágil. Cuando se ha buscado varias veces el ma. cho viejo, que por lo regular vive solitario, sin haber podido cogerle, dice Leydig, el animal, que sucle estar calentándose al sol, se dirige tanto mas pronto á su escondite cuanto mas á menudo se acerca el observador. Y lo mas notable de todo es que el lagarto verde reconoce la diferencia entre un cam. pesino que lleva pesada carga y un ciudadano; de este último huye ripidamente, pero al otro le mira sin cambiar de posi. cion. En la jaula da casi todos los dias pruebas de inteligencia, y seguramente figura entre las especies mas astutas de su órden. Solo cuando, perseguido varias veces, se refugia debajo de una piedra y se levanta esta, resignase con su suertc sin emprender de nuero la fuga Algunas veces queda como espantado en el mismo sitio cuando sin tocarlo se le dirige un golpe, y entonces no es dificil cogerle; pero en este caso se defiende á mordiscos, que si no son peligrosos para los dedos del hombre, pueden ser graves cuando el animal pelea con otros de su especie. Sociable como todos los lagartos, vive por lo regular bastante pacificamente con sus semejantes, pero se vale de sus fuerzas con especies mas débiles $y$ a veces tambien con individuos de su propia especie.

Su alimento ordinario consiste en insectos $y$ sus larvas, caracoles y gusanos; pera tambien amenaza los huevos y las

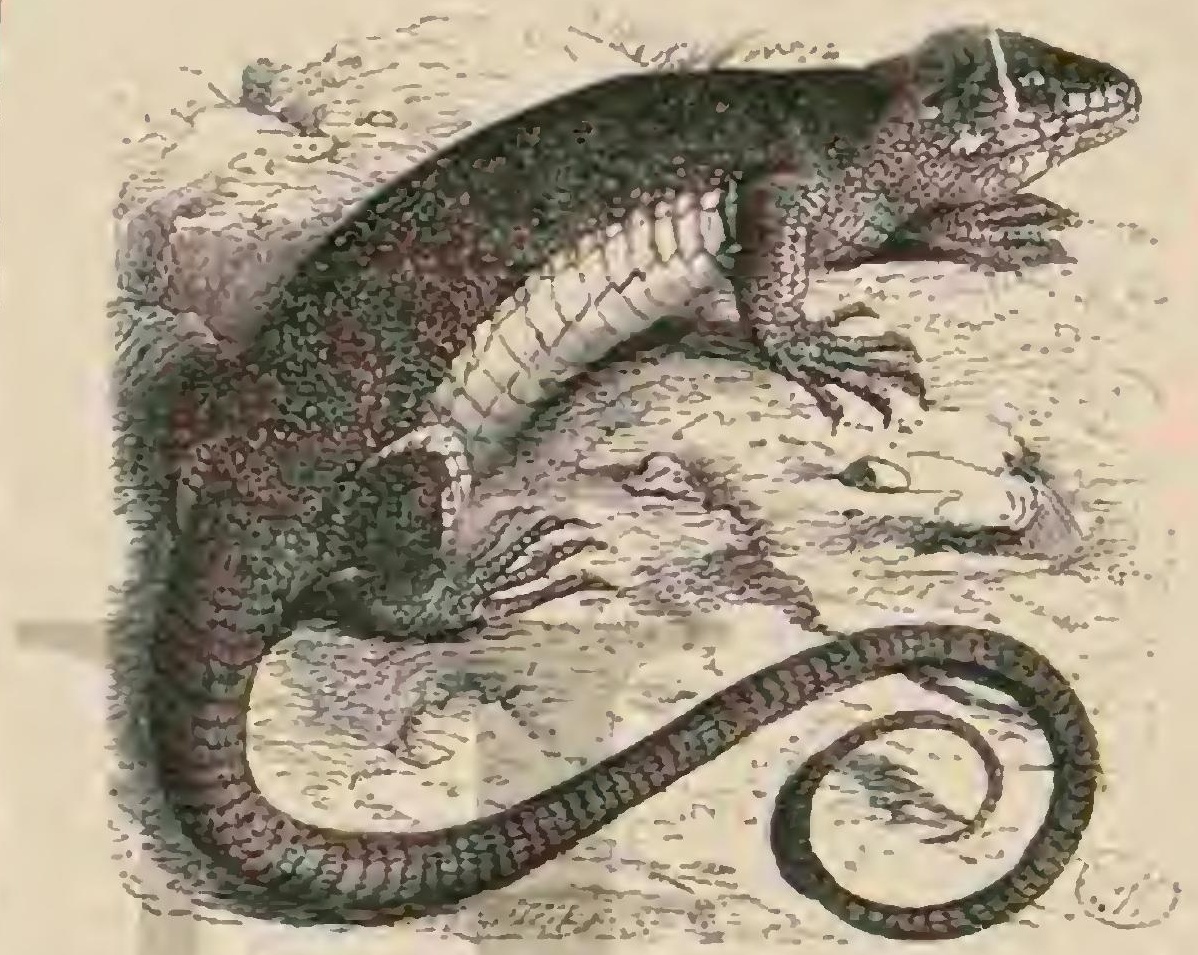

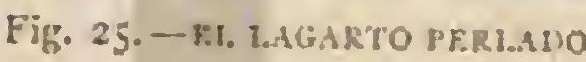

avecillas y derora los lagartos mas pequeños sin escrúpulo; hace sobre todo esto último, segun observó Simons, cunndo está cautivo. Durante la incubacion ocasiona algunas veces grandes destrozos entre los pajarillos; pues la agilidad con que irepa le permite saquear los nidos y su fuerza es bastan. te considerable para que las aves pequeñas no puedan de. fenderse contra él. Los árabes de Siria y de Palestina, que han observado $y$ conocen sus fechorias, creen $y$ aseguran que las aves que cubren con una piel de serpiente las pare. des de su nido hácenlo solo para ahuyentar al lagarto verde, cuyo enemigo mas peligroso es aquel ofidio. Para poder de. vorar una presa tan grande como lo es un lagarto ágil. 6 un lagarto de las paredes, cógele, segun Simons, por el centro del tronco, le hace pasar varias veces por su boca desde la cabcza hasta la cola, aplístale $y$ le devora sin soltarle, con una facilidad sorprendente en este repiil. Frber, que tuyo varios individuos cautivos, á los cuales alimentaba siempre con cierto numero de insectos, reconoció cuánta es la vora. cidad de estos animales: un solo lagarto verde devoró desde febrero hasta noviembre mas de tres mil insectos grandes, $y$ entre ellos dos mil cuarenta gusanos de harina.

En el sur delos Alpes, el lagarto verde se retira por no. viembre para entregarse al sueño invernal, y en Alcmania casi un mes antes; en el sur de Grecia y de España, en cambio, prosigue su vida activa muchas veces casi todo el in. vierno. En Alemania duerme hasta abril, pero en el sur del Tirol se presenta ya en marzo. En mayo ó junio los machos ostentan sus colores mas brillantes y traban encarnizadas lu. chas con sus rivales, dándose a menudo el caso de que uno de los dos, ó ambos combatientes, pierdan su mayor adorno, la cola. En el citado periodo se clectúa el apareamiento; un 
mes mas tarde, en Suiza y Alemania no antes de julio, la hembra deposita de cinco á ocho huevos casi esféricos, del tamaño de una judía y de color pardo sucio, y otro mes mas tarde, es decir en agosto los pequeños salen de la cáscara y se comportan pronto como sus padres.

Todos los enemigos arriba citados persiguen al lagarto verde, pero mas le afligen aun los rigores del invierno ó de un verano frio $y$ himedo. Charpentier dice que este reptil abundaba mucho en los contornos de Bex antes del riguroso invierno de $1 \$_{29}$ â 1830 ; pero que escaseó despues largo tiempo, porque sin duda la major parte habian perecido por el frio que penetró en los agujeros poco profundos.

\section{EL LAGARTO ÁGIL-LAGERTA AGILIS}

CARACTERES, - Este lagarto, comun en todas partes, es mucho mas conocido que la especie verde. Sulongitud no excede nunca de $0^{\circ}, 20$, por lo regular solo alcanza de $0^{n}, 12$ a 0 , 15; la cabeza es relativamente voluminosa, y el hocico obtuso; ála cola corresponde poco mas ó menos la mitad de Ia longitud total. De las cuatro placas de la linea naso-ocular, las anteriores forman un triángulo; el pequeño escudo occipital afecta la figura de un trapecio; la region de las sienes está cubierta de escudos regulares; las escamas del lomo y. de los costados se distinguen esencialmente por su tama. ño, y las placas del vientre constituyen ocho series longitu. dinales. In el intermaxilar hay nueve dientes; en cada maxilar superior diez y seis, en los inferiores hasta veinte; $s$ en el paladar, incluso los pequeños, diez inclinados hácia atrés y adentro. Fn el macho predomina en el lomo un verde mas $\delta$ menos vivo, y en la hembra el gris; la coronilla, una faja del lomo y la cola son siempre pardas; la barba y la cara in ferior del cuerpo verdosas 6 amarillentas La faja del lomo, y cn la hembra tambien los costados, presentan unos puntos blancos dispuestos en series longitudinales, puntos que al. canzan á veces el tamaño de manchas circulares; las regiones inferiores están salpicadas de puntos negros. Se observan muchas variaciones que sin embargo no influyen esencial. mente en el tipo general por los colores y dibujos.

DISTRIBUCION GEOGR ÁFICX. - El lagarto ágil está discminado por el centro y este de Europa, desde los Alpes hasta el sur de Succia, y desde el Cáucaso hasta el golfo de Finlandia; en direccion oeste hasta el este se le encuentra des. de el centro de Francia hasta el Cáucaso; falta del todo en los paises situados al sur de los Alpes, y escasea inas y mas á medida que nos dirigimos al norte En el Tirol septentrional se le encuentra, segun Gredler, hasta una altura de mil doscientos metros en la montaria. Es comun en casi todos los puntos de Alemania, pero no se le ve con igual frecuencia en todos.

USOS, COSTUMBRES Y REGIMEN.-Las pendien. tes de las colinas bañadas por los rayos del sol, sobre todo cuando cstán cubiertas de maleza, los terrenos arenosos y pedregosos, las cercas, los linderos del bosque y de los caminos, son los parajes favoritos del lagarto ágil; pero no falta tampoco en las praderas de escasa vegetacion ó en las turberas donde no haya demasiada humedad, fijándose por regla general en todos los sitios donde puede encontrar su presa. \& Cuando hay algun poste en lugar habitado por un lagarto ágil, dice Leydig, sirve de morada favorita al reptil, que des. cansa sobre él para tomar el sol cuando no se le inquieta, refugiándose debajo de la piedra en caso de peligro, cual si supiera que no le quitarán de alli.»

En cuanto $\{$ la agilidad de esta especie, es tan inferior af la del lagarto verde, que Linnco le hubiera dado sin duda otro nombre cientifico si hubiese observado otras especies del género en libertad. No obstante, tambien cste lagarto es vivaz y ágil, pero no tanto que un observador experto no pueda coger tantos individuos como quiera. Su carrera solo es verdaderamente rápida en terreno descubierto; pero se desliza con mucha destreza entre las yerbas y el ramaje; trepa bastante bien, pero solo sube á los arbustos bajos para calentarse al sol; en caso de necesidad puede naciar, $y$ lo hace ondulando rápidamente el cuerpo; de este modo cruza las charcas, arroyos y hasta riachuelos. Por el conjunto difiere de sus congéneres mucho menos que por sus movimientos, y en su consecuencia correspóndele esencialmente la descrip. cion del lagarto verde.

En Alemania se presenta en los primeros dias de abril, 6 cuando mas tarde a mediados de este mes; llega antes al sur de su área de dispersion, $y$ despues se le ve en el norte; raras veces se-le observa alli antes de fines de marzo, pero aqui se le halla con seguridad hácia fines de abril. Las hembras adultas se presentan, segun Lcydig, una semana mas tarde que los jórenes. En mayo, y cuando el tiempo es favorable á fines de abril, efectuase el apareamiento; y en una noche de junio la hembra deposita de cinco á ocho huevos, de for ma oval obtusa y color blanco, en un sitio expuesto al sol; dejalos en la arena 6 entre las piedras, y segun Schinz, á veces tambien en los nidos de la hormiga negra, que no los toca. A fines de julio ó á primeros de agosto salen los pequeños. Leydig cree que los adultos se retiran despues del periodo del celo á un escondite 6 practican agujeros en el suelo para entregarse á una especie de sueño de verano, tal ver como lo hacen algunas salamandras acuáticas. Eácil. mente puede observarse el hecho de que en la primavera y en ciertos sitios, los lagartos abundan mucho; mientras que mas tarde, hacia fines de julio, escasean bastante, sobre todo cuando el calor ha sido fuerte. Duges observó el hecho hace mucho tiempo, y lo explicó diciendo que estos reptiles se entregan á una especie de letargo ó sueño de verano, ó se retiran á escondites frescos y húmedos.

Entre el innumerable ejército de enemigos que persiguen al lagarto ágil y á sus congéneres pequeños, la coronela y la vibora ocupan el primer lugar. La primera se nutre exclusivamente de lagartos y otros reptiles semejantes, y la viltima persigue solamente á los pequeños, mientras su poca edad no le permite devorar otros animales.

Las martas, los halcones, cuervos, urracas, grajos, gallinas domésticas, pavos indios y reales, las cigüeñas y los patos, persiguen tambien y devoran, al parecer con mucho gusto, esta especie de lagarto.

\section{EL LAGARTO VIVX́PARO - LACFRTA VI-}

CARACTÉRES,-Con el lagarto ágil se encuentra igualmente en muchas regiones de Alemania el lagarto viviparo ó lagarto montañés. Wagler le ha elegido como representante de un género independiente, el de los zootócidos ('Loolvea), porque le faltan los dientes del paladar y porque cubren sus sienes unos escudos pequeños é irregulares en cuyo centro se ve á menudo otro de mayor tamaño. Los zoblogos modernos no dan sin embargo mucha importancia á estos caractéres, ni aprueban semejante separacion. La longitud del lagarto vivi. paro es de $1^{\circ}, 15$ \& $0^{\circ}, 16$, de los cuales corresponden à la cola mas de la mitad; dicha extremidad es en su base de un grosor igual. La cabeza, el tronco y los dedos son de estructura un poco mas delicada y fina qque los del lagarto ágil. En el intermaxilar se cuentan siete dientes; en cada uno de los maxilares superiores die\% y seis, y en los inferiores de diez $y$ scis á veintiuno. Las escamas de la parte posterior del lomo 
son un poco aquilladas y en las del collar se ven ligeros surcos; las del vientre están dispucstas en seis series longitudi. nales en el certro, á las cuales se agrega otra de escudos á cada lado, que algunos naturalistas no consideran como abdominales, porque se parecen casi a las de los costados. El color predominante de las partes superiores es un pardo mas $\delta$ menos oscuro, que á veces tira marcadamente al de pizar. ra; en el centro del lomo y á cada lado se ven siempre fajas mas oscuras. Estas últimas varian mucho, estando limitadas en su parte superior por una linea de color gris claro 6 por manchas claras aisladas on los escudos; en medio de cllas se observan puntos oscuros 6 manchas oculares que á veces forman fajas longitudinales, etc. Isa cara inferior del cuerpo es de color pardusco $\delta$ gris azulado, amarillo de azafran ó blanco amarillento, con puntos negros; la garganta azulada, pero \& menudo tambien de un tinte sonrosado. El macho di. fiere de la hembra por ser mas raquítico, por su cabeza mas plana, por tener la base de la cola mas gruesa, y comunmen. te tambien por sus colores mas vivos.

DISTRIBUCION GEOGRAFICA.-El áca de dispersion del lagarto viviparo comprende la mayor parte de Europa y se extiende por el norte de Siberia. Segun parece, solo falta en el extremo sur de nuestro continente, pero penetra hácia el norte mas que todas las especies de su familia. Nils. son dice que abunda en la Escandinavia central, donde sube en los fjeldis hasta la zona de los abedules. Segun Baernann, aun se le encuentra hasta en los contornos de Arcangel y se le ha observado en los Alpes á una aitura de tres mil metros sobre el nivel del mar. En tales alturas y en el norte, su le. targo invernal dura las tres cuartas partes del ano y apenas disfruta dos, $\delta$ cuando mas tres meses de su existencia. En al. gunas partes de Alemania falta completamente, mientras que abunda en otros sitios, sobre todo en las regiones montanosas y en las turberas. En los Alpes de Suabia, en la selva de Turingia, en el Hartz. y en la montaisa de Glatz, el lagarto viviparo es tan comun como en los Alpes; y en las colinas arenosas de las costas de Holanda, Bélgica y del norte de Francia, abunda tanto como en las turberas de Brandenbur. go, en las llanuras de Hanorer y de Jutlandia 6 en la parte meridional de las estepas de Rusia. Gredler dice con mucha razon que vive con preferencia en las inmediaciones del agua; en las montañas se le ve cerca de los charcos, de los riachue. los $\delta$ de los acueductos; en los valles frecuenta las prade. ras húmedas, las turberas y terraplenes. Lo mismo puede decirse respecto al Tirol, Brandenburgo y Silesia, donde yo le he observado. No sin razon Fitzinger le llama lagarto de los pantanos

USOS, COSTUMBRES Y REGIMEN.-Por su género de vida, sus movimientos § su carḱcter, el lagarto vivipa. ro difiere poco de su congénere el lagarto ágil. No tiene sin cmbargo tanta ligereza, ni trepa tan á menudo; pero cn cambio nada con mas facilidad que aquel. En las montañas altas, segun dicen, es mas perezoso y cachazudo que en las llanuras bajas. Teme muy poco al hombre: en la montaña alta, segun Gredler, su presencia no suele inducirle á emprender la fuga; cuando se descubre de pronto su escondite, déjase coger mas fácilmente que ninguna otra especie.

En los paises septentrionales y en las montañas altas, el lagarto viviparo se presenta en la primavera, tan pronto como lo permite la estacion; $y$ á las llanuras cálidas llega antes que. el lagarto ágil; en el norte de su área de dispersion y en las montanias no se le ve hasta el mes de mayo.

I.a época en que la hembra deposita sus huevos, madura dos ya en la matriz, ó en que, mejor dicho, pare sus hijuelos, varia mucho, lo cual cstá en relacion, aunque no regular, con su salida en primavera. Mejakoff vió ya pequeños lagar. tos en el distrito de Wologd el 29 de junio y hembras pre. nadas en los primeros dias de agosto. Es posible que las hembras viejas paran antes que las jovenes, pero tambien puede ser que el tiempo influya mucho en los actos de la re. produccion. En el sur de Alemania las hembras dan á luz. su progenie por término medio á fines de julio; se compone de ocho, 6 cuando mas diez hijuelos, y siempre paren de noche. El procedimiento en el parto, minuciosamente obserrado por Mlejakoff, es el siguiente: la hembra manifiesta mucha inquietud antes del acto; escarba el suelo, oprimese de tiempo en tiempo contra objetos duros, enrosca la cola cual si quisiera ponerla sobre el lomo, y al fin tranquilizase mas tarde, a reces despues de algunos dias; por último, una no. che se empina sobre sus piés, como si tratara de satisfacer una necesidad, y pare algunos momentos despues, al parecer sin esfuerzos ni dolores, el primer pequeño, que regularmen. te está envuelto aun en la cáscara. Unos dos minutos despues sigue el segundo huevo, y asi sucesiramente los demás. A cada puesta la hembra avanza algunos pasos, de modo que los huevos cubiertos al principio por la cola quedan dispues. tos en fila. Entre tanto los hijuelos se esfuerzan por romper el cascaron del cual salen antes de pasar media hora. La madre, segun parece, no les hace ningun caso, pues se aleja tan pronto como ha puesto el último huevo. Si por casuali. dad vuelve mas tarde á donde están las císcaras, devora de ellas las partes comestibles. Los hijuelos pasan los primeros dias de su vida en completa inercia, echados, con la cola enroscada y durmiendo en las hendiduras y grietas del suelo; parece que son completamente sordo5, pero se inuestran sensibles al mas leve contacto e intentan huir de él. Crecen muy rápidamente, aun sin tomar alimento; algunos individuos que al nacer tenian $0^{m}, 015$ de largo, median \& los quince dias $0^{\mathrm{m}}, 020$. Leydig los alimentó con piojos vegetales quuc devoraban ávidamente.

Segun las observaciones de este último naturalista, la cáscara del hucvo revienta a veces ya dentro de la matriz, en cuyo caso el pequeño nace vivo. Al ver juntos los ocho ó diez hijuelos, dice I.eydig al fin de su descripcion, apenas se comprende cómo tal número de lagartitos bien desarrolla. dos podian caber en la hembra, tan delicada y pequeña.

\section{EL LAGARTO DE LAS PAREDES-LACERTA MURALIS}

CARACTÉRES. - El lagarto de las paredes es originario probablemente tambien de los paises del Mediterrár.co. Al canza una longitud de $0^{m}, 18$ a $0^{\circ}, 20$, y se distingue de sus congéneres alemanes por tener el tronco mas raquítico, la cabeza prolongada, el hocico estrecho y la cola muy puntia. guda, correspondiendo á esta mas de la mitad de la longitud total, de modo que apenas se le puede confundir con otra especie Las tres placas de la línea naso ocular están dispues. tas en una serie; en el centro de las escamas de las sienes sobresale un escudo de mayor tamaño; las escamas del lomo y de los costados son pequeñas y redondeadas, por lo cual el lomo tiene un aspecto granujiento; los escudos abdominales parecen de forma casi cuadrangular y constituyen seis series longitudinales; el collar no es devticulado. Los dientes palatinos faltan por lo iegular; en el intermaxilar se cuen. tan de scis á siete; en cada uno de los maxilares superiores de diez y seis á diez y ocho, y en los inferiores de veinte ś reintitres dientes. El color varia mucho; segun Leydig pre. domina en el lomo el pardo ó gris, con viso verde broncea. do, que resalta sobre todo \&los rayos del sol; en medio de este color pardo ó gris hay unas fajas latemles mas oscuras que parten de la cabeza, y unas manchas mas ó menos mar. 
cadas; en el sitio donde los costados tocan con el vicntre se ve una serie longitudinal de manchas azules; el color del vientre puede ser claro ú oscuro, desde cl blanco de leche y el amarillo hasta un rojo cobrizo, mezclado a menudo con manchas.

Entre el sin numero de variedades, cuya minuciosa des. cripcion no es necesaria, porque no tiene importancia algu. na, merece especial mencion el lagarto arul, que casi carece de manchas y que hasta es de un solo color. Essta variedad fué hallada primero por Erhard en las islas Cicladas, y mas tarde por Eimer y Bodriaga en las rocas de Faraglione, no léjos de Capri; pero tambien se ha obserrado en la prequeña isla de Filfola, cerca de Malta, y en la isla pedregosa de Ayre cerca de Menorca.

DISTRIBUCION GEOGR ÁFICA.- En todos los pai. ses situados al rededor del Mediternáneo, el lagarto de los muros es nuy comun, aunque no mas que las especies de su familia, y está diseminado por todas partes. Se le conoce en toda el Africa septentrional, sur de Europa y noroeste del Asia; en muchas islas pequeñas es la única espeeit que se encuentra Desde el sur de Europa parece haber inmi. grado poco á poco hícia el centro de nuestro continente, fijándose por lo tanto tambien en Alemania.

Sin embargo, no es aqui tan comun como en lirancia y Bégica, exceptuando, segun ha podido averiguarse hasta ahora, el territorio del Khin, sobre todo Baden, Alsacia, el Palatinado, Wurtemberg, Hesse y el Kheingau, y por el norte I ahn. Tambien habita en el valle del Danubio, pero aun dentro de los límites de su teritorio no se le ve en todos los distritos, $y$ segun parece rusultar de varias pruebas es bastante dificil aclimatarle en las regiones donde falta. Segun Gredler y Leydig, en ia montaña sube hasta una al. tura de mas de 1,500 metros sobre el nivel del mar.

USOS, COSTUMBRES Y REGIMEN.-El lagarto de los murus vive en el sur de Europa, donde el numero de estos reptiles asombra; se le encuentra en todas partes, tanto en las islas pedregosas, mas desiertas que pocas veces las visita el hombre, como en medio de las grandes ciudades po. bladas; lo mismo se le ve en las costas maritimas que en el interior del pais, asi en las llanuras como cr las montañas. "Hasta en los fragmentos de roca, dice Leydig, demasiado duros para que en ellos sea posible la vida vegetal ó animal, el lagarto de los muros ha fijado ya su residencia. Muchos de los que visitan el Vesubio, y a quienes interesan todas estas cosas, cuentan que cerca del cráter vuelan aun algunos in. sectos y se deslizan lagartos sobre la lava y el azufrey

Con mucina amenidad habla sobre el particular M. Keypler, viajero del siglo pasado, a cuyo relato se refiere tam bien Leydig. Otra molestia que el pais de Nápoles tiene comun con otras regiones italianas consiste en el gran nú. mero de lagartos, de los cuales una especie verde se encuen. tra por todas partes con frecuencia. Fn la primavera se les ve á centenares en los tejados planos, tomando d sol; suben y bajan por los muros y por este motivo ninguna habitacion que tenga las puertas ó las rentanas abiertas, estả segura de ellos. A mi mismo me sucedió una vez que habiendo puesto mis guantes mojados por la lluvia en la ventana del tercer piso de una casa de piedra, para secarlos al sol, pocos mo mentos despues halle dentro de uno un lagarto. $\mathrm{Ni}$ en el valle del Khin, ni en el del Mosela, Noll encontró nunca el lagarto de las paredes en terreno alto, sino en el fondo del ville, en los agujeros de los cercados de las vinas que no tienen capas de argamasa, y siempre en los sitios donde toca el sol del mediodía.

Todo el que conoce los lagartos debe estar conforme con la opinion de los antiguos de que a estos animalitos les gusta la vecindad del hombre; en ello están de acuerdo tambien los observadores modernos, quienes han reconocido que los lagartos aumentan en número en las inmediaciones de los pueblos y de las casas.

Gredler describe de un modo muy interesante el género de vida de estos animales en el sur del Tirol. Ningun otro animal se presenta antes de un modo tan visible a los ojos del viajero del norte que en verano ú otoño pasa por la cima del Breuner: formando verdaderas legiones, ocupa todos los sitios expuestos al sol; vigas y úrboles, muros antiguos, cercas, barrezas, paredes de las casas y hasta las torres de las iglesias.

Los indigenas de todas condiciones manifiestan una laudable indiferencia of estos animalitos, que en todas partes se encuentran; se les ve correr aqui rápidamente por encima de las legumbres, pasar alli sobre los frutos expuestos al sol para secarlos; y peleando de continuo, introducir el hocico en todos los rincones. La bondad del hombre despierta su confianza; de modo que hasta los lagartos que viven en el campo toman los gusanos, moscas vivas y otros animalitos de la mano que se los ofrece. Gredler habia acostumbrado un lagarto de los muros de tal modo á su persona, que despues de haberle dado algunas veces alimento, presentábase regularmente al mediodia en una estaca del jardin y volvia la cabeza hacia el naturalista hasta que le daba algo. De un modo muy distinto se conducen cstos astutos reptiles alli don. de se les persigue, como sucede, por ejemplo, segun Eimer, en Capri; mientras que en las rocas de Faraglione, rara vez visitadas por el hombre, son tan familiares como en el irirol.

Por sus movimicntos, su géncro de vida y su proceder, el lagarto de los nuros se parece mucho á los de su especie de color de esmeralda. Es bastante superior al comun y al de los bosques por su ligereza y agilidad. Cada uno de sus movimientos es rápido como el rayo, pero sin que carezca por eso de gracia; con una velocidad asombrosa recorre en línea récta una larga distancia, y apenas se observan las líneas serpentinas que entonces traza su cuerpo; pero su mayor destreza se reconoce cuando trepa por los muros verticales. La mas ligera aspereza le basta para apoyar sus dedos largos, delgados y capaces de estirarse mucho, tanto que por esta cualidad podria competir hasta con el geko. Esta ligereza corresponde ś la actividad de su sér. $\Lambda$ causa de su frecuencia 5 de su sociabilidad fundada en parte en esta, y quirás tam. bien por arrebatarse el alimento, este lagarto es el mas pendencicro de sus congeneres alemanes, y casi siempre pelea con los demás de su género, sin que esta costumbre cambie ni aun en cautividad. En todas las ocasiones da pruebas de su inteligencia, notable en un reptil, en cuanto 1 conocer al hombre y las condiciones dominantes en general: tanto la confianza como la desconfianza justificadas le enseñan mas pronto y mejor que á cualquier otro de sus congéneres, pues ninguna otra especic de largarto se familiariza tanto con el hombre. No obstante se deja engañar de una manera casi incomprensible: Eimer, despues de haberse esforzado mucho en Capri por coger lagartos de los muros, muy comunes alli, pero tambien muy tímidos y prudentes, supo que los muchachos de aquella isla se valen de un medio casi infalible para apoderarse de cualquicr número de estos animalitos tan ligeros y ágiles. Cogen un largo tallo de yerba, en cuya extremidad mas delgada hacen un lazo; despues escupen sobre el repetidas veces y forman asi una delgada capa de saliva, que se extiende en el borde del lazo. Apenas ven un lagarto arrodillanse en ticra; en esta posicion se acercan al anima. lito poco á poco, y tendiendo súbitamente el brazo, colocan el iazo delante de su cabcza. El lagarto se para como encan. 
tado y mira sorprendicio aquel objeto; movido por la curiosidad olvida el miedo, y aun se atreve a seguir el tallo, hasta que bruscarnente se le echa el lazo sobre la cabera. Eimer creyó al principio que el brillo de la capa de saliva ó el re. fejo de su imágen en ella atraia al reptil; pero mas tarde reconoció que bastaba tambien un lazo sin la saliva para en. gañarle. Obtuvo un Exito completo en sus cacerias, cuando despues de descubrir la exactitud del hecho se sirvio en adelante de algunos muchachos expertos en esta caza.

En el sur de su área de dispersion el lagarto de los muros no se aletarga en invierno; en el Tirol meridional no se retira antes del mes de diciembre y vuelve a presentarse ya á mediados del mes de febrero; y en lugares bien bañados por el sol se le re tambien alguna vez á mitad del invierno. En el sudoeste de nuestro pais vaga aun al descubierto, al me nos hasta mediados de noviembre y vuelve a salir en los primeros dias de la primavera fuera de su esconditc. Cuando el sol ticne mas calor, el lagarto recobra toda su ligereza y vivacidad, y si se siente otra vez con suficientes fuerzas vuclve á entretenerse en provocar á sus congéneres y pelear con ellos. Segun Gredler, el lagarto desprecia en el invierno los moscar. dones, que tambien como 61 han abandonado sus escondites, pero solo mientras «no ha encontrado agua, es decir mien. tras no ha bebido. Mas tarde, al principio de la primavera, acuando el hambre es grande y los alimentos escasean, se arrancan muchas veces la cola unos á otros, devorándola en el acto. Parece que esta observacion seria mas exacta si se dijera que en el lagarto se despierta muy pronto, si no el ins. tinto de aparearse, por lo inenos la fuerza y el carácter pen. denciero de los machos, que dan lugar á las citadas luchasy a esa comida tan digna de caribes. Toda clase de animales pequeños, insectos, aranas, gusanos y probablemente tambien los pequeños y débiles entre sus congéneres le sirven de alimento.

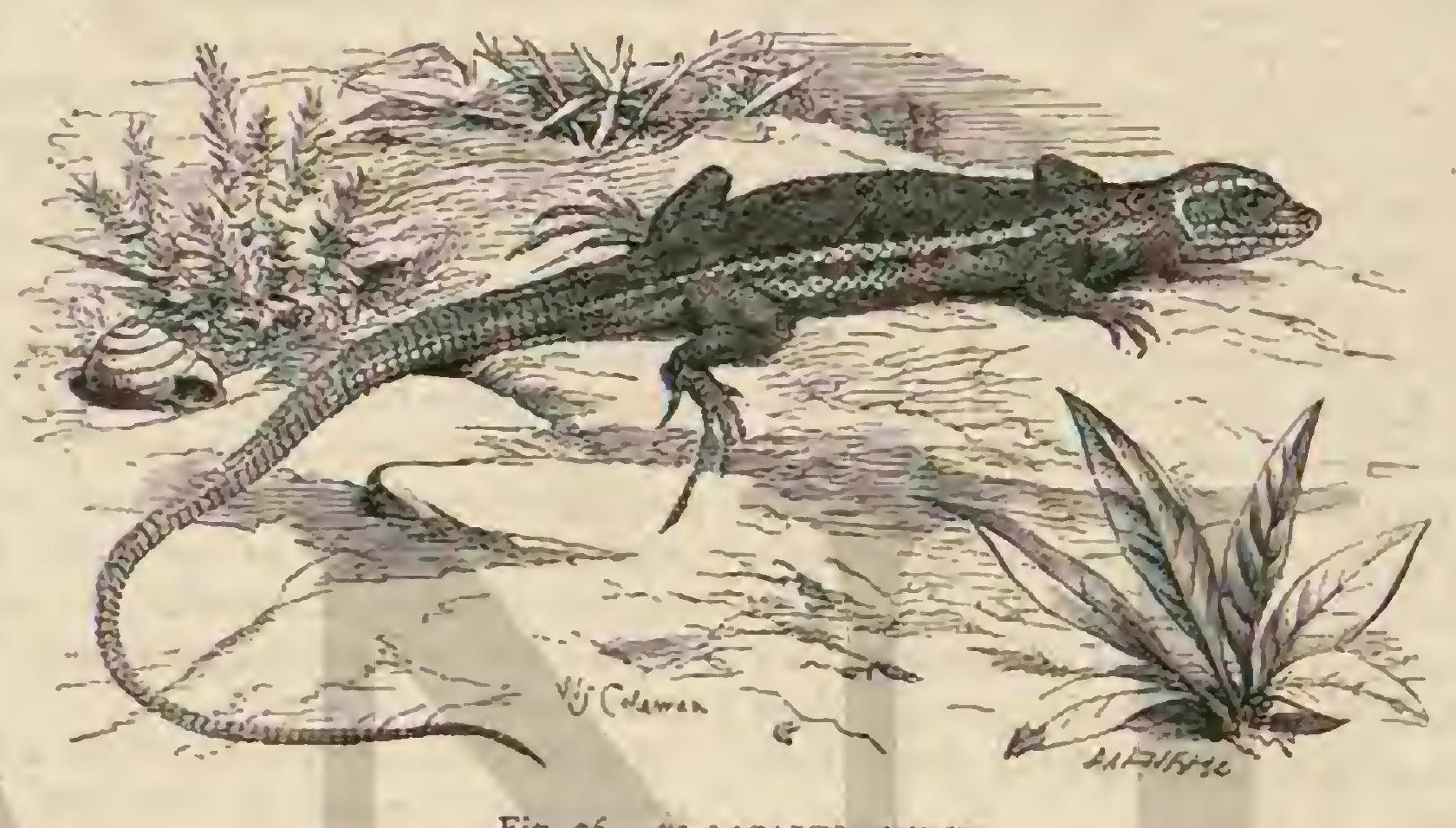

Fitr. 26. - EL LAGARTO AMVISTS

Nada se sabe sobre el periodo del celo; ignoro cuándo se efectúa la puesta y las otras circunstancias de la reproduccion en general. Leydig considera errónea la opinion de al. gunos autores, como por ejemplo de Gloger, en lo de que paren huevos madurados ó hijuelos; Gredler, en cambio, cita el caso de haberse visto un hijuelo, al parecer recien nacido, debajo del cuerpo de un lagarto de los muros, que a) pasar álguien por encima permaneció inmóvil, llamando asi la atencion; y dice que la regla de que algunas especies de lagartos ponen huevos, mientras que otras son viviparas, puede sufrir excepciones. No existen observaciones minucio. sas sobre la reproduccion de esta especie, al menos que yo scpa.

\section{EL LAGARTO PERLADO - LACERTA OGELLATA}

CARACTERES, - En el sudoeste de Europa se reune con las especies citadas hasta ahora una de las mas bonitas y magnificas de la familia, el lagarto perlado, que mide una longitud de $0^{m \prime}, 60$ a $0^{\circ}, 90$ y es uno de los tipos mas graciosos de todo el órden. La parté superior de la cabera está cubierta de anchos escudos, de los que el del occipucio y los Jaterales sobresalen; su color es pardusco y el de los lados de la cabeza verde; el lomo tiene un tinte mas intenso, con lineas enlazadas verdes, tan espesas que à veces predomina cl color claro; en cada costado se ven ademais unas veinticinco manchas azules orilladas de negro; la parte inferior del cuerpo es de un verde amarillento claro; todas las demais regiones de un verde $\delta$ verde gris mas 6 menos vivo(fig. 25).

Tosso $\mathrm{V}$
Los hijuclos difieren de los adultos por tener el color menos vivo y por las manchas mas numerosas.

DISTRIBUCION GEOGRAFICA.-El lagarto perlado habita la peninsula ibérica y el noroeste del Africa, disemi. nándose tambien por el sur de Francia hasta donde se encuentran olivos; en el sur y centro de España abunda casi en todas partes.

USOS, COSTUMBRES Y REGIMEN. - Yo he obser. vado muy á menudo este lagarto. Generalmente se le ve en las inmediaciones de altos árboles, en algunas pequerias ele. vaciones del terreno $y$ hasta trepando por las ramas de aquellos. Cuando divisa al hombre se oculta con toda rapider en su agujero, asomando al poco rato la cabeza para espiar lo que hace aquel. Siempre que puede escaparse lo hace, pero nunca ante el perro 6 el gato; contra estos se prepara resuel. tamente $\&$ la defensa, se precipita sobre cllos y les muerde en el hocico 6 el cuello, obligándoles las mas de las reces á retirarse al primer ataque. Si calcula que no tiene tiempo para refugiarse en su guarida, trepa por el primer árbol que encuentra, subiendo a las ramas mas elevadas, y desde alli vigila hasta que cree que ha desistido su perseguidor; si no ceja este, entonces el lagarto acostumbra saltar al suclo y buscar una cavidad cualquicra para esconderse; si lo hace debajo de las piedras y se levantan estas, suele agarrarse fuertemente al suelo $y$ es fácil apoderarse de ell en aquel mo. mento; pero conviene hacerlo con cuidado, pues si puede clava sus dientes y hasta sus agudas garras.

El alimento de este lagarto consiste en la misma clase de insectos y animales pequeños que llevamos indicado al tra. tar de la especie anterior; sin embargo, debido sin duda á 
su mayor fuerza, se atreve hasta con animales mayores, como ratas, pequenas culebras, ranas y lagartos. « Cuando ve una presa, dice Schinz, acéchala con los ojos chispeantes, fijos en el objeto, y salta sobre ella con la mayor rapidez; cógela con los dientes, sacude varias veces la cabeza violentamente, y devora poco á poco el animal cogido y aplastado. Despues se relame con gran contento como un gato cuando ha bebido leche. Duges ha observado que tambien come los huevos de su propia especie: tenia este naturalista dos lagartos cautivos, uno de ellos hembra que se encontraba á la sazon próxima i desovar; pero con gran sorpresa de aquel, el voláinen de la misma disminuia cada dia sin encontrar rastro de huevo alguno, hasta que acabo por descubrir que se los comia el macho. Mas tarde probó a dartes á comer luevos de otros lagartos y de viboras, y pudo ver cómo se los comian con gran aficion, tragándose enteros los mas pequeños, aunque con alguna dificultad, y rompiendo los mayores para absor. ber su contenido por medio de la lengua, como acostumbran hacerlo con el agua.

REPRODUCCION. - Durante la época del apareamiento pelean entre si los machos con furor, lo mismo cautivos que en libertad, y sus ataques se dirigen por lo comun i la cola del adversario, como suelen hacerlo los demás lagartos. I.os seis ú ocho huevos que acostumbra \&-poner la hembra, los deposita por lo comun en los troncos huecos de los olivos.

CAUTIVIDAD. - Refiere Schinz que en el jardin botanico de Berna se colocaron varios de éstos lagartos con ob. jeto de aclimatarlos. Para su morada se les preparó conve. nientemente un pequeño altozano. Durante los dias calurosos del verano se mostraron tan vivos y retozones como si se encontrasen en su propio pais; pero en los dias frescos y húmedos se manifestaron apúticos, acabando por esconderse completamente con los primeros frios del otoino, y muriendo en el curso del invierno.

Sin embargo, creemos que esta experiencia no puede acep. tarse como concluyente respecto á la aclimatacion de este lagarto, pues el invierno de la Espana central cs casi idéntico al nuestro, no por la fuerza del calor, pero si por la duración, y de consiguiente, no comprendo que esto pudiera ser un obstáculo para la propagacion de esos bonitos y útiles animales en nuestros países. Durante mi permanencia en España, mi hermano Reinaldo y yo hemos cogido á menudo el lagarto perlado, pero nunca le pudimos observar en cautivi. dad, porque las mujeres de nuestras posadas siempre temblaban de miedo cuando llevábamos uno de estos lagartos de nuestras cacerias y soltaban secretamente á los animales $\delta$ los hacian matar. Mas tarde los he tenido repetidas veces; pero mejor es servirme de las palabras de Liebe, porque no me seria posible dar una descripcion tan excelente de su vida en cautividad como lo ha hecho el citado naturalista.

Pronto se acostumbró à mi habitacion, pero molestábame su aficion a trepar por las corcinas, \& cuya extremidad inferior llegaba de un salto; complaciase en brincar, en medio de su carrera, sin causa visible. Cogia su presa siempre saltando cuando esta podia escapar fícilmente, mientras que se acercaba poco á poco ś los insectos corredores, cogiendo. los con un rápido movimiento lateral. Cuando una persona se atravesaba en su camino, enfurccíase á menudo de tal modo que le mordia la punta de los piés ó los pantalones. Desagra. dábale mucho mojarse el cuerpo con agua, aunque se distin. guia del lagarto vulgar por su destreza para nadar cuando se le echaba en un cubo; si le tiraban agua asustábase de tal modo que hacia ranos esfuerzos para trepar por la pared mas próxima. A pesar de eso bebia agua inmergiendo cuidadosa. mente la punta del hocico y chupando el liquido, al parecer con la punta de la lengua; tambien le gustaba la leche. Mu. cho le agradaba el sol: una nube que pasase por delante del mismo bastaba para que el lagarto se retirase bajo el musgo y la hojarasca. Gran trabajo me costaba al principio propor. cionarle el alimento conveniente; comia lombrices de harina, abejorros y sus larras y otros insectos de esta clase, pero nunca muchos a la vez; cansábase muy pronto de los abejor. ros. Aunque turiese mucha hambre no tocaba gusanos, caracoles, ni reptiles de piel desnuda; una sola vez le obliguéá comer un raton pequeño, pero nunca mas. En cambio le gus. taban mucho todas las especics de ortópteros, sobre todo las grandes langostas, las cuales cogia siempre por mitad del tronco; revolvialas con un brusco movimiento de la cabeza, de modo que las largas piernas posteriores se dirigian hácia adelante, y las devoraba despues, rompiendo a menudo la parte inferior de las piernas por una diestra sacudida de la cabeza, Las golosinas preferidas cran, sin embargo, los repti. les, sus propios congéneres, lagartos, escincos, culebras comunes y lisas. Desgraciadamente no he podido encontrar una vibora para hacer esta prueba. Todos estos animales se agarraban, tan luego como su enemigo los habia cogido, á los labios ó a los repliegues del cuello, pero algunos fuertes golpes contra el suelo los aturdian pronto; entonces los es. cincos se hacian siempre pedazos, los cuales recogia el lagarto perlado cuando solo se movian un poco. Llegado el invierno se hizo dificil obtener alimento suficiente para el cautivo; pero lo mas peligroso para él cra sin duda el frio de la noche. Comenzó á cnflaquecer, perdió las ganas de comer, s cayó al fin en un estado letárgico, pero no en cl sueño in. vernal, pues el calor no podia producir ninguna mcjora. Despues de haber permanecido seis semanas en tal estado, murió á fines del invierno; yo le habia cuidado poco mas 6 menos un año.

Gracias á su valor y á sus buenas armas el lagarto perlado tiene menos enemigos que sus congéneres mas pequeños; sus adversarios mas peligrosos son las aves de rapiña, sobre tódo los gipactos y los buzos, á los que se reunen los cuer. vos. Los españoles crejéndole venenoso le temen muchisimo y por lo tanto le matan mas á menudo de lo que deberia desearse.

\section{EL LAGARTO AMYSTES Ú OJO DE SER- PIENTE-OPHIOPS ELEGANS}

CARACTÉRES.-E! carácter distintivo de esta especie, clevada por algunos naturalistas á la categoria de género, es la ausencia de párpados; tampoco tiene dientes palatinos, y no difieren los maxilares e intermaxilares de los de otras especies. La cabeza se asemeja en su configuracion a una pirámide, pues es casi tan ancha como alıa en su base. Tiene las escamas a los lados del cuello bastante pequeñas y las del dorso grandes y distintamente aquilladas. El color del dorso es oliváceo brillante, con dos fajas amarillas que flanquean una línea de manchas negras; las partes inferiores son blan. quecinas. Mide todo el cuerpo, con la cola que representa algo mas de la mitad, de 4 á 5 pulgadas (fig. 26).

DISTRIBUCION GEOGRAFICA.-El ophiops se en. cuentra generalmente en el Asia Menor y en distintas co marcas del Cáucaso; tambien habita parte de la Crimea, y segun algunos naturalistas, varios paises del mediodia de Europa.

USOS, COSTUMBRES Y REGIMEN. - Sobre este punto no se han publicado observaciones que creamos dignas de la atencion de nuestros lectores, siendo de suponer que en poco se diferencian de las de otros individuos de la misma familia. 


\section{LOS ACANTODÁCTILOS-ACAN- THODACTYLE}

CARACTERES.-Los repiles de este género se caracte. rizan por tener la lengua en forma de hicrro de flecha, me. dianamente larga, escotada en el extremo $y$ cubierta de papilas escamiformes imbricadas. Los dientes maxilares son algo comprimidos; las fosas nasales se abren entre la placa naso-rostral, que es única, la primera labial y una naso.frenal; tienen un collar escamoso; láminas ventrales cuadriláte. ras, dispuestas por series, unas veces oblicuas y otras rectili. neas; las patas están provistas de cinco dedos ligeramente comprimidos, carenados por debajo y dentados lateralmente; la cola es ciclotetrágona en su nacimiento y redondeada en el resto de su extension.

\section{EL ACANTODÁCTILO COMUN-ACANTHO- DACTYLUS VULGARIS}

CARACTÉRES. - Además de los caractéres generales indicados para el gencro, esta especie se distingue por formar las dos placas palpebrales un disco sub-oval, guarnecido de granitos por fuera, por delante y en la parte anterior, donde hay unas escamas pequeñas; la placa naso rostral no es menos combada, y la naso-frenal y la primera labial superior son planas. No existen los dientes en el paladar; tiene el párpado inferior escamoso, y el borde anterior de la oreja granujiento; las escamas del lomo son iguales, de forma romboidal, pe queñas y unidas. Jai parte superior de la cabeza y de la cola tienen un tinte pardo mas 6 menos claro, y en el resto del cuerpo predomina un color negro bastante intenso algunas veces. Ias patas están moteadas de blanco, y cuatro rayas del mismo tinte se corren á cada lado del cuello y del tronco, comenzando una de cllas debajo de la oreja. Todas las partes inferiores son blancas; pero con mucha frecuencia, la cola y la parte superior de los muslos ofrecen un tinte rojizo ó ro sado muy bonito, que desaparece cuando muere el animal El acantodáctilo comun mide $11^{m}, 28$ de largo (fig. 27 ).

DISTRIBUCION GEOGRÁFICA.-Este reptil habita en el medindia de Francia, en Italia y en España.

USOS, COSTUMBRES Y RÉGIMEN.-Por su género de vida y sus costumbres ofrece gran semejanza el acanto dáctilo con las especies anteriores.

\section{LOS EREMIAAS - EREMIAS}

CARACTERES. - I Los de este género no difieren apenas de los del anterior: los eremias tienen en la parte anterior del pecho ùn repliegue de la piel trastersal 6 anguloso, formando las láminas ventrales fajas longitudinales rectilineas ó un poco oblicuas. Los dedos, en número de cinco, son desiguales, y no dentados lateralmente.

\section{EL EREMÍAS NAMAQUÉS-EREMIAS NA- MAQUENSIS}

CARACTERES. - Esta especie se hace notar por la mo vilidad y extrenada longitud de la cola; los dedos de sús patas son delgados y nudosos; y la cola ofrece una ligera depresion en su raiz, pero es redondeada en el resto de su extension. Los demás caractércs son los que acabamos de señalar para el género. Ia parte superior del cuerpo y los la. dos ofrecen cinco listas pardas 6 negras, que alternan con seis rayas blancas; la cara superior de las patas posteriores pre. senta una mezcla irregular de blanco y pardusco; toủas las partes inferiores son blancas (fig. $2 S$ ).
DISTRIBUCION GEOGRÁFICA.-Este reptil habita en el cabo de Buena Esperanza, y últimamente fué hallado por el doctor Smith en el pais de los Namaqueses, habien. dosele dado por esa circunstancia el nombre que lleva.

USOS, COSTUMBRES Y REGIMEN. - En cuanto al género de vida de este gracioso reptil, solo podemos decir que vive por lo regular en los arenales del desierto, que pa. rece preferir a los parajes cultivados.

\section{LOS AMEIVIDOS-} AMEIV无

CARACTERES. - Los ameividos representan en cierto modo á los varinidos y lagartos en América; aseméjanse un tanto \& sus congéneres del antiguo mundo por el tamaño, y tambien por la estructura, difiriendo no obstante suficientemente por el sistema dentario y la disposicion y naturaleza de los escudos. I os dientes, que se insertan en el borde de la mandibula, se dirigen oblicuamente hícia fuera y no están huecos; las cscamas son lisas, parecidas á las de los lagartos; las de la cabeza, mas grandes, forman escudos, y las del vientre y de la cola se presentan en series trasversales. En la major parte de las especies se ven dos repliegues trasversales en la garganta, y en muchas unas aberturas glandulosas en el lado superior de los muslos, llamadas poros. Ia lengua, larga y provista de dos puntas, está cubierta de escamas sobrepuestas, y tiene a veces la base ligeramente retráctil. El tambor existe; las órbiras cstán cubiertas de una membrana; las fosas de las sienes no se hallan cerradas por huesos.

DISTRIBUGION GEOGRRFICA.-Todas las especies de esta familia, en número de mas de setenta, habitan las re. giones cálidas de América; las mayores, como fácilmente se explica, se hallan en los paises tropicales.

USOS, COSTUMBRES Y REGIMEN. - Algunos de estos repriles viven solo en llanuras cálidas y arenosas, oiros entre las altas yerbas de las praderas, 6 en bosques, y no po. cos, cuando menos parcialmente, en el agua. Su albergue es una cavidad natural \& construida por el reptil, á la que regu. larmente se refugian en caso de peligro. Por su género de vida y sus costumbres recuerdan tanto los varanos como los lagartos pequeños; son muy rápidos y vivos: las especies ma. yores, en extremo voraces, no solo dan caza a los insectos, gusanos y caracoles, sino tambien if pequeños vertebrados pudiendo hacerse por lo anto hasta nociras; de algunas se dice que comen tambien frutas. De los enemigos grandes, sobre todo del hombre, huyen cuando pueden; pero si se les acosa de cerca é irrita, atacan valerosamente á su agresor y saben hacerse respetar hasta de perros grandes. Depositan sus luuevos en árboles huecos. La carne de algunas especies, sobre todo de las mayores, parece ser sabrosa, y por eso se les caza en algunas partes con regularidad, mientras que \{ las otras no se las persigue.

\section{LOS TEJÚS - TEJUS}

CARACTERES. - Los tejús se caracterizan por tener la cola redondeada en la base y un poco comprimida desde el centro; la piel del cuello forma pliegues; las escamas del lo. mo son lisas y estan dispuestas en fajas trasversales; las del vientre, que afectan la forma cuadrangular, figuran pentágonos; los dicntes palatinos faltan; los incisivos superiores tie nen dos $\delta$ tres escotaduras; los molares presentan tres puntas en los jóvenes y protuberancias en los adultos; la lengua es retráctil en su base. 


\section{EL TEJÚ-TEIUS TEJUIXIN}

CARACTERES. - El tejú, ó salompenter de la Guayana, la especie mas conocida del género, es un escamoso muy grande, de $\mathrm{I}^{\mathrm{m}}, 50$ á dos metros de longitud, correspondiendo a la cola casi dos terceras partes. Su color es muy abigar. rado, mas predomina un negro pardusco que tira un poco al azulado; cn la nuca hay unas manchas blanco-amarilias, y en los lados del cuello y de la cabeza otras blanquizcas, dispues. tas en series; en el lomo se cuentan de nueve á diez fajas trasversales compuestas de manchas redondas de color amarillo; en la cola hay varias de estas, amarillas y de forma irregular, que forman algunas series; los piés presentan pun. tos amarillentos; las regiones inferiores son de un amarillo rojizo con fajas trasversales negras interrumpidas; la garganta y la parte inferior del cuello tienen igualmente fajas amarillas orilladas de blanco.
DISTRIBUCION GEOGRÁFICA - El tejú de los indios de la costa ó lagrarlo de los 'brasileños, está diseminado por la mayor parte de la América del sur, desde la Guayana hasta el Paraguay, siendo muy comun en la mayor parte de los paises, pero segun parece, mas en la costa que en el interior.

USOS, COSTUMBRES Y REGIMEN.-Segun Schomburgk, este reptil busca en las regiones cultivadas las planta. ciones de azúcar y los bosques limitrofes; en el Brasil, al decir del príncipe de Wied, vive en los terrenos secos ó arenosos, fijando su residencia en las espesuras, en los linderos de los bosques $y$ en el mismo interior de las selvas virgenes. Algu. nos autores de otro tiempo pretendieron que le gustaba in. troducirse en el agua, pero el principe no lo cree probable: «A pesar de que á menudo vimos y cazamos estos reptiles cerca del agua, dice, nunca observé tal cosa y tambien me afirmaron todos los indios que el tejú solo vive en la tierra

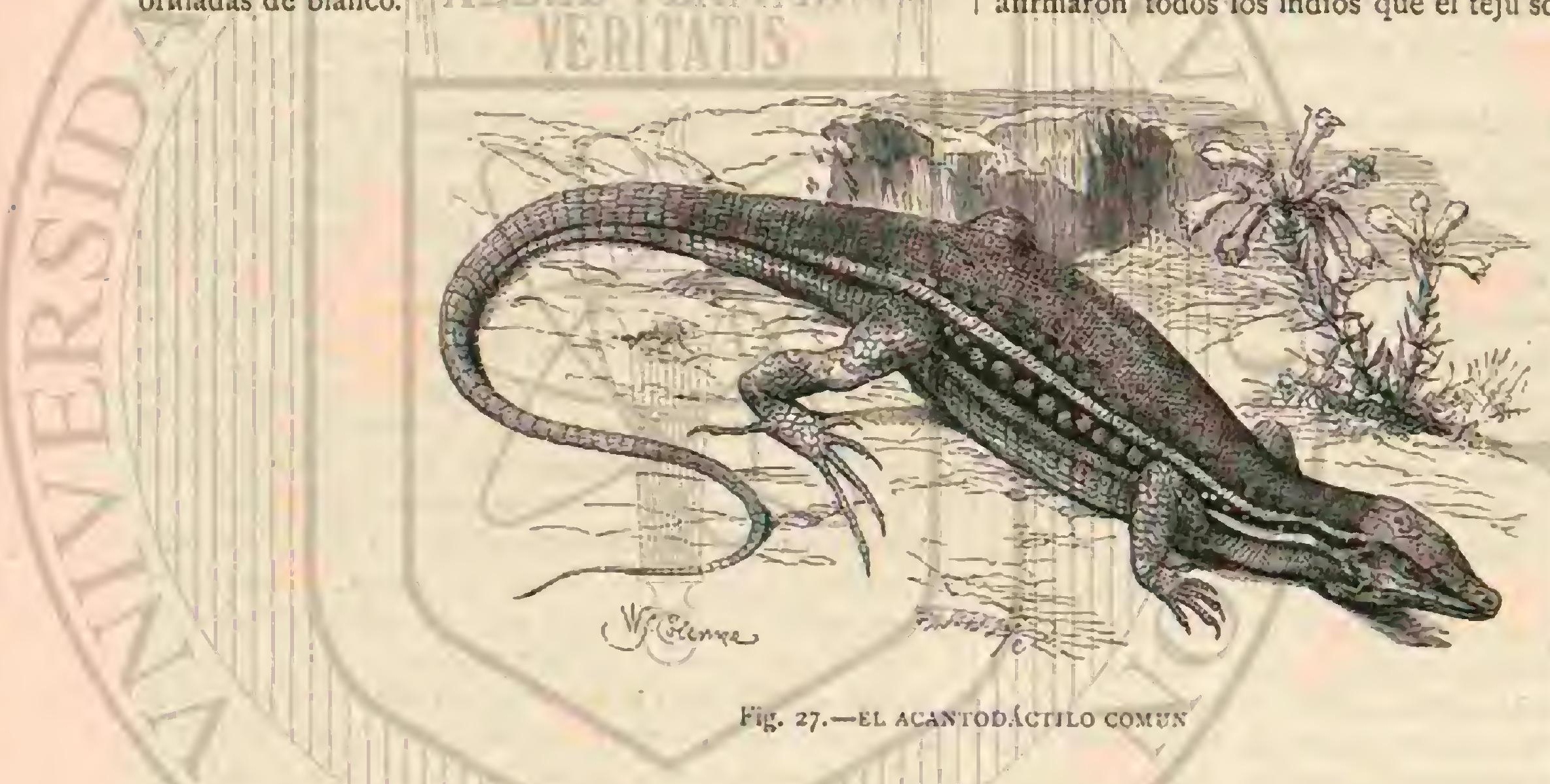

firme y no dentro del agua $D$ Cada individuo habita en una cavidad subterrinea que se abre debajo de las raices de los árboles, y cuya entrada es bastante grande; en esta guarida se refugia cuando se le persigue ó se espanta al ver algun objeto extraño. Fs un reptil vigoroso y ligero, pero en extre. mo timido y miedoso; en las regiones habitadas no espera que el cazador se le acerque, pero una vez acosado de cerca se defiende valerosamente, muerde con sus agudos dientes y puede atravesar fuertes botas, mientras descarga con su vigo. rosa cola fuertes golpes contra los perros que le atacan. Cuando esta quieto tienc la cabera levantada, ofreciendo entonees un aspecto extraīo, aunque agradable, en particular por sus ojos chispeantes; corre con la rapidez de una flecha en linea recta, moviendo el tronco y la larga cola, que arrastra por el suclo ondulando. La lengua está en continua actividad, aunque no baya ninguna razon para ello. El principe no ovó nunca su voz y califica de fábula el aserto de que el tejú advierte á otros animales los peligros.

Lil alimento consiste en frutos y toda clase de animales pequeños, sobre todo ratones, ranas, insectos, etc. El prin. cipe encontró en el cstómago del tejú muerto por él restos de ratones é insectos, y tambien le ciijeron que roba gallinas en las casas de labranza; Schomburgk y Hensel confirman cste último aserto, asegurando que no les gusta á los colonos nada verle cerca de las casas, porque no solo devora los huevos sino que persigue á los volátiles. Los indígenas del Brasil dicen que el tejú se oculta durante la estacion fria en su guarida, donde vive unos cuatro meses con los viveres recogidos, volviendo \& salir poco mas ó menos en agosto.
Hensel observó que en Rio Grande do Sul se retira en invierno y no sale hasta que el ticmpo es muchos dias faro. rable. Como se ha visto que a menudo tiene murilada la cola, que ruelve a crecer despues, se ha inventado la fábula de que este escamoso se come durante el sueño invernal dicho órgano cuando se acaban demasiado pronto las provi siones.

Schomburgk ha hecho algunas observaciones sobre la reproduccion de este reptil. Encontré con frecuencia los hue. vos, dice, en los grandes nidos de térmites construidos no solo en los bosques, sino tambien en los troncos de árboles cortados en las plantaciones hasta a una profundidad de un metro. Este lagarto vacia esos nidos, devora las hormigas y deposita despues sus huevos, en número de 50 \& 60 , en el hueco; luego ensancha las entradas redondas para que al subir por el tronco se pueda entrar cómodamente en él. Los huevos, que son blancos, tienen la cáscara muy dura, y segun Hensel, los de las grandes hembras adultas alcanzan casi la longitud de los de paloma, si bien son mas estrechos y obtusos en ambas extremidades.

CAza. - El tejú es un animal dañino, pues impulsado por su audacia y voracidad se acerca muchas veces a las casas y ocasiona destrozos en la cria de gallinas. Por esto, y mas aun por su carne generalmente apreciada, se le persigue en todas partes con cierta aficion. El cazador se dirige al bosque con algunos perros adiestrados que despues de buscar el reptil le obligan á refugiarse en su guarida, de la cual se le saca con un azadon para matarle despues a golpes, ó cuando hay ocasion, de una perdigonada. Los perros desti. 
nados á la caza del tejú no deben ser demasiado pequeños, pero si estar bien adiestrados, pues los que carecen de experiencia en tal género de caza se espantan por los colctazos del reptil y suelen huir vergonzosamente. La carne bien guisada tiene un sabor análogo á la de la gallina; es blanca y muy apreciada; pero no se utiliza solo como alimento sino tambien como remedio contra los mordiscos de serpiente; la grasa sobre todo es excelente, segun se dice, por este concepto.

CAUTIVIDAD. - Schomburgk tuvo un tejú varios meses en una jaula, y no le agradó nada de este reptil. "Era un animal perverso, dice el citado naturalista, mordedor y salraje; solo comia carne, y bebia con tanta frecuencia como las culebras, de modo que era preciso darle todos los dias agua. Yo he observado muchos años el tejú y puedo confirmar la noticia anterior en lo esencial; pero debo añadir que a pesar de eso he tomado cierto carino a mis cautivos: su descaro y audacia cautiva la atencion del observador. Cuando se satisfacen de un modo conveniente sus necesida. des imprescindibles, dándoles sobre todo el calor necesario y el alimento suticiente, se acostumbran pronto á la jaula y hasta cierto grado tambien á sư guardian, pero nunca toleran que este les incomode, sino que conservan su independencia defendiéndose valerosamente. Un tratamiento descuidado ó riguroso excita su ira: entonces levantan la cabera mas que de ordinario y echândola al mismo tiempo hácia atrás, miran á su adversario con ojos chispeantes sin temer ya nada; dan poderosos saltos hasta de un metro de distancia y de altura; y muerden al fin con tal fuerza, que el hombre á quien cogen queda herido de gravedad, inutilizado tal vez. por varias semanas de una mano ó un pié. Por lo que hace al alimento, solo son exigentes en cuanto á la cantidad; un tejú adulto devora durante el dia, y hasta en una sola comida, de uno á doscientos gramos de carne magra de buey ó de caballo, canti-

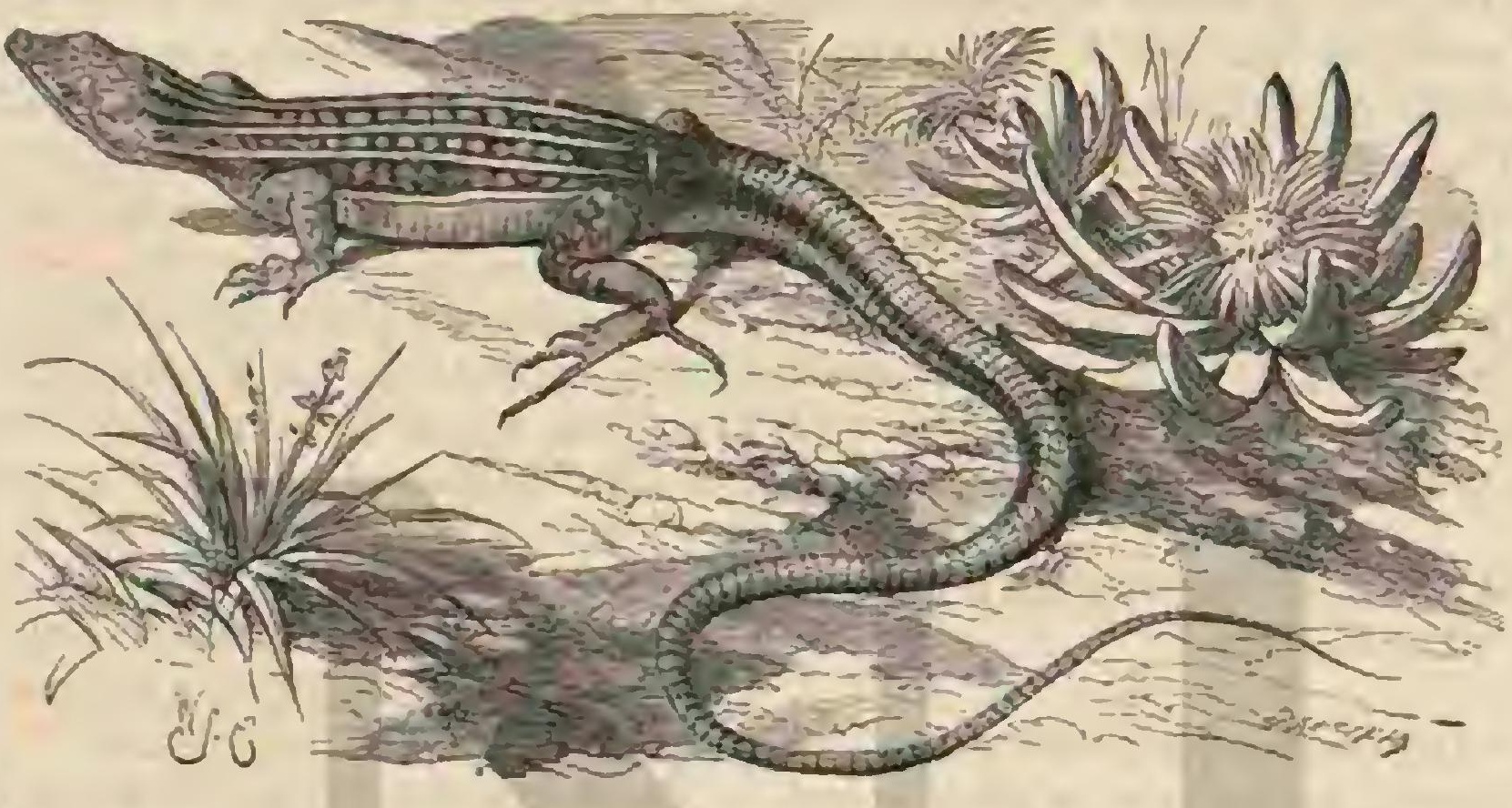

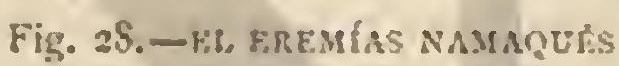

dad que solo le satisface para veinticuatro horas. Los tejus viven en bastante buena armonia con sus iguales, aunque puede suceder que un macho aduito y pendenciero no quic. ra tolerar à ningun otro cerca de si y mate á los mas débiles, 6 cuando menos les muerda de un modo peligroso. I.os in. dividuos de esta especie que se tienen en grandes espacios expuestos al sol y bien abrigados, tambien se reproducen en cautividad; hasta en las jaulas estrechas llegan á poner huevos con bastante frecuencia; pero aun no se ha conseguido, al menos que yo sepa, obtener progenic.

\section{LOS AMEIVAS-AMEIVA}

CARACTERES, - Con este nombre se distinguen las éspecies de la familia que tienen la cola redondeada sin cresta, y dientes pequeños, cónicos, cortados en la corona y con una base de tres puntas.

DISTRIBUCION GEOGRAFICA. - Estos reptiles representan en la América del sur à nuestros lagartos; viven del mismo modo, y los brasileños los llaman tambien así.

\section{EL AMEIVA COMUN-AMEIVA VULGARIS}

CARACTERES. - Ia especie mas numetosa y conocida del género es el ameiva comun, un escamoso de $0^{\circ},{ }_{45}$ a $0^{\circ}, 4^{S}$ de largo, de los cuales corresponden á la cola unos $\left(0^{\circ}, 26 \mathrm{~A} \|\right)^{\prime \prime}, 29$. El lomo es de color verde yerba; los costados azules $\delta$ parduscos, con fajas verticales negras y manchas anıasillas. Los individuos jóvenes tienen en vez de este di- bujo una ancha faja longitudinal de un gris pardo, orillada de un color mas claro.

DISTRIBUCION GEOGRAFICA.-El ameiva comUn se encuentra en todo el Brasil y la Guajana y es muy comun en la mayor parte de sus distritos.

USOS, COSTUMBRES Y REGIMEN.-El habitat, las costumbres, el género de vida, el régimen alimenticio y la manera de reproducirse no difieren apenas de las del teju: este reptil es, como dice el principe de Wied, un tejú en mi. niatura Sucle tener su vivienda debajo de los arbustos, en la hojarasca, en las piedras, en las hendiduras de roca, cn agu. jeros subterráncos y debajo de la madera vieja, prefiriendo las llanuras muy secas, cálidas y arenosas. En la Guayana se le ve sobre todo en jardines y plantaciones, ó en claros de bosques, donde toma el sol: se introduce en el agua lo mismo que el tejú. Cuando le amenaza un peligro se refugia con toda la prisa posible en su guarida, pero si no puede evitar a su enemigo se defiencic at mordiscos. A pesar de que no se le persigue, siempre huye del hombre y por eso el naturalista que quicra apoderarse de él debe servirse del arma de fuego.

Para completar los carnctéres del ameiva reproduciré aquí en extracto la descripcion de Gosse de una especie congené. tica (anciria dorsalis), propia de Jamaica. Este ameiva es uno de los reptiles mas comunes de la isla y tan bonito como numeroso. Su color llama la atencion, pero no es magnifico; su cara tiene una expresion benigna, algo semejamte á la de un ciervo 6 de un antilope; todos sus movimientos son gra. ciosos y alegres; cuando corre libremente, su cuerpo describe graciosas evoluciones, pero si se le asusta huye con unarapi- 
dez tan extraordinaria que parece volar, en el verdadero sentido de la palabra, y que el observador cree ver á un ave.

No está discminado por toda la isla: prefiere los sitios arenosos, por lo cual abunda principalmente cerca de la cosIa, donde remueve de continuo con sus ágiles piés la hojaras. ca y la yerba seca reunidas por el viento $y$ la marea. Es por Io reguiar muy timido $y$ medroso, pero no interrumpe su actividad la presencia de un observador que permanezca del todo quieto y silencioso; corre delante de él por todas partes. Asi como las aves, recoge toda clase de alimento de la arena y cscarba como una gallina moviendo los piés alternativa. mente; algunas veces se pára para rascarse con el pié poste. rior la cabeia y sigue en su ocupacion. Dijeron a Gosse que él mismo abre sus agujeros, por lo cual perjudica lós sembra. dos en el periodo de la germinacion y conve tambien los granos. Cosse, sin embargo, no encontró en el cstómago de todos los ameivas examinados por el sino restos de varjos insectos y alguna vez simientes de bayas.

Fl ameiva no trepa nunca á los árboles ni tampoco entra en el agua sin que la necesidad le obligue. Cierto que puede subir por paredes verticales, pero to hace solo por excepcion; cuando se le echa al agua nada muy bien, avanzando con movimientos serpentinos sin ayuda de las patas; pero se cansa prontó $y$ pierde del todo la respiracion.

Gosse encontró en el vientre de hembras preñadas cuatro inuevos; algunos que se cogieron en las guaridas del ameiva tenian unos $(1 \mathrm{~m}, 02$ de largo; cran del todo ovales, de color blanco, y con cáscara delgada y fiexible.

\section{EL TARAGIRA - CNEMIDOPHORUS SEX- IINEATUS}

CARACTÉRES. - Los ameivas que tienen dientes páatinos componen esta especie. El taragira es un bonito animal, de unas 12 pulgadas de largo inclusa la cola, que mide 7 . Sobre el dorso pardo oscuro, tomasolado de púrpura, tiene seis estrechas fajas amarillas, tres a cada lado; la parte infe. rior del cucrpo es azulada, menos debajo del cuello que es de un blanco de plata (fig. 20).

DISTRIBUCION GEOGRÁFICA.-II taragira habita la mayor parte de la Amérića septentrional y de México, como tambien la isla de ia Martinica.

USOS, COSTUMBRES $\times$ REGIMEN. - Acostumbra esta especic á fijar su morada en los sitios secos y arenosos, segun asegura Holbrook; y su modo de vivir, que describe el mismo naturalista, es tan parecido al de nuestros lagartos europeos, que creemos ocioso dar mas detalles.

\section{LOS TRAQUIDÉRMIDOS -TRACHXDERMIDAE}

CARACTERES.- Lin lagarto conocido ya por Hernan de\% merece nuestra atencion, porque la estructura de sus dientes ofrece analogias con la de las llamadas culebras foisus, grupo de serpientes que segun sospechas son venenosas, circunstancia confirmada al parecer por la arraigada opinion de los indigenas de que el citado lagarto es venenoso. Hasta ahora, sin embargo, nadic ha podido descubrir glandulas ve. nenosas al disecar este reptil, raro en todas las colecciones, y nosotros lo declaramos por lo tanto del todo inofensivo, á pesar de que, segun Deppe, se le teme en México tanto como a la serpiente de cascabel.

El tronco es recogido, la cola redonda $y$ larga, el tercero y cuarto dedo de los piés anteriores y posteriores son los mas largos de todos; el tambor es visible; las escamas, gruesas, aquilladas ó granujientas, están dispuestas en series trasversales; la lengua se divide en su parte anterior en dos puntas cortas y lisas; los dientes no son huecos en la miz; las fosas temporales tienen un puente óseo membranoso.

\section{LOS HELODERMOS-HELODERMA}

CÁRACTÉRES.-La especie de que se trata es tipo del género de los helodermos, que constituyen con otros varios grupos congenéricos la familia descrita. Los caractéres del género son los mismos de la especic.

\section{EL HELODERMO HÓRRIDO-HELODERMA HORRIDUM}

CARACTERES.-El helodermo hórrido, llamado tam. bien lagarto crustácen, el escorpion de los criollos, el fola-shini de los aztiears, puede alcanzar, cuando es adulto, iuna longitud de $T^{*}, 60$. Por su forma se parece mucho a los varanos y ameivas, pero es de estructura mucho mas pesada y se distingue lo bastante por la cola corta y redonda. La cabeza, plana $y$ con hocico romo, presenta en la coronilla escamas promi. nentes y redondeadas; el tronco y las otras partes están cu. biertos de escamitas en forma de perlas; toda la piel es por lo tanto aspera y granujienta al tacto. Los dientes, cónicos, rectos y puntiagudos, so insertan en el borde inferior de los maxilares, y en cl borde interno de la cara anterior presentan un marcado surco. La piel de la parte superior es de un par. do oscuro ó dé tierra, con manchas pequeñas que varian desde el blanco amarillo al pardo rojo, difriendo segun la edad y las variedades; en la cola se ven unas fajas oscuras en forma de anillos; las regiones inferiores son de un pardo de cuerno con manchas amarillentas.

DISTRIBUCION GEOGRAFICA. - Sumichrast ha completado últimamente por todos conceptos la breve y superficial descripcion de Deppe sobre el helodermo hórrido. Este singular lagarto solo vive, segun el primer observador, en la region occidental de las Cordilleras hasta el Pacífico.

USOS, COSTUMBRES Y REGIMEN.-Este reptil no habita sino en regiones secas, y segun parece, no penetra por su gusto en el agua. Es un reptil nocturno que se mueve lenta y pausadamente, arrastrando el vientre por el suelo cuando ya es viejo, y si es hembra; cuando está preñada. De dia se oculta en agujeros que practica al pié de los árboles 6 debajo de restos vegetales $y$ alli permanece sin moverse con las extremidades recogidas. Por la noche sale de su escon. dite para dar caza a toda clase de animales pequeños, insec. tos sin alas, lombrices, cilopodos, pequeñas ranas, etco, que recoge sobre todo en los senderos del bosque; roba tambien los huevos del leguan, y no desprecia las citadas sustancias aunque hayan entrado en descomposicion. En la estacion lluviosa se le ve con mas frecuencia, pero no asi en los meses de noviembre s junio. Parece, por lo tanto, que tambien se entrega al sueño de verano ó invernal, pues el periodo del calor $y$ de la sequia en aquellos paises corresponde à los meses frios de Europa.

El olor muy fuerte y fétido propio del helodermo hórrido aumenta mucho mas en el período del celo. Cuando se le ir. rita expele una saliva blanquizca y pegajosa, segragada por las glándulas salivales, muy desarrolladas; si sele toca echase de espaldas y se enfurece, corno lo prueba su respiracion apresurada; entonces deja oir un silbido y segrega aun mas saliva que antes. Estas cualidades son comunes á los sapos y otros anfibios, y asi por ellas como por su fealdad, es sin duda objeto de la preocupacion de los indigenas que persiguen al inocente reptil, puesto que no es venenoso. 
CaUtrvida D.-Boersch obtuvo, segun me escribió du. rante su estancia en México, un heloderno hórrido vivo des. pues de haber desterrado el temor general de los indigenas ofreciéndoles una buena recompensa. Cuando al fin lo cogie. ron se lo enviaron en un cajon que contenia fruta, pues de lo contrario, ningun arriero le hubiera llevado. Boersch le dió despues de las frutas crustáceos, pequeños lagartos, yemas de huevo y carne cruda; pero solo comió de esta última $y$ bebió un poco de agua Para reconocer si su mordedura en. venenaba mortalmente, como lo indica la supersticion gene. ral, se intentó irritarle ofreciéndole lagartos; no los tocó, ni tampoco quiso acercarse á ellos, pero mordió el dedo á uno de los observadores que quiso tocarle con la mano, y mas tarde á Boersch mismo. Las heridas de ambos sangraban y dolian mucho, pero se curaron sin accidentes, demostrando por lo tanto la sinrazon del parccer del pueblo.

El helodermo hórrido solo muere, segun Sumichrast, á consecuencia de heridas de arma blanca ó de fuego; pues su dura piel le hace casi invulnerable a todos los golpes. La ir. ritabilidad de sus músculos se conserva por espacio de cua. renta y ocho horas despues de separar la cabeza del tronco. Boersch mató sus cautivos en veinte minutos con cloro. formo.

\section{LOS ZONÚRIDOS- ZONURIDE}

CARACTERES.-Sin hacer mencion de tres familias de lagartos americanos y africanos sobre cuyo género de vida solo tenemos noticias muy incompletas, paso á la descripcion de los zonúridos. Asi se llaman los escamosos en cuyos costados se observa regularmente un repliegue cubierto de pequeñas escamas, el cual empieza detrás de las extremidades anteriores y separa los lados del lomo de los del vientre. Sus formas son las de los lagartos, ó se parecen á las de las serpientes á causa de tener la cola muy larga y las extremidades rudimentarias. Los párpados existen en todas las especies; el tambor está situado cn una cavidad y solo alguna vez revestido de una membrana. Unas escamas grandes en forma de pla. cas, casi siempre aquilladas y dispuestas en series trasversa. les, se corren por el lomo; y la cabeza está protegida por escudos regulares.

En esta familia hay algunas especies que difieren poco de la forma primitiva de los lagartos, pero tambien hay otras que ofrecen gran semejanza con las serpientes. Entre estos dos extremos clasificamos algunos tipos medios, en los cuales el tronco es mas 6 menos prolongado y las extremi. dades mas $\delta$ menos rudimentarias. La gran distancia que media entre estas últimas corresponde a la redondez, y pro. longacion del tronco. Las extremidades, sin embargo, solo presentan en pocas especies el desarrollo completo que ve. mos en los lagartos verdaderos; mientras que en otras son rudimentarias, porque en los piés anteriores, ó en estos y los posteriores, no parecen desarrollados sino trés dedos, ó bien porque los unos faltan del todo y los otros solo están indica. dos por apéndices, $\delta$ ya en fin, porque todos los piés faitan, en cuyo caso estos reptiles se parecen exteriormente á los ofidios. No obstante, siempre encontramos caractéres quue impiden reunirlos en un órden con las serpientes. El crineo se parece tambien al de las especies de formas serpentinas, tanto por las articulaciones de las mandibulas como por estar los dientes soldados. El esternon y la pélvis existen; los párpados son rudimentarios solo alguna vez; la lengua corta, gruesa en la base y mas delgada en la extremidad, tiene una escotadura mas ó menos profunda, pero hay casos tambien en que apenas se distingue. El corazon se halla si. tuado muy arriba, y ambos pulmones están bien desarrollados, etc. Por todos estos caractéres se agrupan los zomúridos con los lagartos, pareciendo séres muy distintos de las ser. pientes.

DISTRIBUCION GEOGRAFICA.-La farnilia, compuesta de unas cincuenta especies, habita el antiguo mundo, pero está representada tambien en América por un género.

USOS, COSTUMBRES Y REGIMEN.-Todos los 7.0 . núridos viven como los lagartos, aunque el género de viỏa de las que se asemejan á las serpientes recuerda las costumbres de estas. Los movimientos de las especies de extremidades rudimentarias son en extremo rápidos; los de las que tienen forma de serpiente, quizás un poco mas lentos que los de la culebra, pero sumamente graciosos; y en general, estos reptiles producen una impresion muy agradable. Todas las espe. cies solo viven en terreno llano; cuando mas, podrán subir por una cuesta, pero no trepando, en el verdadero sentido de la palabra. Toman su alimento del reino animal: las especies mas débiles se contentan con insectos, arañas, caracoles des. nudos, gusanos y otros animales; las grandes persiguen tam. bien á los vertebrados, sobre todo as otros reptiles; y algunas son muy útiles porque matan las serpientes venenosas. I'oco sabemos sobre su reproduccion, mas al parecer no difiere esencialmente de la de los lagartos. Algunas especies son propias para la cautividad á causa de sus pocas exigencias y de la escasa impresion que les produce el cambio de condiciones; consérranse muchos años en la jaula hasta con un alimento sencillo, proporcionándoles tan solo una temperatura siempre igual; se acostumbran pronto al guardian, y son en general muy dóciles; si se les pudiera dejar correr libremente por la casa se harian muy útiles, porque matan los parásitos molestos.

\section{LOS ZONUROS - ZONURUS}

CARACTÉRES.-El primer lugar de los géneros de la familia corresponde a los zonuros, especies que por sus formas se parecen à los cicluros; son de estructura recogida, con cuatro piés, cabeza plana, trilateral y cola gruesa, de regular longitud; la parte superior del cucllo y del lono está cubierta regularmente de grandes escamas cuadriláteras, dispuestas en series trasversales; las regiones inferiores presentan grandes escudos planos; la parte superior de las extremidades se halla revestida de escamas aquilladas y sobrepuestas, y la cola de escamas espinosas. Los maxilares están provistos de unos dientes pequeños, cónicos y obtusos, casi iguales entre st; cuéntanse siete en el intermaxilar, diez y ocho á cada lado de la mandibula superior, y veinte en cada uno de la inferior. La lengua, redondeada y plana, se encierra en su base en una especie de estuche, y está provista en la extremidad de una ligera escotadura.

\section{EL ZONURO CORDILO-ZONURUS COR- DYLUS}

CARACTÉRES. - El zonuro cordilo es un escamoso de $0^{\circ}, 25$ de longitud $y$ de un color muy variable. En la mayor parte de los individuos el lomo y la cola son de un amarillo de naranja, la cabeza y los piés del mismo color mas claro; las regiones inferiores son blancas; en otros, las partes superiores son de un pardo negruzco, y en muchos parda, con fajas, etc.

DISTRIBUCION GEOGRAFICA.-Este reptil (iig. 30) habita el cabo de Buena Esperanza, extendiéndose por el nonte hasta Sierra Leona. 
USOS, COSTUMBRES Y REGIMEN. - A. Snith nos da escasas noticias sobre el género de vida de esta especie; todos los zonuros cordilos habitan las regiones pedregosas, y cuando pueden, eligen siempre las pendientes escarpadas, dificilmente accesibles. Vagan por aqqui bastante lentamente en busca del alimento y del calor hasta que cualquier peli gro les asusta y lés obliga á refugiarse en su escondite; aunque este último sea accesible, es dificil apoderarse de esos reptiles, porque saben agarrarse de tal modo, que al cogerlos se tiene mas á menudo la cola que el animal mismo en la mano.

\section{EL FALSO CORDILO-ZONURUS MICROLE- PIDOTUS}

CARACTERES. - El falso cordilo (fig 31 ) es el mayor de sus congéneres: tiene la cabeza deprimida, $y$ á lo largo del lomo un surco estrecho y profundo; la cola, tetrágona y un poco deprimida en su raiz, se aplana, por el contrario, de derecha á izquierda en el resto de su extension: las regiones cervical y dorsal están cubiertas de peq̨ueñas escamas casi ovales. Los repliegues que forma la piel por delante de cada espaldilla son muy marcados, y bajan hasta el borde del pe. cho, donde forman un verdadero collar anguloso, guarnecido de una docena de escamas exágonas. En la abertura de la cloaca hay uno ó dos tubérculos escamosos á cada lado de la base de la cola. El color de la parte superior del cuerpo es de un pardo mas ó menos oscuro que tira al negro; los lados del cuello, del tronco y de la cola están cortados trasversal. mente por fajas de un tinte anaranjado, amiarillento 6 verdo. so, las cuales blanquean cuando se conserva ol animal en al. cohol. La parte superior de la cabera presenta una mezcla de negro, $y$ las otras regiones inferiores de amarillento.

DISTRIBUGION GEOGRÁFICA. - Esta especie habita en el cabo de Buena Esperanza y tambien se encuentra en Sierra Leona.

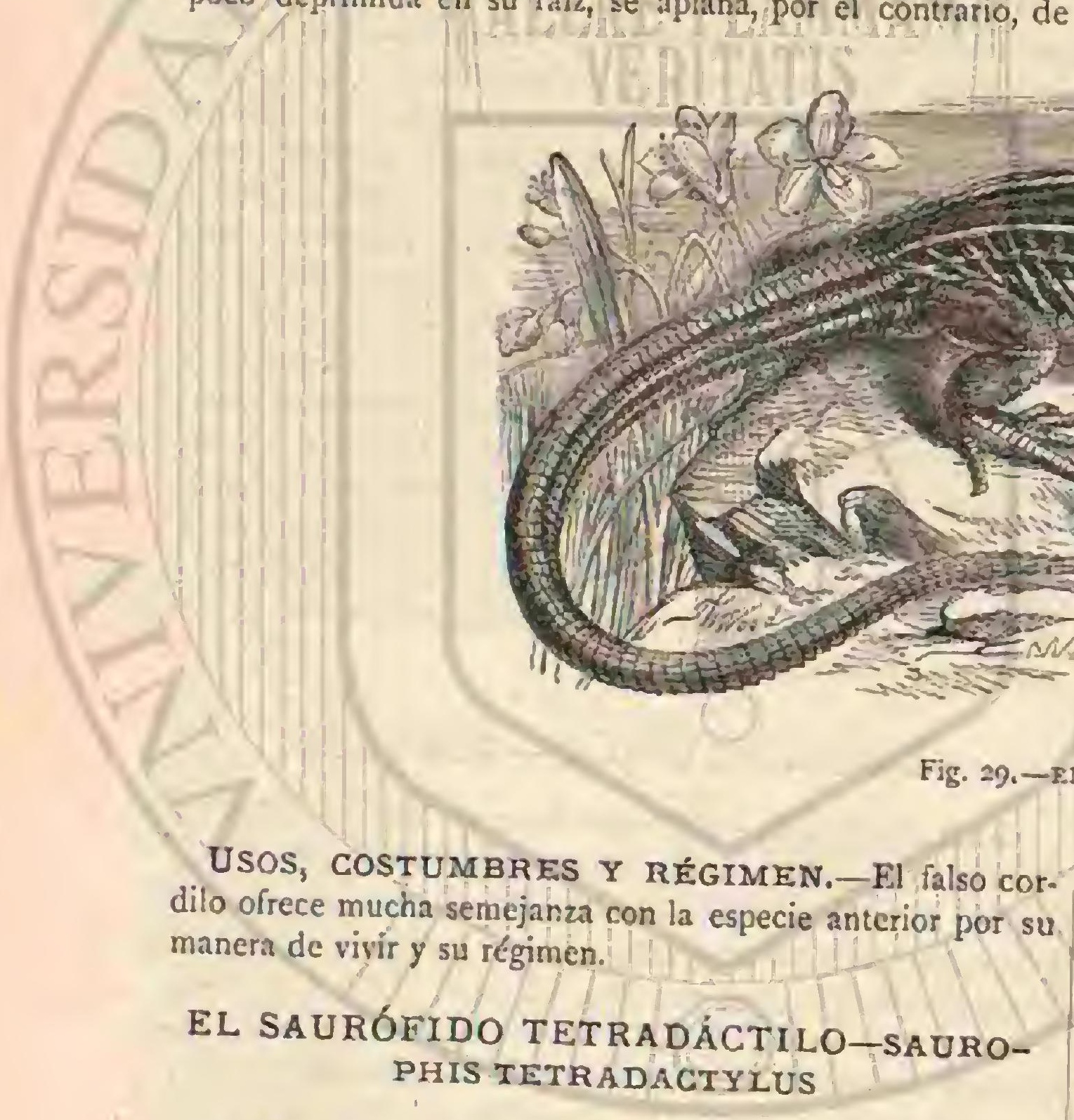

CARACTÉRES.- Forma esta especie única el género de los saurófidos, y se distingue por su tronco prolongado y serpentiforme, con las extremidades debiles y cortas, teniendo tan solo cuatro dedos cada una. La hendidura ó surco lateral, se extiende desce el cuello hasta el orificio de la cloaca. Tiene la parte superior de la cabeza amarilla con puntos pardos, y cuatro manchas mas oscuras, de las cuales dos debajo de los ojos y dos un poco antes de los oidos; el lomo es de un tinte pajizo, formando una especie de enrecolor indicado, las escamas del dorso tienen los bordes del Los saurófidos llegan á medir unos $l^{*}, 40$ de largo oscuras.

USOS, COSTUMBRES Y RÉGIMEN. - Todo lo que sabemos acerca del modo de vivir de estos reptiles, es que habitan el Africa del sur y con preferencia en los sitios donde abundan las plantas herbaiceas, $y$ que en sus costumbres se parecen bastante à nuestro lucion comun, por lo que es considerado como serpiente por los indigenas.

\section{LOS PSEUDOPOS-PSEUDOPUS}

Este género está representado por la especie siguiente.

\section{EL CHELTOPUSIC-PSEUDOPUS APUS}

CARACTERES. Fl cheltopusic se distingue por los siguientes: el tronco se parece al de una serpiente; es largo, cilíndrico algo comprinido lateralmentey casi del inismo grueso del cuello; la cabeza comprimida y cuadrangular, á corta diferencia tan gruesa como larga, y con el hocico prolongado y puntiagudo; la cola un tercio mas larga que el cuerpo, adelgazándose hasta terminar en punta. No hay vestigios de las patas anteriores, $y$ las posteriores están solo representadas por un pequeño muñon. Los ojos tienen la pupila redonda y párpados completamente desarrollados; los oidos, que forman dos pequeñas hendiduras longitudinales, están bien marcados. Cubren la cabeza escudos adheridos á los huesos; las escamas que protegen el tronco son mas ó menos romboida. les, y dispuestas en filas regulares, aquilladas las de la parte superior y lisas, exceptuando en la cola, con el borde posterior algo levantado, las que revisten la parte inferior. Los surcos longitudinales son muy visibles y enipiezan detrás de los oidos, terminando en el orificio de la cloaca. Los dientes, gruesos, redondos y obtusos, son en numero de veintiocho en la mandibula superior y veintiseis en la inferior. El cheltopusic tiene un pulmon mucho mayor que el otro, a semejanza de los ofidios. Su coloracion es, por lo general, un pardo rojizo y á veces amarillo de paja, apareciendo siempre la cabeza de un tinte mas claro que el resto del cuerpo; las partes abdominales tienen un color de carne sucio. Los individuos viejos aparecen despues de mudar la piel, de un color rojo de cobre en el dorso; en la cabeza toma un tinte. 
verdoso. Los jóvenes tienen manchas y fajas pardas sobre fondo gris. La longitud total del cheltopusic pasa algunas veces de un metro; los muñones de las patas posteriores miden unos $0^{\circ}, 02$ de largo (fig. 33).
DISTRIBUCION GEOGRAFICA. - Pallas descubris en los valles sombrios de las estepas de Naryn y Kuman, à orillas del Volga, un zonúrido llamado por los rusos cheliopusic, como todos los animales que se parecen á las serpientes; y

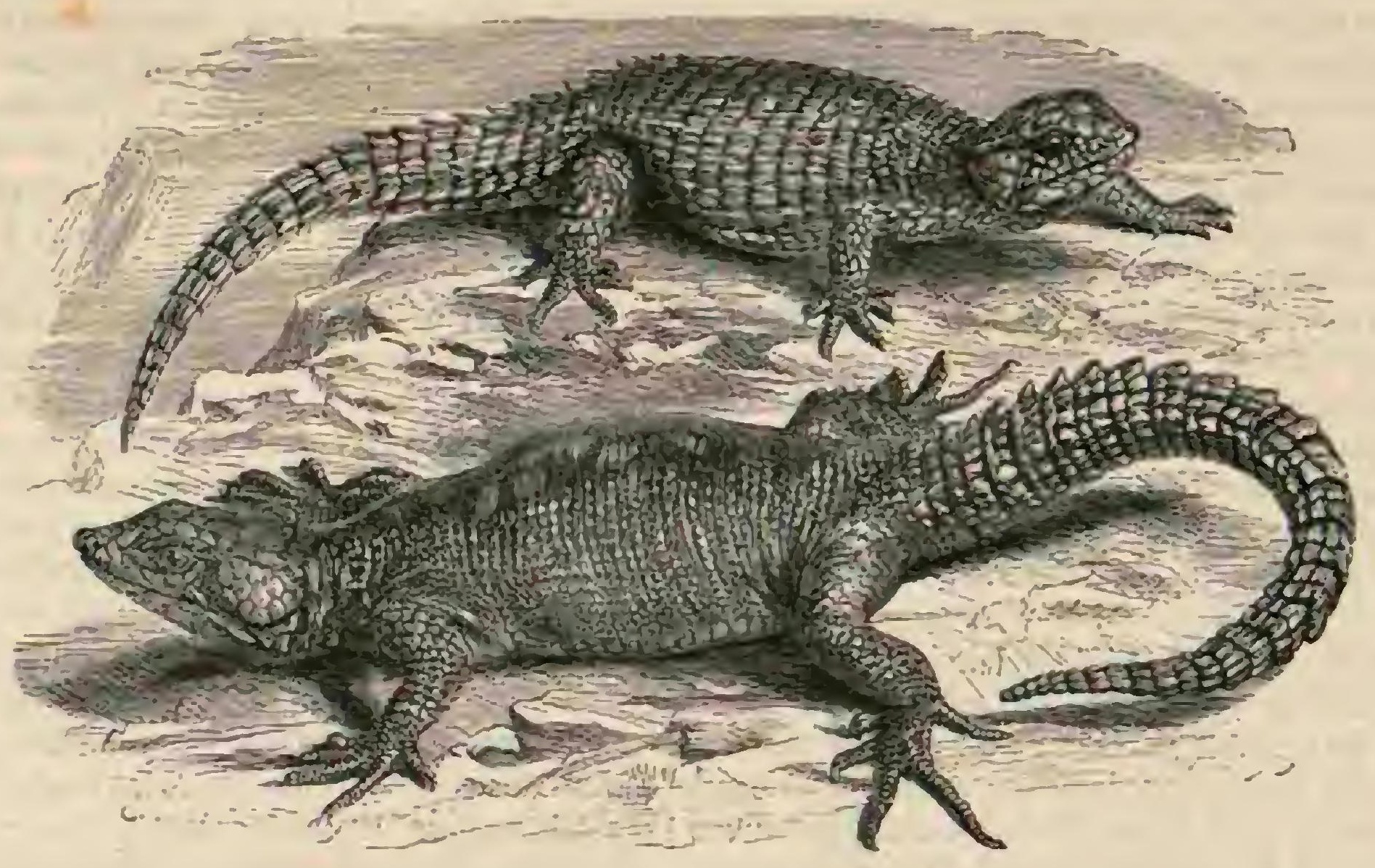

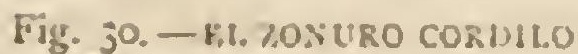

Fig. 31. - EL HAlso CORI)H.O

Inas tarde le encontró á orillas de los rios 'Terek y Sarpa. Otros naturalistas le observason en el sur de Siberia, en Hungria, Istria, Dalmacia, Grecia, Asia Menor, Siria, Palestina y

hasta en Africa. Erber le vió con mas frecuencia cerca del lago de Bocaguazza, no léjos de Zara, en Dalmacia, y tam bien en todo el resto del pais.

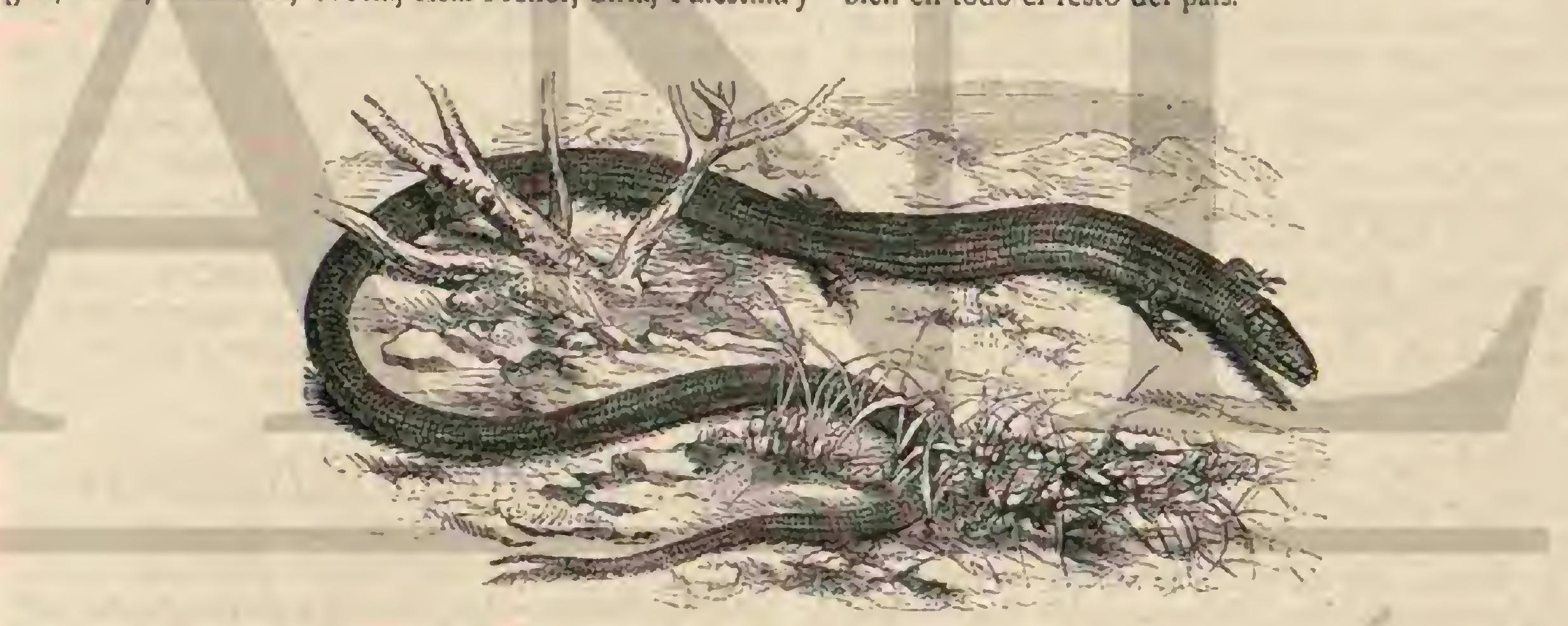

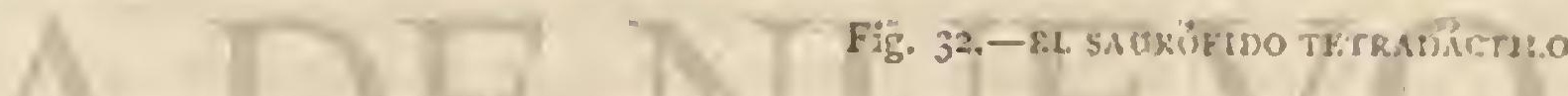

USOS, COSTUMBRES Y REGIMEN. - Los valles poblados de espesos arbustos son la residencia favorita del cheltopusic, y en ellos encuentran tan excelentes guaridas, que á pesar de su taman̄o no es muy fácil descubrirlo, tanto mas cuanto que sabiendo que no puede defenderse suele huir al acercarse un hombre. Todos los obserwadores quele vieron están unánimes en prodigarle elogios; es un reptil de los mas útiles porqque se alimenta principlalmente de animales dañnos; come con preferencia ratones y caracoles, estos últimos con la concha, segun Erber; pero tambien persigue á las wiboras, las mata $y$ las devora sin temor de los dientes vene. nosos, inortales para oiros lagartos. Cierto dia Erber puso un cheltopusic en la jaula de una vibora comun, $y$ los dos reptiles tomaton una actitud amenazadora, siendo asi que ambos se habian mostrado antes indiferentes al ponerlos en тохо $\mathrm{V}$ presencia de otras serpientes. Como nuestro observador solo tenia un cheltopusic no çuiso exponer su vida y le alejó, pero mas tarde parece haber hecho otros experimentos, pues efl es quien nos hizo conocer al citado zonúrido como uno de los mas lítiles exterminadores de viboras. Por mas que el cheltopusic sea un reptil voraz, condúcese con el hombre con una inocencia y docilidad que siempre le cautivan el cariño del aficionado; no muerde nunca, y por lo tanto no se le ha de témer; hasta parece que al cabo de algun tiempo de cautividad llega á demostrar cierto apego a su guardian, y segun Erber, podria hacerse de él un animal doméstico muy recomendable. Difiere mucho de otros escamosos por su agilidad; siempre en continuo movimiento, serpenieando con mucha gracia y sin cesar por su jaula; registra minuciosamente con su lengua todas las hendiduras entre las piedras y el 
musgo; y cuando se le deja libre en la habitacion, comienza al punto su cacería de parásitos de toda clase. Ante todo per. sigue á las repugnantes cucarachas que abundan tanto en muchas habitaciones; las busca en todos sus escondrijos y sigue su pista hasta el interior de la chimenea.

Interesábame obtener mas datos sobre el cheltopusic, y no habiendo recibido ni visto aun la descripcion de la vida en cautividad de este animal, hecha por Guenter, $y$ que en su lugar reproduciremos, me dirigi à Erber rogándole que me comunicase sus observaciones; en contestacion recibi el si. guiente relato, que en efecto nos da á conocer algo exacto sobre la vida en libertad de los pseudopos.

El cheltopusic, que es mi reptil favorito por su utilidad y por lo inofensivo para con el hombre, llama tanto la atencion del observador cuando lo tiene cautivo, como en libertad. Si se le visita á menudo en los sitios que escoge para su mora. da, llega á acostumbrarse de tal modo al hombre, que se deja coger por este sin oponer la menor resistencia, ta única arma que emplea contra nosotros, cuando se le sorprende brusca. mente, es el ano; pues valiéndose de la extraordinaria facilidad con que puede revolverse, tan laego como se siente co. gido, despide un chorro de liquido pestilente, que moja á su agresor, desde los piés á la cabeza. Pero toda su resistencia, siendo verdaderamente extraordinario que no emplee contra el hombre sus fuertes mandibulas: quien ha visto, como yo, la facilidad con que el cheltopusic rompe con sus dientes en dos pedazos la vibora escamosa, debe ex. trañar que no haga uso de csta fuerza en propia defensa contra nosotros.

- Tiene este reptil un modo muy especial para matar los ratones, topos, etc; una vez hecha la presa se revuelve con ella con extraordinaria velocidad, hasta q̨ue el pequeño animal cae completamente aturdido y falto de fuerzas: entonces le aplasta la cabeza, empieza de devorarlo con bastante lentitud, pues solo lo hace á pedazos y no es su dentadura bastante aguda para cortar con facilidad la piel y los músculos. El cheltopusic es un vecino bastante peligroso para los pequeños lagartos, i los que arranca la cola, despreciando el resto de su cuerpo que parece no serle tan apetitoso.

REPRODUCCION. - Dice el mismo naturalista acerca de este particular: «urante la época del apareamiento, se muestra el cheltopusic muy ardiente, olvidándose de todo lo que le rodea, siendo bastante fácil entonces observarlo $y$ hasta cogerlo. Desde un escondite, pude observar como el macho mordia cuantos objetos tenia á su alcance. La union de los sexos es tan intima, merced al fuerte 5 dentado doble pene del macho, que es imposible separar los individuos, antes de terminado el acto, sin causar grave daño á aquel. Ta hembra desova entre los arbustos ó la hojarasca. Los pequeños se diferencian bastante de los adultos, y parecen necesitar vatios años hasta adquirir el aspecto de aquellos; de las observaciones que he verificado, creo poder asegurar que. el cheltopusic no alcanza todo su desarrollo hasta los cuarenta ó sesenta años.

CAUTIVIDAD.-Antes que Erber, Guenter describió la vida en cautividad de este reptil segun observaciones hechas en la coleccion de serpientes del jardin zoológico de Re. gent's.Park: «Una de las jaulas contiene reptiles que por lo visto están mejor en la casa que todos los demás habitantes, porque la temperatura parece la conveniente para ellos; estos reptiles son cuatro cheltopusics. Se distinguen entre todos por ser los mas voraces; basta el ruido mas ligero para ha. cerles salir por debajo de la arena 6 de la alfombra, donde por lo regular se ocultan; entonces alargan sus cabezas y mueven sus ojos vivaces en todas direcciones para ver si ha llegado la hora en que se da el alimento. Cuando se les en. seña un pequeño objeto blanco, que desde léjos pueda parecerles un raton blanco, su alimento ordinario, excitanse mucho, salen de su escondite y recházanse uno á otro cuan. do se estorban en el camino. Solo una vez por semana se les da alimento y esto basta perfectamente, pues cada vez comen de un modo increible, tanto que no he visto nunca á uno de ellos satisfecho. Precipitanse sobre la mano del guardian que tiene una docena de ratoncillos ó de aves, y arrebátanlos antes que tenga tiempo de soltarlos. Sucede entonces á vecés que dos cheltopusics cogen el mismo raton: ninguno suelta la presa; el uno tira por la derecha y el otro por la izquierda; el uno se levanta para quitar con el peso de su cuerpo la víctima al otro; pero es inútil; $y$ siguen tirando hasta que el raton se divide en dos partes: entonces, cada cual devora la suya con la mayor prisa posible. Sin embargo, los dos han perdido con esta porfia, pues mientras tanto, sus compañeros han hecho tabula rasa; pero cuando uno de ellos no ha devorado aun del todo su presa y sobresale una parte de la boca, los otros le persiguen, y la lucha puede comenzar de nuevo, tomando parte en clla hasta tres individuos. Mu. cho tiernpo despues de haberselo comido todo, buscan aun por la jaula para ver si ha quedado algo y apdyanse con. tra el vidrio para observar los movimientos del guardian, que s menudo accede á los ruegos de los espectadores dando una segunda conida. El cuadro tiene bastante semejanza con la escena que ofrece una familia de perrillos ó zorros que deben repartirse por sí mismos el alimento, y que nunca dejan de ladrar mucho, como lo haria este lagarto si la naturaleza le hubiera dotado de voz. El cheltopusic coge su alimento como un lagarto, mascándole con fuerza para romper los huesos, y lo devora déspues entero.

Yo he cuidado diltimamente muchos cheltopusics y puedo confirmar en todos conceptos las observaciones excelentes de Guenter y de Erber. Los movimientos, sin embargo, no me parecieron tan graciosos como dice el relato de este últi. mo, pues el cheltopusic carece de la elasticidad de la ser. piente y de la agilidad de los lagartos; de modo que sus movimientos parcen, segun dice tambien Leydig, bastante torpes, y sus evoluciones pesadas. Debo añadir que se puede encerrar juntos a varios cheltopusics de todas edades sin temor de riñas ó de que los fuertes maten y devoren á los débiles.

\section{LOS TAQUIDROMOS-TAGHY- DROMUS}

CARACTÉRES. - Los individuos de este género se ca. racterizan por iener la lengua medianamente extensible, $y$ dividida en su extremidad en dos pequeños hilos aplanados con superficie que presenta pliegues papilosos; el paladar es unas veces dentado y otras no; los dientes intermaxilares cónicos y sencillos; los maxilares comprimidos; los párpados existen; tienen un collar escamoso dentado; el vientre cstá guarnecido de escamas lisas ó carenadas; la cola es larga y tetrágona.

\section{EL TAQUIDROMO DE SEIS LISTAS-TA- CHYDROMUS SEXIINEATUS}

CARACTÉRES.-Esta especie (iig: 34) tiene las placas parietales oblongas; en el lomo hay cuatro series de grandes escamas casi cuadradas y muy carenadas, como lo son tambien las ventrales. Las formas de este reptil son esbeltas; la cabeza termina por un hocico bastante puntiagudo; la cola es de dos á cuatro veces mas larga que el cuerpo. El lomo es de un tinte 
aceitunado, $y$ en cada uno de sus lados desde el ángulo del occipucio hasta la parte lateral de la base de la cola hay una bonita lista blanca, situada entre dos negras; las otras regiones de las partes laterales del cuello y del tronco son de un tinte azulado con reflejos amarillos; la parte inferior de la cabeza y del cuello, el pecho y el vientre son del mas puro blanco de nácar; la cola, de un color aceitunado por lo regular, presenta otras veces un color cobrizo briliante.

DISTRIBUCION GEOGRÁFICA.-EI taquidromo de seis listas existe en la China, en Cochinchina y en Java.

\section{LOS OFIOSAUROS-OPHIOSAURUS}

CARACTERES. - Los ofiosauros, representados por una sola especie, se parecen mas aun ấ las serpientes que sus otros congéneres, porque en ellos no se ve ringun vestigio de los piés posteriores $y$ solo en el esqueleto puede observarse el hombro y la pélvis. Sin embargo, los párpados movibles y el tambor, bien marcado aun, asi como el repliegue en los costados, caracterizan tambien á esta especie exteriormente como escamoso.

\section{EL OFIOSAURO VENTRUDO-OPHIOSAURUS VENTRALIS}

Caractéres. - Además de los indicados para el gé nero, esta especie se distingue por tener la dentadura compuesta de quince dientes superiores y diez y seis inferiores, cilindricos, encorvados hácia atrás, con punta sencillamente cónica; los dientes palatinos son numerosos; el color varia mucho; algunos individuos son de un verde vivo con manchas negras; otros negros con fajas blancas, y algunos pardos con manchas oculares. La longitud es de un metro (fig. 35).

USOS, COSTUMBRES Y REGIMEN.-Pocos datos tenemos acerca del modo de vivir de los ofiosauros, y esos los debemos en su mayor parte á antiguos naturalistas; pues los modernos parecen haberse ocupado muy ligeramente de este genero de los zonúridos. Catesby dice que el ofiosauro prefiere las localidades muy secas, que le ofrezcan al propio tiempo seguros escondrijos: cstab!ece su guarida en las cavidades de los troncos de los árboles, en las raíces seculares á flor de tierra y en otros sitios parecidos. Sin embargo, abunda igualmente este reptil en los bosques ricos en plantas meno. res, lo que se explica a causa de la facilidad con que en. cuentra alli su alimento que consiste en insectos y reptiles de menor tamaño, especialmente jóvenes escamosos. Aparecen los ofiosauros á principios de la primarera, mucho antes que las verdaderas serpientes.

CAZA. - Es muy dificil apoderarse de este bonito animal porque merece con mucha razon su nombre aleman de liscion rie widrio, es decir que se rompe con suma facilidad al contacto. Say pretende que sin tocarle se puede quebrar su cola, porque basta una sola contraccion para romperla; otros observadores están conformes en que el mas ligero golpe de látigo basta para partir el tronco, siendo hasta casi imposible coger un individuo entero. En efecto los ejemplares sin mutilar son verdaderamente raros en las colecciones; esta debilidad es quizás tambien la causa de que raras veces ó nunca se vea a este gracioso reptil cautivo. Yo, por lo menos, no he oido hablar de ninguno.

\section{LOS CAMESAUROS- CHAM ESAURA}

CARACTERES. - Este gennero tiene por único representante al Camesauro serpentino (fig. 36 ), que se distingue por los siguientes caractéres. Fl cuerpo es excesivamente raquítico y prolongado: Ia piel no forma en los costados repliegues 6 surcos longitudinales, segun se observa en la mayor parte de los grupos genéricos de la familia; está provisto de patas, pero tan cortas y endebles que probablemente no le servirán al reptil para trasladarse de un punto a otro, como no sea en algunos casos particulares; muérese en un todo como las serpientes por medio de ondulaciones laterales que puede producir el cuerpo en la totalidad de su extension. Ias pequeñas patas del camesauro, en número de cuatro, parecen hojas de cortaplumas, en cuya extremidad hay una una puntiaguda, muy corta; las posteriores, algo comprimidas, presentan por debajo, junto a su nacimiento, algunos diminutos poros tubulosos. El tronco y la cola tienen forma algo tetrágona; esta tiltima, en extremo afilada posteriormente, figura por mas de tres cuartas partes en el largo total del reptil. El paladar es perfectamente liso; los dientes iguales, sencillos, cónicos ó sub-cilindricos; se cuentan unos cuarenta y ocho en el contorno de la mandibula superior y reintidos á lo largo de cada rama de la inferior. Los párpados se parecen á los de la mayor parte de las especies de la familia de los calcidianos; el inferior no es trasparente. El número de placas cefálicas superiores entra en la regla comun. En cuanto al color, el cráneo, el lomo, la parte inferior del cuello y la de la cola son pardos; pero estas partes tienen su linea media recorrida por una estrecha faja de un tinte lconado que se extiende, palideciendo un poco, por los lados y las regiones inferiores del cuerpo. Tal es, al menos, la coloracion de los individuos conservados en alcohol.

DISTRIBUCION GEOGRÁFICA.-El camcsauro serpentino es originario del Africa del sur; los ejemplares conocidos proceden del cabo de Buena Esperanza.

USOS, COSTUMBRES Y REGIMEN.-No podemos decir nada seguro sobre el particular, por no ser bien conccido el género de vida de este reptil.

\section{LOS ESCINCOIDEOS- SCINCOIDEA}

CARACTERES. - Ios escincoideos, familia muy rica, pues cuenta unos sesenta géneros y hasta trescientas especies, tienen formas tan variadas como los zonúridos, y demuestran que constituyen los tránsitos sucesivos de los lagartos á las serpientes, asi por la atrofia de sus extremidades como por la prolongacion del tronco. Las piernas, siempre cortas, quedan reducidas á dos en algunas especies; en muchas están atrofiadas, y en varias, por último, faitan del todo. Los dientes se insertan con sus taices en el borde interior del surco dentario; la lengua es corta, de dos puntas ó escotada, escamosa del todo ó en parte; la oreja está casi siempre visible, aunque hay especies que la tienen cubierta por la piel; los ojos se hallan provistos de párpados; el infe. rior, mas grande, puede estar perforado en el centro $\delta$ tener una piel trasparente que forma una especie de abertura. $\mathrm{La}$ cabeza está cubierta de escudos regulares; el lomo de esca. mas sobrepuestas en figura de pentágono; otras semejantes protegen el vientre y los costados; en estos últimos falta el repliegue; los poros de los muslos y de las ingles no existen.

DISTRIBUCYON GEOGRÁFICA,-El área de disper. sion de los escincoideos es muy extensa; habitan todos los continentes, desde el extremo límite de la zona templada hasta el Ecuador; abundan sobre todo en la Nueva Holanda, en Africa y en América; pero tienen pocos representantes en Europa. 
USOS, COSTUMBRES Y REGIMEN. - No conocemos aun bastante su género de vida, lo cual es de sentir mucho, pues las pocas especies que podian observarse algo detenida. mente revelan facultades tan particulares como interesantes.

En general podemos suponer que todos los escincoideos están mas ó menos obligados á vivir en el suelo, y que solo por excepcion trepan, pero aun entonces muy limitadamente; en cambio poseen un don de que carece la mayor parte de los demás escamosos: pueden avanzar por debajo de la su. perficie de la tierra con la agilidad del topo, aunque no con su fuerza. Casi todas las especies conocidas fijan su residen cia en sitios secos, y temen 6 cvitan el agtia, aunque puede suceder que se les encuentre en la costa del mar junto á la linea marcada por la alta marea. Viven con preferencia alli donde una arena fina cubre en gran extension el suclo; asi como en terreno pedregoso $\mathrm{y}$ en medio de las hendiduras de las rocas, ó ya en muros agrictados y otros sitios seme. jantes; pero pocos son los que buscan su refugio y alimento en las mismas grietas ó hendiduras; penetran escarbando en la arena y se mueven a flor de la superficie con una rapidez admirable. Su tronco, cubierto de escamas lisas y mas ó me. nos cónico, sus piernecitas cortas y atrofiadas, y las ventanas trasparentes de los párpados inferiores, permitenles efectuar este trabajo de minero, y solo se comprende su indole, si asi podemos decir, cuando se han observado sus usos y costum. bres. En una jaula ordinaria, cuyo suelo está cubierto de una delgada capa de arena ó de musgo no se pueden notar tales movimientos, pero si se les concede major espacio, ex. teudiendo sobre el piso una capa de seis, ó mejor aun, de diez centímetros de arena fina, se verá con la misma sor.

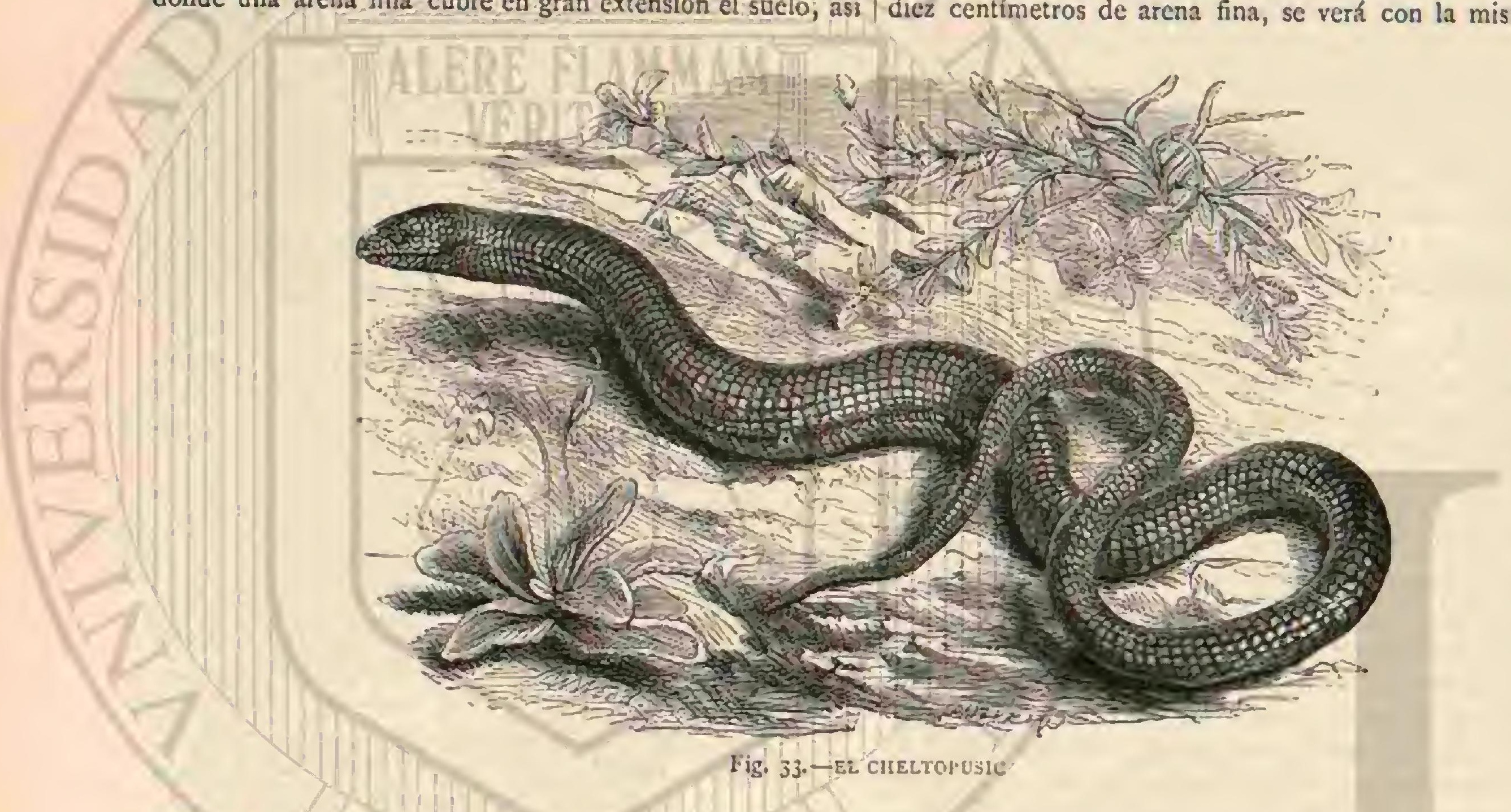

presa que yo experimenté al observar gongilos cautivos (gon gylus ocillatus), que al punto desaparecen en aquella capa de arena, sumergiéndose verdaderamente en ella y pene. trando a una profundidad variable en todas las direcciones. Estos movimientos, sobre todo los horizontales, se efectúan con tal ligereza y rapidez como los de un lagarto no asustado ó perseguido al correr por el suelo. Si estando los escincoi. deos cubiertos de arena, aunque no tanto que no se pueda reconocer bien su marcha por el movimiento de aquella, se les echa una golosina, como por ejemplo gusanos de harina, acércanse al punto á la presa, se elcvan hasta la superficic, tocan el gusano algunas veces con la lengua, que casi siempre es entonces la única parte visible de ellos, alargan despues rápidamente la cabecita en la arena, devoran la víctima y salen entonces completamente de su elemento $\delta$ bien reti ranse con la misma rapidez con que aparecieron. Despues de estas observaciones, indicadas ya antes por pruebas aná. logas, pero no minuciosas, es muy razonable suponer que los escincoideos proceden, por términa medio, del mismo modo, efectuando sus cacerias subterráneamente contra toda clase de animales pequerios, desde el mamifero y el ave hasta el gusano. Es posible que tambien les resulten otras grandes ventajas de su destreza, inferior al parecer á la agi. lidad de otros escamosos: podemos suponer que las grandes especies de estructura pesada que en la jaula aceptan la carne cruda sin grandes cumplimientos, devorándola con ansia, podrán acercarse asi á los veriebrados, no solo sin ser vistos, sino tambien sin infundir sospecha, para cogerlos bruscamente por debajo, por cuyo medio pueden obtener su alimento diario con mucha mas facilidad de la que se su. pondria al juzgar superficialmente por sus formas. $\operatorname{Sin} \mathrm{cm}$. bargo, no debo alejarme del seguro terreno de la observacion, debiendo advertir que este último aserto solo se funda en suposiciones, y no en hechos probados. Los gongilos, asi como los luciones y los eslizones, de que pronto nos ocuparemos, $y$ tambien una especie de la familia propia del centro de América, descrita por Hosse, demuestran, por lo demás, que los escincoideos saben orientarse tambien en la superfi. cie del suelo.

- Muy poco sabemos aun sobre su modo de reproducirse; pero al menos se ha reconocido que excepto una sola especie, todas las observadas hasta aqui son viviparas y no ponen por lo tanto hueros.

El género de vida de estos reptiles, tan distinto por mu. chos conceptos, habrá sido sin duda la causa principal de que los antiguos egipcios, obsersadores sagaces que tanto se complacian en la adivinacion, embalsamasen cuidadosamente el escincoideo, colocándole juntó á sus momias en pequeños féretros graciosamente esculpidos y que en su tapa presentaban la imágen del animal. Es posioble que la especie esfe. nops de cuna (sphenops sapistratus) de los naturalistas, se tuviera entonces por oficinal, como mas tarde otra congenérica de la cual hablaremos á continuacion. Hoy solo vemos en todos los escincoideos unos séres mas ó menos inofensi. 
vos y útiles, $y$ algunos de ellos interesantes en cautividad; mientras que los beduinos del desierto y de las solitarias estepas de Siria y Palestina, que les dan el nombre caracte. ristico de apeces de la arenas, los persiguen con afan para comer su carne blanca, tierna y sabrosa, que les agrada mucho, aunque el devoto recitador del Coran la considera como impura.

Cautividad. - Los escincoideos cautivos son muy gracicsos; la mayor parte de los que se cuidan en estrecha prision consérvanse muy bien, se acostumbran pronto a la perdida de su libertad, familiarizandose tambien con su guardian hasta cierto punto; apenas dan qué hacer, y nos divierten por sus recomendables cualidades; de modo que solo podemos sentir que no lleguen á nuestros mercados mas reptiles de esta especie, y sobre todo las grandes.

\section{EL ESCINCO OFICINAL-SCINCUS OFFICI- NALIS}

Un escincoideo, el escinco oficinal, tipo del género de los escincos (scincus), que solo se compone de dos especies, y de los grupos congenéricos tambien de una sub-familia indepen. diente (scincina), adquirió mucha fama en la antigüedad y la ha conservado largo tiempo.

CARACTERES. - El escinco oficinal es un escamoso de estructura muy recogida con extremidades cortas; los cuatro piés tienen cinco dedos desiguales en longitud, separados hasta la base y provistos en sus lados de una especie de fran. jas; la cola es cónica; la cabeza cunciforme en los lados; la mandibula superior mas larga que la inferior y un poco ob. tusa; las escamas son mas anchas que largas, redondeadas,

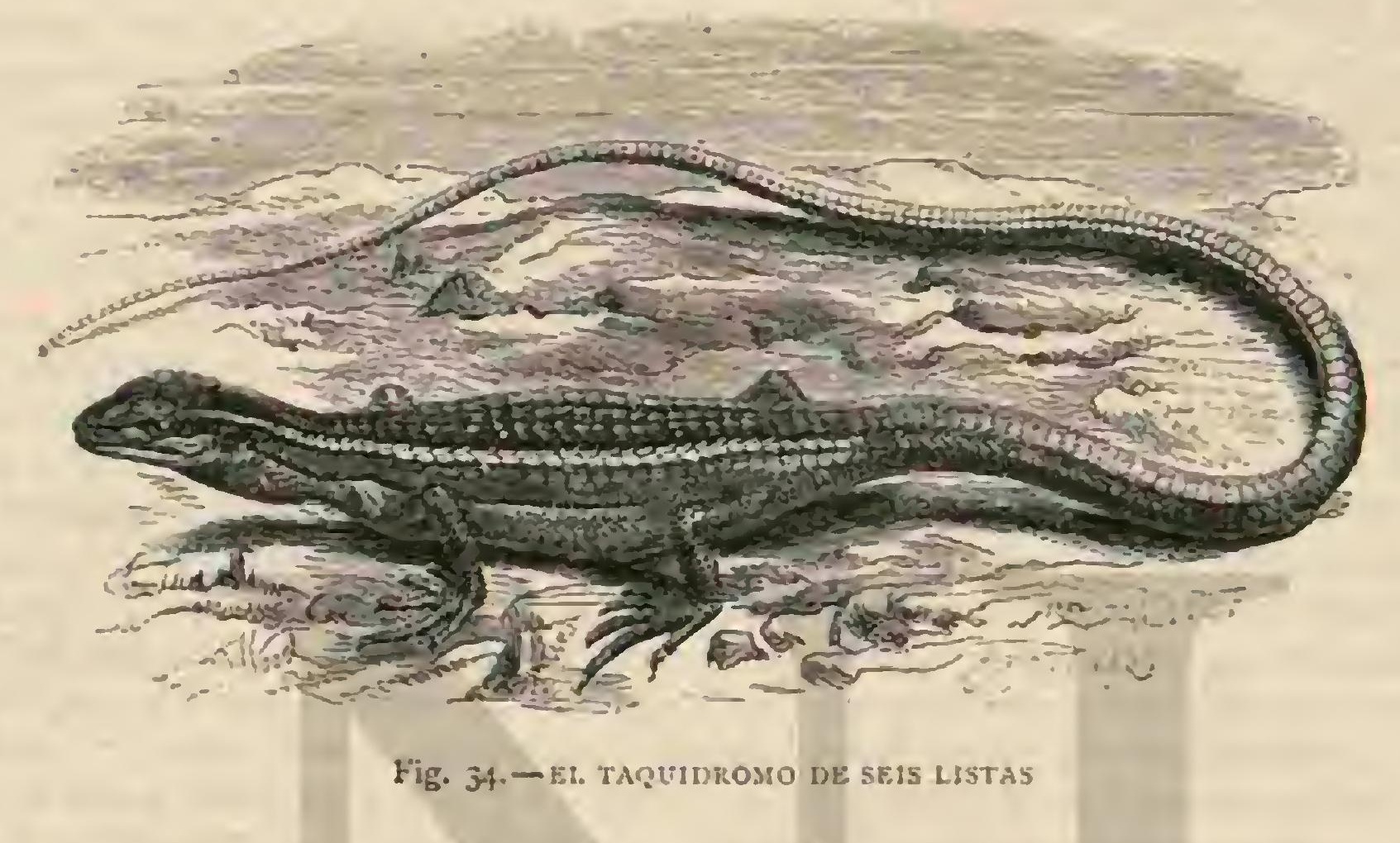

lisas, brillantes y de color gris, con una linea mas clara. En el tronco corren varias fajas trasversales que en el animal vivo son de un color violeta y en el individuo muerto negras. Las regiones inferiores son de un solo color verde sucio. Iil macho difiere por su mayor tamaño y por tener unos puntos negros en los hombros y en los costados; la hembra es de un solo color de arena. Los escincos oficinales adultos alcauzan una longitud de 1$)^{m}, 1_{5}$ (fig. 37).

DISTRIBUCION GEOGRÁFICA.-Bruce refiere que el escinco oficinal se encuentra en increible número en las regiones de Siria limitrofes de Arabia y que una vez vió en el gran patio del templo del Sol de Balbeck muchos miles de individuos que cubrian el suelo de aquellas ruinas; algunos dormian, mientras que los demás retozaban á los ravos del sol. No hay sin embargo seguridad de que el escamoso cita. do por el viajero fuera verdaderamente el escinco, pues pare. ce que su área de dispersion se limita al Africa. Aqui habita en el norte, desde el mar Rojo hasta la costa del Ailántico. No escasea en Egipto, la Nubia y Abisinia, mas no parece muy comun en el desierto de Sahara: además se le ha obser. vado s. orillas del Senegal.

USOS, COSTUMBRES Y REGIMEN.-LLa carne de estos reptiles, dice Gessner, se emplea para algunas medicinas muy eficaces; mézclase tambien con los remedios para com. batir las calenturas intermitentes, y se dice que tiene gran virtud para cxcitar la sensualidad. Este reptil, reducido à ceniza, sirve para hacer cierto ungïento con vinagre ó aceite, el cual se emplea para privar de toda sensibilidad los mien. bros que se deben amputar. I a grasa se emplea tambien como estimulo erótico; y para el uso interno utilizase la hiel, mezclada con miel, porque es una medicina muy buena para cierta enfermedad de los ojos. Los excrementos, que tienen un gusto en extremo agradable, son de color blanco y se lia. man en las farmacias crowúblea: empléanse para embellecer el rostro, quitar las manchas y curar las pústulas.

Una consecuencia natural de esta supersticion, que aun hoy dia predomina en algunos mahometanos, era la tenaz persecucion contra este escincoideo: cogianse miles de individuos y se hacia un importantísimo comercio con sus cada. veres, secados $\delta$ reducidos 1 polvo. A pesar de eso sabemos muy poco aun sobre el género de vida de este reptil. Alejan. dro de Lefebrre, que habia visitado el oasis de Bahharie, aijo \& Dumeril y Bibron que el escinco se encuentra principalmente en las pequeñas colinas de arena movediza, al pié de los árboles y de las cercas que rodean la tierra cultivada; alli se tiende con toda comodidad a los-ardientes rayos del sol, saltando de vez en cuando para coger un escarabajo ú otro insecto. Su carrera es rápida, pero cuando le amenaza un peligro solo busca su salvacion escarbando en la arena, con una agilidad tan admirable que en pocos instantes penetra á la profundidad de varios metros. Tristram, que le observó en el Sahara occidental, confirma las noticias de Lefebvre por todos conceptos. Nunca vió al escinco, llamado por los árabes de aquel pais sararut y salgnga, segun el sexo, en terreno pedregoso, y sí solo alli donde el suelo está cubierto de arena movediza; on tales sitios se ven alguna ver.grandes grupos de estos reptiles. En la estacion fria retirase a sus escondrijos ó galcrias para entregarse al sueño invernal. En verano se le ve de dia echado al sol, pero tambien corre de noche cuando hace luna; si se le espanta hace algunos movimientos serpentinos y desaparece despues como por encanto del modo indicado. Segun dicen los árabes, no solo come escarabajos y otros insectos, sino tambien escorpiones.

CAUTIVIDAD. - En estado cautivo el escinco oficinal 
se conduce como otras especies de su familia, aunque hace esfuerzos para escapar, pero no intenta nunca morder $\delta$ de. fenderse con sus garras.

Usos Y PRODUCros. -. Los árabes del Sahara le aprecian conio alimento tanto como para preparar medicinas; en algunos oasis, por ejemplo en Waregla y Tuat, una parte considerable de la poblacion se ocupa en darle caza. Segun la opinion de Tristram, fundada en observaciones propias, un escinco asado no deja de ser un manjar muy sabroso. Los átabes le desuellan, le secan, y reducen su cadáver á polvo en un mortero mezclíndole con la carne de dátil; despues secan el todo y lo guardan en sacas de cuero, que venden á buenos precios á las caravanas de Tuat y a los traficantes.

\section{LOS PLESTIODONTES PLESTIODON}

CARACTEHES. - Con estos reptiles se ha formado un sub-género, cuyo principal representante es el Plestiodonte de cabesa antha, que se distingue por los/siguientes caractéres. Este reptil tiene la cabeza gruesa; hocico corto y obtuso; lós miembros posteriores de un largo igual á las dos terceras partes de la extension de los costados; la cola es tetrágona en su raiz, $y$ ligeramente comprimida en la parte posterior. Las orejas se reducen á dos agujeros ovales, cuyo borde anterior está guarnecido de tres ó cuatro Iobulos triangulares, muy desarrollados. Las escamas del cuerpo, de forma exરgona, se ensanchan mucho, contándose veintitres scries longitudinales al rededor del tronco; las que pertenecen á la region dorsal presentan en la superficie varios pequeños surcos; los talones están guarnecidos de escamas mas grandes y gruesas que las de la cara inferior de la pierna. El color de las partes superiores consiste en un pardo mas ó menos claro, que tira á leonado; el de una parte de las escamas del lomo es de un tinte naranja en el animal vivo, $y$ amarillento 6 blanquizco despues de la muerte. Esta coloracion simula en algunos individuos grandes manchas, diseminadas irregularmente, $y$ otras, fajas trasversales que en ciertos individuos bajan sobre los costados; todas las regiones inferiores son blancas. Este reptil tiene de 10 á I 2 pulgadas de largo (medida inglesa).

\section{EL PLESTIODONTE DE CABEZA ANCHA- PLESTIODON LATICEPS}

CARACTERES - Además de los que acabamos de indicar, este reptil (fig. 3\$) se caracteriza por tener las orejas vertico-ovales, sin lóbulos ni tubérculos en su borde anterior; las regiones temporales son muy voluminosas en los individuos adultos; la cabeza de color rojizo; las escamas del lomo de un pardo claro, orilladas de amarillo.

DISTRIBUCION GEOGRAFICA. - Este reptil habita en la América del norte, y está diseninado en una gran extension del pais.

USOS, COSTUMBRES Y REGIMEN. -El plestiodonte es uno de aquellos animales á los que mas gustan los árboles; vive por lo regular en algun agujero, en las profundidades del bosque, prefiriendo siempre los que se hallen á treinta $\delta$ cuarenta piés de clevacion sobre el suelo. Solo las personas ignorantes podrian tachar á este reptil de peligroso, pues á decir verdad, es de los mas inofensivos, lo cual no quiere decir que no se defienda vigorosamente si le sorprenden; entonces depone su natural timidez, y haciendo uso de sus armas naturales, muerde con tal tenacidad con sus agudos dientes, araña con tal furia, que bien se pueden temer las heridas que infiere. El dolor producido por ellas es suma- mente intenso durante una ó dos horas, $y$ á ello se debe sin duda ta creencia vulgar de que serian venenosas, lo cual es un error. El plestiodonte se alimenta de los insectos que caza en el árbol donde vive, y cuando no los halla, baja á tierra; pero no tarda en volver á su agujero.

\section{LOS TRAQUISAUROS - TRACHY- SAURUS}

CARACTERES.-Este género, representado por una so. In especie, se distingue sobre todo por la figura particular de su cuello.

\section{EL TRAQUISAURO RUGOSO - TRACHYSAU-} RUS RUGOSUS

CARACTÉRES.-Con mas frecuencia que cualquier otro escincoideo, excepto solo el lucion comun, vemos en nuestras jaulas esta especie. La cabeza, de forma piramidal y obtusa, está marcadamente separada del cuello, que es corto y grueso; el tronco es largo, grueso y aplanado; la cola muy corta, ancha, plana y redondeada en la extremidad; las cuatro piernas son cortas y fuertes; los piés cortos, con cinco dedos poco diferentes entre si, y provistos de uñas muy corvas. Toda la parte superior cstá revestida de unas escamas muy gruesas, ásperas y prominentes; las de las regiones inferiores son mas delgadas $y$ lisas; las primeras presentan sobre un fondo negruzco unas manchas irregulares de un amarillo de ocre, producidas al parecer por el roce, y que pueden exten. derse de tal modo que dicho color predomine; la parte infe. rior es de un amarillo mas ó menos vivo. La longitud total de este reptil es cuando mas de $0^{n}, 40$, de los cuales corres. ponden á la cola poco mas 6 menos la cuarta parte.

DISTRIBUCION GEOGRÁFICA.-El traquisauro ru. goso es originario de la Nueva Holanda

USOS, COSTUMBRES Y REGIMEN.-No tengo nin. guna noticia sobre la vida en libertad de este reptil, y poco hay que decir tambien sobre los individuos cautivos; los he tenido muchas reces, pero nunca observé en ellos ninguna cosa que sea digna de una descripcion detallada. Durante el dia permanecen quietos en el mismo sitio, sin cambiar apenas de postura, y su mirada indica al parecer la mayor indi. ferencia Sus movimientos son por lo regular lentos; se arras. tran de modo que el vientre toca cási al suelo, $y$ sus otras manifestaciones vitales son anślogas; apenas se excitan cuando se les molesta ó se les ofrece el alimento. Comen toda clasc de animales pequeños, sobre todo larvas de inscctos y lombrices; pero tambien les agrada la carne cruda cortada en pedazos pequeños. Parece que poco á poco toman cierto cariño á su guardian, $\delta$ que por lo menos se acostumbran á él. Aunque se les trate con el mayor cuidado, raras veces se conservan en cautividad, y mueren fácilmente sir causa visible, sin que lo pueda evitar un buen tratamiento.

\section{LOS ESLIZONES-SEPS}

Los griegos llamaban chalcis y los romanos seps á un escin. coideo en extreno gracioso que fácilmente pudieron observar, y que fué descrito como un animal terrible. Segun ellos, su mordedura produce la putrefaccion 6 inflamacion instantánea, ocasionando la muerte del enfermo en pocos dias; hasta el sencillo contacto con él es muy peligroso. El pueblo bajo de Italia cree aun hoy dia en esta cualidad, aunque algunos naturalistas, sobre todo Sauvage y Cetti, describieron el reptil como un sér del todo inocente, gra. cioso e inofensivo, 
CARACTÉRES.-Esta especie es tipo del género que nos ocupa, y con varios grupos congenéricos constituye una sub-familia independiente (sepina). Se parece poco mas ó menos á nuestro lucion comun, pero se distingue por sus piés, reducidos á muñones, pareciendo de consiguiente un tránsito de los escincos a los luciones, que carecen de piés.

\section{EL ESLIZON CALCÍDICO - SEPS CHAL- CIDES}

CÁRACTÉRES.-La cabeza es puntiaguda, el tronco redondeado y muy largo; la cola se adelgnza gradualmente hasta su extremidad, que es muy puntiaguda; en cada uno de los cuatro munones que hacen las veces de piés hay tres de. dos atrofiados, provistos de uñas apenas visibles; el paladar carece de dientes, pero los maxilares los tienen sencillos y cónicos; la lengua, plana y en forma de flecha, tiene verru. gas escamosas. Este reptil está revestido de escamas muy pequeñas, lisas, bien formadas y brillantes, que en la cabeza se trasforman en escudos de mayor tamaño, rodeando una placa bastante grande. Las regiones supericres son de un pardo bronceado brillante $\delta$ de un gris plata, con fajas lon. gitudinales estrechas, pero bien marcadas, mientras que las inferiores son blanquizcas con lustre de concha. Cuéntanse poco mas ó menos una docena de placas en el lomo, pero este numero varia, lo mismo que el color. Los individuos adultos pueden alcanzar una longitud de $\left(0^{2}, 30\right.$, de los que la cola ocupa la mitad; los muñones miden apenas $0^{\circ}, 05$. (fig. 39).

DISTRIBUCION GEOGRÁFICA.-El eslizon calci. dico es propio de todos los paises de la costa del Mediter. ráneo; en algunas partes su número es en extremo considerable, como por ejemplo en Cerderia, donde, segun dice Cetti, abunda tanio «como la yerba seca del pais. (1)

USOS, COSTUMBRES Y REGIMEN. - Iija su residencia principalmente en praderas lúmedas, por la sencilla razon de que en ellas encuentra con mas facilidad su presa, que se compone de insectos, pequeños caracoles $y$ lombrices; por sus costumbres se parece mucho á nucstro lucion comun. Es fácil no distinguir sus muñones, de modo que el hombre poco entendido que solo se fija en los movimientos le podrá tomar por una serpiente. En efecto, el eslizon se mueve con las mismas ondulaciones que la culebra, y asi como esta, enróscase cuando descansa.

A pesar de su corta dimension, no le son completamente inútiles los apéndices, pues cuando repta se ven moverse cstos, ayudando perfertamente í la loromocion. Mas que ninguna otra especie de la familia, teme el eslizon cl frio, de modo que desde los primeros dias de octubre desaparece ya por completo, y solo se le puede enconirar, escarbando cui. dadosamente los sitios que suele habitar; una vez entrada la primavera, sale a la superficie para empezar de nuevo su vida de verano.

REPRODUCCION. - No parece haberse hecho un estudio especial de estos reptiles, de modo que son casi nulos los datos que se tienen acerca del modo de reproducirse; sá. bese únicamente que como los luciones, son viviparos.

ENEMIGOS, - A los numerosos que tiene este inofensi. vo escamoso entre los mamiferos, aves y reptiles mayores, hay que agregar al hombre, que parece ser el mas encarniza. do. Aun hoy dia el vulgo ignoranic conserva la creencia de que este pequeño reptil es uno de los mas venenosos, y procura extcrminarlo con todas sus fuerzas. Una de las su.

(1) Hil Sr. Perce dreas en su excelente tratado de Zoologria lo cila en el Liscorial. persticiones en boga hasta entre los campesinos mas ilustrados de Cerdeña, que saben que el eslizon mas veces muerde, y que aun cuando lo hiciera, su mordisco no puede tener consecuencia grave, es la de que no están exentos de prevenciones ridiculas contra este escamoso y procuran disculpar la cruel gucra que le hacen los mas ignorantes; aseguran que á menu. do sucede que el ganado se traga con el forraje algun indivi. duo, causando la inmediata hinchazon del vientre, dolencia que solo cura un experimentado veterinario. No solo las aves de rapina, sino las de corral lo tragan vivo; Sauvage afirma haber visto un gallo que se habia tragado un eslizon, el cual salia viro por el ano, y que engullido de nuevo volvió á apa. recer por el mismo conducto; hasta que irritada el ave, lo destrozó con su pico y se lo tragó despues definitivamente.

Este autor opina que podria emplearse el eslizon como remedio contra ciertas enfermedades, pernvitiéndole recorrer los intestinos del enfermo; pues seguramente obraria con mas actividad que el mercurio. Por excelentes que puedan ser los resultados de la ingeniosa idea del naturalista fran. cés, creemos, sin embargo, bastante dificil encontrar médicos que receten tan extraño procedimiento y enfermos que permitan la introdurcion en su cuerpo de semejante huésped.

\section{LOS LUCIONES-ANGUIS}

CARACTERES. - El cuerpo serpentiforme, la carencia de extremidades, el conducto auditivo cubierto, las penquenas escamas exagonales lisas y brillantes, dispuestas en filas longitudinales, y las placas mayores que protegen la cabeza, son los caractéres exteriores de este género; mientras qque los.intcriores consisten en el esqueleto de lacértido, los dien. tes adelgazados y puntiagudos, en número de nucve los in termaxilares, diez y ocho los maxilares superiores y veintiocho los inferiores, la lengua plana, ancha y ligeramente escotada, y ambos pulmones bien desarrollados.

\section{EL LUCION COMUN-ANGUIS FRAGILIS}

CARACTERES, - Este lucion es conocido vulgarmente con el nombre de serpiente de sidrio. Su coloracion, por lo comun, es en la parte superior de un gris de plomo, convir. tiéndose hácia los lados en un pardo rojizo, y en las regiones abdominales en negro azúlado con puntos amarillentos; varian mucho sin embargo estos colores, siendo muy dificil cncontrar dos luciones completamente iguales en su coloracion. Lenz asegura haber recogido una vez treinta y tres de estos reptiles en un circuito de seiscientos pasos, sin haber hallado ni siquiera dos de igual color y dibujo. Algunos individuos muj viejos presentan en el lomo fajas longitudina. les de puntos y manchas azules, mientras que los jóvenes llevan á menudo en el dotso, sobre fondo amarillento, una faja negra, y tienen la region abdomiual del mismo tinte negro; la coloracion varía igualmente segun el scxo.

Leydig obtuvo hijuelos en cuyo lomo blanco, rayado de negro, aparecieron en la primera noche dos estrechas fajas longitudinales, y observó otros en los que el color castaño del lomo se cambió en pardo amarillo, orillado por dos fajas de un pardusco claro; algunos perdieron y recobraron des. pues su magnifico color. El íris del ojo es amarillo. Los adultos llegan á una longitud de $0^{\prime \prime}, 40$, correspondiendo á la cola poco menos de la mitad (fig. 40).

DISTRIBUCION GEOGRÁFICA.-La serpiente de vidrio lhabita en casi toda la Europa, y desde el sur de Suecia hasta Grecia y la peninsula Ibérica; tambien el Cáucaso, la Georgia y algunos otros puntos de Asia. 
USOS, COSTUMBRES Y REGIMEN. - El lucion vive lo mismo en el valle que en la montaña, prefiriendo, sin embargo, los sitios poblados de pequeñas plantas y yerba, y tambien los pedregosos. Segun las condiciones de la loca. lidad varia su escondrijo: en la tierra hoja practica un agujero mas 6 menos profundo, $y$ en los terrenos cubiertos de altas ycrbas, se oculta entre las planias $y$ las raices, siendo igualmente madriguera favorita de este reptil, en los declives pediregosos, el hueco debajo de una gran piedra; como no teme á las hormigas, no es extraño verle ocupar el nido de estas, sin que dichos insectos, que por lo demás atacan śtoda clase de animales, parezcan hacer caso alguno de él.

$A$ mediados 6 fines de octubre el lucion comun se oculta en agujeros subterríncos, ya hechos 6 - practicados expresa. mente, donde se entrega al sueño invernal. Todas las guari. das que Leydig pudo examirar estaban muy bien situadas, pues no solo se orientaban exactamente hácia el sur, sino que estaban al abrigo de los vientos del norte y del este. Los mismos reptiles practican los agujeros ejecutando movi. mientos circulares con la cabeza. A veces se les encuentra en estrechas cavidades, a $l^{\circ}, 0 ;$ hasta $0^{*}, 30$ de profundidad, y tambien en alguna sinuosa galeria de un metro de largo poco mas $\delta$ menos, cerrada con yerba y tierra; en estc último caso hállanse por lo regular de veinte á treinta individuos reunidos, todos aletargados, algunos de ellos enlazados entre si, y otros tendidos. Los hijuelos se hallan mas cerca de la entrada; despues siguen los individuos masores y por fin se encuentran los mas grandes, un macho y una hembra. Leydig encontró tamuien cierto dia una serpiente de hierro de lanza, enemigo mortal de todos los escamosos débiles, en la gua.

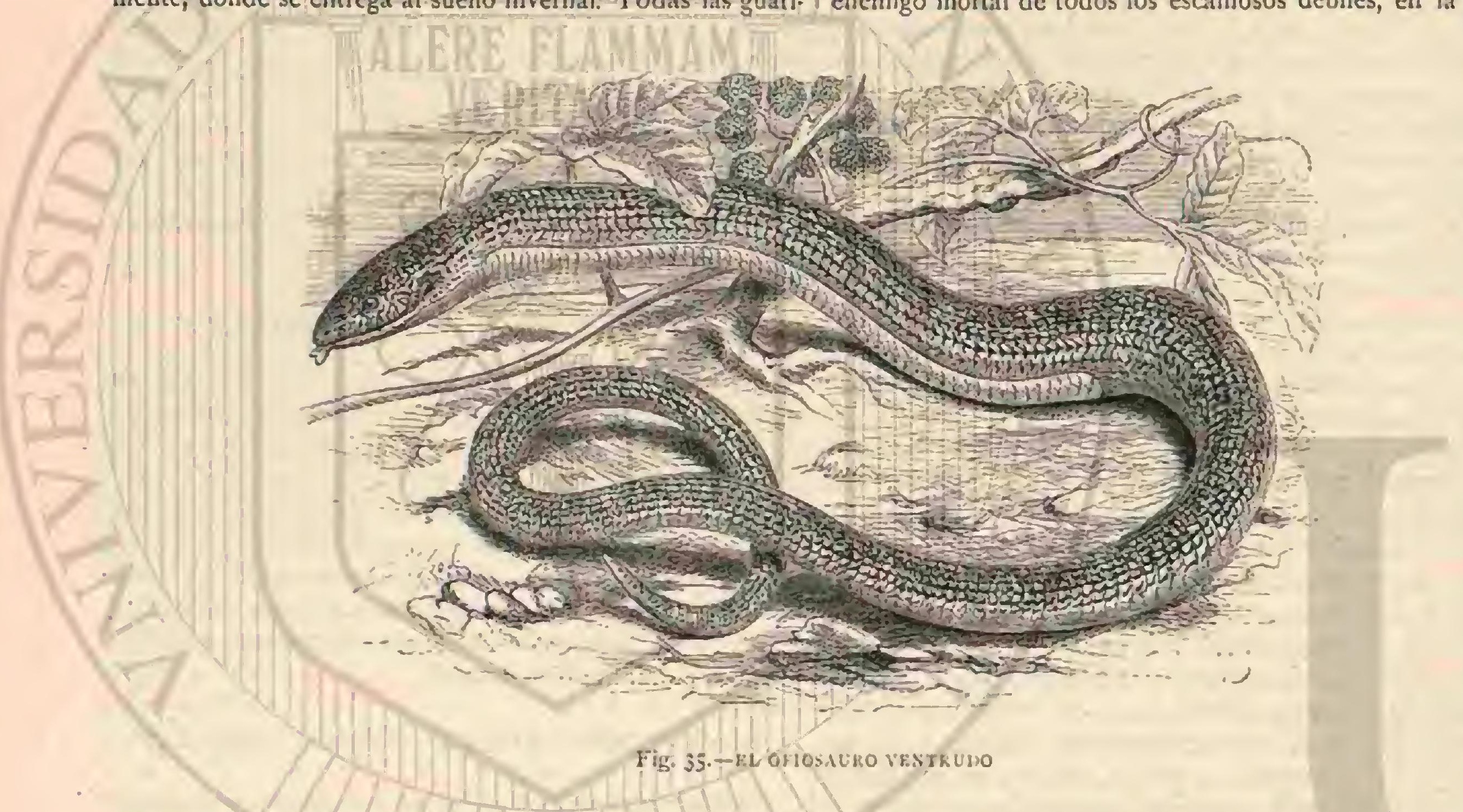

rida de invierno de los luciones. Todos permanecen inmóvi. les cuando hace frio, cual si tuvieran sueño, pero despiertan cuando sienten poco á poco el calor. Lenz hizo varias pruebas en la cstacion fria con veinte individuos de esta especie: todos permanecieron rígidos, como aletargados, bajo uno $y$ medio hasta dos grados de calor, $y$ solo daban senales de vida cuando los tocaban, habiendo unos pocos, que despues de colocados de nuevo en su caja, daban algunas vueltas en aquel estrecho espacio. Todos tenian los párpados cerrados, y solo dos los abrieron un poco cuando su guardian los tomó en la mano, cerrándolos los demás si se los abrian á viva fuerza. Cuando la temperatura hubo bajado á tres grados bajo cero, el observador los encontró ì todos rígidos dentro del salvado que los protegia, sin que llegase á helarse nin. guno de cllos, mientras que varias serpientes propiamente dichas, que ocupaban la misina estancia, perecicron de frio: sin embargo, pocos luciones pueden resistir una temperatura mas rigurosa que la indicada.

En la primavera comienzan $a$ presentarse à mediados de marzo si hace buen tiempo.

El alimento de los luciones se compone casi exclusivamente de caracoles desnudos $y$ lombrices de tierra: tambien comen orugas lisas, pero no pueden alcanzar ningun animal rápido. Lenz observó en los cautivos que se acercan lentamente al gusano que se les echa; tócanle primero con la lengua,y abriendo despues la boca muy despacio recogen por fin la victina. El gusano se resiste con todas sus fuerzas, pero su enemigo espera á que se canse $y$ le devora despues poco á poco, para lo cual inclina la cabeza á derecha é izquierda, mostrando los dientes. Necesita cinco á seis minutos para una sola lombriz, y queda satisfecho con un par de tamaño regular. Bebe agua con tanta frecuencia como los lagartos.

Puede ser que tambien de dia coja y devore alguna presa que se le presente, mas por lo regular no empieza á cazar hasta que anochece. De dia se pone al sol, como otros reptiles, durante horas enteras, inclinando por lo regular la cabeza sobre el suelo con toda comodidad para disfrutar de la influencia benéfica del calor. Sin embargo, no se presenta siempre en dias calurosos y secos, mientras que sale al punto si amenaza tiempo lluvioso. \$Cuando sale muy temprano, dice Leydig, indica un cambio atmosférico y lluvia "Tambien Gredler le considera como indicador del tiempo, bastante seguro, y añade, probablemente con mucha razon, que su presencia durante el cambio de tiempo está en relacion con la salida de las lombrices que constituyen su alimento favorito.

Los movimientos del lucion comun son lentos y no se parecen á los de los lagartos ni a los de las serpientes. Como su piel está revestida de una verdadera capa de cal, dice leydig, sus movimientos no se efectian en cortas lineas onáuladas, cual se observa á veces con las serpientes; en lugar de esto, y en estado normal, traza arcos de bastante 
diámetro. Solo cuando deben deslizarse por un terreno pedregoso 6 por un caos de plantas pueden ejecutar peqqueñas evoluciones, pero aun estas tienen algo de rigido que forma contraste con las de las serpientes. Montaña abajo corre con alguna rapidez; pero en la llanura tan lentamente, que con paso tranquilo se le podria seguir cómodamente; cuando sube por una cuesta sus movimientos son mucho mas lentos aun.
Si se le coloca sobre una placa de vidrio le es muy difícil avanzar, pero poco á poco lo consigue por sus croluciones laterales. No entra voluntariamente en el agua, mas si se le arroja en ella nada encorvándose de lado con bastante rapidez, regularmente con la cabeza levantada sobre la superficie, pero á veces tambien de espalda; de todos modos, siempre procura llegar a tierra firme lo mas pronto posible.

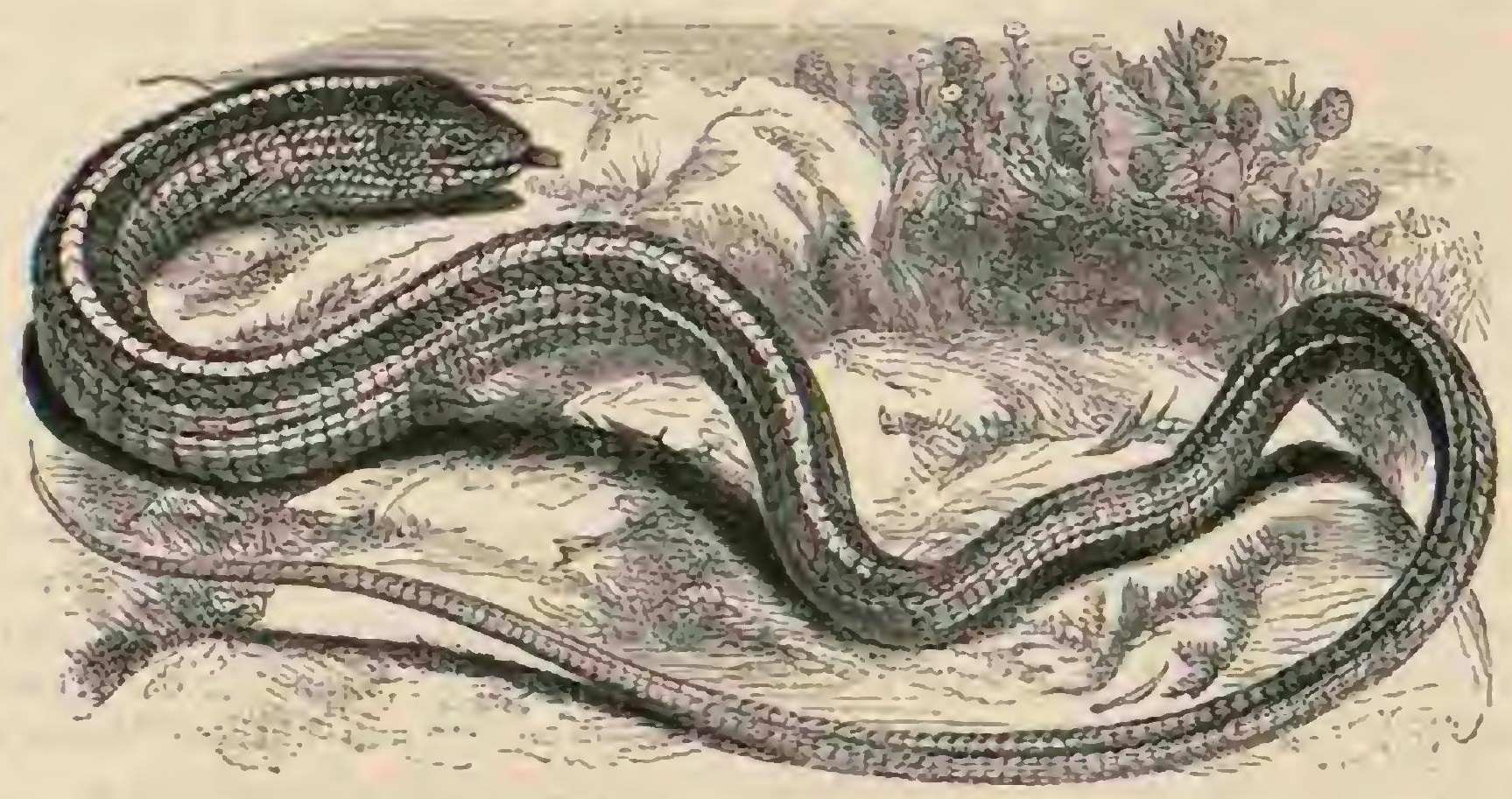

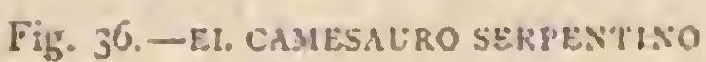

Entre sus sentidos, el de la vista es sin duda el mas des. arrollado, á pesar del incomprensible nombre popular de eslison ciego, que se le dió en Alemania. Tiene los ojos boni- tos, con el iris amarillo de oro y pupila oscura, y re muy bien. Gredler refuta este aserto, porque nunca observó que los luciones cautivos se precipitaran directamente sobre su presa, pero declara, por otra parte, que varios individuos jóvenes vieron muy bien à bastante distancia la mano que se acercó á su jaula de vidrio. Por lo demás, nada dice para probar que este reptil no ve con sus dos claros ojos. Otra cuestion es saber si el lucion distingue los objetos a la luz del sol; el color rojo amarillo de su iris no indica cosa alguna en pro ni en contra de este aserto, pero el proceder torpe del animal á la luz del sol parece demostrar mala vista. Las pruebas hechas en luciones cautivos inducen á suponer que el oido es poco $\sigma$ nada inferior á la vista, pero es dificil formarse una idea exacta sobre este particular y mas dificil aun en cuanto á los otros sentidos, excepto el del tacto.
Bien podemos suponer que la lengua tiene una sensibilidad muy desarrollada, pero no puede decirse lo mismo del tacto y del gusto. Leydig parece haber formado una elevada opinion de sus facultades intelectuales; su proceder difiere por muchos conceptos del de los lagartos, y «sobre todo, dice, es nucho mas reposado en todo su súr.

-Debemos recordar que los lóbulos del cerebro son mucho mas grandes en el lucion que en los lagartos, tomando un término medio.» No puedo decir que haya observado alguna vez facultades intelectuales sobresalientes, aunque $\{$ decir verdad, nunca me ocupé tan detenidamente de esto como puede hacerlo quien solo ha de cuidar un número reducido 
de cautivos. El lucion no se muestra timido, ni menos aun astuto, pero escapa de la mayor parte de sus enernigos solo moviéndose con violencia cuando se le coge; y asi cs como se rompe algun pedazo de su cola. Mientras el pedazo caido, dice Lenz, salta aun lleno de vida, y cl observador le re coge, el reptil halla ocasion de escapar, como puede verse fácilmenie cuando se alimentan varios animales con luciones. Por lo regular se deja coger sin defenderse, pero alguna vez hace uso tambien de sus dientes, aunque sin po der rechazar á ninguno de sus enemigos. En el trascurso del tiempo se acostumbra al cambio de las condiciones, como por ejemplo á la cautividad y a su guardian. Cuando se ha familiarizado con el hombre, dice Lenz, déjase coger deslizándose por la mano, principalmente entre los dedos; enton ces pone la cabéza en la estremidád de la cola cual si buscara un escondite. Vive en perfecta armonia con varias serpien. tes, ranas y lagartos, por la sencilla razon de que parece con. tento cuando ningun otro animal le ataca.

VITALIDAD.-Como la masor parte de los reptiles, tie. ne el lucion extraordinaria vitalidad. "Cundo se abre uno dé estos escamosos en sentido longituâtinal, dice Lenz, y so le arranca el corazon y las visceras, cierra la abertura y repta todavia algunas horas; arrojado al agua, nada bastante tiempo, si bien, como es de suponer, con menor velocidad que en estado normal. Fi jugo del tabaco, que es un tóxico fa. tal para las serpientes, no produce casi efecto alguno en el lucion: el mismo Lenz propinó duranie tres dias consecutivos este ingrediente á dos de sus cautivos, que solo en los pri. meros momentos dieron algunas señales de intoxicacion, res tableciéndose empero muy pronto; otro al que hizo tragar cierta cantidad de petróleo, manifestó en verdad grande agitacion, hasta el punto de rompérsele la cola; pero ni siquiera sintoma alguno de envenenamiento, y continuó viviendo.

REPRODUCCION.-Gessner decia respecto á la repro. duccion del lucion: La experiencia ha demostrado muchas veces que estos reptiles son riviparos.

Parece que al cuarto año no es propio aun para la propa gacion, porque Lenz solo encontró huevos desarrollados en individuos adultos ó casi adultos. El apareamiento se verifi. ca en mayo, y segun Meyer, es como cl de los lagartos. El macho coge á la hembra por el occipucio, ocasionándola una lesion en las escamas; despues acerca su parte posterior al ano de la hembra, y una ver apareado, permanece algunas horas tendido junto á ella sin enlazarse. El nacimiento de los hijuelos ocurre en la segunda mitad de agosto ó en la primera de setiembre; la hembra deposita los huevos con intervalos de algunos minutos, y la progenie sale al punto de la cáscara, membranosa, delgada y trasparente. Los hijuelos sun blanquizcos, con la cabeza y el vientre azulado, y á lo largo del centro del lomo se corre una línea tambien azula. da. En muchas hembras el desarrollo se verifica mas tarde.

Lenz dice que ha obtenido mas de cien hijuelos de una hembia cautiva, pero todos muricron de hambre en el tras. curso de una a seis semanas. Otros aficionados, sobre todo Erber, tuvieron mas suerte, consiguiendo criar los pequeños reptiles; pero esto no es muy fácil, porque los luciones jóre. nes solo pueden comer los insectos mas tiernos, que no se pueden obtener siempre.

CAUTIVIDAD.- Los individuos que se cogen adultos aceptan por lo regular el alimento sin resistencia y se consér. van muchos años cuando se les cuida bien. En una jaula llena en parte de tierra y cubierta de yerba y musgo satisfacen todas sus necesidades, $y$ divierten por su gracioso conjunto: se pueden recomendar á todo el mundo.

USOS Y PRODUCTOS. - Aun hoy dia pasa el lucion a los ojos de hombres ignorantes por un animal en extremo venenoso, $y$ hé aquí porqué se le persigue y mata sin piedad donde se deja ver; mientras que, por el contrario, se le de. beria proteger y cuidar, sobre todo en jardines. Los antiguos sabian ya que el lucion no es renenoso, y Gessner dice que "su mordedura no envenena ni causa gran daño. Sin embargo, creia casi lo mismo que los italianos dicen de este lu. cion. «Cuando el ganado, los buejes y otros animales se echan en el pasto inadvertidamente sobre el reptil, irritanle con el peso de su cuerpo, y entonces muerde, ocasionando una herida que se hincha áveces y supura. En este caso debe abrirse aquella con un hierro puntiagudo, poniendo despues creta 6 tierra blanca mezclada con vinagre En cambio el mismo naturalista reconoce tambien una uilidad en el lucion, aunque no la verdadera, que consiste en exterminar los animales dañinos: dice que se utilizaba para la medicina de entonces;y yo añadiré que lo mismo podria ser con la nues. tra. Algunos, continúa, han preparado una especie de com. posicion con los luciones, empleándola en casos de epidemia con buen resultado en las bebidas sudorificas, puesto que despues de usarla tres ó cuatro veces salvábase á muchos la vida la majoria del pueblo ha olvidado esta opinion, cm. peñandose en que el reptil ha de ser venenoso, cosa que por desgracia afirman aun muchos hombres instruidos.

\section{LOS OFIOFTALMINOS - OPHIOPH- THALMIINA}

CARACTERES. - En esta sub-familia reunen algunos naturalistas los ofioftalminos, reptiles que tienen los párpa. dos atrofiados, cuando no carecen de ellos: estas especies son en general una reproduccion de sus congéneres, pues tambien en ellos las extrenidades presentan mas 6 menos desarrollo ó bien faltan completamente. Asi, por ejemplo, los ablefaros tienen cuatro piés con cinco dedos cada uno: los gimnoftalmos (svmmophthaimus) poseen igualmente cuatro extremidades, pero solo en las posteriores hay cinco dedos, contán. dose en las anteriores cuatro; los pigopos carecen de pies, $y$ en el sitio de los posteriores ticnen unos muñones redondeados; los tiflinos, en fin (typinline), carecen del todo de extremidades; y mientras que en aquucllos se ven aun las orejas, en estos quedan ocultas debajo de la piel 6 faltan del todo.

\section{EL ABLEFARO COMUN - ABLEPHARUS PANNONICUS}

CARACTÉRES. - Entre todos estos escamosos merecen mencion sobre todo los ablefaros, porque tienen un representante en Europa. Es un reptil gracioso, de aspecto agradable, tiene el tronco estirado y cilindrico, destacándose apenas del cuello y de la cola larga, redondeada y aguzada; las extremi. dades se encuentran a gran distancia unas de otras, siendo las anteriores mas cortas. La cabeza ovalada y algo aplanada está protegida por veinte escudos de distintas formas, $\mathrm{y}$ el cuello por cuatro exagonales, que cn el dorso forman cuatro filas longitudinales. La coloracion de la parte superior del cuerpo es pardo verdosa con dos fajas longitudinales negras en el centro; á cada costado corre otra faja, que detrás de la cabeza, de donde arranca, es de un castaño rojizo que hácia la extremidad del cuerpo se va convirtiendo en el color domi. nanie; las partes abdominales aparecen de un blanco rojizo, y la inferior de la cola, gris de plomo. La longitud es de $0^{\circ}, 09$ correspondiendo á la cola poco mas ó menos dos.

DISTRIBUCION GEOGRAEICA.-EI ablefaro comun se encuentra sobre todo en Hungria, en las colinas cubiertas de yerba, pero tambien se le obscrva en otras partes del sudeste de Europa, por ejemplo, en Grecia y en el sur de 
Rusia, quizás con mas frecuencia de lo que se supone. Dícese que no escasea en el parque de Buda-Pesth y en las pendicates de la fortaleza de Ofen.

USOS, COSTUMBRES Y REGIMEN. - No se han hecho aun observaciones minuciosas sobre el género de vida. Erber dice que él no ha cogido aun ninguno de esos reptiles, pero que obtuvo dos individuos vivos, los curales cuidó durante tres meses, alimentándolos con lombrices. Ambos perecieron, sin embargo, en un mismo dia. El mismo naturalista me escribe que últimamente consiguió tambien conservar estos débiles animalitos vivos durante un invierno. I.eydig recono. cio que los ablefaros se asemejan por su proceder mas bien á los luciones que á los lagartos; aunque mucho mas vivaces que nuestro lucion, se parecen, 130 obstante, en su costumbre de permanecer inmóviles mucho tiempo, como escuchan. do, antes de emprender la fuga. $\Lambda$ pesar de toda su agilidad, las evoluciones del tronco de estos reptiles son inferiores en fexibilidad á las de los lagartos verdaderos, á casusa sin duda de las plaquitas óseas de la piel. En su consecuencia son es. cincoideos tambien por este concepto.

\section{LOS PIGOPODINOS - PYGOPODINA}

CARACTÉRES. - Esta sub.familia comprende los pigó. podos (pjegopus), unos escincoideos de la Nueva Holanda, de formas singulares, que se caracterizan por su tronco serpentiro, en el que faltan del todo, al inenos exteriormente, las extrenidades anteriores, mientras que las posteriores están atrofiadas en forma de apéndices y figuran una especic de aletas.

\section{EL PYGÓPODO DE NUEVA HOLANDA- PY- GOPUS LEPIDOPUS}

CARACTERES.-El pigópodo de Nueva Holanda, repril de ()$^{m}, 60$ de largo, tiene una cola que mide dos reces la longitud del tronco, y es la principal de las pocas especies del género y de la sub-familia. La cabeza prolongada, puntiagu. da en el hocico, y apenas separada del tronco, está cubierta en la parte superior de escudos, y en los lados de pequeñas escamas; las orejas no se ven; los párpados están atrofiados y revestidos de escamitas; el tronco, redondo y en extremo delgado, tiene un diánetro casi igual en toda su extension; la cola, muy larga, se adelgaza ligeramente hácia la puntay está cubierta de escamas sobrepuestas; los piés posteriores forman dos apéndices en forma de aletas redondeadas en la extremidad y revestidas de escamas sobrepuestas. El color es pardo cobrizo gris en las regiones superiores; tres manchas negruzcas que se corren desde la cabeza hasta la punta de la cola forman en algunos individuos, pero no en todos, un bonito dibujo; la garganta es blanca, y el resto de las partes in. feriores de un gris oscuro.

DISTRIBUCION GEOGRÁFICA. - Esta especie es propia de la Nueva Holanda. Solo sabemos sobre su género de vida que siempre está en el cieno; pero no he querido pasar por alto esta especie, porque es muy particular su estructura.

\section{EL PIGÓPODO ESTRIADO-PYGOPUS
STRIATUS}

CARACTERES.-A no ser por los dos pequeños apén. dices quue hacen las veces de micmbros posteriores, el pigo. podo estriado tendria todo el aspecto de un lucion: su cabera tiene la forma de una pirámide de cuatro caras, ligeramente truncada en su cimu; la cola, poco distinta del tronco en su nacimiento, es unas tres quintas partes mas larga que el resto del cucrpo, y como disminuye su diámetro poco á poco, resulta ser del todo aguda en su extremidad terminal. El color del pigópodo es gris en todas las partes del cuerpo, mas 6 menos cobrizo, con seis ú ocho rayas longitudinales negras, orilladas de leonado ó blanquizco; la garganta es blanca, el vientre y la cara inferior de la cola grises con listas longitu. dinales pardas (fig. 4 t).

DISTRIBUCION GEOGRÁFIC 1.-Este reptil está di. seminado en una gran parte de la America meridional, en Buenos-Aires y en Montevideo.

\section{EL TIFLINO CIEGO-TYPHLINE COECUS}

CARACTERES.-El tifino ciego, segun se le ha llamado, no tiene ojos, al menos aparentes, ni mas placas cefálicas que las que encajonan toda la cara como en una especie de estuche; tampoco se distinguen los miembros ni los oidos: la mandibula inferior está protegida por una gran placa en forma de comzon, y el cuerpo revestion de varias piezas exa. gomas iguales entre si. Iil color del tifino es amarillento, reti culado de violeta. Mide unos 20 centimetrns (fig. 42).

DISTRIBUCION GEOGRÁFICA.-Este reptil habita en el Africa austral.

\section{LOS AGÁMIDOS - AGA- MIDE}

CARACTERES.-En el sur y este del antiguo continente agrégase á los grupos hasta ahora citados la numerosa familia de los agámidos, de los que actualmente se conocen mas de ciento cincuenta especies. Las formas de este grupo de esca. mosos son en alto grado variables: el tronco puede ser reco. gido 6 prolongado, conıprinido desde arriba abajo ó lateral. mente, pero robusto por lo regular; la cabeza es corta y an. cha; la cola no quebradiza, larga y puntiaguda, 6 bien corta y fuerte; las denás extremidades están bien desarrolladas. La cabeza se halla cubierta de numerosos escudos pequerios, planos ó ligeramente abovedados; el lomo presenta escamas grandes, irregularmente cuadrangulares y sobrepuestas; otras análogas cubren los costados y las partes inferiores del cuerpo. Idemás obsérvanse con suma frecuencia toda clase de formaciones córneas prolongadas, que tan pronto cubren la cabeza de puntas y c5pinas, como forman una cresta en el lomo y en la cola, ó bien se extienden por todo el cuerpo. Los dientes están fijos en los bordes de los maxilares; dos de cllos suelen ser mas grandes y afectan la forma de caninos. En todo lo demás, los agámidos difieren tanto entre si, que no es posible hacer una minuciosa descripcion sino de los géneros.

DISTRIBUCION GEOGRAFICA.-El área de disper. sion de los agámidos empieza en el sur de Europa y se extiende meridionalmente hasta el cabo de Buena Espernnay en el este hasta la China, comprendiendo tambien las islas del Asia del sur y la Nueva Holanda. Precisamente en el Asia meridional la familia llega á su mayor desarrollo, porque aqui se encuentra la mayor parte de las especies conocidas; las otras están diseninadas en la Australia, donde abundan rélativamente estos escamosos, cxtendiéndose por los desiertos del centro y oeste de Asia, asi como por toda el Africa, Grecia y el sur de Rusia.

USOS, COSTUMBRES Y REGIMEN. - Casi todas las especies son reptiles terrestres mas 6 menos exclusiramente; no pocas de ellas habitan hasta en los sitios mas secos y de. solados de su territorio; mientras que otras buscan los terre. 
nos húmedos, donde sin embargo viven por lo regular en árboles. Podemos decir que los agaimidos asi dan vida á los desiertos del Africa y Asia central como constituyen un adorno para los magnificos bosques del Asia meridional. De ellos hablan ya los viajeros mas antiguos con mas 6 menos admiracion, y hoy dia encantan aun á todo aquel que les puede ver en toda su actividad vital, con sus magníicos colores, sujetos a bruscos cambios. Todas las especies deben considerarse como reptiles inofensiros; hasta las mas desarrolladas no perjudican ni al hombre ni á los animales de clase superior. La major parte de ellas se alimentan de insectos de varias clases; muchas, y quizás mas de tas que hasta ahora podemos suponer, comen tambien sustancias vegetales, tanto yerbas como hojas de árboles que cogen en el suelo $\delta$ en el ramaje. Parece que todas ponen huevos que necesitan desarrollarse; pero ninguna especie es vivipara.

\section{LOS DRAGONES - DRACONES}

Dice Herodoto: $\$$ Me contaron que en la ciudad de Butus en Arabia, habia una localidad en la que se veian serpientes voladoras. Fui alli, y encontré una cantidad extraordinaria de huesos y vértebras en numerosos montones. Era aquel un valle rodeado de montañas que tenia salida á las inmensas llanuras de Egipto. Se decia que estas serpientes aladas volaban en la primavera de la Arabia al Egipto, siendo acecha-

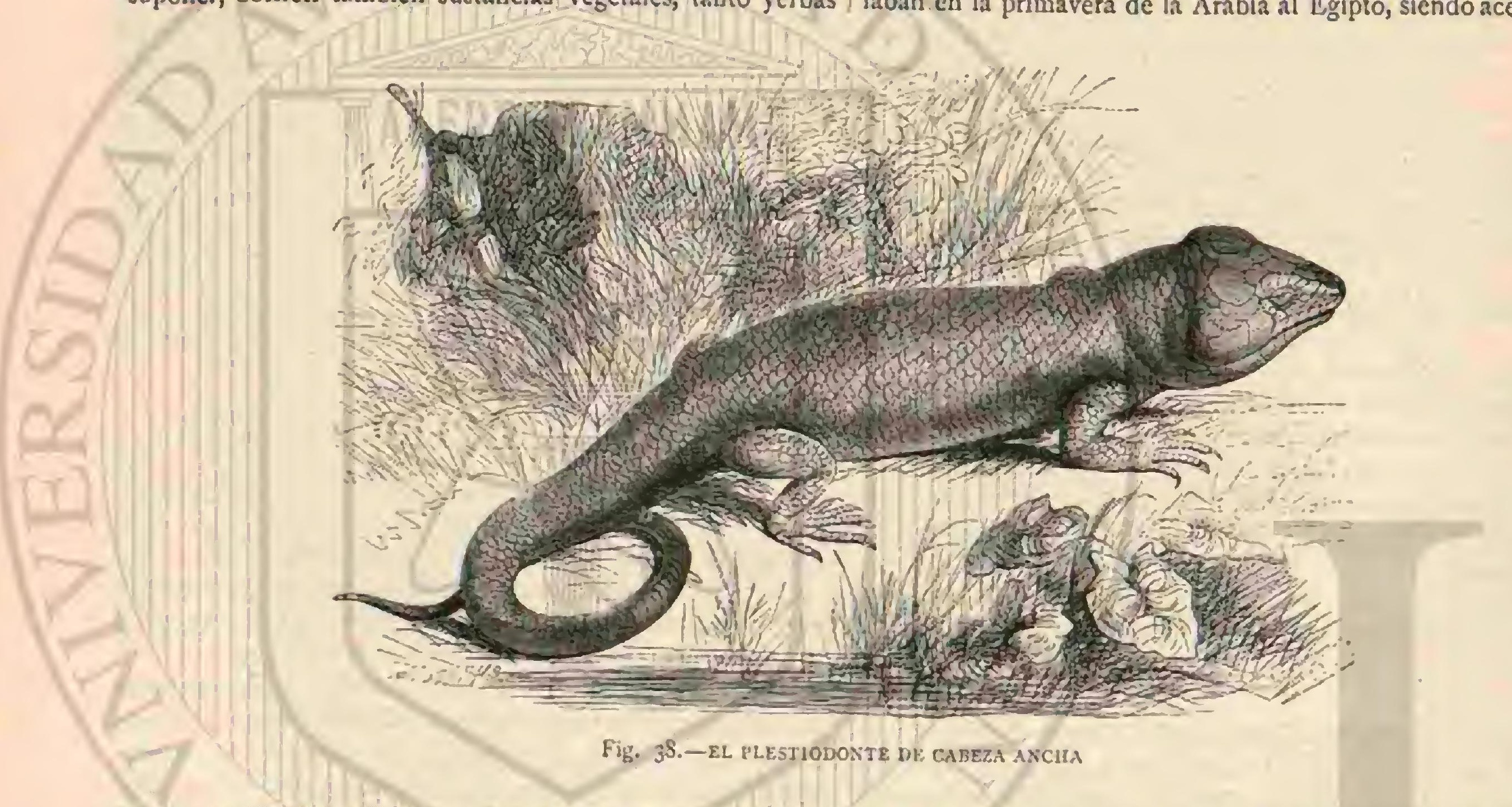

das á la salida del valle por el ibis, que las mataba; por esté motivo dicha ave era tan venerada por los egipcios. Estas serpientes se parecen á las de agua, pero sus alas no tienen plumas, sino que están formadas comolas de los murciélagos. La Arabia produce incienso, mirra, casia y canela: los árboles que producen estas materias son respetados por las serpientes aladas que pasan al Egipto, pero se las hace huir con el humo del estoraque.

A qué clase de animales se refiere el antiguo naturalista, difícil seria averiguarlo en la actualidad; sin embargo, es po. sible que ya entonces fuesen conocidos los pequeños lagartos provistos de una especie de para.caidas, que les da el aspecto de alados, y que habitan en las Indias orientales. Con los dragones de la fábula, que ora se representan como serpien. tes gigantes aladas, ora como crocodilos voladores, no tienen mas relacion los inofensivos reptiles de que vamos á tratar, sino en el nombre, debido á aquellas concepciones fantás. ticas.

CARACTERES. - Las primeras cinco ó seis costillas falsas de cada lado se trasforman en estos animales en una especie de para-caidas semicircular que recuerda la membra. na de la ardilla voladora. Una protuberancia de la piel pende del centro del pecho, y á cada lado de la garganea se ve un repliegue del cuello. La cabeza es voluminosa y alta; el hocico corto \& obtuso; el cuello bastante largo; el tronco delga. disimo; la cola larga y adelgazada gradualmente, hasta la cx. tremidad; las piernas se distinguen por su extremada longitud y delgadez; los piés tienen todos cinco dedos largos y delgados provistos de uñas cortas y corvas; las fosas nasales, que son redondas, desembocan en un solo escudo pequeño y saliente, pero de diverso modo, es decir, tan pronto hácia arriba como en los lados. Los ojos, de un tamaño regular, tienen párpados bien desarrollados; la pupila es redonda, como corres. ponde á las costumbres diurnas de estos animales; el tambor no falta en ninguna especie, pero es desnudo en unas, y está cubierto en otras de pequeñas escamas. Sin embargo, este ca. rácter distintivo cambia en algunas especies segun la edad. Unas escamas muy pequeñas cubren la cabeza y se agrandan en forma de escudos regulares en el borde de los labios; otras, muy finas, protegen el resto del cuerpo; la dentadura se compone de tres $\delta$ cuatro incisivos, dos caninos bien des. arrollados y numerosos molares de tres puntas en cada man. díbula; los poros de los músculos no existen.

El carácter mas distintivo de los dragones es sin duda el para-caidas formado por las costillas falsas, que no se ve en ningun otro animal. Las serpientes son, como se sabe, los únicos séres que se sirven de sus costillas como medio de locomocion, pero, mientras que esos ofidios las utilizan todas á dicho fin, por carecer de otros órganos para el objeto, los dragones solo se valen de las costillas para ayudar á sus extremidades bien desarrolladas. Segun observa Martens, parece sobre todo extraño que precisamente en la patria de los dragones se encuentre tambien la mayor parte de los mamiferos voladores, habiéndose descubierto hasta una rana voladora; mientras que bajo el cálido sol de Africa, solo se encuentran las ardillas voladoras, no existiendo en los paises de la América del sur situados en la misma latitud ninguno de estos cuadripedos. 


\section{EL DRAGON VOLADOR-DRACO VOLANS}

CARACTERES. - Entre las diez y ocho especies del género que hasta ahora se han clasificado, el dragon volador es la mas conocida. Este gracioso reptil no excede, segun Cantor, de $0^{\circ}, 20$ de longitud total, de los que $0^{\circ}, 12$ correspon den á la cola, larga y delgada. Las fosas nasales están situadas lateralmente y dirigidas hácia arriba; el tambor no está cu. bierto. En el macho se puede distinguir una cresta sobre la nariz. Ambos sexos tienen una prominencia corta y pequena en la parte posterior del arco ocular. El tronco estás revestido de escamas casi iguales, ligeramente aquilladas; los costados presentan otras mas grandes, irregularmente cuadrangulares
Y aquilladas tambien. El color varia mucho como en todos los dragones, no solo segun la localidad, sino tambien segun los individuos. Como dice muy bien Cantor, es del todo imposible determinar sus hermosos colores. La cabeza del ani. mal vivo es de un pardo metálico ó verde, con una mancha negra entre los ojos; el lomo y la mitad interior del para-cai. das ofrece una mezcla de pardo oscuro y sonrosado, de brillo metálico, que en algunos individuos forma fajas trasversales alternadas con numerosas manchas negras y lineas cortas. El color de la mitad exterior del para-caidas varía entre el ama. rillo naranja y el sonrosado, con unas manchas irregulares; el borde es platendo. En las extremidades y la cola se corren, pero no en todos los individuos, unas fajas trasversales sor-

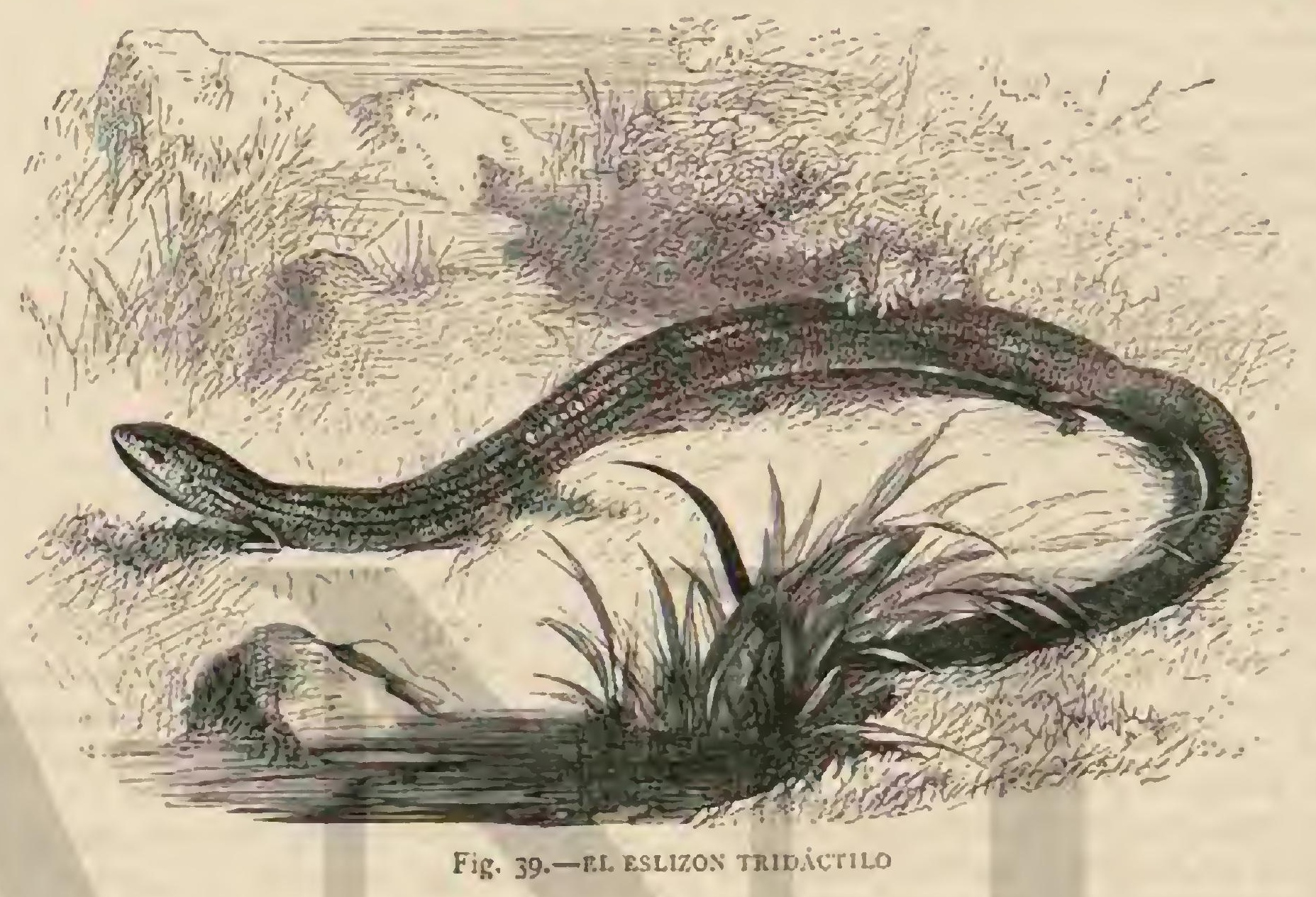

rosadas que alternan con otras pardas; en los párpados se cruzan varias líneas cortas y negras. La papada de la gargan. ta es de un color amarillo vivo, asi como el pecho, que tiene puntos negros. L.as papadas laterales tiran al amarillo ó al sonrosado plateado, presentando tambien manchas negras; otras iguales, pero-majores, adornan el lado inferior del pa. racaidas donde toman á veces un tinte pardusco (fig. 44).

DISTRIBUCION GEOGRÁFICA.-El dragon volador habita, además de las islas de la Sonda, el Penang $y$ Singapore.

USOS, COSTUMBRES Y REGIMEN.-El género de vida es el mismo que el de las otras especies del grupo. Todos los dragones son escamosos arboricolas en la verdadera acepcion de la palabra; no bajan nunca al suelo sin que se les obligue á ello. Lacépede, sin embargo, opina de otro modo. A pesar de que los dedos del dragon están muy oprimidos entre si, dice, no fija su residencia exclusivamente en árboles $\delta$ en terreno seco en general. Su papada dilatada y sus alas extendidas le permiten revolverse á voluntad, sirviéndole muy bien para nadar. Las alas membranosas son por su tamaño unas aletas muy fuertes, y las bolsas situadas debajo de la garganta le hacen mas ligero en el agua. Fstá provisto por lo tanto de todo lo que se necesita para correr, trepar y nadar: la tierra, el aire y el agua son á la vez sus elementos; y nunca puede escapársele su presa, mientras tenga á su disposicion todos los refugios. Cuando se le persigue por ticrra refúgiase en los árboles $\delta$ en el agua y por lo tanto no deben inquietarle mucho sus enemigos. No sé en qué observaciones funda Lacépede su opinion, pues no he hallado nada de esto en los naturalistas antiguos ni modernos. La verdad es que los dragones viven exclusivamente en árboles, y hasła casi siempre en sus copas, por lo cual se les ve mucho menos de lo que podria creerse. A pesar de que suárea de dispersion es muy extensa, no se les descubre fácilmente, por mas que hayan fijado su residencia en los jardines de los europeos, pues siempre están á mucha aitura en las copas de los árboles, donde permanecen inmóviles cuando el sol calienta. El brillo de sus colores no llama entonces la atencion del obscrvador: solo cuando este se acerca mucho verá al reptil echado á la sombra del follaje oprimida contra el tronco y aun asi solo se nota una mezcla de pardo y gris muy semejante al color de la corteza. I.a observacion mas minuciosa no basta para reconocer otra señal de vida, como no sea el conlinuo movimiento de los ojos, que ace. chan los insectos. Cuando uno de cllos se acerca al dragon, este abre súbitamente su para-caidas, $y$ dando un gran salto al aire, coge con una infalibilidad increible la presa, colocándose despues en otra rama. Tampoco entonces se ve nada del brillo de' los colores: para percibirlo se necesita el exámen mas detenido. Segun las noticias de observadores antiguos, los dragones franquean con ayuda de su para-caidas distancias de seis á diez metros, moriendose sin embargo como los demás animales, siempre en direccion diagonal de arriba abajo y careciendo por lo tanto de la facultad de volar, cosa que a lo sumo solo puede hacer en corto grado. Su modo de andar se distingue del de los otros escamosus arbóreos, sobre todo en que no es una carrera continua, sino una seric de saltos mas 6 menos grandes. 
Por indefensos é inofensivos que los dragones nos parez. can, no por eso dejan de ser encarnizadas las luchas de los machos entre sí, y así lo indican ya los apéndices del cuello $y$ del pecho que en todos los reptiles son señales de un ca. rácter muy irritable. Carecemos sin embargo de observacio. nes ciertas acerca de este punto; tan solo sabemos que los machos son á lo que parece mucho mas numerosos que las hembras y que estas ponen de tres á cuatro huevos cilindri. cos, redondeados en las extremidades, de color mas ó menos amarillento y de l," or de !argo, los cuales, segun noticias antiguas, depositan en agujeros de árboles; no conozco da. tos recientes sobre este particular.

Tampoco puedo decir si alguna vez se han tenido drago nes en cautividad $y$ solo he oido decir que son muy delica. dos. Su extraordinaria belleza, su agilidad y to inofensivo de su carácter lés captaria el aprecio de todos los aficionados y probablemente tambien los reconciliaria con las personas demasiado tímidas, asi como 1 las espécies del mismo órden, temidas casi en todas partes, si.fueran algo mas conocidas sus custumbres.

\section{EL DRAGON FRANJEADO-DRACO} FIMBRIATUS

CARACTERES. - Este dragon tiene las escamas del lomo pequeñas, iguales entre si y lisas en su mayor número; y en la parte inferior de la garganta hay varios espacios circulares guarnecidos de granos escamosos. En cuanto á su coloracion, las partes superiores están matizadas de pardo sobre fondo marron ó gris pizarra, ceniciento ó aceitunado; raro es que no se vean algunas fajas pardas $\delta$ negruzcas en la cara superior del cuerpo, el cual está cubierto de puntitos negros, algunos de ellos rodeados de un círculo blanco; en las alas presenta una docena de lineas de estc úl. timo color, y otras negras cortan trasversalmente los dedos; en las regiones inferiores predomina un tinte blanqquizco, y en la cabeza hay una especie de red de color negro intenso (figura 43).

DISTRIBUGION / GEOGRÁFICA.-E! dragon fran. jeado parece originario de las Indias orientales, $\mathrm{y}$ es principalmente comun en Sumatra.

USOS, COSTUMBRES Y RÉGIMEN.-NO difière por este concepto de las especies afines.

\section{LOS CALOTES-CALOTES}

CARACTERES, - Los calotes son igualmente animales arbóreos perfectos. Su estructura es por lo general graciosa; el tronco poco comprimido; la cabeza piramidal, cuadrilá. tera y corta; la cola larga y redonda; las extremidades muy delgadas; las piernas y los dedos largos. El cuerpo está cu. bierto de escamas sobrepuestas, grandes, aquilladas, é irre. gularmente cuadrangulares, que en la arista del lomo se trasforman regularmente en una crêta compuesta de forma. ciones córneas y puntiagudas; tambien en otras partes del cuerpo, por ejemplo en la articulacion de las mandibulas ó en la punta del hocico, están trasformadas á veces en puntas córneas prolongadas.

DISTRIBUCION GEOGRÁFICA.-I Jos calotes, de los que se conocen unas doce especies, habitan con otros tantos congéneres el Asia del sur con sus islas grandes y pequeñas.

\section{EL CÁLOTE DE COLOR VARIABLE- CALOTES VERSICOLOR}

CARACTÉRES, - El calote de color variable, el chupra- dor de sangre de los habitantes de Ceilan, puede conside. rarse la especie mas comun del género:'su longitud es de $0^{n}, 40$, correspondiendo $a ́$ la cola tres cuartas partes. Este reptil se distingue por tener dos grupos de espinas sobre cada oido, separados uno de otro, y una cresta de mediana altura en el cuello y parte anterior de este, cresta que en los individuos adultos se puede correr hasta la cola, en cuyo caso desciende gradualmente desde el centro del lomo. Lo mas notable es el cambio de los colores, tan variado como brusco.

En muchos individuos predonina un tinte aceituna. do, amarillo, pardusco $\delta$ gris, con anchas fajas pardas en el lomo, que en el centro se interrumpen por una faja trasversal amarilla; desde los ojos se corren unas líneas rojas en forma de rayas, $y$ en el vientre hay unas grandes manchas grises que parten de una linea central. Sin embargo, el ca. lote de color variable puede ofrecer los tintes mas diversos, y segun las circunstancias, los mas magnificos; algunas veces, todo el animal tiene un rojo brillante con manchas negras, y estos colores pueden limitarse á la cabeza, ó bien extenderse por todo el cuerpo y la cola. Cuando el «chupador de sangrey está en una cerca ó arbusto, expuesto á los rayos del sol, obsérvanse á menudo los colores siguientes: la cabeza y el cuello son amarillos, con mezcia de rojo; el lomo, los costados y el vientre de este último tinte; $y$ las extremidades y la cola negras. Jerdon y Blyth creen que este brillante cambio de colores solo es propio del macho, $y$ aun solo en la época del celo, que segun dicen tiene lugar en mayo $y$ junio.

DISTRIBUCION GEOGRÁFICA. - El calote de color variable es uno de lós escamosos mas diseminados del Asia meridional, pues súáca de dispersion se extiende desde el Afganistan por todo el Indostan y la India transgangética hasta China.

USOS, COSTUMBRES Y REGIMEN.-Este reptil, muy abundante en Ceilan, no escasea en todos los sitios donde no faltan árboles y cercas. En dias calurosos y de sol se ve á estos animales con la boca abierta, colocados en alguna rama ó sobre un muro; pero si cac un chaparron muéstranse muy activos, cazando toda clase de insectos, para lo cual bajan á menudo al suclo, cosa que no acostumbran sino en este caso. La hembra pone de cinco á diez y seis huevos ovales y de cáscara blanda, depositándolos en aguje. ros de árboles ó en hogos que ella misma practica. Los hi. juelos salen á luz \& las ocho ó nueve semanas. No se ha explicado aun bastante su nombre de chufradores de sangre: Kelard cree que solo se le aplicaron porque su cabeza pre. senta á menudo el color rojo.

Segun parece, tambien luchan los machos de los calotes con furia, ó por lo menos asi' lo indica el nombre de grallos reñidores que les han dado los holandeses de las Indias orien. tales. Es posible que este calificativo se reficra a la costum. bre del animal de morder con violencia cuando se le irrita, sin soltar de ningun modo el objeto cogido, aunque le cos. tara un diente 6 una parte de la mandibula. Sin embargo, los calotes no suelen servirse de su dentadura, sino que huyen del hombre $y$ de cualquier otro enemigo mayor, en cuyo caso demuestran extraordinaria rapidez y agilidad al trepar de rama en rama. Cuando se les persigue muy de cerca desaparecen de la vista súbitamente, y entonces, segun Martens, se ha de mirar primero si se han refugiado en los mismos vestidos del perseguidor. Por dichas cualidades, es. tos reptiles son la especie mas popular del órden. Para el europeo, el cambio de colores será siempre lo mas notable, y por lo tanto parece justificado el nombre de camaleon que con tanta frecuencia se emplea por gente poco entendida. 


\section{LOS ISTIUROS-ISTIURA}

CARACTERES. - Esste género se distingue por su cuerpo comprimido pero bastante elevado, por la cabeza corta y gruesa, y por las patas sólidas, cuyos largos dedos tienen á cada lado una fila de escamas horizontales y salientes; pero muy especialmente por la cresta escamosa que corre a lo largo de todo el cuerpo, y toma tal elevacion en la rair de la cola, que al llegar á la mitad de esta, forma una doble quilla dentada, siendo sostenida alli por las apofisis superiores de las vértebras, extraordinariamente desarrolladas en anquel punto. Cubren el cuerpo pequeñas escamas triangulares, que en la cabeza y en las patas son aquilladas. Cuentan sus mandibulas seis pequeños dientes cónicos y cuatro largos incisivos, además de trece molares.

\section{EL ISTIURO PORTA-CRESTA-ISTIURA AMBOINENSIS}

CARACTÉRES. - Esta es la especie mas conocida del género, y una de las de mayor tamaño, pues mide mas de un metro de largo. Su color es pardo, excepio en la cabeza y cuello que es verde, con rayas blancas; en los costados tiene igualmente algunas manchas blancas.

DISTRIBUCION GEOGRÁFICA.-Como su nombre científico lo indica ya, la patria de este agámido es $\mathrm{Am}$ boina, una de las islas Molucas, situada al este de la Nueva Guinea.

USOS, cOSTUMBRES Y RÉGIMEN,-Ya Valentyn, á principios del siglo pasado, habia publicado algunos datos referentes á este istiuro. Establece su morada en los árboles cerca de los rios, y se nutre de granos y frutas, de plantas acuáticas y de gusanos. Cuando se re perseguido, se precipita en el agua y se esconde alli debajo de las piedras; se deja coger fácilmente, ya con una red, ya con la mano, pues es bastante torpe y timido, y en manera alguna maligno. Los indigenas lo cazan con aficion á causa de su blanca carne, que dicen ser muy sabrosa. Acostumbra á desovar en los sitios arenosos.

\section{LOS CLAMIDOSAUROS- CHLAMYDOSAURI}

CARACTEREs. - La ĺnica especie conocida de este géncro fué descubierta por Allan Cunningham, célebre por sus viajes en Australia $y$ por su desgraciado fin; lleva el mis. mo nombre cientifico de chlarnydosaurus Kingii, y mide algo mas de 3 y medio piés de largo, de los cuales currespunden mas de la mitad à la cola. Se distingue sobre todo por una gran membrana de piel escamosa doblada y dentada en for. ma de collar, teniendo su mayor desartollo en la parte su. perior del cuello, que puede ser extendida en todas direc. ciones hasta unas seis pulgadas, de modo que el animal se cubre á veces con ella la cabeza. En esta lleva un rudimento de cresta, mientras que en el dorso y en la cola apenas se perciben señales de la misma; las patas son largas con dedos igualmente muy desarrollados. Las escamas que cubren el cuerpo son pequeñas é irregulares, apareciendo de major tamaño las de los costados. El agujero auricular es grande, y los ojos vivos y bastante salientes. $\mathrm{L}_{2}$ coloracion del clamidosauro es una mezcla de pardo, amarillo y negro. Las mandibulas llevan tres incisivos, cuatro caninos largos y unos treinta y tres molares trilobulados. El animal joven se dis. tingue del adulto por el nenor tamaño de la membrana del cucllo (6ig. 45).
DISTRIBUCION GEOGRÁFICA.-Este escamoso es originario de Australia, y se encuentra mas especialmente en la Nueva Holanda.

USOS, COSTUMBRES Y REGIMEN. - Pocos son los datos que se tienen aun hoy dia respecto del modo de vivir de este saurio. Segun Grey, habita generalmente en los árbo. les, si bien corre con bastante relocidad por el suelo. Cuando no es molestado, sigue pausadamente su camino, con la membrana del cuello recogida; pero es muy excitable, y tan luego cree ver el peligro extiende dicha membrana y procura trepar por el árbol mas inmediato; si continúa la persecucion, entonces apoja la parte posterior de su cuerpo en el sitio donde se halla, levanta cl cuello y la cabeza todo lo que puede, recogiendo muchas veces la cola por debajo del tronco y enseña tan solo sus temibles mandibulas al enemigo; de estas sabe hacer buen uso, pues es muy listo $y$ muerde con furor. Grcy afirma que el clamidosauro siempre acepta el combate, peleando con resolucion, y llega á imponerse al europeo torpe ó porn conocedor de sus mañas, pues no se contenta con la defensa, sino que aprovecha toda ocasion de poder hincar los dientes en el contrario. La membrana del cuello además de servirle para asustar al enemigo, la emplea tambien como escudo para proteger la cabeza, cuello y patas delanteras.

\section{LOS AGAMAS-AGAMA}

CARACTERES. - Los agamas propiamente dichos ocupan el primer lugar entre las especies que aun nos resta describir. Caracterizanse por su cabeza corta, triangular, dilatada en su parte posterior, muy deprimida hácia adelante y redondeada en la punta del hocico. El tronco es robusto y un poco aplanado; las piernas prolongadas y finas; y la cola mas $\delta$ menos larga y redondeada. Las fosas nasales están próximas; los orificios del oido, en los que queda visible aun el tambor, se reconocen bien. La garganta presenta raras veces un repliegue trasversal desarrollado; el cuello, en cambio, tiene uno ó dos, muy desartollados; los poros de los muslos faltan; la parte superior del tronco está cubierta de escamas marcadamente separadas y sobrepuestas, y mas 6 menos ordenadas; numerosos escudos, en su majoria bastante grandes, rectos 6 prominentes, cubrén la cabeza, $y$ algunas escamas sobrepucstas la cola.

DISTRIBUCION GEOGRÁriCA.-Este género, en el cual se han reconocido unas veinte especies, clasificadas a su vez en sub-géneros, está diseminado por el sur y este de Europa, por toda el Africa, el sudoeste de Asia y la India; las especies sun pur lo regular en extremo numerosas alli donde se encuentran.

\section{EL AGAMA DE LOS COLONOS-AGAMA CO- LONORUM}

- Lino de los fenómenos mas particulares E interesantes para el viajero que despues de una navegacion fatigosa de varios meses pisa la Costa de Oro, me escribe Reichenow, es un escamoso en cxtremo comun alli. Asi como las colonias de tejedores que ocupan las altas copas de la palmera de copa, y el sonoro arrullo de las palomas en las cercas que rodcan los pueblos, encantan el oido y la vista del ornitólogo que visita aquel territorio del misterioso continente, del mismo modo cautiva tambien el agama de cabeza de fuego, tanto a los colonos como al extranjero. Estos magnificos séres lla: man siempre de nuevo la atencion; yo, por lo menos, nunca me cansé de mirarlos. 
CARACTÉRES. - - El macho adulto del agama de los colonos tiene unos colores tan brillantes que seguramente no se podrian imaginar si se juzgase por los individuos que en nuestros museos se conservan en espiritu de vino. Toda la cabeza del animal vivo es de un rojo de fuego; la gargan. ta está salpicada de amarillo; el tronco $y$ las piernas brillan por su oscuro azul metálico; en el lomo se corre una linea clara ó blanca que sin embargo tambien puede faltar. $\mathrm{La}$ parte inferior de la cola, desde el ano hasta el ceutro, es de un amarillo de paja; la superior correspondiente de un azul metálico claro; lo demás de la cola de un rojo de fuego, y la mitad de la punta de un azul oscuro metálico. En los indivi. duos adultos, la mitad de la base de dicho órgano, tanto por arriba como por abajo, de un azul metálico claro; sigue despues una faja roja de fuego que ocupa casi todo el resto de la cola, dejando solo en la extremidad una pequeña parte de un oscuro azul metálico. Las escamas de la hembra son de un pardo sencillo con una linea mas clara en el lomo; los machos jóvenes se parecen à las hembras, pero se distinguen por tencr unas manchas de amarillo claro en la cabeza y en la nuca. En las montanas de Aguapin, en el interior de la Costa de Oro, encontré una bonita variedad del agama de los colonos, y vila siempre en las espesuras del bosque; los machos tenian la cabeza blanca, y la faja de la cola, que por lo regular es de un rojo de fuego, amarilla. La longitud de los machos adultos es de $0^{\circ}, 3^{2}$, de los que la cola ocupa $0^{\circ}, 20$.

DISTRIBUCION GEOGRÁFICA. - No sé hasta dónde se extiende el área de dispersion del agama de los colonos en la costa occidental del Africa; segun mis observaciones escasea cada vez mas hácia el sur. En la region del Kamerun solo encontré individuos aislados, y en el Ecuador he observado algunos pocos durante una larga cstancia; parece por lo tanto que la Costa de Oro es uno de los centros del área de dispersion de estos graciosos reptiles.

USOS, COSTUMBRES Y REGIMEN. - Aquíhabitan los agamas de los colonos todos los pueblos; asi como el gorrion doméstico, estos reptiles dependen de las casas, de la actividad y de las costumbres del hombre. Se les encuentra en los bosques, excepto la variedad ya citada, algunas veces en claros, y en los campos de bananos; pero en la mayor parte de casos tan solo cuando alli hay algunas chozas de vigilantes ó trabajadores; de modo que aun aqui están en contacto con el hombre. La choza del negro, el gorrion $y$ el agama son en la Costa de Oro tres cosas íntimamente unidas. Los agamas son muy numerosos en los pueblos; en to. das partes se les ve en las paredes de las chozas, en los teja. dos de paja y esteras, y en los muros blancos que rodean las casas de los europeos; alli descansan tranquilamente, con toda comodidad, colocados de modo que reciban todo el calor del sol; otras veces se les ve correr con ngilidad por acá y acullá para coger insectos. Muy particulares son los movimien. tos de estos reptiles siempre que notan algo de extraño ó que un hombre se acerca á ellos, pues á pesar de que estín familiarizados con el hombre, maniñestan, sin embargo, tanta timider, como otros de sus congéneres y tratan siempre de escapar de un peligro supuesto. Cuando se les inquicta mueven la cabeza hácia arriba y ábajo, elevando $y$ bajando al mismo tiempo toda la parte anterior del cuerpo sobre las piernas anteriores; entonces parece como si quisicran saludar con su roja cabeza. Cuanto mas se acerca el observador, tanto mas rápidas se hacen las inclinaciones, hasta que el reptil des. aparece súbitamente con la rapidez del rayo en alguna grieta del muro ó en la paja del techo. Cuando al medio dia pasé por las calles de Akkara, viendo en todas partes á estos rep. tiles magníicos inclinarse con movimientos tan extraños, no pude resistir la tentacion de darles caza con la red de mari. posas; pero solo alguna vez tuvieron resultado favorable mis esfuerzos á causa de la agilidad de los agamas. Mas fácilmente me apoderé de ellos con perdigones nuy finos y una escopeta pequena: un solo perdigon que les atravesara el cuerpo solia bastar para matarlos. Lo mismo observé en la caza de las serpientes, por extraño que me pareciese, dada la resistencia vital de los reptiles.

No menos numeroso que en la Costa de Oro, encuéntrase el agama de los colonos en el nordeste del Africa. Yo le encontré con gran frecuencia en Egipto y en la Nubia; y Schweinfurth tambien, en las partes mas interiores de ese continente. «Los mas numerosos, dice, eran los bonitos agamas cuyas continuas inclinaciones de cabeza enojan \& los fanáticos, porque creen que el diablo se burla de sus oraciones. Habia observado la misma especie antes en las pen. dientes pedregosas de los solitarios valles del desierto, en la costa del mar Rojo. Aqui, en el pais de los bogos, habita lo misino en las casas que en los árboles, pero su residencia favorita cra la madera vieja de las cercas, donde se reunian miles de individuos. Muy, astuto es su proceder cuando el observador se acerca al tronco del árbol al que suben y bajan; entonces permanecen en el ládo opuesto, parándose de vez en cuando para mirar por detrás de las ramas: sus grandes ojos tienen en tal momento mucha expresion. No cabe duda que Belon y Hasselquist se refieren à él, no al hardun, cuando hablan de un lagarto odiado por los mahometanos, á causa de sus inclinaciones de cabeza; pero cuyos excrementos se recogen á pesar de eso para preparar con ellos afeites. 
(Debs admirarnos, concluye Reichenow, que ningun europeo habitante en la Costa de Oro haya pensado hasta ahora en traernos agamas vivos, pues scrian un gran adorno para nuestras jaulas, mas que cualquiera otro reptil, tanto por su color como por sus movimientos ya descritos.

- Los agamaś tienen enemigos en algunas aves de rapina, sobre todo en el melierax músico y en los elanos; pero mas que estos, los centropos causan estragos en sus filas. Los individuos pequeños son as menudo presa de los todiramfos que en algunas partes se posan en troncos de árboles 6 sobre anchas hojas del pisan, precipitändose súbitamente sobre el reptil para devorarle.

\section{LOS ESTELIOS - STELLIO}

CARACTÉREs.-El género de los estelios se distingue de los otros agámidos por su tronco mas fuerte $y$ por tener la cola cubierta de escamas algo aquilladas y espinosas, dis. puestas en anillos al rededor de la misma. La cabeza, casi triangular, es plana; en la region de la linea naso-ocular, cóncava, y en la region de las mejillas ligeramente dilatada; el tronco es mas ó menos robusto; el cuello, que forma replie. gues irregulares, es mas delgado que el occipucio y bastante corto; la cola, de longitud regular y aplanada en la base, es en el resto del todo redonda; las piernas son relativamente largas y fuertes; las fosans nasales están situadas á los lados en la punta del hocico; el orificio auricular es bastante grande y en él se reconoce narcadamente el tambor, aunque á cierta profundidad. La parte superior está cubierta de escamas desigualmente aquilladas, la inferior del tronco de escamas sobrepuestas; la cabeza de pequeños escudos cuadrangulares, unos lisos y otros aq̨uillados, que en el occipucio y en las sienes se trasfornan en escamas cónicas ó espinosas; los po. ros de los musios no existen.

\section{EL ESTELIO VULGAR-STELLIO VULGARIS}

CARACTERES. - Entre los cinco cstelios hasta ahora conocidos, el comun es el mas interesante para nosotros, porque tambien se encuentra en Europa. El adulto alcanza una longitud de $\left(1{ }^{\prime}, 45\right.$, de los cuales corresponden ó la cola tres quintas partes. La coloracion varia, como en tantos otros escumosas, de una mancra notable. Las regiones superiores son de un pardo amarillo que puede variar hasta el gris negruzco $\delta$ el isabela; sobre este fondo se vera grandes manchas y. puntos negros; en las piernas y costados suelen tencr un color mas claro; la cola, que siempre tira al pardusco, presenia en la punta unos anillos negruzcos; las regiones inferiores tienen el fondo amarillo, con manchas $y$ otros dibujos mas oscuros, pero la parte inferior de la cola es de un solo color amarillo naranja ó de ocre sucio. El macho se distingue de la hembra sobre todo por su cabeza relativamente mas grande.

DISTRIBUCION GEOGRÁfICA. -El estelio vulgar habita en Europa la Turquía, algunas islas del mar Egeo-y el Cáucaso; además se halla en la mayor parte del Asia Menor y del Africa nordoriental. Segun Ethard, no es raro en las islas Cícladas, pero en ninguna parte abunda tanto como en la isla de Mikonos, donde ha hecho imposible la cria de abejas que antes existia alli, porque los reptiles exterminan Tомо $\mathrm{V}$ estos insectos. Encuéntrase tambien en Paros y Melos; no habita en el resto de las Cicladas ni en el continente griego; mientras que vuelve áser comun en Cefalonia. Los naturales los llaman aun hoy dia crocodilos, como en tiempos de Herodoto.

USOS, COSTUMBRES Y RÉGIMRN. - El estelio vulgar abunda mucho mas en el nordeste de Aírica que en Eu. ropa El hardurr, como le llaman los érabes, es un reptil muy conocido; se le ve casi en todas partes, á menudo á docenas ó en mayor número aun, sobre rocas, en piedras, muros y casas; trepa por las paredes con la misma agilidad que por las superficies inclinadas de las rocas; y aunque pesado al parecer, apenas es inferior en ligereza á nuestros lagartos. Corre con movimientos serpentinos, pero con mucha rapidez, y trepa exactamente como aquellos, porque esta manera de avanzar no es sino una carrera por superficies mas ó menos verticales; el estelio levanta la cabeza cuando corre, ofrecien. do asi el aspecto de un sér atrevido y valeroso.

El alimento del hardur se compone principal, sino exclusivamente, de varios insectos, sobre todo moscas y maripo sas, y como ya hemos dicho, de diversas especies de abejas. Si es útil porque extermina las moscas, ocasiona perjuicios en las islas griegas por sus ataques contra las abejas.

CAUTIVIDAD.-En el Egipto los encantadores de setpientes cogen al hardun, lo mismo que á todos los grandes 
escamosos, para enseñarlos al público. Prescindiendo de esos hombres, solamente los naturalistas europeos se ocupan de ese reptil, que algunas veces llega vivo a nuestras jaulas. Yo mismo le he cuidado mas de una vez, pero no hé tenido oca. sion de ocuparme detenidamente de él, y no me es posible por lo tanto describir por propia experiencia su modo de con ducirse en cautividad. Ciracias a la bondad del doctor Simon, puedo, no obstante, llenar este vacio. \&o tengo actualmente, me escribe, dos harduns que compré en Trieste; son dos in. dividuos adultos, y llegaron en a de junio de $1 \$ 76$. Los co loqué al punto en el terrado que tengo en mi jardin, bien construido y bañado por el sol; el calor era alli casi siempre superior á la atmósfera exterior; pero los harduns han sopor tado tambien en noviembre del año pasado y en fubrero $y$ marzo del piesente una temperatura relativamente baja, es decir, de 4 á $4.5^{\circ} R$, sin que esto turbase su hienestar. Estas chservariones no están conformes con las noticins de Schrei. biri segun las cunles los estelios resisten dificilmente nuestro clima, dejan de comer si la temperatura es baja y mueren. Mis harduns gozan aun ahora de la mejor salud y han creci. do mucho en la cautividad.

DAl principio, los dos reptiles eran tan tímidos, que corrian apresuradamente as sus escondites apenas me divisaban desdc el terrado á diez ó quince pasos. Su lugar favorito era la tapa de una caldera del conducto del agua caliente; á la altura de poco mas 6 menos un centimetro y medio sobre la misma hay una hoja de lata blanca, y tambien en los lados y por detrás la caldera está rodeada de una manta; de inodo que solo por delante puede entrar alguna luz El sitio aquel es mas caliente y menos accesible, aunquc tambien el mas oscuro; pero en el precisamente se han fijado los harduns. A todo trance procuran defenderse en este punto, $y$ aunque se les toque con el dedo ó una varita es dificil hacerlos salir; es tambien el escondite á que vuclven siempre de nuevo. Una vez que los alejé de él ponićndolos en un paraje descubierto del terrado, hicieron grandes esfuerzos tan luego como los solté para escaparse; intentaron saltar por las paredes de vidrio, y no descansaron hasta que al fin encon traron un escondite. En las últimas semanas, no obstante, se habian acostumbrado de tal modo á repetir la prueba, que no emprendian al pronto la fuga, sino que permanecian por lo menos un instante en el mismo sitio antes de huir. No solian abandonar sus escondites hasta que el sol barraba de lleno el terrado;y en el mes de mayo se presentaban tambien cuando el cielo estaba nublado. Para su alimento les doy casi todos los dias una cantidad suficiente de gusanos de harina y alguna vez tambien lombrices de tierra; en agosto, sciembre y octubre del año pasado les proporcioné además grillos, moscas, mariposas, etc; y els vista du buen estado en que se hallan los harduns, debo suponer que les gusta el alimento que se les ofrece. Solo una vez he visto que uno de ellos cogió a la carrera un gusano de harina. No puedo decir si beben agua.

I.os estelios no se han entregado al sueño invernal en el terrado, aunque algunas veces los sometl durante horas enteras á una temperatura poco mas ó menos de cero; aletarga. banse como otros escamosos, pero se despertaban en segui da con el grado de calor que suele reinar en las habita ciones.

×'Todos los movinuientos de los harduns demuestran una fuerza relativamente considerablc. Corren con gran rapiciez y saben trepar muy bien, cualidades que observé claramente en tres tentarivas de fuga hechas por los animales. Una vez, uno de los harduns habia llegado ya á un gran cuadro de trebol bajo cuyo espeso follaje habia desaparecido; de mo do que sole el rumur de las hojas secas me permitió seguir sus huellas, y volver á cogerle. La segunda vez se me escapó introduciéndose en la nieve profunda, por la cual pudo avanzar algunos pasos, aunque habia quizśs metro y medio. La tercera vez. habia desaparecido repentinamente de mi vista, resultando despues que habia trepado á unos tres me. tros de altura por el tronco de un árbol. En ia cuarta ten. lativa de fuga, el 6 de marzo de este año, tuve menos suerte, pues el hardun logró franquear un muro de casi dos metros de altura frustrando desde luego toda persecucion. Todo esto se verificó con una rapidez increible, en un espacio de tiempo cuya duracion no excederia de dos segundos; y por esto me he convencido de que los harduns trepan con mucha mas ligereza que los lagartos de los muros.

\$o crei que el hardun fugado habria muerto hacia mu. cho tiempo, cuando en 20 de junio me sorprendicron con la noticia de que en el jardin vecino se habia situado en un olmo; y al volver de un paseo de media hora dijéronme que habian vuelto á cogerle. En todo caso la tenacidad con que estos animales permanecen en el sitio acostumbrado es tanto mas cxtraña cuando que la naturaleza del lugar les permite marchar en cualquiera direccion.

Da hembra del estelio llamó ya la atencion en abril de este año por el extraordinario volumen de su vientre, y cuan. do, á fines del mes el ensanchamiento de la piel abdominal se hizo mas y mas desigual resultando pequeñas prominen. cias del tamaño de una peseta pude esperar que el reptil pariria pronto. Perdió sin embargo mas y mas su-agilidad, permaneció casi siempre sobre los tubos del calorífero, y en 17 de majo la encontré muerta. Abierto al instante el cadarer, halláronse nueve huevos longitudinales, de color blanco, con un ligero viso amarillento; son mas grandes que los de nuestro lagarto comun y su peso varia entre 77 centi. gramos a I gr., 15. Por las circunstancias debo suponer que los huevos se hubieran depositado á los pocos dias, pero que la hembra no tenia ya la fuera necesaria para poner. Sin embargo, casi no se comprende cómo pudo tener tal número de ellos. Como los dos estelios habian estado casi un año en cautividad, no cabe duda, en mi opinion, que el aparca. miento se efectuó en la jaula.

* Los harduns manifiestan una completa indiferencia para con sus companeros de jaula, que son varios lagartos comu. nes y de los muros, adultos, un geko y un lucion. Muerden con tal fuerza, que pueden hacer sangre en el dedo; cuando se les excita suelen iener abierta la boca dumnte varios mi. nutos.

Yuedo contestar afirmativamente a la pregunta de si el animal cambia de piel, porque en 18 ; 6 observé una muda en la cabeza y noté en este año que el macho fugado tambien estaba en la muda; no he reconocido ningun sintoma de en. fermedad en estos reptiles, ni tampoco las hinchazones que se desarrollan en los lagartos cautivos.

\section{LOS UROMASTIX-UROMASTIX}

CARACTfRRE.-Ios de este género consisten en tener la cabeza trilateral, aplanada, parecida al la de las tortugas, con el hocico corto y redondeado obtusamente; el tronco es pesado, recogido y ancho; la cola aplanida, revestida en su parte superior de varias escamas; las piernas cortas y robustas; los dedos bastante largos y provistos de garras muy corvas. Las fosas nasales dirigidas hácia atrás se abren lateralmente; los orificios auriculares son grandes y comprimidos de ade. lante atrós, de modo que afectan la forma oval verticalmente; el tambor se halla bastante adentro, pero aun nqueda marca. damente visible. El aparato dentario se compone de dos á cuatro dientes anteriores en la mandibula superior, dos ante 
riores $\mathrm{y}$ dos caninos en la inferior, y diez y ocho á veinte molares de forma triangular. La piel es rugosa y está cubierta de escamas iguales de figura cuadrangular redondeada; en la parte superior de la cabeza estas escamas se trasforman en pequeños escudos irregularmente poligonos y lisos, y en la extrenidad posterior de los orificios auriculares en promi. nencias espinosas, ó en forma de joroba. Varias escamas protuberantes cubren las piernas, y otras sobrepuestas y lisas los dedos.

DISTRIBUCION GEOGRÁFICA. - Lais especies mas grandes de estos agamidos habitan las regiones desiestas del sudeste de Europa, el norte de Africa y el centro de la India.

\section{EL UROMASTIX Ó ESTELIO ESPINOSO- UROMASTIX SPINIPES}

CARACTERES. - El uromastix espinoso ó dabl de los árabes puede llegar a una lungirud de 1$)^{10}, 60$, de los que la cola ocupa unos $11^{\prime \prime}, 24 ;$ sus partes superiores son de un color pardo aceituna bastante igual, con manchas pardas; y en li Época del celo de un verde de jerba brillante; las regiones inferiores de un amarillo verdoso.

DISTRIBUCION GEOGRÁRICA.-El uromastix espinoso habita, segun Erhard, las islas de Creta, Melos y Santorin; su verdadera área de dispersion se extiende mas hácia el sur, pues solo en el Asia Menor, Siria y Palestina, en la Arabia Pétrea y en el norte de Africa, desde los paises del Nilo hasta Marruecos, se le encuentra en numero considera ble. Abunda tanto en los desiertos de Judea como en los silios convenientes de ambas orillas del Nilo inferior $\delta$ en los valles pedregosos del Sahara y de los desiertos que rodean la parte septentrional del mar Rojo.

USOS, COSTUMBRES Y. REGIMEN.-Todos los uromastix tienen un aspecto nuy extraño $y$ parecen animales torpes, mas no lo son tanto como se cree. Eligen siempre para su residencia regiones solitarias, desicrtas ó pedregosas, aunque sin evitar los contornos de los pueblos. No se encuentra alli donde predomina el desicrto del todo arenoso; pero con seguridad se les verá en todas las llanuras donde las lluvias desarrollan uma vegetacion, por escasa que sea. Segun parece, este escamoso es uno de los que solo salen a la hora del crepúsculo. De dia se le ve á veces descansando al descubierto cerca de las rocas para tomar el sol, pero con mas frecuencia se le observa adherido à las anchas grietas de las paredes de roca. En los sitios favorables, es decir, donde hay escondites inaccesibles, alberganse a inenudo muchos de estos reptiles; yo recuerdo haber visto docenas de ellos en una misma hendiciura de roca. A falta de tales refugios, este animal abre agujeros en la arena, de los cuales sale de dia solo parn tomar el sol, volviendo á ellos, sin em. bargo, a la hora del meciio dia. Dicese que una especie con genérica es inuy sensible á las influencias atmosféricas y que cierra cuidadosamente las entradas de sus guaridas con arena cuando el ticmpo es frio. No sé si el dabb hace lo nusmo.

Cuando se encuentra un uromastix espinoso, se le ve dirigirse presuroso a su guarida, haciendo movimientos serpen. tinos con el tronco, que parecen muy extrairos a causa de la pesadez. del cuerno y la rigidez de la cola. Cuando aun no ha visto al hombre avanza lentamente, con pasos vacilantes, volviendo la cabeza á uno y otro lado, cual si necesiara la mayor precaucion. Si llega à su escondite permanece del todo tranquilo, por supuesto cuancjo se halla a ciersa profun. didad, pues parece saber muy bien que alli no pueden hacerle nada. Si se le corta casualmente $\delta$ con irtencion la retirada, se opone á su adversario, produciendo un sonoro bufido y se prepara al ataque. Su arma principal es la cola con la que puede dar golpes mas fuertes. Raras veces se de. cide á morder; pero cuando lo hace, dificilmente suelta la presa aunque se le rompa la mandibula.

Todos los uromastix parecen alimentarse de sustancias vegetales, comiendo solo de paso las animales. Ruppell vió a una de las especies mas bonitas comer jerba, y Effidt reconoció con gran disgusto que los individıos que cuidó morian regularmente cunado conian carne. Cierto que co. gian y devoraban los padazos que se les ofrecian, pero ya al dia siguiente, $\delta$ por lo menos en los inmediatos, demostra. ban por su pereza \& indiferencia que habian caido enfermos y ninguno de ellos volvia is sanar. Yo he cuidado última. mente repetidas veces el dabb sin poder obligarle á comer, y por lo tanto no puedo decir si es posible conservarle mu. cho tiempo vivo con alimento vegetal. Iristram dice que un uromastix cautivo que el tenia se alimentaba con preferencia de escarabajos, comiendo sin embargo de paso tambien al. gunas plantas. En otro pasaje añade que el dabb ataca y devorn animales mas grandes, como, por ejemplo, polluelos; pero no dice si esta noticia se funda en su propia observa. cion ó en relatos de otros. Los beduinos del Sahara dijeron al citado naturalista que el animal no bebe nunca, y que el agua hasta le es peligrosa.

Fuera del hombre, el uromastix tiene probablenente pocos eneinigos que pucdan causarle daho. Los beduinos refiricton a 'I'ristram que la vibura cornuda elige con bastante frecuen. cia la guarida del dabb como escondite, aunque paga siempre este atrevimiento con la vida, porque el dueño de la guarida ronipe al intruso la colununa vertebral descargaindole algunos fuertes coletazos.

CAUTIVIDAD. - Un dabb cuidado varios meses por Tristram era muy dócil y obediente; acudia \& la voz y dejá. base tocar sin resistencia Los que jo observé cran mas ó menos salvajes, y solo cuando la debilidad les hacia indife ferentes al mundo exterior mostrábanse mas tranquilos. Se. gun me escribe Klunzinger, los àrabes tienen algunas veces uu dabb cautivo, porque se le considera como un animal que atrae las bendiciones sobre la casa, crejéndose que tic nen alguna relacion los veintiun anillos de sil cola con una leyenda segun la que este número parece favorable.

USOS Y PRODUCTOS, - Los beduinos dan caza i los uromastix por su carne; le cogen y le ceban para comerle despues. Tristram no dice de qué modo se le lace engordar, pero asegura que tambien á ell le ha gustado mucho la carnt, algo parecida i la del pollo.

\section{EL MOLOCH-MOLOCH HORRIDUS}

CARACTERES. - A los agimidos pertenece tambien uno de los escamosos mas particulares, el moloch, tipo de un género del mismo nombre. Ia cabeza es muy pe. queña y estrecha, apenas mas ancha que el cuello; el tronco fuerte, mas ancho en el centro y aplanado, por lo cual tiene la forma de un sapo: la cola, casi ian larga como el ironco, es redondeada y obtusa en su catremidad. las piernas son largas $y$ endebles; los piés tienen cinco dedos cortos. En el centro del cuello sobresale una joroba longi tudinal, yen ambas extremidades se observan otras peque. nass. La cabeza, el cuello y el tranco están cubiertos de cscu. dos irregulares, en cada uno de los cuales subresale una espina bastante recta semejante a la de una rosa; tstas espinas son de diversa longiud y grueso; las mas grandes y corvas cubren ambos lados de la cabezd, como los currnos en los mamiferos; algunas mas grandes ocupan el rentro del 
cuello, extendiéndose otras por las dos jorobas laterales del mismo y át lo largo de toda la cola; las mas pequerias, en fin, cubren las picrnas. Ias partes inferiores son ásperas, pero no espinosas; los colores y dibujos de estos animales no son muy vivos, pero si agradables. Sobre un fondo castaño se corre a lo largo del centro de las costillas una faja estrecha de un color amarillo claro de cuero, que varias veces se ensancha en forma de cuadriláteros irregulares; otra faja de igual color parte de cada lado del cuello, prolongándose por los hombros, donde se ensancha, y una tercera se extiende hácia atrás, rodeando en su extremidad ambos lados de la cola. El color predominante de las regiones inferiores es amarillo claro de ocre; unas anchas fajas longitudinales y trasversales, orilladas de negro, forman figuras irregulares desde el cuello por todo el pecho, ocupando la parte inferior de la cola. La longitud total es de $0^{\circ}, 15$ a $0 \%, 18$.

DISTRIBUCION GEOGRÁFICA.-Esta especie y ge. nero son propios de la Australia.

USOS, COSTUMBRES Y RÉGIMEN.-SOlo liltima. mente hemos recibido noticias sobre el genero de vida del moloch, llamado por los colonos lagyrto espincso ó dinblo espinoso. Wilson recogió durante años seguidos todas las no. ticias que pudo sobre el extraño animal, publicándolas luego con sus propias observaciones. El moloch se encuenira en varios sitios cerca de Puerto Augusta; pero su área de disper sion se extiende sin duda mas de lo que hasta ahora se supo.

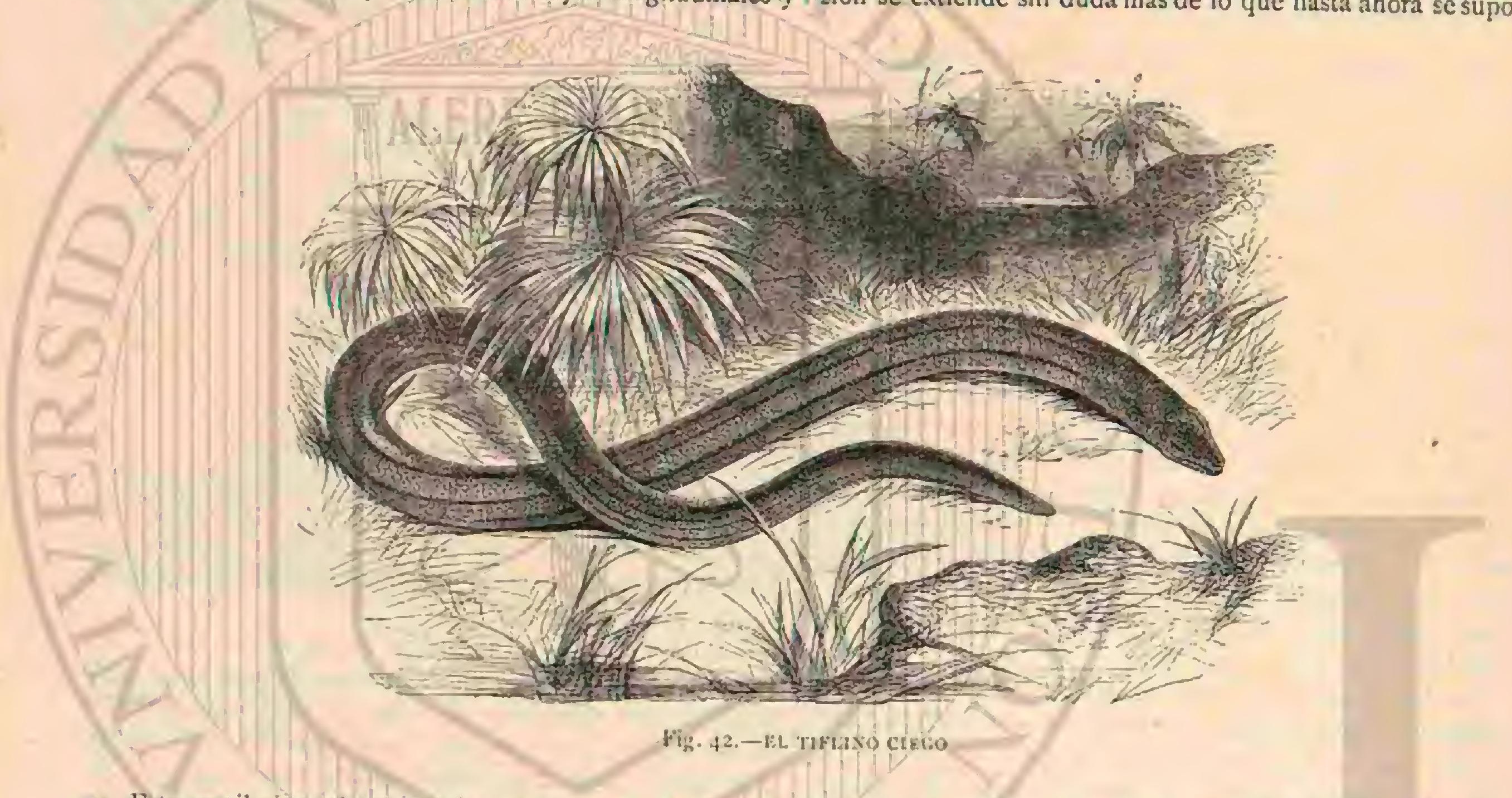

ne. Este reptil vive solo en parajes arenosos; en ciertas ocasiones se ven tambien dos ó tré individuos juntos que en la punta de una pequeña colinal arenosa, cerca del golfo, se exponen al sol. A menudo escarban en ia arena, pero solo penetran a poca profundidad. Sus ojos pequeños, casi ocultos, y todo su sér, indica que son reptiles diumos, que quizás nunca se mueven de noche, como no sea en ciertos casos. Aunque por lo regular son en extremo perezosos, se ha visto tambien que pueden correr con gran agilidad cuando se trata de llegar-á una guarida no demasiado lejana. Mientras descansan tranqutilamente tienen la cabeza levantada, de modo que su lomo forma una superficie oblicua. El alimento se compone, segun dicen, de hormigas; pero tambien se ha ob. servado que el moloch come sustancias vegetales. Los hue vos, que difieren poco de los de otros lagartos, se depositan en la arena.

I'ambien el moloch tiene en cierto grado la facultad de cambiar de color; pero no bruscamente, segun ha observaclo Wilson, y si siempre poco á poco, aunque con bastante frecuencia. El color vivo pasa entonces á un oscuro azul de pizarra ó negro de hollin, perdiéndose del todo las bonitas fajas.

CAUTIVIDAD. - Los cautivos que Wilson cuidó eran muy fastidiosos; no se movian casi nunca; permanecian s menudo en la misma posicion, y parecian en fin del todo in diferentes á lo que pasaba á su alrededor. Solo cuando se les echaba de espaldas hacian los mayores esiuerzos para reco. brar su posicion anterior. Ningun individuo de todos los que enia cantivos el citado baturalista se resolvia f tomar alli- mento; pero á pesar de eso se conservaban todo un mes sin manifestar gran debilidad, lo cual no puede admirarnos nada, atendida la gran resistencia vital de todos los animales de esta clase Extrañó es que no se mostraran tan duros a la influencia del sol; algunos á quienes se habia expuesto todo el dia å sus rayos, muricron poco despues.

El moloch solo merece su nombre por su aspecto terrible, pues su indole es del todo inofensiva. Unicamente ell las espinas tience armas defensivas, pero tambien estas son tan endebles que un cazador experto apenas se puede herir en ellas. El moloch no puede morder, como ya lo indica su pequeña boca.

\section{LOS GRAMATÓFOROS-GRAMMA- TOPHORA}

CARACT LERES.-El género designado con este noubre, el agrama de Cuvier, se caracteriza por los siguientes atribu. tos generales. Cabeza triangular y aplanada; hocico agudo; placas cefálicas, pequeñas, desiguales y angulosas; las lusas nasales están situadas en los lados débajo del ángulo del liocico y un poco detrás de su extrumidad; la lengua es es. cotada en la punta; la membrana del tímpano es grande; la mandibula superior cuenta cinco dientes incisiros, y en la inferior se reducen á cuatro los anteriores; por delante del pecho hay un pliegue trasversal; las cscamas dorsales son imbricadas y crizadas á veces de espinas; la cola es larga, cónica, pero deprimida en su raís orillada de escauas. 
EL GRAMATÓFORO ESPINOSO-GRAMMATOPHORA MURICATA

CARACTERES-Además de los indicados antes, esta especie (fig. 49) se distingue por tener una cresta escamosa sobre la línea media del lomo; las escamas de la garganta no son colgantes; los costados están cubiertos de escamas cortas y levantadas como espinas; el cuello tiene casi la misma an. chura que la parte posterior de la cabeza, y la cola es del todo cónica, excepto en su base que parece ligeramente aplanada en sus cuatro caras, que forman entre si angulos redondeados. El color de este lagarto es algo variable; el lomo suele tener un tinte gris pardusco, con fajas longitudi. nales de este último matiz, $y$ trasversales en las piernas $y$ la cola; en la cara superior de los rniembros predomina un par. do leonado con mezcla de pardo oscuro, color que palidece en las partes laterales del tronco.

DISTRIBUCION GEOGRÁFICA.-Parece que el gramatóforo espinoso esti diseminado en una gran paste de la Nueva Holanda.

USOS, COSTUMBRES Y REGIMEN. - Este reptil se puede considerar como un animal esencialmente arboricola;

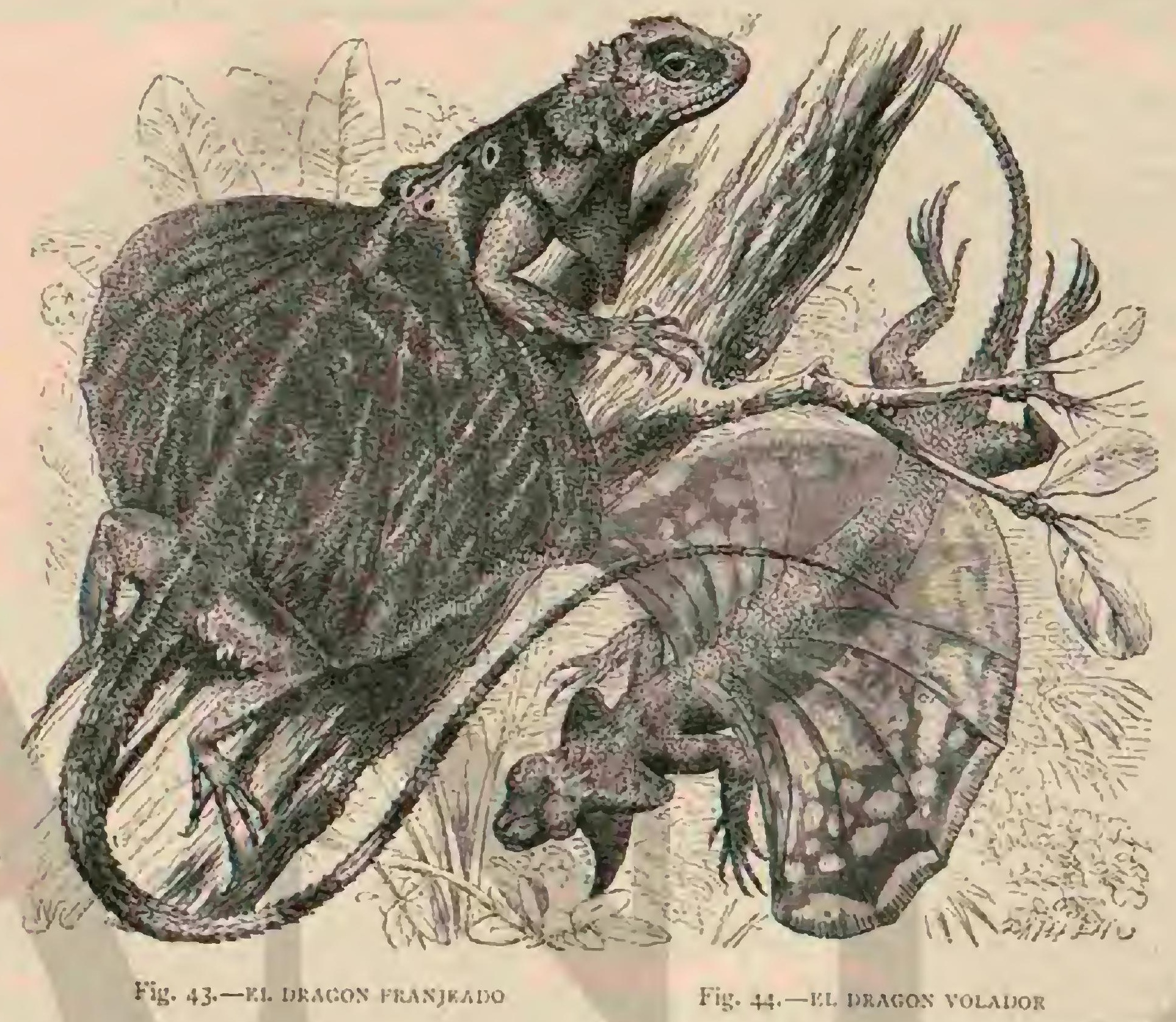

se le ve cruzar entre el samaje is trepas por los troncos con agilidad suma; es muy rápido en sus movimientos, y se alimenta de insectos de los cuales se apodera con la mayor facilidau.

\section{LOS IGUÁNIDOS - IGUA-}

\section{NIDA}

CARACTERES. - LO que los agámidos son para el antiguo continente, lo son los igúnidos para la América, donde sin embargo figuran en mucho mayor número y varieciad que aquellos en su área de dispersion. Sus caractéres generales sun los siguientes: la cabeza está cubicra de numerosos es cudos pequeños; el lomo de escamas de figura muy variable, dispuestas casi siempre et series trasversales. Los ojos tienen párpados bien desarrollados; el tambor es visible; las piernas son mas largas 6 mas corias, $y$ tanto los piés anteriores como los posteriores tienen siempre cinco dedos, por lo regular se. parados. Ia cola varia mucho por su longitud, pero es casi sienipre mas larga que el tronco. Ia lengua es corta, apenas escotada y soldada en toda su longitud. Los dientes redoncios en la base, anchos y comprimidos en la pumia, sc insertan en ul borde interior del surco dentario. Los dientes caninos casi nunca están bien desarrollados, mientras que los palatinos existen casi siempre.

DISTRIBUCION GEOGRÁFICA.-Los iguánidos, de los que se han distinguido unas doscientas cincuenta especies, son en alto grado característicos de la América del sur $y$ central, donde en todas partes abundan muchisimo, exten. diéndose tambien hasta las partes mas cálidas de la América del norte; en el oeste se hallan hasta California, la Colombia inglesa y Arkansas; en el este casi hasta ia frontera septen trional de lus Estados Unidos;-tambien habitan en las islas mas próximas a América, y un género independiente se ha observado en las islas de lidji.

USOS, COSTUMBRES Y REGIMEN.-Como ol area de dispersion de estos escamosos es tan extensa, viven real mente en todas partes donde los reptiles encucntran las con diciones necesarias para su bienestar: tanto en el continente como cn ias islas, en las alturas como en las profundidades, en las lianuras áricias como en las himedas, a la sombra de las selvas virgenes como en la inmediacion de las viviendas humanas, en cindades, pueblos $y$ chozas, lo mismo que en regiones desiertas, se encontrarán estos reptiles. Varias espe. cies pueden considerarse como acuáticas, porque á la manera de los varånidos del antiguo mundo se precipitan en raso de peligro al agua mas próxima y se sumergen y nadan muy 
bien; y hasta existe una especie que busca su alimento en el mar. Tambien hay algunas mal dotadas, perezosas, estúpidas $y$ al parecer indiferentes; pero las mas no son nada inferiores á nuestros lagartos en cuanto á viveza, agilidad y actividad corporal é intelectual. Lo mismo que los agámidos, constitu. yen un gran adorno en los bosques en que habitan, y asi como aquellos, excitan el interés por su gracioso modo de retozar. Su alimento se compone tauto de insectos como de sustan. cias vegetales; parece que algunos géneros se nutren exclusi. vamente de las últimas, mientras que la gran mayoria siempre da caza á los insectos y otros animales pequeños.

En cuanto ála reproduccion, solo sabemos por ahora que todos los iguánidos se deben comprender entre las especies oviparas. Varias de ellas han adquirido bastante importancia para el hombre, por su carne y sus huevos, que se aprecian como alimento; ni una sola especie podria designarse como dañina, mas á pesar de ello sufren muchas persecuciones.

Tenemos iguánidos arboricolas $y$ terrestres, dos grupos representados por varias subfamilias que á continuacion describiremos.

\section{LOS ANOLINOS-ANOLINA}

CARACTERES. - En bosques, espesuras y jardines de todas las regiones mas cálidas de la Ancérica vive una nu. merosa generacion de graciosísimos escamosos a los cuales

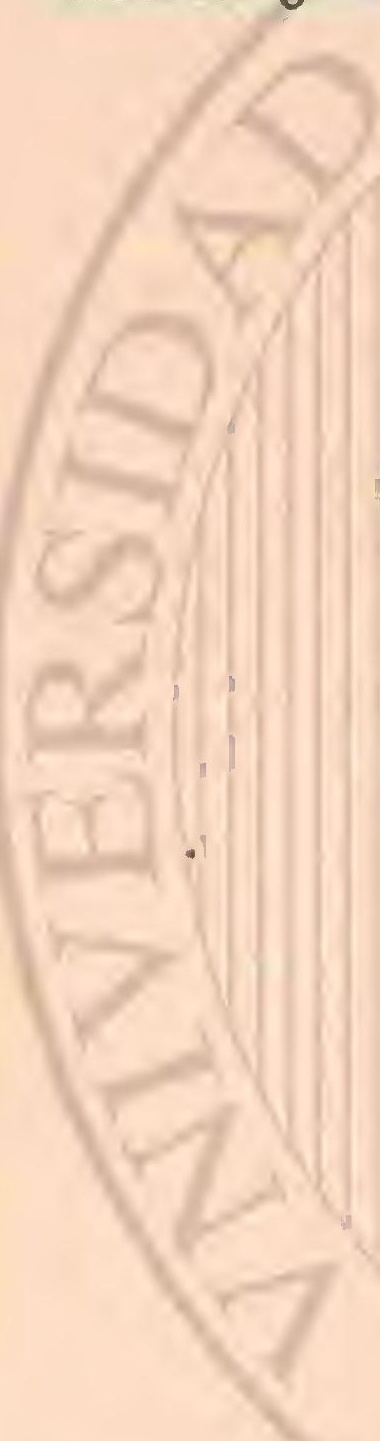

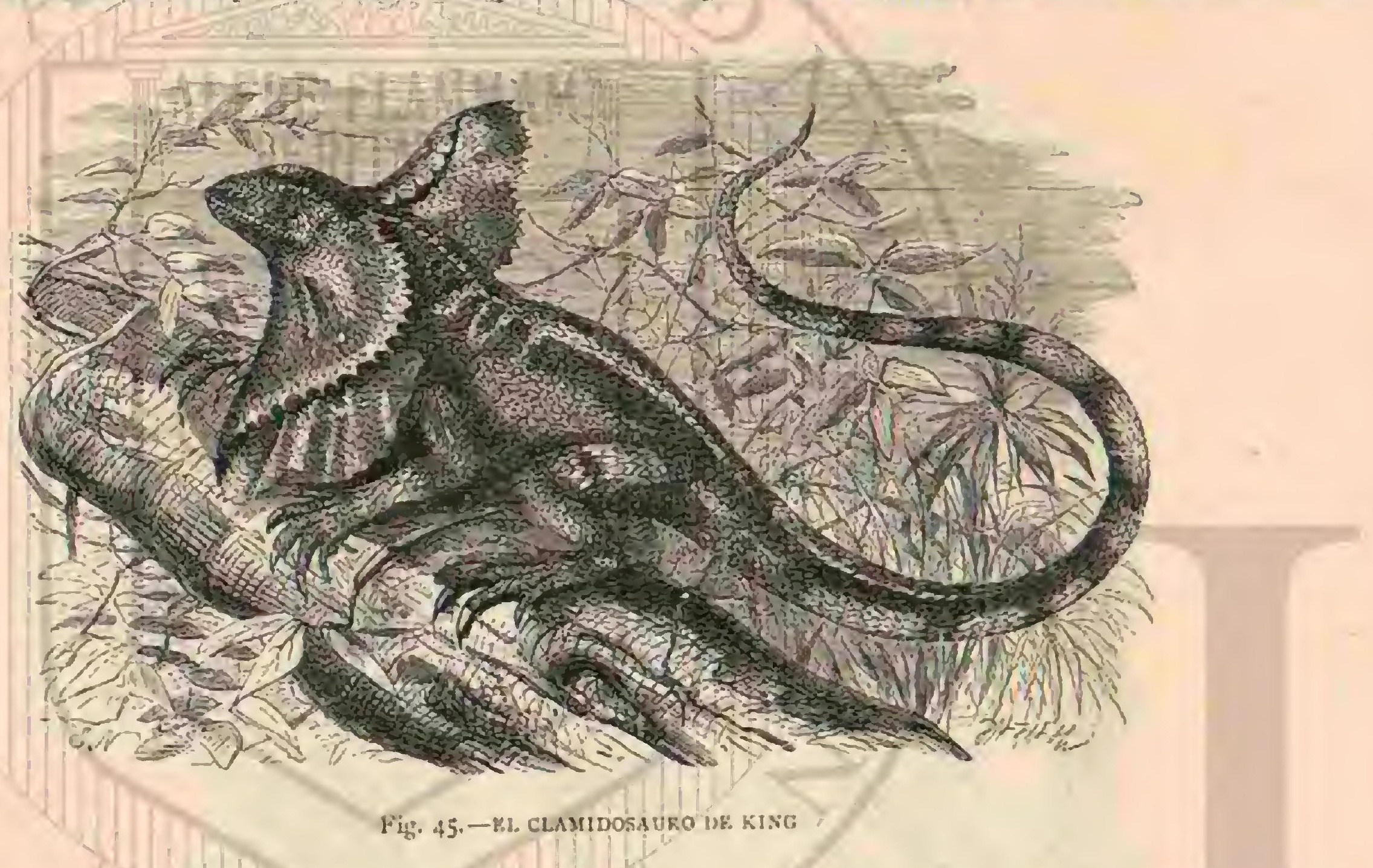

se ha dejado el nomibre de anolis, usado en las sntillas, dain. doles el rango de sub-farniliá.

In cabera de los anolis és de forma piramidal; el cuello de tamaño regular, con una ancha papada en su parte infe. rior; el cuerpo esbelto y la cola larga y blanda. Las escamas que cubren el cuerpo son muy pequenas. Los dientes ante. riores son sencillos, puntiagudos y cónicos, ligeramente encorvados, $y$ los restantes comprimidos con tres lóbulos; hay además una hilera de pequeños dientes palatinos, cónicos y agudos. Algunos anolis llevan cresta escamosa en el centro del dorso, pero ninguno riene poros femorales. La piel brilla por sus colores vistosos, $y$ tiene la facultad de cambiarlos, aun en magor grado que la del camaleon.

DISTRIBUCION GEOGRÁFICA. - La patria de los anolinos es como ga hemos indicado toda la parte cálida de las Américas con sus islas.

USOS, COST UMBRES Y RŔGIMEN.-Todos los via jeros científicos que han recorrido una parte de la América del Sur nos dan á conocer nuevas especies, aun no descritas, de este grupo que comprende mas de ochenta en el área de dispersion de toda la familia. Los anolis viven en todas partes, en cada bosque, en cada plantio de árboles, los cuales tambien abandonan para presentarse en las casas, en las galerias y hasta en las habitaciones, de modo que solo en los bosques mas espesos es posible no apercibirse de ellos. an la profundidad de las selvas virgenes solo por casuali. dad veremos, al fijar nuestras miradas en un punto, alguno de estos animales descansando inmóvil sobre una rama; pero en los contornos de los sitios habitados busca la sociedad del hombre, justificando la expresion de Nicolson de que en cietto modo fijan su atencion en lo que se dice. Con suma viveza, rapider y agilidad cazan los insectos de las mas diferentes clases, cogen aquui una mosca, una mariposa ó un coleóptero; examinan alli una grieta, una cavidad, para apo. derarse de una araña; acechan como el carnicero y preciphtanse sobre la presa como el gato sobre el raton, cogiéndola con una precision casi infalible. Desde la mañana hasta muy entrada la noche están en movimientn continun; traban en. carnizadas luchas, $y$ hasta viven en perpetua guerra con sus semejantes, si podemos dar crédito a algunas observaciones.

Tan luego como un anolis descubre á otro se precipita sobre el, segun Nicolson, aguardándole este resueltamente; antes de empezar el combate están un buen rato mirándose frente $\mathbf{a}$ frente, como acostumbran hacer los gallos, meneando la cabeza de arriba abajo, dilatan cuanto pueden la papada y se dirigen furiosas miradas; luego se echan uno sobre otro, procurando sorprenderse mutuamente. Cuando ambos son de igual fuerza, dura largo rato la pelea, que se verifica por lo comun, en las ramas de los árboles; con frecuencia acércanse durante el combate otros anolis, que sin tomar parte en ell observan tranquilos á los combatientes; estos se muerden algunas veces de al modo, que cuando uno de ellos consigue desprenderse de las mandibulas del otro, estas clior. rean sangre; sin enbargo. al poco rato vuelve á empezar la pelen. El contrario mas débil, cuando sucumbe por completo, es devorado por su rival, y solo en circunstancias muj favo. 
rables suele libiarse con la pérdida de la cola. El anolis que sufre este percance se vuelve timido y melancólico, y por lo general se oculta.

Is muy probable que el objeto de estas peleas sea la posesion de la hembra; en todo caso durante la tpoca de los celos se mucstran mas vivos y salian sin descanso de rama en rama. Ja hembra escarba con sus patas delanteras un pequeño agujero debajo de un írbol ó al pié de un muro, y alli pone sus huevos de un blanco sucio, cubriéndolos lige. ramente despues, y dejando al sol el cuidado de su incuba cion.

Gracias â su carácter inofensivo y familiaridad, los anolis han inspirado confianza hasta en la América del sur, donde segun dice el principe de Wied, casi todos los animales se consideran como daninos; de modo que no los tienen ya por venenosos. En ninguna parte se les mira con aversion, y en algunas regiones hasta se les trata con benerolencia cual si sc apreciaran los buenos servicios que prestan por la destruccion dc inscctos. Por lo mismo sc les perdona el atrevimicnto que demuestran cuando se precipitan sobre el hombre que les persigue agarrándose cies soportan la cautividad bastante tiempo cuando se las cuida de un modo conveniente, y por lo tanto se pueden lle var tambien sin dificultad á Europa

\section{LOS ANOLIS - ANOLIS}

CARACTERES. - Los caractéres de este género son los ya indicados para la sub familia.

\section{EL ANOLIS PRINCIPAL-ANOLIS PRINCIPALIS}

CARACTERES.--Los de esta especie son los siguientes: la cabera es prolongada, triangular y aplonada, en individuos peq̨ueños casi plana, y en los adultos provista de doble quuilla y cubierta de grandes escudos poligonales: cl tambor es vi. sible; el cuello, muy corto, tiene en su parte interior una pequeña papada; el tronco tan alto como ancho, aquillado cn su parte superior y plano por debajo; unas escamas ligeramente aquilladas, pequerias, exłgonas ó redondas, y no so. brepuestas, cubren el lomo; otras semejantes, pero de forma oval, protegen el vientre; la cola, casi redonda, y solo comprimida en la base, está revestida en la punta de pequeñas escamas aquilladas, dispuestas on anillos. En ol individuo vivo la parte superior es de un verde lorillante; la inferior de un blanco puro; la garganta roja y la region de las sienes ne. gra; la cola presenta puntos negros. El color verde puedesin embargo convertirse en pardusco ó pardo, y variar en gene. $\mathrm{ral}$ del modo mas diverso. Cuando el animal se excita su ca. lor varia, segun Schomburgk, desde el gris verdoso al gris oscuro y pardo, pasando por todos los tintes imaginables hasta el verde brillante; del mismo modo varian los dibujos. Ia longitud es de $1 *, 35$, de los que dos terceras partes perteracen a la cola.

DISTRIBUCION GEOGRÁFICA.-Fil anolis principal ó anolis de garganta roja figura en la Carolina entre los esca. mosos mas comunes $y$ habita alli todos los sitios conve. nientes.

USOS, COSTUMBRES Y REGIMEN. - Segun Hol. brouk, este reptil es muy vivaz, agil y pendenciero. Vive generalmente en los śrboles y empalizadas de los jardines, atreviéndose muy á menudo a entrar en las habitaciones, sin cuidarse de la presencia del hombre, trepando â las mesas $y$ otros muebles y dando caza alli á las moscas y otros insectos. Cuando anda por el suelo lo hace con mucha velocidad y con cierta gracia, llevando la cahera levantada, siendo sus movimientos tan ligeros y rápidos, que mas parece volar que correr. En los árboles se mueve con extraordinaria velocidad, saltando de la rama de un árbol a otro, y sabe sostenerse aun cuando no toque mas que una hoja; faror de sús anchos dedos se adhiere á los objetos mas lisos, como el cristal ó la madera pulinentada, y hasta puede correr por los techos de las habitaciones. Su alimento consiste generalmente en insectos, pero parece que ś veces come tambien alguna fruta.

Segun Schomburgk, coge tambien avispas y otros insectos de aguijon, $y$ hasta no teme al escorpion, al cual atrapa con tal habilidad por la cabeza, que cuando quiere defenderse se hiere a si mismo, pero no al anoli.

Durante el periodo del celo su actividad se aumenta en todo concepto, $y$ entonces pelean con el mismo valor y en. carnizamiento que cualquiera otro macho. Ambos combatien. tes levantan la cresta od una altura extraordinaria, hinchan la bolsa de la garganta tanto como pueden, cógense en fin por las mandíbulas, agarrándose de tal modo, que en mucho tiempo no pueden desprenderse. En esta ocasion el cambio de los colnres es el mas rápido y extraño. Sin embargo, hácia el otoño olvidan toda discordia y viven en la mejor armonia con sus iguales, formando à veces grandes grupos reunidos casualmente. Schomburgk encontró raras veces mas de dos huevos en el oviducto, observando que por lo regular uno estaba mas desarrollado que el otro. Ia hembra deja cacr los huevos sin preparativos, de modo que se les encuen. tra lo mismo en la arena quie en las rocas, $y$ hasta en las habitaciones.

Segun dice el uiltimo viajero, los muchachos se aprovechan de la predileccion del anolis por la música para aporicrarse de ellos; se acercan silbando \{l los ágiles animales, y les echan un nudo corredizo á la cabeza.

CAUTIVIDAD. - Los cautiros se domestican en poco tiempo, y por esn se ven á menudo anolis hasta en las jaulas de gente poco aficionada á los reptiles. Tambien llegan á Europa con bastante frecuencia individuos vivos.

Se comportan del mismo modo que nuestros lagartos mas ágiles, \& los que sin embargo son superiores en rapi dez y en habilidad para trepar. Bell los ha descrito muy bien. Una vez, dice, tuve dos anolis vivos de las Indias occidenta les, los que se alimentaron de moscas y otros insectos. Ia viveza con que cazaban excitó en alto grado mi aten. cion: acechahan la presa con la misma cautcla que el gato á la suya, $y^{\text {se }}$ precipitaban sobre la víctima con la rapider del rayo. Un dia les eche, además de las moscas, una araña grande. Uno de los anolis se adelantó para apoderarse de ella, pero solo consiguió cogerla por una pata; la araña se volvió instantáneamente y tejí́ varios hilos al rededor de las patas delanteras de su adversario, mordiendole despues en el labio, tal como acostumbra hacer cuando ella coge pre. sa å su vez El reptil pareció asustarse en gran manera; reti. re, pues, la araña y desligué las patas a mi cautivo. Sin $\mathrm{cm}$. bargo, pocos dias despules lo encontré muerto, sin duda i causa de la herida hecha por la araña, que tal vez fuera venenosa, pues su compañero de cautiverio, que continu6 tan alegre como siempre, le sobrevivió bastante tiempo.

\section{EL ANOLIS DE LA CAROLINA-ANOLIS CAROLINENSIS}

CARACTERES.-Tiene este anolis el hocico largo y deprimido, y si bien esta circunstancia perjudica un poco a su buen aspecto, no deja por eso de set como la especie ante. rior un animal gracioso y agradable \& la vista. Is coloracion 
del dorso, sujeta á variados cambios, es un magnifico verde dorado; la del abdómen es verde tormasolado de blanco. Ia papada, á lo menos cuando el reptil está excitado, tiene un color rojo subido de cereza. Mide unas 7 pulgadas de largo (fig. 48 ).

DISTRIBUCION GEOGRÁFICA. - Habita esta espe. rie parte de la América septentrional, y tambien las Antillas; pero como su nombre lo indica, abunda mas en la Caro lina.

\section{EL ANOLIS DE CRESTA-ANOLIS VELIFER}

CARACTERES. - Esta especie, q:1- Fitzinger coloca en el género Xiphosurus de sus Dacljlode, es una de las mayo. res de sus congéneres, midiendo cerea de dos pics de largo. Su color es azul gris, mas oscuro en los costados, con algu. nas manchas jardas. La cresta empieza ya en la nuca, corre por todo el dorso, y adquiere mayor altura en la cola, que aparece comprimida lateralmente. La cabcza la tiene prote. gida en su parte anterior por placas ásperas, exagonales y puntiagudas; la parte superior del cuerpo está cubierta de escamas aquilladas, convexas y casi cuadradas; las de la parte inferior son lisas (fig. 46).

DISTRIBUCION GEOGRAFICA.-El anolis de cresta abunda en la isla de Santo Domingo, crejéndose general. mente que solo se encuentra alli, pues no se tiene noticia de que haya sido observado en las demas Antillas.

USOS, COSTUMBRES Y REGIMEN.-De las varias relaciones que se conocen respecto al modo de vivir de este escamoso, se deduce que es muy parecido al de los demás individuos de la misma familia. Es muy vivo y àgil, y tan confiado, que corre y caza á la vista del hombre sin preocupar. se de su presencia; todo lo mira y examina, pareciendo ade. más prestar atencion á lo que se hace y se dice delante de

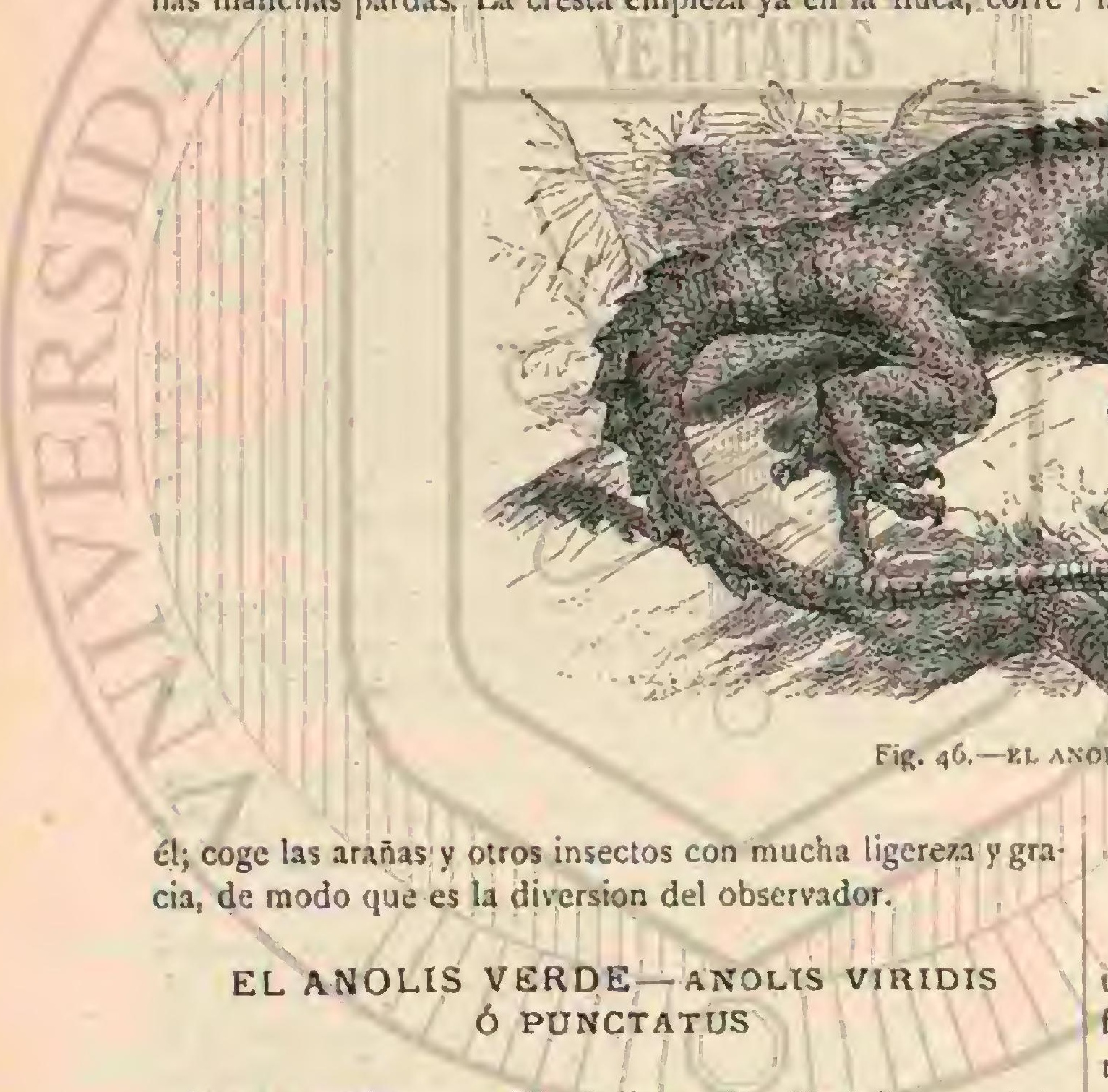

CARACTÉRES. - El anolis verde, Dutyloa punitata, segun Fitzinger, es un bonito animal, esbelto y de unas 18 a 24 pulgadas de largo, de las cuales una tercera parte correspunde al tronco. No lleva cresta en el dorso, y las escamas que le cubren son finas y granosis, mientras qque en la cola son recargadas y puntiagudas. La coloracion de la parte superior del cuerpo es verde brillante; en la parte anterior de la cabeza se convierte en verde gris y en la region abdominal en blanco agrisado; las patas son verdes manchadas y rayadas de pardo; la cola tiene en su raiz puntos y líneas oscuras so bre fondo verde claro y la punta gris oscuro (fig, 47).

DISTRIBUCION GEOGRÁFICA.-Esta especie abun da bastante en los bosques del Brasil.

USOS, COSTUMBRES Y RÉGIMEN.-Véase lo que sobre este punto refiere el principe de Wied: Solo he podido ver á este hermoso anolis en las grandes selvas del Mucuri, donde se le encuentra en gran nimero. Es muy ágil, trepan do con suma rapidez por los árboles que son su morada favorita; $y$ dando grandes saltos. Si es perseguido y llega á verse acorralado, se precipita sobre el adversario y muerde con fuerza, pero sin causar mucho daño.

Algunos indigenas dan à este reptil el nonbre de camaleon, porque suele cambiar á menudo de color; sin embargo, el verde es siempre el tinte dominante.

\section{LOS BASILISCOS-BASILISCUS}

Con este nombre idearon los antiguos griegos y romanos un monstruo horroroso, en figura de serpiente, dotado de fuerzas sobrenaturales y engendrado contra las leyes de la naturaleza; el gallo, la serpiente y el sapo eran considerados como sus progenitores: la gallina ponia huevos disformes, y la serpicnte y el sapo los recogian para incubarlos. Fl basilisco tenia el cuerpo alade, la cabeza coronada, cuatro pićs de gallo, cola de serpiente y ojos fulgurantes de mirada tan venenosa que emponzona ba el aire, matando todo lo mortal que se ponia en contacto con el mismo: las frutas se desjuren. dian de los árboles y se pudrian; la jerba y las plantas se se. caban; los pajaros caian muertos al suelo, y caballo y jinete se asfixiaban. Solo un animal tenia poder bastante para alejar al basilisco y hacerle inofensiro: su progenitor, el gallo. Asi como ante el graznido del basilisco debian huir todos los engendros parorosos de la imaginacion, del nuismo modo se le obligaba á aquel á esconderse en las profundidades de la tierra cuando oia el canto del gallo. Tan absurdos cuentos no han dejado de encontrar gentes crédulas en tienpos mas nodernos, no solo entre los profanos, sino tambien en los llamados hombres de ciencia; asl el naturalista inglés Topsel trazó una descripcion terrorifica del imaginario basilisco de los antiguos, como si realmente hubiese existido. Lutero tambien, y en este es menos de extrañar, empleó el nombré de este animal para traducir algunos pasajes oscuros del Antiguo Testamento.

«iPues mira, so os enviaré serpientes y basiliscos que no scrán conjurados, y os picarán, dice el Señor! Jeremias 
amenaza en nombre de su irritado Dios. alncuban huevos de basilisco, dice Isaias, y hacen tejidos de arana; cuando se comen sus huevos se debe morir y si se aplastan sale una vibora.3 No es posible determinar en que terribles animales pensaron los dos profetas, si es que pensaron en animales; el que ha conocido por propia experiencia la facundia de los orientales y la profusion de palabras insignificantes, tampoco hace ningun esfuerzo para averiguarlo. Como quiera que sea, la moderna zoologia no dejó escapar un nombre tan importante como el de basilisco, thizo uso de él como se ha hecho con los de los dioses y diosas antiguos, héroes, ninfas, duendes, demonios, diablos y otras invenciones de la fan. tasía.

CARACTÉRES. - Los basiliscos llevan en el dorso y á reces tambien en la cola una alta cresta de piel, sostenida por las apófisis espinosas de las vértebras, y en los dedos de las extremidades posteriores una franja escamosa. La cabeza y el cuello son cortos; el cuerpo clevado y seco; la cola muy larga y comprimida lateralmente. Cubren la cabeza pequenas escamas aquilladas y el cuerpo otras romboidales, dispuestas en fajas trasversales. Las mandibulas están guarnecidas de numerosos dientes de igual forma y tamaño, rectos y comprimidos, y con la corona triangular; cada una tiene cuarenta y dos de estos, y se ven además hileras regulares de dientes palatinos.

\section{EL BASILISCO DE CAPUCHA-BASILISCUS MITRATUS}

CARACTÉRES.-Este basilisco tiene en el occipucio

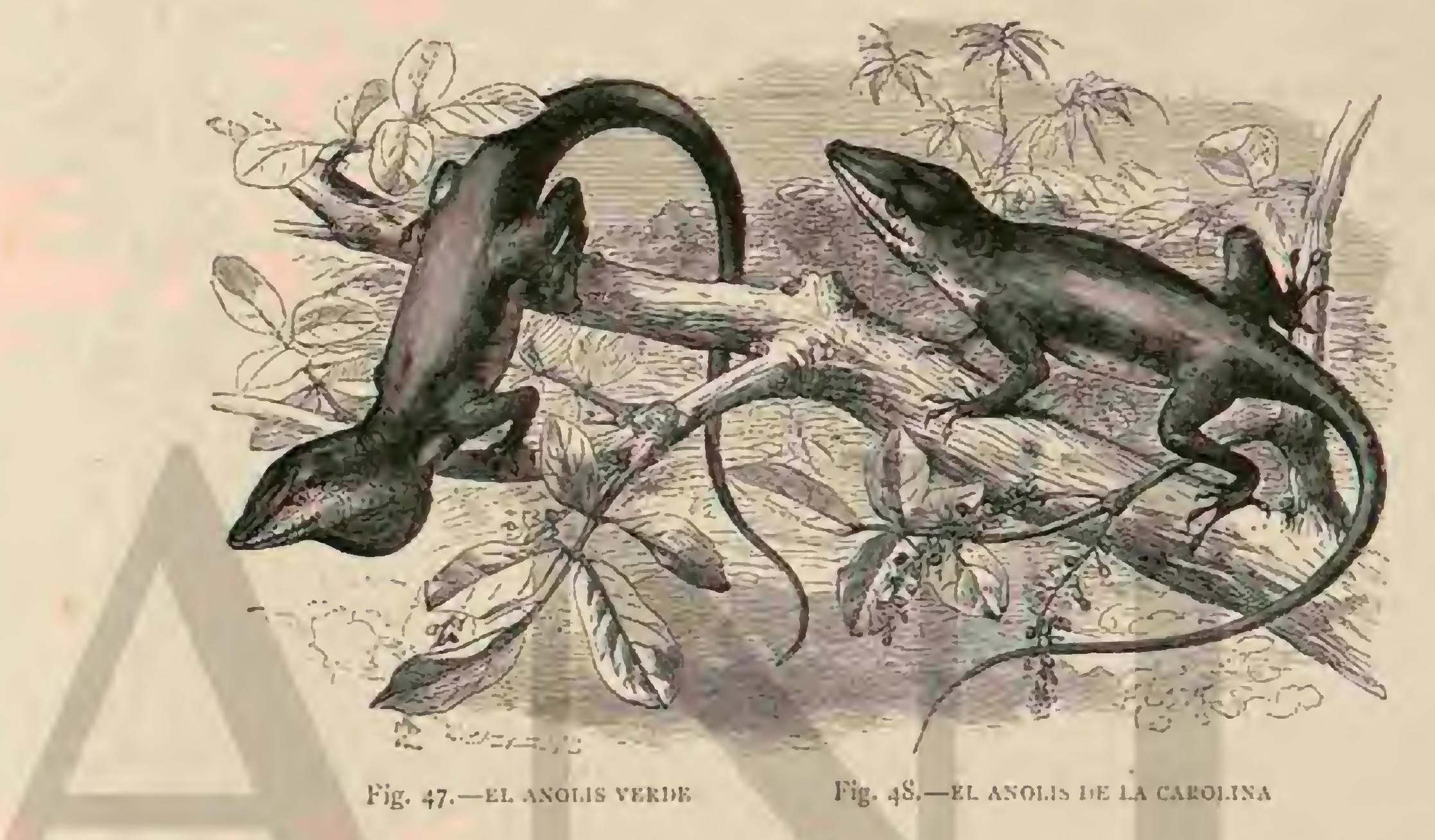

una especie de capucha puntiaguda, cubierta de escamas aquilladas y sostenida por un cóndilo cartilaginoso. Su color primitivo es tal vez verde, pero en los individuos conservados en espiritu de vino, las regiones superiores son de un pardo rojizo, y las inferiores de un blanco sucio; desde el lomo se corren unas fajas irregulares s interrumpidas en los costados; detrás de los ojos se ve una faja blanca y en la parte poste. rior de las mandibulas otra del mismo color. La longitud pasa de $11^{\prime \prime}, 60$, correspondiendo á la cola tres quintas partes.

DISTRIBUCION GEOGRAFICA. - Esta especic vire en la Guayana, la Martinica, gran parte de México y algunos otros puntos de la America meridional.

USOS, COSTUMBRES Y REGIMEN.-Solo úlkima mente hemos recibido algunas noticias sobre el género de vida de los basiliscos. El de capucha, segun Salvin, es tan comun en Guatemala que el naturalista puede sin dificultad matar tantos como quiera. Se les ve posados en las ramas bajas de los árboles $\delta$ sobre los arbustos, donde acechan su presa, $\delta$ ya en los troncos cortados, tomando el sol, Muy á menuido se encuentran cerca de los rios, de cuyos contornos parccen alejarse. Sus movimientos son sin embargo bastante rápidos para que solo el cazador experto pueda apoderarse de algun individuo. Sumichrast describe mas minuciosa. mente uno de sus congéneres trazando los caractéres genera les del grupo: En todas las orillas de los rios de las regiones cálidas y templadas de México encuéntrase con frecuencia cl basilisco. el sumbichii de los indios, el parsa-rios de los me. Tомо $\mathrm{V}$ xicanos, reptil graciosisimo, cuyas costumbres no recuerdan en modo alguno las fábulas de los antiguos. Con mas fa. cilidad se hallan los basiliscos en la primasera, $\delta$ durante el periodo del celo, porque entonces el macho se distingue no solo por sus formas graciosas, sino tambien por sus vivos colores $y$ airosos movimientos. Muy temprano por la mañana salen a cazar; al medio dia suelen tomar el sol á la orilla del agua sobre los troncos de árboles muertos. Apenas oyen ruido levanian la cabeza, dilatan la garganta I mueven la cresta membranosa. Los penetrantes cjos del repiil, con su iris rojizo, reconocen al punto el peligro; y con ln flexibilidad de un muelle, rápido como el rayo, sc precipita al agua. Cuandó nada levanta la cabeza y el pe. cho, golpea las olas con sus patas anteriores á guisa de remo, arrastrando la larga cola como un timon; y entonces parcce bien justificado el nombre de pasa-rios ó fimonero, que le dan los mexicanos.

1. A fines de abril ó principios de mayo, la hembra pone de doce á diez y ocho hlievos en un agujero, al pié de un tronco de árbol, confiando al sol la incubacion. Estos huevos mi. den $(1)^{\circ}, 20$ de ancho por 1$)^{\prime \prime}, 013$ de grueso, pero se parecen por lo demás á los de otros iguánidos. Los hijuelos salen î luz á los pocos dias y se distinguen esencialmente de los adulios por el color, pues la cresta y la cola son iguales a las de las hembras, de un color de aceituna, mientras que en los machos adultos tienen un bonito tinte rojo de sangre.

vil alinento de los basiliscos se compone esencialmente 
de insectos, los cuales saben coger con habilidad cuando se ponen al acecho en las ramas inclinadas sobre el agua

\section{LOS CORITOFANOS- CORYTHOPHANA}

CARACTERES. - Los coritofanos se distinguen de los basiliscos principalmente por tener en el occipucio en vez de la cresta membranosa una apófisis ósea en forma de casco; los dedos ni son mas anchos ni están orillados por una mem. brana. La larga cola, que remata en punta muy fina, no tiene una cresta escamosa, pero existe sin embargo en el lomo, y en algunas especies tambien en la nuca; la piel de la parte inferior del dorso forma unos repliegues trasversiles. Los dientes palatinos existen, pero no los joros de los muslos.

DISTRIBUCION GEOGRÁFICA. - Este grupo tiene el rango de sub-familia y solo se compone de dos géneros, poco diferentes, $y$ de un redúcido número de especies, cuya patria parece limitarse al centro de América con sus islas.

\section{EL CORITÓFANO CAMALEOPSIS - CORY- THOPHANES CHAM ELEOPSIS}

CARACTERES. - Sumichrast nos dió á conocer últimamente el género de vida de esta especie, que alcan$2 a$ una longitud de $0^{\circ}, 2 \mathrm{r}$, correspondiendo à la cola ()$^{\circ}$, I 4 . En el lomo hay una cresta, pero no en el cuello. Este reptil dinere de sus congéneres par los escudos del lomo, desiguales, denticulados y dispuestos en series trasversales; asi como por un pequeno repliegue longitudinal de la parte inferior del muslo. La cabeza se aseneja de tal modo al la del camaleon, que parece justificado que los mexicanos le aplicaran este mismo nombre al hablar del reptil. Distin. guese sin embargo por tener comprimida la apófisis del oc cipucio en forma de cresta ósea con borde agudo. El color, mezcla agradable de pardo, amarillo, negro y blanco, no es brillante y está sujeto a muchos cambios; y tambien varia bajo la influencia de la luz Así, por ejemplo, Sumichrast observó que la garganta de un coritófano cautivo era blanca de dia, pero oscura de noche, como todas las partes blancis del cuerpo.

DISTRIBUCION GEOGRÁFICA. - El coritófano catnaleopsis no es comun en ninguna parte, pero se encuentra en México, en ambos lados de las Cordilleras.

USOS, COSTUMBRES Y REGIMEN.-Esta especie difiere del basilisco, asi como de los iguánidos, por el hecho de vivir en las orillas de los rios, cuando no casi exclusivamente en los bosques, donde se le ve por lo regular en las ro. cas: parece preferir los bosques de encinas, porque aqui el color oscuro de su cuerpo se confunde con el de la hojarasca, lo cual le facilita la caza de los insectos. Es en extrerno vivaz y cuando le queda un medio para escapar solo puede alcanzarle un tiro. Mientras corre levanta el lomo casi verticalmente, arrastrando la cola por tierra, lo cual le comunica un aspecto muy extraño.

La supersticion de los indios no puede menos de atribuir á este pequeño y grotesco sér facultades extraordinarias. A pesar de que esa buena gente terne las heridas inofensivas que ocasionan las espinas situadas en ambos lados de la cabeza, elogia sin embargo la virtud mágica del cuerpo de este ieptil, que una vez secado se lleva como amuleto para combatir el mal de ojo é infinidad de dolencias imaginarias. A la verdad, el animalito es uno de los iguánidos mas graciosos que se co. nocen.

CAUTIVIDAD.-El cautivo que Sumichrast conservo vivo mas de un mes era sumamente inquieto, pero se domes. ticó pronto, de tal modo que acudia para coger moscas y otros insectos que se le ofrecian; hasta se dejaba coger sin resistencia, $y$ agradábale mucho que le hiciesen caricias. Cuando su guardian le cogia con la mano, hubiérase dicho que le magnetizaba el contacto; si le tocaban el vientre cruzaba las patas anteriores como quien lo hace con las manos para orar, permaneciendo en una inmovilidad completa.

\section{LOS IGUANINOS - IGUANINA}

«Dos magnificos ingas en fior habian atraido multitud dein. secios, y estosá su vez hicieron acudir gran número deiguanas. A cada golpe de remo que dábamos se precipitaban tres 6 cuatro de estos animales desde los árboles al agua, 6 desapa. recian con la velocidad del rayo, saltando de rama en rama y escondiéndose en lo mas espeso del follaje; sin embargo, no todos se escapaban al ojo avizor de los indios, y mas de uno tulo que sucumbir herido por sus flechas. En pocos instantes tocio fué vida, movimiento y algazara en aquellas soledades, pues se trataba de proporcionarnos para la comida del dia uno de los manjares mas delicados. Con las armas de fuego no era tan segura la caza como con las flechas, pues las igua. nas tocadas por el plomo, si no caian 'inmediatamente heridas de muerte, se precipitaban en el acto al agua y no vol. vian a aparecer, mientras que las largas flechas entorpecian sus movimientos, impidiéndolas arrojarse al rio. Entre el rico botin que recogimos, se encontraban varios individuos que median de cinco á seis piés de largo y uno de diámetro. i pesar del exterior repugnante del animal, su carne no puede ser mas delicada; sus huevos son igualmente muy sabrosos. Como es de suponer, esta circunstancia hace que se dé álas iguanas una caza muy activa, no solo por los indigenas, sino tambien por los europeos $y$ hombres de color; de modo que de dia en dia es mas raro este reptil. s

Con estas palabras describe Schomburgk su encuentro con la iguana tuberculosa, la especie mas conocida y en cierto modo el tipo de toda la familia y de la sub-familia de los iguaninos, representante ademís del género de las iguanas.

\section{LAS IGUANAS-IGUANA}

CARACTERES. - Este género se distingue por su cuerpo largo y comprimido lateralmente, por la cabeza larga y cuadrangular, por el cuello corto, por las extremidades fuertes y provistas de largos dedos y por la cola larga y comprimida en la raiz. Tiene además como distintivo, una gran papada delgada y colgante debajo del cuello y fuertemente dentada en su parte anterior; $y$ desde la nuca hasta la extremidad de la cola una elevada cresta de escanas puntiagudas y encorvadas hảcia atrás. La cabeza está protegida por placas de varios tamaños $y$ formas, muchas de ellas arqueadas, aquilladas $\mathrm{y}$ algunas hasta puntiagudas; mientras qque los costados llevan escamas pequeñas y lisas y solo algunas lige. ramente aquilladas; en la planta ó parte inferior de los dedos hay varios escuditos tricarenados. Tiene poros femorales, $y$ la membrana del tímpano, grande, redonda, y á flor del agujero auricular. Las ventanas nasales son bastante anchas, y en las mandibulas los primeros dientes maxilares redondos, puntiagudos y un poco arqueados hácia atrís; los demás comprimidos y triangulares en la corona; hay además á cada lado una doble hilera de pequeños dientes palatinos, cuyo número varia segun la edad.

\section{LA IGUANA TUBERCULOSA - IGUANA TUBERCULATA}

CARACTERES. - La iguana alcanza una longitud de 
$1^{\prime \prime}, 60$, de los cuales corresponde á la cola casi un metro. El color predominante de la piel es un bonito verde, que en algunas partes tira al pardo oscuro, verde y gris; las regiones inferiores $y$ las piemas están cruzadas por fajas; otras mas anchas y marcadas rodean la cola. Todos los colores están sujetos á muchas variaciones, tanto mas cuanto que la iguana tiene la facultad de cambiarlos.

lil género de vida de las iguanas, de las que se conocen unas seis especies, parece tan análogo en lo esencial, que podemos permitirnos reunir aqui las noticias conocidas sobre marias especies.

DISTRIBUCION GEOGR ÁFICA. - Todas las iguanas habitan la parte septentrional del Brasil y de los paises situados al rededor del golfo de México 6 de sus islas, y por lo tanto tambien las Antillas.

USOS, COSTUMBRES Y REGIMEN. - Todas las es. pecies viven en árboles y con preferencia en los que están á orillas de las aguas. Alli trepan y saltan con grande agilidad, sabiendo esconderse con mucha astucia entre el follaje, de modo que se hacen invisibles al ojo poco ejercitado. Hácia la tarde acostumbran bajar á tierra donde continúan cazando, pero tan luego como se aperciben del menor peligro, trepan á las cimas de los írboles, ó no siéndoles posible esto, se zambullen en el liquido y permanecen en su fondo durante largo tiempo. En el agua son tan ágiles como el varano, y con su poderosa cola, que les sirve como de timon, adelantan con extraordinaria velocidad y precision. Segun Tyler, no nadan como los demís escamosos; recogen las cuatro patas hácia los costados y trabajan exclusivamente con la cola. A pesar de esto, dominan el agua perfectanente; sumérgense con la misma agilidad con que nadan; permanecen mucho tiempo en la profundidad sin cansarse, y" probablemente escapan por su agiliadad de todos cuantos enemigos les amenazan en este elemento, que en rigor es el suyo; al parecer no hacen caso de los crocodilos 6 caimanes que viven en los rios habitados por ellos; mas no osan introducirse en el mar.

Dumeril dice haber encontrado solo sustancias vegetales en el estómago de las iguanas examinadas por él, y tambien 'Tuler y Sumichrast están conformes con csta observacion. Este último solo hallo en los intestinos de los individuos disecados bayas blancas que á menudo dilatan de un modo extraordinario el intestino recto; Tyler observa que entre las hojas medio digeridas se encuentra un sin numero de pequeños gusanos, que segun supone estaban en las hojas cuando la iguana las comia. Los indios, sin cmbargo, tienen s las iguanas por rapaces, que devoran no solo insectos, sino tambien pequeños lagartos y otros animales de esta clase. Bel. cher vió en la isla Isabel gran número de iguanas, pero como verdaderos omnivoros, deroraban con avider huevos, insectos $y$ las entrañas abandonadas de las aves; Liebmann, por su parte, observó á varias iguanas quue todảs las tardes caza ban langostas; finalmente Schomburgk hace iguales indica ciones.

El aspecto y modo de ser en general de las iguanas es poco atractivo; no demuestran mucho discernimiento, pero sí mucha malignidad. Acostumbran á huir cuando ven al hombre, porque han llegado á conocer que este es su mas temible enemigo; sin embargo, atacadas de cerca, si ven cor. tada la retirada, se preparan resueltamente it la defensa; se hinchan, enderezan su cresta, sin duda para darse un aspecto pavoroso, soplan, silban y saltan sobre su contrario, y procuran hincar en él sus dientes, sin soitar presa, una vez cogida, y hasta saben tambien sacudir con su poderosa cola terribles latigazos.

REPRODUCCION, - Durante la época del apareamien. to, las iguanas se muestran muy excitndas, y por consiguiente mas malignas que en estado normal; acostumbran no aban. donar ni un solo momento la hembra que han escogido, y se precipitan con furia sobre todo el que se les acerca.

Mucho tiempo despues del apareamiento, estas últimas se acercan á los bancos de arena para depositar sus huevos, y este es el tiempo en que se ve a esos reptiles, que por lo regular viven ocultos. En Santa Iucia la puesta se efectría en los meses de febrero, marzo y abril. Los huevos tienen poco mas ó menos el tamaño de los de paloma; son de cáscara blanda y de color blanco ó amarillo de paja ; en cuanto á la naturaleza de su ciscara, parecen de cabritilla, y así como los huevos de la mayor parte de los reptiles, llaman sobre todo la atencion porque su contenido se compone casi todo de yema. Las hembras los colocan en un agujero en la arena que vuelven á cubrir cuidadosamente, pero sin curarse mas de ellos, ni de los hijuclos. Algunos observadores antiguos afirman que el número de huevos ascendia á sesenta y hasta setenta; Schomburgk, sin embargo, dice que en los oviductos de las liembras muertas por ćl, solo encontró el gérmen de diez y ocho hasta veinticuatro.

Segun los experimentos de Tyler las hembras adultas ponen muchos mas huevos que las jóvenes: una que tuvo en cautividad depositó en un solo dia cinco, y cinco dias mas tarde treinta y dos. En el vientre de las hembras disecadas se en. contraron segun el tamaño del animal ocho, catorce, 6 diez y siete huevos de igual tamaño, dispuestos en dos series á cada lado del abdómen. Segun las observaciones de Sumichrast, sucede sin embargo 2 menudo que varias hembras de iguanas ponen en el mismo agujero, de manera que á veces se encuentran hasta dos docenas de huevos en un hoyo. No solamente las hormigas, sino tambien los ratones, y sobre todo las llamadas ratas de almizcle, propias de Santa Lucia, destruyen muchos huevos, y por lo tanto parece creible que las hembras de iguanas busquen con intencion la costa maritima, cuya arena no es tan accesible á los citados enemigos como los bancos de los rios. Los pequeños acostumbran permanecer juntos durante algun tiempo, pues Humboldt refiere que su guia le enseñó un nido de jórenes iguanas de cuatro pulgadas de largo. «Estos animalitos, dice, apenas se distin. guian en su configuracion del lagarto comun; solo se percibian en embrion la cresta dorsal, las grandes escamas rectas y las apófisis, que dan ś la iguana un aspecto tan horrible cuando es adulta.

CAZA. - En las Indias occidentales es bastante general la opinion de que la carne de la iguana es insalubre, contribuyendo a aumentar los casos de ciertas enfermedades; sin enibargo, muchos desprecian esta preocupacion y cazan con afan el reptil, para procurarse su delicada carne. Catesby, que en 1743 escribió una historia natural de la Carolina, dice que las iguanas de aquel pais eran objeto de un comercio regular y productivo, cambiando de manos hasta ser compradas en el interior, a precio bastante elevado, para la mesa de hacendados ricos. Esta carne era considerada alli como muy nutritiva y sabrosa; por lo general se comia asada, y à veces tam. bien cocida. Los huevos, que apenas tienen clara y que no se endurecen con la coccion, sirven generalmente para preparar caldos. Algunos cazadores se dedican especialmenié la caza de la iguana, $y$ emplean varios medios para cogerlas vivas. Dicese, si bien esto deshnce las afirmaciones de Schomburgk reśpecto a la astucia de este reptil, que acostumbran acercarse silbando al sitio donde se encuentra, y que atraido por este sonido muy grato $\sin$ duda á sus oidos, asoma la cabeza y hasta se deja acariciar suavemente el dorso con una vara, la cual tiene en su extremidad un lazo corredizo, que el cazador sujeta al cuello aprovechando el momento oportuno Por medio del lazo se le arranca violentamente del árbol, y 
si bien al principio se revuelca furioso procurando libertarse, con todo, acaba por sujetarlo llevándolo despues al mercado con el hocico atado. Lo que haya de verdad en estas relacio. nes es dificil de asegurar; puede, sin embargo, suceder que este animal, que como ya hemos dicho está dotado de poco discernimiento, cuando habita localidades donde raras veces ha penetrado un cazador, confiando en su propia agilidad, permita que este se le acerque.

Por lo regular se emplean perros adiestrados para la caza, sin cuya ayıda seria dificil $y$ hasta imposible descubrir esos escamosos, tan semejantes á las hojas, Liebmann refiere que en la cosia oeste de la América central se acostumbra á acechar las iguanas por la tarde cuando bajan de los árboles, haciérdolas parar por perros. fyler dice que se adiestra á estos últimos precisamente para esa caceria los perros amiastrados encuentran probablemente las iguanas con facilidad, guiados por el olfato, y ladran cuando los rep. tiles se hallan en los árboles, $\delta$ los paran cuando los ven en el suelo; algunos cogen tambien la iguana sin grandes cum. plimientos por el lomo y la matan á mordiscos; pero hay pocos de estos perros, porque la mayoría teme tanto los fuertes coletazos como los dientes y garras del reptil que furiosa. mente se defiende. Cuando puede huir, se dirige á un árbol, ó à falta de este a un hoyo; pero entonces está perdida en ambos casos, porque es fácil hacerla caer sacudiendo las ra. mas 6 cortándolas; y por otra parte, se cree ya salvada cuando encuentra una cavidad en la que apenas puede ocultar su cabeza. A los animales cogidos de este modo vivos, se les pasa un tallo de yerba á través de la mandibula inferior y de una de las fosas nasales cerrándoles asi la boca, para impedir que muerdan; despues se extraen los tendones de los largos dedos medios para atarles con ellos los piés sobre el lomo; y en tal disposicion, atormentados de esta manera se les lleva al mercado al dia siguiente. Como los mexicanos conocen la resistencia vital de las iguanas, que aun atravesadas de una fuerte perdigonada se escapan à menudo, no vacilan en conservar los cautivos atados de este modo durante meses enteros para venderlos. Estn se hare sobre todo antes de la cua

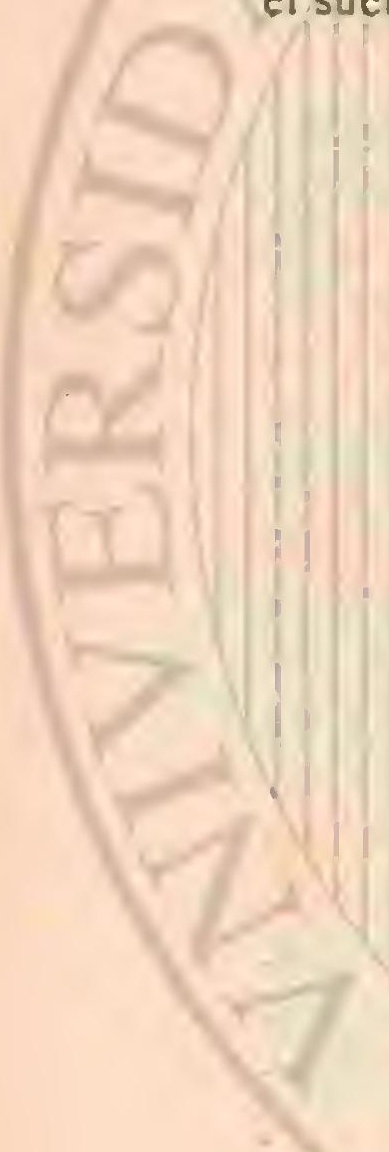

resma, en la cual se compran las iguanas con preferencia: se asan envueltas en una pasta de harina de maiz, para comerlas despues como golosina ó regalarlas como delicados presentes. A veces se encuentran en los intestinos de las iguanas bezoares de la forma de medio huero, que eran considerados antiguamente, y tal vez hoy tambien en algunos puntos, como medicamento muy eficaz contra ciertas enfermedades.

CAUTIVIDAD. - Cuando las iguanas se encuentran en eate estado, se muestran rebeldes durante bastante tiempo; procuran morder á su guardian, y amenazan á todo animal que se les acerca, siendo muchas veces victimas de su voracidad pequeños animales domésticos y hasta sus compañeros de cautiverio. No obstante, poco a poco se va ablandando su furia y llegan á amansarse. Para obligarles empleó con buen éxito el medio de irritarlos hasta que mordian furiosamente; $y$ al abrir la boca agarraban en vez del dedo el alimento que se les tendia, el cual solian devorar sin dificultad, acostumbrándose poco á poco á la comida. Sin embargo, tampoco el citado naturalista logró conservarlos todos vivus mucho tiempo. Algunos murieron despues de comer hojas que quizas no les convendrian y otros cuando devoraron algunas semillas.

En los paises que habitan, se les tiene a meuudo en los jardines y habitaciones, donde son útiles dando caza a toda clase de insectos dañinos; en Europa se les ve algunas veces en los jardines zoológicos ó en las colecciones de los aficionados. Algunos de ellos se ven domesticados hasta el punto de tomar de mano de su guardian toda clase de yerba y ver. duras; sin embargo, nada se nota en su modo de ser.que llame la atencion: acostumbran á permanecer horas enteras en la misma postura, manifestando la mayor indiferencia hacia todo lo que les rodea. Para su bienestar es condicion im. prescindible una temperatura elevada y regular; por poco que baje esta se muestran tristes y abatidos; cuando el frio arrecia se ponen enfermos.

\section{LOS CICLUROS-CYGLURA}

CARACTÉRES. - Los cicluros se distinguen de los iguá. ninos ya descritos por su dentadura y por faltarles la papada de la garganta; pero mas aun por tener la cola muy acoraza. da. La piel de la garganta es ancha y tiene repliegues iras. versales; las escamas se parecen a las de otros iguánidos; las de la parte superior de la cola se distinguen por la circuns. tancia de que con tres 6 cuatro series de escamas regulares se eleva sicmpre un anillo cuyas escamas se han trasformado en espinas de regular longitud, pero agudas. I a cresta del lomo puede cstar interrumpida en la region de los hombros y en la de las caderas. Los dientes, cuyo número parece aumentar con la edad, no carecen de puntas, como en las iguanas, sino que están provistos de dos ó tres prominencias; los palatinos son pequeños, pero numerosos.

\section{EL CICLURO LOFOMA - CYCLURA LO- PHOMA}

CARACTÉRES.-Entre las cuatro especies conocidas de 
este género, que igualmente vive solo en la América central, el cicluro lofoma es la mas importante para nosotros, porte. ner excelentes biógrafos en Gosse y sus amigos.

El animal puede llegar à la longitud de $1^{m}, 30$; se distingue de sus congéneres tanto por el número, órden y forma de los escudos del hocico, como por la cresta del lomo, denticu. lada, no interrumpida en los hombros. Cuatro escudos poligonos y abovedados cubren cada lado del hocico y están divididos, por pequeñas escamas. Varios grandes escudos, cntre los que uno sobresale en el centro, protegen la parte anterior de la cabeza; dos series de placas grandes, irregularmente cuadrangulares, revisten la mandibula inferior. El color pre dominante del tronco $y$ de las extremidades es un verde de hoja, quue en algunas partes pasa al azul de pizarra; algunas lincas oblicuas en los hombros $y$ tres manchas grandes trian- gulares que se corren desde la cresta del lomo hácia el vien. tre, son de un pardo aceitunado oscuro; en la cola se ven a intervalos fajas de un verde accituna mas claro 6 mas oscuro.

DISTRIBUCION GEOGRÁFICA.-Segun las noticias de Gosse, la patria del cicluro lofoma se limita á la isla de Jamaica y aun aqui á ciertas regiones de la misma. Asi, por ejemplo, se encuentra con bastante frecuencia en las montañas calizas que desde el puerto de Kingston se dirigen hácia la llamada isla de las Cabras y que entre otras circunstancias se distinguen por albergar actualmente cabras, cerdos y gallinas rueltos al estado salvaje.

USOS, cOSTUMBRES Y REGIMEN.-Este iguínido abunda bastante en las llanuras situadas entre dichas montañas de la costa y las superiores del interior, porque alli no

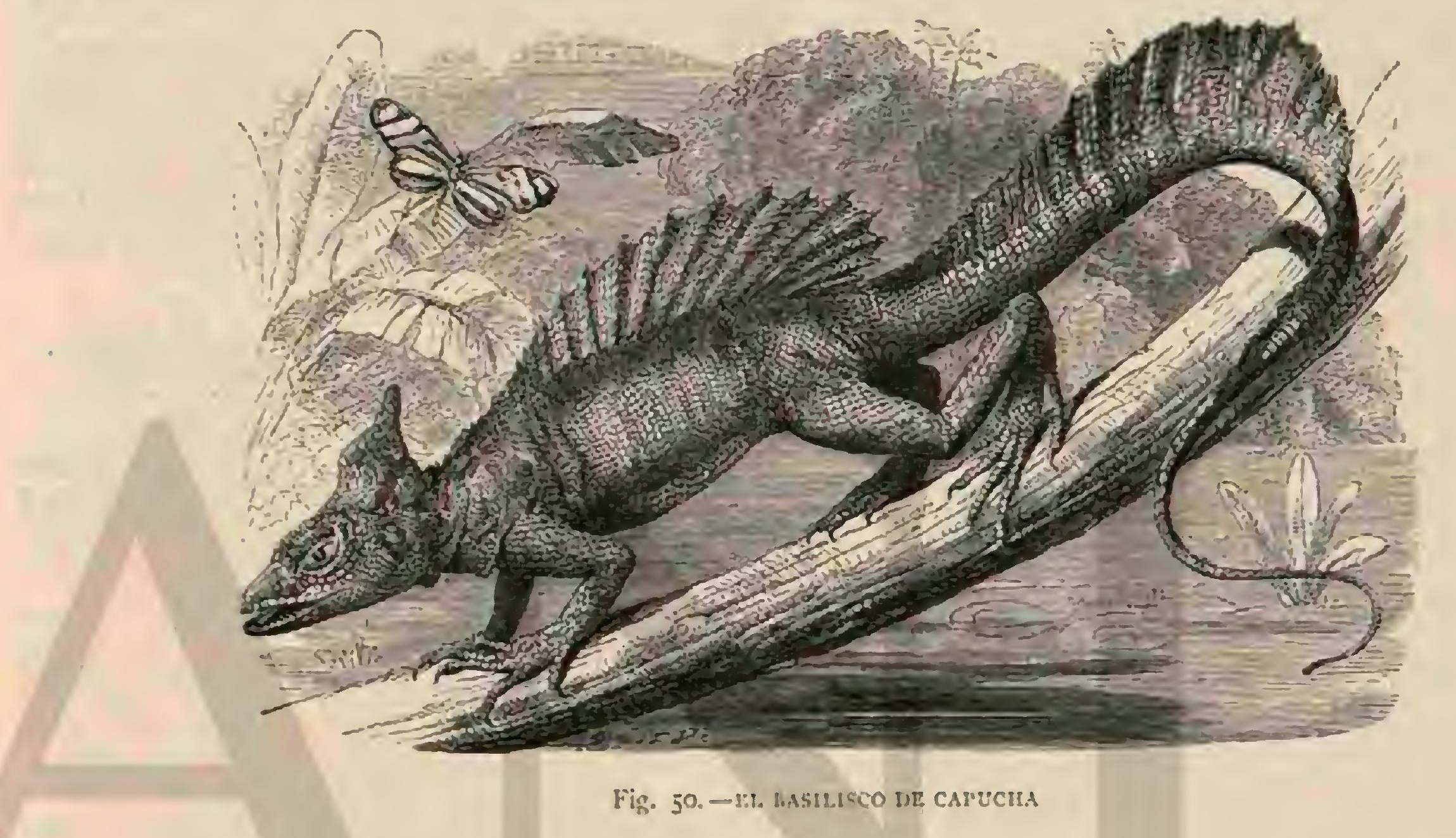

le faltan árboles viejos y huecos. No parece que el animal tiene gran preferencia por el agua, á pesar de que sabe nadar muy bien, como todos sus congéneres. Una feliz casualidad permitió conocer el género de vida del ciciuro lofoma mejor que el de muchos de sus congéneres. En la propiedad de Minot habitaban dos cicluros de esta especie hacia diez y seis meses una añosa acacia, gracias a lo cual su protector pudo observarlos. Uno de los amigos de este último habia descubierto casualmente los dos animales, y espantólos de tal modo de un latigazo que por espacio de algunas semanas solo se presentaron clandestinamente, refugiándose en seguida en el interior del śrbol hueco al acercarse un hombre. Despues que Minot hubo prohibido severamente volver á incomodarlos, olvidaron poco as poco el susto sufrido, haciéndose tan mansos que permitieron un exámen al dueño de su residencia. Tan luego como los dias licgaron á ser inas calurosos, uno de los animales salia fuera del hueco agarrándose a la corteza 6 trepando por una rama seca y delgada para poncrse al sol. Alli permanecia durante todo el dia sin hacer caso de lo que pasaba a su alrededor. Minot no los. vió nunca cazar insectos y solo una vez le fué posible sorprenderles comiendo. Esto sucedió despues de haber caido un chaparron y cuando el sol salia por entre las oscuras nubes secando algun tanto las plantas. Uno de los cicluros abandonó entonces el árbol, avanzó con lento paso unos diez metros por el suelo, y accrcándose á la llamaba yerba de Numidia, devoró una porcion de un solo bocado. Asustado por el observador, \& quien de repente vió, dirigióse apresuradamente hácia el árbol, no corriendo ni andando, sino pot una serie de rápidos saltos, semejantes á los de una rana; luego trepó por el tronco hasta el agujero desapareciendo un momento despues.

Muy notable es, segun Minot, que el cicluro no busque en tal caso el agua como otros congéneres suelen hacerlo en tales circunstancias. En general no se fija mucho en clla, permaneciendo en su seco retiro sin beber. Los dos habitantes del árbol eran sin duda una pareja, pues se distinguian tanto por su tamaño como por su color. Ambos vivian en la mejor armonia; pero nunca salieron al mismo tiempo fuera de la cavidad; siempre quedaba uno en el interior. Un chico puso fin a las observacioncs, accechando i los inofensivos séres cerca del árbol y matándolos uno despues de otro. Minot abrió los cadáveres de los animales y encontró los es. tómagos de ambos llenos de la citada yerba.

$\mathrm{Ni}$ Gosse ni ninguno de sus amigos parecen haber recibido noticias sobre la reproduccion; no podemos decir por lo tanto si el cicluro lofoma difiere por este concepto de sus conge. neres mas afines. Uno de estos, la llamada igruaria negra de los mexicanos (çclura acarthsura), se asemeja en lo esencial, segun las observaciones de Sumichrast, at la iguana; pone como ella comunmente en un hoyo, y solo se distingue por no reunirse regularmente tantas hembras para la puesta, pues 
no es fácil encontrar mas de scis 6 siete docenas de huevos juntos en un nido.

Por grande que sea el temor con que el cicluro lofoma huye del hombre mientras pueda refugiarse, sabe defenderse con valor y buen resultado en caso de necesidad; su cola es un arma bastante temible, de la que hace uso cuando se le obliga, con la mayor fuerza. Muy irritable, como todos los iguánidos, enfurécese cuando se re acosado, dilátase, criza la cresta del lomo, abre la boca para mostrar sus agudos dientes, dirige a su adversario sombrias miradas y se prepara al ataque Si entonces se le excita, vuélvese rápidamente, y con un ligero movimiento lateral de su cola aplica un golpe, volviéndose á reces tambien por él otro lado para repetirle de igual modo. Los negros llamaron la atencion de Hill sobre el carácter peligroso del animal, advirtiéndole que no se acercase á el sin la precaucion necesaria. Ias puntas de la fuerte cola son tan agudas, que el reptil puede causar heridas en extremo graves; los bordes de la cola desgarran ámenudo de una manera horrible a los perros que imprudentemente se acercan, y pueden abrir tambien los núsculos de un hombre hasta lós huesos.

Caza.-El cicluro lofoma exhala un olor tan desagrada. ble, tal vez por causa de su alimento, que ni aun las hormi. gas se acercarian à tocar el cadáver del reptil cuando se le arroja en uno de sus nidos. Parece que no se le persigue con tanta aficion como à sus congéneres de México, entre los cuales la llamada iguana negra ticne una carne muy sa. brosa, segun dicen, por lo cual se la persigue con frecuencia, si hemos de creer á Sumichrast, sobre todo en la cuaresma, que es alli en verano. Se busca al reptil en los agujeros y hendiduras de los árboles, cerca de los charcos de agua, llenos en la estacion lluviosa; apodéranse de la presa del mejor modo posible, y asegúranla del modo acostumbrado.

Usos Y PRODUCTOS. - Mas que la carne, aunque pase por golosina, aprécianse los huevos, y por eso se buscan con preferencia las hembras preñadas, a las cuales se abre el vientre para sacarlos; despues se vuelve a coser la piel y se deja en libertad á los infelices reptiles, con la esperanza de poder hacer lo mismo al año siguiente. Quatrefiges refiere este hecho en un relato que segun parece fué confirmado por el viajero Sallé. Este último entró cierta noche en unas pobres chozas de la América central, dondé solo encontró para su hambriento estómago una sopa; pero se le dijo que el pa. tron sabia complacer á sus huéspedes de una manera extraña, lo cual le causó gran sorpresa, pues ya se habia contentado con su pobre cena. Algunos muchachos, obedeciendo una órden del dueño de la choza, fueron al bosque, del que no tardaron en volver con un colosal lagarto, destinado al pare. cer para servir de cena al huésped. Pero en vez de matar y asar al animal, el patron le abrió sencillamente un pequeño agujero en los costados, é introduciendo los dedos en el in. terior del abcómen sacó cuidadosamente dos cadenas de grandes huevos unidos. Hecho esto el hombre cosió la herida, y poniendo ceniza caliente en los bordes de la misma, dejó en libertad al reptil. I.os huevos se pusieron en la mesa para Sallé, y al pedir este una explicacion, dijéronle que alli se acostumbraba en todas partes á proceder del mismo modo, porque se puede tener la seguridad de obtener al ano si. guiente otra cosecha igual de huevos.

\section{LOS AMBLIRINQUINOS-AMBLY-} RHYNCHINA

Las islas de los Galápagos se puede decir que forman un mundo aparte: casi todos los animales y plantas son peculia- res y no se encuentran en otros paises. Entre aquuellos figuran en primera linea los reptiles, que en cierto modo representan en dichas islas á los mamiferos, que faltan alli por completo, especialmente los herbivoros. Muy pocas son las especies que se encuentran alli, pero en cambio abundan en variedades.

Llaman muy particularmente la atencion cuatro especies de escamosos, pertenecientes á la familia de los iguánidos, y entre ellos en mayor grado dos muy notables, que segun la opinion de Steindachner deben elevarse á representantes de un grupo independiente, es decir, de la sub-familia de los amblirinquinos, porque difieren esencialmente de sus congeneres mas afines, las verdaderas iguanas, por la forma y los escudos de la cabeza, por la solidez de los huesos de esta, y por carecer de la papada de la garganta. No se notan diferencias en cuanto á la estructura general, y ofrecen tambien muchas analogias por sus costumbres.

USOS, COSTUMBRES Y REGIMEN. - Ninguna de las dos especies es muy agil; ambas se alimentan de sustancias regetales, pero cada cual las elige diferentes. La una vive en tierra firme; la otra habita en el agua, siendo el único escamoso que con razon se puede llamar animal marino, y el único tambien gue se alimenta exclusiramente de plantas acuáticas.

\section{EL AMBLIRINCO DE CRESTA-AMBLY- RHYNCHUS CRISTATUS}

CARACTERES. - El amblirinco de cresta, $\delta$ lagarto marino, tipo del género de los amblirincos (amblyrhynelsus), es un iguánido muy grande que alcanza unos $U^{\prime \prime}, 85$ de longitud, tenjendo $0^{\circ}, 53$ solo la cola; puede pesar unos doce kilógramos. Ia cabeza, corta y ancha, presenta un corte vertical en los lados: estréchase hácia adelante y se deprime, vista de lado, en forma de arco, desde la region de la frente hasta el borde obtuso anterior del hocico. Para dar á cono. cer mejor los caractéres, reproduzco los siguientes datos de Steindachner, que ba escrito un tratado particular sobre los escamosos de las islas de la Tortuga: toda la parte superior está cubierta, á manera de mosaico, de escudos poligonales, en su mayor parte de forma cuadrangular, y hasta exágonos muy variables por su tamaño; los mas grandes se hallan en la mitad anterior de la cabeza, y los mas pequeños sobre los ojos. Las fosas nasales, que desembocan en los lados, á bas. tante altura, son ovales y están dispuestas oblicuamente de abajo arriba, rodéndolas un borde membranoso y promi. nente, circuido á su vez de pequeños escudos; nueve ó diez, en figura de pentáguno, cubren el labio superior, $y$ doce ó trece cuadrangulares el inferior; en la region inferior de los ojos hay una serie de escamas aquilladas que llega hasta las sienes; y en el lado inferior de la cabeza se ven unas esca. mas muy pequeñas y aboredadas; el tambor, de forma oval, está situado muy adentro, entre bordes prominentes. La piel del cuerpo, fijada en la garganta y en los lados de la region del cuello mas ó menos ligeramente, forma á veces tambien un repliegue trasversal bien desarrollado por delante del pecho. El tronco es por lo régular muy robusto; en el cuello, en la nuca y en el lomo hay una cresta bastante coniprimida lateralmente, que sin interrupcion se continía hasta la ex. tremidad de la cola, dividida, sin embargo, por escotaduras mas ó menos profundas en la parte cervical, lumbar y caudal. Las demás escamas se distinguen por su reducido tamano; todas las del lomo se elevan en forma de conos; las de los costados son cóncavas, y las del abciómen un poco mas grandes, pero del todo planas. I a cola, larga, comprimida ligeramente en la base y mucho hácia la extremidad, por lo 
cual ofrece el aspecto de una aleta, está cubierta de cscamas aquilladas, grandes, cuadrangulares, y dispuestas, lo mismo que las del lomo, en series trastersales. Las piernas son cor. tas y recogidas; tos dedos, de los cuales el tercero y cuarto tienen igual longitud, sobresalen de los otros, reunidos por una corta membrana natatoria y provistos de garras, fuertes muy corvas. La lengua es gruesa y tiene toda la anchura de la cavidad bucal. Fl aparato dentario se compone de unos dientes fuertes, largos y provistos de tres puntas, que se in. sertan en el repliegue exterior del maxilar, socavado en for.. ma de surco profundo; cada maxilar superior tiene de vein. tidos a veinticinco dientes, y cada inferior de veinte á veinticuatro, de los cuales, sin embargo, seis ú ocho pertenecen á los intermaxilares. Los palatinos, pequeños y poco nume. rosos, caen fácilmente.

El color de los dibujos varín segun la edad. En el indivi. duo jóven, ambos lados de la cabeza, la parte inferior de la misma, y los costados son negros con numerosas manchas de un gris claro que á menudo predominan, dejando solo un espacio negro mas ó menos estrecho. En cl lomo mismo hay unas manchas alternadas de color gris sucio y negras, que forman fajas ó series irasversales mas ó menos regulares. Todo el lado superior é inferior de las picrnas esta salpicado de gris $\delta$ eiene grandes manchas grises; la parte inferior de la cabeza es de un gris oscuro, la region de la garganta ne. gra: las partes inferiores del ironco de un pardo amarillo sucio; la cara superior de los dedos, la inferior de los brazos y de los muslos, y la mayor parte de la mitad de la cola es de un negro intenso; la cresta del lomo presenta fajas alternadas de color amarilio ó gris y negro. Alguna ver se en. cuentran tambien individuos del todo negros.

DISTRIBUCION GECGRAFICA.- I.0s amblirincos viven en considerable número en las islas de los Cialápagos. Darwin los encontró en todas las del grupo visitadas por él; Steintachner en Albemarle, en las islas de Cárlos, Jaime y Jervis: en esta ultima existe un número inmenso y hallanse individuos muy grandes.

USOS, COSTUMBRES Y REGIMEN.-Fstos animales permanecen siempre en las orillas pedregosas del mar $y$ no se encuentran nunca, segun las observaciones de Darwin, a mas distancia de diez pasos de la orilla.

No se pucde llamar bonito ni gracioso al lagarto marino; muy al contrario, es bastante feo; $y$ sus movimientos no son tampoco propios para captarse la benevolencia del hombre. Los velamos, refiere el citado Darwin, muchas veces na. dando a cien pasos de la crilla, ঘ el capitan Colnet asegura que van por el mar á manadas para pescar ó para dirigirse á las rocas donde acostumbran calentarse al sol; pero creo que se equirocaba respecto \& lo de la pesca. Nada este animal con suma agilidad y rapider, por medio de un movimiento ondulado del cuerpo y de li cola, y no con ajuda de las patas que lleva recogidas á los lados, sin servirse de ellas. Un marinero ató un fucrte peso à un amblirinco y lo sumer. gió en el mar, esperando matarle de este modo, pero con gran sorpresa suya, lo encontró lleno de vida, cuando una hora despues lo hubo sacado del agua. Sus miembros y sóli. das unas son muy apropiados para arrastrarse sobre las as. peras y quebradas masas de lava, que forman toda aquella costa. Alli se ven grupos de seis ó siete de estos reptiles, so. bre las negras rocas, a pocos piés de elevacion sobre el nivel del mar, con los miembros estirados tomando el sol.

Abri el estómago de los q̨ue cogi y siempre los encontre llenos de plantas acuáticas, y particularmente de la especie que crece en aglomeraciones en forma de hojas, y que tiene un color verde claro y verde rojizo. Como no recordaba ha. ber visto nunca en cantidad considerable csta planta en las rocas á orillas del mar, debi suponer que crecia en al fondo del mar á poca distancia de tierra, y siendo cierta esta suposicion, queda ya satisfactoriamente demostrado el objeto que se proponen estos reptiles al dirigirse al mar en grandes manadas, como me aseguró el capitan Colnet. Bynoe dice haber enconirado una vez restos de cangrejo en el estómago de un amblirinco marino, pero este caso aislado no basta para prcbar que dicho reptil acostumbre aprovechar esta clase de alimento, pues puede suceder muy bien que entre las plantas acuáticas que come se trague desapercibidamente un peq̨ueño cangrejo ó resto del mismo. La forma de su cola, el hecho incontrovertible de que se ha visto a este escamoso nadar en el mar, y por último las sustancias con que se nutre, prueban suficientemente que es un animal marino; sin embargo, existe una rara contradiccion, y es la de que el amblirinco jamás huye al mar cuando se le persigue en tierra Se le puede acorralar en la punta saliente de una roca, pero antes se dejará coger por la cola que echarse al agua; en cuanto á intentar su defensa mordiendo, es cosa de la que parece que este animal ni siquiera tiene el instinto: cuando se ve acosado, todo lo mas quue hace es expeler algunas gotas de líquido por las ventanas nasales. Un dia me entretuve en arrojar varias veces a un amblirinco que habiamos cogido viro en una cavidad de las rocas que la marea habia llenado de agua; siempre volvia de nuevo en direccion al mismo sitio en que ine encontraba, si bien sin salir del agua, y procurando esconderse entre las planias acuáticas 6 en algun agujero de la roca; cuando creia pasado el peligro, subia á tierra corriendo por la orilla con cierta velocidad y con un movimiento que recordaba el modo de andar de los patos. Varias veces cogi el reptil $y$ lo acorralé en un punto conveniente, pero sin poder conseguir que se arrojase al agua, y cuando a viva fuerza lo alcanzaba, volvia el animal como acabo de describir. Tal vez se puede explicar esta particularidad, admitiendo que el réptil conoce que en tierra tiene menos ene. migos que en el mar, donde á menudo es presa de los numerosos tiburones que habitan aquellas aguas.

x Durante la visita que hicimos al mismo sitio en el mes de octubre, vi muy pocos amblirincos jóvenes y ninguno de estos menor de un año, lo que me hizo sospechar que la epoca de la reproduccion no habia empezado todavia. Me informe de los habitantes de la isia si sabian los puntos en que acostumbraban desovar las hembras, pero me contes: aron que si bien encontraban á menudo huevos de la otra especie terrestre, no tenian conocimiento alguno del modo de propagarse el amblirinco marino: circunstancia por demás extraordinaria si se ticne en cuenta la gran abundancia de esta última especie.

Steindachner, que visit6 las islas de los Galápagos en 1872 , pudo ver que los amblirincos existian i millarcs, como en tiempos de Dampier y de Datwin. Cuando mi companiero de viaje, el doctor Pithins, dice, vió un gran número de es. tos feos animales, que en las rocas tomaban el sol, disparó un tiro á un compacto grupo, y habiendo pasado por el mis. mo sitio al cabo de una hora, observó que ya no habia alli ninguno de estos animales. Todos se habian refugiado en el mar, buscando probablemente un escondite mas seguro. Io mismo suceció en las islas de Jervis y de Jaime, lo cual demuestra qque los amblirincos de cresta, á pesar de su torpeza en los movimientos, y aunque se pueden coger fácilmente sin que se resistan, procuran evitar el peligro que les ame. naza, no volviendo como antes con ciega tenacidad al mismo sitio, cuando ven ocupado este ó las inmediaciones por el enemigo. Cuando reina la calma en el mar se ve con bas. iante frecuencia á estos escamosos nadando y sumergiéndose á gran distancia de la costa. Sus movimientos en el agua se 
parecen superficie, y siempre llevan las piernas recogidas. En la isia de Jervis los vi solamente en la inmediacion del mar, sobre escarpadas moles de lava, reunidos casi siempre en manadas de ciento á ciento cincuenta individuos en un peqqueño es. pacio. En la isla de Jaime encontré solo algunos pequeños individuos á considerable altura, junto al borde de pequeñas cuevas pedregosas cubiertas de yerba y de arbustos, que quizás sirven á estos reptiles para depositar en ellas sus huevos. El estómago y los intestinos solo contienen, como ha dicho Darwin, pequeãas algas rojizas de hojas anchás. ฎ

\section{LOS CONOLOFOS-CONOLOPHUS}

CARACTERES. - El segundo lagarto de las islas de los Galápagos difiere esencialmente del amblirinco de cresta por sus formas generales y por faltarle los dientes palatinos; tambien es mucho mas pesado y torpe. Apto solo para vivir en tierra firme, carece de membranas interdigitales entre los dedos mas cortos de las piernas. La cola es tambien mas corta y medianamente comprimida, por lo cual presenta una forma ovalada en el borde trasversal; el cuello, en cambio, es mucho mas largo, y tiene en'su parte anterior numerosos repliegues; la cabeza, en fin, es mas prolongada, $y$ por lo tanto relativamente menos alta y deprimida desde la region del hocico hasta el borde anterior de la boca. Por todas estas razones, Steindachner opina como los saturalistas que ven en el colonofo terrestre el tipo de un género independiente, el mismo que nos ocupa.

\section{EL CONOLOFO TERRESTRE-CONOLOPHUS SUBCRISTATUS}

CARACTÉRES. - Para caracterizar mejor este reptil Steindachner nos da los datos siguientes. Los escudos de la parte superior de la cabeza son mucho mas pequeños, $y$ por 10. tanto mas numerosos que en el amblirinco de cresta; el escudo de la coronilla es deprimido y está situado detrás de la frente; las anchas fosas nasales desembocan cada una en un escudo grande con bordes prominentes; el aparato dentario se compone de veintitres á veinticuatro dientes delgados, de tres a cuatro puntas, en cada uno de los maxilares superiores, incluso siete que se hallan en el intermaxilar; y de veintitres á veinticuatro en cada maxilar inferior. I.a lengua, oval y cilindrica en la parte supetior, tiene en el centro del borde posterior una ligera escotadura triangular. Las escamas de la region inferior de la cabeza, del cuello, del lomo $y$ de los costados son pequeñas $y$ afectan la forma hemisferica, teniendo sus puntas, segun la posicion, hácia afuera y hácia abajo; las escamas del vientre, mucho mas grandes, planas é irregularmente cuadrangulares, tienen las puntas dirigidas hácia fucra $\mathrm{y}$ dispuestas en series trasversales regula. res. Fn la nuca se eleva una sola serie longitudinal de escamas altas mas ó menos cónicas, pero en su mayor parte aplanadas en el lado posterior, muy cóncavas en el anterior y separadas entre sí por otras escamas mas pequehas; su conjunto forma una cresta interrumpida, que en el centro de la nuca llega á su punto mas alto, disminuycndo despues ràpidamente hácia el lomo. En cuanto al color, el conolofo dinere tambien bastante del amblirinco de cresta: la cabeza tiene un tinte mas 6 menos vivo de limon; el lomo, en los lados de la cresta es de un rojo ladrillo ó de orin, alguna vez con fajas alternadas muy confusas, de color amarillento ó pardo rojizo; hácia los costados, el color pardo rojizo se convierte en un pardo oscuro sucio. En algunas partes se ven puntos ó manchitas negruzcas poco marcadas; los lados del vientre son de un amarillo oscuro con viso pardo rojizo; las piernas anteriores de un amarillo rojizo; las posteriores de un amarillo pardusco; las garras y las patas mas próxinzas ne. gruzcas.

DISTRIBUCION GEOGRÁFICA.-Darwin observó el conolofo terrestre solo en las islas del centro del grupo de las de los Galápagos, es decir, en Albemarle, Jaime $y$ Barrlington.

USOS, COSTUMBRES Y RÉGIMEN. - Abunda en los terrenos llanos y áridos, si bien se encuentra igualmente en las partes mas altas y húmedas de la isla. Dice Darwin, que es tal su abundancia, eque durante mucho tiempo no pudimos encontrar en toda la isla de Jaime un sitio á pro. pósito para colocar nuestra tienda, de tal modo estaba agujereado s socavado el suelo por los conolofos.

En sus movimientos, este reptil es muy tardio y perezoso. Cuando se le espanta, se arrastra pausadamente, ras. pando el suclo con el vientre y la cola; se para á menudo y cierra los ojos durante algunos minutos como si durmiese, estirando al propio tiempo sus patas traseras. Viven estos rep. tiles en cavidades que ellos mismos practican entre las esco rias de la lava, y mas frecuentemente en la arena blanda $y$ volcánica de las llanuras. Estas cavidades no suelen ser muy profundas, y forman una especie de galería que termina en un recodo mas ancho, de modo que el suelo que las cubre cede a cada paso, haciendo muy penoso el andar por aquel terreno. Cuando el conolofo escarba su guarida, trabaja al. ternando las patas de cada lado del cuerpo: una de las de. lanteras separa la arena echándola hácia la trasera del mismo lado, que la tiene colocada de modo que pueda ar. rojar aquella á distancia de la abertura; cuando un lado del cuerpo está cansado empieza á trabajar el otro, $y$ asi conti. núa hasta terminar su tarea. Estuve observando un dia á uno de estós animales que estaba ocupado 'en dicha faena, $y$ cuando tenia todo el tronco dentro del agujero le tiré de la cola; suspendió entonces la operacion, y salió á la superficie, y á pesar de su acostumbrada expresion estúpida, me miró fijamente $y$ de cierto modo, como si quisiera manifestarme su sorpresa y disgusto al verse interrumpido en su intere. sante trabajo.

- Estos conolofos comen de dia y no se separan entonces a gran distancia de su guarida. Si se les espanta, se precipitan hácia el agujero, pero con movimientos torpes y pesados; á causa de la inclinacion que tienen sus extremidades hácia delante, no pueden andar de prisa á no ser subiendo una pe. queña cuesta. La presencia del hombre no parece infundirles recelo alguno; cuando se les observa de cerca, enroscan la cola, levantan el cuerpo sobre las patas delanteras, menean la cabeza en sentido vertical y se dan cierto aspecto repug. nantc, que ellos supondrán tal vez que impone al enenigo, pero que en manera alguna justifican sus hechos; pues con solo pegar un fuerte golpe con el pié, bajan la cola y huyen con toda la velocidad que les permite su torpeza. He obser. vado varias veces en los pequeños lagartos este mismo movimiento de cabeza, cuando algun ruido ti objeto llama su atencion, pero jamás me he podido explicar la razon de porqué lo hacen. Cuando se sujeta á un conolofo y se le excita con un palo, lo agarran con fuerza; sin embargo, he cogido varios de estos animales por la cola, y nunca sucedió que intentasen morderme. Por otra parte, cuando se ponen dos de estos reptiles uno frente del otro y se les excita, suelen pelear entre si y morderse hasta hacerse sangre.

"Todos los conolofos que viven en las tierras bajas, apenas tienen ocasion de probar una gota de agua durante todo $\mathrm{el}$ año, pero comen muchos cactos jugosos, cuyas ramas el viento arroja en abundancia al suclo. Muchas veces me he 
divertido echando á un par de estos reptiles un pedazo de cacto, y daba gusto verlos disputárselo, tal como lo harian dos perros con un hueso. Comen por lo general muy pausadamente, pero sin mascar el alimento. Los pájaros parecen conocer el instinto inofensivo de los conolofos: pude ver una vez. un pinzon que estaba picando en la extremidad de un cacto, mientras que un conolofo se comia la otra, saltando despues el pajaro con la mayor indiferencia al dorso del reptil. En el estómago de varios que examiné, siempre descubri restos de piantas y muy particularmente de una especie de acacias. En la parte mas alta de la isla se nutren en especial del fruto agri-dulce del guayavita, del que tambien vi comer a la tortuga gigante. Para proporcionarse las hojas de acacia, buscan los conolofos árboles enanos, siendo muy frecuente ver á dos 6 tres de ellos á algunos piés de altura colocados sobre las ramas, comiendo con la mayor tranquilidad. Los indigenas refieren que los reptiles que habitan las comarcas húmedas beben agua, pero los que viven en terrenos áridos no acostumbran, como las tortugas, $\{$ ir en busca del li. quido.

\Durante el tiempo de nuestra estancia, encontramos en el cuerpo de las hembras muchos huevos grandes y obion.

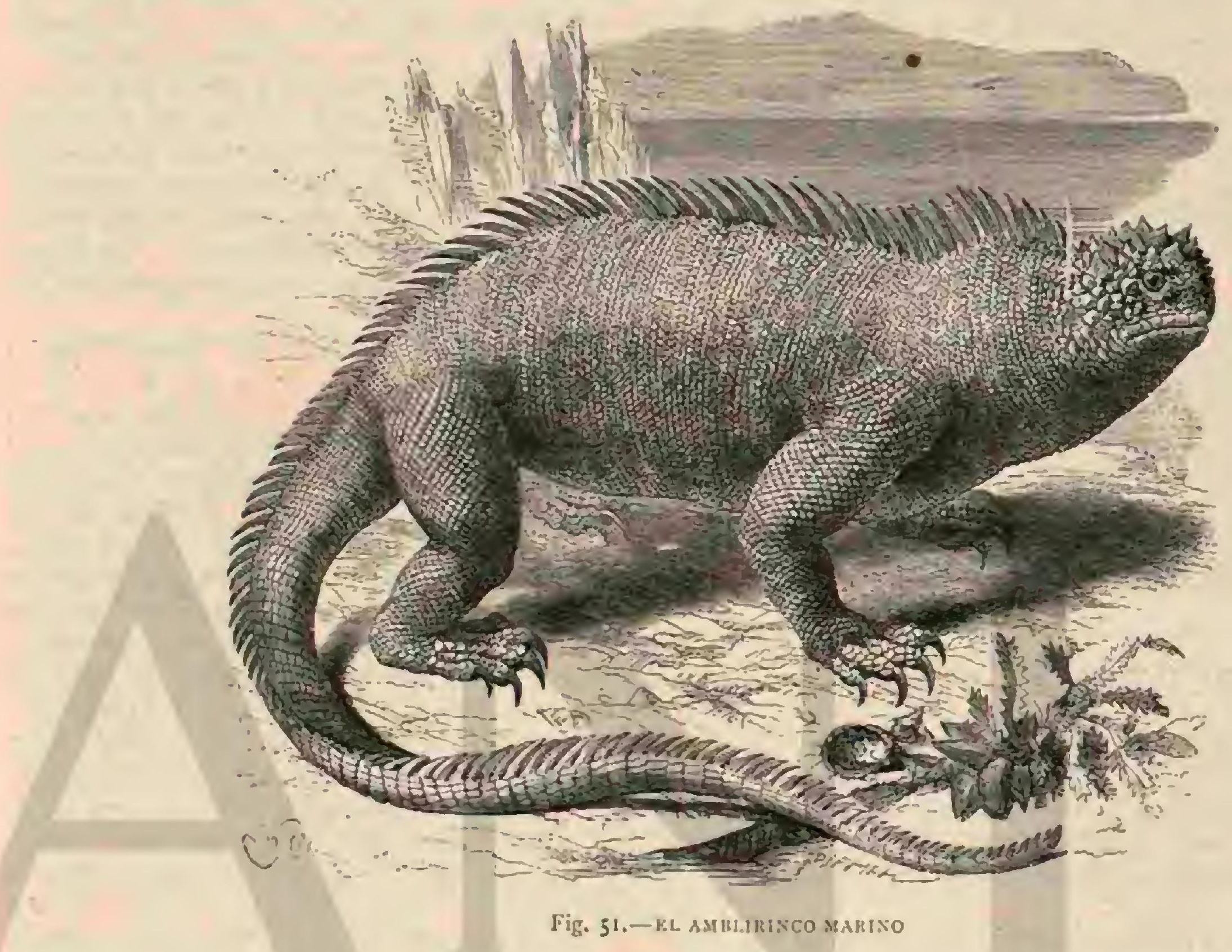

gos, que desovan en sus guaridas, y son buscados por los indigenas para uso culinario. La carne cocida de estos escamosos es blanca, y considerada como plato sabroso por los que tienen un estómago á prueba de toda preocupacion.

\section{LOS HIPSELOPINOS-HYPSELONINA}

CARACTÉRES.-Las especies de iguánidos que constituyen la sub familia de los hipsciopinos tienen la cabera cu bierta de escamas poco prominentes, una cresta cervical, y otra dorsal mas baja: no existen los poros femulares.

\section{EL HIPSIBATO PINTADO-HYPSIBATUS PICTUS}

CARACTERES. - Como tipo del grupo pucde servinos el hipsibato pintado, repril de $0^{*}, 30$ de longitud, de los cuales corresponden a' la cola 0 ", 20. La cabeza es corta y gruesa, mas alta sobre los arcos oculares, como en los sapos; el hocico medianamente oblicuo; la mandibula inferior un poco mas larga que la superior; el tambor oval $\$$ poco cubierto; la garganta tiene una picl ancha, que se dilata cuando el animal se excita, formando una bolsa puntiaguda; las piernas son altas; el tronco bastante enjuto; la cola muy larga y del. Tomo $\mathrm{V}$ gada. Los pies anteriores y posteriores tienen cinco dedos, provistos de garras bastanta fuertes, cortas y comprimidas; el tronco está revestido de escamas pequeñas y finas; las de la cabera son mas grandes, exágonas, cuadrangulares $\delta$ irregu. lares; las que protegen ambos lados de las mandibulas, son tambien grandes; algunas muy pequeñas y puntiagudas cu. bren la bolsa de la garganta; otras cuadrangulares y mas altas, las partes inferiores; la cola, en fin, está cubierta de escami. tas cuadrangulares y aquilladas dispuestas en anillos. En la nuca elévase una cresta baja que llega hasta la base de la cola. El color es verdaderamente magnifico: detrás de la ca. beza y de la nuca, que tienen un color gris claro pardusco, se corre una ancha faja trasversal de un negro aterciopelado, desde los hombros hasta las piernas anteriores; detrás de esta faja hay otra estrecha y clara, de color blanco gris az. lado; a estas dos siguen cuatro trasversales, anchas, de un pardo oscuro, separadas por otras mas estrechas de un blanco gris azuládo y orilladas todas de un color mas intenso; la parte posterior del tronco y de la cola son de un delicado tinte amarillento sonrosado, con once á doce fajas trasversa. les 6 anillos pardo negruzcos ó negros; las piernas posteriores están adornadas de fajas trasversales y manchitas pardas, con borde mas oscuro; las anteriores, de un fondo gris par. dusco, presentan fajas trasversales y manchitas ploco marcadas 
de coloir blanco azulado. La bolsa de la garganta, cuando está encogida, tiene en su centro una mancha redonda de color de naranja, pero si está dilatada ofrece un tinte mucho mas vivo. La garganta y todas las partes inferiores son de un ceniciento azulado con viso rojizo. Un estrecho anillo que hay al rededor de la pupila es amarillo; el resto del fris pardus. co. En los individuos jóvenes se observan.en las fajas pardas unas manchas redondeadas en forma de perlas de color blan. quizco, que desaparecen con la edad.

DISTRIBUCION GEOGRÁFICA. - Solo he visto este iguánido abigarrado con sus bellisimos colores, dice el principe de IVied, en las grandes selvas virgenes de la Lagoa de Arrara, á orillas del Mrocuri, durante mi estancia en el pals, en los meses de febrero y maizó.

USOS, COSTUMBRES Y REGIMEN. - No he observado la especie mas que en dicha region, pero recibia indi viduos muy á menudo y pude sacar un dibujo del natural. Alii le dan el nombre de camaleon, porque cambia un poco de color, sobre todo en los costados, que adquieren un bo. nito tinte sonrosado, si el animal se excita. Este cambio se nota entonces en todas las fajas claras del cuerpo. Vive con. tinuamente en árboles, á los que trepa hábilmenie; sube con ligereza por las ramas a la copa, se sostiene a gran altura, levanta la cabeza y el cucllo y abre mucho los ojos. Cuando no puede evitar un objeto extraño abre la boca, dilata la bolsa de la garganta, produce un silbido y precipltase para el ataque. Parece que este reptil no escasea en las grandes selvas virgenes del Mucuri, pues los indios que iban diaria mente á trabajar solian traer por la noche un par de hipsi batos para complacer, segun decian, á los curiosos extran jeros.

\section{LOS HOPLURINOS-HOPLURINA}

CARACTERES. - La cabera es aplanada y triangular sin repliegues en los lados; la cola está revestida por lo re gular de espinas dispuestas en anillos; el lomo tiene escamas mas ó menos aguilladis, que forman series oblicuas. Algunas especies tienen una cresta dorsal; los poros femulares no existen.

Esta sub familia se compone de varios géneros, de los que describiremos el de los tropiduros (tropidurus).

\section{EL TROPIDURO DE COLLAR-TROPIDURUS TORQUATUS}

CARACTERES. - Esta especie es uno de los iguánidos y reptiles mas comunes en general, propio de la costa orien. tal del Brasil.

El tropiduro de collat ó lagarto, como le llaman los por. tugueses, alcanza una longitud de $0^{\mathrm{m}}, 30 \mathrm{a} 0^{\mathrm{m}}, 36$, correspondiendo a la cola tres quintas partes. Su cólor predominante es gris, con manchas mas claras, bien marcadas; los lados del cuello son negros, y sobre los párpados hay unas fajas de un negro gris. La cola es redonda y está cubierta de escamas espinosas sobrepuestas; las regiones superiores tienen escudos aquillados y puntiagudos; las inferiores carecen de quilla con bordes prominentes; unos escudos mas grandes é irregulares cubren la parte superior de la cabcza; la piel que hay debajo de la garganta forma un repliegue trasversal.

El aparato dentario se compone de cinco á seis dientes anteriores redondeados en la corona y con tres puntas poco marcadas; veinte molares puntiagudos, de tres puntas mar. cadas, en cada maxilar superior, y veinticuatro en cada uno de los inferiores. El color y los dibujos varian. Los individuos pequeños tienen unas fajas manchadas, y los adultos unos punios en forma de perlas; algúnos de estos reptiles apenas presentan manchas, siendo su color casi uniforme; en otros se ven unas lineas traspersales pálidas muy marcadas y dis. puestas una tras otra; la mancha negra que desde la nuca se corre por los lados del cuello hasta el pecho, $y$ las tres fajas verticales negras que se ven sobre los párpados, quedan siem: pre visibles.

USOS, COSTUMBRES Y REGIMEN.-Segun el principe de Wied, habita este escamoso las localidades secas y arenosas, y muy especialmente las ruinas, montones de piedras, grietas de las rocas y los edificios, donde fija su morada en los huecos de las paredes ó de los tejados; á veces se le encuentra en los matorrales y en los bosques, acostumbrando empero a buscar un sitio descubierto para calentarse al sol. El principe encontró al tropiduro de collar en gran número en las aglomeraciones pedregosas que hay a lo largo de la costa y á orillas del rio. Vésele con frecuencia, pues siempre está en movimiento en las inmediaciones de su guarida, pa. rándose de cuando en cuando para estirar el cuello y la cabeza, y sacudiendo esta verticalmente como suelen hacerlo sus congeneres de Europa; corre con grande agilidad, subien. do $y$ bajando por las paredes.

Segun Hensel, este reptil se halla con frecuencia en los contornos de la capital del Brasil, donde se le ve muy cerca de la ciudad, sobre todo en el camino que conduce al Corcovado. $\Lambda 1$ acercarse un hombre, los individuos que en el camino toman el sol emprenden en seguida la fuga, subiendo corr una rapidez casi incomprensible por las paredes de roca completamente verticales, aunque siguiendo siempre una direccion algo oblicua. Su timidez y destreza para trepar son tan extraordinarias, que es muy dificil recoger individuos enteros. Alli donde no se le inquieta, el tropiduro se conduce de otro modo; penetra hasta en las plantaciones, trepa por las paredes de las casas y se acerca al hombre sin miedo.

En una plantacion abandonada del Sertong de Ilheos, concluye el principe su relato, encontré una antigua cabaña de maderos y corteza de árbol, habitada exclusivamente por tropiduros, causando gran estrépito con sus idas y venidas sobre la cubierta medio derruida de la cabaña; algunos de estos reptiles tomaban tranquilamente el sol, colocados en restos de empalizada, y no huian del hombre, cuya presencia en aquel sitio abandonado debia serles cosa nueva.

Los brasileños llaman \& esta especie lagarto, porque ni puede dilatar la bolsa de la garganta ni cambiar de color.

\section{LOS FRINOSOMINOS-PHRY- NOSOMINA}

CARACTÉRES. - Los frinosominos, ó lagartos sapos, ocupar el último lugar en la familia; son en cierto modo los estelios entre los iguánidos; son animales tan extraños como feos, que se caracterizan por su tronco ancho, lleno casi siempre de repliegues ó de otros apéndices en los costados; la cola es gruesa, tan larga como el tronco ó algo menos: las escamas son desiguales y espinosas en algunos géneros; los dientes palatinos no existen.

\section{EL TAPAYA - PHRYNOSOMA ORBICULARE}

CARACTERES-El tipo mas conocido de esta sub-fa milia, que comprende pocos gencros, es el tapaya, señalado ya por Hernandez. y llamado por él tapaya xye, representante al mismo tiempo de un género del mismo nombre. Es un reptil que se parece mas que superficialmente al sapo, y que puede considerarse como el mas pesado de todos los iguánidos. Su cabeza es muy corta, irregularmente cuadrangular, 
casi tan larga como ancha; el cuello corto; el tronco ancho, aplanado, casi ovalado; la cola corta, con la extremidad có nica. Ocho espinas de bastante longitud cubren el occipucio; y una serie sencilla $\delta$ doble de puntas cóneas triangulares protege los costados; las escamas de la parte superior se trasforman en su major parte en espinas obtusas, desiguales en longitud; las de las regiones inferiores son iguales y están sobrepuestas; el cuello tiene en su parte inferior un repliegue trassersal. El aparato dentario se compone de seis incisivos cortos, sencillos, rectos, cónicos é iguales; diez y ocho mola res de igual tamaño, rectos, comprimidos, redondeados, obtusos en la punta é insertos en cada maxilar. Ia parte anterior de la cabeza es de un pardo rojizo; el occipucio puede ser de un solo color pardo amarillo ó estar cubierto además de manchas parduscas. El color dominarte de las regiones superiores es un amarillo de arena ó de cuero sucio; á cada lado de la nuca hay una gran mancha parda; el lomo tiene otras del mismo tinte, porque cada escama espinosa está rodeada de un estrecho anillo del mismo color; cstas cscamas mismas son pardas ó de un gris claro de arena, con rajas trasversales negras, estrechas, ramificadas y reunidas otra vez; en algunos sitios se reducen tambien á manchas (fig. 52).

DISTRIBUCION GEOGRA FICA.-El tapaya es originario de México.

USOS, COSTUMBRES Y REGIMEN.-Hernandernos da ya algunas noticias sobre el género de vida del extraño reptil, y todos los naturalistas sucesiros. hablan de él. Sin embargo, solo en los uitimos tiempos hemos recibido noticias minuciosas sobre su vida en libertad, y debemos sobre todo \& Sumichrast y s. Wallace dos sucintos relatos. E! tapaya habita tanto en las montanas como en las llanuras del centro de México, y con mas frecuencia en las partes areno. sas y expuestas al sol de las mesetas secas y frias en el centro del país. Alli se le encuentra en algunas partes muy á menudo, pero no es fácil descubrirle, porque el color de tierna de su cucrpo pasa desapercibido fácilmente. Poco apto para correr, no posee la agilidad proverbial de los lagartos; su marcha es, al contrario, lenta y torpe. Cuando se le ve correr penosamente por la arena, dice Sumiclırast, compréndese cuán dificil le será proporcionarse su alimento diario. Su lengua gruesa, pegada al paladar, no puede lanzarse como la del camalcon sobre los insectos que llegan â su alcance; su ancho y abultado vientre le impide coger su presa corriendo, como pue. den hacerlo los esbeltos lagartos, y menos aun atrapar una mosca al vuelo como lo hacen los impetuosos anolis. Necesita para cada comida uno de aquellos coleopteros perezosos de arena, que siendo á su rez nuy torpes, se introducen casi en la boca. Esta temperancia obligatoria ha hecho suponer los indigenas que vive del aire. Desprovisto de tudus lus medios defensivos, déjase coger sin tratar de morder; pero en cambio demuestra su enojo de otro modo muy particular. Hernandez nos dice ya que al coger un tapayasalen gotas de sangre de la nariz y de los ojos del reptil, y que estas gotas saltan a menudo á muchos centímetros de distancia; el citado naturalista cree, sin embargo, que la causa de este fenómeno no visto en ningun otro reptil, debe buscarse en la delicadeza de las respectivas partes. Segun las uiltimas observaciones de Wallace, que sin duda no sabia nada del informe de Hernandez, parece no obstante que esas gotas de sangre son un medio defensivo. En cicrtas circunstancias, dice el primero, y al parcecr para defenderse, este animal expele de uno de sus ojos una especie de chorro de un liquido rojo brillante, en extremo parecido á la sangre. Esto lo he observado tres reces en tres individuos diferentes, á pesar de que cogi tambien muchos que no lo hicieron asi. Es dificil poder observar el hecho, $y$ a menudo procuté invitilmente que se reprodujera Por lo regular no se vale de su extraño medio defensiro cuando se le coge del suclo, aunque tambien puede suceder. Asi, por ejemplo, cogi uno que lanzó el liquido $U^{\prime \prime}, 15$ de distancia sobre mi mano, nientras que otro lo arrojó al verme blandir un brillante cuchillo delante de sus ojos. Yo creo que el liquido debe proceder de los ojos; pues no puedo figurarme que salga de otro sitio. Reproduzco estas noticias, confirmadas por dos testigos, sin juzgar de su exactitud; yo no comprendo cuál podria ser la fuerza que arroja un li. quido por los ojos de un animal.

Sumichrast dice que raras veces turo alguno de estos inofensivos escamosos. Por lo regular permanecian en un rincon del cuarto, y cuando una vez desaparecian, su dueño podia estar seguro de encontrarlos pronto en uno de sus 22 patos 0 en los bolsillos de un pantalon. Mas de una vez observó que al echar tapayas hembras en espiritu de vino sa. lieron al punto los hijuclos por el ano, en nútnero de diez ó doce. La misma observacion hizo en un grupo congenérico de los frinosomas, $y$ crec por lo tanto poder suponer quue la mayoria de los lagartos terrestres de México, cuando menos los de las regiones frias, son viviparos.

CAUTXVIDAD.- El tapaya llega tambien con alguna frecuencia á nuestras jaulas. Los alenanes residentes en México compläcense en remitir fo sus parientes estos reptiles, tan singulares como inofensivos: atendiendo a las indicacio. nes de los mexicanos de que ames hemos hablado, envuelven los animales en gruesas capas de lana, colócanlos en una caja y los envian por el correo. Yo he cuidado a veces cinco 6 seis de estos reptiles a la rez, pero por mas que me esforcé, no hubo uno que se hicicra bastante fuerte para tomar vo. luntariamente su alinento. El largo viaje y el consiguiente ayuno los debilitan de tal mocio, que apenas pueden moversé. Indiferentes á todo cuanto pasa á su alrededor, están siempre echados, $y$ de sus ojillos salen tristes miradas; cuando se les toca dan algunos pasos, pero en seguida vuelven a la misma posicion y permanecen inmóviles hasta que un dia.se reconoce por sus ojos mas turbios. que ya han muerto. Despues de hacer todas cestas observaciones en mis cautivos, sorprendióme en alto grado ver cierto dia un tapaya que sin resistencia tomaba alimento, sobre todo gusa. nos de harina y larras, moviéndose voluntariamente. En rales momentos asombrabame sobre todo la gran scmejanza que este reptil ofrecia con los sapos. Cuando el guardian colocaba al tapaya de modo que pudiera tomar el sol, el reptil se erguia é intentaba huir: para esto cjecutaba una seric de saltos muy torpes, cortos y bajos, repetidos seguidamenie del mismo modo ţue los sapos; cuando de esta manera habia iranqueado una pequeña distancia comenzaba is correr, con los piés cruzados y ejecutando movimientos serpentinos, á pesar de su pesado cuerpo. Cierro que ni aun entonces hubiera podido competir en la carrera con un lagarto, pero no dejaba de correr con una rapidez inesperada y sin can sarse. Desgraciadamente, tampoco este tapaya conservó to das sus fuerzas, pues enfermó al poco tiempo á pesar de lo mucho que se le cuidaba; sus movimientos se hicieron mas lentos y raros; sus saitos cesaron del todo y a las pocas se. manas permaneció inmóvil $\mathfrak{E}$ indiferente, como lo habian hecho todos los individuos anteriores observados por mi.

\section{LOS RIPSOGLOSOS- RHIPSOGLOSSI}

CARACTERES. - El sub-órden de los ripsoglosos 6 vermilingües, se caracteriza por tener los arcos cigomáticos bien desarroliados, por un puente óseo que se prolonga 
desde la coronilla hasta el etmoides, y por faltarle el yunque: solo comprende una familia.

\section{LOS CAMALEÓNTIDOS 一 CHAM ÆLEONTID死}

CARACTERES. - Los de esta familia difieren esencialmente de los escamosos hasta ahora descritos, justificándose por lo tanto que se dé al grupo el rango de una division principal.

En rigor los camaleones son poco afines con los otros escamosos: segun Wagler \&el tronco ofrece en su conformacion bastante semejanza con el del cerdo ó el del hormiguero, siendo alto, estrecho y comprinido en sus lados, con el dorso arqueado $y$ saliente, pero asi como dichos mamiferos ofrecen en este sitio largos pelos, los camaleones llevan protuberan. cias córneas, mayores, mas fuertes, en un todo mas desarrolladas que las del resto del cuerpo, formando á lo largo de la espina dorsal una especie de cresta dentada, muy distinta $y$ marcada. La cabeza es gruesa, piramidal, algunas veces muy aguda en la parte del hocico, y sobre todo angulosa en su configuracion; el cucllo es corto y apenas se distingue. Las patas tienen una construccion muy especial: son delga. das, redondeadas y casi de iguales dimensiones; los dedos, cinco en cada pié, se encuentran reunidos en dos haces desiguales, uno de dos y otro de tres, formando pinza, y como la parte interior está cubieata con una piel áspera y granulosa, pueden con gran seguridad y fuerza adherirse à las ramas, constituyendo este carácter uno muy distintivo y único en toda la clase de los reptiles. La cola es cónica, fucte y pren. sil, enroscándose hácia abajo. En vez de las escamas de los individuos del mismo órden, cubren la piel de los camaleo. nes pequerias protuberancias córneas, entre las cuales se en. cuentran á reces algunos escuditos, pero dejando siempre huecos ó espacios libres.

\Los ojos de los camaleones son órganos muy extraordinarios: cubiertos de fuertes párpados salientes, en los que hay una pequeña abertura circular, y enlazados con los mo. vimientos generales $y$ particulares del globo, dan al animal la facultad de dirigirlos, juntos ó por separado, á distintos sitios; de suerte que un ojo puede mirar hácia arriba, mientras el otro mira hácia abajo; $\sigma$ el uno al frente cuando el otro está vuelto hácia atrás.

La construccion interior de este reptil llama tanto ó mas la atencion, que su aspecto exterior. En el cráneo, de forma tan especial, sorprenden á primera vista las grandes órbitas con bordes macizos, los huesos palatinos de desarrollo extraordinario $y$ situados perpendicularmente, el pequeño hueso frontal y los temporales extremadamente deigados. El cuello no tiene mas que dos 6 tres vértebras, el dorso diez y siete ó dicz y ocho; las lumbares no pasan de tres; las sacras siem. pre son dos; la cola tiene de sesenta á sesenta y seis. Ias costillas, en número de diez y siete 6 diez y ocho, se unen entre si en la línea media inferior, por medio de una sustan. cia ternillosa. En la disposicion de los músculos, de los órga. nos respiratorios y digestivos, no encuentro hecho alguno que merezca especial mencion; pero si creo deber hablar algo detalladamente de la lengua, de construccion tan singular y de tanta importancia para la vida de este animal. Por punto general se puede comparar la lengua de los camaleo. nes con la de los hormigueros y picos trepadores, sin em. bargo de que difieren notablemente en sus detalles. En estado de reposo hállase recogida en las fauces, pero cuando
Ha usa el camaleon, la puede proyectar hasta una distancia de seis 1 siete pulgadas; el hioides no está en comunicacion directa con la faringe, y tiene cuatro prolongaciones de una pulgada de largo, y un cuerpo, que se extiende hácia adelante, en forma de asa, como cosa de pulgada y media, sir. viendo de apojo á la lengua cuando está en descanso. Cuar. do esta es lanzada por el animal, tiene el grueso del cañon de una pluma de cisne, su tacto es elástico y aparece roja en el centro con una faja blanca á cada lado, y hácia la punta se ven gruesas venas muy repletas de sangre. Se mueve este órgano por medio de nueve músculos á cada lado, que suje. tan las astas ó prolongaciones del hioides. $\mathrm{I}_{2}$ porcion movi. ble de la lengua se compone de dos partes; una para coger, la otra para sostener y enderezar la anterior; la primera mide una pulgada á una pulgada y cuarto de largo y una de grue. so, no altera su dimension cuando es proyectada, estando encerrada en una vaina membranosa, $\mathrm{y}$ tiene la extremidad cubierta de una piel pegajosa y rugosa, humedecida por una especic de baba, resultado de la secrecion de varias glándu. las; la segunda se encuentra entre la anterior y el hueso lin. gual, y se alarga 6 encoge segun las circunstancias, ocupando mus poco sitio cuando se halla en reposo; pero al entrar en función, las dos arterias de la lengua, que se dividen en la punta en varias ramas, se inyectan de sangre $y$ la dilatan, de modo que el acto de proyectar la lengua se lleva á cabo mediante la rápida injeccion de sangre en la red vascular y no por la absorcion de aire, como algunos autores han pretendido. Los vasos sanguineos se llenan con la misma rapidez con que sube la sangre á las mejillas del hombre; $y$ por consiguiente, la lengua del camaleon puede ser provec- 
tada y retirada en el espacio de cinco a seis segundos. Muchas veces esta el animal todo el dia aguardando con la mayor indiferencia la presa que la casualidad le depare; tan luego se presenta ocasion, escupe, por asi decirlo, con la rapidez del rayo la lengua y recoge el insecto, sin salir al parecer de su impasibiliảad, dejándole imperturbable la sa. tisfaccion que débe sentir despues de haber hecho una presa. Es tal la seguridad con que projecta la lengua y la recoge, y tan ligero el esfuerzo que para ello ticne que hacer, que mientras lo efectúa no se nota desviacion ni movimiento alguno en el cuerpo, que por otra parte, está fuertemente adherido á la rama del àrbol por medio de los piés, articu:lados de un modo tan especial, y de la cola tan fuertemente enroscada al rededor de aquella.

Es muy probable que la singular configuracion del camaleon, su aspecto grave, su modo pausado de andar y la rapidez y seguridad con que se apodera de su presa, llamaran poderosamente la atencion de los griegos, contribuyendo á

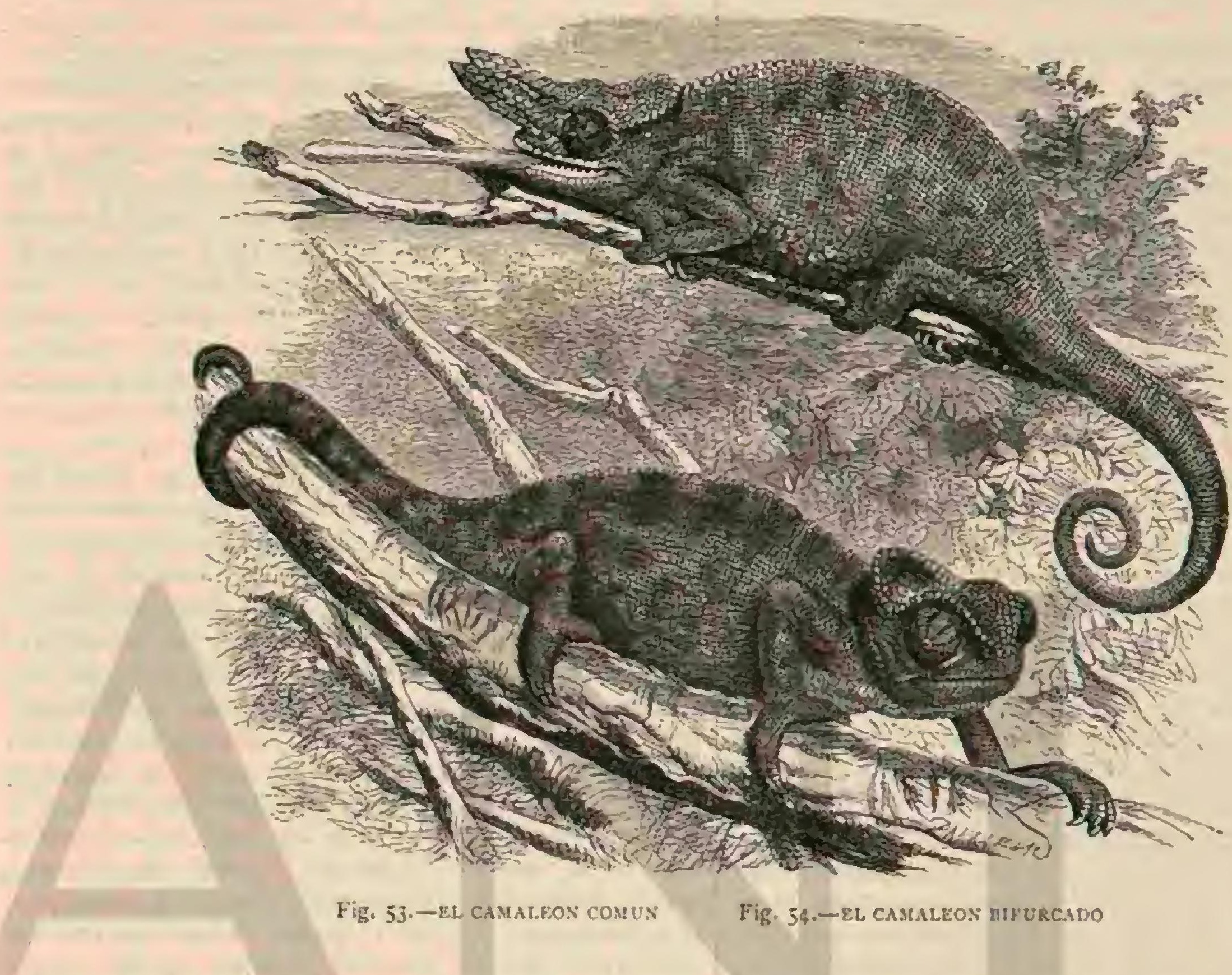

que le dieran el bonito nombre de «pequeño leon; sin em. bargo, lo que mas sorprendia en este animal \& los antiguos, y hasta \& los modernos, se puede decir, es el cambio de su coloracion. Hasta hace muy pocos años, era opinion general que el camaleon podia cambiar á voluntad los colores de su cuerpo, reflejando los de los objetos que ienia mas inmedia. tos, y ocultandose de este modo á sus enemigos. De aqui el que hasta hoy dia se acostumbre a llamar camalcon al hom. bre que cambia de opinion segun las circunstancins, pero siempre del modo mas favorable á sus intereses particulares, usándose dicho nombre como sinónimo de la servil compla. cencia de los lisonjeros y cortesanos; en tiempos mas remo. tos dió el mismo materia a 'Tertuliano para escribir sérias y atinadas consideraciones sobre el falso brillo y atrevimiento de los embaucadores y farsantes. Este cambio de colores ha motivado las mas extrañas manifestaciones de sabios y profanos, hasta que recientemente vinieron las concienzudas observaciones de Brucke á resolver en definitiva el problema. Ia facultad que tiene el camaleon de variar su coloracion, reside en la existencia de dos capas de distintas matcrias colorantes, ó sean pigmentos, de los cuales uno se encuentra debajo de la epidermis y se extiende hácia abajo hasta el tejido celular, y el otro se halla en toda la piel, distribuido en pequeñas celdas; el color del primero es casi blanco, to. mando un tinte amarillo, tanto mas subido cuanto mas se acerca á la piel; el segundo es pardo oscuro. El cambio de colores se verifica segun se hallan distribuidos los pigmentos, ya se encuentren aislados, uno cerca del otro, 6 bien el superior sobrepuesto al inferior, pudiendo variar por lo tanto la distinta coloracion, desde el blanco hasta el pardo oscuro.

DISTRIBUCION GEOGRÁFICA.-Todos los camaleones pertenecen al antiguo continente ó mas bien al he. misterio oriental del globo, no teniendo en América ni congéneres ni representantes en el verdadero sentido de la palabra. Se cuentan entre los animales caracteristicos de Airica y hállanse solo en los paises limitrofes de los contornus vecinos. Las treinta especies que se conocen se distinguen por sus formas; pero no por sus costumbres, y aun estas diferencias son tan pequeñas que los grupos fundados en la forma y naturaleza de las escamas solo podrian elevarse. cuando mas al rango de sub-géneros.

\section{EL CAMALEON COMUN-CHAMALEON VULGARIS}

CARACTERES. - El camaleon se caracteriza por su cresta dorsal denticulada solo en una mitad, por la cresta del vientre, que se corre desde la barba hasta el ano; el casco es obtusamente piramidal y trilateral, formándose por el cóndilo de la coronilla, muy corvo hàcia atrás y saliente; todas las pequeñas escamas, de formacion igual en el tronco, soln son mas grandes en la cabeza. Sobre su coloracion ha. 
blaremos mas tarde, pues no es posible hacer una descrip. cion general de ella. La longitud es de $0^{n *} ; 25$ á $0^{\circ}, 30$, de los cuales corresponde á la cola un poco mas de la mitad.

DISTRIBUCION GEOGRÁFICA.-Su área de disper sion se extiende desde el sur de España por una gran parte de Africa y de Asia: vive en Andalucia, en todos los paises del Africa septentrional, desde Marruecos hasta Egipto, y segun Tennent, tambien en Ceilan. Grohmann pretende ha. berle encontrado en Sicilia, pero como nadie le ha visto mas tarde alli, no puedo asegurar la exactitud de esta noticia.

USOS, COSTUMBRES Y REGIMEN. - lodos los camaleones habitan en paises donde llueve con frecuencia ó en aquellos en que el rocio es tan fuerte que pueden satisfacer siempre la necesidad indispensable de beber s. menudo. Por esta razon abundan sobre todo en los paises de la costa y las -islas. No falian en el desicrto, pero se encueutran exclusivamenté en las partes que aun están bajo la influencia del mar, y donde se desarrolla por consiguiente una escasa vegeta. cion. Tambien necesitan estos reptiles plantas altas, arboles $\delta$ arbustos, ó cuando menos espesuras $\delta$ maleza, pues son verdaderos animales arboricolas, que rara vez bajan al suelo. Suclen abundar en los paises donde habitan; en algunas partes, $y$ en circunstancias favorables, se pueden rer coce nas de ellos en poco tiempo. Acostumbran á situarse en pequeñas sociedades, de tres $\delta$ seis individuos, en un sótillo $\delta$ en la copa de un árbol, inmóviles como si fuesen parte inte. grante del mismo, asidos fucrtemente con las patas y la cola á una $\delta$ varias ramas. Durante dias enteros, se linita todo el movimiento de este reptil a agacharse y erguirse de nuevo en el puesto que ha escogido; y solo cambia de posicion, y alguna vez hasta de sitio, movido por circunstancias muy, especiales. Los lirones y todos los animales parecidos, que viven en los árboles y tienen fama de dórmilones y perezosos, se mueven mucho mas y con mayor frecuencia que los camalcones; estos concentran toda su actividad en los ojos, que siempre están en movimiento, y cn la lengua que proyectaı cada vez que tienen presa a su alcance. Ningun otro vertebrado acecha el botin con tanta tenaciaad como cste; solo se le puede comparar en este punto a algunos moluscos. El que tiene la suerte de ver y estudiar en libertad á este reptil, cosa bastante dificil de conseguir, puede persuadirse de la citmordinaria movilidad de sus ojos, en todas y las mas extrañas direcciones. Si su apetito no está aguzado por largo ajuno, permanece el camaleon en la misma postura aunque descubra à su alrededor una oruga $\delta$ gusano, y aguarda impasible que uno de estos se coloque á distancia conveniente: una vez conscguido esto, vuelve lentamente la cabeza hácia su presa, la fija con sus ojos, y abriendo poco á poco la boca, proyecta la lengua, to que puede verificar hasta la distancia de seis pulgadas, recogiéndola en seguida; luego percibese un rápido movimiento de mandíbulas, y el animal vuelve á aparecer tan tranquilo é impasible como antes. Con todo, si ha estado algun tiempo sin hacer presa, persigue entonces algun insecto rezagado, pero sin abandonar por eso la rama donde se encuentra.

Durante mi estancia en Alejandria, ture unos veinte ca. maleones en mi habitacion. Los recibi todos en un mismo dia, j tan luego como ocuparon el cuarto que les destiné, cada cual se procuró un sitio conveniente, ya en las guarniciones de las ventanas, ya en las molduras de las puertas $\delta$ en las armas y largos tubos de pipa que habia arrimados en un rin. con, ya sobre las mesas, sillas, cajas, etc. Por medio de un vaso lleno de miel, consegui atraer varios insectos, especial. mente moscas, de las que acudieron bastantes; el hambre de mis cautivos parecia insaciable, $\delta$ los puestos de acecho que escogieron debian ser poco favorables, pues se atrevieron a algunas pequeñas excursiones. Al principio estas les fueron provechosas y recogieron varias moscas; pero cuando cerré la rentana, impidiendo de este modo la nueva afluencia de insectos, la caza se hizo bastante dificil, pues las moscas se apercibian de la persecucion $y$ evitaban con mucho tino que se les acercasen sus encmigos. Con este motivo pude admirar la perseverante paciencia de los camaleones. Como uno de estos, fijado en el respaldo de una silla, descubriese, despues de haber dirigido sus ojos en todas direcciones, que habia una mosca encima de una mesa próxima, pareció aguardar durante algun tiempo a que aquella fuera á colocarse en el respaldo de la silla; viendo, empero, que esta esperanza no se realizaba, y comosin duda el hambre apretaba, se decidió á accrcársele: cautclosamente levantó la pata de. lantera y con mucha pausa la colocó uma pulgada mas alla, haciendo despues la misma operacion con la cola y las otras extremidades alternativamente. Con una gravedad verdade. rautente cómica, pero demasiado pesada para el observador, fué descendiendo el paciente animal de la silla, y con grandes esfuerzos pudo conseguir colocarse en el borde superior de la mesa. Una vez alli, volvió los ojos hácia el sitio que ocupaba el insecto, pudiendo observar con satisfaccion que no habia desaparccido este; siguió adelantando, con mayor pausa si cábe que antes, y ya se preparaba sin duda á proyectar la punta de su lengua, cuando en tan crítico momento la mosca, que debia haberle observado, abrió las alas y volo, alejándose de su perseguidor. De nuevo empezó el camaleon á escudrinar con sus ojos arriba y abajo, á derecha izquierda, en todas direcciones, hasta que por fin los. fijó en un rincon algo distante: en efecto, alli habia una mosca, y como si cl reptil estuviese irritado por su mal éxito anterior, apresuró esta vez sus movimientos. Con sorprendente celeridad bajó de la mesa, y se adelantó estirando las patas y apoyándose en la cola, con aparente dificultad, hácia el indicado rincon, pero siempre con mas rapidez que era de esperar de este animal. Llegado alli, un largo tubo de pipa le pareció el camino mas adecuado para acercarse al insecto, y al cabo de pocos segundos consiguió colocarse en su extre. midad; pero, desgraciadamente, y por mas que se alargara el camaleon, la distancia que quedaba entre su hocico y la mosca era el doble de la que podia alcanzar su lengua, y así lo reconoció el reptil, pues ni siquicra probó proyectarla; en aquella dificil postura se manturo mas de veinte minutos, todo el tiempo que la mosca permaneció alli, esperando el camalcon con los ojos fijos en ella y completamente inmóvil é imperturbable á que se pusiera al alcance de su lengua.

Han afirmado varios autores que el camaleon no puede, aunque quisiera, dar sino muy pocos pasos en un dia; esto es un error segun mis observaciones; cuando este reptil quiere, puede andar en una hora un trecho comparativamente largo. Otros naturalistas han manifestaco la opinion de que este animal no puede nadar, porque no solo ambos ojos son inde. pendientes uno del otro, sino que lo mismo sucede con las demás partes del cuerpo; yo creo que si bien no es probable que el camaleon se vea á menudo en la necesidad de tener que atravesar un rio, con todo, si por desgracia llega a caer en el agua, le bastará la dilatacion del cuerpo para salvarse de ir á pique.

Por punto general, hay formada una opinion crrónea respecto al cambio de colores que se observa en la piel del camaleon; se cree que el animal refreja la coloracion de los objetos inmediatos, pudiendo cambiar la suya y graduarla á su antojo, lo cual es un error. El tinte general de este reptil es casi siempre amarillento 6 verde gris, $y$ no puede sustisuirlo por el de los sitios en que se halla; todos los cambios 
de coloracion se verifican con cierta regularidad y obedecen á impresiones ó \& movimientos de su temperamento, como tambien \& manifestaciones del espiritu animal, como hambre, sed, necesidad de descanso, saciedad, celo, etc. La transicion de los varios colores se hace por lo general desde el anaranjado, pasando por el verde amarillo, hasta el verde azul; y las mezclas y matices, pasando cada uno de estos co lores por el gris, ó pardo gris, al negro, blanco, color de came, pardo, lila y azul gris, además de los colores tornasolados que se producen por medio de las celdas exágonas, planas y del. gadas que se encuentran en la piel superior. No todas las partes del cuerpo estàn sujetas a esta alteracion de color: una faja bastante ancha que va desde la barba al ano, y la parte inferior de las manos y de los piés, no cambia nunca, mientras que la parte interior de las extremidades varia muy poco. Van der Hoeven ha hecho observaciones muy exactas sobre este punto, y ordenó pintar una serie de cuadros re. presentando las variaciones de color clarn, flanqueando una linea de puntos oscuros que corre desde la cabcza hasta in cola y por la parte abdominal; estos puntos 6 manchas son las partes mas sujetas á la alteracion. Por la mañana, cuando el animal permanece tranquilo, el color general de su piel es casi.siempre amarillento, $y$ las dos fajas laterales tienen un aspecto rojizo, mientras que la linea de puntos es muy poco perceptible. Mas tarde, el tinte dominante de la piel no ha cambiado, pero las fajas se han vuelto blanquizcas y las man. chas aparecen de verde oscuro, mientras que en el dorso se ven algunas sombras oscuras. Si por la manana se coge al animal $y$ se le tiene durante algun tiempo en las manos aparecen igualmente las manchas verdes. Fn estado de excita. cion el tono general de la piel es verdoso, el abdómen azu. lado, las fajas se muestran mas claras y las manchas negras. Muchas veces domina el color pardo rojizo, mientras que las fajas son de un tinte mas claro, y los puntos y sombras desaparecen casi por completo. Se ha observado por algunos naturalistas que durante el apareamiento, macho $y$ hembra tienen un color blanco de leche y cuando se les excita se vuelven casi negros; mientras que otros observadores afirman haberlos visto en este estado, de un color rojo pálido, con manchas de púrpura y lila. Por lo comun la coloracion y las manchas son mas vivas clianto mas robusto y excitado se muestra el animal; pero tampoco esta regla carece de excep. ciones. La luz y el calor ejercen influencia muy marcada en la coloracion, como varias pruebas lo han demostrado. $₫$ Sise quiere cambiar repentinamente los colores del camaleon, dice lenz, basta tenerlo en un sitio fresco y comunicarle algun calor, ya sea con las manos, ya de otro modo. Como hemos dicho, tambien la luz produce igual resultado, pues basta un pequeño rayo para conseguirlo: si se acerca uno al camaleon micntras duerme de noche y se coloca una luz, aparecen so. bre la piel amarillenta manchas pardas, que paulatinamente se van haciendo mas oscuras, hasta convertirse casi en ne gras; del mismo modo, si se saca de repente al sol un camaleon, encerrado en un sitio oscuro, su tinte general se acentia mas fuertemente pasados pocos minutos. Esta extraordinaria influencia de la luz, como tambien la independencia entre si de ambas mitades del cuerpo, se patentiann claramente cuando se ilumina 6 se calienta tan solo uno de los lados del animal: el expuesto á una de estas influencias es el que cam. bia, mientras que el otro permanece inalterable; y cuando el animal está dormido y se le excita, puede suceder muy bien, como algunos pretenden, que se despierte de un lado mientras continúa durmicndo del otro. Toda clase de excitacion, como tocarle con un palo, salpicarle con agua, ctc., produce cambio de color. De lo expuesto se deduce que la alteracion de colores en la piel del camaleon depende del sistema netvioso, y se produce á consecuencia de la excitacion del mismo. Los camaleones no se conducen entre si mejor que los demás repriles; una rez salidos de la indiferencia que acostumbran demostrar hácia todo lo que no es presa, sucede a menudo que se enfurecen y pelean procurando morderse con sus poderosas mandibulas. Poco antes de la época del apareamiento, dan estos séres de sentidos tan embotados, scôales de celos, y se disputan las hembras. Con los animales de clase distinta viven estos en perfecta paz, 6 mejor dicho, no tienen relaciones algunas con ellos, pues solo se preocupan de los que pueden ser dañinos $\delta$ servir de alimento. Cuando se acerca un enemigo ó asimismo un inofensivo pájaro, sue. len hincharse de tal modo, que el corte de su cuerpo es casi perfectamente redondo, $y$ soplan produciendo una especie de silbido. Si se les coge con la mano cuando están excitados, procuran morder, pero aunque lleguen $\{$ apretar sus mandi. bulas, lo liacen generalmente con poca fuerza sin causar herida alguna. Cuando se hinchan de la manera que hemos dicho, es consiguiente la variacion por completo: las costillas aparecen salientes, y el cuerpo adquiere, en el sentido literal de la palabra, cierta trasparencia, que algunas veces permite distinguir a traves del mismo, como rayas oscuras, los bar. rotes de la jaula.

Asi como la mayor parte de los reptiles, el camaleon pue. de privarse varias semanas $y$ aun meses de todo alimento, sin que esto le haga daño, pero no sucede lo mismo en cuanto a la bebida. Yo recibi una vez de Alejandrí, en ve. rano, un numeroso grupo de estos reptiles, que solo habian estado quince dias en el camino. Mas de una tercera parte de los camaleones cxaminados antes para reconocer su buen estado de salud, y los cuales cstaban sanos 5 robustos, halláronse muertos en el suclo de la jaula construida para el cn. vio; otros se dejaron coger sin resistencia y todos tenian el misno color: su piel presentaba un tinte amarillo de paja gris uniforme sin manchas $y$ sin vireza. Mi suposicion de que los animales habian muerto de hambre, $y$ de que los mas débiles, ya moribundos, sufririan la misma suerte por igual causa, no se confirmó. Aunque las miradas de todos se fijaban en los gusanos, lombrices y orugas, asi como en las moscas que atraian, ninguno de mis cautivos cornió, ninguno hizo la menor tentativa para coger una presa. Como primera prueba, mande mojarlos un poco, produciendo sobre ellos una ligera lluvia artificial con una regadera: ni la primera tempestad despues de una larga sequia, ni el primer sorbo de agua que se da al hombre casi muerto de sed pro. duce un efecto tan mágico y vivificante como el de aquella lluvia. Cada gota que caşo sobre la piel coriácea devolvió su frescura al sitio humedecido y como las brumas se desvanecen por la fuerza del sol, asi sc desvaneció el color de la es. casez, sustituyéndole el brillo de la abundancia. Pero no solo la piel se refrescó por-la humedad virificante; tambien 1a lengua lamió vorazmente las gotas; cuando estas cayeron mas y mas abundantes, los reptiles las recibian ansiosos cn sus duros labios, absorbiéndolas al punto para buscar otras cuando habian aspirido la humedad de las primeras. Des. pues de estas observaciones repitióse la operacion, dando por resultado que todos aquellos reptiles se recrearan y fija. sen ya su atencion en los gusanos de harina y las moscas. Los cuerpos de mis camaleones, resecos como la hojarasca, parecian otros, pues comenzaban á redondearse; las piernas recobraron su perdida fuerza, y la viveza los tristes ojos; enton. ces los camalcones demostraron que despues de un largo ayu. no no solamente comen con roracidad sino que devoran una cantidad rerdaderamente asombrosa. Segun mis observacio. nes y experiencias anteriores, los habia considerado como séres que comen poco: sabia que en libertad solo se alimen. 
tan de insectos pequeños y débiles, sobre todo de moscas, mariposas, escarabajos, langostas, orugas, arañas y quizás tambien de gusanos; y recordé haber leido que deben espe. rar con paciencia hasta que se les ofrece una presa, asi como que nunca pueden coger insectos grandes. Ahora observaba todo lo contrario. Los camaleones subian y bajaban por las ramas, enroscándose entre sí con sus colas cuando les fal. taba espacio; disputábanse los mejores sitios con gestos ame. nazadores; su vista penetrante escudrinaba todos los rinco. nes de las superficies verticales $y$ horizontales; $y$ muchas miradas se fjaban en la misma presa, la mosca escapada de una lengua caia seguramente en alguna de las muchas que la esperaban. Unas fuentes bastante grandes llenas de gusanos de harina quedaban vacias en un instante; el contenido de una espaciosa caja regalada por el jardinero, y llena de oru gas, se desocupó en veinticuatro horas por mis cuarenta camaleones, y á pesar de esto, los ojos miraban con avidez para buscar nueva presa; mis cautivos me parecian nas vo. races que ningun otro reptil conocido.

No he podido averiguar con seguridad de qué modo el camaleon coge su presa Parece que coge con la punta de la lengua el insecto en que su vista se ha fijado, pues la saca con la rapidez del rayo y con la misma prontitud desaparece; otras veces diriase que puede emplear la punta de la lengua á manera de tenazas. Lo cierto es que vi muy á menudo que el insecto tocado por la punta de la lengua está perdido casi sin excepcion., Mis camaleones menudeaban sus ataques contra un platito lleno de gusanos de harina, $y$ nunca se retiró una lengua sin presa; con mucha frecuencia se veian dos ó tres gusanos á la vez en la lengua sin que ninguno de ellos hubiera caido al entrar en la boca. La seguridad de aquel órgano causó asombro á todo el mundo.

Antiguos naturalistas han pretendido que los camaleones daban á luz sus hijuelos vivos, pero observaciones modernas ban demostrado lo contrario; sin embargo, como ya dijimos al tratar de los escamosos en general, este punto es accidental y de ninguna trascendencia; pudiendo muy bien suceder, en casos aislados, que algunos camalcones conserren los huevos en los oviductos hasta el momento de romperse lâ cáscara. El acto del desove ha sido observado repetidas ve. ces, si bien, que sepamos, siempre en animales cautivos. Véase lo que refiere Valliesnieri sobre el particular: o Observé un dia que uno de mis camaleones estaba muy inquieto en las ramas con que habia adornado su jaula, y que por últi. mo con su natural pereza fué bajando al suelo; una vez alii empezó á corrêt de un lado á otro, hasta que se paró en un rincon en el cual no habia ni arena ni polvo, y sentándose alli empezó á escarbar la tierra con su pata delantera Como el terreno era bastante duro, le costó dos dias de trabajo casi incesante, para convertir el agujero en una caridad de unas cuatro pulgadas de diámetro por seis de profundidad, dentro de la cual se colocó depositando en la misma treinta huevos, segun pude averiguar despues. Una vez terminada esta operacion que fuéllevada á cabo con bastante diligen. cia, volvió á cubrir el agujero con las patas traseras, como suclen hacer los gatos cuando quieren tapar su excremento: pero no encontrando esto suficiente, la hembra fué en busca de hojas secas, paja y pequehas astillas, formando un mon. ticulo sobre el agujero que contenia los huevos. Los huevos de los camaleones son redondos y de un gris blanquizco; la cáscara es calcárea, pero muy porosa. Todavia no se sabe á punto fijo el tiempo q̨ue tarda el desarrollo de los gér. menes.

4Camaleon visto, camaleon perdido, dice un refran ita liano, y no deja de ser muy exacto; pues á pesar de sus varios cambios, el color poco llamativo de su piel le protege en gran manera contra el ataque de los numérosos enemigos que acostumbran á acecharle. No tan solo los pequeíos cuadrú. pedos y la mayor parte de las aves de rapina, sino tambien los cucrvos y las garzas reales, las cigüeñas, las grandes serpientes $y$ hasta los varanos y otros reptiles, son cazadores in. fatigables de estos séres inofensivos. El hombre tambien lo caza con tenacidad; pues siendo animal considerado general. mente inofensivo, $y$ llamando tanto la atencion su peculiar configuracion, es muy buscado por los aficionados. Desgraciadamente se hace esta caza de la manera mas brutal: como al camaleon, una vez agarrado á una rama, cuesta algun tra. bajo, y mas maña todavía, separarle de la misma, por lo co. niun se le arranca de su puesto á viva fuerza, $y$ hasta se prueba á echar al suelo á pedradas á los que se hallan fuera del alcance de la mano, es por lo tanto muy dificil obtener individuos de este género que no hayan sufrido algun percance, y la mayor parte se mueren a las pocas semanas, a consecuencia de los malos tratos que han sufrido.

CAUTrVIDAD. - En los primeros dias, se muestran los cautivos muy irritables, soplan s silban cuando se acerca el guardian, y hasta procuran morderle; pero pronto varian de conducta y se acostumbran al hombre, acabando por demos. trar, con el trascurso del tiempo, cierto cariño al que los cuida. Atendidos debidamente pueden permanecer varios años en cautividad; ante todo necesitan un calor templado éigual; debiendo proporcionárseles tambien cantidad suficiente de moscas, arañas, langostas, gusanos, etc. Nunca tocan los camaleones insecto alguno muerto, aunque pertenezca al género mas de su agrado: todo lo que comen ha de ser vivo. Jamesson refiere que un jardinero mantuvo durante todo el invierno a un camaleon con solo cucarachas y gusanos de tierra; sin embargo, creemos que son pocos los individuos de esta familia que resistirian un alimento tan poco variado. A los afícionados que no pueden destinar un local caldeado con regularidad al camaleon que tengan cautivo, recomienda Lenz que le preparen una camita caliente y blanda con un plato $\delta$ cazuela algo grande, $y$ que en lo mas crudo del in. vierno pueda ser calentada por medio de una pequeña lám. para.

En el sur de España se acostumbra tener en las habitacio. nes algunos de estos pequeños reptiles, no tan solo por diversion, sino para aprovechar su actividad en la caza de insectos: se coloca cerca del sitio que se ha destinado al ca. maleon un vaso con miel para atraer las moscas que con infatigable perseverancia recoge aquel con su lengua. Mi hermano me escribe que en Sevilla se ve casi en todas las tiendas uno de estos esclaros domésticos escamosos.

\section{LOS ASCALABOTES- ASCALABOT}

Pocos reptiles han dado pié á tantas consejas y relatos fabulosos como los ascalabotes ó salamanquesas, escamosos de configuracion especial y de vida nocturna, que se encuentran en todas las partes del globo; los antiguos los designa. ban con el nombre de estelios, segun Ovidio, á causa de la pequeña mancha en forma de estrella que tienen en el dorso. Cuenta Aristóteles, que el estelio ó salamanquesa habita en los intersticios de las ventanas, en las habitaciones $y$ en las cuevas; que trepa por las paredes, cayendo à menudo encima de la mesa y dentro de la comida; que duerme en los pesebres y se introduce en las fosas nasales de los asnos, de modo que estos no pueden comer, envenenándolos con su mordedura; que durante los cuatro meses de la estacion fria permanece oculto $y$ no come; que en la primavera $y$ 
otoño muda de piel y se la come. Gessner dice tambien que el estelio era considerado en su tiempo como enemigo natural del cscorpion, y que el aceite dentro del cual se habia hervido el cuerpo de aquel era un curativo eficaz de las he. ridas causadas por este viltimo. Probablemente se referirá Plinio al gecko ó salamanquesa cuando hablando de algunos escamosos, dice que entre los mismos los hay muy venenosos que causan la muerte de poblaciones enteras, pues su. biéndose á los árboles emponzoinan todos los irutos, y cuando caen en una fuente, su agua se convierte on el mas activo veneno.
Hasta tiempos muy recientes se han admitido fábulas parecidas, $y$ aun hoy dia, no faltan crédulos que las aceptan como hechos verídicos. Bantius, í quien por lo demás debe Ia zoologia varios datos importantes, cuenta cosas horrorosas de un ascalabote indio. «Su mordedura es tan venenosa, dice, que en pocas horas causa la muerte, si la parte herida no es amputada $\delta$ cauterizada en el acto. Pude presenciar un hecho parecido en el hospital de Batavia, donde se hallaba un marinero, a quien un ascalabote habia corrido pror el pecho; el cual ofrecia una enorne ampolla, como produ. cida por agua hirviendo, destilando al abrirla una materia

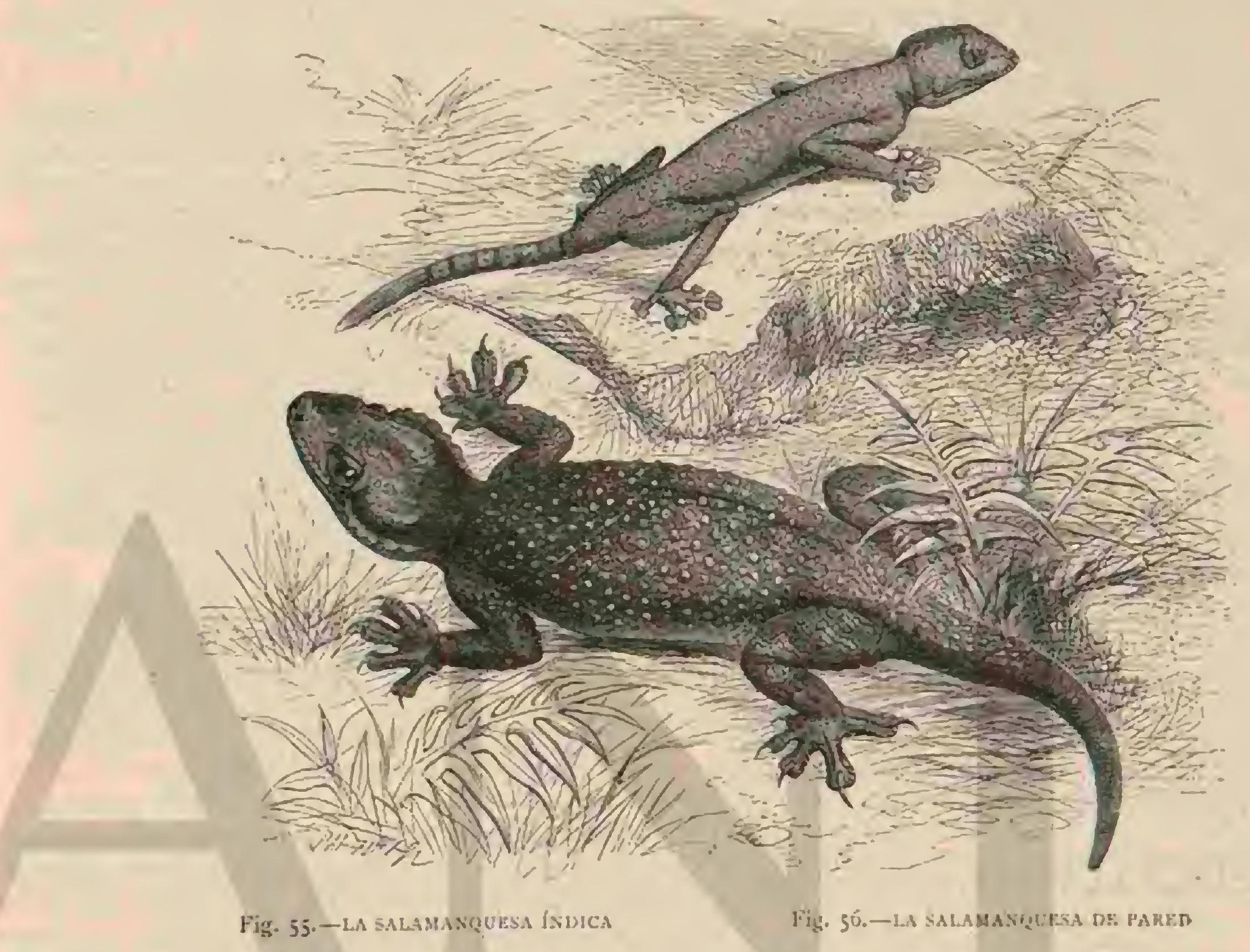

amarilla y de hedor insoportable. La carne que se descubrió tenia un color pardusco y se gangrenó inmediatamente, ca. yendo \& pedazos. Este lagarto tiene dientes tan fuertes y agudos, que su mordisco queda marcado en el acero. Sus fauces son rojas como un horno ardiendo. A menudo corre por las alcobas, obligando ś los habitantes a abandonar la casa; tal es el miedo que infunde. Los javaneses emponzo. ñan sus armas con la sangre y baba de este reptil; los con. feccionadores de veneno, gente desalmada que abunda en este pais, cuelgan á estos lagartos por la cola y recogen la baba pegajosa y amarilla, que destilan en su cólera, en una cazuela, exponiéndola despues á los rayos del sol para soli. dificar la materia La orina de estos animales produce tam. bien ampollas en las partes del cuerpo humano sobre que se aplica:

Hasselquist pretende que las salamanquesas que viven en Egipto supuran veneno por los surcos ó canales de los dientes, y asegura asimismo gue vió i dos mujeres y á una mu. chacha que habian comido queso envenenado por uno de estos escamosos, y que estuvieron ś las puertas de la muerte. Quien come manjares que ha tocado una salamanquesa con sus patas se vuelre leproso. Fábulas parecidas ha re. cogido tambien Peeppig en el Perú: habla de una cuyo solo contacto causa graves enfermedades; el veneno lo tiene en Tono $\mathrm{V}$ la superficie inferior de los dedos, y si bien no tan rápido, no es menos mortal que el de las serpientes venenosas. Ios indios está tan persuadidos de esto, que cuando han cortado las patas al animal, la cogen sin temor alguno con la mano. Asegura Peeppig que felizmente el ascalabote à que se refiere, no busca al hombre, y solo existe el peligro cuando cae encima de él o lo ioca inadvertidamente. Este observador dice que examinó con la lente á uno de ellos muerto, y encontró las escamas perfectamente secas, lo mismo que las patas adyacentes, que disecó chasta donde su seguridad personal lo permitia, sin encontrar tampoco rastro de glán. dulas venenosas: opina por lo tanto que el animal destila el veneno á su antojo. Recomienda asimismo fricciones de aceite caliente, como el mejor remedio para contrarestar el efecto del veneno, que considera que nunca puede ser tan rápido y actiro como el de las viboras, por no tener contacto inmediato con la sangre. Schinz cree que se debe aceptar la relacion de un viaiero y naturalista tan distinguido como Peppig, si bien con alguna reserva; yo creo que esta reserva está muy en su lugar, pues podria suceder qque la diseccion que dice aquel haber practicado en el ascalabote re. sultase tan poco exacta como la medicion que hizo del con. dor, y que tan acerbas críticas le ha valido.

Historias no menos horripilantes que estas se oven en to. 
das partes de America, en Africa, en la India y hasta en la Europa meridional. Cuando una salamanquesa, aseguraban indios y hombres de color á los hermanos Schomburgk, cae desde una viga del techo sobre la piel desnuda del hombre, se abren las láminas de los dedos, que contienen el veneno. y penetran en la carne, causando una grande hinchazon, que produce la muerte. No es, pues, de extranar, que estas gentes teinan á los ascalabotes como á las serpientes mas vénenosas. En el sur de Europa sucede otro tanto: dice Lu. ciano Bonaparte: (No basta que se diga que estos escamosos envenenan la comida que tocan con sus patas, sino que se les achaca tambien, que hacen cuajar instantineamente la sangre del hombre cuyo pecho ha estado en contacto con sus patas. Estos y otros cuentos parecidos relatan diariamente las maores a sus hijos. I Ln una palabra, la descon fianza y el horror que inspiran las salamanquesas son generales, y sin embargo, icuán poco justificado está todo esto! Yá verán nuestros lectores mas adelante cómo estos esca. mosos son completamente inofensivos, y solo deben a su as. pecto poco agradable y á su vida nocturna tan calumniosas impútaciones.

CARACTERES. - Fitzinger forma con los ascalabotes un orden aparte; nosotros vemos en ellos un sub-órden de los escamosos; segun Guenther, se distinguen de sus congéneres por las vértebras convexas en ambos lados, por tener imperfectos los arcos cigomáticos, por los cóndilos pareados de la coronilla; tienen de comun con la mayor parte de las especies el timpano. Hagler opina que no solo se parecen en la confi. guracion general de su cuerpo a los crocodilos, sino que tainbien en la forma de los ojos, de las ventanas nasales, de los oidos, etc, de modo que se pueden llamar pequeños cro. codilos que viven en tierra y no tienen dientes laterales; sin embargo, para descubrir semejante parecido, se necesita mucha fuerza de imagimacion. Con mas razon podria decirse que los ascalabotes tienen bastantes puntos de contacto con las salamandras, si bien dificilmente se puede desconocer la diferencia que existe entre unos y otras.

\section{LOS GECÓTIDOS-GEKO- TID死}

CARACTÉRES. - Los gecótidos son cscamosos de cuer po corto, rechoncho $y$ deprimido y de coloracion oscura. Su cabeza tiene un hocico largo, algo hendido debajo de la frente, aplanado, redondeado, con cierta semejanza al del sollo; llaman sobre rodo la atencion del observador los grandes ojos, cuya pupila, herida por la luz, se contrae en una hendidura linear y vertical, y cuyos párpados están arrollados entre el globo del ojo y el borde óseo; el oido aparece como un intersticio vertical; la boca es muy rasgada. El cuello es muy corto y grueso; el tronco comprimido, redondeado y aplanado de arriba abajo, y á veces franjeado latemlmente; la cola de tamaño regular, gruesa, redondeada en su raiz y en algunos casos aplanada y con pliegues cutáneos a los la dos en forma de festones; las patas se distinguen por su cor tedad, y los dedos por su construccion especial, que consti tuyen el distintivo principal de estos escamosos. En todas las especies se encuentran aquellos, de tamaño casi igual, aplanados y ensanchados en su parte inferior, unidos por medio de una membrana, y protegidos por una especie de cojin, formado con láminas irasversales, que varian de forma, tamano y posicion, permitiendo al animal correr en todos sentidos por las superficies mas lisas; en algunos individuos háliase ensanchada toda la parte inferior de los dedos, mientras que en otros las laminas solo ocupan parte de la misma, en cuyo caso se encuentra dividida en dos porciones; muchos tienen solo la almohadilla en la última falange de los dedos, y en otros aparce sustituida por una especic de verrugas; en una palabra, la configuracion de las extremidades de los gecótidos no puede ser mas variada, dando esto motivo para que los clasificadores cientificos los dividan, segun dichas variaciones, en distintas especies, géneros y hasta sub. familias. En casi todas las especies las uñas son ganchudas, afiladas, movibles y á menudo retráctiles, pero á veces faltan en algunos dedos, y otras en todos. Ia cubierta exterior del cuerpo de los gecótidos consiste en escamas muy pequerias, unidas fuertemente unas á otras y sembradas a veces de otras mayores. Los dientes se distinguen por su gran numero y no por su diversidad, pues casi todos son de la misma forma y de igual tamaño; solo los maxilares aparecen un poco mas cortos que los demás; todos son comprimidos, cortantes en el vértice 6 implantados en el borde interior de las man. dibulas; no tienen los gecótidos ni dientes caninos ni pala. tinos.

El grupo de los gecótidos se divide en varias sub familias que comprenden unos cincuenta géneros y sub-géneros. Esta separacion, sin embargo, solo tiene importancia para el na. turalista, porque las diferencias de los grupos son poco nota. bles; y en cuanto á las costumbres y utilidad para el hombre, ofrecen mucha analogia. Para nuestro fin bastará limitarnos á una breve descripcion de algunas especies.

\section{LOS PLATIDÁCTILOS-PLATYDAC- TYLUS}

CARACTÉRES. - En los platidáctilos la piel membrano sa se extiende sobre toda la superficie inferior de los dedos. de los cuales el primero, segunco y quinto carecen de uñas.

\section{EL PLATIDÁCTILO DE PARED-PIATY- DACTYLUS MAURITANICUS}

CARACTERES.-El piatidàctilo ó salamanquesa de pa red es un reptil pequeño, que solo mide ()$^{n \prime}, 12$ á $0^{\circ}, 15$ de longitud de los cuales corresponde á la cola una mitad: las regiones superiores pueden ser de color mas claro 6 mas oscuro, desde el gris amarillento, pasando por el gris pardo y pardo negruzco hasta un negro mate; en dichas regiones hay fajas, ó bien son de un solo color, en cuyo caso parecen cubiertas de un polvo larinoso; las partes inferiores son de un amarillo sucio. Ia cabeza es muy áspera, el lomo presen: ta unas verrugas compuestas de tres ó cuatro granitos muy unidos; la region abdominal es en cambio escamosa y lisa (fig. 56).

DISTRIBUCION GEOGRÁFICA. - El àrea de dispersion de este reptil se extiende por todos los paises del Me. diterráneo; abunda principalmente en España, Grecia, Dalmacia y el norte del Africa.

\section{LA SALAMANQUESA INDYCA-PLATYDAC- TYLUS GUTTATUS}

CARACTERES. - Una de las especies mayores de las salamanquesas es la indica, que llega a medir un pié inclusa la cola que alcanza la mitad de la dimension total. Esta es. pecie, que fue tan calumniada por Bontius, atribuyéndole toda clase de horrores como llevamos indicado, tíene en la parte superior del cuerpo doce filas longitudinales de tubércu. los puntiagudos y seis en la cola. El lomo aparece moteado de rojo y azul; el tinte de las partes abdominales es gris perla (fig. 55). 
DISTRIBUCION GEOGRÁFICA. - Como lo indica su nombre, este ascalabote es originario de la India, donde abunda en todo el continente $y$ archipiélagos de la misma.

\section{LOS HOMALOCÉFALOS- PTYCHOZOON}

CARACTÉRES. - Este género se distingue por tener un repliegue membranoso á cada lado del cuerpo, que se prolonga por la cola; los dedos están unicios en toda su longitud por una membrana y cuatro de ellos tienen unas.

\section{EL HOMALOCÉFALO-PTYCHOTOON HOMALOCEPHALUM}

CARACTERES. - La única especie conocida del género y á la vez uno de los tipos mas extraños de la familia, el ho. malocéfalo, tiene unos $0^{m}, 18$ á $11^{n}, 20$ de largo; las regiones superiores son de un amarillo verdoso de aceite, que en los costados tira á pardo rojo, con unas fajas trasversales en ziszag ú otros dibujos de color pardo oscuro ó negro; la piel rugosa de las mejillas es de un color claro de carne con puntos de un azul oscuro; la articulacion del brazo presenta un anillo blanquizco; las regiones inferiores son de un gris ama. rillento; el anillo de los ojos de un amarillo de oro (fig. 57).

DISTRIBUCION GEOGRAFICA. - El homalocéfalo es muy comun en la isla de Jasa y se encuentra además en alguras pequeñas islas recinas.

\section{LA TARÁNTULA-TARENTOLA}

CArACTÉrES. - En Italia y Provenza se ha dado el nombre de Turinitula sa este platidsctilo, que se distingue por tener en la cara superior del cuetpo warias fajas trasversales de tubérculos de forma oval, con una fuerte quilla, $y$ rodeados en su base de gruesas escamas ó de otros tubércu. los pequeños; la cabeza está cuevierta de plaquitas poligonas y convexas, y debajo de la garganta hay otras semejantes, aunque del todo planas y lisas. El color de la tarántula ofrece ciertas variaciones; unas veces tienen todas las partes superiores del cuerpo de un gris ceniciento, con las regiones inferiores blanquizcas; y otras son de un pardo oscuro con man. chas grises, que forman fajas trasversales en el lomo y la cola, siendo entonces el vientre de un blanco nas pálido (figura 5 ).

DISTRIBUCION GEOGRAFICA. - Este reptil habita principalmente en el Cabo de Buena Esperanza, y está diseminado en una gran extension del Africa del sur.

USOS, COSTUMBRES Y RÉGIMEN. - La tarántula se introduce algunas veces en las casas, y se la ve correr por las paredes; pero le ofende tanto la luz como le gusta la os. curridad. Aliméntase de toda especie de insectos, y principalmente de moscas y arañas.

\section{LOS HEMIDÁCTILOS- HEMIDACTYLUS}

CARACTÉRES. - En este géncto se reunen las especies cuyos dedos solo están unidos en la mitad de la base por medio de laminillas, mientras que la última y penúltima articulacion quedan libres; el disco 6 cojin se.halla dividido en dos partes por un surco longitudinal; la parte inferior de la cola está cubierta de escudos.

EL HEMIDÁCTILO VERRUGOSO-HEMIDACTYLUS VERRUCUIATUS

CaracterEs. - Lista especie, propia del sur de Eu. ropa, es un gecótido pequeño, de solo $11^{*}, 10$ de largo; dis tínguese de sus demás congéneres europeos por sus escamas de forma triangular é irregulares, dispuestas en series; por las fajas trasversales verrugosas, y por el color rojo de carne con manchas de un gris pardo en las partes superiores.

DISTRIBUCION GEOGRÁFICA. - Habita los mismos paises que la salamanquesa de pared.

DISTRIBUCION GEOGRÁFICA DE LOS GECÓTIDOS F.N GENERAL. - La familia de los gecos, de los que se han distinguido unas doscientas especies, se extiende por todos los paises ćĺlidos de la tierra, poblando no solo los continentes sino tambien las islas situadas dentro de la zona que habitan, incluso las que estản solitarias en medio del GrandeOcéano sin tener ninguna relacion visible con otros continentes. Tambien se encuentran los gecótidos en las grandes extensiones de tierra firme; alli donde viva un escamoso de seguro que tampoco faltan los gecos; habitan asi en los paises bajos como en la montaña, así en el bosque como en el desierto, asi en medio de las grandes ciudades pobladas como en la bóveda del solitario pozo en el camino de la estepa.

USOS, COSTUMBRES Y REGTMEN.-Casi todos los gecótidos escogen iguales sitios para su habitacion, y tienen el mismo modo de vivir. Fijan su morada en las rocas y en los árboles, en las aglomeraciones pedregosas, en las paredes, y con preferencia en las habitaciones del hombre, desde el sótano hasta el tejado. Algunas pocas especies viven solo en los árboles, pero la mayor parte habitan indiferentemente en los varios sitios ya indicados. Je dia se dejan ver poco los gecótidos, pues su verdadera vida solo empieza al anochecer; sin embargo, como les gusta tomar el sol, sobre todo hácia cl medio dia, acostumbran aparecer en los puntos expuestos á los rayos de dicho astro, y en aquellas paredes solo en parte iluminadas, se les puede observar cómo avanzan á medida que se extiende la sombra. En localidades donde no suelen ser molestados, se les ve á centenares en la misma pared, á docenas en el mismo árbol; pues si bien no se puede decir que viven en perfecta paz entre si, con todo, les agrada estar en sociedad, y con el tiempo van escogiendo los sitios mas á propósito para su morada en una misma zona y alli se reunen en grandes agrupaciones. Tan pronto como anochece, empieza la actividad de las salamanquesas y su caza álos insec. tos de toda clase, especialmente moscas, mosquitos, arañas, escarabajos, etc, de los que saben apoderarse con pasmosa seguridad.

Las grandes especies, segun Eduardo de Martens, cazan tambien las pequeñas de su familia; todas en general son tan voraces como cualquiera otro lagarto.

Antes de dar principio á sus trabajos, se anuncian con un chillido bastante fuerte y distinto, que se puede traducir por gek 6 toke, y que cantan alternativamente en tono mas alto ó mas bajo. Sus corterias duran toda la noche y son en verdad extraordinarias: trepan con admirable agilidad por las paredes rectas y lisas, corren por el techo tan fácilmente como por el suelo, se quedan pegadas mas de un minuto en un mismo punto, emprendiendo otra vez su marcha; sacudiendo de un lado á otro la cola y ayudándose en sus movimientos con las ondulaciones del cuerpo; sus grandes y brillantes ojos giran en todas direcciones; escudriñan todos los rincones, espiando sus presas. No es, pues, de extrañar que este inofensivo animal, de quien el viajero ha oido contar tantos horrores, sea repulsivo al que le ve por primera ver; sin embargo, esta impresion desagradable desaparece tan pronto como se observan con interés sus movimientos y desenvoltura. No puedo comprender cómo Schomburgk, observador concienzudo y desapasionado, haya podido dejarse llevar de 
la mala impresion del primer momento para hablar de un modo tan desfavorable de los inofensiros gecótidos. \&Mas repugnantes todavia que las serpientes venenosas, observa Schomburgk, nos era la numerosa aparicion de las salamanqquesas, que desde el principio de la estacion de las lluvias se amontonaban, en el verdadero senticio de la palabra, en las parcdes y en las vigas del techo. Ias horribles historias que nos habian contado los indios, debieron sin duda contribuir á hacernos odioso este reptil, que probablemente es de todo punio inofensivo; de modo que cuando durante nuestras reuniones vespertinas, caia uno de estos huéspedes. encima de la mesa (lo que sucede á menudo con su constante trajin, caźndosey mordićndose mutuamente) era la señal de la dispersion de la tertulia. Era tal el asco que nos infundia animal tan repugnante, que siempre nos acostába. mos vestidos en las hamacas.

Como Schomburgk, he habitado durante semanas y meses casas pobladas por gran número de gecótidos, $y$ no puedo negar la sorpresa que me causaron los primeros que vi: pero muy pronto me acostumbré á los juegos y correrías de estos inocentes reptiles, y algunas horas he pasado distrayéndome con los mismos. Son animales domésticos en el mas com. pleto sentido de la palabra, mas fieles que los ratones y en todo caso mas útiles. De dia concedo que sus movimientos sean torpes y repulsivos, sobre iocio cuando se les amenaza y procuran refugiarse en su escondite, aumentando esta im

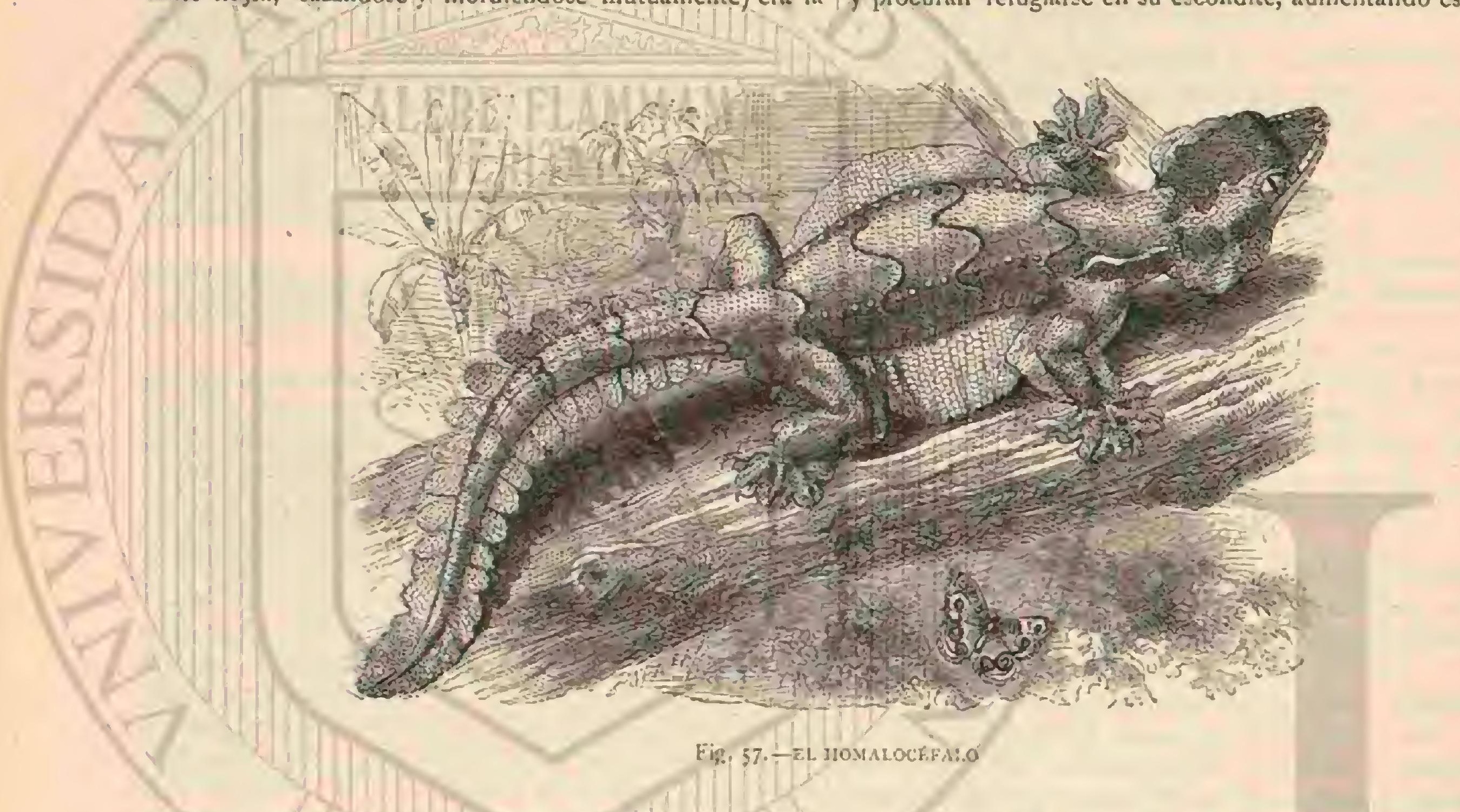

presion desagradable, cuando sobrecogidos de miedo, se dejan caer de repente al suelo como suclen hacer los escarabajos, sucediendo á menudó que en la caida piercen la cola; pero cuando llega la hora dé su activioad, una ves entrada ya la noclie, creo que todo obserwadory verdadero natura lista debe encontrar, si no placer, á lo menos entretenimiento en estudiar su modo de vivir. El mismo Schomburgh reccnoce que la destreza y agilidad con que corren por las pare des, vigas y toda clase de superficies lisas, rayan en lo fabuloso, y que sus movimientos de cabeza, cuando están parados, son por demás extrafios y risibles: debemos confesar que cuando habitábanos el Cairo, Dongola, Charthum y otros puntos del Africa septentrional, siempre sentiamos vivo placer al oir por la noche el primer grito de las salamanquesas, y seguiamos con perseverante constancia todas sus idas y venidas, causándonos cada vez mas admiracion su destreza ¿ incansable actividad.

Los movimientos de los gecos son poco acompasados, pero en extremo rápidos y ágiles. Cuando corren en linea recta, ejecutan movimientos serpentinos muy visibles: pareciendo qque les cuesta trabajo dar pasos; pero cuando se observa la agilidad con que retozan persiguiéndose unos á otros, ó el furor con que pelean, pronto se cambia de opinion. Oprimen su tronco contra el suelo en que se mueven; al trepar por paredes verticales ocupan mucho espacio, pues entreabren las piernas todo lo posible, extendiendo tam. bien los dedos, y se apoyan además con la cola; de modo que se mueven con tanta agilidad como otro lagasto cuando trepa. Segun las observaciones de Cartor, el homalocéfalo, valiéndose de la membrana que reune sus cxtremidades y qque le sirve de paracaidas, puede dar salios 1 bastante distancia; mientras quue las oiras especies pierden regularmente el equilibrio y caen al suelo cuando intentan hacer lo mismo.

A la agilidad corporal de estos animales corresponde la intelectual; son tan inquietos, vivaces 6 irritables de noche como los lagartos, a los que no parecen inferiores por ningun concepto, a pesar de la diferencia de estructura Asi, por ejemplo, su valor é indole pendenciern no ceden al dc dichos escamosos. Las grandes agrupaciones viven casi sicmpre en guerra, se dan caza y persiguense, traban rinas y hacen el mejor uso de sus dientes. I.as especies mas grandes hasta resisten al hombre cuando este las acosa, abren la boca cuanto es posible, dirigen miradas salvajes y muerden cun tal furia, que pueden destrozar la picl del agresor. Asi lo refieren '1'heobald y Martens al hablar del geco punteado, propio de una gran parte del Asia meridional, especie que se teme de un modo verdaderamente riỏiculo, mas aun por sus mordiscos que por su aspecto.

Una infnidad de veces he cogido gecos, los he tenido en las manos tocando y examinando la parte inferior de sus de. dos, sin que jamás experimentara el menor daño de este con. tacto, ni encontrara ese rastro de khumedad pegajosa de que han hecho mencion otros naturalistas. Home, que tambien habia estudiado detenidamente las láminas de los dedos de las salamanquesas, fuci el primero tal ver que indicó qque estas se sostenian en las superficies lisas y perpendiculares median. 
te el vacio que produce la almolsadilla en la parte inferior de los dedos. Nosotros opinamos del mismo modo, y creemos que los qque han propagado la teoria de la materia pegajosa, no han tenido presente que a ser cierto, en vez de contribuir a fijar en la pared las patas del animal no haria sino dificultar su marcha con el polvo y basura que forzosamente se habian de adherir á la superficie pegajosa. El animal solo se adhiere por la presion del aire con el objeto en que trepa.

Mientras estaba escribiendo lo anierior recibi de mi herinano Reinaldo la noticia de que tenia un geco cautiro $y$ como sabia que este naturalista, menos medroso que Pecppig, no vacilaria ante «el peligro de un exámen, le rogué volviese á observar minuciosamente la manera de trepar de estos reptiles, informándome del resultado de su prueba. He aqui lo que me contestó:

«Para cumplir tu deseo he examinado varias veces los piés de la salamanquesa de pared sin hallar vestigio de un liquido pegajoso; la formacion de los decos del animalito es por el contrario de tal naturaleza, que no necesila este liquido para poder sostenerse y moverse en las paredes; todos los dedos que solo se distinguen en los pies pror ser el quinto posterior mas largo que el correspondiente de los piés anteriores, y en general el que mas se prolonga de todos, tienen la facultad de volverse; el geco puede poner el primero y el quinto, de modo que con el segundo y cuarto forma no solo un śngulo recto sino tambien uno muy obtuso; $y$ aun el segundo dedo de cada pie es tan movible que con ell puede traxar aun un segmento de circulo bastante grande, mientras que el tercero y cuarto se separan muy poco uno de otro. Es. tos uiltimos deben ser los dedos de apojo en el acto de trepar, mientras que los otros tres podrian llamarse los dedos fioriciores.

Si esta extraordinaria libertad de los movimientos laterales de los dedos es sumamente v́til, aun lo es mas por la circunstancia de que tambien la inclinacion de los dos pri. meros dedos y del quinto es muy particular en la segunda y tercera articulacion; de mocio que estas tiltimas pueden formar entre si un ángulo recto. I,as laminillas bastante conocidas del disco de los dedos se sobreponen cuando el reptil descan. 5a a manera de un abanico, de manera que los surcos desaparecen casi del todo, siendo marcadamente visibles si cl animalito trata de adherirse á una pared. Ias citadas laminillas parecen al iacto como de terciopelo y quedinn adheridas con muy poca presion en una superficie bastante lisa; del mismo modo se agarra el geco con sus laminillas aterciojeladas a las paredes ásperns. Esto lo facilitan mucho las unas encorvadas en forma de gancho, y muy agudas, de los dedos tercero y cuarto; mientras el reptil descansa estas uñas estan recogidas á modo de una garra de gato, mas aparecen al punio si el animal quicre trepar. Jebo añadir, sin embargo, que el geco solo puede adherirse a superficies asperas, pero no tre. par por las muy lisas, como por ejemplo por los cristales de las ventanss, de los que cae en seguida. A pesar de eso tienes mucha razon al decir que se sostiene en las superficies verticales por la presion del aire, que llege á infuir cuando pone verticalmente las laminillas inclinadas antes en ángulo agudo con el disco de los dedos: de modo que en cste úlímo caso se forman vacios entre las laminillas.

N.My notables son los ojos, grandes y cóncavos, que tienen un color claro de bronce. Fi iris parece bronceado por la galvanoplástia; la pupila es longitudinal y se contrne, al reci. bir una luz muy clara, en forma de una linea vertical que lo divide en dos mitades iguales. Cuando se hace sombra por encima del ojo, la pupila se ensancha rápidamente, hación. dose primero longitudinal, despues circular y ocupando al fin casi todo el espacio del iris, de modo que este yueda visible en ambos lados solo como un fino borde, desapare. ciendo del todo en las partes superior é inferior.s

DOMESTICIDAD. - Eil geco solo hace caso de otros reptiles ó vertebrados en general cuando son mas fuertes que el y entonces ve en ellos enemigos.

En el sur de Europa se hace bastanic dificil el estudio de los ascalabotes, debido sin duda á que sin motivo alguno

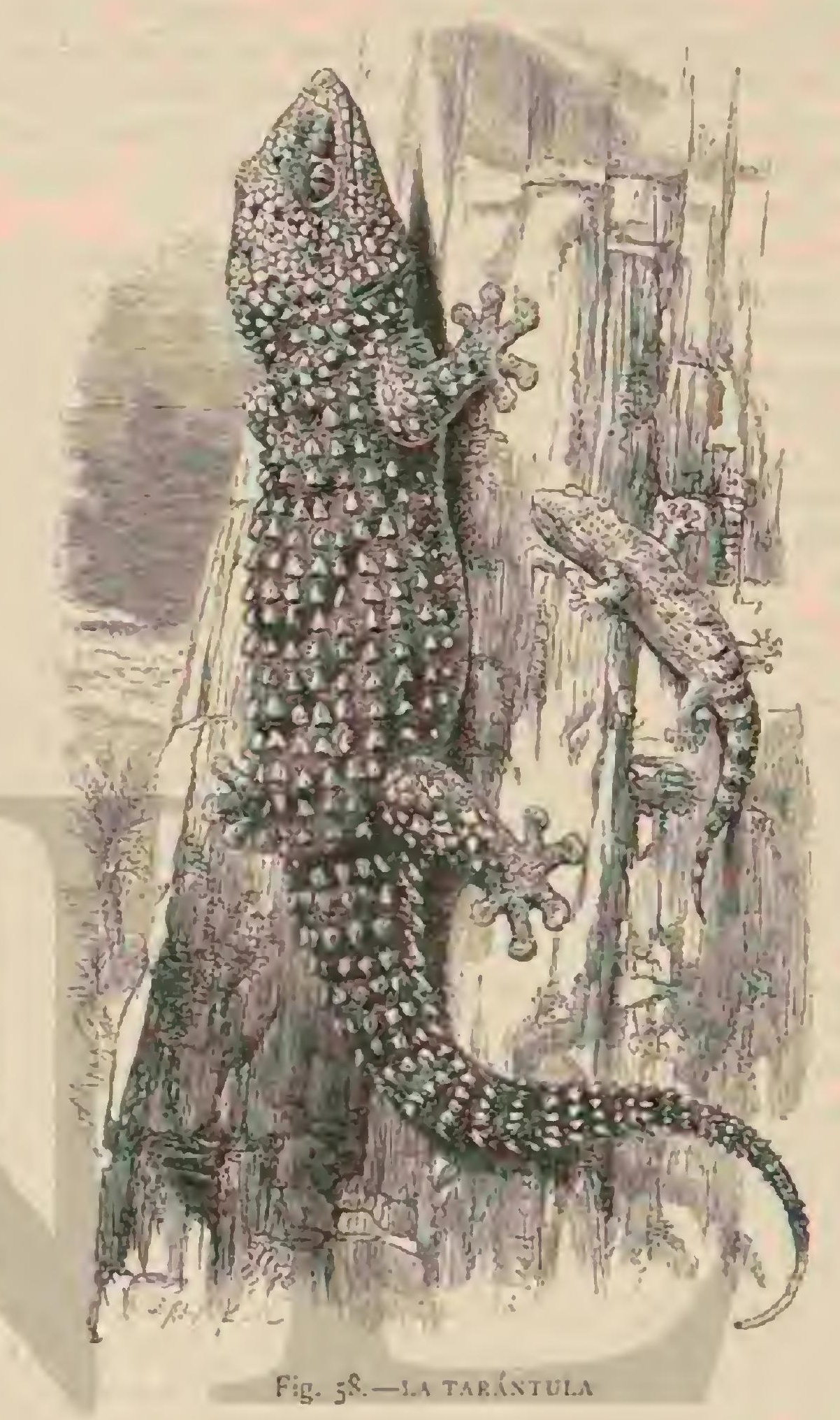

son generalmente perseguidos, y por lo tanto se muestran esquivos y hujen tan luego como perciben al hombre. En Africa, por el contrasio, se dejan acercar fácilmente $y$ hasta llegan a vivir en cierta familiaridad con el hombre kEn la habitacion donde las señoras de mi familia pasaban la vela. da, reficre Tennent, habia fijado su esconoite detrás del gran marco de un cuadro uno de estos pequeños reptiles, lo mas domesticado y divertido que he visto; tan pronto como se encendian las luces, aparecia el ascalabote en la pared, aguar. dando á que le dieran las nigajas de costumbre, y cuando inadvertidamente ó con intencion se le descuidaba alguna rez, solia llamar la atencion con un agudo y recio chic, chich, rhic. En el fuerte de Colombo, habia enseñado la familia de un oficinl \& otro ascalabote a presentarse todas las noches cuando se servia la comida; apenas se sentaban las personas que componian dicha familia, aparecia con constante regu. laridad el pequeño escamoso. Durante algunos mescs aban. donó el oficial y los sujos la habitacion, en cuya ausencia se limpió, pinto y reparó la misma, habiendo tenido que remo. verse gtan parte del tejado; de modo que cuando regresó la citada familia, hubo de suponer que el ascalabote habia des. aparecido despues del gran cambio hecho en la habitacion y 
del abandono en que se le habia tenido durantealgunos meses. No fué, pues, poca su sorpresa y alegria, al ver acudir al fiel reptil, con la puntualidad de siempre, cuando se sentaron por primera vez â la mesa. 'Todas estas observaciones que cualquiera puede comprobar fácilmente, parece que deberian excitar el cariiso de los hombres en favor de estos inofensivos animales, y sin embargo, son perseguidos y destruidos de la manera mas vergonzosa. Con suma sazon dice Luciano Bonaparte: En el ascalabote tenemos otro ejemplo patente de la ingratituddel hombre. Este pequeño escamoso no tiene mas afan que limpiar los sitios donde habita de moscas, mos. quitos, arañas $y$ de toda clase de insectos molestos, $y$ sus buenas obras soa recompensadas con la calumnia y la perse. cucion.

CAUTIVIDAD.-Desgraciadamente es muy dificil con. servar salamanquesas cautivas, y mas dificil todavia que 50brevisan al invierno en los paises mas frios de nuestro continente Ya su captura ofrece bastantes inconvenientes, y solo es jusible realizatla de dia, siempre que se puedan encontrar al alcance de la mano; por la noche está fuera de toda posibilidad la caza de un animal tan ágil y vivo. A esto hay que agregar la facilidad con que se le mutila la cola, pues al me. nor movimiento un poco brusco, se rompe como cristal; sin embargo, esta pérdida no es irreparable, pues á los pocos dias ya apunta otra y al cabo cie un nes tiene la nueva el aspecto exterior de la antigua, si bien le faltan inferiormente las vertebras. Este incidente, que por lo demás no afecta en modo alguno al bienestar del reptil, es con todo un nuevo entorpecimiento para manejarlo, pues al menor descuido se repite el fracaso, pudiéndose decir que es casi imposible trasladar una salamanyuesa de una jaula fotra sin que sufra al. gún percance. Además, la vida en un espacio reducido le pesa sobremanera á un reptil tan vivo y desenvueito; permanece siempre tímido $\mathrm{y}$ asustadiro $\mathrm{y}$-í menudo suele serle fa tal la cautividad. Esta es la causa de gue se vean tan raras veces gecótidos en manos de aficionados. En una casa de fie ras bien arregiada, donde siempre se puede tener igual tem. peratura, no es dificil conservar tambien los gécótidos en invierno.

4Mi cautivo, concluye mi hermano, come moscas, las cua les coge de un brusco/salto despues de observarlas mucho tiempo. No parecen gustarle los gusanos de harina, ó por lo menos los ha despreciado hasta ahora. Añadiré como hecho notable, que la afirmacion de los antiguos de que el geco devora su propia piel para privar de ella al hombre, porque esta piel es un excelente remedio contra la epilepsia, se funda en algo, pues mi cautivo se ha comidn en efecto su pro. pia piel hace pocos dias. La muda empezó en el lomo, exten diëndose desde alli por el cưello s la cabeza, partes en que la piel se conservó mas tiempo. "lan luego como el aninal se sintió del todo libre de'su antiguo traje, devoróle poco á poco, al parecer no sin grandes esfuerzos.

\section{LOS ANILLADOS - ANNULATI}

CARAGTERES. - Los tipos mas inferiores, es decir los menos desarrollados del órden, son los anillados, y por lo tanto este sub-órden ocupa el último lugar entre sus congé neres.

La configuracion exterior de los anillados no es menos variable que la de los lacértidos: su cuerpo cilindrico, estirado, de igual grueso en toda su longirud, excepcion hecha de muy pocas especies, se encuentra cubierto, en vez de es. camas, por una piel fuerte y coriácea, dividida por anillos $\delta$ verticilos, y par líneas longitudinales que cortan aquellos, formando múltiples y diminutos cuadrilongos; raras reces aparecen entre estas impresiones de la piel escudos multangulares, pero casi siempre se halla la cabeza protegida por placas cutáneas. Una sola especie se distingue por la presencia de miembros anteriores; en otras, se encuentran tan solo rudimentos de los pasteriores debajo de la piel. Los dedos en aquellas que los tienen, son constantemente incompletos, cortos y gruesos. El tímpano no es visible exteriormente en ninguno de estos monópneos, que carecen igualniente de párpados. Los ojos son asimismo muy rudimentarios; solo brillan como puntos negros al través de la piel que los cubre, y miran casi siempre hícia arriba. Las ventanas nasales terminan comunmente en la extremidad del hocico.

Fn la estructura anatómica de los anillados, se descubren los siguientes caractéres: el cráneo es largo, deprimido en su centro fuertemente arqueado sobre el hocico, y tiene cierto parecido con el de un mamifero carnivoro, cuanto que se encuentra á to largo de la coronilla una fucrte cresta ósea, y en el occipucio un cóndilo ancho y cortante. La mandibula inferior, maciza y bastante elevada posteriormente, tiene apenas la mitad de la longitud de todo el cráneo; la órbita está abierta en su parte posterior, formando un todo con la fosa temporal; el hueso de este nombie está unido al cráneo y al del timpano; la bóveda del paladar se encuentra siempre casi completa. Algunos anillados tienen esternon, pero otros carecen de el, mientras que en los cscamosos es cons. tante. Las mandibulas están pobladas de numerosos dientes cortos, pero sin extenderse hasta formar ángulo con el ojo, como sucede comunmente en los escamosos; en las especies conocidas hasta el presente no se han encontrado dientes palatinos. La lengua es corta, ancha, aplanada y sin vaina. Al iguál de los ofidios, los anillados tienen un solo pulmon bien desarrollado y las tráqueas muy prolongadas. Sin em. bargo, se distinguen estos de las serpientes por las mandibu. las no dilatables, como tambien por la configuracion de los dientes y de la lengua.

DISTRIBUCION GEOGRÁFICA. - Este sub-órden se compone de pocas familias y cuenta solo algunos géneros y especies que, sin embargo, están diseminados en ambos he. misferios.

USOS, COSTUMBRES Y RÉGIMEN. - Sabemos aun muy poco sobre el género de vida de las diversas especies, y en rigor solo hemos adquirido algunas noticias sobre los usos y costumbres de las de un género. Es posible que todas vivan como las lombrices debajo de tierra y solo salgan alguna vez á la superficie, sobre todo en los nidos de los térmites y de hormigas donde dan caza 2 las larvas de estos insectos y quizás tambien á las de las lombrices. De las especies que carecen de piés se supone que tanto pueden reptar hácia atrás como hácia adelante. Esta particularidad, dice Wagler, es propia en cierto modo de los topos, cuyo lugar ocupan sin duda los anillados en la clase de los reptiles. Además puede comparárselos con las lombrices reticuladas que viven en la tierra y se abren camino escarbando: son largos y cilindricos, y su gruesa piel tambien está reticulada de fajas trasversales $y$ longitudinales.

\section{LOS QUIRÓTIDOS-CHI- ROTIDE}

CARACTER ES. - La farnilia de los quirótidos se distingue de todas las demás por la presencia de piés anteriores, provistos de cuatro dedos atrofiados, pero con uñas y un vestigio del quinto dedo; el tronco es vermiforme, aplanado 
solo un poco en la region abdominal, pero por lo denłás de igual grueso en toda su extension; las mandibulas están provistas de dientes puntiagudos desiguales. Los huesos de los hombros y el esternon existen: desde los hombros hasta la extremidad de la cola se observa a cada lado un ligero surco.

\section{EL QUIROTE MEXICANO-CHIROTES CANA- IICULATUS}

CARACTLRES. Esta especie, la única de la fanilia, llega a una longitud de $\left(1{ }^{\prime \prime}, 25\right.$; tiene las partes superiores de color amarillento con manchas pardas y las inferiores blancas; en el cuello se cuentan cuatro anillos, en el tronco dos. cientos cincuenta y en la cola trcinta y siete.

DISTRIBUCION GEOGRÁFICA. - Este anillado es propio de México.

USOS, COSTUMBRES Y REGIMEN. - Nada se sabe sobre su género de vida.

\section{LOS ANFISBENIDOS- AMPHISB压NID压}

CARACTÉRES.- Llevan este nombre, tipico de la familia, varias especies que viven en América, y cuyos caractéres mas distintivos consisten en el cuerpo cilindrico, la cabeza pequeña y aguzada, la cola gruesa, obtusa y redondeada, y los dientes cónicos, ligernmente encorvados y aplicados contra el borde interno de las mandibulas. Solo la parte anterior de la cabeza se halla protegida por placas, que en la extremidad del hocico se ensanchan formando un grueso escudo, mientras que el cuerpo y la cola están divididos por verticilos córneos, bastante estrechos y cortados por líneas longitudinales en pequeños pliegues cuadriláteros. Todas las especies tienen surco lateral mas ó menos marcado, que por lo general empieza en el cuello y termina en el orificio de la cloaca, habiendo aigunas jocas que llevan una sutura parecida en el dorso. Se citan diferentes especies de este género, pero se diferencian tanto las variedades de cada una, que es muy difícil fijar su número y su límite respectivos.

\section{EL IBIJARA - AMPHISB FNA ALBA}

CARACTERES.-Una de las especies mas conocidas de la familia es el ibijara de los brasileños, reptil de $0 \%, 50$ de largo, de los cuales corresponden á la cabeza $0^{\circ}, 02 \mathrm{y}$ á la cola $1=, 03$. Las regiones superiores son de un pardo amarillo brillante, los lados de un amarillo claro, las partes inferiores de un blanco azulado; la cabeza es mas clara que el lomo. En el tronco se cuentan doscientos veintidos a doscientos reinticuatro anillos y en la cola catorce (fig. 50).

DISTRIBUCION GEOGRÁFICA.-Esta especie abunda en América y muy especialmente en el Brasil.

USOS, COSTUMBRES Y REGIMEN.-LOS anfisbé. nidos que constituyen la familia mas numerosa del sub-ódden y de los que hasta ahora se conocen trece diversas especies, viven debajo de tierra y se presentan probablemente solo de noche en la superficie; sus viviendas ordinarias son los mon. recillos de los termites y de las houmigas, cuyas larvas devoran. Fn el Surinam se ha llamado por eso 1 la especie rey de las hormigas, y á orillas del rio Amazonas emadre de las hormigas, mientras que en el resto de América tiene el nombre de eserpiente de dos cabezas ó doble andadora. En ciertos parajes abunda mucho al parecer.

Como se comprende, su modo especial de vivir dificulta por extremo estudiarla, de manera que no se puede formar un concepto seguro acerca de su mayor ó menor abundancia y de sus usos y costumbres. Los habitantes de las comarcas bañndas po: el rio de las Amazonas creen firmemente, como muchos otros americanos, que los anfisbenas son cuidados y alimentados por las hormigas; dicen, que cuando estos reptiles abancionan un nido de hormigas, ambien ernigran estas dispersándose en todas direcciones.

"Es un fenórneno muy singular, dice Tschudi, atendido el carácter de los térmites, que estos toleren en sus viviendas subterráneas un animal de considerable lamaño, á un anfisbénido, tanto mas cuanto que, por oira parte, esos insec. tos son enemigos encarnizados de todo sér viviente, y vencen y matan f́ todo animal que imprudentemente se acerca \& sus colonias; gracias á su número y su fuerza, pueden hacerlo aunque sus enenigos sean serpientes de mas de un metro de largo 6 mamíferos del tamaño de una ardilla. Ia razon de esta buena armonía de los anfisbenidos y térmites no se ha podido explicar aun, pero no cabe duda de que tanto aquellos como estos obtienen iguales ventajas de su sociabilidad, pues de lo contrario no se observarian estas relaciones amistosas con tanta frecuencia. Debo decir, sin embargo, que ni todos los montecillos de térmites contienen un anfisbénido, ni todo anfisbénido vive con una colonia de hormigas: yo he sacado repelidas veces ibijaras de agujeros poco profun. dos, segun parecia, practicados por el mismo reptil. Por lo que yo sé, estos animales se encuentran con preferencia en las colonias muy viejas, ya en el monton de tierra extraida por las hormigas de sus nidos 6 en una humeda galeria superior, pero muy raras veces en la que está situada a mas profundidad. Aqqui depositan tambien sus hueros. Cuando se introduce humo en un monton de hormigas, segun suele ha. cerse para exterminar estos terribles enemigos de la agricultura, los anfisbénidos huyen apenas sienten el efecto del hurno.

Ios movimientos de estos anillados, muy singulares, pueden ser el origen de la creencia general en toda la América del sur, de que con igual facilidad reptan hácia adelante ó hácia atrás. clos que yo pude ver, dice el principe de Wied, apenas se movian si no los tocaba, y entonces lo hacian como un gusano de tierra, lo que prueba, por otra parte, la debilidad de su vista. Tan lentos como son los anfisbenas en reptar, tan diestros se muestran en agujercar la tierra é introducirse en ella; d este fin les debe ser de mucha utilidad la grande $y$ fuerte placa del hocico.

Hasta ahora no ha sido posible recoger datos auténticos acerca de la reproduccion de cstos animales. 1.os indigenas dicen al contrario de Tschudi, que paren pequenos vivos; pero la misma gente da tantas noticias diferentes sobre estos animales, que no es posible distinguir lo verdadero de lo falso.

Los americanos consideran generalmente á cstos inofensi. vos reptiles como muy venenosos; mas por otra parte, tam. bien les atribuyen una extraordinaria virtud curativa. Es posible que la facultad que tienen estos animales en general, y los anfisbenidos en particular, de reproducir las partes del cuerpo perdidas por cualquier accidente, haja inducido á creer que esos reptiles deben tener propiedades especiales; los indigenas esián en la firme persuasion de que la carne de las dobles andadoras tostada y recucida á polvo muy fino es un renedio infalihie para las fracturas de huesos, heridas profundas y otros males. Sin embargo, no debe estar muy en boga este medicamento cuando raras veces se cazan estus anillados para obtener asi un remedio tan cficaz; tambien en este caso se habla mas de lo q̨ue se debe.

ENEMMGOS. - Verdaderos enemigos no los tienen los anfisbenas, sino entre los demás reptiles, especialnente en 
las serpientes venenosas, cuya presa slielen ser cuando salen por la roche de sus moradas subicrráneass. Bates refiere que encontró un anfisbena completamente conservado en el cuerpo de una serpiente chararaca, que no era mayor que su rictima.

\section{LA DOBLE ANDADORA CENICIENTA- BLANUS CINEREUS}

CARACTÉRES. - El único tipo de la familia y del sub órden que hasta ahora se ha encontrado en el hemisferio oriental es la doble andadora cenicienta, anfisbénido vermi. forme de $0^{\circ}, 25$ i $\left(0^{\infty}, 30\right.$ de largo, de color gris pardusco ó pardo rojizo, que se distingue por la figura de los escudos de la cabeza y por la cola cónica, relativarnente larga. la frente esta cubierta de un gran escudo, y el occipucio de otros yajos cusdrangulares. En el tronco se cuentan ciento treinta y cinco escudos; la cola tiene de diez y ocho á vein. titres; á cada lado del cuerpo sc observa un surco bien marcado; los ojos son muy pequeños; la dentadura se compone de diez y siete dientes en los intermaxilares, diez y seis en cada maxilar superior, y catorce en los inferiores.

DISTRIBUCION GEOGRÁFICA.-Carecemos de observaciones minuciosas sobre el género de vida de este ani. mal; solo se sabe que se encuentra en Espana, en las islas griegas y cn el nordeste de Africa.

USOS, COSTUMBRES Y REGIMEN.-Vive debajo de la superticie de la tierra, soore todo de las piedras, 6 como sus congéneres, en montones de hormigas. A primera vista es fácil tomar á la doble andadora cenicienta por lom. briz, pero reconócese el error tan pronto como el animal se mueve, pues no avanza por medio de contracciones sino ejecutando evoluciones laterales. Su alimento se compone sin duda de pequeños insectos, pero carécese de noticias, tanto por este concepto como en cuanto á la reproduccion.
CARACTÉRES. - La movilidad particular de los huesos de la cara, que permite una extraordinaria dilatacion de la boca, es el distintivo mas importante de las serpientes: La configurcion exterior del cuerpo, si bien parecida il la de varios oiros reptiles, como acabamós de verlo, no deja de llamar tambien la atencion por sus caractéres mas marcados de prolongacion y redondez, destacando apenas del conjunto la caberz y la cola, y además por la gruesa piel escamosa en que está envuelta aquel.

Segun la opinion de naturalistas modernos las serpientes solo constituyen un grupo de particular desarrollo de los escamosos, y no se distinguen de ellos por ningun carácter importante, tanto mas cuanto que la falta de la region de los hombios y de la vejiga, á que antes se atribuia mucha importancia solo puede considerarse como una particularidad que se encuentra ya mas ó menos marcada en otros escamosos.

La cabeza de las serpientés no es nunca muy grande, pero por lo regular mas ancha que cl resto del cuerpo y fácil de distinguir, si bien solo en muy pocas especies se separa marcadamente de este; afecta una forma triangular ú ovalada, \& nienudo comprimida de arriba ahajo; con la boca tan hendi. da que prarece extenderse su abertura mas alla de los limites posteriones de la cabeza; no hay conducto auditivo aparente, y el ojo se encuentra próximo al centro del surco del hocico, hácia el iado y cerca del borde de la mandibula; las venta. nas nasales se hallan siempre muy adelante, y muchas veces en la extremidad del hocico: las escamas de la cabeza difieren constanternente en mayor 6 menor grado de las que cubren el cuerpo. Las serpientes no tienen cuello propiamente dicho; el cuerpo empieza mas bien á inmediata continuacion de la cabeza, y se convierte imperceptiblemente en la cola, mas ó menos prolongada, y cónica, puntiaguda ú obtusa: la longitud total de estas dos partes suele ser treinta y hasta cien veces mayor que el diámetro. Cabeza, cuerpo y cola estan revestidos de una fuerte piel, à la cual, como dice Cárlos Vogt, \&se lia dado impropiamente, hasta cierto punto, el nombre de piel escamosa, mientras que en realidad forma la misma un todo conexo, consistente en una piel coriacea yotra superior que cubre aquella. La coriácea no es lisa ni uniforme en su grueso, sino mas abultada en algunos sitios, donde hay un borde libre á manera de doblez, y ofreciendo el conjunto el aspecto de escamas apojadas unas en las otras en disposicion tectiforme. Como la piel superior sigue las irregularida. des de la inferior, y gana en espesor en los puntos libres, mientras que se adelgaza donde se introduce debajo de los replicgues, hace resaltar la misma aun mas distintamente la indicada disposicion escamosa. Fstas escamas son lisas $\delta$ aquilladas, generalmente mas largas que anchas; toman tam. bien la figura de escudos cuadrangulares y exagonales, que casi siempre cubren la cabeza y la parte abdominal; llevan todos estos escudos y placas, segun su forma, disposicion y parte del cuerpo que protegen, los mismos nombres aproximadamente con que se distinguen los que cubren el cuerpo de los monópneos escamosos. Son especiales de las serpien. tes los escudos acanalados, de los cuales se encuentran, por lo regular, dos pares en el surco de la barba, como tambien a menudo, dos adicionales en ellabio, colocados á cada lado de aquellos.

Respecto a la coloracion y dibujo de la piel, no es posible hacer indicaciones generales, pues están sujetos á extrnordinaria variedad. Hay serpientes de color uniforme, otras sal picadas de varios matices, y por último muchas tienen dis. puestos los varios tintes de su piel en figuras mas ó menos regulares, afectando las de verticios, fajas en distintos sentidos, cuadros, etc; en algunas especies quedan empañados los colores, mientras que en otras son de la mas rica brillantez: por lo regular, color y dibujo están siempre mas ó menos en relacion con la localidad habitada por el reptil. Entre los ofidios que viven en las llanuras áridas domina la colnracion amarillenta de la arena; los que frecuentan los árboles tienen casi todos un tinte verdoso, mientras que los que moran en los terrenos de frondosa vegetacion, presentan su cuerpo matizado de los mas varios y vistosos colores. Sin embargo, 
no se puede hacer de esto una regla general y sin cxcepciones; pues observa con mucha ra\%on Pceppig, que entre las serpientes cavadoras y que pasan una gran parte del tiempo debajo de tierra, las hay que ostentan una coloracion muy viva, al par que otras tienen ur color metúlico como el de acero bruniido. Casi todos los individuos presentan mas ó menos la disposicion tipica en color $y$ dibujo de su especie, pero variando bastante en los detalles; es muy probable que la edad $y$ el sexc influyan en esta diversidad.

La sencillez y uniforınidad de la configuracion exterior están determinadas por la estructura de la armazon ósea. Consiste esta en los huesos de la cabeza, columna vertebral y costillas, pues los muñones que se encuentran en pocas es. pecies, y en los cuales algunos naturalistas creyeron reconocer rudimentos de miembros posteriores, no pueden en manera alguna ser considerados como tales. La parte mas importante del esqueleto, y que al propio tiempo patentiza la forma y la distribucion mas especiales, es el cráneo. Com. pónese este de los huesos occipital, craneales, frontales, temporales, nasales, esfenoides, lagrimales, intermaxilar, maxilar superior y arcos palatinos, como asimismo del mixilar inferior, turido á an̨uellos, y formado de varias partes. « El intermaxilar, dice Cárlos Vogt, está unido á los nasales, mientras que los maxilares superiores, los terigoideos y los palatinos son muy movibles, y pueden funcionar lo mismo hácin los lados que hácia adelante ó atsảs. Igual movilidada se manifiesta en la mandibula inferior. El mastoideo, largo y escamiforme, cstá unido tan solo al cráneo por medio de ligamentos y músculos, y tiene en su extremidad el hueso timprínico, estirado á manera de barra é inclinado hácia

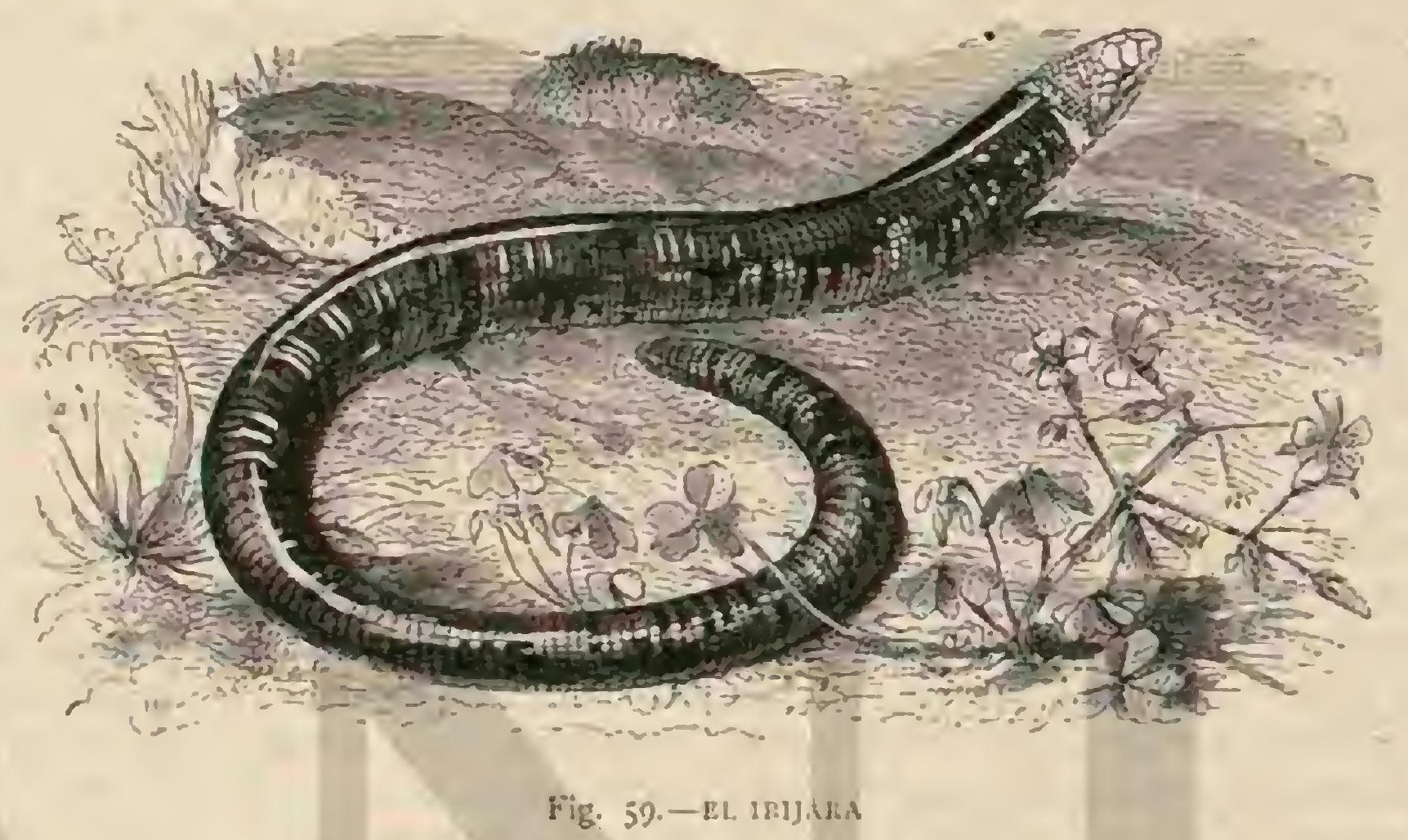

atrás, al que se halla prendida la mandibula inferior. Esta se divide en dos mitades, un poco arqueadas y completamente separadas, que casi siempre se encuentran unidas por medio de tendones laxos, y cuya division se ve por lo general marcada exteriormente por los surcos de la barba, en la superficie inferior de la cabeza. Inmediatamente des. pues del cráneo sigue el tronco, pues ya la segunda vértebra lleva como las demás un par de falsas costillas, que solo se diferencian por su menor tamano de las del tronco propia. mente dicho. Todas las véttebras son de estructura casi igual, y se hallan articuladas entre sí por medio de una ca. beza hemisférica en la parte posterior, que encaja en la cavidad correspondiente anterior de la que sigue. Igual articulacion, que facilita en gran manera la variedad de los movimientos del cuerpo, une \& las vértebras las costillas, que se van atenuando mas y mas on ia region caudal, hasta desaparecer por completo. Varía, dentro de muy anchos limites, segun la especie y tamaño del ofidio, el número de las vértebras: solo muy excepcionalmente suele ser menor de cien, pudiendo en algunas especies llegar ś cuatrocientas. Las serpientes no tienen esternon, terminando libremente las costillas; tampoco existe el menor vestigio de miembros an. teriores.

No menos notables que los huesos del esqueleto son los dientes, que segun las varias familias, afectan esiructura muy distinta y sirven para la clasificacion y agrupamiento de estas; se dividen en sólidos, acanalados, que tienen un surco profundo ó canal desde la raiz hasta el vértice, y huecos, agujereados en la parte anterior de aquella y hendidos en la punta. Todos ellos son agudos, ganchudos y encorvados hácia atrás, pudiendo servir para morder y retener la presa,

'os:o $\mathrm{V}$ pero jamás para despedazar y mascar. Los dientes sólidos 6 macizos forman un cono de masa dura y revestida de un li. gero esmaitc; los acanalados parecen en cierto modo dientes huecos incompletos, pues puede decirse que en estos últimos han ido estirándose y arrollándose los bordes del canal hasta formar un subo ó conducto interior. ¿QGuarda perfecta relacion con esta estructura especial de los dientes, dice Cárlos Vogt, la del aparato maxilar superior. En los ofidios no ve. nenosos, con dientes completamente macizos, vése la man. dibula superior muy larga y provista de una hilera continua de dientes, id la que acompaña otro arco de dientes pala. tinos; los que los tienen acanalados ya presertan una mar.dibula superior mas corta, armada en su parte anterior de pequeños dientes ganchudos, y posteriormente de los mayores asurcados; en varias serpientes venenosas aparece mas colta todavía dicha mandibula, llevando detrás de los grandes dientes venenosos, algunos ganchudos pegueños y sólidos; por último, en las víboras queda reducido el aparato maxilar superior a un hueso extremadamente corto, y provisto tan solo de dientes venenosos, huecos y acanalados. Tratare. mos mas detalladamente este punto al ocuparnos en especial de los ofidios venenosos.

Consecuencia natural de la construccion particular del es. queleto es la abundancia de músculos: cuéntanse tantos in. tercostales como costillas, y corren además á lo largo del dorso varios unísculos nque encuentran numerosos puntos de enlace en las muchas costillas y vértebras, y que no solo pueden desarrollar gran fuetza, sino que funcionan en las mas opuestas direcciones; estos músculos tienen un color muy pŕlido, como sucede por lo regular con los de todos los reptiles. 
A la configuracion prolongada corresponde igual disposicion de las visceras. La tráquea empieza cn el interior de la boca pasando por debajo y al lado del esófago, y se compone de anillos cartilaginosos muy finos y elásticos, cerrados en su parte anterior $y$ unidos en la posterior por una piel; la faringe está poco marcada y no hay epiglotis. Los anillos de la irá. quea se ensanchan paulatinamente hácia abajo y comunican con el pulmon, que tiene el aspecto de un gran saco mem. branoso que se extiende por toda la cavidad abdominal. Muy pocas serpientes tienen dos pulmones, en cuyo caso uno de ellos es mucho inenos voluminoso que el otro. El corazon, pequeno y muy distante de la cabeza, se compone de dos auriculas completamente independientes y un rentriculo solo err parte dividido en dos cavidades. Ft aparato digestivo se distingue por su extraordinara sencillez. Fi esófago es largo y de gran fuerza muscular; cl estómago, que no es sino una

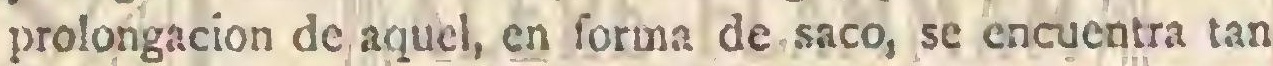
solo separado del intestino, que hace muy corta circunvolucion, por una contraccion de tnin el sistema. Son de forma muy prolongada los riñones, orarios, testiculos y el higado, presentándose igualmente bastante voluminosas la vejiga de la hiel y las glándulas pancreáticas.

De suma impartancia para la vida de las serpientes son las glándulas salivales, que en las especies vencnosas adquieren gran desarrollo. Como em de suponer, estas glándulas han sido objeto de las mas minuciosas obsérvaciones. Del estudio hecho por Mecliel de las mismas resulta, que en la cabeza de los ofidios se cuentan cinco pares de glándulas, de las cuales, si no todas, las mas, aparecen reunidas en una misma especie; á saber: las infra-linguales, las infra-maxiliares 6 labiales inferiores, las lagrimales, que tienen su asiento detrás del ojo $y$ mas frecuentemente detrás de la órbita, y las infra orbitarias, que son las venenosas y están situadas detrás y debajo del ojo, por encima de la mandíbula superior. Estas uiltimas son muy grandes, largas y cubicrtas por un tejido 6 saco aponeu. rótico, y se distinguen sobre todo de las demás por un conducto membranoso, que corre por la superficie exterior de la mandibula superior, y remata en el canal ó tubo interio del diente llamado venenoso; están envueltas por un másculo muy fuerté que, ayudado por el maxilar, sirve para compri mirlas. En algunas serpicntes extiendese tanto hácia atrás esta glándula, que en parte descansa sobre las primeras costillas. Encuéntrase la misma en todas las especies que tienen dientes huecos, mientras que otra parecida la sustituye en aquellas que solo presentan dientes acanalados 6 asurcados: y si bien esta última es igualmente blanda y esponjosa, no posee la cubierta muscular para su compresion, apareciendo por lo tanto menos completa y adccuadá para la inoculacion del lí quido déletéreo en la herida, $y$ pudiendo tan solo ser estru jada en parte por los mísculos temporales anteriores.

En el sistema nervioso, la masa medular sobrepuja conside rablemente á la cerebral. Esta última es muy reducida, mien tras que la otra, correspondiendo á la longitud de la columna vertebral, cuya cavidad ocupa por completo, es cuantiosa y compacta; disposicion que patentiza a primera vista la ex traordinaria irritabilidad de los músculos, el poco desarrollo de los sentidos y la debilidad intelectual. La lengua, que aun pasa en la opinion del rulgo por el arma con que la serpien te hiere y mata su presa, ejerce mas probablemente tan solo el sentido del tacto y en manera alguna el del gusto, y es por lo tanto de gran importancia para el reptil: muy larga, apla naca, dividida en su extremidad en dos filetes delgados y $c u$. bierta de una masa córnea, se oculta en una vaina 6 estuche muscular, que pasa por debajo de la tráquea y desemboca cerca de la punta de la mandibula inferior, pudiendo ser re tirada y proyectada y distinguiéndose por su cxtraordinaria movilidad. Una escotadura en la mandibula superior permite que la lengua pueda salir y entrar, sin abrir la boca. Los órganos visuales de las serpientes, si bien menos completos que en los demás reptiles, no son inferiores en sus respectivas funciones al sentido del tacto ejercido por la lengua. Un carácter especial de dichos órganos es su aparente inmovilidad, dándoles un aspecto vidrioso que infunde pavor á la victima. Sustituye al párpado una piel trasparente, que slo mismo que el cristal de reloj, está engastada en una ranura de la órbita y forma una cápsula, en comunicacion interna con las fosas nasales, por medio de un extenso conducto del canal lagrimal. Esta picl trasparente, sin razon complarada á una lámina córnea por algunos autores y considerada como tal por otros, no es sino una parte de la piel general ó camisa, que se desprende en la Epoca de la muda, aumentando su trasparencia una rez efectuada esta, y disminuyendo gradualmente hasta verificarse la subsiguiente. Hay qque tener en cuenta que una porcion de la cápsula permanece in. tacta durante la muda, de modo que puede ser considerada la misma como una tapa cerrada y trasparente, debajo de la cual gira libremente el ojo. La pupila es redonda en las serpientes diurnas, y linear, vertical ú horizontal, en las noctur. nas. El iris ostenta, por lo regular, colores muy vircs, como dorndo, plateado, rojo ó verdoso. Tienen los ofidios muy imperfectos los órganos del olfato; es muy sencillo todo el aparato, con canales muy cortos, y la mucosa, que reviste estos, apenas cruzada por ramificaciones nerviosas. En las especies acuáticas, las ventanas nasales están mas próximas entre si y al vértice de la cabeza, y cerradas por válvulas ó membranas moribles. Del órgano de la audicion solo se pueden ver los rudinertos séparando las escamas que cubren lateralmen. te la cabeza, pues el corto conducto auditivo está completa. mente oculto debajo de la piel; falta el timpano por compie. to, y tan solo se encuentra un indicio de carncol, muy parecido en su forma al de las aves.

Imprimen los ofidios gran variedad de movimientos á su cuerpo, y merecen, en verdad, mas propiamente el nombre de reptiles que todos los demás animales de la misma clase: 120-reptan tan solo en terreno liano, sino que suben y bajan declives de bastante pendiente, trepan por los árboles y sus ramas, y nadan en la superficie del agua 6 en su profundidad, haciendo todos estos ejercicios con presteza y habilidad. Sus numerosas costillas libres, tan solo articuladas con las vértebras, son de grandisima utilidad para los movimientos del reptil: cada costilla se convierte, por decirlo asi, en un pié, esto es, en un apojo y en una palanca, que no solo sos. tiene el cuerpo, sino que lo impele Ia reptacion se verifica, sin embargo, de un modo distinto al supuesto por los profanos, $y$ hasta representado por pintores poco ilustrados, es decir, por ondulaciones laterales y no de arriba abajo. To. das las vértebras se pueden inclinar en uno ú otro sentido, mieniras que las costillas lo mismo se mueven hacia adelante que hácia atrás. Se cjecuta, pues, el movimiento de repta. cion, extendiendo la serpiente alternativamente todas las costillas, y retorciendo de este modo el cuerpo en una línea ondulada; adelanta en seguida las costillas hasta colocarlas en posicion casi recta, y las inclina bácia atrás en la siguien. te ondulacion: de manera que mueve el ofidio en realidad sus costillas como otros animales los piés. Los bordes cortantes de los escudos 0 escamas, inclinados hácia abajo, facilitan la resistencia contra el suelo, permitiendo todo movimiento adelante, pero impidiendo resbalar en sentido inverso. Si quiere pasar la serpiente por agujeros estrechos que no consienten las ondulaciones laterales de su cuerpo, repta á travís de los mismos apoyando las escamas y adelan. tando las costillas en la medida compatible con lo reducido 
del espacio. Cuando trepa el ofidio, emplea el mismo meca. nismo de la reptacion; un tronco de árbol que le permita cnroscar en al su cuerpo no le ofrece dificultad alguna siem. pre que su corteza no sea completamente lisa: sube por el mismo con rapidez en circunvoluciones espirales, pero siem. pre por medio de movimientos ondulados, y estando perfec. tamente garantido de resbalar gracias 1 los bordes posteriores de los escudos abdominales. Por las ramas repta casi con igual seguridad $y$ presteza que en el suelo, $y$ en especial cuando el ramaje es espeso. Idénticos novimientos cjecuta cuando nada, si bien no es fácil juzgar hasta qué punto utiliza las costillas en su locomocion acuśtica. Todas las espe. cies del brden saben nadar, pero aquellas que no tienen por costumbre frecuentar este clemento, parecen cansarse muy pronto dentro del mismo. En las serpientes marinas, cuya cola se encuentra comprimida lateralnzente y ensanchada por medio de membranas, el mecanismo de la natacion se parece mas al de una anguila que al de los demás incividuos del mismo örden.

«Pocos animales, dice Lacépéde, son tan rápidos como las serpientes: cuando se precipitan sobre su presa 6 huyen de un enemigo aseméjanse \& la Alecha arrojada por vigorosa mano; cada una de sus partes produce entonces cl efecto de un muelle de acero que se tiende con poderoso empuje. Las serpientes parcen rebotar contra todo aquello con qque se ponen en contacto; diriase que vuclan por el aire y solo to. can ligeramente la ticrra. I.legan con mas rapidez que un ave á las copas mas altas de los árboles; tal es su agilidad al trepar por los troncos y las ramas, que apenas puede la vista seguirlas. Este relato recuerda mucho aun las descripciones exageradas de los antiguos, pues ninguna serpiente se mueve en efecto tan rápidamente como qquiere hacerlo crecr Lackpede.

4Como el movimiento de la serpiente, dice Lenz, no se reconoce bien á la simple vista, y como además pocos hom. bres se toman cl trabajo de observar mas cerca la rapidez, créese en general que esta última debe ser mug grande; pero ni una serpiente corre con tal ligereza que no fuera posible seguirla à paso largo sin correr. Son relativamente mas lentas que los lagartos, ranas, ratones y otros; pero corren con mas rapidez sobre el musgo 6 la yerba corta, porque estas plan. tas les ofrecen una base clástica; sus movimientos no son tan veloces en tierra Si se las coloca sobre una superficic de vidrio cuístales mucho avanzar; pero bajan por las paredes de roca mas escarpadas cual si volaran, á veces con tal impetu que hasta es imposible reconocer de qué especic y tamaño son.

Solo algunas especies pueden erguir el tercio anterior de su cuerpo, y por lo tanto podemos considerar como falsas ! exageradas las imágenes que represenian otra cosa. La mayor parte de las serpientes no levantan la cabeza mas de $0^{\prime \prime}$, to sobre el suelo; muy pocas, como por cjemplo la de anteojos, son una excepcion de esta regia, y muchas, en cambio, no pueden siquiera encorvarse de modo que con la cabeza lle. guen á la mano 6 al brazo, cuando se las coge de la cola, dejaindolas colgar.

La respiracion de las serpientes del todo despiertas y en actividad, efectuase sin la menor interrupcion con marcados movimientos de las costillas, que alternativamente suben y bajan; mas por lo regular es poco rápida y solo se acolcra cuando el animal se irrita. Un silbido ronco, prolongado é interrumpicio so!o á intervalos, es la única voz de estos rep. tiles, y la que les sirve para expresar su cólera. Una especie propia del Africa interrumpe tan a menudo su silbido, segun Livingstone, que resuena como el balido de una cabra.

Excepto el tacto, todos los sentidos de la serpientic son imperfectos y débiles, $y$ hasta el del tacto no sirve a estos animales mas que para examinar los objetos con la lengua. Nosotros tambien estamos conformes en spreciar la utilidad que ese órgano tiene para las serpientes, á pesar de que se sabe muy bien que su importancia es muy distinta, y en rea. lidar mucho mas considerable de lo que creian los antiguos. Cierto que las serpientes podrian pasar tambien sin lengua, pero no ejecutar con tanta facilidad sus diversas operaciones, como podrian hacerlo creer las pocas pruebas practicadas hasta aquí. I cenz cortó a una culebra la mitad de la lengua, y el animal se sirviú del resto mutilado del mejor modo posible, manifestando en sus movimientos casi la misma agilidad de antes. Una vibora f que el citado naturalista cortó gran parte de lat lengua, dejando solo un pedacito, no cam. bió en nada visiblemente sus movimicntos. Sin embargo, hemos adquirido tambien datos que prueban lo contrario de lo que Lenz parece deducir del hecho sin decirlo. Entre los ára. bes, que no son encantadores de serpientes ni cazadores urácticos de estos reptiles, predomina tambien como en nuestro pueblo la opinion general de que la lengua es instrumento que puede inferir heridas mortales, $y$ fácilmente se com. prende, por lo tanto, que la corten para despojarla de sus facultades venenosas. I.os individuos mutilados de esta manera, y á veces inofensivos del todo, llegan con bastante frecuencia á nuestras jaulas; en ellas viren aun mucho tiem. po; mueven el muñon de la lengua, que nunca vuelve a crecer, casi como los individuos que tienen este órgano entero; pero nunca comen ni beben; muestranse indiferentes á todo; tan poco caso hacen del alimento como de otro objeto cualquiera, y mueren sin remedio. Sigun mis observaciones y experiencias, la serpiente sin lengua no puede prosperar ni vivir. Es un hecho que todas las serpienies cuando no descansan mueven continuamente la lengua en todas las direcciones para examinar el objeto que tienen delante; que nunca pene. tran en el agua antes de tocar con la lengua la superficie; y que examinan la presa muerta, no solo antes de derorarla, sino tambien antes de matarla 6 envenenarla, con la lengua, si su victima les deja ticmpo de hacerio. Cuando menos, parece hacer su exámen acostumbrado por movimientos continuos con dicho urgano, si teme que el objeto en que se ha fijado puede escapas os su voracidad.

$V$ ćrse lo que sobre este punto dice Lenz: \& I a serpiente no parece tan solo sentir ó tener conocimiento de lo que toca directamente con la lengua, sino tambien de los objetos que se encuentran a media pulgada de distancia de la extremidad de aquella. De esto se puede convencer cualquiera que estudie la manera cómo una serpiente sale de una caja, cofre 6 cosa pareción: tan pronto como asoma la cabeza por fucra del borde de la misma y repara en el vacio delante de si, cstira la lengua continuamente todo lo posible, moviéndo. la pausadamente al propio tiempo que vuelve la cabeza hácia uno y otro lado; una vez convencida de que no tiene otro punto de apoyo sino la pared exterior de la caja, se desliza por la misma, inclinando la cabeza y no cesando de explorar el terreno por medio de la lengua Del mismo modo se ob. serva que la serpiente cuando repta po: los árboles acostum. bra examinar con la lengua las ramas, sin que por eso crea necesario tocarlas materialmente con la misma. Si se encierra uno de estos repilies en una caja con agujeros para la respiracion, se verá como as menudo saca la lengua por uno de ellos como si esperase encontrar salida por aquel punto. Varios ofidios proyectan continuamente la lengua cuando nadan, lo mismo que si estuviesen en tierra, y lo hacen hasta debajo del agıa. Cuanto mas viva y retozona parece una serpiente, mayor es la movilidad de su lengua. Ias viboras, cuando están furiosas, proyectan y retractan con tanta rapidez la 
lengua, que a primera vista cualquiera tomaria aquel continuo centelleo por una chispa eléctrica La repetida contraccion de la lengua obedece indudablemente á la necesidad de nueva salivacion, â fin de aumentar su sensibilidad.

Aparte de la facultad del iacto en la lengua, tienen los ofidios muy poco desarrollada la sensibilidad. Sin embargo, todos los naturalistas saben por experiencia que a pesar de su gruesa cubierta tienen las serpientes conciencia del tacto cxterior, y quue al igual de otros reptiles, buscan con afan el calor; asi las especies nocturnas salen de dia de sus escondrijos, para gorar del que les proporcionan los rayos del sol.

$\Lambda$ pesar de todo, no creo fuese un error suponer que en general se necesia irritar mucho á los ofidios para excitar su sensibiliciad, ó mas bien para ycocer su apatia. Tambien las serpientes participan de ia resistencia vital de otros reptiles; soportan tormentos que serian mortales para otros séres mas desarrollados; resisten las mas graves heridas, aunque sea cortarlas por mitad del cuerpo;y sorprenden por esto aun al observador que conoce la independencia de los centros nerviosos. Boyle puso víboras y culebras en una cámpana de cristal de la que desalojó el aire cuanto le fué posible: el cuerpo de dichos aninuales se dilato en forma de bolsa, y las mandibulas se dislocaron, pero al cabo de algunas horas aun se reconocian señales de vida. El corazon de la serpiente late mucho tiempo despues de haberla muerto; en la cabera cortada de la vibora mućrese áun la lengua y la boca mucrde y envenena; 5 el individuo despojado de sus escamas vive dias enteros. No puede ser por lo tanto muy grande la sensibilidad de un animal de tal complexion.

Casi lo mismo sucede con los demás sentidos. Mucha ra. zon tiene Linck al decir que la sensibilidad de la lengt:a no basta para sustituir del todo á la vista, aunque la lengua de la serpiente, asi ccmo el palo de un ciego, no solo sirre para ayudarse sino para compensar la falta de vista. No es exacta sin embargo la afirmacion de que la serpiente no puede vivir sin ojos, y dificilmente sin la lengua, sin la cual muere pronto: solo diremos que los ojos no tienen nunca para el ofidio la misma importancia que para los demás reptiles, salvo muy pocos. Dursy deduce de la posicion de los ojos la consecuencia de que cada uno de ellos puede dominar un horizonte debiendo moverse independientemente uno de oiro; y cl citado naturalista vió confirmada la exactitud de su opinion por las observaciones. Segun esta, las serpientes pueden vol. ver sus ojos al mismo tiempo en una direccion; pero tambien dirigir una pupila hácia la derecha y la otra hácia la izquier. da, asi como le es dado mover un ojo mientras el otro descansa. Segun esta prueba, podria suponerse que los ofidios son de los animales mejor dotados en cuanto ia la vista, pern no sucede asi en realidad: las facultades del ojo no corresponden a su belleza y movilidad. Todas las observaciones cstán conformes en que la vista es débil y tiene poco desarrollo; y la opinion que se forma por su brillo es falsa.

¿Opino, dice Lenz, que las serpientes ven muy poco, si bien es la vista el sentida que tienen mas desarrollado despues del tacto por medio de la lengua. Solo he podido estudiar las especies de nuestro continente, y de mis investigaciones he deducido, que sus ojos no les dan una idea exacta de los objetos, aunque los distingan perfectamente; parecen tan solo fijarse en los movimientos de estos: así, por ejemplo, reptan con toda la velocidad de que son capaces hacia un hom. bre que se mantenga inmóvil, y solo huyen cuando este hace algun ademan. Encerradas en una caja juntamente con otro aninal, enemigo suyo, se acercan al mismo, y dan vueltas al rededor; si cste parece molestado $y$ las ataca, cntonces escapan para volver cuando creea al otro tranquilizado, huyendo de nuevo si son recibidas del mismo modo. Sucede tambien, que cuando están furiosas, sean ó no venenosas, se dirigen amenazadoras hácia alguna sombra, que toman sin duda por el cuerpo de un enemigo, y muy á menudo creyendo morderle, lo hacen al aire. Poco antes de verificarse la muda, aparece el ojo como cubierto por un velo blanquizco, que proviene de la piel que empieza á desprenderse, y entonces su vista es aun mas imperfecta. No existen otras observa. ciones, dignas de fe, que contradigan las hechas por erpeto. logo tan competente como Lenz, y por lo tanto debemos suponer que lo que afirma este respecto â las serpientes que pudo examinar, es valedero tambien para todas las demás.

Sin cmbargo no se puede atribuir toda la causa de su proceder al órgano de este sentido; probablemente debe buscarse mas bien en la escasa inteligencia de las serpientes. Es posible que los ojos vean mas y á major distancia de lo que creemos; pero la inteligencia poco desarrollada del animal hace incurrir en errores corno los que Lenz ha descrito y todos nosotros hemos observado. Por lo demás, no solo animales de tan poco desarrollo intelectual como las serpientes, sino tambien otros bien dotados y con una vista perfecta, como por ejemplo rumiantes, no distinguen a menudo un objeto hasta que este se mucve. Tambien en otro concepto parece errónea una deciuccion de Lenz: dice que la pupila de los ofidios se cnsancha en la oscuridad, y se contrae expuesta al sol hasta reducirse á una línea apenas perceptible, añadicn. da que si se coloca la cabeza de una serpiente de modo que durante bastante tiempo recioa un ojo brillante luz, mientras que el otro permanezca en la oscuridad, la pupila de este se habrá ensanchado considerablemente, al par quc la del otro aparecerá muy contraida: de esto deduce que no se debe hacer gran caso de in creencia vulgar de que una pupila linear es el distintivo del animal nocturno, caracterizando al diurno la pupila redonda. Con todo, la crecncia vulgar, como la llama Lenz, es exacta; todos los ofidios que tienen la pupila linear son indudablemente nocturnos, aunque puedan ver hasta cicrto punto á la luz del dia. Se han hecho recientemente varias observaciones, que confirman por compleio la regla general.

Por lo que toca á la llamada fascinacion que ejerce la ser. piente por medio de sus ojos, es nuestra opinion que se le ha dado mayor importancia de la que merece.

\& Pocos animales tienen los ojos tan expresivos como csos reptiles, dice Linck, pues en cllos se refleja, no solo la indole sino las impresiones del momento; de mirar tranquilo y benévolo, aunque sin brillo, en las especics pacificas del órden, tienen una expresion sombria en las especies que pueden herir, si no matar; la mirada de la vibora, que lleva la muerte en sus dientes, es amenayadora y terrible.

Sin embargo, hasta las miradas de las serpientes mas dóciles tienen algo de extraño, por efecto de la membrana vidriosa que cubre los ojos y por la rigidez del iris, que con dificultad y no sin gran esfuerzo se mueve como por luerza. Fiste último aserto es del todo exacto, pero la primera opinion del observador es un invento. Fuera del aspecto vidrioso, de que ja hemos hablado, no tiene el ojo del reptil nada de extraordinario: la expresion pavorosa, $\{$ la que algunos atribugen una especic de accion magnética, tiene su origen, no tanto en la construccion del ojo, propiamente dicho, como en la colocacion de las escamas que forman bóveda por encima del mismo y que se encuentran muy desarrolladas en las serpientes nocturnas, produciendo la misma impresion que los huesos prominentes de las cejas de un ave de rapiña. Por lo que podemos juzgar, al sentido de la vista sigue el del oido en cuanto á desarrollo, a pesar de que sus órganos parecen mas atrofiados que los del olfato. La estupidez de las serpientes se reconoce mucho en las pruebas 
que se hacen para cxaminar el desarrolio de sus sentidos, siendo sin embargo dificil para el observador emitir una opinion exacta.

Varios naturalistas, incluso Len\%, han hecho muchas ex. periencias sobre el particular, y el resultado de las mismas ha sido reconocer la poca ó ninguna impresion que causan en estos reptiles los sonidos de toda especie, siempre que estos no produzcan fuertes vibraciones del aire 6 del suelo. Sin embargo, varios viajeros han tenido ocasion de preser. ciar en la India y en Egipto los ejercicios que hacen ejecutar los saltimbanquis a serpientes de varias especies, al compás de un pífano, pareciencio en realidad obedecer á los diferentes toques del mismo. Esto no obstante, debe darse poca importancia a esta opinion, pues yo he podido enga. ñarme muy fácilmente, y Lenzy otros naturalistas que consideran el oido como muy obtuso, podrian tener razon.

Muy dificil es decir algo positivo resuecto al olfato de las serpientes. La construccion del aparato no puede ser menos fuvorable, y las observaciones justilican la opinion formada de antemano acerca de su poca utilidad. He podido convencerme de lo muy débil que es el olfato en las serpientes, dice Lenz; primero, porque el nervio olfatorio es muy corto, y en segundo lugar, porque nunca se ve al reptil buscar ó examinar objeto alguno por medio del olíato, como lo hacen los mamíferos; además me lo ha probado asimisno la experiencia que hice, impregnando unas varitas en jugo de tabaco, que pasé repetidas veces por las ventanas nasales de va. rias viboras de diferentes especies, sin que estas pareciesen recibir impresion alguna. Iodos sabemos que el jugo de iabaco no solo tiene un olor muy fuerte, sino que es fatal para la economia de las viboras; asi pues, cra lógico suponer que á estar el sentido medianamente desarrollado, no dejaria el olor del citado jugo de producirles un efecto repulsivo, tan fuerte que se deberia traslucir por alguna excitacion exte rior.

Debemos fijar, sin embargo, nuestra atencion en otra cir cunstancia, y es que todos los animales ollatean solo cuando respiran el aire por la nariz, ó mejor dicho, cuando los olo res, ó sean los diversos gases, se ponen en contacto con los nervios olfatorios. Sabido es que las serpientes solo respiran muy poco y de un modo irregular, aunque se puede hacer la suposicion de que no hayan respirado durante las prucbas hechas por I.enz. Por otra parte, el proceder regular de los ofidios habla en pro de la deduccion de nuestro excelente naturalista: ninguna serpicnte indica por un movimiento ó cualq̨uiera otra señal que los olores producen la mas minima impresion en ella; à ninguna se la ve olfatear. Las observa. ciones de Dursy, segun las cuales las serpientes retiran su cabera de una botella que haya contenicio espiritu de vino, ó retroceden al percibir el olor de un cigarro, dicen mas en favor del sentido del tacto que del olfato, al menos en mi opinion.

Excepiuandn este último sentido, el del gusto es aquel de que podemos hablar con mas seguridad, sin temor de in. currir en errores, porque esta del todo atrofiado, como lo in. dica el exámen de la lengua en las scrpientes vivas. Aristóte les afirma que la lengua solo está dividida para que la golosa serpiente pueda disfrutar dos veces de los goces de la comida; pero es el caso que en esta lengua no se ha descubierto sun ninguna glándula del gusto, y én tocias las serpientes se puede observar que al devorar su presa retiran la lengua á su estuche. Por otra parte, obsérvase, sin embargo, que hacen diferencia entre varias clases de presa, lo cual no nos autori. za \& atribuir el hecho al sentido del gusto; cuando mas podriamos explicarlo por la sensibilidad. La afirmacion de Aristóteles, en otras cosas observador concienzudo, respecto a que las serpientes son de todos los animales los mas golo. sos, es tan falsa como su aserto de que no conocen limites en el goce del vino y se emborrachan.

4ed astutos como las serpientes y sin malicia como las palomas. Este dicho es inexacto por doble concepto, pero imas la es aun respecto á la inteligencia de las serpientes, por. que esta es tan escasa que apenas se podria decir sobre ella mas de lo que ya hemos dicho. Probablemente no es crrónco suponer que las serpientes son los reptiles menos desarrollados y mas inferiores. Cuando cazan revelan cierto grado de astucia, y al parecer dan pruebas de tener algunas facultades intelectuales si s̊ hallan frente á un enemigo; tambien se acos. tumbran hasta cierto punto \& su guardian; pero en ningura circunstancia demuestran mas inteligencia que otros reptiles. No solo sus sentidos, sino tambien sus facultades son muy liinitados.

DISTRIBUCION GEOGRÁFICA.-Todos los cont:nentes estan poblados de serpientes, pero en cada cual hay un número muy distinto de especies. Tambien estos animales están sujetos a las leyes generales de la diseminacion de los reptiles, $y$ disninuyen tanto mas en especies y en individuos cuanto mas alta es la latitud; pero no a todos los grados iguales de esta se halla tambien un número rclativanente igual de reptiles. Si se dividen los continentes del globo ccmo lo hacen todos los zoólogos de nuestros tiempos, en territorio septenirional del Antiguo mundo, etiópico, indico, septentrional y meridional del Nuero mundo, resulta, segun Guenter, que las serpientes se hallarán poco masó menos del modo siguiente:

En el terrirorio septentrional del Antiguo continente, que comprende desde el norte de Africa hasta el Atlas, Europa, el Asia Menor, Persia, el norte y centro de Asia hasta el Himalaya, la China, el Japon y las islas Aleutienas, habita el menor número de serpientes, tanto por lo que hace á géneros como á especies, y solo se encuentran tipos pequeños y raquiticos, de colores oscuros. Las culebras predominan 5 existen en número cuatro veces mayor que las viboras $y$ reinte mas que los pitónidos. No podria desconocerse la uniformidad de las especies propias del ocste $y$ del este, del sur y del norte; ninguna de ellas se encuentra mas allá de los $67^{\circ}$ de latitud.

En el territorio etiópico, que comprende el Africa meridional, el Alias, las islas Madagascar, Borbon, Mauricio y quizás el sur de Arabia, hasta el golfo Pérsico, nótase la influencia de los paises ecuatoriales. Encuéntranse aqui géneros y especies muy particulares, serpientes gigantescas de magnificos coiores y de un tinte de arena; y hay tambien un gran número de especies arborícolas. Madagascar liene tantas propias y características, que casi podriamos considerar esta isla como un territorio independiente Aun predominan las culébras, que son ocho veces mayores que los pitónidos y once mas que has yiboras, y eso que estas últimas alcanzan un tamaño extraordinario: con ellas viven serpientes vevenosas. Ya desde Egipto se encuentra el ureo, que en un sin numero de variedades se extiende por casi todo el territorio, y en el mar de las costas orientales serpientes marinas. Propios del pais son los équidos, samófidos y varios géneros de las familias de los pitónidos, eritinos, calamarias, dipsádidos, clápidos y culebras. En las islas Canarias, segun aseguran - Bolle y otros observadores, no cxisten serpientes.

El territorio indio que se extiende por todo el sur del Asia, Curma, Malaca, el sur de la China, las islas de la Son. da $y$ las Filipinas, con las pequeñas islas inmediatas, es el pais donde mas abuidan las serpientes, y quizas tambien el mas explorado de la tierra: el sumero de especius que habita en la India es ilimitado, al decir de Eliano. Alli hay veintiuna 
veces mas serpientes que en el territorio septentrional del Antiguo continente; aquella es la verdadera patria de las serpientes marinas, la residencia de las especies venenosas, pertenecientes a diversos grupos del sub órden; alli se cuen. ta por cada seis serpientes inofensivas una temible. Las familias características de aquel territorio son los acrocórdidos y las especies de paladar desnudo; los géneros propios de esas regiones perienecen á las familias de los ericinos, cala marias, dentrófidos, homalópsidos y elápidos; las serpien. tes venenosas que solo se encuentran alli son los búngaros, escolecofidios y botrofidios. La isla de Ceilan está en igual relacion con aquel territorio que la de Madagascar con el Africa, porque en esta isla hay mas serpientes propias de ella que en ninguna o:ra del sur de Asia.

Del territorio austral, al que pertenecen además del con. tinente de Nueva-Holanda, las islas de los Papúes, Tasma nia y todos los otros grupos de islas hasta ahora no citadas del Pacífico, apenas se conocen hoy mas serpientes que las que habitan en las pequeñas islas y en la inmediacion de las costas de las grandes, y por lo tanto no podemos aun dar un informe completo sobre todas las especies propias de csas regiones. Sin embargo, no escascan alli las serpientes, y e territorio es caracteristico por la circunstancia de que al me nos dos terceras partes de todas las especies hasta ahora conocidas son venenosas y pertenecen a la familia de las culcbras, mientras que la mayoria, es decir unas dos terceras partes de las no venenosas, son pitónidos. Semejante proporcion anormal entre las serpientes venenosas y no veneno. sas no se observa en ningun otro territorio; ni tampoco se halla un espacio de tierra situado en los limites de su extension, y tan grande como la Nueva-Zelanda, donde no existen serpientes.

A pesar de que la América del norte, que constituye el territotio septentrional del Nuevo continente, extendiéndose en posicion análoga a la del territorio septentrional del Antiguo mundo, es mucho mas pequeño que este, posee sin embargo muchos mas ofidios. Verdad es que aqui, por 10 que hasta ahora se sabe, ninguna especie se encuentra en e norte mas allá del $60^{\circ}$ de latitud; pero el sur de la zona templada, que puede coasidenarse poco mas ó menos como el límite del territorio, ofrece á las serpientes condiciones en extremo favorabies; de modo que asi se explica su extraño desarrollo en esas regiones. Caracteristica es para el territorio la circunstancia de que predominan las culebras y calamarias en el sub.órden de las serpientes no venenosas: que las culcbras venenosas escasean y las viboras faltan aqui, lo mismo que en el territorio austral y en el meridional del Nuevo mundo: casi todas las serpientes venenosas de la América del norte son crotálidos.

Como puede suponerse, el territorio meridional del Nuevo mundo, que comprende el sur de Mléxico y el centro y sur de América, las islas occidentales, las de los Galápagos y las de Falkland, es muy rico en serpientes y ocupa en realidad el primer lugar despues del indico. Entre las especies no venenosas predominan tambien las culebras y los pitónidos; los elápidos faltan, pero represéntanles los escitálidos, propios de la America del sur; las serpientes venenosas abundan en el género de los escolecofidios.

Para dar ahora círas determinadás añadiré que de las seiscientas treinta y cinco especies de ofidios, numero que calculó Guenter, en $1 \$_{5} \$$, cuarenta habitan en el territorio septentrional del Antiguo mundo; ochenta en el etiópico; doscientas cuarenta en el indio; cincuenta en el austral; setenta y cinco en el septentrional del Nuevo continente $y$ ciento cincuenta en el meridional.

USOS, COSTUMBRES Y REGIMEN,--Además de un alimento abundante las serpientes necesitan guaridas y re. fugios convenientes, y por lo tanto evitan los paises que no les ofrecen estas condiciones. Schreinfurth advirtió con asom. bro que en la tierra de los bogas no hay serpientes, 6 por lo menos muy pocas;y al preguntar la causa, diéronle una explicacion con la que debió contentarse. En aquellos ter. renos -pedregosos falta, segun le dijeron, la tierra negra que en tiempo de la sequia se hunde, ofreciendo a las serpientes los refugios necesarios, y mas aun en el caso de incendios en la estepa. Una cosa análoga sucede tambien en nuestro pais: asi, por ejemplo, la vibora comun abunda mucho en algunos puntos de las inmediaciones de Berlin, mientras que en otros falta del todo; $y$ es porque alli encuentra escondites y aqui no. En general podria decirse tambien de las serpientes que abundan tanto mas cuanto mas cambios ofrece una region. Rara vez faltan del todo, pues habitan tanto en los de. siertos como en los bosques, asi en las montañas como en las llanuras. El calor templado y la hunedad les conviene mas que el calor bochornoso y la sequia; pero tambien pue den soportar hasta lo increible por este último concepto. Aunque carecen de piés saben acomodarseá los terrenos; las unas viven en terreno llano, las otras en pendientes escarpa. das; estas en pantanos, aquellas en el agua de los lagos, de los rios 5 hasta del mar. Hay especies que habitan debajo de la tierra y no pocas en el ramaje. Una vez escogida su morada, parecen fijarse en la misma con cierta tenacidad, de manera que solo recorren un circuito muy reducido. Tambien suelen emigrar á veces, atravesando rios y otras aguas, para esta. blecerse en la orilla opuesta ó en alguna isla, como igualmente abandonan el bosque y el desierto para acercarse á las poblaciones, etc. : sin embargo, por lo gencral, no les gusta cambiar de localidad, sino que escogen para fijarse definitisamente en clla, la que les of́rece un buen escondrijo y favo. rables condiciones para acechar sus presas; siendo lo mas probable que solo emprendan excursiones durante la época del apareamiento y al acercarse el invierno, en busca de clima mas templado, y à veces forzosamente, cuando el cultivo del distrito que habitan les privan de su escondrijo $\delta$ de las facilidades para procurarse alimento y solearse. Por lo gene. ral, siempre se les encuentra léjos de los sitios habitados por el hombre, pero es debido á la persecucion que este les hace, pues no temen ellos la yecindad de este terrible enemigo, á quien por el contrario suelen acosar muy desagradablemente. En nuestro mismo continente, no es cosa rara encontrar serpientes en jardines situados en el centro de poblaciones, sin que sea fácil descubrir el medio cómo se han introduci. do alli: en los paises meridionales se recibe á menudo en las habitaciones una visita tan poco deseada, y especialmente las serpientes nocturnas, las mas peligrosas, suelen ser alli muy molestas.

Mas de una rez me sucedió encontrar en las habitaciones que ocupé durante mi estancia en Africa serpientes que hasta se introducian en mi lecho ó debajo de las alfombras. Otros viajeros que visitaron los paises tropicales hicieron la misma observacion. \&o sínico que inquicta al extranjero en las ca. sas de los tinkas, dice Schweinfurth, es el gran número de serpientes que \& mucha altura sobre la cabeza del viajero hacen ruido en la paja del techo. $A$ Wallace le visitaron to solo en tierra firme sino á bordo de su buque; y una vez solo evitó por una feliz casualidad el peligro de ser mordido por una serpiente venenosa que se habia enroscado en su cama. En la India estas visitas son muy comunes, y no pocos de los hombres que en las colonias inglesas mueren al cabo del año, victimas de las serpientes, fueron mordidos por estas en el interior de sus mismas casas. Aun hoy dia no es la situacion mucho mejor que hace miles de años, y todavia son exictas 
las palabras de Nearco, reproducidas por Estrabon. En la actualidad, lo mismo que en tiempo de aquel autor, puede suceder que con motivo de las inundaciones las scrpientes lleguen en mayor número á las viviendas humanas, obligando á la gente á clevar sus lechos ó abandonar sus casas. Tam. bien la construccion de las camas en el interior del Africa solo se explica por el justificado temor de que las serpientes visiten el interior de las chozas. Las regiones que uno y otro aỉo presentan el mismo aspecto, ofrecen constantemente á estos reptiles iguales ventajas, esto es, alimento suficiente, calor agradable, agua para baniarse, etc., y como consecuen. cia natural de estas condiciones invariables, la vida de la ser. piente se encuentra igualmente exenta de incidentes extraordinarios. No sucede asi en las localidades donde el cambio marcado de las estaciones impone variaciones en el modo de vivir de estos animales. En aquellas comarcas que tienen un invierno mas ó menos riguroso, pero seco, se ven obligadas las serpientes á protegerse contra los efectos del frio ó de la sequia. Todas las cspecics que habitan la parte septentrional de nuestra zona templada, se retiran á principios del in. vierno $\{$ profundas madrigueras, pasando en las mismas la estacion desfavorable en un estado de entorpecimiento. Como ya hemos indicado, ocurre otro tanto en los paises tropicales, pero limitandose alli probablemente á las especies que viven en el agua ó en los terrenos húmedos, y que se sienten mo. lestadas por la sequia. Algunas parecen asociarse para pasar juntas el sueño invernal; sin duda tal vez á causa de la difi. cultad de encontrar varias guaridas á propósito, y obligando por lo tanto a reunirse para este efecto, las rarias serpientes dispersas en un mismo distrito; asi se asegura en la América del norte que las de cascabel se reunen á docenas en una misma madriguera durante el invierno, habiéndose podido observar que algunas viboras de nuestro continente vienen la misma costumbre. Por lo que toca á la duracion y demás circunstancias del sueño invernal, es muy dificil, si no impo. sible, hacer un estudio concienzudo en el campo, ; el naturalista que desee llevarle à cabo no tiene mas recurso que valerse del medio empleado por Lenz, que dió hospitalidad en su casa durante un invierno á ireinta serpientes $y$ of un número casi igual de lagartos escamosos. Véase cómo el mismo reficre el resultado de sus observaciones:

4Escogi para este objeto una habitacion en el piso bajo, cuya ventana miraba al sur $y$ coloqué los reptiles, parte en cajas abiertas y parte en otras con tapa de cristales, teniendo todas en su fondo una capa de salvado de tres pulgadas de espesor y una vasija con agua. Durante las tres primeras semanas de noviembre tuvieron ias serpientes, con la ventana abierta, casi constantemente de dos á cuatro grados de ca. lor, pero de dia en dia se mostraban mas lánguidas y tunian el tacto frio. En la última semana del mismo mes empezó á helar en el campo, y cerré la ventana, consiguiendo sostener de uno y medio a dos grados de calor en la habitacion. Pascé entonces revista, y encontré lo siguiente: Dos viboras que estaban en una caja abierta se habian enterrado en cl salva. do, y parecian bastante rigidas; sin embargo, se movian un poco y sacaban y retiraban la lengua; otra de mayor tamaño, que estaba en una caja tapada con cristales, reptaba todavia un poco, sacaba la lengun y silbaba si se ie excitaba; dos viboras lisas andaban tambien sin esconderse debajo del salvado; las cuatro amarillas parecian/las mas vinaces si bien no dejaban de estar un poco aletargadas; doce víboras negras yacian juntas formando una especie de masa compacta, y algunas que saqué se inflaron, sacando la lengua y silbando, $y$ anduvieron un poco aunque muy despacio; cuatro que ha. bia en una caja y tres mias en otra ya hacia tiempo que estaban enroscadas cada una separadamente y por completo rí. gidas; las negras fueron las únicas que no se enterraron en el salvado.

Pero dias despues habia subido la temperatura hasta cuatro y cinco grados; abri la ventana para renovar la atmósfera de la habitacion, y pude observar que todos mis huéspedes se movian bastante. Mas tranquilos se mostraron cuando hubo bajado otra vez el calor á dos grados; pero cuando es. tuvimos á cero, no fué poca mi sorpresa al ver como todos los reptiles manifestaban gran inquietud, y hasta aquellos que durante mucho tiempo habian permanecido en la misma po. sicion cambiaron de sitio. Tres dias despues habia mas tran. quilidad, y maté tres viboras introduciéndoles en la boca jugo de tabaco; duraron tres veces mas tiempo del que en rerano hubiese bastado para producir su muerte la citada droga.

- El 9 de diciembre sobrevino de repente un frio de dos grados que durante la noche ascendió $\{$ unos tres dentro de la habitacion. A la mañana siguiente pasé revista, temeroso ya de los resultados de frio tan riguroso, y en efecto, encontre la mayor parte de mis viboras heladas; estaban tiesas como palos, algunas mas $\delta$ menos enroscadas, pero sin señal alguna de vida; hasta la negra pupila tenia el color blanquiz: co del hielo, lo que probaba que tambien la humedad del ojo se habia helado. Las que formaban el grupo de doce de que ya he hablado, manifestaban todas alguna vida y movi. miento todavia, y tan solo una de ellas, justamente la que ocupaba el centro, estaba completamente rigida. Todas las que no estaban heladas, se movieron, aunqque poco, cuando las toqué; tenian la pupila todavía negra, y al cuerpo blando. En un principio, á pesar de verlas rigidas y heladas, no creí que todas mis serpientes estuviesen muertas, si bien no dejo de parecerme sospechoso que muchas de ellas presentaban una posicion como si se hubiesen helado mientras procuraban reptar: sin embargo, al tocarlas pude convencerme de que realmente estaban muertas.) De estas observaciones de Lenz, se desprende claramente que las serpientes, lo mismo que los demás animales sujetos á la influencia del sueño invernal, deben ser conserwadas durante la época de su letargo en sitios que estén por completo protegidos contra los efectos de las heladas.

En la Alemania central, cuando la temperatura es favorable, aparecen ya á principios de marzo las serpientes que han abandonado su morada de invierno; se las ve de dia calentarse al sol, siendo muy probable que de noche vuelvan á la misma guarida. No se ocupan entonces en la caza de sus presas, ni en la reproduccion de su especic, pues su verdadera vida activa solo comienza ya entrado el mes de abril. Cuando á fines de otoño se ocultan en sus madrigueras de invierno, cstán gordas y rechonchas, y cuando en la primavera vuelven á salir à la luz del dia, han perdido por lo regular, la mitad de su gordura

A excepcion de las serpientes de gran tamaño, como los boas, los anacondas, etc., se pueden considerar icdas las es. pecies no venenosas como diurnas, y todas las venenosas como nocturnas, exceptuando tan solo las marinas y alguna que oira viperina. Las primeras se retiran á su guarida al oscurecer, pasan la noche descansando y solo se dejan ver al dia siguiente bastante tiempo despucs de salir el sol; las renenosas aparecen a menudo de dia, pero tan solo para solearse, pries su verdadera actividad empieza despues de anochecer. Encendiendo de roche una hoguera en los sitios habitados por las serpientes venenosas, se convence fácil. mente el observador de las cualidades nocturnas de las mis. mas: atraidas por el resplandor de las llamas acuden de todos los lados, y el cazador que en balde se ha cansado todo el dia en busca de una vibora, puece estar seguro de hacer buena caza por la noche. 
Cuando nos vimos obligados á pernoctar en las estepas africanas, la vibora cornuda nos molestó á menudo en ex. tremo; mas de una vez esperamos con una teraza en la mano horas enteras para coger en seguida el reptil y echarlo al fuego. Effeld cogió en los contornos de Berlin la vibora comun, y en Iliria la víbora de arena, valiéndose del mismo medio, es decir, encendiendo fuego para atracr â sus favoritos 6 cazando con una linterna en la mano. Tambien él encontró entonces muchas viboras delante de sus guaridas en sitios en que inútilmente las habia buscado de dia. Todos los aficionados que han tenido en cautiviojad serpientes ve. nenosas, han podido observar que si no exclusivamente, á lo menos como regla general, salo comen de noche, y sobre todo que solo en la oscuridad se manifiestan activas.

Excepstuando solo el acrocórdido de Java, en cuyo estó. mago se han encontrado frutas sir digerir, todas las serpientes cuyo género de vida se conoce, aliméntanse con prefe. rencia de otros animales, con tal que ellas mismas los hayan cogido y muerto. El modo de obtener su alimento diario es muy distinto, segun puede observarse con facilidad cuando se tiene toda clase de serpientes cautivas en gran número. Las mas de ellas acechan la presa que pasa cerca de su escondite, precipitanse de repente sobre ella y la dan el mordisco mortal ó la cogen y devoran ál punto despues de aho. garla. Carecemos aun de observaciones que nos den á conocer bien de qué modo cazan las serpientes venenosas, pues los mas de estos reptiles solo son actiros de noche, por lo cual los vemos siempre en reposo durante el dia. Sin duda por esta razon la pereza de los ofidios venenosos, comparada con la agilidad de las especies no venenosas, que en su mayor parte son serpientes diurnas, nos parece mucho mas grande de lo que es en realidad; lo cual no quiere decir, sin embargo, que la serpiente venenosa no pueda competir en rapidez y agi. lidad con la no venenosa. Aquella no necesita desplegar tanta fuerza como esta; sus armas son tan terribles, que casi basta ya el solo contacto con la víctima; $y$ efectivamente, una herida que apenas tenga $0^{\circ}, 001$ de profundidad, producida por los dientes del veneno, basta para apoderarse de la presa; mientras que la no venenosa se ve obligada mucho mas à menudo á seguirla, y aun cuando la alcance debe hacer esfuerzos para sujetarla- En cambio, le es ventajosa su estructura prolongada, la longitud considerable del cuerpo, relativamente á sus congéneres venenosos, y la agi. lidad consiguiente.

Cuando se cuidan varias especies de un modo convenien. te, proporcionándolas sobre todo el calor necesario, condú. cense probablemente del mismo modo que en libertad. No les gusta pasearse en vano; prefieren permanecer en el mismo sitio. Algunas están horas enteras mas ó menos inmóviles sobre la arcna ó entre las piedras que les ofrecen escondites convenientes, y hasta en el agua; otras descansan enroscadas, mas bien pendientes del ramaje que tendidas en $61, y$ todas parecen estar con comodidad mientras no se las estor. ba, demostrando la mayor indiferencia á todo lo que las rodea. El guardian echa el alimento desde arriba à todos sus prisioneros, segun la especie $y$ las necesidades de estos; en esta jaula una carga de peces; en aquella cierto número de ellos; en las ocupadas por pitónidos y grandes serpientes venenosas, un conejo viro, una paloma í otro vertebrado de sangre caliente. Ias especies venenosas dejan pasar á veces muchas horas sin hacer caso de la victima ofrecida; cuando mas, se inflan, irritadas visiblemente contra el intruso que las estorba en su tranquilidad; mueren algunas veces la lengua, levantan la cabeza con ademan amenazador y vuelven á tomar su posicion anterior. Los pitóizidos y culebrinos, en cambio, no pierden momento cuando tienen un poco de hambre, sino que empiezan en seguida á perseguir la presa que llega á su alcance: los unos se precipitan con todas sus fuerzas y lo mas de prisa posible sobre su victima; los otros se acercan á ella cautelosa y lentamente segun tocas las regias de un experto cazador. Antes de que la rana echada á la jaula se haya hecho cargo de la sociedad en que se halla, una ágil culebra la coge por una de sus extremidades poste. riores, $y$ la victima hace vanos esfuerzos con las otras para escapar de su enemiga; lentamente y con seguridad penetra mas y mas en el esófago de la culebra, moviendo de un modo lastimero sus piés anteriores cual si quisiera despcdirse de la vida. La misma suerte sufren el conejo, la paloma o la gallina que se dan á un pitónido, solo que este los ahoga antes, de la manera que despues indicaremos. Durante la noche muere tambien por lo regular la victima ofrecida á una serpiente venenosa, pero á menudo se observa que esto sucede $\sin$ que el ofidio la hasa tocado. Puede suponerse que el maligno reptil ocasiona la muerte del animal enfure. ciéndose por haberle estorbado.

Es curioso que todas las serpientes sepan muy bien cómo deben proceder con su presa. Devoran viros los peces y ranas; mientras que ahogan antes á los lagartos, mamiferos y aves; $y$ hasta que la serpiente reconoce que han muerto no abre sus anillos para devorar á su victima del modo acosturn. brado.

A pesar de que se comprenderá muy bien por lo dicho que las serpientes devoran su presa entera, debo añadir, sin em. bargo, que ningun ofidio puede despedazar un animal grande ó separar de ell un bocado. No sin avergonzarme del estado en que se halla la instruccion en cuanto á ciencias naturales, lei hace múcho tiempo en importantes periódicos alemanes una historia horripilante, inventada sin duda por un yankee cualquiera, en la cual se contaba que unas serpientes norteamericanas, $\sin$ arredrarse á la visła de un jinete, que por fortuna se salvó, precipitáronse sobre un caballo y le arrancaron la carne á pedazos, hasta que sus dolorosos relinchos se trasformaron en quejas y sucumbió. La historia se propagó sin hallar oposicion, publicándose tambien en periódicos que por otros conceptos tienen un juicio muy sano. Cualquier niño de escuela que hubiese aprendido los rudimentos de la zoologia, debia saber, y probablemente sabria, que todo ol cuento, desde el principio hasta el fin, era una falsedad, por que el hecho no cabia en lo posible.

Segun la especie y el tamaño de las serpientes, la presa que persiguen es muy diferente. Los gigantes del órden puc. den devorar, segun se dice, animales hasta del tamaño de un corzo; los demás se contentan con séres de menor tamaño, sobre todo roedores, aves pequeñas, reptiles de toda clase (excepto quizás las tortugas) y peces; mientras que los ani. males mas pequeños solo tienen enemigos en los escolecofi. dios y calamarias, y quizás en los individuos jórenes de varias especies, que cuando liegan á ser adultos persiguen á los vertebrados. Nuestras observaciones sobre el alimento son aun muy escasas y defectuosas; pero podemos pretender que cada especie de serpiente prefiere poco mas ó menos ciesta clase de animales. \$Todas las culebras acuáticas; me escribe Effeldt, fundándose en observaciones demuchos años, como por ejemplo la culebra comun, la de dados, la viperina y la americana, solo comen peces y ranas, y entre las últimas exclusivamente la especie parda, al paso que retroceden cuando se les ofrece la rana verde acuatica, la cual sueltan aunque tengan nucha hambre, despues de cogerla. La coronela lisa solo come lagartos grises; la verde amarilla y la de coia aquillada, lagartos de esmeraida; cl tartofis vivaz, lagartos grises, ágiles y de los muros; la culebra de Esculapio, la de cuatro lineas, el periops de herradura, el elafis de cuatro fajas y la 
culebra de Argelia comun, animales de sangre caliente, ratcnes y pajaros; el corifodon solo se nutre de ratones. Estos últimos son perseguidos por lodas las serpientes venenosas que observé, por ejemplo la vibora comun, la de arena, la cornuda, el áspid y otras; tenemos una excepcion, sin ensbargo, en el irigonocéfalo piscivoro, cuyo slimento regular son peces, pero que come tambien ratas y hasta scrpientes, incluso las venenosas, no despreciando por otro lado los ratones y los pajaros.

Es muy probable que vierámos lo mismo en las serpientes exóticas, si se las observase con igual detencion que á las europeas. Plinio sabia ya que algunas serpientes comen hue. ros de pájaro, y nos dice de quué modo lo hacen. CLas serpientes, escribe, cugordan con huevos; es preciso admirar cómo proceden; los devoran enteros si solo caben en la boca, rompiéndolos despues en el vientre con movimientos del cuerpo; si la serpicnte es aun demasiado pequeña, roden el huevo con su cuerpo, esirechándolo poco à poco con tal fucrza, que corta una yarte como con un cuchillo, y mientras sujeta el resto, se bebe el comtenido. En el primer caso arro. jan la cáscara, lo mismo que las plumas de las aves deroradas enteras, y esto les cuesta mucho trabajo. Excepto lo de cortar los huevos y arrojar la cáscara, todos los detalles de ese naturalista se han confirmado por las observaciones modernas; estas últimas no dejan duda de que las serpientes roban en efecto huevos, se los llevan, los devoran, los rom. pen en el interior de su cuerpo y los digieren. Además de los veriebrados comen invertebrados y quizas algunas especies de moluscos y crustáceos, y es posible que hagan 10 mismo las especies que por lo regular persiguen presas grandes. Se ha visto que comian al parecer con verdadero gusto larras de hormigas, y tambien se encontraron grillos en los estómagos de algunos de esos reptiles.

Ia creencia en lo milagroso y sobrenatural ha dado origen á una opinion cxtraña que aun hoy predomina cn el çpiritu de muchos. Hasta estos ultimos tiempos algunos naturalistas no han vacilado en pronunciar las palabras «fuerza mágica de las serpientes, refiriéndose \& la manera de coger estos reptiles su simento. Se ha observido que muchos animales, por ejemplo ratones y pájaros, se acerca. ban á las serpientes, que despues los deroraban, y tambien se han visto que algunas aves, poseidas de espanto, revolo. teaban al rededor de serpientes que anenazaban a su cria, $\delta$ at cllas mismas, hasta que el reptil las atrapaba. Comoelins. tinto que advierte al animal todos los peligros que le ame nazan no se ha demostrado en semejantes casos, tanto tratándose del ave como del raton, se ha supuesto que la existencia de una fuerza sobrenatural podia explicar el hecho. Si quisiéramos dar crédito al sinnúmero de relatos que sobre la fucrza mágica de las serpientes nos han hecho varios viajeros, nos veriamos obligados a considerar ciacta la opinion emitida por ellos; mas apenas hayamos rellexionado que si bien las observaciones pueden ser fieles, es po. sible sean falsas las consecucncias deducidas, nos veremos obligados á rechazar en un todo opinion semejante. Segun mis areriguaciones, una infinidad de veees reperidas, la cosa se explica sencillamente por el hecho de que los animales encantados, segun el parecer de aquellos viaje. ros, no reconocen en la serpiente al terrible carnicero que les amenaza. Lichtenstein refiere que en uno de sus via. jes por el sur de Africa observó una serpiente que cazaba un gran raton. \&Fl pobre animalito, alcanzado muy cerea de su agujero, se deturo cratonces súbitamente como paralizado por el temor sin que la serpiente le tocase; csta habia levantado el cucllo y abierto la boca, y parecia fijar sus miradas en la victima Ninguno de los dos se movió durante Toser $y$ aigun tiempo; pero tan luego como el raton hizo un movi. miento para escapar, la cabeza del ofidio le siguí rápidamente cual si quisiera cortar al roedor la retirada; esta maniobra duró unos cuatro minutos hasta que yo me acerqué; la serpiente cogió entonces al punto su presa y escapó con ella a la cercana espesura, sin quue yo pudiese darla alcance para matarla. Como habia leido tanto acerca de la fuerza mágica de la serpiente sobre los pequeños mamiferos, me fué muy importante ver por mis propios ojos un ejemplo. Sin embargo, no discutiré sobre si el aliento renenoso del repril paraliza los movimientos del raton perseguido, $\delta$ si el solo aspecto y la seguridad de la muerte inevitable serán la causa de ella.

E.) relato de Lichtenstein refleja la época (\& principios de nuestro siglo) en que se escribió. Ni el aliento venenoso ni la seguridad de la inuerte inevitable, sino sencillamente la curiosidad, indujo al raton á proceder como lo hizo; de cllo pude convencermc con toda certeza por obsermaciones hechas en mis propios cautivos. Ni el mamilero, ya sea un conejo. imprudente ó una rata vieja y cautelosa, ni un ave cualquicra, aunque sea el gorrion receloso y ensenado por muchas persecuciones, saben lo que es una serpiente. Cuando fijan su atencion en ella, se acercan con curiosidad, la miran ú olfatean, permiten que el reptil les toque con la lengua, y solo retroceden un poco si este órgano les hace cosquillas en un sitio sensible. Las mas viejas y robustas que se echan en la jaula de grandes serpientes no solo no demuestran nin. gun temor, sino que dan á conocer á veces su alrevimiento de un modo inesperado. Una de las que arrojé como alimen. 10 \& una serpiente de cascabul cautiva no hizo ningun caso del rumor y de los silbidos amenazadores de la serpiente, sino que acosada por el hambre abrió un agujero en el cuerpo del reptil reneroso, que murió á consecuencia de esto. No necesito decir que no se debe pensar en lo del aliento venenoso de ninguna serpiente. Cierto que muchos de estos repitiles, sobre todo los venenosos, no huelen as ámbar ni me. nos a incienso, sino que despiden, por el contrario, unos olores muy desagradables, en particular cuando han comido; pero debemos considerar de todo punto imposible que puedan atoniar á un mamifero. De otro mudo, pero con la mis. ma facilidad, se explica el temor observado por dichos viajeros en varias aves cerca del nido, cuando á este se acerca una serpiente. En tales casos aquellos inofensiros séres se valen del disimulo, como todos los observadores saben, para llamar la atencion del enemigo, alejándose de la cria; gritan de un modo lastimero, se acercan al parecer aturdidos al enemigo, revolotean y cojean por el suelo cual si tuvieran paralizadas las alas ó las piernas; déjanse caer como muertos desde la altura del ramaje a la yerba etc., engañando de este modo por lo regular á todo enemigo que no sea muy experto, excepto cl hombre Es posible que tales fucran los casos observados por los viajeros, pero tambien pudiera ser que algun animal que â vista de aquellos se conducia de un modo extraño, cstuvicra ya cogido por la serpiente sin que nadie lo advirtiera. Así, por ejemplo, Kussel observó con asombro que una gallina que habia puesto en la jaula de un driofilido hacia súbitanente varios movimientos como si estuviera en la agonia; y al examinar al ave de cerca, reconoció que el repril habia formado con la extremidad de la cola un lazo al rededor del cuello de la gallina, faltando poco para que la ahogara: en este caso, como en todos, lo milagroso cede an. te la luz de la ciencia.

Como las serpientes engullen su alimento sin despedazar. lo, solo pueden conseguirlo mediante grandes esfucrzos y con gran lentitud. Procuran siempre coger la presa por la cabcza y adclantando primero las mandibulas de un lado y despues 
las del otro, se la van introduciendo poco á poco; á conse. cuencia de la extraordinaria presion destilan copiosamente las glándulas salivales, facilitando de este modo el paso del bocado por la abertura de la boca, que gradualmente se dilata hasta su punto mas extremo. Mientras dura el acto de engullir una presa de gran tamaño, aparece la cabcza del ofidio estirada de una manera informe y los huesos del aparato maxilar fuera de su pucsto. Sticede á veces que algunas serpientes cogen animales que son demasiado grandes para sus fauces tan dilatables; suelen entonces pernanecer largas horas en un mismo sitio con la presa en la boca, procurando engullirsela, si no consiguen separar los dientes y desasirse de la misma sacudicndo fuertemente la cabcra; siendo com. pletamente falso el aserto de algunos autores de que la serpiente no se pucde cieshacer de la presa que ha cogido y en parte engullido, y de que a veces perece asfixiada en estas circunstancias. Las venenosas solo se apoderan de su victima despues de muerta, y cmpiezan á tragársela con mucho cui. dalu; no hacen entonces uso de sus dientes renenosos, sino que los retiran todo lo posible, haciendo funcionar sabre to. do la mandibula inferior.

El procedimiento de la digestion es muy lento, aunque poderoso, siendo digerida primero aquella porcion de la presa que se encuentra en la parte inferior del esiómago, y asi sucede que un pedazo ya disuclto ha pasado al iniestino an. tes que el resto sea sometido á la operacion digestiva. Si la serpiente se ha tragado varios animales consecutivamente, entonces permanecen, segun Len\%, si no son demasiado pe. queños, uno tras del otro, y una vez. lleno el estómago son detenidos en el esólago hasta que puedan pasar mas adelante. 1.as porciones indigeribles y restos del alimento, como plumas y pelos, salen en parte por la cloaca ó vuclven á salir por la boca, como sucede con las presas de dificil quimifica. cion. Tambien depende la nutricion en gran manera de la temperatura, aumentando en igual proporcion que el calor; con todo, no se puede decir que las serpientes sean muy vo. races: es cierto que comen de una vez gran cantidad, pero tam. bien pasan despues semanas y hasta meses sin tomar ali. mento alguno.

En muchas historias naturales se dice que las serpientes no beben; $y$ varios experimentos hechos en culebras y ribo. ras cautivas parecian demostrar que nunca tocan el agua; pero esto no prueba nada, pues repetidas observaciones nos han hecho ver lo contrario. Todas las serpientes beben, las unas chupando a grandes sorbos, con movimientos muy marcados de las mandibulas; las otras recogiendo con su lengua gotas de agua $\delta$ de rocío. Debo dar entero crédito á Effeldt, cuyas facultades dc obscrvador práctico reconozco en un todo, en lo que refirió últimamente a Lenz, manifes. tándole que las serpientes que al beber sumergen la cabeza en el agua no hacen mas que lamer esta; pero jo he observado lo contrario en serpientes de cascabel cuidadas por mi: be bian cuando tenian mucha sed, haciendo con sus mandi. bulas movimientos como para masticar; sorbian y no lamian. Cuando despues de largos viajes en estrechas cajas se coloca á las serpientes en la jaula, bien construida, examinan esta, acosadas por la sed y el hambre, en todas direcciones, $y$ si al fin descubren el agua la prueban primero con la lengua, y sumergen el hocico hasta los ojos ó mas. Entonces beben, y tanto algunas veces, que, segun dice Fffeldt con mucha razon, se hinchan de una manera muy marcada. Muchas especies, por último, enferman y mueren cuando carecen de agua, y otras, en cambio, parecen satisfacer su necesidad solo con algunas gotas para muchos dias y sema. nas. Eiffeldt dió á sus serpientes cautivas agua azucarada, vino y leche, y vió que algunas beben la primera y la segunda, pero solo cuando no tienen otra cosa, despreciando siempre el vino y el agua muy dulce. Una serpiente de cascabel pequeña que no quiso comer, pero que bebió leche, pereció al cabo de algunos meses.

Ia muda de la jiel, de suma importancia para la vida cie las serpientes, es la primera operacion á que está sometido el hijuelo apenas salido del huevo, y que repite el adulto ia. rias veces en el curso del año. Empicza la nuda separándose la piel fina y de color mas claro de los labics. Se forman entonces, segun Lenz, dos especies de solapas, una en la parte superior de la cabeza, y la otra en la mandibula inferior, que se van retorciendo mas y mas, hasta aparecer hácia afuera la parte interna de la piel. Fil animal libre procura deshacerse de csta camisa rozándose contra las plantas y demás asperezas, y consigue de este modo acelerar la muda; el cautivo se esfuerza en vano para conseguir el mismo objeto. Yraras veces se le desprende la piel sin causarla varios rasguños. Segun las observaciones del mismo I.enz, verifican las - serpicntes eurupens generalmente la primera muda de fines de abril á principios de mayo; la segunda un mes mas tarde, la tercera entre los últimos dias de junio y primeros de julio, 5 asi sucesivamente hasta el mes de setiembre: en cuanto los géneros y especies propios de otros climas, poco se sabe sobre el particular. Inmediatamente antes de la muda todas las serpientes están quietas, pero tanto mas vivaces son desjulles.

RERRODUCCION. - Pocos dias despues de la primera murla de la pié, en la primavera, empieza el aparcamiento. Las serpientes manifiestan en dicha época cierto grado de excitacion, pero jamás la que exageradamente les han atribui. do algunos autores. Parece muy probable que algunas especies se reunan entonces en grandes sociedades que permanecen junlas durante bastante tiempo: á lo menos se ha observado que ciertas serpientes veucnosas se enroscan durante el apa. reamiento formando un verdadero ovillo, y que permanceen asi durante horas enteras. Por lo general, se encuentran el macho y la hembra estrechamente enlazados y descansando en las mas variadas posiciones, $y$ muchas veces recibiendo el calor del sol durante varias horas sin hacer el menor movi. miento. La union de ambos sexos es muy intima á causa del doble pene cónico del macho, que en su parte interior esta provisto de duras aristas que se clavan fuertemente en las partes sexuales de la hembra. No se sabe iodavia con preci. sion el liempo que dura el acto del apareamiento, si bien no cabe duda que exige varias horas. Effeldt dice que encontró una tarde doce viboras entrelazadas formando una especie de bola, y que al dia siguiente las vió todavía en el mismo cstado. "Cuando las serpientes están unidas de este modo, dice Lenz, se las puede observar á una distancia regular, siempre que se tenga cuidado de no hacer ruido que las es. pante; pero tan pronto como uno se acerca ó les sacude un golpe, procuran separarse $y$ huir. Sin embargo, esto no es tan fácil, pues en la posicion en que se encuentran no pueden reptar; deşnues de muchos esfuerzos, consiguen desenlazarse, pero como todavía continúan fuertemente unidas por medio del aparato sexual del macho, cada una tira por sul lado, hasta que por último, la mas debil liene que seguir á la mas fuerte: se comprende fácilmente que la retirada no se puede efectuar con gran rayjidez en tales circunstancias. Pegándolas ó pisándolas fucrtemente se consiguc, por fin, que se separen mediante un esfuerzo extraordinario.

Únos cuantos meses despues de la cópula pone la hembra en sitios húmedos y templados sus hueves, en número de seis a cuarenta; csto se refiere of aquellas especics que no son oroviviparas, pues en estas, como ya es sabido, los pequeños rompen la cáscara del huevo en los oviductos de la madre. 
En esta operacion ni les ayuda la madre, ni hace caso de sus hijuclos.

Estos crecen con extraordinaria lentitud, siendo casi se. guro que vayan ganando en tamaño mientras viven, si bien menos rápidamente á medida que van enirando en anos. Es probable que alcancen una longevidad extraordinaria.

UTILIDADES Y PERJUICIOS. - La importancia de las serpientes comparada con la del resto del reino animal es tan poca que bien puede decirse que el sequilibrio de la naturaleza no se interrumpiria aunque no existieran estos reptiles. La utilidad que las serpientes proporcionan al hom. dre destruyendo las ratas $y$ otros roedores, no compensa en manera alguna los grandes perjuicios que ie causan, y muy particularmente las especies venenosas, no pudiénduse tachar de injustificado el odio que en general infunde este orden de reptiles. Honra al hombre la diferencia que establece entre las venenosas y no venenosas, exceptuando á estas de la per. secucion y cxterminio que tiene jurado á las primeras; sin embargo, para distinguir unas de otras, se necesita un conocimiento tan cxacto de sus diversos caractéres, que en justicia no se puede aconsejar demasiada moderacion al profano, va liendo mas el exterminio de dos ó tres especies inofensivas, que la libre propagacion de una sola venenosa. En Alemania donde solo existe una especie venenosa, no es tan dificil cstablecer esta diferencia; pero en los paises meridionales, como el nuestro, donde abundan mas las dañinas, hay algunas de estas tan parecidas a primera vista á otras no venenosas, que hasta el mas inteligente puede padecer una equivocacion, como sucedió á Dunneril, que fué mordido por una víbora, al cogerla descuidadamente, tomándola por un individuo de otra fanilia, y cuya herida le tuvo á las puertas de la muerte. Fin las demás partes de nuestro globo ocurre otro tanto; pues á pesar de los inayores conocimientos que vamos alcanzando todos los dias, se encuentra cl naturalista á cada paso una especie que salo puede clasificar despues de muy detenido cxámen. En resúmen se puede decir, que el que mata todas las serpientes que encuentra no causa perjuicio algumo, mien. tras que el que perdona la vida á una sola venenosa, por equivocarla con otra inofensiva, puede pagar con la suya tan grave error.

OBSERVACIONES GENERALES.-E! hombre ins. truido que comprende que á los ignorantes les pareció siempre de mas importancia el mal que el bien, no debe extrainar que descie las épocas mas remotas representaran las serpien. tes un gran papel en las religiones de los pueblos. No sola mente la tradicion israelita, sino tambien las de todos los paises en general hacen mencion de ellas, ya con temor y odio, 6 bien con cariño y veneracion. Las serpientes se consideraban como simbolos de la rapidez, de la astucia, de la ciencia médica y hasta del tiempo; estos reptiles eran adora. Cos, lo mismo que hoy dia, por los pueblos salvajes; ya en la mas remota antigüedad, los indios tenian á esos reptiles jor simbolo de la sabiduría; otros pueblos veian en ellos la imá. gen de la falsedad, de la perfidia y de la secuecion; y no pocos, como por ejemplo los judios, venerábanlos cual fdolos, segun lo deinuestra el hecho de laber erigido Moisés una serpiente para librar por medio de ella de una plaga al pueblo de Dios.

Los informes de los autores romanos denitestran claramente que este pucb!o hacia ofrendas â las serpientes: eLos dioses, dice Valerio Máximo, han dado á la ciudad de Rona muchas veces pruebas de su gracia particular. Una vez la ciudad fué visitada tres años por una epidemia y ni dioses ni hombres pudieron combatir la terrible calamidad; los $\$ a$ cerdotes consultaron por fin los libros sibilinos y hallaron cn ellos que el pucblo no podria recobrar su anterior 5a- lud sino llamando al dios Esculapio de Epidauro. Envióse pues una embajada para pedir consuelos y socorro; los epidauros recibicron amistosamente á los romanos, y condujeron á los cmbajadores al templo de Esculapio, donde el dios mismo demostró por un milagro su gracia divina. Habiase visto á veces cerca de Epidauro una serpiente, cuya presen. cis atraia cada vez muchas bendiciones sobre la ciudad y la cual era venerada ianto como el mismo Esculapio. Durante la permanencia de los romanos juresentóse esta scrpiente, moviéndose con lentitud pór los sitios mas frecuentados de la ciudad y dirigiendo humildes miradas á su rededor. Esto se répitió ires dias, durante los cuales el pueblo miró al reptil con devocion El deseo de hallar una residencia mas digna comunicó á la serpiente cierta viracidad, y viósela dirigir. se hácia la galera romana. la tripulacion, sorprendida por el ofidio, se asustó mucho; pero el reptil se encaminó sin grandes cumplimientos á la camara del emperador Oguinio y enroscóse alli con la major comodidad. Enionces, viendo los enviados con sus propios ujos que tenian al dios en su mana, quisieron saber cómo debian bacérsele los deỉidos honores, dieron las gracias, y muy satisfechos hiciéronse á la vela alegremente. Despues de una feliz travesía, la galera abordó al Antio, donde la serpiente, que hasta cntonces habia permanecido tranquila en todos los puntos de escala, salió al punto y encaminose á los pórticos ael templo de Esculapio. Allt habia un mirto con abundante ramaje, pero el reptil subió ś una alta palmera, en la cual permaneció tres dias, durante los cuales se la ofreció el alimento ordinario. Los embajadores temicron que no volveria á la galera, pero el reptil, abandonando voluntariamente el árbol, dirigióse a la embarcacion. Por fín abordaron los cnviadus a la desem. bocadura del liber y la serpiente marchó $\{$ una isla, en la cual se le edificó un templo. Consullegada, Roma quedó libre de la epidemia.k

Tales creencias se han conservado hasta los últimos siglos, y existen aun hoy dia en varios pucblos de Europa, Asia y Africa. Es una supersticion bastante general la de que las serpientes son un feliz augurio y atraen bendiciones; los indios y malayos están del todo convencidos de que su muerte ocasiona desgracias. El que mata as un boa, dice Martens, perece pronto, segun la supersticion de los indige. nas de Amboina, á pesar de que el predicador Valentỹn, bastante instruido ya para su época, asegura no haber reco. nocido por esta causa ningun daño, sino el aumento de ranas en su propia casa en la cual habia muerto un pitónido. La supersticion supo explicar el hecho satisfactoriamente, pues se dijo que el espiritu de la serpiente no tiene ningun poder sobre los predicadores. Segun Kragfi, los gallas consideran á este ofidio como madre del género humano, y le profesnn gran veneracion.

Cuando Heuglin mató á un pitónido airicano en la inmediacion de una casa de los negros de la tribu de los dinkas, estos se enojaron mucho, quejándose de que la muerte violenta de su abuelo, que hacia mucho tiempo vivia en paz con ellos, les atraeria desgracia. Schweinfurth añade que las scrpiéntes son los únicos animales á que tanto los dinkas como los chilos de las orillas del sio Franco dis. pensan una especie de veneracion divina. Los dinkas las llaman sus liermanas y creen que el matarlas es un crimen. Varios indigenas, preguntados por Schweinfurth, dijeron que algunas serpientes son conocidas por el propietario de la casa en que han hijado su residencia y que este las llama con diversos nombres, tratando con ellas como animales domés. ticos.

En las regiones situadas a orillas del lago Nianza, segun livingstone, considérase como crimen matar una serpiente 
aunque moleste á los habitantes con sus fechorias. Algunos traficantes que poseen el árabe $y$ visitan aquellas regiones, hasta pretenden que en algunas islas del citado lago viven serpientes que tienen la facultad de hablar y qque en opinion de esa honrada gente traen su origen de aquella serpiente de bronce que sedujo á nuestra madre comun Eva. El que se sintiera inclinado á sonreirse al oir contar tales cosas á csos rudos indigenas, deberá abstenerse por prudencia, pues tienen tan arraigadas sus opiniones como los naturalistas de Cerdeña.

En las reuniones de mujeres de este pais, dice Cetti, se refieren milagros de nuestras serpientes, diciéndosé entre otras cosas que antes fueron profetisas. Yo creo que nuestras muje res instruidas solo cuentan tales cosas por broma ; pero mu chos de nuestros compatriotas ven en las serpientes un objeto digno de carino y de respeto. Cuando un of́dio llega á la choza del labrador $\delta$ del pastor, es un buen agüero y si ál guien pensara en maltratarle se le tacharia de estúpido, por rechazar la suerte que le llega d. su casa. Por eso todas las mujeres de la campina hacen cuanto es posible para conser var la serpiente, llevándola todos los dias con gran cuidado alimento á la entrada de la guarida que eligió como residencia. Yo conozco una muger que durante dos años desem. peñó este servicio. Los labradores rusos, los de 'Turingia ó de la Alemania del sur piensan del mismo modo que los sardos; tambien para ellos la serpiente que llega á una casa pasa por el heraldo de la sucrte que se ofrece.

No podemos pues admirarnos de que en los tiempos mas remotos estas opiniones tuvieran por consecuencia considerar álas serpientes como animales muy distintos de lo que son en efecto. Atribuiaseles toda clase de cualidades, tanto buenas como malas; de modo que representaban tan pronto á un dios como á un diablo; y no solo se les suponian faculades que no posecn, sino que se creia que cada parte de su cuerpo tenia alguna virtud, porque en este punto trabajaba mas la imaginacion que la observacion verdadera. Pará los sacerdotes eran hacia mucho tiempo una fuente de ricas prebendas, porque mas fácilmente que ningun otro sér se podian em. plear para imponer á las masas cicgas la fe; y como ya desde las épocas mas remotas, los sacerdotes $y$ los charlatanes se ocupaban en hacer negocios con esos reptiles para la "ciencia médica, mostróse el mismo af́an que ellos para uti. lizar las serpientes.

No daré ningun indice de todos los remedios curativos y hechizos que segun se creia podian extraerse del tronco y de algunas partes de diversos ofidios; remedios citados por Plinio y otros autores, tanto ronanos como griegos; me limi. taré á indicar que debemos á unos y otros aquellas medi. cinas preparadas con viboras, que se conservaron hasta mu. cho despues de la Edad media. Aun en los últimos siglos, miles y miles de serpientes de la familia de las viboras se cogian en Europa, sobre todo en I talia y Francia, para las farmacias; $y$ cuando las europeas ya no bastaban, comprábase un $\sin$ número de especies venenosas del Egipto. Antonio $\mathrm{Mu}$ sa, el célebre médico del emperador Octavio Augusto, habia empleado ya viboras como medicina; pero solo el médico de cabecera del emperador Andrómaco de Creta inventó el theriak (triaca), que aun en el siglo pasado se preparaba en casi todas las farmacias de Europa bajo la inspeccion de quimicos y médicos que debian examinar todos los ingredientes. Muy célebre era Venecia por la triaca, y poco menos Roma, donde la preparaban los jesuitas que por la autoridad habian obte. nido privilegio contra las imitaciones. La triaca se ordenaba como medicamento para purificar la sangre, combatir las herpes, sarna y escrófula; tambien era un antidoto contra los venenos, y poseia exactamente las mismas virtudes curativas que se atribuian á los remedios milagrosos de nuestros dias. Tambien recetaban los médicos viboras hervidas y asadas, sopas, gelatina, jarabes y polvos hechos con el corazon, el higado, ó con otras partes del cuerpo disueltas en espiritu de vino, las cuales servian para combatir la calentura, la viruela, la epilepsia, la parálisis, la apoplejia y el escorbuto. La grasa se recomendaba como remedio excelente para las contusiones $y$ heridas, para las enfermedades de la vista, etc; tambien servia para los tisicos; $y$ las cortesanas la empleaban como cosmético para hacer desaparecer las arrugas y hermosear el color del cutis.

Hasta los tiltimos tiempos se ha conserwado la creencia en la eficacia de la grasa de víbora como remedio, y un hombie tan despreocupado como nuestro I.enz no pudo des. echarla del todo durante algunos años. En todo caso, esta supersticion, como algunas otras, tenia sus consecuencias buenas, pues contribuia á disminuir el gran número de viboras. Hoy dia ningun hombre razonable cree en estos re. medios de los siglos pasados, porque precisamente la medicina, la bendicion de los adelantos de nuestras ciencias na. turales, ha obtenido sus resultados mas brillantes.

Por eso mismo nos veremos tanto mas obligados á prote. ger cunnto sea posible \& los enemigos naturales de las serpientes.

Para tranquilidad de todos aquellos que temen a las ser. pientes y para alegria de todos los adversarios de estos peligrosos reptiles, el cjército de sus enemigos es muy numeroso. En Alemania los gatos, zorros, martas, comadrejas, hurones, erizos, cerdos domésticos $y$-salvajes; $y$ en las regiones merioionales las civetas y sobre todo las mangostas persiguen con afan a las serpientes y tambien les dan caza con todo empeño los poliboroides, las águilas chillonas, los buzos, cuervos, urracas y grajos, las cigüeñas y otras aves pantanosas, asi como los representantes de estas aves en los pai. ses tropicales. El mas útil y poderoso exterminador de serpientes es el serpentario ó secretario; pero tambien muchos de sus congéneres, como las macaguas, diodontes, melierax y el ja citado poliboroide, los morfuos, hilotarsos, los milvagos, el sarcoranfo y los catartos son muy útiles por este concepto, sin hablar de muchos levirostros, escarbadoras y zancudas, cuya actividad conocemos ya. Todos ellos merecen la proteccion de los hombres considerados, pues la mayor parte de esos animales no solo exterminan las serpientes sino que compensan con creces las utilidades que puedan reportar.

La domesticidad ó cautividad de las serpientes data de tiempos muy remotos. Ya los antiguos egipcios las cuidaron, segun se dice, en sus habitaciones, incluso el terrible ureo. Eliano nos dice que los titiriteros se servian de esta serpiente del mismo modo que se hace hoy dia, y que á veces recibian mordiscos mortales, cono sucede tambien ahora; Marcial renere que las mujeres se ponian á. veces serpientes frias al rededor de su cuello.

El emperador Tiberio tenia, segun Suetonio, una serpiente á la cual apreciaba nucho, y ála que solia dar el alimento en la mano; Elio I ampridio refiere que el emperador Eliogábalo mandó coger á veces muchas serpientes para soltarlas en dias en que el pueblo se reunia para los juegos públicos; divertiale observar el espanto de los hombres, muchos de los cuales perecian de resultas de los mordiscos que recibian ó á causa del tumulto. En las cortes de los príncipes indios, si hemos de dar crédito á los autores antiguos, las serpientes cautivas eran una cosa habitual.

La mayor parte de estos reptiles se acostumbran fácilmen. te á la cautividad, pudiéndose conservar en este estado va. rios años si se les cuida debidamente. 
Por lo general los que se cogen de cierta edad se nicgan á tomar el alimento que se les proporcioma; pero esto, en nuestra opinion, es debido casi sicmpre á no estar dispuesta su morada conrenientemente. Para el bienestar de estos animales, es condicion imprescindible una atmósfera templa. da, al par que húmeda, no debiendo faliar sobre todo un depósito de agua para que puedan baiarse. A fin de acos. tumbrarlos as la comida, débesce empezar por darles animales vivos; una vez conseguido que se apoderen de estos y los engullan, es fácil ir enseñándoles gradualmente á tragárselos muertos, y hasta mas larde tan solo pedazos de carne.

Las serpientes de diferentes especies reunidas en una jau. la viven en buena armonia ó pelean segun las circunstancias; y cuando están en libertad se da el caso de que una devore \& otra. Si se reunen hasta cien culebras de varias especies, agregando á estos reptiles en una misma jaula viarios pequeñas víboras, se observará que conscrvan la mayor indiferen. cia; pero tambien puede saceder lo contrario cuando se anade una sola culebra cuyo alimento favorito no se conoce. Mas de una vez he visto que una culebra pacifica é in. ofensiva en apariencia se precipitó en seguida sobre sus con. géneres para devorarlos cuando cran mas pequeños que clla. Las serpientes venenosas hacen sangre á menudo à sus semejantes 6 matan á individuos de otras especies tanto para devorarlos como por malignidad, ó quuizás por el enojo que les causa su presencia. I as especies grandes de las tres fa. milias terrestres del sub.6rden venenoso no pueden reunirse nunca con otras serpientes, sean venenosas 6 no, si se quieren evitar pérdidas. Hasta las vfboras pequeñas que por lo regular no hacen caso de ninguna de las otras serpientes, muerden ! matan as veces culebras con las que habian vivido meses enteros mostrando la mayor indiferencia. En cambio se observa que siempre viven tranquilas y sosegadas las serpientes de la misma especic.

A los boas, culcbras, y otros ofidios trcpadores del órden les gusta descansar juntos en el ramaje, cionde á menudo se enroscan umas con otras, formando una mole en que nada puede distinguir el ojo humano.

Guenter describe esto perfectamente, segun las observa. ciones que hizo en la coleccion de ofidios del jardin zoológico de Lóndres en un boa de la América central (Cirilabo. thrus inomaliss). Al acercarse a la jaula no se ve por lo pronto ninguno de sus liabitantes, y se comienza por lo tanto á buscarlos en el ramaje que se halla en cierto sitio. \&Allí se ve en el lugar mas alto y oscuro una mole redonda de un tamaño que cvidentemente no puede ser cl de un solo ofidio. Sin embargo, esta inmóvil, y la única cabexa que sobresale del conjunto oprimido de anillos cnlazados no da la más minima seial de vida, aunque se haga ruido tocando en los cristales. Fsa mole ha permanecido on la misma posicion y el mismo sitio hace cinco inos, pero hoy haremos que se mueva. A penas el guardian toca la puerta para abrirla, la primera cabeza visible comienza á sacar la lengua; la scgunda y tercera salen entre los anillos, obsérvase un movimiento del bulto; la respiracion de los reptiles se acelera, y y se puede formar una idea de lo que sucederá. Cuando el guar. dian toca una de las serpientes con un palito, todo el conjunto se desenreda con tal rapider, que la vista no puede seguir los movimientos: seis serpientes de dos metros de largo bajan por las ramas y recorten loda la jaula; al cabo de nedia hora, poco mas ó menos, uno de los ofidios mani. fiesta deseos de volver á su primitivo lugar de descanso; siguele una segunda serpicnte, y despues otra yotra, liasta que al fin se vuelve á formar la misma mole de anies. Yo he visto lo mismo en culebras, observando con verdadera admi. racion estas reuniones y enlazamientos de los reptiles.
Con el tiempo llegan los cautivos á cierto grado de fanilisridad para con su guarcian, cogen el alimento que se les da con la mano ó pyor medio de una tenaza, y se dejan tocar, coger y trasladar de un puesto á otro; y aun se dejan adiestrar hasta cierto punto, etc. Sin embargo, no se observa nunca un apego verdadero al guardian, sino mas bien codo lo contrario, sobre todo en especies fuertes por su tamaño o por sus dientes venenosos. Algunos pilónidos cuidados bajo mi inspeccion demostraban mucha hostilidad contra su guardian; y tambien he visto á las grandes serpientes venenosas alcjarse cuando su guardian se acercaba. La irritacion nacia siempre de la nolestia que les causaba la presencia del hombre, pues á estos reptiles, muy perezosos, no les agrada que se les perturbe; entonces olvidan del todo los beneficios que les dispensa el hombre, y piensan solo en vengarse dél agravio que en su concepto se les ha inferido. Con las serpientes venenosas, irritables y furiosas, rara vez se puede iener alguna confianza, y aunque hayan estado cautivas meses enteros y se las considere domesticadas, muerden á me. nudo. No deja de ser siempre peligroso el roce con ellas y no se puede recomendar demasiado la precaucion al que haya de manejarlas. No aconsejaré á nadie, segun mis experiencias, el contacto con esos reptiles.

CLASIFICACION. - Sobre la clasiticacion de las ser. pientes en sub-órdenes, familias y géneros las opiniones de los erpetólogos modernos difieren tanto como en lo relativo i la determinacion de las especies. Mientras que Guenther fijó en 1858 el número de estas últimas en seiscientas treinta Y Jan, en $196_{3}$, en setecientas ochenta, Wallace cree poder asegurar que la cifra asciende á novecientas setenta; nientras que el urio divide casi todos los géneros en sub géneros, el otro reune varias familias; este acepta solo tres sub-órdenes; aquel forma cuatro. Yo estoy con los que limitan todos los grupos 10 mismo que las especies, como lo hace Strauch re:pecto álos súb.órdenes, pues tambien á mi me parece lo mas natural clasificar los ofidios segun que tengan dientes maci$z 0 s$ solo en una mandíbula $\delta$ en las dos, 6 cuyos dientes estén periorados. Considero las primeras cono el tránsito entre los lagartos y los ofidios; a las segundas como los ofi. dios mas desarrollados, yo las úitimas como los inferiores.

\section{LOS ESCOLECOFIDIOS -SCOLECOPHIDIA}

CARACTERES. - Segun la clasificacion anterior, el primer sub-órden de la generalidad solo comprende los escolecofidios 6 serpien/es iermiformes, dos pequeñas familias que difieren tanto de las demás serpientes como las doble ancadoras de los otros escamosos; de modo que algunos naturalistas los consideran como escamosos y no como pertenecientes al órden de los ofidios. Caracterizanse por tener dientes solo en una inandibula, ya $\mathrm{cm}$ la superior $\delta$ en la inferior; el hueso cuadrado se tija en el mismo cráneo y su boca no cs capaz de ensancharse.

\section{LOS TIFLOPIDOS TIPHLOPIDE}

CONSIDERACIONES GENERALES.-COn el nOm. bre de amplsisbrerra que ya en tiempos de Gessner se tradujo por doble andadora, pero mal comprendido por Wieland, designaban los aniguos, no el anillado que conocemos, sino un escolecofidio tan semejante, que fäcilmente se explica la confusion de nombres producida posteriormente. 
Este ofidio, dice Gessner, no se conoce en los paises alemanes; hállase en Cirecia y sobre todo en la isla de I.emnos, por lo cual conserva en todas las naciones el nombre que le han dado los griegos, que significa un animal que se arrastra.

la mayor parte de los antiguos escritores atribuyen dos cabezas á esta serpiente, una á cada extremidad, y aseguran que se sirve de ellas alternativamente y que lo mismo pue. de andar hácia delante que hácia atrás. Esta opinion equi. rocada fué refutada victoriosamente por el sabio Matiolus. Es posible que entre estas serpientes, que dan í luz tantos hijuelos á la vez, ocurran a veces monstruosidades y apare?. can algunos individuos con dos cabezas y muchos pies, pero estos serán casos extraordinarios j muy aislados, sin que en manera alguna puedan servir de regla gelicral! Sin ouda, los antiguos habian adoptado esta opinion i causa de la semejanna á primera vista de ambas extremidades, pues siendo estas aguzadas igualmente, no es fácil distinguir la cabeza de la cola, tanto menos cuanto que el anfisbena lo mismo repia hácia adelante que hácia âtrás. Así lo dicen tambien Hesiquius y Aecio. Este reptil es de pequeño tamaño y no tiene mas espesor que un grueso gusano de tierra; cúbrele el cuerpo una fuerte piel de color negro rojizo ó pardo oscuro, casi negro, salpicado de muchas inanchas y puntos.

\& Esta doble andadora no teme mucho al frio y sale de sus agujeros antes de que se dejen oir los cuclillos; de aqui puede inferirse que es de naturaleza mas cálida que las otras serpientes. Como de un error toman su origen otros, algunos naturalistas han deducido de la falsa creencia de que este animal tenia dos cabezas, que da \& luz sus hijueios por la boca: se deben rechazar ambos etrores. Io vid es la muerte y perdicion del anfisbena, y no es fácil matarle por otro medio. De esta circunstancia coma su origen la fábula de Baco, segun la cual este dios nató una doble andadora con un tallo de la vid al acometerle y despertarle, cuando aturdido por Juno se durmió. Dicese que si una mujer cmbarazada se asusta al ver un anfisbena, no puede desarrollarse todo el fruto de su vientre y sale antes de tiempo. Plinio asegura que esto no succde si la serpiente se conserva en una caja, y si solo cuando está muerta en el suelo. Si esto sucede debe atribuirse a las emanaciones venenosas que salen del cadáver de la serpiente y ahogan el fruto de la madre. I.a piel de esta serpiente puesta en un tallo de olivo silvestre de. vuclve \& los hombres helados su calor natural; combate el sueño, el temblor y el frio y reblandece tambien las arterias endurecidas. El cadáver de un anfisbena puesto sobre la parte dolorida calma los dolores de las arterias y quita el frio; la misma virtud tiene la piel. Dioscórides y algunos otros creen que porque el veneno de estas serpientes se parece bastante en fuerza y en efectos al de la culebra, debe combatirse casi con iguales medios y que por lo tanto no es preciso preparar medicinas particulares. Aecio, en cambio, dice que su mordedura no es grande sibo peqateña, igual a la picadura de una mosca, por lo cual la herida no causa la muerte, sino solo una hinchazon idéntica á la que produce el aguijon de las abejas; por eso deben emplearse los mismos reme. dios, pero en dósis mas fuertes de las que se usan en este ultimo caso.

De lo anterior resulta evidentemente que los antiguos co. nocian ya al escolecofidio que hoy dia clasificamos entre los tifópidos y que ya sabian algo sobre su género de vida.

CA RAC'rÉRES. - Los tillópidos ó serpientes ciegas se distinguen de los otros escolecofidios por tener solo dientes én la mandibula superior. Su tamaño es reducido; el cuerpo vermiforme; la cabeza parece unida con el tronco; la cola es muy corta; los ojos pequeños, en parte cubiertos por la piel del cuerpo, la lengua marcadamente ahorquillada; el tronco y la cola están cubiertos de pequeñas escamas, redondeadas, lisas, sobrepuestas é iguales en todas las partes; la region anterior de la cabeza presenta grandes escudos: debajo de la piel del cuerpo se observan rudimentos de la pélvis.

DISTRIBUCION GEOGRAFICA. - Hasta ahora se conocen unas setenta especies diferentes de tiflópidos que se han clasificado en cuatro géneros. Ia familia está diseminada en los paises ecuatoriales del globo; se encuentra muy numerosa en los territorios indio y austral, y no tanto en el etiópico y meridional del nuevo mundo; falta del todo en el norte de América, y está representada en el norte del antiguo continente solo por algunas especies, que se limi. tan, segun parece, al sudeste de Furopa y al Japon.

Una especie nos sirve para dar á conocer el género de vida de todas las demás hasta el punto que esto nos es posible hasta ahora.

\section{LA TYFLOPE DOBLE AN DADORA-TYPHLOPS VERMICALIS}

CARACTÉRES. - Esta especie es el tipo de la familia en nuestro territorio Las dos extremidades del cuerpo son de igual grueso, y por lo mismo es dificil distinguir el hocico de Ja cola, porque la boca puede confundirse con el ano si no se fija la atencion en los mayores escudos que cubren el hocico redondeado. I.os ojos se distinguen como puntos apenas visibles de la piel; la cabeza es pequeña; cl hocico es redon. deado cn forma de hemisferio muy abovedado, sobre todo en su parte anterior e inferior, mientras que la superior sobresale en todos sus lados; el tronco, casi cilindrico, es mucho mas corto hácia la cola; esta es corta, con punta cónica, mas an. cha que la cabeza, provista de una pequeña espina y ligeramente encorvada hácia abajo; el número de series de escamas varia entre veintidos y veinticuatro. El color es un amarillo pardo mas oscuro en las partes superiores y mas claro en las inferiores, con un punto negruzco delante de la extre. midad de cada escama dorsal. Este reptil tiene cuando mas $0^{\circ}, 30$ de longitud.

DISTRIBUCION GEOGRÁFICA. - El tillope se ha encontrado hasta ahora en Grecia y varias de sus islas, en Siria, en la Arabia Pétrea, en el Asia Menor, en los países del Cáucaso y hasta en la costa oriental del mar Caspio.

USOS, COSTUMBRES Y REGIMEN. - No se publi. caron aun observaciones minuciosas en este concepto. El ex. celente naturalista Cantor da en cambio algunas noticias sobre las especies indias de la familia. "Todos los tifopes observan iguales usos y costumbres; viven casi siempre debajo de la superficie de la tierra, pero se presentan á veces en sitios frondosos, sobre todo en la estacion lluviosa ó despues de algun chaparron. Su vivacidad es grande y la punta córnea de su cola les sirve segun parece de poderoso instrumento de locomocion; cuando menos la oprimen á menudo contra la mano cuando se las coge y tratan de escaparse. Es fácil con. fundirlas con las lombrices cuando cstàn en el suelo hasta que se-las reconoce por movimientos serpentinos, allevantar la cabeza y mover la lengua Los cautivos rechazan el alimento y la bebida; pero en el estómago de algunos individuos se encontró un poco de tierra y algunos restos de insectos, sobre todo qrilópodos y hormigas. Una hembra jóven tenia en su abdómen una cadena de seis hueros cilindricos, de cáscara blanda y color blanco amarillento. Falkenstein dice que los negros y los colonos europeos de la costa occidental del Africa designan aun à las especies propias de aquellas regiones como serpientes de dos cabezas. Esto es todo cuanto sa. bemos sobre la vida de los tiffópidos, al menos por lo que ha llegado á mi noticia. 


\section{LOS AZEMIOFIDIOS- AZEMIOPHIDIA}

CARACTERES. - En el segundo sub-brden reunimos todas las serpientes que en ambas mandibulas llevan dientes no perforados.

DISTRIBUCION GEOGRÁ FICA. - LOS azemiofidios forıan el grupo principal de la generalidad y se extienden por todos los territorios.

\section{LOS UROPÉLTIDOS- UROPELTIDA}

CARACTERES. - A los escolecufidios siguen los uro. pélidos, unas serpientes delgadas, cilindricas, con la cabeza no separada del tronco y cuya cola corta y obtusa está cu. bierta en la extremidad por un gran escudo ó una escama aquillada. Ambas mandibulas están provistas de dientes; los huesos maxilares son fuertes, pero aun poco capaces de en. sancharse; unos grandes escuclos cubren la cabeza; y varias escamas redondeadas y sobrepuestas el tronco.

\section{ĖL UROPELTIS FILIPINO-UROPELTYS PHI- LIFINUS}

CARACTERES. - Una de las especies mas conocida de la familia es el uropeltis filipino, reptil extraño, con cabeza có. nica, cola obtusa y oblicuamente cortada, cuya placa estŕ provista de espinas. Ia mandibula superior tiene nueve dien. tes y la inferior dos; los ojos, bastante grandes, están cubier. tos cada cual por una placa trasparente; los escudos se disponen en el cuello en veintitres series y en el tronco en reintidos. La coloracion es un bonito pardo oscuro yue ea los costados y regiones inferiores pasa el amarillo, porque aqui los bordes de lns escamas tienen este último color. Los hijuelos uresentan à veces numerosas manchas blancas; al gunos individuos son blancos por arriba y pardos por debajo. Ninguna otra especie de la familia es tan grande como esta, que llega á $11^{\circ}, 50$.

USOS, COSTUMBRES Y RÉGIMEN. - Todos los uropéltidos abundan en las regiones donde habitan. Viren $\$$ modo de los escolecofidios, pero casi sicmpre \& mucha mas profundidad, por lo regular a un metro y medio, 6 inas, por bajo de la superficie de la tiera, por lo cual no es posivie observarlos. Su cabeza cónica, su robusto cuello, su ironco rigido y sobre todo su corta cola fuerte y acorazada, les per. miten observar este género de vida. No sabemos lo que ha. cen y cómo se mueven. Tämbien su alimento consiste en in sectos y gusanos; los huevos se desarrollan tanto en el abdómen que los hijuelos nacen viros.

Entre los indigenas ha motivado la extremada obtusidad de la cola del uropeltis filipino la creencia de que es una variedad de la tenible serpiente de anteojos, porque esta viltima pierde su cola á pedazos, y por lo regular acaba por tener solo un muñon.

\section{LOS TORTRÍCIDOS- TORTRICID住}

CAR ACTERES. - Los tortrícidos constituyen el tránsito entre los escolecofidios y los pitónidos. Su forma recuerda los primeros; la cabeza es vequena, comprimida, redondea. da apenas separada del tronco; la cola muy corta, con pur. ta cónica; la boca está provista defuertes dientes, de lós que dos están en el intermaxilar, nucve á diez en cada maxilar, siete á ocho en el hueso palatino y mayor número aun en las ramas del mismo. En el esqueleto se ven rudimenios de la pélvis y una extrênidad con deco rudimentario, que en los pitónidos está desarrollada mas marcadamente. Los ojos, muy pequenos, tienen la pupila recionda, con cáscara córnea trasparente; dos grandes escudos cubren la frente y seis el labio superior; las escamas, redondeadas y lisas, están sobre. puestas; las del vientre son por lo regular bastante grandes.

\section{LOS TORTRIX - TORTRIX}

CARACTERES.- - Los de este género consisten en tener los dientes en el intermaxilar y los ojillos cubiertos de un pequeño escudo.

\section{EL TORTRIX CORALINO - TORTRIX SCY- TALE}

CARACTERES.-Una de las especies mas comunes de la familia, tipo del género, es el tortrix coralino. Su color es un magnífico rojo de coral, en el que resalian numerosos anillos negros denticulatios en el borde, $\delta$ iajas trasversales anilladas. La longitud es de $0^{m}, 60 \leqslant 0^{*}, 70$.

DISTRIBUCION GEOGRÁFICA.-Dumeril y Bibron dicen que esta serpiente abunda mucho en la Guayana france. sa y hulandesa. J'Orbigny envió tambien un individuo de esta especie desde Buenos Aires. Varios otros natumalistas alirman asimismo que el tortrix que se encuentra en casi todas las colecciones europeas, es originario de la Guayana: parece, pues, muy extraño que el concienzudo Schomburgh, que visito aquel país, no haga mencion alguna de este ofidio.

USOS, COSTU UI BRES X REGIMEN. - Tan solo sabe. mos respecto al modo de vivir del tortrix, que es muy lento en sus movimientos; permaneciendo siempre en las inmediaciones de su guarida, que suele establecer debajo de las rafces de árboles seculares ó en cavidades subterráneas. Ciza ple. queños reptiles, como serpientes vermiformes $y$ otros pareci. dos, y es ovovivigaro. Dice Bates que no es posible formarse una idca de la mannificencia de su coloracion, de la que solo presentan un pálido relejo los individuos conscrvados en espiritu de vino que figuran en nuestras colecciones.

\section{LOS RODILLOS - CYLINDROPHIS}

CARACTSRES. - Los rodillos differen de los tortrix por carecer de dientes en el intermaxilar y por iener descubiertos los ojos; estos se hallan rodendos de un escudo y las cejas de otro, del escudo de la frente y de dos labiales; las fosas nasales están siruadas en un gran escudo no dividido.

\section{EL RODILLO ROJO-CYLINDROPHIS RUFUS}

CARACTERES, - Lil rodillo rojo, considerado generalmente como tipo del género, es un ofidio de $6^{\circ}$, so de largo; de color pardo 6 negro, con un collar rojo coralino; varias fijas irregulares, mas ó menos exiensas, adornan las regiones inferiores, que en la cola son de un rojo de coral; las escamas están dispuestas en diez jueve á veintiuna series longitudinales.

DISTRIBUCION GEOGRÁFICA. - Ista esplecie es pro. pia de Java y de Rengala.

USOS, COSTUMBRES Y RËGIMETH. - LoS rodillos viven debajo de tierra y solo alguna vez salen á la superficic. Aliméntanse de insecios, lombrices, rinónidos y pequeños manıfferos. No sabe nada mas sobre su género de vida. 


\section{LOS CALAMARIDOS- CALAMARID压}

CARACTÉRES.-Por su reducido tamaño clasifico los calamaridos ó serpientes enanas en este lugar. Compréndese bajo este nombre una familia poco conocida que se compo. ne de unas ochenta especies y tiene los caractéres siguientes: El tronco es redondo y recogido, la cabeza muy corta, no separada del cuello; la cola mas 6 menos corta, pero puntiaguda. Unas escamas redondas, lisas $\delta$ aquilladas, mas.ó menos sobrepuestas y dispuestas en 13 a 17 series longitudinales, cubren el tronco y la cola, varios escudos bien desarrollados el vientre, $y$ otros, dispuestos en una ó dos serics, la parte inferior de la cola El número de los escudos de la cabeza, en cambio, es muy reducido, porque á veces se sueldan dos ó varios de ellos. I.os ojos, de pupila redonda, son pequeños; las fosas nasales se hallan a los lados. la dentadura no tiene nada de particular; los dientes de los maxilares son bastante iguales entre si y adcmás existen los palatinos.

Todas las serpientes enanas merecen su nombre, pues ninguna de ellas mide mas de $0^{\circ} 60$, la mayor parte de cllas apenas llegan â la mitad, muchas ni siquiera á un tercio de esta medida.

USOS, COSTUMBRES Y REGIMEN,-Viven a manera de los escolecofidios y rodillos, entre piedras y otros escondites de esta clase, exclusivamente en el suelo 6 deba jo de él. Aliméntanse de insectos y lombrices; caen empero victimas de otras serpientes, sobre todo de pequeñas viboras que habitan los mismos sitios que ellas.

Basta fjarnos en una sola especie de la familia para carac terizarla. Yo elijo para ello una de las mas conocidas de. grupo y tipo del género de las calamarias propiamente dichas (calamaria), que tienc los mismos caractéres generales de la familia.

\section{LA CALAMARIA DE VIENTRE BLANCO- CALAMARIA ALBIVENTER}

CARACTÉRES. - La calamaria de vientre blanco, que alcanza una longitud de $0^{n} ; 28$, tiene cinco escudos en el labio superior, $f \circ$ se distingue además, por estar separados los dos primeros de los labios inferiores de los otros. La cabeza es parda con manchas mas oscuras; el tronco del mismo color, con cuatro rajas longitudinales de un rojo cinabrio; el vientre del individuo viro es de un rojo carmesí la serie de los escudos inferiores de la cola tiene una faja denticulada

DISTRIBUCION GEOGRÁfICA.-La patria de esta serpiente es la India inglesa.

Todas las calamarias que pertenecen al género de que tratamos viven en las islas del archipiélago indio, y muy pocas se encuentran en el continente vecino, por ejemplo en la peninsula de Malaca; faltan del todo en la peninsula indica en Ceilan.

Ninguna especic mide mas de $6^{\mathrm{m}}, 40$ de longitud.

USOS, COSTUMBRES Y RÉGIMEN. - Todas viven en tierra; solo son actiras de dia y se alimentan de pequenos animales vertebrados. Segun las observaciones de Cantor, no se las encuentra en ninguna parte en gran númcro. Son perezosas, muevense tentamente, $y$ aunque se las persiga nunca huyen a gran distancia, prefiriendo echarse y perma necer inmóviles y como mucrtas en el suelo. Nuncar se defien. den contra sus enemigos, ni siquiera intentan morder ó aun escaryarse. Entre todas las serpientes conocidas, estas son quizás las mas débiles, pues ni pueden ayunar mucho tiempo ni soportar el mal tratamiento mas leve.
En el estómago de las especies examinadas por Cantor se encontraron restos de insectos y un proco de arena.

Nada se sabe sobre la reproduccion.

CAUTIVIDAD. - Los individuos cautivos desprecian todo alimento, muriendo por lo tanto pronto; apenas se les puede tocar, porque la mas pequeña presion basta para ma. carlos.

\section{LOS PITÓNIDOS-PTE- ROPODA}

Indudablemente debian aludir los antiguos á los grandes ofidios que componen esta familia, en sus teroorficas des. cripciones de la famosa serpiente dragon. El tamaño extra. ordinario de estos reptiles, su fuerza considerable y el temor general que siempre han infundido las serpientes al vulgo: explican suficientemente las extravagancias de aquellos, asi como las cxagcraciones que se permiten aun en nuestros dias ciertos viajeros y pseudo-naturalistas. De hombres que se sentian débiles ante el supuesto monstruo, no debemos extrañar que su miedo se lo hiciese ver mas que doble y que su imaginacion le adornase con niembros y apénaices de toda clase. Los tarsos ó espolones de las grandes serpientes, que nosotros en la actualidad hemos reconocido como vesti. gios de miembros posteriores, pasaron completamente desapercibidos á los ojos de los antiguos, pero en cambio su fantasía les dotó de piés y alas imaginarios, de las formas mas raras.

Con el trascurso del tiempo, la fantasía dotó álos dragones de mas ricos atributos: la creencia cristiana en el diablo llegó a influir, y de los incomprensibles cuentos de los orientales creábanse poco á poco fantasmas, cuyas imágenes primitivas en vano buscaba el hombre razonable, pues casi se habia perdido la nocion de las serpientes gigantescas. Con mucho mas afan creian los fieles en la absurda descripcion del gran dragon 6 de la serpiente rieja que se llama diablo ó Satanás, y que fué arrojada á la tierra para seducir á todo el mundo; con la idea de dragon uniase poco á poco ia de diablo hasta que al fin aquel nombre se cmpleó como calificativo lisonje. ro para este viltimo. En este sentido se emplea aun hoy dia la palabra por el pueblo, como lo hacen los labradores de Turingia por otros conceptos.

Gessner ha hecho todo lo posible para describir los dragones, tomando de los escritos de los antiguos solamente lo que le parecia importante. No quiero quitar-â estas noticias su originalidad antigua, por lo cual reproduzco las mismas palabras de mi antiguo amigo. Este nombre de track (dragon), dice, tiene su origen entre los griegos; se refiere $a k$ la vista penetrante, y a inenudo à las serpientes en general, pero sobre todo se da este nombre à las especies grandes y pesadas, i las que debe considerarse entre las serpientes como las grandes ballenas entre los peces. Agustino dice que no se encuentra en la tierra animal mas grande que los dragones; Eliano asegura que el pais de los moros produce dragones de treinta pasos de largo; que estos animales no tienen nombre propio entre los moros, pues los llaman matadores de elefan. tes; y que alcanzan una gran longevidad. En tiempos de Alejandro el Grande, un indio tuvo dos grandes dragones, de los que uno media cuarenta y seis codos de largo y el otro ochenta; el indio crió y alimentó dichos monstruos los cuales quiso ver Alejandro el Grande ś causa de su gran tamaño. Los egipcios cuentan, segun Eliano, que bajo el reinado del rey Filadelfo se llevaron a Alejandria dos dragones vivos, el uno de catorce y el otro de trece codos de largo, ambos cogidos en Etiopia. Del mismo modo se condujeron 
alli tres en tiempo de Evergetes, uno de siete y el otro de nucve varas de longitud; el tercero fué criado con grandes gastos y cuiclado en el templo del falso dios Esculapio. Eliano dice tambien que Alejandro el Grande vió y encontró en la India inuchos animales raros, entre ellos un dragon al que perdonó la vida á ruegos de los indios, quienes le consideraban como sagrado: dicen que tenia setenta codos de largo: Cuando oýo acercarse al general de Alcjandro produjo un silbido tan fuerte, que todo el pueblo se asustó; no quiso salir de su cueva; solo sacó la cabeza, y sus ojos tenian el tamaño de un gran escudo.

2La Etiopía produce muchos dragones, sobre todo en el mediodia, á causa del gran calor; la mayor parte de ellos tienen veinte varas de longitud. P'or lo demís se les encuen. tra tambien en la India, la Nubia, Siria y otros países cálidos, donde abundan mucho y llegan á veces á quince pasos de largo y á una gordura extremada, pero los individuos de la India son cn su mayor parte mas grandes y monstruosos que los del pais de los negros. Dividense principalmente en dos géneros: los unos habitan las montañas; son grandes, rápidos y ágiles y tienen cresta, mientras que los otros habitan las charcas y pantanos, son perezosos y carecen de cresta; algunos poseen alas, otros no. Agustino dice: $₫$ El dragon está á menudo en su cueva, pero tan luego como siente la humedad del aire sale y se remonta con ayuda de sus alas por el espacio, alejándose impetuosamente.

-Algunos se arrastran con el pecio ó vientre por el suelo, pucs carecen de piés; otros, en cambio, están provistos de estas extremidades; alguros tienen una boca pequeña semejante á una caña, pero los demás, propios de la India, Litio pia y otros paises análogos, poseen una boca tan grande, que devoran aves y otros animales enteros. Su lengua es bifurcada; los dientes fuertes, grandes, agudos Y punicados como una sierra bien afilada. 'Tienen la vista penetrante y buen oido: raras veces duermen, por lo cual los poetas los llaman vigilantes de los tesoros. Alli donde habitan, el aire se infecta por $5 u$ emanacion venenosa.

- Se nutre de toda clase de alimentos, de yerbas, huevos de diversas clases, cuadrípedos y aves. l'uede pasar mucho tiempo sin comer, sobre todo cuando es aduito y ha llegado á todo su desarrollo; pero si una vez empieza á comer no se satisiace fácilmente. En Frigia se ren dragones de diez pasos de largo, que todos los dias van a la orilla del rio Rindaco a la hora de comer; salen de sus cuevas, se apoyan sobre la cola, euderezan el cuerpo, levantan cl cuello y esperan con la boca auierta las aves que pasan, á las cuales, por rápidas que sean, saben atraer con su respiracion para devurarlas. Asi proceden hasta que se pone el sol y entonces se ocultan acechando el ganado que vuelve a las cuadras:-arre batan y dan unuerte á menudo tambien á los pastores.

\$ Ol iguila es siempre enemiga del dragon, pues tambien ella devora las serpientes. Los dragones están ademśs en con. tinua guerra con los elefantes. Etiopia produce, como ya hemos dicho, dragones de treinta pasas de largo, que no tie nen nombre propio y solo se llaman asesinos de elefantes. Como estos dragones saben muy bien que los elefantes se alimentan de ciertos árboles, buscan uno de estos, suben á ćl, ocultan su cola entre las hojas y el ramaje $y$ dejan pendien. te la parte anterior como una cuerda. Cuando el elcfante se acerca para comer los retoños, el dragon le salıa súbitamente á los ojos, se los arranca y rodea cespues el cuerpo de tal modo con sus anillos que no se puede desprender.

2A menudo acechan à los elefantes en su camino, dejan pasar i los primeros y acometen álos últimos para quue aque. llos no puedan ayudarlos, les sujetan los piés á fin de impedir que anden $y$ los ahogan despues. Plinio dice que alli

Tasso $\mathrm{V}$ son tan grandes que pueden rodear todo el cuerpo del elefante, pero este, en cambio, aplasta y mata al dragon en su caida. Por otra parte, cuando acometen y se enroscan en el paquidermo, este se rasca en una roca ó un árbol, aplastando asl al dragon, que para evitar tal peligro enreda las piernas de su enemigo, á fin de que no se mueva. Ios dragones tienen poco 6 ningun veneno, por lo cual se les cuenta entre las serpientes que mas bien son dañinas por las heridas que infieren que no por el veneno. Debe notarse que los dragones no son venenosos por su naturaleza, si bien en algunos paises se encuentran especies de esa . cualidad; las especies de los países frios no son tan venenosas como las de Africa y otras regiones callidas; Lucano dice: \& Los dragones, que en todo el país se han considerado hasta ahora como inofensivos, son sin embargo en Africa venenosos y dañinos. 3 Cuan. do persiguen á hoinbres 6 animales suelen comer antes yerbas ó raices venenosas; por lo demás hacen mas daño con la cola que con los dientes, ahoganda á todo el que cogen; sus mordiscos no son grandes ni dolorosos, pues tienen la boca pequeña, por lo cual no se defienden con los dientes; su fuerza está sobre todo en la cola.

Si consideramos las ridiculas y exageradas relaciones de algunos viajeros contemporáneos, debemos encontrar muy disculpables las aberraciones de los antiguos. Aun hoy exis. ten autores que nos hablan de serpientes de 50 piés de largo, las cuales atacan, ahogany engullen caballos, novillos y otros cuadrúpedos. Puede ser que en otros tiempos los grandes ofidios hayan alcanzado mayor desarroilo que en los nuestros, en que el hombre, mejor pertrechado que entonces, les hace frente y con sus terribles armas les acorta la vida; pero es de todo punto imposible que jamás existieran serpientes tales como nos las han descrito los antiguos.

Sé por propia experiencia cuán dificil es hacer un cálculo exacto sobre la longitud de una serpiente. Aun los mas expertos en este punto, que comprueban su cílculo con el metro, se equivocan de un modo incomprensible. Hasta en las pequeñns serpientes de un metro de largo, que echadas tranquilamente dejan tiempo sobrado al observador para ini. rarlas minuciosamente, este se inclina con demasiada facili. dad a añadir á la medida exacta mas de un tercio; pero en serpientes de tres metros de longitud las dificultades aumentan y con ellas los errores en el cálculo; cuando cl animal se mueve es de todo punto imposible formarse una idea exacta de su longitud. No sé en qué sé funda esta circunstancia, pero puedo asegurar que sin excepcion todos exageran, que intentan hacer un cólculo $\mathrm{y}$ que incurren en el mismo error aunque le hayan cometido repetidas veces. No podemos extrañar, por lo tanto, que la viva imaginacion de los indigenas de las regiones meridionales reconorca menos limites que la nuestra, exagerando el tamaño verdadero hasta el doble ó el triple. Lt mismo indio 6 sur-americano que asegurn con la apariencia mas formal de confianza y veracidad, haber visto y muerto una serpiente de 50 piés de largo, Ieconoce que la que esta midiendo el naturalista es la mayor que ha encon. trado en toda su vida de cazador; y sin embargo, resulta despues que no alcanza la misma sino 206 todo lo mas veinticuatro piés de largo.

CARACTERES. - En los pitónidos se destaca ya la cabeza mas ó menos del tronco y se prolonga en forma trian. gular y ovalada, deprimida de arriba abajo, y casi siempre aguzada en la parte anterior, con la boca muy hendida. Tie. nen estos reptiles el cuerpo muy fuerte, con gran desarrollo muscular, comprimido lateralmente, algo hundido en el dorso y mas levantado hácia los lados, correspondiendo esta eleva. cion á los fuertes músculos que ocupan aqquellas regiones: la cola es proporcionalmente corta, y el muñon ó miembro atro. 
fiado aparece al exterior, a cacia lado del ano, en forma de espolon cómeo y truncado. La cabeza está protegida por placas y á veces por escamas; el cuerpo siempre se presenta cubicrto de estas, pequeñas y exagonales, y la parte abdominal revestida de escudos largos, estrechos $y$ por lo regular sencillos, que en la region de la cola se encuentran á me nudo dispuestos en dobles filas. Ambas mandibulas, y en algunas especies los huesos palatinos tambien, llevan dientes sólidos que aparecen colocidos, por lo que toca al iamano, de modo que el segundo 6 tercero es el mayor, y los otros se van reduciendo gradualmente hácia atrís. Los ojos, bastante grandes, tienen pupila linear, y las rentanas nasales se abren en la parte supérior. Ambos pulmones se encuentran completamente formados.

DISTRIBUCION GEOGRAFICA.-Excepto los ericinos que tambien pertenocen í la familia que nos ocupa, pero de los cuales no bablaré en la descripcion general, los pitó. nidos se limitan '́l los ierritorios situados en los trópicos, ó por lo menos, no salen mucho de sus limites. No determinaré si su área de dispersion fué en tiempos remotos mas extensa; pero ahora habitan todos los paises cálidos del An. tiguo y Nuevo continentes dondé abunda el agua.

USOS, COSTUMBRES Y REGIMEN. - Buscan con preferencia estos reptiles los grandes bosques y muy especialmente los que son atravesados por rios ó tienen otras aguas abundantes. Hay, sin embargo, algunas especics que viren tambien en comarcas secas. "Con todo, en su mayor parte son los pitónidos verdaderos animaies acuáticos que solo abandonan el pantano, lago ó rio para solearse y dormir, carando sus presas en el agua 6 a orillas de la misma. Otros parecen evitar y hasta temer el elemento liquido. Ia construccion del ojo los designa ya como animales nocturnos, y las observaciones en individuos cautivos lo han probado de una manera indudable. Ciertaménte se ve á los pitónidos moverse durante el dia en los bosques que habitan, y coger alguna presa que la casualidad trac it su alcance; pero su verdadera actividad solo empieza al oscurecer, terminando tan pronto como rompe el dia. Pocas ó ningunas observacio nes se han podido hacer respecto \& este particular, pues los distritos habitados por estos reptiles no son de fácil acceso de noche al hombie, $y$ además la misma oscuridad seria un grave entorpecimiento para el observador; sin embargo, como ya hemos dicho, el estudio de los individuos en cautividad ha demostrado que son realmente nocturnos. Tan apáticos y aficionados al descanso como se presentan durante cl dia, tan activos y desenvucltos se manifiestan una vez empezada la noche. Solo enionces empiezan á moverse y hallíndose en libertad eupiezan a vayar por su dominio para cazar. De dia se les ve enroscados en las mas diversas posiciones descansan. do ó tomando el sol.

Unos buscan con este objeto pedazos de roca, sitios secos ó ramas que se adelanten por encima del agua, y otros suben à los árboles y se cnroscan alli, ya formando una pelota ú ovillo, ya dejando colgar perpendicularmente la parte anterior del cuerpo. Todos se mueven lo menos posible y tan solo para huir del peligro que les pueda amenazar, 6 cuando, habiendo cazado largo tiempo sin resultado, se les acerca una presa. Entonces se deshace de repente el ovillo, y el po. deroso animal se arroja con todo el impulso de su fuerza sobre la victima, la sujeta con su sólida dentadura y se enrosca en clla contorneándola con varias circunroluciones de su cuerpo, contrae este y la ahoga irremisiblemente.

Yo he observado tantas reces tal procedimiento, que por propia experiencia puedo describir cómo se conduce la ser. piente.

'Tan luego como un pitónido: sea de dia $\delta$ a la hora del creprísculo, ve una presa que descuidadamente se aproxima, sus pupilas, estrechadas á la luz en forma de una hendidu. ra, se ensanchan; la lengua empieza á moverse presentándose y desapareciendo alternativamente; se vucive $s$ revuelve tan pronto por un lado como por otro; y tambien la punta de la cola indica, como la del gato en acecho, su inclinacion sanguinaria. Despues de observar cuidadosamente su futura victina, en lo cual puede ocupar mas ó menos tiempo, la serpiente se desenrosca y empieza la persecucion. Lentamente desliza la parte anterior del cuerpo sobre los anillos que la serpiente en descanso habia formado uno sobre otro; poco \& poco se prolonga el cuerpo vermiforme; todos los mísculos trabajan; todas las costillas se oprimen contra el suclo para hacer avanzar la pesada mole; la lengua siempre movible examina el sendero, mientras que los ojos se fijan de continuo en la presa; y mas y mas se aproxima el reptil á ella. La victima no sospecha el peligro que le amenaza, pues no reconoce en la serpiente, que con infatigable seguridad se dirige hácia ella, el terrible enemigo en cuyo poder caerá sin remedio a los pocos instantes. Asombrado de lo que ve, el animal perseguido se detiene, ó cuando mas da algunos pasos 'ó saltos cual si quisiera dejar libre el camino s la serpiente; vuclve á tranquilizarse y no solo permite que el rep. til, cada ver. mas próximo, forme circunvoluciones para ganar la longitud necesaria en el momento del ataquue, sino que á menudo permanece inmóvil cuando la serpiente se halla tan acerca que las puntas de la lengua tocan su cuerpo. Los conejos olfatean en tales casos con curiosidad, segun he visto repetidas veces, el cuerpo del reptil, cual si quisieran contes. tar al exámen que su enemigo hace con la lengua; pero de pronto, la cabeza de la serpiente se lanza hácia adclante; al mismo tiempo ábrese la boca, y antes que la victina com. prénda el peligro queoda cogida y estrechada entre una ó dos circunvoluciones del cuerpo de la serpiente. Fsto sucedecon tal rapide\% que ni aun el espectador pucde apenas formarse idea de cómo pasa. I a serpiente coge al animal, enros. cando en el mismo instante la parte anterior de su cuerpo; vuelve la cabeza con la presa hácia adelante y traza con ella tantos circulos como lazos quiere poner alrededor de su victima. Sin embargo, un segundo despues del ataque el animal cogido queda ya mortalmente estrujado; raras veces se oye un grito de la víctima, y cuando esto sucede, sin duda se debe solo á la terrible presion que hace salir por la laringe el aire contenido en los pulmones.

Lo irresistible de esta presion se reconoce desde luego en la cara del animal comprimido; sus ojos salen de las órbitas, la fuerza del dolor contrae los labios, y las piernas posteriores se agitan convulsivamente cuando no están ligadas. A los pocos instantes pierde el conocimiento, y segun la re. sistencia vital de la presa, los latidos del corazon se debilitan mas ó menos pronto, hasta que al fin cesan del todo y se si. gue la muerte. Inútiles serian entonces los esfuerzos para hacer desenroscar i la serpiente; el vigor inmenso de sus músculos se burla del de mas de un hombre. \&Yo he procurado, dice Hutton, desenroscar un pitónido de mas de dos metros de largo que tenia cogida una perdiz, mas á pesar de que me vali de toda mi fuerza, no obtuve el menor resul tado.

La serpiente calcula exactamente la fuerza que necesita para ahogar una presa y nunca suelta á esta de sus anillos hasta convencerse completamente de su muerte. Los pitóni. dos pequeños enroscan tambien \& sus víctimas del modo descrito; los grandes las estrechan á menudo solo en dos circunvoluciones de la parte anterior del cuerpo y las ahogan poniendo sobre ellas su gran peso; si la presa es grande, rodćanla con mas anillos. 
De una noticia de Hutton resulta claramente que estas serpientes distinguen muy bien entre diferentes presas. Dicho naturalista, con cuyas observaciones están del todo conformes las mias, sacrificó una vez un varano robusto $y$ fuerte para dárselo \& un pitónido cautivo. El saurio intentó escapar saltando sobrc el lomo de su enemigo, mas a pesar de que las agudas uñas del varano le eran visiblemente desagradables, la serpiente permaneció iranquila fijando sus ojos en la victima. Despues de bastante tiempo el varano, cual si hubiera conocido que aquel cra mal sitio, abandonó la serpiente buscando refugio en otro lugar de la jaula. La serpiente se desenroscó entonces, preparándose para el ataque, y el varano le hizo frente, de modo que Hutton tuvo la esperanza de que se trabaria una lucha; pero la serpiente se precipito enroscindose con una rapidez y fuerza tan extraordinarias al rededor del varano que en dos sitios le rompió el cucllo, y la base de la cola se oprimió contra la punta de la nariz. Asombrado al ver una hora mas tarde al ofidio enroscado, el observador cuyiú un bastoncito é intentó obligarle á soltar la presa; pero pronto reconoció la causa de la inmovilidad del reptil: aun vivia el varano; sus piés se mo vian todavia, y tal fué su resistencia vital, que el pitónido no pudo desenroscarse antes de trascurrir tres horas y me dia. Sabia exactamente cuánto tiempo necesitaba para maiar a su victima; un mamifero muere cuando mas en diez mi. nutos, pero regularmente en cinco, y es devorado entonces pronto: un varano necesita veinte veces mas fuerza y a pesar de esto la serpiente no se cansa.

Tan luego como la serpiente se ha convencido de la muerte de su victima, se desenrosca lentamente y examina entonces con la lengua su presa sin soltarla del todo. Nunca he visto que antes de devorarla retozase con ella, como afirmarou los aniguos y repiticron algunos autores modernos. En mi opinion, el exámen con la lengua solo tenia por ob. jeto encontrar el sitio á propósito para dar principio a la deglucion. Este sitio es la cabeza, porque el gran bocado que débe introducirse entero opone menor resistencia cuando la serpiente hace pasar primero dicha parte. Despues de un largo rato de examinarle con la lengua, coge al animal ahogado por la cabeza, abre la boca cuanto le es posible y empieza entonces el trabajo de la deglucion. Adelanta alternativamente una y otra mandibula, oprime los dien. tes, clavándolos hácia atrás en el bocado para sujetarle, y hace entrar asi la presa poco á poco. El arco de la mandibula inferior se ensancha entonces marcadamente, primero por detrás y despues cada vez mas por delante, tendiéndose los ligamentos movibles. I a no se ve nada de las graciosas formas anteriores de la cabeza; su parte superior conserva aproximadamente su figura, pero la mandibula inferioz $y$ la piel de la gargania se ensanchan como en los pelicanos en forma de bolsa $y$ se parecen $\{$ un ancho saco con un anillo fijo en su parte superior. La laringe avanza á medida que la nandibula inferior se ensancha, y todas las glándulas segregan abundante salivi, mojando los pelos ó plumas de la victima à medida que esta va penetrando en la parte posterior de la boca. En los animales grandes los omoplatos, y en las aves las alas, ofrecen grandes dificultades; pero ven. cidas estas, el resto del cuerpo avanza con una rapidez sor; prendente hasta que al fin las piernas y la cola desaparecen tambien. Entonces la cabeza recubra sus formas anteriores; las articulaciones desviadas se reunen, y despues de que la serpiente ha abierto y movido su boca como bostezando varias veces, todo vuelve á su anterior estado. Mientras tanto la presa avanza, como se puede ver marcadamente porfuera en la parte del esófago, hasta llegar al estómago; antes de csto, si la serpiente estaba hambrienta puede haber cogido ya una segunda victima; $y$ despues de un largo ayuno le es dado ambien devorar seis ú ocho animales del tamaño de un conejo 6 paloma, uno despues de otro. Cuando se atan con la victima viva dos ó tres muertas de igual tamaño, como se hace en algunos jardines zoológicos y colecciones ambulantes, la serpiente las devora todas a la vez; cuando se le ofrecen animales vivos, uno despues de otro, los ahoga y devora del mismo modo. Cada vez que ha tragado algo nuevo mueve la lengua con toda satisfaccion y se lame verdaderamente la boca.

A pesar de las cxtraordinarias facultades del pitónido para devorar, la capacidad de las mandibulas para ensancharse tienen sin embargo sus limites. Ias historias horripilantes que se refieren y se creen son falsedades: ningun pitónido puede devorar un hombre adulto, ni una ternera, un caballo $\delta$ un ciervo grande; la deglucion de un animal del tamaño de un corzo ofrece aun $a$ los gigantes de la familia, unas dificultades casi invencibles. Absurdo por demás es el aserto de que los pitúnidos solo pueden devorar á los aninales grandes esperando a que la parte del tronco, que no les coge, entre en descomposicion; y no lo es menos la especie de que la saliva de la serpiente produce muy pronto la putrefaccion del cuerpo animal. Los individuos cautivos, que poco á poco se acostumbran tambien á comer animales muertos, podrán no tener hambre algunas veces y dejat su presa bastante tiempo sin devorarla hasta que la descomposicion ha comenzado. Tales observaciones, sin embargo, no pueden aplicarse a la vida en libertad del ofidio. Lo ciero es que los pitóni. dos, asi como todos sus congéneres del órden, quedan sumidos en un estado de inercia despues de una comida abun. dante, estado que dura hasta que la digestion está casi acabada. En algunas descripciones antiguas de viajes se refiere la fábula de que los pirónidos en libertad ocupados en la di. gestion permanecen tranquilos en el mismo sitio cuando los hombres se acercan; que permiten i estos sentarse sobre sus cuerpos como si fueran troncos caidos, y que solo entonces avanzan lentamente. Tales cuentos se desmienten por si mismos y no puedo comprender que aun $\{$ principios de este siglo y hasta mediados del mismo pudieran creerse Un pito. nido puede comer cuanto quiera sin emperezarse nunca hasta el punto depermitir al hombre acercarse tranquilamente, sin ponerse cuando menos á la defensiva ó emprender la fuga. Posible es que se le pueda pisar, pero no sentarse sobre ćl.

La fuerza de la digestion se puede reconocer en los cautivos. A los cuatro dias, cuando mas, el mayor mamifero que se dé á un pitónido como slimento está del todo descompues. to, excepito algunos pocos pelos que salen con los excremen. tos, y desde este instante la serpiente demuestra otra vez deseos de comer. Sin embargo, no le perjudica un ayuno de varias semanas y hasta meses enteros, sino en el caso de que un guardian torpe le haja condenado ya antes á uma dieta pocas veces interrumpida.

Sobre el apareamiento de los pitónidos en libertad no se han hecho aun, al menos que yo sepa, observaciones minucio. sas. Solo se sabe que algunas especies ponen huevos, de los cuales salen los hijuclos pasado cierto espacio de tiempo, unientras que otras llevan aquellos en los oriductos hasta que los pequeños rompen la cáscara. En los pitónidos cautivos háse observado repetidas veces que la madre cuida nasta cier. to punto de los huevos, los cubre con su cuerpo y contribuye aś en algun modo á la incubacion; una noticia de dos indios parece por lo tanto muy fidedigna. En marzo de $183 \$$, re. fiere Abbott, encontraron los citados indigenas cerca de $\mathrm{Ak}$ yab, en Arracan, debajo de un pedazo de roca, una gran hembra de pitónido de unos cuatro metros de largo, echada sobre una cavidad que contenia cuarenta y ocho huevos. La 
serpiente los cubria sin duda y volvió á hacerlo mas tarde en la cautividad cuando en la jaula se le devolvieron los huevos; durante toda la incubacion no tcmó ningun alimento. $A$ los tres meses, sin embargo, los huevos no estaban maduros aun; al examinar uno, encontré un hijuelo fuerte $y$ bien desarrollado, que habria vivido sino le hubieran muerto.y No puedo decir si el cuidado de la madre se demuestra tambien despues de salir á luz los hijuelos asi incubados, ó si los aban. dona entonces ś su suerte. Ias especies ovoviviparas parecen cuidarse tan poco como otros reptiles de su progenie apenas nacida.

Los hijuelos, que al salir á-luz tienen casi un metro de largo por una pulgada de grueso, empiczan, apenas salidos del cascaron, el género de vida de sus padrés, pero permane. cen al principio bastante tiempo quietos en el mismo lugar, albergándose en tierra ó en el ramaje. Crecen al principio muy rápidamente, pero despues cada vez con mayor lentitud hasta que al fin su tamaño aumenta apenas visiblemente. Únos pitónidos nacidos en cautiridad, y de los cuales habla Té despues mas detenidamente crecian con mas rapidez en los cuatro primeros años de sú vida; luego mas lentamente, Y desde la edad de catorce años de uni modo apenas visible; puede suponerse por lo tanto que los pitónidos de seis á siete metros de largo deben tener al menos doble edad quve la indicada.

CAzA. - Tambien los pitónidos huyen por lo regular del hombre, aunque no siempre En ell Brasil casi todo el mundo está convencido de que manifiestan al señor de la tierra el debido respeto, es decir huyen tan pronto como reconocen su presencia. En ciertos casos sucede no obstante lo contra rio. Conocen muy bien su fuerza y son mucho mas irritables que otras serpientes, lo cual puede observarse en los cautivos con bastante frecuencia; en ciertas ocasiones sucederat lo mismo tambien en libertad.

Cuando Heuglin, seguido de sus compañeros cruzb durante una oscura noche tempestuosa la estepa de Abisinia, vióse obligado a dar un rodeo porque una gran serpiente echada en medio del camino, silbó al acercarse el viajero, haciendo ruido con las escamas: esta circunstancia le indujo a creer que era un pitónido, pues no fué posible ver el animal en la oscuridad de la noche: Los vinjeros que pasaron mas tarde hallaron al reptil aun en el mismo sitio, y dominado por las mismas impresiones. No prede dudarsé, segun las noticias de viajeros fidedignos, que una serpiente ataca en tal caso alguna rez tambien al hombre. Un indigena de Buru, que vivia cerca de mi casa, dice Wallace, me enseñó en su muslo las cicatrices de las heridas que en las inmediaciones de su habitarion le habia inferido una serpiente; esta hahia tenido bastante fuerza para coger el muslo del hombre con la boca, y sin duda le habria muerto $y$ devorado si los vecinos no hubieran acudido á sus gritos, dando muerte al monstruo con sus navajas.

El príncipe Mauricio de Nassau, antes virey del Brasil, ase. gura haber visto cómo una holandesa fué devorada ásu vista por una serpiente; $y$ en un viaje á las Indins se refiere que un marinero habria tenido la misma suerte si sus camaradas no le hubiesen librado de las circunvoluciones de la colosal serpiente. Tambien Schomburgk cuenta una historia parecida que reproduciré mas abajo, y el obispo Pallegoix refiere que un pitónido đevoró un niño dormico junto al lecho de su ma. dre No negaré ni la exactitud de este aserto ni la de las noticias de Schomburgk y Wallace, pero dudo decididamente de todas las demás historias y de otras semejantes. Cuando un pitónido quisiera efectivamente atacar á un hombre con la intencion de devorarle estaria este perdido, como dice Hutton, en todos los casos, pues la fuerza de las circunvoluciones del animal es tan grande que apenas es posible la defensa. Pero en cuanto a devorar, esto me parece aun mas improbable que un ataque con intencion tan hostil, pucs la facultad de ensanchar las mandibulas, como ya queda dicho, tiene sus li. mites, y ninguno de los muchos cuentos quue se refieren, dicién. dose que los pitónidos dán caza tambien al hombre, se ha probado lo bastante para que pudiera ser creible. En todo caso es cierto que ningun cazador de la América del sur los teme; se les persigue con afan, y se aprovechan de varios modos su carne, la grasa y la piel. La primera la comen los indios; In grasa es buscada porque se le atribuyen varias y portentosas virtudes medicinales, y con la piel se preparan toda clase de adornos. En la actualidad casi no se emplea en esta caza otra arma que la de fuego; una carga de perdigones disparada á la cabeza basta para matar un boa, pues proporcionalmente \& su tamaño tiene menos vitalidad que orras es. peciès del mismo órden.

Con la misma frecuencia con que se mata á los pitónidos se les coge vivos sin gran trabajo, ya persiguiéndolos, ya dándolos alcance á la carrera, ó poniendo delante de sus guaridas lazos construidos de modo que dejan pasar la del. gada cabeza, pero no el tronco: estrechándose con tanta mas fuerza cuanto mas violentos son los esfuerzos del animal cuando intenta librarse. No hay miedo de que el reptil pueda ahogarse, porque segun liemos dicho ya mas arriba, todas las serpientes pueden permanecer mucho tiempo sin respirar. :

No se sabe nada hoy dia de los grandiosos preparativos para la caceria de que nos hablan los antiglos; estos datos no serín conocidos de todos mis lectores, mas parecen tan ca. racteristicos de aq̨uella época, que no debo pasarlos en silen. cio. De todas las descripciones, la de Diodoro Siculo es sin duda la mas excelente, tan minuciosa como interesante.

e La gente cuue vive cerca de los desiertos y de las regiones salvajes del pais de los negros, dice que alli hay varias espe. cies de serpientes de un tamaño increible. Algunos hasta pretenden haber visto tales reptiles de cien varas de !ongitud; esta noticia, sin embargo, me parece á mi, lo mismo que a otros hombres concienzudos una falsedad. Anaden que esas serpientes, cuando están enroscadas, parecen descle lejos una colina. Aunque estas son exageraciones, diré por otra parte, lo que sé de las grandes serpientes que se han visto y traido á Alejandria en jaulas construidas al efecto.

\$ Tolomeo II, que fué muy aficionado á la caza de elefantes y recompensaba con generosidad á los que cogian animales mus grandes, obligó á varios cazadores á exponer su vida en la caza de una gran serpiente y llevarla viva á Alejandria. Los cazadores habian observado este reptil, de treinta varas de longitud, que habitaba á orillas de las aguas estan. cadas donde casi siempre estaba entoscado é inmóvil hasta qque llegaba algun animal para apagar su sed. Entonces precipitábase súbitamente sobre la victima, cogiala con los dientes, y la estrechaba en sus circunvoluciones de tal modo que ya no podia moverse. Como el reptil era tan perezoso, se creyó poder apoderarse de él con cuerdas y cadenas. Di. rigiéronse los cazadores valerosamente hácia el monstruo, pero cuando al acercarse vieron sus ojos chispeantes y su lengua, que en todas las direcciones se movia; cuando ojeron el espantoso ruido que produjo con sus rigidas escamas: cuando observaron los colosales dientes y la terrible boca, él horror se apoderó de ellos. Sin embargo, atreviéronse aun. que con iniedo, á echarle cuerdas en la cola; pero entonces el monstruo se volvió produciendo horrisonos silbidos, cogio al primer cazador por la cabeza y devoróle vivo; al huir el segundo, alcanzóle en la fuga, enroscóse al rededor de su cuerpo y le sujetó; todos los demás, en extrenıo espantados, se salvaron á toda corret. 
* Los cazadores, sin embargo, animados por la esperanza de obtener el gran premio ofrecido, no desistieron de su empeño á pesar de la tentativa frustrada, é intentaron alcanzar por astucia lo que no pudicron ejecutar por fuerza. Con gruesas ramas construyeron una especic de jaula 6 trampa de tal capacidad que podia contener en su interior todo el monstruo; habian descubierto la guarida, y sabian tambien su hora de salir á cazar y de volver. Cuando estuvo fucra cerraron la cavidad con tierra y grandes piedras, abrieron en los contomos una cueva y en ella colocaror la trampa de modo quue la entrada cayese hácia fuera. Varios arqueros, honderos, muchos jinetes y otros hombres armados ocupa. ron el camino por donde solia volver la serpiente. Al llegar el monstruo, levantó la cabeza á mas altura que la de los jinetes, y nadie osó acercarse, pero cuando por todos lados se le arrojaron flechas y piedras, cuando los jinetes le rodearon y toda una jauria de perros empezó á ladrar, y cuando las bocinas resonaron, espantóse la serpiente y se dirigió hácia su escondite. Cuanto mas se acercaba, tanto mas acrecia el estrépito de las armas y los gritos y el ruido de las bocinas. La serpiente, hallando cerrada la entrada de su albergue, se rufugió en la trampa; los jinetes acudieron para cerrarla antes de que la prisionera pudiese encontrar la salida; entonces se sacó la jaula de la cueva y se levantó con palancas. il reptil silbaba horriblemente en su estrecha prision, cortaba las ramas con sus dientes y revolviasc furiosamente hácia todos lados; de modo que los hombres que le conducian temian á cada momento que saliese. Para que se alejase de las barras de la trampa, los cazadores empezaron á picarle en la cola, y de este modo se trasladó en fin el extraño y maravilloso animal á la ciudad de Alejandria, donde el rey dió la recompensa merccida á los cazadores. El monstruo, debilitado por el ayuno, se comesticó poco \& poco de una manera asombrosa. Tolomeo se quedó con la serpiente, $y$ mostrábasela á los extranjeros quue vișitaban su imperio corno su mayor curiosidad.

Mas adelante reproducire la descripcion de la caceria de un pitónido indio, relato que demuestra que este reptil pue. de espaniar aun hoy dia a los hombres medrosos, explicain. dose asi mejor la preciosa historia de Diadoro.

CA UTIVIDAD.- En el sur del Asia, asi como en América, se conservan pitónidos con mucha frecuencia en cauti vidad, dejándolos mas libres, porque se les emplea como há. biles cazadores de ratas. Algunos discipulos de Lenz, cuyos padres eran comerciantes en el Brasil, refirieron á este naturalista lo siguiente soore el particular: \&Al recoger el caut chuc los negros se apoderan alguna vez de un boa y se lo llevan á su casa; le ponen en un cajon que se cierra de dia, y llegada la noche dase al reptil la dibertad necesaria para cazar ratas y ratones. Tan luego como se ciern el grancro, un negro entra en él, abre la jaula de la serpiente, saca á esta y la vuelca despues de juguetear a menudo largo rato con ella; en seguida limpia el cajon, vuelve á llenar el plato de agua, sale y cierra la puerta del granero. Cuando una serpienie ha purgado aquel lugar de los parásitos, los negros, que con gran preferencia cuidan esos reptiles, buscan rato nes y ratas muertas para su alimento, y si estos faltan, sc ofrece á la serpiente carne cruda, despues de acostumbrarla á tal alimento. Por la mañana, antes de que se abra el granero, el negro penetra en el interior, coge la serpiente y vuelve á ponerla en el cajon.

- Estos pitónidos, accstumbrados ya à la cautividad, son mucho mas propios para enviarlos a Europa que no los recien cogidos; aquellos se conservan tambien muchos años en la jaula cuando se les cuida de un modo conveniente. Tanto en Firopa como en el norte de Aniérica, encuentran siem. pre compradores en los dueños de colecciones ambulanies, porque estas carecen de su principal atractivo si no tienen boas. Lleno de horror el sencillo campesino, y poscido de espanto, observa cómo el guardian, despues de pronunciar uno de sus curiosos discursos sobre todo el reino animal, y despues de haber recibido la inevitable propina, se dirige á una larga caja, saca de ella la boa envuelta en cubiertas de lana, la pone sobre los hombros, la vuelve por el cuello, y en general maneja al monstruo de una manera que hace erizar los cabellos a muchos espectadores. Por fortuna para los guaroiianes de una coleccion ambulante de fieras, que sin su Loa tendria que renunciar á la mayor parte de las ganancias, el trato con el dragon no es tan peligroso como parece á la multitud. Las jaulas de estos reptiles, á pesar de las botellas caloriferas que nunca les faltan, son tan insuficientes en 10 . das las colecciones ambulantes de fieras, $y$ el tratamiento deja tanto que desear, que los pitónidos se debilitan en corto ticimpo y se hallan al fin en un estado de continuo cansan. cio; entonces permien hacer cuanto ee quiera con ellos, $y$ hasta se dejan verdaderamente maltratar sin resistirse.

No sucede lo mismo cuando, como sucle hacerse en los jardines z.oológicos, se conservan las fuerzas de estas serpientes con una esmerada solicitud; entonces los guardianes corren à reces peligro, porque, segun he dicho antes, esos po. derosos reptiles odian a sus vigilantes, y ro solamente los amenazan, sino que hasta los acometen á veces. Esto se observa en ciertas ocasiones en todos los jardines zoológicos y 10 mismo he podido ver en los pitónidos cuidados bajo $\mathrm{mi}$ inspección. Tales atąques, sin embargo, no son nunca peligrosos para un guardian experto; cuando este ha de entrar en la jaula de un pitónido inaligno, lleva tan solo una colcha grande y gruesa, la cual presenta al reptil tan luego comneste se prepara para morderle, ó bien le coge en un saco de aber. uura ancha dejándole en ell hasta que ha concluido su trabajo. Uno de mis pitónidos llegó á enroscarse una vez en las piernas de su guardian, estrechándolas con tal fuerza que el hombre no pudo moverse y solo con ayuda de sus compane. ros se libro de aquella siruacion tan crítica. En vista de estos hechos me parece creible una desgracia referida por Lenz: parece que una muchacha que debia presentarse $a$ los espectadores como diosa india, con un pitónido enroscado alrede. dor del cuerpo, lué ahogada por la serpiente, cuyos instintos feroces se excitaron al ver un mono escapado.

Los pitónidos que no se cuidan mucho, proporcionándo. les el calor necesario y frecuentes baños en agua tibia, están sujetos.a no pocas enfermedades, y perecen sobre todo, por efecto de una especic de escorbuto. La serpiente ataca. da de este rnal pierde las ganas de comer, probablemente porque el ensanchamiento de la boca le ocasiona agudos do. lores; enflaquece y muere por fin, si no se aplican remedios convenientes por manos expertas. Tambien padecen una en. fermedad de la piel, que algunas reces se declara y se asemeja a los herpes; entonces se ulcera toda la pièl, ábrense profundos agujeros en los mísculos é impiden á la serpiente todo movimiento. Tambien en este caso los baños son el mejor remedio 6 preservativo. Los pitónidos, asi como otras especies de la familia, padecen tambien mucho de la solitaria y otras lombrices que se hallan en los intestinos á veces en número exorbitante; estos parásitos solo pueden matarse untando el animal que debe servir de alinento con el reme. dio que se ha de propinar, pues ya se comprende que no se puede dar la medicina sola á un pitónido.

Asi como la cautividad puede ser enojosa para los pitóni. dos, asi la liberiad completa puede favorecerles hasia en nuestro clima frio. Sobre este particular debemos a Lenz una noticia en alto grado curiosa. Iin los primeros años de nues. 
tro siglo establecióse una coleccion de fieras ambulante en Schlitz, ciudad de Hesse. Un pitónido de mediano tamano que formaba parte de aquella habia enfermado; y cierta no. che, en ausencia del propietario, el guardian encontró á la serpiente muerta al parecer. Temeroso de que se le culpara del percance arrojó el reptil al pequeño rio Schlitz despues de doblar algunas barras de la jaula para que se creyera que el animal habia escapado. El propietario de las fieras hizo recorrer á la mañana siguiente todos los contornos en busca de la serpiente perdida, pero no encontró ninguna huella, $y$ hubo de renunciar al fin ás sus pesquuisas. La serpiente, sin em. bargo, no liabia desaparecido; muy léjos de ello, habiase ar. reglado cómodamenter Sin duda era una de las especies aficionadas al agua, pues se habia fijado en el rioj a veces se la veia nadar en noches serenas, mas no sin dejar huellas de sus paseos nocturnos, que marcadamente pudieron reconocerse en los terrenos arenosos del parque condal. Todas las tentativas para volver á coger $a$ la fugitiva fueron inútiles, y entre tanto llegó la estacion'fria. La scrpicnte habia vuelto á desaparecer y paś otra vez por muerta. En la primavera siguiente, sin embargo, presentóse otra vez, apenas comenzó á sentirse el calor, dejándose ver cerca de Fulda, en el rio donde 1 menudo se banaban los soldados. Las persecucio nes no dieron tanjpoco resultado alguno $y$ en el invierno siguiente perdióse todo vestigio. No cabe duda sobre la exac. titud del hecho referido á Lenz por el jardinero Wimmer y confirmado por personas formales.

\section{LOS ERICINOS-ERICINE}

CARACTÉRES. - El grupo de los pitónidos suele dividirse en tres sub-familias, consideradas por algunos natura. listas tambien como familias independientes. Daremos el primer lugar entre aquellas á los ericinos 6 serpientes de arenal; porque tienen representantes tambien en Europa.

Difieren de los otros pitónidos principalmente por su cola muy corta, que no se enrosca, ni es por lo tanto movible. Su coloracion y su género de vida se asemejan, sin embargo, mucho á los de las especies que acabamos de describir. Tienen el tronco de regular longitud y redondo; la cabeza un poco prolongada; el hocico ancho y redondeado; los ojos pequeños; la pupila vertical, y la hendidura de la boca ancha. La piel está cubierta de escamas pequeñas y cortas; las placas inferiores de la cola presentan una sola serie; hay dientes en ambas mandibulas y en el paladar, pero no en el in. termaxilar: el carácter mas distintivo del grupo consiste en que ninguno de los escudos labiales es convexo.

DISTRIBUCION GEOGRAFICA. - Estasub familia, en la que hasta ahora solo se han determinado seis especies, pertenece al territorio septentrional del Antiguo mundo, al etiópico y al indico; está diseminada por el sur de Europa y norte y este de Africa; y por otra parte hasta la India.

USOS, COSTUMBRES Y RÉGIMEN. - Mientras que los demás pitónidos, es decir los verdaderos pitones, prefieren los paises donde abunda el agua y hay una rica vegeta. cion, visitando solo alguna vez los sitios secos, los ericinos ó serpientes de arenal habitan, segun indica su nombre precisa. mente, los terrenos mas secos y arenosos, en las estepas y desiertos, donde cazan mas bien debajo que en la superficic de la tierra.

\section{EL ERIX FLECHA -ERYX JACULUS}

CARACTÉREs. - Esta especie, tipo del género de los erix, el mas rico en especies, nos da á conocer el género de vida de todo el grupo tan completamente como es posible en el estado actual de nuestra ciencia. El erix tiene una longitud total de $0^{\infty}, 70$, y cuando mas $0^{\infty}, 80$, y se reconoce fácilmente por su cola corta, de punta redondeada; la cabeza es pequeña y no presenta separacion del tronco; está cubierta en el lado superior de pequeños escudos irregulares que mas hácia atrás tienen la forma de escamas. Las fosas nasales se hallan situadas á los lados y son muy estrechas; los ojos pequeños; las escamas ligeramente aquilladas; las que cubren la barba están separadas por un surco situado en el centro.

Ia coloracion principal de las regiones superiores es un amarillento gris mas $\delta$ menos vivo que en algunos indivi. duos tira al rojizo, y en otros al pajizo; la cabeza, excepto una faja negruzca que por cada lado se dirige oblicuamente desde el borde posterior de los ojos hasta los ángulos de la boca es de un solo color, ó presenta en el occipucio dos an. chas fajas negruzcas ó de un pardo oscuro, que se tocan en el centro; las partes superiores del tronco de la cola tienen manchas mas ó menos cuadrangulares y dispuestas en cuatro series longitudinales; estas manchas se reunen del modo mas diverso y representan los mas diferentes dibujos. La parte inferior es siempre mucho mas clara, de un solo color ó con manchas negruzcas. Se han observado muchas varie. dades.

DISTRIBUCION GEOGRÁFICA.-El área de dispersion del erix flecha, único tipo, segun queda dicho, de los pitónidos en Europa, se limita aqui á la peninsula del Balkan, pero se extiende por el este hasta el Altai y por el sur a una parte considerable del Africa del norte. En Europa se ve esta serpiente con mucha frecuencia; habita en Grecia y en varias islas griegas; en Rusia se halla en las estepas, á orilias del mar Caspio y muy á menudo á orillas del Aral; en Asia se la observa en Siria, Palestina, Asia Menor, Arabia y Persia; en el norte de Africa vive en los desiertos á lo largo de toda la costa y tambien en ambas orillas del Nilo, has. ta el territorio de las fuentes de este rio, donde viven las serpientes comunes.

USOS, COSTUMBRES Y REGIMEN.-Segun mis observaciones y las de otros naturalistas, este ofidio se halla siempre en sitios cubiertos de arena blanda, pues no caza en la superficie sino debajo de clla, y persigue con preferencia á los saurios que observan un género de vida análogo.

CAUTrVIDAD. - Ios cautivos que recibi, á veces en gran número, solo salen de dia cuando han padecido hambre mucho tiempo, y quizás tambien cuando por los movimien. tos en la superficie de la arena deducen la presencia de una presa, á la cual atacan despues, ahogándola como to hacen sus grandes congéneres; despues comienza la deglucion del modo acostumbrado. Los árabes cogen esta serpiente y una de las especies mas afines con mucha frecuencia, mutilándo. las casi siempre para cortarles la lengua. Los cautivos viven aun mucho tiempo, pero como no comen, al fín mueren sin remedio; mientras que los individuos no mutilados se con. servan muchos años en la jaula; pero no divierten ni al ob. servador mas aficionado, por la sencilla razon de que no salen á la superficie; cuando se les saca de la arena vuelven á penetrar al-punto en ella. Cuando no se les estorba-se ocul. $\tan a$ veces meses enteros, $y$ cuando se vuelve a enarenar la jaula causa asombro ver que aun existen estos reptiles. Todos los escamosos que viven tambien en la arena suelen haber desaparecido.

\section{LOS BOEINOS-BOAENA}

CARACTERES. - En la segunda sub-familia se reunen los boas a los cuales pertenece una gran parte de los ver- 
daderos pitones. Sus formas son muy prolongadas; la cabeza regular, marcándose bien en los lados la separacion del tronco; cl cuello es relativamente delgado; el tronco comprimido lateralmente y un poco deprimido en el centro; la cola pue. de enroscarse mas 6 menos; là cabeza estả cubjerta à menu. do de escamas en vez de escudos; la parte inferior de la cola tiene escudos anchos, dispuestos en una serie; hay dientes en la mandibula superior é inferior, en el paladar y en las ramas del hueso palatino, pero no el intermaxilar.

\section{EL BOA DIVINO Ó APRETADOR-BOA CONSTRICTOR}

CARACTERES.-El tipo mas conocido de la familia, al menos por el nombre, es el hoa hivino, llamado tambien serfienle real, representante del género de los boas ó englı. fadores que se distingue por su cabeza aplanada, obtusa en la parte anterior y separada marcadamente del cuello, cu. bierta solo en el borde de la boca de escudos rcgularmente dispuestos; las fosas masales estån situadas á los lados entre dos escudos.

El boa divino es una de las serpientes mas hermosas en general. El dibujo de su piel es muy vistoso y agradable, aunque pocos y sencillos los colores que alternan en el mismo. Fs el fondo un bonito rojo gris, corriendo por el dorso una anclia y dentada faja longitudina!, en la que se encuentran manchas amarillentas de figura ovalada. En la cabeza se ven tres líneas oscuras. Estos colores son mas vivos en.los indi viduos jóvenes, y sc encuentran unidas por líneas mas claras las manchas ovaladas. Suele medir el boa divino en todo su desarrollo unos 20 piés de largo, y mucho mas si iuésemos á creer las exageraciones de los indigenas. Con este motivo dice el principe de Wied lo que sigue: \&sta serpiente al. canzaba antes, y aun hoy $\left(1 \$_{25}\right)$ en comarcas completamente desiertas, una longitud de 20 hasta 30 piés y tal vez mas. En la actualidad, todavia se encuentran individuos gruesos como el muslo de un hombre, capaces de apresar un corzo y ahogarle en sus pliegues. En el Sertong de Bahia, Riacho de Resaque, me han asegurado que fué muerto recientemen. te un boa de dicho tamaño. En terrenos y bosques virgenes suelen encontrarse, al proceder a su roturacion, individuos verdaderamente colosales de csta familia. Schomburgk afirma que los boas alcanzan una longitud de seis á diez metros; pero ninguno de los dos viajeros ha medido tal serpiente $y$ ambos solo reproducen las noticias de los indigenas, de cuya exactitud debe dudarse por las razones arriba indicadas.

DISTRIBUCION GEOGRAFICA.-La zona que habita el boa divino es mas limitada de lo que generalmente se crec, pues opinan los erpetólogos mas entendidos en matcria de serpientes, que se confunden por muchos viajeros varias otras especies con esta. Dumeril y Bibron dicen que la verdadera patria de este pitónido es la Guayana, el Brasil y Bue-

" nos Aires. Segun el principe de Wried, abunda en la costa oriental del Brasil, encontrándose además hácia Rio Janeiro y Cabo Frio; y Schomburgk asegura que viveigualmente en la Guayana británica.

USOS, COSTUMBRES Y REGIMEN. - Considerados a la lur de nuestra ciencia actual, los relatos de nuestros viajeros modernos sobre el boa divino nos parecen del todo divertidos; pues precisamente ese reptil ha dado origen à las fábulas mas absurdas. Aun en tiempos de lacépede se creian todas las exageraciones en que incurrian viajeros ignorantes y sobre todo los misioneros. Aunque debe descartarse una buena parte de los cuentos sobre el boa divino, en particu. lar respecto á su insensibilidad y rigidez, para llegar a lo exacto, parece no obstante demostrado que en varias regio. nes, principalmente en el Istmo de Panamá, algunos viajeros encontraron unos boas divinos medio ocultos en las es. pesas yerbas de los bosques; como era la hora en que hacian la digestion, pasaron por encima de los reptiles; y si podemos dar crédito \& los relatos, hasta se sentaron sobre ellos, crejendo que aquellos reptiles eran troncos de árboles cubiertos de yerbas. Todo esto lo hicieron sin que las serpientes se movieran; solo cuando cerca de ellas encendieron fuego, el calor les devolvió la vida y comenzaron á moverse; entonces los viajeros, poseidos de espanto, reconocieron su error $y$ emprendieron la fuga." lacépede funda esta noticin en un cuento del padre Simon, quien refiere que en un bosque de Venezucla diez. y ocho españoles, cansados del viaje, creye. ron sentarse sobre un tronco de árbol caido, pcro luego echaron de ver con terror que el tronco comenzaba a moverse, trasformándose en un boa divino. Debo añadir, en disculpa del citado padre, que aun en obras modernas se han escrito tales cosas.

Lacépede cree que la serpiente real se llamó boa divino porque los mexicanos antiguos la veneraban. eSu terrible fuerza y su colosal tamaño, dice, el brillo de sus escamas y la belleza de sus colores causaron admiracion á varios pueblos que aun no se habian alejado mucho del rudo estado primirivo; pero como todo lo milagroso y terrible, todo aquello en que se re una superioridad produce fảcilmente en las cabezas ignorantes la supersticion, la creencia en un sér sobrenatural, tambien los antiguos habitantes de México consideraban al boa divino como sagrado. Desde entonces tributáronle honores divinos, ya por suponer que una mole tan grande que avanza con tal rapidez no puede moverse sino por un soplo divino, ó bien porque consideraban a esa serpiente como una servidora de los espiritus celestes. A causa de sus excelentes cualidades, diéronle el nombre del emperador; la serpiente se hizo objeto de su culto, y por consiguiente de su atencion particular. Ninguno de sus movimientos, ninguno de sus actos les fue indiferente; tem. blando oian sus largos y peneirantes silbidos, y en su ciega ie, creyeron que todas las manifestaciones de los diversos caprichos de este sér milagroso 5 divino podrian pronosticarles su suerte. El silbido del boa divino pas 6 à los ojos de los mexicanos, como sintoma de una gran desgracia, y á todos causaba espanto; la divinidad superior de los mexica. nos, Muiteliputali se representaba con una serpiente a la derecha: en los templos y altares de este idolo al que se hacian sacrificios humanos se encontró tambien \& menudo la imágen de la serpiente. N No arcriguaré si cectiramente fué el boa divino ú otra especie congenérica, propia de México, la que adoraron losmexicanos, ni tampoco afirmo ni niego que esta vencracion existió en realidad; pero creo justificada tambien la suposicion de que el nombre de boa divino es debido á las costumbres idólatras que los negros observan en el sur y centro de Anérica con las serpientes. Entre los indios de ahora los ofidios no tienen tanta importancia y aun no se sabe si jamás la tuvieton entre los negros, aunque representen todavía cierto papel, como explicaremos en otro lugar.

USOS, COSTUMBRES Y REGIMEN. - I.OS natura. listas citados dicen que el boa divino habita terrenos secos, bosques y matorrales. Fija su morada en las cavidades del suelo, hendiduras de las rocas y otros escondrijos parecidos, formando a veces pequeñas sociedades de cuatro 5 mas individuos. Suele enroscarse en las ramas de los arboles y ace. char desde alli sus presas. Nunca entra en el agua, mientras que varias especies congéneres pasan la mayor parte de su vida en dicho elemento.

Si se pudiera observar la actividad nocturna del boa dj. 
vino, sin duda se tendria de su indole una idea muy distinta de la que hasta aqui se ha formado. Cierto que tampoco de dia deja escapar una presa si se le ofrece, pero su verdadera actividad solo empieza con la hora del crepúsculo. Esto lo prueba bastante su conducta en libertad y en estado cautivo.

Nútrese el boa de pequeños maníferos y ares de varias especies, como tambien de algunos reptiles, especialmente individuos menores del mismo órden y ranas. Los boas de cierta edad se atreven con animales del tamaño de un corzo. Un cazador brasileño refirió al príncipe de Tied, que oyendo un dia aullar á su perro en el bosque, llegóse al sitio ansioso de averiguar lo que ocurria, y vió un constrictor de grandes dimensiones, que despues de haberle mordido en el muslo, lo tenia envuelto en sus pliegues y lo estrujaba con tal fuerza, que la sangre le corria por el cuello; un tiro disparado con acierto libertó al can, que solo pudo restablecerse por completo al cabo de algun tiempo. Historias como las que cuenta Gardner, de que las grandes serpientes americanas se engullen caballos adultos, pertenecen al dominio de la fábula, $y$ son seguramente inventadas por los mismos viajeros af fin de hacer mas interesantes y extraordinarias sus descrip. ciones.

Las serpientes en libertad no comen probablemente sino las presas que ellas mismas hacen, $y$ en manera alguna animales muertos, mientras que á las cautivas se les acustumbra con el tiempo á tragárselos. Asi cuenta Fffeldt que alimentó su boa con ratas muertas, pues las vivas causaban demasiados desperfectos en la caja; no acostumbran las serpientes desperdiciar esta comida, sino que hasta parecen apetecerla en cierto grado de putrefaccion.

REPRODUCCION. - En cuanto a la propagacion del boa divino en cautividad, no conozco dato alguno especial; en los cautivos se ha observado que son ovorivíparos. El principe Waldemaro de Prusia mató un boa hembra preñada que se consideró perteneciente á la especie que nos ocupa; tenia doce huevos ya tan desarrollados, que los hijuelos alcanzaban una longitud de $n^{n}, 30$ á $0^{\circ}, 50$. Westerman turo el gusto de cuidar pequeños boas divinos; la heubra parió su progenie viva, depositando además algunos huevos.

CAzA. - Todos los viajeros que han recorrido los bosques de la América del sur y encontrado este pitónido, aseguran que permanece inmóvil en sú sitio; solo huye cuando tiene al enemigo á muy pocos pasos de distancia, y que se puede matar muy bien á garrotazos. Schomburgk en una de sus excursiones, vió uno de estos reptiles, y hé aquí cómo refiere su encuentro: $8 \mathrm{~A}$ pesar de los consejos del indio que me acompañaba y de la repugnancia de nuestro perro, pronto tomé mi resolucion de intentar siquiera matar el boa, y me armé en el acto de un sólido garrote. Todavia sacaba la serpiente inmóvil la cabeza por encima del seto: me apro. ximé lentamente, preparándome para sacudirle un garrotazo que la dejase atontada, pero en el mismo instante en que iba á poner en obra mi pensamiento, habia desaparecido el animal debajo del césped, $y$ las ondulaciones de este me in. dicaron que huia mi presa; no pudiendo saliar al otro lado, segui la pista tan pegado como pude á la estacada.

¿De repente cesó el movimiento y ruido en la yerba y apareció la cabeza del boa á través del follaje, sin duda para explorar el terreno; un garrotazo que tuve la suerte de descargar con gran acierto en aquella cabeza, atontó al reptil, y antes que tuviese tiempo de reponerse; le sacudi con furia otros cuantos; cogiéndole despues con ambas manos por el cuello lo apreté con rodas mis fuerzas, hasta que el indio, que una vez pasado el momento de verdadero peligro se habia acercado, pudo quitarme uno de mis tirantes y sujetar con él mi presa. El espeso matorral, dificultando ias circun. voluciones que el reptil pretendia imprinir á su cuerpo, ali: geró nuestra tarea para hacernos ducños de él. El principe de Wied dice que en el Brasil acostúmbrase matar el boa divino á garrotazos y á veces tambien con la escopeta de caza, pues un tiro de perdigones basta para rematarlo.

Los buenos cazadores del Brasil se rien cuando se les pregunta si esta serpiente es peligrosa tambien para el hombre, pues solo el pueblo ignorante refiere las historias mas extranas sobre estos reptiles, historias que siempre se rechazan por todo viajero inteligente y observador concienzudo.

En la América del sur se aprovechan de varias maneras los restos de los boas. Los negros suelen comerse su carne; guardan la grasa para emplearla como maravilloso curativo de diversas enfermedades, y con la piel, despues de curtida, se construye calzado, sillas de montar y otros artículos por el mismo estilo; suelen tambien usarla á manera de faja, como preservativo de varias dolencias.

Los individuos de esta especie que se envian vivos å Europa, son, por lo general, cazados con red, la que se coloca delante de la abertura de su guarida En lo liso de los bordes y del suelo de la entrada, se conoce fácilmente si una cavidad estí habitada, adcmás de los otros rastros que siempre deja el grueso y pesado cuerpo del reptil; este suele retorcerse con gran violencia una rez cogido, pero es muy raro que llegue á causarse daño, pues al revés de lo que le sucede con las he. ridas, es bastante iusensible á las contusiones.

El boa divino que Schomburgk tenia fué atado á la puerta de la choza, pues el naturalista queria renovar sus pruebas sobre la resistencia vital de estos reptiles. El resuitado demostró que la precaucion era del todo justificada. «Unas risas estrepitosas y un silbido extraño, dice nuestro naturalista, me despertaron por la mañana en medio de mi sueño; salté de la hamaca presuroso y corri á la puerta. I a serpiente habia recobrado efectivamente el conocimiento, y hacia los mas terribles esfuerzos para escapar. Un círculo de indios que expresaban su ira y furia provocando al boa habiase reunido al rededor del reptil, que con la boca abierta producia unos sonidos horrorosos, semejantes ál los graznidos de la oca; los ojos parecian saltar de sus órbitas, y la lengua estaba en continuo movimiento. Al acercarme percibióse un olor de almizcle; y para acabar lo mas pronto posible con sus esfuerzos le dirigi un tiro á la cabeza.

CAUTIVIDAD.-Ya hemos visto que el boa divino presta buenos servicios como cazador de ratones y ratas en los graneros de los comerciantes y plantadores brasileños, por lo cual se le considera casi como animal doméstico, teniéndose en ciertos casos tal confianza que se le deja por la noche en el dormitorio. Su facultad de poder ayunar meses enteros sin perjuicio, aumenta su valor y facilita su trasporte. Este se verifica del modo mas primitivo. Enciérrase el animal en una caja de dimensiones convenientes, bien clavada y provista de varios agujeros para la respiracion, y queda de este modo el cautivo abandonado á su suerte. Como consecuencia de este trato poco delicado, y tal vez sambien á causa del hambre, suele manifestarse el reptil bastante mal humorado al llegar á su destino, procurando morder al que se le acerca; sin embargo, pronto pasan estos arrebatos, y una vez acostumbrado á sıl guardian, se deja coger y trasladar de un sitio á otro sin la menor resistencia. Necesita el boa para su bienestar una jaula espaciosa y caliente, con troncos y ramas para tre. par, y un depósito de agua practicado en el suelo para ba. niarse. Las cajas que se usan para este fin en las barracas de los domadores ambulantes, no corresponden en manera alguna á las necesidades del reptil, y las mantas de lana en que suelen envolverlo, bajo el pretexto de caientarle, no dejan de ofrecer sus inconvenientes; habiendo sucedido mas de 
una ver que ol boa, cediendo sin duda á los impulsos del hambre, se engulle la manta. Uno de la misma especie de que nos ocupamos, perteneciente á una coleccion de Berlin, conservó durante cinco semanas la manta en su estómago, ctrando la escupió toda entera ayudado por el guardian. Otro tanto ocurrió en el Jardin zoológico de Ióndres y en el del Tardin de Plantas de Paris. El de este último, que tenia Ir piés de largo, se tragó una manta de 5 piés de ancho por 7 de largo, la cual permaneció en el estómago desde el 22 de agosto al 20 de setiembre. En este dia la serpiente abrió la boca é hizo salir la punta de la manta, que cogió el guar- dian, pero sin tirar de ella: el animal entonces enroscó su cola en un árbol que habia en la jauła, y se fué retirando de modo que la manta, completamente conservada, quecóo en manos de aquel. La serpiente despues del suceso turo diez dias de postracion, pero pronto volvió á sus estado normal.

\section{LOS EUNECTES-EUNECTES}

CARACTÉRES. - Los eunectes ó nadadores son individuos muy distintos en su modo de vivir de los demás de la

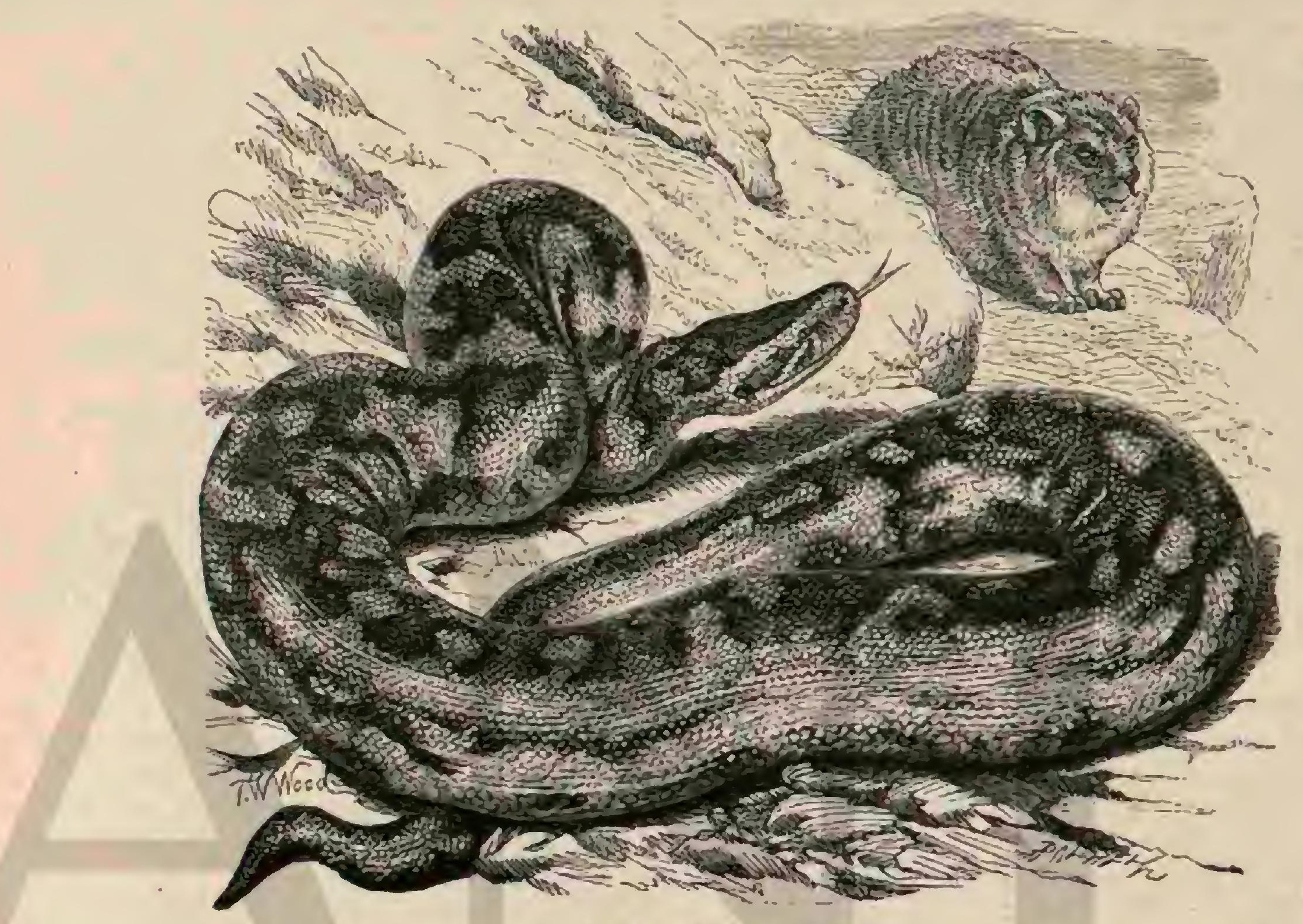

Fig. 6O.-EL BITON DE NATAL

misma familia; diferéncianse principalmente por las fosas nasales, abiertas encima de la punta del hocico entre tres escudos colocados perpendicularmente y que sirven para cer. rarlas herméticamente. La cabeza, protegida por escudos de forma irregular, es bastante pequeña relativamente á lo largo y grueso del cuerpo, cuadrilonga y aplanada, destacando muy poco del cuello, y con el hocico redondeado. El tronco es grueso, y la cola corta $y$ obtusa en su extremidad.

DISTRIBUCION GEOGRÁFICA. - Esste género habita los mismos paises gque el anterior.

\section{EL ANACONDA-EUNECTES MURINUS}

CARACTERES.-El príncipe de Wied ha descrito detalladamente la coloracion de esta única especie del género eunectes; dice que las regiones encineras son de un color oliváceo oscuro, algo gris en los lados de la cabera y amarillento en el borde inferior de la maisdibula; desde el ojo, cuyo íris es oscuro y poco aparente, corre hácia la parte occipital una faja rojo amarillenta, orillada de negro, y por debajo de esta, saliendo igualmente de la region del ojo, pasa oblicuamente por detrás de la boca y se prolonga hácia arriba, otra pardo oscura que destaca vivamente de la anterior; las partes abdominales, hasta la mitad de los costados, estấn salpicadas, sobre fondo amarillo claro, de manchas negruzcas, que en algunos pintos forman dos lineas longitudinales; al lado de estas manclins se ven dos filas de circulos negros con puntos amarillos en el centro, $y$ desde la cabeza hasta la extremidad de la cola corren dos líneas dorsales de manchas, mas 6 menos redondeadas, de color pardo oscuro, que en el cuello y por encima del ano se encuentran dis. pusstas con bastante regularidad, mientras que en las demás partes están mas 6 menos apinadas.

Entre los pitónidos del Nivevo Mundo es el mas colosal el anaconda. Hablan los viajeros mas fidedignos de individuos de esta especie de to metros de largo; debemos, sin embargo, observar que ninguno de ellos logró matar, y por consiguiente medir animal alguno mayor de 5 á 6 metros. Bates examinó uno qque tenia mas de 6 metros. Schomburgk refiere que cazó varios que median 5 metros, siendo tambien parecidas Jas.indicaciones que hace acerea del mis. mo punto el principe de Wied. Estos tres naturalistas dicen que testigos presenciales y dignos de rodo crédito les aseguraron que se habian muerto algunos individuos de esta especie que median mas de to metros de largo; sin embargo, por nuestra parte acostumbramos dar muy poca fe á estas valuaciones de gente profana, por mas que no dudemos de su honradez y veracidad; pues harto sabemos lo engañoso 
que es el ojo en esta clase de medidas, sobre todo tratándose de repiles, cuyas formas y modo de ser impresionan en alto grado las imaginaciones meridionales. Con todo, queda fuem de ducia que el anaconda es una de las principales, si no la primera, entre las serpientes de gran tamaño.

USOS, COSTUMBRES Y REGIMEN. - CTodas las noticias y nombres, dice el principe, que indican una residencia cn el agua se refieren á esta especie; pues vive casi siempre en dicho elemento y puede permanecer largo rato en la profundidad; pero á menudo sale á la orilla para reposar en viejos troncos de árboles, fragmentos de rocá ó mon. tecillos de arena, donde pueda tomar el sol 6 devorar una presa Flotando en el rio, pesca ó se pone al acecho junto a una roca para perseguir á los capibaras, agutis, pacas, y otros animales análogos. En el rio Belmonte, mis cazadores habian visto sobresalir los cuatro piés de un mamifero, que les parecieron los de un cerdo muerto; pero cuando se acercaron vieron que una colosal serpiente oprimia en sus anillos un gran capibara, muerto por el reptil. Dispararon al instante dos tiros al monstruo, $y$ un botocudo le tras. pasó con una flecha; solo entonces abandonó su presa, y sin hacer caso de la herida alejóse rápidamente, como si nada sintiera. Mi gente pescó al capibara que acababa de morir y volvió para comunicarme la noticia del suceso. Como me importaba mucho poseer la extraña serpiente envié en seguida á los cazadores para que volvieran á. buscarla; pero todo su trabajo fué inútil; los perdigones habian perdido en el agua su fuerza, y la flecha se encontró rota en la orilla, don. dela serpiente estaba.

El anaconda se alimenta de varios vertebrados, pero sobre todo de peces, cuyos restos se encuentran en su estómago. Vive mucho tiempo en el fondo de las aguas, donde descansa tranquilamente; \& veces asoma tan solo la cabeza a la superficie y observa la orilla; otras abandona su cuerpo rigido é inmóvil a la corriente, mas ó menos rápida, pero dis. puesto á precipitarse sobre cualquiera presa que pase á su alcance Este reptil es muy odiado por los colonos ribereños a causa de sus frecuentes rapiñas. Schomburgk dió muerte a uno que se habia apoderado de la gineta domesticada de una hacienda y la tenia ya casi ahogada. En otra granja le aseguraron al inismo naturalista, que el anaconda ataca con frecuencia á los cuadrúpedos domésticos y parti. cularmente á los cerdos; otros naturalistas confirman estas noticias. Mientras estábamos al ancla en cl puerto de An. tonio Malagueita, dice Bates, recibimos una visita poco grata. Un fuerte golpe en los costados de mi lancha, al que siguió el rumor de un pesado cuerpo que cae al agua, me despertó á media noche; levantéme presuroso para ver lo que pasaba, pero todo habia vuelto a quedar tranquilo $\mathrm{y}$ solo las gallinas de nuestro cesto de provisiones, que se habia atado á un lado de la embarcacion, í unos dos piés del agua, estaban inquictas y cacareaban. No pude explicarme esto, y como mi gente estaba en la orilla, volvi à la cámara y dormime hasta la mañana. Al despertarme encontré las gallinas pa. seándose por la lancha, $y$ al examinar el cesto observé un gran agujero; faltaban dos de las aves.

* El señor Antonio acusó de la fechoria á un anaconda, que segun aseguró, fué sorprendido hacia algunos meses en aque. lla parte del rio robando una infinidad de patos y gallinas. Al principio no quise creer que fuese uda serpiente el ladron. y acusé ś los caimanes, á pesar de que hacia algun tiempo que no habiamos visto ninguno de estos reptiles en el rio; pero me convenci algunos dias despues de la exactitud del ascrto de Antonio. Los jórenes de las diversas colonias se reunieron para cazar el reptil, y dieron principio á la batida segun todas las reglas del arte; examináronse los islotes en ambas orillas del rio, y encontraron por fin la serpiente en la desembocadura de un riachuelo tomando el sol. Despues de muerta pude examinarla al dia siguiente, y al medirla vi que no era de los individuos mayores, pues soln alcanzaba seis metros de largo por $U^{ \pm}, 40$ de circunferencia. Se pretende que el anaconda ataca al hombre, y es posible que la citada noticia del principe de Nassau se refiera á este reptil.

Schomburgk refiere el siguiente hecho: «Cuando llegamos \& Moroco (una mision en la Guayana), todavia duraba alli la excitacion producida por el ataque de una serpiente contra dos individuos de la mision. Hacia pocos dias que un indio habia ido en su bote, acompañado de su mujer, rio arriba á la caza de ánades y otras aves acuáticas. Herida una de estas, cayó en la orilla, y el cazador fué á recoger su presa, cuando de improviso se ve envuelio en los pliegues de una gran serpiente comtuti, como llaman los indigenas al anaconda; sin arma alguna, pues habia dejado la escopeta en el corial (bote), grita a su esposa que le traiga un cuchillo grande. Apenas llega la mujer á.su lado, fué presa igualmente del reptil, pero, felizmente con mayor libertad entonces el indio, que puede soltar un brazo, asesia varias puñaladas a su agresor, y debilitado, este por las heridas, desiste por fin de la lucha y emprende la fuga. Fué este el único caso, de que he tenido noticia, de haber el anaconda atacado ás hombre al. guno.) Hace bien Schomburgk en calificar este caso de úni. coi a nosotros nos parece tambien muy «singular, y creemos mas probable, de haber succdido tal como se lo contaron, que el ataque de la serpiente iba dirigido al ánade y no al indio; no siendo de extratiar quedase este envuelto en los pliegues del reptil, pues ya hemos dicho al tratar del ór. denlen general, que los ofidios no se distinguen ni por la potencia de su vista ni por la de su inteligencia. En cuanto al hacer presa de su mujer el anaconda, mientras tenia otra aprisionada con su cuerpo, confesamos sinceramente, que con la mejor voluntad no encontramos atenuacion plausible para esta segunda partc. Bates se hace eco igualmente de otro cúento de esta especie; dice que un niño de unos diez años, que se habia quedado en la orilla guardando el bote, mientras el padre se internaba en el bosque para recoger alguna fruta, fué sorprendido por un anaconda: felizmente, sus gritos hicieron acudir al padre, quien cogió resueltamente al reptil par la cabeza y le rompió las mandibulas, no pudiendo llegar mas á tiempo, pues el animal ya comprinia al mucha cho en las circunvoluciones de su cuerpo. Tambien Hum. boldt menciona expresamente lo peligrosas que son las grandes serpientes acuáticas para los indios mientras se banian. Sin embargo, por veridicas que fuesen todas estas historias, no pueden tan raras excepciones destruir la regla general establecida por el principe de Wied, de que el anaconda es inofensivo para el hombre y no infunde temor alguno a los indigenas y cazadores, pudiendo además ser muerto con la mayor facilidad.

Despues de abundante comida, el anaconda, al igual de las demás serpientes, pierde su actividad y permanece casi siem. pre en una misma postura, aunque sin afectar la rigida inmovilidad que algunos le atribuyen.

En todo lo que se ha dicho sobre el alimento y la in. movilidad durante la digestion, hay, segun el príncipe, algo de verdad, pero siempre mucha exageracion. Observa Schom. burgk-que el olor que despide el animal durante su digestion no puede ser mas pestilente, sirviendo de seguro con. ductor para descubrir la guarida de la serpiente. Si este olor proviene de la quimificacion dei alimento, ó de ciertas glán. dulas que se encuentran en las inmediaciones del ano, es cosa que no se ha podido averiguar todavia, segun afirma Waterton. 
Humboldt es el primer naturalista que ha dicho que el anaconda se entiern en el cieno y permanece en letargo, cuando se han secado las aguas que le sirven de morada. a menudo encuentran los indios, dice el misno, enormes pitónidos en dicho estado, y cuéntase qutse procuran irritarlos ó rociarlos con agua á fin de despertarlos. Semejante sutno invernal solo se verifica en determinadas regiones de la América meridional, pero nunca en aquellas donde ni el frio, ni un calor extraordinario perturban la temperatura templada de todo el año. Alli, segun el príncipe de Wied, no hay que esperar variacion alguna en el modo de vivir del anaconda, y cuanto se ha dicho respecto al sueño invernal, no tiene aplicacion á los bosques del Brasil; pues en los valles sombrios del imperio, donde constantemente abunda el agua y donde la serpiente no vive en pantanos propiamente dichos, sino en grandes lagos, rios y corrientes, cuyas márgenes refresca la sombra de árboles sectilares, se muestra tan vivaz y tigil en invierno como en verano. Los habitantes sin embargo saben que en la estacion calurosa. es decir, en los meses de diciembre, enero y febrero se mueve y se presenta mas á menudio que en el resto del año, porque entonces ya se nota el instinto de la reproduccion.

Durante el apareaniento produce un sordo mugido, se. gun el nismo observador y Schomburgk. No tengo ninguna noticia sobre el riempo y la manera de efectuarse el aparea. miento. Schomburgk dice que los hijuclos salen del cascaron, y que su nuínero llega a veces á cien (?). Tambien Schlegel encontró en el abdómen de un anaconda recibido de Suri. nam, no cien pero si unos veinte huevos, en los que los hijuelos estaban casi desarrollados y median una longitud de $0^{m}, 30$ \& $0^{\circ}, 45$. Parece, sin embargo, que la progenie puede nacer hasta en los huevos, porque un individuo de la co. leccion de Dinter puso en 26 de mayo treinta y seis, que envucltos en lana y a ura temperatura de $36^{\circ}$ se maduraron efectivamente hasta el 18 de junio, en cuyo dia el primer hijuelo, que tenia el grueso de un dedo, salió muy bien des. arrollado.

En libertad, suelen los pequeños echarse al agua tan pronto como han roto la cáscara, y vivir en sociedad durante algun ticmpo. «Parecia, añade Schomburgk, que varias hen. bras habian escogido aquel trozo de orilla para dar á luz sus hijuelos, pues multitud de estos ocupaban los árboles, cuyas ramas sobresalian por encima de la superficic del agua; aplicando el hacha á estos, a cada sacudida caian varios peque ños anacondas en nuestros coriales.)

Cuando leemos las descripciones de viajes antiguos no podemos extrañar que aun hoy dia se crea en terribles luchas entre hombres, anacondas y otros pitónidos. El padre Montoya cuenta, como testigo ocular, de qué manera procede el anaconda en la pesca. Arroja grandes cantidades de espuma sobre el agua á fin de atraer los peces; sumérgese despues, y cuando aquella espuma ha hecho su efecto, causa estragos entre los habitantes cscamosos de la profundidad. Una vez el honrado misionero vió cómo un indio adulto que estaba en el agua hasta la cintura fué devorado por una serpiente que al otro dia volvió a arrojarle.

Stedmann describe con vivisimos colores la caza que dió a uno de estos reptiles. Dicho viajero padecia de las fiebres y estaba acostado en su hamaca, cuando el hombre de guardia lé avisó que se veia entre los arbustos en l.2 orilla un bulto negro que parecia un hombre; mandó levar ancla $y$ que un bote se dirigiese al sitio indicado. Un esclavo reconoció que el bulto no era otra cosa sino un pitónido de tamaño muy regular; Stedmann dió órden entonces de regresar 1 la embarcacion; pero insistiendo el esclavo en atacar al reptil, excico de tal mocio el amor propio del jefe, que cste á juesar de sus dolencias, decidió seguir el consejo de aquel, y dirigiéronse á tierra, llevando Siednann una escopcia cargada y un soldado otras tres armas de fuego. Apenas habian adelantado unos cincuenta pasos por el cieno y maleza, cuando gritó el esclavo que tenian cerca á la serpiente. El enorme animal se encontraba á unos doce pasos de distancia, con ojos fulgurantes y moviendo continuamente la lengua. Apo. yando Stedmann su escopeta en una rama, apuntó \& hizo f́ego, pero la bala no incó al reptil en la cabeza, su parte mas vulnerable, sino que le hirió tan solo en el cuerpo. La serpiente sacudio este con tal furia, que las plantas en rede. dor parecian acabadas de segar, y metiendo la cola en el agua arrojó tal cantidad de cieno sobre sus agresores, que estos no tuvieron otro recurso sino emprender la fuga y sal tar al hote. Cuando se hubicron reanimado otra vez, insistió el esclavo en otro ataque: decia que pasados algunos minu. tos el animal estaria mas debilitado y no se atreveria a perseguirlos de nuevo. Stcdmann volvió \& herirle, pero tambien ligeramente, recibiendo al propio tiempo otra lluvia de cieno peor que la anterior. Excitado por el esclavo volvieron los tres â la carga, disparando sus armas â un mismo tiernpo, y con tal sucrte que tocaron al repril en la cabez.s. El negro, brincando de contento, trajo una cucrda, echó un lazo alsededor del cuello de la serpiente, que se reiorcia en sus convulsiones, y con aigun trabajo, ayudado rie sus companeros, pudo arrastrarla hasta el agua; una vez alli ataron la extremidad de la cuerda al bote y se dirigieron á su embarcacion. El anaconda, pues resultó ser un individuo de esta especie, tenia vida todavia y nadaba como una anguila. Añade Stedmann que esta serpiente midió i metros de largo, y que su grueso era tal, que le venia justo por el centro del cuerpo el chale. co de un negrito de doce años.

No podemos admirarnos por tanto de que tambien Schom. burgk al principio tuvicra miedo de atacar á un anaconda descubierto por su gente, y que refiera como sigue su primera caceria: El monstruo estaba en una gruesa rama inclinada por encima del rio, y tenia su cuerpo enroscado como un gran cable. Habia visto ya mas de un anaconda, pero jamás in. dividuo tan colosal. Durante algun tiempo estuve indeciso si le atacaria ó pasaria sin hacerle caso. Todas las espantosas descripciones de la fuerza extraordinaria de estas serpientes, que de niño me habian hecho temblar, volvieron a presen. tarse de nuevo ante mi imaginacion; por otra parte el aviso del indio que me acompañaba, de que si no heriamos mor. talmente al reptil del primer tiro, seriamos atacados por él y tal vez zozobrado nuestro corial, y el espanto que se apoderó del pobre Stockies (mi criado aleman), que me suplicaba, por la memoria de mis padres y de los sujos, no exponernos temerariamente \& tamaños peligros, todas cstas conside. raciones, digo, acabaron por resolverme $a$ desistir del ataque. Pero apenas hubimos dejado á nuestras espaldas aquel sitio, cuando me avergoncé de mi vacilacion y obligué á los remeros á volver la proa. Cargue ambos can̂nones de mi escopeta con perdigones gruesos y algunas postas; lo mismo hizo el mas atrevido de los indios. Nuestro bote se fue acercando lentamente al consabido árbol: todavla estaba alli, sin habes cambiado de postura, la tremenda serpiente. A una seña! convenida, disparamos á un riempo nuestras armas el indio y yo, teniendo la satisfaccion de ver caer en el acto al reptil, que despues de algunas contorsiones fué arrastrado por la corriente. En medio de nuestrus gritos de alegria, volo el 60. rial hácia el anaconda, y pasados pocos minutós lo teniamos ya á bordo. El resultado de la medicion fué: is piés y me. dio de largo por a y medio de circunferencia en la parte mas gruesa. A la eficacia de las postas debimos la facilidad con que despachamos al enorme ofidio, pues encontramos que 
una de cllas le habia roto el espinazo y otra la cabeza: heridas de esta especie, sobre todo en la cabeza, bastan, como tuve frecuentes ocasiones de comprobarlo posteriormente, para dejar en el acto, si no cadáver, á lo menos sin movimiento y completamente indefensa â la serpiente de mayor tamaño. Nuestros gritos y las dos detonaciones hicieron acudir al sitio los botes que nos precedian; Mr. King me reconvino amistosamente, confirmando lo dicho por los indios respecto al peligro á que voluntariamente me habia expuesto, $y$ añadiendo que en uno de sus viajes turo un encuentro parecido con un pitónido de 18 piés de largo, que solo pudo ser muerto al séptimo balazo.s

Despues de tales descripciones, cusa exactitud no quiero discutir, parece necesario agregar aqui algunas noticias del principe de Wied. \& Kegularmente, dice este naturalista, concienzudo por todos conceptos, el anaconda se mata con perdigones, pero los botocudos suelen atacarle con flechas cuando pueden acercarse lo suficiente, porque es muy pesado en tierra; sin embargo, por lo general no bastan estas armas para matar al reptil, habiendo necesidad de dispararle un tiro á la cabeza ó aplastarle á garrotazos. Sucede á nenudo que el animal escapa con una flecha atravesada en el cuerpo, encontrando despues medio de cieshacerse de ella y sanar la herida. Los habitantes de Belmonte, añade el principe, habian cogido varias de estas serpientés, y separádoles casi por com. pleto la cabeza del cuerpo; aun despues de haberles sacado las visceras y la grasa, todavia observábanse movimientos y sacudidas del cuerpo, hasta en algunas á las que se habia despojado de la piel.

CAUTIVIDAD. - En algunas colecciones ambulantes y en las de los jardines zoológicos de Lóndres, Amsterdam, Berlin y Paris, se ven anacondas vivos al lado de los boas divinos. Su tratamiento es idéntico, y lo que hemos dicho respecto á la cautividad de unos, es igualmente valedero para los otros.

\section{LOS SIFOSOMAS-XIPHOSOMA}

CARACTERES, - Bajo esta denominacion ha reunido Wagler dos especies de las que forman la sub-familia de que estamos tratando. Como los boas, tienen estas serpientes la cabeza y el cierpo cubiertos de escamas lisas, que en el hocico se convierten en escudos simétricos y diferenciándose particularmente en que los labiales aparecen con un surco bastante profundo. El cuerpo es nuy comprimido lateral. mente; el vientre corto y estrecho, $y$ la cola prensil. Schomburgk indica además como distintivo de este género, que sus individuos tienen los dientes incisivos de la mandibula inferior mas desarrollados que los de la superior, y que recuerdan en una especie ô las grandes serpientes venenosas.

\section{EL SIFOSOMA CANINO-XIPHOSOMA CANINUS}

CARACTERES. - Esta serpiente llega á alcanzar de tres á cuatro metros de largo, pero raras veces se ha encontrado un individuo de este tamaño. La coloracion de la parte superior del cuerpo cs de un hermoso verde, que se oscurece en el dorso, destacando á los lados manchas dobles ó fajas de un color vivo blanco; las partes inferiores son de un verde amarillo.

DISTRIBUCION GEOGRAFICA. - No se pueden fjar todavia precisamente los límites de la zona habitada por los sifosomas. Abundan sobre todo en el distrito del rio de las Amazonas, extendiéndose desde alli hácia el norte hasta la Guayana y hácia el sur hasta la parte mas septentrional del Brasil.
USOS, COSTUMBRES Y RÉGIMEN.-Un individuo de esta especie que durante algun tiempo se conservó vivo en el Jardin zoologico de Lóndres, descansaba casi siempre enroscado en forma de pelota en las ramas mas elevadas, con la cola agarrada á otra rama mas pequeña, lo que parecia demostrar que en libertad viviria probablemente a la $^{2}$ manera de la otra especie del mismo género (xiphosoma hor. tulanum), que Schomburgk vió constantemente cnroscada del mismo modo en las ramas de los árboles, su morada favori. ta. Es de suponer asimismo, que al igual de esta, prefiera las aves á las demás presas, aunque su calidad de excelente na. dador, no solo en agua dulce, sino tambien en la del mar, indique que el sifosoma canino no ha de despreciar tampoco los peces que pasen á su alcance Spix cogió uno que habia atravesado el Rio Negro, y el teniente del buque Freminui. lle aseguró á Dumeril que vió otro nadando en la rada de Rio Janeiro.

Segun autores mas antiguos, esta serpiente se introduce á menudo en las habitaciones y especialmente en las cabañas de los negros, en busca de alimento, pero sin causar jamás daño alguno al hombre. Sin embargo, si la irritan clava los dientes con fuerza, no siendo de muy fácil curacion la mordedura, como turo ocasion de observar Spix al apoderarse de la que vió en el Rio Negro. Despues que un indio de los que le acompañaban hubo atontado al sifosoma de un gar. rotazo, asestado con mucho acierto en la cabeza, el citado viajero, no pudiendo contener mas su impaciencia, se abalanzó y lo cogió con la mano; en el mismo momento la serpiente se enroscó con tal fuerza en su brazo, que este quedó como paralizado. Felizmente Spix la tenia sujeta por la ca. beza y habia alli cerca un pedazo de madera, que cogiéndolo con la otra mano pudo introducir en la boca del reptil, que clavó en el sus dientes. Por fin, los indios que al principio no se atrevian á acercársele por miedo de que la serpiente soltando al blanco se arrojase sobre ellos, ayudaron á Spix á deshacer los pliegues en que tenia aprisionado el brazo y á sujetar el sifosoma, que acabó de vivir en el esplritu de vino. Cuando en Europa lo sacaron del liquido, todavia apretaba en su boca el pedazo de madera; $y$ al exa. minarle se vió que los dientes lo habian atravesado de parte á parte.

No tengo dato alguno acerca de la reproduccion; Sclater habla muy poca cosa sobre la cautividad, acompañando un magnífico grabado de Wolf; pero no nos dice nada nuevo.

\section{LOS HOMALOQUILOS-HOMALO- CHILUS}

CARACTERES. - Otro tipo de la familia, no conocido hasta estos últimos tiempos, representa el género de los homaloquilos ó bons de labios lisos, cuyos caractéres son los siguientes: la cabeza marcadamente separada del tronco, es mucho mas ancha en la parte posterior que en la anterior; el hocico presenta un corte diagonal hácia abajo; la frente es baja y ligeramente cóncava en el centro; las fosas nasales, situadas lateralmente, hállanse cada una entre tres escudos; el tronco es muy comprimido; la cola fuerte y puede enros. carse mucho.

\section{EL HOMALOQUILO ENJUTO-HOMALOCHI- LUS STRIATUS}

CARACTÉRES. - Además de los del género, esta especie se distingue por los siguientes: solo en el hocico se ren escudos de forma regular; los que hay en la frente y entre los ojos son irregulares y están dispuestos de diverso mo. 
do; los de los labios no son "cóncavos. La parte superior del tronco se halla cubierta de pequeñas escamas que forman de cincuenta y sicte á sesenta y tres series; estas escamas, mas pequeñas en los costados, aumentan otra ver de tamaño hácia cl vientre, que esta protegido por escudos anchos y otros relativamente mas estrechos, dispuestos en una sola serie, los cuales cubren la parte inferior de la cola Tanto las mandibulas como el paladar están provistos de dientes; en cada uno de los maxilares superiores se encuentran veinte, y en los inferiores diez $y$ ocho. El color predominante de este reptil es un bonito rojo cobrizo; la cabeza tiene un solo color, 6 presenta en su parte posterior una mezcla de amarillo, con unas fajas que partiendo de los ojos se dirigen hácia atrás; en toda la extension del lomo se ven otras muchas trasversales muy espesas, rectas ú onduladas, de color blanquirco. La longitud de este reptil puede alcanzar tres metros $y$ mas.

DISTRIBUCION GEOGRÁFICA.-El área de disper. sion del homaloquilo enjuto parece limitarse á las Antillas. De aqui procedian los primeros individuos que dieron á conocer la especie en el mundo científico de Alemania y de alli recibí tambien, por mediacion del señor Pablo Gebhardt, residente en Cabo Haitiano, tres serpientes de esta especie que cuidé y observé bastante tiempo.

USOS, COSTUMBRES Y RÉGIMEN.-Segun las noticias de dicho señor, el homaloquilo enjuto fija su residencia principalmente en las plantaciones de azúcar, pero bastante á menudo tambien se presenta en las chozas de los indigenas, $\delta$ albérgase en los tejados de los edificios ruinosos, como por ejemplo de las iglesias viejas, donde caza las ratas pe. queñas, ares domésticas y otros animales del mismo tamaño, robando tambien los huevos. Durante el dia está muy quieto y descansa perezosamente, por lo cual la designan en su patria con el nombre de serpiente darmilana. Por la noche mués. trase en cambio muy activo y vivar, pues asi como todos sus congéneres, conságrala á sus cacerias. Los individuos recien cogidos son malignos y mordedores, pero familiarizanse pronto con el hombre y llegan á ser mas tarde tan dóciles como cualquiera otra especie de la familia; al principio rehu. san el alimento. Los individuos que yo recibi, s que estuvie ron once meses cautivos en casa del primer poseedor, solo despues de seis se resolvicton á comer una rata, por lo cual llegaron tan demacrados a mi poder, que uno de ellos murió muy pronto. Los otros comian al fin, y observé que al coger, degollar y devorar su presa, procedian exactamente lo mismo que otros pitónidos. En cambiose distinguian bastante de la mayor parte de sus congéneres por su gran destreza para trepar. Los otros pitónidos se sirven tambien del ramaje que se les ofrece para subir por él y descansar en la altura; pero el homaloquilo enjuto necesita mas: diriase que no le es posible vivir sin esta condicion, 6 por lo menos que no puede nunca disfrutar de la comodidad en que viven otras especies, aunque no parezca así al verle descansar perezosamente en el suelo calentado.

No puedo dar mas noticias sobre el género de vida de es. tas serpientes; la descripcion anterior es por lo demás la primera que de ellas se ha publicado.

\section{LOS PITONINOS-PYTHONINAE}

Megastenes dice que en la India las serpientes alcanzan tal tamaño que pueden devorar ciervos y bueyes enteros; Metrodoro refiere que en las orillas del rio Rindaco, en el Ponto, estos reptiles son tan grandes, que cogen en el aire hasta las aves de ruelo alto y rápido.

\&Es un hecho muy sabido que el jefe romano Régulo en
Ia guerra contra Cartago se vió obligado \& sitiar y atacar con gruesos proyectiles como si fuera una ciudad, cerca del rio Bagrada en el Africa septentrional, una serpiente de $\$ 20$ piés de largo. Isa piel y la cabeza de este reptil se conservaron en un templo de Roma hasta la época de la guerra numantina. Esta historia es tanto mas creible, cuanto que en la misma Italia las serpientes llamadas boas adquieren tales dimensiones, que en ticmpo del emperador Claudio fué muerta una en cuyo vientre se encontró un niño entero. El boa se ali. menta cuando jóven de leche de vaca, siendo este el origen de su nombre (de hos). Esto dice Plinio, el naturalista mas concienzudo de la antigüedad, y de sus palabras se desprende que la denominacion de boa deberia aplicarse á las grandes serpientes del viejo mundo. Fn el mismo sentido se expresa Humboldt. La primera noticia de un reptil de pro. porciones colosales, que hace presa del hombre y hasta de cuadrúpedos de gran tamaño, los estruja en los pliegues de su cuerpo rompiéndoles los huesos, y engulle cabras y corzos, dice el mismo, vino en primer lugar de la India y de la costa de Guinea. Por poca importancia que se quiera dar á un nombre, no deja de parecer extraño, que en el hemisferio donde Virgilio cantó los sufrimientos de Laocoonte, repitiendo una leyenda tomada por los griegos asiáticos de otros pueblos que vivian mucho mas hácia el sur, no se encuentra ningun boa constrictor; pues si la serpiente de Plinio era una serpiente africana y europea, entonces hubiera debido Daudin llamar pution al boa americano y hoa al piton indio.s Esta confusion no puede ya deshacerse: cuando la ciencia ha adoptado un nombre, no puede abandonarlo sin motivos muy poderosos que lo justifiquen. Hé aquí explicado por qué designamos bajo la denominacion de piron à los colosos del órden originarios del viejo mundo.

C.A RACTÉRES.-Ios pitones que componen la tercera sub familia de los pitónidos y son considerados por algunos naturalistas como una familia propia, se distinguen principálmente de las especies afines del nuevo mundo, como ya hemos tenido ocasion de observar, por los dientes interma. xilares y las dos filas de escudos infra-caudales; notándose además en estas serpientes, los surcos 6 fosetas en los escu. dos labiales, las ventanas nasales que à veces se abren lateral y otras verticalmente, los escudos desiguales que rodean estas y los simétricos que cubren la cabeza hasta la frente. Ia sub. division de los pitones está basada especialmente en la dis. posicion de las ventanas nasales.

\section{LOS PITONES PROPIAMENTE DICHOS-PYTHON}

CARACTERES. - En estegénero, solo la mitad anterior de la parte superior de la cabeza está cubierta de escudos regulares; la posterior no tiene sino escamas; el escudo del hocico y algunas de las placas superiores é inferiores de los labios presentan cavidades, y las fosas nasales se hallan situadas entre dos escudos de diferente tainaño.

\section{EL PEDAPODA Ó PITON MOLURO--PYTHON MOLURUS}

CARACTERES. - Esta scrpiente, tipo del género anteriot, puede llegar as tener, segun se ha reconocido, una lon. gitud de siete \& ocho metros; probablemente no existen individuos mas grandes, ó por lo menos son muy raros. I.a cabeza tiene un color de carne gris y oliváceo claro en el cráneo y la frente; el lomo es de un pardo claro, con mercla de amarillo gris en el centro y las partes abdominales blan. 
quizcas; una faja de color pardo de aceite se corre desde las fosas nasales á través del ojo y por detrás del ángulo de la boca hácia abajo; debajo de aquel órgano se ve una manclaa triangular del unismo color. y otra mas grande, ahorquillada, por delanie, con la punta dirigida hácia el hocico en forma de $Y, o b$ bien una sencilla mancha longitudinal situada en el occipucio y en la nuca; el lomo presenta una seric de manchas grandes y regularmente cuadradas, de color pardo, orilladas de un tinte mas oscuro y con borde denticulado ó liso; algunas que hay en el centro son de un color amarillo muy vivo; á lo largo de los costados se corre una faja de manchas longitudinales mas pequeñas de igual color: otros caractéres de la especie consisten en tener dos escudos anteriores $y$ dos posteriores en la frente; varias pequeñas plaquitas entre estos últimos y los de la coronilla; unas foselas triangularés en dos de los escudos labiales superiores y en cuatro de los inferiores; las pequeñas escamas dispuustas en sesenta y cinco series en la cara superior del tronco, y otras mucho mas grandes en los costanos.

DISTRIBUCION GEOGRAFICA.-El área de dispersion del pedapoda se exiende desde el sur de la península indica hasta el pié del Himalaya y desde la costa del mar Arábigo hasta el sur de la China.

Es dudosa su existencia en la península Malaya y no pro. baca aun su autenticidad con el piton propio de Ceilan; tambien sele ha encontrado en las islas de la Sonda, pero con menos frecuencia que á sus congéneres.

\section{EL PITON RETICULADO-PYTHON RETICU- IATUS}

CARACTERES.-El piton reticulado ó ularsniva (serpiente de los arrozales) de los malayos, no suele alcanzar una longitud mayor que la del piron nioluro; pero exagérase tambien su largura, suponiéndose que pueda ser hasta de diez metros. El culor predominante es un pardo de nuez $\delta$ aceitunado, 6 bien amarillento claro; una línea longitudinal estrecha de color negro, parte el escudo de la frente y se corre en línca recta hasta el cuello; otra, que comienar en el borde posterior de los ojos, se dirige diagonalmente por el labio superior hácia abajo, desde donde se corre mas ó me. nos directamente á lo largo del centro del cuello; tanto estas lineas como las primeras prolónganse desde luego en una serie de manchas de formas irregulares, ya redondeadas 6 cuadrangulares, que ocupan el centro del lono y resaltan marcadamente, por tener las escamas junto á los bordes negros un color mucho mas claro, casi blanquuizco. A cada lado de este conjunto de manchas hay orra mas pequeña en for. ma de ojo ó de malla, tambien irregular, de color blanquiaco y con borde negro, que contribuyen á completar la figura de la red de todo el dibujo. I a cara inferior del tronco presen. a lateralinente manchas irregulares negras, y la de la cola otras pardas, con dibujos semejantes a los del mármol. Entre los dos cscudos frontales y el de la coronilla se ven dos ó cuatro mas pequeños; cuatro de los superiores y seis de los inferiores de los labios son cóncavos; las escamas, que són pequenas, están dispuestas en setenta y cuatro series.

DISTRIBUCION GEOGRÁFICA.-El pinton reticulado habita no solo en la península de Maluca sino tambien en todas las islas del Océano Indico; se le ha cogido igual. mente en parajes dunde antes no se hallaba, como por ejem. plo Amboina, \& donde le llevaron los chinos.

USOS, COSTUMBRES Y REGIMEN,-Los viajeros é indigenas confunden ś menudo las dos especies de pirones, y por lo tanto no sienij)re es posible deterninar á qué espe. cie se refieren las descripciones. Prescindiendo de la exagc- racion, que fácilmente se puede corregir, hasta en las obras de historia natural hảllanse noticias poco exactas ó erróneas sobre estos reptiles conocidos desde hace muchos siglos.

Aun hoy dia circulan entre los indios historias sobre estas serpientes que recuerdan las fábulas de los antiguos ó igualan las exageraciones de los americanos del sur. De los informes, aun escasos, de naturalistas y viajeros, que se esforzaron por dar solo relatos verídicos, resulıa con bastante evidencia que los dragones del Asia meridional no son en modo alguno mas peligrosos que sus congéneres del nuevo continente; su género de vida estambien semejante al de ellos: habitan con preferencia las regiones pantanosas, los arrozales inundados y en general las cercanías del agua; pero tampo. co evitan las regiones secas; tanio aqui como alli dan caza á los perjueios vertebrados de las dos primeras clases. Los individuos muy grandes se atreven, segun se dice, ô veces á ata. car pequeños munjacs, ! de aqui nacen probablemente esos relatos por los cuales se quiere hacer creer que estas serpientes deroran animales hasta del tamano de un ciervo. Cierio que dichos rumiantes pertenecen a la familia cervina, pero su tamaño no iguala siquiera al de nuestro corzo, $y$ además se ha de tener siempre en cuenta, al hacer mencion de ellos, que en el Asia meridional viven los pequeños almizcleros, designados como ciervos no solamente por los indigenas, sino por lo regular tambien por los europeos de aquellas regiones. Hoy dia en la India circulan aun fábulas sobre ataques de los pitones contra el hombre; célebres pintores representaron unas horribles luchas enire serpientes y lascirs como hechos veridicos, y sus cuadros hasta han servido como de dato en las obras de algunos naturalistas crédulos, a pesar de que una mirada debia bastar para convencerles de la inverosimilitud del hecho; pero iodo esto no inducirá jamás á error ấ quien esté acostumbrado á separar lo verosimil de lo increible. Aunque en una obra lan.excelente como lo es a El viaje de la Novara se ericuentre la noticia de que nuestros compatriotas austriacos han visto en Manila un boa constrictor vivo de cuarenta y ocho piés, es decir unos quince metros de largo, por siete pulgadas ó diez y ocho centimetros de grueso, cualequiera podria rectificar desde luego el aserto diciendo que la citada serpiente no existe como animal propio de la fauna manilense $y$ que seguramente ninguno de los naturalistas que acomprañaron á la expedicion habria leido el informe sin corregirle anies de la impresion de la obra.

De los hechos verdaderamente documentados resulta las. ta la evidencia lo contrario de lo que dicen semejantes descripciones. Schlegel, que en su calidad de coleccionador, $y$ despues director de uno de los mas grandes museos del mundo, podia mejor que nadie emitir un juicio exacto, dice terminantemente que en la India son en extremo raros los pitones de mas de seis metros de longitud, y que su amigo Boje, el cual como viajero y naturalista pasó varios años de su vida en la patria de las dos especies de pitones, fijando especialmente su atencion en los reptiles, no logró nunca á pesar de las averiguaciones mas minuciosas obtener un solo piton moluro ó reticulado del tamaño arriba indicado. Los pequeños mamiferos constituyen el alimento preferido de ambos ofidios, y únicamente los individuos viejos y del todo desarrollados atacan alguna vez á los cerdos jóvenes ó álos hijuelos de las pequeñas especies de ciervos, sobre todo al muntjak. Los hombres y los grandes mamíferos no están nunca expuestos al peligro de ser devorados por esos reptiles; y aun los indigenas aseguran que estos pitónidos ni siquiera atacan a los riños. Despues de tales averiguaciones sérias, cada cual podrá creer lo que debe de las siguientes noticias de Clejer. En el reino de Arracan, en la frontera de Ben- 
gala, dice el citado holandés, vióse una serpiente de tamaño gigantesco atacar a un búfalo en la orilla de un rio. Su lucha era un espectáculo terrible; á la distancia de un tiro de cañon se oyó el estrépito con que crujieron los huesos del bú. falo al sucumbir, sofocado por su enemigo. Yo compré una serpiente de esa especie as un cazador y al disecarla encontré en su estómago un ciervo entero, de tamaño regular, con la piel y los huesos; en otra, un macho cabrio, salvaje, entero, á pesar de sus grandes cuernos; y en una tercera, todo un puerco espin con sus espinas. Fn la isla de Amboina, hasta una mujer embarazada fué victima de un animal de csta es. pecie. De igual manera tambien los viajeros antiguos nos ofrecen sus fábulas, y probablemente fué un recuerdo de estos cuentos lo que indujo á Wallace a dar mayor importan. cia de la que merece al ataque ya referido de uno de los dos pitones contra un hombre. En mi opinion, los ataques de estas serpientes contra el hombre, no son nunca intencionados, sino incidentales, como el que sufrió un guardian llamado Cop en el jardin zoológico de Lóndires. Fste hombre ofreció á uno de sus pitones hambrientos una gallina, segun solia hacerlo al darles el alimento; la serpiente se precipitó sobre la presa; mas no acertó á cogerla, sin duda porque se hallaba en el perfodo próximo á la muda, durantecl cual, como es sabido, no tienen la vista clara; y en vez de la gallina, cogió el pulgar izquierdo del hombre, arrollándole un momento despues el brazo y el cuello. Cop estaba solo, pero sin perder su presencia de ánimo, intentó coger con la otra mano la cabeza de la serpiente para librarse de ella; pero desgraciadamente el animal habia envuelto de tal modo su propia cabeza que el guardian no pudo cogerla, viendose obligado á echarse al suelo de la jaula con la esperanza de poder luchar asi con mas fuerza. Dos guardianes llegaron á tiempo en ayuda del hombre y le libraron, no sin esfuerzos, de su adversario, que de otro modo probablementele habria hecho sufrir la suerte de Laocoonte. Semejantes accidentes suelen ocurrir, segun he reconocido, por observaciones propias; pero estando libre, un piton no atacará al hombre sino en caso de que la necesidad le obligue á ello. No es el propósito de esa serpiente devorar ni al señor de ia tierra, ni á un animal grande, ni tampoco se atrcveráa luchar con el feroz tigre real. Hutton, que durante su permanencia en la India hizo observaciones en ofidios de esta especie, vió como uno de sus cautiros creyó conveniente soltar un gato que habia cogido y estrechado, porque este se defendió de tal modo que su enemigo no supo dominarle.

El informe citado sobre la reproduccion en libertad de los pitones del Asia meridional se confirmó completamente por observaciones en individuos cautivos. E) 1.0 de enero de 1841 se vió por primera rez, segun reficren minuciosamente Valenciennes y Dumeril, el apareaniento de dos pitones molu ros del Jardin de Plantas de Paris. Hasta fin de enero los animales se ajarearon varias veces; desde el 2 de febrero la hembra, que el citado dia habia derorado un conejo y cuatro kilógramos de carne de buey cruda, no comió ya, pero siguió aumentando considcrablemente de volúmen. El 6 de mayo depositó en ires horas y media quince huevos, uno despues de oiro; reuniólos en un munton, y enroscóse sobre ellos de manem que los anillos de su tronco formaron una bóveda plana, cuyo puesto mas aito ocupaba la cabeza. En esta posicion la serpiente permaneció casi dos rneses, desde el 5 de mayo hasta el 3 de julio, en cuyo dia salieron los hi. juelos. Durante este tiemp̧o se midió varias reces la tempe. tura que se habia desarrollado en medio de los repliegues $y$ hallóse que esta uxcedia á veces en $S^{\circ}$ á $10^{\circ}$ á la exterior. El espacio en que la serpiente estaba cubriendo los huevos cra un gran cajon calentado por debajo por medio de bote- llas caloriferas, y en el cual la temperatura podia subir of $20^{\circ}$ ó $25^{\circ}$. Esta última se conservó cuidadosamente durante todo el tiempo, circunstancia que sin duda contribuyó mucho al resultado favorable. De los quince huevos salieron en el citado dia ocho serpientes penueñas de unos $1 \|^{\circ}$, jo de largo; pero crecieron sin tomar alimento durante diez y seis dins; mudaron la piel entre el ij y is de julio, y cuatro re. ces mas hasta diciembre del mismo año, empezando a co. mer despues de la primera muda. Al principio se les dió gorriones, los cuales degollaron como sus padres; mas tarde recibieron carne cruda y peuzueños conejos. Como se les dió cuanto alimento querian, prosperaron muy bien, alcanzando ya en diciembre del mismo año una longitud de $1^{\circ}, 50$ s. ", 55 y hasta dos metros. A los veinte meses, es decir el 5 de marzo de $18_{43}$, la largura de los mas de ellos excedió de dos metros, es decir de cuatro veces la que tenian al nacer; uno llego a medir hasta $2^{\circ}, 34$. Este último individuo consunió en los primeros seis meses de su vida 13,1; kilógramos de alimentos. y en el segundo año 22. De esie hecho deduce Guenther que un piton moluro o reticulado de un poco mas de tres metros de largo debe tener unos cuatro anos de edad, y por observaciones hechas en el Jardin zoológico de Regent's Park sabemos que en los die\% años siguientes de su vida in longitud puede llegar á siete metros.

CAUTIVIDAD. - Ambrs especies de pitones se cogen muy á menudo en el sur del Asia, si bien no en todos los pueblos se les cuida con preferencia. Segun Martens, \& los chinos les gusta tener algun piton en sus barcos, y consi. deran como buen agüero que coma algo, asi como de pronóstico de desgracia si abandona el barco. Tanto aqui como en las casas donde se los cuida, persiguen con afan á las ratas. Valentyn habla de la habilidad con que proceden en esta ocasion: dejan a los roedores pasar soure su cuerpo sin moverse; cógenlos luego súbitamente apenas se ponen a la distancia precisa y devóranlos del modo acostumbrado. En agradecimiento ấ su urilidad se les deja obrar á su antojo en las habitaciones, sobre todo en los graneros, y quizás á consecuencia de esto, y recordando las buenas comidas que reciben en los barcos chinos, visitanlos bastante á me. nudo, como tambien las casas, donde no se quisicra ver. los. En 1840 , por ejemplo, hallóse un piton reticulado en la popa de un buque que habia anclado á unas tres ó cuatio leguas marinas de distancia de la costa, cerca de Singapore; y la tripulacion no supo liacer cosa mejor que matar de un tiro al intruso que habia buscado alli hospitalidad. Del mismo modo, Wallace se asustó mucho cierta noche en su casa de la isla de Amboina al ver que se introducia en ella un piton.

rPor la noche, dicc el citado viajero, solia pasar el rato lejendo en la galeria, dispuesto á coger los insectos atmidos por la luz. Una noche, á eso de las nueve, of un rumor particular sobre mi, semejante al que produce un animal pesado cuando se arrástra lentamente por el techo; pero muy pron. to cesó, y no pensando ya en él me acosté. A la tarde siguiente. poco antes de comer, cuando cansado de las fatigas del dia estaba leyendo echado en el lecho, vi, al mirar hácia arriba, una gran mole que antes no habia observado; y co. mo me fijase mas detenidamente, pude distinguir unas man. chas amarillas y negras. A primera vista parecióme aquello un escudo de tortuga, puesto entre las vigas y el techo para tirarlo; pero al continuar mi observacion reconocl que era una serpiente enroscada y luego pude descubrir la cabeza y los brillantes ojos en medio de los repliegues. Entonces me expliqué cl ruido de la noche anterior; un piton habia trepado por una columna de la casa, siguiendo su camino á un metro de alura sobre mi cabeza hasta colocarse debajo del 
techo, donde se echó cómodamente: yo habia dormido muy bien toda la noche debajo del enorme reptil.

Dlamé á mis dos muchachos, que estaban despellejando unas aves, $y$ dijeles que habia una gran serpiente en el techo; mas apenas les hube enseñado el animal, salieron precipitadamente de la casa, rogándome que la abandonase. Viendo que eran demasiado tímidos para emprender al. go, llamé algunos trabajadores de la plantacion y pronto reuni una docena de hombres, que celebraron consejo. Uno de ellos, indigena de Buru, donde hay mucbas serpientes, dijo que se atreveria á sacar cl reptil de alli, $y$ al punto puso manos á la obra, con todas las reglas y precauciones de un domador de serpientes consumado. Hizo un largo nudo cor. redizo de rotang (especie de bejuco) y cogiéndóle con una mano, nientras empunaba un largo palo con la otra, empujó con este á la serpiente, hasta que poco á poco empezó á desenroscarse. El indigena hizo entonces de modo que el nudo corredizo se ajustase sobre la cabeza del animal, des. lizóle poco á poco hasta el tronro, y lo apretó haciéndola caer al suelo. Cuando la serpiente se agarsó al techo y á la columna para resistir á su enemigo, produjo un gran rumor, pero el hombre la cogíb al fin por la cola, y saliendo de la casa corrió tan rápidamente que el animal pareció es. pantado. El indigena procuró luego estrellar la cabeza contra un árbol, mas no pudiendo conseguirlo vióse obligado á sol. taria, despues de lo cual la serpiente buscó refugio en un tronco muerto que se hallaba al lado. De aqui la hicieron sálir arrastrándola por la cola; oprimiéronla fuertemente contra un árbol, y la remataron despues sin dificultad con un hacha. Este reptil media unos cuatro metros de largo, rera muy grueso, y hubiera podido causar muchas desgracias, devorando ninos y perros.

No sé porqué Wallace acusa a una serpiente tan pequeña de una falta tan grave, pues por lo que yo he visto, en toda su obra no hace ninguna observacion que púdiera justificar tal opgition. He reproducido este pasaje para demostrar cuánto se teme en la India á los pitones. Mas se reconoce aun esto por un relato de Dobson sobre la caza del piton moluro, congénere del anterior. Una de estas serpientes habia llegado $a$ las innediaciones de la ciudad de Calcuta, $́$ é introduciéndose en un jardin đel arrabal, fué a colocarse en un árbol que đaba sombra á un arroyo. Con el fin de ahuyentarla, un hombre subió al árbol para sacudir la rama en que se habia enroscado; pero el reptil la solto al punto y precipitóse en un estang̣ve que habia debajo. El hombre, temiendo que le envolviera con sus anillos, saltó por el otro lado al suelo, expo. niéndose á romperse un hueso. El animal habia desaparecido debajo del agua y no se le volvió á ver por el jronto, ni tampoco en todo un mes, hasta que al fin descubriósele en otro árbol á la orilla del mismo estanque. Cuando Dobson llegó al sitio observó que habia cambiado otra vez de puesto, eligiendo como siempre un árbol favorito, que es el man. gle, en una de cuyas ramas, á considerable altura, habiase enroscado en una horquilia. Los indigenas explicaron su preferencia por estos árboles, diciendo que el piton sube á ellos cuando tiene hambre para coger las aves que al cerrar la noche se posan en el ramaje. Nuestro observador fotogra. fió la serpienté, y como el trabajo no se efectuó sin gran dificultad, hizose demasiado tarde aquel dia para intentar cogeria. Fué preciso contentarse por lo tanto con inducir al jardinero indigena, por medio de una propina, á vigilarla hasta la mañana siguiente. Mientras tanto, la noticia se habia divulg̨ởo, pues al otro dia presentáronse algunos hombres en el jaradin para dar.caza al monstruo, á cuyo efecto solici. taron la ayuda del jardinero dándole otra propina. Despues se esforzaron para inducir á los inoigeras á coger la serpien- te, ofreciendo una buena recompensa, pero no encontraron voluntarios que quisieran acometer tan peligrosa empresa. Para buscar ayuda volvicron á la ciudad, y de esta ausencia se aprovechó el jardinero, codicioso de una tercera propina, para avisar á varios vecinos, de cuyos servicios se habia asegurado Dobson. Estos enviaron á buscar un domador de serpientes, algunas redes y varios criados, esforzándose en frustrar la intencion de los otros. Fl domador trepó al árbol é intentó persuadir á la serpiente á dejar aquel sitio; pero el reptil, sin hacer caso de los descos del honibre, aplicóle un fuerte mordisco en la mano, y desenroscándose rápidamente trató de escapar; pero esta vez, el estanque estaba demasiado léjos, y el animal cayó en tierra. En el mismo instante los kulis la envolvieron en las redes y lleváronla en triunfo, con gran disgusto de los ausentes, que casi al mismo tiempo reaparecieron en escena, trayendo á su vez otro domador de serpientes y varios kulis. Dobson se vió obligado á tener el piton casi un mes en la jaula antes de poderle embarcar. Un capitan á quien quiso inducir á llevar la serpiente á In. glaterra, contestóle que tomaria cualquier cosa á bordo menos uno de aquellos reptiles, y negóse por consiguiente álllevar el animal bien guardado en un cajon; solo otro capitan fué bastante razonable para admitir dicho cajon como un fardo que no podia infundir ningun temor.

\section{LOS PITONES AFRICANOS}

No se sabe aun con seguridad si los pitones africanos constituyen una sola especie 6 son variedades de la misma. Algunos inteligentes distinguen tres especies; otros, solo dos, y varios parecen inclinados á reunirlas en una sola. Fundán dome en las minuciosas descripciones de Dumeril y Bibron, procuraré apuntar aqui los caractéres principales de las dos especies ó variedades mas comunes.

\section{EL PITON DE NATAL-PYTHON NATA- LENSIS}

CARACTÉRES. - En este piton, que solo habita en el sur de Africa, los dos escudos anteriores del hocico son mas largos que los siguientes; los dos frontales están menos des. arrollados aun y los otros son pequeños $y$ de forma irregular; el escudo de la nariz está provisto de dos fosetas, mientras que los dos del labio superior de cada lado solo tienen una. El color predominante del tercio anterior es un bonito pardo amarillo; el resto de la parte superior es de un pardo accituna mas oscuro, y la region abdominal de un bonito blanco rojizo; una mancha de un pardo aceituna, cuya punta se dirige hácia adelante, ocupa la mayor parte de la region superior de la cabeza; una serie de manchas enlazadas en forma de cadena, mas ó menos rectangulares $\&$ irregulares, dispuestas de varias inaneras y de color pardo aceituna, se corre por toda la parte superior y se continúa en forma de faja oscura en medio de otras dos longitudinales amarillas por la punta de la cola (fig. 60).

\section{EL PITON ASSALA - PYTHON SEBAE}

CARACTÉRES.-En este pitónido, diseminado por todo el oeste y centro de Africa, los escudos anteriores del hocico son mas cortos que los siguientes; los dos pares de la parte anterior de la frente, mas pequeños, están atrofiados dé modo que forman uno solo; en la coronilla se cuentan tres pares de placas; las fosetas de los escudos de la narir. y de los labios superiores, en fin, están distribuidos del mismo modo que en el piton de Natal. Una mancha en forma de punta de 
flecha, de color pardo oscuro $\delta$ negruzco, ocupa la parte superior de la cabeza, de modo que á los lados solo queda una faja estrecha de color blanco amarillento; el tronco es de color gris amarillo con manchas parduscas de formas muy variadas, cuyo interior es casi siempre mas claro que el borde, y con fajas trasversales que así como las manchas, parten de cada lado de una iaja oscura que en su parte inferior se toca con una placa de color amarillo claro. La region abdominal es de color amarillo gris.

USOS, COSTUMBRES Y REGIMEN.-Si Bosmann ha sido bien informado, á esta serpiente pertenece de derecho el apellido de divina, pues en varios paises de la costa de Guinea es adorada en templos guardados por gran número de sacerdotes. Segun refiere el francés Marchais, el origen de esta adoracion es el siguiente: Cuando el ejército del rey de
Widah estaba formado en órden de batalla, vino del lado del enemigo una gran serpiente, que se mostró tan familiar y domesticada que se dejaba tocar y acariciar. El gran sacerdote la tomó en sus brazos y la convirtió en idolo. Postráronse los negros para adorar la nueva divinidad, y cuando llegó el momento de la batalla, se arrojaron fanatizados sobre el enemigo dispersảndolo por completo. ¿A quuién sino á la serpiente, podia deberse la victoria? Demostrado pues su poder maravilloso, se consideró necesario erigirle un templo y dotar á este de sacerdotes que fuesen los ministros de su culto. La serpiente fué elevada á la categoria de diosa de la guerra, de la agricultura y del comercio, y debió prestar grandes servi. cios, pues muy pronto no bastó ya un solo templo para albergar à los numerosos peregrinos, que venian de los paises inmediatos a traer ofrendas $y$ adorar la divinidad reptil.

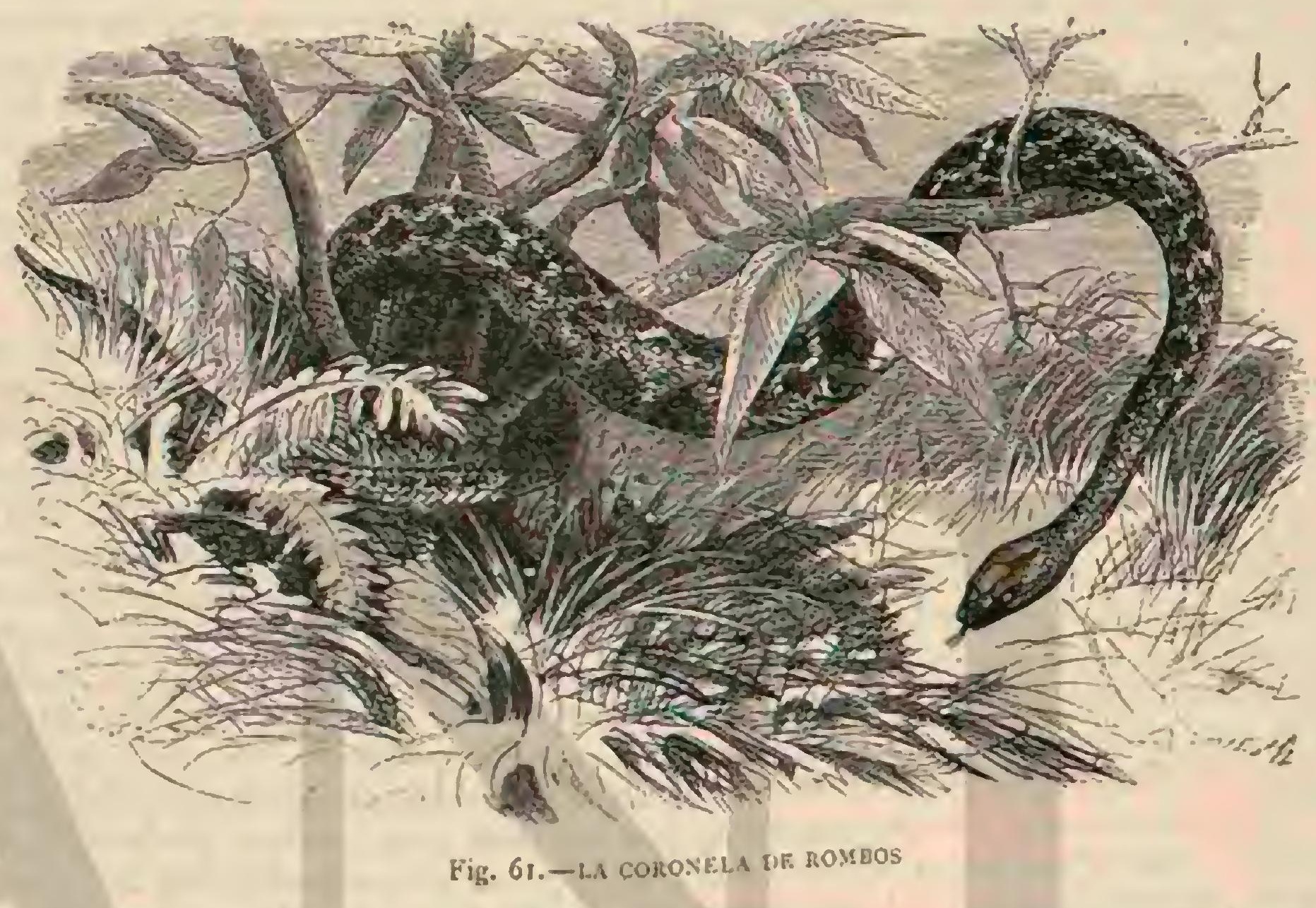

Fuć preciso construir muy pronto nuevos edificios para su culto; sacerdotes y sacerdotisas se presentaron para servirla, y todos los años se eligieron algunas de las virgenes mas hermosas para consagrárselas. Al principio, los creyentes se ofrecieron por su voluntad propia, pero mas tarde se les obligó a servir à la diosa. Armadas de pesadas mazas, las sacerdotisas recorrieron el pais en busca de las virgenes, amena. zando á todo el que se oponia á su santa mision, no con la excomunion ni la hoguera, pero si con el palo. De este modo lleváronse consigo las muchachas mas bonitas, quienes consideraron como un gran honor casarse con el idolo. Por lo pronto se les enseñó á cantar himnos y despues á ejecutar danzas sagradas; cortáronlas el cabello, y grabaron cu su piel marcas sagradas. Despues de haberlas preparado de esta manera dignamente para su enlace con el dios, conducianlas, con estrepitosa música, acompañada de bailes y cantos, cnsalzando su sublime destino, i un oscuro aposento subter. ráneo. Las virgenes que volvian de la santa carerna recibian el titulo de noivits de las serpientes; thas á pesar de esto se las permitia casarse, y el feliz clegido por ellas manifestábales la mayor veneracion $y$ humildad. Sin embargo, se las obligaba á guardar el silencio mas profundo sobre lo que habian visto en la caverna, y cuando osaban decir alguna cosa, los sacerdotes las robaban y mataban, liaciendo creer á todo el mundo que la serpiente se habia vengado de ellas asi. Matthew's nos dice, sin embargo, que no en todas partes se adora y venera fa estas serpientes; en otros paises de la misma region los inТомо $\mathrm{V}$ digenas no las consideran como deidades; muy lejos de ello, cázanlas para comer su carne.

Segun afirma el mismo Bosmann, la terne ó piton de Seba, no solo acomete á las cabras, cameros y cerdos, sino tam. bien á los leopardos; los indígenas hasta pretenden que en los terrenos pantanosos de las comarcas bajas, donde el hom. bre no la persigue, adquicrc un tamaño y una fuerza extraor. dinarios, de modo que engulle un búfalo; en una palabra; aun hoy se crec, o por lo menos se repitc, el antiguo cuento del dragon. Para el hombre, sin embargo, esta serpiente, segun dicen, solo es peligrosa cuando te encuentra durmiendo.

Respecto á su género de vida, sus usos y costunibres y la manera de tragar su presa, Masthews continúa sus fábulas del modo siguiente:

ePor lo regular, dice el mismo, frecuenta el piton los dis. tritos pantanosos, y alli se le puede ver cuando asoma la cabeza por encima de la yerba, alta de diez piés. El modo y manesa de acometer y devorar la presa lo describe este autor con bastante exactitud, pero \& fin de darle mas colorido, asegura que cuando el reptil estruja entre sus pliegues ála presa, le rompe los huesos. Añade tambien que cuando se ha tragado la victima, suele recorrer el terreno en un circuito de una milla de diámetro, para ver si hay algun ene. migo en las inmediaciones. Entre estos es el térmite el mas incómodo; pues cuando la serpiente, despues de haber to. mado su alimento, permanece durante la digestion inmóvil 
y aparentemente sin vida, estado que segun el tamaño y ca. lidad de la presa puede durar tres y custro dias, es atacada por las hormigas que penetran por todas las aberturas del cuerpo, y en muy poco tiempo devoran por completo al indefenso reptil.

De la anterior descripcion se desprende que Matthews no ha reunido observaciones propias, sino que se hace eco de los cuentos ridiculos é insustanciales de los negros, añadien. do tal vez algun detalle de su invencion.

Si damos por sentado que los pitones propios del Africa central constizuyer una sola especie, ó por lo menos observan casi el mismo género de vida, y si reunimos los datos conocidos que á los mismos se refieren, la descripcion de las costumbres de estos reptiles seria la siguiente: $\$ \mathrm{El}$ piton de Natal, el assala o tenne 6 como se le quiera designar, no parece abundar en ninguna parte, pero tampoco es raro y hasta abunda bastante en algunas regiones; ha desaparecido solo completamente en los distritos habitados. Los individuos viejos pueden alcanzar seis metros de longitud ó mas, pero escasean mucho, muy rara vez se ven los que miden cinco. Barth nos habla de un piton de Natal, muerto por su gente a orillas del lago Tschad, que tenia casi seis metros: y Russegger hace mencion de $u n$ individuo en extremo gran de, muerto durante su viaje por Sennar; yo he medido solo dos, uno de $2^{m}, 50$ y el oiro de $3^{3}, 15$, dimensiones que son para los sudaneses las de un verdadero monstruo. Schwein. furth describe un assala muerto por él, que tenia casi cinco metros, y asegura haber visto otro de scis. De esto podemos deducir el crédito quue merecen los, relatos de algunos auto. res que aseguran que estos pitones alcanzan una longitud de diez ádiez $y$ seis metros.

Es probable que el piton abunde mas de lo que generalmente se cree, pues solo se le encuentra de dia cuando ha abandonado los bosques cubiertos de alta yerba ó los espesos matorrales, su morada favorira, para calentarse al sol en sitios mas descubiertos. Si fuera posible penetrar de noche en la zona que habita esta serpiente y observar sus movimientos, se encontraria seguramente que su número no es tan reducido, pues solo despues de ponerse el sol empicza su actividad, y sale en busca de su presa. Todos los assalas que encontramos 6 de que oimos hablar habian sido inguie. tados sin duda durante su reposo diurno, pues procuraban escapar con toda la rapidez posible, apenas observaban que habian sido descubiertos. Bastante á menudo sucede que un peon $\delta$ jinete pasa junto 1 uno de esos reptiles mientras des. cansa, sin echarlo de ver, porque no le es necesario mover. se; pero no cabe duda que se les encontraria con ayuda de caballos expertos $\delta$ perros de fino olfato, que los descubren por el olor que exhalan. Esta particularidad explica los po. cos conocimientos que en toda el Africa se tienen sobre el género de vida del assala. Ni siquiera se pueden recoger datos precisos respecto a los animales á los que suelen acometer, dando lugar esta igrorancia á que la ardiente imagina. cion de los indigenas se complazca en las mas extravagantes historias, que pasan tambien á los relatos de viajeros europeos y hasta $a$ las obras de historia natural.

« Se nos eriza el cabello, dice Lacépede, al leer los relatos de los viajeros que han penetrado hasta el interior del $A$ frica, los cuales dicen cómo el gigantesco animal, senrejante á una enorine y larga viga, se mueve en las altas yerbas. $\mathrm{Ya}$ desde léjos se observa en las plantas deprimidas por su peso una especie de surco producido por los movimientos serpen. tinos de su cuerpo, y manadas enteras de gacelas y de otros animales, que constituyen su presa, hujen precipitadamente al divisar el monstruo. El único medio que resta al hombre en aquellos inmensos desiertos para preservarse de tan terri. ble enemigo se reduce á encender la yerba, medio quemada ya por el sol. I as armas no sirven de nada cuando es preciso habérselas con un individuo adulto, y sobre todo cuando este tiene hambre. Solo es posible escapar de la inuerte en. cendiendo todo el país al rededor, y parapetándose asi por medio del fuego contra la persecucion del monstruo, al que no detienen ni los rios ni los estrechos de mar, pues nada en medio de las olas alborotadas. Los árboles mas altos no sirven tamupoco de refugio, porque la serpiente trepa hasta las mas altas copas.

Lacépede funda esta descripcion, verdaderamente fran. cesa en los relatos de algunos viajeros, quienes aseguran que en los estómagos de los pitones africanos se han encontrado, no solamente mamiferos grandes, como por ejemplo ciervos reales, que como se sabe no son propios del Africa occidental, sino tambien hombres. Hago mencion aquil de estas fa. bulas tan insensatas porque estoy convencido de que podré refutarlas con demasiada frecuencia. Ningun piton africano, cualquiera que sea su nombre y género de vida, da caza á mamíferos mayores que un cabrito de un ano ó un perro de regulares dimensiones, y aun esta presa será sin duda una rara excepcion, pues conozco muy pocos relatos fidedignos que hablen de animales de este tamaño.

Durante los cinco años de su permanencia en los alrededores del Cabo de las Palmas, en el Africa occidental, Savage supo, ya por relatos ó por observaciones propias, que unos pitones de poco mas ó menos cinco metros de largo, labian cogido dos veces perrillos, y en otra oćasion un jóven antilope. Los perros solo pudieron ser salvados de los terribles anillos gólpeando ó hiriendo á la serpicnte; uno de ellos conservó largo tiempo un triste recuerdo de la acometida, pues le espantaba todo el mundo, y todo objeto. Uno de los ata. ques sé éfectuó de dia, y el otro de noche. A las altas horas de esta un piton visitó una vez tambien la casa de una negra, y apoderóse junto á su mismo lecho de una gallina. Schweinfurth describe de un modo interesante otro suceso análogo. \& En medio de unas profundas hendiduras del terreno, que en la estacion lluviosa formaban dos riachuelos confluentes, y en uno de los cuales estaba oculto mi companero con su asno, habia herido, oculto en las altas yerbas, un pequerio cabrito silvestre; vile alejarse al punto, aunque con torpe paso, y esperaba de un momento á otro que cayera, cuando de pronto oile lanzar un corto balido, y en el mismo instante desapareció de mi vista cual si hubiera caido en un foso. Entonces penetré por las altas yerbas hasta el sitio donde le habia visto por última vez, pero no pude encontrar nada. Dos escopetas que llevaba dificultaron mucho mis mo. vimientos; mas como sabia con seguridad que el animal de. bia estar en el sitio limitado entre las dos hendiduras continué buscándole, $y$ al fín le ví á pocos pasos, moviendo con viveza las piernas, aunque sujeto en tierra por un objeto que no pude reconocer. Acercándome un paso mas, vi entonces distintamente el grueso cucrpo de un piton, que en un triple anillo estrechaba al cabrito, oprimiendo la cabeza contra una de las piernas posteriores del cuadrúpedo.

Mas adelante diré de qué modo Schweinfurth mató aquel piton, limitándome á observar aqui que puestos sobre el lo. mo del asno, el reptil y cl antílope se mantenian poco mas ó menos en equilibrio. Falkenstein, en fin, mató, segun me escribe, un individuo de seis metros de largo en cuyo estómago se encontró un tragelafo adulto y tan poco digerido que excepto la cabeza, que faltaba, se pudo aprovechar todo el es. queleto. Repito que el assala rara vez acomete á animales tan grandes y pesados para devorarlos. Por lo regular se con. tenta con victimas mucho mas pequeñas, por ejemplo, liebres, ardillas terrestres, ratones y otros roedores que viven en 
el suelo; además persigue tambien á varias especies de aves terrestres. En el estómago de un individuo examinado por mi encontré una gallinácea. Drayson refiere, que viendo cierto dia en las inmediaciones de Natal una avutarđa pequeña, que repetidas veces emprenaiia el vuelo despues de posarse du. rante algunos instantes, observó al acercarse que el ave era perseguida tenazmente por un piton de esta especie. El viaje. ro acudió al punto y dió muerte á la exquisita ave; la serpien. te, al observar esto, creyó conveniente escapar con toda la rapidez posible, pero el cazador, que hacia mucho tiempo buscaba la ocasion de coger uno de estos ofidios, alcanzóle despues de una corta carrera y le dió muerte, ó por lo menos aturdióle de un garrotazo. Falkenstein me escribe además que en la costa occidental del Africa uno de estos reptiles quiso robar una gallina casi á su vista; y que muy á menudo se les sorprende en los establos, donde los negros los atan con un nudo corredizo, arrastrándolos as! para venderlos á los europeos. Anderson, en fin, reproduciendo algunos rela. tos de los indigenas, refiere que los pitones se alimentan principalmente de hirácidos; es posible que tambien este aserto sea exacto.

REPRODUCCION.-Por lo que recuerdo, los sudaneses no pudieron darme ninguna noticia por este concepto; pero hemos observado en individuos cautivos que no se diferencian en este punto de sus congéneres asiáticos. En junio de 3861 dos pitones de la especie se apareaton en el jardin zoológico de Lóndres y hácia mediados de diciembre vióse que la hembra aumentaba mucho de volúmen en una parte del abdómen, que ocupaba poco mas ó menos =",50 de la longitud total del cuerpo. El guardian, sabiendo que el ofidio no habia comido nada hacia algunas semanas, creyóle enfermo, $y$ solo pocos dias antes del 13 de enero reconoció la verdadera causa de un fenómeno tan extraordinario. En la manada del citado dia el hombre echó de ver que durante la noche anterior la hembra habia depositado un gran número de huevos (cerca de ciento, segun se supo despues), enroscándose sobre ellos del modo ya descrito. la puesta se habia verificado moviéndose la serpiente de continuo en un circulo y depositando asi un huevo despues de otro. Ninguno de ellos estaba unido con otro, pero mas tarde todos se adhirieron compactamente á causa de su piel pegajosa, comprimiéndose además tanto por el peso de la madre, que perdieron del todo su forma al principio redon. da. La hembra permaneció en la misma posicion hasta el 4 de abril; raras veces abandonó los huevos durante todo este tiempo, y solo por breve rato; hizolo sobre todo $\mathrm{el}_{4}$ de marzo, cuando quiso mudar de piel. Lsta operncion que en serpientes sanas exige cuando mas tres $\delta$ cuatro horas, duro aquella vez mas de diez, y la epidermis cayó á pedacitos, lo cual siempre es señal infalible de que una serpiente está enferma Como eran conocidas las observaciones de Valenciennés, en aquella ocasion se midió tambien la temperatura desarrollada entre los anillos del animal, empleando al efecto unos instrumentos sumamente sensibles, hechos expresamente para este fin. Fil resultado del experimento fué muy variado; pero pudo hacerse constar hasta la evidencia que el cuerpo de la hembra tenia mas calor que el del macho y que la temperatura entre los anillos era mas subida que la de las partes exteriores. Asl por ejemplo, con una temperatura exte. rior de $58^{\circ}, 6 \mathrm{~F}$. el calórico de dichas partes en el macho era de $70^{\circ}, 2$ y el de la hembra de $73^{\circ}$; entre los repliegues del primero se obtuvieron $64^{\circ}, 8$ y entre los de la segunda 819,6 . En otra prueba, hecha el 2 de marzo resultaron $60^{\circ}$, de tem. peratura exterior, $71^{\circ}, 6$ en las partes exteriores $y>6^{\circ}$ en las interiores del macho, por $84^{\circ}$ de calor exterior y $96^{\circ}$ interior en la hembra, obteniéndose por lo tanto una diferencia de $\mathrm{I} 2,4$ ó respectivamente $20^{\circ} \mathrm{F}$. para la hembra $\mathrm{El} 4$ de abril se reconoció hasta la evidencia que los huevos se hallaban en estado de putrefaccion, y como la serpiente los habia cubierto unas diez semanas y además ayunado casi treinta y dos, no siendo de esperar un resultado favorable, retiráronse los huevos. Un exámen detenido permitió reconocer que en cinco 6 seis de ellos habia embriones en parte desarrollados, alcanzando uno la longitud de $0^{n}, 29$. Tanto los escudos como el color y los dibujos eran ya visibles y de consiguiente los hijuelos hallabanse casi a punto de salir de la cáscara. Los otros huevos, excepto uno solo, formaban una masa grasosa en estado de putrefaccion y no pudo reconocerse si habian sido fecundados. En aquel huero se halló aun, quince dias despues de habérselo quitado á la madre, un embrion vivo. Cerca de un mes despues, la serpiente, que al quitarle los huevos se mostraba nuy inquieła, mudó por primera vez la piel, comió como de costumbre, y disfrutó desde entonces la mejor salud.

Caza.-Para dar caza a la assala, los sudaneses, sabien. do muy bien que este ofidio no es peligroso, se sirven de un sencillo garrote, porque un solo golpe fuerte en la cabeza del reptil basta para matarle Se nos dijo que con igual facilidad se conseguia esto de una sola perdigonada. Los pitones heridos, sobre todo cuando lo están gravemente, inten. tan al parecer defenderse, á juzgar por la descripcion de Schweinfurth, reproducida ya en parte. Cuando el citado viajero vió en poder del piton el cabrito que buscaba, retro. cedió a la distancia que le pareció conveniente para dispa. rarle un tiro, $y$ apenas lo hubo hecho, vió en el mismo momento al piton enderezarse ante el. \$Despues, continúa Schweinfurth, inclinóse hácia atrás y se precipitó con increible rapidez contra mí; pero solo la mitad anterior parecia movible, mientras que el resto del tronco estaba paralizado en tierra: le habia roto la columna vertebral. Al observar esto cogi mi escopeta, cargada de perdigones, y disparé tiros al monstruo hasta que no se movió. Hube de apuntar como pudiera hacerse contra una sombra nocturna, pues no me era posible seguir con la vista los movimientos del reptil.s En otros casos se convenció tambien Schweinfurth de que los pitones se pueden matar de un tiro con per. digones ordinarios si se les toca la columna vertebral.

USOS Y PRODUCTOS. - Fin el Sudan oriental observé que estas serpientes muertas sirven ante todo para la cocina: la carne se prepara con sal y pimenton, cociéndola hasta que se ablanda mucho: se come con tanto gusto como la carne de crocodilo. Habiéndome elogiado muchos bocado tan exquisito, hice preparar tambien para nosotros un pedazo de carne de la manera indicada. Este manjar tenia un color blanco como la nieve, era muy apetitoso y de un sabor en efecto agradable, algo parecido al de la gallina; pero la carne era tan dura que apénas podiamos mascarla. Segun Heuglin, los negros de Dor, á orillas del rio Blanco, comen tambien la carne de este piton, mientras que los negros del Dinka, habitantes del mismo rio, no consideran comestible, segun reconoció Schweinfurth, ninguna clase de reptil, y sobre todo las serpientes, á las cuales profesan gran veneracion: solo exceptúan las tortugas. En cambio los negros del Africa oc. cidental consideran las serpientes de esta especie como un bocado exquisito, y segun Savage, hasta guisan la piel y los intestinos preparando con ellos una sopa que, segun parece, aprecian mas que ninguna otra. Livingstone sefiere que los bushmans y los bakalaharis comen con gusto el piton de Natal Smith asegura que los indigenas del Africa meridional raras veces se atreven á perseguirle, porque le temen en alto grado; creen que puede ejercer influencia en su suerte, y que todo cl que una vez le haya ofendido sufrirá pron. 
to $\delta$ tarde el castigo de su insolencia. La piel abigarrada tiene para los sudaneses, al parecer, mas importancia que la carne: esos indigenas, así como los negros libres del Nilo Azul y del Bianco, fabrican con ella toda clase de adornos y la emplean de un modo en extremo vistoso como vainas de cuchillo, amuletos, carteras y bolsillos. En algunas tribus, sobre todo entre los namaguas, la grasa del assala tiene fama de poseer grandes virtudes medicinales, por cuya razon se conserva aun mas cuidadosamente que la carne; los enfermos la toman con la mayor fe, $y$ hé aqui porqué en muchos casos produce buen resultado. En el Sudan se cree, segun Schweinfurth, una cosa parecida, pero solamente se emplea la grasa como remedio para las enfermedades del oido.

CAUTIVIDAD. - En los jardines zoológicos y en las co. lecciones ambulantes de fieras, el piton de África no es mas raro que sus congeneres americanos; se acostumbra al guar. dán con la misma facilidad que aquellos, y cuando se le trata bien conservase mucho tiempo.

\section{LOS MORELIAS - MORELIA}

CAR ACTÉRES. - Un pitónido propio de la Nueva Ho. landa ha sido separado por los naturalistas de sus congéneres, á causa de distinguirse la disposicion de las fosas nasales y las escamas de la cabeza. Cada fosa nasal se abre en un escudo; la cabeza no está protegida por escudos mas que en su parte anterior y dos de los escudos labiales tienen fosetas.

\section{EL MORELIA ARGOS - MORELIA ARGUS}

CARACTERES. - Puede considerarse este serpiente co. mo la mas bonita de todos los pitónidos; la cabeza es negra; la cara superior del cuerpo de un negro azul, con manchas de un amarillo brillante; la region abdominal de un amari110 claro 6 de color de paja. Segun Bennett, este reptil puede tener una longitud de cuatro á cinco metros.

Bajo el nombre de serpiente alfombrada se distingue una segunda especie, pero Bennett no reconoce exacta tal separacion.

DISTRIBUCION GEOGRÁFICA.-El morelia argos es propio de la Nueva Holanda.

USOS, COSTUMBRES Y RÉGIMEN.-Segun las ob. servaciones de Lesson, esta serpiente habita con preferencia las regiones húmedas y a veces hasta el agua. Segun noticias del \&iejo buschman, vive en sitios descubiertos y suele frecuentar en tiempo seco las llanuras, donde se la encuen. tra enroscada en alguna caverna. En la estacion del calor suele acercarse \& las aguas, $y$ entonces reúnense varios individuos. Su alimento se compone de pequeños didelfos, ra. tas, ratones $y$ aves; un individuo examinado por Bennett te. nia en su estómago un kuso tan hien conservado, que aun se le pudo embalsamar y colocar en el Museo juntamente con el ofidio. \&Una vez, cuenta el viejo buschman, la vi fas. cinar á una bandada de avecillas. Se hallaba debajo de un árbol caido, en cuyas ramas secas se movia, saltando, revo. loteando y piando, una numerosa bandada de aves. Tamás he visto ondulaciones tan graciosas como las de aquella ser. piente: incorporada en parte, inclinaba la cabeza alternativamente hácia adelante 5 atrás y moviendo la lengua, intentaba atraer á sí una,victima; mas al verme á mi emprendió la fuga.»

No tengo ningun dato sobre la reproduccion de este reptil, y en general parecen muy escasas las observaciones publicadas hasta ahora sobre su género de vida.

CAUTIVIDAD. - Tambien esta especie se acostumbra pronto á la cautividad y aun se domestica hasta cierto pun. to. Bennett tenia un individuo de $2^{m}, 50$ de largo en la jaula, y podia permitirle enroscarse á veces al rededor de su bra. zo, el cual comprimia solo con la intencion de sostenerse; pero tan fuertemente que durante horas enteras el brazo quedaba paralizado.

\section{LOS COLÚBRIDOS - COLUBRIDE}

Linneo reunió todas las serpientes conocidas por él en tres familins, designándolas con los nombres de áfluras, pitones y culebras. Bajo este último nombre comprendemos aun hoy dia el grupo de los ofidios mas numeroso en especies; pero nos limitamos á una serie de géneros de las serpientes no venenosas que difieren de los pitónidos por carecer de las extremidades rudimentarias, por lo caracteristico de sus escamas y por la estructura de los ojos, cuyo iris es redondo.

CARACTERES. - Todos los colúbridos ó culebras se ca. racterizan por su cuerpo esbelto, elástico en toda su extension, del cual se destaca marcadamente la cabeza, que es pequeña, prolongada y de forma regular; la cola se adelgaza, terminando en una punta larga; la piel de las partes superio. res cstá cubierta de escamas sobrepuestas, ya lisas, ya aquilladas, mientras que en las regiones abdominales presenta escudos; estos se hallan separados en la barba por un surco y forman en la parte de la cola dos series. Ambas mandibulas y el paladar están provistos de hernosos dientes, todos iguales en tamaño. Asi puede decirse que entre las serpientes no venenosas las culebras son las que mas se distinguen por la regularidad de las formas y la estructura de todas sus partes, que no despuntan por ningun carácter notable. En cam. bio dificren de otros muchos ofidios por su desenvoltura, su vireza y cierto grado de astucia; de modo que en este concepto pueden designarse quizśs como las serpientes mas desarrolladas; en todo caso no son inferiores á los pitónidos.

DISTRIBUCCON GEOGRÁFICA. - Las culebras, de las cuales se han distinguido mas de doscientas cincuenta espe. cies, están diseminadas por todo el globo, puesto que se las encuentra, aunque pocas, hasta en la region del circulo polar, y algunas especies en Australia y en las islas del Pacifico.

USOS, COSTUMBRES Y RÉGIMEN,-No tienen to das las culebras igual predileccion en cuanto á las localidades donde fijan su morada; muchas especies prefieren los si. tios húmedos y las aguas, mientras que otras frecuentan los terrenos secos. Todas las cunocidas hasta ahora son verdade ros animales diurnos, como ya lo indica la forma del ojo; tan pronto como empieza á oscurecer se retiran á su escondrijo y permanecen alli hasta muy entrada la mañana del dia si guiente. Debido á la influencia de la distinta localidad habitada, diferéncianse bastante entre si las varias especies en su régimen y costumbres, si bien tienen, por otra parte, hábitos y condiciones comunes á todas. Son rápidos y ágiles sus mo. vimientos, reptando con cierta velocidad por el suelo; nadan algunasy trepan otras con extraordinaria perfeccion. Nútrense principalmente de pequeños vertebrados de todas clases, y por lo general de reptiles; sin emibargo, unas cazan con preferencia pequeños mamíferos, otras pájaros, habiéndolas tambien que tienen por presa favorita ślos peces, de tamaño comparativamente grande.

Cuando se introducen en una jaula donde hay distintas especies de culebras animales de varias clases segun conviene para las costumbres y deseos de estos reptiles, puede observarse fácilınente cómo una especie de culebras persigue á esta presa, mientras quie las demás eligen diferentes victimas para 
devorarlas. Ninguna de las culebras que yo conozco acecha f. los animales que casualmente pasan â su lado; todas dan caza al que mas llama su atencion, bien acercándose á ell á hurtadillas, $\delta$ ya persiguiendole á la carrera hasta cogerle. Nótase que las especies que comen ranas ó peces los devoran sin preparativo alguno: si son ranas suelen comenzar por las picrnas posteriores, y si peces, sicmpre principian por la ca. ber.a; las serpientes que persiguen á los lagartos, aves ó ámamíferos, siemprc estrangulan su presa antes de comerla; tra. tándose de otras especies, aun las mas afines, proceden como con los peces, devoríndolas tan rápidamente, que se las puede salvar cogiéndolas á tiempo por la cola y extrayéndolas del esófago ó estómago de su enemigo: una culebra ne. gra de la América del norte devorada ya hasta la extremi. dad de la cola por una coronela, fué salvada por mi de este nodo, y asi como el profeta Jonas, vivió aun varios aìos des. pues de escapar de la boca de su peligroso congénere.

Ias especies mas grandes de la familia son unas rapaces tan hábiles como atrevidas. Una que es propia de la América del norte, la culebra de las montañas (Eilaphis allegha. niensis), se nutre, segun Matthes, de ratones, ratas, ardillas, liebres pequeñas, de aves y sus huevos $y$ asimismo de serpientes, lagartos y ranas. Para coger los nidos de aves y ar. dillas trepa âlos árboles mas altos y apodérase de las licbres pequeñas penetrando en los agujeros subterróneos ó en los huecos de árboles. Los huevos constituyen para este reptil una golosina especial, $\$$ por eso se presenta en las casas de labranza donde hay gallinas; visita los corrales, devorando al punto los huevos donde los encuentra, $y$ hasta se introdu ce por debajo de las lluecas, sin hacer aprecio de los picota20s, envuclve con sus anillos los huevos, y esperando hasta que la gallina se tranquiliza, devóralos uno despues de oiro. Satisfecho su apetito, permanece tranquila debajo del ave, pero cuando esta se resiste con demasiada energia, ahuyéntala del nido. Matthes asegura haber visto cómo una culebra de las montañas, sin hacer caso de la presencia del observa. dor, devoró en la cocina tal cantidad de huevos, que despues quedó inmóvil donde estaba, sin tratar de defenderse 6 de emprender la fuga. «Yo corté, dice Matthes, la cabeza del reptil con unas tijeras, y al abrir su estómago encontré todos los huevos rotos; la serpiente los habia devorado enteros, pero aplastólos al llegar al centro del cuerpo, oprimiendo el vientre contra el suelo. Cuando las gallinas tienen polluelos, la serpiente se presenta de noche y se los come sin atacar á la madre. Tambien de dia intenta estas sorpresas, pero a veces la llueca rechaza el ataque con algunos picotazos ó aletazos fuertes.

En las comarcas mas frias, acostumbran las culebras à re. tirarse en los últimos dias de otoño á su guarida de inviemo, donde permanecen en estado de letargo hasta principios de la primavera.

REPRODUCCION. - A poco de salir del sucío invernal mudan estos ófidios la piel y empieza el apareamiento. Durante esta época algunas especies suclen presentarse muy irritables y dispuestas á acometer animales de major tamaño que sus presas acostumbradis. Algunas semanas despues pone la hembra de diez á ireinta huevos en sitios de liumedad tibia, y cuya incubacion abandona al calor solar. Los hijuelos se alimentan en los primeros tiempos de insectos y gusanos de toda clase, pero muy pronto adopian el modo de vivir de sus majores.

CAUTIVIDAD.-Casi todas las culebras se pueden con. servar en este estado durante muchos anos, pues no rehusan jamás la comida que se les ofrece; acostúmbranse fácilmente á su guardian, y hasta cierto grado se dejan domesticar por este.
UTILIDẢD. - Estos reptiles causan mas bien perjuicios que beneficios al hombre; de modo que solo tiene derecho a protegerlos aquel que sepa distinguirlos perfectamente de las especies muy parecidas de algunas familias venenosas.

Para poder examinar con mas faciidad esta familia tan numerosa, se han clasificado las culebras en varias sub familias sobre cuya importancia y limites varian mucho aun las opiniones de los erpetólogos. Al paso que algunos naturalistas agrupan todos los ofidios que se parecen a las culebras, y aun aquellos cuya dentadura difiere bastante del tipo general, y los reunen cuando mas en sub-familias indepen. dientes, otros elevan los grupos respectivos al rango de familias; y mientras que estos clasifican entre las culebras tambien las serpientes que solo se les parecen por su dentadura, aquellos agrupan las especies en cuestion en otras fanilias. Daré a conocer estas diversas opiniones, pero ateviéndome $\mathbf{a}$ la clasificacion que $a$ mi me parece mas conve. niente.

\section{LAS CORONELINAS-CORONEL-}

\section{LIN.F}

CARACTERES. - Fn la primera sub-familia, clevada por Ian al rango de familia, reunimos las coronelinas 6 culebras lisas, colúbridos relativamente pequeños ó de tamaño regular, cabeza y tronco planos, hocico no separado de la cabera y cscamas lisas.

\section{LAS CORONELAS-CORONELLA}

CARACTÉRES.-El género tipo del grupo comprende las coronelas, culcbras bien formadas y bonitas, con ironco robusto, redondo y no comprimido en el centro, cabeza de longitud regular, bastante plana y marcadamente separada del cuello, hocico redondo, cola de longitud regular, ojos medianamente grandes y pupila redonda; las fosas nasales desembocan entre dos escudos. in la frente hay cuatro, uno en la linea naso ocular y dos ó tres en las sienes; las esca. mas, pequeina, lisas, forman de diez y siete á veintitres se. ries; los escudos de la parte inferior de la cola constituyen dos; los dientes aumentan en tamaño de delante atrás, y el posterior presenta \& veces un surco.

\section{LA CORONELA DE AUSTRIA-CORONELLA AUSTRIACA}

CARACTÉrEs. - En loda Europa, desde el norte de Noruega hasta el sur, encuéntrase cste reptil en los sitios convenientes y en algunos con mucha frecuencia: la corone. la de Austria se designa tambien con el nombre de culebra lisa de Austria ó de 'Turingia Lista serpiente es una de las mas graciosas, ágiles y vivaces de Alemania y llega á una longitud de $0^{\circ}, 60$, ó cuando mas á un metro. El color pre. dominante de las partes superiores suele ser pardo; en la nuca se ve una gran mancha de un tinte mas ascuro, que por atrás se prolonga á menudo en forma de anchas fajas; á lo largo del lomo se corren dos series de manchas de color pardo oscuro, apareadas á veces; una faja del misino color pasa sobre los ojos y llega lasta los lados del cuello; la par. te-infurior del tronco es de un azul metálico o de un rojo amarillenio 6 bien de color blanquizco, á menudo con manchas inas oscuras.

Asi como en la mayor parte de los ofidios, el color $y$ los dibujos varian mucho. Encuéniranse varicdades de todos los. tintes, desde el gris hasta el pardo rojo, y segun Erhart, en 
las Cicladas hay una de un color verdaderamente magnífico, cuyo adorno consiste en dos listas de un rojo vivo de coral que desde el occipucio se corren por todo el lomo. Ian distingue la especie propia de Italia, conocida con el nombre de coronela de la Gironda (Coronella Girondica ó coluber Riccio. li), considerándola como independiente; mientras que las coronelas del Cáucaso y del Egipto (Coronella Cuncasica y Coronella agypliaca) son en su concepto variedades de la especie que nos ocupa.

DISTRIBUCION GEOGRÁfFICA.-En Noruega y Suecia, la coronela, asi como todos sus congéneres del mismo órden, solo se encuentra en sitios muy favorables y en todas partes con poca frecuencia. En Inglaterra, segun Wood, solo habita en las montañas calizas, donde abundan los lagartos; en Alemania no escasea en el Harz y en la selva de Turin. gia; mas hácia el sur se la ve en todas las montañas de me. diana altura, y asimismo en Austria, sobre todo en los paises de los Alpes, es decir por toda la Estiria, el Tirol, Carintia, Carniola y Dalmacia. En Grecia, Itália, Francia y España es conocida tambien; en Rusia habita desde Curlandia, Livonia y Polonia, casi todas las provincias del centro y del sur, hasta el mar Caspio; y en fin, hánla observado en el norte de Africa En los Alpes sube á una altura de 1,200 metros y en cl Cáucaso á la de 2,000.

USOS, COSTUMBRES Y RÉGIMEN.-Esta culebra fija por lo regular su morada en los terrenos secos, en las pendientes pedregosas y en las laderas pobladas de arbustos y expuestas al sol; sin embargo, se la encuentra tambien, aunque excepcionalmente, en las tierras bajas, húmedas $y$ pantanosas. Segun las observaciones de Lenz, la coronela lisa repta mas a menudo que la culebra de collar y la vibora por debajo de las piedras, y se esconde igualmente entre la yerba, asomando apenas la pequeña cabeza, sin duda para sustraerse 2 sus numerosos enemigos.

Es mucho mas ágil y vivaz que la culebra comun, lo cual se observa sobre todo cuando se la coge y levanta por la punta de la cola ó con un baston, en el que se enrosca al pun. to. En el primer caso puede alargar su cabeza rápidamente hasta la mano cuando está sana y no demasiado repleta; en el segundo se sostiene en el palo, segun me escribe Sterki, moviéndose vivamente y estrechándole con sus anillos; pro. cura tocar tierra, y si no lo consigue sostiénese sin caer, como to hace siempre la culebra comun en tales casos. A pesar de esta habilidad no se le ha visto nunca trepar, al menos que yo sepa; tampoco penetra voluntariamente en el agua, pero cuando se la arroja á clla nada rápidamente, apresurándose, sin cmbargo, para llegar cuanto antes á la orilla.

En cuanto al temperamento de este reptil, opinan muy di. versamente los observadores. Muchos lo consideran de carácter dulce $y$ apacible, mientras que otros hacen de ell una descripcion enteramente opuesta \& Es un animal colérico s maligno, dice lenz, que no solo muerde con furor en el acto de cogerlo, sino que semanas y hasta meses despues de tenerlo en cautividad y haberle prodigado toda clase de cuidados, todavía conserva la misma costumbre. Cuando sele tiende el guante ó la punta de la levita, muerde estos objetos con tal fuerza, que á veces queda suspendido de ellos durante ocho y mas minutos. Si bien sus dientes son tan pequeños y sobresalen tan poco de las partes blandas de la mandibula que apenas se perciben en los individuos vivos, sin embargo, son muy afilados y enganchan al mas leve contacto. Con la mayor facilidad se enfurece esta culebra hasta tal punto, que muerde cuanto encuentra á su alcance, individuos de su especie y hasta su mismo cucrpo; a pesar de estas tendencias jamás hinca los dientes en las piedras ni en los pedazos de hierro que sé le presentan. Entre el vulgo tiene muy mala tama, por considerarla venenosa; y en verdad, cuando gira la cabeza de un lado a otro con la boca abierta en busca de presa, es fácil confundirla con una vibora.s

Varias coronelas luchan á menudo entre si, prodigándose con frecuencia fuertes mordiscos. Si en estos combates se co. gen casualmente al mismo tiempo por la cabeza, segun dice Dursy, engánchanse í veces con los dientes corvos, y en este caso la lucha dura muy a menudo largo rato, porque ambos individuos tiran hảcia atrás en direccion opuesta, arrastrando el mas fuerte al mas débil. Pueden provocarse ta. les luchas cogiendo con cada mano una coronela por detrás de la cabeza, y poniendolas una frente a otra, y hasta bastaria irritarlas sencillamente ó arrojarles agua. En este úl. timo caso se precipitan con ira en todas direcciones cogiéndose ciegas de cólera. A este carácter maligno deben su mala fama, y como además se las tiene por venenosas, ié. menlas mucho. En efecto, puede confundirselas fácilmente con la hembra de una vibora cuando intentan morder furiosas.

Con este motivo dice Schinz: Yo mismo he tomado esta culebra a primera vista por una vibora, hasta que pude examinar sus caractéres. Cuando se observa la cabeza de cerca, desaparece toda duda, á lo menos para los erpetólogos; las grandes placas de la cabeza, el cuerpo delgado y brillante, que expuesto al sol refieja varios colores, la distinguen fácilmente; con todo, la equivocacion puede ser fatal, y conviene por lo tanto, examinar el reptil con atencion.

Para conciliar tan encontrados pareccres, podremos decir que la coronela lisa es de humor variable, $\delta$ que lo tiene, al igual del hombre, bueno y malo segun las impresiones que recibe; pues el mismo Lenz. añade lo siguiente á lo que ya hemos copiado: A veces cuando la temperatura es húmeda y fresca, se deja coger pacientemente y sin resistencia; pero, por lo regular, procura escapar, y lo hace con bastante agilidad, aunque en terreno llano sea fácil volver á alcanzarla. En todo caso es mas diestra y lista que la víbora ó la cule. bra de collar: cuando se la tiene suspendida por la extremidad de la cola, sucle levantar la cabeza hasta la altura de la mano.

Comparte á menudo este ofidio su morada con culcbras de otra especie, como la de collar; en cautividad vive en buena armonia con estas y las viboras, á no ser que le acose el hambre, en cuyo caso peligra la seguridad de sus compa. neras.

\$Solo cuando se le introduce en la jaula un raton vivo, dice Lenz, manifiesta gran excitacion y silba con fuerza, aunque solo á intervalos. Por lo demás no es fácil oirla sino cuando se la provoca durante su reposo.

Son los lagartos. su alimento predilecto; sin embargo, tam. bien acomete a las pequeñas serpientes, y segun afirma Erber, hace pasto igualmente de las jóvenes viboras á pesar de los dientes venenosos de estas. Wyder parece haber sido el primer autor que ha publicado observaciones acerca de la manera cómo estas culebras se apoderan de su presa; pero á naturalistas modernos debemos descripciones mas detalladas, y entre estas la mas completa es en nuestra opinion, la de Dursy. De la misma extractamos los siguientes párrafos: $₫ \mathrm{Si}$ se introducen algunos lagartos en la jaula de las coronelas, inmediatamente conocen aquellos el peligro qque les amenaza y corren como locos en todas direcciones en busca de una salida. Ias culebras tambien en el primer momento de sorpresa, procuran huir á toda prisa, y' es tal su precipitacion, que pelean entre si y se muerden unas á otras, sucediendo a veces que en su furor y ceguedad clavan los dientes en su propio cuerpo. A esta ruidosa introduccion sigue la pausa precurson del ataque. Moviendo rápidamente la lengua y 
con la cabeza levantada, parecen las culebras deliberar el plan de ataque, mientras que los lagartos excitados por el miedo, abren la boca y reunen sus fuerzas para desesperada resistencia. De repente precipitase uno de los ofidios sobre la victima que ha elegido; estira el cuello que tenia recogido hácia un lado, deslizase por el suelo con rapidez y coge entre las dilatadas mandibulas al lagarto en su fuga. Revolviéndose entonces en rertiginoso remolino, aprieta la culebra en estrechas circunvoluciones el cuerpo del lagarto que se echó sobre la espalda, $y$ luego no se ve mas que un informe ovillo, del que despuntan tan solo la cabeza $y$ la cola de la victima.

- Viene en seguida el pesado trabajo de la deglucion, pues no es cosa fácil para nuestra culebra engullirse el lagario todo entero; tampoco se da demasiada prisa en empezar, $y$ parece aninarse tentando su presa con la lengua, al propio tiempo que menea la cola, como suele hacer el gaio cuando saborea un buen bocado. Al fin, levanta el cuello, describe con él un arco y coge la cabeza del lagario entre sus manciibulas. Gradualmente se van aflojando los plicgues que suje. tan la victima; desaparece la cabeza de esta, al poco rato sigue el cuerpo, y al cabo de media hora ó poco mas, el pequeño saurio ha pasado todo á través del ancho esó́ago al aparato digestivo del ofidio.

No siempre es la victoria para la culebra, pues el lagar. to, aunque envuelto hasta el cuello en los pliegues de aque Ila, tiene la cabera libre, y con la boca abierta está dispuesto á resistirse tenazmente. Si la coronela no coge bien su presa al primer ataque, suele este colgársele de una de las mandibulas y gracias á sus dientes ganchudos puede sostener su posicion horas enteras. En vano procura desasirse el ofidio de su contrario; ambos animales permanecen asidos como dogos furiosos, y solo suelta su presa el lagarto, cuando exhausta de fuerzas la culebra y aflojando por completo las circunvoluciones de su cuerno, le permite escapar.

Para completar esta descripcion, añadiremos que la coro. nela lisa enrosca, por lo regular, su cuerpo en tres circunvoluciones al rededor de su victima y aprieta estas tan estrechamente, que llegan hasta los huesos, aunque sin cortar la piel, paralizando casi por completo no solo todo movimiento, sino que tambien las pulsaciones del cuerpo de la presa.

Al coger un orveto, la presa mas favorita despues de los lagartos, ensancha los anillos, pero siempre de modo que la cabeza de la víctima quede hácia arriba. Una coronela do. mesticada de Guenther comia tan solo lagartos; nunca quiso un raton ni una rana, si bien los mordia, lo mismo quea los demás animales. Despues de haberla alimentado su amo con lagartos de tamaño regular, quiso probar su fuerza dảndole un individuo muy fuerte $y$ grande: la serpiente le cogio al punto, pero despues de una larga lucha, durante la cual el lagarto, aunque sofocado al parecer por los apretones de la serpiente, pudo retirar siempre su cabeza de la boca de su enemiga, que ya la habia cogido para devorarla; la serpiente, cambiando de táctica, agarro al lagarto por la cola; esta se rompió y fuć devorada en el acto. Enionces, la serpiente se contentó con romper siempre dicha parte $a$ los demás individuos sin atacar ya á los lagartos que carecian de ella. Schlegel encontró tambien en los estómagos de las coronelas de esta especie, examinadas por él, varios ratones y Erber observó cómo se comian estos rocdores. Sin embargo, puede suponerse que mientras tienen lagartos y orvetos solo se alimentan de ellos. Fuerza es por lo tanto dar completo crédito \& Lenz cuando designa á esta culebra como dañina, puesto que no cabe duda de que nos son útiles los lagartos y orvetos a quienes persiguc.
Pretende Linck que nuestra culebra tiene horror a la humedad; arrojada al agua, aunque nada con destreza, procura ganar inmediatamente la orilla; en cautividad cuando se riega el suelo, la espanta una sola gota del liquido que toque su cuerpo, y busca con afan un rincon seco; no bebe nunca, y hasta intenta impedir que la humedad de la atmósfera penetre en su interior; diciendo el mismo autor en compro. bacion de este último aserto, que habia observado cómo uno de sus cautivos, no teniendo tiempo para huir de los vapo. res que producia la regadera, hincaba los dientes en el cuerpo de un compañero á fin de tapar herméticamente su boca. Sin embargo, las repetidas observaciones de otros naturalistas están en completa contradiccion con las anteriores de Linck, de modo que solo debemos considerarlas como una excepcion, y en manera alguna como regla general. Martin observó que una de sus culebras que no queria comer las ranas y ratones con que pretendia alimentarla, recogia ansiosa para apagar el hambre todas las gotas de agua que encontraba en la yerba $\delta$ en la cubierta de cristal, y Dursy menciona expresamente que las coronclas en cautivi. dad suelen beber el agua que se les pone en un cacharro, introduciendo el hocico por completo en el líquido y de. jando percibir un movimiento distinto de deglucion.

REPRODUCCION. - Wyder fué el primero que observó que la coronela lisa era ovovivifura, esto es, que la hembra lieva los huevos hasta el completo desarrollo del gérmen, de modo que los hijuelos rompen la cáscara y salen á luz en el mismo acto de poner la madre el huevo. Lenz encontró \{ mediados de mayo en hembras de gran tamaño, huevos de 7 lineas y media de largo por 3 de grueso: á fines de junio, observó otros que ya tenian una pulgada de largo por media de ancho, $y$ en su interior pequeñas culebras enroscadas, de 2 pulgadas y media de largo, con la cabeza muy gruesa y grandes ojos negros. El desove se verifica á fines de agosto ó á principios de setiembre, saliendo inmediatamente de los huevos pequeños reptiles de 6 pulgadas de largo y del grue. so del cañon de pluma de escribir, en numero de tres hasta trece; si la temperatura es favorable, buscan estos algun ali. mento, y se ocultan despues en un escondrijo adecuado para sustraerse á los rigores del invierno. Es imposible contem. plar séres mas graciosos que estas pequeñas culebras, dice Lenz. Las manchas del dorso aparecen en brillantes y delicadas líneas que terminan en la extremidad de la cola como puntas de aguja; los colores del cráneo, bastante ancho, se destacan vigorosamente, y la vista se recrea en el continuo cambio de arabescos que forma el cuerpo tan articulado del animalito al entrelazarse en los dedos del guardian 6 á través de los pequeños arbustos.

El mismo observador sospecha que la coroncla lisa, formando excepcion a la regla general de su clase, da á luz sus pequeñuelos mas de una vez al año.eEn todos los meses de la estacion calurosa he encontrado siempre jequerias culebras de esta especie; pero lo mas extraordinario es que en 3 de abril de 1845 , despues de un invierno largo y rigo. roso, recibi uno de estos pequeños séres que parecia haber salido del huevo ocho dias antes. ¿Habia nacido en el otoño último y caido a los pocos dias de su existencia en el sueño invernal? Esta suposicion no cra admisible, porque sus colores eran demasiado frescos y vivos para la piel ajada de in vierno, y era demasiado jóven el reptil para que la hubiesc mudado ya segunda ver. ¿Habian tal vez los frios tempranos obligado á la madre á refugiarse en el seno de la tierra lle vando en el suyo los huevos ya maduros, y al salir á la superficie de la primavera dió á luz el fruto de su cuerpo? Dificil es la eleccion entre ambas suposiciones; en todo caso este hecho parece demostrar evidentemente que la actividad 
sexual y el perfodo de gestacion tiene limites muy exten. dibles.

Gredler publica un informe en extremo curioso. El doctor Seterai, observador y aficionado á serpientes, que cuidó muchos años coronelas, obteniendo y criando repatidas ve. ces sus hijuelos, escribe al citado naturalista lo siguiente: «Durante las dos $\delta$ tres primeras sensanas, la hembra se cuida de alimentar á su progenic, comiendo gusanos de harina, pequeños lagartos, etc, los cuales expele al cabo de una 6 dos horas para introducirlos en la boca de los hijuelos. Hasta ahora no se ha observado semejante cosa en ningun reptil: aunque la noticia provenga de un observador instruido, paréceme en extremo dudosa.

CAUTIVIDAD. - Tan fácilmente sucle domesticarse esta culebra, que á los pocos dias ya no procura morder al guardian cuando este la coge con la mano ó la abriga en su seno para calentarla; sin embargo, como ya hemos observado, hay algunos individuos que continuan siempre rebeldes é hincan sus dientes cuantas veces se intenta cogerlos. Con todo, se recomienda este reptil por la hermosura de su coloracion y la gracia y delicadeza de sus movimientos; cuidado debidamente resiste largo tiempo el cautiverio.

USOS Y PRODUCTOS:- Durante algun tiempo, dice Lenz, la hiel de la coronela se ha empleado como remedio contra la epilepsia, por haberlo aconsejado asi un médico húngaro, muerto ya. Entonces, muchos doctores se dirigic: ron a mi para obiener esta hiel, yá fin de satisfacer sus deseos maté poco á poco mis culebras lisas. Al principio las echaba al efecto dentro del agua, pero esto las martirizaba algunas horas antes de morir; $y$ por lo tanto me limité despues á introducirles siempre jugo de tabaco en la boca, sustancia que producia uma gran hinchazon en la cabeza y la garganta; luego arrojaban espuma por las fosas nasales; revolcábanse aturdidas; $y$ al cabo de algunos minutos ú horas morian contrayéndose convulsivamente. Fácil es comprender que la hiel de serpiente no ha producido ningun efecto como remedio.

\section{LA CORONELA DE LA AMÉRICA DEL NOR- TE-CORONELLA GETULUS}

CARACTÉRES. - Esta cspecie es una de las coronelas mas bonitas que conozco, cuya longitud varia de $I^{\prime \prime}$ á $I^{\prime \prime}, 30$, de colores muy vivos y agradables; el que predomina es oscuro y puede variar en todos los tintes desde el pardo rojizo hasta el pardo negrurco y aun el negro. En la cara superior del tronco se ven fajas trasversales estrechas de color amarillo, separadas unas de otras por espacios de 0,02; ustas fajas van á reunirse por cada lado, en el límite de los escu. dos abdominales, con las fajas longitudinales, que forman de este modo una cadena continua hasta la extremidad de la cola. I.os escudos de la parte superior de la cabeza son de un pardo chocolate, con manchas amarillas de formas variables; los de los labios de un blanco opaco ó amarillento, con bordes de un pardo oscuro; los abdominales de un blanco sucio, con manchas pardas en forma de dados.

DISTRIBUCION GEOGRÁFICA.-Esta coroncla está diseminada en una considerable éxtension de la América del Norte y encuéntrase ya en las inmediaciones de Nueva. York.

USOS, COSTUMBRES Y REGIMEN. - Habita las llanuras doncie abundan los bosques y las grandes selvas. A causa de la agilidad de sus inovimientos, los norte-america nos le han dado el nombre de serpiente corredora, calificativo que en efecto merece, por lo menos en la jaula, porque es una de las serpientes mas vivaces y alegres que he visto. En libertad persigue solo segun parece \& los lagartos, y en cau. tividad prefiere tambien este alimento á cualquier otro, pero con el tiempo acostúmbrase á comer ratones y pedacitos de carne cruda.

CAUTIVIDAD.-Esta serpiente llega muchas veces viva á Europa, se conserva en la jaula si se la cuida bien; domesticase con el tiempo mucho y llega á tomar el alimen. to de la mano, distinguiéndose ventajosamente de sus con. géneres porque no es aficionada á morder. Cierto dia que puse a uno de estos bonitos reptiles en la misma jaula con un corifodon constrictor, originario del mismo pais, intentó la fuga al ver á este último, y viendo que no le era posible huir, tomó una posicion amenazadora, pero á los pocos momentos su enenigo se acercó as ella, cogióla por la cabeza y la devoró, tan rápidamente que apenas nos quedú tiempo para cogerla por la cola y extraerla de la boca del corifodon. Salro algunos leves rasgunos en la cabeza, no habia sufrido daño alguno, y vivió aun varios años despues de este accidente.

\section{LA CORONELA DE ROMBOS-CORONELA RHOMBEATA}

CARACTERES, - Ia parte inferior del tronco de esta serpiente es de un color pardo amarillento 6 blanquizco con manchas negras, distribuidas en cuatro series; pero las dos medias se unen confundiéndose algunas veces. La placa rostral, muy prolongada, se estrecha de la base á la cima, aplanándose casi sobre el hocico en una tercera parte de su extension (fig. 61).

DISTRIBUCION GEOGRÁFICA. - Esta serpiente habita en la punta austral de Africa, y abunda sobre todo en los alrededores del cabo de Buena-Esperanza. Mr. Smith asegura que se la encuentra en toda el Africa del sur.

USOS, COSTUMBRES $Y$ REGIMEN.-Parece que la coronela de rombos se alimenta sobre todo de ramas: Mr. Schlegel dice haber reconocido en el estómago de uno de estos reptiles los restos de pequeños mamiferos rocdores. La coronela de que hablamos vive por lo regular en terrenos secos y áridos, aunque sin despreciar aquellos que están cu. biertos de yerba; muérese con mucha rapidez y sabe cazar con destreza los lagartos, insectos y reptiles de pequeño tamaño de que se alimenta.

\section{LAS COLUBRINAS-COI.UBRINAE}

CARACTERES. - La sub-familia de las colubrinas 6 culeuras terrestres no comprende la major parte de las espe. cies, pero si las mas desarroiladas. Tienen el cuerpo de longitud regular ó bastante largo, de estructura simétrica en todas sus partes; la cabeza marcadamente separada del tronco, pero no la cola; la hendidura de la boca es ancha; $y$ en todas las especies existe el escudo de la línea naso-ocular.

\section{LAS CULEBRAS PROPIAMENTE DICHAS - COLUBER}

CARACTÉRES.-Este género se caracteriza por su tron co de longitud regular, redondeado en la parte superior, y de cuya largura total la cola ocupa una quinta parte ó menos. Los ojos son medianamente grandes; Jas pupilas redondas; las fosas nasales, situadas lateralmente, se hallan cada cual entre dos escudos, que suelen proteger la cabeza; los del vientre, lisos 6 ligeramente aquillados, forman de diez y nueve á veintisiete series. Encuéntranse varias especies de este género en nuestro continente. 


\section{LA CULEBRA DE ESCULAPIO - COLUBER ESCULAPII}

CONSIDERACIONES HISTÚRICAS.-Esculapio, cl dios de la medicina, ha sido representado, como ya sabemos, con una varilla en la mano, rodeada por una serpiente, cual simbolo de su actividad. Actualmente ya ro es posible averiguar qué especie del órden seria para los antiguos romanos y griegos dicha serpiente; pero supónese en general que se corisideraba como tipo del género, y que los romanos fueron los primeros en extender su área de dispersion. Cuando bajo los cónsules Flavio y Bruto la peste causó éstragos en Roma, trajeron esta serpiente, como ya hemos indicado, desde Epi. dauro; Tiberio la adoró despues en una isla á fin de apaciguar a los dioses, y segun dicen, aun hoy dia se ven las imágenes en los jardines de un converito dedicado á San Bartolomé. Desde Roma, asi se supone, la serpiente se propagó fijándcse particularmente en los baños de Ems y Schlangenbad (baño de serpientes).

Cierto que la culebra llamada aun hoy dia de Fsculapio se encuentra todavia en las inmediaciones de los bah̆os, en países donde, sin embargo, no se la observa: asi, por ejem.

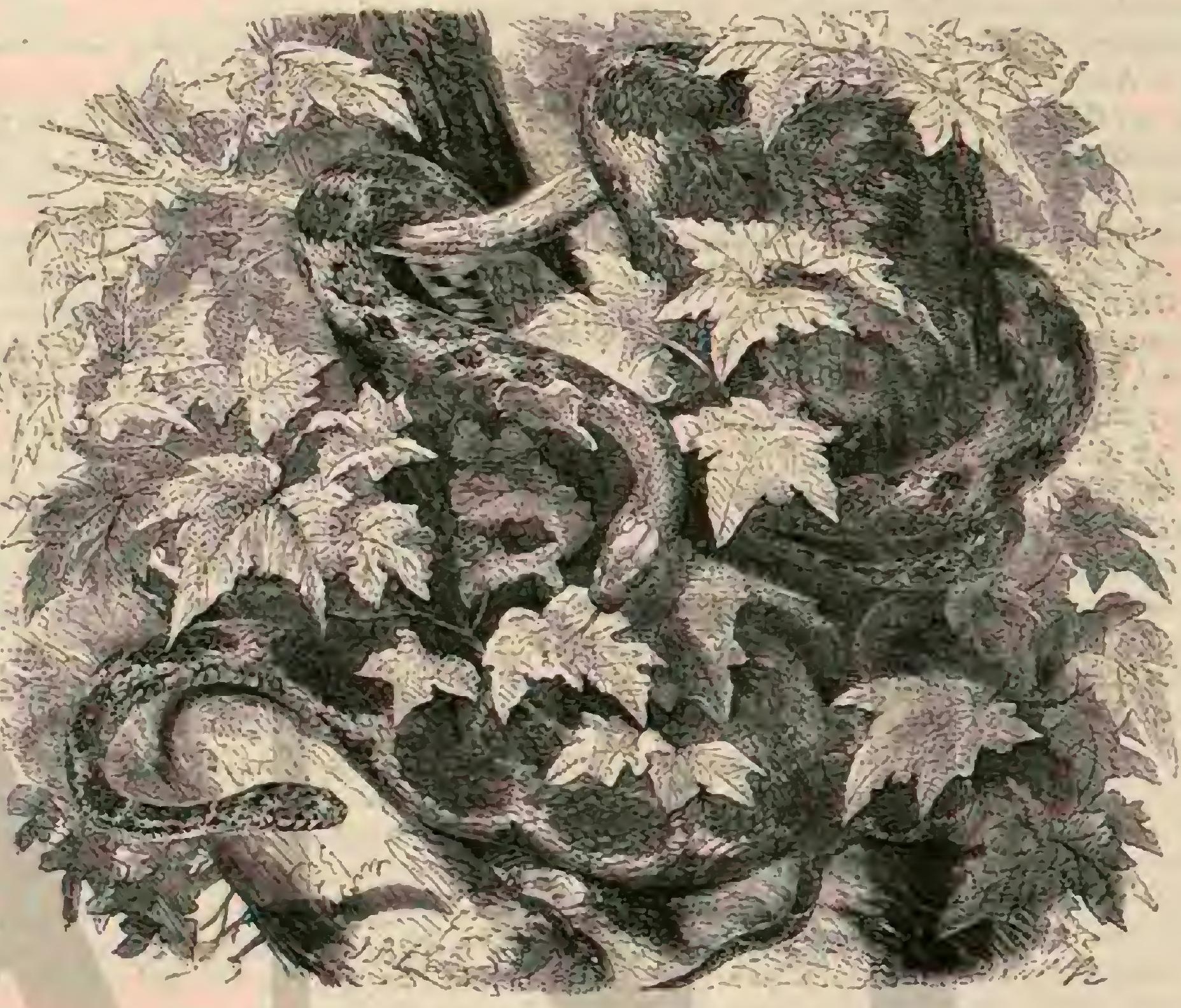

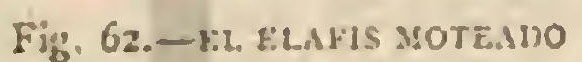

FHg. 63. - LL KLARIS DS. CAIH.X.

plo, existe en Alemania, en los alredeciores de Schlangenbad y Ems; en Austria cerca de Baden, en el Tesino inferior y en el Valais, donde, segun la opinion de Fatio, tampoco habitó en un principio; y cn todos estos lugares se la ve casi exclu. sivamente en medio de las ruinas de los baños romanos. $\Lambda$ decir verdad, en Alemania se halló tambien en 'luringia y en el Harz, y por eso Giebel reuare la opiniun de que los romanos la introdujeron en el norte, jero es muy posible que con el irascurso del tiempo la serpiente se propagara de por si ó fuera conducida por aficionados mas alla de sus primeros limites, escapando despues de la cautividad. En todo caso, se ha dado fíltimamente la prueba de que no es dificil aclimatarla.

El conde de Goertz envió á buscar poco á poco en los años 1853 y 1854 hasta cuarenta de esas culebias de Schlan. genbad, y dejólas en libertad en los alrededores de su quinta de Kichthof, cerca de Schlitz, en el gran ducado de Hesse. Alli encontraron todo cuanto podia hacerles agradable la vida: un terreno cálido y expuesto al sol, árboles anosos con corteza hendida, arbustos, huertos fértiles, pendientes pedregosas y escarpadas, muros viejos agrietados, grictas subter. ráneas, ctc.; y como se las protegia enérgicamente reprodujéronse, no en demasia, pero si continuamenic. Varias veces se observó que tambien de aqui emigraban aigunos indivi.

Toso $V^{\circ}$ duos, pues algunos fucron hallados á la distancia de una hora de camino, y otros hasta mas alla del Funda, el cual era preciso pasar á nado porque no habia puente en las cer. cinias. En su consecuencia, la opinion emitida primero por Hyden, opinion propia tambien de otros muchos naturalis. tas, y segun la cual se alega que los romanos introducirian en Alemania la culebra de Esculapio, no me parece refutada todavia de ningún modo.

CÁRACTrRES, - Ia culebra de Esculapio, llamada tambien culebra amarillenta ó de Schlangenbad, se reconoce muy fácilmentc por su cabeza penueña, pcco separada del cuello y redondeada en el hocico; tiene el tronco robusto, cola larga y delgada y aquilladas las escamas de la cabeza y de los costados.

Ia parte superior del troncoy de la cabeza son por lo regular de un gris amarillo pardusco; la cara inferior del cuerpo blan. quizca; en el occipucio se vé á cada lado una mancha ama. rilla, f en el dorso y los costados hay pequeños puntos blanquizcos, que se marcan mucho en algunos individuos. El color, por lo demás, varía mucho, pues hay cuiebras de Es. culapio muy claras, y tambien casi negras. l.enz cita como carácter notable el hecho de que los escudos abdominales estén casi doblados en ambos lados, por lo cual el vientre, que es plaro, presenta en cada costado un borde cuyoúngl- 
lo puede ser agudo cuando este reptil oprime sus costillas contra él. La longitud del animal es de $\mathrm{I}^{\mathrm{m}}, 50$, pero solamente los individuos de la Europa meridional alcanzan este tamaño considerable.

DISTRIBUCION GEOGRÁFICA. - La verdadera patria de estas serpientes es la Europa meridional, desde Espana hasta las orillas occidentales del Caspio. Encuéntrase en varios parajes del sur de Francia, y asimismo en Suiza y en los puntos ya indicados al este del Waacitland. Tambien habita toda la Italia, excepto algunas regiones, como por ejemplo la llanura de Lombardia; y hasta abunda en los contornos de Roma, en Calabria y las dos grandes islas de Sicilia y Cer. deña; estí diseminada por el sur del Tirol donde subé una altura de 1,050 metros sobre el nivel ael mar; adernás se la ve en Carintia y el Austria superior; escasea mas en la Sile. sia austriaca; pero en Galitzia, el sur de Hungtia y Croacia figura entre los ofidios mas comunes, aunque solo habita los bosques de las montañas. No falta tampoco en la peninsula del Balkan, y es propia, en fin, de varias provincias meridin. nales de Rusia.

USOS, COSTUMBRES Y REGIMEN. - Todos los observadores que vieron la culcbra de Esculapio libre, 6 la observaron en cautividad, están conformes en elogiaria. Las formas de su cuerpo y sus movimientos, dice Linck, se distinguen por su gracia y soltura; en toda in superficie de la piel no se ve ninguna aspereza, nada angúloso en los contomos; todo es liso y suave. La índole de esta serpiente está en ar. monia con sus formas exteriores: es un animal interesante por todos conceptos.

En el sur de Europa la culebra de Esculapio habita con pre: ferencia los terrenos pedregosos, cubiertos de escasa maleza, y. falta k menudo en las regiones que no tienen esta condicion. En los contornos de Schlangenbad le agrada vivir en muros viejos, sobre todo en los de las ruinas de antiguos castiilos. En la citada colonia del conde de Goertz trepa mucho por un muro agrietndo, sube al granero de una pe. queña casa ruinosa circuida de vid silvestre y destinada pára horno; algunas veces visita tambien un monton de vegetales en putrefaccion, formadó á propósito para ella, y alli cria los hijuelos. Se la ve vivir pacíficamente con los abejones èn las grietas, y mas aun en troncos de encinas antiquísimas, huecos probablemente hasta el suelo; deslizase en el interior por una abertura que se halla a unos tres metros de elevacion, y por ella suelen entrar tambien los abejones para llegar à su nido, que está en el hueco del árbol. La culebra de Esculapio no se introduce voluntariamente en el agua, pero cuando se la arroja en ella nada rápidamente y con agilidad hácia la ori. Ila. Sus movimientos en el strelo llano no son muy rápidos ni tampocn se distinguen en otro concepto $y$ liasta podria de. cirse que la rapider de su carrera es inferior a la de otras cu. lebras; en cambio sabe trepar muy bien. Por este concepto es superior á todas las demás serpientes de Alemania, y casi iguala á las arboricolas, que pasan casi toda su vida en el ramaje. Al verla trepar puede observarse 'muy bien cómo sabe hacer uso de sus costillas. «Cuando puse sobre mi pecho una culcbra domesticada de un metro de largo, dice Lenz, y despues de abrochar mi levita, cl animal supo á pesar-de esto sostenerse en esta, oprimiéndose alli donde habia un boton, de tal modo que su cuerpo formaba un ángulo agudo, con el cual se fijó por debajo del boton, siéndole posi. ble sostenerse en uno solo 6 dos, á pesar de su considerable peso; cuando queria trepar mas arriba oprimíase por los botones siguientes. De la misma manera estos repriles pueden subir tambien por los troncos gruesos y verticales del pino liso, oprimiendo siempre el ángulo que forman las grietas de la corteza.y La culebra de Esculapio suele trepar por los troncos de árboles delgados, los cuales rodea con sus ani. llos, subiendo asi hasta el ramaje. En el bosque espeso pasan de un árbol á otro, franqueando de este modo grandes dis. tancias. Por las paredes trepan con una destreza casi incom. prensible, porque la mas pequeña saliente sirve de punto de apoyo.

Núirese esta culebra con preferencia de ratones, pero aco. mete igualmente á los lagartos, y no desprecia tampoco al. gun pájaro cuando lo puede coger; sin embargo, los aficio. nados a este reptil lo recomiendan como un animal útil al hombre, pues si á veces suele destruir los nidos de algunas aves, la caza constante que hace $\{$ los ratones compensa am. pliamente aquel perjuicio.

En los individuos aclimatados por el conde Goertz se pudo observar fácilmente su género de vida. Si el observador se sienta tranquilamente en uno de los cómodos bancos, manteniéndose inmóvil, sin proferir una palabra, estas culebras creen que el hombre es un pedazo de madera ó una piedra, y se acercan á menudo mucho, pero al mas leve movimiento emprenden rápidamente la fuga. Bien se crean ó no observadas, corren por ać́ y por allä, trepan por todas partes, se ponen al sol y cazan como acosturnbran hacerlo. Llegan fácilmente al agujero de la encina introduciendo al trepar sus ángulos por las hendiduras de la corteza. Del mismo modo bajan de los árboles, $\mathrm{y}$ se fjan con preferencia en el tronco vertical de la encina para disfrutar de los rayos del sol.

No se las ha visto aun trepar hasta la copa, pero en cambio buscan el sol en lo mas alto de las espesuras ó de los muros. Tampoco se ha observado à ninguna nadando, comiendo 6 bebiendo, pero si se ha sorprendico varias veces á dos enroscadas una en otra, revolcándose tan rápidamente por el suelo que la vista del espectador 130 podia seguir sus movimientos. Sin duda se hallaba en el interior de aquel c:lindro viviente algun desgraciacio ratoncillo $\delta$ avecilla.

«e todas las serpientes de Alemania, dice Linck, la cllebra de Schlangenbad es la que produce menos hijuelos. Su apareamiento se efectúa de la manera acostumbrada, pero muy tarde, porque es mucho mas sensible al frio que ningena otra especie alemana; raras veces abandona su residencia de invierno antes de principios de junio, es decir, dos meses despues que sus semejantes. Ademas de su congéne. re, la culebra comun, es la única serpiente alemana cuyos huevos necesitan varias semanas despues de la puesta para que los hijuelos puedan salir \& luz. La hembra no suele po. ner mas de siete huevos, los cuales deposita en la madera podrida ó en una espesa capa de musgo seco, abandonándolos despues al azar. Son de forma oval, pero menos ventrudos que los de paloma, $y$ se parecen algo á las larvas de hormiga vistas con microscopio.

CAUTIVIDAD.-Ninguna de las serpientes de Alema. nia se halla tan á menudo cautisa como la culebra de Esculapio. En Schlangenbad, su caza constituye un ramo de industria para la gente pobre que las busca cuando han des. pertado de su sueño invernal; domesticanlas y divierten con ellas á los bañistas, vendiendo tambien algunos individuos. Despues de la temporada del baño se sueltan los cautivos, porque raras veces toman alimento en la jaula: asi lo creen, por lo menos en Schlangenbad, siendo tambien esta la opinion de Lenz y Linck.

Con este motivo dice Lenz: «He tenido á reces una de estas culebras durante un año y mas, sin poder conseguir que comiera. Se me escapó en el mes de agosto una, larga de 3 pies, que la tenia en mi poder desde el otoño anterior, $y$ que el hambre habia extenuado y enflaquecido en gran manera; un mes oiespues la encontró mi jardinero, gruesa y 
vivaz, corriendo por el huerto, y la recogi de nuevo. Linck afirma tambien que los cautivos de csta especie no quieren tomar alimento alguno, y por este motivo, si bien resisten al. gunos meses de ayuno, suelen sucumbir á principios de la primavera Sin embargo, esto no puede considerarse como regla general, pues Erber refiere que dos de estas culcbras que tuvo largo tiempo en cautividad, devoraron en el curso de un verano ciento y ocho ratones y dos lagartos; y otra, que durante catorce meses se negó á comer, cambiando de jiel con regularidad, no enflaqueció en apariencia y acabó por tomar el alimento que se le daba, si bien $\$$ los pocos dias se la encontró muerta en la jaula: sel primer animal de esta especie, anade Erber, que perdi, entre los muchos que he tenido.

Effeldt hizo sufrir hambre meses enteros a sus culebras de Esculapio cautivas, de las cuales tenia sa-veces algunas docenas, ofreciéndoles despues huevos de pajjaros, lagartos, orve. tos, sapos, ranas y otros reptiles, asi como tambien insectos y gusanos, pero ninguna de ellas cogí́ uno solo de estos animales. En cambio, el citado ofidiólogo que poseia una experiencia extraordinaria y singular habilidad para cuidar ser. pientes, las acostumbro pronto á comer ratones y ares, observando que necesitan mucho alimento. ¿Cuando se pone un raton vivo $\delta$ un ave en su jaula, dice Lenz, y bien sea de dia ó de noche, al punto asoman las cabezas de las serpientes y da principio una cmpeñada caceria. El repil mas afor. tunado coge la presa con los dientes por cualquiera parte del cuerpo, y envuélvela con la rapidez del rayo entre seis anillos muy oprimidos, de modo que desaparece a la vista del observador. Cuando la victima ticne mucha resistencia vital y se opone á su enemiga, sucede $\{$ menudo que la serpiente rueda con rapider. frenética por el suelo de la jaula, hasta que la presa le parece sofocada con seguridad. Sin embargo, aun no la suelta; limitase á ensanchar un poco los anillos, busca la cabeza, cógela con los dientes, y conienza en seguida á devorarla del modo acostumbrado. Con bastar. te frecuencia ocurre tambien que dos culebras de Esculapio atrapan ó un tiempo la misma presa y envuélvenla con tal rapidez rodando por el suelo, que el observador no puede distinguir de qué partes se compone aquel cilindro.

Effeldt acostumbró a sus culcbras de Esculapio a comer tambien mamiferos y ares muertas, $y$ hasta pedazos de carne de caballo cruda.

Al principio de su cautirerio se muestra bastante rebelde, procurando siempre morder la mano del guardian. aCuando esiå enfurecida, dice Lenz, ensancha de una manera extraosdinaria la cabeza, formando esta una especie de triangulo, encoge el cuello y lo estira despues con gran rapidez, buscando objeto en que hincar sus dientes. Antes de morder pro. yecta y retira la lengua como sucle hacer la vibora, pero en el propio acto del mordisco, la lengua está recogida. Cuando dos de estos repriles están muy coléricos, suelen á reces morderse el uno al otro; con todo, por lo comun viven en buena armonia entre si y aun con otros animales de la misma clase. La rebeldia que ha desaparecido durante algun tiempo, vucive otra vez cuando la culebra se ve molestada 6 cuando despues de una escapatoria se la encierra de nuevo en la jaula; sin embargo, pocas semanas despues, si se la visita con frecuencia, tratándola debidamente, se presenta tan domesticada y dócil que se deja tocar y hasta inquietar por el guar. dian, sin intentar morderle. Erber asegura que llegada á cste grado de domesticidad, regresa voluntariamente á su prision, despues de algun tiempo. E! mismo naturalista refierc lo si. guiente, en prueba de la facilidad con que este isodonte se acostumbra al hombre: Estudie durante algun tiempo una culebra de Fsculapio que cogi cerca de un riachuelo, y la hallé desde un principio tan dócil, que supuse q̨ue debia ha ber estado sa en cautividad; mas, por trabajadores ocupados en las inmediaciones, supe que ya hacia bastante tiempo que la habian observado, pero que no la inquietaron nunca, porque habian visto que cazaba y devoraba gran número de ratones. Mas tarde fue abandonada por Erber, por no haber podido conseguir que comiese. "No parecia, añade el mismo, alegrarse mucho de la libertad que ?e habian deruelto; se enroscó tranquilamente y permaneció calentándose al sol cerca del sitio donde so estaba, pero con tanta indiferencia que ni tan siquiera se apercibió de mi ausencia, cuando me marcbí de regreso á casa. Pasado un buen rato, volvi al mis. mo sitio y encontré la culebra inmóvil, en la idéntica postura en que la habia dejado; tampoco hizo movimiento alguno al acercarne á ella, y solamente cuando la hube acariciado con la mano, trepó, como era su costumbre en casa, por mi brazo, descansando en el hombro. La sacudi al suelo y la inquicté de mil mancras, pero sin conseguir encolerizaria, ni hacerla huir; por el contrario, subió tentamente por mi picrna, pro. curando ocultarse debajo del chaleco. Abandomando, pues, mi primer propósito, la recogi, y me la llevé otra veza casa. \$ Lenz refiere lo que sigue, de otra que tenia tambien muy domesticada: Solo intentaba morderme, cuando procuraba arrancarla de las ramas del cerczo, donde la dejaba trepar y correr una media hora casi todas las tardes: sentiase alli libre y queria defender su independencia. No tenia mas remedio que subirme al árbol, provisto de una pequeria sierra, y separar la rama en que se encontraba el reptil; aun asi no podia conseguir que se desenroscara, y me veia obligado a meter la rama debajo de agua; solo entonces la soltaba, y una vez en tierra, se dejaba coger fácimente.

Respecto á su destreza en trepar, la elasticidad de su cuerpo y la inclinacion que tienc esta culebra á sustraerse a la tutela de su guardian, refieren lenz y Linck casos muy raros y graciosos. Vease el que extractamos de la obra de este último autor. Linck recibió a principios de junio una hermosa pareja de estos isodontes, que le fué enviada desde Schlan. genbad; sacó los reptiles de la caja, en que venian perfectamente acondicionados entre el musgo, y teniendo que aten. der a otras ocupaciones, los dejó sueltos, pero bien encerrados dentro de un espacioso cuarto. Una hora despues volvió á entrar en el, ansioso de examinar detenidarnente sus nueros huéspedes, pero estos habian desaparecido. No quedó rincon ni escondrijo posible por rebuscar; mas en vano; las culebras no se encontraban. Por fin, al cabo de algun tiempo, se des. cubrió al macho, sobre la barra de una cortina, por cuyos pliegues debia haberse encaramado para llegar á aquella altura, de cerca de diez pies. Continuaron las pesquisas en busca de la hembra, hasta que nuestro naturalista percibib un ruido sordo que procedia del asiento de una silla poltrona; vuelta esta, no fué poca su alegría al encontrar la fugitiva enroscada en los muelles del asiento y dispuesta, á juzgar por los mor. discos que dirigia, á defender su puesto con teson, costando bastante trabajo arrancarla de alli.

La pareja vagabunda fué enjaulada despues en una caja con tapa de enrejado de alambre muy estrecho. Un dia que. dó esta mal cerrada; y separảndola un poco hácia un lado, consiguieron escaparse las culebras. La abertura por donde cfectuaron su fuga era tan pequeira, que \& todos parecia in. creible que un animal de tal tamaño, pudiesc pasar á través de semejante intersticio. Lsta vez las pesquisas duraron varios dias, y fucron completamente inútiles. 8 Tres semanas despues, dice Linck, al pasar de mi alcoba as un cuarto interior, vi á la hembra penosamente atareada en comprimir el cuerpo por debajo de la puerta, para introducirse en la habitacion contigua. Al oir mis pasos se deturo un momento, con la cabeza, 
cuello y parte del cuerpo en el umbral, y el resto dentro de la alcoba, como aplastada debajo de la puerta $y$ sin vida. In. tenté sacarla de alli, pues la puerta no se podia abrir sin da. ñar al animal, pero hubiera tenido que arrancarla a pedazos para conseguirlo; asi pues, la abandoné á sus propias fuerzas, y aprovechando ella la ocasion, desapareció como por ensal. mo. En aquellos cortos instantes pude admirar el cambio de formas de su cuerpo, que tan pronto aparecia aplastado en sentido vertical como en el horizontal, segun se retorcia en uno ú otro sentido. Pero ciónde habia tenido y tiene la culebra, tal vez todavia, su escondrijo? Esto continúa sicndo un enigma para mi, lo mismo que para todos los que conocen exactamente la localidad y todos sus rincones y dependen. cias. Unos ocho dias despues se encontró al macho solén. dose muy satisfecho enciró de algunos haces de leña, cerca del sótano donde esta se guardaba. A juzgar por el volúmen de su cuerpo, parecia haberse cuidado muy bien durante la escapatoria.

\section{LA CULEBRA DE CUATRO RAYAS- COLUBER QUADRILINEATUS}

CARACTERES. - La culebra de cuatro rayas, perteneciente al mismo género, es una especie muy propagada en el sur de Europa, y se distingue por lo gracioso de sus formas, su belleza y su color diferente: puede alcanzar una lon. gitud de $0^{\prime \prime}, 90$.

Entre las muchas variedades hay dos constantes: la una, llamada propiamente culebra de cuatro rayas, tiene, segun Sirauch, un color gris pardusco; con cuatro, ó mas á menudo dos fajas longitudinales del ruismo tinte, mas oscuro 6 de un rojo de sangre, orilladas casi siempre de negro, y que se corren sin interrupcion por todo el lomo ó se cortan en algunos sitios; la arista de esta ultima parte suele ser muy clara y hasta blanca, y en los costados hay manchitas negruzcas; la parte inferior de la cabeza y del primer tercio del tronco es de un blanco amarillento, ó amarillo muy claro; cada uno de los escudos abdominales presenta cuatro 6 cinco manchas longitudinales negruzcas, que mas hácia el vientre aumentan de tamaño, de tal modo, que el centro de aquella parte adquiere un azul metálico oscuro; solamente los bordes exteriores de los escudos conservan el color amarillo.

La variedad manchada ó la culebra leopardina (Coluber leopardisus) es de un pardo claro de caoba; en la parte superior del tronco y de la cola hay unas manchas de color rojo de sangre, orilladas de negro, dispuestas en dos series longitudinales que se reunen formando anchas fajas tras. versales; los costados presentan una serie de puntos peque. noos, en forma de media luna y de color negro, que alternan con las manchas descritas.

DISTRIBUCION GEOGRÁFICA.-El área de dispersion de dichas serpientes está limitada en el oeste por Iralia y en el este por el Asia Menor; en la mayor parte de los paises comprendidos en este territorio encuéntranse ambas variedades juntas; pero en Dalmacia y Grecia vive casi exclusivamente la culebra leopardina. Pallas descubrió la primera variedad en la Rusia meridional; Nordmann la encón. tró en algunas partes en Crimea y en las orillas del mar Caspio; Erber cogio individuos de la especie leopardina en toda la Dalmacia y en la Herzegowina, pero siempre los halló aislados. Erhard la vió una sola vez cerca del pico del monte Pirgos en Sywa, cuya altura es de 500 metros; y go la recibi varias veces de Dalmacia.

USOS, COSTUMBRES Y REGIMEN.-Segun las ob. servaciones de Erher; estas serpientes se alimentan princi- palmente de lagartos, pero atacan tambien a los pequeños ofidios, al menos en la jaula. Erber se interesa por eso en faror de estos reptiles, porque segun dice, no se les puede probar que hacen daño alguno; mientras que por su bonito color son agradables para todo el mundo.

CAUTIVIDAD.-Los individuos cautivos se conservan por lo regular durante el invierno, pero mueren siempre al principio de la primavera por mas cuidado que se tenga en el arreglo de su prision. Entre los ofidios curopeos estas variedades son, si no las mas vivaces y alegres, por lo menos las mas bonitas; y constituyen un adorno para la jaula, tanto mas cuanto que siempre se dejan ver si se aiiende á sus necesidades. Trepa con tanta destreza y habilidad como la culebra de Esculapio, y por eso no permanece en tierra sino en caso necesario; cuando la jaula está provista de ra. mas, 6 mejor aun de plantas verdes, sube en seguida por el tronco hasta la major altura, donde elige un sitio cómodo para descansar; entonces ofrece el aspecto mas gracioso, for. mando muchas circunvoluciones y nudos, y tanto aqui como en liburtad excita el interés de todo observador.

\section{LOS ELAFIS - ELAPHIS}

CARACTERES. - Los elafis, especies afines de los ofi. dios anteriores, difieren sobre todo de las culcbras trepadoras por su tronco mas prolongado y comprimido lateralmente, y de cuya longitud total la cola ocupa un poco menos de la cuarta parte; la separacion entre la cabeza y el cuello se reconoce muy bien; este ultimo es delgado, y aquella tiene por delante de los ojos dos escudos en vez de uno. Ias escamas son mas aquilladas que las de las culebras propiamente dichas.

\section{EL ELAFIS DE CUATRO RAYAS- ELAPHIS QUATRIRADIATUS}

Metaxa, naturalista italiano, supone que el elafis de cuatro rayas es el boa de Plinio, lo cual no quiere decir, sin embargo, que con esta opinion apoye la antigua fábula en que se dice que en tiempo de Claudio se mató una de estas serpientes, en cuyo vientre se encontró un niño. Como ya hemos dicho, Plinio dice con toda intencion que el boa se ali. menta de leche de vaca, a lo cual debe su nombre, y sin embargo, aun hoy dia, segun Erber, se teme mucho al elafis de cuatro rayas en Dalmacia, donde se le persigue y mata sin consideracion alguna, por ser general la creencia de que sigue a las vacas y cabras para chuparles la leche, lo cual le ha valido el nombre de cracioreiza 6 munidorn de iacas.

CARACTÉEES.-El elafis de cuatro rayas es uno de los ofidios mas grandes de Europa, pues alcanza una longitud de dos metros. La cara superior es de color pardusco aceituna, con dos lineas longitudinales pardas en ambos la. dos, y la region inferior de un amarillo de paja. Tambien este color está sujeto á muchas variaciones: Eurber cogió algunos individuos del todo negros, y otros naturalistas observaron que los hijuelos presentan por lo regular en las partes inferiores tres series de manchas pardas, y en los costados otras iguales, siendo la region abdominal de un gris metá. lico negruzco.

DISTRIBUCION GEOGRÁFICA.-El área de dispersion del elafis de cuatro rayas se extiende por todo el sur de Europa, desde la Hungria meridional hasta España; mas no parece abundar en ninguna parte, sin duda á causa de las continuas persecuciones a que se halla expuesto en todos los paises.

USOS, COSTUMBRES Y RÉGIMEN, - Todos loS 
observadores dicen que es un reptil en extremo inofensivo y útil, que no muerde aunque se le coja en libertad; familia. rizase pronto con su guardian y se hace útil, porque extermina las ratas y ratones, si bien persigue además á los to. pos, aves pequeñas y lagartos, animales beneficiosos para el hombre.

«Hace dos años, dice Erber, cogi en Albania una culebra de cuatro rayas, en circunstancias muy especiales; hallába. me cazando insectos en las inmediaciones de un convento; cuando oí cierto ruido en el interior de una canal que bajaba desde el tejado del edificio hasta el suelo. Me mantuve quieto, esperando ver salir de alli, tal vez, algun pequeño cuadrúpedo del paiss, cuando me sorprendió la aparicion de un huevo de gallina y detrás de este el hocico y despues el cuerpo de una culebra de la citada especie, que parecia me- dir á lo menos 5 piés de largo. Fl reptil se internó en un sotillo inmediato, y con bastante trabajo se engulló el huevo enitero; pero lo rompió despues, apoyándose en el tronco de un peq̨ueño árbol. Conñeso que me costó gran esfuerzo de voluntad para no apoderarme en el acto de tan hermosa cu. lebra, pero me decidi á observar sus movimientos durante algun rato. A los pocos minutos, emprendió otra vez el mis. mo camino por la canal hasta el tejado, $y$ alli por un traga. luz se introdujo en el convento. Indudablemente en aquel sitio debia encontrarse el gallinero ó el depósito de huevos, pues no tuve que aguardar mucho para ver bajar de nuevo por el canalon al ofidio, con otro huevo en la boca, que se tragó en el sotillo del mismo modo que el anterior. Siete veces renitió la culebra su rapiña, $y$ tal vez no estaria todavia satisfecha; pero habia yo agotado ya toda mi paciencia,

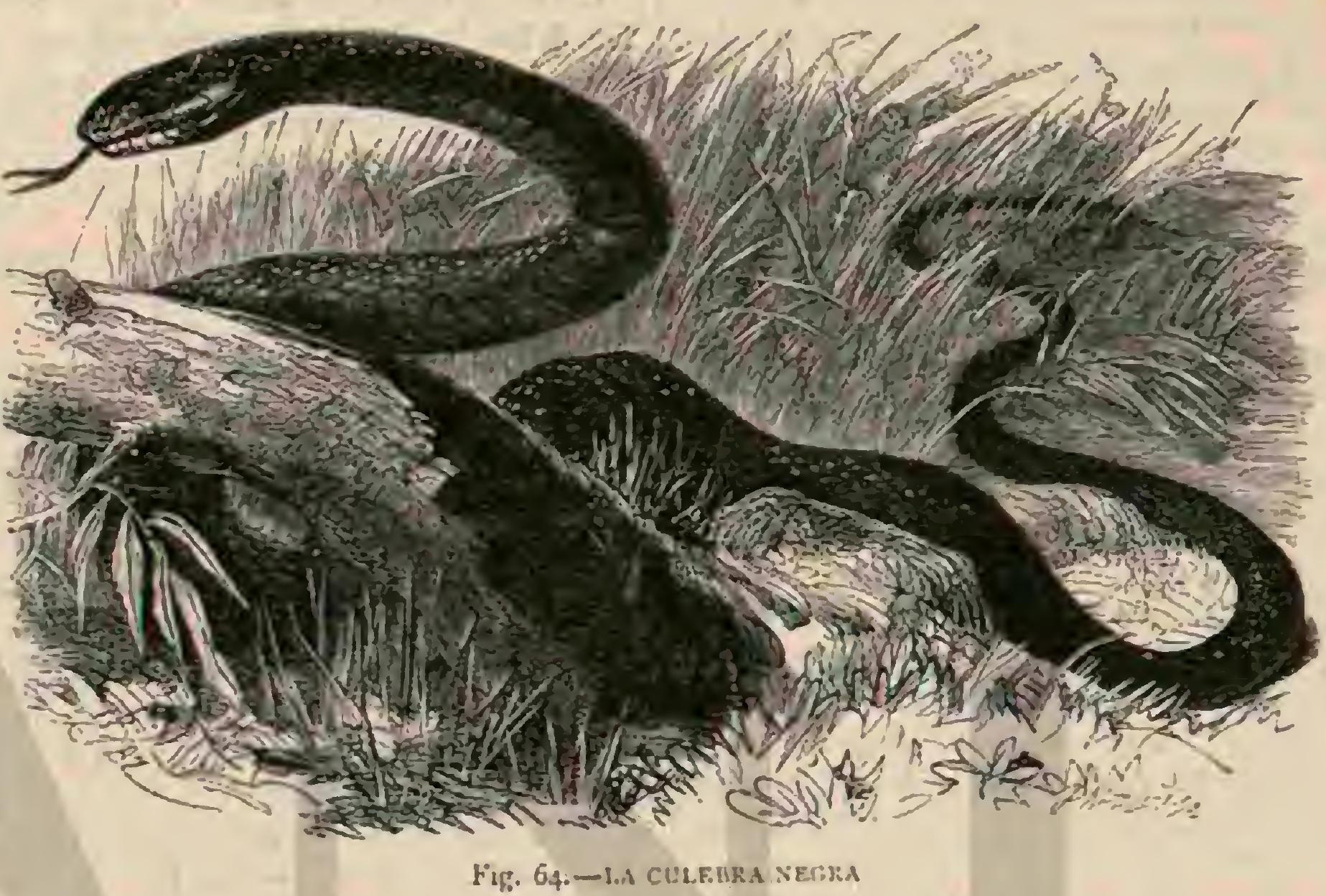

y me apoderé por fin del reptil, sin gran dificultad, gracias a los sicte huevos que se habia tragado. Conso no llevaba saco á propósito, acomodé mi presa, en uno de los bolsillos de mi levita, que son de regular tamaño y provistos de varios botones para poderlos cerrar perfectamente, $\mathrm{y}$ continué bus. cando insectos. Pero al poco rato sentí extraina humedad en un muslo: la culebra habia arrojado la fortilla en mi bolsiIlo. No me costó poco trabajo quitar toda la porquería y la. var aquelia peste de mi levita, tanto mas cuanto que tenia que hacer dobles esfuerzos; pues la culebra, una vez descar: gado su estómago, se habia ruelto muy vivaz, y tenia que sujetarla con un pié.

- En todo caso, dicho reptil, que hoy se encuentra en poder del doctor Steindachner, en el Museo de Viena, donde no le faltarân ni ratones ni huevos, dió pruebas de mucha astucia y gran habilidad en la rapiña, demostrando además la exactitud de una opinion que se habia puesto a menudo en tela de juicio, la de que las culebras tambien roban hueros.s

\section{EL ELAFIS MOTEADO-ELAPH:S GUT- TATUS}

CARAGTÉRES.-Esta serpiente tiene toda la parte superior del tronco cubierta de grandes escamas carenadas, aunque poco aparentes. Los colores de este reptil son brillantes, entre los que predomina un hermoso tinte castaño rojizo; en la region cefálica y en las sienes presenta varias ragas negras, y cubren el lomo numerosas manchas de este íltimo color, mas intenso, orilladas de negro; por los costados se extienden otras amarillas, tambien con circulo negro. Las partes inferiores del cuerpo son de un blanco plateado, con mezcla de negro. Esta serpiente tiene de 5 a 6 piés de largo (medida inglesa) (fig. 62).

DISTRIBUCION GEOGRAFICA. - El elafis moteado habita en la América del norte, y particularmente en los Es. tados Unidos.

USOS, COSTUMBRES Y REGIMEN.-Con mucha frecuencia se vé á este reptil á orilla de los caminos, por la mañana ó hácia la caida de la tarde, pues permanece oculto durante las demás horas del dia. Suele recorrer las cercanias de las casas, en las que penetra alguna vez. Segun Catesby, causa grandes destrozos en los gailineros.

\section{EL ELAFIS DE CADENA-ELAPHIS CAT- TENA}

CARACTERES. - A esta otra especie se le ha dado el nombre con que la designamos, porque las manchas blancas y negras que adornan su cuerpo afectan la disposicion de los eslabones de una cadena. Este reptil tiene muy bonitos colores: á lo largo del cuerpo se corren varias fajas alternadas de un negro intenso $y$ un blanco muy puro, siendo las primeras muy anchas y las segundas angostas; la cabeza ofre- 
ce tambien curiosos dibujos formados por las manchas. El elafis de cadena mide unos a piés (medida inglesa) (fig. 63).

DISTRIBUCION GEOGRÁFICA.-Esta especie habita los mismos paises que la anterior.

USOS, COSTUMBRES Y RÉGIMEN.-Los parajes húmedos y sombrios son de ordinario los que prefiere esta serpiente, que se alimenta de pequerios cuadrúpedos, reptiles $y$ aves, cuando las puede coger. Fs un animal de perversa indole y temible por su ferocidad.

\section{LOS ESPILOTES - SPILOTES}

CARACTERES. - Cón el nombre de espilotes ó culebras manchadas, Wagler forma un género de ofidios, cuyos caractéres son los siguientes: el cucrpo esbelto, fuertemente comprimido en los lados, y por lo tanto elevado en el dorso en forma de quilla; la cabeza prolongada, oval, con el hocico rédondeado y bastante destacada del cuello; ojos grandes; las ventanas nasales recioncias y dispuestas lateralmente en la extremidad del hocico, y la cola de longitud regular, pero esbelta y aguzada. Grandes escudos protegen la cabeza, mientras que el cuerpo aparece cubierto por escamas romboidales, comparativamente pequeñas y angostas, $y$ algo aquilladas en la linea dorsal.

\section{EL ESPILOTES CANINANA-SPILOTES POECI- LOSTONA}

CARACTÉRES. - Como tipo del género elegiremos la culebra manchada propiamente dicha, el caninana de los brasileños, ofidio del que tenemos algunas noticias merced a las observaciones del principe de llied y de Schomburgk.

Esta culcbra, que alcanza hasta 2 y 3 metros de largo, lle. va sobre fondo amarillo-gris, fajas gris azuladas ó negruzcas en forma angular con el vértice inclinado hácia adelante. Desde el ojo hasta el cuello, corre á cada lado un rasgo mas oscuro; los escudos labiales tienen igualmente los bordes oscuros; la parte inferior del cuerpo está manchada de negro, sobre fondo pardo oscuro. En una sub especie ó varie. dad de algunos naturalistas, pero que el príncipe de lVied supone ser el macho, la parte inferior del cuello, la abdominal y los bordes de los escudos labiales aparecen de un tinte amarillento.

OISTRIBUCION GEOGRAFICA. - La caninana es una de las culebras de mayor tamaño y mas comunes del Brasil y de la Guagana. Hasta el presente no se sabe que habite otros paises.

USOS, COSTUMBRES Y RÉGIMEN.-Fija esta culebra su morada, por lo general, en los grandes bosques, $\delta$ en los terrenos húmedos y pantanosos; trepa por los árboles, y nada en el agua con grande agilidad, mientras que en el suelo repta con menos soltura. Consiste su alimento principal en ratas, en pajaros y los huevos de estos, aunque acomete tambien á varias especies de su clase. El príncipe de Wied dice que la vió mas de una vez despues de tragarse un sapo, en completo estado de postracion, $\boldsymbol{s}$ su cuerpo ensanchado de una manera informe. Fs de todo punto inofensiva; deja que el hombre se le acerque hasta muy corta distancia, y no da otra señal de inquietud que levantar un poco la cabeza y dilatar el cuello. Aunque casi todos los indigenas saben que este reptil nada tiene de peligroso para el hom. bre, hay, sin embargo, algunos que se empeñan en conside rarla como venenosa, 6 que realmente la confunden con especies que lo son, y la tratan como si lo fuera.

Algunos observadores mas recientes difieren de la opinion del principe, calificando á este reptil de audaz y maligno.
Todas las especies del género se asemejan por sus usos y costumbres. Una especie afine de la que hemos descrito ha sido llamada por los brasileños deroradora de gallivas, por. que aseguran que manifiesta una preferencia especial por los polluelos. Habita muy a menudo en las inmediaciones de los rios donde causa con frecuencia un espanto terrible á las lavanderas negras, que entretenidas en la conversacion y sin hacer caso de lo que pasa a su derredor, ven aparecer de pronto una serpiente de esa especie. Los brasileños refieren los cuentos mas maravillosos del espilotes, pretendiendo entre otras cosas que visita las mujeres dormidas en su lecho para mamar de sus pechos.

Puede ser que se haya sorprendicio alguna vez á esta cule. bra bebiendo leche; pero á pesar de eso no puede caber duda de que tales cuentos no son sino fábulas que carecen de toda verosimilitud.

CAUTIVIDAD.-Acerca de este punto, véase lo que dice Schomburgk: Durante varios meses he tenido cautiva a una de cstas culturas, que medía 6 piés de largo, y pude estudiarla detenidamente. Lo que mas me llamó la atencion fué su constante deseo de beber, circunstancia de que solo me apercibí por casualidad. Cuando ya hacia algunos dias que la tenia en casa, repare que sus fuerzas vitales habian disminuido bastante: no queria comer y permanecia todo el dia enroscada en un rincon de la jaula. Para refrescarla, la rocié con algunas gotas de agua, é inmediatamente se puso á recoger el líquido que corria por el suclo. Desde entonces cada dia se le daba una racion de agua, como á los demás animales, y jamás dejaba una gota. Consistia su alimento en ratones y pájaros vivos, que en el momento de introducirlos en la jaula, los cogia por la cabeza y se los engullia. Despues de comer, se tranquilizaba y permanecia casi todo el dia en un mismo sitio, sin moverse, hacicndo la digestion, pero despidiendo al propio tiempo un hedor insoportable. Dos ó tres horas despues, se encontraban en el suelo de la jaula, en forma de pelota, las plumas y todo aquello que el estómago no habia podido digerir. Animales muertos no tocaba jamás aunque le apretase el hambre. Esta magnifica culebra, que tenia ga muy domesticada, la perdi desgraciadamente cerca de las costas de Inglaterra; sin duda alguna, el frio fué la causa de su muerte.?

\section{LOS CORIFODONES-CORYPHODON}

CARACTERES. - Llamamos corifodones å las especies de la sub.familia que se distinguen por su gran tamaño, su estructura robusta, y el corte trasversal del tronco, que es redondeado; la separacion de la cabeza se inarca mucho; la cola igualmente adelgazada, mide la tercera parte 6 mas de la longitud total del cuerpo; las cscamas, lisas y ligeramente aquilladas, están dispuestas en quince series longitudinales; las de la cabcza son de forma regular y las del vientre planas; los dientes aumentan en tamaño de adelante atrás.

\section{EL CORIFODON PANTERA-CORYPHODON PANTHERINUS}

CARACTERES - Dicé el principe de Wied que la coloracion de esta culebra es constante, esto es, que no varia, como sucede en otras, segun la edad y el sexo. Es un fondo gris amarillento, con una serie longitudinal de grandes man. chas pardas, orilladas de tinte mas oscuro, que en el cuello afectan la figura de losanges, mientras que en el dorso son de forma irregular, pero flanqueadas sa cada lado de otra mancha parecida. Ios escudos labiales de color amarillo blanquizco tienen un engaste negro, y detrás de cada ojo se 
ve un rasgo pardo oscuro. Fn los individuos jóvenes, las manchas están mas apiñadas, lo que hace aparecer mas oscura la coloracion general.

DISTRIBUCION GEOGRÁFICA.- La culebra pante. ra habita el este del Brasil y la Guayana. El principe de Wied la vió cerca de Rio Janciro, en las alturas cubiertas de ar. bustos que se encuentran detrás de San Cristóbal, y tambien mas al norte en Parahiba y Espiritu Santo.

Wucher la observó cerca de Bahiay Hensel en el Rio Grando do Sul. No es raro á orillas de Espiritu Santo, y cerca de Bahia es una de las especies mas comunes.

USOS, COSTUMBRES Y REGIMEN..-Este reptil frecuenta los terrenos pantanosos y los humedos cubiertos de arbustos y pequeñas plantas. No es tan ágil en sus movimientos como otras especies del mismo género, y fácilmente se le puede uno acercar, sin que por eso dé muestras de inquie. ud. Consiste por lo general su alimento en sapos y ranas, siendo tambien probable que acometa dentro del agua á los peces; parece por consiguiente que en lo esencial observa el mismo género de vida que nuestra culebra comun. En Rio Grande do Sul se le confunde á menudo, segun Hensel, con el chakaraka, serpiente en extremo temida y venenosa.

\section{LA CULEBRA NEGRA-CORYPHODON CONS- TRICTOR}

CARACTERES. - Tiene la parte superior de su cuerpo de un negro azulado, que se conviezte en el abdómen en ceniciento y por debajo del cuello en gris claro; algunos individuos presentan manchas irregulares de tinte mas subido que la coloracion general (fig. 64).

DISTRIBUCION GEOGRÁFICA.-Esta especic es originaria de la América del norte.

USOS, COSTUMBRES Y REGIMEN.-Detodos losofi. dios norte americanos este es el mas extendido y el que mas abunda. Busca con preferencia las localidades ricas en aguas, y fija su morada en las márgenes de los rios y lagos, especialmente donde encuentra arbustos ó maleza en contacto in. mediato con el agua. Lo mismo que muchas culebras de nuestro continente, emprende la especie de que tratamos excursiones \& través de los terrenos secos, siendo entonces cuando se la puede observar en las mas distintas localidades. Si hemos de dar crédito á las relaciones de la mayor parte de los viajeros y naturalistas que han estudiado la vida de este reptil en libertad, debemos reconocerle como el mas ágil de su clase. Repta con la misma velocidad por los terrenos secos y pedregosos, trepa con igual destreza por los árboles y nada y se sumerge con extraordinaria perfeccion. Su alimento es muy variado, consistiendo principalmente en peces, reptiles, pájaros y pequeños mamiferos; acomete á las jórenes serpientes de cascabel y ratas de tamaño muy regular; pero des. truye por otra parte gran número de nidos de pájaros mus útiles al hombre. En algunas partes se le considera como uno de los enemigos mas eficaces de sus temibles congéneres. Geyer, que ha observado detenidamente las costumbres de la serpiente de cascabel, considera muy probable el aserto de otros autores respecio $\{$ la caza qque da la culebra negra a los hijuelos de dicha serpiente, pues los individuos adultos de esta especic persiguen tenazmente á aquella Esia persecu. ción suele terminar con la fuga de la culebra, que escapa trepando á un árbol. Ambos reptiles se persiguen mutuamente en un círculo, cambian rápidamente de direccion, pasando uno al lado del otro, y continuan su carrera hasta que la ser. piente de cascabel ha llegado al mas alto grado de excitacion y ciega de furor no ve su camino, cuando la astuta culebra trepa con gran rapidez al árbol mas cercano y abandona el campo s. su enemigo.
Como consecuencia de la destruccion, que se le atribuye, de. las jóvenes serpientes de cascabel, es considerada generalmente la culebra negra como un animal útil; sin embargo, no en todas partes se la mira con buenos ojos, y en alguna hasta es temida, en primer lugar por sus rapiñas en los corrales, y despues por el furor con que, segun afirman algunos autores, suele acometer en ciertas épocas todo cuanto encuentra delante de si. Refiere Kalm que durante el periodo del celo acostumbra salir como fleclia disparada de entre la maleza y acomete al hombre, persiguiéndole con tal rapidez que ape. nas puede este escaparse; si llega à alcanzarle el reptil, se en. rosca inmediatamente á los piés de aquel, obligándole a caer. Sin embargo, no tiene nada de peligroso su mordedura, pues no causa mas daño que la herida poco profunda hecha con un cuchillo. Como cuando repta con suma velocidad por cncima de la hojarasca produce la culebra negra un ruido parecido al de la serpiente de cascabel, se la confunde algunas reces con esta, causando el consiguiente susto al viajero.

Los observadinres modernos no contradicen este ascrto, muy poco probable, que por consiguiente se halla en todas las obras de historia natural sin que se dude de su cxacti. tud, como en mi opinion deberia hacerse. Puede ser que el corifodon negro se precipite con bastante rapidez. sobre su victima; es posible tambien que merezca el nombre de corredor que se le ha dado, ó que se distinga por sus movimien. tos en extremo rípidos; pero ese cuento es tan extravagante que no se puede creer en su exactitud.

REPRODUCCION. - Hasta ahora pocas son las obser. vaciones que se han hecho sobre este punto, con referencia \& la culebra de que tratamos. Catesby opina que este reptil debe ser ovoviviparo.

CA UTIVIDAD. - $A 1$ igual de las demás especies de la misma familia, se conforma muy pronto la culebra negra con el cstado de cautividad, y cuidada debidamente resiste la misma durante muchos años. Sin embargo, la compañia de otros ofidios en la misma jaula no es muy de su gusto, $y$ usa para con los de menor tamaño el derceho del mas fuerte, esto es, que de cuando en cuando ahoga á uno de sus com. pancros y se lo traga sin contemplacion ninguna.

\section{LOS DIACRANTERAS DIAGRANTERA}

CARACTERES.-Con el nombre de diacranteras desig. nábase antes í las culebras, en que los dientes posteriores de la mandibula superior son mas grandes que los otros, hallándose separados de ellos por un claro. Algunos naturalistas creen de bastante importancia tales caractéres para formar una familia independiente de los ofidios que pertenecen á este grupo, curioso para noso:ros porque en el sur de Euro. pa se halla representado por varias especies. En estas últimas funda Wagler un género especial.

\section{LOS ZAMENIS - ZAMENIS}

CARACTERES, - Los zamenis tienen el cuerpo prolon. gado, la cabeza plana y marcadamente separada del cuello; los ojos de tamaño regular, con pupilas redondas; las fosas nasales se hallan situadas á los lados, cada una entre dos es. cudos; en la cabera se ve además que cada escudo se divide a menudo en dos y hasta tres, y que los ojos están rodeados á veces de pedazos separados de los escudos del labio supe. rior. Las escamas son lisas ó ligeramente aguilladas; los escudos abdominales abovedados; los de los costados afectan tambien un poco la forma de quilla; los de la cara inferior de 
la cola están dispuestos en dos series. Numerosos dientes se cuentan en ambas mandibulas y en el paladar; cl último suele ser el mas grande, y' está separaco de los otros por un pequeño claro.

El zamenis mas comun en Europa es el zamenis de flecha, del que se encuentran dos variedades constantes, considera. das por los naturalistas anteriores como especies.

Una de estas variedades es el zamenis verde amarillo ( /amenis aridiflazus) que se halla en la parte occidental de su área de dispersion; la otra no se describio hasta mas tarde bajo el nombre de culcbra saltadora (Zamenis jaculator). y despues con el de zamenis del Caspio (Zamenis tralualis); esta última habita en la parte oriental del área de dispersion de la especie. Necesitariamos varias pégginas para hacer una descripcion minuciosa de las variedades principales y de se. gundo órden, y por lo tanio nos limitaremos á indicar á con. tinuacion los caractéres de las formas que principalmente deben distinguirse.

\section{EL ZAMENIS VERDE AMARILLO-ZAME- NIS VIRIDIFIAVUS}

CARACTERES.-Esta variedad, segun parece, no al. canza nunca el tamaño del zamenis del Caspio; cuando mas mide $r^{\prime \prime}, 30$ de largo, pero tampaco suelellegar á esta dimen. sion. La cabeza y la nuca són de un color amarillo gris; el dorso y la cola verdes con fajas trasversales ncgras é irregu. lares; las partes abdominales son amarillas, con iguales fajas de un dibujo mas.regular; las manchas forman en la parte posterior del tronco unas rayas que se extienden paralela. mente hasta la extremidad de la cola. En otros individuos predomina en el dorso en vez del verde un bonito verde amarillo, en cuyo caso las regiones inferiores son de un amarillo canario. Otras variedades tienen el lomo de un pardo aceituna sin manchas, $y$ en una llega s ser completamente negro, con el centro del vientre de un amarillo de paja y la cara inferior de la cola, asi como los costados, de un azul metálico.

\section{EL ZAMENIS DEL CASPIO-ZAMENIS} TRABALIS

CARACTERES. - En este ofidio predomina en el dorso un color gris azulado 6 pardusco, con rayas longitudinales mas 6 menos marcadas, porque el centro de cada escama es de distinto color que el de los bordes. Además de las fajas, que pueden ser mas claras $y$ hasta casi blancas 6 bien de un rojo de orin, ó de un pardo rojizo; los individuos jóvenes de esta variedad presentan en el tronco unas manchas negras mas ó menos marcadas y dispuestas en series longitudina. les. La parte superior de la cabeza es siempre pardusca con lineas y puntos amarillos y parduscos que constituyen unos dibujos de mármol. Los escudos de los labios superiores y los que hay delante ó detrás de los ojos tienen siempre un color claro, $\delta$ bien pardusco ó amarillo; los primeros están provistos de bordes estrechos de color mas oscuro; la region abdominal, en cambio, es de un solo color, tan pronto ama rillo pardusco como rojo de ladrillo; los escudos del vientre, en algunos individuos, estín muy otillados de negro en su borde posterior, y además se observan en ellós unas manchas poco marcadas y de color gris.

DISTRIBUCION GEOGRÁFICA DE AMBAS VARIEDADES, - El zamenis verde amarillo está diseminado desde la Hungria occidental por todos los paises del Mediter. ráneo, pero solo en Francia penetra hasta mas alla de los Alpes. Abunda en Croacia, Carniola, el sur de Carintia y el del Tirol; en este último país, segun Gredler, llega áser la culebra que mas á menudo se cncuentra, por cuanto se aproxima airevidamente á las casas. En la parte meridio. nal de Suiza, es decir, en el Tesino y Valais, escasea, y lia. tio cree que alli ha sido importado por los romanos, porque se le encuentra en varios baños; en muchas regiones del sur de Francia, $y$ en el norte, hasta los $50^{\circ}$, este ofidio noes del todo rato; abunda en España y mas alla del Mediterráneo, es decir en Marruecos, Argelia y Túnez; y es muy comun en los contornos de Roma, donde se le ve en las inmediaciones de la ciudad y hasta en los jardines interiores de la misma. En Dalmacia, segun Erber, abunda mas que ningun otro ofidio; tambicn se le ha observado en el Ievante.

Desde Hungria, hácia el este, el zamenis del mar Caspio representa á sus congéneres, extendiéndose por todo el sur de Rusia, y desde el Levante por toda el Asia Menor y la Persia. Si hemos de dar crédito à ciertas noticias, llega has. ta a la India oriental. Se le conoce desde Buda.Pesth por toda la Hungria, Eslavonia, las islas Cicladas, el Asia Menor, los países del Cáucaso, en las regiones interiores del Volga, del Tereck, del Ural, y en general por toda la Rusia meri. dional, desde el Dnieper hasta el mar Caspio. En las estepas del sur de Rusia puede considerarse este ofidio como la ser. piente mas comun. Reuniendo ambas variedades en una es. pecie, como yo propongo, y designando á esta con el nombre de zamenis de flecha, el área de dispersion de esta serpiente se extenderia cuando menos desde la costa occidental de la peninsula Ibérica hasta la costa oriental del mar Caspio y desde los $3^{\circ}$ hasta los 50 de latitud norte.

USOS, COSTUMBRES Y REGIMEN. - El zamenis elige su residencia, al acaso, tal como se la ofrece la localidad. En las estepas de la Rusia habita las llanuras mas secas y cálidas; en Dalmacia 5 el Tirol busca los lugares bañados por el sol, pero no secos, de las regiones cultivadas, fjảncose en los arbustos 6 a lo largo de las cercas, en las calles ó ruinas antiguas y en montones de piedra, tanto de la llanura como de las montañas bajas. Tambien trepa a los árbolcs, $\delta$ por lo menos Gredler asegura haber observado que al sacudir algunos cayeron tales serpientes en vez de insectos.

El alimento de los zamenis se compone, scgun Erber, de lagartos y ratones, pero probablemente tambien de otros of. dios, porque se ha observado en cautividad que ataca á estos últimos. En todo caso parece que prefiere los reptiles á los ratones. Erber y Mctasa observaron como acometia serpien. tes. Metaxa tuvo un zamenis verde amarillo reunido con otros en la nisma jaula, y con gran pesar suỵo echó de ver que el primero habia devorado dos de sus compañeros, entre los cuales se contaba uno de su misma especie. Se acudió cuan. do habia devorado ya la mitad de su segunda victima, $y$ ha. biéndosele obligacio á expelerla, reapareció viva é ilesa; en cuanto á lá primera, extraida del estómago de su enemiga, despues de matar al reptil, aun no estaba muerta. Erber pudo ver como un zamenis le devoró un tarbofis vivaz, observiando que ni siquicra teme á las especies venenosas de su brden y que sobre todo ataca y devora $\{$ Ia vibora de las arenas. Segun las observaciones de Effeldt, los lagartos verdes constituyen su alimento favorito, pero tampoco desprecia de nin. gun modo los ofidios, comiéndose asílos de la misma especie como los de otra cualquiera. Una vez. llegó á ticmpo para ver como un zamenis verde amarillo de mas de un metro de largo estaba devorando otro individuo de la misma especie y de casi igual longitud; á pesar de todos sus esfuerzos no pudo introducirle en el estómago, de modo que el observa. dor se vió obligado á cortar la parte que aun salia de la bcca. Otra vez sorprendió á una que ya habia devorado la mitad de un individuo de la misma especie, y con la esperanza de 
salvaric, obligo al voraz reptil a soltar su presa, que al fin salio viva, aunque en extremo débil. Sin cmbargo, al otro dia las dos serpientes habian muerto. En las islas Cicladas los griegos temen mucho á los zamenis, segun Èrber. No cabe duda, dice, que saqueau los gallineros y palomares, pero quizás sea una exageracion acusarles de robar tambien cordcros.

Segun la afirmacion de Frhard, cuyas noticias están conformes con las de otros naturalistas, of zamenis no tiene nada de la pereza de otros ofidios; muy léjos de ello, sien. pre está en movimiento; persigue á su presa corriendo y sal. tando, con el cuerpo medio erguido; $y$ por eso parece muy bien elegido su nombre aleman de fineilnaticr (culebra. flecha); trepa por los árboles y atraviesa a mado las aguas, cruzando, segun aseguran los pescadores griegos, hasta los brazos de mar. No la infunde uingun temor el hombre; muy por el contrario, le ataca siempre primero, silbando y unfan. do con fierza, como lo hacen, segun se dice, las serpientes venenosas de la India occidental.

Entre las serpientes no venenosas de Europa el zamenis pasa con razon por el mas mordedor y vivaz I.1 pequeña variedad conocida en Alemania bajo el nombre de sornsutfer (culebra irascible, coluber comimusis, o sea la culebra verde amarilla ya citada,) procura generalmente morder al que quicre cogerla; el zamenis del mar Caspio, especie mas gran. de que la anterior, sibien sucle retirarse, no teme al caballo ni al jincte, y hasta osa acometer cuando este último la sorprende. Segun las observaciones de Pallas, entonces se coloca algunas veces en espiral; deja al adversario acercarse y tiende súbitamente la cabeza hácia adelante para morder, cogiéndose á menudo á los labios del caballo, \& la manera de un perro de presa. No podemos extrañar por lo tanto que los zamenis de major tamaño sean temidos en todas partes a causa de su indole maligna; aunque les falta, sirviéndonos

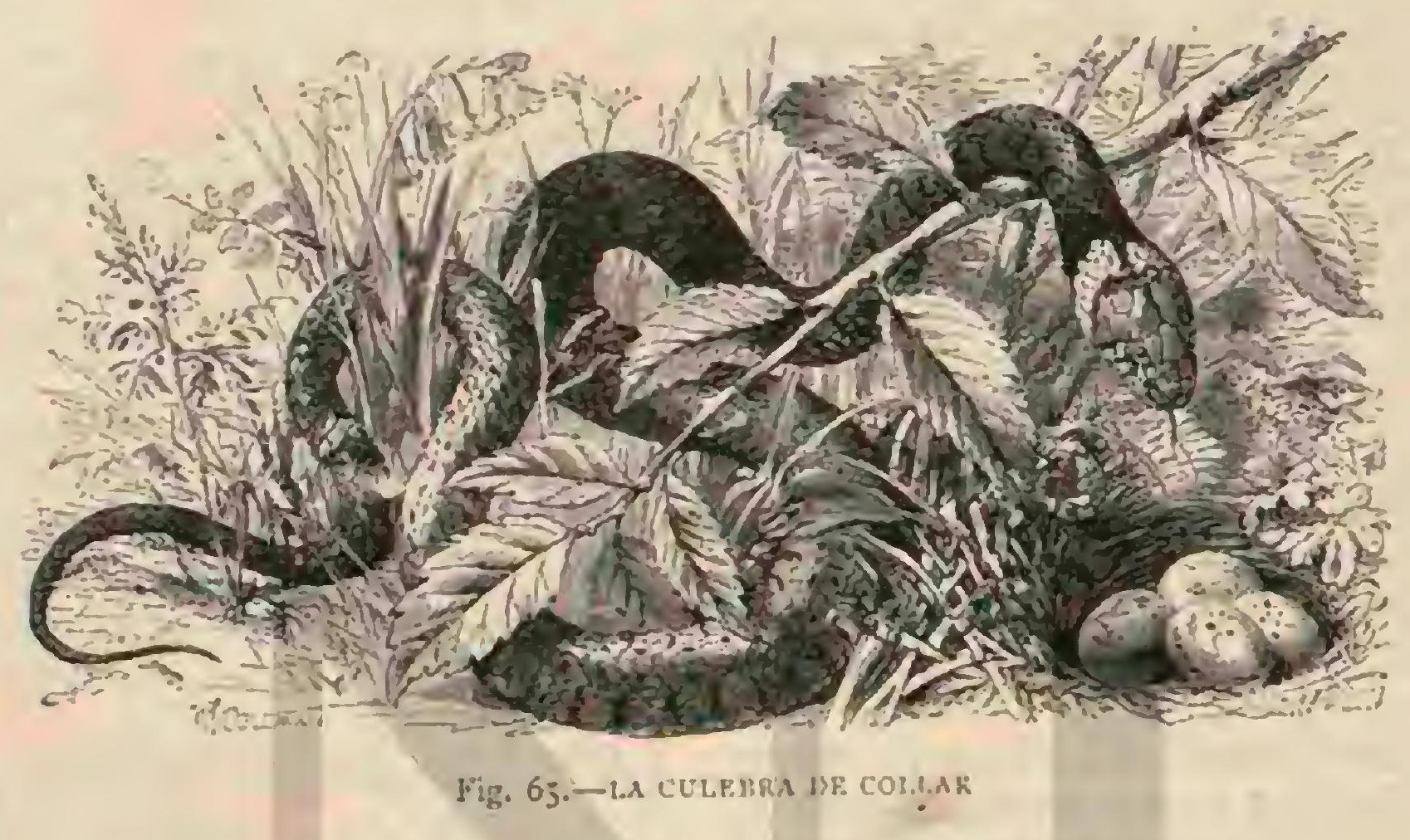

de la expresion de Erhard, el veneno infernal de las viboras de lanza y del laquesis, y aunque sus ataques contra un hom. bre experto solo redundarian en perjuicio del reptil, pueden asustar sin cmbargo bastante á los niños y mujeres ignoran. tes. En las islas Cicladas y en todas las del Mediterráneo en general, sin exceptuar Sicilia y las islas Jónicas, circulan con frecuencia relatos en que se habla de la muerte de alguna ú otra serpiente de tamario extraordinario, tratándose de hacer creer que estos reptiles fucron en otro tiempo el terror de los que habitaban cerca de clios. Asi por cjemplo, cuéntase que en Cefalonia, isla que segun Erhard puede considerarse como un verdadero nido de serpientes, dos hermanos mataron en el pico de una montana, durante su sucĩo, una serpiente que hacia mucho tiempo habia fjado alli su domicilio, haciendo inaccesible durante muchos años la montaña tanto para hombres como para animales; Erhard averiguó en el lugar mismo que la montaña en que al decir de la gente se efectuó la hazaña conservaba todavia el nombre de los dos hermanos, habiendo sido cedida por documento formal a estos y sus descendientes como propiedad perpetua y exenta de contribucion.

Asi tambien se refiere que en la region de Gallipoli, $\dot{a}$ ori. llas del Bósforo, en territorio asiático, se mató hace bastan. tes anos una serpiente solo de una perdigonada dirigida á la cabeza; el reptil arrancó de raiz en su agonia las cepas que le rodeaban, solo con los movimientos convulsivos de su cola: tres hombres no pudicron trasportar su cadiver. No es necesario probar que todos los cuentos de esta clase son cuando menos muj exagerados, pero deben citarse porque probablemente todos se refieren á nuestra culebra.
CaUtividad. - A causa de la indole maligna del za. menis, no es fácil obtener individuos vivos. Erber le tacha además de astuto y cauicloso, alegando que estas cualidades dificultan mucho su cara; añade tambien que en cautividad se muestra siempre tirnido, lo cual no impide que el guardian, aunque el reptil se haya familiarizado al parecer con el, se acerque con precaucion, porque nunca puede estar seguro de sus mordiscos. Acostumbrase sin embargo pronto á comer y pierde tambien pauhatinamente mucho de su iras. cibilidad, pero nunca se domestica verdaderamente y necesita tanto calor, que en los paises septentrionales no resiste el invierno sino cuando se le prodigan todos los cuidados posibles en una jaula bien arreglada.

\section{LOS PERIÓPIDOS-PERIOPS}

CARACTERES. - Wagler separó, bajo el nombre de periópidos, algunas especies de zamenis, formando con ellas un género independiente. Fistas especies se caracterizan por su ironco prolongado y plano en la cara inferior; la cola, fucrte y corta, solo ocupa una quinta parte de la longitud to. tal; los ojos se hallan en cavidades marcadas, separados de los escudos de los labios superiores por tres 6 cuatro escuditos irregulares; las sienes están cubiertas de mucbos escudos escamosos, pequeños é irregulares; las escamas pequeñas, en forma de lanceta y prolongadas, tienen por delante dos fosetas puntifornes y pertenecen a la clase de escamas sobre. puestas; forman de reinticinco a veintisiete series longitudinales. 


\section{EL PERIOPS DE HERRADURA-PERIOPS} HIPPOCREPIS

CARACTERES. - En Europa el género está representado por $\mathrm{cl}$ periops de herradura cuya longitud llega ${ }^{2} 1^{\mathrm{m}}, 30$. El color predominante de las regiones superiores varía desde el amarillo verde ó amarillo gris pasando por el color de naranja hasta el pardo rojizo. En la cabeza suele haber una faja trasversal oscura entre los ojos, y mas atrás otra arquea. da que se corre hácia abajo hasta los lados del cuello; entre los brazos del arco asi formado hay una mancha, de modo que entre esta y la faja se traza un dibujo en forma de herradura, de color claro; en el lomo resalta una serie de man. chas oscuras irregularmente cuadradas ó tedondas, que mas hácia atrás, en la mayor parte de los individios, se reunen y forman una faja longitudinal, comprendiendo en cada-lado una serie de manchas mas pequerias á la cual sigue una tercera seric de otras, dispuestas mas verticalmente, las cuales llegan á los escudos abdominales; asi romo las manchas del centro, son casi siempre muy grandes. El color predominante forma solo anillos estrechos al rededor de aquellas, figurándose de este modo una especie de cadena muy regular y bonita; la region inferior es blanquizca $\delta$ amarillenta, con manchas negras.

DISTRIBUCION GEOGRAFICA, - Tambien el periops de herradura es propio de los paises del Mediterráneo. En Europa parece limitarse á la península Ibérica, Cerdeña \& Grecia; en el Africa cstá diseminado, por in que hasta ahora sabemos, desde Marruecos hasta el Egipto, \& probablemente tambien se le encuentra en la Arabia Pétrea.

USOS, COSTUMBRES Y REGIMEN.-Segun Cantraine, esta especie fija su domicilio en los terrenos secos y pedregosos.

A juzgar por las afirmaciones de este viajero, el periops; al contrario de los zamenis, y á pesar de su vivacidad, es dócil é inofensivo y no intenta nunca morder. Los cautivos se domestican por lo tanto fácilmente; pero no sé que sé hasan hecho observaciones sobre este punta, ni tampoco tengo noticias sobre su género de vida, su régimen y su re. produccion.

\section{LOS RINEQUIS-RHINECHIS}

CARACTÉRES. - Los rinequis tienen el tronco cilin. drico, robusto y recogido; la cola, corta \& obtusa, ocupa cuando mas la sexta parte de la longitud total; la cabeza, unida sin tránsito visible con el cuello, es plana, corta, bastante ancha en su parte posterior y adelgazada en la anterior; -la -mandibula superior es mas larga que la otra; el escudo del hocico, grande, abovedado, se apoya por su parte posterior en los escudos de la nariz y está sesgado ó escotado en el borde de la boca; los demás escudos son de forma regular.

\section{EL RINEQUIS ESCALONADO-RHINECHIS SCALARIS}

Caractéres. - El rinequis escalonado, tipo en que se funda el género anterior, se reconoce por los caractéres de este, $y$ además los siguientes: las escamas, sobrepuestas, prolongadas, irregularmente cuadradas 5 lisas, forman de veintisiete á reintinueve serics longitudinales; los escudos abdominales son anchos y se doblan en los bordes; los inferiores de la cola forman una doble linea. El color $y$ los dibujos varian mucho; el primero, segun la edad, pasa desde el gris claro $\delta$ gris verdoso al pardo rojizo $\delta$ pardo amari- llento hasta el aceituna $\delta$ amarillo rojizo; en la cabeza se ve á menudo una ancha faja ahorquillada, abierta por delante, y una linea que cruzando verticalmente los ojos se ramifica hácia atrás; en la nuca hay una mancha trasversal; una serie de otras iguales se prolonga bastante á lo largo del espinazo; al lado y en medio de cllas resalta en cada costado una serie de manchas mas pequeinas, á las cuales sigue á veces una tercera y cuarta. Con la edad estas manchas se borran mas y mas, primero las del lado, hasta que al fin solo quedan dos lineas de un pardo oscuro 6 negro que se corren desde la nuca hasta la punta de la cola.

DISTRIBUCION GEOGRAFICA.-El área de disper. sion del rinequis escalonado es casi igual á la del periops de herradura. No puedo decir nada sobre su género de vida, régimen y reproduccion, pues no tengo ninguna noticia so. bre este punto.

\section{LOS NATRICINOS-NATRICINA}

CARACTERES. - En la sub-ramilia de los natricinos ó culebras nadadoras, á las que Yan agrega las culebras acuá. ticas, constituyendo asi una familia independiente (Podamo. philide), reunimos las especies de tronco recogido, media. namente largo, cabeza mas ó menos separada, hendidura de la boca muy ancha, escamas por lo regular aquilladas $y$ dis. piestas en diez y nueve series.

USOS, COSTUMBRES Y RLGIMEN. - Todas las es. pecies pertenecientes á esta sub.familia viren con preferencia en las inmediaciones del agua y cazan su presa tanto en este clemento como en tierra firme; aliméntanse en particular de peces, salamandras y ranas, y no destrozan su presa antes de devorarla.

\section{LOS TROPIDONOTOS - TROPIDO- NOTUS}

CARACTÉRES.-Tropidonotos llamamos á las especies cuyas escamas dorsales presentan quillas agudas. La cabcza de estos ofidios, marcadamente separada del cuello, es comprimida de arriba abajo, caracterizándose además por la ancha hendidura de la boca; los ojos, de tamaño regular ó muy grandes, tienen pupilas redondas; las fosas nasales se hallan situadas lateralmente en medio de dos escucios, y es notable la regularidad de las placas; cl tronco tiene la forma redondeada, y la cola bastante larga; el primero cubicrto en su parte superior de escamas sobrepuestas, de tamaño regular y aquilladas, y en su cara inferior de escudos abdominales que no llegan al número de doscienios. Fn las mandibulas $y$ en el paladar hay numerosos dientes; los anteriores son siempre mas cortos y los posteriores mas largos, sin presentar nunca surcos.

\section{EL TROPIDONOTO DE COLLAR-TROPIDO- NOTUS NATRIX}

CARACTERES. - Esta especie, tipo del género y bien conocido de todos a serpiente de todas las serpientes para nuestro pueblo, objeto de sus antiguas fábulas y de sus ma. ravillosos cuentos modernos, causa de su terror, de su odio y de su afan de exterminio es la mas comun de todas las culcbras alemanas. Su longitud puede llegar á ser de $\mathrm{s}^{\prime \prime}, 60$, mas por lo regular, cuando menos en Alemania, no alcanza ni de mucho esta medida y los machos son además siempre mas pequeños que las hembras. Dos manchas blancas 6 amarillas, en forma de media luna, blancas en la hembra, amari. llas en el macho, y que se hallan á cada lado detrás de las 
sienes, manchas que segun la fábula popular representan una corona, caracterizan de tal modo á este ofidio, que nunca se le podria confundir con otro de Alemania. Su color predominante es un gris azulado, con dos series de manchas oscuras que se corren á lo largo del espinazo; mas abajo, en los costados, se ven manchas blancas, y la cara alsciomiual es negra. El color del lomo tira tan pronto al azul como al verdoso 6 al gris arulado, siendo a menudo casi negro, en cuyo caso desaparecen casi del rodo las manchas. Los sexos no difieren mucho, ni tampoco los hijuelos de los adulios.

En las montañas bajas de Suiza existen, segun 'I'schudi, dos ó tres variedades diferentes y constantes, una de color gris aceituna, otra de un gris rojizo y una tercera que guarda el término medio entre ambas. En el sur y sudeste de Europa hay además dos variedades que antes se consideraron como especies: el tropidonoto negro (Tropidonotus ater), propio de las regiones del Volga, que en todas sus partes presenta un fondo de color oscuro, y que solo en la superior de la cabe. za ostenta algunas mancias claras; y el tropiduroto rayado (Tropillonotus persa) que se distingue por dos estrechas fajas longitudinales bien marcadas y paralelas, de color amarillo o blanco amarillento, las cuales partiendo de la nuca se corren por todo el lomo hasta la cola.

DISTRIBUCION GEOGRAFICA.-El f́rea de dispersion del tropidonoto de collar se extiende por toda la Euro. pa, excepto el extremo norte y las islas de Islandia y Cerdeña; por una parte considerable del Asia y por el nordeste de Africa.

Encuéntrase asimismo en toda Alensania, donde habita con suma frecuencia las regiones pantanosas en que abunda el agua; raras veces se le ve en terrenos secos, pero no falta en ninguna parte. En Suiza y en los Alpes, en general, sube hasta una altura de 1,650 netros, y mas allá no falta $\mathrm{cn}$ nin. gun punto de Italia. Asi en toda la Francia, como en la peninsula Ibérica, figura entre las serpientes mas comunes; en Jos paises bajos del Danubio y en la peninsula del Balkan abunda mucho mas aun que entre nosotros, pero solo se encuentra la variedad rayada. Tambien está diseminado has. ta el norte de Suecia; se le ha!la en Rusia y Finlandia; pasa del Cáucrso y del Ural, y vive por consiguiente tanto en las estepas de los kirguises, como en la 'Transcaucasia; solo en Persia y en la pendiente septentrional del Atlas alcanza sus limires meridionales.

USOS, COSTUMBRES Y REGIMEN.-Frecuenta estc reptil con preferencia toda clase de localidades húmcdas, in. clusas las márgenes de los rios y los pantanos, donde suele hallar el alimento de su mayor predileccion; encuéntrasele con todo, tambien, en las altas inontalıas á gran distancia del agua, y no accidentalmente, sino.en todas las.épocas del año, segun afirma l.enz; de modo que debemos suponer que ha fijado alli su morada. Sucle acercarse esta culebra \& las ha. bitaciones, y se la ve f́ menudo en las cuevas y cuadras, en los montones de estiércol y en los agujeros abiertos por las ratas ó los topos.

Segun Struck los gallineros y corrales donde hay patos constituyen uno de sus sitios favoritos; en estos últimos, sobre todo, el citado observador vió docenas de esas culebras, tanto adultas como pequeñas. La paja húmeda y caliente que allf cubre el suelo les gusta mucho. Viven en la mayor armonia con los patos, que no tocan ni aun las culebras pe. queñas a causa de su hedor, $y^{\circ}$ les gusta poner sus huevos debajo de los nidos abandonados de las aves, tanto de los patos como de las gallinas. En cambio, dicho naturalista no ob. servo en ninguna parte que el tropidonoto de collar buscase los establos de vacas y carneros, y esto se explica ya por la sencilla razon de que las serpientes estarian alli dernasiado expuestas á los golpes de las pezuñas de estos mamiferos domésticos. Con menos frecuencia que en los gallineros, aunque bastante \& menudo, hállase el tropidonoto de collar en el interior de las viviendas humanas: lenz reficre que en su juventud habitó una casa en cuyos sóanos vivia hacia mas de un año una pareja de grandes tropidonotos de collar, á los cuales se agregaban alguna vez varios pequeños. \&Estaba pronibido, dice lenz, inquietar á los tales reptiles, pero tam. bien era dificil encontrar criados que quisieran quedarse con semejante compania. Nosotros, los niños, admirábamos sobre todo los animales cuando con gran ruido pasaban sobre los trozos de vidrio de un gran cajon de basura; menos agradable era la presencia de una gran culebra de collar que se arrastraba por debajo de las tablas del suclo de la habitacion de un sacerdote, pariente mio: si se pisaban aquellas con un poco de fuerza exhalábase al punto el conocido hedor de la culebra. Dichas tablas no podian sacarse, porque la casa pertenecia á la comunidad; pero al fin la serpiente enigró voluntariamente. En las casas de labranza de Rusia el tro pidonoto de collar se halla muy á menudo, segun Ficher, porque les agrada \& los campesinos, que toleran sicmpre su presencia; tambien protege al reptil la supersticion de esa gente, que cree se castiga la muerte de uno de estos ofidios. El ruso supone la existencia de un reino de culebras á cuyo frente se halla un soberano que cine una corona adornada de piedras preciosas, la cual brilla deslumbradora á los rayos del sol, siendo súbditas todas las culcbras. Cuando se hace daño a uno de estos reptiles, vengascle castigando al culpable con enfermedades, sequias, incendios y' otros perjuicios. Parece creible que la culebra de collar pueda vivir en buena inteli. gencia con los habitantes de una casa que tengan esta opinion.

El tropidonoto se cuenta entre los reptiles que abrevian tanto como es posible su sueno invernal; en otoño se les ve cuando el tiempo es favorable, y aun en noviembre se exponen á los rajos del sol; en la primavera se presenta á fines de marzo 6 primeros de abril, para disfrutar durante algunas semanas del calor del benélico astro antes de comenzar su vida de verano ó sus cacerias.

Quien haya desechado el temor á las serpientes, por la educacion adquirida, y el que conozca al tropidonuto de collar, le considerará sin reserva como un animal gracioso é interesante.

Es la culebra de collar una de las especies mas vivaces y activas de la familia. En las márgenes frondosas de aguas tranquilas encuentra el obscrvador fácil ocasion de estudiar las costumbres de este reptil. Desde la orilla, donde ha es. tado largo rato gozando del calor del sol, se desliza sin el menor ruido el el agua, ya para delcitarse nadando, ya para satisfacer la necesidad de bañarse. Por lo regular, se mantiene tan cerca de la superficic del agua, que asoma la cabeza por encima de la misma, y se empuja hàcia adelante por me. dio de las ondulaciones laterales de su cuerpo, moviendo al propio tiempo continuamente la lengua; a veces nada entre dos aguas, arrojando à la superficic burbujas de aire y reco. nociendo por el tacto de su lengua los objetos sólidos á que se accrca. Cuando huye espantada, acostumbra å refugiarse en el fondo del agua, y despues de recorrer un trecho del mismo, cuando cree pasado el peligro, vuclve á subir á la superficie, ó permanece alli largo tiempo, pues pasa horas enteras debajo del agua. Esta observacion, dice Lenz, la he podido hacer con toda comodidad en mi casa, donde tenia dentro de una gran cuba medio llena de agua, diez y seis de estos tropidonotos. En el fondo de la cuba habia un poste que sostenia una tabla, y en esta descansaban mis culebras á veces media hora 6 tres cuartos, habiendo algunas que se 
enroscaban al rededor del poste. Cuando tienen que recor. rer largas distancias nadando, como por ejemplo, atravesar un ancho rio $\delta$ un lago, llena la culebra su espacioso pulmon de aire, aumentando. de este modo su volúmen dentro del agua, mientras que por el contrario, cuando quiere sumergir. se desaloja todo el aire que contiene aquel.

No nada tan rápidamente que no se pudiera darle al. cance; pero resiste mucho tiempo sin fatiga, $y$ puede frar quear en el agua distancias mucho mayores de lo que por lo regular se cree; cuando las circunstancias son f:vorables se le puede perseguir tambien nadando mucho tiempo. Asi por ejemplo, Struck observó cierto dia una culebra que nadaba por la orilla, y a compañóla en un trecho de mil ochocientos pasos antes de que desapareciera sumergiéndose súbitamente. Con bastante seguridad se sabe que cruza vastas superficies de agua Schinz le vió nadando en el centro del lago de Zurich; naturalistas ingleses le encontraron repetidas veces en el mar entre el Pais de Gales y Anglesen, y por último el marino dinamarqués $\mathrm{Ir}$. minguer descubrió uno en alta mar á mas de tres millas de distanciá de la costa, pudienđo recogerlo á bordo y envián. dolo despues a Eschricht de Copenhague.

En Mecklenburgo todo el mundo sabe, y Struck lo vió va. rias veces por sus propios ojos, que cuando los tropidonotos pescan en un lago se colocan á veces sobre el dorso de los patos que nadan, sin duda para disfrutar asi del calor de un lecho blando, en el que pueden descansar, y esto sin que aquellas aves se opongan. De esta observacion ha nacido la creencia popular de que los patos se aparean con las cule. bras, y ninguno de los fieles adictos à esta supersticion se atreveria d comer un huevo de pato. El tropidonoto de collar repta con bastante rapidez por el suelo; pero se le puede alcanzar siempre sin grande esfuerzo en la llanura; mientras que en las pendientes se precipita á veces con tal impetu ála profundidad, que muy bien podria comparársele con una flecha. Tambien trepa con bastante habilidad $y$ sube a veces \& árboles altos. Cuando le encontraba en uno, dice Lenz, di. vertiame en hacerlo trepar á la mayor altura; cuando ya no podia subir mas arriba deslizábase rápidamente por el ramaje hácia abajo ó pasaba, si era posible, al arbol mas próximo, bajando por las ramas de este; pero si las inferiores sc hallaban \& mucha altura, en vez de descender por el tronco, precipitábase al suelo.

Se designa el tropidonoto como dócil, porque solo en casos extremos se defiende con sus dientes contra el hombre, $y$ porque tanto en libertad como cautivo vive en buena inteligencia con otros ofidios ó reptiles en general, salamandras, etc.; con estas últimas, al menos, mientras no le atormenta el hambre. Contra los mamiferos $y$-aves rapaces se defiende silbando, $y$ tambien intenta morder, pero si puede, huye siempre de los sćres que le parecen peligrosos, sobre todo de los que le persiguen y devoran. Linck le tiene por un reptil tan pacifico é inofensivo sque se podria dispensarle la mayor confianza siquiera por la tranquilidad con que se acerca á las viviendas humanas, que parece revelar una buena conciencia. El hoin. bre sobre todo, no debe temer sus dientes, y sin recelo puede tocarle con la mano, cogerle, $y$ hasta si quiere llevarle sobre su pecho. No le falta de ningun modo valor para defenderse, pero si se quiere que muerda es preciso recurrir á la astucia y tocarle súbitamente por detrás. Segun las observaciones de Dursy, tampoco muerde cuando oculto delrás de una tabla $\delta$ de una puerta se alarga súbitamente la mano por dentro de la jaula. La noticia de Linck queda sin embargo en pie, pues Lenz asegura que le mordieron á veces asaz inesperada. mente algunos tropidonotos de collar : cierto dia un individuo se dejó coger y solo al cabo de seis minutos mordió, produ. ciendo un ligero silbido, á pesar de que hasta entonces laabia estado quicto en la mano, á la cual infirió una herida san. grienta de un centímetro de largo por uno de profundidad; parecia cortada con un afilado cuchillo; pero muy pronto se curó sin accidente alguno. Contra el hombre no se sirve esta culebra de otra arma que la del hedor insoportable que arroja sobre él, al propio tiempo que sus materias fecales, y que algunos autores atribuyen tambien $\mathbf{z}$ un humor que produce cicrta glándula situada en el borde de la cloaca. En frente de otros animales mayores 6 de aves de rapina se muestra mas atrevido $y$ violento el reptil; silba con fuerza y muerde, pero raras veces consigue hincar los dientes en el contrario. "2Por mas que he observado, dice Lenz, nunca he podido ver que diese un verdadero mordisco á su enemigo, si bien en. cerrado con estc, permanece varios dias seguidos enroscado é inflado, procurando morderle cada vez que se acerca. Si su enemigo, ya sea mamifero 6 ave, se decide 1 cogerlo, no hace la culebra resistencia alguna; $\tan$ solo silba violentamer.te, intenta desasirse ó envuelic á aqucl y le descarga cuanto excremento y podredumbre puede despedir su cuerpo.»

He oido referir tambien hechos que parecen probar lo contrario de las observaciones de Lenz: así, por ejemplo, un guardabosques me dijo que un tropidonoto muy grande se habia enroscado en el cuello de su perro, ahogándole casi, lo cual conviene muy bien con la siguiente noticia de Tschu. di. «Un ejemplo extraño, dice, demostró en mayo de $186_{4}$ cómo sabe defenderse este inofensivo animal. El macho de la pareja de cigüeñas que tenia su nido en la torre de la iglesia de Benken, cogió en el prado contiguo una culebra de collar que sin duda pensaba regalar á su hembra, pero el reptil, aunnque herido, se enroscó con tal fuetza en cl cuello de su agresor, que acabó por ahogario. Encontróse á la cigüeña muerta, todavia estrechamente envuelta en los pliegues de la culebra.s

No quisiera tachar de inverosímiles estas noticias, pero en ningun caso son de gran importancia, ni pueden anular la regla general.

El alimento favorito del tropidonoto se compone de ra. nas, y con preferencia persigue á la rana comun (rana tempo. raria). Segun las observaciones de Lenz, parece preferir la rana silvestre á todas las demás, ó por lo menos, varios individuos que al principio de su cautividad no querian comer, aceptaron el alimento al presentárseles ranas de dichn especie. Cuando viven libres, solo pueden obtener esta golosina durante el periodo de la reproduccion de esos batracios, que entonces bajan al suelo; pero por lo regular, la rana comun ó de las praderas es su caza ordinaria, de la cual se apodera con facilidad. La observacion de Effeldt de quc las culcbras acuáticas temen á la rana verde, \& la cual muerden solo cuando tienen mucha hambre, aunque sin comerla, no se puede aplicar hasta cierto punto al tropidonoto: yo al menos le he visto mas de una vez con ranas acuáticas. Cuando no tiene ranas suficientes coge tambien lagartos y sapos; los primeros se encuentran raras veces en su estómago, $y$ de los seguncos no come sino cuando tiene mucha hambre. En cambio parece que le gustan bastante las salamandras acuát:cas, y sabe apoderarse tanto en tierra firme como en el agua de las tres especies que viven entre nosotros. Tam. bien acomete alguna rez, segun me dice Sterki, a la salamandra de fuego, mas no parece agradarle mucho esta comida, pucs a veces arroja la salamandra perdonándole la vida. Además de los batracios, tambien persigue con preferencia á los pececillos, como todos sus congéneres, lo cual puede causar en algunos parajes verdaderos perjuicios. Linck, que no le ha visto nunca coger peces en el agua, duda que haya personas que fundándose en propias observaciones 
puedan atribuir á este reptil la habilidad necesaria para ello; pero Lenz, observador concienzudo, lo afirma asi, y mi hermano ha visto tantas veces a los tropidonotos pescar, que podemos dar como resuelta esta cuestion. Lenz encontró principalmente en el estómago de tropidonotos, gobios, lo. chas y tencas, observando que algunos individuos recien cogidos arrojaban á menudo estas especies de peces á su vista.

Con la mas detallada exactitud describe Linck la caceria de un tropidonoto que perseguia á una gran rana de las pra. deras, la cual constituye su alimento favorito: \& El batracio sospecha as tiempo la intencion de la culebra que se aproxi. ma, 6 impulsada por su instinto, $\delta$ quizás tambien por el recucrdo de un peligro análogo, que le permite reconocer un enemigo encarnizado, emprende al punto la fuga, tanto mas de prisa cuanto mas disminuje la distancia que le separa de su perseguidor. Fil micdo aturde á la rana de tal modo, que solo da algunos saltos á cortos intervalos, á pesar de que si los diese muy grandes, como de costumbre, podria salvarse fácilmente. Solo redobla su afan de escapar corriendo y dan. do volteretas á cada paso. Muy extraños nos parecen entonces los gritos lastimeros del batracio aterrorizado, gritos que no tienen ninguna analogia con los sonidos que por lo regular producen las ranas y que se asemejan mas bien á los de otro sér; son casi como un quejido lastimero y prolongado. Fsta persecucion, durante la cual la serpiente parece no ver nada de cuanto pasa a su alrededor, raras veces dura mucho tiempo; muy por el contrario, la culebra suele coger su victi. ma al cabo de un minuto y la derora en el acto. Linct: opina que puede haber algo de verdad en la llamada fuera fascinadora de la serpiente, porque una persona digna de crédito le habló de cierta culebra que al devorar una rana muy grande estaba rodeada de otras cinco ó seis, que proferian gritos lastimeros, pero sin hacer ninguna tentativa para escapar de la sucrte de su compañera; de modo que dos ó tres fucron cogidas $y$ devoradas. Yo creo poder sostener lo dicho mas arriba, pues mas de una vez he visto la persecucion de las ranas, descrita por Iinck fielmente. Cuando se ponen una culebra y una rana juntas en una jaula, la última intenta escapar con toda la prisa posible, y solo cuando ve que esto no es posible, se resigna con su suerte sin oponer resis. tencia.

La manera como esta culebra engulle su presa repugna bastante al observador, pues no se detiene en matar antes á la victima, sino que se la introduce viva todavia en el est $\delta$ mago. Por lo general procura coger la rana por la cabeza, pero cuando no lo puede conseguir, se apodera de ella de cualquier manera, por ejemplo, por las patas traseras; y mien. tras se la va tragando lentamente, el batracio patalea como es consiguiente $y$ articula las notas mas lastimosas en tanto que puede abrir la boca La culebra por su parte tiene que hacer grandes esfuerzos para que no se le cscape la presa; con todo, raras reces consigue esta libertarse. Las ranas mas pequeñas, como es natural, las engulle fácilmente la culcbra, y asi como necesita $\{$ reces varias horas para acabar de tra. garse una de gran tamaño, cuando le aprieta el hambre devo. ra una tras otra seis ú ocho de las mas pequeñas. Espantada y perseguida sucle arrojar lo mismo que las demás serpientes, el alimento que acaba de tomar. La culcbra de collar solo devora excepcionalmente pequeños maniferos y aves; a lo menos háse observado en los individuos cautivos que hacen poco caso de las ratas ó pájaros y de los huevos de estos. Struck y otros, en cambio, observaron que lamen con mucho gusto la yema de los huevos rotos. Es posible que en su juventud se alimenten, aunque no con preferencia, de in sectos y de moluscos. Erber vió á sus tropidonotos cautivos comer caracoles y orugas; Struck observó que algunos indi viduos libres acechaban las moscas, mosquitos, ctc., parados en paredes para tomar el sol.

Mucho tiempo se creyó que el tropidonoto no bebia : lenz no ha encontrado nunca agua en el estómago de las culebras examinadas por él, aunque en la estacion calurosa las dejó mucho tiempo sin agua, matándolas despues de habér. sela ofrecido. A pesar de esto no puede dudarse de lo con. trario; un amigo del naturalista citado observó que uno de sus cautivos, despues de padecer de la sed durante quince dias en medio del verano, vació una vasija de agua. A Dursy le parece extraño quue no todos los observadores hayan visto beber al tropidono:o de collar 5 por eso pretende lo contrario. En dias de calor se puede ver como estas serpicntes absorben ávidamente las gotas caidas en el suclo, y tambien se ha notado á menudo que beben de un plato lleno de agua, poco mas 0 menos como lo hacen las coronelas. Los iropidonotos de collar cuidados por mi, los cuales tenia con otras serpientes en la misma jaula, vivian con tanta re. gularidad como sus congéneres. Algunos toman en vez de agua tambien leche, por lo menos cuando no pueden obte. ner otra cosa, y una vez acostumbrados á este liquicio, hasta puede suceder que lo beban con gusto. Èn esta observacion se funda probablemente aquella fábula tan conccida de todos en que se dice que los tropidonotos de collar chupan las mamas de las vacas y de otros animales, á fin de obtener un alimento necesario para su cxistencia. I inck no compren. de cómo tal fábula ha llegado ś figurar entre los documentos de la ciencia, eporque, segun dice, es uno de los hechos mas inverosimiles prohijados por la supersticion, que desde los ticmpos mas remotos oscurece todavia una parte del circulo de la luz que hoy empieza á difundirse. Una generacion dice á la otra que los tropidonotos de collar se deslizan por los establos para exprimir con su propia boca las mamas de los animales domésticos, y que entran en las bodegas para ra. ciar los jarros de leche. Despues, un autor, limitándose á dudar de la destreza de estas serpientes para obtener ese alimento, habla al otro de la voracidad con que beben la leche; $y$ cl inexperto funda historietas interesantes sobre estas fábulas tantas veces oidias y jamás rechazadas, pero que nunca se justificaron con documentos. Durante mucho ticmpo me habia parccido extraño que ninguno de los nume. rosos tropidonotos de collar obscrvados por mi en el transcurso de los años mosirase el mas mínimo deseo de probar el alimento liqquido, al paso que tenian bastante apetito cuan. do se les ofrecia el sólido. Retiré la bebida á varios tropido. notos tan domesticados que cogian los ratones y ratas, no solo a mi vista, sino tambien de mis manos, privandoles de aquella al principio varias semanas, y despues meses enteros: y hasta les quité los baños acostumbrados, a fin de que se acostumbrasen iodo lo posible á la sed. Despues les ofreci leche de diversas maneras, caliente, fresca, hervida y fermentada; pero tocjo fué en vano, pues ningun individuo hizo aprecio de la bebida. Con marcada indiferencia y cnojo se deslizaban sobre la fuente, haciendo visibles esfuerzos para no tocar el liquido con la boca, líquido que segun la creen. cia popular aceptada de buena fe por la ciencia, debia agradarles lo bastante para exponer la libertad y la vida cuando querián apoderarse de una golosina tan deseada Sicmpre que les hice tragar leche por iuerza, en dósis conveniente, arrojáronia con grandes esfuerzos en estado espumoso; cuantas veces repetf los experimentos obtuve el mismo re sultado, sin conseguir nunca obligar à un tropidonoto de collar á beber una sola gota. Me faltaria espacio si quisiera describir minuciosamente todas las pruebas hechas por mi, y por eso me limitare a decir que de mis averiguaciones resulia hasta la evidencia que la pretension de que esta ser- 
piente bebe leche, así como todos los cuentos nacidos de ella pertenecen al dominio de la fábula, donde ocupan el mismo rango con los erizos que con sus espinas recogen las frutas, con las anguilas que olfatean guisantes, y con el fa. moso carruaje de que se habla en la historia de las marmo. tas. Veintitres años antes, Lenz habia hecho ya las mismas observaciones, obteniendo igual resultado, mas parece haber algo de verdad en la cosa, pues hay observaciones que prueban que estas serpientes beben leche y café con leche. En mis cacerias en los contornos de San Petersburgo, dice Fischer, varios campesinos me refirieron que un tropidonoto de collar hacia dos años se presentaba todos los dias en una casa para beber leche de la misma taza del nino $\$$ Tambien Lenz ha conocido un tiecho anàlogo.

«En el pueblecito de Nanseuberg, perteneciente ála comu. nidad de Kaberz, habitaba un tropidonoto de collar en la casa de unos campesinos, debajo de un monton de estiércol medio seco; la gente hacia poco caso del reptil; no le persiguió, y una vez, despues de muchos dias de sequia, acució para lamer un vasito con café, que el niño de la familia, senta. do cn tierra, tenia á su lado. Los padres le observaron in móviles, refirieron el caso á los yecinos, y asi se pudo recnnocer varias veces despues que la culebra iba á beber con la misma confianza. El médico del colegio de Schnepfenthal, nacido en Kaberz, conoce muy bien aquella gente y á los ve. cinos; ha tomado informes minuciosos sobre el hecho y se ha convencido de que no puede pensarse en un error ni tampoco en un engaño. Si de estas dos observaciones parece constar que el tropidonoto de collar no desprecia del todo la leche, por otra parte no se puede ni suponer que ordeña las vacas ó las cabras. Ni una sola serpiente es capa\% de chupar con tanta fuerza como la que se necesita para esto. Dumeril, tomando en consideracion la estructura de la boca y la de los dientes, niega tal facultad \& las serpientes, y en particular al tropidonoto, y todo naturalista que conoce la estructura y la indole de la serpiente debe estar conforme con esta opinion. Yo, por mi parte, ni siquiera creo en la posibilidad supuesta por Lenz de que algunos individuos hambrientos se han acercado por casualidad \& unas vacas echadas, y tomando por carne las mamas, clavaron los dientes, haciendo esfuerzos para comérselas.

Como todos los ofidios, puede la culebra de collar perma necer sin alimento durante meses enteros. Herklotz refiere, como sigue, el experimento que hizo en este sentido con un individuo que cogió en julio de 1864 : Aunque le ofreci toda clase de alimento apropiado, se negó tenazmente á co nier y beber. Duró esta conducta hasta mediados de seticmbre, cuando se decidio á beber un puco de agua, pero continuando en despreciar la comida. Poco despues mudó por completo la piel. La terquedad del reptil llegó á interesarme, y resolvi probar cuánto tiempo podria resistir el hambre, no cuidàndome ya de darle alimento alguno. La jaula, con $\mathrm{cu}$ bierta de cristal, estaba colocada en mi propio cuarto que yo solo habitaba; de modo, que podia estar seguro de que nadie daba de comer á la culebra. Vino el invierno, y si bien el reptil procuró arreglarse un escondrijo debajo de las piedras, no llegó $́$ caer en letargo, pues la temperatura de la habita. cion nunca fué menor de $\delta$ á Io grados Reaumur. Es verdad que daba pocas señales de vida y permanecia dias enteros sin moverse, pero levantando la tapa de la jaula, me probaba que no dormia la rápida proyeccion de su lengua; sin embargo, una vez llegué á creer que habia muerto y mandé retirar el cadáver, pero se reanimó en la mano caliente de mi hijo y empezó á enroscarse; le dimos un poco de agua que bebió con aparente satisfaccion, y continuó del mismo modo, sin alimento alguno, hasta el 26 de abril. En dicho dia la ví tan debilitada, que crei de veras que se iba á morir, y juzgando que habia durado ya bastante el experimento, introduje dos salamandras en la jaula. La culebra se apercibió inmediata. mente de la presa que le ofrecia, desenroseb su cuerpo y dió un par de vueltas al rededor de su prision; parándose luego, restregó varias veces primero un lado de la cabeza y despues el otro contra una piedra, y de este modo fué abriendo gra. dualmente la boca, hasta dilatarla por completo. Con extraordinaria rapidez se precipitó entonces sobre una de las salamandras y la engulló con voracidad; al poco rato el otro batracio habia desaparecido igualmente. Desde aquel dia ha comido mas de una vez, y se encuentra en la actualidad en perfecto estado de salud, despues de haber mudado la piel en II de mayo. Raro será el caso de otro reptil que haya permanecido durante 311 dias sin alimento alguno y sin ha. cer el acostumbrado sueno invernal; por eso he creido que valia la pena hacer público este experimento.»

REPRODUCCION. - Aunque la culebra de collar suele en los añus de temperatura favorable despertar de su sueño invernal $\{$ fines de marzo ó principios de abril y mudar la piel poco tiempo despues, con todo, no se dedica á las fun: ciones del apareamiento antes de los últimos dias de mayo 6 primeros de junio. En esta época se les ve á menudo, álas primeras horas ce la mañana, maclio $y$ hembra intimamente unidos, por lo regular en sitios expuestos á los rayos del sol. Les domina basta tal punto la pasion en aquel momento, que puede el hombre acercárseles entonces hasta muy pocos pasos de distancia, antes que de ello se aperciban y procuren huir, tirando cada uno de su lado, en medio de continuos silbidos. No deja de ejercer tambien la temperatura bastante inflencia en él desove de las hembras, pues á veces ya se ercuentran huevos de este ofidio acabados de poner, en el mes de julio, mientras que en algunos años solo se ven en agosto y setiembre. Las hembras mas jóvenes ponen quince y hasta veinte huevos, llegando las de mayor edad hasta treinta y seis. En figura y tamaño se parecen estos huevos á los de paloma, pero se distinguen como los de todos los rep. tiles, por su cúscara blanda, por consiguiente poco calcírea, y en el interior por la escasa cantidad de clara, que no forma sino una delgada capa en rededor de la jema Expuestos al aire se secan gradualmente $y$ se vuelven hueros; en el agua se pierden tambien, y estas dos causas contribuyen en gran manera á contener la propagacion de la especie, que deberia ser extraordinaria si todos los gérmenes llegasen á desarrollarse.

La hembra de cierta edad escoge con mucho tino los sitios mas adecundos para la incubacion, y pone sus huevos en los montones de estiércol, debajo de tierra floja 6 cntre la yerba húmeda y otros sitios parecidos, expuestos al calor, pero que pueden conservar durante largo ticmpo una humedad moderada. En el acto del desorc, un huevo sigue inmediatamente detrás del otro y está ligado al anterior por una materia gela. tinosa, de modo que aparecen todos unidos en forma de ro. sario. Estos huevos son los que el vulgo ignorante llama huevos de gallo y à los que en su supersticion atribuye ciertas virtudes maravillosas. Tres semanas dura la incubacion, $y$ tan pronto como el pequeñuelo rompe la cáscara, empieza el mismo modo de vivir de sus padres, á no ser que frios tempranos le obliguen á buscarse escondrijo adecuado para pasar el invierno. Cuando salen á luz miden las pequeñas culebras tan solo unas 6 pulgadas, pero ya tienen todos sus dientes completos; de modo que vienen preparadas debidamente para bastarse á si solas, como se ven obligadas á hacerlo, pues. la madre despues de haber desovado no se cuida ya mas de su prole. Si, como ya hemos dicho, la temperatura no permite $a$ los pequeños dedicarse inmediatamente á la busca de 
alimento, los protege la grasa que cubre su cuerpo al salir del huevo, $y$ además su innata vitalidad, propia de todos los repptiles, contra el hambre y la crudeza de la estacion.

CAUTIVIDAD.-El tropidonoto de collar se conserva fácilmente en cautividad, porque desdeluego acepta la comi. da. Un individuo recien cogido no mira con indiferencia la rana que ve pasar s. su lado; si tiene hambre la da caza, cógela, se la come, y parece satisfecho con tal alimento; si des. pues le ofrecen agua para beber y banarse, arreglando su jaula convenientemente, nada mas desea. $\Lambda 1$ principio se sirve de su medio defénsivo bastante molesto, vaciando el contenido hediondo de sus glándulas con mas frecuencia de la que quisiéramos; pero poco á poco pierde esta mala costumbre; y se le puede domesticar verdaderamente al cabo de algun tiem. po. Sterki me escribe que ha cuidado algunos individuos, tan poco deseosos de la libertad, que pudo llevarlos al campo, dejándolos algunas horas libres, sin que inteniaran huir. Yo mismo, cuando era cstudiante, he tenido algunos que me seguian con aficion cuando les ofrecia alimento. Comn el tropidonoto de collar no muerde, sino muy raras veces, no hay tenor en dejárselo á los niños para jugar: parece que este reptil les divierte mucho. Yo sé de tropidonotos de collar que sin cuidado especial se conservaron tres y mas años en cautividad.

UTIZIDAD.-Despues de lo que ya ire dicho no es me. nester hablar mas detenidamente sobre los enemigos del tropidonoto de collar; mas á pesar de eso, pedire de nuevo proteccion para esos reptiles. No quiero abogar por el tropidonoto mismo, porque debo considerarle mas bien como anjmal dañino que útil, pues prescindiendo de su matanza de peces, que alli donde hay estanq̨ues de cria pucden ser verdaderamente sensibles, se alimenta, segun hemos visto, de animales que son indudablemente útiles para el exterminio de caracoles é insectos dañinos. A pesar de eso, recomiendo, asi como Linck, no solo á todo amigo de la naturaleza, sino tambien a todo amigo de una educacion razonable, que tenga en su casa, además de las ares de habizacion, algun rep(i), y sobre todo el tropidonoto de collar, pues opino, con el citado erpetólogo, que de esta manera la instruccion popular se desarrolla, mientras que la supersticion pierde terreno. Ios hechos que el novicio ve con sus propios ojos ó palpa con las manos desterrarán muchas veces la supersticion.

Ias excelentes observaciones hechas por mi hermano en Fspaña sobre la pesca de los tropidonotos, me obligan á hablar de otras dos especies, comunes en el sur de Europa y nue muy á menudo se han confundido una con otra; son estas especies el tropidonoto de dados y el tropidonoto viperino.

EL TROPIDONOTO DE DADOS-TROPIDONOTUS TESSELLATUS

CARACTERES.-El tropidonoto de dados se parece en tamaño y formas a su congénere de collar, pero se distingue segun Strauch, no solo por el número de las placas de los la. bios superiores y de los escudos situados delante de los ojos, sino tambien por la forma de la cabeza y la disposicion de los colores. El número de placas de los labios superiores es por término medio de ocho, raras veces de siete ó nueve; el de los escudos situados delante de los ojos varía de dos á tres. La cabeza es mas estrecha y prolongada, y los lados menos verticales que en el tropidonoto de collar; de modo que los ojos y fosas nasales tienen una posicion diagonal di. rigiendose no solo como en aquel sencillamente hácia afue$\mathrm{r}$, sino al mismo tiempo un poco hácia arriba. El color predominante es un gris aceituna, mas claro ó mas oscuro, que \& menudo tira al gris amarillento. La cabeza es de un color, y solo las placas de los labios superiores son amarillentas, casi siempre con un borde negro mas ó menos ancho. En el ironco se ven cinco series de manchas negras por lo regular cuadradas, raras veces redondeadas; estas manchas alternan entre si de modo que forman como un tablero de damas, pudiendo variar en cuanto \& su figura y tamaño, hasta deEaparecer, excepcion hecha de unas pequeñas lineas negras de la cxtremidad de las escamas, lineas que en ver de tener ese color pueden mezclarse con otras de un gris aceituna claro en la quilla de las escamas. Algunos individuos tienen detrás de la cabeza dos fajas diagonales que en su parte anterior se reunen en un ángulo agudo y que son estrechas, de color ne. gro y mas 6 menos marcadas; en otros, sobre todo en los procedentes de la Europa occidental, vénse en los costados unos puntos amarillentos que ocupan los bordes de algunas escamas, formando á veces lineas transversales. La carn inferior del tronco es de color amarillento, con manchas negras, que à veces similan, pero casi siempre con irregularidad, las casillas de un tablero de ajedrez.

\section{LA CULEBRA VIPERINA-TROPIDONOTUS VIPERINUS}

CARACTERES. - Se distingue esta especie de la anterior por su cuerpo mas corto y la cola delgada que rápida. mente se va adelgarando hasta la cxtremidad; su longitud es raris veces mas de $0^{n}, 60$. La coloracion de la parte dorsal es un gris oscuro con matices mas 6 menos amarillos; sobre este fondo se destacan en la cabeza dos manchas cuadrangulares de tinte mas oscuro, que continúan en el dorso en for. ma de S S, y que hácia la cola se convierten otra vez en man. chas sueltas, disminujendo gradualmente de tamaño. A los lados se ve una faja de manchas redondas de color oscuro, que en el centro tienen un punto blanco mas 6 menos amarillento, y gque a veces se confunden, formando una figura parccida al número S. La parte inferior del cuerpo es de un tinte amarillo, mas oscuro en la region abdominal propiamente dicha, y mas abajo con manchas alternadas de amariHo rojiro y de negro, estas últimas afectando la forma regular de un dado. La mandibula inferior es complctamente blanca.

DISTRIBUCION GEOGRÁFICA.-Hasta últimamente no se han hecho observaciones suficientes sobre el śrea de dispersion del tropidonoto de dados, ţue segun se asegura tiene gran extension, puesto gue esta serpiente, al decir de Strauch, se lialla con el tropidonoto de collar en una gran parte de los lugares donde este habita. Sin embargo, limitase mas a los paises meridionales y no penetra en el norte mas alla del centro de Europa, donde solo se encuentra en ciertos sitios, sin abundar en ninguna parte de todo su dominio. En todos los paises de la Europa meridional siruados al oeste del mar Adriático se le confunde á menudo con el tropidonoto vipe. rino, que habita alli tambien. En Alemania, Hyden fué quien primero le cilcontró cerca de Ems, considerándole como of dio bastante comun en las fuentes termales del rio Lahn y en los canales que se comunican con los baños. Mas tarde Kirschbarn y Noll le observaron i orillas del Rhin, a cierta distancia de la desembocadura del Lalan, cerca de Unterwesle, y muy á menudo cerca de Kreuzburg. Parece, sin embargo, que en Alemania se limita á estas regiones, mientras que es nas numeroso tauto en Austria como en Suiza y Francia. Scgun las noticias de mi hermano, es casi tan comun en Es. paña como en Italia. Además habita el Asia Menor, los países del Cáucaso y las partes de Rusia situadas al rededor del mar Negro, del Cáspio y del Azoff. Su área de dispersion se extiende desde las costas del Ailántico, la península Ibé. 
rica y Francia hasta el Altai y desde los $50^{\circ}$ latitud norte hasta el norte de Africa; pero no se sabe aun de fijo hasta dónde llega por el sur.

El tropidonoto viperino habita en el sudoeste de Europa los mismos sitios; en Italia, el sur de Francia y España figura entre los ofidios mas comunes, $y$ al parecer abunda tambien mucho en el norte de Africa.

USOS, COSTUMBRES Y REGIMEN.-Ia descripcion del género de vida de ambas especies ofrece todavia sus dificultades, unas veces porque carecemos de observaciones minuciosas, $y$ otras porque ambas han sido confundidas mu. chas veces. A orillas del Lahn, segun Vogelsberger, el tropidonoto de dados se encuentra en la primasera, a menudo aparcado debajo de las piedras, las cuates le sirven tambien de refugio en elagua; $\leq$ fines de otoño, en canbio, y á principios de la primavera obsérvasele mas en la montaña, donde se le puede ver en los dias despejados comando sol en los sitios cubiertos de musgo. Geisenheyner le vió en algunos puntos á orillas del Nahe, pero sobre todo en el mismo baño de Kreuznach. Aqui se halla el rio frente al parque; en tiempo seco fórmanse pequeñas islas, mientras que en la orilla izquierda quedan varias charcas. Esta parte del rio es el mejor paraje para observar á ése reptil que pernanece echado sobre las piedras debajo de la superficie del agua, emprendiendo desde aqui sus expediciones á la montaña ve cina. Para que se comprenda cuánto abunda bastará decir que Kreuznack encontró en una sola montaña cinco individuos con la cabeza aplastada. En Dalmacia, segun las observaciones de Erber, vive principalmente a orillas del mar, pues tambien en el agua salada persigue á los peces. Vogelsberger dice, que deposita los hueros en la orilla húmeda; Geisenheyner recibió siete del tamaño de los del tropidonoto de cc. llar, descubiertos en un monton de estiércol, pero no enfila. dos á modo de un cordon de perlas, sino reunidos en monton.

Metaxa es quien primero nos habla sobre el tropidonoto viperino; dice que en la campiña de Roma la llaman tma madora de vacas,s por atribuirle los campesinos supersticio sos la misına propiedad que en otros paises á la oulebra de collar. Tiene el misrio modo de vivir que esta última, no muerde al hombre y se deja donicsticar hasta cierto grado, si bien al principio se muestra un poco rebelde y acostumbra á enroscarse en el brazo del guardian apretándolo con fuerza. Consiste principalmente su alimento en ratones, ranas y sapos. «Tres de estos encontré, dice el profesor, en el estó mago de una culebra viperina; el que estaba mas cerca de la boca tenia vida todaría, y esto me dió ocasion para ob. servar que entre todos los animales engullidos por serpien. tes, los sapos son los que permanecen mas tiempo vivos en el estómago de aquellas. Al examinar una de estas culebras, vimos salir del esófago y echar á correr un sapo, al que le faltaba la pata trasera, que sin duda habia sido digerida."

Estas escasas noticias se completan esencialmente con las ya citadas observaciones de mi hermano. "Ambas culebras y otros dos congéneres, variedades seguramente de la misma especie, viren en las inmediaciones del palacio del Escorial en grandes estanques y fijan alli su morada en los intersticios de las rocas ó de las paredes. En uno de estos deprósitos de agua viven reunidos centenares de estos reptiles: en una sola excursion que hice á la pequenia isla, de treinta piés en cuadro, que acostumbraba á visitar cuando iba ś la caza de ánades, llegué á contar sesenta individuos de esta especie, que tan pronto como me apercibian escapa. ban hácia sus escondrijos ó se arrojaban al agua. Acometen a las ranas, pero son los peces su presa farorita, causando gran destruccion entre ellos. Para cogerlos suelen recorrer el estanque en todas direcciones, como de dos á tres piés de. bajo de la superficie $y$ asomando la cabeza de cuando en cuando; de modo que les dan verdadera caza. Tienen además otra manera de apojerarse de esta presa, coms he observado á menudo, y es colocíndose sobre una piedra situada dentro del agua á corta distancia de su superficic, con el cuerpo atravesado, de modo que la cabeza se encuentra cerca de aquella mientras que la cola está tocando el fondo y el cuerpo sostenido en varias circunvoluciones. En esta postura acometen con rapidez extraordinaria álos peces que pasan y rara es la presa que yerran. Por lo regular cogen al pe\% por el vientre, lo levantan por encima del agua y nadan á tierra para devorar alli su víctima. Desde el punto que habia escogido veia venir varias culebras en mi direccion; todas tenian un pez en la boca. Cuando apercibi la primera culebra, no sabia en realidad qqué animal era el qque se me acercaba, pues solo descubria un objeto ancho y brillante que se movin rápidamente en el agua y tuve que hacer uso de mis gemelos de caza para cerciorarme de que era una culebra. No hay duda de que estos tropidonotos comen tam. bien ranas, pero su alimento favorito y principal son los pe. ces, causando como ya he dicho grandes destrozos en estos habitantes del elemento liquido, y deben ser considerados por lo tanto como animales perniciosos.

Tambien estas serpientes comen insectos, ó por lo menos el tropidonoto viperino. Dieck vió dos veces á un individuo de esta especie coger por la cabeza un pelotero y sacudirle lasta que se hubo vaciado del todo el liquido que á estos escambajos sirve de arma defensiva; de modo que así pudo devorarlo sin dificultad.

CAUTIVIDAD. - Segun las obsernaciones de Erber, el trojidonóto de dados se deja dominar de tal modo por la curiosidad, que á causa de ella, y aunque es muy ágil, se le puede coger fácilmente. Aun en la jaula intenta averiguar la causa de todo estorbo y sube sin miedo sobre la mano que se le tiende. Algunos individuos de mas edad que Geisen. heyner turo cautivos silbaron mucho cuando se les introdujo en la jaula, haciendo despues una serie de desesperadas tentativas para escapar, de las cuales, sin embargo, pronto desistieron, si bien las renovaron por la noche. Segun pue. do asegurar por mis propias observaciones, tambien estos ofidios se acostumbran pronto á la cautividad y cuando se les dan bastantes peces, su alinento favorito, acostimbranse por fin del todo á su nuevo estado. Yo he cuidado muchos individuos, conservándolos mas de un año y no puedo por consiguiente conformarme con el aserto de otros observadores de que los tropidonotos de dados y viperinos son débiles.

\section{LOS HOMALOPSIDOS- HOMALOPSIDE}

CARACTERES.-Mientras que Schlegel reune las culebras nadadoras y las serpientes acuáticas en una sola familia y mientras qque Jan sigue este ejempio, Guenther separa estas úlkimas de las culebras, formando con ellas una familia independiente, la de los homalopsidos que, en efecto, dificre de las culebras por algunos caractéres esenciales. El cuerpo es de longitud regular, cilíndrico, ó un poco comprimido lateralmente; la cabeza muy gruesa, ancha y plana, sin notable separacion del cuello; la cola fuerte, de longitud regular, ó muy larga yo puntinguda, mas ó menos prensil, y en la base mas ancha que alta; los ojos son pequeños; las fosas nasales se hallan en la superficie del hocico, en unos escudos nuy desarrollados que atrofian los inmediatos; tienen además un 
borde membranoso que permite cerrarlas del todo; las escamas, desiguales entre si, se cubren solo un poco unas á otras; los escudos abdominales son estrechos y presentan en algu. nas especies doble quilla; los inferiores de la cola forman dos series. El aparato dentario se parece en lo esencial al de las culebras; pero muchas especies poseen un dicnte mayor con un marcado surco separado de los orros por un pequerio claro.

DISTRYBUCION GEOGR ÁFICA.- Los homalopsidos ó serpientes de agua dulce, llamadas tambien sencillamente serpientes acuáticas, [ueden considenrsé como propias del lerritorio indio, pero tambien se hallan diseminarias por $\mathrm{cl}$ sur y centro de Ambrica y oeste del Africa.

USOS, COSTUMBRES Y RÉGIMEN. - Todas las es pecies conocidas viven casi exclusivamente en el agua, y solo por casmalidad se encuentra algun indjviduo $\mathrm{cm}$ un sitio próximo á la orilla. Varias especies, sobre todo las indias, nadan desde los rios hasta la alta mar, vagando alli emronces como las serpicntes marinas, a las que por otro concepto se asenc. jan tanto, que Gray las reunió con ellas en una familia inde. pendiente. Se distinguen sin dificultad de las culcuras ó ser. pientes que les son mas afines for la posicion de sus fosas

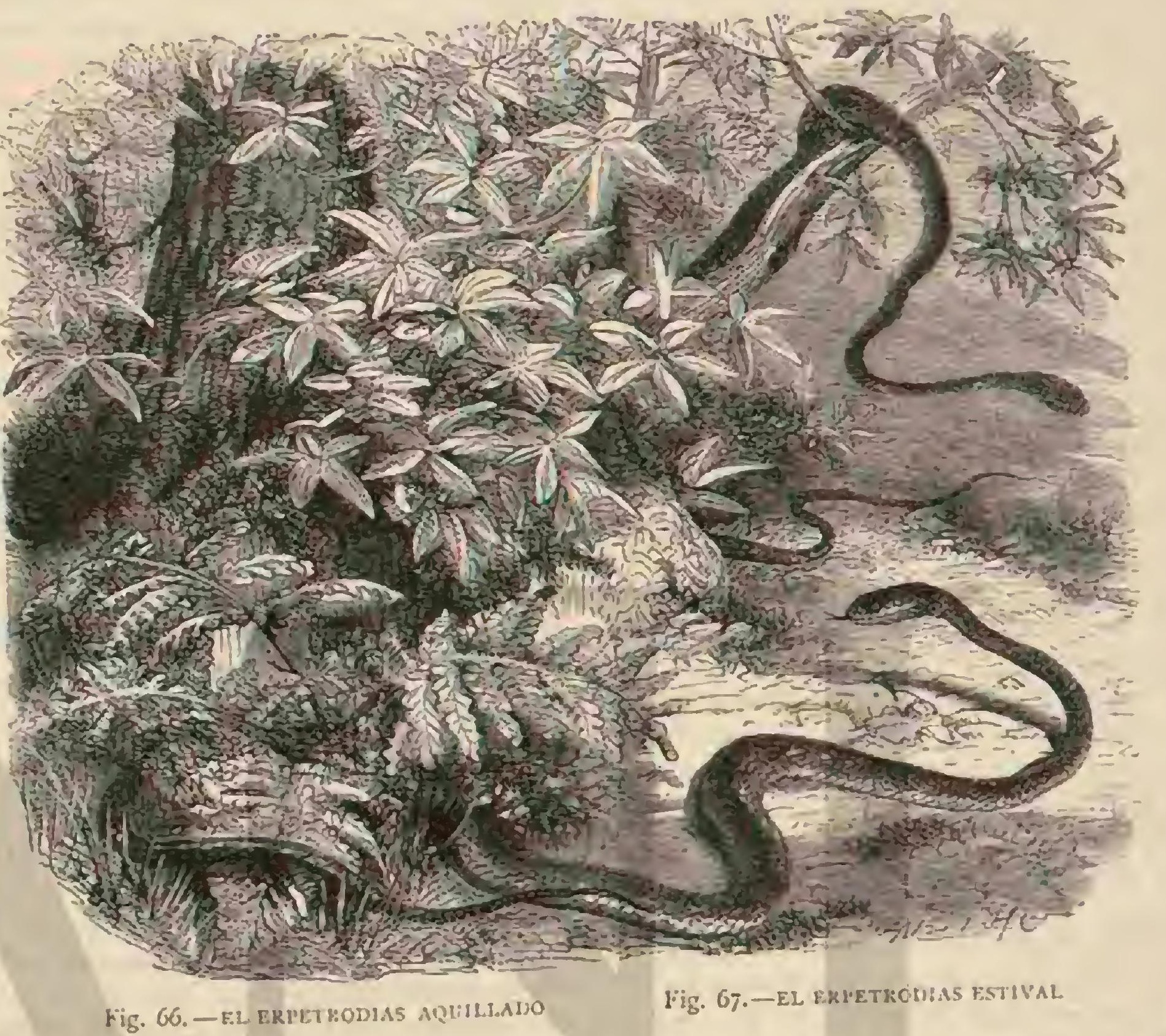

nasales en la cara superior del hocico, lo cual les permite respirar levantando solo una pequeña parte de la cabeza so bre la superficie del agua. Todas las especies nadan muy bien, con movimientos serpentinos, ayudándose esencialmente de su fuerte cola, de la cual tambien se sirven para sostenerse sobre objetos hotantes en el agua. Su alimento se compone solo de peces y crustáccos. Son mas dóciles que la mayor parte de las culcuras, poco mordedoras, graciosas en todo su conjunto y serian un gran adomo para nuestros acuarios si fuem posible hacerlas llegar vivas hasta nosotros: pero esto parece imposible por la sencilla razon de que ya en su patria se conservan muy poco en cautividad, y sobre todo porque rehusan tomar alimento. Todas las especies, to. dos los ofidios en general que viven en el agua son vivípa. ros; mas su reproduccion no es considerable al parecer, pues segun las observaciones de Cantor, ninguna especic produce mas de una docena de hijuclos. Una hembra del mayor ta. maño, que ol citado naturalista twvo cautiva, parió once vivos despues de haber estado seis meses en una vasija de vidrio llena de agua. Durante el parto la madre permaneció echada en el fondo de aquella, pero murió poco tiempo despues, atacada de convulsiores y tambien dos de los hijuclos perecieron a las dos horas poco despues de haberse desprendido el cascaron. Los otros nueve, cuya longitud era de unos $0^{\circ}, 15$ se agarraron debajo del agua al cuerpo de un macho adulto que estaba en la misna vasija, y de vez en cuando sacaban la cabeza \& la superficic para respirar, resistiéndose á lodos los esfuerzos que el macho hacia para librarse de ellos. Sin embargo, conio no querian comer nada, ni peces, ni insectos acuáticos, murieron \& los dos meses.

\section{LOS HELICOPOS-HELXCOPS}

CARACTÉRES. - lin el género de los helicopos 6 ser. pientes bizcas, el tronco es prólongado; la cola muy larga y puntiaguda; la cabeza ancha y comprimida; los ojos peque. fos y situados muy hácia adelante; las fosas nasales, abier. tas en los lados en un gran escudo, por lo regular de forma cuadrada, son tan jequeñas que apenas parecen puntos; el hocico es corto y redondeado. Los lielicopos estín cubiertos en su mayor parte de cscamas aquilladas; en la cara superior de la cabeza se ven además en los escudos nasales ya descritos un ancho escudo triangular por delante de la mariz, otro sencillo, casi de la misma forma, en medio de los nasales, dos cortos, anchos y pentagonales en la frente, uno exagonal en la coronilla y dos occipitales, que suman ocho. El escudo de la línea naso ocular es pequeño, los de las sienes de tamaño regular, y cada mandibula superior esta cubierta de ocho. 


\section{EL HELICOPO DE COLA AQUILLADA -HELICOPUS CARINICAUDUS}

CARACTÉRES.-Esta serpiente tiene poco mas ó me nos un metro de largo; en su parte superior predomina un gris sucio, con una serie de manchitas negras en cada lado; la cara inferior del tronco es de un amarillo pálido, con tres series de manchas negras, dispuestas con regularidad; en cada escudo abdominal se ven tres, siendo la del centro mas pequeria; en la region del cuello y en la cola desaparecen las centrales, y solo se ven dos series de manchas.

DISTRIBUCION GEOGRÁFICA. - El principe de Wied, el primero que describió el helicopo de cola aqui. liada, dice que solo recibió un individuo 2 orillas del rio Itapenirim, y que por lo tanto no puede indicar nada sobre su género de vida.

USOS, COSTUMBRES Y REGIMEN.-Otros naturalistas nos dicen que las especies afines observan el mismo género de vidá de los helicopos de cola aquilladal, ó culebras acuáticas, y que asi como estas, se encuentran principalmente en regiones húmedas y aun en rios, donde persiguen a los peces y ranas. Schomburgk vió una de las especies masarines en un agua de poco fondo, devorando un pez demnsiado voluminoso en proporcion al repsil que habia co. gido fácilmente su presa por estar entorpecida. Hensel, que obseryó igualmente el helicopo de cola aquillada, le consi: dera como serpiente acuática, que nunca se balla en tierra, y si en las bahias tranquilas. Aqui vaga cerca de la orilla, en los fondos bajos, donde se desliza entre las plantas acuáticas cogiendo los peces; cuando se le persigue sumérgese en seguida é intenta ocuitarse en el agua, pero nunca se refugia en tierra firme. Tambien este ofidio es viviparo, como todas las especies de su familia.

\section{LOS SAMOFIDOS-PSAMO- PHIDAE}

CARACTERES:-Samófidos 6 serpientés del desierto, llama Guenter i un grupo de ofidios semejantes das culebras y considerados por él como fanilia. Sus formas son mas $\delta$ menos prolongadas, á veces robustas; el tronco redondo, separado del cuello; la cabeza estrecha ó ancha y gruesa, deprimida siempre en la region naso-ocular; las fosas nasa. les se hallan situadas en los lados; los ojos, de tamaño regular, tienen la pupila redonda ó prolongada verticalmente; la boca es muy hendida; los cscudos de la cabeza regulares; las escamas reclas, dispuestas en quince, diez y siete ó diez $y$ nueve series; los escudos inferiores de la cola forman dos; los pasteriores de la frente son redondeados 6 angulosos en su extremidad posterior; los de la coronilla estrechos, y los de!las cejas salientes. -Mu' notable es el aparato dentario, porque uno de los cuatro ó cinco incisivos es mas largo que los otros y el último diente de cada ladoticne un surco bien marcado.

DISTRIBUCION GEOGRÁFICA. - Hubiéramos podido pasar en silencio esta familia, que principalmente está diseminada en el centro del Africa, si no se hallase repre: sentada en Europa por una especie sobre cuyo género de vida tenemos algunos iniormes, graciás á las observiaciones de Erber: esta especic pertenece al género de los celopelis.

\section{LOS CELOPELTIS-CCELOPELTIS}

CARACTERES.-Los ofidios de este género se caracte. rizan por tener la cabeza muy deprimida por delante de los ojos, por las escamas lisas, en forma de lanceta y cóncavas en el centro, y por la dentadura, en la que los dientes sólidos, anteriores al surcado, son de tamaño casi igual.

\section{EL CELOPELTIS LAGARTINO-CCELOPEL- TIS LAGERTINA}

CARACTERES,-El celopeltis ó culebra lagartina alcanza una longitud de $1^{\prime \prime}, 40$, de los que $0^{\prime \prime}: 35$ corresponden á la cola. Se distingue bien de todos los demás ofidios europeos por tener la frente siempre muy cóncava; y el individuo adulto por las escamas dorsales, tambien cóncavas en sentido longitudinal. El color predominante de las regiones su. periures es un pardo aceituna que tira mas ó menos al pardo rojo; la cabeza presenta dibujos de las formas mas variadas, dificiles de describir, de color pardo oscuro, orilladas de atnarillo; cuyos dibujos resaltan mas ó menos marcada. mente. En la parte superior del tronco y de la cola hay manchitas negruzcas, orilladas casi siempre en uno ú otro lado de amarillo $y$ dispuestas por lo regular en cinco series lon. gitudinales mas ó menos marcadas; de tal modo que las manchas de cada serie alternan con las de la inmediata. En las escamas de las dos últimas series de cada lado se ven ademís manchas amarillas ó blanquizcas de formas irregularés y de tamaño diferente, en mayor ó menor número; estas manchas forman á veces una haja ondulada casi sin interrupcion, $\sigma$ bien se atrofian de modo que solo se ve un estrecho borde. La cara inferior del tronco y de la cola es de un blanco amarillento 6 amarillo pardo, que en los individuos jóvenes presenta manchas de un gris negruzco, dispuestas en series longitudinales, pero de un solo color en los adultos. En la region de la garganta, las manchas suelen constituir tres cortas fajas longitudinales. Una variedad (Calopeltis Nenmayeri) tiene la cara superior de un solo tinte, ó presenta únicamente en la mitad posterior del tronco y en la base de la cola indicios de manchas oscuras, dis. puestas en series longitudinales. Otra variedad (Rhabdodon fuscus) tiene las partes superiores de un pardo oscuro y has. ta pardo negruaco con algunas escamas orilladas de amarillo claro, numerosas sobre todo en los costados, donde forman una estrecha faja longitudinal de un amarillo claro que se corre hasta el ano. Los escudos de los labios superiores son negros, con manchas de un pardo amarillo; las regiones in. feriores de algunos individuos de un solo color negro gris a causa de las manchas mas abundantes de este color.

DISTRIBUCYON GEOGRÁFICA. - EI celopeltis lagartino habita en todos los paises de la costa del Mediterráneo y asimismo en Portugal, en las costas occidentales de Africa, Arabia y Persia; de modo que su área de dispersion se extiende desde la costa del Atlántico, por el sur de Kuropa y norte de Africa hasta el Caspio y el oeste de Arabia y desde los $45^{\circ}$ de latitud norte hasta los desiertos de Africa. Erber le observó con bastante frecuencia en toda la Dalmacia, sin duda porque él mismo se descubre por su fuerte silbido.

Cuando acecha oculta entre los arbustos, los ratones, lagartos y pájaros, pasaria desapercibida para el viajero, si sus fuertes silbidos no anunciasen su presencia. Así cogi en las inmediaciones de Jara, cerca de la aidea de Cosino, un individuo de esta especie de gran tamairo, cuyos fuertes re. soplidos habian llamado mi atencion. Yerseguí al reptil de un arbusto al otro, hasta que se refugió cn una cavidad del terreno, pero teniendo la suctte de poderle atrapar por la cola. Como no queria mutilar al animal, y este se resistiese tenazmente, procurando internarse cada vez mas en el agujero, me costó largo rato de paciencia y de esfuerzos para conseguir arrastrarla pulgada à pulgada hácia fuera. Tan 
pronto como conoció que toda resistencia cra ya inútil, acabó por sacar rápidamente del agujero el resto de su caerpo: yon espantosos silbidos intentó arrojarse sobre mi cara, lo que evité naturalmente; en seguida despidió por todos lados cuanto tenia en su cuerpo. Fntre otros restos, escupió casi enteros cuatro ratoncs y dos lagartos verdes, muriendo át las pocas horas despues de tan terribles esfuer\%os.

CAUTIVIDAD.-Dice el mismo autor que esta serpien. te no se deja jamás domesticar; silba continuamenie y muerde cuantos objetos encuentra á su alcance; resiste poco tiempo á la cautividad, y suele sucumbir durante el invierno. Sin cmbargo, estas observaciones están en completa contra. diccion con el aserto de Duges, que asegura que el celopeltis lacertino se deja domesticar muy facilmente. Este natu. ralista dice además, que la mordedura de csta serpiente no causa daño alguno, ฮaunque tenga posteriormente en cada mandíbula un diente cónico, muy puntiagudo y mucho mayor que los demás, con un surco ó ranura y una vaina, den. tro de la cual se encuentran otros tres dicntes iguales, pero muy pequeños. Tambien Erber hace idéntica afrmacion, lo que demuestra que en manera alguna se pueden comparar estos dientes posteriores con los ganchos venenosos de las especies dañinas.

\section{LOS DRIOFÍLIDOS- DRYOPHILIDE}

CARACTÉRES. - Driolilidos, ó serpientes arboricolas, llamamos a unos ofidios semejanies á las culcbras, pero de formas sumamente enjutas; tienen el tronco en forma de látigo; cabeza larga ó prolongada, muchas veces con el hocico puntiagudo; y el color casi siempre de un verde de hoja ó pardusco. Estos ofidios viven casi cxclusiramente en los árboles; y excepto los driofinos y los dipsádidos, son superiores á todas las demás especies del órden en cuanto á su fa. cilidad para trepar.

DISTRIBUCION GEOGRÁFICA. - Estas serpientes habitan los paises mas cálidos de ambos hemisferios, y en gran abundancia en las localidades quueles son mas adecuadas.

USOS, COSTUMBRES Y RÉGIMEN. - Deben SU nombre st la extraordinaria agilidad con nue trepan por los árboles, donde pasan la mayor parte de su vida. Casi todas las especies que componen la familia son consideradas por los indigenas como muy venenosas, y por lo tanto, muy temidas y odiadas; sin embargo, el mas concienzudo exámen de su dentadura ha demostrado que son complemente in. ofensivas. Esta circunstancia, unida s. sus graciosas formas y \& la delicadeza de sus muvimientos, les atraen, por otra parte, el cariño del observador. Los siameses, que reconocen en ellas estas cualidades, les han dado el poćtico nombre de erajos de sol. Tambien entre los europeos cuentan muchos aficionados estos hermosos animales. Tenia una verdadera satisfaccion, escribe Wucherer â su amigo Tennent, cuando observaba que uno de estos ofidios habia fijado su morada en mi jardin de Bahia. Era una agradable sorpresa, al subir á un árbol para examinar un nido que acababan de abando. nar los jóvenes pajaros, encontrarlo ya ocupado por uno de esos preciosos séres, cujo cuerpo, largo de mas de dos piés, aparecia enroscado en un espacio no mayor que cl hueco de la mano. La serpiente arbórea esta siempre alerta, y en el mismo momento en que uno la descubre, el rípido movimiento de su larga y ahorquilladalengua negra indica que nos ha visto y reconocido. Si se le da entender con el menor movimiento la intencion de molestarla, se refugia en la cima del árbol, corriendo por ranıas y hojas con tal ligereza, que apenas parecen doblarse estas últimas bajo su peso, y un instante despues se la ha perdido por completo de vista. Cuando regrese á Europa, tarde ó temprano, podeis estar seguro de que no faltará en mi invernadero este pequeño animal, tan inofensivo como gracioso.

Son de varias clases las presas de estos reptiles; comen ratones, pajaritos, y con particular preferencia los pequeños lagartos de distintas especies, que viven en la misma loca. lidad.

Segun las observaciones de Smith hechas en una especie africana, las ares los reconocen como enemigos peligrosos y descubren su presencia con agudos gritos. Enionces acuden las aves de todas partes y rodean tambien al enemigo gri. tando hasta que una de cllas cae victima de la serpiente, que con la cabeza erguida las acecha. Smith cree, segun sus observaciones, poder justificar la antigua fábula sobre la fa. cultad fascinadora de las serpientes; $y$ en la imprudencia con que las aves se acercan á esos reptiles solo ve la conse. cuencia de un terror que las atolondra; pero el mismo reconoce la agilidad extraordinaria de los driofilioos para coger al fin las aves aturdidas por su propia excitacion y densasiado atrevimiento: de modo que refuta sus propias deducciones.

No se han hecho observaciones exactas sobre la reproduc. cion; supónese que estas serpientes son viviparas, pero nada se sabe de cierto sobre el particular.

CAUTIVIDAD. - A Guenther debemos un informe in. teresante sobre el genero de vida de estos ofidios en cautividad: A mediados de verano, escribe el citado naturalista, lleváranse para su venta dos driofilidos sud.americanos (Philudryas viridissimsus) al Jardin roológico de Regents Park. A pesar del calor muy grande se mostraron en extremo cansados y tan rigidos, que todo contacto fuerte pareció poder romper su delgado cuerpo. Al ponerlos en la jaula se movieron lentamente hasta llegar á un rincon, donde levantando la parte anterior del cuerpo permanecieron inmó. viles. En opinion del guardian que-parecia haber cuidado ya muchas de las especies congenéricas indias, todas las serpientes verdes mueren. Les habia dado siempre ramas secas, pero no las aprovecharon nunca para descansar sobre ellas. Las escamas verdes de las serpientes hicieron suponer que solo les agradarian plantas vivaces de espeso follaje, y entonces les pusieron dos grandes hortensias en la jaula. Apenas hubo salido la gente cuando uno de los reptiles di. rigió la cabeza hácia las plantas, examinando al parecer rama por rama y hoja por hoja; de repente, con tanta rapidez que la vista no pudo seguir su movimiento, lanzóse sobre la planta, pasó algunas veces por el ramaje y enroscósc al fin en una rama, donde su cuerpo podia descansar casi por completo sobre las hojas verdes. 'Todo este ravimiento fué tan rápido é inesperado, que mientras fijaba mi atencion en una de las serpientes no eche de ver que la otra hacia exac. tamente lo mismo; y entonces, aunque el espacio era muy reducido, debi fijarme mucho para distinguirlas en el folla. je. Desde entonces se encuentran ambas muy bien y nunca mas se las ha visto en el suelo; solo alguna vez una de ellas alarga la parte anterior de su cuerpo fuera de la planta $y$ entonces parece una rama verde desnuda de follaje La teniativa de nutrirlas con ranitas no turo buen éxito, y por lo tanto fué preciso darlas pequeños lagartos, alimento escaso y caro en Inglaterra, pais muy pobre en reptiles. A pesar de que hasta ahora no se las ha visto comer, es indudable que les conviene este alimento, puesto que los lagartos desaparecen de rez en cuando $y$ el estómago de las serpientes se dilata considerablemente. Fs probable que en libertad estu. viesen acostumbradas á un alimento parecido, á los lagartos arboricolas ó anolis: otros preferirán ranas, y algunos ares. 
CLASIFICACION,-Èn cuanto á los limites de la familia, las opiniones de los diversos naturalistas son en extremo contradictorias: mientras que $Y$ an reune todas las serpientes arboricolas en una sola familia, Guenther las separa en rarios grupos de igual valor, considerando algunos géneros como culebras y reuniéndolos con estas en una familia. A mi me parece mas claro el procedimiento de Yan, y no he du dado en seguir su ejemplo, mas á pesar de esto tomaré en cuenta la division de Guenther.

\section{LOS ERPETODRINOS-HERPETO- DRYINYE}

CARACTERES.-Los crpetodrinos, ó driadinos, son los que Guenther clasifica entre las culebras y que nosotros reunimos en la primera sub faunilia. Caracterizanse por tener el tronco ya marcadamente prolongado y enjuto, pero aun robusto, sieudo muy marcada la separacion de la cabeza, al paso que apenas es visible la de la cola; el escudo de la linea naso-ocular falta a veces, y las escamas de la parte inferior de la cola están dispuestas en doble fila; los dientes son casi siempre de igual longitud, pero el posterior puede ser mas largo que los otros y presenta un surco.

DistrIBUCION GEOGRÁFICA. - Esta sub-familia tiene sus representantes sobre todo en el sur $y$ centro de Anérica:

\section{LOS ERPETODRIAS- HERPETODRYAS}

CARACTERES.-Los erpetodrias, ó driadinos propıamente dichos, pertenecen á las especies mas robustas de la familia, á pesar de que su cuerpo es muy enjuto. La cabeza, pequeña, corta y estrecha, estú poco separada del cuello; el hocico redondeado; el cuello muy delgado; el tronco un poco comprimido y mas estrecho en el lomo; la cola casi tan larga como el resto del tronco, delgada, puntiaguda $y$ en forma de lárigo; las fosas nasales se hallan situa das a los lados del hocico; los ojos grandes y vivos son salicntes.

\section{EL ERPETODRIAS AQUILLADO- HERPETODRYAS CARINATUS}

CARACTERES.-En los bosques del Brasil y de la Guayana vive una especie perteneciente al géncro anterior, cl erpetodrias aquillado, ó sipo, driofilido de dos metros de longitud $y$ de aspecto magnifico en todos sus colores, que son-muy variables, dando lugar á que se haya descrito el reptil bajo los nombres mas diferentes.

Segun la descripcion del principe de Wied, tiene la parte superior del cuerpo de un hermoso verde oliváceo con re. flejos pardos, mientras que las regiones inferiores aparecen verỏosas ó amarillas, dominando, por lo general, este último color por debajo de la cabeza, cuello y cola, y el verde en el abdómen propiamente dicho. La coloracion de la parte supe. rior varia entre todos los matices rerdosos hasta el pardo metálico, y lleva muy á menudo varias fajas longitudinales muy oscuras, en número de 6 hasta 12, segun Dumeril (fig. 66).

DISTRIBUCION GEOGRÁFICA.-Abunda csta espe. cie en los bosques del Brasil y de la Guayana. Segun las obserraciones del principe, el sipo es el ofidio, despues de la serpiente coralina, que con mayor frecuencia se encuentra en aquel imperio, especialmente en las inmediaciones de Rio Janeiro, Caoo Frio, Campos del Goaytacas, en Para. hiba y en Capitania en el Espiritu Santo.
USOS, COSTUMBRES Y REGIMEN. - Habita con preferencia la espesura de los arbustos, en terreno arenoso cerca del mar.

Nuestro naturalista vió aqui unos individuos extraordina. riamente grandes, es decir, de dos a tres metros de longitud, por $0^{2,}, 04$ d $0^{10}, 06$ de grueso. Estos ofidios prefieren sobre todo, segun parece, el terreno arenoso, y tambien sitios húmedos y pantanosos cerca del mar, cubiertos de juncos, ca. naverales y oiras plantas análogas, que recuerdan nuestras praderas. Alli se les encuentra á menudo en espesuras donde hay árboles cubiertos de campanillas blancas y clu. sias de anchas hojas, donde se hallan por lo regular descan. sando, en el follaje ó en ramas gruesas, pero á menudo tambiea en el suelo. Cuando se acerca álguien emprende la fuga con tanta rapidez que apenas se le puede seguir, sobre todo en la yerba, mientras que en la arena libre es un poco mas lento. Hensel cree que el sipo no es quizás tan raro como parece en el Brasil meridional, pero que se oculta bajo la maleza y en to mas espeso de los bosques, frustrando rodas las persecuciones por su rapidez casi increible. eCon la agi. lidad del rayo, esta serpiente trepa por el follaje, deslizín. dose entre la espesura de tal modo, que no parece increible que se alimente de aves.\$ El principe encontró á menudo individuos con el cuello muy dilatado, por contener grandes sapos, y por consiguiente es de creer que se alimenten sobre todo de batracios. Is período del celo se declara en octubre.

A pesar de ser considerado este ofidio por los mismos in. digenas como completamente inofensivo, miraban al principe y å sus compañeros con verdadero espanto, cuando estos lo cogian con la mano. Por lo denás, han ocurrido casos en que, atacado por el hombre, el sipo ha tomado la ofensiva, como se desprende del siguiente relato de Schomburgk: \& En una de mis excursiones de caza, vi una serpiente de cerca de 7 piés de largo, que lentamente venia hảcin mi; estaba todavia demasiado distante para poder distinguir si era ó no venenosa. Tenia cargados ambos cañones de mi escopeta; apunté, hice fuego, y tocando el reptil, lo vi retorcerse con desesperacion en su agonla; en aquel momento oi ruido de alas entre las ramas del árbol, debajo del cual me hallaba, y dirigiendo la vista hácia arriba, descubrí dos magnificos papagayos, cuya especie me era desconocida, que sin duda asustados por la detonacion habian huido de la rama en que descansaban, y volvian á colocarse entonces en la extremidad de otra; la serpiente parecia herida mortalmente: pronto dispare el otro cartucho, matando á uno de los pájaros. Observé en seguida que el reptil se arrastraba penosamente hácia un es. peso matorral, desapareciendo de mi vista mientras volvia á cargar la escopeta. En vano le busqué; me aproximé un poco mas, y de improviso, cual flecha disparada, el animal que debió conocer que me dirigia hácia donde estaba y se habria dispuesto ô saltar sobre ıni, lo hizo, obligándome á dar un tremendo salto hácia atrás. Casi paralizado de espanto, y sin saber si estaba herido, ví que el reptil se preparaba para otra acometida; pero un tiro bien ajuntado le dejó cadáver. Des. pues de minucioso exámen, encontré que ni yo estaba heri. do, ni mi tenaz enemigo era una serpiente venenosa, sino sencillamente el inofensiro sipo..

\section{EL ERPETODRIAS ESTIVAL-COLUBER AESTIVUS}

CARACTERES, - El carácter distintivo de este reptil consiste en tener diez y siete series de escamas carenadas; su cuerpo es tan delgado que apenas mide 3 pulgadas en la parte mas gruesa; y se distingue tambien por su bonito verde (fig. 67). 
DISTRIBUCION GEOGRÁFICA. - Esta especie es propia de América.

USOS, COSTUMBRES $\Psi$ REGIMEN. - El erpetodrias estival es muy aficionado a irépar por los ärboles, y lo hace con singular celeridad. Gracias al color de su cuerpo, se confunde con el follaje de tal modo, que si no fuera por sus rápidos movimientos, pasaria muchas veces desapercibido. Se alimenta comunmente de insectos, los cuales caza con mucha destreza.

\section{LOS DENDROFINOS - DENDRO-}

\section{PHINE}

CARACTERES. - Ia sub-familia de los dendrofinos, $\delta$ serpientes arboricolas, elevadas por Guenther al rango de una familia independiente (Dendrophida) se caracteriza por tener el tronco muy prolongado, enjuto, comprimido en los lados, y la cola de formacion currespondiente; la cabeza, por lo regular prolongada, es estrecha y angosta, mas á pesar de esto reconócese muy bien la separacion del cuello; el hocico muy largo, obtuso en su parte anterior ó redondeado; la boca muy hendida; los ojos muy grandes con pupilas redondas; las fosas nasales situadas lateralmente; los escudos de la cabeza no ofrecen nada de particular; el tronco en cambio está cubierto de escamas sobrepuestas muy angostas, que se cu bren bastante unas á otras; el abdómen está cubierto de escudos con dos quillas, por lo cual se elevan en los lados; otros escudos iguales-están dispuestos en dos series en la cara inferior de la cola Ninguno de los dientes se distingue por sil gran tamaño.

\section{LOS DENDROFIS-DENDROPHIS}

CARACTERES, - El tronco, muy largo y enjuto, es an. gosto; la cabeza prolongada, en extreno deprimida, con el hocico redondeado y obtuso; los ojos muy grandes; las fosas nasales se hallan situadas en los lados en medio de dos escudos. Las escamas lisas del dorso forman de trece á quin. ce series; las que se corren á lo largo del espinazo distínguense por su anchura y por la forma triangular $\delta$ cuadrada de sus escamas, mientras que las otras las tienen sobrepuestas, muy prolongadas y estrechas.

\section{EL DENDROFIS PINTADOÓ CHOCARI - DENDROPHIS PICTUS}

CARACTÉRES.-El chocari, tipo del géneto que nos ocupa, es. uns magnifica serpiente arboricula de $t^{\circ}, 30 \mathrm{dc}$ largo, correspondiendo á la cola una tercera parte. El color de las regiones superiores es un pardo metálico brillante, en al cual resalta a veces una fája amarilla que se corre $\$$ lo largo del esprinazo; en los costados se ve una faja amarilla orillada de un estrecho borde negro á cada lado; las partes inferiores son de un solo color amarillo mas ó menos vivo.

DISTRIBUCION GEOGRAFICA.-El chocari es propio de las Indias orientales.

USOS, COSTUMBRES Y RÉGIMEN:-Extraño es que no tengamos ningun informe minucioso sobre el género de vida de esta serpiente, tan bonita como comun, lo cual nos hace supponer que se diferencia poco 6 nada de las demís especies de la familia. Listá muy diseminada en la India orien. เal, y segun las observaciones de Cantor, abunda mucho en los paises donde hay colinas, pero no tanto en las llanuras. Asi como sus congéneres, persigue \& las aves pequeñas, á los lagartos y ranas arboricolas, y durante su juventud á toda clase de insectos. Los individuos adultos parecen muy iras. cibles, y se defienden con todas sus fuerzas si el hombre les ataca, infiríndole mordeduras bastante graves. En tales casos ensanchan, como otros ofidios de la India, la parte anterior dal cuello y del tronco; levantan poco mas ó menos la tercera parte de su longitud sobre el suelo, mueven vivamente la lengua, miden con la vista algunos segundos á su adversario, muerden, retiranse y se preparan para un nuevo ataque. En el cuerpo de una hembra preñada Cantor encontró

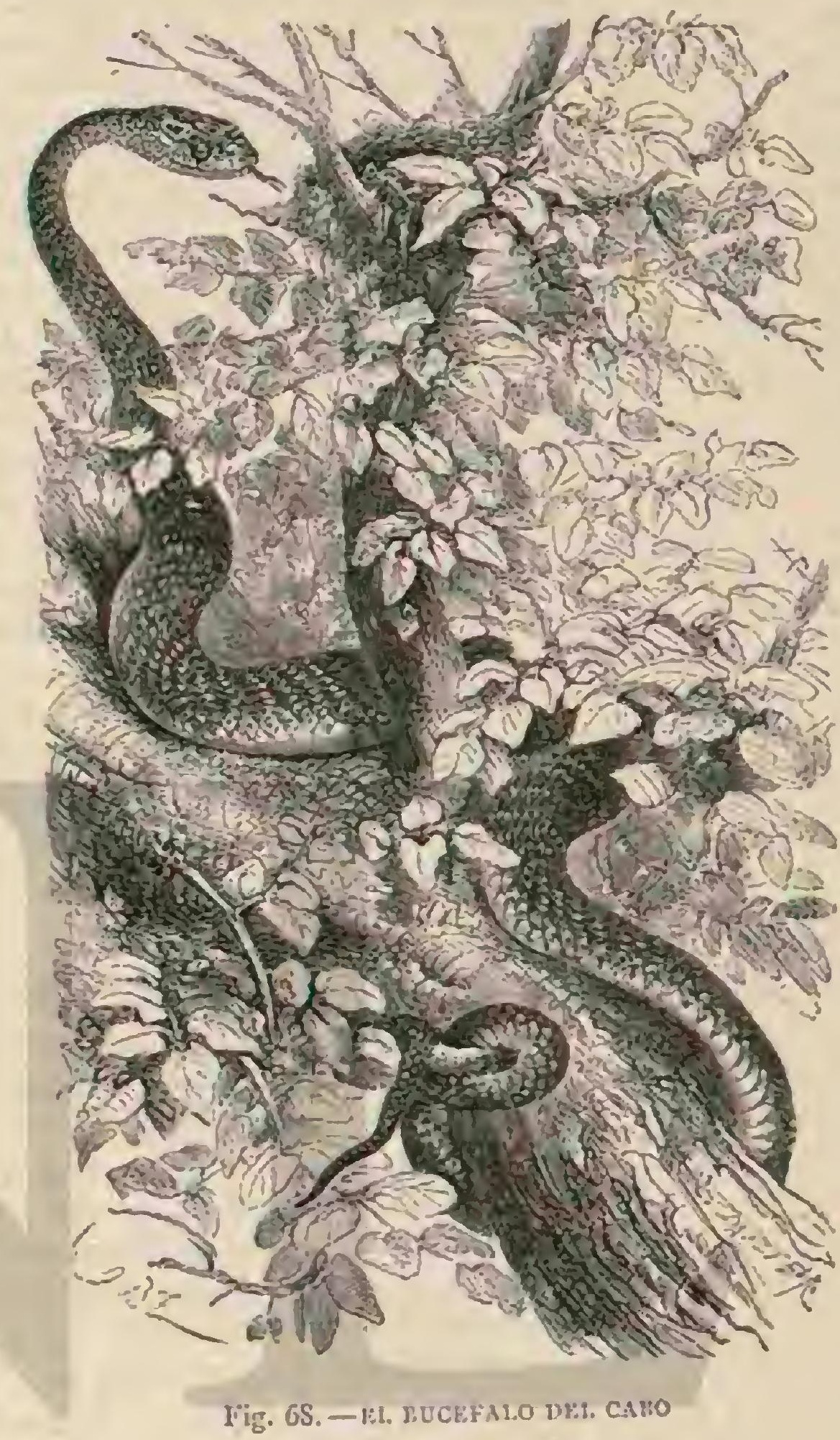

sicte huevos cilindricos de cáscara blanda, y de unos $(i=, 035$ de largo.

A esta sub.familia pertenece el Bucéfalo del Cabo (fig. 68), tipo de un género, que difiere poro del precedente.

\section{LOS DRIOFINOS - DRYOPHINA}

CARACTER ES.-Los driofinos, 6 serpientes de látigo, constituyen la tercera subfatuilia, pero segun la opinion de Guenther, tambien forman una familia independicnte (Dryo. phidac). Estos reptiles tienen el tronco y la cola en extremo Jargos y delgados; la cabeza, muy larga y estrecha, se adelgaza en la punta, prolongándose bastante á menudo en forma de trompa por un escudo muy saliente de la nariz, que en algunas especies se trasforma en un apendice movible; la boca está muy hendida; los ojos son de tamano regular, y en las especies asiáticas la pupila se prolonga verticalmente; las fosas nasales sun pequucnas y se hallan situadas a los lados. Los escudos de la cabeza no tienen, por lo demás, nada de notable; las escamas del tronco, sobrepuestas y muy an. gostas, forman de quince á diez y siete series; los escudos del 
vientre son aquillados 6 lisos; los de la parte inferior de la cola están dispuestos en dos series, como de ordinario. Las especies de esta familia, sobre todo las asiáticas, se caracte. rizan en particular por tener un diente largo semejante ál los caninos de los carniceros, en el centro de la mandibula, y otro muy surcado en la extremidad de la misma.

USOS, COSTUMBRES Y REGIMEN.-LOS driofinos merecen muy bien su nombre aleman de serpientes de látigo, pues en efecto, pueden compararse con el cordon de un láti. go por su tronco en extremo enjuto y prolongado, lo cual se aviene con su costumbre de vivir exclusivamente en las copas de los árboles. En el suelo sus movimientos son torpes y lentos, pero en el ramaje, tan graciosos como ágiles. Enros. cíndose en una rama con algunos anillos de su tronco obtienen para su cuerpo el apoyo necesario, pudiendo así moverle en todas las direcciones posibles; ya para coger su presa, precipitándose hácia adelante, $\delta$ bien para lanzarse á una rama distante, desde la cual continúa su camino aéreo. La estrictura de sus ojos y su dentadura inducen ásuponer q̧ue pertenece a los animales nocturnos, y podemos creer por lo tanto que este reptil es muy peligroso para todos los peque. ños vertebrados, que como el habitan los árboles. Dan caza 1 las ares, lagartos y ranas arboricolas, y en su juventud tam. bien is los insectos. Segun las noticias de Motleys y Dill, son muy voraces, desprendiéndose de otros relatos que tambien inuerden mucho. Precipítanse con furia sobre todo sér que se les acerca, \& muerden cuantos objetos se les ponen por delante, mas á pesar de esto, los niños se divierten en algu. nas partes con este reptil como si fuera un jugucte.

\section{LOS PASERITAS-PASSERITAS}

CARACTERES. - Los de este género, pobre en especies, son los siguientes: el tronco, en extremo enjuto, es algo comprimido en los lados; la cola redonda; la cabeza plana y muy larga; el hocico extraordinariamente prolongado y puntiagu do, provisto en su parte anterior de una protuberancia flexí. ble en forma de trompa; la region de la linea naso-ocular es deprimida, y detrás de ella hállanse los ojos, de tamaño re. gular, cóncaros en seritido horizontal y protegidos por un borde prominente; las fosas nasales, que son pequeñas, están situadas en los lados y desenibocan en la extremidad posterior de un escudo aislado; las escamas dorsales, largas, estrechas, lisas y sobrepuestas, forman quince series; los escudos abdominales carecen de quilla; en la dentadura se ve en el centro de cada maxilar un diente muy fuerte, $s$ en su extremidad otro surcado.

\section{EL PASERITA PURPÚREO-PASSERITA PURPURASGENS}

CARACTÉRES.-Esta especie, tipo del género anterior, puede servir para darnos á conocer los driofinos del Asia meridional En ella remos que la trompa, cuya longitud excede un poco de la mitad del hocico, sin prominencia, se compone esencialmente del escudo de aquel, que es verrugo. so en su parte superior, prolongado, en figura de cuadrilá tero y enroscado; los otros escudos anteriores varian tambien su forma regular. Esta serpiente tiene un color gris pardusco con dibujos purpúreos y puntos mas oscuros pardos, tanto en la parte superior como en la inferior; la piel que hay en medio de las escamas es blanca y negra, por lo cual se forman unas fajas anilladas en que alternan ambos colores cuando el animal se estira; por la linea naso.ocular se corre hácia los ojos una faja de color pardo; los escudos superiores de la cabcza son pardos tambien con un ancho borde amarillo.
La longitud total de este reptil llega á $\mathrm{I}^{\mathrm{n}}, 30$, correspondien do $a$ la cola tres octavas partes (fig. 70).

DISTRIBUCION GEOGRAFICA, - El paserita purpúreo es propio de la isla de Ceilan.

USOS, COSTUMBRES Y RÉGIMEN. - Dificil seria decir para qué sirve la trompa de esta serpiente. Apenas podrá considerarse como órgano del tacto, porque está cubierta de gruesos escudos, ni tampoco debemos ver en ella un instrumento para abrirse camino en lo mas espeso del ramaje. Es probable, sin embargo, que tenga aigun objeto, pero no sabemos cuál; no lo sabrán decir tampoco los discípulos de la doctrina de la conveniencia, que todo quieren explicarlo.

La descripcion que 'T'ennent hace de las serpientes arbo. ricolas se refiere probablemente en lo esencial á esta especie. I.a casa que dicho naturalista habitaba en las inmediaciones de Colombo estaba circuida de algunas altas casuarinas $y$ de otros árboles, en cuyas copas hallảbase á reces un sinnúmero de scrpicntes arborícolas; y como cl ramaje avanzaba hasta tocar las rentanas, Tennent turo la mejor ocasion para observar la actividad de esos reptiles. Esta actividad consiste mas bien en observar de continuo todo cuanto pasa alrede. dor que en una gran ligereza, aunque estas serpientes de. muestran tambien que no carecen de la necesaria. Segun parece, cazan principalmente de noche persiguiendo á los lagartos nocturnos, sobre todo á los gekos, propios de aquella isla, á las pequeñas aves $y$ à sus hijuelos. Nunca dejan voluntariamente los árboles. Ninguna de las especies propias de Ceilan es dañina, pero todas son muy mordedoras $\mathbb{E x}$ traño es, dice Tennent al terminar su relato, que ninguno de los muchos individuos que tenia recogidos para llevarlos á Europa aceptase alimento en la cautividad, mientras que las especies americanas comen sin mucho reparo cuando se ar. roja en sus jaulas algunas ramas verdes.8

La culebra dorada (fig. 69), segunda especie de este género, propia de México, difiere poco de la anterior.

\section{LOS OXIBELIS-OXYBELIS}

CARACTÉRES。-En los oxibelis, de los que hago mencion como tipos sudamericanos de la sub-familia, la cabeza es en extremo angosta, prolongada desde los ojos por el hocico, muy comprimido y largo; la mandibula superior, puntiaguda, pero fija, sobresale un poco de la inferior; el cuello es en extremo delgado y enjuto; el tronco se prolonga mucho $y$ es algo comprimido lateralmente; la cola, fina y delgada, remata en su extremidad en una punta pequeña.

\section{EL OXIBELIS BRILLANTE-OXYBELIS} FULGIDUS

CARACTERES, - El oxibelis brillante se distingue por su magnifico color verde, con una línea longitudinal anuariIla en ambos lados: mide poco mas ó menos 1, "50 de largo. DISTRIBUCION GEOGRÁFICA.-Este ofidio es propio del Brasil y de otras partes de la América del sur.

USOS, COSTUMBRES Y REGIMEN. - Vive casi cX. clusivamente en los árboles, en cuyo ramaje se revuelve con la mayor rapidez: carecemos de noticias minuciosas sobre su género de vida.

\section{LOS DIPSÁDIDOS- DIPSADID死}

CARACTERES. - Aunquue entre las serpientes arborícolas hasta ahora citadas se cuentan muchas especies noctur. 
nas, designamos con el nombre de dipsádidos otras que, siéndolo tambien, constituyen una familia independiente del órden. Son ofidios de tamaño regular, es decir, de unos dos metros de largo; tienen el tronco de mediana longitud, muy comprimido lateralmente; cabeza corta, por lo regular ensanchada en su parte anterior, es decir, casi triangular, con hocico corto y redondo, y separada marcadamente del cue110. I.os ojos son muy salientes, grandes y bien abiertos; la pupila hendida verticalmente; las fosas nasales se hallan situadas a los lados; la boca es muy hendida; la mandibula inferior puede ensancharse mucho; el cuello es muy delgado; la cola tiene una punta dura que se adelgaza hasta tomar la forma de un hilo; los escudos de la cabeza son regula. res; parte de las escamas pequeñas, y grandes las que se corren á lo largo del espinazo; los dientes están muy desarrollados; los posteriores suelen tener surcos, mientras que los anteriores toman la forma de caninos.

DISTRIBUCION GEOGRÁFICA.-Ia zona habitada por los dipsádidos, de los que se conocen cuarenta y una especies, se extiende por ambos hemisferios; son casi tan nu. merosos en el territorio indio como en el sud americano; escasean mas en el ctiópico, y solo se encuentran aisladamente en Australia y en el territorio septentrional del antiguo continente. Por lo tanto, tambien cllos pertenecen en su mayor parte a los paises tropicales.

USOS, COSTUMBRES I RÉGIMEN.-No 5abemos porqué Boje ha dado á estos reptiles, si bien mordedores, graciosos é inofensivos, el nombre de una serpiente difamada en la antigüedad; lo que podemos decir es que las especies que constitujen esta familia no tienen nada de comun con el dipsas de los antiguos; pues no cabe duda que estos designaban alguna vibora con ese nombre, sin pensar en las gra. ciosas serpientes arboricolas. Algunos autores antiguos, dice Gessner, la clasifican entre las culebras, y otros entre los ás. pides; pero no se debe hacer mucho caso de esto.

'lodas las especies conocidas viven en árboles, 9 solo por excepcion bajan al suelo. Los reptiles, sobre todo lagartos 5 ranas arboricolas, constituyen su alimento preferido; algunas cazan exclusivamente aves, otras mamiferos, $y$ las hay tambien que persiguen quizás a los insectos. Guenther pudo probar irrefutablemente que saquean los nidos, pues cogió el huevo bien conservado de un loro en el estómago de un dipsádido. Poco se sabe sobre su género de vida, y esto es tanto mas extraño cuanto que alli donde viven no son nada raros, ni faltan tampoco en nuestros continentes. Segun las experiencias de Wucherer, todos los dipsádidos brasileños merecen su nombre. De dia se retiran a sitios oscuros parn ocultarse; de noche se les ve al descubierto, á menudo en las inmediaciones de las casas y en sus tejados de paja. Un dipsádido que el citado observador tuvo cautivo se ocultaba de dia en un rincon de la jaula, mientras que despues de panerse el sol se mostraba en extremo alcgre y vivaz No tomó alimento ninguno, y al cabo de algunos meses le hallaron muerto en la jaula.

\section{LOS TARBOFIS-TARBOPHIS}

CARACTERES, - L. Fleischmann ha elevado la espe cie europea de la familia a la categoria de género de los tarbofis. Eil tronco, de forma cilindrica, es proporcionalmente corto; la cabeza un poco aplanada, marcandose mucho la separacion del cuello; los ojos son pequenos y tienen la pupila como los gatos; los dientes anteriores de los maxilares inferiores son mucho mas largos y corvos que los siguientes; los superiores largos tambien é igualmente corvos.

\section{EL TARBOFIS VIVAZ-TARBOPHIS VIVAX}

CARACTERES. - El tarbofis vivaz, o sergiense filina, se reconoce fácilmente entre todas las especies curopeas por tel largo escudo de la linea naso-ocular y la pupila hendida verticalmente. El color predominante es un pardusco blanco sucio, de lustre gris, con puntitos muy pequeños $y$ manchas de color castaío en las placas cefálicas; en la nuca hay otra mas grande pardo negruzca $\delta$ rojiza, y varias del mismo tinte, dispuestas en series, á lo largo del dorso; desde los ojos hasta los ángulos de la boca hay una faja oscura y a los lados del tronco una linea de manchas pequellas; las regiones abdo. minales son de un amarillo blanquizco. La longitud de esta serpiente llega por término medio st un metro.

DISTRYBUCION GEOGRÁfICA.-Por lo que hasta ahora se sabe, el área de dispersion del tarbofis vivaz se ex. tiende desde la Istria hasta la peninsula de Apscheron, y desde la costa septentrional del Aírica hasta los $25^{\circ}$ de latitud norte. Hanse recibido ejemplares de Istria, Daluacia, Albania, Turquia y Grecia, como asimismo de Egipto, del Asia Menor y de los distritos montañosos a orillas del mar Niegro y del Caspio.

USOS, COSTUMBRES Y REGIMEN. - Fija con preferencia esta serpiente su monda en las rocas, en las laderas pedregosas y en las paredes viejas. Teme tanto los grandes calores, como los frios excesivos, y por eso durante los me. ses mas calurosos, no abandona su cscondrijo sino duranie lasprimeras horas de la mañana y al anochecer. Ln sus movimientos es mucho mas ágil que las viboras, pero no tanto como las culebras propiamente dichas. Dice Fleischmann, que acomete á los lagartos y pequeños mamíferos, pero Liber asegura que los primeros son su único alimento. Iumeril encontró en el estómago de un individuo, examinado por $\mathrm{cl}$, los restos medio digeridos de una salamanquesa.

El tarbofis es muy mordedor, á cuya circunstancia debe que muchos indigenas lo confundan con las viboras y lo consideren como venenoso, persiguiendole tan tenazmente en algunos paises, que, como en Dalmacia, ya es raro encontrar un individuo de esta especie.

CaUTIVIDAD. - En cste estado se acostumbra muy pronto al guardian, y admite sin repugnancia alguna el alimento que se le da; de modo que cuidado debidamente resiste rarios años el cautiverio. Dice Effeldt que en sus hábitos se parece mucho á algunas culcbras: trepa con suma facili. dad, y se sostiene con tanta fuerza en la ramaen quese enrosca, que es casi imposible arrancarle; acostumbra igualmente ahogar la presa, entre los repliegues dé su cuerpo, antes de devorarla. Erber observó que sus cautivos estaban sujetos al sueño invernal, y conviene hacer mencion de esta circuns. tancia, porque pretende Cantranie que vió en el mes de diciembre una de estas serpientes correr por entre las ruinas de un antiguo castillo de. Dalmacia.

\section{LOS DIPSAS-DIPSAS}

CARACTÉrREs.-Ios dipsas, ó serpientes arboricolas nocturnas propiamente dichas, tienen el tronco largo, la ca. beza plana, con marcada separacion del cuello; el hocico es corto; los ojos bastante grandes; la pupila como siempre hendida; los escudos de la cabeza regulares; el tronco está cubierto de escamas estrechas y lisas, que solo se ensanchan a lo largo del espinazo; las de la parte inferior de la cola se hallan dispuestas en doble fila; el diente posterior tiene surcos. 


\section{EL DIPSA DENTROFILO-DIPSAS DEN- TROPHILA}

CARACTERES.-Como tipo del género citaremos al dipsa dentrófilo, slarburoug de los malayos, serpiente de cc. lores verdaderamente magníficos. Sobre un fondo negro bri llante se ven de cuarenta á noventa fajas circulares estre. chas de color gris claro, que se ensanchan hácia abajo, separadas regularmente por una lirea longitudinal; los escudos de los labios y de la garganta son amarillos, con bordes negros; el abdómen es de un solo color negro, ó presenta dibujos como los del mámol. En cada maxilar hay catorce dientes iguales, de longitud regular; en su parte anterior un canino y en la posterior un diente surcado; el paladar está cubierto de pequeños dientes. Las escamas forman rejntiuna series; los individuos adultos llegan a una longitud de dos métros, ó mas, correspondiendo á la cola por lo menos la cuarta parte.

DISTRIBUCION GEOGRÁFICA. - El uiarburoug habita todas las grandes islas de los grupos del mar de la India oriental; pero tambien se encuentra en la península de Malaca, en Singapore y Pinang.

USOS, COSTUMBRES Y REGIMEN, - En Java fre cuentả en gran número todos los bosques y ya principia en el jardin de plantas de Buitonzorg, residencia del gobernador holandes; mordedor como todos sus congeneres, se prepara en seguida al ataque cuando se acerca un enemigo; enróscase como las serpientes venenosas; mueve temblando la cola; in clina la cabeza hácia atrás cuanto le es posible; la balancea de un lado á otro; saca la lengua; revuelve los anillos ante. riores y se precipita hácia adelante en direccion oblicua, pero muchas veces no toca el objeto de su ira, porque la luz le ciega. En Java todo el mundo sabe que su mordedura no es peligrosa. Nadie le teme, mas en cambio uno de sus congé. neres pasa por ser en extremo venenoso: esto es una prueba, segun dice Schlegel, de la poca importancia que debe darse a la declaracion de gentes en quien las preccupaciones inve. teradas merecen mas crédito que los hechos palpables.

\section{LOS ESCITÁLIDOS-SCY- TALID压}

CARACTERES. - Plinio designó con este calificativo, oscuro para nosotros, cierta especie de serpientes cuyo nombre se aplicó mas tarde á una espacie sudamericana del ór. den que actualmente figura como tipo de una familia independiente. Los brasilênos dan a dicha especie $\mathrm{cl}$ nombre de serpicnte de Jurar, adoptado en Alemania para toda la familia.

Las especies pertenecientes á esa familia se caracterizan por su cabeza plana, con hocico redondeado; cuello delgado; tronco bastante grueso y cola de longitud regular. En el apa. rato dentario vénse delante de los dientes asurcados otros mas delgados de casi igual longitud. La forma de las escamas varia bastante en los diferentes géneros.

\section{LOS ESCÍTALOS-SCYTALE}

CARACTERES. - Los escitalos, 6 serpientes pálidas, tienen el tronco proporcionalmenté enjuto y un poco comprimido; el lomo anguloso; la cabeza, pequeña, pero destacada del cuello y mas ancha en su parte posterior, se adelgaza hácia el hocico, que es redondeado; la mandibula superior sobresale mucho de la inferior, y está cortada diagonalmente hácia arriba, desde el borde del labio superior; los escudos de la parte inferior de la cola están dispuestos en una sola scrie.

\section{EL ESCÍTALO CORONADO-SCYTALE CORONATA}

CARACTÉRES. - El tipo mạs conocido del género anterior es el escitalo coromado, ó la serpiente de lunar de los brasileños. Su longitud es por término medio de un metro; el color predominante de los individuos jóvenes es un rojo uniforme pálido, en el cual resalta vivamente una mancha casi oval de color pardusco oscuro en la nuca, un anillo trasversal pardo oscurö, situado mas hácia atrás, y varias manchitas irregulares del mismo tinte. El color se oscurece sin embargo con la edad, hasta que en las partes superiores predomina el negro, $y$ en las inferiores el blanco; las manchas desaparecen al mismo tiempo casi del todo.

DISTRIBUCION GEOGRÁFICA. - Esta especie es propia de la América del sur.

USOS, COSTUMBRES $\mathbf{Y}$ REGIMEN.-Del género de vida del escitalo coronado solo nos habla Wucherer, al menos yue yo sepa. El ptincipe de Wied le vió en las regiones arenosas entre los rios San Mateo y Rio Doce, pero no le encontró nunca mas despues. El escitalo coronado, comun en los contornos de Bahia, dice Wucherer, es notable por el cambio que sufre á medida quue avanza en edad. Los individuos jórenes de esta especic son de un rojo de clavel pálido; los viejos, al contrario, casi negros en su parte superior, y, blancos en la inferior. Se alimentan de lagartos como todas las especies de su familia. Le he tenido muy á menudo en cautividad, lo mismo que un congénere suyo. Fs serpiente rasi nocturna que persigue su presa, si no de noche, al menos despues de ponerse el sol, á la hora del crepúsculo. No estrangula \& los Iagartos cogidos, á no ser que la victima le oponga resistencia. Tomando en consideracion la vitalidad de todos los lagartos, muchas reces me he admirado de que un individuo cogido por la serpicnte solo de una pierna no se resisticse, pareciendo, por el contrario, verdaderamente paralizado. Si agita sus piernas, la serpiente le enrosca al punto dos anillos al rededor del tronco para sofocarle; pero si desiste de todo esfuerzo, se desenrolla y le coge lentamente por la cabeza para devorarle. Falta saber si los ofidios con dientes asurcados son rerdaderamente inofensivos, 6 por lo menos no venenosos para con animales de sangre fria.

\section{LOS RAQUIODONES RACHIODON}

CARACTERES.-Dientes maxilares superiores, muy raquíticos $y$ en reducido número, que se van acortando de atrás adelante, donde faltan por completo; apófisis espinosas inferiores, con cierto número de vértcbras salientes en la faringe, y cubiertas de una capa de esmalte, son los caractéres esenciales del género raquiodon, representado por la siguiente especie:

\section{EL RAQUIODON ASPERO-RAGHIODON SCABER}

CARACTERES. - Los que acabamos de indicar para el género, son aplicables á esta especie. La jarte inferior $y$ los costados son de un color pardo rojizo, mas claro en los in dividuos jóvenes que en los adultos; á lo largo del lomo y de la cola se ven de sesenta á ochenta manchas negras, angulosas, irregulares y mus variables, que unas veces cstán muy unidas, hasta el punto de formar una faja, y otras bas. tante separadas; la parte inferior del tronco y de la cola son de un blanco sucio, con mezcla de manchas negras tambien observándose que ciertos individuos tienen la barba mo teada de este último color (fig. 7 I). 
DISTRIBUCION GEOGRÁFICA. - Esta especie es originaria del Africa del sur, y se la encuentra en los alrededo. res del Cabo.

USOS, COSTUMBRES Y REGIMEN.-El raquiodon áspero no se limita á recorrer los campos y bosques, sino que penetra, á lo que parece, en el interior de las habitacio. nes, con el único objeto, segun dicen, de robar los huevos en los gallineros y palomares, pues constituyen su principal alimento.

\section{LOS ACROCÓRDIDOS- ACROCHORDID压}

CARACTERES. - Los acrocórdidios $\delta$ serpientes de verrugas constituyen una pequeña familia del territorio indio, que solo comprende tres especies $y$ dos gencros. Todos ob. servan poco mas 6 menos el mismo género de viơa que las serpientes de agua dulce. El tronco, medianamente largo, es

Fig. 69.-La cusroks Doksms

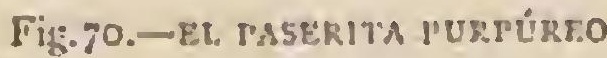

cilindrico $\delta$ algo comprimido en los lados; la cola prensil y muy corta; la cabera pequeña y no destacada del cuello; los ojos estrechos; las fosas nasales desembocan una junto a otra, en la punta del hocico. No solo la parte superior é inferior del tronco, sino tambien toda la cabeza, están cubier. tas de pequeñas escamas vertugosas, encorradas ó espinosas, no sobrepuestas. Los maxilares y el paladar están provistos de dientes cortos, pero fuertes, de longitud desigual.

DISTRIBUCION GEOGRÁFICA. - Los acrocórdidos habitan al parecer en poco número, los rios y las costas maritinas y iodas las islas del-Archipielago recino, desde la costa oriental de la India del sur y la peninsula de Malaca hasta las Filipinas y la Nueva Guinca.

USOS, COSTUMBRES Y REGIMEN.-Pasän su vida exclusiramente en el agua $y$ hállanse á veces á tres $\delta$ cuatro leguas marinas de ia costa; aliméntanse principalmente de los peces que cogen, segun parece, á todas las profundidades. Por sus movimientos !su indole aseméjanse álas serpientes marinas, de las cuales difieren bastante por lo inofensivos; pues a pesar de que se les haya acusado muchas veces, no son nada venenusus, si bien no podemos decir que scan dóciles. Todas las especies son viviparas.

\section{EL ACROCORDO DE IAVA-ACROCHORDUS JAVANICUS}

CARACTÉRES. - La especie tipo de la familia, a la que esta debe su nombre, y que representa además el género de los acrocordos, se distingue de otra muy afine por no tener en la primera parte del tronco, ligeramente comprimida, un borde membranoso que en la segunda especic existe en la region superior de la cola. Cada escama se eleva en el centro en forma de una quilia fuerte trilateral y espinosa; $y$ en muchas escamas se encuentra otro par de espinas mas pequeñas. La cabeza es corta y ancha; el hocico cn extremo corto; los ojos están muy adelante; las fosas nasales se tocan casi y hállanse situadas en el centro de un pequeñoescudo redondeado en la parte superior del hocico. La hendidura 
de la boca es de anchura regular; la mandibula superior redonda, con una escotadura junto al centro $y$ en los lados en dos sitios; en dichas escotaduras se encajan unas pro. minencias de la mandibula inferior. El color predoninante de los individuos adultos es un pardo uniforme que en los lados tira al amarillento. Los hijuelos son de un color pardo, con grandes manchas irregulares mas oscuras, que se rell nen en el dorso formando otras onduladas no interrumpidas, que con la edad se decoloran mas y mas, desapareciendo al fin del todo. Los individuos completamente adultos llegan á una longitud de $2^{\mathrm{E}}, 50$.

USOS, COSTUMBRES X RÉGIMEN. - Elacrocordo de Java se oculta sin duda siempre, pues pocas veces se le encuentra en los sitios donde vive. Así se lo aseguraron los malayos de Pinang al sabio viajero Cantor, y lo mismo reconoció Mongomery, quien durante una estancia de cinco años en Singapore solo una vez pudo observar esta serpien. te. Cantor compara la expresion de la cara 'del acrocordo de Java con la de un bulldog de raza pura, y se convenció de que tambien su indole corresponde á esta expresion. Tan luego como se le toca intenta morder; pero como su pupila se achica mucho á la luz del dia, no toca por lo regular al objeto de su ira. Es probable que no deje nunca el agua voluntariamente; pero puede moverse bieu sin gran dificultad cn tierra firme. Su alimento se compone de peces y otros auimales acuáticos y marinos; Hornstedt encontro cn el estómago de un individuo disecado algunas frutas no digeridas. Una hembra que Cantor obtuvo viva movió las costillas posteriores de un modo particular despues de ponerla en el suelo, dando á luz veintisiete hijuelos en el espacio de veinticinco minutos; estos hijuclos, excepto dos, nacieron de cabeza y tenian por término medio $0^{\circ}, 45$ de largo. Manifestáronse en extremo vivaces y se aprovecharon al punto de sus dientes, completamente desarrollados, para morder cuanto se ponia delante. Poco despues del nacimiento los cascarones cayeron á pedazos, como suele suceder tambien en otras serpientes acuáticas recien nacidas. A los hijuelos no parecia gustarles el agua $\delta$ al menos hacian grandes esfuerzos para ganar la tierra firme.

\section{LAS SERPIENTES VENE- NOSAS}

Dumeril, que ha dedicado toda su vida al estudio de los ofidios, cogió, durante un paseo en los alrededores de Paris, una vibora de la especie Pelios Berus; creyendo habérselas tan solo con-una culebra viperina (Tropidonotus Viperinus), fué mordido por el reptil, y esturo en peligro su vida duran te algunos dias. Este caso debe tenerse siempre presente, porque demuestra palmariamente que los distintivos exteriores entre las serpientes venenosas y las no renenosas son por demás insignificantes.

Es imposible reconocer toda serpiente venenosa como tal considerándola tan solo por sus caractéres exteriores. Cierto que esto no sucede con todas las especies 6 familias, porque las serpientes marinas, los crotálidos y viboras tambien exteriormente se pueden conocer hasta cierto punto, pero precisamente el pelias, que un naturalista tan experto como Du. meril tomó por un tropidonoto, pertenccia á esta familia.

En muchos tratados de Historia natural se designan con singular ligereza los caractéres de las serpientes venenosas. Es cierto que las especies nocturnas tienen, por lo comun, el cuerpo corto, grueso en el centro y de corte triangular; que en la configuracion de sus escamas se diferencian bastante de las no venenosas; que los grandes ojos con la pupila hendida perpendicularmente, $y$ á menudo protegida por escamas superciliares, les da un aspecto maligno y artero: todos estos distintivos son muy exactos, en verdad, pero tan solo con referencia á las especies indicadas, y en manera alguna aplicables á las diurnas, marinas \& otras, pues la mayor parte de estas se presentan, á primera vista, tan inofensivas como cualquiera serpiente de las no venenosas. Algunas hay, y por desgracia muy abundantes, de cuya malignidad hemos debido convencernos al fin, por mas que su aspecto enganador y apacible hubiera logrado captaries la proteccion de reputados naturalistas, los que para defender su irocencio no han desdeñado hacerse eco de antiguas historias, en las cuales apare. cen estos ofidios sirviendo de juguete á los niños ó de adorno $\{$ las mujeres.

Tan solo el exámen de la dentadura ofrece en todo caso los indicios exactos sobre el carácter venenoso 6 no venenoso de una serpiente.

Hemos creido oportuno hacer estas observaciones, por via de introduccion á la sucinta monografia que vamos á presen. tar de las serpientes venenosas, a fin de advertir una vez mas, al profano y al principiante el exquisito cuidado con que de. ben proceder al exámen de animales tan peligrosos.

El que sabe qué inmenso número de hombres mueren anualmente por la mordedura de serpientes venenosas, $y$ cuántos seres humanos, aun en nuestros paises, quedan enfermos muchos años á consecuencia de las heridas causadas por esos reptiles, comprende el terror que se apodera dei que no conoce estos animales al ver una serpiente, y explicase tambien los cuentos, tradiciones y poesias de los pueblos antiguos y modernos que hablan de serpientes. Cierto que estas, 6 mas bien las especies venenosas, no pueden despoblar un pais, pero ponen en peligro á los habitantes de la region frecuentada por ellas en número extraordinario, y esto de una manera de que nosotros los que vivimos en el norte, donde escasean las serpientes venenosas, no podemos formarnos una idea. Fayrer, médico inglés, se ha ocupado muchos años en experimentos sobre el efecto del veneno de las serpientes, esforzándose durante su estancia en la India por averiguar el número de hombres mordidos todos los años por las serpientes $\delta$ muertos á consecuencia de las heridas. El resultado obtenido con ayuda del gobierno es horroroso. Fayrer pidió solo informes $\{$ las autoridades de ocho distritos, pero no todas contestaron, ó lo hicieron de un modo que no daba clara idea del asunto; mas el resultado obtenido por estas averiguaciones causa horror. Las noticias mas exactas, aunque no del todo completas, llegaron de la presidencia de Bengala, donde fueron recogidas en cuarenta y ocho distritos. Alli habian muerto solo en el año $x 86 y$, nada menos que seis mil doscientas diez y nueve personas, mordidas por serpientes, contándose dos mil trescientos setenta y cuatro varones y dos mil quinientas setenta y seis hembras, seiscientos sesenta y tres niños y seiscientas seis niñas de menos de dos años. Las mujeres ancianas figuraban en el mayor número de victimas, y en el menor las niñas. Entre los muertos hallábanse perso. nas de cien años y niños de tres meses. La serpiente mas peligrosa resultaba ser la de anteojos, que habia ocasionado novecientas cincuenta y nucve sictimas, mientras que el Krait, que por su carácter peligroso ocupa el segundolugar, mató ciento sesenta personas, atribuyéndose los demás casos à sus congéneres que no habian podido reconocerse 6 no se habian visto.

De la presidencia de Orissa Fayrer solo recibió las noticias recogidas en tres distritos. Aqui el número de los muer. ios ascendió en el mismo año à trescientos cincuenta, á saber, ciento treinta y siete hombres, ciento treinta y ocho mujeres, cuarenta y cuatro niños y treinta y una niñas; ciento 
veintiocho de estas muertes se atribuyeron a la serpiente de anteojos, dos al krail, cincuenta y dos a otras serpientes y ciento sesenta y ocho á especies no conocidas.

De Assam se recibieron las noticias de siete distritos, donde se habian contado setenta y seis casos de muerte, es decir cincuenta de hombres, catorce de mujeres, nueve de ninos y tres de niñas: doce de estos casos se atribuyeron á la ser. piente de anteojos ó al krait, y el resto á especies desconocidas.

En doce distritos de Ouda se registraron doce mil cinco heridas causadas por las serpientes, que produjeron la muerte de irescientos sesenta y cuatro hombres, quinientas cincuenta y ocho mujeres, ciento treinta y sicte ninos y ciento cuarenta y seis niȟs: atribuyéronse á la serpiente de anteojos seiscientos siete casos, al krait ciento cinco, á otras especies veinte, $y$ a las desconocidas cuatrocientos setenta y tres. Entre los muertos contábanse niños que aun no habian llegado a la edad de un mes; en un solo distrito sucumbieron doscientas seis personas.

En catorce distritos de la India central solo se registraron noventa casos de muerte, correspondiendo treinta y ocho ś varones, treinta y seis á hembras, ocho á niños y ocho á ni. ñas: de veintiuno de estos casos se acusó $\{$ la serpiente de anteojos, de ireinta y siete a otras varias serpientes veneno. sas, y de treinta y dos a especies desconocidas.

De las provincias interiores Fayrer solo recibió la noticia de que seiscientas seis personas habian sido victimas de serpientes venenosas.

De las provincias del noroeste se recibió la estadística de treinta y ocho distritos. El número de casos de muerte ascendió \& mil novecientos noventa y cinco, á saber: seiscientos cincuenta y cuatro varones, novecientas cincuenta y dos hembras, ciento noventa y nueve niños y ciento noventa niñas: ochocientos cincuenta y cuatro casos se debieron á la serpiente de anteojos, noventa y dos al krait, sesenta y tres 2 especies afines y novecientas ochenta $y$ seis a las desconocidas.

De Birmania llegaron las noticias recogidns en Aracau, Pegú Y Tenasserim. Aqui solo se contaron ciento veinte defunciones: noventa y cinco hombres, veintidos hembras y tres niños: cuarenta y cinco se achacaron 1 la serpiente de anteojos, uno a la de una serpiente marina y todo el resto $a$ la del Daboja.

En treinta y dos distritos del Punjab se contaron setecien. tas cincuenta y cinco mordeduras de serpiente, de las que cuatrocientas treinta y cuatro se infiricron á hombres, ciento ochenta y cuatro á mujeres, setenta y siete á niños y treinta y dos á niñas: de veintiocho difuntos no se indicó el sexo, y entre los mordidos contábase un niño que aun no tenia un dia de edad.

La suma total de las mordeduras de serpiente en un solo año se elevó nada menos que á once mil cuatrocientas diez y seis, cifra que sin embargo no llega ni con mucho á la realidad, segun la conviccion de Fayrer. Muchos casos ni si. quiera se apuntaron, pues los empleados indigenas del gobicrno rara vez hacen caso de accidentes tan comunes, y los naturales se resignan con tal tranqquilidad, que no los creen bastante importantes para ocuparse mucho deellos. Fayrer, por ejemplo, cree deber suponer que en un solo año perecieron lo menos veinte mil hombres mordidos por las serpientes. Aunque la poblacion es muy numerosa, calculándose la de las provincias citadas en poco mas 6 menos ciento reinte millones de almas, este hecho no pierde nada de su importancia y demuestra la exactitud de la opinion emitida ya por los romanos de que las serpientes venenosas en la India se cuentan entre las plagas mas terribles. Yo añadire que en comparacion con aquellas, los tigres, panteras y lobos son animales inofensivos é insignificantes. Si quisiéramos 6 pu. diéramos hacer las mismas averiguaciones en otros paises frecuentadospor muchas serpientes renenosas, obtendriamos, aunque en menor escala, resultados muy análogos. Todos los viajeros, $y$ últimamente tambien Tschudi, aseguran que las condiciones del Brasil, por ejemplo, son semejantes. IDe las noticias obtenidas sobre las serpientes venenosas, dice el citado naturalista, no debe deducirse la consecuencia de que en cada paseo se corre peligro de que uno de estos reptiles nos hiera, ni que una expedicion á las sclvas virgenes sea una continua lucha con los surukukus y chararakas. La viva fantasia de algunos viajeros ha exagerado mucho, pero si es exacto que las serpientes abundan mucho en el Brasil y que todos los años ocasionan centenares de víctimas en todo el imperio. Uno de mis amigos cogió en Rio Janeiro, en el jar. din de su casa, en pocos años, mas de treinta individuos en que se contaban nueve especies distintas, y que conservó en espiritu de vino. Todos los propietarios del Brasil saben que en losjardines $\delta$ parqques se albergan muchos de estos reptiles. Debe aconsejarse mucho al naturalista viajero que penetra en las selvas, examina las espesuras y revuclve las piedras, lle. var consigo en sus expediciones algunos metros de vendas estrechas y una botellita con espiritu de amoniaco.

A pesar de toda la diferencia de las formas exteriores, de la estructura y del género de vida, las serpientes ponzoñosas tienen en los dientes del veneno una señal caracteristica por la que se puedereconocerlas fácilmente con seguridad distin. guiéndolas de las otras. Por eso constitugen un sub-órden del todo natural (1oxicoplidia) que se caracteriza por tener las especies pertenecientes á é en la mandibula superior, además de los dientes macizos, otros perforados.

CARACTERES.- Las serpientes venenosas tienen la indicada mandibula comparativamente corta, apareciendo en las nocturnas reducida á un pequeño hueso, pero que en unas y otras ticne gran movilidad, y se apoya en los nasales y preorbitarios cuando lc impelen hácia adelante los tcrigoideos externos ó transversos, los cuales están muy desarrollados. En las especies diumas se encuentra el diente mas sólidamentc unido á la mandibula que en las nocturnas, pero lo nismo en estas que en aquellas, no por inedio de implanta. cion, sino tan solo por ligamentos. Dicho diente no tiene movimiento propio; cuando retrocede es obedeciendo al que le imprime la mandibula. Esta tiene á cada lado de su su. perficic inferior dos hoyos poco profundos, muy cerca uno del otro, parn recibir las raices del diente. Por lo regular solo existe uno completamente desarsollado, en cada hueso supra.maxilar, pero como alli se hallan varios otros en gérmen, puede suceder que dos de estos acaben de formarse en el hoyo destinado â uno solo, y funcionen \& un mismo tiempo. Entre estos dientes de repuesto, que están sueltos en el hueso, siempre aparece mas desarrollado el mas próximo al gancho venenoso. Este se halla envuelto por una vaina membranosa en la encia, dentro de la cual se recoge, cuando la mandibula retrocede.

Los dientes venenosos difieren siempre de los otros por su gran tamano y su figura corva, mas ofreciendo, segun Strauch, el mismo tipo fundamental. Además de una cavi. dad que hay en la base, destinada para la alimentacion del diente, y que es propia sin excepcion de todos los ofidios, cada diente tiene una canal situada en la parte anterior $y$ encorvada de aquel, que desemboca hácia afuera en dos aberturas; una de estas, que presenta un corte trasversal mas ó menos rédondeado, se halla cerca de la base del diente, y clérase al abrirse la boca, en cuyo caso cambia tambien la posicion de aquel, que levantándose sobre el orificio de la 
glándula venenosa, facilita la entrada de la ponzona; la abertura inferior, en cambio, situada en la punta del diente, $y$ que da salida al veneno, tiene mas bien la forma de una hen. didura. En la mayoria de las serpientes venenosas, estas dos aberturas están unidas por una canal muy fina y con frecuencia apenas visible, en cuyo caso el conducto del veneno no se halla del todo cerrado hácia adelante; mientras que en el menor número de especies parece estarlo del todo, y en rez de la hendidura se ve cuando rnas una linea. Los dientes venenosos se dividen pues en surcados y. lisos, es decir, unos cuyo conducto presenta en la parte anterior una hendidura, y otros en que aquel está cerrado por todas partes. La hendidura de los dientes venenosos surcados apenas tiene, no obstante, importancia tisiologica, porque siempre es tan estrecha que no es posible que el veneno pueda salir por ella, y de consiguiente, su existencia debe reconocer otra causa, que sin dificultád se encuentra, pudiéndose demos. trar que el surco es sencillamente el resto de un embrion anterior. Todos los naturalistas que han hecho averiguaciones sobre la manera de crecer, $\mathbf{y}$ desarrollarse los dientes venenosos eslán conformes en que á la formacion de la canal siempre precede la de un surco y que aquella se hace por la circunstancia de que los bordes se aproximan uno á otro ó se sueldan. Segun el eximen de Schlegel, cada diente se compone en la primera fase de su desarrollo de una ancha superficic con los bordes dirigidos hácia adentro, ofreciendo por lo tanto en su cara anterior un ancho surco, que desaparece ya muy pronto en los dientes macizos, persis. tiendo en los posteriores surcados; en los no venenosos; mientras que en los venenosos lisos permanece abierto mas riempo, cerrándose casi siempre tan luego como el diente llega a su completo desarrollo, y solo en los dientes surcados se conserva la forma de una hendioura casi siempre en ex tremo fina.

Son los ganchos veneriosos mas 6 menos largos, segun el tamaño del animal, aunque esta proporcion no sea siempre constante y exacta; asi, en las especies nocturnas son comparativamente mayores que en las diurnas. Los del Pelias Berus suelen medir de una y media á dos lineas, mientras que algunos brotofidios los tienen de una pulgada de largo. Vidriosos, tersos y quebradizos, pero extraordinariámente puntiagudos, penetran estos dienies con la facilidad de una aguja en|los objetos blandos, mientras que resbalan ó se rom. pen á menudo en los duros; cuando pierde el reptil uno de ellos, inmediatamente ocupa su lugar uno de los de repuesto, soliendo verificarse este cambio con cierta regularidad una y mas veces al año, sin que sea provocado por causa alguna exterior. Suele ser muy rápido: lenz no encontró ganchos venenosos en pequeñas viboras que extrajo del cuerpo de la madre, segun su cálculo, cinco ó seis dias antes de su naci miento, cuando otras que examinó y que solo podian tener muy pocos dias de vida, ya los poseian completamente des. arrollados.

Con la misma rapidez que la formacion nueva verificase la reconstruccion de los ganchos venenosos perdidos ó arrancados; si solo se rompen sustitúyeles otro diente á los tres dias, ó cuando mas tarde a las seis semanas; y solo cuando, como suelen hacerlo los encantadores de serpientes, se corta tambien el repliegue de la mucosa en la cual está situado el gancho, 6 cuando se destruye la parte de la man. dibula y con ella todos los gérmenes de dientes, ya no vuel. ven á crecer.

Cada glándula segrega una cantidad relativamente pequena de veneno: las de una serpiente de cascabel de casi dos metros de largo y completamente sana, vierten cuando mas de cuatro á seis gotas, pero la mas pequeña parte de una basta para descomponer en pocos minutos la sangre de un gran mamifero; la glándula está henchida de veneno cuando hace mucho tiempo que la serpiente no ha mordido, j la ponzona misma es entonces mas eficaz que en el caso con. trario: la compensacion de la cantidad gastada se efectúa sin embargo muy rápidamente y el veneno recien producido es tambien en alto grado eficaz.

El veneno, análogo á la saliva, es un liquido muy flúido, trasparente, amarillento ó verdoso, y mas pesado que el agua, volviéndola lechosa una vez mezclada con él. Compónesc, segun las investigaciones de Mitchell, de una nateria viscosa como clara de huevo, la parte mas activa, que se disuelve en alcohol puro, mas no á clevadas temperaturas; de otra pare. cida, si bien compuesta, que no produce efecto alguno y so. luble de ambas maneras; de una materia colorante, y de otra no determinada todavia, que se disuelven en alcohol, grasa, ácidos, sales, cloro y fósforo. Se seca fácilmente, volviéndose lustroso como un barnix, adhiriéndose de este modo á los cuerpos y conservanio, segun afirma Mangili, por muchos años su virtud.

Segun Armstrong y Brunter, á quienes layrer envió el ve. neno de la serpiente de anteojos para examinarlo, este últi. wo consiste en un liquido pardusco parccido á la melaza, compuesto de cuarenta y tres a cuarenta y cinco centésimos de ácido carbónico y de trece á catorce de nirrógeno: mez. c!́trdole con ácido de salitre y espíritu de vino, ó bien ex. poniéndole al calor, el vereno se descompone. Ios citados náturalistas no pudieron de ningun modo preparar una ma teria cristalizable del mismo. Varios ensayos demostraron la presencia de sustancias de clara de huevo. El veneno, asi como los componentes mezclados, conservan siempre, segun las pruebas que se hicieron, todas sus cualidades invariables y con la misma fuerza, segun los experimentos de Taylor, Pavy y Christinson, hasta por espacio de doce á quince años. Segun Shott, el veneno de la serpiente de anteojos consiste en un líquido algo aceitoso, claro, de color amarillo y semejante á la clara del huevo; posee las mismas cualida. des de un ácido y no contiene sustancias viscosas, pero si de clara de hucro, produciendo, cuando se pone en contacto con la lengua, una fuerte irritacion, vejigas y una especie de insensibilidad en el sitio tocado. Una mezcla del veneno con una solucion de álcali le quita siempre su fuerza, unientras que el uso interior 6 exterior de dicha solucion no produce ningun efecto en las heridas en que se ha infiltrado la pon zoña. El exámen de esta con un microscopio de mucho au. mento permite reconocer unas células flotantes en una sustancia semejante á la clara de hucvo.

Halford sosturo la lésis de que con el veneno de las ser. pientes llegan gérmenes de fermentacion al cuerpo del animal mordido, donde se desarrollan rápidamente formando células que aumentan con asombrosa rapidez, roban ála san. gre todo el oxigeno y producen una muerte análoga á la de la asfixia. Este aserio no se confirma, al decir de Fayrer, porque segun los experimentos de este, la trasformacion de la sangre despues del envenenamiento por la mordedura de serpiente consiste sobre todo en que aquella se descompone rápidamente en varias especies, aunque debe notarse que en algunas venenosas se ha observado precisamente lo conirario. La sangre de un animal envenenado por una mordedura de serpiente envenena otros animales si se les inocula, y segun las observaciones de Fayrer, esta inoculacion pucde repetirśe tres ó cuatro veces con el mismo efecto. Exactamente lo mismo sucede respecto á la leche: los niños de pecho cuyas madres fueron mordidas murieron con los mismos sintomas. En cambio puede conerse la carne de los anima. les envenenados; las gallinas y otras especies comestibles 
empleadas por Fayrer en sus ensayos sirvieron de alimento á sus ayudantes y guardianes, que no experimentaron nin. gun malestar.

A pesar de los repetidos análisis que se han practicado, no ha sido posible averiguar todavia qué matcria deletérca es la que encierra esta sccrecion de las serpientes; de suerte que solo conocemos este veneno por su apariencia y pror sus efectos. Por lo que se refiere á estos, parece ya demostrado que son tanto mas violentos, cuanto mayor es la serpiente y mas cálida la temperatura, pero ỵue no varian segun la tes. pecie del ofidio que inocula el virus. Durante algun tiempo se ha creioo que podia ser tragado impunemente este veneno, pero experimentos modernos han probado que introdu. cido el mismo en el estómago, aunque diluido en gran can. licad de agua, produce todavía terribles ejectos, causando dolores al engullirlo y entorpeciendo la actividad cereural.

Ias membranas mucosas lo absorben de modo que siem pre pueden producirse accidentes peligrosos. Segun los ex: perimentos de Farrer, produce la inuerte cuando se introduce en cantiajad suficiente en el cstómago, en el ojo 6 en el diafragma.

No obstante, queda en pié la antigua afirmacion, de que solo puede peligrar la vida del herido, cuando el veneno se pone en contacto inmediato con la sangre; cuanto mas rápida y completa es la circulacion de esta, mas terrible es la accion de aquel: los animales de sangre calienic sucumben con mayor rapidez, á consecuencia de la mordedura de la serpientc, que los reptiles y peces, mientras que en los lla. mados de sangre blanca, esto es, los anillados, no causa el veneno efecto alguno. Dos serpientes venenosas de la nisma especie pueden morderse mutuamente sin consecuencias in. tales para ninguna de ellas: el antiguo cuento de la célebre serpiente del Africa que mordia á todos los animales sin inotivo, y hasta se mordia á si misma, no es sino una fábula

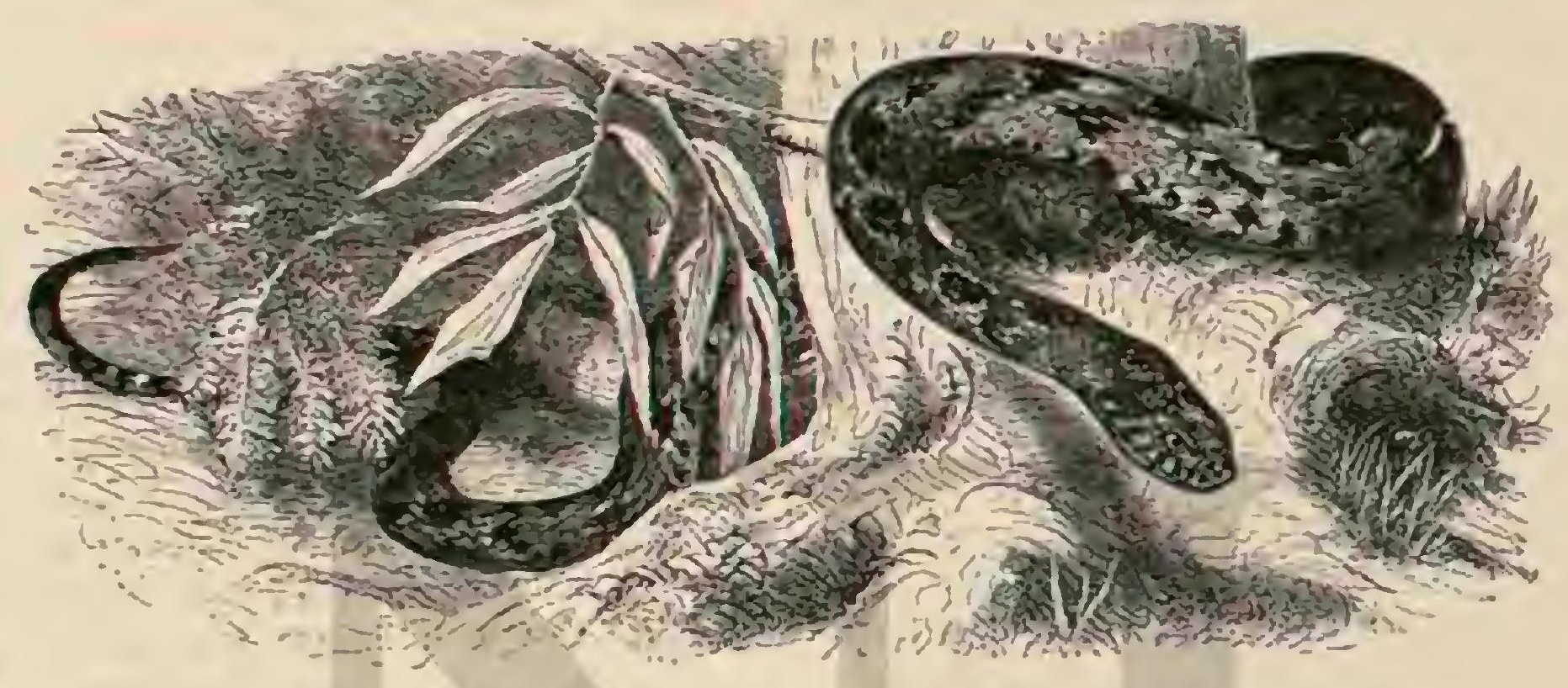

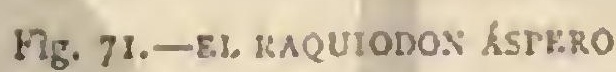

absurda. Las serpientes enfurecidas se muerden en efecto con nucha frecuencia en la parte posterior del cuerpo sin sufrir consecuencias iunestas. No sucede asi cuando una de gran tanıño muerde á otra mas pequeña, ó tan solo de diferente linaje, segun pretenden algunos auiores: la accion dèl veneno se hace sentir en las respectivas víctimas del mismo modo que en otro animni cualquiera. Del áspid de Egipto ó de Cleopatra (sajo haje) se asegura que acomete y devora á la terrible vibora eclsilsa arielarss, asegurándose tambien que la de cascabel hace lo mismo con la vibora acuática (trigo rocephalus pisciaoris), ia cual devora sin temor, segun las observaciones de Effeldi, serpientes vencnosas de menor ta. maño, despues de haberlas mordido y muerto 6 cuando menos paralizado del todo por el veneno. Tambien yo he observado que algunas grandes especies venenosas mataban al las mas pequeñas, el mokassin, yor ejemplo, \& la víbora comun; pero debo añadir que \& menudo dudo de si en electo la muerte de una serpiente venenosa se produce á consecuencia del mordisco de otra $u$ no. Fayrer opina del mismo modo, declarando no haber podido explicarse del todo despues de muchos experimentos si las serpientes venenosas son del todo insensibles á las mordeduras de sus semejantes, es decir, de individuos de su mismá especie; pero cree que no succde asi. He dejado as varias serpientes de anteojos, dice, morderse con otras sin observar daño alguno; pero debo creer que el veneno de las especies mas corpulentas es pernicioso para las de menor tamaño, pues aunque he visto varias veces que un bungar quedó sano y salvo des. pues de haberle mordido una serpiente de anteojos, en oiros casos observé tambien que el animal murió á consecuencia de la mordedura.
Parece que algunos mamíferos y aves resisten el cfecto del veneno de la serpiente de un modo incomprensible para nosotros, como sucede, por ejemplo, con el veso y el erizo. Es dudoso, sin embargo, que las consecuencias que decucimos de los experimentos notables hechos por nuestro ofidió. logo Lenz puedan considerarse como regla, pues apenas nos es dado suponer que la sangre de varios mamíferos y aves difiera esencialmente en cuanto á sus cualidades; pero la diferencia deberia existir ya por la misma naturaleza del he. cho si la sangre de un animal se descompone, mientras que la de otro no se altera.

En general, pratentizase de un modo anúlogo en todos los animales la accion de la ponzoña de las serpientes, si bien los ć́ćctos inmediatos à la mordedura pueden ser de diferente indole, 6 parecer que lo són. Segun la opinion de los antiguos, el efecto de la mordedura era diverso en todas las especies de scrpicntes venenośas. Esto es lo que se despren. de de un relato de Lucano en que describela expedicion de Caton por los desiertos africanos despues de la batalla de Farsalia. luego de haber descrito la fábula del origen de las serpientes venenosas pintando de un modo muy interesante cómo de las gotas de sangre que caian de la cabeza cortada de Medusa se desarrollaron los terribles reptiles renenosos, Lucano se ocupa de algunos casos de mordeduras de serpientes, de las desgracias producidas por ellas, y continúa literalmente de este modo: \& Por entre estos horribles mons. truos Caton condujo su aguerrido ejército, y vió morir muchos de los suyos miserablemente á consecuencia de peque. nas heridas. El alférez $A$ lulo pisb un dipsas, que revolviéndose al junto le mordió. Fin el momento de sentir la picadura del reptil, $y$ ver la herida, parecióle esta de muy poca im- 
portancia; pero pronto le atacó la ponzoña hasta la médula de los huesos; el paladar y la lengua comenzaron á secarse, y tambien el sudor de la piel; el infeliz, sin derramar una lágrima, dejó caer la bandera al suelo, y atormentado por la sed mas horrible, corrib como un loco en busca de agua. Bebió y bebió y siempre aumentaba mas su sed; pinchóse despues las venas y bebió su propia sangre, pero tampoco así halló remedio. Caton llenó de horror, mandó al ejército continuar rápidamente la marcha; pero pronto la muerte de. bió presentársele bajo-una forma mas terrible aun. Un pe. queño seps mordió la pierna de Sabclo; este arrancó el reptil con la mano y le atravesó con la lanza; el seps era pequeño, pero al rededor de la herida cayó al punto la piel á pedaros; de modo que pudieron verse los huesos; la llaga se cxtendió cada vez mas; la carne se convirtió en una sustancia fétida, y cuando hubo desaparecido tambien de la cabeza, los huesos se pudrieron y disolviéronse de modo que ni siquiera quedó el cadáver del hombre, y si solo una mancha cubierta por la terrible sustancia. In prester pich al guerrero marso Nasidio; una mancha roja como el fuego se extendió por su rostro, hinchatido la piel; corrióse pronto por todo el cuerpo, de modo que ya no pudieron reconocerse las formas, y despues ofreció solo á las miradas de] asombrado ejército una enorme masá inerte. Nadic se atrevió á llevar á la hoguera el cadáver, que siempre iba au. mentando en tamaño, y todos buscaron su salvacion en la fuga. Un hemorrois hirió a Tulo; de toda la piel salio en seguida un liquido rajizo, que llenó los ojos, la boca y la nariz. El desgraciado Levo murió herido por una serpiente, perdiendo al punto los sentidos. De un tronco de árbol precipitóse la serpiente llamada por los africanos jaculics; bajo con mas rapidez que una fiecha detribando á Paulo y pasando por su cabeza. Murro atravesó con la lanza un basilisco; d veneno penetró por la lanza hasta la mano, ia cual se cortó el hombre mismo con la espada. Inútil es rlecir qué es. tos hechos no han sucedido tales como los cuenta Lucano, pero resulta claramente de ellos que se fundan en la observacion de otros éfectivos, exagerados no obstante del mismo modo que hacen hoy dia los que cuentan como creibles los hechos mas fabulosos.

Como sin embargo desgraciadamente suceden con harta frecuencia los casos de envenenamiento por esta especie en los hombres, conocemos con exactitud, además de los signos anteriores, los padecimientos y sensaciones de la víctima. In. mediatamente despues de la mordedura, sucle sentir el herido un fuerte dolor que no tiene comparacion con otro alguno, $y$ que recorre todo el cuerpo como una descarga eléctrica; pero $\{$ veces por el contrario, la persona mordida cree haher recibido un arañazo de alguna espina, y no parece sentir casi dolor alguno. Sin embargo, muy pronto se presentan los primeros sintomas iníalibles de la descomposicion de la sangre, que empieza á verificarse, como cansancio general de todo el cuerpo y rápido desfallecimiento de todas las fuerzas; muy frecuentemente siguen á estos los vómitos, de sangre á veces, y la diarrea, y tambien en muchos casos hemorragias de boca, nariz $y$ oidos. El desfallecimiento se señala tambien por una soñolencia $\{$ la que apenas puede resistir el paciente, $y$ por una manifesta disminucion de la actividad cerebral; la accion de los sentidos aparece mermada en alto grado; de suerte que á menudo se presenta completa ceguera $\delta$ sordera. A medida que las fuerzas se van debilitando, disminuye la sensacion del dolor, y cuando se acerca el fin del envenenado, parece estc libre de todo sufrimiento, muriendo lentamente, postrado en la mas profunda insensibilidad. Cuando la descompo. sicion de la sangre se verifica con rapidez, por lo regular se hincha muy poco la parte mordida, pero si aquella se opera gradualmente, esta última se vuelve una masa informe, co. munícándose casi siempre la hinchazon á otras partes del cuerpo. En muchas personas envenenadas de esta suerte se han observario, no tan solo un aspecto cadavérico, sino que tambien una frialdad particular del cuerpo, consecuencia na. tural del entorpecimiento de la circulacion de la sangrc, pues cl envenenamiento no es mas que la descomposicion de esta, y sus efectos los de una fiebre pútrida que la acelera. No siempre son idénticas las fases que atraviesa el paciente: su. cede á menudo que durante largas horas es presa de los mas terribles dolores, y tiene tan excitado su sistema nervioso, que todo movimiento, el mas leve ruido que se haga a su al. rededor, le causa un verdadero martirio. Algunos hombres mordidos por una víbora dan espantosos gritos; los perros, que han recibido igual herida, hacen oir horas enteras sus lastimeros plañidos, hasta que se presentan la postracion y la insensibilidad, siguiendo despues una muerte comparativa. mente tranquila.

Cuanto mas grande y poderosa es la serpicnte tanto mas abundante es su veneno; cuanto mas tiempo ha pasado sin morder, cuanto mas calor hace y mas furioso es el reptil, tan. to mas rápidos y terribles son los efectos de su veneno. Los sintomas principales del mal se asemejan tambien álos ya descritos; pero el envenenamiento es mucho mas rápido y de consiguiente presenta tambien otros accidentes. Casi inme. diatamente despues de la mo:dedura experiméntase cierto aturdimiento y malestar extremado; se hacen evacuaciones involuntarias de orina y de excremento; dilátanse ó se es: trechan las pupilas; la respiracion es lenta; prodícense convulsiones, temblor de los músculos é insensibilidad de la piel; pero el conocimiento y la actividad de los sentidos se conservan hasta el último momento. Al fin se declara la parálisis, acompañada 6 no de convulsiones, y siguese la muerte, producida de ordinario por la asfixia, pues la actividad del corazon dura mas que la respiracion. De varios experi. mentos consta además que los animales á que se habia inoculado el veneno de serpiente pudieron conservarse vivos aun bastante tiempo por una respiracion artificial que mitigaba las convulsiones. La muerte puede ocurrir ś los veinte minu. tos despues de la mordedura, y tambien al minuto si el veneno llega á una arteria. Segun Jones, el calor del cuerpo aumenta un poco al breve rato de haberse infiltrado la ponzoña, pero disminuye luego considerablemente. La actividad del corazon es apresurada, pero débil, y á menudo se produ. cen evacuaciones de sangre en el estómago y segregacion de la hiel. Con bastante frecuencia se observa entre los primeros síntomas tambien la imposibilidad de hablar, que á veces persiste aun despues de haber desaparecido los demás accidentes. Al abrir el cadáver no se nota ninguna rigidez, pero en la auricula derecha del corazon hállase sangre ligeramen. te descompuesta, que tiene alguna semejanza con el alquitran, mientras que la izquierda suele estar vacía. Los vasos del cerebro y de las membranas cerebrales están llenos de sangre oscura; en el higado y los pulmones es tambien abun. dante; el primero está hinchado y tiene un color oscuro.

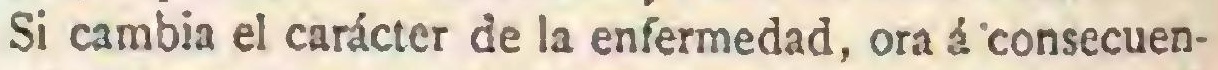
cia de los remedios empleados, ora por la insuficiencia de la pequeña cantidad de veneno introducido en la herida, sigue a los primeros sintomas ya indicados un largo periodo de postracion, antes del completo restablecimiento; desgraciadamente sucede muy á menudo, que el paciente sufre semanas, meses y hasta años las consecuencias de la mordedura de la serpiente, de modo que bien puede decirse, en el sentido mas literal de la palabra, que solo una pequeña gota de la temible secrecion 4 le ha envenenado toda su vida.

Innumerables son los remedios que desde remotas épocas 
se han usado y se usan todavia hoy para combatir la mor. dedura de la serpiente venenosa, mas por desgracia, en esto ha entrado tambien por mucho la supersticion. As! como en otros tiempos los hombres ignorantes impetraban el auxi. lio de los dioses, ast tambien ahora se cree poder con. trarestar los efectos de un veneno tan eficaz recitando algu. nas docenas de ePadre nuestros ó Ave Marias Añadamos, no obstante, que tambien se hace uso de otros medios: se corta y quema la herida, se ponen piedras de serpiente, rai. ces machacadas y hojas; administranse como medicamento interno jugos vegetales, espiritu de amoniaco, cloruro, arse. nico y otras cosas, pero hasta ahora no se conoce un solo remedio que pueda recomendarse como verdaderamente probado é infalible Sin embargo, el mas cficaz. de todos parece ser el espiritu de vino, introducido en gran cantidad en el estómago del paciente, en el modo y forma que mas á mano se tenga: el alcohol, el ron, el arac, el cognac, el aguardiente $y$ hasta el vino fuerte y generoso, parecen igualmente recomendables. Este remedio no es nuevo, pues ya se conocia en tiempos remo:os, habiéndole usado las personas inexpertas mucho antes quue los médicos, en las mas diversas regiones de la tierra. Marco Porcio Caton el Censor aconsejaba ya dar á un hombre $\delta$ animal doméstico mordido por una serpiente anís negru mezclado con vino; Celso recomienda vino compuesto con pimienta y jugo de ajo; los dálmatas mordidos por una vibora beben vino hasta $\mathrm{cm}$. briagarse y se curan de este modo; los cazadores de viboras solo emplean vino para combatir los éectos de esa terrible ponzona; los norte-americanos hacen poco caso de una mordedura de la serpiente de cascabel cuando tienen una buena cantidad de nguardiente á su disposicion, del cual beben tanto como es posible, duermen hasta que les pasa la borrachera $s$ no sufren ya las consecuencias del veneno. Los habitantes de la India por mas remedios que cmplean, no conocen ninguno tan eficaz como el aguardiente destilado conlinosilvestre ó tabaco. Los malayos de Borneo consideran como salvado á un hombre mordido por una serpiente ve. nenosa tan luego como cste bebe aguardiente hasta embria: garse; los indigenas que estando completamente borrachos fueron mordidos repetidas veces no experimentaron ningun daño. En los últimos tiempos, tambien los médicos emplean el espiritu de vino en cualquier forma y con el mejor Éxito. Los experimentos han demostrado que el alcohol no produce los efectos de un antidoto, es decir, no combate el veneno de la serpiente; pero aumenta la actividad de los nervios, paralizada por la ponzoña del reptil, con mas y mas sapidez que ningun otro estimulanie; presta por lo tanto excelentes servicios; y merece emplearse, tanto mas cuanto que en cualquier pueblo se encuentra aguardiente.

Despues de haber hecho un sinnúmero de experimentos, Fayrer da en pocas palabras los siguientes consejos para el tratamiento y la curacion de un hombre mordido por una serpiente venenosa: con una venda cualqquiera se fajará el miembro herido por encima del sitio lastimado, oprimicndo con la mayor fuerza posible $y$ si es necesario con unas tabli. llas de madera; á intervalos se pondrán tambien varias vendas mas arriba de la primera, apretíndolas del mismo modo. Despues se hace un ligero corte en la herida, deján. dola sangrar, 6 se chupa flor otra persona, 6 bien se cauteriza con lumbre, hierro candente, piedra infernal us otro medio. Cuando una serpiente, reconocida como venenosa, ha mordido un dedo, lo mejor es cortarle al punto, y si esto no es posible se hará cuando menos una incision en la herida a la mayor profundidad posible. Dejese descansar al enfermo, sin permitirle hacer ninguna clase de ejercicio, $y$ al presentarse los primeros sintomas del enienenamiento sc le dará agua de Lucio, espiritu de amoniaco, $\delta$ mejor aun espiritu de vino, aguardiente, vino hervido con agua, etc, no demasiado á la vez sino en pequeñas dósis y a intervalos muy cortos. Cuando se presenta el desmayo apliquense trapos calientes y mostaza sobre el vientre, $\delta$ bien una corriente eléctrica en el corazon y el diafragma; tambien se puede emplear baños de chorro frios. Si el enfermo quiere tomar antidotos en cuyos efectos cree, es preciso dárselos; pero mas importante es hacerle concebir siempre buenas esperanzas.

Los budhistas, cuya religion prohibe matar un animal, ponen una serpiente renenosa en un cesto hecho con hojas de palmera, abandonándole $\{$ las aguas de un rio. Tambien entre nosotros hay gente loca $y$ yo mismo be sido victima de sus ataq̧ues; esa gente pide con mucha instancia el perdion de la víbora comun porque nos es útil para el exterminio de ratones, $\delta$ cuando menos se atreven d vituperar la matanza de las serpientes en general como una crueldad inútil. ๔Coged piedras y paloz y atacad con vigor a la mala cria, aunque os amenace y silbe con el cuello dilatado, dice Virgilio; y nosotros somos de la misma opinion. Mata. mos a las serpientes venenosas $y$ hacemos bien procediendo asi. El hombre razonable no puede perdonarlas, pues solo una encarnizada guerra de exterminio nos puede resguardar.

Por fortuna no todos los indios piensan del mismo modo que los locos devotos de su puebio, pues tambien en la India hay muchas personas de la clase inferior que estimuladas por las recompensas que el gobierno ofrece se dedican al exterminio de las serpientes. En el norte y sur de América no hay nunca perdon para esos reptiles; en la América del norte, el que ve una serpiente venenosa no se ahorra la mo. lestia de apearse del caballo 6 bajar del carro para matarla, y todo aquel que en el Brasil puede coger una, la inmola con tanta cólera como odio mortal, aunque no sin miedo. Miuchas scrpientes no renenosas son victimas de tan iracunda saña; pero equién podrá considerar esto como una crueldad en gente que todos los años toca las consecuencias de la mordedura de las serpientes? Fl hombre no puede vanagloriarse aun de haber alcanzado la victoria sobre las serpientes venenosas, 5 mientras dura la guerra de exterminio contra ellas no se puede exigir el perdon de las inofensivas. Jamás podremos exterminar del todo á esos reptiles venenosos, pero si es posible reducir su número como se ha probado en los países donde el agricultor se ha establecido, sobre todo en los Estados de la Union y en el Brasil. El nú. mero de las serpientes en general, y particularmente el de las venenosas disminuse considerablemente merced at los progresos de la agricultura; de modo que con el tiempo el hombre podrá vivir hasta en las regiones donde mas abun. dan estos reptiles, al menos sin el continno temor de poner en peligto su vida. Hasta entonces, nosotros y todos los hombres sensatos opinaremos como Virgilio.

\section{LOS CONOCERCOS- ELAPIDE}

CARACTERES. - En la primera familia agrupamos las culebras venenosas $\delta$ conoccrcos. Estos oñdios tienen el cuerpo bastanie prolongado, cilíndrico, 6 que a reces por medio de la elcracion de la columna vertebral afecta una forma triangular, con la cabeza pequễa y la cola corta. Tienen las ventanas de la nariz á los lados del hocico redondeado, y la cabeza protegida por grandes placas; por lo regular, faltan las frenales. La escamacion del cuerpo varia en gran nianera. los ojos pequeños, $y$ de pupila redonda, solo oval cn al. 
gunas especies, hállanse situados en linea vertical; los dien. tes venenosos tienen por lo regular un surco que corresponde con la canal del veneno en el interior.

DISTRIBUCION GEOGRÁFXCA.-Esta familia está diseminada por ambos hemisferios, pero desarrollśndose en mayor número $y$ variedad en el austral; felizmente no se encuentra representada en Europa.

USOS, COSTUMBRES Y REGIMEN.-Pasan los conocercos la mayor parte de su vida en el suelo, $y$ si bien algunos trepan con regular facilidad, solo excepcionalmente suben á los árboles.

Los de major tamaño acometen á pequeños vertebrados, y los mas débiles suclen alimentarse de coleópteros, caraco- les, etc; aquellos acechan sus victimas, las persiguen á veces un buen trecho, las muerden y aguardan el efecto de su ve. neno antes de devorarlas, mientras que los otros buscan sus presas, se apoderan de ellas, y solo las envenenan al tragarlas. Hasta ahora no tenemos noticias seguras sobre la reproduccion de estas especies; solo sabemos que los conocercos depositan sus huevos antes de madurarse.

\section{LOS ELAPS-ELAPS}

CARACTÉRES. - Las especies de cste primer género de los conocercos, que son indudablemente los reptiles que po. seen mayor riqueza 8 hermosura de colores, presentan un

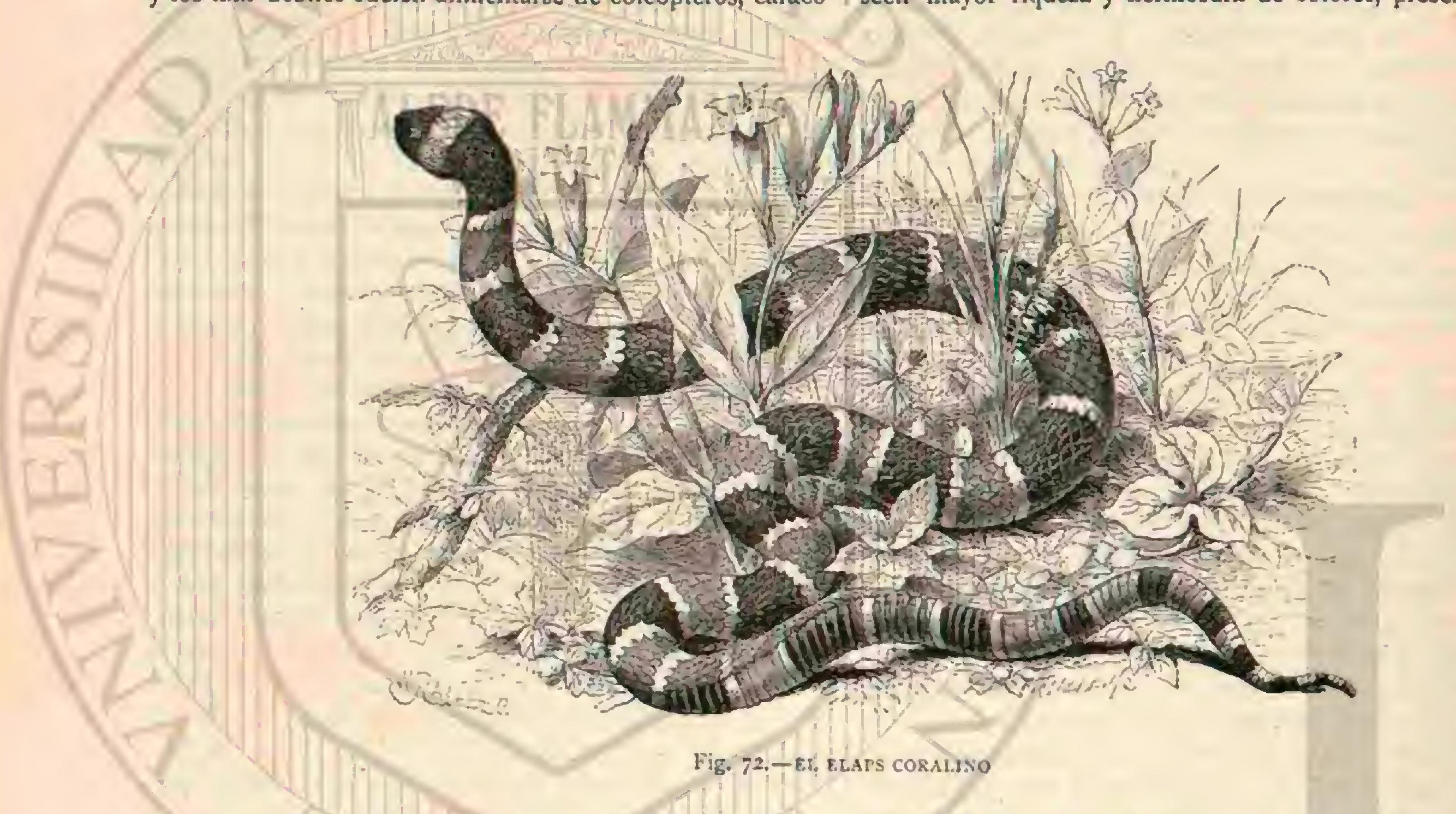

cuerpo redondo, corto $y$ algo rechoncho, con la cabeza de forma graciosa, apenas destacada del cuello, y la cola poco larga. Cubren el cuerpo escamas lisas $\in$ iguales, que se hallan colocadas en doble fila debajo de la cola, y que en la cabera se convieıten en pequeños escudos. La abertura bucal es muy corta, $y$ la mandibula poco dilatable, debido á la disposicion de los huesos cuadrados y mastoideos. Detrás de los dientes venenosos se encuentran algunos mas pequeños, pero sólidos $y$ sin surco. Ios naturalistas han estado discordes durante algun tiempo respecto \& la venenosidad de los ganchos de los elaps; varios, entre ellos el príncipe de Wied, aseguran que el mas minucioso exámen de djichos dientes no ha permitido descubrir perforacion ni ranura alguna en los mismos. Como es consiguiente, el principe considera estos ofidios como completamente inof́nsivos, y dice: sun cuando tuviesen los dientes perforados y venenosos, poco temibles se. rian estos animales a causa de la pequeñez de la abertura bucal, que no les permite morder sino á animales muy pe. queños. Los elaps, de los cuales he llevado muchos en mis manos, sin que me causaran el menor daño, se parecen en su configuracion general á las dobleandadoras, siendo sus carac. téres bastante análogos: la cabeza plana y rédondcada por delante, el ojo pequeño $y$ la boca diminuta que apenas puede abrirse.

Los observadores modernos no consideran \& los elaps como las serpientes venenosas mas peligrosas, pero están unánimes en que su ponzoña es tan eficaz como la de otras serpientes del mismo tamaño provistas de dientes perforados.

\section{EL ELAPS CORALINO - ELAPS CORÁLIINUS}

CARACTERES. - Una de las especies mas magnificas del género es el elaps coralino, serpiente de $0^{\circ}, 60\left\{10^{\circ}, 70\right.$ de longitud, correspondiendo s. la cola $\left(0^{\mathrm{m}}, 10\right.$. $\mathrm{El}$ fondo de la coloracion de todo el animal, dice el principe de Wied, es un magnífico rojo cinabrio de brillo muy vivo, menos en la region ahdorninal, donde aparece algo matc. Este bonito color alterna en el tronco, y á intervalos bastante regulares, rnn diezy seis $y$ hasta diez $y$ nueve anillos negros, de cuatro \& seis pul. gadas de ancho, que aparecen separados, en ambos bordes; del fondo rojo, por otro anillo, muy estrecho, blanco verdoso. Todos los anillos rojos ó verdosos están moteados de negro, pues cada escama tiene una punta negra. La parte anterior de la cabeza es de un negro azulado, lo mismo que las placas cef́licas; cerca de los dos escudos occipitales empieza un rasgo blanco verdoso, que pasa por detrás del ojo y comunica su color á toda la mandibula inferior; detrás de esta faja se encuentra un collar negro 6 sea el primer anillo de dicho tinte, al que sigue otro rojo, y asi sucesivamente. Ia cola por lo comun no tiene coloracion roja, sino que presenta unos ocho anillos blanquizcos sobre fondo negro, con su extremidad corta, puntiaguda y blanca. Estos colores y dibujo parecen ser muy constantes en todos los individuos de la misma especie (fig. 72 ).

DISTRIBUCION GEOGRÁFICA. - Segun el citado príncipe, habita esta serpiente los grandes bosques y espesuras de arbustos en las inmediaciones de Rio Janeiro, Cabo 
Frio y las márgenes del Parahioa, pero se encuentra asimis. mo en México y en algunos otros puntos de la América del sur.

USOS, COSTUMBRES Y REGIMEN.-Raras veces aparece el claps coralino en los. sitios descubiertos, aung̨ue excepcionalmente se acerque á ellos y hasta 2 las habitaciones del hombre. Frecuenta con preferencia el suelo húmedo $y$ fresco de los bosques, donde las plantas y la hojarasca le ofrecen numerosos escondrijos. El cazador, refiere el principe, que recorre dichos bosques se ve agradablemente sorprendido cuando descubre entre el verde de las plantas los brillantes anillos rojos de este delicado reptil, y tan solo la incertidumbre respecto á la malignidad del animal, le impide en un principio extender la mano para apoderarse de tan hermoso sér; por nuestra parte, pronto nos convencimos de que no habia en ello peligro alguno, y cogiamos estas serpientes $y$ las trasportábamos vivas en nuestros bolsillos. Hemos encontrado muy á menudo en ruestras cacerias el elaps coralino, aunque mas frecuentemente en la estacion calurosa que en la fria, pudiendo observar que no es de las serpientes mas veloces ni ágiles, pues muy fácilmente se la coge, no siéndole dable trepar por los árboles, como suelen hacerlo otras espe-

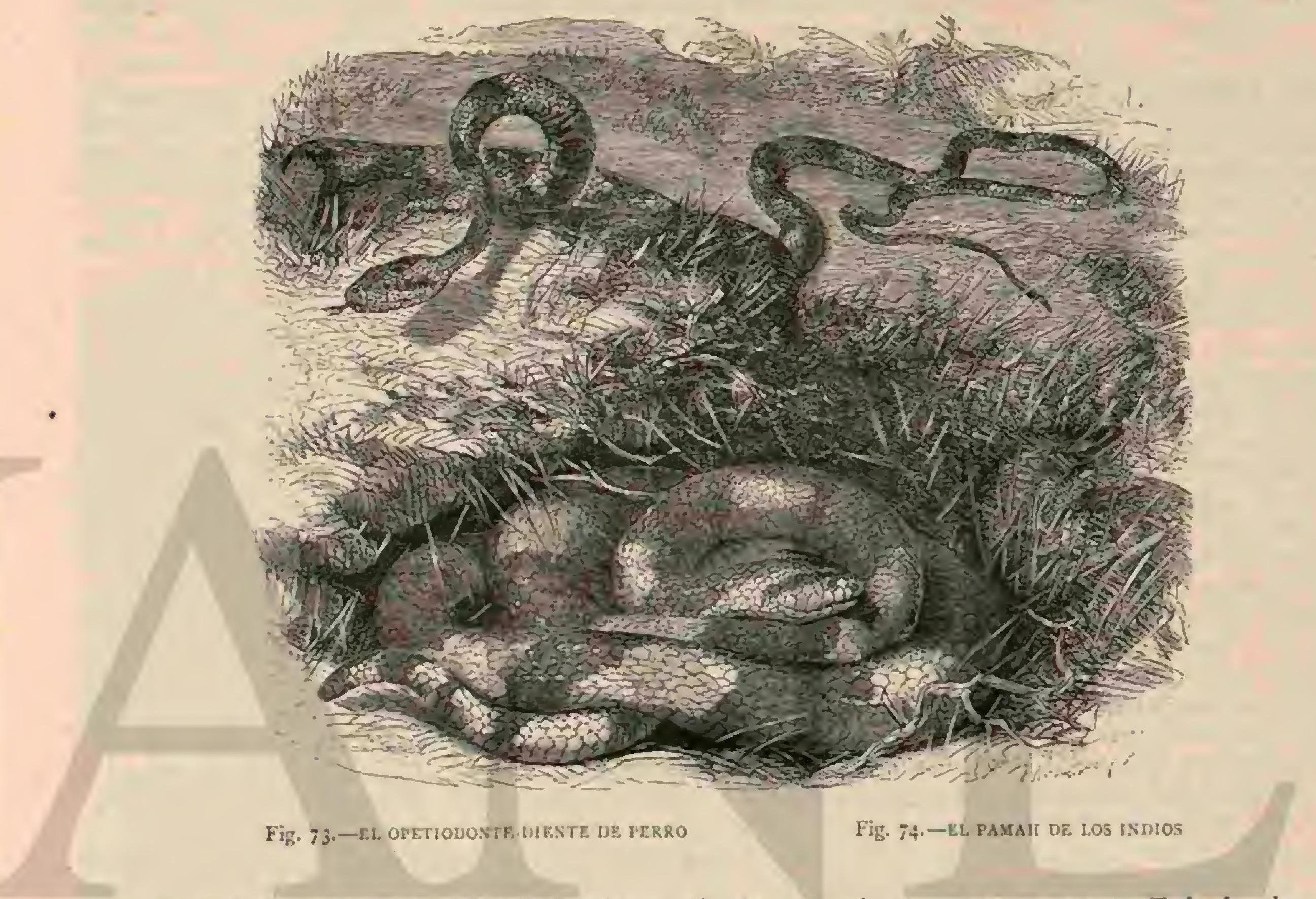

cies afines en las selvas virgenes del Brasil. Consiste su alimento en pequeños animales, pues la estructura de su boca no le permic engullir los de mayor tamano; es muy proba ble que se nutra, como las dobleandadoras, de hormigas $y$ térmites.

No he observado cque estas serpientes despicieran un olor especial durante la época del apareamiento, pero si he visto a menudo lleno de huevos el cuerpo de las liembras.

- Los brasileños considerabian cl elaps coralino como venenoso, siendo por lo demás esta su opinion general respecto de todas las serpientes, pues hasta hay habitantes de aquella region que preterden que este ofidio lleva en el cuello otra serpienic mas pequeña que tambien muerde; con todo, debo repetir una vez mas, que cuantos elaps coralinos he visto y tenido en mis manos, eran completamente inofensivos.

Uno de los elaps mas comunes en el Rio Grande del sur es igualmente temido en alto grado como reptil muy vene. noso: los brasileios creen, sin embargo, que en vez de los dientes de la ponzoña tiene un aguijon de hierro en la punta del hocico, con el cual hicre mortalmente. A pesar de todas mis investigaciones, dice Hensel, nunca he hallado persona alguna que hubiera sido testigo ocular de un envenenamiento por la mordedura de esta serniente, y mis rejectidas prue.

Toso $v$ bas no confirman que esto sea exacto. Todos los claps coralinos muertos por mi tampoco me opusieron resistencia; buscaban siempre su salvacion en la fuga; de modo que los cuentos que circulan sobre los peligtos que ofrece este reptil me parecen inventados, ó cuando menos exageradus.

Segun el relato de Seba, las indias se sirven de otra espe. cie del mismo género (Elaps ligice) para refrescarse en la estacion calurosa poniéndoseta al cuello, porque no mucrde: parece que tambien el principe ha visto algo de esto, puesto que refiese que emuerta y arrollada al cuello oscuro de las negras y de las indias, se parece esta hermosa serpiente á los brillantes collares que los naturales de Owayhi fabricaban con plumas de pajaro, cuando visitó aquellas tiersas el capitan Cook. ?

CAUTIVIDAD. - Un tralicante en animales me facilitó las siguientes noticias: IqRecibi una de estas serpientes de tan hermosa coloracion, dentro de un gran vaso de cristal, y la cuidaba con toda asiduidad, temiendo no poderla conservar viva durante mucho tiempo. Al principio no hizo caso alguno el reptil de los insectos y pedacitos de carne que le ofre. cia, pero cuando le presenté un raton sc animó súbitamente, y sc dispuso en cl acto á matarle, observando, por cierto, que en vez de morderla $\delta$ ahogarle entre las circunvoluciones de 
su cuerpo, lo comprimió con fuerza contra la pared de la jaula hasta dejarlo sin vida; hecho esto, lo magulló y estrujó, hasta ponerlo en disposicion de que pudiera pasar por su estrecha boca. Con su guardian se mostró siempre apacible y dócil; no mordia nunca, \& por lo general, sus há. bitos y modo de ser no parecian los de una serpiente venenosa. $\$$

En los museos de Europa no puede formarse idea exacta de la magnifica coloracion de estos ofidios: si se les quita la piel, palidecen muy pronto los anillos rojos; conservados en espiritu de vino sucede otro tanto, 1 legando á veces aparecer aquellos por completo. La materia colorante, pare. ce que la disuelve el espiritu de vino, ya que este siele tomar un color rojo claro.

\section{LOS OPETIODONTES-OPETIODON}

CARACTERES. - Los esenciales de este gencro consis. ten en tener los primeros dientes anteriores del hueso palatino, asi como los de la mandibula inferior, sumamente des arrollados; los demás van disminuyendo sucesivamente en fuerza y longitud, sin presentar un espacio libre intermediario. Ias escamas son lisas; las de la seric del centro del lomo presentan seis caras, y son mayores que las otras, las cuales afectan una forma romboidal. Las fosas nasales, situadas á los lados, están circunscritas por las dos placas correspondientes; la pupila es oval y tiene un gran diámetro.

\section{EL OPETIODONTE DIENTE DE PERRO- OPETIODON CYNODON}

CARACTERES. - El tronco es muy comprimido; el lo mo forma saliente y le protege una serie de grandes placas carenadas; los dientes palatinos anteriores son mucho mas largos que los otros. Los colores de esta serpiente no son brillantes; pero sí suaves $y$ agradables; predomina un tinte gris, con fajas pardas de distintos matices, que à veces tiran al negro; en la cabeza hay una mezcla de pardo, y desde el ojo $\{$ la boca se corren varias listas oscuras (fig. 73).

DISTRIBUCION GEOGRÁFICA. - Esta serpiente se encuentra á menudo en Java y Borneo.

\section{LOS CALOFIS-CALLOPIIS}

CARACTERES. - Los tipos asiáticos de las serpientes descritas son los calofis 6 serpientes de adorno. En rigor solo difieren de sus congéneres por el número de las series de escamas, que en las especies de este género ascienden á i 3 , mientras que en los elaps llegan á i 5 .

El tronco es redondeado, muy largo y delgado; la cabeza obtusa y apenas separada del cuello; la cola muy corta; las fosas nasales anchas y situadas entre los escudos; los ojos, pequeños y de pupila redonda, están rodeados de un escudo anterior y dos posteriores. Los escudos de la cabeza son regulares aunque falta la placa de la linea naso-ocular: los de las sienes están dispuestos en una serie longitudinal; los la. bios superiores presentan de seis á ocho escudos; las escamas son lisas y están poco sobrepuestas; las que cubren el centro del lomo son un poco mas grandes.

Muy notable parece la formacion de las glándulas veneno. sas, que segun el examen de Meyer, no difieren del tipo general en algunas especies del grupo, mientras que en otras alcanzan un tamaño extraotdinario, ocupando una tercera parte, $y$ hasta la mitad de toda la longitud del cuerpo; se prolongan hasta la cavidad abdominal é influyen mucho en la posicion de los intestinos, desviando tambien el corazon muy hácia atrás. Asimismo es muy curioso que estas enormes glándulas se hallen en algunas serpientes de los grupos que se asemejan mucho á otros en que las glándulas tienen un tamaño regular. El conocimiento de esta particularidad es aun tan reciente que solo las averiguaciones posteriores podrán decirnos si en ella se han de fundar diferencias de género 6 no.

\section{EL CALOFIS DE MACCELLAND-CALLO- PHIS MACCELLANDII}

CARACTERES. - Esta especie, una de las mas comunes y diseminadas del género, nide sobre $0^{n}, 5^{\circ}$ de longitud, correspondiendo à la cola $\theta^{m}, 04$. El número de los escudos del labio es de siete; la coloracion varia mucho; la parte superior de la cabeza y del cuello suele ser negra, con una faja trasversal amarilla que empieza por detrás de los ojos; el tronco y la cola son de un pardo rojizo con una lírea negra que desde la nuca se corre por todo el espinazo hasta la punta de la cola; las regiones inferiores son amarillas, con manchas cuadrangulares y longitudinales, $\delta$ bien fajas trassersales mas estrechas.

En otros indiriduos los dibujos del vientre forman unas fajas trasfersales negras no interrumpidas, limitadas en la parte inferior ó que se prolongan hasta los lados del abdómen, de modo que abarcan cuatro series de las escamas de los castados $y$ forman otra de manchas negras longitudinales á lo largo de aquellos; las tres últimas fajas se extienden hasta la línea central de lá region superior, formando anillos cerrados; en una variedad de la especie, estos anillos cubren todo el cuerpo, siendo su número de veintidos á veintiocho, en cuyo caso desaparece la línea central ió solo queda indicada por manchas.

DISTRIBUCION GECGRÁFICA.-La patria de esta especie es el Nepal, Dardjiling y Assam.

\section{EL CALOFIS DE ANILLOS-CALLOPHIS ANNULARIS}

CARACTERES. - En csta segunda especie el labio superior está cubierto de seis escudos; la parte superior de la cabeza y del cuello son negras, con una ancha faja trasversal amarilla por detrás de los ojos; el tronco y la cola son de un pardo rojizo sin faja central, pero con cuarenta anillos estrechos, negros, orillados de blan6o y situados á intervalos regulares; cada cual tiene la anchura de la longitud de una escama dorsal y ocupa precisamente un escudo abdominal; las regiones inferiores son amarillas, con unas fajas trasversales negras en medio de cada anillo, curas fajas ocupan igualmente un escudo abdominal; de modo que poco mas $\delta$ menos un tercio de toda la parte inferior es de color ne. gro. La longitud de este reptil es de $0^{\prime \prime}, 02 \leqslant 0^{*}, 03$ mas que la especie anterior.

DISTRIBUCION GEOGRÁFICA.-IOS calofis abundan mucho en el continente indio, donde parecen bastante mas numerosos que en las grandes islas vecinas.

USOS, COSTUMBRES X REGIMEN, - LOS calofis se parecen mucho á las serpientes enanas por su género de vida; habitan los mismos parajes que estas, con tanta mas razon cuanto que, segun parece, constituyen exclusisamente su alimento. Ambos grupos tienen la misma área de dispersion, y las serpientes venenosas dependen de tal modo de las otras, que faltan alli donde no se encuentran, como sucede en Ceilan. Si podemos permitirnos calcular por el número de individuos de ambos grupos que llegan á nuestras colecciones la abundancia de esos reptiles, podemos decir con Guen 
ther, que las especies de serpientes enanas son doble mas numerosas que los calofis que viven en las mismas regiones.

Segun las experiencias de Cantor, estos últimos no son muy comunes, aunque tampoco podria decirse que escasean. Son serpientes terrestres en la verdadera acepcion de la pa. labra; suelen ocultarse debajo de las raíces de los árboles, 6 de las piedras, ast como en las grietas de las rocas; parecen muy perezosas, jues mueven su tronco largo y delgado pesa. damente. Por lo regular se las encuentra sin movimiento con el cuerpo muy encorvado, pero no enroscadas en el suelo. A pesar de que debemos considerar estos reptiles como ser. pientes diurnas, su vista parece tan débil como su oido, $\delta$ por lo menos es fácil acercarse á ellas sin que manifiesten temor. Cuando se las toca con un baston hacen violentos esfuerzos para huir; pero pronto se detienen de nuevo, y si entonces se continúa la persecucion muévense con irregularidad, cual si verdaderamente tuvieran convulsiones: munca intentan morder. Solo en una ocasion vió Cantor como una de esas serpientes elevaba su cabeza á unos $0^{\circ 0}, 0_{4}$ sobre el suelo.

En la cautividad desprecian el alimento y el agua y mueren al poco tiempo. En el estómago de varios individuos examinados por Cantor halláronse solo una vez los restos de una pequeña serpiente, cuya especie no se podia reconocer ya; Schlegel, en cambio, sacó serpientes enanas.

Unicamente la boca, bastante estrecha, hace crecr que esta serpiente es inofensiva; pero su veneno suele ser tan eficaz. como el de cualquier otro individuo de la familia: las especies en que la glándula venenosa alcanza un desarro110 extraordinario pueden sin duda, á pesar de sus dientes muy p̧equeños, dar mordiscos en alto grado peligrosos, pero tambiená las otras les es fácil matar un animal grande. Des. pues de haber hecho varias tentativas inútiles para obligar á los calofis a morder, Cantor introdujo los dientes venenosos de un individuo en un repliegue de la piel del muslo de una gallina: a causa de la estrecha boca y de la dificultad que oírecia el experimento, pareció dudoso que el gancho venenoso hubiera penetrado en la piel, y por lo tanto se obligó á la serpiente, al cabo de un cuarto de hora, á herir á la galli. na debajo del ojo derecho. Veinte minutos despues se reco. noció en el ave el primer indicio de envenenamiento; la gallina expelió sus excrementos, levantó con marcadas expresiones de dolor la pierna herida, y recogióla hácia el tronco. A los veintiocho minutos de la primera mordedura, que ha. bia dejado una herida apenas visible, el ave cayó al suelo, haciendo inútilnente esfuerzos para levantarse; y diez minutos despues declaráronse las convulsiones; la pupila se estrechó, sucediéronse los sintomas del envenenamiento, y al cabo de una hora ocurrió la muerte. Otras galihinas mordidas por calofis muricron con sintomas semejantes en un espacio de ochenta minutos, algunas de tres horas; pero tambien todas las serpientes empleadas en estos experimentos perecieron poco despues.

\section{LOS BUNGAROS - BUNGARUS}

CARACTERES. - Con el nomure de bungarsu ó bungar designan los indios una serpiente de su pais, de gran tamaño y muy peligrosa; este nombre se ha latinizado y aplicado al género del cual es la especie típica el mencionado de los indios.

Tienen estas serpientes la cabeza mas ancha que el cuello, pequeña, ovalada, con el hocico corto y obtuso; el cuerpo cilindrico, algo comprimido y aquillado en el dorso, casi de un grueso uniforme hasta la cola, $y$ esta comparativamente corta. Cubren la cabeza diez anchas placas, escamas exago- nales la parte mas elevada del dorso, 5 una sola fila de urostegas la parte inferior de la cola. La abertura de la boca es corta ó cuando mas de mediana anchura; la mandibula inferior mas corta que la superior, y la dentadura mas débil en esta que en aquella $A$ parecen varios dientes lisos detrás de los ganchos venenosos, que en su parte corva tienen surco ó ranura muy marcado y en su raiz un pequeño hoyo y que, en proporcion al tamaño del animal, son bastante pequeños y proyectan muy poco fuera de su vaina.

\section{EL PAMAH Ó BUNGARUN PAMAH DE LOS INDIOS-BUNGARUS ANNULARIS}

CARACTÉRES.-Esta especie, la mayor de la familia, pues mide 2 metros de largo, llewa anillos amarillentos sobre fondo negro ó azul oscuro; la cabeza, que es tambien azul negruzca, tiene una raya amarillo clara, que empieza en el centro de las placas occipitales y corre ácrada ladn, acabando por constituir un collar; el resto del cuerpo presenta, á intervalos regulares, anillos azul oscuros y amarillos de igual an. chura (fig. 74).

\section{EL PARAGUDU, PACTA-PULA Ó KRAIT- BUNGARUS CCERULEUS}

CARACTÉRES.--Esta segunda especie alcanza tan solo una longitud de $t^{\prime \prime}, 50$. El color varia mucho; las regiones superiores son por lo regular de un negro azulado ó pardus. co, de un solo color, á veces con fajas trasversales mas ó menos numerosas, muy estrechas y de color blanco, que parten de una mancha en el lomo; las regiones inferiores son blan. cas. Hay, sin embargo, individuos que tienen las regiones superiores de un solo color pardo y la cabeza blanca, con una faja trasversal negra: en otras variedades la parte supe. rior presenta fajas trasversales sencillas ó dobles.

DISTRYBUCION GEOGRAFICA.-El pamah abunda en las Indias orientales, Siam, China, Java y las islas adva. centes al continente indico. El paragudu habita los mismos paises quue el pamah, si bien se le encuentra con mas frecuencia en el continente que en las islas: $y$ abunda especialmente en Bengala y en la costa de Malabar.

USOS, COSTUMBRES Y REGIMEN.-EI pamah y el parugudu tienen iguales costumbres y modo de vivir. Dice Cantor que ambas especies fijan con preferencia su morada en los terrenos secos, donde acechan á los pequeños mamiferos y reptiles, particularmente ofidios y ranas. El mismo naturalista los considcra como animales nocturnos a pesar de su pupila redonda, pues acostumbran ocultarse de dia en sus escondrijos, huyendo del sol y buscando la sombra, Fayrer al contrario les designa como animales diurnos. Al igual de todas las demás serpientes venenosas, son animales muy co. léricos, que excitados se enfurecen extraordinariamente, pero que en su estado normal suelen emprender la fuga tan pronto cono se perciben de la presencia del hombre. Cuando se ven atacados 6 acosados en sus madrigueras, procuran abandonarlas, dando señales de viva cólera, y moviéndose con gran rapidez. y destreza. Antes de acometer, retiran la cabeza. proyectan despues, inclinándose á un lado, la parte ante. rior del cuerpo, é intentan morder al enemigo. Pretenden los indios que la mordedura de estas serpientes es infaliblemente mortal y las temen mucho;. los cortos ganchos venenosos, sin embargo, dejan mas esperanza de vida que los de una serpiente de anteojos.

Los experimentos practicados por Rusell, Fayrer y otros prueban bastante el carácter peligroso de las mordeduras de los bungaros. 
Una gallina mordida por un pamah, al cabo de diez minutos y despues de una fuerte diarrea, no podia ya tenerse en pié; le temblaba la cabeza, y á los veinticinco minutos murió en medio de fuertes convulsiones. Un perro de gran talla y muy robusto, al que mordió en el muslo un paragu. $d u$, empezó $a$ aullar fuertemente apenas se sintió herido; diez minutos despues encogí́ el miembro mordido, pero continuó todavia moviéndose. A los veinticinco minutos, am. bas patas traseras estaban paralizadas, $y$ durante la segunda hora vomitó varias veces, aumentando la parálisis y desfalle. cimiento general, hasta que sobrevino la muerte, a las dos horas de inoculado el veneno. Iguales sintomas se-reprodu. jeron en una perra mordida en el costado, y que falleció al cabo de una hora.

Los experimentos Fayrer, muy numerosos y detenidos, cstán esencialmente conformes con los de Kusell. Varios perros mordidos coinenzaron á respirar aceleradamente y con ansia a los veintitres minutos; declarátonse vónitos à los tres cuartos de hora; manifestóse un marcado malestar y soñolencia; siguiéronse al fin las convulsiones y múrieron álas cin. cuenta y cuatro 6 cincuenta y cinco horas. Los gatos mordidos abrian la boca, alargaban la lengua mucho, intentaban huir, echábanse despues tranqquilamente y morian en poco mas ó menos el mismo tiempo. Las garzas reales heridas en el muslo estiraban tres minutos despues la pierna, respiraban mas rápidamente é intentaban huir, á los seis minutos manifestabase el primer indicio de debilidad, abrian el pico, erizaban el plumaje, se posaban en el suelo, cerraban convulsivamente los dedos y movian con estremecimientos la piel del cuello; una hora mas tarde quedaban del todo para. lizadas y á la hora y media despues de la mordedura morian. Al examinar el muslo mordido veiase que estaba sumamen. te hinchado, y tan lleno de gases, que al comprimir la piel escapábanse con ruido; la sangre era acuosa, como regularmente se observa en los animales û hombres muertos á consecuencia de mordeduras de las serpientes venenosas. Dos minutos despues de ser heridas las gallinas manifestaban ya gran excitacion, y corrian espantadas de una parte á otraj á los ocho minutos cinpezaban ś vacilar, de tal modo que debian sostenerse con el pico aposado en tierra y cinco minutos despues caian paralizadas; 占 los quince declarábanse las convulsiones, y morian \& los veintiseis nimutos, $\delta$ \& los diez 5. sicte algunas; pero todas, cuando mas tarde, sa la hora y media despues de ser mordidas. Un gato herido por uno de esos reptiles cstuvo enfermo durante tres dias, mas no murib, sin duda por no haberse introducido bastante veneno en la herida. I.o mismo sucederá algunas vecés cuando una serpiente muerde á un hombre y este no sucumbe por efecto del-veneno. ESi al gato, dice Fayrer, se le hubiesen propinado antidotos, á estos se hubiera atribuido, y sin razon, el efecto favorable.»

De todos estos experimentos cuya enumcracion cansaria sin decirnos nada nuevo, resulta que el veneno de los bungaros no produce efectos tan rápidos y fuertes como el de la serpiente de anteojos, circunstancia que sin embargo solo estriba en la poca longitud de los ganchos venenosos. En to. dos los casos las heridas causadas por estas serpientes son siempre en extremo peligrosas; y no dejan de tener las consecuencias mas funestas, aunque los dientes solo hayan ras. gado la piel.

Algunos bungaros mordidos por serpientes de anteojos morian al dia siguiente; pero otros conservaban la vida, lo cual induce á Fayrer á creer que la muerte de los primeros se debió al hecho de ser mas profunda la mordedura de la scrpiente, opinion del todo justificada segun mis observaciones.

Dificil es calcular cuantas de las numerosas desgracias que todos los años ocurren en la India deben atribuirse á los bungaros; pero probablemente no será un error considerar. los como las mas temibles de todas las serpientes venenosas de las Indias Orientales, despues de la especie de anteojos. Fácil es que el tamaño relativamente reducido, la forma poco particular de la cabeza, el aspecto inofensiro, y quizás tam. bien la belleza de los colores, engañen a muchos en su opinion sobre los bungaros, que sa causa de su vida diurna hállanse mas á menudo en el canino del hombre que otras serpientes venenosas de igual tamaño.

\&La regla que rige en Europa, dice Martens, sobre que las serpientes venenosas se pueden reconocer por la cabeza ancha, y separada marcadamente del cuello, no es aplicable en el sur de Asia: un oficial holandés de Ambaraiva pagó bien cara, poco tiempo antes de nuestra llegada á Java, la insuf. cencia de sus conocimientos zoológicos, costándole la vida el considerar como inofensivo á un búngaro á causa de su pequeña cabeza. Como las extremidades anterior y posterior de estas serpientes no difieren mucho á primera vista, el pueblo cree que tienen dos cabezas, y advierte á todos que huyan de las doble andadoras porque son sumamente peligrosas.

De las noticias de Kayrer sobre los bungaros de las Indias Orientales resulta evidentemente que la advertencia es justificada, aunque se funde en una opinion falsa. En los partes oficiales que llegan á manos de las autoridades, los bungaros, y sobre todo la segunda especie, ocupan el segundo lugar. Raras veces se recibe aviso de casos debidos al pamah; nientras que los envenenamientos por el krait se repiten con suma frecuencia. Todos los informes de los empleados de seguridad acusan un número espantoso de desgracias ocasio. nadas por esa serpiente relativamente pequeña. Debemos añadir que esta especie es comun en toda la India ; cruza con mas frecuencia que cualquier otra el camino del viajero; penetra no solo en la choza abierta, sino tambien en la casa cerrada; enróscase en el unbral de la puerta, en el rincon de la habitacion, en los cofres; penetra en los dormitorios y en los baños; y aparécese con demasiada frecuencia como ángel de la muerte. Una señora que despues de haber viajado toda la noche dejó su asiento y comenzó á recoger sus efectos, vió debajo de su cojin un krait enroscado. | El peligroso reptil habia sido su compañero de viaje toda la noche!

\section{LOS SEUDOEQUIS-PSEUDECHIS}

CARACTÉRES. - Los de este género consisten en ser el tronco muy prolongado, cilindrico, con la cola relativamente larga y alelgazada; la caleza, pequeña y poco separada del cuello, está cubierta de grandes escudos; las escamas lisas son cuadrangulares y estín dispuestas en diez y siete series; los escudos de la cola forman primero dos, despues una, y por uitimo otra ver dos.

DISTRIBUCION GEOGRÁFICA.-Este género es pro. pio de Australia.

\section{EL SEUDOEQUIS NEGRO-PSEUDEGHIS PORPHYREUS}

CARACTERES. - Ia longitud de esta especie varia, se. gun Bennett, de $1^{\prime \prime}, 60$ á $2^{\circ}, 50$; su coloracion es de un mag. nífico negro con reflejos azulados en la parte superior del cuerpo, y rojo pálido, pero tambien muy brillante, en las regiones abdominales. Los ganchos venenosos son proporcionalmente pegueños y débiles.

DISTRIBUCION GEOGRA FICA.-El pseudoequis negro es una de las serpientes mas abundantes de Nueva Ho. landa.

USOS, COSTUMBRES X REGIMEN. - Es la opinion 
general de todos los naturalistas, viajeros y cazadores, que no hay pais alguno que produzca tantas serpientes venenosas como Nueva Holanda. I as cuatro quintas partes de todas las que se han coleccionado hasta ahora en varios puntos de aquel continente, son venenosas, perteneciendo muchas de ellas à las especies mas peligrosas de todo el brden. En to. das partes, dice el aricjo busthman, lo mismo en el bosque que en la pradera, á orillas de los rios, ó en los estanques y pantanos, está seguro el viajero ó cazador de encontrar su mas temible $y$ odiado enemigo, la serpiente negra. Esta penetra hasta en la cabaĩa del cazador, y se oculta bajo la manta de su cama: no hay sitio alguno que ofrezca seguridad contra sus asechanzas, y admira, en verdad, que no sea mayor el número de las personas que pierden la vida de resultas de su mordedura. Segun afirma el mismo observador, todas las serpientes de Australia se aletargan en invier. no, desaparecen en el mes de marzo, y no se las vuelvé ver antes de setiembre. Poco tiempo despues verificase el apareamiento; pasada cuya época, empieza su vida activa de verano, que ofrece la particularidad de que, obligadas por el calor que va en aumento y seca las aguas, á seguir en pos de sus presas, emigran las serpientes de un pantano 6 es tanque á otro. Fil pseudoenuis negro, cuya hembra es designada vulgarmente con el nombre de serpiente parda, á causa de su coloracion, parece ser el ofiảio mas extendido y mas abundante en Nueva Holanda; á lo menos es el que se ve mas frecuentemente, tal ver por razon de su vida diurna. Sus movimientos son mucho mas rápidos y śgiles que los de otras serpientes venenosas, pues, si son exactas las observaciones de los viajeros, abandonan á menudo el suelo para trepar por los árboles ó nadar en el agua. «En verano, dice Bennett, frecuentan, como todas las serpientes de Australia, las inmediaciones de las aguas, y cuando estaba cn acecho de ánades, las veia muchas veces cómo iban ś apagar su sed. Un dia maté de un tiro dos de dichas aves, una de las cuales fué á caer en la márgen opuesta; como no llevaba perro, me desnudé y nadando me dirigí en busca de mi caza. Mientras nadaba divisé un objeto en la superficie del agua, que al pronto tomé por un palo, pero al acercarme reconoci que era una serpiente negra, que descansaba completamente inmóvil y estirada á lo largo; aunque pasé á muy corta distancia de ella, no hizo el menor movimiento. Este encuentro casual me explicó la causa de la agitacion que varias veces habia notado en los ánades, sin saber á qué atribuirla. La observacion de Bennett no se relaciona, sin embargo, con el alimento del pseudoquis, pues hasta ahora solo se sabe que consiste en pequcños manif́cros, pájaros y reptiles.

Las serpientes venenosas de Australia causan muchos danos $y$ numerosas desgracias, razon que las hace.ser temidas $y$ perseguidas. De las muchas cabezas de ganado lanar $y$ bo vino quue en el verano se ven, agonizando unas, y otras muer tas ya en las llanuras, la mayor parte pierden la vida de resultas de la mordedura de las serpientes; aquellas, sobre todo los carneros, no dejan tampoco de matar bastantes de estas, saltando con las cuatro patas encima de ellas $y$ piso. teándolas.

Los negros temen mucho a todas las serpientes, aunque raras veces los muerden, por la sencilla razon de que siempre andan con la mayor precaucion y distinguen al punto con sus ojos de águila todo lo que delanie de ellos se mueve ó no: nunca pasan junto á un hoyo; jamás se introducen en una cavidad sin enterarse de lo que puede contener. $\mathrm{Co}$. men la carne de las serpientes que ellos mismos han muerto, pero segun Bennett, nunca las que se han mordido à si mismo, como lo hacen á menudo en la agonía.

CAZA. - Essta serpiente por regla general huye á toda prisa cuando ve á un hombre ú oye sus pisadas; pero, excitada por una larga persecucion, $\delta$ acornlada, suele volverse contra su agresor $y$ atacarle ś su vez; por eso los colonos le han dado cl nombre de serpiente saltadora. Bennett, por su parte, asegura que una sola ve飞 pudo presenciar cónıo saltaba un pseudoequis, con intencionde morder á un perro: estaba con el cuerpo medio levantado del suelo, y con la rapidez del rayo, se arrojó hácia adelante entoda su extension.

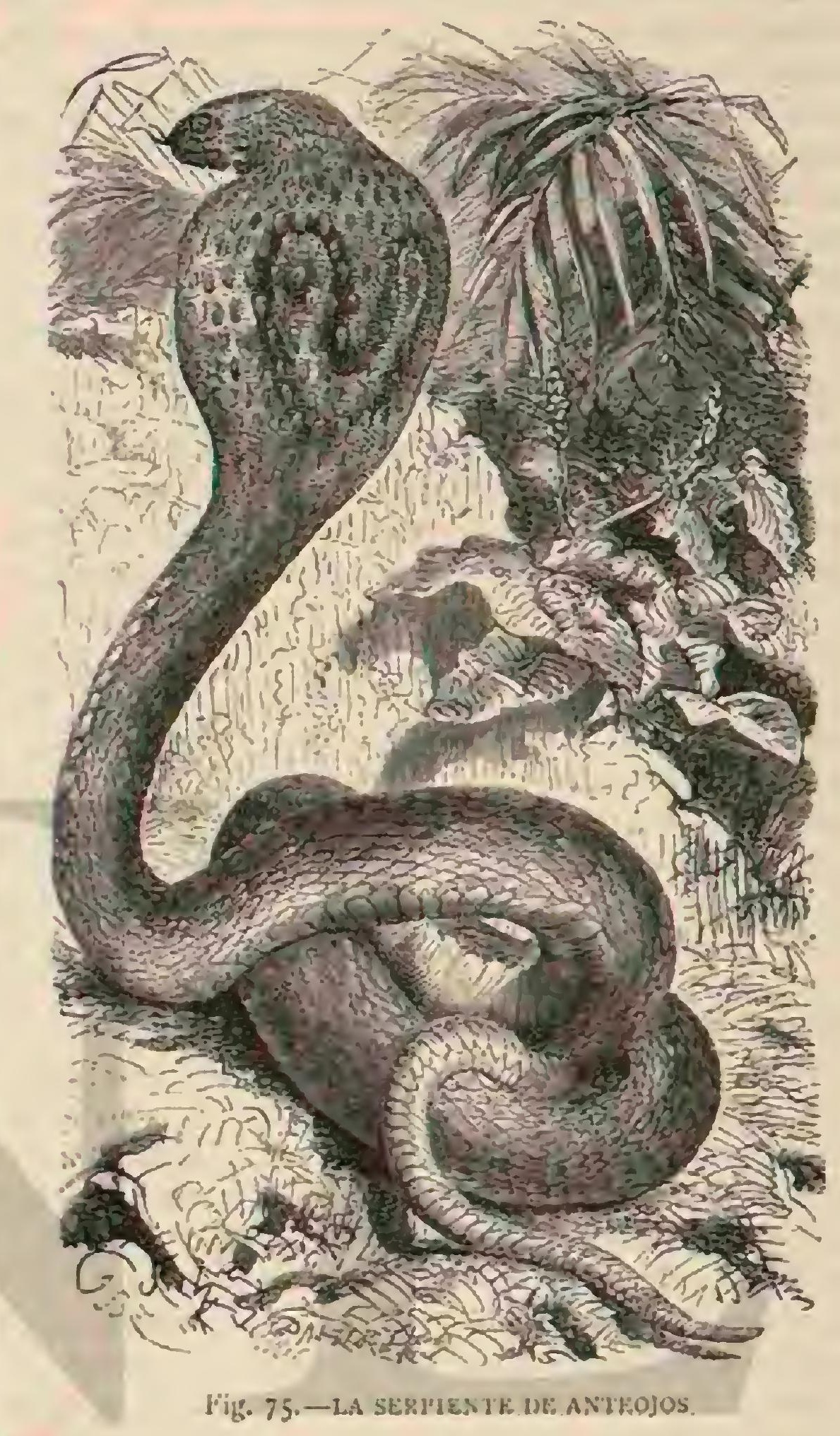

Muchos perros tienen gran destreza en coger y matar ser. pientes venenosas, sin exponerse á ser mordidos; pero casi todos, tarde 6 temprano, pagan con la vida su arrojo: pues haciéndose con el tiempo demasiado atrevidos, el menor descuido les es fatal. El indicado observador, á quien hemos citado ya tantas veces, reficre que un perro acostumbrado á matar serpientes, tuvo un dia una larga pelea con un pseudoequis negro, que tenia todo el cuerpo, menos la cabeza, escondido debajo de un monton de leña menuda, aca. bando por cogerlo y sacarlo de su escondrijo, pero recibió tambien dos mordeduras, una en la lengua $y$ otra en una para. El pobre can se vió muy prontoatacado de fuertes convulsiones; hincháronsele todos sus miembros, poniéndosele la lenguá y boca completamente negras, y espiró veinte minutos despues. Este perro, que tenia gran fama como matador de serpientes, habia podido librarse hasta aquel dia de todo peligro, combatiendo con sus temibles enemigos en canıpo raso, pero fuéle fatal esta primera tentativa de atacar. los en su madriguera. Vicjos perros de bosque rastrean las serpientes, se mantienen á una distancia respetuosa y ladran hasta que llega el cazador.

Los indigenas pretenden que la mordedura de esta scr. 
piente raras veces tiene consecuencias fatales en cl hombre, y en efecto, Bennett recuerda algunos casos de personas mordidas por la misma, que se restablecieron por completo sin ayuda de medicacion alguna. Sin embargo, está fuera de toda duda que, desgraciadamente, la inoculacion del veneno del pseudoequis produce siempre, si no la muerte, los mas graves trastornos en la cconomia del individuo. \&Un colono de las inmediaciones del rio Clarence, segun el citado naturalista, sabiendo que se habia introducido en su casa una serpiente negra, la buscó y se dispuso, armado de un buen garrote, para matarla, pero no procedió con la debida cautela y fué mordido en un pie por el rẹtil. Los efectos del veneno se manifestaron muy pronto por el desfallecimiento y soñolencia de que fué presa el paciente. Adninistráronle espiritu de amoniaco exterior é interiormente, haciéndoie incisiones en el sitio de la herida, al propio icmpo q̨ue una fuerte ligadura, y obligfronle 1 andar, no obstante los deseos que mostraba de querer dormir, siendo su aspecto general el de un envenenado por el opio. Permancció en el mismo estado duranie algunas horas, hasta que fue disminuyendo gradualmente cl mal, y recobró poco \& póco sus fuer\%as. Los negros suelen tratar de un modo parecido á los suyos, cuando se encuentran en igual caso. Despues de haber chupado la herida, obligan al paciente á estar en continuo mo vimiento, para impedir, segun ellos dicen, que el sueño se apodere de el, y contrarestar la accion del reneno. No des. cuidan tampoco la parte mordida, que suelen cauterizar o hacer incisiones en la rnisma, dejando que sangre durante largo tiempo.

A pesar del buen exito obtenido en casos aislados, no por eso deja de ser una verdad la rapidez y terrible accion del veneno de estas serpientes, comprobada en rarios experimentos. Srneathman observó los efectos de la mordedura del pseudoequis en un robusto dingo, cuya resistencia vital es de todos conocida; í las I y 35 minutos fué inoculado el virus, y á las 12 el miemoro mordido estaba ya completamente paralizado; vcinte minutos despues yacia el pobre animal.sobre un costado, con la lengua fuera de la boca, y arrojando gran cantidad de saliva; un fuerte temblor agitaba todo el cuerpo, sucediendo despues conrulsiones, desfallecimiento $\mathrm{y}$ pérdida de los sentidos; hasta que al cabo de una hora y cuarenta minutos, dejó de vivir el dingo. Cuando se exarninó el cadárer al dia siguiente, solo se pudo distinguir la parte mordida por algunas gotas de sangre que habia vertido la herida; el cuerpo no estaba hinchado. Muchos experimentos dieron resultados parecidos.

Entre los enemigos naturales de estas survientes el dacelo gigante ocupa el primer lugar, al menos en la opinion de los cazadores é indigenas; tambien les persigue un gran lagarto con saña y mata gran número de ellas. Cuéntase de este que iiene el mismo don que el ınungo, de distinguir varias plantas con propiedades curativas, de las que se sirve cuando ha recibido alguna mordedura de serpiente. Mucho mas eficaz que todos estos enemigos es el fuego, que todos los años se prende á inmensas praderas, para limpiarlas de la serba seca y convertirla en cenizas que fertilizan aquellas tierras: todos losaños millares de serpientes venenosas șon victimas del vo. raz elemento, y todos los amigos de Australia confian que el aumeato de la poblacion y cl consiguiente cultivo regular $y$ sistemático de la tierra contribuirsn tambien eficazmente à disminuir de dia en dia la raza de tan dañinos animales.

\section{LAS NAYAS Ó SERPIENTES DE TOCA - NAJA}

CARACTERES. - Cobra de capello es el nombre que die. ron los portugueses â una serpiente de Ceilan, extendiendolo mas tarde á congéneres de la misma que encontraron en Africa Si bien esta nueva denominacion era bastante apro. piada, no tenian, sin embargo, necesidad los portugueses de inventarla, pues lo mismo las especies indias que las africanas eran conocidas desde tiempos muy remotos $y$ habian sido ya apellidadas en sus respectivos paises; particularmen. te la originaria del Africa septentrional y oriental habia al. canzado gran fama en los anales del antiguo Egipto.

El distintivo exterior mas caracterizado de estas serpientes consiste en que, elcvando verticalmente la parte anterior de su cuerpo, pueden ensanchar su cucllo en forma de disco, extendiendo las primeras ocho costillas en sentido lateral. En esta postura, coloca siempre la serpiente su cabeza horizontalmente, y en efecto, aparece como si llevara un sombrero rèdondo, sobre todo mirada por detrás. Sin embargo, solo se recibe esta impresion, cuando se la mira así, mien. tras que, vista por delante, el disco parece mas bien un escudo, por lo cual deberia decirse cobra de escudo.

Tienen las nayas el cuerpo prolongado y redondeado, en el centro algo rias abultado; el cuello, cuando el reptil está en su estado normal, poco destacado de la cabeza; esta es pequéra, ovalada y bastante plana, en su conjunto muy pa. recida é la de las culebras, y la cola; larga, cónica y adelgazada. I a escamacion consiste en grandes placas cefálicas, en pequeñas escamas dispuestas en filas diagonales en el cuello, y otras colocndas del mismo modo, pero de forma romboidal en el dorso, mientras que la parte inferior aparece cubierta de grandes escudós que se prolongan formando una fila, nenos hácia la extremidad de la cola donde se hallan divididos en dos. La abertura bucal es proporcionlanente grande; la dentadura de la mandibula superior se compone de dos $y$ hasta de tres dientes lisos y sólidos, detrás de los ganchos venenosos asurcados.

El que ha observado estas serpientes, cuando espantadas y encolerizadas á la vista de un enemigo, y en particular del hombre, levantando verticalmente parte de su cuerpo, con el cuello dilatado, reptando majestuosamente, dispuestas siempre al ataque ó por lo menos $\{$ la defensiva, hácia el objeto que ha excitado su furor, con la parte levantada del șuelo tiesa y derecha como una columna y funcionando poderosamente todos los músculos del resto del cuerpo; el que ha observado, repetimos, csos reptiles, y sabe que su mordedura es tan mortal como la de la serpiente de hierro de lanza 6 de cascabel, comprenderá que en tadas las epocas debieron llamar la atencion de los hombres, explicándose porquué se les tributaban honores divinos, utilizándolas para engaủar \& los hombres que no conocian el carácter y las par. ticularidades de la serpiente.

Lin sér tan extraño por su estructura y su indole debia excitar la curiosidad de todo pensador; y la experiencia de los efectos mortales de su mordedura proporcionó al ambi. cioso sacerdote $\delta$ al astuto farsante. el medio de presentar el reptil como imágen de una deidad. i El milagro empicza alli donde la razon deja de ser!

\section{LA SERPIENTE DE ANTEOJOS-NAJA TRIPUDYANS}

CARACTÉRES, - La cohra de copello, ó sencillamente colra, la serpiente de anteojos ó tschinta.négu de los indios, es un ofidio de $1^{\prime \prime}, 40$ á $1^{m}$, So de longitud y de un color amarillo oscuro que a cierta luz presenta un viso ceniciento azulado; este color parece sin embargo mas pálido porque los intervalos de las escamas son de un amarillo claro ó blancas, coloracion que se extiende á menudo por los angulos de al. 
gunas escamas. En la nuca domina el matiz mas claro, y alli se re un dibujo que representa con bastante exactitud unos anteojos: están figurados estos por dos líneas negras que rodean una superficic blanquizca, $y$ las partes que corresponden $\&$ los lentes, ó aparecen completamente negras ó con un punto claro en el centro. Los escidos abdominales son blanquizcos, $y$ algunos manchados de negro (fig. $75^{\circ}$ ).

Los indigenas, que tienen ocasion de ver mas á menudo y mas de cerca estos ofidios, distinguen numerosas variedades de la serpiente de anteojos. Russell, que es el autor que mas detalladamente ha descrito esta serpiente, hace mencion de diez variedades. El arigionigu, que vive en la costa de Coromandel, tiene los anteojos negros, orillados de gris, $y$ dos manchas negras ovaladas debajo del cuello; el kisdum. rigu, originario del mismo punto, presenta la coloracion mas oscura, la piel amarilla entre las escamas, y cl dibujo dc los anteojos formado por un doble arco negro; el murlib-nigu, se distingue principalmente por las manchas grises de las pla. cas occipitales, $y$ las cuatro del centro gris azuladas: el melle-regu, de color pardo claro, lleva varios escudos oscuros debajo del cuello, y pequeñas manchas en forma de anteojos; el kcmbu-nighl, se da a conocer por los escudos oscuros de la nuca y una coloracion general con reflejos azulados; el jemne negu, por el color anaranjado del cuello; el nelletes. pem, por el tinte negro de la misma region, el krrie-n'́gu, por la estrecher de las placas sincipitales y la anchura de las occipitales, y por último, el senku-négu, difiere de todos los demás por no presentar dibujo ó mancha alguna en el cue. llo. Ultimamente se han descrito algunas mriedades nuevas.

DISTRIBUCION GEOGRAFICA.- La serpiente de anteojos se extiende por toda cl Asia del sur é islas adyacentes, exceptuando las Molucas, Célebes, Timor y NuevaGuinea.

USOS, COSTUMBRES Y RE.GIMEN. - La naya de anteojos, al igual de casi todas las demís serpientes, no parece depender de localidades determinadas, sino que fija su morada en todas partes donde encuentra una madriguera apropiada y suficiente alimento. Busca con alguna preferencia los nidos abandonados de los térnites, cuso hueco le proporciona un buen escondrijo. Dice Tennent que en Ceilan esta es la única serpiente, despues de la llamada (ratoneraz (coryphodus: Blumenhacinii), que se acerca à las habitaciones del hombre, atraida sin duda por las cloacas donde espera hacer buenas presas de ratas y ratones. Si no se la molesta, acostumbra permanecer estirada perezosamente delante de la entrada de su escondrijo; pero tan pronto como ve aparecer al hombre, se oculia lo mas pronto posible, y solo cuando se le corta la retirnda, suele arrojarse sobre su agresor.

Cuando no se excita, como por ejemplo mientras se ocupa en la caza, deslizase por tierra con la cabeza apenas levantada y el cuello no dilatado, pero si se la irrita ó tan solo espanta, toma al punto la posicion de ataque propia de estos ofidios. Aunque es serpiente diurna, evita, sin embargo, el calor del medio dia 6 los ardientes rayos del sol en general, y no emprende sus cacerias hasta liltima hora de la tarde; entonces parece estar mas contenta, y a menudo vaga toda. via à las altas horas de la noclie por los contornos. He aqui porqué algunos observadores la consideran como animal nocturno.

Todos los naturalistas que la han observado dicen que los movimientos de la naya son lentos y hasta pesados; sin embargo, es mucho mas ágil de lo que generalmente se le supone, pues no solo sabe hadar, sino que tambien trepa hasta cierto grado.

Una de estas serpientes, que habia caido en un foso, por cuyas paredes perpendiculares no podia subir, csturo nadar- do horas enteras con la major facilidad, sacardo la cabeza y parte del cuello fuera del agua. A veces, suele entrar volun. tariamente en el mar. Estando un dia el buque de la marina inglesa (Wellington anclado en la bahia de Cudremele, á un cuarto de milla de tiera, vieron los de $\mathbf{a}$ bordo una hora antes de la puesta del sol, una serpiente de anteojos que avanzaba nadando en linea recta hácia el buque, al que se acercó hasta una distancia de doce raras; acosada por los tarugos.y otros proyectiles que le arrojaban los marineros, turo que regresar mas que de prisa á tierra. Al dia siguiente se distinguia perfectamente en la playa el rastro del reptil al salir del agua, y se le podia seguir hasta la espesura inmedia. ta. En otra ocasion mataron á bordo del mismo buque una nava, que solo podia haberse introducido en él subiendo por la cadena del áncora, lo cual prueba su agilidad en trepar.

A Tennent le dijeron que una vez se encontró un indi. viduo en la copa de una palmera, atraido, segun se decia, por el jugn que se acahaba de extraer»; pero seguramente porque quiso cazar aves 6 saquear sus nidos. Con bastante frecuencia se las halla en los tejados de las casas.

El alimento de la cobra se compone solo de animales pequeños, y segun parece principalmente de reptiles y batra. cios; Tennent dice que come lagartos, ranas y sapos; Fayrer dice que los peces y reptiles son la presa preferida. De las noticias del primero de los citados naturalistas reproducidas ya por mi, resulta claramente que este ofidio es peligroso para los pollos, las ratas 5 ratones; liayrer dice que tambien saquea los nidos de las aves visitando sobre todo los gallineros y palomares para buscar los huevos. Hace poco caso de otras serpientes y por lo tanto parece que no las persigue. Bebe mucho, pero tambien puede resistir la sed semanas y hasta meses enteros sin sufrir dano alguno, segun lo han demostrado las observaciones hechas en individuos cautiros.

REPRODUCCION. - Fayrer es entre todos los autores que conozco el línico que habla sobre la reproduccion, di. ciendo que la cobra pone hasta diez. y ocho huevos ovales, de color blanco, cáscara blanda y tamaño semejante al de los de la paloma doméstica. Exactamente lo mismo que los antiguos dijeron del kspid, dicen los indios de la cobra: ma. cho $y$ hembra se manifiestan mutuamente cierto cariño; donde se encuentra una serpiente de anteojos pronto se descubre otra de sexo distinto, etc.; en una palabra, los sexos viven como si dijéramos matrimonialmente, 6 cuando menos en union. Tennent asegura que tuvo dos veces ocasion de comprobar la exactitud de la antigua leyenda. Mataron en Co. lombo en el salon de baño del palacio del Gobierno una naya, y al dia siguiente apareció en el mismo sitio su ccom. pañera; sucediendo otro tanto con la que, segun hemos re. ferido ya, cayó en el foso de las murállas, pues en la misma mañana se descubrió su ecónyuge en otro foso inmediato. Cierto que Tennent no dice si esto sucedió en el periodo del celo; de modo que no sabemos hasta qué punto obedeció csto a la casualidad.

I.os naturales de Ceilan pretenden que los hijuelos no son venenosos antes del dia décimotercero despues de efectuarse la primera muda.

Asi como en la antigiedad, tambien hoy la serpiente de anteojos es objeto de una veneracion respetuosa y casi divi. na, representando un papel importante en las leyendas religiosas de los indios. Una de las fábulas mas graciosas de esta clase es la siguiente: «Paseándose una vez. Budda por la tierra, y como se durmiese en la parte donde toca el sol del mediodia, presenióse una cobra y extendió su escudo, cu. briendo asi de sombra al rostro divino. El dios, agradecido á esta solicitud, prometió al reptil una gracia cxtraordinaria; pero pronto olvidó su promesa y ia serpiente se vió obligada 
á recordársela, pues precisamente entonces los milanos cau. saron terribles destrozos entre sus semejantes. Para protegerla contra estas aves de rapina Budda concedió á la cobra los anteojos de los que aquellas tienen iniedo.»

Otra fábula habla de una piedra preciosa, llamada NegeMenik.Kya, que á veces se encuentra en el estómago de la cobra, pero la cual oculta cuidadosamente porque su brillo, imposible de describir, atraeria como una luz radiante á todo el mundo, poniendo en peligro al reptil. Asi en este como en otros cuentos los indios creen con una devocion digna de reconocimiento.

Durante la estancia de Dellon á Kuranur, poco mas 6 menos á mediados del siglo xvir, un secretano del príncine. fué mordido por una serpiente de anteojos, que encerrada en una jaula fué conducida al mismo tienpo que el paciente at la ciudad. El principe sintio mucho el percance é hizo llamar \&los bramines, quienes explicaron a la serpiente de un modo conmovedor que la vida del secretario herida era de suma importancia para el Estado. A estos ruegos siguieron las amenazas necesarias: declaróse á la serpiente que la quemarian en una misma boguera con el enfermo, si su mordedura causaba la muerte; pero cl animal divino no hizo caso ni de las súplicas ni de las amenazas y el hombre murió. Una profunda tristeza se apoderó del principe; mas al fin ocurrióle la idea de que quizás el muerto se habia atraido la ira de los dioses por alguna falta secreta, y que la serpiente solo habria ejecitado una órden divina. Entonces pascaron la jaula por delante de la casa y pusieron en libertad al reptil, pidiendole perdon con profundas inclinaciones.

Cuando un indigena de Malabar encuentra una-serpiente venenosa en su casa, la ruega con muchos cumplidos que salga; si esto no produce efecto, ofrecela alimento á fin de atraerla fuera, $y$ si ni aun con esto consigue su deseo, busca los servidores devotos de una de sus deidades, que mediante el pago de la cantidad requerida, ruegan á la serpiente con instancia Segun ha reconocido Fayrer, las opiniones de los indos, excepto de algunas castas, no han cambiado hasta hoy dia. Muchos indos no matan de ningun modo a una serpiente de anteojos, cuando encuentran una en su casa la tranquilizan como pueden, aliméntanla y la protegen, cual si una ofensa ai reptil debiera atraer una désgracia sobre la casa Si el temor al peligroso y maligno huésped predomina sobre la supersticion, y si la cobra ocasiona la muerte de un habitante de la casa, se la coge; pern aun entonces la tratan con respeto y consideracion; llevanla á un sitio apartado $y$ se la pone en libertad para que siga en paz su ca. mino.

No debemos extrañarnos que con ;al pueblo los sacerdotes y titiriteros puedan hacer muy buen negocio; la ciega multitud considera los artificios de esa gente como magia, y los bramines apoyan semejante creeticia con todas sus fuerzas.

CAUTIVIDAD Y DOMESTICIDAD. - No se puede negar que los aojadores y trotaferias indios proceden con estos peligrosos reptiles de una manera q̨ue llega á imponer cierto respeto hasta al europeo mas incrédulo y despreocupado; todo su arte, sin embargo, consiste sencillamente en el exacto conocimiento del modo de ser y de las costumbres y caprichos de la serpiente. Varios autores han pretendido que á la naya de anteojos, lo mismo que á su congénere, el áspid de Egipto, le arrancaban los domadores los ganchos venenosos, para que su mordedura no pudiese dañar: pero ya Davy negó rotundamente esta suposicion, y modernos observadores apoyan la refutacion de este.

Es posible que los encantadores rompan alguna vez los dientes á esos reptiles, mas por lo regular la cobra conserva sus armas mortales y las puede emplear, pues aunque la en. señen, dificilmente se la impide morder. La enseñanza se efectúa en realidad; pero seguramente no da por resultado evitar que el reptil haga uso de sus dientes, y solo la agilidad y la destreza del titiritero libran á este del peligro que provoca tan audazmente, aunque no en todos los casos. Mu. chos de estos hombres pierden su vida heridos por la cobra.

《Et aojador, dice Davy, excita á la serpiente golpe:índola con una vara 6 amenazándola con rápidos movimientos de la mano, $y$ la calma despues con su voz, con ademanes mas lentos y pausados y con golpes suaves. Cuando está irritada, evita el hombre muy diestramente sus acometidas, y solo juega con clla cuando se ha tranquilizado; entonces acerca la frente al reptil y lo toca con su cara. El vulgo ignorante cree que aquel hombre posee un talisman, que le permite mane. jar impunemente la serpiente; el europeo ilustrado se buria de todo aquello y considera al domador como un charlatan de mala fe, que ha arrancado los dientes venenosos a la serpiente; sin embargo, el enganado es él y el vulgo tiene ra. zon: he examinado repetidas veces estas nayas, y siempre he hallado completa su dentadura. El trotaferias posee en reali. dad un talisman, no sobrenatural, sino el del valor y de la confianza en si mismo. Colloce este perfectamente todos los hábitos $y$ las debilidades del reptil, $y$ sabe que no hace uso de sus temibles armas, sino despues cie provocado una y otra vez. El que posee la confianza y agilidad de estos hombres puede imitarlos sin temor alguro; yo lo he hecho mas de una vez. Eśtos titiriterós repiten sus habilidades con todas las serpientes de anteojos, ora recien cogidas, ora cautivas de larga fecha; pero jamás se atreven con serpientes venenosas de otra especie. (La verdad de los asertos de Davj, anade Tennent, tuvo una triste confirmacion durante mi estancia en Ceilan, donde un infeliz titiritero, que habia adquiricio gran fama por la habilidad extraordinaria con que manejaba las serpientes, fué mordido por una de ellas en el pecho, y murío de sus resultas el misno dia.

Rondut trazó una relacion muy interesante de uno de es. tos espectáculos: «A las seis de la tarde, dice, se presenta á bordo un titiritero indio, pobremente vestido, pero luce un turbante adornado con tres plumas de pavo real y varios collarés con escapularios. En un cesto plano lleva encerrada una serpiente de anteojos. Se instala nuestro hombre en la cubierta, nosotros nos sentamos en un banco y los marineros forman corro.

Destapado el cesto, se ve cn el fondo la serpiente enros. cada. El indio acurrucado á pocos pasus de distancia, empie. za á tocar en una especie de clarinete una melodía lenta, nlanidera y monótona. El reptil se mueve poco á poco y acaba por enderezar parte del cuerpo; diriase que está sen. tado sobre la cola replegada en espiral; no sale del cesto, y comienza á manifestar cierta inquietud; procura reconocer el sitio donde se halla, se agita é hincha el cuello, dilatándolo en forma de disco. Por fin, se muestra irritado, da fuertes re. soplidos, mueve con gran rapidez la lengua, y arrójase varias reces con violencia hácia adelante, como si quisiera morder al hombre, sacudiendo al propio tiempo bruscamente el cuerpo. El indio no quita la vista de la serpiente, en la que tiene clavados los ojos con singular fijeza. Al cabo de diez 6 doce minutos, la naya parece menos agitada, balancea el cuerpo como si fuera sensible a la cadencia lenta y monótona del músico, pero continúa proyectando la lengua, y gradualmente cae en un estado parecido al de la soniolencia. Sus ojos, que al principio parecian espiar al titiritero para sorprenderle, se presentan ahora, en cierta manera, como si hubiesen perdido toda movilidad y fascinados por la mirada del hombre. El indio aprovecha este momento de estupor del reptil para 
acercársele lentamente, sin cesar de tocar su instrumento, y pasa, primero la nariz, y despues la lengua por encima de la cabeza de la naya. Esto no dura mas que un breve instante, pero en el mismo despicrta la serpiente sobresaltada, y a du. ras penas tiene tiempo el aojador para retroceder y esquivar la acometida de aquella, que enfurecida se arroja sobre él.

Cuaudo terminaba su trabajo el indio, procurando apaci. guar la serpiente, llega uno de los oficiales de la corbeta, y manifiesta el deseo de ver al hombre tocar con la lengua la cabeza escamosa del ofidio. El pobre diablo empieza otra vez su monótona tocata y á mirar con hijeza la naya, pero todos sus esfuerzos son vanos; $\mathrm{cl}$ animal se encuentra en un estado de exasperacion extrema, no hace caso de nada y quuiere salir del cesto: no hay mas remedio que bajar la tapa.

- Como dudíramos de que la serpiente tuviese sus gan. chos venenosos, ofrecimos un duro al indio para que dejara que aquella mordiese a dos gallinas, y habiendo consentido, fué mordida primero una negra, que murib a los seis minutos, despues de haber vomitado, y lıego otra, que solo sucumbió al cabo de ocho minutos, si bien la naya leclavó dos reces sus ganchos venenosos.

El conde Cárlos de Goertz refiere, en su \&Viaje al rede. dor del Mundo. de distinta manera este espectáculo. Dice que los aojadores que vió en Madrás, sacaban de sus respec. tivos cestos las serpientes, cuatro ó cinco á la ver., y cogiéndolas por la cabeza las extendian en el suelo. El edirector de la compañia producia entonces los mas ingratos sonidos con un clarinete singular, que tenia en su extremidad una pequeña calabaza; los animales se erguian al oir tan melodiosus acordes, y levantaban cabeza y cuello como cosa de un pić sobre el suelo, miraban al hombre fijamente en la cara é hinchaban el cuello, sin hacer otro movimicnto. El indio les presentaba despues cl puño delante del hocico, al que se aba. lanzaban los ofidios como si quisieran morderlo; pero sin abrir la boca No procuraba este titiritero iascinar con su mirada las serpientes, sino que las cogia de cualquiera manera, y hasta se las colocaba alredector del cuello, despues de pasarles tambien la nariz y la lengua por la cabeza. Las nayas no bailaban, ni hacian inovimiento alguno, pero manifesta. ban toda la ferocidad y mala indole propias de su raza, y el gran respeto que les inspiraba el domador; de modo que fà. cilmente se comprendia quue las domesticaba haciéndoles morder en objetos duros ó calientes. ¿Habianles arrancado, añade el conde, los dientes venenosos, como pude convencerme examinándolas y me confesaron voluntariamente sus direnos. 8

El siguiente caso, referido por Johnson, confirma este último aserto del conde de Goertz: e Un indio hacia bailar una serpiente de antẻojos de gran tamaño delante de una numerosa concurrencia. Su hijo, nin̄o de diez años, irritú de tal manera al reptil, que este enfurecido, le mordió, causan. do su muerte al cabo de una hora. El padre aseguraba que era imposible que su hijo hubiese muerto de resultas de la inordedura del ofidio, pues no tenia este dientes, y tanto el chico como el mismo, habian sido mordidos varias veces sin consecuencia alguna. Sin embargo, examinada la naya se encontró que los dientes venenosos arrancados habian sido sustiruidos por otros, que si bien no despuntaban mucho todavia, fueron lo bastante para causar la herida mortal del muchacho.s

Segun los informes de un indio instruido, publicados por Fayrer, en Bengala hay cuatro clases de gente que coge serpientes para venderlas ó explotar con ellas al público: la primera, y á la vez. la mas entendida, es la de los mal, casta inferior de los indios que ganan la vida con la caza y venta de serpientes, sin utilizarlas nunca para la magia ó la mediтомо $\mathrm{V}$ cina. Los mal son hombres pobres y dignos de compasion, condenados a una vida ragabunda; pero que no roban ni por lo regular infunden sospechas. En el noroeste de Bengala les sustituyen los modaris, algunos de los cuales van tambien á Calcutta. Rajendrala Mitra, el citado indio, no tuvo nunca ocasion de observar á esos indigenas minuciosa. mente, y por lo tanto no sabe decir nada de ellos, sino que es fácil confundirlos á menudo con los gitanos, que son titiriteros, juglares, vendedores de yerbas, médicos uxilagrosos para curar la gota, la parálisis y otros males, maestros en los hechizos y la magia, barberos y cirujanos; asimismo conju. ran serpientes; y en general hacen todo lo posible para no ponerse en pugna con los agentes de órden público, pues en realidad son hábiles ladrones, aunque no tengan fama de tales. Distínguense de los mal por hacer trabajar tambien á sus mujeres, mientras que los otros se abstienen de ello. Ios verdaderos encantadores de serpientes son los sanjis, llamados en Bengala tubriatilahs: probablemente son originarios tambien del noroeste de Bengala, reconociéndose por su traje amarillo y su gran turbante; llevan tambien la conocida flauta, con la cual, segun dicen ellos, dominan á las serpien. tes y las hacen salir de sus guaridas. Para purgar una casa de serpientes, llevan varios de esos instrumentos en los anchos pliegues de su ropaje. En su camino sellevan cuanto les viene á la mano, mas í pesar de eso no se les puede condenar como ladrones. Vagan por todo el pais, y tan pronto se les ve en el noroeste como en el sur de la India. Los mas anti. guos libros del sanscrito hablan ya de ellos, y por lo tanto es posible que su arte date de la mas remota antigiedad. Ia flauta que llevan debe considerarse como un signo característico; porque no la vemos en los mal, ni en los modaris, ni en los hedijors ó gitanos.

Ia cobra es la favorita de toda esa gente, porque les parece la especie mas extraña entre todas las serpientes venenosas, y porque gracias á su abundancia jamás carecen de ella los encantadores de serpientes. Tambien tienen á veces alguna naya oficifaga que posec las mismas cualidades de la cobra, solo que es mas salvaje aun. A los individuos des. rinados para los espectáculos se les arrancan casi siempre los ganchos venenosos y además se les corta el repliegue en cl cual se insertan y en el que se desarrollan los dientes nue. vos. Sin embargo, debe coníesarse que los encantadores \$2. ben manejar muy bien las serpientes que tienen todavia toda su fuerza diabólica: la agilidad q̨ue denuestran cogiendo solo con la mano y sin herirse una serpiente venenosa que répidamente se desliza por la espesa yerba, y el aplomo con que despues la nanejan son en extremo admirables. Esos lrombres conocen muy bien el peligro a que se exponen, y saben mejor que nadie que no hay antidoto eficaz, aunque pretenden venderlos. Además de las especies venenosas, en. sefian tambien serpientes quue no lo son, pero nunca sin ha. cer resonar su flauta.

Además de los titiriteros, los bramanes se ocupan tam. bien en cazar y domar la serpiente de anteojos. Segun Iohnson, los cazadores examinan cuidadosamente todas las cavidades que tienen scinales de estar habitadasporias serpien. tes; cuando han descubierto alguna de estas, empiezan s. cavar con mucha cautela liasta dar con ella, procurando entonces sujetarla fuertemente por la cola con la mano izquierda y por el centro del cuerno con la derecha, la que escurren rápidamente hasta tener cogida la nuca entre cl pulgar y el indice. Johnson asegura que de este modo ha visto coger varias serpientes en medio del campo. Además los cazado. res van siempre provistos de todos los útiles y medios nece. sarios, para el caso de una mordedura. Algunos suelen llevar un pequeño brasero, en el que se conserva siempre canden. 
te un pedazo de hierro, de forma parecida al diente del ofidio, para cauterizar la herida, despues de exprimir y clupar la sangre de la misma, y haber ligado debidamente la parte mordida. Otros se contentan con colocar sobre ia herida una piedra llamada epiedra de serpientes, de la que ya tendremos ocasion de hablar. Al propio tiempo suelen beber una infusion de cáñamo silvestre, ó tabaco, en espiritu de be20ar, que produce muy buenos resultados, segun dice el mismo Johnson.

Refiere Reyne que los cazadores de serpientes se sirven à menudo de una especie de pito para atraer á la de anteojos fuera de su escondrijo: elin aojador, dice, se presentó un dia, en 1854 , en mi búugalo, me pidió permiso para bailar sus animales en mi presencia. Como ya habia presen. ciado repetidas veces estas habilidades, le contesté que estaba dispuesto \& darle una rupia si qqueria acompañarme al campo para coger una serpiente de anteojos, cuya morada me cra conocida. El hombre aceptó mi proposicion, y yo tice cuidé de contar sus nayas y confiarlas á un guardian para que no las perdiera de vista hasta nuestro regreso, habiendo tambien registrado al titiritero $a$ fin de convencerme de que no llevaba! ninguna consigo. Llegados al sitio, emper.6 mi hombre á soplar con un pequeño instrumento parecido á un clarincte, y despues de un buen rato de discordantes sonidos, apareció en efecto, delínte del montículo de térmites la gran serpiente de anteojos, que yo sabia habitaba alll. Cuando vió al indio procuró escaparse, peró este la cogió en el acto por la cola, $y$ haciéndola girar continuamente por encima de su cabeza, como suelen hacer los muchachos con Tas hondas, la llevó de este modo hasta mi búngalo; alli la hizo bailar, pero antes de haberla podido dominar por completo, recibió un mordisco en el muslo. $\%$.

Todo esto demuestra que no hay verdadera domesticidad en las serpientes que hacen bailar los titiriteros; véase ahora to que dice Kaempfer respecto al modo que se emplea para quitarles las ganas de morder: đUn brama cultivaba, además de la ensenanza de los creyentes, la de las nayas, que vendia á buen precio despues de adiestradas. 'lenia veintidos de ellas en otras tantas ollas de barro, provistas de sus corres pondientes tapas, $;$ bastante grandes para permitir cierto mo vimiento á las serpientes. Cuando la temperatura no era de masiado elerada, dejábalas salir una tras otra de su prision, y las ejercitaba mas ó menos tiempo, segun los progresos que habian hecho en el arte. Tan pronto como uno de los reptiles sacaba todo el cuerpo del cacharro y procuraba huir, el brama, golpeándole con una varita, le hacia volver la cabeza hácia el, y cuando enfurecido se disponia á morderle, le presentaba la olla, de la que se servia como de un escudo para parar los mordiscos. Pronto se convencia la naya de la impotencia de su cólera, y retrocedia. Fste duclo entre hom. bre y serpiente duraba un cuarto de hora, y a veces treinta minutos, durante cuyo tiempo esta permanencia continua. mente derecha, con el cuello dilatado y dispuesta á clavar sus temibles ganchos, siguiendo todos los movimientos de la olla; así se iba acostumbrando gradualmente á levantar el cuerpo, cada vez que le ponia el cacharro delante del hocico. Pasado algun tiempo, el domador le presentaba la mano en vez de la olla, pero el animal no se atrevia á precipitarse sobre aquella, temeroso de tropezar otra vez con el duro bar. ro. El brama titiritero acompañaba siempre sus movimientos con un canto monótono, para engañar mas fácilmente al reptil. A pesar de toda su habilidad y cautela, tenia siempre miedo de ser mordido, y acostumbraba presentar primero un trapo á sus discipulos mas rebeldes, para que clavaran en él sus ganchos y descargaran el veneno. No quiero decir cuán. ta verdad hay en este relato. Sin embargo, me parece que no se funda en observaciones propias sino en noticias reco gidas.

Puede suceder muy bien, segun se desprende del anterios relato, que las serpientes de toca sean mas susceptibles, que las demás venenosas, de cierto grado de domesticidad; con todo, parécenos muy dudoso que su cerebro pequeño y débil sea capaz de conservar durante largo tiempo las impresiones recibidas; en otros términos, no creemos que sea du radero en ellas el efecto del castigo, ủ otros medios de que puedan valerse sus domadores para obligarlas á tal 6 cual ejercicio. Por esto comprenderín nuestros lectores el poco crédito que nos han de merecer cuentos, como el que refie. re el comandante Skinner en una carta dirigida á Tennent, viHa oido V. hablar de serpientes de anteojos domestica. das, que entran y salen cuando les place, y viven en compania de los demás habitantes de la casa? Un hombre bastante rico que vive en las cercanias de Negombo y suele guardar considerables cantidades de dinero en su casa, tiene una de esas serpientes, en lugar de perro, para vigilar sus tesoros. No es este un caso aislado; hace muy pocos dias que una persona de toda mi confianza me refirió otro parecido. Las serpientes recorren toda la casa, sirviendo de espantajo para los ladrones, pero sin intentar jamás morder a los legitimos habitantes de la rnisma. Sin embargo, es nuy probable que en el fondo de esta fábula haya un pocode verdad. Un hom. bre rico é ilustrado, que conoce la ignorancia y supersticion del vulgo, sobre todo en aquellos paises, hace circular un cuento de esta especie, para precaverse de visitas desagradables; y si conviene, hasta guarda, pero bien encerradas, algunas serpientes de anteojos en su casa, las que casualmente se enseñan á los que la frecuentan, á fin de hacer mas verosímil la supercheria: este es el pequeño asomo de verdad que puede haber en todo el cuento del comandante Skinner:

VENENO Y SUS ANTIDOTOS.—RUSSell, Johnson, Breton, Fayrer $y$ otros han hecho numerosos experimentos que han demóstrado de una manera indudable la malignicad del veneno de la serpiente de anteojos. Mordidas por este reptil, sucumben las palomas al cabo de tres ó cuatro minutos; las gallinas á los seis, y los perros á los veinte por regla general; no obstante, sucede á menudo que estos resisten una 6 dos horas. Las personas que mueren de resultas de una herida de esta clase, suelen padecer durante largas horas los mas terribles males. Johnson dice que el veneno pierde gradualmente su accion mortifera, cuando se obliga á la mis. ma serpicate á morder sucesivamente varios animales; y cree poder afirmar, como resultado de sus experimentos, qque el veneno se vuelve mas activo cuanto mas tiempo permanece en las glándulas, y mas liquido es proporcionalmente á la elevacion de la temperatura; dependiendo de estas circuns. tancias la accion mas $\delta$ menos mortifera del virus inoculado. Breton pudo convencerse tambien del menor efecto de las mordeduras sucesivas: hizo que una serpiente de las llamadas de agua fuese mordida por una de anteojos; al cabo de hora y media ya no podia mover aquella la parte mordida, mu. riendo a las dos horas y cuarto. Un conejo mordido inme. dintamente despues por el mismo ofidio, sucumbió álos once minutos, despues de parálisis, desfallecimiento y consulsio. nes. Al conejo siguió una paloma, que falleció á los veinti. siete minutos; despues de esta, otra, que vivió una hora y once minutos, y luego una tercera que resistió tres horas y cuarenta y dos minutos; dos mas, en las que ciavó sucesiva. mente sus ganchos la naya, no manifestaron sintoma alguno de envenenamiento, ni les produjo tampoco la herida efecto alguno fatal. La misma serpiente de anteojos mordió tam. bien á otras varias venenosas, pero sin que se presentara 
ninguna señal de la inoculacion ponzoñosa. Russell hizo igual experimento en un cerdo, que murió una hora despues de recibir la mordedura. Varias gallinas y palomas, en cuya san. gre se introdujo, por medio de punturas é incisiones, vene. no extraido de las glándulas de la naya, sufrieron los mismos cfectos de la inoculacion directa, muriendo tambien todas aquellas en las que la operacion fué llevada á cabo con toda escrupulosidad. Bellanger, médico y director del Jardin de Plantas de Pondichery, ha demostrado tambien en otra serie de experimentos, que dos granos de veneno de la serpiente de anteojos aplicado á la superficie del aparato auditivo de un perro, pueden causar su muerte produciendo efectos muy extraordinarios; que algunas diminutas gotas del mismo ve. neno que se dejen caer sobre la superficie del ojo, de la lengua, ocasionan igualmente trastornos muy grares.

Fayrer ha hecho tres años seguidos los experimentos mas minuciosos para averiguar cuáles son los efectos del veneno de las serpientes indias y sobre todo de la cobra. Empleárunse para estos experimentos con preferencia perros y gallinas, y además caballos, bueges, cabras, cerdos, gatos, mustélidos, mungos, conejos, ratas, milanos, garzas reales, hagartos, serpientes venenosas y no venenosas, ranas, sapos, peces y caracoles, y todas las observaciones se apuntaron cuidadosamente, pero en un desórden tal, que es una verdadera con. fusion para el lector de la obra, y dificil formarse una idea sobre el asunto. De los informes resulta que el veneno de la cobra produce efecto en todos los animales con que se hicie. ron las pruebas; que este efecto es muy poderoso y casi siempre tambien mus rápido; que los antidotos de las mas diversas clases no producen resultados, 6 cuando mas muy débil; y por último, que cuando los dientes tocan un arteria debe considerarse en todos los casos la herida mortal. Fayrer ha reconocido con toda seguridad que la opinion de que el ve-' neno de serpiente solo produce sus efectos cuando se inocula desde luego en la sangre, es del todo errónea, pues no solo le absorben todas las mucosas sino tambien el estómago.

En las personas suclen manifestarse los éectos de la mordedura de la serpiente de distinto modo que en los animales; nótase generalmente una frialdad cadarérica en el cuerpo, mientras que en los perros, por ejemplo, obsérvase, por el contrario, un estado calenturiento. Como en la India, por desgracia, son muchas las víctimas humanas que anualmente causa la serpiente de anteojos, abundan las observaciones respecto al curso y fases de la enfermedad de los heridos; haremos pues mencion de algunos de estos casos que no tu. vieron término fatal, por considerarlos mas instructivos que otros.

Duffin visitó una mujer diez minutos despues de haber sido mordida en la planta del pié. Habia perdido yalos sen. tidos del tacto $y$ de la vista; no podia tampoco tragar liquido alguno, de modo que fué de todo punto imposible introdu. cirle ningun medicamento. No sufria convulsiones, pero desde un principio se apoder 6 de ella una fuerte soñolencia que aumentaba por momentos. Se ensanchó la herida, aplicandole mercurio, y púdose conseguir, pasado un rato, hacer tragar algunas pilldoras á la infeliz mujer; las primeras no produje. ron efecto alguno, pero 1 la tercera siguieron algunas evacua. ciones, notándose tambien cierta hamedad en la piel. Diez y ocho horas despues de la mordedura recobró la enferma el tacto y la vista, al propio tiempo que ya podia engullir con bastante facilidad; durante los dos ó tres dias siguientes, continuóse provocando las evacuaciones, y al cabo de unos ocho dias fueron aumentando las fuerzas de la paciente, que gradualmente se restableció por completo.

Un indio, mordido en el tobillo. tenia ya un cuarto de hora despues las mandibulas fuertemente cerradas, y parecia muer- to ; sin embargo, dió algunas señales de vida cuando le humedecieron con agua de lucio las cuatro grandes mordeduras que habia recibido. Abriéronle despues à viva fuerza las man. dibulas, y artificialmente pudieron introducirsele en el estó. mago dos botellas de Madera caliente, continuando al mismo tiempo, sin interrupcion, el uso externo del agua de lucio. El paciente habia perdido de tal modo toda sensibilidad, que se le hubiese creido cadáver, á no ser por las cortas respira. ciones que se observaban de cuando en cuando; en este estado permaneció cuarenta horas, empezando entonces a dar señales de volver en si. Doce horas despues principió á hablar, y continu6 todavia durante algunos dias débil y postracio. En este parece haber obrado milagros el espiritu de vino: tienen, pues, razon los médicos modernos que lo recomiendan para accidenies de esta naturalcza.

Ios indios, especialmente los cazadores de serpientes y titiriteros, cmplean otros muchos antidotos contra las mordeduras de las serpientes; pero hacen gran mistcrio de los mismos, de modo que aun hoy dia no se conocen á ciencia cierta ni su naturaleza, ni sus efectos. Úno de estos antidotos es la piedra llamada en Ceilan pembrekeli, cujo uso han aprendido probablemente los cingaleses de los aojadores que vienen de la costa de Coromandel. QMas de un caso proba. do del buen éxito obtenido con esta piedra, dice Tennent, me ha sido referido por testigos presenciales. En marzo de 1854 , vió uno de mis amigos que atravesaba \& caballo una espesura en las inmediaciones de Bintene, á un tamil, que con otro compañero suyo se habia unido a la cómitiva; pe. netró de repente en el bosque y al poro rato apareció con una serpiente de anteojos, la que sujetaba con ambas manos por la cabeza y la cola. Llamó á su camarada para que le ayudara á meterla en un pequeño cesto; pero procedió en esta operacion con tan poco cuidado, que el reptil le mordió en un dedo, y de tal modo que tuvo los dientes clavados en el mismo durante algunos instantes, como si le costase tra. bajo retirarlos. Salió bastante sangre de la herida que en el acto comenzó á doler fuertemente al tamil; su compañēro abrió al punto su cinturon de cuero, y sacó de él tpiedras de serpientey, del tamano de almendras negruzcas y muy pulidas, que colocó una tras otra sobre la mordedura. Muy pronto quedaron pegadas, $y$ absorbieron toda la sangre que manaba de la herida, permaneciendo fijas durante tres 6 cuatro minutos, cuando se desprendicron por si mismas, mientras el amigo del paciente le friccionaba y sobaba el brazo desde el hombro hasta el dedo. Cesaron los dolores del herido, moviendo este la mano, estirando los dedos, y continú su camino como si nada hubiese sucedido. Mientras se verificaba la curacion, otro indio de la comitiva sacó de una especie de alforja un pequeno pedazo de palo, parecido á una raiz, y lo acercó con mucho tiento al hocico de la serpiente, que al punto bajó la cabeza y la pegó al suelo; el hombre cogió entonces la naya sin apariencia de recelo al. guno y la enroscó con sus manos en el fondo del cesto. La raiz, de la que dijo que le garantia la mas completa seguridad contra la serpiente, la llamaba nayalalii calango, ó sea raiz de la planta de la serpiente.

Otro caso, sucedido en 1853 , fué comunicado à T'ennent por Lavalliere, que lo presenció. Este último, juez del distrito de Kenty, dió con un aojador de serpientes en el bosque, cerca de la ciudad, que iba á caza de las de anteojos; si. guióle y vió cómo se apoderaba de uno de dichos reptiles, pero recibiendo al propio tiempo una mordedura en el muslo, que le causó alguna hemorragia. Inmediatamente aplicó el indio á su herida la spiedra de la serpiented, que durante unos diez minutos permaneció adherida á aquella, absorbiendo la sangre mientras que el hombre pasaba y rc- 
pasaba por encima de la misma raíz que tenia en la mano. Cuando se desprendió la piedra, aseguró el aojador al europeo que ja habia pasado todo el peligro, y se la regaló para que tuviese un recuerdo. Lavalliere vio al indio repeti. das veces despues, gozando de la mas completa salud.

Tambien aquel otro indio de quien refiere Reyne que fué mordido de un modo análogo al anterior, se sirvió de la pie. dra pemba-kelii, pero ligando el mienbro herido mas arriba de la mordedura. Durante algunos minutos pareció sufrir grandes dolores, pero fuć mejorando gradualmente hasta que se desprendio la piedra. Luego que hubo recobrado algun tanto sus fuerzas, presentó à la serpiente un trapo, en el que esta mordió al punto; la cogió entonces, antes đque se hubiese desprendido, por la nuca; y le arrancó los ganchos venenosos en presencia de Reyne. Liste observó con la inayor atencion todos estos detalles, siendo tambien testigos ocula res sus ayudantes y dos ó tres personas mas.

Las piedras y las raíces que sirvieron en los primcros casos que hemos referido, vinieron á parar mas tarde á manos de Tonnent. Véase lo que dice este accrca de las mismas: Lás raices no son de igual especie. Una de cllas parece ser un pedaro de rama de aristoloquia; la otra está tan seca, que es dificil su clasificacion; sin embargo, tiene alguna semejanza con la brionia. Tiempo liá que varias especies de aristoloquia, particularmente la originaria de América (aristoloihia serpentaria), tienen la fama de encaz antidoto contra la mordedura de serpientes, y justamente la especie indiana de este género (aristolochia irdica) es de la que, en opinion del vulgo, se sirve el mungo para curarse sus heridas. Ten. nent aniade que no cree en la eficacia de la raiz, sino que está convencido de que toda su virtud consiste en el valor $y$ la confianza en su propia habilidad que inspira su posesion al cazador de serpientes.

En cuanto á la naturaleza y caractéres de la pemún kelí, ya Barrow y Hardy habian publicado bastantes pormenores, que han sido confirmados posteriormente por las investigaciones de Tennent. El vicjo Kolbe habia dicho tambien muchos ahos antes, que los curopeos que vivian en cl Cabo de Buena Esperanza se scrvian de dicha piedra, procedente de la India, donde era preparada por los brahmanes, pero. añadia: Es una verdadera lástima que estos hagan tanto mistcrio de estas piedras, y que el secreto de su composi. cion no sea conocido de los cristianos, pues no hay duda que producen maravillosos efectos. Sigue una descripcion de la manera de servirse de esta piedra, que es en un todo parecida a la que hemos cxtractado de autores mas moder. nos. Thunberg, que visitó el Cabo despues de Kolbe, hace mencion tambien de la "piedra de serpiente, indica como carácter de'su legitimidad, que cuando se la coloca dentro del agua, produce pequenas burbujas de aire, y que introdu. cida en la boca se adhiere al paladar. Aplicada á la parte mordida por la serpiente, dice, se pega á la herida, absorbe el veneno y se desprende por sí misma, cuando está com. pletamente impregnada. Segun afirma Johnson, la prepa. racion de estas piedras es un secreto inuy guardado por los bramines, á quienes produce su venta considerables benefi cios. Sin embargo, hoy dia no existe ya tal secreto: nuestros químicos han analizado esta composicion, y, reconocido que consiste en huesos quemados, cal y resina preparada de una manera especial, materia que gracias álas células ó pequenoos huccos que presenta en su interior, absorbe todo liqui. do, y por lo tanto la sangre y el mismo veneno. El viajero Hardy; que turo ocasion de enterarse del modo de preparar la "piedra ponzoña,» que es la empleada en México contra la mordedura de las serpientes, explica como sigue su compo sicion: Tómase un pedazo cualquiera de cuerno de ciervo, y bien envuelto en yerba ó heno, se encierra en un pedazo de plancha de cobre; colbcase despues en un fuego viro, hasta que el cuerno quede bastante quemado, y puesto a enfriar mas tarde s separada la capa que envuelve el asta, se tiene ya la epiedra ponzoña dispuesta para el uso. En este estado, forma una masa clara y porosa, de color negro, que conserva la forma y tamaño del primitivo pedazo de cuer. no. Lo mismo en el Cabo que en México tienen además los naturales la precaucion de ensanchar la herida por me. dio de una incision; tambien acostumbran á lavar con agua ó leche la piedra que ya ha servido, y que despues de seca vuelven a aplicar á la mordedura. No se puede dudar del efecto que produce la accion absorbente de esta piedra, pero que debe ser muy inferior al de una sencilla ventosa. Los. casos que acabamos de referir tan solo demuestran que los enfermos salyados por la piedra de serpiente habian sido heridos muy levemente, siendo por lo tanto tambien eecasa la cantidad de virus inoculado. Fayrer es de la misma opinion.

De mayor importancia que todos estos cuentos de las «piedras de serpiente nos parece ser la siguiente relacion acerca de la eficacia de la planta india que ya hemos indicado (aristolochia indica), comunicada por el funcionario del gobierno inglés Lowther.

«Condujeron a mi casa en unas angarillas a una jóven india que habia sido mordida por una serpiente. La encontré en un estado de tan completa insensibilidad, que no tuve reparo alguno en negarle mi ministerio, aprobando mi decision un oficial dal ejército, que á la sazon se hallaba en mi casa, á fin de no desprestigiar mi antidoto á los ojos del pueblo. La mujer estaba fria como un márnol, y no habia la menor señal de la circulacion de la sangre; todo su aspecto cra el de un cadáver.

¿ El esposo de la herida manifestaba la mas profunda aflic. cion, y me rogó y suplicó que á lo menos probase de darle una pequeña cantidad de mi medicamento. Le expliqué los motivos que tenia para no encargarme de la curacion de su esposa, sin ocultarle que estaba convencido de que la misma habia dado ya el último suspiro antes de llegar á mi casa. Sin embargo, compadeciéndome de su desesperacion, abri á viva fueraa las mandibulas de la victima, y le introduje al. gunas gotas de mi especifico, compuesto de tres hojas de aristoloquia molidas y diez granos de pimienta, desleido todo en una onza de agua. Mandé colocar despues la mujer en postura reclinada, y aguardé con alguna ansiedad, aunque sin esperanza de buen éxito. Al cabo de ocho ó dièz minutos percibi una ligera pulsacion en el Jabio inferior; dispuse inmediatamente que el marido, ayudado por mi criado, probase $\mathfrak{a}$ hacer andar á la paciente, á fin de acelerar la circulacion de lar sangre. Sostenida por los dos la llevaban de una extremidad á otra de la habitacion, con los piés arrastrando por el suelo. Pasados algunos minutos observé que la enferma hacia una débil tentativa de mover un pié; trascurrieron algunos minutos mas, $y$ un fuerte suspiro, acompa nado de un grito singular, nos anunció que recobraba los sentidos. Gritó poco despues que le ardian las entrainas, y acercándome á ella reconoci que lanto el pecho como los brazos estaban todavia frios como los de un cadíver; administréle en el acto la decoccion de otra hoja de aristoloquia, cuya bebida pareció aliviarle los ardientes dolores del estómago. Indicó. me entonces la parse donde habia sido herida, que mandé friccionar con la aristoloquia, y al poco rato ja podia andar. Despues de obligarla á pasearse un par de horas mas, la despedi asegurándole que la consideraba completamente curada.

Lowther refiere codavia algunos casos parecidos y afirma 

entregaran muchas que no lo eran, pero las autoridades pretendieron haber procedido con el mayor cuidado en el exámen de los individuos, y calculóse que probablemente se habrian gastado 40,000 rupias mas si no se hubieran pagado exclusivamente las especies venenosas.

\section{EL ÁSPID DE EGIPTO Ó NAYA HAYA- NAJA HAJE}

CONSIDERACIONES GENERALES.-Todos los dias festivos puede. verse en las plazas públicas del Cairo un espectáculo semejante al que ofrecen los encantadores indios de serpientes: unos sonidos roncos que se producen con una gran concha llaman la atencion hácia un hombre que se dis. pone á dar un espectáculo favorito de los hijos é hijas de la gloriosa capital y madre del mundo. eMfuy pronto se forman circulos al rededor de un havi ó encantador, y la re. presentacion comienza. Un muchacho cubierto de andrajos hace el papel de polichinela, permitiendose los chistes mas groseros y soeces, que muy graciosos para la mayoria de los espectadores, no solo son acogidos con risas sino tarnbien con aplausos. Un babuino de crin luce sus habilidades, y to. dos los ayudantes del encantador se preparan á recoger el premio, que consiste en monedas de cobre-de poco valor. Sin embargo, aun falta lo milagroso, la magia del hombre, considerado por muchos con cierto temor. Haciendo alarde de su ligereza el encantador, el polichinela y el mono cor. ren saltando el uno sobre el otro y arrojándose diversos objetos, hasta que el haui coge por fin uno de los sacos de cuero en que guarda todos sus instrumentos, arrojale en medio del círculo, deshace el lazo que hasta entonces le su. jetaba, coge en vez de la concha la sumarra, instrumento inventado por demonios enemigos de la música, y empicza Ł. tocar su monótona melodia. En el saco se mueve alguna cosa, que poco á poco se acerca á la abertura, y por fin dé jase ver la pequeña cabeza oval de una serpiente, á la cabeza sigue el cuello y la parte anterior del tronco, y tan luego como esta queda en descubierto, el reptil se endereza exactamente lo mismo que la serpiente de anteojos. Despues se desliza del todo fuera del saco y se pasea lentamente en un círculo trazado, si asi podemos decir, por el titiritero, balan. ceando con orgullo la pequeña cabeza sobre el cuello dilatado, y siguiendo con ojos chispeantes los movimientos del hombre. Un terror general se apodera de los presentes, pues todo $\mathrm{cl}$ mundo sabe que csta serpiente es la especie temida con tanta razon; mas apenas hay quien crea posible que el encantador nse burlarse, habiendo peligro, de la ira del reptil, y supónese que habrá tenido la prudencia de quitarle antes los ganchos venenosos. Fil encantador vuelve $y$ revuel. ve la serpiente como suelen hacerlo en Europa los dueños de las colecciones armbulantes de fieras, para demostrar su docilidad, la coge por el cuello, la escupe, mojala con agua, y de repente, sin que lo echen de ver los espectadores, la comprime en cierto sitio de la nuca. En el mismo momento, la serpiente se tiende en toda su longitud, y entonces expll. case al punto aquel antiguo pasaje que dice: «aron arrojó su palo delante de Faraon y sus servidores, y el palo se convirtió en una serpiente; luego Faran llamó ś los sabios y hechiceros, y los hechiceros egipcios hicieron lo mismo; cada cual arrojó su palo-al suelo. y estos se trasformaron en serpientes.

Ia serpiente con que Moisés y Aaron hicieron sus manifestaciones delante de Faraon, como hos dia lo hace el hari, es el célebre dsspid de los griegos y romanos, el ara ó la levantada de los antiguos egipcios, el simbolo de la supremacia, cuya imágen se ve esculpida en los templos junto al globo terrestre y cuya figura llevaba el rey en la frente como signo distintivo de su majestad y soberania; el urro, como mas tarde se llamó á imitacion de la antigua palabra egipcia; era en suma la serpiente mas afamada de la tierra.

No sabemos lo que habrá influido mas en la imaginacion de aquel extraordinario pueblo del Nilo para otorgar al sspid tal preferencia sobre todos los demás animales: si la extraña, á la par que arrogante y pretenciosa postura, que suele tomar este reptil cuando está excitado por las pasiones; si la gratitud que tal vez sentian hácia él por librarles de las ra. tas, rerdadera plaga en aquellos tiempos, que producia inmensos cstragos y hasta completas carestias, of el terror $y$ respeto que les inspiraban sus terribles dientes venenosos; lo cierto es que griegos y romanos continuaron y aumenta. ron mas tarde las maravillosas leyendas de los egipcios, perpetuánidolas sus mas célebres poetas en incomparables versos. No hay escritor antiguo que no cuente del áspid, de su modo de vivir y costumbres, de los efectos de su temible veneno, y de la veneracion en que lo tenian algunos pueblos, los mas extravagantes detalles, mezclando lo verdadero con lo falso, y añadiencio al sano fruto de la experiencia, los abortos de la supersticion y de la ignorancia.

Eliano dice que se encuentran áspides de cinco varas de largo; la mayor parte de ellos negros ó cenicientos, pero algunos de color de fuego. «Figuraos el sangriento áspid, dice Nicandro, con sus horribles escamas; cuando oge ruido se enrosca en círculo y levanta en medio su terrible cabeza; entonces se le dilata la nuca; el reptil silba furiosamente $y$ amenaza con la muerte ś cualquiera que alcances Este terrible animal, añade Plinio, demuestra sin embargo sentimientos mas tiernos por otro estilo, vive en fiel matrimonio, y solo la muerte puede separar á los esposos. Si el hombre mata s uno de ellos, el otro le persigue para vengar la muerte de su compañero, y aunque le halle en medio de la mayor multitud vence todas las dificultades sin retroceder ante nada; entonces no hay otro medio de sustraerse a $_{\text {su furor }}$ que huir a través de un rio.»

Dificil es determinar si la naturaleza dotó á estos ofidios mas bien favorable que desfavorablemente. Asi, por ejemplo, ha dado á esa peligrosa serpiente unos ojos dispuestos de mocio que solo puede ver por los lados y no hícia adielante, por lo cual sucede á menudo que no ve al hombre hasta que este la pisa. Los egipcios, dice Eliano, domestican estos reptiles, profesándolos gran veneracion $y$ cariño; los crian con los niños; no hacen daño alguno á estos y salen de sus agujeros cuando se les llama con una palmada, pues nunca se hace uso de la voz para esto. Despues de la comida de familia les sirven en la misma mesa un alimento compuesto de pan, vino y miel, llamándolos de la manera dicha, cual si fueran huéspedes. Los áspides salen al punto de sus escondrijos, rodean la mesa, é irguiendo la cabeza y parte del cuerpo, déjanse besar y satisfacen su apetito tranquilamente. Sucede tambien que cuando de noche se levanta algun habitante de la casa, ó en cualquiera otra ocasion tiene que recorrer en la oscuridad la misma, suele advertir á las ser. pientes, dando palmadas tambien, para que se retiren á sus agujeros, á fin de no pisarlas 6 causarles otro daño. La es. pecie de áspid llamada por los egipcios thermusthis se vene. ra por ellos como sagrada y la colocan como una diadema alrededor de la cabeza de Isis. Pretenden que no fueron creadas para perjudicar á la humanidad, pero que es un error asegurar que perdona á los busenos y mata á los malos; algunos dicen que Isis los envia á los criminales mas empe-
dernidos.

Los egipcios cuentan nada menus que diez y seis diferen. tes especies de áspides, pero solo del thermuthis aseguran 
que es inmortal. En cada rincon de los templos preparan, segun se dice, una habitacion para cstas serpientes: âlas cuales alimentan con sebn de terncra. Plinio dice que, segun el relato de Filarco, un áspid tomó la costumbre de acercarse á la mesa de un egipcio para comer cuanto podia; mas arde dió 1 lur sus hijuelos, y uno de estos mató al hijo del due. no. Cuando la serpiente llegó para tomar su comida y echó de ver la desgracia, dió muerte al culpable y no volvió mas á la casa. Ningun hombre mordido por un áspid, añade Eliano, puede salvar su vida; por eso llevaban los reyes egip. cios en su diadema la imágen del áspid para indicar la per. petuidad de su reino. Cuando el áspid dilata el cuello mata á todo aquel á quien alcance su aliento. Los dientes veneno sos están rodeados de una delgada cubierta parecida à una membrana; cuando el áspid muerde, la membrana se desvia para dar salida al veneno y' despues vuelve á cubrir los dientes. La herida producida por el áspid es apenas perceprible, porque ségun se pretende su mortal veneno se exticnde muy rápidamente por el cuerpo, de modo que en la piel solo quedan ligeras huellas. He aqui por qué los comisionados que Augusto envió á reconocer á Cleopatra solo pudieron distin. guir dos puntos apenas visibles, por los que pudieron explicarse el enigma de su muerte.

El que está mordido por un áspid, dice Dioscórides, solo ve unos puntitos; de la herida no sale sino un poco de sangre negra; pero la muerte ocurre antes de trascurrir una tercera parte del dia. Plinio dice que los mordidos por un áspid se alctargan. Este reptil tiene el veneno mas mortal; introducido en una herida reciente mata al momento, pero si se pone en úlceras antiguas produce el efecto lentamente. Sin embargo, se puede beber tanto de ese veneno como se quiera sin suŕrir daño, $y$ tambien comer la carne del animal muerto á consecuencia de una mordedura de áspid. Aristó teles asegura que con la saliva de estas serpientes se prepara un veneno contra el cual no hay remeòio. Cuando en Ale. jandría se impone $d$ un criminal la pena de muerte, dice Galeno, le ponen sobre el pecho un áspid á fin de abreviar su martirio. El gran político ateniense y célebre sabio Demetrio Falerio, se dió muerte, segun pretende Ciceron, hacièndose morder por un íspid.

Todos los autores antiguos indican al icneumon como el enemigo mas temible de esta serpiente: Aristóteles dice que siempre busca compañeros antes de atacar al repill veneno. so, y que nunca se acerca á él sin haberse cubierto con una capa de cieno.

CARACTERES. - Excede esta naỹa en tamaño a su congénere asiática, pues mide mas de 2 metros de largo. Respecto á su coloracion, es tan difícil de determinar como en - la serpiente de anteojos. El áspid de Egipto, propiamente dicho, tiene casi siempre la parte superior del cuerpo de color pajizo y la inferior de un tinte mas claro, con fajas trasversales, de color oscuro, en la region del cuello. Existen, sin embargo, variedades que presentan en el dorso todos los matices intermedios, desde el amarillo de paja hasta el pardo oscuro, ofreciendo igual variedad de coloracion en la parte abdominal.

Muchos autores han formado especies distintas con las variedades; pero estas son tan numerosas que, segun Guen ther, hasta podria dudarse de si se tiene delante una ser. piente de anteojos ó un aspid. Una comparacion minuciosa de setenta individuos de esta especie, conservados en el mu. seo de Lóndres, demostró al citado naturalista el poco fun. damento que tienen todas esas llamadas especies.

DISTRIBUCION GEOGRÁFICA. - Si consideramos todos los áspides como variedades de una misma especie, debemos asignar á esta como zona habitable toda el Africa oriental. Abunda mucho en las tierras del Nilo, siendo asimismo muy comun hácia el sur y en el Cabo; no falta en ningun punto de la costa occidental; livingstone la observó re. petidas veces en el interior del Africa.

USOS, COSTUMBRES Y REGIMEN.-Habita el áspid muy distintas localidades. En el bajo Egipto se le encuentra en los campos y en el desierto, buscando sus escondrijos entre las ruinas $\delta$ debajo de las rocas $y$ aprovechando tambien para este fin las madrigueras de las ratas y otros pequeños roedores; en el sur y en el Cabo frecuenta los bosques, donde fija su morada en los huecos de las raices de los grandes árboles, y mas á menudo en los escondrijos de peq̨ueños ma. miferos; en la montaña se oculta debajo de las grandes ma. sas de piedra 6 cntre la espesura de las plantas que cubren alli el suelo. En todas partes abunda; sin embargo, no se le encuentra con tanta frecuencia como generalmente se cree. Yo $v$ individuos de esta especie en las inmediaciones de va. rios tcmplos antiguos, en las selvas virgenes y en las tierras alias de $A$ bisinia, donde pude matar de una perdigonada una serpiente de 2 metros de largo, que \& pesar de la distinta coloracion supongo que era un áspid. Geoffroy asegura que los fellahs egipcios no interrumpen en manera alguna la faena que están haciendo, cuando lo encuentran en el campo, por. que saben que no acomete, si uno se mantiene á cicrta dis. tancia, sino que permanece tranquilo con la cabeza levanta. da, pero siguiendo siempre con la vista al hombre. Sin embargo, este aserto no lo confirman otros obscrvadores: la haya es muy temida de todos los cgipcios, que la matan siempre que tienen oportunidad para ello; y en cuanto á lo de no acometer, hay que observar que si bien, por lo regu. lar, suele huir, y muy de prisa, cuando ve al hombre, se endereza al punto y se prepara á la defensa tan pronto como conoce que va a ser atacada, dando señales manifiestas de su cólera y furor. Además, siempre que cree poder causar daño al contrario, se arroja sobre el, segun afirman varios cazadores de serpientes, y tiene que andar muy listo $\mathrm{el} \mathrm{hom.}$ bre para esquivar su acometida. Smith, Anderson y Livingstone $\delta$ mas bien Wallner, que publicó las últimas noticias de este viajero, confirman esa opinion de los egipcios. Smith dice que el áspid no huye nunca, y que de la defensiva pasa a menudo a la ofensiva; Anderson y Livingstone refieren tambien hechos que demuestran lo mismo.

tino de mis amigos, muy aficionado a recoger ulantas, dice el primero, á duras penas pudo salvarse una vez de la mordedura de una de estas serpientes. Fstando un dia ocupado en arrancar una planta muy rara, se precipitó un áspid sobre su mano; no tuvo tiempo para volverse, sino que huyo retrocediendo, tan de prisa como se lo permitia postura tan incómoda. La serpiente le seguia de cerca, y le hubiera se. guramente alcanzado, as no ser que tropezando en un monticulo de hormigas, cayó de espaldas; en el mismo monento pudo ver como la haja pasaba, veloz como una saeta, á su lado. A. Smith asegura haber observado siempre que el áspid huje raras veces, y que a menudo su defensa se convicr. te en ataque. Ios colonos del Cabo de Buena Esperanza creen tambien como los antiguos, que el sspid escupe su veneno, causando de este modo grave daño al agresor. Gordon Curming afirma por su parte, que le sucedió un per. cance de esta clase, de cuyas resultas pasó una noche vícti. ma de los mas terribles dolores; pero Gordon Cumming ha afirmado tantas cosas extrañas, que tenemos derecho para dudar algun tanto de sus asertos.

Los informes de Livingstone ó de Wallner demuestran mejor aun que los relatos anteriores el carácter ofensivo del aspid. «Una muchacha halló su muerte de un modo terrible; avanzaba en línea con los cargadores, cuando de pronto 
se lanzó contra clia una gran serpiente, mordióla y desapa. reció en una cavidad inmediata. Aquella mordedura bastó para herir de muerte \& la pobre niña; a pesar de los reme. dios aplicacios, en menos de diez minutos sucumbió. Este hecho es positivo y prueba la veracidad de las noticias de varios viajeros que han recorrido diversas partes del Africa. Los indigenas aseguran que una gran serpiente venenosa persigue su presa con la rapide? del rayo y la alcanza. y que cuantos conocen su ligereza y ferocidad procuran no acercarse a sus guaridas. Un árabo refirió ả los cargadores de Livingstone, á quienes encontró una tarde en Zanzibar, que poco icmpo antes habia pasado por cl camino donde habia sido mordida la muchacha, y que uno de sus lombres fié atacado en el mismo paraje y por la misma serpiente, mu. riendo tambien poco despues. El árabe no dijo si aquella serpiente era aspid, pero seguramente no podia ser otra.

«Los áspides, me escribe Reichenow, son muy comunes en la Costa de Oro; habitan las estepas y aléjanse del bosque espesa A la hora del medio dia les gusta salir ä los caminos para tomar el sol; si alguno se acerca enderéranse verticalmente, silban, dilatan el cuello y arrojan \& la distancia de un metro cierto liquido contra el agresor, dirigiéndole, segun parece, s los ojos. La cantidad de este líquido es bastante considerable, pues las serpientes le arrojan a menudo tres veces seguidas, de modo que la saliva les gotea al fin de la boca. Según a firman los misioneros de la Cósta de Oroy los indigenas, la saliva basta para cegar si toca en los ojos. Debo anadir que tambien Effeldt me ha dado cuenta de ensayos sobre este hecho, practicados con serpientes de cascabcl, y asegura que esa saliva, tal vez mezciada con veneno, no produce en los ojos mas efecto que cualquier otro cáustico. Falkenstein conforme con Reichenow me refiere tambien que el áspid arroja un liquido, lo cual considera como un hecho bastante comun. QCuando arroja su saliva sobre un negro, este se lava, segun me dijeron, con leche de mujer, considerada convo remedio infalible. $x$

Respecto s movilidad. son las condiciones de la haya muy parecidas a las de la scrpiente de anteojos: es muy ágil en el suelo, entra igualmente en el agua, nada y trepa con bastante perieccion, y tal vez con mayor frecuencia $y$ habilidad que su ya citada congénere.

Las presas del asspid consisten en toda clase de pequeños animales, particularmente en ratas y otros roedorcs, pajjaros que viven en el suelo y sus crias, lagartos, otras serpientes, ranas y sapos, segun la localidad y la ocasion. Por lo general, podrain ser sus rapiñas, como las de todas las serpientes ve. nenosas, litiles al humbre, pero el beneficio que proporciona de este modo no merece ser tenido en cuenta, y la persecucion que en todas partes se hace hoy dia al áspid esta com. pletamente justificada.

CAZA. - Cada titiritero egipcio se procura él mismo los áspides que necesita para exhibir ante el público; el medio que emplea para apoderarse del reptil no puede ser mas sen. cillo. Armado de una larga y fuerte vara de mimosa, que ellos llaman naturt, recorre los sitios que suele habitar aquel y es. cudriña todos los agujeros hasta topar con una naya. En una de las extremidades del palo ha fijado el hombre un pequeño lio de trapos, $y$ es el que presenta al áspid cuando este se levanta amenazador y manifiesta intencion de atacar; en su furia muerde en los trapos, y al punto retira el cazador, con un rápido movimiento la vara, procurando de este modo ar. rancar los dientes al reptil. Jamás se da por satisfecho con una sola tentativa, sino que continua irritando á la serpiente $y$ la obliga a morder varias veces en el trapo, hasta que cono. ce que ha perdido ya sus ganchos venenosos y agotado sus fuerzas; entonces, con el palo le aprieta fuertemente la cabe. za contra el suelo, se acerca cauteloso, la coge por el cuello. y comprimiéndole la nuca, la hace entrar en una especie de sueño acompañado de rigidez instantánea de los músculos del espinazo, que le permite examinar con detencion la boca para cerciorarse de que efectivamente han desaparecido sus temibles dientes. Como cl aojador sabe que estos se renuevan mas tarde, no se descuida de repetir de cuando en cuando la mis. ma operacion, á fin de precaverse contra las mordeduras de la haya.

Yo nunca me he convencido de la verdad de las palabras anteriores. Durante nuestra estancia en Fajum, a orillas del lago de Muris, se presentó un dia en nuestra habitacion un havi, aojador egipcio, pidiéndonos perniso para ahuyentar las serpientes que él sabia que tenian sus escondrijos en la misma; le contesté, que ya nos habiamos cuidado nosotros de esta aperacion, pero que tendriamos mucho gusto en presenciar las habilidades de sus discipulos En efecto, abriendo al punto un saco que traia, salicron del mismo unos seis ú ocho áspides que el «maestro hizo abailar de. lante de nosotros. Pedile entonces que me proporcionara uno que tuviera todavia los dientes venenosos, pues sabia que sus adiscipulos no los tenian ya. Protesto el hari que me equirocaba, hasta que por fin le di á entender que mi amigo el doctor y yo éramos tambien aojadores de scrpientes de Frankistan, la tierra de los europeos, y por lo tanto \&colegasxi suyos. Nuestro hombre, guiñando entonces los ojos con cierta expresion muy significativa, murmuró algunas frases, como \&vivir y dejar vivir, sinconstancia de la fortuna, \&di. ficultad de ganarse el pan coridiano, kimbecilidad del pue. blo, \&hijos, nietos, biznietos y demás progenie de los asnos (aludiendo, sin duda, al público que presenciaba sus habili. dades) yotras parecidas, y acabó por prometernos, seguramente movido mas por el cebo de la recompensa ofrecida que por el companerismo de profesion, que nos tracria una hasa de gran tamaño y provista de sus dientes veneno. sos. Efectivamente, al dia siguiente ya compareció en nuestro alojamiento, con el consabido saco de cuero á cuestas; colo. có este en el suelo, y abriéndolo sin muecas ni ridículas farsas, sino por el contrario, con mucho tiento y cuidado, disprisose convenientemente, palo en mano, y aguardó que saliera la serpiente. Asomó la graciosa cabecita del áspid; pero, antes que este pudiese sacar fuera bastante cuerpo para convertirse en $\approx \delta a$, esto es, erguir la parte del mismo que acostumbra \& levantar cuando se dispone para acometer, ya el hasi lo tenia sujeto contra el suelo con su vara; cogióle entonces con la diestra por la nuca, y agarrándole con la otra mano por el medio del cuerpo, tal como estaba envuel. to dentro del saco, nos lo presentó: el reptil, obedeciendo á la presion de la mano en la nuca, tenia la boca abierta, y alli asomaban intactos ambos ganchos venenosos. - Ya lo ves, hermano mio, me dijo el colega egipcio, mi palabra es la verdad; mi frase no tiene engaño. Yo la he cogido, la temible, é ilesa te la traigo. ;Dios, el Altísimo, es grande, y Mahoma su profeta!

Poco rato despues, nadaba la hava en un ancho frasco lleno de espiritu de vino, esforzándose vanamente en hacer saltar el tapon que lo cerraba. Durante algunos minutos, el espiritu de vino no parecia ejercer infuencia alguna en el áspid; pero, pasado un cuarto de hora, ya los movimientos de este cran mas pesados, y sus fucras habian disminuido, y á la media hora yacia enroscado é inmóvil en el fondo del frasco.

A pesar de todas las precauciones que toma el hasi en la caza y despues cuando exhibe ante el público sus serpientes, sucede á veces que recibe alguna mordedura de estas, y sue. len serle fatales sus consecuencias, pues no se sabe que esta 
gente emplee antidoto alguno. In las ticras del Cabo se usan varios medios para atajar los efectos ponzoñosos de la haya: los ingleses se sirven del agua de lucio, del espiritu de amoninco y otros corrosivos; los colonos holandeses, segun dice Anderson, abren el pecho á una gallina viva y la colocan sobre la herida, convencidos de que si esta es venenosa, cl ave siente inmediatamente sus efectos y los da a conocer dejando cacr desfallecida la cabeza y muriendo al poco rato, en cuyo caso repiten la misma operacion con otra gallina, y así sucesivamente con varias hasta que una de ellas no pre. sente sintoma alguno de envenenamiento; entonces consideran ya á la persona mordida fuera de peligro. Otros sustituyen á las aves las ranas, obteniendo igual resultado, esto es, ninguno a nuestro modo de ver. Una especie de haba blanca, que se encuentra en varias localidades de la colonia, llamada shaba de senores, es tambien un antidoto muy el boga; se aplica desmenuzada sobre la herida, auhiriéndose á esta con tal fuerza, que dificilmente se pucde arrancar de la misma, pero cae por si sola cuando ha absorbido el veneno. En otros tiempos tenian los indigenas mucha fe en la sangre de tortuga para la curacion de las mordeduras de la haya, y no emprendian viaje alguno $\sin$ ir provistos de este ingre. diente, que en caso necesario empleaban simultáneamenie como remedio interior y exterior.

CA UTIVIDAD. - El áspid llega á menudo \& Europa vivo, pero por lo general sin los dientes venenosos. Sucunbe casi siempre muy pronto, aunque es la serpiente renenosa que mas fácilmente se conforma con el estado de cautividad, acostumbríndose poco is poco i la comida y acabando por reconciliarse con su suerte, si podemos expresarnos asi. Fis

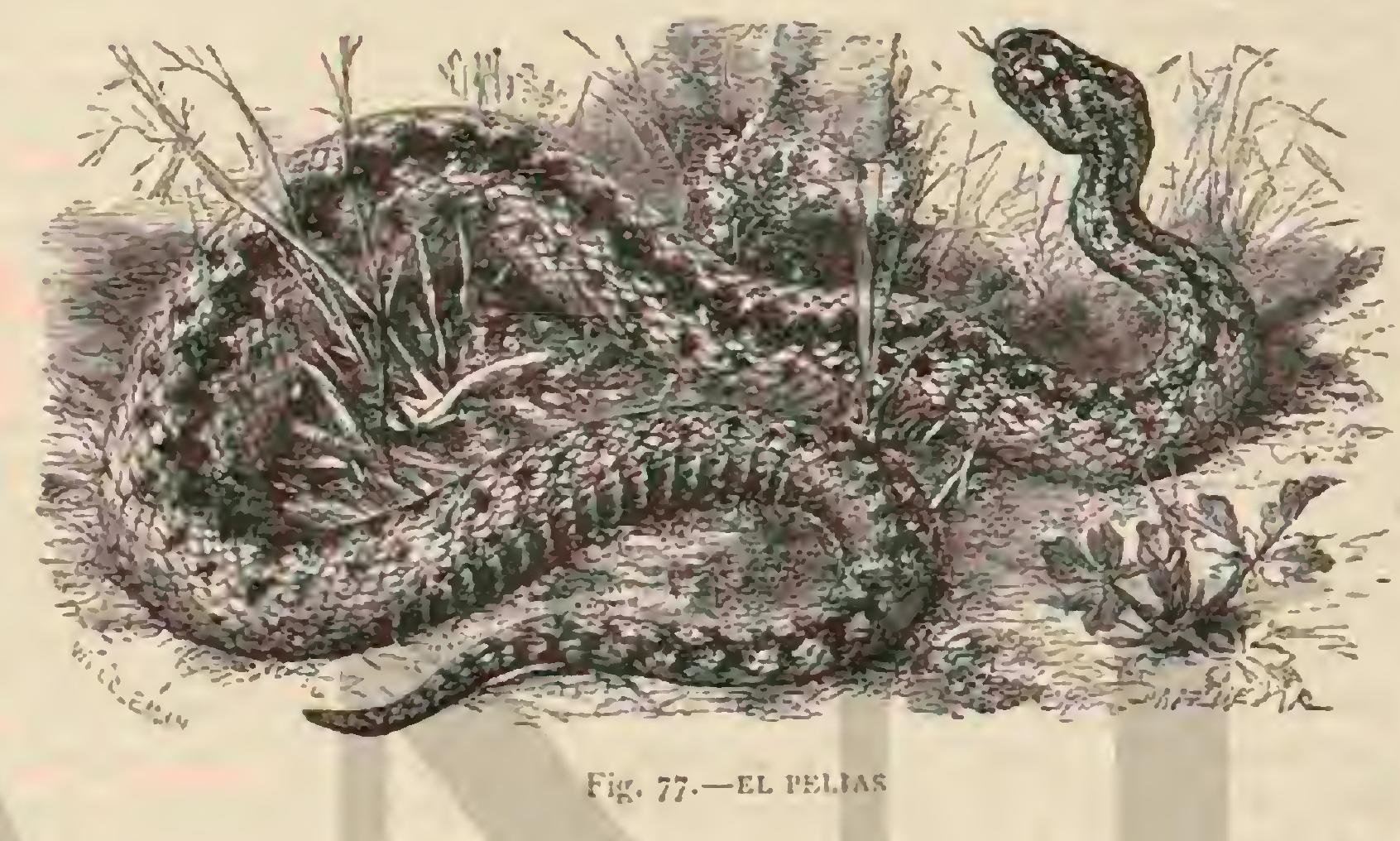

verdad que al principio cuantas veces se acerca el guardian a su prision, se convierte en aza y permanece, aunque sean-horas enteras, con parte del cuerpo erguido mientras aquel no se alcje á distancia conveniente; sin embargo, con el tiempo un perdiendo su salvajismo, si bien jamás llega á -star en relaciones anistosas con el hombre.

Refiere Effeldt que algunos áspides que turo él cautivos, aunque ya habian perdido sus ganchos venenosos, se acos tumbraron muy pronto \& comer, derorando primero ratas y pájaros vivos, y despues los cadaveres de estos mismos ani males; daban la preferencia a los mamiferos y despreciaban los reptiles, a lo menos no los tocaban $y$ hasta retrocedian con marcadas scuales de repugnancia cuando estos jasaban muy cerca de ellos. El agua parecia ser condicion esencial para su bienestar, pues se bañaban todos los dias permane. ciendo horas enteras en el liquido. Al cabo de un año se habian desarrollado ya nuevos dientes venenosos, y tenia que andar muy precavido el guardian al acercarse á las hayas, á fin de evitar sus acometidas, que, como es sabido, suelen hacer de improviso y con la rapidez del rayo, merced a la facilidad con que pucden estirar y levantar la cabeza á destancias muy regulares.

CAUTIVIDAD.-Guenther nos da un relato minucioso interesante sobre la vida de estos reptiles en cautividad; segun las observaciones hechas en el jardin zoológico de Lóndres.

Extraño contraste ofrecen con las perezosas viboras acua. ticas, dice, sus peligrosos vecinos, dos magnificos individuos de la variedad negra del áspid, que por su vivacidad y su ta. maño necesitan un espacio bastante grande. Ios vidrios de la jaula están pintados al óleo hasta un tercio de su altura, tanto para impedir que las serpientes se encolericen con deTomo $\mathrm{V}$ masiada frecuencia, como para obligarlas á enderezarse has. ta la parte trasparente de los vidrios si se excitan. Fsto sucede siempre por la mas pequena causa. Si en tal ocasion $\delta$ cuando se les da alimento una se acerca á la otra, empiezan a luchar; revuélvense con el cuerpo erguido, dilatan sus cuellos tanto como pueden y la una trata siempre de elevarse á mas ajtura que su contraria, dirigiéndose mutuamente y de continuo furiosos mordiscos. Es de extrañar que estos reptiles no se hieran; pero habiéndose puesto hace poco tiempo un tercer individuo en la jaula, trabóse una lucha en la que este debió recibir una herida, pues le hallaron muerto à la mañana siguiente. Matan todos los animales que se les entregan aunque 110 los coman. Fl movimiento para morder se ejecuta con una rapidez. extrzordinariá, $y$ aunquue el observa. dor vea al reptil tocar \& su victima, no prede creer que en efecto la haya mordido, hasta que a los pocos segundos comienzan las convulsiones. La hoca se abre muy poco al morder y la herida es mas bien un rasguno hecho con. la punta de una aguja que atravesara la epidermis sin introducirse en la carne. Los áspides permanecen á menudo largo rato en el agua: solo en invierno se ocultan del todo debajo de las alfombras.

\section{LOS OFIOFAGOS-OPHIOPHAGUS}

CARACTERES. - De las nayas se ha separado últimamente una serpiente venenosa, propia tambien del Asia del sur, quizis la mas terrible, 6 cuando menos la mas larga de todas, clevándola á la categoria de ripo de un géncro inde. pendiente (ofhioghigrys).

El tronco es muy prolongado; la cola de una longitud regular; los escudos del occipucio estan rodeados de tres pares 
de placas muy grandes, de los cuales los dos anteriores cu. bren las siencs. Las escarnas, lisas y muy sobrepuestas, forman quince series longitudinales oblicuas; los escudos anteriores de la cara inferior de la cola solo una, y los posteriores dos. A cierta distancia de los garachos venenosos, largos y provistos en su lado anterior de un surco, hállase un scgundo diente pequeño y macizo. A estas diferencias se reducen los caractîres del género.

\section{EL OFIOFAGO REAL-OPHIOPHAGUS ELAPS}

CARACTERES.-Esta especic, que fácilmente se reco: noce por los grandes cscudos del occipucio, alcanza en rea. lidad una longitud enorme para una serpiente venenosa, pues mide 4 metros. El mayor Beddorne asegura haber muerto un individuo de 14 piés.ó 4 ",35 de largo. El disco del cuello es relatiramente mas perueño que en las nayas; la coloracion varia mucho, pero es por lo regular de un verde accituna en las partes superiores y de un verde pálido en las inferiores. Todos los escudos de la cabeza y las escamas del cuello, parte posterior del tronco y de la cola están orillados de ne gro; el tronco y la cola presentan numerosas fajas blancas, aliernadas con otras negras y oblicuas que se reunen hácia la cabera; los escudos del pecho tienen dibujos negruzcos. Tos individos de este color se encuentran en la península de Malaca, en Bengala y en el sur de la India. Isas especies propias de las Filipinas tienen la parte anterior del tronco de color aceituna pardusco; las escamas de la parte posterior están orilladis de negro, y en las de la cola hay una mancha ocular muy marcada, blanca y orillada de negro. Los indi. viduos originarios de Borneo se distinguen por un color par. do amarillento en las partes superiores, amarillo en la barba y lia garganta, negro en las regiones inferiores y un poco mas claro en el centro de cada escama, en la parte posterior del tronco y en la cola.

En los ofiofagos pequeños el color varia aun mucho mas; algunos son negros, con numerosas fajas trastersales blancas, estrechas, dispuestas á intervalos iguales $y$ dirigidas oblicuamente hícia atras; en la cabeza hay cuatro, blancas tambien, de las que la prinera pasa por la punta del hocico, la segunda por los escudos anteriores de la frente, la tercera á través de la coronilla y la cuarta por el occipucio, llegando á los ángulos de la boca. En otros individuos el vientre es negro, y las fajas trasversales blancas se ensanchan en el lomo; algunos tienen la region abdominal blanca y cada es. cudo orillado de negrur.co. Muchos pequeños se parecen notablementc, scgun Beldome, á una especie inofensiva de serpientes arboricolas.

DISTRXBUCION GEOGRÁFICA. - El área de dispersion de esta serpiente se extiende por casi todas las partes del continente indio y del archipiclago de las Indins Orien. tales. Se la ha visto en la India, en las istas de Andaman, en Java, Sumatra, Borneo, islas Filipinas y hasta en la Nueva Guinea. Parece comun en Sikim y Assam y asimismo en Birmania. En algunos puntos de Bengala abunda mas de lo que podria desearse; acćrcase tambien à los pueblos y aun ¿ las grandes ciudades. Anderson recibió una del Jardin de Plantas de Calcutta y otra de los contornos de Mutlah. En Dargiling sube hasta una altura de 2,000 metros sobre el nivel del mar. Los indigenas de Assam la llaman dabi serp; los kutcharis garomge sim y los bengaleses sunkerchor ó rompedor de críneos.

USOS, COSTUMBRES Y REGIMEN. - $\mathbf{\text { J juzgar por }}$ las noticias basta ahora recogidas, esta serpiente habita con preferencia los bosques poco poblados, ó los canaverales donde abunda la yerba; agrádale mucho introdurirse en los árboles huccos, porqque trepar muy bien ó cuando menos se la ve á menudo descansar en el ramaje. Entra tambien en el agua de vez en cuando, pues nada perfectanente. Un amigo de Fayrer refirió á este que hacia poco tiempo labia ob. servado un ofiofago real en un rio, cuando en una lancha cruzó la corriente. El reptil nadaba con la cabeza crguida y sin dificultad, pero cuando le hirieron de una perdigonada se dirigió rápidamente á tierra firme, donde la mataron.

El alimento del ofofago real consiste principalmente en otros olidios, pero no cabe duda de que tampóco desprecia los mamiferos y aves pequeñas. En el hecho de perseguir à otras serpientes se funda la creencia general en la India de que se le tributan honores reales entre sus semejantes. Un indio muy intcligente aseguró á Torrens haber visto con sus pro. pios ojos cúmo el ofiofago real recibia tributo de sus semejantes. El indfgena tenia entonces catorce años de edad y hallíbase en el terrado de su casa cuando un gran ofiofago que no podia haherle visto, se presentó cerca de la habitacion, levantó la cabeza, ensanchó el disco del mismo modo que suelen hacerlo las nayas, $y$ produjo despues un silbido, al que acudieron inmediatamente diez 6 doce serpientes, que llegando de diferentes puntos se reunicron alrededor de su rey. Este las miro un breve rato, y precipitándose sobre una de cllas la devoró.

La observacion del indio puede ser exacta: pero la deduc. cion es naturalmente crrónea: el indigena vió sencillamente cómo el supuestó rey persiguió á otros ofidios. Varios natu. ralistas fidedignos demuestran por sus propias observaciones que el ofrofago real devora otros individuos de'su órden.

QDurante algun tiempo, refiere Cantor, tuve en cautividad dos individúos de esta especie, á los que cada quince dias les daba una serpiente, fuese ó no venenosa l'an pronto como apercibian la victima, empezaban á silbar, dilataban el cuello, irguiendo la parte anterior del cuerpo, y permanecian en esta postura, como si se preparasen á la acometida; despues de observar durante un rato los movimientos de la presa, se arrojaban sobre ella del mismo modo que suele hacerlo la serpiente de anteojos. Una vez herida con sus dientes vene. nosos, aguardaban su muerte y se la tragaban despues, permaneciendo entonces durante unas doce horas medio ale. targadas.

CAUTIVIDAD. - Los individuos cautivos que tuvo Faj. rer no conservaban sus ganchos venenosos, pues los encantadores se los habian arrancado antes; los reptiles no tenian ya la vivacidad que les es propia; parecian subyugados por cl poder de sus amos, y conducianse del mismo modo que las cubras con que hacen sus habilidades los aojadores. Dos veces devoraron en presencia de layrer serpientes muertas por la especie de anteojos. Su guardian puso la cabeza de individuos arborícolas en la boca del ofiofago y este las de. vorb en menos de un cuarto de hora, balanceando la cabeza de un lado al otro y ensanciando su disco.

Comprimiendo la glándula venenosa pudose obtener algunas gotas de veneno, que se inocularon en una gallina. Tres horas despues el ave habia muerto con los mismos sintomas que se presentan despues de una mordedura de la cobra; la sangre cstaba descompuesta segun resultó del exánen practicado.

Mas tarde Fayrer recibió otro ofiofago real de solo 2 metros de largo; parecia perezoso y poco dispuesto a morder, pero se levantaba de ver. en cuando y ensanchando su disco silbaba. No mordió á una serpiente arboricola viva, ni tampoco du un perro que introdujeron en su jaula; en una palabra parecia evitar todo estorbo, agradándole sin duda la soledad. El cazador de serpientes le cogia con visible repugnancia y prudencia en vista de la fuerza y del carácter peligroso del 
reptil; tampoco entró nunca solo en la jaula, sino que pedia siempre la ayuda de un compañero cuando se le mandaba coger la serpiente. Con el tiempo llegó á manejarla del modo acostumbrado, pero solo cuando otro aojador la sujetaba por la cola.

Tal precaucion está sin duda justificada, pues el ofiofago real es un repril tan furioso como temible, que no solo se defiende cuando se le ataca sino que persigue á sus adrersarios tan luego como estos vuelven la espalda. Cantor y todos los otros observadores que conocen ese ofidio están unánimes en confirmarla así. Un oficial fué atacado en Assam por un ofiofago real que le puso en el mayor peligro; un indigena bir. man refirió ś los ingleses que uno de estos reptiles habia perseguido largo tiempo á un companero suyo. Este último habia descubierto cierto número de ofiofagos pequeños, que segun creyo estaban vigilados por la madre, y en efecto, esta se lanzó al punto contra el istruso, que huyó con toda la rapidez posiblc por vallcs y colinas, prados y espesuras; el miedo ponia alas en sus piés. De este medo llegó á un pequeño rio, el cual cruzó á nado. Pero tampoco cl agua impidió á la furiosa serpiente seguir al fugitivo, que ya creyó ver los ojos chispeantes y los dientes del monstruo. Como último medio de salvacion arrojó su turbante al suelo: el reptil se precipitó con furia sobre ell y mordió repetidas veces el lige. so tejido; el indigena pudo asi ganar tiempo, y de este modo zuvo la suerte de escapar. Comprendo que este relato fué hecho bajo la influencia del cspanto, y es exagerado en parte; pero no cabe duda, segun parece, que esta serpiente persigue en realidad.

Et veneno del ofiofago es en extremo eficaz, segun lo demuestran los experimentos de Cantor. Lin perro muere álos catorce minutos despues de haber recibido el murdisco, aun. que sea en la estacion fria, en la cual, segun se sabe, el veneno de todas las serpientes no es tan peligroso como en los meses de calor.

\section{LOS ALECTOS Ó FURIAS -ALECTO}

CARACTÉRES. - 1 la Australia, tan rica en serpientes venenosas, pertenece un género numeroso de ofidios que en su exterior se asenjejan bastante \& la vibora, por lo cual muchos naturalistas los clasificaron entre estas. Sin embargo, ahora se sabe que tienen los dientes surcados. Wagler les dió el nombre de furia alceto y nosotros les llamamos por lo tanto sencillaniente furins.

Por la forma y estructura de los dientes diriase yue son el tránsito entre las nayas $y$ las viboras; pero se distinguen de unas y otras lo bastante para.justificar su-separacion, sobre todo \& causa de los pequeños dientes ganchudos, pero no surcados, que tienen detrís de los cortos venenosos, acanalados en la parte anterior de la mandibula superior. Ia cabeza es irregularmente cuadrangular, aplanada, y redon. deada en el borde de la boca; el tronco fuerte; la cola corta y gruesa, como en las víboras. Las escamas del dorso están dispuestas en $15 \delta$ 2 r series; las de la arista del lomo se pa. recen a las otras; la cola tiene una sencilla de urostegas.

\section{EL ALECTO CORTO-ALECTO CURTA}

CARACTERES.-Fsta especie, la mas conocida y temible del género, mide de I metro $\left\{x^{\prime \prime}, 50\right.$ de largo, $y$ tiene la parte superior del cuerpo de un verde aceitunado oscuro uniforme, y la abdominal amarillo blanquizco; distinguese además por sus escamas grandes, lisas y redondeadas.

DrSTRIBUCION GEOGRÁFICA. - La gran variedad de numbres con que los colonos de Nueva Holanda designan á esta serpiente confundiéndola à menudo con otras congéneres, hace que sea dificil fijar de una manera precisa la zona habitada por la misma; sin embargo, está fuera de toda duda que abunda especialmente en la Tasmania, donde Ver. reaux coleccionó, durante la corta estancia quue hizo en aquel distrito, mas de cuarenta individuos de esta especie.

USOS, COSTUMBRES Y RÉGIMEN.-Segun Bennett, este alecto es muy temido de los colonos, á causa de las graves consecuencias que suele tener su mordedur. En octubre de ${ } \$_{5} S$ fué mordido en Sidney por una de estas serpientes un muchacho de nueve anios; sus padres no supieron $\delta$ no pudieron, desgraciaciamente, aplicarle en el acto remedio alguno, y lo enviaron á un médico que vivia à dos millas de distancia. Cuando este pudo prestarle los auxilios de la ciencia, se encontraba ya el infeliz muchacho en estado nuy deplorab!e dominado por la soñolencia, y habia perdido la vista en el ojo derecho, manifestando ademnis todos los sin tomas mas graves del envenenamiento. Fn el cedo meñique, donde tenia la morciedura, apenas se distinguian dos peque. ìas punturas, sin irritacion alguna. Practicaronse algunas incisiones, chupóse la herida, aplicándole espiritu de amo. niaco y otros corrosivos, y obligando al pobre chico a andar sin descanso, á fin de impedir que la tendencia al suero acabara por dominarle, pero todo fué en vano: á las oclso horas acometiéronle nuevas convulsiones y espiró.

\section{LOS ACANTÓFIS-ACANTHOPHIS}

CARACTERES. - Consisten los caractéres distintivos de este género, en la ancha cabeza, cubierta en su mitad ante. rior de grandes placas; en las ventanas de la nari\% dispuestas lateralmente en el centro de un gran escudo; en la cola muy aguzada y torminada por una espina córnca muy puntiaguda, $y$ finalmente en la disposicion de las urostegas, que en la raiz de la cola aparecen en una sola fila, mientras que hácia la extremidad se presentan pareadas.

\section{EL ACANTÓFIS CERASTINO-ACANTHOPHIS CERASTINUS}

CARACTÉRES, - Esta scrpiente, dice Bennett, es en mi opinion la mas peligrosa de toda la Australia, lo que jarece justificar el nombre dado por los indigenas de sserpiente de la muerte. lis un reptil asqueroso, muy fornido re. lativamente a su longitud, con ojos de un amarillo muy vivo. La coloncion del lono es dificil de describir, consistiendo en una meacla de lirntas uscuras, con fajas estrechas de color negro; la region abdominal es de un amarillo claso rojizo. Mide $\left(1^{\circ}, 66\right.$ \{ 1 metro de largo, y unos ()$^{m}, 12$ de circunferencia (fig. 78).

DISTRIBUCYON GEOGRÁFICA.-El acantófis cs.un reptil muy comun en la Nueva Gales del sur, que abunda hasta en las inmediaciones de Sidney.

USOS, COSTUMBRES Y REGIMEN. -- Encuéntrase esta especie en los sitios secos y arcnosos, y muy as menudo en las carretcras y veredas, donde permanece de dia arrollado, sin moverse aun cuando se le aproxime un enemigo: circunstancia que le hace mucho mas peligroso. "Yo mismo, dice Bennett, por poco no pisé la primera de estas serpientes que vi en aquel paiss; felizınente me advirtieron á tiempo del peligro que tenia tan cercano. Su cuerpo corto y grueso, y de coloracion tan especial, lo mismo que su ancha cabeza y la maligna expresion de sus ojos previenen ya al profano. Consiste su principal alimento en batracios y pequeños pájaros; í lo menos encontré restos de estos animales en el estómago de los individuos que examiné. 
Pretenden los indigenas que no es mortal para el hombre la mordedura de este reptil, $y$ que las personas heridas tan solo aparecen afectadas durante algun tiempo de una espe. cie de somnolencia, pero q̨ue muy pronso recuperan su estado normal; sin embargo, los europeos opinan distintamente, y el mismo Bennett, como hemos observado ya, es uno de los que consideran al acantónis como la serpiente mas peligrosa de Australia.

Cunningham refiere un caso muy extraño: afirma que durante la época del apareamiento de esta serpiente un perro de caza descibrio un macho en compañia de la hembra, con sus ladridos llamo la atencion de su dueño; acudiós este $y$ cortó In cabeza á uno de los reptiles, pero pudo escapar graciás á su astucia; diez minutos despues pasó por el mismo sitio otro perro, y coino atrapase un pedizo de la cabeza cortada, murió de sus resultas al corto rato, en medio de los mas horrorosos aullidos y convulsiones.

\section{LOS PLATICERCOS HYDRINI}

CARACTÉRES.-Si dificil es la clasificacion de las serpientes, la de las especies marinas, en cambio, no ofrece dudas: su cola comprimida lateralmente en forma de remo es un carácter distintivo tan marcado que no es posible confundirlas con las terrestres a primera vista, se asemejan mas á peces anguiliformes que a serpientes. Su cabeza es proporcionalmente pequeña, el tronco corto, comprimido lateralmente, $y$ la cola nuy corta tambien, comparable por su aspecto al de la pala de un remo colocado verticalmentc. Las ventanas nasales se abren en la parte superior de las placas de aquella rezion; los ojos son pequeños y tienen la pupila redonda. La cabeza está protegiđa por grandes pla. cas, y el cuerpo por pequeñas escamas, que solo en algunas pocas especies se convierten en escudos hácia la parte abdominal. Su dentadura se compone de dos ganchos veneno. sos, con otros rarios mas pequeños ligeramente surcádos detrás de aquellos; 12 mandibula inferior está provistá en toda su extension de dientés sólidos:

Las serviemtes marinas nó tienen rada de comun con los monstruos f́nbulosos qque de ver en cuando surgen, no en cl inar, sino en la imaginacion de los navegantes y en los rela. tos de algunos periódicos. Ninguna de las cincuenta especies conocidas alcanza la longitud de 4 metros; las que llegan à 2 metros $\delta 2^{2}{ }_{25}$ o se cuentan y'a como fenómenos raros. Las diferencias entre los géneros son muy escasas, y las de las especies ticnen aun menos importancin.

DISTRIBUGION GEOGRÁFICA. - A la notable es. tructura corresponden la residencia y el género de vida de estos repriles, de modo que la familia dilicre de otras por todos conceptos.

Todos los platicercos $\delta$ serpientes marinas viven, segun to dice su nombre, exclusivamente en el mar; nosalen nunca a tierra firme, ni tampoco remontan los rios. Su patria principal son los Océanos Indico y Pacifico, desde las costas de Madagascar hastael istmo de Panamá; tambien habitan los parajes situados entre las costas chinas y las del nurte dé Australia.

USOS, COSTUMBRES Y RÉGIMEN.-Todas las, es pecies parecen asemejarse en su género de vida, 6 al menos no hemos podido reconocer las diferencias existentes por las observaciones hechas hasta ahora. No es posible pues hacer una. descripcion de sus usos y costumbres para los géneros ó especies, sino una aplicable á toda la familia.

Parn la clasificacion de esta en géneros y especies nos ate. nemos á las diferencias que ofrecen el aparato dentario y las escamas.

\section{LOS PLATUROS-PLATURUS}

CARACTÉRES. - En los platuros el cuerpo es casi cilindrico, elevado en el dorso en forma de tejadillo anguloso; los escudios y las escamas se parecen á los de otras serpien. tes, de modo que este género puede considerarse como el tránsito entre los ofidios terrestres y los marinos. La cabeza está cubierta de escudos casi regulares en cuanto al número y á la disposicion; las fosas nasales se hallan situadas a los lados en la parte superior del hocico $y$ se abren en medio de un escudo separado del segundo por las placas anteriores de la frente. El tronco está revestido en su parte superior de escamas sobrepuestas, y en la inferior de escudos bien desarrollados, que debajo de la cola forman dos series. De. trás de los ganchos venenosos se ve en ambos maxilares, á muclia dístancia otro diente, pero cae con jacilidad y puede faltair por consiguiente á menudo.

\section{EL PLATURo DE COLA ANCHA-PLATURUS IATICAUDATUS}

CARACTERES. - IJe las dos especies conocidas del gentro, el platuro de cola anclia 6 anillado es la mas comun. Puede tener una longitud de $x^{\prime \prime}, 60$, pero de ordinario no alcanza esta medida. Fil color predominante de las regiones superiores es un gris azulado ó verdoso mas ó menos vivo; el de las inferiores un blanco amarillento 6 amarillo oscuro; el dibujo consiste en veinticinco á cincuenta anillos negros, que rodean tódo el cuerpo; una mancha negra en la coroni. lla se une con otra trasversal en el occipucio, y una tercera en la nuca, por una faja longitudinal del mismo color que parte de la barba; ustas manchas y fajas, y una raya negra en la linca naso-ocular resaltan vivamente sobre el color amarillo del hocico.

DISTRIBUGION GEOGRÁFICA.-El área de dispersion dél platuro de cola ancha se extiende desde el golfo de Bengala hasta el mar de la China $y$ la costa de la NuevaZelanda.

Segun Cantor, habitan los platuros en el golfo de Rengala, la costa de Pondichery, las de las islas Nicobar, Molucas, Timor, Célebes, Nueva Guinea y de la China.

\section{LOS HIDRÓFIDOS-HIDROPHIS}

CARACTÉRES. - Las especies de este género tienen la cabeza pequenia y prolongada; la parte anterior del tronco delgada y redonda; la pusterior mas gruesa y comprimida; la cola muy ancha, y las escamas diferentes segun las espe. cies. Los escudos de la nariz, en los que desembocan las fosas nasales, se tocan de mocio que solo dejan lugar para un par de escudos frontales. Las escamas, casi siempre aquj. lladas $\dot{o}$ tuberculosas, pero nunca lisas, están sobrepuestas en forma de tejas; los escudos abdominales, si existen, son muy pequetios ó atrofiados.

\section{EL HIDROFIS DE ANILLOS NEGROS- - HXDROPHIS CXANOCINCTA}

CARACTERES. - Entre las numerosas especies de este género, el mas importante de la familia, el hidrófis de anillos negros es la mas notable, por ser la mas comun de todas las serpientes marinas. Su longitud puede exceder de 2 metros. Las partes superiores son de un verde aceituna; las in- 
feriores de un amarillo verdoso; el dibujo se compone de cincuenta á setenta fajas trasiersales negras que varian mucho y forman en los individuos jovenes anillos; á menudo están reunidas por una linea que se corre $\mathbf{a}$ lo largo del vientre; en los individuos adultos desaparecen mas y mas en las regiones inferiores; se borran ó resuélvense en manchas; mas por lo regular llegan hasta la mitad del tronco y son mas anchas en el centro del mismo.

DIstribucion GEOGRÁFICA.-El árer de dispersion se extiende desde Ceilan hasta el mar Japonés. Abunda esta especie en las costas de la citada isla, en el golio de Bengala y en el archipiélago de las Indias oricntales.

\section{LOS PELAMIDOS - PELAMIS}

CARACTERES. - En los pelamidos la cabeza es plana; el hocico, muy largo, tiene la forma de azadon; el tronco, de longitud regular, es fuerte y muy comprimido; forma en su parte superior un ángulo obtuso $y$ en la inferior uno agudo. Los escudos nasales, que c'stán unidos, son mas largos yue anchos y los atraviesan en su parte posterior las fosas nasa. les; en la frente solo existen dos escudos; las escamas no son lisas ni angulosas, sino tuberculosas ó convexas; los escudos abdominales, si existen, están muy atrofindos. Por detrás de los ganchos venenosos hay muchos dientes pequeños y só. lidos.

\section{EL PELAMIDO BICOLOR-PELAMIS BICOLOR}

CARACTERES. - I.a coloracion de este tipo, el mas conocido del género, es en el dorso negro pardusca, la de las regiones inferiores, pardo.clara, amarillo de ocre 6 blanquiz. ca; estos colores que se destacan de una manera regular at lo largo del cuerpo, se mezclan en la region de la cola, formando alli injas y manchas varias. Rara vez alcanza esie reptil In longitud de I metro.

DISTRIBUCION GEOGRÁEYCA. - Los pelamidos son los indivicuos mas conocidos $y$ mas abundantes de toda la familia; se les encuentra desde Otahiti hasta la India, y con mucha frecuencia cerca de las costas de Bengala, Malabar, Sumatra, Java, Célebes, China y Puerto-Jackison.

USOS, COSTUMBRES Y REGIMEN.-IOS marinos que frecuentan el Océano Índico tienen por senal segura de la proximidad de la costa cuando descubren una bandada de ésias serpientes, pues solo excepcionalmente se alejan es. tas de la misma. Recorren con preférencia los brazos de mar entre las islas, sin duda a causa de la menor agitacion de las aguas; es verdad que a veces se las ha encontrado en alta mar, pero es debido á fuertes temporales que las han arrebatado de las inmediaciones de las costas. En $1 S_{37}$ los colo nos de Nueva Zelanda tuvieron la desagradable sorpresa de descubrir en las cercanias de la isla grandes bandas de ser. pientes marinas; $\sin$ embargo, no duraron mucho los temores que infundia tan peiigrosa vecindad, pues mıy pronto desaparecieron los platicercos, ya fuera nue regresaran \& sus aguas habituales, ya que sucumbieran víctimas del cambio de clima. Oiro tanto parece haber sucedido tambien en las cercanias de Panamá; con todo, no se tiene todavia noticia de que una sola: de estas serpientes haya sido vista en el Océano Atlóntico. Sucede á menudo que la maren las cm. puja hácia la corriente de los rios, pero permanecen poco tiempo alli, no siéndoles posible vivir muchos dias en agma dulce. Todas las serpientes marinas coleccionadas por Rus. sell y Cantor, murieron al segundo ó tercer dia despues de cogidas, por mas qué las turicran en depósitos de agua salada; otras muchas observaciones han demostrado que estos ofidios son animales marinos en el misuo grado que las ballenas $y$ las aves océnicas, y que no pueden vivir fuera del mar.

Guenther cree poder suponer que los platuros viven temporalmente en tierra lirme, porque la estructura, sobre todo la de los escudos abdominales, muy desarrollados, y las fosas násales dispuestas lateralmente, lo indican asi; tambien cree posible al menos para las especies de un género, que cacen algun tiempo en el cieno, pero no puede apoyar su parecer en ninguna obserracion que permita confirmar el heclio.

No es de extrañar que no tengamos aun noticias suficientes sobre el género de vida de estos ofidios, pues suelen estar reunidos a veces en considerable número, formando grupos que á cierta distancia ocupan verdaderamente un 
gran espacio con sus masas, distinguiéndose en esto de los otros congéneres del orden. Nadan con la cabera levantada, moviéndose uniformemente como otros ofidios; son superiores sin embargo á estos, al menos á todas las especies que no pasan toda su vida en el agua, por la facilidad 5 gracia con que cortan las olas. Su ancha cola a modo de remo, las fosas nasales situadas en la parte superior y que pueden ccrmare con una especic de tapa; los espaciosos pulmones, la pequeña cabeza, la delgada parte anterior del tronco, que es cilindrica, la compresion lateral de todo el cuerpo y qui. zás tambien la estructura particular de las escamas; todo en fin contribuye á que estos reptiles sean el tipo de rapaces marinos muy bien dotados. I a cola que en muchas especies puede servir de órgano prensil, sirve por locos conceptos como la de los jeces; gracias á clla, esos ofidios cortan las olas con la rapidez de una flecha. y tambien hace las veces de ancla cuando quieren descansar sobre arrecifes de coral $\delta$ rocas; las fosas nasales, síluadas hácia arriba, les permiten respirar de la manera mas cómoda; sus espaciosos pulmones les hacen posible permanecer debajo de la superficie mas tiempo que todas las otras serpientes; $;$ cl delgado cuello, en fin, les facilita coger con seguridad, o cuando menos he. rir mostalmente of su presa, efectuando un brusco movi. miento hicia adelante ó una evolucion lateral. Cuantos observadores vieron á esos ofidios nadar en aglan clara están unánimes en admirar su agilidad y rapidez. Cuando reina la calma permanecen al parecer dórmidos en la superficic; no son muy timidos, pero si cautelosos. Algunas reces pasa un buque porien medio de ellos sin que ésto les inquiete, micntras que otras se excitan al mas leve ruido que parece sospechoso; por ejemplo cuando se acerca una lancha, entonces vacian sus pulmones, bajan a la profundidad, y solo una serie de burbujas de aire indica su existencia El exámen de su esiomago ha demostrado que se sumergen a muy considerables profundidades; y de observaciones fidedignas resulia que iambien descansan mucho rato debajo del agua.

Cuando se intentó construir un faro sobre las rocas de Bassels, resto de las islas de Giri, destruidas por las olas, hallá. ronse en la primcra visita, entre los centenares y miles de peces que habitaban las numerosas cavidades de aquellas rocas, una irfinidad de serpientes marinas, y entre ellas al. gunas de 1 ",50 de largo, que enroscadas descansaban tran. quilamente. Irritadas por la molestia que se les ocasionaba, mordieron furiosamente las sondas que penetraban en las cavidades. Los ceilaneses que servian de guias a los arquitectos europeos, aseguraron que las serpientes marinas no solo envenenan mortalmente sino que tambien estrechan a sus adversarios con sus anillos á fin de ahogarlos. En gene. ral, los observadores modernos estin conformes en que es tas serpientes no son nada perezosas ni dóciles, sino al con. trario muy ágiles 5 furiosas; que en su elemento, lo mismo que sus congéneres en tierra firme, muerden a todo enemigo supuesto ó verdadero, hiriéndose tambien à veces a si mis. mas. Cierto que, atendida su abundancia, rara vez sucede que muerdan á un hombre; paro esto es muy fácil si se las molesta en su elemento, porque son muy irritables. No es fácil que un pescador penetre en el agua freclientada por ellas, aunque las mismas serpientes se retiran casi siempre cuando se acerca un barco; pero sucede bastante á menudo que los platicercos muerden s. los que se baũan sin la pre caucion necesaria. Los individuos cogidos en las redes cau. sarian tambien muchos estragos si los pescadores no com. prendieran el peligro que puede resultar de no proceder prudentemente con unos reptiles que tan a menudo se cogen en número demasiado crecido. El temor de todos los pesca. dores indigenas $\$$ las serpientes marinas es del todo funda. do, pues sus mordeduras producen exactamente los mismos efectos que las de otros ofidios de dientes surcados. Los naturalistas indios, sobre todo Russell y Cantor, han recono. cido esto suficientemente, $y$ aunque Siebold observó que algunos marinos cogian esas serpientes con la mano. sin que les mordieran, sabemos por otra parte que unos navegantes ingleses, menos afortunados, perdieron la vida á consecuen. cia de la mordedura.

Cuando en $18_{37}$ el buque de guerra inglés Algerina es. taba anclado delante del puerto de Madrás, se cogió una serpiente marina de dos metros de largo, of la que uno de los marinos miró y examinó tan de cerca; que el reptil le mor. dió en el indice de la mano derecha. Hizo poco caso de la pequeña herida, tanto menos cuanto que le parecia recordar que otra vez je habian mordido serpientes acuáticas, sin experimentar ninguna mala consecuencia. Media hora despues del mordisco ainzorzo, vistióse, y â las dos horas subió sobre cubierta; pero aqui comenzb á provocar de pronin; poco despues disminuyó el pulso y cesó algunas veces del todo; las pupilas se dilataron y volvicron á estrecharse bajo la influencia de la luz; la piel se inundó de un sudor frio, y en el rostro se pintó una expresion de angustia; en una palabra, se presentaron todos los sintomas de una enfermedad grave. Pronto sobrevino tambien una parálisis de la laringe, que dificultó en extremo la respiracion; los bordes de la herida y las partes innediatas a la mano se hincharon; la inflama. cion se extendio mas tarde por todo el costado derecho, y el cuello y el rostro tomaron un color purpúreo oscuro y gris. El médico ordenó varios remedios; el enfermo hizo tam. bien todos los esfuerzos para tomarlos, pero sin resultado; solo despues de un largo baño caliente pudo tomar las me. dicinas, pero arrojólas de nuevo, mezcladas con un liquido oscuro yegajoso. Unos rcinte minutos despues del baño aumentaron las convulsiones, que habian comenzado ya des. de el principio, el color oscuro se extendió por todo cl cuerpo; la respiracion se hizo mas y mas dificil; un líquido pardo oscuro fibroso salió de la boca; el infeliz perdió el conoci. miento y murió á las cuatro horas.

Un segundo caso, con un resultido del todo análogo, ocurrió en majo de i $\$ 69$ con un capitan de buque, mordido al tomar un baño. La herida dolia an poco que el hombre creyó que un cangrejo le habia pellizcado; mas tarde no obscrvó tampoco ningun sintonıa de envenenamiento, habló mucho tiempa con uno de sus amigos, jugó y canto, encon. tróse del mcjor humor del mundo; solo á veces sentia un ardor singular que se extendió por todo su cuerpo, pero que parccia mas bien agradable que penoso. Al volver al buque, sin embargo, unas tres horas despues del baño, se observó que se le entorpecia la lengua, circunstancia que le impidió hablar claramente; poco á poco sintió tambien cierta rigj. dez, al principio apcnas perceptible, pero que luego se ex. tendió mas $\mathrm{y}$ mas por los miembros. Tomó un poco de aguardiente y mandó llamar al médico, que al pronto se pre. sento para recetar una medicina; pero mas tarde, un natural de Birmania llamó su atencion sobre la verdadera causa del mal. Al examinar minuciosamente el punto mordido, al lado del tendon de Aquiles, cerca del tobillo, distinguiéronse dos pequeñas heridas que apenas habian caltsado inflamacion y tan solo ofrecian el aspecto de picaduras de mosquito. Enton. ces el médico propinó los remedios que le parecieron conve. nientes, haciendo beber al enfermo aguardiente en abundancia y un cocimiento de linaza; pero todo esto no produjo ya efecto. Lil capitan, empeorando cada vez mas, sucumbió al fin á las setenta y una horas despues de ser mordido.

Cantor obligó \& una serpiente marina de un metro cin. cuenta centimetros de longitud \& morder \& un ave, que 
presentó inmediatamente despues los síntomas de la parảlisis y murió al cabo de cuatro minutos atacada de convulsiones; una segunda ave mordida por la misma serpiente, murió á los diez minutos; una tercera, envenenada por un platicerco de otra especie, á los siete minutos, etc. Muy notables son los experimentos que el mismo observador hizo en reptiles y peces. Una tortuga blanda (Trions:x gonge/ferus), mordida en el hocico por una serpiente marina (Hidrophys schistosus), comenzó cinco minutos despues á rascar la parte herida con el pié, continuando algun tiempo en esta ocupacion; pero á los diez minutos ya no pudo hacerlo porque sus extremidades estaban paralizadas é inmóviles; al cabo de catorce minutos estaba muerta. Era tan insignificante el cambio que habia sufrido la parte mordida que no se observó nada de particular en el cadáver del animal. Otra tortuga de la misma especic murió cuarenta y seis minutos despues de la mordedura. Un dipsádido experimentó cierta inquietud tres minutus despues de ser herido; se arrastró desde un rincon de su jaula hasta el otro; pero al corto rato ya no pudo mover la parte posterior del tronco; diez y seis nuinutos despues del envenenamiento abrió convulsivamente la boca, yurió al cabo de media hora. Un gran pez Tetrao don fotoca, mordido por un hidrofido de 1 ",50 de largo, nadó durante los primeros tres minutos despues del mordisco, en un cubo lleno de agua de mar; luego movió con violencia la cola y ya no pudo seguir una misma direccion, muriendo diez minutos despues de haber recibido la herida.

De todos estos experimentos resulta que las serpientes marinas son tan terribles en su elemento como sus congé. neres las serpientes venenosas en tierra firme.

No hay que decir que el alimento de todos los platicercos se compone de peces y crustíceos; los individuos adultos persiguen í los primeros, y los jóvenes á los segundos. Guenther encontró en el estómago abierto de varias ser. pientes marinas pececitos de casi todas las familias que con aquellas habitan, $y$ enire ellos, individuos con espinas muy fucrtes y agudas ú otras formaciones córneas. Tal armadura no puede proteger $\mathbf{s}$ los peces contra las serpientes marinas, ni tampoco impedir á estas que deroren su presa. Matan con el venenó, y no hacen ningun caso de las armas de su victima, ni antes ni despues de la muerte; en cl último caso aun menos, porque devoran los peces empezando por la cabeza.

Todos los platicercos son muy voraces; por lo regular ca. zan en las capas superiores del agua, pero cuando reinan teınpestades bajan á mayor profundidad. En los individuos cautivos se ha observado que los ojos pueden ensancharse $y$ estrecharse considerablemente, de inodo que prestan sus servicios en las profundidades mas diferentes. La plena luz del dia, es decir, la que no está interrumpida por el agua, produ. ce un efecto tan sensible en el ojo, que la pupila disminuye hasta parecer un puntito; de modo que los animales quedan del todo cegados, á juzgar por sus movimientos torpes.

Los naturalistas han tenido durante mucho tiempo sus dudas sobre la reproduccion de los platiccrcos; pero al fin se han aclarado illtimamente. Los hidrofis tantas veces citados en las descripciones anteriores (Hydrophys schisfosus) sc aparean, segun las observaciones de Cantor, en febreroy unarzo; enlázanse durante el acto, y,vagan unidos mucho tiempo por las aguas, avanzando con motimientós uniformes.

Cantor no ha podido averiguar con exactitud el tienipo de la gestacion, pero supone que scrs de unos siete meses; por lo que toca \& la ovoviviparidad de estas especies no cabe duda alguna, pues ha sido perfectamente observada varias reces.

No se conocen mas enemigos de los platicercos que las águilas de mar de la India oriental y los tiburones; en cl estómago de uno de estos últimos encontró Peron restos de estos ofidios, que sin duda sorprendidos en su sueño, fueron devorados sin temor á los ganchos venenosos, por el roraz escualo.

No menos peligrosas que los terribles camiceros del mar parecen ser las iempestades violéntas que á menudo arrojan un gran número de esos reptiles a la costa, donde están perdidos si una ola amiga no vuelve a llevarlos a las profundidades de su elemento. A pesar de la gran agilidad que en él demuestran, son extremadamente torpes en tierra firmé; apenas intentan arrastrarse por el suelo ni mover uma parte de su cuerpo; al principio muerden furiosamente, pero se cansan pronto, y hasta se olvidan entonces de hacer uso de sus terribles armas. Ia luz los ciega; en tierra pierden no solo la fucrza sino tambien, segun parece, el conocimiento. A los pocos dias mueren con la misma seguriciad que la ballena encallada en la costi..

A estos inconvenientes se agrega la persecucion del hombre. Ningun pescador indigena vuelve á tirar las serpientes marinas que entre toda clase de peces saca en lin red, sino que mata cuantas puedc. Sin embargo, ni esta sana, ni todos los enemigos causan grandes perjuicios a estos reptiles; el mar los proiege desgraciadamente, mejor de lo que pociria. mos desear, y su reproduccion, bastante considerable, conı. pensa muy pronto todas las pérdidas que sufren.

\section{LOS VIPERIDOS -VIPERIDE}

CARACTERES.-COn las viboras empicza, segun nues. tra clasificacion, la serie de las serpientes venenosas, conside. radas por algumos naturalistas como un orden independien. te. Su tronco es grueso; la cabeza plana, triangular y no cubierta de escudos; la cola cora y obtusa; la mandibula superior atrofiada y provisła únicamente de ganclios yeneno. sos no acanalados; y' los ojos situados verticalmente. "lodos estos caraciéres los distinguen en general, pero no en todos los casos, de las culebras venenosas y serpientes marinas; algunas especies de las primeras tiguran además como tipos de transicion; de modo que no nos parecen fundadas las razones para una separacion tan importante. No dividimos de consiguiente el sub-órden de las serpientes venenosas, y consideramos las viboras y sus congéneres mas afines como ía. milia de ayuellas.

Los vipéridos son serpientes venenosas perfectamente caracterizadas, que se distinguen sobre todo por la estructura muy comprimida, y á veces informe de su fornido cuerpo; la. cabeza es triangular, 6 mejor dicho cuadrangular, aplanada, escamosa en la parte superior del hocico ó provistia de numerosos escudos pequeños, de forma y distribucion comple. tamente irregular; la cola es corta, obtusa, cónica, y rara vez prensil. Se diferencian de los trigonocéralos, únicas serpientes con que podrian confundirse, por la falta de una fosa rodea da de escanas que se encuentra en la region comprendida entre el orificio nasal y el ojo.

Segun las detalladas investigaciones de Strauch, quien recientemente ha estudiado $y$ descrito estos reptiles, y como siempre de la manera mas acabada, la familia de las vi. boras no cuenta sino veintidos especies conocidas, dos de las cunles se hallan en Europa, sin extenderse por Asia ni Africa: doce habitan en este último continente, y cuatro en el otro, perteneciendo las demás en comun á los dos. Sis área general de dispersinn no se divide sin embargo segun las partes del mundo, sino en el territorio comprendido des- 
de el Mediterráneo hasta el Océnno Pacifico, en el norte, y en el etiópico del sur de Asia. Fn el primern, que tiene en cierto modo su centro en los paises mediterráneos, viven nueve esprecies; en el sur de $A$ sia dos y en Ftiopia once. Estos datos, no obstante, deben rectificarse, despues de quedar sentado que dos especies de Africa y de la India Oriental, consideradas como distintas, no constituyen sino una sola.

A excepcion de tres especies poco conocidas aun y pertenecientes a un género especial, cuyos individuos son arbori. colas, las viboras son serpientes venenosas pesadas, que viven siempre en tierra y observan el género de vida de los anima. les nocturnos, no mostrándose actiras hasta despues de po. nerse el sol. Los veriebrados, sobre todo los pegueños mami. feros y las avecillas, y algunas veces tambien los lagartos, pero no los peces, constituyen esencialmente su alimento. Solo las especies mas pequerias y mas ágiles emprenden largas cacerias: tienen la costumbre de acechar pacientemente su presa; apenas la divisan precipitanse sobre ella, muérdenla con sus terribles dientes y esperan tranquilas el efecto del veneno, casi siempre mortal. Son mas perezosas que las demás serpientes de la familia, pero por lo mismo mas traidoras que todos sus congéneres, á lo cual se une su irascibilidad, su carácter furioso y su perfidia A pesar de su terrible armaduray de su veneno, que no es inferior a ninguno por su cficacia, son mucho menos funestas para el hombre que la culebra rénenosa, y tambien menos peligrosas que sus congéneres mas afines, los bothrops, lo cual no impide que ocasionen hartas desgracias. Todas justifican su nombre, pues todas dan á luz su progenie viva; sú reproduccion no es muy con. siderable, pero su resistencia contra las influencias peligrosas muy notable $y$ el número de sus enemigos relativamente reduciản, por lo que se explica fácilmente la abundancia de esos repiles. Por eso se recomienda encarecidamente la apli. cacion de todos los medios de exterminio de que se pucde valer el hombre como un deber imprescindible.

\section{LAS VÍBORAS Ó PELIAS-VIPERA}

CARACTÉRES. - El género de las zilloras (iphra) constituye el núcleo de ia familia, cuyo carácter distíntivo diferencial se funda en los escudos de la cola, divididos y distribuidos en dos series longiludinales. Pertenecen â esta subdivision de la familia, que comprende muchos subgéne. ros, nada menos que diez y sicte especies, siendo de notar que todos los viperidos que habitan en Europa son viboras.

\section{LA VÍBORA COMUN-VIPERA BERUS}

CARACTERES. - Consideramos á la vihora comun (थjfera birus) como prototipo del género de las viborns y de toda la farrilia en general. Reppresenta al subgénero de los, pelias (Pdirss), llamados asi por la lanza de Aquiles, cuya asta procedia del monte Pelion. Se caracteriza esia vibora por tener las escamas de la parte anterior de la cabeza convertidas en escudos, y por no existir sino una serie de escudos entre el ojo y los del labio superior que se hallan debajo del mismo. La coloracion es muy variada, pero siempre sé ve ś lo largo de todo el dorso una faja en rig-zag, que muy bien puecie considerarse como un carácter distintivo.

Presenta esta serpiente la cabeza en su parte posterior mucho mas ancha que el cucllo, bastante aplanada y ligera. mente redondeada por delante; el cuello marcadamente destacado y algo comprimido por los lados; el cuerpo grueso en las inmediaciones del cuello, mas aplanado en el centro, de modo que aparece alli mas ancho quue alto; la region ab. dominal igualmente aplanada, y la cola, que en proporcion a la longitud total del cuerpo parece corta, se adelgara bruscamente en el último tercio de su extension, terminando en una punta corta y dura. Diferéncianse macho y hembra en que el primero presenta el cuerpo mas corto y eshelto, mientras que su cola es relativamente mas larga y inas grue. sa que en esta última. Mide el macho en todo su desarrollo unos $0^{r 2}, 62$, raras veces dos ó tres centimetros mas, ý á menudo algunos menos; la hembra suele alcanzar una longitud total de $: 75$.

Podemos, pues, decir que la cabera de esta vibora representa una vigésima parte de dicha dimension, mientras que en la hembra dicho apéndice no alcanza sino un octavo. Por lo que toca á la escamacion, presenta el pelias el escudo labial con tres puntas redondeadas, y recortado por debajo en forma de arco para dejar paso á la lengua; à cada lado del mismo se encuentran dos escudos en forma de pentágo. no y cerca de su borde las grandes ventanas nasales. I a parte anterior de la cabeza lleva tres pequeños escudus triangulares, de los cuales el anterior prolonga una de sus extremidades entre los dos que le siguen. Entre las aberturns de la nariz forman semicirculo seis pequeños escudos redon. deádos, y entre estos y las grandes placas superciliares aparecen btros ocho de forma parecida. Las escamas que cubren el resto del cuespo afectan por lo general una forma ovalada, que se estrecha y prolonga en la region dorsal, mientras que aparece mas ensanchada hácia los lados y en la cola. Todas las escamas tienen una quilla longitudinal mas 6 menos niarcada, estándolo muy ligeramente en las que componen la fila mas próxima á los escudos abdominales; toda la parte inferior del cuerpo está protegida por anchos escudos trasversales, que en la cola se hallan dispues. tos en doble fila. El número de estos escudos oscila entre extremos tan apartados, que no se puede en manera alguna fjarle limites aproximados, no siendo menos variable el nú. meto y la configuracion de las placas cefálicas.

Muy pocas culcbras habrá que varien tanto en su coloracion como la víbora comun, pero se puede consignar como regla que el color predominante del macho es siempre claro, y el de la hembra oscuro; en el primero se observan los tin. tes blanco, gris plateado, gris ceniciento oscuro, verde mar, amarillo claro y pardo; en la segunda predomina el gris pardo, pardo rojo, verdoso de aceite, pardo negro y otros. Sin embargo, por variado que sea el fondo, la faja longitudinal denticulada resalta moderadamente, no siendo impercepti. ble 6 poco visible sino en las hembras de un color muy os. curo. Esta faja, «signo de Cain» en nuestras culebras vene. nosas de Furopa segun la llamó Linck, se corre en zig-zag desde la nuca hasta la extremidad de la cola a lo largo de todo el dorso, y hállase cubierta en ambos lados por una serie longitudinal de manchas oscuras. Sin embargo, no solo varía su anchura, sino tambicn la forma de cada una de las manchas que la componen. Este distintivo sucle consistir en un cordon de figuras cuadrangulares sucesivas, que alternan. do irregularmente afectan la forma de rombos, dispuestos los unos diagonalmente y los otros en ángulo recto; algunas veces la faja se resuelve en manchas trasversales ó redondeadas; las de los lados, que por lo regular alternan con las grandes, se dividen iambien en pequeños puntos. La coloracion de la faja depende, segun Strauch, del color que predomina en el individuo; de modo que en los pelias de color pardo amarillento claro ó de arena las fajas y manchas son de un castaño claro; en los individuos de color mas oscuro, de un pardo mas 6 menos intenso, y en los individuos nuy oscuros, completamente negras. Además de esta faja en zig. zag, llama la atencion el dibujo de la cabeza, al que este reptil debe su nombre aleman de vibora de Crus: son dos 
fajas longitudinales rodeadas de manchas y lineas irregulares parten del centro de la coronilla donde á veces casi se to. can; desde los escudos oculares se corren otras fajas hácia el centro del occipucio, uniéndose en algunos individuos por medio de una mancha de igual color y volviendo despues á separarse, de tal manera que hácia atrás forman un marcado triángulo, cuyo ángulo agudo se dirige hícia delanie, mien. tras que los dos lados abarcan el primer cuadrado del lomo. Las regiones inferiores del pelias son casi siempre de un gris oscuro 6 casi negro; pero cada escudo presenta por lo regu. lar varias manchas amarilleatas de formas en extremo varia- das, aisladas ó reunidas. Las viboras de esta especie que tienen las regiones superiores muy claras, son tambien de un color mucho mas claro en la cara inferior del cuerpo, donde cada uno de los escudos presenta pequeñas manchas de color oscuro, y hasta negruzco.

Para demostrar lo mucho que varia la coloracion de estos reptiles, citaremos la comparacion que hizo linck entre diez individuos que tuvo s⿱ la vez delante de sí. Uno de los machos presentaba sobre fondo azul plateado la línea sinuosa de color negro de azabache, el segundo blanco verdoso y negro pardo, el tercero amarillo blanquizo y negro azulado,

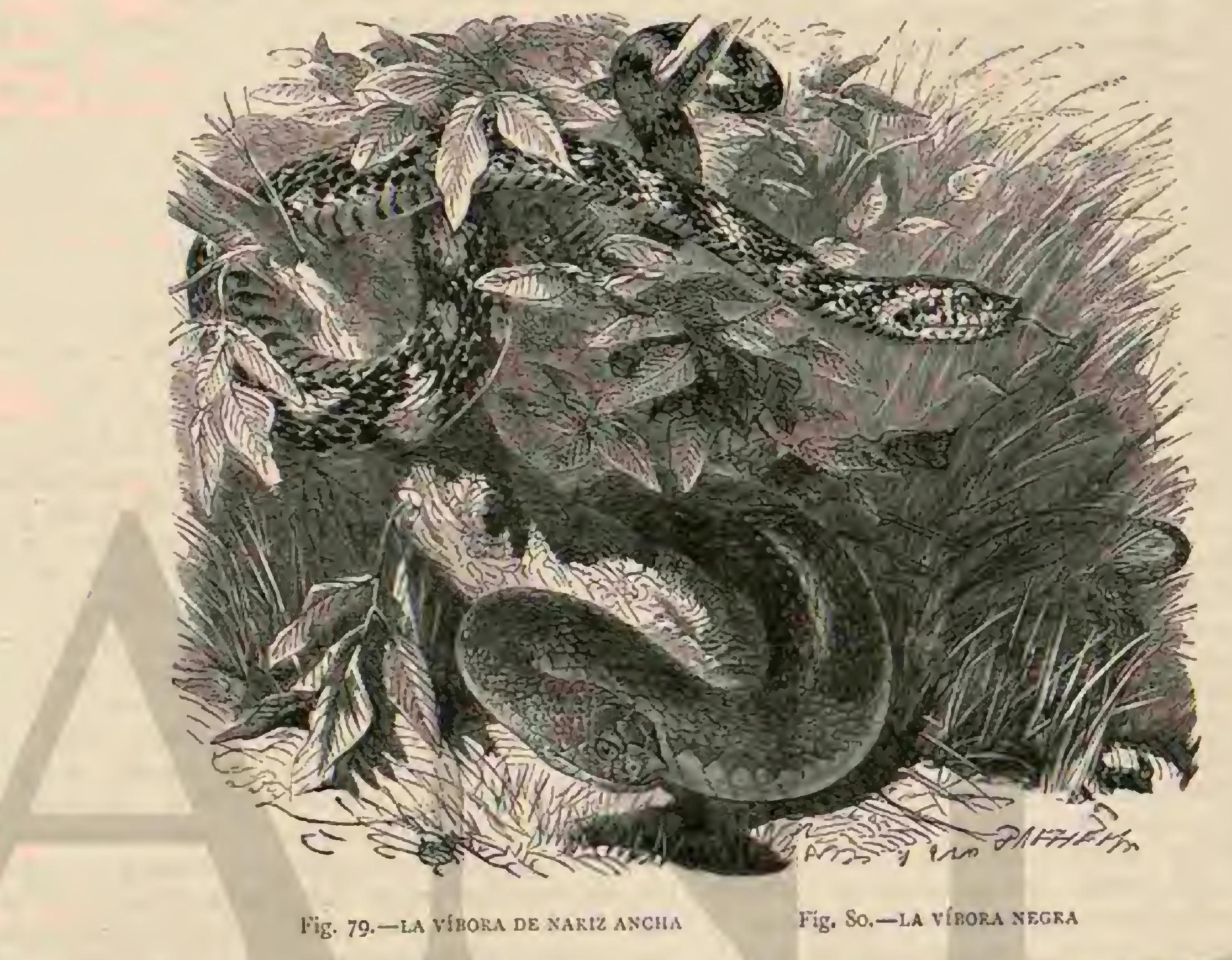

y el cuarto blanco pardusco y negro rojizo, respectivamente; mientras que en las seis hembras se observaban las siguien. tes combinaciones: pardo gris y negro ceniciento, pardo claro mezclado de verde $\mathrm{y}$ gris sucio, pardo gris mezclado de verde aceituna y gris negruzco, pardo y pardo oscuro, verde oscuro y negro mate, $y$, por último, en la sexta, ape. nas se distinguia el dibujo del fondo, siendo ambos casi de la misma tinta negra. Los escudos abdominales son, por lo general, negros azulados, salpicados de blanco en los bordes, pero esta coloracion no es constante en lodos los indi. viduos, y está sujeta á gran variedad.

El ojo grande, redondo y vivo, comunica á la placa superciliar saliente, que lo cubre, cierta expresion maligna y provocadora, que aumenta la forma linear de la pupila é inclinacion de abajo arriba, y hácia atrás de la misma. A la luz del sol, la pupila apenas es perceptible, mientras que en la oscuridad se ensancha extraordinariamente. El iris aparece, por lo comun, rojo vivo de fuego, $y$ las hembras, de coloracion mas oscura, lo tienen pardo rojizo.

Entre las muchas variedades de la especie, la mas oscura ha sido la mas distinguida por varios erpetólogos, conside. sándola como una especic aparte, \& la que habian dado el nombre de Visera presler (fig. So); sin embargo, llamaba la atencion de los observadores que todos los individuos de

Томо $\mathrm{V}$ esta especie fueran hembras, hasta que, habiéndose recibido algunas prenacias, reconocióse que los hijuelos no se diferenciaban en manera alguna de otros pelias; de modo que se demostró que la supuesta especie no cra sino una variedad.

DISTRIBUCION GEOGRÁ FICA.-El área de dispersion del pelias no solo es mas extensa que la de todos los demás congéneres propios de Europa, sino mas tambien que la de cualquiera otra serpiente terrestre, pues se prolonga, segun Strauch, desde Portugal hasta el este de la isla de Sakhalien; en Escandinavia pasa del circulo polar, y en el sur llega por un lado hasta el mediodia de España, y por el otro hasta la frontera septentrional de Persia.

En Alemania no faita en ningun pais, aunque parece escasear su Nassau y en los paises del Rhin en general; asi por ejemplo, no se ha observacio hasta ahora en el Palatinado bávaro, mientras que abunda en Baden, sobre todo en la Selva Negra, y no menos en Wurtemberg, donde se ven nu. merosos individuos, particularmente en los Alpes de Suabia y en el Rauhin. Habitan en todos los distritos de Baviera, excepto en el Palatinado, y asimismo se encuentran en el norte de Alemania, en ciertos puntos con cxtremada abundancia; en el centro y el este de nuestra patria; en Thurin. gia, Sajonia, Silesia, Pomerania, Posen y la Prusia Oriental y Occidental; viren además en casi todos los Estados del 
Austria, sobre todo en los dos archiducados de este nombre, en toda la Bohemia, Moravia, Silesia alstriaca, Carintia, Carniola, Tirol, Hungria, Galitzia, la Buccwina, Transilvania y la Frontera militar. Parece que en Croacia, Istria y Dalnacia está representada la especie por dos de sus congé. neres. El årea de dispersion de ese viperido comprende por otro lado la Bélgica, toda la Francia, excepto los distritos limitrofes de Alsacia y Lorena y las provincias septentrio. nales donde hasta alora no se ha observado aun; encuéntrasele en algunos puntos de Suiza, en Italia, y en el sur hasta los Abruzzos, pasando de los Pirineos.

Además dél continente, el pelias habita tambien las islas europeas excepto las pequeñas del norte y la Islandia; es comun sobre todo en Inglaterra, Escocia y las islas danesas, y penetra en Escandinavia mas que ninguna otra serpiente conocida, diseminándose hácia cl norte, donde los $67^{\circ}$ de $\mathrm{ta}$ titud forman el limite de su frea de dispersion: Habita tambien toda la Rusia desde la Polonia hasta el Ural y desde el mar Biarico hasta el Negro; pasa por un lado del Cáucaso, y por otro del Ural, volviendo á encontrarse en las estepas del centro y sur de Siberia y del nortédel Turquestan. Segun mis propias observaciones, abunda en la Mongolia, y visita, por último las orillas del Amor, no faltando tampoco en ningun punto de la Siberia, situadó entre aquel rio y cl Obi. De lo dicho resulta que el áres de dispersion del pelias se extiende desde los $9^{\circ}$ de longitud este hasta los $150^{\circ}$ y ciesde los $38^{\circ}$ latitud norte hasta los $67^{\circ}$.

Dentro de esta inmensa extension el pelias solo falta en algunos puntos muv reducidos.

USOS, COSTUMBRES Y RÉGIMEN. - LOS pelias habitan los sitios mas diversos: los bosq̨ues, las viñas, las praderas $y$ los campos, las turberas $y$ hasta las estepas. Suben á los Alpes, segun lo asegura Schinz, y elévanse \& la altura de dos mil metros sobre el nivel del mar, al decir de T'schudi, por lo cual se les encuentra á menudo aun mas allá de los limites de los bosques, y por lo tanto les agradan ter. renos donde puedan disfrutar de la vida tranquilamente al menos tres meses del año, pasando el resto entregados al sueño invernal. Las mismas condiciones necesitan estos' rep. tiles en el norte de Europa y en las estepas de la Siberia central. Escondrijos adecuados, alimento suficiente y el calor del sol, es cuanto requiere el pelias para su bienestar, de modo que fácilmente encuentra localidad ấ proposito para establecer en ella'su morada. Terrenos pedregosos y laderas roquizas, cubiertas de arbustos $\delta$ de plantas frondosas, los llanos yrotegidos por espesuras de toda esprecie, mientras ofrezcan sicmpre algunos sitios libres donde pueda gozar del calor del sol, y muy especialmente las localidades pantano. sas, son los mas frecuentados por estos viperidos, donde suele encontrárseles ấ veces en número verdaderamente espantoso: en el bosque de Brennerstaedi, en la provincia de Luneburgo, se mataron en trés dias, en una superficie de pocas hectúreas, al empezar la siega del heno, lo menos treinta individuos. En el norte de Alemania existen extensos matorrales temidos de aquellos habitantes, por la abundancia con que habitan en ellos las víboras; en las cercanías de Berlin hay bosques por donde no se atreven á pasar las mu. jeres dedicadas á las faenas del campo, sino provistas de bo. tas muy alias, á causa del gran número de estas serpientes que anidan en los mismos.

Sin embargo, los parajes mas temidos de este país no son tan frecuentados por esos temibles reptiles como las estepas de la Siberia meridional y del Turquestan, donde con el trigonocéfalo se encuentran en un núnero enorme. No ha. bitan los bosques altos á no ser que su suelo esté cubierto de matorrales; emigran poco á poco á parajes donde antes no se habian visto, y donde las condiciones del suelo cambian de modo, que encuentran alimento y seguridad; tan pronto como les falta esto abandonan su residencia.

"En la selva de 'Turingia, dice Lenz, se tavoreció antes la reproduccion de estos reptiles, por la circunstancia de que alli donde se habian cortado los árboles el suelo quedó cubierto de muchos restos, debajo de los cuales se albergaron en seguida lagartos y ratones y por fin tambien pelias. Este sistema no se emplea ya por nuestros guardabosques; pues actualmente se sustituyen los úrboles cortados con otros jóvenes; el terreno se allana, la maleza desaparece, y asi el número de viboras ha disminuido muchísimo.

Establece el pelias su morada en las cavidades que encuentra debajo de las raíces de los árboles, en las madrigueras de las ratas y topos, y en las de las zorras y conejos abando. nadas por estos, siempre que en sus alrededores se encuentre un pequeno sitio libre, donde pueda exponer á los rayos del sol su cuerpo neresitado de calor. Cuando no le excita la pasion del celo, se le encuentra frecuentemente de dia cerca de su escondrijo, en el que se refugia cuando vislumbra el peligro, con toda la precipitacion que le permiten su soñolencia y natural pereza. Segun Lenz, suele emprender pequeñas excursiones a los primeros anuncios de una tem. pestad.

Opina Lenz que el pelias es un animal diurno, eque hay pocos que tan constantemente se les vea calentándose al sol, $y$ añade: $\mathbf{t}$ No pongo en duda que en noches bochornosas puedan permanicer las viboras al aire libre ó tan solo guarecerse debajo de la yerba ó de la tierra suelta. He observa. do á la claridad de la luna las que tengo cautivas, encontrándolas generalmente muy tranquilas, pero tambicn á veces bastante vivarachas y recorriendo la jaula; he visitado dos veces de noche sitjos que sabia eran habitados por pelias, emplendo todas las precauciones posibles para ocultar mi presencia, pero jamás he encontrado individuo alguno de esta cspecie; con todo, no pretendo que la cuestion quede juzgada definitivamente, pues todos sabemos que hasta de dia y con el tiempo mas hermoso no es fácil ver estos reptiles. Lo cierto es que los que se dedican á la caza de serpientes, raras veces las encuentran despues de anochecido al aire libre; suelen estar entonces ocultas entre las yerbas y la maleza.s A esto puedo contestar que si Ienz hubiese en una noclee oscura encendido un gran fuego en los mismos sitios que visito iluminados por la luna, opinaria muy distintamente. La predileccion que muestran las viboras por la luz del sol, tan solo prueba que al igual de los demís individuos del mismo órden necesitan y anhelan ante todo el calor, y que procuran proporcionarse su goce siempre que pueden, $y$ no en manera alguna que sean diurnos. 'odos los de igual condicion son amantes del sol, por mas que ternan y huyan la luz; los gatos y los mochuelas son ejemplos muy patentes: á. menudo sucumben mochuelos enjaulados, por haberles privado del sol durante largo tiempo. Ahora bien, para las víboras, y aun para los reptiles en general, cuyo calor pro. pio está sujeto á las variaciones de la temperatura que los roden, es una necesidad imprescindible poder estirar su cuerpo bajo la accion benéfica de los rayos del sol, proporcionándose el calor que no les puede comunicar una sangre de tan lenta circulacion; pero no por eso dejan de ser animales nocturnos estas serpientes, como lo son todas las de esta seccion: no en balde tienen sus ojos la propiedad de extraordinaria dilatacion y contraccion, y están protegidos por placas superciliares salientes; pues toda disposicion, toda capacidad que posee un animal, la sabe aprovechar, y conforme á ella es su género de vida.

La actividad del pelias berus empicza con la puesta del 
sol, cuando se dedica á la caza de sus presas. De esta rerdad se puede convencer cualquiera que tenga algunos individuos de esta especie cautivos y disponga su jaula de manera que pueda observarlos sin ser apercibido de ellos, asi como tam. bien el cazador que encienda una hoguera en los sitios que suelen frecuentar los mismos. El inusitado resplandor sorprende á los reptiles entonces alegres y activos, y acuden para ver de cerca la aparicion extraordinaria; reptan hasta el mismo borde de la fogata, fijando atónitos sus ojos en las llamas, y con dificultad se deciden á abandonar aquel espectáculo. Quien muestra empeño en coger viboras consigue su objeto mucho mas fácilmente de noche, por medio del fuego, que de dia, $y$ lo obtiene asimismo en aquellos puntos en que va namente buscaria á los reptiles i mirad del dia, siempre que la localidad esté realmente habitada por viboras y serpientes nocturnas en general.

Las mismas observaciones que se han podido hacer respecto a las propiedades y genero de vida de estos reptiles, confirman en parte la rectificacion del error que algunos autores padecen por lo que toca á las horas en que desarrollan los mismos toda su actividad. Quien solo los ha observado de dia, dice la verdad al describirlos como animales perezosos, enemigos de todo ejercicio, torpes y obtusos de sentidos; pero el que ha podido estudiarlos de noche, muy pronto adquiere la opinion contraria. Naturalmente no pueden competir en destreza y rapidez de movimientos con las serpientes culcbrifornes, de construccion esbelta: pero no se repara tampoco aquel abandono, aquella soinolencia y aqueila repug. nancia a cambiar de postura, que en efecto les son propias durante las horas de mayor calor. Muéstranse entonces muy vivarachos $y$ listos en sus movimientos, recorriendo su jaula en todos sentidos, y por lo tanto, en libertad recorrerán tam. bien los sitios donde suelen hacer sus presas; $y$ al revés de su indolente indiferencia durante el dia, observan y fijan su atencion en todo cuanto pasa en su alrededor. Varios experimentos y observaciones han demostrado que reptan con bastante velocidad en terreno llano, y que si bien no pueden trepar, con todo, saben encaramarse por los troncos inclina. dos, asi como tambien agudarse dentro del agua. No es el pelias una serpiente acuática, como los tropidonotos, pero no teme tampoco este elemento, y no le arredra tener que nadar de una márgen á óra de los pantanos y grandes charcos.

Refiriéndome ahora al desarrollo de los sentidos de estos reptiles, puedo repetir cuanto acabo de exponer en tésis general; dudo mucho de que tengamos un conocimiento exacto sobre la vista, y no soy de la opinion de los naturalistas que enganiados por experimentos hechos de dia les atribuyen una vista débil. Tambien nuestro juicio sobre las facultades intelectuales de estos reptiles deberá confirmarse aún. «Apenas podrá hablarse, dije antes, de la inteligencia de esta ser. piente; una observacion despreocupada nos la da a conocer coino un animal sumanente estúpido. Un furor insensato es el rasgo inas caracteristico de su indole; rodo objeto desacos. tumbrado excita su ira; pero no distingue, y se deja engañar del modo mas torpe, sin aprender nunca con la experiencia. Con la misma furia con que muerde á un sér animado se agarra al baston qque se le tiende ó se precipita sobre el dedo que se le enseña por detrás de su jaula. Se hace sangre en el hocico al arrojarse sobre un objeto duro sin reconocer que su ira es inútil. Mfuerde cuando se lé excita hasta en el aire, cuando ya no hay nada que morder. Su espiritu no es capaz de distinguir lo peligroso de lo que no lo es, y por eso no conoce apenas el miedo, ni siquiera huye de un enemigo inucho mas poderoso. No hay animal que pueda cogerse 6 matarse mas fácilmente que el pelias comun; espera sin temor las cosas que se le acercan y olvida á menudo del todo los ob. jetos que le rodean. Sin embargo, nos engañariamos si quisiéramos ver valor en este proceder, porque no existe; no es mas que terquedad. Tampoco es astuto, como muchos de sus congéneres. Antes de prepararse á morder su presa silba por lo regular con la nisma fuerza que cuando se ve obliga. do á defenderse. Cualquicra excitacion significa en este rep. til el furor. No necesito decir que ese animal no puede nunca trabar relaciones con otro, porque es indomable y tiene el espiritu muy poco desarrollado.

No cabe duda nque esta descripcion es exacta cuando se trata de la vida diurna del pelias comun; pero creo que no sucede lo mismo tratándose de la actividad nocturna de este reptil. El que observara un galápago, un murcićlago, ó un buho durante las horas del dia seguramente que no podria formarse una idea exacta del modo de ser $y$ de vivir de esos animales y lo mismo creo debemos suponer respecto á los reptiles nocturnos. Ias pruebas insuficientes hechas con pelias rautiuns han venido á modificar apreciaciones erróneas. ¡Cuántas mas no se rectificarian si nos fuera dable estudiar f́ estos reptiles en libertad! Segun mis opiniones actuales creo que todas las serpientes nocturnas, $y$ por lo tanto tambien los pelias, tienen á ciertas horas poco mas 6 menos los mismos usos y costumbres que las serpientes diurnas cuya actividad podemos observar; tambien darán caza a su presa sin contentarse tan solo, como nos inducen à creer las observaciones liechas hasta ahora, con las victimas que puedan pasar á su alcance mientras están en acecho. Ahora puedo citar una observacion fidedigma en pro de mi opinion. En una hermosa noche de verano, iluminada por la luz de la luna, Struck pasó con un amigo por un ancho camino en me dio de bosques de diversa vegetacion. A las once, los ami. gos se ccharon \& la orilla del camino para descansar, y pasado algun tiempo, oycron un ligero ruido á unos diez. y siete pasus de distancia, donde vieroná un raton perseguido con rapidez por una serpiente. Despues de recorrer unos quince pasos, el reptil alcanzó al roedor y silbando se apo. deró de su víctima. El compañero dic Struck, un guarda-bos. que, echó mano á su escopeta, hizo fuego, y al acercarse ha. 116 un raton muerto $y$ un pelias moribundo. El mismo observador reconoció tambien que los pelias se acercan á las hogueras encendidas para ahujentar de nochea los animales del trigo, pero solo cuando la gente permanecia quieta, mientras que suele emprender la fuga tan luego como álguien se dirige hácia ellos con un palo.

El aspecto de este repril es muy repugnante, y por demás horroroso cuando, excitado, manifiesta el ciego furor de que sc halla poseido. EUn dia, refiere Lenz, cstuve durante una hora entera irritando una vibora, sin que dejase esta ni un solo monento de resoplar y morder en el aire, intentando hacerlo en ni mano; al cabo de la hora abandoné ian extra. no pasaticmpo, hastiado ya del mismo, pero la vibora continuó todavia largo rato dando señales de su cólera. Lin este estado muerde el reptil continuamentc, aun despnes de alejado el objeto que le ha irritado, en el aire, en la yerba, y. muy espucialmente cuando la escena ocurte á la luz del sol, en direccion de su propia sombra $\delta$ de la que proyectan otros objetos. Suele tener entonces el cuerpo arroliado y el cuello encogido en el centro del disco que forma de este moco, para poder, a cada mordisco, adelantarlo con rapidé, comio de 3 \& 6 , pulgadas. La accion de encoger el cuello es siempre ía serial de la intencion de morder, de tal modo, que casi nunca umerde la vibora sin primero haberse preparado de esta mancra, recogiéndolo despues con igual ravidez, á menos que, no encontrando el objeto que pretendia herir, linga estirado aquel demasiado para poderlo retirar en el acıo. Cuando está furiosa, y quicre morder, no solo en. 
coge el cuello, sino quue teniendo ticmpo para cxaminar el objeto que pretende acometer, y no acercándosele este de improviso, projecta tambien râpidamente la lengua ì una distancia igual al largo de su cabeza, brillando entonces sus ojos como áscuas ; pero mientras mucrde tiene la levgua recogida, y muy raras veces toca con ella al enemigo antes de morderle. Los silbidos ó resoplidos, los da generalmente con la boca cerrada, y son producidos por la inspiracion y espiracion mas fuertes que de costumbre; consisten en dos sonidos distintos, pero bastante parecidos, que alternan aproximadamente en el mismo espacio de tiempo que necesi. ta el hombre para verificar sus movimientos respiratorios. Al espirar el aire, el sonido es mas fllerte y mas jrofundo; mien. tras que la inspiracion 10 produce mas débil y mas alto. Coloqué una vez, sujeta en la punta de un baston, una plunilla de ganso delante de la nariz de una vibora que silbaba con viólencia, y pude distinguir perfectamente los movimien. tos respiratorios, pero observando que la agitacion del aire era muy ténue. Por lo demás, la vibora siempre que está irritada se hincha extraordinariamente, de manera que hasta la mas descarnada, aparece entonces llena y gruesa. Lo mis. mo sucede, y en mayor grado, cuando se la arroja al agua, pero en este caso es debido á la gran cantidad de aire que inspim para aligerar relativamente el peso de su cuerpo den. tro del liquido. Siempre está precavida y dispuesta á la de. fensa y al ataque; asi es que raras veces se la encuentra, aun cuando parece mas abandonada á su natural inojolencia, sin que tenga la cabeza inclinada de un lado hácia arriba. Si bien tiene muy poco desarrollado el sentido de la vista (de dia, querra decir Lenz), sabe, con todn, distinguir los obje. tos que se le acercan, y háse observado perfectamente que clava sus ganchos venenosos con preferencia en los animales de snngre caliente, escogiendo entre estos con predileccion particular á las ratas. Del mismo modo, cuando se coloca detrás de un cristal de muy clara transparencia, acomete jreferentemente contra la mano que se acerque al mismo, que si, por ejemplo, se toca el cristal con la manga de la le. vita, el baston ú otro objeto.

- Escreencia general que la vibora salta y persigue, cuando enfurecida, á su victima hasta largas distancias. Ni yo, ni mi cazador de serpientes, hemos visto jamás semejante cosa, ni tampoco lo he oido contar á persona alguna que haya ob. servado de cerca los usos y el género de vida de estos repiles. Varias veces he probado, no solo en casa, sino en el campo tambien, á irritarlas continuamente, deseando conseguir que saltaran, pero sicmpre en vano. Ln estas ocasiones me he distraido bastante, provocandu cun la punta de una vara á alguna vibora que sorprendia descansando en perfecia tranquilidad. Suele recoger entonces todo el cuerpo en un monton, formando conio una pequeña torre, en cuya extrenidad aparece la cabeza anmenazadora, pero tambien se arrolla en el suelo formando disco. Todos suś músculos están en continuo movimiento, de modo que es dificil distinguir su coloracion, y sin cesar estira el cuello, y muerde en direc. cion al agresor; pero jamás he visto que ni siquiera haya $s a l$ tado, intencionalmente, la distancia de un pié hácia adelan. te, si bien sucede a veces, que sorprendida con el cuerpo conipletamente estirado, no pierde el tiempo en enrollarlo, sino que tan solo encoge el cucllo y lo projecta para morder, con gran rapidez, imprimiendo esta fuerte sacudida un pequeño movimiento de progresion á todo el cuerpo.

* A menudo denuncia la misma vibora su presencia, lleva. da de su malignidad, cuando oculta entre la yerba ó la maleza, en vez de permanecer silenciosa, da fuertes resoplidos al procurar morder al transeunte que pasa á su lado sin ohservarla; de manera, que por lo regular, cuando este se apercibe de la proximidad de tan temible enemigo, el reptil ya le ha clavado sus dientes en las botas ó en la ropa, si no le ha llegado al cucrpo. A reces huye la víbora despues del primero $\delta$ segundo mordisco, pero suele casi siempre em. prender la fuga tan pronto como conoce que se le acerca el hombre. Esto último es mas probable que suceda generalmente de noche, cuando gracias á la activa caza que ha dado a sus presas favoritas, se encuentra el reptil en mejor disposicion de ánimo; siendo esta qquizá la causa de que de noche sean muy raros los casos de mordeduras de este animal, lo que se explica asimismo por lo poco que visita el hombre á esas horas los sitios frecuentados por aquel.

El alimento de este reptil consiste principal, aunque no exclusivamente, en animales de sangre calicnte, sobre todo en mias, que son su nanjar favorito, musgaños y jóvenes topos.

Los ratones silvestres son, segun I enz, los que mas tienen Inie sufrit, porque son los mas torpes é inofensivos de nues. tras especies de roedores y mucho menos astutos que la especie de los campos. Tampo perdona á las musarañas. No he encontrado hasta ahora ningun topo en el estómago de las viboras, pero no dudo que se atracan del delicioso manjar cuando encuentran un nido con pequeños.

De las inrestigaciones de Lenz se desprende que la vibora no caza las ratas tan solo en el suelo, sino que tambien debajo del inismo, pues el citado naturalista afirma que encon. tró con frecuencia en el estómago de individuos disecados por él pequeños rato:ses y musganos sin pelo alguno, que solo podian haberse proporcionado en madrigueras subterráneas. Es igualmente muy probable que sean presa de estos reptiles los jóvenes pájaros, y que con este objeto roben los nidos, en particular de las especies que los construyen a escasa altura del suelo, siendo esta seguramente la causa del mucho ruido que hacen y de la viva inquietud que manifiestan los pájaros adultos cuando descubren una vibora. Solo en su jurentud comen lagartos las víboras, $y$ las ranas no las devoran sino en última extremidad, cuando no pueden pro. curarse presas mas predilectas. Es digno de observarse, dice el mismo Lenz, el afan que tienen por matar ratones. Hasta en cautividad, cuando voluntariamente se condenan á morir de hambre, y muy raras veces persiguen á otro aninal, si no se las provoca, tan pronto como aparece en la jaula una tata, empiezan á brillar sus ojos con siniestro fulgor, y inordisco tras mordisco hieren al inofensivo animalito, hasta que lo matan con verdadera pasion, pero no lo tocan jamás des. pues de muerto. Varias reces he presenciado escenas de esta clase. Saltaba de improviso una rata dentro de cajas, en las que vivian diez $y$ hasta veinte viboras en compania de otras varias serpientes dobleandadoras, lagartos, ranas, etc; corria el pequeño animal de un lado á otro sin recelo alguno, creyendo encontrarse en buena sociedad, y hasta se atrevia á snitar encima del cuerpo y de la cabcza de las viboras. De repente encogian estas cuello y cabeza, ardian sus ojos, y rá. pidamente proyectaban y retiraban la lengua; en todos los rincones se oia silbar, y pronto un mordisco, y luego otro, eran dirigidos al pequeño mamifero, que al principio podia c.squivarlos; pero, por fin le herian los ganchos venenosos, y al poco rato, despues de grande hinchazon y convulsiones, caia de costado y acababa de vivir, La agitacion duraba to. davia algun tiempo entre las viboras, de cuando en cuando se oia silbar una de ellas, otra aun mordia en el aire, pero muy pronto, con la muerte del enemigo, volvian á reinar la tranquilidad y la paz en la caja de los reptiles. Estas vibo. ras, al igual de otras serpientes, pueden permanecer largo tiempo sin alimento; pero tambien cuando la caza les ha sido favorable, aprovechan la ocasion, y se atracan espanto- 
samente. Lenz encontró en el canal digestivo de una vibora tres ratas adultas, una detrás de la otra.

La vida de verano no empieza hasta abril; si la primavera es templada se le ve ya a mediados de marzo fucra de su escondrijo de invierno, y si es muy benigna salc alguna vez antes y aun en medio de la estacion fria. En ig de enero de 1875 , me escribe el médico comandante Grimm, à las tres de la tarde, hallábame en un encinar muy anoso, donde abundaban los troncos cortados y medio putrefactos; el sol era bastante caliente y aunque todos los campos estaban cubiertos de nieve, la capa de esta habia desaparecido ya en un lado del bosque situado en una ligera pendiente, donde al suelo estaba seco del todo. Cerca de uno de los troncos mas exteriores vi un pelias, que sin enroscarse $y$ al parecer sin vida, tomaba el sol. Cuando le toqué con un palo intentó escaparse con bastante rapidez al arbusto mas próximo; y mientras procuraba impedir su fuga para cogerlo vivo, uno de los batidores se acercó y mató al animal venenoso antes de que pudiera detencrle.

Acostumbra reunirse en sociedad bastante numerosa para pasar el sueño invernal. Véase lo que dice con este motivo el pastor evangelico Treisze: «En 1816 trabajaban varios leña. dores en la recomposicion de un camino y al efecto tuvieron que hacer un corte en piedra arenisca; en las hendiduras de esta hallaron, de 2 \& 6 piés debajo del nivel del suclo, diez viboras pelias en letargo. Al principio creyeron los leñadores que eran cuerdas, pero cuando hubieron sacado con su pico la primera y reconocido que era una serpiente venenosa, co. gieron del mismo modo las demásy las mataron. A los lados de la pared de piedra no habia hendidura alguna, y por lo tanto debieron introducirse los reptiles por la parte de arri. la, donde se veian varias aberturas.s Fil doctor Wagner refiere tambien lo siguiente: «En el invierno de $1 \$ 29$ á I 830 se encontraron en el distrito de Schweidnitz, à una legua de distancia de la ciudad de Schlieben, nueve viboras en rerreno pantanoso, por encima del nivel del agua, dentro de uñ tronco viejo. Alli estaban apinadas unas encima de otras, no daban señal alguna de vida y fueron muertas todas teniendo igual suertc un veso, que sin duda habia ido alli en busca de su alimento favorito. $\mathrm{A}$. von Homeyer me escribe lo si. guiente: «He hablado con mi hermano, como $\mathrm{V}$. deseaba que lo hiciera, respecto á las viboras de nuestro país. Mi anterior comunicacion es completamente exacta. Segun las observiaciones de mi hermano, encuéntranse de 15 is 25 individuos de esta especie juntos debajo de las mices del enebro y de viejos troncos podridos de álamos blanco y negro, donde se refugian tan pronto como empieza el frio hasta la vuelta de la primavera. Suclen los lenadores, cuando arrancan raíces y troncos viejos, encontrar estos campamentos de invierno, $y$, como puede $V$. presumir, no perdonan la vida á ninguna. Con verdadera satisfaccion he sabido que el reso está mas al corriente de esta circunstancia que no. lo estábamos nosotros hasta aquif. Durante el invierno busca este de. pósitos de los que saca provisiones á medida de su necesidad: mi hermano encontró, naturalmente en medio de! invierno, en la madriguera de uno de estos animales aigunas ranas y tres viboras, \& las q̨ue habia tenido la precaucion de romper las vértebrä́ de la nuca. Por filtimo, me resta observar, que el sueio invernal de la vibora no es muy profundo; por póco que se la moleste levinnta la cabeza, repta perezo samente y saca la lengua; con todo, el ojo aparcce cansado y lánguido.

El apareamiento solo se verifica cuando la primavera se ha fjado, por lo regular desde principios de abril hasta fines de este mes y aun á principios de mayo. Alguna vez. se apa. rean los pelias tambien fuera de este tiempo. Effeldt encon tró en el año caluroso de $1 \$ 46$ una pareja de víboras entrelazadas el dia 15 de marzo, y Lenz recuerda un caso en que vió el i $S$ de diciembre dos de estos reptiles unidos en el acto de la cópula. Este último cree por lo mismo probable que á veces puedan las viboras dar á luz sus hijuelos en la primavera; pero lo regular es que lo verifiquen en agosto y setiembre. El apareamiento empieza sin duda durante la no. che, pero como los reptiles permanecen varias horas estre. chamente enlazados, se les encuentra en la misma postura á la mañana siguiente. Como ya hemos dicho, sucede que va. rias parcjas de viboras se juntan mientras dura la cópula, formando una pelota ú ovillo; véase lo que refiere Effeld acerca del particular: En abril de $18_{37}$ me dirigia, segun mi costumbre en aquella época, á la aldea de Johannisthal, milla y media distante de Berlin, para coger serpientes. Entonces llegaba hasta las primeras casas del pueblo un bosque consistente en su mayor parte en ślamos negros, cruzado por espesas matas de zarzamoras, y tan infestado de viboras, que todos los años habia á lo menos un recino de la aldea mordido por ellas, y sucediendo \& menudo, como en los paises mas meridionales de nuestro continente, que hasta se introducian en las habitaciones. Atravesando dicho bosque enconirt al guarda, antiguo conocido mio, quien luego que me vió me saludó diciéndome: «Llega usted oportunamente, pues si viene á buscar viboras le enseñaré un monton de ellas que acabo de ver. In efecto, aceptando como era na. tural su oferta, me acompañó al sitio indicado, mantenién. dose, sin embargo, à respetuosa distancia, «pues, decia ćl, por todo el dinero del mundo no me acercaria ́á uno de esos montones, ni me atreveria disparar mi escopeta sobre él, porque los malditos reptiles acometen inmediatamente al hombre y le persiguen largo trecho. Despues de buscar durante algun tiempo, descubri el ovillo de las viboras, convenciéndome de que no me habia enganado ni hombre. $\Lambda$ pié de un tronco de álamo, rodeado de verdes retonos, al borde del sendero, yacian seis ú ocho viboras arrolladas y entrelazadas unas con otras de la nanera mas extraña: machos y hembras revueltos, algunas parejas en el acto del apareamiento, $y$ las otras enroscadas en estas. Cuando me acerqué, todas levantaron la cabeza, sacando la lengua y silbando, pero sin moverse, ji siquiera intentar huir una so. la de ellas: probé irritarlas tocándolas con una vara, pero no hicieron caso alguno de mi provocacion. Como el dia esta. ba muy adelantado uada pude hacer aquella tarde; volví á la mañana siguiente, no creyendo encontrar ya el ovillo, pero con la esperanza de hallar alguna de las víboras que habia visto el dia anterior. Cuál fué mi sorpresa, cuando al acercarme al sitio, no solo ví las serpientes en la misma postura, sino que su número habia aumentado durante la noche. Bajo la influencia de los rayos del sol los reptiles se mostraban mas pacificos 6 indiferentes que en la tarde anterior, de modo que me fué bastante fácil apoderarme de todos ellos. Una ver los tuve bien encerrados en mi caja, empren. di inmediatamente mi regreso á Berlin ansioso de saber si las continuas sacudidas del camino producirian algun cfecto: al llegar á casa encontré quue el ovillo se habia desenredado por compleio. Diez minutos despues supe por el nue. vo guardabosque, sucesor de mi antiguo conocido, que habia observado un caso idéntico.

Resulta de las investigaciones de 1.enz que el apareamiento de las viboras solo se verifica cuando ya han alcanzado casi todo su desarrollo: jamás encontró alguna menor de $11^{\star}, 50$ que llevase huevos á propósito para una completa gestacion. El número de huevos 6 pequeñuelos que da áluz una hem. bra depende de la edad y del tamaño de la misma: las mas jovenes paren de 5 a $6 \mathrm{y}$ las mas viejas $12 \mathrm{y} 14$. Lenz ha 
observado esta funcion importante y la describe muy deta. lladamente. «a vibora, dice, yace con el cuerpo completa. mente estirado y expele un huevo tras otro por la abertura del canal en la que desembocan los oviductos, sin duda alternando, de modo que cuando ha puesto el procedente de un oviducto, el siguiente sale del otro. En cl acto mismo del desove levanta la cola algo inclinada y á veces en forma de arco, mientras que el cuerpo descansa en el suelo. Entre la puesta de cada huevo nótase el intervalo como de varios minutos, y á veces de un cuarto $y$ hasta de horas enteras. Mientras dura esta operacion he observado constantemente que el reptil pierde toda su ferocidad. Apenas sale el huevo del cuerpo de la madre, ya se estira el viborezno que encier. ra aquel, rompe la delgada císcara y saca el cuerpo fuera, arrastrando todavía la túnica interior de la yetna, que pierde luego, cortando el cordon umbilical en los primeros esfuerzos que hace para reptar; librc ga de este entorpecimiento y completo el pequeño animal en todas sus partes, empieza en el acto á virir de cuenta propia sin curarse de sus progenitores.

* Debo observar que la vibora nace feroz y continúa siéndolo hasta el término de su viđa. He visto viboreznos, toda. via hámedos del huevo que acababan de abandonar, que al tocarles ya empezaban á silbar 5 ámorder, siendo muy di. vertido observar cómo estos peçueños animales al dar, por decirlo asi, sus primeros pasos en este mundo, no se descuidan de abrir de cuando en cuando la boca, sacando los dientes venenosos y ensanchando il parte posterior de la cabeza, ensayándose desde el primer dia de su vida en el uso que han de hacer de tan mortiferas armas.

- Cuando nacen miden unas 7 pulgadas, antes mas que menos, de largo, y 4 lineas y cuarto de grueso en el centro del cuerpo. Cabeza, escudos, escamas, dientes, etc., están formados tal como en los adultos, pero todo cl animalito aparece cubietto de una piel muy delgada, trasparente y po. co adherioda al cuerpo, á través de la cual presenta la coloracion un tinte mas claro. Pocas horas, y á veces minutos, despues de nacer se despojan de esta piel de la misma ma. nera que suelen hacerlo los adultos, siendo esta la primera operacion importante de su vidal.

- Entre los viboreznos nácidos en mi casa he encontrado siempre tan solo una quinta parte de inachos; tambien en el campo he podido observar constantemente mayor número de hembras que machos jóvenes, mientras que en los adultos están los sexos casi equilibrados. ¿A qué causa podrá atri. buirse este fenómeno?

- Debo advertir tambien que en las viboras no hay indicio alguno de amor de familia. Tan pronto como el viborezno sale del huevo, tira por su lado, sin tener la menor pretension al cariño de la madre, que tampoco se cuida de sus hijuelos, y sin entretenerse con sus hermanos. Encuéntranse estos pequeños animales aislados, cada uno por su camino, poseidos de aquel valor y de aquella confianza en sí mismos que presta la conciencia de la propia fuerza. Deseoso de saber si tan jóvenes eran ya dueños del veneno mortal con cuya eficacia parecian contar, hice con este motivo varios experimentos. Saqué del cuerpo de la madre á un pequeñue. lo, que segun mis cálculos debiera nacer cinco dias mas tarde, pasé una aguja repetidas veces por el sitio de la cabeza donde se encuentran las glándulas venenosas, $y$ heri con ella á un pico cruzado, pero sin que este sintiera efecto alguno; hice igual operacion en otro reptil y otro pájaro, obteniendo idéntico resultado. Encerré despues una pequeña rata en una caja que contenia diez y seis viboreznos nacidos en casa, los que por término medio solo contaban seis dias de vida. El raton no demostró al principio recelo alguno, pero mientras saltaba de un lado á otro empezó ś cundir un silbido de mal agüero entre los pequeños reptiles, que le miraban furiosos, y cada vez que se les acercaba le tiraban mordiscos. El roedor esquivaba como podia los ataques, pero por fin recibió dos mordeduras, penetrando algunas de las mas fuertes en el hocico y el pie izquierdo, y sucedió dos veces que uno de los viboreznos claró con tal furia sus dientes en el raton, que este le arrastró un buen trecho. Saqqué por último de la caja al pequeño mamifero, que cojeaba y se limpiaba á menudo el hocico y el pié herido; fué languideciendo, y murró al cabo de una hora. Introduje otro raton en una caja que encerraba veinticuatro viboreznos de igual edad que los anteriores, $y$ el resultado fué casi idéntico.

Otros observadores están conformes con el anterior; de un experimento hecho por Kiroch resulta que tambien los pelias recien nacidos pueden envenenar mortalmenie.

Petry nos ha hecho una descripcion notable sobre la re. produccion de los pelias. Este observador iuvo un individuo adulto, que un amigo suyo creyó haber muerto de un palo, pues le hirió de tal modo, que en muchas. horas despues el animal no se movio. Petry pudo reconocer por los ojos que el reptil vivia aun; púsole en su jaula de serpientes é hizo rodos los esfuerzos para volverle á la vida, humedeciéndole con agua fresca la parte therida del lomo. Al medio dia siguiente encontró el reptil un poco enroscado, en posicion natural, y la los ocho dias el pelias estaba otra vez tan alegre y deseoso de morder como si nada hubiese tenido. Trascur. rido un mes, la serpiente dió śluz en un solo dia diez hijuelos de los que cuatro estaban muertos, sucumbiendo los otros poco despues; 4 la noche siguiente, la hembra parió otro in. dividuo, que sé distinguio como todos sus congéneres por su carácter irascible; dejósele en la misma jaula con la madre, hasta que esta, llegacio el 6 de diciembre, murió de debilidad. Con gran asombro del observador halláronse el 12 de diciembre otros dos hijuelos bien desarrollados, aunque muertos, que la madre solo pudo dar śluz en los últimos dias frios, pues uno de los hijuelos se hallaba todavia cn una masa blanda y sangrienta. El pelias habia dado á luz por lo tanto, quince semanas despues del primer parto, tres lijuelos del todo desarrollados. Petry explica este hecho extraño, sin duda con razon, por la herida de la hembra y la posicion probable de los tres huevos, cuyn desarrollo se interrumpió quizás hasta la curacion completa de la herida.

CAUTIVIDAD.-Los cautivos justifican por completo lo dicho por Lenz de que la vibora no depone su ferocidad sino con la muerte, aunque pasando el tiempo, la modera algun tanto, mordiendo monos frecuentemente que al principio; sin embargo, jamás se deja domesticar en el verdadero sentido de la palabra, siendo de todo punto imposible conseguir que deje de tirar mordiscos á su guardian, lo que hace que su trato sea siempre peligroso. No es menos notable la resistencia que oprone á tomar alimento alguno en la jaula. CDiríase, escribe Lenz, que desde el momento en que pierde su libertad ha formado la firme resolucion de dejarse morir de hambre; pues casi siempre inmediatamente. u ho. ras y hasta dias despues, arroja la comida que ha tomado, por mas precauciones que se cmpleen al cogerla, y aunque solo se le apriete la extremidad de la cola. A veces arroja ya el conienido de su estómago cuando se la levanta por la punta de dicho apéndice, oiras en el saco ó caja en que se la encierra para trasportarla á casa, y muy frecuentemente despues de haber pasado algun tiempo tranquila en la vi. vienda que se le ha preparado. En cautividad he presentado á la víbora, además de ratones, pájaros, ranas, lagartos, etc., varios otros alimentos como insectos de toda especie, gu. sanos, huevos de hormiga, de pájaros, de lagartos, peque. 
nas serpientes de otras especies, etc., pero jamás conscguí excitar su apetito; tan solo devoraba á veces los huevos de hormiga, jero sin digerirlos por completo. Tambien probé de introducir á viva fuerza en el cuerpo de una vibora que no comia desde mucho tiempo pequeños ratones, cogiéndola con la mano izquierda por la nuca y empujando con la derecha al raton, por inedio de unas tenazas y despues de un palo en el esb́ago del reptil; sin embargo, perdi el ticmpo, pues al poco rato escupió la víbora el cembutiỏo. Lsta tenacidad en rehusar todo alimento es la regla general, que como todas tiene tambien sus excepciones: cuando se le prepara ó la vibora una córcel bastante cómoda, arreglán dole el suelo á imitacion de los terrenos pantanosos, se de cide á reces á tomar algun alimento. Asi lo cxperimentaron Erber y Effeldt y tambien yo. \$Habiéndome asegurado, dice el primero, varios entendidos erpętólogos que nuestra vibora alemana nunca devoraba alimento alguno en cautividad, descuidaba generalmente proveerla del mismo. Cun tudu, solić un dia un par de jórenes ratones en la jaula, y no fué poca mi sorpresa al inspeccionarla aigun tiempo despues, contemplar cómo el reptil devoraba cómodamente á uno de los roedores. Efieldt afirma tambien que entre las muchas que habia tenido cautivas encontró algunas que acabaron por aceptar las presas que se les presentaban, habiéndolas que hacian sus comidas con toda regularidad. Sin embargo, estas no son sino excepciones, pues por regla general las vi. boras cautivas se condenan a morir de hambre, por lo que. raras reces se consigue mantenerlas vivas for mas tiempo que unos nueve meses.

UTILIDADES Y PERJUICIOS، - Entre todas las serpientes de nuestro pais, la vibora pelias es la que mas contribuye $\{$ la destruccion de toda clase de animales dañinos, y sin embargo, nadie le agradece eștos servicios, procurando todos extinguir su raza en la parte que pueden. En verdad, en ningun otro animal de nuéstro pais está mas justificada esta persecucion tan constante y sin miramiento alguno. Actualniente es raro en Alcmania que un hombre pierda la vida por la acometida de un animal feroz; con todo, en los últi. mos años se conocen cincuenta casos de vidas humanas sa. crificadas por la mordedura de una vibora, y otros antos pueden haber sucumbido de igual muerte sin que de ello haya habido noticia oficial. Linck riene tal vez razon al supo. ner que en Alemania mueren anualmente dos hombres de los efectos ponzoñosos de la mordedura de la vibora, y que otros veinte son envenenados de igual modo, pero consiguiendo salvar la vida.

T'enemos una descripcion minuciosa sobre los efectos del veneno, tanto mas importante cuatato proviene de un médico que experimentó lus efectos en su propia persona. Un pelias adulto mordió à Heinrel, segun él mismo refiere, el $2 S$ de junio a la una de la tarde, infiriéndolè la herida junto a la uña del dedo pulgar de lá mano dercecha; el dia era caluroso; el reptil, corpulento é irritado, no habia mordido hacia tres dias; y al clavar los dientes pudo coger todo el dedo con sus mandibulas, introduciendo los dientes en toda su longitud. Las heridas estaban situadas de tal modo, que solo las pocas gotas de sangre que poco á poco llenaron el surco de la una, indicaron el sitio dañado, aunque el dolor fué agudo. El observador hizo algunos movimientos convulsivos cual si le hubiera peneirado una corriente clectrica, pues en el momento de clavarse los dientes experimento un dolor á lo largo del pulgar, dolor que llegó hasta el codo y el sobaco. Estreché ligeramente el pulgar, dice, por debajo de la herida, chupando la sangre de esta; pero no practiqué ninguna incision, ni tampoco cautericé la herida, porque no me daba cuidado la senal de los dientes del reptil; habia forma. do una opinion errónea de los efectos del veneno, y me parecieron innecesarios los remedios; pero desde el momento en que recibi el mordisco quedé como atolondrado, y a los diez minutos me sobrevinieron ligeros vértigos y un desma. yo el cual pasé sentado. Estos vértigos no cesaron hasta el mediodia del 30 de junio, y entonces, á eso de las dos de la tarde, me desmasé por segunda vez. La herida habia adqui. rido entre tanto un color gris azulado y en todo el pulgar tenia una inflamacion acompañada de un dolor agudo; des. de entonces los desmayos se repiticron con mas frecuencia y duraron mas tiempo. Desde las dos á las tres se hincha. ron toda la mano y el brazo hasta el hombro, de tal manera que apenas pude levantarlos; á las dos y media perdi de tal modo la voz que apenas me pudieron comprender, y solo con grandes esfuerzos consegui emitirla. Al mismo tienpo empezó tambien á hincharse el estómago entre agudos dolo. res; a las ires dadas arrojé por primera vez, y à poco se declarb la diarrea. Siguierun las convulsiones sin dolor, en una parte de los núsculos abdominales, en varios sitios del cuerpo, siendo continua la de la vejiga. Al fin, perdi las fucrzas; estuve casi siempre tendido en el suelo, sin ver apenas ni oir; experimenté una sed abrasadora y un continuo frio en todo el cuerpo, asi como en el brazo hinchado, en el cual, exactamente en la dircccion marcada por el primer dolor, se estancó la sangre. Solo senti entonces malestar en el es. tónago hinchado; la aspiracion era libre, y tampoco turc palpitaciones de corazon ni dolor de cabeza.

Las pcrsonas que me rodeaban dijéronme que in descom. posicion de mi rostro era tal que no fuć posible reconocer. me. Tambien me aseguraron que habia delirado \& menudo, aunque conservado todas mis facultades intelectuales excepto cuando me sobrevino el desmayo. Muchas veces quise ha. blar sin poder acabar la frase por debilidad. A las siete, es decir, seis horas despues del inordisco, cesaron los desmayos, las convulsiones gencrales, los vómitos y la diarrea y poco despues tambien el dolor de estómago; bebi algunos tragos de tintura de opio; pasć la noche sin dormir aunque tranqui. lo en la cama, y solo me nolestaron los dolores del cuerpo que iba hinchándose. Estas inflamaciones se sucedieron del modo siguiente: cuando $a$ las siete examiné mi brazo, asi es. te como los dedos y la mano habian adquirido doble tama. no del natural; la herida presentaba un color negro de sangre y de ella partia una serie de puntos rojos y rojizos que continuándose por la cara interior del carpo llegaba hasta el codo y el sobaco, el cual tambien estaba hinchado en toda su extension; en ninguna parte iuve las venas endurecidas ni aglomeracion en las glaindulas.

Durante la primera noche el brazo se hinchó aun mas, y de tal modo se estancó la sangre, que toda esta extremidad prescnió manchas rojas y azules, que asi como la hinchazon se habian extendido desde el sobaco, pasando por el pecho hasta cerca de las costillas, y al dia siguiente hasta las caderas. Los dolores de las partes hinchadas cuyo calor no dife. ria mucho del del resto del cuerpo, habian aumentado y solo cuando el enfermo sudaba sentia algun alivio; la hinchazon disminuyó despues de aplicarse una untura ordena. da por el médico, pero cuando el paciente trataba de levantarse experimentaba vértigos 6 un largo desmayo. El enfermo sentia necesidad de sudar y cuando lo conseguia mitigában. se considerablemente los dolores. Continuaba la dificultad para orinar; el pulso era débil; el apctito bueno, y el sueno muy agitado. El 30 de junio persistia la hinchazon y la estancacion de la sangre en las paredes abdominales, extendiéndose por la cadera hasta la mitad del muslo; en los dedos comenró á disminuir marcadamente la hinchazon. Despues de suciar mucho rato desapareció al medio dia el vértigo y por 
la tarde el enfermo pudo levantarse algunas horas. El brazo le dolia mucho aun; el pulso era débil, y existia de nuevo el desagradable sintoma del frio, mientras que disminuia la di. ficultad para orinar; el apetito era bueno y la sed se habia calmado. El I. ${ }^{\circ}$ de julio cedió la hinchazon de la cadera y de la pared abdominal, y al mismo tiempo desaparecieron los dolores de la vejiga. La débilidad sin embargo era aún considerable y por lo demas seguia la enfermedad su curso anterior. El 8 de julio la hinchazon habia desaparecido de todo el pecho, y por uluma vez se observaron las estanca. ciones de la sangre que de continuo se habian formado en los ires últimos dias. El sueño fué mas tranquilo á pesar de los agudos dolores en el brazo, y aunque se notaba todavia mucho la descomposición y patidez del fostro. En los ocho dias siguientes la hinchazon y las estancaciones de la sangre desaparecieron del todo, y solo se produjeron durante tres semanas ligeros dolores de vientrc.

Hoy 10 de agosto, seis scmanas despues de la mordedura, concluye el citado médico, obsétrase por la noche una ligera hinchazon en la mano derecha; la piel tiene un color sucio en todas las partes dañadas y es muy sensible á la pre. sion y al cambio de teinperatura No puedo echarme del lado derecho; el brazo está débil y duele a veces horas ente. ras. Estoy mucho mas faco que antes $y$ no he perdido aun del todo la impresion del frio; á menudo me siento debil durante muchos dias $\mathrm{g}$ el color de mi rostro continua cam. biado. Tengo la conviccion de que la mordecura me inte. resa una grande arteria, lo cual produce casi siempre la muerte, porque ningun remedio surte efecto.

Segun las experiuncias de Bollinger, en los envenenamientos por el mordisco del pelias comun qué producen la muerte, esta parece inminente algunas veces ea el espacio de dos 6 tres semanas. De seiscientos diez mordidos de que Bollinger tuvo noticia, murieron cincuenta $y$ nueve; de modo que la mortandad fué por lo tanto de un diez por ciento.

Un caso referido por Lenz, y que reproduzco aqui, demuestra cuál es la duracion de los clectos del mordisco de un pelias y cómo una pequeńa gota del virus destilado por el diente de la vibora puede emponzonar toda una larga vida.

Marta Isabel Yaeger de Walthershausen, que tenia sesenta años cuando Lenz escribió su tratado de las serpientes, habia sido mordida por una vibora cuando muchacha de diez y nueve, al atravesar descalza unos matorrales. En los pri. meros momentos no hizo gran caso de su herida, pero muy pronto empezó a hinchársele el pié, llegando mas tarde la hinchazon y el dolor hasta la parte superior del cuerpo, de modo que cayó al suelo sin filerzas para poder andar. Feliz. mente su madre estaba alli cerca y la lleró a casa, llamando al cirujano quien le ordenó varios remerios internos y externos. Fl estado de la enferma fué mejorando con el tiempo, pero hasta los cuarenta años tuvo siempre la pierria dariada con grandes dolores y presentando á veces manchas amarillas, otras azules y rojas; cmpleando en el curso de tantos anos los varios medicamenios caseros que le recomendaban los parientes y amigos. Por aquella época desapareció de re pente el mal de la pierna y aluyó á los ojos, perdiendo por úl timo, despues de sufrir mucho ticmpo, la vista, y permane ciendo durante dos años en completa ceguera. Pasados estos, empezaron los ojos á sanar, y recuperó la enferma la vista, pero el mal se extendió por todo el cuerpo y en los miembros; en este estado ha permanecido, perdiendo casi por completo el oido posteriormente. En su familia es, por decirlo asi, hereditaria la edad avanzada, de modo que está rodeada de parientes que recuerdan perfectamente todas las fases de la enfermedad. Es realmente extraordinario que una persona achacada de tan terrible mal pueda vivir tantos años, pero tambien es muy, triste que tenga que sobrellevar una vida tan horrorosa. Creo que todos los que oyen esta triste relacion opinarán conmigo que se deben adoptar medi. das muy enúrgicas para impedir desgracias como esta.

Ciertamente, quien llevado de un exagerado cariño hácia los animales pretende defender las serpientes, falta á los hom. bres. Es preferible mil veces que todas, lo mismo las inofensivas que las venenosas, sean exterminadas, à que perezca un solo hombre de resultas de la mordedura de una de ellas, $\delta$ que la vida de un solo sér humano se convierta en un mar. tirio perpetuo gracias a la inoculacion de tan terrible vene. no. Debemos, por lo tanto, toda proteccion a los enemigos naturales de las viboras, como el iltis ó reso, el erizo, el ser. pentario, etc, y constante persecucion á ellas y á toda su familia lodo maestro de escuela debiera enseñar á sus discipulos cómo, sin arriesgarse en lo mas minimo, puede des. truir animales tan perniciosos; todo padre estå obligado á explicar á sus hijos cómo un solo recio golpe aplicado con una vara al esuinazo de la vibora basta para matar este te. mible repuil. Conviene tambien recomendar a todos mucho cuidado al levantar la víbora herida, pues conserva todavia durante bastante tiempo despues de recibido el golpe mor. tal gran parte de su movilidad, y aunque se scpare la cabeza del cuerpo, los dientes venenosos no han perdido nada de su mortitera propiedad. La cabeza cortada de la serpiente muerde todavia con la misma ferocidad que cuando está unida al cuerpo, abriéndose y cerrándose largo rato despues, demostrando de este modo que el reducido yo poco desarrollado cerebro no pierde tampoco su actividad.

Es un aspecio horroroso, dice Linch, el de una de estas cabezas sanguinolentas, con la rabia y desesperacion chis. peando de sus ardientes ojos, separando violentamente las mancibulas, y levantando los temibles ganchos venenosos, que, con la misma furia de siempre, sc esfuerza por clavar en los dedos que tiene delante Tampoco pierde el veneno en manera alguna su eficacia despues de muerto el animal; pues, seco y reblandecido otra vez, tiene suficiente fucrza, como varios experimentos lo han demostrado, para inficionar la sangre de un mamifero de órden superior. Débese por lo tanto recomendar toda precaucion á los que por aficion ó necesidad se dedican al exterminio de las serpientes venenosas; aconsejando, por otra parte, à los que habitan locali. dades infestadas por viboras que les den caza de noche. Encendiendo grandes fogatas se atrae álos reptiles, y enton. ces, provistos los cazadores de largas botas que lleguen has. ta la rodilla $y$ de un buen garrote, pueden impunemente proceder á la destruccion de animales tan perniciosos.

Por lo que toca al tratamiento de las personas que tengan la desgracia de ser mordidas por una vibora, recomendamos. otra vez el uso, en grandes dósis, del espiritu de vino, en la forma que se tenga mas å mano, como àrac, conac, ron, aguardiente, etc, que numerosos experimentos han demostrado ser el aniidoto mas eficaz, y que cualquiera puede administrar al herido, pues en la mas reducida aldea siempre se encuentra aguardiente. Segun varios autores alemanes, en los distritos montañosos de la alta Baviera es muy conocido este remedio y empleado con el mejor Exito. Para tranquilidad de los que teman que el uso de los espirituosos pueda producir en estos casos las peores consecuencias de la em. briaguez, podemos asegurarles que la persona mordida por uno de estos reptiles no siente en manera alguna, aun despues de absorber copiosas cantidades de bebidas alcohólicas el menor sintoma de beodez. Creemos por demás repetir que conviene asimismo en los primeros momentos extraer la sangre de la herida, ensanchándola y cauterizándola del me. 
jor modo posible, $\delta$ \& lo menos, hasta que se obtenga la ayuda facultativa, ligar un objeto duro, como una piedra, por ejemplo, sobre la misma, tan fuertemente como pueda resistirlo el paciente.

\section{LAS VÍBORAS PROPIAMENTE DICHAS - VIPERA}

CARACTERES. - Las viboras propiamente dichas, segun la generaliỏad de los autores, se reducen á las demás especics curopeas de los viperidos, excepcion hecha del pelias berus que acabamos de describir. Su denominacion cientifica, vifera, parece ser una contraccion de ririfrara, 4a que pare viros, como la llamaban los romanos. Son de tan escasa importancia las diferencias entre los individuos de este género y los pelias, que se encuentra completamen. te justificado el proceder de Ian, quien no dando á aquellas valor alguno, reune ambos géneros en uno solo. En las vibo. ras, la parte anterior de la cabeza estí revestida de escamas de configuracion análoga á las del cuerpo, mientras que los pelias, como hemos visto, la tienen protegida por pequeñas placas, y asi como en estos aparecen las ventanas nasales de tamario muy reducido, aquellas las presentan bastante grandes y de forma algo distinta: á estas desigualdades se limitan los caractéres distintivos que separan los dos géneros, pues en lo demás, aseméjanse como individuos de una misma es. necie; examinando y comparando mas minuciosamente se encuentran, si, otras diferencias, pero tales, como reremos al describir las especies siguientes, que ro pueden en manera alguna calificarse de géneros.

\section{LA VÍBORA ÁSPID-VIPERA ASPIS}

CARACTEREs. - Ia vibora áspid llega casi al mismo tamaño del pelias comun, pero tiene estructura mas tecogida y la cabeza mas ancha. El distintivo mas seguro de ambas especies consiste, segun el exámen de Strauch, en las series de escamas que separan el ojo de los escudos del labio superior, y cuyo número en la víbora siempre es dedos, mientras que en el pelias se reduce á una; los demás caractéres no citados son los siguientes: las escamas de la vibora no están dispuestas nunca en mas de veintiuna series longitudinales, y su dorso no presenta, al menos tan á menudo como en $\mathrm{cl}$ pelias, una faja en zig.2ag, sino grandes manchas separa das, aunque dispuestas del mismo modo que las que unidas entre si forman la capa dorsal del pelias. La coloracion del fondo, sobre el nue se destaca el dibujo en tinta mas oscura, ofrece los mas varios matices, desde el pardo claro basta el rojo de cobre ó pardo negruzco, y, lo mismo que en el géne. ro anterior, suelen dominar en los machos los colores claros, mientras que las hembras, por lo general, ostentan los mas oscuros. Véase la descripcion que hace Schinz de algunos individuos vivos: $\$$ Presenta el dorso cuatro listas longitudina. les de manchas negras 6 pardo.negruzcas, de las cuales las que componen las dos lineas del centro son casi cuadradas y están cólocadas muy cerca unas de otras, pero sin llegar a formar una faja en zig-zag, si bien algunas casi se tocan y i reces se ven unidas sus extremidades por otra linea negra mas estrecha, que pasa por el certro mismo del dorso; las manchas laterales son mas pequcinas; las regiones abdomina. les, por lo general, negras, salpicadas de blanco, y tambiená menudo con manchas rojas de orin. I I longitud varia de ()$^{m}, 50$ \& $\left(1^{\circ}, 60\right.$; la cola ocupa igualmente la sexta ú octaya parie de esta dimension.

Debemos añadir que Linreo dió á la vibora el nombre de aspia (celuhicr aspiss) y que por lo tanto podemos designarla como tal si no nos fijamos en la historia antigua. Puedo añadir además que el nombre de ripera prester se emplea tanto al hablar del jelias como de la vibora. En la major parte de las obras de Erpetologia, la segunda figura con el nombre de vifiern Redif en honor de un sabio italiano a quien debemos excelentes cbservaciones sobre ese reptil y sobre los efecios de su mordedura.

DISTRIBUCION GEOGRÁlCA.- - Mientras que el pelias, dice Strauch, habita las regiones septentrionales de los continentes de Furopa y del Asia y solo en una parte relativancnte pequeña de su área de dispersion pertenece álos paises del Mediterránco, la vibora se encuentra exclusiva. mente en los últimos y solo traspasa sus limites en lirancia. Su área de dispersion se cxticnde poco mas ó menos desde los $9^{\circ}$ hasta los $24^{\circ}$ de longitud este del Ferrol y llega por el norte hasta los $49^{\circ}$ latitud, al paso que en el sur se aleja muy poco de los $37^{\circ}$ de latitud norte. l.a víbora vive en Pcrtugal y. 
España; está diseminada por una gran parte de Francia, y principalmente por las provincias orientales, mientras que escasea en las septentrionales; se la encuentra aun en los contornos de Mctz; abunda en todas las regiones montañosas de Suiza, sobre todo en el Jura en algunas partes de las cercanias de Waadt y del Valais; en Italia es la serpiente renenosa mas comun; excepto en la isla de Cerderia, donde no existen estos reptiles, habita toda la peninsula y las islas meridionales; escasea bastanic en Grecia; habita todavia en el norte de Africa, pero hasta ahora no se han hallado individuos en la parte septentrional de Argelia.

En Alemania habita solo, al menos por lo que hasta ahora se sabe, la Lorena, el Palatinado s el sur de Baviera. En Austria se propaga; segun parece, mas de lo que hasta ahora se supone. Gredler dice que en el Tirol meridional, en la parte de los Alpes, es el ofidio venenoso mas comun, vién. dosele en todos los sitios favorables; se le conoce además en Carintia, Istria y Dalmacia; segun Schinz no se le ve en las altas montañas de Suiza; pero Gredler vió uno cogido en la cordillera de liers á mas de tres mil metros sobre el nive! del mar, confirmándose la noticia de Wyder de que se le encuentra en todas las regiones montañosas de Suiza.

USOS, COSTUMBRES Y REGIMEŃ. - La vibora habita principalmente, segun Schinz, en las montañas de Jum, y por eso puede justificarse en cierto modó el nombre de ribora del. Jurc que algunos naturalistas le han dado. Ha. cia el invierno abandona, segun Wyder, las alturas y baja mas hacia la llanura y las viviendas humanas para pasar alli 12 estacion fria. Se la encuentra en sitios secos y pedregosos, con mas frecuencia á lo largo de las cercas y en la inınedia. cion de los muros y montones de piedra queen los bosques y espesuras; en la primavera queda casi siempre apareada, de modo que cuando se descubre un macho pronto se observa tambien la hembra. Gredler, apoyándose en el hecho de ha. ber cogido una pareja cuya guarida descubrió uno de los reptiles, puede afirmar del todo esta última noticia. El mis. mo naturalista observó a las nueve de la noche una vibora, circunstancia de que solo hago mencion porque creo importante citar todas las observaciones que prueban ó indican la vida nocturna de las viboras. En sus hábitos y género de vi da se parece por completo al pelias berus. «Son tardios y pesados, dice Schinz, los movimientos de este reptil asusta. dizo que procura siemprehuir, y que solo cuando esto no le es posible $y$ le tocan o pisan casualmente, hace frente $y$ muerde, clarando tambien sus ganchos en el palo ú otro objeto con que se pretende cogerlo.

Es probable que la vibora busque las mismas presas queel pelias, acometiendo con preferencia varias especies de pequeños roedores. Segun Wyder, se alimenta principalmente de topos, que mueren heridos, pero no ataca ningun reptil, pues su veneno solo tiene accion en los animales de sangre caliente. Tambien Settari pretende que el vensno de las viboras no perjudica a los gatos, y asegura haber hecho varias prucbas que segun él revelan la exactitud del aserto. Dudo de la reracidad de ambas noticias, porque, apoyándome en los resultados hasta ahora adquiridos, no puedo explicarme por qué el veneno de la vibora produciria distinto efecto que el del pelias. Mas cxacta es en todo caso otra noticia de Settari, quien dice: هLa víbora caza en las praderas con afan los ratones, y en dias calurosos permanece debajo de la yerba segada y casi seca, por lo cual los segadores reciben á menudo mordiscos en las manos s en los piés.

Wyder no sabe decir de qué viren las viboras pequeñas que aun no pueden tragar animales grandes; yo creo probable que los hijuelos se alimentan al principio de pequeños lagartos.
Fl apareamiento se verifica en abril, y segun pudo observar Wyder, el acto de la cópula suele durar algo mas de tres horas, siendo tan fuerte la union, que dificilmente se pueden separar macho y hembra. Cuatro meses despues pare esta de doce $\{$ quince pequeñuelos, completamente formados $y$ de 8 pulgadas de largo, los que desde el primer dia de su vida manifiestan ya su instinto perverso, mordiendo en cuantos objetos tienen á su alcance.

Ca UTIVIDAD.-En este estado muéstrase la víbora tan rebelde como el pelias, y aunque al cabo de algunos meses la perdido ya parte de su vivacidad, con todo, despues de medio año de cautiverio suele todavia tirar mordiscos $\{$ su guardian, $y$ dificilmente se consigue que tome alimento. Cruve, dice Wyder, algunas en mi poder, que durante diez y scis meses no comieron nada, si bien bebian á menudo. En el momento de ser cogida, tambien acostumbra la vibora á arrojar las presas que acaba de devorar. El citado naturalista cogió en cierta ocasion una vibora bastante gruesa, que, no hallando vasija mas á propósito en la posada, introdujo en una botella de cuello ancho; al dia siguiente no fué poca su sorpresa al ver dentro de la botella un topo de buen tamaño, costandole mas trabajo sacar el rocdor, que no le ha. bia causado la introduccion del reptil con la presa dentro del cuerpo.

Una vibora cautiva cncerrada por Gredler en una estrecha jaula no confirmó por ningun concepto las observacio. nes de Wyder, sino gue comió en seguida tres lagartos.

En la jaula, lo mismo que en el campo, suele vivir la vi. bora en paz con otras serpientes, y no parece tampoco ser temida por estas; pero la presencia de un raton $\delta$ de una rata le hace fomar al punto una actitud amenazadora. Un raton casero sucumbe á los cinco minutos despues de mor. dido, una rata de regular tamano tan solo á los veinte, y raras veces sin haberse vengado antes de su enemigo. id Du. rante un invierno, refiere Wsder, tuve en una caja de cristal cinco riboras de mediana corpulencia, á las que añadi mas tarde una rata bastante gruesa, pensando que muy pronto seria mordida y devorada por las serpientes; pero no sucedió asi, viviendo tan extraña sociedad en la mas perfecta armo. nia. Acostumbraba alimentar la rata con pan y otros comes. tibles; un viaje que me obligó ś ausentarme durante ocho dias, y por consiguiente â privar de mis cuidados al roedor, fué causa de qque se turbase la paz en la jaula. A mi regreso encontré al pequeño mamífero muy sano y alegre, pero de las cinco viboras solo quedan algunas vértebras.

VENENOSIDAD.-La vibora fue la serpiente renenosa en que se fijó Redi para hacer sus célebres experimentos.

El gran duque de Toscana Fernando II, muy amante de la verdad, auxilio con todas sus fuerzas á los hombres sábios en las averiguaciones respecto a la vibora. Hasta esta Época (siglo xvu) solo se conocian las noticias de los antiguos en las que se creia sin pensar en averiguar la verdad por obser. vaciones propias.

Algumos de los hombres científicos con quienes alternaba Redi, pretendian que los dientes contenian el veneno; otros decian que los dientes no eran de sl venenosos, pero que la ponzona estabi en el humor que destilaba el corte de los mismos, y que procedia de la vejiga biliar, pues, que la hicl de la vibora, hasta bebida, obraba como terrible tósigo; no pocos opinaban que el veneno lo producia la saliva, mientras que los demás se afermban \& la teoria antigua, de que la extremidad de la cola era el asiento de todo el mal. Empezaron los experimentos con la hiel, pues la mayor parte de los convocados eran partidarios de esta teoria, apoyándose en los asertos de Galeno, Plinio, Aricena, Rhases, Aly-abas, Albucaris, Guillermo de Plasencia, Cardenal de 
San Pancracio, Bertrucio Bononiense, Cesalpino, Baldo, Angelo Abacio, Cardano, Julio César Claudino y muchas otras lumbreras de la ciencia de curar. Este diluvio de nombres tan venerados, dice Redi, era verdaderamente capaz de intimidar al mas atrevido; pero Jacobo Sozzi, el cazador de viboras, que, de pié en un rincon, habia oido las sabias disertaciones, se adelantó sonriendo, cogí́ una hiel de víbo$\mathrm{ra}$, la echó en un vaso de agua, $\mathrm{y}$ habiéndosela bebido, se ofreció ś repetir la operacion una y otra rez. Esta prueba parecia que debia ser concluyente; sin embargo, aquellos señores desconfiaban todavía, sospechando que el hombre podia haber tomado de antemano un antidoto. Propinaron á varios animales hiel de vibora, pero sin resultado alguno: todos continuaron tan sanos como antes.

\& Por último, la derrota de los que creian en la venenosidad de la hiel fué completa, cuando hubieron introducido algunas gotas de la misma en las heridas hechas á distintos animales y vieron que cstos no manifestaban sintoma algu. no de envenenamiento.

El cazzdor puso igualmente pronto termino á la contienda respecto al humor que se encuentra en las fáuces de la vibora: cogió uno de estos reptiles de buen tamaño y que parecia muy furioso, lavóle bien la boca y dientes con vino y bebióse este despues muy satisfecho, haciendo lo mismo al dia siguiente con otras tres viboras. Tampoco sufricron accidente alguno varios animales, á los que hicicron igual preparacion; pero cuando se introdujo en las heridas hechas á varias gallinas y palomas el humor amarillento encontrado en los dientes de viboras vivas y muertas, todas estas aves perecieron. Habian, pues, descubierto por fin el verdadero sitio del veneno. A fin de desvirtuar de una ver para siempre los desvarios de los antiguos, Redi hizo numerosos experimentos: probó toda clase de plantas que se recomendaban como eficaces antidotos, y demostró que no tenian valor alguno; mató varias viboras, reduciendo su carne $y$ huesos á cenizas, y trató las sales obtenidas de las mismas para con. vencerse de que estas no poseian mas virtud que iguales materias procedentes de otros animales; durante quince dias introdujo saliva humana en las fáuces de varias viboras sin que estas padeciesen en lo mas minimo, á pesar de que era considerada como mortal para los animales venenosos por Aristóteles, Nicandeo, Galeno, Plinio, Pablo Aegineta, Serapion, Avicena, Lucrecio, y otros muchos célebres autores; destruyó, en una palabra, una tras otra, todas las aberracio. nes de los antiguos, que hasta entonces habian sido consideradas como verdades cientificas.

A fines del siglo xvin, Fontana continuó los experimenttos de Redi con tanto celo y habilidad, que aún hoy dia son muy considerados. El veneno de la vibora, dice el mismo, no es ácido: no enrojece el tornasol de Holanda, que solo tine ligeramente de amarillo con su propio color, ni altera e! del jarabe de violetas, que apenas se vuelve un poco amarillento, ś reces, si se le añade demasiado veneno. En contacto con los alcalinos, no bulle, y se mezcla con cllos muy lentamente; dentro del agua baja inmediamente al fondo. No arde; cuando fresco es un poco pegajoso y seco, amarillento, trasparente $y$ viscoso como pez; se conserva durante años en los dientes de la víbora muerta, sin perder su color; ni su trasparencia; puede reblandecerse en agua tibia, $y$ es to. davía mortifero.) De los numerosos experimentos que hizo este naturalista, deduce él nismo las siguientes conclusiones: En igualdad de circunstancias la vibora de mayor tamaño es la mas peligrosa. Iá efícacia del veneno aumenta con el furor del animal. Cuanto mas tiempo permanecen los dientes dentro de la herida, tanto mas activo es el efecto del veneno. Respecto $\&$ la accion del veneno, dice Fontana que se coagula la sangre del animal mordido; el suero se scpara de los glóbulos y se extiende por el tejido celular, destruyendo de este modo la circulacion y produciendo en su consecuencia la muerte. La sangre, dividida de este modo en una porcion coagulada y en otra acuosa, se corrompe fácilmente y acelera la putrefaccion de todo el cuerpo. Los batracios resisten mas tiempo la mordedura de la víbora que los animales de sangre caliente, porque pueden prescindir durante largo intervalo de la respiracion y de la circulacion de la sangre.

Para poder formarse una idea de la importancia de los experimentos hechos por este eminente erpetólogo, basta enumerar que empleó en ellos mas de tres mil víboras, consiguiendo que mordieran estas unos cuatro mil animales de distintas especies y clases; probó todos los antídotos de que turo noticia, no aisladamente en un solo animal, sino en docenas á la vez, llegando á convencerse de que en realidad no existia contraveneno, propiamente dicho, para la morde. dura de la vibora. En su opinion, no muere la persona mordida por una sola vibora, sino que se necesita la mordedura de cinco ó seis para matar á un hombre; sin embargo, des. graciadamente no es exacto este aserto, pues si bien pocos comparativamente, con todo, son bastantes los casos conocidos de personas fallecidas de resultas de la mordedura de una sola vibora.

\section{LA VÍBORA AMMODITES 6 CORNUDA- VIPERA AMMODYTES}

CARACTERES, - La tercera serpiente venenosa de Europa, la vibora cornuda, elevada al rango de género independiente (thimechis) is causa de tener una excrecencia cutánea cubierta de escamas, semejante á una verruga, difiere del pelias por la escamacion de la cabeza, en la que no se ven mas escudos que los superciliares. Su coloracion, tan variable como en todas las viboras, es, por lo general, ama. rillo pardusca; en algunos individuos mas $\delta$ menos rojiza, $y$ á veces de una tinta rosa verdaderamente espléndida. El dibujo consiste en una faja dentada, de color mas oscuro, que empieza en la nuca y corre por todo el tronco y cola, formada por una seric de manchas romboidales, que se unen unas a otras por sus ángulos mas salientes. A cada lado hay una linea de tinta mas oscura, que hace destacar mas vivamente del fondo la faja central (fig. 8I).

Los escudos abdominales son amarillentos, punteados de negro. Suele esta especie medir algunas pulgadas mas de longitud que la vibora comun; con todo, es bastante raro encontrar individuos que alcancen mas de dos piés.

DISTRIBUCION GEOGRÁfICA. - Lavibora cornuda habita la Carintia, el Tirol, Hungria, Istria, Dalmacia, Grecia, Italia, la Turquia, el norte de Africa y probablemente tambien el Asia Menor. Vive principalmente en las monta. ñas donde sube á considerables alturas.

Segun Gallenstein, es la serpiente venenosa mas comun en Carintia, abunda en Camiola E Istria; en el Tirol, segun Gredler, su área de dispersion se reduce ś las inmediaciones de Boren, donde no escasea; es comun en Hungría, Istria y Dalmacia. Effeldt la vió en Hungria desde Presburgo hácia el sur, abundando sobre todo en las inmediaciones de Meha. dia, en la frontera militar. Erber la encontró frecuentemente en Dalnacia, Erhard en los vinedos de las Cicladas, y Bory de San Vicente en Grecia. En Italia esta mucho mas diseminada de lo que por lo regular se supone, encontrandose del mismo modo en cl norte de esta península que en el sur de Sicilia; escasea mas en Francia, donde solo vive en el sur del pais; en España y Portugal, en cambio se en- 
cuentra en todas partes, hasta en las inmediaciones de los pueblos y ciudades, en las cuales penetra algunas veces. Así, por ejemplo, Machado dice que existe en Sevilla, y segun noticias de mi hermano, que mató una \& los piés de su hija, hállase en los jardines de Madrid y en el Escorial. Tambien se la ha visto en el mediodia, en los Pirineos, y se la ha encontrado en Argelia y Siria. Su área de dispersion se extiende por lo tanto desde los $9^{\prime \prime}$ hasta $\operatorname{los} 65^{\circ}$ longitud orien. tal del Ferrol y desde los $34^{\circ}$ hasta los $48^{\circ}$ latitud norte.

USOS, COSTUMBRES X REGIMEN:-La vibora cornuda suele vivir sola si bien en mayo todavia, segun Effeldt, cuando ya ha pasado la época del apareamiento se ve á menudo macho y hembra juntos; buscase escondrijos debajo de las piedras y en las cavidades de suelo, en las espesuras y hasta en les bosques lo misno que en los campos, pero con gran preferencia en los vinedos. En el Tirol, se presenta, segun Gredler, en marzo y permanece hasta muy entrado el otoño; en lás Cicladas y en el sur de España casi no se alcharga, sino que queda todo el ano en actividad.

Effeld no pủdo jamás observar sus costumbres y género de vida durante las horas del dia, pero si por la mañana temprano y despues de anochecido, sucediéndole á menudo que en los mismos sitios donde en vano la habia buscado de dia, la encontraba en gran cantidad cuando los recorria, provisto de una linterna, en las noches calurosas Este método de caza, dice el mismo, me fue indicado por un campesino húngaro, que me aseguró que, siendo tan dificil coger estos repriles de dia, no habia cosa mas sencilla despues de entrada la noche; pues encendiendo una hoguera, se acercaban á esta en tropel y podiase entonces hacer abundante caza. Puse en practica el consejo aquella misma noche, y el resultado confirmó plenamente la indicacion del campesino: mi cazador de serpientes y yo llegamos \& recoger veintiuna viboras.?

Segun Erber, nútrese esta serpiente de ratones, pájaros y lagartos, demostrando bastante astucia en la manera cómo sorprende a los pequeños alados, que hiere \& menudo mien. tras están cantando.

a El pajaro suele emprender el vuelo, chillando lastimosamente, pero cae mus pronto al suclo, y muere a los pocos minutos, siendo devorado poco despues por la viboras

Respecto á la reproduccion de esta especie no conocemos datos concretos, pero de las indicáciones de Effeldt y Erber puédese deducir que la época del apareamiento es la misma que la de otras viboras, y que los hijuelos nacen en agosto 6 setiembre. En este úlimo mes parió una hembra, que tenia Erber en cautividad, dos pequeñuelos, pero desgraciada. mente ya muertos y tal vez no desarrollados por completo, pues estaban todavia envueltos en las túnicas interiores de huevo.

CAUTIVIDAD. - Los primeros cautivos que recibio Efieldit de esta especie, le fueron enviados con la advertercia de que jamis tomaban alimento alguno una vez perdida su libertad; pero justamente los mismos individuos desmin. tieron este aserto, pues uno de ellos, apenas le echaron un raton se apoderó de él y lo devoró. Mas tarde hizo Eiffeldt igual observacion con otras viboras de la misma especie, al. gunas de las cuales se mostraron tan voraces, que disputaban las presas hasta \& los individuos de su propia familia, arrancíndoles de la boca los ratones ya medio engullidos, é imponiéndose con sus silbidos y furiosas sacudidas a los mas débiles, de modo que se atmaban y engordaban, mientras que estos ayunaban y enflaquecian visiblemente. Como los reptiles no mataban inmediatamente todos los ratones que Effeldt les proporcionaba, $y$ estos se entretenian en roer la caja, el guardian se decidió por echarlos muertos, siendo devorados tambien en este estado; las viboras se acostum. braron de tal modo á este nuevo pasto, que cuando se apoderaban de una de sus víctimas la engullian ávidamente sin cuidarse de si estaba ya muerta o todavia se movia. Un dia arrojo Effeldt á sus serpientes un raton, al que solo habia aturdido dándole un fuerte golpe en la cabeza; precipitóse al punto una víbora sobre la presa y se la tragó, pero entre tanto habia vuelto en si el roedor, y movíase y pataleaba dentro del cuerpo del oiro animal; este, que lo habia cogido por la parte trasera é introducidoselo en esta forma, hacia grandes esfuerzos para impedir que se abriese camino. Por fin, al cabo de algun ticmpo, turo que decidirse la serpiente por arrojar la presa, que se habia tragado á repelo. El raton, todavia vivo, apareció como una masa informe, todo cubierto de saliva; pataleó un poco y murió al cabo de algunos minu. tos; pero tambien la víbora dió señales de malestar y cesó ce vivir ál las tres horas, sin duda á causa de alguna lesion interior, producida por los violentos esfuerzos del roedor.

Segun las observaciones de Fffeldt, la vibora cornuda vive en buena armonia con otras serpientes, hasta con las no venenosas; es relativamente un animal pacifico que no se ocupa de los que le rodean, exceptuando naturalmente los ratones y pajjaros, siempre que no se vea molestado. Desde un prin. cipio se muestra menos rebelde que el pelias, y hasta con el tiempo es susceptible de cierto grado de domesticidad; de modo que se cuenta entre las pocas serpientes venenosas que proporcionan verdadera distraccion al aficionado, si bien no deja por eso de ser peligroso su roce, como lo demuestra el hecho que reñere Eirber.

\& En setiembre de $1 \$_{57}$, dice el citado naturalista, recibi de Dalmacia una pareja de víboras cornudas, y á principios de diciembre me enviaron otro individuo de la misma espe. cie. No se aletargaron en ningun invierno, aunque las tenia en un sitio bastante fresco, sino que devoraban con toda re. gularidad un raton cada semana. Los roedores no solian sobrevivir mas alla de unos cinco minutos despues de mor. didos. Dos veces pude observar que cuando recibia la mordedura en la cabeza, el raton caia instantáncamente muerto. Solo uno ó dos dias despues solia la vibora devorar su vic. tima, costándole no poco trabajo engullir el animal ya completamente rígido; pero siempre hacia esta operacion de noche: á lo menos jamás pude ver que estas serpientes comiesen de dia. Ia noche es su verdadero tiempo, mos. trándose entonces mucho mas activas y vivarachas. Beben muy á menudo, y no acostumbran manifestarse coléricas hácia el hombre, pero si con otros animales; asi, la presencia de un perro, por cjemplo, cicita sufuror, el que dan á cono. cer con violentos silbidos y levantando parte del cuerpo. Si se les amenaza no huyen, sino que se ponen en actitud de ataque, la que solo abandonan si la fuerza.

VENENOSIDAD. - Véase lo que dice Erber: en di cicmbre de 1857 me trajeron una rata de gran tamaño co. gida por una pata en la trampa; el roedor se mostraba bastante violento, esforzándose por recuperar su libertad. Sag̣ué de la jaula una de mis viboras cornudas y la coloqué en el suelo de mi habitacion, cerca de la rata: puisose inmediatamente en actitud amenazadora, y muy pronto hubo clavado sus ganchos venenosos en el mamifero. Volvía encerrar la serpiente, y puse al raton en libertad. En un principio pro. curó esconderse el pobre animal, pero al poco rato, por el contrario, parecia buscar la complaña del hombre. Bebió con avidez un poco de agua que le presenté. Pasados algunos ininutos, empezó ya á manifestar inquietud, crizándosele el pelo; encogióse despues en el suelo, y estirando el cuerpo una ó dos veces, acabó de vivir, cosa de un cuarto de hora despues de haber sido mordido. 
Respecto \& la accion del veneno en otros reptiles, he obtenido los siguientes resultados. En casi todas las serpientes de nuestro pais no causa éfecto alguno la mordedura de esta vibora; en los lagartos, por el contrario, la parálisis es casi instantánea, siguiéndose muy pronto la muerte. Los batra. cios tan solo enferman durante algunos dias, restableciéndose luego despues por completo. Las salamandras de agua, que despues de mordidas vuelven á su elemento, no presentan otro sintona que su mas frecuente aparicion á la superficie del liquicio para respirar aire, ó sea cada dos minutos aproximadamente, mientras que en su estado normal suelen permanecer ocho y diez minutos en el fondo; pero si se las coloca en la jerba, espiran al cabo de poco tiempo, sucediendo lo propio con las salamandras terricolas, que se cubren de espuma blanca poco antes de morir. Los cadáreres de estos animales se vuelven muy pronto rigidos.

Con referencia á los efectos que produce la mordedura de esta vibora en las personas, solo puedo citar un caso, en el que desgraciadamente fué mi mujer la victima. Hé aquí cómo ella misma lo refiere: Durante la ausencia de mi ma. rido, me encargué de dar de comer á sus reptiles y limpiarles la jaula. Estaba ocupada en renovar el agua de las vibo. ras ammodiics $y$ habia ya introducido la vasija por medio de unas largas tenazas, cuando llamaron a la puerta; en mi precinitacion por ir á abrirla, me olvidé de cerrar la jaula de las viboras. Cuando volvi me horroricé al ver que una de estas habia ya sacado la mitad del cuerpo fuera de la caja; el niedo me quitó toda reflexion, y sin pensar en las tenazas, coji al reptil con la mano y lo arrojé dentro de la jaula. Esto fué obra de un momento, pero cuando me disponia á cerrar aquella, la vibora saltó como movida por un resorte, y me mordió en el brazo izquierdo. Me asusté de tal modo ante la repentina acometida de la serpiente, que durante un buen rato estuve contemplando mi herida, sin saber qué liacerme.

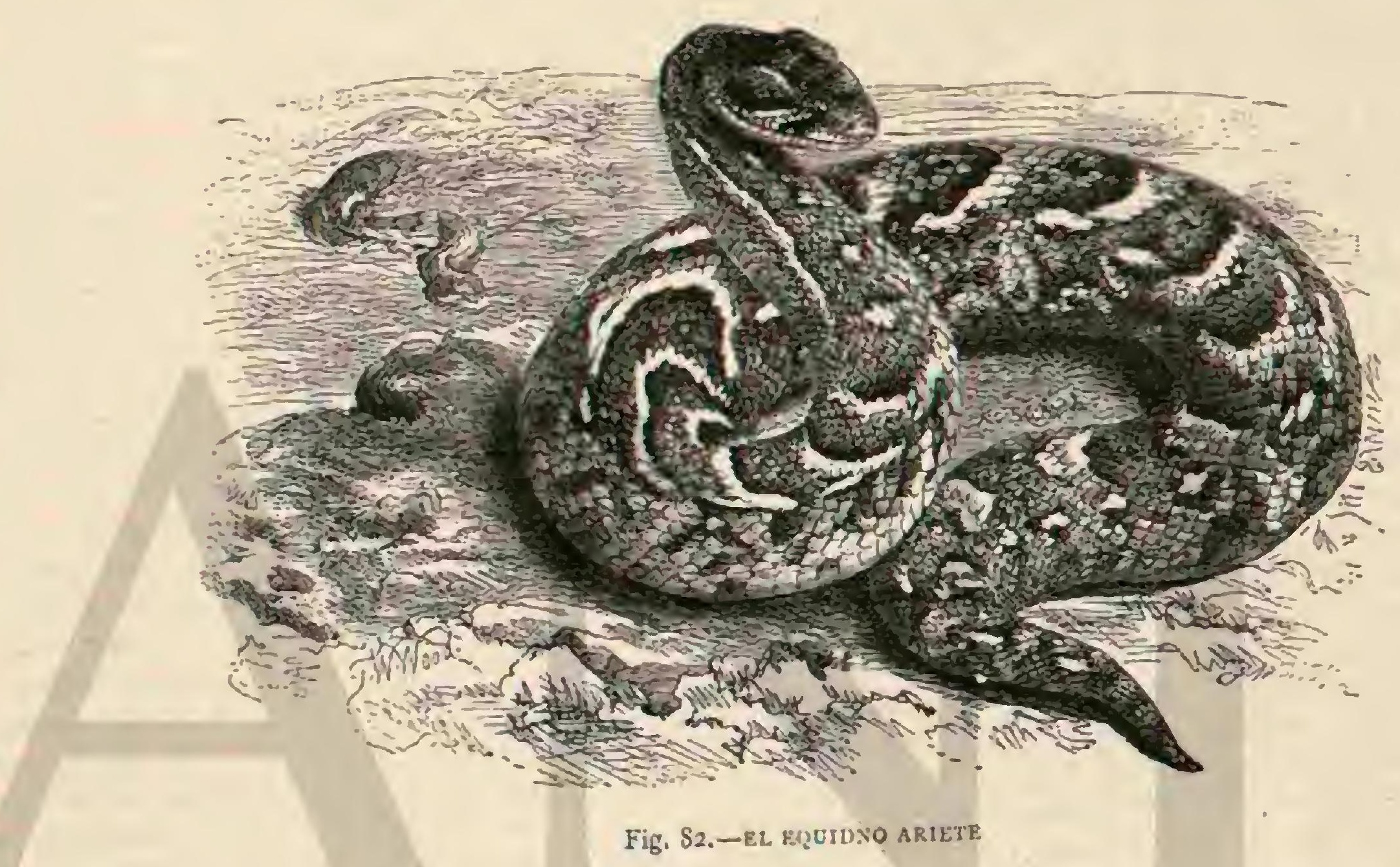

Poco á poco me fuí calmando, y como no sintiese dolor al. guno, ni la parte herida presentase otro aspecto que el de un ligero arañazo de alfiler, consideré que no podia ser peligrosa, y acabé por tranquilizarme por completo. Muy pronto, sin embargo, sentí desvanecimiento, viéndome obligada á sentarme; al propio tiempo la mordedura me causaba violentos dolores, y noté que se volvia verdosa la carne del rededor, mientras que el pequeño rasguño parecia disminuir de tamano en medio dé la mancha. Como el dolor iba au. mentando, reconocl que ja no me quedaba otro recurso que emplear uno de los remedios violentos que requieren las mordeduras venenosas, esto $\mathrm{es}$, la incision, la succion $\delta$ la cauterizacion. Cogi, pues, una plancha que justamente esta. ba en el hornillo, y armándome de valor la puse en contacto con Ia herida. La quemadura produjo una amnolla grande y oscura, $y$ otras mas pequenas y rojizas al rededor de aque. lla. La tension de la piel me fué ya insoportable al poco ra. io, y pinché, por lo mismo, la ampolla, destilando esta un humor negruzco, que á pesar del dolor exprimi cuanto me permitian mis fuerzas. Vendé mi herida, y pasados ocho dias tuve la satisfaccion de ver que estaba completamente sanada.

De las indicaciones de Erhard se desprende que no siem. pre son tan fáciles de curar las mordeduras de estas víboras.
Los vendimindores, dice el mismo, que suelen trabajar descalzos, y especialmente los niños, son á menudo victimas de la vibora cornuda; su ponzona es mucho nas activa que la de su congénere italiana, y sobre todo en la estacion calurosa se puede considerar como mortal su mordedura en los niños ó $\mathrm{en}$ las personas de débil constitucion. Afortunadamente este reptil es muy lento $y$ perczoso, y denuncia su presencia un fuerte olor de ajo.)

Como nunca ataca s solo muerde cuando casualmente se la pisa, podria considerárséla como inofensiva si no fueran tantos los descuidos. Ejemplo de ello es el caso de un pastor que mordicio hace aî̀os por una vibora cornuda, tuvo á con: secuencia de esto un hinchazon en la lengua y en el paladar que cada ano aumentó precisamente en los dias del mismo mes en que habia recibido el mordisco. Aunque conocia muy bien la causa de su sufrimiento, fué bastante impru. dente para dejarse morder otra vez, lo cual le puso casi álas puertas de la muerte.

\section{LOS DABOYAS-DABOIA}

CARACTERES.-Una vibora de las Indias orientales, otra africana y dos propias del sur de los paises del Mediterráneo se han comprendido últimamente en el grupo de 
los daboyas, el cual se ha elevado al rango de género; pero el único carácter que distingue $i$ las respectisas especies de todas las denás consiste, segun Strauch, en que la region superciliar está cubierta en su borde exterior siempre de un escudo sencillo ó dividido.

\section{EL DABOYA DE RUSELL-DABOIA RUSELIII}

CARACTERES. - Esta especie, el dabioyn y ticholonga de los ccilaneses, jessur y ulu-bora de los bengalases, el kurund: oyrian 6 mibo:a de sidrio, el katuri-pambu 6 serpiente de tijeras y kalukia rokula-joda de los indios, el cobrra-manil de los colonos portugueses, etc., es uno de los tipos mas gran. des y hermosos de șu familia, pues puede alcanzar una longitud de $2^{n}, 10$.

La cabeza es regularmente larga y muy alta, un poco mas ancha en su parte posterior $y$ solo algo separada del cuello; la punta del hocico truncada diagonalmente; los ojos grandes, separádos por los escudos del labio superior por tres 6 cuatro scries de escamas; las fosas nasales están situadas la. teralmente y circuidas de tres escudos; son ovales y mus grandes; el tronco no es muy delgado, pero la cola se estrecha mucho. Suele presentar su dorso, sobre fondo pardo amarillento, una serie de manchas romboidales, unidas entre si en la misma forma que las que componen la faja en zig. zag del pelias; estas manchas son comunmente pardas orilladas de negro $y$ recamadas de blanco en sus extremidades mas salientes. Corre á cada costado una fila de manchas, parecidas a las del centro, pero redondeadas y separadas unas de otras. Los cscudos abdominales son de un amarillo claro maculado de tinta mas oscura. Al igual de Jos demás individuos de la misma familia, el lic-polonga yaria en gran manera sta coloracion; los cingaleses distinguen numerosas variedades con los nombres de Nidi, Geru, Lay, Alu, Culu, Nil, Pulla, Polonga, etc.

DISTRIBUCION GEOGRÁFICA.-El área de dispersion de esta vibora se extiende por toda la India oriental desde Bombay hasta Bengala, incluso Ccilan, y tambien por la India mas allá del Ganges, Siam, Java y Sumatra. Su abundancia es verdaderamente extraordinaria en algunas comarcas, como por ejemplo en los contornos de Rangun y de Chingleput, en las montanas de Scherwaray 6 en el Himalaya, donde sube hasta la altura de I, 600 metros. Ten. nent asegura que el juez del distrito de Trincomalia se vió obligado ấ cambiar su residencia oficial á causa de esta serpiente.

USOS, COSTUMBRES Y REGMMEN. - LaS yerbas constituyen uno de los sitios favoritos del daboya porque le protegen completamente contra todos los enemigos; penetra sin embargo tambien en los pueblos; se le ha cogido varias veces en el Jardin de plantas de Calcuta. En los sitios des. cubiertos se oculta debajo de las piedras 6 en las grietas de las rocas; de dia reposa perezosamente como todas las demás viboras, dormitando dentro de sus escondrijos; parece enojarle mucho la menor molestia, pues silba de un modo terrible cuando un hombre $\delta$ animal se acerca, aunque solo muerde si se le ataca.

Tres perros de Daly, propietario de la India oriental, atacaron a una de esas viboras y fueron mordidos por ella antes de que su amo la pudiera matar; el primero murió en seguida, el segundo dos horas mas tarde y el tercero estuvo enfermo meses enteros, pero volvió à sanar. Shortt, á quịen Daly refirió el caso, obserwó mas tarde un daboja defendiéndose de un ataque. Una señora con su niño en el brazo volvia acompañada de un jóven buldog á la hora del crepúsculo, y estaba ya cerca de su casa, cuando de repente el perro se paró y empezó á ladrar furiosamente. Aunque la mujer no vió nada, sospechó y pidió auxilio al citado viajero, que se hallaba de huésped en la casa. Cuando Shortt llegó al sitio, vió á la vibora enroscada en medio del camino por el cual habia llegado la señora: tenia el cuello como por lo regular inclinado hácia atrás, la cabera erguida y los ojos chispean. tes; seguia con la vista todos los movimientos del perro, á cuyos ladridos contestó con algunos silbidos: asi esperaba el reptil, tan furioso como espantado, el momento de dar el mordisco mortal á su adversario. Shortt llamó al perro, y tan luego como este volvió la cabeza, el reptil desapareció con la rapidez del rayo en las altas yerbas. Al dia siguiente se le mató en el mismo jardin.

Aunque en la India muy pocas de las desgracias causadas por mordiscos de serpientes se atribuyen $\{$ esta especie, los indios la temen mucho mas que á la serpiente de anteojos, seguramente a causa de su vida nocturna, que la hace aparecer mas astuta de lo que en realidad es; sin embargo, no hay duda que á ella se deben atribuir la mayor parte de las desgracias que ocurren en Ceilan debidas á la mordedu. ra de serpientes, pues como casi todas las venenosas, el dir. boya sucle introducirse en las habitaciones del hombre, y muy. á menudo se le encuentra alli durmiendo. Un amigo de Ten. nent, al abrir una caja para sácar un objeto de la misma, la vió ocupada por un lićpoloriga, que cómodamente enroscado parecia descansar. Pretenden los cingaleses que esta serpiente y la de cascabel son enemigos declarados, siendo el dabo. ya generalmente, el agrésor, dando lugar csta creencia. tal ve?. errónea, al dicho popular: Se odian como saya y ficpolonga.»

En Ceilan la tradicion popular explica la malicia del daboya por una historia graciosa. Cierto dia, hallíndose un niño jugando en ausencia de su madre junto á un charco de ber y el inocente niño intentó ahuyentarla con la mano; la cobra bebió y se fué sin molestar al niño, pero antes de llegar $a$ su guarida, encontró un tic-polonga que la preguntó dónde habia bebidn. La cobra, conociendo bien la perversidá de la otra serpiente, y temiendo que esta mordiese al inocente niño que ella habia respetado, rehusó noticiárselo, mas por fin se lo dijo, á condicion de que el tic-polonga no tocara al niño. Ia serpiente lo prometió, mas apenas hubo Jlegado al agua se precipitó sobre el sér indefenso y le hirio

$\mathrm{El}$ alimento ordinario del dabosa consiste en pequeños vertebrados, ratones, ratas, pájaros, ranas ; sapos. Shortt encontró en el estómago de un individuo examinado por él una rana, en el de otro una rata, y en el de un tercero un enorme sapo. El cazador de serpientes Fayrer pretende que tambien entra en el agua; mas parece que solo persigue su presa en tierra firme $\delta$ en los árboles.

Russell y Fayrer han hecho muchas pruebas para estudiar los efectos del reneno, resultando de ellas que el daboya, provisto casi siempre de terribles ganchos venenosos de doble tamaño, no es inferior á ninguna otra serpiente veneno. sa. Una gallina sacrificada por Russell y mordida por el tic. polonga en un ala, sufrió al punto convulsiones, y murió á los treinta y seis segundos. Un perro grande que inmediata. mente despues recibió un mordisco del mismo reptil, ofreció á los cinco minutos las consecuencias del envenenamiento; encogió la extremidad mordida, $y$ poco despues no pudo ya moverla; echóse en el suelo, aulló de un modo lastimero, lamió la herida, hizo vanos esfuerzos para levantarse, empezó de nuevo á ladrar, respiró con dificultad, oprimió las man. dibulas convulsivamente y murió veintiseis minutos despues. Un caballo mordido en la nariz, sufrió dos dias de un modo terrible, mejoró al dia tercero y murió á los cinco. 
Las gallinas que Fayrer empleó en sus experimentos murieron á los treinta y cinco segundos, $y$ algunas a los pocos minutos; varios perros resisticron siete minutos, y otros algunas horas; los gatos sucumbieron $\$$ tos y los caballos á las once horas. La sangre de las víctimas era siempre líquida. Los hombres débiles ó mordidos profundamente no se salvan casi nunca; los heridos de menos gravedad alguna vez.

Muy extraña considera Shortt la gran debilidad de esta serpiente $\tan$ grande y temible. Un ligero golpe la mata casi infaliblemente y tambien muere cuando se le pasa un lazo por el cuello para llevársela ó levantarla tan solo del suelo. En cambio puede ayunar mucho tiempo sin disminucion visible de su fuerza y venenosidad; un individuo cautivo de Fagrer rechazó todo alimento y bebida y vivió á pesar de eso todo un año, mostrándose furioso é inclinado á morder hasta su muerte; sucumbió de repente en la escuela de artes donde la iban á copiar.

\section{LOS EQUIDNOS-ECHIDNA}

CARACTERES. - Wagler considera al equidno ariete como tipo de los equidnos, y Gray de los clotos (clotho), y ambos conceden á los citados grupos el rango de géneros. El equidno ariete 6 la viblora hinchada, segun la llaman los alemanes, $y$ las otras especies designadas por algunos natu. ralistas como congenéricas, se distinguen sin embargo solo por caractéres poco importantes, de modo quue nosotros tan solo podemos concederles el rango de sub-género. Elijo para caracterizar al grupo la ya citada víbora.

\section{EL EQUIDNO ARIETE-ECHIDNA ARIETANS}

CARACTERES. - Esta vibora, si bien es de un tamaño bastante considerable, no alcanza sin embargo la medida de la especie anterior $y$ de otras congéneres. Yo mismo he cuidado el mayor individuo que ha llegado á una coleccion, y que despues de su muerte media $\mathrm{I}^{10}, 57$. Baker asegura haber muerto un individuo mas grande, pues tenia $\mathrm{I}^{7}, 63$; este es sin duda el limite extremo del tamaño á que puede llegar la especie. Es la única vibora cuyas fosas nasales, relativamente pequeñas, estån situadas en la parte superior del hocico por detrảs de la punta del mismo y dirigidas hácia arriba ; distin. guese de sus congéneres mas afines por tener los escudos do la parte superior de la nariz sencillamente aquillados, y de los dahoyas por tener cubierta la region de las cejas de pequenos escuditos erectiles en forma de cuernos. Con justa razon se la designa como la mas fea de todas las serpientes, pero esto se refiere solo á la forma y no á la coloracion.

«El que ha calificado, dice Guenther, á las viboras de sapos entre las serpientes, ha hecho muy bien esta comparacion refiriéndose à la vibora hinchada.) $\mathrm{Y}$ en efecto, puede com. pararse muy bien con un sapo de ojos desmesuradamente grandes, de cabeza aplanada y ancha y de cuerpo disforme $\$$ grueso. La cabera, casi triangular, 6 mejor dicho irregu. larmente cuadrangular, redondeada en la punta del hocico, séparase marcadamente del cuello, pero este no es delgado sino grueso; el tronco, que desde el cuello aumenta rápida. mente de tamaño, no guarda proporcion alguna en su grueso y anchura, porque su corte trasversal presenta un triángulo oblicuo redondeado en los ángulos, cuya base es mas an. cha; la cola, en fin, en la que el tronco se continúa sin separacion marcada, puede compararse con un cono obtuso aplanado en la parte inferior. La cabeza y el tronco están cubiertos de escamas aquilladas y sobrepuestas de formas parecidas, pero de tamaño diferente, dispuestas en el tronco en $3^{\mathrm{t}}$ a 33 series longitudinales; y entre los ojos y los escudos del labio superior en tres 6 cuatro filas. La coloracion y los matices varian hasta cierto grado, pero no de un modo muy particular. Poco despues de la muda, el color predo. minante de todo el cuerpo es un amarillo de arena vivo y agradable, que hasta la próxima muda se oscurece mas ó menos, convirtiéndose en un pardo gris sucio; uma faja ne. gruzca $\delta$ de un pardo oscuro se corre 2 través de la parte anterior del hocico $y$ de los ojos, tocándose inmediatamente con un dibujo en forma de lira que casi llega de un ojo al otro y que desde aqui se dirige por la region de las sienes $y$ volviéndose hácia abajo alcanza á la extremidad de la boca, encerrando en sus dos lados un espacio de color igualmente oscuro. Del cuello parten tres series de dibujos; la del centro tiene dirigidas las puntas hácia atrás, mientras que en las series laterales los ángulos se abren hácia abajo. En medio de ellas se observan fajas y manchas de formas mas variadas. Encuéntranse, sin embargo, las coloracioncs mas diferentes, pero la variedad de las mismas no tiene importancia, $y$ aunque puede decirse que apenas dos de estas víboras se parecen por el color y los matices, debemos aña. dir que el tipo, tanto de estas como de aquel, se conserva esencialmente el mismo en todos los individuos (fig. $\mathrm{S} 2$ ).

DISTRIBUCION GEOGRÁFICA. - Estaserpiente habi. ta toda el Africa, desde los $19^{\circ}$ de latitud norte, escascando sin embargo al mediodia de este continente. Es comun en la costa occidental, no falta en ninguna parte del sudeste y se extiende sin duda por todo el interior.

USOS, COSTUMBRES Y REGIMEN. - Se puede decir que el equidno ariete es la mas temible de las serpientes venenosas de Africa. Sobrepuja en malignidad á la de anteojos, y causa tantas mas desgracias cuanto que permanece de dia en un mismo puesto, sin hacer el menor movimien. to, acometiendo de improviso al hombre que pasa á su al. cance, $y$ siendo su mordedura generalmente mortal. No hay duda que es mas peligrosa para el ganado que está pastando, que para el hombre, á lo menos para el europeo, que viaja siempre en coche ó á caballo. Cuando está furiosa acos. tumbra á inflarse, $y$ ensancha de tal modo el cuello, que ad. quiere este cerca de un pié de circunferencia; lo que dió motivo a Burchell para apellidarla vifpera inflafa; levanta al propio tiempo la cabeza unas doce pulgadas sobre el suelo, y sigue con ojos fulgurantes todos los movimientos del adversario que se le acerca, aguardando el momento oportuno para acometer. Rics asegura que no solo ensancha la cabeza, como suelen hacerlo otras serpientes, sino que cambia de color, volviéndose roja y morada.

Esta noticia, sin embargo, es del todo ctrónea, segun he reconocido de un modo suficiente en mis observaciones he. chas en individuos cautivos.

Poco sabemos sobre la vida en libertad de la víbora hinchada. Frytsch fué el primero que me dió una descripcion de esta serpiente. "En el sur de Africa, me escribe el distinguido viajero, el equidno ariete escasea en el Cabo; pero abunda en las provincias orientales y es mas frecuente hácia el interior. Distinguese por su pereza; se mueve con suma len. titud, $y$ solo cuando quiere morder se lanza con la rapidez del rayo sobre su presa, girando siempre sobre si mismo. De dia permanece oculto en las espesuras 6 en las altas yerbas, pero de noche sale y llega entonces á la inmediacion de las viviendas, donde a menudo causn desgracias. Una mujer del Transvaal que pisó al salir de su casa en la oscuridad á uno de estos reptiles, fué mordida y murió al dia siguiente. Mas peligrosa aun es la serpiente para el ganado menor $\delta$ para los perros de caza contra los cuales se resiste con valor. Un caballero de Bloemfontein perdió así dos de sus perros, de 
los cuales el uno murió á los diez minutos y el otro algunas horas despues.

\&Un observador muy fidedigno se paseaba un dia, segun él mismo refiere, por el bosque, y vió con asombro que un gran raton silvestre quedó parado á poca distancia de él. Al buscar la causa vió á los pocos pasos un gran equidno ariete que tenia fija su vista en el raton. $\mathrm{Al}$ poco rato precipitóse sobre su presa, la cogió y desapareció con ella en la espesura antes de que el sorprendido observador pudiera ha. cer uso de su palo. Parcce que la serpiente habia visto muy bien á su enemigo, pero que no habia querido dejar escapar su presa, por lo cual se la llevó consigo en vez de morderla y de esperar su muerte despues del mordisco.

Tal agilidad en este reptil es una excepcion: 10 mismo estuve sentado una ver al lado de una de estas viboras me: dio adulta, enroscada en las altas yerbas y que durante me. dia hora no se movió del sitio. Cuando para entrar en la somera avancé un puco, la toqué casi con el codo y solo en. tonces ví el reptil. Me levanté con precaucion para apcderarme de mi baston ; ni aun entonces se movió. Un golpe aplicado con fuerza la mató al instante.

Tambien las otras noticias, por lo demás muy escasas, están conformes con esta descripcion. Anderson reficre que su buey de montar fué inordido una vez por esta serpiente, que echada en medio del canino no se movió á pesar de que él buey casi la pisó. Otra vez, la mujer de uno de los criados del viajero encontró uno de estos asquerosos animales en los repliegues del delantal.

En cuanto al alimento s probablemente tambien respecto á la propagacion, esta vibora no difiere mucho de otras serpientes; tambien su presa consiste en animales pequeños de todas clases, pero prefiere generalmente los ratones, ratas, ardillas y otros roedores; tambien coge alguna que otra avc, cuando imprudentemente se acerca á ella. No creo que coma otras serpientes $\delta$ reptiles en general, pues su conducta en la jaula no confirma esta opinion.

Dícese que los cazadores indigenas persiguen esta vibora para proporcionarse el reneno con que emponzonan sus fle. chas. Dan prucbas estos hombres de mucho valor y sagacidad en la manera de apoderarse de la serpiente, á la que se acercan cautclosamente, ponjéndole de improviso el pié sobre la nuca, y separando por medio de un corte rápido y seguro, la cabeza del cuerpo. Dice tambien Wood, aunque nos resistimos á creerlo, que los hotentotes acostumbran á matar esta vibora con jugo de tabaco.

Drayson, que asegura q̨ue no hay espectáculo mas horro. roso que el que ofrece el equidno ariete cuando está furioso, refiere lo siguiente: Pude ver un dia una hembra de esta especie poseida de la mas viva cólera Algunos cafres la habian descubierto y obligádola à abandonar con sus pequenuelos el escondrijo que ocupaba; el reptil parecia decidido á defenderse resueltamente. Llegué en el momento en que los hombres discutian el modo cómo destruir sin peligro para ellos la madre $y$ toda su prole: dispuse inmediatamente el ataque, mandando recoger gran cantidad de piedras, $y$ con estas dimos principio á la batalla. A los pocos minutos yacian en el suelo los cadáveres de nuestros enemigos, que echamos á una hoguera para consumirlos por completo, a fin de evitar que algun hombre descalzo pisase por casualidad una de las cabezas y se hiriese con los ganchos vene. nosos.

Drayson hace notar que á pesar de ser el Africa meridional un pais infestado de serpientes venenosas, raras veces se oge referir una desgracia causada por las mismas. A nuestro modo de ver, esto consiste tan solo en que estos temibles animales son nocturnos, y el hembre viaja poco de noche en aquellos paises, y cuando acampa al aire libre, encierra el campamento en un circulo de hogueras, que si bien atraen los reptiles, con todo, protegen tambien el interior de aqquel, pues las serpientes retroceden tan pronto cono sienten demasiado vivo el ardor de las llamas.

CAUTIVIDAD.-Entre las viboras que hasta ahora se han tenido cautivas, el equidno ariete es una de las especies que con mas facilidad aceptan el alimento, probablemente porque no es dificil satisfacer sus exigencias. Una jaula bien caldeada, cuyo suelo esté cubierto de arena y piedras pequcñas, es para ese reptil una vivienda del todo cómoda, y cuando entonces se le ofrece una presa, raras veces vacila mu. cho tiempo en aceptarla. Por esta razon se la ve regular. mente en todos los jardines zoológicos donde hayserpientes. Parece que no es difícil cazarla, ni tampoco su trasporte, pues pueden passar meses entcros sin comer. Yo mismo he cuidado varios años dos equidnos arietes, habiendolos observado muy minuciosamente en este ticmpo. Ambos ani. males habian sido bastante tiempo propiedad de Effeldt, el cual los habia acostumbrado a la cautividad aunque sin do. mesticarlos. TTan luego como álguien se acercaba á su jaula demostraban con sus bufidos la ciega furia propia de las ser. pientes verienosas; pero al menos ya no mordian como lo habian hecho antes. Es imposible dar idea de la pereza que demuestran de dia; permanecen desde la mañana hasta la no. che en el mismo sitio, al parecer dormidos, y no es fácil hacerles abandonar su sitio; si esto se intenta, encolerizanse mucho.

Guenther refiere que una vez examinó las serpientes llega. das hacia poco á bordo de un buque en cuya ocasion fuć preciso ábrir las cajas. Una de estas, que contenia áspides, se hubo de cerrar al punto, porque las serpientes intentaron al instante morder; la otra caja, empero, donde habia de 20 i 30 equidnos, pudo quedar abierta, pues las serpientes no hicieron ademan de escaparse ni de morder, á pesar de que Guenther las sacó con el baston. Puedo afirmar estas obseryaciones, porque tampoco mis equidnos arietes eran inclinados á morder. Solo se ponian furiosos, aunq̨ue sin moverse de su puesto, cuando se les inquietaba. Son las mas perezosas de todas las serpientes que conorco y solo se mueven de dia cuando se les obliga á ello. De noche se pasean lenta. mente por su jaula con cierta perseverancia, que en mis cautivos pude reconocer por el hecho de haber aplanado la arena recien puesta. De dia no hacen caso ni de las serpientes de la jaula inmediata ni de los espectadores. Mientras que una serpiente de cascabel, aln despues de muchos ainos de cautividad, empieza á mover su cola cuando un hombre entra en el espacio en el que está su jaula, el equidno solo manifiesta las primeras señales de su cólera cuando repetidas veces se le ha irritado. Su pereza es mas visible cuando de dia se le ofrece un animal destinado a su alimento. Solo nuerde y mata regularmente su presa cuando tiene hambre; si el dia anterior ha comido, deja retozar á los conejos sin hacer uso de sus terribles armas. $A$ veces pasan dos $\delta$ tres semanas sin que un equidno se resuelva á comer; $y$ cuando al fin mata á un pequeño mamífero al que habia tolcrado en la jaula, no lo hace sino porque le ha irritado. Solo cuan. do tiene mucha hambre muerde en séguida a su victima y empieza à devorarla.

A causa de esta pereza y templanza el acto de dar alimentoá un equidno es un espectáculo en extremo interesante. El conejo que se le ofrece no tiene ninguna idea del peligro que le amenaza, pues su titulado instinto le abandona del todo; con curiosidad se acerca á la serpiente, porque nunca ha visto el reptil, y por eso puede explicarse fácilmente su deseo de conocerle; olfatea á su cnemigo sin saber que lo es, 
y entre tanto la serpiente levanta la cabeza triangular, y con el cuello isclinado hácia atrás toma posicion de ataque. El conejo, sin sospechar aun nada, olfatea, se hace mas atrevido y acérczic a la cabeza de la serpiente. El equidno saca la lengua, socando el mostacho del conejo, que, imágen de la inocencia, permanece parado ante el terrible reptil. La serpicnte se excita mas y mas; respira ruidosamente, de modo que el tronco se levanta y baja, se ensancha y estrecha alternativmente; bufa cual si quisiera advertir al cone. jo, pero tambien esta amenaza es inuitil, porque el roedor no hace caso de ella. La serpiente vuelve a bajar la cabeza para tomar utra posicion; sus costillas se oprimen contra el suelo y lentamente avanza; el conejo se para, salta de lado, fija sus ojos en el objeto para él desconocido; sus orejas vuelven á enderezarse, olfatea, dirige sus mostachos hácia todos lados y se tranquiliza por fin de nuevo. La serpiente, inmóvil hasta enionces, se accrca á la curiosa victima; de nuevo le. vanta la cabeza para el ataque, mueve la lengua, amenaza, y otra vez se acaba el encuentro como antes. El roedor ha en. contrado agua y ha bebido; se cstira despues en la ardiente arena, $y$ come tambien un poco de una zanahoria que encuentra. Parece que le gusta la jaula; se vuelve impertinen. te, salta por encima de la serpiente y por fin sobre su lomo. El reptil, irritado por tanta audacia, abalánzase furiosamente y bufa con todos sus esfuerzos; cl conejo queda inmóvil o:ra vez, husmea de continuo, no se convence aun del peligro y vuelve á examinar á su adrersario. Esto se prolonga á veces horas enteras, $y$ cuanto mas dura tanto mas atrevido se hace el conejo y tanto mas se excita la serpiente, la cual recuerda por fin que tiene hambre y se dirige decididamente sobre su victima. El conejo la espera como antes y hasta le sale al encuentro; el reptil levanta la cabeza y á poco rato se precipita sobre su victima. Al avanzar abre la boca, y sus ganchos venenosos, de dos centímetros de largo, penetran profunda.

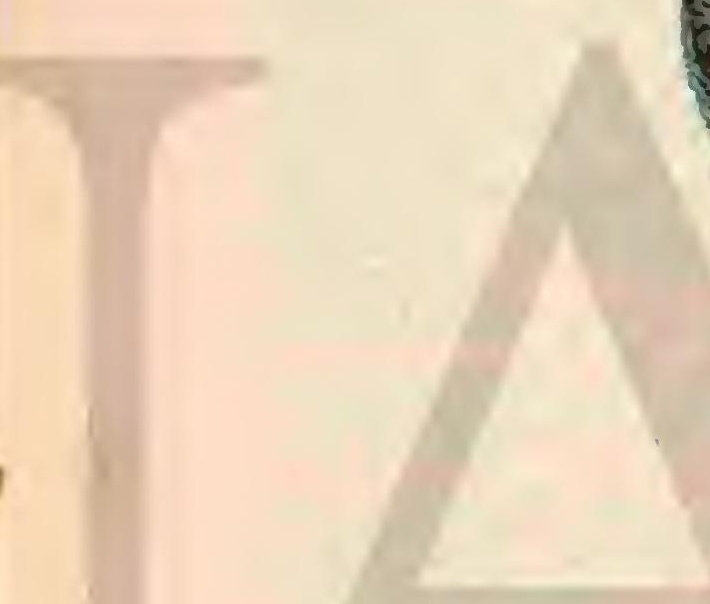

mente en el cuerpo de la presa. Con la misma rapidez con que avanzó sobre el conejo retira la cabeza para apoyarla en el suclo, y fjando sus miradas en la victima, espera la muerte de esta. Todo su cuerpo queda inmóvil, y solo la punta de. la cola se mueve.

Despues de un solo grito que ha lanzado el conejo, cste da algunos salios y se para; sus orejas se inclinan, los párpados se cierran; despues de mover una ó dos veces la ca. beza picrde cl conocimiento; se inclina á un lado, y queda quieto; $\{$ los quince segundos, 0 cuando mas veinte, agitase convulsivamente por última vez y muere. La gota infernal ha hecho su é́cto.

\section{LOS CERASTES-CERASTES}

CARACTERES، - Despues del áspid, ninguna otra serpiente venenosa ocupó mas á los antiguos que el cerastes egipcio, una de las especies mas comunes y mas conocidas de la familia de los viperidos. Sus pequeñas fosas nasales en forma de medialuna, situadas en la punta del hocico; las escamas dispuestas en los costados en series diagonales y las quillas cortas que no llegan a la punta de las cscamas, han inducido à Gray a formas con estos ofidios un género dependiente, al que concedemos un rango de subgénero.

\section{EL CERASTES DE EGIPTO-CAERASTES EGIPTIACUS}

CARACTÉRES, - El cerastes ó la i̊ibora cornudia alcanTOMO Y ra una longitud de $6^{m}, 650$ cuando mas $0^{\circ}, 70 y$ se la reconoce á primera vista como hija del desierto; pues el color de la arena se refleja, por decirlo asi, en sus escamas.

Presenta sobre fondo gris ammaillento, manchas trasrersales de color oscuro y forma irregular; vése àcbajo de cada ojo un rasgo pardo oscuro, y en la parte superior de la cabeza una raya pardo claro amarillento, que se divide hácia los lados del cuello y acaba por unirse con otra que vicne desde la barba. Las escamas que rodean la boca son amarillo claras, y de una tinta parecida los escudos abdominales. En el centro del lomo se corren las series de escamas, de las que se cuentan de veintinucve á treinta, dos de ellas rectas.

La imágen del cerastes se representa á menudo en la es. critura sagrada de los antiguos egipcios, porque su nombre prinuitivo fi se empleó mas tarde para cxpresar la consonan. te f. Parece que este repril tuvo tambien cierta importancia entre los antiguos. Herodoto hace mencion de él, diciendo que vive en los contornos de Tebas; que tiene dos cuernos en la cabeza y no es peligroso para el hombre; lambien le designa como sagrado, sin decir porque; los otros autores antiguos solo le describen cientificamente.

DISTRIBUCION GEOGRAFICA.-SL área de dis. persion se extiende por todo el noroeste del Africa y la Aravia Felir, extendiéndose sin embargo mas allá de la zona de los desicrtos, porque se ie encuentra tambien en las estepas del Sudan oriental y en las del Kordofan. Segun mis propias experiencias, aquí abunda mucho mas de lo que podria descar el viajero.

USOS, COSTUMBRES Y REGIMEN. - El Africa, 
dice Gessner, estállena de estas serpientes, y en algunos de. siertos apenas se ven otros cornudos. Dícese que esos reptiles se encontraban antiguamente en gran número en Figipto, infestando una parte considerable del pais, de tal modo que nadie podia vivir alli. Por lo regular habitan en los parajes arenosos ó á orilia de los caminos, á fin de lanzarse sobre los viajeros. Aunque este ofidio es renenoso y muy irascible, ninguna otra serpienie puede permanecer tanto riempo sin beber. Es vivfpara, lo mismo que la culebra: repta con bastante facilidad, haciendo muchins evoluciones, por lo cual algunos creen que no tiene espinazo; en su marcha produce mucho ruido, semejnite al de un binue impelido por las olas; y acecha las aves oculiando el cuerpo de bajo de la arena, y atric á sus victinas con los cucrnos, única parte que déja ver. Aborrece al hombre, pues le persigue siempre, excepcion hecha de los indigenas de Pesilli, pues aunque los muerdan, no les hacen daño; la herida se cura fácilmente. Estos indigenas ofrecen sus ninos à lis ser. pientes para probar la castidad de sus mujeres del mismo modo que el oro se prucua por el fuego.

La primera parte de estas noticias es exactn en lo esen. cial. Sabemos que el cerastes abunda en Africa y sobre todo en Egipto; que habita principalmente el desierto, ocultándose de dia en la arena, en sitios nuy lejanos del agtaz; y tambien que su marcha produce un ruido notable, probablemente por el róce de las escamas.

Bruce ya habia indicado gue el cerastes como todas las serpientes de esta seccion, era un animal nocturno, pues ha. bia observado cómo se acercaba de noche, al fuego de su campamento.

En todas mis cacerias por el desicto 6 la estepa no vi nunca un cerastes, porque me faltaba la experiencia de los cazadores de serpientes; pero de noche me encolerizaron á menudo.

Es menester saber lo que es una jornada á través del de. sierto, para comprender cuán deseado es el descanso al acer. carse la noche. Despues de haber cabalgado incómoda. mente sobre el camello, desde la manana temprano hasia el mediodia y desde las tres de la tarde hasta la puesta del sol, humedeciendo tan solo lós abrasados labios con el agua tibia y fétida de los odres, y acallando con un poco de arroz el aguijon del hambre, agotadas todas las fuerzas bajo el asfi. xiante calor de todo el dia, durante el cual se ha procurado reanimar aquellas con la perspectiva del lecho en la arena, llégase, por fin, al sitio fijado para pasar la noche la caravana, descárganse los bultos, y enciendesc una gran hoguera; cada cual se arregla su puesto de descanso, lo cubre con su manta, y tiéndese encima de esta para saborear una pipa de tabaco; entréganse entonces los ánimos á cietto estado de beatitud; $y$ hasta el cocinero que prepara la frugal colacion, canta \& media voz algunos versiculos del Coran, cuya monó. tona melodia contribuye á adormecer los sentidos.... cunndo de repente una terrible imprecacion interrumpe el canto. 4Qué hay, muchacho? - Dios la maldiga, y à su padre, á sus hermanos y á toda su raza, y la envie para siempre al fondo de los abismos! i Una serpiente, señor: pero ya se está tostando en el fuego:s Todo el campamento se mueve, cada cual se encarama en el fardo ó caja que tiene mas cerca, aguardando lo que ha de venir. Y se van acercando las malditas a docenas; imposible es decir de dónde salen tantas serpientes. Cautelosamente se les acercan los mas atrcvidos, tenazas en mano, y aprovechando el momento oportuno las atrapan por la nuca, y las arrojan s las liamas, con la misma maligna alegria que debian sentir los fanáticos de otro tiempo cuando asistian af un auto de fe y oian chisporrotear las car. nes de los herejes. \$Poco caso hachamos, dice por su parte
Dumichen, de los escorpiones que de noche acudian alrededor de nuestra cama; pero la Fi nos ha causado mas de un susto ó mi criado y á mi. He pasado meses enteros en los templos y entre las ruinas, dihujando, excavando, etc, sin poder ver una sola de estas serpientes de dia; pero, tan pronto como encendiamos nuestra hoguera de noche, aparecian en tropel al rededor de la misma.

Dificil seria decir qué clase de alimento se proporciona el cerastes en el desierto; lo mas probable es que donde no encuentre ratones, que $a$ buen seguro serán sus presas favoritas en las localidades habitadas, como lo son para los de. más individuos de la misma familia, se contente con los lagartos y pájaros que pueda atrapar.

Tampoco tenemos datos positivos por lo que toca d la reproduccion de esta especie. Los cazadores de serpientes en el mismo Egipto dicen que da á luz viros los hijuelos, asi como las demís viboras; pero Dumeril observó que las hem. bras que existian cautivas en la casa de fieras del Museo de historia natural de Paris, ponian huevos; con todo, como ni una sola rez lograra verlos desarrollados, parécenos que tal vez puedan ser exactas las indicaciones de los cazadores egipcios; pues no podemos dar demasiada importancia á la diferencia en la reproduccion de los reptiles.

CAUTIVIDAD. - El cerastes la soporta con la misma facilidad que cualquiera de sus congéneres, y puede ayunar muchisimo tiempo: Shaw pretende haber visto dos individuos en la jaula de un aficionado en Venecia que habian pasado cinco años sin tomar alimento, siempre viraces y mudando la piel con la misma regularidad que si acabasen de ser cogidos; otros observadores reconocieron que un ri. guroso ayuno de mecio año no les perjudicaba. I.a mayor parte de los cernstes que llegan vivos á Europa no tienen sus ganchos vencrosos, pues los cazadores de serpientes se los arrancan en séguida; hé aqui la causa de que csas serpientes nó coman al principio, pero tan luego como salen los nue. vos dientes aceptan el alimento sin dificultad y envenenan todo raton que se les presenta para devorarlo. Viven en buena armonia con otras serpientes, así como con los lagar. tos; mientras que los pequeños animales de sangre caliente llaman en seguida su atencion y excitan sus carnivoros instintos.

Lo mismo q̧ue cuando están libres, introducen todo el cuerpo en la arena de modo que solo los ojos, los dos cuernecillos y quizás uno ú otro punto de la línea dorsal quedan visibles; el cerastes se introduce en la arena hacien. do unos movimientos laterales muy extraños; ensanclia y estrecha alternativamente el cuerpo y ábrese de este modo camino; estos movimientos se suceden sin embargo tan rápi. damente que en diez, 6 cuando mas veinte segundos, el animal queda oculto debajo de la arena. Aunque no se introduzca del todo, desaparece compleiamente á la vista. En una jaula de cuatro metros cuadrados de superficie cubierta de fina arena es preciso buscar mucho tiempo antes de en. contrar la serpiente, y cuando el observador dirige la mirada a otro lado, vuelve á perderla de vista al punto. Segun estas observaciones, hechas durante muchos meses, me parece muy creible que la afirmacion de los antiguos sea fundada y que en efecto una pequeña ave puede engañarse respecto a los cuernos que sobresalen de la arena, tomándolos por la extremidad de un gusano 6 de una larva, error que le cuesta la vida. Los cuernos tienen sin duda gran importancia para la serpiente misma: le sirven de órganos del tacto, y le avisan todo peligro en el caso de que los ojos, deslumbrados por la clara luz del dia, no lo adviertan. Inútil parece decir que esta serpiente, tan venenosa $y$ del todo oculta, es en ex. tremo peligrosa para el hombre que calzado solo con alpar. 
gatas pasa por el desierto. Es posible que tambien por este concepto nos hayan dicho los antiguos alguna verdad.

\section{LOS EQUIS-ECHIS}

CARACTÉRES. - Con el ceraste se encuentra en Egipto otra vibora, la efa, que á primera vista puede confundirse fácilmente con aqquel, perteneciendo sin embargo á otro gé nero. Las urostegas de esta serpiente están dispuestas en una serie; todos los demás caractéres son los de la vibora, pero llama la atencion del naturalista la esbeltez relativa de sus formas. Las series de escamas, cuyo número varía de veinticinco á treinta y cuatro, se corren de la misma manera que en los cerastes.

\section{EL EQUIS EFA-ECHIS ARENICOLA}

CARACTÉRES, - El efa es una serpiente pequeña, pero preciosa, de unos $0^{\mathrm{m}}, 60$ de largo y de un color de arena muy variable; es decir, de un pardo amarillo mas ó menos claro, con fajas, lineas y puntos irregulares de color pardo oscuro $\delta$ negro; las regiones inferiores son de un color amarillo claro, con puntos negros, que a veces forman fajas; la coronilla tiene una mancha amarillenta ó pardusca, orillada de un pardo oscuro, y que afecta mas 6 menos marcadamente la forma de cruz; en el centro del lomo se observa una serie de manchas mas pequeñas de forma cuadrangular ú oval, de color amarillo pardusco con el borde pardo oscuro, dispuestas á intervalos iguales; á lo largo de cada costa. do se corre una faja ondulada del mismo color que las manchas, orillada de pardo; tambien en esta víbora se observan muchas variaciones en el color y en los matices.

\section{EL EQUIS AQUILLADO-ECHIS CARINATA}

CARACTÉRES. - Esta variedad del efa, propia de la India, llamada aqui afac, y en Sind kuppur, se distinguió hasta hace poco como especie independiente, á pesar de que solo se distingue por el número diferente de las urostegas. Segun las observaciones de Guenther, el efa tenia cuando menos ciento sesenta y tres, el afae solo ciento cincuenta y tres de estas escamas. Anderson encontró últimamente en la In. dia equis de ciento sesenta y tres urostegas; creo probado pues que ambas serpientes pertenecen á una especie.

DISTRIBUCION GEOGRÁFICA. - Suponiendo exact3 la opinion expuesta, resulta que el área de dispersion del efa no es mucho menor que la del pelias comun; pues he visto al equis en todo el norte y centro del Africa; en el sur hasta Abisinia y el Kordofan, Palestina, Arabia y Persia, y hasta en la peninsula indica.

USOS, COSTUMBRES X REGIMEN.-Cuando la caravana de los peregrinos se prepara para su viaje de la salvacion, $y$ el califa elegido ó jefe de los peregrinos pasa en solemne cortejo por el Cairo, reúnense regularmente miles de hombres para ofrecer sus bendiciones á los via. jeros \& acompañarlos hasta delante de las puertas de la Madre del musdo. Entonces comienza una solemnidad muy particular: el califa, sentado en un magnífico corcel, avanza á la cabeza de rodo su pueblo, pero no por tierra, sino so bre un puente compuesto, en el verdadero sentido de la palabra, de cuerpos humanos. Conducido por dos criados ricamente vestidos, que tambien pasan por aquel, el noble cuadrúpedo camina cuidadosamente, mas á pesar de esto sucede que los cascos del bruto hieren á algunos de los de. votos locos, lo cual prueba á todos que el herido no estaba confirmado aun en la fe, porque todo el que cree no solo puede trasplantar montañas sino tambien estar al abrigo de toda herida y desgracia.

Para el hombre civilizado, el aspecto de esos hombres fanáticos tiene algo que le infunde aversion, induciéndole á despreciar la humanidad al ver tantas hechuras de Dios rebajarse á un grado inferior al del animal. Sin embargo, algunos de los derotos vagabundos contribuyen a liamar la atencion sobre el espectáculo, aunque tambien ellos dan pruebas de bestialidad. El eTus el chalifa, segun se llama este cortejo del príncipe de la fe, adquiere mayor ostenta. cion gracias á los encantadores de serpientes, los cuales prueban que no hay nada imposible ante Alá, ejecutando sus habilidades de un modo no acostumbrado.

Ceñidas sus caderas con un paño, y desnudas las demás partes del cuerpo, bailan y saltan, imitando los ademanes de los locos; corren por delante del cortejo, pasando sobre el puente lumano y aplican á cada uno de los devotos que le forman el puntapié nerecido en el sitio convcnicntc. Despues sacan de un saco que llevan á la espalda cierto número de serpientes, las cuales agitan con furiosos movimientos en todas direcciones; las permiten rodearles el brazo y el cuello; se las aplican al pecho y las dejan morder tanto como pueden; de repente cogen una con ambas maros, le cortan con sus dientes la cabeza para comerla ó arrancan un peda. zo de la mitad de su cuerpo, profiriendo su CAlha hu akbarb (iDios es grande!) y otras exclamaciones religiosas, hasta que la espuma de su boca se mezcla con la sangre de la serpiente, muriendo por fin el reptil á la vista del mismo espectador. Todo eso se hace en honor de Dios y del prcfeta. Las serpientes que se emplean en este drama 6 mas bien tragedia son cobras $y$ éas, á las que se han arrancado los ganchos renenosos. Todo el juego de los encantadores de serpientes está muy bien calculado; el pueblo, cuyo cerebro se oscurece por todo el espectículo, manifiestase mas dis. puesto que por lo regular á vaciar sus bolsillos y el hami puede contar con una pingüe'ganancia, por lo cual hace to. dos los esfuerzos posibles. Los predicadores de la fe mahometana, con su califa al frente, permiten con mucho gusto el abominable engaño, porque tambien entre los musulmanes corren parejas los embustes de los sacerdotes con los engaños de los seglares.

Es probable que los encantadores de serpientes se sirvan con preferencia del éá, porque todo habitante del Cairo les conoce como serpientes venenosas. El animal abunda en todo Egipto y no solamente en los desiertos sino tamuien en los pueblos; es frecuente en el mismo Cairo y bastante á menudo sucede que muerde una persona. Lo primero que debe bacer el que pasa á ocupar una casa que cuurante algun tiempo ha estado sin habitar, es proceder of la mas exquisita limpieza de la misma, sin que por eso se crea asegurado contra las visitas de esta vibota Mas de una vez me encontré la efa en nuestra casa de Cartum, muy á menudo al recoger la alfombra sobre la que habia pasado la noche. Una de estas al pasar por un corredor oscuro de nuestra lrabitacion, pisé una de dichas serpientes, que no me mor. dió, scncillamente porque tenia ya la boca llena con nuestra golondrina casera, sin que me haya podido explicar cómo se apoderó el reptil del pobre pájaro: otra vez, encontré una pareja de efas detrás del almohadón que formaba el respal. do del divan. Temiamos mucho mas á esta pequeña vibora que f́l la famosa noyra haja, y que á todo otro animal dañino, incluso nuestro fiel y constante compañero de casa, el escorpion; la odiábamos, la maldeciamos y perseguiamos te. nazmente; cuando la matábamos lo haciamos con verdadero placer: hubiéramos inventado y apliḉdole un martirio especial, si el miedo que nos infundia este reptil no nos excitara 
¿́acabar con su vida lo mas pronto posible. El egipcio, sin embargo, no se decide á proceder tan radicalmente contra estos intrusos: el espanto se apodera de todos los liabitantes de la casa tan pronto como corre la voz de que en ella ha anidado una serpiente, $y$ el jefe de la familia no encuentra mejor expediente que acudir al punto á un hari, para que por medio de sus artes maravillosas consiga que el terrible animal abandone la habitacion. No hay que decir que el charlatan saca todo el provecho que puede del servicio que le piden: se hace pagar bonitamente su trabajo, como de justicia; 9 segun las circunstancias, hace valer su industria soltando primero en la casa una serpiente, y comunicando ¿espues al propietario ó inquilino, que gracias á su poderosa ciencia la descubierto que en la finca tia anidado una ter. rible vibora; fijase entonces el yrecio de la expulsion del anonstruo, y empieza luego el ojeo hasta que aparce el in. cruso.

Geoffroy réficre tambien con csec motivo un gracioso cuen 60. Descando convencerse de si realmente los havis sabian Eacer el reclamo á las serpientes, Bonaparte mandó que se liamarn á uno de ellos y se le encargase la expulsion de una que debia encontrarse en los sótanos del palacio. El mismo Geofroy fué el cncargado de vigilar al ojeador. Desnudaron zeste, para esaminar detenidamente su ropa y ver sillevaba escondióa alguna serpiente; y terminada csta operacion preliminar, empezó la del ojeo. El pobre hombre pare cia asustado y preguntaba á cada momento. 8 Perosino hay serpiente alguna en la casa, qué he de hacer?D. Procuraron tranquilizarle, anticipándole parte de sus honomrios, y duante dos horas estuvo el inieliz haciendio el reclamo, especalmente en los sitios mas luímedos, silbando ora alto y iuerte, como los machos, ora en tono mas bajo y ronco, cowo las hembras; hasta que, por fin, contestó efectivamente zna serpiente, que muy pronto se dejó ver. Dice Geoffroy que ern una escena verdaderamente cómica contemplar eneonces al hasi, poco tiempo antes tan apenado $y$ temeroso, estirarse orgulloso y mirar con cierto aire de triunfo á los circunstantes, como queriéndoles decir que solo su ciencia podia haber conseguido tan maravilloso resultado.

Lo mismo que pasaba hace anios sucede aun hoy dia: el รุue quiere gastar una pequeña suma puede dejarse engañar divertirse con el titiritero.

Por pequeño que sea el efa es, sin cmbargo, una vibora irascible y peligrosa. En algunas provincias de la India, so. Lee todo en la del Sind, se le atribuye la mayor parte de las muertes causadas por las serpientes. Los labradores, en parLieular, están muy expuestos á sus mordiscos. Es en extremo feriosa en comparacion á su tamaño, y aun cuando solo pa. sece pensar en la defensa, se inclina siempre á clavar sus ganchos venenosos aun en el adversario mas grande y fuer. te. Tan luego como se cree amenazada, enróscase, pero no Cal modo que otras viboras, sino formando una especic de aedia luna en cuyo centro coloca la cabeza en posicion de ataque. No permanece, sin embargo, quieta ni un momento, sino que se agita continuamente, produciendo un rumor taálogo al que emiten los cerastes. Mientras un hombre 6 snimal se halle ceren conserva su posicion de ataque; asi termo el pelias, se eniurece cada vez mas y muerde todo ob. itto que se le presenta; tambien se dice que puede saltar á mas de la mitad de la longitud de su cuerpo. Fayrer la con. sidera como la serpiente venenosa mas vivaz y pendenciera Ţa jamás conoció, y tambien los otros observadores están conformes con este aserto. De los experimentos hechos por ei citado naturalista resulta la venenosidad de este reptil: en gallina mordida por un cfa murió en cuatro minutos, wtak en dos $y$ un perro en cuatro horas.

\section{LOS CROTÁLIDOS-CRO- TALIDE}

CARACTERES. - Una fosa bastante profunda entre las ventanas de la nariz y los ojos, pero que no tiene comunica. cion con ninguno de estos órganos, formando un seno sin salida, constituye el carácter mas distintivo de esta familia que abriga las especies mas peligrosas de los solenoglifos. Diferénciase asimismo de la anterior, por la mayor esbeltez de su cuerpo, como tambien, en muchas especies, por la longitud relativamente extraordinaria de su cola. Tienen los crotálidios la cabeza ovalada ó triangular obtusa, ensancha. da cn su parte posterior y destacada muy marcadamente del cuello; las ventanas nasales se presentan dispuestas lateral. mente, y la escamacion, en lo mas esencial, análoga á la de los viperidos.

DISTRIBUCION GEOGRÁFICA.-Los crotálidos, de los que se conocen unas cuarenta especies, son muy numero. sos en el territorio indio; faltan del todo en el etiópico y cn el austral, estando representados en el sepientrional del ar.tiguo mundo solo por algunas especies, y se encuentran ade. nás en los dos territorios del nuevo mundo, sobre todo en el norte. Wallias cree poder deducir de esta circunstancia que la familia tiene su origen en los paises indo chinos, extendiéndose desde aquí por el nordeste de América hasta el sur de este continente, donde no ha tenido tiempo aun para desarrollarse del mismo modo que en los demás puntos de su área de dispersion: nosotros no damos importancia á es. tas deducciones, bastándonos saber cuáles son los limites efectivos del territorio que habita.

USOS, COSTUMBRES Y RÉGIMEN. - El género de vida de estos solenoglifos es muy análogo al de los viperidos. Son igualmente perfectos animales nocturnos, y pasan las horas del dia durmiendo ó en una especie de letargo, ya ocultos en sus escondrijos, ya arrollados delante de la entrada de estos, á fin de proporcionarse el benéfico calor del sol; parece, sin embargo, que si no todas, á lo menos algunas especies de esta familia son menos indolentes que los viperidos. No pocos crotálidos son trepadores, y algunos, cuya coloracion verde parece designarlos ya como arbóreos, pasan parte de su vida en árboles de regular altura; otros nadan casi con igual perfeccion que los tropidonotos, y se alimentan principalmente de peces; con todo, la mayor parte de estos reptiles no abandonan la tierra firme y dan caza á toda clase de pequeños mamifcros y pájaros. La reproduccion se verifica al igual de la de los viperidos, pues tambien llevan sus hembras los huevos hasta que desarrollados suff. cientemente los pequeñuelos, puedan romper la cáscara en el nismo acto del desove.

Si bien en perversidad podrán dificilmente sobrepujar los crotálidos algunas especies de la familia anterior, como los equidnos por ejemplo, con todo, son considerados gencral. mente como las mas temibles serpientes de nuestro globo, teniendo en realidad desarrollado en muy alto grado su apa. rato venenoso. No has duda que se ha exagerado en gran manera la ferocidad de algunas especies de esta familia; sin einbargo los terribles holiops hierro de ianza y laguesis mbsdo parecen justificar en verdad el horror que va unido á sus nombres: son considerados como la maldicion de los países que infestan, entorpeciendo el cultivo de inınensos distritos y causando anualmente numerosas victimas.

\section{LOS CRÓTALOS-CROTALUS}

CARACTERES، - Los crotálidos mas conocidos son los 
crótalos propiamente dichos 6 serpientes de cascabel, que se distinguen por el extraño apendice que llevan en la extremidad de la cola, cascabel ó matraca, compuesto de capsulas delgadas y córneas, cuya significacion no han podido explicarse todavia los hombres de la ciencia: algunos lo conside. ran como una apónsis de la columna vertebral, otros como verticilos escamosos imperfectamente desarrollados; siendo dificil decidir cuál de estas opiniones es la verdadera. Con. siste este aparato en un número, mayor ó menor, de piezas córneas, encajadas entre si, y de forma parecida a conos huecos, algo aplanados, con tres rehenchimientos exteriores y la cima hácia la cxtremidad terminal de la cola, parecien. do como envainados, por decirlo asi, unos en los otros; cada uno de estos conos descansa sobre dos rehenchimien. tos del que le sigue en direccion al cuerpo del animal, pero unidos libremente, de modo que todos son movibles y pue. den rozarse entre sí. Supónese que el cascabel, ó como se le quitera llamar, adquiere cada año. y hasta segun algunos na. turalistas, despues de cada muda de piel, una pieza mas, enrollándose la espesa capa de epidermis desprendida que se forma sobre la última, \& la que permanece adherida, $y$ adoptando la configuracion cónica que esta le da; pero no pasa esto de una suposicion que necesita ser confirmada, tanto mas, cuanto que es cosa segura que el número de los verticilos $\delta$ conos no sucle guardar proporcion con la edad de la serpiente. En individuos cautivos háse observado que el animal ganaba en tamaño, sin que aumentaran las piezas de su cascabel ó matraca. Hoy dia es ya muy raro encon trar una de estas serpientes que tenga de quince a diez y ocho conos en su aparato caudal, y parece, por lo tanto, muy dudoso que pueda aumentar este número, como un antiguo grabado pretende hacernos creer. Si consideramos, dice Gejer, el cascabel como una apónisis de la columna vertebral, hemos de suponer necesariamente que su acrecentamiento solo depende de la nutricion y del desarrollo del animal, que circunstancias desfavorables pueden interrumpir, asi como otras mas propicias fomentar, sin que sea dable fijarle condiciones absolutas de tiempo. Serpientes de cascabel que segun mis cálculos debian tener de cinco á seis años de edad, presentaban siempre una sola pieza del cascabel completa. mente desarrollada, y no podian todavia producir sonido alguno con la misma. Signiendo esta proporcion, una serpiente de seis piés de largo con once piezas 6 conos en su apéndice caudal deberia tener de sesenta a setenta años. Como se ve, este juicio de un observador concienzudo, que tuvo sobradas ocasiones para estudiar los crótalos, viene á demostrai que en la actualidad, es igual nuestra ignorancia respecto a la formacion del cascabel de estos ofidios, como por lo que toca $i$ su utilidad.

¿Hay muchas personas, dice. Jiebel, que creen ver en el cascabel un órgano destinado á advertir á los hombres el peligro; pero no nos dicen cuáles son los órganos que en otras scrpientes no ménos peligrosas, y que acechan su presa, nos preservan de sus mordiscos. Los crótalos, asi como la ma. yor parte de las demás serpientes venenosas, no atacan al hombre si este no los excita, y ademis fijan su residencia en regiones secas y descubicrtas, donde el hombre nada tiene que buscar $y$ donde con mas facilidad puecie ver à su ene miga A estas palabras nada hay que añadir porque lasta el hombre no pensador las comprende.

Al lado del singular apéndice que acabamos de describir, aparecen menos importantes los demás distintivos de estas serpientes. Cubren su cabeza, en la parte anterior y superior, placas de mayor ó menor tamaño, nientras que el dorso está revestido de escamas ovaladas y aquilladas, y la region abdominal de anchos cscudos; el cuello destaca marcadamen te, siendo el cuerpo fornido, si bien bastante esbclto para solenoglifos, y el aparato venenoso tan desarrollado, que Dumeril lo designa como el mas perfecto.

DISTRIBUCION GEOGRÁFYCA.-Encuéntranse estos temibles reptiles tan solo en América, pero lo mismo en la septentrional g̨ue en la del sur.

USOS, COSTUMBRES Y REGIMEN, - Habitan los crótalos principalmente los terrenos yermos, arenosos 6 pedregosos, y tambien los cubiertos cie cortas plantas, buscando entonces las inmediaciones del agua.

Respecto á sus hábitos y género de vida daremos mas detalles al hablar de las dos especics mas conocidas; pero no puedo salir garante de la exactitud de todas las noticias reproducidas for mí.

Como seria dificil trazar una descripcion general de cual. quiera especie de los crótalos, porque el color y los matices varian de un modo extraordinario, para distinguirlas nos fijaremos en la formacion de los escudos de la cabeza.

\section{EL CRÓTALO DURISO - GROTALUS DƯ- RISSUS}

CARACTERES.-Ei crótalo duriso se caracteriza por la circunstancia de que además de los grandes escudos en la region de las cejas, tienen en la parte posterior del hocico dos pares de placas grandes situadas entre las pequeñas. Al gran escudo triangular de la nariz sigue á cada lado una placa cuadrilátera y hácia atrís otro escudo que nos parece im. portante, porque entre 6 ly el nasal se hallan los orificios de las fosas nasales. El espacio entre los dos últimos escudos está ocupado por otros mas peq̨ueños, irregulares y un poco mas grandes en los lados; entre los escudos de las cejas co. mienzan las escamas aquilladas y solurepuestas, de forma rom. boidal prolongada, que cubren toda la parte superior y for. man veintisiete scrics longitudinales.

El fondo de la coloracion del dorso es un pardo gris oscuro, con fajas trasrersales negras é irregulares, que se confunden en la tinta mas oscura de la cola; la parte abdominal es amarillento blanquizca con pequeñas puntas negras.

Las hembras de mucha edad alcanzan sa veces dos metros de largo; pero son ya bastante raros los individuos que miden $t^{\prime \prime}, 60$.

DISTRIBUCION GEOGRÁFIC $\Lambda_{0}$ - El ârea de disper. sion de la serpiente de cascabel se extiende desde el golfo de México hícia el norte hasta los $46^{\circ}$ latitud norte, aunque solo en la América occidental; lodos los autores están uná. nimes en reconocer que esta serpiente no se ve sino hácin el oriente 6 en el litoral del Atlántico, todo lo mas hasta el lago Champlain.

Puédese fjjar como regla general, dice Gejer, que el círculo de dispersion de este reptil ternina donde cesa el cultivo de maía á causa de las frecuentes heladas de verano.

USOS, COSTUMBRES Y REGIMEN, - Aun en los primeros decenios de nuestro siglo este crótalo era tan frecuente en los terrenos no cultivados, que dos hombres, que á causa de la muy apreciada grasa de serpiente cazaban con regularidad al crótalo duriso, mataron en tres dias nil ciento cuatro individuos. A los progresos de la agricultura y al aumento de los cerdos debe atribuirse la disminucion conti. nua de estos reptiles.

4La residencia favorita de la serpiente de cascabel, continúa Gejer, son las localidades donde hay elevaciones ó ccilinas rocosas, bañadas por el sol y limitadas por ralles ricos de yerba, rios 6 riachuelos, y solo se la encuentra en las grandes llanuras cuando estas son humedecidas regular. mente por fuertes rocios. Es un animal muy sensible al cam- 
bio de temperatura, mudando de sitio casi á cada hora. Ėn la mañana hermosa s clara de un dia caluroso, se refresca en el rocio $y$ busca despues un puesto á propósito en un sendero ó cncima de una ancha piedra para solearse; mas tarde, hácin la hora del mediodia, le gusta reposar en sitios secos y sombrios, pero cerca de los calentados por el sol. Cuando durante varias noches no ha caido rociada, encuéntrasele á menudo á orillas de los charcos y rios, pero solo entra en el agua para cazar sus presas. Fija su morada lo mismo en las tierras cultivadas, que en las pobladas y en los desiertos; viviendo en unos puntos aislado, en otros en sociedad; á menudo en escondrijos que se busca, y otras veces en madrigueras tomadas á viva fuerza de otros animales, como los perros de las praderas, las ardillas, las ratas 5 tambien las golond̛oinas ribereñas, aunque los nidos de estas liltimas parezcan inaccesibles a los individuos de mayor tamaño: pero nuestra serpiente, gracias á la sólida escamacion de su cabeza y cuerpo, perfora fácilmente la tierra ó la piedra arenisca noja, sobre todo cuando se Irata de ensanchar los agujeros.

¿En una vertiente, refiere Geyer, de piedra arenisca y de escasa vegetacion a orillas del Maine, en el Estado de lowa, y de unos 250 piés de altura, vimos numerosas serpientes de cascabel que asomaban la cabeza por los agujeros ensanchados por las golondrinas ribereñas. Raras veces se les ve en gran nímero cerca de los sitios halitados, á no ser durante la época del apareamiento, a fines de abril ó princi. pios de mayo. En este caso ocúltanse en las hendiduras de las rocás, en las paredes y debajo de las constmicciones, en el hueco de los árboles y en los montones de leña, enconirándoselas á veces hasta debajo del suelo de las habitacio. nés y en los escondrijos de las ratas. Su morada invernal puede ser á menudo casual, como sucede con las demás ser. pientes: el reptil atraido por algunos dias calurosos de octu. bre, abandona el esconarijo que ya se habia preparado, y sorprendido de impiroviso por el frio, se ve obligado a va. lerse del primer refugio que encuentra; asi se descubren á menudo debajo de piedras aisladas en las praderas, serpien. tes de cascabel, que con el cstómago repleto se han abrigado alli para pasar el invierno. Su letargo es completamente parecido al de otros reptiles, solo que siempre que pueden se buscan una madriguera seca y retirada, 8

De Audubon, que ha descrito muy detalladamente la vida de este animal, copiamos lo siguiente: Me encontraba un invierno cazando ánades en compañia de varios conocidos. Cuando quisimos preparar nuestra comida, encendimos fue. go cerca del lago y empezamos à desplumar un ánade. Al moverse un tronco para acercarlo al fuego, uno de mis com. panicros descubrió una gran serpiente de cascabel, arrollada y rigida; estaba tiesa como un palo, $y$ la meti en el morral que llevaba á cuestas, para estudiarla mas tarde con mayor detencion. Poco rato despues, mientras astabamos nuestros patos, me apercibí de que algo se meneaba detrás de mí; recordando en el acto la serpiente, me quité con presteza el morral $\xi$ lo arrojé léjos de mí. El reptil habia recobrado por completo su fuerza vital, y saliendo del saco, empezó á sonar su cascabel, mientras que estiraba la cabeza, enroscaba el cuerpo y se preparaba al ataque. Como estaba á regular distancia del fuego, pensé que el frio la amansaria nuy pronto; en efecto, antes de haber terminado nuestro asado, ya habia enmudecido el cascabel y buscábase un escondrijo. Pocos instantes despues estaba la serpiente tan rigida como antes. Nos la llevamos á casa, y por el camino la desperta. mos varias veces acercándola al fuego.

Palissot de Beaurois se expresa como sigue: \&La serpiente de cascabel procura pasar el sueño invernal en las inmedia. ciones del agua. Excavamos narias de sus madrigueras á orillas del Mauricio. Galerias curvas conducian á una especie de cámara, que distaba de seis á ocho piés de la entrada; alli descansaban varias serpientes sobre el suelo húmedo, sin movimiento alguno. Nuestro guia nos llevó despues å un alio pantano cubierto de musgo que tenia de diez á doce pulgadas de alto; la superficie de este se habia endurecido con la helada; pero debajo de la misma encontramos varias serpientes de cascabel que reptaban en el 'fondo no helado $y$ humedecido por el agua. Ocúltanse en otono antes del equinoccio, despues de haber mudado la piel, para volver à la vida activa en la primavera.

Geyer considera esta serpiente como animal diumo, y asegura que pasa todas las noches en su escondrijo, con una regularidad comparable á la que suelen observar los anima. lés domésticos, pues el mismo vió durante cuatro semanas como uno de estos ofidios se acercaba cada noche al pié de un árbul hueco, mientras que de dia no le fué posible po. nerle la vista encima jamás. Que la consecuencia que Gejer pretende sacar de esta observacion, respecto á la vida diurna de esta serpiente, es errónea, lo demuestran sobradamente las demás indicaciones que él mismo hace acerca de las costumbres dèl crótalo. Véase la siguiente aventura que re. fiere, como comprobante de la sociabilidad de la serpiente de cascabel: \& A mi regreso de una expedicion que hice para recoger caballos, llegué el 22 de agosto al pié de una alta montaña bañada por el ruidoso Spoken. Decidi pasar alli la noche en un prado rodeado de malezas. Luego que me hube apeado, me dirigi al rio para apagar mi sed; llamúme la atencion una planta, y buscando otras, topé con una serpien. te de cascabel en postura amenazadora, la que maté al punto. Pocos momentos despues, cuando estaba tomando mi ligera colacion, of algun ruido: un mulo que habia atado alli cerca, dio scriales de viva inquietud; pero no quise in. terrumpir mi comida, y solo cuando hube terminado, cogi mi vaso para llenarlo de agua del rio. El ruido que todavia se dejaba oir, parecia cerca y comparable al que harian varios palos arrastrados por el suelo. Apenas sali del prado y me encontré al borde de la márgen, elevada de tres á cuatro piés, descubri multitud de crótalos que se agitaban en la superficie arenosa á mis piés. La luna brillaba con todo su esplendor, y pude ver muy distintamente cómo los reptiles serpenteaban al lado y por encima unos de otros, sobre todo en las inmediaciones de los grandes pedazos de granito que yacian por allí dispersos, rozándolos con su cuerpo y sacudiendo algunos sus cascabeles contra las piedras. Aumentaba este ruido el roce de sus cuerpos escamosos sobre la arena; el hedor era atroz É insoportable. F! miedo me hizo retirar hácia mi hoguera, y me envolvi en mi manta de lana, pues temia que se les ocurriese á aquellos huéspedes visitar mi fuego y atacarme durante el sueño. El estrépito continuó hasta cerca de las diez, y poco á poco desapareció por com. pleto; entonces me acosté y dormi. Levantéme al amanecer, ensillé al mulo y me fuí en búsca de mis cabalios, contento de abandonar campamento tan desagradable, pero, despues de una infructuosa correrla de varias horas, sin haber cncontrado aquellos, ture que volver al mismo sitio y perma. necer allí. Empecé cntonces á examinar la orilla del rio, que hallé tan tranquila y solitaria como en la mañana anterior; solo se veia alli la serpiente que habia muerto. Poco satis. fecho de este primer exámen, corté una gruesa rama para que sirviera de palanca, $y$ levante con ella las pesadas pie. dras que habia en la orilla, casi seguro de encontrar los reptiles debajo de las mismas; pero todos mis esfuerzos fueron vanos, pues no vil uno solo. Algunos dias despues de esta aventura, ture el gusto de encontrar al jefe de factoría; 
M. Macdonald, en el fuerte de Colville, $y$ habiendosela referido, me contó él à su vez que el 2 I de agosto, esto es, un dia antes que yo, le habia sucedido otro tanto $\&$ orillas del Columbia.

Casi todos los observadores describen esta serpiente como un animal por demás perezoso y lento en sus movimientos: Beauvois hasta parece que quicra darnos á entender que no hay otro de disposicion tan apacible. BJamás acomete animales que no necesite para su nutricion, y solo muerde cuando se la espanta ó se la provoca. A menudo he pasado á un pié de distancia de ella, sin que hiciese la serpiente señal alguna de querer morder. El sonido de sus cascabeles me ha advertido siempre con anticipacion su presencia, $y$ mientras me alejaba del sitio, sin apresurarme, no se movia, y me daba tiempo para cortar una vara con que matarla. Naturalmente, esta indicacion solo puede referirse a las horas en que el reptil suele estar indolente y deseoso de reposo: pues cuando se encuentra animado y activo, seguramente que las cosas pasarán de otra manera

«a serpiente de cascabel, dice Geyer, es muy rápida en sus movimientos de progresion, sin esforzarse ni torcerse de. masiado; esta viltima circunstancia es la que la hace apare. cer lenta, pero si se considera la distancia que recorre en un segundo, se deduce fácilmente su considerable rapidez. Precipitase sobre su presa con una relocidad progresiva, que acaba por igualar al vuelo de un pájaro. Asl ví una vez arro. jarse una de estas serpientes, desde un árbol, en el corral de un colono, sobre una gallina, y cogiéndola por el ala, llevársela, con la rapidez. del rayo, hácia un pedazo de roca, de modo que apenas pude seguirla. Una piedra que le tiré, con bastante acierto, la paró en su carrera; envolvió entonces la presa entre los pliegues de su cuerpo, desprendiendo los dientes de ella; pero mordióle en la cabeza al poco mto, en vista de mi inmovilidad. Una pedrada, disparada con mas fuerza que la anterior, la obligó á soltar de nuevo la presa, y enroscando el cuerpo, $y$ levantando la cabeza, se preparó á la defensa; acerquéme entonces, y la rematé. Audubon refiere como sigue la caza que da este ofidio $a$ la ardilla: Ia serpiente de cascabel caza á menudo en nuestros bosques las ardillas grises, de las que se apodera sin gran dificultad. En I $\$ 21$, tuve la satisfaccion de presenciar esta caza. Me habia echado en el suelo para mejor observar los movimientos de un pájaro nuevo para mí de repente llamóme la atencion un fuerte ruido cerca del sitio donde estaba, $y$ al inquirir la causa, vi salir de una espesura una ardilla gris, de regular tamano, quec, dando largos saltos, huia de una serpiente de cascabel, la que la seguia en línea recta á unos veinte piés de distancia. Arrastrábase esta con tal velocidad por el suelo, que á cada momento se acercaba inas á la ardilla. Por fin, el mamifero consiguió arrimarse á un árbol, y muy pronto trepó por él hasta su cima; la serpiente le siguió con menor rapidez; pero, con todo, bastante veloz para que la ardilla, asustada, se parase, con sus ojos fijos en los del enemigo, que se le iba acercando. Cuando el reptil esturo á pocas varas de distancia, saltó el roedor á oira rama, siguiéndole inmediatamente su adversario, que estiró en el aire buenas dos terceras partes de sul cuerpo, mientras tgue con la cola se sostenia en la rama que iba a abandonar. La ardilla saltaba con extraordinaria presteza de una a otra rama, introduciéndose al propio tiempo en varias cavidades del árbol, pero salia inmediatamente de ellas, pues parecia convencida de que la serpiente la seguiria tambien allf; por último, se dejó caer de un iremendo salto en el suelo, pero extendiendo todo lo posible piés y cola, áfin de de: tener la caida. En cl mismo instante se soltó tambien el reptil, de modo, que cuando empezó á correr el mamífero, se encontraba ya á pocos pasos de cé. Repilióse entonces la carrera en el suclo, pero antes que la ardilla hubiese podido alcanzar otro árbol, ya la serpiente la tenia cogida por la nuca, y envućltola con tal rapidez en sus pliegues, que oia yo distintamente los chillidos del pequeño roedor, sin poder ver parte alguna de su cuerpo. Era tal la avidez de la serpiente, que no se apercibió de que me acercaba para observarla con mayor comodidad y detencion. Pasados algunos minutos, allojó las circunvoluciones de su cuerpo, y levantando algunas pulgadas la cabeza, la estiró en .warias direcciones por encima del cadáver, para convencerse de que ya no habia vida en él; cogiólo entonces por la catremidad de la cola, engulló esta, y con algunos esfuerzos los piés y toda la parte trasera, ensanchando, para conseguirlo, de tal modo sus fauces, que el resto del cucrpo pasó con aparente facilidad.\$

Debo declarar que me siento inclinado á creer que Au. dubon ha confundido en este caso la culebra negra con una serpiente de cascabel. Todos los demás observadores pre. tenden que esta serpiente no es trepadora; mas bien entra en el agua que sube á los árboles. Ya el viejo Kalm habia indicado, lo que hoy está demostrado suficientemente, que esta serpiente atraviesa á menudo lagos y rios, y que nada con rapidez.

Consiste su alimento en pequeños mamíferos, pájaros y batracios. Kalm pretende que hasta se encontró en su estó. mago un vison, pero añade, cual si quisiera probar la fal. sedad de su noticia, que este reptil solo devora la mitad de los animales grandes como ardillas y licbres, esperando á que esta parte esté digerida para devorar despues el resto.

Aun hoy dia circulan fábulas sobre la fuerza mágica de este reptil, aunque todos los observadores despreocupados niegan tal facultad. No aseguraré que en efecto ahogue las victimas cogidas, como las serpientes no venenosas, ó si cs. pera el efecto de su mordisco; pero con todo me inclino d creer lo último. En mis cautivos no he observado nunca que hubieran ahogacio una presa, pero á menudo sucedió que no se tomaban el trabajo de envenenar su víctima, sino que la devoraron viva. Schmidt ha hecho la misma observacion en sus crótalos durisos.

Despues de copiosa comida es tal el hedor que arroja de si, que no solo los animales de olfato fino, sino que el hombre tambien lo distingue a gran distancia. Este aserto de rarios observadores es negado rotundamente por otros. La. cepede habla de una horrible cmanacion de cstos reptiles, y atribuye a clla la pretendida fascinacion que algunos les prestan; Polvell refiere por su parte, que visitó una cueva, en la que se ocultaban debajo de las piedras mas de cien crótalos. En menos de cinco minutos, lo mismo él que sus compañeros, sintieron náuseas a causa del fuerte hedor que despe. dian lasserpientes, llegando Porell casi á perder los sentidos, y á duras penas pudo salvarse del peligro que le amenazaba. En esto habrá su exageracion; pero, seguramente tambien, algo de verdad; pues háse observado que loz animales, an tes de ver la serpiente, conocen ya su presencia: así, por cjemplo, los caballos se espantan y saitan de lado, cuando pasan por delante de uno de estos reptiles á varios piés de distancia. Si algunos, dice Geyer, pretenden negar la pestilente emanacion de la serpiente de cascabel, yo puedoafirmatlo, aunque tenga bastante embotado el sentido del olfato. Creo que depende este hedor del alimento del reptil; si se ha iragado una ardilla, se comprende que despida mal olor; además suele tambien devorar animales muertos, $y$ no se debe extrañar que en igualdad de circunstancias, le suceda lo propio que a los vulturinos. Con todo, debemos mani. festar, por nuestra parte, que en crótalos cautivos no se nota hedor alguno, $y$ esto mismo lo afirman varios observadores. 
El apareamiento empieza en los prineros meses de la pri. mavera, efectuándose la union sexual exactamente del mismo modo que en las viboras. $\mathbb{L a}$ cópula de estos animales, caice Audubon, es tan repugnante, que no haria mencion de ella, á no ser por la importancia que tiene para la ciencia. A principios de la primavera, aparecen las serpientes, despues de haber mudado la epidermis, en todo el esplendor de su colo. racion, llenas de vida, $y$ con ojos fulgurantes. Machos $y$ hembras vagan por los claros de los bosques bañados por el sol, y se enlazan cuando se encuentran, hasta que se juntan de este modo en asqueroso ovillo, veinte ó treinta individuos; las cabezas se vuelien entonces hácia fuera en todas direcciones, con las fauces abiertas, silbando y agiando al propio tiempo las colas sus cascabeles. En esia postura permanecen varios dias en el mismo sitio, j se expondria al major de los peligros el que se atreviese a acercarse of uno de estos grupos; pues tan prónto como divisan al enemigo, se sueltan todos con presteza, y le dan caza. Esto último nus parece poco probable; pero la agrupacion de los crótalos en la época de los celos, creemos que no es discutible; pues varios observa. dores 10 confirman, entre otros Geyer, que reproduce los datos que pudo recoger de los indios sobre el parricular. El desove se verifica en el mes de agosto, rompiendo los peque. nuclos la cáscara pocos minutos despues, y sin que la madre se cuide mas de ellos. Palissot de Beauvois pretende probar la contrario, pero nos parece poco digna de crédito la aven tura que refiere en los siguientes términos: «En el primer viaje que hice al pais de los iroqueses, habiendo percibido a lo léjos una serpiente de cascabel, me acerque haciendo el menor ruido posible; pero grande fue mi sorpresa, cuando, teniendo ya levantado el brazo para herirla, vi que se agitaba, haciendo sonar sus cascabeles, y abriendo en seguida su ancha boca para recibir en ella cinco pequeñuelos, que apenas tenian el grueso de un cañon de pluma. Sorprendido portan inesperado espectáculo, retrocedi algunos pasos para ocultarme detrás de un árbol; al cabo de pocos ninutos, creyéncose el reptil, lo mismo que su progenitura, libre de todo riesgo, abrió la boca, y dejó salir a los pequeñuelos que alli se hábian refugiado. Dejéme ser de nuevo, y otra rez entró la prole en su escondrijo; la madre, llevándose cntonces su precioso tesoro, se escapó á traves de las jerbas, que me la ocultaron. Varios plantadores americanos me habian ya comunicado esta costumbre de la serpiente, pero no quise crecrlo; despues el viajero Guilicmard la ha confirmado. Hasta ahora no se ha observado cosa parecida en ninguna oira serpiente, y scria, en verdad, extraordinario que el cró. talo hiciera una excepcion de la regla general. Merece mas fe que este cucnto, que por lo demás ha encomtrado bastantes cridulos, la siguiente relacion que hace Geyer de un hecho presenciado por él mismo: Tan solo una vez tuve ocasion de observar el nacimiento de los pequeñuelos: era en el mes de agosto, $j$ en las inmediaciones de una vivienda abandonada por los mormones, á orillas del Misouri. Una hembra se soleaba delante de la entrada de la cabaña, y al acercarme se escondió debajo del umbral de la puerta; entonces vi en el mismo sitio una pequeña serpiente de seis pulgadas de largo. Introduje un palo por debajo del umbral, y of como sacudia la hembra los cascabeles en su huida, descubriendo al propio tiempo varios pequeñuclos; hice volar un pedazo del marco de la puerta, y encontré sobre la tierra seca, y entre algunas piedras, unos cuarenta huevos, muchos de ellos ya vacios. Teniar distintas formas, y eran del tamaño de los de paloma y de color pajizo. Los jóvenes crótalos mostraban ya tal aficion a morder, que me causó verdadera sorpresa. No tienc, puts, fundanchio di aserto de gue la serpienti di casiabe!, al icrise anmernazada, oculla los hijuclos cn sus fauses: ent al caso gue acalio de referiv, la madie twio orasion parn foiter hacerlo; pero, for el contravio, iny'e, ahandondindoles.

Fil cnemigo mas temible de la serpiente de cascabel, dice el mismo observador, es un invierno riguroso, sobre todo cuando se presenta tempranoy de improviso; las grandes inundaciones en la primaverale son igualmente perjudiciales, lo mismo que los incendios de los bosques y de las praderas. Hay varios ejemplos de distritos que quedaron limpios de crótalos, despues de un invierno cruel, de inundaciones o de incendios. Cuéntase generalmente que los cerdos matan y devoran estas sernientes, y que el veneno de estas no les causa daño alguno, cuentos á los que han dado crédito varios naturalistas. Los muchos experimentos que he hecho con este motivo, me han dado siempre igual resultado, esto es, que los cerdos, lo mismo que otros animales domésticos, no solo temen la serpiente de cascabel cuando viva, pero que ni siquiera se atreven á tocarla muerta y despedaindin.s.

No he querido pasar por alto las últimas noticias de Gever; peró debo añadir que ya los primeros naturalistas reconocen la utilidad del cerdo como exterminador de las serpientes de cascabel, y los observaciores participan de la misma opinion. Elan luego como la serpiente ve un cerdo, dice $\mathrm{Kalm}$, pierde todo su valor y emprende la fuga. Los cerdos las olfatean ya desde léjos, precipítanse sobre ellas y las acometen á dentelladas. Cuando las han cogido sacúdenlas con fuerza y lis devoran despues sin que les produzca ningun mal efecto; bien es verdad que no comen la cabeza. Los colonos recien llegados se proveen al punto de cerdos con la seguridad de que exterminarán en poco tiempo los crótalos ouve existan en sus terrenos. Las serpientes muerden á veces a algun cerdo, pero casi nunca le causan daño. No veo nada de inverosinil en este relato de Kalm; los obser. vadores unodernos confirman esta opinion.

«ingun punto del Oregon, dice Brown, estaba mas inféstado en otro tienapo de serpientes de cascabel que los valies del rio Columbia; estos reptiles molestaban al principio mucho á los colonos, llegando hasta el interior de las casas. Todos los esfuerzos para exterminarlas fueron inútiles, hasta que los cerdos se propagaron como animales doméslicos. Kistos útiles animales eran conducidos ‘l los bosques para engordarlos, dejándolos alli en libertad, y desde aquella época el número de serpientes de cascabel ha disminuido de tal modo, que en mi excursion á través del jaís no vi duranic quince dias, en una extension de scis 6 siete leguas inglesas, al menos gulle yo recuerde, ni siquiera unn de estọs crotálidos. Solo en las regiones donde no habia cerdos csas serpientes abundaban. Parece que hay una aversion natural entre los cerdos y' esos reptiles, pues apenas uno de los primeros dirisa una serpiente, cae sobre ella antes cieque pueda hacer uso de sus ganchos venenosos; le pone un pié en la nuca, aplástala y la devora despues tranquilamente. Los in. dios conocen muy bien esta enemistad y mas de dos reces he visto á una india rogar á los colonos la diesen un pedazo de carne de cerdo fresca para atársela á los tobillos y preservarse asi de los mordiscos del crótalo al buscar bayas en el bosque. En el Oregon meridional existe la opinion, poco probable, de que la carne de cerdo hasta es un antidoto contra el veneno de las serpientes. Sin embargo puede ser exacto que la espesa capa de grasa preserve al cerdo mismo de las mordeduras de los crótalos, por no poder penetrar los gauchos venenosos hasta la sangre.s

De la misma opinion es Bruhin. eLos crótalos, dice, abundaban antes bastante en el condado de Milwankec, mientras que ahora han desaparecido casi del todo á causa de la persecucion por parte del hombre y de los cerdos. Por 
lo menos no consegui durante cinco años coger un solo individuo, a pesar de que crucé el país en todas direcciones y aunque tambien en la nueva colonia se encuentra alguna serpiente de cascabel. En vista de estos datos tan conformes de varios observadores, desconocidos al parecer uno de otro, y segun noticias análogas de otras regiones, creo que Gejer no ha sabido apreciar bastante la utilidad de los cerdos.

«Citanse además, prosigue Geyer, como enemigos de las scrpientes de cascabel á las comadrejas y los tejones, especialmente el tejon negro de bosque: jamás he creido que las primeras se atrevieran con estos temibles ofidios, y por lo que toca $a$ los tejones, he practicado tambien experimentos con el de bosque, obteniendo igual exito que con los cerdos. No es menos erróneo todo lo que se dice respecto śl los enemigos que tiene la serpiente de cascabel entre las aves de rapiña; exceptuando el busardo y el serpentario, todos los demás que se citan son demasiado débiles para poder ata. carla. Una especie de buitre, que gora la fama usurpada de gran destructor de crótalos, la he encontrado casi siempre muy abundante en los puntos donde raras veces aparecen dichos reptiles; con todo, es nuy probable que las aves de rapiisa devoren las jorenes serpientes, que tambien serán presa de los grandes mochuelos de las praderas.

Muchos son los reptiles de esta especie que mueren en las carreteras, ya sea sa manos del hombre, 6 ya aplastados bajo las ruedas de los carros. A nadic le duele apearse del caballo, para tener la satisfaccion de disminuir el número de animales tan perniciosos. A pesar de los muchos que he visto y que he muerto, jamás pude dominar por completo el horror que me causaban estos reptiles, aunque solo una vez me mordió uno de ellos en la punta de la bota, pero sin llegar á herirme. Con todo, en América tan solo se retrocede al percibir una serpiente de cascabel, con la intencion de buscar una piedra $\delta$ un palo para matarla. Cualquier chico se atreve con ella, de modo que no es tanto el miedo que infunde. Además, en las tierras habitadas de la América del norte, ya es una rareza encontrar un crótalo; pues no ha dejado de producir su efecto la continua persecucion que se ha hecho á su especie. Segun Castelnau, en todos los terri. torios que se van á cultivar por primera vez, empiézase ante todo por cazar en grande escala à cstos temibles huéspedes, y no se ceja hasta haber dejado todo un distrito completa. mente limpio de ellos. Anade Geyer, que en un solo dia fueron muertos, en las inmediaciones del lago Jorge, cuatro. cientos crótalos, y que entre tantos cadíveres como vió de estos reptiles, jamás pudo observar que otros animales los comicran; tan solo un escarabajo, ancho y aplanado, de color ceniciento, suele hacer pasto de sus restos.

Los indigenas, dice tambien este excelente observador, temen mas la serpiente de cascabel que los blancos, pues entre ellos encuéntranse algunos que, despreciando la mordedura venenosa que les pudieran causar, las cogen con la mano desnuda. Un hijo del célebre general Clark, que formaba parte de nuestra caravana à las Montañas Pedrego. sas, llevaba siempre los bolsillos llenos de cascabeles de crótalos: ajenas percibia uno de estos, echaba á correr de. trás de ét, le ponia el pié izquierdo sobre la cabeza, le ar rancaba con la mano derecha el aparato caudal, y lo soltaba en seguida, sin que jamás tuviese la desgracia de ser.mor. dido.

1 1 os siux $\delta$ dacotas no matan ninguna scrpiente de cascabel, venerándola, por el contrario, á causa de su astucia, y tienen por buen aguiero cuando encuentran uno de estos reptiles. A esta circunstancia deben estos indios el nombre de «nadoresyu», que les han puesto las tribus enemigas, no Toso V siendo el de siux otra cosa que la última silaba de aquel. Ninguna otra tribu india rinde culto s estos animales, ni siquiera los chachonis, conocidos tambien bajo la designacion mas vulgar de «indios serpientes.

Muchos animales conocen y temen á la serpiente de cascabel. Ios caballos y los novillos se espantan al verla, y huyen; los perros la paran, pero conservándose sicmpre á respetuosa distancia; los pájaros empiczan á chillar lastimosamente, tan pronto como notan su presencia. $\$$ unos veinte pasos de mi casa, refiere Duden, vi un crótalo que mediria tal ver cinco piés de largo, enrollado al pié de un nogal, y que habia tomado una actitud amenazadora \& la vista de mis perros. Tenia la cola en continuo movimiento, y producia con ella un ruido semejante al que hace un amolador cuando pasa unas tijeras por su muela de afilar; al propio tiempo estiraba hácia los dos perros su cabeza, con las fauces abier. tas. Estos, inmóviles, la miraban, pero sin atreverse á ata. carla, aunque ninguno de ellos se hubiese jamàs mostrndo cobarde para dejar de aconcter a los lobos. Habia tambien dos gatos alli cerca, que parecian poseidos de igual admira. cion. Estaba ya temeroso por la suerte de mis animales do. mésticos, cuando la serpiente cambió de repente de posturs, y siguió su camino. Los perros y los gatos la dejaron pasar, pero la siguieron despues, si bien aparentemente, tan solo por curiosidad. Disparé entonces al reptil una perdigonada que lo cogió de lieno, y lo rematé despues á estacaros. No pude conseguir que ninguno de mis animales se acercase al cadáver, causándoles este igual repugnancia que la serpiente viva.

VENENOSIDAD.-Pretenden algunos observadores que el crótalo acostumbra siempre sacudir sus cascabeles antes de morder, pero esto no es exacto; vease lo que dice Gejer: «Cuando repta con lentitud, arrastra por el suelo el apéndi. ce caudal; pero cuando huye lo levanta y lo hace sonar tambien, y tan solo cuando persigue su presa, no deja oir ruido alguno. El sonido del llamado cascabel se parece al que hace un amolador con su instrumento; en las praderas del alto Misouri existen unas pequeñas langostas, que cuando vuelan producen un ruido idéntico. Ia serpiente no anuncia siempre su presencia, y sí tan solo cuando se espanta 6 se re atacada. A menudo he descubierto uno de estos reptiles a tres pulgadas apenas de distancia del sitio que ocupaba yo un momento antes.) Los indios pretenden, se. gun dice Kalm, que el crótalo no agita su aparato caudal cuando premedita atacar: aserto que parece estar en consonancia con las cualidades de astucia y prudencia que ellos tanto admiran en dicho animal, pero que no tiene funda. mento alguno. A nuestro modo de ver las sacudidas que im. prime el crótalo \& su cola, haciendo sonar los cascabeles, no son mas que una señal de viva agitacion interior, la que tam. bien se manifiesta de igual modo en otras serpientes, aunque sin producir ruido alguno.

Los crótalos cuidados por mi hacian siempre ruido con la cola cuando se les molestaba, y apenas álguien se introdu. cia en la habitacion donde estaba la jaula. El ruido de los apéndices, que en mi opinion puede compararse con el que produce la langosta, siendo sin embargo mas sonoro, resulta de los movimientos laterales de la cola, siempre tan rápidos que la vista apenas puede divisar el cascabel. Verdade ramente admirable es la perseverancia con que el crótalo continúa produciendo ese rumor, pues lo hace hasta que se cree fuera de peligro. Me he entretenido á menudo en probar su paciencia, pero yo fú quien antes se cansó. Al alejarme un poco de la serpiente excitada, el ruido disminuia, mientras que aumentaba tan luego como me acercaba otra ver, acreciendo al propio tiempo la cólera del reptil. Segun mis 
observaciones, creo poder suponer que siempre produce el citado ruido cuando divisa oportunamente al hombre que se acerca, y que muerde silenciosa, cuando aquel le sorprende.

La mordedura de este ofidio es siempre muy peligrosa; pues sus dientes extraordinariamente largos y.aguzados pe. netran à través del paño recio y de gruesas pieles. Muerde, dice (jeyer, con una fuerza de la que no se le creeria capaz. Una vez convencido de que no podia saltar el crótalo, me entretuve en estudiar su manera de morder. Encontré que no se rompen tan fácilmente sus ganchos venenosos, aun cuando clavados en un palo se den rápidas vueltas í este: la serpiente se retuerce con cl palo y hasta se deja levantar del suelo suspendida de él. Un crótalo, de unos cinco ás seis piés de largo y con doce piezas en su apéndice caudal, hincó mas de ireinta veces los dientes en un recio palo de pulgada y media de diámetro, arrancando un pedazo de corteza, y yolvió \& morder de nuevo. Cuanto mas dura este experimento mas se excita la serpiente, que furiosa repite sus mordiscos con extraordinaria rapidez, hasta que finalmente, pierde las fucraas y parece acobardada.

*n las praderas del Misouri tuve ocasion de admirar una vez inas la fuerza con que clava sus dientes el crótalo. Vivenir hácia mi un buey, que parecia furioso; á fin de evi. tar el contacto de sus astas, incliné mi caballo hícia un lado, haciéndole tomar al propio tiempo un buen trote. El buey pasó mi lado casi rozándome, y percibi entonces que llevaba colgando detrás de la barba una gran serpiente de cascabel. Volvi grupas para seguirle, y pude ver cómo describiendo un ancho semicirculo, rompia stravés de unos zarzales; consiguiendo librarse de este modo de su enemigo. Deseoso de observar las consécuencias de la mordedura, apeéme de mi caballo. El buey se dirigió primero lentamente hácia el de más ganado que estaba alli pastando, pero sin tocar la yerba pocos minutos despues se paró, dejando caer la cabeza inclinándola hácia él lado opuesto al que tenia herido; per. cibi entonces cierto temblor desde las rodillas hasta los piés. que fué aumentando cuando le obligué á andar adelante. $\mathbf{E}$ sitio de la mordedura estaba ya hinchado fuertemente hasta Ia oreja Esto sucedia entre nueve y diex de la mañana. Vol vi al mismo punto á las cuatro de la tarde del dia siguiente, y encontré al animal todavia en el mismo puesto, estirado en el suelo, con la boca abierta y seca, la lengua hinchada y colgando, cubierta de tierra seca, y debajo un hoyo en el suelo que debia haber hecho con aqquella. La herida supura. ba, y la cubrian enjambres de moscas. Como no habia habi tacion alguna alli cerca, nada pude hacer por el pobre ani. mal, y me contentécon cortar un poco de yerba, quehumedeci con agua $y$ le introduje en la boca.

Los efectos del veneno varian segun el grado de irrita cion de la serpiente. Considérase generalmente menos ponzoñosa la mordedura en tiempo húmedo y fresco,y por el contrario, muy peligrosa durante los dias calurosos de agosto y cuando acaba de abandonar el reptil su guarida invernal: en estas épocas, las de mayor excitacion de la serpiente, se muestra acometedora y se adelanta á veces algunos pasos hácia el viajero, sacudiendo sus cascabeles. Vi una vezá un muchacho indio que habia sido mordido en el citado mes de agosto; todos los medios que emplearon sus compatriotas fueron infructuosos. Ofrecia el chico un espectáculo horro. roso, pues la gangrena se habia ya comido la carne en la parte herida hasta el hueso, $s$ se veia materialmente cómo el cuerpo se iba pudriendo de abajo arriba. Era tan repug. nante el olor que despedian sus heridas, que se necesitaba gran fuerza de voluntad para acercársele. El martirio del in. feliz muchacho duró unas seis semanas.

Tampoco poseen los indios un antidoto seguro contra la mordedura de la serpiente de cascabel. Con todo, sábese que se han empleado varias plantas con singular éxito, como la Aristolochia serpentaria, Prenanthes serpentaria, Eilinncea purpurea, Serotina angustifolia y Eryngium ayuaticusm; la Polygula Senega y $P$. purpurea no se consideran tan eficaces como aquellas. Lo mas particular es, que de todas estas plantas solo se hace uso de sus raíces, las que secas llevan siem. pre consigo los indios, reduciéndolas á pasta con los dientes en el acto de aplicarlas á la herida. En opinion de los cazadores americanos, el antídoto mas seguro, si bien el mas doloroso igualmente, es quemar un montecillo de pólvora humedecida sobre la mordedura; al propio tiempo, suelen propinar al paciente, como medicamento interno, cierta can. tidad del mismo ingrediente, cosa de una carga de escopleta de una vez Sin embargo, como estos cazadores suelen tener la pólvora en gran aprecio, es de temer que la atribuyan de. masiada eficacia; con todo, la cauterizacion de la herida en los primeros momentos produce siempre muy buenos resul. tados.

Feliamente, va siendo ya muy conocido entre los americanos el uso del remedio que hasta ahora se ha mostrado mas eficaz: la toma en grandes dósis de los alcohólicos. «En setiembre de 1820 , refiere Magrand, of de noche los gritos angustiosos de una mujer, y pocos minutos despues me avisaron que el esclavo Essex habia sido mordido por una serpiente de cascabel, y parecia moribundo. Iue encontré cfec. tivamente en muy inal estado, con las quijadas cerradas y sin movimiento alguno; el pulso irregular $y$ apenas percepti. ble. La luumanidad por un lado, y mi propio interés por otro, exigiéronme que hiciese cuanto estuviera á mi alcance para salvar al infeliz. Habia oido hablar de la eficacia de las bebidas espirituosis, y resolvi por lo tanto, hacer uso de los mas poderosos excitantes que tenia á mano; mezclé una pequeña cucharada de pimienta española, molida muy fina, con un vaso de aguardiente, $\mathrm{y}$ sep̧arando a viva fuerza las mandi. bulas de Essex, le introduje la pocion. Esta primera toma y las tres $\delta$ cuatro siguientes fueron arrojadas, pero la quinta, por fin, permaneció en el estómago. El pulso subió despues de haber propinado al paciente cinco ó seis vasos mas, pero volvió á bajar luego; por lo que continué administrándole mi remedio. No dejaba de temer fatales resultados de la gran cantidad de excitante, pero como el pulso bajaba cada vez que demoraba una toma de aquel me veja obligado s. no interrumpirlas. Despues de haberse tragado el enfermo mas de una botella de aguardiente pimentado, empezó á hablar con los demás negros; dos horas mas tarde, durante las cusles habia continuado tomando el mismo remedio, se encontraba el pobre Essex tan restaurado, que pude abandonarle al cui. dado de sus compatriotas. Al dia siguiente su estado habia mejorado considerablemente; pcro sus fuerzas no habian vuelto todaria. No dejé, pues, de darle cada hora una pe. queña toma de espiritu de cuerno de cicrvo, como tambien viandas nutritivas. Durante la noche se consumieron unas tres botellas de aguardiente. Apoderóse la gangrena de par. te de la carne debajo de la barba, y al rededor de la herida perdió el paciente un pedazo del tamaño de un duro; con todo, la cura fué muy pronto completa, mediante cataplas. mas y lociones con la decoccion de la corteza de la encina roja.

Un año despues, fui llamado tambien de noche para sal. var á otro negro mordido por una serpiente de la misma es. pecic. El enfermo se quejaba de fuertes dolores en el pecho y arrojó gran cantidad de humor bilioso. Mrandé adminisirarle repetidas tomas de aguardiente con pimienta verde, hasta que yolvió el pulso; disminuyeron los dolores, y des. pues de haber tragado el hombre seis vasos de la pocion, se 
encontró muy aliviado; poco á poco cesaron los dolores y los vómitos, y al cabo de doce họras estaba el paciente fucra de peligro. Bebió en todo como una botella de aguardiente pi. mentado.

\Por un amigo tuve noticia del siguiente caso: Encontróse a un hombre, que acababa de ser mordido repetidas veces por una serpiente de cascabel, y fué lievado á su casa en concepto de moribundo; al corto rato volvió en si, en perfecto estado de salud. Sus compañeros dijeron que habia sa. lido de casa completamente ebrio, $y$ probablemente tropezado y caido encima de la serpiente; el excitante que tenia en el cuerpo habia, sin duda alguna, neutralizado la accion del veneno. $\$$

CAUTIYIDAD. - Los crótalos cautivos suelen rehusar durante mucho tiempo la alimentacion, pero por fin la aceptan cuando su jaula está construida de un modo conveniente. Un individuo que yo compré no comió nada por espacio de siete meses aunque mató á los animales que le presenté; solo cuando hubo enflaquecido de tal manera que parecia un esqueleto, devoró una rata despues de envenenarla. Aunque ya habia soportado antes dos meses de cautividad, un ayuno de otros nueve no le perjudicó en manera alguna. Durante su abstinencia voluntaria bebia agua á menudo, bañábase, y nutdó la piel varias veces; despues de cada muda parecia necesitar alimento; mostrábase mas vivaracho é inclinado á morder; mató varios animales, dejándolos abandonados en el suelo, y por fin devoró una rata, comenzando desde entonces á comer con tal regularidad, que al cabo de dos meses habia vuelto á recobrar toda su gordura. Tambien en otra ocasion observé la pereza del crótalo: aunque advertido por Effeldt, quien me aseguró haber ob́servado una cosa análoga, mandé cchar en la jaula de mis serpientes de cascabel cautivas algunas ratas vivas, á las cuales se alimentó, hasta que por fin fueron víctimas de la ira del reptil. Los roedores se acostumbraron pronto á su nueva vivienda, y el ruido que producia la serpiente solo parecia causarles curiosidad, pero no micdo. Trataban al ofidio cual si no existiern; corrian por encima de él, saltaban sobre sulomo, y por fin dejaron de hacer aprecio de la cólera del reptil, que $\{$ veces llego á tomar su posicion de ataque, permaneciendo en ella horas enteras. Cierta mañana, al acercarme á la jaula de mi crótalo, observé que no hacia ruido con su cola, segun acostumbraba tan pronto como me veia; estaba tendido en toda su longitud en el sue 10, y al parecer enfermo, pues no hacia ningun movimiento, y solo sus ojos, siempre muy vivos, conservaban su expresion maligna. Al medio dia el reptil murió en el mismo sitio; y al sacarle de la jaula vióse en su cuerpo una grande y profunda herida, que debió causar su muerte. La rata habia empezado a comerse viva a la terrible serpiente venenosa. Ef feldt, á quien di cuenta del hecho, se alegró mucho de ver confirmada de tal modo su profecía, y me advirtió de nuevo que no pusiera en la jaula de las serpientes venenosas otros mamíferos que los que no pueden causar daño, tanto mas cuanto que todos estos reptiles de gran tamanio se acostum. bran pronto á devorar tambien animales inuertos y aun pe. dazos de carne humana.

Cuando se las cuida como conviene, las serpientes de cas. cabel se conservan muy bien en cautividad. Sábese de al. gunos individuos que han podido resistir de este modo doce años de cautiverio. Al principio se muestran, como las víboras, muy rebeldes; pero con el tiempo va cediendo su ferocidad, llegando por último á conocer á su guardian, y ya no procuran morderle cuando se acerca á la jaula. Con sus congéneres viven en perfecta armonía. eTreinta y cinco de estas serpientes, dice Mitchell, que tuve reunidas cn una misma jaula, nunca manifestaron seōal alguna de enemistad entre sí, aun cuando se arrojase de repente entre las antiguas una nueva compañera de la misma especie, mientras que la apa. ricion de un conejo, una paloma, etc., producia en el acto gran alboroto. Por lo general, su estado regular era el de la mas completa indolencia. Bajo una temperatura calurosa se mostraban mas animadas, y retorciéndose y enlazśndose unas con otras en forma de ovillo, cambiaban alguna que otra vez de postura, pero con mayor frecuencia permanecian largos ratos en la mas absoluta inmovilidad. Esta quietud es tanto mas temible cuanto que está en chocante contradiccion con la extraordinaria rapidez de la acometida de estos ani. males, é infunde una confianza engañosa al aficionado, que puede serle fatal alguna vez.

Un tal Neale, que habia tenido cautivos muchos individuos de esta especie, adquirió el convencimiento de que eran susceptibles de domesticacion. Pretendia que la música ejercia tambien influencia en estos reptiles, y aseguraba que tratándolos con dulzura se amansaban los mas furiosns. Por último, parece que efectivamente este hombre presentó en público crótalos domesticados. «La mansedumbre de estos animales, refiere un testigo presencial, llega al punto, que despues de decirles su domador algunas palabras $y$ de acariciarles con la mano, se dejan coger por él y manejar como si fueran cuerdas. El hombre hace que las serpientes suban por su pecho y se le enrosquen alrededor del cuello, las besa, y repite estos cjercicios con todas, una tras otra; y estos temibles ofidios, en vez de procurar hacer mal á su dueño, parecen, por el contrario, demostrar cierto cariño thácia él. Este les abre la boca y enseña sus ganchos venenosos, etcé. tera. La seguridad del domador consiste además cn el eficaz antidoto que dice él poseer contra la mordedura de estas serpientes, y del que no hace misterio alguno. Ante todo, asegura Neale, debe lavarse bien la boca con aceitc caliente y chupar entonces la herida, bebiendo despues de una decoccion de la raiz de la serpentaria, hasta que se presenten fuertes vómitos; una vez conśeguido esto, ya no hay que temer.

No creemos del todo imposible que tratándolas debida. mente se lleguen á domesticar hasta cierto punto las serpien. tes de cascabel; con todo, su roce no deja por eso de ser siempre muy peligroso, 5 casi todos estos domadores pagan un dia ú otro con su vida la menor imprudencia.

\section{EL CRÓTALO DE DIAMANTE-CROTALUS ADAMANTEUS}

De las seis especies de crótalos que se cunucent, nada me. nos que cuatro pertenecen á la mitad septentrional del con. tinente, $y$ solo una se encuentra mas allá del istmo de $\mathrm{Pa}$ namá. En el sur de los Estados Unidos se observa ya el crótalo de diamante, cusa área de dispersion se toca en la América central con la del crótalo hórrido, única especie que hasta ahora se ha encontrado en la América del sur.

CARACTÉRES. - El crótalo de diamante es sin duda la especie mas bonia del género, $y$ tambien es superior todas las demás en tarnaño, porque no son raras las hembras de $2^{n}, 3^{\circ}$ de largo. Distínguese de la serpiente de cascabel por tener la cabeza muy grande y prolongada, con suś escudos poco desarrollados, y además por el color y los matices; de tal modo quie apenas es posible confundir ambas especies. El pequeño escudo de la punta del hocico es triangu. lar; los frontales, poco desarrollados, afectan la forma cuadrilátera; los grandes escudos de ias ccjas presentan un borde muy saliente; la coloracion, despues de la muda, consiste en un magnífico pardo verdoso, que en algunos individuos es pardo dorado y se oscurece mas y mas hasta la pró. 
xima muda de la epidermis perdiendo al mismo tiempo gran parte de los matices, consistentes en una cadena triple de rombos cuyos bordes, de un amarillo dorado, se desta. can maravillosamente sobre el fondo muy oscuro de los cuadrados irregulares. Una faja de igual color se corre desde la punta del hocico por encima de los ojos lıasta los ángulos de la boca; la parte superior de la cabeza presenta manchas, figuras $y$ fajas oscuras é irregulares.

\section{EL CRÓTALO HÓRRIDO-CROTALUS HORRIDUS}

CARACTERES.-El crótalo hórrido se parece á su congénere norte anericano respécto á la formacion de los escidos de la cabeza, y al crótalo de diamante por el color y los matices, distinguiéndose sin embargo del primero por tener los escudos de la parte anterior del hocico mezclados con otros mas pequucảos, y del segundo por ser los rombos mucho mas grandes; con bordes mas anchos y de color mas ciaro, es decir, de un amarilo blanquizco ó amarillo gris claro. Dos tajas de un pardo oscuro 6 negras, anchas y paralelas, parten de cada ojo y se corren por la cabeza y el cuello: las regiones inferiores son de un blanco amarillento. Iil tamaño es el mismo que el de la serpiente de cascabel.

USOS, COSTUMBRES Y REGIMEN.-Como todas las especiesidel género se asemejan en su género de vida, bastarí decir que el crótalo de diamante fija su residencia principarmente en terrenos húmedos, en las cercanias delos rios, lagos y pantanos, ó en la costa del mar; es tan peligroso y mas venenoso aun que sus congéneres, pero por lo demás apenas se distingue de la especie ya descrita. Lo mismo sucede con el crótalo hórrido, del cual tenemos tan. tos dalos curiosos sobre su género de vida, que nos parece justificada una descripcion minuciosa de sus usos y cos. tumbres.

\$El crótalo hórrido, dice el principe de Wied, está dise. minado por casi toda la América del sur; habita todo lo in. terior del Brasil; aparece en Minas Geraes y encuéntrase al norte hasta la Guayana y á orillas del Maranon.

Por Azara, Burmeister y Hensel sabemos que tampoco escasea en el sur, abundando especialmente en los Estados de la Plata; Schomburgk dice que prefiere en la Guayana los mismos sitios que en el Brasil.

«Fn los bosques húmedos de las costas, sigue diciendo el principe, no suele encontrarse este reptil, y si mas bien de trís de estos, en los ierrenos secos y pedregosos del Serton. Con esta noticia está conforme Tschudi cuando dice que $\mathrm{cl}$ crótalo hórrido prefiere los parajes frescos de los campos a las calurosas selvas virgenes, por lo cual se le encuentra principalmente en el interior del imperio. En Rio Grande do Sul escrisca, segun Hensel, mucho mas que los otros dos crotálidos propios de aquellas regiones, el surukukk y chiaragrala, abundando mas cerca de la colonia de Santa Cruz; tambien aqui busca con preferencia los sitios desculsiertos con espesas yerbas y rodeados de rocas y maleza.

En la Guayana vive en la sabana y en los sotillos que ofrece esta, hasta una altura de seis mil pies sobre el nivel del mar; alli, lo mismo que en el Brasil, no aparece en los espesos bosques del litoral.

De dia, solo se ve $\{$ esta serpiente en cstado de reposo. Yace enrollada $\varepsilon$ indolente en un mismo sitio, y solo muerde lo que se accrca á su alcance. A menudo, refiere el prin. cipe, se han perdido de este modo varias cabezas de ganado en un mismo dia, que eran mordidas al pasar por cierto sitio del camino $\delta$ del prado donde pastaban; llamando la atencion circunstancia tan singular, inquiriase la causa, y por úl. timo, descubríase la serpiente, que, como se puede suponer, era muerta al punto. No acercíndosele casualmente dema. siado, ó percibiéndola á distancia de algunos pasos, no hay qué temer: pues, poco antes de disponerse á morder, da con las sacudidas de su cola el conocido aviso, si bien no tan recio que se pueda oir á cierta distancia. Sin embargo, su. cede á veces que, á pesar del mayor cuidado que se tenga, se acerca uno involuntariamente al alcance de uno de estos reptiles, y recibe un mordisco en el pié. Este percance no ocurre tan solo á los blancos que no tienen la vista tan ejer. citada, sino que tambien, como pudo presenciarlo Schom. burgk, á los indigenas, á cuya mirada de águila no es tan fácil que pase desapercibida cosa alguna.

$\$$ A veces me he aproximado, dice el naturalista que acabamos de nombrar, á la cascabella ó maraca, como la llaman los indigenas, hasta cinco 6 seis piés de distancia y obser. vádola con toda tranquilidad. Naturalmente, no quitaba la vista el reptil àe encima de ml, todo el tiempo que duraba mi inspeccion, pero no mostraba tampoco deseo de morderme. Con todo, la menor provocacion, tan solo acercársele repentinamente, excita al punto su furor: retorciendose entonces como las roscas de un tornillo, levanta la cabeza y el cuello, abre la boca cuanio puede, y dando un silbido particular, mira colérico á uno y otro lado, espiando el momento oportuno para morder; ratas veces yerra, y sus fuertes ganchos venenosos penetran a través de los vestidos mas gruesos y del mas recio calzado. La agitacion de su cola produce ciertamente algun ruido, pero no de naturalez. para ser oido a cierta distancia. Ios tres avisos que, segun algunos, acostumbra á dár la serpiente antes de morder, son tanta paparruchá como la fascinacion magnética que otros le atribusen.

El rumor de la cola, que precede al ataque, suele advertir al hombre, segun áfirma tambien Tschudi, pero no siempre a tiempo, pues a reces sucede que de pronto se pisa al reptil dormido, y entonces muerde sin prévia advertencia.

los perguenos mamiferos constituyen el alimento principal del crótalo hórrido, que en el sur se nutre exclusivamente de ellos; tambien persigue todas las aves que cree poder en. ganar.

En cuanto á la reproduccion de esta especie, es aplicable cuanto hemos dicho de la serpiente de cascabel.

Sus individuos suelen agruparse tambien durante la época del aparcamiento; pues refiere Gardner que en un bosque, no muy léjos de Rio Jauciro, oyó extraños silbidos y fuerte estrépito, que su compañero de viaje, un indigena, le dijo procedian de serpientes de cascabel. Incaramáronse en un árbol, y efectivamente desde alli pudicron observar unos veinte crótałos, cnlazados en informe ovillo, que silbaban cón las cabezas levantadas y sacudian sus cascabeles. Las ficchas del brasileño y la escopeta de dos canones de Gardner deja ron sin vida á trece serpientes, hiriendo á varias otras, que despues mataron los viajeros á garrotazos. En el abdómen de las que abrieron, hallaron restos de pájaros y pequeños ma-
miferos.

VENENOSIDAD. - Schomburgh refiere el siguiente caso: REl sol se acercaba al horizonte, y Esciamaipn no habia re. gresado todavia; lo que no llamó sin embargo nuestra aten. cion, hasta que vimos à otro indio que en rípida carrera se acercaba al pueblo: señal infalible de una importante nove. dad ó aviso de una desgracia, pues el indio, fuera de estos casos excepcionales, jamás camina hácia una aldea sino con paso grave y mesurado. Llego el hombre y nos dijo que habia encontrado á Esetamaipn sin sentidos en la sabana, mordido por una serpiente. Provistos de toda clase de auxilios, marchamos inmediatamente hácia el sitio de la desgracia, y alli 
encontramos al infeliz todaria en el mismo triste estado. Una herida, ensanchada con el cuchillo de una manera verdaderamente horrorosa, por encima del tobillo derecho, y venda. da con una tira del pedazo de tela que componia todo su traje, nos indicaba la parte mordida por el reptil. Is pierna estaba hinchada, y violentas convulsiones sacudian todo el cuerpo del pobre indio, á quien apenas pudimos reconocer, tal era la contraccion de sus facciones. Al pasar por la saba. na, Esetamaipn habia pisado una serpiente de cascabel, s llerado del sentimiento de venganza, la habia muerto primeto, y cortado y vendado despues su herida con la sangre fria 6 impasibilidad propias de todo indio. Como el suceso habia renido lugar en la parte mas elevada de la sabana, penosa mente se habia arrastrado el herido hácia el sendero, espe. rando ser encontrado alli, y perdidas las fuerzas, cayó en el sitio donde le velamos. A juzgar por la sangre derramada, debian haber pasado ya varias horas despues de la mordedu. ra, de modo que la succion y la cauterizacion estaban ya fuera de tiempo; lavamos, pues, la herida con amoniaco, é hicimos tragar tambien al paciente, todavia desfallecido, algunas gotas mezcladas con un poco de agua. Este remedio no dejó de producir muy pronto sus efectos; rolvieron los sentidos y Esetamaipn, que se quejó de dolores en el pecho y en la espalda, como tambien de tirantez en los miembros, fué llevado en su hamaca á Pizara. Permaneció la pierna varios dias hinchada, como masa informe y sin movimiento alguno; al propio tiempo, la mas leve sacudida causaba terribles dolores al enfermo. Pasadas tres semanas, el uso con. tinuo de cataplasmas emolientes habia conseguido, no tan solo bajar la hinchazon, sino que tambien hacer desaparecer los dolores y el aspecto cadarírico del rostro; al cabo de cinco semanas se cicatrizó la herida, y pudo el paciente hacer uso de su pit otra vez.

Hace algunos años, segun dice T'schudi en su \&Viaje por la América del sur, publicado en $\mathbf{1} \$ 6 \%$, un suceso causó mucho asombro en Rio Janeiro. Un ral Mariano José Ma. chado, que hacia muchos años padecia una eufermedad de la piel, resolvió despues de una permanencia de cuatro años en el hospital de la ciudad, hacer una uftima tentativa para la curacion de su terrible mal. La creencia popular atribuye en algunas regiones del Brasil â la mordeciura de las serpien. tes vencnosas la virtud de curar la lepra; y Machado, despues de haber oido decir que en la capital se hallaba un crótalo vivo, declaró su firme resolucion de hacerse morder por el reptil. Inútiles fueron todas las instancias de su familia y de varios médicos para lacerle desistir; cansacio de la vida, fué sordo á todas las súplicas; y acompañado de varios hombres, entre ellos tambien algunos médicos, se dirigió á la casa designada, donde hizo extender una solemne acta por notario, en la que deciaraba que daba aquel paso por su propia voluntad, despues de liaberlo pensado mucho, y que solo él seria responsable del resultado: esta escritura se firmó por el interesado y varios testigos. Machado era un hombre de mediana estatura y de unos cincuenta años de edad; todo su cuerpo estaba inradido por la lepra; tenia el rostro completamente desfigurado; y en las extremidades las pústulas se habian aglomerado de tal modo, que la epidermis podia desprenderse con facilidad. El hastio a la vida habia llegado va en el paciente ś su colmo. Cumplicia debidamente dicha formalidad, Machado puso sin vacilar la ma. no cn la jaula del crótalo, pero este, cual si le infundicra repugnancia el enfermo, retrocedió. El hombre cogió despues la serpiente, pero esta se limitó á mover la lengua, y solo cuando el enfermo la excitó oprimiéndola varias veces, mordiỏle en la base del dedo meñique.

Machado no sintió nada de la herida, de modo que los presentes hubieron de llamarle la atencion sobre ella. Esto sucedió \& las once y cincuenta minutos: al retirar la mano de la jaula se observó en la herida una pequena hinchazon; á los cinco minutos, el paciente experimentó frio en la mano, que desde este momento se inflamó rípidamente, adquiriendo al cabo de un cuarto de hora un tamaño espantoso. $A$ las doce y veintiocho minutos la hincharon se extendió por todo el brazo hasta el hombro; y la descomposicion del semblante y los movimientos convulsivos demostraron que los efectos del veneno iban en aumento. A la una y veinte minutos notóse un temblor y una sensibilidad extraordinaria en todo el cuerpo; diez y seis minutos despues perturbaironse las fa. cultades intelectuales del enfermo, que inovia con dificultad los labios; prodújose la soñolencia y una contraccion del esófago. A las dos y cinco minutos se entorpeció la deglu. cion y el habla; el paciente se quejó de angustia y un copio. so sudor inundó su pecho. Treinta minutos mas tarde el malcstar habia llegado á su colmo; al mismo tiempo se pro. dujeron vértigos; la sangre manaba por la nariz accidente que se repitio a los cuatro minutos; y los dolores del brazo se hicieron tan agudos, que el enfermo exhalaba involuntariamente gemidos. A las tres y treinta y cinco minutos extendióse por todo el cuerpo un color amarillo, y de una de las pústulas de debajo del brazo comenzó á salir sangre. El enfermo bebió sin dificultad un poco de vino con agua, pero pronto no pudo ya tragar; la respiracion se hizo penosa, los do lores del brazo casi insoportables y el color amarillo de la piel empezó á oscurecerse, sobre todo en el brazo mordido. Las pulsaciones que despues de las dos ascendian a noventa y ocho, subieron a ciento cuatro por minuto. Prodújose entonces un gran calor en todo el cuerpo; á las cinco y treinta minu. tos una secrecion considerable de orina, y ś las siete una sonolencia invencible. Pasado algun tiempo, durante el cual el enfermo se habia quejado de continuo, despertóse en fuerza de sus agudos dolores en el pecho y estrechez de la garganta, de modo gue le era imposible tragar; las secreciones de orina se repitieron, y tambien las evacuaciones de sangre por la nariz. En tal estado, cuando el enfermo, asi como los medicos presentes, parecian convencidos de que el envenenamiento tendria por resultado la muerte, hizose con el consentimiento de Machado una úlima prucba para cvitarla.si cra posible. A las diez. se le dieron por lo tanto tres cucharadas de una coccion de huncs (miknaia huaco) y una hora despues cuatro mas. A la media noche sobrevino el sueino; al cabo de media hora el enfermo despertó con una angustia indecible, gritó ruidosamente y jididió un confesor. Pasó el resto de la noche sumamente inquieto: á las nueve de la mañana apoderóse del enfermo un gran desfallecimiento; la orina era sangrienta, y las convulsiones se repitieron, interesando sobre todo in mandibula inferior y las cxtrensidades inferiores. A las diez y treinta minutos, cunndo aun no ha. bian trascurrido veinticuatro horas, el enfermo murió, des. pues de haber sido atormentado por toda clase de remedios, habiendosele obligado tambien à tomar algunas onzas de aceite de lagarto. El cadáver se hinchó pronto de un modo extraordinario, entrando rápidamente en descomposicion; á los pocos minutos se cubrió de manchas.

Runque se salve el herido, dice Schomburgk, por la pionta aplicacion de remedios, las consecuencias persisten toda la vida, yasta puede sucumbir el paciente al cabo de varios años. En casi todos los casos la herida se abre de nuevo y el miembro dañado se resiente del cambio de tiempo. Además de los remedios usuales y conocidos de todos, como tambien el jugo fresco de la calia de azúcar, que segun afirman los indios es muy cficaz igualmente contra el envenenamiento por medio de las flechas emponzonadas, posece 
cada tribu sus antidotos particulares, de los cuales una buena parte no son mas que ridiculas supersticiones. Asi, en algunas tribus ni el herido, ni sus hijos, padres $y$ hermanos, siempre que habiten bajo el mismo techo, pueden beber agua, ni bañarse, ni tan siquiera acercarse al liquido, durante los primeros dias de su enfermedad; tan solo \& su mujer le es permitido hacer uso del agua. Una especic de caldo ó pasta poco espesa de calabaza es lo único que, tomado ca. liente, debe emplearse para apagar la sed, asi como tambien solo pueden comer cierta fruta asada durante el mismo tiempo. Si el herido ha chupado caña de azúcar para contrarestar el efecto de la mordedura, debe privarse despues de todo otro dulce. Hay tribus en las que la leche de mujer goza la fama de ser el mas enérgico contrarcneno, f la usan conjuntamente con cataplasmas emolienies; otras dan la preferencia al jugo extraido de las raices y hojas del Draconsiusu dubium. Empléase tambien nuy generalmente contra la mordedura del crótalo una decoccion de la Byrsomina crassifolia y de la Mourcila, lo mismo que de la Quelistea ginnensis. Pero parece que la accion curativa de todos estos medios depende en gran manera de la robustez y constitu. cion del herido, pues las mujeres y los hombres débiles raras veces logran salvarse.

Tschudi no duda que los indios de las selvas, tan expues. tos á los mordiscos de serpiente, tengan un antidoto eficaz que hasta ahora no conocemos. "Sabido es, dice, que los indios de Columbia y del Perú poseen un excelente remedio contra la mordedura de ciertos ofidios; es el hejure de hunco (mikania huacio), remedio que raras veces deja de tener felices resultados Anade que miles de veces se ha emplea: do con brillante éxito, y al hablar del caso de Machado dice que entonces no produjo efecto por habersé empleado cuando ya era tarde para salvar el enfermo. \&El huaco pudo retardar la muerte, pero no salvar al enfermo.»

(Los brasileños, observa el príncipe de Wied, fucra de nuchas ridiculeces y supersticiones, conocen algunos remedios verdaderamente eficaces contra la mordedura de las serpientes, entre otros, la incision y cauterizacion de la herida, y varias infusiones de plantas, que emplean en forma de cataplasmas algunas, y otras como medicamento interno, que en este caso obran como sudorificos. Estas plantas son en número considerable, y forman entre ellas varias especies de las Aristolochio, Bignonia, Jacaranda: como, por ejemplo, el Angelim branco, la Plumeria, la Verbena Vingata, etc.

En su descripcion de viaje el principe refiere varios casos de hombres mordidns por serpientes que pudiernn salvarsc. A un jóven puri se le vendó el pié mordido, hízose una incision, se chupó la herida, y á falta de un sudorífico se le dió aguardiente. ¿Despues de cauterizada dos veces con póivora, colocóse al enfermo en una hamaca, cubriendo la herida con cantárida pulverizada. El pié se binchó nucho; un mi nero alli presente trajo dos clases de rair, de las que la una parecia ser la del aristolochica ringens, la cual sirvió para preparar una tisana muy cargada; siguiéronse vómitos, pero era dificil reconocer si fueron causados por la bebida, por el aguardiente ú por el mismo reneno. Despues de una noche tranquila, el pié y el muslo se hincharon hasta ofrecer doble tamaño; el enfermo se irritó de tal manera que gritaba y lloraba al mas leve ruido; ; como empezaba á echar sangre por la boca no se le dieron mas remedios. Sobre el pié se le pusieron hojas de la Rumeria obocala, que le aliviaron mu. cho; en la herida echóse un polvo de la raiz de esta planta, y el enfermo sanó poco despues.

En un corto viaje por las cercanias de Rio Janciro, Sellow encontró un negro mordido por una serpiente; estaba desfa llecido y echado en tierra; tenia el rostro hinchado; respiraba con fuerza y habia echado sangre por la boca, nariz y oidos. Se le dió luego grasa del gran tejú, propinándole antes una tisana de verbena como sudorífico.

\&lo dicho nos dará una idea de los medios empleados por los campesinos brasileños para estas curaciones. Sucede alli lo mismo que entre nosotros; cada cual conoce. un medicamento preferible al de su vecino, remedio que con seguridad cura y que a menudo se tiene como secreto. Sobre todo se recomienda rezar cierto número de Ave Marias, Padre nuestros, etc.

Un farmacéutico aleman, Peckolt, residente en Cantagallo, ha preparado, segun 'Tschudi, con una planta empleada á veces con éxito por los indios como antidoto, una tintura que vende bajo el nombre de poligonaion, acompañándola de una ventosa que se debe aplicar al punto sobre la herida, ensanchada por aigunas incisiones, despues de vendar el miembro mordido. La tintura se toma, segun la violencia de los sintomas, a intervalos mas 6 menos largos, y ha tenido un exito brillante en mas de setenta casos ocurridos en las cercanias de Cantagallo. Aunque se usó tarde, cuando los sintomas ya habian adquirido su carácter mas peligroso, comenzando los vómitos de sangre, salvó a menudo al en. fermo.

Segun dice el mismo naturalista, los indios y los negros afirman que la mordedura del crótalo es mas peligrosa en las épocas de gran calor, cuando las hembras llevan los huevos, cuando mudan la piel y en los cambios de luna. Ios brasileños, al igual de aquellos, dicen tambien que las serpientes escupen el veneno cuando quieren beber; que el herido de su mordedura debe evitar, mientras dure su curacion, la vista de las mujeres; que el veneno conserva durante largo tiempo su eficacia, $y$ refieren i veces en apojo de estos asertos las mas ridículas historias. El ya gastado cuento del par de botas que hizo viuda tres veces á una mujer, porque al morder una scrpiente de cascabel al primer dueño de aquellas, dejó clavados en el cuero sus ganchos venenosos, corre todavia de boca en boca entre brasileños y norte-americanos, siendo oido siempre con la mejor buena fe del inundo, y sin que nadie se atreva á oponer la menor objecion.

En cuanto a los enemigos que suelen atacar á esta ser. piente, ni el principe de Wied, ni Schomburgk, dicen cosa alguna, pero podemos suponer que tengan los mismos 6 pa. recidos que su congénere norte-americano. El hombre la mata siempre, donde sea que la encuentre, sin sacar ningun otro provecho de ella. Ningun americano come su carne, ni sirjuiera el indin salvaje. T.os cascabeles de sus cola, segun indica el príncipe, se recogen siempreque se puede, pues al. gunos los pagan à muy buen precio, atribuyéndoles ciertas propiedades curativas.

Ca Utividad.-En la América del sur, solo los negros tienen aficion \& educar las serpientes venenosas, aDicese que los negros han traido de su pais, observa Schomburgk, el arte de domar estos reptiles, pues entre ellos no es cosa muy rara tener serpientes de cascabel que, sin arrancarles sus dientes, han domesticado hasta el punto de dejarlas enroscarse en sus brazos, y viven con ellas en la mayor inti. midad.

\section{LOS LAQUESIS - LAGHESIS}

CARACTÉRES.-Crótalo mudo (Crotalus mutus) llamó Linneo a esta especie, la mas temible tal vez de todos los botrofidios de la América del sur, y que tiene, en efecto, todos los caractéres de los crótalos, menos los cascabeles, sus. tituidos por cuatro, hasta cinco escamas, mas perqueñas y puntiagudas, y una espina córnea en la extremidad terminal 
de la cola; siendo este último distintivo el que ha dado pié á Daudin para adoptar el nombre de la parca Lachesis como denominacion cientifica del género, en que ha aislado estas serpientes, separíndolas de los crótalos.

Como los laquesis forman una especie única, que pasamos á describir á continuacion, creemos que scria sobrada redun. dancia si entrárnmos ahora en otros pormenores.

\section{EL LAQUESIS MUDO-LACHESIS MUTUS Ó RHOMBEATUS}

CARACTERES. - El surucucu, como lo llaman los brasilenos, suele alcanzar una longitud de $2 ", 50$, y á veces mas, y un grueso como el del muslo de un hombre, segun indica el principe de Wied; lo que nos parece algo exagerado. Tiene el dorso de un amarillo rojizo, con una serie longitudinal de grandes manchas romboidales, pardo negruzcas, conteniendo cada una de estas, dos mas pequeñas y de tinta mas clara; la region abdominal es amarillenta pálida, y brillante como si fuera de porcelana. La coloracion del dorso adquiere un matiz mas oscuro por encima del cuello, y el dibujo degenera en la cabeza en manchas irregulares, pero siempre de la misma tinta pardo negruzca.

\$ La cabeza, en forma de corazon, dice Schomburgk, en. sanchada extraordinariamente por las poderosas glándulas, repletas de veneno, y que destaca marcadamente del cuello, lo mismo que los dientes venenosos, largos de mas de media pulgada, anuncian ya á primera vista la peligrosa condicion de esta serniente.

DISTRIBUCION GEOGRÁFICA.-en el Brasil, dice el principe de Wied, vive esta serpiente en todas partes; pues en todos los distritos que recorri me dieron noticias de ella, y mis cazadores la mataron en los bosques á orillas del Iritiba, del Itapemirim, del Rio Doce, del Peruhype, y aun mas hácia el norte. Markgrave la encontró asimismo en las inmediaciones de Pernambuco. Segun Schomburgk, abunda igualmente en la Guayana.

USOS, COSTUMBRES Y RÉGIMEN.-Véase lo que dice el principe: « El surucueu fija con preferencia su morada en los bosques frescos y sombrios, donde suele encontrársele enrollado en el suelo, descansando. Jamás trepa por los árboles. En sus hábitos y género de vida, se parece mucho á los crótalos. Pretenden algunos que de noche le atraen las hogueras, y este es el motivo porque muchos brasileños no encienden fuego alguno, cuando pasan la noche en el bosque. Dicese tambien que acostumbra arrojar el veneno cuando quiere beber, y otras ridiculeces por el mismo estilo. Algunos portugueses creen tambien que el reptil hiere con la espina de su cola; pero los indios y los negros, á quienes hice preguntas sobre este punto, me indicaron siempre el verdadero sitio del veneno y la perforacion de los temibles ganchos.

* Respecto al régimen y reproduccion de esta hermosa serpiente, no he tenido oportunidad de hacer observacion alguna; pero es de suponer, como ya he indicado, que sus costumbres sean muy análogas á las de la serpiente de cas. cabel. Considerando el tamaño y la robustez de su cuerpo, asi como la potencia de sus terribles armas; se puede deducir que se atreverá con animales de regular volúmen y fuerza.

Parece que la época de la muda de estos reptiles coincide con la de los pájaros, en el Brasil; pues en la selva virgen de Morro de Arara, encontré en el mes de marzo una piel re. cien despojada, en la que todavia estaban muy visibles las impresiones de las escamas.

(Si no viviese, dice Schomburgk, casi exclusivamente en los grandes bosquues este temible animal, \& cada paso se en. contraria el viajero en peligro de muerte; pues, segun el aserto general de los indios, el surucucu no huye, como las demás serpientes, á la vista del hombre, sino que retorcido en circunvoluciones parccidas á las roscas de un tornillo, aguarda tranquilamente al viandante que se le acerca, para arrojarse sobre él de improviso, con la velocidad del rayo. Seguramente es el laquesis el botrofidio mas venenoso y mas temible de la Guayana, y su mordedura suele considerarse como fatalmente mortal.

aLa mordedura de esta serpiente, dice por su parte el principe de Wied, produce la muerte en muy breve tiempo. Cerca de Rio Janeiro murió un negro en seis horas, y otro en doce, de resultas de la misma, refiriéndose varios otros casos análogos. Los heridos suelen arrojar sangre por la boca, nariz y orejas. A veces sanan los pacientes, cuando la cura puede empezar inmediatamente despues de haber sido mordidos; con todo, es muy dificil distinguir la verdad de la ficcion, en medio de tanto cuento y conseja que corren de boca en boca.

De la obra del mismo principe, copiamos tambien los siguientes datos que acerca de esta especie le fueron comunicados por un hacendado holandés de la Guayana: a Feliz. mente, dice este, cl surusucu no abunda en las inmediaciones de las haciendas, pues frecuenta mas las selvas. Con todo, como aqui existen varias sierras de agua y residen muchos negociantes en madera, sucede á veces que la serpiente hace alguna victima entre los que se dedican á este comercio. Un indio que habia entrado en casa del señor Moll en calidad de cazador, se fuć una mañana al bosque para cumplir los deberes de su cargo. Al poco rato, su perro empezó á aullar, señal manifiesta de que habia descubierto una serpiente. El indio, temiendo por su perro, acudió en su auxjlio, escopeta en mano; pero la serpiente, antes que él pudiese verla, se arrojó sobre el cazador y le pegó un fuerte mordisco en el brazo desnudo, mas arriba del codo, huyendo en seguida. El hombre, que no sentia todavia dolor alguno, persiguió al reptil, y habiéndolo muerto, por último, le abrió el cuerpo, y se fregó la herida con la piel del animal; recogió su caza, y se dispuso á regresar á la hacienda. Sin embargo, á los pocos pasos, perdió los sentidos y cayó al suelo; el perro, creyendo muerto, sin duda, â su amo, echó á correr bácia su casa, donde su agitacion y sus alaridos hicieron suponer al punto que habia acaccido alguna desgracia al cazador. Moll se hizo acompañar por uno de sus hombres, y siguió el camino que le enseñaba el perro. Al cabo de media hora encontra. ron al indio, estirado en el suelo y completamente rigido, pero dueño de sus facultades. Despues de haberle oido referir el suceso, le condujeron á casa de su amo; alli le pro. digaron toda clase de auxilios, pero sin conseguir resultado alguno: el veneno habia penetrado ya en la sangre, 5 como ya habian pasado algunas horas desde el momento en que fué mordido, la muerte del paciente era inevitable.

A pesar de lo peligroso de la mordedura de esta ser. piente, se puede salvar al herido, haciendo uso de los me. dios que indico a continuacion, siempre que puedan ser aplicados durante la primera hora despues de recibida la mordedura. Se prepara inmediatamente un par de botellas de leche, bien mezclada con unas seis cucharadas de aceite de oliva, que se propina en el acto al paciente en dósis regulares, pero muy seguidas, y si se tiene á mano, se le da \& mascar caña de azúcar, 6 en su lugar, una naranja agria; hácense profundas incisiones en la herida, aplicandole un veji. gatorio de hojas de tabaco, maceradas con la raiz de la Argenone moxicana, $y$ humedecidas con benjui y tintura de alcanfor; cada cuarto de hora se renueva este parche, y se añade un poco de láudano, si se percibe que la herida ad. 
quiere un borde negro. Al propio tiempo, se administran al enfermo purgantes y eméticos, y durante algunos dias se man. tiene artificialmente la herida abierta.s Parécenos muy dudosa la eficacia de estos medicamentos; sobre todo, teniendo presente la indicacion de Schomburgk respecto á la accion mortal del veneno del laquesis. Este naturalista refiere tam. bien el extraño caso siguiente: \&Durante mi primera estancia en Bartika Grove, encontré alli s un hombre de color, cuyo hijo havia sido mordido pocas semanas antes de mi ilegada, por un individuo de esta especie. El padre, habiendo encontrado al hijo sin sentidos, chupóle la herida causada por la serpiente. A los quince minutos, ya sentia cl hombre los mas atroces dolores, hincbándosele la cabeza de una manera horrorosa, y manifestando todos los sintomas del envenena: miento, que, en efecto, habia tenido lugar, como se demos. tró despues, por medio de un diente ngujereado, en el que debió penetrar alguna partícula del-veneno chupado de la lierida del hijo; este murio, y el padre, cuando visité recien. temente aquel pais, arsastraba todavia una vida raquitica $y$ emponzoñada, en el mas genuino sentido dé esta palabra.

eLos indios y negros, dice además el principe de Wied, comen silveces la carne del surusacu, despues de haberle corlado la cabeza en los primeros momentos. Siempre que se encuentra este reptil se le envia una perdigonada; pues, cono animal temido y odiado, a causa de su tamaño y peligrosas condiciones, nadie le perdona $/ 2$ vida. A veces se deja coger en las trampas dispuestas para otros animales, y entonces deniuestra la vitalidad de que está dotado.

El laquesis se recibe en Europa con mischa menos fre. cuencia de la que desearian los charlatanes, pues en honor de esta serpiente llamaron à una de sus medicinas laquesis, quizás porque Hering fué el primero que tomó veneno de un taquesis para hacer una prueba. Por lo que ahora dire. mos se podra deducir cuáles son los asombrosos efectos de dicha medicina:

«Cuarido reflexionamos sobre los antiguos remedios populares, dice Hering, vemos que niuchos peces debieron servir de medicina, pero mas aun jos anfibios. Estos repugnantes séres tienen, segun se dice, la racultad de curar las enfermedades mas terribles. Estudiando mas detenidamente las tradiciones antiguas, vemos que los sapos asados, los hagartos secados, la grasa de las serpientes, la sangre de las tortugas, y sobre todo la hiel de estos animales, se recomiendan para toda clase de enfermedades cutáneas. Entre todos los vene. nos de animales, el de la serpiente ocupa el primer lugar, pero nunca podremos atrevernos â servirnos de ell como medicina, debiendo añadir que muchos mordidos que se salvaron tuvieron casi toda su vida erupciones cutáneas en la parte dañada $\delta$ un color de fuego que segun se dice es el de la serpiente. Considerando además que las grandes cantidades de estos venenos pueden matar con la rapidez del rayo, producir hinchiazones é irritaciones, debe desearse disminuir de tal modo la cantidad de veneno que los efectos sean menos violentos. Mucho antes de hacer un viaje al sur fué mi mas vivo deseo poder examinar este célebre veneno. Las pruebas hechas con el de la serpiente, mezclada con azúcar y leche, nos dan á conocer no solo los efectos que produce en el hombre, sino tambien la posibilidad de tratar con buen exito á los mordidos y de elegir entre el sin nu. mero de antidotos, los mas convenientes. Quizás llegue á ser tambien el veneno de serpiente una importante medicina. Solo recuerdo aqui la historia citada en la obra de Galeno, donde se dice que un enfermo de la lepra curó con el vino en que una culebra se habia ahogado. Aqui, en Paramaribo se descubrió un gran secreto, y es que la cabeza asada de una serpiente venenosa, reducida á polvo, es una sustancia principal y un remedio eficacisimo: basta frotar la piel con este polvo para preservarse de los mordiscos de serpiente, y hasta produce buen efecto despues de recibirse la herida. Además he visto un leproso perfectamente curado de su enfermedad, y segun se dijo, consiguiólo con los polvos de la serpiente. No debemos despreciar los remedios populares, porque antes de Hahnemann fueron casi la única fuente de la materia médica s aun hoy dia podemos aprender mucho de ellos. A menudo el instinto ha enseñado al hombre re. medios que no habria encontrado con los experimentos de siglos enteros. No cesó pues mi impaciencia hasta obtener una gran serpiente vencnosa viva.

Tal introduccion nos lance esperar mucho y Hering no nos engaña en su detallado relato. En I $\$ 28$ extrajo de un laque. sis el veneno, mezcló diez gotas con cien granos de azúcar de leche, lo batió tòdo durante una hora, mezcló despues diez gotas de esta composicion con cien granos de dicha leche, y asi obtuvo una sustancia de cien partes en cada gota de veneno, que se podia considerar como unidad de grano.

Por fortuna para la humanidad, el inventor de esta medi. cina experimentó los efectos en su misma persona. \$Al mo. ler el veneno, dice, absorbí involuntariamente una parte del polvo, que me produjo en la parte posterior del paladar una sensacion muy extraina y como cierta aspereza; una hora despues senti dolor en el cuello, y otro mas ligero al lado derecho del esófago, dolor que no aumentó al tragar, pero si al comprimir la parte. Pasadas algunas horas, y al dar un paseo en coche senti cierto malestar, como si debiera sobrevenirme un accidente grave; y esta desazon me atormentó mucho durante nias de una hora. Llegada la noche experimenté una especie de frenesi que rayaba casi en locura, y despues el mayor cansancio y soñolencia acompañados de un vivo deseo de hablar que ine hizo decir los mayores desatinos. Mas tar. de causdme aversion todo alimento, s senti una sensacion desagradable en el estómago, con deseos de beber cerveza. Cuando me hube acostado no pude conciliar el sueño porque en ninguna postura estaba bien, pareciéndome tener un peso en la nuca y el cuello. Cuando algo me tocaba en la laringe experimentaba una sensacion tan viva que parecia que me ahogaba, sufriendo dolor en la parte posterior del cuello. Las palmas de las manos, las plantas de los piés y el vientre exhalaron mucho calor durante toda la noche. Era ya muy tarde cuando consegui dormirne, y desperté muy temprano. A la mañana siguiente hice una ligera evacuacion cenagosa de vientre; al otro din tuve diarrea, 5 por la tarde pude dormir: tuve unos sueños muy alegres.

Al ensayar por primera vez, su remedio, el doctor experimentó descos de fumar, cólera, desconfianza, escalofrios en la espalda y picor en la punta de la nariz; las lágrimas se agolparon á sus ojos y estos se cargaron nuucho; á las doce de la noche acometióle una diarrea y tuvo deseo de beber vino; al comprimir la region del corazon dolíale mucho; se constipó y tuvo otra vez diarrea, sintomas que quizás prueban que la dósis era demasiado fuerte. En los otros experimentos produjéronse toda clase de accidentes posibles y muy extraños.

Esta historia convencerł en mi opinion, aun â los mas incrédulos, de que nuestros charlatanes modernos pueden aprender mucho sobre el particular.

\section{LOS TRIGONOCÉFALOS - TRIGO- NOCEPHALUS}

La ciudad montañosa de Schlangenberg (montaña de las serpientes), en el dominio imperial del Altai, tornó su nom. bre, segun refiere Renovantz, de las muchas scrpientes que 
al principio habitaban aquella montaña, en tan considerable número que fué preciso amontonarlas y quemarlas para exterminarlas. Cuando Finsch, el conde de Waldburg.Zeil y yo, visitamos el sitio en el verano de $1 \$ 76$, resolvimos averiguar si aun hoy dia merece su nombre, y por lo tanto rogóse a nuestro anfitrion, Mr. Iwanoff, empleado de minas, que enviara algunos howbres, sin ocupacion entonces, para ver si cazarian serpientes. A pesar de que el dia cra tempestuo. so, nos trajeron al poco rato mas de estos reptiles de los que nos convenian; todas eran serpientes renenosas, de la especic del pelias comun y además de otra especie bastante parecida, pero del todo diferente, único tipo de los crotálidos en Europa.

CARACTÉRES. - El hales representa el géneto de los trigonocéfalos. Oppel, que introdujo este nombre en la ciencia, designa con él todos los crotálidos sin cascabel, tomando por tipo la serpiente de hierro de lanza de las Antillas, tan conocida y mas temible que cualquier otra. Fitzinger, sin embargo, limita el génern ś un reducido número de crotải. dos, del que hasta ahora no se conocen mas que cuatro especies, propias de las partes meridionales del territorio in. dico.

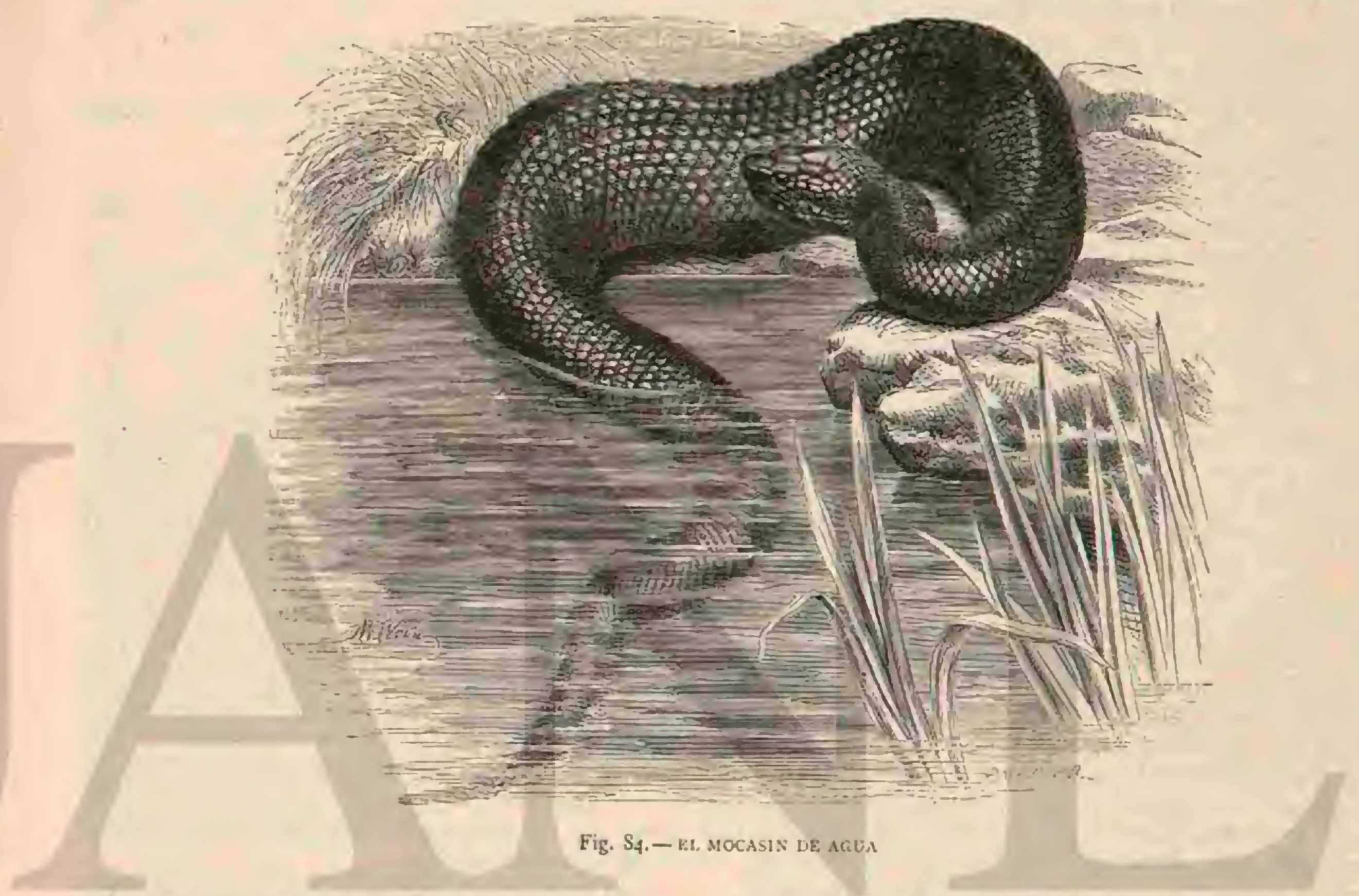

Los caractéres de estas serpientes consisten en tener cabeza ancha, hocico obtuso, cubierto en su parte superior de un número regular de escudos; tronco medianamente lar. go con escamas aquilladas, que forman de 23 á 27 series, y la cola no prensil, muy corta, cuyas urostegas se disponen en dos filas y cuya punta córnea representa, en opinion de algunos naturalistas, un cascabel no desarrollado.

\section{EL TRIGONOCEFALO HALES-TRIGONOCE- PHALUS HALYS}

CARACTERES.-Esta especic no es nucho mas grande que el pelias comun, pues su longitud no pasa de $0^{m}, 75$. La cabeza, del todo triangular, es muy aplanada; en la extremidad del hocico se trunca oblicuamente; es cóncava en la superficie y está cubierta por lo regular de nueve escudos.

Los caractétes distintivos de la especie, segun Strauch, cuy'a descripcion minuciosa reproduzco en extracto, consis. ten en ser los escudos frontales anteriores, estrechos y cóncaros, formando en su conjunto una figura de media luna, la cual representa una prominencia que consunica á todo el hocico un aspecto mas ó menos marcado de silla de montar. La cabeza no se confunde con el cuello, que es ligeramente comprimido; el tronco, bastanic prolongado, casi cjlindrico Tosso $\mathrm{V}$ en su centro y un poco mas grueso hảcia la cola; esta es muy corta y cónica, presentando en su extremidad una apó. fisis córnea, bastante larga, ligeramente corva y cónica; en ambos lados bay marcados surcos. La coloracion de las re. giones superiores consiste en un amarillo gris pardusco, algo mas oscuro en el centro del lomo; la de las inferiores en un blanco amarillento mas $\delta$ menos oscuro que en las escamas posteriores, con unos punios negros finos mas ó menos numerosos quue ambien adornan los bordes de las escamas la. biales. Los matices de la cabeza se reducen s. una gran mancha de forma cuadrada que se extiende por los dos pares de escudos frontales; una faja trasversal ancha $y$ cortada, en el centro, se corre desde una ceja à otra; una segunda, muy ancha, se prolonga desde el borde posterior de los ojos por las sienes y los angulos de la boca hasta los lados del cuello. Todos estos matices tienen el color del lomo, con bordes amarillentos mas ó menos marcados. $A$ lo largo de todo el lomo se ve un gran número de fajas trasversales, $\{$ menudo interrumpidas o cruzadas, en forma de red; en los lados del tronco se tocan con lineas longitudinales pardas ó de un pardo gris, la primera manclia de la nuca se distingue de las otras por su forma de herradura. Encuéntranse muchas variedades tambien en esta especie.

DISTRIBUCION GEOGRÁFICA.-El área de disper- 
sion de esta serpiente, descubierta por Pallás en la parte su. perior del Jenisei y observada mas tarde en las inmediacio. nes de la desembocadura del Volga, se extiende desde este rio orientalmente hasta el Jenisei y desde los $58^{\circ}$ latitud norte $\{$ mucha distancia hácia el sur, sin que se sepa aun hasta dónde. En Europa habita solo las estepas situadas entre el Volga y el rio Ural. Su verdadera patria es el Asia, es decir, el sur de Siberia, el norte del Turkestan y la Mongolia. Puede considerarse como el ofidio mas comun despues del pelias en la estepa de los kirguises, sobre todo de la parte sur oriental de la misma; y tambien es la serpiente que mas abunda en las estepas det dominio imperial del Altai.

USOS, COSTUMBRES Y RÉGIMEN.-Segun nuestras observaciones, por cierto poco minuciosas, el trigonocéfelo hales no busca en rigor guaridas, sino que descansa de dia en cualquier sitio, ensoscindose ligeramente en la yerba de la estepa. Cuando acompañados de nuestros kirguises atravesamos la provincia de Siete Rios, cruzando despues por el valle de Emilio, vimos todos los dias varias veces á algun indigena sacar de repente su ancha y larga navaja, é inclinándose desde el caballo sobre el suelo, descargar un rápido golpe sobre una serpiente venenosa, el pelias ó el tri. gonocéfalo hales. $A 1$ informarme sobre esto, los kirguises me dijeron que ambos reptiles eran muy abundantes en aquellas regionts. Estos nómadas odian tanto al uno como al otro ofidio, y con mucha razon, jues con harta frecuencia pierden carneros y cabras peq̨ueñas, aunque estos animales domésticos conocen, segun se dice, à los reptiles y los evitan. Los kirguises á quienes yo pregunté no me supieron decir nada sobre el alimento del trigonocéfalo, y por lo tanto solo pude suponer que el hales, lo mismo que el pelias, persigue á los ratones, las arecillas, sobre todo alondras, y tambien cierta especie de lagarto muy abundante en las estepas.

In cambio, los kirguises conocian snuy bien el género de vida de ambas serpientes venenosas; sabian que son reptiles nocturnos, que duermen de dia, añadiendo queen la estacion calurosa del año solo en las primeras horas de la mañana, ó en las últimas de ia tarde salen á tomar el sol, mientras que al medio dia se ocultan en la sombra de las espesuras 0 de. bajo de las piedras, 6 bien se dirigen hảcia el agua para descansar junto á ella. Su mordedura es muy temida porque se conoce su carácter peligroso, sabiéndose que no hay ningun antidoto en rigor eficaz contra la misma. Primero se corta la parte rnordida ó tambien se chupa para extraer el veneno; despues se propinan gotas de opio, bañando la herida con agua hasta que la hinchazon vuclic á disminuir, de modo que se puedan hacer las fricciones con grasa de serpiente. Duranie la enfermedad serccitan pasajes del Koran; pero como por lo regular solo se conoce la primera sura, el enfermo se cansa pronto de esta lectura. Los nordidos padecen á menudo mucho tiempo y á veces algunos años.

Es singular que los rusos, que en la inmediacion de las montañas de las serpientes cogieron viboras y trigonocéfalos, no participaran del temor de los kirguises, cogiéndolos con un descuido punible. Para llevarlos cómodamente $y$ con se. guridad, servianse de tenazas muy bien construidas, de ramas flexibles, con las cuales cogian el cuello del reptil, sujetán. dole tan perfectamente por la nuca, que con'gran dificultad hubiera podido morder. Con esto creian haber hecho lo suficiente; no hacian caso de los ganchos venenosos y maneja. ban los animales como si no supiesen que eran venenosos. Segun se me dijo, son muchos los hombres que todos los años reciben mordeduras de este trigonocéfalo; pero los in. digenas creen poder cvitar las consecuencias funestas cu. briendo la herida de alquitran, y por lo tanto hacen muy poco caso de tales accidentes.

\section{LOS CENCRIS-CENCHRIS}

CARACTERES. - Los cencris, propios de América, son afines del trigonocéfalo hales, pero mucho mas grandes y fuertes, distinguiéndose de él principalmente por la conformacion de los escudos y de las escamas. Los escudos se limitan igualmente á la parte posterior de la cabeza; el gran escudo central está rodeado de otros seis casi iguales en tamaño, que por delante se tocan con los del hocico, y en la parte posterior con un considerable número de pequeños es. cudos bastante regulares, los cuales cubren la mayor parte del occipucio. El tronco está revestido de escamas sobrepuestas longitudinalmente, de forma oval, muy aquilladas, bastante mas grandes á lo largo del dorso y dispuestas en veintiuna á veinticinco series longitudinales.

\section{EL MOGASIN COMUN-TRIGONOCEPHALUS CONTORTRIX}

CARACTERES. - Una de las especies mas conocidas y diseminadas del grupo de los cencris es el mocasin comun, llamado tambien cabeza de colbre, aientre de cobre, aibora reja, etcétera. La longitud excede raras veces de un metro. El tronco es'grueso, la cola bastante corta, provista en su extremidad tambien de un escudo córneo ó puntiagudo; la cabeza triangular y prolongacia, marcadamente separada del cuello, se aplana poco en la parte superior; el foso, situado entre el labio superior y uno de los escudos anteriores de los ojos, es poco profundo, y la boca muy hendida. Un bonito pardo cobrizo mas claro en los costados, es el color predominante de la parte superior del cuerpo; los matices consisten en unas diez y seis fajas trasversales de un pardo rojizo con bordes mas oscuros, que se extienden por el lomo, regularmente por los costados; á estas fajas debe su nombre la serpiente, y por ellas se la conjparó con un mocasin 6 o polaina de cuero; extiéncense hasta la cola y en medio de ellas se observan unas manchas del mismo color, dispuestas á intervalos irrregulares. Los escudos del vientre son de un rojo cobrizo pálido, con manchas poligonas ó casi redondas de color oscuro. La cabeza es regularmente un poco menos oscura que el resto del cuerpo y se distingue por una faja clara que desde el ho. cico se corre por todo el lado.

DISTRIBUCION GEOGRÁFICA.-El área de dispersion del mocasin comun se extiende desde los $45^{\circ}$ latitud norte hasta el extremo sur de los Estados-Unidos.

USOS, COSTUMBRES Y REGIMEN.-Esta serpiente suele vivir en las regiones pantanosas, sobre todo en los extensos pastos y praderas, alimentándose de ratones, ares, ranas y probablemente tambien de jeces. Los americanos la temen mucho mas que á la cobra á causa de su agilidad: cl veneno de ambas especies produce poco mas 6 menos los mismos efectos; Kary hace mencion de un caso en que un caballo mordido por un mocasin, murió à las pocas horas. Sus movimientos, aunque mucho mas rápidos que los de la cobra, son, sin embargo, bastante lentos; sus usos y costum. bres no difieren de los de otras serpientes venenosas é irasci. bles. Cuando se acerca un hombre toma en seguida la posicion de ataque, levanta su cabeza triangular, mueve con frecuencia la lengua, $y$ algunas veces la extremidad de la cóla.

No tengo noticia alguna sobre la reproduccion, pero no creo que esta difiera de la de otras especies de la familia y del género.

EL MOCASIN DE AGUA-TRIGONOGEPHALUS PISCIVORUS

CaraGtéres. - Esta especie, propia tambien de la 
América del norte donde habita exclusivamente en los pan. tanos, rios y lagos, es mucho mas conocida que la anterior; tambien es bastante grande, pues llega regularmente à I ${ }^{m}, 50$ de largo. Su color cambia mucho segun lo prueban diferentes variedades constantes. Tiene generalmente el fondo de un hermoso y brillante verde pardo, consistiendo el dibujo en fajas de tinta mas oscura. Una rariedad llamada por los americanos víbora acuática, es de un color pardo de tierra oscuro 6 de un negro mate, $y$ sus fajas solo resaltan un poco despues de la muda. En otra variedad predomina un bonito color castaño que cambia hasta el de aceituna oscuro y tira en la parte inferior al pardo amarillento, coloracion que por lo regular solo se observa en los individuos jóvenes conservándose sin embargo en algunos de mucláa edad.

DISTRIBUCYON GEOGRAFICA. - Segun Holbrook, su zona de habitacion se extiende desde el rio Pedre, en la Carolina del norte, hácia el sur por toda la América septen. trional, $s$ en direccion al occidente, hasta las Montañas Pe. dregosas; pero solo se le encuentra en las cercanias del agua, 6 dentro del mismo elemento.

USOS, COSTUMBRES Y REGIMEN. - I AS orillas, islas é islotes de los lagos, pantanos, estanques, rios y otras corrientes son los sitios donde fija su morada el mocasin; jamás se le encuentra en los terrenos secos $y$ áridos. En verano se le véa menudo sobre las ramas quue cuelgan for encima del agua; pero apenas conoce que el hombre se le acerca, déjase caer en el líquido y huye, nadando con igual elegancia que presteza. Catesby supone que se coloca alli en aceclio; pero parécenos mas probable que busque estas ra. mas para solearse, pues en los terrenos pantanosos sin árboles y en los arrozales, acostumbra al empezar la tarde dirigirse á un sitio mas elevado y seco, para exponerse álos rayos del sol.

Consiste principalmente su alimento en peces $y$ batracios, pero hace tambien presa de pájaros y pequeños mamíferos; sobre 'todo, no deja escapar ningun vertebrado que pueda dominar. Segun afirman todos los naturalistas y viajeros, esta serpiente es el terror de los negros, y de los cultivado. res de arroz muy particularmente, siendo mucho mas temida que la de cascabel: pues esta solo muerde cuando se le irrita, mientras que el mocasin ataca de improviso, y procura siempre herir á todo sér que se le acerca. De este temor participan tambien todos los animales que viven en los panianos $\delta$ que frecuentan las inmediaciones del agua, lo mismo los mamiferos que las aves, los reptiles de todo órden que los peces, pues $\mathbf{a}$ todos acomete.

CAUTIVIDAD.-De todas las serpientes venenosas, el mocasin de agua es la que mas fácilmente se acostumbra á la vida de cautivo, aceptando al cabo de muy corto tiempo toda clase de alimento, y reproduciéndose casi con la misma regularidad que en cl campo. Una pareja que existia en el Jardin zoológico de Lóndres produjo varios peq̨ueñuelos, de los que recibió cuatro Effeldit. En la actualidad tienen estos botrofidios unos seis años de edad; hánse apareado ya varias veces, demostrando de este modo que son capaces de reproducirse. Comen animales de todas clases, pero especialmente peces, que parecen ser su alimento de mayor preferencia. Effeldt dice que son los mas peligrosos vecinos para toda clase de animales; pues hieren y envenenan no solo á los mamíferos y pajjaros, sino que tambien á los reptiles y peces, no exceptuando las demás serpientes, lo mismo las no venenosas que los solenoglifos. Con este motivo me refirió Effeldt, que habiendo desaparecidosalgunas de las viboras ammodites que tenia en la misma jaula de los mocasines, se puso en observacion, presenciando, al fin, un dia como uno de estos mordia a una de las viboras: curioso de saber si la mordedura produciria algun efecto, continuó observando, y á los pocos minutos notó, con no poca sorpresa, los sintomas infalibles del envenenamiento; muy pronto se paralizaron los movimientos de la vibora, y poco despues ya no ofrecia resistencia alguna. Cogíbla entonces el mocasin por en me. dio del cuerpo, y sin soltarla de entre sus mandibulas, fué retirando la boca hasta la cabeza de la víctima, y rol. viendo esta de modo que la puso en línea recta con sus fauces, empezó á engullirscla. El mismo erpetólogo me dijo tambien que en el Jardin zoológico de Berlin, tuvicron que separar los mocasines de los crótalos, que en un principio habian colocado en una misma jaula; pucs estos últimos, á pesar de su mayor tamaño, eran víctimas de los otros, que los atacaban y maltrataban continuamente. Las culebras y otras serpientes inofensivas, lo mismo que los lagartos, dan serbales de gran temor cuando se les introduce en la jaula de los mocasines, y procuran huir de estos; pero mas pronto ó mas tarde reciben la fatal herida. Los trigonocéfalos de esta especie jamás dan señales del furor, ciego y loco, propio de las viboras y de las serpientes de cascabel; sin manifestar exteriormente irritacion alguna, tienen la vista clavada en su victima, y de repente caen sobre ella y la muerden, proyec. tando la mitad del cuerpo adelanie. Por lo demás, son tan crueles y feroces con los pequeños sćres, como las viboras; asl, aun cuando hayan satisfecho su apctito, no dejan con vida s ninguno de los pájaros y peces que se introducen en su jaula.

Fin sus cautivos observó Effeld que se apareaban mas de una vez al año $y$ en distintas estaciones: en la primavera, en el verano y hasta en otoño. Aquui tambien se dió el ejemplo de entrelazarse $y$ amontonarse en forma de ovillo varias serpientes durante la cópula. A la primera pareja, que habia ya habitado durante algun tiempo la jaula, se añadieron mas tarde dos individuos mas que parecian ser hembras: tomaron parte en el primer apareamiento que presenciaron, entrela. anndo sus cuerpos con los de la pareja que verificaba el ac. to. Tan pronto como una pareja se dispone \& unirse sexual. mente, acércanse los demás individuos de la misma especie, con la intencion manifiesta de participar en el acto, $y$ así lo verifican en realidad cuando los dos sexos se encuentran representados; pues parece que al empezar una pareja, se apodera igual pasion de todas las demás serpientes. Los in. dividuos unidos sexualmente permanecen en este estado una hora a lo sumo.

Los mocasines se muestran extraordinariamente dóciles, y hasta podriase decir agradecidos, para con su guardian. Pierden mas pronto que toda otra serpiente venenosa la aficion á morder, acostumbrándose tambien con mucha mayor facilidad que los demás individuos de la misma seccion á recibir su alimento de manos de anquel. Yo mismo he visto, euando Efieldt presentaba con unas tenazas peces ó carne cruda á sus cautivos, cómo estos se acercaban inmediata. mente y tomaban el alimento, dando ya señales de agitacion cuando se aproximaba para abrir la puerta de la jaula. So. lian coger los primeros bocados con cierta delicadeza, engulléndoselos despues rápidamente; pero luego se mostraban mas ávidos, pues tambien al ellos l'appetit aiest en nangernt. Sucede entonces, \& veces, que muerden en las tenazas, pero tan solo a causa de la misma precipitacion con que se apo. deran de la comida; pues los mismos animales, segun me aseguró Effeldt, jamás habian intentado morder å su guardisn, mostrándose, por el contrario, tan inofensiros, que aquel dejaba á menudo la puerta abierta cuando les daba de comer, de modo enue los mocasines sacaban la mitad del cuerpo fuera de la jaula. En una de esias ocasiones, Wagenfuhr sintio de repente algo frio que tocaba su mano, resul- 
tando ser la lengua de una de las serpientes, que sin duda se cercioraba de si en la mano habia pasto para ella, pero sin intencion alguna de causar daño al hombre. Dificilmente se habrá observado tanta domesticidad en otras serpientes.

Effeldt ha hecho últimamente preciosas observaciones tambien sobre la variedad pardo-cobriza. Ln noviembre de 1871, el célebre erpetólogo recibió un macho del mocasin de agua de color pardo-cobrizo, y en junio delaño siguiente adquirió tambien una hembra de la misma variedad. En 21 . de enero de 1873 , dia muy caluroso, ambas serpientes se aparearon, y en 6 de julio el observador encontró con gran alegría ocho hijuelos vivos nacidos en la jaula. Estos animales en extremo graciosos, median unos 26 centimetros por ${ }_{15}$ centimetros de grueso. El color, diferente del de los padres, era de un rojizo pálido de carne, el de la cabeza un poco mas rojo; unas fajas en zig-zag de un pardo negruzco formaban los matices. Despues de la primera muda, que se veri. ficó \& los quince dias del nacimiento, el color del tronco pasó al pardo rojo, y despues de la segunda, es decir unas cinco semanas mas tarde, tomó un tinte pardó rojizo; aun entonces el color de la cabeza se conservó mas viro. Esta coloracion no cambí hasta el segundo año y solo entonces se oscurecio mas y mas hasta llegar à la arriba descrita.

En los primeros quince dias los pequeños mocasines no aceptaton ningun alimento; pasado este tiempo empezaron a comer ranillas, ranas verdes, despreciando del todo los peces. Al cabo de dos moses habian llegado á tener casi 34 centi. metros; pero su cabeza era mucho mas grande que la de un pelias adulto y por lo tanto podian devorar ya ranas de mediano tamaño!

《Apenas hubieron nacido, dice Effeldt, saqué de la jaula los hijuelos excepto uno, pues temia que los padres se los comieran, dada su voracidad. Los primeros dias no vi nada del pequeno que habia dejado con los adultos, y solo ocho dias despues le encontré cchado sobre el cuerpo del macho, observando que este, cual si quisiera acariciarle, le tocaba en todas partes con su lengua. Este hecho me demuestra que tienen cariño ás sus hijuelos, al paso que viven enernigos de todos los demás séres, sin exceptuar otras especies de serpientes; y atacan no solo a todo aninal, sino tambien al hombre. Cuando reuni varias serpientes de igual variedad vivieron en la mejor armonia, pero tan luego como puse un individuo de otra fué inmediatamente atacadoy mordido. Ia mordedura nunca tuvo consecuencia funesta, mientras que otras especies que introduje en su jaula, por ejemplo, la cobra ó la serpiente de hierro de lanza, sucumbieron siempre á los efectos del veneno.y

Effeldt obligó á sus mocasines de agua â morder varios animales. Una rata puesta en la jaula de esas serpientes fué mordida solo por un gancho venenoso, segun resultó del exámen del cadaver: apenas herida, la rota corrió de un puesto s otro; al cabo de algunos minutos ya tenia paralizada la parte mordida; diez minutos mas tarde se acurrucó en un rincon con el pelaje erizado, sin moverse; á los diez y siete despues de recibir el mordisco, sobrevinieron las convulsiones, y á los cuarenta la muerte. Menos peligrosa fué la morde dura de un mocasin de dos meses de edad, inferida tambien por un gancho. Cinco minutos despues se paralizó la pata del roedor, hinchándose mucho; á las seis horas la inflamacion empezó å supurar, pero luego ya no hubo peligro. Al día siguiente la rata volvió á comer, cojeando solo un poco de la pata mordida. Otro rocdor, en cambio, herido en la cabeza por una serpiente peqqueña, murió à los dos minutos; y otra, mordida en el mismo sitio por un individuo adulto, sucumbiơ á los cuatro minutos. Las ranas mordidas experimentaron al punto convulsiones y murieron poco despues. Como com. pré á Effeldt varios mocasines, cuidándolos mucho tiempo, puedo confirmar casi todas las noticias del citado naturalista y poco debo añadir. Los mocasines de agua son tambien animales nocturnos, tan perezosos y dormilones de dia como otras serpientes venenosas de esta familia ó víboras. Una vez acostumbrados a la jaula y a un alimento regular, apenas dejan el que se les ofrece de dia, sino que acuden en seguida para comerlo. Los peces constituyen el alimento favorito de los individuos adultos que de ordinario los devoran empezando por la cabeza sin envenenarlos antes; no desprecian tampoco las ranas, pero las muerden antes de comerlas; devoran tambien los pequeños mamiferos, y nunca sin morder. los antes.

En la estacion calurosa $\delta$ cuando se caldea mucho la jaula pasan casi todo el dia en la fuente, donde si esta es bastante grande, descansan en las mas diversas posiciones imaginables, una junto á otra ó agrupadas; de modo que á menudo se ve solo una mole, de la cual sobresale alguna cabeza de serpiente. El baño parece agradarles mucho, y por lo tanto no toleran ninguna molestia mientras cstán en el agua. Cuando falta el espacio suficiente se disputan i veces el baño, por buena que sea la armonia en que viven los in. dividuos acostumbrados unos á otros y por poco caso qque hagan cuando uno pasa sobre el otro ó cuando un compa. inero esté comiendo. Una vez irritados pasan en seguida al ataque, y apenas entran en el periodo del celo, en cuyo es. tado aumenta su irascibilidad, se hacen muy comunes las luchas. Para pelcar no permanecen mucho tiempo en la posicion de ataque sino que se muerden al punto; hiriéndose á menudo de tal modo que la sangre brota de muchas partes del cuerpo. No he observado nunca, sin embargo, que una serpiente profundamente herida manifestase sintomas de envenenamiento, y por lo tanto estoy conforme en un todo con Effílat cuando dice que estas serpientes no se causan daño con sus mordiscos.

Fn el período del celo los mocasines de agua son en extremo vivarachos, paséanse tambien entonces de dia casi continuamente por la jaula, mordiéndose unos á otros, la. men ś la hembra elegida con mucha ternura y enróscanse por fin del modo acostumbrado en las serpientes, efectuán. dose al poco rato el apareamiento. La duracion de este pa. rece diferir mucho, pero cuando menos es de algunas horas. El desarrollo de la progenie depende principalmente de la temperatura, apresurándose cuando esta sube y retardảndose cuando baja.

\section{LOS BOTROPS - BOTHROPS}

CARACTŔRES.-Este género es el thas rico en espe. cies. Los crotślidos pertenecientes á ella son de estructura relativamente delgada, con la cabeza triangular, cubierta solo de pequeñas escamas, pero no de escudos; excepto la extremidad del hocico y la region de las cejas; la cola, de longitud regular, es á menudo prensil. Estos dos caractéres son los mas importantes de todos, pero debo añadir que el tronco está cubierto de escamas mas ó menos aquilladas, dispuestas an séries cuyo número varia de diez y siete á veintisiete, y que lins urostegas forman dos filas.

DISTRIBUCION GEOGRÁFICA. - Todos los ofidios pertenecientes a este grupo viven en los territorios indio $y$ sud-americano.

USOS, COSTUMBRES Y RÉGYMEN.-Se asemejan tanto por su género de vida como por sus formas y colora. cion. Muchas de estas serpientes son arboricolas, segun lo indica ya su cola prensil; estas especies pasan la mayor parte de su vida en el ramaje de los árboles ó sobre las plantas en 
general, y rara vez en tierra. Otras, á su vez, viven exclusivamentc en ella.

Este grupo se ha dividido en dos sub-géneros que com. prenden las especies trepadoras $y$ las que no lo son; ambas se parecen, sin embargo, por todos los caractéres principales, aunque su coloracion difiera.

\section{LOS TRIMERESUROS - TRIME- RESURUS}

CaRACTÉRES.-Para describir los caractéres y género de vida de los trimeresuros ó botrops trepadores, basta expo. ner todo cuanto ste sobre una especie del grupo.

\section{EL BOTROPS VERDE-BOTHROPS VIRIDIS}

CARACTERES.-El botrops ierde ó Judiu-prom de los malayos, alcanza una longitud de $0^{\infty}, S_{5}$ y tiene las partes superiotes de un verde de yerba un poco mas claro en los lados, y' las inferiores de un blanco verdoso. Desde el labio superior se corre una linea por los ojos y los lados de la cabeza hasta el occipucio y tambien se ve por lo reguular una linea compuesta de puntos blancos ó amarillos que separa las escamas dorsales, dispuestas en 21623 series, de los escudos abdominales. Las hembras adultas no tienen, segun Guenther, estos distintivos.

DISTRIBUCION GEOGRÁAFICA.-El área de disper. sion del botrops verde, se extiende desde la peninsula india hasta la China. Se conoce esta serpiente en el delta del Ganges, en la region de Mulmein, en Siam, China, Java y Pinang; Fayrer asegura que tambien se encuentra en las islas $\mathrm{Ni}$. cobar.

USOS, COSTUMBRES Y REGIMEN.-Segun las observaciones de Stoliczlia, abunda mucho en las colinas cerca de Mulmein, donde se la ve casi exclusivamente cu los ár. boles. Su color se asemeja tanto al follaje de muchos, que apenas se la puede distinguir. Stoliczka vió serpientes jóvenes de esta especie sobre plantas bajas, y Cantor las observó igualmente en el suclo. Ocupan del todo el ramaje de los árboles, pues no solamente trepan de un modo muy fácil, sino que tambien saben tomar las mas cómodas posiciones. Se agarran con la cola prensil a una rama $\delta$ á la parte supe. rior del tallo de otra planta, para sostener el cuerpo, y este descansa entonces tendido $\delta$ enroscado sobre las anchas ho. jas $\delta$ ranas, cual si formara parte del tronco.

Un trimeresuro que de este modo descansa ó duerme, solo hace caso de lo que le rodea cuando esto le parece absolutamente necesario. Sin moverse permite á los hombres acercarse, $y$ hasta se deja coger sin resistencia; solo cuando se le oprime con un palo ó le pellizcan con una tenaza intenta morder. Una vez excitado, manifiesta tambien la iras. cibilidad de todas las serpientes renenosas; y scgun Marten, abre la boca de tal modo, que la mandibula superior é inferior casi forman una linea recta, ofreciendo entonces con sus ganchos venenosos puntiagudos, que sobresalen de la sonrosada encia, un aspecto verdaderamente terrible. Muerde con tal fuerza en el palo, que el mismo se rómpe los ganchios venenosos.

Tan soñoliento es el butru-pim de dia como activo de noche, pues solo entonces empieza su caceria à pequeñas aves, mamiferos, ranas y tambien $s$ insectos, que segun Stoliczka constituyen la base de su régimen alimenticio. El citado naturalista no encontró nunca los restos de vertebrados en el estómago de los trimeresuros, pero no duda que matan tambien animales de clases superiores cuando pueden.
Generalmente se considera el veneno del trimeresuro verde como poco eficaz; pero no cabe duda que tambien puede ser peligroso. Como este reptil es arboricola, pocas veces se pone el hombre en contacto con él; pero ocurren casos en que prueba tambien al señor de la creacion que puede hacerle mucho daño. \&Su mordedura, escribe el mi. sionero Haensel, es muy venenosa, pues he visto morir á una mujer mordida en media hora. Habia subido á un árbol para cogerfruta y enel mismo instante un trimeresuro la clavo los dientes en el brazo; conocia muy bien lo peligroso de ial mordedura y bajó del arbol; mas apenas hubo llegado al suelo cuando la sobrevinieron vértigos, cual si estuviese borracha; llevironla á mi domicilio, pero murió cuando le aplicaba las ventosas. Este caso es el único mortal que se conoce, en cuanto á esa especie de serpiente. Todos los de. más informes están contextes en que los hombres mordidos por esta serpiente sufren mucho, pero muy raras veces mueren.

Russell ha hecho varios experimentos con referencia a la venenosidad de la mordedura del budru. Una gallina herida en un muslo, encogió inmediatamente el miembro, se dejó cacr dos minutos despues, y aunque intentó luego levantarse otre vez, no pudo ya conseguirlo, muriendo á los ocho minutos. Un cerdo mordido por la misma serpiente en una pata delantera, á los siete minutos daba ya señales de desfa. llecimiento, $y$ un cuarto de hora despues parecia haber perdido los sentidos. Duró este estado unos siete cuartos de hora; el animal probó à levantarse, pero le faltaban las fuer. zas; durante la tercera hora pareció empeorar, volviendo á desfallecer: pasadas otras dos horas se mostró mas aliviado, se levantó y dió algunos pasos, acabando por restablecerse por completo, á las sictc horas despues de haber recibido la mordedura. Otra gallina mordida por la serpiente despues del cerdo, murió al cabo de treinta y tres minutos. Pasados algunos dias, se repitió el experimento con un perro; diezy seis minutos despues de mordido en el muslo, le sobrevino un temblor en la cabeza y las patas delanteras; veinticinco minutos despues, el temblor se habia extendido \& todo el cuerpo; el can estiraba el cuello y levantaba la boca como para bostezar. Durante la segunda hora permaneció echado y parecia dormir, pero movia de cuando en cuando alguno de sus miembros, y tenia sacudidas nerviosas; pasada la tercera hora, disminujeron los sintomas y emperó la reaccion favorable. Dos dias despues, se hizo morder a este perro en ambos muslos por la misma serpiente, que en este intervalo habia envenenado tres gallinas. El can sufrió durante tres horas los mismos accidentes de la vez anterior.

Cantor habla de otra serie de experimentos hechos para estudiar los efectos del veneno del budri-pam y de otras especies afines, habiendo obtenido diversos resultados. Una de estas serpientes mordió à una gallina que solo tuvo un ligero dolor, sin ningun sintoma de envenenamiento. O:ra gallina sufrió durante veintiun minutos despues de la mor. dedura, pero sanó del todo y lo mismo sucedió con otra de estas aves. Varias gallinas mordidas por especies afines sucumbieron, mientras que los perros se salvaron, aunque no sin auxilio de sus ducrios.

\section{LOS BOTROPS PROPIAMENTE}

\section{DICHOS - BOTHROPS}

Los botrops propiamente dichos son los representantes del subgénero anterior en el sur y centro de América inclusas las Antillas. 


\section{EL BOTROPS HIERRO DE LANZA - BOTHROPS LANCEOLATUS}

CARACTÉRES. - La coloracion de esta serpiente, que alcanza á reces 8 piés de longitud y el grueso del brazo re. gular de un hombre, es muy variable, hasta entre los peque. n̂uelos de una misma camada: suele ser el fondo'de la nuisma un amarillo rojizo, mas 6 menos intenso y modificado; con. sistiendo el dibujo en un rasgo, que á manera de bigote nace cerca de la nariz, por debajo del ojo, y se dirige hácia la nuca, y en varias manchas irregulares de tintas mas claras; algunos individuos tienen los costados de un magnifico color rojo.

DISTRIBUCION GEOGRÁFICA.- REn las dos islas de la Martinica y Santa Lucía, dice el doctor Rufz, el bo. trops de hierro dé lanza habita en las espesuras y los boscques, y aun alli donde el hombre tiene sus moradas y cultiva la tierra; nadie puede descansar á la fresca sombra de los árbo les, nadie pasearse por los campos sin acompañamiento de esclavos, nadie divertirse en la caza. De noche nos atormentan los mas horrorosos sueños, porque de dia oimos espan tosas historias.

USOS, COSTUMBRES Y REGIMEN.-Abunda extra oroinariamente el thierro de lanzas os serpiente amarilla, comó la llaman los colonos, en las dos islas que acabamos de citar, pues, segun Moreau de Jonnés, irecuenta los terrenos cultivados, los pantanos, los bosques, las orillas de rios, en una palabra, tado el territorio, desde el nivel del mar hasta las altas montañas. Vésela nadar en los rios, balancear. se en las ramas de los árboles, y lasta reptar por el mismo borde de los cráteres de los volcanes humeantes; aproximase álas ciudades, y en el campo, no es cosa rara encontrarla en el interior de las habitaciones rodeadas de arbustos ó yerbas altas. Dice Rufz que el verdadero rancho de estas serpientes está en las montañas de San Pedro. Tienen estas de 4 á 5,000 piés de altura, y están hendidas en abismos de miles de piés de profundidad; hállanse cubiertas de bosques de ar bustos $\mathrm{y}$ árboles, atravesados en todas direcciones por enredaderas que entrelazan estos y los ligan unos á otros, como si lo fueran por una inmensa red de cucrdas; el suelo primitivo ha desaparecido bajo una gruesa capa de carcoma $y$ restos de vegetacion, que se ha ido formando desde los tiem. pos mas remotos, presentándose ahora cubierto de plantas, unas medio podridas ya, y otras frescas y lozanas que osten. tan las mas variadas $y$ hermosas formas, asi como los mas espléndidos matices; pero tan juntas y espesas que reina de. bajo dc cllas una tenebrosidad, donde mas bien se aspira el hálito pútrido de la muerte, que el ambiente sano y fresco de la vida. El silencio sepulcral de esta soledad es tan solo interrumpido por las sencillas notas de un pájaro, al que lla. man el fsilbador de la montaña); raras veces llegan alli otras aves. En este oscuro desicrto, donde jamás penctró el hom. bre, han sentado sus reales las serpientes amarillas 6 hierro de lanza, sin que sér viviente alguno les dispute su dominio.

En las tierras cultivadas, ofrecen las plantaciones de caña de azúcar á esta temible serpiente su morada predilecta; pero encuéntrasela tambien muy á menudo en los bosqueci. llos de toda clase que le proporcionen buenos escondrijos. Basstale un árbol hueco, la madriguera de las ratas ó de otros animales, como tambien las cavidades de las rocas, alber. gándose igualmente, muy á menudo, en los establos $y$ habi. taciones de los cultivadores; pues de noche suele hacer largas excursiones, y muy frecuentemente por los caminos que recorren de dia multitud de personas.

Cuando descansa de dia, tiene el hierro de lanza su cuer. po arrollado, con la cabeza en el centro; pero si le molestan, se distiende con la velocidad del rayo sobre su enemigo, alcanzando de este modo hasta una distancia casi igual á la longitud de su cuerpo, y recogiéndolo inmediatamente. Si se pasa á corta distancia de ella, cuando la serpiente descansa en esta postura, se vuelve continuamente, sin que uno pueda explicarse cómo, de manera que siempre enseña la cara. Cuando repta, lleva la cabeza levantada, lo que le da un aspecto gracioso y arrogante. Se mueve sobre el suelo con tal ligereza, que no se oye el menor ruido ni se percibe la mas leve huella. Por lo que toca \& su agilidad en el agua, véase lo que dice Rufz: Arrojé un dia al mar desde un bote, á un tiro de fusil de la ciudad de San Pedro, un hierro de lanza que tenia cuatro piés de largo. Nadó con bastante rapidez y muy airosamente hácia la orilla; cuantas veces alcanzamos la serpiente, se paraba al punto, se arrollaba sobre las ondas con la misma facilidad que si estuviese en ticrra firme, y le. rantaba la cabeza amenaźndonos. No deja de ser bastante extraño que la serpiente no aproveche esta agilidad para trasladarse a las islas vecinas, algunas de ellas muy poco distantes.

La epoca del apareamiento de estos reptiles es el mes de enero, y el desove se verifica en julio. Los pequeñuclos rom. pen la cáscara del huevo en el mismo momento de ser pues. to por la hembra. Muchos, la mayor parte se puede decir, sucumben antes de llegar á la edad adulta, pues la madre no se cuida de su prole, y son victimas hasta de animales muy débiles, como las aves danésticas, por ejemplo; cs, sin embargo, tan extraordinaria la propagacion de estas serpientes, que estas pérdidas pronto se equilibran. Moreau afirma ha. ber encontrado de jo $\$ 60$ huevos en el cuerpo de varias hembras. Bonoder halló tambien de 20 á 60 , segun el tamano de la niadre; Huc examinó una hembra que contenia 67 huevos, y Rufz otras con 36 hasta 47 . Ios pequeñuclos al nacer miden unas 86 ro pulgadas, y son ya muy agiles y mordedores.

En su primera edad nutrense estos botrops de lagartos; mas tarde de pequeios pajjaros, y por último casi exclusiva. vamente de ratas, que importadas en las islas por los barcos europeos, se han propagado de una manera espantosa; pero acometen tambien á las aves domésticas, y cuando han ad. quirido todo su desarrollo, pueden tragarse gallinas enteras y hasta pavos y roedores de tamaño muy regular. Si bien prestan algun servicio en la destruccion de las ratas, con todo nadie tomará su defensa, pues son demasiado peligrosos para el hombre. No hay duda, dice Rufz, que esta serpien. te muerde á todo hombre que se le acerca; pero creo que deben ser muy raros los casos en que se arroje desde léjos sobre las personas, y persiga \& los que hugen, pues de lo. contrario, las islas en que viven serian de todo punto inha. bitables para el hombre. He pedido informes a los curas y á las autoridades locales acerca de los casos fatales que en Ia actualidad ( $18_{43}$ ) causa anualmente la serpiente amarilla, y resulta que cada municipalidad de la isla pierce todos los años de una á tres personas, victimas de dicho ofidio. $\mathrm{El}$ número de heridos que escapan con vida, es ciertamente diez veces mayor, pero como aun en el caso mas favorable, siempre conserva el paciente restos de la enfermedad, 'y á menudo tambien tiene que hacer el sacrificio de algun miem. bro, resulta que estos mismos casos, vienen á aumentar la pérdida que sufre la colonia. Hay además años mucho mas fatales que otros, como por ejemplo el actual, en el que la mordedura es mas activa y mortífera; de modo, que el alcalde Venancourt me escribe que en su distrito han fallecido, en menos de siete meses, diez y ocho personas de resultas de haber sido mordidas por serpientes. El doctor Clerville 
participa, asimismo, que en Vauclin han sucumbido casi todos los heridos. $\mathrm{Y}$ con todo, la devastacion que causan las ratas este año no puede ser mas espantosa; de manera, que ni aquella ventaja que podiamos esperar de los botrops de esta especie, tiene importancia alguna.

Durante la \%afra, trabajan siempre los negros en fila, uno detrás del otro, procurando el capataz que estén alternados los sexos; de cuando en cuando aquel les llama la atencion, para que vigilen si se acerca alguna serpiente. Cuando llega á descubrirse alguno de estos reptiles, huye toda la fila, en medio de la griteria de las mujeres; el negro mas atrevido se adelanta $y$ da muerte al monstruo, que a pesar de todo aquel ruido ha estado quedo, sin retroceder una sola pulgada.

Cuando la serpiente está enfurecicia, abre la boca de un modo terrible, muerde con vehemencia y se prepara para un nuevo ataque. Ruf asegura tambien haber presenciado mas de una vez cómo el hierro de lanza aprieta entre los pliegues de su cuerpo la victima de su furor, particularmente cuando ha de habérselas con perros. Los efectos de la mordedura son horrorosos: hinchazon extraordinaria de la parte herida, que muy pronto se vuelve azulada y gangrenosa; vómitos, convulsiones, dolor de corazon, somnolencia irresistible, y por último, la muerte; $\delta$ en el caso mas favorable, largos años de sufrimientos de toda clase, como desvanecimientos continuos, parálisis, raquitismo, etc.

Se hace uso de un sinnúmero de remedios, casi todos ve getales, para combatir los efectos de la mordedura. Algun tiempo, el huaco (Mikania Guaco) infundió grandes espe. ranzas, por lo cual se importó de Nueva-Granada, Venezuela y Trinidad en grandes cantidades, á fin de aclimatarle en la Martinica; pero una larga experiencia demostró la nulidad de este remedio.

«F muy triste, dice el conde de Goertz, que no se haya podido encontrar todavia un antidoto eficaz, y que los heridos no tengan otro recurso que ponerse en manos de los charlatanes negros, llamados panseurs. Las autoriciades de la isla tuvieron la feliz idea de importar de Africa algunos fal cónidos serpentarios, pero hubo desocupados en la Martinica que se entretuvieron en cazar tan preciosas aves. Quéjase tambien el conde de qune en las islas no se opone bastante resistencia á la propagacion de la serpiente, y Lenz reco mienda la aclimatacion de mamiferos serpentarios, como el veso, el erizo y ciertas especies de tejones, que harian doble guerra \& los reptiles, pues gustando tambien de las ratas, les irian acortando la racion. Sin embargo, no pucde descono. cerse que los isleños se oponen cuanto pueden ála libre pro. pagacion de animal tan pernicioso; véase, sino, lo que dice Rufz: \&i amigo Hayot mata todos los años tres ó cuatro serpientes en cada campo de caina, y mi otro amigo Duchatel destruyó en una semana, 5 en un solo campo, veintitres de estos monstruos》 Además, segun el doctor Guyon, que llevaba cuenta exacta de las serpientes hierro de lanza muertas en el fuerte Barbon y su territorio, ascendio el total de los individuos adultos, cuyos cadáveres habian presentado los eazadores, en los tres años de ISIS a 1S21, a 370; de $1 \$ 22$ á I $\$ 25$, entre adultos y. menores, \& 2,026; esto es, en ocho años, 2,396 serpientes en un distrito tan limitado. Por aquel mismo tiempo, bajo la administracion de Donze. lot, se ofreció un preinio por cabeza de hierro de lanza, y Vianés, el encargado de satisfacer dicho premio en la demarcacion del fuerte Royal, asegura que cada tres meses se le presentaban 70 cabezas. Segun Lalaurette, en la plantacion dependiente de la quinta de Pecul, se mataron en un año 600 de estos botrofidios, y en el siguiente 300 mas.

CAUTIVIDAD. - El mismo doctor Rufz dice tambien que esta serpiente, cuando ha perdido su libertad, rehusa todo alimento, pudiendo vivir algunos meses en este estado. En algunas colecciones de Europa se han conserrado varios años; Goertz vió cuatro hermosos individuos de esta especic en casa de Barillet, director del jardin zoológico de San Pe. dro, dentro de una jaula de alambre; y presenció tambien la caza de dos individuos mas, un macho muy rebelde de 6 piés de largo, y una hembra de 5 y medio. Para poder domar, hasta cierto punto, sus cautivos, Barillet se servia de dos tenazas de hierro largas de tres piés.

\section{EL BOTROPS JARARACA-BOTHROPS BRASI- LIENSIS}

CARACTÉRES.-El jararaca alcanza, segun el principe de Wied, $1^{n}, 42$ de largo, pero puede llegar, al decir de 'Ischudi, a I",So. Su cabeza ancha, oral y separada marcadamente del cuello, es un poco mas estrecha por delante de los ojos; la punta del hocico redondeada, un poco prominen. te y truncada; el tronco algo delgado, casi triangular, porque el espinazo sobresale en forma de quilla; la cola, corta y no prensil, es delgada y puntiaguda. El numero de los escudos del labio superior, segun el principe de Wied, asciende śsicte; Schlegel, Gray y Wucherer indican ocho; Hensel \& su vez encontró en una de estas serpientes ocho escudos en un lado y nueve en el otro del labio. El número de series longitudi. nales de escamas, segun Schlegel, Dumeril y Bibron, es de veintisiete. El color y los matices parecen variar mucho. Wied dice que el jararaca tiene la cabeza de color pardo ce. niciento, con varios puntos y rayas de tinte mas oscuro en la region frontal; el dorso tambien ceniciento, á veces mas 05. curo y otras con reflejos azulados; consiste el dibujo en grandes manchas triangulares, pardo oscuras, que tienen su lado mas ancho cerca de los escudos abdominales, estrechándose hácia la linea dorsal, dispuestas alternativamente á cada lado la mayor parte, habiendo algunas, por el contrario, que se unen por la punta que representa el vértice del iriangulo, ó si estos no llegan ố tocarse, por unas manchas tambien de color parecido, pero con un punto mas oscuro en su centro, las que aparecen muy marcadas en el tronco, menos distin. tas en el cuello y convertidas en fajas trasrersales en la cola. Ia coloracion amarillo blanquizca de la region abdominal, cuyos escudos llevan dos manchas grises cada uno, esta separada por una serie de otras manchas redondeadas y pardas, de tinte mas oscuro, de la parte superior del cuerpo.

En los individuos jóvenes la punta de la cola es blanca.

\section{EL BOTROPS ATROZ - BOTHROPS ATROX}

CARACTÉRES.-La segunda especie, llamada tambien labaria, tiene siempre siete escudos, segun Wucherer, en el labio superior, y no de veintinueve \& treinta y dos series lon. gitudinales de escamas, como dicen Dumeril y Bibron, sino solo de veinticinco á veintisiete.

Segun el principe de Wied, tiene los mismos caractéres que la especie anterior, siendo hasta idéntica la disposicion de los colores; tan solo la region abdominal del labaria no es blanquizca, sino de una tinia mas oscura, con dos series de pequeñas mánchas blancas à cada lado. Presenta además en la cabeza un ancho rasgo pardo oscuro, que nace debajo del ojo y se corre hasta la comisura de la boca.

DISTRIBUCION GEOGRAFICA. - Las dos especies anteriores, muy semejantes y propias del continente americano, no son en mi concepto sino variedades, asi como una tercera que tiene la misma área de dispersion. Este aserto se funda en las averiguaciones de Wucherer y Hensel, que si 
bien no atacan la independencia de esos reptiles como espe. cies, alegan que despues de haber comparado un mayor nú. mero de los respectivos crotálidos sud-americanos, conside ran insuficientes las descripciones que hasta ahora se han hecho, y por otra parte indican los tránsitos de una $\mathbf{a}$ otra especie. Sin embargo, no constando aun la unidad de estas serpientes como especies, \& no teniendo lo necesario para la comparacion, he descrito separadamente las dos formas mas conocidas y diseminadas.

USOS, COSTUMBRES Y REGIMEN. - El genero de vida de ambas especies ó variedades no difiere por ningún concepto; de modo que no debemos vacilar en aplicar á-una lo que sabemios de la otra. El jararaca, ségun el principe de Wied, es la serpiente renenosa mas comun del Brasil, y asi vive en las espesuras secas como en las selvas virgenes, hímedas y oscuras. El labaria se encuentra, segun Schomburgh, en toda la Gúayana; abunda tanto en la costa como en el interior, y tambien habita la estepa, aunque parece preferir los bosques espesos.

De dia se les ve enroscados descansando en el suelo: solo se preparan para el ataque cuando el hombre se acerca demasiado.

Sus movimientos son por demás perezosos en las horas que dedica a su descanso, pero al acometer arroja adelante parte de su cuerpo, con aquella rapidez prodigiosa, propia de todas las serpientes venenosas. Ni el principe, ni Schomburgk, la vieron jamás trepar, pero este último pudo observarla nadando en el rio Haiama: «Al principio, dice el mismo, no podia distinguir la serpiente en el agua, pero pronto la seconoci; unas veces desaparecia debajo de la superficie, para dejarse ver de nuevo al poco rato. Esturo nadando en todas direcciones, hasta que por fin se dirigió á la orilla, donde la segui y maté pocos minutos despues. Era realmente el labaria, y confirmindose la indicacion que me habia hecho la india que me acompañaba, al abrir cl cuerpo del animal encontré en su estómago dos pequeños peces. Que casi todas las serpientes nadan con perfeccion, cs cosa sabida de todos, pero no habia oido decir jamás que tambien las venenosas buscasen sus presas en el elemento líquido.

Por lo regular ambos reptiles buscan su alimento en tierra firme, persiguiendo como sus congéneres con preferencia ślos pequeños mamíferos; no tengo sin embargo noticias ciertas sobre este particular, ni tampoco respecto á la reproduccion puedo decir mas sino que tambien estos crotálidos ponen huevos desarrollados 6 paren hijuelos vivos.

Ambas serpientes son muy temidas en sus respectivos paises. "Los indios $y$ hasta los cazadores portugueses, observa el principe, caminan siempre descalzos; los zapatos y las medias son aqui para el hombre del campo objetos raros y caros, un adorno que solo se gasta los dias de fiesta; por eso, esta gente está muy expuesta á la mordedura de las serpientes, que á menudo se esconden debajo de la hojarasca; sin embargo, no son tan frecuentes las desgracias, corno pareceria temerse. Habia disparado un dia sobre un tapir, y dirigidome a la orilla con un cazador indio para seguir las huellas del animal herido, cuando de repente of la voz de mi compañero que pedia socorro. Se habia aproximado casualmente á un jararaca, de unos cinco piés de largo, y en su turbacion no acertaba á salir bastante de prisa de la espesura. Feliz. mente para úl, mi primera mirada descubrió la serpiente, que tenia ya abierta la boca con los ganchos venenosos in. clinados hácia afuera, y que con parte del cuerpo erguido, á dos pasos del cazador, se disponia a arrojarse sobre el; pero en el mismo momento un tiro de mi escopeta la tendió muerta en el suelo. El indio estaba tan paralizado de espan. to, yue solo pudo reponerse al cabo de bastante tiempo, y esto me prueba la gran influencia que puede ejercer en animales mas pequeños el miedo causado por la inesperada aparicion de uno de estos horrorosos séres, sin que haya ne. cesidad de recurrir à la creencia de una extraña fuerza fascinadora. Sólidas botas $y$ anchos pantalones son prendas in. dispensables para el cazador en estos paises, pues le protegen mucho contra la mordedura de las serpientes venerosas.

La mordedura de ambas especies no causa siempre la muerte, pero produce en todos casos los mas funestos accidentes, si no se propinan al momento los antidotos convenientes. Tschudi supone que unas dos terceras partes de todos los mordidos que no emplean al instante los remedios á propósito pierden la vida, pero añade que !a mordedura permite algun tiempo al tratamiento médico é infunde mas es. peranza de salvacion. En la América del sur se confunde á menudo con el jararaca una culcbra muy furiosa, atribuyén. dose á esta á menudo las mordeduras causadas por aquel. ril'odos los casos, dice Hensel, de cuya descripcion tomo las noticias anteriores, en que la mordedura del jararaca no tuvo funestas consecuencias, gracias á los remedios emplea. dos, se explican sin excepcion'por la circunstancia de que se confundió la culebra con el crotallido. Schomburgk nos re. fiere cuáles son los perniciosos efectos de una mordedura que no produce la muerte. Un antiguo compañero de mi hermano, dice, que fué mordido en el pié por un labaria, su. cumbió pocos dias anies de nuestra llegada, de resultas de la enfermedad que le habia ocasionado la herida venenosa siete años antes. Sufria los tnas terribles dolores apenas se efectuaba el mas pequeño cambio de temperatura, y cada vez se le abria de nievo la herida, segregando siempre un liquido fétido.

Durante su propio viaje presenció el mismo Schomourgk un suceso muy triste. Despues de haber atravesado el Murre, dice $6 l$, nos dirigimos mas hácia el noroeste, cruzando una sabana muy ondulada, en la que turimos que pasar otro pequeño rio, de unos diez piés de ancho. En medio de la corriente habia un gran pedazo de piedra arenisca, del que los primeros indios de nuestra comitiva se habian servido ya para atravesar á la otra orilla. Yo era el décimosexto en la fila, y detrás de mí venia la jóven india Kate, que á causa de su amable y alegre carácter, habia recibido permiso para seguir á su marido. Esta jóven era muy querida y respetada entre nosotros.

\Cuando llegué á la orilla llamaron mi atencion algunas flores y para cerciorarme de si ya las tenia en mi coleccion, me entretuve alginos instantes á fin de examinarlas, hasta que salté sobre la piedra en medio del rio, instado por Kate que en tono de broma me dijo que no perdiese el tiempo quedándome parado al cada momento delante de la mas pe. queña flor, entorpeciendo la marcha de los demás. Iba ya á dar el segundo salto para trasladarme á la orilla opuesta, cuando un grito penetrante de Kate me dejó parado, y al mismo tiempo oi la terrible exclamacion del indio que la seguia: «iAkuyis (serpiente). Al volverme vi á Kate sentada en la picdra á mi lado, pálida como la muerte, indicándome la orilla que acababa de abandonar, y repitiendo el mismo grito: ejAkuy/ Cuando atonta đo, le pregunté si estaba herida, se puso á llorar, 8 entonces descubri en su pierna derecha, cerca de la rodilla, algunas gotas de sangre. Solo una serpiente venenosa podia haber hecho aqquella herida, y solo los mas prontos auxilios podian salvar la vida á nuestra querida india. Ia fatalidad quiso que Fryer $y$ mi hermano se encontrasen los últimos, y el indio con el botiquin uno de los primeros en la larga fila. No pudiendo hacer otra cosa, me quité al punto uno de mis tirantes, y con ál véndé lo mejor que pude el miembro por encima de la herida, la que 
inmediatamente empezaron á chupar los indios. Creo que en los primeros momentos no conocio la infeliz que estaba herida, aunņue la serpiente acometió dos veces, mordiéndola primero por encima de los cordones de perlas que llevaba en la pierna un poco mas abajo de la rodilla, y despues cer. ca del tobillo.

- La agitacion y las corridas en busca del botiquin, excitaron la curiosidad de los indios que estaban en las extremidades de la comitiva, y fueron acudiendo donde estábamos; entre ellos apareció el marido de Kate, 5 aunque la vista de su querida mujer le llenó de angustia, con todo supo con. centrarla en su interior. Pálido como la muerte, se le acercó inmediatamente y le chupó la sangre de la herida. Entre tanto habian llegado Fryer y mi hermano, como tambien el indio que llevaba el botiquin: liryer cortaba la herida; los indios parecian como siempre impasibles, y uno tras otro chuparon 12 herida: aquel circulo de caras en apariencia indiferentes y con los labios chorreando sangre, tenia un aspecto horroroso.

Aunque inmediatamente cmpleamos el amoniaco exte rior é interiormente, todos nuestros esfuerzos fueron infructuosos. A los pocos minutos se manifestaron los sintomas infalibles de envenenamiento: un violento tembior se apo- deró de todo el cuerpo, la cara adquiria por momentos el aspecto cadavérico, un frio sudor inundaba todo el cuerpo, al propio tiempo que la pobre mujer se quejaba de fuertes dolores en todo el lado donde tenia el miembro herido, en la region del corazon y en la espalda. Sobrevinieron los ró mitos, que muy pronto fueron de sangre; esta no tardó tam. poco en aparecer en los ojos, $y$ en salir por la nariz y las orejas; las pulsaciones llegaban á ciento veinte y ciento treinta por minuto. Antes del cuarto de hora, la infeliz mu. jer habia cambiado su semblante, habiendo perdido ya la voz cuando empezaron los vómitos de sangre.

¿n el interin los demás indios habian dado nuerte á la serpiente, la que encontraron á pocos pasos del camino. Sin duda habia tocado yo al animal al saltar sobre la piedra y se habia arrojado sobre Kate, ó tal vez la misma infeliz le habia molestado involuntariamente. Catorce indios y Goodall habian pasado por delante del reptil sin verlo ni pisarlo. Kate fué la victima.

- La desgraciada mujer fué llevada en su hamaca, ya completamente desvanecida, a nuestra aldea, de la cual pocas horas antes habia salido tan llena de vida y alegre. i Ia mirada que echamos entonces sobre la infeliz, bien sabiamos todos que era la última!

\section{LOS BATRACIOS}

CONSIDERACIONES GENERALES. U Un profundo abismo separa los vertebrados hasta ahora descrios, de los que nos resta describir. Aquellos respiran por pulmones en todas las fases de la vida; los mas de los batracios lo ha. cen por branquias hasta cierta edad. En la clase de que nos ocuparemos se observa por lo tanto casi siempre una meta. morfósis, muy general por lo demás en los animales invertebrados; en otros términos, los séres de esta clase no tienen aun al salir del huevo la estructura de sus padres, que solo adquieren mas tarde, á consecuencia de un tránsito del es tado de renacuajos al de adultos.

Ins batracios sc asemejan á los peces en mayor grado aun que los reptiles, que por lo regular se agrupan con ellos en una rnisma clase. Su vida en la juventud es la de un pez y solo en la edad madura son anfibios, aunque entonces los mas de cllos no se pueden alcjar completamente del agua.

CARACTERES. - Sus formas varian mucho, porque, segun dice Cárlos Vogt, «por un lado se observa la com. pleta falta de extremidades 6 una marcada atrofia de las mismas, como en la forma cilindrica de un gusano; mientras que por otro existen órganos de movimiento mus desarrolla. dos en una forma aplanada del cucrpo, y semejantes á un disco. En los ceciloides, que carecen de extremidades y viven exclusivamente en tierra, todo el cuerpo, compuesto solo de un tronco y sin cola, se asemeja al de la lombriz; micntras que en los proteos anguiformes que visen en el agua y tienen la figura prolongada de una anguila, una cola comprimida lateralmente, y provista á menudo de una mem. brana vertical, sirve para la locomocion en el agua. Obsérvanse además los piés en todos los grados del desarrollo, pero inútiles al principio para servir de apoyo al cuerpo y provis. tos solo de un reducido número de pequeños dedos atrofia. Tomo V dos. A veces solo existen los piés anteriores, que en forma de diminutos munones penden del cuello; en otros casos solo existen los pies posicriores. Cuanto mas se desarrollan estos, tantos mas se recoge el cuerpo aplaníndose al mismo tiempo. En las ranas $y$ sus afines la cola desaparece del todo en los adultos, de modo que no queda vestigio de ella, y el ano se halla como en los ceciloides inmediatamente en la extremidad posterior del cuerpo. Los piés posteriores son en estos animales, mucho mas largos que los anteriores, pequeños, cortos y recogidos casi siempre hácia adentro; no suelen tener por lo regular sino cuatro dedos, mientras que en los posteriores hay casi siempre cinco. La locomocion en tierra tirme se efectúa casi siempre á saltos bastante largos.

Mientras los reptiles $y$ batracios se consideraron como per. tenecientes á una misma clase, con justa razon se llamó á estos ültimos reptiles desnudos; y en efecto, en muy pocos batracios se encuentran vestigios 6 señales de formaciones córneas, tales como las que cubren generalmente el cuerpo de los reptiles, mamiferos ó ares, ó arman los pies en forma de garras 6 uñas. Solo en algunas especies se ven verruguitas de la piel coriácea; esta última, que nunca se desarrolla mucho, tiene en algunos batracios unas glándulas llenas de cierta sustancia mucosa; hállanse situadas entre dos capas de la piel y se extienden como una red por todo el cuerpo; en otros bay unas celdillas profundas, donde se desarrollan los hijue. los; y en varios, por último, vénse unos anillos con bordes prominentes, en cuya parte cóncava se encuentran unas for. mas duras, semejantes á las escamas de los peces.

Solo en algunas especies de sapos existen osificaciones; en las ranas y salamandras la piel coriácea es mucosa, blanda, casi siempre muy ancha, compuesta de tendones fibrosos muy elásticos, y bastante delgada, de modo que en las espe. 
cies cuyo cuerpo se oprime pueden verse los músculos. Una epidermis incolora, formada por celdillas, $y$ en la cual se observan à menudo capas de color verde, azul, amarillo, ó pardo, cubre la piel coriácea. Muchos animales desnudos y raniformes tienen en la piel giandulas que segregan un li. quido espeso de un olor mas ó menos anúlogo al del ajo. Por lo regular, estas glàndulas, como se obscrva por ejemplo en los sapos y salamandras, están distribuidas por todo el cuerpo, pero á menudo se aglomeran además en ambos lados del grueso cuello, en cuyo caso se les llama glándulas auri. culares. Además se observan en varias especies unas celdillas donde se desarrollan los huevos; pero tampoco estas son otra cosa sino glandulas trasformadas, que solo se desarrollan en el periodo del celo.

La piel desnuda y sus glándulas tienen una gran importancia para la vida de los batracios, que mueren cuando se paraliza la actividad de aquellas. Por lo que hasta ahora sa. bemos ningun batracio vive dcl modo ordinario; recibe toda el agua quénecesita para subsistir exclusivamente por medio de la piel; esta absorbe y segrega la humedad. Towson fué quien primero démostró este hecho pormuchos cxperimentos.

Una ranaque se conserva en un espacio seco enflaquece y se debilita, $y$ solo recobra su fuerza y alegria cuando se la permite tomar un baño. Es cicro que las ranas, asi como los reptiles, se ponen al sol, pero solo $\mathrm{cn}$ las inmediaciones del agua, a la cual vuelven tan luego como les parece ne. cesario. Todos los batracios pasan la mayor parte de su vida en tjerra firme, y no salen de sus escondites hasta que la noche, con su humedad, les preserva de la fuerza de los rayos del sol. Towson observó que algunas mas privadas. del agua muricron a los pocos dias, mientras que se conservaron vivas mucho mas tiempo cuando pudieron ocultarse debajo de rirutas si estas se nojaban. Si se colocaba un trapo húmedo á su lado, corrian hicia él para refrescarse Fácilmente puede observarse por experimentos convenientes cuán considerable es la cantidad de agua que absorben por la piel. Una rana casi seca cxaminada por Towson pesó noventa y cinco gramos, pero cuando se le puso en contacto con el agua, tuvo al cabo de una hiora 67 mas. En una caja cerrada pueden vivir de veinte á cuarenia dias, tan solo por la actividad de su piel, cuando la temperatura es húmeda y no excede de 10 a 12 grados, aunnue se corte toda co. municacion entre el aire $y$ los pulmones. Cuando en cambjo se deja penetrar la humedad por estos últimos, mueren con una temperatura seca á los pocos dias, y si se les arranca la piel, al cabo de algunas horas. El peso de un batracio ex. puesto $a$ un calor seco disminuye con suma rapicez $\{$ proporcion del descenso de la temperatura misma. En un espa. cio sin aire, la traspiracion de los batracios es considerable y por lo tanto mueren alli mas pronto que en el agua donde falta el aire; pero si la traspiracion de la piel se impide, por ejemplo, cubriendo el cucrpo con una especie de barniz, consérvanse mas tiempo vivos. Un órgano particular, que sin razon se llama vejiga, parece servir de depósito de agua.

La piel scgrega además del agua pura un líquido mucoso en mayor 6 menor cantidad; cn los sapos y salamandras esta secrecion es, gracias al mayor nuimero de glándulas, mucho mas considerable que en todos los demás bairacios, y puede además aumentarse aun por las irritaciones de la piel. Si se pone, por ejemplo, una salamandrá 6 un sapo so. bre la lumbre, el liquido mucoso que segrega sale en maror cantidad, $y$ de aqui la antigua fábula de que la salamandra puede vivir en el fuego. Segun parece, el batracio puede aumentar á su antojo la secrecion de la piel, y quizís em. pleaila como arma defensiva contra sus enemigos; porque este liquido es probablemente un ácido grasoso, no solo de un olor penetrante, sino tan cáustico que los sapos y sala. mandras han adquirido por esto la fama de animales venenosos. Sin embargo no debe considemrse esta secrecion mucosa como un veneno verdadero, aunque ocasiona dolor en las partes sensibles de la epidermis y escuece en la lengua.

Davy, que examinó la secrecion del sapo, dice que produ. ce en la lengua los efectos de la digital; es insoluble en agua y vino; conserva su propiedad picante en el amoniaco y se vuclre roja en el ácido salitroso. Segun los experimentos hechos por Gratiolet y Chloez, la secrecion de las glándulas del sapo mata pronto á las avecillas cuando se les inocula en la piel y produce efecto aunque antes de la inoculacion se haya secado. Roebbeler ha reconocido tambien que la materia mucosa produce efectos mortales cuando se introduce por medio de incisiones en perrillos, conejos de Indias, ranas y salamandras acuáticas, obscrvando además que la secrecion de la salamandra aplicada del mismo modo al sapo pro. duce un efecto mortal. Pallas refiere que tuvo un doguilia tal que no pudo impedir que matara sapos, lo cual le produjo una jnflamacion en los labios que le ocasionó la muerte. Lenz añade $\mathfrak{a}$ estas noticias algunas observaciones propias que parecen confirmarlas. \&Por el siguiente hecho se ve que no se debe poner á las delicadas ares de jaula arena que haya estado en contacto con la humedad que se desprende de los sapos. En 1859 envic á buscar arena fresca para inis canarios, y puse parte de la misna en un jarro dejando el resto en un cobertizo cubierto con tablas, para que no se ensuciara. En el invicrno y verano, las aves recibicron á menudo arena del jarro, y seguian disfrutando de la mejor salud. I. legado el verano de/1860, un enorme sapo fjó su residencia debajo de las tablas; salia todas las noches, y despues de ocultarse un rato entre la madera, paseábase toda la noche por el patio y el jardin. Como iba á menudo á visitar la en. trada de su guarida, el batracio se familiarizó pronto. En el otoño se acabó la arena del jarro; entonces levanté la tabla y encontré debajo de ella al sapo en la cavidad que habia practicado. La arena no estaba seca como yo esperaba, sino empapada en la humedad producida sin duda por su hués. ped. Las galerias hechas por el sapo, se corrian solo por la superficiè, y para mayor seguridad lesanté una capa de quince centimetros de la arena, sacando de la mas profunda para ponérsela á tres canarios. Estos comenzaron á picar en ella, y murió uno de ellos; los otros dos, aunque quité la arena en seguida, sucumbieron a las pocas semanas. No creo que los experimentos anteriores prueben la verdadera venenosi. dad de la secrecion de los batracios, aunque no negaré que el citado liquido tenga propiedades causticas que producen ciertos efectos en la actividad vital de animales pequenos. ESQUELETO.- Muy particular es el esquelcto de los batracios respecto á su formacion, pues en esta se notan pro. porciones parecidas á las que rigen en los peces. ren las sa. lamandras de branquias, dice Vogt, se encuentran vértebras que por su forma no pueden distinguirse de las de los peces; en las verdaderas salamandras, en cambio, se ven ya vérte. bras del todo desarrolladas. L̀n todos los batracios de cuerpo prolongado el número de las vértebras es muy considerable, mientras que en los raniformes solo existen de siete á nueve vértebras dorsales; en cambio, el sacro es muy largo; com. puesto, segun parece, de varias vértebras soldadas y relacio. nado con un largo bueso en forma de sable que constiture la continuacion de la columna vertebral hasta el ano. Ias apófisis trasversales de las vértebras están muy bien desarrolladas en todos los batracios, y á veces son en extremo largas, sustituyendo de este modo á las costillas, que solo en algunas especies se hallan representadas por pequeiros apéndices cartilaginosos. 
Respecto à la formacion del cráneo, of récense tambien varios grados de desarrollo en el grupo de los batracios, grados que sobre todo se fundan en el hecho de que los primitivos apéndices cartilaginosos desaparecen puco á poco. Como distintivo caracteristico para toda la clase y en contraste con los reptiles se presenta aqui la formacion de dos cóndilos laterales en el occipucio debidos al hueso occipital del lado, siempre osificado, y el cual encaja en dos cavidades de la primera vértebra cervical, que afecta la forma de anillo. El cráneo mismo es siempre muy ancho y aplanado; las órbitas por lo regular en cxtremo grandes y sin paredes posteriores, de modo que vistas desde arriba, las mandíbulas forman un semicirculo cortado en el centro por una cápsula longitudinal que es el verdadero cráneo.

Refiriéndonos ahora á cada uno de los huesos, diremos que el esfenoides forma en la superficie inferior del cráneo una hoja ancha 6 en forma de cruz, cubierta casi siempre de cartilago en su carn superior, es decir, en la que se dirige al cráneo. La tapa de este se compone de dos parietales, á menudo muy atrofiados, $y$ dos frontales; en los ccciloides existe tambien el etmoides que á menudo llega \& un considera. ble tamaño, pero sin sobresalir de la superficie del cráneo. Las caras laterales de este constan en los batracios de branquias, casi del todo cartilaginosas, presentando en el ala anterior del esfenoides $y$ en la anterior de los huesos frontales una osificacion, mientras que en los raniformes el peñasco y tambien las alas del esfenoides se osifican, dejando sin cm. bargo intervalos membranosos.

\# En la cavidad palatina todos los huesos están soldados con el cráneo, de modo que el intermaxilar y los maxilares superiores constituyen el borde de la boca, y por lo regular el hueso palatino forma en su parte interior un segundo arco paralelo. Los batracios carecen del todo de un verdadero eśenoides; los hucsos palatinos y los maxilares superiores están provistos de dientes. La mandibula inferior se compone por lo menos de dos huesos, pero á veces tambien de mas, suspendidos de un arco que nunca se osifica del todo, componiéndose del hueso cuadrado y del tambor. Ia formacion úsea de este modo compuesta, y que afecta la figura de un tamiz, está reunida estrechamente con el cráneo y se inclina regularmente hácia atris, de modo que la hendidura de la boca se extiende á menudo á bastante distancia del cráneo, el cual puede asi abrirse mucho.

"Las extremidades, cuando existen, se componen siempre de la region del hombro 6 de la pélvis y de los miembros propiamente dichos; estos faltan del todo en los ceciloides mientras que en muchas salamandras de branquias solo exis. ten piés anteriores. La region del hombro, compuesta de los. omoplatos y de las anchas clarículas, se fija lateralmente en la última vértebra cervical. En las salamandras solo está osificada en parte y se compone de un omoplato, de una ancha clavicula y del hueso coracoideo, entre los cuales se inserta á menudo un esternon impar. En las ranas, la region de los hombros forma una ancha armazon del pecho, compuesto de muchas piezas, a menudo osificadas en parte. Las extremidades anteriores se componen de un sencillo húmero, de dos huesos del ante-brazo, á veces soldados, de un carpo que á menudo se conserva cartilaginoso y de dedos cuyo número es casi siempre de cuatro y raras veces de tres.

La region de la pélvis esta poco desarrollada en las salamandras, y las vértebras sacro-coxigeas difieren apenas en su formacion de las otras; la pélvis se mantiene además casi siempre cartilaginosa y se compone solo de dos ileos reunidos entre si por un hueso central. Mas caracteristica es aun la formacion de la pélvis en las ranas, pues en ella encajan los fuertes huesos de los muslos con sus músculos. Ia estructu. ra de los huesos del pié es la misma que la de las extremidades anteriores, aunque se observan mas variaciones, porque en algunas salamandras de branquias solo existen dos, tres ó cuatro, pero en las verdaderas salamandras ó en las ranas siempre hay cinco dedos en las extremidades posteriores. Solo en muy pocos géneros se ven unas, las cuales encajan en las extremidades de los dedos como en un dedal; en la mayor parte de los batracios los dedos están del todo des. nudos, rcunidos con frecuencia por membranas natatorias y provistos á menudo en su cara inferior de una protuberancia que sirve para cogerse á las rocas, piedras, etc.

- Los músculos de los batracios corresponden á la forma de su cuerpo. En las especies acuáticas del órden predomi. nan los músculos laterales; en las ranas los de los piés. Tie. nen un color blanco rojizo algo mas pálido aun que en los reptiles; su fucrza es considerable, y su sensibilidad exquisi. ta, segun lo demuestran los muchos experimeatos hechos con estos reptiles.

El cerebro es muy prolongado y sus circunvoluciones están situadas una detrás de otra: el cerebelo está representa. do solo por un estrecho puente irasversal; delante de este hällanse las cuatro protuberancias que en su parte posterior rodean la glándula pineal; junto d esta se ven las protube. rancias pares de la parte anterior del cerebro, que por lo re. gular es mas grande que la posterior. La médula espinal es en proporcion mucho mayor que el cerebro.

SENTIDOS. - A ningun batracio le faltan los tres órganos superiorts, aunque en algunos, los ojos, muy atrofiados, están ocultos por una piel trasparente. I.os raniformes son los que tienen los ojos mas desarrollados; grandes y muy movibles, suelen estar protegidos por dos párpados, de los cuales el inferior, que es el mas grande, delgado y trasparen. te, presenta además en el ángulo interior de la piel la mem. brana nictitante en forma de un repliegue membmnoso pe. queño, sencillo é inmóvil. Los órganos del oido varian aun mas que los de la vista. En los batracios de cola solo existe el timpano; en los raniformes una cavidad con timjano, y una corta trompa de Fustaçuio. El laberinto mismo se compone de tres tubos en forma de semicirculo y una bolsa llena de pequeños cristales de cal; tiene una abertura oval cubierta por una váliula 6 una membrana delgada ó bien por músculos ó por la piel.

La nariz se abre en la parte anterior del hocico y en la cavidad bucal, en dos fosas separadas una de otra por una pared divisoria.

En muchos batracios el conducto nasal puede cerrarse por membranas en forma de válrulas.

La lengua, que apenas puede considerarse como órgano del gusto, falta solo en las especies de una familia, mas por lo regular está bien desarrollada; es sobre iodo muy ancha, ocupa todo el espacio entre los dos maxilares, y tiene am. bien bastante movilidad, distinguiéndose sin embargo de la lengua de los rertebrados superiores, en que está fija, no por su parte posterior sino por la anterior; de modo que su extre. midad posterior puede salir de la cavidad bucal; solo en al. gunas salamandras se fija en el fondo de esta uilima.

ESTRUCTURA INTERNA.-Algunos batracios son desdentados, pero los mas tienen dientes en la mandibula súperiot $y$ en el hueso palatino, dispuestos en dos arcos completos. Siempre afectan la forma de ganchos, peçueños; sencillos, puntiagudos y encorvados hácia atrás, teniendo muy poca importancia para la vida de estos animales. El intestino es regularmente corto; el csbfago largo y ancho; el estómago sencillo, de piel gruesa, provisto de un repliegue longitudinal; el intestino grueso se ensancha solo alguna vez en forma de bolsa. El hígado está dividido casi siempre en 
dos lóbulos; la vojiga de la hiel, el páncreas, el bazo y los rinones existen siempre.

Las partes genitales situadas en la region dorsal de la cavidad estomacal, se distinguen por su estructura sencilla. Los testículos se componen de cortos cordones espermá. ticos; presentan á veces divisiones $y$ se trasforman con bas. tante frecuencia en muy finas partículas espermáticas que por un repliegue del peritoneo pasan al riñon, donde se ramifican en forma de red $s$ penetran despues en la uretra en la cual casi siempre hay además unos orificios en forma de tubos. Los ovarios afectan la forma de uva y están del todo encerrados, formando en los batracios de cola una bolsa con una sola abertura por la cual se introducen los huevos ma. duros en la cavidad abdominal, mientras que en los raniformes, cada uno de esos huevos está rodeado de una cápsula. Los oviductos, siempre separados de los ovarios, son muy largos, semejantes $\alpha$ un intestino con muchas circunsoluciones, y se abren en la cavidad abdominal en figura de un an. cho embudo que, por decirlo asi, absorbe los huevos; delan. te de su abertura, es decir, en la cloaca, presentan á menudo un ensanchamiento en forma de matriz, en el cual se desarrollan realmente los hijuelos en la salarnandra. Los órganos genitales exteriores faltan del todo.

RESPIRACION Y CIRCULACION DE IA SANGRE. - Muy importantes para la vida de los batracios son los órganos de la circulacion de la sangre y de la respira. cion. El corazon difiere poco del de los reptiles; se compone de dos cavidades de piel delgada, no siempre separadas del todo, y de otra sencilla de paredes gruesas, que impele la sangre á las arterias. Estas se trasforman mucho durante la metamorfósis por que deben pasar todos los batracios, y al mismo tiempo se trasforman tambien los pulmones, que en la primera fase se sustituyen por branquias y en algunas es. pecies no alcanzan hasta muy tarde todo su desarrollo. Este depende de tal modo del de los animales mismos, que en primera linea debemos ocuparnos de él.

REPRODUCCION. - El verdadero apareamiento y la fe. cundacion de los huevos en el vientre de la madre no exis. ten, al parecer, sino en las salamandras terrestres viviparas, s quizás tambien en las ranas, que sin verdadera metamorfósis nacen inmediatamente de los huevos; las observaciones he. chas respecto al extraño modo de reproducirse estos anima les son, sin embargo, demasiado recientes para que no nos pudiéramos instruir del todo sobre este particular. Por regla general, los huevos de los batracios, asi como los de los pe. ces, solo se fecundizan cuando ja han salido del vientre de la madre. 'Todas las especies carecen de órganos genitales visibles, ni tan solo desarrollados, y la fecundacion de los huevos se efectúa, por to tanto, comunmente, pero no en todos los casos, en el agua; dura mucho tiempo y hace olvidar á los animales á menudo todo cuanto les rodea. Rara vez cuidan los padres los huevos con cierta solicitud, pues por lo regular los abandonan al agua y al sol. Como la facilidad con que el observador puede adquirir los de los batra. cios es tan grande, cl desarrollo de los mismos ha sido objeto de mucho estudio. \&os huevos maduros, dice Vogt, forman una yema cónica que en la mayor parte de las especies presenta un depósito de colores oscuros en su capa exterior, tan intenso sobre todo en su mitad, que el huevo parece alli del todo negro. La masa de la yema se compone de un liquido espeso que en parte consiste en clara de huevo y en el cual se encuentran muchisimas particulas de yema mas sólidas, de naturaleza sebácea y de figura casi siempre cua. drangular aplanada. Al pasar por los largos oviductos, que forman muchas circunvoluciones, los huevos se rodean de una masa gelatinosa, que solo en algunas especies se conso.

lida, representando entonces un cordon elástico, mientras que en las mas se dilata en extremo en el agua, formando las grandes masas de freza que en la primavera encontramos en los fosos y estanques. Esta masa gelatinosa no es mas tarde en el desarrollo sino una cubierta, y está siempre empapada de agua como una esponja. Tan luego como el renacuajo ha sufrido la primera fase de su desarrollo, rompe la cubierta y se la come en parte para vivir despues libremente en el agua. La yema se divide en dos mitades esféricas y esta division persiste hasta que termina la definitiva formacion de las celdillas del embrion. Toda la capa de la yena interviene en el desarrollo de aquel, encerrando la materia central de la yema, que poco á poco se consume en su interior. No existe, por lo tanto, nunca una verdadera bolsa de la yema. La region abdominal está mas ó menos dilatada segun la

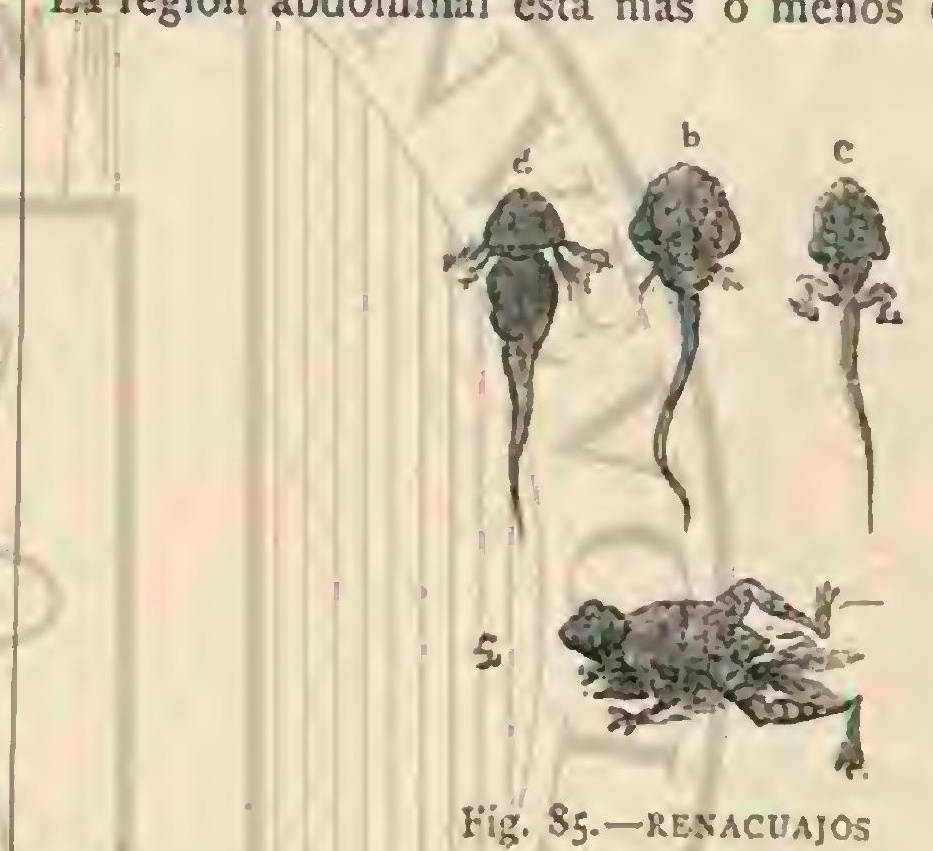

cdad del renacuajo, porque en su interior contiene la yema. El primer desarrollo se verifica con bastante rapidez, pues á los pocos dias de la fecundacion, toda la parte espesa de la jema se trasforma en un renacuajo, cuya cabeza plana, deprimida y provista de una pequeña boca, se confunde al punto con el vientre, el cual afecta la forma de bolsa, y en cuya extremidad posterior hay una cola aplanada en figura de remo, rodeada en toda su longitud de un apcho borde membranoso que ofrece el aspecto de una aleta vertical (fig. 85 ). Esta cola presenta la misma disposicion en zig-zag de los ligamentos musculosos que se observan en los peces. Del cuello parten las branquias en forma de arbolitos verrugosos, pero desaparecen pronto en los renacuajos, siendo sustituidos por branquias internas; en las salamandras jórenes se conservan mucho mas tiempo. El desarrollo del renacuajo se efectúa hácia adelante, sobre todo cn la formacion de la cola y en la lenta trasformacion de la yema. El borde membranoso de la aleta caudal se eleva mucho; el cuerpo se estrecha; y poco á poco se forman las extremidades, que al principio están ocultas debajo de la piel; en las ranas y sala mandras se prescntan en forma inversa, apareciendo en las segundas las piernas anteriores antes que las posteriores; mientras que en las primeras sucede lo contrario.

$\gg$ En los renacuajos de los raniformes las piernas posteriores existen mucho tiempo antes que las anteriores; pero la cola es siempre el principal órgano del movimiento. Entonces empieza la metamoríosis del renacuajo nadador y plantivoro, que se convierte en animal saltador é insectívoro. Las bran. quias estaban provistas hasta aqui de unos extraños dien. tes córneos que entonces caen; la cola se atrofia poco á poco, sécase $y$ desaparece por fin completamente.

$\gg$ En cuanto al desarrollo de los órganos internos del rena. cuajo raniforme, la formacion del embrion empieza tambicn en cierto punto, donde se presenta primero el surco dorsal con sus prominencias limitadas, y despues el tendon vertebral, como principio del esqueleto. Las masas celulares del 
embrion aparecen pronto en toda la longitud de la yema en forma de paredes abdominales y đel sistema dérmico; el huevo se hace entonces longitudinal, mientras que la placa dorsal se cierra por arriba formando así el espacio destinado al ce. rebro y la médula espinal. Distinguense marcadamente las tres divisiones del cerebro con los órganos correspondientes de los sentidos, la nariz, los ojos y las orejas, reconociéndose ya entonces la preponderancia de la parte anterior del cerebro sobre las otras. El desarrollo de este y de los órganos de los sentidos se asemeja mucho al de los peces, y la formacion del esqueleto es análoga á la de estos. En la cola, que desaparece, no se forman nunca vértebras, mientras que en el tronco se hallan en forma de anillos completos, que pasan entre los conos dobles que en las salamandras de branquias se conservan enteros 6 toman la forma de mediosanillos, de modo que los restos del tendon vertebral se hallan como en un surco en la cara de las vértebras dirigidas hácia el vientre.

El espacio central del primitivo cráneo cartilaginoso, en el cual penetra la extremidad del tendon vertebral y que está ocupado por el apéndice cercbral, tiene un tamaño considerable y la forma oval. Los cóndilos laterales del cráneo son estrechos; los espacios intermedios entre ellos y el arco cigomático, que encierra la órbita, muy anchos; la parte de la cara es pequeña y corta. Los huesos de la cabeza se des. arrollan en su mayor parte como tapa, $y$ en la menor como osificaciones del cráneo primitiro, que en la mayoria de los géneros se conserva durante toda la vida en algunos restos.

El corazon se forma en los renacuajos muy pronto de una nasa celular depositada entre la cara inferior de la ca. beza y la yema, comenzando desde luego su actividad. Al principio solo tiene la forma de bolsa, pero mas tarde se desarrollan las divisiones. El tallo de la aorta se continua inmediatamente en los arcos branquiales que al principio llevan la sangre á las branquias exteriores, y mas tarde á las interiores; de los vasos branquiales anteriores se forman las arterias de la cabeza, mientras que las posteriores se reunen para la formacion de la aorta. La sangre del cuerpo circula á lo largo de la cola por la vena y se ramifica luego, como en los peces, en la superficie de la yema, volviendo despues por la vena de esta à la auricula del corazon. Du rante el estado de renacuajo esta circulacion es la misma en sus movimientos principales, con la única diferencia de que las venas del higado y de los rimones comienzan poco \& poco a funcionar. Los pulmones se desarrollan entonces lentamente y sus arterias aumentan en tamano visib!emente. I.a respiracion por los pulmones empieza mientras las branquias se secan, $y$ por lo tanto las arterias pulmonares se desarrollan mucho mas; los arcos branquiales anteriores se trasforman del todo en las arterias de la cabera y de los ojos, al paso que los del centro forman la aorta Mientras que en los renacuajos toda la masa de la sangre qque sale del corazon pasa por las branguias y no se distribuye por el cuerpo sino despues de pasar por ellas, en los animales adultos todas las partes del cuerpo solo reciben sangre mezclada, porque la division de las cavidades del corazon no existe. Es cierto que la sangre nue sale del corazon penetra en el ventriculo derecho y la que llega de los pulmones en el izquierdo; pero ambas se mezclan en la bolsa sencilla del corazon desde la cual vuelven al cuerpo y á los órganos res. piratorios.y

DISTRIBUCION GEOGRÁFICA.-Pocos restos de ba tracios fósiles se han encontrado hasta ahora; de modo que apenas podemos emitir un juicio sobre la historia prinitiva de esta clase. En la actualidad habita todos los continentes, y excepto las regiones mas septentrionales de la tierra, está di seminada por todas las otras. El calor y el agua son, en mayor grado aun que para las demás clases, las condiciones necesarias para su vida y prosperidad. Su dependencia del agua es tan grande que no podrian subsistir fucra de dicho elemento, pues con pocas excepciones en el pasan su primera jurentud. Ia segunda condicion vital del calor explica que su número aumente extraordinariamente hícia el Fcuador, de modo que casi podria decirse que los paises tropicales son su verdadera patria; pero siempre eligen las aguas ciulces para su residencia $\delta$ para criar en ellas su progenie, evitando. por lo que hasta ahora sabemos, el mar y las aguas saladas en general. Muchos batracios permanecen en el agua durante todas las fases de su vida; pero la mayoría vive fuera de este elemento despues de la metamorfósis, aunque solo en regio. nes húmedas; alli donde el desierto predomina ya no hay batracios, mientras que en las regiones en que abunda el agua. aunque solo sea temporalmente, no faltan casi nunca. Así como en nuestros paises pasan el invierno sumidos en un le. targo profundo, en otros se ocultan durante la estacion seca en el cicno ó en cavidades, donde se entregan à un sterno parecido á la inuerte, del cual despiertan al principio de la primavera. En todas las regiones de los paises tropicales donde la época lluviosa divide el año en estaciones, desaparecen del todo al principio de la sequía y vuelven á presentarse despues de la primera lluvia como por encanto, diseminándose en vastas extensiones donde el dia anterior apenas se habria sospechado su existencia.

Pero en todos estos países su número es limitado, si se compara con el que se cncuentra en las selras virgenes don. de abunda el igua, y que durante todo el año conservan poco mas ó menos la misma humedad, ofreciéndoles por lo tanto aun en las copas de los árboles la posibilidad de reproducirse. Los inmensos bosques de la América del sur, asi como las selvas virgenes del Asia meridional, albergan muchas fa. milias en extremo numerosas, tanto en especies como en in. dividuos, que utilizan el agua recogida en las anchas hojas, en los huecos de los árboles ó en otros sitios para depositar su freza 5 vivir alli. Aqui todos los sitios, nun los mas pequeños, están poblados; las aguas, el suelo, los parajes hưme. dos del mismo y los huecos y copas de los árboles, mientras que en los bosques del Africa relativamente secos, se observan muchos menos batracios. Los pantanos y las selvas vír. genes húmedas del centro y sur de la América son realmen. te el verdadero paraiso de los raniformes; mientras que estos faltan casi en absoluto en vastas extensiones del Africa. Sin embargo, debo añadir que cada año se liacen nuevos des. cubrimientos y que por lo tanto aun no podemos determinar con toda seguridad el área de dispersion de esta clase de animales.

Si, guiándonos por el excelente trabajo de Guenther, inten. tamos trazar un cuadro de la distribucion general de los batracios, observamos desde luego que ninguna otra clase de vertebrados ofrece tan pocas formas propias de ciertos ter. ritorios. Fl hemisferio septentrional se distingue por los ba. tracios de cola, que le son caracteristicos; las regiones cálidas por sus especies gigantescas; la América del sur por su riqueza en ranas arboricolas, y el Africa por su escasez. de batracios en general.

Los géneros tienen \& menudo, y las familias casi siempre, tipos correspondientes $a$ varios territorios; $y$ las especies se hallan diseminadas á menudo de un modo sorprendente, aunque al parecer dependen de ciertos parajes. Sin cmbargo, no existe ningun batracio que pueda llamarse cosmopolita, ni tampoco hay ningun género que tenga representantes en todos los territorios. Ias ranas arboricolas y acuáticas y los sapos, son los que mas diseminados están, pero precisamen. 
te estos viltimos dos géneros faltan del todo en Australia, donde, en cambio, las ranas arboricolas alcanzan un desar. rollo muy particular.

Caracteristicos del territorio septentrional del antiguo continente son los pelobates, los campaneros, los alites, varias salamandras y tritones, las salamandras acuáticas, el proteo y otros géneros 6 especies de que no podremos ocuparnos en nuestra obra. Con pocas excepciones viven en Eu. ropa tipos de los géneros propios de tocio el territorio. Algu. nas especies se extienden en él tanto como es posible para los batracios, como sucedé con la rana de zarzal. Los batracios de cola vienen á ser un doble mas numerosos gue los raniformes. De las 380 especies que Guenther distinguió en 1858 , cuarenta y cinco pertenecen a ese territorio. En el etiópico solo existen raniformes, pero en un número tan reducido de especies que Guenther no contó apenas sesenta. No me detengo a énumerar los géneros caracteristicos, porque solo haré mencion superficialmente de las ranas africanas. Ias especies arboricolas faltan, segun queda dicho, completamente, pero tienen representantes afines.

En proporcion álos reptiles, tampoco el territorio indio parecerico; aqui escascan los batracios; el número de especies no es mas considerable que en el territorio ćtiópico, por favorables que parezcan el clima 5 la vegetacion para el desarrollo de la clase: algunas especies, sin embargo, son tan numerosas como en cualquiera otra parte. Fin Ceilan abun. dan relativamente, pero ninguna de ellas es característica de la isla. En el territorio indio faltan las ranas arboricolas pro. piamente dichas.

Australia, donde solo se ha podido explorar hasta ahora una pequeña parte, no puede llamarse pobre en batracios: solo se presentan los raniformes, pero estos en variedad y número de géneros relativamente considerables. Los congéneres de nuestra rana acuática y del sapo faltan por completo. El número de especies llega poco mas ó menos ấ la mitad de las que habitan el territorio indio. En la Nueva Zelanda no hay batracios.

La mayor parte de los que existen en el territorio septentrional del Nuevo Mundó se parecen mucha a los de las regiones análogas del antiguo continenté; una especie como la rana de zarzal es comun hlos dos. Una serie de gèneros raniformes le son característicos y los batracios de cola llegan en aquellas regiones \& su mayor desarrollo. Como formas propias solo de este pais citare los acris, amblisto. mas, ictioideos, anfumas, menobrancos y las sirenas.

Fl nímero de especies asciende, segun el cálculo de Guenther en el citado año, á unas 70, es decir, 20 ranifor. mes y 50 de batracios de cola.

Mas que en todos los demas territorios, los batracios abundan en el meridional del Nuevo Mundo, aunque tam bien aqui faltan por completo los batracios de cola. En can. bio se presentan los raniformes mucho mas numerosos, y además se observan los ceciloides. Varios géneros particulares de ranas y sapos se agregan á los que tambien pertenecen á otros territorios; las ranas de zarzal $\mathrm{y}$ las arborícolas en general han llegado aqui á su mayor desarrollo. Las man gigantescas y unos sapos muy particulares deben considerarse como formas caracteristicas del territorio donde los ce. ciloides tienen su verdadera patria. En los ultimos veinte años el número de las especies de batracios descritas aumen tó de tal modo que Wallace calculó ascendian en $38 ; 6$ á casi setecientas; pero no se han cambiado los limites principales del årea de dispersion trazada por Guenther.

USOS, COSTUMBRES Y REGIMEN.-Aunque mu. chos batracios tienen un área de dispersion muy extendida, los individuos no se alejan fícilmente de su residencia acos- tumbrada. Esta se limita á menudo á un espacio de pocos metros cuadrados: un estanque de mediana extension, $y$ hasta un charco que con regularidad recibe el agua, pueden constituir el àrea de dispersion de centenares de estos séres sin que les ocurra emigrar; un solo árbol en la selva virgen da albergue à otros todo el año, tanto á los adultos como á los jóvenes. Hay especies que vagan en major extension, mas parece que siempre vuelven á su escondite. Rara vez em. prenden los batracios largos viajes; sin duda lo hacen solo en el caso de que el sitio de su residencia sufra tal cambio que ya no les ofreaca lo necesario para la vida. Por otra parte, no puede desconocerse q̨ue tambien estos reptiles pueden extenderse mas $\delta$ menos en una region, y que asimismo se dirigen á ciertos sitios, sobre todo donde hay aguas que antes no existian.

El género de vida de los batracios parece aun mas monótono que el de los reptiles, aunque la mayor parte son supe. riores por su actividad a varios de estos. Atendido su género de rida acuático, todos son excelentes nadadores, con la sola excepcion quizás de los ceciloides, y no solamente en su primer estado, durante el cual son casi peces, sino tambien en el de adultos. Los renacuajos nadan con ajuda de la cola, ejecutando movimientos laterales, es decir, á la manera de los peces; algunos de los adultos, por ejemplo los batracios de cola, siempre nadan del mismo modo, mientras que los ra. niformes lo lacen como el hombre, sirviéndose sin embargo casi exclusivamente de las extremidades posteriores. No cabe duda que tambien los ceciloides saben nadar, porque todo animal vermiforme puede sostenerse en el agua, pero son muy inferiores por este concepto á los tipos de los otros ór. denes.

La progresion en tierra firme se efectía por movimientos muy diferentes. Todos los batracios de cola andan arrastrándose pesadamente, mientras que los raniformes dan saltos mas 6 menos largos; entre ellos hay tambien trepadores que saben muy bien subir \& la copa de los śrboles altos; pero el acto de trepar se verifica sin embargo de distinto modo que en todos los vertebrados hasta ahora descritos: dan tambien saltos desde un punto de descanso á otro, situado á mas altura. Por un concepto, los mas de los batracios aventajan s. los reptiles, pues mientras que solo algunos de estos tienen voz en el verdadero sentido de la palabra, la gran mayoria de los batracios, sobre todo los del primer órden, poseen la facultad casi sorprendente de producir unos sonidos fuertes y llenos, mas 6 menos agradables. Su voz acompaña de no. che en la selva virgen á la de otros murchos animales, y re. suena igualmente en nuestros paises en las calurosas noches de verano. Varias especies de la clase hacen tan continuo uso de su facultad que turban el silencio de la noche, $\delta$ infunden temor álos medrosos. Debo añadir, sin embargo, en este lugar, que solamente los adultos pueden gritar, mien. tras que los renacuajos y los jovenes son del todo mudos.

No tenemos aun observaciones suficientes para formar un juicio exacto sobre las facultades intelectuales de los batra. cios. Hemos visto que todos los cinco sentidos, sobre todo los tres superiores, están bien desarrollados; no puede ne. garse que la actividad de su cerebro se manifiesta de un mo. do que indica cierto conocimiento del mundo exterior, de. mostrando cierta inteligencia; y tambien es cierto que se dejan domesticar ó adiestrarse en un grado limitado, lo cual prueba que reconocen el cambio de circunstancias y se acomodan á él. A pesar de esto, es notorio que los batracios figuran entre los mas estúpidos de todos los vertebrados, y que en inteligencia son apenas superiores á los peces.

Lo que al hablar de los reptiles hemos dicho sobre las fa. cultades intelectuales de estos, puede aplicarse en general 
tambien à los batracios, respecto á los cuales nuestro juicio es sin embargo mas desfavorable. No podemos hablar en rigor de una sociabilidad entre esos animales; el mismo sitio los reune, pero no el afecto; tan luego como han satisfecho su necesidad de reproducirse, ra no hacen caso uno de otro. La solicitud que algunos manifiestan á sus hijuclos no debe apreciarse demasiado, aunque nosotros no podemos deter. minar hasta qué punto esta solicitud es intencionada. Ia manera de cuidar algunas veces de su progenie hace creer dispensable, aunque no explicable, la infundada suposicion de una fuerza superior que cuida del aninal y le protege; mas fundada nos parece la opinion de los que atribuyen cierto grado de inteligencia de que no tenemos ningun indicio al observar el género de vida de los batracios.

Es probable que entre estos reptiles no haya ningun animal diurno. Su actividad empieza poco antes del crepúsculo respertino ó á esta hora, y dura hasta el amanecer; de dia descansan todas las especies conocidas, aunque de dis. tinto modo: mientras que los unos se ocultan sencilla. mente permaneciendo en su escondite hasta la noche, otros se exponen á los rasos del sol, á cuyo efecto buscan los sitios convenientes; pasan el dia dormitando, pero nunca lo bas. tante para exponerse imprudentemente á un peligro ó dejar de coger um pieza que se les presentara. Pero tambien ellos demuestran por su actividad y por su voz que la luna es su sol $y$ que la noche es el tiempo que dedican á sus queha. ceres.

La alimentacion guarda ciertas proporciones con la metamorfósis. Todos los batracios son rapaces, pero. la presa que persiguen varia mucho segun la edad. Los renacuajos se ali. mentan en su primera juventud, al decir de Lejdig, de toda clase de animalejos. «si como las lombrices, escribe, llenan su intestino de tierra cenagosa, con la cual tragan infusorios, dáfnidos y tambien diatomeas en gran número. El conteni. do del intestino de varios renacuajos examinados por Leydig, fut siempre mas $\delta$ menos el mismo; la existencia de algias y otras plantas parecidas en el intestino explica la suposicion, considerada ya generalmente exacta, de que los renacuajos se alimentan exclusivamente de sustancias vegetales y que solo despues de la metamorfósis llegan á ser voraces. Es cierto que los renacuajos pueden vivir mucho tiempo con un alimento exclusivamente vegetal, y sobre todo con migas de pan, y que en apariencia gozan de perfecta salud; pero pronto exigen otra cosa mas sólida, es decir, nutricion animal, si se quiere que prosperen y resistan la metamorfósis. El observador que pucde estudiarles mucho tiempo, los re. conoce en su primera juventud como rapaces; pues ya en. tonces devoran larvas mas débiles ó individuos de su misma especic. Una vez trasformados, todos los batracios cazan animales vivos de las mas diferentes clases, desde el gusano hasta el vertebrado, los unos persiguiéndolos á nado, los otros cogiendo la presa de un salto ó por un movimiento rápido de la lengua. Entonces perdonan segun parece á sus iguales, pero no á sus congéncres, á los que devoran lo mismo que á cualquier otro animal que puedan coger. De algunas especies raniformes se sabe que dan caza a otras ranas, y casi puede suponerse que sucede otro tanto con las salaman. dras. Asi como en los reptiles, auméntase tambien en ellos el apetito cuando sube la temperatura. En los meses de verano, nuestros batracios son carniceros verdaderamente vo. races; en la primavera y el otoño toman poco alimento, aun. que podria suponerse lo contrario á causa del letargo pasado ó siguiente.

Terminado aquel, despiértase en ellos el instinto de la reproduccion, que tambicn excita á estos séres estupidos. En ese periodo reina á menudo, por lo menos en el norte un tiempo riguroso; la temperatura cxcede apenas de dos grados sobre cero; grandes témpanos de hielo cubren aun las aguas: pero esto molesta poco á los batracios, pues, segun los experimentos hechos, parece que un descenso en la tempe. ratura del agua apresura el apareamiento. Tan luego como quedan depositados los huevos, separanse las parejas, aun aquellas que parecen profesarse el mayor cariño, y cada sexo se va por su lado.

I.as especies icrrestres abandonan el agua; las ranas del campo se dirigen á las praderas y á los sembrados; las arboricolas suben á las copas de los árboles; las salamandras bus. can los sitios converientes para cazar; y todos observan en adelante su género de vida de verano, tan monótono y á pe. sar de eso tan cómodo al parecer, hasta que el inviemo, ó sea el frio en las regiones septentrionales, y la sequia en las tropicales, vuelve d obligarlos á buscar una guarida que les proteja en la estacion desfavorable.

Por grande que sea la rapidez con que los batracios pasan su primera juventud, por pocas que sean las semanas que el renacuajo necesita para la metamorfósis, el animal trasforinado crece sin embargo con mucha lentitud. Las ranas solo son aptas para la reproduccion en el quinto ano de su vida, pero continúan creciendo y no alcanzan su mayor tamaño hasta el décimo ó duodécimo año; las salamandras necesitan mas tiempo aun para llegar a él, y la especie gigantesca del Japon no se desarrolla quizás del todo hasta la edad de treinta años ó mas. En cambio, salvo el caso de muerte violenta, viven muchisimos años en condiciones que se harian mortales para todo otro animal. Es verdad que algunos sapos encerrados en cuevas se conservan viros solo con un poco de humedad y con ella se alimentan: las observaciones démuestran que unos sapos encerrados en cuevas artificiales vivieron todo un año en ellas sin sucumbir al hambre, por lo tanto, su resistencia vital es superior la de todos los demás vertebrados. Sabemos de algunos reptiles cuyas extremidacies cortadas, sobre todo la cola, vuelven a crecer hasta cierto punto, es decir, que se forma un muñon semejante á la cola, dustinguiéndose de clla sin embargo por carecer de vértebras; en algunos batracios, en cambio, fórmanse, cuando se les mutila, nuevas extremidades con huesos y articulaciones, tanto en los in dividuos jóvenes como en los adultos, lo mismo en los renacuajos que en los ya metamorfoseados. Cuando se les corta una pierna $\delta$ la cola, estas partes vuelren á crecer, aunque lentamente, $y$ si se repite la operacion, la naturaleza ayuda por segunda vez. Las heridas que á otros vertebrados causarian la muerte sin remedio, apenas molestan a los batracios; el ojo que se les arranca vuelve $a$ formarse. Fsta propiedad ha hecho inírires de la ciencia a las especies mas accesibles para nosotros, sobre todo á las ranas: en ellas se hacian y se hacen los experimentos que obtuvieron los mas excelentes resultados respecto da la actividad de los órganos; ellas son las que por eso excitan a los hombres igno. rantes contra la ciencia y sus representantes; y quizás las quejas de estos harian cierta impresion si pudiera hablarse de crueldad al tratar de séres tan insensibles.

Una rana á la que se descubre el espinazo salta aun ale. gremente; una salamandra mutilada dcl modo mas terrible sigue viviendo poco mas 6 menos del mismo modo que antes. Solo los animales malignos mas inferiores aventajan en este concepto $\mathfrak{a}$ los batracios. Del mismo modo se demuestra la resistencia vital de algunas especies de la clase respecto á la influencia de la temperatura. Lina salamandra helada en el agua ruelve à la vida con el deshielo: otras especies pue. den secarse, convirtiéndose en una masa informe $y$ sin movi. miento, y sin embargo recobran la vida cuando se las moja 
con agua. Hasta en el estómago de sus enemigos demuestran su resistencia vital los batracios: de las serpientes disecadas salen los sapos todavia vivos, aunque las piernas posteriores estén ya digeridas.

Tambien los batracios, tan parecidos por muchos concep. tos ál los reptiles, deben sufrir las consecuencias del odio que estos excitan en el hombre con $\delta$ sin razon. Ninguna de todas las especies es nociva, ninguna puede causar perjuicios, y á pesar de eso se las persigue $y$ mata cruelmente. Desde las épocas mas remotas se nos han trasmitido opiniones que si bien del todo injustificadas son admitidas aun por los lla. mados hombres instruidos. Mientras que el jardinero inteli. gente protege y cuida el sapo, y el inglés lo compra á cente. nares para purgar su jardin de toda clase de animalejos dañinos, el hombre ignorante mata al efeo bicho donde le encuentra, cual si quisiera prestar su auxilio á la cigüeña, que en estos animales se ensafia de un modo casi incomprensiblc. Para los observadores verdaderos, todos los batracios se han granjeado el mismo afecto $y$ amistad que generalmente se profesa as las ranas, aunque los otros congéneres de la cla. se lo merecen en tan alto grado como aquellas.

I.a materia mucosa que muchas especies segregan les pro. lege contra la mayor parte de los carniceros; pero las que no tienen esa piel venenosa son victimas de gran número de los animales mas diversos; de la rana podria decirse lo mismo que de la liebre: «todos la quieren comer.» Por fortuna para su especie, y quizàs tambien para nosotros, su enorme reproduccion compensa pronto todas las pérdidas.

\section{s VBRTIMTLS}

\section{PRIMERA SUB-CLASE
ANUROS}

CARACTÉrES. - El que ha observado con atencion una rana conoce todos los tipos del primer órden de nuestra clase. Las diferencias de estructura que en esta division se no. tan, si bien no carecen de importancia, no $50 n$ tan conside. rables para que puedan confundirse los anuros 6 batracios sin cola con otras especies.

Un tronco pesado, casi cuadrangular, cabeza aplanada, ancha, redondeada en el hocico y con una boca grande, que confundiéndose con el cuello se reune con el tronco; cuatro extremidades bien desarroiladas, y una piel mas ó menos lisa, desnuda y mucosa, constituyen los caractéres de todos los séres pertenecientes á cste órden. Los ojos, relativamente grandes y muy movibles, pueden concentrarse mucho en las órbitas y tienen por lo regular una expresion viva; las fosas nasales, situadas en la parte anterior del hocico, pueden cerrarse casi siempre por una especie de rálvulas; los orificios auriculares son grandes y se distinguen por el timpano apla-
nado.

La formacion de las patas varia mucho segun las familias, sobre todo respecto á la proporcion de las extremidades posteriores, al número, longitud y forma de los dedos y á la manera de unirse estos entre si. La piel difiere tambien bas. tante respecto \& la lisura, el grueso y la presencia de glán. dulas mucosas; la epidermis se distingue por su ligera com. posicion, propiedades que dificultan su separacion de la piel coriácea, porque separada de esta se disuelve verdadera. mente.

Muchas especies tienen la facultad de cambiar sus colores. Se observa que su piel se confunde hasta cierto punto, y à menudo del todo, con el color de los objetos que les rodean, notándose adentás que las cxcitaciones de sus instintos y sentimientos se expresan por el cambio del color, aunque hasta ahora no se sabe si esta mudanza se verifica voluntariamente ó no.

La estructura del esqueleto es en extremo sencilla La cabeza se aplana en extremo porque el hueso palatino $y$ el cigomático se extienden mucho; las órbitas son sumamente anchas, están dispuestas casi en linea horizontal; el cráneo es muy aplanado; el cuello se indica solo por una vértebra cervical, el atlas; la columna vertebral se compone regularmente de seis á siete vértebras que no pueden clasificarse porque no hay diferencia entre las de la region del pecho y las del vientré; el sacro está trasformado en un largo hueso en forma de barra, en cuyos dos lados se apoyan los huesos de la pélris, de igual forma, y reunidos entre sí en la parte posterior 6 inferior; el armazon de las patas anteriores se fija en una région mas ó menos cartilaginosa, reunida con la columna vertebral por medio de partes blandas que cons. tituyen un esternon compuesto de varias piezas; las costillas no existen, porque no se pueden considerar como tales las apofisis laterales de las vertebras.

Fn la mandibula superior existen de ordinario, y en la in. ferior $y$ el hueso palatino solo alguna vez, unos dientes pequeños y ganchudos. La lengua existe por lo regular, pero raras veces se fija en toda su longitud en el ángulo de la mandibula inferior, y si casi siempre en su parte anterior, quedando libre su borde posterior, de modo que puede salir fuera de la boca; el esófago es corto; el estómago ancho y membranoso; el intestino tiente pocas circunvoluciones. Desde los riñones se dirige la uretra al intestino grueso, pero no al depósito de agua, considerado sin razon como vejiga que nunca contiene orina, y sí un liquido tan puro como agua destilada, liquido del que obtienen en ticmpo de sequía to. dos los batracios la humedad tan necesaria para ellos.

Casi todos los anuros tienen pulmones muy grandes en forma de bolsa y una laringe bien desarrollada provista á menudo de bolsas y de cavidades que les permiten emitir su voz fuerte y sonora. El cerebro es bastante grande en proporcion al reducido tamaño del animal.

DISTRIBUCION GEOGRAFICA.-Apenas tendré necesidad de añadir algo sobre el area de dispersion de los anuros. Son cosmopolitas $y$ no faltan por lo tanto en ningun continente, ni tampoco en ninguna zona de latitud $y$ longitud; en los paises tropicales llegan a su major desarrollo y sobre todo en la América del sur se presentan en el mayor número de especies 6 individuos.

USOS, COSTUMBRES Y REGIMEN, - LOS anuros dependen menos que otros batracios de ciertos parajes, por- 
que su estructura les permite moverse mas libremente. Las menos de las especies habitan de continuo el agua en que pasaron su juventud; las mas vagan por un espacio limitado si en él encuentran la humedad necesaria para su vida. Ha. bitan los sitios mas diferentes; viven \& orillas de las aguas, en los campos, praderas y espesuras, entre los árboles y las yerbas, en el ramaje, en agujeros y debajo de las piedras; en una palabra, en cuantos sitios encuentran un alinento y escondite convenientes. Su vida en verano difiere mucho de la de invierno, sea por causa del frio ó de la sequia. En nuestros paises, la mayor parte de los anuros se retiran en otono al cieno de los estanques, donde pasan la estacion fria sumidos en un letargo. En los paises meridionales la sequia les obliga igualmente a buscar escondites; pero aqui pasan el invicrno, no solo a considerable profundidad debajo del suelo hasta donde pueden llegar mientras se conserva cena. goso, sino tambien en agujeros, bajo las piedras, en los hue. cos de los árboles, y en grietas ocultas por la corteza de estos. Cuando llega la primavera aparecen de repente en numero tal, que es cosa fícil explicarmos la opinion de los indigenas, quienes creen qque la infinidad de anuros de cuya existencia el dia antcrior no se tenia ninguna noticia, baja con la lluvia del cielo.

La sociabilidad es un rasgo caracteristico de todos los anuros que viven en el agua ó á orillas de la misma; no forman sin embargo nunca familias, como se observa en los vertebrados superiores; cacia cual vive á su modo sin hacer caso del otro. Las ranas y los sapos arboricolas vagabundos solo se reunen en la época del celo; y cuando en otro tiem. po se ven muchos individuos en un mismo sitio, solo la na.

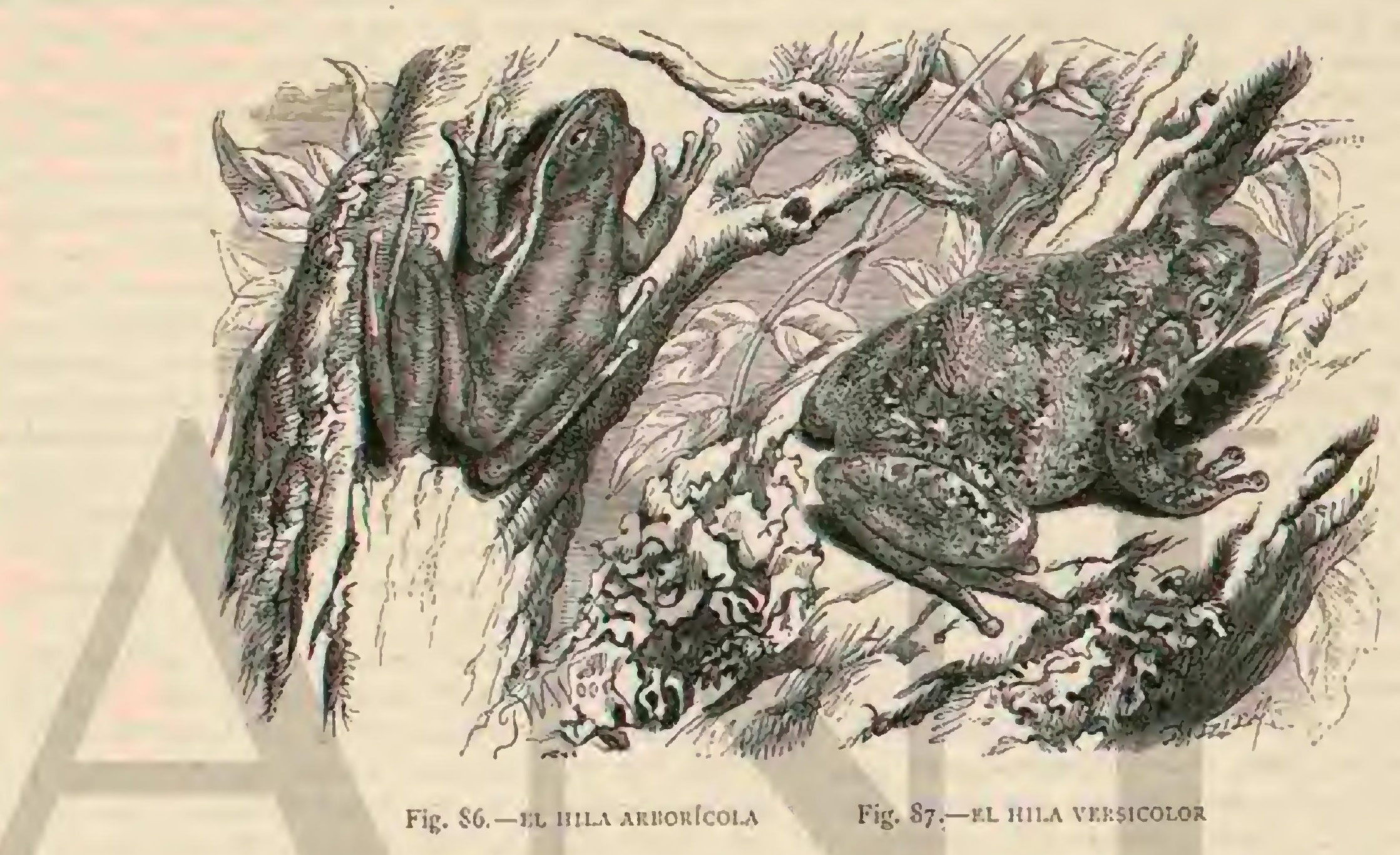

turaleza del lugar y la perspectiva de un alimento abundante serán los motivos que los rcunicron.

Fl alimento se compone de vertebrados, lombrices y ca. racoles, y además de freza y pequeños peces; las especies mas grandes del órden hasta osan niacar pequeños mamiferos y aves. Como rapaces perfectos solo toman la presa viva y cogida por ellos mismos, y no vacilan tampoco en sacrificar as su voracidad individuos penueños de su misma especie ó cuando menos de otras afines. Sigunas ramas arboricolas, por ejemplo el hila dondo (hyla auria), se alimentan segun Karefft, casi exclusivamente de otros batracios, con prefe. rencia de especies afines, $y$ tambien de reptiles, sobre todo lagartos; las grandes ranas lisas y los sapos procećen de un modo análogo.

Mas que ninguna otra funcion vital, la reproducion de es. tos animales debe llamar nuestra atencion. La solicitud de los aduitos con su cria, de la cual hablé mas arriba, se reficre principalmente a las especies de este órden. En todos los anuros, el macho toma gran parte en la reproduccion, no solamente porque fecunda los huevos, sino tambien porque ayuda a la hembra en el parto y se cuida de la cria. El numero de huevos que una hembra pone es en cxtremo considerable; cuando está preñada presenta gran volúmen antes de la puesta, porque los huevos alcanzan todo su desarrollo en el vientre de la madre, llenando del toco los oviductos. Durante el pario, el macho sirve de comadron, en

el verdadero sentido de la palabra; colócase sobre el lomo de la hembra, cruar sus patas anteriores por debajo del vientre de esta, y comprime el tronco de tal manera que los ovi. ductos se desprenden de su contenido. Al pasar los huevos por ellos, se rodean de la cubierta mucosa, fecundíndolos inmediatamente el macho sl salir.

La metamorfósis de los renacuajos en animales adultos se verifica del modo arriba indicado; debo añadir, no obstante, que las palas posteriores se presentan primero $z$ que la cola, persistente en las salamandras, sécase poco á poco y desaparece por fin del todo. Esta trasformacion dura ircs, cuatro 6 cinco meses, y á veces mas; despues abandonan los hijuelos, que entonces lian adquirido la forma de sus padres para enpezar el mismo género de vida que estos.

Esta es la regla, pero no falsan tampoco excepciones. En la cleccion de las aguas predominan condiciones muy dife. rentes: mientras que muchas especies solo depositan sus huevos en estanques, losos ó charcos, que por lo menos du. rante el tiempo que la progenie necesita para su desarrollo conservan continuamente el agua, otras se contentan con la poca canticiad recogida en las hojas 6 en los huecos de los áruoles, y algunas no ponen sus huevos nunca en el agua.

En los espesos bosques a lo largo de la costa arenosa del Brasil se oye durante el dia, segun la obserracion del prín. cipe de Wied, y lambien por la noche, la 102 fuerte, ronca interrumpicia, pero repetida á menudo, de una rana llamada 
sapo, y al acercarse al sitio de donde parte, se encuentra al animal entre las hojas de las bromelias; pues aqui se recoge siempre agua, y aun en el mayor calor y sequia consérvase allí un líquido negro y sucio, que despues de llover mucho se clarifica, utilizándose en gran cantidad hasta para beber. «En esta agua, dice el príncipe, que se recoge en el ángulo de las hojas de la planta, la citada rana deposita sus huevos, segun con gran sorpresa nuestra reconocimos cuando en enero, a causa del gran calor $y$ de la falta deagua, examinamos aquel líquido $y$ lo pusimos en copas. Los pequeños batracios ya nacidos no nos impidieron beber: despues de pasarla por un trapo con un poco de azicar y jugo de limon era muy agra. dable cuando cansados de lá marcha tomábanos este refres. co à las horas mas calurosas de un dia de enero, sentados a la ardiente sombra de la espesura para reposar. Se puede volver una bromelia en que se hia oido gritar á estas ranitas de modo que el agua, los insectos y cangrejos, porque estos viven tambien aqui, caigan al suelo; el sapo se retira enton. ces siempre mas entre las hojas, cogiéndose de tal modo que es preciso romperlas para encontrarle. El hueco de un árbol donde se recoge el agua basta del todo para la cria y la me. tamorfósis:

UUn sonoro mugido, que tenia mucha semejanza con el de una vaca, refiere Schomburgk, \& que se repetia á cortos intersalos regulares, me habia impedido sa varias veces dormir, induciéndome $\&$ hacer las suposicione's mas extrañas sobre la causa del extraño rumor, del todo desconocido para mi. Con impaciencia esperé por lo tanto la vuelta de los indigenas, y cuando pregunté sobre aqquel mugido, contestáronme que le producia una rana. Cref que la gente se buriaba de mi, mas á pesar de mis dudas, los caribes volvieron at repetir que cra el konobo-aru, el cual habita cierta especie de árboles cuyo tronco es hueco y está lleno de agua, y ofrecie. ronme convencerme en seguida de la veracidad del hecho. Rápidamente nos dirigimos al cercano bosque de la llanura y pronto nos hallamos delante de una alta liliácea, de hojas grandes, que aun no habia visto en ninguna parte, $y$ que examinada por mi de cerca resultó ser una nueva especie (Badelschaingra). Es propiedad de este airbol ahuecarse su tronco tan luego como llega a tener cierta circunéencia: uno de los indios trepó al árbol para ccrrar un agujero redondo de una rama que se hallaba á unos doce métros de altura, y los otros pusieron manos á la obra para cortar el árbol. El tronco hueco contenia una cantidad considerable de agua en la cual no encontramos la rana, pero sí unos veinte rena. cuajos. En vano buscamos al padre ó à la madre y tuve que esperar hasta la noche, hora en que, segun me aseguraron mis compañeros, se presentarian los anuros con seguridad, anunciando su presencia con mugidos Debo confesar que hacia mucho tiempo no habia esperado con tanta impacien. cia la noche como entonces; cran poco mas 6 menos las nueve cuando la voz volvió á interrumpir el silencio; provis. to de una lur me dirigi al árbol acompañado de algunos caribes; el claro brillo de la luz pareció desiumbrar al reptil, y dejóse coger sin resistencia; era un individuo de la magnífica especie parda.

Mas notables son aun las condiciones bajo las cuales se trasforma una rana arboricola del Africa occidental. Puch. holz vio ś orillas del Kametun, en los últimos dias de junio, en las hojas de un árbol bajo que se hallaba en parte sumergido en el agua, algunos bultos blancos bastante grandes, y al examinarlos de cerca pareciéronle una ligera masa espu. mosa endurecida por el aire; el viajero creyó encontrat un insecto en los mismos, pero ¡cuśl no seria su sorpresa cuan. do vió que eran renacuajos que acababan de salir de los hue. vos y que se encontraban en cierto número en la masa liqui. da de los mismos! Un exámen mas minucioso hizo reconocer tambien numerosos huevos diseminados en el bulto que hasta entonces no se habian observado á causa de su completa trasparencia. Para estudiar el curso del desarrollo el naturalista se llevó la masa á su donicilio, conservóla cuidadosa. mente en un plato, $y$ vió á los tres ó cuatro dias que de la maria de los huevos habian salido renacuajos, volviéndose al mismo tiempo líquida la mayor parte de la masa espumosa. Los pequeños animales nadaron entonces por elliquido; llegaron á tener una larga cola de remo, branquias, etc, conduciéndose del mismo modo que los renacuajos comunes; aun despues de haberlos puesto en el agua se desarrollaron con toda regularidad. La masa espumosa correspondia por lo tanto del todo á la cubierta gelatinosa en la cual se presenta envuelta por lo regular la freza de las ranas en el agua, pero sin duda no era suficiente para alimentar las larvas mas que algunos dias despues de nacer y precisamente el desarrollo debia continuar en el agua. Puchholz supone, y sin duda con razon, que los renacuajos caen con el liquido del rama. je de los árboles al agua en la estacion lluviosa, llegando de este modo al elemento propio de todos los batracios. Desde el tiempo citado hasta el mes de julio el observador vió en varios árboles á orillas del estanque y à menudo á una altura de tres metros $y$ mas, iguales masas espumosas, que con frecuencia se habian pegado ó varias hojas. Puchholz creyó que provenian de una rana arboricola parda (C\%iromantis guincensis) que vive en los mismos árboles. Como la puesta siempre sé efectúa de noche, era dificil esclarecer el hecho, pero nuestro naturalista tuvo la suerte de encontrar cierto dia por la mañana á la rana misma ocupada con la puesta. La masa tenia el tamaño de la madie, pero estaba aun me. dio líquida; cra de naturaleza espumosa y solo se endureció por el aire durante el dia.

El cuidado de ambos sexos con su cria no acaba, sin em. bargo, en todos los anuros con la puesta de los huevos; hay por el contrario especies en que tanto el macho como la hembra han de representar aun despues cierto papel. Las hembras de algunas especies tienen en el lomo una bolsa ó piel celulosa que sirve para conservar los huevos fecunda. dos y para proteger álos hijuclosen su primera juventud. Las bolsas 6 celdillas de la piel se llenan con los huevos de la hembra, ó bien el macho mismo se rodea la parte posterior de su cuerpo con los huevos reunidos en cordones por me. dio de la masa gelatinosa encargándose de este modo del cuidado de la cria. En aquelios anuros los hijuelos perma. necen durante su estado de renacuajos en la bolsa ó en las celdillas; en estos, el macho lleva los hueros consigo probablemente solo hasta el nacimiento de la progenie; depositándolos despues en el agua para que continúe aqui su des. arrollo.

No determinare si en este ejercicio puede considerarse tal solicitud como un resultado de la inteligencia en el anu. ro ó si solo debe tenerse en cuenta el instinto hereditario, pero estos animales demuestran en algunas circunstancias cierto cariño á su cria, y tambien á la puesta.

\& En mi ciudad natal, Treptow, a orillas del Tollense, en la Pomerania superior, me escribe el profesor Schrocder, haje extensas turberas pobladas de numerosas ranas. Cuando era estudiante pasé una vez con mi padre por aquellos pra. dos y observé en el agua una rana ocupada en depositar sus huevos, los cuales abandonó tan luego como se deshizo de su carga. Me interesaba observar de una vez la freza recien puesta, 5 por lo tanto traspasé con mi baston la masa flotan. te para sacarla á la orilla. La rana, que se habia alejado unos treinta centímetros, lo advirtió en seguida, volvió s precipitóse rápidamente de cabeza sobre mi baston; pero al retirarle 
retrocedió la rana. Mi padre, que no habia presenciado el hecho, no quiso creer que el batracio habia demostrado ca. riño maternal; hice por lo tanto otra vez el mismo experimento y la rana volvió, precipitándose lo mismo que la primera vez sobre el baston enemigo; de modo que mi padre se convenció de la exactitud de mi primera observacion. En mi concepto la rana demostró el cariño maternal porque no habia perdido aun de vista los hucros recien puestos, y porque quizás sentia aun en su cuerpo las sensaciones del parto que se acababa de verificar.

Yo he reproducido esta noticia tal como la recibi. No se ha observado aun cosa semejante, al menos que yo sepa, pero esta circunstancia no dice nada en contra de la suposicion de Schroeder. Cuantos mas progresos hacen nuestros conocimientos respecto : los batracios tantas mas explicaciones nos dan sobre la reproduccion de estos animales, tan particular por muchos conceptos.

Tambien en los anuros la trasformacion de los renacuajos puede retardarse por varias circunstancias muy poco importantes. Asi, por ejemplo, el profesor Martens recibió en noviembre, y aun el 17 de diciembre, renacuajos vivos de sapo, que con otros congéneres habian vivido en un estan. que de paredes tan verticales que no pudieron abandonar el agua, circunstancia que probablemente habia retardado su desarrollo. Roesel que observó minuciosamente la metamor. fósis, demuestra que desde la puesta de los huevos, â mediados de abril, hasta la desaparicion de la cola y hasta que los renacuajos salen del agua, pasan mas de tres meses, porque los animalitos no suelen dejar aquella antes de fines de julio, $y$ aun en el caso de que hayan tenido que ayunar duranic un mes. El estado de desarrollo que ofrecian los renacuajos que Martens recibió en noviembre 6 diciembre se parecia al de otros individuos de la misma especie tales como se encuentran á fines de julio. Consta por muchos hechos que la temperatura fria $\delta$ el agua que lo está retardan el crecimiento de los renacuajos. Los quue deben desarrollarse en las aguas de una sierra situada á mucha altura se ven precisados á menudo á pasar el invierno en su primer estado, y no pueden abandonar el agua hasta la primavera siguiente.

Los anuros son por lo regular animales vivarachos y alcgres, que si bien nocturnos, como sus congéneres, desplicgan en parte tambien de dia una actividad tal como no se observa en las otras familias de la clase. Son mas activos q̨ue todos los demás; andan mejor, y saltan á bastante altura y distancia; unas ranas arboricolas de Australia (Siloria), que Kreffi llamó por esta causa kanguros entre las ranas, se elevan en sus saltos a menudo á la aliura de un hombre, $y$ los racoforos (rhaeophorus), cuyas membranas natatorias sirven de paracaidas, pueder competir en este concepto con las ardillas voladoras; los anuros nadan y se sumergen perfec. tamente, pudiendo pasar horas enteras en la profundidad de las aguas $\sin$ que esto les moleste; su vista, oido ; olfato, estan bien desarrollados; tienen cierto grado de sensibilidad, y tampoco les falta el gusto. Mientras que en otros congéneres parece dificil reconocer un vestigio de facultades intelectuales, los anuros saben elegir diferentes sitios, tienen memoria y sacan partido de la expericncia; son tímidos y prudentes en el trato con otros animales, y ui aun les falta cicria astucia para evitar los peligros y apoderarse de su presa.

Agrádanles los sonidos fuertes, segun lo demuestran con sus conciertos nocturnos, y por todas estas cualidades son mas agradables que todos sus congéneres.

Al parecer son séres alegres y vivaces que con gusto se entregan à su recreo, dando a conocer su bienestar a todo el mundo con sus gritos, $\delta$, hasta podria decirse, con una espe- cie de canto. Su voz, aunque no tan diversa como la de las aves, no tiene nada que envidiar á la de la mayor parte de los mamiferos y son muy superiores por ella a los gekos. Desde el sonoro mugido hasta el canto, y desde el claro sil. bido hasta la queja, pueden oirse todos los sonidos imaginables. Una especie produce una voz ronca; la otra notas sonoras; esta canta como un grillo; aquella muge como un buey; el pelobates emite sonidos entrecortados, mientras que la rana de los estanques deja oir verdaderos cantos. En las selvas virgenes de la América del sur, las voces de los anu. ros se consideran como los sonidos mas caracteristicos, y lo mismo sucede en los paises tropicales cie Asia y de Africa, en Australia y hasta en Europa. Una extraña voz de are me parecieron los sonidos nocturnos de un anuro de las estepas del oeste de 1 sia; y golpes sobre un timbal las voces de una rana del $\Lambda$ frica central; la de una rana acuática sud.ameri. cana se asemeja mucho, segun Hensel, al canto de un grillo; la de oira a un extraño quejido que casi resuena como los lejanos ayes de una criatura, $\delta$ que podrian creerse producidos por una cigarra. La voz de una tercera especie es analoga al sonidn que hace el agua al salir de una botella de cuello estrecho; y la de un sapo á un gorjeo sonoro; la de una rana arborícola recuerda el tanido de una campanilla; la de otra los martillazos aplicados sobre hojalata. Fn una palabra, cada especie entona la melodía que le es propia, y por triste que resuene en nuestro oido, siempre es la expre. sion del bienestar, por no decir del carácter alegre del ani. mal: en todas las circunstancias siempre es mas sonora cuando en dias calurosos amenaza lluvia.

USOS Y PRODUCTOS. - La inofensiva alegría propia de todos los anuros y aun de los sospechosos sapos y difamados pelobates, granjéales nuestra benevolencia; pero mas aun la circunstancia de çue no perjudican en modo alguno al hombre; léjos de ello, hasta le son útiles de una manera que sin ciuda no apreciamos aun bastante. Solo las especies mas grandes pueden perjudicarnos alguna vez; pero todas las demás son probablemente mas útiles que los animales que las persiguen. No solo los franceses saben apreciar la came de los anuros sino tambien los indigenas de Australia, que de noche, al resplandor del fuego, cogen centenares de individuos de cierta especie de fancroglosos 5 se los comen con gusto.

Kreffts, de cuya obra tomo este dato, cree que Burke y Wills, que en su viaje de exploracion por el interior de la Nueva Holanda perecieron de hambre, no habrian muerto si hubiesen sabido qué medin de salvacion les ofrecian las ranas; pero quizás aquellos mártires de la ciencia despreciaron aun 2 las puertas de la muerte un alimento tan sabroso y saludable como lo son las ancas de rana.

CLASIFICACION. - Como son muy incompletas las noticias que tenemos sobre el género de vida de los anuros, solo podre ocuparme de un reducido número de especies. Por lo tanto no me parece conveniente seguir en todas sus partes la clasificacion del órden fundada últimamente en las proposiciones de Guenther, pues solo son importantes para el hombre de ciencia y por eso añado solo que doy á las fa. milias mas amplitud y que de algunas de ellas no haré mencion, sin perjudicar, no obstante, el plan de la $\$$ Vida de los animales.

Considero los anuros arboricolas como los mas desarrollados, y por lo tanto me ocuparé de los faneroglosos antes de hablar de los aglosos: los primeros, que tienen rango de sub-órden, distinguense de los segundos por tener la lengua fija en la base de la cavidad bucal, movible solo en la parte posterior y rara vez en la anterior; mientras que los aglosos carccen de este órgano. 


\section{LOS HILIDOS-HYLIDE}

CARACTÉRES. - Ios hilidus son ranas de estruciura graciosa, de color de noja verde, y difieren de los otros ti. pos del orden por tener en la cxtremidad de sus dedos un ensanchamiento en forma de disco, que permite al rentil agarrarse a superficies lisas. Además se caracterizan todas las especies de la familia por la presencia de numerosas verrugitas con un poro en su ceniro, que cubien toda la cara abdominal y sirven segun se supone para absorber las gotas de rocio que las hojas conservan, proporcionando asi ai cuerpo la humedad necesaria. Las extremidades posteriores son mucho mas largas que las anteriores; jos dedos libres ó reunidos por membranas natatorias, mas ó nichos extendidas, son á menudo muy grandes. La mardibula superior, y por lo regular tambien el paladar, tienen dientes, mientras que la mandibula inferior carece de ellos. La lengua, que es carnosa, solo se oprime en la parte anterior de la barba; las glándulas auriculares faltan casi siempre, pero tambien pueden existir.

DISTRIBUGION GEOGRÁFICA.-En Europa esta numerosa familia tiene por único representante al hila arbo. rico!a: en los paises meridionales, en cambio, existe una va. ricalad asombrosa, \& la América sobre todo, produce un número extraordinario de hilidos. Además de la América del sur, estos reptiles abundan mucho en Australia, pero tampoco faltan en el Africa y en el sur de Asia, aunque aqui no representa un papel tan importante como podria suponerse.

USOS, COSTUMBRES Y RÉGIMEN.-LOS hílidos
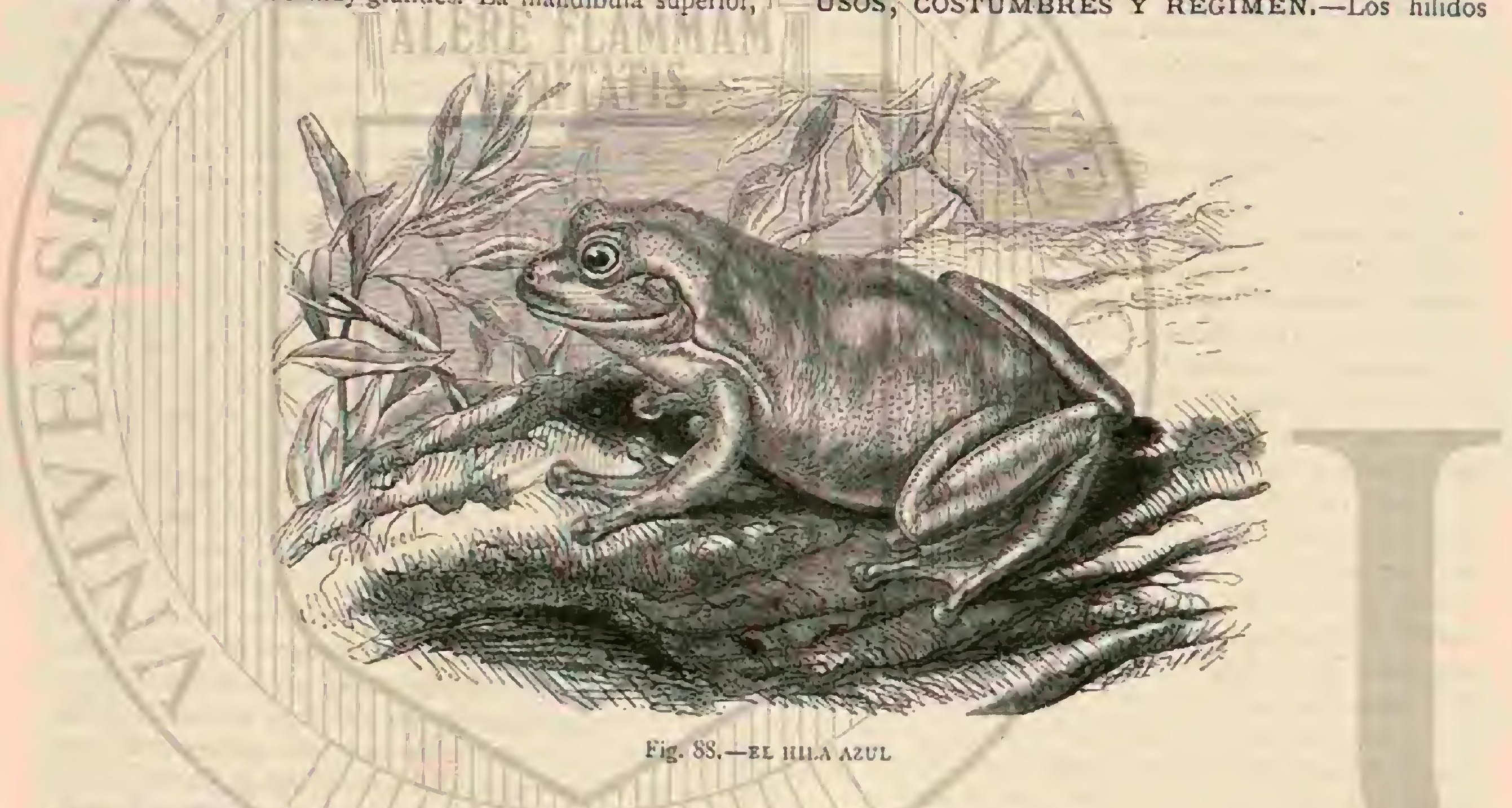

son los tipos mas inquietos, graciosos y de colores mas bo. nitos de la clase; a causa de estas propiedades se han gran jeado el cariño del hombre en tan alto grado, que algunos de ellos se tienen como animales domésticos en las habita ciones.

En el Brasil, dice el principe de Wied, habitan en nú. mero muy considerable las espesuras de los contornos de las casas, las orillas de los rios y la costa maritima, pero con mas frecuencia aun las selvas virgenes. Aqui viven cspecies de la tamilia de los mas variados tamaños, formas, colores y roces, cuyos múltiples sonidos forman en la oscuridad de las noches calurosas, sobte todo en la estacion lluviosa, un coro en extremo singular. Ia mayor parte de cstos reptiles viven en las copas de los árboles altos, donde se ocultan entre las hojas de las bromelias. Muchas de las pequeñas especies crian sus hijuelus aun en el agua negra y ustancada que se recoge en los ángulos de las hojas de la citada planta; otras bajan durante el periodo del celo de su residencia aérea y se dirigen á los pantanos, estanques y charcos ocultos entre la rica regetacion de las selvins virge nes. Aqui renuevan entonces su concierto y esta es la ocasion mas favorable para coger las diferentes especies, que en otro tiempo es dificil adquirir, mientras que ahora se las puede reconocer por su roz.»

Fuera del periodo del celo, que tambien conduce \& la nayor parte de los hilidos al agua, ó bien del invierno, que les obliga á refugiarse en el cieno, debajo de las piedras, de la corteza de los árboles y dé otros sitios inaccesibles a la sequia, pasan su vida en la altura de los árboles, donde fijándose en las hojas convenientes, se ocupan en la caza de los animalillos que constituyen su alimento.

Su coloracion, por variada que sea, aseméjase siempre á la del follaje que habitan; $y$ hasta se confunde con él com. pletamente segun la estacion y las circuristancias, pues todas las especies tienen la facultad de cambiar su color de un modo sorprendente y con mucha mas rapidez que el célebre camalcon. Un hilido verde como la hoja en que se pone puede presentar poco despues el tinte de la corteza. Uno dé estos graciosos séres, dice Tennent, que se colocó en el pí́ de una lámpam, tomó à los pocos minutos el color dorado de los adornos, de modo que apenas se le podia distinguir. El que ha visto los hilidos con sus magnificos colores rojos y azules, con manchas $y$ motas pardas, etc, se inclina á dudar de la veracidad de las palabras anteriores; pero el que conoce la magnificencia de los colores de aquellas selvas tropicales comprende que tambien el hilido mas abigarrado lo mismo que nuestro hila a:boricola, encuentre hojas de las que no puede distinguirse su coloracion. Fl brillo de sus propios matices solo es un reflejo del ramaje y su variada coloracion, que solo puede reconocer la vista mas penetrante, es la mejor defensa contra los peligros que le amenazan.

Si fuera posible escribir ya hoy una historia natural com. pleta de los hilidos y si los hubiéramos observado tanto 
como á nuestro hila arboricola, la descripcion que resultaria fuera en alto grado interesante. A pesar de la gran seme. janza, aparente ó verdadera, en el género de vida de las diversas especies, cada una de estas ofrece algo de particular, la una respecto á la voz, la otra por la alimentacion, y una tercera por la reproduccion. La descripcion exterior de estos animales, la de sus formas y colores, nos interesa porque nos hace reconocer $y$ admirar la infinita variedad de la naturaleza; pero si pudiéramos añadir el relato de los usos y costumbres, esa descripcion seria mucho mas completa, como lo prueban las especies mas conocidas.

Segun la última clasificacion, el grupo se divide en varias familias, cuyos caractéres deben buscarse en la diferencia del desarrollo de las apófisis trasversales del sacro, de las membranas natatorias de los dedos posteriores, mas ó menos grandes, y de los órganos del oido mas 6 menos desarro. llados.

\section{LOS HILINOS-HILIN死}

CARACT ERES.-Los lilinos 6 ranas arboricolas pro. piamente dichas, que en opinion de Guenther constitusen una familia, se caracterizan por las apofisis trasversales.del sacro, triangulares y aplanadas; por las membranas natatorias de entre los dedos de las patas posteriores, por los órganos del oido del todo desarrollados y por la falta de las glándulas auriculares.

\section{EL HILA ARBORÍCOLA-HYLA ARBOREA}

CARACTERES. - Nuestro hila arboricola es para nos-

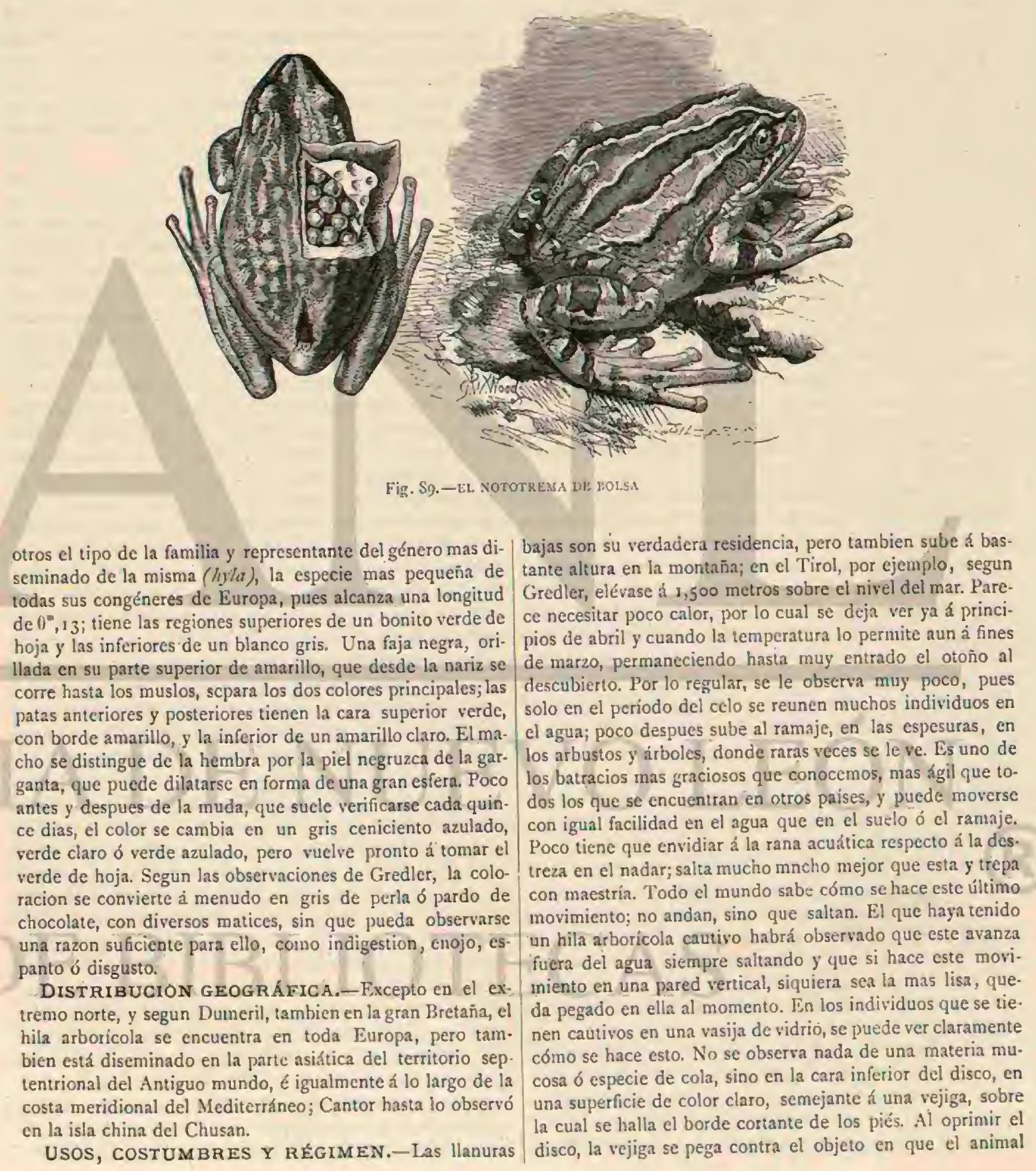


quiere fijarse; la atmósfera exterior oprime el borde y asi le sujeta, porque todos los discos de los dedos trabajan á la vez. En caso necesario el hila se sirve tambien de la piel de la garganta, oprimiéndola contra la superficie, y de este mo. do nunca le es difícil sostenerse en tal posicion. La máquina pneumática demuestra q̨ue solo trabaja la presion del aire, y que no existe una humedad pegajosa. Al poner la máquina y despues de hacer el vacio, el animal ya no puede sostenerse, porque entonces la presion del escaso aire que siempre queda es demasiado pequeña en proporcion al peso del cuerpo y no le presta ya el apoyo necesario. Un hi. la que al salir del agua salta á una superficie lisa, creal prin. cipio, pero solo porque el agua que tiene en los discos de los dedos no le permite practicar entre estos y la superficic un vacio suficiente. De este modo sube el hila 2 los árboles sal. tando de hoja en hoja; comienza en la espesura baja, trepa desde ella á los arbustos mas altos y elévase por fin hasta la copa.

En las alturas aéreas pasa cómodàmente el verano, posán. dose cuando el tiempo es favorable en la cara superior de las hojas, y si llueve en la inferior, pero esto solo cuando la lluvia no dura demasiado; si se hace molesta refígiase en el agua para escapar de la lluvia.

E.l que le oye gritar en un arbusto bajo y mucho tiempo, hace vanos esfuerzos para verle, $y$ si lo consigue podrá reco. nocer hasta qué punto el color del animal se confunde con cl del follaje El hila conoce muy bien esta ventaja y se aprovecha de ella tanto como puede; sabe que un salto le descubrirá y por eso prefiere, al acercarse su enemigo ú otro sér sospechoso, oprimirse contra la hoja y permanecer con los brillantes ojos fijos en el adversario hasta que el peligro haja pasado: Solo en un caso extremo se resuelve \& saltar, haciéndolo entonces con tal habilidad que casi siempre se salva.

El alimento del thila arboricola se compone de toda clase de insectos, sobre todo de moscas, colcópteros, mariposas y orugas lisas.

Toda presa que coja debe estar viva y moverse; no toca animales muertos ó que no se muevan. Su vista penetrante, y segun parece su fino oido, le permiten descubrir la mosca que se acerca; la observa con atención $y$ salta de repente hácia ella, casi siempre con acierto, y de modo que vuelve a caer sobre otra hoja. Para ayudar ấ la lengua se sirve tam. bien de los dedos de los piés anteriores, llevando con ellos como con una mano el alimento á la boca. Gredler observó esto en cautivos al ofrecerles moscas grandes y lo mismo vió Guenther en un congénere de Australia. En verano el hila necesita bastante alimento, por lo cual se mantiene tam. bien de dia en acecho, aunque su verdadera actividad no comienza hasta la puesta del sol.

Generalmente se cree que el bila arboricola anuncia con seguridad el cambio de tiempo, asi como el de la tempera. tura por su voz: el aserto no es del todo exacto. Fste anuro deja oir sobre todo su voz en el período del celo, pero no guarda silencio tampoco en verano, y tanto en tiempo seco y fijo como cuando amenaza lluvia, emite sin interrupcion casi toda la noche $y$ con la garganta dilatada, su continuo kirack, que casi suena como el tañido de campanillas y recuerda el canto de las cigarras. Solo cuando amenaza una tempestad grita mas qque de ordinario, mientras enmudece durante la lluvia.

A fines de otoño el hila abandona la copa de los árboles, baja al suelo y se dirige al agua mas próxima para ocultarse, como sus congéneres, en el cieno, donde pasa el invierno en un letargo, sin que por lo regular el frio le moleste; pero aun en el caso contrario no muere siempre. Su resistencia vital es tan extraordinaria que le hace vencer peligros a que sucum. birian sin remedio otros animales de superior desarrollo. Un observador que solo ha indicado su nombre, olvidó, segun dice, poner su hila cautivo, que le servia de barómetro, en un espacio abrigado, cuando se declaró el frio riguroso; $y$ al fin observó que el pobre animal, no habiendo podido salir de su prision, se hallaba con las piernas estiradas en medio del hielo formado en la vasija. Esta fué colocada entonces en una habitacion de temperatura templada, en la cual poco á poco se derritió el hielo, pero la mayor parte se conservó hasta la noche. Cuando á la mañana siguiente se examinó la vasija, el hila, muy vivo, se hallaba en la parte superior del cristal cual si nada le hubiera sucedido. Es de suponer que ln mismo sucedera en libertad y que tambien aquí le salva esta resistencia vital. Su pronta aparicion en la primavera demuestra que no es muy sensible al frio.

Se presenta antes que otros muchos anuros y ocúpase ante todo en la reproduccion: para ella elige si le es posible los estanques cuyas orillas están rodeadas de espesuras y árbo. les, probablemente porque le es dificil dar en el agua expresion á todo su amoroso entusiasmo. Por lo regular, los machos abandonan en abril sus cuarteles de invierno, antes ell los años favorables, y si persiste el frio, un poco mas tarde, pero siempre antes de las hembras, que llegan seis ú ocho dias despues, y entonces se verifica el apareamiento. El ma. cho coge $\{$ la hembra por debajo de los sobacos y nada con ella dos 6 tres dias hasta que saien los huevos y pueden fecundarse por él. La puesta misma dura por lo regular poco tiempo, es decir unas doș horas, pero á veces tambien mucho mas, prolongándose hasta cuarenta y ocho; en este caso el macho se cansa ? y deja 1 la hembra y los huevos que esta pone si no los cree fecundados. Unas dos horas despues de salir estos del vientre de la madre, la sustancia mucosa que los envuelve está tan llena de agua y tan dilatada que se trasparenta. Entonces se observa en ella el verdadero hue. vo, del tamaño de un grano de mostaza, y al rededor del mis. mo la cubierta, que tiene poco mas 6 menos el tamaño de una arveja. La freza forma puntos deformes y queda en la profundidad del agua hasta que han salido los renacuajos.

Como en los otros batracios, el desarrollo de los huevos $y$ de los hijuelos exige poco tiempo. En unos huevos puestos en 27 de abril se observó ya en $\mathrm{I}^{\circ}$ de mayo el embrion con cabeza y cola, que se desarrolla de la yema; el 4 de mayose movió en la planta mucosa; el 8 salió nadando por los con. tornos y comiendo de la sustancia mucosa; el to del mismo mes aparecicron los ojos, y detrás de la boca tres verruguitas que permitieron al animalito agarrarse á la yerba y otros objetos; el mismo dia se vio la aleta de la cola, el 82 las fibras branquiales, una á cada lado de la cabeza, cuyas fibras pronto desaparecieron, $y$ manchas blancas y negras; el $15 \mathrm{la}$ boca y la nariz estaban desarrolladas y el renacuajo comió mucho; el $\mathrm{S}$ los ojos negros presentaron un borde amarillo; el $z 0$ se desarrolló el ano y el tronco se rodeó de una mem. brana delgada llena de agua que desapareció el 29. Los animalitos tenian en este dia centimetro y medio de largo y roian las lentejas acuáticas. El za de junio salieron las piernas posteriores; el dia 16 del siguiente mes los renacuajos habian llegado á casi todo su desarrollo y tenian unos dos centímetros de largo; el 25 se completaron tambien los dis$\cos y$ vieronse los vestigios de los piés anteriores que salieron el 30 . El lomo era verdoso, el vientre amarillento. Subie. ron ya á menudo á la superficie para respirar. El I. de agosto la cola era la mitad mas pequeña y pocos dias despues estaba del todo seca y entonces la mita habia llegado á su desarrollo y cra capaz para su vida terrestre.

Sin embargo, no llega hasta el cuarto año á ser adulta; an- 
tes de este tiempo no grita ni se aparea. Segun las experien. cias de Fischer se reproduce en los alrededores de San Petersburgo, donde ha sido importada; Jos hijuelos nacidos alli en libertad se acostumbran de tal modo al clima que no será dificil aclimatar el hila arboricola en el norte de Rusia.

CAUTIVIDAD.-Ei hila arboricola es tan poco exigente que se le puede conservar vivo muchos años en un sencillo vaso de cristal dándole el alimento necesario. Por lo demás necesita poco cuidado, pues soporta segun hemos visto no solamente el frio y el hielo, sino tambien el calor y la sequía de un modo admirable. Un hila arboricola cuidado por Credler desapareció un dia de su depósito de agua y solo al cabo de algunos dias se le encontró comprimido en una hendidura, del todo seco y en apariencia muerto. Se le volvió al agua, $y$ al cabo de algunas horas nadó otra vez tan alegremente cual si nada le hubiera sucedido.

No es tampoco exigente en cuanto al alimento, se le nutre con moscas y gusanos de harina porque estos pueden adqui. rirse con mas facilidad; pero tambien se les puede dar otros insectos hasta de un considerable tamaño, porque el hila los come todos. Es preciso proparcionarle en verano mucho ali. mento para que pueda pasar fácilmente el invierno, pero tampoco entonces debe olvidarse darle algun gusano de hari$n a$, una araña $\delta$ una mosca. Despues de una larga cautividad conoce no solaniente a su guardian sino tambien el vaso en que este conserva los gusanos de harina, y comparece cuando se coge una mosca para dársela. Un amigo de mi padre observó que su hila arboricola cautivo se movia cada ver con violencia cuando llevaba alimento á sus aves de jau. la; dió cntonces al animal el gusano de harina, $\$$ acostumbróle desce entonces de tal modo á su persona, que la rana tomó el alimento no solamentede la mano sino tambien dela de otros, conocicado al fin hasta la hora acostumbrada para la distribucion de la comida. Para facilitarle la salida del vaso se colgó una tablilla con cuatro cordones; el hila trepaba por ella, quedando suspendido hasta que recibia el gusano. Cuando se le ponia un duro por la abertura para provocarle mordia, $y$ si se abria su prision salia de ella, subia $y$ bajaba por las paredes de la habitacion; saltaba de una silla A otra ó sobre las manos de su amigo, esperando con tranquilidad hasta que este le daba alguna cosa; solo entonces se retiraba \& su vaso, demostrando asi que no. le faltaba la memoria ni la facultad de distinguir.

Tambien Glaser, observador muy aficionado, atribuye al hila arboricola una-inteligencia muy grande. Un cautivo cui. dado durante tres años por este autor, se habia acositumbra. do de tal modo á El, que conocia su intencion cuando se acercaba, poniéndose en seguida en disposicion de devorar el insecto que se le ofrecia; cuando llegó el buen tiempoy se levantó la tapa de su prision, pasaba horas enteras en el borde de la misma, fijando su atencion en todo cuanto le ró deaba; y de noche emprendia verdaderos viajes. Una maña. na el hila desapareció sin que fuera posible encontrarle, por lo cual se crejó que durante la noche se habia escapado por debajo de la puerta. Dejósesinembargo su vasosobrela cstufa fria. A la manana siguiente observó uno de los niños, que la rana habia vuelto al vaso y al examinarla de cerca, se la vió negra y con ligeras rozaduras en algunos puntos, de suerte que no fué dificil averiguar dónde habia pasado el dia y la noche anteriores. Habia subido por el tubo de la estufa ocultándose a las miradas de los que le buscaban; pero sin tiendo la necesidad de agua, habia vuelto \& su elemento Desde entonces el animal salió á menudo, volviendo siempre voluntariamente, y los niños ya no tuvicron miedo de que se escapase. Algunos cautivos se han conservado viros de ocho á diez años.

\section{EL HILA VERSICOLOR-HYLA VERSICOLOR}

CARACTERES. - El hila versicolor (fig. $S_{7}$ ) tiene formas mas pesadas aun y recogidas que las de la especie preceden. te; y unido esto al gran número de verrugas que cubren sus partes posteriores, contribuye todo à comunicarle un aspecto particular. La cabera es un poco menos larga que ancha; la boca no tan grande como la del hila arboricola; pero la lengua alcanza mas desarrollo á proporcion; es muy gruesa y marcadamente escotada. La piel del pecho forma un ancho pliegue trasversal un poco arqueado; la de la garganta, muy lacia, se repliega diversamente en los machos, y al dilatarse constituye una especie de gran papada cuando aquellos lle. nan de aire la vejiga bucal de que están provistos. Los discos terminales de los dedos son casi tan grandes como el timpano; la membrana natatoria de las manos se extiende hasta la última falange del cuarto dedo y la penuiltima de los tres primeros; la de los piés deja libres las dos últimas falanges del cuarto y la del primero. La cabeza, el lomo, los cos. tados y la parte inferior de los miembros están cubiertos de pequeñas verrugas redondendas; la parte anterior y posterior de los muslos son lisas; pero las regiones femorales inferio. res cstán sembradas, asi como el vientre, el pecho y la garganta, de tubírculos granuliformes. El color de este reptil parece ofrecer una gran varicdad; segun Mr. Holbrook, tiene comunmente sobre los ojos una mancha pardo-oscura; la mandíbula superior del mismo tinte, manchada de blanco, poco mas ó menos como la inferior; el timpano es pardo, la pupila negra y el íris amarillo de oro. Las extremidades son de un tinte ceniciento, presentando las posteriores algunas fajas; la parte superior de la cabeza y el tronco ofrecen una mexcla variada de pardo sobre fondo gris, que se cambia en blanco a voluntad del animal; la cara inferior de los miem. bros es amarilla, asi como los lados del abdómen. El hila versicolor tiene unas a pulgadas de largo total (medida inglesa).

DISTRIBUCION GEOGRÁFICA.-Esta especie parece habitar todos los paises de la América del norte; se la encuentra hasta en el Canadá, é igualmente en el sur de Mé. xico.

USOS, COSTUMBRES Y REGIMEN. - El hila versicolor habita comunmente en los árboles ó en los peĩascos cubiertos de musgo: aunque la especie sea comun, como tiene la singular facultad, segun aseguran, de tomar el tinte de los objetos en que reposa, suele pasar desapercibida mus á menudo en parajes conde hay gran número de individuos. Varios observadores dicen que la piel de este reptil cambia en poco tiempo su color blanco en pardo oscuro, pasando por todos los visos. El hila versicolor parece preforir algunos árboles frutales, particularmente los ciruelos añosos, sin duda porque en ellos encuentra en abundancia los insectos de cjue se alimenta Los natumles de los paises donde vive la espe. cic de que hablamos consideran á este reptil como una.es. pecie de barómetro, porque tiene la costumbre de cantar mucho y muy ruidosamente antes de llover; su voz tiene un sonido particular con el que parece repetir mucho la letra l, terminando con una especic de monosílabo agudo y corto. Durante el periodo del celo, abandona este reptil los árboles para retirarse á las charcas, donde se oje su canto á las altas horas. Llegado el invierno, sepultase debajo de la tierra hú meda y alli permanece hasta la primavera, sumido en una especic de letargo.

\section{EL HILA AZUL-HYLA CAERULEA}

CARACTERES. - El hila azul es tan grande como el 
paimeado, pero tiene la cabeza un poco menos larga que ancha por detrás, los ojos son á proporcion mas pequeños y menos salientes; la boca es ligeramente hendida; la lengua eliptica, redondeada en los dos extremos y con una pequeria escotadura angulosa en su márgen posterior. I a piel forma

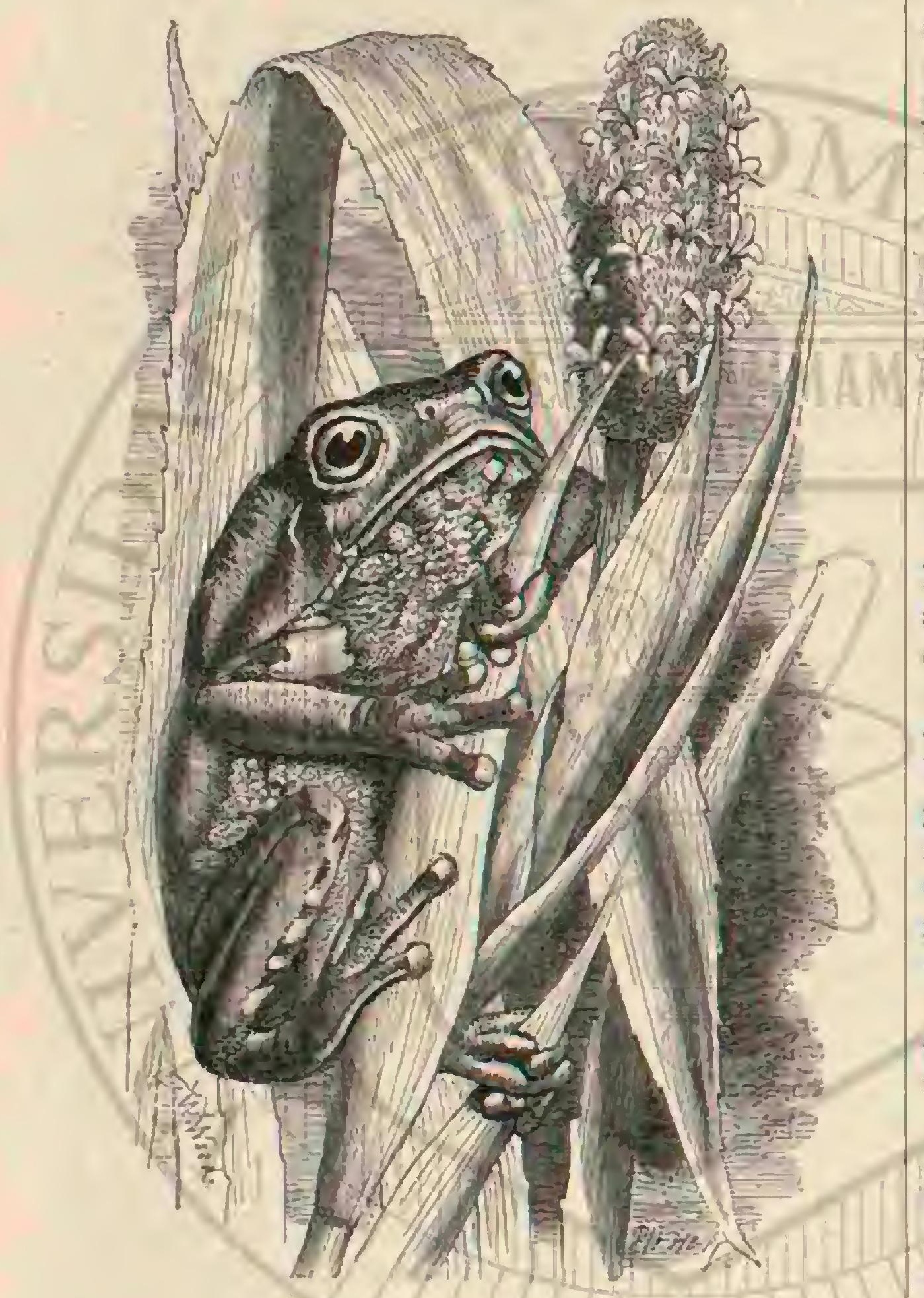

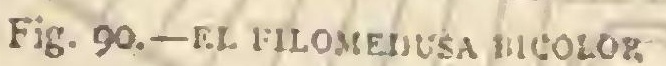

un repliegue sobre el timpano; los costados, el vientre y las regiones femorales posteriores ofrecen tubérculos granuliformes, pero todas las demás partes del cuerpo son lisas. Los machos están provistos de una vejiga bucal, cuyos orificios, á cada.lado de la lengua, son bastante grandes y longitudinales. La coloracion de esta especie es bastante variada: unas reces predomina en la cabeza, el lomo y la cara supe. rior de los miembros un sinte azul claro ú oscuro, y otras verde ó violeta. En la mayoria de los individuos se ve en el borde de la mandibula inferior una raya blanca que se prolonga un poco á cada lado por detrás del ángulo de la boca; en otros hay una lista del mismo tinte á lo largo del tarso, con manchas del mismo color en el borde interno de la pierna. Las regiones inferiores son blancas. El hila azul tiene unas 3 pulgadas y media de largo (medida inglesa) (fig. S8).

DISTRIBUCION GEOGRAFICA. - El hila azut habita en la Nueva Holanda, en la Nueva Guinea y en la isla de Timor; es comun en Australia, conde le dieron los indige. nas el nombre de rana azul a causa del color de su piel.

\section{EL HILA LEUCÓFILO- HYLA LEUCOPHYL. IATA}

CARACTÉRES. - Esta especic, uno de los hílidos mas graciosos de la América del sur, es un animalito que apenas llega al tamaño de nuestro hila arboricola y se distingue por su tronco enjuto y por la parte anterior de la cabeza obtusa. El color de las partes superiores es un bonito pardo rojo orillado en ambos lados de una faja blanca amarillenta, á veces plateada, que empieza sobre los ojos y corrí́ndose á lo largo de los costados remata en un ángulo puntiagudo en la extre. midad del cuerpo, donde asi como en los ojos forma una mancha triangular; las piernas tienen en su cara exterior fa. jas longitudinales anńlogas; las regiones inferiores son dẹ un blanco amarillento. La longitud es, segun el principe de Wied, de unos $11^{\circ}, 02$.

DISTRIBUCION GFOGRÁFICA. - El hila leucófilo está diseminado por la Guayana y el Brasil, habitando en los bosques, y se fija en las copas de los árboles. No tenemos aun noticia sobre su género de vida, y solo he hecho men. cion de esta especie á causa de su bonita coloracion.

\section{EL HILA PALMEADO-HXLA PALMATA}

CARACTERES. - Las mismas regiones albergan uno de los tipos mas grandes de la familia, el hila palmeado, llamado asíá causa de sus anchos discos; en el Brasil se le conoce brjo el nombre de herrio y en la Guajana bajo el de remero.

Sus formas son pesadas; la cabeza aplanada y mas ancha que el tronco; las extrenidades se distinguen por su fuerza. Un amarillo pálido con una faja espinal y algunas lineas ne. gras irregulares constituyen el color de las regiones superio. res, mientras que las inferiores son de un blanco amarillento. Otros individuos, probablemente hembras, presentan en un fondo igual matices de un pardo aceituna. Su longitud es de $0^{20}, 08$ a $0^{*}, 09$.

DISTRIBUCION GEOGRÁFICA.-El hila palmeado ó herrero habita en los mismos paises que la especie ante. rior.

Usos, cosTUMBRES Y RÉGIMEN.-Fuera del periodo del celo vive en árloles altos de hojas fuertes, sobre todo en los situados á orillas de los rios y pantanos; segun Schomburgk, abunda mas en los parajes de la costa que en el interior, $y$ al decir del principe de Wied se le ve en todos las puntos de las selvas virgenes; se fija sin embargo en ár. boles determinados cuyas hojas fuertes ofrecen suficiente apoyo á esos batracios. En la estacion lluviosa estos hilidos

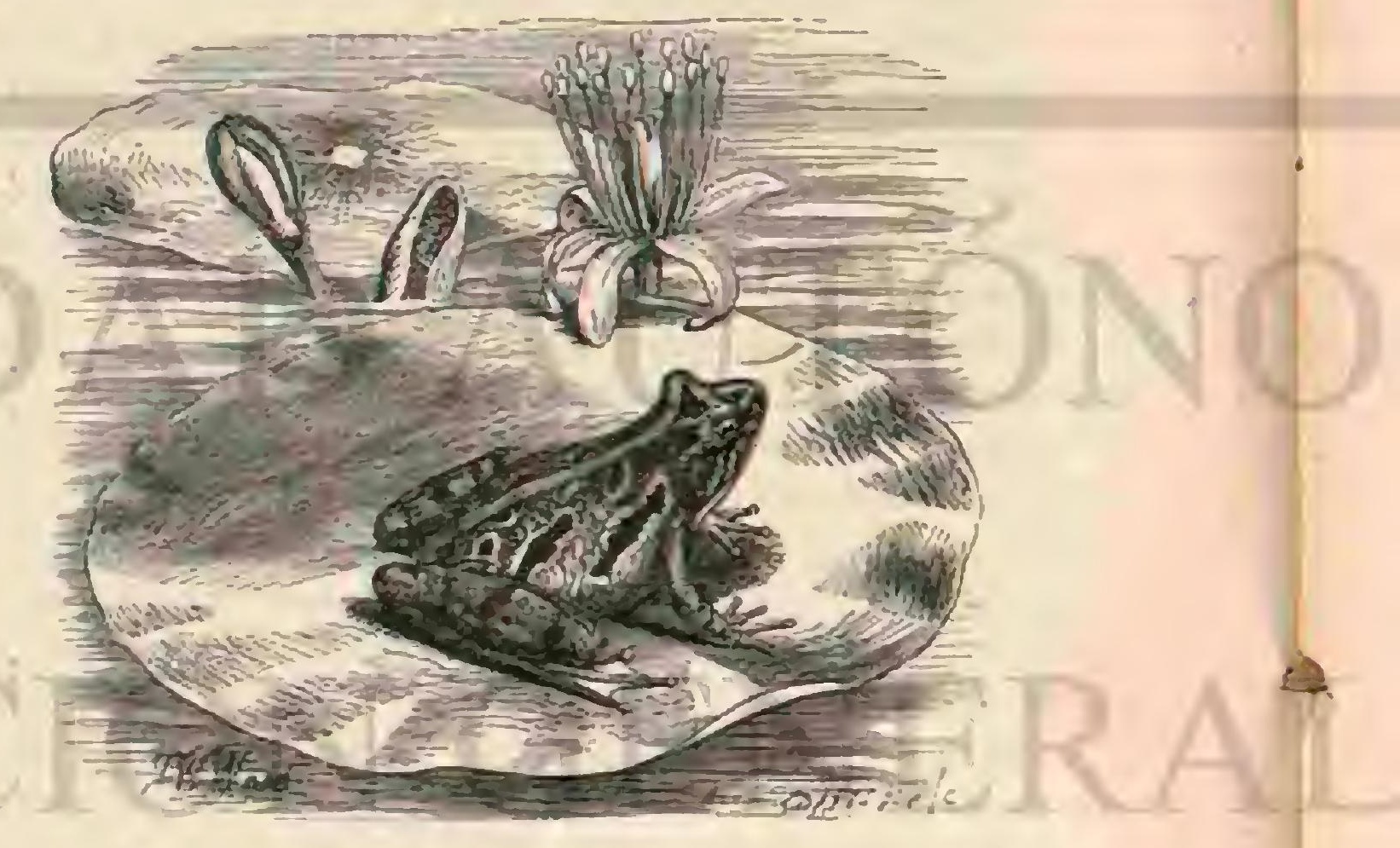

Fig. 91. - E.L ACKIS GRILLO

abundan mucho, por lo que dice el principe, en todos los pantanos y durante la noche se oye el coro ruidoso de sus voces sonoras y metálicas, cujo rumor se asemeja al que pro. duciria cierto número de hojalateros trabajando activamente. 
En la parte meridional, el príncipe no le encontró con tanta frecuencia como otras especies de la familia, y al contrario de Schomburgk, notó que escaseaba mas en la costa que en las selvas virgenes, circunstancia sin embargo que solo cra debida a la naturaleza de los parajes. Despues del periodo del celo este anuro fija su residencia en las espesuras cuyo ramaje se inclina sobre la superficie de los rios. Cuando se le persigue refúgiase siempre en el agua aunque en seguida vuclve al ramaje. Schomburgk comparasu voz al ruido que producen los remos al caer sobre el agua, y asegura que muy á menudo se ha engañado al oiria. ¿Los remeros tocan á cada golpe de reno el borde de la lancha, produciendo un extrano sonido hueco, y aunque aquella vaya tripulada por seis, ocho ó diez remeros siempre se ose un solo golpe, acom. pasado y rápidamente repetido; por este rumor se reconoce, sobre todo durante la noche, y a mucha distancia, la llegada de una barca. La voz que la rana emite a intervalos cortosy acompasados se parece del todo á ese ruido.

El principe dice que al principio deseó mucho conocer el animal, y que por eso los brasileños que le acompañaban daban caza de noche, provistos de antorchas, al hila palmea. do, cogiendo muchos individuos de la especie.

\section{LOS NOTOTREMAS - NOTOTREMA}

CARACTÉRES. - Toda lo rariada que puede ser la reproduccion de los hílidos, lo demuestra entre otros ejemplos el nototrema, propio de la $A$ mérica central, y único repre. sentante del género de los nototremas ó ranas de bolsa. No se distingue esencialmente de los hilidos hasta ahora descritos; pero la hembra tiene en el lomo una bolsa abierta hácia atrás, de un centimetro de profundidad, anśloga por todos conceptos a la de los kanguros, sirviendo tambien para conservar los huevos en el primer estado de su desarrollo.

\section{EL NOTOTREMA DE BOLSA - NOTOTREMA MARSUPIATA}

CARACTERES.-Esta especie es una de las mas abigarradas de la familia. El color que predomina en las partes superiores es un bonito azul verdoso, mas oscuro en algunas regiones, sobre todo en la cabeza y en el centro del lomo. Los matices se componen de lineas longitudinales amarillas que sa se acercan ó se alejan una de otra, formando asi liguras regulares; las piernas presentan anillos, fajas, manchas y puntos mas oscuros (fig. 89 ).

En algunos individuos, sobre todo en los machos, los campos formados por las lineas amarillas son mas pequeños ć irrcgulares. Tambien el color parece variar mucho.

USOS, COSTUMBRES Y REGIMEN.-Dumeril no conocia al describir el notairema de bolsa el objeto de esta, y solo pudo suponerlo. Es muy probable que el macho in. troduzca durante el aparenmiento los huevos fecundados, valiéndose de las extremidades posteriores; la bolsa se cxtiende, segun lo han demostrado algunos individuos durante el desarrollo de los huevos, por todo el lomo, comunicando al batracio un aspecto disforme. No se lia podido averiguar aun, como en otros anuros, en qué periodo la hembra deposita su cria, si mas tarde la lleva al agua, $\delta$ si la conserva en la bolsa hasta que termina la metamorfósis; tampoco tenemos noticias particulares sobre el género de vida del nototrema.

Hace algunos años que Wiailand habló sobre el estado de embrion del nototrema. Entre un pequeño número de anuros que se enviaron al museo de Berlin hallabase una de estas ranas, que se distinguib por su considerable volúmen. Esto era debido, segun pudo verse por el exámen, á numerosos TOsso $\mathrm{V}$ huevos, cuyo tamaño excedia al de los guisantes, y que lle. naban el abdómen. Semejante dimension en los huevos de rana, en el vientre de la hembra, era ya extraña, y mas aun su posicion, pues se reconoció que no solamente se hallaban en los costados sino tambien sobre la columna vertebral. Esta singularidad indujo à un exámen mas minucioso, del cual resultó el descubrimiento de la abertura hendida en la parte posterior del lomo, y de unas bolsas à derecha é iz. quierda de dicha abertura, quue se extendian por los costados sin estar en relacion con la cavidad abdominal, presentán. dose tan solo como un ancho saco formado por la piel del cuerpo. En ambas bolsas se encontraron grandes huevos unidos de tres en tres y de cuatro en cuatro, y en ellos

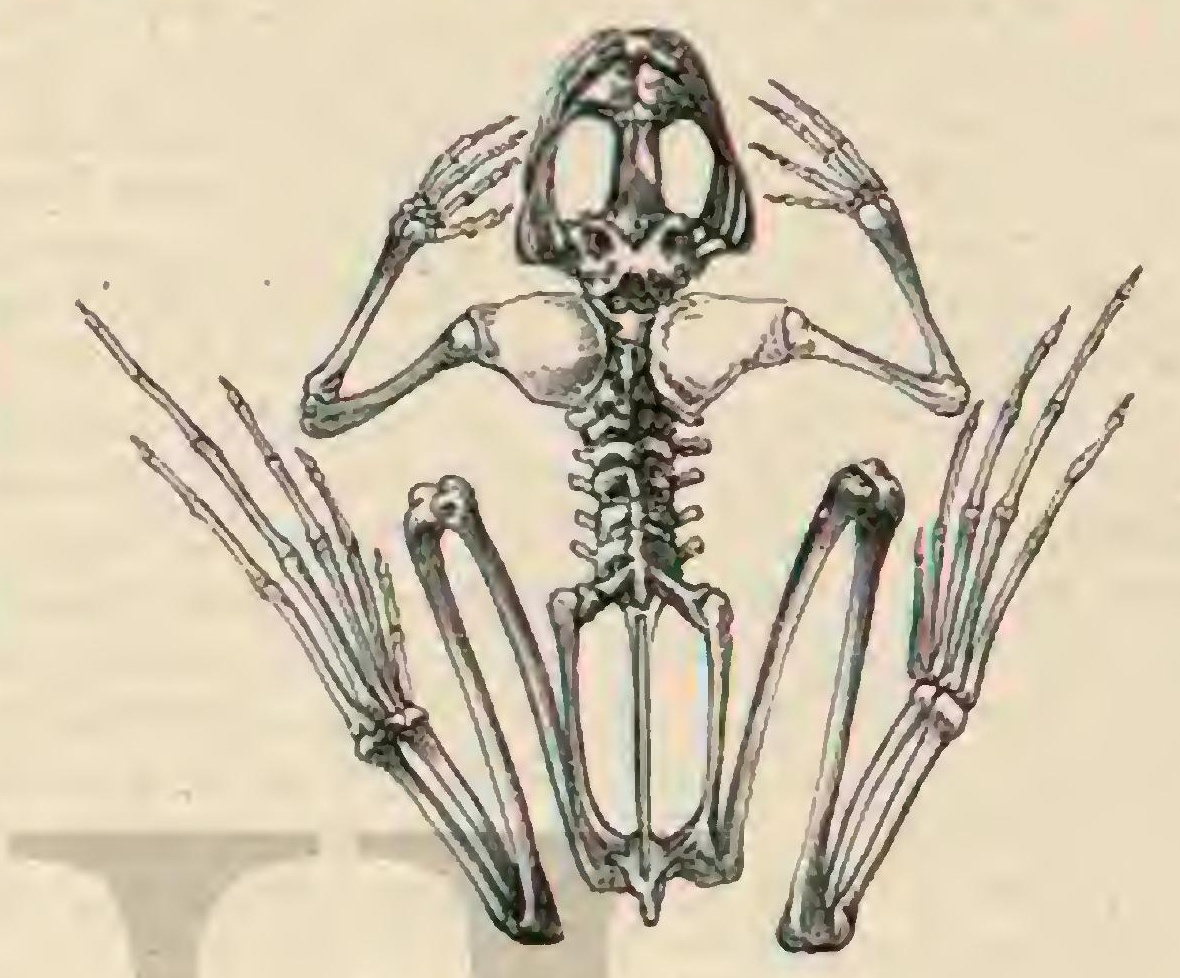

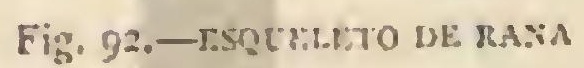

se reconoció ya marcadamente el renacuajo con ojos y cola. El número de huevos cra de quince; no tenian ninguna relacion con la piel interior de las anchas bolsas, $y$ distinguianse por su extraordinario tamaño, pues tenian casi un centimetro de diametro y estaban todos en el mismo estado de desarrollo. Toda la longitud del embrion, cuyos ojos, patas y cola ya estaban bastante desarrollados, media un centimetro y medio, la de la cabeza cuatro milinetros, y un tnilimetro el diámetro de los ojos. El embrion ocupa. ba sin embargo solo una octava parte del espacio del huevo; todo el resto se componia de una yema amarilla. El embrion mismo indicaba su formacion, no menos cxtraña que el as. pecto de la hembra; al levantar la piel de la jema se vieron en la nuca dos discos membranosos plegados, que se pudie. ron desprender fácilmente, aunque estaban unidos por dos largos ligamentos en la parte inferior, al parecer en la garganta. Pata averiguar el hecho se separó la cabeza del ba. tracio de la jema, y entonces observóse que los ligamentos desaparecian debajo de una tapa trasversal de las branquias. Al levantar tambien esta viéronse á cada lado tres arcos branquiales con las correspondientes hendiduras, y en los dos arcos anteriores de cada lado se insertaban los ligamen. tos, el uno en el primero y el otro en el segundo; el tercer arco solo presentaba cl principio de unas hojitas branquiales, probablemente de las branquias internas que mas adelante debian desarrollarse.

Los discos membranosos arriba citados, unidos por los ligamentos con los arcos branquiales, se ensanchan al sobre. nadar en el agua, formando una especic de embudo 6 campana, que Wailand comparó con la for de la campanilla, solo que en csta el tallo que lleva la for es doble. El punto en que los ligamentos se insertan en los arcos branquiales, in. dicó al instante una relacion con la respiracion, y del exámen rnicroscópico resultó lo siguiente: cada ligamento era un 
tubo en el cual se encerraban dos vasos que en la campana se perdian en una espesared fibrosa de venas. No cabe duda de que cada ligamento consta de una arteria y una vena; pero el tubo que las encicra se compone de las nismas celdas que forman la piel general del embrion y tambien la parte de la campanilla que no se compone de vasos reticulares. Por el tubo se corren en toda la longitud varios gruesos hacecillos de fibras musculares trasversales que parecen indicar que el animal conserva estos órganos en un estado aun en que puede moverlos á su antojo. Mientras se halla en el huevo, esto es imposible, pues los ligamentos y la campana están unidos y oprimidos contra el embrion por la piel de la yema; pero la circunstancia de que tanto los vasos como la red de venas están llenos de glóbulos de sangre, y que cstos eran tan numerosos en el ligamento mayor que solo podian verse los granos de los glóbulos, demuestran que los citados hacecillos estaban ya en actividad. Estas campanillas bran. quiales con sus ligamentós corresponden \& las branquias ramificadas en forma de arbolitos que los renacuajos de los anuros llevan ya en el huevo y aun algun tiempo en el agua, hasta que se sustituyen por hojitas branquiales internas mas numerosas. Extraña cra, por último, la posicion del intestino. Wailand no encontró en el huevo de ninguna otra rana tal aglomeracion de alimento para los animales durante su estado de embrion. Toda la yema amarilla, es decir las sicte octavas partes del huero, no son otra cosa sino el intestino doblado en circunvoluciones y en forma de esfera y lleno de yema. Esta circunstancia parece indicar el mayor desarrollo del animal en el tiempo en que aun no puede tomar alimento.

Si quisiéramos ocuparnos minuciosamente de la diferencia de las formas nos veríamos obligados á describir un considerable número de hílidos sobre cuso género de vida no tenemos noticia; basta por lo tanto ocuparnos de algunos que se distinguen, ora por su forma extrańa, ora por las particu. laridades de su género de vida.

\section{LOS HILODES-HYLODES}

CARACTERES.- Este género, considerado por Guenther como familia independiente (hylodinida) 6 sub familia (hylodina), se caracteriza por sus dedos libres en forma de $T$ y por la carencia de giándulas auriculares.

\section{EL HILODES DE LA MARTINICA-HYLODES MARTINISENSIS}

CARACTERES. - Esta especie, tipo del género que con sus congéneres se distingue por los pequenos discos de los dedos, por tener el hueso palatino provisto de dientes, y por las pequeñas trompas de Eustaquio, es un animalito pequeño de $0^{\circ}, 05$ de largo, de color gris blanquizco, con matices muy variables, consistentes en manchas pardas; una muy grande, de igual color, cubre el occipucio, y algunas mas pequeñas, irregulares, los lados de la parte superior del lomo que están orillados á derecha é izquierda pordos fajas blancas, las cuales, partienco de la punta de la nariz y pa. sando por los ojos $y$ las orejas, se corren hasta los muslos; los brazos y las piernas tienen fajas trasversales alternativa. mente pardas y de un blanco sucio.

DISTRIBUCION GEOGRÁFICA. - El hilodes de la Martinica se observó primero en esta isla, pero se encuentra tambien en Haiti, Puerto-Rico, San Vicente y la Barbada; no parece escasear en ninguna parte y se conoce en todas las islas citadas bajo el nombre de coqus.

USOS, COSTUMBRES Y RÉGIMIEN.-Carecemos de observaciones minuciosas sobre su género de vida; pero he. mos recibido últimamente noticias en alto grado notables sobre la reproduccion. Hace ahora seis años $(1871)$ que el doctor Pellio anunció que los hijuelos del coqui salen ya del todo desarrollados de los huevos y capaces para vivir al aire libre, sin sufrir, por lo tanto, ninguna metamorfósis fuera del huevo. En $1 S_{70}$, dice, observé en el jardin un hilido de esta especie sobre una hoja de lirio en la cual se hallaban unos treinta huevos envueltos en una capa que parecia de algodon. La madre permanecia cerca de los huevos cual si quisiera cubrirlos. Pocos dias despues encontré los hijuelos recien nacidos de 6 \& 7 milimetros de largo, que desarrollados ya del todo, saltaban y disfrutaban de su vida al aire libre. A los pocos dias alcanzaron su tamaño regular. El jardin estaba cercado de un muro de dos metros de alto y no habia agua en él; solo mi lirio contenia siempre un poco en el ángulo de las hojas, pero no es planta acuática.s

Martens, quien debemos esta noticia, cree con razon deber añadir que la verdadera salida de los renacuajos nose ha visto aun, y que en los pocos dias que mediaron entre la observacion de los huevos y de las ranas pequeñas, pudo haberse verificado la breve metamorfósis, tanto mas cuanto que tambien el desarrollo posterior se efectuó con rapidez. extraordinaria. El hecho referido por Pcllio es sin embargo del todo exacto, pues Gundiach, ese observador concienzudo tantas veces citado por mi, confirma del todo dicho aserto en una carta dirigida a Peters. $k E l$ is de mayo de $1 \$ j 6$, me es. cribe, oi sonidos particulares semejantes á los que produce una avecilla y me acerque a la voz; entre dos grandes hojas de naranjo vi una rána, $y$ alargando la mano cogi tres machos y una heinbra del coqui. Los puse en una vasija de cristal con tapa, pero húmeda, y muy pronto el macho se colocó sobre la hembra, cogiéndose á ella; poco despues esta puso de $15^{2}: 0$ huevos, que sin embargo pronto desaparecieron excepto tres. Siguieron despues quince huevos redondos, con cáscara trasparente, los cuales saqué de la vasija para ponetlos sobre cieno mojado. El interior de la yema es blanquizco $\delta$ de un color de paja pálido, pero se contrae siempre un poco, y entonces se ve por la cáscara trasparente la cola ya formada, y que álos ocho dias alcanza su desarrollo. Tambien se distinguen los ojos y los vasos de la sangre, de color rojizo, y por último, reconócense los vestigios de las patas. Cuando despues de un viaje de algunos dias' volví el 6 de junio, ví por la noche aun los huevos, y a! dia siguiente los hijuclos, que presentaban el resto de una colita.

D. Mas tarde corté una hoja de una grande amarilidea, que contenia veinte huevos sobre los cuales estaba la madre, que sin embargo se escapó en seguida; coloqué los huevos en. una vasija de cristal, cuyo fondo cubri de tierra húmeda; al décimotercio dia examiné los huevos por la mañana muy temprano, y cuando sa las nueve volvi de un paseo, todos habian salido. En las ranitas solo observé una colita blanca que por la tarde habia desaparecido. Gundlach envió cua. tro huevos con embriones á Peters. Segun la descripcion de estc, forman como una vejiga trasparente de cuatro á cinco nilimetros de diámetro, rodeada en parte de una masa no trasparente semejante a la clara de un huero. La vejiga está llena de un liquido claro, que permite reconocer perfecta. mente todas las partes del embrion, semejante al de los ma. miferos, encorvado hácia el lado del abdómen; de modo que la cabeza se aproxima á las extremidades posteriores, que, así como las anteriores, se oprimen contra el vientre Lacola está igualmente encorvada á derecha é izquierda y entre una parte de las extremidades posteriores. En tres huevos las cxtremidades estaban del todo desarrolladas y presentaban tambien los discos en las puntas de los dedos; cn un cuarto 
huevo las cuatro patas estaban representadas por otros tantos muñones sin vestigio de dedos; mientras que por lo regular en los anuros las extremidades y dedos posteriones aparecen antes que los anteriores. No excontre vestigio de las branquias ni de los orificios branquiales; pero la cola era en este embrion mucho mas grande que en los otros, oprimiéndose con su ancha superficie contra las paredes de la vejiga; esta. ba tambien provista de tantos rasos, que en mi opinion no cabe duda que sirven de órganos respiratorios. Durante el desarrollo la yema y la cola se achican; de modo que cuando el animalito, que descie el hocico hasta el ano mide cinco milimetros de longitud, rompe la membrans del huevo, solotiene $\theta^{*}, 008$; pocas horas despues $U^{\prime \prime}, 003, y$ luego se seca del todo durante el mismo dia. Otros huevos de la misma puesta, que á los ocho dias de salir se pusieron en espiritu de vino, median una longitud de 7 a 7,5 milimetros, circunstancia de la cual resulta que eldesarrollo no se verifica mas rápidamente qque en otras especies de los anuros.

*l desarrollo de este hilido, concluye Peters, sin metamorfósis, sin branquias, con la formacion de todas las patas a. Ia vez, que como en los vertebrados se cfectúa dentro de una vejiga y de un liquido semejante al que llena la placenta. es en extremo notable, pero quizás no tan raro como hasta ahora se suponia.y

\section{LOS FILOMEDUSAS - PHYLLO- MEDUSA}

CARACTERFS. - Se distingue csencialmente este género por un carácter particular, cual es el de tener el primer dedo de la mano y los dos primeros del pie oponibles a los otros tres. Gracias á esta estructura, los filomedusas pueden, lo mismo que cicrtos mamíferos, como por ejemplo los monos, extender sus dedos horizontalmente para coger las ramas de los árboles, morada habitual de estos batracios.

Ia cabeza del filomedusa se ensancha considerablemente en su parte posterior por dos enormes parótidas, que toman nacimiento, una á la derecha y otra á la izquierda, en el ångulo posterior de la órbita, corriéndose $\$$ lo largo de la parte superior del costado despues de dilatarse en toda la region escapular. Los machos tienen á cada lado de la lengua una abertura longitudinal que da entrada al aire destinado á in. flar la bolsa que hay debajo de la garganta, y que no es apa. rente por fuera. I.os filomedusas se asemejan evidentemente á los sapos por la forma de su lengua y la presencia de esas grandes glándulas que hemos llamado parótidas.

\section{EL FILOMEDUSA BICOLOR-PHYLLOME- DUSA BICOLOR}

CARACTERES.-La rabeza es grande y deprimida; los ojos grandes, muy poco salientes, é inclinados oblicuamente hácia la punta de la nariz; la boca está muy hendida; los niembros son raquíticos; la parte superior del cráneo y el lomo forman un solo y mismo plano horizontal perfectamente unido; las patas anteriores son lisas por encima y debajo, asi como los miembros postcriores, excepto en la cara inferior de los muslos, cuya piel, lo mismo que la del vientre, está cubierta de pequeños tubérculos glandulosos. En todas las partes superiores $y$ laterales de la cabeza $y$ del tronco predomina un bonito color azul; en los costados se ven grandes 6 pequeñas manchas redondeadas, blancas, orilladas de pardo castaño, como las que hay en las piernas y los tarsos. En algunos individuos son del todo biancas las partes infe riores ó con una variada mezcla de castaño particularmente en la garganta y el pecho; por el borde externo de la pierna, del antebrazo $\mathrm{y}$ del tarso se corre una línea blanca orillada de pardo (fig. 90).

DISTRIBUCION GEOGRßFICA.-La América meridional es la patria de este batracio, que se encuentráá menu. do en el Brasil.

\section{LOS RACOFOROS - RHACOPHORUS}

CARACTÉRES.-Todos los anuros que perienecen este género se distinguen por sus formas enjutas, por la piel lisa, membranas interdigitales muy grandes, discos y órga. nos del oido muy desarrollados; y los machos por tener una bolsa laringea situada en el centro de la garganta. Los dien. tes palatinos están dispuestos en dos series.

\section{EL RACOFORO DE REINWARDT-RHACO- PHORUS REINWARDTII}

CARACTÉRES, - Uno de los batracios mas raros $y^{\circ}$ notables, dice Wallace, que encontré en Borneo, era un gran hilido que me trajo un trabajador chino, ascgurándome que le habia visto bajar casi al vuelo en direccion oblicua desde un árbol. Cuando le examiné mas de cerca, vi que tenia los dedos muy grandes y provistos de membranas interdigitales hasta las puntas, membranas que extendidas presentaban tanta superficie como todo el cuerpo, el cual podia dilatarse mucho. El lomo y la extremidades cran de un color verde urillante; la parte inferior y el interior de los dedos, amarillos; en las membranas natatorias habia fajas negras y ama. rillas; la longitud del cuerpo era de $0^{\circ}$, ro; las membranas extendidas de los piés posteriores ocupaban cada cual una superficic de (1), 28 cuadrados, y las de todos, de unos $\left({ }^{\circ}, 5\right.$ ! cuadrados. Como las extremidades de los dedos tienen gran. des discos para agarrarse, los cuales convierten á esta rana en rerdadero hílido, no podemos suponer que sus grandes membranas sirvan solo para nadar, $y$ por lo tanto parece exacto el aserto del chino, que decia haber visto al anuro bajar al vuclo desde un árbol.

$\checkmark$ Este es, al menos que go sepa, cl primer cjemplo de una rana voladora y que merece la atencion general, pues revela que los dedos que emplean para trepar y nadar algunas es. pecies, sirven tambien á otra para cruzar el aire á la manera de un lagarto rolador.

El anuro descrito de este modo por Wallace, y considera. do por él como especie nueva y desconocida, es sin duda el racóforo de Reinwardt, conocido hace tanto tiempo, y tipo del género anterior.

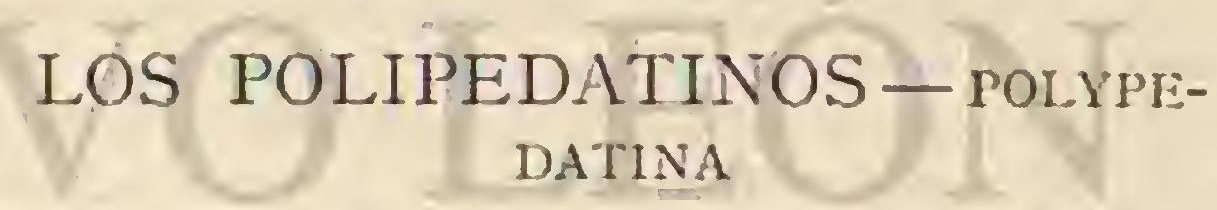

CARACTERES. - Los de esta sub-familia consisten en tener los órganos del oido bien desarrollados y las apófisis trasversales del sacro aplanadas, careciendo de glándulas au. riculares. A esta sub-familia pertenecen

\section{LOS ACRIS-ACRIS}

CARACTÉRES-Las especies de este género tienen dientes palatinos $y$ dedos libres, es decir, sin membranas na. tatorias en las patas anteriores, mientras que los de las posteriores están provistos de ellas; el tímpano es poco marcado; la lengua grande y cordiforme; los machos tienen una bolsa en la laringe. 


\section{EL ACRIS GRILLO-ACRIS GRYLLUS}

CARACTERES. - Esta especie es una de las mas conocidas del grupo: las regiones superiores son de un pardo rojizo ó pardo con grandes manchas longitudinalcs é irregulares, mas oscuras y marcadas en los costados; las extremidades presentan fajas de igual color; las regiones inferiores son amarillentas 6 pardas. El tamaño del animal es el de nuestro hila arboricola (fig. 91).

DISTRIBUCION GEOGRÁFICA.-El acris grillo se extiende probablemente por toda la América del norte, 6 por lo menos se le ha observado en las partes mas diferentes de los Estados Unidos.

USOS, COSTUMBRES Y REGIMEN. - Este anUIO abunda en todas partes donde se encuentra, y no siempre para recreo de los humanos que viven cerca de él, porque es tan cantador como nuestra rana acuática y cmite su voz toda la noche sin cansarse, voz que se parece al zumbido de una langosta: Habita con preferencia las orillas pobladas de maleza de las aguas estancadas, donde se fija casi siempre en las hojas flotantes de las plantas acuáticas, subiendo a veces támbien hasta los arbustos inmediatos; aunque no alcan. za en destreza al hila arboricola en cuanto a trepar. En cambio salta mejor, y à menudo á larga distancia.

Cautrvidad. - En tal estado este anuro es tan viva. racho como cuando vive libre; deja oir tambien á menudo su roz y cuando guarda silencio puede obligársele en seguida á cantar otra vez mojándole con agua.

Noconozco noticias ciertas sobre su modo de reproduccion.

\section{LOS RÁNIDOS-RANID瓜}

CARACTERES:-En los ránidos ó anuros lisos las pun. tas de los dedos no se ensanchan en forma de discos; el tronco es relativamente enjuto; la cabeza corta y plana, la boca ancha; las patas anteriores muy cortas en proporcion a las posteriores, cuyos dedos tienen por lo regular membranas natatorias; la piel de las regiones inferiores es lisa; la de las superiores suele estar provista de glándulas. Todas las especies tienen dientes en la mandibula superior $y$ en el pa. ladar.

DISTRIBUCION GEOGR ́́FICA. - Lasespecies de esta segunda familia, menos numerosas que las de los hílidos, habitan en gran número las aguas de los paises templados y cálidos, y por lo tanto todos los continentes excepto la Nue. va.Holanda.

USOS, COSTUMBRES Y REGIMEN.-Viven en to. dos los sitios donde hay agua; su canto nocturno se oye en todos los terrenos en que pueden subsistir, pues del mismo modo que en Alemania la rana acuática, fijan su residen. cia tanto en las llanuras como en las montañas, en las aguas corrientes y cstancadas, pero no en las saladas. Hay, $\sin \mathrm{cm}$. bargo, muchas especies de la familia que, imitando á los hilidos solo en el periodo del celo, habitan el agua, vagando despues por los campos, praderas y bosques humedos; descansan alli donde la luz del dia les sorprende y continuan su marcha á la hora del crepúsculo vespertino. De un modo ex traño resuena el canto de estas ranas en el oido del extranjero que por primera vez pisa el suelo de otro continente, pues á las voces conocidas de la patria agréganse otras singulares, por las que se reconoce al punto à los ránidos, aunque se distinguen en alto grado $y$ de un modo característico, lo cual fué causa de que los primeros colonos y tambien los naturalistas dieran nombres significativos a los respectivos cantores.
En todas partes el género de vida de los ránidos acuáticos es poco mas $\delta$ menos el mismo: alegre y divertido en la primavera y el verano, $y$ siempre muy ruidoso; menos agrada. ble es en otoño, y cuando quedan sumidos en un letargo de muchos meses en el cieno de las aguas heladas, hasta que los céfiros de la primavera rompen la costra de hielo 6 la primera lluvia vuelve á unir la capa de cieno agrietada, despertando á los séres ocultos en la profundidad para que recobren nueva vida, pues asi como en nuestros paises apenas llegada la primavera, la tierra se cubre de nueva vegetacion, tambien en las regiones tropicales al principio de la estacion lluviosa despiertan todas las fuerzas de la naturaleza. Cuando en el interior de Africa el ardor de la cestacion seca lleva con. siga el invierno, que consume la yerba, trasforma en hojarasca el ramaje frondoso de los árbolea, expulsa las aves que buscan regiones mas propicias y obliga à los reptiles, batracios y mamiferos á refugiarse en sus cuarteles de invierno, el hombre y el animal que se ven precisados á soportar los ri. gores de tal calor se desesperan bajo el peso del invierno; mas por fin selagrupan oscuras nubes en cl horizonte, que llegando en alas de furiosas tempestades, atraen la benéfica lluvia al exhausto sueio, y con ella la primavera. Por espacio de muchas hotas, el agua cae ruidosamente desde las alturas; en los llanos se forman riachuelos y corrientes, charcos y lagos que conservan muchos dias el agua recogida; y antes de que el cielo vuelva á mostrar su rostro sereno, antes de que las últimas gotas de lluvia hayan caido del ramaje de los árboles, la primavera ha despertado á los séres que dormitaban.

En la noche del primer dia de lluvia, miles y miles de voces resuenan en cada lago y cada charco, y de toda corriente que con regularidad se llena de agua: por doquiera llega de continuo al oido del observador el gonk, gunk, gonk de las ranas; miles de ranillas pululan alrededor de las aguas ó nadan por la superficie; y casi podria creerse que con júbilo saludan el tiempo en que pueden disfrutar de la vida. A penas han despertado, se aparean, vagan alegremente por su elemento y vuelven á desaparecer con la última gota de agua.

Livingstone refiere que los buschmans le han hecho conocer el cuartel de invierno de una rana á la que despues encontró ś menudo en huecos de árboles, cuyos agujeros estaban habitados al mismo tiempo por arañas, que en parte los habian cubierto con sus tejidos. El viajero expresa su asombro de que una rana pueda vivir en las partes mas secas del pais, y asegura que al principio siempre esperaba encontrar agua clando oia la fuerte voz del animal en el silencio de la noche. Muy á menudo se engañó, y por eso supuso que este anuro pasa tambien una parte de la estacion seca despierto. Esta última opinion no será exacta del todo, pues podemos creer que tambien en el sur de Africa el período de la sequia es idéntico al del invierno, y que por lo tanto un anuro solo despierta despues de haber llovido. Livingsto. ne está conforme con mis observaciones de que tambien los charcos pequeños que pronto vuelven á secarse contienen miles de estos batracios. Poco mas ó menos lo mismo suce. de en todos los paises donde las estaciones difieren marca. damente, mientras que alli donde bajo un cielo benigno casi todo el año hace el mismo tiempo, el alegre pueblo vive en actividad casi sin interrupcion, emitiendo sin cansarse su canto y reproduciendose casi todos los meses del año. En la América del sur, que es abundante en agua, el concierto de las ranas se oye toda la noche ó cuando menos con seguridad despues de llover; en las llanuras húmedas de la India se le oye todo el año.

En nuestros paises los ránidos solo pueden molestarnos 
por su continuo canto; en otros continentes sucede lo mismo, pero en mayor escala, porque alli sus roces son muy sonoras $y$ fuertes. $Y$ mientras que las especies que viven en. tre nosotros se pueden considerar con mucha razon como animales útiles, que solo alguna vez causan daños de poca consideracion, los tipos gigantescos de la familia, propios de la América y de la India, perjudican con bastante frecuencia la propiedad del hombre, atreviendose hasta con las aves de corral s otros animales domésticos. A pesar de esto, no tie. nen en rigor enemigos en ninguna parte; ningun pueblo los mira con aversion, porque sus usos y costumbres agradan á la mayor parte de los hombres. Aun alli donde el señor de la tierra no les persigue para apoderarse de su sabrosa carne, protégelos y se hace ansigo de ellos.

Respecto á la reproduccion, los ránidos se parecen esencialmente a los hilidos, con.la sola diferencia de que regularmente eligen verdaderas aguas para depositar sus huevos, no contentándose con pequeños depósitos del elemento necesario para su progenie. Esta es la razon de que la distribucion de algunas especies sca muy desigual, pues la rana de las praderis, por ejemplo, sube $\{$ mas de 2,000 metros de altura en la montaña, mientras que su congénere la rana

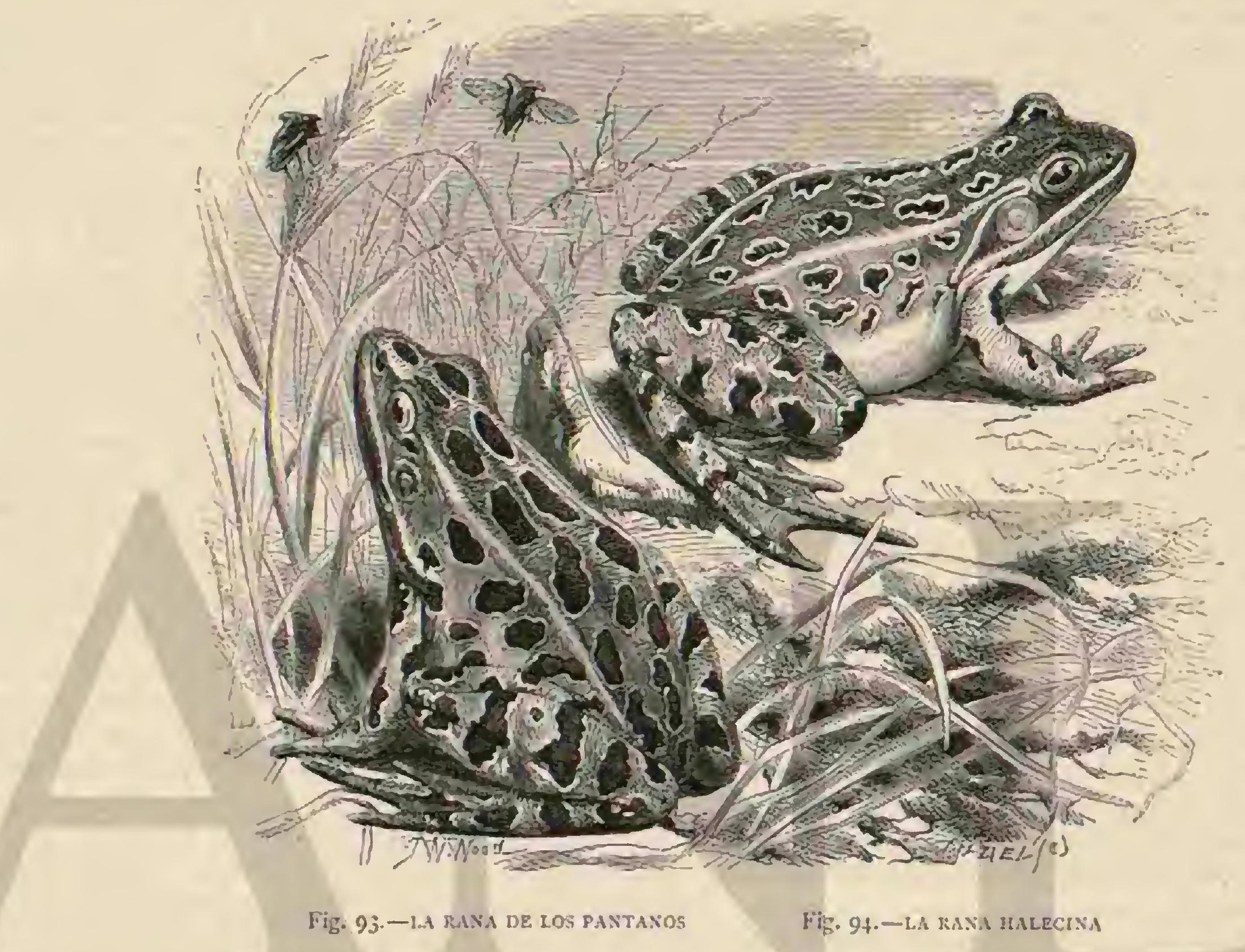

verde pertenece mas bien \& la llanura. Tambien hay algunas que se cuidan de su cria, llevando los huevos muchas sema. nas consigo; pero la mayoria los deposita-resucltamente en el agua sin hacer ya caso de ellos.

Sobre el desarrollo de la progenie, quue en general es el ya descrito, solo debo añadir que la metamorfósis se retarda mucho en las regiones frias 6 situadas á mucha altura, necesitando mas del doble de ticmpo qque en las favorables basta para la trasformacion. Lo mismo sucede cuando se colocan los renacuajos en un depósito pequeño sin darles el alimento necesario.

CAUTIVIDAD.-Hasta últimamente no se ha extendido tambien â los ránidos, la aficion del hombré á otros animales. los tipos de la familia propios de nuestros paises solo servian 1 f los hombres de la ciencia parasus variados experimentos y su cautividad era casi siempre tambien su sentencia de muerte. Ahora se conservan en jaulas construidas al efecto, queles ofrecen las mayores comodidades posibles; cuando se les trata bien se acostumbran al poco tiempo á su guardian lo mismo que los hilidos.

\section{LOS RANINOS-RANINA}

CARACTÉRES.---La rana comun ó rana verde, tipo de

las ranas acuáticas (rana) es, en la opinion de Guenther, cl tipo primitivo de una familia independiente que se distin. gue de sus congéneres por las apófisis trasversales del sacro, algo mas anchas en su parte exterior, por las pupilas rcdon. das y por la falta de las glándulas auriculares. A causa de esto nosotros la consideramos como sub-samilia.

\section{LA RANA VERDE-RANA VIRIDIS}

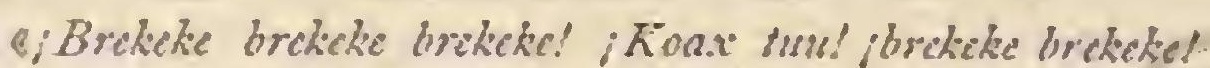

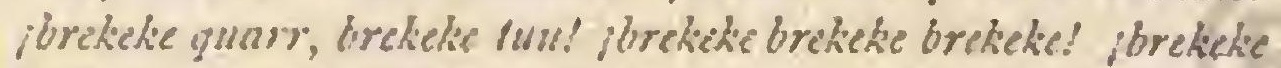

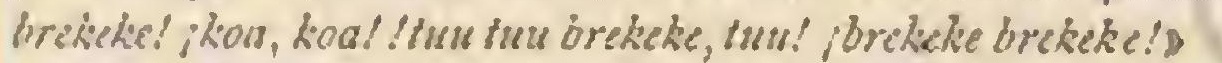

Ias hijas del estanque comienzan á vivir apenas ven apa. recer el magnifico astro de la noche. ¿Y quién podrá ser su enemign? Es cierto que Oken dice que cree hallarse cerca de ú manicomio cuando llega á las orillas de un estanque po. biado de ranas; pero ell mi opinion su voz y su canto son uno de los atributos de la noche de primarera, así como las melodias del ruiseñor. Esos sencillos tonos cxpresan una ale. gría ilimitada y hasta son armoniosos en su conjunto, por áspera que parezca la roz de cada individuo. Brckeke, comienza á cantar el jefe de la familia, y todas las demás le escuchan en silencio, pero solo para acompaniarle un momen. to despues con la misma estrofa, ó con el sonoro guar, con- 
tinuando en su cancion del modo conocido de todo el mundo. Con la frescura de la noche empieza el canto gene. ral, prolongándose sin interrupcion toda la noche; solo por la mañana los habitantes de los estanques guardan silencio, si bien aun entonces alguno deja oir un guar a medias, cual si le complaciera recordar la maestria demostrada durante la noche.

No negaré que hay gente nerviosa à quien le impresiona desagradablemente el oir todas las noches templadas de ve. rano siempre la misma música; pero yo no me hallo en este caso, pues siempre me divierte oir á los entusiasmados cantores, y creo que cuantos layan pasado su juventud en el campo deben estar de acuerdo conmigo.

CARACTERES. - La rana verde alcanza una longitud. de $0^{\circ}, 09$ \& $0^{\circ}, 100^{\circ}$ mas si se alimenta bien en todas las fases de su vida; no cuento las patas posteriores, que cuando me. nos miden $\theta^{*}, 10$. Las regiones superiores son de un bonito verde con'manchns ncgras y tres fajas lungitudinales amari. llas, de las que una se corre a - lo largo del cspinazo y otra d cada ladó del tronco; la cabeza presenia dos fajas negras; las regiones inferiores son blancas 6 amarillentas. Despues del periodo del celo el color es mas brillante, pero con el tiempo palidece ó se oscurece tirando al pardo; tambien pre. domina algun otro tinte; de modo que la rana verde varia mucho segun la estacion 6 las condiciones en que vive. Los grandes ojos tienen el iris de un color dorado viro; su expresion es inteligente y alegre.

DISTRIBUCION GEOGRAFICA.-No solamente la Europa es patria de la rana verde, sino tambien el noroeste del Africa y una buena parte del Asia, y probablemente toda el Asia Central hasta el Japon. En el sur de este continente y en el centro del Africa existen especies congenéricas; hacin el norte, el circulo polar constituye el limite de su área de dispersion, que ratas veces traspasa.

USOS, COSTUMBRES Y REGIMEN.-No puedo decir liasta qué altura sube en la montaña. Segun 'Tschudi, se encuentra en las de Suiza on todas partes hasta la aitura de 1,300 metros sobre el nivel del mar; segun Gredler, solo en los valles situados á mucha elevacion ccde su puesto á Ia rana de las pradcras.

En todas partes donde vive abunda mucho, cual si le agra. dara la sociabilidad, pero la causa es debida a su reproduc. cion, tan extraordinaria, que el estanque donde se establece una pareja puéblase muy pronto con su progenie. Poco exigente por lo regular, elige sin embargo muy bien las aguas en que quiere instalar su albergue; faita en pocas, pero solo las puebla en gran número cuando su orilla estál llena de altas yerbas ó de juncos y cuando la superficie se halla cubierta de plantas acuáticas, sobre todo Rotantes. Tambien vive en las aguas un poco saladas, evitando las muy salobres. Los pequeños estanques rodeados de arbustos y en cuya superficie se extienden los lirios acuáticos; y los fosos que, cuando menos la mayor parte del año, conticnen agua, son los sitios favoritos de la rana verde; agrádanle asimismo los pantanos, los charcos y lodazales; en el sur prefiere sobre todo los campos de arroz cubiertos durante meses enteros de agua, y poblados, como aquellos estanques, de animales que le sirven de alimento.

En tales aguas llama mucho la atencion no solo de la vista sino tambien del oido: agrádale mucho el calor y procura aprovecharse de todo rayo de sol, por lo cual sube regularmente a la superficie, donde asoma la cabeza y se sostiene en un mismo punto, 6 bien se sitúa sobre una ancha hoja ó una roca en la orilla. Cuando no se le estorba, permanece muchas horas sin moverse, pero si ve llegar una presa lánzase de un poderoso salto de casi dos metros de distancia al agua, su. mergiéndose en direccion oblicua hasta la profundidad para ocultarse en el cieno. Entonces puede suceder, segun observó Brubin, que sus patas anteriores se introduzcan entre en las conchas abiertas de un molusco, que muy sensible á toda molestia, hace prisionero al pobre anuro; mas por lo regular, el blando cieno le preserva muy bien del enemigo, pues se oculta del toco \& las miradas. Pero nunca permanece en la profundidad mas ticmpo del que le parece necesario; al poco rato vuelve á la superficie para ocupar otra vez su sitio despues de haber examinado los contornos. Al acercarse la noche, ó cuando despues de una lluvia refresca el tiempo, todos los habitantes de un estanque se reunen á cierta distancia de la orilla en medio de las plantas para cantar. Así lo hace desde mediados de abril hasta fin de octubre, en cuyo tiempo se refugia en el cieno $\delta$ en una cavidad á fin de pasar alli il invierno. En el sur. de Europa se presenta mucho antes y desaparece mas tarde; en las regiones del Africa septentrional, donde las aguas no se agotan, no se aletarga, manteniéndose todo el año en actividad: en el periodo del celo se dis. tingue por sus gritos mas fuertes y continuos.

La rana verde es un animal bien dotado, cuyos movimien. tos indican fuerza y agilidad $y$ cuya conducta revela cierto grado de inteligencia. Así como la mayor parte de sus congéneres, muévese en tierra á saltos, siempre acompasados y algo cortos. En el agua nada rápidamente sobre todo á cierta profundidad, sirviéndose para ello solo de sus patas posteriores; en la superficio se mueve con lentitud, pero tambien tiene la facultad de saltar desde el agua a bastante altura, ayudándose con sus pies posteriores ya para coger un insecto ó para colocarse en un sitio elevado.

Sus sentidos alcanzan el mayor desarrollo posible en las especies de esta clase. La vista distingue desde bastante léjos, segun lo hacen suponer los bonitos y bien formados ojos que perciben objetos muy pequeños; el oido se reconoce tan claramente en los conciertos nocturnos que no puede dudarse de su desarrollo; el olfato no parece atrofiado, $y$ solo cl tacto y el gusto pueden ofrecer dudas, porque es dificil averiguar el grado de desarrollo á que llegan.

Al observar mucho tiempo la rana verde, el naturalista se convence pronto de su inteligencia, pues tambien sabe re. girse por las circunstancias. Allí donde nadie la inquieta se hace por fin tan importuna que permite al hombre acercarse s.ella a un pié de distancia antes de dar un poderoso salto para emprender la fuga; pero donde se la persigue, huye desde léjos, y aunque descanse en medio de un pequeño estanque, se sumerge tan luego como su enemigo se presenta en la orilla. Las ranas de mas edad son siempre mas prudentes que las jóvenes y avisan â estas, como los mamiferos y aves expertas, en caso de peligro; hasta los hijuelos son bastante inteligentes para comprender que para cllos lo mejor es imitar á los prudentes de su familia. Tambien se guardan bien de los animales que pueden ser peligrosos; en los estanques visitados regularmente por las cigüeñas, huyen tan rápidamente \& la llegada de las aves como cuando se pre. senta un hombre. $\Lambda$ menudo cogen su presa con cierta astu. cia: la acechan como una rapaz, pasan silenciosamente por debajo de la superficie del agua precipitándose con ligereza sobre su victima, 5 tambien saben arreglarse muy bien cuando les es dificil dominar un animal ya cogido. Ași pór ejem. plo, dicen Naumann y Grafe, una gran rana verde demostró verdadera inteligencia al querer devorar una ranita: cogió á su congénere por la parte posterior, pero la resistencia era tal, que á pesar de todos los esfuerzos la cabeza de la vía tima salia de la boca medio abierta; nuestra rana debió pensar en algun medio; sin duda lo encontró dando algunos saltos contra un árbol de modo que la victima chocase con. 
tra él, y cuando la hubo aturdido, devoróla En cautividad, la rana verde conoce poco á poco à su guardian y sabe cuál es el jarro que contiene los gusanos de harina; va demostrando cierto apego â su dueño; toma el alimento de la mano; dejáse coger $y$ acostúmbrase por fin a tomar la presa muerta en ve\% de viva; Gredler, que alimentó ranas verdes cautivas con obleas y pedacitos de carne, cree que solo la envidia dirigió la atencion de sus cautivos á la circunstancia de que tambien la presa inmóvil pucde co. merse, fundando este parecer en la notable observacion de que las ranitas no cogian á menudo una mosca que vagaba mucho tiempo por la superficic del agua, hasta que otro animal se dirigia hácia ella para devorarla. La persecucion tenaz y los mordiscos aplicados a su rival, i menudo antes de que este hubiera cogido la presa, demostraban del mismo modo la pasion indicada. No cabe duda, atendida la obser. vacion de Gredler, que ningun rasgo es tan característico en la rana verde como la envidia, por la cual se distingue mas que por su agilidad $\epsilon$ indole alegre.

En proporcion á su tamaño la rana verde merece el cali. ficativo de rapaz; solo come la presa que ella misma coge y solo los animales vivos; lo que no se mueve no llama su atencion. Como todos los séres de poca inteligencia en general, no reconoce un animal vivo sino por sus movimientos; huye en seguida del hombre que anda, y no hace caso de una persona que tranquilamente está pescando con anzuelo hasta que se levanta la caña. Desde su sitio de descanso, la rana verde fija su atencion en todo cuanto pasa a su alrededor, como si estuviera en acecho; al acercarse una presa se precipita sobre ella y la coge con la lengua 6 con ambas mandibulas.

El alimento principal se compone por lo regular de insectos, y segun las observaciones de Credler, tambien de abe. jas, avispas, arañas y caracoles, por lo cual contrae grandes múritos. En cambio tambien perjudica, porque su voracidad le induce \& causar daños á la propiedad del hombre. Rusel, naturalista que observó muy cuidadosamente estos séres, asegura que las ranas verdes adultas deroran pequeños ra. tones $\mathrm{y}$ gorriones $\mathrm{y}$ hasta intentan apoderarse de los polluelos del pato aunque no pueden devorarlos, sino cuando mas ahogarlos. Tiene nuy pocas consideraciones para con los hijuclos, sean de su especie 6 de otras congéneres; todo cuanto se mueve y puede comerse le gusta, por grandes que sean los bocados. En los estanques de cria causa perjuicios, porque lo mismo persigue s. los pececillos que á los insectos, ramas y salamandras. Gredler observó en una rana verde cautiva que daba caza á estas victimas, en una estacion en que aun habia moscas; de modo que no podia tener hambre.

REPRODUCCION. - Solo cuando ha entrado ya la pri mavera, y por lo tanto mas tarde que el hila, es decir, rara vez antes de fin de mayo,y si en junio, la rana verde se aparea. Su instinto de reproduccion es, como en la major parte de sus congéneres, tan vehemente que $a$ falta de una hembra de su propia especie abraza estrechamente á otros batracios y hasta á los peces. Una rana verde cuidada por Gredler, mos. tró ya en febrero deseos de aparearse; quiso hacerlo con un sapo y al mismo riempo con un hila; en otros individuos se observaron iguales tendencias. El apareamiento se verifica como en otras sanas, pero dura mas tiempo; la puesta retar. dada debilita á menudo á la hembra de tal modo que se muere en el parto. El macho la abraza estrechamente y hace salir los hucvos por la fuerza de sus brazos y el peso de su cuerpo; los huevos son de color amarillo claro con un lado mas oscuro; al pasar por los oviductos se cubren de una sus. tancia gelatinosa y caen al suelo. Son un poco mas pequeños que los de los hilidos, pero mas numerosos, y en tiempo fa. rorable se desarrollan tantos renacuajos y ranas, que no se debe temer la extincion de la especie. El embrion se mueve ya al cuarto dia; al quinto ó al sexto se rompe el huevo, y poco despues empieza á nadar el renacuajo. Desde este momento el desarrollo del mismo se verifica muy rápidamente; al cabo de un mes, sin embargo, se retarda la trasforma. cion; cuando el individuo alcanza una longitud de seis â sie. te centímetros, las patas están del todo desarrolladas, pero la cola, aun mas larga que el tronco, y comprimida lateralmente, hállase muy alta. Despues sécase poco á poco y desaparece por fin sin que se observe un aumento del tronco; nuy por el contrario, jarece que la pequeña rana es aun de menor tamaño que el renacuajo. Hasta los cuatro meses no termina la metamorfósis; al cabo de cinco años, la rana ha alcanzado su tamaño regular, pero continúa creciendo, sin duda hasta su muerte.

Tas tendencias sexuales arriba citadas de la rana verdc perjudican s. veces mas en nuestros estanques de cria que su voracidad. Tenemos observaciones fidedignas que demuestran que estas ranas pueden causar daños considerables en los citados estanques, sobre todo en los de carpas.

Nordmann, propietario de un doninio feudal que tiene una importante pesqueria en las inmediaciones de Altemburgo, pudo conrencerse de ello, segun Schlegel, en las dos pri. maveras de $1 \$ 5 \hat{y}$ y I $\$ 54$, cuando á causa del mal tiempo solo á fines de abril y á principios de maso fué posible pescar los peces que sobraban. En cl citado estanque invernaban unas 1,200 carpas de media libra de peso cada una; algunos dias antes de pescarlas, un labrador dijo al propictario que en un pequeño estanque habia visto nadar una carpa, que \& pesar de todos sus esfuerzos no habia podido desprenderse de una rana que llevaba sobre el dorso. Ia duda de Nordmann sobre la veracidad de este relato se desvaneció con gran asombro suyo durante la pesca, pues entonces vió que casi todas las carpas llevaban una rana, y algunas dos, que con sus patas anteriores se habian agarrado á los ojos ó tal vez à las branquias, mientras que con singulares movimientos de las pos. ieriores sacaban las escamas del lomo de los peces. Algunas se agarraban tambien a la cabeza y todas con tal fuerza, que apenas fué posible separarlas con la mano. La mayor parte de la hermosa cria de carpas estaba mas 6 menos desoliada, de modo que hubicron de vendierse $\alpha$ poco precio. Novecientos peces a los que las ranas liabian sacado los ojos, estropeado las branquias, ó arrancado un gran número de es. camas, no sirvicron para la cria por temor de qque murieran 6 cuando menos no crecicran. En la segunda primarera el daño no fué tan grande como en la anterior, pero tambien bastante sensible. La circunstancia de que estas observaciones se hacen muy raras veces, se explica sencillamente por el hecho de que en gencral no comienza el apareamiento de las ranas hasta que los peces se han trasladado á otros estanques. Tambien en ellos sufrirán mucho, pero no se observa tanto como en los estanques pequeños.

Pocas ranas verdes perecen de una muerte natural; las mas pierden la vida cntre los dientes, el pico ó las garras de un rapaz. Su resistencia vital es extraordinaria; tambien cllas pueden helarse en el agua y volver á la vida con el deshielo; iambien ellas son capaces de soportar durante mucho tiempo la sequia, caso que sin embargo solo se da en el sur, porque en el norte se dirigen à otros parajes.

Hasta las mas graves heridas se curan pronto en esos batracios y las mutilaciones mas terribles no causan la muerte sino despues de muchas horas. Spallanzani cortó la cabcza á una rana que estaba apareándose; á pesar de esto no soltó con sus patas anteriores $\{$ la hembra hasta que hubieron tras. currido siete horas, cuando la hembra cesó de poner huevos; 
separado entonces el tronco, aun siguió moviéndose durante cuatro horas mas.

En cambio tienen incansables enemigos en los carniceros de todas clases. La nutria, el veso y la rata acuática se apo. deran de ellas, lo mismo que las águilas, los buz.os, los cuer. vos, las cigüeñas y las garzas reales; las truchas, los sollos y otros peces rapaces las devoran con ansia.

USOS Y PRODUCTOS. - En Alemania el hombre se contenta con sacar la freza del agua dejảndola perecer en tierra para impedir una reproduccion demasiado grande de estos anuros; pero ya en ol sur de este pais y en toda la Eu. ropa meridional se les persigue por su carne sabrosa y salu. dable, que no es, como pretendé Ciessner, sun alimento re pugrante é insano, que produce un color gris de plomo en el cuerpo de los que le toman. \&. Es cierio que en algunas partes del sur, por ejemplo en I.iguria, se tiene aversion títal alimento, pero hay oiras regiones, por ejemplo el Piamonte, donde se le considera como una golosina Los franceses apre. cian mucho esta carne y prueba de cllo es que el verbo gronouiller no significa solo beber copiosamente, sino tambien coger ranas para la cocina. En el otonio, particularmente cuando las ramas estín mas gordas, cógense en gran núnero del modo mas diferente, con cañas, anzuelos, arcos y redes. Es muy fácil apoderarse de cllas con el anzuelo colocando en êl un trapito rojo. Matarlas con una llecha atada al arco con un hilo exige ya major cjercicio, y la pesca con la red solo da resultados al principio, porque pronto recelan y se oculian entonces en el cieno. In Alemania solo se comen las ancas, mieneras que en Italia se aprovecha toda la rana despues de sacar la tripa.

\section{LA RANA HALECINA-RANA HALECINA}

CARACTÉRES.—Hé aqui una cspecie (fig. 94) que pa.

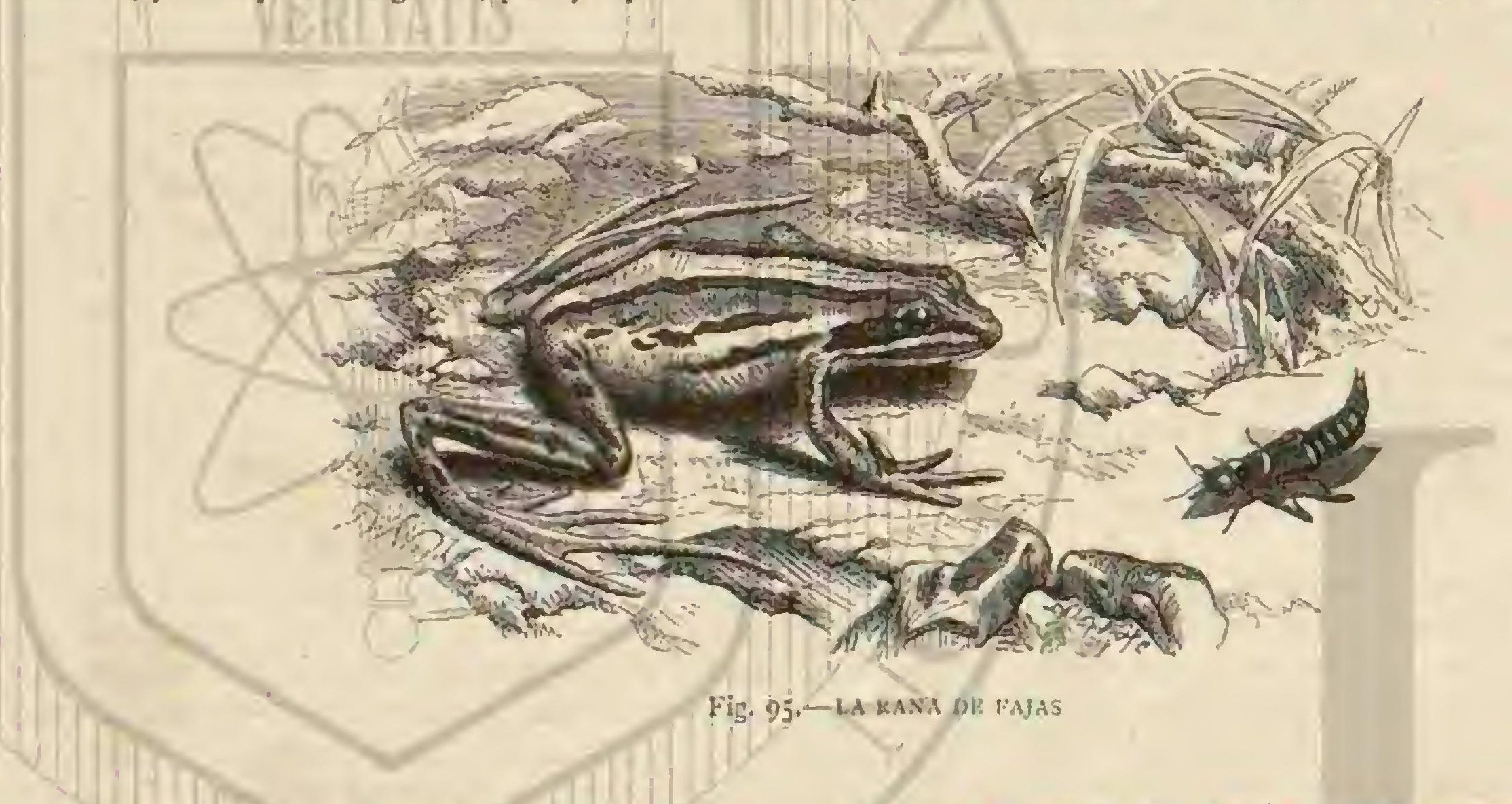

rece ser la que representa en la América del norte á nuestra rana verde: liene la misma talla, iguales formas en su-con. junto, $y$ la coloracion muy semejante; pero difiere, no obs. tante, por varios conceptos. Lo primero que se observa al examinar las dos especies comparativamente, es que la rana halecina no ticne en los ángulos de la boca las aberturas que permiten á los machos dejar salir exteriormente las boisas bucales, segun se observa en la rana verde; la cabeza de aquella es en proporcion mas larga y puntiaguda, la mem. brana palmar de los piés mas coria, los dedos mas raquiticos, y menos marcada la saliente que hace el primer hueso cunciforme. En cuanto i los demás caractéres, el lomo es liso, ó forma varios ligeros pliegues longitudinales; un cordon glanduloso mas estrecho que el de la rana verde, se extiende en línea recta desde el ángulo posterior del ojo hasta la extremidad del tronco; el orificio por donde penetra el aire en las vejigas bucales esta situado en el ángulo de la boca. Por lo que hace al color, obsérvanse bastantes variaciones: algunos individuos tienen el fondo de las partes superiores de un pardo oscuro, siendo el de otros aceitunado; en estos es de un gris verdoso, en aquellos de un tinte ro. jizo que tira mas 6 menos al castano, pero todos presentan en el lomo grandes manchas negras mas 6 menos redondeadas, como las que hay en los costados, las cuales son mas pequerias. Desde el extremo del hocico hasta el śngulo ante. rior del ojo se ve una raya negra, y otra forma como una horquilla en su extremo posterior. Las mandibulas estín como salpicadas de negro y blanquizco; á cada lado de la cabeza hay una raya blanco amarillenta; y los miembros, particularmente los posteriores, están ornados de manchas negras orilladas de blanquizco. La pupila es negra y el iris de un dorado brillante.

DISTRIBUCION GEOGRÁFICA.-El área de dispersion de esta especie es bastante extensa, pues se halla diseminada en todos los puntos de los Estados-Unidos, y abunda sobre todo en Pensilvania.

USOS, COSTUMBRES Y REGIMEN. - I Ja rana halecima necesita mucha humedad para vivir, y rara vez se aleja mucho de los rios ó charcas que le sirven de albergue. Algunas veces, no obstante, cuando hay demasiado rocio en la yerba, dirigese á los campos a buscar un sitio conveniente alejado del agua; pero apresúrase á volver al paraje acostumbrado antes que los ardores del sol sequen del todo la yerba. Es un animal muy activo y vivaz; cuando se le persigue da saltos de ocho á diez piés de altura y no es ian fácil apo. derarse de él.

\section{LA RANA DE LOS PANTANOS-RANA PA-} LUSTRIS

CARACTÉRES. - - Ofrece algunas dudas separar esta especie (fig. 93) de la anterior; mas para ello se pueden te. ner en cuenta las siguientes razones: el hocico es siempre mas corto, mas obtuso ó redondeado; el tímpano mas peque. ño, no tiene del todo en diámetro la anchura del párpado superior; los dos grupos que forman los dientes vomerianos son mas angostos; las protuberancias glandulosas que bor. dean el lomo en cada lado, mas anchas; y por último, la coloracion es diferente, y distinto el olor que exhala la rana 
de los pantanos. El fondo de la parte superior del cuerpo consiste en un pardo gris aceitunado rojizo; desde la punta del hocico hasta el ángulo anterior del ojo se extiende una faja negra; sobre cada ó:bita se ve otra, y las que cubren la cabeza y el lomo forman dos series longitudinales, siendo por lo general su forma oblonga.

DISTRIBUCION GEOGRAFICA.-Esta bonita espe. cie existe en varios puntos de la América meridional, pareciendo abundar mas en los Estados atlanticos de Maine Virginia.

USOS, COSTUMBRES X REGIMEN.-Hasta hace algun tiempo sc creyó que este batracio vivia siempre en los pantanos salados 6 cerca de ellos; pero se ha reconocido despues que habita igualniente las orillas de los estanques $y$ los rios. En todas sus demás costumbres no difiere de la rana halecina; y observa el mismo régimen que ella. Se dis. tingue, sin embargo, por exhalar un olor muy desagradable, lo cual no impide que se aprecie su carne, que tiene fama de ser muy sabrosa.

\section{LA RANA DE FAJAS-RANA FASCIATA}

CARACTÉRES, - En ninguna especie del género que nos ocupa son las extremidades posteriores tan raquíticas y tan desmesuradamente largas, por decirio así, como en la rana de fajas (fig. 95), pues miden dos veces, y hasta dos $y$ media la extension del resto del cuerpo, sin que las patas delanteras excedan de las dimensiones ordinarias. El tronco es angosto, la cabeza una tercera parte menos larga que aquel, deprimida y ligeramente convexa en su parte posterior; las fosas nasales están situadas á igual distancia del ojo y de la punta de la nariz; el timpano es pequeño; la lengua se divide en dos pequeñas puntas por detrás; la picl suele ser lisa, pero algunas reces forma pequeños pliegues longitudinales bastante parecidos á los que se observan en la especie anterior. La coloracion es muy variable; pero obserr. vase que todos los individues sin excepcion tienen una man. cha negra de forma oblonga en la region del timpano, 5 que debajo de elia existe una raya blanca que avanza mas 6 menos por el lado del hocico. Esta rana mide cerca de 2 pul. gadas.

DISTRIBUCION GEOGRÁFICA.-La rana de fajas existe principalmente en el Cabo de Buena Esperanza y se halla diseminada por todo el sur de Africa.

USOS, COSTUMBRES Y REGIMEN.-Nada sabemos con seguridad acerca del género de vida de este reptil; pero por la conformacion de sus miembros posteriores, debe suponerse que sus costumbres son poco acuáticas.

\section{LA RANA TEMPORARIA-RANA} TEMPORARIA

CARACTERES.-T.a rana temporaria tiene el mismo tamaño de la rana verde, distinguiéndose de ella sin embargo por su color y género de vida, de tal modo que nadie puede confundir ambas especies. Las partes superiores son de un color pardo rojo con manchas de un pardo oscuro ó claro; las sienes presentan una faja longitudinal del mismo color; en las patas hay fajas trasversales mas intensas; el pe. cho y el vientre son de un blanco gris en el macho y de color rojizo con dibujos pardo-amarillos en la hembra, que es un poco mayor.

Stenstrupp pretendió uiltimamente que las ranas tenıpararias se dividen en dos especies, caracterizadas por el hocico mas ó menos puntiagudo: la que le tienc de esta forma (rana oxyrhinus), se distingue por ser su mandibula supe Toso $v$ rior mas larga que la inferior; la base de los dedos exteriores está provista de grandes protuberancias cartilaginosas; $y$ las membranas intercigitales llegan en el macho hasta la pen. última articulacion del dedo mas largo. La especie de hocico obtuso (raka platyrhinses), tiene en cambio la cabeza an. cha, redondeada, con hocico obtuso, protuberancias mas pe. queñas y membranas natatorias que en ambos sexos llegan hasta la segunda articulacion del dedo mas largo. En el macho, los huesos frontales son abovedados y estrechos; en la hembra planos y hasta cóncavos y muy anchos. Excitada su curiosidad por esta noticia del naturalista danés, algunos se

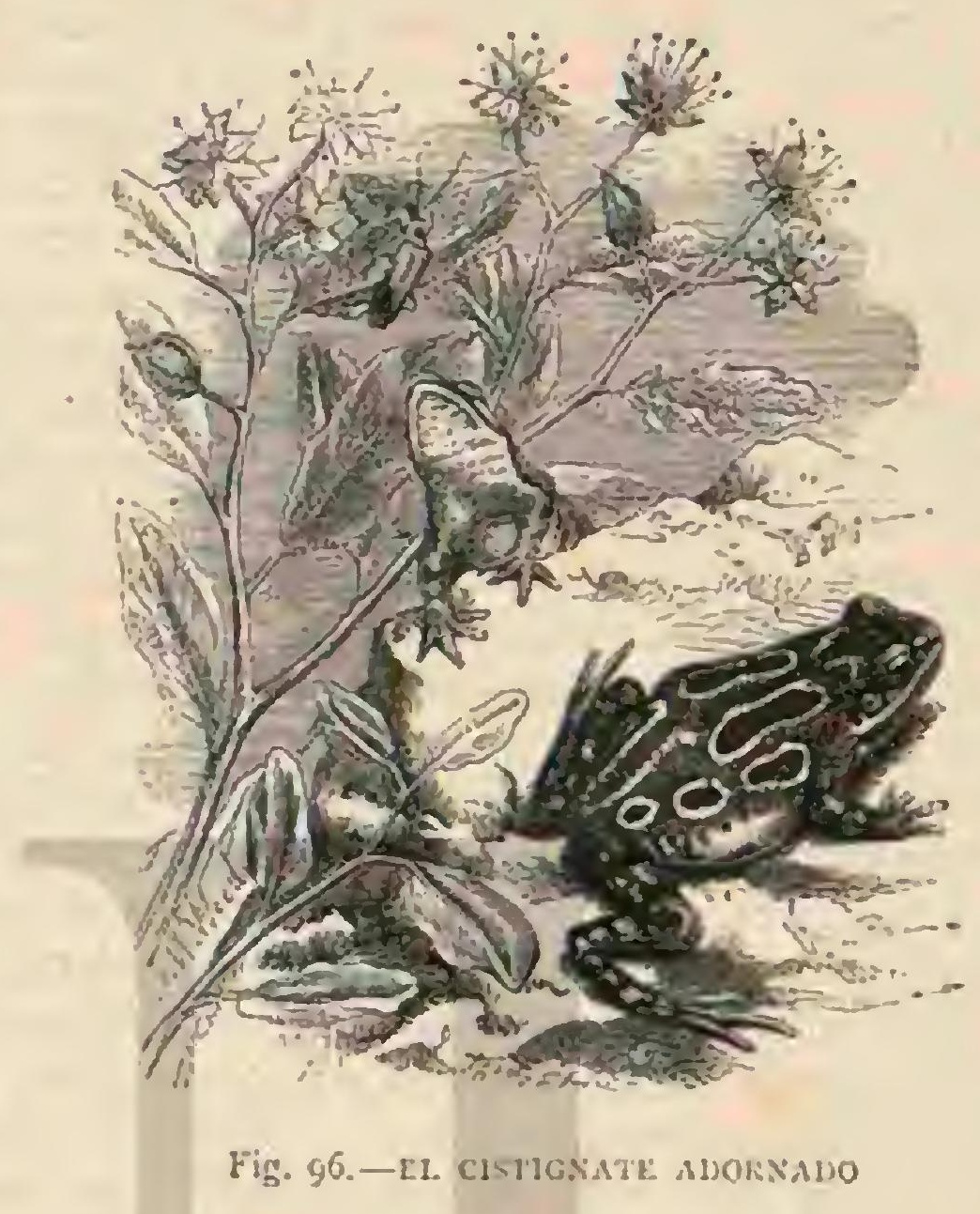

ocuparon en observar la rana temporaria; y no solamente se han confirmado como exactas las citadas díerencias, sino que tambien se ha reconocido que ambas especies tienen un género de vida distinto. Ultimamente se ha separado una tercera forma, descrita ya por naturalistas anteriores, porque su hocico es bastante puntiagudo y prolongado, la frente ancha y aplanada, con los ojos situados muy atrás, y porque el paladar tiene casi sicmpre cuatro 6 cinco series para. lelas de dientes, mas largos y grandes que los observados en las especics anteriores. $A$ estos importantes caractéres se agregan algunos otros: tamaño mediano, tronco mas enjuto, color amarillento que hasta tira al sonrosado, las regiones inferiores blancas ó amarillentas, sin manchas, las piernas con fajas trasversales regulares, etc. Esta especie parece limitarsc mas al sur segun Schreiber, j se encuentra sobre todo en Suiza, Francia, Dalmacia é Italia : vive con preferencia en los pantanos y se presenta y aparece mas tarde que las oiras dos.

Por diferentes que sean las tres formas entre si, al examinarlas en individuos elegidos no podemos considerarlos como de especies independientes, si queremos adoptar las opiniones actuales, pues entre ellos se observan todos los tránsitos posibles. Lo mismo sucede con la rana acuática de la Auérica del norte (rana sylialica) que, segun Guenther, se distingue á primera vista tambien esencialmente de nues. tra rana temporaria, pero despues de muchos experimentos y comparaciones resulta ser una varicuad de ella.

DISTRIBUCION GEOGRAFICA.-Toda la Europa, segun Noel, desde el Cabo Norte hasta el extremo sur, una parte del Asia no determinada aun que en el este se extien. de hasta el Japon, y por último, el oriente de los Estados. 
Unidos, desde Maine hasta la Virginia, y quizás mas hácia el Sur, son la patria de la rana temporaria.

USOS, COSTUMBRES Y RÉGIMEN.-Esta especie sube a la montaña hasta una altura de 2,000 metros sobre el nivel del mar $y$ hasta se encuentra en el Grinsel $\delta$ en los la. gos alpestres del San Gotardo, aunque estos lagos están cubiertos de hielo a menudo hasta el mes de julio. Lo mismo sucede, segun Levona y Salvadori, en los Alpes del Piamon. te. En la llanura solo permanece en cl agua durante el período del celo, en invierno; en las montainas altas en cambio representa en cierto modo a la rana verde y apenas abandona el agua. Su relativa insensibilidad al frio le permite discminarse de esta manera. Es el prinucro de todos los anuros cque se des. pierta del letargo y sale de sus escondites; se apurea aun antes del deshiclo, y su progenie sale â luz mas pronto que sus demás congéneres hagan la puesti. Tambien los, renacuajos se desarróllan mas tápidamente que los de otras ranas, y de este modo le es posible fjar su residencia jermanente en regiones donde el verano apenas dura algunas scmanas, como por ejemplo en la altura de dichos lagos alpestres. La rana verde, que se aparea mucho despnes $\because$ necesita mas tienipo para la metamorfósis, apenas podria desar. rollarse en tales parajes; mas para la rana temporaria, el corto vemno es bástante lárgo, y cuando una rez el fin se presenta antes de tiempo, tambien el renacuajo pasa el invierno sin trasförmárse.

En la llanura el periodo del celo empieza ya a principios 6 mediados de marzo, as no ser que el invierno sea muy ri. guroso. Los huevos salen con suma rapider, de niodo que, segun las pruebas de Roesel, todos quedan fecundados en meros de un cuarta de hora. El celo parece muy violento en ambos sexos, porque apenas es posible separar al macho de la hembra cuando está cogido á ella, $y$ si al fin se le separa vuelven en seguida í rcunirse. Roesel obscrvó que una hembra puede correr peligro por los fuertes apretones del macho, porque si este es mas grande que aquella, la puede reventar con la presion. Tambien observó que algunos machos se dejan arrancar una pata antes que soltarla hembra. A falta de hem. bras los machos se abrazan entre si, 6 con hembras muéras 6 sapos, y cuando los no apareados encuentran una pareja reunida coggense \& menudo á clla, formando un conjunto desordenado. Los huevos, mas grandes, pero merios numerosos que los de la rana verde, caen despues de la puesta al fondo del agua; pero luego la cubierta mucosa se liena del flúido, y entonces vuclven á subir í la superficie, donde forinan espesas masas. En la temperatura baja de la primavera se retarda el desarrollo, y solo al cabo de quince dias se puede ver el renacuajo que sale del huevo; a las tres 6 cuatro semanas nada por los contornos, pero vuelve de vez en cuan. do à la sustancia mucosa, que probablementele sirve de ali. mento. Desde entonces sc apresura el desarrollo, pues pasa. dos los tres meses los renacuajos se han trasformado en ranas. Estas abandonan el agua cuando las circunstancias son favorables, en tal número que ficilmente se explica la antigua fábula de la lluvia de ranas.

La ranita vive en adclante como sus padres, y al contrario de sus congéneres, raga as menudo à mucha distancia del agua, por los jardines, las praderas, los campos, los bosques, las malezas y otros sitios semejantes, ocultándose en dias ca. lurosos debajo de las picdras, las raices de árboles, y otros escondites. Por la noche sale a cazar; persigue los insectos de las mas diferentes clases, babosas y otros animales pequeños, y por lo tanto es útil, quirais mas de lo que creemos. Coge su presa poniéndose al acecho, sin perseguirla, y distingue muy bien las especies, devorando, por ejemplo, las abejas, mientras que desprecia las avispas.
En mi concepto, la rana temporaria es inferior á sus con. géneres, hasta por el canto. Solo en ciertos periodos, sobre tolo en el del apareamiento, deja oir un gruñido muy infe. rior al canto de la rana verde, einitido tanto por la hembra como por el macho. Al contrario de la rana verde, se la po. dria creer muda, sobre todo en verano, durante el cual lo hace todo silenciosamente.

Ningun anuro tiene mas enemigos que la rana tempiora. ria: todos los rapaces le pérsiguen en las diversas fases de su vida, tanto en el agua como en lierra firme, y solo se libra de sus ataques cuando se retira al cieno para entregarse al sueño invernal. Todas las aves que se alimentan de reptiles ó batracios tienen en ella una presa que fácilmente pueden coger; lns serpientes que buscan este alimento parecen preferir esa especic á la verde; esta tiltima la persigue tambien, como hemos visto, por lo menos en los primeros años de su vida; $y$ hasta los cangrejos la cligen para su alimento.

A este numeroso ejército de cnemigos agrẻgase además el hombre, pues tambien la rana temporaria es buscada por su carne. Ademas de esta persecucion, bien justificada, es blanco de la aversion que infunden los sapos que con ella habitan en los mismos/sitios, recomnensảndose así los beneficios con la muerte. Sin embargo, aunque mueran muchas, no disminuye afortunadamente el número de estos útiles animales; una primavera favorable cubre las pérdidas de diez años pasados.

\section{LA RANA MUGIDORA-RANA MUGIENS}

CARACTERES. - Nuestras ranas curopeas son cnanas en comparacion de ciertos congéneres americanos é indios, enanas respecto a su tamaño y débiles en cuanto á su voz. Entre las mas notables de la familia figura una de la América del norte, la rana mugidora, cuya voz le ha valido tambien el nombre de rana bsuey. No sé por propia experiencia hasta qué punto este calificativo se justifica, pero los naturalistas y viajeras americanos están acordes en que un concierto de unas quinientas ranas mugidoras no puecic compararse con ia música de nuestros estanques. En los diferentes autores se lec tanto de noches pasadas sin dormir, eic, que bien pucde suponerse que la voz de la rana mugidora guarda con la de nuestras ranas la misma proporcion que su tamaño respectivo.

La rana mugidora alcanza una longitud de $0^{*}, 20$ if $\theta^{\infty}, 22$ por $0^{\circ}, 25$ las patas posteriores. La parte superior es de un verde aceituna con grandes manchas de un pardo oscuro ó negruzcas y una linea amarilla que se corre a lo largo del espinazo; las partes inferiores son de un blanco amarillento, y los ojos rojizos, con un circulo amarillo. Se hallan tambien á veces variedades de esta rana.

DISTRIBUCION GEOGRAFICA. - La patria de la rana mugidora se extiende por todo el este de la América del norte, y desde Nuevn York hasta Nueva Orleans, mas parece que en ninguna parte se encuentra en tanto número como nuestra rana verde, por la sencilla mzon de quue seria dificil se alimentasen tantos animales tan grandes y voraces.

USOS, COSTUMBRES Y REGIMEN.-- Habila-segun Audubon todos los países de los Estados. Unidos, pero abunda mas en las regiones meridionales que en las septentrionales. Por lo regular nija su residencia en las corrientes claras, cuyas orillas están pobladas de espesuras; aqui se sitúa á la hora del medio dia con la cara hácia el agua á la cual se precipita al menor indicio de peligro, sumergiéndose hasta el fondo y nadando hácia la orilla opuesta. Su voz, mas fuerte que la de cualquicra otra rana, se oje a mucha distancia, en los Estados meridionales durante todo el año, 
y sobre todo en la primavera y el verano; en los septentrio. nales en verano, y particularmente en el periodo del celo, durante el cual se reunen algunos centenares de estas ranas. En ese periodo el gigante muge sin interrupcion toda la noche, desesperando á los habitantes nerviosos. Despues de poner los huevos se dispersan y vuelven á los sitios acos. tumbrados.

Todo campesino de los alrededores conoce la voracidad de la rana mugidora. Su alimento principal se compone de insectos y caracoles, pero no se contenta con esta presa, pues persigue \& todos los séres vivos que cree poder dominar. Devora los polluelos del pato que nadan en la superficie del agua; coge de un salto los pollos de la gallina y los sumerge en la profundidad antes que la madre pueda protegerlos. Dumeril encontró en el estómago de cinco ó seis ranas mu gidoras, examinadas por él, restos de toda clase de insectos, cararoles y conchas, partes del esqueleto de peces y además huevos de aves; Harlam asegura haber matado una de estas ranas en el momento en qque acababa de engullirse una culebra; y los campesinos afirman que causa mas estragos entre las avecillas acuaticas que ciertos carniceros. Tal voracidad es muy a menudo su perdicion, pues se deja cogè fácilmente con un anzuelo, cayendo en poder de aquel á quien perjudicaba, que se come su carne, en extremo sabrosa Esta rana, que pesa generalmente unos trescicntos gramos, vale tambien la pena de una perdigonada, aunque solo se comen sus ancas; tambien se la caza con redes y trampas. Además del hombre, la persiguen con afan varios grandes carniceros, pero sobre todo los peces voraces, i los que al parecer gusta su carne tanto como á los gastrónomos. Segun Audubion. no hay mejor cebo para coger tiburones que una rana mugidora.

CAUTIVIDAD.- Ultimamente llegan individuos vivos de esta especie á Europa, donde los aficionados los cuidan. Yo he tenido varios y pude observarlos mucho tiempo, pero siempre halle que no se distinguen esencialmente de la rana verde. A causa de su mayor tamaño necesitan masalimento, y por eso son doblemente voraces que aquella, aunque se les parecen del todo en su género de vida, usos y costumbres. No cxigen mucho cuidado y solo es preciso darles alimento suficiente y agua para que a todas horas puedan refrescar su picl. Con ranas verdes y temporarias, peces y pajjaros vivos, se conservan en buen estado $y$ hasta se les puede engordar porque en tiempo caluroso raras veces desprecian lo que se les ofrece. No seria dificil aclimatarios en nuestros palses si esto ofreciera tan solo un poco de utilidad.

\section{LOS CISTIGNATES-CYSTIG- NATHUS}

CARACTERES. - Wagler reune en este grupo un núme. ro bastante considerable de ránidos que habitan no solo en las dos mitades de América, sino tambien en Africa y Aus. tralia, pudiendose considerar por lo tanto casi como cosmopolitas. Distínguense bastante por su estructura, pues hay especies de cuerpo delgado y gracioso y otras de formas recogidas; el carácter comun á todas es el escaso desarrollo de la membrana interdigital, que falta por completo en algunas especies, mientras que en otras se atrofia, formando solo un estrecho borde. I.a cabeza es de forma triangular; los cuatro dedos se distinguen por su-relativa longitud y delgadez; ta lengua es de forma oval apenas escotada en su parte posterior, y los dientes palatinos están dispuestos en dos series trasversales arqueadas.

\section{EL CISTIGNATE ORNADO-CYSTIGNATHUS ORNATUS}

CARACTERES. - Fste gracioso animalito, que puede alcanzar una longitud de casi $0^{n}, 03$, tiene las partes superiores de color pardo rojizo con manchas longitudinales de un verde oscuro y bordes de un amarillo dorado; las inferiores son de un blanco plateado con puntos grises (fig. 96).

DISTRIBUCION GEOGRAFICA. - Esta especic es propia de la América del norte.

USOS, COSTUMBRES Y REGIMEN. - El cistignate ornado vive siempre en terrenos secos, evitando el agua, tanto que en seguida se dirige d la orilla cuando se le arroja en este elemento.

No tengo datos minuciosos sobre su género de vida, pero supongo que no diferirá mucho del de otras especies de su gênero.

\section{EL CISTYGNATE MOTEADO-CYSTIGNATHUS OCELLATUS}

CARACTERES. - Esta especie es sin duda la mas conocida del género; se caracieriza por sus formas enjutas; mide unos $0^{\circ}, 03$ de largo, y se distingue por tener siete quillas ó prominencins de la jiel que se corren por el lomo; otras dos se prolongan á lo largo de los costados; las primeras son de color pardo oscuro de aceite, y las segundas de un blanco amarillento; el resto de las partes superiores es de un verde de aceite; en la cabeza y en el lomo hay líneas poco marcadas con borde negro; las regiones posteriores tienen un fondo gris verdoso con manchas de un gris negruzco; las inferiores son de un blanco amarillento con mezcla de negro en la region de la garganta.

DISTRIBUCION GEOGRAFICA.-El cistignate mo. teado está diseminado por todo el centro y sur de América, incluso las Artillas, y es muy comun en todas las partes don. de se le encuentra, como por ejemp!o, en muchas regiones de la costa oriental del Brasil: el principe de Wied no le vió en el interior del pais.

USOS, COSTUMBRES Y RÉGIMEN. - Este batracio parece en extremo torpe en el agua, pero en cambio mué. vese con rapidez y agilidad en tierra firme, $s$ da grandes sal. tos, franqueando distancias asombrosas. De dia se oculta en los charcos, pantanos y aguas cstancadas, mas, si el tiempo es húmedo abandona su cscondrijo tan luego como siente el fresco de la noche y saita sobre la yerba de los contornos. Entonces se oye tambien su voz, un silbido nuy extraño, caracteristico y muy distinto de la voz de todas las demás ranas; creeriase que es el silbido de un hombre que llania á un perro. Durante el periodo del celo, que se pasa en el agua, produce sin embargo una voz del todo diferente. Tales son las noticias del príncipe de Wied, primer naturalista qute dió una descripcion minuciosa de este batracio. Hensel ha podido ampliar nuestros conocimientos sobre su género de vida: este naturalista describe el cistignate motcado con otro nombre; mas á juzgar por sus indicaciones sobre la voz, de. dúcese que se reficre á la especie descrita por el principe.

Segun sus noticias este cistignate no penetra nunca en el agua, ni deposita por lo tanio su ireza en los charcos; cerca de estos, y siempre en los limites á que puede llegar el agua despues de los grandes aguaceros, practica cavidades del tamaño de una taza regular, debajo de las piedras, de tron$\cos$ de árboles podridos, etc.; $y$ alli deposita su freza, que tiene gran senejanza con la clara de huevo batido. En el centro de esta sustancia espumosa se hallan los huevos, de color amarillo pálido. Los renacuajos tienen al principio el mismo tinte, pero pronto se oscurecen en la parte superior, tomando despues un color pardo verdoso, y mas tarde un. blanco gris, casi plateados; de modo que se asemejan bas: tante por su aspecto \& los renacuajos de la rana verde, con 
la única diferencia de que su aleta caudal no parece tan desarrollada. Cuando el agua del charco sube hasta el nido pe. netra en este, y entonces, el género de vida de los renacuajos no difiere del de los demás anuros. Solo se observa en ellos una secrecion mucosa mas abundante, y mayor resis. tencia vital, resultante sin duda de aquella, pues cuando los charcos poco profundos llegan a secarse por falta de lluvia, los renacuajos de los otros batracios mueren, mientras que no sucede asi con los del cistignate moteado. Estos se refugian debajo de los objetos que pueden preservarlos, como por ejemplo, troncos de árboles, hoyos, etc, donde reunidos èn grupos, esperan la lluvia Al levantar el objeto que lés oculta todos se mueven confusaménte, y entonces se ve que aun disfrutaban de bastante humedad. Cuanto mas crecen los renacuajos en los nidos, tanto mins desaparece la sustancia mucosa que les sirve de alimento. Heinsel no ha observado, sin embargu, si pueden trasformarse del todo sin entrar nunca en el agua, mas a penas podria suponerse asl, porque los pequeños batracios están provistos aun, hasta alcanzar un tamaño bastante considerable, de branquias $\mathrm{Y}$ del resto de la cola

Para completar la descripcion de los cistignates en general reprodurco las noticias de Hensel y de Guendlach-sobre la reproduccion de algunas especies congenéricas. Hago mencion por lo tanto de un hílido llamado por Hensel cystigna. thus ocellatus, cuya voz, que se oye desde léjos, compara con el ruido que producen los carpinteros al cortar una viga a golpes acompasados. Esta rana difiere en cuanto â su repro. duccion de la especic anterior, porque al despertar en la primavera del letargo en que yace, cuando menos en Rio Grande do Sul, no deposita sus huevos inmediatamente en el charco que habita durante el periodo del celo, sino que abre en la orilla cenagosa unas cavidades de unos treinta centimetros de diámetro, que aunque tambien están llenas de agua, quedan separadas del gran depósito por una especie de terraplen; aqui deposita su freza, y mientras los renacuajos nacidos esperan que un aguacero ponga en comunicacion su nido con el charco, alcanzan sa un tamaño que les permite escapar de la major parte de los peligros que les amenazan. Cuando las lluvias de la prinavera tardan demasiado, sécanse muchos charcos y la cria perece. Guendlach, en fin, encontró en 4 de noviembre varios huevos de color amarillo de paja de otra especie, o'stignathus fiplionirus, rodeados de una sustan. cia esponjosa, que se hallaban en una cavidad húmeda, y obserró tambien el desarrollo de la cola y de las branquias. Jos renacuajos nadaban en el agua y comian con ansia pedacitos de carne. En 25 de noviembre Guendlach observó los primeros vestigios de las patas posteriores, y el 3 de di ciembre los pequeños batracios se asemejaion por sus formas á la rana y subian por el cristal.

\section{LOS PIXICÉFALOS-PYXICEPHALUS}

CARACTERES.-Los pixicéfalos son en cierto modo ranas de cabeza grande, cuerpo fornido, hocico ancho, corto, muy convexo por fuera, cóncavo interiormente, $y$ de hueso cunciforme desarrollado en la parte exterior, en forma de disco oval de borde cortante. I'jenen dos grupos de dientes vomerianos; la lengua es grande, ovalar, libre, dividida en dos lóbulos, $\delta$ bien escotada simplemente en la parte próxi ma á la garganta; el timpano es pequeño y no se distingue algunas veces á través de la picl; los dedos, cujo número es de cuatro, están separados; y reunidos por una membrana los del pié, en la primera mitad de su extension. Ja gargan. ta de los machos contiene una vejiga bucal susceptible de dilatarse mucho, y cuyos dos orificios se hallan d cada lado de la lengua.

\section{EL PIXICÉFALO SALPICADO-PYXICEPHA- LUS ASPERSUS}

CARACTERES.-Miembros cortos, cabeza voluminosa, hocico mus arqueado, ojos grandes y poco salientes, y mem. brana del timpano bastante visible, son los atributos esencia. les que caracterizan á esta especic (fig. 97). Las regiones superiores de este batracio tienen un tinte verde botella oscuro con puntos blancos; y desde la punta del hocico hasta la extremidad posterior del lomo se corre una línea del mismo color; unas veces son del rodo blancas las partes inferiores, y en otros individuos están cubiertas de manchas negras. El pixicúralo salpicado mide uras seis pulgadas cuando alcanza su completo desarrollo (medida inglesa).

DISTRIBUCION GEOGRÁFICA.-El área de cispersion de esta especie comprende todo el sur de Africa.

USOS, COSTUMBRES Y REGIMEN.-El pixicéfalo de Africa, segun se ha llamado tambien ś este batracio, se encuentra por lo regular en las charcas próximas á las corrientes; es un animal aficionado á la humedad, de modo que cuando la sequia se prolonga mucho, como estas ranas tienen la piel muy fina y les nerjudica la aridez del terreno, reúnen. se varios individuos en algun estanque $\delta$ pantano y entiérran. se en el cieno hasta que las próximas lluvias les permiten volver ála vida activa. Se ha dado el caso de encontrar en una pequeña charca hastá cincuenta individuos juntos, muy lejos de toda corriente; y no cabe duda que deben tener algun sitio para ocultarse, pues siempre aparecen en gran número despucs de una lluvia copiosa. El célebre viajero Livingstone habla de esta especie en el relato de uno de sus viajes por el Africa del sur, y como nos parecen muy curiosos los detalles que nos da, ramos á reproducirlos integros. Estas grandes ranas, dice, objeto de admiracion de nues. tros hijos, son conocidas en el pais con el nombre de Mrat. lankello, y tienen tales dimensiones, que algunas parecen pollitos; los indigenas creen que caen de las nubes, porque despues de una lluvia copiosa, las charcas que conservan agua algunos dias se llenan materialmente de individuos de la especie, que aturden los oidos con su incesante canto. Este fenómeno ocurre en los parajes mas secos del desierto, y donde el observador indiferente no sospecha que pueda existir ningun sér animado. Hallíndome cierto dia en el dis. trito de los Kalahari, lugar en que faliaba el agua para nuestros ganados, sorprendiome oir una tarde el canto de las ranas; sali de mi tienda con la esperanza de encontrar algu. na charca alii cerca; pero no vi absolutamente nada. Los indigenas me dijeron que el matlametlo practica un agujero en la raiz de ciertos arbustos y se alberga alli durante los meses de sequí. Una araña de las mayores especies. se utiliza tambien del agujero, y fabrica su tela de tal modo que cubre el orificio; este hecho es bicn conocido de los leiado. res; pero las personas que no están en el secreto no podrian suponer nunca que debajo de una telaraña se puede ocultar uno de estos batracios. La presencia del matlametio en el desierto, en tiempo de sequia, me dib a conocer que habia estado en un error respecto á las costumbres de este animal, pues siempre habia supuesto que cantaba en el agua. A los viajeros que iban con las caravanas les era muy grato oir la voz de cste reptil despues de cruzar los inmensos arenales del desierto; y entonces comprendi las simpatias de Esopo, que segun sabemos era africano, por esta especie de animales.

los individuos de csta notable especie van perdiendo gradualmente su color pardo verdoso segun avanzan en edad; se cambia en un tinte mas pálido perdiendo su brillantez. 


\section{LOS CERATOFRIS-CERATOPHRYS}

CARACTERES.-Entre otros tipos americanos de la familia se distinguen sobre todo los ceratorris, $\delta$ ranas cornudas, por su tamaño, sus formas particulares y su belleza. Tienen el cuerpo recogido y semejante al de los sapos; la cabeza en extremo grande y ancha, lo mismo que la boca; el borde de la mandibula superior denticulado; el de la inferior liso: las extremidades son de un grueso regular; las patas anteriores tienen cuatro dedos $y$ las posteriores cinco; los primeros están separados, y los segundos se hallan unidos por cortas membranas interdigitales. Su nombre de rana cornuda es debido á las extrañas protuberancias situadas en ambos lados de los ojos, y que no son otra cosa sino los párpados prolongados en punta. Unas altas crestas verrugo. sas y varias suturas en la cabeza y en el lomo completan en

\section{EL CERATOFRIS CORNUDO-CERATOPHRYS CORNUTA}

CARACTERES. - El ceratofris cornudo (fig. 98), la itea. reia de los brasileños, anuro muy grande de $0^{\circ}, 15$ a $0^{10}$, 20 de longitud, es una de las especies mas magnificas del órden. Una ancha faja que desde el hocico se corre por el lomo es de un amarillo naranja con manchas verdosas en algunas partes; varias fajas y manchas en los lados de la cabeza y en los hombros son de un verde rojizo; las fajas que separan la mancha en la linea central tienen un color pardo negruzco;
los costados son de un tinte pardo gris, con manchas de un

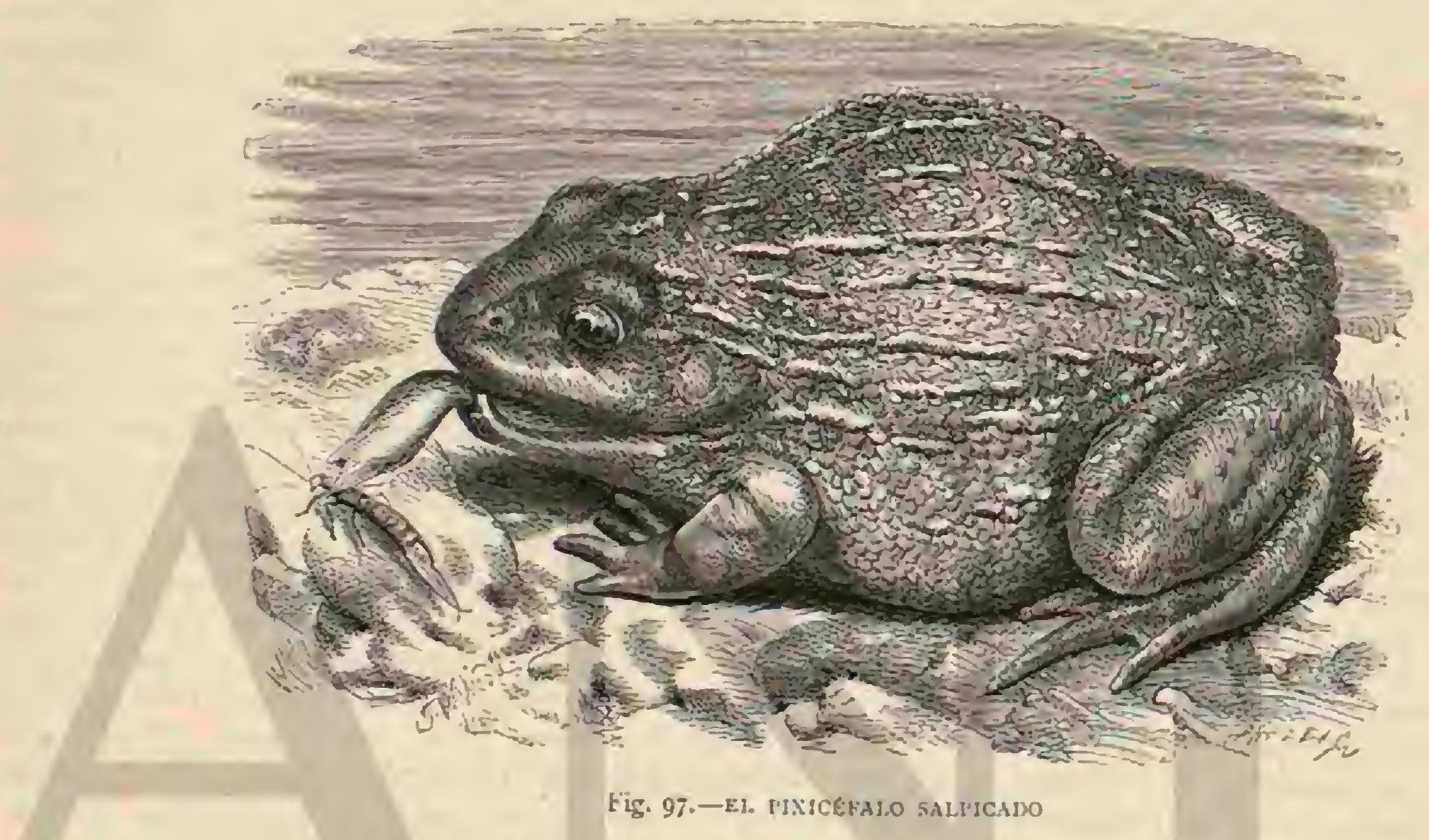

negro verdoso orilladas de un gris rojizo pálido. Las patas posteriores son verdosas, con fajas trasversales de un vivo color verde de yerba; el vientre es de un blanco amarillento en el centro y amarillo en los lados, con manchas y puntos de un verde rojizo.

La hembra, mas grande $y$ bonita, tiene, sobre un fondo pardo gris oscuro, una faja dorsal de color verde brillante que desde los ojos se ramifica por cada ladoen una faja la teral del mismo tinte; los ojos presentan un borde verde claro; en las mejillas se ven unas manchas redondendas verdes; desde la nariz hasta los ojos se corre una faja pardo negruzca, separada del color del fondo por una linea blanca; en las regiones anteriores hay dos fajas trasversales verdes orilladas de pardo rojo, y una línea longitudinal blanca que se corre a lo largo de la cara exterior de las fajas; las ancas son de un pardo castaño; los tarsos verdes, con dos fajas pardas.

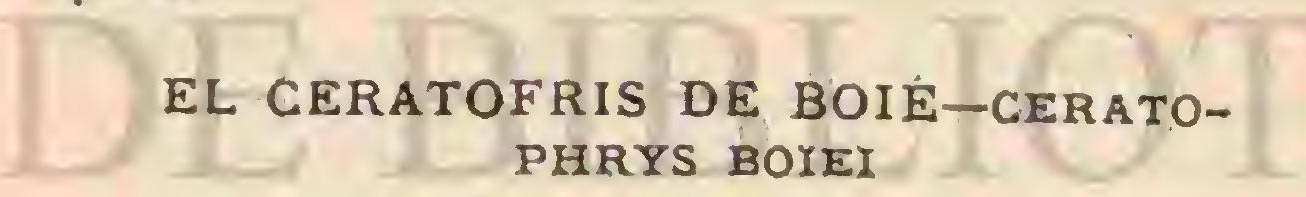

CARACTERES.-El ceratofris de Boie, llamado tam bien rana de letras, se distingue principalmente por el color muy claro de la cara y por la posicion diferente de las pro. minencias verrugosas: los demás caractéres son análogos á los de la especie anterior, tanto que puede suponerse que al fin resultará pertenecer a la misma.
DISTRIBUCION GEOGRÁFICA. - Segun ha obser vado el principe de Wied, el ceratofris cornudo está diseminado por todas las regiones meridionales del Brasil desde Paraguay. Rio Janeiro; segun Azara, hállase tambien en el Usos, existe en la Guayana.

USOS, COSTUMBRES Y REGIMEN.- - He obser. riores de Bahia dice aquel naturalista, en los bosques intedas, y virgenes, oscuras y hume. partes, incluso los bosqu pantanos, pero vaga por todas partes, incluso los bosques secos de Catinga. En las grandes del ro Itheos, y en el camino que se prolonga a lo largo hallarse en Abareda, no suele despues de un liempo caluroso y seco ni un solo sapo; pero despues de una ligera lluvia aparecen al punto individuos partes partes. Fl ceratofris cornudo adulto tiene una boca tan enorme que, segun se asegura, podria devorar un pollo; queños che a silencio de la no. che a menudo su voz sonora, sobre todo en las grandes sclvas virgenes; asemejase \& un graznido y es muy monó-

Tambien este lindo animal es objeto de la aversion de los brasileños; mientras que, segun Dupons, los indigenas primitivos de la Guayana española le adoraban como sagrado 6 le conscrvaban á menudo cautivo, juntamente con otros sapos, en grandes jarras; dicese que les servian de barómetro, 
y que los maltrataban cuando, siendo necesaria el agua ó el buen tiempo, no anunciaban ni una cosa ni otra.

\section{LOS ALITIDOS-ALYTID死}

Ioitzinger separa de los ránidos los anuros de tronco grue. so y extremidades cortas, semejantes á los sapos, agrupados en un principio por Dumeril, porque tienen dientes en la mandibula superior. I.as especies de esta familia tienen la mandibula superior denticulada, dientes palatinos, $g$ las avófisis trasversales del sacro triangulares, planas y convexas en su parte superior. Son en rigor sapos, sobre tado por su forma, y tambien por su género de vida.

\section{LOS ALITES-ALYTES}

CARACTÉRES. - Fil género de los alites se caracteriza por las formas recogidas, tronco pesado y extrcmidades cortas y fuertes; los piés tienen cuatro dedos y gruesas membranas natatorias; la piel es verrugosa ; la lengua está fija en su base.

\section{EL ALITES COMADRON - ALYTES OBSTE- TRICANS}

CARACTERES. - Esta especie, tipo europeo del grupo y muy pequeña, nide unos $0^{\mathrm{m}}, 0,35$ de largo: Las regiones superiores son de un ceniciento azulado; las inferiores de un blanco sucio; las verrugas tienen un tinte mas oscuro, $y$ las que en una serie longitudinal se reunen desde el ojo hasta las ancas son blanquizcas.

DISTRIBUCION GEOGRÁFICA.-Por lo que sabe. mos hasta ahora, el alites comadron solo se encuentra en la Europa central. Es comun en Francia, sobre todo en los alrededores de Paris, así como en Iralia, pero tambien se halla en Suiza, en algunos puntos de la Prusia renana, particularmente en Nassau, y por ultimo en España: de este últi. mo país recibi individuos vivos por conducto de Effeld:.

USOS, COSTUMBRES Y REGIMEN:-Este batracio vive en agujeros, en sitios frondosos, debajo de piedras y troncos de arboles, $\delta$ entre las cepas. Agassiz encontró cerca de Noemburgo á medio metro de profundidad, en una excavacion, unos treinta individuos reunidos, mas no pudo descubrir la entrada, por lo cual supone, probablemente con ra. zon, que estos animales saben socavar mejor que sus congéneres. Si la estacion no es propicia se les halla en agujeros abiertos, de los que salen cuando llueve, pero nunca antes de la noche. Sus movimientos son lentos y pesados como los de nuestro sapo comun. La voz, no desagradable, se parece al tanido de una campanilla de vidrio.

El alites comadron tiene bien merecido su nombre. Demurs presentó en r778 a la Academia francesa, observaciones so. bre la reproduccion de este batracio, que causaron general asombro, y mas tarde confirmáronse del todo por Brongniart y Agassiz.

El primer naturalista encontró en el Jardin de Plantas de Paris dos alites comadrones que estaban aparcándose y vió con asoinbro que el macho, que estaba sobre el lomo de h hembra, cogió el primer huevo, enlazado con el siguiente y los otros por un cordon muy fino, valiéndose de los dos de. dos medios de una pata posterior; retirando esta, extrajo parte del cordon, y despues hizo uso alternativamente de ambas patas hasta que todo aquel hubo salido. Al mismo tiempo que le sacaba arrollábalo, despues de fecundar los huevos, alrededor de sus ancas haciéndole describir varias figuras idénticas, cada una de las cuales representaba exac. tamente un 8 ; en esta forma los llevó durante muchos dias. la sustancia gelatinosa que reune los huevos se reseca, de modio q̨ue estos, colocados en intervalos de poco inas 6 menos un centimetro, quedan como en un tubo en forma de hilo.

Los huevos, dice Agassiz, son al principio pequeños y de color amarillo de yema, y en su parte superior se reconocen dos puntos negros como pinchazos de aguja. Llevando su preciosa carga, el macho se retira á una cavidad subierránea y alli permanece oculto algunos dias hasta que los huevos alcanzan cierto desarrollo. El amarillo de yema se vuelre mas oscuro y adquiere pronto un color pardo amarillo; al tercer dia se pueden distinguir ya en el embrion la cabeza, el tronco, y la cola; los movimientos se hacen mas vivos; distinguense con claridad los latidos del corazon, los movimien. tos de las branquias, ctc. Al cabo de ocho dias el desarrollo ha llegado á tal punto que el padre puede desembarazarse de su carga: para ello penetra en cl agua, nada con mas m. pider que de ordinario por todas partes, haciendo salir asi los renacuajos; despues quita la cubierta de los hucvos y sale á tierra firme, sin hacer caso ya de su progenie. Esta se dis. tingue poco por sus formas de los renacuajos de otros anuros q̨ue se desarrollan de la manera acostumbrada.

L'Isle ha recogido últimamente datos sobre los huevos y la reproduccion del alites comadron, dando los mas minuciosos detalles acerca del asunto, y yo reproducire lo mas importante. Tschudi encontró seis meses despues del periodo del celo un macho con cordones de huevos, lo cual le indis. jo á creer que el alites comadron pone dos veces al año: segun las observaciones de L'Isle, sin cmbargo, la reproduc. cion dura seis meses, desde marzo hasta agosto; la hembra deposita sus huevos entres $\delta$ cuatro intervalos, pues cuan. do se la examina en el periodo de la puesta, hállanse aun dos cordones del mismo tamano que los que acaba de poner, y además un cuarto con huevos que estín próximos al estado de madurez. L'Isle cree, que entre las puestas de los diversos cordones trascurren algunas semanas, suponien. do que en este tieimpo descansan las glándulas mucosas. Una hembra del todo adulta empieza á poner en marzo, cor tinúa hasta mayo, y por lo tanto solo tiene á fines de este més los últimos huevos en el ovario. Las hembras mas jóve nes solo ponen tres veces. El número de puestas depende no solo del estado de desarrollo de la hemibra, sino tambien del alimento, del clima y de otras circunstancias, observándose además que cuando la puesta se verifica en tales intervalos el desirrollo de los hijuelos es desigual: lus que salen de los huevos puestos en marzo, abril y majo acaban de desarro. llarse desde fines de julio hasta principios de octubre.

Despucs de guardar silencio unos seis meses, el macho del alites comadron vuelve a dejar oir su voz sin cesar desde últimos de febrero hasta fines de agosto. Al mismo tiempo em. pieza tambien, al menos en los alrededores de Nantes, la pues. ta de huevos, y siempre se depositan mas en la primavera que en los meses siguientes: la hembra los pone en dos cordo. nes semejantes á rosarios y que salen al mismo tiempo. Cada uno de estos corciones tiene una longitud de $\theta^{\prime \prime}, 80$ a $I^{\circ}, 70$, pro se puede estirar sin romperse hasta que-tiene doble largo. Los huevos están dispuestos en intervalos de curatroá siete centimetros y su número varia de dicz y ocho a cincuenta y cuatro. El ovario contiene de I 20 \& I 50 que maduran en un año.

En el perlodo del celo los machos se disputan con furia la posesion de las hembras: L'Isle vió una vez cuatro agarra. dos unos a otros. Los que no pueden apoderarse de la hembra porque no encuentran sitio en su lomo, cógenla lo mejor que pueden por los costados. Rechazados por su rival 
se alejan un poco, pero vuelven pronto al ataque. El mas afortunado $6 \mathrm{cl}$ mas agil abraza â la hembra como hemos di. cho, comienza en seguida á frotarla el ano con sus piernas posteriores, é introduce á menudo los pulgares en el interior de la cloaca. A la media hora de hacer este ejercicio, comprime de pronto el vientre de la hembra haciendo salir los huevos; y al mismo tiempo los recoge entre sus piernas posteriores para la fecundacion.

L'Isle describe despues detalladamente la manera de proceder del macho al encargarse de los cordones para confiarlos despues á la hembra, lo que por lo regular sucede una hora despues del principio del apareamiento. Al contrario de algunos observadores anteriores, asegura que el macio no se oculta debajo del suelo, sino que lleva la carga consigo comunicando á los huevos la humedad necesaria par el roce de la yerba impregnada de rocio. La carga en el lomo no crs. torpece su actividad ni le impide correr, saltar y coger alimento. Alli donde hay muchos alites comadrones, un macho ayuda á dos $y$ hasta tres hembras en el parto, encargándose de sus huevos. L'Isle encontró varias veces machos que se disputaban la posesion de la hembra; que dos estaban ya cargados de huevos, y que algunos hasta llevaban una segun. da porcion detrás de la primera. El cesarrollo de los rena. cuajos depende del tiempo, de modo que puecie durar de tres á cuatro semanas. Desde el cuarto al sexto dia se reco. noce el primer embrion del esqueleto: del séptimo al noveno aparecen dilataciones en los sitios donde han de salir las branquias, que se desarrollan desde el noveno al décimotercero dia, y desde el decimoséptimo los animalitos están en disposicion de romper la cáscara. Entonces, el macho que los lleva se introduce en el agua; los hijuclos abandonan en pocos minutos los huevos, rompiendolos con algunos movimientos de la cola, y nadan libremente á la mancra de otros renacuajos: el macho se desembaraza de la cubierta y pasa el resto del verano como otros anuros.

\section{LOS BOMBINATORIDOS -BOMBINATORID瓜}

CARACTERES,-Del mismo modo que Fitzinger scpa ra al alites comadron de las ranas y sapos, Guenther lo hace con los pelobates, formando una familia independiente. Los órganos del oido de los bombinatoridos son imperfectos; las apófisis trasversales del sacro se ensanchan casi siempre en forma de paleta; la lengua es libre en su parte posterior; las extremidades posteriores tienen membranas interdigitales; $y$ las glándulas auriculares no existen.

\section{LOS PELOBATES-PELOBATES}

CARACTERES. - Los pelobates se parecen por sus for mas a los sapos, pero tienen las patas posteriores relativamente largas con dedos unidos por grandes membranas na. tatorias; la lengua es redonda y libre en su parte josterior; $\mathrm{cl}$ timpano esta cubierto; la piel del lomo presenta varias ver. ruguitas.

\section{EL PELOBATES OSCURO-PELOBATES FUSCUS}

CARACTÉRES. - El pelobates oscuro, tipo del género, es una especie muy abigarrada de $0^{\circ}, 07$ de largo; sus regio. nes superiores son de un pardo amarillo 6 gris claro, con mu. chas manchas pequeñas y grandes, de formas irregulares y de un color pardo oscuro vivo, reunidas $\delta$ aisladas y que, segun la expresion de Schinz, están diseminadas como las islas en un mapa.

DISTRIBUCION GEOGRÁFICA.-El airea de disper. sion del pelobates oscuro comprenide la Alcmania, Firancia, Italia y España; pero no se encuentra en todas partes sino que falta en muchas regiones del todo; en Suiza, por ejem. plo, no se ie ha observado aun segun Schinz, y tampoco en el 'Tirol, al decir de Gredler; abunda mucho en ciertos puntos, como por ejemplo en los alrededores de Nuremberg y de Berlin.

USOS, COSTUMBRES Y REGIMEN, - Vive mucho tiempo en el agua, en la cual permanece sobre todo en la primavera, pero en verano sale á tierra firme $y$ vaga preferentemente por los campos arenosos, donde se oculta de dia en agujeros mientras que de noche va en busca de su alimento. Por su manera de moverse es muy superior a los verdaderos sapos, y por este concepto parécese menos à ellos qque á las ranas. Da grandes saltos, mada rápidamente $y$ es muy diestro para ocultarse en la arena ó en el cieno.

Su alimento se compone principalmente de insectos y babosas, pero es de suponer que tambien persiga á otras ranas pequeñas, sobre todo a la temporaria.

En mi concepto, sin embargo, se asemeja á los sapos verdaderos: exhala un olor de ajo muy repugnante, por lo cual se le llama tambien srfo dil ajo. Este hedor es tan fuerte que antes se descubre al batracio por el olfato que por la vista; al acercarse á cierta distancia, el olor hace saltar las lágrimas lo mismo que cuando se pica cebolla. Parece que este olor proviene principalmente de la parte posterior del cuerpo, ó por lo menos, el animal dirige esta parte hácia el enenigo cuando este le toca. Al practicar la diseccion no se nota sin embargo el hedor, y por lo tanto pueden comerse las ancas.

Entre los batracios de nuestros paises el pelobates oscuro es el que antes da principio á la reproduccion; se aparea en marzo ó cuando menos en abril. En este tiempo ambos sexos permanecen en el agua, en cuyo fondo han pasado el invierno; entonces asoman la cabeza á la surperficie y eniren un sonido desagradable y ligero, semejante al grito de la rana temporaria y a la voz del hila arborícola. Si se les coge con una tenaza por el pie, obsérvase que tambien pueden emitir otros; entonces gritan con voz lastimera, análoga al maullido de un gato pequeño.

En el apareamiento el macho abraza á la hembra por los costados. Los huevos salen en un cordon grueso de mediu metro de largo, en cuya sustancia gelatinosa están aglomera. dos; el macho los coge, a medida que van saliendo, con las patas posteriores y los fecunda, depositándolos despues en las cañas y otras plantas acuáticas, a corta distancia de la orilla. Los renacuajos salen á los cinco 6 seis dias, vagan reunidos por el agua y sepáranse á los diez y oclro dias; en. tonces pierden las branquias; en la novena semana salen las patas posteriores y dos despues las anteriores. Efectuada la inuda de la piel salen á principios del cuarto mes de su vida acuática, provistos aun de una colita, que sin embargo desaparece pronto.

CAUTIVIDAD.-Lós pelobates oscuros se conservan muy bien en la jaula cuando se les cuida; pero necesitan mucho alimento, pues no son menos voraces que cualquiera otra especie del órden.

\section{LOS CAMPANEROS- BOMBINATOR}

CARACTERES. - Este género se distingue de los otros por tener el tímpano cubierto y por la lengua circular, del- 
gada y adherida en toda su cara inferior; está provista de dos pequeños grupos de dientes palatinos y las patas poste. rores tienen membranas interdigitales completas.

\section{EL CAMPANERO IGNEO-BOMBINATOR IGNEUS}

CARACTERES. - La piel de esta especie está cubierta en el lomo de gruesas verrigas; el color de las regiones su- periores es de un bonito gris oscuro ó pardo de aceite, mien. tras que las inferiores tienen verrugas prominentes blanquiz. cas sobre fondo negro ó pardo gris, con manchas reunidas de un color de naranja vivo. Ia longitud es de $10^{\circ}, 03$.

DistRIBUCION GEOGRÁFICA.-Desde la parte meridional de la isla de Schonen hácia el mediodía, el campanero se encuentra en toda la Europa.

USOS, COSTUMBRES Y REGIMEN. - Buerger no sabe describir las destempladas melodias de un canto infer-
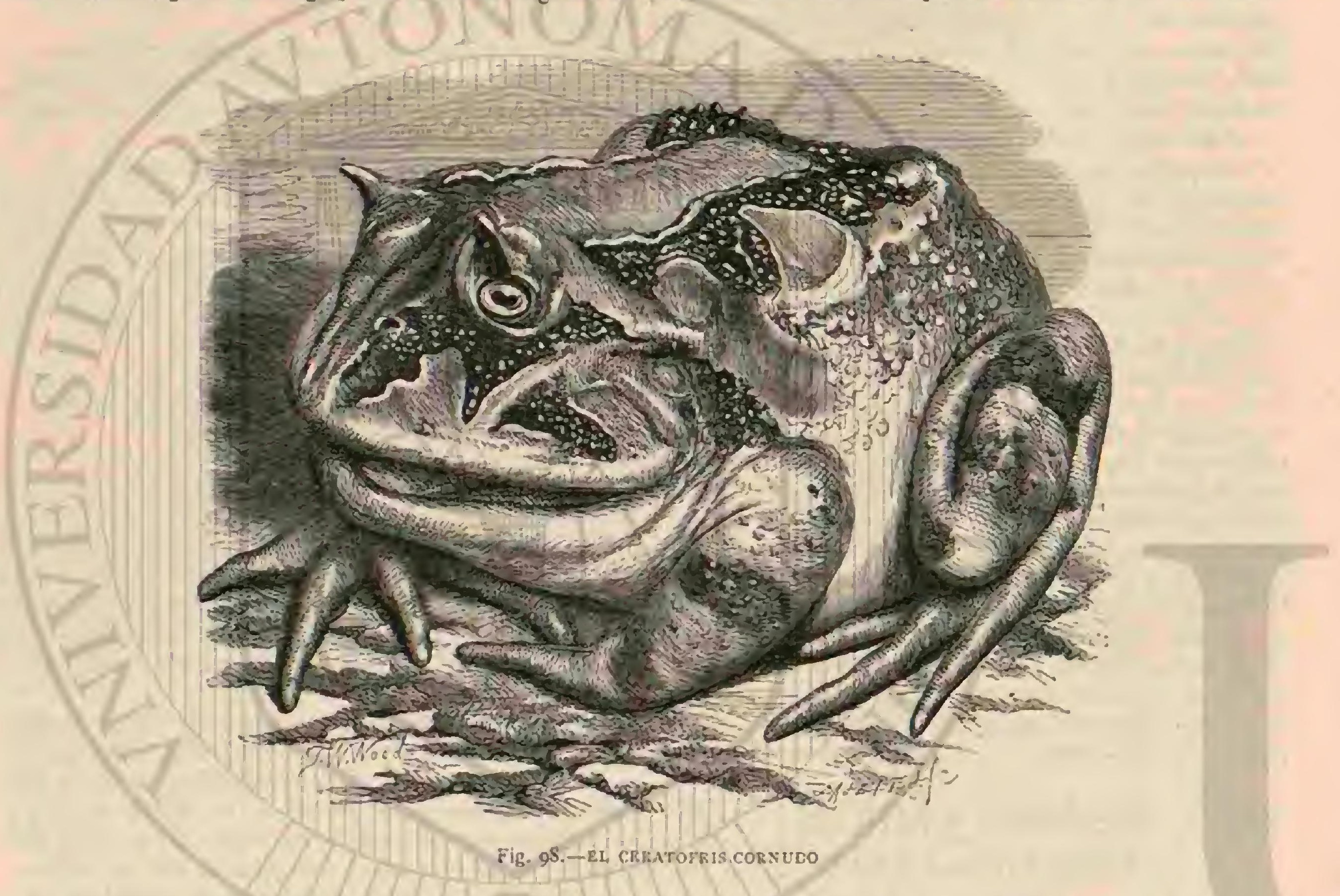

(en la profundidad para ocultarse en el cieno. Aqquel que sin

nal sin compararlas con la vor del campanero, habitante de los estanqques, sin duda porque el canto de este batracio ofendió su oido; pero tal vez ese poeta quiere menos expre. sar su propia opinion que referirse a una antiquísima supersticion del pueblo que con el campanero y su gérero de vida pone en relacion hechos espaniosos y horribles sin saber porqué. Cierto es, no obstante, que á esta especie le agrada fijar su residencia en los parajes mas recónditos de las tur-

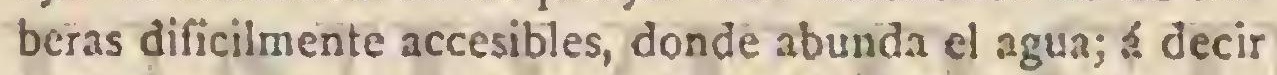
verdad, su voz no es alegre como la de la rana verde, sino melancólica y triste; pero quien se haya tomado la molestia de observar al gracioso batracio con sus bonitos colores, no estará conforme con la aversion que á algunos inspira $y$ nadie que le encuentre en tierra firme, podrá considerar desagradable su voz, muy sonora aunque poco fuerte.

El campanero igneo habita tanto en los pequeños fosos de agua como en los extensos pantanos 6 turberas, tanto en la llanura como en la montaña, hasta una altura de $\mathrm{x}, 500$ metros sobre el nivel del mar. Como verdadero batracio acuá. tico vive casi todo el verano en los charcos, estanques y pan. tanos, y solo en otono vaga temporalmente en tierra firme, donde salta con mucha agilidad con asuda de sus pataspos. teriores, bastante largas. En el agua se le ve por lo regulará cierta distancia de la orilla, asomando en la superficie parte de la cabeza; por la noche deja oir su sencillo canto, y al menor indicio de peligro sumérgese con la rapidez del rayo moverse observara al campanero que ha emprendido asi la fuga, verá como vuelve á salir al poco rato $y$ ocupa el mis. mo sitio para examinar los contornos con sus pequeños ojos dorados. Su canto se ose por lo regular solo durante la tarde y toda la noche, prueba de que tambien este batracio es nocturno; la voz no tiene nada de desagradable, pero puede cansar por su monotonía; cada sonido se podria expresar poco mas $\delta$ menos for $k u-u h$, se parece bastante al que produciria una campana de cristal; es relativamente debil, y solo se oye por lo tanto á pocos pasos de distancia. Cada campanero grita todo lo mas tres ó cuatro veces por minu. to y emite siempre el mismo sonido; pero todos los machos que quieren expresar su alegría gritan al mismo tiempo y asi se forma el continuo concierto que se oyt.

Este anuro se mueve con gran facilidad en el agua aun. que no puede competir en este concepto con la rana verde; pero nada muy bien y sabe niejor aun penetras en el cieno. En tierra firme se mueve apresuradamicrite, dando saltitos cortos, a menudo repetidos. Una ilimitada timidez parece el rasgo mas caracteristico de su sér; solo en caso de necesidad busca agua clara, prefiriendo las superficies cubiertas de lentejas acuáticas, porque cstas le ocultan á la vista mas pe. netrante. El observador que permanece quicto en la orilla puede convencerse de la veracidad de este aserto: engañado por la débil roz, busca al batracio, á menudo mucho tiempo 
en vano, y advierte luego con cierto asombro que delante de El un campanero asoma la cabeza entre las lentejas, quizás en el mismo sitio en que varias veces habia fijado el observador sus miradas. El batracio se sirve de la astucia para ocultarse en los nidos de sus adversarios, y si no puede al canzar á ticmpo el agua, oprimese contra el suelo, cuyo color es análogo al de su piel. Cuando se le inquieta cruza los piés sobre el lonso encorvado, de modo que solo se ven los lados del vientre, y el animal ofrece entonces un aspecto del todo diferente; en tan extraña posicion permanece algunos minu. tos hasta que ha pasado el peligro, y entonces vuelve \& pc. nerse en movimiento. Cuando se le espanta mucho segrega de la cara superior verrugosa de las ancas una espuma semejante a la del jabon, y que asi como la de la mayor parte de sus congeneres, tiene cierta propiedad cáustica.
Su alimento se compone de insectos, caracoles y pequenos gusanos, de modo que figura entre los animales mas útiles.

Hasta el tercer año de su edad el campanero ígneo no es apto para la reproduccion, y entonces se aparea en mayo y junio. El macho coge a la hembra por los costados, fecunda la freza y abandona despues á la hembra sin hacer yaca. so de ella La freza se queda en el fondo del agua 5 se des. arrolla con bastante rapidez; al quinto dia se ve el renacuajo, que al noveno abandona el huevo; fínes de setiembre ó á principios de octubre las piernas están desarrolladas y las branquias y la cola han desaparecido, pero algunos dias antes salen á tierra firme, ó cuando menos á la orilla del agua. Los renacuajos que Gredler puso en un acuario se alimentaban raspando el cieno y las algas de los cristales del depósito,

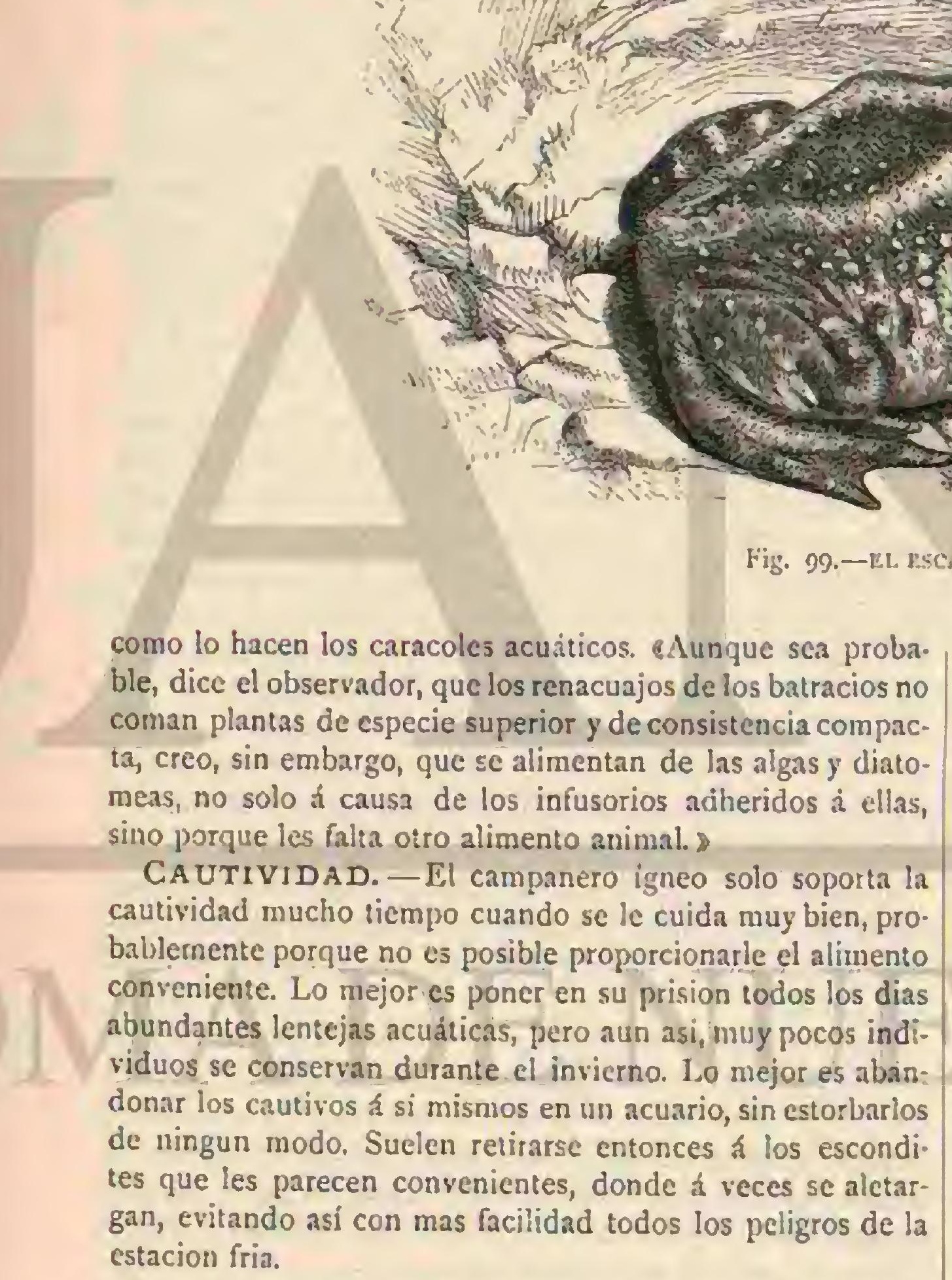
estacion fria.

\section{LOS ESCAFIOPES-SCAPHIOPUS}

CARACTERES.-El géneto designado con este nombre difiere de todos los anteriores por la empalmadura de las manos, cujos cuatro dedos son cortos, deprimidos y sin pro. tuberancias en su cara inferior; los dos primeros y ei último son casi iguales, y el tercero una tercera parte mas largo; no hay restigio de pulgar por fuera; pero se encuentra debajo de la piel, reducido, como se observa por lo regular, al la úlToso $V$ tima falange. Los escafiopes se asemejan á los pelobates por la rugosidad de su region fronial, asi como por la forma de su lengua, que es casi circular y ligeramente escotada en su borde posterior. I os machos tienen debajo de la garganta, aunque interiormente, una vejiga bucal que comunica con la boca por dos grandes aberturas longitudinales, situadas una á la izquierda y otra à la derecha de la lengua. En esta espe. cie, contrariamente a lo que se observa en la mayor parte de los otros raniformes, el párpado inferior es el mas corto y el superior mas largo, de lo cual resulta náturalmente que en el movimiento que hacen no sube el primero sino que baja el segundo. Las fosas temporales no están ocultas debajo de una bóveda huesosa, y las apófisis trasversas de la novena vértebra forman una gran paleta triangular a cada lado de la pélvis.

\section{EL ESCAFIOPE SOLITARIO-SCAPHIOPUS SOLTTARIUS}

CARACTERES. - I a cabeza de esta especic (fig. 99), parecida a la de muchos hileformes, es corta, gruesa, ancha y cortada verticalmente á cada lado por detrás de los ojos, que son granties ! salientes; ra cada lado de la nuca hay una gran glándula porosa, y otras pequeñas en la region próxima al borde posterior de la membrana del timpano. El escafio pe solitario tiene el lomo de color verde amarillento, sembra. do de manchas confluentes de un pardo oscuro con mezcla 
de un tinte rojizo anaranjado; desde la órbita al orificio anal se extienden dos rayas de un amarillo pálido, una á la izquierda y otra it la derecha; el timpano es de un verde amarillento; la garganta blanquizca, lo mismo que el abdómen; los miembros son del mismo color del lomo, solo que las manchas pardas de los posteriores se dilatan en forma de fajas irasversales. El iris presenta un circulo dorado que se divide en cuatro partes por dos líneas de color negro, como el de la pupila. El tamaño de esta especie no pasa de unas a pulgadas (medida inglesa).

DISTRIBUGION GEOGRAFICA. - El área de disper. sion es muy extensa, pues comprende - una gran parte de la América del Norte; Carolina, Georgia y el Teunessee son los Estados donde mas abunda.

USOS, COSTUMBRES X REGMMEN. - El escafiope solitario no frecuenta las aguas ni se aproxima á ellas sino en la época de la reproduccion; fuera de este período se al. berga en agujeros de cinco it seis pulgadas. de profundidad, que practica con el auxilio de sus espolones cortantes; los cuales hacen el oficio de azadas, y de sus piernas, que le sir. ven como de palas. A nenos de prolongarse la lluvia, apenas sale de su tetiro hasta la tarde, pues pasa todo el dia acechando á los insectos para devorar á los que se acercan imprudentemente á su guarida. Este reptil salta poco, y por lo general no son sus movimientos mus vivaces. Sucle dejarse ver én el mes de marzo, despues de las copiosas lluvias de la primarera; y entonces se buscan inmediatamente los dos sexos.

\section{LOS BUFONIDOS-BUFO- NID死}

Ninguna familia de animales la tenido que-sufrir tanto como esta desde la antiguiedad basta hoy dia por la aversion general que el hombre les tiene; ninguna ha sido perseguida con tanto encarnizamiento y $\tan \sin$ razon como la de los bufónidos 6 sapos.

- Este batracio, dice Gessner, de una especie la mas co. mun de la familia, es un animal en extremo frio $y$ húmedo, del todo venenoso, sumamente feo y del todo dañino, Cuando se toca este animal, irrítase de tal modo que se orina sobure el hombre ó le envenena con su aliento; las partes de la piel tocadas por su orina se pudren, y la cura es muy dificultosa; mientras que la introducida en el cuerpo produce efectos mortales. La mirada de este animal es peligrosa, tanto que hace palidecer al hombre y le pone en peligro. Envenena tambien la yerba, y las hojas que come 6 las que toca. Una vez un fraile llevó ásu celda unos hacecillos de juncos, en. tre los cuales se hallaba un sapo; extendiólos en el suclo, y cuando hubo comido se echó encima para descansar y dor. mir. Poco despues salió el sapo, púsose sobre ia boca del fraile, agarróse con las patas anteriores al labio superior, $y$ con las posteriores al inferior. Arrancar el sapo hubiera pro. ducido la muerte del hombre, pero dejarle era peor que la muerte misma. Entonces dieronalgunos el consejo de llevar al fraile á la ventana, donde una gran araña tenia su tela; hizose asi, y tan luego como el insecto vió al batracio, bajó por un hilo, colocóse sobre el sapo y le picó, lo cual hizo que el repiil se dilatara, pero sin soltar su presa. A la segundá picada de la araña el sapo se hinchó mas aun, aunque tampoco se le obligó á soltar al fraile; $y$ solo cuando la araña le picó por tercera vez, cayó y murió. Tal fué el beneficio que la arana hizo al dueño de su casa. Sucede tambien á veces que los hombres beben en el agua huevos de sapos $y$ ranas sin saberlo; estos huevos se desarrollan despues en el estó- mago y conviértense en animales que ocasionan crueles tormentos; para la cura es preciso extraerlos con fuertes me. dicinas, de modo que se arrojen por vómitos ó en los excre. mentos.

No se comprende cómo hombres razonables han podido escribir semejantes absurdos, y menos aun podemos explicarnos el porqué aun hoy dia hay miles de personas dema. siado inclinadas á creer tales necedades, pues la actividad nocturna de los sapos, comparada con la de las ranas, no puede ser la razon de que estos animales inofensivos y en extremo útiles sean calumniados de continuo. $Y$ á pesar de todo, no puede negarse un hecho, cual es que todos los hombres, los llamados instruidos y los ignorantes, los euroDeos y los americanos, los blancos, los negros y los de raza amarilla, profesan igual aversion á los sapos, y con ciego furor los persiguen y los matan. Ninguno de los que con cierto orgullo presume de sabio, se ha tomado jamás el tra. bajo de reflexionar sobre las fábulas que circulan; ninguno ha observado cl sapo ni su género de vida; ninguno ha leido $\delta$ por lo menos comprendido una buena historia natural, pues de lo contrario necesariamente se habria instruido. Precisamente los sapos son un ejemplo evidente del valor de nuestra decantada instruccion moderna y sobre todo de los conocimientos que tenemos de la naturaleza y de sus productos; los sapos nos, demuestran cómo se enseña en nuestras escuelas la mas importante de todas las ciencias.

CARACTERES. - Los bufónidos se distinguen de los anuros hasta ahora descritos por la falta de dientes, por te. ner las formas recogidas y pesadas, patas gruesas y despro. porcionadas, casi iguales en longitud, y la piel muy glandulosa cubierta de verrugas en su parte cxterior.

DISTRIBUCION GEOGRÁFICA. - Habitan todos los continentes excepto el de Australia.

USOS, COSTUMBRES Y RÉGIMEN.-LOS sapos son en las regiones cálidas mas numerosos que en las frias; viven en el agua solo en el periodo del celo y son animales noctúmos que rara vez abandonan sus escondites. Por sus mo. vimientos son inferiores a las ranas y à los campaneros, pues casi se arrastran por el suelo en vez de saltar; nadan mal y parecen por consiguiente pesados y perezosos, aunque en rigor no son ni lo uno ni lo otro. Su alimento se compo. ne de parásitos de varias clases, sobre todo gusanos, caracoles, insectos y pequeños vertebrados; con estos últimos solo se atreven las especies grandes. Necesitan mucho alimento y son por lo tanto en extremo útiles para nosotros.

El apareamiento y el desarrollo de los hijuelos se efectua como en sus congéneres, pero la hembra no deposita los huevos en masa, sino en cordones que el macho fecunda uno por uno.

Asi como otros batracios, los bufónidos pueden pasar mucho tienpo sin humedad, mientras que en los espacios que la tienen se conservan tambien con un alimento escaso. A menudo se encontraron sapos vivos en cavidades que al parecer no tenian entrada, y este hecho ha dado lugar á muchas fábulas, pero tambien se han practicado experimentos cuyo resultado no se esperaba.

En noviembre de 1825 . Buckland, de Oxford, hizo prac. ticar en un fragmento de piedra caliza doce cavidades redon. das de trece centímetros de diámetro por un metro de profun. didad; en su borde se abrió un surco circular, en el que en. cajaban un cristal $y$ un disco de pizarra; los bordes se cubrieron con barro, y formóse asi una tapa impermeable, que tampoco dejaba penetrar el aire. En otro fragmento de pie. dra compacta y arenosa se abrieron tambien doce celdillas de solo quince centimetros de profundidad, cubriéndolas del mismo modo. Las tapas de cristal tenian por objeto per. 
mitir la observacion de los animales sin que el alinento pudiera introducirse en su prision. El 24 de noviembre se puso en cada una de las veinticuatro celdillas un sapo vivo, cerrándose despues con las tapas; las dos piedras se colocaron á un metro de profundidad de la superficie del suelo, cubrién dolas con tierra, y examináronse por primera vez el to de diciembre del año siguiente. En las celdillas de la piedra arenosa muy compacta todos los sapos estaban muertos, y los mas en tal estado de descomposicion, que debia suponer. se que hacia meses que habian perecido; cn las celdillas de la piedra caliza porosa los mas de los sapos vivian, y mien. tras algunos habian perdido en peso, en otros era este ma yor, particularmente en uno. In tapa de cristal de la celdilla de cste último estaba un poco rota, y por lo tanto existia la posibilidad de que se hubieran introducido peque. ños insectos; no se encontraron en la celdilla indicada, pero si en otra cuya tapa de cristal cstaba del todo rota y cuyo habitante habia muerto. Al cabo de trece meses todos los sapos sucumbieron tanto los encerrados en la pic. dra caliza como los de la piedra compacta. Despues del primer exámen se les observó repetidas veces sin levantar la tapa de vidrio: parecian siempre alegres, $\delta$ por lo menos tenian los ojos abiertos, pero enflaqueciendo mas y mas, murieron al fin por consuncion. Poco mas 6 menos al mis mo tiempo pusiéronse cuatro sapos en tres agujeros abiertos en el lado septentrional de un manzano, agujeros de doce centimetros de profundidad por doce de ancho, los cuales se cerraron despues con una cuña tan cuidadosamen. te, que ni el aire ni los insectos podian penetrar: al exami. nar estos mártires de la ciencia al cabo de un año, todos es. taban muertos y en estado de descomposicion.

De estos experimentos resulta que la resistencia vital de los sapos no es tan grande como se creia, y que ninguno de cstos animales puede vivir muchos años en un espacio cerrado y sin aire, ni pasar dos sin alimento alguno; tambien prueban que al encontrar sapos en cavidades pedregosas no se averiguaron con bastante cuidado las circunstancias, y que todo cuanto se dice sobre sapos que a mucha profundidad vivicron siglos enteros encerrados en cavidades de piedra, no es mas que pura fábula.

\section{LOS BUFOS-BUFO}

Ia familia se divide en bastantes sub-familias y géneros, inas para nosotros será suficiente ocuparnos tan solo de las especies mas importantes.

CARACTÉRES. - Los de este género consisten en iener las membranas natatorias menos desarrolladas en los pies posteriores.

\section{EL SAPO VULGAR-BUFO VULGARIS}

CARACTERES. - El sapo vulgar, tipo del género de los bufos y adenás de un sub-género (Phrine), puede alcanzar bastante tamaño, es decir de $0^{m}, 08$ á $0^{n}, 12$ de longitud por $0^{\circ}, 0630^{\circ}, 07$ de ancho, y sus formas parecen mas pesadas aun que las de las especies congenéricas. Todo cl cuerpo está cubierto de gruesas verrugas, que dejan descubicrta una glándula detrás de las orejas; las regiones superiores son de un color gris rojo $\delta$ pardo rojo opaco, que á veces tira al verde de aceite ó al negro, con manchas oscuras poco marcadas; las inferiores son de un gris muy claro con manchas mas oscuras en la hembra. El iris es de un rojo brillante de naranja (íg. 100).

DISTRIBUCION GEOGRÁFICA.-Excepto los paises mas septentrionales, el sapo no falta en ningun punto de
Europa, hallándose diseminado tambien por el Asia Central y el Japon.

USOS, COSTUMBRES X RÉGXMEN. - Las viviendas del sapo son tan diversas, que podemos decir que este ba. tracio se halla en todas partes. Vive en los bosques, en las espesuras y cercas, en los campos, praderas y jardines, en las bodegas, cuevas y grietas, cn muros ruinosos y montones de piedras, debajo de los árboles; y en una palabra, donde quicra que haya escondite $\delta$ pueda practicarlo, pues alli donde faltan los escondrijos abre agujeros mas $\delta$ menos jrc. fundos en ierra, ocultándose en ellos como el zorro en su guarida. Siempre que le es posible elige los sitios húnedos y frondosos, por lo cual se le halla con mucha frecuencia debajo de plantas cuyas anchas hojas no solamente prestan sombra, sino que le cubren completamente. Manifiesta gran predileccion por las yerbas de olor fuerte, tales como la sal. via y la cicuta, á las que probablementc debc tambien parte de su mala fama.

Como verdadcro animal nocturno oculltase siempre de dia, á no ser que alguna lluvia acabe de humedecer el suelo, y las nubes cubran el sol que tanto le molesta. En tales circunstancias sale tambien de dia en busca de su alimento, aunque rara ver; su vida activa no comienza hasta bastante tiempo despues de la puesta del sol. Torpe en sus movimientos, apenas es capaz. de ejecutar grandes saltos; es pesado y evita largos viajes; en cambio examina del modo mas minucioso su pequeño dominio, y es por lo tanto una ver. dadera bendicion para los sitios en que habita, porque consunie mucho alimento. Por efecto de su torpeza, á menudo cae en los sóianos, pozos, minas y cuevas de los que entonces no hay fuga posible para él, debiendo contentarse alli con la escasa presa que á su vez cae casualmente en la profundidad. A pesar de esto, puede vivir mucho tiempo, y hasta engorda verdaderamente. Así, por ejemplo, Erber halló en Dalmacia, cuando visitaba las cuevas, à una profundidad de noventa brazas 6 mas, varios sapos vulgares muy grandes y siempre bien alimentados; circunstancia inexplicable atendida la gran voracidad que estos animales manifiestan cuando es. tín cautivos, porque en muy pocas cuevas se suelen encontrar insectos.

Su alimento consiste, scgun Fothergill, en pequeños gusanos, avispas, abejas, arañas y colébicros, y en general en toda especie de insectos, excepto las mariposas, que al parecer no le gustan, porque el pólen.de sus alas se adhiere á su lengua mucosa, dificultando la deglucion. A pesar de su v'n. racidad desprecia los animales nuertos. Se ha hecho un experimento para ver si el hambre le haria cambiar su costunbre:-á este fin se cncerró un gran sapo en un tiesto, poniendo en 41 cierto númcro de abejas recien muertas; pero al cabo de scis 6 sicte dias no habia tocado ninguna, mientras que cogia al punto los insectos vivos de esta especie, devurándo los al parecer sin diticultad, aunque segun las observaciones de Bell, el sapo hace movimientos convulsivos cuando recibe un pinchazo en el estómago 6 en el esórago.

Es fácil observar cómo el sapo coge su presa, porque aun de dia no deja pasar ningun animal que pueda servirle de alimento, sino que se precipita sobre todos cuantos se ponen s. su alcance $y$ hasta les persigue en un corto trecho. Sus ojos, muy movibles, divisan en la sombra todos los animali. tos, por cualquier lado que se acerquen, y la lengua se lanza tan rápidamente, que raras veces pueden escaparse. El que presente à un sapo oculto, sin molestarle, un gusano, una oruga ú otro insecto, podrá reconocer toda su actividad. Al punto comienzan á brillar sus ojos; el animal despierta de su aparente soliolencia, y se dirige con una rapidez no acostumbrada sobre su presa. Al llegar á cierta distancia se para, 
fija sus miradas en la victima, saca la lengua, coge con ella el insecto, introdúccle en la boca y lo devora al instante. Si el bocado es muy voluminoso ó largo, como por ejemplo, cuando coge una lombriz y esta sobresale de la boca, haccla enirar, segun observó Sterki, dándola un rápido y seguro golpe con una pata anterior. El insecto desaparece al punto y el sapo toma inmediatamente su posicion de acecho, exa minando de nuevo los alrededores. Cuando no acierta á co. ger la victima, come sucede bastante á menudo, ó solamente la aturde de un golpe de su lengua, en vez de perseguirla suele dejarla huir, aunque vuelve contra ella apenas el insecto se mueve mucho; 2 veces saca la lengua dos 6 tres reces para coger la presa.

Este batracio devora una infinidad increible de toda clase de parásitos: además de los ya dichos, parecen agradarle las babosas; persigue lambien los pequeños reptiles y batracios, y segun afirmán algunos observadores, hasta los hijuelos de su misma especic, aunque por to regular vive en buena ar. monia con sus semejantes. No se excita de ninguna manera ni disputa con otro individuo de su especie, coítio lo prueba el siguiente relato. Para observar á un sapo, cuya vivienda se conocia, cuando cazaba inscctos, púsosé una hoja cubierta de miel a la entrada de su escondite: Is mid atrajo pron. to gran número de moscas y avispas que fueron devoradas por el habitante de la cueva; y como una ver llegase otro sapo para zomar parte en el festin, echáronse muchos insectos en medio de ambos, llamando asi su aterion al mismo tiempo. Entonces sucedió que los dos persiguieron á un mismo insecto, sin que nunca mostrase enojo el ménos aforturiado. En general, nunca se ha visto s. dos sapos disputar. Esta indiferencia, que tambien podria llamarse estupidez, es comiun á muchos pero no á todos los sapos: su conducta dependic del estómigo. Siempre procuran devorar una presa que se aproxima, y lo hacen cuando pueden, mas por su par. te, no la buscan; porque en este batracio no existe la inteligencia ó apenas se reconoce Sin embargo, no puede decirse que carezcan de toda aclividad intelectual; distinguen entre los diversos séres con que se ponen en contacto $y$ adaptan sus costumbres á las condiciones en que se hallan. Mas que otros batracios huyen de todo animal, y conociendo su debi. lidad, no se atreven a resistirse contra un enemigo fuerte; tambien comprenden los beneficios que se les hacen y pier den poco à poco todo temor á la persona que les trata con carino. Bell domesticó un sapo de tal modo, que tranquilamentc se colocaba sobre una mano, aceptando las moscas que se le ofrecian con la otra.

Varios aficionados á estos animales tan despreciados acos. tumbraron of sus cautivos a presentarse cuando se les llamaba para recibir su alimento. Fothergill llega hasta creer que los sapos domesticados pueden distinguir á su amo y â su fami. lia de las personas extrañas. Cierto dia, al levantar casual. mente una maceta de la cual faltaba un pedazo, advirtió que servia de escondite á un sapo, y como le ocurriera observar. le, empezó á darle insectos, acostumbrándole pronto de tal modo å su persona, que sin ningun temoracudia cuando le lla. maba para darle alimento. Por la noche abandonaba su escondrijo é iba á pasear en el jardin, volviendo reguiarnuente á la maceta por la mañana. Esto duró semanas enteras hasta que cierto dia unos huéspedes de fothergill desearon ver cómo se alimentaba el sapo. El animal manifestó mucha timidez e inquietud al ver gente desconocida, abandonó por la soche su vivienda y no se le vió ya en todo el año. El ve rano siguiente volvió el mismo individuo, $\delta$ cuando menos otro muy semejante, colocóse debajo de la maceta, y se le alimentó como antes muy cuidadosamente. lin lo sucesivo presentábase siempre á primeros de mayo y desaparecia ś mediados de seticmbre Así manifestó marcadamente que coniaba en su guardian, pues ademis permitia que este le acariciase 6 tocara con un bastoncito, sin ocultarse, como lo bracen otros sapos en casos análogos.

Cunndo se le encierra en una prision mas reducida domes. ticase aun mas pronto y en mas alto grado que cuando se le deja correr por el jardin. No es dificil mantenerle, pues no desprecia ninguno de los pequeños animales que se le ofre. cen, con tal que se muevan, y por otra parte puede ayunar sin que esto le perjudique. Vive en perfecta armonía con sus congéneres de la misma y de otras especies.

El sapo pasa el invierno léjos del agua en cavidades subterrineas: ocúltase á fines de setiembre ó principios de octu. bre en guaridas que encuentra, ó practicadas por el, cuya entrada tapa con tierra para preservarse del frio, mientras yace en su letargo, que dura hasta marzo ó abril. Penetra en el sticlo con ay'uda de las patas posteriores y salc del mismo modo, impulsado segun parece por el instinto de la repro duccion, pues antes de llegar ála superficie comienza á gritar. Tan luego como ba abandonado su residencia de invierno sc aparea, para lo cual se introduce en el agua mas próxima, contentándose hasta con el mas pequeño charco. El deseo de aparearse se denuestra desde luego por unos gritos des. agradables que los machos emiten dia y noche; mientras tanto cada cual elige una hembra, si la encuentra, y la coge del inodo acostumbrado entre los anuros, pero con tal vigor que los dedos penetran verdaderamente en la piel, $y$ la suje. ta, segun aseguran observadores fidedignos, hasta que empie. za la puesta. A filta de una hembra de su especie, colócase como la rana verde, sobre otros animales, sobre todo peces. a los cuales puede ahogar, como 'Toerster observó en sus pe. ces dorados.

La reez sale en dos cordones de los que cada cual se forma en un ovario; pero la puesta se efectua ś intervalos, y el macho fecunda por lo tanto siempre una parte del cor. don despues de otra. Cuando ha salido una, macho y hem. bra tomán la posicion mas cómoda, clevándose á la super. ficic delagua para descansar; despues vuclven ambos it la profundidad para continuar la operacion, que se repite ocho $\delta$ diez veces, pero luego que el último huevo ha salido, el macho abandona á la hembra y ambos salen á tierra firme. Los cordones de huevos tienen el grueso de un tallo de paja, miden $1 ", 50$ de longitud y contienen muchos centenares de huevos. Durante el apareamiento, los padres los fijan en plantas acuáticas, sujetíndolos en la profundidad. A los dos ó tres dias aumentan mucho en tamaño; álos 170 is los renacuajos salen de los huevos, a los veinte tambien de la sustancia urucosa. Desde este momento su desarrollo se ve. rifica del modo regular, hasta que á fines de junio se desarrollan las patas y los hijuelos hacen la vida de sus padres. Crecen muy lentamente, aunque tambien son susceptibles de reproducirse á los cinco años. Resel supone que pueden llegar álos quince de edad, pero en los individuos cautivos se ha observado que vivieron mucho mas tiempo. Así, por ejemplo, Pennant habla de un individuo que se conservó treinta y seis en cautividad y que aun hubiera vivido mas tiempo si no hubiese muerto por un accidente casual.

La larga vida del sapo se atribuye, asi como la conservá. cion de su especie, a sus pocos enemigos, álos cuales aleja la secreción de sus gltíndulas; pero la reproduccion es relatiramente escasa, pues por el descuido de los padres perecen á inenudo miles de renacuajos cuando se agotan las aguas. El peor de todos los enemigos es el hombre, preocuplado y san. guinario, que precisamente persigue á los sapos adultos prepios para la reproduccion, lo cusl dice poco en favor de su instrucciony sensater, pues con ello se perjudica á si mismo. 
Para dessanecer el supersticioso afan de cxterminio de los enemigos del sapo debe hacérseles notar que este batra. cio solo coge las abejas que le introducen por decirlo asi cn la boca, mientras que en sus expediciones nocturnas ni tan solo encuentra insectos útiles y por lo tanto no puede causar daño. Ja absurda preocupacion de que arroja veneno al vaciar su llamada regija; la opinion de que la sustancia mucosa de sus glándulas puede envenenar; la creencia de que visitan las cuadras para chupar las mamas de las vacas ó $\mathrm{ca}$. bras, son otras tantas calumnias que no pueden servir de pretexto para exterminar el sapo; los experimentos mas cuidadosos han demostrado que el sapo no arroja veneno, que la secrecion glandulosa aplicada á la piel escuece, pero no es peligrosa; en una palabra, que este anuro ro puede hacernos daño de ninguna manera. I.os jardineros ingleses, mas razo. nables que los nuestros, han reconocido hace tiempo la gran utilidad de estos animales incansables, que exterminan toda clase de parásitos dañinos, y compran anualmente muchas docenas de estos batracios para hacerles trabajar en sus jardines. Sus colegas alemanes quizás llegarản á comprender lo mismo y e5 de esperar que algun maestro de escucla encuentre el tiempo necesario para hacer entender á sus disci. pulos la utilidad de estos animales, contribujendo asi á des. terrar la supersticion de que son objeto los sapos.

\section{LOS DENDROBATES-DENDRO- BATES}

CARACTERES.-Ios dendrobates son, con los hile. dáctilos, los únicos batracios de esta familia, que así como

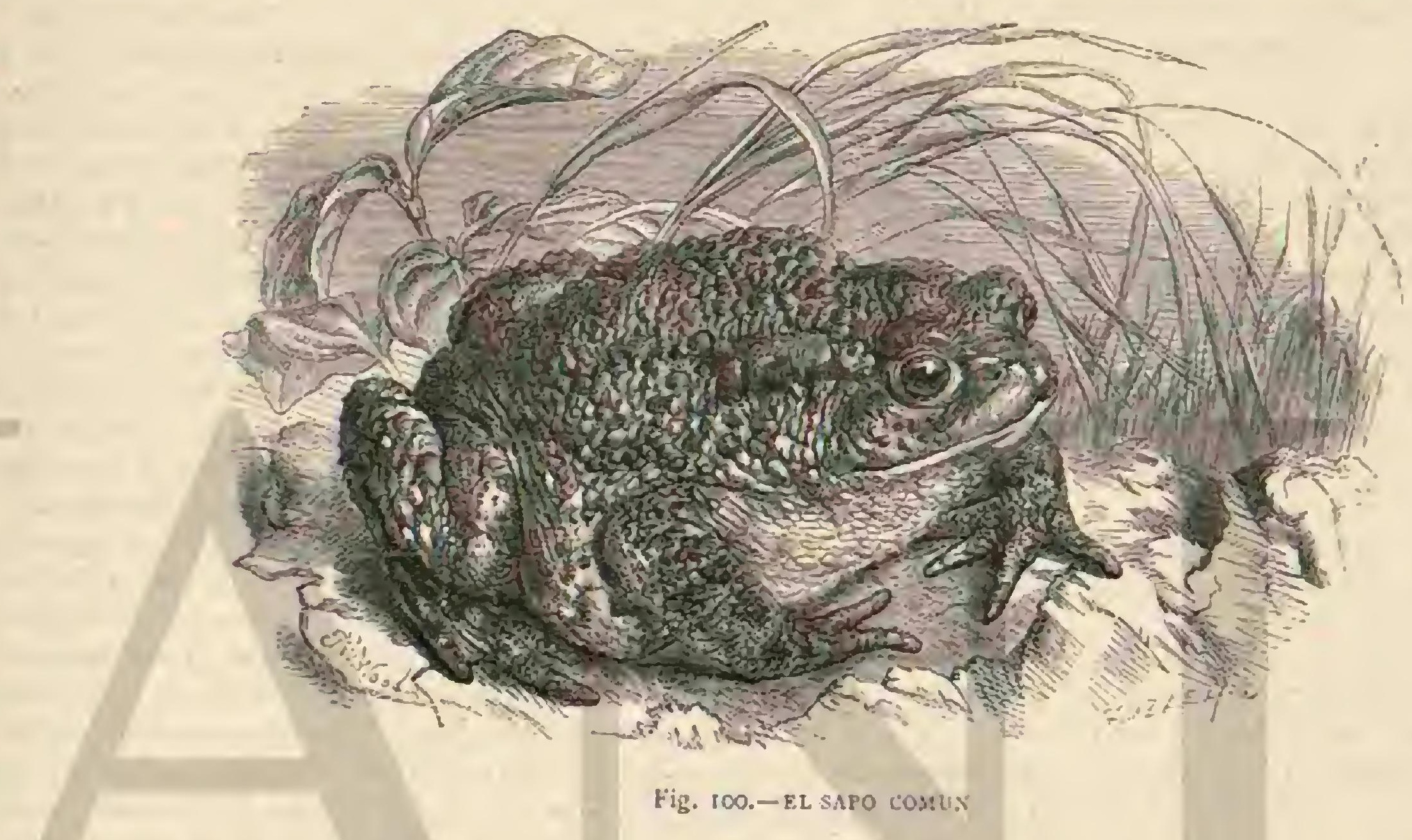

los hileformes, tienen un ensanchamiento en la extremidad libre de todos sus dedos; ni las patas antcriores ni las poste riores presentan el menor rudimento de membranas natatorias; los dedos de las manos y de los piés son endebles, an gostos y ligeramente deprimidos; la lengua parece una cinta oblonga, mas ó merios gruesa, redondeada, entera en sus dos extremidades $y$ libre en la segunda porcion de su longitud. El paladar es liso, sin surco longitudinal á cada lado del esfenoides. En los machos se observa á cada lado de la lengua una abertura que da cntrada al aire destinado $a$ infiar la vec. jiga bucal contenida en la garganta, cuya piel no forma sin embargo pliegues, lo cual indica que este órgano productor de la roz no es susceptible de una gran dilatacion. Los miembros, medianamente prolongados, son por lo general bastante fuertes; la cabeza y el tronco se confunden entre sí; los ojos son grandes y no forman protuberancias visibles sc. bre el cráneco. Las regiones jectoral y abdominal no están cubicrtas de glándulas granuliformes, ni se ven tampoco en los lados del cuello esas prominencias llamadas impropia. mente parótidas que tienén los mas de los batracios cuya boca carece por completo de dientes.

\section{EL DENDROBATE OSCURO - DENDROBATES OBSCURUS}

CARACTÉRÉS. - Además de los atributos indicados para el género, esta especie (fig. IOß) se caracteriza por te- ner un ligero cordon glanduloso á cada lado del lomo, cubierta la superficie de este y la cabeza de pequeñas verru. gas; los ensanchamientos digitales son muy pequeños y los micmbros delgados. Todo el cuerpo de este batracio tiene un fondo pardo oscuro, con un ligero tinte blanquizco en los cordones glandulosos que se exticnden á lo largo del lomo. El dendrobate oscuro tiene cerca de dos pulgadas de largo (medida inglesa).

DISTRIBUCION GEOGRÁFICA.-No se sabeá. pun. to fijo cuál es la patria de este reptil; pero segun aseguran, se le encuentra en el Africa del sur y en las inmediaciones del Cabo.

USOS, COSTUMBRES Y REGIMEN.-Este batracio suele vivir en los troncos de los árboles huecos ó en algun agujero próximo, á juzgar por lo dice Mr. Smith en el siguiente párafo del relato de uno de sus viajes: Cierto dia, hallándome.en las orillas del Limpopo, rio proximo al trópico de Capricornio, fué preciso contar un árbol sa fin de re. parar las averias de nuestro barco. El hombre encargado de la operacion comenzó \& ascrar el tronco longitudinalmente, pero al llegar al centro notó que estaba hueco; y ya se disponia á ir en busca de otro, cuando á instancias mias, pro. siguió su trabajo, para ver si se podria aprovechar de algun modo. A los pocos minutos observó que habia un agujero grande, $y$ al examinarlo, vióse que contenia cinco reptiles de la especie descrita. Entonces registré el tronco por todas partes â fin de ver si existia comunicacion alguna exterior 
con la cavidad; mas no pude encontrar ninguna; la superfi. cie interior de aquella habia adquirido un color negruz $\mathrm{CO}_{\text {, }}$ lo mismo que toda la madera próxima. Al ser descubiertos aquellos batracios, parecian inanimados; pero la influencia del calor del sol les devolvió el movimiento, $y$ a las pocas horas manifestaron cierta actividad para trasladarse de un punto a otro.s

\section{LOS SAPOS PROPIAMENTE DI- CHOS-BUFO}

CARACTERES. - El carácier principal de éste subgénero es la carencia de membranas interdigitales en las patas posteriores.

\section{EL SAPO DE LOS PANTANOS - BUFO
CALANUTA}

CARACTERES - ES un animal de $0^{\circ}, 06\left\{0^{\circ}, 07\right.$ de largo, con las partes superiores de un verde aceituna, ex cepto una faja de un amarillo claro que se corre por el cen tro del lomo y carece de verrugas; las partes inferiores son de un gris blanquizco con manchas mas oscuras en los muslos y en los lados del vientre. I as verrugas son rojizas con pun tos blancos en el centro, y los ojos de un gris verdoso; el primero y segundo dedo de las patas tienen poco mas 6 menos la misina longitud; las glándulas auriculares son muy grandes, ovales y aplanadas, y las de los muslos se marcan mucho.

\section{EL SAPO VARIABLE-BUFO VARIABILIS}

CARACTERES.-Esta especic, muy afine de la anterior, tiene las tegiones superiores de un blanco gris con grandes manchas verdes, y las inferiores blancas con manchas verdes mas pequeñas; caracterizase además por tener las glándulas auriculares en forma de rinones y por la longitud del dedo anterior que es mucho mas largo que el se gundo. Los individuos europeos se distinguen por tener los colores mas vivos que los de/Alemania; las manchas mas marcadas y orilladas por lo regular de un borde oscuro, de modo que el sapo variable aleman viene a ser solo una pobre imitacion de los de la Europa del sur.

DISTRIBUCION GEOGRAFICA.- El sapo rariable solo se encuentra en algunas partes de Europa y falta del todo en ciertas regiones; el sapo de los pantanos, en cam. bio, se ha observado no solo en todos los paises donde vive el sapo vulgar, sino tambien en el norte de Africa, extendien. dose por lo tanto en tres continentes. Segun dicen Lessona y Salvadori, la primera de estas especies no pasa del territorio de los Aipes, mientras que la segunda es comun en toda la Italia y quizás la única que se encuentra en la isla de Cerdeña. Gredler no encontró en el sur del 'Tirol mas que el sapo rariable; nunca el de los panianos.

USOS, COSTUMBRES Y REGIMEN.-Despues de lo dicho sobre el sapo vulgar, poco tendre que anadir sobre los usos y costumbres del sapo variable, pues las dos espe. cies se asemejan casi por todos los conceptos, aunque se nota que la segunda es mas ágil, alegre y vivaz qué la primera; de dia se ocultan tambien, á menudo en sociedad en agujeros convenientes, mientras que de noche vagan por un territorio bastante extenso. Corren mas bien que brincan, aunque pueden dar saitos relativamente grandes. Asimismo saben trepar, cuando menos el sapo de los pantanos, con bastante destreza. Esta última especie habita con preferen. cia en las grietas de los muros y de las rocas, aunque estén situadas á un metro ó mas de altura del suelo, en una pared vertical. Para llegar á la entrada, inaccesible para el sapo vulgar, se agarra con los dedos á las hendiduras de las piedras, y oprimiendo el vientre pegajoso y húmedo contra la superficie, trepa con lentitud, pero con seguridad, hasta su vivienda. Rasel cree, y sin duda con razon, que trepa como los hilas, valiéndose de la presion del aire. La observacion de Gredler de que el sapo variable no trepa nunca, es una prueba de que este anuro y el sapo de los pantanos son es. pecies distintas.

Al ver un enemigo el sapo de los pantanos intenta huir con la mayor rapidez posible, pero cuando se le alcanza é inquicta recoge de tal modo su piel que todas las glándulas se vacian cubriendo al animal de una sustancia blanca y es. pumosa de un olor f́tido. Roesel le compara con el de la pólvora quemada, Dumeril con el de una pipa de tabaco usada múcho tiempo ó con el del arsénico azufrado: de todos modos el hedor de este sapo es muy particular 6 insoportable. No cabe duda que esta secrecion es la mejor defensa de nuestro animal, pues con ella goza de una seguridad que no tienen sus congéneres. Asi, por ejemplo, no creo que el buro serpentario coma sapos, aunque segun Gredler, una rapaz cautiva de esta especie preferia el sapo variable a toda otra carne. Hasta muy tarde, es decir, al mismo tiempo que la rana verde, no comienza el. sapo de los pantanos la reproduccion. Ambos sexos se presentan \& fine de mayo ó principios de junio en las aguas cubiertas de plantas, y de poca profun. didad, i lo largo de las orillas, donde permanecen varios dias haciendo mucho ruido, porque los machos dejan oir dic continuo su roz, semejante a la del hila arboricola y comparable a las sílabas krak, krak, krak. Cuando se acerca un hombre ó un mamírero grande, todos los individuos que advierten su presencia guardán al punio silencio; pero hay algunos tan excitados que aun siguen cantando cuando ya se les tiene cautivos en la mano. Los embriones se desarrollan rápida. mente, y al quinto dia muévense los renacuajos, que al cabo de seis ú ocho dias abandonan los huevos. A las siete sema. nas quedan formadas las patas posteriores, un mes mas tarde desaparece la cola, y los renacuajos salen átierra firme; \$los cuatro ó cinco años son propios para la reproduccion aunque siguen creciendo $y$ llegan probablemente ś mucha edad.

USOS Y PRODUCTOS.-Respecto a la utilidad, el sapo de los pantanos iguala á sus congéneres y merece por lo tan. to lo mismo que estos la proteccion de todo hombre razo. nable.

\section{LOS DOCIDOFRINES - DOCIDO- PHRYINE}

CARACTERES. - Aun los mayores sapos pulgares que se encuentran en algunas partes y sobre todo en la Europa meridional, nos parecen pequeños en comparacion con algunas especies cxóticas que con razon pueden llamarse sapos gigantes. Su tamaño ha dado lugar â que algunos naturalis. tas los agrupen en un género independiente, pero como sus caractéres son del todo análogos álos de los sapos propiamente dichos, la separacion de ambos grupos no parece jus. tificada.

\section{EL SAPO AGUA-BUFO AQUA}

CARACTERES. - Esta especie, el mas grande de todos los anuros hasta ahora descritos, es un batracio superior en tamaño á muchas tortugas y que puede alcanzar una longitud de $0^{\circ}, 200$ mas, por $11^{\circ}, 12$ de ancho. El color es un ama. 
rillo gris azufrado; las regiones superiores tienen grandes manchas parduscas ó de un negro de hollin, y en lasinferiores hay otras pequeñas de un pardo gris rojizo; las puntas de los dedos son de un pardo negruzco, y unas líneas prominen. tes que se corren desde el ojo \& la nariz, de un pardo rojizo. Inmediatamente despues de la muda los colores del animal, antes fios, son entonces agradables; mas tarde se vuelven opacos y sucios. En el macho, las verrugas de las regiones superiores del cuerpo y de la cara exterior de las extremida des presentan numerosas puntitas cómeas que faltan en la hembra.

DISTRIBUCION GEOGRÁ FICA.-El sapo agua, llamado tambien aga, es propio de todos los paises y de la ma yor parte de las islas de la América central y meridional.

Dumeril le recibió de Buenos Aires, del Brasil, de la Gua yana y de la Martinica; otros naturalistas le vieron en Vene. zucla, Costa-Rica, etc.

USOS, COSTUMBRES Y REGIMEN. - Segun las ob servaciones del principe de Wied y de Schomburgk, el aga se oculta de dia en sus escondites; pero tan luego como se siente el fresco de la noche abandona su albergue, apare ciendo entonces en número tan asombroso que, segun el principe, \& menudo el suelo queda cubierto de estos animales. Abunda sobre todo, al decir de Schomburgk, en Geor getown, capital de la Guayana inglesa; todas las noches se le encuentra alli en medio de las calles, $y$ hasta parece que escasea fuera de las ciudades $y$ en los pueblos. En la esta cion lluviosa visita, como nuestro sapo, el interior de las habitaciones. Con los repugnantes gekos, dice Schomburgh, presentáronse tambien numerosos sapos. Aunque de dia se ocuitaban en los rincones mas oscuros de la choza, formando verdaderas guaridas debajo de los muchos cajones, comenzaban sus cacerias al cerrar la noche; si se pisa entonces invo. luntariamente uno de estos animales lanza un grito de dolor que al principio atemoriza.

- Es singular que estos desagradables huéspedes se sitúen casi siempre en medio de las botellas y jarros de agua, mientras que evitan la humedad de las sabanas. Al sacar un cajon que no estaba bien puesto hallábanse por lo regular escon. drijos de sapos, gekos, lagartos, escorpiones y serpientes; y alli reunidos en perfecta armonia entregábanse al descanso. A quel cáos de animales desnudos y repugnantes nos causaba al principio verdadero horror, hasta que la costumbre nos hizo olvidar esta debilidad, enseñánodome á servirme de un buen palo, el mejor medio para deshacerse de tan desagradables visitas.

Cuando se irrita al aga segrega una sustancia muy temida de los indigenas. A pesar de su pesada estructura, el aga se mueve con relativa agilidad, es decir a saltos; es en general un batracioalegre y vivaracho, y entre los congéneres de su familia el que hace mas ruido. En el periodo del celo emite, sobre todo de noche, una especic de ladrido fuerte $y$ ronco, que tambien deja oir en cautividad, lo mismo que el sapo de los pantanos, cuando se le excita.

Es, de suponer que la voracidad de este sapo está en relacion con su tamaño; pero no tengo noticias sobre cual sea su alimento. Wood dice que se ha intentado aclinatarle en la Jamaica para exterminar las ratas; mas que al importar los primeros individuos infundió aversion á todo ci mundo, llenando de horror á los plantadores y á los tímidos negros, que con sus gritos atemorizaban los ánimos.

A principios de la estacion lluviosa, en las partes meridio. nales de su área de dispersion, ó sea $\{$ fines del invierno, el aga penetra en el agua para depositar su freza. Segun Hen. scl, el periodo de la reproduccion comienza en Rio Crande por junio y dura varios meses, de modo que aun en octubre pueden encontrarse los largos cordones de huevos. Solo cuando la temperatura baja mas de cero y cuando los charcos se cubren de nieve interrumpese la reproduccion. El macho guarda entonces silencio y se retira con las hembras á sus viviendas, cerca del agua, para esperar una temperatu. ra mas calurosa.

Los renacuajos del aga, de color negro, en su juventud son relativamente pequeños en proporcion al tamaño de los adultos, pues su metamorfósis acaba cuando llegan á una longitud de 0 " , oro, pero aun los que alcanzan triple tamaño difieren por su color completamente de los padres. Las partes superiores son parciuscas $\delta$ de un gris amarillento con igual número de manchas de un pardo nscuro en ambos la. dos, mas oscuras en los bordes y orilladas de un color mas claro; á veces se ve una entre los ojos, dividida en dos mi. tades iguales; á esta sigue otra mas estrecha á cada lado de la extremiciad anterior de las glándulas auriculares, y des. pues dos manchas pequeñas, á menudo reunidas muy cerca de la linea central del lomo. Adenás vense iguales tres pares de manchas, la última de las cuales está situada en ambos lados de la extremidad del sacro. En medio de las manchas grandes hay otras mas pequeñas é irregula. res. Io cara anterior de las ancas presenta fajas trastersales del color de aquellas manchas, y la parte inferior del muslo tiene a veces tres de estas. La region inferior del cuerpo es gris, salpicada de puntitos de un blanco amarillento, à veces tan espesos que ocultan mas 6 menos el color del fondo.

\section{LOS RINOFRINOS -RHINOPHRYNE}

CARACTERES.-Dumeril fué el primero que nos dió á conocer un anuro mexicano que de todos los otros se distingue por tener la lengua fija en su parte posterior $y$ movible en la anterior.

\section{EL RINOFRINO DORSAL-RHINOPHRYNE DORSALIS}

CARACTERES.-Este animal, tipo del género y consi. derado por algunos como representante de una familia independiente (Rhinoplirynida), es una de las especies mas deformes del órden. Su tronco es casi oval, la cabeza, sol. dada con 61 , se prolonga en forma de pico; las extremidades anteriores, pesadas y cortas, tienen cuatro dedos; las posteriores son gruesas y cuentan cinco, largos y reunidos por anchas membranas natatorias; en la planta sobresale una uña córnea; las grandes glándulas auriculares apenas se ven. El color es de un pardo uniforme con una faja longitudinal en el centro del lomo y varias manchas en los costados. Ia longitud es de $0^{\circ}, 05$ (fig. IC2).

USOS, COSTUMBRIES Y REGIMEN.-Carecemos de toda noticia sobre el género de vida de cste batracio.

\section{LOS AGLOSOS-AGLOSSA}

En $1705^{\text {la }}$ señorita Sibila de Merian describió en una obra sobre los insectos del Surinam un anuro bufoniforme y su metamorfósis, en extremo singular. Desde aquella época el animal lia sido objeto de las observaciones mas minucio. sas, pero desgraciadamente no han podido hacerse en individuos libres, sino conservados en espiritu de vino; de modo que aun hoy no tenemos noticias verdaderamente exactas sobre este batracio.

El animal de que se trata es el asterodáctilo pipa, que con un congénere africano y otro de la Australia, constituye la familia de los aglosos 6 anuros sin lengua. 
EL ASTERODÁCTILO PIPA-ASTERODACTYLUS PIPA

CARACTERES. - Este animal se caracteriza en su exte. rior por su tronco deforme, casi cuadrangular y en extrenso aplanado, que sin tránsito visible se une con la cabeza ancha $y$ el hocico puntiagudo; las patas anteriores son ende. bles y delgadas $y$ sus dedos están divididos en la punta en cuatro partes, carácter ấ que debe este animal su nombre de asterodáctilo 6 sarpo de ciedos csirelladus. Las patas posteriores son mas gruesas y bastante largas con cinco dedos re- unidos por membranas natatorias completas; la piel es rugo. sa, sobre todo en los adultos $y$ hasta celulosa en las hembras viejas; en cada lado de la mandibula superior se ven barbillas y otra formacion igual en cada ángulo de la boca. A la fealdad del animal contribuyen los ojos, que sobresalen cerca del borde de la mandíbula y que apenas pueden moverse; el macho tiene además la laringe disforme, semejante á una caja ósea, triangular. Las mandibulas carecen de dientes y no existe la lengua Ambos sexos son de un color pardo negruzco, opaco. La hembra puede alcanzar, segun se dice, if 20 de longitud (fig. 103).
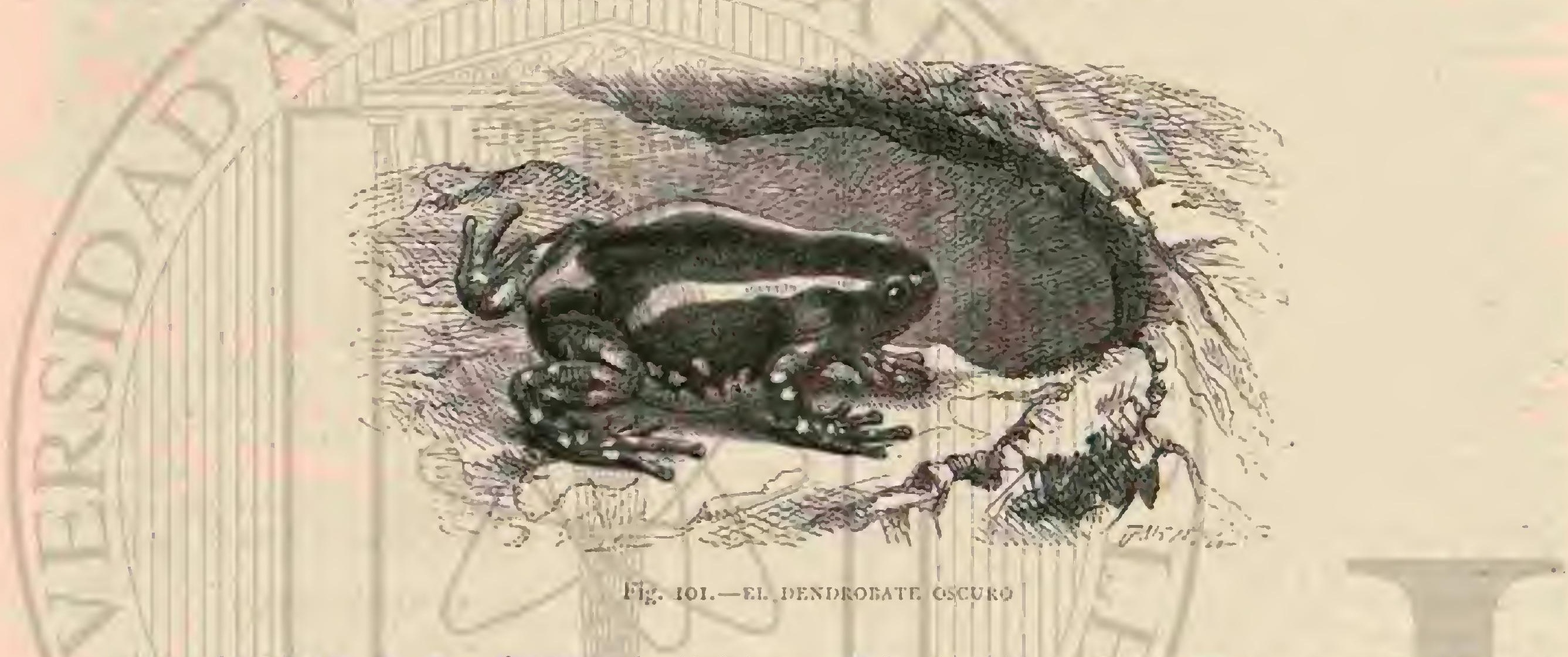

USOS, COSTUMBRES Y REGIMEN. - Si Schomburgk no se hubiern dejado dominar por su invencible aver. sion a los batracios y hubiese observado el pipa, dificil. mente se habria contentado con decirnos: abunda en la costa, sobre toda en los canales de riego de las plantaciones. lin vez de eso nos hubiera hecho una descripcion exacta de un animal tan notable; peroicomo se abstuvo, no sabemos aum hasta qué punto son ciertos los datos de los viajeros an. teriores. Estos dicen que el pipa habita los pantrnos de los bosques; que sus morimientos en el suelo san lentos y torpes, y que exhala un olor de azufre, por lo demás solo se ocupan de la reproduccion, á la verdad muy particular, confirmando en un todo las noticias de la señorita de Merian y rectificando tan solo el crror de que los hijuelos crecen en el lomo de la madre.

Ia reproduccion y desarrollo de los hijuclos se verifican del modo siguiente: asi como la mayor parte de los demás amuros, los asterodáctilos depositan su freza en el agua; y el

macho fecunda los hueros cuando salen, colocándolos sc. bre el lomó verrugoso de la hembra. Aqui se forma probablemente, á causa de la irritacion de la piel, una celdilla para cada huevo, la cual adquiere pronto la forma exágona de las celdas de la abcija, y como estas se cierra por encima con una tapa. En esa celdilla se trasforma el pipa pequeño, hasta que romupe la tapa, saca un pié ó la cabeza y sale por fin dicl todo.

Fermin dice que la hembra pone los huevos en la arena y que entonces el macho acude en seguida, coge los huevos con las patas posteriores, los coloca sobre el lomo de la hembras y volviéndose de espaldas se frota sobre el dorso de su compañera para fecundar despues los huevos. Los sesenta ó seterita hijuelos abandonan $a$ los ochenta y dos dias $\{$ la madre, la cual se desprende de los restos de las celdas, ro. zíndose contra piedras 6 plantas y mudando despues la niel.

No sé hasta qué punto son exactas estas noticias.
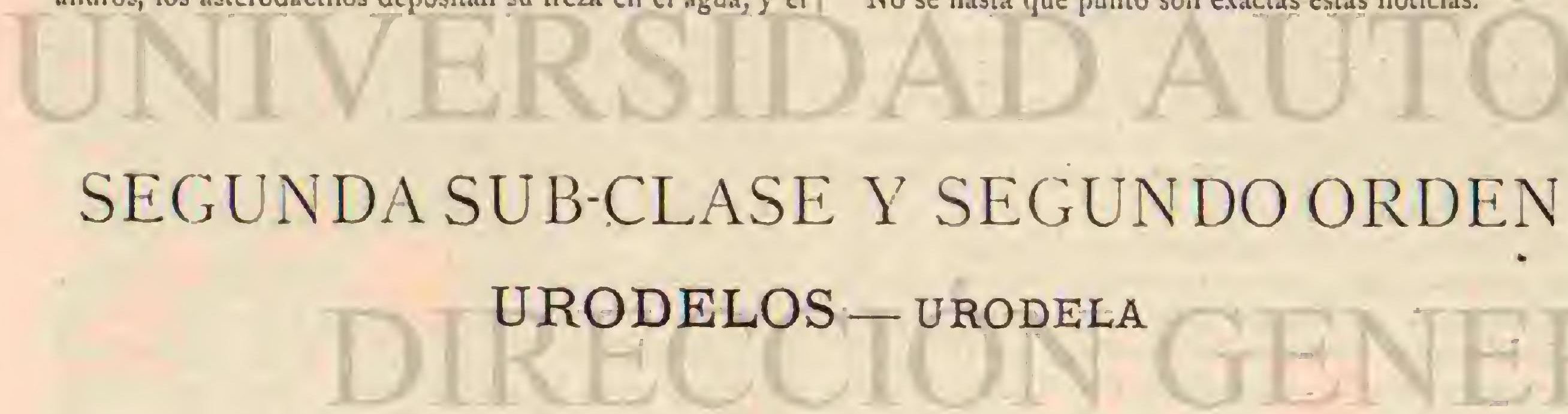

ma proporcion con los lagartos que los loros con los monos,

CARACTERES. - En la semejanza superficial que existe entre los lagartos y las salamandras se funda probablemente la opinion de los naturalistas que consideran los reptiles y batracios como pertenecientes $\mathbf{a}$ una misma clase. Oividan sin embargo que las salamandras 6 urodelos guardan la mis. los buhos con los gatos, los ánades con los ornirornicos, y los pingüinos con las focas ó para hacer la comparacion dentro de la misma clase; las tortugas y caimanes con los crocodi. los, $y$ las serpientes con las dobleandadoras, etc. I as diferen. 
cias que existen entre los urodelos y los saurios son sin embargo mucho mas importantes que las que resultan al comparar estos últimos animales, y se notan aunque no fijemos nuestra atencion en la marcha de su desarrollo. Es cierto que los urodelos tienen tambien un tronco prolongado, cilíndrico, con cabeza marcadamente separada, una cola mas 6 menos redonda, y cuatro extremidades, rara vez dos, como los saurios; pero la piel mucosa, sin escamas, y mas aun la falta de la cavidad del timpano, los distingue tan marcadamente de aquellos, que con dificultad podemos considerarlos como congéneres.

Los caractéres de los urodelos son los siguientes: tronco mas ó menos prolongado, redondeado, bastante cilindrico, y a reces un poco pesado; cabeza relativamente grande, por lo regular muy aplanada y redondeada; el cuello no se con- funde con la cabeza, por ser mas delgado que esta y que el tronco; la cola, mas ó menos larga, redondeada y comprimida lateralniente, sc aplana á veces en forma de aleta; las piernas tienen las formas pesadas de las extremidades de to. dos los batracios, pero son poco mas ó menos de la misma longitud; las patas anteriores suelen tener de tres á cuatro dedos; las posteriores, que pueden faltar alguna vez, de dos á cinco.

In piel exterior difiere poco de la de los anuros; por 10 regular fina y delgada, es a veces tambien verrugosa. Las verrugas se reunen en algunas especies y no son otra cosa sino glándulas muy desarrolladas que segregan una sustancia mucosa, pegajosa y muy particular, semejante á la clara de huevo. Asi como en los anuros, la piel se cambia ś menudo, de ordinario parcialmente, por lo cual se observa poco la

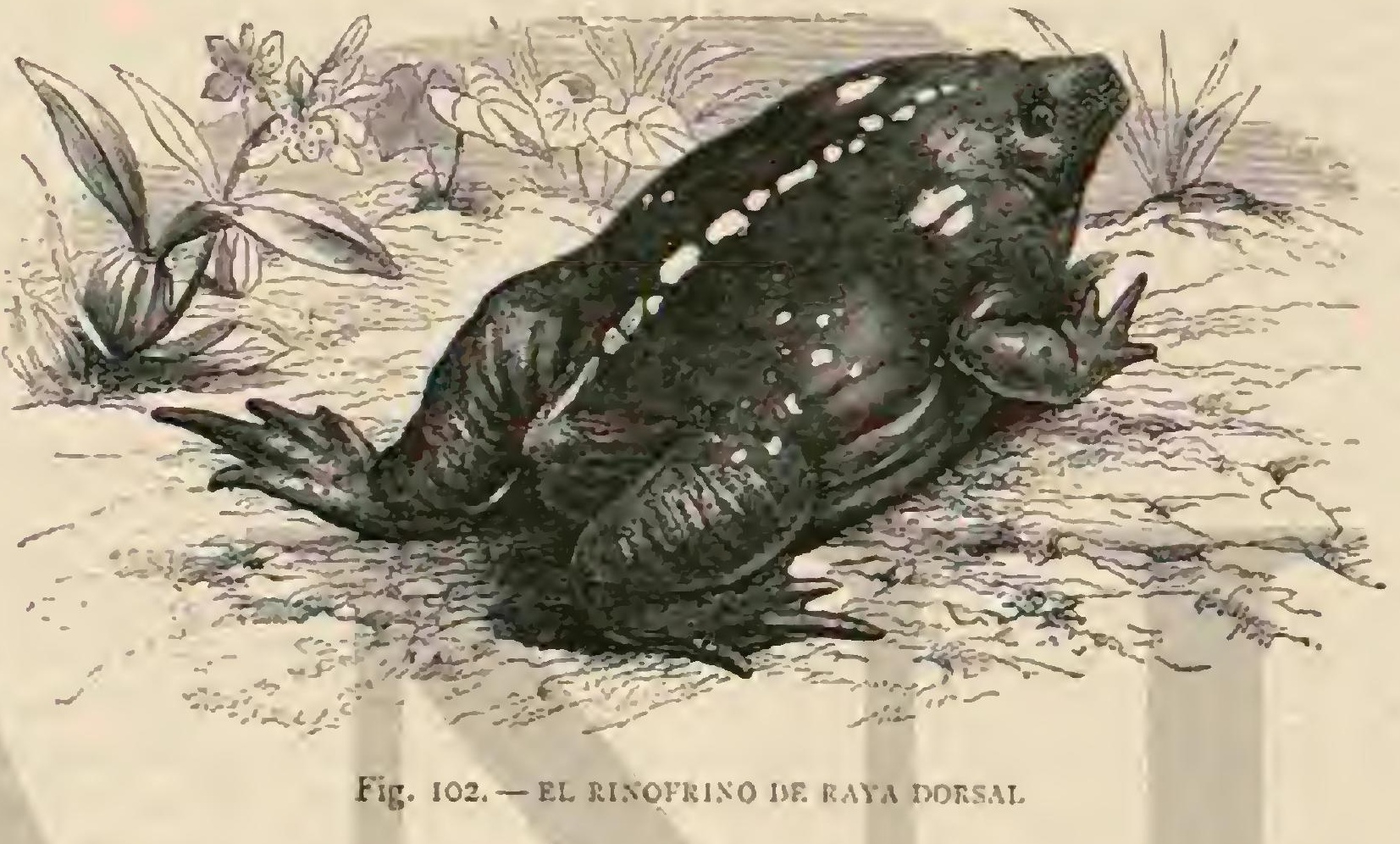

muda. En el color de la piel predominan los matices oscuros, comunmente con fajas y manchas claras y raras veces se observa un solo color.

En el cráneo se distinguen los huesos parietales y fronta. les $y$ por lo regular tambien el esfenoides, mientras que las mandibulas superiores están à menudo muy atrofiadas. Ia columna vertebral se compone de cincuenta vértebras por lo menos, llegando á veces casi á cicnto, provistas en las espe cies superiores de costillas cortas y obtusas, que en las especies inferiores se ven á lo menos en una parte de las vér. tehras. El verdadero esternon no existe, pero está sustituido por los omoplatos que en su extremidad inferior se ensan chan en forma de un disco cartilaginoso horizontal. La pélvis difiere de la de los anuros respecto á-su disposicion y forma, y tampoco se inserta siempre en una misma vérte bra. En las patas anteriores el cúbito y el radio, y en las posteriores la tibia y el peroné están completamente separados; los huesos carpianos empero suelen alcanzar muy poco desatrollo.

Los ojos presentan varios grados de desarrollo: pequeños y atrofiados, están cubiertos por la piel en unas especies; en otras son mas grandes ó están mejor formados, sobresa liendo de la cabeza en semi-esferas provistas de párpados completos y retráctiles como en las ranas; su piel córnea es muy grande en proporcion al globo del ojo; el iris, de un color dorado ó cobrizo, es rojizo ó amarillo en las especies mas desarrolladas; la pupila suele ser redonda. Ias fosas nasales están á los lados, en la parte posterior del hocico; los oidos están cubiertos siempre por la piel exterior y salen de la ca vidad del timpano, existiendo solo el laberinto. I. parte in ferior de la cavidad bucal está ocupada casi completamente por la lengua, que tiene formas muy variadas: es ancha $y$ Tosso $V$ recionda ó prolongada y estreclia, oval, ó en forma de corazon; se fija solo en el centro, siendo muy movible en los bordes anterior $y$ laterales, 6 bien se halla adherida en su ma. yor parte, en cugo caso es poco movible.

Todos los urodelos tienen en la mandibula y los huesos palatinos dientes pequefros y muy poco inclinados hácia atrás; á menudo se reconocen mas bien por el tacto que por la vista, y solo pueden servir para coger y sujetar la presa. Los dientes palatinos forman arcos paralelos iguales, dis. puestos trasversai ólongitudinalmentc. El esofago cs bastan. te largo; el estómago es un yran saco longitudinal sin intes. tino ciego, que se prolonga hácia el duodeno pasando poco á poco por el corto intestino recto; el higadoes relativamen. te grande, tanto que ocupa la mayor parte del est6mago; la vejiga de la hiel existe siempre y está muy desarrollada, asi como la glándula salival del estómago, dividida en lóbulos irregulares; de los riñones, estrechos y muy largos, parten los cortos conductos de la orina en direccion a la cloaca, donde desembocan junto á la vejiga, que es muy grande, de pare. des delgadas y rica en vasos, que cuando están llenos ocupan casi la mitad de la parte inferior del abdómen, pero no contiene nunca orina sino un líquido claro, inodoro y sin sabor, sirviendo probablemente como depósito para la humedad necesaria.

Los órganos de la respiracion son esencialmente análogos á los de los anuros, con la diferencia de que algunas especies conscrvan además de los pulmones, toda su vida, las bran. quias externas ó internas. Hasta los últimos tiempos nadie se atrevió á dudar de que estas formaciones branquiales fuc. ran constantes; pero la netamorfósis observada mientras tanto en el axololl (siredonis mexicanis) ha demostrado que no podemos considerar aun como acabadas nuestras averi- 
guaciones por este concepto. Fs cierto que hasta ahora no se ha observado que ademís del axolotl haya otro de sus afines que pierda sus bmnquias externas, pero en cambio sc ha reconocido que tambien varias especies, sobre cuya metamorfósis regular no puede haber duda, se conservan en su estado de juventud. Asi por ejemplo Filippi encontró en un pantano del lago Maggiore cincuenta tritones de los que solo dos tenian la estructura de la salamandra acuática adulta, mieniras que todos los demás tenian aun sus branquias, á pesar de que su cuerpo, su dimension y el desarrollo de los órganos genitales era igual al de los animales adultos. Estos renacuajos tan desarrollados en sus órganos sexuales y entre los que se distinguieron machos y hembras, habian conservado por lo demás todos los atributos de animales jóvenes no metanorfoseados. Sullien pescó en 180 g cuatro renacuajos de la salamandra rayada que terian los órganos genitales del todo desarrollados y llevaban en sus ovarios huevos madu. ros. Dos dé estas hembras depositaron en efecto sus huevos; cuatro renacuajos machos del mismo pantano se presentaron taubien muy desarrollados respecto á su tamano, pero no tenian aun fibras, sino solo celdas espermáticas. Ahora bien; si podemos observar tal suceso en los renacuajos de aquellos batracios que todos los dias tenemos a la vista, parece muy justificada la suposicion de que lo mismo que sucedeen una especie puede suceder con mas ó menos cambios taubien en otra, ó en otras palabras, que un urodelo que hasta ahora solo hemos cncontrado con branquias puede resultar como renacuajo capaz aun de trasformarse.

DISTRIBUCION GEOGRÁfICA.-El área de disper. sion de los urodelos se limita, segun ya hemos dicho en otra parte, al hemisferio septentrional de la tierra. Aqui habitan, segun Straucin, todas las regiones cálidas, templadas y liasta las frias del antiguo $f$ del nuevo mundo. El limite polar de esta área de dispersion, que sin duda debe buscarse en una latitud muy alta, no sé podria determinar, ni siquiern aproximadamente, por las noticias que hasta ahora tenemos; del limite meridional, en cambio, se conocen cuando menos algunas partes; el punto mas meridional donde en el hemisfe. rio occidental se han visto aun urodelos, es en Nueva Gra. nada, es decirálos $5^{\circ}$ latitud norte, mientras que en el oriental, el norte de la Argelia, á los $36^{\circ}$ latitud norte, y el reino de Siam a los $15^{\circ}$ latitud norte, constituyen dicho limite. Si se toman en consideracion las salamandras en particular y los urodelos en general, el área de dispersion de estos animales podrá dividirse en cuatro regiones caracterizadas por especies propias de ellas, y de las que dos pertenccen al sepientrion del antiguo continente $s$ dos al nuero mundo. Las dos regiones de aquel estain separadas por las estepas uralo-caspias, de tal modo que no solo ninguno de ellos tiene una especie comun sino que cada cual se distingue por géneros diferen. tes. Las montañas Pedregosas forman el limite entre las dos regiones del territorio septentrional del nuevo mundo, pero esta separacion no es tan exclusiva, porque algunosgéneros, y hasta especies, se encuentran en cada una de aquellas. La parte del área de clispersion que mas nos interesa, es decir la Europa, excepto el extremo norte, la costa norte-occidental del Africa, la Armenia, la Transcaucasiay el norte de Persia, puede dividirse en zonas que, si bien tienen muchas especies comunes, poseen tambien otras propias de cada cual. Entre estas zonas, la africana es la menos rica, la del Asia poco menos abundante, mientras que cn la europea se cuentan muchas especies de urodelos. Asi como todos los congéneres de la clase en general, el número de urodelos aumenta de un modo notable desde el norte hácia el sur. Mientras que la Europa septentrional solo está habitada por cinco especies de tritones, el número de estas sube en el centro de
Europa a ocho, y en el sur del continente á quince, porque en las tres peninsulas europeas se encuentran todas las especies de urodelos propios de la region europea. Semejante aumento de especies se observa tambien desde el este hácia el oeste. En el norte $y$ este de la Rusia solo existen dos especies de estos batracios; en la Escandinavia tres; en Ingla. terra cuatro; en el centro de Europa seis; en Francia nueve; y en la peninsula pirenaica quince, entre las cuales hay tres ó cuatro propias exclusivamente de la zona europea. De aqui resulta que algunas salamandras tienen un área de dispersion muy extensa, mientras que la de la gran mayoria es bastante limitada.

La segunda zona del territorio septentrional del antiguo mundo, 6 sen la asiática, que comprende el sur de la Sibe. ria, el Kamtschatka meridional, el Japon, algunas partes de la China, y finalmente el Siam, y que aun es bastante desco. nócida respecto á los urodelos que en clla cxistcn, puede di vidirse tarnbien en tres regiones que comprenden los territo rios situados entre las estepas mencionadas y el lago Baikal, los paises que hay entre este lago y el Kamtschatka meridio. nal hasta la frontera chima, y finalmente, las islas japonesas. Tambien aqui aumenta el numero de las especies de norte á sur, nero poco podria decirse sobre su diseminacion; debe. mos suponer que por término medio tienen limites bastante reducidos.

En el occidente, ó sea en América, donde los urodelos abundan mucho, las condiciones son otras que en oriente, porque aqui se encuentran mas especies en el norte que en el sur; pero debo advertir que el norte ha sido mucho mas explorado que el mediodia de este pais. Lo mismo podrin decirse del este de América al compararle con el oeste. No podemos determinar aun si las condiciones conocidas hasta ahora se cambiarian al explorar mas minuciosamente $\mathrm{cl}$ norte y centro de América. Hasta ahora, el número de urodelos propios del territorio septentrional del nuevo mundo es poco mas 6 ménos doble del que existe en el del antiguo conti. nente.

USOS, COSTUMBRES Y RÉGIMEN. - Aunqque no todos, la mayor parte de los batracios hasta ahora cono. cidos habitan el agua toda su vida; muchos viven ell los pantanos cenagosos de poca profundidad, otros en lagos pro. fundos y algunos en aguas que se hallan a varios centenares de metros sobre ei nivel del mar. Todos, sin excepcion, son animales nocturnos que de dir permanecen quictos y ocul. tos en sus escondrijos, ó descansan en el fondo del agua, ó bien despliegan su actividad solo de noche $\delta$ despues de ha. ber llovido: es dificil observarlos, como lo demuestran las especics propias de nuestros paises, que pueden vivir en gran número en sitios donde no se sospecha su presencia. Las especies que llamamos terrestres prefieren las regiones oscu. ras y hủmedas, poco bañadas porlos rayos del sol, es decir, los valles estrechos 6 los bosques, donde se ocultan debajo de las piedras, en los troncos de árboles muertos 6 en agujeros subterráneos. Una salamandra propia del norte de Amé. rica dificre de todos los demás anuros por vivir como los topos debajo de tierra, abriéndose agui sus galerias con no table rapidez. Las salamandras acuáticas abandonan rara vez sus aguas, y si lo hacen ocúltanse sicmpre lo mas pronto posible en los alrededores de la orilla ó vuelven á su dominio. Sin embargo, es mas fácil descubrirlas, porque todos los ani. males acuáticos distinguen menos entre el dia y la noche, entre la oscuridad y la claridad que los animales terrestres, ! porque los urodelos acuáticos vense obligados a subir alguna vez á la superficie para respirar, 6 mantenerse en las capas superiores de su elemento á fin de disfrutar de los ra. yos del sol. En el norte de su área de dispersion se aletargan 
a principios del invierno; en el sur sucede lo mismo cuando el calor agota las aguas que habitan. La admirable resisten. cia vital que les es propia permiteles soportar tales cambios: pueden secarse con el cieno y helarse con el agua, y á pesar de esto la primera lluvia ó el primer rayo ardiente de sol les libra pronto de la inuerte. De ellos podria decirse con justi. cia lo que antes expuse sobre la resistencia vital; estos son los batracios cuyas extremidades vuelven a crecer cuando se les arrancan, aunque se haga varias veces.

Créese en general que los movimientos de los urodelos son cachazudos y pesados, pero esto solo puede decirse de algunas especies: muchas salamandiras corren con tal rapidez que recuerdan los lagartos. En el agua se mueven todos con mucha agilidad; superiores por este concepto son naturalmente las especies acuáticas; pero tambien las salamandras saben maniobrar muy bien en este elemento, avanzando no solo á la carrera en el fondo del agua, sino taubien nadando con movimientos serpentinos de su cola. Sin embargo, ni un solo urodelo puede trepar; ninguno fijar su residencia, ni aun temporalmente, en el ramaje aéreo.

El alimento se compone de moluscos, gusanos, arañas, insectos y toda clase de vertebrados. Algunas especies son excelentes rapaces, y la masor parte devoran hastálos indi. viduos débiles de su propia especie. Son muy voraces porque digieren con rapidez, pero aunque los urodelos comen mucho en ciertas épocas, pueden ayunar tambien largo tiempo.

Muy particular y poco conforme es la reproduccion de estos animales. No se efectua un aparcamiento verdadero, á lo menos que sepamos: los machos persiguen á las hembras, se desembarazan del licor prolifico y las hembras depositan sus huevos en el agua fecundándolos asi en cierto modo; tambien recogen con el ano el agua donde está la esperma, $y$ de este modo fecundan los huevos que llevan en el ab. dómen. Las salamandras vuelven i salir del agua despues del período del celo; pero las hembras se dirigen otra ver á ella despues de bastante tiempo para depositar sus hijuelos, que mientras tanto se han desarrollado en su vientre. Los urode. los acuáticos, en cambio, ponen huevos y solo pocos di la vez, fijándolos por medio de una sustancia pegajosa en las hojas de las plantas. Tanto las especes terrestres como las acuáticas pasan su primera juventud en el agua y no la aban. donan hasta que se han desarrollado sus pulmones y pueden respirar bien. Durante el estado de renacuajos los diferentes urodelos difieren muy poco, y por eso no parece justificado clasificar los salamandrinos y los proteidos ell subúrdenes distintos, pues los proteidos que aun $\{$ la mayor edad tienen branquias deben considerarse en cierto modo como urodelos no metamorfoseados.

Seria dificil citar una especie de este órden que perjudique mucho al hombre. Algunas de las especies mayores se alimen. tan de peces, pero estas habitan en regiones donde no se les debe disputar el alimento que necesitan. Mas bien se les debe considerar como animales útiles porque devoran multi. tud de parásitos molestos ó dañinos para las plantas. Despues reremos que á pesar de las fábulas que desde la antigüedad circulan sobre el particular, la secrecion de sus glándulas no. puede hacer daño \& nadie.

Entre los enemigos que persiguen á los, urodelos solo algunos peces y serpientes son peligrosos para ellos; los mamiferos y las aves no devoran mas que las especies acuáticas y desprecian las terrestres á causa de la secrecion de sus glán. dulas; mientras que las serpientes no hacen aprecio de ella. Fl hombre ignorante manifiesta gran arersion á las salaman. dras y sus congéneres, pero afortunadamente no puede aplacar su odio de la manera que acostumbra, es decir por el exterminio de los animales; el hombre instruido y despreocupado solo persigue con afan \& los urodelos porque se conservan muchos años en cautividad.

CLASIFICACION. - Ultimamente se hadividido el órden de los urodelos, no solo en cuatro familias, sino tambien en dos sub-órdenes; pero creo mas conveniente prescindir de esta separacion, admitiendo solo dos fanilias; la de los salaman. dridos y la de los proteidos; cada una de estas familias puede dividirse en dos sub-familias.

\section{LOS SALAMANDRIDOS- SALAMAN DRID死}

CARACTÉRES. - Los salamandridos, á los que pertenecen la major parte de los urodelos, aunque no las especies mas extraias, se caracterizan por la estructura casi siempre recogida del cuerpo; sus formas, raras veces pesadas, aseme. janse \& las de los lagartos; la cabeza es grande, ancha, aplanada y redondeada; el hocico corto; los ojos, relativamente grandes y muy salientes, cstán provistos siempre de párpados bien desarrollados; las fosas nasales, que desembocan en la extremidad del hocico, son pequeñas, las orejas nunca visi. bles; el cuello mas ó menos estrecho y separado comunmen. te de la garganta por un repliegue membranoso muy desarrollado; el tronco es delgado y cilindrico; las piernas, en número de cuatro, están relativamente poco desarrolladas; los piés anteriores tienen siempre cuatro dedos, y los posteriores, en la. mayoria de casos, cinco; rara vez se cuentan solo cuatro; pueden ser largos 6 cortos, y por lo regular están libres; pocos individuos los tienen reunidos por membranas interdigitales; las uñas no existen; la cola está siempre muy desarrollada; comunmente es mas larga que el ironco, redondeada en la extremidad ó puntiaguda en forma de lanceta, mas 6 menos comprinida generalmente y raras veces cilindrica.

Ia piel, siempre húmeda, está cubierta de gran número de glándulas y verrugas y por lo tanto sucle ser blanda $y$ àspera, pero hay tambien muchas especies que la tienen de? todo lisa. En los lados del occipucio se ven à veces grandes aglomeraciones de glándulas, análogas á las llamadas glándulas auriculares de los sapos, y las cuales se designan con el mismo nombre.

Las mandibulas están provistas de muchos äientes; además hay otros pequeños en el borde posterior de los huesos pala. tinus, en diversa posicion: unas veces se insertan en el bor. de interior de dos apófisis largas del hueso, mas separadas en la parte postcrior, en cuyo caso están dispuestos longitudinalmente; $y$ otras ocupan solo el borde posterior del hueso palatino, formando entonces series oblicuas ó trasversales. Iả lengua, redondeada ú oval, está fija en su cara anterior en varias especies, ó bien con una faja menos ancha en el centro, por lo cual solamente los bordes quedan mas 6 , me. nos libres; en otras especies reposan en cl centro sobre una especie de tallo semejindose por lo tanto á una seta; en este caso queda libre en todas partes ó se njja solo por su parte posterior en el ángulo de la barba.

Strauch, cuya descripcion me ha servido de guia al trazar. los caractéres de estos batracios, propone dividir los sala. mandridos en dos sub-familias, reuniendo en la primera los mecodontos ó especies con dientes largos.

\section{LOS MECODONTOS-MECODONTA}

CARACTERES. - Los mecodontos se caracterizan por la circunstancia de que los dientes palatinos se insertan en el borde interior de dos apófisis del hueso palatino que se 
inclinan hácia atrás y cstán separadas, presentando de consiguiente dos series longitudinales.

\section{LAS SALAMANDRAS-SALAMANDRA}

CARACTÉRES. - Los de este género, segun Strauch, son los siguientes: la estructura es bastante pesada; la cola cilindrica, cónica y redondéada en la extremidad, sin borde membranoso, y asi como el tronco, mas ó menos anillada, es decir provista en la cara superior é inferior de ciertas depresiones en forma de lineas. Las exiremidades anteriores tie. nen cuatro dedos y las posteriores cinco. La piel es glandulosa; las glándulas auriculares grandes, marcadamente limi. tadas y con grandes poros; otras, dispuestas en series longitudinales, ocupan cada lado del tronco, tanto á lo largo de la linea dorsal comoen la parte superior de los costados. Los huesos palatinos forman tambien dos series, separadas en la region posterior y muy corvas, en forma de $S$, series que similan la figura de una campana. Ias extremidades in. feriores de ambas lineas de dientes se hallan separadas por un intervalo mas ó menos grande y sobresalen siempre un poco del borde anterior de la abertura nasal interna. La len.

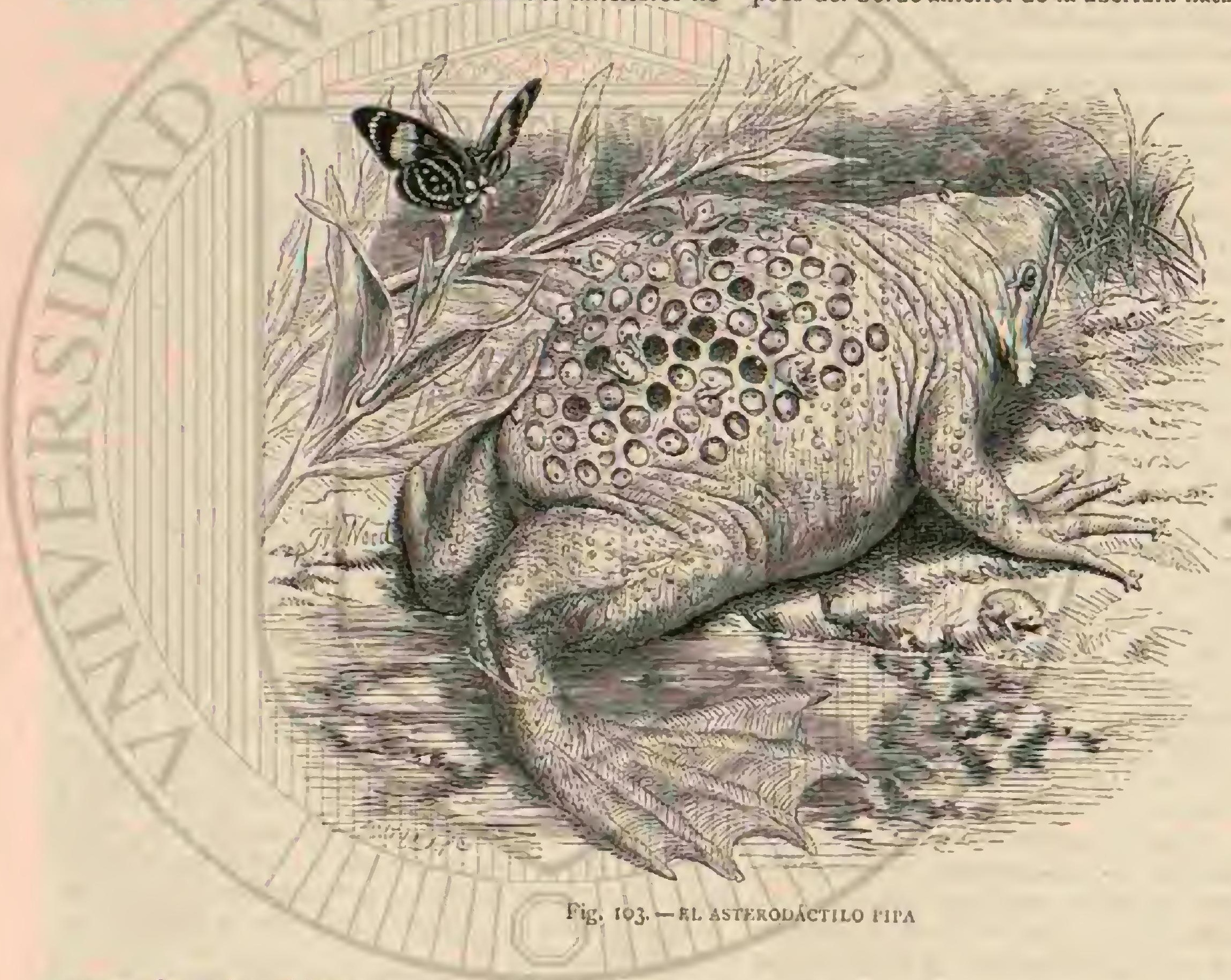

gua grande, casi semicircular en la parte anterior, se arquea ligeramente, y hasta se trunca en la parte posterior, fijándose en el fondo de la cavidad bucal por mecio de una faja central bastante ancha; su cara inferior queda libre solo en los bordes laterales.

\section{LA SALAMANDRA MANCHADA-SALA- MANDRA MACULOSA}

- Ia salamandra, batracio cuyas formas se asemejan a las del lagarto $y$ que tiene en la piel unos dibujos en figura de estrellas, solo se deja ver despues de una copiosa lluvia; nunca sale en tiempo seco. Es un animal tan frio, que asi como el hielo, apaga la lumbre con su solo contacto. I,a sustancia mucosa que semejante á leche sale de su boca, hace caer el vello de todo el cuerpo huinano; la parte humedecida pierde su color y conserva una serial. De todos los animales venenosos las salamandras son los mas malignos: varios de aquellos hieren á un hombre ó le matan, pero á su vez perecen y no se les vuelve a ver por la tierra; la sala. mandra, en cambio, puede exterminar pucblos enteros si estos no toman sus precauciones. Cuando trepa á un árbol, envenena todas las frutas, y el que las come mucre de frio: hasta cuando se cuece pan con leña tocada por el pié de una salamandra envenénase tambien, y lo mismo sucede con el agua del pozo donde ha caido una de estas. Sin embargo, este sér tan ponzoñoso sirve de alimento à otros animales, como por ejemplo á los cerdos; y es probable que su veneno se neutralice principalmente por los animales que a las sala. mandras sirven de pasto. Si fuese fundado lo que dicen los magos, quienes proponen emplear ciertas partes de la salamandra como medio contra los incendios, porque es el único animal que extingue el fuego, mucho tiempo haria que Roma habria hecho tal experimento. Sextio dice que una salamandra despojada de los intestinos, de los piés y la cabeza, y conscrvada en miel, produce efectos cxcitantes al comerla, pero nicga que pueda extinguir el fuego.

Estas son las palabras de Plinio y desde su ćpoca hasta nuestros dias, muchos han tenido por ciertas estas noticias, siendo muy pocos los incrédulos. Ia salamandra se ha tenido y se tiene por un animal terrible y hórroroso. Segun las leyes romanas, el que diera i otro cualquier parte de la salamandra para comer, era declarado envenenador y sentencia. banle a muerte.

Aun áfines del siglo pasado, una mujer intentó envenenar á su esposo con una salamandra, cuya carne habia mezclado en la comida; mas por fortuna para el hombre, despues de comer quedó muy satisfecho, sin experimentar daño alguno. 
Francisco I eligió como divisa una salamandra entre llamas con la inscripcion: Nulrio et estingu. Los alquimistas que. maban el pobre animal por una costumbre ridicula, y creian poder hacer oro poniendo la salamandra sobre el fuego $y$ echando despues de bastante rato gotas de mercurio sobre el gusino venenoso; pero aseguraban que la mezcla obtenida asl era en extremo peligrosa. En los incendios, el animal era tambien mártir de la supersticion, pues arrojábanle en las llamas, creyendo apagarlas así. El que se atrevió á ridiculizar tantas locuras fué tachado de estúpido y agobiado de insultos. QQuien considere tales cosas como fábulas y mentiras, decia cierto doctor Scheeffers, enojado al saber las opiniones razonables de algunas personas, debe ser un estúpido, y manifiesta que no ha visto mucho mundo, ni menos tratado con sabios ó personas que hayan viajado mucho. La creencia en ciertas supercherias explica estas fábulas sobre la salamandra: cl que crec una ncccdad cs capaz tambien de creer en otra; el que cree en cosas sobrenaturales no hace nunca caso de lo que la observacion y el recio juicio le en. señan.

CARACTERES.-I, salamandea manchada, tipo primitivo de su familia y gérero, alcanza una longitud de $U^{\prime \prime}, 12$ á $0^{*}, 17$; sobre el fondo negro muy oscuro y aterciopelado de su piel, presenta unas grandes manchas irregulares de un magnífico color amarillo de oro, que suelen formar fajas ó series mas ó menos murcadas; parten de la punta del hocico y se corren hasta la extremidad de la cola. Las extremidades presentan casi siempre en cada articulacion principal, es decir, en el huimero ó el muslo, en el brazo 0 en el tarso, en el pié ó en la mano, una mancha amarilla.

La garganta tiene siempre manchas regulares; en la parte inferior del tronco las hay irregulares.

DISTRIBUCION GEOGRÁFICA.-La patria de la salamandra manchada se extiende por toda Luropa, desde cl

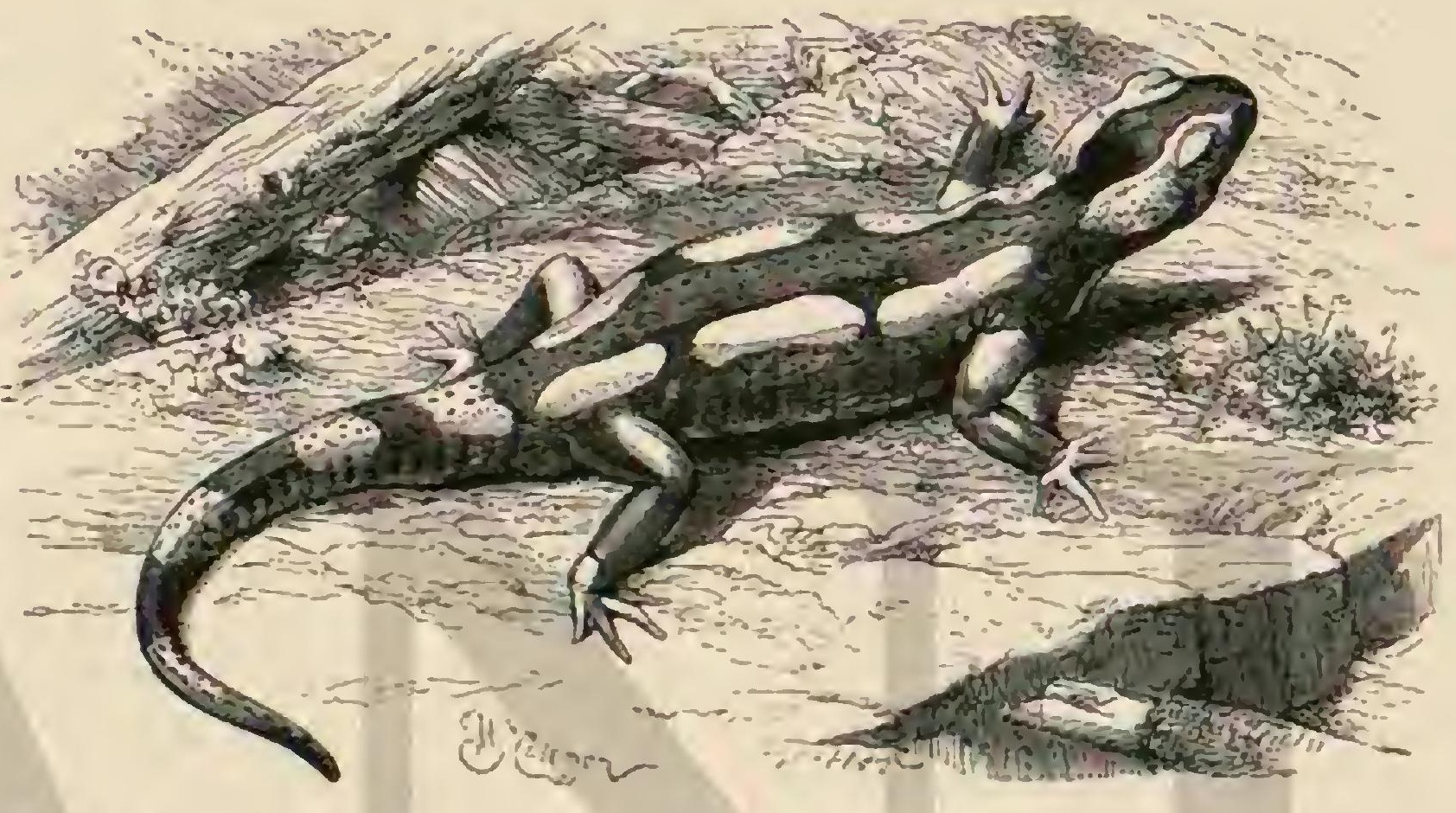

Fig. IOq.-LA SALAMANURA SIRNCHADA

sur de Suecia hasta España, Italia y Grecia, prolongándose tambien hasta el noroeste del Africa.

USOS, COSTUMBRES Y REGIMEN.-No escasea en rigor en ninguna parte de su área de dispersion, pero abunda solo en los puntos que mas le convienen. Habita los sitios húmedos y oscuros, los estrechos valles $\delta$ los bosques frondosos, fijando su vivienda en agujeros debajo de las raices y piedras, en las guaridas de diferentes animales, ctc. De dia sale solo despues de llover, pues tambien su actividad es en rigor nocturna. El calor seco $\delta$ la infuencia del sol roban á su cuerpo rápidamente tanta humedad, que ponen en peligro su existencia; si pasan muchos dias sin llover sc la ve flaca y débil, aunque su piel se humedece con el rocío; mientras qque despues de una lluvia ofrece el aspecto de bienestar y salud. Sus movimientos son lentos y pesados; arrástrase por el suelo con movimientos laterales; nada, por decirlo asi, andando por el agua, sirviéndose de la cola como órgano principal en este género de locomocion.

Todas las facultades superiores parecen poco desarrolla. das; los sentidos son bastante obtusos, la inteligencia no menos escasa. Aunque á menudo se la ve reunida con otras de su especie, no se le puede llamar apenas sociable, pues no hace caso de otro individuo; el fuerte se precipita sobre el débil cuando tiene hambre y lo derora al punto. Solo en el periodo del celo se buscan los sexos; pero tan luego como han satisfecho su instinto cesa toda relacion, y solo se re. unen por convenirles las condiciones de una localidad.

El alimento se compone de animalejos que se mueran lentamente; prefieren los caracoles, lombrices y coleópteros y en ciertas circunstancias tambien los vertebrados pequeños. Las salamandras consumen á veces grandes cantidades de alimento, mientras que en otras circunstancias agunan semanas y ineses enteros.

Todavia carecemos de noticias enteramente exactas acer. ca de la reproduccion de la salamandra manchada: hasta el presente jamás se ha observado su apareamiento, y es probable que tampoco lo haya en realidad; la suposicion de al. gunos naturalistas de que los machos y las hembras se tocan con los bordes del ano, hinchados en el periodo del celo, no está probada, a lo menos que jo sepa; y ni la mas probable de que los órganos genitales de la hembra absorban la esperma vaciada por el macho en el agua, produciendo asi la fecundacion de los huevos, está todavia completamen. te justificada. Asi por ejemplo, parece extraño que una salamandra hembra separada del macho por espacio de cinco meses, dé á luz huevos con los renacuajos desarrollados, por que apenas puede suponerse que el desarrollo de los hueros en el vientre de la madre necesite tanto tiempo, y mas extraño aun es que despues de este parto pueda haber otro en ciertas circunstancias. Para explicarse este heclio, solo es permitido suponer que una misma fecundacion sigue produ. ciendo sus efectos por espacio de mucho tiempo, extendiéndose en cierto modo tambien a los huevos, que al verificarse aquella, no estaban maduros ni en disposicion de recibirla. El número de los embriones segregados al mismo tiempo es considerable: se han encontrado ya hasta ciento en los oviductos de una hembra. Lina salamandra cuidada por Noll se puso junto al cristal que le servia de prision sobre una 
piedra saliente, de modo que la parte posterior de su cuerpo estaba clz el agua y la anterior al aire; en esta posicion co menzó de noche á poner huevos, continuando asi hasta que á la tarde siguiente habia puesto cuarenta y dos. Regularmente salen á luz de treinta a cincuenta á la ver, $\delta$ cuando menos á cortos intervalos, en un espacio de dos dias, todos de tamaño casi igual é igualmente desarrollados; sin embargo, alguna que otra vez sucede, aunqque quizas solo en los cautivos, que las hembras de salamandra ponen embriones y huevos. Esto es lo que observó Erber, quien pudo ver que el nilmero de huevos cra cxactamente el mismo que el de los renacuajos, es decir treinta y cuatro. Los huevos grandes aparecen uno a uno, y son tan trasparentes que se pueden reconocer muy bien los renacuajos del fodo desarrolladios; antes del parto están separados en los oviductos, que se ensanchan en su parte inferior; y cada embrion se enrosca de modo que la punta de la cola envuelve la cabeza. Cuando el huevo se agranda un poco en el agua, el embrion rompe la capa por medio de un morimiento de la cola y aparece en. tonces como renacuajo, provisto ya de cuatro patas y del to. do capaz para moverse en el agua donde ha nacido, y á la manera de los renacuajos muy desarrollados. Ĺ niadre pre. fiere el agua fria de las fuentes para depositar en ellas sus hijuclos cual si supjera que el desarrollo tiene varias fases y que por eso debe elegir un agua que nunca se agota. Cuando falta el agua donde esta la hembra, esta dupósita sus hijuelos, segun aseguran varios observadores, en sitios húmedos. El renacuajo es de color gris negruzco que tira mas ó merios al verdoso; su piel tiene sin embargo en la parte superior un verdadero brillo, producido por pequeñas nianchas doradas; este brillo aparece mas tarde tambien en los costados y el vientre. Poco á poco forman en medio de las manchas dora. das otras amarillas; la piel pierde su lisura, se vuelve mas aspera y verrugosa y el renacuajo sale entoncés á tierra firme, aunque sus branqquias no están secas aun.

A menudo se encuentran renacuajos hastn octubre en esas aguas; mas por lo regular làs branquias se resecan en agosto $\delta$ á principios de setiembre, y los animalitos procuran bus. car entonces los mismos sitios que habitan sus padres, cuso color han adquirido antes de este tiempo. Cuando se han metamorfoseado aparecen á veces mas pequeños que en su último periodo de renacuajos. Dificil es determinar cuánto tiempo crecen los hijuelos; y como no se les encuentra á me. nudo, supónese que pasan los dos primeros años de su vida muy ocultos. Las sala mandras nacidas en cautividad se tras. forman, sin duda á ciausa del mayor calor, con mucha mas rapidez que las que nacen en libertad, y al cabo de tres semanas pueden salir á tierra firme.

La humedad cáustica que, segregan las glándulas de la piel protege á estos batracios de muchos encmigos, porque es desagradable y hasta peligrosa para ellos. Cuando se coge una salamandra por el cuello y se la oprime, sale al punto el liquido; cl animal puede vaciar, sin embargo, tambien sus glándulas voluntariamente $y$ lo hace siempre cuando se cs. panta para defenderse de los ataques. Los efectos del cita. do veneno se han exagerado muchas veces, 5 hasta Oken no ha vacilado en decir que unos niños que habian bebido agua en un poro habitado por salamandras, muricron. MLuchos experimentos, sin embargo, han demostrado que este líquido escuece mucho en las pieles mucosas, produciendo una inflamacion de la que pueden morir los pájaros, reptiles y batracios pequeños y débiles. Unos lagartos obligados por Jaurenti á morder salamandras fueron atacados de convulsiones y murieron, mientras que los perros, gallos de Indias y gallinas que habian comido pedazos de salamandras, las digirieron sin experimentar daño, aunque á veces los perros vomitaron. Abini, que uitimamente volvio \& examinar el ve. neno, ha publicado los resultados de estos estudios.

\&Una vez vencida la aversion natural que estos séres infunden, con sus ojos fijos, á casi todos los hombres y cuando entonces se les pone sobre la palma de la mano, permanecen por lo regular inmóviles, y hasta parece que el calor de la mano les agrada; pero cuando se les coge con temor y temblorosa mano, oprimiéndoles mucho en ciertos sitios, expelen varias gotas de un jugo blanco, que pronto se reseca; y entonces se percibe el agradable olor del coleóptero conocido con el nombre de Cerambyrx moschatus. Cuando se quiere atar una salamandra à una tabla, resistese con todas sus fuerzas y arroja entonces á menudo su liquido á una dis. tancia de treinta $y$ cinco centimetros, de modo que solo al. gunas gotas tocan en los poros de la piel. Como me habia convencido de que las salamandras vacian su jugo siempre por movimientos voluntarios de sus músculos, intenté obte. ner mayor cantidad por medio de la electricidad; para esto lavé varios individuos cuidadosamente, los puse uno despues de otro en una copa de cristal limpia, cubierta con una hoja de vidrio; por una abertura introduje los alambres de la má. quina eléctrica, $y$ de este modo pude exponer los animales á la corriente segun mi voluntad, Las salamandras arrojaron su liquido á las paredes de cristal de la copa y á la tapa

La secrecion obtenida de este modo se examinó, resultan. do venenosa tanto al inocularla en la sangre como al aplj. carla al estómago; Abini hasta observó que los efectos eran mucho mas rápidos y violentos que cuando se introducia el líquido en la boca de los pájaros y ranas. Los animales que comieron carne delos séres muertos por el veneno de la salaman. dra queclaton sanos, aunque en los experimentos hechos se tuvo la precaucion de cortar la extremidad en que se habia ino. culado el veneno, $\delta$ el esófago y estómago. Abini deduce de todos estos experimentos los hechos siguientes: el veneno produce efectos en la parte en que se aplica, segun lo prue. ba la fuerte irritación de la piel mucosa de la boca y de la lengua de las ranas en que se inocularon algunas gotas del liquido 6 un extracto claro del mismo en la boca; tambien lo indican así los sacudimientos de la cabeza y del pico de las aves, que se abre de continuo despues de introducirse el liquido.

Si se aplican grandes dósis y se sigue con rapidez la muerte que por lo regular ocurre en las aves, prodúcense antes convulsiones acompanadas de manifestaciones de dolor y de una gran excitacion, siendo la respiracion y los latidos del corazon mas rápicios y frecuentes. El ave puede volar enton. ces, pero no sostenerse en los piés; estos se contraen por lo regular, así como los dedos, y cuando el volátil envenenado quiere moverse del sitio donde se halla, cac de lado. Inmediatamente despues del cnvenenamiento el ave lanza fuertes gritos y. muere al minuto; pero aun entonces persisten los latidos del corazon algun tiempo, y cuando cesan pueden producirse otra vez por medio de irritaciones. Cuando la dósis es pequeña y el efecto lento, como se observa en las ranas, la respiracion y la circulacion de la sangre aumentan al principio; despues comienza la rigidez de las extremida. des, y en seguida las convulsiones, cortas al principio, pero mas tarde se siguen sin interrupcion dias enteros, hasta que la circulacion de la sangre disminuye, sobreviniendo despues la muerte. Las ranas cambian en esta ocasion mucho el color de su piel, que siempre se aclara, y hasta se adelgaza escaseando la transpiracion.

Abini no se atreve aun á decir mas sobre el particular, porque piensa comprobar y ampliar antes las experiencias adquiridas hasta ahora. El residuo de la sustancia mucosa, destilada primero con agua clara y despues con alcohol puro, 
no presentó ya cualidades venenosas. El extracto de alcohol era mucho mas venenoso que el hecho con agua; en aquel se formaron un dia agujas que flotaban sep̧aradas por un líquido y que despues de la evaporacion completa del alcohol se aglomeraron en porciones granujientas. Estas finas agujas tienen al parecer propiedades muy venenosas en el alcohol, en el agua y en el éter; la solucion con agua tomó el carácter de ácido; el álcali, el bicarbonato y el amoniaco no atacan los cristales. Su efecto es en extremo rápido y se manifiesta desde luego por vómitos.

CAUTIVIDAD. - Ia salamandra cautiva se conserva rarios años si se la cuida bien: necesita una jaula con un pequeño depósito de agua y algunos escondites, como los que busca cuando cstó en libertad. Para alimentarla bastan gusanos de harina, lombrices, insectos y caracoles; tambien derora los individuos pequeños de su propia especie.

Es singular que este batracio tan insensible por varios conceptos sucumba al punto a ciertas infucncias, y que la sal sobre todo sea en extremo veacnosa para ese animal: para matar una salamandra basta cubriria de sal.

\section{LA SALAMANDRA NEGRA-SALAMANDRA ATRA}

CARACTÉRES.-En los Alpes, la salamandra mancha. da tiene por representante una especie congenérica, la sala. mandra negra, muy semejante, pero de un color negro aterciopelado oscuro sin manchas; es un poco mas pequeña $y$ raras veces pasa de $\theta^{m}, \tau_{\hat{\jmath}}$.

DISTRIBUCION GEOGRÁFICA.-El árę de dispersion de esta especie se extiende por los Alpes de Suiza, Saboya, el 'Tirol, Estiria, Carintia, Salzburgo, el Austria superior y algunas montañas que se comunican con los Alpes ó son promontorios de los mismos. Además se encuentra, segun dicen, en la montaña alı de la Bucorina y tambien se ha observado en la Suabin superior como habitante continuo de las montañas de este pais.

USOS, COSTUMBRES Y RÉGIMEN. - Habita en gran número los sitios conrenientes de los Alpes situados á una altura de seiscientos á dos mil metros sobre el nivel del mar; en el 'lirol, segun Gredler, vive en los bosques húme. dos $\delta$ en los desfiladeros cruzados por riachuclos. Casi siem pre se reunen varias docenas de individuos debajo de las piedras, del musgo y la maleza, lo nismo que sus congéne res. Esta salauandra es un batracio perezoso, cachazudo al parecer y dormilon, que solo sale en tiempo húmedo de sus escondites, perjudicándole el ticmpo seco. $A$ causa de su pereza los habitantes del Tirol le dan el nombre de tailermann $\delta$ fattermandl, que significa hombre muerto, $\delta$ en la acepcion popular, estropajo.

La salamandra negra se diferencia de la manchada, segun Schreiber, por la manera de reproducirse. Tambien da ia luz sus hijuelos vivos, pero nunca mas de dos ó tres á la vez. Aunque los ovarios de la hembra son tan grandes como los de la salamandra manchada, $y$ aunque no lleguen menos huevos a la rez s los oviductos, en cada uno de estos se desarrolla un cmbrion s. costa de los otros huevos, porque estos se reunen en una yema que rodea el embrion hasta que rom pe la cáscara y puede moverse libremente. Veinte ó mas huevos quedan por lo tanto sin fecundar en los oviductos, constituyendo el alimento del embrion, que los ha consumido del todo á la hora del parto.

Cada embrion se desarrolla no solo completamente sino que tambien crece hasta medir de $0^{n}, 045$ a $11^{\circ}, 050, y$ llena la extremidad posterior del oviducto, que tiene $(\eta=, 035$ de largo por $0^{\circ}$, or de diametro; alli se le ve con la cola oprimida contra el cuerpo, y á menudo doblada dos veces; muévese libremente con viveza; se revuelse con frecuencia del todo, y tan pronto nace de cabeza como de cola Las branquias, semejantes a las de la salamandra manchada, son mas grandes y llegan casi á la mitad de la longitud de todo el cuerpo, toda vez que el arbolillo posterior alcanza hasta las ancas; pero estas branquias desaparecen antes del nacimiento, apareciendo en los recien nacidos en forma de pequeños muño. nes; de modo que para ver el animal en el estado de rena. cuajo es preciso examinarle en el vientre de la madre $A$ este efecto se mata la hembra con espíritu de vino, el cual pro. duce tan poco efecto en los hijuelos, que aun fucra del vientre de la madre continuan viviendo algunas semanas. Esta asombrosa resistencia vital demuestra que esos animalitos pueden prescindir del agua, y en efecto, la hembra deposita sus embriones siempre en un sitio seco, aun en cautividad, cuando se le ofrece abundante agua. Observamos por lo tanto en la salamandra negra un modo extraño de reproducirse que aun no se ha visto en ninguna otra especie del órden.

El desarrollo de los huevos dura el mismo tiempo que necesitan los de la salamandra manchada, pero el periodo del cmbarazo desde la fecundacion hasta el parto es mucho mas largo, porque los pequeños permanecen en el vientre de la madre hasta que termina la metamorfósis y alcanzan considerable tamaño.

Raras veces se encuentran antes de agosto hembras prenaadas con hijuelos desartollados; la fecundacion se verifica á menudo muy tarde, 5 por lo tanto, no solamente la falta de agua, sino tambien cl clima, son circunstancias que explican en parte esta reproduccion tan distinta.

Por lo regular, los hijuelos de una hembra son de igual tamaño y fuerza en ambos oviductos, $y$ ś menudo nacen tambien á la misma hora; se da, no obstante, el caso, alguna vez, de que el desarrollo de ambos sea desigual, y que el uno nazca algunos dias y hasta semanas despues del otro. Esta diferencia resulta segun parece de la circunstancia de que el primer hucro fecundado se malogró y que se desarrolla otro en su lugar. Bastante á menudo se encueniran en un mismo oviducto dos, y hasta tres huevos en un estado diferente de desarrollo; nientras que los otros son mas ó menos planosó disformes, ó se hallan reunidos en una masa. De aqui resulta que todos los huevos de una misma cria se fecundan al mismo tiempo en los oviductos ú ovarios, aunque siempre se desarrollan solo dos. La manera misma de fecundarse es un enigma, porque en la salamandra negra tampoco se observan órganos genitales exteriores en el macho, y à pesar de esto la fecundacion debe verificarse en el interior y la esperma ha de penetrar por lo tanto sin concurso del agua. Por lo dentís se ha observado que el macho de la salamandra negra abraza á la hembra como las ranas que se aparean, agarraindola precisamente por delante de las patas anteriores, con las cuales la hembra coge las anteriores del macho. Abraza. dos asi, los dos se dirigen desde tierra firme al agun donde permanecen á menudo horas enteras, ya nadando ó bien descansando hasta que han satisfecho su instinto.

Por todos los demás conceptos la salamandra negra es enteramente análoga á sus congéneres.

\section{LOS PLEURODELOS - PLEURO- DELES}

Michahelles, excelente naturalista, publicó en $1 \$_{30}$ la descripcion de un urodelo acuático que eligió por tipo de un género independiente, habiéndole considerado los naturalis. tas posteriores como tipo primitivo de una familia. Este batracio es el pleurodelo de W'altl. 
CARACTERES - Las especies de este género tienen el tronco delgado y prolongado, pero bastante sólido; la cabeza un poco mas larga que ancha; la punta del hocico cortada obtusamente $y$ en la hembra plana y redondeada; la cola comprimida en forma de cuchillo, redondeada en la extre. midad y provista tanto por arriba como por abajo de una marcada cresta membranosa. Las patas anteriores tienen cuatro dedos libres $y$ las posteriores cinco.

\section{EL PLEURODELO DE WALTL-PLEURODE LES WAITITI}

CARACTERES. - Iá piel glandulosa y granujienta de este batracio se distingue sobre todo por una serie de grartdes protuberancias córneas que se corren a cada labio á lo largo de la linea divisoria del lomo y del aboúmen; hállanse situadas exactamente en las partes clonkle las extrenidades de las costillas tocan la piel interna, por lo cual algunos naturalistas han cometido el error de considerarlas como las extremidades de las mismas costillas.

Los dientes palatinos forman dos series longitudinales casi recias, pero separadas en su parte posterior y cuyas extremi. dades anteriores se desvian en un espacio bastante ancho, aranzando tanto hácia adelante qque sobresalen mucho del borde posterior de las aberturas iniernas de la nariz I a len. gua es pequeña, fija en su parte anterior y mas ó menos libre en los lados y en la extremidad posterior.

Michahelles dice que el color es un pardo sucio que tira un poco 2 gris, con manchas poco niarcadas"en el tomo, mien. tras que la cara abdominal presenta sobre ius fondo amarillo unas pequenas manchas redondas de color gris negruzco. Dumeríl, que en 1852 recibió tambien un pleurodelo vivo, presentó un grabado segun el cual el color de las regiones superiores es gris verdoso con fajas trasversales y longitudi. nales amarillas; las puntas córneas de las glándulas laterales están rodeadas de un circulo rojo: $y$ las regiones inferiores son amarillas con matices mas oscuros y fajas trasversales de un negro verdoso. La cabeza, ciyo fondo es gris oscuro, presenta manchas de un amarillo claro. Schreiber, en fin, que pudo disponer de mayor número de individuos, dice que el color predominante de las regiones superiores es por lo regular amarillo sucio, que en las hembras adultas tira mas al gris, pero en los machos al rojo, y á nenudo tambien el pardo aceituna $y$ hasta negruzco. Las partes inferiores, por lo regular mas pálidas q̨ue las superiores, tienen unas manchas muy pequeñas con bordes irregulares y de color bas. tante negruzco, casi siempre aisladas, pero á reces mas ó menos reunidas $y$ en algun individuo tan aglomeradas que cubren parte del color principal ś ocupan casi todo su cuerpo. El borde inferior de la aleta de la cola y la punta de los dedos tienen un tinte amarillento; las numerosas-verrugas del cuerpo presentan en la punta una especie de costra córnea de color negro.

Los hijuelos se distinguen de los adultos por tener las partes superiores mas claras, por lo regular de un rojo la drillo, $y$ las regiones inferiores de un solo color. Los rena cuajos del todo desarrollados tienen sobre un fondin blanco ó amarillento claro numerosas manchas, en su mayor parte de un color ceniciento oscuro; las regiones inferiores son blancas salpicadas de puntitos grises. En los tres hacecillos de branquias el del centro es el mas pequeño, mientras que el inferior y mas largo llega hasta detrás del codo. La cola, de la misma longitud del cuerpo, es muy comprimida lateralmente, y el borde superior de su cola es muy subido. La picl es casi lisa.

Los adultos pueden alcanzar una longitud de $0^{\circ}, 26$ : tales individuos se encuentran sobre todo en el Africa. Los hijuelos mas pequeños que acaban de trasformarse tienen $0^{\circ}, 06$ de largo; pero ámenudo se encientran renacuajos bastante análogos por su tamaño á los individuos casi adultos, ó que cuando menos son el doble mas largos que los hijuelos me. tamorfoseados, aventajándolos tambien por su volúmen, de seis á ocho veces mayor.

Mucho mas que por su forma exterior y sus colores, dis. tínguese el pleurodelo por su esqueleto de los otros uro. delos. Cuenta el considerable número de cincuenta y seis vértebras; la primera de estas carece de costillas; las catorce siguientes llevan en sus apófisis laterales costillas desarrolla. das que rematan en una punta aguda y miden ocho millime. tros de largo. En la fuerte apófisis trasversal de la décima. sexta vértebra se insertan las extremidades posteriores; el resto de las vértebras pertenece á la larga cola Ningun otro urodelo tiene tantas costillas desarrolladas ni un número tan considerable de vértebras.

El cráneo es por lo regular mas redondeado y aplanado que el de los otros urodelos $y$ se distingue por tener un arco óseo, que por lo demás solo existe en algunas especies de crocodilos. Los bordes de las mandibulas tienen dientes puntiagudos, que en muchos individuos llegan al numero de 48 á 60 en cada maxilar; los individuos adultos no cuentan tantos como los jóvenes. En estos últimos se ven tambien en cada hueso palatino doce dientes afilados, puntiagudos y muy pequeños, mientras qque en otros individuos el borde del palatino solo es denticulado como una sierra.

DISTRIBUCION GEOGRAFICA.-El pleurodelo de Waltl se ha encontrado hasta ahora solo en Espana, Portu. gal y Marruecos, donde habita únicamente ciertas partes del pais.

USOS, COSTUMBRES Y REGIMEN.-Waltl, que des. cubrió este batracio; por lo cual se le dió su nombre, hallóle en las cisternas que se usan en toda Andalucia. Algunos de estos depósitos de agua tienen una profundidad de seis á diez $y$ hasta treinta metros y solo la menor parte está construida, de modo que con un largo baston y una red se pudieran coger los urodelos que las habitan. Las salamandras viven en gran número en aquellas cisternas, mas por la indi. cada razon es dificil pescarlas, de manera que el naturalis:a ha de contentarse por lo regular con verlas. Mas tarde se re. conoció que no solo se encuentra el pleurodelo en las cisternas sino tambien en charcos mas accesibles.

Carecemos aun de toda noticia sobrc su genero de vida. El considerable tanaño de los renacuajos permite sin embargo suponer que observa poco nas ó menos el del axolotl, del cual hablaré despues mas minuciosamente. Entre cierto número de pleurodelos cogidos en Andalucián la vez y en el mismo charco, halláronse, segun las noticias de Schreiber, que recibió estos animales, casi tantos renacuajos grandes como pleurodelos metumorfoseados, circunstancia por la cual el citado naturalista deduce que estos batracios existen quizás con tanta frecuencia en la forma de renacuajo como en la de individuo metamorfoseado.

\section{LOS AMBISTOMES - AMBYSTOMA}

Las especies que representan este género son todas ame. ricanas, $y$ han sido descritas por algunos autores con cl nombre de salamandras. Solo citaremos aqui las mas notables.

CARACTÉRES. - Estos batracios tienen la lengua redondeada, y solo libre en los bordes; una parótida poco saliente, recorrida en su longitud por un surco que sigue la direccion de la abertura de la boca; los dedos, en número de cinco, son todos endebles 5 cortos, pero se marcan bien; la 
piel, con frecuencia lisa, forma surcos trasversales en los cos tados: la cola es gruesa en la base y corta, aunque compri mida, hácia su iercio terminal.

\section{EL AMBISTOME NEGRO-AMBYSTOMA NIGRUM}

CARACTERES.-Este batracio es del todo negro en la parte superior del cuerpo, sin mancha alguna, y de un tinte rojizo mas pálido en las regiones inferiores, con pequeñas marcas blanquizcas en los bordes; la cola es gruesa y redonda en la base, pero sumamente comprimida en el resto de su extension.

DISTRIBUCION GEOGRÁFICA.-Se ha encontrado cl ambistome negro en todos los Estados de la Union hasta los $45^{\circ}$ de latitud; tambien se le ha visto en el golfo de México, en la Luisiana, en Pensilvania, en Georgia y en la Ca. rolina.

USOS, COSTUMBRES Y RÉGIMEN. - E; de creet que esta especie parece destinada a vivir igualmente en el agua, al menos á juzgar por la estructura de su cola. Nada se sabe con seguridad acerca de sus costumbies, pues no ha sido observado ningun individuo vivo.

\section{EL AMBISTOME ATIGRADO-AMBYSTOMA TIGRIINUM}

CARACTÉRES. - El ambistome atigrado tiene el cuer po negro, con grandes y numerosas manchas amarillas, que sé corren por la cola, la cual es corta y muy gruesa en la

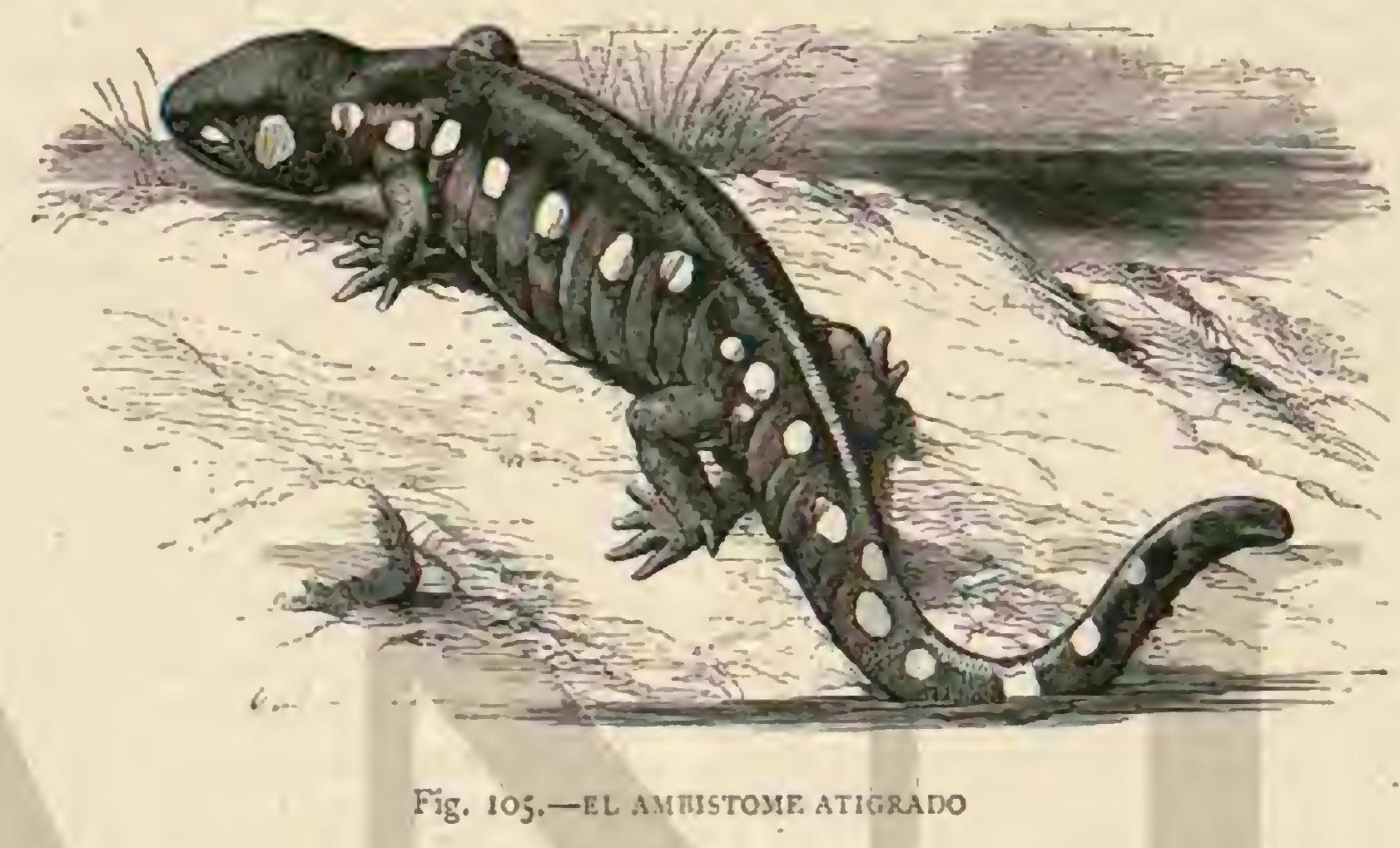

base; la cara inferior del tronco $y$ las patas son de un tinte gris azulado oscuro, sin mancha alguna. Este reptil mide $0^{7}, 13$ de largo total (fig. 105).

DISTRIBUCION GEOGRÁFICA.-Se encuentra el ambistome atigrado en Nueva-York y en Nueva-Jersey.

\section{LOS TRITONES-TRITON}

CARACTERES. - Los tritones se distinguen por tener el tronco prolongado; las extremidades anteriores provistas de cuatro dedos y las posteriores de cinco; la cola es muy comprimida y alta; la piel mas ó menos lisa; en el lomo hay una cresta membranosa desarrollada, cuando menos en los machos durante el periodo del celo; la lengua, de tamaño regular, redondeada ú oval, está fija por toda, su cara in. terior en el fondo de la cavidad bucal ó solo en los lados y en el borde posterior, mas 6 menos libre, ó fijada por-una faja longitudinal en el centro, en cujo caso los lados quedan libres en bastante extension. Al considerar el género en su conjunto, como lo hacen actualmente la mayor parte de los naturalistas, debo notar que la cola de los tritones verdaderos puede ser muy gruesa y casi cilindrica, pero siempre lle va en su parte superior e inferior una cresia membranosa. Ki tronen es en algunas especies casi anillado y en vez de la piel lisa se ve á menudo tambien una piel glandulosa y verrugosa. En Alemania viven cuatro especies pertenecientes á este género.

\section{EL TRITON DE CRESTA-TRITON CRISTATUS}

CARACTÉRES.-El triton de cresta (fig. 106), llamado tambien gran salamandra acuática, llega á una longitud de Tosso $\mathrm{V}$
$6^{17}, 13$ a $6^{n}, 17$ y se distingue por la cabeza aplanada, redondeada en su parte inferior y scmejante á la del sapo; la piel está cubierta de granos gruesos. El color predominante del lomo, de los costados, de la cola y de las partes inferiores de las extremidades es de un pardo oscuro; los matices se reducen á manchas grandes, negras y blancas, reunidas á menudo en grupos. La parte inferior, desde la garganta pre. senta sobre un fondo amarillo manchas negras de tamaño $y$ formas diferentes. El iris es de un amarilio dorado.

En el período del celo, el triton de cresta se trasforma esencialmente. Fn su parte superior y en la cola elévase una alta cresta membranosa y denticulada, que partiendo de la cabeza, entre los ojos, se extiende hasta la extremidad de la cola, comprimiéndose-bastante en la base de la misma. El color amarillo de las partes inferiores se convierte en un naranja muy oscuro, y en los lados de la cola hay unas fajas de color blanco azulado de nácar; en la garganta se ven además de las manchas oscuras, muy numetosas, unas verrugui. tas blancas. La hernbra carece tambien en el periodo del celo de cresta; y el amarillo de la cara abdominal tira mas á un color de azufre, cxtendiéndose sin embargo hasta la pun. ta de la cola; las fajas blancas laterales de aquella solo es. tán indicadas; en la garganta no hay mas que manchas oscu. ras y carece de verrugas.

Se han observado diferentes variedades: Reichenbach, por ejemplo, vió un triton en que el color amarillo rojo de las partes inferiores se extendia tambien por las superiores, donde al principio tuvo algunas manchas de un negro amarillento; pero poco a poco predominaron los colores regulares.

DISTRIBUCION GEOGRÁFICA.-El área de dispersion del triton de cresta se extiende por Alemania, Suiza, Francia, Bélgica, Holanda, Dinamarca, Inglaterra, Escandi- 
navia, Rusia é Itália; ilega por el este hasta la Transcau. casia.

\section{EL TRITON DE LOS ALPES-TRITON AL- PESTRIS}

CARACTERES.--Esta especie, mucho mas pequeña que la anterior, mide solo de $0^{m}, 0 S$ a $0^{\circ}, 09,5$ la hembra cuando mas $0^{n}$, ro: la cola se parece aun mas a la del sapo.

El color predominante del lomo es un gris de pizarra, con manchas denticuladas de color pardusco oscuro, que en los lados de la cabeza y en la cara superior de las extremidades se trasforman en manchas redondeadas negras. Las partes in feriores son de un rojo de naranja sin manchas; el iris de un amarillo dorado con riso negruzco.

En el periodo del celo se eleva en el dorso del macho una cresta baja y lisa, que parte de la region posterior de la cabeza y se piérde en el borde de la cola. Su color es un blanco amarillento con cortas fajas negras y verticales, en cuyo centro hay á menudo manchas triangulares oscuras. El gris pizarra del fondo tira al pardo y puede trasformarse en los lados del vientre en pardo claro; el color naranja de la cara abdominal se vuelve rojo de fuego; los bordes superior é in ferior de la cola son de un amarillo blanquizco con manchas mas oscuras; al lado de la cola hállase una serie de manchas blanco azulaidas.

- El color predominante de la hembra, en las regiones superiores, consiste en un gris claro ú oscuro que se ve en todas partes, salpicado de puntos oscuros; la serie de manchas negras de los costados se toca inmediatamente con el amarillo de naranja del vientre; á menudo forman una faja blanquizca ó cuarido menos están rodeadas de puntos blanquizcos; el anarillo del vientre se extiende hasta la punta de la cola, cortado por algunas manchas negras.

DISTRIBUGION GEOGRAFICA.-El triton de los A1pes se extiende por Alemania, Suiza, Francia, Bélgica, Italia y el sur de Suecia.

\section{EL TRITON MOTEADO - TRITON TEL- NIATUS}

CARACTERES. - El triton moteado (fig. 107) ó pequeña salamandra acuática llega solo á $10^{m} 67$ de longitud, raras veces á $0^{\prime \prime}, O S$, distinguiéndose por su estructura delicada y raquitica; la cabeza, semejante mas bien í la de los peces que á la de los sapos, tiene una doble serie regular de glándulas deprimidas; la cola es larga, casi filiforme y puntinguda en la extremidad. Las partes superiores son de un verde aceituna ó pardo que en los costados pasa á un blanco amarillo delicado, con ligero viso plateado; las inferiores de un amarillo de naranja: en todo el cuerpo hay manchas ne gras; una de estas, longitudinal y dispuesta verticalmente, resalta por su color sonrosado en la base de las patas posteriores.

En el periodo del celo se ensancha la cola del macho y se desarrolla la cresta, que comienza en la nuca; es mas alta sobre el ano y constituge una membrana floja; tambien los dedos de las patas posteriores tienen entonces el borde membranoso. Toda la piel se presenta cubierta de puntos blanquizcos; el color de las regiones inferiores pasa á un verde aceituna muy oscuro; el del centro del vientre a un tinte naranja viro que se continúa en forma de faja por la parte inferior de la cola. Unas manchas oscuras, grandes $y$ redon. deadas, resaltan en el vientre y la cola en series longitudinales y se reunen en la parte superior $y$ en los lados de la cabeza, formando fajas longitudinales; la cola se distingue además por una faja de un azul de nácar que se corre sobre el borde amarillo, cortada á veces por manchas oscuras.

La hembra carece en el periodo del celo de la cresta dor. sal y tambien la cola presenta solo en la cara superior é in. ferior un borde membranoso poco desarrollado; los dedos de las extremidades posteriores carecen del borde. El lomo es de un verde aceituna claro ó pardo; el color amarillo blanco de los costados ofrece un ligero viso dorado; el co. lor de naranja del vientre es menos intenso que en el macho; las manchas oscuras son pequeñas pero espesas y numerosas, no solo en la cabeza sino tambien en el tronco y en la cola, donde forman aglomeraciones denticuladas.

DISTRIBUGION GEOGRÁFICA. - Entre nuestros tri. tones alemanes el moteado es el mas extendido, porque no solamente habita la Alemania, Austria, Suiza, Francia, Bélgica, Holanda, Inglaterra, Dinamarca, Escandinavia y Rusia, sino tambien la Italia, el Portugal y la Grecia, haIlándose por el este hasta la Armenia.

\section{EL TRITON DE SUIZA-TRITON HELVETICUS}

CARACTERES. - El triton de Suiza tiene el mismo ta. maño que el de los Alpes y una estructura delicada; la cabe. 7.a se parece a la de la rana y se distingue de la de sus congéneres alemanes por una linea longitudinal que se corre á cada lado del espinazo. De la extremidad truncada de la cola sobresale una punta disforme de variable longitud. El color predominante de las regiones superiores es un pardo. aceituna que tirn mas ó menos al amarillo, con ligero brillo dorado, manchas $\mathrm{y}$ fajas mas oscuras; las partes inferiores tienen un color amarillo de naranja mate.

En el lomo del macho se eleva durante el periodo del celo en vez de la cresta una protuberancia que en la cola se reune con el borde superior de la aleta; al mismo tiempo se desarrolla en las partes posteriores una membrana natatoria completa entre los dedos. El color de las partes superiores se trasforma en amarillo con lustre metálico, mientras que Ja mitad inferior de los costados es de un blanquizco brillante y el vientre de un amarillo naranja. Unas manchas mas oscuras comunican á la cabeza un aspecto marmóreo, asi como á las extremidades anteriores.

En la hembra la cola es mas baja; la membrana natatoria de las patas posteriores no está desarrollada, y el color es mas monótono, porque el del fondo se extiende mas sobre los costados, y porque las pequeñas manchas resaltan menos marcadamente. Solo las regiones inferiores son de un color mas vivo que en el macho, porque el amarillo de naranja del vientre se extiende por el borde inferior de la cola hasta. el liltimo tercio.

DISTRIBUCION GEOGRAFIGA.-El triton de Suiza vive en el sur de Alemania, Bélgica, Inglaterra y Portugal. El centro de su área de dispersion es la Francia, segun parece. En Alemania habita solo, por lo que hasta ahora sabe. moș, la Suabia y el centro del Rhin, faltando del todo en las demás regiones.

USOS, COSTUMBRES Y REGIMEN.-Los tritones se diferencian tan poco por su généro de vida que al describir las costumbres de una especie se puede formar idea sobre las de todas. Ocupándome primero del triton de cresta, completaré mi descripcion añadiendo las observaciones hechas en otras especies alemanas.

Considérase á los tritones por lo regular como animales acuáticos, y no sin razon, porqque pasan el periodo del celo, y además varios meses, siempre en el agua, que en ciertas circunstancias no abandonan nunca; no debemos olvidar, sin embargo, que pasan tambien mucho tiempo, $y$ algunas espe- 
cies todo el resto del año, ocupados en la reproduccion en tierra firme. Mientras se aparean y ponen los huevos prefic. ren las aguas claras donde abunde la espesura y encuentren el alimento necesario; en rigor solo se alejan de los rios de corriente impetuosa. Son torpes y pesados en tierra firme, pero se mueven en el agua con mucha rapidez, especial. mente con ayuda de su ancha cola; suben á menudo verticalmente \& la superficie para respirar, y cuando lo hacen en la profundidad producen algunas burbujas; bajan con movimientos serpentinos al fondo, donde persiguen su pieza. En verano abandonan las aguas para buscar escondrijos debajo de piedras y ramas de árboles, ó en cavidades de la orilla, etc., donde mas tarde, en otoño, se reunen para pasar el invierno; pero los que habitan en estanques ó fuentes pasan aqui tambien la estacion fria. Segun las observaciones de Leydig, los tritones pueden vivir mucho tiempo sin agua. \&He nota. do, dice este ilustre naturalista, y mas de una vez, que va. rios charcos habitados por gran número de estos animales se secaron del todo en verano, y estuvieron algunos años sin agua. Estos charcos estaban del todo aislados, y hallábanse en sitios en que no habia agua á mucha distancia. Con gran asombro vi entonces que cuando al cabo de tan largo tiempo los charcos volvieron á llenarse por las lluvias de majo, viéronse de nuevo los tritones.

Con la misma facilidad soportan el frio mas riguroso: repetidas veces se han encontrado individuos del todo helados, y muertos al parecer, que recobraron la vida con el deshielo; las aguas que se hielan hasta el fondo pueden servirles por lo tanto de residencia de invierno, sin que les cause daño.

Las especies que no salen á tierra firme se presentan por lo regular á fines de febrero $y$ dan principio á sus retozos amorosos. Cuando varios machos encuentran una hembra, el uno procura rechazar al otro, y el mas fuerte se reune despues algun tiempo con su compañera: esto es lo que se observa durante todo el periodo del celo.

Gacher notó que los machos en celo levantan su cresta moviéndola rápidamenic; despues acercan la cabeza al hocico de la hembra, y agárranse con la boca á las plantas para sostenerse en la misma posicion. Su cola se mueve entre tanto continuamente $y$ se encorva de tal modo que toca los costados de la hembra; las cabezas de los dos se aproxi. man hasta tocarse, separándose sin embargo en la parte postcrior del cuerpo, de modo que forman un ángulo agudo. Al cabo de bastante tiempo el macho arroja en el agua la es. perma yue llega á las partes genitales de la hembra, fecun. dando los huevos.

Rusconi, fundándose en cuidadosas observaciones, nos da noticias, en una obra especial, sobre la puesta de los huevos del triton de cresta y el desarrollo de los renacuajos. Nuestro naturalista adquirió varias hembras, en su concepto fecundadas, y las colocó en una gran vasija llena de agua. Tres dias despues vió en el fondo unos treinta huevos reunidos de tres en tres ó de cuatro en cuatro, los cuales puso en una vasija mas pequueña llena de la misma agua. Dos dias despues habian aumentado en tamaño y la superficie, antes lisa, se convirtió en rugosa, de modo que pareció que se des. arrollarian; pero al cabo de cinco à seis dias las cáscaras se volvieron opacas, $y$ todo indicó que los huevos no estaban fecundados. Las hembras habian puesto entre tanto otros huevos, $y$ entonces Rusconi intentó una fecundacion artificial vaciando la esperma de un macho sobre los huevos por medio de compresion; pero este $y$ otro experimento no tu. vieron tampoco buen resultado.

Entre tanto, el observador notó que las hembras de la salamandra ponian de vez en cuando sus patas posteriores de. bajo del cuerpo cual si quisieran cubrir el ano, y que poco despues depositaban huevos, los cuales no siempre caian al fondo de la vasija, sino que se mantenian á veces un corto rato suspendidos del ano; de modo que á menudo llevaban dos $\delta$ tres huevos en el orificio. Al cerrar la noche mostra. banse inquietas y buscaban una salida de su prision; entonces se las veia en posicion vertical, apoyadas en las patas posteriores y sosteniéndose con las anteriores en la pared del depósito. El movimiento de excitacion de las extremidades posteriores parecia tener por objeto facilitar la puesta de los huevos, pero pronto se vió que era otro el tin. Para que la cautividad fuese mas agradable habianse colocado plantas en el depósito, sujetándolas al fondo por medio de una piedra. Los tritones se aprovecharon en seguida de esta innoracion, y poniéndose sobre la piedra, asomaban el hocico en la superficie del agua. Cuando entonces Rusconi qui. so fecundar varios huevos no vió ninguno en el fondo del vaso, pero notó que una hembra se acercaba ślas plantas ol. fateando el follaje; á poco se colocó debajo de aquellas, cogió una lroja, y despues de permanecer un minuto en la misma posicion repitió lo mismo al cabo de tres minutos en otra. Rusconi vió además que las hojas se inclinaban, y al cxaminarlas encontró entre los dos lados de cada una un huevo adherido en su capa pegajosa. Entonces examinó el fondo y pudo ver que muchas hojas tenian huevos: esto le ofrecia materia suficiente para otras observaciones.

El huevo recien puesto, al principio esférico y de color blan. co amarillento, está rodeado de una sustancia pegajosa, pero no adherido a esta. Si se le da vuelias queda siempre del mis. mo lado en que estaba antes, $y$ entonces se nota tambien que es blanco por una parte y pardo por la otra, lo cual se produce por la clara del hucvo y la yema oscura; á esta última es debida la revolucion aparente, pues baja por su mayor peso. Al cabo de tres dias la forma del huevo ha cambiado un poco, y con un microscopio se ve la forma del embrion; este se arquea al quinto dia, y entonces ya pucde distinguirse la parte posterior del vientre, la cabeza $y$ la cola, y en esta última los indicios de las branquias y de las patas posteriores. El dia noveno el embrion cambia de postura y las partes inferiores de la cabeza y del vientre son $g a$ vi. sibles, al mismo tiempo se mueve, y el corazon se contrae y ensancha alternativamente. El dia décimo los movimientos son mas frecuentes; el embrion cambia $\mathrm{cn} 24$ horas tres 6 cuatro veces de postura; las partes inferiores se cubren de manchas negras y en los lados de la cabeza se ven cuntro hilos que sirven al renacuajo para agarrarse. Al dia siguientc se desarrollan las hojitas de las branquias; y la circulacion de la sangre, que aun es blanquizca, se distingue bien. El dia duodécimo aparecen las hojitas laterales de las dos branquias grandes mas marcadas; los movimientos son en extremo ra. pidos y dilatan las paredes del huevo, que se rompen al dia siguiente; el renacuajo sale y se agarra á las hojas y á otros objetos; á veces tambien cae al suelo permaneciendo en él como muerto. Los ojos están apenas abiertos, la boca poco hendida; las patas anteriores parecen muñones; las hojas de las branquias se aumentan con el desarrollo de los intestinos, que se veriñca al mismo tiempo; manifiéstase la vida animal con mas fuerza; poco á poco se desarrollan las patas anteriores; y mas tarde, cuando el renacuajo tiene ya dos centimetros de largo, las posteriores. Al cabo de tres sema. nas termina la metamorfósis.

Entre otros naturalistas, tambien Laydig ha continuado las observaciones de Rusconi extendiéndolas á las demás especies. Que el huevo se desarrolle mas ó menos rápidamente, dice al hablar del triton de cresta, depende mucho de la temperatura. Los tritones de cresta cautivos ponian los huevos a principios de abril, en una labitacion donde el ter- 
mómetro marcaba $15^{\circ}$ Reaumur, mientras quue la misma cspecic depositó los primeros huevos al aire libre á una tem. peratura de $11^{\circ}$ Reaumur, à medio dia $y$ á la sombra. En libertad, la hembra del triton de cresta fija sus huevos en objetos que se encuentran en el agua; en cautividad empe. ro, y cuando se la espanta, pare los mas reunidos en un cor. to cordon a la vez y los deja caer al fondo. Los renacuajos se distinguen sa en su primera jurentud de los de las espe. cies congenéricas. El animal conserva todavia algun tienzpo al salir del huevo el color verde amarillo de la yema, y se dis- tingue mas tarde por un borde blanquizco muy estrecho quie rodea la alcta de la cola.

A mediados cie julio los renacuajos han alcanzado una lon. gitud de $11^{\circ}, 05 \mathrm{y}$ tienen un aspecio muy bonito. En las cur. tro piernas los dedos son relativamente muy largos y delica. dos, y las branquias, sobre todo en las superiores, ofrecen gran desartollo. En la cola se ensancha el borde blanco y se desarrolla un hilo de un centimetro de longitud, mas delgado en la punta, ademís de la fina red negruzca que se extiende sobre la aleta de la cola; distinguese tambien cicto

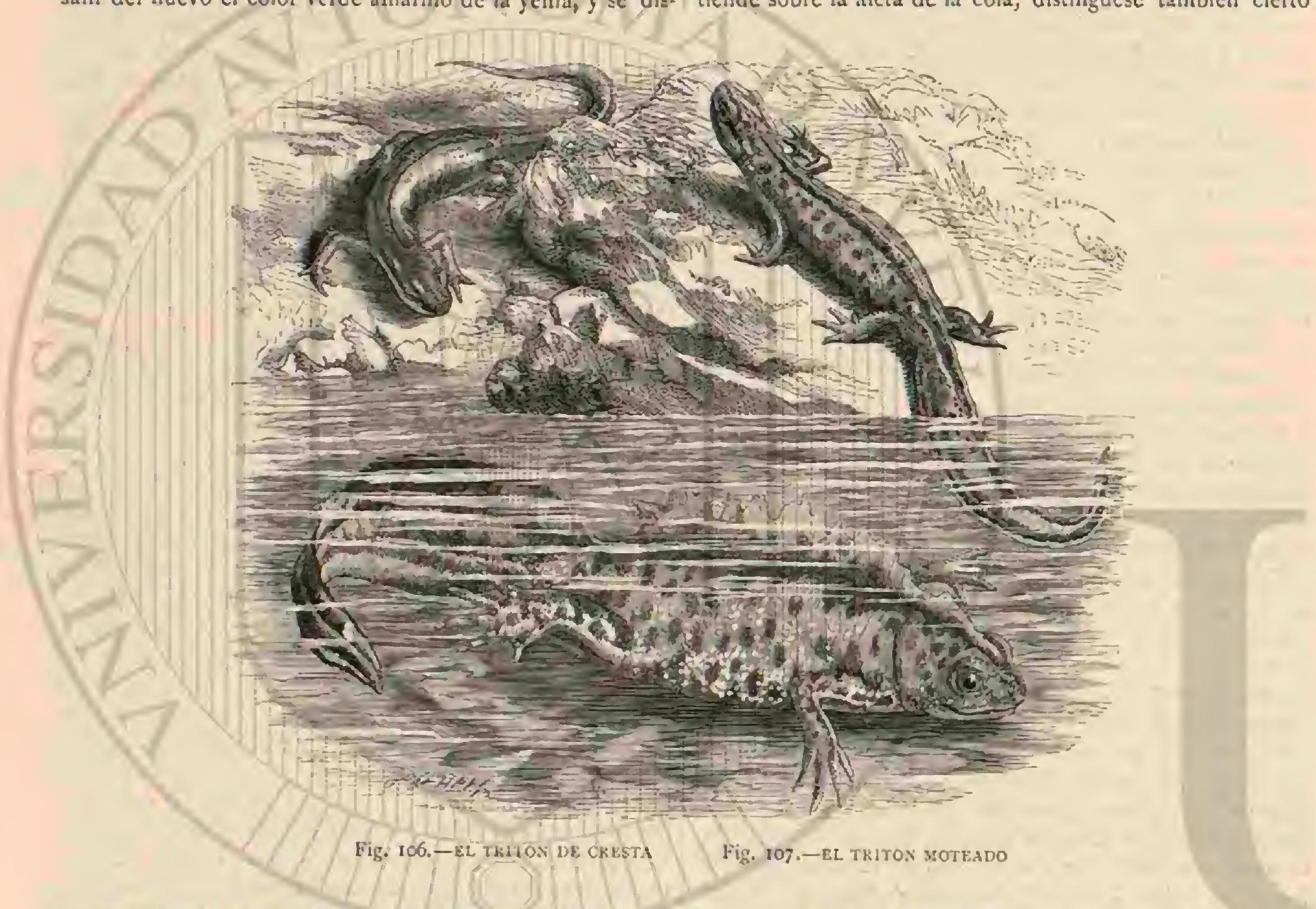

número de grandes motas negras y una serie de puntitos amarillos en los lados de la cola. El color predominante del lomo es por lo demás un pardo accituna claro sobre el cual resaltan algunos puntos claros; los iallos de las branquias, los costados y el vientre tienen un brillo dorado. A principios de setiembre desaparece el lustre metálico; el color del fondo se convierte en un gris aceituna claro, $y$ junto $\{$ las manchas negras resaltan unos puntos bianquizcos poco marcados. En el vientre se presenta ya la señal del color amari llo por unas manchas oscuras, y en el centro del lomo una linea lorgitudinal de un amarillo mate. Entonces tambien se observan las verruguitas blancas en la piel de los costados; la forma exterior es esencialmente la de los adultos; las bran. quias han desaparecido en parte, y con el aspecto de pez desapareció tambien el color de este, el lustre plateado y dorado.

El triton alpestre fué entre las especies cuidadas por Leydig el primero que depositó sus huevos, haciéndolo a princi. pios de abril. A mediados de mayo hubo un descanso; en los primeros dias de junio, cuando aumentó el calor, la hembra deposiló una infiniỏad de huevos en las plantas acuáticas; su color era gris pardo. I.os renacuajos recien nacidos son de un tinte pardusco, con dos líners dorsales oscuras. En los renacuajos medio adultos el fondo de las regiones superiores es pardo aceituna claro; el de las inferiores y de los costa. dos ofrece además un brillo plateado. La cola presenta sobre un fondo aceituna claro una espesa red de manchas de co. lor mas oscuro. En el mes de agosto los renacuajos tienen un aspecto caracteristico por las manchas mas claras, de for mas irregulares y bastante grandes, diseminadas en los cos. tados; estas manchas se aciaran cada vez mas, aumentan en dimension, y-reúnense á veces unas con oiras, resaltando de un modo muy agradable el color predominante. Ya antes no es dificil distinguir los renacuajos del triton alpestre de los del de cresta, y del moteado, aunque todos tengan el mismo tamaño. La cola es obtusa en la punta: el borde blanquirco de la extremidad de la aleta no existe $y$ la red negruzea de la misma es mas igual y espesa sin preșentar manchas. Cuan. do en los lados del tronco han aparccido las manchas claras sobre un fondo pardo oscuro, los animales se reconocen á primera vista.

Los renacuajos del triton moteado, provistos de cuatro pátas, son inferiores en tamaño á los del triton alpestre y tienen una estructura mucho mas raquitica y delicada: Su color es pardo aceituna claro; la cola presenta solamenie algunos puntos negros, pero se distingue en particular de la de los re. nacuajos del triton alpestre por tener una serie de puntos amarillos que en el tronco se corren á lo largo de la línea lateral, y avanzando por la base de la cola, se continuan hasia la extremidad de esta. 
De todas las especies propias de nuestros paises, el triton de Suiza es el que mas tarda en poner, no haciéndolo hasta fin de abril. A mediados de mayo, cuando el tiempo refres ca, síguese un breve intervalo; en junio, las hembras deposi tan muchos mas huevos que antes en las plantas acuáticas; y entonces los machos comienzan á perseguirlas del mismo modo que en la primavera: Leydig observó una vez que un macho de la especie moteada rondaba a una hembra de la especie suiza cual si no perteneciera a otra diferente. Los huevos tienen menos tamaño que los de las demás especics. Leydig recibió en setiembre renacuajos que estaban perdiendo las branquias y se caracterizaban por las dos prominencias laterales. El fondo del centro del lomo era pardo de cuero claro; to largo de la línea central del dorso se corria una linea mas oscura, y en ambos lados de las dos trasversa. les veiase una serie de manchas ligeramente plateadas que se extendian hasta la extremidad de la cola. Hácia los lados del tronco aumentaba el número de puntos blancos y el vientre presentaba un bonito brillo dorado; en el borde infe. rior de la cola habia una faja amarilla.

Los tritores son ya desde su primera jurentud rapaces que se alimentan exclusivamente de materias animales. Al principio dan caza á los pequeños crustáceos, á sus congéne. res y á las larvas de inscctos y gusanos. Mas tarde se atreven con presas mas grandes, como insectos que nadan en la superficie del agua, caracoles, moluscos en general, pececillos,

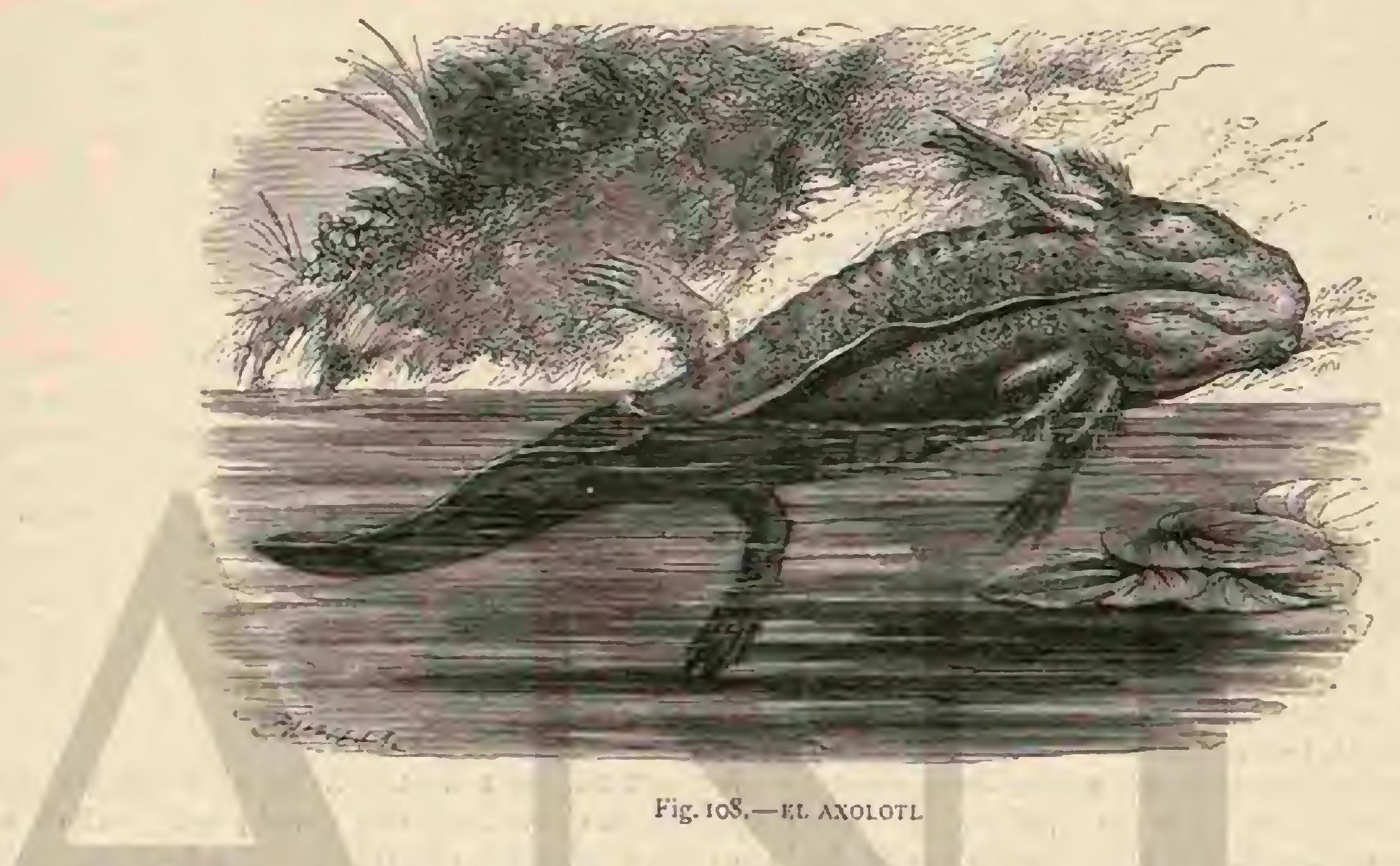

y quizás tambien pequeños renacuajos de su propia especie. No hacen daño en ninguna parte porque necesitan poco alimento; muy por el contrario, pueden considerarse como útiles.

Además de los cambios que los tritones ofrecen durante el periodo del celo, tienen la propiedad de variar mas 6 menos voluntariamente su color. Cuando I.eydig puso su triton de cresta que se hallaba en celo en una vasija mas pequeña, á fin de pintarle con mas comodidad, observó con sorpresa que el triton, moviéndose con temor, habia perdido algo del brillo de sus colores. Al colocar de nuevo el batracio en su vivienda anterior adornada de plantas acuáticas, calmóse poco a poco su excitacion, y al cabo de una media hora te. nia la misma coloracion brillante que antes presentaba. Esta observacion debió recordar á Leydig las que habia hecho en el hila arboricola, pero pronto advirtio un cambio mas brusco en los matices. 'Todos los individuos caurivos que vivian en el espacio frio tenian un color mucho mas claro que aquellos cuya prision era mas calida; y cuando Leydig quiso pintar algunos individuos sobre un fondo gris claro con manchas de un pardo oscuro, llevándolos al efecto á una habitacion bien abrigada, trasformóse el gris de pizarra claro en un gris oscuro y las manchas desaparecieron; en una palabra, el ani. mal cambió del todo de color. Este último, en opinion de Lejdig, sufre la influencia del sistena nervioso y depende del humor del individuo; la excitacion, el miedo, el espanto y la temperatura influyen poderosamente. Los batracios de los paises cálidos se distinguen de los de nuestras regiones solo por tener un cambio de colores mas vivos.
La muda de los tritones se rerifica en la primarera cada dos ú ocho dias, pero despues del apareamicnto menos á menudo, y aunque se efectua con bastante rapide\% parece ocuparles mucho, porque manifiestan mucha pereza. Antes de comenzar la muda, la piel se oscurece, pierde los colores y se desprende poco á poco, produciendio una sensacion des. agradable para el animal. Cuando ha llegado el tiempo, trata de practicar con ayuda de sus patas anteriores una abertura en la piel en la region de la mandibula; despues quecia la de la cabeza; y entonces, moviéndose á derecha é izquierda, se sacude á menudo, asomando aquella sobre la superficie del agta quizás con la intencion de hacer entrar aire en las partes ya separadas de la picl. Por los continuos movimien. tos del cuerpo, y con ayuda de las patas anteriores, desprende lentamente la piel, y despues sacude con tal fuerza el tronco, que la piel, rugosa ya, sale por la extremidad de la cola; el animal la coge entonces con la boca y desnúdase como quien se quita la camisa. La muda se efectua á menudo en una hora, pero a veces dura tres 6 mas, en cuyo caso fatigase mucho el animal. Se da el caso de que algunos individuos ayuden á otros á desnudarse; devoran la piel que han cogido con la boca, y arrójanila despues \& menudo sin digerir, y no siempre sin grandes csfuerzos. A veces sucede que la piel que devoran les cuelga despues en el ano, obligándoles a maniobrar mucho con la boca y las patas para desprenderse de ella. Essta observacion ha inducido á creer que mudan tambien el intestino. Cuando todo va bien y rápidamente, la piel desprendida tiene un aspecto muy bonito, porqque solo esta revuelta y no rota en ninguna parte, de modo que 
se pueden distinguir todos los dedos; únicamente en la re. gion de los ojos hay dos agujeros.

Por lo regular los iritones no emiten grito alguno, pero no por eso carecen de voz. Cuando se les toca un poco brusca. mente producen un sonido claro, análogo al de otros batracios; pero en libertad gritan durante el periodo del celo, siendo su voz tan semejante á la de los pelobates, que á me. nudo se les confunde con ellos, pues en muy pocas obras se da algun dato sobre este particular. La voz del iriton alpes. tre se parece, segun Glaser, á un tono claro de flauta, suave zuando resuena bajo los montones de piedra, en grietas de las rocas 6 en los agujeros subterráneos á poca distancia del agua.

CAUTIVIDAD.-Glaser és quien mejor ha descrito Ia vida en cautividad de los tritones. Segun ha observado, estos animales son muy tranquilos, y pueden tenerse por lo tanto sin dificultades en un sencillo acuario en el cual divierten muchó al observador. Son en extremo voraces y se domestican por lo tanto pronto cuando se cuida mucho de ellos dándoles con frecuencia de comer. Si alguien se acerca páranse en el fondo del agua mirando hácia arriba, y asi como los perros, fijan su vista en toda persona con la espe. ranza de que esta les dé alimento. En la primera época de su cautividad manifiestan timidez y están de continuo ocultos, saliendo solo cada quince minutos a la superície del agua para respirar y volver en seguida á su cscondite Cuando el hambre les obliga á salir y se les presenta ocasion de satisfacerla, muéstranse tan dóciles que todo el dia se pasean por d agua para ver si se les da algo. Estos animales acostumbrados á la oscuridad de las cuevas de los pozos ren muy poco con sus ojillos; tambien son muy torpes para co ger $y$ devorar su presa, y les cuesta mucho trabajo la deglucion. De vez en cuando se les ve bostezar, en) el verdadero sentido de la palabra, y en general son modelos de pereza y esiupidez. Todo alimento les gusta; comen con voracidad pequeños peces muertos, migas de pan y pedacitos de carne cruda, etc., y no es dificil por lo tanto conservarles en invierno en una habiacion caldeada.

Por temor á los grandes tritones, lós pequeños, tanto de la propia especie cómo de otra, se ocultan continuamente. Un triton negro de mediano tamaño devoró, ségun Glaser, casi al mas grande de la mișma especie, excepto la extremidad de la cabeza y los dedos anteriores. El observador atormentó al triton con un palo, y oprimiéndole contra la pa. red, obligóle á vomitar á su compañero devorado; este se hallaba cubicrto de una espuma blanquizca y medio muerto, pero pronto recobró las fucrzas y comió al cabo de algunos dias, cual si nada hubiera sucedido, las moscas que se le ofrecian en su escondite. Los aduitos devoraron pronto una media docena de pequeijos tritones negros de tres centímetros de largo, y Glaser observó tambien cómo los tritones grandes deroraban los moteados, sin que pudiera impedirlo. Otros tritones no pueden vivir juntos con el triton de cresta.

Un espectáculo muy divertido ofrece la alimentacion de los tritones con lombrices, porque entonces, y tambien cuan do se les dan moscas, disputan entre si: el uno coge al oiro con la boca por las piernas, $j$ todos se revuelven confusa. mente hasta que al fin se sueltan. A veces se da el caso de que la rana verde, que con ellos comparte la misma prision, se apodere de la presa apetecida. Como los tritones son muy cortos de vista, cuéstales mucho trabajo divisar los objetos que se les ofrecen; para que los distingan es preciso removerlos con la punta del baston, el cual muerden á menudo con voracidad, dejándose levantar en el aire. Glaser vió algunas vices cómo los tritones de cresta sacaban con grandes es. fucrzos los caracoles de su concha. Estos animales sacar. mucho la parte anterior de su cuerpo, y nadan en busca de las planias ó se pasean; y si entonces encuentran un triton hambriento que busca una presa, el batracio, á pesar de su torpeza, coge al caracol con la boca, sujétale, y sacudiendo violenta. mente la cabeza, lo saca poco á poco de la concha para derorarlo. Además de los individuos jóvenes y pequeños de su propia familia, estos caracoles constituyen sin duda el ali. mento principal de los tritones que en sus correrias nocturnas y durante su estancia en ticrra firme comen con preferen. cia caracoles y lombrices. Los tritones de cresta cautiros de Glaser, pasaban la canicula en las cavidades, donde perma. necian del todo ocultos sin hacer caso de las cosas que pasaban á su alrededor. Solo cuando el tiempo habia refrescado mucho volvian á presentarse y pedian alimento; agradábanles mucho unas moscas que abundaban en las habitaciones. Glaser obserió que un triton arrojo cierto dia varias veces una hormiga alada, acabando por no aceptarla, aunque todavia se movia en el agua. Tampoco les gustan, segun las experiencias de Glaser, las larvas secas de hormigas con que en invicrno se puede alimentar á los peces dorados y á los batracios. Sterki nos habla de lo envidiosos que son los tritones tratándose del alimento: véase lo que me dice en una carta. "Cuando se les dan muchas lombrices, escribe, pelean á menudo con gran furia antes de que ninguno consiga tocar una presa, lo cual no es fácil mientras no haya suff. ciente para todos. A menudo se cogen uno á otro por la mandibula sujerior, luchando hasta que se aplaca su furor, y entonces comienzan a comer tranquilamente hasta que am. bos, al devorar las extremidades de una lombriz, se encuen. tran en el centro; la presa no se rompe por lo regular, pero un triton la saca de la boca del otro. 3 Los tritones peque. nos se conducen en cautividad esencialmente como los de cresta.

RESISTENCIA VITAL.-En los tritones se han hecho experimentos sobre su resistencia vital y la facultad de sus. ittuir las partes perdidas con otras nuevas. Su insensibilidad contra las influencias del tiempo, la resistencia con que pueden soportar los efectos del calor ó frio, son propiedades que se habian observado antes, observándose asimismo que las extremidades cortadas volvianá crecer. Esta propiedad fué la que precisamente indujo á los naturalistas a practicar amputacio. nes en cuanto pudiese soportarlas un batracio vivo. Spallanza. ni y Blumenbach les cortaron las piernas y la cola, sacaironles los ojos, etc., demostrando con tales experimentos que todas estas partes vuelven á crecer con todo su desarrollo, pues no se forman munones, sino verdaderos miembros con todos los huesos y articulaciones. Una cola cortada se susti. tuge por otra nueva, tan larga como la anterior y con nucvas vértebras; en las piernas cortadas vuelven a formarse to. dos los huesos varias reces seguidas; y hasta las mandibulas separadas se forman de nuevo. Spallanzani hizo producir á sus tritones cautivos en tres meses 687 huesos; Blumenbach cortó á un triton las cuatro quintas partes del ojo, y al cabo de diez meses vió que el animal tenia un nuevo globo con membrana córnea, iris, pupila, y en una palabra un ojo nue. vo, que solo se diferenciaba del primero por su menor ta. maño.

Erber refiere un ejemplo de la resistencia vital de estos animales. UUna culebra, dice, devoró un triton, con el cual escapó: al cabo de un mes, al sacar de la cocina una caja, arrancóse una pata anterior al mismo batracio, vomitado sin duda por la culebra. El triton estaba del todo seco, pero notí una señal de vida y púsele por de pronto sobre una maceta. Cuando mas tarde regué las flores mojando al mismo tiem. po al triton, este recobró algun vigor é intentó moverse. En- 
tonces le introduje en agua fresca y alimentéle con lombrices. Al cabo de algunos dias estaba muy alegre, y a las tres semanas creció en el sitio del pié un pequeño muñon defor. me, el principio de una pata nueva que cuatro meses mas tarde se habia desarrollado del todo.

Desde entonces cuidé mucho del animal, y pronto se acos. tumbró a subir cuando tenia hambre por las paredes del cristal, para tomar el alimento de las manos. Ia vasija estaba en medio de las rentanas; á últimos de otoño se lieló de no. che el agua en que vivia el batracio y el cristal se rompió. Tambien el triton estaba helado; pero como queria guardar. lo en espiritu de vino, puse la vasija en otra mas grande co. locándola sobre la estufa para derretir el hielo; olvidé, sin embargo, mi triton, y cuando fuĺ á buscarle encontré el agua muy caliente; cl calor, sin embargo, habia ruelto á la vida al animal que hacia todos los esfuerzos posibles para escapar de un baño tan desagradable; entonces lo puse otra vez en agua fresca, donde vivió aun todo el año.

\section{LOS SALAMANDRINOS-SALAMAN- DRINA}

CARACTÉRES. - Ia existencia de cuatro dedos en las extremidades es el carácter mas saliente de los salamandrinos, que además se distinguen por el tronco prolongado; la cola casi cilindrica y puntiaguda, pero provista tanto por ar. riba como por abajo de un borde agudo; las glándulas auriculares están bien marcadas y la piel es muy granujienta. Los dientes palatinos forman dos series longitudinales paralelas en la primera mitad y despues miy separadas, cuya extremidad anterior no sobresale de las aberturas interiores de la nariz. La lengua es grande, prolongada, mas estrecha por delante, redondeada en forma de ligero arco en la parte posterior, y fija solo en la anterior, de modo, que no solo la mitad posterior sino tambien los bordes de los lados quedan libres.

\section{EL SALAMANDRINO DE ANTEOJOS-SALA-} MANDRINA PERSPICILLATA

CARACTERES. - La única especie del género es el sa. lamandrino de anteojos 6 la tarantuliva de los italianos. El color de las regiones superiores es un negro mate en el cual resalta marcadamente un matiz amarillo rojizo en forma de anteojos; la garganta negra, con una mancha blanca, las tegiones inferiores de color claro, con muchas manchas irregulares y puntos negros; la cara anterior de las piernas y la interior de la cola son de un bonito rojo oscuro. Este animalito es mucho mas pequeño que nuestro salamandron aleman; su longitud no pasa de $0^{\prime \prime}, 08$, de la que la cola ocupa mas de la mitad.

DISTRIBUCION GEOGRÁFICA.-La Peninsula itálica, $y$ las islas vecinas, y segun Gray, tambien la Dalmacia, son la patria de esta graciosa salamandra.

USOS, COSTUMBRES Y REGIMEN. - Habita los sitios de la montaña, frescos y frondosos, pero parece que no se encuentra á nuestra altura, sino que prefiere las colinas, $y$ en general las regiones escabrosas. Hasta el año $186_{3}$ solo se habian publicado muy pocas observaciones sobre el gé. nero de vida del bonito animal; $y$ tambien la obrita de $R$. morino, entonces estudiante de ciencias naturales y ahora catedrático de Buenos.Aires, publicada en el mismo año, lla. mó la atencion sobre el asunto. Solo Lesson, ilustre natu. ralista italiano, que en compañia de Salvadori hizo la mejor traduccion hasta ahora publicada de la eVida de los animales, dió áluz en r 868 una descripcion del género de vida de este animal, que apenas deja algo que desear, aunque mas tarde la completó.

El salamandrino de anteojos es comun en los contornos de Génova y abunda mucho en las montañas que rodean esta bonita ciudad en forma de anfiteatro. De esas montañas precipitanse pequeños rios hácia el mar, que como todas las aguas montañosas, se trasforman despues de una borrasca en rápidas corrientes, secándose luego casi del todo y conservan. do tan solo en su cauce algun charco en cuyas aguas crecen muchas plantas y por lo tanto tambien larras de insectos. Las montañas no lienen bosques, ni siquiera espesuras, y muy cerca de los citados charcos viven los salamandrinos de an. tcojos, ocultos debajo de piedras 6 en el cieno húmedo. En dias de lluvia, sobre todo en la primavera y en otoño, salen de su escondite, pero en verano solo despues de una lluvia tempestuosa, muy rara en la citada estacion en los alrededores de Génova. Con mucha mas frecuencia se los ve en los hermosos y tranquilos dias de invierno, hasta en enero.

Aliméntanse con preferencia de hormigas y pequeñas ara. ñas. En los primeros dias hermosos de la primavera, es decir en mayo, entran en el agua para depositar sus huevos, y entonces se ven las hembras en algunos de los citados charcos. Los que llegan primero eligen los mejores sitios, es decir las paredes de roca puestas á la entrada del agua; de modo que aun despues de un chaparron los huevos no pueden ser ar. rastrados por el agua. Ocupados una vez los sitios mejores, las hembras que llegan despues deben contentarse con los que quedan, y depositan sus huevos en donde pueden, sea en las ramas que se encuentran en el agua ó en las hojas secas del suelo, etc Sucede a menudo en este caso que el agua arrastra gran número de los huevos hasta cl mar, y tambien perecen muchos, aunque raras veces, cuando los charcos sc agotan. Segun las observaciones de Lesson, solo las hembras entran en el agua, ó por lo menos, ni el citado natura. lista ni ninguno de sus ayudantes encontró jamás un macho en ella.

El aparcamiento débe por lo tanto verificarse en tierra firme y ser interno, es decir, completo. Los huevos puestos están rodeados de una sustancia parecida á los de las ramas, y sufren con poca diferencia tambien los mismos cambios, 6 en otras palabras, el mismo desarrollo. En una temperatura de quince grados aparece al cabo de cuarenta y ocho horas el primer surco central; veinticuatro despues la prominencia del lomo; y entonces se efectua el desarrollo del modo regular. El renacuajo sale á los veinte 6 reintitres dias; $y$ al tercero de nacer se les ve echados y fijos con ayuda de los dos apéndices que les sirven para agarrarse. El dia décimooctavo de su vida están desarrollados los dedos, y á los cincuenta ó cincuenta y dos llegan á su completo desarrollo. Los rena. cuajos del salamandrino son en general mas perezosos que los de la rana; descansan mucho tiempo en el fondò del agua sobre una piedra, y solo se levantan alguna que otra vez para coger una presa. No cabe duda, segun la opinion de Lesson, de quue se alimenta exclusivamente de pequeños animales, siendo por lo tanto muy carnivoro. Lesson ha visto cómo devo. raban larvas de insectos, y otras personas le dijeron que estos animales perecen sin alimento animal. Un tal Lorenzo Camerano, despues de perder casi todos los renacuajos que tenia cautiros, ofreció á los otros, que tendrian unos cuaren. ta dias de edad, pedacitos muy diminutos de carne, los cuales fijó en alambres moviendolos en el agua para que pare. ciesen presa viva. Las larvas devoraron los bocados, $y$ despues de alimentarse durante dos semanas de carne cruda, terminaron su metamorfósis el dia vigésimoquinto de su vida. Cinco dias antes, las branquias estaban casi del todo secas, y los renacuajos se presentaban á menudo en la superficie 
del agua para respirar, aunque habian hecho lo mismo ya algunos dias antes.

En junio se encuentran ya en los sitios convenientes los salamandrinos pequenos del mismo año, que quizás al siguiente llegan á su mayor tamaño. Corren con extremada lentitud y nadan con movimientos serpentinos muy laterales. Despues del periodo del celo mudan la piel. Esta segrega una sustancia mucosa parecida a la de la salamandra terres. tre, pero en menos cantidad y de color sonrosado en rez de blanco de leche.

La facultad de sustituir las partes que se cortan por otras nuevas es propia tambien del salaniandrino de anteojos, y. su resistencia vital es asimismo tan grande como la de cualquier otro urodelo. Lesson vió salamandrinos de anteojos que aun corrian con el vientre abicrto arrastrando los intes: tinos. Un salamandrino de anteojos muerto no entra nunica en descomposicion; resúcase como una momia.

\section{LOS LECRIODONTOS - LECHRIO.}

\section{DONTA}

CARAGTERES. - A continuacion demostraremos de un modo irrefutable que un urodelo considerado hasta ahora como animal perfecto solo es el renacuajo de una especie de estos batracios; podemos por lo tanto darle ahora el lugar que le corresponde en nuestro sistema. Fi animal de que hablamos es el axolotl de los mexicanos.

Segun las averiguaciones de Dumeril perenece al género de los amblistomas, muy rico en especies y muy extendido en el norte de América que con otros congéneres constituye la sub-familia de los lecriodontos, la misma de yue nos ocupamos.

Los caractéres de esta sub familia son, segun Strauch, los siguientes: los dientes palatinos se insertán \& lo largo del borde posterior del hueso de ese nombre, que se distingue por una apófisis triangular dirigida hácia atrás, y forman por lo tanto series trasversales ú oblicuas mas $\delta$ menos se paradas en su parte posterior. El esfenoides está provisto en varias especies de una hoja particular ósea o cartilaginosa que :iene dientes.

\section{LOS AMBLISTOMAS -AMBLYSTOMA}

CARACTÉRES، - la estructura de los amblistomas ó lecriodontos propiamente dichos es recogida; la piel lisa; la aglomeracion de las glándulas auriculares existe por lo regular, pero á menudo muy poco marcada; el tronco estå anillado por un nútncro de repliegues verticales de la piel, la cola es gruesa, casi cilindrica en la base y mas 6 menos comprimida en su parte posterior, redondeada en la extreinidad y nunca provista de bordes membranosos; las extremidades anteriores tienen cuatro dedos libres y las pos. teriores cinco. Los huesos palatinos forman dos series trasyersales rectas ó ligeramentc arnqueadas, cuyas extremida. des anteriores se tocan en el centro del hueso palatino ó cuando menos están muy poco separadas, formando en su conjunto una serie trasversal recta $\delta$ un arco cuyas lineas, muy poco corvas, se dirigen hácia atrás. Hay sin embargo especies en que cada seric está interrumpida en su extremidad anterior. El esfenoides carece de dientes; la lengua, grande y oval, tiene fija toda su cara anterior en el fondo de la cavidad bucal, de modo que excepto su borde posterior, solamente los laterales están libres en muy poca extension.

Determinado ya el género, debe cambiarse el nombre cientifico del renacuajo; en vez del usado hasta ahora
Gyrisius mevicunus, Siren pisciformis, Siredon Axolotl y oxoloil, será mejor darle el de un animal meiamorfoseado, que es el de amblistoma mexicano.

\section{EL AMBLISTOMA MEXICANO-AMBLYS- TOMA MEXICANUS}

CARAGTÉRES.-En los alrededores de la ciudad de México, dice Hernandez, hay una especic de peces con piel blanca y cuatro patas como las de los lagartos; este animal llamado axolotl, tiene un palmo de largo por una pul. gada de grueso; la cabeza deprimida y grande; los dedos de la misma estructura que los de las rayas; y el color negro, con manchins pardas. El animal toma nombre de su forma extraordinaria y grotesca. Su carne, semejante á la de la anguila, es saludable y sabrosa y se come frita, asada ó her. vida; los españoles la guisan por lo regular con vinagre, pi. mienta y claro; los mexicanos con pimiento picante. En otro pasaje habla el mismo autor de renacuajos que los indios co. men con mucho gusto y que hasta se llevan \& los mercados.

Durante mucho tiempo nadie hizo caso de estas noticias, hasta que el animal descrito llegó s. Inglaterra dándose á conocer en el mundo cientifico. Cuvier hizo una descripcion exacta en vista de los individuos traidos de México por Alejandro de Humboidt: tenian el tamaño de un triton de ctesta y la forma de un renacuajo ó urodelo, y como tales los consideraron Humboldt y Cuvier. Ell hocico era recogido, la ca. beza plana y relntivamente mas ancha que en los urodelos; la cola comprimida y provista en su parte inferior de una ligera cresta que se corria sobre el lomo. Ias patas anterio. res tenian cuaro dedos y las posteriores cinco. El color era un pardo verde bastante uniforme, con manchas negras y puntos blancos.

Desplues de estos dos individuos llegaron otros muchos á Europn, $y$ todos se parecian á los descritos; circunstancia que indujo á crecr que esta forma de renacuajo era la cons. tante del animal, opinion confirmada por otros ejemplares de que tampoco se conocian sino renacuajos. De este modo Cuvier mismo se vió obligado á clasificar al axolotl entre los batracios con branquias, pero no lo hizo sin expresar sus du. das excusaindose con las palabras: eme veo obligado a clasificar al sxolotl entre los géneros con branquias constantes, ya quue tantos testigos aseguran que no las pierde.

Tales fueron las noticias conocidas sobre el animal hasta cl año $\$ \$ 6_{5}$. Algun otro raturalista seguia el ejemplo de Cuvier; Baird dijo que el axolotl tenia el tipo demasiado caracteristico de renacuajo, y que la circunstancia de no cncontrarse el animal desarrollado no probaba que no existiesc; $y$ otros afirmaron que algunas areriguaciones mas minuciosas habian demostrado que cl axolotl no se metamor foseaba. Los escasos datos que entre tanto habiamos recibido respecto al género de vida en libertad de ese animal habla ban en pro de esta última opinion. Segun todos los informes f noticias mas recientes de Saussure, el axolotl no se ha visto nunca en México en estado de metamorfósis, ni tampoco se encontró ningun urodelo que la hubiese sufrido, al recorrer los alrededores de los lagos; mientras que el axolotl es tan comun que se llevan millares de individuos al mercado para la venta.

En el Jardin de aclimatacion de Paris se recibieron scis axolotles vivos, cinco machos y una hembra, que fueron agregados a la abundante coleccion de reptiles y batracios vivos. Durante un año, los animales vivieron en cautividad, comiendo y conduciéndose lo mismo que otros renacuajos de urodelos, cuando de repente, el is de febrero de IS6 5 se observó grande cxcitacion entre ellos: los machos y la hem. 
bra terian en extremo hinchacios los bordes del ano, y los primeros perseguian con afan á la segunda, arrojando su esperma al agua. Ia hembra comenzó al dia siguiente á poner los huevos, como lo hacen los tritonesy veinticuatro horas des. pues terminó su tarea. Seis semanas mas tarde se repitieron los mismos sucesos. Dumeril hizo retirar cada vez las plantas en que se habian fijado los hueros, para trasladarlas á un de pósito separado, y del exámen resultó que casi todos los huevos estaban fecundados. Veintiocho ó treinta dias mas tarde los renacuajos comenzaron á salir; primero se desarrollaron las branquias; algunos dias despues se abrió la hen- didura de la boca y los animalitos empezaron a coger con voracidad los insectos que habia en el agua. Desde entonces ei desarrollo siguió su curso regular, y á principios de setiembre los hijuelos habian llegado casi al tamaño de sus procreadores.

A mediados de setiembre presentóse en un hijuelo un cambio sumamente singular. I.as branquuias, la cresta del lomo y la cola se resecaron; la forma de la cabeza varió un poco, $\mathrm{z}$ en el color oscuro del fondo de la piel aparecieron pequeñas manchas en gran numero; de un tinte blanco amarillento.

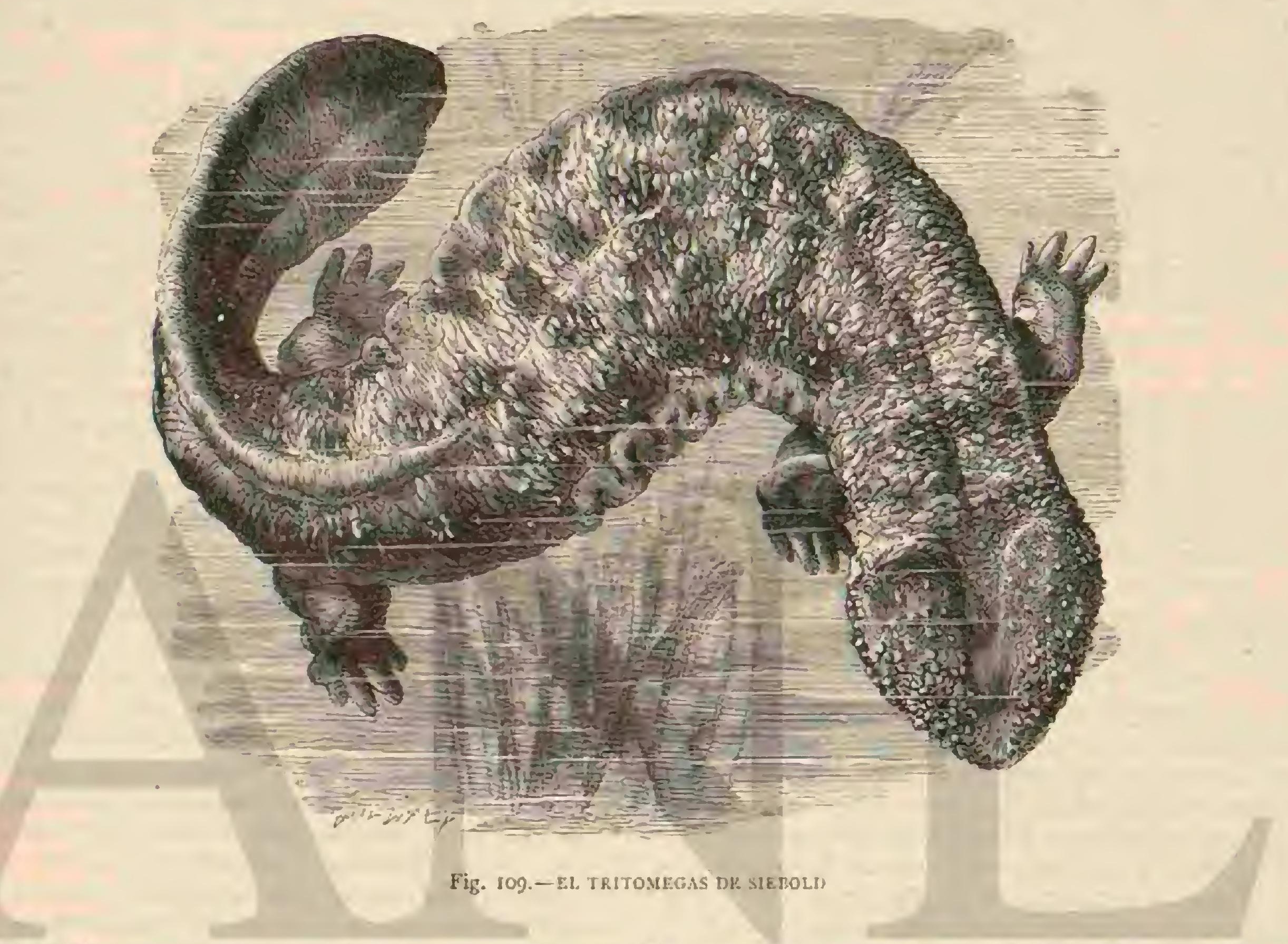

$\mathrm{El}$ as de setiembre notóse una trasformacion igual en otro individuo; en $j$ de octubre sucedió lo mismo con un terce ro, y en 10 de octubre, finalmente, en el cuarto. Los cuatro se inctamorfosearon del mismo modo en animales desarro llados como otros urodelos: y de esta manera se demostró la exactitud de la opinion de Humboldt y Cuvier.

Uno de los primeros experimentos hechos por Dumeril tuvo por objeto saber si por medios artificiales podria apresurarse el desarrollo. Al efecto cortó á varios axolotles las branquias de un lado, y mas tarde las del otro, lo cual le demostró que estas formaciones vuelven â crecer, aunque se corten cinco ó seis veces, sin que esto ponga en peligro la vida del renacuajo. Algunos individuos se trasformaron tam. bien por fin, pero dificilmente se justificará la suposicion de que esto se pueda obtener pot la mutilacion de las brarquiais.

Lo que Dumeril ro consiguió sino incompletamente fus posible para una señora bien conocida por sus cuidadosas observaciones en los insectos, y elogiada por iodos los hom. bres de la ciencia: me refiero a la señorita Chaubain, de Friburgo, en el Breigau. Weissman habia concebido la idea de si no seria posible obligar á todos los renacuajos del axolotl ó cuando menos à la mayor parte, á sufrir la metamorfósis sometiéndolos a condiciones que les dificultaran el uso de. TOMO $\mathrm{V}$
Jas branquias, facilitándoles cl de los pulmones y obligándo. les por lo tanto a vivir desde cierta edad la mitad del ciempo en tierra firme. Fl citado sabio habia hecho experimentos en este sentido sin obtener resultado, porque, segun reconoció muy pronto, se necesitaba una observacion muy detenida $y$ continuada durante varios meses, Ln señorita de Chaubain dió principio à sus experinentos con cinco renacuajos de axolotl, de unos ocho dias de tiempro, únicos que sobrevivian de los doce que habia recibido. -Como estos animales son en extremo delicados, escribe la señora, la naturaleza $y$ la temperatura del agua, la calidad y cantidad del alimento, ejer. cen, sobrc todo al principio, la mayor influencia, de modo que no es posible tratarlos con bastante precaucion. Los ani. malitos estaban en una rasija de cristal de unos $10^{\mathrm{m}}, 30$ de diámetro, brjo una temperatura conveniente; se alimentaban al principio de dafnias, y mas tarde comieron animalejos acuíticos mas grandes. Todos los cinco renacuajos prosperaban muy bien, $y$ á fines de junio se presentó en los mas fuertes el principio de las regiones anteriores; y en 9 de julio salicron tambien las patas posteriores. En los primeros dias de noviembre la señora observó que un axolotl permanecia continuamente en la superficie del agua y esto la indujo á suponer que habia llegado la hora oportuna de prepararle para la metamorfósis. Al efecto se le puso en $10^{\circ}$ de noviem. 
bre en una vasija de cristal mucho mas grande, y de fondo plano, la cual se colocó llena de agua de modo que el ani. mal no pudiera sumergirse compictamerte, sino en un punto, mientras que al salir con frecuencin del fondo de la vasija llegaba á ponerse mas ó menos en contacto con el aire. En los dias siguientes se disminuyó el agua paulatinamente, $y$ en este tiempo manifestáronse en el animal las primeras trasfor. maciones; las branquias comenaaban a resecarse, y el rena. cuajo se esforzó por llegar á sitios donde el agua era un poco profunda $\mathrm{El}+$ de noviembre salió del lodo á tierra firme, ocultándose en el musgo húmedo que se habia colocado en el punto mas alto del fondo sobre una capa de arena. Fn. este tiempo se verificó la primera muda, y desde el $1 .{ }^{\circ}$ al if de noviembre se observó un cambio particular én el exterior. Las brinquias se resécaron casi del todo; la cresta del lomo desaparcció, y lá cola, ancha hasta entonces, redondeóse. El color pardo gris del cuerpo se convirtió en negruzco poco á jucto, y aparecieron unas inanchas ajsladas blancas. Cuando el 4 de noviembre el axolotl sairo del agua, los orificios de las branquias estaban aun abiertos, pero se cerraron poco á poco y ya no pudieron observarse al cabo de ocho dias, porque la piel los cubria.

De. los otros renacuajos, tres ofrecicron á fines de noviembre el mismo estado de desarrallo que el primero, y la sehora creyó reconocer que tambien para ellos habia llegado la hora de apresurar la metamorfósis. En su consecuencia sometiéronse al mismo tratamiento: uno de cllos se trasfor. mó tambien en igual tiempo y del mismo mnilo exactamente que el primero: a los cuatro dias se habian rescado casi por completo las branquias; el animal salió entonces a tiern firme y adquirio al cabo de diez dias la forma completa de salamandra. Mientras tanto tomaba alimento, pero solo cuando se le obligaba á ello. En otros dos individuos el des. arrollo se verificó mas lentamente; ninguno de ellos buscaba con tanta frecuencia los sitios poco profundos, ni permane. cia tanto tiempo al aire libre; de modo que pasó la mayor parte de enero antes que salieran del todo á ticra firme. Sin embargo las branquias se resecaron en el mismo tiempo que en los otros individuos y se verificó tambien en seguida la primera muda. El Ĺltimo axolotl, que desde un principio tenia el aspecto mas débil que los otros, y que estaba muy atrasado en el desarrollo, se diferenció aun mucho mas en la trasformacion. Necesitó quince dias en vez de cuatro para poder salir del agua; cra mucho mas sensible que sus com. pañeros, y cuando se le exponia demasiado tiempo al aire, tomaba un colar mas claro, exhalando además un olor parti. cular, semejante al que despiden las salamandras cuando se las asusta. Si se le volvia al agua, sumergiase en seguida y recobraba pronto sus fuerzas, pero las branquias se desarro. llaban entonces nuevamente.

Repitióse el mismo experimento varias reces y siempre dió identico resultado, circunstancia de la cual puede dedu. cirse que el ejercicio demasiado violento para apresurar la metamorísis produce una suspension y hasta la muerte, cuando se prolonga con exceso.

La señorita de Chabain deduce de estas observaciones lo siguiente: los renacuajos del axolotl llevan á cabo su trasformacion, si no todos, los mas, cuando salen sanos del huevo y se les alimenta de un modo conveniente, adoptándose precauciones para obligarles a respirar fuera del agua.

Weissman deduce de todo esto varias suposiciones: considera el axolotl, no como una forma progresiva sino como una forma retrógrada y cree que los individuos que hoy habitan los lagos de México eran en otro tiempo urodelos del todo desarrollados, pero que volvieron $\&$ su estado anterior de ictioideos á consecuencia de un cambio en sus condiciones vitales. Este cambio se produjo, en su opinion, por la circunstancia de que se pritó al axolotl de la facilidad de salir a tierra firme obligándole a permanecer en el agua. En los lagos de Mérico el agua salada y la circunstancia de agotanse temporalmente una parte de las aguas, son condiciones para ello. El fondo seco de los lagos es entonces una superficie desierta, sin alimento, sin escondite, ni vegetacion, $y$ cubierta de una capa de sal que haria de todo punto impo. sible la nutricion de los animales en tierra firme. Por Hunaboldt sabemos que la superficie del lago de México estaba no hace mucho tiempo situada á mucha mas altura que hoy, y además nos dice que la meseta se hallaba cubierta de bos. que, que en la actualidad no existe. Ahora bien, dice Weissman, si podemos suponer que poco mas ó menos en la época diluvial los bosques montañosos que se extendian hasta la orilla del lago, profundo entonces, y con mucha menos sal, ofrecian unas condiciones vitales, no snlo esen. cialmente distintas de las de hos dia, sino tambien tales que eran muy favorables para el desarrollo de una forma de salamandrinos, nos sers dado suponer tambien con alguna certeza que aun al principio de la época diluviana los bos. ques de México en los alredeciores de los lagos estaban po. blados de amblistomas, pero que á estos, cuando mas tarde los lagos se secarony el aire perdió la humedad, fuéles siempre mas dificil vivir en tierra firme. Hubićranse extinguido del todo si por un retroceso a la forma de ictioideos no hubiesen podido vivir de nuevo en el agua.

Solo hago mencion de esta hipótesis para citar una nueva prueba del hecho lamentable de que cierto número no escaso de los naturalistas modernos, que creen seguir las huellas de Darwin, no solo quieren explicarlo todo sino tambien po. derlo explicar. Es posible que las suposiciones de Weissman sean justificadas, pero no se han demostrado. Lo que actual. mente sabemos cs que el axolotl en su estado de renacuajo puede poner huevos maduros y por lo tanto propagarse, permaneciendo no obstante en el mismo estado; y tambien sabemos que algunos renacuajos se convierten cn salamandrinos. Lo que podria decirse además no pasaria de una deduccion ingeniosa, sin aumentar nuestros conocimientos sobre este animal. Poco significa que en México no se haya visto todavia ningun axolotl metamorfoseado, pues una ex. ploracion mas minuciosa en este país tan poco conocido po. dria dar otro resultado en alguno de los lagos que el axolotl habita.

A consecuencia de la reproducción extraordinaria del axolotl, que solo en el Jardin de Plantas de Paris puso en dos años y nueve meses nada menos que 3,300 huevos, el renacuajo de este urodelo ha llegado desde entonces á ma. nos de muchos. Tambien yo he tenido algun tiempo varios individuos, pero mis muchas ocupaciones no me permitian nunca hacer apuntes sobre ellos. Sin embargo, añadiré algu. nas observaciones de Rochrig sobre su modo de proceder en cautividad, porque estoy conforme con ellas en un todo.

Los renacuajos del axolotl reptan de dia, por lo regular perezosamente, pero cuando encuentran en su camino algo extrañc huyen con tal rapidez que comunmente chocan con. tra las piedras 6 el cristal de sus depósitos. De noche se agarran á cualquiera planta cerca de la superficie, probablemente para respirar con mas facilidad, pues á menudo su. ben á ella aspirando el aire con tal fuerza que a veces producen un verdadero ruido; y despues vuelven con la rapidez del sapo à la profundidad, siempre de cabcza.

Aliméntanse de todos los animales quue pueden dominar y devorar; son tan voraces como nuestros tritones, pero no pueden engullir bocados tan grandes como el triton de cresta. Comen lombrices, pequeúos crustáceos, larvas de hormi. 
ga, gusanillos, renacuajos, ranitas, etc. ; y î falta de cste alimento tambien toman carne cortada en tiritas en forma de lombriz. En el periodo del celo, que en nuestros paises no parece regirse por las estaciones, el macho depone su esperma en forma de conos, cuya base forma una sustancia gela. tinosa, mientras que la punta contiene las fibras espermaiticas. Al cabo de algunos dias se abre la punta del cono; las fibras espermáticas salen y se distribuyen en el agua, donde se ponen en coutacto con los huevos. Los embriones rompen la capa de aquellos mas ó menos pronto, segun la tempera. tura, y entonces viven á la manera de los renacuajos de mas edad ́s los que se parecen desde un principio por su color y aspecto.

\section{LOS ICTIOIDEOS- ICHTYOID死}

Además del infalible testimonio de la palabra de Dios, tenemos otros muchos del terrible diluvio universal, como por ejemplo, países, ciudades, aldeas, montañas, valles, canteras, etc, sin contar un sin número de plantas, peces, cuadrúpedos, parásitos, conchas y caracoles, mientras que solo se han encontrado muy pocos restos de los hombres que pe. recieron entonces. Flotaban sus cadáveres sobre la superficie del agua y se descomponian de tal modo que no siempre es posible reconocer los huesos que en algunas partes se encuentran. Esta figura que se ofrece \& la contemplacion de los sabios y de los curiosos, periectamente grabada, representa una de las reliquias mas seguras y hasta infalibles del diluvio; en este grabado se ven trazados algunos contornos, de cuyo exímen se deducirá, si bien se considera, no solo cierto parecido con el hombre, sino tambien una analogia tal y tan proporcionada con el esqueleto humano, que hasta las piernas se ven vaciadas en la piedra (la cual se extrajo de la cantera de Huninga); asimismo se han conservado al natural algunas partes mas blandas que pueden distinguirse fácilmente de la otra piedra. Este hombre, cuyo sepulcro es superior en antigüedad y autenticidad á todos los monu. mentos romanos y gricgos y aun \& los egipcios ú otros de los orientales, se presenta de frente.

Las anteriores palabras dan la explicacion de un grabado que Juan Jacobo Scheuchzer, doctor en medicina, miembro de muchas sociedades científicas, crejo deber añadir a una ohra publicada en 1720 con el título de RHomo diluriti tes: tis para que todo el mundo pudiese convencerse por sus pro. pios ojos de la veracidad de sus palabras. Desgraciadamente he buscado en vano otro pasaje que empieza del mocio siguiente: C'riste csqueleto de un antiguo pecador, ablanda el corazon de los modernos hijos de la iniquidad, 'y que sin duda contiene muchas cosas bonitas y edificantes, aun. que no ha llenado su objeto, que era el de ablandar cl corazon de los modernos hijos de la iniquidad; pues el \$Homo diluali Pestis no hizo meditar mucho sa los sabios y curiosos, porque el moderno hijo de la iniquidad, Cuvier, le despojó de todo su carácter humano, clasificando el atriste esque. leto de un antiguo pecador como huesos fósiles de una salamandra. Esta especie, llamada por los arqueólogos Antrias Selierudieieri, pertenece á los ictioideos ó salamandras.feces.

CARACTÉRES. - Estos animales que forman la segunda familia del órden, difieren de tal modo que muchos natura. listas los dividen en varias familias, debiendo nosotros adop. tar dos sub-familias. Singular es sobre todo la debilidad de las extremidades en proporcion á la longitud del tronco; la distancia entre aquellas impide casi la locomocion, aunq̨ue están bien desarrolladas. Tambien los órganos de los senti. dos ofrecen muy poco desarrollo. I,os ojos faltan del todo ó son en extremo pequeños, sin que haya ningun vestigio de párpados, indicíndose solo por un repliegue en extremo corto de la piel. La cavidad nasal está limitada en su parte posterior por huesos; las orejas siempre se hallan muy ocul. tas y están poco desarrolladas, porque la entrada del laberinto se cierra con una pequeña tapa; la lengua no q̨ueda libre mas que en la punta. Los huesos palatinos forman, segun Strauch, una estrecha faja arqueada que se inserta en el borde anterior de aquellos; hállanse unidos casi siempre por una sutura ó bien están aglomerados en forma de cepillo, y cubren toda la superficie de unas hojas óseas en el paladar. En la extre. midad posterior del hueso de la lengua hay de dos a cuntro arcos branquiales osificados del todo 6 en parte, y la mayor parte de las especies tienen además orificios branquiales ó tambien branquias exteriores en los lados del cuello.

l'odos los urodelos pertenecientes a esta familia viven ex. clusivamente en el agua y respiran casi siempre por pulmo. nes y branquias al mismo tiempo.

\section{LOS CRIPTOBRANQUIATOS -}

\section{CRYPTOBRANCHIATA}

CARACTÉRES.—Las especies de la primera sub-familia se caracterizan por la presencia de los huesos maxilares infe. riores y la carencia de las branquias exteriores, en cuya region hay un orificio branquial que en algunas especies se conserva toda la vida abierto; mientras que en otras se cierra con la edad.

\section{LOS CRIPTOBRANCOS-CRYPTO- BRANCHUS}

CARACTERES.-I Los de este géneto son los siguientes: cabeza grande, deprimida y muy ancha, que se redondea formando una punta obtusa : cuello corto, mucho mas estre. cho que el occipucio y el tronco; cste último, plano y cilindrico, tiene en cada lado una gran prominencia longitudinal; la cola, que ocupa poco mas ó menos una tercera parte de la largura del cuerpo, es corta y comprimida en los lados, de modo que forma un ancho remo; los piés; pesados y fuertes, cstán provistos de dedos bien desarrollacios, contándose cua. tro en los anteriores $y$ cinco en los posteriores; las fosas nasales se ballan situadas en la parte anterior del hocico: los ojos, en extremo pequeños y sin párpados, están sep̧arados uno del otro casi por toda la anchura de la cabeza. Unos dientes muy pequeños se insertan en las mandibulas, $y$ una segunda serie paralcha en el paladar; la lengua está fija en todas sus partes.

El esqueleto recuerda tanto el de las salamandras como el del criptobranco hórrido, segun Schlegel, pern el cráneo di. fiere por una anchura relativamente grande y por otra particularidad. La columna vertcbral se compone de veinte vértebras dorsales y de veinticuntro caudales que en su parte anterior y posterior presentan surcos y en los lados unas apófisis trasversales largas, que tienen las sceñales de las costillas; la pélvis se fija en la vértebra vigésimaprimera. La piel es blanda y desigual, y en la cabeza se ven marcadas verrugas.

\section{EL CRIPTOBRANCO MÁXIMO-CRYPTO- BRANCHUS MAXIMUS}

CARACTÉRES. - Como congénere mas afince del testigo del diluvio debemos considerar quuirảs al criptobranco máximo, llamado tambien tritornegas de Siebold, lantracio suma- 
mente deforme, pesado y grueso, de $1^{n}, 40 \mathbf{a l}^{\mathrm{m}}, 60$ de longitud (iig. rog).

Las regiones superiores son de un gris pardo claro mas bien moteado que manchado y cil ciertos sitios mas oscuro; las regiones inferiores son de un gris claro. Los individuos jóvenes se distinguen, segun Kein y Roret', por tener la piel lisa, con arrugas de color pardo cancla y escasas manchas de an tinte oscuro; los ojos son relativamente grandes $y$ salientes. Cuanto mas aumenta el tamaño del animal, tanto mas verrugosa se hace la piel, que scoscurece tambien mas, aumentan. do la dimension de las manchas.

DISTRIBUCION GEOGRAFICA.-Siebold descubrio al mas grande de todos los batrácios viros, en el segundo'de. cenio de nuestro siglo, en la isla de Nippon, reconociendo que alli habita los rios montañosos $y$ las profundas aguas es. tancadas, sobre todo en los cráteres de volcanes apagados.

USOS, COSTUMBRES Y REGIMEN.-Siebold supo tambien que los japoneses le dan cama y venden su carne, que es muy ajreciada en todos los mercados, pero no pudo averiguar nada de cierto sobre el género de vida de este uro. delo y su reproduccion. Los muchos extranjeros instruidos que sirven al Japon, no nos han proporcionado hasta ahora - mas datos sobre la residencia, género de vida y modo de des. arrollarse del criptobranco máximo; de modo que debemos contentarnos con las noticias de Siebold. Este autor, sin embargo, segun dicen Reiny Roretz, no ha visto el batracio nunca

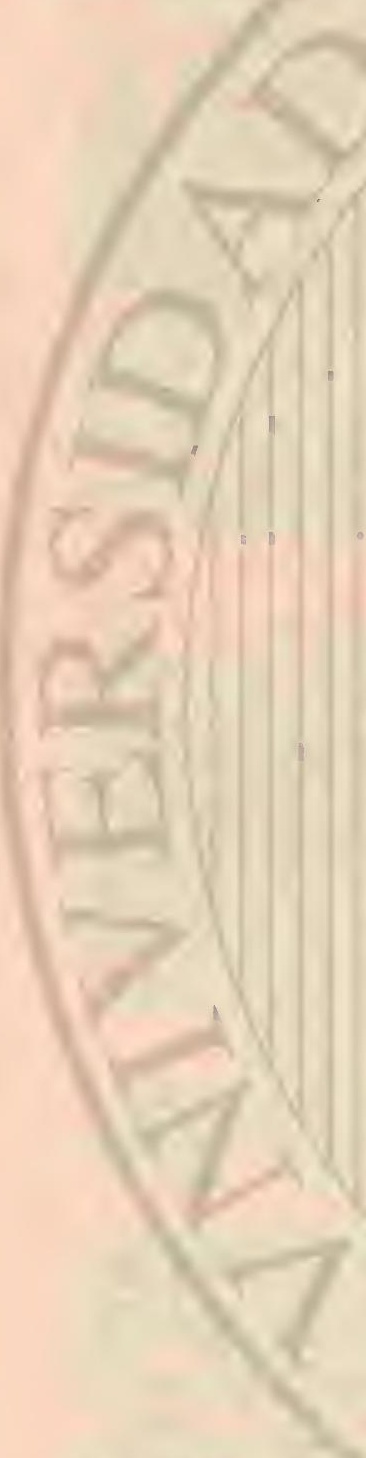

en los sitios que habia, y solo obtuvo datos de los japone ses. Sin embargo, es muy dificil adquirir informes ciertos de los indigenas en asuntos de historia natural, y asi es natural que tambien en la descripcion dé Siebold, nunque bastante exacta, se hayan deslizado errores de alguna imporiancia. lil criptobranco máximo no abunda mucho. de modo que la mayor parte de los extranjeros residentes en el Japon no ven nunca el animal; el nombre japonés de sansho naio empleado por Siebold, no se refiere en la mayor parte de las provincias á este animal sinál un congénere mas pequeño, circunstancia que induce a errores. Por todas estas razones debemos estar agradecidos \& los citados naturalistas, quue durante su estancia en el Japon se esforzaron por conocer el animal. - Tanto por las noticias de Siebold como por los informes que nosotros tomamos, dicen los dos viajeros, el criptobranco maximo solo se encuentra en la mitad meridional de ia isla de Nippon. Se le conoce en Iga bajo el nombre de hastkod, en Mimasaka se le llama hansaki, en Iwonni hansake y en Tamba hodakusu ó anyo. Mino, Schinano, Iamalchiro é Iga son las principales provincias donde se le encuentra, Despues de haber hecho muchos esfuerzos inútiles, nuestros naturalistas tuvicron la sucrte de llegar por Ise, Iga y Iama. to \{ una region montañosa, donde todos conocen el criptobranco máximo bajo el nombre de hasckes; pudieron comprar una docena de individuos, y asistieron a la caceria de uno en companila de un hombre práctico. A continuacion dare un extracto de las observaciones hechas y de las nuticias recibidas por personas de confianza.
El criptobranco máximo se encuentra en varios puntos de la frontera entre el territorio de las costas de San-ju-dound, San-yo-do, en las aguas de Hida, y in lo largo de todo el li. mite que separa los rios costeros que desde Ise se dirigen al mar del territorio del rio Vodogama. Este último es sin duda el sitio donde mas se les encuentra. Nuestros viajeros halla. ron al animal en los limites de las provincias de Ise é Iga, donde vive en la parte superior de todos los rios, sobre todo en los riachuelos que constituyen las fuentes del Kizugawa. Este territorio se compone de granito muy rico en cuarro, desgastado en algunos puntos, y al que siguen á mas pro. fundidad rocas de pizarra bastante antiguas, pero cn Ise, al este de Iga, hällase piedra arenosa en capas casi horizontales, con restos de animales fósiles. Ninguna de las montañas de esta cordillera llega a mil metros de altura, ni tampoco el Suzugayana, de donde Sicbold recibió el primer individuo. Las piedras parecen faltar del todo en esta sierra, y Siebold ha incurrido en un error, ianto respecto $a$ la altura co. mo en lo de que el criptobranco máximo vive en estanques y lagos que se hallan en los cráteres de volcanes apagados, pues tambien las otras cordilieras en cuyas aguas se cncuentra este animal se conponen de piedras cristalinas ó de pizarra.

El animal se halla siempre en aguas corrientes, frias y claras, á la altura de dos a sciscientos metros, pero en la frontera de Hida se le encuentra aun a la elevacion de mil quinientos metros sobre el nivel del mar. Aqui vive en los pequeños riachuelos claros, en los sitios donde estos tienen 
una anchura de $11^{\prime}, 13$, en canales de riego, en pendientes aliombradas de yerba, donde el césped cubre casi del todo los riachuelos y tambien en un sitio donde la reunion de los canales ha formado un hermoso rio rico en truchas, cuyas aguas, sombreadas por las espesuras, deslizanse con agradable murmullo entre fragmentos de roca. Debajo de estos, en la misma orilla, viven los animales adultos, mientras que los jóvenes pretieren los pozos pequeños. Al decir de la gente, raras veces abandonan la residencia elegida y no salen nunca á tierra firme. Se alimentan de gusanos é insectos, peces y r̦anas.

CAZA.-Los criptobrancos máximos se cogen desviando el agua y sacándolos entonces de debajo de las piedras y agujeros, 0 bien sirviéndose del anzuelo. Este último se compone de un gancho ordinario sujeto en una cuerda delgada, y poniendo por cebo una lombriz; la punta libre del gancho se coloca en la extremidad abierta de una caña de bambú de metro y medio de largo, al rededor de la cual se arrolla la cuerda varias veces; despues se introduce el anzuelo en todos los agujeros y cavidades en que se supone hay salamandras. Cuando esta quiere coger la lombriz, el gancho cae de la caña y queda prendido en su boca. El criptobranco máximo se coge tanto por su carne sabrosa, a la que se atribuyen tambien propiedades medicinales, como para echar. le en los pozos á fin de purgar el agua de parásitos lo mismo que en nuestros paises se hace con los urodelos. Los incivi.

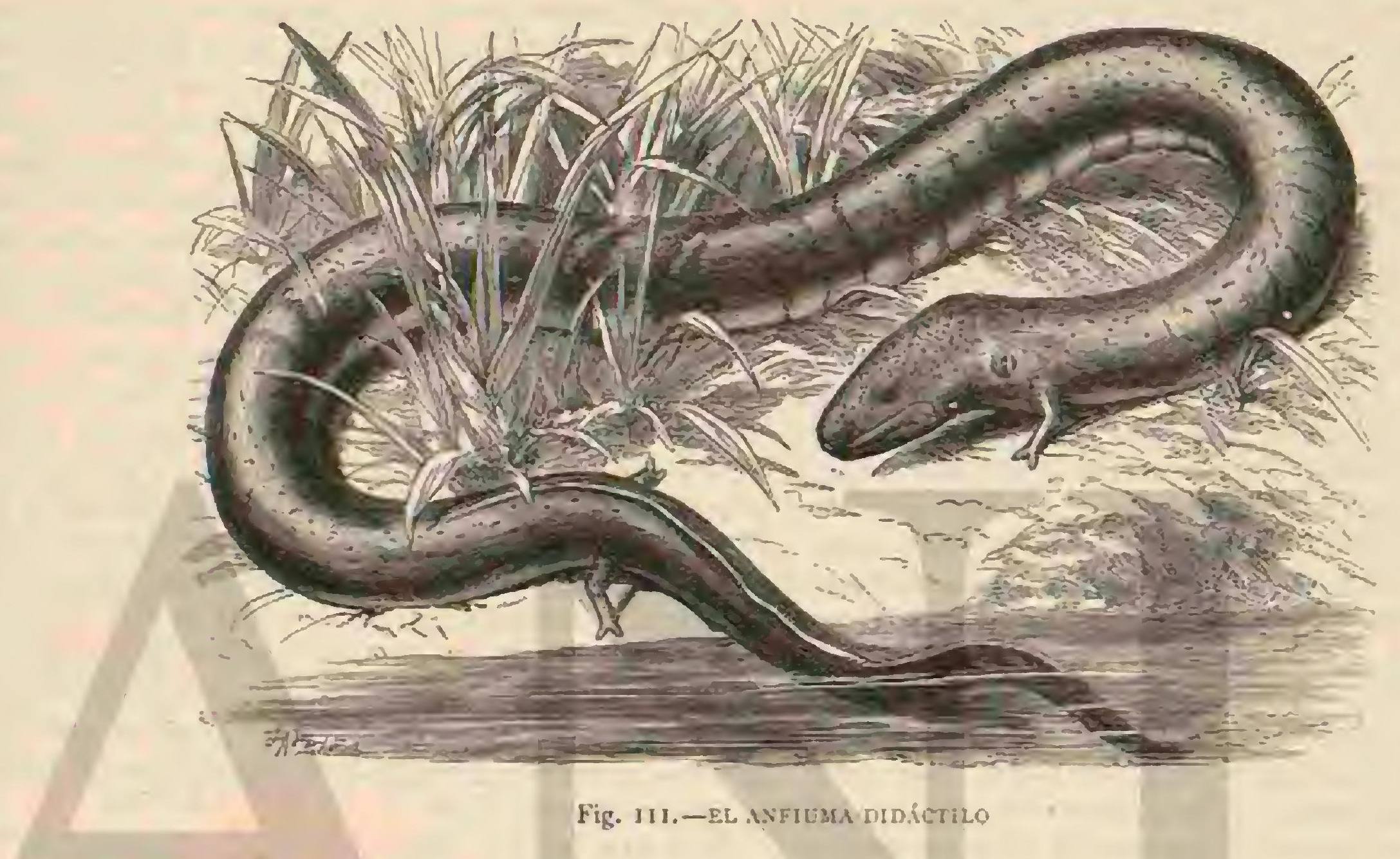

duos mas grandes se reciben en Kioto, Osaka y Kobe, donde con frecuencia se les ve en las colecciones de fieras. Envianse del mismo modo que las langostas, en cestos cubiertos de hojas y muy huimedos.

Segun numerosas averiguaciones, los criptobrancos mas pequenos que hasta ahora se han encontrado tenian una longitud de $11^{\prime \prime}$, I 5 ; eran del todo semejantes á los-individuos adultos. Segun parece, el criptobranco maximo no tiene tampoco en su juventud branq̨uias externas; no se sabe si pare hijuelos vivos 6 si pone huevos.

Solo tengo que añadir á cstas importantes voticias, que Buettcher ha reconocido por el exímen de varios criptobrancos pequenos la existencia de aberturas branquiales exterio. res. Estas se componen, en un individuo de $0^{\circ}$, io de largo, de ligeras hendiduras de dos milimetros y medio de longi. tud, que se corren por el nuismo sitio que en los congéneres americanos en direccion longitudinal.

Siebold llevó en 1829 dos criptobrancos máximos vivos al Japon á fin de traerlos a Europa. Hábia reunido para ali. mentarlos muchos peces de agua dulce, pero cuando estos comenzaroa a faltar, el macho se comió la hembra, ayunan. do despues hasta su llegada \& Europa sin experimentar da. noo alguno. En Lejden se arregló para el animal un depósito con agua dulce, alimentándolo con pequeños peces. $A$ su llegada tenia 1 i" $^{\circ}, 3^{\circ}$ de largo, seis años mas tarde $1^{\prime \prime}$, y desde entonces creció lentamente, y quizá continua creciendo, pues aun existe vivo en el Jardin zoológico de Amsterdam.

Mas tarcie, sobre todo en los últimos diez anos, han llega- do a nosotros algunos de estos sćres, y actualmente se les puede ver en el Jardin de Plantas de Paris y en los jardines zoológicos de loóndres, Berlin, Francfort y otros puntos. Yo he observado varios cautivos durante mucho tiempo, convenciéndome de que no inspiraban ningun interés al espec. tador.

Weinland ha dado una descripcion excelente sobre la indole de este animal. A la major parte de los batracios, como sabemos, es muy dificil obligarles á comer y por lo tanto turinos mucho cuidado en ofrecer a nuestro precioso cautivo un alimento lo mas agradable posible. Dimosle por lo tanto en seguida una lombriz que el urodelo aceptó sin viacilar, devorándoia en tres bucados. En este mismo dia solo comió otra lombriz; el segundo seis; y el tercero nueve, comiéndolas siempre en los mismos intervalos. luvimos por lo tanto la esperanza de conservar vivo al criptobranco máximo, pero no nos pareció conveniente ofrecerle un alimento mas súlido. En su consecuencia se juso en el depósito un per. vivo de quince centimetros de largo, pues se observó al alimentarle con lombrices que solo cogia la presa que se mo. via, colocándosela sobre el hocico para veria mejor con sus pequcios ojos, y despreciándola cuando caia al fondo. A penas entró el pez dióle un mordisco, haciendo un rápido movi. miento con la cabeza, del todo inesperado en un animal tan perezoso; y despues abríb la boca lo menos dos centimetros. io mismo que un tiburon que coge su presa de lndo; pero el pez escapó. Sin duda era demasiado fuerte, y los dientes de la salamandra muy pequeños para sujetarle, pues ya del 
primer mordisco le habia cogiclo por la mitad del cuerpo. Retiramos por lo tanto el pez, y a falta de otro mas conve niente se puso una rana. Tambien esta vez atacó la salamandra, pero habiendo cogido una de las patas anteriores vióse obligada ấ ceder í la resistencia de la rara y ásoltarla; la vic tima saltó á un rincon del depósito y la salamandra se dirigió casualmente, segun me parecio, al mismo punto; entonces cogióla de nuevo, esta vez por la cabeza, y devoróla en quince minutos; pero la deglucion fué mas trabajosa, pues la salamandra hubo de oprimir las patas anteriores, asi como el hocico, contra el suelo del deposito, para dar nias fuerza á los movimientos: despues descansó detras de una piedra. El criptobranco máximo parece no atenerse $i$ la costumbre que tienen los neces y batracios rapaces de coger su presa siempre por la cabea, ó por lo menos se observó que devoró un pez empezando por la cola.

Excepto en 10 relativo \& la alimentacion, mus pocas ob: servaciones pueden hacerse en este animal perezoso, y al parecer estúpido. Todos sus movimientos son en extremo lentos cxcepto cuando coge un pez; 'y siempre descansa en el fondo del depósito, en el sitio mas oscuro. De vez en cuando, es decir á intervalos de diez minutos, sube a la superficie para respirar, volviendo en scguida á sumergirse. Ade. más sele ve á veces hacer movimientos laterales, como se observa en los elefantes, osos, etc. cautivos. Mudó poco despues de sullegada, en cuya ocasion la epidermis se desprendió á grandes pedazos.

La experiencia nos la enseñado que tambien el cripto. branco máximo es un batracio de mucha resistencia vital. Uno de los que yo tuve se deslizó cierto dia por el borde de su depósito, cayendo desde una altura de metro y medio al suelo, donde á la mañana siguiente se le encontró casi sin movimiento; pero recobró pronto sus fuerzas cunndo se le volvió al agua. De otro se sabe que un frio muy riguroso apenas le perjudicó mas que á nuestros tritones. Dos cautivos que yo cuide murieron de la misma enfermedad: su piel se cubrió de una especie de hongos que en forma de manchi tas al principio, extcudiéronse sin embargo pronto por todo el cuerpo, de modo que parecia cubierto de escarcha. Desde que se manifestó el primer sintoma de esia enfermedad, ambas salamandras perdieron el apetito: inantuvicronse ir.móviles en un sitio, $y$ al fin se las encontró muertas en î misma posicion. No habia remedio para extirpar los hongos, producidos sin duda por las propiedades del agua; y todo animal infestado por esta planta parásita debia perecer sin remedio.

Salvo tales accidentes, el criptobranco necesita poco cuidado. Acepta sin dificultad todo alimento vivo, y cuando varias seces ha satisfecho bien el hambre durante algunas semanas, no liace caso de los peces que destinados à su alimentacion nadan por el depósito; pero de repente vuelve ś comer un considerable numero. Sin embargo, parece que sabe distinguir muy bien entre la diversa clase de alimento, pues prefiere ante todo las truchas a otros peces no tan sa. brosos. 'Tanta irregularidad observa para tomar su alimento como para hacer sus deposiciones, pero cada ver expele una cantidad asombrosa de cxcrementos, sin forma, blandos y de
color pardo. color pardo.

Aunque es probablemente un animal mas bien nocturno que diurno, procede en la oscuridad casi lo mismo que de dia, conservando su asombrosa pereza despues de la puesta del sol. A veces abandona su oscuro escondite y sale muy despacio por una piedra saliente, con la intencion quizás de respirar mas libremente, pero puede pasar tambien scmanas enteras sin cambiar de posicion. Si se le expulsa forzosamente de su escondite vuelve a él con mucha imnquilidad, y cuando se le descompone su lecho cubriéndole de piedras y de arena gruesa, retiralas y arregla de nuevo su cama. Las continuas molestias acaban por irritarle, y entonces procura defenderse y muerde con fucra el palo que le presentan, sin soltarle fảcilmente. No es de suponer que distingue a su guardian de otras personas.

El criptobranco máximo de que hemos hablado ya, vive actualmente en Amsterdam con otro individuo, segun se supone hembra, de su propia especic y se espera que se reproducirán.

\section{EL CRIPTOBRANCO HÓRRIDO-CRYPTO- BRANCHUS HORRIDUS}

CARÃCTÉRES. - Segun la mayor ó menor importancia que se atribuye al orificio constante de las hendiduras bran. quiales, agrifpase en el mismo género la especie afine del criptobranco máximo. Este animal, relativamente bien formado, alcanza una longitud de $0 \%, 60$; tiene la cabeza grande, plana y redondeada en el hocico; tronco muy grueso y carnoso; y cola tambien fuerte y muy comprimida en los lados; asi como los tritones, tienc una cresta menubra. nosa lisa, que desde la nuca corre hasta la extremidad de la cola. I os ojos son mas oscuros que en los tritones y se pa. recen \&. los del renacuajo del axolotl; las fosas nasales se hallan en la punta del hocico y se abren en su parte interna detrás de una serie de dientes. El estómago es ancho; el in. testino forma muchas circunvoluciones; cl higado tiene una gran vejiga de hiel. Diez y ocho de las diez y nueve vértebras dorsales presentan niuñones de costillas; las vértebras cau. dales existen en número de veinticuatro. El color predomi. nante es gris de pizarra opaco; los matices se componen de manchas negras poco marcadas y de una línea naso-ocular mas oscura, que pasa por los ojos (fig. Iro). Ün individuo de pocos meses de edad examinado por Harlan no tenia ya branquias externas.

DISTRIBUGION GEOGRAFICA.- Est? especic es propia del sur de los Estados Unidos.

USOS, COSTUMBRES Y REGIMEN, - Debemos \& Barton, que describió al criptobranco horrido en $1 \$ 12$, la primera noticia sobre este animal, que vive en los rios del mediodia de los Estados Unidos donde se pasea lentamente por el agua, aunq̨ue tambien puede permanecer 24 horas en tierra firme. Se alimenta de gusanos, crustáceos y pececillos; es nuy voraz, y asi como los peces rapaces muerde á menudo el anzuelo, con gran cnojo de los pescadores. Esto es todo lo que se sabe respecto al género de vida de este animal, y ni aun Holbrook, que describió una variedad del criptobranco hórrido, ha podido añadir nada al relato ante. rior. Solo sabemos que los pescadores americanos le temen, y que aigunos le tierien por venenoso, como los nuestros al triton de cresta.

CAUTIVIDAD. - Ultimamente se han tenido cripto. brancos hórridos cautivos que llegaron en buen estado á Europa, cl primero en 1869 . Yo mismo no he visto nunca individuos cautivos, ni tampoco tengo noticia de su proceder en la jaula.

\section{LOS AMFIUMAS}

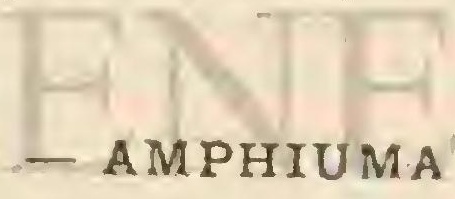

CARACTERES. - I Los tipos del segundo y tercer gúnero se han llamado amfiuma ó ambiformes, porque el tronco es bastante parecido al de una anguila, es decir muy prolonga. do; las cuatro extremidades, muy cortas, apenas merecen el nombre de tales, aunque los piés tienen dedos. Los ojos, atrofiados, están cubiertos de la piel general, tan delgada en 
la region ocular, que se pueden ver los ojos. Además de los dientes maxilares tienen dos series longitudinales de pala. tinos.

Distinguense dos especies, cl amfuuma didáctilo (fig. I I I) y el tridáctilo, porque se supone que el númcro de los dedos no es constante y por haberse observado que una especie tiene 99 y la otra 112 vértebras. Ambas alcanzan casi un metro de longitud; sus partes superiores son de un gris oscuro con viso verdoso, y las inferiores de color mas claro.

DISTRIBUCION GEOGRÁ FICA. - Lo que sabemos so bre su área de dispersion se reduce á losiguiente: los amfiumas habitan los pantanos y otras aguas estancadas de Nueva Orleans, Georgia y el sur de la Carolina.

USOS, COSTUMBRES Y REGIMEN.-Nadan como la anguila con bastanic viveza, pero penetran tambien á me. nudo en el cieno, en invierno á varios metros de profundidad algunas veces. Los individuos cautivos que casualmente habian caido de su depósito vivieron varios dias en tierra firme sin perjudicarse, soportando muy bien su viaje á Euro. pa. El alimento se compone de toda clase de animales pe. queños.

Los negros consideran á los amfiumas como venenosos; los llaman serpientes del Congo y les temen mucho.

\section{LOS FANEROBRANQUIATOS- PHANEROBRANCHIA}

CARACTÉRES.-Los fancrobranquiatos, que constitusen la segunda sub-familia, tienen á cada lado del cuello tres branquias, que se supone conservan toda la vida.

El tronco de estos séres, muy prolongado, tiene de dos á cuatro patas endebles; la cola presenta en su parte superior é inferior un borde membranoso; la piel cubre los ojos y las fosas nasales sin perforar; el paladar óseo. La laringe es mem. branosa; los pulmones se componen de dos bolsas largas en cuya cara interior los vasos de la sangre forman una red de anchas mallas.

\section{LOS PROTEOS-PROTEUS}

CARACTERES.-Lste gencro se pareceá los amfiumas por su tronco prolongado y sus patas separadas; las anterio. res tienen tres dedos sin unas $y$ las posteriores dos; distinguese sin embargo, por su hocico de sollo y por la pequenez desus ojos ocultos del todo bajo la piel de la cabeza é invisibles exteriormente.

\section{EL PROTEO ANGUIFORME-PROTEUS} ANGUINEUS

Hace unos doscientos años que Valvasor habló del ex. traño sér que hoy dia llamamos olsn, como propuso Oken.

Los habitantes de Carniola habian referido al autor de la "Honra del Ducado de Carintia algo sobre unos dragones ó serpientes que de vez en cuando salen de la profundidad de la tierra para causar desgracias. Valvasor examinó el astinto jencontró que el supuesto dragon era an pará. sito pequeno de un palmo de largo y parecido á un lagareo.p Mlas tarde, en 1786, supimos por Steinberg que en la inun. dacion de 178 i el pescador Sicherl habia cogido en el rio Unz una vez cinco peces desconocidos de un palmo de largo, de color blanco de nieve, pero provistos de cuatro patas. Los campesinos del pueblo de Sittech, en Carniola, llamaron despues la atencion de Scopoli sobre el olm y cste naturalista envió un indiriduo al canónigo de Gurk, Scgismundo de Hochenwarth, cujo individuo fué enscóado al mundo cientíico de Viena llamándoscle froleus anguineus. Probable. mente del mismo punto recibió tambien Schrciber el indiviđuso descrito por êl minuciosamente en 1800 . Desde entonces todos los naturalistas esperan con ansia cualquier descubrimiento nuevo respecto á este extrano animal. Hasta ahora se conoce unos treinta parajes donde estos animales se mantienen, y segun supone el conde de Hochenwarth, se han enviado mas de cuatro mil proteos, ya vivos, ya conservados en espiritu de vino, $\mathbf{s}$ todas las regiones, habiendolos examinado del modo mas cuidadoso aunque sin conocerlos.

CARAGTERES. - La hendidura de la boca, dice Wagler, es bastante pequenia; el labio superior, muy grueso, cubre todo el inferior; las fosas nasales son dos hendiduras paralelas con el borde del labio superior. En cada lado del cuello se observan tres arbolitos branquiales cortos y divididos en tres ramas. La cola es corta en proporcion á la longitud del cuerpo, y está circuida de una aleta grasosa. El esqueleto se parece al de la salamandra, cxceptuando la ca. beza, la forma y mayor número de las vértebras, y los carpos y tarsos, que como en los amfiumas, forman una sola pieza. La cabeza tiene una estructura muy extraña y particular; los maxilares superiores faltan del todo, mientras que el contra. maxilar se ensancha y prolonga, constituyendo casi todo el borde de la mandibula superior. Los huesos palatinos no existen tampoco; las fosas nasales no tienen rebordes óseos en su cara inferior y exterior y penetran entre el hueso labial y el esfenoides en la cavidad bucal. Tanto en el borde del hueso intermaxilar como en el de la mandibula inferior se encuentran numerosos dientecitos iguales, córneos y un poco inclinados; en los bordes exteriores del esfenoides hay otra serie longitudinal sencilla. En la extremidad posterior del esfenoides se fija un estrecho etmoides que se toca en su parte posterior con el borde posterior del tambor, dejando sin embargo libre un pequeiro espacio en la superficie del cráneo. Toda la region superior de la cabeza está formada por el esfenoides, aplanado en forma de escudo. E! tambor se compone de un hueso bastante largo, un poco mas grueso en ambas extremidades y que se dirige oblicuamente hácia la mandibula inferior; esta se parece á la de la salamandra.

* El estómago del proteo anguiforme es un sencillo ensanchamiento del intestino, que en una direccion casi recta se extiende desde una extremidad del abdómen hasta la otra; el esófago presenta en su interior repliegues. Ia verdadera laringe no existe $y$ en su lugar hay solo una cavidad mem. branosa en forma de media luna, que pur medio de una pe. queña hendidura se abre en el esófago y hícia atrás, convir. tiéndose en dos largos tubos que á su vez rematan en las bolsas pulmonares, muy delgadas $y$ pobres en vasus.

La mayor parte de los proteos anguiformes son de un cclor blanco amarillento ó rojizo claro de carne, que cambia, sin embargo, cuando se les ponc a la luz; algunos presentan entonces un tinic pardo rojo, y otros tienen manchas mas oscuras, por lo regular de un color negruzco con manchas de un amarillo dorado, etc. Segun Schreiber, el color del fondo varía desde blanco amarillento fino ó sucio, pasando por el blanco rojizo $\delta$ rojo de carne, hasta el violeta en todos los matices posibles. Muy á menudo se ven sobre este color del fondo manchas regulares ó irregulares de color ama. rillento gris 0 rojizo, ya numerosas $\delta$ escasas que se distribu. yen por todo el cuerpo y \& menudo se reunen. Las branquias son de un rojo de sangre en los individuos vivos, pero pali. decen cuando se les pone al aire. La longitud puede llegar á $11^{21}, 13, y$ no excede por lo regular de $\|^{ \pm}, 25$ (fig. 112).

DISTRIBUCION GEOGRÁFICA. - El proteo anguiforme se ha encontrado hasta ahora exclusivamente en aguas subterráneas de Carniola y Dalmacia, sobre todo en las cue. 
vas de la montaña de Karst, cerca de Adelsberg, en la gruta de Magdalena, en Oberalben, en Tuembeln, cerca de Haas. berg, en los alrededores de Lase donde el rio llamado aqui Unz se precipita en profundidades subterráneas de que no vuclve i salir hasta llegar sus aguas cerca de Oberladbach, $\mathfrak{a}$ la inmediaciacion de las llamadas Ventanas marinors del pantano de Laibach, y en canales de riego que se comuni. can con el rio del mismo nombre, cerca de Altenmarkt, Rupa, Vir, Dal, Sagratz, Leitsch, Gradisch, Seifenburg, Schiza, Yoshetorajama, Karlobza, Petanshajama; tambicn habita cerca de Kaumpolje, Sign, en Dalmacia, étc Los campesi. nos, que conocen muy bien à proteo anguiforme. ó segun cllos le llaman pisecilla hombre, S esculritiodora dil regua de las finichlas, porque consideran su caza cono medio de.ga. uar dinero, dicen que solo se encuentran con regularidad estos animales en las partes profundas de las cuevas y que no salen con el agua sino despues de fuertes chaparrones.
Dasy cree que todos los proteos anguiformes provienen de un gran lago subterráneo descie el cual salen á las muchas aguas que se comunican con él; pero no podria asegurar nada, pues le parece misteriosa la presencia temporal de los proteos en ciertos sitios. Aunque viven exclusivamente en el agua, salen sin embargo, segun dicen los guias de los viajeros cuando se acerca una tempestad; se les ve entonces en la orilla, donde se pasean por el suclo húmedo á la manera de las anguilas, con movimientos torpes.

Actualmente los campesinos examinan, despues de una copiosa lluvia, ciertos charcos que se llenan de agua, ó las desembocaduras de los rios subterráneos; y se cogen alli los proteos que el agua arroja a la orilla; tambien penetran con antorchas en el interior de las grutas cruzadas por rios 6 donde se forman charcos, iluminan el agua y cogen los batracios con una red en forma de saco, ó bien con la mano. Los cautiros ze conservan y envian despucs cn rasijas de

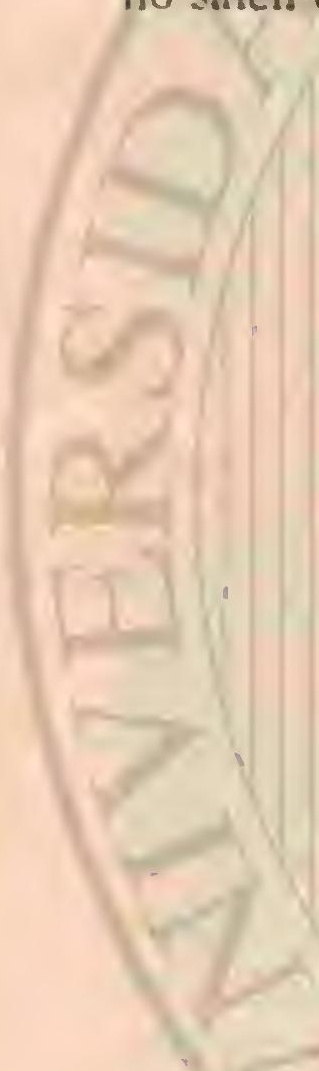

cristal medio llenas de agua, cubiertas con tinas redes. Muchos aficionados y naturalistas han conservado sus pro. teos largo tiempo, algunos hasta seis ú ocho años, en senci. llos depósitos, y hasta en vasijas, donde los observaban cuidadosamente. Por lo regular permanecen en el fondo de su prision, tendidos á la larga en el mismo sitio. De dia están muy quietos, cuando su vasija se halla en un sitio oscuro; todo rayo de fuz los excita, obligándolos á buscar con la mayor rapidez posible un sitio donde no les ofenda. En un depósito cuyas aguassemudan raras veces, suben á menudo á la superficie para respirar; si se renuevan a menudo 6 son pro. fundas, las branquuias absorben bastante oxigeno para la res. piracion, y por eso los animales no salen nunca a la superfi. cic. Si se les saca del agua mueren infaliblemente a las cuatro horas, 6 antes; pero segun Schreiber, se pueden conservar muy bien vivos en agua de muy poco fondo; en tal caso sus pulmônes se ensanchan y agrandan, mientras que si permanecen de continuo debajo del agua las branquias vuelven s. desarrollarse mas. Se han hecho varios experimentos para obligar $\{$ los proteos anguiformes á metamorfoscarse, atín. doles por ejemiplo las branquias, paro nunca se ha obtenido el resultado; muy por el contrario, se ha producido regular. mente la muerte al emplear mediostan violentos. A pesar de esto, me parece que tarde ó remprano se conseguirála metamoríosis del animal.

los sentidos del proteco anguiforme están en general poco desarrollados, y precisamente los que se consideran como del todo atrofiados revelan una facultad sorprendente. Asi, por ejemplo, los animales advierten al punto cuando se echa alimento en su depósito, dirigense en linea recta hácia el mismo y lo cogen con una seguridad casi infalible; de modo que se podria suponer un desarrollo notable del olfato y del tacto, pues de unos ojos tan pequeños y ocultos como los suyos, apenas debe esperarse una vista tan perspicaz. I.os cautivos comen pececillos, gusanos y caracoles, y segun las observaciones de Welker, prefieren los puduridos, que pulu. lan en todas las plantas acúticas muy espesas. Dos cautivos del citado observador solian nadar en lineas circulares muy rípidamente cuando se les inquietaba, recorriendo las pare. des de su depósito de cristal; entonces su guardian observa. ba que se dirigian presurosos hacia el alimento ofrecido, $\mathrm{cl}$ cual cogian moviendo la cabeza á derecha e izguicrda. Nun. ca se vió que hicieran caso de un animal quicto y por lo tanto es bastante probable que precisamente el moviniento de los puduridos los incite á comer. Algunos proteos angui. formes rechazan todo alimento, conservándose á pesar de esto algunos años, cuando se les da siempre agua fresca; no se comprende cómo viven. En sus cuevas se han observado varios animalitos muy particulares que les sirven de alimento, notíndose que algunos individuos rompian pequeñas conchas, mas a pesar de csto no tenemos aun las noticias apetecidas sobre su modo de alimentarse.

Tampoco sabemos nada respecto á la reproduccion. Una ver se dijo que un campesino habia observado que uno de sus proteos cautivos daba a luz hijuclos viros. Fi hombre habló de un individuo recien cogido que se movia con vio. lencia y que era tambien mucho mas grueso que todos cuan. tos hasta entonces habia visto. Por la noche el animal estuvo inquieto, inclinó la cabeza hácia el fondo, y elevando el lomo formó una especie de arco. En el ano se observó una peque. na dilatacion del tamaño de un guisante; mas tarde salieron tres vejigas de color rojo pálido de cinabrio, reunidas por 
hilos, y poco despues apareció un proteo de $0^{\circ}, 04$ de largo del todo semejante al individuo adulto; con su cubierta cayo al fondo, $y$ allí permaneció quieto. La madre intentó despren. der con sus patas anteriores la cubierta de su hijuelo; poco despues nació otro hijuelo del mismo tamaño y por la ma. ñana la familia se aumentó con un individuo mas. Ia madre pareció muy cariñosa con su progenie, intentando siempre tenerla reunida entre las patas anteriores. Por la tarde el agua se enturbió, y al examinarla, vióse un gran número de mem. branas que ocupaban casi todo el espacio y se componian en parte de una red giutinosa de mas de cien globulillos del tamaño de un grano de mijo y reunidos por hilos. La madre parecib ocuparse mucho de sus endebles hijuelos, al parecer medio muertos. Sin que lo supicra cl hombre qque refiere es. ta historia, las mujeres de la casa arrojaron los animales, que de este modo se perdieron.

A pesar de la apariencia de veracidad que tiene este relato, las noticias del campesino resultaron mas tarde ser erró. neas. No sé decir por qué conducto se demostró esto, pero lo cierto es que actualmente ningun naturalista cree ya esa historia Algunos observadores muy expertos hallaron ova. rios al disecar algunas hembras, pero nunca huevos desarro. llados, y por lo tanto tampoco este descubrimiento ha servi. do para nada. Mluchos años se han tenicio docenas de proteos anguiformes en el mismo depósito, y tambien se les ha visto retozar, pero ninguno se apareó. El primer guia de las cue.

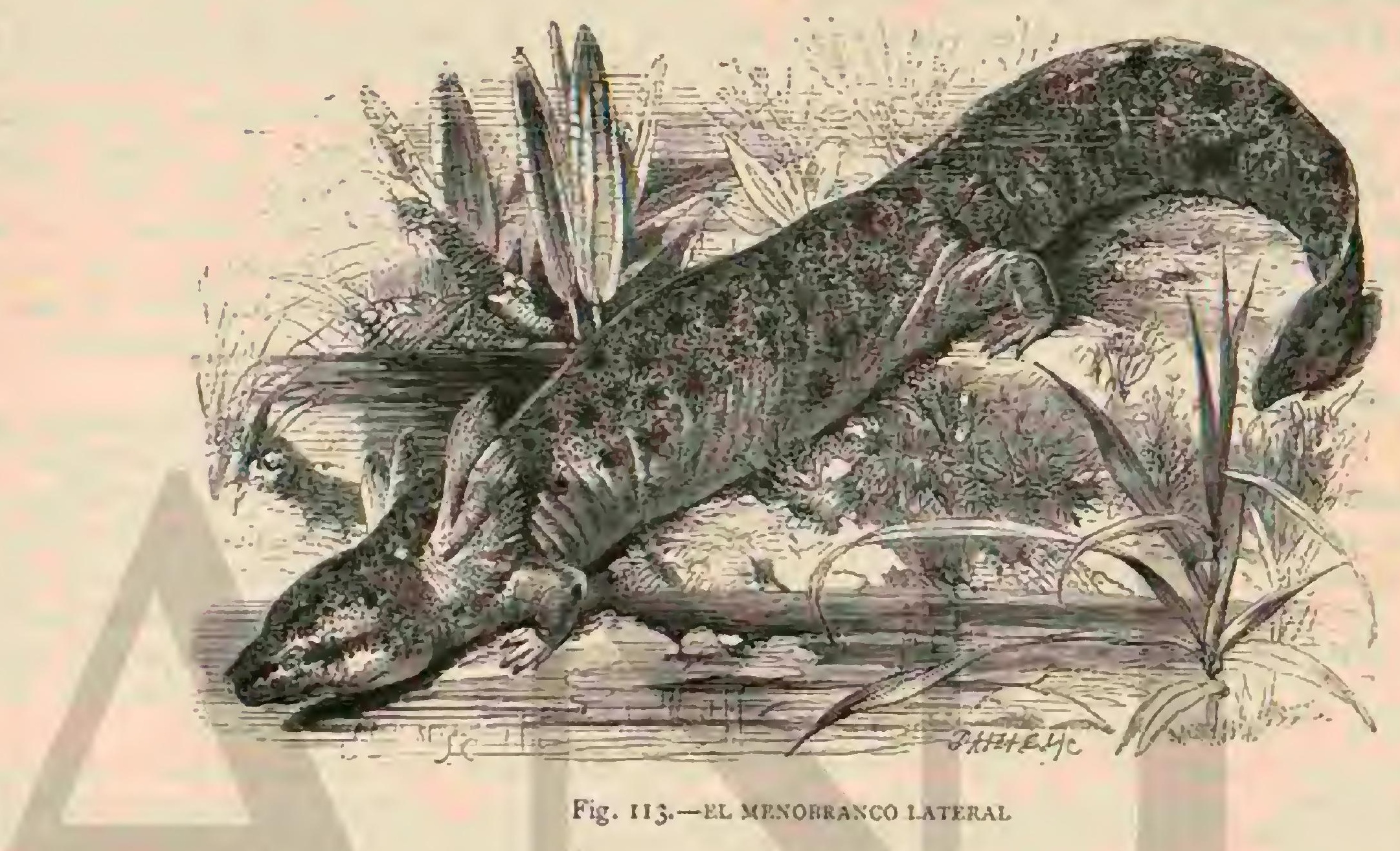

vas, Prelessnig, sin embargo, ha observado últimamente que esos animales ponen huevos. Me tomo la libertad, me es. cribe dicho guia con fecha g de mayo de $\mathrm{S}_{75}$, de dar $\{$ us ted cuenta de un caso que aun no habia ocurrido anqui. Hace unas tres semanas pude coger dos proteos anguiformes de la gruta de Magdalena cerca de Adelsberg. El viérnes pasado saqué los dos individuos de la fuente nara enseñarios a los visitantes de la gruta, $y$ con gran asombro hallé cuarenta huevos. No supe explicnrme al punio el hecho, porque estos huevos eran parecidos á los granos de cebada, pero saqué los dos individuos para ponerlos en otra vasija. Durante la noche siguiente depositaron doce huevos mas, y al otro dia traslade los dos proteos á la primera fuente, donde estaban los cuarenta huevos; alrededor de estos se forman pequeñas redes como telas de araña, y entre los huevos y aquellasse ve algo parecido á la clara de un huevo de gallina. Nudo el agua todos los dias sin sacar los animales ni tocar los huevos; retiro con mucho cuidado el agua y la cambió por otra fresca. Pronto veremos lo que saldris de estos huevos.

Once dias despues me refirió el mismo hombre que el is de mayo habian puesto otros cuatro y él ig dos mas, com. poniendo por lo tanto un total de cincuenta y ocho. Preless nig envió algunos de elios á Viena para hacerlos examinar; en los otros reconoció que con el tiempo aumentaban un poco de tamaño, pero pronto entraron en descomposicion. No cabe duda, por lo tanto, que aunno cstaban fecundados, ó no habian tenido las condiciones necesarias para su des. arrollo.

\section{EL MENOBRANCO LATERAL-MENOBRAN- CHUS LATERALIS}

CARACTÉRES. - En el norte de América vive el meno. branco lateral, criptobranquiato de casi doble tamaño, de es. tructura relativamentc fuerte, con cuatro extremidades, provista cada cual de cuatro dedos; la cabeza es oval adelgazada en su parte anterior y redondeacia en el occipucio; el cuello presenta una marcada separacion, y el tronco se asemeja al de la salamandra. Su color general es gris pardusco, con manchas negras en algunas partes y matices oscuros; las par. tes superiores del tronco y la cara exterior de las patas son pardas, con manchas negras irregulares; una faja oscura que parte de las fosas nasales cruza los ojos, y corriéndose á lo largo de los costados, se pierde en la cola; una línea negra denticulada se extiende sobre la nuca y el lomo; las partes inferiores son de un color de carne pálido. Los individuos aduitos alcanzan una longitud de (1),60 ó mas (fig. 113).

La lengua, libre y carnosa, es redondeada; las dos man dibulas tienen dientes, $y$ en la superior hay dos series. El número de vértebras es relativamente reducido ( 19 dorsales y de 20 \& 35 caudales); la estructura del esquelcto se parece tanto á la de la salamandra, que Dumeril solo puede indicar como carácter distintivo los cuatro dedos y las branquias constantes, por lo que hasta ahora sabemos.

USOS, COSTUMBRES Y RÉGIMEN,-Son miy esca. sas aun las noticias qule tenemos sobre el género de vida del menobranco latcral y sus congéneres. Mitchell dice, que en 
los lagos norte americanos se coge á reces el animal con an zuelos, parn enseñarle despues como una curiosidad. Gippes recibió una especie congénere (menouranchuss punchalus), co. gida en los arrozales de la parte meridional del rio Santi, $y$ dice que los negros tienen un miedo tan infundado como ridiculo de este urodelo $y$ de sus congéneres, porque los consideran como muy vencnosos. La gamella de madera en que se habia puesto el primer cautivo perdió, por causa del terrible animal, todo su valor para el propietario, quien la rompió para que nadie pudiera ya comer en ella. Mas tarde se cogieron otros individuos, conservíndose algunos meses vivos en un depósito de agua. Cuando estaban quijetos tenian extendidas sus magnificas branquias rojas, pero ha menor molestia las hacia perder su coior brillante. Solo por casta. lidad subia algun individuo a la superficie del agua; abria la boca para respirar y volviá á sumergirse. Al cabo de algunos meses murieron.

No se sabe aun nada sobre la reproduccion, pero es muy probable que se asemeje a la del axolotl. Es cierto que se lian encontrado individuos de muy diferente tamaño y que por lo tanto puede hablarse de pengueños y de adultos; pero eso no prueba que este renacuajo, pues como tal considero al menobranco, pueda metamorfoscarse mas adelante.

\section{LAS SIRENAS-SIREN}

CARACTERES. - Este género recuerda por su estructu ra la del amfiuma, pero se distingue de él por carecer de las extremidades posteriores.

\section{LA SIRENA LACERTINA-SIREN LACERTINA}

CARACTERES. - La táltima especie de esta familia es la sirena lacertina, tipo del género que nos ocupa. El tronco parece ser largo, cilindrico, con dos extremidades anteriores, provistas de cuatro do de tres dedos, adelgazado ó aplanado en su parte posterior; en el esilueleto no hay vestigio de las patas posteriores; las fosas nasales estan situadas cerca del borde del labio superior y se abren junto $a$ la boca; los pequeños ojos son redondos y se ocuitan bajó la piel trasparente que los cubre. Las aberturas branquiales son cortas y tras. versales, $y$ en su ángulo superior se insertan las branquias, muy ramificadas. En la mandíbula inferior y en el paladar hay dientes. Las vértebras se parecen por su estructura á las del proteo anyuiforme; ocho de ellas, comenzando por la segunda, tienen pequeñas apófisis costillares (fig. 114).

DISTRIBUGION GEOGRAFICA.-Este reptil es pro- pio de la América del norte $y$ abunda principalmente en la Carolina.

USOS, COSTUMBRES $X$ REGIMEN.-Garden nos dió á conocer en 1765 la sirena lacertina, descubierta en la Carolina meridional, enviando dos individuos á Ellis, en Lóndres. Manifesto á este que el animal se encuentra en si. tios pantanosos, sobre todo debajo de troncos viejos de árboles; que trepa á reces sobre ellos, colocandose en el rama. je, y que cuando en verano se agotan las aguas produce un sonido lastimero como los patos pequeños, pero $\mathrm{con}$ mas fuerza. Considera à este sér como pe\%, error en qque tambien incurrió Linneo. Pallias creyó mas tarde reconocer en el animal el renacuajo de una salamandra grande, pero Cuvier opinó que se le debia considerar como animal desarrollado. Zn junio de $1 \$ 25$ llegó una sirena viva de $0^{\prime \prime}, 50$ de largo á Ingiaterra, donde Neill la cuidó, observåndola durante seis anios. Al principio la tenia este naturalista en un cubo lleno de agua, colocado de modo que el animal pudicra salir à tierra firme; pero pronto se observó que preferia el musgo, y como cra preciso renovarle continuamente, se le dió otra planta siempre verde bajo cuyas hojas flotantes se ocuitaba. Comia lornbrices, pececillos y renacuajos del triton; pero ayunaba desde mediados de octubre hasta fines de abril. Al tocarle la cola lanząa burbujas de aire, avanzando lenta. mente.

El is de mayo de $1 \$ 26$ salió del cubo despues de haber comiado, y cayó cesde la altura de mas de un metro: â la mañana siguiente se le encontró en un sendero fuera de la casa y viósc que habia abierto una galería de un metro de largo, debajo de una pequeña bóveda del muro. A conse. cuencia del frio estaba rigido y apenas daba señales de vida; respiraba con dificultad en el agua, clevándose ś la superficie; pero cuando hubo permanecido algunas horas en la profundidad, mostróse tan vivaz como antes.

Cuando en 1827 se le colocó en un invernadero se puso mas alegre aun y comenzó á cantar como una rana, es decir, á emitir algunos. sonidos iguales. En este verano comia de dos i cuatro pequeñas lombrices a la vez y era en general mucho mas ágil que antes; apenas veia una lombriz se acercaba cautelosamente y parándose un momento cual si estuviera en acecho se precipitaba de repente sobre ella; por lo demás, solo comia una vez cada ocho ó diez dias. Por lo regular descansaba horas enteras sin producir burbujas de aire; en. tonces se observaba dos veces por minutos una ligera corrien. te por detrás de las branquias. Al tocarle avanzaba con tal rapidez que arrojaba el agua. Fl 22 de octubre de I 83 I se le encontró muerto fuera del cubo con las branquias resecadas. En los seis años habia crecido $0^{\circ}, 10$.

\section{UNI

\section{GIMNOFIONIDOS-GYMNOPHIONA}

CARACTERES. - Si algun grupo de batracios merece la categoria de órden, dice Wagler, seguramente es el de los gimnofionidos, pues si por su exterior parecen serpientes, $\delta$ mas bien dobleandadoras, su estructura interna ofrece gran. des analogias con la de los batracios. Aunque se asemejan en general a las dobleandadoras, difieren de ellas, sin embargo, por su cuerpo desnudo, por carecer de todo indicio de cola y por tener el ano redondo en la extremidad; el cuerpo afecta la forma de un cilindro obtuso en sus dos extremos, presentando unas depresiones mas ó menos numerosas en 
figura de anillos; tambien puede ser del todo liso, y en los individuos vivos está cubierto de una sustancia pegajosa.

-Todos los gimnofionidos tienen dientes iguales, huecos, fuertes, cónicos, inclinados con la punta hácia atràs y quese insertan en el lado interior de las mandibulas; la lengua estå fija con toda su cara interior en la barba y no puede por lo tanto sacarse. Tambien hay clientes palatinos dispuestos en forma de herradura, como en algunos ictioideos. El hueso de la lengur es notable por componerse de tres pares de arcos que indican la existencia de branquias en la primera juven. tud, y una metamorfósis. Las fosas nasales descrubocan fuera, en los lados ó en la extremidad de la cabeza, y en el paladar. Los ojos faltan del todo, ó están cubiertos por la piel de la cabeza, de modo que no sirven como brganos de la vista; delante de ellos se distingue un pequeño orificio ó una espe. cie de antenas que pueden alargarse $y$ recogerse. Ias orejas están ocultas, como en las salamandiras, dehajn de la piel coriácea del tímpano y se componen solo de una hojita car. tilaginosa.

La cabeza tiene una estructura muy particular: los maxi. lares cubren los huesos parietales de modo que todo el cráneo parece compuesto de una sola pieza ósea en forma de escudo. Los ojos están situados, cuando existen, en una cavidad Jor. gitudinal que se halla en la extremidad superior de los maxilares; el tambor está intercalado entre los otros huesos del cráneo, y las apófisis de la mandibula superior se reunen en su extremidad por medio de cartilagos. El cóndilo del occipucio se divide por su mitad en dos partes como en las ranas.

\Las vértebras dorsales son cóncavas en ambas extremidades y se comunican entre sí por medio de una hoja cartiliginosa; las costillas solo existen en forma de munones; el esternon, la pélvis $y$ las extremidades faltan del todo; y de Ins pulmones solo eviste $u n$ alo.

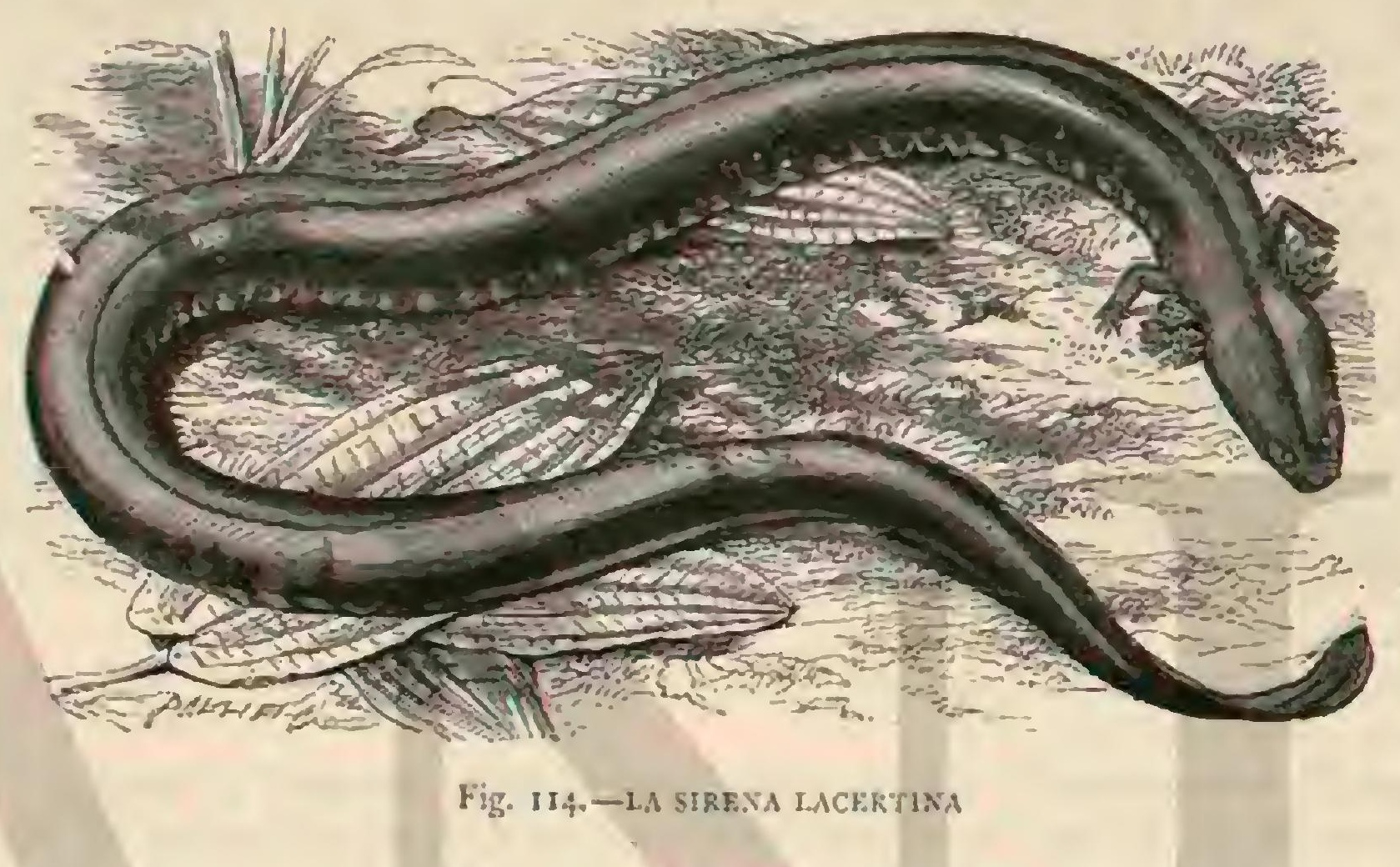

Los caracteres anteriores descritos por Wagler, fundador. del órden, son válidos aun ahora. Solo debo añadir que el nímero de vértebras, muy considerable, puede llegar á 250, de modo que la metamorfósis debe ser mucho menos completa que en los dos órdenes anteriores, pues los hijuelos ofrecen desde un principio el aspecto de los adultos. Las branquias son extremo pequeñas, no salen de las aberturas, y como desaparecen muy pronto, podemos suponer que estos animales no viven nunca en el agua como los batracios. Cuando las branquias han desaparecido se forma, como en la mayor parte de los batracios, un ala en el pulmon, que en algunos individuos casi sicmpre parece atrofiada.

Iodos estos caractéres son tan particulares, que algunos naturalistas los consideran de bastante importancia para eri. gir elórden en una clase independiente de vertebrados.

DISTRIBUCION GEOGRAFICA.-Habitan los paises tropicales de América, Asia y Africa.

USOS, COSTUMBRES Y REGIMEN.-Viven debajo de tierra como las lombrices $\mathrm{y}$ por eso es muy dificil observarlos. Sus movimientos son en extremo lentos. Su alimento se compone de gusanos $y$ otros animales pequeños $y$ en par. te tambien de sustancias regetales. Algunas especies paren hijuelos viros, pero no sabemos aun que esta sea regla general.

\section{LOS SIFONOPS-SIPHONOPS}

CARACTERES. - I Los caractéres de la familia son los mismos del órden, y tambien la diferencia entre los gíneros es de muy poca importancia. Los sifonops tienen un peque- ño orificio junto á los ojos, atrofiado, y cortas antenas al lado de la nariz.

\section{EL SIFONOPS ANILLADO-SIPHONOPS ANNULATA}

CARACTERES. - La piel de este animal presenta unos norenta anillos; es de color negruzco con los surcos blan. quizcos.

DISTRIBUCION GEOGRAFICA.-Esta especie es propia de la América del Sur.

\section{LAS CECILIAS-CAEILIA}

CARACTERES.-Las espécies de este génera tienen un hoyo debajo de cada fosa nasal, y ademês se distinguen por su cuerpo muy prolongado.

\section{LA CECILIA LOMBRICOIDE-CAECILIA IOM- BRICOIDEA}

CARACTERES. - Esta especie, que mide $0 m, 60$ de lar. go, siendo su diámetro el de una lombriz, tiene solo las par. tes posteriores anilladas y es de color pardusco (fig. I I5).

\section{LA CECILIA DE VIENTRE BLANCO-CAE- CILIA ALBIVENTRIS}

CARACTÉRES.-La cecilia de vientre blanco dista mucho de ser tan delgada como la lombricoide: por la cabeza, 
la lengua, los dientes y las fosas nasales, se asemeja á la especie anterior; $y$ asi como ella, tiene el orificio de la cloaca situado debajo de la extremidad terminal del tronco; toda la extension de su cuerpo presenta pliegues, pero solo un corto número le ciñen por completo; cuéntanse entre todos unos ciento cincuenta, siendo del todo circulares los noventa primeros y los diez y seis úitimos. Hácia la region de la cola se distinguen mas fácilmente las escamas, que son grandes, cuadriláteras, oblongas, de ángulos redondeados y muy im- bricadas de derecha á izquierda; su superficie presenta un pequeño relieve, cuso dibujo consiste en una red de mallas muy diminutas, que se desprenden del cuerpo con facilidad. Esta cecilia es de color pardo negruzco, con el vientre man. chado de blanco. El largo total de este reptil es de unos $0 \%, 60$ (fig. 115).

DISTRIBUCION GEOGRÁFICA. - La cecilia de vientre blanco habita en la América del sur, y se encuentra principalmente en Surinam, como la especie anterior.

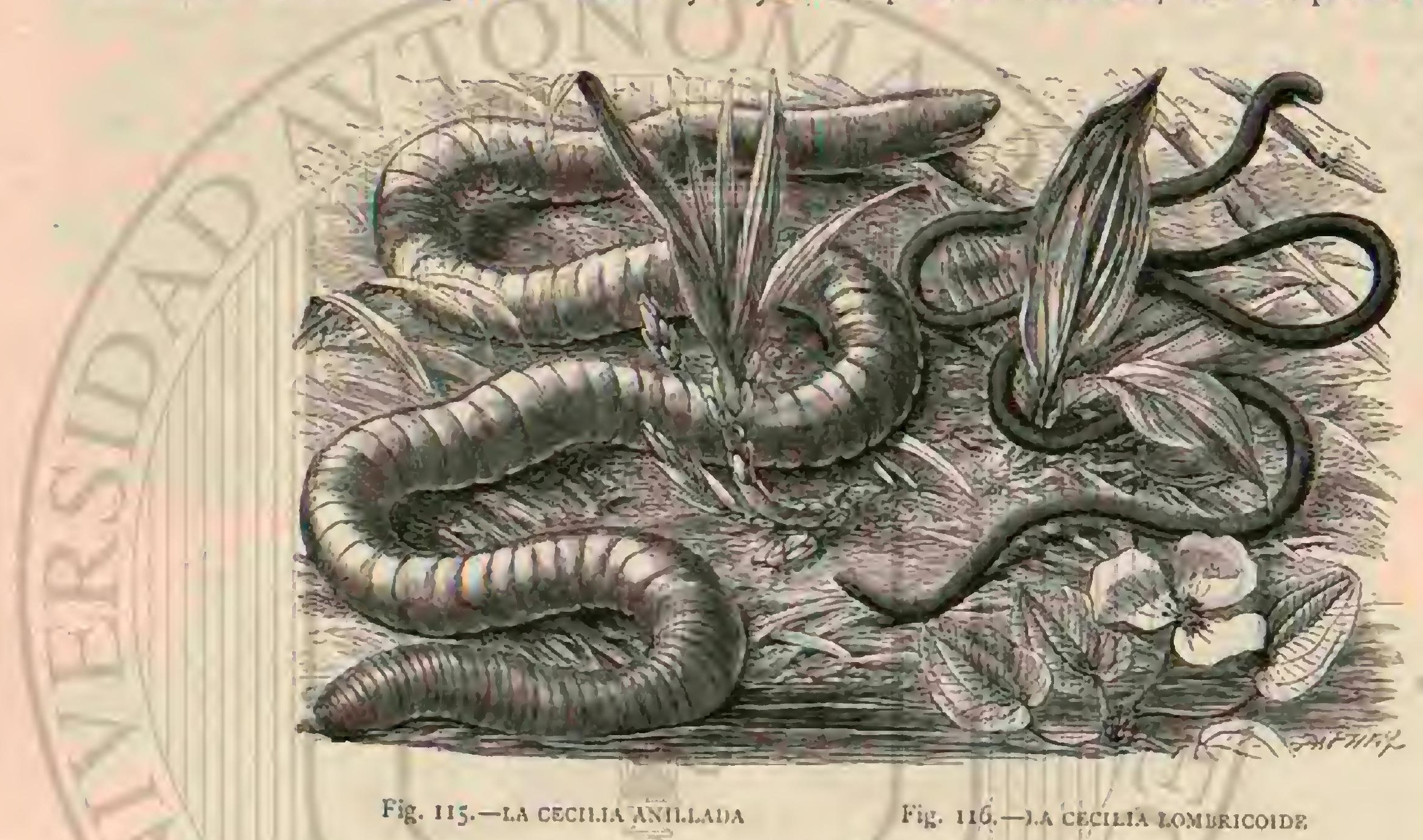

USOS, COSTUMBRES Y REGIMEN. - Sabemos aun muy poco sobre el género de vida de estos séres extraños; viven a la manera de nuestras lombrices debajo de tierra, donde socavan con una fuerza y rapidez relativamente notable. Sigun experimentó el principe de Wied, elevan un poco el suelo sobre sus galerias, como lo hacen nuestros ratones campestres. Ja cecilia lombricoide, única especie de que el principe recibió noticias, no parece existir mas al sur de Sertong de Bahia, donde se designa con el nombre de doble. andadora 6 serpiente de dos cabezas. Tampoco yo, dice Schomburgk, pude obtener mas noticias de los indigenas negros: solo me dijeron que estos animales viven en tierra, so. bre todo en los montones de hormigas. Yo mismo me con. venci mas tarde de la exactitud de este informe y Colliens aseguró que cuando quiso exterminar aquellos parásitos encontró á menudo una cecilia en medio de ellos. Es posible que el batracio busque los inontones de hormigas por el calor animal, ó por la atmósfera particular, 6 bien á causa del suelo blando: consta solo quelas hormigas no la atacan y que viven en la mejor armonia.z

El sifonops anillado habita, segun Tschudi, los sitios humedos, á una profundidad de 30 a 60 centimetros bajo la su. perficie del suelo. Los brasileños le temen tanto como á la doble andadora, aunque cs tan inofensiro como ella.

\section{UNIVERSIDAD}
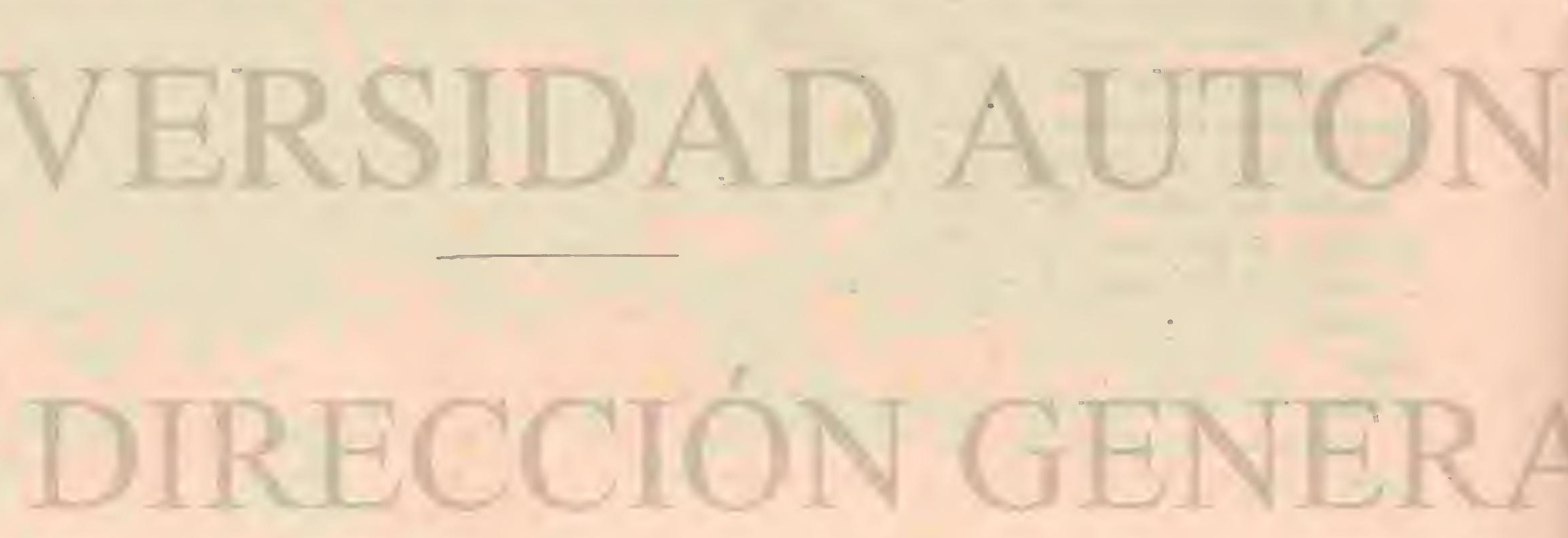


\title{
LOS PECES
}

\author{
OJEADA GENERAL SOBRE LA VIDA DE LOS PECES
}

CARACTERES GENERALES. - L Los peces son animales que respiran siempre por branquias 6 agallas, y en su major parte solo por ellas. Estas pocas palabras designan la última clase del grupo primero de los animales con mucha mas precision que pudiera hacerlo una descripcion circunstanciada y exacta de sus órganos interiores y exteriores.

Aquel que solo conoce los peces de rio no puede tener idea, a pesar de la variedad de estos, de las diferencias de formas de los animales vertebrados provistos de escamas y de aletas. Bajo este concepio no ceden la primacía á nin. guna otra clase de vertebrados. Verdad es que la mayor parte, á semejanza de nuestros peces comunes de agua dulce, tienen forma de huso ú oblonga, pero esta forma fundatnen. tal admite las variaciones mas numerosas y pasa á las formas mas singulares, incluso aquellas que son al parecer feisimas extravagancias. En unas especies el cuerpo se alarga hasia adquirir el aspecto de serpiente $\delta$ gusano; en otras aplánase lateralmente hasta asemejarse á una cinta, $\delta$ acortándose al propio tiempo en longitud, llega $a ́$ parecer un disco; $\delta$ bien se deprime en sentido vertical ensanchándose horizontal. mente y aumentando su volúmen con apéndices en forma de aletas; ó sa, en fin, solo ciertas partes aumentan desmesuradamente en largura hasta resultar informes, exageradas Y extravagantes; mientras que otras se juntan y confunden entre sí, reduciéndose á reces hasta desaparecer del todo. Ninguna clase de vertebrados presenta apéndices tan extraỉos 6 incomprensibles ni tantas agregaciones \& la estructura regular; únicamente los peces ofrecen semejante multiplicidad en la disposicion de los miembros y de los sentidos. Puede considerarse como carácter distintivo de la forma del pez la dificultad de reconoccrse en su cuerpo las exiremida. des. La cabeza en ningun caso está separada del cucrpo por un cuello, y en cuanto á la cola, solo se la observa excepcionalmente bien marcada en su punto de insercion; por regla general, asi la cola como la cabeza están unidas al tronco, formando el todo como una sola pieza. Tratándose de peces dificilmente puede hablarse de articulacion en el sentido en que esta palabra se usa cuando se trata de la gran mayoria de los demás vertebrados, pudiendo considerarse las aletas solo como indicio de las extremidades de esos séres.

Estas membranas, sostenidas y movidas por espinas ó radios cartilaginosos 6 huesosos, y casi exclusivas de los peces, se dividen mas fácilmente, segun su colocacion $y$ disposi. cion, en pares 6 impares. Las primeras, que son las que corresponden á las cxtremidades de los demás vertebrados, se diferencian completamente de las impares, si bien con. cuerdan con estas por estar formadas de espinas 6 radios. Las aletas del pecho ó torácicas que existen casi siempre y se insertan detrás de las branquias d cada lado del tronco, consisten en el fondo en tres partes: en la axila, en una parte media dispuesta en dos hileras de un modo desigual, y en una serie de piececitas cilindricas, en las que van arti. culadas espinas $\delta$ radios; las aletas abulominales descansan por el contrario en una pieza única, ya cartilaginosa, ya huesosa, inserta simplemente en los músculos abdominales, ha. llándose en la mayoria de los peces debajo del vientre, aproximadamente en medio del cuerpo y próximas al ano; $y$ por excepcion alguna vez delante de las aletas torácicas, en particular en el cuello, por cuja razon se dividen ciertos peces en peces de aleta torácica $y$ en peces de aleta en el cuello. Las aletas impares salen de la linea media del cuerpoy llevan los nombres de aleta dorsal, caudal s anal; la primera puede ser doble; pues cabalmente presentan los peces la major variedad en la colocacion, formas, estruciura y cxtension de las aletas impares. Hasta las espinas ó radios ofre. cen una variedad análoga á las aletas; en algunos peces son córneas, no articuladas, blandas y fiexibles, y en otros pun. rantes, huesosas, articuladas y quebradizas, partidas, divididas como en cerdas, etc. 'lodas se articulan en huesos especiales colocados en la linea media del cuerpo entre las grandes masas musculares, y están movidas por músculos débiles.

La cubierta mas comun de los peces consiste en escamas de forma y estructura muy variadas. Estos cuerpos extraños pueden estar dispuestos en lineas regulares y reclas, ya longitudinales, ya trasversales, ya corriendo en direccion oblicua desde la espalda hasta el vientre; con frecuencia imbricadas ó sea á manera de tejas, otras veces unidas en sus bordes, ó dilatadas en grandes placas ó escudos, ó bien separadas por espacios sin cubrir entre una y otra, y tambien disminuyendo progresivamente hasta llegar a ser imperceptibles, $\sigma$ bien pueden faltar completamente. En cuanto a su forma y estructura se distinguen en escamas redondas, aserradias, y de csmalke. Las primeras son. las mas comunes y presentan en su superficie gran número de líneas que se penetran mutuamente y forman circulos mas ó menos cerrados al rededor de un centro situado hácia atrás, juntó con otras lineas á manera de radios; las escamas aserradas se diferencian de las anteriores en tener el borde posterior guarnecido de espinitas que tan pronto son á modo de púas dispuestas como los dientes de una sierra, como aguijones sobrepuestos; las escamas de esmalte finalmente son gruesas, duras y contienen corpúsculos huesosos bien determinados y cubiertos de una capa de esmalte trasparen. te. Cuando estas últimas llegan á extenderse en la superficie, y cuando al juntarse forman una coraza se llaman escamas 
de hueso ó de coraza. La piel consiste en una capa coriácea muy resistente y otra epidermica que en su superficie se vuelve viscosa. Las materias colorantes se hallan en parte en la capa coriacea y en parte entre esta y la epidérmica; solo el color plateado lo producen plaquitas especiales y delgadas.

Por lo que respecta \& la coloracion, puede decirse en general que dificilmente la aventaja en magnificencia, belleza, variedad y tornasolado la de cualquier otro animal. No parece sino que todo el brillo de las piedras preciosas y de los metales, y todos los colores del arco iris se reflejan en los peces. A la inagnificencia de la coloracion se junta la belleza. y la variedad del dibujo y en no pocos hasta la facultad de poder mudar de color, como apenas lo poseen en igual grado los reptiles $y$ anfibios. Las investigaciones de Siebold han demostrada quie este cambio de color, cuya causa puede depender en parte de ciertas condiciones vitales interiores y en parte de circunstancias exteriores, está intimamente ligado con los depósitos de la materia colorante, huecos situndos tanto en las capas superíciales como en las mas profundas de la piel y que contienen granitos finisimos de la materia colorante, poseyendo además muy á nenudo un alto grado de contractilidad.

Esoúuนto:- El esqueleto de los peces (fig.-I I 7), dice Yogh, merece una atencion especialisima, aungue solo sea porque en él se manifiesta este carácter esencial de los ver. tebrados en su sencillez mas primitiva, y porque nos permite seguir uno a uno todos los grados de desarrollo del esquele. to desde su forma mas primitiva hasta las configuraciones mas complicadas, tanto en los individuos adultos como en los germenes de los animales superiores. En efecto, con di. ficultad se prestará parte alguna para demostrar tan claramente como el esqueleto la completa concordancia de las formaciones cmbrionarias con las estructuras que presentan los tipos inferiores; concordancia tan manifiesta que casi se veria uno precisado á repetir literalmente la descripcion del esqueleto en el embrión y en cada familia de por sí. El. per-lanceta nos ofrece el grado mas inferior de formacion del espinazo; solo tienc un cordon-eje, una cuerda vertebral cartilaginosa celular que atraviesa en linea recta el cuerpo de extremo á extremo, acaba en ambos extremos en punta y está cnvuelta en una túnica que hácia arriba remata en una envoltura membranosa sin ninguna estructura fija. No tiene cráneo porque la columna vertebral llega hasta el último extremo del cuerpo, ni presenta su túnica dilatacion alguna lateral, ni casanchamiento notable el tubo nervioso. Los peces de boca redonda (ciclostomos) poseen una pieza craniana que contiene la dilatacion cerebral, $y$ tambien se observan unos listones cartilaginosos en número par opuestos unos á otros a manera de prolongaciones rudimentarias superiores arquendas de las vértebras. En los esturiones y en muchos peces antidiluvianos no se encuentra ningun vestigio de pic. zas vertebrales, y si solo una cucrda vertebral que atraviesa cl cuerpo, pero ya se completan mutuamente las piezas arqueadas superiores é inferiores, y encima de estos arcos, en la region dorsal, se forman prolongaciones sencillas y carti. laginosas espinales, mientras que en el vientre se ven rudimentos de costillas. Con los holocéfalos empiera ya la estructura vertebral en forma de placas anulares que nacen en la capa exterior de la cuerda vertebral. En los tiburones se ve la columna vertebral dividida interiormente por tabiques membranosos agujereados en su centro; en todos los demás peces se osifica nıas 6 menos completamente, resultando en lugar de una cuerda vertebral una sarta de piczas vertebrales con una fosa cónica en cada extremo, dispuesta de manera que sus puntas lleguen sa tocarse en el centro del eje de la vértebra; de suerte que las piezas vertebrales solo se tocan en sus bordes extremos dejando libres unas cavidades cónicas dobles, llenas de un liquido gelatinoso, residuo del cordon primitivo vertebral. Entre todos los peces conocidos hoy dia solo hay uno, el sollo huesoso, que tiene una estructura mas perfecta, pues lleva piezas vertebrales con una apófisis articular en la parte anterior y una cavidad esférica articular en la posterior. Las costillas no faltan, solo que nunca se reunen en una pieza esternal, acabando por lo contrario libremente en la carne. Además de las costillas se encuentran en muchos peces espinas $\delta$ estiletes especiales huesosos mas ó menos unidos a aquellas, que nacen en las láminas tendinosas de los músculos: estas son propiamente, las respinas de pez.

Fi cráneo es la repeticion de la estructura de la columna vertebral. Alli donde se manificsta una dilatacion para cl ce. rebro fucrtemente apelotonsdo, se observan tambien piezas cartilaginosas que primero se desarrollan en la base, pero que poco ś poco suben y se cierran á manera de bóveda para for. mar finalmente una capsula completamente cerrada ó bien con algunos espacios sin cubrir. En los peces de boca tras. versal es esta cápsula cartilaginosa y tiene en la parte posterior una articulacion para su union con la cuerda vertebral ó con la primera vértebra cervical; el cráneo de los esturiones consiste tambien, es verdad, en una cápsula cartilaginosa sin articulacion, pero está cubierto, tanto en su lado inferior co. mo en el superior, de placas huesosas; y finalmente, puede comprobarse en todos los peces óseos la osificacion pro. gresiva y gradual. Casi en todos queda entre los huesos que se juntan para formar una cápsula craniana mas ó menos completa, una base cartilaginosa quue tambien envuelve el cerebro, pero los huesos que sostiene están, á pesar de sus formas exteriores, en extremo variadas, siempre construidos bajo el mismo plan fundamental y corresponden al hueso craniano de los vertebrados superiores. La pieza principal del cráneo la forma un hueso en cuya cara posterior se vela misma cavidad que en los cuerpos vertebrales; encima de él descansan los huesos occipitales laterales que envuclicn la médula oblongada, la cual queda cerrada en la parte superior por un hueso casi siempre en forma de peine, $\delta$ sea la espina occipital. Entre esta espina y las piezas laterales se insertan casi siempre dos piezas suplementarias, los huesos occipitales externos. I as grandes y pequeñas alas del esfenoides, que forman casi siempre el fondo de la cavidad del ojo presentan otra vértebra incompleta, no desarrollada, mientras que la vértebra craniana anterior está representada por un huesecito único, el etmoides posterior. Junto con estos huesos que suelen considerarse como vértebras trasformadas, existen los llamados opérculos, placas tapaderas, el esfenoides, el romer, los dos occipitales superiores, los dos fronta. les, la escama llamada temporal, el hueso de la nariz y otros. ¿El cránco formado con estos huesos, dice Vogt, viene á presentar una caja completa que envuelve completamente el cerebro y los oidos, y que tiene para los ojos y la nariz fosas mas 6 menos hondas. Habitualmente se encuentran las fosas nasales perfectamente separadas, prolongándose hảcia atrás por medio de una masa cartilaginosa que forma la base del hocico, en dos conductos atravesados solamente por los nervios olfatorios, hasta desembocar en las grandes órbitas ó cavidades de los ojos, separadas casi siempre solo por un tabique membranoso, por manera que se corren en un solo aguje. ro dentro del cráneo huesoso, agujero cubierto en su parte superior por los dos huesos frontales, y en la parte inferior por los esfenoides. Forman las cavidades destinadas a los brganos auditivos en parte los huesos laterales y en parte los cartilagos, de tal suerte que una parte de ellas se confunde has- 
ta con la cavidad cerebral. En la parte exterior del críneo se observan alternando senos, crestas y bandas ó listones cuya forma sirve frecuentemente para distinguir los grupos y las tamilias entre si. En la línea media del occipucio se le vania comunmente una cresta formada por el hueso occipital superior, y que se prolonga á veces sobre todo el cráneo, además de estar frecuentemente acompanada de otras dos crestas laterales separadas por profundos surcos.

Como apéndices especiales del cráneo se presentan además dos grupos de piezas sólidas, el cartilago labial de la mayor parte de los peces cartilaginosos y los huesos de los tubos de mucosidad de la mayor parte de los peces óscos. Aquellos, tanto mas formados cuanto mas inferior es el grado que ocupan en la serie, constituyen en los peces de boca redonda, ó ciclostomos, la mayor parte del cráneo, particularmente los soportes fijos de los tentáculos y de los hilos labiales, y desaparecen gradualmente en los peces de boca trasversal, especialmente en las rayas. Los huesos de tubo mucoso son aquellos que describiendo un semicirculo, circuyen el borde inferior de las órbitas, y que en algunos peces se extienden hasta unirse con la parte posterior del escudo anterior. A estos huesos se juntan oiros mas pequeños situados en su mayor parte en la posterior del cránco encima de las órbitas 6 sobre la nariz formando tubos alrededor de los conductos de inucosidad de la cabeza. Se agregan á estos los huesos de la cara, generalmente movibles, unidos al cráneo, y que formando una serie de arcos convexos hácia la parte inferior, constituyen anillos mas 6 menos completos y ocupan la entrada de la cavidad digestiva. La base ósea de la cara de los peces se distingue de la de los demás animales vertebrados en que un gran número de huesos, que en los animales superiores carecen de movimiento, lo tienen en los peces. El aparatopalato. branquial consiste, cuando se cxamina con atencion, en tres arcos; el arco branquial superior, el palatino y el branquial inferior. En los peces de boca re donda sustituye el cartilago labial al primero; pero en los tiburones no está desarrollado, independiente del cráneo y unido á la mandibula inferior por una articulacion; en los peces óseos forma el borde superior de la boca, y en este caso consiste en dos pares de huesos, los maxilares y los intermaxilares. El arco palatino se compone del tueso palatino, el trasverso y el alado; en los peces de boca trasversal se va reduciendo hasta formar una placa que viene á constituir la bóveda palatina que hay que considerar como el hueso alado, estando formado en una clase de esturiones de una sola pieza. Las dos mitades de la mandibula inferior rara vez se encuentran sólidamente reunidas en el centro, pero sí por una masa fibrosa ó una sutura. I.a mandibula inferior consiste siempre en varias piezas, habitualmente en tres, a veces en cuatro, y frecuentemente en seis. Una de estas lleva los dientes, otra la articulacion, estando completada hícia atrás por la pieza angular. Ia artículacion de la man dibula inferior no suele permitir otro movimiento que el de palanca de abajo arriba.

Quitando todos estos huesos, se presenta la carldad bucal de los peces óseos limitada por muchos arcos múltiples, de los cuales la mayor parte, nunca empero el arco anterior llamado lingual, llevan flecos ó sean hojuelas branquiales. Los extremos de este arco se reunen en lá parte anterior con el hueso lingual consistente en una serie impar de piezas óseas colocadas una trás otra en la línea media, y que se continua hácia adelante en el hueso lingual, llevando los demás arcos branquiales. Fn el borde exterior de los cuer nos del hueso lingual se encuertran articulaciones óseas $l l a$ nas, encorvadas á manera de sable, y poco variadas en cuanto al número, que sirven para la tension de la membrana branquióstega, la cual cierra la hendidura branquial. En algunos peces se hallan reemplazados estos radios por placas óseas triangulares, que en los peces cartilaginosos son tam. bien cartilaginosos. Detrás del hioides (arco del hueso lin. gual) siguen cuatro arcos duros, compuestos en la mayor parte de los peces cartilaginosos de dos, y en los peces úseos de cuatro piezas que llevan en su parte superior hojuelas branquiales, y en la anterior comunmente espinas ó dientes: los arcos branquiales están fijados al cráneo en la parte su. perior por unos huesecillos especiales. Estos últimos alcan. zan en algunos peces un tamaño extraordinario, distinguiéndose en este caso por sus curvas helicoidales en forma de hojas. Finalmente, hay un arco incompleto, el hueso inferior del esరfago que abraza la enirada de este conducto por debajo.

En ambos lados de la columna vertebral hay vigorosisimos mísculos, general y respectivamente en dos secciones, por manera que pueden distinguirse cuatro masas musculates, dos superiores que forman la espalda ó dorsn, y dos inferio. res que forman las paredes abdominales $y$ la parte inferior de la cola. Estas masas musculares tienen una formacion especial, descomponiéndose en cierto modo en una multitud de anillos, separados uno de otro por membranas tendino. sas, y son principalmente las que facilitan el movimiento de natacion en cuanto permiten robustos movimientos laterales.

En los peces, mas que en todos los otros vertebrados, prepondera la médula oblongada, cordiforme y encerrada en la cavidad 6 tubo superior de la columna vertebral sobre el cerebro; es pequcira y no llena con mucho la cavidad craniana. Se distingue en el cerebro el anterior, el medio ó encéfalo y el posterior ó cerebelo. La continuacion inmediata del primero es el nervio del olfato; siguen las dilataciones inajores del cerebro medio donde nacen los nervios ópticos, despues viene el cerebro posterior, casi siempre formado de dos partes y que puede estar muy desarrollado. Los nervios están dispuestos de la misma manera que en los otros verte. brados y trabajan como en cllos y probablemente de la misma manera tambien.

ÓRGANOS DE LOS SENTIDOS.-Si bicn los aparatos de los sentidos de los peces son inf́criores á los de los animales superiores, no faltan casi nunca, y solo muy rara vez son de formas incompletas. Los ojos, casi siempre grandes, aplanados por delante y faltos de párpados, se hallan solo en los llamados peces ciegos cubiertos de una membrana opaca, ostentando comunmente su íris colores en extremo brillantes y metálicos. En los miemuros mas inferiores de la clase forma la nariz una fosa en forma de copa, y en los denás un tubo dispuesto en el cartilago de la parte anterior del ho. cico, que á veces se cicrta por una valivula, mientras que en los peces con branquias pectiniformes conducen las fosas nasales a una ancha cápsula cuyos dos conductos desembo. can en la parte inferior de la cavidad bucal. El aparato del oido, encerrado sin excepcion en el cráneo, consiste solo en el laberinto, que excepcionalmente comunica por uno $\delta$ dos canales con una fosa situada en la parte posterior de la ca. beza que es el primer rudimento de la oreja.

Especiales á la clase de los peces son los órganos eléctricos, columnitas ó pílas gelatinosas encerradas en membranas ricas en vasos, dividialas por numerosos tabiques membra. nosos y separadas por otros llenos de ramificaciones de nervios extraordinariamente ténues.

APARATO RESPIRATORIO.-Las branquias (aga. llas) colocadas sobre arcos que abrazan la gargania y los ra. dios branquiales, son laminitas blandas, membranosas y salientes en las que se ramifican los vasos respiratorios. Respecto de su formacion se observan varias diferencias. Los hay que vienen a ser tubos anchos que en su parte posterior 
desembocan inmediatamente en el esófago, y cuyos costados están formados/de listones cartilaginosos, particularmente en la cavidad branquial cubierta de mucosa, y con aberturas al exterior ya comunes ya separadas, esto es, hendiduras branquiales desde cuyas comunicaciones intermedias se dirigen laminitas hácia el interior y en las que se insertan las hojuelas branqquiales, etc. En los peces mas elevados están protegidas estas hendiduras hácia fuera por piezas óseas, los opérculos, quedando de este modo encerradas en una cavi. dad que comunica con el exterior por una rendija mas 6 menos estrecha. Por lo comun hay cuatro arcos branquiales guarnecidos de una doble hilera de hojuelas; en muchos peces óseos solo hay tres y medio y hasta los hay que solo lienen dos, mientras que ciertos tiburones tienen seis 6 sietc. Fuera de los peces torácicos, ningun miembro de toda la clase tiene vejiga respiratoria que reciba sangre carbónica y la despida acidulada, pero cn cambio se encuentra frecuente. mente un órgano especial en forma de bolsa, la rejiga nata. toria, que sil bien contiene aire, no tiene selacion alguna con la respiracion, y a lo mas con el conducto auditivo 6 con el esófago y sirve probablemente para regular el peso de los peces conforme la altura del agus. No cabe duda que el aire de la rejiga natatoria es expelido por sus vasos, dado que consiste en carbono $\delta$ ázoe y acaso en muy poco oxígeno. Rondelet fué el primero que observó que esie aparato tan enigmático por muchos conceptos se encuentra con mas frecuencia en los peces de agua dulce que en los de agua salada!

A PARATO CIRCULATORIO. - Con excepcion del pez lanceta, tienen todos una bolsa que encierra un corazon con una auricula no dividida y de pared delgada y un ventriculo de gran fuerza muscular, que por medio de una aber. tura concluye en la arteria branquial ó, como se llama tam. bien, el pediculo arterial, dilatada casi siempre en forma de bulbo y en la que se distinguen dos formas fundamentales y esencialmente distintas de estructura. Io cierto es que en los peces óseos y en los de bioca anular se encuentran en la émbocadura dos vályulas en forma de media luna, y en los de escama de esmalte y de boca trasversal un número considerable de estas válvulas. La sangte pasa del corazon por la gran arteria branquial y corre por ambos lados a los arcos vasculares que alimentan las ramificaciones branquiales de la vena cava, para irse reuniendo despues en un solo tronco principal, la aorta, que se extiende inmediatamente debajo de la columna vertebral hácia atrás. Las arterias de la cabeza suclen nacer por lo comun antes de formarse la vena cava del primer arco. La sangre vuelve al corazon por una vena, simple en la cola, pero que se divide hácia delante por lo comun en dos ramas despues de haber pasado una parte por el sistema llamado de la vena porta. Ia sangre que acude a los intestinos se reune en las venas que se di. suelven á su ver dentro del higado en las redes capilares del sistema de la vena porta para reunirse luego en la vena del higado que desemboca casi inmediatamente en la auricula del corazon.

DIENTES. - Por sencillo que sea en su conjunto el aparato digestivo no deja de ofrecer variaciones su diferente grado de desarrollo, especialmente en cuanto se refiere a la dentadura; y es que de todos los numerosos huesos de la cavidad bucal y del esófago talvez no haya uno que no pudiese cstar guarnecido de dientes. Por supuesto hay peces que no tienen diente alguno, otros que solo los tienen en ciertos hucsos, pero tambien los hay que los llevan en todos los huesos capaces de contenerlos. Comunmente se observan ar. cos dentales de igual direccion en la bóveda palatina, el uno pertenece á los intermaxilares y el otro al hueso palatino y al vómer, mientras que la mandibula inferior y el hueso lingual suelen llevar un arco único. La parte posterior sucle estar toda ella tapizada de dientes, pues los llevan todos los arcos branquiales y los huesos faringeos. A pesar de su gran variedad se distinguen los dientes fácilmente en colmillos y molares. Los primeros suelen tener la forma de gancho puntiagudo, encorvado hácia atrás y mas ó menos cortante en el borde anterior, pero tambien pueden tener la punta á ma. nera de cortafrio, ó varias puntas y ganchos. Por lo comun están colocados en simple fila y de manera que los de una mandibula pasen sobre los de la otra mientras que el espacio intermedio de uno al o:ro está lleno de numerosos dientes menores; pero tambien se reunen cuando son muy delgados y finos hasta formar un verdadero cepillo, y hasta pueden tener novimiento como solo lo ticnen los dientes de las serpientes venenosas, pudiendo doblarse hácia atrás cuando la boca se cierra. Se dividen segun su longitud y fuer\%a en largos y fuertes ó dientes de pira, en mas cortos y fuertes ó dientes de raspa, en finos y largos ó de cepillo y en muy finos ó de teriopiclo. Comparados con ellos aparecen los molares ya como discos bajos, ja crestados $y$ altos, y á veces en forma de cono iruncado, pero en cuanto á la estructura y colocacion pueden tambien ofrecer grandisimas variacio. nes, ser grandes y estar aislados, ó pequeños y reunidos como adoquinés, fa veces semejantes al pico de un ave $\delta$ de una tortuga, tener en la parte anterior un borde cortante $y$ hácia la posterior presentar una superficie plana que sirve para triturar. En algunos peces consisten los dientes en una masa córnea, en otros es calcárea, trasparente, cubierta de un esmalte viörioso y quebradizo, y entre estas dos se en. cuentra frecuentemente una materia mas blanda conectiva. El diente forma un cono hueco, en cuya cavidad se halla la pulpa cónica dental. Mas complicados se presentan los dien. tes de pliegues, en los que la masa dental va colocada en graciosos plieguecitos al rededor de la cavidad medular; y además tienen algunos peces dientes con tubos medulares reticulados en las que ya no existe cavidad medular, pero sf vasos y nervios que atraviesan la masa desde la pulpa en todas direcciones. Finalmente hay tambien dientes compues. tos, cilindros sueltos y huecos que se elevan, ya aisladamiente, ya desde una red vascular comun, y van unidos entre si en una masa comun por algun conectivo. Todos estos dientes carecen de raiz; à menudo se hallan simplemente colocados sobre la mucosa de la boca, pero por lo regular están im. piantados en mucosas espesas y sostenidas por numerosos hilos tendinosos. El desarrollo de los dientes continua al parecer en los peces durante toda su vida.

APARATO DIGESTIVO.-El aparato digestivo consta de tres partes; el intestino bucal compuesto de la faringe, del esófago y estómago; el intestino medio ó delgado y el ano ó intestino grueso y el recto. La faringe, á veces ensanchada á manera de embudo, está por lo regular guarnecida de replicgues longitudinales lo mismo que el estónıgo, pa. sando á este tan imperceptiblemente que apenas se distingue de $\ell l, y$ sin que pueda determinarse dónde acaba uno y em. pieza el otro, mientras que este último se divide general. mente con bastante precision en dos partes, la dél esófago y la del piloro. En este punto, indicado por un repliegue en forma de gancho, se encuentra un intestino cicgo mas 6 me. nos considerable, y al cxtremo del píloro una válvula mem. branosa y una almohadilla muscular robusta, el esfinter, que sirve para cerrar. Inmediatamente detrís del piloro salen unas manguitas cerradas ś manera de ciegos, los apéndices pilóricos, cuyo número puede variar de uno solo á mas de sesenta. Estos ciegos son por lo general simples cilindros, pero otras veces están tan ramificados que mas bien tienen el 
aspecto de una glándula, y efectivamente corresponden â la glándula salival ó pancreática a la que reemplazan en algu. nos peces óseos y en los cartilaginosos de boca trasversal. lin algunos peces tiene la mitad anterior del recto una vál. vula retorcida como una rosca. El bazo y el higado existen siempre, y salvo raras excepciones, tampoco falta nunca la vejiga de la hiel. Como órganos esenciales de secrecion se disringuen ante todo los riñones, de los cuales parten á manera dc ramas los conductos de la orina, los uréteres, para volver á reunirse en el extremo posterior de la cavidad abdominal y luego dilatarse en la vejiga cuyo conducto de salida des. emboca detrás del ano en una verruga $\delta$ bien en el recto.

ÓRGANOS SEXUALES، - Los órganos sexuales están siempre dispuestos con arreglo a un mismo plan fundamen. tal, siendo los de un sexo tan semejantes á los del otro que con frecuencia no pueden distinguirse sino despues de un exámen minuciosisimo. Los ovarios y testiculos se hallan co. locados dentro de la cavidad abdominal inmediatamente debajo de los riñones y encima de los repliegues del intest:no, pero no es siempre áácil encontrarlos, porøque solo auinentan de volúmen, si bien considerablemente, en la época de la reproduccion para reducirse despues otra vez. En algunos peces, especialmente en los ciclostomos (de boca anular), las anguilas y salmones, consiste el ovario solo en una folicula media, otras veces en dos foliculas membranosas laterales que no comunican con ningun conducto de salida, encerradas como están por la piel abdominal. En estos casos los huevos desarrollados atraviesan los tabiques del ovario, caen en la cavidad abdominal y son expelidos fuera al traves de una hendidura media 6 por dos laterales. En los ciclosto-

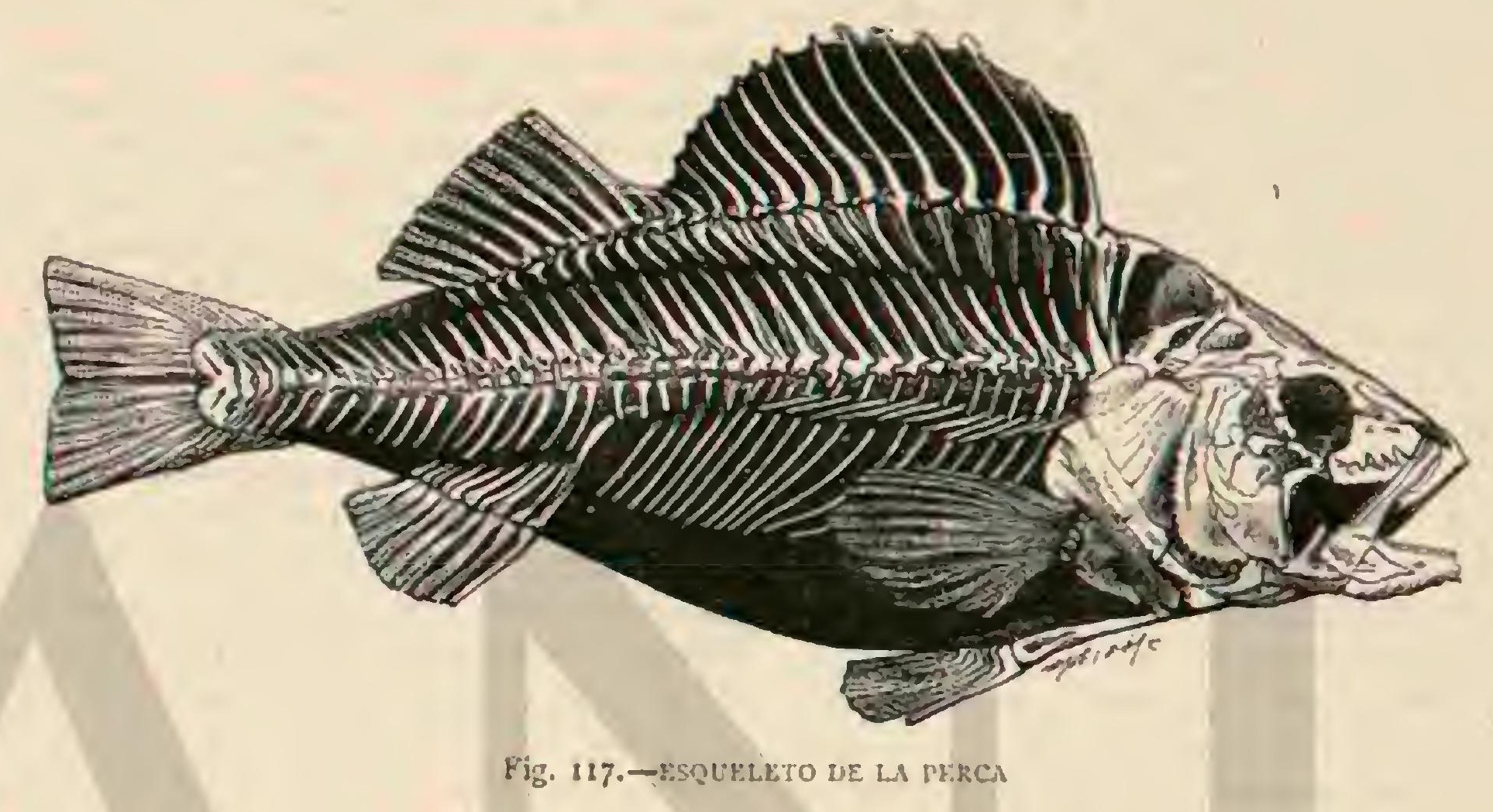

mos tampoco tienen conducto de salida los testiculos, pero en los salmones sí. Sin embargo, en la mayor parte de los peces no sucede asi, porque el ovario forma en ellos una bolsa, cuya superficie interior tan pronto tiene repliegues como apendices membranosos de muclias caras, en las que se desarrollan los huevos de tal manera que al romper su envoltura cuando han llegado á su desarrollo, caen dentro de la bolsa del ovario, y esta se prolonga en seguida en el oviducto que á mayor $\delta$ menor distancia se junta con el otro para desembocar inmediatamente detrás del ano entre este y la verruga que da salida a la orina. En algunos peces óscos viviparos se ensancha el extremo posterior del oviducto para dar cabida á los huevos destinados á desarrollar. se. En varios ganoideos (peces de escama de csmalte) forma el ovario una masa aislada, sicndo cl oviducto comunmente muy largo y retorcido en espiral con una abertura á cada lado en forma de trompa en la cavidad abdominal, $x$ donde llegan los huevos para ser expelidos fuera. Los de boca tras. versa tienen el ovario, ya par, ya impar, y sin comunicacion inmediata con los oviductos pares. En cada uno se encuen. tra una glándula gruesa y bien formada que sin duda separa la envoltura de los huevos. Mas abajo forma cada ovidúcto dilatándose una matriz en la cual siguen desarrollándose los pequeñuelos, desembocando despues ambos oviductos juutos en la pared posterior del recto. En la mayor parte de los peces óscos forman los testículos unas bolsas membranosas, atravesadas por numerosos canales que les dan un aspecto esponjoso. La desembocadura exterior es comun á ambos cordones seminales. En los peces de boca trasversa el aparato sexual masculino se presenta mas perfeccionado, pues se desarrollan sus espermatozoos no en canales ramificados Toso $\mathrm{V}$ como en aquellos, sino en pequeñas vejiguillas encerradas dentro de otras, cuyos conductos de salida forman un testiculo secundario desde el cual arranca el conducto seminal para desembocar en la cloaca; además tienen un verdadero aparato de cópula, es decir, dos apéndices cartilaginosos largos y cilindricos colocados al lado de las aletas abdominales junto á la raiz de la cola.

MOVIMIENTOS. - Segun los principios manifestados repetidas veces, no podemos decir que los peces sean animales-muy favorecidos por la naturaleza, Su movilidad se limita en rigor $\hat{\alpha}$ la natacion, y de consiguiente está reducida á un solo modo de moverse. Varias especies de peces de mar pueden elevarse sobre el agua y aun atravesar alguna dis. tancia volando en cierto modo; pero en el fondo su vuelo no es mas que una especic de salto que facilitan las grandes alétas abdominales con el impulso de arranque que reciben antes por el movimiento natatorio, por manera que la su. puesta ventaja sobre los demás es de poca consideracion.

Tambien se conocen muchas especies que pueden arras. trarse y avanzar sobre las olas, y algunas que auxiliándose de un modo especial con sus aletas, se mueven en tierra fir. me y aun suben pendientés, pero este arrastre dista tanto del airoso movimiento de reptacion de una culebra, como del ligero ruclo de las aves. Sólo en el agua es donde los peces se mueven con soltura y facilidad cuando nadan, en cuyo ejercicio son maestros consumados. Dicen que el salmon puede franquear en un scgundo una distancia de ocho metros, ó lo que es lo mismo, en una hora veinticinco mil metros, $\mathrm{s}$ en cuanto á la primera distancia es muy probable que no se haya exagerado, porque en efecto, este pez corta las olas con la velocidad dela sacta. Sus poderosos músculos de 
ambos costados, n̨ue se unen i la vigorosa aleta caudal, pro. duciendo resultados tan eficaces, permiten reslizar en efecto esfuerzos sorprendentes y hasta saltos fuera del agua á considerablc altura, mientras que lns demás aleias regulan la direccion. Como 6 , siquiera con menor rapidey, nadan casi todos los demís peces, siempre que se nuevan aproximadamente en una misma capa de agua; pues los movimientos de zambullirse á capas inferiores y los de subir a las superiores los realizan probablemente por mèdio de la compresion y dilatacion de la vejiga natatoria. Y'ero exisien varios peces, en especial los que tienen forma oblonga 6 de huso y aletas pequerias, que nadan de un modo enteramente diferente, ya serpentcando con toco su cuerpo, ya ondulando sus largas y bajas aletas dotsales, y tambien peces de cuerpo comprimido en sentido vertical, en forma de disco que ejecutan es. tos movimientos ondulatorios de arriba abajo en lugar de. hacerlos de un lado al ctro. En cuanto il aguante, quizis aventajan los peces á todos los demás animales, aunque res. piren muchisimo menos, es decir aunque consumen menos oxigeno que estos y aunque la circulacion se efectúa con mucha mayor lenitud. Verdad es que en cambio los auxilia on su movimiento su modo de respirar, la faciilidad de acceso yue tione el oxigeno mexclado con el agua para llegar à las agailas, y cl impulso propulsor que ies comunica la expulsion del agia por las aberturas de las branquias.

Hay que tener muy presente que los pecas, al respirar, no descomponen el agua en sus elementos parcabsorber el oxi. geno que necesitan, sino que consumen exclusivamente in escasa cantidad de aire atmosférico que contiene el agua en. tre sus moleculas, y si bien se contentan, como ya lo prueba su sangte fria proporcionalmente, con muy poco oxigeno, han de tener sin embargo mucha agua a su disposicion para encontrarse bien. Metidos en poca agua la privan muy pronto de las escasas prarticulas de aire que contiene, y se ahogan despues infaliblemste como los animales que viven y res. piran al aire libre cunndo se hallan privados de él. Fuera del agua mueren porque al secárseles las branquias, lo que suce. de muy pronio al aire libre, estas ya no pueden funcionar.

Una consecuencia necesaria de la respiracion branquial es que los peces no pueden tener voz. Verdad es que algunas especies producen sonidos, ó mejor dicho, ruido, una especie de grunido, jero ni uno ni otro puede razonablemente compararse con los sonidos que producen los animales ver. tebrados superiores, siendo solo resultado del roce entre los ophírculos duros de las brannquias ó quizais de las aletas y es. camas, parecido en cierto modo al chirrido $\delta$ canto de los animales articulados de la familia de las langostas y grillos. El adagio: (mudo como un pez) es en efecto verdadero de todo punto.

SENTIDOS.-La capacidad intelectual del pez es proporcional al escaso tamaño de su cercbro; pero se observa actividad en todos los sentidos; siendo probable que la suti. leza $\delta$ finura de ellos, sea major de lo que comunmente se supone. Aunque los ojos, en general grandes y con un iris de mucha superficie, sean solo en muy pocos peces movi. bles, como por ejemplo en las suclas, no dejan los peces de ver muy bien, y lo que es mas, hasta en las capas mas pro. fundas del agua, porque gracias \& su dilatada pupila, utilizan alli hasta los rajos luminicos tan notablemente debilitados.

No cabe duda tampoco que los peces oyen a pesar de no tener ni impano ni los huesecillos del oido, puesto que los peces domesticados acuden al oir el sonido de una campana; y se observa que otros mas ariscos huyen al menor ruido; pero todo esto $n o$ autoriza $\{$ admitir que puedan distinguir los sonidos.

El olfato y cl gusto están probablemente muy poco desar- rollados, sin que por esto se hallen atrofiados. Verdad es que el agua no irasmite al olfato los gases del mismo modo quue el aire, pero no impide de ningun modo su difusion, y asi puede admitirse que los peces perciben determinados olores a bastante distancia.

En cuanto al gusto, nada sabemos. No puede suponerse que medie disolucion ó descomposicion química de los alimentos en animales que lo tragan todo sin desmenuzar; mas bien pucde admitise que el sentido del tacto suple al del gusto; y efectivamente jarece que aquel se halla en los peces mas desarrollado que todos los demás sentidos, excepto la vista, y esto tanto respecto de la capacidad sensitiva como de la del tacto. Que los peces tienen conciencia de todo contacto exterior cstá fuera de toda duda; pero la capaciủad sensitiva no solo es accesible ś influencias de tanto bulto, sino tambien a otras mucho mas sutiles, y lo prueba suficien. temente la facultad que ticnen los peces de cambiar de co. lor, facultad tan generalmente sabida como poco discutidaé investigada. Muchas especies que viven de continuo en el fondo del mar, despues de pasar algun tiempo en un suelo arenoso, adquieren cierta coloracion casi enteramente igual \$. la de la arena, cambiándola rapidisimamente cuando se los lleva ó cuando se trasladan ellos à oiro fondo, como por ejemplo, a uno que tenga guijarros de granito de color gris claro. Igual sensibiliciad á la influencia de la luz se observa en la epidermis de otros peces, en especial de las truchas, que se vuclven mas pardas en aguas muy oscuras ó dentro de un depósito cubierto, y que palidecen al llegar a un agua alum. brada por el sol 6 cuando se las expone a la luz en depósi. tos descubiertos. Estos cámbios repentinos en el color pue. den proceder asimismo de influencias mecanicas, por ejemplo de apretar ó frotar la piel a un pez vivo; y iambien ejcrcen su influencia en la epidérnis las excitaciones é irritaciones interiores, como el deseo de propagarse ó de desovar, el acto dé expulsar la freza y el liquido seminal, el espanto y la an. gustia, callsando contraccion $\delta$ dilatacion en los depósitos de materia colorante, lo que en último resultado es debido A la actividad de los nervios de la superficie. Para el tacto se sirven estos animales de los labios, de los apendices filiformes ó barbillas que muchos tienen y de las alctas.

INTELIGENCIA.-Tambien tienen los peces inteligencia, pero muy poca. Pueden distinguir sus enemigos de los séres que les son inofensivos; conocen que se les persigue y tambien reconocen cuando se los protege; se acostumbran á la persona que los cuida y a la campana que los llama á re. cibir su comida; eligen sitios propicios para encontrar alimento; tienen maña para cscogerlos; se ponen en acccho para engañar á su presa; aprenden á rencer obstáculos y á evitar peligros; forman cierta union con sus semejantes auxi. liándose mutuamente, y muestran fiulmente cierta solicitud, carino y afecto á su cria; en una palabra, manifiestan cierta actividad intelectual. Pero reconocer esta actividad y formarnos un exacto juicio de ella descle nuestro punto de vista, es cosa cifficil, ya porque la mayor parte de los peces escapan á la observacion, ja porque los que podemos observar, no los hemos examinado como fuera menester para cmitir un juicio exacto acerca de su capacidad intelectual.

DISTRIBUCION GEOGRÁFICA. - Todos los peces pasan su vida exciusivamente ó por lo menos casi exclusiva. mente en el agua. Aquellos que poseen la cualidad de poder abandonar su elemento por mas $\delta$ menos tiempo, ya por hun. dirse en el limo ó bien por envolverse en una cubierta de esta misma materia para pasar el inviemo en tal prision, aun en. dureciéndola la sequedad, en un estado semejante al de los animales vertebrados mas elevados en la escala de la creacion, apenas merecen tomarse en cuenta, porque su número 
es harto insignificante en comparacion con las especies que forzosamente tienen que permanecer constantemente en el agua $\delta$ que solo pueden abandonarla por corto tiempo. la verdadera patria de estos séres es el mar desde el extremo norte hasta el ecuador, el océano y todas las ramificaciones y bahías, lleven el nombre que quieran. Esto no quicre decir que las aguas dulces de nuestro planeta carezcan de peces, sino que el número de individuos de las aguas estancadas 8 corrientes del interior apenas admite comparacion con la riqueza del mar. Es probable que solo conozcamos una pequeña parte de todos los peces que existen, y que por consi. guiente no tengamos una idea ni remotamente aproximada de la abundancin y variedad de esta clase; pero esto no impide que podamos admitir conto exacto lo dicho anteriormente. El número de especies de peces marinos comparado con el de las de agua dulce corresponde efectivamente á la diferencin que hay entre la superficie del mar y su masa, y las de los lagos y corrientes de agua dulce.

La facultad que tienen los peces de poder vivir en las aguas mas distintas y en las circunstancias mas rariadas es tan extraordinaria como lo es la facilidad con que se adaptan las aves á condiciones exteriores. Existen muy pocas aguas donde no se encuentren peces. Suben desde las aguas bajas rio arriba hasta alturas de cinco mil metros $y$ se hunden en el mar a profundidades que por falta de medios escapan hasta hoy dia à nuestro exámen. Hay peces que prefieren las capas superiores del agua, pero otros permanecen con prefe. rencia en las mas bajas donde viven bajo una presion de agua cuyo peso podemos calcular, pero no comprender. Verdad es que a 300 metros de profundidad ya no hay peces, segun se dice, pero esta opinion se basa en una suposicion refutada tiempo ha por observaciones indudables, a pesar de la insu. ficiencia de nuestros medios de inrestigacion. Segun las in. vestigaciones mas recientes, hemos de creer que las profundidades de los mares están mucho mas pobladas de lo que nos figuramos. $\mathrm{Ni}$ son obstáculo las latitudes elevadas ś la dispersion de los peces. Es indudable que los mares de la zona tórrida y de la templada los tienen en mayor abundan. cia que los glaciales, pero tambien en estos viren incalculables masas de ellos, llevando la vida en número infinito á todas las partes del mar. Pueden valorarse en cifras los ejercitos de mamiferos y aves, las comunidades de reptiles y anfibios, pero para calcular la masa de los peces carecemos en absoluto de base, porque de lo que vemos no podemos atre. vernos á sacar consecuencias relativamente á lo que permanece oculto á nuestra vista.

Ia extension de una misma especie aparece mas reducida de lo que se podrá suponer en atencion á la gran facilidad que da ci agua á séres tan movibles para viajar, y á quecada per. tiene la propiedad mas 6 menos grande de vivir en distintas aguas ó por lo menos en partes de cllas. Pero en el mar infinito hay tambica limites. Insensiblemente reemplaza una especic á otra especie afine, y csta es sustituida mas allá por otra y otra $s$ otra; al paso que a una forma se agrega tambien otra forma diferente. Pocos son los peces que se encuentran en todas las costas de un mismo océano, ó lo que viene â ser lo mismo, pocos atraviesan dichas sábanas de agua, por mas que sean capaces de ello. Tambien se afi. cionan á ciertos distritos y parecen téner cariño al sitio donde nacieron, fenómeno cuya explicacion no se ha encon. trado todavia. No cabe duda alguna de que los salmones nacidos en un rio vuclven mas tarde al mismo cuando quieren propagarse, jamás á otro, aunque este otro desemboque cer. ca del suyo. Esto solo se explica admitiendo que los peque. nos salmones, despues de haber entrado en ol mar permanecen proximos á la desembocadura de su rio natal; que continúan por lo tanto en un espacio sumamente reducido atendida su capacidad para moverse, $y$ qque por regla general no salen de él. No puede negarse que algunos géneros emprenden expediciones bastante largas, y por ejemplo hay tiburones que siguen $\&$ los buques ó $a$ los troncos flotantes por espacio de centenares de leguas marinas, desde lós ina res meridionales a los equinocciales y vice-versa; otros se presentan extraviados en costas que no son las suyas, llegando rerbigracia ajgunos peces propios del Mediterráneo á las costas de la Gran Bretaña; pero todos estos ejemplos sou cxcepciones; porque en general los peces de mar se limitąn á vivir en determinadas zonas, y hasta en partes de zonas, como sucede con ciertos peces de agua dulce, que no salen de determinados lagos y rios, y los viajes que emprenden desde ellos son seguramente mas insignificanies de lo que creemos.

Fil punto de residencia habitual de los peces concuerda siempre con su forma. Los que viven en los mares ecuato. riales tienen distinta forma que aquellos cuga patria se halla en la proximidad de los polos; y los de mar difierén por lo comun de los nue habitan en agua dulce. Verdad es que hay muchos que pueden vivir tan bien en el niar como en los rios ó lagos del interior, y que presentan diferencias menos notables; pero no existe uno solo de estos peces ulfernantes, como podriamos llamarios, que pase su vida entera 6 en el mar 6 en el agua dulce. Desde el mar penetran en los rios para depositar su freza; y de los rios pasan otros con igual objeto al mar, y cuando algo les impide esta trasmigracion dejan de cumplir la condicion principal de su vida; resultando que tambien tienen una patria fija, ya sea esta el mar $\delta$ el agua dulce. Una prueba de la dependencia en que viven los peces de las aguas donde se les encuentra la tenemos en las especies que moran en nuestros rios y lagos, y á las que por consiguiente podemos obserbar mejor; pues se admite como un axioma que la trucha solo puede vivir en aguas puras; el glano en estanques de aguas turbias; el gobio sobre fondo de guijarros, no siendo menos cridente, para la persona que gusta de hacer comparaciones, que habrá peces que con preferencia, por no decir exclusivamente, se re. crean en el fondo del mar, mientras que otros prefieren las capas superiores del agua, que la sucla de hecho se adhiere al lecho del mar, y que el pez yolador huye de las profunài. dades. Observaciones exactas, sobre todo hechas en peces cautivos, hn demostrado que todos llegan hasta a acostumbrarse poco a poco á determinadas viviendas donde escogen sus sitios para descansar 6 para ocultarse, $y$ a los que vuelven siempre puntualmente.

Lo que es verdad para un distrito reducido se confirma si consideramos otro mayor. Tambien los peces pueden carac. terizar ciertos distritos y ciertos mares, aunque no sea tan pronunciada en ellos la dependencia del clima y de la regetacion correspondientes como en las demás clases de anima. les vertebrados; pero las diferencias que ofrecen las distintas regiones ecuatoriales entre si se manifiestan tambien visiblemente en los peces. En los mares situados entre los trópicos viven los peces que mas se apartan de la forma fundamenial a que estamos acostumbrados. Cierto que la luz y el calor, estas fuerzas creadoras primitivas, ejercen tambien en las profundidades del mar una influencia que en nuestros grados de latitud no podemos apreciar en toda su importancia. La composicion del agua, tan idéntica en todas partes, y su temperatura que en las diferentes zonas oscila mucho menos que la del aire, explica por quue no faltan tampoco en los mares del norte peces de forma cxtraña, pero la multitud de formas en las clases solo la vemos en las latitudes bajas. Ya el Mediterránco cria muchisimas especies que le son enteramente especiales y que ni siquiera se encuentran en el Atlán. 
tico ó por lo menos no se han encontrado todavía. Mayor es aun la individualidad en la clase de los peces que nos dan á conocer las exploraciones hechas en el Océano Indico, s especialmente en el mar Rojo, en el golfo de México, en los estrechos que separan las islas de la Sonda, en las aguas del Japon, etc. Algunos de estos mares sirven de habitacion á familias constituidas por numerosisimas especies que hasta hoy no se han observado en otros puntos; otras aguas tienen estas familias en comun con las aguas limítrofes, pero siendo posible siempre trazar un limite al dominio que ocupan cier. tas familias.

USOS, COSTUMBRES Y RÉGIMEN.-POr uniformes y monótonas que parezcan-a primera vista las costumbrés y híbitos de los peces, no dejan de mostrarse variadas y va. riables al observarlas con mayor atencion. De nuestros peces de rio sabemos ya que cada uno lleva una vida mas ó menos determinada $\mathrm{y}$ fija, y puede adimitirse con toda certeza que entre los peces de mar han de ser aun mayores las discrepancins en las costumbres por poquísimo que sepamos y podamos juzgar de su modo de vivir, y aun de sus hábitos. Cada per. hace uso del modo mas conveniente, al igual de cualquicr otro animal, de las cualidades inherentes a su forma y estructura, y tomando estas disposiciones por base de cál. culo, podemos sacar consecuencias mas ó menos acertadas respecto de sus modos de vivir; aun cuando con esto no lo. gremos por desgracia formarnos una idea exacta de su mé. todo de vida y no nos sea por consiguiente licito proclamar como verdad lo que nos parece solo probable.

De contado y hablando en términos generales, la vida de los peces es mucho mas sencilla y monótona que la de los mamiferos, aves, reptiles y anfibios. La actividad que recla. ma su alimentacion prevalece sin duda sobre todo lo demás, y á ella dedican tambien los peces con preferencia la mayor parte de su vida Hablando de ellos no se puede prefijar nada acerca de la distribucion de tiempo, si bien es cierto que á ratos trabajan, descansando otros, 6 que al igual de los otros vertebrados cazan y duermen. La caza requiere por lo conıun mas tiempo que el sueño; el pez mientras nada, caza; hasta jugando, ó sea en aquel cjercicio que tomamos por juego, no deja escapar cuantas presas pasen á su alcance. Cuando está ya harto ó rendidó de cansancio se entrega al descanso que sin duda corresponde al suchio de los animales superiores vertebrados y que es preciso designar con el nombre de tal por diferente que sea su modo de efectuario. La inmensa mayoria de los peces son animales nocturnos, pero no por esto deja de haber muchos diurnos; aquellos empie. zan solo al oscurecer su actividad y descansan durante el dia en sitios determinados, muchos en escondrijos, con el vien. tre sobre el fondo, echados, algunos metidos en el limo ú ocultos y enterrados dentro, 6 bien nadando 6 mejor dicho flotando en el agua libre; los otros, es decir los diumos, obran al revés. Unos y otros permanecen horas enteras en la posicion que escogen para dormir, sin que los saquen de ella determinadas excitaciones exteriores; pero observándolos atentamente se conoce fácilmente que sus ojos faltos de párpados no cesan de recibir las impresiones que proceden del exterior.

Casi todos los peces son zoóragos y cazadores tan activos como hábiles. Es verdad que no pocas especies comen tambien sustancias vegetales, pero dificilmente existe un solo pez que se alimente exclusivamente de ellas. Las especies mas débiles recogen en las plantas acuáticas pequeíos moluscos, 6 revuelven el légamo en busca de toda clase de gusanos, es decir, de animales invertebrados de toda clase; otros mas robustos recogen caracoles y conchas, $y$ todos los demás dan caza en la acepcion usual de esta palabra á otros peces, y cuando no, por lo menos á animales invertebrados dotados de moviniento de traslacion, practicando el derecho del mas fuerte sin la menor consideracion; el pequeño devora al que es mas pequeño que él y el grande al que no lo es tanto.

Ningun zoófago respeta su propia cria. Muchos peces están tan acorazados y llevan tan terribles armas que es peligroso para el señor de la creacion meterse con ellos: y sin embargo son devorados! Los dientes del mas fuerte quie. bran y trituran la coraza, embotan y rompen las espinas, púas y clavos; pues 1 los medios de defensa corresponden los de ataque. La vida de los peces es una carnicería eterna sin merced ni misericordia; cada individuo zoófago ó carni. voro, y de consiguiente la inmensa mayoria de ellos, es tan gloton como osado; porque no es el poderoso tiburon el único á quien deben temer el hombre y los animales corpu. lentos, sino que tambien hay peces enanos que amenazan la vida del señor de la tierra, procurando arrancarle la carne del cuerpo a pedazos sucesivos, y cuando ya no puede esca. par le devoran. En ninguna parte se echa de ver esa guerra cterna, sin tregua, que existe en la naturaleza, tan clara y ma. nifiestamente como en el agua, en el mar.

En el modo de vivir de los peces introduce un notable cambio la época de la reproduccion, motivo que los excita tambien á ellos de un fnodo sorprendente, trasformando al individuo pacifico en pendenciero, al indolente en actiro, al voraz en indiferente á la presa que le convida, impulsando s unos á emprender viajes, à dejar el mar para remontar el curso de los rios ó vice versa, despertando en ellos cariño materno é instinto de construccion, y cambiando con esto todo su modo dé ser, bien que por otra parte le regala en. tonces la madre naturaleza en muchos casos su llamado traje de boda. En los mares ecuatoriales sobrevienen tambien otros cambios en su vida habitual; alli puede verse el pez obligado a llevar temporalmente una vida en cierto modo fuera del órden natural y retirarse al interior de la ticra como ciurtos mamíferus que pasan el invierno durmiendo, para conservar su vida, que de otro modo peligraria. Ýa se conoce un número bastante regular de peces que positivamente tienen un sueño invernal, esto es, que se ocultan en el cieno cuando se secan los sitios donde viven, cayendo entonces en un estadio de letargo en el cual continuan hasta que la primavera con sus abundantes lluvias vuelve á llenar sus anteriores viviendas de agua para resucitarlos á nueva vida. Tambien en nuestro pais puede suceder una cosa análoga; pero en el interior del Africa y en la India no es nin. guna rareza el que algunas especies pasen el invierno durmiendo, lo cual se observa alli en todas las aguas del interior que comunican con rios y que se secan á temporadas, ni se limita esta costumbre de ningun modo á los individuos del orden que llamamos dipneos ó de pulmones.

Muchos de los primeros, en cierta manera mas favorecidos que otros peces, pertenecen á aquellos que en algunos casos pueden atravesar mayores ó menores distancias por tierra firme con el objeto de encontrar otra balsa provista aun de agua, y que de consiguiente emprenden viajes que tienen una débil-analogia con cl paso de las aves. Tambien recuerdan este paso ciertas traslaciones á otros sitios que efectuan los peces de nuestras aguas dulces y mares, habiendo muchos que segun la estacion del año ó segun ciertas eventualidades cambian de morada, subiendo por ejemplo del mar rios arriba ó volviendo de estos al mar. Pero de ninguna manera pueden compararse estas traslaciones con el paso $g$ viajes de las aves, porque no obedecen 1 ó otra causa sino pura y simplemente al impulso de reproduccion.

Los peces dependen menos que los demás vertebrados de 
la alternativa de las estaciones. Para los mamiferos, aves, reptiles y anfibios, la primavera es generalmente el tiempo si no del amor, por lo menos el de la procreacion y del nacimiento de la cria; pero no puede decirse lo mismo de los peces. Verdad es que para la mayor parte cac la época de la reproduccion en la estacion mas favorable del año; en nues. tro pais en la primavera y el verano; pero nuestros peces de agua dulce, sin ir mas léjos, desovan, excepto en los meses de enero, febrero y agosto, en todos los demás meses del año, e indudablemente habrá entre ellos algunos que ni si. quiera obserren tal excepcion, ya sea por desovar antes ó despues, realizando de consiguiente esta operacion importante fuera del tiempo regular; y como los peces cmprenden sus viajes con el único objeto de deponer su freza en los sitios apropiados, resulta que seria equivocado hablar de un tiempo fijo y general para tales viajes, como sucede con las cmigraciones de las aves. No es la inopinada escasez de alimento en un distrito dado, efecto de una época determinada del año, lo que impulsa álos peces áviajar, sino única y exclusivamente el ovario repleto de la hembra y los testi culos henchidos de esperma del macho. Por esto pues, se gun la época en que tiene lugar su reproduccion, los peces suben de las profundidades de los mares $\delta$ de los fondos frios de los lagos del interior a las capas superiores, ó re montan los rios tanto como pueden, en busca de sitios propósito para deponer su freza, volviendo despues de haber cumplido con su instinto de reproduccion á sus residencias anteriores enviando delante sus crias, llevándolas á remolgue si me es licito expresarme as!. Tambien hemos visto gue puede suceder lo contrario, es decir que peces de agua dulce se sientan impulsados á pasar al mar, pero la causa de la traslacion es siempre la misma. Ya hemos dicho que antes se creia que los viajes de los peces se extendian á grandes distancias, mientras que ahora ya no se cree en esos largos viajes, abstraccion hecha de algunos individuos sueltos 5 extraviados como por ejemplo los que se dejan llevar por la corriente del golfo; admiticndo en cambio que dichos peces no hacen mas que subir de las capas inferiores a las superio res. Solo desde que sabemos que cl instinto de la reproduccion es la única causa de sus viajes, nos explicamos su com. portamiento tan incomprensible de otra manera, su prisa, el afan con que se empujan sin consideracion alguna para pasar adelante, tanto que parecen avanzar á ciegas. Fste instinto, tan poderoso tambien en otros animales, es pues lo que los hace olvidar complctamente su modo labitual de vivir y obrar tan en abierta contradiccion con sus hábitos usuales.

Lo que no se explica con la misma facilidad es el regreso de las crias, la sociabilidad sorprendente de que entonces dan prueba, la gran regularidad de sus marchas y su afan de salvar todos los obstáculos por poco que les sea posible. Al observar estos viajes, casi se escapa de los labios la palabra instinto, esa palabra que se nos ocurre siempre que no com. prendemos algo, por mas que estcmos convencidos de que si puede satisfacer á las personas de una fe ciega, jamis basta al sabio que investiga.

Sobre el modo de organizarse y hacerse estos viajes no se han reunido todavia observaciones suficientes; a pesar de esto se sabe que se realizan con cierta regularidad sistemática, que algunas especies nadan formando cuña del mismo modo que vuelan las bandadas de grullas, y que otras adelantan en tropel confuso y apelotonado; que los machos van separados de las hembras, nadando los unos en las capas superiores $y$ las otras debajo, que en otras bandadas los machos siguená las hembras, etc. Todos los peces cuando viajan se distinguen por la inquietud con que lo hacen, lo que induce á creer que no van voluntariamente sino por fuerza.
REPRODUCCION.-Si los orientales hubiesen tenido una idea del número de huevos que tiene una sola hembra de pez, no habrian comparado probablemente con la vid la fecundidad de las mujeres tan anhelada por ellos, sino mas bien con la de los peces. Claro está que no todas las espe. cies son igualmente fecundas, pero esta fecundidad es siem. pre increible por lo grande. I.os salmones y las truchas forman parte de las especies que ponen poros huevos, porque el número de los de una hembra excede apenas de veinticinco mil; en cambio una tenca produce ja cosa de setenta mil, un sollo cien mil, una perca trescientos mil, un glano, es. turion ó cazon, millones. Se ha dicho que el mar no bastaria para dar cabida \& los peces si todos los hueros que ponen las hembras diesen una cria y si los nacidos alcanzasen el ta. maño de sus padres.

Durante $\delta$ al fin de su viaje escogen los peces un sitio su gusto para poner sus huevos; el salmon y la trucha por ejemplo un fondo cascajoso y con agua tranquila; otros en partes donde el agua está llena de plantas acuáticas, etc. En cambio hay algunos que construyen un verdadero nido ya entre plantas acuáticas de agua dulce 6 bien en el mar, ya en grietas de roca $\delta$ en sitios por este estilo; mientras que otros guardan la freza despues de expelida en una bolsa es. pecial que la naturaleza les ha dado para este efecto hasta su total desarrollo. Nuestros peces de rio efectúan el desove con preferencia de noche y especialmente en las de luna. I.a trucha cava, moviendo la cola de un ladóa otro, un pequeño hueco donde pone las huevas, acudiendo luego el macho para fecundarlas; los salmones (ooregromus) se juntan en parejas y saltan vientre contra vientre fuera del agua en cuyo acto despiden juntos y simultáneamente la freza y el liquido seminal; los gobios de rio nadan rápidamente contra la cor. riente rozando el cascajo del fondo con el vientre $y$ descargan asi las huevas y la lechada; los sollos se frotan el vientre uno contra el otro batiendo la cola al emitir la freza; las percas y algunos peces afines pegan las huevas a plantas acuáticas, madera ó piedras; muchos peces del mar desovan nadando en gran tropel y de tal modo que las huevas despedidas por las hembras que van nadando encima de los ma. chos, al caer hayan de llegar a la capa de agua ocupada por estos y que se halla mezclada con su líquido seminal.

Para el desarrollo de las huevas son indispensables calor, humedad y suficiente aire puro, porque la hucra tambien absorbe oxigeno durante su desarrollo y despide ácido carbónico. Segun las especies podrá y deberá ser nuy diferente el calor necesario; hay peces cuyas huevas se desarrollan su agua de una temperatura muy baja, mientras que otros re. quieren otra mas elevada; pero no siempre quedan satisfe. chas estas condiciones en la reproduccion natural de los pe. ces, a menos de intervenir el hombre, y de los millones de las huevas puestas queda una gran parte sin fecundar, mien. tras que otra parte no menos grande de las fecundadas queda sin desarrollar por considerable que sea la resistencia de la hueva contra las influencias exteriores; aparte de esto, las olas las arrojan á millares á las orillas, donde se secan; otras bajan á una profundidad excesiva donde tampoco se desarrollan, $y$ á las demás las aguarda un innumerable cjército de eriemigos de toda clase y especie: as pues, la incalculable multitud de huevas pucstas no es de ningun modo excesiva.

la hueva reciente que acaba de abandonar el seno materno presenta, segun las observaciones de Cárlos Vogt, una yema clara, pero que contiene siempre una ó mas gotas oleo. sas que hotan en medio de un líquido albuminoso. La misma yema está encerrada en una membrana extraordinariamente fina envuelta á su vez en una piel dura y frecuentemente coriåcea, que al momento de caer al agua la absorbe, apartán- 
dose con esto un poco de la yema, la cual desde este instante flota libremente dentro de esta membrana-cáscara, y se revuelve en seguida hasta quedar el punto donde se hallan las gotas olcosas en la parte superior: debajo de la segunda nembrana aparece el embrion formancio al principio una protuberancia redonda de pequeñas células trasparentes que van extendiéndose sin parar y tomando la forma de disco sobre la yema hasta constituir una membrana embrionaria que envuelve poco is poco toda la yema. Entre tanto se ciectua en la protuberancia primitiva una subdivision, fraccionándose el embrion primero en dos, despues en cuatro, ocho $y$ finalmente en un gran número decelulas embrionales provistas de un núcleo, de las cuales van resultando los órganos del futuro pez. Fin el centro adquiere cuerpo la mancha enibrionaria y se extiende; se reconoce un eje s una ranura media, la llamada ranura dorsal; á ambos lados se forman dos bultos longitudinales que se van separando en uno de sus extremos, y que subiendo mas y mas acaban por reunirse dejando entre sí un canal. Al mismo tiempo aparece debajo de la ranura él rudimento de un cordon longitudinal yue al cabo de poco tiempo se desarrolla en una vauina con un núcleo en su interior, resultando ser el cordon vertebral. Con el des. arrollo de los órganos interiores se dibuja támbien la forma exterior y se distinguen la cabeza, el trenco y lá cola; la jema se va reduciendo á nacdida que crece el embrión que le en. vucive poco a poco en su totalidad $\delta$ parcinlmente con sus paredes abdominales, por manera que acaba por ser solo un insignificante apéndice del embrion, despues de haber cons. tituido antes su masa principal. Entre tanto se han ido formando todos los órganos interiores de una manera muy anả. loga al de los embriones de los vertebrados superiores. Tan pronto como el embrion llega á su completo desarrollo, rompe la cáscara del huevo y se presenta en forma oblonga y tras. parente con una gran bolsa debajo del vientre como provision de alimento para el primer tiempo de su existencia.

Mientras dura esta provision se mantiene el jóven animal casi siempre inmóvil en el fondo del agua moviendo solo las aletas pectorales para llamar el agua de abajo arriba a fin de renovar la que necesita para su respiracion. La truchá jóven reabsorbe en el primer mes las tres cuartas partes de su bol. sa; á las scis semanas no queda ya casi nada de ella, $y$ hasta entonces no siente el animal la necesidad de comer, empezando ga à vivir como sus progenitores, esto es, empieza á cazar con gran afan todo lo que sa su juicio puede servirle de pasto. Cuanto mas abundante es su caza tanto mas va cre. ciendo; los que tienen mas suerte en procurarse alimento, adelantan pronto \& los que pasan hambre, y con el mayor desarrollo adquieren tambien mas vigor $y$ mas agilidad. Al cabo de un año, ó antes si el pez es de clase pequeña, y mas tarde si es grande, han adquirido los jóvenes pececillos el ropaje de sus mayores, siendo de consiguiente en un todo semejantes á ellos.

Pero tambien hay peces, como por ejemplo algunas rayas y tiburones, cuyas crias siguen en su desarrollo una marcha enteramente distinta. Puede hablarse de peces viviparos con el mismo derecho que se habla de reptiles y anfibios viripa. ros. Los peces de esta clase llevan las huevas en la dilatacion del oviducto mas arriba mencionado hasta la epoca en que el nuevo per, ha concluida su vida embrionaria y es capar. de romper su envoltura para nacer. Las quimeras (ho locéralos), como tambien los tiburones y rayas que ponen huevas, las tienen formadas de una cáscara muy espesa y córnea que por lo comun es cuadrada y plana con rendijas en los lados á fin de que pueda penetrar el agua de mar en el interior. El desarrollo de estas huevas no empieza sino hasta que han sido puestas. La reproduccion de los tiburo. nes viviparos es distinta segun la estructura de la hueva. En unos tiene esta una cáscara córnea, extraordinariamente fina y trasparente, y una forma aplanada y prolongada como un tubo 6 estuche de sietéá ocho veces mayor quue la yema que contie. nen. Ën el centro de este estuche ó cáscara con pliegues en su borde está la yema, de forma prolongada, en medio de la albúmina ó de la clara, que se prolonga hícia un lado a ma. nera de cinta. Esta albúmina absorbe mucho liquido, au. mentando de consiguiente su grandor y peso. La cáscara fina se conserva en estos tiburones todo el tiempo que dura el desarrollo, mientras que desaparece pronto en otros, dejando el embrion desnudo dentro de la matriz. Otra particu. laridad de los embriones de los peces de boca trasversa consiste en que la bolsa exterior de yema, por lo comun de forma de pera, comunica por un largo pedículo con el cuer. po, donde desemboca en el tubo intestinal. En la mayor narte de los tiburones $y$ rayas se dilata un conducto de la yema en el interior de la cavidad abdominal, formando alli una segunda bolsa interior de yema. El pediculo de esta bolsa tiene, además del conducto que desemboca en el tubo intestinal, una arteria y una vena para extender la circula. cion sanguínealá la yema. En una de las especies se ha des. cubierto el extranio fenómeno de que sobre la bolsa de yema nacen folículos que se articulan con otros foliculos opuestos a ellos, colocados en la pared del oviducto con vasos de yema entrelazados, por manera que resulta una verdadera placenta. Por último, haremos notar muy especialmente que los embriones de todos los peces de boca trasversa tienen en cierta época de su vida branquias exteriores insertas en for. ma de hilos finos en los bordes de las hendiduras branquia. les y que sirven sin la menor duda para respirar.

USOS Y PRODUCTOS. - Los peces, séres tan sangui. narios y voraces que se matan y se devoran unos á otros, tienen, como todo en csta tierra, por enemigo mas terrible al hombre lét es, él solo quien opone límites â su sorprendente y colosal propagacion, ya directa, ya indirectamente. Verdad es que además de él y de los mismos peces de rapiña los persiguen tambien mamiferos, aves, reptiles y anfibios y no pocos animales acuáticos invertebrados, pero todos estos enemigos no siendo de su propia clase no producen ni con mucho en sus filas tan terribles claros como el hombre. Este ha despoblado rios y lagos de agua dulce, alli donde ejerce su dominio, y hasta tal punto que ahora tiene que estudiar cómo repoblarlos artificialmente; pues si posible fuera hasta despoblaria los mares.

Los peces son indispensables para el hombre. Pueblos en. teros hay que verian comprometida su existencia si no los tuviesen; sin ellos algunos estados desaparecerian; y á pesar de eso no se ha llegado aun hoy á apreciarlos en todo lo que valen, cosa verdaderamente incomprensible! Los ingleses, escandinavos, americanos, franceses, italianos y españoles, gricgos y rusos, lapones, esquimales, el salvaje de bronceada te\% de la Oceania, todos saben apreciarlos, - el aleman no. Se comprende fácilmente que el aleman desconozca la utilidad del innumerable ejército de las aves, 6 que por lo me. nos apenas haga caso de él al compararlo con la utilidad de los namíferos, aunque la gallina de su corral ó la paloma posada en su tejado debiera hacer que la comprendiera el hambre de mas ruda inteligencia, asi como abrirle los ojos la mas superficial observacion de las costumbres de cualquier ave cantora del bosque; no obstante, esto tiene hasta cierto punto su explicacion, porque la mayoria de los hombres no se toman el trabajo de observar ni de calcular; pero el no haberse apreciado todavia en Alemania la importancia de los peces, y que léjos de haber derrochado los infinitos tesoros del mar, ni se hayan siquiera cxplotado todavia; que 
la pesca en la costas de Alemania apenas se efectue mas racionalmente que en las playas de la Nucra Zelanda, esto es incomprensible; incomprensible aun cuando quiera darse por excusa la multiplicidad de gobiernos que hemos sufrido; porque no es el poder del estado el que funda las pesquerías, el que las reglamenta y organiza, sino el espiritu de empresa del individuo; porque en todos aquellos paises donde florece la pesca, el gobierno se limita solo á protegerla. Holanda debió su pasada grandeza a la pesca del arenque; Noruega saca de su pesca por lo menos cinco veces tantas pesetas como número de habitantes cuenta; se valua el beneficio de la pesca en el banco de Terranova en quince millones de duros, pudiendo formarse una idea de lo que es la pesca de mar en Inglaterra al saber que Lóndres solo consume quinientos mil sollos, veinticinco millones de caballas, cien millones de lenguados, ochenta y cinco millones de platijas, doscientos millones de gados,aparte de las innumerables cantidades de las demás especies que aqui no citamos porque son peces que no se llevan al mercado con la regularidad de aquellos. In pesca del arenque en Escocia $y$ en la isla de Man ocupaba en i $862: 9,067$ barcas y 43,468 pescadores, abstraccion he cha de 22,47 I individuos ocupados en la salazon, embala. je, etc.

Los ingleses se llevan ahora la palma. No solamente es su pesca la mas considerable de todas las naciones, sino que sus disposiciones para abastecer los mercados de las ciudades del interior están tan bien entendidas, que en ellos se pueden obtener muchos pescados con mayor facilidad que en los pueblos de la costa.

Las ventajas que de esto resultan son debidas al espiritu rasto de enupresa de los ingleses que sabe vencer y que ven. ce todos los obstáculos. Fil trasporte maritimo tan fácil y rápido que facilitan las costas de la Gran Bretaña, quita á los ferro-carriles una parte considerable de trasporte y entre otros el del pescado, as pesar de lo cual se expidicron en un año, segun Bertram, por la línea Iondon-Brighton, 5, 174 to. neladas de pescado, por la linea Grande Oeste 2, $\$ 8_{5}$ toncla. das, por la North British $\$, 3 \circ 3$, por la Gran Norte 1I,930, por la del Nordeste 27,896 , por la del Sudoeste 3,218 , por la del Gran Este 29,086; en todo 88,492 toneladas de pescado: En frente de tales datos aparecen insignificantes y pobres la pesca y el comercio de pescado tal como hoy se verifican en Alemania.

Un aspecto algo mejor, aunque no mucho, ofrece la pesca en las aguas duices alemanas, especialmente en aquellos distritos en que predomina el clemento católico; pero hay que confesar que en este punto no puede citarse ningun pro. greso notable, y símas bien atraso, porque es general la queja de que nuestras aguas dulces son ahora mas escasas en peces de lo que eran antes, y que van empobreciéndose de año en año cada vez mas; à lo que contribuyen muchisimas causas. A consecuencia del creciente aumento del valor de las tierras se reducen los espacios ocupados por las aguas $\delta$ se suprimen del todo, y particularmente los puestos de freza, ya sea saneando pantanos, ya sea desecando lagos de agua dulce; el establecimiento de fábricas cuyo número aumenta de año en año crea á los peces para su acto de desove invencibles obstáculos en forma de presas, ó bien emponzona los riachuelos y arroyos; los vapores que recor. ren los rios mayores incomodan á los peces y arrojan una multitud de huevas y de crias atrasadas todavia a' las orillas, donde perecen sin remedio; los pescadores destruyen millones de huevas y de embriones destinados \& repoblar las aguas, cogiendo peces poco antes del tiempo del desore; $y$ nuestras condiciones de vida tan cambiadas $y$ que favorecen mas bien la pesca maritima, no contribuyen poco á mermar el número de los peces de agun dulce. Antes que hubiera ferro carriles tenia razon aparente la idea errónea de la ri. queza inagotable de las aguas; la venta del pescado tan expuesto s. averiarse pronto, se limitaba á un reducido espacio; Ia provision suficiente para el consumo de pescado no ofrecia dificultad, de suerte que no habia que pensar en una explotacion sin misericordia de las aguas. Hoy, empero, se remiten los peces á centenares de kilómetros y esto por si solo basta para que sca imposible abastecer el consumo cada vez mayor de una manera suficiente; por otra parte es evi. dente que la subida de precio de todas las sustancias ali. menticias influyc tambien en la pesca y obliga á las perso. nas que se ocupan de ella, obedeciendo á la necesidad de hoy, s sacar todo el partido posible del presente sin consideracion al porvenir; y la consecuencia es el empleo indis. tinto de cualquier medio de destruccion sin mirar si se destruyen peces adultos ó crias, como son las redes de ma. llas angostas y las descargas explosivas debajo del agua. Eil pescador furtivo perjudica tambien al pescador de oficio reduciendo la ya escasa cosecha, á la par que ambos quicren coger sin sembrar. «Considerando el alimento que en forma de peces nada en nuestras aguas, dice Cárlos Vogt, nos hallamos iodavia en la situacion del cazador 6 á lo mas en la del nómada, que atento solo \& buscar sitios de abrigo para sus rebaños, abandona todo lo demás al cuidado de la natu. ralera; y lo que esta nos da sin gran trabajo en las aguas lo aprovechamos tan bien como podemos, contentándonos á lo sumo con establecer en las aguas dulces estanques para depúsitos de peces, dejando a su cuidado procurarse el alimen to como puedan. Nuestras leyes son todavia denasiado in completas, demasiado recientes y mal adaptadas $\&$ las necesidades generales para que puedan remediar todos los males conocidos hoy; por otra parte no se observan siempre las disposiciones acertadas, eludiendo las prescripciones y las prohibiciones. Es sa tiempo de intervenir con mano rigorosa en este asunto, de establecer y propagar la reda y la cria de peces para remediar en cuanto sea posible la situacion comprometida en que ambas se hallan. Esto no será fácil, pero tampoco imposible.

Nuestra ley mas reciente de pesca proporciona los medios mas adecuados para fomentar la riqueza de pesca en general; prohibe acercarse á los sitios de freza asi como á los pasos que conducen s ellos; veda tambien el uso de redes de mallas demasiado compactas y otros medios y arreos de pes. ca, el empleo de materias venenosas en arroyos y rios; dispone cl estableciniento de sescalas para salmones fija épocas de reda para las diferentes especies de pescado; pero perjudica por un lado sensiblemente á los pescadores, mientras que por otro no facilita medios suficientes para garantir su ejecucion, por manera que la buena intencion del legis. lador quedarí sin resultado mientras los esfuerzos individua. les no coadyuven y concurran, contribuyendo cada uno al bien general. Por esto tienen razon los gobiernos cuando excitan y fomentan la organizacion de asociaciones pesqueras en cuya mano estara adoptar aquellas disposiciones que sin perjudicar notablemente intereses individuales redunden en provecho de lodos. Precisamente han de ser favorab?es 6. nuestra pesca todas estas asociaciones de hombres inteligentes, aun cuando solo sea porque excitan al individuo á meditar sobre un objeto de tan grandisima importancia, induciéndole á prestar su apoyo y cooperacion á los esfuerzos comunes y á observar y estudiar lcs peces y sus costumbres.

Aun queda mucho por bacer bajo este último concepto, pues sabemos mas sobre el género y condiciones de vida de todos los demás vertebrados que sobre la vida, las costum. bres y necesidades de los peces. \&uchas cuestiones oscu. 
ras para pescadores y sabios, y de la mayor importancia para el fomento de la pesca, dice Benecke, aguardan todavía su solucion. Ias condiciones que en distintas aguas infuyen en la prosperidad de los peces son tan poco conocidas como el alimento favorito ó mas conveniente de algunas, $\delta$ mejor dicho, de todas las especies, y esta ignorancia será probable. mente el motivo principal de que hayan salido completamen. te frustradas varias tentativas de aclimatacion de especies de gran mérito, por mucho que se hayan hecho con medios abundantes. Nada sabemos sobre la mortandad repentina de peces en rios y lagos, debiendo decirse otro tanto respecto de las causas que impulsan á veces á los peces á emprender emigraciones repentinas que no están en sus costumbres, como succde con las anguilas, que hallándose por lo comun ocultas en el limo durante el invierno, nadan á lo mejor librernente en los puertos de los alfaques de Prusia, donde las cogen con las grandes redes de invierno. De sucrte que si se puede hacer algo para fomentar el aumento de los peces en aguas distinias, solo podran determinarlo aquellas personas peritas que se dedican con todo su ahinco á observar dichos animales. Por este concepto nos hallamos muy atrasados respecto de Francia, Inglaterra y América, pues en todos estos paises se facilitan tales medios á los es. tudios mencionados, que los designados por los gobiernos alemanes aparecen de todo punto insignificantes.

CRIA ARTIFICIA - Un medio de repobiar nuestros rios y'arrojos, medio cuya eficacia exageran mucho, sin que por esto deje de tencrla, es la cria artificial de peces practicada en China siglos hace Desde el año I 733 se habia ocupacio el agricultor Jacobi de Lippe-Detmold, en la fecundacion artificial de la freza de trucha, y treinta años despues publi. có sus observaciones. Su descubrimiento, si- bien logró ser confirmado por Bufion, Dubamel y otros sabios, cayó casi en complèto olvido. Los resultados de la cria artificial continuada durante una generacion por el cura Armack en el distrito occidental de Sajonia-Altenburgo, en 'luringia, no se publicaron, y solo se volviós hablar de ellos cuando Shaw en Escocia en $18_{3} \%$, Remy en Francia en $1 \$_{4} 8$ y Saudun. gen en Noruega en 1850 habian descubierto, á su vez, el mismo procedimiento. Entonces fué el gobierno francés el primero que facilitó los unedios necesarios para hacer ensayos en grande escala, y gracias a los esfuerzos de Coste pudo fundarse en Huninga, en Alsacia, el primer establecimiento de cria artificial de peces. Ayuntamientos y propietarios íranceses se apresuraron á seguir el ejemplo; en Ingla. Lerra y América se dedicaron con celo y éxito á esta industria interesantísima, y en vista de todo esto se acordaron de esta invencion alemana tambien en Alemania y Austria.Hungria, conde ahora existe un número regular de establecimientos de cria artificial de peces, algunos de ellos muy considerables.

La cria artificial de peces, continúa Benecke, emperó por Ia fecundacion artificial de la freza de peces de la familia de los salmones $y$ aun hoy dia se dedica la mayor parte de es. tos establecimientos casi exclusivamente a dichos peces y sus afines. Ellos son los que deparan frecuentes ocasiones de estudiar sus costumbres en sus sitios naturales de desove, siruados en aguas poco profundas, pero de mucha corriente. Tan luego conio una hembra empieza a arrojar en continuado chorro sus huevas comparativamente de bastante tamaño, descarga tambien un macho su lechada que se di suelve en el agua, formando una blanca nube. Fn cada gotita de sémen ó de la lechada que derraman en abundan. cia, se encuentran innumerables corpúsculos scminales su mamente diminutos, muy parecidos a renacuajos con cabeza gruesa y cola delgada que moviendo esta última á manera de culebras, se mueven con gran viveza y al penetrar en una hueva la fecundan. Todas las huevas no fecundadas mueren mas ó menos pronto sin que se desarrolle el embrion, y como en el desove natural las huevas $y$ la lechada quedan á merced de la corriente que las arrastra cuando no van al fondo, resulta que con frecuencia solo una parte minima de las huevas recibe el contacto de la lechada, al paso que en la fecundacion astificial se tiene la completa seguridad de ha. cer entrar todas las huevas en el liquido fecundante.

No pocos criadores de peces son aun hoy decididamente de opinion de que la cria artificial de peces requiere gastos considerables y no menores conocimientos si ha de dar bue. nos resultados; cuando el asunto en sí es sencillisimo, pu. diendo instalarla en todas partes donde se dispone de un arroyo de agua pura de fuente $y$ de un calor aproximada. merte constante, de corriente fuerte $y$ de fondo pedregoso. Con este arroyo, que tambien puede suplirse con una corriente de agua de manantial, se alimentan varios estangues profundos cuyia agua no llegue á congelarse en invierno y que han de ir aumentando en superficie principiando por el mas pequeño; en el caso de que en el sitio elegido no haya al. gun estanque natural, se construye artificialmente, se lim. pian sus foncios del limo y se planta en sus orillas algun bosquecillo para dar sómbra, echaindose además piedras de modo que formen huecos para servir $\$$ los peces de escon. drijos. Fin cstos estanques se guardan los peces padres, por ejemplo las truchas de difercinte edad, $y$ de tal suerte que las de una misma se junten en el mismo estanque, donde se les da el alimento recesario, se las vigila y protege de todos sus enemigos, \& fin de que lleguen al tiempo del desove ro. bustas y sanas. Si se quiere quitar la freza a otras clases de salmones, se ponen estos poco antes de su empleo en los estanques ó en cajas hotantes de depósito donde se suelen guardar comunmente para la venta los peces cogidos viros.

En un punto farorable, por donde pasa ó se hace pasar un ramal derivado del arrojo, y donde existe ó se puede arreglar una corriente fuerte, se levanta una casilla con paredes y tejado capaces de resguardar el interior de las heladas, y con tauta luz como necesita el exámen de las huevas des. tinadas á ser fecundadas. Alli, en el interior de la casilla, se conduce el una cañeria d agua suficiente para llenar conti nuamente un número mas ó menos grande de pequeños de. pósitos de fecundacion. Para el caso habrå un kiosko y aun un simple armario de los llamados de hielo, mientras que los pequeños depósitos de fecundacion pueden ser cajas de madera con fondo de la misma ó de vidrio, vasijas llanas de barro cocido, ó tambien construidos con unos cuantos la. drillos y cemento; y en último extremo barrenos, cubos, etc.; lo principal es que sean fácilmente manejables, accesibles y a propósito para poderlos mudar de sitio sin dificultad.

Cuando ha llegado el tiempo del desove naiural, se ven los aparatos sexuales de machos y hembras llenos hasta reventar de lechada y de huevas, y en la mayor parte de las especies de salmones basta el mas suave roce en la parte inferior del cuerpo para vaciarlos y fecundarlos respectiva. mentc. Entonces se toma una vasija llana de barro ó de por. celana, se colocan á mano los peces de cria en grandes cubos separando ambos sexos si es posible, $y$ se coge una hembra con cuidado por la parte anterior del cuerpo sobre el cual se ha cchado un paño seco; $y$ mientras un auxiliar aguanta el pez por la cola para impedir que golpee, se pasa la mano derecha suavemente á lo largo del vientre desde la cabeza á la cola, todo el tiempo que el pez suelte huevas, las cuales salen a chorro sin el menor esfuerzo. Otros dos auxiliares proceden entre tanto á ejecutar la misma operacion con un macho, cayendo asi en la vasija á un mismo tiempo las hue. vas y el sémen. Basta luego agitar suavemente la vasija ó re. 
volver las huevas con precaucion con la mano o la barba de una pluma para repartir la lechada de manera que gran parte de las huevas llegue á ser fecundada, lo cual se consigue asi mucho mejor y mas completamente de lo que les es po sible á los peces que arrojan su freza naturalmente y cn esta. do de libertad. Como quiera que los salmones nunca sueltan de una sola vez todos sus materiales de reproduccion, se repetirá la misma operacion con intervalos de tres á cinco dias con aquellas especies que puedan guardarse sin dificultad durante este tiempo en sitio conveniente.

\&uego de haber mezclado suficientemente la lechada y las huevas, dice Benecke, se llena la vasija de agua á la misma temperatura que aquella en que estaban los peces antes de la operacion, $y$ se dejan reposar las materias semi nales un cuarto ó media hora; luego se decanta el agua turbia y líctea, renovándola con precaucion hasta que quede clara Tas hnevas aparecen cutonces, por haber absorbirin mucha agua, mucho mas grandes que cuando salieron del cuerpo de la hembra, y al paso que entonces no presentaban ningun espacio entre la cáscara y la yema, se ve ahora en el interior de la membrana de la hueva distendida como bola ó globo henchidos, un gran espacio lleno de agua clara en la cual fota libremente la yema. Junto con el agua han penetrado corpúsculos seminales que han efectuado la fecun. dacion. Al poco tiempo se observan alteraciones en las hue. vas y con ellas el principio del desarrollo del embrion.

- Si la cantidad de freza que hay que quitar á los peces es considerable, se pueden muy bien escurrir las-huevas de un número mayor de hembras en una fuente, y la lechada del nú. mero correspondiente de machos en otra, mezclando entonces toda la masa de una ve\%. Tambien es posible emplear peces muertos de la especie de los vivos en la fecundacion artificial, con tal que se hayan conservado en sitio fresco aun dos ó tres dias despues de nuertos, y hasta se puede, lo que segun

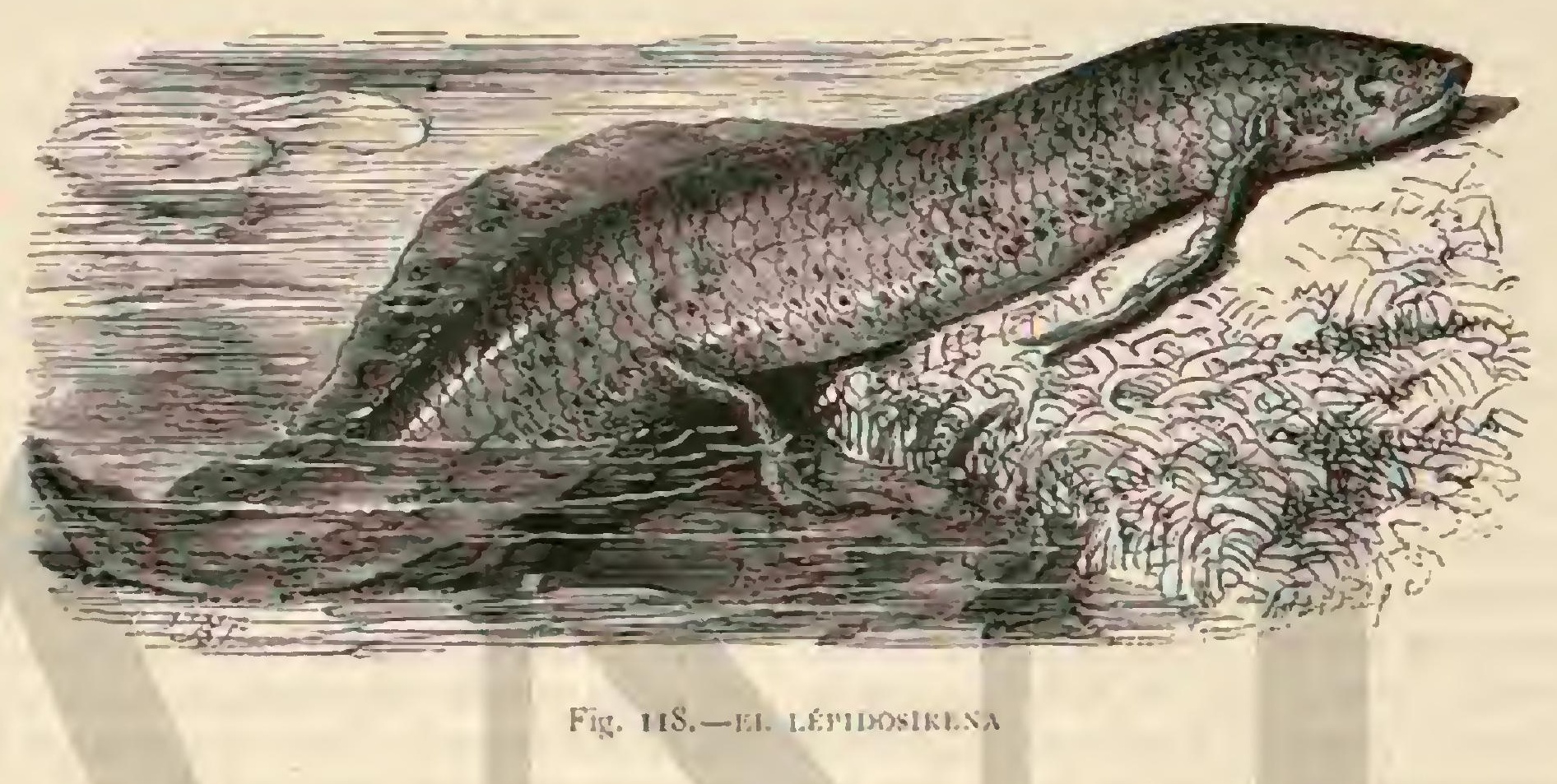

las circunstancias es muy importante, conservar la freza de ambos sexos muchos dias, si se tuvo ia precaucion de vaciar. la en frascos bien secos, llenos hasta el borde, bien tapados y guardados en sitio fresco. En la mezcla de freza descrita es condicion indispensable que cada hueva se halle perfecta. mente rodeada de corpúsculos seminales, los cuales han de haber penetrado en su interior junto con el agua, cuando se añadió; pues si las huevas y la lechada entran por separado en el agua, pierden muy pronto su energía vital; las primeras se llenan de liquido y ga no pueden absorber los corpúsculos seminales, y estos pierden luego su movilidad y con ella su calidad fecundante. Esta es precisamente la razon de que se haya abandonado $\mathrm{cl}$ método practicado anteriormen. te, de hacer cacr al agua simultáneamente las huevas y la lechada.

Si se quisiese entregar las huevas artificialmente fecunda. das is su elemento y en los sitios de freza naturales, se procederia con evidente acierto, porque asi se expondria un número de huevas fecundadas muchisimo mayor de lo que habrian logrado los peces mismos; pero los peligros antes mencionados exigen su colocacion en depósitos de cria.

Depende su desarrollo de la constancia con que se los provec de agua fresca, lo que supone una corriente continua y de la vigilancia con que se las resguarda de infuencias da. ninas en cuanto puedan evitarse. Si bien el frio no esteriliza fácilmente las huevas, la temperatura del depósito de incu. bacion, no debe bajar a cero, sino mantenerse entre 4 y 6 grados Reaunur; ni debe ser tampoco mayor, porque enton. ces se apresuraria el desarrollo de las huevas y en nuestro tierra nacerian los pequeñuelos, y habrian consumido subol sa de yema antes de la primavera, resultando que los pece. томо $\mathrm{V}$ cillos ya formados sufririan las funestas consecuencias de una temperatura baja. Ni es menos importante que reciban sin interrupcion agua aireada, pues la hueva respira tam. bien, es decir, dentro de ella hay cambio de materia; abso:ben el oxigeno del aire contenido en el agua, y exhalan en cambio acido carbónico. Para dar al agua aire $\delta$ sea oxigeno basta proporcionarle una corriente algo caudalosa, ó bien se hace desembocar por un tubo con boquilla angosta para que salte con cierta fuerza deniro del depósito de cria, porque asi se produce un chorro vigoroso que arrastra con sigo partículas de aire. De aqui resulta la conveniencia de disponer para cada depósito de cria de un caño de agua es. pecial, pues sibien se puede aprovechar el agua que sale de la hilera superior de los depósitos de cria, para alimentar otra segunda hilcra mas baja y ast sucesivamente, la experiencia ha probado que procediendo asi se retarda el desasrollo de los huevos en las hileras mas bajas, aumentando el trabajo del encargado de la cria. Si se cumplen las condicio. nes citadas el resultado favorable es seguro. Sin embargo, aun hay otra cosa que tener en cuenta, y es resguardar las huevas de sus enemigos y de influencias dañinas. El local de las incubadoras ha de estar bien cerrado $\mathrm{y}$ no permitir que penetren en el interior enemigos pequeños, como rato. nes de agua; esto es consiguiente, pero hay que advertir que dichos ladrones no son los peores enemigos de las huevas, sino mas bicn las plantas parásitas, ciertos hongos que cre. cen sobre las huevas y las matan. Durante los primeros dias de desarrollo es cuando mas particularmente hay que aten. der con mayor solicitud \& las huevas de cria, apartando todas las averiadas que se distinguen por su aspecto turbio blanquuizco. Esto se hace con unas pequeñas pinzas de resorte 
6 con un sifon, cosa que se aprende pronto, y que exige poco tiempo, con tal que las incubadoras estén cómodamente instaladas. Una persona medianamente práctica podrá sacar durante los primeros dias y en cosa de una hora hasta cien mil huevas averiadas. Para precaver en cuanto sea posible la propagacion del moho tan fatal, se recomienda hacer pasar el agua antes de su entrada al través de lienzos de tejido fino, y tambien limpiar con un pincelito suave de pelo de tejon el poso que va dejando el agua diariamente sobrc las huevas. Hasta hace poco tiempo se seguia el método de Jacobi que se proponia imitar en cuanto podia á la naturaleza, cubriendo el fondo de las incubadoras con arena fina; pero ahora se ha desistido de ello porque las huevas no tienen ninguna necesidad de un lecho blando, y porque la arena perjudica y entorpece su mas fácil inspeccion. Puede decirse que se han vencido ya todas las dificultades cuando al entrar en la segunda parte del desarrollo se dibujan los ojos, al través de la cáscara, en forma de dus puntos de tamaño desproporcio. nado; entonces suele ya proseguir el desarrollo con mas regularidad y menos sujeto $\mathbf{s}$ influencias externas; $y$ en este estado pueden remitirse las huevas bien ácondicionađảs en musgo húmédo á gran distancia, y aun de una parte del mundo á otra.

Segun el calor del local de incubacion y del agua que se complea nace la cria mas temprano 6 mas tarde, taras veces antes de seis semanas, $a$ veces à las ocho, $y$ desde entonces sigue el desarrollo como se ha dicho antes. Mientras el pececillo lleva la bolsa de yema no necesita alimento, pero tan pronto como esta queda consumida y' se ha igualado el vientre, sienten los animalitos la necesidad de alimentarse. Antes de llegar este momento debe trasladar el criador los peque. ñuelos a otros depósitos mayores, alimentados sin interrup. cion con agua fresca, y variar cuidadosamente el depósito de incubacion, $\delta$ lo que es preferible, introducirlo y colocarlo en el fondo de depósitos mas grancies, procurando que esté enteramente debajo de agua. Mientras que los pequeños se nutren de su bolsa de yema continúan casi inmóviles en el fondo; mas tan luego como se manifiesta en ellos la necesidad de alimento, despiértanse tambien los instintos induda. bles de ferocidad. Todos los animales antes citados son ahora presa suya En estado de libertad se han de buscar cllos mismos la presa, pero en el espacio reducido en que los tiene el criador, incumbe à este procurárselo á cllos, y como no es nada fácil proporcionarles su alimento natural, es preciso suplirlo con otro. A este fin se presta mejor que nada la cecina de buey, cie carnero ó de caballo finamente raspada, asi como la sangre cuajada raspada tambien $y$ los sesos desecados de estos animales y yema de huevo, solo qque esta última ha de darse siempre en poca cantidad. De este alimento se echan diferentes veces al dia algunas pequeñas porciones, lo que cabe en la punta de un cuchillo, encima del agua, s se observa el consumo para fijar la cantidad ne. cesaria y siempre creciente de la racion. Cuando los salmon. citos son ya un poco mayores se añaden larvas de hormigas, gusanos blancos y sucesiramente todos los articulados que el criador conoce ó no conoce, tantos como puedan obte. nerse. Durante la alimentacion artificial citada, que se conti. núa todo el ticmpo que los jécecillos están en depósitos estrechos, hay que tener muchísimo cuidado con que la corriente del agua tenga bastante fuerza, porque de lo contrario se posarian fácilmente estos alimentos, de cuya pu. trefaccion resultaria un barniz mucilaginoso que causa la mucrte de muchos peces. En general se colige de todas las experiencias reunidas y hechas hasta hoy que lo mas ventajoso es trasladar los pececillos nacidos, luego que el ticmpo lo permita, á un estanque suficientemente grande, bien saneado y limpio, ó si posible es, á zanjas de prado alimenta. das con agua de fuente. Tanto en estas como en aquel se picrde la mitad de la cria introducida, pero se ahorra por este método tanto trabajo, que aquella pérdida se compensa con ventaja. Finalmente cuando los pececillos han llegadoá adquirir suficiente desarrollo se les introduce en aguas donde están destinados á vivir definitivamente.

El procedimiento resulta enteramente distinto cuando en lugar de huevos de peces que desovan en invierno se trata de huevos de peces que echan su freza en verano, por ejem. plo, de carpas en el sentido mas general. Sueltan su freza en las orillhs llanas de las aguas $y$ la pegan por medio de una materia especial aglutinante á las hojas y tallos de diferentes plantas acuáticas. Como que estos huevos, segun Benecke, nacen ya a los cinco hasta ocho dias, y como los pececillos al nacer llevan solo una bolsa pequeña de yema, siendo de consiguiente mucho mas ágiles que las crias de todas las es. pecies de salmon, les basta este modo de fijar los huevos para evitar que vayan al fondo. Por esto no hay necesidad tampoco de tomar otras precaucioncs para asegurar el desarrollo de los huevos en estanques donde no hay peces de rapiña ni donde son de temer las incursiones de los patos. Pero si se quierc fomentar la cria de peces de la clase de carpas en depósitos de agua mas considerables, donde es imposible librarlos de peces de rapiña ni- de aves que se mantienen de huevas, se logra mejor echando antes de la época del desove en los sitios de costumbre ramas de pino, y llevando despues á estanques de cria pequeños, fáciles de vigilar y abundantes en alimento para los pequeñuelos que se cuidan alli hasta el primer otoño. No se necesita fecun. dar artificialmente los huevos de carpa por la sencilla razon de que pueden recogerse en masa huevos fecundados natu. ralmente.

No habiéndose puesto en práctica la cria artificial de peces sino de poco tiempo á csta parte, tampoco es posible todavia formar un juicio exacto sobre ella, pero desde luego se puede afirmar que podrá y que llegará á ser uno de los medios mas eficaces para aumentar nuestra tan menguada riqueza de pesca.

CLASIFICACION. - Se conocen umas nueve mil espe. cies de peces que riven en la época actual, y como unas dos mil antediluvianas, porque estos vertebrados, como los mas imperfectos de todos y habitantes exclusivos del agua, de. bieron existir sobre la tierra y poblar el mar primitivo antes que los animales mas perfectos. En las formaciones mas an. tiguas de la costra terrestre solo se encuentran peces cartila. ginosos, tiburones y rasas, ganoideos y peces acorazados muy especiales; á estos suceden los ganoideos con esqueleto óseo, que son reemplazados poco á poco por peces óseos, los cua. les forman ahora la mayor parte de su clase.

Sobre la division de los peces caben opiniones muy encuntradas, porque justamente los cartilaginosos que se colocan en la seccion mas inferior, presentan en el desarrollo de sus aparatos de reproduccion formas superiores á las de los peces óseos, y que se parecen hasta cierto punto á las de los mamiferos maritimos. Tambien es dificil hacer una exacta separacion de los órdenes, familias y tribus, que dista aun mucho de haberse fijado con completa seguridad. La division adoptada por mif corresponde en lo principal á lo admitido por la mayor parte de los inteligentes en este asunto. 


\title{
PRIMERA SUBCLASE-DIPNEOS
}

\author{
PRIMER ORDEN
}

\section{SIRENOIDEOS-SIRENOIDEI}

In el año 1835 sc descubrieron en la $\Lambda$ mérica del sud y en el Africa occidental dos vertebrados sobre cuya clasifica. cion y significacion los naturalistas no están aun hoy acordes. Si hay miembros que sirven de eslabon entre las diferentes clases de animales, lo son cicrtamente estos dos, pues se hallan á no dudarlo en medio de la division que existe entre los anfibios y los peces, y ofrecen señales caracteristicas de ambas clases. Su estructura es la de los peces y la funcion respiratoria que corresponde á su aparato es la de los anfibios. Su regimen, carácter y usos se parecen tanto á los de los unos como á los de los otros. Juan Mueller y otros investigadores han demostrado definitivamente que el carác. ter de pez prepondera en su estructura, y por esto les hemos designado el puesto que ocupan en esta clase.

CARACTERES. - Los peces de pulmon ó sirenoideos, de los que solo se conocen dos especies, forman una sola familia tambien, la de los protopterideos (Protopleridie), a la que podria llamarse de los feces anfibios. Su forma exterior es en un todo semejante á la de los peces; su cabeza es triangular y ancha; la boca de una anchura desproporcionada, el ojo pequeño como el de los anfibios; las mejillas como el resto del cuerpo cubiertas de escamas; las aberturas de las branquias pequenas y verticales; una de las especies las tiene interiores, y la otra exteriores y llevan unos como arbolitos pequeños, con flecos ú hojuelas á manera de barbilla de plu. ma que se ranifican fuera de la abertura branquial, mieniras que en la otra se hallan en el interior. Detrís de las bran. quias están las extremidades toracicas, dos huesos en forma de pediculos y puntiagudos en cuya cara interior se observa una barba de aleta muy reducida, corta, sostenida por radios córneos y oculta en la aleta epidérnica. Las extremidades posteriores, formadas de idéntica manera, están colocadas inmediatas y al lado del ano. Ia aleta dorsal está reempla. zada por un bordillo epidérmico sostenido por radios cór. neos; empieza á poca diferencia á la mitad de la espalda y corrc perdiéndose hasta la aleta caudal, repitiéndose en el lado inferior de csta hasta terminar en el ano. Todo el cuerpo estí cubierto de cscatmas anchas, redondendas, sobrepuestas á manera de tejas y que semejan un mosaico de va. rias piezas. La columna vertebral es un tallo cartilaginoso sin divisiones, envuelto en una túnica fibrosa de la cual salen hácia arriba y abajo arcos vertebrales huesosos que abrazan la médula espinal y la aorta; el cordon vertebral se prolonga inunediatamente dentro del cráneo formado de una cápsula cartilaginosa única, en la cual hay osificadas algunas placas oper. culares sueltas. Muy singular es la dentadura, porque tiene placas dentales cortantes, verticales y altas, soldadas a la parte inferior y anterior del cráneo, répresentada por la unan. dibula superior; á las que corresponden placas semejantes en la inferior. Detrús de la abertura branquial se encuentran tres arcos bicn desarrollados de hileras de livjuelas branquiales entre las cuales, absolutamente como en los demás peces, pasan las aberturas branquiales al esófago; existen adc. más dos 6 tres arcos branquiales que no tienen hojuclas, $y$ cuyas arterias pasan sin ramificarse á la aorta, por manera que la sangre que viene del corazon se dirige á las hojuelas branquiales, ó bien cuando estas no funcionan, pasan inme. diatamente por las arterias de los arcos branquiales sin hojuelas á las arterias pulmonares.

Hasta aqui, observa Cirlos Vogt, al que he seguido tam. bien en lo que precede, todos los caractéres concuerdan con la naturaleza de pez; pero investigando mas, se encuentran diferencias esenciales, porque las fosas nasales conducen á una ancha cápsula nasal cuyos dos conductos estrín abicrtos haicia abajo dentro de la cavidad bucal, inmediatamente de. trás de la punta del hocico. Detrás de las aberturas branquiales se cncuentra en el tabique anterior del esófago una glotis que conduce á una ancha caja de resonancia sostenida por cartilagos, y á dos bolsas pulmonares bien desarrolladas y llenas de células, alimentadas por sangre puramente venosa desde el corazon, y que vierten sangre arterial en la corriente de la aorta De esto resulta que cuando la boca está cerrada existe una comunicacion para el aire al través de las fosas nasales, lo que no se encientra en pe\% alguno, como tampo. co ninguno de estos posee un pulmon abierto en ei tabique anterior del esófago, y que contenga sangre venosa. En cam. bio, son idénticas las condiciones de la respiracion y de la circulacion en los peces anfibios a las que vemos en semipeces 6 larvas anfibias, que tiencn á la vez pulmones y bran. quias.

\section{EL. LEPIDOSIRENA Ó DOCO-PROTOPTERUS ANN ECTENS}

CARACTERES. - De las dos especies la mas conocida es el lepidosirena (fig. I 18), llamado por los negros del Nilo Blanco foco y comloc, per de un metro de longitud. Su forma es la de la anguila, solo mas rechoncha; en lugar de las aletas torácicas y abdominales tiene otras largas, algo compri. midas y filiformes, de un palmo de largo, con un bordillo radial; la aleta dorsal, que empieza como á la mitad de la parte anterior del tronco se confunde en la cola con la aleta abdóminal. En la boca, transversa, mas bien pequer̃a que grande, sobre la cual se adelanta la nariz, hay cuatro colmillos robustos, cónicos y un tanto movibles kintre los seis ar. cos branquiales hay cinco aberturas branquiales. Eil cuerpo está cubierto de escamas pequucias y presenta numerosas manchitas grises redondeadas y difusas sobre un fondo pardo oscuro, que hácia la parte inferior se vuelve mas claro. Li ojo es de color castaño. 
DISTRIBUCION GEOGRÁFICA.- $-\mathrm{El}$ doco $\delta$ pez anfibio, que se sabe existe en toda la Africa central é interior, escribe Heuglin, vive tambien en el Nilo Blanco y' sus alluentes al sud de los $9^{\text {(b }}$ de latitud norte, siendo al parecer alli frecuente.

USOS, COSTUMBRES Y REGIMEN. - Se encuentra este pez singular en el légamo, rara vez en agua despejada; pero de noche suele acercarse álos barcos, probablemente para comerse los desperdicios que se arrojan desde ellos. Durante la estacion seca permanece en agujeros verticales ů horizontales de un metro de profundidad, que el animal se hace probablemente él mismo, en las orillas elevadas de las balsas de agua de lluvia; ó tambien entre follaje húmedo. De noche abandona su retiro para coger ranas, inoluscos y cangrejos que constituyen su alimento principal. Durante la temporada de las lluvias se abre verdaderos caminos en el cieno. Sus movimientos en tierra firme no son muy ágiles, pero si vigorosos, si bien se conoce que le cuesta trabajo deslizarse por eminencias algo elevadas, lo que realiza levantando la parte anterior del cuerpo y arrastrando el resto con movimientos serpentinos. Raras veces se ven juntos varios individuos, pues son en alto grado insociables, por manera que no bien se encuentran por casualidad arman pendencias estroperandose por regla general en términos de que es raro encontrar uno que tenga toda la cola. Tambien se defiende el doco cuando le ataca el hombre, muerde si se le pisa ca. sualmente y silba al propio tiempo como las serpientes, 1 las que se parece tambien por su agilidad al arrastrarse. Los ne. gros lo cogen con venablo, porque su sabrosa carne les gusta mucho; pero tambien muerde en el anzuelo.

Cuando se secan las aguas que habita el lepidosirena se en. vuelve en una cápsula de barro en la cual pasa la temporada seca. En estas cápsulas se reciben estos peces vivos de al. gunos años a esta parte en Europa. En ellas está el animal

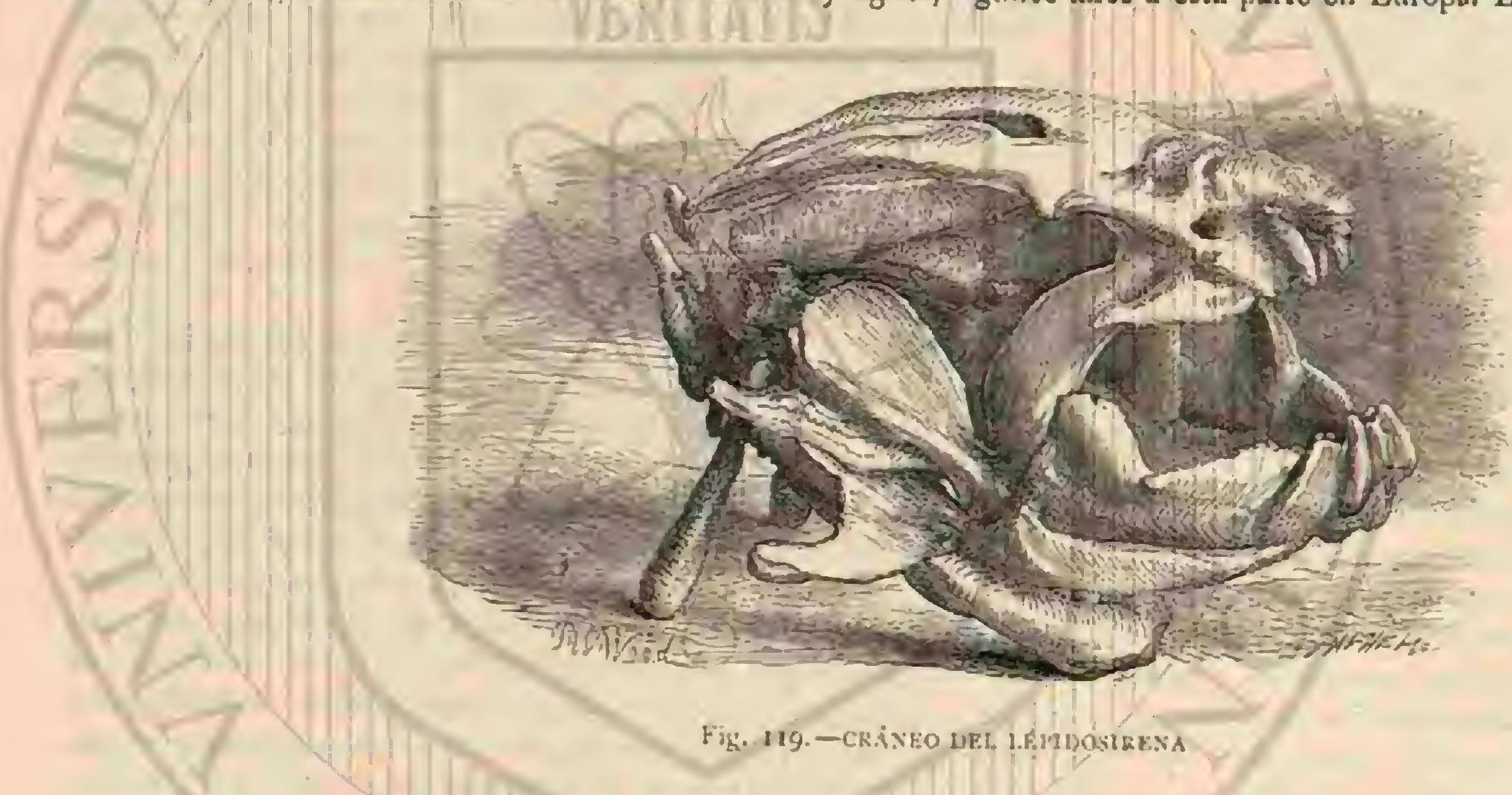

enrollado, pasada la cola en parte por in cabeza, y ocupando todo él un espacio tan/reducido que diffcimente se podria jügar del tamaño del pé L La pared de la cápsula es de lé. gamo comun, pero el interior está revestido de una masa mucosa. No se sabe cuanto tiempo dura el sueño ó aletar gamiento invernal, pero si que este animal puede permane. cer varios meses en tan estrecha cárcel sin perjudicarse.

Si se pone una de estas cápsulas en una vasija con agua á una temperatum ajuroximadamente igual á la del centro del Africa, revive el pe\% muy en breve, porque su envoltorio se disuclve pronto, al principio se muestra extraordinariamente perezoso, como embotado por el sueño, pero al cabó de una hora está completamente despierto y la recobrado su agilidad, aunque sigue todavia buscando los puntos mas oscuros de la vasija, y permanece largo rato en el fondo. $\mathrm{Al}$ cabo de algunos dias se despierta en el el hambre y desde este momento llama su atencion cualquier movimiento en la superficic, porque supone que lo produzca alguna presa. Agil y listo sube serpenteando á la superficie, moviendo alternativamente las aletas y el bordillo dorsal, para buscar que co. mer, y toma en seguida el animalito ó el pedazo de carne que se le da y que traga, volviendo en seguida ásu puesto anterior. En el Palacio de Cristal de Ióndres se han tenido cautivos durante algunos años estos peces anfibios y se ha observado minuciosamente su modo de vivir.

Uno de cstos peces vivió tres años y habria vivido mas si le hubiesen podido dejar en su depósito. Al principio se le alimentaba con pedazos de carne que le arrojaban despues de haber llamado su atencion moviéndolos, agitando rápida.

mente la superficie; mas tarde le dieron mas y peces. Cogia los pedazos de carne con sus robustos y agudos dienies delanteros, despues movia todas las partes del hocico como si chupase el jugo de la carne, mordiendo entre tanto con vigor, soltaba luego el bocado y lo volvia á coger, y á chupar hasta que por fin se lo tragaba. Cuando lo trasladaron á un depúsito habitado por peces de colores, empezó en seguida á cazarlos, y no solo los pequeños sino tambicn-los mayores que él A pesar de sus movimientos lentos sabia apoderarse del pez que se habia propuesto atrapar. Se ponia á observar. lo con atencion mientras nadaba encima de él; subia serpenteando graciosanicnte hasta haber llegado cerca del vientre de su victima; entonces embestia y cogia al desgraciado per exactamente por debajo de las aletas torácicas, arrancándole de un fuerte mordisco un pedazo del vientré, volviendo á bajar con él en la boca \& la profundidad, mientras que el pobre animal mortalmente herido, fotaba á los pocos segundos cadáver en la superficie. De la misma manera cogia tam. bien las ranas, y no iardó asi en despoblar su depósito antes tan poblado. Como satisfacia á su gusto su feroz voracidad, creció y aumentó en peso con gran rapidez: cuando le pusieron en el depósito, tenia $0 \%, 25$ de longitud; álos tres años media ya casi un metro y pesaba mas de tres kilogramos.

Creyendo que le seria quizás necesario ó agradable pasar una parte del año durmiendo, se le proveyó de barro y légamo á propósito; pero el doco no pensaba en dejar el agua donde por lo visto se encontraba tan bien, mostrándosetodo el año despierto y activo. No se comportaron asi los peces anfibios que cuidó Dumeril. Estos empezaron en tiempo re. 
gular, á fin de Setiembre á mostrarse inquietos, se movian vivamente y segregaban una cantidad extraordinaria de materia mucosa esforzándose por cavarse un retiro en el suelo húmedo. Su guardian los ayudó, procurando initar la desecacion de las aguas de su patria, á cuyo fin sacaba paulatinamente el agua de su depósito. A las tres semanas se habia endurecido y agrietado en muchos puntos el barro que habia en el fondo del depósito, y los animales permanecieron mu. cho tiempo ocultos en el. Sesenta y dos dias mas tarde se examinó el suelo y se encontró á cada pez dentro de una cápsula; cuando se abrieron estas, dieron los dos peces seinales poco perceptibles de vida, y murieron poco despues.

\title{
SEGUNDA SUBCLASE-TELEOSTEOS
}

\author{
SEGUNI)O ORDEN
}

\section{ACANTOPTERIGIOS-ACANTHOPTERI}

CARACTERES.-Fintre todos los peces conocidos consideramos los de aleta espinosa como los mas perfectos, porque además de tener los caractéres interiores de la serie indicados, son á la vez los peces de formas mas regulares, es decir que en su estructura se apartan menos del tipo general $y$ únicamente en ciertos casos exceden de las proporciones regulares.

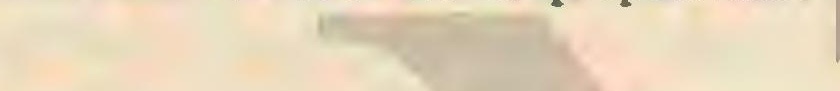

Son de tamaño regular, raras veces pasa su longitud de dos metros y casi siempre son mas cortos; hállanse cubiertos de escamas por lo general de colores vivos; sus branquias son pectiniformes, los huesos inferiores del esófago estản se. parados; los radios anteriores de la aleta dorsal no están articulados, a reces libres y espinosos, y cuando hay dos aletas es la primera la que aparece asi; las aletas torácicas están
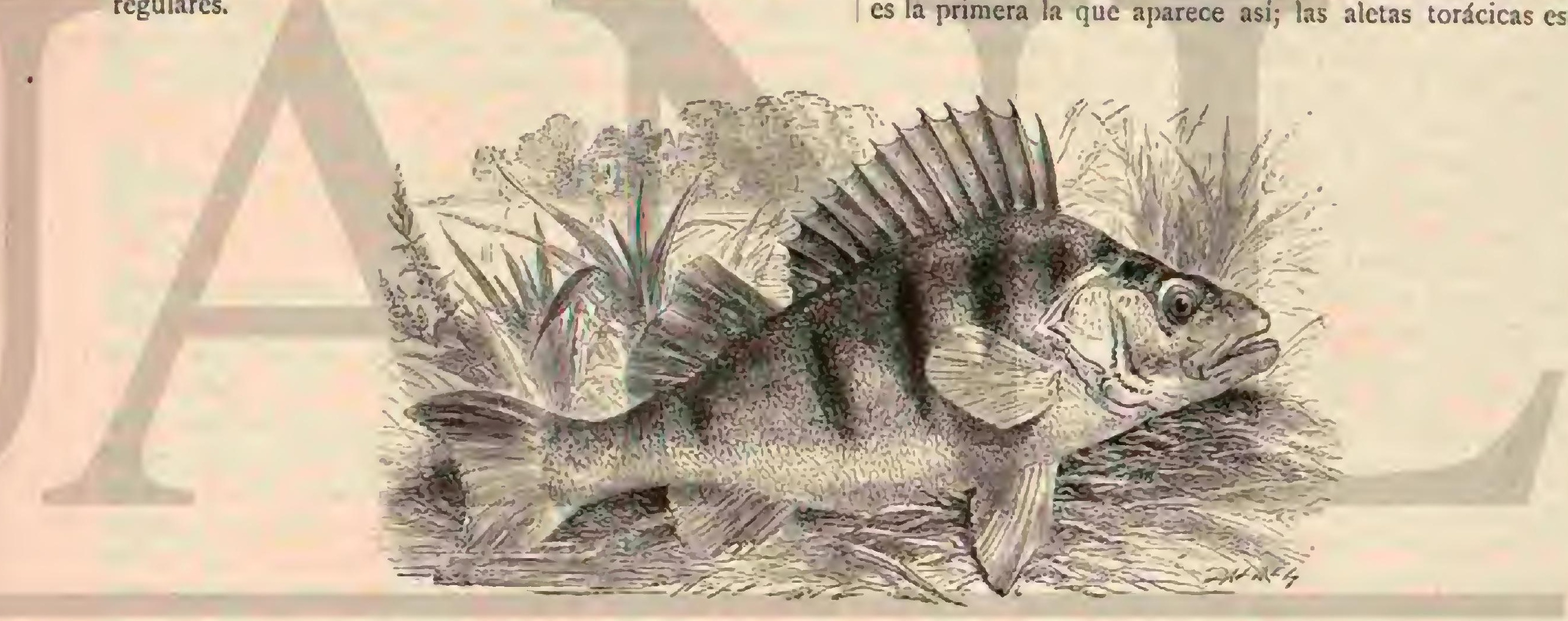

Fig. 120, - BA rrica comu:

por lo comun dirigidas hácia delante de las abdominales, $y$. cuando estas ban alcanzado todo su desarrollo llevan un radio espinoso, que por lo regular tambien existe en gran número en la aleta anal. La cubierta escamosa suele ser ís. pera, y en el masor número de especies presentan las escamas sus bordes posteriores dentados ó pectiniformes. Siempre existe la vejiga natatoria.

DISTRIBUCION GEOGRÁFICA.-la inmensa mayoría de acantopterigios habita los mares, en especial los situados en latitudes bajas, donde este órden presenta su mayor riqueza de formas; pero tampoco faltan miembros de este órden en las aguas dulces, pertereciendo á él cabalmente varias especies en parte muy notables.

USOS, COSTUMBRES Y REGIMEN.-Todos los in. dividuos son sin excepcion zoofagos, muchos extraordinariamente voraces $y$ feroces, sin que esto impida que varios de ellos sean muy apetecidos en la mesa. Puede decirse que casi ninguno de los peces de alcta espinosa recibe del bom. bre especiales cuidados, pues este doja \& la naturaleza el de velar por su propagacion.

\section{LOS PÉRCIDOS-PERCID AE}

CARACTERES. - En honor del pez mas frecuente de nuestros rios se ha dado el nombre de fércidos ó percas á la primera familia tan abundante en tribus y géneros. I.os ras. gos caracteristicos de todos los peces pertenecientes á esta familia son: cuerpo prolongado y fuertemente aplanado, cu. bierto por lo rezular de escamas duras y pectiniformes; opérculos branquiales dentados ó espinosos; dientes en ambos intermaxilares, en la mandibula inferior, en el vómer medio, situado en la bóveda palatina, y en ambos palatinos latera. les; una abertura brarqquial ancha y sicic radios branquiales \& cada lado. I.as aletas abdominales insertas debajo de las torácicas, la hendidura bucal ancha, junto con un tubo di. gestivo corto y de pocas circunvoluciones y cuyo estómago, en 
forma de bolsa, lleva cerca del piloro solo tres y hasta seis ciegos en forma de manga, contribuyen por otra parte á distinguir estos peces.

DISTRIBUCION GEOGRÁFICA.-Todos los mares y la mayor parte de los rios y lagos de agua dulce del mundo antiguo y nuevo albergan algunos miembros de esta familia. Los géneros se distinguen tanto por la belleza de su colora. cion como por su movilidad y rapacidad. Se mantienen de otros peces, sin exceptuar su propia cria, de freza, gusanos y articulados, ponen un número considerable de huevos, multiplicindose de consiguiente mucho, si bien sufren bastante reduccion pór los ataques de numerosos eneinigos No sirven los pércidos para la poblacion y erplotacion de estanques por lo dificil que es subvenir a su manutencion; en cambio. desempeñan un papel bastante regular en $/ 2$ industria pesquera, teniendo su carne justa fama de apetitosa y sama y considerinduse la de algunas especies como una de las mas excelentes

\section{LA PERCA COMUN Ó DE RIO-PERCA} FLUVIATILIS

CÁRACTERES.-Fsta especie, tipo del género ferca, se halla extendida por ambos continentes. Se distingue por tener dos aletas dorsales mas.ó menos próximas una á otra, acaso reunidas por una membrana baja; por el preopérculo aserrado y è opérculó espinoso de las branquias, así como por los numerosos y espesos dientes de cepillo que guarnecen la boca. Su cuerpo rechoncho y aplastado en los lados ostenta, sobre un fondo verdoso 6 amarillo de laton, que tira en los costados al amarillo de oro, al blanco en el vientre $\mathrm{y}$ a un tinte mas oscuro en la espalda, de cinco as nueve fajas transversales que corren descle la espalda hácia el vientre, de longitud y anchura desigual, y frecuentemente reernplazadas solo por inanchas negruzcas difusas. La prime. ra aleta dorsal es de un gris rojizo azulado con una mancha mas oscura entre los dos últimos radios; la segunda ofrece un tinte amarillo-verdoso, las torícicas son de color amari llo-rojo; la abdominal $y$ anal de un rojo de minio y de cina. brio. En la primera aleta dorsal se cuentan de trece $a$ quince radios, en la segunda de trece a catorce, en cada abdominal cinco, un la anal de ocho á nueve y en la caudal diez y siete. No se distinguen con certeza los machos de las hembras, sin embargo, los primcros parecen ser un poco mas altos proporcionalmente $\dot{a}$ su longitud que las últimas. Las percas de nuestras aguas raras veces exceden de $0^{m}, 25$ de largo y su peso de un kilógramo, pero se pescan en ciertos lagos indi. viduos de kilógramo y medio ó dos, como en el lago de Zelle, distrito de Linz; y segun Yarrell, en diferentes aguas de Inglaterra, donde segun dicen, se han cogido de mayor peso; Penant asegura que se pescó un individuo de cuatro kilógramos.

DISTRIBUCION GEOGRÁFICA.-El área de dispersion de la perca de rio se extiende por toda la Luropa y una gran parte del Asia septentrional. Segun Yarrell es rara en Iiscocia, faltando completamente en las islas Orkney y las de Shetland; en cambio existe en todas las aguas dulces de la peninsula escandinava, aun en las situadas mucho mas al norte que aquellas. En Alemania se encuentra én todos los rios y lagos propicios, y comunmente con frecuencia, excepto en los muy elevados y en algunos distritos de las llanuras bajas; en los Alpes solo evita las aguas situadas a mas de mil metros sobre el nivel del mar. Los lagos de agua ciara son st vivienda favorita, y ell ellos prospera mas; pero no falta en los rios ui tampoco en arroyos profundos, estan. ques, aguas salobrenas, $y$ aun en mares poco salados, como el Báltico, donde por el contrario parece hallarse muy á su gusto; cuando menos se distingue de sus congéneres de agua dulce por su tamaño mas considerable y su carne mas grasa y sabrosa

USOS, COSTUMBRES Y RÉGIMEN.-En los rios prefiere las orillas y los remansos mas bien que la parte central 6 de rápida corriente; y en los lagos las capas superiores, aunque tambien cs capaz de bajar á grandes profundidades, donde no es raro pescarla; entonces presenta señales de una prolongada permanencia. Gessner decia ya: «Los pescadores del lago de Ginebra aseguran que las percas cogidas en red durante el invierno sacan de la boca una hojita encarnada, lo cual las obliga a subir á las aguas superiores, creyendose alle que esto lo hacen por rabia.) Siebold ha confirmado la exactitud de lo dicho por los pescadores y re. fiere lo siguiente:

《En todas las percas cogidas por casualidad en la pesca del coregonus hiemalis (de la tribu coregonus, familia salmon), per que se halla en las grandes profundidades del lago de Constanza, observé un cuerpo extraño parecido á una lengua hinchada, que llenaba el esófago, y que en algu. nos individuos hasta salia de la boca. Al examinarlo me convenci que este cuerpo cónico tan distendido era el estó. mago de estos peces, $\delta$ vieito al revés y hácia fuera $A$ bri el cuerpo y pude reconocer además que los tabiques de la ve. jiga natatoria estaban distendidos demasiado y que al fin ha. bian reventado a causat de la fuerte dilatacion del aire dcbida al caubio de presion al subir desde una profundidad de treinta á cuarenta toesas; el aire habia llenado toda la cavidad abdominal, obligando à la bolsa del estómago á volverse al revés y á salir fuera de la boca.

Comunmente se encuentran las percas reunidas en pequeñas bandadás que nadan, y segun parece cazan tambien juntas en buena armonia. Ia perca nada en las capas superiores con mucha ligercza, pero á intervalos, detiénese de repente y continua bastante rato parada sin moverse del sitio, para lanzarse despues de nuevo. A veces se la ve durante al. gunos minutos en los huecos de la orilla y en sitios umbrosos debajo de rocas y piedras salientes $y$ en otros escondrijos; sin duda acecha, pues si por algun motivo abandona estos lugares, siempre vuelve a ellos. Si se aproxima un enjambre de pececillos, precipitase sobre ellos como el rayo, y si no se apodera de alguno fí la primera acometida, los persigue. Estos ataques de las percas siembran no pocas veces el espanto y la confusion en las numerosas bandadas de alburnos (alburnus lusidus), cuandio tranquilamente nadan debajo de la superficie del agua; muchos tratan de salvarse de la voracidad del cazador dando un salto fuera del agua; pero. tambien encuentra a veces la perca el castigo de su ferocidad, pues sucede que al querer tragar con demasiada ansia el pececilla cogido, este pasa desgraciadamente desde la abierta boca á una abertura branyuial lateral, donde ha de morir á la vez que su raptor.» Tambien sucede, segun Bloch, que sorprende por descuido algun gasierosten, el cual le hiere mortalmente con sus espinas dorsales levantadas, pues dicen que este pez procura defenderse hasta del solla (esox lucivis), el mas voraz de los peces de nuestras aguas dulces, irguiendo sus espinas, ya para imponerle con š aspecto amenazador, 6 bien para herirle mortalmente, si no renuncia al ataque. Además de alimentarse la perca de pececillos y de todos los demás animales acuáticos de ỵue se puede apoderar, come en su primera edad gusanos y larvas de articulados; despues cangrejos y anfibios; y al fin hasta maniferos, como por cjemplo ratas de agua. Su voracidad es tan grande, que le ha valido en Alemania el sobrenombre de "Anbeiss" (lsinaritintes), porque muerde en cualquier 
cebo sin escarmentar en sus semejantes cuando á su misma vista son victimas de su propia voracidad.

CAUTIVIDAD. - Cautivas y colocadas en un depósito, las percas toman á los pocos dias gusanos de la mano de la persona quue las cuida, domesticándose liasta cierto grado.

REPRODUCCION. - La perca puede procrear \& los tres añosy tiene entonces aproximadamente una longitud de $0^{*}, 15$. La época de la freza puede oscilar entre ciertos limites, segun la situacion del agua que la especic habita, segun la temperatura de aquella y la de la atmósfera, cayendo por regla general en los meses de marzo, abril y mayo; puede haber algunas que quizás frecen ya en febrero, y otras toda. via en junio y julio. Para este acto escogen las hembras ob. jetos duros, piedras, madera ó a ambien cañas, $\{$ fin de apre. tar contra ellas el cuerpo y hacerle soltar la freza, y de que quede esta pegada á las mismas. La freza se desprende en sartas ó cordones aglutinados cntre sí como redes, y teniendo frecuentemente una longitud de uno á dos metros. Las hue. vas son dél tamaño de la semilla de adormidera, y á pesar de ser tan pequeñas pesa la freza de una hembra algo creci. da, de un kilógramo hasta uno $y$ doscientos gramos y aun mas, siendo en este caso el número de las huevas conio de trescientas mil. Hamers pretende haber contado ó calculado en uno de estos peces de solo media libra de peso doscien. tos mil huevas. Muchas percas sirven de alimento a otros peces $y$ aves acuáticas, y como por otra parte las relaciones de observadores atentos están contestes en que los machos se encuentran en algunos distritos en sorprendente minoria, puede suceder qque solo una pequeña parte de las huevas sal. ga fecundada, y' á esta causa deberí atribuirse el que no aumente mas el numero de las percas.

Además del sollo(esor lucius), son enemigos peligrosos de la perca la nutria, el águila marina, la garza y la cigücn̉a; quizás tambien los salmones y otros peces de rapiña. No me. nos peligroso es para la perca un pequeño crustáceo, el piojo de mar, que anida en el delicado tejido de sus agallas, aca. bando por destruirlas. Además de estos se han encontrado en sus entrañas siete clases de entozoarios parásitos.

Usos Y PRODUCTOS. - La perca es la alegría de todos los pescadores de caña principiantes, porque clla es la que a menudo corona su torpeza con buen éxito. En los puntos donde se presenta pueden cogerse muchas con anzuelo, $y$ en bastante mayor número con una red que lleva su nombre $\delta$ con una nasa algo grande. Como quiera que aguanta algun tiempo fuera del agua, se la puede enviar á largas distancias con tal que durante el viaje se la moje de tiempo en tiempo; y tambien se la conserva dias y semanas enteras en cajones á propósito estrechos, siendo de consiguiente una de las especies mas cómodas para el pescador. Su came es sa. brosa y se vende fácilmente desde cuarenta peniques hasta dos marcos el kilógramo. Los individuos mas jóvenes que no se aprecian para la mesa, se utilizan de otra manera, pues de su piel se hace una cola de pescado muy resistente, y las escamas se emplean en trabajos mujeriles; en cambio las de mayor tamaño tambien pasan en nuestros tiempos por muy sabrosas, aunque no estamos del todo acordes con Ausonio cuando canta:

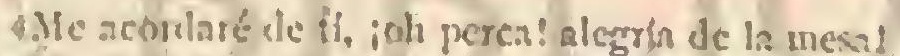

$\rightarrow$ Hijer ric rocomparable a les peces del riar.

- Línica émula de los tarrbos rojizos del Océaro:?

\section{LAS LUCIOPERCAS-LUCIOPERCA}

\& Este per aleman singular tiene la cabeza de sollo y el resto del cuerpo la forma de una perca. Con estas paiabras empieza el vicjo Gessner su descripcion de la lucioperca (luciopera) uno de nuestros mas excelentes peces de agua dulce y que justifica su nombre cientifico de lucioperca que le dib aquel autor $y$ que aun hoy sirve para designar el gé. nero.

CARACTÉRES.-Además de su forma prolongada, sc distinguen los peces que á él pertenecen por tencrdos aletas dorsales separadas, preopérculo aserrado simple y por sus dientes largos y puntiagudos que guarnecen, junto con los dientes finos de cepillo 6 de terciopelo, los huesos branquizles y palatinos, y reunen positivamente los distintivos dearnbas especies, de las percas y de las lisas, recordando muy especialmente í estos últimos con su cuerpo prolongado y sus dientes de presa de aguda punta.

\section{LA LUCIOPERCA COMUN-LUCIOPERCA SANDRA}

CARACTÉRES. - Esta especic (fig. 121) alcanza una

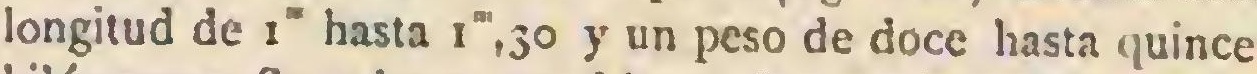
kilógramos. Su color es en el lomo de un gris verdoso, hácia el vientre blanco plateado, en la parte gris tiene listas parduscas formando como nubes y a veces á modo de verdade. res cintas oscuras; en ambos lados de la cabeza el color es jaspeado pardo y en las membranas que unen los radios de las alctas tienen manchas negruzcas. La primera aleta dorsal tiene catorce radios, la segunda de veintiuno a veintidos, la torácica quince, la abdominal de uno á cinco, la anal de dos á once y la caudal die\% y siete.

DISTRIBUCION GEOGRÁFICA.-Ia lucioperca ha. bita los grandes rios de la parte nordeste y central de Europa, en la Alemania del norte, las cuencas del Elba, del Oder, del Vistula y de los lagos próximos a ellas; en la Alemania meridional el Danubio, pero falta en la cuenca del Khiu $y$ del Weser y en toda la Furopa occidental, y en las regiones que habita tampoco se la halla en los rios pequeños de fuerte corriente. En los rios de Rusia, especialmente en el Vol. ga y el Dniester, la representa una especie afine, tal vez idéntica al Bercliok de los rusos (hucioperen ziolgensis).

USOS, COSTUMBRES X REGIMEN.-La lucioperca prefiere aguas profundas, limpias y corrientes; permanece habitualmente en las capas inferiores, y aparece solo en el tiempo de la freza que ocurre entre los meses de abril y junio, en sitios pantanosos de la orilla, cubicrtos de plantas acuáticas para desovar alli. Como es pez extraordinariamen. te voraz, que persigue a todos los mas pequeños que él de su clase, sin perdonar siquiera su propia cria, y mucho me. nos á cualquiera que puede alcanzar, claro es que crece con rapidez; alcanzando, segun Heckel, en las aguas profundas y en los juncales y cañizales, al primer año un peso de tres cuartos de kilógramo y al segundo un kilógramo, mientras que no llega de mucho á cstos pesos, aun al fin del primer año, en el Danubio y en el agua baja. Se propaga considera. blemente.

Si bien Blok contó en una hembra que pesaba kilógramo y medio como cuarenta mil huevos, no es la propagacion de este sabroso pez tan abundante como podria desearse, tal vez porque los vicjos persiguen 1 sus propios hijuclos con el mismo afan que despliegan los sollos, glanos, percas y otros peces de presa en la persecucion de ellos. . Con razon vitupe. ra Sicbold que los que crian artificialmente peces no se ha. yan ocupado todavia de la lucioperca, ya que sin ella será dificil extender á otras aguas este pez tan exquisito. I as lu. ciopercas cautivas mueren al poco tiempo y de consiguiente no es posible remitirlas a grances distancias, lo que puede empero hacerse sin dificultad con sus huevos. En aguas de alguna extension, lagos menores $y$ estanques abundantes en 
peces ordinatios in inferiores en calidad como alburnos, leu. ciscos, escardineos, eperlanos, gobios de rio y otras especies, seria muy productiva la cria artificial de este pez.

Usos Y PRODUCTOS.-La carne de la lucioperca que se paga desde sesenia peniques hasta dos marcos (de 80 céntimos de peseta á 10 reales) el kilogramo es mejor y mas gra. sa antes de la frezz que despues y por consiguiente en otoño é invierno; pero se ha de consumir fresca, porque pierde mucho de su. mérito cuando está salada ó ahumada. En Alemania pocas veces se la ve en la mesa, pero en el Elba inferior se estima al igual del salmon, porque en proporcion se cogen pocas luciopercas. Io contrario sucede en los alfaques de la Prusia oriental y mas particularmente en los rios de la Rusia meridional donde se cogen a reces tantás lucioper. cas que ni aun los pobres las quieren, y solo sirven cocién. dolas para aprovechar la grasa. Fin Astrakian consideran la carne del berchik como malsana.

\section{LOS RÓBALOS - LABRAX}

CARACTERES. - De la perca de rio y de sus afines se distinguen los rótralos por su forma mas oblonga, escamas inas pecqueñas, por el opérculo provisto en la parte posterior de dos espinas y cubierto además de escamas, por, mediar unayor distancia entre las aletas dorsales y por tener la len gua áspera.

\section{EL RÓBALO COMUN-IRBRAX LUPUS}

CARACTÉRES. - Como representante de este género sé adnite la fera marina, lubina, llubina ó róbalo (fig. 12 I), per. conocido s de los antiguos que se coge en el Mediterrá neo, en el Atlántico y tambien en las costas de Inglaterra tione de $0^{\mathrm{m}}, 50$ á 1 il de largo y pesa hasta diéa kilógramos. Su color es un hermoso gris de plata que tira en el lomóá azul y en el vientre s blanquizco, las aletas son pardo claras. Ea la primera dorsal se cuentan nueve radios, en la segunda un radio duro $\mathrm{y}$ doce blandos, en la torácica diez y seis, en la abdominal un radio duro y cinco blandos, en la anal tres duros y once blandos y en la caudal dice y seis.

Aristóteles cita el róbalo con el nombre de labrax, Plinio lo llama lupuss. Ambos sabios le alaban con muchísima razon por su carne deliciosa, y segun Plinio se estimaban particularmente róbalos que se pescaban en el Tiber cerca de Roma ó en la ciudad misma, porque se cebaban con los residuos de las letrinas. En general se preferian, y en esto tenian razon, los que se cogian en agua dulce $\{$ los cogidos en el mar, por cuya causa se vigilaba con gran cuidado su aparicion en las desembocaduras de los rios.

Los antiguos decian que los róbalos vivian solitarios y que de puro voraces tenian la boca siempre abierta por lo cual se les habia dado el nombre de (lobos》; que no solo comian carne sino tambien plantas marinas y hasta excrementos y que en busca de cstos subian hasta Roma; que eran mas in. teligentes que otros peces: $y$ que sabian evitar muy bien las persecuciones; que estando despiertos oian muy bien; pero que dormian a menudo s entonces los punzaban con lanzas; que cuando colgaban del anzuclo se revolvian tan terriblemente que ensanchaban la herida y de esta manera se libra ban del anzuelo; que tambien sabian evadirse de las re des, etc. Los observadores modernos han podido confirmar algunos de estos asertos.

DISTRIBUCION GEOGRAFICA.-Segun Yarrell se encuentra el róbalo en todas las costas meridionales de Inglaterra, é igualmente en los canales de Bristol y de San Jorge; á veces se le pesca todavia mas al norte. Es pez muy conocido en las costas de Irlanda y se le suele coger á menudo en gran uúmero en las redes paradas para salmones y sus afines.

USOS, COSTUMBRES Y REGIMEN.-Por lo co. mun no se aleja de las costas, prefiriendo los sitios de poca agua á los profundos; entra tambien en las desembocaduras de los rios subiendo entonces rio arriba hasta grandes dis. tancias. Su régimen alimenticio consiste en cangrejos, gusa. nos y peces menores. Para apoderarse de los primeros nada cuando soplan fuertes vientos hasta cerca de las costas, porque entonces arrancan las olas enfurecidas muchos de estos crustáceos de las rocas y los llevan a su alcance. Su Época del desove es en medio del verano.

Como el róbalo no cede en voracidad à sus afines, se le coge tambien fácilmente con el anzuelo, y en este caso, emplea en éfecto, como refieren los romanos, todas sus fuer. zas para escapar nadando con extraordinario vigor. de una parte á otra obligando al pescador á valerse de toda su maña para asegurarse su presa.

\section{LOS CENTROPOMOS -CENTROPOMUS}

CARACTÉRES.-I - acépéde ha llamado centroponos a las percas de dos aletas dorsales, caracterizando este género por un opérculo que no termina en punta.

\section{EL CENTROPOMO UNDECIMAL- CENTROPOMUS UNDECIMALIS}

CARACTERES. - Esta especie (fig. 123), as! llamada por los once rádios de que consta su segunda dorsal, es de un color plateado ligeramente matizado de pardusco 6 verdoso en el lomo, realzado por una linea parda bastante an. cha que forma en ell la linea lateral. Las aletas son amarillentas con puntos negros en los bordes, y la primera dorsal estŕ toda ella manchada de negro sobre fondo gris. Su hoci. co es aplanado horizontalmente; su cabeza estrecha; los oidos bien rasgados, teniendo su membrana siete rádios. La parte ósea del opérculo termina redondeándose, y sin nin. guna espina.

DISTRIBUCION GEOGRÁFICA. - Esta especic se halla en todas las costas de la América meridional.

USOS, COSTUMBRES Y REGIMEN.-El centropomo undecimal, llamado róbalo por los españoles de Cubay Puerto Rico así como por los brasileños, suele vivir en las cmbocaduras de los rios, remontándose algunas reces por ellos hasta el punto de que muchos le consideren como per. de agua dulce. Aliméntase de presas vivas, y engorda mu. cho; pone dos veces al año, siendo su puesta muy abundan. te. Esta especic es muy apreciada en todas partes, y crece bastante, cogiéndose algunos individuos de veinticinco libras y aun mas, los cuales se venden à tajadas. Pison asegura que su carne conviene no menos á los cnfermos que á los sanos. Los mejores son los que tienen unos dos piés de largo, sirviéndose en las mesas de mas lujo. Los huevos se salan para hacer con ellos una especie de embutido conoci. do en cl Mediterráneo con el nombre de hotarge.

\section{LOS APRONES-APRO}

CARACTÉRES.-Llámanse asf unos peces de esta familia que tienen el cuerpo fusiforme, el morro saliente, opérculo espinoso y prcopérculo poco aserrado; dos aletas dorsales separadas y dientes de terciopelo en ambas mandi. bulas, en el vómer y en los palatinos. 
EL APRON CINGLO-ASPRO ZINGEL

CARACTERES. - Este pez tiene $0^{\mathrm{m}}$ :30 de longitud, y un peso de un kilógramo. La primera aleta dorsal lleva de trece á catorce radios, la segunda además de medio radio, diez y ocho hasta veinte, la torácica catorce, la abdominal uno y cinco, la anal unoy doce á trece y la caudal veintiuno. El color del lomo y de los costados es amarillo gris, el del vientre blanquizco; el cibujo consiste en cuatro fajas de un negro pardusco que corren oblicunmente de arriba abajo y por delante sobre los costados.

\section{EL APRON COMUN-ASPRO VULGARIS}

CARACTERES.-Esta especie solamente tiene $0=15$ de largo con un peso de sesenta á cien gramos; en la primera aleta dorsal lleva nueve, en la segunda ademís de medio radio, doce à trece, en la torácica catorce, en la ab. dominal uno y cinco, en la anal uno y doce, $y$ en la caudal diez y siete; fuera de esto se distingue de sus afines por su cola muy esbelta, pero se parece á cllos en la coloracion que es en el lomo amarillo parda ó rojiza, en los costados ama. rillo-blanquizca, y tambien le adornan de cuatro á cinco fajas anchas que corren por los costados.

DISTRIBUCION GEOGRÁFICA. - Hasta hoy solo se ha encontrado d estos dos aprones en la cuenca del Danu. bio, aunque tampoco figuran entre los peces mas frecuentes, tanto en el rio principal como en sus afluentes.

USOS, COSTUMBRES Y REGIMEN.-Ies gusta el agua pura y corriente, viven á considerable profundidad y se

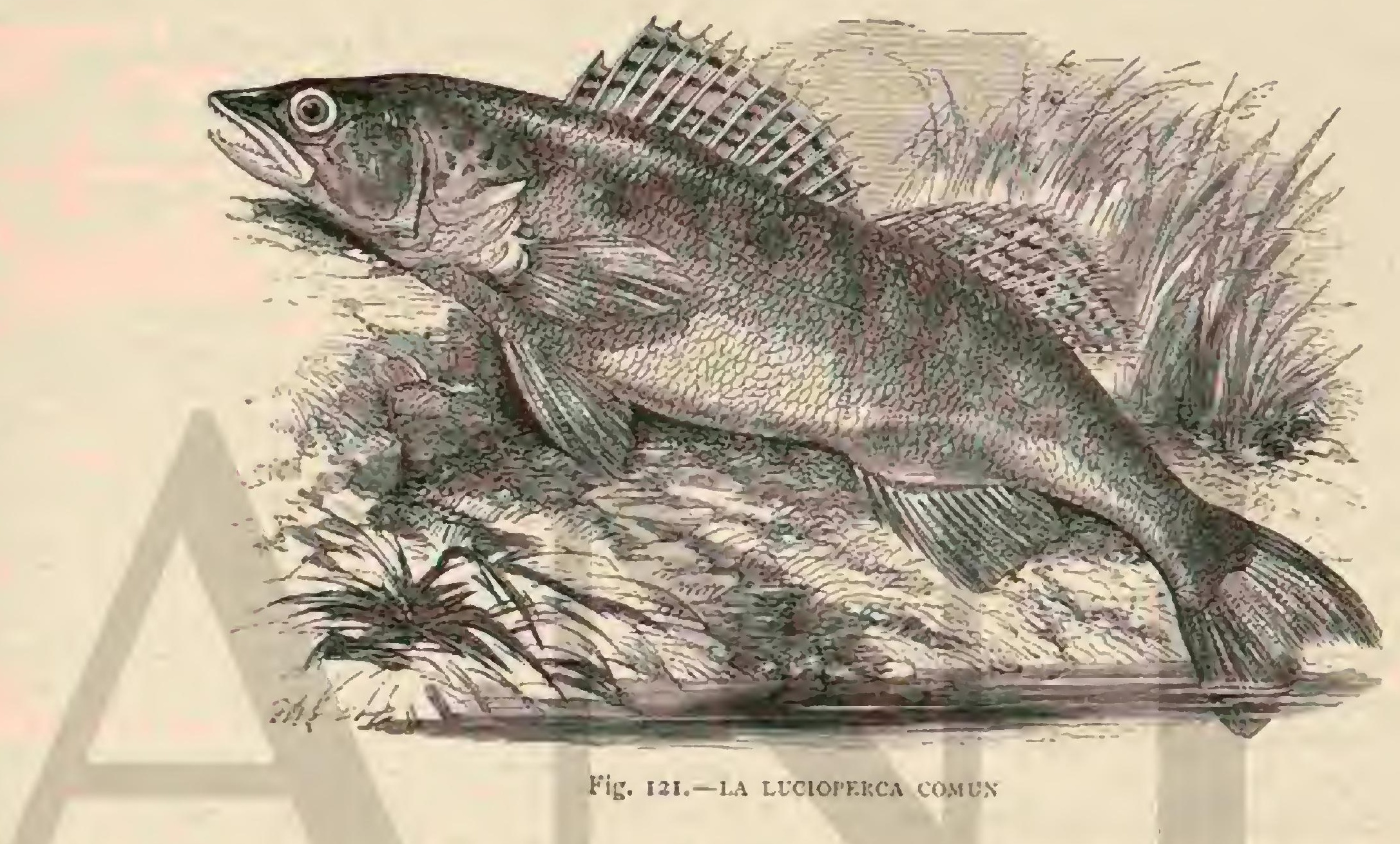

mantienen de peces pequeños y de gusanos; desovan en abril. La carne de ambas especies es sabrosa y de fácil digestion; pero no compensan el trabajo de pescarlas, por cuya razon en ninguna parte las cogen sistemáticamente.

\section{LAS ACERINAS-ACERINA}

CARACTERES، - En las acerinas las dos aletas dorsales no forman mas que una; el preoperculo y el opérculo son espinosos: los huesos de la cabeza rienen depresiones; los branquiales y el vómer están guarnecidos de dientes de terciopelo; el pecho y el vientre están mas ó menos desprovis tos de escamas. Concuerdan estos peces con los mencionados hasta ahora en cuanto á la colocacion de las aletas abdomi. nales $y$ torácicas, número de radios branquiales y colocacion de las escamas.

\section{LA ACERINA COMUN-ACERINA VULGARIS}

CARACTÉRES.-El conocidisimo representante de este género, la acerina comun, alcanza una longitud de $10^{\circ}, 20 \mathrm{a}$ $11^{\prime \prime}, 25$, y un peso de ciento veinte á ciento cincuenta gramos; el cuerpo es corto $y$ rechoncho; el hocico romo; espalda y costados son de color verde de oliva con mancias y puntos oscuros distribuidos sin órden; el lomo y las aletas caudales presentan puntos dispuestos en lineas. La aleta dorsal tiene de doce á catorce radios duros $\mathrm{y}$ espinosos y de once 6 caтомо $\mathrm{V}$ torce blandos, la torf́cica tienc trece, la abdominal uno y cinco, la anal dos y cinco á seis, y la caudal diez y sicte.

\section{LA ACERINA SCHRAITSER-ACERINA SCHRAITSERI}

CARACTÉRES.-Otra especie idéntica á la anterior en cuanto a sus costumbres, pero limitada a la cuenca del Da. nubio es la acerina Schraitser, que se diferencia de clia por su cuerpo y hocico muy prolongados, por la aleta que ocupa el lomo en casi toda su longitud, y por el color amarillclimon de sus costados á lo largo de los cuales corren de tres á cuatro lineas negruzcas. En la aleta dorsal se cuentan diez. y ocho á diez y nueve radios duros y cspinosos y de doce á trece blandos, en la torácica de trece á catcrce, en la abdcminal uno y cinco, en la anal dos y seis á sicte, y en la cau. dal dicz y sicte. En cuanto \& tamaño cxcede con mucho \& su congencre, y su peso puede llegar á doscientos cincuenta gramos.

DISTRIBUCION GEOGRÁFICA.-La acerina se ex. tiende por toda la Europa central, occidental y septentrio. nal; se presenta tambien muy abundante en Siberia. En Alc. mania no falta en ningun rio mayor, ni por lo general en las aguas dulces, á excepcion del alto $\mathrm{Rhin}$, porque le impide la cascada de este rio subir mas arriba; además escasea en las aguas de los Alpes.

USOS, COSTUMBRES Y REGIMEN. - Sus costum- 
bres se parecen á las de la perca de rio. Prefiere los lagos profundos y claros a las aguas bajas y corrientes, que visita sin embargo durante la época del desove en abril y mayo, trasladándose entonces habitualmente en bandadas; pero fuera de este tiempo suele vivir mas aislada. Le gusta permanecer en los rios y arroyos hasta cerca del otono, mas en invierno escoge aguas mas profundas, por cuyo motivo suele volver á sus lagos.

Para cogerla se ceba el anzuelo con lombrices de tierra y se usan redes de mallas angostas; se la pesca generalmente. en verano, pero en ciertos lagos, por lo contrario y con preferencia, en invierno. Respęcto de esto refiere Klein que una vez habian cogido en los alfaques cerca de Danzig debajo del hielo una cantidad extraordinatia de acerinas y de pequeños salmones hasta llenar con ellos seteciertas ochenta pipas. Segun Beerbohm se valen los pescadores de los alfa. ques de Kur de la cualidad especial que tiene la acerina de acercarse al oir ruidos fuestes para cogetla, á cuyo fin fijan cierto número de redes en diferentes direcciones, $y$ despues elevan cerca de ellas una pértiga muy larga en el fondo, en la que cuelgan un armatoste con muchos aros de hierro con los cuales hacen un gran ruido. Al oirlo, dicen, acuden las ace. rinas en tan gran número que du veces se cóge un pez por cada malla. Este pez, que tambien se emplea mucho como cebo, la desa parecido casi completamente de la costa de la Poinerania nueva anterior y la isla de Ruegen por la excesiva persecricion que alli ha sufrido; $y$ tambien ha llegado a ser raro en otras partes de Alemania; pero donde se le encuentra en grandísima cantidad es en los rios de la Siberia occidental. Su carne se paga poco, á veces solo diez jeniques y á lo mins un marco el kilógramo, pero es apreciada, teniendo fama de sabrosa y de sana.

Ia acerina es á propósito para la explotacion de estan. ques; verdad es que no se multiplica muchó y que crece con lentitud, pero no es exigente, es inofensiva y resiste mucho; cualidades que la lacen propia para la cria artificial.

\section{LOS SERRANOS-SERRANUS}

Entre los peces mas notables de esta familia tanto por la belleza de los colores, como por su exquisita carne, figuran en primera linea los serranos, que forman un grupo abundantisimo en especies, subdividido en extremo por algunos investigadores, y que se distingue por tener la aleta dorsal simple, el preopérculo aserrado, el opérculo armado de dos ó tres cspinas, los dientes de jresa largos y puntiagudos en medio de otros finos de cerda, y finalmente por estar cubierto de escamas hasta en el opérculo.

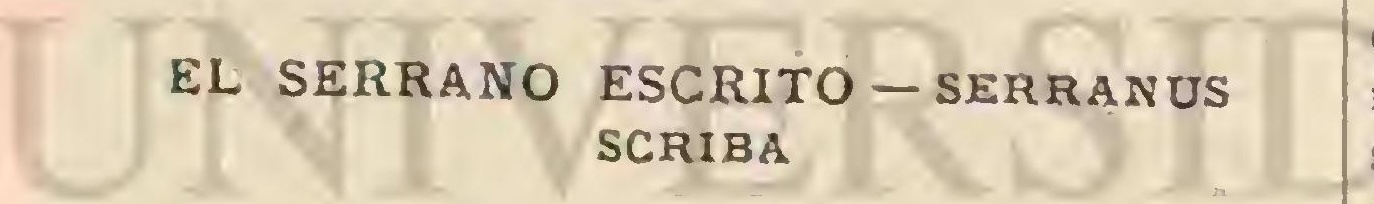

CARACTERES. - Una de las especies comunes es el serrano escrito, representante del género del mismo nombre y pez verciacieramente magnifico, que tiene de $\left(1^{\mathrm{m}}, 20 \leqslant 1\right)^{\mathrm{m}}, 30$ de longitud, y pesa de 300 \& 500 gramos. Lleva sobre un fondo rojo de ladrillo, mas oscuro cn ln région dorsal, fajas tras. versales anchas de color azul negruzco y dibujos imitandn caractéres de letra y curvas de color azul lapislázuli; la parte inferior es amarillenta; debajo de todo, sobre fondo amarillo, y muy particularmente en la mandibula inferior, se dibujan puntos encarnados, y cn las aletas, que son amari. llas, manchas orladas de rojo azulado. La aleta dorsal tiene diez. espinas punzantes y catorce blandas, la torácica de once a doce, la abdominal seis, la anal tres y siete y la caudal diez y sicte.
USOS, COSTUMBRES Y REGIMEN. - I.as costas perascosas del Mediterráneo abundantes en peces pequeños, cangrejos, $y$ sobre todo en crustáceos y cn las que hay agujecos á propósito para escondrijos son los sitios favoritos del serrano escrito; allí se les pesca á grandes protundidades todo el año para la venta en los mercados, pues su carne no cede en bondad à la de sus congéneres. Por lo demás, lo quie se sabe de la vida y particularmente de la propagacion de este pez es muy insignificante. Lo verdaderamente cu. rioso es que se le crejó mucho tiempo hermafrudita, porque se tomaba un apéndice blanco y glanduloso que tiene junto a los ovarios por los depósitos espermáticos del macho, hasta que un exámen mas exacto hizo ver el error. Un serrano escrito cautivo que cuidé bastante tiempo se compor. iaba en general como isuestra perca fluvial.

\section{LA ESCORPINA Ó POLIPRION PARDO -POLIPRION CERNUUM}

CARACTÉRES. - Un representante de las percas gigantes (polyprion) es la escorpina (fig. 124), pez marino de dos metros de largo $y$ de un peso de mas de cincuenta kilógra. mos. Los caractéres del género consisten en las espinas a manera de dientes en el preopérculo y opérculo, en una cresta afilada y bifurcada que corre à lo largo del opérculo, en la cabeza enteramente áspera, en las escamas pequeñas y ásperas, en sus dientes de cerda y de terciopelo que guarnecen los huesos de la mandíbula y los palatinos y en particu. lar la parte anterior del vómer.

La escorpina ticrie una longitud tres reces mayor que su altura; su color es un gris pardo, y cuando jóven tiene man. chas 6 vetas jaspeadas sobre fondo pardo; la cola cstá orlada de color blanquizco. Su aleta dorsal consiste en once radios duros y doce biandos, la torácica en diez y seis, la abdominal en uno y cinco, la anal en tres y nueve y la caudal en diez y sicte.

DISTRIBUCION GEOGRÁFICA.- Los antiguos, que se ocupaban de los peces con gran minuciosidad y que acer. ca de muchos de ellos sabian tanto como nosotros hoy dia, no mencionan la escorpina á pesar de no ser pez raro en las costas de Italia y de la Francia meridional. Solo Risso que lo describió reficre que habita principalmente en las costas pedregosas de Italia, pero en profundidades de mil metros; que se alimenta de moluscos y de peces pequeños, en especial de anchoas; que le atormentan ciertos entozoarios roji. zos; que su carne es exquisita por-lo cual se le tiene por un pez de los mas apreciados en aquel pais. Por investigadores mas nodernos sabemos que su área de dispersion es mas extensa de lo que se creia antes, y que no es de ningun modo raro en las costas de Inglaterra. \&La escorpina, dice Couch, se acerca \& las costas de Cornualles en cireunstancias muy especiales, siguiendo á los maderos de buqques naufragados en regiones meridionales, arrastrados por las corrientes. Se la ve jugar con sus compañeros al rededor de estos trozos de buque, y a veces sucede que huyendo unos de otros se echa alguno de ellos sobre la madera donde permanece en seco hasta que una ola le pone otra vez á flote; 5 como siempre se ven las escorpinas donde haya maderas cubiertas de con. chas, debe suponerse que estas y los moluscos constituyen su alimento predilecto. Sin embargo, cn muchas que se examinaron solo se encontraron peces pequeĩos; por esto puede ser tambien que estos últimos son los que siguen á las made. ras y que las escorpinas sigan a estos.y Lo cierto es que las escorpinas merecen su nombre aleman de pez náufrago; pues siempre se les encuentra junto á las reliquias de los naufra. gios. Ia tripulacion del buque Providence observó tambien 
un gran tronco de caoba, al cual se habian pegado dichos moluscos y que estaba rodeado de un gran número de estos peces, de los cuales cogieron cuatro ó cinco. El marino Nicholls vió asimismo durante una calma cerca de la costa de Portugal que un buque vicjo muy cubierto de conchas estuvo circuido dos semanas de percas gigantes. La tripula. cion aproveció la ocasion para alimentarse durante doce ó catorce dias principalmente con la carne de los peces que cogió.

\section{LOS PERCOFIS-PERCOPHIS}

CARACTÉRES.-Los peces que forman este género se asemejan en cierto modo ia primera vista $\$$ los esfirenas, de que hablaremos despues. El cuerpo es prolongado, la cabeza puntiaguda, la mandibula inferior prominente y los dientes ganchudos; pero la posicion yugular de las aletas ventralcs, y la longitud de la dorsal $s$ de la anal bastan para recono rer desde luego q̧ue estos peces constituyen un género dis. tinto.

\section{EL PERCOFIS DEL BRASIL-PERCOPHIS BRASILIANUS}

CARACTÉRES. - El percofis del Brasil (fig. 125), único representante del género, tiene el cuerpo prolongados cilin. drico; cabeza deprimida 5 larga, con la boca hendida hasta debajo del ojo; las dos mandibulas son algo puntiagudas por delante, sobresaliendo la inferior de la otra, que tiene en su parte anterior cinco dientes sólidos, ganchudos y rematados en punta, además de los aterciopelados, que en su mayoría son compactos, delgados y puntiagudos; los del vómer for. man por delante un ancho triángulo, y en cada palatino constituyen una faja, que presenta en su borde externo una serie de otros mas finos, tan comprimidos como los del in. termaxilar; la mandibula inferior ofrece tambien una linea de dientes puntiagucios. El preopérculo es redondeado, y su hueso carece de dientes, pero su borde se ensancha un poco por una pequeña membrana fina $y$ dentada; el opérculo husesoso termina en punta plana; los oidos ofrecen mucha hen. didura. La aleta pectoral es obtusa; la ventral algo corta; la primera dorsal comienza en el centro de la pectoral, $y$ sus primeros radios, que son los mas elevados, tienen la altura del cuerpo; la segunda se continúa hasta muy cerca de la calldal; la anal es mucho mas larga; la caudal está guarneci. da en su base de escamas pequeñas; toda la cabeza está protegida tambien por ellas, excepto las mandibulas y la mem. brana de las branquias.

Eil percofis es de color gris pardo oscuro en las regiones superiores del cuerpo, y de un gris plateado en las inferio. res.- Mide unas doce ó catorce pulgadas por lo regular.

DISTRIBUCION GEOGRÁFICA.-Fsta especie se en. cuentra en las costas del Brasil, á lo cual debe el nombre con que se la designa.

\section{LOS SILAGOS - SILLAGO}

CARACTÉrES.-Se ha designado con este nombre un género de percidos del mar de las Indias que se reconocen por su cabeza de forma cónica, por su boca pequeña, guarnecida de labios carnosos, y por tener dos dorsales contiguas, siendo los radios de la primera bastante delgados y la segunda un poco alta. La mandibula superior es algo protráctil ; la inferior tiene sus articulacion fuerte por deiante del ojo, y ambas están guarnecidas de dientes aterciopelados, presentando algunas veces una linea exterior de otros que son cónicos: tambien los hay delante del vómer. El opérculo termina en una punta bastante aguda; el preopér. culo dentado en su borde montante se encorva por debajo: en los oidos se cuentan seis radios. Fl cuerpo, ligeramente comprimicio, está cubierto de escamas medianas y un poco oblicuas.

\section{EL SYLAGO SEÑORA-SILAGO DOMTNA}

CARACTERES. - Se ha designado esta especie con el nombre que lleva porque su carne agradaba mucho á la se ñora de la Bourdonnaye, esposa del célebre gobernador de Pondichery; y este mismo calificativo se ha conservado hasta aquí.

El silago señora (fig. 126) tiene los ojos mas pequeños, los dientes de la linea exterior fuertes, el hocico ancho $y$ deprimido, y todas las formas prolongadas, sin coutar el largo filete que forma el segundo radio de su aleta dorsal. El ho. cico, plano y obtuso, tiene el contorno horizontal parabóli. co. Las aletas pectorales son puntiagudas y constan de quince radios; las ventrales una tercera parte mas cortas; y la anal tiene dos espinas y veintiseis radios blandos. Este pez es de un color pardo uniforme con un reflejo amarillento. El tamaño varia de 12 á I 4 pulgadas.

DISTRIBUCYON GEOGRÁFICA. - Este curioso pez se encuentra en varios puntos desde el mar Kojo á la costa de Australia; existe en todas las aguas de la India, asi como tarnhien en la bahia de Bengala y cerca de la embocadura del Ganges.

UTILIDADES. - Iambien es muy apreciada la carne de este pez, por ser muy digcrible y sabrosa.

\section{LOS MÚLIDOS-MULLIDE}

CARACTERES. - Todos los mares de las zonas tórrida y templada de ambos henisferios albergan peces de forma hermosa que han recibido el nombre de múlidos. Su cuerpo, poco comprimido por los costados, es oblongo: la parte del hocico tambien prolongada; la boca, situada muy abajo, es pequeña, la dentadura variable, comunmente formada de dientes fiojos; la barba, $\delta$ sea la sinfisis de la mandibula, dotada de dos barbillas 6 prolongaciones á manera de ten. táculos, mas $\delta$ menos largas é insertas en el extremo anterior del hueso lingual; la parte anterior de la cabeza y el cuello desnudos y el resto de aquella así como todo el cuerpo cubierto de escamas finamente aserradas; el borde del preopérculo de las branquias cicloideo ó sea liso, el posterior provisto de un operculiso; la membrana branquióstega que cuenta \& lo mas cuatro radios, está partida hasta el extremo anterior del inter.opérculo; la aleta dorsal anterior va inserta en una ranura y protegida por radios espinosos, $y$ la posterior por radios mas blandos; semejante í esta última es la estruc. tura de la aleta anal; la caudal, bifurcada, con quince radios, está cubierta de escamas hasta muy cerca del extremo pos. terior; la alcta abdominal se halla situada muy adelante, por manera que casi viene á caer debajo de la torácica; y el color que predomina es un hermoso y pálido carmin. I a cstructura interior es mus sencilla; el estómago no viene á ser mas que una dilatacion del esófago; el tubo digestivo no es muy largo; el higado grande y dividido en dos lobulos desiguales; el piloro circuido de muchos apéndices, y falta la rejiga natatoria.

USOS, COSTUMBRES Y REGIMEN.-Los múlidos, como peces en extremo sociables, se presentan en bandadas numerosas, por lo comun compuestas de inillares de indivjduos, haciendo pocas correrias, pero visian en lo mas fuerte 
del verano los sitios arenosos y llanos de la costa, á menudo en cantidad innumerable, para desovar alli.

Buscan su alimento que parece consistir en pequeños can. grejos y moluscos como tambien en materias animales y ve. getales en putrefaccion, registrando el limo, operacion que hacen en posicion horizontal, pero metiéndose frecuentemente tan adentro que enturbian el agua hasta grandes dis. tancias en sitios donde no es muy profunda. Muchos peces rapaces son un constante peligro para estas especies propor. cionalmente pequeñas, pues siguen sus bandadas semanas enteras. El hombre los persigue tambien en todas partes, cogiéndolos en grandes cantidades en redes de mallas estre. chas. Su carne es muy apreciada, y si acaso se la desceña un tanto es despues del tiempo de la freza.

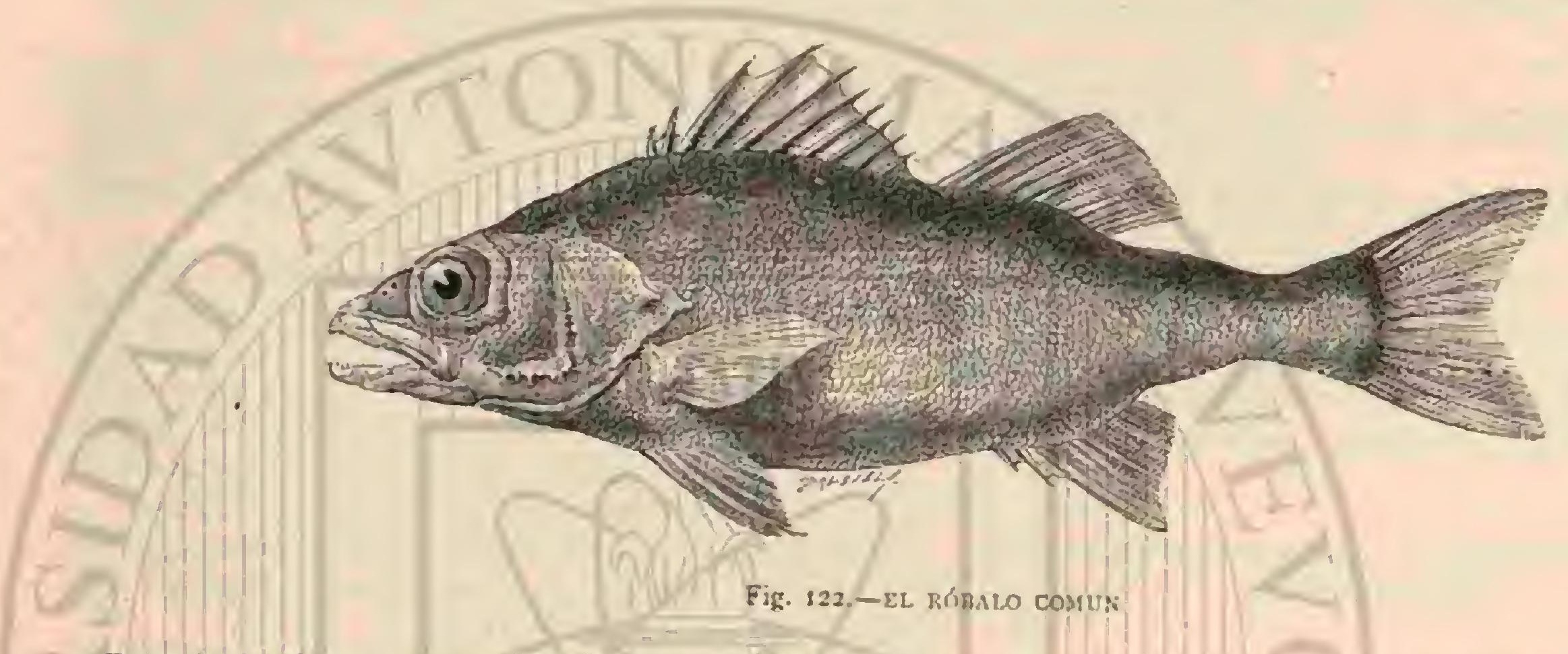

Entre los antiguos romanos gozaban los múlidos de la mayor estima, no solo por su deliciosa carne, sino tambien por su maguifica coloracion «Ia carne de éstos animales,

dice Gessner al trascribir los relatos antiguos, se tiene en grandísimo aprecio, tanto que en ciertas épecas se han com.

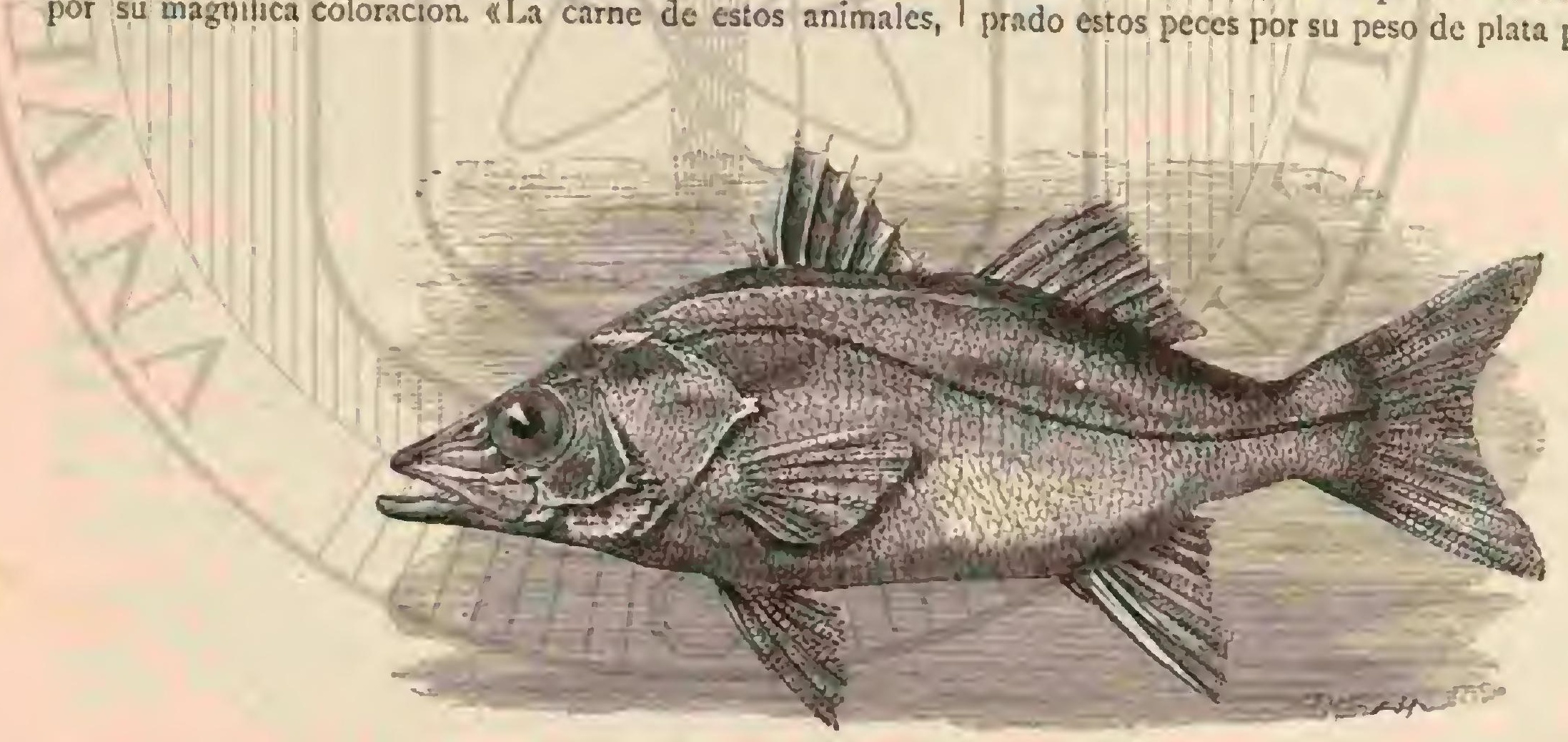

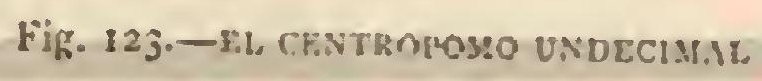

son apreciadisimos por su carne, sino tambien para recrear In vista en ellos, con cuyo objeto los colocaban vivos en vasijas trasparentes de vidrio y bien cerradas para observar cómo jerecian, pues maravillan en efecto a causa de los cam. bios sucesivos del hermoso color de sus escamas hasta su definitiva muerte Para recrear la vista de los convidados se ponian en el comedor múlidos en vasijas de vidrio, dándo. los despues á las mujeres que los dejaban espirar en sus manos con objeto de contemplar el cambio mencionado de sus colores. Primero se observaban sus movimientos en las vasi. jas provocando este espectáculo grandes caclamaciones de admiracion; despues se llamaban mutuamente la atencion sobre cl color encendido de sus escamas y d brillo de las agallas; $y$ cuando habian muerto se corria á llevarlos á la cocina sin perder un momento para guisarlos, porque el múlido cogido por la mañana no se consideraba fresco si habia muerto ya; por esto era preciso que los convidados los hubiesen visto vivos. $\mathbb{i}^{\mathrm{Nada}}$ más bello, exclama Séneca, que un múlido moribundo! Se defiende contra la muerte que se le accra, y estos esfuerzos difunden por su cuerpo el mas hermoso color de púrpura que va cambiando despues en una palidez general $y$ pasando por todos los matices mientras dura la agonia.s

Los múlidos dieron motivo á que se estableciesen debajo de las camas sobre las que estaban echados los convidados, depósitos expresamente hechos para peces, los cuales comu. nicaban con estanques situados en el exterior en los que se guardaban las provisiones. Con frecuencia se traian múlidos grandes desde mares muy distantes, guardandolos por de pronto en los estanques, si bien no resistian mucho su cauti. verio, pues de muchos miles apenas quedaban unos cuantos vivos. Ciceron censura á los romanos por semejantes pucrili. dades, diciendo que los ricos se figuraban tener el cielo co. gido con las manos cuando en sus estanques tenian málidos que acudian al llamarlos su amo. A consecuencia de este capricho, yagábanse por ellos precios increibles. Un múlido que pesaba un kilógramo costaba mucho dinero; uno de ki. logramo y medio excitaba la admiracion general; y uno de 
mas de dos kilógramos, no habia dinero con que pagarlo. Respecto de estos precios tenemos datos exactos, porque Séneca refiere que Tiberio movido de avaricia habia manda. do á la plaza un múlido de aquel peso, que le habian regalado, designando el mismo á los compradores; y efectivamente Apicio y Octavio, los dos gastrónomos designados por él, pujaron á porfia; Octavio tuvo la inmensa gloria de quedarse por el precio de cinco mil sestercios ó sean aproximadamente mil marcos de nuestra moneda ( 5,000 reales), un pez que rendia el emperador y que Apicio era incapaz de pagar. Juve- nal habla tambien de un múlido que fué comprado por seis mil sestercios; verdad es que pesaba casi tres kilógramos.

En tiempo de Caligula compró Asino Celer, segun refiere Plinio, uno de estos peces por ocho mil sestercios; i pero qué mas! el valor fué subicndo hasta que Tiberio se creyó obligado á publicar leyes expresas destinadas a regular los pre. cios de los comestibles en los mercados. Segun opinion de los romanos, pasaba el múlido por el mejor de todos los pe. ces, y la cabeza e higado por la golosina mas delicada de cuantas se conocian; pero este concepto no era mas que

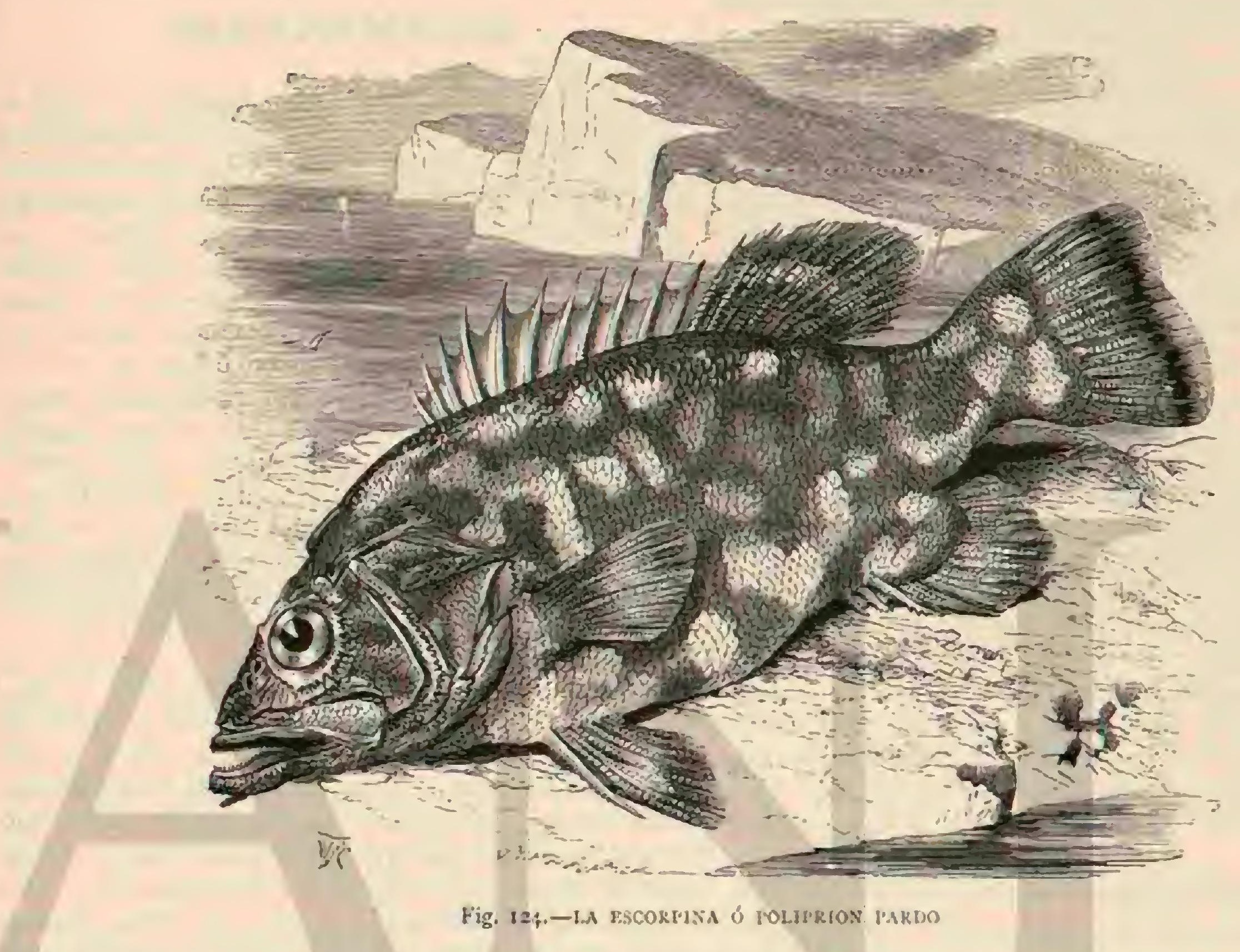

puro capricho de la moda, porque mas tarde se perdió com. pletamente.

\section{LOS SALMONETES-MULLUS}

CARACTERES. - I OS salmonetes encarnados, que los antiguos apreciaban tanto, se distinguen por la falta de dien. tes en la mandíbula superior. En las aguas europeas se cono. cen dos especies de este género: el salmonete de barbas y el salmonete de listas 6 el de roca y el de fango.

\section{EL SALMONETE DE BARBAS-MULLUS BARBATUS}

CARACTÉRES.-Esta especie se distingue por su frente casi vertical y sus escamas proporcionalmente estrechas. Alcanza de 0,30 a $0^{\circ}, 40$ de largo y tiene un color de carmin igual, con brillo plateado en la parte inferior; las aletas son amarillentas. En la primera dorsal se cuentan sicte radios, en la segunda uno y ocho, en la torícica diez y seis, en la abdominal seis, en la anal uno y seis y en la caudal quince.

\section{EL SALMONETE DE LISTAS-MULLUS SUR- MULETUS}

CARACTERES.-Este salmonete (fig. 12g) tienc á poca diferencia un tamano igual al anterior; está cubierto de es. camas grandes y lleva sobre un fondo hermoso encarnado pálido tres listones de oro muy marcados en especial en el tiempo de la freza; las aletas son encarnadas; las abdominales y caudales enrarnario amarillentas, por lo comun con dos fajas amarillas ó pardas; la primera aleta dorsal tienc siete radios, la segunda uno y ocho, cada torácica dier y sietc, la abdominal uno y cinco, la anal dos y seis y la caudal trece.

DISTRIBUCION GEOGRAFICA. - Iil salmoncte de barbas pertenece al Mediterráneo habitando en iodas partes donde el fondo es arcilloso ó limoso; se encuentra tambien en el Atlíntico á lo largo de la costa francesa, pero raras veces se coge en la proximidad de Inglaterra; por cl contrario, el de listas qque habita igualmente en el Mediterráneo donde se presenta en varios puntos con mayor frecuencia aun que su congénere, se extiende desde alli hácia el norte hasta Inglaterra en cuyas costas se presenta a veces en gran número. Se le encuentra, segun Yarrell, en las capas mas diferentes del mar. Muchos se cogen en la superícic con redes empleadas en la pesca de caballa, pero la mayor parte se ha de pescar á gran profundidad.

USOS, COSTUMBRES Y REGIMEN.-En Cornualles se aproxima durante el verano en gran número á las costas, pero vuclve al acercarse el invierno á mayor profun. didad, donde se le coge rara vez. La época del desove de estas especies es en la primavera, y á fines de octubre se 
encuentran ga hijuelos de $0^{ \pm}, 12$ de largo. Parece que su alimento consiste en cangrejos blandos y diferentes moluscos; para encontrarlos le prestan probablemente muy buen servicio sus barbillas. El salmonete de barbas, asegura Oppiano, come con aficion todo lo que se pudre y hiede en el mar, particularmente los cađáreres de náufragos; por esto se le pesca con cebo podrido y se le compara con justicia con el cerdo que vive al igual de él de cosas asquerosas, á pesar de lo cual tiene una carne excelentes

Alguna vez sucede que en Inglaterra se hace una abundan te pesca cogiendo tan estimados múlidos en gran cantidad; como acontecí en Weymouthbay donde se cogieron en una sola noche, el \& de agosto de 1819 , cinco mil múlidos, y tambien en Yarmorth en el mes de mayo de $185 \mathrm{r}$, desde cuyo punto se cnviaron en una semana a la pescadería de Ióndres diez mil de estos peces. En Italia se cogen ambas especies de múlidos todo el año con redes, nasas y anzuclos que se celan con colas de cangrejo. Siendo positivo que estos peces despues de cogidos se echan a perder muy pronto, suelen hervirlos inn luego como los han sacado del agua, y espolvorearlos con harina, quedando de este modo envueltos en una pasta en cuyo estado son expedidos, exactamente como se hacia siglos atrís. ISus partes interiores se corrompen en muy corto ticmpo, por cusa razon no se los guarda mucho ni se les envia léjos del mar, sino que suelen meterlos en pasteles ó cortas bien espolroreados con espe. cias y asi los envian a las ciudades.

Pasan en el dia por los mejores múlidos los cogidos en las costas de Provenza, en especial en las cercanias de Toton, pero tambien en Italia tiene razon el adagio que dice: "No come el pez el que lo coge.

CAUTIVIDAD.-Guardados en un recinto estrecho se conservan los múlidos cautivos, pero hay que conservarlos en un estanque de agua de mar acondicionado y abundantemente alimentado. Se conoce que los romanos sabian esto muy bien, pues Marcial exclama:

Perezoso respira el múlido barbado en agua salada y quieta.

- ¿Se va muriendo? pues dale la mar viva, y estará lleno de vigor.:

\section{LOS UPENEOS - UPENEUS}

CARACTERES,-Los mares de los paises cálidos alimentan muchos múlidos que, cosa notable, conservan todos los caractéres que acabamos de indicar, lo mismo en las. In. dias que en la América. Tienen dientes en la mandíbula su. perior $y$ en la inferior; su vómer no los tiene en forma de enladrillado; pero en algunos individuos se ven dos peque. nos grupos de otros pequeños, y á veces en los palatinos. Su opérculo termina comunmente en punta aguda, y los mas tienen una gran vejiga natatoria, mientras que los múlidos de Europa carecen de ella, siendo de notar que varias especies alcanzan un gran tamaño.

\section{EL UPENEO DE TRES FAJAS-UPENEUS} TRIFASCIATUS

CARACTERES.-El upeneo de tres fajas (fig. 12S) se distingue principalmente por el carácter que le da el nombre: la frente cs conbada; las barbillas se prolongan bastante, pasando del opérculo; el sub-orbitario presenta muchos poros pequeños, que forman varias líneas; la punta de la segunda dorsal es bastante aguda, y los arbúsculos de la linea latera! no muy ramosos. El color dominante de este pez es negro: detrás del ojo hay una mancha oblonga del mismo tinte; en la cola se ve una ancha faja; otra parte desde la frente hácia la primera dorsal, y en la segunda se halla la tercera. Entre estns fajas son las escamas blancas ó amarillas; la anal está adornada tambien de listas negras. El upeneo de tres fajas ticne unas 12 pulgadas de largo.

DISTRIBUCION GEOGRÁFICA.-La especie existe en los nares de la India, en las costas de China, Amboina, Célebes y Ceilan. Se encuentra igualmente en las islas de Sandurich y en las Carolinas.

\section{LOS ESCAMIPENES- SQUAMIPINNES}

CARACTERES. - Toda la magnificencia de colores de las regiones equinocciales se reune en la familia de los es. camiperies ó feces de aleta essamosa. Su cubierta compite en hermosura con las de los pájaros de mas brillante plumaje y de las mariposas de colores mas abigarrados. Adornan el mar como los colibris $y$ las aves del paraiso las selvas virgenes; solo que sus colores parecen ser todavia mas puros y brillantes, así como en su distribucion se nota una admirable regularidad. Sobre fondo de purisimo oro 6 plata se destacan manchas, cintas, listas y anillos azules, lapislázuli, purpú. reos, negros aterciopelados; on las escamas de estos animales se ha copiado el azul del cielo meridional y el azul ultmmarino de las olas del mar; en ellas se refleja el delicado color de las rosás y del arco iris con todos sus matices. A la her. mosura s magnificencia de los colores, a la elegancia y va. riedad del dibujo, se agrega una forma singularísima para nosotros; habitantes del norte, completamente extrañ.

El cuerpo es compritnido lateralmente de un modo extraordinario, y en cambio ensanchado hícia arriba y abajo; de consiguiente prolongado $\delta$ redondo como un disco; las aletas dorsal y anal forman en cierto modo parte de este dis. $c 0$, estando la cabeza, al igual del cuerpo, cubierta de esca. mas á menudo prolongadas y exageradas de la manera mas extraña, y notables además por sus espinas duras $\delta$ prolongadas, de suerte que en rigor solo quedan las aletas torácicas, la caudal y la abdominal, pudiendo esta última además ser reemplazada por una sola espina 6 aguijon, parecido $a$ la forma usual y comun. Ia cabeza termina comunmente en un hocico 6 trompa con boca muy pequeña, que en algunas especies se prolonga en una especie de pico, mientras quue en otras apenas sobresale del perfil del cuerpo. Predominan los dientes de cerda, pero tambien se presentan a veces dien. tes de carda ó de terciopelo en su lugar, llevándolos asimis. mo la region palatina. In estas diferencias de la dentadura se han buscado las bases para dividir esta familia, exiraordi. nariamente variada, en distintos grupos. Además ofrecen im. portantes caractéres para los diferentes grupos la configura. cion misma, la forma de la boca y de las aletas, y hasta en
algunos la de los huesos.

Ia escasez de datos sobre la vida y costumbres de cstos notabilisimos peces, aconsejan pasar primero revista it los géneros y especies mas importantes, y despues reunir en una sola la descripcion de la vida y costumbres de todos los es. camipenes con réerencia especial á las especies sucltas.

\section{LOS QUETODONES-CHETODON}

CARACTÉRES.-Linneo reunió todos los escamipenes, de los cuales se conocen ahora como unas ciento treinta es. pecies, con el nombre de peces de dientes cerdasos ó yuelodo. nes. Hoy se comprende bajo dicho nombre un solo género, aunque a la verdad muy abundante en especies. Los rasgos 
caracteristicos de las especies que ál pertenecen consisten en su cuerpo de forma ovalada con hocico de trompa; en su boca pequeña y nada saliente, cuyas mandibulas llevan dien. tes cerdosos muy apiñados y encorvados hácia atrás; en sus preopérculos cubiertos de escamas al igual que los costados de la cara 6 indefensos; en la aleta dorsal achatada que recorre todo el lado superior y cuya parte anterior sostienen radios espinosos robustos; en la aleta anal redondeada, la caudal recortada en linea recta y de mediana longitud, y en las escamas grandes y finamente aserradas, lisas en su borde posterior ó sea cicloideas.

\section{EL QUETODON SEDOSO - CHATODON SETIFER}

CARACTÉRES. - Pé bandera llaman los pescadores árabes del mar Rojo á una especie de este género, extendida por todo el Occano Indico y por el Pacifico occidental. Sobre un fondo blanco mate corren en diferentes direcciones fajas oscuras: una faja negra orlada en su borde posterior de blanco y que se ensancha desde la region cervical al través del ojo hasta el cucllo; otras cinco ó seis de color negruzco que corren oblicuamente desde arriba hácia la region

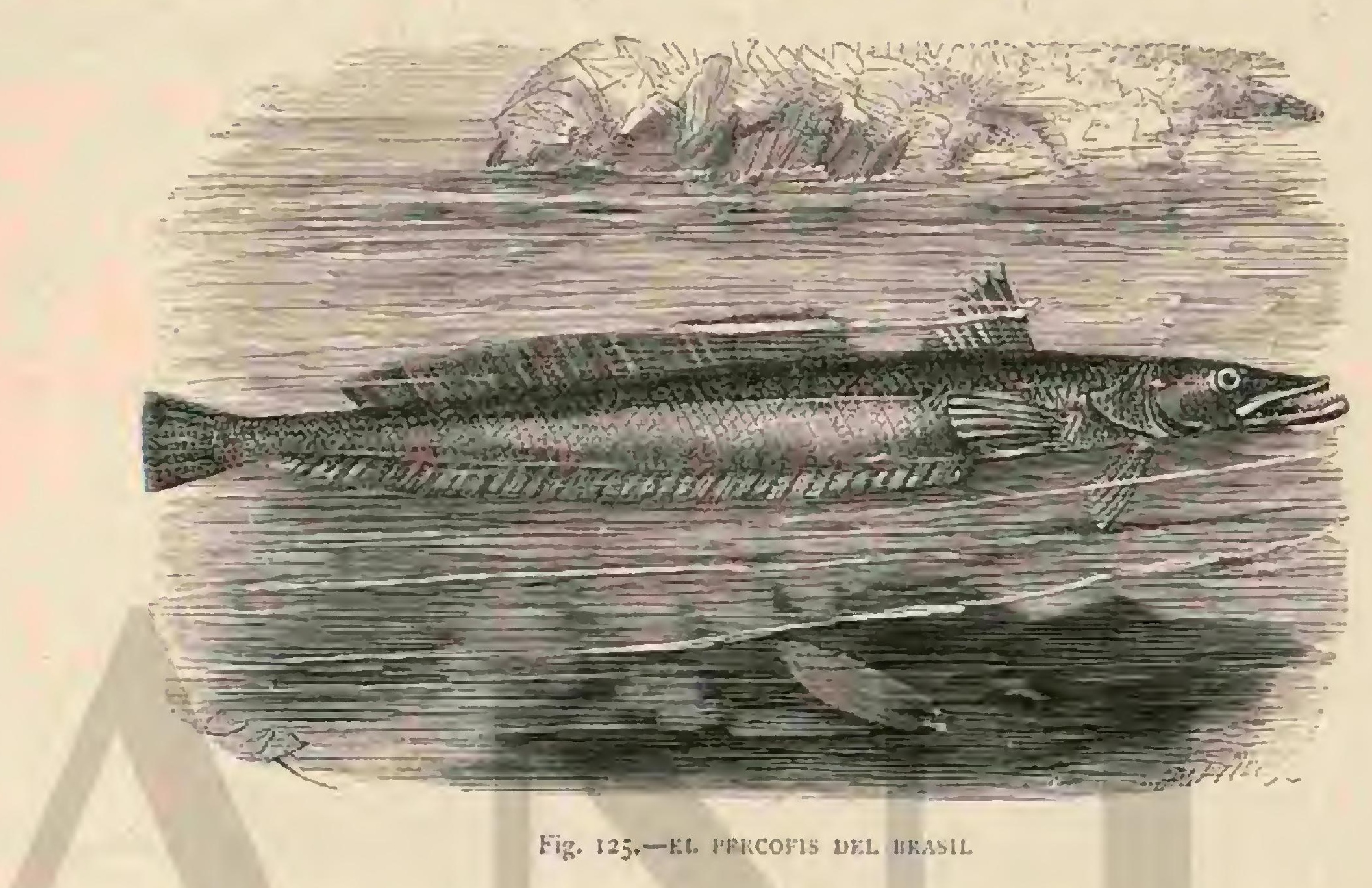

posterior; otras ocho hasta diez colocadas casi en ángulo recio con las anteriores que tambien se dirigen desde la par. te anterior hácia la posterior; $y$ además cuatro lincas trasver. sales de color de naranja que adornan la region encima del ojo. La parte posterior de la aleta dorsal, que a menudo ostenta una mancha negra orlada de blanco, es de color de limon y hácia arriba rojo cncendido y orlada de negro; la caudal es de color de limon hermoseado hácia atrás y al re. dedor del borde de color blanco gris rojizo con un cinturon fusiforme pardo oscuro con orla negra; la aleta torácica y la abdominal son de un blanco gris rojizo. La dorsal contiene trece radios espinosos y veinticinco blandos, la anal tres espinosos y veinte blandos, la torácica diez y seis, la abdominal seis y la caudal diez y siete. Su longitud es de $0^{\mathrm{m}}, 20$.

\section{EL PEZ CORAL-CHATODON FASCIATUS}

CARACTERES. - Este quetodon alcanza una longitud de $0^{*}, 16$ próximamente. El fondo blanco de la cabeza se halla adornado de una ancha lista negra sobre los ojos, la cual se extiende desde el occipucio hasta el preopérculo; y el cuerpo ostenta sobre fondo amarillo vivo de nueve á doce franjas negras parduscas que corren oblicuantiente de delante atrás hasta perderse en las aletas, que son amarillas; los la bios son de color de rosa; las alctas blandas dorsal y anal tieren un borde negro, $y$ la primera además sobre la base de insercion una banda arqueada negra pardusca; la caudal tiene hácia su extremo un dibujo trasversal negro y lenticu lar. Doce radios duros yo veinticinco blandos sostienen la alcta dorsal, $y$ tres $y$ diez y nueve la anal.

DISTRIBUGION GEOGRÁFICA. - Esta especic se halla desde el mar Rojo hasta China.

\section{EL QUETODON DE FAJAS-CHATODON VITATUS}

CARACTERES - Histe quetodon, que tiene $0^{\circ}$, II de largo, ostenta sobre fondo color de limon unas trece fajas longitudinales negruzcas; en la cabeza otra sobre los ojos, ancha $y$ arqueada, $y$ detrís otra mas angosta; en la frente de tres a cuatro lineas trasversales negras como aqquellas y como la boca; la parte blanda de la aleta dorsal, de color amarillo, está adornada con una lista negra en el borde y una orla de color de naranja; la aleta anal, que es negra, está hermo. seada por una lista amarilla clara que corre á lo largo de la raíz, y tiene una orla de color de naranja; por fin la caudal, negra tambien, presenta un borde ancho de color de rosa. Trece radios duros y veintiuno blandos sostienen la espina dorsal, y tres y diez y nueve la anal.

DISTRIBUCION GEOGRÁFICA.--Este hermoso pez babita desde el Africa occidental hasta Taiti.

\section{LOS QUELMONES - CHELMO}

CARACTERES. - Difieren los individuos de este géneto de los del anterior principalmente por su hocico muy salicnte en forma de pico, hendido horizontalmenie en su parte an. terior.

\section{EL QUELMON LONGIROSTRO-CHELMO IONGIROSTRIS}

CARACTERES. - Este quelmon alcanza una longitud de $0^{\circ}, 15 a^{\prime \prime}, 25$, de los cuales corresponde la quinta parte 
al hocico. La coloracion es de un amarillo limon muy hermoso, y el dibujo consiste en una mancha triangular de co. lor negro pardusco, con una punta dirigida hácia el hocico, otra á la espalda y una tercera á la cola Los lados de la cara $y$ la frente son de color gris plateado, las partes blandas de las aletas dorsales $y$ anales están orladas de negro pardusco, y la primera lleva además una mancha negra orlada de blanco, semejante á un ojo hácia su borde posterior. Èn

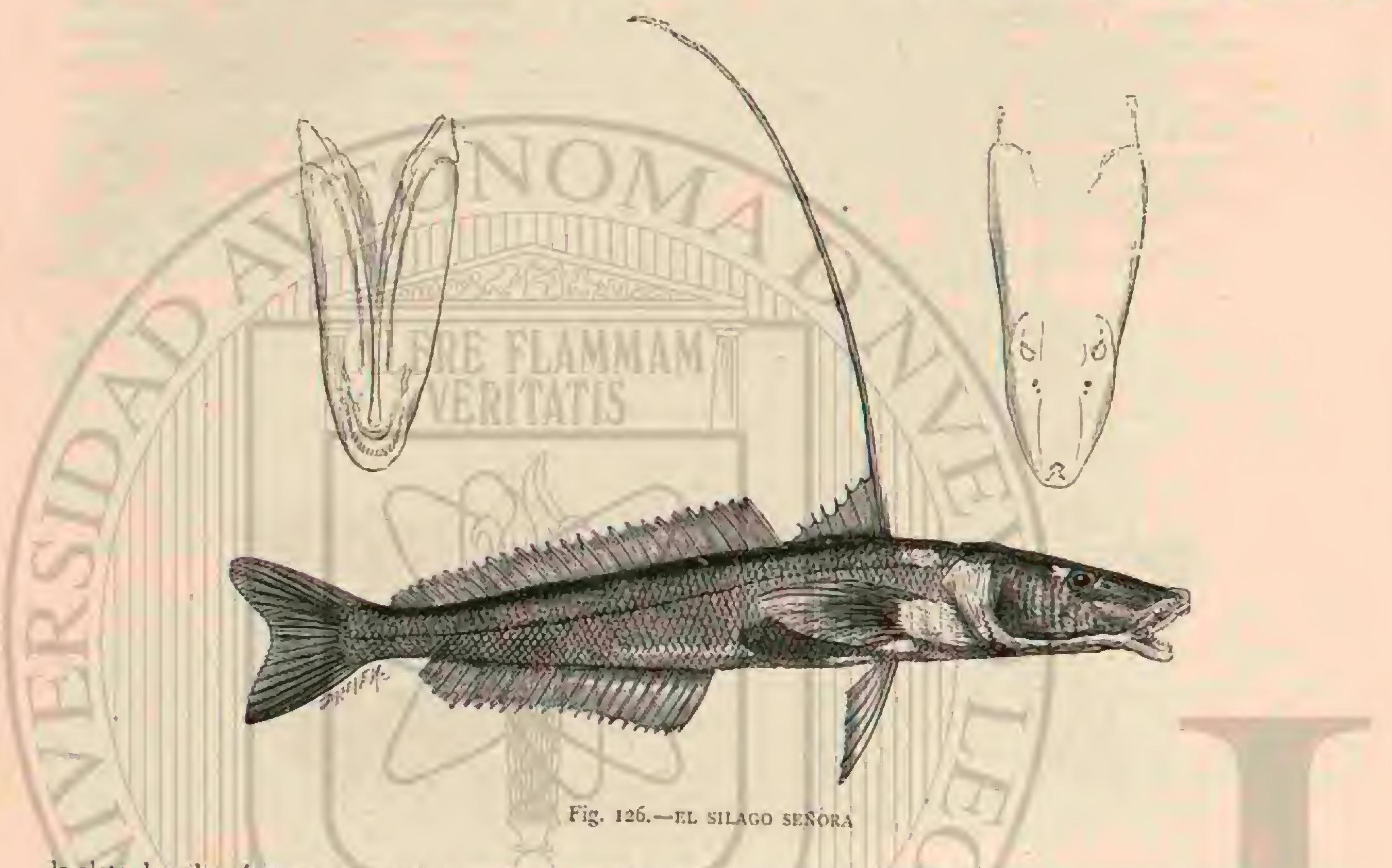

la aleta dorsal cuéntanse doce radios espinosos y veintidos y tambien la abdominal contiene radios trasformados en es blandos; en la anal ties radios duros y diez y ocho blandos, 1 pinas.

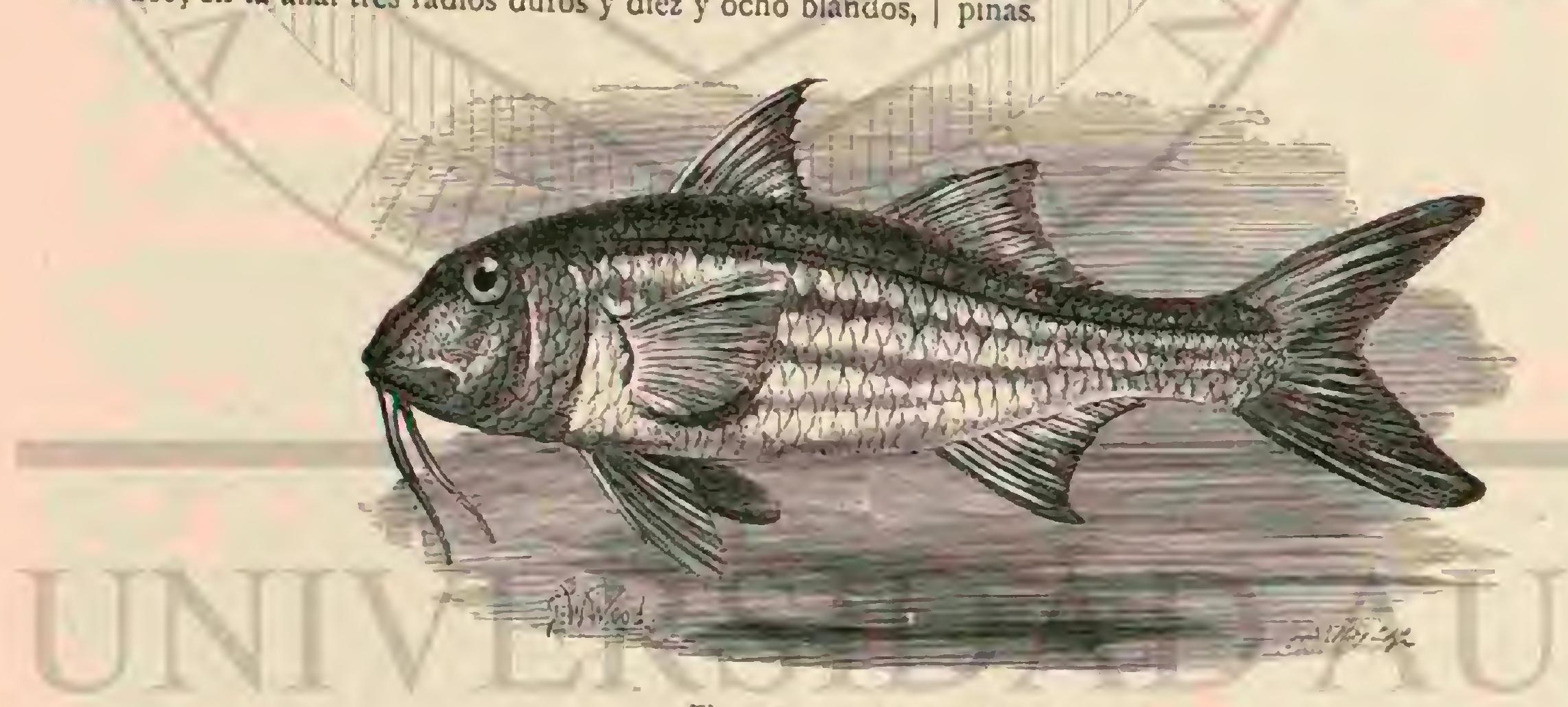

Fig. 127. -8.L SALMONGTE DE B.15TAS

DISTRIBUCION GEOGRÁFICA. - Su área de disper. sion se extiende desde la isla Mauricio hasta la Polinesia.

\section{LOS HENIOCOS-HENIOCHUS}

CARACTEREs. - Los de los feres láfiges ó heniocos consisten en la prolongacion extraordinaria del cuarto radio dorsal, y en la trompa corta; la boca lleva dientes cerdosos.

\section{EL HENIOCO AZOTADOR-HENIOCHUS MA- CROLEPIDO'TUS}

CARACTERES, - Como representante de esté grupo se admite al asotador, que tiene $0^{4}, 24$ de longitud. El color que predomina es amarillo tirando á gris que en el pecho y la garganta pasa a blanco un tanto plateado; la cabeza es, ya toda, ya en parte, negra, los lados de la boca claros, la region maxilar oscura. Corren por todo el cuerpo y las aletas corréspondientes dos fajas negras oblicuas; la una desde la nuca al vientre y la otra casi paralela, pero colocada mas hácia atrás, desde la quinta hasta la octava espina dorsal á la par. te posterior de la alcta anal. Las aletas son de un color de limon alli donde no corresponden á las fajas negras. Once $y$ veinticinco radios sostienen la aleta dorsal, tres y diez y seis la anal, diez y siete la torácica y otros tantos la caudal. 
DISTRIBUCION GEOGRÁFICA.-Este pez habita todo el Océano Indico.

\section{EL HENIOCO UNICORNIO-HENIOCHUS MONOCERUS}

CARACTERES. - Por sus formas y el nuimero de radios no difiere el henioco unicomio (fig. 129) de la especic comun; pero tiene en el centro de su cresta frontal una saliente có. nica, obtusa, y del todo característica. I.os colores negro y blanco no están distribuidos completamente del mismo modo; una faja parda ocupa toda la cresta anterior del cráneo; despues hay otra trasversal pálida; todo el hocico es de este tinte sobre la órbita, excepto los labios; la gran faja anterior del tronco termina como en la especic comun, y la segunda no remonta sobre la dorsal ni ocupa la parte posterior del tronco. El henioco unicornio viene á tenar unas siete pulga. das de largo.

DISTRIBUGION GEOGRÁFICA.-Donde mas se ha visto este pez es en las aguas de la isla de Francia.

\section{LOS EMPERADORES-HOLACAN- THUS}

CARACTÉRES.-Los cimperadores difieten de los peces de dientes cerdosos $\delta$ quetodones por una espina ó aguijon saliente, envuelto en una vaina membranosa y situado en el ángulo del preopérculo. Los dientes son mas voluminosos, mas resistentes y tienen la punta vaciada á manera de cuchara; las aletas dorsal y anal cstán cubiertas completamen.

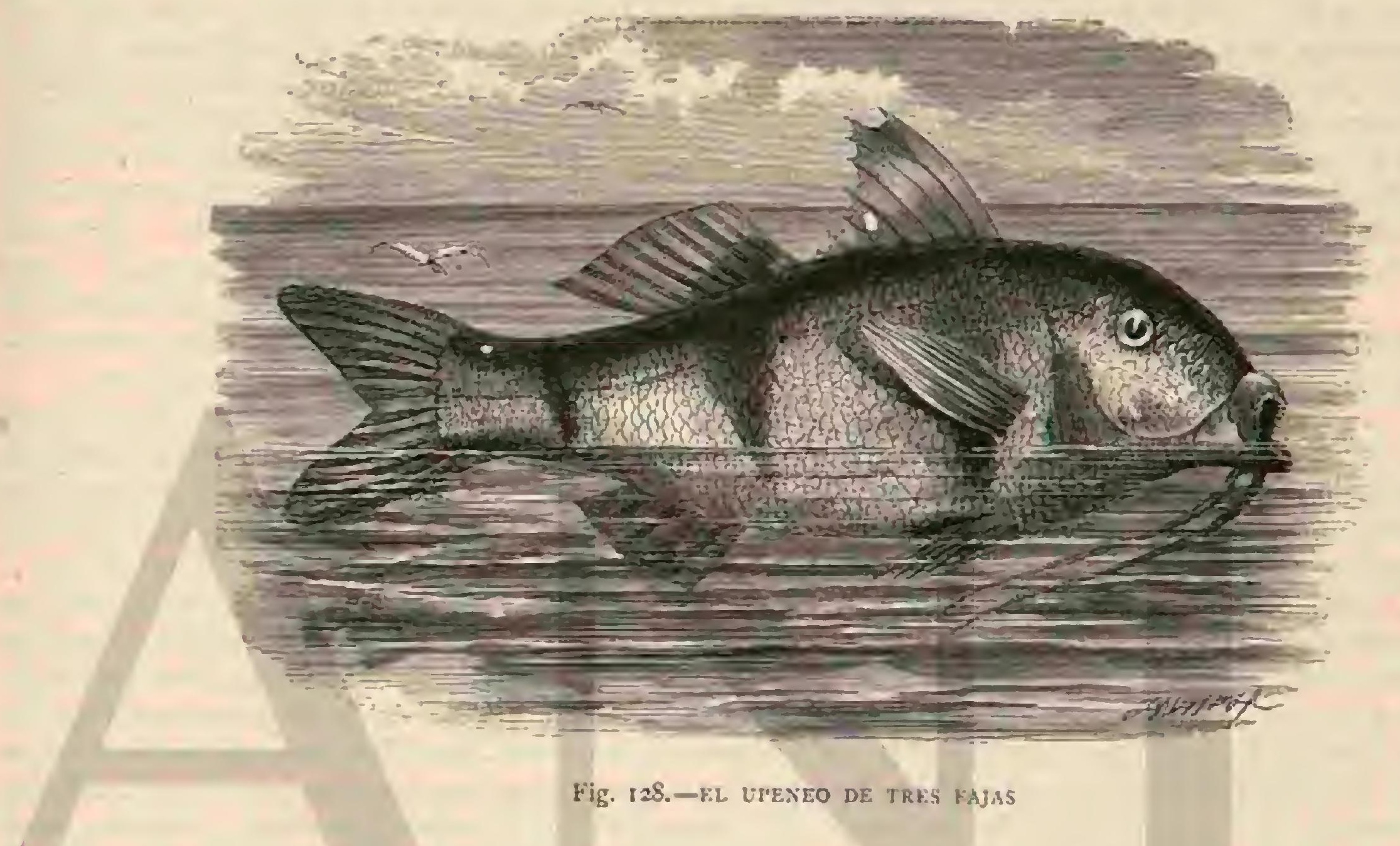

te de escamas, teniendo aqquella de doce á quince, y esta de tres á cuatro radios.

\section{EL HOLACANTO DUQUE-HOLACANTHUS DIACANTHUS}

CARACTERES. - El dugue alcanza una longitud de $0^{m}, 20$. El color del fondo es amarillo de limon con ocho hasta nueve fajas trasversales de color azul pálido y bordes anchos y negros, que á veces están bifurcadas; la parte superior de la cabeza ofrece un dibujo magnifico de líneas azu. les longitudinales y trasversales; otra linea azul rodea el ojo, y otra baja por el borde del preopérculo. Las aletas torácica, abdominal y caudal son de color amarillo de limon; la parte blanda de la aleta dorsal es pardo oscura, salpicada en el borde de negro y azul, y en el resto de este último color; la alcta anal, que es parda, está-adornada de seis dt siete listas trasversales, arqueadas, de color pardo claro. Catorce radios duros y diez y nueve blandos sostienen la aleta dorsal, y tres y diez y nueve la anal.

\section{EL HOLACANTO EMPERADOR - HOLACAN- THUS IMPERATOR}

CARACTERES. - Mas brillante que el anterior es el emperador. Una cinta negro pardusca orlada en sus extreTosso V mos de azul claro adorna la frente y los ojos sobre fondo amarillo azufre sucio como color de la cabeza; una mancha grande y oblonga completamente negra, pero orlada de ama. rillo, se destaca por encima de la aleta torácica sobre el fondo azul-violeta del cuerpo, y causa, junto con las listas longitudinales $y$ asqueadas de color amarillo que adornan los costados, un efecto magnifico. El, vientre y el pecho son pardo-rerdosos; las aletas azuladas, pero los radios mas claros 6 mas oscuros desde el anaranjado al negro; la alcta abdominal es parda y adornada de lineas longitudinales arquea. das y azules; la anal, de color de naranja, tiene una orla mas clara.

DISTRIBUCION GEOGRÁFICA.-Tanto este como el anterior habitan el Océano Indico.

\section{EL HOLAGANTO DE SEMICÍRCULOS-HO- LACANTHUS SEMICIRCULATUS}

CARACTERES. - La especie de este nombre (fig. 130) se diferencia muy poco de la que acabamos de describir: tiene la nuca mas alta, el hocico mas obtuso, y el preopér culo mas corto, aunque con la espina muy fuerte y aguda. La forma de las aletas viene á ser la misma, y las escamas son igualmente pequeñas. En este pez no se ven colores bri. llantes; mas no por eso dejan de producir un notable con. traste los tintes negro y blanco, con mezcla de azul, que 
predominan en el cuerpo. El fondo es un negro intenso, y sobre él se destacan varias lineas curvas concéntricas de un blanco muy puro, mezcladas con otras azules mas estrechas, las cuales describen como unos semicirculos; la aleta anal es negra tambien, con listas blancas. El tamaño de la especie es de unas 4 ó 5 pulgadas de largo.

DISTRIBUCION GEOGRAFICA.-Parece que este holacanto habita igualmente en los mares de la India y en la Polinesia.

\section{LOS ARQUEROS-TOXOTINA}

CARACTERES. - Antes de terminar la descripcion de la familia de los peces de aletas cubiertas de escamas $\delta$ sean los escamipenes; debo mencionar todavía los peces araucros. Tienen una estructura relativamente mas oblonga, por cuanto su longitud es mayor que la altura. Su carácter principal cunsiste en la posicion de la alcta dorsal colocada mucho mas hácia atrás, $y$ sostenida en la parte anterior por radios muy fuertes $y$ espinosos, $y$ por otros blandos en la parte pos. terior. La boca es corta y aplastada, sobresaliendo la mandibula inferior de la superior; ambas tienen dientes de terciopelo, lo mismo que el extremo del vómer, los luesos palatinos, los alados y la léngua.

\section{EL ARQUERO SAGITARIO-TOXOTES IA-}

CARAGTERES. - La especie mas comun de este géne. ro es el arquero sagitario (fig. 131 ), conocido ya de mucho tiempo, porque en su patria, la isla de Java, le tienen los ha. bitantes como adorno de sus habitaciones metido en globos de cristal. Tiene una longitud de $0^{n}, 20$ aproximadamente, $y$ su color es un gris verdoso, algo mas oscuro en la parte su. perior, y tirando á plateado en la inferior. El dibujo consis. te en manchas mas oscuras dispuestas en lincas. En la aleta dorsal hay cinco radios espinosos y trece blandos; en la anal tres espinosos y diez $y$ seis blandos; trece radios en cada aleta torícica, seis en la abdominal y diez y siete en la anal.

USOS, COSTUMBRES Y REGIMEN DE LOS ESCAMIPENES. - Con pocas excepciones viven los peces de esta familia en las capas superiores del mary próximos á la costa; algunas especies suben por casualidad los rios, y otras pasan de la costa á la alta mar siguiendo á los buques para comer to que se arroja de ellos ó persiguiendo alguna utra presa; pero la mayor parte, en particular las especies mas vistosas de la familia, se encuentran siempre junto fes ó. en bajos donde se solazan al sol, con tanta vireza que no parece sino que les gusta lucir sus magnificos colores cuya belleza aumenta considerablemente con sus movimientos; $y$ hé aquil por qué todas las personas que los han podido observar vivos hablan de ellos con tanto entusiasmo. Heuglin dice que en el mar Rojo se mantienen principalmente en sitios donde el agua es profunda á mancera de pozos entre los bancos de coral, pues alli se conserva tranquila y clara aun cuando el mar esté agitado, á causa del verdadero bos. que de árboles de coral de que están sembrados aquellos sitios. Cuando el buque echa anclas entre estos arrecifes en noches oscuras se conoce la presencia de dichos peces por la refulgencia del mar. Se observan manchas de un resplan. dor incierto y opaco á veces á gran profundidad, que súbitamente se dispersan como chispas, para pasear despues len tamente de una parte á otra, reunirse otra vez poco á poco y volverse á dispersar.

Todos los peces de aletas escamosas, salro quizás alguna excepcion, se alimentan de otros animales, $y$ la mayor parte probablemente de especies marinas que carecen de tubo di. gestivo, es decir, de pequeñas medusas, hidras, anémomas, poliperos coraligenos, etc.; y alli donde la orilla del mar se halla poblada de bosques se dedican cuando frecuentan es tas costas á la caza de articulados. Los primeros, dice Heuglin, juguetcan al rededor de las ramificaciones coralinas del propio modo que los pájaros revolotean en los bosques al rededor de las copas de los árboles; se paran en bandadas algunos momentos delante de una rama, precipitanse despues suibitamente sobre cierto punto, barrenan ó muerden las flores vivas del polipero, $y$ abandonan desplues este sitio con la rapidez del rayo todos a una como si obedecieran á una sola voluntad, para repetir lo mismo en otro punto. Klunzinger se inclina s creer que frecuentan los bancos de coral mas bien por las algas que crecen sobre y entre las ra. mas que no por sus pólipos; dice que comen las algas, pero con esto no contradice lo observado por Heuglin. Esto en cuanto á las especies que viven entre los corales; el modo de vivir de otros géneros afines es distinto, como por ejemplo el de los quelmos $y$ arqueros, que han adquirido desde lar. ga fecha cierta celebridad por el modo cómo buscan su alimento, habiendose captado la voluntad de los habitantes de acquellas regiones en tanto grado que han sido admitidos por ellos entre sus animales domésticos. Hommel, director del hospital de Batavia, fue el primero que describió sus cos. tumbres, confirmadas despues por Mitchell y otros.

'Tan luego como el arqquero columbra una mosca ú oiro insecto posado en una hoja de planta inclinada sobre el agua, se aproxima hasta metro ó metro y medio de distancia y arroja de su boca tubulaŕ algunas gotas de agua al animalillo con tanta fuerza y acierto que rarísina vez yerra el tiro; y por esto tienen los javaneses dichos peces en sus habitaciones, conservándolos para su recreo en pequeños depósitos en cuyo centro hay un palo guarnecido de púas de madera y que sob́resale unos $\left(0^{2}, 60\right.$ del agua. Los insectos que se destinán álos peces se fijan ligeramente en las púns; apenas hecho esto, se acercan los peces, y nadan al rededor del palo; despues salen à la superficie, permanecen inmóviles en un puesto con la mirada fija en el insecto, $y$ de repente le arro. jan unas cuantas gotas de agua, lo hacen caer y se lo tragan. Si no aciestan vuelven á rodear el palo, se plantan de nuevo y despiden el liqquido otra vez, siendo pasmosa la seguridad con que arrojan el chorrito á su victima. Para observarlos fijó Hommel una mosca con un alfiler en el palo y vió cómo todus los peces se hacian la competencia para derribarla, arrojando sin parar y sin jamás errar su blanco gotas de agua al insecto. En el estómago de los arqueros hánse cncontrado grandes cantidades de animales articulados de la clase de los piojos de mar, de suerte que su alimento predilecto y natural parece consistir en articulados.

En ninguna descripcion encuentro datos relativos á su re. produccion.

PESCA. - En cuanto á la manera de cogerlos, solo puedo comunicar lo que supe de Heuglin. Muerden śvidamente toda clase de cebo si conocen que pueden tragarlo, y particularmente si se hace bajar mucho; mas á pesar de esto no es siempre abundante la pesca, porque tan luego como el animal se siente cogido se mete en agujeros entre rocas 6 corales, tan angostos que es imposible sacarlo. Heuglin asegura que es muy interesante la pesca en noches oscuras. Dice que pueden distinguirse los peces que se reunen al re. dedor del anzuelo á muchas toesas de profundidad á la luz fosforescente del agua;y que antes de sentirse la tension de la cuerda, se conoce por el fulgor momentáneo que despide esta á manera de pajuela inflamada que ha mordido un pez. 
Pero Klunzinger lo contradice diciendo que estos peces se cogen raras veces, porque no mucrden el cebo. Algunas es. pecies de la familia que nos ocupa son muy perseguidas por el hombre por lo mucho que se aprecia su carne, mientras que otras son despreciadas $\delta a$ lo sumo las comen las personas que ignoran las costumbres $y$ las materias asquerosas de que se alimentan; otras gozan hasta de una verdadera vene. racion por parte de los pescadores por sus hermosisimos di. bujos, y a otras finalmente se las seca $\delta$ reduce a cenizas para utilizarlas como medicamento.

\section{LOS ESPÁRIDOS- SPARIDE}

CARACTERES. - Los espáridos constituyen una familia de peces marinos divididos en muchos géneros, cuyos dis. tintivos generales consisten en lo siguiente. El cuerpo es oblongo y fuertemente comprimido en sentido lateral; el hocico y las mandibulas están desnudos, y el resto del cuerpo cubierto de escamas bastante grandes y dentadas en el borde posterior, y cuya direccion de crecimiento es oblicua hácia los bordes superior e inferior. El opérculo lleva una espina casi sicmpre roma a inancra de escama. No hay mas que una aleta dorsal inserta en un surco; la torácica forma punta, y la caudal es bifurcada. Los radios branquiales son comunmente en número de seis, pero á veces tambien de cinco. Las mandíbulas van armadas, ya de dientes cerdosos, ya de colmillos y de dientes cónicos afilados y puntiagudos, ya de incisivos anchos semejantes á los del hombre, ya de dientes obtusos y redondos en forma de enladrillado. Ni el paladar ni el rómer tienen dientes.

DISTRIBUCION GEOGRÁFICẢ.-Los espiridos se hallan en casi todos los mares, $y$ en ciertos puntos se pre. sentan determinadas especies en gran número.

USOS, COSTUMBRES Y RÉGIMEN.-Se alimentan de moluscos y crustáceos 6 de plantas marinas; algunas es. pecies acaso persigan tambien peces pequeños. Lit carne de muchas de ellas es muy apreciada; la de otras no. Las que habitan el Mediterráneo eran ya en su mayor parte conocidas de los antiguos que propalaban toda clase de fábulas extranias sobre su género de vida. Opiano dice: Habitan las rocas cubiertas de algas, son indolentes, pero en el tiempo del desove riñen los machos por las hembras con gran coraje, precipitándose mutuamente en las redes de los pescadores; tan preocupados se hallan con sus amores que los buzos pueden cogerlos con las manos. Para depositar la freza visitan dos veces al año las costas, en primavera y en otoño; pero fuera de estas temporadas habitan a mayor profundidad, yendo casi siempre detrás de los barbos porque se alimentan de lo que estos dejan al revolver el limo. Tienen una aficion especial á las cabras y se accrcan a bandadas á la costa cuando las oyen balar; saltan alegres á la playa, las acarician, y gimen cuando las cabras vuelven al establo. Por esto se revisten los pastores de pieles de cabra y hacen cabriolas en la playa para coger estos peces incautos. En vano se esfuerza uno para descubrir un motivo que haya podido dar lugar í semejantes cuentos, pues nada de esto han visto los observadores modernos.

\section{LAS DORADAS-CHRYSOPHRYS}

CARACTERES,-I.0s dientes anteriores de estos peces son cónicos en número de cuatro ó seis en cada mandíbula; los molares colocados mas atrás forman cuando menos tres hileras y tienen la punta roma. Los radios branquiales son en número de seis. Tienen desnudos la frente, el hocico, las mandibulas y el borde del preopérculo, en los que se vell depresiones ligeras; las mejillas están cubiertas de escamas bastante grandes y finisimamente dentadas. Doce radios sostienen la aleta dorsal y tres la anal; las torácicas son largas y acaban en punta. El representante de este géncro es

\section{LA DORADA COMUN-CHRYSOPHRYS AURATA}

CARACTÉRES.-La dorada, aurata de los antiguos, es un pez de $0^{n}$, $30 \leqslant \theta^{\star}$, 40 y rara vez de $0^{m}, 60$ de largo; pesa de cuatro á ocho kilógramos; su coloracion es magnífica y el dibujo muy elegante. El color del fondo viene á ser un gris plateado con viso verdoso, mas oscuro en el lomo y que pasa á plateado en el vientre; una mancha dorada, ova. lada y vertical adorna cl opérculo, una cinta amarilla de oro la frente entre los ojos, y diez y ocho hasta veinte listas lon. gitudinales de igual color los costados; la aleta dorsal es azulada y en la parte superior junto á las puntas de las espinas radiales listada de pardo; la anal es negra, y las torácicas y abdominales de color de violeta. En la aleta dorsal hay once radios espinosos y trece blandos; en cada torácica hay veinte, en la abdominal uno y cinco, en la anal tres y once, y en la caudal diez y siete.

\section{LOS SARGOS - SARGUS}

CARACTÉRES. - El género sargo, muy afine del anterior, difiere de él por tener los incisivos anchos, formacios en la parte anterior en hilera sencilla, y las muclas voluminosas, esféricas y de diferente grandor, dispuestas en varias hileras en ambos lados de las mandibulas. La cubierta esca. mosa es en general igual á la del género anterior; la aleta dorsal tiene de dicz a once radios y la anal tres. Los radios branquiales son cinco.

\section{EL SARGO ANULAR-SARGUS ANNULARIS}

CARACTERES.-Fl sargo anular es una de las espe. cies mas pequeñas del género; su color es en general amarillento como el laton, tírando en el lomo, el vientre $y$ los costados á gris platcado. Cada escama tiene encima de la línea del lado una orla pardusca, y la cola ostenta un semicírculo oscuro. Las aletas dorsal, torácicas y caudal son grises, y de color amarillo vivo las aletas abdominales y anal.

DISTRIBUCION GEOGRAFICA. - La dorada es per. muy conocido en todas las costas del Mediterráneo y en las del Africa bañadas por el Atlántico desde Gibraltar hasta el Cabo de Buena Esperanza. Hácia el norte se la ve rara ver. aunque en algunos casos se la ba cogido en las aguas de Inglaterra.

USOS, COSTUMBRES Y RÉGIMEN.-Rondelut dice que las doradas no se apartan de las costas, antes al contra. rio se meten en los estanques y charcos salinos que comunican con el mar, donde engordan rápidamente. Duhamel re. fiere que levantan la arena con la cola en sitios de poca agua para comerse las conchas que asi cncuentran y que les gus. tan extraordinariamente. Los pescadores oyen a veces el ruido que hacen al quebrantar las conchas cuando las cc. men. Las que yo he tenido cautivas algunos anos me han dado diariamente pruebas de la exactitud de estas noticias, porque si bien comian tambien gusanos y otros animales inrertebrados, se conocia que les gustaban mas que todo las conchas, que recogen con mucha destreza del fondo del mar, no mostrando menos destreza en desprender las que 
están adheridas á las rocas. Cuando han cogido la concha con los bordes del hocico, la pasan moviendo la boca como si la mascasen, hasta las fauces, donde la colocan del modo mas conveniente para aplastarla de un solo mordisco; en seguida arrojan las conchas quebradas y se tragan el molusco, volviendo al punto donde la encontraron para pescar mas.

El frio rigoroso es fatal para las doradas y por esto se re- tiran á mayores profundidades cuando se aproxima el invierno, alejándose cuidadosamente de todos los sitios de poca agua, donde, segun se dice, suelen sucumbir si las sorprende el frio antes de ticmpo.

PESCA. - Se pesca la dorada en las costas de Francia todo el año con redes y anzuelos que se ceban con conchas y cuando no las hay con cangrejos 6 trozos de atun. La car.

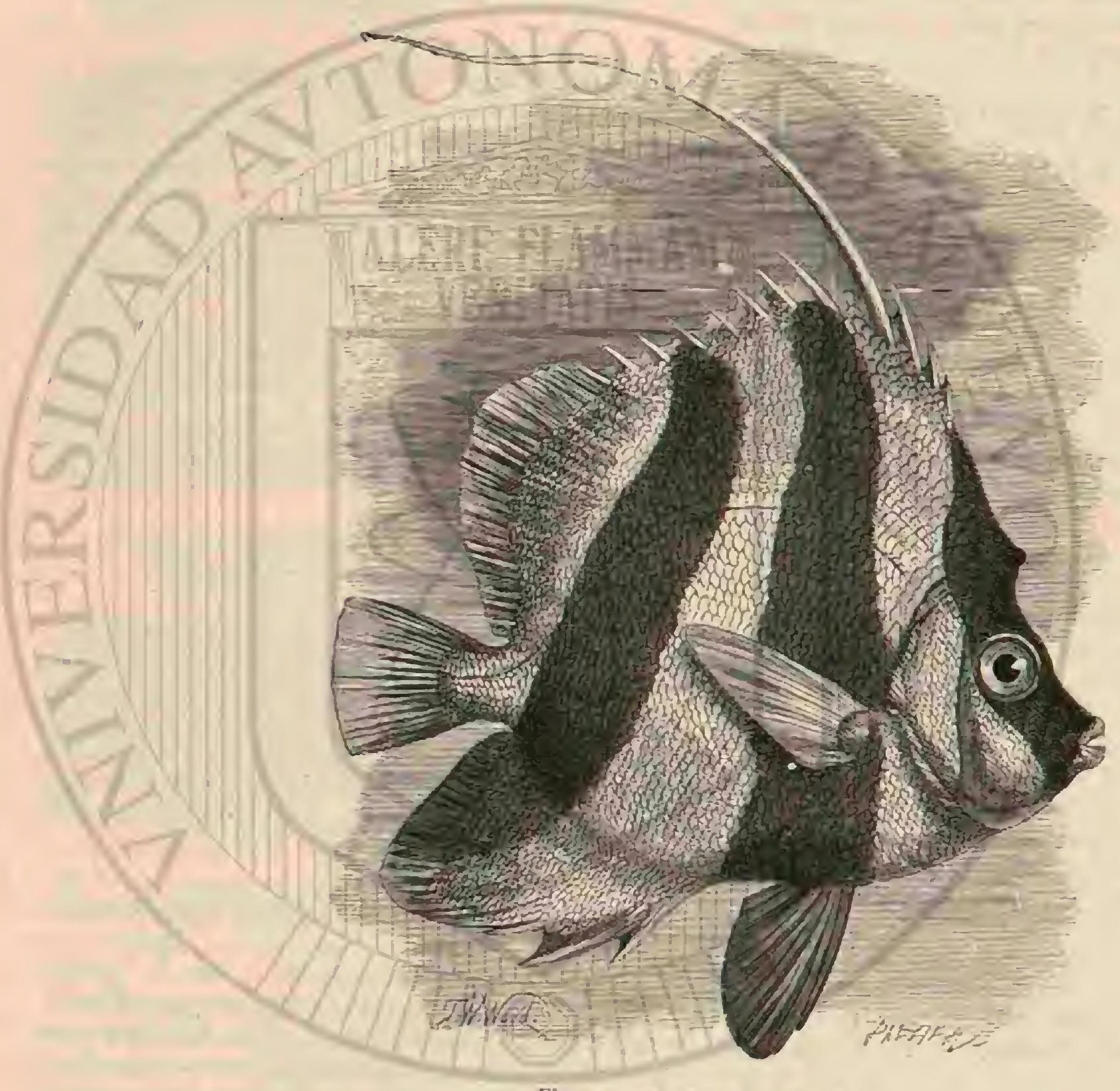

Fig. 129. - E1. HExiocio Lxicorsio

ne de dorada es algo seca, pero de cualquicr mocio que se prepare, sabrosa, por cuya razon es muy apetecida. Pasan por mas finas las cogidas en salinas y en la orilla del mar Mediterráneo; pero no las del Océano Atlántico. Marciał ya decia:

No todas las doradas merecen ser alabadas, $\$$ Sino solo las que comen conchas en el lago Lucrino. Martens dice que junto á Venecia se crian doradas en es tanques profundos como se hacia ya en la epoca romana.

Se dice tambien que los plateros engastan los dientes de dorada en sortijas, despues de haberles dado un color negro por medio del agua fuerte, $y$ las venden como dientes de ser. piente á las gentes supersticiosas que son bastante ignorantes para atribuirles milagrosas virtudes.

\section{LOS PAJELES-PAGELLUS}

CARACTERES. - Este gencro se distingue de sus afines ya descritos por los dientes anteriores de púa, y los posteriores colocados en dos $\delta$ mas filas, $y$ muy pequeños.

\section{EL PAJEL COMUN-PAGELLUS VULGARIS}

CARACTERES. - La especie mas conocicia del género es el pajel comun (fig. 132) que vive en el Mediterráneoy alcanza una longitud de (1) lomo es un hermoso carmin, y el de los costados, vientre y. aletas rosado. La aleta dorsal tiene doce y diez radios, quin. ce cada torácica, la abdominal uno 5 cinco, la anal tres $y$ ocho, y la caudal diez y siete.

\section{EL DENTON--PAGELLUS CENTRODONTES}

CARACTÉRES.-Difiere del pajel el denton comun por su hocico mas obtuso, el menor numero de dientes en las mandibulas a la par que por ser estos mas finos, y finalmen te por la coloracion. El lomo es pardo gris tirando á rojo, la cabeza pardo oscura, los costados gris de plata, con una 6 mas manchas pardo negruzcas al principio de la linea del cos. tado. Esta mancha sirve para distinguir la especie, aun cuan. do el color principal sea rosado con brillo de plata como á veces sucede. Las aletas anal y dorsal son parduscas; la cau- 
dal y las torácicas rojizas, y gris claras las aboiominales. Doce radios duros y trece blandos sostienen la aleta dorsal; la torícica dier y siete; la abdominal uno duro y cinco blandos; tres duros y doce blandos la anal, y diez y siete la caudal.

DISTRIBUCION GEOGRÁ FICA.-El denton, pez muy comun en el Mediterráneo, se presenta tambien en las 'costas occidentales y septentrionales de Francia, en las de Holan. da, de Inglaterra, de Alemania y de Jutlandia. Es posible que en todas estas costas haya inmigrado, desde el mediodia, pero lo cierto es que ya está completamente naturalizado en ellas.

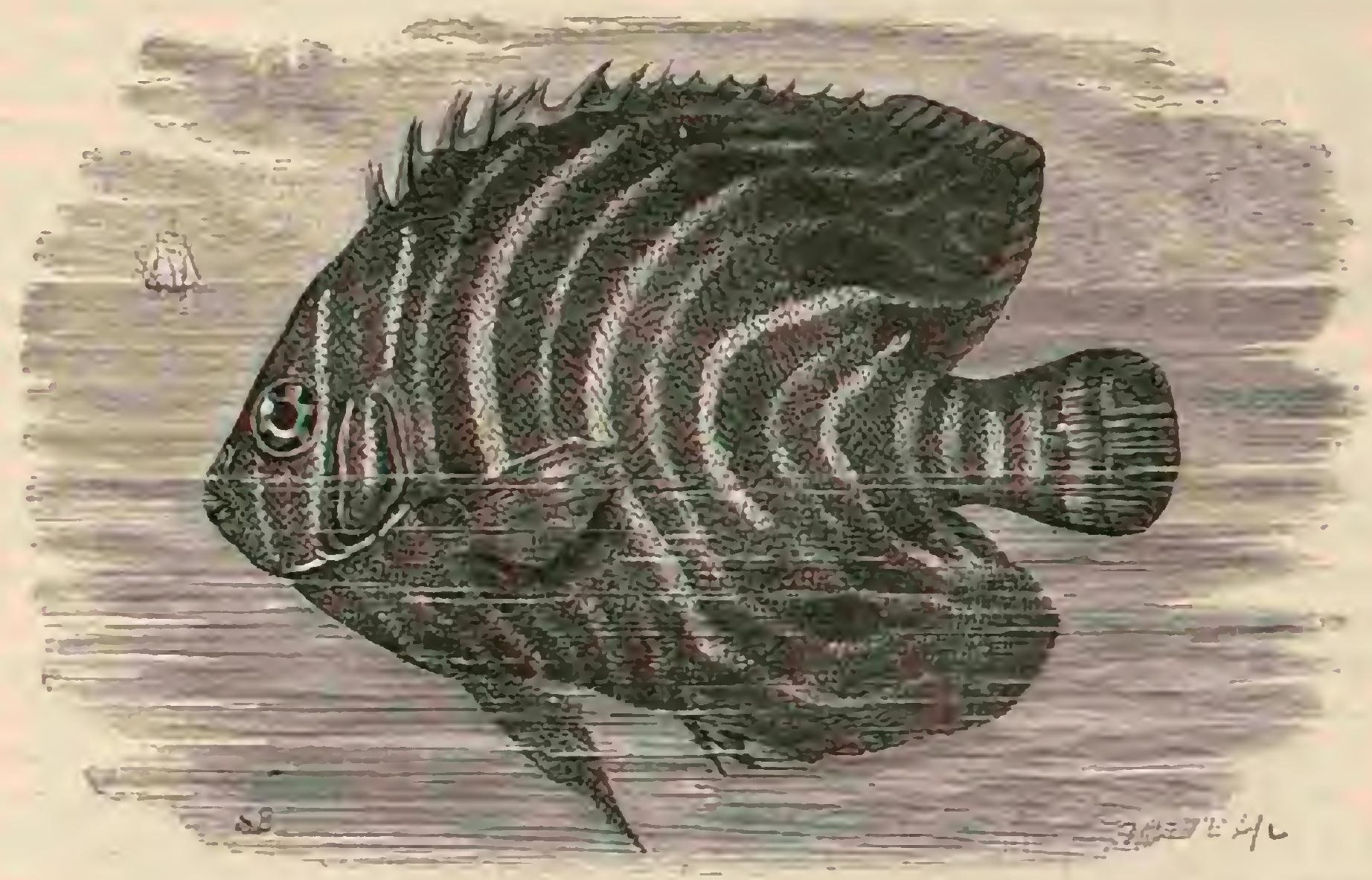

Fig. 130.-EL holacasto DE SEMHclrculos

USOS, COSTUMBRES Y REGIMEN.-Dice Couch | mas frecuencia en verano y otono, puesto que al empezar el que ren la costa occidental de Inglatcra se ve este género de dornda maritima todo el año, aunque naturalmente con

frio se retira. Depone su freza al principio de invicrno en sitios donde el agua es profunda; en enero se encuentran en los

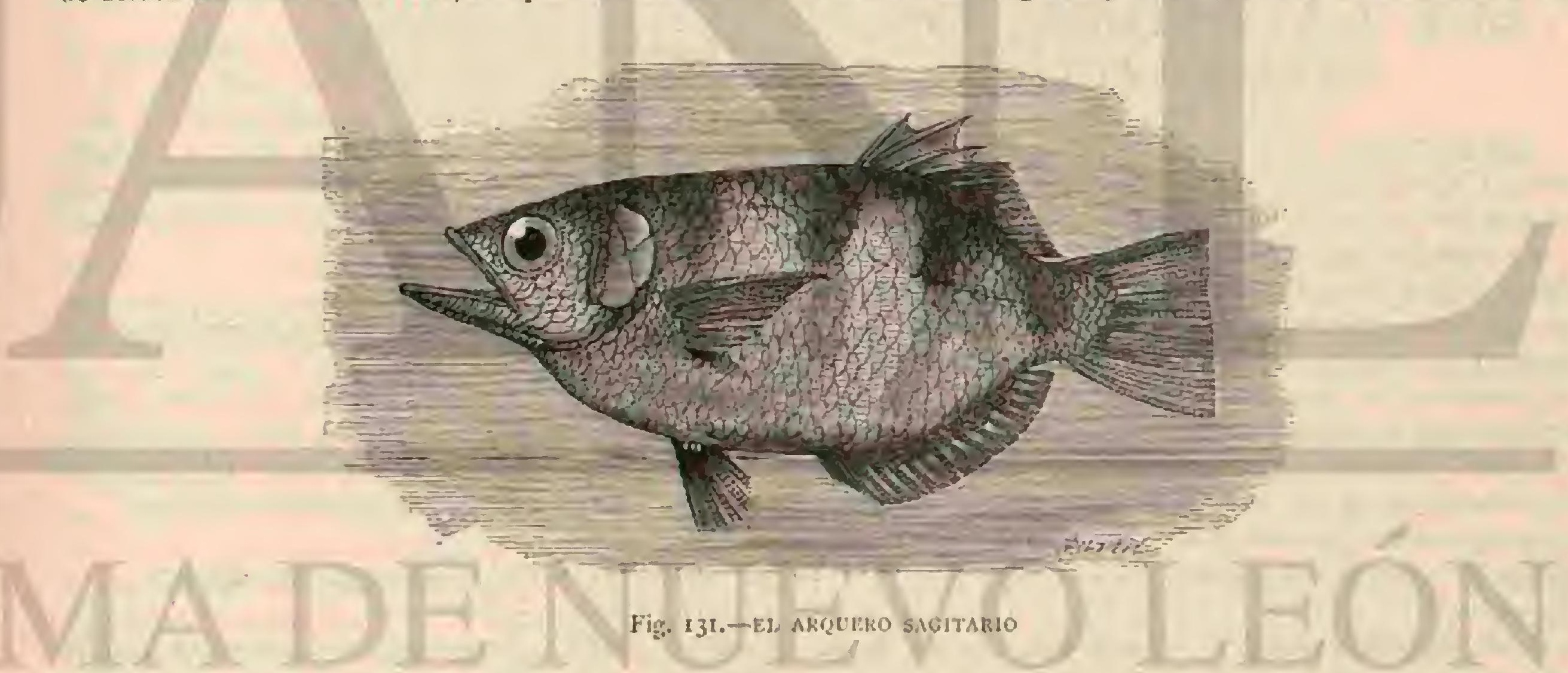

estómagos de peces mayores cogidos á dos leguas maritimas de la costa, pequeños dentones de $0^{\circ}, 02$ de largo, que en Inglaterra llaman chads. Durante el verano, cuando han adquirido una longitud de $0^{\infty}, 10<0^{\circ}, 12$, invaden en número incalculable las costas $\mathrm{y}$ aun el interior de los puertos con gran satisfaccion de los pescadores de caña, porque muerden cualquier cebo. No se limitan solo á comer sustancias animales, sino que tambien comen algas verdes que arrancan fácilmente con su dentadura tan especial. En general podria decirse que el denton es un pez solitario, pero los pescadores han observado á veces numerosas bandadas que se mueven lentamente cerca de la superficie como si fuesen á cumplir una mision importante. Se enccientran estas bandadas con preferencia donde el agua es profunda y el fondo de roca.r.
USOS Y PROVECHO.-El denton no es pez de gran estima para la mesa, ni tampoco se sala. Couch dice que á veces se venden á dos chelines y medio los cincuenta kiló gramos. Pero Yarrell asegura que esta opinion desfavorable acerca de la bondad de la carne de este pez reconoce úni. camente por causa el modo irracional de aderezarla, pues cuando se limpia por la boca y se presenta entero $y$ hervido en agua, tiene un gusto muy agradable, siendo tambien mas fácil desprenderle las escamas.

\section{LAS BOGAS - BOX}

CARACTÉRES.--Verdaderos herbivoros son las bogas, doradas oblongas, de boca pequeña y de ojos grandes, cujo 
distintivo principal consiste en la dentadura compuesta solamente de una hilera de dientes llanos, surcados y cortan. tes, propios para comer plantas marinas, á las que correspon. den el tubo intestinal muy largo y el estómago pequeño con pocos apéndices.

\section{LA BOGA COMUN-BOX VULGARIS}

CARAGTERES.-La boga tiene á reces hasta n" :40 de longitud; y lleva, sobre fondo de color amarillento verdoso, plateado en la parte inferior, tres $\delta$ cuatro listas longitudina. les de brillo de oro, asi como una mancha paràa negruzca en la axila de la aleta torícica. Las aletas dorsal, abdominales y anal son amarillas, Jas torácicas y caudal verdosas, estando esta última por lo general orlada de amarillo indeterminado; además sostienen la dorsal catorce y quince radios; diez y ocho la torácica, uno y cinco la abdominal; tres $y$ diez 5 seis la anal, y quince la caudal.

USOS, COSTUMBRES Y REGIMEN. - I a boga es uno de los peces mas comunes del Mediterráneo; pero se presenta tambien en considerable número en la costa de Madeira y puebla la occidental de Portugal y de Esspaña como la sep tentrional de esta, descic donde, aunque rära vez, se extravia hasta Inglaterra. Se acerca dos veces at año ä las costas de Trancia para deponer su freza, en cuya ocasion los pescadores la cogen en gran número, si bien su carne es poco apre. ciada. Los pescadores franceses suelen adornar sus barcas con una boga de plata batida, costumbre que tal vez tenga su explicacion en la belleza de este pez. Segun datos de los mejores observadores, solo se encuentran restos de vegetales en los estómagos de estos pleces.

\section{LOS CATAFRACTOS- CATAPHRACTI}

CARÁCTERES.- Llámase catafractos, ó caras acorazadas, a aquellos peces que tienen el hueso infraorbital prolongado hácia abajo, unido al preopérculo por una articulacion, 5 mas $\delta$ menos armado, al igual de los operculos y de toda la cabeza, de espinas. Las numerosas asperezas de la cara cuando se desarrollan en espinas, constituyen otras tantas armas no despreciables, que dan a la cara una expresion singularísima, á la que se agrega la forma mas $\delta$ menos $\mathrm{cx}$. travagante de las aletas y escamas. En el lomo suele haber do3 aletas, y cuando no, se divide la única aleta dorsal en dos partes distintas; las aletas abdominales están insertas en la region torácica. Las mandibulas van armadas de dientes débiles de púa, tara vez cónicos. Muchas veces falta la ve. jiga natatoria.

USOS, COSTUMBRES Y REGIMEN.-Exceptuando los miembros de un solo género, son todos los demás catafractos peces marinos que viven á muy diferente profundi. dad; unas especies siempre sobre el fondo, otras suben de cuando en cuando á las capas supcriores, y hasta abandonan por momentos el agua para volar, segun suele decirse de su clevacion momentánea sobre la superficie. Por lo comun se mantienen inmóviles 6 indolentes mas ó menos hundidos en el limo ó arena, ú ocultos entre las rocas en el fondo del mar, aguardando sus presas; al acercarse una se levantan y se dirigen presurosos, serpenteando con la cola, hácia ella, reci. biéndola en sus fauces desmesuradamente grandes, despues de lo cual se dejan ir otra vez al fondo. Tambien pucden mudar de color, tomando el de los objetos que los rodean, con lo cual las especies armadas de agudas espinas se hacen peligrosas al hombre cuando entra descalzo en el agua, de suerte que algunas son mas temidas que todos los demás peces, como sucede con la especie per migico (Synancija cerrucosn ) del género escurpina que vive en el mar Rojo, y á la que atribuyen los pescadores árabes cualidades análogas S. las de la vibora. Tambien permanece ocuito este catafrac. to, como todos los miembros de la familia, entre las piedras y algas del fondo del mar, adquiriendo cl color de lo que le rodea hasta tal punto que el pescador que cntra en el agua no lo percibe hasta que le ha pisado y cuando el pez, lerantándose súbitamente, le ha infericio con sus espinas una he. rida dolorosísima. «La punzada de sus espinas dorsales, dice Klunzinger, duele muchas horas mas que una picadura de alacran, conforme me consta por experiencia propia. Ha habido personas á las que esta punzada ha hecho perder los sentidos; s segin lo que la gente cuenta, ocurrió una vez un caso de muerte que si no era causada inmediatamente por la herida, lo fué por la gangrena que invadió la llaga mal cuidada lo todos modos hay motivo para contar á este pez entre los animales venenosos con igual derecho que el alacran. Un pescador que tengo por muy veraz me asegura, que ha visto claramente cómo sale un liquido ó pus lechoso del pliegue de la piel donde está el aguijon por lo general oculto hasta que se endereza. No he podido verlo á pesar de mis observaciones repetidas, pero si se confirmara lo dicho por el pescador, tendriamos en este caso un verdadero aguijon venenoso comparable con los dientes surcados de las serpientes venenosas.

Sobre la reproduccion de los catafractos se sabe poco, lo propio que de su género de vida. Para la pesca tienen estos peces una importancia muy secundaria.

\section{LOS COTOS-COTTINI}

CARACTERES. - Empezando por las especies mas conocidas, procederé la descripcion de los catafractos con los cotos, grupo que se ha elevado is sub familia. Se distinguen de sus afines pertenecientes a la familia por el poco desartollo de la parte espinosa de la alcta dorsal comparada con la parte blanda, y por los radios articulados que exclusivamen. te sostienen la gran aleta anal.

\section{LOS COTOS DE RIO-COTTUS}

CARACTERES.-Se distinguen por su cabera comprimida y ancha, su cuerpo rechoncho y cubierto de escamas, las dos aletas dorsales unidas en una sola, y finalmente por los dientes de terciopelo en las mandibulas y el róner.

\section{EL COTO DE RIO-COTTUS GOBIO}

CARACTÉRES.-Representa este género el coto de nuestras aguas dulces (fig. 133). Es un pez de 0 ; 12 \& 0 \%, 1 4 de longitud, cuyo color general es gris con puntos 6 motas pardas que á veces se unen formando fajas trasversales visibles frecuentemente hasta en el vientre, que es blanquuizco. Las aletas dorsal, torácicas y caudal presentan otras listas pardas en direccion de los radios, siendo las abdominales ge. neralmente de un solo color. Por lo demás varia mucho la coloracion segun el pais, el fondo del agua y aun ségun la disposicion en que se encuentra el pez En la primera aleta dorsal se cuentan de seis a nueve radios, en la segunda de quince á veinte, en cada torácica de trece á catorce, en cada abdominal uno y cuatro, en la anal de docéá trece y en la caudal trece.

DISTRIBUCION GEOGRÁFICA._-El cotohabita todas las aguas dulces de la Europa central y" septentrional, y á 
excepcion de algunos arroyos, sicmpre en gran número; en las montañas viven hasta à mas de mil metros de elevacion, encontrándose en lagos como por ejemplo el de Luener en el Tirol que está casi a dos mil metros sobre el nivel del mar y cuyas aguas habita el coto con exclusion de todo otro pescado. En Irlanda es tan raro, que Thomson jamás pudo lograr un ejemplar, pero con todo existe allí. Hácia el mediodía y el oeste le sustituyen otras especies ó variedades afines.

USOS, COSTUMBRES Y REGIMEN.-Le gusta el agua limpida y el fondo arenoso ó pedregoso, puesto que acostumbra ocultarse entre las piedras, tanto que á causa de ellas busca los arroyuelos mas insignificantes y mas pobres de agua. Sus movimientos son rapidísimos. a l'asa como una bala de un punto á otro, dice Gessner, con tanta rapider que casi no hay pez que compia con él. \$
Tampoco cede is ningun otroen roracidad, y cl vicjo Gess. ner tiene asimismo razon cuando dice: Los cotos son omnivoros, y tambien se comen el uno al otro, el mas gran. de al mas pequeño; porque si bien se alimentan principalmente de insectos, en especial de larvas de libélulas, no perdonan á pesar de esto á ningun pez mas débil que ellos, ni á su propia cria. Son una gran plaga para los piscicultores que crian truchas, porque destruyen la freza de estos peces. Respecto de la reproduccion difieren los cotos de la major parte de los peces en que cl macho se cuida de la cria. Lin. neo ya decia que el coto construge un nido y que antes pier. de la vida que abandonar las huevas, y Marsigli y Fabricius dicen á su vez, que el macho es el guardian de las huevas. El tiempo de la freza cae en marzo y abril; la hembra la de. posita debajo de piedras $\delta$ en un agujero á propósito, y el

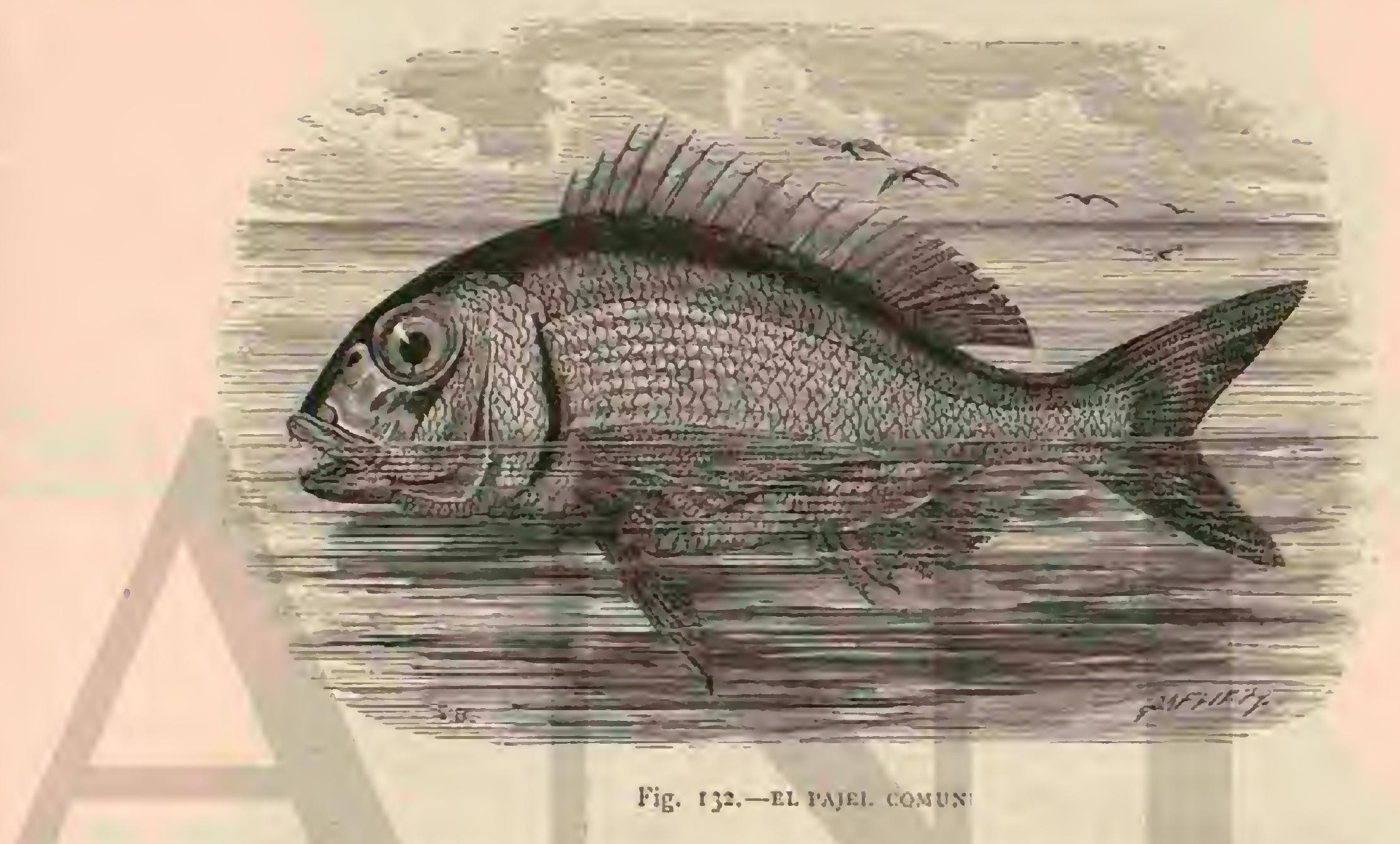

macho se encarga de cuidarla. Unos pescadores del rio Traun de reconocida experiencia dijeron á Heckel y Kner lo que sigue: \&En la época de la freza se coloca el macho en un agujero entre piedras donde mas tarde la hembra depositará sus huevas y lo defiende contra todos cuantos intenten apode rarse del nido, con un denuedo que origina frecuentemente una prolongada pelea y acaba á menudo con la muerte de uno de los dos combatientes. Durante esta época no es raro coger cotos que tienen la cabeza de su adversario en la boca ś pesar de que no puéden tragarla. Yero llega la hembra, y el macho ya es otro; la recibe, la deja deposilar su freza y no la molesta cuando se marcha despues de esta operacion. Desde aquel punto el macho hace las veces de madre, sin apartarse de las huevas sino cuando le es forzoso buscarse su alimento. La incubacion dura de cuatro á cinco semanas y durante este tiempo protege el macho las huevas con un valor $y^{\prime}$ una constancia tan grandes que muerde el palo con el cual se procura apartarle de su puesto y solo cede cuando ya to hay resistencia posible, $\delta$ se deja matar antes que aban. donar las huevas.

Gessner sigue diciendo: Se cogen los cotos de muchas maneras, con las manos, con un hierro, con red y otros ob. jetos. En noches de luna no cuesta ningun trabajo cogerlos, porque entonces han abandonado sus escondrijos entre las piedras y corren por el agua, por manera que no es menester girar las piedras 6 removerlas. Tambien se cogen en buitrones ó bien con pequeños haces de rama ó de leña que se colocan en el fondo para que los pececillos se metan y se enreden dentro; y cuando al cabo de cierto tiempo se sacan, no hay mas que sacudirlas para hacerlos caer. Su carne es sana y agradable, y aunque no deban contarse propiamente cntre los peces que llaman «de guijarros》 por ser de piel viscosa, no dejan por esto de ser muy apreciados y preferidos entre todos los peces que viven en aguas currientes. Hoy dia se considera el coto como pescado de cscaso $\delta$ nin. gun valor, probablemente por su pequeñer, de suerte que rara rez se pagan á mas de dos reales y medio el kilógramo, pues se emplea mas como cebo que para alimento. Pallas dice que el pueblo bajo en Rusia los utiliza contra la mor. dedura de vibora, y que lleva estos peces como amuleto sobre el pecho.

\section{LOS COTOS ESPINOSOS- ACAN'THOCOTTUS}

CARACTERES, - Por lo comun tienen estos peces la cabeza mas alta que ancha con dos pares de excrecencias huesosas 6 espinas en la parte superior, y otras en la cara y en los opérculos. I.a boca es mas hendida que en los cotos de rio, pero en todo lo demás se parecen tanto los unos á los otros que muchos distinguidos naturalistas los incluyen à ambos en un mismo género. 


\section{EL COTO ESCORPION-AGANTHOCOTTUS SCORPIUS}

CARACTERES. - La especie mas conocida del género es el escorpion, pez muy feo, $y$ de ()$^{m}, 15$ a $0^{m}, 25$ de largo, de color pardo rojizo, algo mas claro en la parte inferior y sem. brado de manchas mas oscuras. En las aletas dorsales se cuentan nueve y quince radios, en cada torícica diez y siete, en cada abdominal cuatro, la anal once, $y$ doce la caudal.

DISTRIBUCION GEOGRÁFICA. - El escorpion abunda en todas partes desde el golfo de Vizcaya hasta la Lapo. nia, tanto en el Atlantico como en el mar polar y en los que comunican con ambos, siendo tan frecuente en el Búltico como en el mar del Norte.

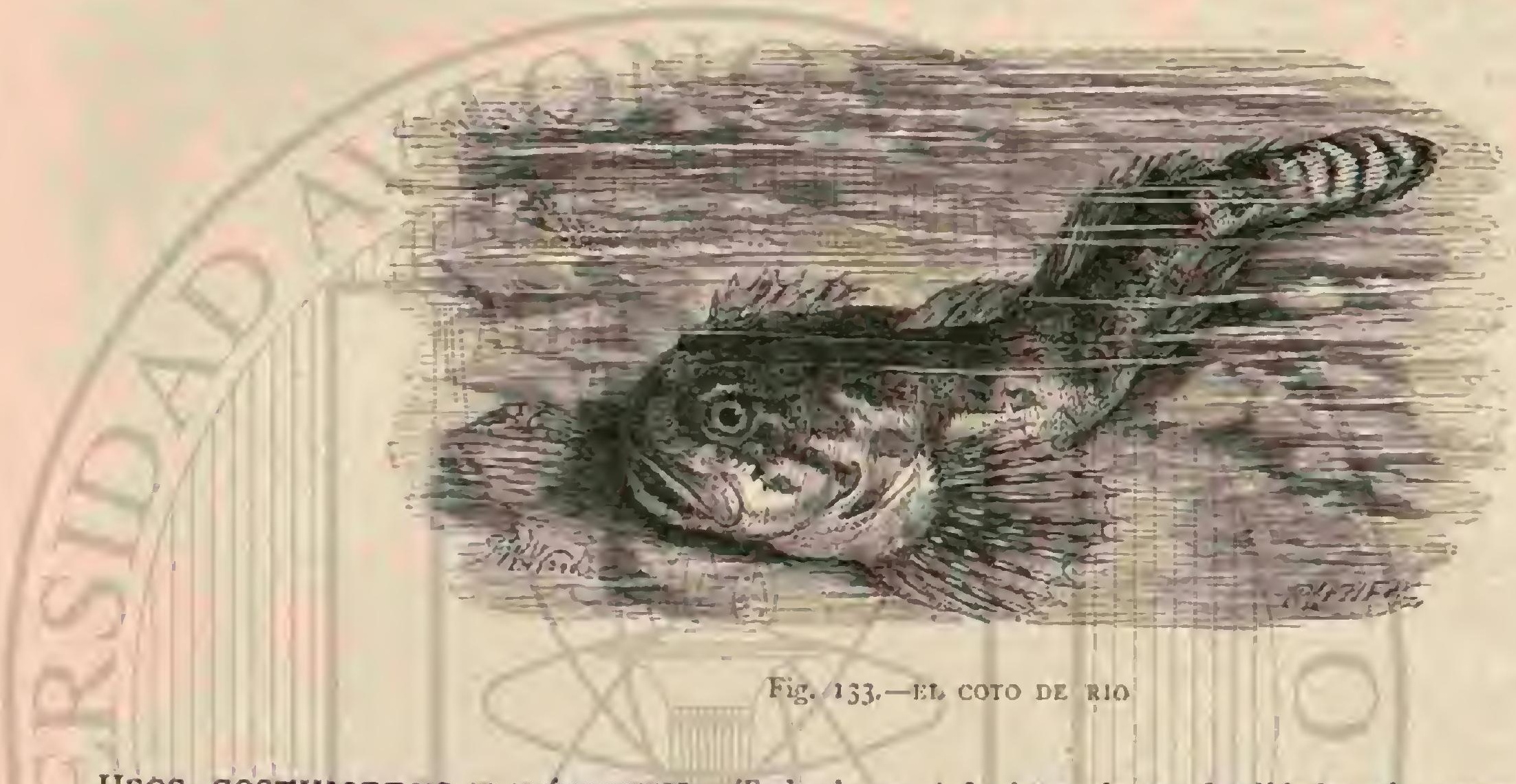

USOS, COSTUMBRES Y RÉGIMEN.-'Todos los co. tos espinosos llevan á poca diferencia el rnismo género de vida. Les gusta permanecer en fondos pedregosos, y á menu.

do à grandes profundidades, sin que por esto dejen de subir tambien á las capas superiores. Echados sobre las piedras, ú

que pase una presa. Cuando ven que se acerca alguna no se abalanzan rápidamente sobre clla, sino que acuden con una velocidad regular moviendo sus poderosas aletas y alcan. zan con mucha destreza á su víctima, que á veces es tan grande como ellos, haciéndola desaparecer al mismo instante en su boca, proporcionalmente colosal. Su voracidad es pas. mosa; lo tragan literalmente todo por poco que sea comestible, peces, cangrejos y otros crustáccos, gusanos, etc., lo mismo que los desperdicios de cocina que arrojan desde los buques y lanchas al agua. La época de su reproduccion cae en la estacion mas cálida del año, pero alguños desovan \& últimos de otono y aun en noviembre; cn esta época es cuan. do se los ve en grandisimo número en todos los puntos de la costa que les parecen á propósito. Luego que se han desem. barazado de las huevas se vuelven álas profundidades donde acostumbran pasar el resto del año.

PESCA. - Los pescadores cogen los escorpiones en bas. tante cantidad, pero en todas partes sin q̨uererlo, porque les tienen odio, á causa de no valer nada su carne y sí solo el higado, por cuya razon los consumen ellos mismos; los odian además porque los consideran destructores de peces vítiles, $Y$ tambien á causa de sus armas, pues las heridas que causan suelen ser peligrosas. Rondelet asegura que su punzada es venenosa y que él mismo ha curado una criatura herida peligrosamente y envenenada por un escorpion. Pontoppidan dice que en Noruega solo se aprovecha el higado, que da un excelente aceite.

Estos peces, lo mismo que sus afines de mayor tamaño, producen un ruido especial cuando se los coge con la mano, solo que es menos perceptible Subsisten vivos bastante tiempo fuera del agua, lo que permite remitirlos álargas distan. cias. Son comunes y excitan la curiosidad en nuestros acuarios de agua salada, donde viven perfectamente aun cuando su cárcel sea de reducidas dimensiones, pues poco se les da del espacio y de poder moverse con tal que tengan abundante alimento. 


\section{LOS PLATICÉFALOS-PLATICE- PHALUS}

CARACTÉRES.-El pez que debe servir de tipo á este sub-género fué descubierto por Forskal en el mar kojo: consideróle como un coto á causa de la forma deprimida de su cabeza y de sus dorsales; pero hay motivo para separärle por varias diferencias de importancia. Entre ellas vemos desde luego que la membrana de los oidos tiene siete radios en vez de scis, $y$ las ventrales cinco en lugar de cuatro; la forma singularmente larga y ensanchada de los liuesos de la pélvis es causa de que dichas aletas estén muy separadas unas de otras; y esto constituye tambien un carácter distintivo.
EL PLATICÉFALO DE GRANDE ESPINAPLATICERHALUS GRANDISPINIS

CARACTERES,-Esta es la especie mas notable del género (fig. 134 ). Fil sub-orbitario anterior presenta por delante un diente corto, aunque bastante puntiagudo, y dos muy pequeños en el lada. La espina externa del preopérculo es cuatro veces mas gruesa y larga que la otra, $y$ se extiende casi hasta el borde del opérculo. La caudal, lo mismo que las otras alctas, está manchada de pardo sobre fondo pálido; y el color dominante es menos pardo que en la anterior.

DISTRIBUCION GEOGRÁFICA.-No podemos indicar con exactitud en qué aguas habita esta especie.

\section{LOS HEMITRIPTEROS-HEMI- TRIPTERUS}

CARACTERES. - Uno de los peces mas singulares de la gran familia que nos ocupa, y que constituye realmente un termino medio entre los cotos y las escorpenas, fue ya descrito por Mr. Mitchill con el nombre de smrhica flaia. y mas detcnidamente despues por varios autores. I a separa cion de las dos aletas del dorso, la primera de las cuales está subdividida, $y$ la anchura de la cabeza son caractéres por los que pareceria que deben figurar junto á los cotos; pero sus numerosos y diversos tentáculos y los dientes de sus palatinos les comunican mas afinidad con las escorpenas, constituyendo estos peces un verdadero tránsito de aquel género al que nos ocupa.

\section{EL HEMITRIPTERO AMERICANO-HEMI- TRIPTERUS AMERICANUS}

CARACTERES. - El cuerpo de este pez (fig. 135) es oblongo, mas delgado en su parte posterior, y con el abdómen voluminoso; la cabeza es grande, una quinta parte-menos ancha que larga, $y$ tan erizada como la de una escorpe na: tiene una espina en cada nasal, dos fuertes tubérculos en la órbita, otros tantos en cada lado del cráneo, tres en la sien, algunos pequeños en el sub orbitario anterior, uno pla no en el posterior, que acoraza la parte mas alta de la meji$11 a, y$ uno en 10 mas bajo del hueso supra-escapular. El preoperculo, redondeado como en las escorpenas, presenta tres Tomo $\mathrm{V}$ puntas; el opérculo termina en un ángulo bastante romo. Anchas fajas de pequenos dientes guarnecen ambas mandl. bulas, la parte anterior del vómer y los palatinos; en los fa. ringeos hay tambien unas fuertes placas; pero la lengua, an. cha, gruesa, obtusa y libre, no presenta nirguno. La primera dorsal comienza inmediatamente sobre la nuca, y sus dos primeros radios son los mas altos, bajando los demás brus. camente hasta el cuarto ó quinto, y volviendo luego du subir para disminuir de nuevo, por lo cual resulta una profunda escotadura. La segunda dorsal es un poco mas alta que la segunda parte de la primera; y las espinas de ambas son bas. tante puntiagudas Ia aleta anal tiene catorce radios; la car. dal es de forma redondeada, con doce; lns pectorales.forman anchos óvalos un poco oblicuos; las ventrales, mucho mas cortas que las pectorales, están como truncadas y no se componen sino de una espina y tres radios blandos. Este pez está revestido de una piel blanda, con granulaciones muy finas, entre las cuales se ven pequeños tubérculos cónicos, contándose cuarenta y circo mas gruesos sobre la línea lateral; en la cabeza no hay casi ninguno; la picl del vientre es blanda $y$ lisa, sin pequeños granos ni tubérculos. Sobre los ojos y al rededor de las mandibulas se ven varias de esas barbillas carnosas que tienen las escorpenas; dos en la extremidad anterior del hocico; una cerca de cada espina nasal; dos en cada órbita; una pequeña en el centro de cada maxilar y otra grande en el extremo; tambien presenta una la punta exterior del maxilar, y cuatro grandes debajo; hay dos pequeñas en medio de la mejilla.

Fl color de este pez está sujeto á bastantes variaciones: en 
unos individuos predomina el color amarillo de limon, salpicado de pardo 6 negruzco en los costados y las aletas; otros ofrecen un tinte rojo carmin muy brillante, mas oscuro en el lomo, y su vientre es blanquizco. El tamaño de la especie es de unas 12 \& 4 pulgadas.

DISTRIBUCION GEOGRÁFICA.EI hemitriptero se encuentra en las aguas de América y en las costas del Atlánti. co, asi como tambien en Terranova. Casi siempre se le pesca en las redes que se tienden para el bacalao.

\section{LAS ESCORPINAS - SCORPENINA}

CARACTÉRES.-Son los peces que mas se parecen á los cotos, feos y extraños, con cabeza y cuerpo comprimidos lateralmente y la parte espinosa de la aleta dorsal mas des. arrollada 6 por lo menos tanto como la parte blanda de la misma y la anal no prolongada.

\section{LOS SEBASTES-SEBASTES}

CARACTÉRES.-Entre todas las especies de la sub. familia de las escorpinas merecen los sebastes el primer puesto por la formacion de los huesos de la cara, si bien respecto á lo demás se asemejan casi tanto á las percas como á sus afines. La cabeza no es excesivamente grande; tiene escamas en las mejillas, opúrculo, preopérculo y region occipi-

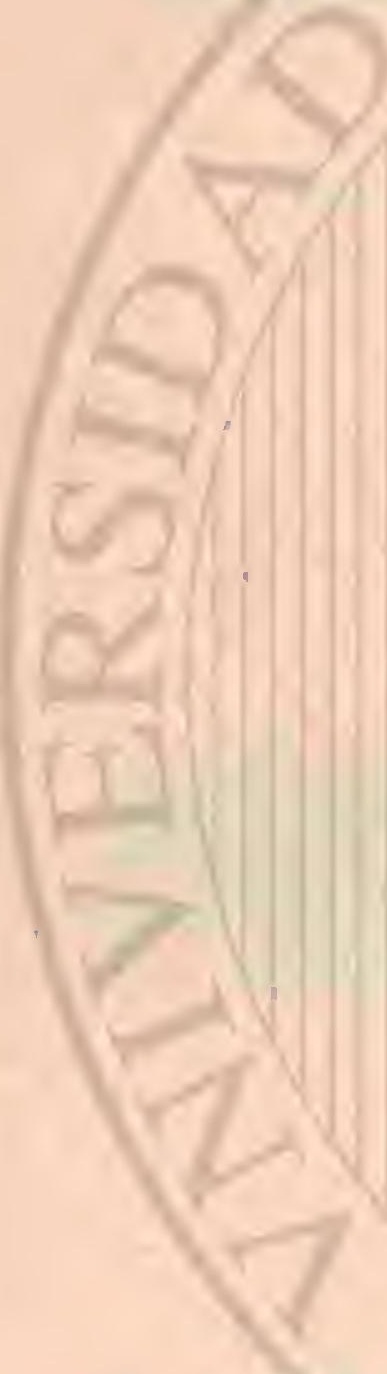

tal; y el resto tan pronto cubierto de escamas como desnudo, 6 guarnecido de protuberancias espinosas, pero romas ó granujientas; el hueso infraorbital lleva siempre espinas. Ambis mandibulas tienen dientes de terciopelo y lo mismo la parte anterior del vómer y cl borde exterior del hueso palatino.

\section{EL SEBASTES NORUEGO-SEBASTES NORWEGICUS}

CARACTERES. - Esta especie alcanza una longitud de $0^{\circ}, 50$ á $U^{\prime \prime}, 60, y$ ostenta un magnifico color carmesí que hácia el lomo se vuelve pardusco y hácia el vientre mas cla. ro. Se cuentan quince radios espinosos y otros tantos blan dos en la aleta dorsal, diez y nueve en cada toricica, en cada abdominal uno y cinco, tres y ocho cn la anal, y cator. ce en la caudal. Un congénere muy afine habita el Mediterránco.

USOS, COSTUMBRES X RÉGIMEN. - El primer naturalista que descubrió el sebastes noruego en las aguas de Groenlandia fué Fabricius, que tambien comunico detalles sobre su género de vida; mas tarde lo observó Faber en la costa de Islandia. Este pez habita exclusivamente los mares mas septentrionales á una profundidad de ochenta á cien toesas, pero es tan conocido de los babitantes de aquellas costas que ga lo menciona la Edda(1). Se alimenta de peces

(1) Eidda significa a Madre de la cienciss, y erel documctito mas anligtro de lilanelia; consta de dos libros, enntiene las tradiciones épucas. liervioas y mitológicas de los pucblos escandinasoas y data del siglo di de nuestrn ers. (N. hel T.) y de crustáceos. La época del desove cae en la primavera, pero no es el instinto de reproduccion el que hace caer as estc pez tan apreciado en la red del pescador, sino los violentos temporales que, cono suele decirse, remueven la mar hasta su fondo, y que probablemente le obligan á subir á la superficie, causándole un efecto análogo al de las percas pescadas a gran profundidad; es decir que la excesiva y rápida dilaı cion y distension de la vejiga natatoria cmpuja el estómago, le vuelve al revés é impidiendo la respiracion produce la muerte del pez. En Groenlandia é Islandia se ven despues de un temporal centenares de estos peces flotando, siendo por fin arrojados á las playas, donde los recogen los habitan. tes que suelen comerlos frescos. A Faber le pareció su carne seca, pero bastante sabrosa, si bien luego le repugnó cuando vió la multitud de helmintos que pululaban entre los músculos.

\section{LAS ESCORPENAS PROPIAMEN -}

\section{TE DICHAS - SCORPENA}

CARACTERES. - El genero tipico que ha dado el nom. bre á la sub-familia presente se distingue por la estructura oblonga de su cuerpo un tanto comprimido lateraimente, por su cabeza grande cubierta solo en pocos puntos de escamas, por la frente hundida 6 cóncava, y una depresion ó fosa en la parte superior de la cabeza. La boca es muy grande y casi siempre oblicua, armada en ambas mandibulas de dientes de púa y de terciopelo; el rómer lleva siempre dientes, pero el 
hueso palatino solo en determinadas especies. Defienden la cabeza muchas espinas $y$ aguijones de diferente direccion; el cuerpo está cubierto de escamas de tamaño regular, denta. das y rara vez cicloideas, es decir con borde liso. Diferentes apéndices membranosos af́ean frecuentemente la caheza y el cuerpo. la membrana branquial hendida hasta la rama de la mandibula inferior encierra sicte radios: en la aleta dorsal se cuentan casi siempre once radios principales y de tres á nue ve falsos; en las abdominales insertas debajo de las toráci. cas de uno á cinco y en la caudal once. No tienen vejiga na. tatoria.

\section{LA ESCORPENA ROJA-SCORPANA PORCUS}

CARACTERES. - La escorpena roja (fig. 136 ) es un pez muy comun y en algunos puntos hasta muy frecuente, en el Meditcráneo y Allántico, de una longitud de $0^{m}, 20$ á $0^{n}, 25$ y de color pardo tirando hácia el vientre á rosado, cubierto de numerosas manchas. En la alcta dorsal cuéntanse once radios duros y nueve blandos, en la torácica nueve, en la ab. dominal uno $y$ cinco, en la anal tres y cinco $y$ en la caudal once.

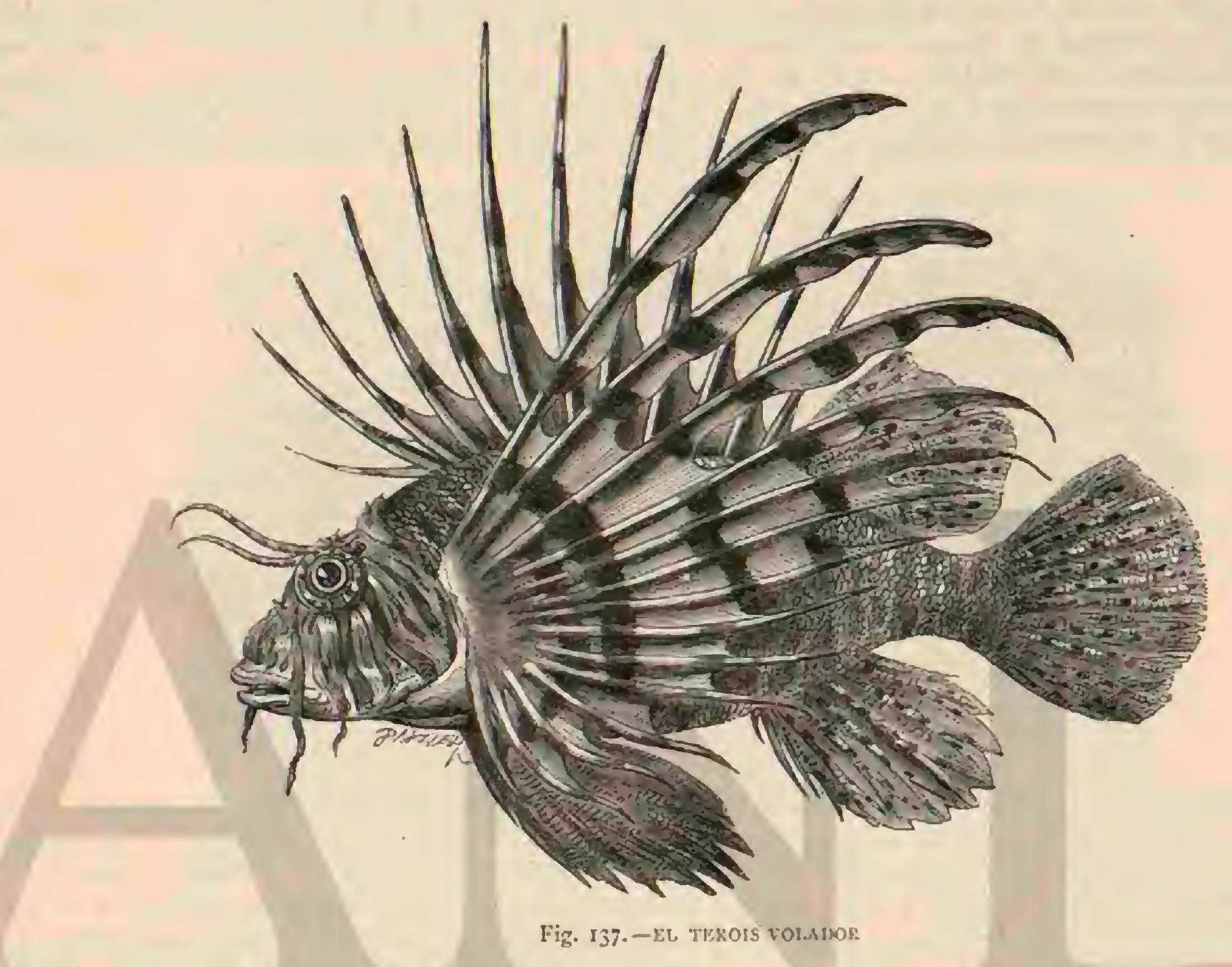

género de vida véase la descripcion general de la familia (página $3 i_{2}$ ), porque es dificil decir acerca de esta escorpena algo que no se haya dicho ya alli. Los antiguos estaban persuadidos de que todas las escorpenas y en especial la roja eran venenosas, $y$ esta opinion prevalecia aun en tiempo de Gessner; vénse lo que dice:

eEs peligroso coget estos, peces, porque su punzada es venenosa; y para curarse hay que beber una infusion de ajenjo en vino; tambien se espolvorea la herida con albayalde, to. mando interiormente cocimiento de salvia; orro buen medicamento es la misma carne del pez puesta sobre la herida; 0 bien se lava con orina de niño. Plinio cita como remedio el higado del pez colocado sobre la lesion, y Ciessner alaba tambien la hiel de este pez como medicamento superior ála hiel de tódos los demás peces, porque res remedio poderoso contra las manchas en los ojos (cataratas); hace desaparecer las serrugas y renacer los cabellos, etc.; y hasta su carne he. cha ceniza y bebida en vino cura muchisimos males. En Italia se come este pescado, que se vende alli junto con el otro, y su carne se tiene por sabrosa aunquie algo correosa.

\section{LOS COTOS ALADOS-PTEROIS}

CARACTÉRES. - Fste género de peces es uno de los mas brillantes y magnificos que pucblan el mar Indico, á pesar de su forma extravagante y bajo cierto aspecto fea. El cuerpo es oblongo, la cabeza comprimida y guarnecida de muchas espinas y apéndices cutaneos; el operculo lleva un aguijon romo, y estai cubierto de escamas al igual de las mejillas, á excepcion de una faja longitudinal armada de espinas y de protuberancias oblongas, $y$ del resto de la cabeza que esta desnudo. La aleta dorsal está sostenida por doce ó trece radios esbeltos, largos y muy afilados; la anal por solo tres radios; las torícicas son prolongadas á manera de alas, pero como deshilachadas por sus radios muy largos, que están unidos solo en parte por su membrana. El vómer tiene dientes pero no el paladar, $y$ las escamas ostenian los colores mas variados y brillantes.

\section{EL TEROIS VOLADOR - PTEROIS VOLITANS}

CARACTERES.-Una especie muy conocida del género de los peces alados es el terois rolador (fig. 137), que suele tener una longitud de 1$)^{m}, 20 \leqslant\left(1^{\circ}, 3^{\circ}\right.$ y el peso de un kilogramo. Su coloracion es magnifica. Sobre fondo pardo rojizo 6 pardo oscuro corren hasta reintidos fajas color de rosa apro. ximadas de dos en dos, segun Klunzinger, en muchos puntos mas anchas que el fondo, y en la cabeza oblicuas. En la bar- 
ba y garganta el fondo es rojizo y el dibujo compuesto de lineas onduladas pardas; en el nacimiento de las aletas torá. cicas se distingue una mancha redonda y blanca. Estas alctas son negras tirando a gris con manchas indeterminadas de color mas claro; en los radios alterna el color general del fondo con el rojizo; pero la superficie interior es negra adornada de manchas enteramente blancas; las aletas abdomiuales son negro-parduscas con manchas blancas en ambas caras; los radios de la aleta dorsal están anillados alternativamente de color de rosa y de negro, mientras que la membrana que los une tiene sobre fondo negro listas rojizas; las demais aletas son atigradas de amarillo pálido y de negro; los apéndices de la cabera estín anillados ó vetéados de negro, encar nado y blanco. Fil ojo presenta un dibujo de radios alfernativamenic pardos y claros. Én la aleta dorsal se distinguen trece radios duros extraordinariamente largos y puntiagudos, y doce blandos; en la anal tres radios espinosos y siete blan. dos; en cada torácica cinco radios sueltos, muy largos y hácia el extremo encorvados, y otros diez unidos por una membrana: en cada abdominal siete y en la caudal doce.

DISTRIBUCION GEOGRÁFICA. - Vive este pez en el mar Indico desde las costas de Africa hasta la Australia y fuera de este ámbito es tambien bastante comun.

USOS, COSTUMBRES Y REGIMEN. - En un prin. cipio se tenia este pez por volador, pero luego se conoció que esto era un crror, porque sus alctas partidas son impro. pias para volar; ni siquiera es nadador velo\%, sino que prefiere, segun Klunzinger, esconderse en los huecos del coral, por cuya razon escoge para morada predilecta los arrecifes y las cavidades profundas que dejan entre si los grupos de coral. Nadando y moviendo pausadamente sus aletas tan grandes y abigarradas, ofrece un aspecto por demás encan. tador. Muy iemidas son las punzadas de los radios de sus aletas, que como acaban en punta tan aguda, particularmente

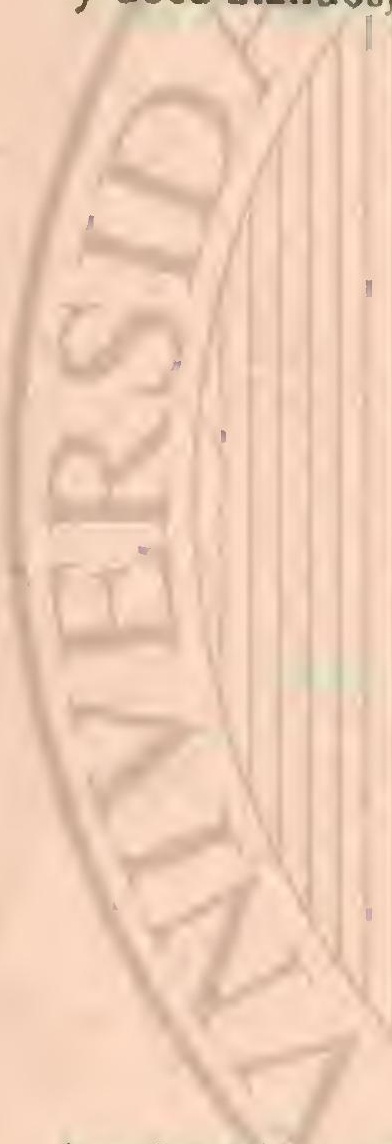

las del dorso, quicbranse con facilidad y quedan en la heri da; y tanto es asĭ, que rara vez se coge uno de estos peces sin que le faleen algunas puntas, si bien parece que vuelven á crecer. Los pescadorés drabes no comen este pez, pêro à pesar de esto dicen que su carne es buena.

\section{LOS BLEPSIAS - BLEPSIAS}

Eutre el grun número de peces extraordinarios que habitan en el norte del Ockano Pacifico, en las costas de Kamts chatka, de las islas Aleutienas, de la tierra de Jesso y laícia las islas del Japon, pocos hay tan singulares como los que designamos con este nombre.

CARACTERES. - Tienen el preopérculo espinoso: cabeza comprimida: mejilla acorazada; dientes palatinos; ndios sencillos, cortos y medio separados de la parte inferior de sus grandes pectoraies, y barbillas carnosas que penden del hocico. Por todos estos caractéres se parecen á las escorpenas; pero distinguense entre estas por los cinco radios de la membrana branquióstega, y por su aleta dorsal, dividida en tres lóbulos desiguales; mientras que $5 u$ cabeza comprimida les separa de aquellos peces.

\section{EL BLEPSIAS TRILOBADO-BLEPSIAS TRILOBUS}

CARACTERES - Las formas de este pez (fig. i 38 ) le comunican un aspecto de los mas singulares: su cuerpo es prolongado y comprimido: la cabeza bastante pequeĩa as proporcion; las alutas dorsal y anal altas; las pectorales y la caudal grandes; lai ventrales muy pequeñas. Los ojos esian i los hados; el maxilar presenta una truncadura, pero se ensaricha joco por detrás; pequeños dientes guarnecen las dos mandíbulas, la parte anterior dul vómer y los dos palatinos, mas no los hay en la lengua. La aleta pectoral cs casi una tercera parte tan larga como el pez; las ventrales cortas; la dorsal comienza en la nuca y consta de siete radios espino. sos y veinticuatro articulados, siendo los cuatro primeros tan alios como el cuerpo; luego baja mucho in membrana, vol. viendose á elevar mas en la primera porcion. Las demás aletas no ofrecen mada de particular. Este pez no tiencescamas; pero en la superficie de su cuerpo hay varias asperidades compactas y puntiagudas; tambien se ven debajo de la garganta y en una parte de la sien y las mejillas. Jos tentáculos tienen la forma de filetes delgados; cxisten dos en la extremidad de la mandibula superior y cinco en la inferior. El fondo del color de este pez. consiste en un pardo rojizo, con fajas azuladas en la mejilla y una mancha del mismo tinte en la extremidad del opérculo; las que presentan las pectorales y caudales, en número de seis, son pardas y blan. cas. El blepsias trilobado mide coinunmente de cinco á seis pulgadas.

DYSTRIBUCION GEOGRAFICA.- Se ha encontrado la cespecie en las costas de América, en el golfo de Aratscha y en la embocadura del Uika.

USOS, COSTUMBRES Y REGIMEN, - Como este pez ha sido poco observado, por escasear nuucho los individuos, nada podemos decir con seguridad acerca de sus rostumbres y genero de vida. 


\section{EL PEZ DIABLO-PELOR FILAMENTOSUM}

CARACTERES. - Esta escorpena (fig. 139), demuestra hasta dónde puede ilegar la fealdad entre estos animales; pues su figura es positivamente horrorosa; la cabeza es hundida á manera de silla de caballo, por cuya razon Brehm la ha dado en aleman el nombre de cabezo de silla cie caliallo. No hay palabras para describir este monstruoso sér ni se acabaria munca con la enumcracion de todas sus espinas, excrecencias, apéndices, ctc, ctc. El hocico se parece al del hipopótamo, y la cabeza en general apenas se asemeja a la de un pez; los ojos se hallan colocados como al extremo de un palo, uno junto al otro y vueltos hácia arriba; el cucrpo es oblongo, pero el vientre parece hinchado, el lomo es mu cho mas alto que la cabeza. Las mandibulas llevan dientes finos de terciopelo. La membrana branquial tiene siete radios. La aleta dorsal, que empieza en la nuca ; continua hasta la cola, tiene quince radios rectos, reforzados, agudos y provistos de ganchos, y ocho radios blandos y ramificados; la aleta torácica, que es grandisima y relativamente muy an. cha, tiene dos espinas sueltas y diez radios unidos por la membrana; la abdominal tiene una espina 5 cinco radios; la anal tres radios espinosos y siete blandos, y la caudal, que guarda analogía con la torácica, tiene doce radios. La piel es blanda y esponjosa con apéndices en varios sitios, contri. buyendo í aumentar la fealdad del animal. Sobre fondo de color gris hay manchas pardas borrosas y veteadas, con otras blancas salpicadas de puntas del mismo color, pasando en la cabeza por diferentes matices hasta el color de tosa; la cara interior de la aleta torácica es blanca con viso rosado $y^{\prime}$

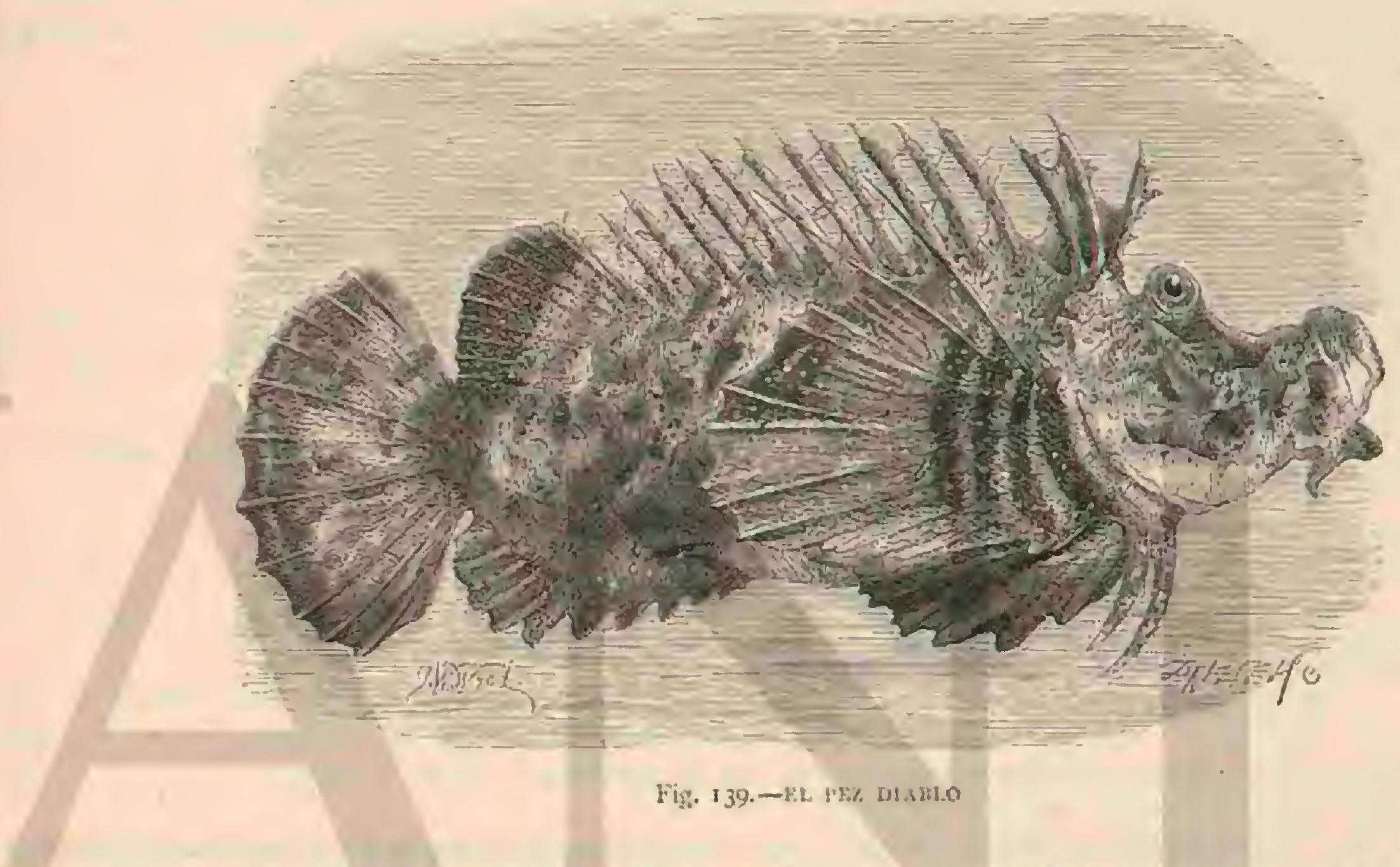

manchas negras en el borde; las alctas abdominales y anal son pardas; y la caudal presenta sobre un fondo claro man chas igualmente claras.

Hasta ahora solo se ha cogido este animal repugnante en el Occano Indico, sin que se sepa nada sobre sus costumbres. En su estómago hánse encontrado cangrejos pequeños.

\section{LOS MONOCENTROS-MONO- CENTRIS}

CA RACTERES.-Los representantes de este género no tienen solo la mejilla acorazada, sino el cuerpo entero, y por este carácter nada tienen que envidiar á las especies mejor armadas. Se distinguen esencialmente por la forma combada de su cráneo y de sus dos dorsales, que cuentan ocho radios ramosos; no les faltan los dientes palatinos; la primera dorsal está rcemplazada por espinas libres, y están provistos de otras grandes en las ventrales; el sub-orbitario se une con su preopérculo lo mismo que en los otros géneros de la familia.

\section{EL MONOCENTRO DEL JAPON-MONOCEN- TRIS JAPONICUS}

CARACTERES. - El cuerpo del monocentro (fig. 1.40) es corto, comprimido s termina en una pequeña cola; las es. pinas que reemplazan a la primera dorsal están situadas casi en el centro del lomo. Las aristas de la cabéza son salientes, con las espinas muy ásperas, á causa de los primeros granos compactos de que están erizadas. Ia boca, hendida hasta debajo del ojo, toma una forma casi circular cuando se abre; los dientes de las dos mandibulas son pequeños, ocupan una faja estrecha, y cada palatino tiene en su centro otra semejante, siendo lo mas extraño que no haya ninguna delante del vómer. Las escarnas del cuerpo, anchas, angulosas, y ásperas, tienen una dureza huesosa, formando su conjunto una coraza muy fija; el pecho y el vientre están protegidos del mismo modo, presentando el segundo, desde las ventrales hasta el ano, tres aristas fuertes. 'La primera dorsal consta de cinco ó seis espinas gruesas, ásperas y estriadas; la segunda tiene once radios blandos, la anal diez; la caudal vêinte enteros; las pectorales doce ó trece; $y$ las ventrales consisten en una gruesa espina estriada. El monocentro del Japon es de un color gris amarillento, $y$ las lineas angulosas que separan sus escamas de un pardo oscuro; las aletas tienen el mismo tinte del fondo. Mide unas 6 ó 7 pulgadas de largo.

DISTRIBUCION GEOGRÁFICA.-Este pez extraordi. nario no se ha visto sino en los mares del Japon.

USOS, COSTUMBRES Y RÉGIMEN, - Nada absolutamente se sabe acerca de las costumbres de este pez, ni tampoco ha sido posible estudiar su estructura anarómica, por la dificultad de obtener un individuo. 


\section{LOS OREOSOMES - OREOSOMA}

CARACTERES. - Hé aqui otro de esos séres de figura extravagante, que se considerarian mas bien como el producto monstruoso de una imaginacion calenturienta, que no una realidad existente en la naturaleza. Figurémonos un pez peq̨ueño, $\tan$ alto $\mathrm{como}$ ancho, erizado de gruesos conos se. mejantes á pilones de azúcar, y se comenzará à formar una idea de lo que es el oreosome, ó pes montañoso, pues este es el nombre que resulta de las dos palabras griegas de que aquel se deriva.

\section{EL OREOSOME DEL ATLÁNTICO-OREOSO- ME ATLANTICUM}

CARACTERES. - La cabeza de este pez (fig. 141) tiene el perfil recto y casi horizontal; su boca está hendida verticalmente sobre la extremidad del hocico; su frente es plana y bastante ancha entre los ojes, sobre cada uno de los cuales hay un pequeño cuerno cónico: ni en los sub-orbitarios ni en el preopérculo se ven espinas, y apenas podria decirse que la mejilla está acorazada. El cuerpo puede dividirse en tron. co y cola; esta, de forma comprimida, forma una lámina vertical muy plana; el tronco es bastante grueso y lleva en su parte dorsal cuatro de los conos de que hemos hablado, viéndose uno pequeño entre los dos posteriores y una redu. cida dorsal de cuatro ó cinco espinas. En la parte inferior del tronco, mas ancha que la superior, hay una serie de cinco grandes conos, y por delante de ella dos pequeños, detrás de los que se hallan las ventrales; tambien se ren dos ma. yores en los lados del ano, 5 otros cinco ó seis de menor ta-

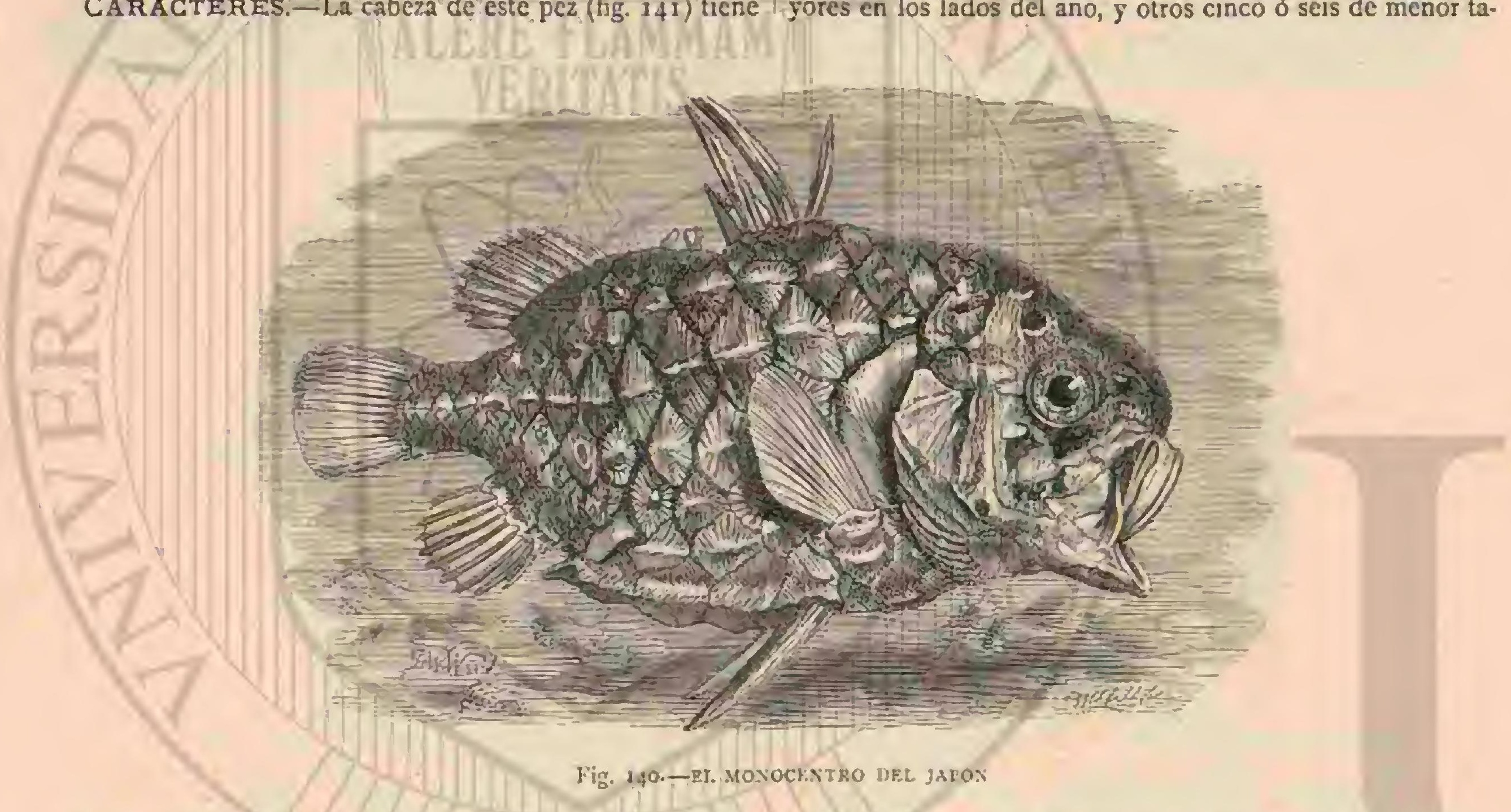

maño, quue forman dos lineas longitudinales. Esste pequeño pez carece de escamas; su piel es granujienta en el tronco, pero casi lisa en todas las demás partes, y clla es ta que forma, al cndurecerse, una especie de bocios $\delta$ conchas que producen los conos, los cuales se desprenden fácilmente y están estria. dos por circulos paralelos s. su base. Las mandibulas, el romer y el paladar tienen dientes. El color del orcosome consiste en un gris ceniciento; el iris es dorado. Iil único individuo observado media 16 lineas.

DISTRIBUCION GEOGRÁFICA. - No se ha encon. trado la especie sino en las aguas del mar que le da nombre.

USOS, COSTUMBRES Y REGIMEN. - Nada absolutamente podemos decir acerca de este pez extraordinario, en lo que toca a sus costumbres, pues ni en los relatos de via jeros ni en las descripciones de los naturalistas encontramos cosa alguna que á la especie se refiera. El único ejemplar observado se debe al infatigable celo de Mr. Perón, que des. cubrió ese pez en el Atlíntico.

\section{LOS HOPLOSTETES - HOPLOSTETHUS}

En este género vemos una nueva muestra de esas riquezas quue el Mediterranco oculta en sus abismos, y que solo esperan, para ser conocidas de los maturalistas, ojos que las sepan ver y plumas que quieran anunciar su existencia. Es. te pez debe ser sumamente raro, pues no vemos su descrip. cion en los autores, $y$ apenas se ha encontrado un individuo que sirviern de ejemplar.

CARACTERES. - La parte inferior del torax presenta fuertes escamas, y de este carácter se deriva su nombre genérico, tomado de dos palabras griegas que significan armadura y pecho. Es de advertir, no obstante, que la especic de coraza que protege a este pez se halla mas bien debajo de la pelvis que del verdadero pecho.

\section{EL HOPLOSTETE DEL MEDITERRÁNEO- HOPLOSTETHUS MEDITERRANEUS}

CARACTERES. - A no ser pos la cola, el cuerpo de este pez (fig. 142) formaria un bonito óvalo, cuya cabeza solo ocupa las dos quintas partes; la frente y el hocico son trasversalmente convexos, $y$ el segundo combado sobre la boca, viéndose äbajo de esta convexidad aristas salientes de bordes ásperos, dos de las cuales parten de la nuca para reunirse entre los ojos en una sola. El opérculo tiene una arista trasversal que remata en una espina, y en el supraescapular hay otra áspera y plana. Los ojos son muy grandes; la boca sumamente hendida; el maxilar forma un anchotriángulo; la mandibula inferior tiene, en vez de dientes, una estrecha faja ligeramente áspera, y en su extremidad una tuberosidad que corresponde á la escotadura de la superior. No hay dientes en el vómer, ni existe sampoco una verdadera lengua, pero la extremidad del hioides forma una saliente con- 
siderable. Los dientes faringeos superiores é inferiores son pequenos y raros. La dorsal tienc seis espinas ásperas y pun. tiagudas, que aumentan de tamaño desde la primera; la anal tres radios espinosos estriados y diez blandos; las demás ale. tas no ofrecen ningun carácter particular. Ni en estas últimas ni en la cabeza se re ninguna escama; las del cuerpo son lisas, mas anchas que largas, irregularmente ovales $y$ sin truncadura, distinguiéndose las de la linea lateral por ser mayores. Desde las ventrales hasta el ano está la especie de coraza que caracteriza principalmente al género, y que se compone de once piezas escamosas, con carenas inferiores cortantes, terminada cada cual por una pequeña espina corta y puntiaguda. La cola es sumamente ahorquillada El color de este pez es argentado, con un ligero tinte rojizo en el lomo, y las aletas amarillentas; el íris dorado; en el paladar, la lengua $s$ los arcos branquiales hay mezcla de negro.

DISTRIBUCION GEOGRÁFICA._La especie es pro pia del mar cuyo nombre lleva, y se encuentra muy á menudo en las costas de Madera.

\section{LOS CATAFRACTOS PROPIAMEN- TE DICHOS-CATAPHRACTI}

CARACTERES.-Fstos peces que tienen todo el cuer. po cubierto de placas reforzadas con un nervio, quilla ó cres. ta en el centro, forman otra sub-familia.

\section{LOS COTOS ACORAZADOS- ASPIDOPHORUS}

CARACTERES. - Los individuos de este géneto viven en los mares que bañan las costas de Alemania. Su cuerpo es oblongo y cubierto de escudetes huesosos formando hile. ras, lo que les da un aspecto prismático-poligonal; la cabeza excede del cuerpo en grosor y" está provista tambien de es. pinas en su parte superior, y de otras encorvadas junto á la boca; la dentadura se limita álas mandibulas.

\section{EL COTO ACORAZADO-ASPIDOPHORUS CATAPHRACTUS}

CARACTERES. - El representante del género de los aspidóforos es el coto acorazado, de figura octogonal, de $11^{m}, 15$ de Inngitud y de color pardo mas claro y liasta tirando á blanco en la parte inferior con listas pardas oscuras longitudinales en el lomo; las aletas dorsales, de color pardo claro, ticnen manchas pardo oscuras y las torácicas retas del mismo color. La primera aleta dorsal tiene quince, la segun. da siete, $y$ la torácica quince radios; la abdominal tiene uno y dos, la anal siete $y$ la caudal once.

USOS, COSTUMBRES Y REGIMEN.- Ya en el año 1624 publicó Schonevelde, médico aleman, una descripcion bastante exacta de este pez, teniendo a la vista uno que habia cogido en la desembocadura del Elba. Ahora ya sabemos que se encuentra en el mar del Norte y en el Báltico; que vive durante el verano à una profundidad reguiar, con preferencia cerca de las desembocaduras de los rios, y que se retira en invierno á mayores profundidades. Segun Eckstroem, no se acercan los machos á las costas comolo hacen las hembras, excepto en el tiempo de la freza, en abril ó mayo, pero entonces en bastante número. Su reproduccion es poco abundante, pues Kroeyer solo encontró trescientas huevas en una hembra vieja. En cuanto á voracidad compite con sus congŕneres; solo que ha de limitarse á animales pe. queños. Su carne no tiene estima, por cuya razon los pesca dores los suelen arrojar otra vez, al mar $\delta$ emplearlos ślo sunio como cebo. Cautivo no suele resistir mucho tiempo.

\section{LOS ACORAZADOS - PERISTEDION}

CARACTERES.-Los peces de este grupo tienen todo el cuerpo cubierto de grandes escuditos óseos, dos piczas óseas salientes en los dos lados de la cola, la boca sin dien-

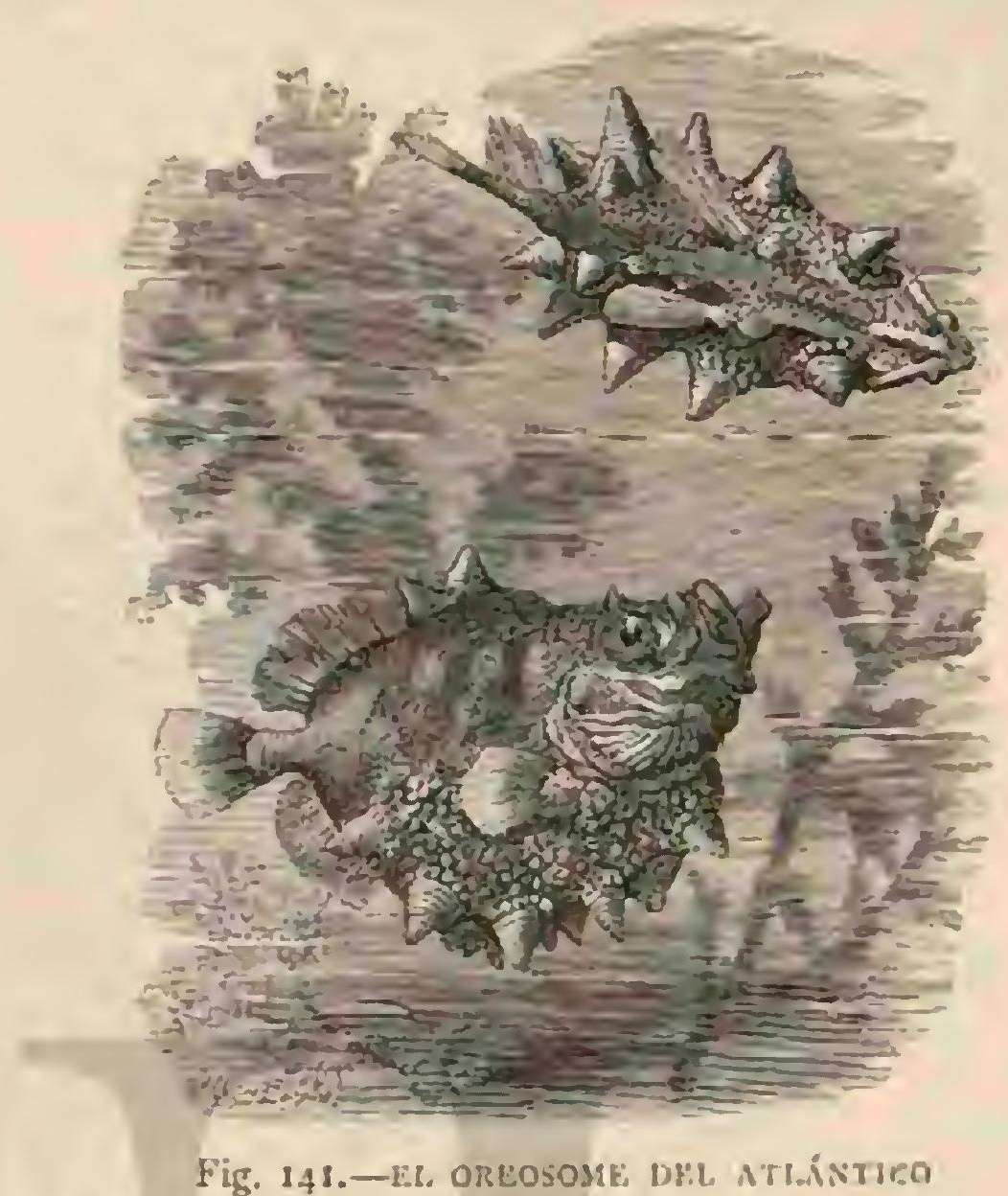

tes $y$ algunos apéndices en la mandíbula inferior. Como representante y tipo del género sc admite:

\section{EL ACORAZADO-PERISTETHUS CATA- PHRACTUM}

CARACTERES. - El acorazado ó malnrmat merece bien el nombre que lleva, pues no hay otro pezen las aguas euro. peas tan bien defendido como él. Tiene el cuerpo oblongo que cortado trasversalmente presenta un octógono casi regu. lar; la mandibula superior es bifurcada y sobresale mucho de la inferior; la boca es semicircular; de la mandibula infe. rior cuclgan algunos apéndices de los cuales uno mas desarrollado que los otros tiene varias ramificaciones. La coraza consiste en escudetes dispuestos en ocho hileras que forman en sus cantos otras tantas crestas clcvadas óaristas salientes y pectiniformes. La primera aleta dorsal tiene siete radios delgados y Rexibles que acaban fuera de la epidermis en cerdas; en la segunda se cuentan dicz y sicte ó diez. y ocho; en las torácicas, de longitud mediana, se cuentan dicz radios y dos espinosos delante y sueltos; en las abdominales uno ! cinco; en la anal diez y ocho y en la caudal once. Li color es en la parte superior un encarnado magnifico que pasa en los costados á dorado y en el vientre á plateado; las aletas torácicas son encarnadas, las dorsales color violcta pardusco, y las abdominales y la anal son blancas. La longitud es de $0^{\circ}, 30$ aproximadamente.

DISTRIBUGION GEOGRÁFICA. - Es pe\% bastante frecuente en el Mediterránco y se presenta en las costas de Francia y en las meridionales de Italia con regularidad; se le pesca en el Adriático, en la parte meridional del Atlánti. co y se extravia hasta Inglaterra.

USOS, COSTUMBRES Y RÉGIMEN.-Risso comU. nica algo sobre su género de vida $y$ dice que vive comunmente á gran profundidad, de la que se aleja únicamente 
cuando se acerca å la costa para deshacerse de su freza, es decir, en la época equinoccial. Dificre de sus congéneres por vivir aislado, y nada con una velocidad tan increible que, segun dicen, no es raro que con el empuje se quiebren no pocos la prolongacion bifurcada de su hocico contra las rocas. Se alimenta principalmente de moluscos desnudos y de hidras.

Los antiguos no debian tener noticia de este per, pues á no ser asi de seguro que lo mencionarian; y aun los habitan. tes actuales de aquellas costas lo consideran como una cosa extrana y digna de conservar, ya desecado ó de otro modo, 5 eso que se interesan muchisina meruós que los antiguos por las cosas de la naturaleza. Parece que se pesca durante todo el año en las cosias de España y de Provenza, donde se dice le tienen en gran estima por su excelente carae, si bien su coraza, que desafia el cuchillo de la cocinera, obliga à guisar. lo de un modo especial que consiste en cocerlo primero y escamarlo despues; ó si hay que freirlo, se limpia por la boca y se llena por la misma de manteca, se vuelve á la sarten y se frie hasta que saltan las cscamas.

\section{LOS TRIGLINOS - TRIGLINAE}

CARACTÉRES.-Forman esta última sub-familia peces pequeños 6 a lo mas de tamaño regular, pero rechonchos, con cabeza casi cuadrada, relativamente muy gruesa y toda acorazada de placas bastas y łsperas; tienen dos aletas dorsales separadas, y delante de las torícicas, que están nuy desarrolladas, tres radios sueltos y articulados; dientes de tercio. pelo en las mandíbulas y en el vómer.

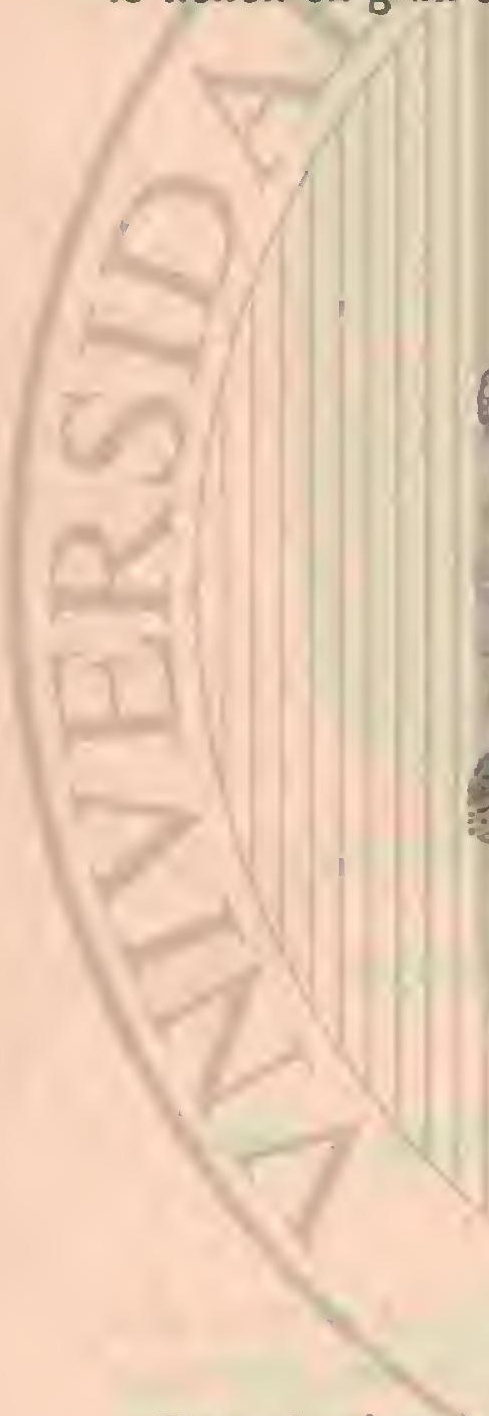

En todo tiempo han llamado estos peces la atencion por el ruido extraño que hacen cuandó se los saca del agua, ruido producido por el roce de los huesos operculares entre si 5 que se parece 2 un gruñido. Se dice que algunas especies son fosforcscentes.

\section{EL TRIGLA GOLONDRINA - TRYGLA HIRUNDO}

CARACTERES:- La especie europen mas grande del género trigla es la golondrins (fig. 1.43), que tiene de $0^{\circ}, 50$ á $0^{m}, 60$ de longiud, $y$ es de color rojizo gris ó pardusco en el lomo, rosa ó blanquizco en el vientre, que unido a las aletas dorsales y la caudal de color rojo, la abdominal y la anal blancas, $y$ las torácicas negras orladas interiormente de azul, dan a este pez un aspecto muy vistoso. En la primera aleta dorsal se cuentan nueve y en la segunda diez y seis radios; en la torácica ires radios sueltos y once unidos; en la abdo. minal un radio duro y cinco blandos; en la anal guince y en la caudal once.

\section{EL TRIGLA GUNARDO-TRIGLA GUNARDUS}

CARACTERES.-Muy afine del precedente es el gW. nario, que alcanza como la mitad de la longitud de aquel, $y$ tiene la parte superior de color gris pardusco salpicado de blanco, que en la region malar afecta la forma de estrellitas, siendo blanca la parte inferior del cuerpo. Una arisia aserrada de puntas muy afiladas corre á lo largo de los costados. La primera aleta dorsal es parda a veces con manchas negras; las aletas torácicas relativamente cortas tienen un color gris oscuro, las abdominales y la anal son casi blancas. Sc cuentan ocho radios en la primera aleta dorsal; veinte en la segunda; tres espinosos sueltos y diez unidos en cada tork. cica; en cada abdominal uno y cinco; veinte en la anal $y$ once en la caudal.

\section{EL TRIGLA LIRA-TRIGLA ITRA}

CARACTERES. - Esta especie (fig. 144) tiene la cabeza muy voluminosa; y la cola, disminuyendo gradualmente, se adelgaza mucho cerca de la caudal. Los lóbulos del hocico avanzan mas, y la escotadura que los separa es mas profunda que en los otros triglas; cada uno de ellos tiene su borde dividido en doce ó quince dientes, siendo los del centro largos y puntiagudos. Todas las partes de la cabeza ofrecen yranu. laciones finas, y del punto conde divergen los radios de la mejilla parte una arista horizontal que atraviesa la parte baja del preopérculo s termina en su ángulo en una punta muy corta. Este pez tiene las aletas pectorales muy grandes; los radios de la primera dorsal son en extremo cortantes, un poco arqueados y lisos, cxcepto el primero y el segundo, cuyo borde anterior parece dentado; el segundo y el tercero son iguales, y el cuarto no se diferencia mucho; el número 
total de ellos es de nueve. Las demás aletas no ofrecen nada de particular. Todos los autores dicen que este pez es de un hermoso color rojo en la parte superior del cuerpo, dorado ó amarillento en la cabeza y de un blanco plateado en el vientre; las aletas tienen un tinte mas oscuro, $y$ en algunos individuos son las rentrales de un blanco azulado.

DISTRIBUCION GEOGR ÁFICA.-Estos triglas viven en el Mediterråneo, Atlántico, mar del Norte y Báltico. Son comunes en las costas de Inglaterra; bastante frecuentes en la isla de Heligoland $y$ a lo largo de las costas de Frisia, Oldemburgo y Holstein; raros en las costas arenosas meridionales del Báltico.
USOS, COSTUMBRES Y REGIMEN.-LES gusia el fondo arenoso, pero profundo, donde persiguen crustaceos, y cuando no, conchas y otros moluscos, hasta hidras. Nadan con mucha gracia, aunque con cierta lentitud, sirviéndose de sus grandes aletas torácicas como de alas que pliegan y despliegan alternativamente. Dicen que lirillon camo es. trellas $\delta$ producen como un surco brillante y muy largo cuando se mueven de noche en sitios de poca agua. Mas notable y mas extraño es su modo de moverse á rastras, pues los tres radios suelios que hay delante de las aletas torácicas no son en el fondo otra cosa que patas con cuya ayuda andan estos peces. Para efectuar este movimiento alzan un

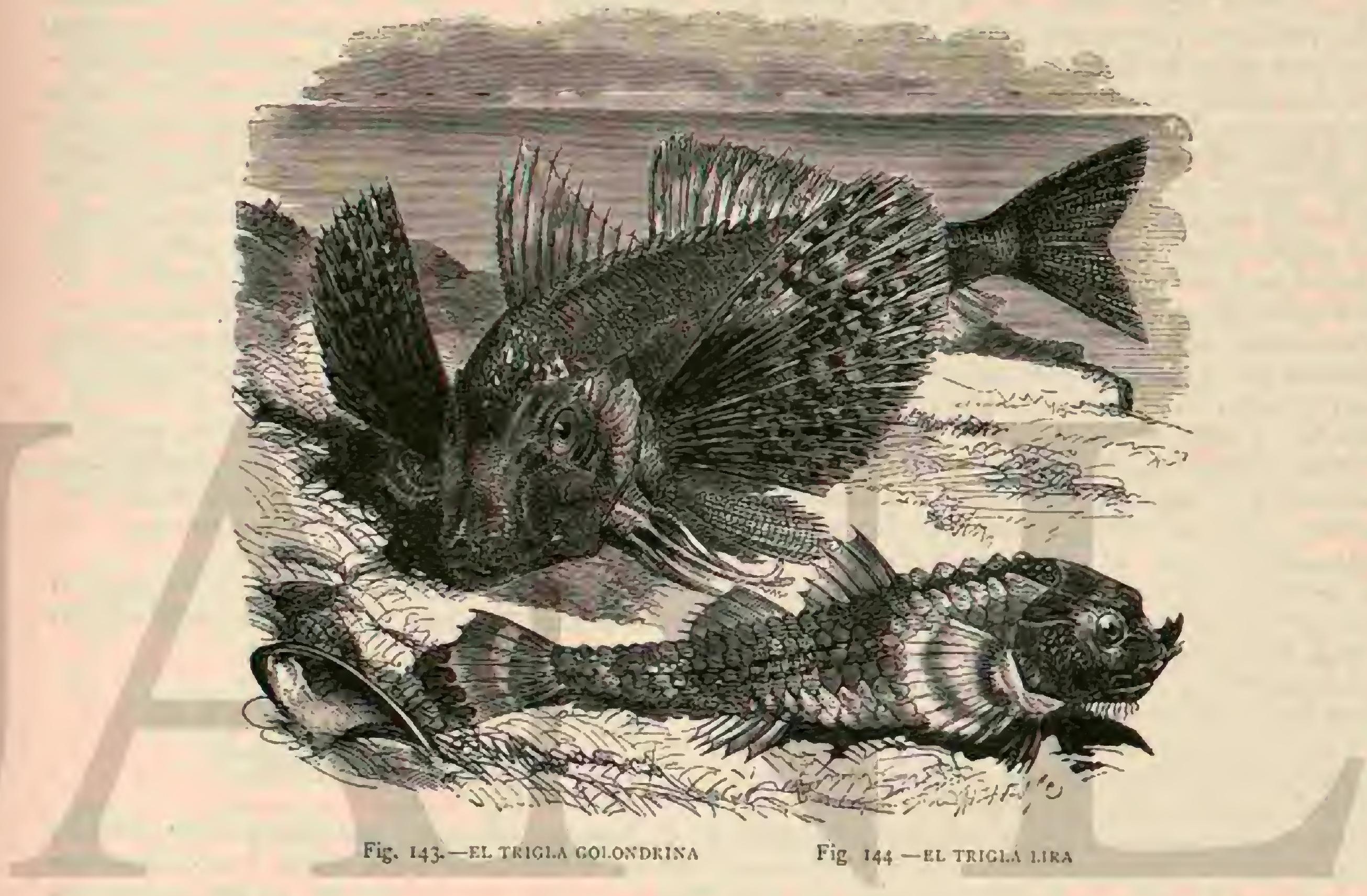

poco la parte posterior del cuerpo, en seguida mueven los tres radios rápida y separadamente uno del otro y se ayudau con un ligerísimo movimiento lateral de la cola. Verdad es quue andan con lentitud, porque los radios son cortos, pero con suficiente sapidez para atravesar distancias muy reguia. res en pocos minutos. No existen observaciones de otros naturalistas sobre este movimiento trasiatorio del pez, pero puede admitirse que le ha de servir para algo y especial. mente para atrapar algunas presas. El tiempo del desove cae en los meses de majo y junio; pues en noviembre se cogen pequeños de $0^{*}, 08 \& 6^{m}, 10$ de largo, que no difieren en nada de los viejos.

PESCA. - La carne de estos triglas, $\&$ mas particular. mente la del primero, es algo dura y seca, a pesar de lo cual es estimada, por cuya razon se pescan en todas partes. En Inglaterra se emplean redes barrederas de cinco metros de largo, pero en Italia se prefiere pescarlos con anzuelo. Fuera de esto puede suceder que dichos peces se hallen accidentalmente en las capas superiores, en cuyo caso dan motivo \& una verdadera caza. Refiere un observador que cuando e] tiempo es bonancible, los triglas suelen sacar la cabeza del agua, y despues de haber producido su extrano gruñido que se oje á gran distancia, sevuelven á hundir hasta cosa de me- dio metro; asi es que con un poco de atencion se los puede lirar sin gran trabajo con la escopeta y matar en poco tiempo un número considerable.

CAUTIVIDAD. - Es raro poder conservar estos animales mucho ticmpo vivos á no ser que se tengan en un vivero de muy escasa profundidad dorde el agua se renueve sin cesar y con rapidez, á fin de procurarles la cantidad de oxigeno que necesitan.

\section{LOS PECES VOLADORES - DACTYLOPTERUS}

CARACTERES. - Los distintivos de estos peces consisten en un desarrollo extraordinario de las aletas torácicas que vienen á formar un abanico doble, y cuja parte anterior tiene pocos radios mientras que la posterior se halla scste. nida $y$ distendida por radios casi tan largos como el cuerpo mismo. Las aletas dorsales son pequen̉as, pero van precedidas de algunos aguijones ó radios duros y streltos; el opér. culo no tiene espinas, pero el preopérculo las ticne muy lasgas. In cuanto à la dentadura, solo hay dientes de adoquin en las mandibulas. 
EL DACTILÓPTERO VOLADOR-DACTYLOPTERUS VOLITANS

CARAGTERES, - La especie mas conocida del género dactilóptero es el volador comun (fig. 1.45) que habita el Mediterránco. Su afinidad con los demás catafractos parece á primera vista menor de lo que es en realidad, porque la impresion gुue causa su aspecto en conjunto es bien diferente de la de sus afines. El hocico es corto y muy achatado; la parte superior del cráneo es plana, y solo una parte de la region malar está cubierta de escamas; ell opérculo es pequeño y redondeado; la boca pequefia tambien; el cuerpo bastante oblongo y cubierto de escamas duras, con borde recortado en ondas $y$ en parte crestadas. El lomo tiene un hermoso color pardo claro con manchas oscuras; los lados de la cabeza y del cuerpo son de color fojo claro con viso plateado y la parte inferior color de rosa. Las grandes aletas torácicas presentan sobre fondo oscuro manchas, lineas y vetas azules, las dorsales sobre fondo gris manchas difusas pardas, $y$ la caudal manchas dispuestas en hilera sobre fondo pardo roji20. En la primera aleta dorsal hay sicte radios espinosos, los dos primeros separados de los cinco restantes que son al propio tiempo mas robustos y mas largos; - 1 a segunda tiene ocho radios; las abdominales, que son muy pequeiras y se hallan insertas debajo de las torácicas, tienen uno y cuatro cada una; las torácicas seis y veintinueve a treinta; la anal seis $y$ la caudal once $y$ doce. Hay individuos que llegan af adquirir una longitud de $0^{\circ}, 50$.

USOS, COSTUMBRES - Y REGIMEN. - Tanto los autores de la antigüedad que se ocupaban de historia natural, como todos los viajeros modernos que han cruzado el Mediterráneo, hablan del pez volador, porque además de ser comun en aquel mar, llama forzosamente la atencion hasta de las personas mas indiferentes y legas en la materia. A pesar de esto es fícilque se confundan frecuentemente unos voladores con otros á los cuales se asemejan probablemente en sus costumbres.

A reces se observa desde la cubierta de un buque cómo se levanta súbitamente del agua una bandada de estos peces mas 6 menos próxima, hasta una altura de cuatro ó cinco metros, y que despues de haber recorrido una distancia de ciento á ciento veinte metros con el ruido propio de su aleteo, se vuelve á hundir en el elemento liquido de donde salió. A menudo se va repitiendo este espectáculo con mucha rapidez, levantándose una segunda, lercera y cuarta bandada, una en ipos de otra, antes que la primera haya vuelto á,caer en el agua. Cuando estos vuelos se suceden en una misma direccion puede admitirse que los voladores se ven perseguiỏos por un pez de rapiña y tratan de salvarse volando ó, mas correctamente dicho, saltando; pero utras veces se los ve aparecer sin regla ni direccion fijas $y$ como hácia todas partes; en este caso debe suponerse que lo hacen retozando como otros peces que suelen saltar fuera del agua. Estas bandadias no tardan en llamar la atencion de las gaviotas y cuervos marinos que acuden a cazar los peces voladores, en cuyo momento tiene el espectáculo su mayor atractivo, porque las aves han de apelar á toda su destreza en el vuelo para apoderarse de los peces, que con la velocidad con que atraviesan la distancia aérea burlan continuamente los es. fuerzos de sus enemigos.

Poco ó nada tienen que temer del hombre los voladores, porgue su carne seca y dura no compensa el trabajo de pescarlos en un mar que, como el Mediterráneo, es tan ábundante en peces; pero con todo, siempre se enreda alguno que otro en las redes del pescador. Se alimentan de pequeños crustáceos y de moluscos. En ninguna parte encuentro datos

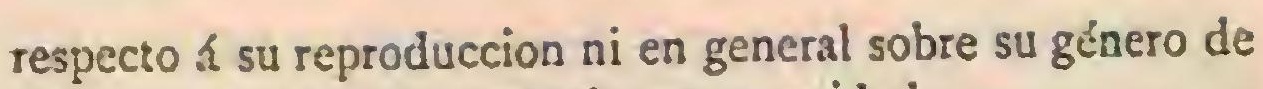
vida que está todavía envueito en oscuridad.

\section{EL DACTILÓPTERO ORIENTAL-DACTYLOP- TERUS ORIENTALIS}

CARACTERES. - El carácter mas marcado de este dactilóptero (fig. 146), consiste en que el casco óseo de'su cabeza está escotado por detrás mucho mas profundamente, y hasta por encima del ángulo superior del preopérculo, de moda que de adelante atrás en la línea media, el cráneo, de anchura igual, no tiene apenas mas de la mitad del largo de la especie comun. El primer radio dorsal es tambien mu. cho mas largo, y mide casi el triple de la altura del cuerpo en el sitio correspondiente. El hocico de este pez es tambien mucho menos saliente; los supra-escapulares mas redondea. dos hácia la punta, como sucede asimismo cun las escamas; las ventrales algo mas angostas y las alas un poco mas largas, no estando tan separada su parte anterior. En todo lo demás se asemejan nucho ambas especies. El dactilóptero oriental tiene un color rojo pardo en la parte superior del cuerpo, con mezcla de negruzco; las grandes alctas están cubiertas de manchas pardas $y$ de otras blanquizcas $\delta$ azuladas, mas pequeñas que en la especie de nuestros mares. Algunos indi. viduos ofrecen en la punta de cada escama una manchita pardo roja, y en otros son grandes y negruzcas las que hay en el lomo.

DISTRIBUCION GEOGRÁFICA. - Esta especic se encuentra en todo/el Océano Indico y en el archipiélago. Tambien se pescan algunos individuos en la isla de Francia; pero escasea mucho en las costas de Coromandel y de Orixa.

USOS, COSTUMBRES Y REGIMEN.-Por su género de vida se asemeja en un todo esta especie al dactilóptero volador.

\section{LOS - TRAQUÍNIDOS - TRACHINID死}

CARACTERES. - Posecmos la descripcion de unascien especies pertenecientes á esta familia, y es probable que constituyan solo una pequeña parte de ella; sus distintivos conunes son los siguientes: el cuerpo afecta la forma de cuchillo ó bien la de embudo comprimido en sentido ya longitudinal, ya trasversal, á, expensas de una cola enorme; la cabcza corta y gruesa con la boca dirigida oblicuamente hácia arriba, y los ojos colocados tambien en la parte superior; seis $\delta$ siete, rara vez cinco, radios branquiales; dientes aterciopelados en ambas mandibulas y en el paladar; dos aletas dorsales, pareciendo la segunda aumentada a costa de la primera, que falta en algunas especies; las aletas abdominales suelen hallarse insertas comunmente delante de las torácicas; y el desarrollo desproporcionado de la segunda aleta dorsal y de la anal comparativamente à la longitud de la cola.

USOS, COSTUMBRES X REGIMEN.-Todas las especies de esta farnilia viven sobre el fondo del mar, prefiriendo los sitios poco profundos $y$ arenosos, $y$ hasta aquellos que quedan en las mareas bajas en seco. Alli aguardan estos peces hundidos hasta la cabeza en la arena y con ojo avizor la presa que acierte á pasar sea nadando $\delta$ arrastrando por encima de ellos; quizás la atraigan tambien con el juego de sus aletas y apéndices. Cuando la divisan salen súbitamente de su arenoso lecho, y se arrojan sobre ella tan certeramente que casi nunca se les escapa. Poco ó nada se sabe sobre su 
modo de reproducirse, quizás porque los pescadores los temen y odian, á pesar de su fina y sabrosa carne, por las heridas tan dolorosas que causan con su primera aleta dorsal que desde antiguo se ha tenido por venenosa.

\section{LOS TRAQUINOS-TRACHINUS}

CARACTERES-Representa a la familia en las aguas alemanas el género iraquino. El cuerpo imita la forma de cuchillo por tener muy comprimidos los costados en proporcion de su longitud. Los ojos se hallan colocados en la parte superior muy cerca uno del otro; los opérculos llevan espinas, pero no tan temibles como los radios de la primera aleta dorsal que pueden causar tan dolorosas heridas cuando no se tiene cuidado al manejarlos, que antiguamente pres. cribia una ley en Francia que se cortaran estas aletas antes de presentar dichos peces á la venta. Tas mandíluulas, el espacio anterior del vómer, el paladar y los huesos alados llevan dientes aterciopelados.

\section{EL TRAQUINO DRAGON-TRACHINUS DRACO}

CARACTERES. - En las aguas europeas se conocen cuatro especies muy afines, pero que pueden distinguirse per. fectamente por sciiales invariables. Dos de ellas se encuen. tran en los mares del norte; el traguino dragon y el traguino aibora. El cuerpo del primero (fig. 147) es seis veces mas largo que alto, el dorso forma una línea casi recta y el vien. tre una ligera curva. La primera aleta dorsal, muy corta, tiene seis espinas delgadas, pero muy duras, siendo las dos primeras las mas largas; los radios de la aleta dorsal segunda son en número de veintinueve hasta treinta y uno ýa poca diferencia de igual altura; la aleta torácica tiene quince radios; la abdominal un radio espinoso y cinco blandos; la anal uno duro y treinta hasta treinta 8 tres blandos; ia caudal tiene catorce radios. En cuanto á coloracion puede competir con gran número de otros peces; el fondo es rojizo tirando a gris que hácia el dorso toma un tinte pardusco, y blanquizco hácia el vientre, jaspeado en todo el cuerpo de manchas indeterminadas $y$ negruzcas, a las que se agregan en las regiones orbital y temporal, en los opérculos y hom. bros lineas curvas de color azul y otras amarillentas en los costados y el vientre. En cuanto á longitud puede alcanzar hasta $0^{\circ}, \dot{40}$.

\section{EL TRAQUINO VÍBORA-TRAGHINUS VIPERA}

CARACTERES. - Esta especie (fig. 148) se distingue de la anterior por su cabeza mas aplanada y cl perfil del vientre mas curvo; la distancia entre la primera y segunda aleta dorsal es tambien mayor que en la precedente. El número de radios es en la primera aleta dorsal de cinco á seis; en la segunda de veinticuatro; en cada torácica de quince; en cada abdominal de uno a cinco; en la anal de uno y veinticuatro, y en la caudal de once. El color gris rojizo del dorso pasa \$ blanco de plata en los costados y el vientre, estando además el dorso manchado de pardo; la primera aleta dorsal es negra; la segunda lleva al igual de la anal una orla negra. La longitud és de $0^{\circ}, 12$ \& $10^{\circ}, 15$.

USOS, COSTUMBRES Y REGIMEN. - El traquino dragon prefiere las aguas profundas aunque se le encuentre y pesque en los fondos arenosos de poca agua del Atlántico, Mediterráneo, mar del Norte y Báltico; pero de todos modos vive como sus congéneres sobre el fondo del mar 6 mejor dicho dentro del fondo, oculto en la arena hasta los ojos. En junio es cuando se acerca \& las playas bajas para echar su freza, y se le encuentra en la baja mar en los puntos de. jados en seco. Su alimento consiste en pequeños crustáceos, acaso tambien pececillos, que deja aproximar antes de saltar fuera de la arena, lo que hace con una rapidez tan sorprendente que a pesar de ser en apariencia un pez muy indolen. te, hay que calificarle como en extremo movible, confirmán. dolo tambien así la rapidez con quue se vuelve á ocultar dentro de la arena apenas se ha apoderado de su presa. Los que yo pude observar yacian todo el dia en un mismo sitio tan hundidos en el fondo del acuario, que era menester bus. car largo rato antes de divisar sus ojos, que era lo único que dejaban visible. Cuando se les incomodaba, se alzaban muy de prisa ejecutando unos movimientos como si tratasen de herir á su adversario con sus aletas dorsales espinosas; despues nadaban por aqui y alla, subian y bajaban, se dejaban caer finalmente sobre la arena, plegaban las aletas torácicas, y onderindo la anal, en un momento tenian hecho otra vez el hueco para oculiarse.

eliste pez pertenece al númcro de animales marinos que hieren al hombre con fatal vencno, dice el viejo Gessner; esta opinion es todavia hoy la de todos los pescadores, y con razon, porque es un hecho que la punzada de estos peces causa grandísimo dolor $y$ una infiamacion violenta, no solo en el sitio de la herida sino en todo el miembro, que des. pues de hincharse. tarda mucho tiempo en rebajarse lo mis. mo que el dolor. Couch dice: Yo ne conocido tres hombres á quienes un nismo pez infirió una punzada en la mano, y sintieron a los pocos minutos dolor en todo el brazo, pero curaron pronto con fricciones de aceite. Otros pescadores frotan la herida con arena mojada. Ninguno de ellos duda que estos peces son venenosos, por cuya razon los temen al igual de las viboras.

Ia carne del traquino dragon es apetecida, no solo porque es sabrosa sino tambien porque tiene fama de sana. En el Báltico se coge este pez con trainas; en el mar del Norte se le pesca todo el año, pero sin que se lleve apenas á los mercacios, en cuyo caso se vende á cuarenta céntimos de marco el kilógramo. Su nombre aleman que viene a significar $P_{l}$. riguillo, dicen que procede de una antigua costumbre de los pescadores holandeses, los cuales le arrojaban otra vez al mar como pez de ningun valor y hacian de él ofrenda á San Pedro.

\section{LAS RATAS Ó URANÓSCOPOS -URANOSCOPUS}

CARACTERES, - Este género es muy afine del anterior, difiriendo del mismo por su cabeza disforne y por tener el cuerpo cónico y mas redondo a manera de cmbudo. I.a cabeza es tan ancha como larga, ademas dura y áspera y como acorazada; la hendidura de lá boca es rertical, ; la membrana branquióstega tiene siete radios. Cuando existen dos aletas dorsales, es muy reducida la primera, pero en algunas especies se confunden las dos en una. Las aletas torácicas se distinguen por su tamaño. En el hombro existe un aguijon fuerte, por lo comun con incisiones.

\section{LA RATA COMUN - URANOSCOPUS SCABER}

CAIRACTERES. - La rof́c comun (fig. 149) alcanza una longitud de $0 ", 30$; tiene dos aletas dorsales, $y$ una membrana filiforme delante de la lengua con la cual dicen que atrac á los peces. La primera aleta dorsal corsta de tres radios débiles, la segunda de catorce ramificados, la anal de trece, la torácica de diez y siete ramificados tambien, y la caudal, de corte recto, de diez. F.l color general es pardo con viso gris 
como espolvoreado de harina; ála largo de los costados corre una linea de manchas blancas irregulares; el vientre es blanco; la primara aleta dorsal completamente negra con una mancha blanca; la segunda las tiene de color gris pardusco, y la abdominal es gris amarillenta.

USOS, COSTUMBRES Y REGIMEN. - Este pez, dice Gessner, tiene su nombre de uranúscopo, porque sus ojos miran siempre al cielo colocados como están en la parte superior de la cabeza. Por lo demás es feo y repugnante, vive en el limo y el barro donde persigue álos demás peces, pues dicen que su voracidad no conoce límites, lo que puede inferirse de su boca, fauces y estómago descomunales; es tan insaciable que traga, aun cautivo, todo lo que se le echa para comer hasta que le vuelve á salir por la boca. Tiene tambien una vitalidad tan grande que sigue moviendose aun despues de haber sido destripado. Muchas personas desprecian este pescado porque vive en el barro, crejendo que su carne ha de tener mal gusto y sabor terroso, pero se equirocan, pues
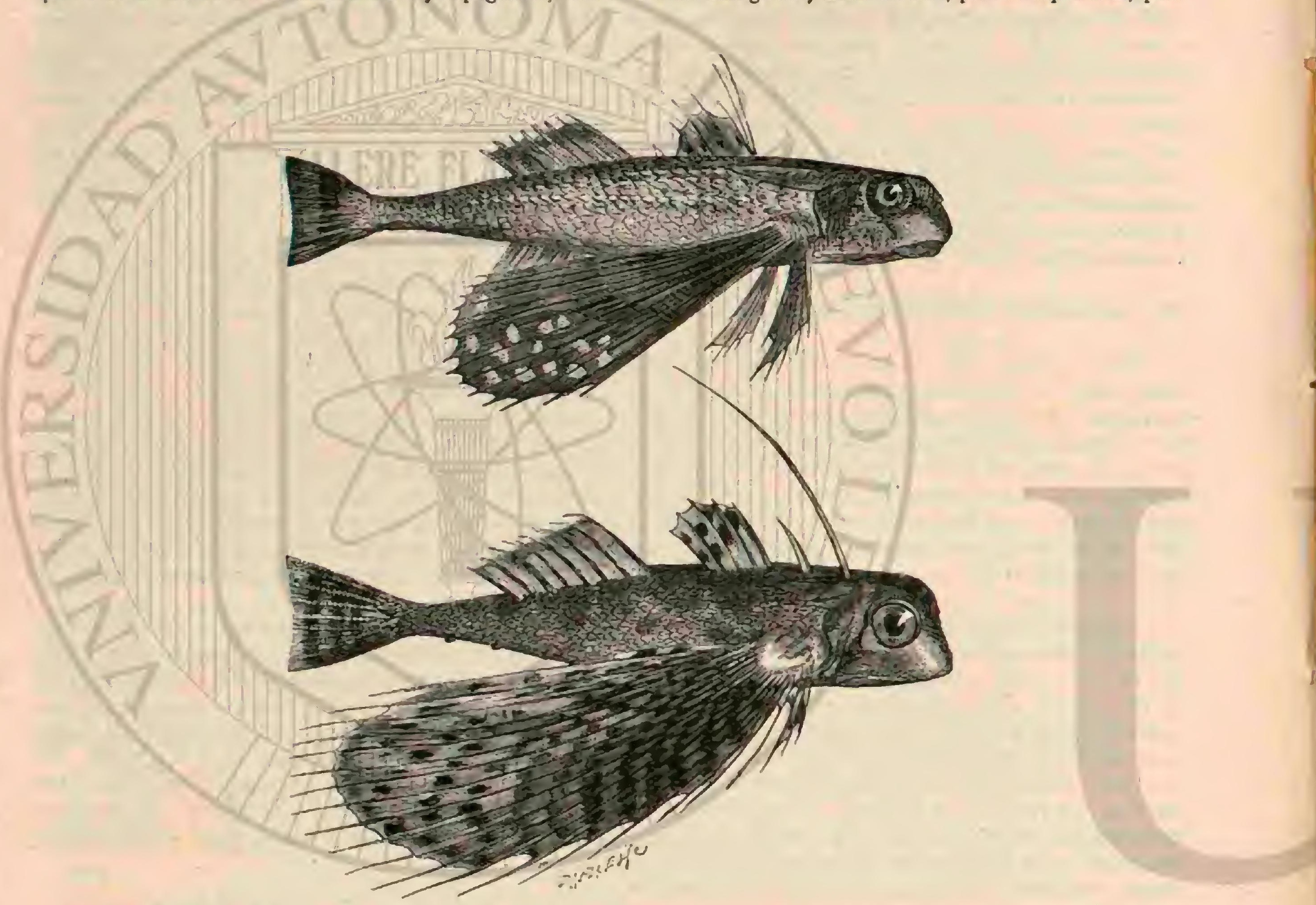

Fig. 145.-EL DACTIĹ́tTERo VOLAHOR

Fig. 846. -EI. MACTHLOUTERO ORIENTAL

al contrario se dice que es en extremo suculento y agradable al paladar y no daña; Hipócrates lo recomendaba para las personas que padecian de mucosidades blancas. Tambien hay quien pretende que con la hiel de este pez. recobró la vista el anciano Tobias, segun consta en el Antiguo 'lesta mento, porque es la mejor medicina para la vista y el oido.

Hoy dia no sabemos mas que Gessner sobre el género de vida de la rata $\delta$ uranóscopo. Habita el Mediterráneo donde, segun Risso, vive en los fondos cenagosos; se le coge todo el año, pero es poco apreciado por el mal olor que despide su carne, de suerte que solo lo comen los pobres. En cautividad vive poco, y permanece todo el dia oculto en el fondo, de donde sale á lo mas por la noche.

\section{LOS ESCIÉNIDOS- SCI死NID压}

CARACTERES.-Esta familia es muy numerosa y com prende mas de cien especies, que son en cierta manera una repeticion de los pércidos, pero con algunas diferencias de terminadas. Exteriormente se parecen mucho unos a otros, no solo por su forma $y$ la estructura de las alctas, sino tam. bien en cuanto á la cubierta escamosa y la defensa de los opérculos; pero los esciénidos difieren por su cabeza muy abovedada y el hocico un tanto prolongado á consecuencia de la estructura especial de los huesos de la cabeza y de la cara que contienen una multitud de células y otros huccos llenos de mucosidad. El distintivo mas notable y mas importante estriba en la dentadura, pues en ningun caso tienen dientes ni el vómer ni los huesos palatinos; otra particulari. dad singular consiste en la vejiga natatoria, que en la mayor parte de los peces de esta familia está ramificada de una manera muy extraña.

USOS, COSTUMBRES Y REGIMEN. - Todas las es. pecies habitan el mar y esta es cabalmente la razon de que conozcamos tan poco sus costumbres; pero al parecer se asemejan tambien por este concepto al las percas, si bien hay motivos para suponerles menos rapacidad y voracidad, contentándose cuando menos con presas mas pequeñas como 
son los animales invertebrados. Respecto is su reproduccion, nuestros conocimientos son nulos, y hasta contradictorios los datos que tenemos referentes á su época de desovar, á pesar de lo cual los escienidos merecen nuestra atencion por la importancia que tienen para la industria pesquera á causa de su exquisita carne.

\section{LAS ESCIENAS - SCIIENA}

CARACTERES.-El género de las escrenas propiamente dichas ocupa el primer puesto; entre sus miembros figuran los gigantes de la familia, que se distinguen por el cuerpo oblongo, dos aletas dorsales, la primera muy arqueada; pre. opérculo dentado y el postopérculo puntiagudo; dientes có. nicos robustos $y$ afilados junto con otros aterciopelados en la mandibula superior, y una vejiga natatoria muy com. plicada.

USOS, COSTUMBRES Y REGIMEN. - Vivia en Roma en tiempo del papa Sixto IV, segun cuenta Paulo Jovio, un parásito llamado Tamisio, cuya principal ocupacion consistia en procurar con el debido cálculo que no faltase regalo alguno é su cuerpo sin comprometer su bolsillo.

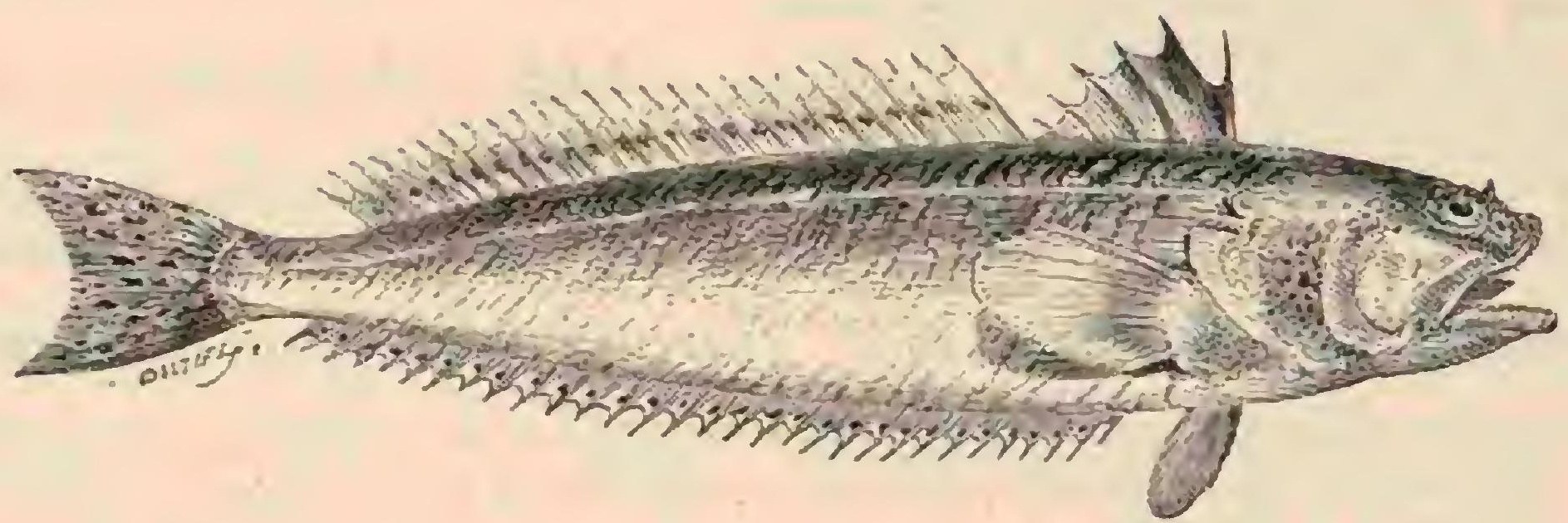

Fig. 847. - RI. TRAกQU1RO DKAGON

Ocurriósele que seria muy conducente á su objeto vigilar hasta los preparativos que hacian en casa de sus amigos para la mesa, y desde entonces mandó á su criado á la plaza para que indagara las casas adonde iban á parar los mejores comestibles. Tan luego como recibia el aviso, se ponia Ta. misio en marcha para hacerse convidar en la casa cuyo coci-

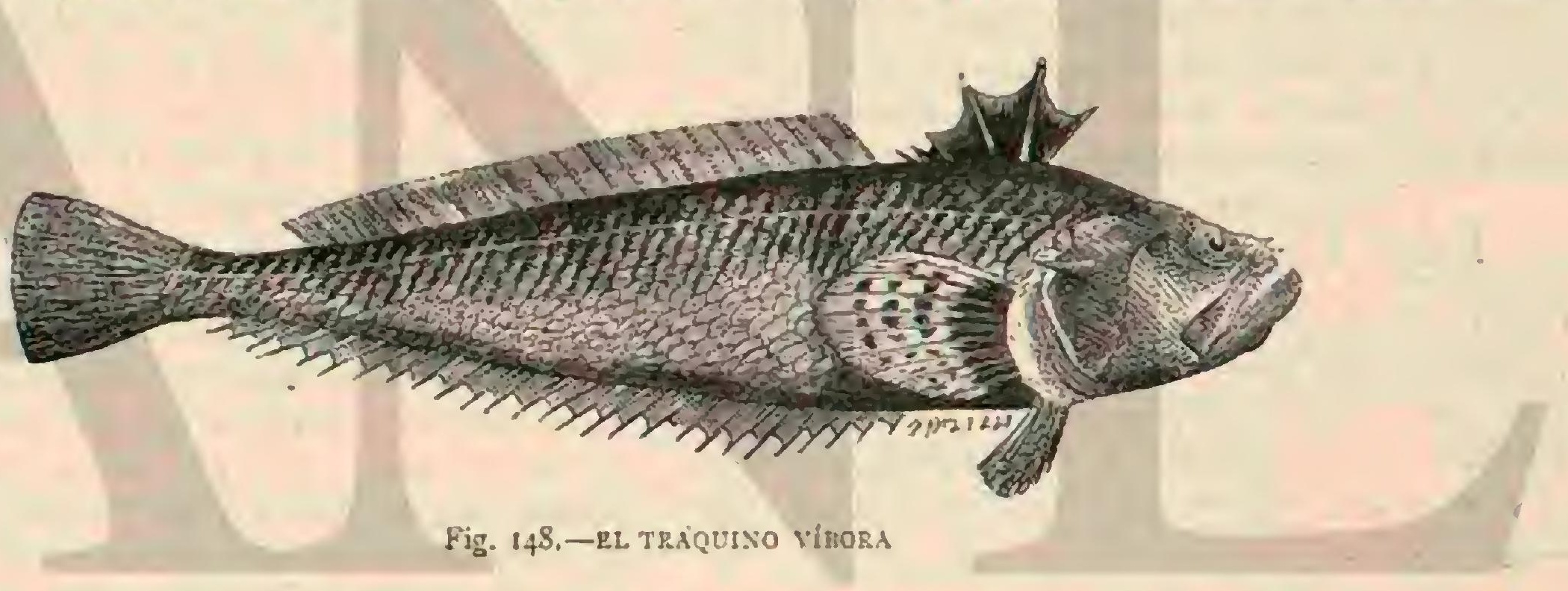

nero habia comprado lo mejor de la plaza. Un dia supo que habian llevado al mercado una esciena-águila de tamaño extraordinario, por cusa razon se hábia enviado à los individuos del ayuntamiento. Al momento fué s hacerles una visita con la esperanza de que le convidarian al festin que sin duda se celebraria para consumir un pez tan raro, pero se engañó: al despedirse vió la cabeza, el mejor bocado del pez, en maños de un criado encargado de llevarlo al cardenal Ricario. Co. nocido como era de este principe de la Iglesia, acompañó al criado á casa de su amo, pero alli turo el disgusto de ver que este enviaba el regalo á su colega Severino, y el buen Tamisio hubo de correr de nuevo para saludar á este último, pero como Severino debia una respetable cantidad al banquero Chigi le mandó la rara pieza como muestra de atencion y de aprecio. Pero no bien recibió Chigi el regalo se lo envió \& sú querida. Resultado: que Tamisio, hombre grueso y viejo, tuvo que recorrer la ciudad eterna, arrostrando. los ardores de un sol canicular, para disfrutar por último del anhelado manjar en la mesa de una cortesana.

Este episodio no tiene mas objeto que probar cuán gran. de era en tiempos pasados la estima en que se tenia á dicho pez; y hacer resaltar el hecho notabilisimo de que posteriormente haya podido caer en completo olvido, como sucedió en efecto, $\delta$ por lo menos debió de confundirse con otros \{ pesar de las alabanzas y del cuidado con que los inteligentes en la materia lo habian descrito.

DISTRIBUCION GEOGRAFICA.-Hoy se le pesca todavia en todas las costas de Italia, Francia meridional, España y Portugal y á veces hasta en las aguas inglesas, y las personas que lo han probado confirman todas las alaban. zas de los antiguos.

USOS, COSTUMBRES Y REGIMEN. - Duhanel dice que por espacio de inuchos años habia abandonado la esciena las costas francesas por las de Berberia, pero no adu. ce pruebas de su aserto. Bonaparte fué el primero que volvió á publicar algo sobre el género de vida de este pez. Segun dicho naturalista, se presenta con frecuencia en las costas de Italia, particularmente en los puntos de fondo bajo y mas aun en las desembocaduras de los rios. Por lo comun aparece a bandadas, y cuando se traslada una de csias á otro punto, se ove un ruido tan perceptible que puede llamarse mugido por ser mucho mas fuerte que el gruñido de los triglinos. Este ruido guia à los pescadores, pues, segun dicen, se oye aun cuando los peces se hallen á una profundidad de diez a doce metros, por cuya razon escuchan los pescadores aplicando el oido al borde de sus lanchas. Son peces 
de gran fuerza, tanto que los individuos grandes pueden derribar á un hombre de un solo coletazo; para evitar desgra. cias los matan tan luego como los han cogido, pues en cierta ocasion acontecí́ que una esciena enredada en la red se revolvió con tanta furia que arrojó al agua al pescador mas próximo, el cual necesitó el auxilio de sus compañeros para salvarse, primero, y luego para poner tambien el pez á salvo. En el Mediterráneo indica la presencia de este pez la pronta llegada de las anchoas, á causa sin duda de la persecucion que cstas sufren por parte de aquellos. Muchos ictiólogos hablan de los grandes viajes, que realizan estos peces con motivo de su reproduccion; $y$ tambien hay quien pretende que siempre se han cogido individuos grandes en las costas septentrionales del Mediterráneo, y pequeños en las meridionales, suponiendo que van del norte al sur para desovar y volver luego al punto de donde partieron; pero contra esta afirmacion alega Bonayarte que en las costas de Italia se cogen individuos desde $0^{\circ}, 35$ hasta dos metros.

\section{LA ESCIENA-AGUILA-SCIRNA AQUILA}

CARACTERES. - El dguila alcanza una longitud de dos metros y mas, y un peso de veinte kilógramos, admiziendo como exactos los informes que recogib Warrell relativos á un individuo de estas dimensiones que fué cogido en Mevagissey (Inglaterra) en el otoño del año $\mathrm{r}_{4} 4$, segun afirma Couch. El color de esta esciena es blanco plateado mas claro en el vientre y con un matiz algo pardusco en el dorso; las aletas son pardas tirando á rojizo. En la dorsal hay nuere radios y en la segunda ventisiete; diez y seis en cada torácica; uno y cinco en cada abdominal; uno $y$ ocho en la anal, $y$ diez y siete en la caudal. La vejiga natatoria lleva en ambos lados una multitud de apéndices á manera de flecos.

\section{LAS CORVINAS-CORVINA}

CARACTERES. - Este género difiere del anterior por la carencia de los grandes dientes anteriores, y por tencr trasformado en espina el primer radio de la alcta anal. La dentadura consiste en dientes de cerda en ambas mandibulas, $y$ además en la superior una hilera de dientes fuertes $y$ puntiagudos.

\section{LA CORVINA NEGRA-CORVINA NIGRA}

CARACTÉRES. - Esta especie alcanza una longitud de $6^{m}, 50$ y un peso de tres kilógramos. Su color es un pardo oscuro especial, que como siempre se vuelve mas claro hácia el vientre donde se convierte en plateado, pero que, segun dicen, se trasforma en dorado purpúreo cuando se saca al pez del agua. Cada escama está salpicada de manchitas oscuras que juntas producen el tinte general. Las aletas son pardas, salvo la anal y caudal que son negras con una orla algo mas oscura que el resto. La primera dorsal tiene diez radios; la segunda veintiseis, en cada torácica se cuentan diez y seis; uno y cinco en cada abdominal; dos y ocho en la anal, y diez y siete en la caudal.

USOS, COSTUMBRES Y REGIMEN. - Catecemos de datos suficientes acerca del género de vida de este pez tan comun en todo el Mediterráneo y que se pesca s vende en todas partes por mas que se le considere de calidad infe. rior. Gessner se hace eco de las relaciones de los autores antiguos diciendo que la corvina se mete tambien en las charcas salobies y sube rios arriba, siendo las que se cogen en el Nilo y otras aguas dulces mejores que las pescadas en el mar, por tener estas la carne dura; pero Marcial las alaba, diciendo: Duros trabajos cuestas, tú, principe de los merca dos del Nilo.

No existe bocado mas famoso para el paladar peléo:

En otros ticmpos se tenian tambien en grande estima las piedras voluminosas del oido de la corvina que se llevaban engarzadas en oro 6 plata; decian asimismo que machacadas y tomadas interiormente tenian mucha virtud contra el dolor de costado; que curaban el dolor de vientre y de la matriz, que impedian la formacion de piedras en los riñones y si las habia las expulsaban.y Este pez se alimenta de peque. ños cangrejos y de algas, y deposita su freza entre las algas y piedras que las olas acumulan en las playas.

\section{LAS OMBRINAS-UMBRINA}

CARACTERES, - El representante de este género, que se distingue por una verruga en la mandibula inferior, es

\section{LA OMBRINA COMUN-UMBRINA VULGARIS}

Caracteres.-Esta especie es un pez tan hermoso á la vista como exquisito al paladar; participa de los distintivos de las corvinas y su color es un amarillo claro muy vis. toso con lineas plateadas que corren desde la parte anterior t́ inferior oblicuamente hácia arriba y à la parte posterior, tomando un tinte azul en el dorso. El vientre es blanco; la primera aleta dorsal parda; la segunda lleva sobre igual fordo una reta y orla blancas; las aletas torácicas, abdominales 5 caudal son negras y la anal encarnada. Se cuentan diez radios en la primera dorsal, veintiuno en la segunda; diez y siete en cada torácica; uno y seis en cada abdominal; dos y siete en la anal; y diez y siete en la caudal. Esta ombrina suele, tener $0^{\circ}, 66$ de longitud y un peso de diez á quince $y$ aun mas kilógramos.

USOS, COSTUMBRES Y REGIMEN. - Es uno de los peces mas apreciados del Mediterráneo, no tanto por su magnifica coloracion cuanto por su carne blanca y suculenta. Vive á mediana profundidad $y$ prefiere fondos arenosos; nada con mucha gracia, y se alimenta de pececillos, moluscos, gusanos y segun dicen de algas. Desova en junio y julio. S? le pesca todo el año, especialmente en las desembocaduras de rios y con mayor frecuencia cuando estos van turbios á consecuencia de una tempestad. Gessner asegura que es pez muy miedoso: «y tan tonto qu cu cuandio tiene miedio mete la cabeza entre las piedras 6 plantas marinas creyendo ocultarse asi del todo, como los niños que creen que nadie los ve cuando se tapan los ojos, y por esta razon le cogen los pescadores fácilmente con las manos, Cuenta cste antiguo naturalista la historia del noble caballero Tamisio refiriéndola à este pez, pero en términos tan claros y directos que al trascribirla he procurado hacerlo de modo que no hiriera la sus. ceptibilidad pudorosa de algunos de mis lectores.

\section{LOS CABALLEROS-EQUES}

CARACTERES. - Respecto de este génera sabemos aun menos que sobre las corvinas, y lo menciono aqui solo por su figura extraña. Se distinguen por su cuerpo oblongo, comprimido lateralmente, elevado en los hombros, y muy puntiagudo hácia el extremo de la cola; los dientes son aterciopelados; la espina dorsal está muy desarrollada, en tér. minos de parecer un sable; la aleta caudal es romboidea, las aletas están parcialmente cubiertas de escamas y la coloracion es brillante. 


\section{EL CABALLERO DE TALABARTE-EQUES IANCEOLATUS}

CARACTERES. - El color fundamental de este pez (fig. ijo), es un amarillo gris con tres listas anchas, pardas, orladas de blanco gris, una que corre por el lomo, y otra en cada costado; la cabeza va ornada como la de la especie que precede. La primera aleta dorsal tiene diez y seis radios, la segunda cincuenta y cuatro; quince cada alcta torácica, la anal doce y la caudal diez, y nueve.

\section{LOS POGONIAS - POGONIAS}

CARACTERES, - Nos hallábamos en abril de I 860 en el Pontiniak, que es el rio mas caudaloso de la costa occi. dental de Borneo, cuenta Preger, cuando oimos claramente durante la marea alta una música cuyas notas subian y bajaban $y$ tan pronto parecian resonar á lo léjos como proseder de cerca. De la profundidad del mar salia á modo de un canto de sirena; otras veces creiamos escuchar los acordes llenos y robustos de un órgano y otras las vibraciones de un arpa cuyas cuerdas pulsara la brisa. Se oian mucho mejor si se sumergia la cabeza en el agua, y entonces se distinguian con facilidad roces diferentes que formaban coro. Segun las explicaciones de los habitantes del pais, confirmadas por naturalistas concienzudos, son peces los autores de esta mú. sica. $\$$

$Y$ en efecto son peces, llamados tambores, ó pogonias, que habitan el Atlántico y el Océano Indico; los músicos que pro. ducen sonidos tan perceptibles. Hunboldt dice: $\mathrm{El} 20$ de febrero de 1803 , f eso de las siete de la tarde, toda la tripulacion comenzó á inquietarse al oir un ruido extraordinario, semejante á un redoble de tambores en las regiones aéreas; atribuyóse al principio la causáa unas rompientes; pero bien pronto se percibio en el buque, y sobre todo hácia la popa; hubiérase dicho que le producia el aire que se escapa de un liquido en ebullicion. 'Temióse entonces que se hubiese abierto aiguna via de agua en el buque, mas no se encontraba nada, hasta que por fin, á eso de las nueve, cesó del todo el rumor. 8

El teniente de navfo John White, durante su viaje a China, oyó sonidos análogos, y los compara á los de un brgano, al toque de campanas, á los de un arpa colosal y al canto de las ranas, porque tan pronto se parecian á los unos como á los otros, y tan fuertes eran, que todos creian que el casco del buque vibraba; poco \& poco fueron aumentando en in. tensidad y extendiéndose por tódos los lados y la bodega; y no disminuyeron sino cuando el buque subió el rio Cambodja, donde finalmente cesaron. El intérprete que llevaban á bordo explicó el enigma á los viajeros diciendo que lo que producia semejantes rumores era una especie de peces de forna ovalada y llana que nadan a bandadas y pueden adherirse á objetos duros.

Varias veces se han visto tambores cerca de las costas norte-americanas, merced a lo cual ha sido posible determinar y clasificar por lo menos algunos de ellos. Forman en efecto bandadas y se reunen alrededor de los buques prorumpiendo entonces en su música sin interrupcion, y sobre todo en las noches tranquilas. No se sabe cómo producen tales sonidos, pero se calcula que no son extraños á ellos los dientes voluminosos que tienen junto al esófago.

Los tambores se diferencian de las ombrinas por las nu. merosas barbillas que tienen en la sinfisis de la mandibula inferior, y por los dientes medios superiores fuertes y volu. minosos que guarnecen el esólago; pero en los demás carac. téres principales concuerdan ambios géneros.
EL GRAN POGONIA-POGONIAS GIGAS

CARACTERES.-Este pez se asemeja mucho à la cor. vina, pero tiene una longitud de dos hasta dos y medio metros y un peso de cuarenta a sesenta kilogramos. El color es gris plomizo tirando á rojizo, sombreado en el dorso de negro; las aletas son rojizas. Diez radios espinosos sostienen la primera aleta dorsal y veintitres la segunda; diez y siete cada torácica 8 la caudal, y nueve la anal. Las barbillas son en número de veinte aproximadamente.

\section{LOS HEMULONES-HCMULON}

CARACTERES. - Los peces que forman este géneto tienen el cuerpo oblongo, bastante alto en la parte anterior, y algo comprimido; el sub-orbitario es bastante grande, pero no dentado; le cubren la piel y las escamas y se une á la mejilla por una membrana comun. Los labios son carnosos; en ambas mandibulas hay dientes aterciopelados, y exteriormente una serie de otros mas sólidos; el opérculo termina en dos salientes angulosas, planas y obtusas, que no se recono. cen a traves de la membrana. En el paladar no hay dientes. La aleta dorsal, aunque escotada, no parece doble; sus espinas son fuertes y se oculian en parte entre las escamas del lomo. La segunda espina de la anal es fuerte; la caudal, de forma ahorquillada, esta cubierta de escamas pequeñas; la pectoral, bastante grande, remata en punta; la ventral co. mienza casi debajo de su base. Las escamas que protegen el cuerpo son grandes $y$ no faltan sino en los labios y en la parte anterior del hocico, desde los ojos. La línea lateral se marca por dos ó tres pequerios tubos que en cada escama afectan la forma de abanico.

\section{EL HEMULON DECUATRO LÍNEAS-HCEMU- LON QUADRILINEATUM}

CARACTÉRES. - Esta especie (fig. $15 \mathrm{I}$ ) tiene el cuerpo prolongado, la cabeza corta, la boca hendida, y el perfil ligeramente combado. Sus dientes son muy finos. Se distingue además por tener cuatro lineas longitudinales, una que parte del hocico, corriéndose por la línea lateral, lo mismo que las otras; la segunda desde la parte superior de la órbita; la tercera desde el centro de aquella, y la cuarta arranca de la pectoral, siendo mas ancha que las otras. Estas lineas reinan sobre un fondo argentado que tira á gris hàcia cl lomo; la caudal es parda y las otras aletas blanquizcas. El hemulon de cuatro lineas tiene de seis a sicte pulgadas de largo.

DISTRIBUCION GEOGRÁFICA.- Habita en las aguas de Santo Domingo.

USOS, COSTUMBRES Y REGIMEN.-Segun Duhamel, esta especie sealimenta de pececillos, de cebo, devarechs y de limo; y acostumbra a estar siempre entre las rocas.

UTILIDADES.-La carne de este pez es blanca y de buen gusto, pero algo blanda y necesita mucho condimento.

\section{LOS DIAGRAMAS-DIAGRAMMA}

CARACTERES.-Este género está representado por peces que se distinguen desde luego por tener debajo de la mandibula inferior dos pequeños poros y despues cuatro mas grandes á cada lado, sin foscta impar; su preopérculo es dentado, y el opérculo carece de espinas.

\section{EL DIAGRAMA LISTADO-DIAGRAMMA II- NEATUM}

CARACTERES. - Este diagrama (fig. 152), lo mismo que todas las especies del género que hábitan en los mares 
orientales, tiene las escamas mucho mas pequeñas, y difiere redonda mas bien que hendida; los ojos son altos y el pre. tambien por la estructura de la cabeza. La frente y la nuca se continían en un solo arco convexo, cóncavo en el hocico; este último es bastante corto, y la abertura de la boca opérculo redondeado. El cuerpo es por lo general negro, con cuatro fajas blancas en cada lado, dispuestas en línea recta; en la mejilla hay tres; la dorsal está orillada de blanco, y

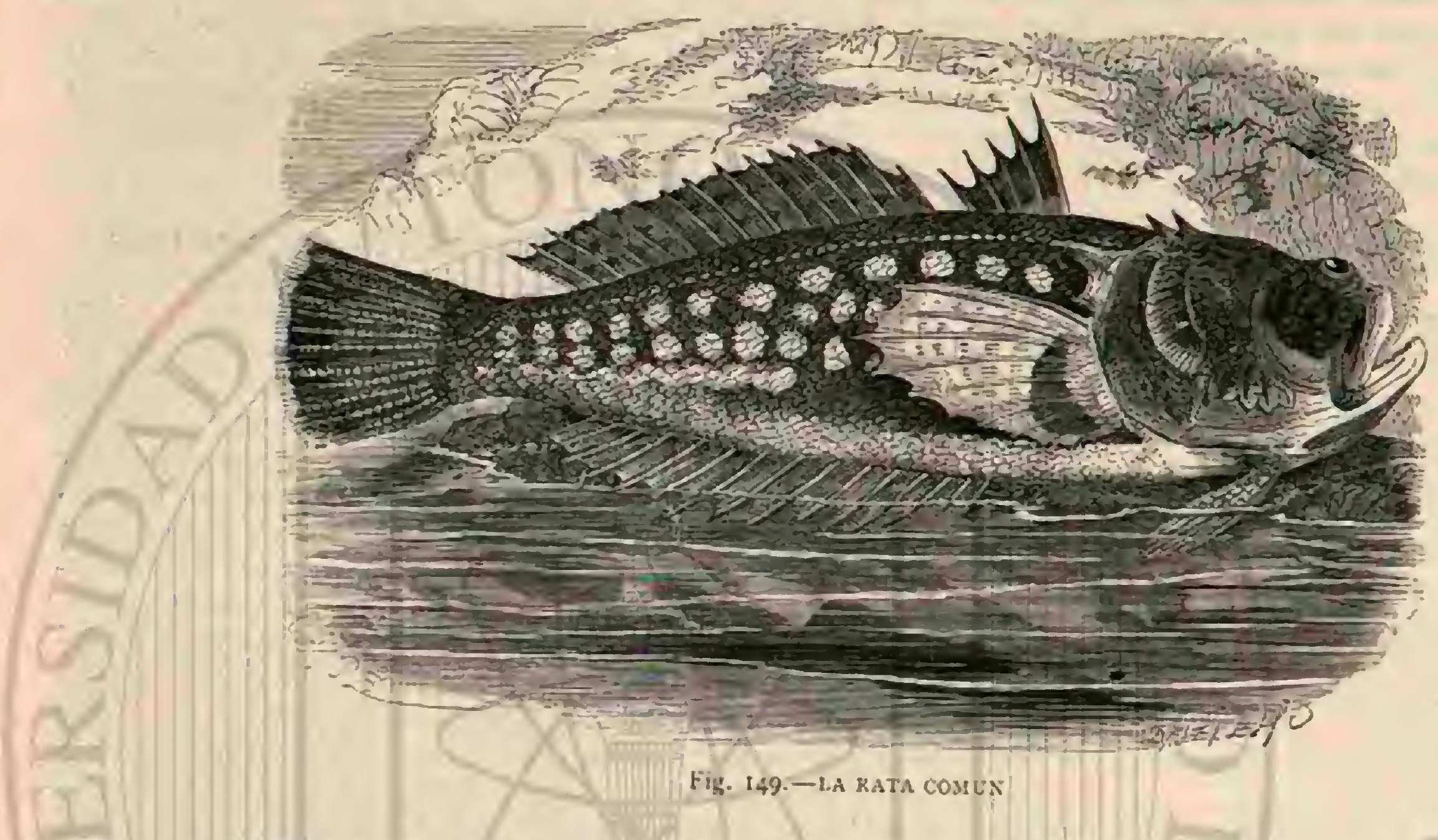

sobre su parte blanda se corre una faja oblicua de color negro. La especie mide por lo regular unas diez y ocho ó veinte pulgadas de largo.

DISTRIBUCION GEOGRÁFICA.-Ëldiagrama listado se encuentra en la mayor parte de las aguas de la India, y á veces se le ve por las costas de Ceilan.

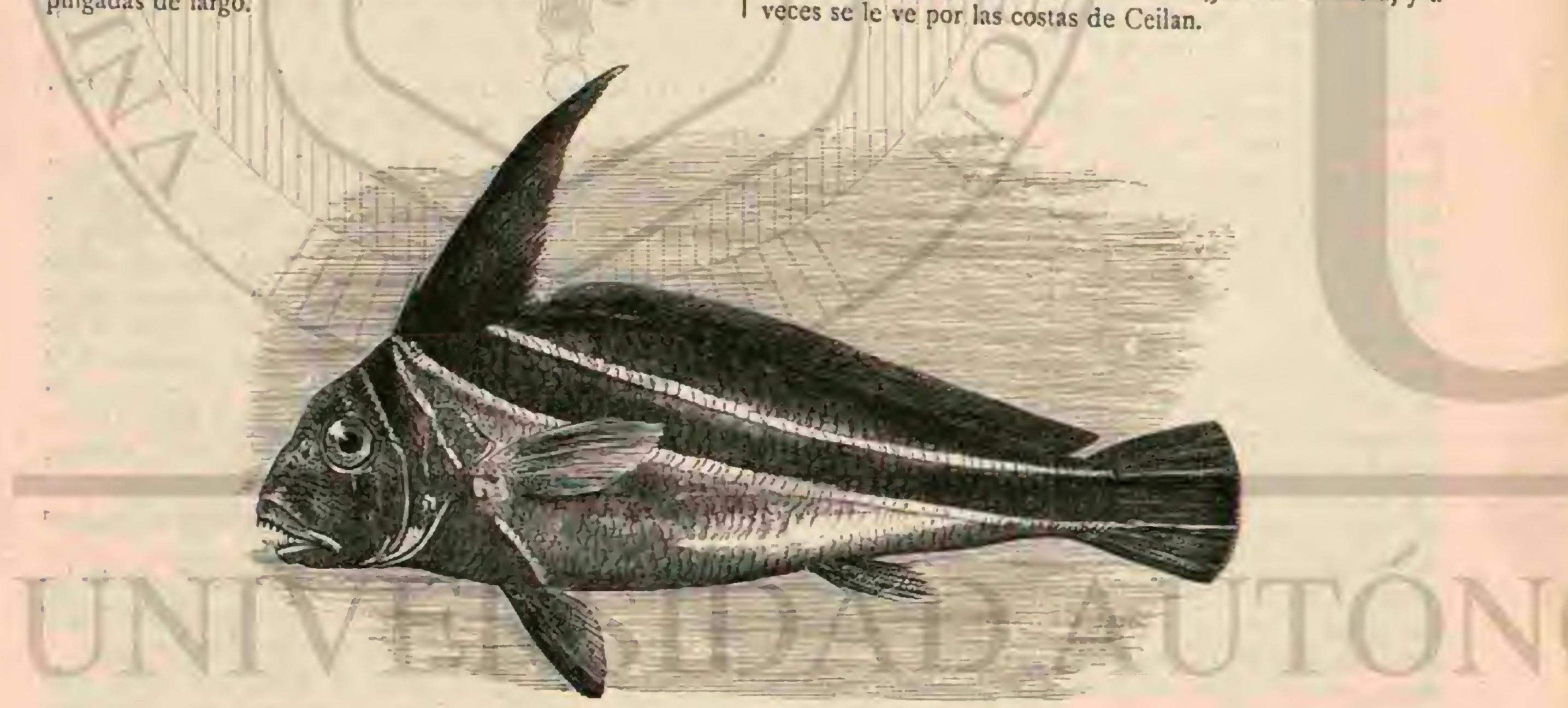

Fir. 150.-EL CABALLEO DE. TALWBARTE

\section{LOS ESFIRÉNIDOS- SPHYRENIDE}

CARACTÉRES. - Los esfírénidos se llaman tambien so llos-sactas por la semejanza que positivamente tienen con los sollos, tanto por la forma general como por el sistema dentarjo. El cuerpo es oblongo, casi cilindrico, cubierto de esca. mas pequenas cicloideas; la cabeza es puntiaguda. la boca ancha; las dos aletas dorsales estan separadas una de otra; la segunda, al igual de la anal y de las iorácicas, inserta muy atrás; los dientes son muy ganchudos y puntiagudos, $y$ dos de ellos, colocados en la punta de la mandibula, tan desar rollados que vienen a ser verdaderos caninos.

USOS, COSTUMBRES Y REGIMEN.-Poco se sabe sobre el género de vida de los sollos-saetas 6 esfirénidos, no llegando á veinte las especies que se conocen, todas las cuales pertenecen á un mismo género. Habitan los mares de las zonas tórridas y templadas; preficren la alta mar sin que por esto renuncien á las costas, y son carniceros terribles y osa. dos que se alimentan exclusivamente de animales vivos. Las especies de mas talla despedazan su presa de un solo mor. 
disco, y no es raro que apliquen sus robustas mandibulas al hombre, y aun que le maten. Su carne es bastante apreciada, pero no puede comerse en todas las épocas.

\section{LA ESFIRENA COMUN-SPHYRAENA VULGARIS}

CARACTERES. - Esta especie (íg. 153) vive en el Me. diterráneo, y alcanza un metro de longitud. El lomo es de color plomizo oscuro, y el vientre blanco y plateado; las ale. tas son pardas, la primera dorsal está sostenida por cinco radios, la segunda por nueve; cada torácica por trece; cada abdominal por un radio duro y cinco blandos; la anal por nueve $y$ la caudal por dicz $y$ siete.

USOS, COSTUMBRES Y REGTMEN.-Es carnicero terrible conforme ya se puede colegir por su estructura

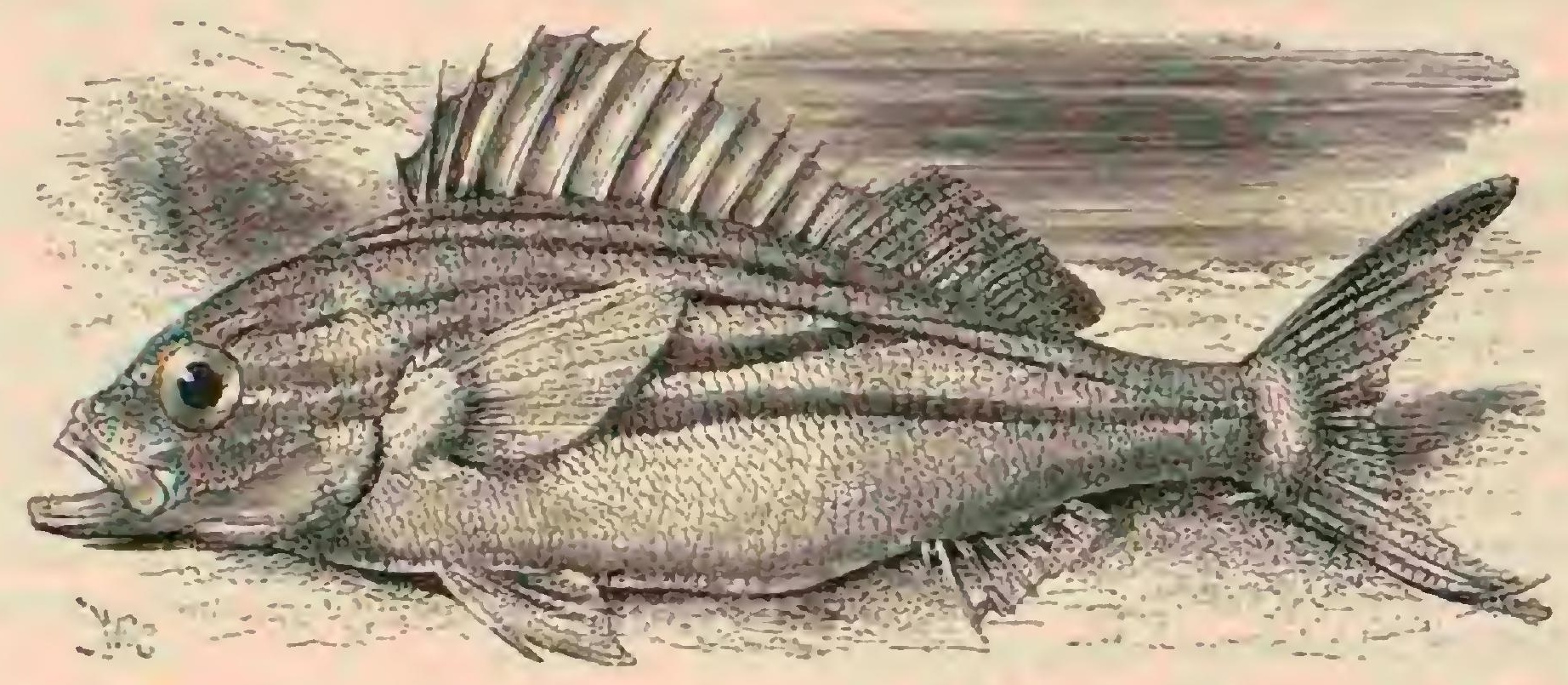

Fig. 151.-F.L HEMULION UE CUATRO LEREAS

prolongada y su poderosa dentadura. Atraviesa las olas con nada casi siempre en linea recta. Su carne se come, pero no la relocidad de la saeta, á la que le comparaban los antiguos; es apreciada.

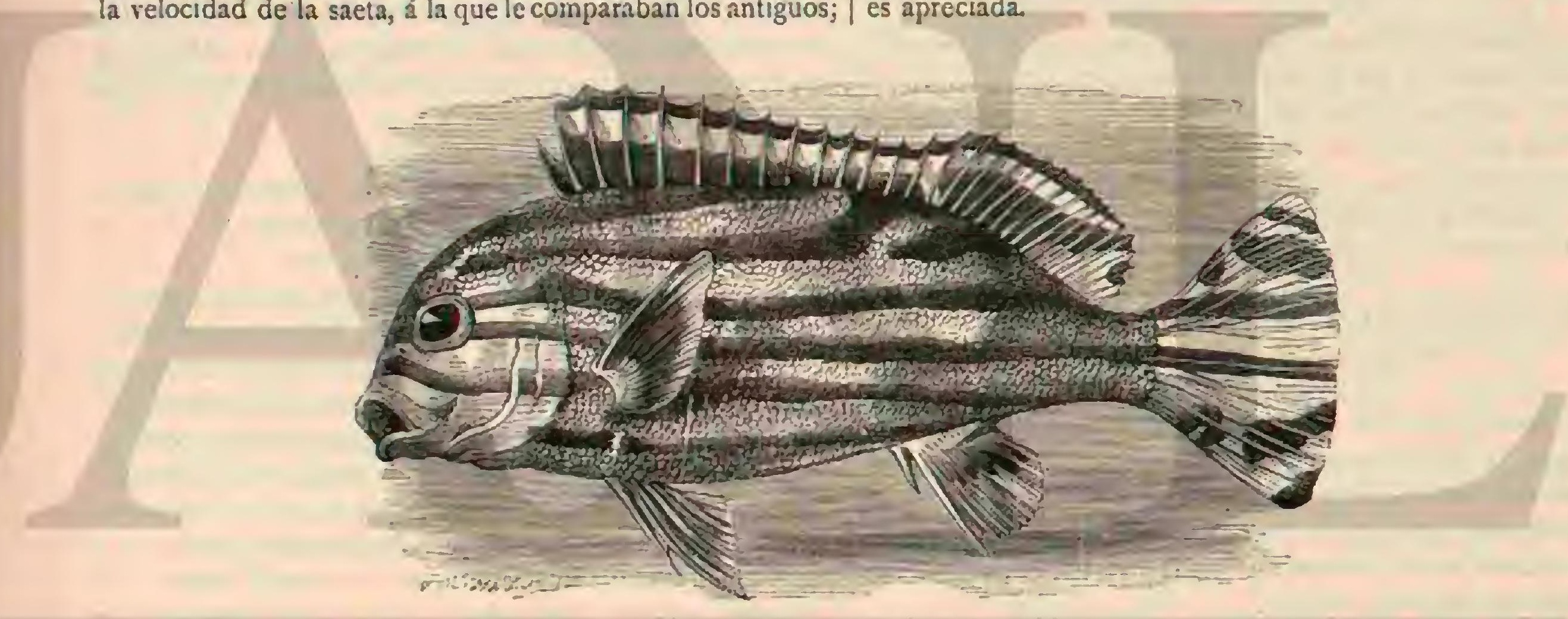

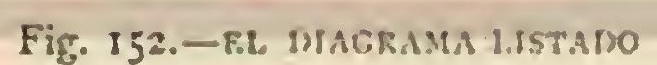

LA ESFIRENA PICUDA-SPHYR ENA PIGUDA

CARACTERES. - Vive en el mar delas Antillas donde, segun se dice, alcanza una longitud de tres metros. El color es gris plomizo tirando á verdoso en el dorso y à plateado en el vientre; muchos individuos presentan manchas negras parduscas en los costados.

Segun los autores de aquellas islas, se teme alli este pezal igual del tiburon porque penetra descaradamente en los puertos, ataca y derora á las personas que encuentra baũándose, y lo que le hace mas temible que el tiburon es que el ruido en lúgar de espantarle le arrae, segun dice Dutertre.

USOS Y PROVECHO.-Dicen que su carne se parece S la del sollo de rio, muy comun en Alemania, pero que en ciertas épocas es renenosa, conforme aseguran todos los autores. Rochefort añade que antes de comerlo es menester asegurarse de si la carne es ponzonosa ó no, á cuyo fin se examinan los dientes y la hiel; aquellos han de ser blancos y esta amarga.
Se ignora la causa que produce la ponzona: es creencia general que este pez come de cuando en cuando la fruta del manzanillo y que el veneno de este árbol se comunica â su carne; pero esto es una mera suposicion que pierde mucho de su peso, por cuanto la carne fuertemente salada no daña ya. Muchas personas tienen miedo de comer este pescado, dice Cuvier refiriendose \& lo que dice un tal Plee, porque es positivo que sucle causar enfermedades y á veces la muertc. Esta cualidad extrana depende del estado en que se le coge; pero segun aseguran todos los inteligentes en la materia, hay una señal infalible para conocer si el pez tiene propiedades tóxicas 6 no. Las tiene cuando al abrirlo sale una agua blanca y purulemta. Del-Norte hizo experimentos con esta carne en perros y nunca le faltó esta señal. Los sintomas del envenenamiento consisten en un temblor general, náuseas, vónito y dolores agudos en las articulaciones del brazo y de la mano. Cuando su término no es la muerte, lo que felizmente sucede raras veces, sobrevienen á menudo accidentes por demás extraños: los dolores son mas fuertes, 
las uñas de los dedos de las manos y piés caen lo mismo que los cabellos; y estos accidentes se repiten con frecuen. cia durante una serie de años. Jamás se han observado estos efectos en las personas que comen la carne de la picuda despues de salada, por cuya razon no la comen muchas sin esta precaucion.

\section{LOS TRIQUIÚRIDOS 一TRICHIURID死}

CARACTERES.-El cuerpo de estos peces es muy prolongado y comprimido lateralmente, y en unas especies está desnudo, y en otras cubierto de escamas muy dininutas; las aletas dorsales, unidas en una sola, se extienden casi so. bre todo el dorso; las torácicas son pequeñas; las abdominales, cuando existen, son rudimentarias; y las alctas anal y caudal ó faltan ó están bien desarrolladas. La boca es muy hendida y los dientes de las mandibulas son robustos, cortantes y de punta muy afilada; en cambio los dientes que guarnecen los huesos paladiales son muy finos. Llevan de siete a ocho radios branquiales.

DISTRIBUCION GEOGRÁFICA.-Estos peces singu. lares habitan los mares ccuatoriales, desde los cuales algu nas especies se extienden hasta la zona templada.

\section{LOS TRIQUIUROS-TRICHIURUS}

CARACTERES. - Se llaman asi las especies cuya cola acaba una punta tan larga y delgada que puede compararse con un cabello. Además se diferencian de sus congeneres en la falta absoluta de las aletas abdominales, anal y caudal; pues las únicas que existen bien desarrolladas son la dorsal y las torácicas, mientras que la anal apenas está indicacia por una seric de radios cortos que casi no pasan de la piel.

\section{EL TRIQUIURO PLATEADO-TRICHIURUS LEPTURUS Y ARGENTEUS}

CARACTERES.-Este pez, represcatante del género triquiuro, alcanza una longitud de un metro. Ciento treintaly cinco ó ciento treinta y seis radios sostienen la aleta dorsal, y once cada torácica. El color es blanco plateado lustroso; las aletas son amarillentas con matiz gris; entre los primeros radios hay manchas oscuras.

USOS, cOSTUMBRES X REGIMEN. - Poquisimo se sabe sobre el género de vida de los triquiúridos. Se observan con mas frecuencia en los mares ecuatoriales, no son raros en el Mediterráneo, pero muy escasos mas al norte, como por ejemplo en Inglaterra donde se han encontrado algunas especies muertas en las playas despues de grandes tempestades. Risso dice que se coge á veces una esjecie, el lepidopo de cola (Ixpidosus roudalus) (fig. 154) en las costas de Provenza, donde se acercan en abril y mayo, si bien anade que viven $s$ desovan en aguas profundas. En la costa de Devon mataron en 1808 uno de un golpe de remo en la cabeza, la cual sacaba el pez fuera del agua mientras nadaba con extraordinaria velocidad. Tambien se cuenta del triquiuro que nada con gran rapider, dando á veces tan grandes saltos fuera del agua que ha solido caer en las lanchas de los pescadores.

La robusta dentadura de los triquiúridos indica su vo. racidad é instinto carnicero, puaiendo admitirse que no re. troceden ante animales bastante grandes; pero á su vez tic. nen enemigos y adversarios muy molestos en los diferentes helmintos, lombrices y ténias que viven en sus intestinos. La carne de las dos especies citadas tiene fama de blanca, compacta y sabrosa, segun las personas que ta han comido. A esto se limitan los datos que tenemos respecto á cstos animales singulares.

\section{LOS GASTEROSTÉIDOS-GASTE- ROSTEIDAE}

CÁRACTERES. - Los antiguos ictiólogos colocan los gasterostéidos entre los escómbridos, pero los modernos, siguiendo el método de Guenther, forman con ellos una familia especial. El cuerpo de estos pececillos es fusiforme y comprimido lateralmente. La boca es puntiaguda, y la parte del cuerpo que corresponde ála cola muy delgada. Las mandibulas llevan una angosta fila de dientes aterciopelados. Espinas sueltas y en número variable sobresalen del dorso, siguiendo á cllas la aleta dorsal; las aletas abdominales consisten por lo regular en un solo radio espinoso y se hallan insertas a poca diferencia en la mitad del cuerpo; los radios branquiales son tres. En algunas especies se observan en los costados dèl cuerpo, que siempre es liso, cuatro ó cinco hileras de escudetes.

Se conocen aproximadamente unas dos docenas de espe. cies de gasterostéidos, si bien no se han descrito con la exac. titud necesaria para distinguirlos perfectamente.

USOS, COSTUMBRES Y REGIMEN. - Viven estos peces en las aguas dulces, en las salobres $y$ en los mares del hemisferio septentrional, concordando todos bastante en su género de vida que conocemos muy bien por las especies de nuestro pals.

\section{EL GASTEROSTEO DE COLA AGUDA-GAS- TEROSTEUS ACULEATUS}

CARA CTERES. - Se dislingue esta especic (fig. 155) por tres radios espinosos sueltos delante de la aleta dorsal, sien. do el mas largo el del medio, y hallándose el primero inserto sobre la aleta torácica. Existen al parccer algunas rariedades fijas de este pez que alcanza una longitud de $0^{\circ}, 0$ o \& $\left(1^{ \pm}, 08\right.$ y a lo sumo $0^{n}$, og. Su color es pardo verdoso ó azul negruz. co en la parte superior, plateado en los costados y vientre, y de rosa pálido á rojo de sangre en la garganta y pecho; pero esta coloracion no es constante, sino que varía mucho y es en general siempre mas viva en la época de la freza. La segunda aleia dorsal contiene de once a doce radios, cada torácica de nueve á diez, cada abdominal uno duro espinoso y uno blando, la anal uno duro y ocho blancos y la caudal doce.

DISTRIBUCION GEOGRÁFICA.-Su área de disper. sion se extiende sobre la mayor parte de Europa, á excep. cion del sistema hidrográńco del Danubio, donde hasta ahora no se ha encontrado. Por lo demás es frecuente y en cir. cunstancias favorables tanto en las aguas dulces como en el mar.

\section{EL GASTEROSTEO DE NUEVE ESPINAS- GASTEROSTEUS PUNGITIUS}

CARACTERES. - Es uno de los peces mas pequeños de agua dulce (fig. I 56) que tiene lo mas 0",06 de largo, di. firiendo en cuanto á estructura del anterior por los nueve \& once radios espinosos de igual longitud que lleva delante de la aleta dorsal. Ia coloracion es verdosa en la parte superior, plateada en la inferior, y una y otra frecuentemente manchadas con cintas trasversales irregulares y borradas en 
los bordes. El color plateado de la parte inferior pasa á ser en el macho de un matiz negro durante el verano. Los radios son once en la aleta dorsal; nueve á diez en cada torá. cica; en cada abdominal hay uno duro espinoso y uno blando; en la anal nueve duros y once blandos, $y$ doce en la caudal.

DISTRIBUCION GEOGRÁFICA.-Este pequeño pez es muy numeroso en el mar del Norte y el Báltico; sube tam. bien rios arriba a largas distancias, estableciéndose al parecer perennemente en las aguas dulces al igual de muchos congéneres suyos.

\section{EL GASTEROSTEO DE HOCICO LARGO- GASTEROSTEUS SPINACHIA}

CARA C.TERES.-Es la especie de mas talla de su génein (fig. 157); tiene el cuerpo $y$ hocico muy largos y quince espinas sueltas en el lomo, cuyo color, como el de toda la parte superior, es pardo verdoso. Los costados son amarillen. tos; y blancos plateados la region malar, los opérculos, la garganta y el vientre. La segunda aleta dorsal $y$ la anal tienen una mancha oscura en la parte anterior. Fn las costas de Suecia existe una variedad que se distingue por lo vistoso de su coloracion. Su longitud es de $0^{\circ}, 15 \hat{a} 0^{\circ}, 18$, y seis el número de radios en la segunda aleta dorsal; diez en cada torácica; dos en cada abdominal; en la anal se cuenta un radio duro y sicte blandos, $y$ en la caudal doce.

DISTRIBUCION GEOGRAFICA.- La patria de este gasterosteo es el mar del Norte y el Báltico; desde alli se extiende y se extravia hácia el sur hasta el golfo de Vizcaya. Es pez exclusivamente marino que se aleja decidiciamente de las aguas dulces, por lo cual apenas entra en los rios.

USOS, COSTUMBRES Y REGIMEN.-Pocos peces reunen cualidades tan interesantes como los gasterosteos marinos. Son animales vivaces y en extremo movibles, diestros, rapaces, pendencieros, valientes y soberbios, fiados en su arma defensiva tan terrible para los demás peces, pero de una ternura incomparable para su prole, cualidades todas que explican por qué son tan buscados para los acuarios y por qué los conocemos tan bien.

Cuando el vivero ó depósito donde quiere conservarse á estos peces es espacioso y recibe abundancia de agua nueva, es posible acostumbrarlos á la cautividad, lo que me consta por experiencia propia; pero no cuando el espacio es reducido; entonces mueren muchos desde los primeros dias, principalmente por el sentimiento que les causa la pérdida de su libertad y el cambio de las circunstancias á que están habi tuados, conforme sucedió á Evers, observador inteligentisimo con gran pesadumbre suya, porque él mismo dice con mucha razon que son animales en extremo excitables y violentos; casi todos sin excepcion se comportan como locos furiosos al principio. Los habia que nadaban horas enteras como furias de un extremo i atro, siempre con la calseza dirigida contra la pared de cristal del acuario, sin que hubiese sido posible distraerlos un momento ni aun dándoles presas escogidas. De nada valian mis esfuerzos, y cuanto mas los multiplicaba para calmarlos, solo conseguia aumentar su furor. No me cabe ninguna duda de que esta furia $y$ disgusto fueron la causa única de que se me muriesen tantos. Habia algunos que se destrozaban la boca contra el cristal cuando les apuntaba el dedo desde la parte de fuera. En cuanto á mi no he obser. vado tan insensata conducta, porque los meti en un depósito espacioso. Alli empezaron á nadar juntos por todo el ámbito tan luego como los hube introducido, é inspeccionaban todos los rincones y accidentes como para reconocer el terreno y ver cómo se establecerian. De pronto se decide uno á ocupar un rincon ú otro sitio determinado, $y$ desde aquel punto embiste furioso \& todos cunntos se le acercan y le molestan. En estos combates, que á veces duran muchos minutos, nadan los dos adversarios con extraordinaria velocidad uno al rededor y al lado del otro, buscando la ocasion de clavarse sus terribles espinas en los costados. Cuando uno de ambos cede, le persigue el vencedor con rencor indescriptible, sin dejarle reposo hasta que no puede mas. No suele ser raro que traspasen de un golpe á su contrario dejándole muerto en el acto. Poco á poco va escogiendo cada cual su puesto, resul. tando que en un mismo receptáculo vivan tres 6 cuatro de estos pequeños déspotas, vigilándose mutuamente para acometerse á la mas lere intrusion del uno en el dominio del otro con la misma belicosa furia de antes.

(Estos duelos son peligrosisimos, dice Evers, especialmen. te cuando los combatientes son machos, y el motivo los celos; es de ver entonces la rapidez vertiginosa de sus movimientos, sobre todo cuando el sol alumbra la escena haciendo relucir las espinas y escamas, de modo que parecen aq̨uellas espadas y estas una armadura bruñida. La major parte de las veces termina el lance sin ulteriores consecuencias, porque la parte mas débil cede y huye perseguida por el vence. dor lleno de coraje, hasta que ha salido de sus aguas $6 \mathrm{cn}$. contrado un escondrijo seguro. Mas de una ver. he observado cómo un fugitivo se paraba de repente y se ponia como ul timo recurso de costado como amenazando á su perseguidor con su espina abdominal, bastando esto para hacer que aquel desistiera y retrocedicsc; pero tambien habia adversario que embestia furiosamente al amenazador aguijon y le cogia con la boca como si quisiera arrancarlo, aunque siempre inútilmente en cuanto he podido ver, por lo que al fin y al cabo no le quedaba tampoco otro recurso sino renunciar al com. bate, pero coma quien ha dado pruebas de fortaleza. Jamás he visio, conforme algunos me han dicho, que los gasteros. teos se hubiesen destrozado y devorado.

Otros observadores y yo tambien creiamos que solo reñian entre si los machos, pero Evers prueba lo contrario. Bien es verdad que las hembras, que generalmente se reunen en grupos inmediatamente debajo de la superficie, no son tan vio. lentas como los machos, pero su aparente indiferencia dista mucho de ser prueba de indole pacifica. CNo es menester que vislumbren alguna presa para que todas ellas armen la pendencia mas atroz, sino que basta el motivo mas insignifi. cante, $y$ hasta puede decirse que las hembras están continuamente acechando la ocasion de repartir algun golpe ma. ligno. Ellas son, segun dice Evers, las que mas persiguen á los pececillos que se echan en su recepiaculo; todo lo observan con mirada penetrante, y cuando les parece, se aba. lanzan tambien rabiosas sobre los machos mientras estos riñen, ya para dar un golpe al que huye, ya para hacer frente al victorioso perseguidor; no parece sino que ellas son las que gobiernan. Dos hembras de mayor talla y de aguijon mas largo, que habia entre los gasterosteos que Evers tenia, se arrogaron el predominio sobre todos y solo se respetaban la una á la otra, atacando y acobardando á todos sus compañeros en términos de que tambien las otras hembras se escondian cuando se les daba la racion hasta que aquellas dos aspias se retiraban hartas. Mucho habian de sufrir tambien los machos, sobre todo aquellos que no poseian dom: cilio propio y fijo, y aun cuando, perseguidos por los otros machos, tratasen de refugiarse entre las hembras. Evers no iuvo mas remedio que quitarles de alli.

Las excitaciones interiores ejercen gran influencia en la coloracion de los gasterosicos, que cambia con el humor del animal. Cuando los anima el coraje de la victoria se convierte el color verdoso y plateado del vientre y de la mandi- 
bula inferior en un encarnado encerdido, y en el lomo en amarillo rojizo $y$ verde, $y$ el iris habitualmente blanco brilla con un hermosisimo verde. El retroceso al color usual es tan rápido como el cambio primero. Cuando el vencedor se tras. forma en vencido, su color palidece. Evers ha hecho tambien observaciones concienzudas respecto de estos cambios de color, que en sus peces correspondian tan exactamente $\$$ los sentimientos que los dominaban, que podian serrir de verdadero animómetro. Tan luego como un macho habia conquistado un puesto determinado ostentaba los matices mas brillantes, mientras que los que carecian de el y tenian que estarse entre las hembras participaban de la palidez de estas. No bien adquiria alguno un ligero tinte rosado era se. guro que meditaba un proyecto de conquista; su color iba subiendo á medida que adelantaba, pero desaparecia si fracasaba en su empresa. Lo mismo sucedia con los machos

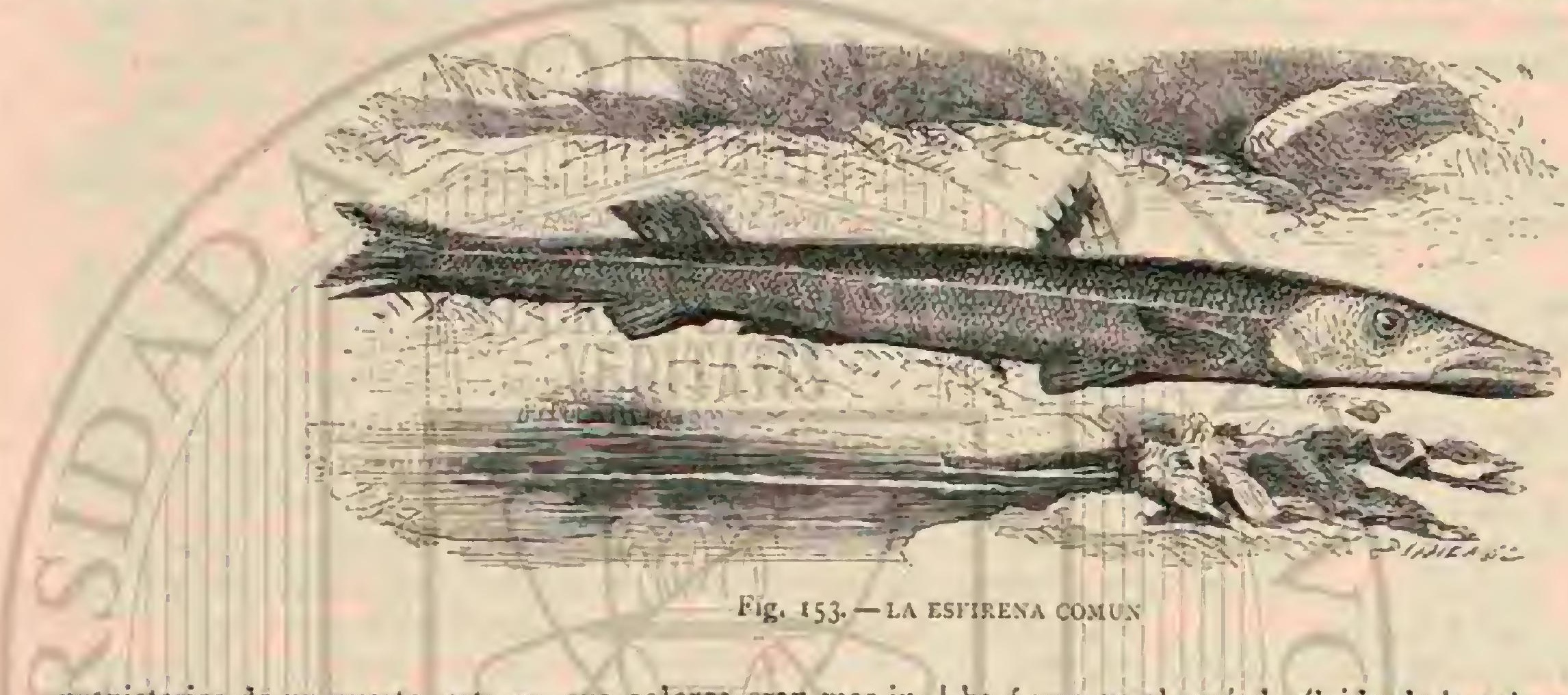

propietarios de un puesto, esto es, sus colores eran mas in. l ba á uno en el periodo álgido de la coloracion á otro receptensos cuando meditaban alguna empresa. Si Evers traslada- táculo, desaparecian rápidamente los colores hermosos y no

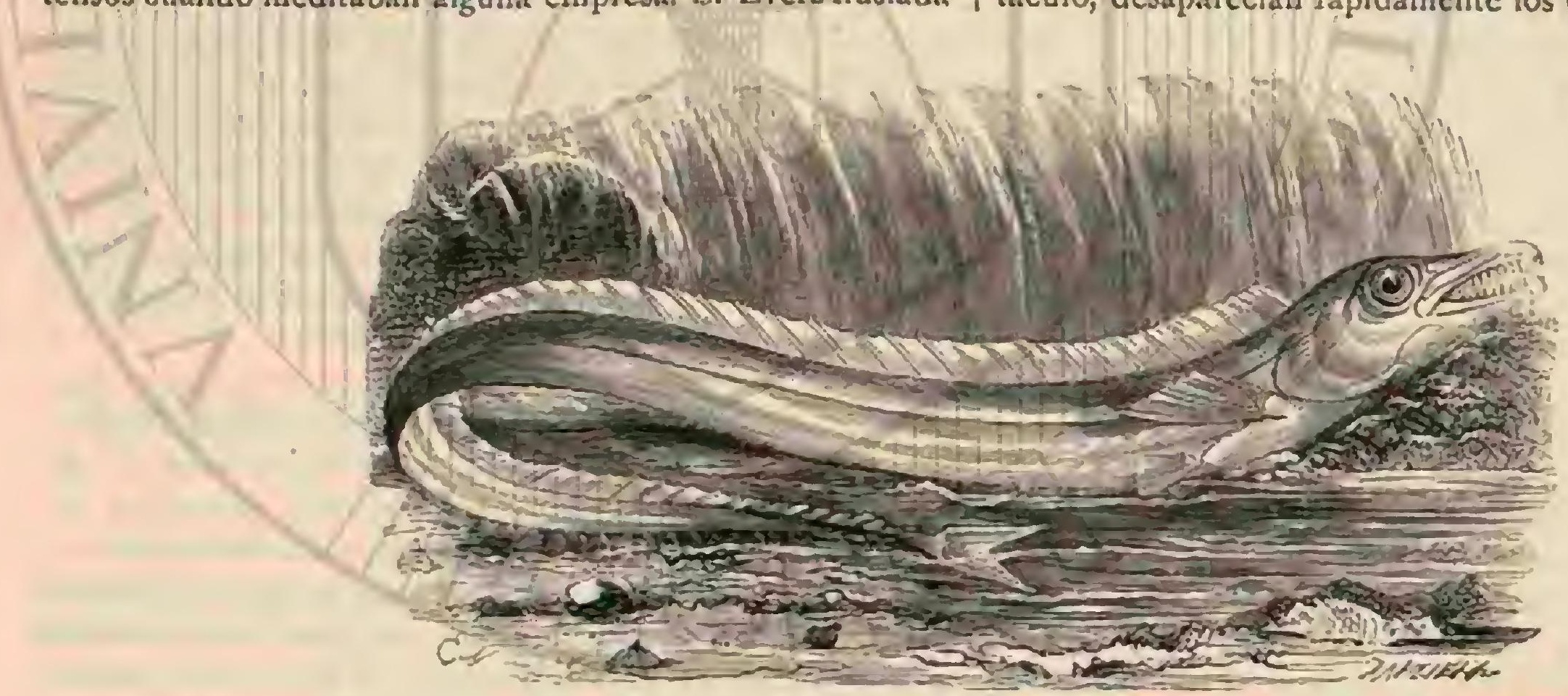

FIg. 154. -E. LEPIDOEO BE COLA

volvian mientras el pez continuaba quieto; pero á veces ofrecian tambien estos solitarios una trasformacion y subida en sus colores sin que fuese posible acertar la causa de esta mu. danza. A veces solo consistia en que al uno le irritaba una hoja de espadaña doblada $y$ movida por el viento, y al otro a)gun granito de arena que probablemente no estaba colo. cado $\{$ su gusto, y a un tercero en fin le incomodaba la som. bra de la persona que le estaba observandio.

Los gasterosteos nadan con gran destreza y rapidez cuan. do tienen mucho espacio, como en el mar $\delta$ en un vasto depósito; saltan fuera del agua y se divierten jugando, pero sin dejar de vigilar cuanto pasa á su alrededor, sobre todo la cria de otros peces que es su alimento predilecto. En general preocúpanse muy poco de los peces rapaces mayores que ellos, probablemente $\{$ causa de la conciencia que tienen de su defensa, pues hay quien asegura haber observado que hasta los respetan especies tan voraces como la merluza, que todo lo atacan y devoran, pero que temen las espinas peligrosas del gasterosteo; $y$ únicamente los que son de mayor talla, como el bacalao y salmon, los devoran sin cuidado. A pesar de su terrible defensa y aparente indiferencia, no de. jan de conocer perfectamente á sus enemigos, pues apenas divisan un pez que creen peligroso, enderezan sus espinas. Un dia que Erers puso un bacalao en su acuario, no hicie. ron el menor caso de él los peces de color que habia dentro; las lisas muy poco, pero con los gasterosteos ya fué otra cosa, pues mientras el bacalao describia sus circulos con si. niestra tranquilidad, con los ojos rojizos y centellantes y el hocico abierto como codicioso de una presa, aquellos se fue. ron reuniendo y formando estrecho grupo, observando atentamente $\mathbf{a}$ su adversario con sus colores subidos como en. cendidos de ira, y las espinas enhiestas. Dieron al olvido sus contiendas fratricidas, y todo el tiempo que el bacalao per. maneció en el mismo acuario no hubo riñas entre ellos, manteniéndose todos en las capas superiores del agua, con pre. ferencia entre las plantas acuáticas, y formando los machos la linea de defensa, sin que dejara de haber algunos tan atrevidos que se salian del grupo con objeto de seguir al enemigo un buen trecho. Para mi, dice Evers, es una gran prueba de inteligencia en estos peces el que sepan dirigir 
toda su atencion al peligro que les amenaza. La misma decision que muestran snte los peces de rapiña, se observa tambien en ellos cuando fjon su atencion en una presa. Cazan todo animal al que creen poder vencer y su roracidad es verdaderamente sorprendente. Backer asegura haber observado un gasterosteo que en el espacio de cinco horas devoró setenta y cuatro pececillos acabados de nacer de cosa de ocho nilimetros de largo. Acecha sus presas, segun dice
Couch, colocado entre algas y piedras en todas las posturas imaginables, y se precipita hasta sobre peces de igual talla que él. Segun contaron â Ramage, persigue apasionadamente las sanguijuelas jóvenes y engulle las de unos doce mill. metros sin titubear. Apenas se echaba una sanguijuela en el receptáculo en que habia un gasterosteo, cuando ya empeza. ba este à mirar por dónde cogerla; y si la sanguijuela se habia agarrado al cristal, la arrancaba, la mordia y sacudia

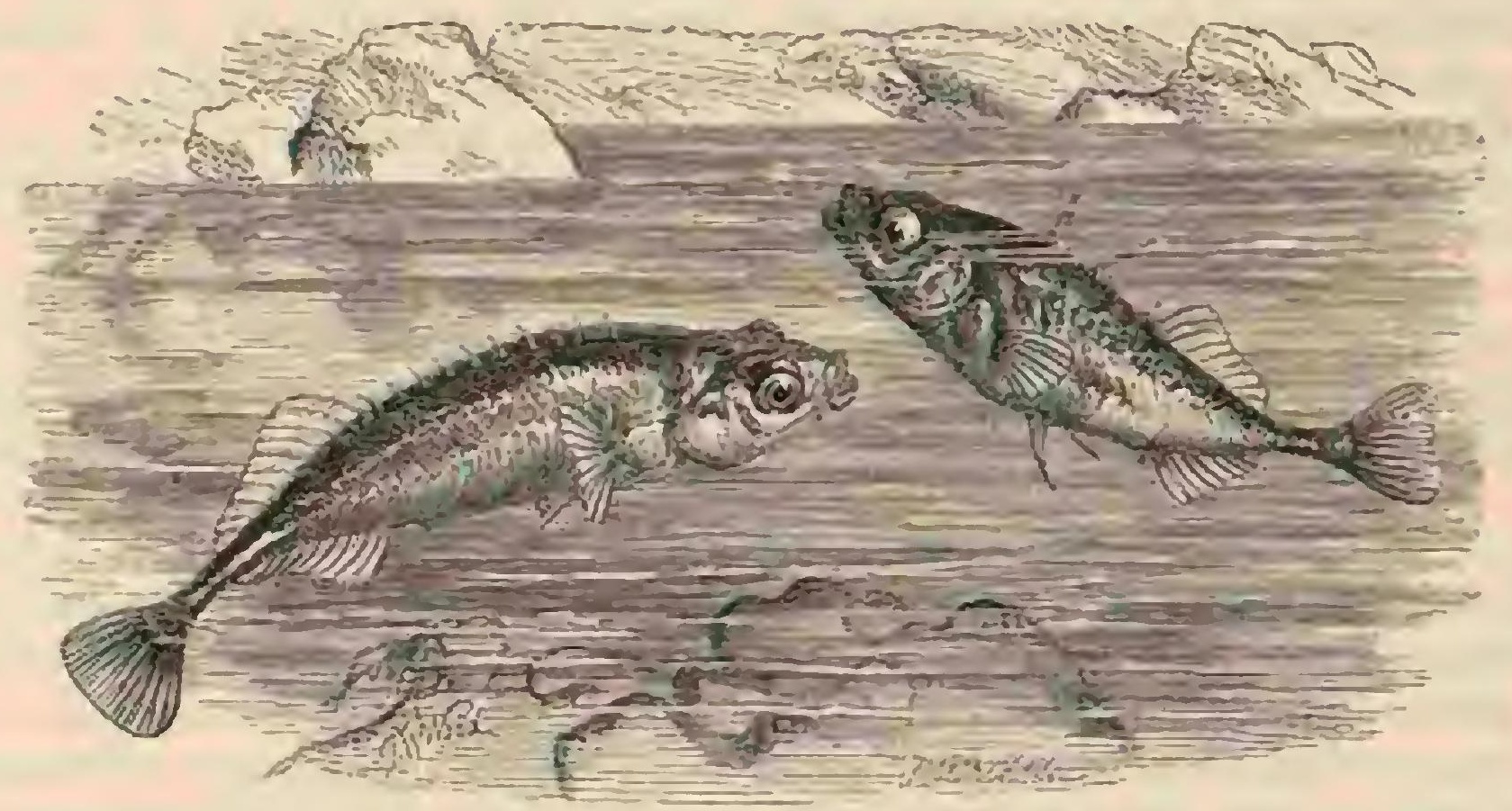

Fig. 155. - EL G.35TEROSTEO DE COLA AGUMA

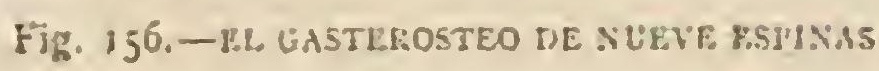

como haria un perro con una rata, hasta que el pobre Sucedéá veces que la sanguijuela se pega al pez; entonces anillado ya no oponia resistencia, $y$ entonces se lo engullia. son de ver los esfuerzos que hace este para deshacerse de

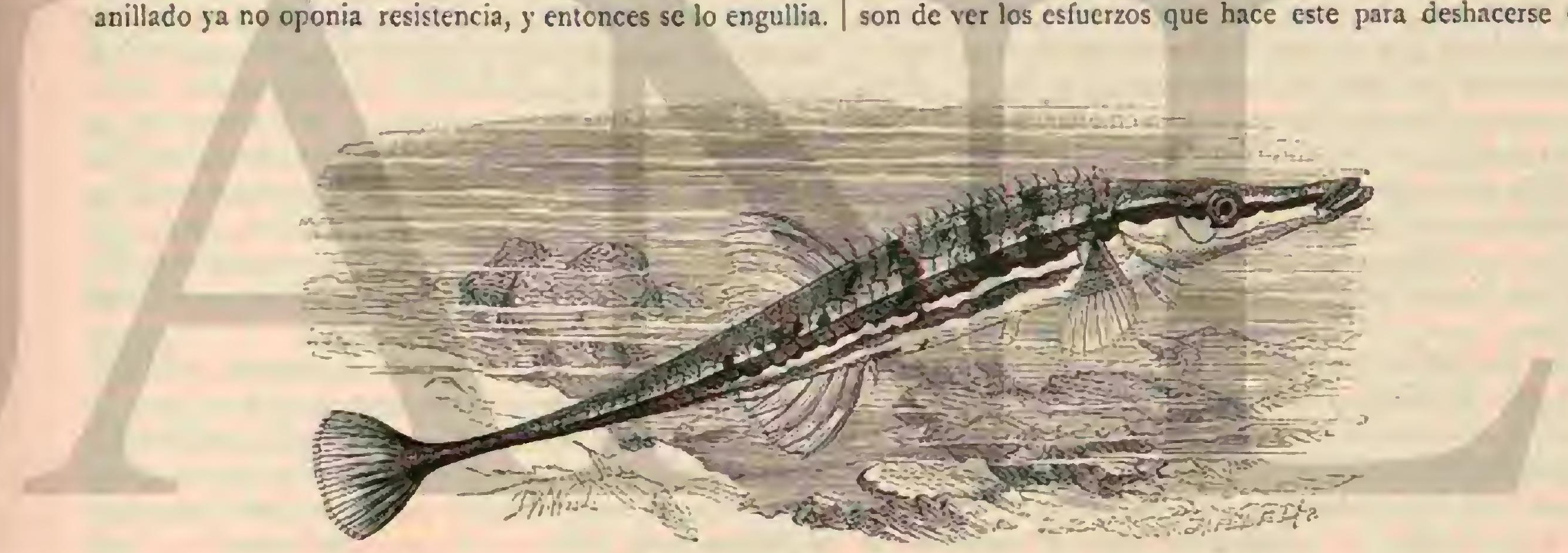

Iig. 157.- - LL LASLRROSTEO DE JIOCICO LAKGO

clla, cosa que sucle lograr pronto. Couch dí á uno de estos pececillos una anguilita de unos ocho centimetros de largo; tan pronto como la vió, la cogió por la cabeza y se la engulló hasta donde pudo, pero como cra bocado demasiado grande para él, le quedó una parte colgando fuera de la boca $y$ al fin tuvo que arrojarla; pero no lo hizo sino cuando una parte de la anguila engullida estaba ya digerida. Atrapaba al punto todas las polillas y mariposas que caian al agua, les quitaba las alas y se las tragaba. Los pescaciores obserradores están convencidos de que los gasterosteos son enemigos peligrosisimos de las frezas y crias de casi todas las especies de pescado; 5 algunos aficionados los acusan de que atacan, muerden y hasta matan los indefensos peces de color $y$ de que les arrancan las escamas. Podemos admitir como exacta la opinion de aquellos por estar basadas en la experiencia y en observaciones exactas; pero las acusaciones de los ultimos no son siempre justas, porque hay tambien ejem. plos en que se ha visto á los gasterosteos y sus congéneres vivir en paz con peces de color en un mismo acuario, sin que esto empero menguara su rapacidad respecto á toda otra presa que se considerasen capaces de devorar, incluso las crias de su misma especie; no cabiendo duda de que si tu. viesen solo la talla del bacalao, despoblarian muy pronto nuestras aguas y de que todo el atractivo de sus demás cualidades desapareceria ante los incalculables perjuicios que nos causarian.

La parte mas notable de las costumbres de los gasteros. téidos es indudablemente su modo de incubar y de criar, de lo cual no se ha tenido cabal conocimiento hasta hace muy poco ticmpo. Ya hace muchisimos años que varios natura. listas alemanes 6 ingleses describieron los nidos que construyen estos peces y la solicitud con que los vigilan; pero como suele suceder, no se habló de cllo hasta que un fran. cés hubo publicado sus observaciones respecto ś este asunto en la Academia de ciencias de su pais, y no seria extraño que la eGran Nacion se envaneciera hoy dia del descubrimiento del modo de reproducirse los gasterostéidos y de haberlo descrito uno de los suyos antes que nadie; pero en el terreno 
de la ciencia no valen sorpresas de este género; en él, el de. recho de prioridad es inalienable, y por esto conviene recordar que mas de un siglo antes de la citada descripcion de Coste, cuyo mérito estoy por lo demís muy léjos de querer empequeñecer, habia publicado ya el inglés John Hall una descripcion y dibujo del nido del gasterosteo de hocico largo, que en I $\$ 29$ se observó su modo de criar en Fscocia y tambien en $1 \$_{32}$ cerca de Wurzgburg, mientras que Coste no publicó su descubrimiento hasta $\$ 844$.

Va dije en la introduccion que no era cosa tan extraordi. naria la construccion de nidos y la tierna solicitud de los peces para con sus crias, pero siempre es basiante notable para permitirme entrar en mayores detalles sobre el modo de criar de ios gasterosteidos. Yo he observado cómo constru. yen su nido, puesto que en cautividad emplean el mismo celo que cuando libres, pero no quiero nquitar su mérito á los observadores anteriores \& me contentaré con reunir los datos publicados por ellos sin atenerme estrictamente á su orden de narracion.

Al aproximarse la época del desove escóge cada macho un sitio determinado que defiende desde aquel momento, con la tenacidad y arrojo que le conocemos, contra todo pez de su especie y género que intentara arrojarle de alli. El sitio elegido puede reunir distintas condiciones. Los gasterostéldos que desovan en agua dulce escogen un puesto de poca agua y de gran corriente con fondo arenoso $\delta$ pedregoso, y á falta de corriente, un punto donde el agua esté en movimiento; alli construyen el nido, ya sobre el fondo, ya medio oculto en la arena, ó tambien suspendido entre plan. tas acuáticas. Ios de agua salada escogen sitios análogos y aprovechan las confervas galgas cerca de la playa ó un cabo de maroma deshilachado que cuelga en el agua para fijar en ellos su nido, Couch encontró uno dentro de estos cabos que colgaba unos sesenta centimetros dentro del agua cuya pro. fundidad era alli de cuatro a cinco roesas, lo que hacia su. poner un trabajo considerable en el pequeño arquitecto, por cuanto sin duda tuvo que subir todos los materiales desde el. fondo.

En estado libre sucle el macho ocultar el nido en su mayor parte en el limo, y esta sera la causa de que nadie notara antes la gran solicitud con que atiende á sus pequeñuelos. 《Visitando yo un dia del año $1 \delta_{3} 8$ un estánque de fondo arenoso en los alrededores de Dantzig, cuenta Siebold, me llamaron la atencion algunos gasterosteos que estaban suspendidos, inmóviles y aislados en el agua, sin que por nada se movieran del mismo puesto. Al punto recordé lo que ha. bia leido hacia poco sobre los nidos que estos peces constru. yen y supuse que tal vez estuvieran aquellos pececillos de guardia cerca de su nido, pero por clara que fuese el agua no pude descubrir en su arenoso fondo vestigio alguno de nido. Al remover con mi baston la arena observé que siempre que lo acercaba al pez, seguia este sus movimientos con la mayor atencion. Ya no dudé de que él mismo me descubriria el ni. do si continuaba revolviendo el fondo, y efectivamente al poco rato se abalanzó violentamente contra el baston, por lo que pude suponer que habia dado con el sitio, como asi fué, pues al quitar de alli un poco mas de arena apareció un nido hecho de raicillas y otros restos de regetales que contenia huevos en incubacion. De la twisma manera logré quie otros gasterosteos del estanque me descubriesen su nido, y distinguí tambien despues un pequeño agujero en la arena, del cual salian fibrillas de raices que hasta entonces me habian pasado desapercibidas y que indicaban el sitio del nido.

Warrington, Coste y Evers que observaron cómo construian sus nidos sus gasterosteos cautivos, nos han ilustrado acerca del sistema que al efecto cmpleaban. Fl macho, que durante la época de la freza ostenta sus mas bellos colores y que manifiesta en todo una actividad extraordinaria, reune pri. mero algunas raices y otros residuos vegetales, algunos mas largos que él, teniendo á menudo que ir á buscarlos á bastan. te distancia; los arranca con gran trabajo y si es menester de la planta viva, y para apreciar su peso, los deja caer primero y utiliza despues los que pesan mas, desechando los que le parcen demasiado ligeros. El pequeño artista examina atentamente todos los materiales, escoge los mas á propósito, los amontona y vuelve á amontonar hasta que el trabajo le satis. face. Si ha determinado establecer el nido en el fondo, lo fija con arena y guijarros; s perfecciona el hueco interior, la forma general y la solidez de toda la obra nadando lentamente por encima, puliéndolo y aglutinándolo todo con el roce de su cuerpo. Evers observó distintamente que siempre que el pez añadia una capa de material sacudia sus aletas, y alzando la cabeza y la rolin, encorvaba indo el ruerpn para pasar me. jor sobre su obra y alisarla con el vientre, del que salia en tal momento una gota de materia viscosa claramente visible en el agua $y$ cuyo efecto agiutinante se conocia en seguida. De vez en cuando examinaba su solidez sacudiéndola y rolvién. dola a comprimir, 6 bien nadaba por encima moviendo el agua rápidamente con sus aletas para lavar la arena y los ta. llos demasiado ligeros y poco adherentes, y los colocaba mejor. El acarreo de los diferentes materiales requiere unas cuatro horas, durante cuyo tiempo queda tambien hecha la traza del nido, pero despues necesita el animal unos cuantos dias para acabarlo, retirar lo que no tiene suficiente peso, colocar bien cada 1allo, entrelazar sus extremos salientes y reforzarlos con aréna Durante este trabajo no se preocupa el animal de otra cosa que de evitar toda interrupcion; traba. jando con afan observa receloso cuanto se le acerca, ya sea uno de sus congéneres, ó un anfibio, un escarabajo acuático (hidrófilo), una larva, y ya rengan con intenciones pacificas, ora con propósitos hostiles, nada escapa á su vigilancia. Un macho de Lvers cogió y llevó un alacran ó escorpion acuáti. co mas de treinta veces al extremo opuesto del acuario para apartarlo del nido que estaba construyendo.

El tamaño del nido varia segun las circunstancias del sitio Y la clase de materiales; pero vendrá á tener el de un puño por término medio. Su forma suele ser oralada, cerrado com. pletamente por la parte superior, pero con un agujero lateral de entrada y otro de salida. Al principio no se ve mas que el primero, despues tambien el otro, por la razon que luego diré. Cuando cl gasterosteo ha concluido el nido va en bus. ca de una hembra. Warrington dice que el nido concluido llama la atencion de las hembras, pero Coste asegura que el macho ha de ir en busca de una de ellas y que tan luego co. mo la ha encontrado la introduce en el aposento nupcial con infinitos halagos, en lo cual están acordes los dos auto. res. Es entonces tan grande la satisfaccion del macho, que no sabe que hacerse; da continuas vueltas alrededor de su compañera; se mete en el nido, lo limpia, vuelve á salir y finalmente procura empujarla con el hocico para que entre tambien; si es demasiado esquiva se vale hasta del aguijon ó cuando menos de la aleta caudal, y si sus esfnerzos son infructuosos va en busca de otra. Luego que la hembra ha entrado, deposita algunos huevos, segun Coste dos ó tres, horada despues el nido por el lado opuesto al de la entrada y sale ; desde este momento pues tiene el nido las dos aber. turas citadas mas arriba, que proporcionan á las huevas de. positadas, una corriente ó renovacion de agua. Al dia siguien. te se repite lo mismo; el macho sale á conquistar á otra hembra, y si la suerte le es favorable trae dos, obligándolas de bueno ó mal grado á deponer tambien su freza, y de este modo va atrayendo hembras hasta que tiene suficiente nú- 
mero de hueras reunidas. Cada vez que tiene una hembra dentro del nido, penetra él tambien 6 lo hace tan luego como ella ha salido, refriega su costado contra el de la hembra y pasa sobre las huevas para fecundarlas.

Desde este momento redobla su celo y vigilancia, porque entonces mas que nunca necesita proteger y defender las huevas de todo ataque. Se abalanza furioso contra todo gasterosteo que se acerca, y no pára, hasta ahuyentarlo sin dis. tinguir entre machos y hembras, pues todos son igualmente peligrosos y aun tal vez son las últimas las mas aficionadas á la freza 6 á los pequeñuelos. Pero no limita el macho su solicitud a la defensa, sino que a ratos se entretieneen poner el nido en buen estado, recomponiendo con el hocico cualquiera averia casual 6 hecha de intento por algun observador; se planta delante de la abertura 6 dentro del nido moriendo sus aletas torácicas para aumentar la renovacion del aguaen el interinr, como si supiese que las huevas tienen necesidad de nuevas cantidades de oxigeno. Couch quedó agradablemen. te sorprendido al observar que un gasterosteo que habia es. tablecido su nido un poco mas alto que la marea mas baja, la cual le obligaba tambien a abandonarlo á interialos, volvia puntualmente con la marea creciente á inspeccionar la cuna de sus hijos, á recomponerla y custodiarla. Todo el tiempo que dura la incubacion es para estos fieles animalitos una época de incesante lucha á causa de las frecuentes tentativas de ataque de otros machos envidiosos $\delta \mathrm{de} \mathrm{hem.}$ bras madres rapaces.

Cuando concluye la incubacion, tiene cuidados nuevos, porque entonces ha de proteger á los pequeñuelos indefen. sos y alejar de cllos todo peligro. En el vivero de Warrington desovó una hembra en la noche del 8 de mayo y al dia siguiente el macho la rechazó con violencia, y se constituyó en guardian del nido hasta el 18 del mismo mes, dia en que se puso á destruir el nido hasta llegar ́l los tallos que forma. ban la base del mismo, apartando y alejando cuidadosamen. te con el hocico toda la arena $y$ limo en un espacio de $0^{20}, 08$ de diámetro; Warrington estaba muy admirado del extraño proceder de un padre tan solicito, cuando con ayuda de una lente de aumento descubrió la cria que acababa de nacer. Desde este momento no hacia el macho mas que cruzar en todas las direcciones por encima del sitio limpiado, rechazando con creciente vigilancia cuantos peces acertaban á acercarse a cierta distancia. Cuando los hijuelos hubieron medrado algo parecia que trataban de dispersarse, pero el viejo sabia impedir todas las tentativas hechas en este sentido; cogia $\&$ los desertores con su boca, se los tragaba y los rolvia á vomitar sanos y salvos sobre el nido; hasta que hubo trascurrido algun tiempo y la cria supo ra nadar con soltura, no empezó á menguar paulatinamente la vigilancia de su guardian; finalmente cuando los pequeñuelos fueron ya capaces de atender por si mismos á su subsistencia, los abando. nó sin preocuparse mas de ellos.

Interesantísima es una observacion que pudo hacer Evers favorecido por una casualidad. En uno de sus viveros acababa de construirse un nido de gasterosteo, cuando hubo necesidad de trasladar toda su poblacion a otro receptáculo. De la inspeccion del nido, que el macho trató de impedir con sus furiosos ataquues, resultó que contenia huevas, circunstancia que causó a Evers verdadera com. pasion y no pequeño temor; pero no habia remedio; se sacó primero el macho que se revolvia como un loco, palideciendo sus colores al poco rato; en seguida se extrajo el nido con todas las precauciones posibles, se colocó en el nuevo depósito y detrás del nido el padre. Los gasterosteos, tanto machos como hembras, que habitaban el nuevo depósito, habian estado observando atentos y con cierta excitacion
Ia traslacion del nido, y no bien terminó esta, cuancio todos se precipitaron sobre el montoncito, tirando con tanta vio. lencia de los tallitos, que lo habrian destruido al momento si Evers no lo hubiese cubierto á toda prisa con una paletada de arena para resguardarlo de su roracidad. Al trasladar el macho custodio del nido se precipitaron las hembras sobre él con tanta furia que Evers hubo de intervenir con un palito y una red para tenerlas á raya, y aun hubo necesidad de sacar las hembras mas enconadas; pero á pesar de esta proteccion no tenia reposo el pobre expatriado, que estaba incon. solable y nadaba desesperado so lo largo de las paredes de cristal del acuario. Por fin, se tranquilizó un poco, rechazó los ataques de sus contrarios y á veces se paraba y parecia buscar. ¿'Buscaria acaso su nido? No. Paulatinamente se iba poniendo algun tanto colorado, por supuesto siempre con accesos de furor, pero Evers creyó ya llegado el momento de fijar su atencion en el nido; hizo el primer ensayo en esta direccion en presencia de varios amigos aficionados, pero no consiguió otra cosa sino atraer á las ávidas hembras; el se. gundo ensayo infundió alguna esperanza, y el tercero obturo un resultado sorprendente. Cuando el gasterosteo se aproxi. mó por tercera vez. al nido, hurgoneó Evers en el monton é hizo salir rápidamente algunas huevas del interior, aguar. dando á ver lo que sucederia. đJamás habriamos dado cré dito álo que emtonces ocurrió, dice en su descripcion, á no haberlo visto con nuestros propios ojos. Apenas retiré el bas. ton cuando se precipitaron al sitio dos hembras para devo. rar su propia cria, pero antes que pudiesen llegar a las hue. vas estaba ya alli el padre pronto como el rayo á defender heróicamente su cria, y era de ver cómo arrojó de alli á los voraces animales aturdidos con las hábiles maniobras del macho, y atemorizados al ver sus espinas erizadas, su boca abierta y sus movimientos veloces con todos sus cambios instantáneos de direccion. Desde aqquel momento no cesó ya el combatc; era una luclia continua de uno contra tantos; pero el éxito fué sorprendente: al poco rato logró el macho inponerse \& todos sus enemigos que huyeron, reuniendose en el rincon mas distante del acuario; los machos, sorpren. didos, atemorizados, y palidecidos sus colores, desistieron de todo plan de agresion; el vencedor se manifestaba contento y teñido su cuerpo de brillante púrpura. Acto continuo se puso á recomponer su nido; introdujo mas en ef las hueras, arregló las fibras regetales que hallaba en desórden, las cu. brió de arena, las aglutinó y practicó la abertura. :Cuánta admiracion nos causó ver cómo trabajaba para que la incubacion entrara otra vez en su marcha normal! El animalito se mantenia en una posicion casi vertical encima de la aber. tura del nido, agitando sus delicadas aletas con tal fuerza que el mosimiento del agua iba dispersando como polvo toda la parte fangosa y ligera, para limpiar de ella el nido que en breve quedó cubierto solaménte de una superficic arenosa, limpia y lisa. ¡Qué perseverancia! Nosotros, que le vémos trabajar con tanta energía y decision, sin tregua ni reposo, no pudimos menos de sentirnos poseidos de un verdadero respeto hácia el.

Lo que no podemos asegurar es si cl animal habia re. conocido el nido como suyo, ó si lo habia adoptado en lugar del que acababa de nerder; pero en uno ú otro caso no se puede negar a estos peces una capacidad é inteligencia muy notables.

Triste y lameniable fin turo aquel pequeño héroe. Cierto dia cayeron sobre él á la vez todos los demís gasterosteos, que vivian en el nismo depósito, segun observó la familia de Evers en ausencia suya, y mientras rechazaba á los unos, los otros se precipitaron sobre el nido, lo destrozaron 5 las hembras devoraron los huevos. Cuando Evers volvió encon: 
tró al macho descolorido, nadando coma un loco furioso a lo largo de los cristales, y à los pocos dias murió.

Tambien recogió Evers gasterosteos libres con sus nidos, y los trasladó á su acuario, pero ninguno quiso seguir desem. peñando sus funciones de incubador, lo que prueba que no reconocieron el nido como suyo; todos murieron victimas de su pesadumbre $y$ furor indomable; pero los individuos que labian construido nidos y criado en el vivero se encargaron de las huevas de aquellos como si fuesen suyas. Uno de los machos que se habia encolerizado cuando se cambió el agua falta de oxigeno del vivero, reconocio su nido no bien se hubo renovado el agua, se coloró otra ver de púrpura y se. dedicó á la incubacion con el mismo celo que si nada hu. biese sucedido, y lo clue es mas, se acostumbró en el espacio de quince dias tan perfectamente a las mareas artificiales producidas por la renovacion del agua, que no se decoloraba ya en los intervalos, y si bien demostraba alguna inquietud, no era ni con mucho aquel furor ciego y loco de anies. Una mañana se le encontró inmóvil enicima de un hoyuclo que ocupaba cl mismo sitio en que el dia antes estaba todavia el nido cuyos materiales yacian dispersos al rededor. Istaba atis. bando una pequeña nubecilla en el agua, que resultó ser un ejército de pececillos apenas visibles. Como padre fiel esturo nadando el animalillo dias enteros al rededor de la diminuta bandada, tan insensible al hambre, al cansancio y demás necesidades como lo habia estado durante la incubacion, y re chazando \&́ todo intruso por diminuto que fuese. Cuando los pequeñuclos tuvicron ya álos ocho dias una longitud de cuatro á cinco milimetros, y se iban apartando del centro, á medida que crecian, los seguia el viejo inquieto, los cogia con la boca, se los tragaba, y volviendo al sitio de cria, los volvia $\&$ arrojar ilesos dentro del hoyuelo; cuatro semanas mas tarde tenian ya la forma y aspecto de los adultos; ende. rezaban ya sus espinitas apenas visibles, y se mostraban, por su destreza y rapidez de movimientos, dignos hijos de sis padres. Otro macho abandonó las huevas despues de haber cuidado solicitamente de su incubacion durante quince dias y con menos celo la tercera semana, porque se convenció de que se habian cchado a perder.

Los gasterostcos ponen, en comparacion con otros peces, pocos huevos, de sesenta a ochenta; y no solo tienen que hacer frente á especies enemigas de mayor tamaño que ellos, sino tambien á otras mas pequeñas, pero no menos temibles, como son las ténias; por otra parte su vida apenas dura tres años, segun dice Bloch; mas á pesar de esto aumentan á veces de una manera casi increible, sobre todo en calas de rios, estanques, lagunas y fosos de fortalezas. En los estanques perjudican notabiemente las crias de peces útiles, y una ver establecidos en ellos es dificil exterminarlos. En tienupo de Gessner creia la gente \&que estos pececillos nacian es. pontáneamente y que trascurridos algunos años se trasformaban en otros peces sin haber tenido contacto alguno con ellos. Lo cierro es que con su reproduccion pasa lo mismo que con la de los ratones; las primeras crias se hacen sin que nadie las incomode; la progenie crece y se reproduce à su vez, y he aqui cómo hormiguean súbitamente los gasterosteos alli donde antes no se veian. Hay anos que se los pesca en Holstein, Slesvig, Suecia 6 Inglaterra en tan grandes can. tidades que la gente alimenta con cllos los cerdos, las gallinas, los patos, 6 los aprovecha para extraer su aceite ó bien como abono. Pennant dice que un hombre del condado de Lincoln ganó durante largo tiempo cuatro chelines diarios con la pesca de gasterosteos, si bien los agricultores no le pagaban mas que una peseta por cincuenta fanegas. En Ho. lauda encienden fogatas en las playas para atraer a estos peces y cogerlos en masa, ya para aprovechar el aceite çue dan, ya para abonar las tierras. La carne se considera en to. das partes como impropia para el alimento del hombre, por cuya razon se vende el kilógramo por lo regular á diez cuarios, $y$ à lo sumo à tres reales. En Dantzig contaron á Siebold para pintarle la miseria que alli se habia pasado en el último sitio, que los habitantes pobres habian de valerse de los gasterosteos que pescaban en los fosos para aplacar el hambre que padecian por la escasez de viveres. Otros autores sostic. nen que a pesar de despreciarlos tanto, su carne no es mal manjar, antes bien es sabrosa con tal de guisarla bien.

\section{LOS ESCÓMBRIDOS- SCOMBRID死}

CARACTERES. - Hase reunido un número dastante ronsiderable de peces de formas muy propnrcionadias en una familia, dándole el apelativo de escómbridos, sacado del nombre cientifico scumber del género conocidísimo de las en. liallas. Su cuerpo es fusiforme, comprimido lateralmente, inuy adelgazado hácia la cola y cubierto de escamas tan pe. queñas que á primera vista parece liso. Pueden citarse como otros distintivos, los opérculos que son lisos, es decir no aserrados $y$ sin espinas; la abertura branquial casi enteramente cerrada; los radios duros de la aleta dorsal menos desarrollados que los blandos y que los de la aleta anal, y á reces aislados; $y$ las aletas abdominales, insertas en el pecho, muchas veces solo rudimentarias ó faltando completamente.

USOS, COSTUMBRES Y REGIMEN. - Los escóm. bridos habitan todos los grandes mares sin distincion de zo. nas ni de costas. Casi todas las especies, cuyo número pasa de ciento, viven en sociedad, algunas en bandadas innumera. bles, muchas en grandes profundidades $y$ otras en las capas superiores:

Todós nadan bien, $y$ todos sin excepcion son rapaces, si bien su voracidad y rapacidad no estín siempre en propor. cion de su talla, pues justamente las especies mayores de la familia suelen contentarse con las presas mas pequeñas; en cambio liay algunas que son para los peces de que se ali mentan como los lobos para las ovcjas. El doraque (Gybium Commersonii) que es uno de ellos, y tiene un metro de largo, acccha las bandadas de peces, segun cuentan los pesca. dores árabes del mar Rojo donde vive, y cuando las tiene as la distancia que quiere, se precipita sobre ellas con la velo. cidad del rayo, ya desde las capas superiores, 6 bien subien. do desde el fondo como una flecha; distribuye mordiscos á derecha e izquierda, dejando los peces partidos con sus aff. lados dientes, pero sin engullirlos, y cuando los demás se desbandan y' huyen, los persigue a algunos metros del punto donde hace la matanza, volviendo despues para recoger $y$ devorar los pedazos de las víctimas.

Los escómbridos se multiplican rápidamente, lo que aumenta la importancia que tienen para los pescadores; algu. nas especies son en determinadas costas los peces mas im. portantes; otras tienen una importancia secundaria, como sucede en el norte, donde los consideran inmediatamente despues de los arenques, pudiendo decirse que ninguna especie es despreciada por las poblaciones maritimas.

\section{LAS CABALLAS-SCOMBER}

CARACTERES. - Este género sirve de tipo \& la familia y se distingue por su forma oblonga, sus dos aletas dorsales muy separadas entre sí, la segunda descompuesta en varias aletas falsas ó falsas pimulas, quillas débiles á los lados de la cola; los opérculos carecen de espinas, los dientes mandibu. 
lares forman una hilera simple y son cónicos; los radios branquiales son en número de siete, $y$ las escamas pequeñas

\section{LA CABALLA - SCOMBER SCOMBRUS}

CARACTERES. - Este pez (fig. I58), tan hermoso por su forma como por su coloracion, es el representante mas notable de su género. Su longitud varia entre $\left(1{ }^{\prime \prime}, 40\right.$ y $11^{\prime \prime}, 45$ y llega á lo mas à $11^{\prime \prime}, 50 \mathrm{y}$ a un peso medio de un kilógramo. La parte superior es azul con viso dorado y listas trasversa les oscuras, la inferior es blanca y plateada. Diez à doce ra dios espinosos sostienen la primera aleta dorsal; de doce á trece blandos y unicios la segunda; trece cada torácica; seis cada abdominal; once la aual, veintitres la caudal, y además se cuentan entre estas dos últimas cinco radios falsos $y$ libres.
USOS, COSTUMBRES Y RÉGIMEN. - Suponiase, á juzgar por las relaciones de pescadores y de otros observa. dores, que la verdadera patria de las caballas era el mar Cla. cial, desde donde emprendian sus larguisimos viajes anuales hácia los mares meridionales; y partiendo de esta suposicion se habia ideado hasta la ruta que estos peces habian de seguir. Se creia que al abandonar el mar Glacial pasaban pri. mero por las costas de Islandia, seguian por las de Fiscocia É Irlanda, desde alli atravesaban el Atlántico hácia el mediodia para volver á presentarse en las costas de Espana y de Portugal y penetrar en el Mediterráneo. Entre tanto se dirigia otra corriente principal desde el mar Glacial por el del Norte al Báltico, y otra, pasando igualmente por el mar del Norte, debia dirigirse á las costas alemanas, holandesas y francesas. El almirante Pleville, que habia pasado cincuenta años en el mar, llegó á asegurar que habia descubiertn hasta los cuarteles de invierno de las caballas; $y$

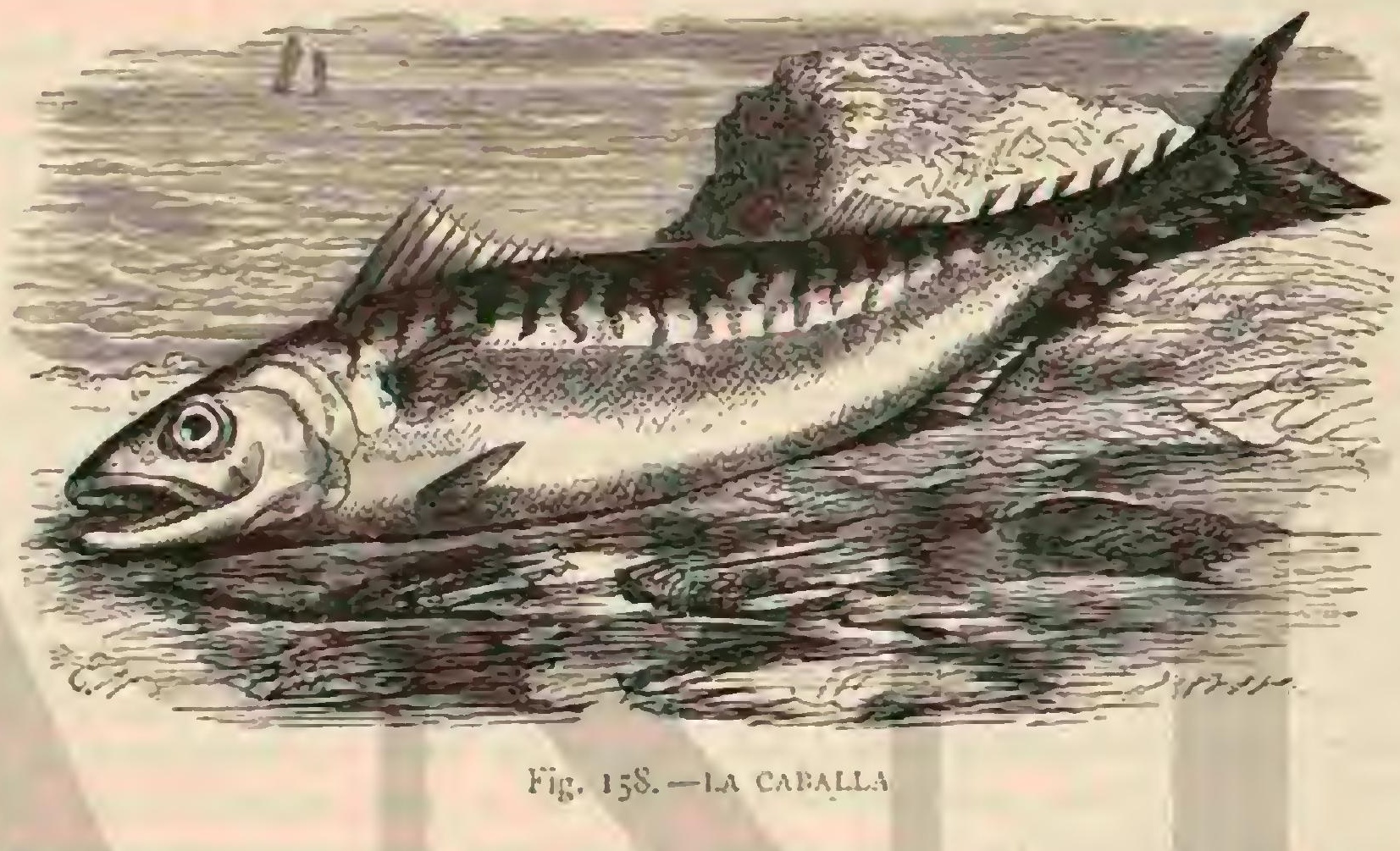

decia que cuando el mar estaba tranquilo en las peqqueñas calas de las costas peñascosas de Groenlandia se veian en la estacion fria asomar estos peces á millares, sacando medio cuerpo fuera del agua, tan espesos $\&$ inmóviles cual si fuesen innumerables estacas clavadas en el fondo, hasta el punto de que sus marineros no querian al principio entrar con sus botes en dichas calas porque creian que estas ca. ballas eran una especie particular de arrecifes que podian destronar sus embarcaciones. Excusado es añadir que este aserto del viejo marino no pasa de ser una mera fábula, y en el dia ni siquiera se da crédito à los viajes de estos y de otros peces; pues lo cierto es que pescando í considerable profundidad se cogen siempre caballas tanto en el Báltico, como en el mar del Norte 5 como en cl Atlántico y en el Mediterráneo; si bien no pucde negarse que á medida que se pasa a levante cscascan mas y mas y que á la isla de Ruegen ya no acuden con regularidad; pero donde se presentan lo hacen casi simultáncamente en las costas septentrionales y meridionales, por manera que todo indica que viven habitualmente à grandes profundidades, de las que únicamente se alejan para desovar junto á las costas, del mismo modo que to hacen los arenques y otros peces. En la costa oriental de Frisia se cogen caballas desde la primavera hasta el otono; en la desembocadura del Weser de mayo á julio; en Ruegen y Stralsund de junio á setiembre, y en Travemunda se presentan en bandadas solo en agosto, $y$ algunos años hasta faltan del todo, habiéndose observado por otra parte que acuden á la isla de Ruegen en mayor nú. mero cuando el viento sopla del noroeste.

PESCA. - Su aparicion en las costas es un grato aconteTomo $\mathrm{V}$ cimiento, porque la caballa es un pez de mar de los mejores y mas importantes, y su pesca ha tenido siempre grandisima importancia tanto en la antigüedad como ahora. En las po. blaciones maritimas suscita su aparicion una animacion general, sin distincion de edad ni de clases. Inmediatamente se aprestan centenares y millares de lanchas para pescar el precioso pez, y en todas las costas, en todas las calas, cusenadas y bahias se despliega una actividad inusitada; cada embarcacion mayor va acompanada de varias lanchas que han de llevar la pesca á tierra y al mercado i- medida que se $\operatorname{coge}$, y hasta se reunen las tripulaciones de varias embarcriciones para alquilar un vapor pequeño y andador que con la mayor carga reunida por los asociados, lleva ya á las cinco y seis horas de principiada la pesea, el primer cargamento al mercado, porque en el norte, es decir en las costas de Inglaterra, de Holanda y de Francia, no se consume la caballa sino cuando está muy fresca, y como se pasa y corrompe pronto, es menester venderla antes, y esta es la razon pornqué varia el beneficio de esta pesca entre tan extremos límites.

En el mediodia de Europa es diferente; alli salan este pescado. En el norte, donde solo lo consumen fresco, se pagan las primeras partidas á precios muy elevados que van bajan. do sucesivamente á medida que el mercado se va abasteciendo, por manera que puede suceder que una barca gane en una sola noche, en años de pesca escasa, hasta dos mil marcos (2,500 pesetas), mientras que en años de grande abundancia el beneficio queda reducido á poca cosa. Segun Yarrell, en mayo de 1 So 7 se vendieron en la pescadería gran. de de I óndres cien caballas por cuarenta guineas (S00 pesetas), pero la lancha que llegó despues de esta primera no sacó mas 
que trece guineas ( 260 pesetas) por el ciento de caballas. En el año isos fué tan abundante esta pesca, que podian comprarse en Dover sesenta cabalias por un chelin ( 5 rea. les). En el mismo año sucedió en Brighton que la red de una lancha se llenó tanto que los tripulantes no pudieron sacarla y hubieron de perder red y peces, pérdida que podia estimarse aquel dia, sin contar el valor del pescado, en se. senta libras esterlinas ( 1200 pesctas). Fn el año i $S_{2}$ I cxce. dió la pesca de la caballa i la de todos los años anteriores, pues recogieron diea y seis lanchas el dia 30 de julio por valor de 5,252 libras esterlinas de caballas ( 105.040 pesetas). El año 1834 fué tambien uno de los mas ábundantes, cogiendose tantas caballas que durante tres meses se vendicron por las calles de Lóndres tres piezas por ún chalin. Solo de Noruega saleo dos mil quinicntos pescadores a pescar la caballa y cogen anualmente por término medio de treinta á treinta y cinco mil caherns, cuyo valor pasa de cinco millo. nes de pesetas, y que embaladas en hielo se expiden casi en su totalidad a Inglaterra. En Noruega valen las caballas una con otra veinte céntimos de peseta, 5 en las costas del Bál. tico, treinta y dos hasta cincuenta céntimos.

En las costas de Inglaterra se emplean por ío comun redes de jorro 6 barrederas de unos seis metros de ancho y cua. renta de largo; cada barca lleva de coce á quince, que van añadiéncose sucesivamente a medida que se sumergen; despues marchan con el viento llevando las redes suspendidas verticalmente en el agua y abiertas hácia delante; por lo regular se pesca de noche. A veces tambien se emplea junto a tierra el volantin, atendido que la caballa muerde el cebo con avidez.

En las costas de Inglaterra aparece la caballa ya en marzo $y$ aun en febrero, pero la pesca verdadera no principia hasta mayo ó junio, y mas al nortc un mes mas tarde. Il desove se efectúa en las regiones mas meridionales en junio. El numero de huevos que lleva una hembra es aproximadamente de medio millon. A firies de agosto se ven ja caballas peque.

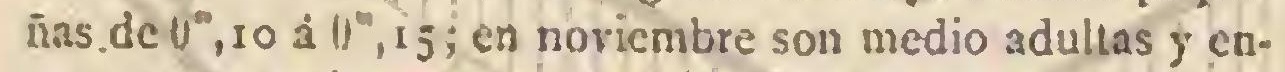
tonces yat se retiran, excepto muy pocas, á las aguas profundas. Parece que su alimento consiste principalnuente en las crias de otros peces, atendido que persiguen 1- las especies mas pequeñas de la familia de los arenques, por manera que a al. gunas de estas se les ha dado cl nombre de guias ac las caúrllas. La caballa es en extremo voraz, por cuja razon se des. arrolla rapidamente.

La opinion que prevalece hoy dia respecto 2 la carne de este escombrido es que se ha de comer cuanto antes, mien. tras que los romanos la dejaban corromperse mezclada con la sangre $y$ los intestinos para componer despues la tan fa. mosa salsa que liamaban «garum $\%$. Li mejor se llamaba ga. rum español, negro ó noble, y dós medidas ó cuartillas costaban mas de ochocientas pesetas, en especial por las especias de la India que se mezclaban con el mismo, de suerte que fuera de las esencias no habia otro liquido en el mercado de Roma que alcanzase precio tan subido. Esta salsa se echaba á los guisados de carne, y tambien la bebian en la comida mezclada con agua ó vino, pero se dice que su olor era suma. mente desagradable.

\section{LOS ATUNES - THYNNUS}

CARACTERES. - Una especie gigantesca de caballas vive en los mares meridionales y es para muchas costas, especialmente para las del Mediterráneo, de una importancia extmordinaria. Dicha especie es la de los atunes (Tizynurs), que se distingue de las caballas propiamente dichas por las dos alctas dorsales nus aproximadas entre si, y un nimero proporcionalmente considerable de falsas pinulas, por un peto grande formado de escamas mates que acaba hácis la parte posterior en puntas, por una quilla en ambos costados de la cola, y además porque falta la espina libre antes de la cola que se encuentra en las demás caballas ó escombridos. Los dientes pequeños y puntiagudos de las mandibulas forman hilera simple.

\section{EL ATUN COMUN-THYNNUS VULGARIS}

CARACTERES. - Los antiguos conocian y pescaban la especie masimportante de los atunes, el atun comun (fig. 159), el mayor de todos los peces que se pescan para utilizar su carne, pues alcanza una longitud de dos á tres metros, y se. gun pretenden algunos hasta de cuatro y mas, con un peso de ciento hasta seiscientos kilógramos. El dorso es de color azu! negruzco, el peto azul blanquizco; los costados y el vien. tre tienen sobre fondo gris manchas blancas plateadas que forman listas; la primera aleta dorsal y la anal son de color de carne, las falsas pinulas amarillas color de azufre orladas de negro. En la primera aleta dorsal hay catorce ra. dios duros, en la segunda un radio duro y trece blandos, y además de ocho á diez falsas pinulas; cada aleta iorácica tiene treinta $y$ un radios; uno y cinco la abdominal; la anal dos y doce, y como continuacion ocho a diez aletas falsas; la caudal tiene diez 8 nueve radios.

DISTRIBUCION GEOGRÁFICA. - La patria verdadera del atun es el Mediterránco, pues parece que no abunda tanto en cl Atlántico, donde le reemplazan especies afines. Los pescadores opinan que inmigra cada año en gran número en el Mediterráneo viniendo del Océano por è estre. cho de Gibraltar, porque solo así pueden explicarse, comolo hacian tambien los antiguos, la aparicion súbita de los atu. nes en las costas del Mediterráneo; pero en la actualidad prevalece la crecncia de que estos, corno tantos otros peces, permanecen largas temporadas en las profundidades 6 en medio del mar y que solo se acercan á las costas en la época del desove. Verdad es que cuando aparece el atun sigue cierta ruta fija, determinada segun toda probabilidad por los valles ó depresiones submarinas, porque no puede ya admitirse que viaje en el sentido que creian los antiguos, lo que no excluye la posibilidad de que muchos atunes del Atlántico pasen al Mediterráneo y de este al mar Negro; pero siempre queda subsistente el hecho de que se encuentren atunes todo el año en el Mediterráneo con mayor frecuencia que en otros mares, como en las costas meridionales del At. lintico. Cuando se presenta en regiones mas septentrionales es por casualidad, como sucede en las costas de Inglaterra, aurique en ellas se le observa con mas frecuencia que en el mar del Norte donde ya es muy raro; en 1869 se cogió en la costa de Jasmund uno que tenia tres metros de largo.

USOS, COSTUMBRES Y REGIMEN.-I.a importan. cia que el atun tiene y la consiguiente atencion que dedican todas las poblaciones del Mediterráneo as su aparicion y pesca han sido causa de que se haya observado la primera con particular esmero, lo mismo que la ruta que sigue, pero a pesar de esto es muy poco lo que sabemos sobre su género de. vida.

Se sabe que viajan en bandadas mas 6 menos numero. sas, que á veces constan de miles de individuos; que sus movimientos son bastante diestros; que persiguen principalmente las sardinas, anchoas $y$ otros peces pequeños, y alguna vez caballas y peces voladores, y acaso coman tambien con. chas; se sabe además con bastante exactitud cỏmo se repro. ducen; que son \& su vez perseguidos, tanto los grandes como los pequeños, por los tiburones y delfines; $y$ que viven en 
buena armonia con el pez espada, por cuya razon se los ve á menudo juntos, pero á esto se reducen todas nuestras noticias.

Está fuera de duda qque el atun solo aparece en la costa para la operacion del desove, y si bien al principio se en. cuentran poco desarrolladas las huevas, se ha observado que su crecimiento definitivo es muy rápido. En los atunes cogidos en abril pesan las huevas unas quince onzas, pero en los que caen en las redes en mayo excede ya su peso de seis kilógramos. El número de huevos es do veces muy conside. rable.

«amás he dudado al ver la abundancia y plenitud de sus huevas, dice el abate Cetti al que debemos la primera descripcion detallada del atun y desu pesca, que si las inspec. cionara la rista penetrante de Leeuwenhoek encontraria en cllas este sabio un nimero tan inmenso de huevas como el que encontró en el gadus aeglefinus (especic de bacalao); lo que quiere decir que cada hembra lieva cientos de miles de huevas.

A mediados de junio se ven machos y hembras en continuo movimiento, ya dentro del agua, ya saltando fuera, porque entonces se mantienen junto á la superficie y se desprenden de su freza, que segun parce, deposita la hembra en las algas, pasando luego el macho á fecundarla. Los pequenuclos macen en junio, y pocos dias despues pesan onza y media; en agosto pesan cuatro y en octubre treinta. Se ignora la marcha de su crecimiento posterior, pero puede supo. nerse que ha de ser muy rápido. Tambien se ignora el tiempo que necesita para adquirir todo su desarrollo, pero deben ser muy pronto aptos para la reproduccion, porquue entre los viejos se cogen siempre otros mas jóvenes y mas pequeños qque no se hallarian ni viajarian en compañia de aquellos si no estuviesen impulsados por el mismo instinto cie reproduc cion.

PESCA.-No puede describirse el genero de vida del atun sin hacer la descripcion de su pesca, porque todo lo que se sabe respecto de la vida de este pe\%. se funda en las observaciones hechas cu aquella. I.os antiguos practicaban la pesca de atun con mucho celo en ambos extremos del Mediterráneo, en el estrecho de Gibraliat y en los Dardanclos. Aristóteles creia que todos los atunes efectuaban su repro. duccion en el mar Negro y en las costas de España, y Estra. bon dice que seguian las costas del Asia Menor y que se les pescaba sucesivamente cerca de Trebisonda, despues en Sinope $y$ finalmente en Constantinopla donde se reunian prin. cipalmente en el golfo, el puerto actual. De ahi resulta el hecho positivo de que los atunes acuden cada ano al Cuerno de Oro, y que son alli mas frecuentes, dice Gyllius, que en las costas francesas, tanto que segun él pueden llenarse en un dia reinte embarcaciones con ellos, que pueden cogerse con las manos, matarios á pedradas 6 pescarlos con anzuelos desde las ventanas de las casas que dan al agun, é izarlos cespues á las mismas en canastas grandes. Los fenicios practicaban la pesca del atun principalmente en las costas de Espana, donde se ha continuado este ramo productivo de industria liasta la época moderna. Habia almadrabas célebres $y$ algunos grandes de -Eşraia sacaban de ellas la mayor parte de sus-rentas; pero poco a poco fué disminuyendo la activi. dad, sobre todo despues del terrible terremoto de Lisboa en el ano de r 755 , que se dijo habia cambiado de tal manera la disposicion de la costa, que los atunes no podian ya encontrar sitios á propósito para desovar: pero con todo existen todavia en el dia almadrabas de atun cerca de Cádiz, Tarifa, Cibraitar, en la orilla opuesta cerca de Ceuta, y además en algunos puntos de Cataluña.

Ia pesca se hace de diferente manera segun las condicio. nes locales $y$ la estacion. En las costas de Francia lo mismo que en Istria se colocan vigias en puntos clevados al acer. carse el tiempo de la pesca para que avisen cuando llegan los atunes $y$ en qué direccion. $A$ la primera señal se hacen al agua las lanchas que á este efecto se tienen ya preparadas en gran número y que a las órdenes de un jefe, forman en el mar un vasto semicirculo y echan sus redes de modo que quedan los peces encerrados. En seguida bogan hácia la orilla reduciendo el círculo mas y mas, empujando los peces siempre por delante. Cuando ya no hay mas que alguaas brazas de agua y estân próximos á la orilla, extienden la última red (la almadraba de tiro), la cual se saca \& tierra con los peces que contiene, haciéndose una horrible matanza de ellos en la playa.

En las costas de Italia esta pesca es mas grandiosa. Alli se cierra el camino á los atunes con redes descomunales y cuan. do la pesca es farorable se los coge tambien a miles. El abate antes citado ha descrito esta pesca de mano maestra y su descripcion inmcjorable, que es aun hoy aplicable en todos sus detalles a dicha pesca, forma la base de lo que sigue.

Las redes que se emplean mas bien pueden llamarse edificios hechos de cuerdas y mallas; son tonairas colosales ó almadrabas que se dividen scgun su posicion en anteriores ó posteriores. Es preciso que el mar tenga una profundidad por lo menos de trcinta $y$ tres metros alli donde quiere esta. blecerse uno de cstos atrevidos artincios, porque la anchura de la red que ha de formar pared ó redil es de cincuenta metros, puesto que una parte ha de quedar tendida y fija en el fondo para servir de suelo al espacio subdividido en muchos compartimientos. Uno de estos, el mas cercano á la orilla, furma suejo completo, siendo tambicn mas sỏlido que los otros; consiste en una red hecha de cuerdas de cáñamo muy sólidas y de mallas mas estrechas, porque tiene que resistir al movimiento y los esfuernos desesperados que hacen los atunes alli reunidos en gran número, asi como al peso de estos, porque es la red en que se sacan á tierra. Este compartimientó se llama el de la muerte. De él parten otras dos redes muy largas que forman hácia la alta mar un pasadizo que se va ensanchando en su extremo á noodo de cmibudo y facilita la entrada de los atunes á la verdadera almadraba; teniendo $\{$ veces una longitud de una legua marina a fin de recoger hasta los peces que pasan mas lćjos de la orilla.

Al aproximarse ia época de esia pesca se nota un movi. miento extraordinario en las playas de la isla de Cercieña. En los puntos de la costa donde se coge el atun hace mucho tiempo no faltan edificios mas $\delta$ menos grandes y ii juropósito para albergar á la muchedumbre que acude, ya scan pescadores, ya coinpradores ó especuladores, ó ya meros curiosos. Hasta fines de mayo rcima alli la soledad y el silencio, pero llega el mes de abril y la playn se irasforma en un mercado, en una feria donde se reune gente de todas las clases de la sociedad; los hijos del pais y los forasteros llenan pronto las casas y barracas; en la playa se levantan barracones y chozas y el mar se cubre de embarcaciones grandes y penue. nias. En todas partes se oye el estruendo del trabajo; aqqui se dedican á sus faenas los herreros, alli los cuberos; mas allá alijan barriles de sal, que los cargadores van rodando y colocando en la playa; otros se ocupan en el acarreo de tone. les vacios y otros efectos; aculla trabaja una muchedumbre en enormes redes que hay que remendar, extender y reunir. El patron ó propietario de la pesqueria lo recorre $c$ inspec. ciona todo, dispone y distribuge los trabajos, cuida de que su gente esté debidamente mantenida, y procura que no le falte tampoco el culto divino, en la persuasion de que su omision podria comprometer el buen exito de la pesca. Secundan al patron algunos hombres de su mayor confianza; 
son los capataces, que vigilan los trabajos, comunican sus órdenes y procuran que se ejecuten con exactitud. El mas importante de todos ellos es el reis ó capataz de los pesca. dores. Reis es roz árabe y significa capitan, jefe; y su empleo da á entender que los árabes debian ejercer esta pesca en grande escala. Al reis incumbe todo lo que se refiere a la pesca del atun; su fidelidad ha de estar á prueba de toda corrupcion y de cunntas tentativas hicieran los propietarios de otras almadrabas para quo las favoreciera en perjuicio de su amo; csto sin contar con que ha de conocer á fondo la industria y las costumbres del atun, y posecr una perspicacia nada comun, pues ha de estar atento o las circunstancias mas insignificantes rclativas a la pesca, conocer cada depresion ó eminencia del fondo del niar, su color y los numerosos detalles que influyen en el resultado y que ha de exa. minar antes, $y$, finalmente, ha de tener genio y talento para construir en el agua el imponente edificio de redes para que dé el resultado deseado y resista al embate de las olas aun en los temporales. Hecho todo esto debe vigilar incesantemente su obra, y luego depende de su experiencia la eleccion del momento mas económico y a propósito para dar principio á todos los trabajos. Ha de conocer asimismo el tiempo a fin de no exponer su obra inútilmente á un tempo. ral y tenerla que recomponer cuando seria mas necesaria para la pesca, durante la cual asume en si todo el mando. El dia de pesca es el reis dictador y autócrata, porque de sus conocimientos, aptitud y disposiciones depende todo el éxi. lo; por esta razon se le trata con la mayor atencion, y el fo. rastero casi no oye pronunciar mas nombre que el suyo en todas las conversaciones. Por regla general las personas que

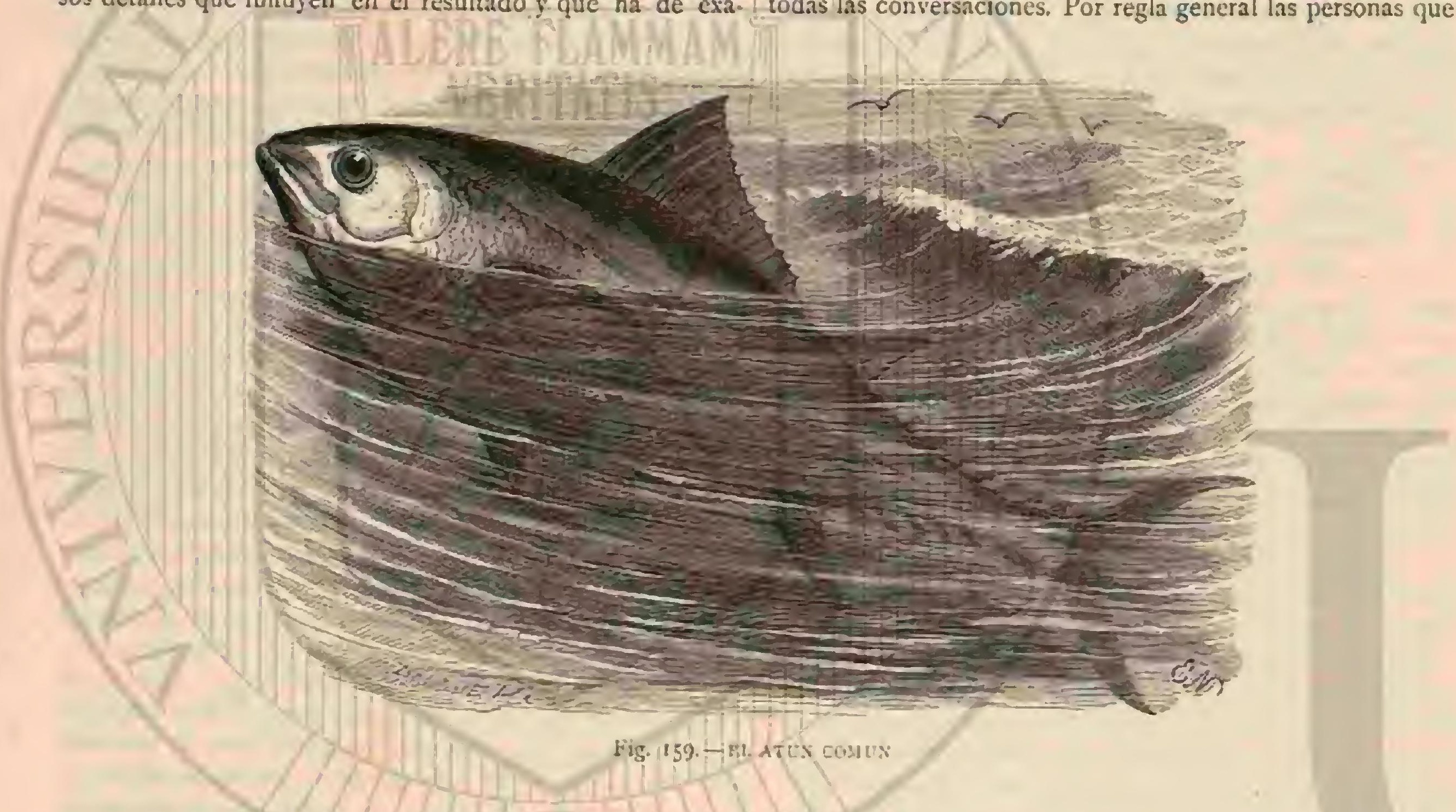

ocupan tan importante puesto han practicado en una escue la de pesca, y las que funcionan en la isla de Cerdeña suelen proceder de Génova ó de Sicilia.

Todo el mes de abril se dedica á los preparativos; à primeros de mayo se traza la almadraba ó tonaira, como la lla man, que es una línea en el aguid que sirve de guia para la colocacion de las redes, á cuyo fin se extienden y fijan sobre el mar largas clierdas paralelas entre 5i. Cuando están ya colocadas las cuerdas y scinalado por consiguiente el sitio de las redes, que al dia siguiente son bendecidas por el clero, se embarcan, se tienden y se sujetan con anclas.

Fil atun efectua su viaje con gran regularidad aunque no ron tanta como creian los antiguos, los cuales decian que viajaba en una sola direccion, teniendo siempre la playa á su derecha; ó segun dice kiliano, tan pronto á manera de los lobos como de las cabras, con lo cual quiere decir que viajan o de dos en dos, 6 bien de tres en tres $\delta$ en bandadas. Lo cierto es que cuando hay calma no viajan sino que cazan para comer; pero cuando hace viento siguen su ruta general. mente en direccion de aquel, y este es el motiro de que para su pesca no convenga ni la calma ni la tempestad, sino un viento regular, por supuesto en la direccion mas ventajosa para cada almadraba.

Los atunes que llegan y dan contra la red la siguen hasta llegar al primer compartimiento porque casi nunca se vuel. ven atras; una vez dentro buscan la salida, pero lo único que consiguen es meterse en los compartimientos interiores donde si no encuentran compañia no tarcan en recibirla. Unos vigilantes especiales colocados en lanchas junto á lo que llaman la isla á la entrada del primer compartimiento, llevan cuenta exacta de los peces que entran, y esos hombres distinguen los atunes con una vista tan perspicar. que ni siquiera se les esca. pan los que se hallan á tal profundidad que desde la superfi. cie no parecen mayores que anchoas; pieza por pieza los cuen. tan como el pastor su rebaño en medio de la mayor baraunda. A veces tienen que emplear, ellos 6 el reis que cada noche se junta con ellos, varios recursos para distinguir los peces dentro del agua, es decir que cubren la lancha con un paño negro para amortiguar el reflejo de la luz, 6 bajan una piedra con un hueso blanco de atun atado á una cuerda, para alumbmr la profundidad, â lo que llaman bajar la linterna. Cuando conoce el reis que los compartimientos anteriores están demasiado llenos, procura hacer entrar los atunes en el siguiente á fin de que se haga sitio para los nuevos que van entrando. Para ello se les arrojan puñados de arena, porque al sentirse estos peces los granitos en el lomo se espantan de tal manera que parece que el cielo les cae encima ; si acaso este medio no produce efecto, se hace un espantajo con una piel de cordero que bajan al agua, y finalmente cuando este recurso resulta inútil, echan mano del último que consiste en estrechar el espacio del compartimicnto por medio de una red especial, obligando así a los atunes á ceder y a pasar. 
Despues de cada inspeccion, pasa el reis a la habitacion del amo para enterarle secretamenic de la marcha de la pesca; le participa el número de los peces cogidos, el modo cómo están repartidos, las disposiciones que ha tonado, etc.

Cuando la almadraba esta ya suficientemente poblada, empieza la matanza, para la cual se requiere un dia de calma. No solo la problacion de la playa sino tambien la de todo el distrito participa de la excitacion de los pescadores;y llegan desde gran äistancia personas distinguidas para presenciar un espectáculo tan conmovedor. En todas las almadrabas se sigue el principio de recibir al forastero con la mayor amabili. dad $y$ de hacerie un regalo cuando parte. I a noche que pre. cede al dia de la matanza hace el reis que se introduzcan todos los atunes destinados á morir en la cámara de oro como la llaman, ó mas bien en la antesala de la muerte, que es el penúltimo cotupartimiento, llamado de oro porque en esta partc de la almadraba estinn los atunes tan seguros para el pescador como si tuviese ya el dinero en el bolsillo. Vialta empero otra cosa importantisima antes de emprender la operacion decisiva, y es elegir el santo que ha de patrocinarla. Para esto se echan los nombres de varios santos en un pu. chero, se saca un papelito y se proclama cl santo que es el único que debe invocarse al dia siguiente.

Por fín llega ol dia tan deseado de la matanza. Al rayar el alba se embarca el reis para la llamada isla con objeto de arrojar desde alli á los atunes hácia la cámara de la muerte, trabajo dificil y de gran compromiso para el reis, porque no parece sino q̨ue los peces presientan las consecuencias que les ha de acarrear el paso de una cámara a la orra. Ia multitud que se aglomera en la playa va aumentando por momen tos, y armados unos de antcojos, otros fiados solo en su vista natural, no apartan los ojos del reis para no perder ninguno de sus movimientos: tan luego como este conoce que todo está en órden y à su gusto, iza una bandera. Al verla la

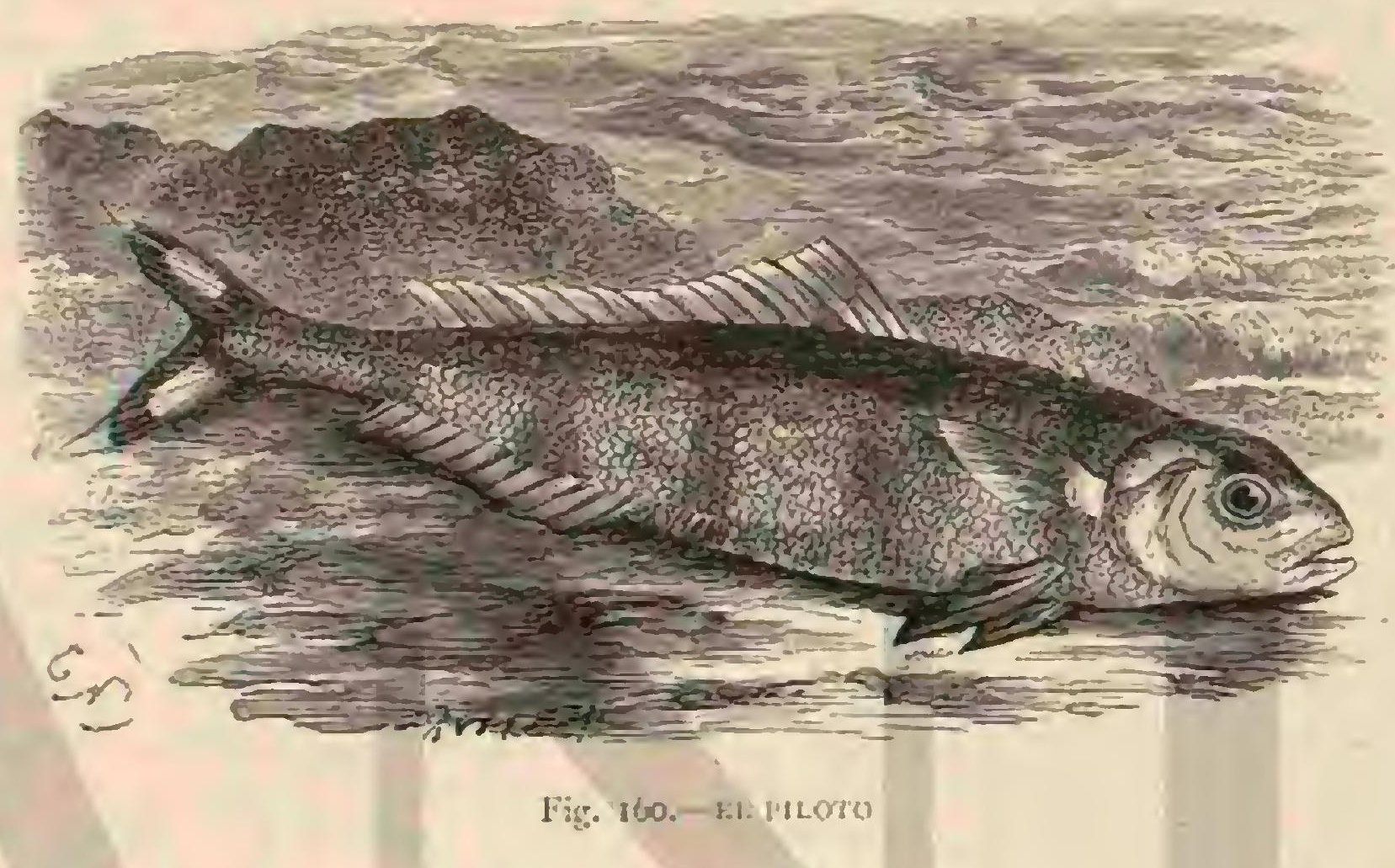

gente desde la orilla se pone en movimiento, todos corren de una parte a oira y numerosas embarcaciones tripuladas por pescadores y por muchos expectadores se dirigen con presteza a ocupar sus respectivas posiciones al rededor del compartimiento de la muerte; dos de ellas llevan capataces que se colocan de suerte que las demás barcas se hallen en tre ellos; el reis con su lancha se sitúa en el centro, pues é ha de dar la serial de ataque como un almirante la da el dia de una batalla naval.

Entre la griteria de todos los pescadores se tira de la cámara de la muerte para sacarla fuera del agua, operacion què se hace muy poco á poco y de "una manera bien igual; mientras tanto el reis vigila la maniobra, recorre con su lancha todos los puestos, $s$ tan pronto se le ve cerca de la orilla como en el punto mas distante, ora \& la derecha, ó bien sa la izquierda, regañando al uno, maldiciendo del otro, e increpando á los mas torpes. Poco á poco sube la cámara de la muerte á la superficie y el circulo de las embarcaciones se cierra al rededor de ella. Lin hervor incesante de la superficic indica la proximidad de los peces. Desdu este momento pasan los matadores armados de pesadas mazas en cuyo extremo hay un gancho de hierro, á las lanchas principales de ambos cxtremos, desde donde empicza el ataque estando todos poseidos de la major agitacion.

En esto da el reis la señal; y al punto estalla un estruendo como de una gran tempestad. Lo producen los peces de ma. yores dimensiones azotando el agua con sus poderosas colas y sus confusos movimientos conforme se van aglomerando, al verse perdidos; el agua que levantan en su loca desespera. cion inunda las lanchas; pero los matadores, sin hacer caso de ello, distribuyen garrotazos á diestro y siniestro con increible furor y como su participacion en el botines tanto mayor cuantos mas peces matan y cuanto mas grandes son estos, procuran despachar todos los que pueden empezando por los de mas talla. Por cierto quue si en estos momentos algun desgraciado cayera al agua no serian ellos los que correrian en su auxilio, al igual del soldado que en el calor del combate nu lace calso del compaisero que cae heridu. Cumo fucra de si y prorumpiendo en salvaje griteria se ensañan con los animales, sacándolos aturdidos $\delta$ muertos del agua para proseguir en su carniceria: Cuando cmpiczan á disminuir los peces, suspenden la matanza; los tiradores de la red la suben otro tanto para estrechar los peces que quedan, y entonces se repitc la agitacion de cstos en el agua, seguida de nueva matanza. Asi aliernan los tiradores de la red y los matadores en su trabajo hasta que ya no queda atun viro; $\mathrm{cl}$ fondo de la red llega a la superficie y la sangre de tantas victimas tine el agua á gran distancia. Todo ha sido obra de una hora. Ios embarcaciones se dirigen á tierra, en donde se las recibe con salvas de morteretes.

Anies de proceder á la descarga se da á cada pescador su parte, que selleva su casa en seguida; el patron da bien una parte al santo que tan eficazmente ha protegido la empresa; y despucs acuden los granujas y merodeadores para escamotear la parte que nadic les da. Al llegar aqui dice el abate literalmente: "Puede decirse que en las alma. drabas twos son ladrones; robar no es alli ninguna deshonra ni delito; el ladron cogido no corre otro riesgo sino el de 
perder el pez que ha huriado, cuando le cogen con el cuerpo del delito, pues si lo tiene ya en su choza, cs suyo. Fin esto hay cierta justicia, por cuanto el salario de esta gente no guarda proporcion con el trabajo que hace, de suerte que en rigor mereceria una gratificacion sobre el escaso jornal que gana; y lié aqui porqué el patron consiente tácita. mente que le roben con tal que él no lo vea. A pesar de esto, el patron y sus empleados vigilan de una manera extraordinaria para coger á los que roban y rescatar su propiedad antes que el ladron se ponga $\alpha$ salvo, pero este por su paste no escasea maña ni destreza para no ser cogido; y eso que no se conientan con robar trozos de pescado, sino que emplean mil astucias para apodurarse de atunes enteros que saben hacer desaparecer con la habilidad de un prestidigizador y con la misma facilidad que si juesen sardinas.

A cada matanza, cxcepto en la liltima de la temporada, dejan sicmpre como un centenar de atunes, y aun mas, en la red para servir de reclamo á los que siguen; y cuancio vuelve á haber bastante número se repite la matanza, mientras dura el paso de los atunes, que en la isla de Cerdena es hasta mediados de junio. Hay almadrabas donde se eícctuan ocho matanzas durante la temporada, cada una como de quinien. tos átunes, en otras hasta die\% y ocho y cada una de ochocientos peces, por manera que el productó de esta pesca es muy considerablc. Concluida ia campaña, sacan la red que constituia el compartinicnto de la muerte,pero las demás quedan en el mar.

Enire los compradores que acuden a esta pesca hay frecuentemenie extranjeros, que salan los peces â su manera. Para el resto se escoge un sitio a la sombra donde se despezan y se salan. P'rimero se les corta ia cabeza, los huesos y la carrie situnda entre las aletas, despues se cuelga el corpulento pez de una cuerda atada á la cola y se hacen seis cor. tes verticales, dos desde el ano á la cola, dos a lo largo del lomo tŕcia abajo, y dos hácia la cola, pero estos tan juntos que solo quedan entre ellos las falsas pinulas, y fimalmente dos cortes de arriba abrio en los costados. De esta manera se sacan trozos de carme de muy diferente valor y merito. Es increible, dice Cetti, las clases de carne yue tiene el atun; en cuantos puntos se corta, la carne es diferente, y en cada punto a su vez segun la profundidad, tan pronto es dura como blanda, pareciéndose en unos â la carne de ternera y en otros á la de cerdo.\$ Cada clase se sala tambien de diferente manera; la mejor es la del vientre, que es realmentc cxquisita, blanda, jugosa, sabrosa y sustanciosa, pagándose siempre á doble precio de la clase que la sigue en mérito. Se coloca la carne en barriles dejínànin de ocho a diez dias al sol y al sereno: despues se saca y se hace escurrir sobre tablas inclinadas, y se vuelve á colocar en los barriles definiti. vos donde se apisona y se cierra despues de llenar completamente de sal el barril. Los luesos y la picl se cuecen para extract el aceite. Cinco barriles con diferentes clases de carne forman un lote.

Tan sana como es la carne de atun fresca 6 bien salada, tan perjudicial es la pasada ó corrompida, que se conoce des. de lucgo por las espinas que se ponen encarnadas, por su gusto tan picante como si se hubiese echado pimienta, y mas aun por sus consecuencias, pues produce cólicos, inflamacion del esófago, dolor de estómago y hasta la muerte. Por esta razon inspecciona la autoridad en muchas ciudades de Italia los preces antes de que vayan al mercado, particularmente en Siroceo, y si estản pasados los manda arrojar al mar.

La carne de atun cruda tiene el aspecto de la de vaca, liero al guisarla se pone mas 6 menos blanca. Yo la he pro. bado varias veces, pero no me gustó, ni pucde compararse con la carne de los demás peces de! Mediterránco que se sirven en las mesas, porque tiene un gusto crudo y de aceite de pescado; segun parece, opinan los italianos instruidos como yo y jejan esta carne para las clases pobres a las que siene cuenta á causa de su bajo precio. Los italianos dan excelentes muestras de sus conocimientos culinarios al con. dimentar este pescado, porque preparan con él sopas muy buenas, asados magníficos, estofados suculentos, lo comen cocido, frito, ahumado con sal y pimienta á manera de salmon, etc.

\section{EL BONITO - THYNNUS PELAMYS}

CARACTÉRES. - Dtra especie del mismo género es el bonito ó bonitalo, tan conocido de todos los marinos y viajeros que cruzan el mar. Por su forma se asemeja al atun, solo que es mucho mas pequeño, pues raras veces pasa de $0^{m}$, So. El dorso y los costados son azules con visos verdes y cncar. nados; el vientre es plateado con cuatro listas pardas a cada lado que van desde la garganta hasta la aleta caudal. Dicese que es imposible describir el brillo de los colores y la belleza general de este pez. La primera aleta dorsal, tiene quince radios; la segunda uno y doce; cada torácica veintisiete: cada abdominal uno y cinco; la anal doce y dos y la caudal treinta y cinco; ocho son las falsas pinulas en el vientre y siete en el dorso:

DistRIBUCION GEOGRÁFICA. - No se sabe con exactitud si se encuentra el bonito tambien en el Mediterráneo; peró en el Ailántico es uno de los peces mas fre. cuentes.

USOS, COSTUMBRES Y REGIMEN.-Kittit\% dice que sigue pertinamente á los buques, que al parecer son sus guias al trasés del Océano, en compania dic los atunes, pero no mezclándose con ellos, sino formando bandada bien ordenada aparte, y haciéndose luego muy visible, porque es uno de los perseguidores mas encarnizados de los peces voladores. liuera de estos se alimenta tambien de congene. rés sujos, de jibias, mariscos y aun de vegetales, pero su caza principal son siempre los voladores. Los atunes, dice Kittlity, sean atunes comumes $\delta$ bonitos, se precipitan sobre los peces voladores con una velocidad prodigiosa, y remedan el vuelo de aquellos con saltos muy clevados y tan diestros que no pocas reces cogen sus víctimas en el aire Esta caza ofrece un especticulo interesante. Los continuos chorros de agua que levantan tantos peces que cazan ó que son perseguidos, y los chas yuidos que producen al rolver í caer al mar, unidos al movimiento que imprime el viento ś la superficie, forman un conjunto por demás curioso. Pasma ver la multitud de peces voladores que caen victimas de los bonitos, de lo cual saben aprovecharse los marineros pára coger ś estos lílimos colganco sobre el agua un pedazo de corcho cubierto de papel reluciente y de !lumas, lo que le da una lejana scmcjan. za con el pez rolador, sobre todo cuando el buque navega de prisa. $A l$ divisarlo los honitos saltan hasta un metro fuera del agua y siempre queda alguno cogido del anzuelo oculto. Asegúrase que la carne es seca y sosa, y á reces hasta renenosa. Lesson dice que la oficialidad de un buque cayó en. ferma despues de haber comido de este pescado-- Merola ya observo que á reces puede causar una muerte rápida.s

Respecto de la reproduccion lo línico que se sabe es que este per desora en julio. Couch examinó un bonito que se habia extraviado en la costa de Inglaterra en dicho mes y le encontró los ovarios llenisimos.

\section{LA ALBACORA-THYNNUS ALELONGA}

CARACTÉRES, - Esta especie se asemeja al atun, pero 
difiere de él por la longitud de sus aletas torácicas que miden una tercera parte de la de su cuerpo; tienen la forma de una hoz, y han motivado por su longitud su nombre cieutifico y el popular que le dan en Italia. La longitud de la albacora raras veces pasa de un metro, $y$ el peso apenas excede de cincuenta kilógramos; el cinturon torácico es me. nos pronunciado que en los demás atunes; la coloracion menos brillante, azul negruzca en el lomo, y plateada hácia el vientre. La primera aleta dorsal tiene catorce radios; la segunda tres y doce, cada torácica treinta y siete; la abdominal uno y cinco; la anal tres $y$ doce, $y$ la caudal cuarenta: además existen ocho falsas pínulas en el lado superior y otras tantas en el inferior.

DISTRIBUCION GEOGRÁFICA. -Péscase la albacora en las costas francesas del Mediterráneo y del Atlíntico con mas frecuencia que á sus demás congéneres.

USOS, COSTUMBRES Y REGIMEN. - Es extraño que antes de los trabajos de los ictiólogos modernos se hubiera confundido siempre el atun con la albacora; como esta últi. ma se coge en mucho mayor número que el primero, habria sido natural que los antiguos, que lo observaban todo tan escrupulosamente, hubiesen notado la diferencia. En el Mediterránco y en una gran parte del Atlántico vive al parecer à considerable profundidad, excepto en la época de la freza, es decir, desde mediados de junio, que es cuando se acerca en bandadas á la costa donde permanece hasta octubre, en cuyo mes se retira otra vez á las profundidades del mar. Su alinento consiste en toda clase de peces que viven en bandadas, especialmente anchoas, barbos de mar, voladores y otros por el estilo; por manera que cuando los peces volado res aumentan es señal de que no tardarin en venir las albacoras.

PESGA.-En las costas de Italia las cogen en almadrabas, y en las de España y Francia principalmente con anzuelo que ceban con pedacitos de paño ó con anguila salada. Cielo cubierto, viento fresco y mar agitada son considerados como circunstancias muy favorables para esta pesca.

La carne de las albacoras cogidas en julio y agosto es mas blanca y inas sabrosa que la del atun, $y$ segun se asegura vale mucho mas que cuando se las coge en junio ó setiembre. En el golfo de Vizcaga se cogen anualmente unas treinta á cuarenta mil albacoras que se venden en cuanto es po. sible frescas; las que no se despachan en seguida se salan para el invierno.

\section{LOS PILOTOS-NAUCRATES}

Los antiguos hablan dé un pez llamado pompilo, que sigue á los buques, y como dice Gessner: ctiene la costumbre extraña de habitar las regiones profundas del inar y de no acercarse nunca á la costa como si tuviese odio fi la tierra. Tambien manifiestan estos peces una grande aficion à los buqques que atraviesan el mar, porque los rodean y acompaùan hasta que conocen que sube el fondo ó está cerca la tierra firme, de suerte que los navegantes que los observan, si ven que se agrupan detrás del buque $y$ desisten de acompanarlo mas léjos, conocen a su vez que no está léjos la orilla ó que disminuye la profundidad; además les indican estos peces buen tienipo, calma y un viaje prósperó. n Es muy probable que este pez sea cl argonauta 6 piloto que efectivamente sigue í los buqques, pero con mas constancia á los tiburones, meréciendo con razon los nombres que le dan.

\section{EL PILOTO-NAUCRATES DUCTOR}

CARACTERES. - El piloto (fig. I60) representa el ge nero Naucrates, que cuenta pocas especies y se distingue por los caractéres siguientes: la forma del cuerpo es nvoidea, el hocico obtuso; la primera aleta dorsal se reduce á pocos ra. dios aislados; la cola tiene. ́c cada lado una quilla; las escamas son pequeñas y de diferentes clases; la boca está surcada de dientes cortos de terciopelo, que forman una lista estrecha en cada mandibula y palatino, y ancha en el vómer y en el centro de la lengua.

El piloto comparte con otros escómbridos la belleza desu cubierta escamosa El color del fondo es gris plata azulado que hácia el vientre es plateado blanco; el dibujo consiste en cinco fajas de color azul oscuro que dan la ruelta á todo el cuerpo continuándose hasta en las aletas dorsales $y$ anal; las aletas torácicas son de color negruzco; la caudal es azul cerca de su nacimiento y hácia el extremo mas oscura a manera de orla. La primera aleta dorsal se compone de tres 6 cuatro espinas, la segunda de veintiseis; la torácica tiene diez y ocho radios; la abdominal uno y cinco; la anal dos radios espinosos $y$ diez y seis blandos y la caudal diez y siete. La longitud es de $0^{\circ}, 20$. $11^{\circ}, 130$.

\&Siempre habia tenido por fábula lo que cuentran del pi. loto y del tiburon, dice Commerson, pero ahora quelo he visto con mis propios ojos, no puedo dudar de la veracidad de estas noticias. Se comprende que el piloto coma lo que el tiburon deja caer, pero no se comprende cómo este no devora ślos pilotos que cruzan siempre delante de su hocico. He visto á menudo cómo un piloto se acerca al pedazo de toci. no salado que se arroja como cebo, y cómo despues de inspeccionarlo regresa junto al tiburon que no tarda en acudir. Si se le coge, le siguen sus pilotos y no se marchan hasta que le ven izaco ya en el aire; y si no encuentran otro tiburonal que poder agregarse, siguen al buque muchos dias hasta que la suerte les depara otro amo. En esto están acordes todos los observadores que habian de este pez, y Bennett completa sus relaciones diciendo que los tiburones sueltos van siempre acompañados de sus pilotos, pero que no se ve nin. guno de estos cuando van reunidos varios tiburones.

Se ha explicado de distinta manera la causa del lazo de amistad que existe entre ambas especies. Algunos creen que el piloto guia al tiburon á donde está la presa con la esperanza de cobrar su parte, y otros, probablemente con mas razon, dicen que escogen la compañia de tan terrible animal para librarse de las persecuciones de enemigos mas peligro. sos, porque cerca del tiburon estos no pueden cogerlos, atendida la mayor destreza de su prolectur en el nadar. Sea como quiera, no puede dudarse quue entre ambos peces existen ciertos vinculos, pucs segun parece no es solo el piloto el que se interesa por el tiburon, sino tambien este por ăquel. rCuando fuimos á Egipto, cuenta Geoffros, vino hácia nues. tro barco durante una calma un tiburon con un piloto 3 cada lado que conservaban constantemente una distancia fija. Al llegar junto al buque dieron los pilotos dos vuelias al rededor, inspeccionándolo de uno á otro extremo, y como no er:contrasen nada que comer, se marcharon, llevándose á su tiburon; pero en esto habia tenido tiempo un marinero de cebar un arpon con un trozo de tocino, y al oir el ruido que hizo en el agua, volvieron atrás para ver lo qque era, marchándose en seguida á dar aviso á su amo que se entreienia en revolcarse en la superficie; al punto volvió el tiburon atrás, llevando a cada lado uno de sus pequeños amigos, los cuales le guiaban hácia donde estaba el tocino, pues por lo visto no lo habia olido; le arrancó un pedazo, en seguida le dí́ otro mordisco, quedando cogido, y al poco rato estaba sobre cubierta. Dos horas despues se cogió tambien uno de los dos pilotos que no habian abandonado todavia el buque. . Otros observadores cuentan á poca diferencia lo mismo. 
Mayen dice que comunmente precede el piloto al tiburon, $y$ que por regla general va siempre delante de su hocico, adelantándose à veces ora á la derecha ó bien á la izquierda como quien va de descubierta, pero sin dejar nunca de reunirse en seguida con su tiburon. Un dia siguió al buque en que se hallaba el citado naturalista un tiburon á una distancia de cuarenta metros; le echaron un anzuelo cebado, y veloz como el rayo, acudió el piloto, no solo $\{$ inspeccionarlo, sino que hasta pareció probarlo, rolviendo despues junto a! tiburon, alrededor del cual se puso à car vueltas azotando con su cola el agua hasta que logró que aquel se pusiera $\mathrm{cn}$ movimiento, si bien para que śl los pocos minutos fúese victima de su voracidad.

La mayor parte de los escritores suponen que el piloto se alimenta de los excrementos del tiburon, pero Bennett cree haber reconocido pececillos en los restos que encontró en el estómago de un pilutu. Cabte en lo jusible que coma unos y atros.

Es muy natural qque entre ambos peces nazca poco ś poco cierto afecto, porque tenemos muchas pruebas de la inteligencia de los peces en general, y no es raro que entre los aninales superiores de muy distintas clases exista una amistosa' intimidad que va estrechándose aun mas y mas por el hábito, porque el piloto sigue á los buques casi con la misma fidelidad que al tiburon, y probablemente no solo cuando ha perdido á su compañero, sino como dice liessner epor puro afecto »; quizás por el mismo motivo á que obedece el tiburon, es decir, por recoger algo de lo que arrojén de á bordo. El piloto no habita los mares septentrionales, pero muchos han acompañado buques hasta dentro del canal de la Man. cha. En enéro de $1 \$_{31}$ entró en el puerto de Plymouth el buque \&El Perús, que venia de Alejandria despues de una travesia de ochenta y dos dias. A los dos dias de su salida se le habian agregado dos pilotos, uno a cada lado, y lo fueron siguiendo \& poca diferencia siempre á la misma distancia, siendo tanto lo que se acostumbraron a el que por último se pudo coger uno desde un pequeño bote, si bien se escapó a! momento gracias áchaber dado un brinco oportuno; pero desde aquel momento se separaton los dos peces, y unotras otro fucron cogidos definitivamente. Benett asegura que solo es posible coger estos animales tan listos despues de haberse apoderado de un tiburon, por cuanto sus pequeños y fieles compañeros no quieren separarse de él y le siguen dando continuas vueltas hasta muy cerca de la superficie, de suerte que à veres es fárit congerlos con esparavel-de mango largo.

Los que han tenido la rara suerte de comer de este pescado convienen en que su carne es tan buena como la de caballa.

\section{OS EQUENEIDOS-IECHENEIN}

-Del mismo modo que se cogen en nuestro país las lie bres con perros $y$ las aves con halcones, asi tambien cogen ciertas naciones insulares los peces del mar con otros peces adiestrados $y$ acostumbrados á cstc trabajo. Dicese que uno de estos últimos se parece á una anguila grande, solo que tiene la cabeza mas voluminosa, y en la nuca una piel ó mem brana á manera de bolsa muy grande y ancha. Se les sue le llevar por el agua atados desde el barco á una cuerda de modo que no estén fuera de su elemento porque no so portan mucho rato el aire ni la luz. Luego que la tripulacion divisa una tortuga grande ó un pez, deja ir cuerda y el pez cazador al notarlo se precipita como una saeta sobre la presa, cogiéndola con tanta fuerza con su piel ó bolsa, que por muchos esfuerzos que aquella haga le es imposible desprenderse de su cnemigo; los del barco al verlo tiran de la cuer- da y los suben a bordo, donde el pez cazador abandona la presa a los marineros, y estos lo vuelven al agua á ocupar su puesto, pero dándole un trozo de la presa atrapada. Dícese que en poco tiempo cogen muchos peces con uno de aquellos.

Asi dice Gessner repitiendo un cuento que en su tiempo $y$ hasta mucho mas tarde era creido por todo el mundo; pues Colombo, Dampier, Commerson, Seoane y otros viajeros pretenden haber visto en las costas de Africa y de América cómo la gente tenia peces en barriles llenos de agua marina y los hacian servir para cazar en el mar, exactamente como Gessner refiere, es decir que los tenian atados á una cuerda que aflojaban tan luego como veian llegar una tortuga $A$ ! sentirse los peces con mas libertad, lo primero de que tratan es de huir, y cuando ven que no pueden desprenderse de la cuerda se agarran tan fuertemente à la tortuga que los del barco pueden fácilneate subir los dos á bordo.

Los antiguos ya conocian la rémora, que es el pez al que Gessner y los demás autores se refieren, y no hay duda de que debe su nombre à su cualidad de adherirse á los buques y peces grandes, que ha dado origen á todas estas fábulas. Tampoco faltaba en la antigiedad quien creyera que este pez era realmente capaz de ser una verdadera rémora que impedia á los buques avanzar, y mas adelante debió propalarse la especie de que se le podria utilizar en la caza de otros animales marinos, pues no de otra suerte se explica la concordancia gue existe entre los relatos de varios viajeros anti guos, dado que es muy dudoso que ninguno de ellos presen. ciara el empleo descrito de estos peces, por la razon de que ninguno de los navegantes modernos ha visto confirmadas sus relaciones.

Algunos naturalistas reunen las rémoras á los gobioideos en su acepcion mas lata y á los discobolos en particular, sin que dejen de conocer que no existe afinidad entre ellas y los dos grupos indicados; por lo tanto será mas acertado seguir á los ictiólogos ingleses y colocarlas aqui, pero como representan tes de una sub-fanilia particular, con el nombre de Equentes des bo rimuras.

\section{LAS RÉMORAS-ECHENEIS}

CARACTERES. - Iil único géncro de esta sub-familia lo forman naturalmente unos peces cuyos distintivos son: un disco plano y de forma oval que emperando sobre las fosas nasales cubre toda la cabeza $y$ hasta una parte del lomo: este disco tiene un borde flexible, con diez hasta veintisicte arrugas trasversales, movibles y guarnecidas en su cresta de finísimos dientecillos, $y$ hace las reces de ventosa para agararse el animal a objetos extraños. No existe la primera aleta dorsal; la segunda se halla colocada muy atrás, exactamenie encima de la anal; las aletas torácicas y abdominales son pequeñas; la caudal es relativamente grande y puede ser escotada ó re. dondeada. La mandíbula inferior sobresale de la superior, y ambas están armadas de dientes finos de púa, como los lleva tambien el vómer; los de la lengua son de terciopelo y mas finos. I a boca es ancha y abierta. La membrana branquial tiene ocho radios. Bl estómago es grande y el conducto digestivo corto $y$ ancho. Falta la vejiga natatoria.

\section{LA REMORA COMUN-ECHENEIS REMORA}

CARACTERES. - Es la especie mas comun de su género (fig. I 6r) y sub.familia, $y$ la que conocian los antiguos por habitar el Mediterráneo. Su longitud es aproximadamente de $11^{\circ}, 30$; las escamas pequenas y lustrosas están cubiertas de una materia viscosa y su color oscila entre un 
amarillo pardusco y pardo oscuro. El disco-rentosa suele $/$ veinticuatro arrugas. El color es en el dorso verde aceituna. tener diez y ocho arrugas.

\section{LA REMORA AUSTRAL-ECHENEIS NAUCRATES}

CARACTERES.-Esta especie, muy afine de la ante. rior, alcanza una longitud de $U^{\prime \prime}, 20$ á $l^{\prime \prime}, 25$, y su disco tiene do y en el vientre blanquizco.

DISTRIBUCION GEOGRÁFICA.- I a rémora austral habita el Atlántico y el Pacifico.

USOS, COSTUMBRES Y REGIMEN. Jodas las Témoras tienen el mismo género de vida. Se adhieren como los discobolos a otros objetos, regularmente á los cascos de

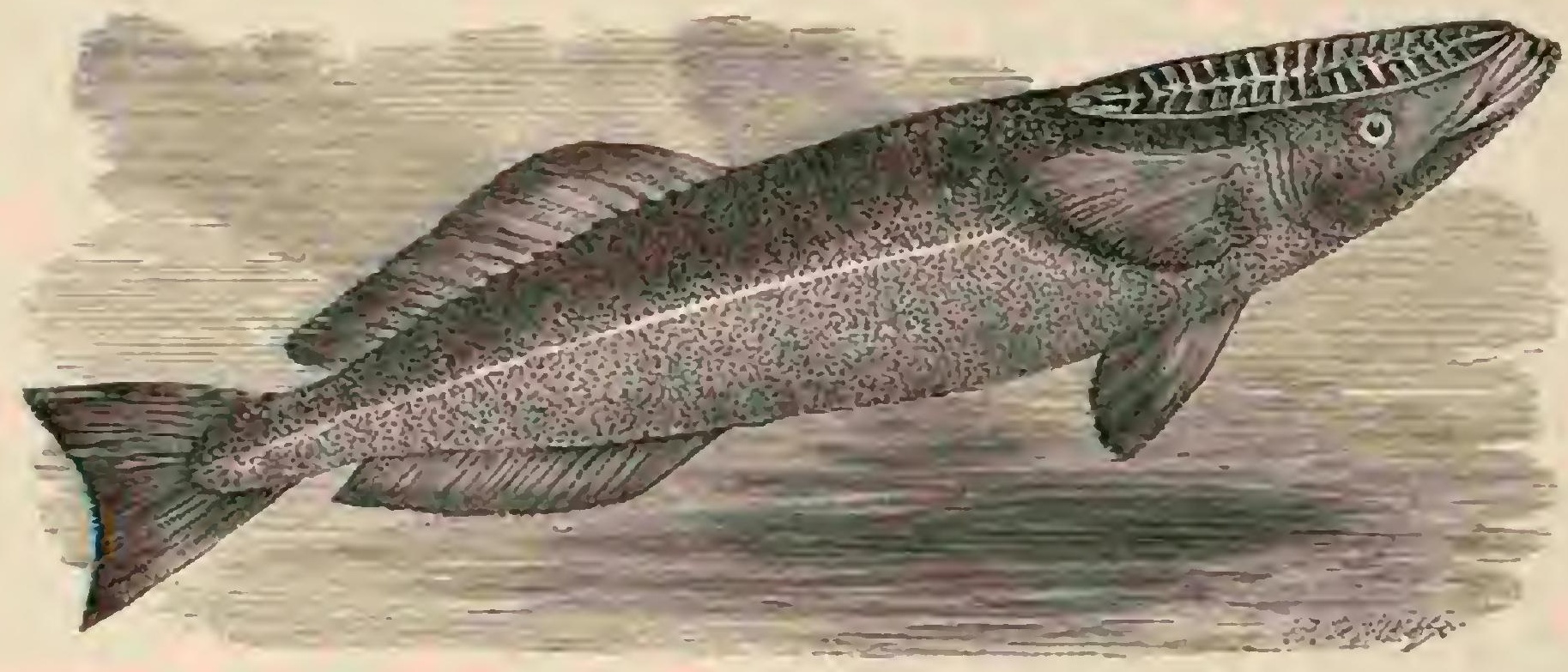

Fig. 168. - I.i ki.Moris

buques y á los tiburones, y alguna vez á las rocas y piedras. Es raro ver un tiburon sin estos parásitos; en cambio á veces están literalmente cubiertos de ellos. Probablemente les facilita su rugosa piel la adherencia y su movilidad la ocasion

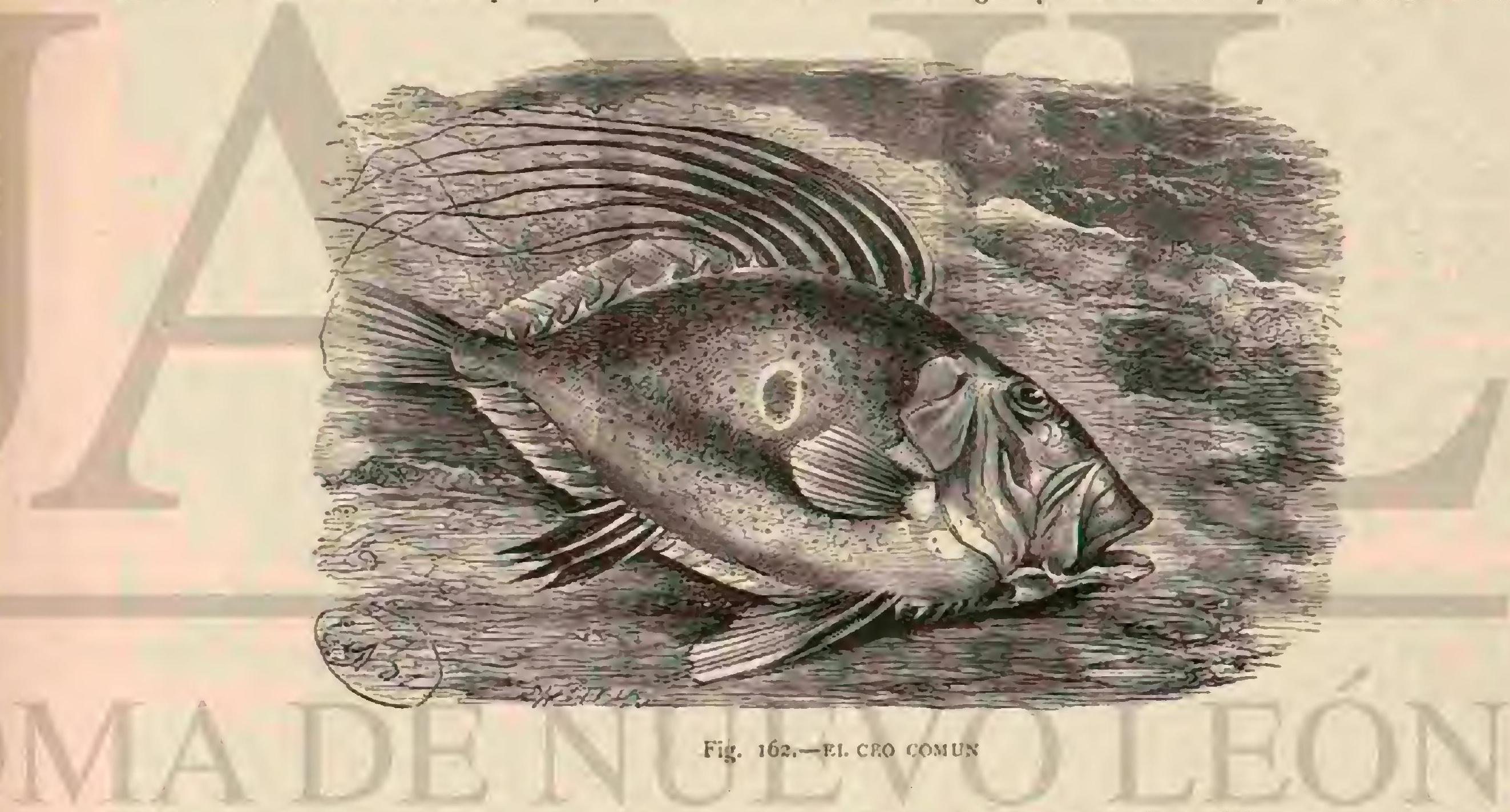

de pescar continuamente en nuevos sitios. Adheridos, ya sea á tiburones, ya s los buques, hacen largos viajes, y como los pilotos, pasan de este modo á mares que les son en realidad extranos, lo que explica por qué la rémora figura tambien entre los peces de Inglaterra siendo mas bien del Mediterráneo, pues no de otra manera se comprende su extraordinaria dispersion. Por lo demás, no se ha podido todavia averiguar satisfactoriamente la causa que los muere a adherirse á buques y tiburones. Se comprende que se adhicran ciertos objetos por la razon de que todo animal sabe hacer el uso mas conveniente de las dotes que la naturaleza le ha concedido, pero dificil es decir porqué hacen lo propio con objetos movibles, pues la razon que se da de que asi suple su poca habilidad en $\mathrm{cl}$ andar, es una mera suposicion que no se ha demostrado todavia, por mas que sea probable. Tosso $\mathrm{V}$
Kittlitz dice acerca de ellos: Mientras qque la parte supe rior de la cabeza cstá adherida, las mandibulas guardan su ficiente libertad para coger los objetos pequenos de que se alimentan y que pasan á su alcance, para lo cual están perfectamente adaptadas. El cuerpo de las rémoras parece en cierto nuodo invertido; su vientre se asemeja al dorso de otros peces, pues no solo forma como un lomo, sino que su color es mas oscuro que la parte superior del cuerpo, la cual suele estar sicmpre adherida á otros cuerpos, siendo tal el instinto del pez en este punto que casi nunca se puede ver su dorso por tenerlo constantemente unido á otra cosa mientras el animal vive; en términos de que hasta se ad. hiere á una vasija llena de agua de mar, es decir con la es palda hácia abajo y el vientre hácia arriba, en cuya posi. cion invertida permanece muy tranquilo. 
Parece que las remoras pasan toda su vida en esta posicion acaso con insignificantes interrupciones, siendo tan grande la fuerza de su órgano chupador que hasta despues de muertas continuan intimamente pegadas a cunlquier ob. jeto. El modo de adherirse se explica con facilidad, porque su disco obra, no precisamente como una ventosa, aunque si de un modo semejante. Para ello bajan los hojitas del borde del disco que se pone llano; y apretando entonces la superficie lisa contra el objeto al que quieren adherirse y levan tando oira vez las hojitas y cl borde, resulta un hueco que hace que la presion del agua exterior produzca el efecio de adherencia. No son tan torpes para madar como pudiera creerse, si bien los movinientos que producen exclusiva. mente con la aleta caudal parecen pesados y torpes. $A$ veces se los ve nadar delante $\delta$ al lado de un tiburon $\delta$ al rede dor de un buque con bastante rapidez $g$ destreza. No es fácil confundirlns ronn otros peres, porque hasta nadando parece que se mantienen con el vientre arriba y el dorso abajo. Cuando el cocinero del buque arroja al mar las aguas sucias de la cocina, se desprenden las rémoras á docenas del buque al que están adheridas, y surcan las olas culebreando para aprovechar las gotas de grasa que pueden alcanzar. Tambien se las puede hacer abandonar su puesto y cogerlas con un anzuelo cebado con tocino. Su robusta dentadura in dica su naturalera rapaz, aunque Bennett no encontró cn su estómago mas que crustáceos y conchas pequeñas. Cuando han cogido una presa, vuelven á su sitio, quedando al momento tan fuertementc adheridas como antes. Cuando se coge el tithuron al que estín pegadas, se cesprenden de 4 y se unen al buque, no bien sale del agua el cuerpo del mons truo al izarlo á bordo: pero tambien puede suceder lo con. trario, segun observó Kittlitz, porque las vió utan adheridas a un tiburon cuando ya estaba suspendido en el aire, que fué inenester arrancarlas a la fucra.

Nada de fijo se sabe respecto de su reproduccion; Bennett solo dice que son viviparas segun se cree.

La mayor parte de los navegantes se resisten 2 comer rémoras á causa de su pobre apariencia, pero los que no se dejan dominar por esta preocupacion, están acordes en que no tienen mal gusto, y algunos, de cuya opinion participa tambien Bennett, dicen que son muy sabrosas.

\section{LOS CEOS-ZEUS}

Una leyenda piadosa reficre que un dia el apóstol San Pedro se vió obligado a pagar una contribucion, 5 que en lugar de meter la mano en el bolsillo, la metió en el agua, y cogiendo un pez, le sacó de la boca la moneda que necesitaba. Este suceso extraño debió de ocurrir en el mar, y por otra parte, el santo apóstol cogeria sin duda con gran fuerza el pez en cuestion, porque este que vive en el Mediterráneo, tiene en cada costado una mancha negra y redonda que, se. gun la leyenda, representan las impresiones de los dedos, siendo esta sin duda la causa de haberle dado el nombre del santo en algunos paises. En Grecia lo llaman pez de Cristo, en España de San Martin y en la Alemania del norte rey de los arenques. Acaso lleve su nombre de familia (Zeus) con mucho derecho, lo que probaria que los antiguos debian con. siderarlo ya como un per, excelente.

\section{EL CEO Ó PEZ DE SAN PEDRO-ZEUS FABER}

CARACTERES.-Este pez (fig. 162) es el representante de la sub-familia de los citinos y del género ceo. Tiene dos aletas dorsales separadas, distinguiendose la primera por sus radios prolongados que acaban en hilos; dos aletas ana. les un tanto separadas y que repiten en cierto modo la forma de las dorsales, puesto que los radios de la primera se pro. longan tambien; las abdominales son grandes y se hallan insertas debajo de las torácicas que son pequeñas y redondeadas. La linea media del dorso y la del vientre llevan espinas bifurcadas, estandoel resto del cuerpo cubierto deescamas nuy pequeũas. El color varía segun la estacion y region que el per. habita; en el Mediterraineo es frecuentemente todo dorado, y en el norte por lo comun amarillo gris. Muy notable es la mancha negrisima que ostenta en cada costado. I as aletas son negruzcas. En la primera dorsal hay de nueve á diez radios espinosos; en la segunda de veintidos á veintitres radios blandos; de cuatro á cinco espinosos en la primera anal, $y$ en lá segunda veintiun blandos; en la torácica se cuentan trece radios, en la abdominal nueve y en la caudal trece. Segun dicen, alcanza este pez. una Inngitud de un metro y un peso de quince se veinte kilógramos.

DISTRIBUCION GEOGRAFICA.-Desde el Mediter. ránco se extiendén estos peces hasta una parte del Atlántico y hácia el norte hasta Inglaterra, donde se les ve constante. mente y se cogen en bastante nímero. No son peces comunes, pero tampoco raros en verano.

USOS, coSTUMBRES Y REGIMEN.-Por las relaciones de observadores y pescadores del Mediterráneo sabemos que prefiere el ceo la alta mar á las costas, y que es pez solitario. Couch dice que solo se acerca á las costas con una especie de arenques, por manera que no es pez de paso, esto es, no viaja con regularidad, sino que sus excursiones son accidentales. Segun dicho ictiólogo, se cogieron en otoño del año 1829 en una sola redada, sesenta de estos peces, en. tre ellos varios de considerable tamaño. A juzgar por su figura, podria creérsele nadador lento, pero no es asi, pues se mueve con gran viveza y destreza, por mancra que no cede en nada à la citada clase de arenques, y por lo demás coge tambien jibias, animales muy listos y vigilantes que, juntamente con peces pequenos y crustáceos, constituyen su ali. mento favorito.

USOS Y PROVECHO.- Montagu dice que el primero que ha sabido apreciar la deliciosa carne del pez de San Pedro fue el célebre actor ingles Quin, debiéndose á él la gran fama que ahora goza entre los gastrónomos de aquel pais, y que desde Inglaterra la moda pasase á Francia y mas tarde a Italia; pero el nombre latino antiguo indica que los habi. tantes del Mediterríneo conocian su mérito mucho antes nue Quin, y además tenemos á Paulo Jovio que califica este pez como uno de los mas sabrosos del Mediterráneo. Esto no impide que á algunas personas les repugnara a causa de su aspecto poco apetitoso, y que hasta hace poco tiempo no se haya vencido una repugnancia que podrá haber predominado durante cierto tiempo, pero que hoy no existe, puesto que se les pesca con gran ahinco a pesar de no prestarse mucho á una pesca regular, toda vez que si se les coge se debe mas al acaso que $\mathbf{a}$ la inteligencia y maña.

\section{LAS CORIFENAS-CORYPHANINAE}

CARACTERES. - Los individuos de esta sub.familia tienen el cuerpo oblongo y comprimido lateralmente y la cabeza chata, porque la region frontal está poco inclinada. La aleta dorsal, sostenida por radios flexibles, si bien todavia espinosos, se extiende por todo el lomo; las abdominales cuando no faltan completamente, son reducidisimas, pero en cambio se halla muy desarrollada la aral, y lo mismo sucede con las torácicas y la caudal. En algunas especies están las aletas verticales en parte cubiertas de escamas. Las mandibu. 
las, y en la mayor parte de las especies tambien los huesos palatinos y el hioides, están armadas de dientes de pria, y la lengua y arcos branquióstegos de dientes de terciopelo. En muchas especies falta la vejiga natatoria.

\section{LOS DORADOS-CORYPHANA}

CARACTÉRES. - Para la descripcion de todo el grupo basta la del presente género de los dorados, de cuyo aspecto sorprendente hablan todos los marinos y viajeros diciendo unosy otros que no encuentran palabras para pintar tanta belleza. Igual impresion causaban estos peces ya á los antiguos, pues los dedicaron á la diosa de la hermosura. Sus rasgos caracteristicos consisten en la aleta dorsal muy larga qque empieza encima de los ojos; en las aletas torácicas encorvadas a manera de hoz; en la insercion de las abdominales debajo de las torácicas, en la muy pronunciada bifurcacion de la caudal, en los dientes pequeños de gancho que se encuentran en las mandibulas, con dientes de púa detrás, que guarnecen tambien el palatino $y$ el hioides, $y$ finalmente en los dientes de terciopelo sobre la lengua. Algunas especies carecen de vejiga natatoria.

\section{LA LAMPUGA - CORYPHENA HIPPURUS}

CARACTERES.-La lampuga, lampugo, $\delta$ dorado, al. canza una longitud de algo mas de metro y medio y un peso de quince á veinte kilógramos. Su coloracion varía con la inflexion de la luz. En la calma, dice Bennett, brilla la lampuga, cuando nada en la superficie, con un color azul magnifico y de púrpura con viso metálico que varia hasta lo infinito, segun que se halle el pez expuesto á la luz del sol 6 á la sombra, mientras que la cola conserva inalterable su color amarillo de oro. Fuera del agua y sobre la cubierta sarian estos colores, cambiándose en otros tan bellos como los pri. meros. El color encendido de púrpura y el amarillo de oro pasan a un plateado brillantisimo tornasolado del primitivo color de púrpura y de oro. Estas variaciones duran bastante tiempo; despues van poco á poco menguando para acabar en un color gris oscuro coriaceo.

DISTRIBUCION GEOGRÁFICA.-La lampuga puebla todos los océanos de las zonas tropical y templadas como tambien el Mediterráneo y el mar Rojo.

USOS, COSTUMBRES Y REGIMEN.-En las costaS se la observa solo durante el periodo del desove; en las dewås épocas del año y cuando el agua está agitada, cn alta mar; tanto que los marinos al verla junto al buque la toman por precursora de la tempestad. Se alimenta de coda especie de peces pequeños, y particularmente de voladores. Bennett en. contró en su estómago tambien cefáópodos, en especial jibias y argonautas. La lampuga es la mayoria de las veces causa de que salgan del agua los peces voladores. Respecto de esto cuenta Hall lo que sigue: ¿Una lampuga grande que venia acompañando á nuestro bunque y que nus habia hecho ver repetidas reces el brillo maravilloso de sus colores, ob. servó de repente una bandada de peces voladores y volvió la cabeza en direccion de ellos; subió en seguida ála superficie y salto con tal velocidad fuera del agua que no parecia sino que una bala de cañon atravesaba el aire. La longitud del salto podia ser de unos seis metros, mas bien mas que menos, pero no fué bastante para alcanzar la presa. Apenas hu bo vuelto á caer en el agua, se la vió deslizarse como el rayo al través de las olas, y se conocia fácilmente que despues de cada salto iba aumentando Ia rapidez con que nadaba. El mar cstaba terso como un espejo, de suerte que se podian observar todos los movimientos hasta gran distancia. Los peces voladores, conociendo perfectamente la furiosa perse- cucion de que eran objeto, ya no nadaban, sino que estaban casi constantemente en cl aire, interrumpiendo solo su vuelo para caer un instante en el agua y levantarse al momento otra vez. Los pobres animales excitaban la compasion de los de \{ bordo, tanto mas cuanto que á cada vuelo tomaban una direccion diferente, procurando asi escapar de su enemigo hambriento, que los seguia sin misericordia, variando tambien de direccion cuando notaba que ya no tenia delante \& los rola. dores. Pronto se fué acortando la distancia entre estos y aquel; su vuelo iba siendo cada vez mas corto, vacilante é incierto, mientras que los saltos descomunales de la lampuga parecian indicar que su fuerza y rapidez iban en itumento. El experto cazador sabia calcular sus saltos de tal manera que caia al agua exactamente en el punto en donde habian de caer tambien los voladores. Esta parte de la lucha tuvo lugar demasiado léjos del buque, pero subiendo á los aparejos se veia muy bien cómo la lampuga devoraba al fin una presa tras otra.

La fuerza muscular de este pez es maravillosa; Boteler y toda la oficialidad del buque de guerna que mandaba, uvie. ron una prueba de ella que los dejó á todos pasmados. «Le. vantóse una lampuga inmediatamente delante de la popa del buque y saltando en direccion de la proa dió con tanta fuerza contra el castillo que de seguro habria lastimado sériamente \& la persona que alli se hubiera encontrado. Cayó á los piés del timonel aturdida por el golpe, pero en seguida empezó á moverse tan de prisa y con tanta fiserza que lué menester darla algunos hachazos en la cabeza antes que hu. biera sido prudente cogerla con las manos. I.a altura máxima que alcanzó su terrible salto fué de seis metros $y$ su longi. tud hubiera sido forzosamente de cincuenta metros á nolraber tropezado en su camino con el obstáculo qque la hizo caer."

Además de los peces voladores tambien come la lampuga el excremento de los otros peces, pues en voracidad iguala al tiburon; basta decir que se encontraron en el estomago de una cogida con arpon clavos de hierro de doce centime. tros de largo.

Hácia el otono se acercan los dorados a las costas para desprenderse de la freza. En el Meditcrríneo se ha observa. do que escugen invariablemente orillas peñascosas alejándo se cuidadosamente de las playas llanas, y hé aqui por qué se los pesca en las costas de Provenza y no en las del languedoc. En alta mar emplean los marineros como cebo para co. gerlos un pez volador artificial, ó los arponean desde la proa, 6 finalmente se valen de un anzuclo rastrcro. En las costas se los coge solo con redes. Gessner dice que en ciertas partes colocan lampugas pequeñas en viveros y estanques llenos de agua de mar, que las crian asi y que su desarrollo es nas rápido que el de todos los otros peces. Hay quien dice que lo propio se hace hoy dia; pero me resisto á creerlo. La came de la lampuga es mus apreciada y alcanza clevados precios. Pennett dice que en especial los trozos inmediatos. á las aletas tienen fama de exquisitos.

\section{LOS TERACLIS-PTERACLIS}

CARACTERES. - Los teraclis no se ascmejan a las lampugas sino por la prolongacion de su cuerpo comprimicio, la presencia de dientes en forma de carda en las mandibulas y los palatinos, varias asperezas en la lengua, y sobre todo la extension de la dorsal, que comenzando en la nuca termina en la cola

\section{EL TERACLIS DE MANCHA-PTERACLIS OCELLATUS}

CARACTERES.-Este pez singular (fig. 16.3) tiene la 
cabeza tan alta como larga; los ojos bastante grandes; la abertura de la boca desciende oblicuamentc, y el maxilar llega casi hasta debajo del barde posterior del ojo. La dor. sal y la anal secorren entre dos series de escamas majores que las otras, que forman una especie de canal, donde po. drian acaso replegarse dichas aletas por completo; la del lomo comienza en el extremo mismo del hocico, por delante del ojo; las ventrales son muy endebles y están muy próxi. mas; las pectorales estrechas y puntiagudas; la caudal alyor. quillada. El cuerpo, la cabeza, el hocico, y hasta el maxilarse hallan protegidos por escamas regularmente dispuestas. Este pe\% tiene todo el cuerpo de un bonito argentado muy bri. llante; los radios de las aletas son negruzcos; la membrana agrisada; $y$ hácia la punta superior de la dorsal se ve una mancha redondeada de color azul claro; las pectorales y la caudal son amarillentas. El teraclis de mancha mide cuatro pulgadas de largo poco mas ó menos.

DISTRIBUCION GEOGR ÁFICA .- Los únicosejempla. res que se han visto proceden de la costa de Mozambique.
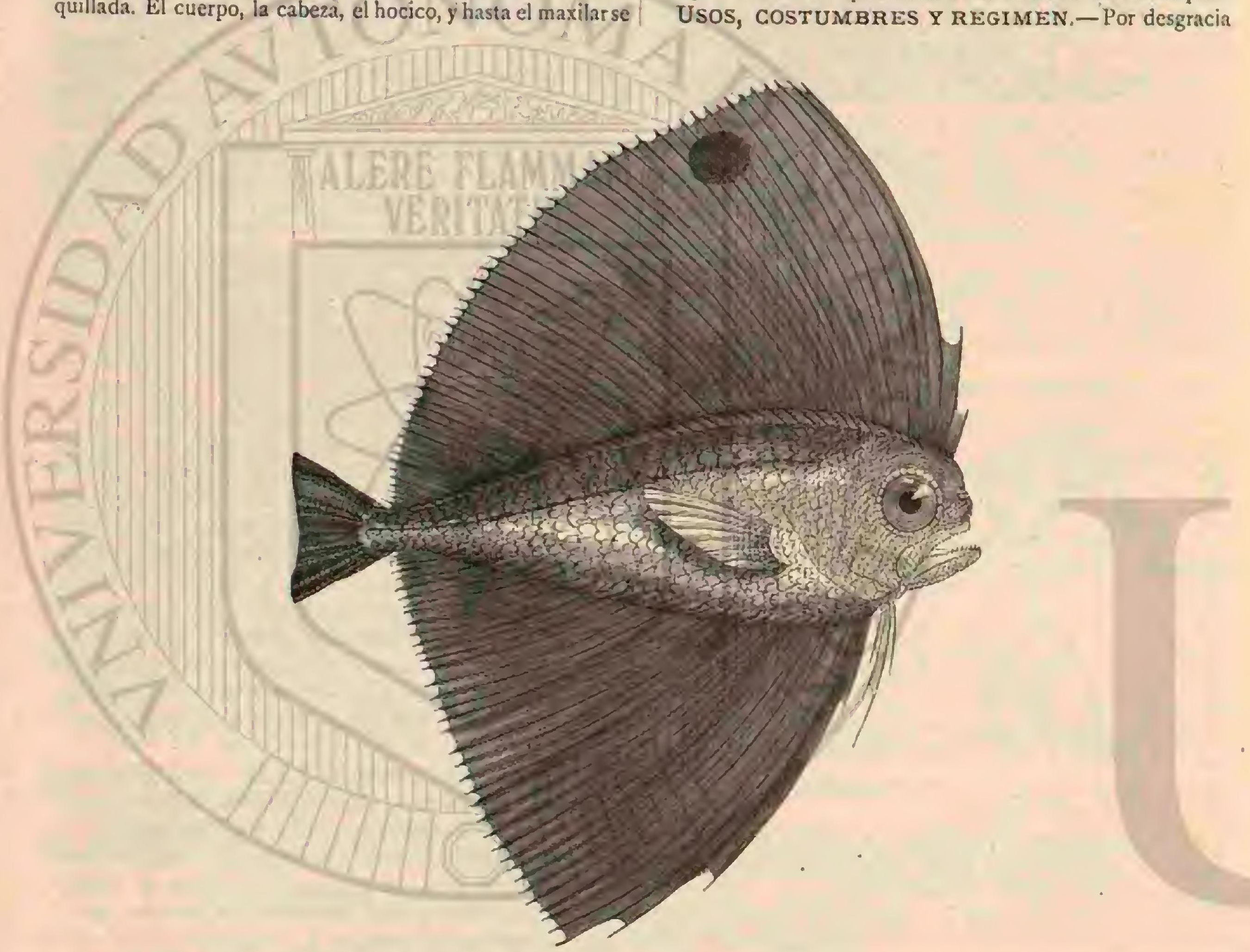

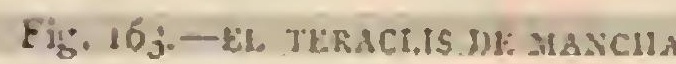

es tan rara esta especie, que no se ha podido estudiarla bien ni tencmos apenas ningun dato que nos de a conocer sus usos y costumbres.

\section{LOS GALLOS DE MAR-LAMPRIS}

CERACTERES. - En la Eidda se menciona ya otra especie de la presente sub-familia, con el nombre de salmon de Dios, que conserva aun en el dia en Islandia Pertenece al género de los gallos de mas (Lampris) que difieren del anterior en puntos muy esenciales, si bien se parecen en la forma exte. rior del cuerpo. Las diferencias consisten en que su boca está desprovista de dientes y no puede prolongarse tanto corno en los peces del género precedente: no tienen radios espinosos; la aleta dorsal es sencilla, pero tiene los radios primeros prolongados y unidos por una membrana cormun de tal suerte que la parte anterior adquiere la forma de una hoz mientras que la posterior sigue of una misma altura paralela á la curva de la linea media del dorso; las aletas torá. cicas son cortas, pero tambien algo encorvadas; las abdominales son largas, en forma de hor y situadas muy bácia atrás; la anal corresponde a la parte posterior de la dorsal, y la caudal tiene forma de media luna. Las escamas son muy pequeñas, delgadas, y caen tan frecuente y fácilmente que pocas veces se encuentran. No tienen dientes.

\section{EL GALLO DE MAR COMUN-LAMPRIS LUNA}

CARACTÉRES. - Este pez alcanza una longitud dé dos metros y un peso de cerca de cien kilógramos, siendo de consiguiente una especic de gran talla. En cuanto á belleza de coloracion, compite con inuchos peces que habitan mares meridionales. La parte superior del cuerpo tiene un color magnifico de azul de acero brillante que pasa en los costados a azul violeta y en el vientre á rosa. Sobre este fondo se destacan numerosas manchas ovales de color blanco de leche cou viso plateado, mientras que las alctas ostentan un 
magnífico color encarnado de coral. 1.a primera aleta dorsal tiene dos radios duros y cincuenta y dos blandos; cada to rácica tiene veintiocho, la abdominal uno y nueve, la anal uno y veinticinco y la caudal treinta.

DISTRIBUCION GEOGRÁFICA.-Refiere Mortimer que cuando presentó à la Sociedad Real en el año 1750 un gallo de mar cogido en Leith, hubo alli un principe de Anamabu de la costa occidental de Africa, que á la sazon se hallaba en lóndres, el cual reconoció instantáneamente este animal tan raro por ser un habitante muy frecuente de las costas de sa pais, donde era muy conocido con el nombre de opak. Si esto es cierto, resultaria ser tambien meridional la patria de este pez que hasta ahora se habia creido solo propio del norte, pues se le coge con mayor frecuencia en las costas de Noruega y de Islandia que en Inglaterra, por cuyo motivo se creia que venia de los mares mas septentrionales donde vivia á grän prolundidad y no se acercaba á las costas sino en el tiempo del desove 6 cuando se veia perseguido.

USOS, COSTUMBRES Y REGIMEN. - Faltan observaciones sobre su género de vida. Algunos que se han exa. minado tenian en el estómago jibias y otros cefalópodos.

La carne riene fama de ser muy sabrosa, y de igual mérito que la del salmon, y ademas segun los islandeses, la cxcelente cualidad de ser un preservatiro de muchisimas enfer. medades.

\section{LOS CRÁNGIDOS- CRANGID尼}

CARACTÉREs. - Antes se contaban entre los es. cómbridos tambien los crángidos, reunidos hace poco por Guenther en una familia especial, que difiere de aquella por su esqucleto, y especialmente por su mayor número de vér. tebras, mientras que la semejanza solo cxiste en el aspecto exterior. El cuerpo es comprimido lateralmente, oblongo ó bien corto y alto, cubierto de escamas pequeñas 6 desnudo. En las aletas se asemejan nucho á las caballas.

USOS, COSTUMBRES Y REGIMEN.-Se conocen mas de ciento sesenta especies que habitan los mares de todas las zonas y cuyo género de vida se parece en general al de los escombros; viven en su mayor parte en las capas pro. fundas, se junian en bandadas y persiguen á los peces pe. queños con tanta furia que cuando suben tras cllos, sacan a veces la cabeza fuera del agua. No persiguen peces sueltos, pero las bandadas no sufren menos de ellos que de las caballas. Su carne es apreciada, pero inferior a la de aquellas.

\section{LOS CARANGAS - CARANX}

CARACTERES. - Se distinguen principalmente por tener en cada costado un arma\%on compuesto de escamas-es. cudetes crestadas, provistas de una espina y dispuestas en una linea «tan áspera, segun se expresa Gessner, como una sierra. Existen las dos alctas dorsales, pero faltan las falsas pinulas; hay dos espinas sueltas delante de la aleta anal; las torácicas son grandes y largas. Las escamas, excepto las men. cionadas de escudete, son pequeñas.

\section{EL WUREL COMUN-GARANX TRAGHURUS}

CARACTERES. - Se ascmeja por su forma a las caba. llas; su cuerpo es fusiforme, la cabeza puntiaguda, la cola delgada y su aleta robusta. Su longitud viene á ser de $v^{2}{ }_{3}, 30$. El color es gris azulado en la parte superior y plateado en la inferior; las alctas tienen un tinte gris, y están sostenidas, la primera dorsal por ocho radios; la segunda por medio racio duro y treinta y dos enteros; cada torácica por veintiuno, cada abdominal por uno y cinco; la anal por dos espinosos, un' medio radio y veintiseis enteros, y la caudal por diez $y$ siete.

DISTRIBUCION GEOGRÁFICA. - Respecto de su area de dispersion concuerda el jurel á poca diferencia tam.

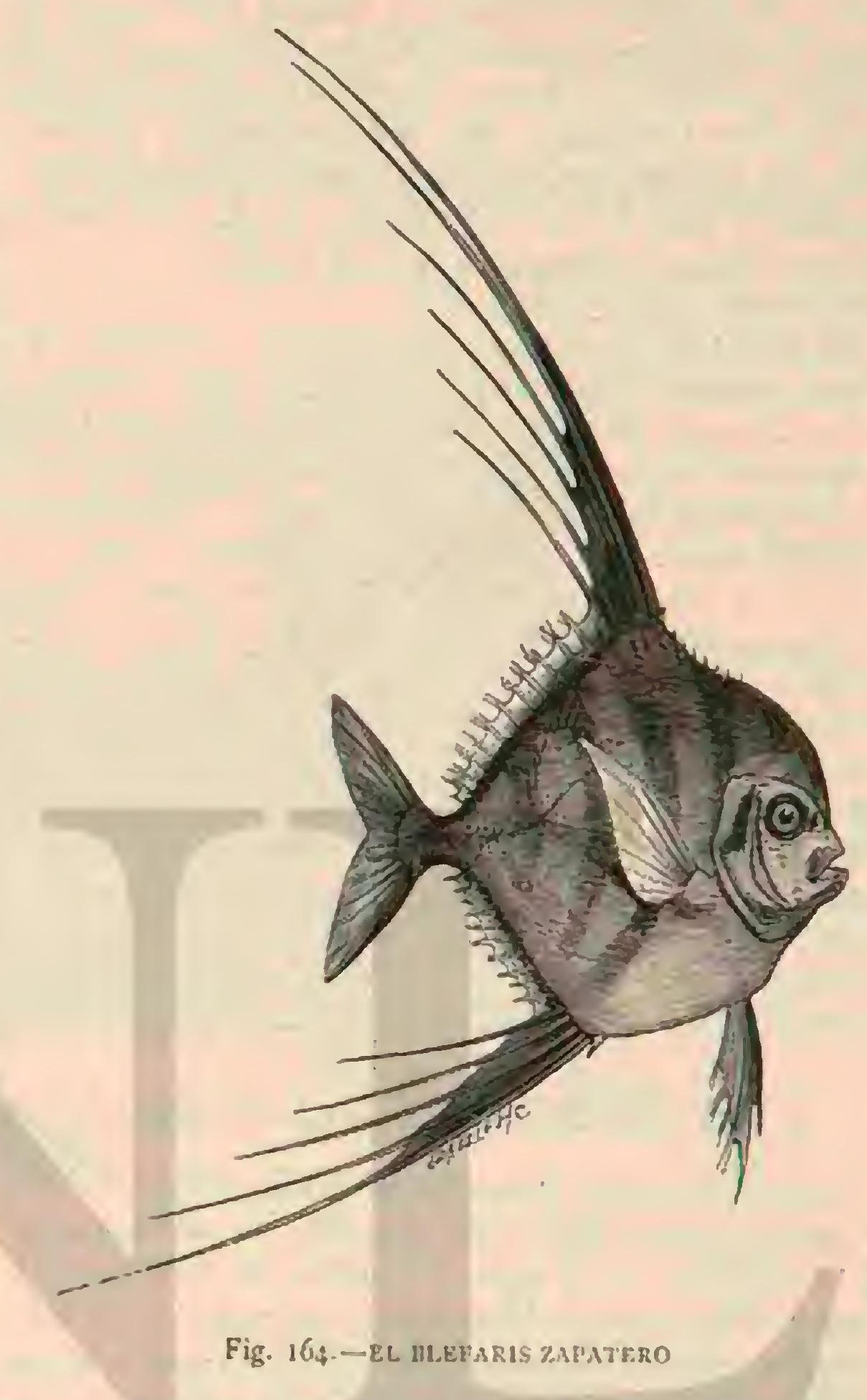

bien con la caballa; se le encuentra lo mismo en el Mediter. ráneo que en el Atlántico incluso el mar del Norte; pero es muy raro en el Báltico. Se presenta, segun Couch, con regu. laridad en las costas de Cornualles y de Levon, por lo comun aisladamente, siquiera á veces en cantidades extraordinarias.

USOS, COSTUMBRES Y REGIMEN.-Pocas veces se encuentra el jurel en abril, pero es frecuente en todo el resto del año. Su siicio favorito es junto $\mathbf{s}$ la orilla, $y$ a veces se acerca tanto que se le puede coger con la mano; en una tarde de agosto se cogieron próximamente diez mil con una red de mano, y al dia siguiente apareció oiro enjambre en la orilla, y entonces entraron hombres y mujeres, viejos y jóve. nes, grandes y pequeños en el agua para cogerlos, mientras que otros se llevaban los pescados en red y los que les ar. rojaba la gente desde el agua. Bicheno cuenta que en clano ${ } 8_{3}+$ se aproxinjó una legion innumerable de estos peces á las costas de Irlanda, $y$ hasta dondealcanzaba la vista parecia hervir el mar; se acercaron tanto que las personas que podian mantenersesobrealguna roca saliente, no tenian mas que toe. ter la mano en el agua y cerrarla para coger un pez, y no solo uno sino, empleando alguna destreza, liasta tres y cuatro a la vez. I os bañistas sufrian mil molestias a causa de ellos en todo sucuerpo, porque la superficie del mar no parecia de agua si. no compuesta de peces. La masa oscura que formaban estos peces llenaba las capas superiores del mar hasta una distan- 
cia incalculable. Toda clase de redes fué buena para pescarlos, pero habia que sacarlas sin llenar, porque el peso las ha. bria roto sin que se pudiernn aprovechar ni recoger todos los peces; y aun hubo que arrastrar muchas redes fuera del agua, para vaciarlas en la playa. Una traina de malla ancha fué la que mejor resultado dió, porque en cada malla tenia un jurel, por manera que aquella red quedó trasformada en una verdadera pared de peces que tambien fué menester ar. rastrar á la playa para extraerlos de ella. Siendo imposible de todo punto contar los peces, su cantidad se calculó por carretadas. Esta abundancia duró toda una semana, observan. dose que las horas de la mañana y de la tarde debian ser aquellas en que los jureles buscaban su alimento, porque entoncés iban en persecucion de los arenques pequeños, lle. nándose el cuerpo de ellos.

No sé si estas excursiones tienen que ver con la época del desove, porque en ninguna parte encuentro datos respecto á su reproduccion, pero es probable que exista alguna relacion entre, ambos hechos, pues se ha observado que por lo regular permanecen los jureles cerca del fondo y raras veces se presentan en tan grandes masas.

La carne del jurel no puede competir con la de la caballa, $y$ en Inglaterra apenas se vende en la plaza; en muchos pun. tos de la costa no lo quieren ni las personas mas pobres; pero Yarrell, que es el autor de cuya obra he sacado lo que precede, asegura que su carne participa en algo de la de caballa, solo que no es tan fina. Por lo demís los antiguos tenian formado el nismo concepto de este pez que los habitantes actuales de la costa; $y$ Gessner dice tambien que las caballis bastardas como llama \& los jureles, \&tienen la carne nias dura que las caballas verdaderas, por cuya razon los italianos, griegos y franceses no los comen sino salados.

\section{LOS BLEFARIS-BLEPHARIS}

CARACTERES. - Este género se caracteriza por tener su primera dorsal espinas muy pequeñas; los primeros modios de la segunda y de la anal prolongados en forma de fila. mentos sueltos; las ventrales muy prolongadas, y el perfil cortante, pero encorvadó á manera de arco convexo de una mediana elcvacion. Pertenecen al reducido mímero de peces cuya historia y sinonimia no dan lugar a ninguna discusion nor no haber sido descrito mas que un solo individuo $y$ por un solo autor, de quien todos los demás han tomado cuanto se ha dicho acerca de cllos.

\section{EL BLEFARIS DE LA INDIA-BLEPHARIS}

$$
\text { INDICUS }
$$

CARACTERES. - El cuerpo de este per puede compararse ấ un rombo, formando dos de sus ángulos el hocico y la cola, y los otros dos, la parte media de la línea del vientre, I la misma parte de la del lomo. La dorsal y la anal ocupan los dos lados posteriores del rombo, que son casi rectilineos; los anteriores forman una curva mas con vexa, sobre todo el superior, que comprende la parte anterior del lomo descendiendo en línea recta, la nuca $y$ la cresta del cráneo que forman un arco de círculb, y el hocico que desciende casi perpendicularmente. 1,a boca baja asimismo de pronto, de suerte que la mandíbula inferior se remonta casi vericalmente, formando con el hocico un íngulo muy obtuso. El blefaris es vez y media mas largo que alto: tiene la boca muy poco hendida, su protractilidad es mediana, y el maxilas aplanado, largo, y truncado por fuera. Cada mandibula está provista de una íaja de dientes atercicpelados, habiendo otra en cada palatino y un grupo cie ellos delante del vómer. La aleta caudal es muy ahorquillada, y sus lóbulos se mantienen muy separados, tanto, que entre una punta y otra hay casi la mitad de la longitud total.

Todo este pez esta revestido de una piel brillante y sin escamas apenas. Su color es un plomizo metálico sobre el lomo, y un plateado vistoso en los lados de la cabeza, los costados y el vientre. Las alctas son de un pardo amariIlento. Esta especie suele medir cinco pulgadas desde el ho. cico hasta el extremo de la caudal, y sus largos filamentos algo mas de siete.

DISTRIBUCION GEOGRÁFICA.-COMo su nombre 10 indica, este blefaris vive en los mares de las Indias.

USOS, COSTUMBRES Y REGIMEN.-M. I acepede, investigando el uso á que podria suponerse que el blefaris aplicaba los largos filamentos en que terminan muchos de los radios de sus aletas, discurre si podria pensarse que le sirven para fijarse en las puntas de las rocas ó en las ramas de las vegetaciones maritimas, y para atraer con ellos á los pequeinos peces que tal vez los tomasen por gusanos. Como esos filamentos no tienen al parecer músculos propios, se hace poco verosimil la primera de esas conjeturas; la se. gunda podria ser mas razonable; pero los peces, ; sobre todo, los que como el blefaris deben nadar con rapidez, encuentran fácilmente alimentos en un mar en que abundan prodigiosamente los animalillos de toda especic. Por otra parte, hay en los peces tantos apéndices cuyo uso no es posible determinar, que esa clase de conjeturas serán siempre muy vagas para que no se les puedan oponer otras de distinto género.

UTIIIDADES. - Ia carne del blefaris, segun el doctor Ḱcenig, es magra, coriácea, ć insipida: los habitantes de Su. rate no hacen ningun caso de ella.

\section{EL BLEFARIS ZAPATERO-BLEPHARIS SUTOR}

CARACTÉRES.-Con dificultad se parecerá un pez à otro mas de lo que este blefaris sc parece al anterior; sus caractéres son los mismos, diferenciandose únicamente en que su altura es mas considerable á proporcion de su longitud, y en que en los individuos jóvenes se notan sobre el color plomizo del lomo cuatro anchas fajas rerticales mas negruzcas, pero asimismo metálicas. Sus ventrales son tan largas at proporcion como en la especic precedente, y el semicirculo de su línea lateral un poco ondulado (fig. 164).

El zapatero debe su nombre \& las prolongadas y agudas espinas de sus aletas dorsal y anal, por la semejanza que se cree observar entre cllas y las leznas de los zapateros.

DISTRIBUCION GFOGRÁFICA.-El bléaris zapa. tero habita en las aguas de la Martinica, donde se le designa con este calificativo.

\section{LAS LIQUIAS-LICHIA}

CARACTERES.-El distintivo principal de las liquias consiste en la atrofia de la primera aleta dorsal en radios cortos 5 espinosos. Fuera de esto se distinguen las contadas especies de este género por su cuerpo oblongo oroideo, muy comprimido lateralmente $y$ sin quillas ó aristas salientes en 12 cola; escamas coriáceas y dientes aterciopelados en las mandibulas, en el paladar y vómer. La aleta dorsal está pro fundamente bifurcada; la dorsal ofrece la particularidad de que el primer radio va dirigido adelante, mientras que los oiros van unidos en la parte posterior al lomo por una pe. queña membrana de tension. No hay falsas pinulas.

\section{LA LIQUIA AZUL-LICHIA GLAUCA}

CARACTERES. - Esta especic es una de las mas pe queñas de su género y alcanza una longitud de $(1)^{\prime \prime}, 40$ a $11^{*}, 45$ 
El dorso es de un hermoso azul gris, y el resto del cuerpo plateado con cuatro manchas negruzcas formando una linea en el costado. Ias espinas dorsal y anal son de color amari110 blanquizco en su parte anterior, salvo una mancha oscura; las abdominales son de un amarillo gris, $y$ las torácicas de color amarillo pálido; la caudal es azul en el nacimiento y negra en su extremo. El número de radios es en la primera dorsal de cinco á seis espinosos, en la segunda de veinticua. tro á veinticinco blandos, en cada torácica veintiuno, en cada abdominal seis y en la caudal diez y siete.

USOS, COSTUMBRES Y REGIMEN. - Sobre el género de vida de estos peces tenemos solo alguna noticia incompleta, pues ni siquiera ha podido fijarse su śrea de dis. persion. Se sabe que pertenecen al Mediterráneo y que se extienden a lo largo de la costa de Africa, pero que atravie- san tambien el estrecho, desde donde pasan hácia el norte, presentándose tambien en las aguas inglesas. Gessner, refiriéndose $\{$ las observaciones de Rondelet, dice que este pez vive en sociedad, hallándose siempre en bandadas, que tiene afecto a los de su especie a los cuales defiende y auxilia en los peligros y luchas. Despues de esto entra dicho naturalista en detalles sobre los cumbates que el «atun luchador segun llama s la liquia, sostiene con otros animales marinos, como escualos y delfines; pero su relato es tan fabuloso, que vale mas pasarlo por alto; tanto mas cuanto que nada de esto mencionan los modernos.

\section{LOS JÍFIDOS-XIPHIDA}

CARACTERES. - Antes tambien se agregaban à los es.

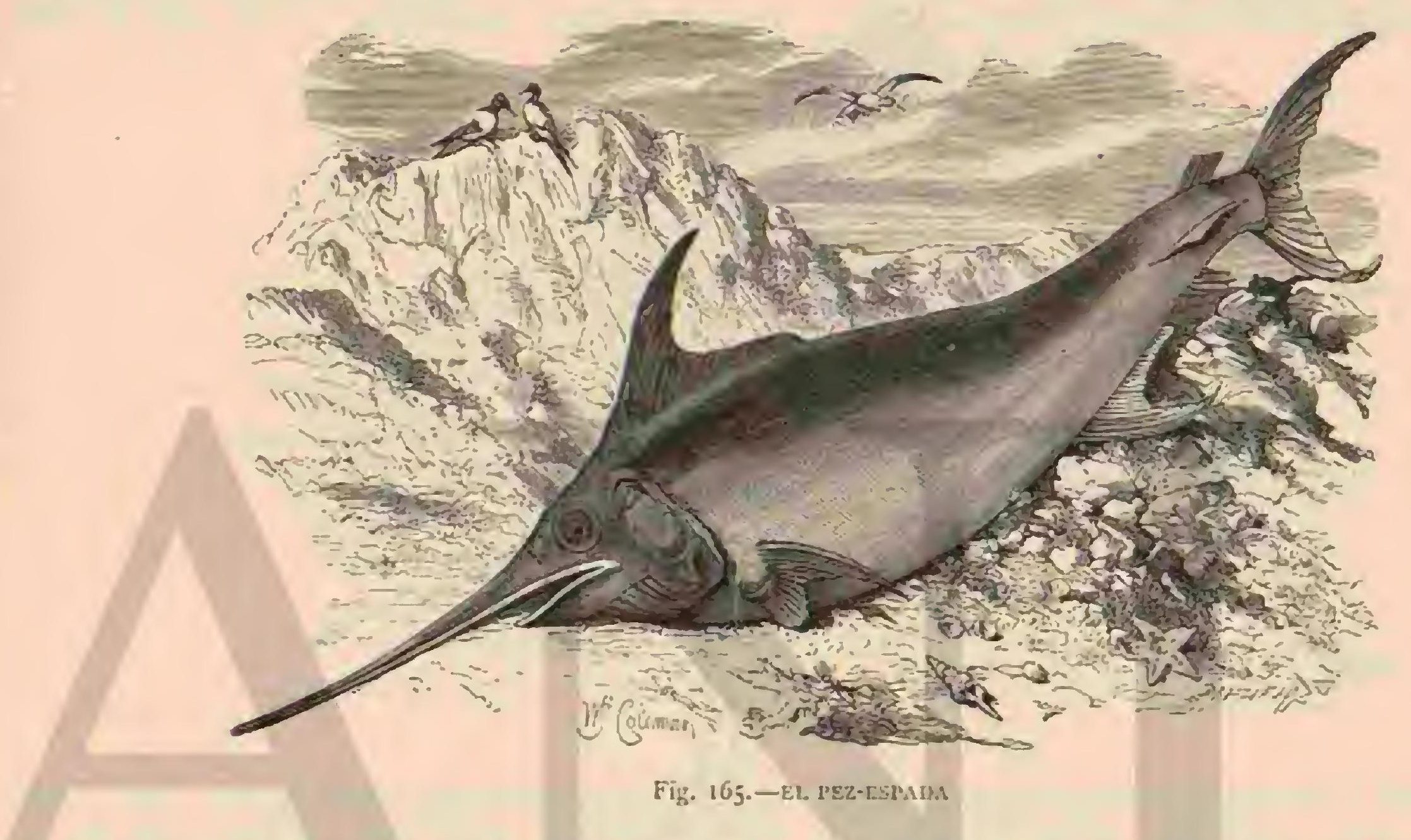

cómbridas los jifidos $\delta$ peces de espada, porque ambos grupos concuerdan en su estructura; pero los segundos tienen particularidades que justifican su separacion. No es la forma de su mandibula superior el único distintivo notable, sino tambien la de las aletas y la falta de dientes. El cuerpo de los jifidos, de cuya familia hay descritas unas diez especies, es oblongo, un tanto comprimido lateralmente, casi redondo en la parte posterior; tiene la parte anterior del dorso, desde la primera aleta hasta la cabeza, un poco hundida, y la mandibula superior prolongada a manera de espada; consistiendo esta prolongacion, á la que coucurren los huesos frontales an. teriores, el etmoides y el vómer, en una placa surcada longitudinalmente en su parte inferior, cuya placa va disminuyen. do desde su naciniento, donde es llana y aun hundida, hasta acabar en punta roma. Los bordes de esta espada son cortantes y finamenté aserrados; la parte superior es estriada. La estructura interior de la espada es celular y con. siste en una serie de huecos formados por una materia ósea muy sólida, atravesada por-cuatro canales longitudinales para los vasos alimenticios La parte inferior de la boca no es prolongada y su abertura arranca mucho mas allá de los ojos, que son á su vez muy grandes. En la disposicion de las branquuias sorprende desde luego una particularidad, que consiste en que sus foliculos no están simplemente colocados uno al lado de otro á manera de fleco, sino atravesados por otros foliculos trasversales a manera de red. El ojo tambien tiene la estructura particular siguiente: en la esclerótica hay dos piezas cartilaginosas y además dos huesosas que rodean la cavidad, dejando una abertura redonda delante para la cór. nea inasparente, y otra detrás para el paso del nervio óptico. I.as aletas tambien merecen llamar la atencion, no tanto por su extraña configuracion, sino porque son diferentes en los peces jóvenes como si con el uso y tiempo se gastasen, desgaste que no se obseria en todas las especies, de suerte que hay individuos de esta familia quue en la rejez presentan los distintivos de los jóvenes y otros no. He creido poder entrar aqui en estos detalles, puesto que el género de vida parece ser igual en todos los jífidos.

\section{LAS JIFIAS-XIPHIAS}

CARACTERES. - lienen la parte anterior del cuerpo relativamente robusta. Ja primera aleta dorsal, en forma de ho\%, está en apariencia dividida en dos, pero en realidạd solo en ura, bien que los radios primeros conservan una longitud considerable comparada con la de los otros que se desgastan del todo ó por lo menos se rasgan y destrozan. No hay aletas abdominales, $y$ la anal es grande y en forma de media luna. No se observa ningun desgaste en la primera alcta dorsal en el género de los veleros (Histiophorys). que la tienen extendida como una vela ó abanico sobre el dorso, siendo sus radios tres y cuatro veces mas largos que el diametro del cuerpo, que á la verdad no es muy grueso en la parte anterior, mientras que los últimos radios se juntan casi 
con la segunda dorsal. Los peces de este género tienen aletas abdominales formadas de dos apéndices largos y filiformes; la anal es mayor que en los peces espada y mas corva. Es excusado citar otros géneros porque vienen â constituir tér. minos medios entre los que preceden.

\section{EL PEZ-ESPADA COMUN-XIPHIAS GI.ADIUS Y RONDELETII}

CARACTERES.-El representante del género es el pez. espada, como lo llaman en iodos los idiomas (fig. 365), animal poderoso, de tres á cuatro metros de longitud, de la que corresponde algo mas de la cuarta parte ́. la espada; y de un peso de 200 á 400 kilógramos. Su color es arulado, mas cla. ro en la parte inferior; ya las escamas suple una piel áspera.
La fórmula para las aletas es: la dorsal cuarenta y tres ra. dios, cada torácica diez y seis, la anal dos y quince, y la cau. dal diez. y siete.

\section{EL VELERO DE LAS INDIAS-HISTIOPHO- RIUS INDICUS}

CARACTERES. - Tennent dice que esta especie alcanza unalongitud de seis metros y que conserva durante toda su vida su desmesurada aleta dorsal de metro y medio de altura. Su color no difiere de los otros jifidos, salvo que es muy lustro. so, pero se distingue de sus congéneres en que su aleta-vela es de color liso en lugar de tener manchas oscuras sobre fon. do claro (fig. 166).

DISTRIBUCION GEOGRÁFICA.-Hasta hoy no han

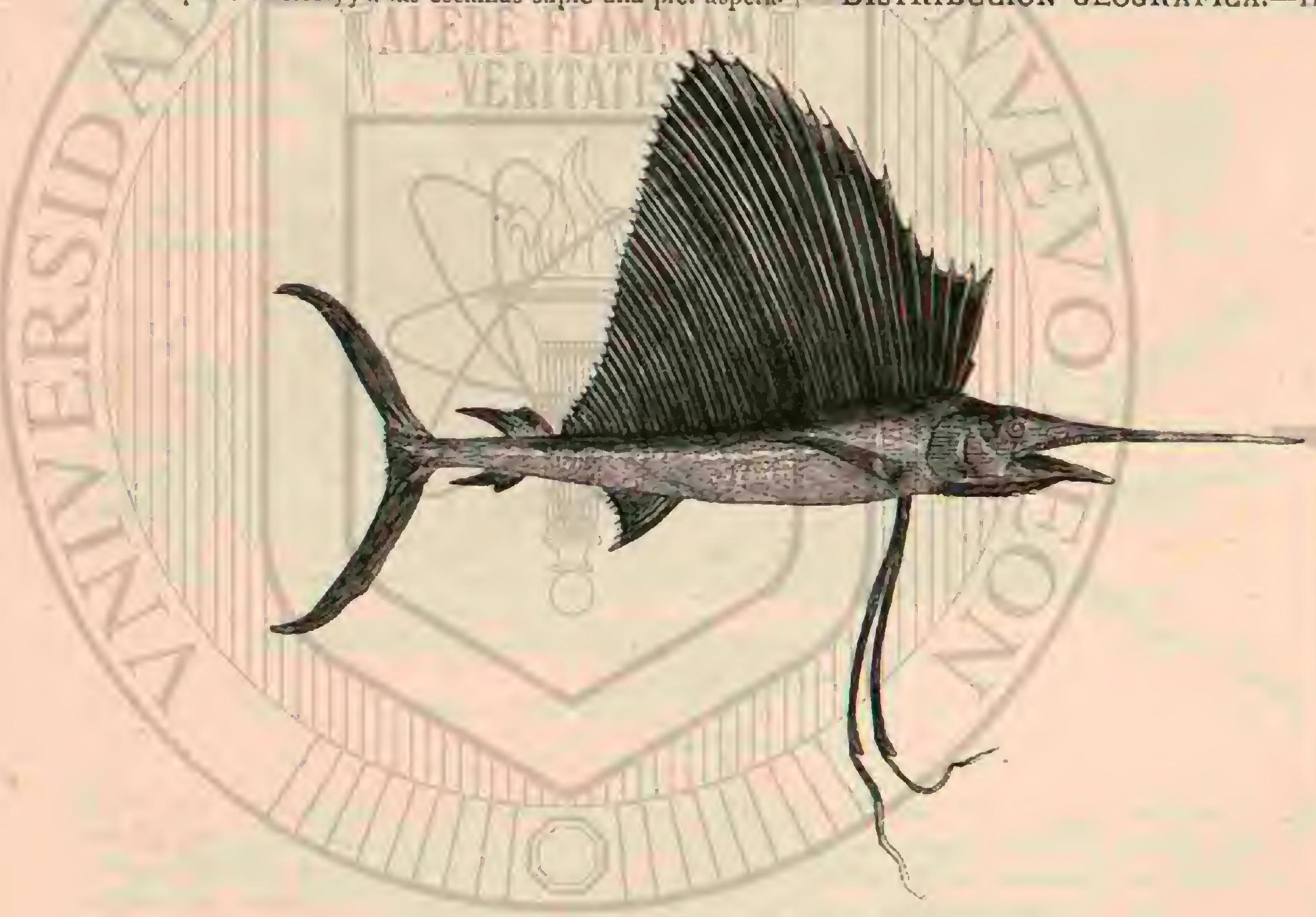

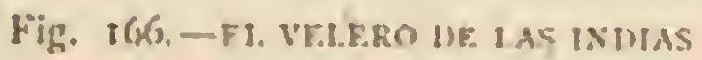

podido fijarse los límites del área de dispersion del pez-espada. Habita el Mediterráneo; no es raro al rededor de Sicilia, y se observa y pesca durante todo el año junto à Génova y Niza; pero no se limita á esta vasta cuenca, sino que recorre tambien el Allántico y hácia el norte, hasta Inglaterra y No ruega, y aun penetra en el Báltico: por otra parte se le obser va tambien, segun parece, en lodas las costas del Africa y en todo el Océano Indico. El velero puebla los mares ecuato riales, especialmente el Océann Indico, extraviándose solo rarisima vez por latitudes mas altas.

USOS, COSTUMBRES Y REGIMEN.-Se dice que ambas especies viven casi exclusivamente en las capas superiores del mar, de suerte que șt aleta dorsal sobresale comun. mente del agua; y los releros se sirven de ella positivamente a modo de vela, segun dice Tennent. Las dos especiés figu. ran entre los peces mas veloces, $\mathbf{s}$ en proporcion á su gran talla tambien entre los mas listos, por cuya razon les es posible apoderarse de peces menores que, junto con varias espe. cies de jibias, constitugen su alimento favorito. Los pescadores del unar Rojo cuentan del relero que se le ve comunmente en alta mar nadando despacio, pero que se pone de costado cuando se le acerca una lancha pescadora, dando en esta misma posicion brincos, comunmente tres, y atravesando dis. tancias de tres y cuatro metros por uno de elevacion. Del per-espada comun dicen que se le encuentra siempre en compañia de otro, suponiéndolos macho y hembra. No se sabe nada sobre la relacion que existe entre los dos sexos, y en cuanto a la reproduccion, lo único de que se tiene noticia es que los jifidos que habitan cl Mediterráneo desovan en julio y que su multiplicacion parece ser considerable.

Al leer las descripciones del pez-espada que poseemos de los antiguos, se siente uno dispuesto a considerarlas todas sin excepcion como puras fábulas, pero ninguno de los animales descritos por ellos ha confirmado mas su veracidad y cxactitud que el pez-espada. Estoy muy léjos de admitir todas las relaciones que tenemos de los obiservadores modernos, pero lo que sl está fuera de toda duda es que han venido á confirmar casi sin excepcion lo que nos cuentan los antiguos de estos mismos peces. Será pues bueno que empecemos nuestra descripcion de sus usos y costumbres, reproduciendo los relatos mas antiguos, para lo cual dejaremos la palabra a su excelente intérprete Gessner. 
Es un pez hermosisimo, poderoso, interesante y noble que debe su nombre á su forma, porque su mandibula supe. rior adquiere una longitud igual á la de ura afilada esnada. Otras naciones le llaman en su idioma guerrero, capitan ó emperador de los mares, tanto por su gran espada y fuerza como por los daños que causa. Dicese que en la estacion de los fuertes calores 5 la canicula hace sufrir tanto á este pez un pequeño animal llamado asilo que se fija entre sus oidos y agallas, que á veces muere de dolor ó se arroja en su de. sesperacion en tierra 6 sobre los barcos. Tambien dicen que la ballena teme al pez-espada como á su enemigo mortal, si bien este participa del mismo temor respecto deaquella, por manera que clava su pico ó espada en el forcio, manteniéndose inmóvil cuando la ve pasar, s fin de que siga adelante sin dañarle, creyéndole algun otro oljeto inanimado.

\$Segun se dice alcanzan estos peces en el mar Indico tal desarrollo que pueden atravesar con su cspada buques por. tugueses cuyo casco tiene un espesor de palmo y medio; y tambien dicen que existen relaciones de personajes célebres, instruidos y fidedignos, que hablan de hombres, que nadan. do junto al buque, fueron cortados en dos por el pez espada. Lo que en resumidas cuentas esta fuera de duda es que en este animal se ha observado una fuerza colosal y una espada cortante, dura y fuerte.

Tambien se cuenta de estos peces que son tan inteligentes que hasta conocen los diferentes idiomas, porque unos italianos que presenciaron en la orilla del lago Lucrino cómo se pescaba á estos animales, observaron que les gustaba la lengua griega, mientras que huian cuando oian hablar italia. no, que es una jerga horrorosa.

Los pescadores los temen mucho porque al caer en sus redes, las destrozan con su gran fuerza y su espada, bien que alguna vez. se les coge cuando son jóvenes.

¿En la mar narbonense suelen construir barquitos de la

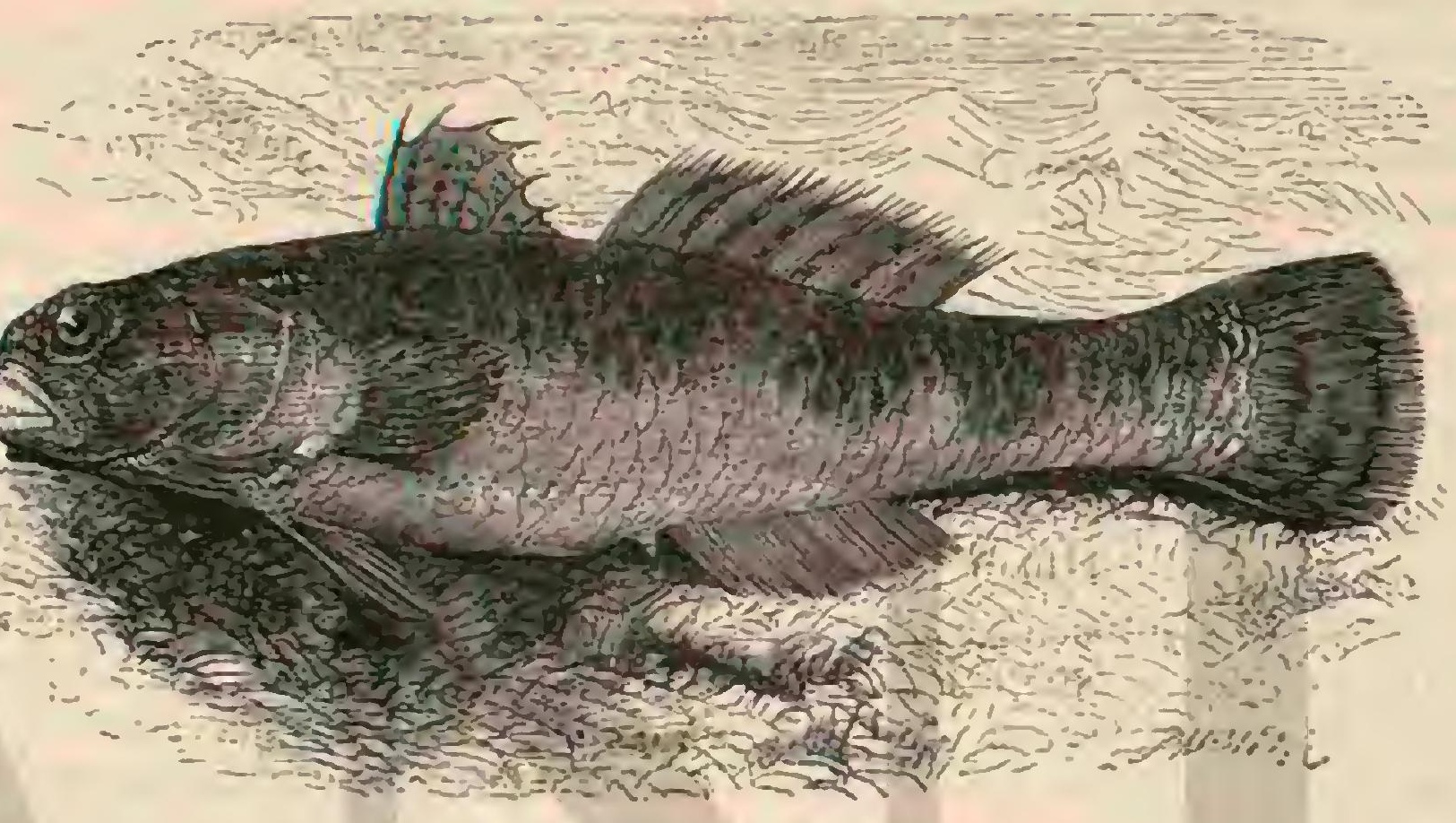

Fü. 167.-EL GODIO SHCGRO

misma forma de estos peces con su pico y cola, etc., para emplearlos en su cara, la cual hemos presenciado s menudo con gran satisfaccion; la forma de estas embarcacio nes engaña a los peces que creen ver en ellas compañeros suyos y no picnsan en huir, de suerte que se les piede cercar y matar, aunque tambien sucede con frecuercia que cmbisten $y$ atraviesan estas embarcaciones, pero enicsces les cortan los pescadores la espada de un hachazo r tapan el agujero con un clavo de forma apropiada preparsco para esta eventualidad, no siendo raro tampoco que los hombres salgan heridos de tales combates por dichos peces. Tambien suelen cogerlos con arpones $\sigma$ nechas atadas a cuerdas que les cla. van en el lomo $\delta$ en el costado, pues nadan, al igual de todas las grandes ballenas, con medio cuetpo fuera del agua.

I.os observadores inodernos concuerdan en considerar el pez-espada en general como un animal inofensivo y timido, pero que, á consecuencia de los tormentos que le causan multitud de parásitos, tiene accesos extraños de furia y de destruccion que le hacen cometer positivamedie todas las ferocidades que se le atribuyen, ya que es del toso imposible que la codicia y el hambre le hagan acometer a otros ani. males marinos peligrosos 6 inofensiros, coniorme consta que lo hace.

Al describir el atun menciona tambien el ritjo Gessner que dicho pez tiene mucho mieco de la jifiá ó pez espada, y este aserto será el primero que pasaremos é examinar. Cetti lo niega en absoluto, $y$ dice que Paulo Jovio, enganado por lo que asegura Estrabon, atribuye á este miedo la traslacion de los atunes del Aliántico al Mediterráneo que, томо $\mathrm{r}$ segun el mismo, es su refugio, donde se ponen al abrigo de las persecuciones de su enemigo cruel el pez.espada, al cual acusa de hacer tanto destrozo entre los atunes, que sus ban. dadas, presas del mayor espanto, pasan en apinada inuche. dumbre y sin saber lo que se hacen por el estrecho de Gi. braltar. De cualquiera parte que Jovio haya sacado su aserto, ha incurrido en un completo error. El reis que Cetti con. sultó sohre esto le aseguró que no habia nada de verdad en ello, porque la indole de ambos peces era completamente distinta. Cada cual sigue camino diferente y no pueden encontrarse. El atun atraviesa el mar por sus capas inferiores y el pez-espada nada por las superiores, habitando asi cada una de las dos especies una region distinta y conforme á su naturaleza; por manera que siempre se hallan separados por un espacio de agua bastante regular. No es empero esta la. razon que me obliga a impugnar la opinion de Jovio, pues con ella no queda probada la imposibilidad de que el pezespada pueda bajar de la superficic á aguas mas profundas: mejor refutacion es una circunstancia que denuestra todo lo contrario, y es que cntre el atun 5 el pez-espada no existe enemistad ni aversion alguna, como se ha probado; el atun no teme al pez-espada y este no le hace ningun danio, de lo cual es fácil convencerse observando los pocos peces espada que vienen junto con los atunes á las costas de Cerdena y donde se cogen en las mismas redes. La vista, la presencia y. sociedad del pez-espada no sorprenden á los atunes en lo mas minimo; no parece sino que ven en él á uno de los suyos, y en lugar de demostrar enemistad, se compor. tan con la mayor sociabilidad y cariijo. De seguro que los 
pescadores temerian al pez-espada al igual del tiburon, si fuese tan cruel enemigo del atun como Jovio supone; scria para ellos otro monstruo capaz de hacer los mayores destrozos entre los atunes, de dispersar y apartar bandadas enteras de su camino, sembrando entre ellas un espanto igual al que las causa el tiburon, y se emplearian contra él conjuros idénticos y tan terribles como los que emplean contra aquel. No puede en verdad negarse que la presencia del pez-espada preocupa á los pescadores; pero es porque puede entras junto con los atunes en las redes, romperlas con su arma y abrir asiá estos un boquete por donde escapar; eventualidad que ya inducia á los pescadores de la antigitedad à rogar á Neptuno que les preservase de ella; en cuanto álos atunes, el pez espada les prestaria un gran servicio con ello.

Bennett opina en sentido opuesto basándose en sus propias observaciones. Es muy frecuente, dice, ver apinarse los âtunes al rededor del buque como si acudiesen á buscar alli un refugio contra los ataques de su mayor enemigo, el pez.espada, que cabalmente aprovecha esta circunstancia para precipitarse sobre ellos y atravesar gran numero de individuos. No hay duda que es un enemigo terrible de todos los atunes y de sus afines, no siendo en modo alguno raro ver cómo los atraviesa con su espada uno tras otro.

Recientemente se ha confirmado tambien el hecho de que él pez.espada ataca á la ballena, pero bueno será poner en cuarentena la única observacion sobre este particular de. bida á un tal Crow, marino inglés, atendido que podria muy bien referirse, no as nuestro pez espada, sino al tiburon que lleva el mismo nombre en inglés. «Una mañana, dice Crow, durante una calma que nos sorprendió junto á las islas Hébridas, se reunió toda la tripulacion para presenciar una batalla entre una ballena gigantesca por una parte y va. rios tiburones de la especie zorro y algunos peces-espada por otra. Era en verano, hacia un tiempo hermoso y sereno, y la escena pasaba próxima à nuestro buque, por manera que la ocasion no podia presentarse mejor. Tan pronto como aparecia el lomo de la ballena sobre la superficie del mar, saltaban los tiburones-zorros algunos metros fícra del agua para precipitarse con fuerza sobre el objeto de su odio, descargándole terribles golpes con sus largas colas, coletazos que resonaban sobre el cuerpo de la victima como descargas de fusil oidas descie alguna distancia. Los peces-espada atacaban por su parte á la desgraciada ballena por debajo, tanto que en breve no supo esta ya cómo defenderse, y sitiada y herida por todas partes, se fué apartando de nosotros con sus encarnizados enemigos, dejando tras si la mar teñida de sangre. Era indudable que la pobre no saldria viva del combate, aunque la perdimos de vista $\$$ El autor de este relato emplea el verbo stá que significa: «matar con arma punzante, pinchando»; pero li alta latitud donde tuvolugar el drama suscita legitimas dudas; si bien es cosa probada que el pez-espada traspasa animales grandes con su terrible arma, pues entre otros casos cuenta Daniel el de un hombre que se estaba bañando en el rio Serern no léjos de Worces. ter $"$ que no solo fué atravesado de parte ś parte por un pez-espada, sino q̨ue este fué cogido inmediatamente despues de haber cometido su crímen, por manera que quedó disipada toda duda.

Muchas embarcaciones han sido taladradas por peces.es. pada, $y$ en varios museos se enseñan tablas con el arma del per hincada en ellas. Cuando se hubo de recomponer el buque de guerra Leoparilo en el año 1725 , se encontró en una tabla del costado la espada rota de uno de estos anima. les, que habia atravesado, además de la tabla de una pulgada de grueso, un poste de ocho y una cuaderna de diez centi. metros de espesor; $y$ en un buque que habia vuelto del $\mathrm{Pa}$ - cífico se descubrió otra espada de tan temible monstruo que no solamente habia traspasado la tablazon de ocho centimetros de grueso, sino tambien una cuaderna de treinta centimetros y adeinás el fondo de un barril de brea. Fl peligro que causaria un golpe de tal fuerza si el pez pudiera sacar su arma, lo que por fortuna parece serle imposible, equival. dria poco mas ó menos al que causaria en el casco una em. bestida contra un arrecife; y en efecto, la sacudida que el barco recibe de tan tremenda arma es análoga á una de aquellas. Como siempre se ha encontrado el arma rota, puede ad. mitirse que tan furioso animal paga estos ataques con su vida. No sucede lo mismo cuando se ensaña con barcas de pescar, pues dicen que existen casos en que se ha probado judicialmente que habia sido el pez-cspada la causa del nau. fragio.

Finalmente, en lo que se refiere al conocimiento que es. tos peces tienen die Ins idinmas, sábese que aun en el dia creen los pescadores sicilianos que es indispensable cantar ciertas palabras, por cierto algo semejantes a roces griegas, para coger dicho monstruo; por de contado que esto no pasa de ser una supersticion, $y$ las palabras que recitan no son mas que una especie de conjuro compuesto de vocablos de varios idiomas, como los usan en otros casos; pero los yescadores creen hay como antes en su eficacia, persuadidos de que con él atraen al pez espada, y que este desaparece en la profundidad cuando se añade al conjuro una sola palabra italiana. Ios pescadores del mar Rojo cogen las jifias con ganchos cebados con algun animal vivo, y han observado que cuando han mordido el anzuelo tratan de huir, dando saltos como los descritós mas arriba.

El viejo Gessner concluye su relacion sobre este animal diciendo que ssu carne es mala, perjudicial, de dificil diges. tion, hedionda y grasienta como la de cerdo. Algo mejor es si se conserva en salmuera, pero espesa la sangre, si bien se mejora guisándola con regetales picantes como cebollas, ajos, mostaza, etc. En general es carne muy parecida á la del delfin. $A$ esto he de añadir que en el dia siene fama de excelente la carne de los peces-espada jóvenes y quue los antiguos consideraban como una golosina una parte de la cola y los músculos que rodean las aletas.

\section{LOS GÓBIDOS -GOBIID死}

CARACTÉRES.-Los peces pertenecientes á esta familia son en su mayor parte de pequeña talla y de cuerpo muy oblongo, con piel viscosa, ya desnuda, ya cubierta de esca. mas; ticnen dos aletas dorsales, de las cuales la primera lleva frecuentemente radios Rexibles, y se une en algunas especies á la segunda; las aletas pectorales son muy salientes, unidas en su nacimiento $\delta$ en toda su extension en una, for. mando juntas un cmbudo $\delta$ disco cóncavo. En los machos, y en algunos géneros tambien en las hembras, se observa junto al ano una verruga sexual; y cn algunas especies difieren ambos sexos muy notablemente.

USOS, COSTUMBRES $\mathrm{X}$ REGIMEN.-Ia inmensa mayoria de los góbidos, de los cuales se conocen próxima. mente unas trescientas especies, vive en el mar; pocas ha. bitan constantemente los rios ó en general las aguas dulces. Prefieren fondos pedregosos donde se alojan en los huecos cazando gusanos y crustáceos; pero comen tambien freza y algas, viven en sociedad y vuelven á reunirse cuando á con. secuencia de algun susto se han desbandado de pronto, para huir juntos. Nadan con gran destreza, y tambien saben moverse con agilidad sobre fondo cenagoso, sirviéndose de sus aletas pectorales á guisa de piernas. Pueden subsistir horas y dias fuera del agua como los peces dipneos y laberinticos, 
y es hasta posible que puedan respirar el aire atmosférico directamente. Se multiplican mucho, siendo notable su re. produccion por tomar gran parte los machos en la incuba. cion, especialmente en la custodia de las huevas. Son de es. casa importancia parala economia doméstica, primero, porque su pesca es dificil atendido su género de vida, $y$ despues, porque su carne no es apreciada, siendo muy pocas las es. pecies que se consideran como comestibles.

\section{LOS GOBIOS - GOBIUS}

CARACTERES. - Los peces pertenecientes á este géne. ro tienen confundidas en una sola y en toda su longitud las aletas pectorales. Una cabeza redondeada con las mejillas salientes; dientes puntiagudos dispuestos en fajas estrechas en las mandíbulas intermaxilar é inferior; ojos aproximados uno al otro $y$ salientes, escamas de fieco $y$ la ausencia de la vejiga natatoria, son otros tantos distintivos de este género.

\section{EL GOBIO COMUN Ó NEGRO-GOBIUS NIGER}

CARACTERES.-Esta especie (fig. 167) es una de las mas comunes y conocidas del género numeroso de los go. bios. Es un pececillo de unos $0^{\prime \prime}, 10$ a ()$^{m}, 126$ is lo sumo $0^{\infty}, 15$ de largo, de color oscuro, mas claro en el vientre $y$ con manchas difusas por lo general pardo-oscuras, pero a veces mas pálidas; las aletas dorsales y caudal están listadas de negro, y las abdominales de color aceitunado oscuro, cu. biertas de lineas pardas. Seis radios sostienen la primera aleta dorsal; diez y siete la segunda, y otros tantos la pectoral; doce la abdominal, igual número la anal, 5 quince la caudal.

DISTRIBUCION GEOGRAFICA.-El gobio comun es muy numeroso en el Mediterráneo y en el mar del Norte, encontrándose tambien en el Allántico, en el canal de la Mancha y en el mar Báltico, si bien en este último solo se le coge en pocos sitios, como en la bahia de Kiel y en la cos. ta de la Pomerania anterior.

USOS, COSTUMBRES Y REGMMEN.-Vive exclusi. vamente en fondos pehascosos donde permanece simplemen. te echado sin adherirse á ellos. Ie gustan las desembocadu. ras de los rios, pero no pasa, segun parece, al agua dulce. Se alimenta de pequeños crustáceos, de toda especie de gusanos y otras cosas por el estiln. Couch dice quue atisba sus presas desde un escondrijo a donde vuclve puntualmente con su botin para devorarlo. Desova en mayo 6 junio. Abandonando entonces las peñas que habita, se traslada a la costa don. de escoge los sitios poblados de algas para cavarse alli una vivienda profunda y espaciosa, cuya bóveda la forman raices de plantas acuáticas, segun observó Olivi; y alli deposita sus huevos. El macho es, como en los gasterosteos, el arquitecto y el guardian; plantado á la entrada del nido atisba las hem. bras que buscan donde desovar y las atrae, dejándolas libre la entrada; y luego que una ha penetrado para depositar su freza, cntra el a fecundarla y despues sigue alli cosa de dos meses como fiel guardador de la cria confiada a su cuidado, que defiende heróicamente contra todos los enemigos. Du. rante este tiempo enfiaquece visiblemente y parece ya com. pletamente exhausto cuando la cria se halla en estado de abandonar la morada paterna y le releva de sus cuidados. Cuando la concurrencia de las hembras es grande, ensancha el macho la vivienda y aumenta el nimero de salidas; en caso contrario abandona el nido para construir otro $\mathrm{cr}_{\mathrm{s}}$ sitio mas á propósito.

El gobio ha sido siempre un plato farorito de los venecia. nos, pero menospreciado de los romanos, pues Marcial ya dijo:

Verdad es que en el Veneciado son opiparos los ban. quetes;

2. Pero el gobio siempre ha de ser el primer plato.

En el dia dan los italianos mucho valor al higado de este pez, que lo tiene muy grande y suculento, por cuya razon le pescan con gran actividad ya con redes, ya con el anzuclo, si bien se necesita mucha habilidad para coger los gobios con este último. Nosotros participamos de la opinion de los ro. manos, y despreciamos este pez como alimento, utilizándolo á lo mas como cebo para peces mayores y de mas mérito. Los gobios se conservan cautivos mucho tiempo si el vivero reune las necesarias condiciones.

\section{EL GOBIO DE RIO-GOBIUS FLUVIATILIS}

CARAGTÉRES.-El máximo de longitud que alcanza esta especie no pasa de $0^{\circ}, \mathrm{oS}$; su color es un verde amarillento pálido, mas oscuro y manchado de diferentes maneras en el dorso; la primera aleta dorsal ostenta una orla ancha, y la anal otra estrecha, pero poco determinada; la segunda dorsal y la caudal llevan marcados muchos puntos negros; la membrana branquial es á menudo de color negro pardusco. Seis radios sostienen la primern aleta dorsal; uno y diez. la segunda; trece ó catorce cada pectoral; diez cada abdominal, uno $y$ siete $u$ ocho la anal, $y$ de dicz y seis hasta diez $y$ ocho la caudal.

USOS, COSTUMBRES Y REGIMEN.-El gobio de rio, que los italianos llaman botlola, es en los lagos, rios y canales de aquel pais un pez muy comun. Tambien vive por lo comun oculto entre las piedras mientras no se le inquieta, 6 le haga salir de su escondrijo alguna presa; la hembra aglutina alli sus huevas, pero el macho no las custodia, segun parece. En el trascurso de la incubacion cambian su forma en fusisorme, y en este estado de su desarrollo flotan aglomeradas libremente en el agua hasta que en junio nacen de ellas los pequeñuelos. Su carne tiene fama de sabrosa.

\section{LOS PERIOFTALMOS - PERIOPH- TALMUS}

En los pantanos costaneros y marismas de los paises ecua. toriales, especialmente en el Africa oriental y occidental, como tambien en muchas islas del Océano Índico y Pacifico, habitan ciertos gobios que pueden vivir aun mas tiempo fuera del agua que sus afines, pasando, graciasála estructura de sus branquias, la mayor parte del dia en el limo húmedo, donde se mueven de un modo bastante original. Se llaman mapos ó perioftalmos.

CARACTERES.-Sus aletas pectorales son muy largas, casi podria calificárselas de brazos, y están cubiertas de es. camas; las abdominales se confunden en una sola; la cabeza tiene escamas en ambos lados; los ojos, colocados el uno cerca del otro, son salientes y se cubren con un párpado in. ferior. Las agallas forman una rendija, y los dientes cónicos están insertos verticalmente en las mandibulas. El representante de este género es

\section{EL MAPO COMUN Ó LINEADO-PERIOPH- TALMUS KCELREUTERT}

CARACTERES.-Es un pez de unoș $0^{\circ}$, I5 de largo, de color y dibujo muy rariados; generalmente presenta sobre un fondo pardo claro manchas plateadas y pardas, con una cinta longitudinal regra, o:lada de blanco en la mitad supe. 
rior de la segunda aleta dorsal, con manchas y puntitos en | tas pectorales parecen hechas adrede para este movimiento, las aletas torácicas y abdominales. En la primera aleta dorsal hay diez radios; en la segunda doce; en la pectoral diez y seis; en la abdominal seis; en la anal once y en la caudal diez y nueve.

USOS, COSTUMBRES Y REGMMEN. - Si hay un pez que merezca el calificativo de trepador es este; sus alc-

porque mas bien vienen á ser patas que nadaderas, y como patas las usan. Todos los mapos cazan principalmente en tierra. Viven como anfibios echados casi siempre en el limo ó corren por el mismo ó por la playa como lagartos, precipitándose sobre sus presas con tal rapidez que casi nunca las yerran. Cuando se los persigue pasan como fiechas sobre el

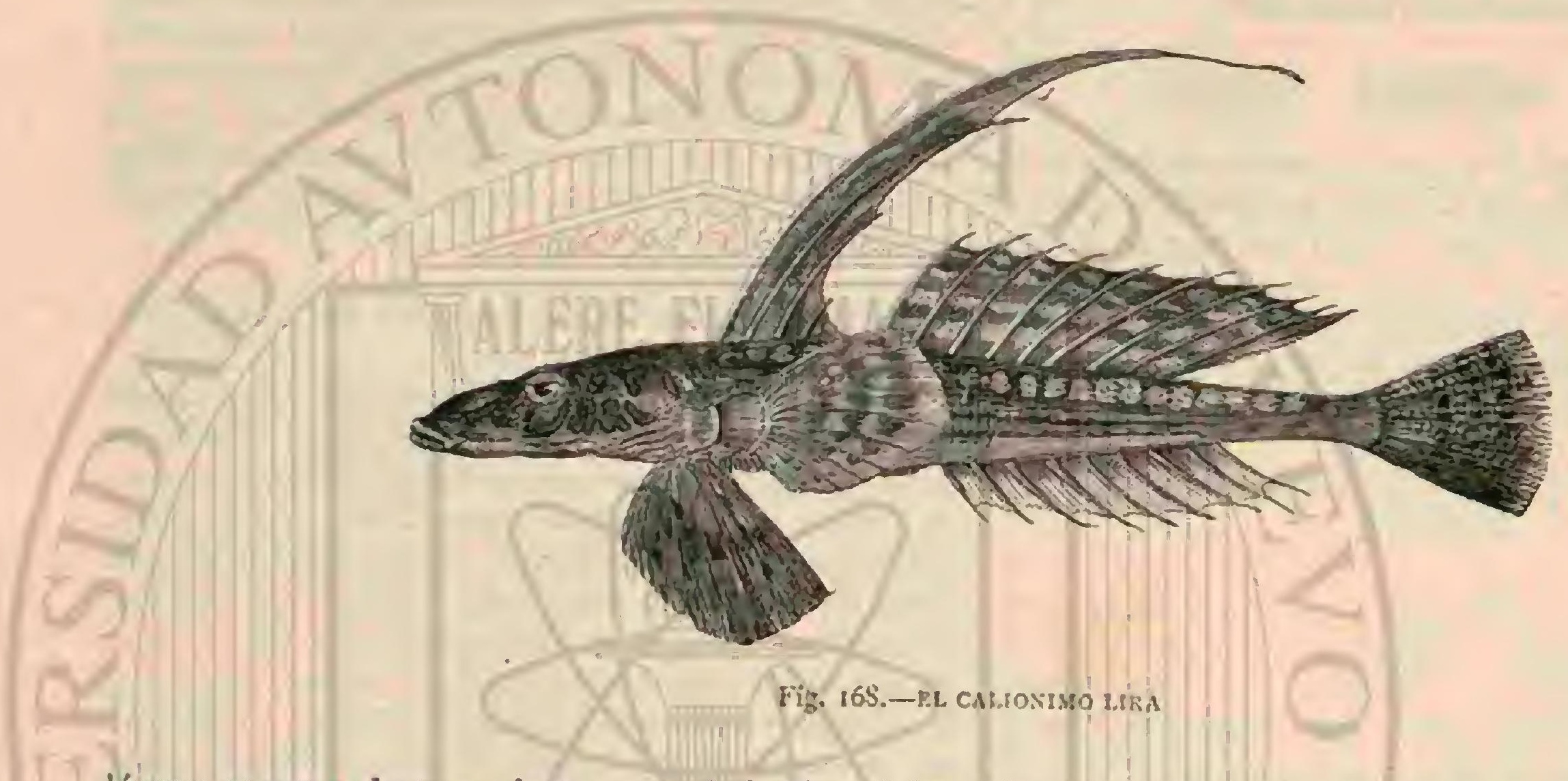

légamo, se meten dentro y desaparecen de la vista. Sobre / siempre en las aguas meacladas en las embocaduras de los esto me escribe Pechuel-Ioesche: \$Nunca he cncontrado á rios y sus ramales, donde parece preferir las raices de los este pez en lagunas y marismas excesivamente saladas, sino manglares, y donde mas le he observado fue en las desem-

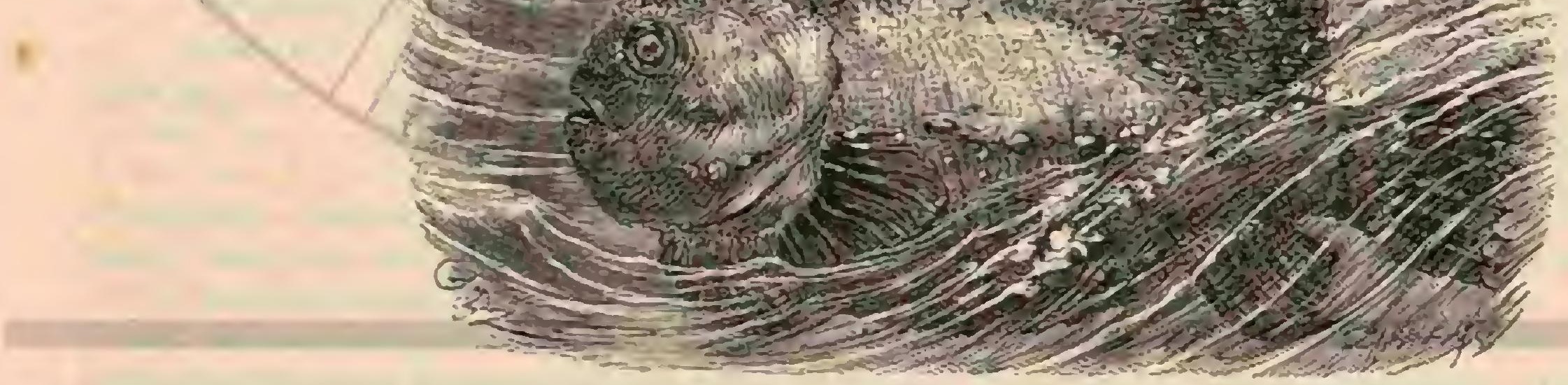

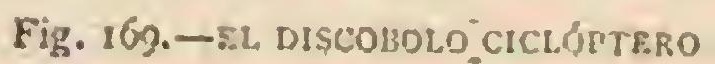

bocaduras del Chiloango y del Cuilu en la costa de Loango. Alli se les ve i docenas, particularmente en las bajas mareas y en tiempo de calma en las partes llanas y mojadas de la playa dejadas en seco por la marea, próximas al agua y \& la sombra de los manglares, en cuyas espesuras pueden jugar en todo tiempo á sus anchas, y evitar sin dificultad el suelo cubierto de yerba. Segun parece se juntan estos peces en grupos mas ó menos numerosos de igual talla ó edad. Cuando se creen seguros se entretienen dando saltitos, encorvando un poco el cuerpo y estirándolo alternativamente, apoyándose al propio tiempo sobre la cola y las aletas; de estc modo adelantan dejando tras sí un rastro en el cieno; otras veces es tán echados al parecer cómodamente á su modo; de repente se ponen á retozar, saltan en confusion como si jugasen, y entonces sucede tambien que un mapo se endereza de pronto y se coloca de un salto sobre una raiz de mangle que dista del suelo una longitud igual á la de su cuerno, agarrándose í ella con sus aletas. No he podido ver cómo se arreglan estos animales para subir mas; pero atendido á que nunca su. ben sino por raices delgadas, supongo que lo verifican abra. zando la raiz con sus aletas y empinándose un tanto sobre la cola, exactamente como se trasladan por tierra. Lo cierto es que los he visto caer de alturas de un metro cuando se asustan, $y$ tambien me he convencido de que pueden pasar muchas horas fuera del agua. Son muy espantadizos; si se acerca á ellos alguna persona que les inspira sospechas, se salvan de un modo muy gracioso, levantándose un poco con el auxilio de sus alctas, y cuando el observador queda ente. ramente inmóvil y los espanta repentinamente al cabo de un rato, ya tosiendo, golpeando 6 silbando, se agazapan al punto, permanecen un rato quictos, $y$ en seguida huyen con apresurados brincos al agua profunda donde desaparecen. Estos brincos pueden ser dos ó tres veces mayores que la longitud de su cuerpo y acaso mas. En sus huidas presuro- 
sas atraviesan tambien á saltos las aguas bajas, aun cuando podrian nadar, y producen el ruido consiguiente al caer, ruido particular que se hace mas notable cuando se ahuyenta á toda una bandada. Jamás pudimos atrapar ninguno de es. tos peces del todo ileso, pero como los muchachos negritos les disparaban fiechas ligeras cuando lo deseábamos, teniamos a menudo peces solo levemente heridos que continua. ban saltando alegremente encima de nuestra mesa.

Por otros observadores sabemos que los mapos se alimen. tan de cangrejos y articulados; pero todavía carecemos de noticias respecto a su reproduccion.

\section{LOS CALIONIMINOS-CALLIONY- MINA}

CARACTERES. - Se reune en esta sub familia una clase de gobios grandes, de cabeza aplanada, cuerpo corto, cola larga y aletas grandes, pero de pocos radios. Pueden prolongar mucho la boca, y el número de radios branquiales oscila entre seis y siete. Los de la primera y segunda aleta dorsal suelen terminar en largos apéndices filiformes. Ias aletas abdominales, insertas delante de las pectorales, son mayores que estas; la caudal es con frecuencia mas larga y

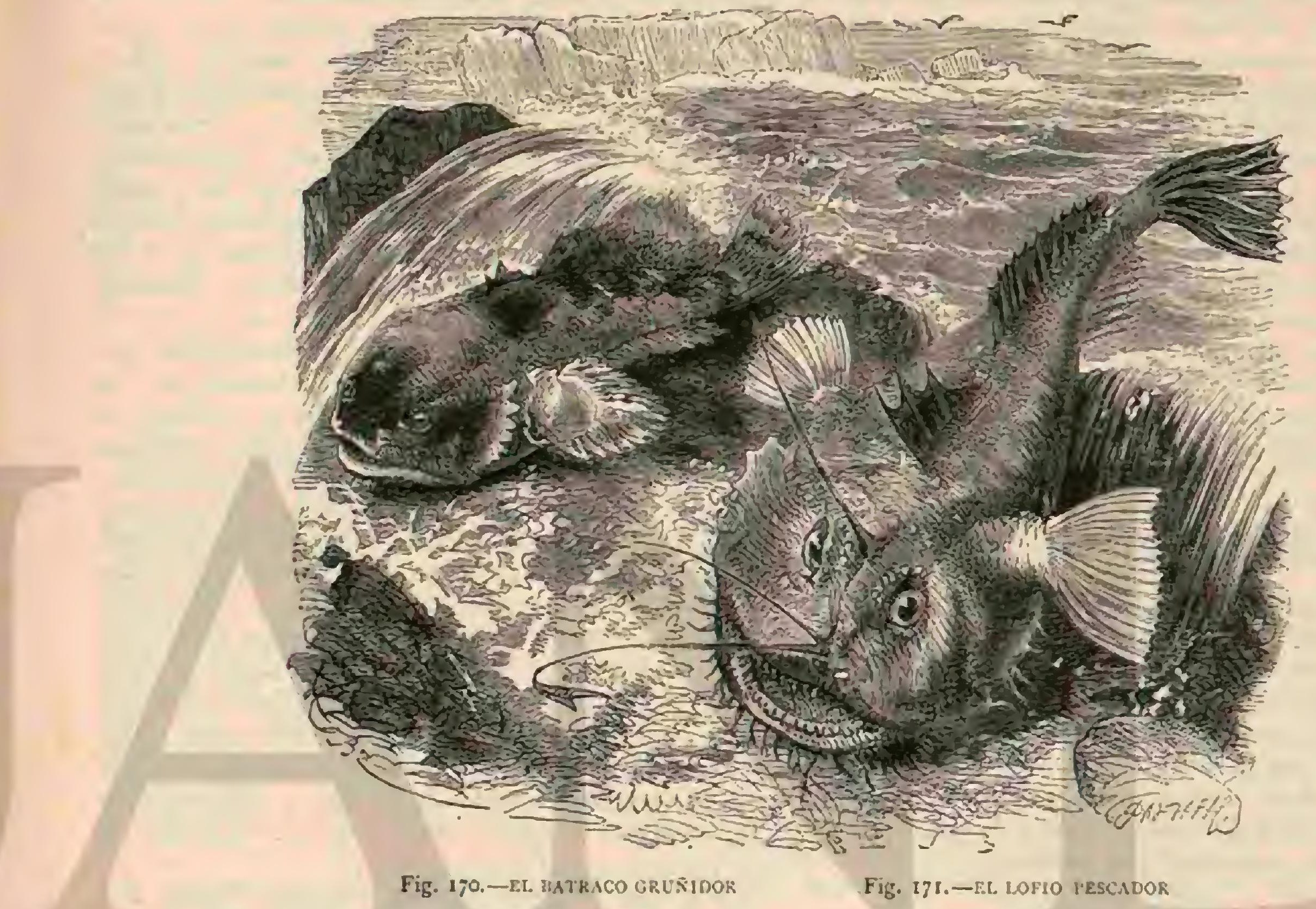

puntiaguda. La cubierta consiste, ya en escamas, ya en la piel desnuda. No existe vejiga natatoria.

\section{LOS CALIONIMOS-CALLIONYMUS}

CARACTERES. - Los peces de este género forman el núcleo de la subfamilia y se distinguen por las aberturas branquiales atrotiadas hasta degenerar en un simple agujero que se abre en la nuca. Tienen los ojos muy juntos; dientes de terciopelo en las mandibulas, pero no en el paladar; seis radios branquiales; la primera aleta dorsal muy prolongada y por lo comun una piel muy lisa que en muchas especies ostenta colores brillantísimos. Es fácil distinguir los machos de las hembras.

\section{EL CALIONIMO LIRA-CALLIONYMUS IYRA}

CARACTERES.-Este pez (fig. 16S) alcanza una lon. gitud de $0^{\circ}, 30$ à $0^{\circ}, 35$, y lleva sobre fondo amarillo, pardusco en las regiones superiores y claro en las inferiores, listas y manchas de un azul de zafiro; la membrana de las aletas dorsales es de color pardo pálido con listas longitudinales oscuras, y la de las aletas abdominales, anal y caudal es de color negro azulado. La primera aleta dorsal consta de cua.

tro radios, la segunda de nueve, cada pectoral de veinte, cada abdominal de cinco, la anal de nueve y la caudal de diez. DISTRIBUCION GEOGRÁFICA.-Los antiguos ictió. logos conocian el calionimo lira solo como habitante del Mediterráneo, pero los modernos lo han encontrado tambien en mares mas septentrionales, especialmente en las costas de Inglaterra y de Noruega Los pescadores ingleses le dan diferentes nombres, de los que solo uno, «novio, prueba que esta gente sencilla sabe tambien apreciar la belleza de este pez que, segun Yarrell, no es comun en las costas británicas. USOS, COSTUMBRES Y REGIMEN.-Couch y otros naturalistas han observado que habita en aguas profundas donde suele vivir en el iondo ó cerca de él cazando toda clase de animalejos que acecha desde un punto elegido á propósito y que no abandona sino con la rapidez del rayo, sin alejarse mucho y volviendo al mismo por poco que pueda. Acecha desde su puesto favorito a manera de gato; nada escapa á su vista; se precipita rápidamente sobre su presa; pero no la ataca de frente cuando no puede sorprenderla, asemejándose tambien en esto à los gatos. Se alimenta con preferencia, cuando no exclusivamente, de conchas y otros moluscos y tambien de gusanos; sirviendo á su vez de ali. mento á peces mayores y mas fuertes que él. Ninguna noticia encuentro respecto á su reproduccion. 
Su pesca viene á ser mas bien efecto de la casualidad, porque este pez apenas muerde el cebo, de suerte que cuan. do se le coge es en la red barredera. Su carne es blanca y sabrosa, pero esto no impide que este pez carezca de importancia, cuando menos en los mares septentrionales.

\section{LOS DISCOBOLOS - DISCOBOLI}

CARACTÉRES. - Cuvier reune como una docena de especies de gobios en una familia especial, porque tienen las dos aletas abdominales reunidas en una sola en forma de disco y los llama discoholos. Aparte de la extraña formacion de sus aletas, estos peces difieren de los verdaderos góbi. dos por las aletas pectorales que son muy grandes y casi tambien unidas en una sola; por la aleta dorsal muy atrofiada cuando no falta completamente, y por la forma de los radios branquiales.

USOS, COSTUMBRES Y REGIMEN, - En cuanto k su género de vida, se asemejan mucho los discobolos à los góbidos; viven como estos exclusivamente sobre fondo peñascoso al que se adhieren con su disco, en cuya posicion continuan dias enteros, cuando no los saca de alli alguna presa que se les acerca. Algunas especies se muestran tan solicitas como los gobios para su cria. Su carne se aprecia poco, á pesar de que la de la mayor parte no es mala segun dicen.

\section{LOS CICLÓPTEROS-CYCLOPTERUS}

CARACTERES. - Estos peces, de forma extraña y tosca, ocupan el primer puesto en la familia. Se distinguen por su disco grande, hendido en ambos costados $y$ formado por los radios de las aletas abdominales insertas al rededor de la pélvis; por lo reducido de-sus aletas dorsal y anal, ancha boca, sistema dentario consistente en dientes pequeños y puntiagudos que guarnecen las mandibulas y huesos faríngeos, opérculos pequeños, piel viscosa cubierta de numerosas nu. dosidades y por su esqueleto casi cartilaginoso.

\section{EL DISCOBOLO CICLÓPTERO-CYCLOPTE- RUS LUMPUS}

CARACTERES.-Es un pez (fig. 169 ) de unos $A^{\circ}, 60$ de largo, de un peso de tres s. cuatro kilógramos, y por cxcep. cion hasta de seis a siete; es de un color gris negruzco, hácia abajo amarillento, pero en general variable. Su primera aleta dorsal se halla completamente atrofiada; la segunda tiene once radios, la torácica veinte, la anal nueve y la caudal diez.

DISTRIBUCION GEOGRÁFICA. - El discobolo se encuentra en todos los mares septentrionales como el del Norte y el Báltico; pudiendo admitirse que ha de ser muy frecuente porque su multiplicacion es pasmosa, si bien se le coge raras veces a causa de su género de vida particular.

USOS, COSTUMBRES Y REGIMEN.-Es mal nada. dor y poco movible; cuando quiere trasladarse, lo hace con lentitud y meneando su cola que es bastante débil, por cuya razon prefiere permanecer adherido \& las peñas y piedras por medio de su aleta abdominal que le sirve de ventosa, aguar. dando asi sus presas. La adherencia entre su disco y los ob. jetos extraños es muy grande, y Hannox ha calculado que para arrancar de su puesto $\left\{\right.$ un discobolo de $0^{\circ}, 20$ de largo se necesitaba una fuerza de treinta y seis kilógramos. Pennant dice que al coger uno de estos peces que se habia adherido al fondo de un cubo lleno de agua, alzaron con él el cubo y el agua sin que se desprendiera del fondo. Otro individuo que se cogió tenia pegadi á la frente una rama de alga que crecia alli como adherida á otro objeto cualquicra, por lo cual se suponia que el pez debia haber estado inmóvil en un mismo sitio dias y semanas aguardando que las hidras y pe. cecillos de que se alimenta penetraran por sí mismos en su boca.

En cautividad se adhieren en seguida á un sitio del acua. rio que les parece á propósito, aunque sea al cristal mas liso, donde permanecen horas y horas sin mover otra cosa que sus agallas; pero cuando se les echa su racion se deciden a aban. donar su puesto. En viveros pescan la carne y los gusanos, pero casi nunca hacen caso de los pececillos.

Hácia el mes de marzo cambia el discobolo de color y de costumbres; aquel pasa á rojizo, y el pez abandona su habitacion para buscar en las costas sitios de poca agua y a pro. pósito para deponer su freza. Fabricius dice que estos peces acuden a las calas y ensenadas peñascosas de Groenlandia á fines de abril 6 principios de mayo, presentándose primero las hembras é inmediatamente despues los machos; aquellas desovan entre las'algas mas grandes, especialmente en las grietas de las peñas, pasando luego los machos á fecundar las hucvas y á establecerse, ya sobre ellas $\delta$ ya á su lado. No me entretendré en discutir la exactitud de los cálculos que se han hecho para averiguar el número de huevas, pero en lo que no cabe la menor duda es en que la multiplicacion de estos peces es extraordinaria. La freza de una hembra de tres kilógramos de peso, pesaba un kilógramo, y como el tamaño de la hueva es como un perdigon, resulta que toda la cantidad ha de evaluarse por cientos de miles. Fabricius dice que el macho custodia las huevas con gran fidelidad, dando pruebas de verdadero heroismo, pues ataca al terrible lobo marino, al que asesta golpes mortales, llevado de su amor paternal. Lacepede cree deber poner este detalle en duda, pero observaciones recientes lo confirman en un todo. Johns. ton dice que los pescadores aseguran que el macho cubre las huevas hasta que nacen los pequeños, los cuales se adhie. ren á los costados 5 espaldas de su padre que lleva su pre. ciosa carga á sitios mas profundos y seguros. A últimos de noviembre miden los pequeños $0^{\star}$, IO.

No se pesca el discobolo sistemáticamente. Couch dice que casi nunca muerde el anzuelo, por cuya razon es esta pesca muy insegura. Fn Groenlandia é Islandia lo cogen con redes, ó cuando se le ve entre las plantas marinas, con arpon. Peor encimigo que el hombre es para él la foca, que pa. rece aficionada á su carne á pesar de que le cuesta despellejarla. La carne de las hembras es seca y mala, la de los machos grasa y sabrosa; los islandeses la consideran como exquisita, sobre todo cuando ha estado algunos dias en sal y suelen pre. sentarla en la mesa cuando tienen forasteros. Los pescadores ingleses la comen solo mientras el pez tiene el color encarnado, por cuya razon distinguen ellos dos especies de este pez.

\section{LOS BATRÁQUIDOS-BA- TRACHIDE}

CARACTERES. - Guenther ha formado una familia, llamada por él de los batráquidos, con una docena de peces aproximadamente, los cuales difieren de los góbidos por tener la cabeza muy grande y aplanada, boca muy hendida, dientes pequeños ó á lo mas medianos, cónicos, un tanto encorvados hácia adentro, puntiagudos y dispuestos en dos filas; opérculos espinosos; una seric de tentáculos filiformes en la mandibula inferior; aletas torácicas estrechas insertas en 
la garganta; dos dorsales, la primera con solo tres radios es. pinosos. La segunda dorsal y la anal son muy largas; la abertura branquial viene a ser una hendidura, los radios de la membrana branquióstega son seis, y la piel está por lo comun desnuda.

\section{EL BATRACO GRUÑIDOR-BATRACUS GRUN- NIENS}

CARACTERES. -Este pez (fig. 1 7o) representa cl géne. ro batraco, que es el que cuenta el mayor número de especies de su familia Alcanza una longitud de $0^{\mathrm{T}}, 30$; el color de la cabeza y del dorso es pardo; el de los costados veteado de blanco y pardo; las alctas tienen manchas pardas, las torácicas sobre fondo rojizo y las demás sobre fondo gris.

USOS, COSTUMBRES Y REGIMEN.-Parece que es pez comun en todas las partes del mar Indico, y muy nume roso en algunas. Debe su nombre al gruñido especial que pro duce con el roce entre sus opérculos cuando se le coge con la mano. Sobre su género de vida no sabemos nada y solo podemos suponer que diferira poco del de las familias afines. La carne es gorda $y$ tiene fama de sabrosa, pero dicen que el hígado es venenoso.

\section{LOS PEDICULADOS- PEDICULATI}

CARACTERES.-Estos peces son los mas feos y defor. mes de su clase. El viejo Gessner dice al hablar de las especies de esta familia que viven en nuestros mares: «icen que los pejes-sapos son animales por demás horribles $\mathrm{g}$ feos, que en algunos sitios alcanzan hasta tres varas de longitud, y tic. nen una boca tan grande que son capaces de tragarse un perro de caza. Su carne es coriácen, su cabeza grande y gruesa, por manera que el pez casi no presenta mas que cabeza $y$ buche. La mandibula inferior se prolonga mas que la supe. rior a consecuencia de tener siempre la boca abierta. Tiene muchas espinas en la cabeza y al rededor de los ojos, y sus mandibulas, las fauces y la lengua están erizadas de dientes. Sobre la cabeza tiene dos radios y tambien algunos en la parte posterior del lomo, que segun dicen son en extremo hediondos. Cuando estos peces se desuellan y se extiende la piel con una vela colocada dentro, se obtiene un farol horripilante, como que por lo comun tienen un aspecto horrible, tanto que en diferentes tierras los llaman diablos marinos. Segun dicen, vive dicha especie en las playas cubiertas de yerbas, y es muy voraz, persigue al hombre, atisba a los que están nadando, los coge y los lleva al fondo para devorarlos. Tambien suelen tragar tantos individuos de otras especics que los habitantes de las costas, cuando cogen uno de gran talla, le abren para sacar los peces frescos que llevan en el buche. Muchos hay que se alimentan $s$ viven valiéndose de las mañas que la naturaleza les ha dado, pero á todos ganan los pejes-sapos, porque segun cuentan tienen junto á la boca apéndices ó cuernecitos que mueven mientras se hallan ocul. tos en el limo, como si se moviesen gusanos, para engañar á los peces pequeños á fin de que se acerquen y les sea mas fácil devorarlos. Dicen que la carne de estos peces no se come, que es sanguinolenta, desagradable y de muy mal olor; la mejor es la del vientre.

Esta descripcion es en el fondo exacta, porque los pedi. culados viven efectivamente de la manera que Gessner los pinta; su aspecto causa tanto horror hoy como antes, y su voracidad es tal, que tambien hoy dia les abren los pescado. res ingleses el vientre, tal como dice Gessner, para aprovechar los peces que se hubiesen tragado.
El distintivo mas importante de la familia, que no cuenta mas que una docena de especies, consiste en los huesos carpianos prolongados de las aletas pectorales que vienen a formar una especie de pié, y que de hecho sirven al pez. de apovo, $y$ hasta le facultan para arrastrarse a la manera de los mamíferos sobre el cieno. La primera aleta dorsal suele consistir solo en algunos radios aislados cuando existe; las pectorales se hallan insertas en la garganta. La cabeza, de una anchura descomunal, lleva unos apéndices singulares que de hecho sirven para atraer á otros peces; los opérculos solo dan acceso á una pequeña cavidad circular debajo de las alctas torácicas; el hueso infraorbital no existe; el resto del esqueleto es semi-cartilaginoso y la piel desnuda, pero cubierta en algunas especies de protuberancias huesosas ó de espinas de base muy gruesa. I a boca es descomunal, el estómago un saco holgado, y el tubo intestinal cortisimo.

Pocas especies viven en los mares septentrionales, pues esta familia pertenece tambien con preferencia â la region ecuatorial, donde despliega gran variedad. En cuanto á su género de vida solo existen observaciones relativas ś una cs. pecie, que biastan empero para probar que la indole de estos peces concuerda con su forma, es decir, que la una es tan especial y singular como la otra.

\section{LOS PECES SAPOS - LOPHXUS}

CARACTERES.-Gessner llama sal pez tan horrible y feo que describe, Diablo, 5 este nombre le ha quedado en muchos idiomas. La cabeza y lá de sus congéneres (Lopirius) es grandisima, ancha, aplanada y espinosa, la boca enorme y guarnecida de numerosos dientes movibles, puntingudos, afilados, encorvados hácia adentro y distribuidos entre las mandibulas, los huesos palatinos y el vómer. La primera aleta dorsal consiste en tres radios unidos, pero deben contarse tambien como pertenecientes á ella varios hilos colocados delante, movibles á voluntad del per y de consiguiente articulados en su base. Ins aletas pectorales están mucho mas hácia atrás que las abdominales. La membrana bran. quuial forma una bolsa ancha, abierta hácia atrás y sostenida por seis radios muy largos. Inmediatamente detrás de la cabeza empieza el cuerpo á adelgazarse y hácia la cola está comprimido tambier lateralmente.

\section{EL LOFIO PESCADOR-LOPHIUS PISCATORIUS}

CARACTERES,-El color de esta especie (fig. 171) es en la parte superior un pardo liso que se oscurece única. mente un poquito en las aletas; la parte inferior con las ale. tas.torácicas $y$ abdominales es blanca y la aleta caudal parda oscura, casi negra. En la primera aleta dorsal cuéntanse tres radios espinosos; en la segunda doce algo mas blandos; en cada pectoral veinte, en cada abdominal cinco; en la anal ocho é igual número en la caudal. La longitud de este pez puede llegar casi á dos metros, pero es muy raro que se coja uno de este tamaño.

\section{LOS QUIRONECTES - CHIRONECTES}

CARACTERES. - Los quironectes, ó antemarius de Cuvier, se reconocen desde luego por su cabeza comprimida verticalmente en vez de ser deprimida, y porque detrás de los tres radios libres de la parte superior de la cabeza no hajo otra aleta espinosa separada de la blanda, como la que presenta el verdadero lofio delante del lomo. En estos peces no se ven ya esa enorme cabeza $\epsilon$ inmensa boca de los individuos del 
género anterior que atemorizan á primera vista; pero en cambio tiènen todos la facultad de dilatar su cuerpo como un globo, tragando aire, y de llenar con este fúido un gran estómago membranoso. Por la posicion respectiva de sus aletas ventrales y pectorales, y por los pedículos en que estas últimas aletas se sostienen, parece que los quironectes tienen cuatro pies, representando las ventrales los anteriores, de modo que el empleo de las cuatro extremidades se encuentra en ellos completamente invertido. La pequeñez de su orificio branquial, reducido a un agujero redondo, oculto en la pectoral, les permite permanecer largo tiempo al aire libre, de cuya circunstancia se aprovechan para arrastrarse sobre el cieno y la arena y perseguir a su presa. La boca está hendida mas ó metros verticalnjente: los intermaxilares, la mandibula infe. rior, el extremo anterior del fómer, los palatinos y los fatin. geos, tienen dientes muy finos, en varias series, compactos y puntiagudos; pero no existe ninguno en la lengua. Los ojos son pequeños y están próximos \& la frente; no se ven espinas en ninguna parte de la cabeza ni en los opérculos, y todas las piezas operculares se hallan ocultas debajo de la piel. La parte posterior del cuerpo no se adelgaza lo mismo que en el lofio comun, lo cual establece otra diferencia entre ambos géneros. La dorsal ocupa una gran parte del lomo; las proporciones de los radios libres de la parte superior de la cabcza, asi como los tentáculos, varian mucho segun las especies. La pectoral está sostenida por una especie de brazo formado por la pro. longacion de dos huesos del carpo; pero se oculta en gran parte debajo de la piel, á menos que el animal quiera hacerle. salir. Sus radios, en número de diez i once, están dispuestos en forma de abanico, y sus puntas salen de la membrana

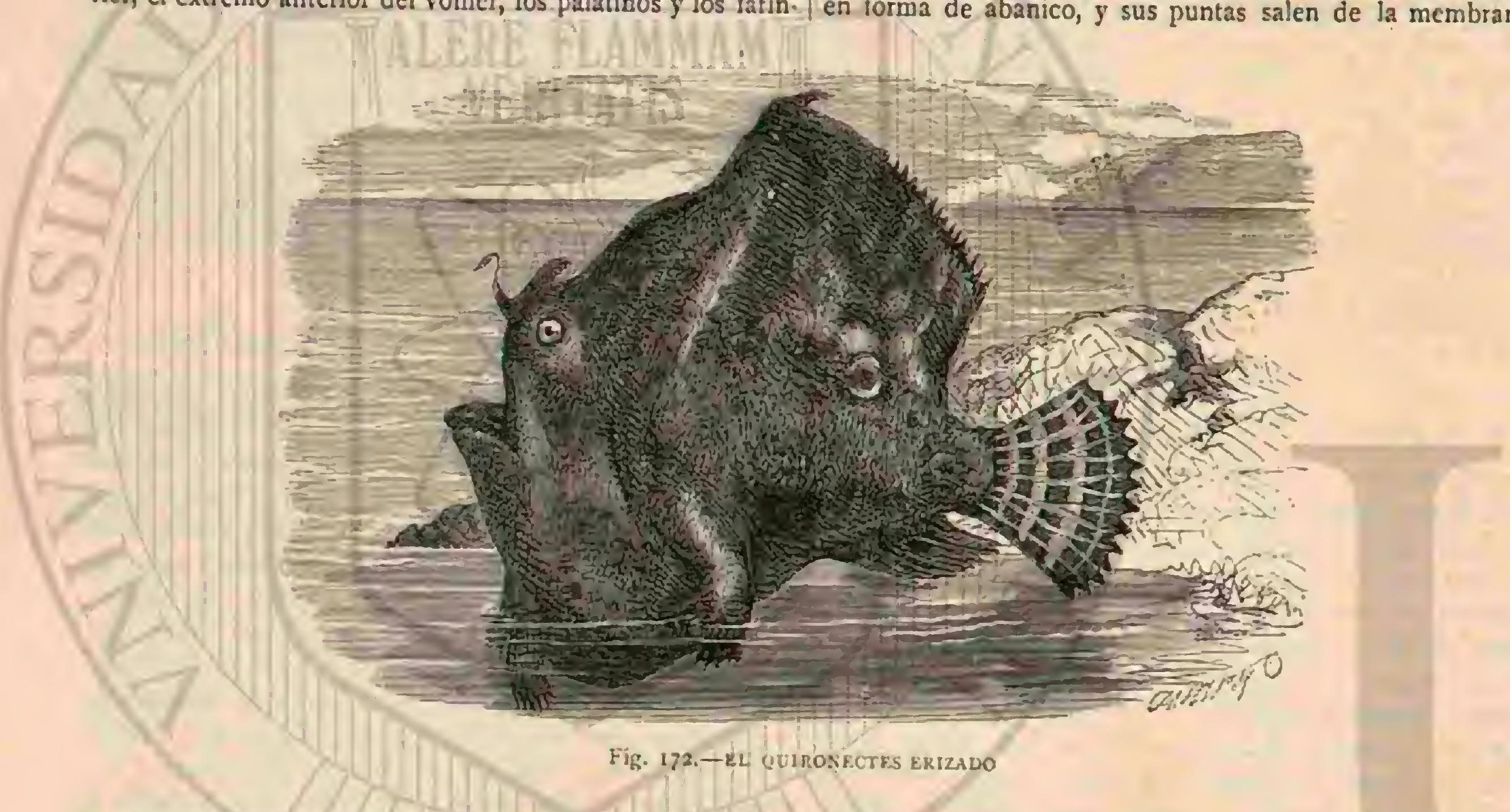

figurando peqqueñas uñas; 10 mismo sucede con los de los radios de la ventral, y parece que esta estructura contribuye a que el pez cjecute ese movimiento que se ha comparado con la reptacion.

\section{EL QUIRONECTES ERIZADO-GHIRONECTES HISPXDUS}

CARACTERES.-Este quironectes (fig. 172) se diferencia de los otros por sus formas mas cortas y fornidas. Parece que puede dilatar mas su vientre, y toda su piel hállase guarnecida de asperidades compactas. En el hocico comienza una serie de tubérculos que se continúa hasta la sien, formando despues una especie de línea lateral; otm serie semejante, en la mejilla, marca en cierto modo la curva del preopérculo; y en algunos sitios, sobre todo hácia la garganta, se ven apén. dices cutíneos muy pequeños. El fondo del color de este pez consiste en un amarillo pardo, con manchas $\sigma$ líneas negras distribuidas con cierta irregularidad; las del crisneo, de la nuca y del lomo, son trasiersales y se corren verticalmente sobre la dorsal, donde se dividen á veces en manchas; las de la mejilla parten en sentido oblicuo, como las de los costados; en la pectoral $y$ la anal hay pequeñas manchas, $y$ hasta se ven en la lengua; pero la cara inferior de la garganta y el vientre son de un amarillo de ocre uniforme. Suele medir 8 6 9 put gadas de largo.

DISTRIBUCION GEOGRÁFICA.-El quironectes eri zado habita en el Océano Atlántico y en el Indico. Tambien se han pescado individuos de la especie en Pondichery, dorde los llaman peres de reca. Commerson los vió en la isla de los Toneleros y cerca de la isla de Francia; existen también en las Molucas, en Ceilan y en Amboina.

\section{LOS MURCIÉLAGOS DE MAR - MALTHE}

CARACTERES. - Este género difiere de los lofios prin. cipalmente por los huesos nasales tan salientes que vie. nen à formar como una trompa; entre estos huesos funciona en un hueco correspondiente un tentáculo movible. Falta la primera aleta dorsal, y los tentáculos sobre la cabeza que se encuentran debajo de la boca. La picl es dura y cubierta de protuberancias; las branquias se abren encima de las aletas torácicas.

\section{EL MALTO ESCORPION-MALTHE VESPERTILIO}

CARACTERES. - Ticne la boca relativamente pequeña, pero la parte de las aletas torácicas, que viene á ser el brazo, mas larga que en los peces-sapos, $y$ encima de cada fosa nasal hay un botoncito córneo. La coloracion de la parte superior es de un pardo gris claro bastante agradable, y rojo 
claro la de la parte inferior. Ia aleta dorsal $y$ la anal tienen cuatro radios cada una, $y$ la caudal nueve.

USOS, COSTUMBRES $Y$ RERGIMEN.-Como hasta ahora no se han verificado observaciones exactas acerca de las costumbres de las diferentes especies de pediculados 6 peces de aletas articuladas, nos hemos de valer del lofio si queremos tener una idea del género de vida de estos peces. Se encuentra en todos los mares europeos, particularmente en el Mediterráneo y Atlántico, donde abunda, sin que sea precisamente raro en las costas de Inglaterra, donde es á veces hasta comun y bien conocido de los pescadores, como sucede en los puertos de Portsmouth y Southampton. Habita los fondos cenagosos del mar, del modo que Gessner lo describe; con ayuda de sus alctas torácicas se mete dentro y desde alli atisba sus presas. Cuando se acerca un pez de ra. piña, empieza á mover sus tentáculos en diferentes direcciones para atraerlo, se precipita sobre él en el momento favo. rable y le hace desaparecer en su anchisimo esófago. Para él todos los peces son buena presa, tanto los grandes como los pequeños y de la especie que quiera. Couch cuenta que un pescador habia cogido un bacalao con el anzuelo; al sacarlo del agua sintió repentinamente que el peso aumentaba y

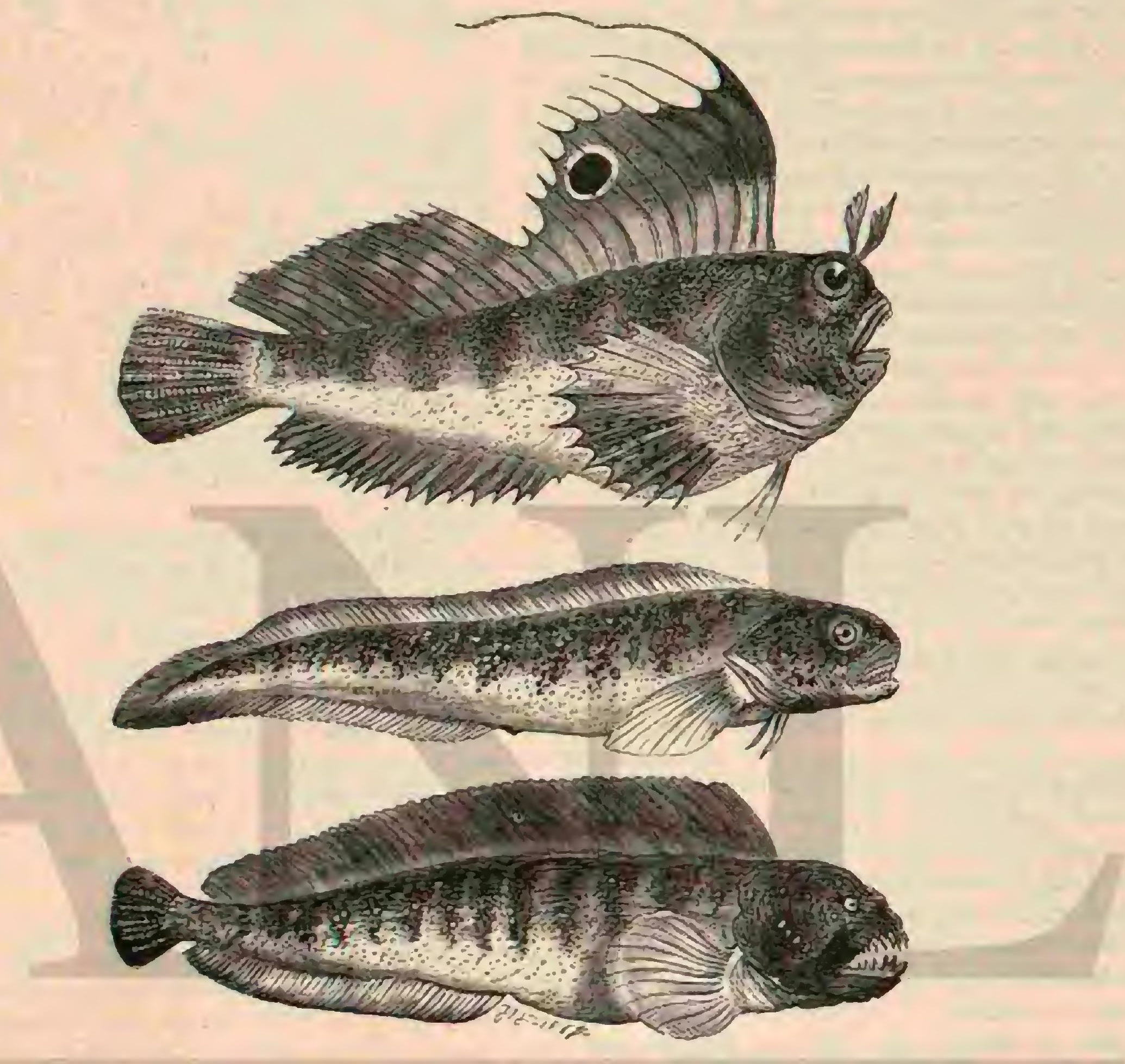

Fig. 173. -F.L BLEN1S MARREOSA

Fig. 174. - EL ZOARCES VIVIPARO

Fig. 175. -EL LOBBO MARINO

entonces vió que la causa era un pez-sapo que se habia tragado todo el bacalao, sin soitar su presa hasta que el hombre le hubo descargado algunos porrazos en la cabeza. Otra vez se tragó un pez-sapo á una anguila de mar que acababa de morder el anzuelo; pero csta, encerrada en las fauces des. comunaies del otro, no se daba por vencida y bregaba por escaparse abriéndose camino por entre las hojas branquiales, lo que habia logrado ya á medias cuando ambos peces fue. ron sacados juntos del agua. Otros pescadores contaron â Couch que el pez-sapo se traga á većes las boyas 6 rodajas de corcho que se fjan en las redes para tenerlas 1 flote y se le coge así. $\mathrm{Ni}$ aun cogido dentro de la red cesa este pez de dar pruebas de su voracidad, pues se traga algunos de sus compañeros de cautividad, en especial platijas; entonces no le perdonan los pescadores, le abren el vientre y sacan los peces que ha devorado, mientras que por lo comun le dejan la vida arrojándole otra vez al mar, primero porque no se come su carne y despues porque creen que caza y extermina Tos:o V los tiburones 6 escualos llamados perros (Syliumi canicula). Respecto à la reproduccion solo sabemos que ponen gran número de huevas envueltas en una membrana dura y reunidas en grandes pelotas, lo que facilita su destruccion por otros peces que las devoran, por cujo motivo dicen que su multiplicacion es muy escasa.

Como ya hemos dicho, no se aprovechan estos peces en el norte, pero en el Mediterráneo los comen, siquiera sean los pobres.

\section{LOS MUCOSOS Ó BLÉNI- DOS - BLENNIIDE}

CARACTERES.-Esta familia merece su nombre con mucha razon atendido que la mayoria de sus individuos tiene la piel viscosa desnuda ó bien cubierta de escamas dimi. nutas y redondas. El cuerpo es oblongo y comprimido late- 
ralmente; la cabeza grande $y$ tosca. Las aletas abdominales, compuestas solo de dos á tres radios flexibles, se hallan insertas en la garganta; las dorsales están confundidas en una sola, si bien dejan distinguir dos partes distintas, la anterior y'la posterior; sus radios son tambien blandos y fexibles; las otras aleias, es decir las torácicas, la anal ! caudal suelen ser grandes y vigorosas. La dentadura consiste en dientes largos, colocados uno junto á otro y formando hilera sencilla en ambas mandibulas. Delante de los ojos, y â veces junto á las fosas nasales ó en las mejillas, llevan algunos tentáculos filiformes de variadas formas. Hay seis arcos branquiales y faltan la vejiga natatoria y el intestino ciego. Por lo comun es muy visible la diferencia entre los dos sexo, distinguién. dose los machos de lás hembras particularmente por cierto número de crestas ó verrugas mas 6 menos altas y numero sas que tienen junto á la embocadura del conducto seminal.

Distribucion GEOGRAFICA.-Los biénidos habitan todos casi exclusivarmente el mar; pocas especies se encuentran en aglias dulces á la vez que en las marinas. Como unos treinta géneros con mas de doscientas especies pueblan las costas maritimas de todas las zonas, siendo algunas de bastante importancia para la industria pesquera.

USOS, COSTUMBRES Y REGIMEN. - Todos son peces múy rapaces, algunas especies hásta malignas, morde. doras y por ende temidas de los pescadores. Se alimentan de otros peces $y$ de toda clase de invertebrados marinos, especialmente de gusanos y moluscos.

Varias especies de blénidos, no todas, son viviparas; otras construyen un nido $y$ cuidan solicitas las huevas. De esto parece resultar que en las primeras ha de tener lugar la fecundacion dentro del cuerpo, quizàs por medio de un coito, \& cuyo acto concurren tal vez los apénaices mencionados junto al extremo de los conductos seminales. No se sabe to. davia cómo se juntan los dos sexos 5 en particular cómo se comporta la hembra. Algunos naturalistas opinan con cierta razon que las hembras de los blénidos se fecundan como las salamanquesas de agua; es decir que el macho suelta la le. chada en el agua y alli es absorbida por las partés sexuales de la hembra Se multiplican rápida y considerablemente, pues en algunas hernbras se han encontrado hasta trescientos pequeñuelos. Otras especies hay que desovan del modo usual, pero el aumento de su coloracion exterior en esta épo. ca demuestra que el acto de la reproduccion ejerce en ellos una influencia notable.

Su género de vida es â poca diferencia el mismo que el de los discobolos y gúbidos; tambien se mantienen en gru. pos $\delta$ pequeñas bandadas sobre fondos peñascosos; pueden quedarse en seco en las mareas bajas, y les gusta ocultarse entre rocas donde acechan y se precipitan súbitamente sobre sus presas, etc. Ias especies mayores, cuya carne es blanca y agradable, son objeto de pesca.

\section{LOS TREPADORES - ANARRHYCHAS}

Gessner recibió una vez «del mar aleman un pez nucoso que los habitantes de aquel pais llaman klipffisch que significa pez de peria: esea porque sube á las peñas segun cuen. tan, ó porque vire entre ellas. Apoyándose en cste dato le dió el nombre de anarilsilhas, que quiere decir tripador. La ciencia ha conservado este nombre para designar el género, y para el pez citado con mas razon el de lobo marino.

CAR A CTERES. - Este género exeede ấ todos sus afines en tamaño y defensas. Su cuerpo es oblongo y comprimido; la aleta dorsal ocupa toda la parte superior aunque sin confundirse con la caudal, como sucede tambien con la anal, que es mas corta; las pectorales son grandes y las abclominales no existen. Como distintivo especial $y$ deterninante hay que mirar la dentadura, que es de lás mas terribles que ofrece toda la clase entera de los peces. Consiste en poderosos dien. tes cónicos insertos en las mandibulas y detrás de ellos varias filas de dientes cónicos romos en los huesos palatinos y en el rómer. La membrana branquial contiene seis radios.

\section{EL LOBO TREPADOR - ANARRHICHAS LUPUS}

CARACTÉRES,-El lobo marino (fig. I75) alcanza una longitud de dos metros, segun dicen; pero los que pasan de un metro son sa mus raros en los mares meridionales. El color es un amarillo oscuro en la parte superior de la cabeza, en los costados, en el lomo y en las aletas; las partes inferio. res son de un gris blanquecino; las aletas dorsal y anal tienen listas en número de nueve à once y cstán además salpicadas de puntos pardos como el resto del cucrpo. Hay setenta y cuatro radios en la aleta dorsal, veinte en cada torácica, cua. renta y seis en la anal, y die\% y seis en la caudal.

DISTRIBUCION GEOGRÁFICA.-En la Escocia sep. tentrional ya no es raro este pez; se le encuentra accidental. mente en varios puntos de las costas de Alemania, Dinamar. ca s Noruega; es comun al redecior de Islandia y de las costas de Groenlandia y de Laponia, y de alli se extiende, pasando por el estrecho de Behring, por las costas septentrionales del Pacifico.

USOS, COSTUMBRES Y REGIMEN.-Conforme á la indole de la familia, habita los fondos, y con preferencia los peñascosos, acechando oculto en sus grietas sus presas 6 bien las arranca de las piedras, porque se alimenta principalınente de crustáceos y mariscos, cuyas conchas quebrantan fácilmen. te sus terribles dientes. Es probable que persiga tambien pe. ces, porque nada con bastante velocidad, si bien serpenteando, para alcanzarlos. Durante el invierno habita los fondos á gran profundidad, en majo y junio se aproxima à las costas mas llanas para desovar, 5 algunos meses mas tarde se ven sus pequeñuclos de color verdoso en bastante número entre las algas.

No se ha dado a este pez su nombre de lobo á.causa de sus terribles dientes, sino por la furia indecible que se apo. dera de él cuando se ve amenazado. Su mirada tiene algo de protervo y traidor, y su Indole no la desmiente. Cuando se le coge parece loco furioso, trata de romper la red, y muerde todos los objetos que se le presentan con la destreza y rencor de la serpiente. Los pescadores se abstienen de cogerlo con las manos, y sin perder ticmpo le rematan con el remo $\delta$ el arpon luego que ven que ha caido uno en la red. No hacien. dolo así vive el lobo marino muchisimas horas meneándose y brincando dentro de la barca, porque puede tambien pasar largo tiempo fuera del agua y conserva su indole rabiosa hasta el úlitimo aliento.

Neill dice que se encuentran lobos marinos pequeños con frecuencia en la pescaderia de Edimburgo, donde al punto hallan compradores, porque las personas que no se dejan influir por su aspecto, alaban mucho su carne. Tambien se come en otros puertos del norte, pero es menester ciesollarlo prime. ro y no hacer caso del olor repugnante que despide, pues desaparece al guisarlo. Con la piel se hacen bolsas, 6 se cuece para cola de pez.

\section{LA BLENIA MARIPOSA-BLENNIUS OCELLARIS}

CARACTERES. - Este bonito representante de los 
peces mucosos propiamente dichos (fig. 173), vive en el Mediterráneo y se presenta tambien en las costas de Ingla. terma donde le llaman marifusa marina. Tiene forma oblonga, pero ventruda, cabeza gruesa, achatada por delante, por lo regular, con dos apéndices membranosos y la region malar abultada. La dentadura consiste eri dientes robustos, sencillos y colocados uno junto á otro, figurando el último como canino fuerte $y$ de gancho. La aleta dorsal se extiende por todo el lomo siendo los radios sencillos y Rexibles; las abdominales se reducen á dos radios. La longitud es de $0^{\mathrm{m}}, 15$, y el color del cuerpo pardo pálido con manchas irregu. lares oscuras; las aletas tord́cicas y abdominales son mas oscuras que las otras. Entre el sexto y octavo radio de la aleta dorsal hay una mancha recionda de color pardo oscuro con un anillo mas claro que el resto de la membrana. Difiere la aleta dorsal de la de sus congéneres por la prolongacion del primer radio que pasa por encima de los demás, y por el seno que forma en el décimo ú onceno radio. El número total de estos es veintiscis; cada torácica tiene doce, la abdo. minal dos, la anal diez y siete y la caudal once.

DISTRIBUCION GEOGRÁfICA.-En el Mediterráneo se encuentra el blenia mariposa en todas las costas pe. ñascosas, siendo por esta razon un pez conocidisimo; en el Atlántico parece ser mas raro, presentándose solo de cuando en cuando en número regular eu las costas de Inglaterra, donde fue observado la primera vez por Montagu como ha bitante de las aguas inglesas; Yarrell recibió repetidas veces estos blenias, y Thompson dice que durante algun tiempo han sido bastante frecuentes en la bahia de Weymouth.

USOS, COSTUMBRES Y RÉGIMEN.-Vive como sus congéneres junto á la orilla sobre las peñas y entre las algas, donde. caza cangrejos pequeños y moluscos. Desova en primavera. Su carne blanda y mucosa es sosa, por cuya razon solo la come la gente pobre cuando no tiene otro pescado.

\section{LAS ALONDRAS MARINAS - PHOLIS}

CARACTERES. - Gessner llama á estos blénicios alon. dras marinas, lo que autoriza el uso de este nombre siquiera para. designar un género ó sub.genero de la familia, tan afine del anterior que en el fondo solo difiere de él por la falta de los apéndices membranosos. Como representante de este género admitiremos la éspecie siguiente, conocida por

\section{EL ADONIS-PHOLIS IAEVIS Ó ADONIS}

CARACTERES. - Es pez muy frecuente en el Mediterráneo y en el Atlántico; en las cośtas de Inglaterra se le co: noce bastante, aun cuando no abunda. Alcanza $0^{\circ}, 15$ de longitud; su coloracion varia muchísimo segun el fondo que habita i otras circunstancias, tanto que Montagu, entre mas de veinte de estos peces que examinó una vez juntos, no pudo distinguir dos que se pareciesen en un todo; los habia que presentaban un dibujo elegante de manchitas de color pardo rojizo $y$ otros eran unicoloros sin dibujo alguno. En general puede decirse que sobre fondo de color verdoso es. tán salpicados y manchados de pardo. En la aleta dorsal cuéntanse treinta y un radios, en cada torácica trece, en cada abdominal dos, en la anal diez y nueve y en la caudal once.

USOS, COSTUMBRES Y REGIMEN.-Careciendo el adonis de vejiga natatoria, vive, segun Couch, en el fondo del agua, donde elige una piedra ó periasco á propósito, en cuyas grietas pueda refugiarse y salvarse de aves $y$ peces de rapina, si bien algunos cuervos marinos saben tambien sacarlo de estos escondrijos. En la marea baja se reunen estos peces entre las piedras ó en los charquitos; los mas viejos salen del agua, se arrastran bastante léjos con el auxilio de sus aletas torácicas, y se encaminan directamente con gran rapidez y destreza \& determinados huecos donde aguarda cada pez meticio en el suyo la vuelta de la marea. Cuando se les incomoda se meten mas adentro movienda el cucr. po de una manera especial. Montagu ya habia observado que el adonis tenia la vida muy dura, pudiendo vivir fuera del agua dias enteros sobre arena 6 musgo húmedo. Couch confirma este dato, añadiendo que ha conservado estos peces teniéndolos mas de treinta horas en una vasija de hojalata enteramente seca; en cambio les es fatal el agua dulce, donde mueren á los pocos minutos. Parece que para el adonis es una verdadera necesidad la permanencia temporal fuera del agua. Uno que Ross tenia cautivo en un acuario lleno de agua de mar, se puso a las pocas horas muy inquieto saltando repetidas veces a la superficie, lo que indujo al natu. ralista á colocar una gruesa piecira en el agua de modo que sobresaliese de ella, y.al momento salt6 el pez encima, per. maneciendo alli muchas horas en seco. Luego vió Ross que su prisionero observaba exactamente las mareas colocándose sobre la picdra cuando la marea empezaba á subir. Great. wood observó en estas mudanzas el cambio que producian en la coloracion del pez. Dentro del agua era el color pardo pálido, pero al aire libre se iba oscureciendo al tiempo que aparecia una hilera de manchas blancas en cada costado.

Sus dientes incisivos largos y robustos le permiten despren der de las rocas conchas y otros moluscos que constituyen su verdadero alimento; si bien parece que tampoco perdona á los animales que nadan libremente en el agua. Los que se han observado cautivos mostraron siempre mucho apetito, y uno que Guyon guardó cosa de seis meses, tragava con igual roracidad moluscos, arañas, cién piés, escarabajos, en una palabra todo articulado vivo, y además carne de mamiferos y de aves.

Bajo cierto punto de vista, es decir, bajo el de la facultad de poder mover cada ojo en las direcciones mas variadas, parécese el adonis á las platijas y especialmente al camaleon.

Desovan en verano cligiendo para esta operacion alguna pequeña cavidad en la roca, situada por lo comun un poquito mas alta que el nivel mas bajo de las aguas; $y$ alli depcsita sus huevas hemisféricas, brillantes y ambarinas que no tardan en trasformarse en pececillos.

\section{LOS CENTRONOTOS-CENTRO- NOTUS}

Los pescadores ingleses comparan una especic de blenidos con la quilla de una barca plana que en su idioma se llama grnnel; los suecos y noruegos comparan la misma es pecie con la hoja de una espada; asi es que aquellos llaman á dicho pez gurrell y estos per loja de ispada. En españoi el pez en cuestion es el gunelio, y el género \& que pertenece se llama rentronoto; que significa de dorso esfinoso. Brehm adop. ta para su idioma el de peces de hoja de cspada.

CARACTERES - Se distinguen por su cuerpo largo y comprimido lateralmente, cabeza pequeña, la aleta dorsal muy baja, pero ocupa el lomo en toda su longitud; la abdo. minal reducida \& un radio único; los dientes de púa en las mandibulas, de terciopelo en el palatino, el vómer y la lengua.

\section{EL GUNELIO COMUN-CENTRONOTUS GUNELIUS}

CARACTERES. - El gunelio habita los mares polar y germánico, encontrándose accidentalmente en el Atlántico 
hasta las costas francesas. Alcanza, segun dicen, una longitud de $0^{\circ}, 25$, pero por lo general no pasa de $0^{\circ}, 20$. El color dominante es una mezcla de pardo amarillo y de purpura, mas pálido en la garganta y vientre que en el resto; á lo lar. go del dorso hay de nueve á doce manchas redondas, bien marcadas y orladas de blanco y otras indeterminadas en el resto del cuerpo. Aquellas se hallan en algunos individuos en la aleta dorsal, $y$ á veces en la aleta y en el lomo. Setenta y ocho radios espinosos sostienen la aleta dorsal, once cada torácica; un radio rudimentario y otro completo cada abdo. minal; tres radios de los primeros y cuarenta y tres radios de los segundos la anal y quince la caudal. Hay que advertir empero que el número de radios de las aletas dorsal y anal es muy variable.

USOS, COSTUMBRES Y REGIMEN. - El gunelio al igual de todas las especies de su clase prefiere fondos pe: nascosos, pero á veces se le cncucntra en sitios cenagosos. En la marea mas baja se le ve echado en cliarquitos, debajo de piedras 6 entre las algas, como si alli aguardase la vuelta de la marea. No le incomoda la privacion de su elemento, pero no se expone al aire seco con la decision de sus afines, sino que procura meterse en sitios húmedos, en grietas y entre algas. Sús movimientos en el agua son rápidos y ágiles, lo que hace difícil apoderarse de el aun en charcos de poca agua; á esto hay que añadir la extraordinaria lubricidad de su cuerpo que no permite asirlo con fuerza; $y$ despues es bastante astuto para refugiarse en alguna grieta cuando se ve perseguido sériamente Se alimenta tambien de pequeños moluscos, cria de peces $y$ de huevas, si bien no parece ser tan voraz como otros afines suyos. No he podido encontrar dato alguno respecto á su reproduccion.

Muchios cnemigos tiene el gunelio entre los peces de rapi. ia $y$ aves marinas; los cormoranes y colimbos le persiguen durante la marea alta, $y$ las gaviotas con sus afines durante la baja. Dicen que el coto marino (A. scorpus) es su enemigo mas terrible; habita los mismos sitios que el, y no tiene consideracion alguna a su indefenso vecino. Poco tiene que temer del hombre, no porque su carne sea mala sino por'su pequeñer, que no compensa el trabajo de cogerlo. I os groen landeses suelen pescar el gunclio para secarlo para el invierno, y los pescadores en general lo emplean para cebo destinado a peces mayores, cuando no disponen de otra cosa mejor.

\section{EL ZOARCE VIVÍPARO-ZOARCES VIVIPARUS}

CARACTERES.-Este pez (fig. 174) anguiliforme y re. presentante del género Zoarces, merece una atencion especial por pertenecer al reducido número de los peces viviparos; esto es, á los que paren pequeñuelos perfectamente desarrollacios y vivaces. Los distintivos del género consisten en el cucrpo oblongo, un tanto comprimido lateralmente, escamas diminutas como simples puntas, aisladas y diseminadas de. bajo de la piel, la aleta dorsal que se extiende casi por todo el lomo; la abdominal inserta en la garganta $y$ formada solo de dos hasta tres radios; las pectorales largas y estrechas; y la anal que ocupa la mitad de la parte inferior y que se con. funde como la dorsal con la caudal. I os dientes cónicos forman hilera simple en cada rama de la mandibula; el paladar y la lengua carecen de dientes. Ia membrana branquial contiene seis radios. Tambien merece ser citada una pequeña verruga detrâs del ano, la cual encierra los conductos para la lechada y las huevas. Se hincha en la época de la freza y parcce servir de aparato sexual en la fecundacion, si bien no se han hecho todavia observaciones fijas sobre este punto. La longitud del pez oscila entre $0^{\prime \prime}, 20^{\circ}$ y $0^{\circ}, 40$, pero los de esta última medida son rarisimos. El color general es un pardo pálido con manchas y listas mas oscuras en el dorso y en los costados y que desaparecen hácia el vientre. Las listas se repiten en la aleta dorsal, mientras que las torácicas y abdominal son unicolores. Entre las aletas dorsal, caudal y anal cuéntanse como doscientos radios; en cada torácica diez y ocho y en la abdominal tres radios blandos; la distribucion de los radios entre las tres primeras es aproximadamente de ciento nueve para la dorsal, de ocho á diez para la caudal y unos ochenta para la anal.

DISTRIBUCION GEOGRAFICA.-Hasta ahora se ha encontrado al zoarce solo en los mares septentrionales, par. ticularmente en el mar del Norte y el Báltico y en el Canal; no se menciona entre los peces de Islandia y de Groenlan. dia. Sube en casos excepcionales rios arriba, pues se ha cogido junto a Spandau en el Havel. Es frecuente en los sitios á propósito para él en las costas de Iuglaterra, y bastante conocido en el Báltico.

USOS, COSTUMBRES Y REGIMEN.-Prefiere los puntos pedregosos y en general liene las mismas costumbres que sus afines, tal vez con la única diferencia de que se oculta mas entre las aigas. Se alimenta de pececillos, conchas, gusanos y freza.

Por el tiempo del equinoccio son todavia muy pequeñas las huevas; a mediados de mayo ya han aumentado bas. tante, se han vuelto encarnadas y blandas, y presentan ya dos puntitos, que son los ojos del cmbrion envuelto en una membrana especial dentro del huevo. Hácia el otoño han adquirido los embriones todo su desarrollo y nacen uno tras otro, saliendo de cabezz por la abertura del oviducto como peces completos. Yarrell observa con mucha razon que basta la presion mas tenue para hacer salir los pequeñuclós de una hembra en el último estado de gestacion, y que hasta pudo extraerlos de una de estas hembras que con. servaba hacia meses en espiritu de vino. A veces se atrasa el desarrollo, tanto que el parto no ticne lugar sino en febrero. Los pequeñuelos miden al nacer $0^{ \pm}, 03$, pero pueden tener casi doble longitud si la hembra es muy grande. Al nacer son ya muy viraces, pero todavia tan trasparentes que es fácil observar en ellos la circulacion sanguinea con una lente de aumento. Crecen con tanta rapider que á los quince dias tienen ya una longitud tres veces mayor que cuando na. cieron.

Es fácil observar el parto de las hembras en viveros de agua salada acondicionados á propósito. Pocas hnias antes se va el pez, indolente de si, á un sitio determinado donde queda inmóvil hasta que todos 6 por lo menos la mayor parte de los pequeños han salido. Estos nacen de cabeza en rápida sucesion cayendo á derecha é izquierda de la madre, que alza algun tanto la cola, al fondo, donde permanecen unas cuantas horas, quizás un dia casi sin moverse. Cuando hay varios de cstos peces en un mismo depósito, se observa con gran admiracion que dos 6 mas se acercan \& la hembra comprimiéndola con sus cuerpos por los dos lados, es decir que hacen realmente el oficio de comadrones, por supuesto para devorar los pequeños á medida que nacen; cosa que hace tambien la propia madre si no se la ha dado antes mucho alimento. Casi siempre pare toda la cria de una sola vez sin intervalo alguno, pero tambien hay casos en que paren primero cierto numero, y uno 6 mas dias despues otra serie, ó bien todo el resto.

Ios zoarces no tienen importancia para la industria pes. quera, aunque se tenga su carne por sabrosa y se vendan en algunos puntos en las plagas. Por la coccion toman los hue. sos un color verde, por cuya circunstancia llaman á este pez en algunos puntos: hueso zerite. 


\section{EL COMEFORO DE BAIKAL-COMEPHORUS BAIKALENSIS}

CARACTERES.-Esta especie, presentada por Guenther como representante de la familia de los comefóridos, se pa. rece por muchos conccptos á las caballas ó escómbridos; pero difiere de ellas por su esqueleto blando, y por el número de vértebras, es decir ocho torácicas y treinta y cinco caudales. En general se asemeja á los calionimidos, distinguiéndose de ellos por tener el cuerpo comprimido lateralmente la cabeza grande con boca ancha y aplanada; la prolonga cion de varios radios de la segunda aleta; las torácicas muy grandes, la ausencia de las abdominales, y la caudal bifur cada. Se cuentan ocho radios en la primera dorsal, vein tiocho en la segunda, quince de los cuales acaban en hilos largos y delgados como cabellos; trece en cada torácica; treinta y dos en la anal y trece en la caudal. Ia cabeza, apla. nada por encima y los costados, lleva en la region temporal dos pequehas protuberancias. La dentadura consiste en dientes ganchudos pequeños y puntiagudos, colocados en las mandibulas, vómer $g$ hueso palatino. La membrana branquial tiene seis radios. El color es de un verde sucio uniforme y la longitud de unos $(1), 30$.

USOS, COSTUMBRES Y REGIMEN.-EI comeforo habita, por lo que se sabe hasta hoy, exclusivamente el lago Baikal, eligiendo en invierno los sitios mas profundos, y aproximándose en verano en grandes masas á la costa para efectuar el desove. Nada con extraordinaria rapidez, y puede dar grandes saltos fuera del agua con el auxilio de sus aletas pectorales muy grandes, por manera que bajo este concepto se asemeja á los peces voladores; mas á pesar de esto no puede resistir al cmpuje de las olas en las grandes tormentas

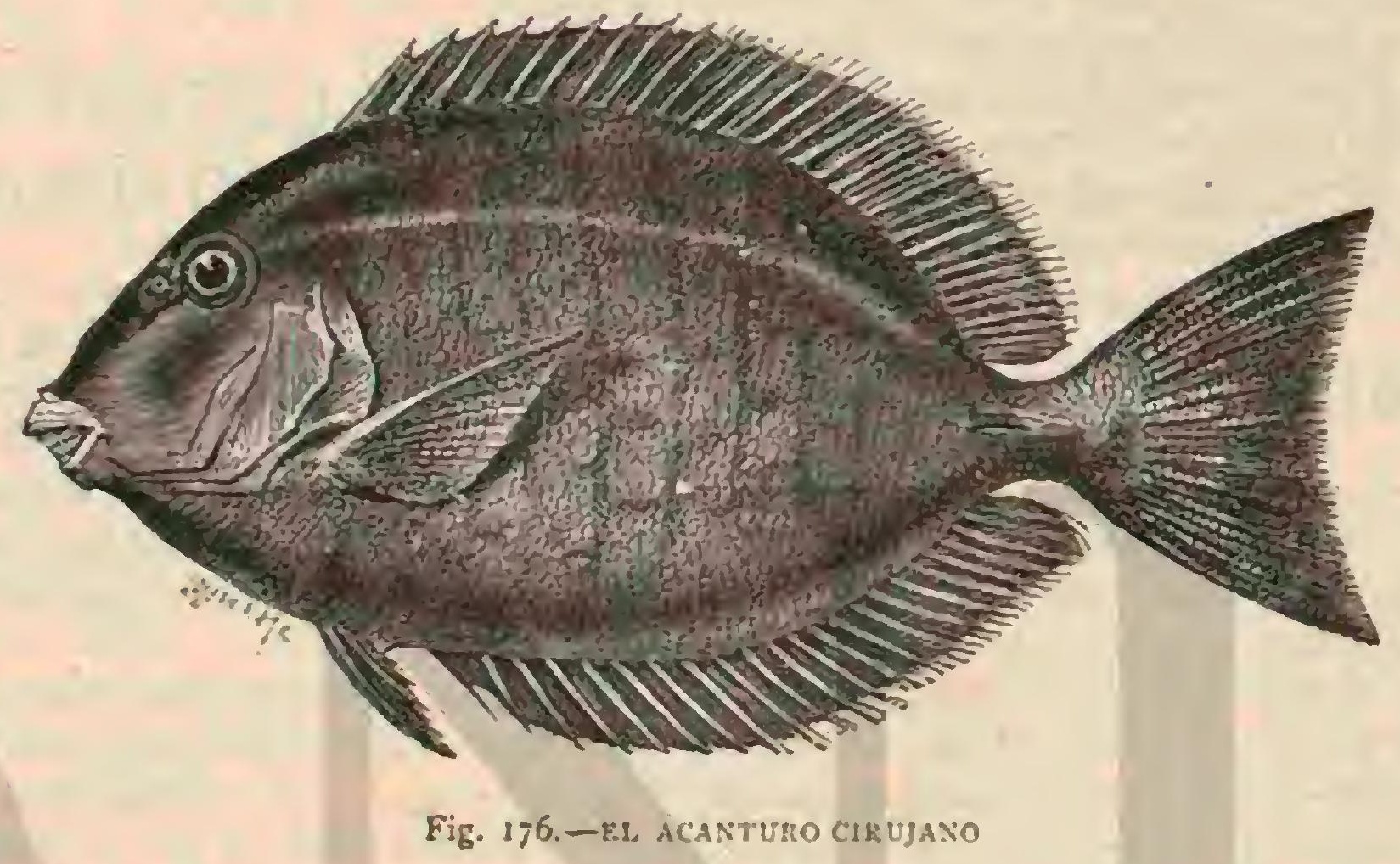

que le arrojan á la playa, donde los habitantes le recogen con afan considerándole como una fuente de aceite, que extraen de él prensándole.

\section{LOS TRAQUIPTÉRIDOS -TRACHYPTERIDE}

CARACTERFS,-Los peces de esta reducida familia, de la cual conocemos unas diez y seis especies, ofrecen un aspecto por demás extraño. Hasta ahora no han podido deter. minarse bien los caractéres que separan esta familia de las demás por la razon de que conocemos muy poco los singu. larisimos individuos que la constitujen y cuyos distintivos son los siguientes: cuerpo desnudo, muy largo, alto $y$ tan comprimido por los costados que parece una cinta; la cabeza y la boca son relativamente pequeñas, los ojos saltones; las aber. turas branquiales anchas y con seis radios; la aleta dorsal se extiende desde la cabeza hasta el extremo de la cola, la sos. tienen radios inarticulados, y tiene la parte anterior muy desarrollada; las abdominales están insertas en la region to. rácica, y la caudal, muy menguada, no se halla en la prolongacion del eje del cuerpo; los dientes son débiles, las verte. bras numerosisimas, y los huesos blandos.

USOS, COSTUMBRES Y REGIMEN.-De la rareza extraordinaria de estos animales puede inferirse que han de vivir a considerables profundidades. Es de suponer que ha. bitan todos los mares $y$ que son mas numerosos de lo que se cree, solo que no abandonan sus regiones profundas para acercarse á capas superiores y á las costas sino en el tiempo de la freza. Es muy raro que se coja algun individuo de esta familia, y mas raro que llegue á manos del naturalista; por cuya razon solo se han podido examinar pocas especies y es. tas muy imperfectamerite, por lo cual ignoramos las diferen. tes fases de su desarrollo y sus costumbres.

\section{EL PEZ-CORREA - REGALECUS BANYSII}

CARACTERES.-En 23 de febrero del año i j88 fué arrojado a la costa de Inglaterra un pescado de $2{ }^{\circ}, 50$ de longitud y $0^{m}, 24$ de altura por $0^{\circ}, 06$ de grueso $y$ un peso de veinte kilógramos. Nunca habian visto semejante pez los pes. cadores de aquuella costa, pero le llamaron pez-correa. En 18 de marzo de 1796 encontraron unas mujeres otro pez de la misma especic de mas de $4^{\circ}$ de largo, $0^{\circ}, 3^{\circ}$ de alto y $0^{\circ}, 08$ de grueso. Desde entonces las olas han arrojado repetidas reces estos animales á la costa, entre otros algunos de casi seis metros de longitud, pero sin que hubiese sido dable de. terminar si todos eran de una misma especie. En el fez-correa tiene la cabeza una longiiud igual á la décimasexta parte de la longitud total, y la altura del cuerpo la décimatercia. lil hocico es achatado, $y$ la hendidurs de la boca, desprovista de dientes, es vertical; la mandibula superior puede correrse. El ojo, grande y colocado en el costado hácia delante y arriba, ocupa nada menos que la sexta parte de la longitud de la cabeza. A lo largo del vientre corre una orla membranosa. De la aleta dorsal, que se extiende por toda la longitud del cuerpo, se levantan de doce \& quince radios encima de los demás, otros doscientos sesenta y cuatro hasta doscientos noventa se inclinan en la parte posterior hácia atrás ensan. 
chándose de paso en la cabeza hasta tener un grueso doble de los primeros; unos van unidos hasta la punta por una memorana, otros están libres, mientras que los radios bajos sostienen una aleta de una anchura igual en todas sus partes; cada aleta torácica tiene once radios, cada abdominal solo uno muy largo y puntiagudo. Iil cuerpo está cubierto de nu. merosos escudetes angulosos, de los cuales los mayores estan sobre cuatro aristas salientes que corren á lo largo de cada costado del cuerpo, mientras los menores se hallan distribuidos con irregularidad. Il color es blanco con brillo plateado, y el dibujo consiste en listas oscuras interrumpidas. Las aletas son anaranjadas.

USOS, COSTUMBRES Y REGIMEN, - Por supuesto, nada se ha podido observar respecto A su género de vida. Dicese que ciertas especies alines, que viven en el Mediterrá. neo, se mueven con gran viveza y que pueden pasar bastante tiempo fuera del agua, Los autores que de ellos hablan no encuentran palabras para pintar su hermosura, pues cuando en tiempo de calma se acercan á las costas parecen cintas de plata guarnecidas de flecos encarnados ó de piedras precio. sas, que serpentean con movimiento siempre variado en el mar. Iambien dicen que su carne tiene mal sabor y que se corrompe con extraordinaria rapidez, por cuya razon no se los persigue.

\section{LOS TRAQUIPTEROS - TRACHYP- TERUS}

CARACTÉRES. - Tan escasas son las noticias que te. nemos acerca de este género como sobre el anterior. Is ale. ta dorsal ocupa tambien toda la longitud del cuerpo; no fal tan las torácicas, pero siempre muy pequeñas; en cambio las abdominales están en algunas especies muy bien desarrolla. das, pero en otras se reduce cada una \& un radio largo con trozos de membrana á manera de banderola; la aleta caudal, cuando existe, no tiene forma determinada. Además pueden servir de distintivo la boca pequeña y prolongable, y la man dibula supcrior que se cnsancha hácia atrás formando una placa que cubre las mejillas. La piel parece a simple vista desnuda por cubrirla escamas casi imperceptibles; el estó mago tiene forma de bolsa; los numerósisimos apéndices del piloro forman reunidos una verdadera glóndula, y falta la ve jiga natatoria.

Los iraquipteros tienen dos aletas dorsales; la primera, sostenida por radios espinosos, empieza casi sobre la frentey se prolonga considerablemente por encina de la segunda que es mas baja; la caudal, en forma de abanico, va dirigida hácia arriba; las pectorales son muy pequchas, las abdominales largas y en forma de abanico, y la anal no existe. Ia linea media del cterpo está protegida por escudetes peque nos y por espinas. Las mandibulas tienen dientes bastante visibles, $y$ la membrana branquial seis 6 siete radios.

\section{EL TRAQUÍPTERO ÁRTICO-TRACHYPTE- RUS ARTICUS}

CARACTÉRES. - Los ingleses han dado el nombre de pez-viruta á un pescado cogido varias veces en sus costas y que representa el grupo de los traquipteros. Habita al parecer los mares septentrionales, siendo solo su longitud $I^{\circ}, 50$, su altura $0^{m}, 20$ y el grueso solo $\left(0^{\circ}, 02\right.$, por manera que verdacieramente parece una astilla $\delta$ viruta ancha. La coloracion es de un blanco de plata en la cabeza y el cuerpo, la primera algo veteada de gris; en cada costado hay dos manchas ovales colocadas oblicuamenie; las aletas son de un encarnado claro. En la alcta dorsal hay ciento setenta y dos radios, en cacia pectoral de diez á once, y en cada abdomi. nal scis.

USOS, COSTUMBRES Y RÉGIMEN.-Fil pez-viruta, que hasta ahora se ha encontrado ínicamente en mares sep. tentrionales, se halla representado en el Mediterráneo por especies muy afines. Se supone que tambien babita las gran. des profundidades $\mathrm{y}$ que solo por casualidad se acerca á las costas, con preferencia donde hay playas arenosas. A reces el mar arroja uno lí otro á la costa, sobre todo \& las de Is. landia y Escandinavia, pero aun alli es este pez considerado siempre como una rareza. Olafien dice que los islandeses le tienel por venenoso, por haber observado que los cuervos no le comen. Lo que es muy particular en este animal es su cualidad de quebrarse con extraordinaria facilidad; pues el mismo pez puede con un esfuerzo de sus músculos reducirse a pedazos como la vibora vidriosa; y los radios de sus aletas parecen mas bien formados de vidrio muy frinble que no de cartilagos.

\section{LOS ACRONÚRIDOS- ACRONURIDE}

CARACTERES.-Estos peces tienen el cucrpo ovalado, muy comprimido y cubierto, bien de una piel coriácea ó de pequenas escamas solidamente unidas al cuerpo; la boca es pequeña y las mandibulas armadas de una fila sencilla de dientes. Todas las especies tienen solamente una aleta dorsal, muchas espinas afiladas al lado de la cola, y prolonga. ciones especiales en la parte superior del hocico. Hay cinco radios branquiales.

Un rasgo caracteristico muy importante ha sido descubierto por. Doenitz en la estructura del esqueleto de las ale. tas dorsal y anal, cuyas articulaciones encadenadas difieren en los primeros radios de las de otros peces, por permitir que el segundo radio se eche sobre el primero. Con esta dis. posicion puede el pez apuntalar la aleta cuando la tiene enhiesta, pero necesita á su ver de un músculo inserto en este segundo radio para doblar y bajar la aleta.

Se conocen unas setenta especies de esta familia, todas las cuales habitan la zona tórrida, y cn su mayor parte el Océano Índico. Su alimento parece consistir exclusivamente en algas ú otras plantas marinas. Varias especics son objeto de pesca, pero su carne no tiene fama de sabrosa y solo la consumen los indigenas de color de aquellas costas.

\section{LOS ACANTUROS- AGANTHURUS}

CARACTERES. - Los rasgos caracteristicos de cste ge. nero, que habita los mares cálidos de ambos hemisferios, consisten en sus dientes incisivos de borde recto, y en un aguijon ó espina movible y afiladisima ś cada lado de la cola, y que causa gravisimas heridas. La cubierta consiste en escamas muy pequeñas. Representa el género la especie bas. tante conocida de:

\section{EL ACANTURO CIRUJANO-ACANTHURUS CHIRURGUS}

CARACTÉRES.-Este pez (fig. 176) alcanza una longi. tud de $0^{\circ}, 20$ á $0^{\mathrm{m}}: 30$; su color es pardo oscuro ó amarillento con varias fajas oscuras y verticales en cada costado; líncas negras en la alcta dorsal de fondo mas claro; las abdomina. les son negras, la caudal amarillenta con orla mas oscura. Nueve $y$ veintidos ó veintitres radios sostienen la dorsal; quince cada torácica; veintidos 6 veintitres la anal y diez y 
seis la caudal. El aguijon afiladisimo y fuertemente comprimido, de cuya base sale otra punta pequeña, se mueve en una articulacion, de suerte que el pez puede llevarlo echado hácia delante dentro de una ranura $\delta$ vaina cuando así le conviene.

DISTRIBUGION GEOGRÁFICA.-El trea de disper sion del cirujano no parece pasar mucho del mar de las Antillas, donde es pez comun en todas partes, conocido de todos los pescadores $y$ habitantes de la costa y temido casi al igual de las serpientes venenosas, porque las heridas que causa con su aguijon no solo producen violentos dolores, sino que son dificiles 5 lentas de curar.

USOS, COSTUMBRES Y REGIMEN.-Dicen que todos los peces de rapiña huyen del cirujano \& causa de su terrible aguijon, á excepcion de la picuda cuya tremenda dentadura se burla de él. En cambio hiere frecuentemente á otros individuns de su misma especie, como sucede tambicn con otra afine que habita el mar Rojo, dondelos pescadores cogen á veces dos acanturos que se han clavado uno al otro su aguijon y no pueden desprenderse. No es el cirujano ob. jeto de pesca expresa; su peso raras veces pasa de medio kilógramo y su carne es tan poco apreciada que á nadie se le ocurre cxponerse inútilmente a heridas dolorosisimas.

\section{LOS NASONES - NASEUS}

CARACTÉRES. - Siquiera por su figura singular no quiero dejar de mencionar este género tan afine del anterior. Su rasgo caracteristico, si bien no lo tienen todas lás espe cies, consiste en un cuerno voluminoso y muy saliente que lleva sobre la nariz. Por otra parte no tienen mas que cuatro radios branquuiales; la piel es coriácca y desnuda; foliculas cortantes reemplazan los aguijones al lado de la cola, y los dientes son cóniços.

\section{EL NASON UNICORNIO-NASEUS UNICORNIS}

CARACTERES. - El nason mide de $0^{\circ}, 2,4$ á $0^{\circ}, 60$, y su cuerno como $0^{\circ}, 0 \$$; lleva á cada lado de la cola tres protu. berancias huesosas ovoideas con una placa triangular muy cortante. Su color es ceniciento mas 6 merios vivo, y las ale tas dorsal y anal están orladas de azul; aquella tiene seis ra dios duros y veintisiete blandos y esta dos duros y veinti ocho blandos; cada abdominal uno espinoso y tres blandos, cada torácica diez y ocho y la caudal dier y seis.

DISTRIBUCION GEOGRÁFICA. - El nason se en cuentra en todas partes desde la isla de Mauricio hasta Djeddah en la costa del mar Rojo, donde abunda en algunos puntos.

USOS, COSTUMBRES Y REGIMEN. - A veces se le ve en bandadas de algunos centenares en la proximidad de islas, acaso en sitios de poca agua, pues siendo estos los que le proporcionan su alimento no es natural que se alcje mu cho de cllos. En Djeddah es donde se le pesca con mas trecuencia en grandes trainas, $y$ en algunos otros puntos con renablo, segun se dice. El anzuelo es completamente ineficar, porque este pez no muerde ningun cebo, sino que pace literalmente. Se le sala, pero solo para el consumo de la clase pobre, porque para la mesa de las personas acomodadas liene el Océano Índico mejores peces que este.

\section{LOS LABERÍNTICOS- LABYRINTHICI}

Aristóteles habla de peces que se encuentran junto á He- raclea Póntica, que al secarse los rios 6 lagos se meten en busca de humedad dentro del fango, donde quedan aletar. gados mientras la superficie se ra endureciendo, pero que se mueven cuando se los interrumpe en su reposo. "De esta manera es, dice Teofrasto, ampliando los datos de su maestro, como estos animales se reproducen. Dejan su freza en. terrada profundamente en el cieno para que se desarrolle cuando se vuelve a llenar otra vez de agua el lecho deseca. do. Así es que hay peces en India que al veces abandonan los rios y atraviesan como las ranas el pais para buscarse otras aguas.

Esto es lo que dicen los excelentes autores antiguos cuyos datos eran creidos por algunos \& principalmente por los griegos, y puestos en duda por la mayoria y en especial por los romanos. Séneca, por ejemplo, se burla de los datos de Tcofrasto diciendo que en adelante serí menester ir á pes. car con cl azadon en lugar de la red; pero lu dicho por los citados autores muestra el celo y exactitud que empleaban en sus observaciones, y no cabe duda que debieron enterar. se de estos detalles durante la campaña asiatica de Alejan. dro Magno, pues es un hecho que hay peces en India que se trasladan a otras aguas cuando quedan en seco los lechos que habitan, y que con tal motivo atraviesan tierras, ó se hunden en el fango, donde quedan muchos meses aletarga. dos hasta que la época de las lluvias los llama a nueva vida.

Desde luego hay que admitir que estos peces deben tener una organizacion especial diferente de la de otros peces. Verdad es que no tienen puimon, pero si otros brganos que, si no reemplazan \& este aparato respiratorio, lo representan y suplen en parte. Los peces que se sacan del agua mueren porque se sccan sus agallas que, en este cstado, inipiden la circulacion sanguinea, exactannente como se ahoga cualquuier animal vertebrado superior cuando se le estrangula; en los peces es tanto mas rápida la muerte cuanto mas grande la abertura branquial y cuanto mas fina la ramificacion de las agallas. Los hay cuya muerte es poco menos que instanta. nea fuera del agua, mientras que otros subsisten vivos horas enteras, y nuestras carpas pueden remitirse a grandes distancias si van envucltas en paños mojados. Ahora bien, lo que sor en este caso los paños húmedos para las carpas, son pa. ra los peces laberínticos de que hablan Aristóteles, y "eo. frasto, unas celdillas especiales muy ramificadas, de paredes foliculares, situadas en la faringe, que se llenan de agua en el acto de la respiracion $y$ la ceden poco á poco déspues á las foliculas branquiales, con lo cual conservan estas su hu. medad; la circulacion sanguínea queda despejada y el ani. mal vive. La misma cstructura se observa en otra familia que frecuentemente se ha reunido at la de los laberínticos; y cu. yos miembros gozan por consiguiente de las mismas ren. tajas.

CARACTERES. - Ios laberínticos tienen el cuerpo oblongo y ovoidco, aletas dorsal y anal por lo comun muy largas y cubiertas de escamas en sus paries blandas y radia. les, y aletas abdominales, ya regulares, ya con el primer radio muchisimo mas largo que todos los demás $y$ que los re. cmplaza en parte.

DISTRIBUCION GEOGRÁFICA.-Todas las especies de esta familia pertenecen al mundo antiguo, habiéndose encontrado hasta ahora mas especialmente en la India, en los paises limirrofes y en el Africa meridional, siendo proba. ble que tambien se hallen representadas en el Africa central.

\section{LOS ANABAS-ANABAS}

CARACTÉRES.--Se distingue este gencto por su cuetpo ovalado, poco comprimido lateralmente; preopérculo ci: 
cloideo $y$ opérculo aserrado; tiene en las mandíbulas dientes pequeños, asi como en la puntà y parte posterior del vó. mer; las aletas dorsal y anal son muy largas, y su parte anterior está distendida por muchos radios robustos y puntiagudos; las aletas pectorales, abdominales y anal son algo reducidas, pero bien formadas.

\section{EL ANABAS SENAL-ANABAS SCANDENS}

Caracteres. - Este pez (fig. 1,i) Hlamado pamieti ó senal por los tamiles, carcya por los cingaleses, coi por otras naciones indicas, alcanza una longitud de (1), 15 próxi. mamente; su color es en el lomo verde pardusco y en el vientre amarillento; las aletas dorsal y anal son moradas, las torácicas y abdominales rojizas y la caudal del mismo color que el dorso. Hay individuos que no presentan dibujo algu. no, otros tienen listas oscuras y manchas mas claras. Las alc. tas dorsales están sostenidas por diez y siete radios duros y diez blandos, la anal por once espinosos y diez blandos, cada torácica por quince, cada abdominal por seis, y la caudal por dicz y seis.

DISTRIBUCION GEOGRÁFICA. - No han podido fijarse todavia los limites del área de dispersion de este pez, atendido a que en la India y paises limitrofes se encuentran varias especies muy semejantes.

USOS, COSTUMBRES X REGIMEN.-Dos viajeros árabes, Soliman y otro cuyo nombre se ignora, que recorrieron la India a fines del siglo $\mathrm{Ix}$, oyeron alli hablar de un pez que salia del agua, y se dirigia por tierra á los cocote. ros, á los que subia para beber el vino de palmera, regre.

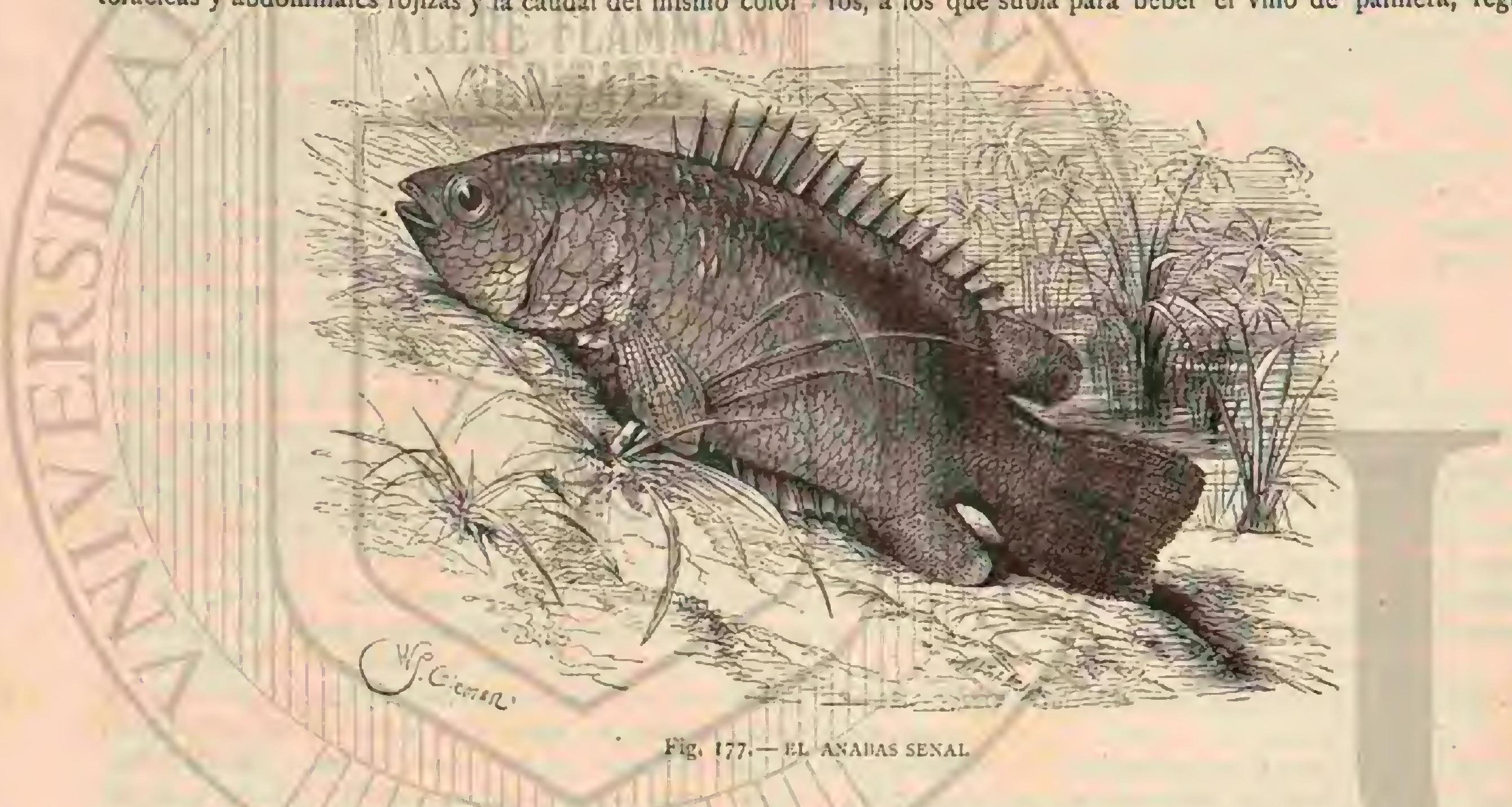

sando despues al agua. No se dice si volvia curio ó no. Nueve siglos despues menciona un tál Daldorf al mismo pez, y describiéndolo dice haberlo encontrádo en Tranque. bar en el momento en que subia por el surco de una palmera no'léjos de un estanque, agarrándose con las espinas de sus opérculos extendidos á los dos lados del surco; añade nue movia la cola de una parte á otra, y apoyándose con las cspinas de la aleta anal en la corteza del arbol, iba adelantando un poco; despues volvia á apoyar los opérculos y repetia los movimientos indicados y continuaba subiendo. Cuando se le cogió, siguió corriendo por el arenoso suelo de un pórtico.

El misionero John, que recorria tambien la India para predicar el Evangelio, obturo varios de estos peces y con ellos el honor de que su nombre figurara en los libros científicos. Mandó cinco de estos atrepadores á Bloch, diciéndole en su carta que este nombre era la traduccion del que el pez tenia en el idioma de aguel pais, porque efectivamente tre. paba á las palmeras mientras corrian las gotas de lluvia por sus troncos, auxiliándose en la subida con sus opérculos. aserrados y aletas punzantes; y que podia vivir muchas horas fuera del agua arrastrándose con extrañas contorsiones de su cuerpo. Por lo demás, decia que vivia en el cieno de los estanques, donde se le cogia para que figurase como plate escogido en la mesa.

Nada dicen del trepador los viajeros y naturalistas poste riores, $y$ hasta algunos niegan lo dicho por Daldorf y John, ya disculpándolos, ya satirizándolos, pero están conformes con cllos en lo de las excursiones terrestres del senal, con lo cual confirman tambien lo dicho por Aristóteles y 'Teofrasto respecto ś su costumbre de ocultarse en el fango de los lechos de rios y de balsas secas. Tennent, que recientemente ha hecho ó por lo menos reunido observaciones exactas sobre este animal, da detalles fidedignos sobre sus costumbres.

Entre otros le cscribe un tal Morris, representante del go. bierno en Trinconomali, diciendo: "Hace poco que estuve ocupado en inspeccionar las riberas de una gran laguna cuyo dique necesitaba un arreglo. El agua toda se habia eva. porado hasta reducirse á un pequeno charquito y el lecho restante estaba seco. Hallándonos en un punto mas elevado para dejar pasar una tormenta, observamos en el borde del charquito un pelicano que se estaba hartando con marcada satisfaccion; llamó esto la atencion de los indios que nos acompañaban y en scguida corricron al sitio gritando: (peces, peces $\$$ Fumos alla y vimos una multitud de peces arras. trándose por los surcos que la lluvia habia abierto en el fango, y por la yerba.

- Apenas los cubria el agua, á pesar de lo cual adelantaban bastante. Los hombres que nos acompañaban recogieron como dos fanegas, casi todos a una distancia de treinta metros del charco donde se esforzaban en subir el dique como lo habrian conseguido sin duda, y bajando luego por el otro lado habrian llegado a la próxima balsa, si no lo hubiesen impedido, primero, el pelícano, y despues mi gente. No po. 
dia dudarse que eran de la misma clase de los que se encuentran en las balsas secas.

* Cuanto mas se seca y disminuye el agua en alguna par. te, mayor número de peces se va aglomerando en los peque. ños charcos $y$ baches que quedan, 6 en el fango húmedo; allí se pueden ver entonces à millares, moviéndose en el barro semi-líquido, y cuando este se seca â su vez, emigran en busca de otra balsa con agua. En cierto punto vi yo centenares de ellos, que habian abandonado una de estas balsas, moviéndose y dispersándose en diferentes direcciones adelantando siempre á pesar de las dificultades y obstáculos que se les oponian. La balsa citada habia servido hasta entonces de abrevadero à los animales domésticos y silvestres de las cercanias; y seca como estaba, se veia la superficie cubierta de huellas de pisadas, algunas bastante profundas, en las que caian los peces y de donde no tenian medio de salir, por manera que los milanos y corncjas celebraban alli un verdadero festin. Creo firmemente que estos peces solo viajan de noche, pues cuando yo los he observado andando ha sido siempre en las primeras horas de la mañana, y tam. bien los que recogi para conservarlos vivos en cubas, es. taban de dia muy quietos, y de noche hacian esfuerzos para escaparse, como en efecto lo lograron repetidas veces.

s'Tengo que mencionar todavia otra particularidad de estos peces que pueden llamarse trasinumantes, la cual consiste en que tienen las agallas abiertas.

Gracias á las investigaciones de Tennent, sabemos ahora que los anabas son los mismos peces que se retiran y entierran en el fango. Antes de hacerlo habrian buscado agua, 6 quizás, renunciando desde luego á encontrarla, se habrianin. troducido en el fondo en busca de humedad, taladrándolo con el hocico. De los datos que pudo recoger Tennent resulta que se meten hasta medio metro $\mathrm{y}$ aun mas en el fon. do, segun sea su consistencia. La capa superior se agriera por la desecacion y se pone tan seca y quebradiza que se reduce á polvo cuando se la toca, pero á la profundidad en que están los peces hay siempre alguna humedad, aunque ni esta les es indispensable para conservar su vitalidad.

La gente del pais, que conoce muy bien esta costumbre del pez, va á los estanques cuando están secos y cara en los puntos mas hondos, por manera que realmente pesca con cl azadon en lugar de red, $y$ la pesca no es menos abundante por esto. Ios peces están aletargados, pero al notarse libres de su envoltura cmpiezan á moverse en seguida.

$\Lambda$ sl sc cxplica por qué los ceilaneses se apresuran á ir á pescar luego que ha caido la primera lluvia y a las pocas horas ó cuando mas á los pocos dias de haberse llenado de agua las balsas y cstanques, sirviéndose de un cesto de mimbres sin fondo que introducen á manera de tubo con sus puntas \$a. lientes en el agua y cogen con las manos los peces que pue. den entrar en el desde el fordo, repitiendo esta operacion á medida que van avanzando por el agua. Buchanan ya dijo que los peces laberinticos pueden conservarse vivos cinco 6 seis dias en vasijas vacias, por cuya razon los compran tambien los juglares para enseñarlos á los habitantes de las ciudades grandes poco al corriente de las cosas de la naturaleza.

\section{EL. MACROPO COMUN-MACROPUS VIRI- DIAURATUS}

Los macropos solo son conocidos como peces domésticos y de adorno; quizás no sean mas que resultado de un conti. nuado cultivo por parte del hombre, y traigan su origen de una especic de poliaiantus (poliannthus) segun suponen muchos naturalistas; pues nada se sabe acerca de ellos en esta. Tозо $\mathrm{V}$ do libre. Lo único de que se tiene noticia es de que son muy comunes en China, donde se les tiene co las casas como peces de color, con la diferencia de que se reproducen con mas facilidad que estos, además de que su cualidad de vivir en el agua mas pobre de oxígeno y aun veinte minutos fuera de ella, les hace mas propios para peces domésticos que todos los demás animales de su clase; basta decir que Ge. raud trajo veintidos de estos peces vivos de ciento que $\mathrm{cm}$. barcó en China, los que no pudo cuidar durante tan larga travesía, ni alimentar convenientemente, ni darles el espacio necesario. A estos veintidos debemos todos los peces del paraiso $\delta$ macropos que viven en nuestros acuarios y globos, despues que Carbonnier logró que se reprodujeran.

CARACTERES. - El cuerpo es oblongo y comprimido lateralmente; la dentadura, limitada a las mandibulas, con. siste en dientes pequeños. Trece radios espinosos y sietc blandos sosticnen la aleta dorsal; diez y sicte ó diez y ocho duros y quince blandos la anal y uno espinoso muy prolon. gado y cinco blandos cada abdominal. La caudal es muy grande, bilobular y de forma de media luna. El color, pardusco en la parte superior, pasa á verde gris en la inferior, y el dibujo consiste en fajas trasversales alternativamente verdes amarillas $\delta$ azuladas y rojizas; los opérculos son vicres con borde amarillo. Las aletas de la hembra son algo mas peque. inas y sus colores menos vivos que los del macho. La longitud es de $0^{\mathrm{m}}, 08$ à $0^{\mathrm{m}}, 09$.

CAUTIVIDAD.-Mucho se ha escrito recientemente $y$ excelentes y numerosas observaciones se han publicado sobre este pez; pero haré caso omiso de todo cuanto he leido res. pecto a el y me limitaré á dar la descripcion que Bennecke ha escrito expresamente para esta obra. Hé aqqui lo que me dice:

¿En mayo de 1878 compré una pareja de peces del paraí. so para poder disponer siempre de freza reciente que necesi. taba para mis trabajos fisiológicos, pues habia oido decir que cstos peces desovaban cada quince dias durante todo el verano. Los animalitos llegaron en perfecta salud y puestos en un depósito de cabida de cuarenta litros, se aplicaron inmediatamente á cazar los pequeños crustáceos, larvas de mosquitos y gusanos que nadaban entre las plantas acuáticas. Durante los primeros dias se conocia que iban observando y haciéndosé cargo de las nucvas circunstancias que les rodea. ban. Cuando hubieron concluido con los animalillos de $5 u$ depósito, reemplacé estos con otros pequeños cangrejos, pul. gas acuáticas (dafnias) y paguros, vulgarmente llamados Ber. nardos ermitaños, álosque sin duda veian entonces por vez pri. mera, porque los cogian y los soliaban, meneando siempre la cabeza, pero dos dias despues cambiaron de proceder; deja. bar todas las pulgas acuśticas que yo les daba en abundancia y solo querian bermardos, si bien muy de tarde en tarde pe. gaban algun mordisco is una de aquellas cuando les parecia mas gorda que las demás. Me habia formado una idea poco exacta de su apetito, y pronto la hube de rectificar cuando un dia me fue imposible darles cangrejitos y larvas, pues aquel dia se pusieron á comer con gran satisfaccion lombri. ces de tierra, y no solo las pequeñas sino tambien las grandes de $0^{\circ}, 05$ a $0^{m}, 08$ de largo y de $0^{m}, 002$ de grueso. Les daba las de mayor tamaño cortadas ya en pedazos, y era cosa de ver cómo sabian comerlas extrayéndoles antes los excrementos del conducto intestinal, á cuyo fin las cogian por un extremo y hacian salir por el otro, merced a un movimiento de masticacion, la porqueria que renia a formar delante de ellos como una ligera nube; cuando ya se habian tragado todo el gusano, seguian mascando para expeler la mucosidad y suciedad de la parte exterior de dicha presa. Si los cogian del fondo 6 los recibian muy sucios, cuidaban siempre de 
limpiarlos, primero sacudiéndolos $y$ soltándolos repetidas veces ó arrojándoloș desde abajo arriba para desprender la arena de su cuerpo, y solo despues de hacer estos preparativos empezaban á tragarlos. Cuando se resistia el animal, lo golpeaban contra las plantas acuáticas $\delta$ contra las paredes de su vivero. No menos divertido era el espectáculo que ofrecian cuando lograban coger por la cola una lombriz tan larga como ellos, Ja cual hacia vanos esfuerzos para escapar mientras el pez. se la iba engullendo poco à poco.

- No tardaron mucho en entregarse á sus juegos amorosos, tan interesantes sobre todo por la mañana, cuando el sol daba á intervalos en su vivero. Al sacarlos de la vasija en que me los trajeron cra por demás menguada su apariencia; tenian un color pardusco pálico, color que luego se fue oscureciendo, primero el del macho, despues el de la hembra, y a medida que se avivaba el tinte general, iban saliendo y résaltando mas las listas oscuras de color verde con viso de oro. los matices de estos peces adquieren mayor brillo' cuando juegan, y palidecen cuando se los separa, como sucede con otras especies. En general el macho se aparea con una sola hembra, pero á veces tambien con varias. Al acercarse a su compañera extiende la cola y todas las aletas al paso que se va oscureciendo por minutos su color; entre tanto la hembra se pone casi vertical, con las aletas tan plegadas como puede $\mathrm{y}$ dando vueltas, ó bien nada en direccion contraria al macho. En este último caso gira uno al rededor del otro lentamente. Cuando sus juegos los excitan mucho, el macho se pone como tembloroso, y hace lo que vulgarmente se llama la rueda, extendiendo la cola y las aletas, como el gallo cuando hace el amor 1 la gallina Ia hembra suele imitar al macho poniendose temblorosa tam. bien; pero si no tiene deseos de jugar, se pone casi vertical al acercarse á ella el macho, girando sobre sf misma, y mientras él nada á su al rededor, ella se ladea en iérminos de que avanza á la manera de una platija.

A las tres semanas próximamente de haber llegado, la hembra adquirió mayor volúmen y entonces el macho em. pezó á ocuparse del nido. Con este objeto sube á lá superfi. cie, se llena la boca de aire y bajando otra yez, lo expulsa en pequeñas burbujus encerrádas dentro dè una delgadísima membranita de saliva y forma/asi sucesivamente toda una capita de burbujitas flotantes á cierta profundidad, que re. nueva de cuando en cuando. Debajo de esta capa de burbujas estaba habitualmente el macho en un rincon del vi. vero, mientras que la hembra permanecia en el rincon opuesto, juntándose ambos á ratos en el centro libre de plantas acuáticas, para jugar.

- Por lo pronto no se cumplió mi deseo de asistir al desore de estos peces, porque una mañana encontré muerto en el suclo al macho que habia saltado por el horde bastante elevado del vivero. Hice venir otro macho, pero hube de tomar una pareja que junté con la viuda, $y$ al poco tiempo se habian arreglado los peces de mancra que las dos hembras ocupaban rincones opuestos, siendo el macho tan pronto huésped de la una como de la otra, y aquellas no solo vi. vian en par, sino que á veces hasta jugaban como si fuesen macho y hembra en la posicion antes indicada, con las aletas abiertas y el temblor mencionado.

- A los pocos dias observé que el macho éstaba muy excitado, no cesaba de asomar a la superficie, de llenarse la boca de aire y expulsarle en innumerables perias debajo del agua, ya por la boca, ya por las agallas, nadando durante este tiempo con gran viveza y á sacudidas, y poniendo muy rigidas las aletas abdominales cada ver que se paraba; imitíndole la hembra que con êl habia renido. Cuando pasaban algun rato jugando de este modo el macho solia embestir á la hembra, y abriendo ambos la boca, cogia cada uno un labio del otro con los dientes, y de esta manera estaban nadando sin soltarse diez, veinte $y$ hasta cuarenta minutos á veces, meneando vivamente las colas $\dot{c}$ inclinánoose tan pronto á un lado como al otro. Dos dias seguidos repitieron esta maniobra con una frecuencia extraordinaria; tan pronto cogia el macho el labio superior de la hembra cono esta el del macho, $y$ una vez cogidos no se soltaban antes del tiempo indicado, siendo tanta la violencia con que se asian que ambos llevaban pedazos de piel del labio colgando delante de la boca. Yo no podia menos de considerar este entretenimiento como una especie de besos que se daban con toda su fuerza amorosa, y no quedé poco adnirado cuando observé des. pues que á pesar de la armonla que reinaba entre cllos, pasaban meses sin que renovasen sus cariñosas demostra. ciones.

- Poco á poco cambiaron de cumpurtamiento, cesú lí cur. dialidad $y$ hube de separar la mas débil de las hemoras para evitar riñas de las que salian con las aletas y las colas destrozadas, si bien no tardaban en curarse. Primero traté de separarlas por medio de un cristal, pero las dos hembras se embestian con tal iuria y olvidaban tan completamente la separacion de cristal, que tuve que cubrirlo con una tela os. cura, a fin de que no se viesen siquiera; pero la hembra que estaba en compañia del macho no tardó en descubrir que podia levantar la tela, $y$ desde entonces se colocaba constan. temente entre esta y el vidrio, aunque solo fuese para lanzar miradas de ira y de odio á su rival. Puse una placa de vidrio opaco en lugar de la otra y de la tela; pero tambien fue menester cubrirla con papel, porque la sola sombra que pro. yectaba la viuda sobre la placa segun le daba el sol, bastaba para irritar ála otra. Ni el papel bastó. Un dia encontré á ambas hembras peleando furiosamente, porque la viuda ha. bia saltado la barrera á pesar de sobresalir doce centímetros de la superficie del agua, de modo que ya no q̨uedaba otro recurso sino cambiarla de vivero.

No tuvo Benecke la dicha de ver sus peces del paraiso proceder al desore, $y$ hé aqui por qué he de dar una descrip. cion de csta funcion, segun los datos que me ha sido posible recoger en otros autores.

No son solo las hembras las que rinen entre si, sino que tambien se traban serias peleas entre dos individuos aparea. dos. El macho elegido por la hembra se convierte á veces para ella en un tirano cruel. Cuando ve que su irabajo de construccion del nido no tiene el éxito que deseaba, se impacien. ta, persigue y maltrata á la hembra bárbaramenie destrozándole las aletas y arrancándole los ojos, y cuando el ducño no interviene, la mata sin remedio; pero no sucede así cuando las huevas se desarrollan en la hembra á su tiempo y conforme-á los deseos del macho; entorices no se acuerda este de reñir ni golpear, sino que todos sus pensantientos se concentran en los cuidados que necesita su prole en via de forma. cion. Despues de haber jugado macho $y$ hembra de la manera que dice Benecke, se echa la hembra, cuando esta 1 punto de desovar, oblicuamente de espalda y el macho nada por encima de ella de tal mancra que al pasar se tocan las aberturas sexuales de ambos. Despues se abrazan con sus largas aletas caudales; el macho tiembla bastante rato de un modo particular, luego suelta a la hembra, y esta cae rendica al fondo: donde expele un número de huevas que por lo general suben por el agua quedando detenidas al llegar al notante y áereo nido hecho de burbujas, debajo del cual tiene invariablemente lugar el acto descrito. Rara vez caen las huevas al fondo, y en este caso el macho las recoge y las coloca de bajo del nido. Pasado algun rato se repite la misma operacion, por lo menos diez veces al dia, ocupándose el macho 
en los intervalos, to mismo que durante todo el tiempo de incubacion, en recomponer y perfeccionar el nido; arregla y dispone las huevas de modo que cada una esté colocada debajo de su correspondiente burbujita y custodia el nido y cria con celosa solicitud. A las veinticuairo horas aproximadamente se observa en la yema de color amarillo pálido la mancha oscura del embrion; al dia siguiente se distinguen las pulsaciones del corazon, y de doce a diez s ocho horas despues salen los pececillos, por lo pronto sin boca y comparables á renacuajos diminutos, pasados cinco ó seis dias ya tienen la forma de sus progenitores, $y$ ł los ocho meses son adultos. Mientras necesitan del auxilio de sus padres, el ma. cho no los abandona y los cuida sacrificándose por ellos; $y$ del mismo modo que el gasterosteo de hocico agudo (gastirostess aculentus) vigila su diminuta cria y la tiene en órden y reunida, asi tambien procede el pez del paraiso. Cuando ano de los pececillos se separa del grupo, el macho corrc detrás de él, lo coge con la boca, se lo traga y lo escupe ó vomita otra vez en el nido protector hecho de espuma, sien. do tanta su solicitud que vigila y cuida hasta a sus hijuelos enfermos $\delta$ débiles envolviéndolos en una vejiguilla de aire que forma al efecto, y dándoles asín nuevo ambiente vital; pero cuando los pequeñuelos llegan á poder prescindir de su auxilio, no solo los abandona as su suerte, sino que no tiene entonces el menor escrúpulo, lo mismo que la hembra, en devorarlos tranquilamente.

Al principio se alimentan los pequeñuelos de la misma espuma que constituje su nido, despues de infusorios invisibles á la simple vista, luego de animalillos visibles y final. mente de los mismos animales que sus padres.

Los peces del paraiso se recomiendan s. los aficionados, no solo por sus costumbres, sino por su sorprendente fecundidad. Dicese que una pareja que cuidó Windsteig desovó seis veces en un solo verano, obteniendo cada rez crias de cuatro á seiscientos pequeñuelos; por manera que tuvo en tan pocotiempo nada menos que tres mil descendientes. De todo ello resulta que este pez tiene un gran porvenir y es posible que llegue a suplantar en todo $\delta$ en parte al pez de color.

\section{LOS OSFROMENOS-OSPHROMENUS}

CARACTERES. - Commerson ha descrito cientifica. mente un pez laberintico, dándole el nombre de osphremsenus olfar. 6 sea olfateador, porque creia que las celdillas foliáceas del hueso faringeo de este pez debian contribuir á aumentar su olfato. Brehm conserva como es natural el nombre científico para la especie, pero para el género establece, conforme á su modo de crear nombres alcmanes, uno que viene á significar: peies lionidecis. Los rasgos caracteristicos de este género consisten en tener el cuerpo de forma ovalada irregular, mas arqueado en el vientre que en el lomo, y comprimido lateralmente; la boca pequeña con la mandibula inferior un tanto saliente y algo deslizable; los dientes aterciopelados en ambas mandíbulas, el borde finamente aserrado del preopérculo y del luveso infra orbital, la aleta anal mayor que la dorsal, $y$ la disposicion de las abdominales, que tienen el primer radio muy largo y cerdoso.

\section{EL GURAMI-OSPHROMENUS OLFAX}

CARACTERES.-Es el pez descrito por Commerson; tiene gran talla y puede, segun se dice, alcanzar una longitud de dos metros y un peso de mas de diez kilógramos; su color es un rojo pardo en el dorso con listas trasversales mas oscuras; el vientre blanco y plateado presenta manchas par- das a manera de lunas, porque las escamas claras tienen el borde pardo, y además es notable una mancha negra irregular en el nacimiento de la aleta abdominal. La dorsal tiene catorce radios espinosos y doce blandos; la anal once espi. nosos y die\% y nueve blandos; cada torácica diez y seis; cada abdominal seis y la caudal diez y seis.

USOS, COSTUMBRES Y REGIMEN.-Commerson opina que la patria primitiva del gurami es la China, desde donde se ha llevado á la isla de Java á causa de su carne excelente; pero se equivoca, por cuanto este per habita las aguas dulces de las islas grandes de la Sonda, donde, segun dicen, vive á manera de nuestras carpas en aguas tranquilas y abundantes en plantas acuáticas, prefiriendo las mas puras, aunque prospera tambien en estanques y balsas fangosos. Le gusta ocultarse en huecos y se alimenta de vegetales. A causa de su carne que, segun Commerson, es superior á la de todos los demás peces, ya sean de agua dulce ó ya de mar, le tienen los holandeses de los alrededores de Batavia en vireros y en grandes tinajas, cuya agua renuevan cada dia, y donde alimentan sus cautivos con una planta de agua dulce, la Pistia natens. Por otro lado supo Dupetit-Thouars que los guramis no comen solo estas plantas, sino tambien y con mucha codicia los excrementos humanos que por las cloacas ran á parar á las aguas en que habitan, si bien en tales casos su carne adquiria un sabor pésimo. Observaciones ulteriores han probado que cuando les faltan las plantas de su pais, comen tambien berzas, ensaladas, acederas, nabos, salvado, pan, arroz, mair, judias, patatas cocidas; y de paso tambien gusanos, cocos, pececillos, ranas $\delta$ carne cruda 60 cocida.

El gurami se distingue, al igual del gasterosteo y del coto ó gobio, por su solicitud paternal para con su cria. En un ấn' gulo ó bien entre las plantas acuáticas flotantes de su estanque $\delta$ vivero, prepara el macho, probablemente sin el concurso de la hembra, en cinco ó seis dias un nido ovoideo, en el cual deposita esta sus ochocientas ó mil huevas, y cuyos materiales están destinados á servir de primer alimento á la cria despues de nacida.

La facilidad con que se alimenta el gurami, lo bien que resis. te cualquier cambio de régimen, y lo sabroso de su carne, han hecho nacer la idea de aclimatarlo en otros paises, con tanta mas razon, cuanto que la abonan los resultados obtenidos en Pinang, Malaca y en Mauricio, donde los guramis introducidos en el año $1 ; 61$ se habian escapado de sus viveros y lle. gado \& los riachuelos de la isla, en los cuales se establecie. ron tan completamente que prosperaban como en los viveros, multiplichndose con rapidez, de suerte que su desarrollo excedio á todas las esperanzas.

Otro experimento heciso en ISto para introducir y aclimatar este pez en la Martinica no tuvo igual éxito; allí pros. peró perfectamente, pero no se reprodujo, sin que se sepa por qué. En el año 1859 , el capitan Philibert, encargado por el gobierno francés de llevar diferentes animales y plantas de la region oriental á Cayenne, embarcó cien guramis en la isla de Mauricio. Este experimento turo el mejor éxito, pues durante la travesia solo murieron veintitres, y los restantes se aclimatarón nuy bien. En el año i $S G_{i}$ se echaron guramis en algunos lagos de Ceilan y recientemente se han traido otros á Europa, peró no sé si los resultados en esta última parte del globo han sido favorables, si bien no dudo que al fin y al cabo han de serlo si los experimentos se hacen con tino.

De todos modos, scria convenienic llanar otra vez la atencion sobre este animal y con mas razon aliora que el clamo reo sobre la despoblacion de los rios se hace general y la aplicacion del remedio es cada dia mas urgente, atendida la 
uscasez muy sensible de esta clase de alimento. Para aclima. tar el gurami en nuestro pais seria necesario empezar por su introduccion en el mediodia de Europa y extenderlo desde alli paulatinamente al nortc, à fín de acostumbrar la especie leutamente a los rigores del clima septentrional.

\section{LOS ATERINIDIDOS-ATHE- RINID瓜}

CARACTÉRES, - Entre los peces acantopterigios de aletas abdominales insertas en la parte posterior del abdó. men, de los que se conocen aproximadamente cuarenta es pecies, plieden citarse en primer iugar los aterinidos, que son peces pequeizos, oblongos, bien redondeados, revestidos de escamas bastante regulares, y adornados en cada lado con una lista ó mancha longitudinal plateada que se lia com. parado algo atrevidamente con una espiga y que ha dado motivo para llamar á esta familia peciesespigr. Otros distinti. vos son la boca medianamente ancha, la dentadura compues. ta de dientes débiles, los ojos bien formados y colocados en los costados, la abertura branquial ancha con cinco 6 seis rádios, dos álctas dorsales sostenidas por radios débiles, las abdominales sostenidas por un radio espinoso y cinco blandos y finalmente el gran número de vertebras caudales.

\section{LOS ATERINIOS-ATHERINTNAE}

CARACTERES. - Esta primera sub familia comprende las especies que tienen el cuerpo cubierto de escamas cicloideas y cuya primera aleta dorsal está perfectamente separada de la segunda.

\section{LOS ATERINOS-ATHERINA}

CARACTÉRES.-Componen esté género les peces de hocico achatado y boca hendida hasta el borde anterior del ojo; la dentadura, compuesta de dientes débiles, guarnece la mandibula en forma de faja, y el rómer en forma de banda arqueada, con pocos dientes 6 ninguro en el paladar.

\section{EL CARAMEL-ATHERINA HEPSETUS}

CARACTÉRES.-El caramel, conocido ya en la anti güedad, no pasa de $0^{m}, 15$ de longitud. Es hialino 6 traslúci. do; en la parte superior de color pardo amarillento y claro salpicado de negro, en ia inferior blanco con viso rojizo y un tanto plateado. La banda de brillo plateado, que algunas personas comparan con una espiga y que ocupa la quinta hilcra de escamas por entero, y la cuarta y sexta por mitad, estả oriada de azul en la parte superior. La primera aleta dorsal que se levanta en la mitad del cuerpo está sostenida por ocho hasta nueve radios; la segunda dorsal, colocada en frente de la anal, tiene doce 6 trece; diez y seis tiene cada torácica, once la anal y diez y siete la caudal.

USOS, COSTUMBRES Y REGIMEN.-El género de vida de todos los aterinios es á poca diferencia tan idéntico, quue la descripcion de las costumbres y régimen del caramel se aplica perfectamente á toda la sub-familia. En todos los mares que se han estudiado con alguna exactitud se encuen. tran estos peces. El caramel en especial vive en bandadas incalculables en el Atlíntico y Mediterráneo así como en el mar Negro y Caspio. En todas sus costas, bahias, puertos y marismas se presentan dichas bandadas que literalmente llenan trechos de muchísimos metros de superficie, y miles de millones sirven de alimento al hombre, a las gaviotas y 1 otras aves maritimas, á los patos y por supuesto á ntros pe. ces de rapina. Tan grandes son las masas que presentan, que los antiguos creian que estos peces nacian espontánea. mente. Los pequeñuelos, que luego de haber salido del hue vo, nadan y forman ga bandadas, se pescan simplemente con cubos que se llenan de ellos como si fuese de agua, de suerte que además de servir de alimento al hombre y formar un plato favorito en los palses que bordean el Mediterranco, se les destina tambien para engordar cerdos. Cuando adultos, se les emplea como cebo y mucho mas para alimento de los habitantes de la costa que los comen, ya frescos, ya salados, ya en conserva en latas y los consideran como manjar cxcelente. Nuestro viejo Gessner dice que \&su carne tiene fama de buena; es algo seca, pero en cambio sabro. say șana. Muchos ensalzan estos pececillos como alimen. to para los enfermos por ser fáciles de digerir y nada flatuleatos. Unicamente los desprecian completamente los pes. cadorés-árabes del mar Rojo.

\section{LOS TETRAGONUROS-TETRAGO- NURUS}

CARACTERES. - Los peces que Guenther reune en esta sub familia se distinguen por su cuerpo fusiforme cubicrto de escamas enhiestas y rayadas; por las dos aletas dorsales reunidas, en una sola; por una arista 6 canto muy saliente en cada lado de la cola, y por su dentadura singular. Las dos ramas de la mandibula inferior se levantan verticalmente y están armadas de una hilera de dientes agudos y cortanies, formando reunidos una especie de sierra, y que al cerrar la boca se meten entre los de la mandibula superior; además llevan una hilera de dientes puntiagudos en cada hueso palatino, y dos en el rómer. El esófago está guarnecido interiormente de verrugas duras y puntiagudas. El cstó. mago forma pliegues.

\section{EL TETRAGONURO DE CUVIER- TETRAGONURUS CUVIERI}

CARACTERES.-Este per es el representante del género en el Mediterránco. Tiene aproximadamente $0^{\circ 1}, 25$ de longitud y un color rojo oscuro de vino, hácia la parte inferior verdoso con visos de plata $\delta$ de oro. Las aletas son amarillas de oro ó rerdosas con orla negra. La dorsal se compone de quince á veintiun radios espinosos y trece blan dos, con la particularidad de que los primeros pueden me. terse completamente en una ranura que hay en el lomo; la aleta anal tiene de diez á doce radios.

USOS, COSTUMBRES Y REGIMEN.-Segun Risso que es quien ha descrito este pez cientificamente $y$ le ha dado el nombre que lleva, el tetragonuro vive en el Mediter ráneo, donde habita solitario en la profundidad de la cual sale en agosto para acercarse a la costa y desovar. Sus mo. vimientos son lentos. Este per es notable por pertenecer à los venenosos, siquiera temporalnente. Risso asegura haber tenido repetidas veces violentos dolores de vientre, especial mente en la region del ombligo, despues de haber comido de su carne. El vientre se le hinchó, sintió un ardor insoportable en el cuello y esófago seguido de vómitos de mu. cosidades, náuseas, retencion de vientre $y$ abatimiento gene. ral; y estas dolencias no desaparecieron sino despues de algunos dias. Cree Risso poder indicar como causa de esto las medusas y particularmente las hidras que, como se sabe, segregan un liquido irritante, y que acaso sirven de alimento a este pez, no teniendo nada de particular que no danen tambien al mismo. 


\section{LOS MUGILIDOS- MUGILID压}

CARACTERES.-Forman esta familia unas ochenta especies diferentes de formas proporcionadas, cuerpo oblongo y redondeado con escamas grandes hasta en la cabeza. Tienen dos aletas dorsales muy separadas una de otra, constando la primera solo de cuatro radios; las abdominales son cortas y están inmediatamente detrás de las pectorales; la boca es trasversal, angulosa y los labios gruesos; los dientes, cuando los hay, son pequeños y finos. Las mas de las especies se distinguen tambien por la formacion singularisima de su aparato digestivo; los huesos faringeos son de forma angulosa como la boca, con lo cual se disminuye el hueco del esbfago, por cuya razon han de alimentarse los mugilidos exclusivamente de sustancias líquidas, licuadas $\delta$ bien muy diminutas. El estómago es musculoso y acaba en un ante-estómago, como el glanduloso $\delta$ ventriculo subcenturiado de las aves; los apéndices del plloro son poco numerosos, y el tubo intestinal forma muchas circunvoluciones.

USOS, COSTUMBRES Y REGIMEN. - LOS mugili. dos no solo viven en las aguas saladas de las ensenadas poco profundas, calas, puertos y otros sitios de las costas, sino tambien en las aguas dulces cuando comunican con el mar. Suelen reunirse en bandadas en compañia de los salmonetes y otras especies inofensivas, acercarse con las mareas altas á la orilla, y volverse con las bajas al mar, segun dicen los pescadores del mar Rojo, de lo que se desprende qque bus. can siempre sitios de poca agua donde sus enemigos natura- les, los peces de rapiña, no pueden seguirlos. No se atreven á pasar á alta mar, ni bajan jamás à capas profundas cuando se ven obligados á abandonar las aguas bajas donde se encuentran decididamente mas á su gusto, porque se les ve alli jugar $y$ saliar a veces fuera del agua cruzando distancias regulares. Su alimento consiste en fango $y$ arena, ó mejor dicho, en las materias animales y vegetales que estos contie. nen, por cuya razon suelen reunirse en gran número donde algun arroyo turbio desemboca en el mar. Revuelven el fondo as manera de las caspas, manteniéndose en posicion horizon. tal. En el mar Rojo empieza su época de desove, que dura dos meses, á últimos de inarzo, $y$ en las costas septentriona. les de Europa a principios del verano. Antes de empezar la freza se los ve en grandes bandadas en los sitios que fre. cuentan; pero despues solo en grupos pequeños de ocho ó diez individuos. Su carne es buena tanto fresca como salada. La pesca exige mucha práctica $y$ redes especiales, porque los mújoles suelen saltar por encima de las redes ordinarias que son tan fatales para otros peces. Además del hombre los persiguen todos los peces de rapiña y diferentes parásitos.

\section{LOS MÚJOLES - MUGIL}

CARACTÉRES. - Este género es el mas numeroso é importante de la familia. Ias especies que á él pertenecen tienen la boca pequeña con la hendidura algo plegada en el centro; el labio inferior tiene asperezas ó protuberancias, que corresponden $a$ varios huecos en la mandibula superior; los dientes son pequeños y tan apartados uno del otro que apenas se tocan.

\section{EL MÚJOL Ó CAPITON-MUGIL CAPITO}

CARACTERES. - Esta especie (fíg. i 78) habita el Mediterráneo y el Atlántico; se presenta tambien en el mar del Norte y rara vez llega hasta el Báltico. Ios italianos le llaman Ramado. Su longitud es de $0^{*}, 40$ á $\theta^{\prime \prime}, 50$; el color gris azulado en el lomo, $y$ bianco plateado en los costados $y$ vientre con lineas negras longitudinales en todo el cuerpo. La primera aleta dorsal tiene cuatro 6 cinco radios; la se. gunda ocho; cada torácica dicz y siete; cada abdominal seis, la anal tres y nueve y la caudal catorce.

\section{EL MÚJOL CABEZUDO-MUGIL CEPHALUS}

CARACTERES. - Esta especie, afine de la primera, se encuentra solo en el Mediterránco; es mayor que aquella, pero de idéntica coloracion y dibujo. Tiene los ojos cubier tos de una membrana viscosa, y las aletas torácicas en su base de una escama larga y crestada. La primera aleta dorsal lleva cuatro radios, la segunda nueve.y la anal once.

En esta especie se puede observar muy bien la estructura 
particular del aparato digestivo. La mandibula inferior tiene en el centro una protuberancia que encaja en un hueco de la superior y la lengua se adhiere casi enteramente. I.os huesecillos entre los arcos branquiales, 6 sean los huesos farín. geos superiores, llevan en lugar de dientecillos una doble hilera de cerdas tiesas que cierran la cavidad bucal a manera de tamiz, y los de arriba forman con sus bordes posteriores una especie de tapadera ó válvula dirigida hácia atrás. La piel interior de la faringe es blanda y esta cưbierta de verruguillas, el esófago es al principio liso, despues cubierto de hilos blandos que á su vez están deshilachados; el estómago se parece al de las aves y el intestino es angosto y largo.

USOS, COSTUMBRES Y REGIMEN.-Gracias \& las investigaciones hechas por Cuvier, ha sido posible fijar las diferentes especies de mújoles; los antiguos, que los conocian bien, llamaban á todas las especies que viven en el Mediterráneo mújoles (mugil). De los escritos que tenemos de los griegos y romanos resulta que estos peces fueron en todo tiempo muy apreciados y por ende cuidadosamente observados, si bien no sin que anduviera alguna fábula de por me. dio, como lo que cuenta Plinio diciendo que los mújoles viven durante la época de la freza en numerosas bandadas y se aproximan \& las costas, como es cierto, y tambien que los delfines los persiguen; pero despues añade que en una de estas ocasiones habian formado los delifnes un ancho circulo al rededor de los mújoles y aprorechando los pescadores está oportunidad hicieron una abundantisima pesca, de suerte que agradecidos a los delfines, les habian dado una parte del botin, mas estos, no satisfechos, volvieron al dia si. guiente para reclamar mas. Se puede explicar este cuento al saber que los delfines suelen cazar reunidos, situándose á veces delante de las desembocaduras de los rios, con lo cual es fácil que hayan dado a los pescadores ocasion de hacer una gran pesca con poco trabajo.

Dicen tambien los antiguos, y con mucha razon, que los mújoles huyen del anzuelo y que se salvan de las redes dando tremendos saltos. Asimismo se explica su creencia de que estos peces solo se alimentan de fango y agua.

Recientemente ha observado Couch $\dot{a}$ los mujoles $y$ en es. pecial al capiton, y a śl debemos una excelente descripcion de sus costumbres y de su pesca. Esta especie se presenta en grandes masas en las costas de Cornualles y del condado de Devon, cogiéndose además en todos los puntos de las costas de Inglaterra y de Irlanda. Jamás, dice este naturalista, se aleja mucho de la costa, porque le gustan los sitios de poca agua y mas cuando el tiempo es hermoso $y$ hace calor; entonces se ven fácilmente los hoyuelos que deja en el fondo despues de registrarlo. A veces sube por los rios, pero vuelve al mar con la marea baja. Carew, historiador de Cornua. lles, tenia un estanque de agua salada que le servia de vire. ro para estos peces, los cuales estaban tan habituados á su amo, por darles este cada noche de comer siempre en el mis. mo sitio, que bastaba un pequeño ruido para atraerlos y re. unirlos.

Otra prucba de su inteligencia es su vigilancia y la destreza con que saben huir de los peligros; tan luego como se ven cogidos en una red de jorro, apresúranse á volver atrás y saltan por encima de la red; basta que uno solo haya enconirado medio de escaparse para que le sigan todos, y estos brin. cos son una cosa natural en ellos, porque los dan ya cuando todavia son pequeñitos; Couch mismo vió cómo un mújol saltó repetidas veces en el vivero por encima de una separacion que sobresalia $0^{m}, 03$ de la superficie.

Es muy frecuente que los mújoles pasen del mar á un es. tanque ó marisma grande, como las hay en las costas de Cornualles, que comunican con el mar; y no bien los maro. res han descubierto el camino, les siguen los otros, repitién dose estas visitas con regularidad; pero cuando el mar se retira y la comunicacion se cierra por medio de alguna com. puerta, se observa que quedan instantảneamente sobrecogidos de terror; registran ansiosos toda la orilla, su inquietud crece, y hasta prueban á saltar por encima del dique, lo cual causa la muerte de gran número de ellos; lo propio hacen cuando se ven cogidos en una red y despues de haber esca. pado algunos se impide la huida de los demás; entonces ins. peccionan cada malla y cada pliegue de la red que llega hasta el fondo; retroceden como para embestir mejor 5 procuran en su desesperacion atravesar las mallas, con lo cual acaban por enredarse completamente en ellas.

Su alimento predilecto son sustancias blandas y grasas, y mucho mas si están ya en descomposicion. Como lo sacan casi todo del fondo, se puede inferir que el sentido del tacto ha de estar muy desarrollado en sus labios. Couch opina que los mújoles son los únicos peces que escogen para su alimento auimales muertos, y cuando se tragan algun anélido es una pura excepcion.

PESCA.-Apenas se coge alguno con el anzuelo, porque aunque muerdan el cebo no lo tragan, sino que lo palpan con gran detencion arrojándolo repetidas veces de la boca para volver \& palparlo, 8 si por casualidad 6 por descuido se les clava la punta un poco en la boca, se la desprenden con los esfuerzos que hacen auxiliados por su peso considerable. Ei cebo que da mejores resultados consiste en tripas de pescado ó en hojas de col cocidas en caldo; en los rios muerden tambien las moscas artificiales y hasta las grandes que se usan para los salmones, pero aun despues de haberlas mordido se necesita la mayor destreza para sacarlos. En Italia se cogen del mismo modo hoy que en la antigüedad, es de. cir en los estanques y balsas \& la orilla del mar, especialmente en invierno. Tambien tienen fama bajo este concepto los estanques de la costa del Languedoc. A reces suben en tan gran cantidád por los rios Garona, Loira, Sena, Ródano y Soma, que estos parecen enteramente cubiertos de ellos, costándoles á los pescadores mucho subir las redes por el gran peso de los peces, pero semejante abundancia no suele durar mas que dos 6 tres dias. Las redes mas usadas se com. ponen de gran número de sacos con prolongaciones a guisa de mamparas fuera del agua. Tambien se emplean fogatas para atraerlos de noche.

Su carne es en todas partes apreciadisima y se consume tanto en estado fresco como salada, teniendo fama de tierna, grasa y suculenia. Las huevas se reunen por separado, se prensan s se salan, y constituyen, sobre todo en la Provenza, despues de guisadas, un manjar favorito.

Sin ninguna duda es el instinto sexual la causa que reune a los mujjoles en tan gran número y que los mueve $a$ ir en busca de los rios y bahías. En el Mediterráneo desovan á principios de verano, y en las costas de Inglaterra en julio. En agosto se ven alli innumerables bandadas de pequeñue los de $0^{\circ}, 02$ de largo en las desembocaduras de los rios y en estos mismos, pero se retiran con la marea baja. Couch opina que la alternativa de agua salada y dulce les ha de ser precisamente farorable, lo cual pretende probar con experi. mentos hechos con peces cautivos; por otra parte consta tambien que los mújoles soportan muy bien el agua dulce, porque un tal Arnould puso en un estanque de agua dulce, de tres cuartos de hectárea, una multitud de mújoles de un dedo de largo, y à los pocos años pudo coger individuos que pesaban dos kilógramos, y eran mas grandes, mas gordos y de un color un poco diferente, que los pescados en el mar. He aqui pues un experimento que merece llamar la atencion particularmente en Alemania, donde la adquisicion de un 
pez de mar tan suculento como poco exigente en cuanto a alimentacion seria sin duda alguna de gran valor.

\section{LOS OFIOCEFÁLIDOS - OPHIOCEPHALID瓜}

CARACTERES. - Se conocen aproximadamente veinticinco especies de esta familia; tienen el cuerpo bastante largo, redondo en la parte anterior y algo aplansdo lateralmente en la posterior; la cabeza ancha, llana y por encima cubierta de escudetes; ia boca muy hendida; dientes cerdosos en las mandíbulas y en el paladar, con caninos algo mas fuertes; los opérculos cubiertos de escamas cicloideas y sin espinas; cinco radios en las branquias. Las aletas difieren de las de todos los peces del mismo órden por la falta de radios espinusos. La dorsal ocupa casi toda la longitud del cuerpo; la anal tambien es muy larga, la caudal redondeada, las toráci. cas y abdominales están bien formadas. La cavidad abdomi. nal se prolonga casi hasta el extremo de la cola; cl estómago es una simple bolsa, $y$ junto al piloro se encuentran dos ciegos bastante largos.

\section{LOS OFIOCÉFALOS-OPHIOCE- PHALUS}

Para nuestro objeto el género mas importante de esta familia, tan pobre en especies, es el de los ofrocifalos ó de cabeza de serfiente, porque comprende las especies cuyo género de vida conocemos mejor, como:

\section{EL VARAL-OPHIOCEPHALUS PUNCTATUS}

CARACTERES. - Habita el continente indico y las islas proximas, en particular Ceilan, y alcanza una longitud de $0^{n}, 50$ a $0^{\circ}, 70$. El color, es verdoso en la parte superior, y gris blanquizco en la inferior con fajas oblicuas mas oscuras que corren desde arriba y desde delante hácia abajo y atrás. La aleta dorsal tiene por lo comun treinta radios, la anal veinte, cada torácica diez y seis, cada abdominal seis y la caudal veinte, si bien parece que estas cifras pueden variar.

\section{EL OFIOCÉFALO MAYOR-OPHIOCEPHALUS STRIATUS}

CARACTERES. - Es mas grande que el anterior y difiere tambien por el mayor número de radios de sus aletas, pues la dorsal tiene hasta cuarenta y cinco, la anal hasta vein tiscis; y su longitud llega á un metro y aun mas. La parte superior es de color gris verdoso y la inferior blanca amari llenta; asimismo tiene fajas no interrumpidas que se continuan en las aletas en forma de puntos y manchas. Tambien parece ser mayor su área de dispersion que la del anterior, pues se encuentra en Coromandel, Bengala, Pegú y las Cé. lebes; en estas últimas islas hasta á seiscientos metros sobre el nivel del mar.

USOS, COSTUMBRES Y REGIMEN.-EI periódico de la Sociedad Asiática de Bengala publicó en el año 1839 la descripcion de un pez que los indigcnas de la parte extrema sudoeste del Himalaya llaman borachung, y los euro peos alli establecidos pez berrestre. Los butaneses pretenden que este pez. no vive en los rios, sino en tierra perfectamente seca, en medio de espesos matorrales cubiertos de yerba, á veces dos y mas millas inglesas distantes del agua. La gente busca en estos sitios agujeros abiertos en el suelo, y cuando los encuentra, cara hasta dar con agua, porque cntonces no está léjos el borachung con su companera; pues es de adver. tir que por general van siempre dos juntos. Cuando se les pone en el suelo despues de sacarlos, corren culebreando con notable velocidad. Esta relacion es de un testigo ocular.

Algunos años despues rectificó Campbell esta descripcion segun observaciones hechas por él misrno. Confirma que este pez habita en agujeros, pero junto á las orillas de rios de poca corriente ó de lagos, y generalmente dispuestos de manera que la entrada se halle a algunos centímetros debajo de la superficie del agua, por manera que el pez puede pasar siempre desde su guarida al agua sin dificultad; en cuanto a lo demás, confirma Campbell que siempre se encuentran estos peces a pares y por lo comun enroscados como las serpientes; y que no son ellos los que abren los agujeros, sino que aprovechan los que hacen cicrtos cangrejos terrestres.

Fs muy probable que el borachung sea un ofiocéfalo, porque los datos que se tienen no se aplican á ninguna otra especic, y no carecerá de fundamento lo que dicen los buta. neses, de que encueniran el borachung léjos del agua, porque mas de una vez se han observado ofiocéfalos en terreno seco arrastrándose como serpientes para trasladarse de unas aguas A otras; por otro lado podria ser que aquellos sitios secos hubiesen cstado inundados en la epoca de las lluvias, y que el borachung, sorprendido por la desecacion, no tuviese otro remedio que aguardar en su guarida, que antes comunicaba con el agua, la vuelta de esta, ya que se sabe que puede aguantar mucho tiempo en terreno seco. Cuando el pueblo encuentra estos peces en su camino cree que han caido del cielo; y los juglares de la India le hacen arrastrarse por el suelo para excitar la admiracion de los espectado. res. Buchanow dice que no pucde ponderarse bastante la vitalidad de estos peces; continúan arrastrándose aunque se les hayan quitado los intestinos, y cortados en pedazos se mueven todavia al cabo de media hora. Los vendedores de la plazalos descuartizan para venderlos. sueltos, porque su carne blanca y de fácil digestion, sin ser precisamente sabro. sa, es muy apeiecida y los compradores exigen que el pez ó pedazo se muera todavia, pues no siendo asi nadie lo com. pra. Los curopeos nolo comen, porque les repugna la scme. janza de este pez con las serpientes.

\section{LOS CEPÓLIDOS- CEPOLID㠪}

CARACTERES. - Guenther eleva los peies decinfa, ócefillidos (cipolida) al rango de familia, a pesar de que apenas se conocen escasamente diez especies del único género (cepola) que comprende. Conforme lo indica su nombre, tiene el cuerpo la forma de una cinta, siendo muy largo y muy comprimido lateralmente; la cabeza es en proporción pequenisima, pero los ojos grandes; el hocico es obtuso, la boca oblicua, pequeña y guarnecida de dientes delgados, puntiagudos, bastante largos y formando en cada mandibula una hilera bastante irregular; la abertura branquial es ancha, y el cuerpo está cubierto de escamas cicloideas pequeñas. La aleta dorsal, larguisima y sostenida por muchos radios blan. dos, acaba como la anal, que le cede poco en longitud, asi como la caudal que tambien es muy larga; las abdominales se hallan insertas en la region torácica.

\section{EL CÉPOLA ROJIZO-CEPOLA RUBESCENS}

CARACTERES.-Es el pez mas conocido de la familia; la mayor longitud que adquiere no excede de $0^{\prime \prime}, 50$. Su ca lor es un rojo trasparente que pasa en los costados á azafra. 
nado y ceniciento rojizo. La aleta dorsal es amarilla, orlada de morado y sostenida por sesenta y siete hasta sesenta $y$ nueve radios, de los cuales solo los tres primeros son algo mas fuertes y mas espinosos que los restantes; la anal, de co. lor amarillo gris, tiene sesenta radios; cada torácica diez y ocho; cada abdominal seis, de los cuales uno forma aguijon, y la caudal once.

USOS, COSTUMBRES Y RÉGTMEN.-El cépola se coge todo el año y á menudo en número bastante regular en el Mediterráneo, y en las costas del Atlántico hasta las aguas inglesas, mas á pesar de esto sabemos muy poco acerca de su género de vida. Se dice que vive constantemente en com. pañia de anguilas de mar, que se alimenta de crustáceos y de arémonas marinas, y que desova en la primavera y en la costa A pesar de lo poco sabroso de su carne, acaso se uti- lizaria este pez singular para alimento del hombre si no fuera tan sumamente deigado que en realidad no vale el trabajo de prepararlo.

\section{LOS GOBIESÓCIDOS- GOBIESOCIDE}

CARACTERES. - Antes se contaban entre los disco. bolos todos los peces que tienen en su parte inferior un disco por cuyo medio se adhieren á objetos extraños; pero Guenther y otros ictiólogos reconocieron luego que este disco 6 ventosa no tiene en todas las especies la misma estructura; y fundados en esta particularidad separaron unas veinte especies de aquellos y las reunieron en una familia

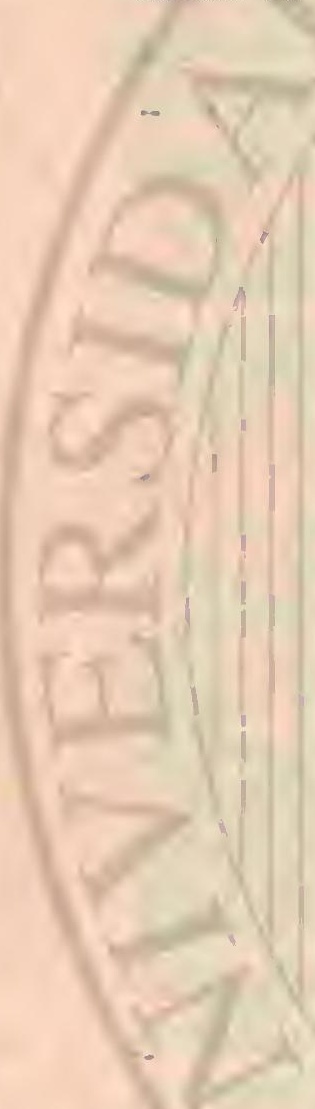

especial con el nombre de Gobiessicidos (Gobiesecida). E disco de estos peces se asemeja á primera vista al de los orros, pero examinándolo mas de cerca presenta diferencias notables y esenciales, pues mientras las aletas abdominales de los discobolos forman la parte media del disco, se en cuentran tan apartadas en los gobiesócidos que solo llegan á formar una parte de la circunferencia, y el disco propiamente dicho viene $\mathbf{a}$ ser en sustancia una degeneracion cartilaginosa de los huesos coracoideos. Adeniús de esta diferencia capital distinguese tambien por su tamaño, pues ocupa una tercera parte de la longitud total del pez; es un poco mas largo que ancho, casi redondo, y un seno profundo, en su circunferencia, situado detrás de las aletas ventrales, lo di. vide en una parte anterior $y$ otra posterior. Fsta ultima está formada de cuatro radios, de la membrana que los une, y de oira bastante ancha á manera de orla que tiene as cada lado del disco un radio atrofiado de la aleta ventral. La parte anterior está formada por una placa movible $y$ ancha que forma una sola pieza con el coracoideos detrás de la aleta pectoral. La parte media la constituye una membrana muy musculosa, y otra epidérnica muy gruesa cubre todo el disco. Ademis de esta particularidad importante y principal se distinguen los gobiesócidos por su cuerpo desnudo, oblongo y hácia la parte posterior comprimido; por los dientes cónicos ó comprimidos lateralmente y por una sola aleta dorsal de radios blandos, colocada en la region caudal.

DISTRIBUCION GEOGRÁFICA.-La mayor parte de los gobiesócidos pueblan los mares de ambas zonas templa. das, $y$ solo dos especies de las conocidas hasta ahora viven tambien en la zona tórrida.

Ėr cuanto à su género de vida se parecen los gobiesócidos a los discobolos.

\section{LOS LEPADOGASTROS -LEPADOGASTER}

CARACTERES. - Los distintivos consisten en la cabeza voluminosa y aplanada y en la boca que es protráctil. Los dientes son agudos y se hallan en la mandibula superior é intermaxilar. La membrana branquial tiene de cuatro á cinco radios.

\section{EL LEPADOGASTRO MANCHADO- LEPADOGASTER BIMACULATUS}

CARACTERES. - El color de este pez es de un hermoso carmin, que degenera en un tono de carne hácia la parte inferior, claro entre los ojos, y en el resto del cuerpo manchado irregularmente. La aleta dorsal tienc seis radios, Ia pectoral diez y nueve, la anal seis $y$ la caudal diez la longitud es de $0^{\circ}$, os poco mas $\delta$ menos.

USOS, COSTUMBRES Y REGIMEN.-Son los lepadogastros peces perezosos a manera de los lumpenos; pero prefieren sitios de poca agua, y al parecer aquellos donde la marea baja descubre $y$ deja en seco una gran superficic de playa ; á pesar de que esto los obliga á quedar bastantes horas fuera del agua la especie de que se trata aqui puebla en compañía de otra congénere las costas de Inglaterra y otras que baña el mar del Norte, donde elige los iondos peñasco. sos, $y$ vive adherida á las piedras ó conchas viejas, posicion que solo abandona para apoderarse de alguna presa ó para escapar á algun enemigo. Se alimenta de pequeños crustáceos y otros mariscos por el estilo, acaso tambien de pececillos. Se reproduce en marzo depositando su freza en los si. tios donde acostumbra vivir $y$ á veces en el hueco de las conchas desparramadas por el fondo. 
La pequeirez de estos peces unida á la dificultad que ofrece su pesca hacen que esta no compense el trabajo, mas á pesar de esto los cogen los pescadores para divertirse con ellos, porque se adhieren al momento al primer objeto que se les presenta, aun á la mano de la persona que los coge. Esta adherencia á los cuerpos del fondo donde permanecen, dificulta hasta el tenerlos cautivos, pues segun las observaciones de Montagu, suelen quedar adheridos, inmóviles hasta la muerte, al sitio que habian escogido, y aun despues continuan en la misma posicion. Cuando se mete el dedo entre ellos y el objeto, se pegan al punto a aquel y se dejan sacar asi del agua sin cambiar de posicion.

\section{LOS CENTRÍSCIDOS- CENTRISCID死}

CARACTERES.-Hay peces acantopterigios que difieren de los demás por la prolongacion considerable de la mandibula intermaxilar y los huesos palatinos, de suerte que una $y$ otros forman un tubo angosto $y$ prolongado en cuyo extremo se encuentra la boca, que forzosamente es muy pequeña. Se habian reunido en un principio en una sola $f_{2}$. milia las especies que presentan esta estructura, pero ahora forman dos que difieren principalmente en los puntos siguien. tes: los individuos de la una tienen el cuerpo oblongo, muy comprimido lateralmente y cubierto de escamas bien marcadas 6 de escudetes de coraza, y los de la otra son de cucrpo anguiliforme, redondo y cubierto de escamas, ora grandes, ora diminutas e impercejuibles á la simple vista. El hocico tu. bular $y$ la colocacion de las aletas dorsal y abdominal en la parte extrema del cuerpo son comunes á ambos grupos.

La primera familia ó grupo lo forman los centriscidos, de cuerpo corto, alto y comprimido; tienen dos alctas dorsales colocadas en la parte posterior y sostenidas por pocos $r 2$ dins, siendo el primero un verdadero aguijon movible, fuertemente dentado é inserto en el omoplato. La caudal es redondeada, y el cuerpo está cubierto de pequeinas escamas, á

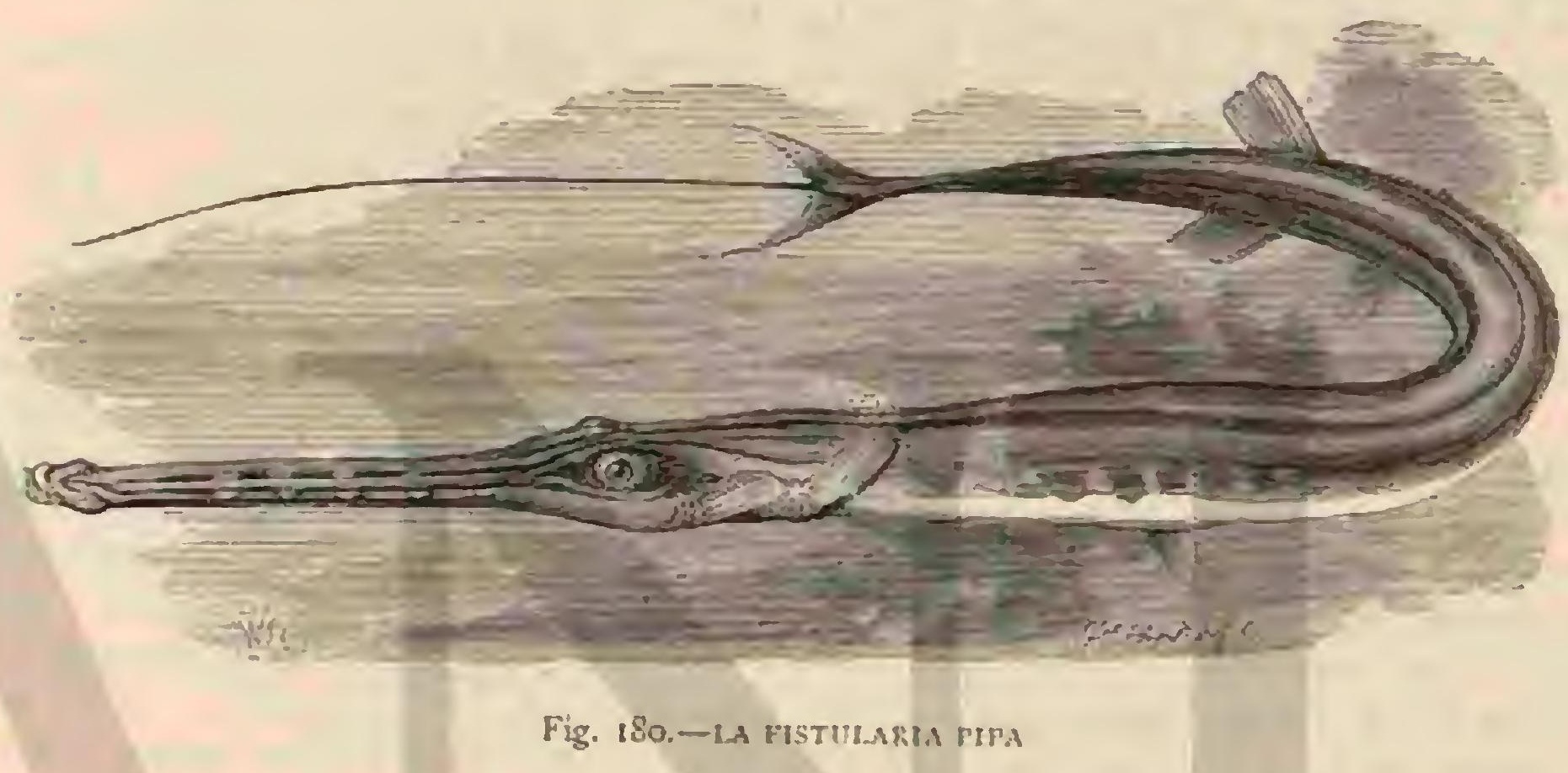

excepcion de la region del hombro donde hay algunos escudetes anchos y dentados. Esta familia comprende solo seis especies, y su representante es el género y especie de

\section{EL TROMPETERO - GENTRISCUS SCOLOPAX}

CARACTÉRES. - Brehm llama á esta especie y su género chocha marina, que es tambien el sentido de su nombre científico, por alusion á su hocico que se asemeja al pico de anguella ave. Es un pececillo de ()$^{m}, 15$ de longitud, muy bo nito, de color encarnado claro en el dorso y plateado en los costados y vientre. La primera aleta dorsal tiene de tres á cuatro radios espinosos, y la segunda doce; la pectoral diez y siete, la abdominal cuatro, la anal diez y ocho y la caudal diez y seis, todos mas blandos que los de la primera dorsal (figura 179).

USOS, COSTUMBRES Y REGIMEN. - El trompetero habita el Mediterráneo, donde parece abundar algo en los sitios que le convienen. Hasta ahora seha estudiado muy poco su género de vida, á pesar de ser per. conocido ya de Ron. delet. Risso, a quien se deben las mejores noticias sobre los peces del Mediterráneo, dice que los trompeteros prefieren un fondo cenagoso, de mediana profundidad y que desovan en la primavera. Las crias frecuentan la costa, en otoño, en bandadas y siempre cerca del sitio donde han nacido, por ser peces que no viajan. Dicho autor no dice nada respecto de su alimentacion, pero se supone que este animal se mantiene de pequenas conchas de toda clase y de otros moluscos, acaso tambien de freza y sustancias por el estilo que saca de Tомо $\mathrm{V}$ entre las algas. Gessner dice que su came es «blanca, sana, fácilmente digerible y que cria buena sangre. A pesar de esto se ven raras veces en las mesas á causa de su pequeñez, y hoy como en tiempo de aquel autor a se conservan disecados como una curiosidad.

\section{LOS FISTULÁRIDOS- FISTU.LARIID死}

CARACTERES, - Cinco especies sé conocen de esta familia, seprarada ahora de la anterior. Tienen una sola aleta dorsal colocada en la parte posterior, y la cola prolongada de una manera especial, pues remata en un hilo cerdoso que sale de entre los lóbulos de la aleta caudal, y que en algunas especies es tan largo como el cuerpo del pez. Fl tubo del hocico es muy largo tambien; el hueso intermaxilar y la mandibula inferior están armados de dientes pequeños, y el cuerpo parece liso à causa de la extraordinaria pequeñez de las escamas.

\section{LA FISTULARIA PIPA-FISTULARIA TABACCARIA}

CARACTÉRES. - Esta especie es el representante mas conocido de la familia y de uno de sus géneros. Puede llegar á una longitud de un metro, de la cual corresponde por supuesto la mitad al hilo caudal. El dorso es de color pardo con ires filas de manchas azules, y el abdómen blanco pla- 
teado. Catorce radios sostienen la reducida aleta dorsal, quince la pectoral, seis la abdominal, trece la anal y quince la caudal (fig. 180).

DISTRIBUCION GEOGR ÁFICA.-El género fistularia se extiende por aquellas partes del Atiantico y del Océano indico que se hallan dentro de la zona tórrida, 5 la especic fistularia pipa en particular habita las costas de América bañadas por aquellos mares.

USOS, COSTUMBRES Y REGIMEN. - Nada sé res. pecto á su género de vida. Commerson encontró en su estó. mago peces pequeños, y otros observadores dicen que cazan tambien diferentes especies de cangrejos.

\section{FARINGEOS - PHARINGOGNATHI}

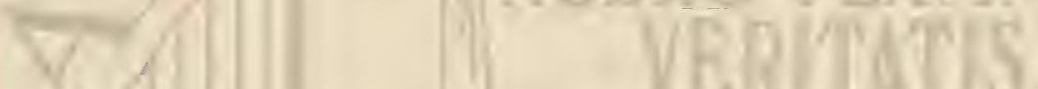

CARACTERES. - Hay un número proporcionalmente pequeño de peces que se distinguen de los demás por tener los huesos faríngeos inferiores confundidos en una sola pieza ó cuarido menos unidos por una sutura. Cuvier formó con cllos una fámilia; pero Mueller los elevó al rango de órden especial que comprende, segun su opinion, la mayor parte de los miembros de esta familia y además otras especies que presentan el mismo distintivo principal, conı tambien otro comun á todos, que consiste en la vejiga natatoria constantemente cerrada.

Entre las pocas familias que componen este órden hay una que habita los rios; las demas viven en el mar donde prefie. ren el fondo peñascoso cubierto de plañtas marinas, por encontrar alli su alimento favorito, es decir, pequeños can. grejos y conchas. Todas estas familias recorren en gran número los mares de las zonas mas diversas; pero pueblan con especial abundancia las aguas de las latitudes mas bajas, por cuya razon deben considerarse en realidad como peces de las zonas tórridas y templadas. No tienen importancia para la economia lumana, si bien se aprecia la carne de algunas especies, y por estó bastará á nuestro propósito conocer algunas de las que habitan nuestros mares.

\section{LOS LÁBRIDOS- LABRID死}

CARACTERES. - Los peces de esta familia, tan notables por su forma, su cubierta de escamas, y magnifica coloracion, forman el nícleo del órden, al cual ne limito. Su forma di. fiere poco de la de nuestros peces de rio, $y$ su cubierta consiste en escamas redondas. Su única aleta dorsal va sostenida principalmente por radios espinosos que suelen tener casi siempre trocitos de membrana en la parte posterior. Las aletas abdominales están debajo de las pectorales; las mandíbulas acaban en labios carnosos; la dentadura consiste en dientes de adoquin ó bien en placas trasversales; el paladar carece de ellos. Hay una vejiga sencilla. El estómago no tiene apréndice ciego, ni hay intestinos ciegos.

DISTRIBUGION GEOGRAFICA. - Ia familia de los lábridos, representada por unas cuatrocientas especies, se encuentra en casi todos los mares y de consiguiente tambien en nuestras costas europeas, especialmente en las del Mediterráneo y del mar del Norte donde el fondo peńascoso esta cubierto de plantas marinas, pero abundan generalmente en las aguas de la zona tórrida y en las regiones limitrofes de las templadas. En nuestras latitudes se observan relativamen- ic pocos lábridos, y mas allá de los circulos polares no se han visto nunca en punto alguno.

USOS, COSTUMBRES Y REGIMEN,-Además de la magnificencia de sus colores, se distinguen los lábridos por su viveza y movilidad al nadar de una planta á otra en los bosques sub-marinos que habitan y de los cuales no suelen alejarse. La mayor parte de las especies se mantienen de conchas, cual corresponde á su aparato dentario que les permite triturarlas con facilidad despues de haberlas cogido del fondo ó de las plantas con sus labios movibles. Hay tambien especies herbivoras, pero no lo son tan exclusivamente que rehusen el alimento anjmal en absoluto. Hacia la Época de la freza, que suele coincidir con la primavera de la region que habitan, aumenta el brillo de sus colores y la facultad que tienen de cambiarlos repentinamente. Sts carne goza de poca estima por ser muy sosa, lo que no impide que en muchos puntos se, haga un gran consumo de estos peces.

\section{LOS LABROS-LABRUS}

Entre los peces labroicicos propianente dichos (Labrince) merece una atencion especial la especie siguiente, por cuanto se la encuentra tambien en los mares septentrionales.

\section{EL BUDION Ó LABRO RAYADO-LABRUS MIXTUS}

CARACTÉRES-Los rasgos característicos de este pe\% consisten en sus labios gruesos, carnosos y como dobles; en los dientes cónicos en las mandibulas; en el opérculo y preopérculo lisos 6 cicloideos, desprovistos de espinas y cubiertos de escamas; en la mentbrana branquial que liene cinco radios, y muy especialmente en la diferente coloracion de los dos sexos. El color del macho es pardo rojizo con magnificas listas longitudinales azules que á menudo constituyen la tinta dominante: la hembra es de color rojo pálido con tres manchas oscuras en la parte posterior del dorso. La aleta dorsal tiene diez y siete radios espinosos y trece blandos; cada pectoral tiene quince, cada tentral uno y cinco, la anal tres y diez, y la caudal once y scis repartidos por igual arriba y abajo. Su longitud llega aproximadamente a $i^{*}, 30$ y su peso á un kilógramo y á veces mas.

DISTRIBUCION GEOGRA FICA.-Se considera el Me. diterráneo como la patria verdadera del budion, que desde alli se extiende por el Ailántico hácia el norte hasta las cos. tas de Inglaterra y de Noruega.

USOS, COSTUMBRES Y REGIMEN.--Asi como sus 
congéneres, elige este pez por domicilio peñas submarinas en cuyos agujeros y grictas cubiertas de regetacion acuática vive con preferencia; si bien cambia de vivienda si la esta. cion le obliga á ello, pues, segun Couch, pasa en verano á las pequeñas ensenadas donde vaga entre las piedras de la misma orilla, retirándose durante el otoño é invierno á sitios medianamente profundos. En las costas británicas desova en marzo y abril, pero en el Mediterránco no debe tener época fija, porque alli, segun dice Kisso, hace dos crias al año. Las diferentes especies pequeỉas de cangrejos son su alimento favorito, lo que no obsta para que coma tambien peces y gu. sanos de mar.

PESCA.-Como todos los lábridos, muerde el budion el anzuelo con la mayor facilidad, por cuya razon cuesta poco cogerlo, pero en ninguna parte se le pesca en grande escala á causa de la poca estima en que se tiene su carne, por manera que solo suele servir á los pescadores de cebo para coger peces de mas mérito.

CAUTIVIDAD. - Es muy apreciado este pez para los acuarios principalmente á causa de su hermosisimo colorido, y despues porque reune, como pocos animales de su clase, circunstancias para conservarlo cautivo si el depósito de agua salada cstá dispuesto á propósito, pues se le mantiene fácil. mente con moluscos y gusanos. Durante la época del celo es cuando ofrece mas interés observarlo. Sobre esto dice nuestro amigo Gessner eque á pesar de ser particularmente aficionado s. tener gran número de hembras, es en extremo celoso», y tiene mucha razon este viejo autor, pues tan pacificamente como por lo comun suele vivir con sus comparieros, tan celoso y pendenciero es antes y durante la época de

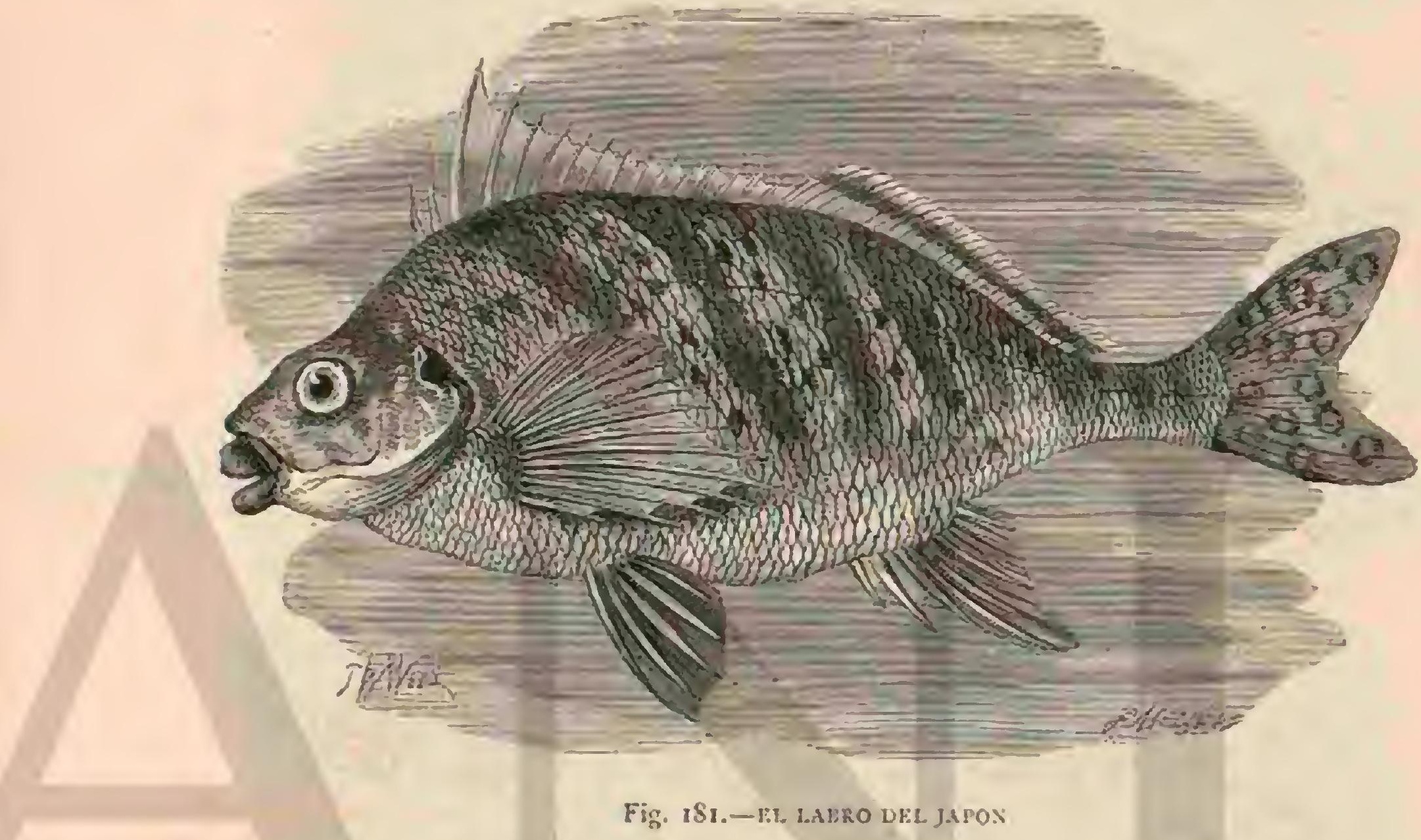

la freza. Una vez conquistada la hembra, lo que no logra sino despues de luchar mucho con otros pretendientes, la acom. paña \& cualquiera parte â donde ella raya, sin apartarse de su lado y ostentando un brillo verdaderamente extraordinario. Desde este momento no sufre rival $y$ ataca con furia á los otros machos que se le aproximan y con los cuales empeña en caso necesario una lucha á muerte; pero si el amor aumentaba el brillo y magnificencia de sus colores, no asi los celos, porque sa la vista del adversario se vuelve casi todo su cuerpo de color gris igual. Tambien dice Gessner, reu niendo como suele los datos de los autores antiguos, que cl budion etienc fama de profesar gran cariño á su cria antes $y$ despues de nacida. Ia hembra se encierra en un agujero para depositar alli su freza y el macho guarda la sa. lida mucho tiempo aun sin comer, como si tuviera conciencia de que le incumbe proteger la cria. Es fácil que estos da. tos sean hijos de observaciones directas, si bien las que he mos hecho en budiones cautiros no nos jermiten confirmarlos.

\section{EL LABRO DEL JAPON-LABRUS JAPONICUS}

CARACTÉRES. - Liste labro (fig. 18r) se caracteriza en parte por tener cuntro caninos muy fuertes y un pequeno diente detrás; el del ángulo de la mandibula superior es tambien muy sólido; las escamas, de igual tamaño, presentan en la superficie estrias nuy finas, $y$ la linea lateral arbúsculos muy cortos. El color de la especie es pardo rojizo en el lomo; la caudal mas oscura, y la anal tiene un tinte violado en su base, siendo el centro amarillo. El tamaño de este pez, varia entre dicz y doce pulgadas.

DISTRIBUCION GEOGRÁFICA.-Los individuos observados procedian de la aguas del Japon, como ya lo indica cl nombre del pez.

\section{LOS CRENILABROS-CRENILABRUS}

CARACTERES. - Este genero difiere del anterior por su forma mas rechoncha, preopérculo dentado y una hilera de dientes cónicos en las mandibulas. Casi todas las especies son de poco tamaño y a lo mas de volúmen regular, pero adomadas de los colores mas bellos. Sus escamas y aletas compiten en magnificencia con los colores del arco iris y de los metales; y esta belleza aumenta todavia considerablemen. te en el periodo del celo. La culoracion suele ser distinta en los dos sexos, circunstancia que hace muy dificil precisar las diferentes especies, á no ser que el naturalista mismo las pesque y óbserve en la mar, atendido que los cjemplares que se conscrvan en espiritu de vino pierden casi toda su hermosura ó cambian de color, y algunas especies presentan solo toda su coloracion mientras se sienten en plena seguridad y nadan sin temor en su elemento; perdiendo ya parte de su dibujo en el momento en que se las saca del agua, con. forme observaron liries y Eckstroem en un pez de las espe. 
cies que frecuentan las costas escandinasas, y que tenia manchas dispuestas en hileras cuando nadaba descuidado; pero que desaparecian instantáneamente al inquietar a! ani. mal, reapareciendo luego que volvia s creerse seguro. Saca. do del agua perdió el dibujo por completo.

\section{EL TORDO DE MAR - CRENILABRUS MELOPS}

CARACTERES، - Alcanza a lo sumo una longitud de $0^{m}, 18$, pero no cede á sus congéneres respecto i su magnifica coloracion ni à la variabilidad de la nisma. Acabado de sacar del agua, es su color dominante un hermosisimo verde que pasa å azul en el dorso y tiene visos de oro producidos por los bordes claros de las escamas. Lineas oblicuas verdes adornan la cabeza amarillenta, además de una mancha negra detrás del ojo. Las aletas son amarillas con manchas verdes y azules. Al cabo de muy poco rato palidecen todos estos colores confundiéndose en uno pardo $\delta$ ceniciento indeter

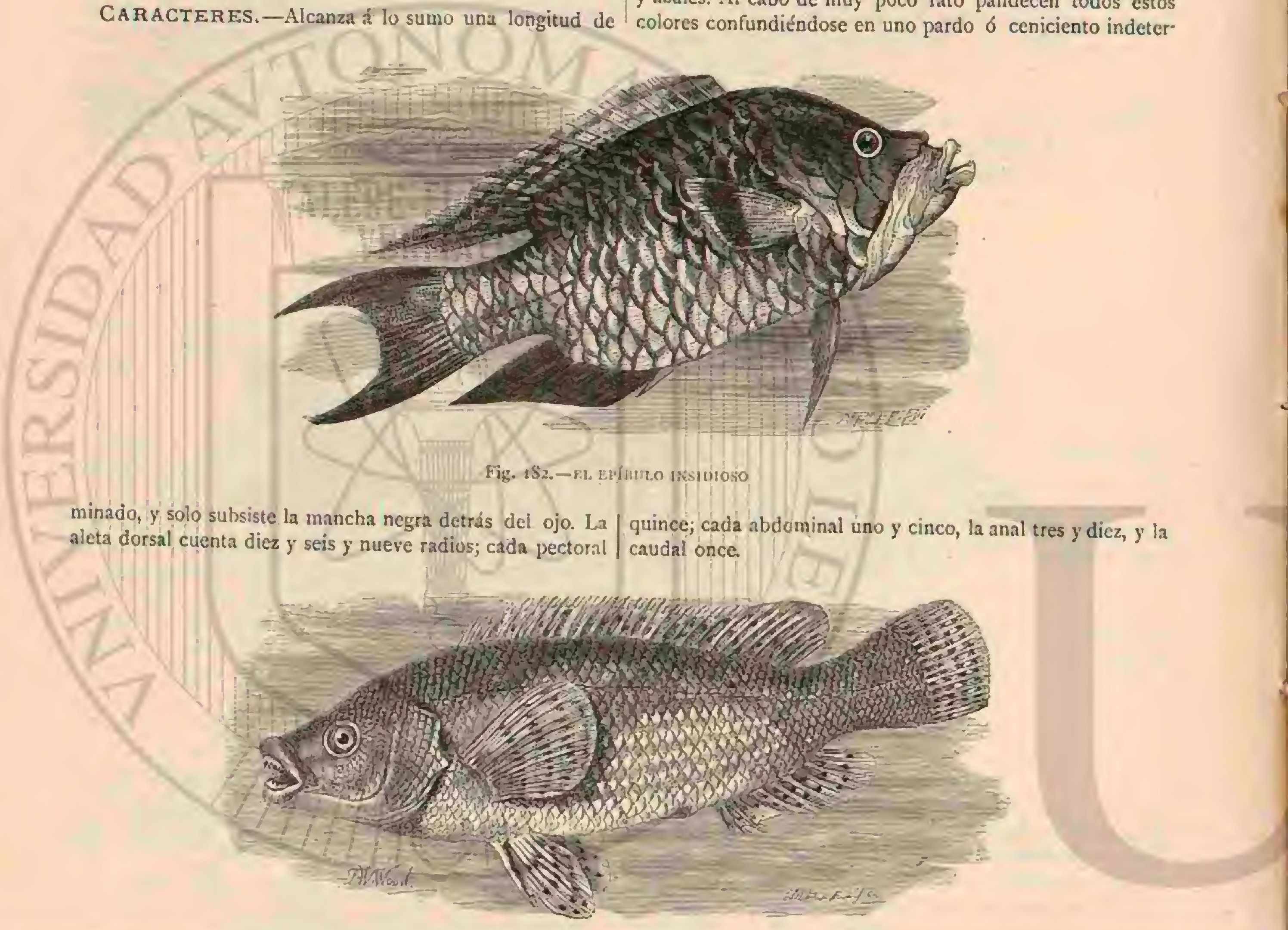

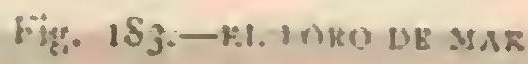

DISTRIBUCION GEOGR ÁFICA. - Desde el Mediterráneo se extiende cl tordo de mar á lo largo de la costa curopea del Atlántico hasta las agüas inglesas, siendo frecuente en las costas meridionales de Inglaterra, del concado de Gales ó de Irlanda; en Escocia se le observa en algunos puntos, pero mas al norte escasea y en la latitud de las islas Orcadas, corno tambien a lo largo de la costa de Noruega, solo se observan ejemplares sueltos, $y$ dificilmente alguno mas allá del paralelo 62 .

USOS, COSTUMBRES Y REGIMEN.-En el Me. diterráneo habita el tordo indiferentemente fondos arenosos y peñascosos. Se alimenta casi exclusivamente de pequeños cangrejos. Se le coge por lo general en canastas donde se conservan langostas, pero su pequeiro tamaño y carne ordinaria no compensan la pesca hecha en regla.

\section{LOS JIRELES-JULIDINA}

CARA CTÉRES.-Este género, cuyos individuos parecen reunir la magnificencia y belleza de todos los lábridos, se distingue por su forma oblonga, los opérculos desnudos y la dentadura que consiste en una primera hilera exterior de dientes cónicos muy robustos y otra hilera interior de dien. tes redondeados á modo de protuberancias y colocados sobre el hueso palatino.

\section{LA JIRELA VULGAR Ó EL JIREL- CORIS IULIS}

CARACTERES.-Sobre esta especie, la mas conocida del género ó mas bien sub familia de los jireles, tan abun. dante en especies, principalmente en el mar Indico, dice el autor antiguo tan frecuentemente citado: De todos los peces del mar es este el mas bello en cuanto á coloracion y forma; circunstancia que le ha valido su nombre en todas las naciones. La variedad de colores que ostenta en el dorso han hecho que se le compare con el arco iris.s En efecto, merece el nombre de pez arco-fris que lleva en diferentes 
paises, por la dificultad que hay de describir sus colores que pasan insensiblemente de uno á otro y varian segun la direccion ell que les toca la luz. El lomo es de color azul verdoso con una ancha lista longitudinal anaranjada. En los costados es el fondo plateado con otras listas longitudinales color de violeta; la cabeza es amarilla tirando á parda con dibujos azules y plateados; la aleta dorsal lleva sobre fondo rojo de mármol manchas de púrpura; ias demás aletas son, cual mas, cual menos, de color azul rojizo y todos estos colores pasan tan insensiblemente de uno á otro que es imposible decir dónde comienzan y dónde acaban, lo propio que su. cede con los del arco.iris. La aleta dorsal está sostenida por nueve y doce ó trece radios respectivamente duros y blan. dos; cada torácica tiene de doce a trece; cada abdoninal uno y cinco; la anal respectivaniente dos $\delta$ tres y doce ó ire. ce, y la caudal trece ó catorce. La longitud de este pez pasa raras veces de $U^{ \pm}$, i $\mathrm{S}$.

DISTRIBUCION GEOGRÁFICA.-Se sabe que la jirela ss muy comun en el Mediterránco y Atlántico, y que á veces se extravia hasta las costas inglesas.

USOS, COSTUMBRES Y REGIMEN.-Todo lo qque sabemos de csta especie es que vive entre las peñas cubiertas de algas donde se mantiene de crustáceos y de pececillos; que desova en primavera, y muerde fácilmente el an zuelo. Hablando de una especie afine a la jircla dijeron unos pescadores árabes del mar Rojo á Klunzinger que se presentan siempre en cierto número, como de diez á veinte, y cuando atisban una presa ó cebo, persiguen al afortunado que logra cogerla; que cuando esta es un bocado dema. siado grande, el aprehensor muerde, meneando la cabeza, un

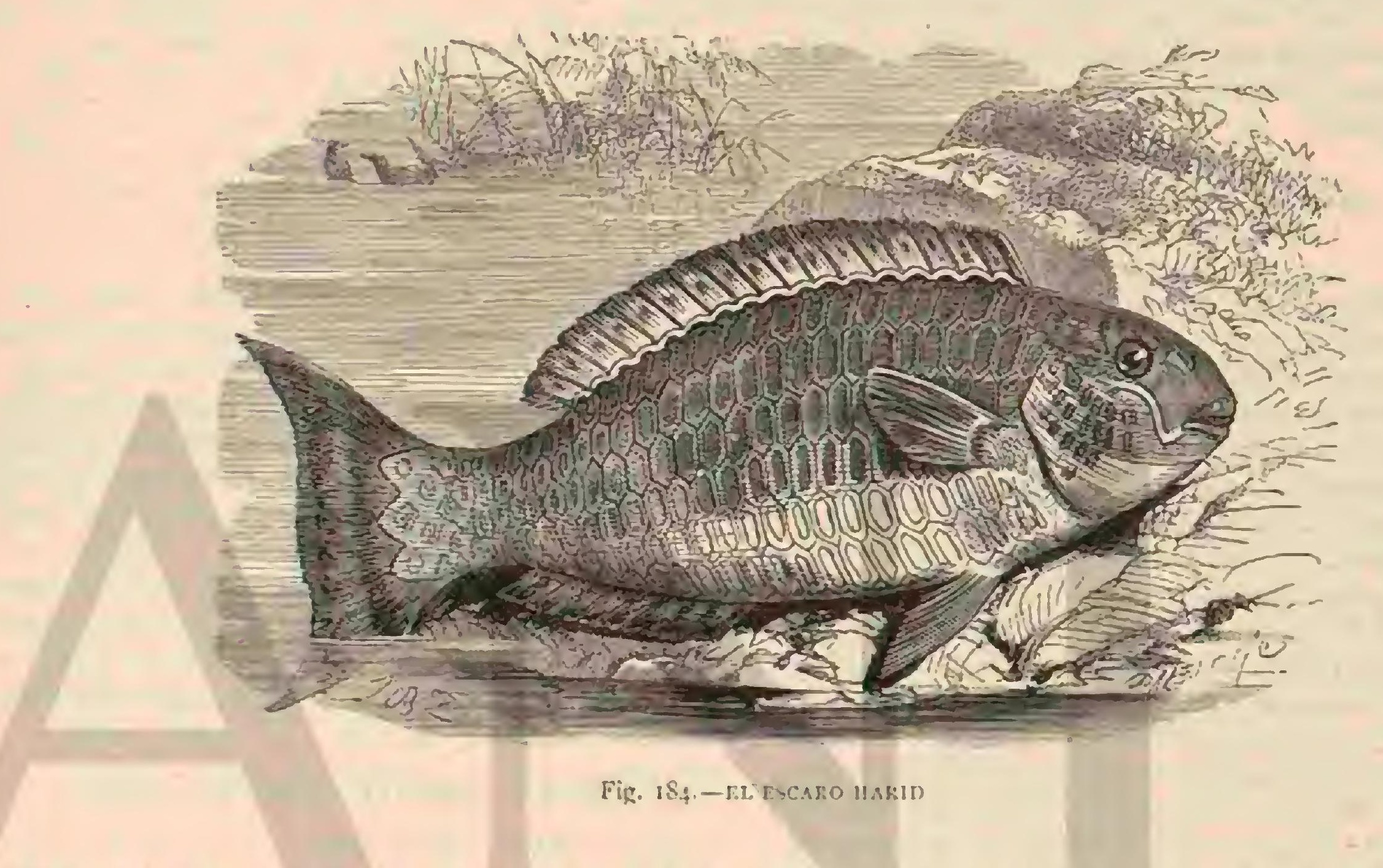

pedazo y suelta cl resto á sus perseguidores para que le dejen en paz. Si la atrapó á alguna distancia de las rocas protecto. ras que habitan, se retiran todos alli a toda prisa apenas se han apoderado de ella. Ignoramos hasta dónde pueden aplicarse eitos datos á la especie que nos ocupa, y tampoco podemos emitir juicio sobre la exactitud de las relaciones que nos han dejado los naturalistas antiguos. Conforme dice Numenio nadan estos peces en grandes bandadas cual si fuesen mosquitos; viven entre peñas y son en extremo vora. ces; esto escribe Gessner y sigue diciendo: «Se dice que muerden $y$ pican á manera de abejas $y$ avispas a las personas que se bañan, y que acuden precipitadamente apenas las ven. La circunstancia de durar bastante rato el dolor que causan con sus mordiscos, al igual de lo que sucede con las picaduras de los insectos citados, ha sido causa de que algunos autores bayan dicho que estos peces, asi como todo lo mordido por ellos, es renenoso é inservibie para alimento. Los médicos atribuyen á su carne muchas cualidades buenas y saludables, entre ellas la de ser tierna y fácilmente di. gerible, conforme sucede con casi todos los peces de roca. ?

\section{LOS EPIBULOS-EPIBULUS}

CARACTÉRES. - En los mares indicos se presenta un lábrido que se distingue de todos los demás de su familia por la protractilidad de su hocico, pues pueden prolon- garlo á su albedrio hasta formar una especie de tubo con el auxilio de las mandibulas e intermaxilar que por medio de músculos se cstiran ó encogen. Ia boca está armada de dien. tes pequeños con otros dos grandes, rectos y cónicos en medio; el cuerpo como la cabera se hallan cubiertos de escamas grandes, y la membrana branquióstega encierra cinco radios. La única especie conocida de este género es:

\section{EL EPIBULO INSIDIOSO-EPIBULUS INSIDIATOR}

CARACTÉRES. - La longitud de esta especic (fig. 182) llega de $0^{2}, 25 \& 0^{\circ}, 30$. El color es rojo en el dorso; blanco con viso verdoso brillante en los costados á causa de los bordes verdes de las escamas; amarillo con ondas verdes en las aletas dorsal y anal, y amarillento en las demás. La dorsal tiene nueve y quince radios; cada pectoral, la anal y la caudal, que es muy cóncava, once, y cada abdominal seis.

USOS, COSTUMBRES Y REGIMEN.-Antes se creia haber observado que el epibulo se servia de su hocico tubu. lar á manera de los toxotes 6 arqueros para hacer caer los insectos posacios en las rocas y plantas $f$ fin de apoderarse de cllos; pero ahora prevalece la suposicion de que acecha los peces pequeños, oculto entre plantas marinas, y que los atrapa con maravilloso acierto cuando se acercan, dilatando instantáneamente su tubo bucal. 


\section{LOS LOROS DE MAR - SCARINA}

CARACTERES. - Con el nombre expresiro de loros se comprenden lábridos tan notables por su dentadura como por la belleza de sus escamas y la magnificencia de sus co lores. En general presentan los caractéres de los lábridos, pero difieren de ellos por la estructura de la boca, pues los maxilares é intermaxilares forman mandíbulas arqueadas y redondeadas, cuyo borde $y$-superficie exterior están armados de dientes que, por lo espesos y juntos, parecen adheridos á manera de una sola placa, con la particularidad de que la primera hilera, la mas exterior, salta cuando la que tiene de trás llega i su desarrollo regular. Para hacer mas singular esta dentadura, réforzada como está por dos escudos guarnecidos de laminitas inasversales, y colocados en la faringe, la cubren todavia en gran parte membranas carnosas.

DISTRIBUCION GEOGRÁFICA. - Este género perte nece propiamente á la zona tórrida, $y$ solo contadas especies lo representan en las aguas europeas, siendo la mas notable de ellas la siguiente.

\section{EL LORO DE MAR Ó ESCARO CRETENSE -SCARUS cRETENSIS}

CARACTÉRES. - La forma de este pez. (fig. i $S_{3}$ ) es ovalada, un tanto oblonga, casi semejante ála de una carpa robusta, con la sola diferencia de que la aleta dorsal es mucho mas grande; el hocico pequeño y redondo, de la misma forma ovalada que la cabeza; los labios delgndos, que pare. cen dobles, cubren las mandibulas hasta los dientes. Ia frente, el hocico y toda la region bucal están desnudos y el resto de la cabeza y del cuerpo se halla cubierto de escamas grandes, ovaladas, cicloideas y dispuestas en ocho hileras longitudinales. El dorso es de color de púrpura, los costados morados, porque el centro de las escamas es de este color sobre fondo rosado; las aletas pectorales y abdominales son anaranjadas, con lineas color de violeta en las últimas; la dorsal $y$ anal tienen manchas rosadas sobre fondo violado, $y$ la últina además una orla blanca. Nueve radios duros y diez blandos sostienen la aleta dorsal; doce blandos cada pectoral, uno duro y cinco blandos cada abdominal; dos y nueve la anal, $y$ trece la caudal. 'I a longitud es de 0 , 40 poco mas ó menos.

DISTRIBUCION GEOGRÁFICA. - Ia patria de esta especie es el archipiélago griego. Antiguamente debia ser frecuente tambien en las costas italianas; pero dicese que en el dia ya no se coge ninguno.

USOS, COSTUMBRES Y REGIMEN.-Plinio escribe sobre este pez lo que sigue: «Ahora se atribuye el ${ }^{-}$primer puesto al loro de mar, el único pez, segun dicen, que rumia y que es exclusivamente herbivoro: Como no abandona su region y no pasa mas allá del promontorio de Troya, mandó Tiberio Claudio á Optato con cierto número de buques para traer esta clase de peces y soltarlos en la costa de Campania, operacion (que se ha ido repitiendo durante cinco años, por manera que ahora son frecuentes estos animales en las costas italianas donde antes no se cogia ninguno. De este modo se ha procurado con este pez una variacion para el paladar, y se ha dado al mar un nuevo habitante $s$ fin de que no digan que en Koma solo se sabe aclimatar y reproducir aves extrañas. Además de estos datos de Plinio cuentan los antiguos que los loros de mar se aman mucho uno al otro, tanto que se auxilian para sacar de la red á los que se hallan cogidos, lo cual logran del modo siguiente; los peces de la red se cogen con los dientes á la cola que les presentan los de fuera, que los sacan asi; $y_{\text {añaden }}$ que se dejan coger fácilmente con una hembra atada á un cordel que se hace nadar por el mar, porque entonces se reunen los machos á su alrededor y caen en manos del pescador; y otras cosas por el estilo. Los gastrónomos antiguos no hacian mas caso de la carne del loro que de los otros labros; por lo me. nos leemos en Marcial:

Lo mejor que ofrece el escaro debilitado por las olas cuando llega,

$\gg$ Es solo el higado; lo demás es de pésimo gusto.

He aqui ahora lo que nos dicen los observadores moder. nos: Todas las especies de este grupo, que con dificultad merece ser considerado como suh-familia, viven como los demás lábridos en las costas peñascosas, donde habitan en las grietas y huecos de los escollos submarinos, entre los arrecifes madrepóricos y particularmente en los pozos profundos que hay entre ellos. Son en extremso sociables, por manera que anenas ó muy rara vez se encuentran aislados. Con la marea alta suben de su profundo y seguro retiro para pacer las plantas que tapizan las rocas y la plaga cubiertas entonces de agua. Comen en posicion vertical boca abajo porque asi les es mas fácil arrancar las plantas de las rocas, puesto que ya se ha dicho que su alimentacion parece ser principal. mente vegetal. Cuando se presentan en la superficie y en agua poco profunda se les pesca con el esparavel y tambien con arpon. Su carne no es precisamente mala, pero sí muy blanda, por cuya razon es mejor comerlos fritos $\delta$ asados en parrillas que no cocidos, y esto hace que no alcancen gran precio: Ahora, lo propio que en la antigüedad, se aprecia mas el higado que la carne. En las costas del mar Rojo se salan y se secan, y pudiendo mandarlos así mas léjos, resulta qué alli se pescan con mas aficion, tanto que se ven llegar con mucha frecuencia á aquellos puertos barcos cargados exclusivamente de estos peces abiertos ya y salados.

Durante la exposicion universal de r 867 se enseñó uno de estos pecés tan magnificos vivo, pero solo resistió la cautividad algunos dias; quizás porque no habia medio de alimentarle convenientemente.

\section{EL ESCARO HARID-SCARUS HARID}

Caractéres. - El escaro harid (fig. 184) tiene el cuerpo algo mas prolongado que el anterior, $y$ la caudal ahorquillada como él; pero se caracteriza particularmente, porque la parte superior de la nuca forma una prominencia constante y muy marcada detrás de los ojos. Las mandíbulas tiencn el borde liso y no presentan dientes hácia el ángu. 10. Las escamas de este pez son granujientas, con estrias muy finas. En este pez predomina el color azul, con dibujos ama rillentos de forma exágona; la cabeza es de un amarillo brillante, moteada de azul; las aletas dorsal y anal pardas, orilladas de verde; $y$ en las ventrales $y$ pectorales predominan tambien estos dos tintes; la aleta de la cola es del todo rerde. Fil tamaño de este escaro varia de $1 \mathcal{S}$ á 20 pulgadas.

DISTRIBUCION GEOGR ÁFICA-El escaro harid ha bita en las costas de Ceilan; se le ha visto en el mar Rojo, donde parecen ser numerosas las especies; tambien se le ha pescado en las aguas de Madagascar y en las de la isla de Francia.

\section{LOS TAUTOGAS-TAUTOGA}

CARACTERES. - Los tautogas son labroideos cuyo carácter genérico consiste en la doble fila de dientes en las dos mandibulas; distinguense tambien por tener desnuda y sin escamas la espesa piel quie cubre el opérculo, el sub-opérculo y el inter opérculo; las que protegen el preopérculo son muy escasas. 
DISTRIBUCION GEOGRÁFICA.-Parece que solo habita en el Atlántico una especie, al menos que conorca. mos, la cual ofrece numerosas variedades; pero en el mar de las Indias existen otras varias que presentan todas el mismo caråcter genérico.

\section{EL TAUTOGA DE FAJAS-TAUTOGA FASCIATA}

CARACTERES. - La especie de este nombre (fig. 185) tiene el hocico puntiagudo; el sub-orbitario pequeno y los huesos rugosos; la dorsal y anal altas; la caudal larga y ancha, y las ventrales algo prolongadas. Los colores de este pez son bonitos: el dorso oirece un tinte verde brillante, que se cam bia en amarillento de oro hácia el abdómen; cn el cuerpo hay manchas púrpura y grises; las de la cabeza, y varias lí. neas mezcladas tienen un precioso color de naranja; la dorsa! presenta listas longitudinales de carmin sobre fondo gris sonrosado; la anal es parda, como las fajas verticales del cuerpo; las pectorales $\mathrm{y}$ las ventrales amarillas. El tautoga de fajas no alcanza grandes dimensiones, pues parece que ninguno pasa de unas 15 pulgadas de largo.

DISTRIBUCION GEOGRÁFICA.-Los individuos observados procedian de las costas de Ceilan.

\section{ANACANTINOS -ANACANTHINI}

CARACTERES. - Anacantinos se llaman los peces que en su estructura interior concuerdan con los acantopterigios, cuya vejiga natatoria carece de conducto néreo, y cugas ale tas están sostenidas exclusivamente por radios blandos; y que cuando tienen aletas abdominales se hallan insertas en el pecho 6 en la garganta. Hé aqui las palabras con que caracteriza Juan Mueller el presente órden establecido por él. Si d d á ellas agregamos como complemento que los peces perte necientes al mismo tienen siempre separados los huesos faringeos inferiores, habremos dicho todo lo que puede citarse como carácter general.

Si las diferencias características entre este órden y el anterior son tan escasas, no sucede lo mismo respecto de la importancia que tienen para nosotros los anacantinos. A pesar de contar pocas familias este órden, y estas muy pocas especies, es grandisima su importancia para la industria pes. quera, pues los anacantinos son los que proveen todo el año nuestras pescaderias y mercados de los peces mas apreciados y buscados, para cuya pesca se arman millares de buques que á su vez dan trabajo y jornal á centenares de miles de hombres. Esta pesca hace que se reunan cada año en determinados sitios las flotas mas gtandes que jamás se han visto, $y$ que los marinos y pescadores desafien las tormentas mas espantosas y los peligros que estas traen consigo. El comercio que se hace con estos peces ha puesto en con. tacto desde remotos siglos los pueblos mas apartados; ha sido siempre el recurso principal y la causa del bienestar de ciertos distritos y naciones, y continuará siéndolo mientras haya ayunos forzosos y personas aficionadas á esta alimen. tacion.

\section{LOS GÁDIDOS-GADID屟}

CONSIDERAGIONES GENERALES. - La confusion de isletas, escollos y peñascos que guarnecen cual espesa guirnalda la costa noruega, presenta un aspecto muy distinto al navegante que se dirige hácia el norte cuando llega á latitudes en las cuales alumbra el sol de media noche, durante los meses de verano, las cúspides de las montañas y donde durante el invierno solo un tenue crepúsculo recuerda á los séres humanos que en otras latitudes mas bajas vive $y$ brilla toda la naturaleza en pleno y refulgante dia. Alli reemplazan islotes y peñas de poca circunferencia, pero de mil y mas metros de altura sobre el nivel del mar, á las rocas de base mas ancha, pero que rara rez exceden de cien metros de elevacion, que hasta aquella latitud dificultan el acceso ála costa. Desde léjos se destacan del horizonte sus masas oscuras con sus cumbres cubiertas de cterna nieve, manantiales perpetuos de rios y cascadas de hielo que semejantes á inmensas cintas de plata bajan al océano. Un brazo de mar de pocas leguas de ancho separa estas islas, las Lofoden, del continente, y parece, á despecho de su fuerte corriente, un tranquilo lago si se le compara con el mar abierto, llamado Glacial y siem: pre alborotado. Desde la cubierta del vapor, que tan pronto se acerca á la costa como vuelve à entrar en alta mar para satisfacer el servicio postal tan bien organizado en Noruega, á pesar de su poblacion escasa, conoce el viajero que se encuentra en un archipiélago en el cual cada isleta aparece como una madre rodeada de innumerables hijos, los islotes y peñascos que se levantan del mar al rededor de la principal, así como hasta alli se alzaban junto a la costa.

La abundancia y fertilidad del mediodia es desconocida en aquel mar $y$ aquellas islas, pero no por esto carecen de cierta belleza y encanto, especialmente en las altas horas de la noche, cuando el disco grande 5 enrojecido del sol continua en el horizonte y refleja su amortiguado brillo en el mary en las cimas heladas de las montañas. Contribuyen á realzar este maravilloso espectáculo los caserios desparramados que se destacan, á los rojizos rayos del bajo sol, del fondo formado por las montanas que por contraste aparecen negras, y de color azulado oscuro las cumbres cubiertas de hielo que se levantan detrás de aquellas. El extranjero se admira al observar que esos caserios son mas grandes y mejor acondiciona. dos que los que vió en los valles mas fértiles de la Escandinavia meridional, á pesar de no estar rodeados de tierras de labor, que en aquella region á duras penas ven madurar la cebada que se las confia durante los cuatro meses de veranc, en que el sol se levanta un tanto mas del horizonte. Lo que aumenta su asombro es que los edificios mas espaciosos y opulentos se hallen precisamente situados en isletas peque. ñas, donde la árida roca está cubierta á lo sumo de húmeda turba $y$ donde el suelo ingrato apenas permite cultivar un miscro y reducido huertecito.

El enigma se explica cuando se sabe que los campos de 
aquellas casas son el mar, que alli no se siembra ni se recoge el fruto en verano, sino en medio del invierno, durante aquella noche tan larga que no da lugar á la aurora, cuando en vez del sol alumbra el paisaje solo el misterioso y frio resplan. dor de la luna 6 cuando el sorprendente fulgor de la aurora boreal inflama la bóveda celeste. E! enigma consiste en que

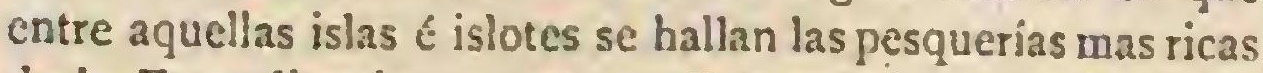
de la Escandinavia, y que aquellos caserios son las trojes donde se almacena la cosecha que se saca del nuar.

Durante el verano nadie vive all, pero en irvierno hormi. guean en cl mar los buques y embaraciones menores y en las islas innumerables trabajadores. En verano vigilan millo. nes de aves desde las rocas la superficie del mar, y en invierno trabajan afanosos noche y dia al pic de las mismas rocas innumerables brazos humanos. Alli se reune por Navidad la poblacion pescadora de toda la costa, y por grandes que sean las granjas son insuficiontes para dar albergue $\{$ tanta muche- dumbre, que en parte se aloja en los buques y en chozas pequeñas levantadas rústicamente en tierra, además del nú mero mucho mayor de individuos ocupados en los trabajos de tan gran cosecha.

Este movimiento continúa meses y meses, durante los cuales es aquella region un no interrumpido mercado, porque con los pescadores han llegado tambien los compradores y traficantes; los buques destinados 1 llevarse la cosecha del mar han acudido cargados de los productos de! mediodia; los habitantes del pais cambian los tesoros del mar por los del sur, y cada uno se provee para todo el año de lo que ne. cesita. Solo cuando vuelve a mostrarse el sol hácia el sur llevando tambien á este pais su primavera, cesa el ruido y se restablece el silencio; un buque tras otro, cargado hasta la cubièrta, leva anclas, iza las velas y cmprende el rumbo hácia el mediodia, y cuando las aves marinas reaparecen en las penas, no huella ya la planta humana aquellas playas desoladas.

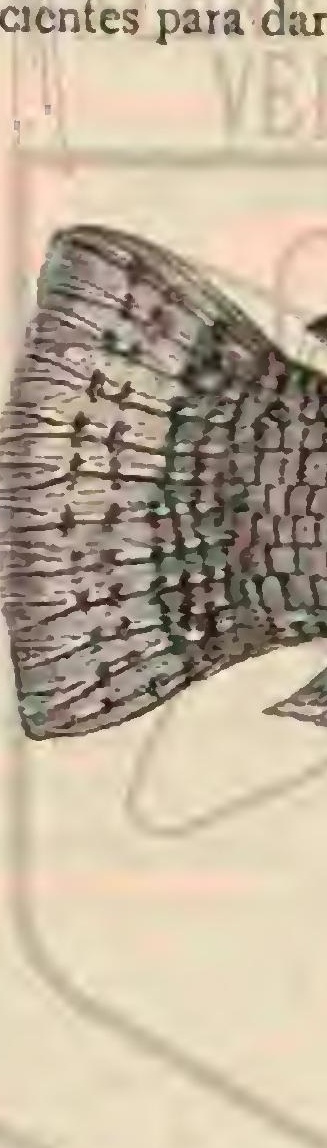

Cuando esto sucede cmpieza á poca diferencia un movi miento idéntico al otro lado del mar, en el banco de Terra. nova, con la diferencia de que alli comparecen todas las naciones maritimas y pescadoras del norte, mientras que d las Lofoden acuden principalmente noruegos. Solo de Ingla. terra van cada año mas de dos mil buques a lerranova; Francia envia alli la mitad de este número; Bélgica y $\mathrm{Ho}$ landa unos seiscientos, $y$ los norte-americanos tantos como Inglaterra y Francia juntas. Se reune pues en aquel punto una fiota que cuenta mas buques que toda la marina mercante de Alemania, y un ejército de márinos de cien mil hombres próximamente.

Añádase á esto que el mismo objeto que reune tanta gente $y$ buques en las Lofoden $y$ en el banco de Terranova, se persigue con una actividad enteramente especial durante todo cl año en la costa occidental francesa, en las de Bélgica, Holanda, Alemania, Jutlandia, en las aguas inglesas y en el banco de Rockall situado en el mar del Norte á ciento sesenta leguas de la isla de Kilda; es decir en todas partes donde hay esperanza de lograr algun beneficio, y todo esto para apoderarse de una sola clase de pescado.

Este pescado es el macalao; uno de los mas importantes del globo, que se pesca sin descanso mas de tres siglos hace; que ha motivado sangrientas guerras; del cual se cogen y consumen anualmente de cuatrocientos á seiscientos millones de indivicuos, y que hasta ahora ha resistido a tan encarnizada persecucion porque su increible fecundidad vuelve conti. nuamente, por lo menos hasta hoy, á llenar los claros que en sus innumerables huestes causa la codicia del hombre.

CARACTERES. - La familia de los gádidos, cuya espe- cie mas importante ya que no mas anoble es indudable. mente el bacalao, se distingue por su cuerpo mas ó menos obiongo cubierto de escamas pequeñas, blandas y dentadas; por una, dos ó tres aletas dorsales; aletas abdominales pequeías colocadas en la garganta; una $\delta$ dos anales $y$ una caudal mas ó menos cóncava, y raras veces redondeada. Las mandibulas, la punta del vómer y en algunas especies ilasta los huesos palatinos, están armados de pequeños dientes de púa. La membrana branquial contiene cinco radios; el estómago es ancho; el número de apéndices pilóricos considcrable, el intestino largo y la vejiga natatoria espesa.

\section{LOS ABADEJOS Ó BACALAOS -GADUS}

CARACTERES. - Distinguense los individuos de este género por tener tres aletas dorsales y dos abdominales; la caudal está bien separada de las segundas aletas dorsal y anal, y por un barbillon en el extremo de la mandibula inferior.

\section{EL ABADEJO Ó BACALAO COMUN-GNDUS MORRHUA}

CARACTERES.-Es un pez de un metro 6 metro y ne. dio de longitud (fig. I 86) y de un peso que llega hasta cuarenta kilógramos; su color es gris salpicado de pequeñas manchas amarillentas, con una rasa blanca en cada costado; el vientre es claro y sin manchas. El número de los radios es en la primera aleta dorsal de diez á quince; en la segunda 
de diez. y scis á veinticios; en la tercera de diez y ocho á veintiuno; en cada pectoral veinte; scis en la abdominal; en la primera anal de veinte á veintitres; en la segunda de dier $y$ seis á diez y nueve, y veintiseis en la caudal.

DISTRIBUCION GEOGRAFICA. - Fl bacalao habita todas las partes del Atlántico desde los $40^{\circ}$ latitud norte hasta los $70^{\circ}$ en el mar Glacial, al parecer con igual frecuen cia en toda esta vasta region. En cl Báltico le reemplaza una variedad, á lo menos convienen unánimemente en ello los naturalistas escandinavos, en quienes podemos suponer perfecto conocimiento de este pez, pues no merece otra calificacion el Dorsch ( Morrhua callaris). En el Mediterráneo falta la especie por completo y solo por casualidad se extravía uno ú otro hasta la latitud del mediodia de nuestra penin sula.
USOS, COSTUMBRES Y REGIMEN.-Deben con. siderarse como morada propia del bacalao las majores pro fundidades de los mares arriba citados, pues sus inmigracic. nes en las bahias de nuenor fondo $\delta$ su reunion en los bajios como son los bancos de 'lerranova y de Rockall, no obede. cen á otra causa sino á su reproduccion, $y$ aun entonces se alcja de los sitios de poco fondo y prefiere profundidades de veinticinco à cuarenta ó cincuenta brazas para deshacerse de su freza. Dificilmente le gana per alguno en fecundidad: Loewenhoel dice haber encontrado en una hembra cerca de nueve millones de huevas, y Bradley evalua su nuinimo en cuatro millones. El tiempo del desove cae, en la parte oriental del Atlíntico y del mar Glacial, en el mes de febrero, y desde principios de enero se acercan alli los bacalaos á las costas; en la parte occidental desoyan mas tarde, en mayo y

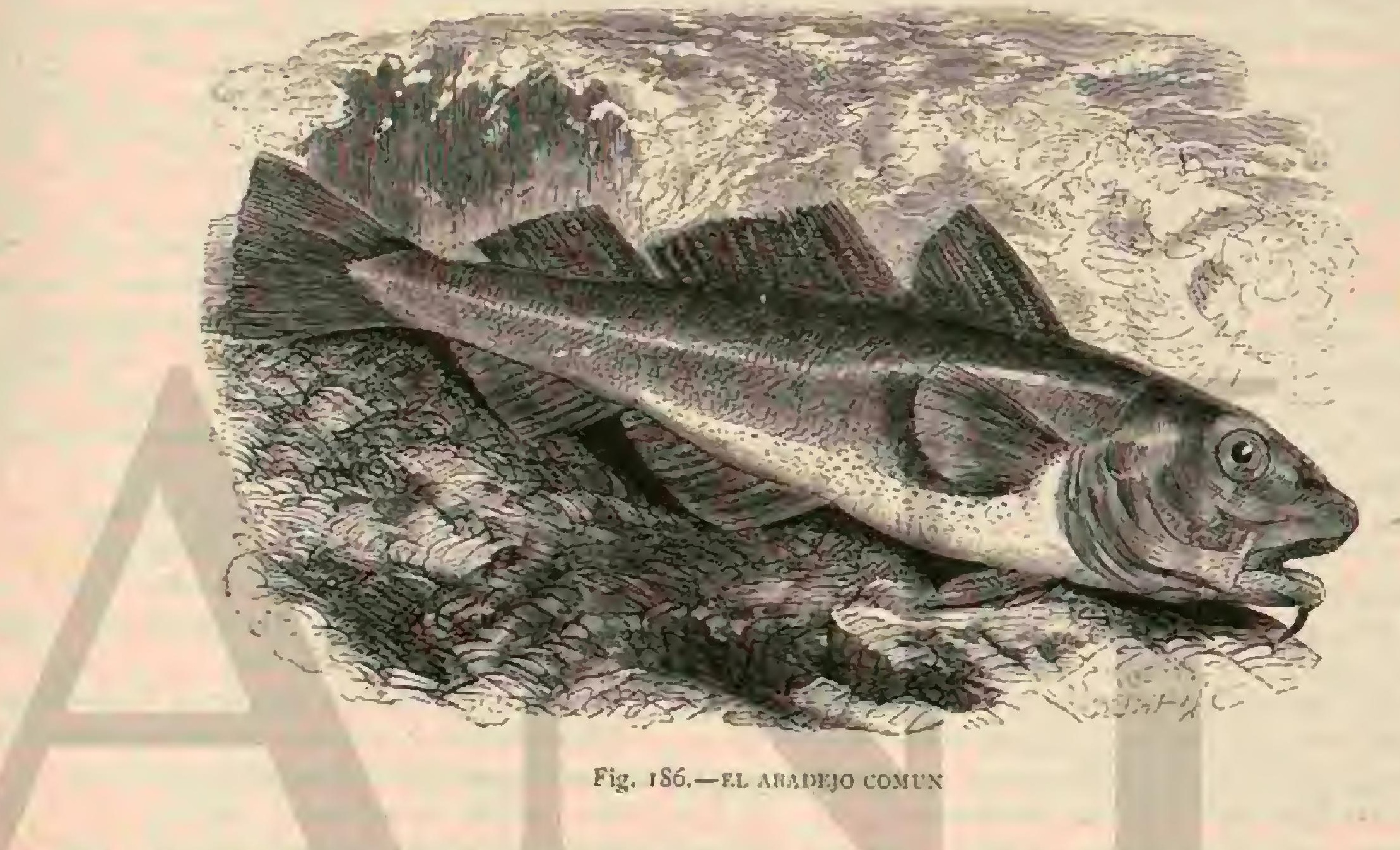

junio, probablemente por la razon de no llerar alli la corriente del golfo (gulfstream) el calor vivificador de sus aguas. A los seis meses han alcanzado los pequeñuelos una longitud de $\left(\mathrm{cm}^{\mathrm{m}}, 20 \mathrm{y}\right.$ al tercer ano se hallan en estado de reproducirse.

En la época del desove se presentan estos peces en masas incalculables, formando montañas como dicen los noruegos. Nadan tan compacios, unos encima de otros, que las bandadas se presentan ell la costa ó en los bancos ocupando una anchura de una legua marina con un espesor de varios me. ircs. Alli vagan algunos dias, otros los reemplazan y poco á poco vuelven á desaparecer. Dos animales motivan en la costa norte-americana la aparicion de estas bandadas; el primero es una especie de salmon que habita el mar Glacial en número increible, llamado en el norte «capelan) (Mallotus villosus), \& que acude a dichas costas con idéntico objeto, es decir, para desovar, y el otro es un caracol llamado de tinta. Bi capelan viene á servir de alimento exclusivo à los bacalaos, y el caracol acude cuando el otro se retira, como si tuviese la . mision de reemplazar á aquel para dejarse comer por los mismos peces.

En la época de la freza es cuando se pesca el abadejo, operacion en extremo productiva á causa de la insaciabie voracidad de este animal, que traga $\delta$ por lo menos muerde todo lo que le parece poder coger, hasta cosas completamen te indigeribles con tal que exciten su atencion, como por $\operatorname{Tr} \sin v$ ejemplo objetos brillantes 6 de colores vivos. En el Báltico se presenta la variedad Dorsch en todos los puntos donde hay arenques, pero á falta de estos llena su estómago hasta reventar de gasterosteos, conchas, moluscos desnudos, cangrejos, fucos $y$ otras algas, y como es natural tarupuco respc. ta su propia prole.

PESCA.- Para ella se usan redes en las costas norue. gas, pero en todos los demás puntos sedales de mano y de fondo que se emplean tambien en las Loffoden junto con aquellas. Los sedales de fondo van atados á veces hasta en núnero de mil doscientos á una recia cucrda que se echa al fondo donde se la sujeta con anclas á propósito. Cada seis horas se saca, se quitan los peces cogidos, se ceban los an. zuelos de nuevo, y se vuelve a echar al fondo. En los interralos se ocupan los pescadores en echar sedales de mano, uno en cada mano, los sacan rápidamente cuando sienten la sacudida, $y$ los vuelren á arrojar de nuevo sin perder un mo. mento. Atendido el número incalculable de peces, no es raro que cada uno de los tripulantes de un bote coja diariamente de tres á cuatrocientos. Mientras que adelanta esta pesca se hace lo propio en otros puntos respecto del «capelan y del caracol de tinta, que se emplean á manera de cebo como en otras partes el arenque, y a falta de unos y otros se emplean los intestinos de los mismos abadejos cogidos.

Luego de pescados, empieza la preparacion de los abadc. jos. Primero se separan las cabezas que se arrojan en tinas 6 58 
barriles especiales, luego se destripan y se abren de una sola cuchillada en dos mitades longitudinales, á veces tambien en cuatro pencas. Los higados se reunen por separado en un barril y las huevas en otro; el resto de los intestinos se corta en pedazos para emplearlos oportunamente como cebo. Durante la gran pesca de invierno se preparan solo pez-palos, por lo menos en las Loffoden. A este fin lleva cada buque un gran número de horquillas y perchas para suplir con ellas los andamios perennes siempre insuficientes, establecidos en tierra. Alll se cuelgan los abadejos paridos hasta la cola y lavados préviamente con agua de mar para hacerlos secar, al aire libre en las islas, 5 en algunas otras partes debajo de tinglados. Esta operacion requicre tiempo, tanto que cuando la temperatura no es muy favorable se ren las perchas car. gadas hasta el mes de julio. Solo cuando el pescado está completamente seco, se forman haces y se almacena en pilas tan altas como casas. Cuando la pesca es sumamente prc. ductiva, y se pucblan rápidamente todos los andamios, se preparan los últimos abadejos de un modo semejante al que conocemos nosotros, es decir, salados y secos. A este fin se les abre álo largo del espinazo, se les sala durante algunos dias en tinas grandes y se extienden sobre las rocas para ponetlos á secar, dándoles otra capa de sal si es menester. Si hay abundaricia de barriles, se pone una partida en salmuera, colocando los peces partidos en capas alternadas con otras de sal, y cuando las vasijas están llenas, se cierran. Muchos comcrciantes rusos de Arkangel no dejan ningun año de visitar las pesquerias noruegas y finlandesas para comprar estos y otros peces, contentándose con colocarlos sin mas preparativo en la bodega misma, alternando las capas de ellos con sal y apisonándolas con sus pesadas botas de agua.

Eu Noruega se utilizan las cabezas casi exclusivamento para alimento del ganado; los hígados se reunen, concluida yala pesca, en grandes cubas ó tinas que con gran sentimiento de las personas venidas de paises nas meridionales, cujos nervios olfatorios son siempre mas delicados, se colocan con frecuencia tranquilamente en las calles y plazas de las po. blaciones, donde despiden un hedor insoportable luego que entran en putrefaccion. Alli los tienen aguardando que such. ten y suba á la superficie el aceite grasiento que contierien y que separan á medida que se reune, para colarlo y guar dario en barriles distintos, segun su calidad. Se comprende que la mejor clase es aquella que se recoge á los pocos dias de haberse declarado la descomposicion, y la peor la que se saca al final por la.coccion.

Pasado el tiempo de la pesca principal se sigue pescando en las Loffoden en menor escala y entonces se preparan los abadejos, ya de un modo, ya de otro, segun el estado de la atmósfera. Excuso añadir detalles relativos á la pesca en el banco de Terranova, ya que tanto esta como la preparacion de los peces se hace alli siguiendo a poca diferencia los mis mos métodos que acabo de describir.

En el año 1861 estuvicron ocupados en las Loffoden mas de veinte mil hombres que tripulaban unas cinco mil embarcaciones y cogieron y prepararon mas de nueve millones de pez-palo (bacalao secado al sol) é igual númcro entre ba calao salado, seco $y$ en salmuera, consumiendo durante la temporada para su propio alimento un millon de abadejos frescos. En el año isiz ascendió el total de la cosecha reinticinco millones. Segun Cornak producia la pesca en Terranova á principios de este siglo mas de trescientos millones de peces, sin contar cien millones que se cogian en el golfo de San Lorenzo. Comparada con estos resultados, apa. rece la pesca en las aguas alemanas del todo insignificante, pues en la costa de Frisia en el mar del Norte apenas excede de seis mil el número de abadejos cogidos anualmente, y en el Báltico no se ha empezado hasta ahora á dar importancia á la variedad Dorsch que se presenta alli en cantidad bas tante notable, pero su pesca es aun insignificante. El precio que alcanza este pez en nuestras costas oscila entre seis y treinta céntimos de marco $(8 \mathrm{~F} 45$ céntimos de pescta) el kilógramo.

Dificil es emitir juicio sobre el porvenir de esta pesca, pero puede admitirse que con el tiempo se salarán menos abadejos, pues, como ya se ha dicho antes, deben su principal importancia á los ayunos que prescribe la Iglesia católica. Verdad es que hay tambien aficionados á este pez, pero son raros aun en los países mas católicos. En el tiempo que flo. recia la inquisicion en España no se atrevia nadic á comer en los dias de ayuno carne de mamiferos ó de aves, pero cuando se permitió en i 825 á los españoles comer carne en viérnes, disminuyó la importacion del abadejo, de ochocientos mil quintales à trescientos mil. Por otro lado se aumentará y ge. nezalizará la pesca de este pez y de sus congéneres, pues en. tre otras sucederá que sc introducira tambien en nuestras costas la pesca con embarcaciones como las usan hace años los ingleses y holandeses, que permiten conservar los abade. jos vivos en la parte media del bunque llena de agua y en co. municacion con la del mar por muchos agujeros. Así llegan al puerto y pueden expecirse al interior vivos 6 por lo menos frescos, dando \& los habitantes un nuevo alimento tan barato como sabroso, pues tan mala como es la carne del abadejo cuando seca $y$, salada, tan sabrosa es cuando fresca, to que la hace muy buscada en todas las pescaderias de las poblacio. nes maritimas.

CAUTIVIDAD. - Yarrell cuenta que en diferentes puntos de Escocia se han conservado largo tiempo, dando mus buenos resultados, abadejos vivos en estanques de agua salada. A medida que se pescaban se echaban los que estaion menos heriōos $\delta$ estropeados en los depósitos destinados á ellos, donde se los alimentaba con conchas y otros mariscos. Pronto se acostumbraron al espacio reducido, gozaban al parecer de muy buena salud y aprendieron á conocer la hora en que se les daba la racion, por manera que cuando llegaba la persona encargada de ello, la recibian sacando los hambrientos hocicos fuera del agua. Dicese que uno de ellos vivió asi doce años. A juzgar por las prucbas que yo he lie. cho con abadejos del Báltico cautiros, no tengo ninguna dificultad en creer exactos los datos que preceden. No hay pez que mas fácilmente se acostumbre á la cautividad en si. tio reducido, que tome el alimento con mas aficion, ni que coma y medre mas, que el bacalao. Procurando tencr el agua del depósito suficientemente fresca y dándole abun. dante racion, no solo medra visiblemente, sino que aguanta muchos años aunque el cspacio de que dispone sea mani. fiestamente estrecho para $\mathrm{dl}$.

\section{EL ANON-GADUS AELEFINUS}

CARACTERES.-Diferénciase esta especic de la anterior por su menor tamaño, mayor esbeltez y configuracion mas puntiaguda de su primera aleta dorsal, como tambien por su distinta coloracion, pardusca en el lomo y gris plata $\{$ los lados, con una raya negra en cada costado y una man. cha del mismo tinte entre las aletas pectorales y la primera dorsal. Tiene esta quince radios, la segunda veintiuno, la tercera diez y nueve; cada pectoral diez y ocho, cada abdo. minal seis; la primera anal veinticuatro, la segunda diez y ocho y la caudal veinticinco. In longitud oscila entre $0^{m}, 5^{\circ}$ y 0 \%,60 y su peso puede llegar á ocho kilógramos.

DISTRIBUCION GEOGRÁFICA.- Habita este pez 
todo el mar del Norte. Sin ser raro en ningun punto, es en cambio trecuente en muchos. En el Báltico se le encuentra raras veces y solo en la parte meridional, hasta Kicl; es de. cir, alli donde el agua es mas salada.

USOS, COSTUMBRES Y RÉGIMEN. - Acostum. bra esta especie à reunirse tambien en inmensos bancos y parece vivir en constante emigracion; porque, asi como los cuacirúpedos en tierra, arrasa completamente una parte de. terminada del fondo del mar, devorando todos los mariscos de que se alimenta y ahuyentando los peces pequeños que tambien le sirven de pasto, lo cual le obliga a pasar luego á otra parte. En las costas de Frisia se presenta en los meses de marzo, abril y mayo, acaso hasta principios de julio, des. apareciendo despues, sin duda para pasar la estacion calu. rosa en aguas mas frescas á una profundidad mayor de reinte brazas, para reaparecer á principios de octubre en los mismos sitios que habitaba antes $y$ donde continuia hasta enero. Por lo general no se acerca á la costa á menor dis. tancia de cuatro á cinco leguas marinas; pero en febrero $y$ marzo que es su época de desove, acude á las mismas ribe. ras, en cuyas aguas le cogen en gran cantidad. Jamás falta cste pez en ninguna pescadería de la Alemania del norte, de Holanda, Noruega, Inglaterra y del nordeste de Francia;y para nuestra industria pesquera no hay otro que tenga tanta importancia. Verdad es que los pescadores de las costas del mar del Norte se quejan de su constante disminucion, com. parando el producto de hoy con el de otros tiempos; mas á pesar de esto se expiden todavia anualmente del solo puerto de Emden unos doscientos mil kilógramos de este abadejo, que vienen á representar un valor de unos setenta y cinco mil marcos; y si los pescadores alemanes se quejan de la notable disminucion en este ramo, serả porque permitimos á las embarcaciones inglesas pescar en nuestras aguas.

PESCA. - Tambien se emplean sedales de mano y de foncio en el mar del Norte para la pesca del anon. $y$ redes de jorro alguna que otra vez. En el mar de Groenlandia la pesca es mas fácil, pues dicen que alli basta hacer agujeros en el hielo para coger estos peces que no tardan en acudir para respirar en agua mas saturada de aire que la de debajo del hiclo. Ia carne del anon es blanca, gruesa, de gusto agradable $y$ de fácil digestion, lo que hace que se la prefiera en todas partes á la del abadejo, alcanzando el kilógramo sin dificultad el precio de veinte á cuarenta céntimos de marco. No se presta tan bien como el abadejo á ser trasfor. mado en pez-palo, pero sí á la salazon.

CAUTIVIDAD.-Se ha observado en los estanques criaderos de agua de mar existentes en Escocia, segun ya hemos dicho, que el anon se distingue de los demás peces, en espe. cial de los abadejos, por su mayor domesticidad, y que no tarda en mostrar afecto á la persona que le cuida llegando hasta s. tomar el alimento de la mano.

\section{EL ABADEJO LUSCO-GADUS LUSCUS}

CARACTERES.-Es pCr semejante al anon, del cual difiere por su forma mas rechoncha $y$ sus aletas mas largas $y$ mas estrechas.

DISTRIBUCION GEOGRÁFICA.-Mabiia los mares del Norte y Glacial donde es frecuente, y visita tambien el Báltico.

\section{LA NARVAJA Ó ABADEJO PEQUEÑO- GADUS MINUTUS}

CARACTERES. - A pesar de no tener gran importancia para la pesca, no debemos pasar por alto este abadejo, cl mas pequeño de todos, pues raras veces excede su longitud de $0^{\circ}, 15$ a $\left(0^{\prime \prime}, 18\right.$, con un peso de doscientos granos 6 poco mas. El color del dorso es un pardo amarillento agradable; los costados son blancos plateados y salpicados de negro; el vientre es de un blanco sucio; las aletas dorsales, pectorales y anales son pardo amarillas con orla mas oscura, y las ven. trales y la anal tienen una tinta blanca amarillenta sucia. En la primera aleta dorsal se cuentan doce radios, en la segunda diez y nueve y en la tercera diez y siete; en cada torácica catorce, en cada abdominal seis; en la primera veinticinco, en la segunda diez y sicie, y en la caudal diez y ocho. Como particularidad especial hay que notar que la pared abdominal tiene una tinta roja oscura casi negra.

DISTRIBUCION GEOGRAFICA.- Divergen las opiniones sobre el área de displersion 5 sitios que habita la narvaja, pero se la encuentra regularmente en las costas inglesás, holandesas, suecas y noruegas, lo mismo en el Báltico que en el mar del Norte. Se pretende tambien haberla observado en las costas norte americanas: pero que tan pronto abunda en un punto como en otro, mientras que en algunos falta por completo. Es muy comun en el Mediterráneo, donde se le pesca todo el año á pesar de que acostumbra vivir con pre. ferencia en profundidades que pasan de trescientos metros.

USOS, COSTUMBRES Y REGIMEN. - Nútrese la narvaja de las mismas presas que sus congéneres de mayor tamaño, á los que á su vez sirve ś menudo de pasto.

PESCA.-En la Época del desore acude á veces el aba. dejo pequeño con tal profusion á las costas, que apenas re. cogen los pescadores en sus redes individuos de otra especie de la misma clase. 4 En 1545 , dice un antiguo autor, fué tal el número de estos peces que se cogieron en las costas de Montpellier. que durante dos meses no se pescó otra especie, viéndose por último obligados los pescadores a enterrar in mensas cantidades en completa putrefaccion. Segun Bloch, los pescadores del Báltico celebran gozosos la aparicion de la narvaja, como precursora de los abadejos de gran tamaño y otros peces de igual importancia para la pesca. Su carne, aunque inuy gustosa, no es apreciada generalmente como se merece y sirve de ordinario de cebo para otros peces. La re. produccion de esta especic se verifica en los meses de abril y mayo.

\section{LOS MERLANGOS Ó MERLANES -MERLANGUS}

CARACTERES. - Son una especie de anones, de los cuales difieren por la carencia de barbillas. Su representante es:

\section{LA PESCADILLA Ó MERLANGO COMUN- GADUS MERLANGUS}

CARACTERES. - Esta especie, bien distinta de la merluza jóven que tambien suele Jlamarse pescadilla, alcanza una longitud de $0^{m}, 30$ a $0^{m}, 40 \mathrm{y}$ un peso que rarísimas veces llega á tres kilogramos; su color es un pardo rojizo pálido pasando á ceniciento, y a blanco plateado en los costados, notảndose además manchas oscuras en la raír de las aletas torácicas.

DISTRIBUCION GEOGRÁFICA.-La pescadilla es comun en todos los mares de la Europa occidental, encontrándosela tambien, pero con menos frecuencia, en el Báltico y mar del Norte, por no ser tan sociable como sus congéne. res. Hácia el norte parecen limitar su área de dispersion las Orcadas y hácia el sur las costas de Portugal. En las aguas británicas se presenta á veces en gran número, aunque nunca en bandadas. 
USOS, COSTUMBRES Y REgIMEN, - En la tempo. rada de su reproduccion, que cae en los meses de enero y febrero, suele reunirse en mayor número $\mathrm{g}$ acercarse hasta la distancia de media milla de la costa. Se nutre de crustáceos, gusanos y pececillos hasta del tamaño de una sardina, á las que tiene tanta aficion que abandona sus sitios favoritos, los fondos arenosos, para cazarlas.

PESGA. - Se hace por lo general con sedal, raras veces con redes, y es muy productiva, porque se aprecia mucho cste pez por su carne sabrosisima y de fácil digestion, superior á la de todas las demás especies congéneres. Cuando la pesca ha sido abundante suelen en algunas partes secar la pescadilla, pero en tal estado pierde aun mas de su sabrosidad que el bacalao en el de pez-palo, de modo que solo to consumen los misnos pescadores:

\section{EL MERLAN NEGRO-GADUS VIRENS}

\section{CARACTERES. - Tiene esta especie el distintiro que la}

separa de la anterior, en la coloracion oscura de su dorsoo, á la que debe el nombre que lleva, siendo además de tamaño algo masor que aquella.

DISTRIBUCION GEOGRÁFICA.-Este merlan pertenece mas a los mares septentrionales, si bien se le encuentra igualmente en el mar del Norte, el Báltico y el Atlántico. En las costas de Islandia, Groenlandia y Finlandia abunda bas. tante, pero en el Spitzberg es, si no el único, álo menos el mas importante g numeroso de los peces que visitan aquellos parajes. En direccion occidental se extiende hasta las costas de los Estados Unidos.

USOS, COSTUMBRES Y REGIMEN.- Este gádido suele frecuentar, segun afirma Couch, los fondos pedregosos de mediana profundidad, y especialmente cerca de los pe. ñáscos azotados por las olas; pues acostumbra, como muchos peces voraces, á permanecer en sitios abrigados que lo oculten, observando atentamente la corriente, para precipitarse subre la primera presa que se presente, sea viva 6 muerta. Thomson encontró en el estómago de los merlanes principal

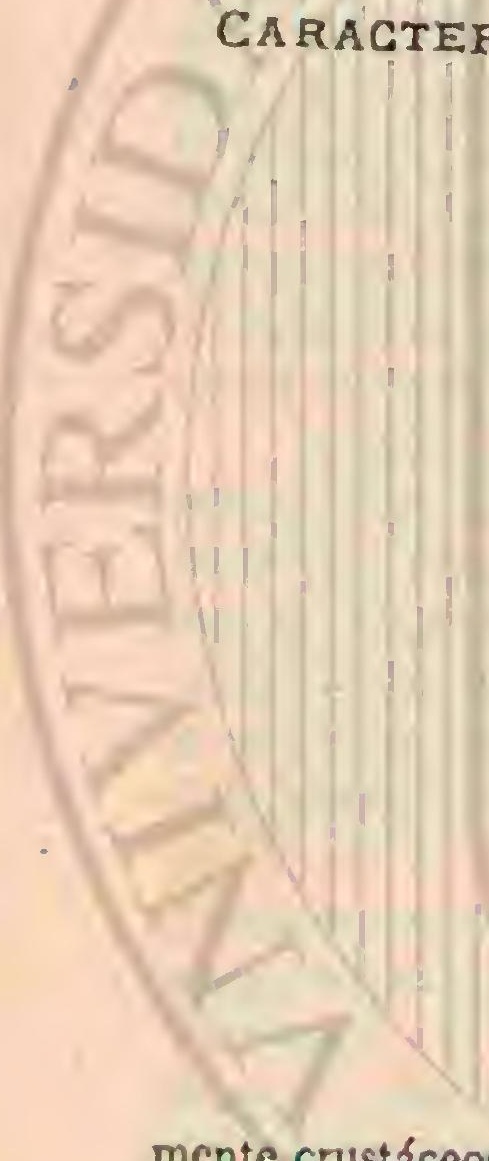

mente crustáccos, pero tambien á veces moluscos, $\mathrm{y}$ durante la época de la freza peces mas pequeños, casi siempre del género de los arenques. El desove de esta especie se verifica en la primavera, y en mayo y junio se ven ya muchos de sus pequeñuelos.

La carne del merlan negro se pucde decir que es la mas desabrida de todos los gádidos, y en particular, la de los in. dividuos de alguna edad tiene muy pocos aficionados cuando fresca, por lo que suélese curarla como baraino.

Los habitantes mas acomodados del norte son los consu. midores de los merlanes jovenes, particularmente de los cogidos desde octubre á diciembre. Los mayores, que no dejan de ser sabrosos, se venden á bajo precio á los pobres de las mismas costas, por ser la pesca de esta especie tan producti. va como fácil, habiéndose dado caso de que cuatro pescaderes hayan podido recoger en pocas horas mas de una tone-
lada.

CAUTIVIDAD.-El merlan negro se habitúa muy pronto a los estanques de agua de mar donde nada pausada y majestuosamente de una parte á otra hasta la hora de la racion; entonces traga con voracidad el alimento que se arroja y aprende pronto á acudir á la orilla á pedir mas, llegando hasta á tomar la racion de la mano de la persona encargada.

\section{LAS MERLUZAS-MERLUCIUS}

CARACTERES. - Reconócense las merluzas por su cuerpo oblongo, cabeza achatada, dos aletas dorsales, ocu. pando la segunda, al igual de la anal, mas de la mitad del cuerpo; despues por las escamas y dientes relativamente grandes, estos últimos colocados casi en una sola hilera, y finalmente por la carencia de la barbilla. El representante mas conocido de este género es:

\section{LA MERLUZA COMUN-MERLUCIUS VULGARIS}

CARACTÉRES. -- Prescnta esta especie, la mas conocida y apreciada del género, un color pardo gris en el dorso, que empieza á clarear en los costados hasta convertirse en blanco de plata en el vientre; las aletas superiores, son oscuras, mientras que las inferiores aparecen de un pardo claro. Están sostenidas por diez radios la primera dorsal, veintinueve la segunda, once las pectorales, siete las ventrales, veintiuna la anal $y$ diez y nueve la caudal. La merluza llega a medir como $\mathrm{I}^{\prime \prime}, 20$ y alcanza un peso hasta de diez y seis kilógramos.

DISTRIBUCION GEOGRÁFICA، - Este pez, que ya habia descrito Rondelet, es uno de los mas abundantes y de mayor importancia para la pesca en el Mediterráneo, si bien frecuenta igualmente el Atlántico á lo largo de las costas eu. ropeas y las aguas británicas y escandínavas; recorre asimismo, segun Couch, las costas de Cornualles, si bien con bas. tante irregularidad.

USOS, COSTUMBRES Y REGIMEN. - Desde enero hasta abril, que es la época de su reproduccion, suele permanecer en el fondo del mar y no da casi señal alguna de su extraordinaria voracidad; á lo menos muerde raras veces 
el anzuelo y solo puede ser pescado con redes de jorro; mientras que en la temporada en que las sardinas se acercan a las costas, las persigue y devora grandes cantidades de ellas, siendo cosa muy frecuente encontrar merluzas en las trainas y tonairas. Couch saco una ver diez y siete de estos clúpeos del estómago de una merluza de tamaño regular. Su fuerza digestiva guarda la debida relacion con su desmesu. rada voracidad, acostumbrando por otra parte a arrojar las presas recien tragadas, cuando se cree en peligro, para poder escapar con mayor ligereza; de este modo se explica la ca rencia de toda materia en el estómago de centenares de estos peces pescados con sedales de fondo.

Tiene considerable importancia la pesca de la merluza, gracias á lo delicado y sabroso de su carne, aunque no posea esta última cualidad en tan alto grado como otras especies de la misma familia En el norte, suelen salarla y secarla como el abadejo, siendo de bastante consideracion las can. tidades que asi preparadas vienen á nuestros mercados. En las costas del mediodia de Francia, es tambien costumbre envolver las merluzas acabadas de pescar en ciertas plantas

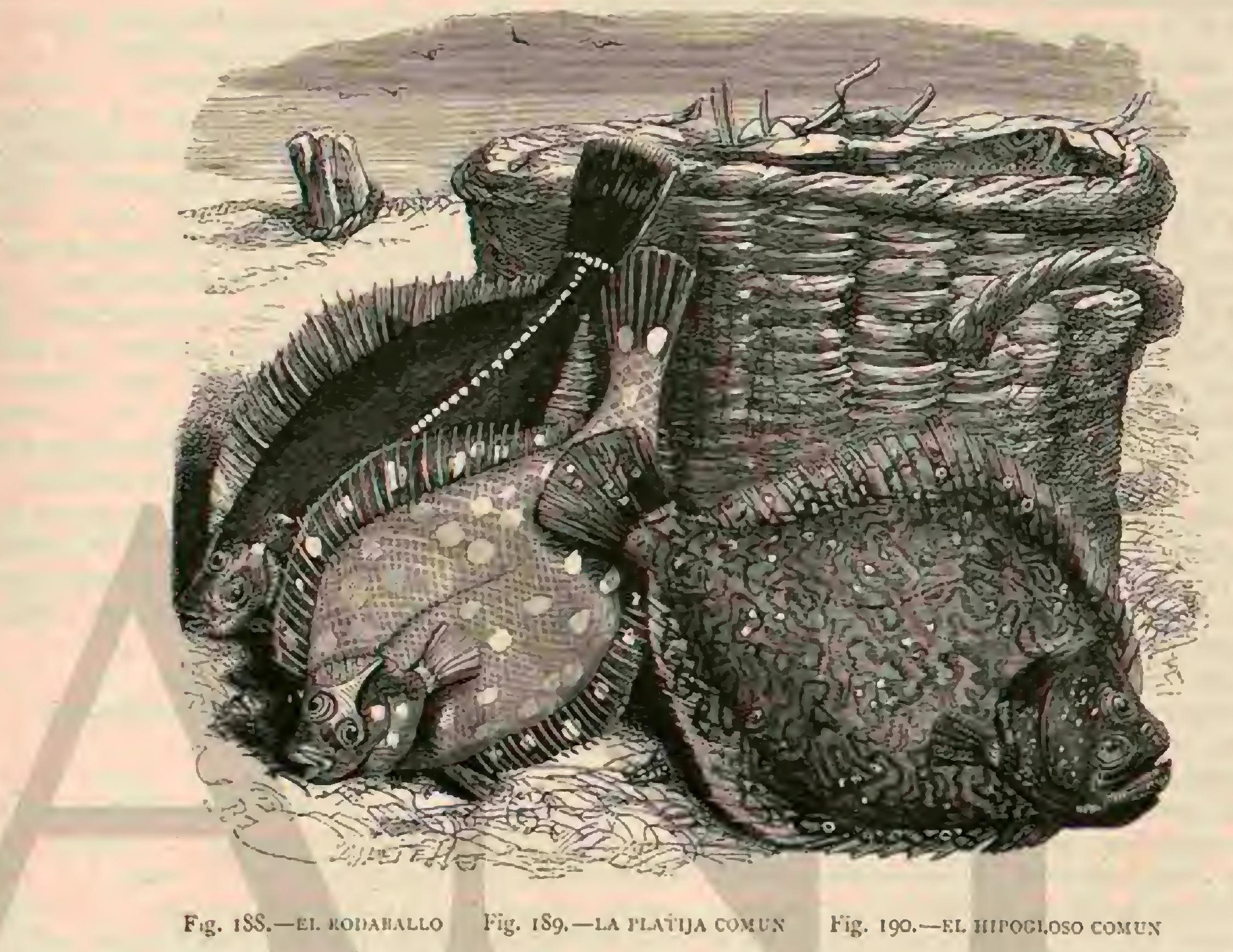

odoriferas, creyendo de este modo comunicar mas sabor á su carne.

\section{LAS LOTAS - LOTA}

CARACTERES.-Estos gádidos tienen el cuerpo relativamente muy prolongado, guarnecido de diminutas escamas y con la cabera bastante pequeria; tienen tambien, como el genero anterior, dos dorsales y una sola anal, esta última de regular dimension y la segunda de aquellas algo mas larga, con la caudal redondeada y á veces apuntada, distinguién. dose particularmente por sus numerosas barbillas y los dien. tes dispuestos en una sola fila en los bordes de ambas mandibulas.

\section{LA LOTA COMUN Ó DE RIO-LOTA FLU- VIATILIS}

CARACTERES. - Este pez, el único de los gádidos que habita el agua dulce, tiene el dorso, los costados y las aletas superiores de un verde oliváceo mas $\delta$ menos subido, salpicado de manchas pardo negruzcas, $y$ la region abdominal y las alctas ventrales blanquizcas. Sostienen de doce a catorce radios la primera dorsal, de sesenta y ocho á setenta y cua- tro la segunda, quince á veinte cada una de las pectorales, cinco á seis cada ventral, scsenta y seis á setenta la anal y treinta y seis a cuarenta la caudal. Alcanza en todo su des. arrollo hasta 6,60 y un peso de ocho kilógramos, si bien solo se encuentran individuos de este volúmen en las aguas de mayor profundidad.

DISTRIBUCION GEOGRÁFICA.-Pocas especies de esta clase tienen una zona de dispersion tan extensa como la lota, pues habita todos los rios y lagos de Europa y Asia centrales, $y$ hasta se la encuentra en las aguas dulces de la India. Frecuenta por lo comun aguas de mucha superficiey profundidad, en los lagos las quue pasan de treinta á cuarenta brazas, y solo permanece en corrientes de poca anchura cuando le pueden ofrecer esta riltima circunstancia. En la Gran Bretana no es de los peces mas abundantes, pero en el Alto Rhin y en el Danubio encuéntrasela en todas partes. Segun Tschudi, aparece en Suiza en aguas situadas a mas de 1,200 piés de altura sobre el nivel del mar.

USOS, COSTUMBRES Y REGIMEN.-Como ya hemos dicho en el párrafo anterior, la lota solo fija su morada en aguas de bastante profundidad y con preferencia en fondos de lagos que alcancen de treinta á cuarenta brazas álo menos; otra condicion que necesita, es que el agua sea clara, y por eso abunda mas en las comarcas montañosas que en las lla 
nuras. De dia suele permanecer escondida debajo de las piedras ú otros objetos que se encuentren en el agua. \& Si se levanta, dice Schinz, una de estas piedras con cautela, la lota permanece un momento inmóvil, pero salta luego con la velocidad del rajo y se oculta debajo de otra piedra 6 en el limo. Ios individuos adultos permanecen en los fondos, pero los jórenes en las aguas mas bajas, cerca de la orilla. Por la noche, abandona la lota su sitio de reposo y recorre en todos sentidos las aguas que habita, siendo muy voraz y el terror de los peces mas pequeños, sin exceptuar los de su propia especie. En los estanques, suclen los cautivos, si no se les proporciona suficiente alimento, derorar los mas fuertes á los mas débiles.

Respecto \& esto cuenta Schinz, que un dia rolvio una criada que habian mandado al virero por lotas, muy asustrada diciendo que se habia introducido un verdadero mons. truo en el vivero, una lota sin cabera, pero con dos colas. Al ir f́ enterarse del caso encontraron que una lota se habia tragado á una compañera hasta la mitad del cuerpo. Los pequeñuelos se mantienen principalmente de freza y de gusanos.

La Epoca de la freza se fija de distinto modo por unos y otros autores, oscilando enire los meses de noviembre y marzo; debemos, pues, suponer que varta aquella de esta. cion segun la localidad y la mayor 6 menor elevacion de la temperatura. Tan poco sociables como se muestran cstos peces conunmente, reúnense, sin embargo, en tropel para el acto de la reproduccion, a veces hasta cien individuos, entrelazando sus cuerpos como anguilas y formando un informe ovillo, á manera de las viboras en iguales circunstancias. Es muy probable que el apareamiento sea de una duracion relativamente extraordinaria; \& lo menos la observacion hecha por Steinbuch, poco conocida hasta que Siebold la hubo publicado recientemente, ofrece motivo para esta creencia. Refiere este naturalista, que habiendo pescado con el garabato lo que el pensaba ser una lota, en el Brinz, cerca de Heidenheim, se encontró con dos peces de esta especie unidos intimamente á lo largo de sus respectivas regiones abdominales, formando una sola masa. Examinándolos mas de cerca, descubrió una especie de cordon 6 faja en forma de anillo, que enlazaba tan estrechamente ambos peces por el centro del cuerpo, que era imposible separarlos; las superfi. cies inferiores de ambos peces estaban tan comprimidas una contra otra por medio del citado cordon, que el todo tenia una configuracion casi completamente cilindrica. Por fin, haciendo escurrir, con toda precaucioa para no estropeario, el anillo ó cordon hácia las colas, consiguió á fuerza de pa. ciencia, desprenderlo de los dos cuerpos, que conservaban las señales de su compresion. Itamóle al punto la atencion la disposicion respectiva de cada una de las aberturas sexuales, que indicaba á primera vista que una de ellas debió encontrarse exactamente encima de la otra mientras los cuerpos estuvieron juntos; notó además que al separarlos, mana. ba de aquellas un humor lechoso. De todas estas observaciones dedujo Steinbuch, que los dos peces estaban unidos cn el acto del apareamiento, $y$ que el cordon en forma de anillo con que los encontró unidos habia sido formado por las emanaciones de la piel, debidas á una larga excitacion y al roce continuo de las aletas ventrales. Siebold añade, por su parte, que la suposicion de Steinbuch merece ser cstudiada, pues no es la primera vez que se han observado en otros peces emanaciones del mismo género en igual época.

Calculase en 130,000 huevos aproximadamente el pro. ducto de cada hembra; con todo, la reproduccion de lotas no parece ser considerable, debido sin duda á que los peque. nos apenas salidos del huero son pasto en su mayor parte de los adultos y de otros peces roraces. Su desarrollo es bas. tante lento, y solo al cuarto año adquieren la facultad de reproducirse.

PESCA.-Durante la temporada de la freza es cuando la pesca proporciona mayores beneficios, verificándose así con el anzuclo como con la red 6 la nasa, y sirviendo de cebo peces de menor tamaño y cangrejos.

En Alemania varian las opiniones sobre su mérito, por cuya razon se paga el kilógramo segun la localidad desde cuarenta céntinos hasta cuatro marcos (50 céntimos de pe. seta hasta 5 pesetas). Hé aqui lo que refiere Gessner: «Las lotas que se cogen en aguas corrientes son mas sabrosas, mas blancas y mas sanas. El higado es un bocado tan exquisito que hubo una condesa que gastó en esta golosina todas sus propiedades y dinero, rentas, censos y diezmos. En nuestro pais se come el higado de este pez alrededor de Navidad, que es antes del desove, porque despues no tienen mérito, y se llenan de pústulas por efecto de una enfermedad comun en esta especie. Tambien se cuelga el hígado dentro de un frasco al sol 6 junto a la estufa, lo que le hace soltar un acei. te amarillo muy hermoso y utilisimo contra las manchas en los ojos y la catarata. Al estómago de estos peces se atribuye una virtud extraordinaria en todas las enfermedades de la matriz, y tomado en bebida disminuye los dolores del parto. Por supuesto que hoy dia no cree ya nadic en tales virtudes maravillosas, pero se recogen los hígados y se saca de cllos un accite excelente que en efecto sc empleo en medicina.

Erman pudo observar un modo especial de aprovechar ciertas partes de este pez en Siberia; pues entre los burictas reemplaza la piel los cristales de las ventanas, y entre los ca. vases llevan ambos sexos el calzado, los pantalones y gaba. nes hechos de la misma piel de lota.

\section{LA MOLVA COMUN (LENG) - MOLVA VULGARIS}

CARACTÉRES.-En los mares septentrionales se ha. llan representadas las lotas por esta especie, designada por algunos autores con el nombre de abadejo largo, que mide comunmente de tres á cuatro piés; pero que a veces suele alcanzar la extrnordinaria longitud de uno $\hat{\alpha}$ dos metros y un peso de hasta 25 kilógramos. Tiene color gris con refle. jos amarillos y verdosos, y blanca la region abdominal, dis. tinguiendose muy especialmente por las aletas oscuras, orilladas de un tinte mas claro. La primera aleta dorsal está formada por quince radios, la segunda por sesenta y cinco, las pectorales por quince, las ventrales por seis, la anal por noventa y siete y la caudal por treinta y nueve.

DISTRIBUCION GEOGRÁFICA,-Este gídido figura entre los peces mas estimados de los mares septentrionales, siendo especialmente de suma importancia para los ha. bitantes de las islas de Shetland y Orkney, de Islandia y Noruega.

USOS, COSTUMBRES Y REGIMEN. - Habita la molva principalmente las grandes profundidades donde aco. mete á cangrejos y peces, y particularmente de estos, los que frecuentan los fondos, como las platijas, las triglas y otros; aproximase, sin embargo, en la primavera á la costa para fre. zar, dando orfgen entonces á una pesca de las mas, benefi. ciosas.

En las aguas de Cornualles suele verificarse la pesca de la molva en los meses de enero y febrero, mientras que en Shetland ocurre entre mayo y agosto; aquella es muy fácil, puesto que esta lota es uno de los peces mas voraces, y atra. pa todo cuanto tiene vida $\delta$ parece tenerla. Una buena parte del botin se consume en estado fresco, y lo restante se pre- 
para del mismo modo que el abadejo, beneficiándose tam. bien el aceite de su higado.

\section{LAS MOTELAS-MOTELLA}

CARACTERES. - Diferénciase este género del anterior por la atrofia de la primera aleta dorsal, mientras que la se. gunda, lo mismo que la anal, ocupa la mayor parte del cuerpo uniéndose casi con la caudal; tiene tambien de tres á cinco barbillones en la sinfisis, cxtremo 6 barba de la mandibula inferior.

\section{LA MOTELA COMUN Ó COMADREJA DEMAR - MOTELLA VULGARIS}

CARACTERES. - Mide este pez de $0^{m}, 35 \& 0^{\circ}, 40$ de largo, y tiene de un hermoso pardo amarillento la parte su. perior con grandes manchas pardo oscuras a lo largo del dorso $y$ en las aletas pectorales, dorsales y caudal, mientras que la inferior presenta el mismo matiz pero mas claro, inclusas las aletas ventrales y anal, manchada à veces de ama. rillo blanquizco. La segunda aleta dorsal se compone de cincuenta y cinco radios, las pectorales de veinte, las ventrales de siete, la anal de cuarenta y dos y la caudal de diez y ocho.

DISTRIBUCION GEOGRÁFICA.-Péscase esta especie en todos los mares europeos, muy especialmente en el Mediterráneo, $y$ en inenor abundancia en las aguas brita. nicas.

USOS, COSTUMBRES Y REGIMEN. - Frecuenta con preferencia los fondos pedregosos y provistos de algas y otras plantas, por entre las cuales y las piedras se nueve con presteza y agilidad, permaneciendo casi siempre en las aguas poco profundas, sin duda \& causa del alinento mas abundante que le ofrecen estas. Durante mucho tiempo se conserva inmóvil en un mismo sitio, agitando levemente sus barbilias y diminuta aleta dorsal, aparentemente para atraer á los pequeños peces y cangrejos, que son sus presas favoritas. La época de la freza de estos peces es el invierno, ade lantándose y retardándose algunas semanas, segun la locali. dad y temperatura. Thomson encontró en octubre los testículos de los machos repletos de lechaza, y Bloch obser. va que el tiempo de la freza cae aun antes.

Segun refiere Pennant, los pescadores de la costa de Cor nualles proceden de un modo especial en la pesca de la mote la: suclen silbar y pronunciar determinadas palabras, en la firme creencia de que el producto de aquella será de este modo mas benelicioso, tal como lo hacen tambien sus colegas sicilianos para engañar al pez-espada.

\section{LOS. BROSMIOS-BROSMIUS}

CARACTERES. - Son los distintivos de este género, el último que me propongo mencionar de esta familia tan numerosa, una larga aleta dorsal que ocupa tres cuartas partes de la longitud total del pez; una anal de la mitad del tamano de aquella, un barbillon en el extremo de la mandibula inferior, y escamas relativamente grandes.

\section{EL BROSMIO COMUN-BROSMIUS BROSME}

CARACTERES. - La coloracion de este gádido, que suele medir unos $\left(^{\circ}, 60\right.$ de longitud, es de un amarillo par. dusco en el dorso, y en la parte inferior de una tinta amarillenta clara, con las aletas dorsal, anal y caudal orilladas de blanco, con rayas y manchas negras en el centro. La primera cuenta cuarenta y nueve radios, la segunda, treinta y siete, la última treinta y siete tambien, las pectorales veintiuno y las ventrales cinco.

DISTRIBUCION GEOGRÁFICA.- Esta especie se en cuentra principalmente entre los grados 60 y 73 latitud nor. te, pero baja á menudo hácia el sur; no siendo rara en las inmediaciones de las Orcadas, y llegando á veces al Forth. Abunda en las costas de Noruega y Finlandia, en las aguas al rededor de las islas Foroe y en las costas occidentales y meridionales de Islandia.

USOS, COSTUMBRES Y REGIMEN.-En el mes de encro, se ve aparecer ya á cste gádido en grandes masas que se aproximan á las costas islandesas, y permanecen alli, para el desove, hasta la primevera. Aun cuando se encuentra en la proximidad de la costa, no abandona el brosmio las grandes profundidades, y no es por lo tanto tan abundante su pesca como lo desearian ins habitantes de aquellas costas. Acos. tumbra á depositar sus huevos entre las plantas marinas cer. ca de tierra.

PESCA. - Para su pesca se emplean los mismos anzuelos que en la del abadejo; pero mayor botin que el anzuelo y se. dal de fondo proporcionan á los pescadores los fuertes tem. porales, que lo arrojan en cantidades inmensas a las playas. En Noruega se sala y seca este gídido lo mismo que el aba. dejo, pero no se exporta; en Islandia suelen comerlo fresco. Su carne es consistente y seca, pero muy gustosa, j curada pierde muy poco 6 nada de su bondad.

\section{LOS OFÍDIDOS-OPHIDII}

CARACTERES. - Por su estructura interna resuitan es. tos peces afines de la familia de los gádidos. Forman una familia reducida, de pocos géneros, con unas reinticinco es. pecies. Se distinguen por su cuerpo muy prolongado, comprimido lateralmente y falto de aletas abdominales; las aletas dorsal y anal son muy bajas y a menudo confundidas con la caudal; las escamas, muy pequeñas, están ocultas en la piel. No tienen estos peces importancia alguna para la economia humana, y por lo tanto me limitaré \& mencionas aqui solo las especies mas conocidas.

\section{LA BARBADA-OPHIDIUM BARBATUM}

CARACTERES. - Esta especie, representante de la familia de los ofididos, tiene el cuerpo muy comprimido late. ralmente á manera de hoja de cuchillo y cuyas aletas dorsal y anal se confunden con la caudal y están sostenidas por ra. dios articulados. Las aletas torácicas son muy reducidas y puntiagudas. En la punta de la mandibula inicrior hay cuatro barbillas. La coloracion cs un rosa claro de brillo plateado, con manchas difusas y poco aparentes. Su longitud es de $0^{\circ}, 20$ próximamente.

DISTRIBUCION GEOGRÁFICA.-Abunda este animal en todo el Mediterráneo y muy especialmente en el Adriático; desde donde sucle á menudo visitar la parte mas inmediata del Océano Atlántico, llegando á veces hasta las aguas de la Gran Bretaña.

USOS, COSTUMBRES Y REGIMEN. - Carecemos por completo de datos respecto al género de vida y hábitos de este pez, que ya habia sido descrito por Plinio; solo sabemos que sucle alimentarse de pequeños cangrejos y de peces.

En las costas italianas se pesca este ofidido durante el ve. rano, con redes $y$ anzuelos cebados con gusanos, pues alli encuentra alicionados su carne, si bien dura, blanca y bas. tante sabrosa; pero no tiene importancia alguna esta pesca. 
LOS AMODITINOS

- AMMODYTIN 瓜

CARACTERES.-Bajo este nombre agrega Guenther a la familia de los ofididos unos peces anguiliformes sin aletas abdominales y sin rejiga natatoria; con aletas pectora. les reducidas, una dorsal muy larga, una anal de longitud regular y la caudal bien desarrollada.

\section{EL PEZ DE TOBIAS-AMMODYTES TOBIANUS}

\section{EL AMODITES LANCEOLADO - AMMODYTES} IANCEOLATUS

CARACTERES. L La segunda de estas dos especies (fig. 187 ) es mas frecuente que la primera, harto peđueñita, si bien graciosá, y que en algunas partes la credulidad po pular se complace en tomar por aquel corpulento habitante del Tigris que espantó y amenazó tragarse al piadoso Tobias hasta yue esté siguiendo el consejo del ángel le cogió por la aleta, y despues de haberlo sacado del agua, lo partió y le quitó el corazon, la hiel y el hígado.

Se distinguen las dos especies por la aleta dorsal que en el pez de Tóbias es mas grande que en la otra, y además inserta sobre las torícicas, mientras que en aquel lo está de trás de estas. El numero de radios es respectivamente en el primero: cincuenta y cinco en la dorsal, quince en la pectoral, veintinueve en la anal y diez y siete en la caudal; y en el segundo: cincuenta y uno en la dorsal, en la pectoral tre ce, en la anal veinticinco $y$ en la caudal quince. La longitud que alcanzan es para el primero de $0^{\circ}, 40$, y para el segundo de $0,2626,31$.

DISTRIBUCION GEOGRÁFICA. - Ambas especies habitan los mares septentrionales.

USOS, COSTUMBRES Y REGIMEN.-Una y otra viven junto á las costas arenosas y de poca agua donde se ocultan en la arena aguardando la marea alta para cazar, a menudo en gran número, toda clase de gusanos y cria de otros peces, divirtiéndose además en las tardes apacibles y calurosas en dar repetidos y alegres saltos fuera del agua

Sobre su reproduccion no se sabe nada de fijo, pero se supone que desovan en los meses de majo, agosto y diciem bre. Lo que hay de cierto es que en abril se ven pequeriue. los de unos $0^{\circ}, 10$, que se supone sean de la cria del año anterior.

UTILIDAD. - Los pescadores de las costas de Alemania emplean los amodites únicamente para cebo de otros peces Dícese que en el Mediterránco se come la especie que all representa á la familia; en las costas de Groenlandia sirven las dos especies que citamos para alimento, ya frescas, ya secas.

\section{LOS PLEURONÉCTIDOS -PLEURONECTID在}

Con razon se dice que la disposicion simétrica de los miembros es uno de los rasgos caracteristicos mas esenciales de todos los animales rertebrados; su configuracion podra ser todo lo exagerada y extraña que se qquiera, pero lo cierto es que siempre se parece mas ó menos una mitad de su cuerpo á la otra. Pues bien, una familia de peces se distingue por ser una excepcion de esta regla. A primera vista parece que estos animales tienen el cuerpo comprimido en sentido vertical y ensanchado horizontalmente, perobasta mirar la cabera que como Gessner dice, está «colocada contra toda regla para convencerse de que no es asi, y al inspeccionar el es- queleto, aunque se haga en un ejemplar frito, se vcrá que estos animales son de una estructura entcramente anormal.

CARACTERES. - Las platijas ó pleuroniclides ó sea pe. ces yue madan de lado, segun la significacion de esta palabra, se caracterizan por su cuerpo fuertememente comprimido, $y$ por su cabeza colocada de un modo tan extraño, que los dos ojos se encuentran $\delta$ en el lado derecho 6 en el izquierdo segun la especie, pero siempre en el lado que se distingue por la presencia ó mayor desarrollo de las aletas y de los huesos. La aleta dorsal ocupa la afilada cresta del dorso $y$ la abdominal la parte correspondiente, pero aplanada, del vien. tre; la caudal ofrece distinto aspecto en sus dos lados correspondientes á los costados del per, si bien su estructura no deja de ser regular. Ia membrara branquial sucle tener sicte radios. La boca va armada de diferentes dientes ra fuertes, ya de cerda I a cavidad abdominal ocupa reducido espacio, pero se prolonga hasta la region caudal. El aparato digestivo es sencillo y falta por complcto la vejiga natacoria.

USOS, COSTUMBRES Y REGIMEN.-Desde luego puede suponerse que una configuracion tan chocante y rara impone á estos peces un género de vida tambien especial, 6 como algunos suclen decir, que esta forma se explica por $\mathrm{el}$ género de vida. La verdad es que en el fondo difieren poco de otros peces de forma regular, pero armonizan perfectamente por su estructura. Las platijas ó pleuronéctidos pueblan en número de mas de ciento ochenta especies distintas las costas de todos los mares y suben los rios, viviendo en todas partes en el fondo, atisbando continuamente agachados de un lado contra el suclo, y del otro que tiene los ojos hácia arriba, moviéndose solo cuando pueden pillar una presa ó cuando se han de resguardar de otros peces mas grandes que ellos.

Todins las especies tienen iguales usos y costumbres, por grande que sea su número y notable su divergencia en estructura, cubierta escamosa y coloracion; por esto bastará que me limite á describir algunas especies, y á bosquejar un cuadro general de su género de vida serialando de paso los rasgos principales de varias de ellas.

\section{LOS HIPOGLOSOS-HIPPOGLOSSUS}

CARACTERES. - Si se toma por principio de clasifica. cion la dentadura, mercen el primer puesto aquellos géne. ros de la familia que presentan las mandibulas y dientes aproximadamente en igual estado de desarrollo en ambos lados, y por esta razon empezaremos por los hipoglosos. Las dos especies de este género se caracterizan por los rasgos si. guientes: tienen los ojos en el costado derecho, la abertura bucal es ancha, $y$ los dientes, que en la mandibula superior se presentan en doble hilera, y que faltan completamente en el paladar y en el vómer, se hallan en la superiór particularmente desarrollados en la parte anterior, y en la mandibula inferior en los lados; la aleta dorsal arranca de encima de los ojos y la sostienen al igual de la anal radios sencillos.

\section{EL HIPOGLOSO COMUN-HIPPOGLOSSUS}

\section{VULGARIS}

CARACTERES.-Esta especic, representante del géncro, viene á ser el gigante de la familia; pues su longitud os. cila entre un metro y medio y dos meiros. Pontoppidan ha bla de un individuo de esta especie que cubria toda una lancha, y otras observaciones inducen a creerlo. El color del lacio de los ojos ofrece variaciones de pardo claro y oscuro; el del otro lado es blanco. Tienden la aleta dorsal ciento 
cuatro radios, la abdominal diez y seis; la torácica seis, la Dishenta y uno y la caudal veintiseis (fig. 190).

DISTRIBUCION GEOGRÁFICA. - Debe considerarse el mar Glacial como la verdadera patria de este pez, aunque frecuente las costas británicas $y$ las de Dinamarca siendo hasta permanente en algunos puntos; pero solo abunda en las regiones mas septentrionales, como en las costas de No. ruega $y$ al rededor de Islandia. En las costas alemanas es especic rara, pero conocida de todos los pescadores, y aun en el mismo Báltico, á pesar de no cogerse alli sino en la ba. hia de Kiel.

\section{LOS ROMBOS-RHOMBUS}

CARACTERES. - Los individuos de este género son los mas aplanados y anchos de todas las platijas en general; además los caracterizan sus dientes aterciopelados 6 bien de púa en las mandíbulas y la faringe, una aleta dorsal muy prolongada que arranca desde el hocico, notable por su gran abertura bucal; una anal tambien grande, y la estructura de los radios de ambas aletas que son partidos ó bifurcados. Las aletas dorsales presentan igual estructura que las aletas principales y verticales. Los ojos se hallan colocados en el costado izquierdo; el espacio que media entre ellos es reducido, $\mathrm{y}$ las escamas son de borde liso (cicloideas).

\section{EL ROMBO MAYOR-RHOMBUS MAXIMUS}

CARACTERES. - Es la especie mas apreciada de su ge. nero. El costado donde se hallan los ojos presenta muchas

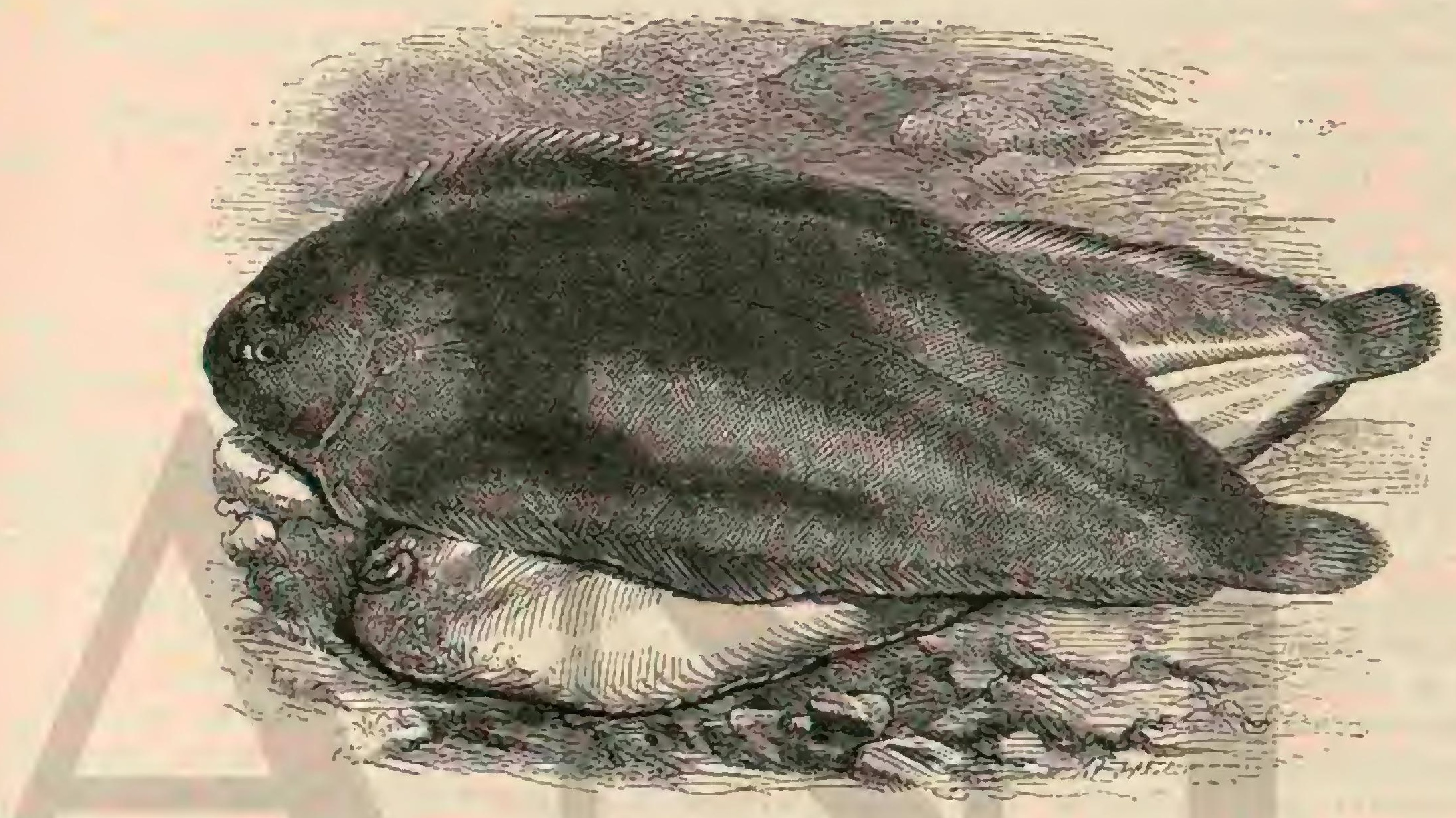

Fig. 191. - EL LEXGUADO COMU:

proiuberancias; el color es un pardo variado, mas claro en las aletas, con manchas difusas veteadas y otras claras bien marcadas y de diferentes tamaños; el otro costado es unifor. memenie blanco. La longitud puede pasar de un metro, $\mathrm{s}$ el pesollegar hasta treinta y cinco kilógramos. Rondelet asegura haber visto uno de estos rombos que media tres metros de largo, dos de ancho, y casi uno de grueso. El número de ra. dios en la aleta dorsal es de sesenta y cuatro, la pectoral tiene doce, la abdominal seis, la anal cuarenta y ocho y la caudal quince.

DISTRIBUCION GEOGRAFICA.-Se pesca esta espe. cie en el mar del Norte, en el Báltico y tambien en el Mediterráneo, pero donde se coge en mas cantidad es en el pri. mero, como igualmente en cl canal de la Mancha, en la costa noroeste de Francia y en las de la Frisia oriental, junto á Norderney y Heligoland, y en las desembocaduras del Weser y del (ieeste, mientras que se presenta solo aisladamente en el Sleswig occidental, y en el Búltico única pero constantemente en la bahia de Kiel.

\section{EL RODABALLO Ó ROMBO COMUN-RHOM- BUS INEVIS}

CARACTÉRES, - Esta especie (îg. I88), añne de la anterior, difiere de ella por su piel lisa, siendo su coloracion un pardo rojizo sucio veteado de pardo oscuro con manchi. tas claras redondas como perlas. Cuando jóren, liene solo un color pardo rojizo pálido con manchas negras $\mathrm{g}$ pardo os. curas. Se cuentan en la aleta dorsal setenta y scis radios, en la pectoral seis, en la anal cincuenta y nueve, y en la caudal diez y seis. Su tamaño es mucho menor que el de la especie anterior, pasando raras veces de $(i)$,40, mientras que su peso excede en muy raros casos de cuatro kilógramos.

DISTRIBUCION GEOGRÁFICA.-Su krea de disper. sion comprende el Mediterráneo, el Atlántico, el mar del Norte donde es frecuente en todas las costas alcmanas, sicn. do raro en el Báltico.

\section{LAS PLATIJAS PROPIAMENTE DICHAS-PLATESSA}

CARACTERES.-Con este nombre, que se usa tambien frecuentemente para designar toda la familia, se compren. den las especies de configuracion romboidea, cuadrada ú oralada, con aletas dorsal y anal anchas, sostenidas en su totalidad ó en gran parte por radios sencillos, y que no llegan hasta la caudal. La dentadura, mas desarrollada en el costado reverso que en el principal al igual de las mandibr:las, consiste en dientes incisivos dispuestos en una hilera y en dientes de adoquin en los huesos faringeos. Por lo regu. lar se hallan los ojos separados uno del otro por una eleva. 
cion $\sigma$ liston en el costado derecho. Las escamas pueden ser ó lisas ó dentadas.

\section{LA PLATIJA COMUN-PLATESSA VULGARIS}

CARACTERES. - Este pleuronecto (fig, 189) ocispa el primer lugar entre los que se cogen en las costas de Alemania. Su longitud excede raras veces de 0 , 60 , y su peso apenas llega á siete kilógramos. Su color varia segun la localidad; por lo comun es pardo en el costado donde están los ojos con dibujo jaspeado gris $y^{\prime}$ manchas redondas $y$ amarillas que se extienden hasta sobre las alctas dorsal, anal y caudal; el reverso es uniformemente amarillento ó de lun blanco ceniciento. Hay setenta y tres radios en la dorsal, once en la torácica, seis en la abdominal, uno y cincuenta y circo en la anal, y diez y seis en la caudal.

DISTRIBUCION GEOGRÁFICA.-EI área de disper. sion de este pez comprende una gran parte del Atlíntico, el Mediterráneo, el mardel Norte y el Báltico. Respecto al mar del Norte, se pesca la platija comun en todas partes, pero es mas abundante en unas que en otras; en el Bático se encuentra hasta la costa de la Pomerania anterior en el sur, y hasta los islotes de la costa de Suecia en el norte.

\section{LA PLATIJA SALPICADA - PLATESSA FLESUS}

CARACTERES. - Esta especie, que habita los mismos mares que la anterior en los puntos apropiados á su género de vida, siendo quizás mas frecuente que aquella, sube ade. más $\left\{\right.$ las aguas dulces. Su longitud pasa raras veces de $0^{\circ}, 30$, y su peso casi nunca excede de tres kilógramos. El color principal es un pardo claro variable que pucde llegar á ser muy oscuro con manchas que lo son mas todavia. Las aletas ofrecen siempre un tinte mas claro que el cuerpo, pero con sus correspondientes manchas; el reverso es entre amarillo y blanco amarillento salpicado de puntos negros. La mayoria de estos peces tienen los ojos en el costado derecho, pero Wittmack encontró nada menos que siete individuos entre sesenta y cuatro pescados en la misma red que los tenian on el lado izquierdo. La aleta dorsal tiene cincuenta y cinco radios, la torácica once, la abdominal seis, la anal uno s cua. renta $y$ uno y la caudal catorce.

\section{LA LIMANDELA-PLATESSA IIMANDA}

CARACTERES. - Debe su nombre á sus escamas ásperas, dentadas é irregulares. El lado anverso ó superior es de un pardo pálido uniforme, y el inferior blanco. En la aleta dorsal cuéntanse setenta y seis radios, en la torácica once, en la abdominal seis, en la anal cincuenta $y$ nueve, y catorce en la caudal. Alcanza una longitud de $0^{\circ}, 25$ a $0^{\circ}, 3^{\circ} \mathrm{y}$ un peso de dos á tres kilógramos.

DISTRIBUCION GEOGRÁFICA, - Puebla esta pla. tija las costas escandinavas, británicas e islandesas; tambien penetra en las lagunas salobres del Sleswig, pero pocas reces en el Báltico, y cuando lo hace, no llega tanto al norte ni al este como la especie anterior.

\section{LOS LENGUADOS Ó SUELAS -SOLEA}

CARACTERES. - Así se llama una especie de platijas oblongas con hocico redondeado á manera de pico de ave, y aleta dorsal que arranca de delante de los ojos; la anal tambien es muy larga, la caudal redondeada y las torácicas, cujos radios son partidos, igualmente desarroliadas en am- bos lados. La cubierta es escamosa, y la dentadura tiene de especial que solo existe en la parte de la boca que corres. ponde al lado inferior ó anverso del animal, componiéndola dientes de púa dispuestos en varias hileras. Los ojos se halian en el costado derecho.

\section{EL LENGUADO Ó SUELA COMUN-SOLEA VULGARIS}

CARACTÉRES. - Este pez.(fig. IgI) alcanza a lo mas una longitud de $0^{\circ}, 60$ y un peso de cuatro kilógramos. El color es negro en el lado anverso ó principal, como lo son tambien los extremos de las aletas torácicas. El reverso es pardusco. En la alcta dorsal hay ochenta y cuatro radios, en la torácica sicte, en la abdominal cinco, en la anal sesenta y siete, $y$ en la caudal diez $y$ siete.

DISTRIBUCION GEOGRÁFICA. - El lenguado no falta en ninguna costa de la Europa occidental desde el Mediterráneo hasta el mar Glacial; en el mar del Norte es co. mun y penetra en los rios que en el mismo desembocan; pero en el Búltico se presenta solo hasta Kiel, sin alcanzar alli el volúmen que tiene en otras aguas.

USOS, COSTUMBRES Y REGIMEN.-Los pleuronéctidos se presentan en mayor número de especies $y$ de in. dividuos en los mares de la zona templada, sin que por esto falten en la tórrida. Hácia el norte disminuye su número rápidamente, ya que, segun Yarrell, se encuentran en las aguas inglesas diez y seis especies, en el estrecho del Categat solo trece, en la costa de Noruega dier, junto śla Islandia cinco, y en las costas de Groenlandia tan solo tres. Atendido lo poco que sabemos hasta ahora sobre los peces platijas de otras regiones, no podemos blasonar de tener un conocimiento general $y$ algo regular de esta familia, pero por lo que se ve puede decirse que la fuerza creadora de las latitudes bajas se hace sentir tambien en ella; como lo prueba la coloracion que en muchas especies corresponde perfecta. mente al mayor ó menor brillo y variedad de los séres que pueblan el fondo de los mares segun la latitud. Asi por cjem. plo, se encuentra en las aguas chinas y de la India que ofre. cen una abundancia pasmosa de peces de brillantes colores y forma extraña, un lenguado que con mucha justicia llaman lenguado cetra (Synaphura Zebra) (fig. I 92), porque presenta en el costado de los ojos fajas trasversales alternativamente claras $y$ oscuras, que continuan en las aletas dorsal y anal confundidas con la caudal.

Todas las especies de pleuronéctidos que dejamos descritas, á excepcion del hipogloso comun, prefieren paramorada sitios arenosos 6 cuando menos aquellos cuyo fondo no está cubierto de un fango semi-liquido y profundo. Algunas, en. tre ellas el lenguado y la platija salpicada, buscanlas desernbocaduras de los rios, y'la última emprende a veces, desafian. do la corriente, viajes bastante largos rios arriba, penetrando bastante en el interior del continente y presentándose cons. tantemente en los rios ingleses; en Alemania en el Elba y Weser inferior, y en el Rhin hasta la frontera alemana; pero además se le ha pescado repetidas veces fuera de este radio en la parte superior de dichos rios, como por ejemplo en el Elba mas arriba de Magdeburgo, en el Rhin cerca de Ma. guncia, y en sus afluentes el Mosela y el Mein. Se ve pues que estos peces tan perezosos no dejan de ser muy aficionados a viajar; circunstancia que ha llamado poco la atencion á causa de la abundancia extraordinaria de estos peces en el mar, donde los pescadores los observan con preferencia Asi es que de mucho tiempo á esta parte se sabe que el hipo. gloso comun, pez tan importante para la alimentacion de los pueblos del norte, pasa el invierno en la profundidad y se 
acerca y entra en las bahias en la primavera. Llega junta. mente con el abadejo a las costas meridionales y occidentales en marzo; va engrosando sus bandadas durante el siguiente mes de abril, y no se retira hasta pasado el verano; al norte de la isla empieza á llegar en mayo, y en la costa oriental no se le ve antes del mes de julio. En mayo y junio es tambien cuando acudél los bajlos y sitios de poco fondo cerca de las islas Feroe, de donde vuelve á desaparecer con la estacion mas fria. En el Báltico, particularmente en la bahia de Kiel, no se le pesca en número regular sino en los tres ultimos meses del año. Del mismo modo que el rombo mayor, aparecen y se van las otras platijas que hasta ahora se han observado con algun interés; pues los pescado. res saben perfectamente que aquel sube de las profundidades del mar del Norte á los bajios meridionales á últimos de marzo y un poco nas tarde á los situados mas al norte de donde se retira á su morada habitual cuando arrecia el calor. En cuanto al rodaballo, se ha notado que se presenta en mayor número en los bancos de la desembocadura del Elba des. de abril y en los del Weser desde mayo á julio; pero en los Greifswald (Pomerania en el Báltico) desde mayo hasta agosto. De la platija comun saben los pescadores experimentados que no solamente acude puntualmente en epocas fijas a determinadas pesquerias de donde desaparece con la mis. ma puntualidad, sino que emprende desde los bajios mas elevados cxcursiones regulares á otros puntos, por cuya razon los distinguen en rodaballos de verano y de invierno.

No me entretendré en discutir la veracidad de lo que ma. nifestó un viejo marino á Hilkelmann, director de una pesqueria; á saber: que en cierta ocasion habia estado viendo todo un dia un verdadero banco de rombos tan numerosos que no dejaban ver el fonco ciel mar á pesar de la trasparencia del agua que en aquel punto permite divisarlo siem. pre; pero con lo que estoy del todo conforme es con las observaciones de los pescadores respecto de la aparicion y desaparicion puntual de la platija comun, sin tener tampoco motivo para poner en duda otro dato del citado director de pesca, esto es, que el rombo viaja rápidamerte en un nismo verano de un punto á otro, por manera que alli donde un dia se cogen muchos al siguiente apenas se pescan algunos. Para presentar datos fijos diré, apoyándome en una coleccion de datos hecha por Wittmack, quie la platija comun es frecuente junto a Busum. con el nombre de platija de bajio en los meses de noviembre $y$ diciembre, y en verano con el nombre de platija de mar; en los bajos de Flensburg es abundante en febrero y marzo; en la bahia de Kiel desde mayo á agosto, y junto a Stralsund desde febrero á abril, sin que esto obste para que se pesque este pleuronéctido tambien en otros meses del año. Segun Hilkelmann, sepresenta La platija de inviemo en las ensenadas del Báltico cerca de Flensburg en noviembre, permaneciendo alli hasta el verano que es cuando desaparece poco á poco, rolviendo probable. mentéa sitios mas profundos. Lo propio que la platija, asi llega y desaparece el lenguado; pero hasta hoy no se sabe hasta que punto influye en estas traslaciones periódicas la reproduccion, porque tambien puede ser que dichos cambios obedezcan á la necesidad de buscar nuevos pastos.

Todos los pleuronéctidos tienen idénticos usos y costum. bres; $y$ todos se mueven de la misma manera, pues hasta ahora nada se ha observado que lo contradiga. Yacen inmóviles en el fondo en que habitan, mas ó menos cubiertos de arena, dejando solo los ojos fuera de ella, hasta que les hace salir de su posicion una presa ó algun animal terrible para ellos. Es de ver la rapider con que se hunden en la arena haciendo un movimiento ondulatorio con sus aletas dorsal y anal. Para salir y sacudir la arena les basta un movimiento único, pero vigoroso, $\mathrm{y}$ una vez fuera progresa este pez ondulando siempre las dos aletas principales asi como la robus. ta caudal, y manteniéndose con el costado principal hácia arriba. Para sus movimientos repentinos se vale de la cola que es su principal aparato motor, y se guia despues con las otras dos aletas principales, atravesando el agua como una saeta. Todos los pleuronéctidos que he observado cautivos se movian siempre de este modo que en rigor es nadar decos. tado. Yarrall pretende que tambien se mueven en el sentido opuesto, que de repente cambian de posicion colocando los dos costados planos, es decir, verticalmente, y que cortan asi las olas como el rayo, para ponerseotra vez planos y dejarse ir al fondo. No pretendo averiguar si emplean este cambio de posicion siempre que quieren ejecutar un movimiento rípido ó si es casual; lo que si me parece cierto es que no tienen ninguna necesidad de nadar de este modo, $s$ que el otro, su manera normal de moverse, es muy suficiente para que progresen en su elemento. Cuando nadan mus despacio toma parte todo el cuerpo en el movimiento ondulatorio de las aletas, y cuando se apresuran trabajan solo con la cola.

Es muj divertido observar una platija mecio hundida en la arena y moviendo sus ojos sin cesar, bien diferentes en esto de los demás peces, que los tienen inmóviles. A esto se agrega que un ojo es casi siempre mayor que el otro, su ccloracion viva, con cierta expresion inteligente y astuta, y' que no solamente el animal los muere a su voluntad dentro de la órbita, sino que puede tambien hacerlos salir y entrar co. mo lo hacen las ranas, moviéndolos en todas direcciones: los protege un verdadero párpado ó membrana conjuntiva muy desarrollada. Los ojos son en rigor todo lo que se ve cuando el pez se oculta entre la arena, porque la coloracion del costado superior se adapta á la del fondo del agua, como el color del pelaje de la liebre al del campo labrado y el plu. maje de la perdiz de las nieves al color de las laderas alpinas; con la diferencia de que el color de la platija no cambia, como el de esta última, dos reces al año, sino siempre que muda de sitio. Todo lo que nos complacemos en atribuir erróneamente al camaleon, es en la platija realidad. Si se echa por ejemplo sobre fondo arenoso, se ve cómo cam. bia su color y dibujo hasta que se adaptan á él; el color amarillo sale, y el oscuro desaparecc. Si despues se traslada el pez, como sucede con frecuencia en los acuarios reducidos, á otro sitio que tenga el fondo de cascajo granítico gris, se verá que el color del costado de los ojos se trasforma en el del cascajo; la platija, rombo ó lengundo, antes amarillos, vuelven á ser de color gris. No desaparece total. mente en estos cambios cl carácter de la coloracion, pero si varla, y no hay observador que no se convenza desde luego de que en esta familia el color es de poca importancia. Los pescadores saben muy bien que una misma especie es segun el tono general del fondo, oscura en un sitio y clara en otro; por esto en Inglaterra dan á las platijas comunes cogidas en el condado de Sussex, en un sitio llamado fondo diamantino, el nombre de flatijas diamantes, á causa de la pureza de su color pardo y el brillo de sus manchas que corresponden tan bien con el fondo donde viven y que las distinguen de todas las de su misma especie, tanto que á no ser cosa tan sabida la variabilidad del color, se las podria considerar como es. pecie ó por lo menos como variedad aparte.

Esta propiedad de adaptar el color á las circunstancias, explica acaso mejor que otra cosa la desproporcion en el número de los pleuronéctidos, que no solamente no son mas fecundos que otros peces, sino que distan mucho de poder competir con otros en cuanto al número de huevas; en cambio se libran sus crias en mucho mayor número de la voracidad de sus enemigos, pudiendo alcanzar asi el desarrollo 
que les permite atender por si mismos a su propia segu. ridad.

Todas las platijas son animales rapaces, y las especies grandes además tan atreridas que hasta atacan á peces del tamaño del abadejo; las pequer̉as, que lan de contentarse con diferentes especies de cangrejos, conchas y gusanos, son por lo menos excesivamente voraces. En cuanto á ferocidad y rapacidad, compiten las especies pequeras con las grandes; todas persiguen lo que creen poder rendir, aunque sean in. dividuos de su propia especie, porque entre los pescadores noruegos es cosa admitida y fuera de toda duda que las le. siones que muchos pleuroréctidos presentan tan á menudo en sus costados y region caudal, son causadas por sus compañeros de mayor talla. Hasta los enemigos mas terribles de esta familia, las lobas marinas y las focas, encuentran en ella individuos que saben tomar yenganza de la destruccion que causan entre los suyos; el hipoglošo comun es en particular un perseguidor encarnizado de las focas, cuyo género de vida se parece tanto al suyo.

La reproduccion de los pleuronéctidos tiene lugar en dis. tintos meses, pero en general cae en la estacion mas bonan. cible, es decir en la primavera y principio de verano; á saber: para el hipogloso comun y lenguado en los meses de majo á julio; para el rombo y rodaballo, de narzo á mayo; para la platija comun y la salpicada, de enero ś junio. En estas épo. cas ocupan los ovarios en las hembras casi toda la cavidad del cuerpo, y en los testiculos de los machos apenas si cabe el liquido seminal. Deposiaan la freza en el fondo que habitan en aquel momento, y por lo tanto con preferencia en la arena, pero en caso necesario tambien entre yerbas marinas y aun en las mallas de redes tendidas perennemente. Cuando acaba el verano se ven los pequeñuelos durante la marea baja, porque perezosos como sus progenitores, prefieren a menudo hundirse en la arena y esperar la marea alta á vol-

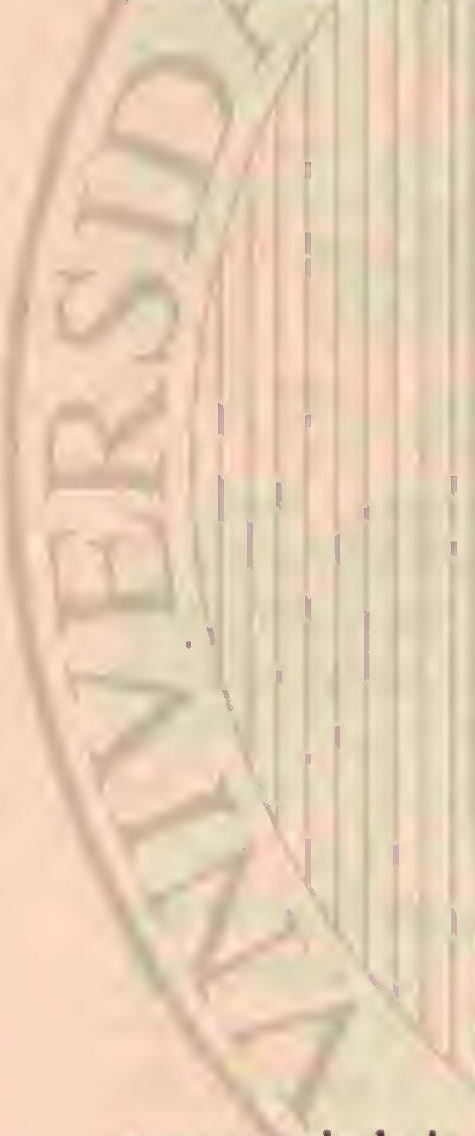

verse con la baja para buscar aguas profundas. No puede darse cosa mas bonita que un pequeñuelo de esta clase. Abstraccion hecha del tamaño, se parecen en coloracion, dibujo, género de vida y usos y costumbres á los padres, solo que son mas hermosos, mas movibles y por consiguien. te mas graciosos.

CAUTIVIDAD. - Apenas hay pez de mar que se acomode mas fácilmente i la cautividad que esta familia, que ni siquiera exige agua de mar, pues se acostumbra al agua dulce de los estanques y rios, donde se mantiene perfectamente con tal que no le falte alimento; por cuya razon no podemos menos de recomendar estos peces \& los añcionados, es decir, las platijas, rombos $y$ lenguados nuestros.

UTILIDADES. - La importancia de los pleuronéctidos para la economia humana es grandisima. La carne de Lodas las especies es fina, la de algunas exquisita, con la ventaja de que se conserva algunos dias sin corromperse, lo que per. mite expedir estos peces á largas distancias. Casi en todas las costas se comen frescos, pero en los paises muy septentrionales, donde lo que se recoge en verano constituye el alimento de todo el año, se curan las platijas mayores cortándolas en tiras, que se salan, se secan al aire como el pezpalo ó se ahuman. Son mas preferidos la platija comun, la limandela y el rombo mayor, sin que por esto se desprecien en ninguna parte las demás especies. Solamente los holan. deses, que son los que mas se ocupan en esta pesca, llevan al mercado de Lóndres anualmente por valor de ochenia mil libras esterlinas ( 2 millones de pesetas) y los dinamar. queses por quince mil libras ( 375,000 pesetas), sin contar los que cogen los pescadores ingleses, puesto que los holande- sas no abastecen con los suyos mas que la cuarta parte del consumo que en aquella capital se hace de estos peces; tam. bien hay que tener presente que en las ochenta mil libras que cobran los holandeses no entran las platijas de toda es pecie que venden en alta mar á los pescadores ingleses para eludir el derecho que pagan en aquel país los importadores extranjeros. Es imposible fijar la cantidad de rombos que se consumen en Holanda misma, en Alemania, Francia y Jutlandia; pero puede muy bien admitirse que el valor total de esta pesca asciende á tres millones de marcos próximamente, por cuanto el kilógramo de este pescado se paga ahora á bordo hasta dos marcos (10 reales). Mayor ha de ser el va. lor de otras especies de pleuronéctidos, como las platijas co. munes, las salpicadas y los lenguados, por baratos que se vendan en los mercados de las poblaciones maritimas, a saber, los lenguados, de un marco hasta marco y medio el kilógramo, 8 las platijas comunes y salpicadas frescas, de uno á cuatro y de uno á dos marcos respectiramente cada partida de sesenta, puesto que se venden ś piezas y no al pe. so. Hay ocasiones en que se pescan cantidades extraordini rias. Un dia, dice Yarrell, se presentaron tantas platijas co. munes en la plaza de Lóndres que quedaron centenares de fanegas sin vender. Se vendieron grandes partidas á un penique la docena (ro á I I céntimos de peseta) y eso que el per mas pequeño pesaba lo menos lilógramo y medio, viniendo dé resultar el kilógramo î́ poco mas de medio cénti. mo de peseta. A pesar de tan bajo precio no se encontraron ya compradores, y fué menester que el alcalde mayor dispesiera el reparto del resto entre los pobres de la ciudad. Se. gun Yarrell, se venden anualmente en la lonja de pescadores 
de I_óndres ures ochenta y seis mil fanegas de platijas pro. piamente dictas La pesca del hipogloso es tambien a reces muy productira, porque se sacan con el solo volantin á me. nudo tres, curro ó tambien cinco de estos grandes pescados, de un solo golpe.

Mucho falu para que los pescadores alemanes puedan equipararse cola los ingleses, holandeses y daneses tocante al producto de exa pesca. En nuestras costas apenas merece mencionarse a hipogloso comun; del rombo mayor se remiten anualmen: al interior solo unos tres mil kilógramos; de las platijas cowen y salpicada unos veinte mil kilos de cada una, y unos cizz mil lenguados. A últimos de verano es la carne de esto peces mas gorỏa y mas inferior; en algunos puntos hasta impropia para el consumo á fines de otoño, siendo csta última la temporada en que mas platijas sepescan.

PESCA. - Esta se hace de muchas maneras segun el sitio, abundancia y especie de pescado. El procedimiento usado en algunos peatos se parece al de los salvajes; consiste en vadear descalsos las balsąs y charcos de la playa, aplastar con el pié a los peces que se tocan y recogerlos. Hay puntos donde este méodo primitivo da á menudo abundante cose. cha; pero mas productivo es otro que consiste en el empleo de un chuzo con que el pescador, que recorre en tiempo de calma en un bote el bajio $\delta$ la playa ligeramente inundada, traspasa los peces que descubre. En lugar del chuzo se usa á veces un insirumento armado de púas, lastrado con plo. mo y atado a una cuerda que arrojan sobre la platija. Cuando el fondo es llano se usa una red de jorro especial, y en aguas profundas el sedal de mano ó bien de fondo.

CAUTIVIDAD.-Repetidas observaciones y ensajos he. chos han dado por resultado que los pleuronéctidos se conservan perfectamente en el agua dulce. Es facilisimo remitirlos vivos á grandes distancias puesto que su fuerza vital es sumamente grande. Muchas circunstancias abogan en favor de la opinion de Siebold, de que cuando menos la platija salpicada podria criarse en nuestros estanques y lagos, y yo por mi parte ni siquiera participo de la duda de este naturalista de que un pez tan voraz no ha de encontrar suficiente alimento en nuestras aguas dulces, puesto que los cnsayos he. chos en Inglaterra han dado resultados favorabilisimos, por manera que a falta de conchas y gusanos marinos bien deben haber encontrado estos extranos huéspedes otro alimento en cantidad suficiente. Mac Culloch dice, hablando de los len. guados que se habian conservado durante algunos años en un estanque de jardin, que habian adquirido doble tamaño y suculencia, lo cual no habria sucedido si hubiesen perma. necido igual espacio de tiempo en el mar. Yarrell por su parte cuenta de un pescador que se ocupó mas de diez años seguidos en trasladar lenguados á agua dulce y que no tan solo prosperaban perfectamente en los rios aumentando su peso considerablemente, sino que tambien procrearon. Lo cierto es que esta idea merece positivamente la atencion de todos los criadores de peces.

Por lo que toca ádepósitos ó acuarios, siempre reducidos, no cabe duda de que los pleuronéctidos se mautienen con tanta facilidad como cualquier otro per. Pronto se acostumbran di la estrechez de su depósito, donde escogen un sitio predilecto, y segun supongo llegan a conocer a la persona que los cuida como tambien la hora de la racion, y hasta to. man el alimento de la mano que se lo ofrece.

\section{FISOSTOMOS-PHYSOSTOMI}

Al examinar detenidamente los peces reunidos por Cuvier en el órden llamado anacantinos 6 peces de radios blandos, vió Juan Mueller que un número considerable de ellos se distinguia del resto por tener su vejiga un conducto aéreo. Sobre este carácter fundó cl órden de que ahora vamos á ocuparnos y cuyo nombre científico se refiere al mismo. Brehm, en lugar de traducir este nombre al aleman como tiene por costumbre, llama á esta division de peces en su idio. ma: peces preciosos ó finos como diriamos hablando de piedras: «piedras preciosas 6 finas $\$$, porque dice que por una parte no es necesario que el nombre aleman y el cientifico signifiquen lo mismo, y por otra, que esta familia com. prende realmente los peces mas preciosos de todos y en especial la inmensa mayoria de los que habitan los rios alemanes. El norrbre cientifico viene \& significar apeces cuya vejiga natatoria comunica con la cavidad bucal); pero deje mos la palabra al autor.

En cuanto ä la importancia de este carácter puede haber divergencias. EJay motivos para creer poco convenienteser. virse de la vejiga natatoria como carácter distintivo en la clasificacion, por cuanto este órgano es uno de los que ofrecen mas variacion, dice Juan Mueller; á lo cual contesto, que si bajo ningun cos cepto merece ser considerada como de gran peso, no es merios positivo que su estructura, alli donde exis. te, está sujeta \& leyes invariables, leyes que nos son conoci. das desde el momento en que conocemos los órdenes y familias verdaderos de los peces. Ahora bien, segun estas mismas lejes, la vejiga lleva un conducto aéreo en todos los peces que la tienen y que pertenecen al presente órden; y tambien está, segun estas leyes, dividida trasversaimente en los ciprinidos y caracinidos (salmónidos); y además, y sin excepcion, unida - cuando existe-al oido por una serie de huesecillos auditivos. Quiero decir que he derivado el nombre de fisos. tomos de un carácter principal del brden; sin que con esto haya pretendido significar que la vejiga representa el carácter dominante y exclusiva. Otros distintivos ofrecen los huesos faringeos que están constantemente separados; las branquias pectiniformes, las aletas blandas, la colocacion de las abdo. minales, cuando existen, detrás de las pectorales, $\mathrm{y}$ la cubierta consistente en escamas redondas en todas las especies que las tienen. La configuracion de los peces que forman este órden justifica tambien el nombre aleman qque le he dado, porque es proporcional y simétrica; el cuerpo es oblongo, cilindrico 6 comprimido, y la cabeza y las nadaderas proporcionadas al resto. Verdad es que ni las escamas ni la colora. cion se distinguen, aquellas por una forma particular y esta por su magnificencia, pero son elegantes y agraciadas.

En cuanto á variedad de formas, no quueda muy en zaga 
este órden al mas rico de todos, el de los acantopterigios; pero si tocante al número de especies, por lo menos segun el es. tado actual de la ciencia, si bien es de suponer que descubrimientos posteriores le enriquecerán con preferencia s. los demás, porque los fisostomos pertenecen, si no en totalidad, en su mayor parte á las aguas dulces, y pueblan los lagos, esLanques, rios y arroyos de todos los paises del globo. Pues bien, hoy por hoy no conocemos todavia bien las especies europeas, cuanto menos aquellas que viven en las aguas dul. ces de las otras partes del mundo, y de ahi se sigue que cada año se enriquece la ciencia considerablemente por este lado, y que cada viajero descubre nuevas especies a medida que registra los grandes rios de aquellos paises lejanos. Como ejemplo citaré á Agassiz, cusos recientes estudios sobre los peces del rio de las Amazonas han venido a arrojar nueva luz sobre esta parte de la zoologia, porque este naturalista, ayudado por un auxiliar, pudo encontrar en aquel rio gigante, si no micnten las noticias de América, cerca de mil doscientas especies en su mayoria desconocidas hasta entonces y casi todas las cuales pertenecerán probablemente al órden que ahora nos ocupa:

USOS, COSTUMBRES Y REGIMEN:-Creo que po. dré dispensarme de presentar aquí un cuaciro general del ié. gimen, usos, costumbres y reproduccion de los fisostomos, porque tendria que repetir lo que es general a toda la clase. Dirk solamente que el presente brden ofrece bajo este con. cepto, segun las especies, todas las particularidades que pue. den verse en los peces en general. Hay fisostomos que no pueden prescindir de su elemento, el agua, y los hay que pueden permanecer bastante tiempo en tierra firme; unos viajan por el agua y otros se trasladan por tierra. Cuenta este órden especies carniceras y feroces, y especies inofensivas y herbivoras; las hay de poca y de extrnordinaria fecundidad; oviparas y yiriparas, de gusto exquisito y desagradables al paladar.

USOS Y PROVECHOS. - Para los pajses del interior tienen mucha mas importancia los fisostomos que todos los demás peces, y no deja de ser notable que este órden comprenda tambien el arenque, el mas importante de iodos los peces del mar. Mucho mavor seria su importancia si los pue. blos llegasen a comprender sus interesés y protegiesen las crias, impidiendo la guerra de exterminio que se les hace, y fomentando de paso la cria artificial. Cuando por todas partes se oyen tan justas quejas sobre la disminucion de los peces, deberia ñjarse la atencion con preferencia en los de este órden por ser tmas susceptibles de acrecentarse y de re. poblar los rios 5 lagos; pero ja llegará el tiempo en que hasta el labrador comprenda que la repoblacion de nues. tras aguas necesita del trabajo y enérgica intervencion del hombre al igual del ganado terrestre, y que como no pueden criarse rebaños de carneros ni aves de corral sin trabajo, tampoco puede haber peces si el sér racional, el hombre, no se aplica aे su cria.

\section{LOS SILÚRIDOS- SILURIDE}

Los mismos motivos que habrán determinado 1 algunos ornitólogos a encabezar la clase de las aves con las de ra. pira, empezando por las mas grandes, á saber, los feos y es. túpicos buitres, deben haber inducido tambien á aquellos ictiólogos que abren el brden de los fisostomos con los silú ridos, porque léjos de ser estos peces los mas preciosos ó los mas distinguidos del órden, son los mas informes, pero tam. bien los mayores.
CARACTÉRES. - Se caracteriza esta familia por su cuerpo voluminoso, tosco y desnudo ó cubierto de escude. tes óseos, en lugar de escamas; por la cabeza grande y la boca desmesurada con la mandíbula superior y los huesos mandibulares atrofiados hasta reducirse á rudimentarios, ó prolongados y trasformados en tentriculos; por las barbillas mas ó menos numerosas y largas, variando igualmente en cuanto á su colocacion; por los opérculos compuestos de tres piezas, y la carencia del sub-opérculo; por la vejiga natatoria que comunica con el oido por los huesecillos de este; y final. mente por la ancha faringe y el estómago en forma de saco. En muchas especies se presenta el primer radio de la aleta pectoral muy robusto, dentado é inserto en la clavicula, de modo que el pez puede moverlo, es decir, aproximarlo al euerpo $\delta$ enderezario a voluntad y emplearlo como arma vi. gorosa que causa crueles heridas. Otras especies tienen, ade. más de la dorsal, otra adiposa. Notabilísima y tan particular como inexplicable hasta ahora cs una abertura detrás é inmediatamente encima de la raíz de ambas pectorales, que conduce á un espacio hueco muy largo.

DISTRIBUCION GEOGRAFICA.-La familia de los silúricios, que cuenta como quinientas especies distribuidas en mas de cien géneros; habita en gran número y multitud de especies las aguas de América, Asia, Oceania y Africa, mientras que en Europa la representa una sola especie.

USOS, COSTUMBRES Y REGIMEN.-Prefieren las aguas mansas 6 estancadas con fondo cenagoso, sin que por esto falten en las de mas corriente $y$ aun en los torrentes, cncontrándose á todas las alturas á donde pueda llegar cualquier otro pez Especies hay que son mas frecuentes en los fondos arenosos ó cenagosos próximos á las desembocadu. ras de los rios, y otras que prefieren fondo de roca donde se ocuitan debajo de las piedras á manera de la molva comun; algunas son exclusivas de los rios, otras viven solo en lagos, y otras indistintamente en rios y lagos. Las especies grandes de forma tosca se mueven con pesadez; las pequeñas son, al contrario, muy listas y rápidas; otras laay que aventajan \& los laberinticos y ofididos en la facultad de poder emprender viajes por la tierra húmeda, fangosa y hasta seca, ú ocultarse cuando no hay otro remedio en el limo para aguardar la vuelta del agua. Todos los peces de esta fatnilia son rapaces y carniceros; la mayor parte se mantienen inmóviles en acecho, haciendo solo jugar sus tentáculos $\delta$ barbillas para atraer otros peces y devorarlos en el momento favorable, y algunas especies tienen la cualidad de poder descargar sacudidas eléctricas para aturäir à sus victimas.

La multiplicacion es al parecer relativamente cscasa, á pesar de que las hembras producen un considerable número de huevos; el creciniento tambien es lento, pero en cambio estos peces llegan a vivir muchos años.

UTILIDAD.-Para nosotros los europeos es poca, pero en ciertas partes de Africa, Asia y América constituyen los silúridos un alimento muy buscado, porque la carne de los pequeños y jóvenes es excelente sin duda alguna, mientras que la de los viejos es poco propia para los estómagos euro. peos, a no ser que se prepare cuidadosa y convenientemente.

\section{LOS SILUROS-SILURUS}

CARACTERES. - El carácter comun consiste en el cuerpo desnudo, aleta dorsal corta sin radios espinosos; anal muy larga; boca muy ancha y dientes de carda dispuestos en fajas en el rómer, mandibula inferior é intermaxilar.

EL GLANO-SILURUS GLANIS

CARACTERES.-Esta especie(fig. 193), que es la euro. 
pea, viene á ser el tipo fundamental de la familia y el mayor de los peces que pueblan los rios de Europa. Gessner dice de él: Este aninal horrible podria llamarse la ballena de Alemania. Es pez muy grande, de boca y cabeza deformes, carece de dientes que están reemplazados por asperezas en las mandibulas, $\mathrm{y}$ en toda su forma se asemeja á la lota en cuanto un animal tan grande puede compararse con otro tan pequeño como es esta. No tiene escamas, sino una piel lisa y resbaladiza. La verdad es que el glano no ticne nada de hermoso ni de agradable, pero mucho antes de Gessner ya habia llamado la atencion por su tamaño, inspirando hasta á los poetas. Hé aquí á Ausonio:

هAhora te ensalzan á $\mathrm{t}$, glano potente, que pareces un delfin de rio con tu lomo grasiento como si estuviese untado de aceite ático. Nadas con pesadez arrastrando la masá de tu cuerpo vigoroso y encontrando obstáculos ya en el agua poco profunda, ya entre las espadañas; pero cuando llevado por la corriente profunda te mueves majestuosamente, te admiran sorprendidos la verde ribera, las bandadas azules de los peces $y$ el agua trasparente. I as oleadas se rompen en la orilla y la cubren, como sucede cuando la ballena, su. biendo de las profundidades del Atlántico, se acerca á la costa impulsada por el viento ó por su capricho; tambien entonces desaloja el agua, obligándola á elevarse y formando olas tan altas, que las montañas vecinas temen desaparecer bajo ellas. La ballena pacifica de nuestro Mosela, léjos de llevar la desolacion por donde nada, solo es adorno del hermoso rio.

En cuanto á tamaño, solo puede compararse el esiurion con el glano entre los peces de Europa. Este último adquiere en el Danubio, segun Heckel y Kner. un volúmen tal que dos hombres apenas pueden abarcarlo, y muchas reces una longitud de tres metros con un peso de doscientos hasta doscientos cincuenta kilógramos. La region occipital, el dorso y los bordes de las aletas son de color negro azul; los costados de un negro verdoso, y hácia el vientre con man. chas de verde aceitunado sobre fondo mas claro; la parte inferior es, ó rojiza, ó de color blanco amarillento, jaspeada de negro azulado; las aletas abdominales y anal tienen en su centro una faja mas clara amarillenta; los dos tentículos de la mandibula superior son blanquizcos y las cuatro barbillas cortas de la inferior rojizas. La dorsal tiene un radio duro $\mathrm{y}$ cuatro blandos; la torácica uno duro y diez y siete blandos; la abdominal de once á trece; la anal de noventa á noventa y dos; y la caudal desde diez y siete hasta diez y nueve.

DISTRIBUCION GEOGRAFICA. - Principiando por ia Suecia meridional, se extiende el área de dispersion por toda la Europa meridional y oriental, y una parte del Asia occidental, excepto en algunos distritos, como por ejemplo en las cuencas hidrográficas del Weser y del Rhin, donde falta casi por completo. No se encuentra en Francia, España, Portugal ni en Italia; en la Gran Bretaña se ha cogido una sola vez. En cambio es muy frecuente en el curso inferior del Danubio, sin que falte en el superior ni en los afluentes y lagos que comunican con estos y con el rio principal. Tambien se pesca en el lago de Constanza, á pesar de ser un huésped rarisimo en el Rhin. No visita nuestros mares conforme se ha probado, $y$ hasta evita los alfaques (Haffe) tan poco salobres del Báltico, cuando no falta en el mar Negro y Caspio, donde segun los puntos forma hasta un ramo de pesca importante.

USOS, COSTUMBRES Y RIEGIMEN.-Al glano le gusta el agua profunda y mansa con fondo cenagoso. Alli acecha sus presas oculto detrás de piedras, troncos de árbo. les ó restos de buques sumergidos, haciendo funcionar sus barbillas y dando certeros mordiscos cuando algun pez iluso quiere morderlas. A falta de peces devora todo lo que llega \{su alcance y que puede engullir, como cangrejos, ranas, aves acuáticas, etc. Siguiendo en su relacion dice Gessner: «as. ta mirar la forma de este pez para convencerse de su indole feroz, cruel y voraz. UTna vez se encontró en el estómago de un glano una cabeza humana y una mano derecha con dos sortijas de oro todavía en los dedos, pues devoran todo lo quue se les presenta: gansos, patos y aun el ganado que se lleva al agua para abrevarlo ó lavarlo, habiéndose dado el caso de que estos peces precipitaran hasta un caballo al fondo, haciendo otro tanto con las personas si pueden llegar á ellas. En esto no hay ninguna exageracion porque no faltan casos que lo confirmen. Segun Heckel y Kner, se encontra. ron en un glano cogido en las cercanias de Pressburg (Hun. gría) los restos de un niño, en otro un perro de aguas, y en un tercero gansos que habia ahogado primero y tragado despues. Los citados naturalistas añaden que los habitantes de las tierras que atraviesa el Danubiu y lus de otrus distritos temen al glano, y hasta existe una antigua supersticion entre los pescadores que en otro tiempo creian que habia de morir uno de ellos cuando se cogia un glano. En otros dis. tritos no participan de este temor supersticioso, pero creen que el glano indica mal tiempo, probablemente porque solo abandona las profundidades y sube á la superficie cuando la atmósfera está cargada de electricidad.

La época de la freza comprende los meses desde mayo as julio $y$ en todo este tiempo se ven los glanos acercarse por parejas á la orilla parâ deponer las huevas entre los juncos y espadañas, y permanecer durante el dia en los sitios de poca agua, lo quue no suelen hacer en los demás meses del año. Se han contado las huevas y se ha visto que una hem. bra pone solamente como diez y siete mil, de las cuales nacen á los siete ó nueve dias los pequeñuelos, séres extraños que se ascmcjan extraordinariamente á los renacuajos. En mucha agua adquiere la cria al cabo del primer año un peso de setecientos gramos y a los dos años pesan ya un kilógramo y medio, mientras que en poca agun estos pesos no lle. gan sino á doscientos cincuenta gramos y lo mas ấ un kilógramo respectivamente. Los mismos naturalistas, Heckel y Kner, supicron por los pescadores húngaros que los glanos viven de diez á doce años; dato erróneo, puesto que Baldoner cita uno de estos peces de un pié de longitud cogido en el III junto á Estrasburgo, que se conservó vivo en un estanque donde se le colocó desde el año 1569 hasta 1620 , habiendo adquirido en este tiempo una longitud de metro y medio. De este dato puede colegirse que los glanos de tres metros, conforme se han pescado en el Danubio, deben tener una edad muchísimo mayor, aun admitiendo que crezcan mucho mas rápidamente en estado libre y en rios donde pueden moverse y cebarse á sus anchas, que cautiros en estrecho estánque. Acaso lleguen pócos á tan avanzada edad, con gran provecho para la pesca, porque los que nacen de las huevas escapadas á la voracidad de otros peces, sirven en gran parte de pasto á las lotas y otras especies carnivoras, y los jóvenes son quizás devorados por sus mismos progenitores; ademis de los muchos que cren en poder de los pescadores, y de los que en mayor nimero sucumben tal vez ś multitud de enfermedades que en los grandes calores se hacen no pocas veces epidémicas y causan numerosas victimas.

UTILIDAD. - A pesar del poco mérito que tiene la carne del glano, muy gorda en los animales jóvenes, y coriá. cea y aceitosa en los viejos, se persigue à estos siluros por su grasa, que se emplea en la fabricacion de cueros. De la vejiga se hace cola de pez. En Pomerania y en la Prusia oriental se paga el kilogramo de glano desde treinta á ochenta céntimos de marco $(0,24$ \& 1,00 peseta); en Sajonia de 
ochenta a cien céntimos ( $\mathrm{I}, 00$ á $\mathrm{I}, 25$ peseta) y en Baviera de ciento veinte hasta ciento ochenta peniques $(1,50$ a 2,25 pesetas).

PESCA. - Los glanos jóvenes se cogen casi siempre con el anzuelo, y los viejos con arpon, generalmente de noche durante la época de la freza. Los de gran tamaño dan mucho trabajo; Richter dice que vió cómo uno, que habia mordicio el anzuclo, hizo yozobrar una lancha con sus coletazos.

CAUtividá. - El glano de Europa, á semejanza de casi todos los siluros, resiste mucho tiempo fuera del agua, lo que permite trasportarle léjos y aclimatarle en aguas don. de no existe, como, scgun se dice, se ha hecho recientemente en Francia con glanos recibidos de Prusia. I.os glanos jórenes bien alimentados se conservan medianamente en espa. cios reducidos.

\section{LOS CLARIINOS-CLARIINAE}

CARACTÉRES. - Esta subfamilia comprende las espe. cies que además de las branquias comunes tienen haces de vasos ramificados en la rama superior del tercer ó cuarto arco branquial, un escudo muy ancho en la cabeza, ocho bar. billas, y espinas en las aletas torácicas, pero no en la dorsal, que en algunas especies es larga, $\mathrm{y}$ corta en otras. En este último caso existe una aleta adiposa. Hay dientes en las mandibulas $y$ en el paladar.

\section{EL GLANO-ANGUILA-CLARIAS ANGUIL- LARIS}

CARACTERES. - Este pez, representante del grupo, alcanza una longitud de $0^{\circ}, 60 ; \mathrm{el}$ dorso es negro azulado, y

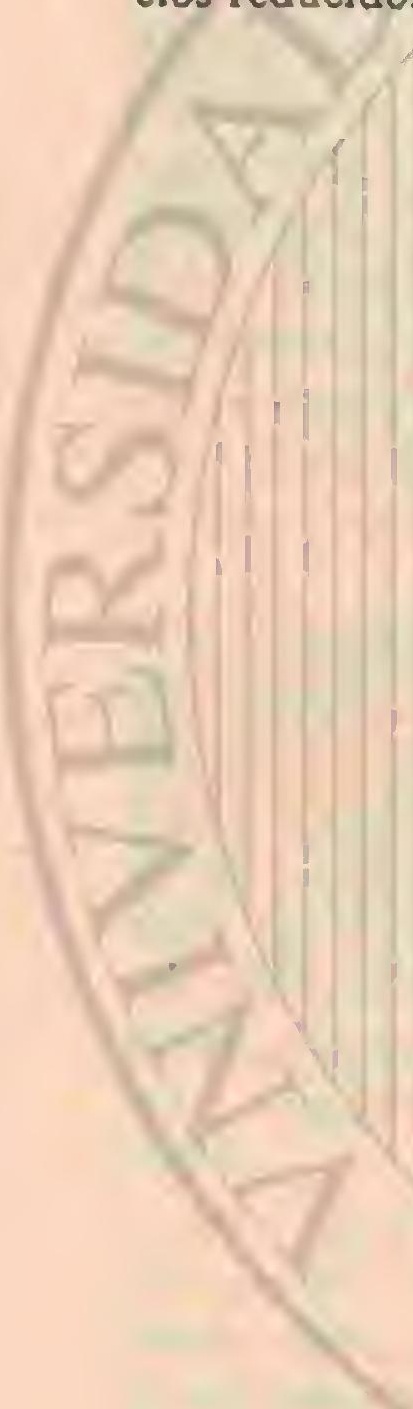

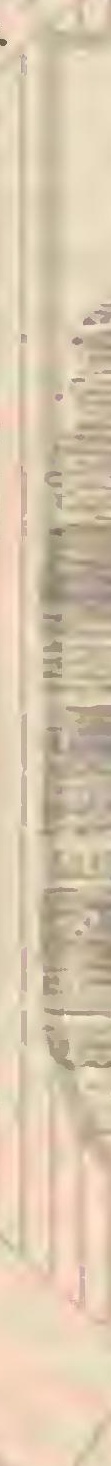

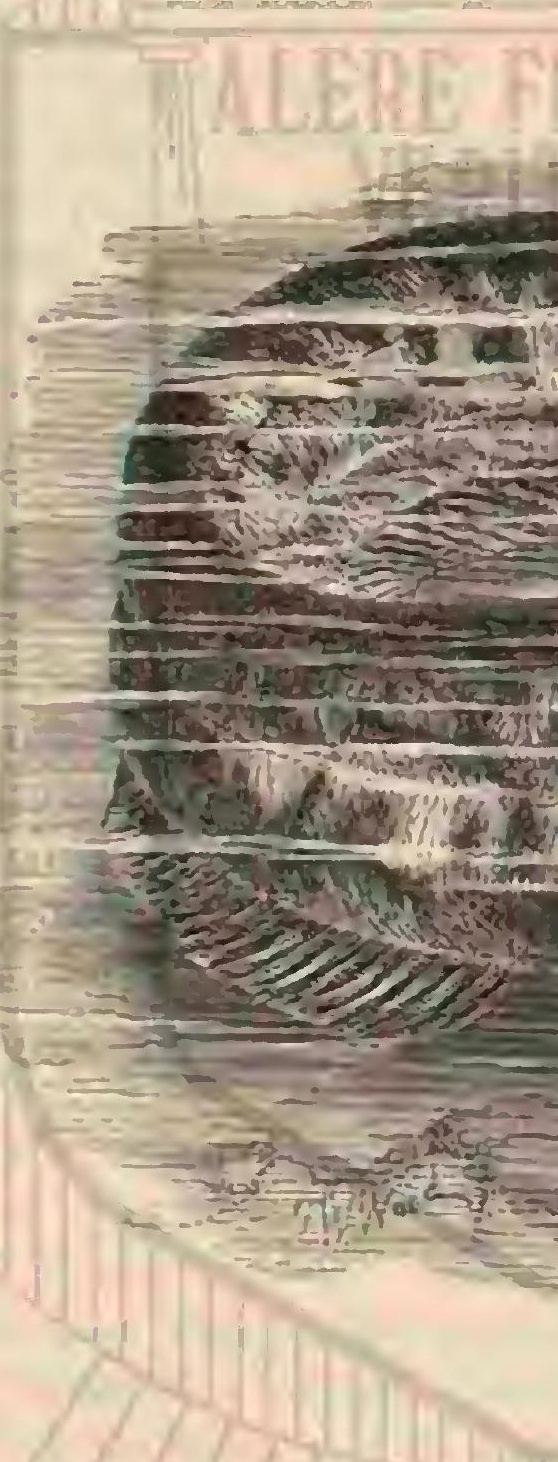

blanco cl lado inferior; cuando jóven, es el fondo mas claro con manchas negras. Hay cuarenta y siete radios en la aleta dorsal, seis en cada torácica, en cada ábdomínal y en la cau. dal, y cincuenta y siete en la anal.

USOS, COSTUMBRES Y REGIMEN, - Entre las va. rias especies de siluros que pueblan el Nilo, este es uno de los mas comunes, y como es indolente á la par de voraz, se le coge con mucha frecuencia. Habita en gran número las acequias que cada inundacion del Nilo llena de agua y mu. cho mas en los pantanos del Delta naue circuyen los lagos del Egipto inferior, como tambien estos mismos lagos que albergan un número increible de peces. Cuando en verano el delta y las acequias quedan sin agua, emigra este glano an. dando 6 arrastrándose sobre el fango humedo, ayudándose con sus aletas y serpenteando el cuerpo; asi va caminando hasta que vuelve $s$ encontrar agua. Durante estas emigraciones se cogen muchisimos; pero además le busca la gente del pais tambien en el agua cuanco no es profunda y entonces le coge con las manos, y en caso contrario con el sedal, casi siempre con buen éxito. Su carne es gorda y blanda sin de. jar de ser sabrosa, por cuya razon se consume mucho cn Egipto, aunque mas por la clase pobre, puesto que los lagos abundan en toda clase de pescado.

\section{LOS BAGRINOS-BAGRINE}

CARACTERES.-Los peces de este grupo se distinguen de los siluros por los dientes de púa que guarnecen su man. dibula inferior e intermaxilar, por una lista de dientes análogos en el paladar, por un aguijon muy fuerte en las aletas pectorales y dorsal, por otra adiposa muy bien desarrollada detrás de aquella, y por seis á ocho barbillas. I.a dorsal, co. locada muy hácia atrás, cuenta doce radios. La cubierta de la cabeza es en muchas especies huesosa.

DISTRIBUCION GEOGRÁFICA.-Casi todas las es. pecies de esta sub-familia habitan la zona tórrida.

\section{EL BAGRO ARIETE-ARIUS HERZBERGII}

CARACTERES. - Esta especic habita un área muy di. latada, pues se encuentra en Cayena, Surinam, Para y en general en las Indias occidentales. Se caracteriza por su ca beza muy plana y ancha con seis barbillas. En la aleta dor. sal se levanta un aguijon bastante robusto, ligeramente den. tado y de una longitud igual á la mitad de la cabeza; oiros aguijones mas vigorosos y dentados en ambos lados salen de las aletas torácicas. La adiposa es á poca diferencia tan larga como la dorsal; las abdominales son mucho mas pequeñas que las torácicas. La coloracion consiste en un gris difuso que varia segun la localidad. La longitud puede llegar á un metro.

USOS, cosTUMBRES Y REGLMEN.-Respecto de csta especie refiere Schomburgh lo que sigue: Ruestra pesca cra nuy abundante cada noche, pues jamás sacábamos un 
sedal del fondo sin encontrar un pez. Un siluro de estos, de muy regulares proporciones, se distinguia particularmente por su glotonería. Cada vez que los indios sacaban un sedal con su correspondiente pez, observaba yo que le descarga. ban sendos garrotazos en las aletas abdominales con el objeto, segun me convenci al inspeccionar el pez mas derenidamente, de inutilizar el aguijon guarnecido de pequeños ganchos curvos que ocupan el puesto de los primeros radios en las aletas abdominales $y$ la dorsal, y que sirven al animal de arma defensiva muy eficaz. Si el pescador agarra el pez impremeditadamente antes de que este haya perdido su fuer-

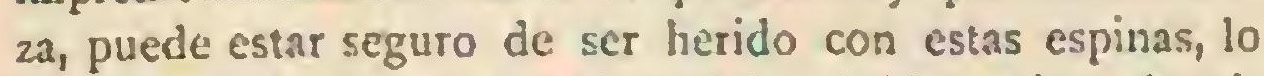
que no solamente la causará un dolor vivísimo, sino además una hinchazon é inflamacion considerables, conforme Sto eckle tuvo ocasion de convencerse por si propio.

- A la caida de la tarde ibamos casi siempre á la playa provistos de nuestros sedales, lo que no tardó en despertar en la inaginacion de Stoeckle el deseo de tomar parte en el entretenimiento. Al poco rato sacó á tiersa un bagro bastante regular, pero el animal pudo desprenderse del anzuelo $\$$ se puso á correr apresuradamente para saltar otra vez al agua. Irritado Stoeckle por nuestras risas, se precipitó sobre el animal asiéndolo fuertemente con ambas manos; pero al momento lo soltó dando un brinco como si le hubiese pica. do una tarántula, y corriendo y moviendo las manos de una parte á otra como un loco, daba lastimeros gritos. Cuando le hubimos cogido y parado, vimos que tenia dos heridas en el ténar del puigar de la mano derecha. Sobrevino luego la inflamacion y costó trabajo hacerla desaparecer al cabo de seis dias. Desde entonces perdió Stoeckle las ganas de pescar, y tampoco pude inducirle jamás á tocar un pez, si yo no le habia tocado primero.

NNo pasaron muchos dias sin que no tuviesemos ya nece. sidad de colocar sedales, porque los peces acudian en tan

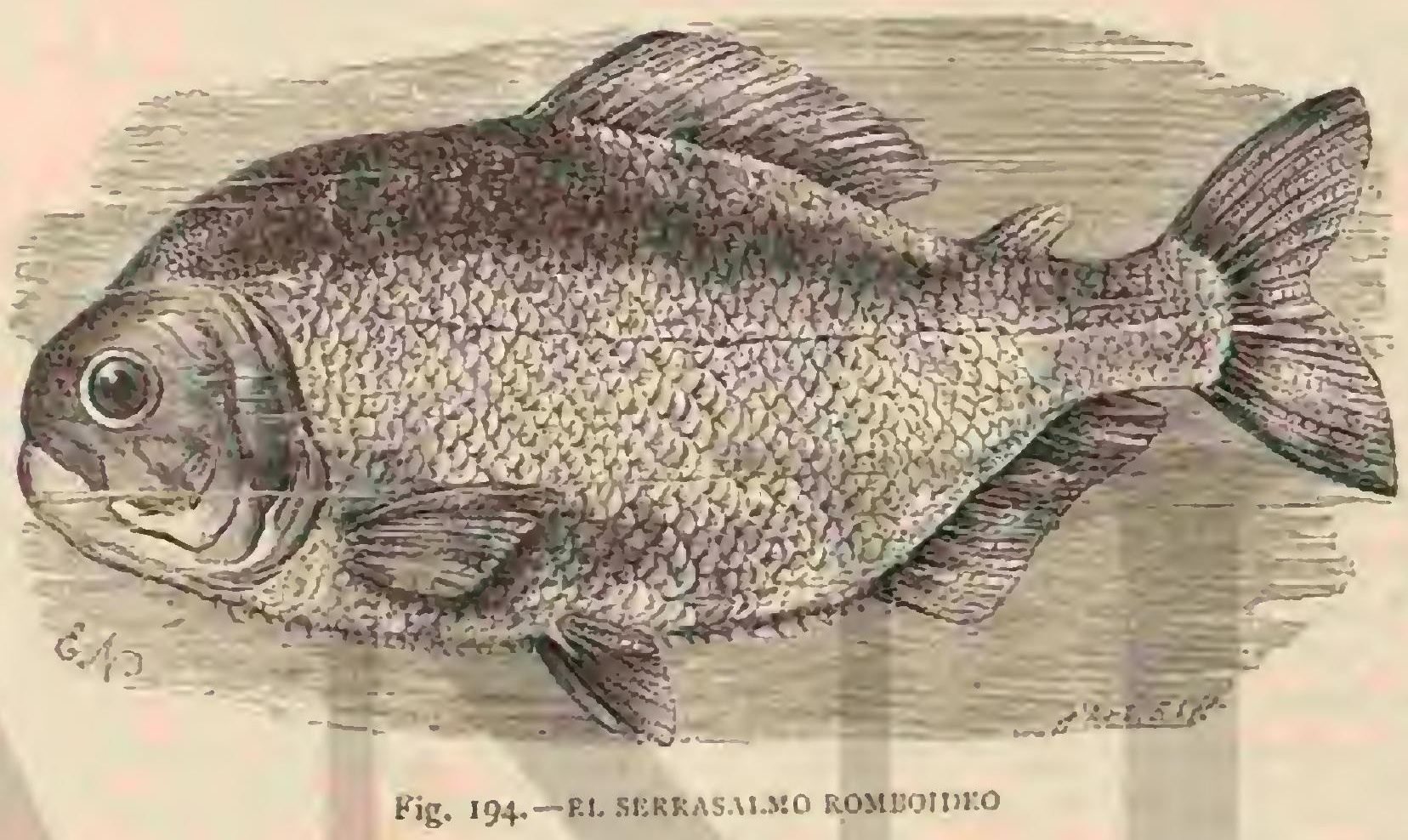

gran nuimero à la orilla, que bastaba que nuestros indios pe. netrasen algun tanto en el agua repartiendo porrazos entre la espesa multitud de bagros; para que tuviéscmos el suficien. te número de peces para la cena.s

\section{LA. PREÑADILLA - STYGOGENES CYCLOPUM}

CARACTERES.-Se distingue esta especie de sus congéneres, los bagrinos, por la carencia de dientes en el paladar. Fs un pez de $0^{m}, 10$ de largo, muy aplanario y de color verde aceitunado salpicado de negro. Tiene la boca ancha con dos barbillas en los extremos, dientes diminutos y aleia caudal hendida. La dorsal cuenta seis radios, la torácica nueve, la abdominal cinco, la anal siete y la caudal doce.

DISTRIBUCION GEOGRÁ FICA.-Entre los volcanes de los Andes solo los mas pequeños y mas bajos arrojan lava, y los majores, que son tambien los mas numerosos, piedra pómez, basalto ó escorias de pórfido junto con agua, arcilla y fango con acompañamiento de estampidos terroríícos. A todo esto anaden los volcanes de Quito de cuando en cuando cantidades innumerables de peces, tanto yue en algunos puntos ilegan å infestar el aire á gran distancia de miasmas deletéreos, causando fiebres tifoideas cuando entran en putrefaccion. En los anales de las ciudades de aquel país se registran crupciones en las cuales han sido arrojados miles de peces junto con el fango. Brehm da á esta especie el nom. bre de estigrigeno ciclop̣c. Los que arroja el Cotopaxi no parccen haber pasado por una temperatura muy elevada porque se presentan casi intactos. La gente del país asegura que esta especie de siluridos habita los arroyos que corren al pie de Tomo $\mathrm{V}$
Los volcanes, y que se encuentran hasta en los que hay á tres mil metros de elevacion, pero que por su viscosidad y aspecto repugnante solo los comen los indios pobres. Es probable que cl mismo per pueble tambien estanques subterráncos que en las erupciones son vaciados por el cráter, pues de otro modo no se explica este fenómeno.

\section{LOS DORADINOS - DORADINF}

CARACTERES. - Se caracterizan los miembros de este grupo por tener la cabeza y nuca cubiertas de una linea de piezas huesosas, cada una con una arista ó cresta saliente $y$ espinosa; la alcta dorsal y las pectorales están tambien fuertemente dentadas, y ambas mandibulas, ó bien solo la inferior segun la especie, llevan dientes aterciopelados. La aleta ndi. posa existe en todas.

\section{EL DORAS DE COSTADOS HUESOSOS DORAS COSTATUS}

CARACTERES.- Este representante del género doras es conocido ja de bastante ticmpo ack. Alcanza una longitud de $(1 \%, 30$ y su coloracion es en la parte superior del cuerpo parda, en la inferior mas clara y en la cabeza de un azulado rojizo. Hay siete radios en la dorsal y en cada abdominal, ocho en cada torácica y doce en la anal.

USOS, COSTUMBRES Y REGIMEN.-No es la con. figuración de este pez la que me ha impulsado á mencionarlo aqui, sino su género de vida particular. Harcock ya refiere, y Schomburgk confirma sus datos, que esta especie, al 
igual de otras afines, abandona los pantanos 5 rios cuando quedan secos, para buscar nuevas aguas, aunque sea atrave sando algunas leguas de ticrra. Dice que encontró una vez á tres horas de la costa una manada numerosa de estos peces que adelantaba impulsánđose con su cola flexible y apoyán dose sobre las espinas y las aletas pectorales á manera de los lagartos de dos piés. Caminaban con una velocidad igual a la del paso regular de un hombre. Eran tan numerosos que los negros que acompañaban al citado naturalista pudieron llenar con ellos varias cestas. \&Se ha dicho, dice Schomburgh, que estos animales tienen la facultad de retener agua cn una bolsa membranosa que rodea las foliculas branquiales que de este modo conservan su humedad durante el viaje Segun parece emigra toda la poblacion cada vez que se seca el pantano que habita. Cuando no encuentran agua se ocultan en terreno blando y fangóso donde aguardan aletargados la vuelta del agua. Sé por propia experiencia que pueden pasar diez horas fuera del água sin menoscabar en lo mas mínimo su salud.

\section{EL MALAPTERURO ELÉCTRICO - MALAP- TERUS ELECTRICUS}

CARAGTERJES. - Esta es una de las especies mas notables de la familia por la facultad que tiene de comunicar conmociones eléctricas, por cuya razon la llaman los árabes

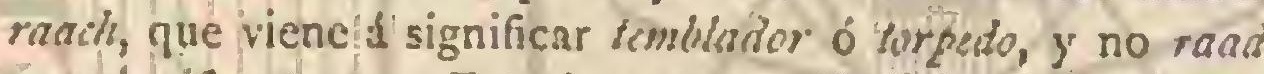
ụue significa trueno. Exteriormente se distingue de los demás silúridos por la carencia de la aleta dorsal que está en cierto modo rcemplazada por una pequeña adiposa, y además por la falta de radios en las aletas pectorales. Interiormente ya es otra cosa, pues tiene entre la piel y los músculos un tejido delgado parecido á una capa de grasa, compuesto de seis o mas membranas superpuestas y separadas por una masa gelatinosa alinelitada por una vena cava y una arteria especiales y dirigida por ún nervio ramificadísimo. El color de la piel, lisa y viscosa, es un gris dificil de describir, con manchas negras muy numerosas á lo largo de la línea del costado, pero que se encuentran tambien en las alctas. Cuéntanse nueve radios en cada torácica, seis en cada abdominal, doce en la anal y dier y siete en la caudal. La longitud es de $0^{\circ}, 30$ á $0^{m}, 50$.

DISTRIBUCION GEOGRAFICA. - Forskal descubrió este pez en el Nilo, y Adanson en el Senegal. En algunos puntos es bastante comun, y falta en otros, particularmente donde el fondo es arenoso.

USOS, COSTUMBRES Y REGIMEN. - Este pez, como ya se ha indicado, comunica, cuando se le toca con la mano y cuando él quiere, conmociones eléctricas de fuerza muy variable, semejantes á las de la pila galvánica; pues á veces se le puede asir sin recibir descarga algurı, y otras se experimenta el efecto de su malhumor al mas leve contacto, $y$ hasta sucede que varias personas pueden ienerlo sucesiva. mente en la mano, siendo la última la única que recibe el golpe, que por lo demás no incomoda mucho $y$ solo puede ser peligroso para animales pequeños.

USOS Y PROVECHO.-Se come, pero su carne no tiene gran fama; en cambio se atribuye una virtud curativa al tejido celular en el cual reside la fuerza eléctrica. Para aplicarlo se quema sobre ascuas, fumigando el cuerpo de la persona enferma con los gases que se desprenden por la combustion.

\section{LOS HIPOSTOMATINOS- HYPOSTOMATINA}

CARACTERES. - Este grupo es muy afine de los doradinos en cuanto ấ su configuracion y género de vida y debe su nombre á cuatro hileras de escudetes ó placas que defienden á manera de armadura sus costados, además de la cabeza acorazada tambien, quedando solo el vientre y la cola indefensos. La aleta dorsal tiene en su parte anterior un solo radio muy"robusto, $y$ la torácica un aguijon. Dientes finos componen la dentadura, y completan los caractéres de esta sub-familia cuatro barbillas.

\section{EL HASAR-CHAETOSTOMUS PICTUS}

CARACTERES. - Schomburgk descubrió este pez en su viaje á la Guayana. Su longitud es de $n^{m}, 10$ á 1$)^{n}, 15, y$ se caracieriza por las espinas finas que guarnecen la parte supe. rior de la cabeza, el omoplato, el pecho y las placas de los costados. El color es un pardo manchado de amarillo en el pecho, costados 5 vientre; siendo blanca la parte inferior. La aleta dorsal tiene un radio duro y siete blandos, la to. rácica cuatro y la anal uno duro y seis blandos.

USOS, COSTUMBRES Y REGIMEN.- ¿Este animal, dice Schomburgk, no se contenta con construir para su prole un nido de plantas acuáticas en toda regla, sino que lo vigila y defiende contra todos los ataques, con el cariño y decision maternal mas grandes hasta que la cria ha nacido. Este nido tiene mucha semejanza con el de la urraca y es una verdadera obra artistica Empieza el pez. su construccion en abril, un poco debajo de la superficie del agua, entre plantas acuáticas y cañaverales, hasta que adquiere la forma de una bola algo aplanada, cuya parte superior toca á la su. perficic. Úna abertura proporcionada á la hemibra conduce al interior. El material es todo de yerba fina. Cuando el pez ha depositado sus huevas, ya no las abandona hasta que nacen, sino álgunos momentos para aplacar el hambre. Este amor maternal es su desgracia, porque facilita su pesca, la cual se hace por medio de una pequena cesta que se sostiene con una mano delante del nido nada dificil de encon trar, mientras se dan en él golpecitos con la otra; el animal sale furioso con las aletas desplegadas que pueden causar heridas muy dolorosas, y se precipita en la cesta

El hasar habita con preferencia las aguas remansadias en la costa y las acequias de las plantaciones.

Otra particularidad que distingue tambien esta especic es que, al igual del doras de costados huesosos, emprende via. jes por tierra en busca de otras aguas cuando se desecan los sitios que habita.

\section{LAS LORICARIAS - LORICARIA}

CARACTERES. - La boca de estos peces se abre.en la parte inferior del hocico, pero está rodeada de una pequeñn membrana y velos labiales barbudos. Ia mandibula inferior y la intermaxilar estín separadas en el centro y guarnecidas de dientes reforzados con un ganchito cerca de la punta.

\section{LA LORIGA ACORAZADA-IORIGARIA CATAPHRACTA}

CARACTÉRES.-Este pez que tomamos por representante del género, alcanza una longitud de 1$)^{10}, 20$ a $(1)^{2}, 25$; su color en el lomo es uniformemente pardo, át veces con fajas trasversales difusas; en el vientre es mas clara la tinta. Cuéntanse ocho radios en la aleta dorsal, siete en la torácica, seis en cada abdominal $y$ en la anal, $y$ doce en la caudal, con la particularidad de que el primero de estos es tan largo como todo el cuerpo.

DISTRIBUCION GEOGRÁFICA Y COSTUMBRES. - Parece ser especie bastante comun en los rios y torrentes 
de la América del Sur. Schomburgk le encontró á menudo en los bancos de arena del Rupumunis, á veces á muchos metros de la orilla, recreándose sobre la arena húmeda donde pudo cogerlo con la mayor facilidad. Esta circunstancia induce a creer que este pez, al igual del doras, emprende viajes por tierra cuando quicre mudar de agua.

\section{LOS CARACINIDOS-CHA- RACINIDE}

CARACTÉRES. - Ademís del conducto aćreo de estos peces, llama principalmente nuestra atencion, por su importancia para la clasificacion, la presencia de huesecillos auditivos que tiene la vejiga en algunas familias. Esta disposicion es tan particular y se presenta con tanta regularidad en ciertas familias naturales, que una vez sabida, permite descubrir fácilmente diferencias sistemáticas en el esqueleto, y reintegrar estos peces inal clasificados en su verdadero puesto y entre sus afnes, con los cuales concuerdan efectivamente aun en los caractéres exteriores. La comunicacion de la ve jiga matatoria con el brgano auditivo por medio de una serie de pequeños huesos, se encuentra, segun mis observaciones, no solo en las carpas y en los siluros, sino tambien en otra nueva familia, que yo apellido de los sharacini, y que es una de las mas naturales y bien deturminadas de los peces. Tiene ademís otros distintivos exteriores, por los que se la reco. noce fácilmente antes de examinar su esqueleto Fisto es lo que dice Müller, que fija despues, cono sigue, los caractéres de las especies que ha reunido en esta familia creada por él: «eces escamosos, sin branıuiales supletorias aparentes, y cuya boca esta limitada en el centro por el borde del hueso intermaxilar y hácia fuera hasta la comisura por la mandi. bula superior. Ia formacion de su dentadura varia bastante, pero casi todos llevan dientes faringèos superiores é inferiores. La vejiga natatoria está dividida trasversalmente, formando dos compartimientos, y jresenta una serie de pe queños huesos que la ponen en comunicacion con cl aparato auditivo. El intestino lleva numerosos ciegos. Casi todas las especies poscen una aleta adiposa, además de la dorsal.

DISTRIBUCION GEOGRAFICA.-Estos peces notienen representante alguno en Europa; todos habitan las aguas dulces de Africa y de la América del sur.

Abundan considerablemunte en determinados puntos de los rios, sirviendo casi todas las especies de alimento al hombre y siendo algunas nhjetn de una pesca muy importante.

Hay empero un grupo recientemente dividido en varios géneros, gue se hace notable por su insaciable voracidad,y que á pésar de su reducida talla es tan terrible como el tibu. ron y otros gigantes del mar y mucho mas que los crocodi. los que habitan las mismas aguas que él; terrible hasta para estos mismos reptiles feroces y que se alimenta preferente mente de peces, segun ahora sabemos. Por este motivo no podemos menos de ocuparnos de la familia de los caracinidos.

\section{LOS SERRASALMOS-SERRASALMO}

CARACTERES. - Se da el nombre de serrasalmos á to. das las especies de esta familia, de cucrpo jiboso y deigado, que tienen dientes grandes, incisivos, triangulares y dispuestos en una hilera en ambas mandibulas, con una fila de otms semejantes en el paladar. Las escamas son muy pequeñas y lienen apendices laterales. Hay una aleta dorsal muy alta y colocada muy atrás; una anal muy larga; dos eșinas delan. te de esta úitima y una delante de la dorsal.

\section{EL PIRAYA-SERRASALMO PIRAYA}

CARACTERES:- Es pez muy jiboso, rechoncho, de hocico corto $y$ obtuso, de unos $0^{\mathrm{m}}, 30$ de largo $y$ de color azulado en la parte superior y amarillento en la infericr, con manchas oscuras en ambas. La aleia dorsal tiene de diez y siete ś diez y ocho radios, la torácica diez y seis, la abdominal seis, la anal treinta y tres y la caudal veinticinco.

DISTRIBUCION GEOGR ÁFICA.-Todos los serrasalthos viven en los rios de la América central y del sur, raras veces ó mas bien nunca en la proximidad de las desemboca. duras; mas bien y gencralmente, de cuarenta í sesenta leguas hácia el interior.

USOS, COSTUMBRES X REGIMEN.-PORlocomUn permanecen en el fondo en los remansos de los rios; con preferencia en ensenadas rodeadas ó atravesadas de peñas;y alli suben á miles á la superficic tan pronto como atisban una presa. In los rios grandes rodean y acompañan a las embar. caciones, siempre dispuestos a coger cualquier alimento que de ellas caiga Alientras no se les arroja nada, dice Bates, se ven apenas ilgunos individuos sueltos, todos con la cabeza fuera del agua y vigilantes; pero tan pronto como se les han echado algunos desperdicios desde la lancha al agua, oscurécese esta con la multitud de pirayas que aparecen, y que empiezan una lucha terrible por un mísero bocado, logrando alguno arrancarlo da otro que lo tenia ya medio tragado. Apenas vuela una abeja ó mosca cerca de la superficie, cuando todos saltan con verdadero estruendo para atraparla, y tan simultáneamente que parecen movidos por un resorte eléctrico. Mucho antes que Bates, refirió Humboldt cosas análogas, como por ejemplo: «Si se eciran unas pocas gotas de sangre al agua acuden niles de pirayas, y esto en parajes donde el rio parecia antes enternmente trasparente sin dejar ver ni un solo pez. Cuando echábamos algunos pedacitos de carne sanguinolenia al agua, se veian á los pocos minutos numerosas bandadas de caribitos que se los disputaban.

Schomburgk los califica con mucha razon de los peces mas feroces, de hienas de agua dulce; pero comparados con ullos son animales modestos los buitres, é inofensivas las hienas. Es imposible formarse una idea de su voracidad; cualyuier animal, sea el que fuere, corre peligro de ser devorado desde el momento en que invade su dominio, aunque fuesen peces diez veces mas grandes que ellos. Cuancio atacan, dice este viajero, $a$ un pez mayor que ellos, empiezan por quitarle la aleta caudal y con ella su aparato principal de locomocion; entre tanto se precipitan ya los otros como arpias sobre la victima y la destrozan y devoran hasta la cabeza. No hay cuadrúpado que intente atravesar el rio á nado que escapéá su feroz voracidad, ni están seguros de cllos los piés de los palmipedos, de las tortugas, ni los dedos del caiman. Este último, al verse atacado, sucle echarse en seguida de espalda, para poner í salvo sus extremidades. Para Schomburgk consiste la prueba mas evidente de su ferocidad en el hecho de que no perdonan siquiera á sus propios compañeros cuando los ven heridos, pues dice: 2 Ocupado una noche en pescar con caña, saqué un pirai (serrasnlmo niger) nuy regular. Crei haberlo muerto de algunos golpes vigorosos en la cabeza y le puse sobre una piedra a mi lado, pero volvió a moverse, y antes de poder impedirlo, habia saltado al agua y nadaba de una parte i otra, aunque medio aturdido. En un abrir $y$ cerrar de ojos se halló rodeado de diez y seis á veinte compañeros y a los pocos minutos no quedaba ya de él mas que la cabeza.z

eNio es cosa rara, segun refiere Gumila, que fué el primero que describió este pez, que el buey, tapir, ó cualquier otro animal mayor sean devorados cuando, al atravesar el 
rio á nado, topan con una bandada de ellos, porque inutili. zado y desangrado por las innumerables mordeduras, no hay ya salvacion para el mamifero que sin remedio se ahoga. Se ha dado tambien el caso de que sucumbieran animales de estos cuando apenas distaban treinta 6 cuarenta pasos de la orilla, y si alguna vez lograban llegar à la orilla opuesta, era solo para caer exánimes convertidos en esqueletos. Los animales que habitan cerca de los rios, conocen muy bien los peligros que corren $\mathbf{a}$ causa de estos peces, 5 se abstienen con cuidado de remover el agua y mucho menos de enturbiarla para no atraer á sus terribles enemigos. Los caba. llos y perros revuelven violentamente el agua en un punto determinado, 5 tan pronto como acuden los serrasalmos, huyen para beber en otro sitio, calculando que estarán alli seguros por haber atraido 105 peces al primer punto; á pesar de esta precalicion es frecuente que los pirayas les arran. quen trozos de la nariz y de los labios. (iumila opina que estos peces no atacan al hombre, pero Dobrizhofer prueba lo contrario citando el caso de dos soldados españoles que pasando el rio á nado al lado de sus monturas, fueron atacados y devorados por los pirayas, Humboldt dice: «El cara. bito (serrasmimo thombens) (fig. 194) acomete sin temor á los bañistas y nadadores, arrancíndoles con frecuencia gran. des pedazos de carne; $y$ aunque un hombre sea herido lige ramente, rara vez sale del agua, si es que puede escapar, sin recibir las mas graves heridas. Los indios temen muchisimo á los peces caribes; y para justificar el terror que les inspi. ran, me enseñaron varios de ellos las piernas para que viese las profundas cicatrices resultantes de las heridas causadas por los serrasalmos. Martius cuenta que un piraya arrancó la primera articulacion de un dedo á uno de sus indios que no habia hecho mas que tocar imprudentemente el agua donde poco antes se habian lavado gallinas muertas. Por otra parte refiere Schomburgk: "Tambien vimos pirayas hendiendo las olas, $y$ estos animales descarnaron casi total mente dos dedos al pobre Pureca cuando quiso lavarse las manos que chorreaban sangre. Durante gran parte del viajc no pudo el infeliz servirse de ellas, además del gran dolór que le causaron. $Y$ en otra parte: Eran para nosotros un gran recreo las frescas olas del Pirara, pornue el calor era in. soportable, pero bien pronto se nos acibaró este placer cuando los voraces pirayas arrancaron $t$ un niño indio que nos habia seguido, un gran pedazo de carne del pie al atra. vesar el rio à nado. Al oir el horrible grito del muchacho cuandio se sintió herido, temimos que hubiese sido victima de un caiman. A duras penas pudo llegar á la orilla, loco de espanto $y$ de dolor.

En vista de la concordancia de tantas relaciones se com. prende que los serrasalmos sean mas temidos que cualquier otro animal feroz; $y$ mas aun que la serpiente mas venenosa. «Si se reflexiona, dice Humboldt, cuán inmenso es el número de estos peces, siquiera el tamaño de los mas voraces no exceda de cinco 6 seis pulgadas, la forma triangular de sus dientes cortantes y puntiagudos, y la anchura de su boca, no causa extrañeza el temor que los caribes inspiran á los habitan. ress de las márgenes del Apure y del Orinoco, y que nadie se atreva á bañarse en los sitios giue frecuentan, debiendo con. siderarlos como una de las mayores plagas de aquellos distritos.y

USOS Y PROVECHO. - La utilidad que saca el horn. bre de estos peces no merece ser tomadia en cuenta en vista del daño que causan. Se come su carne llena de espinas, y segun refiere Humboldt, algunas tribus indias se aprovechan de su voracidad de un modo bien extraño. Al hablar de ciertas cuevas llenas de huesos, especie de catacumbas, dice este sabio: Algunas tribus de la cuenca del Orinoco con- servan la costumbre que en la antigiiedad tenian fos masagetas, de separar cuidadosamente la carne de los huesos de sus difuntos, y se dice, sin que haya motivo para dudar de la veracidad de ello, que los guaranis sumergen sus cadáveres envueltos en redes en el rio donde los pequeños caribitos se comen en pocos dias la carne y dejan el esqueleto perfecta. mente limpio.

PrSCA. - Es inútil decir que estos peces se cogen con la mayor facilidad. Cualquier cebo es bueno, $y$ hasta se dice que una tira de paño encarnado echada al agua reune al mo. mento miles de sersasalmos de los cuales se cogen tantos como se quieren.

\section{LOS SALMÓNIDOS- SALMONID死}

CARACTERES. - I os peces que representan esta fami. lia, la mas noble como dice Brehm, de todo el órden, son escamosos, de cuerpo prolongado y cilindrico, con una aleta adíposa sin radios detrás de la dorsal, y con la aberıu. ra de las branquias hendida hasta cerca del esófago; la vejiga natatoria es sencilla, y el ovario carece de canal de salida. En cuanto á la denticion; divídense los salmónidos en dos grupos mus caracterizados: uno, cuya boca pequeña solo presenta dientes muy débiles é incompletos, cuando no fal. tan totalmente; y otro que los presenta fuertes y muy desarrollados. Los primeros tienen mucha analogia con las carpas ; los arengues; los otros, que constituyen el núcleo de la fa. milia, son verdaderos peces voraces. La escamacion guarda cierta armonia con la déntadura, pues el primer grupo tiene grandes escamas, mientras que el de los voraces suele presentarlas, por lo comun, relativamente pequerias, diferencia bien conocida de los pescadores, y q̨ue suele servirles de normia para la valoracion de sus presas.

La coloracion de las distintas especies no solo varia con respecto á la edad, sino que tambien segun la época de la freza. Con este motivo dice Siebold lo siguiente: \& En ningun otro pez de nuestras aguas se nota tan extraordinario cambio de coloracion, segun las influencias del alimento, de la luz, del agua y del calor, como en los salmónidos, espe. cialmente en las especies provistas de fuerte dentadura; hasta el color de la carne presenta en una misrna especie los varios matices desde el rojo rosado hasta el de naranja, segun las aguas frecuentadas por el pez. En algunas especies de la Siberia y de la América del norte es muy marcada esta va. riacion de color; en el Kaintschatka existe una especie ( Sabmo Errylrkizers), ó pez rojo, que á excepcion de la cabeza, que es verde oscura, merece verdaderamente durante la freza el nombre que le han dado los indigenas, por el viro rojo que adquiere durante la citada época, pasada la cual se convierte aquel tinte en un azul oscuro en la parte superior y en un matiz mas claro de la misma tinia en la region abdominal. El cambio es tan chocante que los karnchadales han procurado explicarlo á su manera diciendo que el pez trabaja tanto para subir las corrientes rápidas, que la sangte afluye á la superficie y la tiñe de rojo. La piel se ruelve mas espesa y densa a medida que sube el color, lo que da al pez un aspecto como si se le hubiesen caido las éscamas.

En la estructura interior de estos peces, lo mas notable es la disposicion del aparato sexual, y mas especialmente los ovarios. No sucede aqui, como en la mayor parte de los peces, que los huevos se desarrollan en bolsas cerradas, sino en repliegues salientes de la piel abdominal, de los que se sepa. ran en su sazon, yendo ś parar forzosamente á la cavidad ventral, de la que son expelidos por una abertura detrás 
del ano. Esta disposicion tiene la rentaja de facilitar la ope racion artificial del desove, haciendo que dichos peces sean tan eminentemente propios para la cria artificial.

DISTRIBUCION GEOGRÁFIGA.-LOS salmónidos, cxceptuando solo tres especies, habitan en las aguas del he misferio boreal. Frecuentan 10 mismo las saladas que las dulces, siempre que estas sean claras y limpidas, y en mayor mar Glacial la parte mas septentrional del Norte, en el Báltico, y en parecen tener muy limital del Atlántico. Algunas especies índose a determing circulo de dispersion, concre das en otras por sus congua, si bien se hallan representa ha podido fijar detenidanéneres, que todavia hoy dia no se solo variedades de aquellas. si son especies distintas ó tan

USOS, COSTUMBRES

mónidos acostumures tes y rios, durante la épa desde el mar a las corrien prodiccion, siendo de de la freza, para efectuar su re surele vole siendo de notar que, por lo comun, cada pez instinto de emigas mismas aguas que fueron su cuna. Este tende regresar hay obstáculos que aguas de las montañas donde nació no rando vencerlos hasta conan desistir de su propósito, procu. mónidos que subasta con peligio de su vida. Tocios los sa! los que cavan suben por los rios deponen su freza en hoyue. pruebas de inteligencing ó cascajo, dando en su eleccion el contrario, solo abandona habilidad. Otras especies, por los lagos que habitan, aunque buscando sara su reproduccion los rios mas adyrantes en la temporadyacentes. Hay, por último, otras especies que la superficie del de Ja freza aparecen en inmenso núméro en nen debajo es de pocos cuidarse de si la profundidad que tiecontra otros, sacos piés $\delta$ de varias brazas; apinananse unos la parte abdominal ruera del agua, tocándose mutuamente tal cantidad que enturbian a un tiempo las huevas, en aguas del mar.

Este modo de desovar permite suponer que ciertos peces marinos se reproducen de un modo anålogo, por ejemplo los irenques, de los cuales se creia que venian de regiones leja. nas para desovar cn nuestras costas, mientras que con ellos pucede lo mismo que con los salmónidos, cuya reproduccion ivamente que virenodo presenciar y vigilar, sabiendo posididades de nuestros hasta la epoca de la freza en las profundesore suben ligos y que solo para la operacion del Los salmón o menos á la superficic del agua.

ars bien como las dentadura débil éincompleta se nutren coda clase de gos carpas que como carniceros, es decir de mo taumbien de anater pequeños crustáceos y moluscos, co con mandibulas armadas vegetales, mientras que los otros cen en sus primeros aios de fuertes dientes solo se satisfa tarde acometen as a anos con esta clase de alimento, $y$ mas cies mayores de esta inas voraces, señalindose mas bon comparativamente las menor tamaío, y entre estas bien como tales algunas de monada (limilis drutlia). pecies de esta familia suma importancia casi todas las esespinas y de fácil dia. Su carne delicada, sabrosa, libre de odos los dema digestion, no tiene superior entre las de muestro painas peces, y tnuy pocas llegan a igualarla. En los distritos cs bocado raro, por desgracia, por lo inenos en pero en las costus léjos de arroyos, rios y lagos elevados; estos peces la escandinavas y en las de Rusia constituyen tantes, turiendo aun mayor importancia en este sentido en lgunas comarcas de la Siberia Para las poblaciones ribarena y del noroeste de Anuerica. nas del inar Glacial y del Pacifiesta familia, pudiendose innensa utilidad varias especies de pende principan que en ciertas localidades de de los habitantes. de los habitantes. Fil trabajo mas importante de estas gentes es la pesca y la preparacion de distintas maneras de los sal mones durante el verano, para almacenar en granojes canti. dades este comestible tan indispensable para su alimento en

Si se ojen tantas quejas respecto del empobrecimiento cada dia mas sensible $y$ creciente de nuesiras aguas, hay que atribuirlas principalmente a la disminucion de las especies de salmónidos. Los documentos de los pasados siglos conces de los quecir que entonces las aguas albergaban mas pe. en las cuales esta rigueonălumo, y mencionan otras épocas siglos que peces que hubieron de promulgarse lejes para proteger estos aguas, que sujetos á desaparecer, por lo menos de ciertas troduccion dos demás; pero como ya se dijo en la Introduccion, dichas le!es no han dado resultados cficaces, y ahora se vengan cruelnente de nuestra negligencia e indiferencia, haviéndose hecho ya indispensable buscar remedio al mal. En algunos puntos se observa alguna mejora gracias al conocimiento y aplicacion dela cria artificial, como en los rios tanto tiempo empobrecidos de Escocia, donde se tocan ya los resultados debidos a la intervencion de la mano del hom. bre, y en Alemania se empieza à seguir este ejemplo. Los ensayos hechos con feliz exito enseñan lo que podra lograr. se: se han remitido á lejanos paises allende el Occano hue. vas fecundadas de diferentes especies de salmúnidos para aclimatarlas en aguas que ofrecen condiciones muy dis. tintas de las de donde proceden las huevas. Hé aqui ya un paso en la via del progreso.

\section{LOS SALMONES-SALMO}

CARACTÉRES. - Dáse el nombre de salmones propia mente dichos a los peces cuya configuracion presenta las proporciones mas graciosas y tipicas de esta clase de anima. les, y que se caracterizan además por sus escamas pequeñas, boca hendida hasta debajo del ojo, provista de una denta. dura bien desarrollada y formada de dientes conicos que guarnecen ambas mandíbulas, los huesos palatinos, el vóuter á catorce.

Ningun grupo de peces presenta tantas dificultades á los ictiólogos para la clasificacion en especies y para saber a punto fijo su género de vida, y en ninguna tiènen tanta im portáncia para la determinacion de las especies el sexo, la edad, la habitacion, el régincn, la reproduccion, las enfermedades, la inclinacion de especies distintas a desovar jun. no decir consiguiente produccion de mestizos, que acaso, por no decir probablemente, fecundados \& su vez, se aparean en tre si y con las especies fijas, produciendo nuevos cruza. mientos que requieren toda la inteligencia del especialista, y explican la divergencia y confusion cxtraordinarias que, pesar de 10 mucho que se ha escrito sobre los salmónidos, reinan entre peritos y legos, entre naturalistas y pescadores. Esto consiste en que la coloracion y aun la misma configu. racion de las diferentes partes sueltas, que deberian creerse invariables, cambian notablemente segun el sexo, la edad, la estacion, la morada y el réginen; y lo propio que las propor. ciones entre las diferentes partes del cuerpo, varian tambien el tamaño y el peso. Y no tan solo es lo instable el número de dientes, sino que las mismas mandibulas presentan cambios 
que jnmás se observan en otros peces; las aletas participan de esta inconstancia, ya en su forma, ya en el número de ra. dios; las escamas à su vez son tan pronto peq̨ueiras como grandes; la piel cstá sujeia á diferencias muy esenciales, y por último, ni siquiera es constante el número de vértebras. En presencia de tales dificultades no parecerá ya extraña la divergencia entre los ictiólogos, los cuales, segun Siebold, tan pronto admiten un número como otro de especies de salnones. Este naturalisła dice: Inclinśndome âla opinion de que las pocas cspecics curopeas de salmon varian extraordinariamente segun su distribucion geogrífica, diré que Agassiz no está ciertamente muy equivocado cuando dice que los salmones con dientes del continente europeo se re. ducen solo á seis, especies, a pesar de que se atribuye á cada país la suya prónia. De todos modos, las opiniones encon tradas de los ictiólogos respecto á la determinacion de las especies altorizan á creer que nuestros ronocimientos en esta materia, $\mathrm{g}$ en especial acerca de las formas que pueden presentar los salmones, son muy defectuosos.i"

\section{EL SALMON COMUN-SALMO SALAR}

CARACTERES. - Es la especic mas notable de su ge. nero.

Sus caractéres consisten en tener el cuerpo mus prolon gado y mas 6 menos comprimido lateralmente; en la peque ñez relativa de la cabeza comparada con el cuerpo, el hocico delgado y afiado, la placa corta y pentagonal del vómer desprovista de dicnies, y el mango de este mismo hueso guarnecido de una hilera sencilla de dientes que caen muy pronto. El color es gris azulado en el dorso, plateado en los costados y de un blanco reluciente en el vientre; el dibujo en los individuos adultos se reduce á unas pocas manchas negras. Las aletas dorsales, adiposa y caudal tienen un tinte gris oscuro, las otras son mas claras; la dorsal ofrece en ca sos excepcionales algunas manchas redondas y negras. La sostieneri respectivamente tres ó cuatro y nueve hasła once radios; la pectoral uno y trece, la abdominal uno y ocho, la anal tres $y$ sicte if ocho $y$ la caudal dicr. y nueve. En cuanto á longitud, puede el salmon tener hasta un metro y medio, 5 respecto al peso, hasia cuarenta y cince kilógramos, pero solo se pescan hoy individuos de estas proporciones en los rios del norte de Rusia, pues en el resto de Furopa hace tiempo que tales gigantes no existen ya; en Alemania se considera como una rareza el salmon que llega á un metro de largo y çuince ó die\% y" seis kilógramos de peso.

DISTRIBUCION GEOGRAFICA. - Ia patria del sal mon es indudabiemente el mar Glacial y la parte septentrional del Atlántico incluso el mar del Norte y e! Báltico, si bien pasa mas tiempo en las aguas dulces que en las saladas $y$ it pesar de que cadarno sale del mas para remontar, hasta donde le es posible, ci curso de los rios en los cuales pasa tambien el primer periodo de su vida. Los que visita en Ale. mania son ei Khin, el Oder y el Vístula, siquiera no falte del todo en el llieser ni en el Elba. Además de los rios mencionados visita tambien sus afluentes mas notables mientras no le privan el paso esclusas 6 cascádas. Mas frecuente que en Alemania es en las corrientes de Inglaterra, Rusia, Escandinavia, Islandia y Groennlandia, siendo en cambio raro en las de la lirancia occidental y del norte de España. En la Gran Bretaña, donde antes era tan comun que apenas se ha. cia caso de él, ha disminuido tanto á causa de lo mucho que se le ha perseguido, que su escaser. en el 'Tey, Tweed, Sey y Esk, rios que antes preferia, empicza ả llamar la atencion $y$ ha sido necesario dictar leyes rigurosas con objeto de fo memar su cria y multiplicacion. En Rusia desova en todos los rios que descmbocan en el Báltico y en el mar Blanco aquende el Ural, puesto que no se le encuentra ya en el $\mathrm{Ob}$. En la Escandinavia, to mismo que en Islandia $y$ en Groen. landia, es el salmon uno de los peces mas comunes aun en la actualidad; en Francia remonta los rios quie desembocan en el Atlántico, y en Éspaña es bastante numeroso en las corrientes que van á parar al golfo de Vizcnya, pero falta en las que pasan por Portugal para desembocar en el mar, $\delta$ si se encuentra en ellas, es un caso tan aislado que bien puede tomarse por limite sur de su área de dispersion el cabo de Finisterre.

USOS, COSTUMBRES Y REGIMEN.-Se ignora el género de vida del salmon en el mar, á pesar de la exquisita solicitud con que se ha observado este per, el mas precioso de las aguas dulces; pero lo que puede admitirse como fijo es que nunca se aleja mucho del sitio donde nació, que no viaja, como antes se creia, hasta el polo norte, sino que se limita a bajar $a$ las profundidades del mar en la proximidad de las desembocaduras de los rios, donde se ceba de una manera sin ejemplo hasta entre los peces. Consta por inves. tigaciones hechas por naturalistas suecos que cl salmon se alimenta en el mar de toda clase de crustáceos y de peces como anguilas, gasterosteos, y tambien arenques, siendo probable que no se limite á estas especies, sino que devore todo cuanto pueda coger.

Su comportamiento es muy diferente cuando se halla en agua dulce donde se han podido estudiar sus costumbres al. go mas. Alli se distingue poco de sus afines, particularmente de las truchas, á las que se asemeja tambien exteriormente. Nada con la misma ligereza que ellas y las sobrepuja en destreza para saltar; le gusta, como á sus congéneres, vivir en sociedad; solo durante el primer periodo de su vida se muestra voraz como la trucha; cuando adulto ya es otra cosa, pues se abstiene casi rompletamente de todo alimento mientras permanece fuera del mar $y$ en especial durante $y$ despues de la freza; de lo cual se infiere que sus viajes periódicos son una condicion esencial de su existencia: en el mar se alimenta $y$ en el agua dulce se reproduce.

En todas las épocas del año pueden verse salmones re. montando los rios, pero la gran masa abandona el mar en los meses de marzo, abril y mayo, un poco antes 6 despues, segun las circunstancias atmosféricas y el calor de las aguas corrientes que remonta. Cuando los rios se deshielan, acércanse los salmones en grupos de treinta y cuarenta á has desemboca. duras donde permanecen una temporada, acudiendo al agua dulce con la marea alta y volviéndose con la baja al mar, como si tuviesen que acostumbrarse gradualmente al nuevo medio en que han de ir s vivir. Se ha-observado que las hembras son las primeras que penetran en los rios y que los pequeños que pasaron pocas semanas ó meses antes del agua dulce ì la salada, vuelven ș la primera antes que los viejos, y los individuos mas robustos y de mas cdad antes que los de cria mas reciente 6 , aunqque mas adultos, mas débiles; de modo que cuando estos penetran en la desembocadura del rio, aquellos le han remontado ya hasta donde les ha sido posible.

Se conocen los salmones que acaban de dejar el mar por su coloracion plateada, la poca adherencia de las escamas á la piel y á menudo por un parásito que suelen tener agarrado al cuerpo y que muere al poco tiempo de estar fuera de su elemento salado. Gracias á estas señales se distinguen de sus compañeros que los han precedido y se les puede estudiar en todo el trayecto que recorren. Se dice que en su viaje guar. dan cierto órden formando dos hileras convergentes y unidas por delante con un individuo viejo y robusto que va á la ca. beza, al que siguen los dernás á mayor ó menor distancia. 
Cuando se interrumpe una fila, se paran los que van delante para aguardar á los rezagados; luego se reunen otra vez y la bandada siguc su marcha. Si encuentran algun obstáculo, se valen de todas sus fuerzas para vencerlo y denuestran una destreza y perseverancia pasinosas. Rompen las redes ó buscan un paso por debajo de ellas, y salvan á saltos las corrientes rípidas, las presas y cascadas. Penetran desplegando todo su vigor dentro de la corriente mas fuerte hasta llegar al pié del sitio donde desembocan las aguas rápidas, y una vezalli, apóyanse si pueden hasta con la cola contra una piedra, para dar un salto de dos á tres metros de altura y cacr s. cuatro, cinco ó seis metros de distancia corriente arriba, sin que les arredre el mal éxito, pues vuelven á ensayar hasta lograr. su intento, pagando frecuentemente su tenacidad con la vida cuando al caer dan con toda su fuerza contra la roca desnuda, ó en uno de los armadijos, buitrones 6 bolechas que en tales sitios les colocan los pescadores si pasan los puntos rápidos con mas ó menos dificultad, no sucede lo mismo con las cascadas verticales que ponen término á su viaje, como el hombre no les facilite el paso con el artificio llamado esenlcir de sulmon, que consiste en tablas ó planchas de metal fijadas sólidamente con grapas á la peña y á ambos lados de la cas. cada. Estos escalones reciben y amortiguan el golpe del agua que cae, dejando debajo de cada uno un puesto resguardado que el pez recorre hasta llegar de salto en salto y dando rodeos al nivel del agua superior. Si el rio atraviesa un lago, le siguen esios peces á la salida de esie para llegar hasta los afluentes superiores que son los que buscan para deponer su freza, y donde tardan en llegar, à pesar de ser cxcelentes na. dadores, porque viajan con mucha calma y sin apresurarse. Asi es que empiezan á penetrar en el Rhin en abril, en mayo se los ve cerca de Basilea y rara rez llegan a los afluentes menores antes de fin de agosto. En la cuenca hidrográfica del Rhin visitan puntualmente, entre otras corrientes, el Lim. mat, atraviesan el lago de Zurich, penetran en el Linth, en. tran con este en el lago de Wallenstaett y atravesándolo, penetran en el Seetz que remontan hasta donde pueden. Otro grupo recorre el Reuss y cl Aar, cruza los lagos de los Cuatro Cantones y de Thun y sube otra vez por los rios anteriormente citados; en el primero, segun Tschudi, hasta la altura de 1,300 metros sobre el nivel del mar, pasando innumerables saltos y remolinos. En la cuenca del Weser termina su as. cension en el Tulda, el Werra y sus afiuentes. En la del Elba, suben tambien muchisimo corriente arriba, por una parte hasta la sierra del lichtelgebirge y por otra penetrando en el Moldau y sus afluentes; sucediendo lo mismo en los rios que desembocan en el Báltico, el mas frecuentado de los cuales es el Memel. Las presas nuevas no provistas de esca. lcras de salmon les hacen cambiar su ruta acostumbrada; y aun cuando se apliquen á ellas las citadas escaleras, no las aprovechan los salmones en seguida; siendo mas bien proba ble que los que estaban arriba $y$ han tenido que bajar por ellas, sean los que primero se aventuren al año siguiente á subirlas.

En muchos rios se ha notado quue los saimones que los recorren se presentan en distintas épocas en sus puestos res. pectivos. Asi es que los salmones qua no tienen todavia la cdad necesaria para reproducirse, buscan las aguas dulces, ya en los meses de invierno desde noviembre á febrero, y no desovan hasta haber permanecido casi un ano en el rio, sin que esta prolongada ausencia del mar les perjudique al parecer en lo mas minimo. Hay criador de peces que cree, contra la opinion de todos los naturalistas, que los salmones pueden acostumbrarse a no dejar nunca los rios, aduciendo como ejemplo los que habitan el lago de Wener en Suecia, que, segun se dice, no pucden bajar al mar ni subir de este lago. Basåndose en este hecho, se echó hace unos veinte años cierto número de salmones en el lago de Cinebra que desagua por un canal subterráneo muy largo llamado el Rí dano ferdido, y efectivamente se cogieron al cabo de algu. nos años hembras a punto de desovar. Por lo que toca allago de Wener, no cabe duda que los salmones suben desde el mismo á los rios que desembocan en su freza en puntos situados mas arriba, lo que dice mucho en favor de la opinion de los naturalistas mas antiguos, que creian que la permanencia prolongada en los rios es condicion indispensable para el desarrollo de los elementos de fe. cundidad. Cuando los huevos han llegado á su madurez, apresuran los salmones su viaje rio arriba, y solo desovan en sitios inferiores cuando se les oponen obstáculos inven. cibles.

A medida que se acerca el tiempo del desove se observa en los salmones un cambio exterior; su coloracion cambia, se vuclve mas oscura y con frecuencia aparecen manchas rojas en los costados y opérculos. Los machos muy viejos ad. quieren en la época del celo, segun Siebold, una colora. cion magnifica, $y$ no solamente se tine la region abdominal de púrpura, sino que las manchas encarnadas que salen en la cabeza se van aglomerando y confundiendo hasta formar lineas sinuosas en forma de $\mathrm{S} S$ que se destacan vivamente del fondo azulado; además la base de la aleta anal, el borde anterior de las abdominales y el superior $e$ inferior de la caudal, adquieren un viso rojizo, al paso que la piel se vuelve mas espesa en el lomo y en las aletas.

La hembra, acompañada por lo regular de un macho adulto y de muchos jóvenes, elige en los meses desde octubre a febrero un sitio arenoso 6 guijarroso de poca agua pa. ra formar el hoyo ancho y poco profundo destinado á reci. bir las huevas. La hembrn ejecuta este trabajo con la cola, mientras cl macho vigila para ahuyentar a sus rivales. Tan luego como la primera se prepara para el acto del desove, acude el segundo á fecundar la freza que en seguida cubren ambos de arena con ayuda de la cola. 'Tambien sucede que una hembra vaya rodeada de machos pequeños que apenas han llegado á la edad de reproducirse y no han estado toda. via en el mar. Hay observadores que atribuyen á estos machos un papel importante, análogo al que desempenan los ciervos jóvenes micntras se desafian á muerte dos viejos por una manada de hembras. Lo cierto es que entre los salmo. nes cada vicjo vigila celosamente á la hembra que se dispo. ne á desorar, para tener á raya á los rivales, con los que combate, si llegan á acercarse, con tanto furor que la sangre del uno ó del otro tine cl agua, ó hasta que uno de los dos paga su obstinacion con la vida. Ia hembra entre tanto no hace el menor caso de ellos, y satisfecha al parecer de verse rodeada de machos apenas adultos, continuia desovando, echándose á intervalos de algunos minutos tan pronto lado como al otro, expulsando cada vez una serie de luevas que al momento son fecundadas por los jóvenes, y cubiertas en seguida por la hembra, al volverse del otro lado, con una delgada capa de arena. Pero á pesar de esto se incurriria en un error si se infiriese de lo dicho que dichos jóvenes bastan á la hembra, porque esta interrumpe el desove en el momento en que ve que el macho viejo sucumbe en la pelea ó que es presa del pescador; en este caso abandona el sitio para dirigirse al próximo renanso como p̧unto de reunion, de donde vuelve luego en compania de otro macho adulto para conti. nuar el desove bajo su vigilancia.

Young ha observado que en semejantes circunstancias una hembra fué $\mathbb{1}$ buscar sucesivamente durante la opera. cion del desove hasta nueve machos vicjos, y cuando el til. timo de estos fué víctima del anzuelo como sus predeceso. 
res, se marchó anuella otra vez y rolvió con una gran trucha macho. Como se ve, no arrojan todas las huevas de una vez, sino á intervalos, de modo que toda la operacion dura, segun unos, tres 6 cuatro dias, y ocho a diez, segun otros.

Verificada la reproduccion se encuentran los salmones tan debilitados que no tienen fuerza ni para cazar ni para nadar y se dejan llevar por la corriente hasta el remanso proximo, donde descansan hasta recobrar sus fuerzas perdidas á fin de poder cmprender la vuelta al $\mathrm{mar}$, aprovechando las crecidas de inviernoy de primavera que tienen menos fucrza y les permiten viajar con mas calma y evitar mas fácilmente saltos y parajes de rípida corriente. Asilllegan al mar despues de ha. ber permanecido todavia algurtiempo en el agua, entre 5alobre y dulce, de la desembocadura; por supuesto, si en el trayecto 130 han sido víctimas de los pescadores ó de otro contratiempo desgraciado. Hasta este momento, me dice Pietsch, consejera de obras públicas, abstiénensc los salmones de todo alimento, por lo menos nacia se encuentra en los estó. magos de los individuos que se cogen en tales circunstancias. A esto añade: Su carne, que es de un hermoso color rojo cuando suben á los rios, tiene entonces un color blanco sucioy un gusto que la hace completamente desagradable para los paladares delicados. Las manchas oscuras de la piel aumentan en nímero, adquieren un matiz mas rojo é invaden liasta las aletas; el gancho de la punta de la mandibula se prolonga y hace retroceder la superior de tal modo, que los peces no pueden cerrar la boca bien, ni coger por consiguiente con fuerza sus presas, ni menos despedazarlas, lo cual contri. buyc a aumentar su debilichad hasta el punto de que \& me. nudo se dejan coger con la mano sin oposicion ni intentar la fuga. Un gran número de salmones perece en su viaje de vueita al mar, porqque despues del déshielo se encuentran muchísimos de estos preciosos animales muertos en los ban. $\cos y$ orillas guijarrosos.

Jos que llegan al mar se rehacen con una rapidez pasmosa; pierden los gusanos blancos y otros parásitos que infestan sus agallas en el agua dulce y que mueren en la salada; sus mandibulas se cstiran, las, manchas desaparecen, se hartan con afan, y cuando vuelve la epoca de la subida los encuenira ya mas robustos que nunca.

Ins huevas se desarrollan en mas o menos tiempo, segun cl estado de la atmósfera, pero por lo regular requicre la incubacion cerca de cuatro meses. Los pequeños tienen $0^{\circ}$, or de largo al poco tiempo de haber salido ś luz; entonces la cabeza, los ojos y la bolsa 6 vesicula vitelina son aun muy voluminosos; el color del cuerpo es un pardo pálido con nueve $\delta$ diez listas oblicuas de color gris pardusco en los costados. En los que se han tenido en vivero reducido, se ha visto que al cabo del primer verano alcanzan a lo mas una longitud de $0^{\circ}$, ro y que desde entonces medran ya con mas rapidez, de modo que a los diez meses miden como $i^{*}, 40$. Entonces adquicren la coloracion de los aduitos y se des. pierta en cllos el instinto de viajar que los impulsa hácia el mar, al q̨ue llegan muy despacio y despues de haberse en. tretenido algunas scmanas en la desembocadura para acos. tumbrarse paulatinamente al agua salada, puesto que el tránsito les es al parecer fatal cuando se efectúa subitamente, segun resulta de experiencias hechas en salmones jóvenes, qque, trasladados inmediatamente del agua dulce so la salada, murieron todos al cabo de poco tiempo, á pesar de ser esta última perfectamente limpia y clara. $Y_{a}$ hemos visto que una permanencia temporal en el mar no es condicion vital para estos peces, pero sí de gran importancia, porqque no cabe duda que alli encuentran tanta abundancia de alimento que en cortísimo tiempo aumentan de una manera sorprendente en tamaño $y$ peso. Los ingleses, que con fundado mc- tivo denuestran un especial interés por este pez precioso, han hecho experimentos con el objeto de saber lo que au. mentan en volúmen durante su permanencia en el mar, y á este fin han marcado con alguna seĩal muchos de estos pe. ces al bajar los riós, ya pasando anillos por sus aletas, ya cortándoles la adiposa ó de otra manera; y se han convencido asi de que su peso habia aumentado desde dos hasta siete kilógramos, y eso que la mayor parte de ellos no habian permanecido mas que ocho semanas en el mar. El magnate a quicn se deben estos datos, que forman parte de un informe, dice que habiendo cogido, señalado y soltado otra vez un saimon a cuarenta millas inglesas de la orilla del mar, este mismo pez mordió à los treinta y siete dias el anzuelo de vuelta del mar, y en tan poco ticmpo habia aumentado su peso en cerca de seis kilogramos.

Pasó mucho tiempo antes que en Inglaterra se conociesen los ealmones jóvenes, á los que tomaban por otra especie de peces, lo mismo que los que se hallaban ya en via de trasfor. macion; los pescaban en grandísimas cantidades, y cuando no podian venderlos, abonaban con ellos los campos, de suerte que causaron un daño incalculable. Un pastor, James Hogg, fué el primero que hizo patente el crror; porque mientras custodiaba su rebaño tuvo ocasion de observar los peces y de adquirir no poca destreza en cogerlos. Así fué como liamaron su atención los salmones pequeños que se hallaban en la primera muda y los que pasaban de esta á la colora. cion de los adultos, y para cerciorarse del fundamento de sus sospechas, sébaló y solı́ de nuevo los que cogia; viendo con gran satisfaccion que los mismos volvian al cabo de cierto tiempo a morder el anzuelo, trasformados en salmones verdaderos. Este descubrimiento fué recibido con mofa é incredulidad hasta que algun naturalista se dignó ocupar. se del asunto, viendo poco despues con auxilio de la cria artificial que el pastor tenia razon. No hay para qué decir que desde entonces se cuida mucho de no exterminar los saimones jórenes, y muy al contrario, de protegerlos, lo que empieza ya á producir resultados por dernás halagueños.

ENEMIGOS Y CULTIVO.-Los enemigos que persiguen à los demás peces de agua dulce perjudican tambien 1 los salmones, destrozando probablemente hasta un noventa por ciento de las huevas y cria. Pero el adversario mas peligroso es, como se comprenderá, el hombre. La inmensa mayoría de los pescadores no puede determinarse ấ observar una veda oportuna, y precisamente se dedican á la pesca con mas afan en la época de la reproduccion, sin perdonar á aquellos salmones que están desovando, puesto que entonces se cogen con mas facilidad, absorbidos como están ente ramente por su instinto de propagacion.

En el dia tratan en la Gran Bretaña todos los grandes. propietarios territoriales de reunirse en accion comun para observar una veda rigorosa en la época que conocen ser la mas adecuada, if fin de proteger las crias con mas eficacia de lo que lo hace la legislacion existente, porque alli prepon. dera la opinion de que el único medio de repoblar de salmo. nes los rios, es abstenerse durante cinco años de toda pesca en absoluto; pero esta supresion prolongada es dificil de realizar cuando muchos grandes propietarios sacan, como alli sucede, una parte muy importante de sus rentas de la pesca de esta especie, que asegura á algunos de ellos hasta veinte mil libras anuales (medio millon de pesetas) de bene. ficio; y la pérdida de una suma semejante durante cinco años constituse un sacrificio que ni los opulentos lores ingleses pueden hacer, sin contar que, aunque se resolviesen á ello, no les podrian imitar aquellos que son menos pudien. tes.

Fil salmon es un pez que se extermina en ciertas corrien- 
tes con mas facilidad que todas las otras especies Segun parece, está ya probado y puesto fuera de toda duda que cada salmon vuelve para reproducirse invariablemente al mismo rio donde nació. No conocemos las causas de este fenómeno, pero un crecido número de observaciones así cono amargas experiencias confirman su exactitud; y como un rio mediano ha de tener de diez á quince mil parejas de salmo. nes adultos para conservar la fecundidad y reproduccion al nivel de la explotacion, segun los cálculos de ingleses peri. tos en la materia, resulta que pescando continuamente $y$ sin consideracion los salmones que suben del mar, se llega en muy poco tiempo a despoblar completamente un rio de estos peces. Por fortuna puede volver a poblarse una corriente con la misma seguridad de buen exito por medio de la piscicultura y la remocion de los obstículos que se opo. nen \& la multiplicacion de los salmones, en apoyo de lo cual tenemos el rio Moy que desemboca en la costa norte de Ir- landa, cuya longitud no pasa de 50 à 60 kilómetros y que á causa de una cascada muy elevada no habia albergado nurca salmones, porque aquel obstáculo les oponia una barrera insuperable.

Varios aficionados á la pesca tomaron el rio en arriendo por una serie de años, establecieron en la cascada una es. calera de salmon, exterminaron los peces carniceros tan completamente como pudieron y depositaron en los sitios mas á propósito 200,000 huevas de salmon, que llegaron a buen término; los pececillos nacieron, se fueron al mar $y$ volvieron \&s su tiempo rio arriba merced á la escalera, para hacer su desove en el sitio donde habian salido a luz, y á los cinco años de haber colocado las huevas, la pesca de salmon en dicho rio produjo una renta de 625,000 pesetas. Este solo ejemplo bastará para probar la utilidad de la pis. cicultura aplicada con discernimiento.

Gracias á la cria artificial se ha logrado aclimatar el sal-

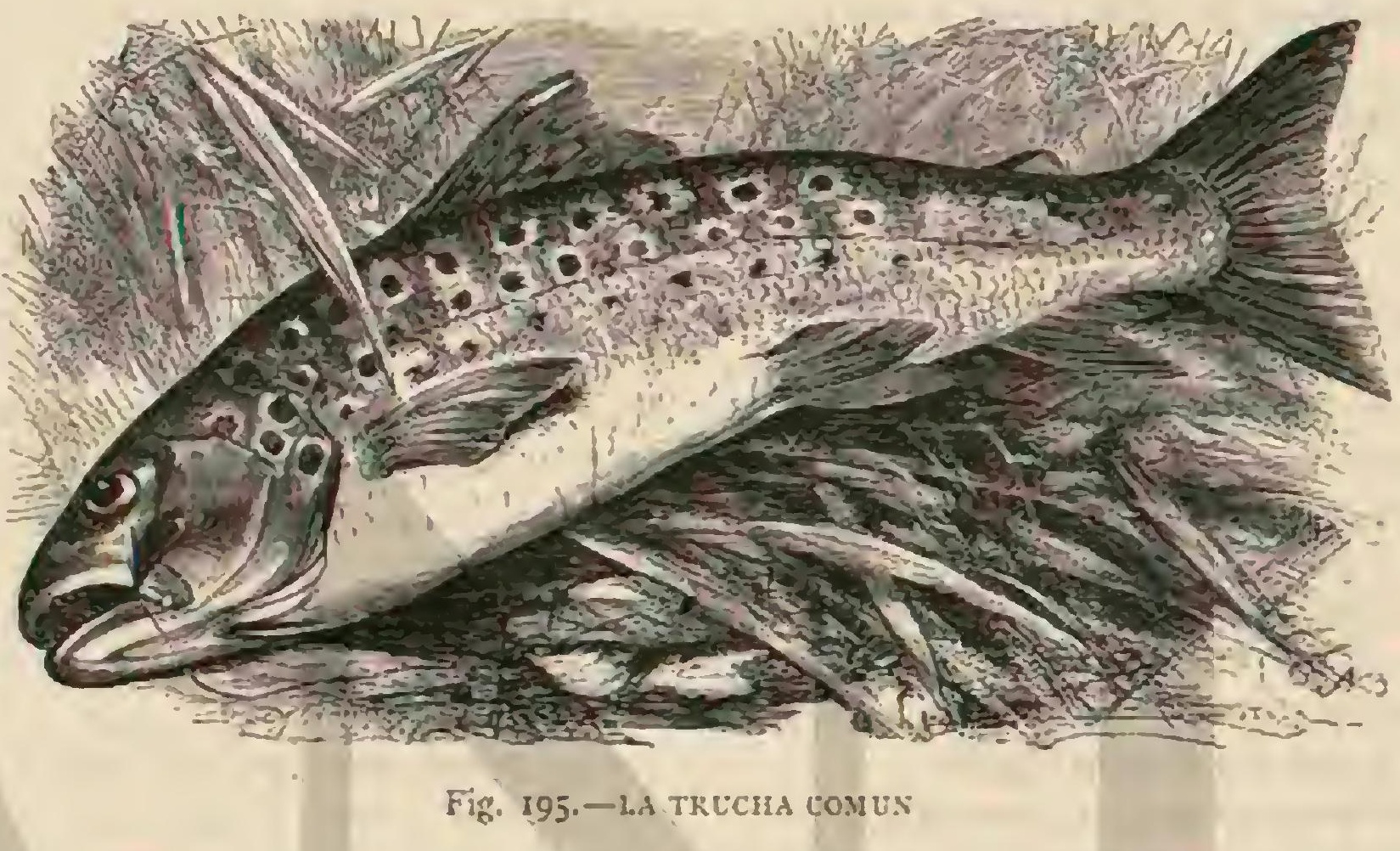

mon en Australia. Claro es que este experimento exigió una perseverancia a toda prueba y grandes gastos, pero se logró el objeto. Solo una pequeña parte de las huevas que se habian expedido desde Europa empaquetadas entre hielo, llegaron vivas á Australia, donde se desarrollaron y dieron á luz una cria bastante robusta para adaptarse á las nuevas circunstancias y medrar con el régimen, nucro tambien, que les ofrecieron aquellas aguas. Es indudable, dice Siebold que ha recopilado los resultados contenidos en los diferentes escritos redactados respecto de este asumto, que los peces han encontrado en aquellas aguas lejanas un alimento abundantisimo á juzgar por su rápido crecimiento que no se es. peraba; y no solamente han medrado bajo este concepto, sino que el instinto de procreacion se ha despertado en ellos con la mayor puntualidad al llegar a la edad adulta y se han reproducido del propio modo que sus progenitores, he cho tanto mas notable cuanto que tampoco han desmentido el instinto heredado de sus padres respecto al viaje al mar despues de haber pasado su juventud en los rios de Austra. lia, para buscarse la vida en el agua salada. Su vuelta al rio se esperaba con tanta mayor inquietud cuanto que era de presumir que en la parte del mar à donde se habian dirigido podian esperaries peligros y enemigos desconocidos y acaso superiores a sus fuerzas, â los que era muy fácil sucumbie. sen; pero pronto se vió por su vuelta al rio que habian sa lido victoriosos del combate inevitable por la existencia y conservado el instinto admirable de sus padres de reconocer las localidades, pues volvieron exactamente al mismo sitio donde habian nacido para depositar alli su freza.

PESCA. - Se cogen los salmones de muchas maneras, томо $\mathrm{V}$ con diferentes clases de redes, con nasas, trampas y armadijos que se colocan en la parte superior de las presas, de ma. nera que los peces, al saltar arriba, han de caer dentro; ade. más con una especie de venablos que se les arroja desde el bote despues de haberlos atraido con luz, pero la pesca prin. cipal se hace con anzuelo arreglado y preparado á propósito y mancjado por los ingleses con una destreza y habilidad extraordinarias. En ningun pais se dedican tanto á la pesca del salmon, ni se tiene esta tan en cucnta como en Inglater ra; en ninguna otra parte existen tantos y tan apasionados pescadores de salmon como alli; para satisfacer esta pasion no se contentan con las corrientes de su patria, sino que acuden a todos los rios que albergan salmones en general. Yo he visto á estos pescadores impertérritos sentados en el ex tremo norte, á orillas del Tana Elf cerca del cabo Norte, en medio de enjambres de mosquitos, como rodeados de una aureola de mártir, envueltos en un trasparente velo para res guardarse mas 6 menos de estos insectos sanguinarios, y pes. cando con afan. Cerca de los puntos de corriente rápida habian levantado sus tiendas de camparia en medio de bos. ques de abedules con las provisiones mas indispensables para muchas senianas y soportando como héroes todas las intem. peries, la soledad, los mosquitos, alimentos miscros, faltos de sociedad y de comunicacion, pagando á los noruegos mi. les de pesetas por el permiso para poder pescar alli durante seis semanas, y regalando despues la mayor parte de su pesca á los dueños de los caserios mas inmediatos.

UTILIDAD Y PROVECHO. - Ia carne de salmon goza con razon de la fama de ser la mas excelente de todos los peces de nuestro pais, pero no tiene el mérito de la tru- 
cha asalmonada y del salmonete de lago y mucho menos de la trucha comun, del timalo y murena, y menos que todo del salmonete negro. Solo tiene valor mientras es encarnada; cuando se vuelve blanca no solamente no tiene mérito, sino que es perjudicial, segun dicen las personas entendidas. Pietsch asegura que los pescadores del Weser no tier.en el menor escrúpulo en recoger los salmones que encuentran muertos ó espirando y venderlos por poco qque su apariencia lo permita, $y$ asi se explica porqué se venden y compran tantos salmones en el Weser inferior cabalmente en los me. ses de enero, febrero y marzo. El que haja probado estos peces una vez, no volverá por cierto á reincidir, y yo por mi parte añado que en vista de tan mala calidad el precio de 2,50 á 5 pesetas por kilógramo de pescado muerto es demasiado clevado. Nadie ignora que, for lo comun, el salimon es pescado caro, y unicamente se veride á poco precio en la Po. merania y Prusia oriental, donde se paga el kilogramo á peseta hasta dos y media, mientras que á orillas del Rhin su precio es de 4 á i pesetas y de consiguiente exagerado.

\section{EL SALMONETE DE LAGO-SALMO LACUSTRIS}

CARA CTERES. - Con gran dificultad se distinguen dos especies de salmon que habitan las aguas alemanas y a las que por esta razon se las suele confundir con muchisima frecuencia la presente es una de ellas, la que sigue la otra. Ya Ausonio dice del salmon de lago: đSér ambiguo, tránsito entre dos especies, no es ni la una ni la otra, no es salmon ni tampoco trucha. $Y$ hoy no han podido todavia ponerse de acuerdo los naturalistas sobre el carácter ambiguo ó mas bien múltiple de este pez. Yo creo que será preferible seguir a Siebold, cuyos estudios parecen ofrecer la mejor garantia para circunscribir los caractéres de esta especie.

Segun este distinguido uaturalista, se caracteriza el salmo. nete de lago por su configuracion mas tosca y rechoncha. El volúmen de la cabeza es considerable si se compara con el resto del cucrpo; el hocico es rélativamente obtuso a causa del hueso intermaxilar muy desarrollado; la placa anterior y corta del vómer es triangular y guarnecida de tres á cuatro dientes en su borde posterior, y el mango, robusto y muy prolongado, está un tanto ahuccado en la cara del paladar y además provisto de un refuerzo ó liston longirudinal bastan. te alto y guarnecido de dientes muy robustos colocados por delante, casi siempre en hilera sencilla y por detrás doble; siendo raro que estén en hilera sencilla en toda la longitud, y mas raro todavia que se hallen en hilera doble de uno á otro extremo. En el dorso, de color verde $\delta$ azul agrisado, $y$ en los costados, de reflejo plateado, vénse manchas mas ó menos numerosas, redondas ó angulosas, de color negro, orladas á veces de un tinte anaranjado, pero semiborrado. En los individuos jóvenes se ve tambien alguna que oira man. clia anaranjada en los costados, y sus aletas pectorales, abdo. minales $y$ anal son de un tinte pálido, pero en los mayores de color gris mas ó menos oscuro que el de las aletas dorsal y caudal, las cuales tienen siempre este mismo color ú otro mas oscuro. En la aleta dorsal obsérvase siempre gran nú. mero de manchas negras y reciondas, mientras que la caudal presenta solo algunas veces puntitos oscuros y medio borrados.

Estos son los caractéres de los saimonetes fecundos; pero los hay estériles que presentan otros nuy distintos. El cuerpo de estos últimos es mas esbelto y lateraimente mas com. primido por tener menos carne que los otros; el hocico tam. bien aparece mas largo y la boca mas hendida; además la cola conserva mucho mas tiempo su ligera escotadura, y cuando son viejos no tienen tan caracteristicamente prolongado el hocico como el salmonete fecundo en igual periodo ni forma gancho el extremo de la mandíbula inferior. La mayor diferencia existe empero en la coloracion; el lomo del salmonete estéril no presenta nunca manchas tan oscuras y negras ni tan numerosas como el fecundo. En los costados se ven solo algunas escasas manchas negras muy aisladas y borradas, si es que no faltan completamente, en cuyo caso brillan los opérculos y costados como una sola superficie plateada. Las aletas pares son mas largas, afectando mas una forma puntiaguda, é incoloras, pero algo difusas en los indivi. duos viejos; la dorsal y caudal son de un gris oscuro, la primera con manchas negras, redondas, pero casi siempre en menor número que en los individuos fecundos. En la aleta dorsal hay de tres á cuatro radios espinosos y de ocho á diez blandos, en la pectoral uno y trece, en la audominal uno $y$ ocho, en la anal tres $y$ sicte ú ocho, y en la caudal diez y nueve. El tamaño puede llegar á ser muy regular, pues no son raros los individuos de $0^{\circ}, 80$ de largo con un peso de 12 \& 15 kilógramos.

DISTRIBUCION GEOGRÁFICA. - Respecto à esta puede admitirse como cierto que la especie habita los lagos y corrientes mayores y profundos de los Alpes y de sus ramificaciones inmediatas, hasta la altura de 3,500 metros sobre el nivel del mar. Cuando Linneo describió esta especie despues de darle el nombre científico, debió de tener a la vista indiriduos suecos y no suizos, de lo que se infiere que existe tambien en los lagos de aquel país; é igualmente puede admitirse que tampoco falta en los lagos mayores y mas profundos de Escocia.

USOS, COSTUMBRES Y REGIMEN.-En los lagos de los Alpes vive el salmonete por lo comun en las grandes profundidades, porque alli habitan los rencos, sus presas favoritas, siendo muy raro encontrarle en capas que tengan mas de reinte brazas de profundidad. Claro es que tambien persigue cualquiera otra especie de pez, pero cuando llega á ser viejo, prefiere aquellos afines suyos, mientras que en la juventud se ciñe mas á los alburnos. Cuando los salmone. tes de lago topan con una bandada de estos peces, dice He. ckel, arrójanse tras ellos con tanto ardor que llegan hasta la orilla apenas cubierta de agua; los alburnos por su parte se dispersan como el rayo, y procuran salvarse dando grandes saltos fuera del agua; pero no les vale, porque el enemigo, no menos veloz que ellos, coge su presa por la cola, le da una rápida y hábil vuelta y se la engulle empezando por la cabeza. Clianda su peso llega de ra hasta I 5 kilógramos ya no se contentan con peces tan pequeños, sino que cazan aquellos que pesan casi un kilógramo.

Los salmonetes de lago abandonaná principios desetiembre las aguas que habitan y rémontan los rios para soltar su fre2a. En los que son capaces de reproducirse se presenta este instinto muy luego, manifestándose exteriormente en los jóvenes como en los individuos viejos, es decir, por un cambio de coloracion y de la piel. Se ruelven mas oscuros, á menudo aparecen como tiznados en la parte inferior desde la barba hasta el extremo de la cola, y á las capas inferiores de la piel trasluce un tinte anaranjado, por cuya razon los 112. man entonces, segun Siebold, a orillas del lago de Chiem, salmones dorndos: aumentan considerablemente en grueso las callosidades en el lomo y vientre de las hembras, extendién. dose hasta á las aletas. Efectúan su viaje en comun, bien que los peres mayores preceden á los pequeños; y como al pare. cet ni unos ni otros tienen prisa por llegar, avanzan con mucha lentitud, pero suben hasta bastante altura, segun Tschudi hasta 800 metros sobre el nivel del mar en la cuenca del Rhin, y muchisimo mas en la del Inn, porque alli habitan 
todavia lagos cuyos niveles se hallan á 1,600 metros sobre el nivel del mar. No penetran en los arroyos pequeños, pues prefieren los lechos guijarrosos de rios de mucha corrientc. Verifican la puesta como las truchas comunes, es decir, hacen hoyos en la arena \& medida que despiden sus huevas amarillentas $y$ viscosas del tamaño de un guisante; estos hojos son tan grandes que cabe un hombre echado en los que abre un salmonete de diez kilógramos. Los pescadores los conocen bien $y$ tambien los mismos peces, porque las hem bras que llegan de las primeras suelen aprovecharlos a su vez. Hé aqui lo que dice Vogt sobre este particular:

- Casi inmediatamente delante de la casa que habitaba en Souterre, se encuentra uno de estos huecos y alli pueden observarse siempre en la época de la freza hembras grandes seguidas por lo comun de varios machos pequeños. Alli retozan y depositan sucesivamente las huevas que al momento son fecundadas por los machos. Hecho el desove no vuelven los viejos a su lago sino al cabo de cierto tiempo para pasar el verano é invierno en sus profundidades, mientras que los pequeños nacidos en el mismo año y los del anterior se quedan en el rio y no pasan al lago hasta el segundo invierno de su vida. A la vuelta se dejan llevar por la corrien. te de espaldas á ella, lo que hace que la cola se desgaste mucho en este viaje.

La vitalidad del salmonete de lago es mucho mayor que la de la trucha comun, puesto que sacado del agua no muere tan pronto como esta, lo cual le hace mas propio para el trasporte $y$ traslacion a otras aguas, aparte de que medra tambien en estanques profundos de fondo siliceo, $y$ alimen. tados por muchos manantiales.

La carne de este pez es muy apreciada, conforme leemos ya en Gessner, quien dice: «Estos peees tienen una carne sumamente buena y sana, casi superior á la de todos los de. más yeces, sobre todo en verano cuando tienen color rojizo, color que desaparece en invierno y en la época de la freza. Son mas estimados los que se cogen á gran profundidad. Se guisan de muchas maneras, pero en general me parece que son mejores cuando se comen frios.

PESCA.-Es muy considerable. En el Rhin se cogen anualmente entre Rheineck y Chur hasta dos mil cabezas, $Y$ en otras aldeas junto á este rio, solo durante la segunda mi. tad de otoño, hasta mil individuos por aldea. La pesca varia con el sitio; en el lago de Halberstadt se pesca con redes y de dia á la sombra de las montañas cuando el tiempo es bo. nancible; porque entonces los peces buscan aquellos sitios y los pescadores no tienen mas que seguirlos, mientras que en invierno emplean volantines cebados con alburnos 6 escar. dinias vivos. Se comprende que el mayor número se coja cuando remontan los rios cuyo lecho se estrecha con vallas de mimbre colocadas oblicuamente, de modo que en medio del rio dejan una abertura angosta, produciendo asi una corriente mas fuerte en la cual se coloca el buitron. En los afluentes de poca profundidad se les tira con bala. El precio de esta carne oscila, segun las localidades y temporada, entre 2'50 y' i'so el kilógramo.

\section{LA TRUCHA ASALMONADA-SALMOTRUTTA}

CARACTÉRES, - La gran semejanza que esta especie tiene con la anterior hace dificil caracterizarla con precision. La estructura de esta es relativamente mas maciza y la for. ma del cuerpo casi redonda; la cabeza es achatada; la hendidura de la boca no llega mas que hasta debajo del ojo; las escamas son mas grandes y los dientes mas débiles que en el salmonete de lago, siendo su colocacion en la placa anterior y el mango del vómer igual en ambas especies. I a coloracion de la trucha asalmonada concuerda casi por completo, segun Siebold, con la del salmonete esteril. Su lomo gris azulado y los costados plateados presentan pocas manchas negras, a veces ninguna; la parte inferior es completamente blanca; las aletas pares y la anal son incoloras; la pectoral es gris en los individuos viejos, la dorsal y caudal de un gris oscuro, la primera con algunas manchas sucltas. Las aletas de los pequeños tienen un tinte de vino pálido y los costados algu. nas manchas anaranjadas hasta la edad de la reproduccion, como sucerie con la trucha comun. Antes, cuando no se conocia la diferente coloracion segun la edad, se admitian otras especies, particularmente en Inglaterra, hasta que Shaw, por medio de la cria artificial, pudo hacer observaciones fidedignas y convencerse de que el mismo pez varia de colores segun su edad. Es muy probable que haya tambien entre las truchas asalmonadas individuos estériles; por lo menos se tienen por tales aquellos que difieren de los demás por su color claro y plateado, la escotadura considerable de la cola Y la poca adherencia de sus escamas. Sostienen la aleta dor. sal tres y nueve hasta once radios; la pectoral uno y doce 6 trecc; la abdominal uno y ocho; la anal tres y ocho ó nueve, y la caudal diez y nueve. La longitud puede llegar, segun Yarrell, hasta á un metro y el peso hasta quince kilógramos.

DISTRIBUCION GEOGRAFICA.-La trucha asalmonada es para el mar lo que el salmonete de lago es para estos. Alli vive durante la última parte del verano, y remonta despues los rios para desovar, de lo cual resulta que su área de dispersion sea mayor que la de su congénere anterior. Habita el Báltico, el Atlántico septentrional incluso los estrechos y canales que rodean la Gran Bretaña, el mar del Norte, el Glacial hasta el Blanco, no es rara en las costas alemanas, y abunda en las escandinavas, inglesas, escocesas, irlandesas, laponas y rusas como tambien en los rios respectivos, tanto que viene á ser la plaga de los pescadores ingleses de salmon, porque muerde el anzuelo en lugar de estos peces codiciados, burlando las esperanzas del aficionado. Se alimentan de los mismos animales que los salmones; desovan en noviembre $y$ diciembre, remontan los rios en mayo, junio y julio y regre. san al mar despues del deshielo. Penetran en todos los rios alemanes, pero no los remontan tanto como el salmon, siendo de consiguiente raras en la parte superior de las corrientes. La reproduccion no difiere en nada de la de sus congéneres.

PROVECHO X PESCA.-La carne de este pez notiene entre nosotros la fama que merece, segun indica su bajo precio. En Escandinavia ya es otra cosa; alli se aprecia mas la carne de la trucha asalmonada que la del salmon y con mu. cha razon á mi modo de ver; de consiguiente se pesca allí con afan y constituye, como es numerosa, un ramo importan. te y lucrativo. A csto hay que añadir que dicho pez se aclimata, ya en estado adulto, ya por la cria artificial, en lagos algo grandes $y$ hasta en estanques si son profundos, con la misma facilidad que la trucha comun, lo que le asegura un porvenir mas importante que el del salmon.

\section{LA TRUCHA COMUN - SALMO FARIO}

CARACTERES.-De todos los salmónidos de Alemania, este es $\mathrm{el} \mathrm{que} \mathrm{tiene} \mathrm{la} \mathrm{forma} \mathrm{mas} \mathrm{maciza} \mathrm{y} \mathrm{rechoncha} \mathrm{(fig.} \mathrm{395).}$ El cuerpo es mas ó menos comprimido lateralmente; el ho. cico corto y muy achatado, la placa anterior del vómer corta, triangular y guarnecida de tres 6 cuatro dientes en su canto trasversal posterior, y de una doble hilera de otros muy robustos en el mango un tanto ahuecado del lado del paladar. Es imposible decir algo de general tocante á coloracion. Tschudi llama á la trucha el cansaleon de los peces.y bien podia haber anadido: con la diferencia de que es mas variạble la 
coloracion de este pez nque la de aquel reptil tan conocido por esta cualidad. Puede admitirse como mas acertado y preciso que la coloracion variable de la trucha no es mas que el refiejo de los colores que dominan en el sitio que habita, como sucede tambien con la platija, cuyo color indica el del fondo donde vive Véase lo que dice Gessner: A pesar de ser las truchas peces comunes y conocidisimos, no dejan de ofrecer grandes diferencias segun su sexo y aspecto, pues las hay blancas, amarillentas, negruzcas, doradas, manchadas de negro, de dorado $y$ sin manchas. Jas negruzcas y manchadas de negro se llaman truchas negras, porque otras son-negruzcas con manchas rojas; $y$ á las que las tienen doradas se-las llama ast.

- Las que se cogen en medio de los bosques se conocen por truchas de este nombre. Interiormente poca diferencia ofrecen, solo que las hay de carne blanca y de roja, siendo estas últimas las mejores.

Completaremos estos datos de Gessner con ins de Tschu. di. Nos remos en un aprieto cuando hemos de describir la coloracion de la trucha comun. Las hay cuyo lomo mancha. do de negro presenta puntos de color gris aceitunado, y en los costados otros de un tinte amarillo verdosu o rojo ó do. rado; otros de color gris blanquizco en el vientre, de amari. 110 subido en las aletas abdominales, $y$ otros en la dorsal que puede tener una orla mas clara; las hay cuyo color es casi uniforme oscuro, y en casos muy raros del todo negro. A menudo son los puntos negros, rojos y blancos, como los presentan algunas truchas de los lagos alpinos, que en este caso difieren tambien de las otras por la forma y color del íris. En otras predomina el color amarillo, el rojizo o el blanquizco, y entonces se las designa con los rombres de los colores que predominan sin atender á los inñnitos iránsitos del uno al otro. En general puede decirse que es oscuro el lomo, claros y sembrados de puntos los costados, y el vientre todavia mas claro. Los pescadores creen que el color depende ante todo del agun en que la trucha habita, color que es constante en cada sitio, como lo demuestran por ejem. plo las que se cogen en cl $\mathrm{Aa}$ de Engelberg, que están siem. pre manchadas de azul, y las que se cogen en el riachualo de Erlenbach, afluente del $A a$, que presentan invariablemente manchas rojas. Cuanto mas cristalina y pura es el agua, tan. to mas claro el color. La misma influencia se observa en el de la carne, que es rojiza en las truchas doradas, ó clara con puntos dorados y encarnados, en otras es amarillenta, $y$ por regla general blanquisima sin sufrir variacion por la coccion.

Las truchas del lago Blanco en la Bernina, cuya agua es de un blanco lechoso á causa de la arena removida por las aguas de los glaciares, son siempre de una coloracion mas clara que las que viven en los lagos negros próximos cuyo fondo cs turboso; la carne empero es en estas, como en anuellas, blanca, mientras que las truchas tan celebradas del lago de Poschiavo la tienen siempre amarilla rojiza. Se ha observado que la carne blanca de las truchas se vuelve roja, si se trasladan estos peces á agua pobre en oxigeno, y Saussure dice que las truchas pequeñas y pálidas del lago de Ginebra se llenan de puntos rojos cuando remontan determinados arro. yos affuentes del Ródano, al paso que en otros se vuelven uniformemente verdes negruzcas, y finalmente que en otros continúan blancas. Colocadas en viveros 6 mas bien depósitos flotantes de madera, les salen a algunas en seguida pun tos pardos, otras se vuelven pardas en todo un costado ó con listas oscuras trasversales sobre el lomo, que desaparecen cuando los peces vuelven al agua fresca y corriente. Tambien se han encontrado truchas casi del todo incoloras, otras enteramente pardas, $y$ finalmente hasta moradas con reflejo metálico cobrizo. En una palabra, la variabilidad y multiplicidad de coloracion de estos peces son la desesperacion del nasuralista.

A menudo aparecen gran número de truchas incoloras 6 de color gris blanquizco en el lago de Sentis, que desagua en el interior de las montañas y que probablemente comuni. ca con un vasto depósito subterrínco de agua. A todo esto hay que agregar que si la coloracion general varia segun las circunstancias, no sucede lo mismo con la distribucion de los puntos y listas del dibujo, que es mucho mas constante. En la primera influyen, además de la constitucion quimica del agua, la estacion, la luz directa del sol y la edad. La trucha de arroyo adquiere una coloracion especial y subida cuando se acerca la época del cclo, su jaspeado se marca mas y tambien cambia el matiz segun las posturas y movi. mientos del pez, llegando a su máximo cuando sufre alguna excitacion súbita y extraordinaria. Agassiz atribuye el color constante á la Janinita córnea delgada que produce reflejos de luz, y el accidental y variable a los aceites que el orga. nismo va produciendo y depositando gota á gota y que son la verdadera materia colorante.

Las aletas ventrales y pectorales de la trucha comun, las de sus dos variedades constantes, el yuriardo (Salmo fario Gaimarai) y la trusina dib ho Leman (Salmo fario Auscrii), cuyos colores se han descrito, son muy anchas y redondea. das; la caudal varía de forma con la edad, siendo muy esco tada en los individuos jóvenes, achatada recta en los mas adultos $y$ hasta algo/redondeada convexamente en los vie. jos. Los machos difieren de las hembras casi siempre por su cabeza mas grande, dientes robustos y numerosos, pero co. lacados confusamente, y por la mandíbula inferior cuso extremo se alanga hácia arriba con la vejez. Segun Siebold, hay en la aleta dorsal tres hasta cuatro radios recios $y$ de nucre $\{$ diez y seis articulados, en la pectoral uno y doce, en la ventral uno y ocho, en la anal uno y siete ú ocho, y en la caudal diez y nueve. El tamaño varía como el color segun el punto de residencia; alli donde la trucha ha de conten. tarse con poca agua, como en arroyos pequeĩos y de cor. riente rápida, alcanza apenas $\theta^{\circ}, 40$ de largo y el peso de un kilógramo á lo sumo, mientras qৃue en aguas profundas, sean lagos 6 estanques, con abundancia de alimento suclen tener $0^{\circ}, 90$ con cinco á seis kilógramos de peso. Xarrell menciona varias truchas gigantescas, como un macho de $0^{m}, 73$ de largo y solo $5 \mathrm{r} / 2$ kilógramos de peso, y una hembra que media $0 ", 88$ y pesaba I 5 kilogramos. Heckel cuenta de una trucha cogida en el Fischa cerca de Wiener Neustadt, que tenia $\|^{*}, 9^{2}$ de largo, $0^{*}, 24$ de alto y i i kilogramos de peso, $y$ Valenciennes hasta habla de una cuya longitud era $z$ ",04. Unicamente los individuos que cuentan muchísimos años de existencia llegan a tener tan descomunales dimensiones; los pescadores creen que la trucha vive á lo mas veinte años, pero hay ejemplos que prueban que estos peces pueden vivir mucho mas: así por cjemplo, Oliver habla de una trucha que se conservó en los fosos de un castillo veintinueve años y que en tan largo trascurso de tiempo se habja domesticado muchísimo, y Mossop menciona otra que vivió en circunstancias análogas cincuenta y tres años.

DISTRIBUCION GEOGRÁFICA.-Las observaciones hechas y reunidas hasta hoy son insuficientes para fijar el área de dispersion de la trucha; $y$ solo se sabe que cxiste en Europa en todas las aguas á propósito desde el cabo Norte hasta el de Tarifa, además en el Asia Menor y probable. mente tambien en otros continentes.

USOS, COSTUMBRES Y REGIMEN,-La trucha necesita para su existencia agua cristalina, corriente y muy oxigenada; por esto se la encuentra en lodos los rios de montaña, y en los lagos alimentados por corrientes que los 
atraviesan 6 por abundantes manantiales interiores, porque en uno y otro caso se remueve el agua lo bastante para aumentar su contacto con cl aire atmosférico y de consiguiente la absorcion del mismo $\delta$ sea de su oxigeno. Los ensayos de cria artificial, tan numerosos de algun tiempo acá, han pro. bado suficientemente que la trucha inedra muy bien en agua clarificada y, por decirlo asi, batida, ya provenga de manantiales frescos, de arroyos 6 bien de estanques.

Segun Tschudi, encuéntrase la trucha en las cordilleras elevadas hasta la region alpina, en Suiza hasta la altura de 2,000 metros sobre el nivel del mar, porque alli empiezan ya las superficies de los lagos a estar cubiertas de hielo perpetwo, bien que vive todavia en el hermoso lago de Lucendro en el monte de San Gotardo, y del cual nace treinta metros mas abajo el Reuss, como igualmente en otros muchos lagos alpinos de Saboya, de los Alpes réticos, en el de Murg donde acaba la zona de los abetos, en el de Alp, debajo de la cumbre del Stockhorn, y en casi todos los lagos alpinos dentro de esta zona y en ambos lados de la cordillera, con tal que dichos lagos tengan un desagüe visible y no subterráneo. ¿Cómo ha llegado la trucha á estos lagos elevados que comunican con las corrientes inferiores solo por cas. cadas escarpadias? Solo se sabe fijamente de algunos donde fueron llevadas las primeras truchas por el hombre, como el Olegi de Arriba á I,400 metros sobre el nivel del mar, y el de Engstlen á I,Soo metros de elevacion y algunos otros. No cabe duda que la trucha es un pez vivaz, emprendedor y que salta admirablemente, segun se puede ver en dias calurosos en todos los sitios donde se encuentra, $y$ Sreinmueller asegura haber visto en la cumbre de Muertschen cómo una trucha se arrojaba de un brinco y dando un par de solteretas á la par. te superior de una cascada muy elevada; pero hay lagos poblados de truchas donde es materialmente imposible que hayan subido ni aun dando semejantes saltos deede las aguas inferiores. Por otra parte 10 puede negarse que el hombre ha contribuido á extender esta y otras especies de peces, pues antes de la epoca de la Reforma se procuraba con gran cui dado que no faltasen peces en la cuaresma y dias de ayuno, á cuyo fin se trasladaron muchas crias á lagos y estanques que carecian de ellos. En el Tirol sube la trucha a 300 y 400 metros mas que en Suiza, 5 en los arroyos de las sierras de Gredos y Nevada hasta a 3,000 metros sobre el nivel del mar.

En las corrientes de nuestras sierras medianas no se ha podido notar nada en las truchas que se parezca á traslacion sistemática. No muy léjos de mi putblo nacen en un vallo situado entre dos montañas de mediana elevacion, dos manantiales abundantes, los cuales se juntan en un arroyo que mueve un inolino y que luego desemboca en el Roda, cuyas aguas, muy turbias por lo comun, contribuye un poco a cla. rificar. Pues bien, en este arroyo viven iruchas desde tiempo inmemorial, pero solo en un trecho de ocho kilómetros a lo sumo; mas arriba 5 mas abajo solo se ve alguna que otra por casualidad, $\mathrm{g}$ además en la época de la freza se observa que remontan el Roda para desovar en su parte superior, siquiera no les falten sitios de los mas á propósito dentro del trecho del arroyyo que habitan. Se comprende que en las aguas cristalinas de las verdaderas corrientes de montana se extienda mucho mas el espacio en que se múven las truchas, pero jamás llegan estas á merecer el nombre de peces viajeros en la Alemania central. En Suiza no sucede lo propio, segun parece, pues hé aqui lo que dice Tschudi:

"Poco se sabe de fijo sobre la costumbre de las truchas de salir de sus lagos para remontar los arroyos, ni hasta dónde suben. Parece que husen del agua turbia que los glaciares envian á los lagos, y que prefieren el agua cristalina de los manantiales, porque tan luego como se enturbian los arroyos, cuando en marzo empiezan á derretirse la nieve y el hielo, estos peces los abandonan, como sucede por ejemplo en los afluentes del Ródano, de los cuales se alejan las tru. chas en masa en dicha época para trasladarse al lago de G:nebra, donde permanecen hasta el otono para abandonarlo á su vez en los ultimos meses del año é ir ả penetrar por el Ródano en sus afluentes donde se deshacen de su freza. En cambio, estos peces viven, y por cierto en gran número, en los lagos de los Alpes alimentados exclusivamente por las aguas que les envian los glaciares, y en arrosos que no tienen mas origen que el agua de nieve y de hielo. $\$$ Lo que se de. duce de estos datos de Tschudi es que las truchas se adap. tan á las circunstancias y cambian su género de vida segun las mismas, pero que se ignora la ley que preside a estos cambios, 6 lo que viene \& ser lo mismo, que no conocemos las causas verdaderas que los determinan.

Si hay algunas especies afines que arentajan á la trucha en destreza y rapider, no puede alabarse de ello ningun jez de agua dulce. Todas las observaciones concuerdan en que es pez nocturno, es decir, que solo al anochecer empieza á desplegar toda su viracidad, y que durante la noche se dedica á buscar su alimento. De dia le gusta ocultarse debajo de piedras y rocas salientes de la orilla, y en general en agujeros que forman las piedras, pero cuando reina el silencio en todo el contorno, viga tambien de dia por el agua, sicmpre de cabeza contra la corriente, en cuya posicion suele permanecer un cuarto de hora ó mas, inmóvil en apariencia, pero en realidad moviendo las aletas para conservarse en el mismo puesto, ó bien atraviesa de repente el agua como una sacta, siguiendo con admirable tino la mayor corriente, lo que la permite encontrar un camino en arroyos de tan poca agua que parece imposible pueda vivir en ellos. Cuando se la espanta, suele ocultarse corriendo en el primer escondrijo que puede, pues es uno de los peces mas cautos y ariscos que hay. Dos modos emplea para ir rio abajo, ó bien se abandona á la corriente con la cabeza dirigida hácia atrás, ó bien se lanza hácia adelante con tal fucrza que su velocidad re. sulta mayor que la del agua. Mientras está quicta, acecha $y$ vigila cuidadosamente al rededor el agua que tiene delante, la que pasa por su lado, la que está encina y el aire; no se mueve aunque se aproxime un insecto, hasta que llega á su alcance; pero entonces se abalanza como el rajo sobre la victima, atravesando la distancia que la separa de ella de uno ó varios coletazos vigorosos, ga dentro del agua, ya saltando fuera de ella. Cuando pequeña, caza con frecuencia insectos, gusanos, sanguijuelas, limazas, freza, pececillos y ranas, pero cuando ha adquirido ya un peso de un kilógramo ó mas, no hay pez carnicero de igual talla que le gane en voracidad, incluso el lucio, y embiste á todo animal que cree poder do. minar aunque sea su propia prole, sin renunciar por ello á los insectos y sus larvas acuáticas ni á los pequeños crustáceos que continuan formando la parte principal de su régi. men, sobre todo los primeros, los cuales le gustan tanto que llega a enflaquecer cuando se multiplican demasiado en sus aguas otros peces tambien aficionados á insectos, aun en el caso de que estos mismos peces constituyan uno de sus ali. mentos favoritos.

El periodo del celo de la trucha empieza á mediados de octubre y dura en ciertas circunstancias hasta diciembre. Cuando tienen solo la longitud de $0^{\circ}, 20$ y un peso de 150 gramos, ya son adultas y se hallan en estado de reproducirse, bien que muchisimas son entonces $\delta$ continúan siendo siempre esteriles y no desovan, porque segun Siebold, si bien existen las partes genitales en forma de testiculos y ovarios, son todavia impropias para la reproduccion. Las huevas de 
estas truchas estériles no pasan nunca del tam2noo de granos de mijo, $y$ en los mismos ovarios se ve que nunca han desprendido huevas. Fivera del tiempo de la freza se distinguen las truchas estériles de las que no lo son por su cuerpo mas corto, el lomo redondeado hácia los costados, las aletas me nos anchas y sostenidas por radios mas endebles; la hendi. dura de la boca, menos ancha, acaba debajo del ojo y no pasa mas allá; la cabeza es pequeña y no guarda la menor proporcion con cl cuerpo, mas rechoncho, porque al parecer no han llegado á su verdadero desarrollo ni los huesos de la mandibula, ni los opérculos, ni los ojos; ni se prolonga con la edad la sinfisis de la mandibula del macho que le distingue de la hembra cuando es fecundo. La cubierta escamosa continúa todo el año igual, to mismo que la verruga genital, ocuita dentro de su cavidad correspondiente. En cuanto coloracion y dibujo concuerdan las estériles con las fecundas, $y$ tambien es probable que su esterilidad sea solo tem. poral. Fn las truchas fecundas obsérvanse, además del au mento de volúmen de la verruga genital, cambios notables en la piel; las escamas del macho, especialmente las del lomo y del vientre, desaparecen debajo de un-desarrollo excesivo de la piel; una hipertrofia análoga cubre la base y borde anterior de la aleta anal, y los bordes superior é inferior de la caudal; dicho desarrollo epidérmiéo se observa tambien en las hembras cuando desovan, míentras que la hipertrofia de la piel es menos pronunciada y cubre solo en parte las escamas.

Las truchas depositan la freza sobre fondo guijarroso $\delta$ al abrigo de piedras algo grandes en sitios donde el agua es poca y de mucha corriente. Mientras la hembra busca un sitio á propósito, va seguida por lo comun de cierto número de machos jóvenes que acuden, no solamente para fecundar sus huevas, sino tambien para ver si las pueden devorar. Los pescadores aseguran que la hembra muestra preferencia á uno de ellos y rechaza à los demás, quizás porque sabe que cuando son numerosos corren mas peligro las huevas. Antes de efectuar la puesta abre la hembra, moviendo la cola, un hogo mas 6 menos profundo en el cual deja caer las huevas para ceder luego su puesto al macho que las rocia inmediatamente con un poco de sémen, y en seguida las cubre la hem. bra con un poco de arena con auxilio de la cola. Nunca pone la hembra todas las huevas de una vez, sino en varias y á intervalos, pero siempre en el espacio de ocho dias, de no. che y si puede ser cuando hay luna.

Al cabo de seis semanas, segun el estado de la atmósfera antes ó despues, salen á luz los pequerios que continúan mas ó menos inmóviles, es decir meneando solo los muño. nes de lo que será aleta pectoral, en el sitio donde nacieron, hasta que la vesicula vitelina queda reabsorbida y sienten necesidad de otro alimento. Entonces les bastan los animaJillos acuáticos mas diminutos; mas adelante comen gusani. llos, despues insectos y cria de otros peces, y á medida que medran va aumentando su rapacidad. A los tres meses se han trasformado los pequeños, en un principio informes, en pececillos proporcionados y airosos, cuya coloracion presenta listas trasversales pardas oscuras, y es mas tarde reemplazada por otra, como sucede con todos los salmónidos A esta mis. ma edad empiezan ya á separarse los hermanos de una misma cria, para buscar escondrijos y observar el género de vida de sus mayores.

ENEMIGOS. - Muchos enemigos acechan la cria de las truchas; antes de nacer la devoran los peces de otras espe. cies que habitan el fondo del agua, sobre todo las lotas. El cinclo acuático pesca algunas, y hasta la inofensiva aguzanieves las pica probablemente de cuando en cuando. Una vez salidos á luz los pequeños, se asocian á las lotas los denás peces rapaces, entre ellos las mismas truchas adultas, y despues, cuando los que han salido con vida de tantos peligros, empiezan á vivir à su vez de la rapiña, los acechan el mus. gaño, la rata de agua y la nutria como enemigos superiores á sus fuerzas.

USOS Y PRODUCTOS. - Es muy digno de notar que los antiguos, á pesar de ser tan gastrónomos, no hablen de la trucha, citada solo por Ausonio en su Mosela, de modo que es permitido suponer, 6 que no conocian este pez ó que no sabian apreciarlo como se merece. Algo mas tarde cobró la imprortancia á que le hace acreedor la delicadeza de su carne, porque Gessner dice: \&En todas las naciones goza la trucha de grandísima fama en cualquiera estacion que se coge, pero mas si es en abril ó mayo. No cabe duda de que es uno de los mejores peces de agua dulce, puesto que se le recomienda á cualquier enfermo como alinento saludable.

Las fundadas quejas respecto á la disminucion de los peces de agua dulce deben tambien aplicarse por desgracia á la trucha, pero media la ventaja de que es mas fácil repoblar con esta especie las aguas á propósito y cultivarla con méto. do y buen éxito; pues ninguna otra de la familia de los salmó. nidos ofrece iguales facilidades para la cria artificial como ella, que medra con la misma rapidez en estanques de manan. tiales abundantes que en arroyos; siendo su carne $\tan$. 5 saculenta que el précio de cuatroú seis pesetas el kilógramo segun la localidad puede pasar por muy aceptable.

\section{EL SALMONETE ROJO-SALMO SALVELINUS}

CARACTERES. - El cuerpo de este pez es prolongado y comprimido lateralmente, pero sujeto â muchisimas varjaciones segun la edad, el sexu y la morada; las aletas son bas. tante largas, las ventrales se hallan debajo de la dorsal y la anal conserva aun en los individuos mas vicjos su forma escotada. En la placa anterior del vómer hay de cinco á siete dientes encorvados, y en el mango se observa una placa longitudinal guarnecida de muchos dientes pequeños. En cuanto a coloracion, varia este salmonete de una manera extraordinaria, pero la mas frecuente es segun Siebold la siguiente: El color gris azulado del lomo pasa en los costados insensiblemente á un blanco mas ó menos amarillento, y este en el vicntre á rojo anaranjado muy vivo, sobre todo en la época del celo. A menudo presentan en los costados manchas claras redondeadas que cerca del vientre, segun la coloracion de este, son blanquizcas, ó amarillentas, ó anaranjadas; estas manchas se repiten á veces en la parte inferior de la aleta dorsal; $y$ cn los peces pequeños pueden llegar á tocarse formando un dibujo jaspeado. El color anaranjado del vientre puede pasar a bermellon, y el del lomo á verde pardo oscuro. La aleta dorsal está sostenida por tres y nueve ó diez radios, la pectoral por uno 8 doce hasta quince, la abdominal por uno y ocho, la anal por tres y ocho $\delta$ nueve, y la caudal por diez y nueve. El salmonete rojo puede alcanzar una longitud de $0^{n}, 80 \mathrm{y}$ un peso de diez kilógramos, si bien por lo regular no pasa de $1,7,30$ y el peso de unos quinientos gramos.

Algunos ictiólogos reconocian $\delta$ reconocen diferentes es. pecies, no solamente entre los salmonetes rojos segun los lagos y paises donde se producen, sino tambien entre los de una misma comarca; pero poco á poco va prevaleciendo con justicia la opinion de que no existe diferencia alguna que autorice dicha separacion entre los salmonetes rojos de Suiza, Baviera, Austria, Escandinavia, Laponia, Finlandia 6 los que proceden de aguas análogas de la Gran Bretaña

Sucede con estos lo que con los demás salmónidos, estoes, que ciertos distintivos se hacen hereditarios y pueden inducir fácilmente á errores de esta clase, preto ahora se sabe que 
la situacion de los lagos entre montañas mas ó menos eleva. das $\delta$ distantes, asi como la profundidad y limpidez de las aguas, ejercen cierta influencia en la coloracion y aspecto de estos peces.

DISTRIBUCION GEOGRÁFICA.-LOS salmonetes to jos se crian en los lagos alpinos tanto de la Europa central como del extremo norte, en los que se hallen encerrados en tre las montañas de la Rusia septentrional y de la Escandinavia; pero solo en verdaderos lagos de montaña hasta la altura de dos mil metros sobre el nivel del mar, no abandonándolos por lo regular ni siquiera en el tiempo de la freza para remontar los rios que en ellos desembocan.

USOS, COSTUMBRES Y REGIMEN.-A semejanza de los rencos viven los salmonetes rojos en las profundidades de las aguas que los producen, y como aquellos, aliméntanse principalmente de animales pequeños, con preferencia de diferentes cangrejos parásitos. Linneo, que ignoraba esto, tenia razon en admirarse de que viviesen en los lagos muertos de Laponia como únicos animales de su clase, lo que no obsta para que tambien coman peces pequeños alli donde los encuentran, y acaso constituyen estos el alimento princi pal de los salmonetes majores.

El perfodo del celo empieza á fines de octubre y dura todo cl mes de noviembre y mas quizás, segun la localidad. Entonces suben á la superficie y depositan su freza en sitios de poca agua a la orilla; pudiendo suceder tambien, segun Yarrell, que en ciertas circunstancias entren en los rios y los remonten hasta distancias muy considerables para efectuar allf la operacion del desove, y aun hay casos, si bien raros, en que toman la direccion opuesta; pues Yarrell asegura, que los salmonetes rojos abandonaron cierto lago despues de haberse dirigido al mismo las aguas sucias de unas minas de coore, y que bajaron por las corrientes alimentadas por el lago hasta el mar donde se cogieron varios. Son peces que se multiplican mucho, pero que crecen con menos rapidez que las truchas, con las cuales suelen vivis en las mis mas aguas aunque sin aparearse espontáncamente con ellas; pero hace poco se han obtenido mestizos por medio de la piscicultura, merced á la cual se han repoblado tambien no. tablemente algunos lagos. Se atribuyen a estos mestizos de trucha y salmonete cualidades muy superiores á ambas espe cies, como por ejemplo un desarrollo mas rápido que el de estos últimos y una carne mas suculenta que la de las primeras.

PESCA. - Por regla general se pescan los salmonetes rojos en el tiempo de la freza con red de jorro cuyos extremos son remolcados á tierra por dos lanchas tripulada cada una por dos remeros, con lo cual se obtiene á menudo una co secha mus abundante.

USOS Y PRODUCTOS. - I,a carne de estos peces es superior á la de las mejores truchas y á la de todos los peces de agua dulce en general. Cuando los benedictinos de Ad. mont en Estiria renunciaron á todos sus derechos de pesca en aquel pais, seserváronse expresamente todos los lagos donde se crian salmonetes rojos; y el que haya probado estos peces comprenderá en seguida la importancia de semejante dispo sicion. Para paladares finos es tan superior este pez à la trucha como esta al salmon, lo cual explica porque hasta en los Alpes, donde tanto abundan las truchas, se paga el salmo nete rojo con gusto de razon de cuatro $\mathfrak{a}$ siete pesetas y media el kilógramo.

Heckel y Kner dicen que estos peces tienen bastante vitalidad para quesea fácil, no tan solo trasladarlos de un lago á otro, sino tambien que medren mas en el nuevo que en el antiguo. I.os ha habido que sacados de un lago situado a 1,300 metros sobre el nivel del mar, y trasladados a otro del Elm, alcanzaron en poco tiempo un peso de dos kilógramos, y ex. cedieron muy luego en tamaño a los de su lago natal. He aqui otra prueba de que la cria repetida en unas mismas aguas produce individuos raquiticos.

\section{EL HUCO - SALMO HUCHO}

CARACTERES. - El cuerpo de este salmon es prolongado, cilindrico, y en el dorso de color pardo oscuro verdoso ó gris azulado, que pasa imperceptiblenente al blanco plateado en el vientre. El tronco y la cabeza están cubiertos de punti. tos negruzcos ó de un gris oscuro mas ó menos numerosos, entre los cuales, especialmente en el occipucio, opérculos y lomo, se ven manchas mas grandes y negras que hácia el vien. tre y la cola toman poco á poco la forma de media luna Fl color general se trasforma en los individuos muy viejos en un encarnado pálido. Las aletas son blanquizcas, y carecen de manchas, el color de la dorsal y caudal es algo oscuro. El número de radios es en la dorsal cuatro y nueve hasta diez y seis; en la pectoral uno y catorce hasta diez y seis; en la abdominal uno y ocho ó nueve; en la anal cuatro 6 cinco y siete hasta nueve, y en la caudal diez y nueve. La longitud llega a $i^{m}, 50$ hasta $2 " y$ cl peso à 20 hasta 50 kilógramos.

DISTRIBUCION GEOGRÁFICA.-Pallas dice que este pezse encontraba tambien en los rios que desembocan en cl mar Caspio, pero los observadores modernos solo le conocen como pez propio de la cuenca del Danubio, y dudan que vaya al mar, siendo muy probable que se limite su área a dicho rio y á aquellos de sus afluentes que bajan de los $\AA 1$. pes. Es verdad que se le ha cogido alguna que otra vez en los rios que descienden del norte para desembocar en el Danubio, pero son casos excepcionales. Quizás suba en la época de la freza del rio principal á los afluentes, pero en este caso los remontará dificilmente mas allá de una elevacion de 1,000 meiros sobre el nivel del mar.

USOS, COSTUMBRES Y REGIMEN. - Este pez no desmiente en sus costumbres su naturaleza de salmon, solo que aventaja á todos sus congéneres en voracidad, conforme corresponde por otra parte a su mayor talla. Davy encontró en un huco que habia pescado, un orfo, un timalo, dos alburnos y dos carpas pequeñas; $s$ á Siebold le contaron los pesca. dores que mas de una vez habian encontrado ratas de agua en el estómago del huco.

Desova en los meses de abril y mayo, pero si el tiempo es favorable empieza en marzo, en lo cual difiere de sus congé. neres. Cuando se acerca esta época abandona el pez las cor rienies fucrtes que es donde mas le gusta estar, y busca sitios de muy poca agua con fondo guijarroso 6 siliceo cerca de la orilla. Alli escarba con la cola abriendo hoyos donde deposi. ta la freza con tanto afan que se vuelve ciego y sordo para todo lo demás, hasta el punto de que puedan pasar las lanchas por encima de el sin ahuyentarle. Los pequeños crecen rápidamente y pueden reproducirse cuando llegan a tcner un peso de dos kilógramos.

USOS Y PRODUCTOS.-La carne es blanquecina y no tiene el mérito de la del salmon, ni se aprecia anto conso la de la trucha asalmonada. Se coge este pez con grandes redes, con anzuelo, con fisga y, cuando se está quicto en el fondo, se le tira tambieri con bala. Dayy dice que es pezinteligenie y espantadizo, y que no muerde dos veces el anzuelo, por cuya razon solo pucde cogerse en la época de la freza, $y$ en otoño, pero no en verano.

Si no fuera tan voraz y cazador, y no sucumbiera con gran facilidad á cierta enfermedad cutánea muy frecuente entre los peces, seria, segun dicen Heckel y Kner, pez.muy propio para la piscicultura, porque el agua pura de las montañas no 
le es absolutamente necesaria, puesto que se sabe que prospera muy bien en estanques con tal que el agua se vaya re novando continuamente. Para esto se ha de hacer el traslado en invierno, y los pequeños no han de pesar mas de 500 gramos, esto si no se prefiere incubar directamente las huevas. Valiéndose de cria del peso indicado, aumenta en mas de un kilógramo al año y mas aun á medida que crece, mientras no le falte alimento, es decir: gobios, alburnos, dóbulos, carasios, escardinios y otros ciprinidos de poco valor.

Todos los ensayos de aclinatacion del huco en otros rios no han dado hasta ahora mas que resultados negativos.

\section{LOS OSMEROS-OSMERUS}

CARACTERES. - Dificren los peces de este grupo de las especies anteriores de la misma familia por la dentadura y la cubierta escamosa. La mandibula superior é intermaxilar tienen dientes muy finos colocados en hilera simple; mientras que la inferior lleva una hilera exterior de dientes mas grandes y otra interior en que los hay mas robustos; o:ros mas fuertes y puntiagudos guarnecen el vómer, el pa. ladar y las aletas del hueso palatino. Ias cscamas son me. dianas, endebles y poco adheridas a la piel.

\section{EL EPERLANO-OSMERUS EPERLANUS}

CARACTERES.-El perfil del cuerpo y de la cabeza, el tamaño y el color de este pez están sujcios á tantas variacio. nes, que Bloch formó con ellos dos grupos, que en el dia se reconocen como verdaderas especies distintaș. Ellomo es por lo regular gris, los costados plateados con reliejo verdoso ó azulado, y el vientre rojizo. En la aleta dorsal se cuentan tres y siete $u$ ocho radios; en la pectoral uno y nueve 6 diez; en la abdominal dos y sicte; en la anal tres $y$ once hastatre. $c e, y$ en la caudal diez y nueve. Ia longitud oscila enire $0^{\circ}, 13$ y $0 \%, 20,5$ llega en casos excepcionales hasta $0^{\circ}, 255$ $0^{\circ}, 30$.

DISTRIBUCION GEOGRAFICA.-LOS mares donde al parecer es mas frecuente este pez son el del Norte $y$ el Báltico; en el canal de la Mancha no es raro, y aun se ba aclimatado en mayor 6 menor número en los alfaques de Prusia y en muchos lagos grandes de agua dulce.

USOS, COSTUMBRES Y REGIMEN. - Los eperlanos marinos difieren de los de agua dulce por su major talla y ciertas particularidades en su género de vida. Unos y otros se ven en Alemania en número muy variable segun los años, pero donde suelen presentarse siempre con mas frecuencia es en las desembocaduras del Elba y del Weser, rara ver. en las costas de Holstcin, Meklemburgo y Pomerania; en cam. bio son numerosisimos en el alfaque de Kur en la misma costa del Báltico, cuya laguna visita tambien el eperlano de rio que puebla los lagos de agua dulce de aquella parte de Prusia, de Pomerania, provincia de Brandenburgo, Meklem. burgo y Holstein, sin visitar en ninguna parte mas que alli el agua salada. Ambos eperlanos forman bandadas numerosas; se ocultan durante el invieroo en los sitios profundos para aparecer en marzo y abril en las capas superiores y remontar los rios con el fin de desovar; y si bien no los remontan hasta una region elevada, como hacen los salmones, no de. jan de penetrar hasta muy adentro del pais, como por ejem. plo en el Elba hasta Anbalt y Sajonia, en el Weser hasta Minden, y en el Sena hasta Paris. Hay años en que se presentan estos peces en cantidad innumerable en los alfaques y desembocaduras de rios, mientras que en otros apenas se ven algunos, sin que se sepa á qué atribuir esta anomalia. Beerbohm dice que cuando se presentan los eperlanos muy numerosos en el alfaque de Kur para visitar sus puestos de desove, se retiran todos los demás peces, á excepcion de las anguilas y de los carasios. A principios de abril empiezan los eperlanos la puesta, depositando sus huevas pequeñas y amarillas en sitios arenosos para volver los unos al mar y los otros á sus lagos del interior. La incubacion adelanta mucho mejor cuando el agua experimenta una crecida permanente; cuando se retira, quedan miles de millones de huevas sin incubar. Los pequeños que nacen siguen en agosto las hue. llas de los viejos; pero si son eperlanos marinos, segun dice Yarrell, pasan una temporada en las desembocadiras, penetrando con la marea alta en los rios y volviendo con la baja al mar.

PESCA Y PRODUCTOS. - Cuando los eperlanos remontan los rios, se les coge muchas veces en cantidades increibles é inundan entonces los mercados, donde encuentran siempre compradores, gracias á lo sabroso de su carne y los pepinos podridos. La pesca se hace de muchas maneras y siemprecon bu'en éxito, puesto que estos peces se presen. tan en masas tan incalculables que cualquiera red de malla angosta es buena. En Pomerania se paga el kilógramo de eperlanosádos y raedio hasta cuatro céntimos de peseta, pero en las demás provincias de la Alemania del Norte sube hasta 15 yaun' 5 clentimos, y cn algunos puntos alcanza ${ }_{3} S$ centimos y entonces es esta pesca muy productiva; en cambio hay ocasiones en que es tan abundante, que el precio baja hasta el punto de no poderse colocar estos peces á medio céntimo el kilógranio, $y$ hande venderse por último pasa abo. no de la tierra. Mas beneficio se saca de esta pesca si se echan los eperlanos vivos todavia en los estanques donde se crian peces de mas mérito, para servirles de alimento; y los experimentos hechos en Inglaterra prueban que medran asi perfectamente y que sus afines de mayor talla ú otros peces carniceros útiles los devoran con mucha codicia.

\section{LOS LODOS-MALLOTUS}

CARACTERES. - Forma oblonga, escamas pequeñas, aletas pectorales muy grandes y redondeadas, dorsales colo cadas muy hácia atrás, y las mandibulas, el paladar y lengua con dientes endebles de cerda: tales son los caractéres de este género.

\section{EL CAPELAN-MALLOTUS VILLOSUS}

CARACTERES.-Esta especie, representante del géne. ro Mollotus, es una de las mas pequeñas de la familia de los salmónidos. El color del lomo es verde oscuro con reflejo pardusco, los costados y el vientre son blanco de plata salpicados de negro; las aletas grises orilladas de negro. El na. cho y la hembra difieren notablemente: el primera es esbelio, cabezudo y su hocico punciagudo. En el perlodo del celo le sa. le de los costados un fteco longitudinal de color verde oscuro formado de jirones largos, puntiagudos, semejantes ả mecho. nes 6 greñas que brotan de la membrana epidérmica. I a hembra es mas corta y su hocico obtuso. En la aleta dorsal se cuentan catorce radios, en la pectoral diez y nueve, en la abdominal ocho, en la anal veintidos, y en la caudal muy bifurcada veintisiete. La longitud oscila cntre $0^{m}, 14$ y $0^{\circ}, 18$.

DISTRIBUCION GEOGRÁFICA.-Este pez habita los mares septentrionales entre los grados 64 Y 75 de latitud; es muy conocido en las costas de Finnmark, Islandia, Groen. landia y en el banco de Terranova, donde acude en la épo. ca de la freza en cantidad verdaderamente maravillosa.

USOS, COSTUMBRES Y REGIMEN.-El capelan vive 
durante el invierno, á semejanza de los demás salmónidos, en la profundidad del mar que abandona en marzo para desovar en puntos de poca agua, pero en número tan crecido que forma bandadas, ó mejor dicho, bancos de una longitud $y$ ancho de 50 millas inglesas (So kilómetros $\delta$ I 6 leguas de ancho y largo). Estos ejércitos penetran en masas compactas en todas las bahias y desembocaduras de rio, tiñendo las ca pas superiores del agua de amarillo con sus huevas de este color, que arrojadas en masa á la orilla, forman frecuentemente grandes montones, mientras que los peces se dejan sacar literalmente á millones con una bolecha pequeña y sirven álos pobres habitantes de Grocnlandia de alimento, constituyendo poco menos que su pan diario. En Noruega no es asi; alli se desprecia el capelan ya por su pequeñez, ya por su olor repugnante; en Islandia se come fresco cuando no hay otros peces, pero en Groenlandia lo secan al aire y lo guardan como provision importante para el invierno. La principal utilidad estriba en su empleo como cebo para la pesca del abadejo. Gaviotas, golondrinas de mar, lobos tna. rinos y todo un ejército de peces de rapiña de todas clases siguen á estos bancos de capelanes y se alimentan exclusivamente de ellos mientras dura la época del desove. En el banco de Terranova se pesca la mitad de todos los abadejos con cebo de capelan, y además de los millones de estos peces que se invierten en tal objeto, se salan y secan al sol, se cmbalan y almacenan otros millones para destinarlos mas tarde al mismo uso.

\section{LOS RENCOS - COREGONUS}

CARACTÉRES.-Este género comprende salmónidos de talla pequeña y mediana, con cuerpo un tanto comprimi.

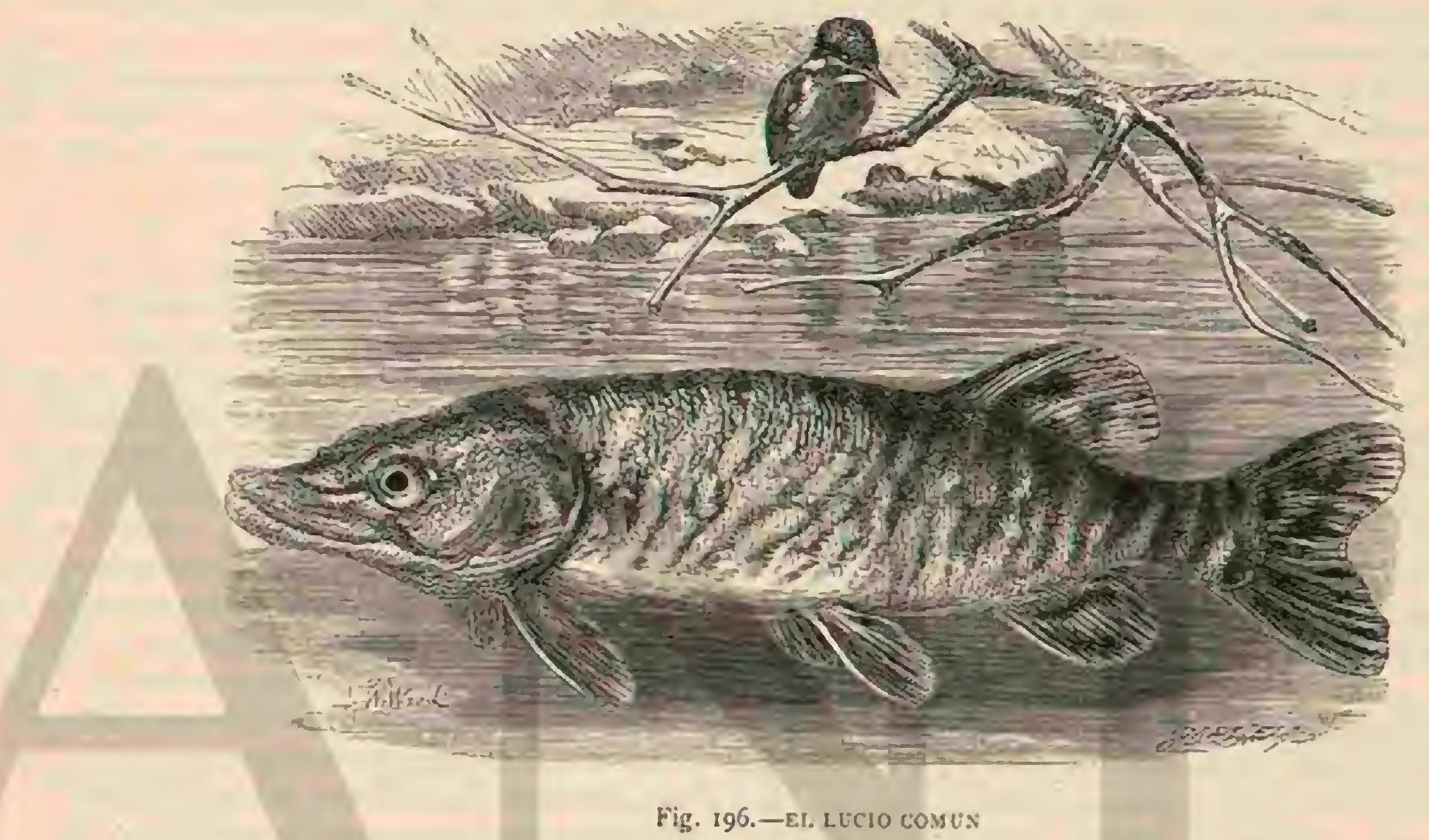

do; boca pequeña, angosta, armada de dientes muy finos y transitorios, $\delta$ sin ellos; escamas medianas y poco adheridas; alcta adiposa reducida, $y$ la dorsal muy alta que principia un poco antes de las abdominales. A pesar de los estudios mas concienzudos, no es posible todavia separar cun jlena segu. ridad las diferentes especies y variedades de los peces que componen este grupo $y$ que en número notable pueblan las aguas del hemisferio boreal.

DISTRIBUCION GEOGRÅFICA.-Seis especies por lo menos viven en Alemania. Los rencos que habitan los la. gos de Inglaterra, Escocia, Irlanda, Escandinavia y Rusia se consideran en su mayor parte como especies distintas de las alemanas.

USOS, COSTUMBRES Y RÉGIMEN. - Ia viỏa ocul. ta de estos peces, que solo abandonan las profundidades donde habitan en una época determinada para deshacerse de la freza; la dificultad de coger los pequeños, y la semejanza de especies reconocidas como tales, explican sufi. cientemente la reserva prudente que muestran ahora nues. tros naturalistas cuando hablan de los rencos. En lo que sigue adopto los estudios de Siebold, limitándome à aquellos miembros europeos del grupo que este autor considera como especies; antes, empero, creo conducente mencionar algunos rencos propios de Siberia, porque se los tiene por los peces mas importantes del Asia seprentrional, y servirán de este Tomo $\mathrm{V}$ modo para hacer mas patente la importancia que este género tiene para la industria pesquera y el comercio.

\section{LOS RENCOS DEL NORTE DE ASIA}

El poderoso Ob y sus afluentes son los rios donde los rencos desempeñan el papel mas importante. Este caudaloso rio es la patria de miles de millones de peces; pero proporcionalmente a su volúmen de aguas y a la extension vastísi. ma de su cuenca y red hidrográfica, es reducido el número de especies. En cuanio a salmones propiamente dichos, hoy encontramos la trucha-renco (Salmo coregunoides) junto con el timalo (Thymallus amlgaris) en los lagos y riachuelos del Altai; mas por lo que hace á los rencos ya es otra cosa; alli pueblan en número infinito el Ob y el Irtich desde el golfo del primero de estos rios, hasta los afluentes mas superiores, particularmente las especies inlma (Coregonss leucieththys of Nielma), el siroume (Corganus Sirok), el moksun (Coregonus Mussun), el chácor (Coregonus nasus) y el sicid (Cureronus Merkii); sobre todo las primeras que alcanzan un tamaño considerable $y$ son de la major importancia para la industria pesquera de aquellos paises.

USOS, COSTUMBRES Y REGIMEN. - Cada año, antes ó despues del deshiclo, empiezan los rencos su viaje renontando en bandadas innumerables el rio, quedaindose 
algunas al parecer en los primeros afluentes y continuando otras hasta la parte mas elevada de la cuenca, donde llegan a últimos de verano; entonces proveen a su reproduccion y vuclven lentamente i su morada de invierno, que se ignora todavia si es el mar Glacial 6 el golfo del Ob; en favor del primero está el número infinito de estos peces, y en el del último su preferencia á las aguas dulces ó cuando menos poco saladas. Es positivo que solo emprenden estos rencos el viaje, que para algunas secciones viene á ser de $7,000 \mathrm{ki}$. lómetros entre ida y vuelta, con el fín exclusivo de su repro. duccion, $y$ de ninguna manera para buscar nuevos alimen tos, porque muchos sucumben durante el viaje extenuados por el desove y la falıa de alimento, a pesar de no ser absoluta su abstinencin durante el tiaje, conforme se sabe por el exámen de los que se cogen y que alguna vez lienen el estó mago lleno de sustancias varias y en especial de conchas pequeñas. Lós naturales de aquel pais no atribuyen á estas causas, tan fatalcs a otros muchos peces, la inmensa morta. lidad que diezma en determinados años los rencos durante su viaje, sino á, lo que llaman ala muerté del rio, enten. diendo que el agua del $\mathrm{Ob}$ y de sus afuéntes, cubierta de hielo, de corriente perezosa y saturada con exceso de mate. rias solubles, se corrompe y mata los peces. Asi creen tambien que los rencos suben por los rios hiyendo de la heluga que pérsigue sus bandadas hasta muy al interior. El viaje de los rencos depende de la temperatura del agua, por cuya razon no ocurre siempre en la misma época; si el deshielo sobreviene temprano, sucede í veces que los rencos no solo efectuan su viaje por debajo de la capa helada, sino tambien por el agua que rebasa y corre entonces por encima, donde mucren miserablemente cuando vuelve á congelarse. Mu. chos ostiacos curiosos creen haber observado que el hiclo levanta en masa $y$ arroja á la orilla en determinados sitios fijos muchas bandadas de rencos, siempre de las mismas es. pecies. Cuando el deshielo va seguido de lluvia fuerte y per. sistente, apresuran los rencos su viaje mucho mas de lo que conviene á los pescadorés; lo contrario sucede cuardo llueve poco. La aparición del beluga es para los rusos y ostiacos la señal de la aproximacion de los rencos; este delfin es a sus ojos el precursor obligado 6 cuando menos infalible de dichos peces, por cuja razon no le persiguen, lo cual sabe el animal muy bien, puesto que apenas se aparta cuando llega una lancha de pescadores, y la presencia y trabajo del hom. bre no le interrumpen lo mas mínimo en sus ocupaciones. Los pescadores prácticos por una larga experiencia aseguran que cada año visitan en verano las aguas del Ob inferior unas cinco à seis tribus de este delín, compuestas de unos cuarenta individuos; que todos se mantienen en el centro de la corriente principal al igual de los peces emigrantes mas robustos, mientras que los mas débiles y jórenes siguen â lo largo de las orillas, por cuya razon se pescan tambien estos úlitimos en cantidades fabulosas tanto mayores cuanto mas cerca del golfo se trabaja; siendo, por el contrario, mas con. siderable la pesca de rencos grandes en la parte superior del rio. La retirada empieza generalmente á fines de agosto, pero entonces se subdividen estos peces en grupos reducidos y mas mezclados. En otoño siguen â los pequeños, que hasta entonces pueblan en grandes masas todos los rios y arrojos de escaso caudal, y todos los sitios de poca agua que comu nican con el rio principal.

PESCA. - Toda la poblacion de Sibcria de origen ruso se ocupa en la pesca, cuando no todo el año por lo menos en verano, es decir, mientras.las aguas están libres de hielo: pero los ostiacos $y$ samoyedos pescan tambien en invierno debajo del hiclo, el cual casi siempre tiene un espesor que hace imposible el empleo de redes, y solo algura que otra vez permite el uso de nasas y buitrones; asi es que hasta des. pues del deshielo no empieza el verdadero movimiento á orillas del rio, y desde Tobolsk hasta Obdorsk se aprestan á la pesca todas las poblaciones grandes y pequeñas. La primera de las ciudades citadas es la que suministra el mayor contingente de hombres $y$ de barcas; Berosoff y Obdorsk se quedan casi desiertas, pues mas de la mitad de los hombres y una importante fraccion de la poblacion femenina de am. bas abandonan sus moradas para dedicarse en algun punto à la pesca

Entonces bajan por el rio desde Tobolsk barcas grandes, toscas, informes y apenas manejables, muchas de ellas carga. das de toda clase de géneros que sus dueños esperan vender a los ostiacos y samoyedos; los remeros, gente alquilada para todo el verano, porque se necesitan tambien para la pesca, no hacen mas que tener la barca en la corriente y dejarla varar cuando llegan al punto destinado, donde echan el ancla para aseguratla. En seguida se ocupan todos los brazos en levantar tinglados para depositar los peces que se cogen y cabañas para la gente. Estas construcciones no son tan sólidas como las hechas con troncos de árboles, conocidas con el nombire de blirkhaus, que son tan comunes en Rusia, ni ofrecen comodidad alguna, sino tan soln el abrigo puramente indispensable contra la intemperie; las que tienen alguna rentana con vidrios, y acașo hasta una estufa, son ya vivien. das de lujo, que demuestran la posicion desahogada de su dueño. La mayoría no viene á ser mas que un espacio vacio formado por paredes toscas trenzadas de mimbres, y con un misero techo de corteza de abedul; otras reces no tiene el empresario mas albergue que su barca rústica, mientras que los braceros se recogen en una choza en forma de horno y tan baja que sola pueden moverse dentro á rastras, y que sentados sobre ramas de sauce y matas de romero, tocan con la cabeza al techo. En casos excepcionales completa las construcciones un establo para una vaca y algunas gallinas. Tan misera condicion sc explica por la necesidad de vivir a la mayor proximidad posible del rio ó de una arenca como alli lo llaman, y que significa un trozo de playa arenosa, llana, sin charcas, ni lagunas, ni peñascos, con piedras grandes ó troncos de árboles abandonados por las avenidas, puesto que los rusos no pescan en otros sitios, y como estos suelen ser propiedad de los indigenas que no sufren ninguna merma en sus derechos, y por otra parte están sujetos á grandes varia. ciones é invasiones de las aguas del rio, 6 se hallan situados accidentalmente en islas que quedan sumergidas en las avenidas, resulta que solo en casos muy extraordinarios seria prudente erigir construcciones sólidas y duraderas.

Las condiciones que se estipulan entre el empresario y el propietario de la arena varian segun las circunstancias. Si el primero lleva sus braceros, se obliga à pagar al segundo una cantidad en dinero por el arriendo de la arena y pesca, ade. más del pescado y á veces tambien del pan que este y su familia puedan consumir, de lo cual suele indemnizarse el ar. rendatario vendiéndole aguardiente y otros géneros á precios para él tan ventajosos que contrabalancean por completosus obligaciones. Otro sistema mas favorable es el de cuenta y mitad; en este caso paga el propictario á cada sociedad de. pescadores una suma determinada por toda la campaña, y les facilita la redaja, verdadera traina de ciento cincuenta brazas, recibiendo en cambio la mitad de todos los peces que se cogen y que han de pasar de $0^{*}, 25$. Los pescadores indi. genas que acuden tambien, levantan sus chozas de corteza de abedul, llamadas chum, á alguna distancia del campamento de los rusos, cuando no habitan cerca en algun blockhaus sobre un arenal al abrigo de las invasiones del rio.

Tan luego como el nivel del agua, que las masas de nieve 
derretida habian hecloo subir, ha bajado bastante para poder trabajar con la traina, empieza la pesca, á la que se dedican los rusos durante el verano en todos los puntos del Ob inferior, siempre de la misma manera. I a red barredera y de tiro tiene por término medio una longitud de 160 metros, de $0^{*}, 05$ hasta $0^{n}, 07$ de ancho cada malla, y fota sostenida por boyas de corteza de álamo blanco $\delta$ de tabla, adaptándola á las irregularidades del fondo por medio de rainas y pesos de barro cocido hechos para el caso y metidos en bolsas de la citada corteza. Segun las dimensiones de la red se necesitan para su manejo de cuatro á veinte hombres, por término medio de ocho á doce. Estos llevan la red plegada en una barca bastante grande al extremo superior de la playa, y alli uno de los hombres fija la punta en la arena con un chuzo, los demás bogan hảcia la orilla opuesta, sumergiendo el resto, cuyo extremo, abandonado á nuerced de la corriente, describe una curva encerrando cierto número de peces; as! lo llevan á la parte inferior de la playa donde saltan con êl en tierra, tirando hasta que una bolsa adaptada junto a la cola primera llegue \& ser el centro; entonces se sacan las dos co. las á tierra, y se vacia el contenido de la bolsa en un bote que lo lleva inmediatamente al depósito, en tanto que los demás hombres repiten la misma operacion. De esta suerte ran trabajando noche $y$ dia mientras dura el paso de los pe. ces, hasta que al terminar estc, solo se hacen cuatro 6 cinco pescas al dia, y despues las suspenden definitivamente.

Los ostiacos pescan tambien con red de tiro, pero con otra especie de jorros bolsa muy particular, $y$ además con nasas que saben hacer y manejar muy bien, y finalmente con presas portatiles $\delta$ mas bien vallas de mimbres que cierran pequeños brazos del rio hasta dejar solo una abertura angosta por la cual los peces han de pasar para meterse en nasas $y$ buitrones.

Los peces que los rusos cogen 6 compran, son inmediata y metódicamente preparados, cortados y salados; los ostiacos y samogedos cortan tambien los suyos, pero los secan al aire, s unos y otros consumen no pocos guisados ó crudos en el sitio de la pesca. Ni los rencos salados ni los secados al aire son cosa exquisita; tan suculentos como son guisados cuando frescos, tan sosos son despues de curados; a lo cual debe tambien contribuir no poco la sal recogida en la estepay llena de impurezas como sulfato de magnesia y de sosa, y mas todavia el poco cuidado que se tiene en la preparacion y cura De los higados, que alli se comen tambien en gran cantidad crudos con el mismo gusto que nosotros comemos las ostras, se saca un aceite excelente, y otro inferior de los demás intestinos despues de dejarlos corromper; aquel y a reces tam bien este sirven á los ostiacos y samoyedos de condimento, ya coman pescado seco ó pan tostado.

En las poblaciones ribereñas del Irtich se conscrva en es. tanques hasta el invierno una parte de los rencos cogidos en otofio; entonces los vuelven á pescar, los embalan con nieve en trineos, $y$ despues de rociar estos $y$ los peces con agua que al momento queda helada, lo trasforman todo en una sola mole de hielo que se remite asi hasta Moscou y San Pe. tersburgo. Si quisiesen podrian enviar los peces de este modo mucho mas léjos, por ejemplo hasta Alemania, conforme se ha probado ya con completo éxito, esto es, sin desmercecr el género.

USOS Y PROVECHO.-La pesca de rencos es, à pesar del precio por demás infimo de estos peces, un ramo impor. tantisimo de la riqueza de Siberia, pues dificilmente bajará su valor anual de un millon de rublos, suma que podria du plicarse y triplicarse, si alli se determinasen á curar estos pe. ces exquisitos, ya sea salándolos, ya ahumándolos, $\delta$ poniéndolos en conserva de un modo mejor de como lo hacen, a fin de que pudiesen conquistarse nuevos mercados, pero acaso no cste distante el tiempo en que comamos en Alemania rencos de Siberia bien curados y apetitosos, lo que no contribuirá poco á aumentar todavía mas la justa fama y aprecio que gozan las especies europeas de rencos ả cuya descripcion paso ahora.

\section{E.L RENCO COMUN-COREGONUS WART- MANNI}

CARACTERES. - Es el mas oblongo de los rencos que viven en las aguas alemanas; la cabeza es relativamente baja y pequeña; tiene el hocico delgado y achatado verticalmente en la punta; la abertura bucal es pequeña y está desprovista de dientes, salro los de púa muy finos que guarnecen la lengua; la aleta dorsal es mas alta que larga, y escamas grandes, finas y poco adheridas forman la cuhierta. La coloracion es azul clara con brillo de plata en la cabeza y lomo, plateada solamente en los costados de la cabeza y en el vientre; la linea del costado está punteada de negro, y las aletas son de un blanco amarillento con una orla negra y ancha. El número de radios es respectivamente en la dorsal cuatro $y$ diez i once, en la pectoral uno y catorce ó quince, en la abdominal dos y diez ú once, en la anal cuatro y once a doce, y en la caudal diez y nueve. En cuanto à longitud puede llegar ś $\left(1^{\circ}, 75\right.$, y respecto á peso, a dos ó tres kilógramos. Además hay que notar que ni la forma ni la coloracion de este pez son fjas.

DISTRIBUCION GEOGRÁFICA.-El renco comun se encuentra en casi todos los lagos mayores de Suiza, Bavicra y Austria situados en la pendiente septentrional de los Alpes $y$ de sus ramificaciones, faltando por completo en algunos como en los lagos Konigsee y Schlier; por otra parte viven rencos en los lagos de Suecia y de la Gran Bretaña, que bien podrian ser de la misma especie, aun cuando los ictiólogos de aquellos paises los clasifican aparte.

USOS, COSTUMBRES Y REGIMEN, - Por lo regular permanecen los rencos comunes, como casi todos sus afines, en 10 mas profundo de los lagos, á menudo á cien brazas de la superficie, y solo por casualidad suben à las capas que hay entre veinte y cincuenta brazas de profundidad, pero durante la tempestad y lluvia calurosa se dice que suben hasta doce y aun menos brazas para volver á su abismo cuando la atmósfera refresca. Como no penetran nunca en ningun rio, tampoco pueden trasladarse a otros lagos unidos al suyo por alguna corriente.

Su régimen consiste principalmente en animalillos acuáti. cos muy diminutos que viven en el fondo de los lagos, y de los cuales muchos eran ignorados de los naturalistas hasta que los descubrieron en el estómago de los rencos. Además de estos animales, aliméntanse tambien de la muco. sidad que se encuentra en el fondo de los lagos y que no es otra cosa sino un mundo vegetal y animal rudimentario, es decir plasma; y alguna que otra vez de cangrejos pequeños; limazas, gusanos y larvas de insectos.

En la época del celo aseméjanse en su comportamiento á los arenques; el instinto de procreacion se hace tan imperioso 7. predominante, que estos peces cambian completamente su género de vida usual. Como otros salmónidos, no toman el menor alimento durante varias semanas, ni antes ni durante esta época, segun dice Siebold; sus intestinos se contraen y se encogen; sus proprorciones y volúmen cambian tanto, que su aspecto es totalmente distinto de lo que es en el resto del año, ni conticnen otra cosa que las secreciones del mismo aparato digestivo. Preséntanse en innumerables masas en la superficie de su lago, desde mediados de noviembre hasta 
muy entrado diciembre, segun el estado del tiempo que influje mucho en el adelanto ó retraso de la operacion del desove, llegando hasta a sacar sus aletas dorsales fuera del agua. Si les asusta el frio de las capas superiores, la nieve, los témpanos de hielo ú otros accidentes, vuelven ámenudo á bajar algunos metros aglomerándose en masas tan compactas, que se lastiman unos ó otros y con el roce se arrancan las escamas y se desgastan las hinertrofias y callosidades de la piel, en términos de llegar á cubrir y enturbiar con estos restos grandes extensiones de agua, dándose el caso de que muchos rencos queden aplastados.

Cárlos Vogt dice: (He presenciado muchas veces el acto del desove de estos peces en el lago de Neuenburg (Ncufchatel), en los puntos de menos agua en la orilla Siempre de dos en dos, saltaban vientre conira vientre fucra del agua hasta la altura de un metro, soltando de paso huevas y sémen simultáneamente. Es un espectáculo interesantisimo, sobre todo en las noches de luna, que es cuando mas peces desoran, cl ver estos animales plateados salir rápidos como cohetes del agua para sumergirse otra vez. Las huevas fecundadas van lentamente al fondo.\$

No cabe duda de que esta manera de fecundar ha de dar un resultado muy inferior al que podria esperarse, pues necesaria. mente han de quedar la major parte, millones de huevas, infecundas, a pesar de lo cual multiplicanse estos rencos de un modo tan exiraordinario que hasta hoy no se ha nbservado Ia menor disminucion.

CRIA ARTIFICIAL.-Ios ensayos de Cárlos Vogt patentizan que puede aclimatarse cl renco comun sin ninguna dificultady con exito completo en los lagos donde todavia no existe, y gracias á los progresos de la piscicultura es fácil comprar á los pescadores suizos cualquier númiero de huevas fecundadas y lograr asi la cria que se desea.

PESCA Y UTILIDAD.- Tiene razon Wartmann cuando dice que el renco comun es para el lago de Constanza lo que el arenque para el mar del Norte; pudiendose decir otro tanto de la pesca. Durante el verano aparejan diariamente de catorce á diez y ocho barcas y cada una vuelve por térmi. no medio con cien peces, El frio disminuye la pesca, y el tiempo malo la hace imposible, porque los rencos bajan entonces a profundidades para las cuales nose ha llegado todavía á construir redes apropiadas. Las que se emplean en el tiempo de la freza son jábegas que cogen á menudo a cada tirada algunos centenares de estos peces. Comparado con la bondad de la carne, puede decirse que el precio es relativamente bajo, puesto que se paga el kilógraino de sicte á ocho reales, frecuentemente solo \& $5, y$ cuando se paga mucho es a 10 reales. Gessner dice: En octubre tiencel renco la carne mas exquisita, bien que se la alaba en todo tiempo, aunque provenga de estanque y preparado de cualquier modo, coci do, frito $\delta$ en empanada; frito es mas sabroso y puede conservarse mas dias. Tambien se salan y se expiden lejos; se ahuman $y$ finalmente se sirven en las mesas de los principes Y grandes señores.)

\section{EL RENCO DE FONDO - COREGONUS FERA}

CARACTERES, - Difiere este pe\% del anterior por su hocico mas corto y mas obtuso, y la cola tambien mas corta y maciza. El color es casi idéntico, solo que el tinte oscuro del dorso es menos vivo y mas limitado a la parte superior. Sostienen la aleta dorsal respectivamente cuatro y once ra. dios, la pectoral uno y quince, la abdominal dos y dier, la anal cuatro $y$ once 6 doce, $y$ la caudal diez y nueve. Su talla es mayor que la de la especie comun, pues alcanza por térnino medio una longitud de $\left(0^{*}, 60 y\right.$ un peso de tres $y$ mas kilógramos.
DISTRIBUCION GEOGRÁFICA.-Este renco habita los lagos de Suiza, y ahora con auxilio de la cria artificial tambien los de la Prusia oriental y de Polonia.

USOS, COSTUMBRES Y REGIMEN. - Vive por 10 general á una profundidad de cuarenta brazas, sin que esto le impida bajar en alguna circunstancia hasta lo mas pro. fundo del lago. Sc alimenta de los mismos animales que la especie anterior, y dicese que en verano sube mas à menudo á la superficie para atrapar insectos; entonces el aire que llena la vejiga natatoria se dilata con demasiada rapidey, y arroja 3 estos peces á la superficie donde quedan detenidos largo rato hasta que el aire interior se ha equilibrado con el exterior. Schinz asegura que despues vuclven á bajar. Cuando al pescarlos se les sube con rapidez, sucede natural. mente lo misno, y su caridad abdominal, particularmente la parte anterior por ser mas espaciosa y elástica, se dilata desmesuradamente á manera de papada ó buche hinchado cumo el de ciertas aves. Segun opinion de los pescadores, esta particularidad es la que cabalmente distingue á este renco del anterior, como decia ya Mangold: Cuando se pesca el renco de fondo va á parar arriba, y cuando se pesca el comun se va al fondo.y

En el mes de noviembre sube el de fondo á los sitios de poca agua en la orilla para desovar, con preferencia en los puntos donde el fondo bajo pasa repentinamente á profundo. Depositan las huevas sobre el lecho pedregoso o de guijarros, $y$ de ahí les vicne el nombre de renco de fondo.

PESCA - Schinz incluye \& este renco entre los mejores peces que viven en los lagos suizos, y lo que aumenta su importancia es que se le pesca todo el año hasta en medio del invierno, cuando no pueden cogerse rencos comunes; en esta estacion se le coge con redes, en rerano, sobre todo en mayo $y$ junio, con anzuelos fijados al extremo de rainales hechos de cuerda de tripa bastante largos para poder bajar a unuchas brazas, y nue se suben con la cuerda principal en. rollśndola en un torno que permite tambien graduar los anzuelos a la profundidad que se quiere; en lugar de cebo se emplea una ccrda $\delta$ crin negra que se enrosca hasta presen. tar poco mas $\delta$ menos la apariencia de una mosca. El renco de fondo, al sentirse cogido, trabaja con todas sus fuerzas para desprenderse, y el pescador no tiene que hacer mas sino is aflojando la cuerda, pero procurando que quede siempre tendida hasta que el pez se cansa, á fin de que no rompa el rainal; entonces se le sube poco á poco y se saca con bo. lecha; pero mueren en el acto por grande que sea el cuidado que se emplee para conservarlos vivos.

En cuanto a la bondad de su carne divergen las opiniones. Hay quien da la preferencia á esie renco sobre el co. mun, y otros opinan lo contrario; entre estos figura Siebold, quien cree encontrar una grandisima diferencia entre anbas especies.

\section{EL RENCO MARENA-COREGONUS MARAENA}

CARACTERES. - No está decidido todavia si este renco es solo una variedad del anterior $\delta$ una especic propia. En favor de la primera opinion hablan la forma, el género de vida, y en general lo insignificante de las diferencias que se han podido encontrar entre ambos, $y$ que consisten, segun Siebold, en el perfil del hocico que es mas fornido 5 ancho, en los dos interopérculos que no bajan oblicuamente hácia atrás, y en las dos ramas de la mandibula superior que pa. recen en la marena algo mas largas que en el renco de fondo. El dorso es azulado y el vientre plateado; la linea del costado está punteada de blanco. En la aleta dorsal hay cuatro y diez ú once radios respectivamente; en la pectoral 
uno y diez y seis ó diez y siete; en la abdominal dos y nueve ó diez; en la anal cuatro y de diez á doce, y en la caudal die? y nueve. La longitud es de $\theta^{\text {a }}, 60$ y mas; el peso de sicte á ocho kilógramos.

DISTRIBUCION GEOGRÁFICA.-Originaria la marena del lago de Schaal en el Luneburgo y del de Madne, situado entre Stargard y Stettin en Pomerania, la han aclima tado desde este último en diferentes lagos de la misma provincia y de Brandeburgo.

USOS, COSTUMBRES Y RËGIMEN.-Como su afine el renco de fondo, vive la marena en la profundidad del lago que habita, pero sube \& mediados de noviembre á sitios de poca agua y á corta distancia de la orilla para efectuar el des. ove. Se alimenta de animales análogos á los que comen sus congéneres.

PESCA.--Se hace principalmente en invierno debajo del hielo con redes grandes; en algunos años se pesca tambien en primavera y otono. Al salir del agua mueren estos peces al momento, pero se remiten bastante léjos embalados en nieve $y$ hiclo, $y$ tambien curados con sal $\delta$ al humo. Se cree que son mejores en la primavera, pero en todo tiempo se venden fácilmente $a 2,50$ hasta 4 pesetas el kilógramo.

\section{EL RENCO GLACIAL-COREGONUS HIEMALIS}

CARACTERES.-Nide i lo mas $0^{\circ}, 40$, aun cuando los individuos de esta longitud son raros, de consiguiente resulta esta tercera especie mucho mas pequena que las anteriores, de las que difiere tambien por su cuerpo mas corto y el lomo bastante arqueado. El color es blanco amarillento en la parte superior de la cabeza, los costados y opérculos son plateados y el resto del cuerpo de un gris pardusco claro; las aletas son incoloras, salvo las pectorales, pero orladas de un tinte negruzco. El número de mdios es de cuatro, y de nueve 2 trece en la dorsal, de uno $y$ quince 6 diez. y seis en la pectoral, de dos y diez ú once en la abdominal, en la anal cuatroy nueve hasta trece, y diez y nueve en la caudal.

DISTRIBUCION GEOGRÁFICA.-Antes de los estudios de Siebold se conocia esta especie solo en el lago de Constanza, pero este la ha encontradotambien en el lago de Ammer y cree que habita igualmente otros lagos alpinos.

USOS, COSTUMBRES Y REGIMEN.-Estos rencos viven todo el año â una profundidad de cuarenta á cuarenta y cinco brazas, lo que explica la incertidumbre respecto da su presencia en ciertos lagos. Solo suben a capas mas altas hácia últimos de setiembre para desovar. Segun los análisis verifi. cados del contenido de su estómago é intestinos, resulta que su régimen armoniza perfectamenic con su vida en la.profundidad, puesto que se alimenta de penueños caracoles, conchas y fango que encuentra en el fondo del lago.

Como este renco habita, segun parece, los sitios mas pro. fundos de los lagos, dice Siebold, se halla tambien mas sujeto a morir de neumatosis cuando se le sube con la red, y esto le ha valido el nombre de renco de huche entre los pescadores del lago de Constanza. A cuarenta tocsas de profundidad soportan estos peces y su vejiga natatoria llena de aire una presion de 7 y media atmósferas. Pues bien, cuando se sacan del paraje que habitan a la superficic donde la presion es solo de una atmósfera, disminuse la presion sobre la rejiga en 6 y media atmósferas, el aire que contiene se dilata en la misma proporcion, y como las paredes delgadas de la vejiga y del abdómen no pueden resistir à semejante dilatacion, resulta que el vientre se hincha hasta quedar informe y dis. locados todos los intestinos, lo cual junto con la presion sobre los vasos sanguineos ha de causar infaliblemenie la muerte del pez.l

\section{EL RENCO ENANO-COREGONUS ALBULA}

CARACTERES.-Esta especie se distingue de todos sus congencres de la Europa centra! por la mandíbula inferior que sobresale tanto de la superior que su sinfisis viene a formar la punta del hocico. In coloracion no difiere de la de las anteriores: el dorso es gris azulado, y los costados y vientre de un blanco plateado brillante; las aletas dorsal y caudal son de color gris, las demás blanquizcas. Fil número de radios es de cuatro s ocho á nueve en la dorsal; uno y catorce 6 quince en la pectoral; dos y diez en la abdominal; cuatro $y$ once á doce en la anal y diez y nueve en la caudal. Ia largura no pasa por lo comun de $0^{m}, 1560^{m}, 20$, pero puede llegar en algunos casos cxcepcionales $40^{\circ}, 25$ y aun algo mas.

DISTRIBUCION GEOGRÁFICA. - Se encuentra este rénco pequeño en Alemania en los lagos de las provincias de Posen, Silesia, Brandenburgo, Mecklemburgn yolstein, y probablemente será idéntico al que vive en los lagos de la península escandinava y de la Rusia septentrional. Tambien habita algunos lagos de Escocia donde se cree que le intro. dujo María Estuardo.

USÓS, COSTUMBRES Y RÉGIMEN.-Bajo cste con. cepto no difierc la especie enana de las otras congéneres que viven en lagos. Fuera de la Época del desove permanece en la profundidad, $y$ en los meses de noviembre $y$ diciembre acude en masas compactas a la superficie causando un ruido perceptible á bastante distancia, y trasladándose á veces de un lago á otro si hay comunicacion y el segundo es mayor. Deja caer la freza al agua y el mal tiempo influye mucho en su comportamiento.

PESCA - No es rana la fama que tiene este pez de sa. brosísimo, y recompensa el trabajo que cuesta su pesca, la cual se efectúa en Pomerania y Mecklemburgo en invierno y debajo del hielo; pero en la Prusia oriental durante su traslacion de un lago as otro. Se remiten muy lejos ya emba. lados en nieve $y$ hielo, ya curados durante $\&$ y 10 horas al humo, atravesado cicrto número de un palito despues de ha. berlos escamado cuidadosamente, lavado en agua fria y puesto una noche en salmuera. Se consideran buenos cuan. do el humo les ha comunicado un tinte dorado 6 pardusco; la operacion misma se hace en estufas ú hornos a propósito y en su defecto en grandes toneles ó bocoyes.

PISCICULTURA.-Mucho antes que otros peces se ha trasladado con el mejor exito el renco enano á lagos donde no existia. Hé aqui lo que me escribe el dueño de uno de ellus: Los primeros rencos enanos que ahora pueblan en tan gran número el lago de Dolgen, que tiene una superficie de cincuenta hectáreas y una profundidad de quince-á vein. tidos toesas, fueron trasladados alli hace cincuenta años por mi difunto padre que los sacó del lago de Wilm distante un cuarto de hora, valiérdose de cubas llenas de agua de dicho lago. Estos peces ienian de dos a tres años; y debo decit que en este pais pasa por cosa muy sabida que á esta edad se dejan trasportar y aclimatar en otros lagos muy fácilmen. te, conforme se ha probado repetidas veces. Es sin embar go muy particular que estos rencos trasladados, en ningun otro lago medren como en el mio, tanto respecto á tamaño como a grasa y sahor delicado, lo cual podria muy bien explicarse por la limpidex y profundidad de las aguas de dicho lago, por la gran vegetacion acuática y su fondo calcáreo. Las demás cspecies de peces que se crian en el mismo lago distinguense tambien por idénticas cualidades. No dejo pes. car en la época de la freza que ocurre desde mediados de noviembre hasta mediados de diciembre.

Como prueba de la superioridad de los rencos enanos del lago de Dolgen añadiré que los del vecino de Wilm y de 
otros de este país se pagan á tres y à cinco reales cada par. tida de sesenta, mientras que igual cantidad de los mios se paga desde 7,50 hasta 15 pesetas.

\section{EL RENCO HOCICUDO-COREGONUS OXYRHYNCHUS}

CARACTERES.-Pertenece á los rencos marinos que remontan puntualnente los rios para desovar, y se caracte. riza por la notable prolongacion de la manáibula superior que sobresale de la inferior y termina en un hocico blando y cónico. La longitud es de $\left(\pi, 40\right.$ a $l^{2}, 50$, á lo mas 0,60 , con un peso de tres cuartos a un kilógramo. El color es azulado, y en la época del celo negro azulado. El número de radios que sostienen la aleta dorsal es de cuatro á diez; en la pectoral cuéntanse uno y quince $\delta$ diez y seis, en la ventral dos $y$ diez ú once; en la anal cuatro y diez hasta irece, y en la caudal diez y nueve.

DISTRIBUGION GEOGRÁFICA.-Debemos conside. rar el mar del Norte y el Báltico como patria de este renco.

USOS, COSTUMBRES Y REGIMEN:-Ya en mayo, mucho tiempo antes de la énoca del desove, que cac en los meses de setiembre hasta diciembre, penetra el renco hocicudo en mayor ó menor número en los aliaques y corrientes que descmbocan en los dos mares, para reniontarlas. Efectuan este viaje, segun dicen, con cierto método, formándose, como las bandadas de grullas, en triángulo 6 falange; pero con mucha lentitud; tanta, que en venticuntro horas apenas adelanian cuatro kilómetros. Cuando el tiempo es malo, bajan al fondo para descansar; despues vielven á reunirse y continuan su ruta, que no los lleva nunca muy adentro ni 5. la parte elevada de los rios como sucede con los salmones, porque en el Elba apenas llegan liasta cerca de Magdeburgo ó de Torgau, en el Weser hasta la confluencia del Werra y del Fulda y en el Rhin hasta Espira. Efectuado el desove, re. gresan con mas ó menos calma al mar. Los pequeños toman el mismo camino cuando han alcanzado una longitud do $0^{\prime \prime}, 80$, y no vuelven al rio sino cuando son adultos.

PESCA Y PRODUCTOS.-Se paga la carne de renco hocicudo, tan blanca, delicada, sabrosa y estimada, de dosá cuatro reales el kilógramo: y se come fresca, salada y cura. da al humo, por cuya razon tiene mucla importancia esta pesca en toda la Alemania del Norte. Hé aquíl lo que me es. cribe Pietsch, consejero de Obras pisblicas: eTan luego como llegan los rencos hocicudos â Velthcim, aldea situada á orillas del Weser mas arriba de Minden, acude toda la poblacion sin diferencia de edad, armada de anzuelos de toda cla. se, pues solo se necesita arrojarlos vigorosamente al agua para sacarlos con dos ó cuatro peces. En Veltheim se consume solo una pequeña parte de la pesca; la gran masa se lleva á las ciudades próximas. El grupo principal de los peces llega alli entre el 15 y 20 de mayo; $y$ tres semanas mas tarde pasa otro.»

\section{LOS TÍMALOS -. THYMALLUS}

CARACTERES. - Lo mas notable de los individuos de este genero es la gran altura y langitud de la aleta dorsal inserta mucho mas adelante que las abdominales; las es. camas inedianas, rigiảas y bien adheridas; la hendidura pequeña de la boca, y la dentadura fina que guarnece los huesos inandibulares, palatinos y el vómer.

\section{EL TÍMALO COMUN-THXMALLUS VULGARIS}

CARACTERES, - Lib caveza de este pez es pequeña, y la mandibula superior se prolonga sobre la inferior. La aleta dorsal es mas del doble mas larga que la anal. La coloracion varia considerablemente segun la morada, la estacion y la edad. Por lo comun predomina un pardo verdusco en el dorso, que pasa en los costados á gris y en el vientre á blan. co brillante y plateado. En la parte superior hay manchas parduscas, en los costados de la misma hay otras negras so. bre fondo amarillento que continuan en la parte anterior del cuerpo y forman, ordenándose segun las hileras de escamas, listas longitudinales de color gris pardusco. La coloracion de la aleta dorsal es magníica y presta á este pez un aspecto hermosisimo; su color dominante es púrpura realzado por tres ó cuatro listas formadas de puntos negros; las aletas pa. res son de un rojo amarillento sucio; la anal y caudal son moradas. Sostienen la dorsal de seis a ocho radios simples $y$ diez $y$ seis hasta diez y siete articulados, la pectoral uno y catorce $\delta$ quince; la abdominal uno y diez; la anal tres á cuatro, y nucre d diez: $y$ diez, y nueve la caudal. La longitud suele pasar poco de ()$^{\circ}, 30$, pero puede llegar hasta $1^{\circ}, 60$, mientras que su peso oscila entro 0'75 y r'50 kilógramos.

DISTRIBUCION GEOGRÁFICA. El timalo es la especie mas extendida de todos los salmónidos de Eurropa, puesto que se encuentra en toda la parte central y oriental de nuestro continente; asi en las aguas de los Alpes, como en las que interrumpen las llanuras de la Alemania del Norte y de Rusia; en el continente lo propio que en la Gran Breta. ña; además en todos los rios y arroyos de montaña que afluyen directa ó indirectamentc al gigantesco Oben Asia, como por ejemplo, en aquellos que vierten sus aguas en el Marca. cul del Altai chino, conforme resulta de mis propias obser. vaciones:

Habita a poca diferencia las mismas aguas que convienen á la trucha; pero no se encuentran ambas especies siempre juntas, y hasta se cree en Suiza que donde el timalo vive desaparece aquella. Tschudi dice que desde que se aclimató en el Inn hasta Steinzberg, lugar situado á 1,500 metros sobre el nivel del mar, han desaparecido alli las truchas. En Inglaterra suponen que los frailes trabajaron mucho en su tiempo para introducir csta especie en muchas corrientes, pero lo único positivo es nque siempre preferian establecer sus conventos y monasterios en sitios montañosos y cerca de corrientes cristalinas que son las que apetece tambien el if malo; pues en Irlanda y Escocia, donde los conventos eran tan numerosos, ni siquiera existe este pez tan suculento.

USOS, COSTUMBRES Y REGIMEN, - El timalo es verdadero pez de rio, que no existe ni prospern en lagos ma. yores, ni en estanques ni charcas, segun experimentos hechos en Inglaterra. Rara vez falta en las aguas de montaña, mientras que en las del llano solo se encuentra cuando son limpidas, de profundidad regulary de fondo pedregoso. Legus. tan rios cuya agua no es demasiado fria ni demasiado caliente, y donde alternan corrientes fuertes con remarsos, con fon. do siliceo, margoso ó arcilloso, sin que esto quiera decir que huya de las aguas turbias. En general no sube á tanta altura como la trucha, á la que se asemeja mucho en sus costumbres. Como ella, nada con gran rapidez, y como ella perma- nece a veces horas enteras con la cabeza dirigida contra la corriente, en un mismo sitio, tan quieto y tranquilo que se le puede coger con la mano. Se alimenta de larvas de diferenies insectos acuáticos y de estos mismos, de limazas, conchas, gusanos y hasta de cria de peces. Como su afine, salta fuera del agua para atrapar un insecto al vuelo, y muerde de consiguiente el anzuelo fácilmente. En la época del celo au. menta el brillo de sus colores que adquieren en todo el cuer. po un reflejo general verde de oro, el cual tendrá su origen, como en los demás salmónidos, en un aumento de energía 
de las funciones cutáneas. Cuando la primavera se presenta favorable, empieza á desovar ya en marzo, y en caso contrario retarda esta operacion hasta últimos de abril. Macho y hembra, que por lo comun se están siempre juntos, subiendo y bajando en un trecho muy reducido de la corriente, abren con la cola hoyos en la arena; en ellos deposita sus huevas la segunda, el macho las fecunda, y ambos las cubren en seguida con arena $y$ piedrecillas. Los pequeños suclen salir á luz en junio, y se mantienen al principio en los sitios de menos agua; pero como medran muy rápidamente, adoptan luego el género de vida de los viejos.

ENEMIGOS Y USOS. - Muchos rapaces y aves acuáticas persiguen al timalo, particularmente sus propios congéneres, y el hombre, que estima su carne tanto como la de la trucha, es decir, como uno de los manjares mas exquisitos. "Los timalos, dice Gessner, tienen una carne buena, sana, deliciosa y preferible á la de todos los peces de agua dulce, de igual mérito que la de los maritimos de roca; despues del tímalo viene el alburno y en tercera línea la trucha. En toda estacion es manjar saludable, y su fama ha dado origen al adagio: «El timalo es un magnate del Rhin. Algunos autoros antiguos dicen que este pez come oro, lo que en mi con. cepto quiere decir que derora las riquezas y los bienes de aquellos que gastan todo lo que poseen en buenos bocados. Es muy cierto que antiguamente se apreciaba este per. mas que todos los de rio: En el Trann habia disminuido tanto por lo mucho que se le perseguia, que la corte prohibió su pesca bajo la multa de cinco horines por cada timalo cogido, y el que no poseia esta suma habia de presentar una pesca de igual valor. Despues se prohibió la del timalo en absolu. to durante cierto tiempo, á fin de que se multiplicara, y finalmente se vedó pescar los que no tuvieran un año, es de. cir, đde un abril á otro, á no ser quue fuesen para la mesa del señor, para un enfermo ó mujer embarazada. Despues de la carne, tenia tambien grandisima fama la grasa: ela parte mas principal de este pez, que se emplea en la medicina, es su grasa para curar toda clase de males de la vista y del oido, sarpullido, eczemas, manchas, flujos, zumbidos, calor inflamatorio, etc. Además se la emplea tambien en toda clase de quemaduras, ya provengan de fuego, ya de agua hirviendo. Hoy se paga el kilógramo de este per, segun la localidad y estacion, desde \& \& 15 reales.

\section{LOS ESOCCIDOS - ESOCID瓜}

CARACTERES. - De los muchos géneros con q̨ue $\mathrm{Cu}$ vier habia formado esta familia, Muller solo ha conservado el que lleva el mismo nombre, uniéndolo con otro que Cuvier agrupó sin comprender el por qué, entre los ciprinidos. Entendemos, pues, actualmente, segun Muller, por esóceos unos peces escamosos, sin aleta adiposa con branquiales supletorias, gruesas y glandulares, la boca orillada en el centro por el intermaxilar y hácia los lados por la mandibula superior, vejiga natatoria sencilla, esiómago sin buche é intestino sin conducto ciego.

Todas las especies que forman esta familia; que son en número de diez, habitan el agua dulce, siendo su génèro de vida poco mas 6 menos el mismo del lucio.

\section{LOS LUCIOS-ESOX}

CARACTERES.-Este género se distingue por su dentadura completa, escamas pequeñas $y$ bien adheridas; las branquias supletorias son invisibles, las aletas abdominales se hallan insertas en medio del vientre, la dorsal y anal hícia el extremo del cuerpo cerca de la caudal que es muy grande y escotada en el ceniro.

\section{EL LUCIO-ESOX LUCIUS}

CARACTÉRES. - Es el pez mas rapaz y mas temido, (el tiburon de los rios y lagos de Europa. Caracterizase principalmente por su cabeza aplanada y hocico ancho y grande (fig. 196). Su coloracion y dibujo varian extraordinariamente, de modo que en sentido general solo puede de. cirse que tiene el lomo mas ó menos uniformemente negruz. $c o$, los costados de color gris con manchas veteadas 6 tras. versales y el vientre blanco con puntitos negros. Inas aletas pectorales $y$ abdominales son rojizas, la dorsal y anal par. duscas, y la anal suele tener en el borde superior manchas negras. Sostienen la dorsal de siete a ocho y de trece à quin. ce radios respectivamente, la abdominal unn y ocho, la anal de cuatro á cinco $y$ de doce á trece, y la caudal diez y nucve. En cuanto á longitud, no cede el lucio á ningun salmó. nido, y en peso \& lo mas al salmon comun y al huco, puesto que aquella puede llegar a dos metros, y este a 35 kilógramos; aunque generalmente se consideran ya como ejempla. res raros los lucios de 1 ", 30 y 25 kilógramos.

DISTRIBUCION GEOGRÁFICA.-Exceptuando la Is. landia, y segun se dice tambien España, encuéntrase el lucio en todas las aguas dulces de Europa, $y$ aun en algunos pun. tos aisladamente en el mar, segun Pallas en el Caspio y Glacial, y segun mis propias obserwaciones, en la parte inferior del Ob. En los Alpes sube hasta 1,500 metros sobre el nivel del rnar, y acaso mas alto en las cordilleras de la Europa meridional. En ninguna parte es raro, sino mas bien frecuente en todas, y si en alguna abuncia, es únicamente en el $\mathrm{Ob}$ y sus afluentes, donde tambien se reunen todas las circunstan. cias á propósito para asegurarle la vida mas regalada. Porlo demás es pez que sabe adaptarse en todas partes a las circunstancias locales y se encuentra al parecer tan á sus anchas en agua poco profunda y pantanosa como en la cristalina é insondable del lago alpino. Nadador robusto y hábil, sus sentidos están muy desarrollados lo mismo que su rapacidad. Gracias a su cola poderosa, reforzada por las aletas dorsal y anal, atraviesa las olas como una flecha, atisbando en todas las direcciones y precipitíndose sobre su presa con una seguridad infalible. Su voracidad excede á la de todos los peces de agua dulce. Nada desprecia, devora peces de toda especie y hasta de la suya propia, ranas, aves y mamiferos, con tal que pueda abarcarlos con su hocico abierto; segun se ha podido observar en Inglaterra, coge la cabeza sumergida del cisne y no la suelta por mucho que bregue y resista el ave orgullosa y pulcra, hasta que la ahoga; lucha con la nutria, muerde el pié descalzo ó la mano de la labradora que trabaja ó se lava en el rio, y hasta ataca á los mamíferos grandes. Gessner dice: « Se ha dado el caso de que una mula mordida en el labio inferior por un lucio, al huir espantada del agua, se lo llevara colgando del hocico hasta que, dando una sacudida, lo hizo caer, recogiéndolo entonces el arriero que se lo llevó á su casa.

En su, estómago se han encontrado á menudo gansos, pa. tos, gallinetas de agua pequeñas y otras aves, y culebras, pero nunca sapos. No engulle en seguida los peces de dor. sal espinosa, sino que los tiene sujetos con los dientes hasta que mueren, pero no molesta al gasterosteo de hocico agudo que puede retozar á su alrededor, para lo cual media una causa justa, puesto que Bloch cogió un lucio jóven que falto de experiencia habia dado una hocicada a uno de aquellos peces cuya espina dorsal le iraspasaba el paladar, saliéndole por las fosas nasales. 
Solo se puede formar una idea de lo que necesita un Iucio para vivir cuando se le tiene cautivo y hay que alimentarle $\delta$ si se quiere aplacar su voracidad insaciable. \&Ocho lucios, dice Jesse, todos de dos años, necesitaron en tres semanas unos Soo gobios de rio. Su voracidad no tenia limite. Una mañana arrojé á uno de ellos cinco leuciscos de unos (1),10 uno tras otro. Se tragó cuatro, cogió el quinto, y despues de tenerle un rato en el hocico se lo tragó tambien. 》 Dada se. mejante voracidad, no es extrano que estos peces crezcan con mucha rapidez hasta alcanzar al primer año un peso de un kilógramo, dos al segundo año, y-cuando no le falta alimento hasta cuatro $y$ cinco kilógramos!

La época de la freza cae á prinćipios de primavera, y segun el caso puede prolongarse liasta majo; cntonces toda la vida del lucio se concentra en el único objeto de la repro. duccion, y á pesar de ser por lo general bastante cauto, no ve ni oje entonces y á veces se deja coger con la mano. En una hernbra que pesaba cuatro kilogramos se contaron como 150,000 huevas. Las depositan en sitios de poca agua entre cañas y otras plantas acuáticas, dondé á los pocos dias salen a luz los pequerios, los cuales suelen ir sa parar al estó. mago de lucios viejos y jórenes que medran mucho con tanta abundancia de alimento. Se pretende que llegan estos peces á una edad muy avanzada, y autores hay que hablan de lucios que pasaban de cien años.

USOS Y PROVECHO.-Poco estimada era la carne de lucio en tiempo de los romanos, puesto que Ausonio dice:

* Aquí vive tambien el habitante de aguas estancadas, el venemigo hereditario de las ranas afligidas, metiỏo en agujesros, oculto entre carrizo y fango, el lucio, que por su nom. v bre de saron romano es blanco de burlas, no figura jamás Den la mesa del rico, y su olor solo se mezcia con los del asqueroso bodegon.

Nas tarde se pensó de otra manera, y por espacio de siglos enteros tuvo el lucio mas fama de suculento que el sal. mon; por lo menos en Inglaterra. Hoy dia pasa todavia un lucio bien guisado por ser un manjar exquisito, y se paga de dos á diez y aun mas reales el kilogramo, por manera que no se le persigue solo por el daño que causa, sino tambien por el lucro que ofrece su venta.

PESCA. - Se coge el lucio de muchas maneras; pero aparte de la red y de la nasa, lo que mas se emplea es el anzuelo. Para la descripcion de esta pesca dejaré la palabra a Cárlos Mueller: e El arreglo de este anzueio es muy senciIlo; se toma una caña ó pértiga muy larga y robusta; el cordel, fucrte tambien, pero no muy grueso, se tiene algunos dias antes de usarlo en aceite de linaza; el anzuelo es de un gancho, grueso y afilado; entre el tapon flotador y el anzuelo se doblan algunas laininitas de plomoalrededor del cordel, de modo que el cebo cuelgue $\{$ determinada profundidad. Para cebo se toma un pececillo de $11^{*}, 05$ \& $11^{\prime \prime}, 08$ de largo, y se le pasa el gancho por debajo la piel, en el costado junto al lo. mo hasta la cabeza, por donde se hace salir el contragancho. Segun el sitio, se baja el cebo uno ó dos metros. El pececi. llo nada describiendo circulos si bien procurando siempre ocultarse en la orilla, el márgen ó las espadanas, lo que ha de impedir el pescador echando el cebo en sitio donde no pueda suceder esto. Para cebo lo mejor son bremos, que tienen la costumbre de quedarse en el agua profunda; $\{$ fal. ta de estos pueden usarse escardinias, pero los demás cipri. nidos buscan siempre la superficic $y$ rnueren tambien mas pronto. Para explotar un trecho largo es menester proveerse de un cajon agujereado con gran número de pececillos, ya que solo pueden cogerse en sitios determinados.

- Preparado todo, se traslada el pescador á la orilla del rio, pero es inútil que vaya antes de las diez de la mañana y de las tres de la tarde, porque el lucio pica con preferencia á medio dia y por la noche. Figurémonos ahora que estamos en otoño, á principios de octubre, en cuya época el lucio se retira á sitios tranquilos y profundos, uno de los cuales hemos de elegir para la pesca. Nos vamos acercando con mucha cautela y sin ruido, la caña en la mano derecha y el an. zuelo cebado en la izquierda. Haciendo puntería arrojamos el cebo de manera que haga el menor ruico posible al cacr al agua, y apenas flota el tapon, síntese ya el tiron debajo del agua; entonces, sorprendidos, nos descuidamos un momento y sacamos la caña cuando el pez ha desaparecido con el cebo. Colocamos otro pececillo sin apartar la vista del tapon. Por espacio de dos ó tres minutos sigue el pececillo describiendo sus circulos, y de pronto se revuelve inquieto: seinal de que se le acerca el enemigo; el tapon se sumerge, percibimos la resistencia en la caña, la sacamos, y vemos el lucio con la mitad del cuerpo sobre el agua, pero dando un fuerte cole. tazo, rompe el anzuelo y la presa se escapa para no volverá picar tan pronto.

- Venga otro anzuelo y otro pececillo y probemos otra vez en el mismo sitio. Pasá un cuarto de hora y nos resolvemos ya ia sacar la caña y á buscar otro puesto mejor, cuando des. aparcce el tajon tirado con mucha fuerza, y con un movimiento rápido sacamos un lucio de cuatro kilógramos, haciéndolo pasar por encima de nuestras cabezas para estrellarlo detrás de nosotros contra el suelo. Le quitamos el anzuelo que, como de costumbre, está enganchado en el borde inferior de la boca; y volvemos á echarlo con cebo fresco, porque si los lucios estản dispuestos á picar y nosotros tenemos suerte cogeremos mas. Para el pescador de lucios no hay como unó de estos dias de otono apacibles con una pequueña brisa del suró sudoeste, en uno de los cuales cogí en com. pañía de mi padre en octubre de $1 \$ 59$ oclio lucios; enton. ces picabar en el cebo en cualquier punto que echásemos el anzuelo, y los sacibamos sin el menor contratiempo.

- En la primavera sucede lo contrario; entonces abandona cl hucio la profundidad para dirigirse á puntos de poca agua y sobre todo á los recodos del rio junto á puntos salientesde la orilla donde la corriente es mas fuerte y puede acechar mejor sus presas; echar tambien el anzuelo en las desembocaduras de las zan. jas y conductos de presas de inulinos, en las que se acerca este pez hasta á las mismas ruedas. Mi padre echaba el anzuelo hasta en verano en sitios de poçuisima agua si alli ob. servaba que algun lucio cazaba, y otras veces nasta en medio de la corriente, y siempre con éxito; pero para esto se ha de ser maestro.

Tschudi dice que en Suiza disparan balazos al lucio en el tiempo de la freza. Allf se verá cómo al rayar el alba abandonan los cazadores y pescadores las liogueras que tenian encendidas para pasar junto a ellas la noche, empezando á dar la vuelta al lago hasta medicdía con la carabina o la escopeta cargada de balines dirigida oblicuamente conIra la superície cristalina. De pronto notan que se riza ligeramente: es un lucio que á pocos centimetros de profundidad se dirige á los carrizos para desovar. El cazador hace la puntería cuatro dedos mas alta, contando con la refraccion que la luz experimenta en el agua, y dispara. Es raro que la bala hicra al pea, porque pierde la fuerza en el agua, pero el estrẻpito y el empuje del líquido le aturden tanto que se queda iurbado un rato. El cazador aprovecha este momento para atraerlo con una rama à la orilla, donde le remata.

Piscicultura.-El lucio se presta muy bien para ser criado en estanque donde no puede causar perjuicios y encuentra suficientes peces para alimentarse, porque se adapta al agua estancada como à la corriente, mientras no 
se le traslade á ella en el tiempo de la freza. Ya hemos visto que en los estanques donde se crian carpas se tiene siempre un lucio para que mantenga á estos peces en ciertogrado de agitacion, mas para esto es preciso emplear solo lucios pe. queños que no pueden causar perjuicios, y recogerlos y quitarlos cuando se hace la pesca general y antes de renovar la cria. Sobre esto refiere Lenz el siguiente caso: « Hace pocos años, al sacar las carpas de un estanque, no se cncontró b́ uno de los lucios; crejeron que no habia otro y se introdujo una nueva cria de carpas, pero cuando se sacaron álos dos años se encontraron muy pocas y en su lugar un lucio enor. me con una boca desmesurada, pues á fuerza de tragarse una carpa tras otra, dernasiado crecidas para el, se le habian agrandado las fauces con el trascurso del tiempo de una manera enteramente anómala.s

\section{LA UMBRA DE KRAMER-UMBRA CRAMERI}

CARACTERES.-Es el único pez que ahora se considera como afine de los esócidos, y suele ser clasifícado en la misma familia; el grupo que representa se considera tambien como género, sub-familia y familia. Es pequeño y mide á lo mas $11^{\prime \prime}$, os $60^{\prime \prime}, 09$; de cuerpo rechoncho; dorsal ancha y co. locada muy atrais; la abdominal y anal están debajo de ella; la caudal es redondeada; la cubierta consiste en escamas grandes, que cubren tambien la parte superior de la cabeza, la region maxilar y los opérculos. Ia mandibula inferior é intermaxilar, el vómer $y$ el hueso palatino están armados de dientes aterciopelados fínos. El color es pardo rojizo, os. curo en el lomo, y claro en el vientre; el dibujo consiste en manchas y puntos pardo oscuros é irregulares, y en una saya

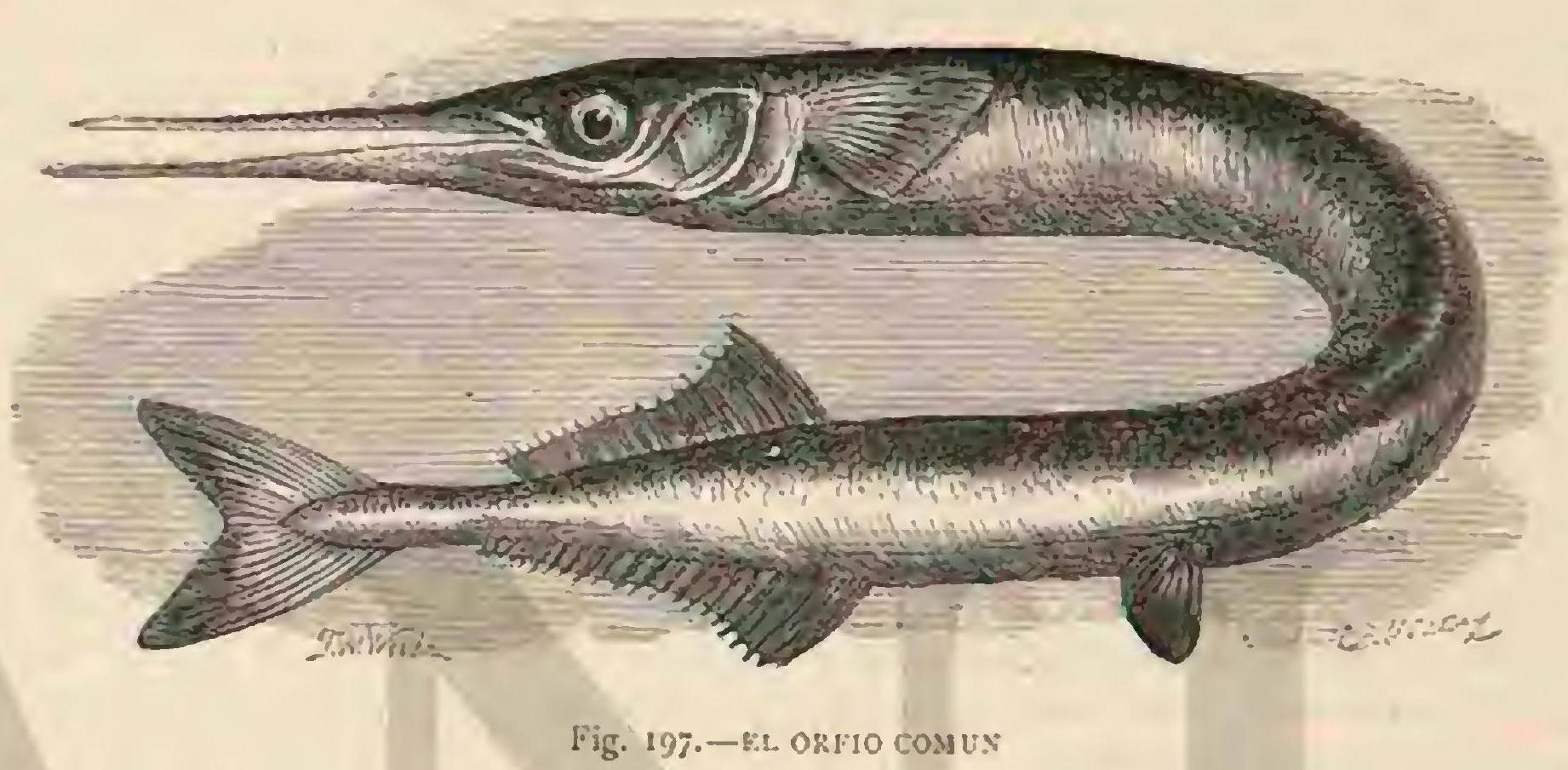

à lo largo del costado mas amarillenta, y a veces cobriza Las aletas dorsal y caudal son parduscas, y la primera en parte con manchas mas oscuras; las demas son de un tinte mas claro. Sostienen la dorsal tres y doce hasta trece radios, la pectoral uno y doce, la abdominal uno y cinco, la anal dos y cinco hasta seis, 5 la caudal diez y seis.

DISTRIBƯCION GEOGRÁFICA.-La umbra ó gobio canino, dicen Heckel y Kner, á quienes se debe, en cuanto yo sepa, la única descripcion de su vida y costumbres, habita junta con cotos, carasios y lochas, en las charcas de las turberas y pantanos que se encuentran al rededor de los la. gos de Neusicdel y de Plation.

USOS, COSTUMBRES Y REGIMEN. - Es especie muy rara, y vive sobre el fondo fangoso donde el agua es cla. ra y algo profunda. En un mismo charco ó agujero se encuen. tran \& lo mas cinco ó seis individuos, pero que por lo ariscos y ligeros son difíciles de coger, puesto que en un momento desaparecen en el fango $\sigma$ debajo de plantas inaccesibles. Cuando nada este per mueve alternativamente las aletas pectorales ýabdominales, á manera de patas, lo que le ha hecho comparar á un perro que corre; la aleta dorsal agita por su parte todos sus radios sucesivamente, lo que produce un movimiento ondulatorio rápido tal como se observi en los caballos y agujas marinos, para lo cual cada radio tiene su músculo particular. Hasta cuando este pececillo se está quicto, muévense como involuntariamente los tres 6 cuatro uilit. mos radios de igual modo, y esta posicion, que puede durar horas, es tan pronto horizontal como vertical, ya cabeza arriba 6 abajo; de repente abandonan todos a la rez el fondo para subir como flechas á la superficie, donde inhalan aire que vuelven a cxpulsar al sumergirse por las aberturas branquiales en forma de burbujas, despues de lo cual respiran durante algun tiempo muy pausadamente.

Tomo $\mathrm{V}$
CAUTIVIDA D.-Colocados en número de tres ó cuatro en una vasija de vidrio espaciosa, habituanse estos peces pronto a la cautividad, tanto que pudimos conservar los nuestros año y medio alimentándolos con pedacitos muy diminutos de carne cruda, que dejaban caer al fondo para recogerlos despues. En poco tiempo se vuelven tan mansos $y$ confiados que al acercarse una persona conocida aproximanse todos al cristal y le toman el alimento de la mano; pero no desovan en la cautividad; una hembra que se habia conservado un año en una pequeña fuente de jardin, murió porque no podia desovar, llena de huevas del tamano de granos de mijo. Cuando uno de los cautivos muere, le siguen pronio los demás.

USOS Y PRODUCTOS.-Antes se llevaban estos peces con mas frecuencia que ahora al mercado, pero siempre en corto número y entre partidas grandes de lochas pescadas en los pantanos junto al lago de Neusiedel; los pescadores los separan ahora con gran cuidado, porque como los creen venenosos, temen que su presencia haga desmerecer á las lochas; y si álguien les pide umbras directamente, lo toman a insulto.

\section{LOS ESCOMBRESÓ- CIDOS - SCOMBERESOCIDE}

CARACTERES. - Esta familia, creada por Juan Mueller, comprende unas ciento cincuenta especies de aletas blandas, en general de cuerpo muy oblongo, cuyos huesos faríngeos están soldados en uno solo; tienen además en cada lado del vientre una hilera de escamas crestadas y sus alctas abdominalcs están sostenidas solo por radios articulados. 


\section{LOS ORFIOS-BELONE}

CARACTERES. - Este género comprende las cuarenta especies mas tipicas de la presente familia. Se caracterizan por su cuerpo anguiliforme, por los huesos intermaxilares degenerados en pico largo y armados de dientes puntiagudos, mientras la faringe los tiene adoquinados, y por las escamas apenas visibles, excepto las crestadas que, segun hemos dicho, forman una hilera en cada costado.

\section{EL ORFIO - BELONE VULGARIS}

CARACTÉRES:-Esta especic la mas conocida del grupo, porque se encuentra en todos los mares europeos, al. canza una longitud de mas de un metro con un peso rara vez mayor de un kilógramo; tiene la parte superior del cuerpo de color verde azulado y la inferior de blanco plateado. La dorsal tiene dicz y siete radios, Iz pectoral trece, la abdominal seis, la anal veintiuno y la cola quince (fig. 197).

DISTRIBUCION GEOGRÁFICA-Es pez comun en el Mediterráneo, bastante frecuente en las aguas británicas, particularmente en la costa de Cornualles, $y$ de ningun modo raro en el mar del Norte y Báltico.

USOS, COSTUMBRES Y REGIMEN.-Suele presentarse en las costas europens junto con las caballas, por cuya razon se le toma por su guia y en muchas partes se le da un nombre alusivo a esta creencia. Se presenta en major $6 \mathrm{me}$ nor número'segun la localidad. Couch dice que suele acudir a la costa en bandadas numerosas, que nada cerca de la superficic con gran rapidez á manera de las culebras, y que se divierte dando repetidos saltos inuy particulares, segun observa Balli porque sale del agua verticalmente y vuelve á caer del misnio modo con la cola hácia ábajo. Todo objeto que flota delante de él excita su curiosidad ó su ira. Couch dice que á veces juega largo rato con una paja que encuen. tra, y Seoane refiere el caso de que uno de estos peces cla. vara su hocico puntiagudo con tanta violencia y tan profun. damente en una barca pescadora que murió de resultas del golpe.

En vano se esforzó Yarrell por averiguar algo de cierto sobre su régimen, pero supo por Couch que estos peces no perdonan ningun sér viviente que puedan engullir aunque sea con mucho trabajo. En general no se tragan la presa en seguida, sino que procuran, teniéndola fuertemente cogida, devorarla gradualmente, pues aunque no les es posible partirla \& mordiscos, sc arrcglan sin embargo para desmenu. zarla, segun se ve en los cebos que destrozan á menudo completamente. Los esfuerzos que hacen para desprenderse cuando han mordido el anzuelo, les obligan á arrojar todo lo que tienen en el estómngo, gracias â lo cual se ha sabido que devoran peces pequeños, como por ejemplo gasterosteos. Carecemos de datos exactos sobre su reproduccion, que se verifica á fines de primavera. Clarke encontró en el mes de junio tres orfios comunes muy pequeños de ()$^{a}, 02$ de longitud, y Yarrell en diciembre otros que median $\mathrm{i}^{\circ}, \mathrm{i} 6$.

PESCA. - Se emplean para ella redes de pescar arenques, ó anzuelos, ó bien una fitora con reinte púas; esta última solo de noche con fogatas que atraen á estos peces. Tonna dice que en las islas Jónicas stelen construir un barquito triangular hecho de tres cañas en cuyo centro se eleva un palo con velitas latinas. Cuando el viento sopla de tierra, lleva el pescador este aparato al mar donde lo deja flotar, teniéndolo sujeto con un cordel muy largo en el cual hay de trecho en trecho bornoles que à su vez llevan sedales cebados. Cuando un orfio pica un anzuelo, hace que el bornol se sumerja, pero pronto se conforma con su suerte, con lo cual da tiempo al pescador para esperar que muerdan otros, y cuando este ve que han quedado prendidos dier. 6 doce tira el armadijo hácia sí, desengancha los peces, vuelve á cebar los anzuelos y echa otra vez al mar la extrania trampa. Ase. gura Tonna haber visto en Paxo à un muchacho que en me. dia hora solamente cogió de esta manera unos cincuenta á sesenta orfios. En este aserto hay un dato que está en contradiccion con otras observaciones, de las que resulta que cuando estos peces se ven cogidos no se conforman de ninguna manera con su suerte, sino que se ponen furiosísimos haciendo los mayores esfuerzos para desprenderse del an. zuelo, y si lo logran retozan largo rato en la superficie, haciendo los movimientos mas singulares como si quuisiesen demostrar su alegría por haberse librado de tan gran peligro. Los que se cogen con la red mueren tan luego como se los saca del agua, y si se los coloca en vasijas, sus furiosos mo vimientos les causan la muerte, por lo cual es imposib!e te. nerlos cautivos.

Usos Y PRODUCTOS. - A pesar de despedir estos peces un blor repugnante cuando se les saca del agua y de ser su carne tan seca y dura, que sirve mejor para cebo que para alimento, se pescan en cantidades bastante regulares. A ve. ces llegan á la pescaderia de Lóndres partidas muy considerables que no tardan en venderse, ya por su baratura, ya por la curiosidad que excitan y porque las espinas toman con la coccion un color verde. En las costas del Báltico se come fresco, encurtido y curado al humo; en el primer caso se paga el kilógramo á un real, en el últino a tres, rigiendo la milad de estos precios en las costas del mar del Norte.

\section{LOS ESCOMBRESÓCIDOS PRO- PIAMENTE DICHOS- SCOMBERESOX}

CARACTERES. - I os individuos de este género se parecen á los del anterior, menos en las aletas dorsal y annl, cuya parte posterior se separa en falsas pínulas como las presentan las caballas.

\section{EL ESCOMBRESOCIO LAGARTO Ó DE CAM- PAR-SCOMBERESOX SAURUS}

CARACTERES. - Este pez alcanza una longitud de $0^{*}, 30$ a $0^{\circ}, 40$ con el grueso correspondiente. La region ma. xilar y los opérculos son de color blanco plateado brillaste; el dorso es azul oscuro; los costados tienen un tinte mas cla. ro con un reflejo verdoso; el vientre es blanco de plata y las aletas de un pardo oscuro. La dorsal consta de doce radios unidos y cinco falsas pinulas, la anal respectivamente de doce y siete; la pectoral de trece; la abdominal de seis, y la caudal de diez y nueve.

DISTRIBUGION GEOGRÁFYCA. - Se asigna á este pez solo el Atlántico por patria, porque se admite la especie que se encuentra en el Mediterráneo como independiente; pero es fácil que ambas no sean mas que variedades de una nuisma especie. En ciertas épocas no es raro en las aguas británicas, á cuyas playas le arrojan a veces las tormentasen grandes masas.

USOS, COSTUMBRES Y REGIMEN.-COn MAS Tazon que al anterior se considera á este pez como viajero, segun opinion de Couch, porque rara vez, $\delta$ mejor dicho nunca se le re antes del mes de julio en el canal de la Mancha donde se le pesca á millares desde este mes hasta otoño. Nada à cierta profundidad, $y$ tiene muchos puntos de seme. janza con el volador; es inofensiro como este, muestra el 
mismo espanto cuando huye de otros peces que le persiguen, es muy sociable y se le ve á menudo en bandadas numero. sisimas en la misma superficic. Interesantisimo es el espectáculo que olrecen estas bandadas cuando las acosa la lija ó el atun y el bonitalo, mas listos, movedizos y porfiados que aquellas; entonces despliega el escombresocio toda su destreza; todos acuden á la superficie, oprimiéndose entre sí llenos de la mayor angustia, y huyendo á porfia, saltan uno tras otro fuera del agua para ganar la delantera \& los que les preceden, viclven a caer $y$ á confundirse con ellos, $y$ asi van repitiendo estos saltos; pero como todos sus compañeros se hallan poseidos del mismo pavor, y obedecen á igual instinto y procuran adelantar camino á fuerza de saltos y brin. cos, resulta una confusion indescriptible, sobre todo cuando el peligro llega á su apogeo, y todos se deslizan mas bien por la superficie que por dentro del agua. Al fin llega el enemigo voraz, y, cansado de la persecucion, procura adelantarlos haciendo un esfuerzo supremo para cruzar la bandada atacándola de flanco, cuando de repente todos desaparecen en la profundidad; pero entre tanta multitud siempre hay algu. nos que quedan cogidos con tanta mayor facilidad cuanto que el enemigo es tambien numeroso y prefiere cazar en sociedad. Al contemplar un escombresocio y la forma de sus aletas pequeñas, aunque numerosas, no se comprende cómo puede efectuar los movinientos que ejecuta, si bien tiene un auxiliar muy poderoso y principal en su cola vigorosa $y$ ancha.

USOS, PRODUCTO Y PESCA.-Este pez tiene la carne grasa semejante á la de caballa, siendo por esto muy apreciado y pescado con alan. Se pesca con red de fondo, porque no suele picar el anzuelo. I vive en el Mediterráneo forma un artículo considerable de pesca en la isla de Lissa en el Adriático, donde se coge en gran número, se sala, se coloca en barriles y se remité ó otros puntos.

\section{LOS EXOCETOS - EXOCCETUS}

CARACTERES.-Los peces voladores que suelen ver cuantas personas viajan por mar, pertenecen en su mayoria al presente genero. Los caracteriza el desarrollo extraordina. rio de sus aleias, en particular el de las pectorales que son muy puntiagudas, cuya longitud es igual á las dos terceras partes del cuerpo, y la anchura á otra tercera, y cujo movi. miento es mucho mas libre y f́́cil que el de los demás peces por hallarse insertis en un cinturon huesoso muy robusto, oculto debajo de gruesos músculos. La anal ocupa el punto opuesto de la dorsal que es bastante ancha; las abdominales se hallan debajo de las pectorales; la caudal está profundamente bifurcada y su lóbulo inferior es mayor que el superior. Las dos mandibulas llevan dientes muy peque. ños; el paladar y la lengua ninguno. Abstraccion hecha de las aletas, se asemejan los exócidos mucho al arenque, y el nombre de arenusres zoladores que les dan es muy acertado. Sin embargo, su estructura. es mas fornida, el hocico mas grtueso, mas obtuso y en general mas tosco; los ojos son muy grandes, lo mismo que el opérculo y preopérculo; además difieren por sus escamas poco adheridas, $y$ por una hilera de las mismas que corre a lo largo del costado con una cresta bastante elevada.

En su estructura interior llama desde luego la atencion, como ya lo notó Humboldt, el tamaño excesivo de la vejiga natatoria cuyas dimensiones eran en el individuo que este sabio examinó s que media $0^{\circ}, 16$ solamente, $0^{\infty}, 09$ de largo por ()$^{\mathrm{m}}, 025$ de diametro, encerrando de consiguiente unos $U^{\prime \prime}, 60$ cúbicos dè aire. Iـa vejiga, dice, ocupa la mitad de la cavidad del cuerpo, contribuyendo en gran parte al poco peso de este pez. Hay motivo para creer que cste depósito de aire sirve mas para el vuelo que para nadar, porque los experimentos que hicimos Provenzal y yo, prueban que este órgano no es de ningun modo necesario para los morimientos en la superficie del agua en las especies que lo tienen. Lis naturaleza ha dispuesto un espacio adecuado y particular para dar cabida á una vejiga tan extraordinaria, espacio que no se ha observado todavia en ningun otro per, y que consiste en que las apófisis trasversas de las vértebras caudales forman á modo de un anillo donde penetra la vejiga.

Las diferentes especies de exocetos se parecen tanto que hasta hace poco tiempo se distinguian solo algunas pocas. Valenciennes que en union de Cuvier publicó la primera obra detallada sobre esta clase de animales, los examinó mas es. crupulosamente y separó unas treinta especies; otros estudios posteriores agregaron á estas algunas mas, y en la actualidad asciende su número á cincuenta poco mas ó menos.

DISTRIBUCION GEOGRÁFICA.-Pueblan estos pe. ces los mares situados en la zona templada, y aun los de la tórrida, sobre todo el Océano, en número incalculable, y no solamente junto á las costas, sino léjos de ellas, de modo que puede decirse que llenan todos los ámbitos del mar. Rara vez. llegan á los mares septentrionales, y en las costas británicas solo se han observado hasta hoy dos especies.

USOS, COSTUMBRES Y REGIMEN. - Todos ellos observan á poca diferencia el mismo género de vida, á juzgar por lo poco que se conoce, pues nada sabemos subre su modo de nadar, su vida en el agua ni su reproduccion; todos los datos que accrca de ellos tenemos se limitan en rigor á su vida en el aire, es decir, à su modo de volar, ó sea de cazar $y$ de huir.

Es singular su costumbre de salir del agua. Cuando se penetra en los mares que habitan, se los ve al rededor del buque, en todas direcciones $y$ hasta donde alcanza la vista, levantarse sobre el agua aqui, allá y acıllı́, ya uno, ya muchos á la ver., para bajar otra vez; y tan rápidos son estas ascensiorses $y$ descensos que parece que el mismo pez no hace mas que tocar al agua para levantarse de nuevo y como para tomar nuevo impulso, cuando en realidad son otros los que saltan por encima de los que se ocultan otra vez en el agua; porqque al observarlos con cuidado cuando vujelan á centenares ó á millares como sucede con frecuencia, se ve que muchos de ellos vuelven á caer al agua despues de dar un salto corto, mientras que las demás continuan su viclo para bajar \& su elemento á una distancia muchísimo mayor y variable. Cuando vuelan con calma levántanse como a un metro sobre el mar, de modo que rasan las crestas de las pequeñas olas y caen á una distancia de seis metros; pero si quieren emplear todas sus fuerzas, levántanse tambien hasta seis metros, y describiendo un arco muy rebajado, atraviesan distancias de ciento hasta ciento veinte metros, y aun algo mas, en casos á la verdad excepcionales. Por lo regular vuelan en una direccion fija, pero pueden cambiarla, solo que entonces caen en seguida al agua. En el aire llevan extendidas horizontalmente las aletas pectorales $y$ abdominales, pero sin aletear como las aves. Humboldt asegura que, no obstante la velo. cidad del vuelo, puede muy bien distinguirse cómo el exoce. to extiende y encoge alternativamente las aletas cuando salta 6 vucla, pero Bennett dice que solo extiende las pectorales y abcominales cuando se levanta, produciendo con este movi. miento un ruido que se oye distintamente, y que una vez le. vantado el pez solo tienen sus aletas un movimiento tembloroso; «pues si estos peces batiesen el aire con sus aletas, añade este observador, forzosamente lo habria visto yo cuan. do pasaban por la popa, como lo hacian con frecucricia. 
Solo en último extremo varian de direccion durante el salto, como para evitar un choqque contra algun objeto extraño, ó huir de algun ave de rapina, porque entonces el esfuerzo que tienen que hacer con la cola les hace perder el equilibrio y caer al agua. Cuando quiere este per. describir curvas, procede de otra suerte; traza un poligono ó mejor dicho cambia á caça saito de direccion, dándolos cortos \& solo como de un metro de altura. Mientras no les amenaza peligro alguno, tienen los exocetos el vuelo muy seguro, tanto que en realidad se aseneja al de las aves, mas apenas se ven perseguidos ó espantados por algun buque, su salto ad. quiere un carícter irregular, rigido; torpe y como tembloroso, y entonces cac el pez mas á menudo al agua, de la cual se vuelve á levantar para seyuir adelante.

Agassiz no está enteramente conforme con esta relacion, y dice lo siguiente: "He tenido frecuentes ocasiones de ob. servar los peces voladores, y me he convencido de que no solamente son capaces de cambiar á su albedrio de direccion, sino tambien de que pueden subir y bajar como quieran sin tocar el agua. A mi me han parecido todos sus movimientos voluntarios. Se levantan sobre el agua merced á sus coletazos repetidos $e^{f}$ instantáneos, y mas de una vez los he visto dejarse caer hasta la superficie del agua para renovar este empuje, por cuyo medio podian continuar su marcha aéres durante mucho ticmpo.

\El cambio de direccion, ya á la derecha, ya á la izquierda, hácia arriba 6 hácia abajo, no es efecto de ningun aleteo de las pectorales, sino sinplemente de un movimiento en su superfície debido á los músculos correspondientes, que varía $\mathrm{el}$ plano de inclinacion segun lo requiere la presion que tienen

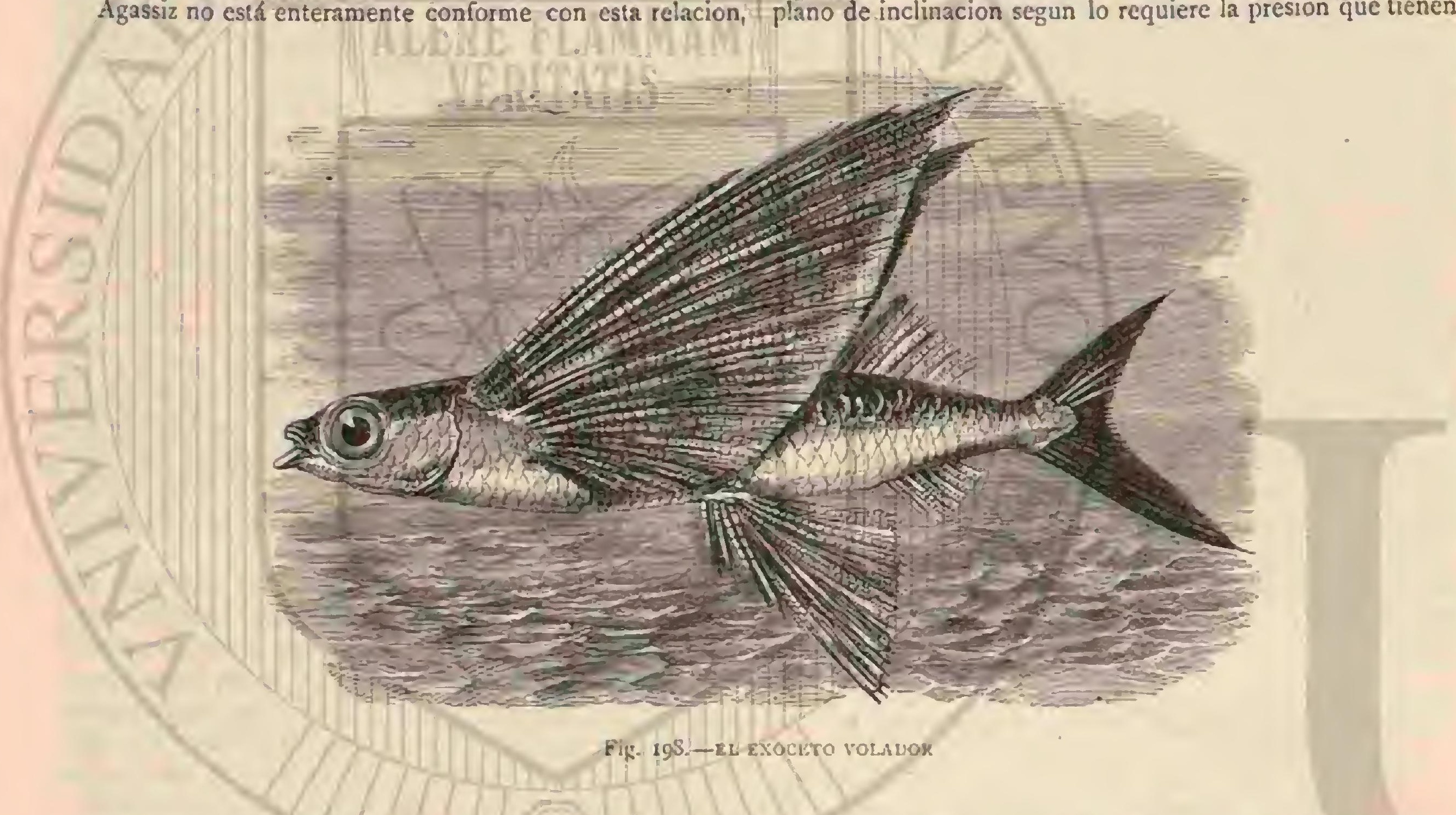

que ejercer contra el aire para lograr la desviacion que desean. Los peces voladores no son ni mas ni menos que una especie dic volante como los que se usan en el juego de raqueta, pero volante vivo, que por un movimiento giratorio de las aletas cambia de direccion. Probablemente se sostie. nen en el aire hasta que la necesidad de réspiras los obliga á volver al agua. Nada prueba mejor la independencia completa de sus movimientos, como el hecho de que en lugar de pasar sobre las olas encrespadas describiendo una sola curva, adaptan su vuelo á ellas con la mayor exactitud. Igualmente parece un error que caigan al agua cuando se les ha terminado la fuerza de impulso, sino que por el contrario se sumergen cuando quieren, voluntariamente, á veces á poca distancia, y otras despues de un gran vuelo $y$ de cambiar muchas veces de direccion. Ahora, que he estudiado sus mo vimientos comprendo el porqué de la desigualdad de los dos lóbulos de la cola: reo claramente que la mayor longitud del lóbulo inferior de esta aleta facilita al pez el movimiento de empuje para salir del agua $y$ atravesar el aire, y que la gran superficie de las pectorales ha de servirle de apoyo cuando atraviesa el medio mas ligero, es decir, el aire.

Oigamos ahora à Humboldt que dice: $\$$ Los exocetos pasan una gran parte de su vida en el aire, pero no por eso mejoran su miserable condicion; pues si abandonan el agua para escapar de las caballas doradas tan voraces, topan con las fragatas, albatros $y$ otras aves maritimas. Kittlitz viene á apoyar este aserto diciendo: «El vuelo parece ser el último recurso de estos peces para escapar á sus perseguidores que no los dejan respirar. Su número considerable excita en pro. porcion la roracidad de los peces de rapiña, y forzoso es que se multipliquen de un modo extraordinario cuando son tan numerosos á pesar de esta persecucion conjatante y continua, pues no solo los acosan sus enemigos acuáticos, sino que les amenazan tambien otros aśrcos muy numerosos, es decir, todas aquellas aves que al parecer cifran su existencia en estos peces, y que hacen de ellos su principal alimento, conforme vemos en este mismo momento que un gran procelárido los está cazando con una destreza sin igual. En otro paraje dice el mismo autor que el freton etéreo figura tambien entre los enemigos mas activos y peligrosos de los exocetos.

Bennett es de opinion contraria s se cree autorizado para contradecir las relaciones de Humboldt, de Kittlitz y de todos los autores que hablan de tales persecuciones, diciendo que ya es cosa corriente figurarse á los pobres exocetos $\delta$ voladores como victimas que no bien salen del agua, cuando ya se ven atacados por innumerables bandadas de gaviotas; faetones, fragatas y otros enemigos alados, mientras que los pocos que escapan y pueden volver à su elemento natural, caen en las bocas abicrtas de los delfines, atunes, bonitos y otros peces, que los esperan. lin vista de esto es extraño que esta familia de peces no esté ya completamente exterminada. «Yo me inclino à dudarlo, dice este autor, porque aun 
dado caso de que alguna que otra vez ocurran tales cace. rias, he visto en cambio saltar grandes bandadas de exocetos fuera del agua, sin que les hubiese obligado ningun pez á ello ni perseguido ave alguna, siendo por el contrario ellos los que cazaban, puesto que encontré en los estómagos de los que cogimos restos de peces pequeños, de crustáccos y de inoluscos, con lo cual se explica porqué esa supuesta guerra de exterminio no ha disminuido todavia su número. Mas de una vez vimos nuestro buque rodeado de voladores y de atunes en grandisimo numero; pero cuando cogimos uno de estos últimos, jamás encontramos exocetos en su estómago, sino siempre cefalópodos y otros animales de esta clase, no quedando por consiguiente duda de que los voladores son bastante listos para librarse de aquellos enemigos tan voraces. Es fácil que un observador poco exacto crea ver que el atun persigue peces voladores, cuando en realidad solo caza calamares. Sin embargo, no niego que á veces, pero en casos raros y siempre cerca de la orilla, una bandada de voladores se vea realmente perseguida en el agua por atunes, delfines $y$ bonitos, $y$ en el aire por enemigos alados.

Hay que convenir en que esta explicacion de Bennett, observador tan concienzudo, tiene mucho en su favor, pero no es nueva, porque Humboldt ya dijo: 1 Dudo que los pe. ces voladores se lancen fuera del agua tan solo para sustraet. se á la persecucion de los enemigos. Semejantes á bandadas de golondrinas, agitanse á millares en linea recta y en una direccion opuesta siempre á la de las olas: en nuestros climas se ve con frecuencia cómo los peces alados, que no tienen motivo aiguno de temor, saltan sobre la superficie de las aguas, cual si lescomplaciese respirar el airepuro; y al ob. servar el hecho ¿por qué no hemos de creer que los exocetos se lanzan en los aires por puro juego 6 diversion, tanto mas cuanto que la forma de sus aletas pectorales y su poco peso especifico les permiten recorrer fácilmente el espacio aéreo?

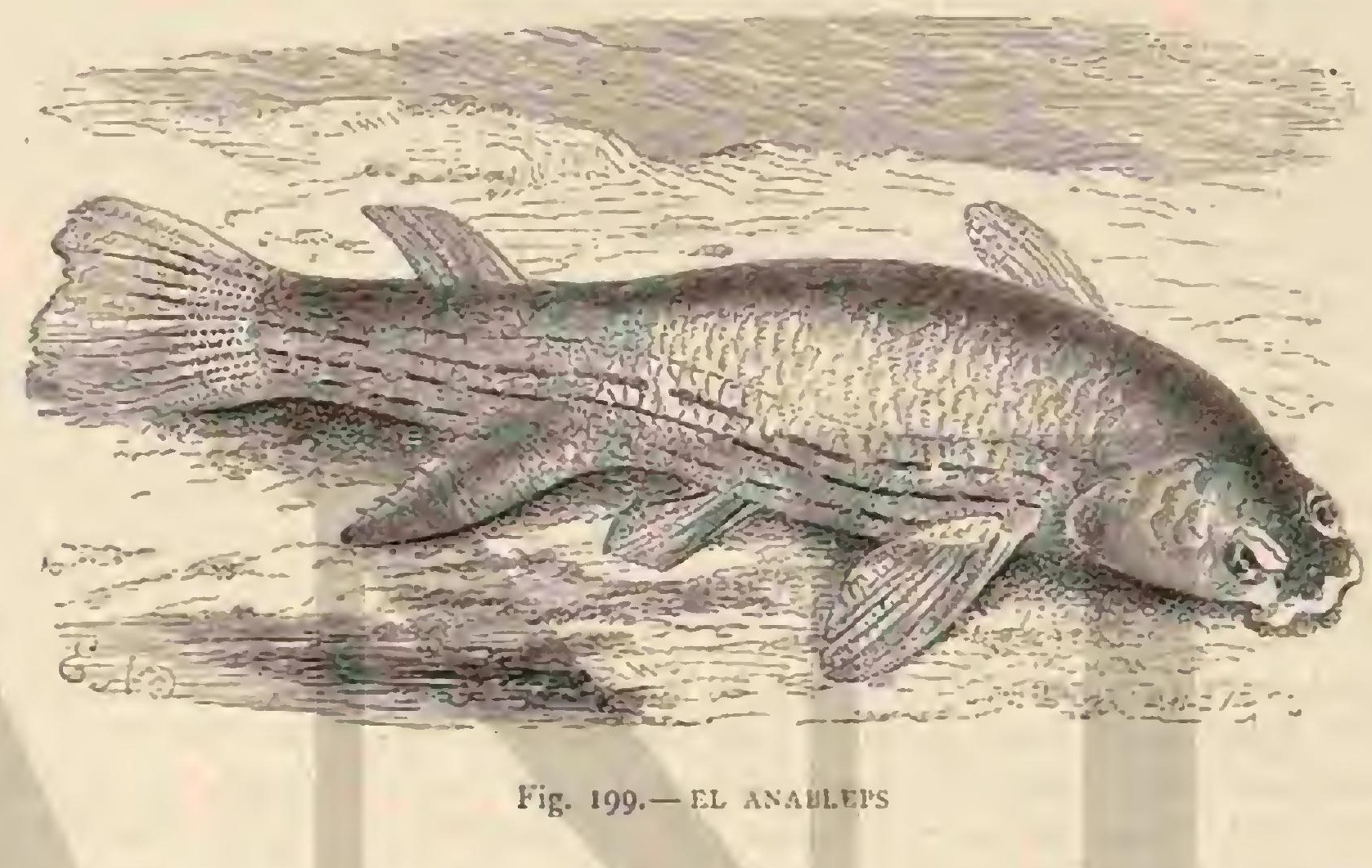

No hay duda que el vuelo es una parte integrante de la vida de estos peces, y que al igual de todos los animales ejercen cllos sus facultades naturales, pero tampoco es dudoso que empleen ante todo esta facultad tan extraordinaria para es quivar los peligros que mas de cerca les amenazan.

Por grande que sea el cuidado y habilidad con que estos peces huyen durante el dia de tropezar con buques, no dejan de caer á menudo de noche sobre la cubierta atraidos probablemente por la laz de los faroles de á bordo; 5 tanto es asi que para cogerlos el mejor medio es encender de noche fogatas en un bote con la rela desplegada; entonces los atrae la lim, y la vela los detiene.

USOS Y PROVECHOS.-Por lo general no se comen los voladores que saltan sobre la cubierta, pero en todas las costas de la América central y meridional pasan con razon por manjar muy delicado. Humboldt añade á su relacion que los grumetes se divierten en cortarles un pedazo de la aleta pecioral y arrojarlos otra vez al agua, porque, segun dicen, les vuelve á crecer. En el Brasil los enganchan vivos por via de cebo al anzuelo y cogen con ellos peces mas fínos, como bonitos y caballas doradas, que, como ya dijimos en su lugar, se dejan engañar hasta por una grosera imitacion.

\section{EL EXOCETO VOLADOR-EXOCGTUS VOLI- TANS}

CARACTÉRES. - Esta especie (fig. I98), la mas cono cida de la familia, habita el Mediterránco. Su longitud llega á lo sumo à $10^{\mathrm{m}} ; 50$. La parte superior del cuerpo es azul, la inferior blanco-plateada La epidermis de las aletas pectora. les es de un color traslúcido muy hermoso. Cuéntanse once radios en la dorsal, quince en la pectoral, seis en la abdomi. nal, nueve en la anal, y reintidos en la caudal.

\section{LOS CIPRINODÓNTIDOS -CYPRINODONTIDE}

CARACTERES.-Los peces de esta familia, que cuen. ta mas de cien especics, se asemejan en general á las carpas ó ciprinidos, solo que no tienen dientes faringeos ni la llamada ficho de carpa, sino solo dientes en las mandibulas $y$ faringeos superiores é inferiores de puia. Las mandibulas tienen la misma estructura que en los ciprinidos; la intermaxilar forma el borde de la superior; la boca es protráctil, no hay branquias accesorias, la vejiga es sencilla sin huesecillos auditivos, el estómago carece de buche y el canal di. gestivo de ciegos.

DISTRIBUCION GEOGRÁFICA.-La verdadera pa. tria de los ciprinodóntidos es América, donde habitan el mar, los rios y los lagos; en los Andes hasta t,000 metros sobre el nivel del mar, como por ejemplo en el lago de Tiricaca. En Europa los representa un solo género.

REGIMEN Y UTILIDAD.-Estos peces se alimentan principal cuando no exclusivamente de materias animales. Algunas especies son viviparas. Para la economia doméstica no tienen importancia ninguna, $y$ si no fuese por la estructura singular del ojo de una especie no mencionaria siquuiera esta familia. 
EL ANABLEPS-ANABLEPS TETROPHTALMUS

CARACTERES, - Esta especie (fig. 199), una de las tres que se conocen del género de ojos.dobles, tiene una es. tructura análoga à la de la locha lobo ó de barbilla. El cuerpo es oblongo y ahusado; la cabeza plana, el hocico obtuso: la boca no es protráctil, pero si hocicuda: la aleta dorsal es muy pequeña y está colocada mas atrás que la anal; la caudal es sencilla sin escotadura, la torácica está cubierta en parte de escamas; el cuerpo lo está por otras de forma re: donda, radiadas cesde un punto céntrico y dispuestas en hileras longitudinales; los dientes de la hilera exterior san mo. vibles y aterciopelados; los que cubren los huesos faringeos son de púa y muy anilados; pero mas notable que todosestos caracteres es la estructura del ojo. Es salton y metido en una cavidad orbital formada por el frontal inferior. Una lista casi horizontal, formada por el conectivo del mismo globo, pare. ce dividir la córnea y el iris en dos mitades casi del todo iguales; pero no hay mas que una sola pupila $y$ un solo cris. talino; estructura que no presenta ningun ótro animal sea de la clase que fuere.

El color principal es un amarillo verdoso sucio, sobre el cual se destacan en cada costado cinco listas estrechas pardas negruzcas. El numero de radios es en la aleta corsal de nueve; en la torácica de veintidos; en la abdominal de scis; en la anal de nueve y en la caudal de veintiocho. Is longitud uscila, segun Schomburgk, entre 1$)^{2}$, I5 $_{5}$ y 1$)^{2}, 20$.

USOS, COSTUMBRES Y RLGIMEN.-El anableps ojo-doble es conocido casi desde el mismo descubrimiento de América, pero poco es lo que se sabe sobre su género de vida. Schomburgk dice que habita la Guayana y el norte del Brasil, especialmente los bancos fangosos y desembocaduras de los rios en el Océano, tan cerca de la playa como es po. sible, $y$ en ciertos sitios en número incalculable; tanto que siempre quedan muchos en la playa rezagados cuando la marea baja los sorprende, teniendo que dar despues tremen: dos saltos para alcanzar su elemento, lo que cuesta la vida á muchos que llegan á ser victimas de sus enemigos alados, mas veloces que ellos.

En las poblaciones de la costa se venden estos peces con mucha frecuencia, á pesar de no tener fama de sabrosos. Sa. bemos por naturalistas de épocas pasadas que el anableps es viviparo y quue los pequeños al nacer miden $0^{\circ}, 05$; estando perfectamente formados, excepto en las partes genitales. In bolsa que encierra los pequeños durante la gestacion es grande, delgada 5 al parecer dividida en dos mitades, en las cuales se hallan los embriones en gran número, encerrado cada uno en una membrana especial. Se multiplican de un modo considerable. Hé aqui todo lo que me ha sido posible averiguar acerca de estos animales.

\section{LOS CIPRINIDOS - CIPRI-} NID.E

CARACTERES. - Los peces de esta familia tienen forma oroidea oblonga, bien pequeña, escamas grandes y redondas, ınandibulas débiles desprovistas de dientes, $y$ cuyo borde lo forma la internaxilar que está delante de la superior. Reem. plazan á los dientes mandibulares otros suplementarios que forman parte del hueso faringeo inferior y que se apoyan contra una prolongacion del cráneo cubierta de una placa córnea y llamada fiedra de carpa. El estómago no tiene bu. che, ni ciego el canal digestivo; la vejiga natatoria está por lo comun dividida en una mitad anterior y otra posterior, y unida al aparato auditivo por una serie de huesecillos.

De todos estos caractéres los mas importantes para la subdivision son la estructura de la boca $y$ los huesos farin. geos; la primera puede estar rodeada de labios carnosos y abultados ó de los bordes de las mandibulas delgados y cortantes y frecuentemente cubiertos de cartilagos; los segundos pueden variar por su forma, número y colocacion, dando lugar á diferencias tan fijas y seguras que pueden servir perfectamente para distinguir las diferentes especies. $\mathrm{Ni}$ el desgaste y renovacion regular de los dientes, ni las deformida. des casuales y raras de los mismos impiden, segun Heckel y Kner, lo mas minimo su empleo para dicho objeto; antes bien sirven para determinar los géneros y especies de esta familia con mas fijeza de lo que puede hacerse con ninguna otra. El número de los huesos faríngeos es reducido, salvo contadas excepciones; casi siempre hay en cada lado de cua. tro hasta diez, bien que su numero no es siempre igual en ambos lacoos, y están dispuestos, segun las especies, en fila simple, doble 6 triple. A estos caracteres se agregan los derivados de la cubierta escamosa, de la presencia $\delta$ falta de barbillas, etc.

DISTRIBUCION GEOGRAFICA.-LOS ciprinidos forman la inmensa mayoría de los peces de agua dulce de la Europa meridional, una parte notable de los que pueblan las aguas del interior del Asia y de ciertas comarcas del Africa y de la América del norte.

USOS, COSTUMBRES X REGIMEN. - Las mil especies de esta familia que poco mas ó menos se han descrito, buscan siempre aguas estancadas de fondo blando, cenagoso ó arenoso, rico en gusanos, larvas de insectos, y vegetales en putrefaccion; tambien se encuentran en rios de corriente mansa, pero se apartan en lo posible de las aguas que descienden de las sierras. Viven casi siempre en sociedad y forman á menudo numerosas bandadas que nadan, cazan y aun pasan juntas la estacion mas cruda, metiéndose sus individuos uno junto a otro en el cieno, donde se entregan á una especie de sueño invernal. Su régimen los obliga á pasar mucho tiempo inmediatamente sobre el fondo, de donde ticnen que sacar la mayor parte de su alimento con la cabeza metida en él ó hurgoneándolo. Hácia la época de la freza se dividen en grupos mas reducidos; las hembras pasan delante, los machos las siguen por lo regular en mayor número, por ejemplo, dos ó tres machos para cada hembra, y si el número respectivo es demasiado desigual, puede suceder que se apareen especies afines en la operacion del desove; por lo menos se admite ahora que muchos ciprínidos mencionados en las obras de naturalistas doctos como especies diferentes no son mas que mestizos. Acaso se explique esta inclinacion de las diferentes especies de ciprínidos á aparearse entre si, por el instinto prolifico muy pronunciado en ellos, pues des. de tiempos remotisimos vemos el tipo fundamontal de la familia, la carpa', figurando como emblema de fecundidad, dedicada á Vénus, á lo cual alude tambien su nombre, que del idioma griego pasó al latino y de este á los nuestros. En la freza de una hembra de tres libras se han contado 337,000 huevas, $y$ en otras adultas $y$ del todo desarrolladas hasta 700,000. Tanta abundancia explica tambien la vivisina inquietud, el cambio notable en otros conceptos y lo poco escrupulosos que se muestran estos peces, en el tiempo del desove, \& mezclarse con diferentes especies.

A estos cruzamientos numerosos, que han dado lugar a variedades hereditarias, contribuye otra causa importante: la de la cria doméstica que el hombre practica con ellos desde hace muchos siglos, dando lugar con la dispersion artificial, cualidad especial de las aguas de los estanquues y lagos, trato diferente, etc., á variedades que en el trascurso del tiempo se han heclio fijas, aumentando de paso su número hasta $\mathrm{el}$ grado de ser mayor en esta familia que en todas las demás. 
USOS Y PROVECHO. - Excepto algunas pocas espe. cies bien conocidas de nuestros pescadores y dueñas de casa, todos los ciprinidos tienen la carne blanda y muy suculenta, y gracias â su extraordinaria vitalidad pueden remitirse á grandes distancias $\mathrm{g}$ aclimatarse en las aguas mas diferentes mucho mejor que todos los demás peces; se multiplican, como se ha dicho ya, en proporcion asombrosa, se contentan con un régimen comparativamente sencillo $y$ ba. rato, crecen con suma rapidez $y$ engordan pronto, por manera que reunen todas las condiciones apetecibles para la cria artificial. En las carperas y otras aguas donde el hombre los cuida están sujetos cstos peces á muchas enfermedades, pero en cambio sufren poca persecucion cuando son grandes, si bien cuando pequeños todo el resto de la poblacion acuśtica los acecha. Por esta razon sucede rara vez que su cria deje de dar el resultado apetecido, por manera que pue. de decirse que los ciprínidos son propiamente los peces pre. dilectos del pequeño agricultor; y' si la cria se hiciese con mas inteligencia, si se proporcionasen à los peces puestos adecuados para el desove, cosa tan fácil de arreglar, si se separasen los majores de los pequeños y se procurase que no les faltara un alimento apropiado, el beneficio que el propie. tario de una carpera obtiene hoy, seria mucho masor por cierto de lo que es.

\section{LAS CARPAS-CYPRINUS}

CARACTERES. - Consisten estos en la boca que se halla en el extremo del hocico, en cuatro barbillas ó tentá. culos en la mandibula superior, cinco dientes faríngeos co. locados en tres hileras, uno en la primera y segunda hilera de cada hueso faringeo $y$ tres en la tercera; $y$ finalmente en los primeros radios huesosos y fuertemente dentados de las aletas dorsal $\mathrm{g}$ anal.

\section{LA CARPA COMUN-GYPRINUS CARPIO}

CARACTERES. - Este representante del grupo (figura 200), conocido desde remotisimo tiempo, alcanza, haciendo caso omiso de algunas especies gigantescas que, segun se dice, median $t^{\prime \prime}, 50$ de largo y $0^{\circ}, 60$ de ancho con un peso de 35 kilógramos, una longitud de cosa de un metro y un peso de $r 5$ a 20 kilógramos. La boca es ancha, de labios abultados, y está rodeada de barbillas recias y largas; la aleta caudal está profundamente escotada á manera de media luna; el radio huesuso de la aleta dorsal y amal es den. tado, la coloracion y forma son variables, la primera pasa desde el amarillo de oro hasta el verde azulado. Fl dorso $y$ las aletas tienen generalmente un tinte gris, los labios y el vientre son amarillentos; las aletas de un viso rojizo; las es. camas presentan á menudo una mancha negra en el centro y á veces están orilladas de negruzco en la parte poste. rior. En la aleta dorsal hay de tres a cuatro ndios imper. fectos y de quince á diez $y$ seis blandos; en la abdominal dos duros $y$ ocho $\delta$ nueve blandos, en la anal respectivamente tres $y$ cinco, $y$ en la caudal de diez y siete hasta diez y nueve, todos artículados y ensanchados hácia arriba.

Hasta hace muy poco tiempo se habian considerado mu chos mestiros y tipos alterados como especies independien. tes, pero las investigaciones minuciosas de Siebold han he. cho patente lo erróneo de este modo de ver. Hé aqui lo que dice este naturalista. Hace ya tiempo que estamos acostumbrados á considerar únicamente como variedades y no como especies, segun se creia antes, las carpas especulares (Cyprinus specularis of Cyprinus rear oprinorum), cubiertas de escamas relativamente grandes y poco numerosas; las carpas lisas (Cyprinus mudus), desprovistas enteramente de escamas; pero algunos ictiólogos se resisten á crecr que ciertas carpas puedan variar hasta de perfil, de lo cual nos presentan á menudo ejemplos extraordinarios nuestros animales domésticos de sangre caliente. La carpa, que presenta por lo regular y como carácter típico prinutivo una forma oblonga un tanto comprimida lateralmente, puede alargarse mas ó volverse mas cort2, mediando influencias especiales; en el primer caso con el lomo mas bajo y recondeado hácia los costados, y en el segundo mas comprimido y mas elevado. Una de estas razas que presenta los primeros caractéres en muy alto grado, ha sido admitida por Heckel como especie distinta y llamada carpa de IIungria (Cyprinus hungaricus). Es pez muy frecuente en las pescaderias de Viena; pero tambien se ve en las de Munich y Baviera de cuando en cuando; cstas carpas proceden de Suabia y no se diferencian en nada de aquellas, pues presentan la misma forma casi cilindrica de cuerpo, el lomo casi recto cuyo punto mas alto cae mucho antes de la aleta dorsal, el hocico obtuso con la hendidura bucal que solo por delante se eleva un poco hácia arriba, y el perfil recto del vientre; en fin todos los caractéres que Heckel cita como particulares de su espe. cie. Bonaparte elevó á especie con el nombre de reina de las caupas (Cyprinus regina) otra forma de estos peces que vienc á ser el término medio entre la carpa corta de estan. que y la húngara, pero tambien se distinguen estas carpas sin mucho trabajo entre las muchas que traen a estas pesca. derias de Baviera, Suabia, Palatinado de arriba, Franconia y Bohemia. Otra serie de variedades que pueden resultar de la carpa criada artificialmente comprende las de cuerpo corto y lomo elevado ó giboso, entre las cuales se distingue como la mas corta y gibosa la que describieron Heckel y Kner con el nombre de corpa pusutiaguda (Cyprinus acuminabus), y cuya patria es el Danubio y los lagos de Neusiedel $y$ de Platten, $y$ tambien pude encontrar diferentes veces in. dividuos que correspondian perfectamente á la descripcion de estos naturalistas, entre las carpas de estanque, de cuerpo corto y lomo alto, que junto con las especulares, se venden en esta provenientes de los alrededores de Dinkelsbuhl. Exactamente lo mismo puede decirse, segun Steindachner, respecto de muchas carpas llamadas especies por otros natu. ralistas, $y$ que son simples variedades. El encontrarse todas estas formas en el norte y mediodia, en el este y oeste, se explica por la extraordinaria facilidad con que este pez puede remitirse vivo y aclimatarse en lejanas aguas, asi como por el hecho de que circunstancias 5 causas iguales pueden producir fenómenos y efectos iguales tambien.

DISTRIBUGION.GEOGRÁFICA.-I,os antiguos gric. gos y romanos conocian la carpa, pero no la apreciaban tan. to como nosotros. De ahi han sacado algunos naturalistas la consecuencia de que este pez ha - venido s. Francia y Alema. nia desde la Europa meridional; pero tambien puede ser que pueble desde las épocas mas remotas nuestros rios principa: les, cuando menos el Danubio. Pallas dice que se encuentra en grandisimo número en e! mat Caspio y sus afluentes, pues. to que medra tambien en los pantanos mas salobres. No es menos frecuente en los rios que desembocan en el mar $\mathrm{Ne}$. gro, pero si rara en este último. En verano busca alli los sitios de poca agua entre los bancos de arena, y en otoño remonta los rios para pasar el invierno léjos del mar. No existe en el norte de Rusia, segun dicen, pero la hemos encontrado en Siberia en la cuenca del Ob, particularmente en el Irtich, y en aquellos rios que se dirigen á levante $y$ des. embocan en aqquella parte del Océano. En lo que no cabe duda es en que ha sido aclimatada en la Europa septentrional, llevandola de otras regiones. En la parte antigua de 
Prusia fué introducida la carpa al rededor del año $\tau_{7} 69$, seyun dicen, y mas tarde en las provincias rusas del Báltico. Desde Alemania y Dinamarca fué llevada á Suecia é Inglaterra, a este último pais, segun unos, al rededor del año $\mathrm{J} 496$, y segun otros, en 1521 . Hoy no falta este pez en ninguno de nuestros rios y lagos de la Europa central, siendo la causa principal de esta dispersion, no tanto su delicada came como la facilidad con que se presta á la cria en estanque, en la que no la iguala pez alguno.

USOS, COSTUMBRES Y REGIMEN - La carpa prefiere estanques 6 lagos de poca profundidad con fondo cena. goso, de poca sombra y poblados a trechos de plantas acuaticas; tambien prospera en corrientes mansas y de fondo liso; las aguas cristalinas y de mucha corriente le son completamente contrarias. Se ceba durante el verano $y$ despues de la freza para acumular"grasa para el invierno, á cuyo fin recorre en espesas bandadas los sitios de menos agua en busca de insectos entre las plantas acuáticas, removiendo el cieno; acaso cace tambien anfibios y otras sabanoijas. Tambien le gustan las sustancias regetales, las mismas plantas acuáticas en putrefaccion, fruta pasada, patatas cocidas, pan, etc. En las carperas la alimentan con las dejecciones de los carneros, bien que en rigor solo las comen estos peces por los insectos y gusanos que crian, lo mismo que comen el cieno, no por ef sino porlos animales que contiene, $y$ aun parece que las materias terrosas les son necesarias. En el mar es probable que se alimenten de gusanos y pequeños moluscos.

Cuando no la falta alimento, puede la carpa reproducirsc al tercer año; los cinco tiene la hembra ya 300,000 huevas y mas tarde puede poner un número doble, segun Bloch. Durante la epoca de la freza le salen al macho en la cubierta mucosa de la piel, en el occipucio, mejillas, opérculos y por lo regular tambien en ambos lados de las aletas pectorales, una multitud de verrugas pequeñas, irregulares y disemi. nadas; la coloracion adquiere un tinte mas subido, se despierta el instinto de emigracion, y procura subir rio arriba hasta donde puede, venciendo a menudo obstáculos bastante gran. des. La hembra deposita'su freza en sitios de poca agua cu. biertos de espesa vegetacion acuática, y solo cuando estos sitios abundan sale bien la cria.

No todas las carpas sienen la fecundidad asombrosa que en la antigüedad las hizo parecer dignás de ser consagradas a la diosa del amor, pues las hay en gran número que son estériles y asi continuan probablemente toda su vida; circunstancia que ya conocia Aristóteles, como tambien que estas carpas son mas finas y,suculentas que las otras. Los autores de la Edad-media llaman à las carpas estériles niosas, y tambien dicen que son mejores que las otras; pero respecto 1 la causa de la esterilidad no concordaban sus pareceres. «En algunos estanques, dice Gesswer, se .cogen carpas que no ofrecen aparato alguno sexual, y serán sin duda peces que nacen espontáneamente. En Inglaterra se castran adrede, cortíndoles los vasos seminales y ovarios, para producir ar. tificialmente estos peces castrados. En Alemania se vende el kilógramo de estos tálimos desde cuatro hasta diez y mas reales.

PESCA.-En los rios y lagos se hace la pesca de las carpas con redes de tiro y nasas, cebando los anzuelos con gusanos, pedacitos de carne 6 de fruta curada al sol. Para atraerlas al punto de pesca échase tambien en tales sitios al. gun cebo, como guisantes secos y cocidos. En el mar Cas. pio se cogen con la fitora; pero toda esta pesca no tiene im. portancia en ninguna parte, por lo menos en Alemania, donde se crian y cultivan las carpas en estanques y carperas indus. trialmente y en muchísimo mayor número que toda otra es. pecie de pez.
PISCICULTURA.- Ia cria de carpas supone cuando menos dos clases de estanques, los unos de poca y los otros de mayor profundidad, que se dividen en estanques de cria, de desarrollo, de invernacion y de depósito para la venta. I.os primeros han de ir ahondảndose hácia cl centro á fin de que los peces puedan retirarse alli cuando empieza á helar y no tengan que sufrir del frio, aunque sin exceder la profundidad dos metros; no han de faltar trechos de poca agua cubiertos de yerba, a fin de que las carpas de cria puedan poner alli sus huevas; otra condicion muy perentoria es que afluya constantemente a estas carperas agua corricnte cuya temperatura es siempre mas alta que la de los estanques donde queda detenida, siendo cosa probada que la carpa no medra en agua demasiado fria nı mucho menos en estanques alimentados por manantiales interiores, de iondo ó de fuera. Cuando se dispone de varios estanqques se destinan los de menos agua al desove y cria, y los mayores y mas profundos á carperas de desarrollo, pero de todos modos, los unos y los otros han de tener sitios algo profundos donde el agua quede liquida en los grandes frios, porque de otra suerte seria indispensable trasladar todas las carpas á un depósito mas profundo a la aproximacion del invierno. A un estanque de cria de 200 áreas de superficie suelen destinarse cinco carpas de cria, un macho y cuatro hembras de cuatro á coce años de edad; pero dicen, y esto se explica muy bien, que los resultados son mejores cuando el número de maclios es igual al de hembras. A pesar de la extraordinaria fecun. didad de estas carpas, solo se obtienen en circunstancias favorables de 1,200 á 3,300 pequenos de cada hembra de cria, probablemente porque no se atiende debidamente á preparar sitios adecuados para el desove. Algunos ducrios de estanques han obtenido resultados muy superiores colocando horizontalmente á unos veinte centimetros debajo de Is superficie unos cañizos ó esteras hechos de mimbres y cubiertos de muchas ramitas de abeto que las carpas utilizaron en seguida para desovar alli. Importa mucho sostener invariable el nivel del agua durante la incubacion para que las huevas no queden alguna vez á descubierto y se pierdan. Una vez nacidos los pequeñuelos, hay que cuidar mucho de alejar todos los animales enemigos de las carpas y de la cria. Los pequeños adquieren en el primer verano, suponiendo la temperatura favorable, una longitud de $6^{\mathrm{m}}$, os hasta $0^{\mathrm{m}}, 12$, que al cabo de otro año llega á $0^{\prime \prime}, 30$ y mas, con tal que r.o haya en un mismo estanque un número excesivo de hijuclos y que no falte alimenio abundante; á contar desde el tercer verano son ya vendibles y se trasladan con este objeto á las carperas propiamente dichas ó sean depósitos de cebo, donde continuan uno ó dos meses. Se juntan con los peces jo. venes hácia el invierno otros mas viejos, á fin de que estos les hagan el lecho de invierno.

Recientemente se han introducido las carpas en California donde han dado resultados por demás lisonjeros, pucs se desarrollaron de un modo pasmoso, ya por ser el clima mas benigno, ya por la mayor abundancia de alimento, por cuya razon se reprodujeron tambien mas pronto que en nuestro pais.

ENEMIGOS. - Persiguen á las carpas principalmente la nutria, el águila acuática y garzas de toda cspecic; despues las ratas de agua, los musgaños, las cigüeñas negras, los patos, los busardos y hasta las ranas, sin hablar de los peces carniceros. En casi todas las carperas pónense uno 6 varios lucios, porque se cree que estos contribuyen á despertar á las carpas de su indolencia natural, haciendo asi que se desarrollen mejor; pero hay que tener muchisimo cuidado en la eleccion de estos lucios, porque si encuentran abundante alimento en el estanque pueden crecer en poco tiempo tanto que lleguen 
á devorar las carpas y á causar entre ellas una devastacion in. creible. Muchos criadores de carpas tienen particular cuidado en que no haya en las carperas otros peces que carpas, porque dicen con razon que aquellos no dejan de consumir una parte proporcional de alimento, y por el mismo motivo exterminan las tanas acuáticas, recogiendo $y$ arrojando su freza.

CAUTIVIDAD.- Las carpas que se crian en pequerios estanques de jardin se acostumbran muy pronto a conocer el sitio donde se les echa la comida $y$ la persona que las cuida; aprenden à acudir cuando se las llana, ya a roces, ya con silbidos ó con una campana, y á aguardar alli reunidas su racion.

\section{LOS CARASIOS - CARASSIUS}

CARACTERES.-Consisten estos en tener la boca sizua da en el extremo del hocico; cuatro dientes faringeos á modo de espátula formando en cada lado una hilera, y un radio huesoso, dentado, hácia atrís en las aletas dorsal y anal.

\section{EL CARASIO COMUN-CARASSIUS VULGARIS}

CARACTERES. - Caracterizase este per por su hocico muy obtuso, de abertura bucal angosta y labios delgados; la frente muy ancha y cola ligeramente escotada. El color es muy variable viniendo as ser un amarillo de laton mas $\delta$ menos oscuro que pasa en el lomo ágris de acero, y presenta un viso rojizo en las a!etas. El numero de radios es en la dorsal de tres $y$ de catorce hasta veintiuno; en la pectoral de uno $y$ doce ó trece; en la audominal de dos y siete ú ocho; en la anal de tres $y$ cinco 6 seis, y en la caudal de diez y nueve á veinte. En cuanto á longitud, rara vez pasa de $0^{\mathrm{m}}, 20 \mathrm{y}$ el peso

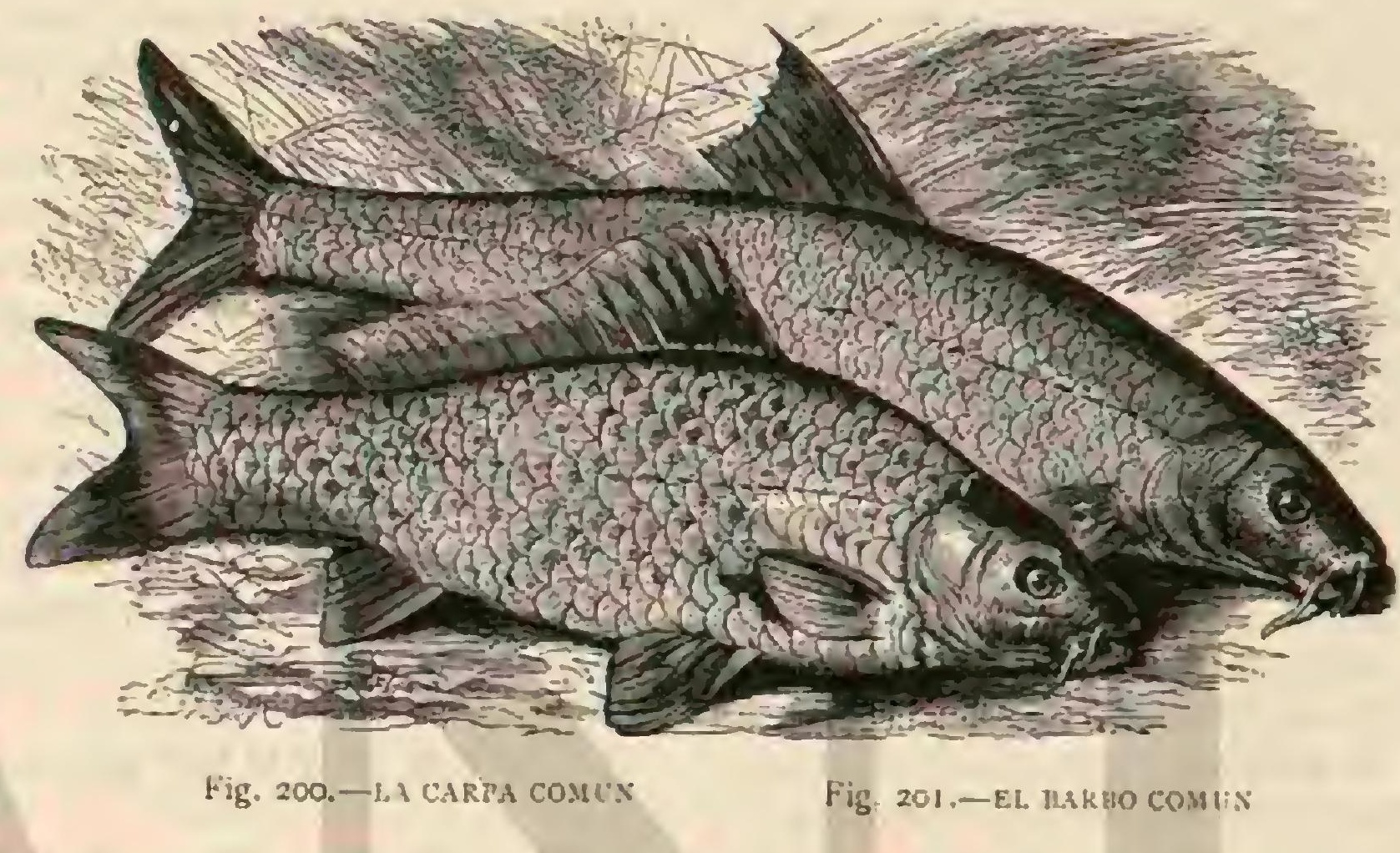

de 700 gramos. A Eckstrocm le dieron uno que pesaba un kilógramo, y otro que recibió Yarrell excedia de este peso, siendo su longitud de $\left(0^{m}, 25\right.$ y su altura máxima de $0^{m}, 11$.

El rarasio gibelio (Curassius Gioblio) y la carpa carasina. (Cjprinus Kollari), la primera considerada como especie for Bloch, no son otra cosa sino variedades, mestizos de carpa y de carasio, conforme resulta del análisis comparativo y minucioso de ictiólogos modernos, y como además está prubado que los carasios, al igual de las carpas, pueden pro. ducir variedades muy distintas del tipo fundamental por $l_{a}$ cria artificial, no duda ya nadie de la identidad especifica de estas dos formas con las anteriores.

DISTRIBUCION GEOGRÁFICA. - El carasio habita el centro, norte $y$ este de Europa y es frecuente en las corrientes, estanques $\mathrm{y}$ lagos de las cuencas del Rhin $y$ ciel Danubio, en la Prusia oriental y en toda la Rusia y la Siberia.

USOS, COSTUMBRES Y RÉGIMEN.-Gústanles á estos peces las aguas detenidas y principalmente los lagos de orillas pantanosas y brazos muertos de rios, y se le encuentra hasta en estanques pequeños, charcos, balsas, pan tanos y tierras turbosas cubiertas de aguas encharcadas; vi ven y prosperan en las aguas mas diferentes, mas impuras y turbias, donde el alimento que encuentran es siempre sucio y cenagoso; y que consiste en gusanos, larvas, materias ve getales en putrefaccion y lama, por cuya razon pasan la mayor parte de su vida en cl fondo, donde tambien se quedan aletargados durante el invierno, $y$ segun Pallas hasta pueden quedar yertos entre el hielo sin perjuicio de despertar en la primavera á nueva vida. Solo aparecen á la superficie en la época del desove que cac en el mes de junio en la Europa Toso $v$ meridional, y en julio en el norte. Entonces buscan los sitios de poca agua, pero cubiertos de vegetacion, donde retozan en bandadas, cazan, juegan y chasquean los labios hasta que empiezan el desove.

El número de huevas es relativamente pequeño, habien. dose contado por término medio cerca de 100,000 en cada hembra; á pesar de lo cual multiplicanse mucho estos peces, produciendo regularmente un número de mestizos por el cruzamiento con las carpas, y esto junto con su tendencia a devorar la cria de estas, motiva que se les aleje cuidadosamente y desde tiempos remotos de las carperas. Gessner ya dice: \& En los estanques carperos es muy perjudicial el cara. sio, pues uno solo, aunque pequeño, es capaz de ahuyentar la carpa mas grande, lo cual saben muy bien los dueños de tales carperas, teniendo gran cuidado de que no se eche alli ninguno de estos peces. La cria se desarrolla con lentiud, pero á los dos años están los pequeños en estado de repro. ducirse. Viven de seis á diez años.

PIScicultura Y PESCA.-La cria metódica decarasios, que en Alemania se renden desde uno hasta siete reales 5 medio el kilógramo, no tiene importancia sino en aquellos distritos donde el agua está demasiado corrompida y putrefacta:para carpas; esta agua no perjudica en nada el buen sabor de la carne de los primeros, pero sucederia lo con. trario con la de las segundas; fuera de esto pueden criarse tam). bien con muy buen resultado en aguas donde se crian tru. chas á las que sirven de alimento, con lo cual no dejan de dar muy buena utilidad. Su gran resistencia vital permite tambien remitirlos viros á grandes distancias y en cualquiera estacion con tal que se les envuelva y embale entre musgo ú hojas frescas y humedas; $y$ aun de todos modos viven muchas horas. 
El carasio es muy apreciado en Rusia donde puebla todas las aguas de las estepas. En los alrededores de Irkutsk se pesca principalmente en invierno con redes puestas debajo del hielo préviamente roto á este fin; se sacan los individuos mas grandes y se vuelven á arrojar los pequeños al agua para que crien.

\section{LOS PECES DE COLOR - CARASSIUS AU- RATUS}

CARACTERES. - La forma es aproximadamente la de la carpa, la longitud de $0^{\infty}, 25$ a $0^{\circ}, 30$, a lo mas de $0^{\circ}, 40, \mathrm{y}$ la coloracion bermellon con un refiejo de oro magnífico; pero hay muchisimas variedades, $y$ hasta pueden producirse con crias sucesivas razas mas ó menos fijas, como las producen los chinos, maestros en este ramo, siglos hace. En la aleta dorsal hay cuatro $y$ diez y seis radios, en la torácica diez y ocho, en la abciominal diez, en la anal tres y cinco, y en la caudal veintiseis. Los dientes faringeos son delgados, de una sola punta, y dispuestos en una hilera de tres dientes á cada lado.

DISTRIBUCION GEOGRÁFICA.-El primer autor que habla de un pez hermoso de adorno, de color amarillo de oro, es el viejo Kaempfer; este pez es el kingryo que crian en el Japon $\mathrm{y}$ en China en estanques de jardin, y lo consideran en cierto modo como animal doméstico. Mas adelante habla Du Halde en su Hisloria de China detalladamente de este pez: «Los principes y grandes del celeste imperio tienen en sus jardines estanques construidos expresamente para los peces de color, $y$ los tienen tambien en magnificos jarrones de porcelana, donde se renueva el agua dos ó tres veces á la semana. Estos señores de larga trenza pasan muchos ratos contemplando los movimientos graciosos de estos peces, y se entretienen y recrean dándoles de comer y amansándolos, como que son los chinos en general muy amigos de animales.

El king jo 6 sea nuestro pes de color, pas 6 probablemente de la China, primero a Portugal desde donde se extendió paulatinamente por toda la Europa; mencionando algunos autores el año I6Ir, otros el año 16gr y aun el del 1728 como la época de su introduccion. Lo cierto es que ya exis. tia en Francia en el tiempo de la famosa Pompadour, como lo prueban documentos fehacientes, diciendo que regalaron á esta señora cierto número de ellos como objetos rarísimos. En Inglaterra los introdujo Felipe Worth en el año $1 ;=8$. En el dia se encuentran en todo el mundo civilizado, y en los paises cálidos de la zona templada se les puede considerar como perfectamente aclimatados. Los franceses Hevaron este pez á la isla de Mauricio donde puebla ahora todas las corrientes, lagos y estanques, y lo mismo sucede en muchas aguas de Portugal.

PiscrCULTURA.-En muchas partes los crian industrialmente en grandisimo número, como en la Francia meri dional y occidental; en los alrededores del Havre, desde donde se provec el consumo inglés casi exclusivamente; $y$ tambien en algunos puntos de Alemania, particularmente en Prusia en los distritos de Mohrung, Konigsberg, Nimptsch, Hirschbergy Liebenwerda; Cristian Wagner de Oldenburgo ha logrado muchas razas nuevas y fijas, y vende anual. mente unos 300,000 peces de color.

La cria se hace en general por el estilo de la de las carpas, solo que los estanques son mas reducidos y su número mayor. asi como los cuidados han de ser mas solicitos tambien. Con una direccion hábil é inteligente se logra que estos peces hagan cada verano de tres a cuatro crias, que adquieren pronto su coloracion definitiva, y que la varian dentro de ciertos límites. De todos modos produce mas la cria de estos peces, cuando marcha bien, que la de las carpas, porque á medida que se generaliza $y$ dispersa, aumenta tambien el número de aficionados, y si bien parece que con la introduc. cion del macropo de Java se le presenta un competidor ter. rible, no deja de conquistarse el pez de color cada dia nuevos amigos, pormanera que su cria tiene para mucho tiempo el porvenir asegurado.

CAUTIVIDAD. - En las habitaciones se tienen estos peces por lo comun en globos de cristal, pero mejor es em. plear acuarios, algo mayores, adornados y provistos de plan. tas acuáticas. Como alimento se les da diariamente unas cuantas larvas de hormiga desmenuzadas, migajitas de pan ó de oblea, pero se ha de ser muy parco, porque la poca cantidad de agua de que disponen se corrompe sin que se contribuya á ello con cuerpos extraños, de suerte que otros peces mas delicados sucumbirian muy pronto en ella; y el mu. cillago producido por un exceso de alimento es mucho peor y no lo soportan tampoco los peces de color. Para conservarlos es pues indispensable cambiarles el agua á intervalos $y$ aun introducir en ella aire varias veces al dia con un pe queño fuelle de punta fina. Cuando el acuario es algo mayor y contiene plantas acuáticas puede dispensarse de esta últi ma operacion, atendido que los vegetales exhalan suficiente oxigeno para el caso. Los peces de color no soportan que se les manosee y moleste, y como son sociables conviene jun. tar por lo menos dos ó tres, y mas si el espacio lo permite y aun asi cuando muere uno suelen seguirle en breve sus compañeros. Cuando se les cuida bien acostúmbranse muy pronto ásu amo, y con un poco de paciencia se llega á en. senarlos á tomar el alimento de la mano 6 acudir, si se les tiene en depósitos mayores como surtidores 6 balsas, cuando se los llama con una campana.

\section{LAS TENCAS - TINCA}

CARACTERES. - Tienen la boca en la punta del hocico; escamas pequeñas, dos barbillas en los dos extremos de la boca, dientes faringeos en forma de porra colocados en número de cuatro y de cinco en hilera simple á cada lado, caracterizánoose además por una capa epidérmica mucilaginosa, gruesa y trasparente.

\section{LA TENCA COMUN-TINCA VULGARIS}

CARACTERES. - Es la unica especie de su género que habita en Furopa (fig. 204). La longitud mayor que puede alcanzar es de $0^{\prime \prime}, 70, y$ el pesn 3 hasta 4 , en casos raros $5 y$ aun 6 kilógramos. La coloracion es mas variable en estos ciprinidos que en todos los otros y depende de las circunstan. cias de su morada; pero en general es de un verde oscuro aceitoso al través del cual brilla un reflejo dorado. En los costados pasa esta coloracion á gris claro ó rojizo con viso morado. No son raros otros individuos de color mas claro con brillo dorado débil, y en algunos distritos, como en Bohemia y la Silesia alia, se cria una variedad tan magnifica que sin duda alguna figura entre los peces mas hermosos de Europa: es la tenca dorada (Tinca cirrysitis) y tiene escamas mas grandes que la comun, y además delgadas y trasparen. tes; las aletas son ninas y de membrana delgada; los labios de color de rosa, la coloracion general es amarilla de oro ó roja, y el dibujo consiste en manchas oscuras poco espesas y que se continuan en las aletas. Muchas tienen la region de las fosas nasales de color de carmin, la frente negruzca, la region maxilar amarilla, el lomo negro hasta la aleta y despues pardo amarillo; los costados amarillos de oro 6 de laton y cubiertos de manchas, conforme ya se ha dicho. Sostienen la aleta dorsal 4 y 8 ó 9 radios respectivamente; la torảci. 
ca I y 15 á 86 ; la abdominal 2 y 8 ó 9 ; la anal 4 y 6 ó \% y la caudal 19. Los sexos difieren en la estructura de las ale. tas, en la coloracion que sucle ser mas clara en los machos, y en las aletas abdominales que están mas desarrolladas en la hembra, sobre todo el segundo radio, que es mas grueso y aplanado.

DISTRIBUCION GEOGRÁFICA.-De todos los ciprinidos, es la tenca la especie mas extendida, puesto que se encuentra en la mayor parte de Europa, desde el mediodia de Italia hasta la Suecia meridional y central; en Rusia es uno de los peces mas comunes de estanque, y segun yo mis. mo he visto, habita tambien la Siberia occidental, en especial el $\mathrm{Ob}$, donde hay individuos de gran tamaño. En las montañas sube hasta mil metros sobre el nivel del mar, á pesar de ser pez de llanura.

USOS, COSTUMBRES Y REGIMEN.-Latenca preficre el agua estancada \& la corriente, así como los lagos, estanques y pantanos de fondo cenagoso ó arcilloso, donde haya cañas $y$ espadañas, sin que dominen toda la superficie. En los rios se retirá á los remansos defondo cenagoso, atendido que alli encuentra su alimento. Dicen que medra extraordinariamente en alfares abandonados que las lluvias llenan de agua. Es pez perezoso que permanece casi siempre en el fondo mismo, donde pasa tambien el invierno metido en la lama. Solo en la epoca de la freza 6 cuando hace muy buen tiempo sube alguna vez á la superficie. A semejanza de la locha, prospera la tenca en aguas que repugnan á otros peces y aun a las carpas, por la razon de que tiene menos ne. cesidad de oxigeno y de consiguiente de respirar. Sobre esto refiere Yarrell un caso que demuestra admirablemente has ta dónde llega la poca exigencia de la tenca. Habiase deci. dido limpiar y llenar de tierra una vieja balsa. Nadie pensaba encontrar alli otros peces sino unas cuantas anguilas; pero cuando se hubo sacado la leña y madera podrida que la lie naba mas que el agua, se encontraron unas cuatrocientas tencas, $y$ entre estas una tan enredada entre las raices de una mata, que estaba condenada as la mas completa inmovi lidad, habiendo adquirido en esta situacion con el tiempo una forma fenomenal amoldada al hueco que quedaba libre entre las raices. Media $0^{\infty}, 85$ de largo y $\theta^{\infty}, 70$ de circunferencia en la region próxima a la cola, con un peso de cerca de seis kilógramos. No cabia duda que este pez extraordinario debia haber vivido muchos años en tan terrible prision; se le sacó con cuidado y se le echó en un estanque donde se repuso y donde vivia todavia un año despues.

Durantc cl invicrno sc ocultan las tencas como sus afines de la misma familia en el cieno donde pasan la estacion fria medio alctargadas, y una cosa análoga les pasa á veces tam. bien en verano, como obscrvó Sicbold, que vió tencas metidas profundamente en la lama del fondo de un estanque en pleno dia, y que se dejaban sacar de alli con una pértiga larga sin moverse á pesar de ello. Sacadas del estanque con. tinuaron como muertas fotando de costado en la superficie, hasta que merced á algunos empujones rudos con la pértiga despertaron de su letargo y fueron á ocultarse otra vez en el cieno. ¿ ¿No seria esto, dice Siebold, una especie de sueño diurno 6 de verano?

Tocante á régimen, se parece la tenca enteramente \& la carpa; come toda clase de gusanos y sabandijas, sustancias regetales en putrefaccion y cieno.

La época del desove cae ell los meses de marzo á julio, por lo general cuando florece el trigo, y segun el tiempo algo mas temprano ó mas tarde. Entonces se puede ver $\{$ la hem. bra, seguida por lo regular de dos machos, pasando de una mata de junco $\delta$ de cañas a otra para deshacerse de la freza, yendo todos tan embarazados por el instinto de reproduc cion que deponen todo recelo y se les puede coger a menu. do con un buitron. Bloch calcula que una hembra de dos kilógramos deposita como 300,000 huevas, lo que explica la rápida multiplicacion de estos peces. Los pequeños se des. arrollan bastante de prisa, pero solo \& los cuatro años se ha. llan en estado de reproducirse. Al primer año llegan $\{$ pesar 200 gramos, al segundo 750 y al tercero I'50 kilógramo. Dicese que viven de seis á diez años, pero este dato pecará ciertamente por demasiado bajo.

USOS Y PROVECHO.-Hé aqui lo que dice nuestro autor antiguo: \&La carne de las tencas es mala, perjudicial, sabe á cieno y barro y da calentura. Es manjar de gente ba. ja, bien que algunos paladares la apetecen. A estos últimos pertenecen los ingleses, aun cuando tienen a mano peces mejores. Yarrell encomia mucho la tenca, y Eckstroem participa de su opinion. Yo por mi parte confieso que me inclino á la de Gessner, y únicamente puedo calificar esta carne de sabrosa cuando el per, ha pasado cierto tiempo en agua pura; pero diré tambien que las tencas de rio son exquisitas. En general se hace poco caso de estos peces en Alemania, por cuya razon no se los cria con vigor; apenas se pagan las tencas al precio de los carasios, siendo aquellas indudablemente mejores. Para la piscicultura no hay pez menos exigente que este de todos cuantos existen en nuestro planeta, $y$ fuera de la anguila no hay otro que pueda aprovecharse co. mo el para aguas pantanosas y otras que à lo mas sirven para criar carasios; y esta circunstancia es ya de bastante peso por si sola para recomendar su cultivo.

Desde tiempos remotos subsisten algunas supersticiones que aun hoy dia obtienen crédito; Gessner dice: \&Las tencas y lucios se profesan mutuamente gran amistad, por manera que estos ulitimos persiguen y devoran todos los peces menos a las primeras, llegando a tal extremo su intimidad que por lo regular se cogen juntos en la misma red. Dicese acerca de esto que cuando el lucio tiene alguna herida, se frota contra una tenca y con la viscosidad de esta se cura, de donde han derivado los frisones el adagio: «La tenca es el médico de todos los peces. Todavia creen muchos piscicultores en este proverbio, hasta los que han sabido descchar otras supersticiones.

\section{LOS BARBOS-BARBUS}

CARACTÉRES.-Es el género mas numeroso de la fami. lia, esta dispersado por todo el antiguo continente y se subdivide en mas de ciento cincuenta especies, carncterizadas por cuatro barbillas en la mandíbula superior, la cual sobresaic de la boca; despues por las aletas dorsal y anal que son cortas, la primera con un radio huesoso bastante recio, y ade. más por los dientes faríngeos cónicos, encorrados hácia atrás, donde están ahuecados ś manera de cuchara, y que se hallan dispuestos en tres hileras en cada lado de dos, tres y cinco dientes respectivamente.

\section{EL BARBO COMUN Ó DE RIO-BARBUS VULGARIS}

CARACTERES, - Alcanza esta especie (fig. 201) una longitud de $0^{\circ}, 60$ a $0^{\circ}, 70$ y un peso de cuatro a cinco, y excepcionalmente hasta nueve y aun doce kilógramos. El cuerpo es oblongo y el color verde aceituna en el lomo, mas cla. ro, es decir, blanco verduzco en los costados y vientre; en la garganta blanco; las aletas dorsal y anal son azuladas, pero la segunda orlada de negro, y las demás son rojizas. El número de radios es de cuatro $y$ nueve en la dorsal, uno $y$ diez y seis en la pectoral, dos y ocho en la abdominal, tres y cinco en la anal, y diez y nueve en la caudal. 


\section{EL BARBO DE PETENYI - BARBUS PE- TENYI}

CARACTERES. - Esta especie, afine de la anterior, di. fiere de ella por su menor talla, cuerpo mas largo, cabeza y parte anterior del lomo mas anchos, aleta anal y caudal de radios largos, y por la carencia del radio huesoso dentado. El color es gris amarillento cubierto de espesas manchas grandes negras parduscas en la parte superior del cuerpo que á menudo se confunden, mientras que faltan en la infe. rior. Sostienen la aleta dorsal tres $y$ ocho radios respectivamente; la torícica uno y catorce; la abdominal dos y ocho; la anal tres y ocho, $y$ ha caudal diez $y$ nueve.

DISTRIBUCION GEOGRAFICA. - Tive en las aguas de Transilvania $g$ de Hungria, particularmente en los montes Carpatos en ambas vertientes, y tambien en la cuenca del Vistula.

\section{EL BARBO CABALLERO-BARBUS EQUES}

CARAGTERES. - Tiene el cuerpo mas rechoncho, el hocico mas corto y obtuso, y las escamas mas pequeñas que el barbo comun. La coloracion es la misma, solo que tiene los costados y las aletas dorsal y caudal salpicadas de nume. rosos puntitos pardo negruzcos. El número de radios es tambien el mismo que el de su congénere comun, excepto en la dorsal donde es de tres y ocho respectivamente:

DISTRIBUCION GEOGRAFICA.--Este barbo reemplaza á sus congéneres en el mediodia de Europa, particularmente en Italia y Dalmacia

USOS, COSTUMBRES Y REGIMEN DEL BARBO COMUN. - Este barbo habita todos los rios de Alemania y se aluja de las aguas estancadas. Schinz dice: \& En Suiza prefieren los barbos las corrientes que salen de los lagos, reuniéndose en las desembocaduras, pero no pasan á ellos. Prosperan mas en las corrientes de fondo arenoso ó guijar. roso. Durante el verano les gusta vivir entre las plantas acuś ticas, pero cuando estas mueren en otoño, buscan dichos peces sitios mas profundos donde se guarecen detrás ó debajo de piedras, en huecos ó abren un agujero cerca de la orilla: hozan como cerdos, dice Gessner. Sucede \& veces que se reunen de esta manera en sitios favorables en tanto número que se ponen unos encima de otros para pasar alli el invierno aletargados hasta cierto punto. Respecto de esto cuenta Schinz que en i 8 ir se encontró el cajon de una rueda hidráu. lica junto a un puente de Zurich tan atestado de barbos que se cogieron en pocas horas mas de diez quintales, sin contar los pequeños que fueron arrojados otra vez al agua; estaban unos encima de otros formando entre todos una capa de un metro de grueso.

Ll barbo es el mas vivaz y movedizo de los ciprinidos alo. manes, á pesar de que se le puede tachar tambien de indo. lente. Por lo regular está quieto durante el dia; pero por lo mismo se mueve mas de noche para buscar el alimento que necesita y que consiste en pececillos, gusanos, cieno, restos animales, como por cjemplo, los excrementos del hombre. Heckel dice que se ven á bandadas los barbos cerca del convento de Zweitel en los puntos donde desembocan las letrinas en el arroyo de Kamp, donde medran extraordinaria mente.

La época del celo ocurre en los meses de mayo y junio; algunos empiezan ya á desovar en marzo y ahril, $s$ otros, acaso por segunda vez, en julio $y$ agosto. Entonces forman los barbos bandadas de cien y mas individuos, que se siguen unos á otros formando una larga hilera; las hembras viejas abren la marcha seguidas de los machos de mas edad, tras estos van otros mas jóvenes y cierran la marcha los pequeños. No parece que ia multiplicacion sea grande, pues Bloch contó solo unas 80,000 huevas en las frezas. En otono miden las tencas nuevas unos $0^{\circ}, 08 ;$ al cuarto año pueden reproducirse y entonces pesan de 700 á 1,500 gramos.

USOS Y PRODUCTOS. - Los barbos no son manjar que guste át todo el mundo, prescindiendo de que tienen muchas espinas; el precio corresponde à esta circunstancia, variando entre real y medio hasta tres reales el kilógramo; alguna vez llega á 7 y medio reales, pero otras veces se han de dar estos peces al ganado 6 emplearlos como abono del campo. Particular es, $y$ no ha podido cxplicarse todavia, que la freza tenga cualidades tóxicas. Gessner dice respecto de esto: «Sus huevas son muy dañinas, causan grandísimos do. lores y aun la muerte; etnbotan el cuerpo y el espíritu, produciendo una sensacion de angustia, conforme lo enseña hasta la saciedad la experiencia diaria. Esto es perfectamente exacto, riase de ello quien quiera; pues yo he tenido oca. sion de experimentarlo asi en mi mismo y en mi familia.

PISCicultURA.- la utilidad del barbo en la piscicultura estriba en que puede sustituir al lucio en las carperas, esto es, que sirve para animar y excitar á estos peces indolentes, lo cual los preserva, segun se pretende, de muchas enfermedades.

Cautivo se conserva muy bien y divierte mucho con su movilidad y carícter retozon.

\section{LOS GOBIOS DE RIO-GOBIO}

CARACTÉRES. - Distínguese este grupo de los barbos por las barbillas largas que se ven en los ángulos de la boca, por los ojos colocados á bastante altura, por la carencia del radio espinoso en la dorsal, por sus escamas mas grandes, \& por los dientes faringeos ganchudos distribuidos en ambos lados en dos hileras respectivamente de dos 6 tres y de cinco dientes.

\section{EL GOBIO COMUN - GOBYO FLUVIATILIS}

CARACTERES.-Esta especie, que se llama tambien cadoz, cadoce, gobia y goifon, alcanza una longitud de $l^{\prime \prime}, 12$ a $0^{\circ}, 15$, y á lo mas $0^{\circ}, 18$. La parte superior del cuerpo es gris negruzco con manchas de color azul negruzco 6 verde oscuro, muy visibles á lo largo de la linea del costado; la in. ferior es plateada con viso rojizo mas 6 menos marcado; la aleta dorsal y la caudal son amarillentas manchadas de pardo negruzco; las otras aletas son simplemente de un amarillo pálido ó rojas. Sostienen la dorsal respectivamente tres y siete radios, la pectoral uno y catorce, la abdominal dos y diez y siete, la anal tres y seis, $y$ la caudal diez y nueve.

DISTRIBUCION GEOGRÁFICA.-El gobio habita una gran parte de los lagos, rios y arroyos de Europa y del Asia occidental; sin que falte en los pantanos y hasta en aguas subterráneas, como por ejemplo en la cueva de Adelsberg (Bohemia). Es pez comun en las corrientes de Alemania, en la Gran Bretaña como en el continente, tampoco es raro en Rusia, 5 segun he podido yo mismo observar en el Altai, es por demás comun en la Siberia occidental y la Mongolia.

USOS, COSTUMBRES Y REGIMEN. - Prefiere las aguas limpidas con fondo arenoso 6 guijarroso, por cuya ra2.0n varía su distribucion, siendo raro en algunos puntos y por demás abundante en otros. Se le ve casi siempre en ban. dadas numerosas y compactas, siendo la sociedad para el, segun parece, una necesidad. Se alimenta de cria de peces, gusanos y sustancias animales $y$ vegetales en putrefaccion. 
Es tan grande su aficion á la carne podrida que en algunas partes le llaman enferrador. Cuando despues del sitio de Viena en $168_{3}$, se arrojaron los turcos y los caballos muertos al Danubio para desembarazarse de ellos, se encontró al poco tiempo un crecidisimo número de gobios en los puntos donde estaban los cadáreres, y hasta dentro de estos; y se observó además que preferian los humanos á los de los ani. males.

En la primavera salen los gobios de los lagos y remontan los rios para efectuar alli el desove. Entonces se oscurecen mas sus colores, y obsérvase en el occipucio, en las escamas del lomo y de los costados, lo propio que en los radios de las aletas torácicas, una erupcion granulosa, y además una hipertrofia epidérmica particular. El desove, que efectuan á intervalos, dura aproximadamente cuatro semanas. Cuando yo vivia en Defio, dice Rusconi, fui muy tempranito un dia del mes de julio 2 dar un paseo por las orillas del pequeño lago de la quinta Traversi, y de repente me llamó la aten. cion un ruido. Al principio crei que álguien golpeaba el agua con un palo ó con la paleta de un remo, pero pronto descubri la causa verdadera y el sitio de donde procedia el ruido: eran peces que desovaban. Curioso de ver este espec. táculo desde mas cerca, me aproximé con cautela, y gracias á los arbustos y matas que adornan aquellas orillas llegué tan cerca que pude observarlos perfectamente sin ser visto de ellos. Estaban en la desembocadura de un arroyuelo de agua fresca y límpida, bien que tan escasa que los guijarros pequeños de su lecho casi sobresalian de la superficie Los peces eran gobios. Se iban aproximando á la desemboca. dura y daban bruscas y rápidas sacudidas como para tomat impulso y subir merced á él, sin necesidad de saltar un tre. cho de cosa de un metro dentro del arroyo, deslizándose so. bre los guijarros. Hecho esto parábanse, doblaban alternativamente el cucrpo y la cola á derecha é izquierda, y frotaban asi el vientre contra las piedras, con todo el cuerpo fuera del agua excepto el abdómen ‘y la parte inferior de la cabeza. En esta posicion permanecian siete ú ocho minutos, despues descargaban en el fondo del arroyo un coletazo tan fuerte que el agua salpicaba en todas direcciones; luego se revolvian, entraban otra vez en el lago $y$ al poco rato repetian de nuevo el mismo ejercicio. Un naturalista ha dicho que los peces se echan de lado cuando desovan a fin de que el vientre del macho pueda tocar $\delta$ por lo menos estar muy cerca del de la hembra. Yo no impugnaré este hecho, pero lo que puedo asegurar es que ninguno de los peces que yo estaba observando hacia tal movimiento. Macho $g$ hembra entraban en el arroyo del modo que tengo dicho, aquel soltaba el liquido seminal, $y$ esta las huevas. $t$

Las huevas, que son muy pequeñitas, tienen un tinte azul en Alemania, y como se hallan tan expuestas al sol, nacen pronto los pequeños. A principios de agosto ga se ven hijuelos de $0^{\circ}, 02$ en bandadas tan densas que parece increible. Concluido el desove y la cria, vuclve el gobio al agua profunda y por lo regular estancada en que habita.

PESCA, - En el nordeste de Alemania se pesca el gobio hácia fin de año en gran cantidad y con regularidad. En verano se hace mas uso del anzuelo, porque este.pez es de aquellos que recompensan el trabajo hasta del pescador de caña mas torpe Los ingleses, cuandó quieren pescar gobios, suelen revolver préviamente el fondo con un azadon, porque estos peces se paran en semejantes sitios cuando pasan, para buscar alii los animalillos de que se alimentan. Con un poco de destreza es fácil coger en poco tiempo algunas docenas de gobios.

USOS X PRODUCTOS.-En todas partes cuenta el go. bio con aficionados, á causa de su carne sabrosa à pesar de ser pez pequeño. Se paga el kilógramo en la Alemania del norte á dos reales por término medio, á veces solo ámedio real y otras hasta á peseta; en la Alemania del sur es mas estimado y con mucha razon alcanza alli doble precio. Tambien se emplea con mucha ventaja en la piscicultura para alimentar peces de mas valor. Su vitalidad permite además conservarle bastante tiempo cautivo, y los pescadores ingleses le guardan meses enteros en grandes artesas comunes, por las que cruza constantemente agua nueva.

\section{EL GOBIO URANÓSCOPO - GOBIO URANOS- COPUS}

CARACTERES. - Esta especic difiere de la anterior por su cuerpo mas estirado, barbillas mas largas, y los ojos colo. cados oblicuamente y mas altos contra la frente jue es mas angosta. Puede carecer de manchas ó tener una hilera de ellas, muy grandes, de color pardo \$ lo largo del dorso y de la linea lateral. Hay dos y siete radios en la dorsal, dos y cinco en la anal, siendo el número de los demás igual al del gobio comun, sucediendo otro tanto respecto al tamaño y al color.

DISTRIBUCION GEOGRAFICA.-Agassiz descubrió esta especie en el Isar (Baviera); mas adelante se la ha encontrado tambien en el Salzach, Save E Idria (AustriaHungria).

USOS, COSTUMBRES Y REGIMEN.-Se ignora si en su género de vida difiere este pez de la especie comun.

\section{LOS RODIOS Ó BERMEJUELAS - RHODEUS}

CARACTERES. - El cuerpo de estos ciprínidos es re. choncho y giboso; la boca se halla algo debajo de la mandi. bula superior yo carece de barbillas; la aleta dorsal está colo. cada encima de las abdominales, siendo de igual longitud que la anal, y sus primeros radios huesosos $y$ lisos; los dientes faringeos tienen la corona comprimida lateralmente $y$ la superficie plana y oblicua, formando una hilera simple de cinco dientes en cada lado.

\section{LA BERMEJUELA - RHODEUS AMARUS}

CARACTERES.-Pocos peces de nuestros rios pueden competir con la bermejuela en cuanto á formas graciosas y belleza de colores; no incurriénduse en exageracion cuando se dice, que este ciprinido enano, que no mide mas que $0^{\circ}, 05$, sobrepuja en magnificencia al célebre pez de color. La forma del cuerpo se asemeja á la del carasio. La aleta dorsal tiene respectivamente tres y nueve $\delta$ diez radios; la pectoral uno y diez; la abdominal dos y seis; la anal tres y nueve, y la caudal diez y nueve La coloracion es varia, segun el sexo y la estacion. Sobre csto dice Sicbold, que ha descrito los rodios reciente y minuciosamente:

\& Fuera de la época del celo presentan ambos sexos una coloracion idéntica; es decir, el dorso un verde agrisado y los costados un blanco de plata brillante; pero lo mas nota. ble es una lista longitudinal verde y brillante que se extiende én cada costado desde el centro hasta la cola. Las aletas son de un tinte rojizo pálido, la dorsal está toda ella cubierta de un pigmento negruzco, y solo lo tiene en la base la cau. dal. Esta coloracion sencilla desaparece completamente en la época del celo en el macho, para ser reemplazada por otra tan magnífica $y$ brillante que es dificil describirla. Toda la superficie del cuerpo refleja entonces los colores del arcoiris, dominando el azul acero y el morado, al paso que resal- 
ta mas la lista del costado de color verde esmeralda; el pecho y el vientre ostentan un hermoso tinte anaranjado, $y$ las aleias dorsal y anal un encarnado viro con orla negra.

- Simultáneamente con el cambio de coloracion se presen. ta otra diferencia entre los dos sexos, que consiste en una alteracion de la piel inmediaiamente encima del labio superior; alli se levanta poco á poco en ambos extremos de la mandibula superior una especie de protuberancia formada de ocho hasta trece verrugas blanquisimas $y$ de diferente ta. maño, otras dos 6 tres verrugas idénticas salen en el borde superior de la fosa orbital, siendo unas y otras simplemente una acumulacion de células epidérmicas superpuestas. Des. pues de la reproduccion desaparecen, dejando hoyuelos doncie vuelven a nacer en las epocas sucesivas del celo.

* La hembra de la bermejuela conserva sus primitivos colo. res tambien durante el riempo de la freza, contrastando en. tonces no poco con el inacho tan engalanado, pero en cam. bio presenta otra particularidad por deniás extraña queá pesar de ser harto visible no ha sido notada sino hasta hace poco por Krauss. Consiste en un tubo largo y rojizo, especie de oviducto, que empieza a desarrollarse en la hembra al principiar el celo y que cuelga de la parte posterior, delante de la aleta anal, como una cuerda ó tripa vermiforme, teniendo de $D^{*}, 001$ hasta $0^{*}, 015$ de largo en las hembras del tamaño de 10,05 . En outras mas grandes he risto yo este apendice de $0^{\circ}, 040$ hasta $0^{\prime}, 055, y$ entonces sobresale á menudo este ór. gano de la punta extrema de la cola, dando al pez cuando nada un aspecto como si le saliese del ano una lombriz de tierra sin digerir 6 un pedazo de tripa. 8 Recorriendo un dia Siebold la pescaderia de Strasburgo, cuando cabalmente ha. bia alli una cantidad extraordinaria de bermejuelas, pudo convencerse de que este tubo es un verdadero oviducto, 6 mejor dicha, tubo ponedor de huevas. Hábia alli muchisimas hembras nue desovaban; tenian el citado tubo hinchado y lleno de un extremo al otro de huevas amarillas. Ias huevas formaban en su interior como un rosario, y estaban tan pren. sadas que se habian aplanado, pero despues de haber sido expelidas volvian á tomar sú forma esférica. Noll fué quien descubrió la utilidad del conducto. En los útimos decenios del siglo pasado hasta mediados de este habian encontrado muchos naturalistas, en los compartimientos valvares in. teriores de las conchas de pintor; mas 6 menos huevas de pez 6 cria en diferente estado de desarrollo, sin que hubiesen podido explicarse qué especie de peces eran, ni cómo se habian introducido las huevas entre las valvas; solo despues que Siebold hubo descrito las huevas de la bermejuela como cuerpos amarillos, ovoideos, de $0^{\circ}, 003$ de largo por $0^{\circ}, 002$ de diámetro, dijo Noll que no podia ser sino este pez el que ponia sus huevas en la citada concha, 6 incubarlas en clla Noll hizo experimentos que confirmaron su aserto y la supo. sicion de que el tubo mencionado habia de ser el aparato por medio del cual el pez introduce sus huevas entre las valvas del molusco. Guardó cierto nimero de estos con sus huevas en viveros separados y al cabo de bastante tiem. po llenaronse de bermejuelas pequenitas incubadas en el in. terior de las conchas. En otros vireros habia bermejuelas acultas, y cuando se preparaban al desore, se echaron al vi. vero los moluscos, pudiendo asi observarse sus costumbres hasta haber efectuado esta operacion, con lo cual quedó resueito el enigma, desapareciendo todas las dudas.

DISTRIBUCION GEOGRAFICA.-Por lo que hasta ahora se sabe, extiéndese el área de disnersion de este pez por toda la Europa central y oriental, j una gran parte del Asia; es frecuente en determinados puntos de las cuencas hidrográficas del Danubio, Rhin, Elba y Vistula, Cigualmen. te en la Tauria (Rusia) donde hay aguas a propósito para el.
USOS, COSTUMBRES Y REGIMEN. - Prefiere el agua limpida y corriente con fondo pedregoso, y segun Sie. bold, los brazos muertos de los rios y arrovos. Desde la llanura va pasando á regiones mas elevadas hasta las corrientes de las sierras de altura media, y su extraordinnria vitalidad le permite arrostrar el calor y el frio. Taeckel le vió debajo del hielo en una zanja de muy poca agua que sin duda al. guna debia estar helada hasta cerca del mismo fondo, $¥$ otra vez vió que una bermejuela habia soportado durante una hora sin recibir daño alguno, el trasporte en una caja de herborista, sin agua ni siquiera musgo húmedo, en un dia cálido de otoño.

Las excelentes observaciones y experimentos de Noll han probado que la bermejuela se acostumbra muy pronto al acuario si está bien dispuesto. Al principio se ocultan estos peces todo lo posible durante el dia dehajo de las hojas que flotan en la superficic, y solo de noche despliegan su activi. dad; pero á los pocos dias acuden ya, atraidos por la racion, al agua despejada, $y$ desde aquel momento deponen todo recelo permitiendo hasta que el dueño haga toda clase de arreglos en el vivero, sin dar muestra de la menor excitacion. Cogen pulgones acuáticos con mucha destreza y acierto; sacan del cieno de su vivero los gusanillos de arroyo, y acep. tan sin dificultad larvas de hormiga, pedacitos de carne des. menuzada y migajitas de pan. Cuando tienen hambre registran todos los rircones y objetos de su vivero, y al comer demuestran su codicia, mas violenta en la hembra que en el macho, dando á siss compañeros cabezadas á diestro y sinics. tro.

El macho y la hembra retozan y dan brincos fucra del agua, lo cual les suele costar muy caro cuando el vivero no está tapado. A la aproximacion del periodo del celo empieza a aumentar su vivacidad, el brillo de los colores del ma. cho y el tubo genital de la hembra aparecen, mientras que sus costados se redondean. El tubo crece al principio impercep. tiblemente, luego va mas de prisa y al fin acaba por adquirir su completo desarrollo con extraordinaria rapidez; efectuado el desove decrece en pocas horas hasta quedar reducido s. una pequeñisima parte de la longitud que poco antes tenia. El último periodo del rápido crecimiento del tubo es para el macho motivo de la mayor excitacion, que se manifiesta como en otros peces por un aumento de coloracion, de brillo, de inquietud y de celos; persigue furioso á los de su mismo sexo, y empuja con no menos violencia á su hem. bra predilecta, hasta que esta, por lo regular muy tranquila $e$ indolente, se inflama tambien y se acerca 2 la roncha que el macho le tiene destinada, para depositar en ella sus huevas. Al penetrar un huevecillo en el tubo se pone este rigido has. ta que aquel ha sido expulsado. A este efecto se coloca ha hembra verticalmente y caheza abajo sobre la concha, la ob. serva mucho rato, $y$ cuando siente que penetra un hueveci. llo en el tubo y que este se pone tieso, precipitase como el rayo sobre el molusco que ha de servir de nodriza, desliza la punta del tubo en su rendija respiratoria, suelta el hueve. cillo y retira con premura el tubo. No siempre les sale bien la maniobra, en cuyo caso retrocede el huevecillo otra vez al tubo, pasando entonces a menudo mucho tiempo antes que este vuclva á excitarse para repetir la operacion. El macho entre tanto lo observa todo con la mayor atencion, y apenas ha abandonado la hembra la concha, cuando acude él tem. blando visiblemente, con las aletas dilatadas, para suspenderse un momento sobre las valvas, y poder arrojar su sémen sobre la abertura fecundando asi el buevo. Hecho esto, reti ranse ambos desfallecidos á la intrincada espesura de las plantas acuáticas, dando evidentes muestras de espanto y re. celo; el macho pierde sus brillantes colores, y el tubo de la 
hembra se pone lacio y encogido, hasta que pasados algunos dias repiten la operacion, siguiendo asi á intervalos has. ta terminar la freza. La época de esta son los meses desde abril hasta junio, y antes si los peces están cautivos, concluyendo en este caso mas pronto como es natural. Hasta ahora no ha sido posible saber el tiempo que las huevas $y$ los pequeños embriones permanecen en la concha.

USOS Y PRODUCTOS.-No se suele comer la carne de estos peces á causa de su sabor amargo, por lo cual apenas se los pesca, sirviendo solo de cebo para coger otros peces. La consideracion que merece la bermejuela como pez de adorno se justifica por lo que queda dicho.

\section{LOS BREMOS-ABRAMIS}

CARACTERES. - Este género de ciprinidos es uno de los que cuentan con mayor numero de especies. Se caracte. rizan los bremos por su cuerpo alto, giboso s compritnido lateraimente; su boca oblicua carece de barbillas; la aleta dorsal está cortada hácia atrás verticalmente, la anal es de una longitud mucho mayor que la dorsal, la caudal tiene los dos lóbulos desiguales y está profundamente bifurcada; las escamas en la parte anterior del lomo dejan en el centro una raya longitudinal sin cubrir estando salpicada únicamente de escamas pequenas. En la parte inferior existe otra raya ans. loga desde las aletas abdominales hasta el ano, formando un śngulo bastante agudo con el perfil restante del vientre. Los dientes faringeos tienen la corona comprimida lateralmente y de plano oblicuo, dispuestos en dos hileras de cinco diea. tes, una á cada lado.

\section{EL BREMO COMUN-ABRAMIS BRAMA}

CARACTERES. - Esta especie (fig. 203), Ia mas exten tendida $y$ frecuente, se considera como el tipo fundamental del género. Es un ciprinido gallardo, de $0^{n}, 60$ hasta $t^{n}$ de longitud, y de un peso de 4 hasta 10 kilógramos; que se ca racteriza por su cuerpo muy comprimido lateralmente y de grande aliura; la coloracion es negruzca en todo el dorso y parte superior de la cabeza; blanco amarillenta con brillo plateado y punteada de negro en los costados, rojiza en la garganta, blanca en el vientre, y azul negruzca en las aletas. Los machos varian algo en la época del celo, saliéndoles en la superficie epidérmica hipertrofias en forma de verrugas cónicas obtusas, en un principio de color blanquizco que pasa á amarillo de ámbar á medida que se endurecen, y que no son otra cosa sino células epidérmicas acumuladas y superpuestas. Las de mayor tamaño salen en el hocico y occipucio, y las mas pequeñas sobre los radios de las aletas, sin contar las que nacen en los operculos y en la mayor parte de las escamas.

DISTRIBUCION GEOGRAFICA. - La patria de este pez es toda la Europa central, como tambien el norte y el este.

No se encuentra al sur de los Alpes al igual de sus con. generes $y$ afines, pero si en la cuenca del Ródano. En todos los rios alemanes, en sus afluentes y lagos que comunican con ellos es frecuente, pero siempre en los sitios arcillosos, lo que ya sabia Gessner, el cual dice: rque es el fondo que elios buscan. Eckstrocm asegura que se coge cerca de Suecia y Noruega, tambien en el mar, bien que este es un caso excepcional.

USOS, COSTUMBRES Y REGIMEN. - Durante el verano permanece el bremo en la profundidad cerca de ciertas plantas acuáticas que por esta circunstancia se llaman yerba de bremos en Alemania. Alli hurgonea y hoza el cieno enturbiando el agua hasta muy léjos, por lo cual Gessner dí- ce: $\$$ Cuando los bremos observan que los persigue el lucio, dirigense en seguida al fondo, revuelven el barro y enturbian el agua tras sí, a fin de escapar á la persecucion. Es muy probable que procedan asi para buscar su alimento que consiste en gusanos, larmas de insectos, plantas acuáticas y cieno.

Casi siempre se encuentran estos peces en numerosas tri. bus, pero al principiar el tiempo de la freza, que ocurre en los meses de abril, mayo y junio, reúnense bandadas con bandadas y forman cjércitos innumerables. Cerca de la orilla donde hay poca agua y abundancia de yerba acuática vénse llegar primero algunos machos, despues hembras; aquellos ostentan su coloracion mas brillante y numerosas verrugas largas á manera de espinas, por lo cual los llaman entonces en Baviera bremos perlados: y cada hembra suele llevar tras si, segun Yarrell, tres ó cuatro machos; luego el movimiento se hace general, se puebla toda la orilla y pronto no parece sino que todos forman una sola masa en la cual ya no se distinguen lus individuos de por si. Suelen desovar de noche y la excitacion llega entonces á su colmo, azotan el agua con la cola y chasquean los labios, produciendo con esto un estrépito que se oye desde léjos y que dura hasta que las hen. bras han depositado entre las plantas acuáticas sus pequerias huevecitas amarillentas, en número de $\$ \$ 0,000$ cada una á poca diferencia. Cuando el tiempo es favorable concluye el desove en tres ó cuatro dias, pero si cambia súbitamente, retíranse todos á sus profundidades sin haber desovado, haciendo lo propio cuando se los molesta $\delta$ espanta, por cuya razon se ha prohibido en Suecia, segun dicen, hasta echar á vuelo las campanas en la proximidad de los lagos. A los pccos dias de haberse retirado los bremos, nacen los pequeños á millones y hormiguean en toda la orilla, donde continuan por algun tiempo hasta que siguen á sus progenitores á los sitios profundos, siendo probable que pasen alli estos peces una parte del invierno metidos en el limo, segun se desprende de una expresion de Gessner que hasta hoy nadie ha contradicho.

USOS Y PRODUCTOS. - Algunas personas ensalzan la carne de bremo como bocado muy exquisito, otros la menosprecian; aquellas dicen que el bremo es el pez de rio mas delicioso despues de la carpa, y estas que apenas es posible comerlos á causa de sus muchas espinas. Gessner opina como los primeros diciendo: «n nuestro pais son muy apreciados los bremos porque su came no es mala, pueden figurar muy bien en las mesas de príncipes y magnates, y son un alimen. to muy apreciable para el hombre. Es probable que juicios tan opuestos tengan su explicacion en la diferencia de tama. ño y de la localidad donde se crian estos peces, por cuanto la carne de los bremos grandes es mejor que la de los pequeños, y la de los quue han vivido antes de ser cogidos en agua cenagosa adquiere cierto sabor desagradable de humedad. En la Alemania del norte y oriental alcanza el bremo el precio de dos y medio hasta cuatro reales el kilógramo, y mas aun en la Alemania meridional y Austria. En todas partes se le pesca con afan; en Inglaterra es el pez favorito de los pescadores de caña, porque muerde fácilmente el cebo. En el norte y levante de Alemania se pesca por lo regular con redes grandes y siempre con provecho. Segun el caso los salan ó los ahuman, 6 bien los remiten frescos a grandes distancias embalados en nieve con un pedacito de pan mojado en aguardiente en la boca, con la misma facilidad que se expiden las carpas y carasios. En la piscicultura no se emplea esta ni otra especie alguna del género Abramis.

\section{EL BREMO VIMBA - ABRAMIS VIMBA}

CARACTERES. - Conócese esta especie por su nariz gruesa y prolongada que sobresale de la hendidura bucal, y 
por la aleta anal colocada muy atrás. Ė color del occipucio y dorso es azul ó pardo sucio; los costados son mas claros, la parte inferior con brillo plateado; las aletas dorsal y cau. dal son azuladas, las abdominales 5 la anal blancas amarillentas y las pectorales amarillas rojizas en la base. Pero icuán distinto es el aspecto de estos peces en el tiempo del celo, que ocurre á fines de mayo ó principios de junio! Entonces, dice Siebold, la parte superior del cuerpo, el hocico, la cabeza, y los costados hasta mucho mas abajo de las dos lineas laterales, se cubren de un pigmento negrisimo, con un brillo sedoso particular de color oscuro en la parte inferior de los costados. Contrasta con cste color negro de un modo singular el anaranjado de los labios, garganta, pecho, arista ventral, asi como una lista debajo de la cola y de las aletas pares. Este cambio de coloracion se efectúa á medida quese desarrolla el a parato geniral, y no depende en modo alguno del cambio de morada en dicha énoca. Durante ella ambos sexos presentan igual coloracion; y los machos además cierta erupcion granujienta que consiste en una multitud de pro. minencias pequeñisimas en el occipucio, branquias, bordes de las escamas y de los radios en la superficie interior de las aletas pares. Hé aqui ahora el número de estos: 3 y 5 respectivamente en la dorsal; 1 y 15 en la pectoral; 2 y 9 á 10 en la abdominal; 3 y if hasta 20 en la anal, y 19 en la caudal. No alcanza esta especie con mucho el tamaño de la comun, pues su longitud llega solo en casos excepciónales á $0^{\circ}, 40$ y rara vez pasa su peso de 500 gramos.

DISTRIBUCION GEOGRAFICA.-Extiéndese este bremo por toda la Europa, pero principalmente por la parte septentrional, y no solamente vive en las aguas dulces, sino tambien en la salada y la salobreña de las embocaduras de los riós.

USOS, COSTUMBRES Y REGIMEN. - En ciertas aguas dulces parece ser estacionario el bremo vimba, pero los in dividuos que habitan el mar remontan los rios en la prima. vera para deshacerse de su freza. y regresan en otoño á las profundidades del mat donde pasan el invierno. En los lagos suele habitar este bremo los fondos entre 10 y 20 toesas de profundidad con tal que sean cenagosos, porque á semejanza de sus afines, busca su alimento hozando con tanto afan e] fango, y enturbiando el agua de tal manera, que cl mismo se descubre. En la época de la freza reúnense estos peces en bandadas, y entonces es cuando su pesca es productiva. Se. gun Bloch, pone cada hembra cerca de 300,000 huevas en los sitios pedregosos y de poca agua de los rios, siempre en mayo y junio, mostrándose durante este tiempo tan violen. tas y ruidosas como los bremos comunes.

PESCA Y PRODUCTOS.-Pallas dice que en Rusia se pesca este bremo en cantidad incalculable en todos los rios que desembocan en el mar Negro. Se le sala ó se le seca y se remite a carretadas a todos los extremos de aquel vasto pais. A menudo es tan abundante csta pesca que los comerciantes al contratar con los pescadores se ven obligados \& incluir en las estipulaciones la condicion de que solo tomarán de cada pesca hasta 70,000 peces, por la imposibilidad de salar y cmbalar mayor cantidad entre una pesca y otra. La carne se conceptúa igual a la del bremo comun.

\section{EL BREMO LARGO-ABRAMIS ELONGATUS}

CARACTERES, - Es per. muy semejante al anterior Algunos ictiólogos le reconocen como especie independien. te, y otros, acaso con mas fundamento, solo como variedad de la especie vimba.

DISTRIBUCION GEOGRÁFICA. - Vive en el Danubio $y$ en algunos lagos de la Alta Baviera.

\section{EL BREMO SAPA-ABRAMIS SAPA}

CARACTÉRES. - Difiere este de todos sus congéneres por la aleta anal mucho mas larga y que empieza antes de la dorsal; por el lóbulo inferior de la cola muy prolongado tambien, el hocico muy obtuso y la boca abierta debajo de la mandibula superior. Su longitud rara vez pasa de $0^{\mathrm{n}}, 30, \mathrm{y}$ la coloracion principal es un gris plateado y anacarado; las aletas dorsal, anal y caudal están orladas de negro. El nú. mero de radios en la anal es de 3 y $3 S$ hasta 45 respectivamente.

DISTRIBUCION GEOGRÁfICA.-Su área de dispersion comprende los rios tributarios del mar Negro, siendo pez comun en los rusos, j nada raro en el Danubio.

USOS Y PRODUCTOS.-Como alimento tiene esta es. pecic poca importancia por las muchas espinas que encierra su carne, pero sus escamas se emplean en la fabricacion de las perlas imitadas.

\section{EL BREMO BALERO-ABRAMIS BALLERUS}

CARAGTERES, - Alcanza esta especie una longitud de $n^{\prime \prime}, 30\left\{.0^{\prime \prime}, 40\right.$ y un peso de un kilógramo aproximada. mente, y la caracteriza su cabeza pequeña, la boca hendida oblicuamente hácia arriba, y la aleta caudal muy larga. La coloracion es semejante $a ́$ la de las especies congéneres; el dorso es azulado, los costados y el vientre plateados, las ale. tas pares son amarillentas $y$ las otras blanquizcas, pero todas orladas de negro. El número de radios es respectivamente 3 y 5 en la dorsal; 1 y 15 en la torácica; 2 y 8 en la abdomi. nal 3 y 40 hasta 41 en la anal, y 19 en la caudal.

DISTRIBUCION GEOGRAFICA.-Se encuentra este bremo en todós los rios principales de la Europa central, sobre todo junto á las desembocaduras y rara vez en el curso superior. Asíes que en el Danubio no pasa de la Alta Austria, faltando de consiguiente en Baviera; en el Rhin parece que no pasa mas allá de Holanda, y en el Elba pés. casele alguna que otra vez junto à Magdeburgo; cmpero es muy frecuente á lo largo del Báltico, tanto en los alfaques como en los lagos de agua dulce que comunican con el mar por algun rio $\delta$ arroyo.

USOS, COSTUMBRES Y REGIMEN.-Por este concepto se parece á las dos especies descritas.

USOS Y PRODUCrOS. - I a carne de este pez es des. preciada á causa de sus muchas espinas.

\section{EL BREMO BLICA - ABRAMIS BLICCA}

CARACTERES. - Difiere este bremo de sus congénerés por los dientes faringeos distribuidos en dos hileras de dos, rara rez de tres 6 de cinco dientes en cada lado; los de la hilera interior tienen la corona cortada oblicuamente con la superficie estrecha y con un surco inmediato \& la punta, y la boca está colocada en el extremo del hocico, por lo cual se le considera tambien como representante de un subgenero (Blicca). No alcanza mayor longitud que de $0^{\circ}, 2030^{\circ}, 30$ y un máximum de peso de un kilógramo. El color es en el lomo azul con viso pardusco, en los costados azul plateado, y en el vientre blanco; las alctas anal y caudal tienen un tin. te azul gris, $y$ las pectorales y abdominales son rojizas en la base. Sostienen la dorsal tres y ocho radios respectivamente; la torácica uno y quince; la abdominal dos y ocho; la anal tres $y$ diez $y$ nueve hasta veintitres, $y$ la caudal diez $y$ nueve.

DISTRIBUCION GEOGRÁFICA. - Es uno de los peces mas comunes de las aguas dulces de Alemania. 
USOS, COSTUMBRES Y REGIMEN.-La blica habita los lagos, estanqques $y$ rios mansos con fondo arenoso ó arcilloso. Le gusta vivir en la profundidad donde revuelve el cieno en busca de gusanos, freza y sustancias vegetales que constituyen su régimen alimenticio. En la primavera, esto es, en mayo y junio se acerca á los sitios de poca agua en la orilla, prefiriendo los que están cubiertos de juncos para deponer alli su freza. Entonces cambia completamente de costumbres. En lugar de arisca y precavida, en lugar de huir y ocultarse en el fondo como suele à la mas leve sospecha, se vuelve tan vivaz é imprudente que hasta alguna vez se deja coger con la mano. Siebold dice que estos peces son muy precoces, pues encontró machos y hembras de $0^{\prime \prime}, 13$ de longitud con el aparato genital en pleno ejercicio. Bloch contó en la freza de una hembra mediana mas de cien mil huevas. Los individuos viejos empiezan ấ desovar á principios de ju. nio $y$ concluyen tres 6 cuatro dias mas tarde, si no sobreviene un frio que los haga huir en seguida. Una semana despues llegan los individuos medianos, y al cabo de otros ocho dias los pequeños. Unos y otros desovan en las horas que nedian entre la salida del sol hasta las diez de la mañana.

PESCA y USOS.-Eckstroem dice que la blica es la es-

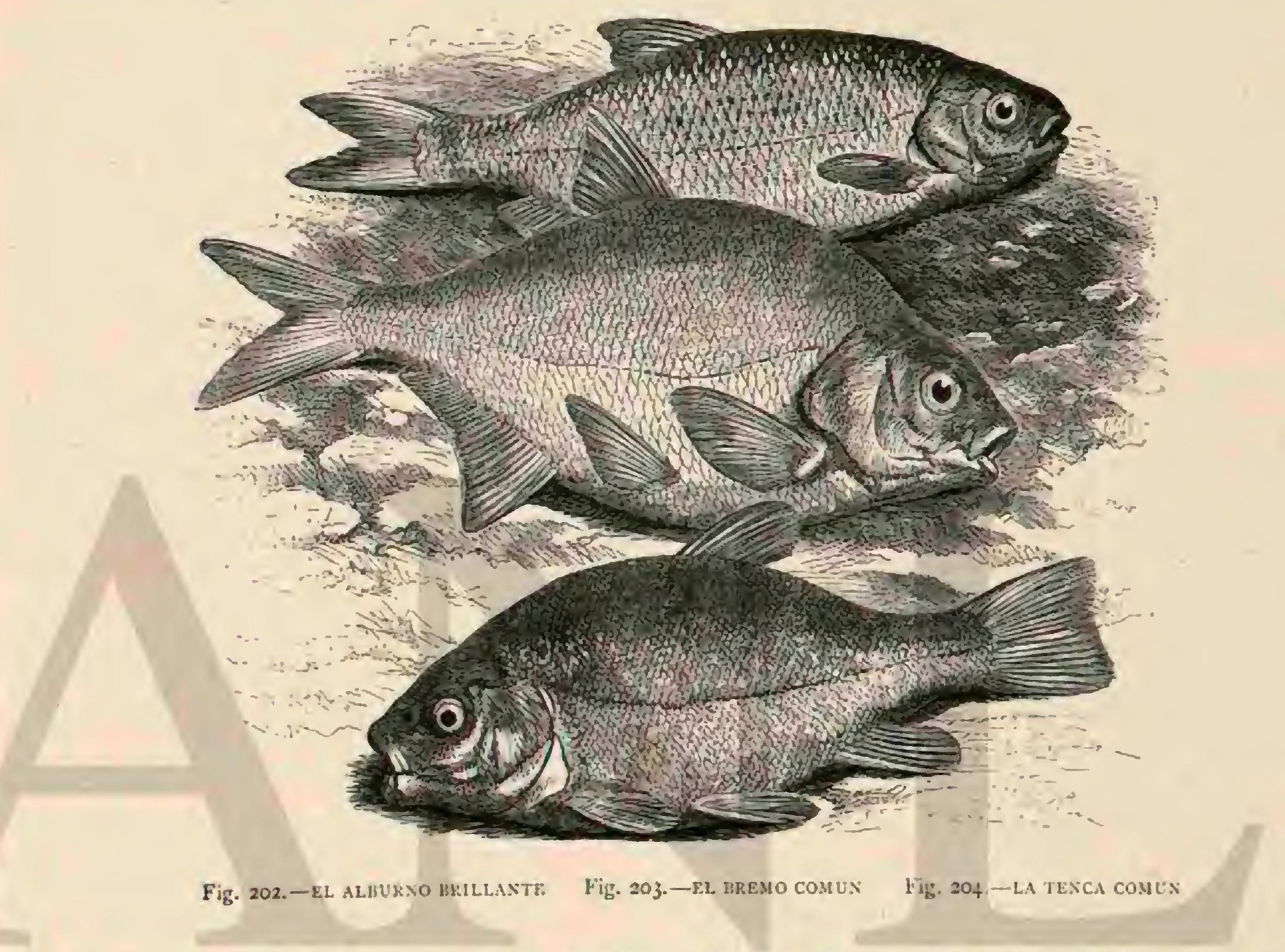

pecie mas voraz de todos los ciprinidos, y su pesca de consiguiente fácil y sencilla, $y$ cualquier cebo bueno. No se pesca nunca en grande escala, porque como alimento nadie la quicre aunque solo fuese por las ténias que se encuentran á menudo en número de seis á ocho en su vientre; pero puede cmplearse útilmente para alimento de truchas y otros peces que se crian en estanques industrialmente.

\section{LOS PELECOS - PELECUS}

CARACTÉRES. - Pertenecen á este género peces que si bien son ciprinidos, difieren en muchos puntos considerablemsente de sus afines. El perfil del dorso es recto y el del vientre, por el contrario, muy convexo, siendo esto causa de que en Alensania se diera á estos peces el nombre de hos ó iuchill, la hendidura de la boca es poco menos que vertical, con la sinfisis de la mandibula inferior formando punta sa. liente; las aletas torácicas son largas y estrechas, teniendo tambien algo de la forma de una hoz; la dorsal es corta y está inserta muy atrás; las escamas están poco adheridas, y ios dientes faringeos dispuestos en dos hileras en cada lado con dos y cinco dientes respectivamente, de forma ganchuda y corona profundamente surcada á manera de sierra.

Tomo $V$

\section{EL PELECO COMUN-PELECUS GULTRATUS}

CARACTERES. - Ess el único representante del género; tiene el cuerpo oblongo y comprimido lateralmente. El color es azul de acero 6 verde azulado en la nuca; gris pardusco en el lomo y con brillo de plata en los costados; agrisado en las aletas dorsal y caudal, y rojizo en las demás. La primera tiene respectivamente tres y siete radios; la torácica uno y quince; la abdominal dos y siete; la anal tres y reintiocho; y la caudal diez y nueve. La longitud es de $60,46 \mathrm{y}$ cl peso ilega hasta á un kilógramio.

DISTRIBUCION GEOGRÁFICA. - Esta especie está dispersada de un modo muy singular. En el norte de la Europa central habita solo el Báltico y los lagos de agua dulce que comunican con este mar, y remonta los rios tributarios del mismo. Por otra parte vive tambien en el mar Negro y en los rios que desembocan en él. Pallas dice que abunda en los rios y lagos de la Rusia Europea, y Nordmann refiere lo mismo de los de Crimea. Segun Heckel y Kner aparece en grandes bandadas en el lago de Platten cuando los otros peces escasean en $\mathrm{El}$, constituyendo entonces el alimento principal de la poblacion pobre. Siebold dice que á veces se extravia el peleco por el alto Danubio, pero casi nunca por 
sus afluentes. No es habitante exclusiro del mar ni del agua dulce; en ambos se encuentra al parecer igualmente bien.

USOS, COSTUMBRES Y REGIMEN.-Para morada escoge este pez sitios inmediatos \& la orilla, donde el agua es clara y se renueva constantemente. En sus costumbres y régimen concuerda con las carpas. La época del celo cae en mayo; el peleco se parece tambien á sus afines en todo lo re. lativo \& la reproduccion, mas á pesar de las cien mil huevas que cada hembra pone por término medio, segun Bloch, no parece multiplicarse notablemente, puesto que es relativa. mente raro en nuestros rios; Jo cual cxplican Heckel y Kner, atribuyéndolo á su incapacidad completa de defenderse, $y$ al brillo plateado tan viro que le descubre y entrega á sus enemigos acuáticos alados. Por otra parte se dice que no vive mas allı́ de cuatro 6 cinco años.

USOS Y PRODUCTOS. La carne del peleco es fofa $y_{i}$ espinosa, por cuya razon no es productiva la pesca, que tam. poco se ve con buen ojo en ciertos distritos de Alemania y en particular de Austria, atendido que allí miran los pescadores á este pez con la misma supersticion que los cazadores de pájaros al ampelis, con la añadidura de que segun ellos el péleco solo aparece cada sicte años y entonces pre. sagia guerra, hambre, peste $y$ otras calamidades.

\section{LOS ALBURNOS-ALBURNUS}

CARACTERES. - Los albumos tienen el lomo menos convexo que el vientre; la aleta dorsal es corta y se halla in. serta mas hácia atrás que las abdominales, mientras que la anal, bastante larga, lo está mucho mas 6 debajo de la dorsal. Las escamas, poco adherentes, presentan radios elevados que divergen de un centro; la boca está dirigida hácia arriba, y la punta saliente de la mandibula inferior encaja en un hueco a propósito de la intermaxilar; los dientes faringeos forman doble hilera de dos y cinco dientes respectivamente; los posteriores de las hileras interiores son ganchu. dos y vienen á ser una especie de colmillos.

\section{EL ALBURNO BRILLANTE-ALBURNUS LUCIDUS}

CARACTERES. - Fste pez (fig. 202), cl mas importante de su género, tiene el dorso azul de acero que pasa á plateado en los costados y el vientre; las aletas dorsal y caudal son de color gris, y las otras amarillentas. Esto como dato general, porque este alburno varia muchísimo no solamente de color sino de forma, ofreciendo casi en cada rio $y$ lago otro aspecto, y siendo algunas de estas variedades tan fijas que se han admitido como especies independientes. I.a aleta dorsal está sostenida por tres y ocho radios respectivamente; la torácica por uno y quince; la abdominal por dos y ocho; la anal por tres y diez y sicte hasta veinte, y la cau. dal por diez y nueve. La longitud oscila entre $0^{m}$, ro y 0 , i 8 .

\section{EL ALBURNO DE FAJAS-ALBURNUS FASCIATUS}

CARACTERES. - Difiere este alburno del anterior por su cuerpo mas rechoncho y coloracion particular. El dorso es gris oscuro, color que pasa en los costados a un gris de plata y en el vientre á plateado puro; la linea del costado 6 faja está arriba $y$ abajo orlada de negro, lo cual le da el as. pecto de una costura $y$ ha motivado el nombre de este pez, que en Alemania se llama pes sastre o pez zapatero, amén de otros muchos. Sostienen la aleta dorsal tres $y$ ocho radios respectivamente; la pectoral uno $y$ catorce; la abdominal dos y siete as ocho; la anal tres y quince à diez y siete; $y$ la caudal dicz y nueve. Respecto á tamaño, no hay diferencia entre esta $y$ la especic anterior.

DISTRIBUCION GEOGRÁFICA.-No ha podido fjarse todavia con exactitud el área de dispersion de este pez, que á menudo se encuentra mezclado y se confunde con otros afines suros. Fs frecuente en la mayor parte de las cor. rientes y lagos de la Furopa central en toda su extension de oeste á este, con tal que tengan agua clara, corriente y poco ruidosa: y como en algunas de estas no se le ve en invierno. se supone que pasa la estacion fria aletargado y oculto en el fango.

USOS, COSTUMBRES Y REGIMEN DE LOS ALBURNOS EN GENERAL. - Las dos especies descritas, y en general todos los alburnos, mas sociables que muchisi. mos otros peces, encuéntranse siempre en grandes bandadas, a menudo innumerables, retozando en dias apacibles y callidos cerca de la superficie, y cugicndo insectus y utras sustan. cias de que se alimentan, porque son tan voraces como de natural curioso y confiado, segun Heckel y Kner; aunque se hayan espantado vuelven al momento si se les echa alguna cosa, la cual atrapan al punto volviéndola a arrojar si no es de su gusto, por manera que para el pescador de caña, cuyo objeto es solo coger muchos peces, no hay otros mejores, puesto que siempre muerden cualquier cebo. Desovan en mayo y junio, pero en circunstancias excepcionales pueden empezar tambien en marzo y continuar hasta agosto. Enton. ces se reunen y remontan los rios en compactas bandadas a fin de escoger sitios á propósito para el desove. En estos viajes les pueden ser fatales las industrias modemas que con sus desperdicios envenenan los riachuelos y arroyos, como sucede á los que remontan el Wupper cuando llegan, segun dice Cornelius, al distrito de Eversaue y se meten en el agua empon. 7.0nada por los ácidos y colores de las tintorerias de Barmen y Elberfeld, de donde regresa gran número de peces muer. tos $\delta$ moribundos, arrastrados por. la corriente, á veces en tanta cantidad que los cadáveres flotantes, arrojacios á la ori. lla ó detenidos en los remansos, inf́estan el aire á grandes distancias con sus emanaciones pútridas. Para deponer su freza eligen sitios de fondo pedregoso ó la dejan entre plantas acuáticas de varias especies; entonces - se muestran mas excitados y movedizos que en las demás epocas del año, y rebotan á menudo fuera del agua.

La operacion propia del desove se verifica en tres tandas con intervalos de duracion variable; los peces mas viejos son los primeros que desovan y los mas jóvenes los últimos. Multiplicanse sobremanera, pero su vida es cortísima, mucho mas de lo que debiera ser, porque permaneciendo en grandes masas, sobre todo en las capas superiores, son victimas de los peces $y$ aves rapaces que acechan y persiguen sin tregua estas bandadas. Cuando los embiste una perca ávida y rapaz suelen saltar fuera del agua, y escapan de este modo á me. nudo á sus perseguidores, solo que entonces les pasa lo que á los voladores, es decir, que los atrapan las aves, gavio:as y golondrinas de mar, no menos vigilantes que aquellos peces rapaces; «en cambio, dice Siebold, se quedan tambien con una ténia, la lingula simplicissima, que vive suelta en la cavidad abdominal de los alburnos y pasa asi al intestino de las aves.

USOS Y PRODUCTOS:- Por lo regular no tienen los alburnos valor alguno como alimento, pero en algunas partes se pescan, ya sea para comerlos, ya para emplearlos como cebo para otros peces, ya, por fin, desde el siglo pasado, para la fabricacion de la esencia orienhal, en cuyo caso se paga el kilógramo de estos pececillos á tres, cuatro y en Silesia has. ta sicte y medio reales. En el distrito del Aar y de otros 
afluentes del Rhin los cogen junto con otros peces á millo nes, vendiéndolos despues de cocidos y secos envueltos en hojas frescas, y cada paquete en corteza de árbol; en la Prusia oriental los curan al humo, y los venden tambien en conserva; $y$ en la Pomerania y alto Rhin se utilizan sus escamas.

Se fabrican las perlas falsas con la llamada esencia orienial, cuya composicion fué durante mucho tiempo un secreto. Las perlas falsas fabricadas con esta esencia pueden imitar å las verdaderas con la mayor naturalidad $y$ han hecho bajar su precio considerablemente. La invencion de revestir las perlas de vidrio interiormente de escamas de pez reducidas a polvo, con lo cual adquieren el color y matiz de verdaderas perlas, se debe á un francés, fabricante de rosarios, que vivia á me. diados del siglo pasado, $y$ desde entonces se explota esta nueva industria en mayor ó menor escala. Hé aquí cómo se prepara la esencia citada: Se cscaman los alburnos y se meten las escamas en una vasija con agua, donde se desmenuzan hasta donde es posible. Pronto adquiere el agua un tinte pla. teado, y al cabo de algunas horas se forma un poso, que, despues de decantar el agua reposada y clarificada, aparece como un liquido espeso y accitoso. Este liquido es la esencia oriental. Su empleo se basa en la particularidad de que no cambia en contacto del amoniaco. De los datos recogidos por Siebold cerca del Rhin medio, resuita que 50 kilógramos de alburnos dan 2 kilógramos de escamas; y que para 500 gramos de esencia se necesitan de 18 á 20,000 pececillos; cantidad que gracias á la abundancia de cstos peces, es segun las circunstancias fácil de obtener en una sola pesca, porque en el lago de Constanza ha habido ocasion en que se han cogido de una vez mas de cinco hectólitros.

CAUTIVIDAD. - Los alburnos son peces excelentes para acuarios, puesto que no hay otros tan juguetones y divertidos como ellos; continuamente están en movimiento, todo lo miran, saltan detrás de cada mosca ó de cualquier cosa que se les eche, $y$ en general son tan incantables como alegres

\section{EL ALBURNO MENTO - ALBURNUS MENTO}

CARACTERES. - Fsta especie es mayor que el alburno brillante, pues alcanza de $0^{\circ}, 15$ á $0^{\mathrm{m}}$, IS y en algunos casos ()$^{\circ}, 20$ y aun $0^{m}, 25$ de longitud. El cuerpo es oblongo, un tanto comprimido lateralmente; la boca está dirigida hácia arriba, y la barba es saliente y gruesa. La cabeza y el lomo son verde-oscuros con viso azul de acero; los costados y vientre plateados y brillantes; las aletas dorsal y caudal están orladas de negro. En la primera hay respectivamente tres y ocho radios; en la torácica uno y quince; en la abdominal dos y ocho 6 nueve; en la anal tres y catorce hasta diez y seis; y en la caudal diez y nueve.

DISTRIBUCION GEOGRÁFICA.-Desde los lagos de Baviera se extiende esta especie por la Europa oriental hasta varios rios de Crimea.

USOS, COSTUMBRES Y REGIMEN. - Es pez muY frecuente en los lagos del distrito austriaco llamado Salzkam. mergut, desde donde pasa raras veces a las corrientes mayo res; en cambio le gustan los affuentes de estos rios, $y$ en especial los limpidos, frios y de fondo pedregoso, en cuyas aguas se le ve, segun Heckel y Kner, largos ratos inmóvil, con la cabeza dirigida contra la corriente, para marchar de pronto en línea recta con una velocidad pasmosa. En la épo ca de la freza, que cae en los meses de mayo y junio, se forma en la piel del macho una crupcion análoga á la de otros ciprínidos. Ambos sexos se reunen para el desove en sitios de poca agua con fondo pedregoso, y colocándose verticalmente cabeza abajo uno junto á otro, sueltan la freza, agitando las colas; hecho esto abandonan el sitio donde los reemplaza otra bandada, seguida á su vez de otra y otra. Lo propio que sus afines, olvidan estos ciprinidos durante el acto de la repro. duccion su recelo habitual, lo que facilita extraordinariamente su pesca, pero como se encuentran en aguas donde abundan peces de mas mérito, no se les hace caso.

\section{EL ASPIO RAPAZ - ASPIUS RAPAX}

\section{CARACTERES. - Caracterizase este per, representante} del género de los aspios que cuenta muy pocas especies, por su cuerpo oblongo, algo comprimido lateralmente; por la boca dirigida hácia arriba; la mandibula inferior saliente, cuyo extremo encaja en un hueco de la superior; por la aleta anal corta que empieza detrás de las abdominales, por sus escamas pequeñas y por los dientes faringeos con las coronas proiongadas, cónicos, ganchudos, y sin surcos, colocados en dos hileras de tres y cinco dientes respectivamente. Alcanza el aspio comunmente una longitud de $0^{n}, 60$ a $6^{\circ}, 70 \mathrm{y}$ un peso hasta de seis kilógramos. El color del dorso es azul negruzco, el de los costados blanco azulado; el vientre es blanco; las aletas dorsal y caudal son azules, $y$ las otras tienen un viso rojizo. El número de los radios es respectivamente en la dorsal de cuatro y ocho 6 nueve; en la anal tres y catorce: y en la caudal diez y nueve.

DISTRIBUGION GEOGRÁFICA. - Ha sido observado este pez en todos los rios y lagos mayores del continente curopeo, desde la parte central hasta la Laponia. Por lo que hasta ahora se sabe falta en las islas Británicas. Habita en núnero muy regular los lagos de Bavieray Austria, es frecuente en el Danubio, y se le encuentra en toda la Alemania del norte desde donde se dispersa hácia levante por las aguas dulces de Rusia, donde alcanza á veces un tamaño colosal.

USOS, COSTUMBRES Y REGIMEN. - Si los ciprinidos son en general peces inofensivos, no deja de haber en la familia alguras especies rapaces, aunque contadas: una de ellas es el aspio rofas, que como se alimenta de sustancias vegetales, sabandijas menudas y peces, busca los parajes donde el agua es pura y de mansa corriente. Dicese que per. sigue á los alburnos con tanta violencia y ceguedad, que no viendo estos otro refugio sino la playa, él mismo se abalanza tras ellos y queda en seco. Hácia la época de la freza que cae en los meses de abril y mayo, pero que puede principiar tambien en marzo y prolongarse hasta junio, empieza \& su vez el aspio á viajar, abandonando los lagos para remontar los rios, $\delta$ bien subiendo simplemente de los sitios profundos en busca de otros de poca agua. Entonces se manifiesta en los machos la correspondiente erupcion, que consiste en granitos pequeños hemisféricos, y que cubre principalmente el lomo, las ramas de la mandibula inferior, las mejillas, los opércu. los, el borde posterior de las escamas del dorso, y la parte descubierta de las de la cola. Efectuan el desove en banda$\mathrm{da}$, y segun dicen los pescadores dura tres dias. Los peque. ños se desarrollan con rapider, pero como son de complexion delicada, no se dejan trasladar á otras aguas.

PESCA Y UTIIIDAD. - Se pescan los aspios con red y sedal, con particular abundancia en la época de la freza, porque entonces son menos recelosos, y además se dice que es mas consistente su carne siempre blanca y sabrosa, pero que fucra de este tiempo se deshace fácilmente con la coccion, y para evitarlo se pone el pez á la lumbre con agua fria Se paga cl kilógramo, segun la localidad, de dos a cinco reales.

\section{EL LEUCASPIO RAYADO-LEUCASPIUS DE- IINEATUS}

CARACTERES. - Este pez, representante del genero leucaspio, tiene una apariencia por demás modesta; es pe 
queño, de cuerpo prolongado y comprinido lateralmente, con arista abdominal, linea lateral incompleta, y escamas poco adherentes; la aleta dorsal es corta, colocada muy hácia atrás y carece de radio espinoso; la mandibula inferior es prominente; los dientes faríngeos están dispuestos de un mo. do singular, bien en una sola hilera de cinco dientes á ca. da lado, $\delta$ en dos de cuatro y cinco; las coronas de estos, y si están en dos hileras, las de la interior, son de punta ganchuda, comprimidas y surcadas a manera de sierra. El lomo y parte superior de la cabeza son pardo-verdosos, los costados y el vientre blancos y plateados, y una lista en la parte posterior de los costados azul de acero. Sostienen la aleta dorsal tres y ocho radios; cada torácica uno y trece; cada abdominal dos y ocho; la anal tres y once hastatrece, y diez y nueve la caudal. La longitud es de $0^{\circ}, 07 a^{\circ} 0^{*}, 08, a$ á lo mas de $0^{\circ}, 09$.

DisTRIBUGION GEOGRAFICA, - El foco del área de dispersion del leucaspio parece ser la Rusia, donde scgun parece puebla todas las corrientes. Nosotros le observamos \& millares en la parte baja del Ob á principios de setiembre, remontando el rio a lo largo de la orilla. Desde alli se ex. tiende por un lado hasta Grecia y por el otro hasta cl noroeste de Alemania, y como es probable que habite tambien otras corrientes de Siberia, viene á ser uno de los peces de agua dulce mas diseminados. Puede admitirse tambien como cierto que es mas frecuente en Alemania de lo que hasta ahora se habia creido por no haber hecho caso de él. Siebold, que le ha cogido en la Prusia oriental, y ha recibido otros del pais de Brunsvik, cree que este pez era mas conocido en épocas pasadas que ahora. En las obras antiguas que tratan del asunto se mencionan ciertos pececillos que se creia nacian espontáneamente del cieno y de las materias en des. composicion, pero las descripciones son tan defectuosas que es difícil determinar su especie; los pescadores, tanto en Prusia como en Brunsvik, designan aun hoy dia el leucaspio con el nombre de aquel pececillo fabuloso $\mathrm{y}$ acaso crean muchos de ellos todavia aquel cuento de su nacimiento espontáneo.

USOS, COSTUMBRES Y REGIMEN.-Respecto de este punto faltan datos. Dicen que este pez abunda en algu. nos distritos de nuestro país, tanto en los sios como en las zanjas de desaguie de los terrenos turbosos, \& que desova en abril y mayo.

\section{LOS ORFOS-IDUS}

CARACTERES. - Tienen el cuerpo medianamente oblongo y poco comprimido; frente ancha, boca oblicua en la punta del hocico; la aleta anal empieza mas hácia atrás que el extremo final de la dorsal; los dientes faríngeos forman en cada lado tres hileras de tres $y$ cinco dientes, cuyas coronas, lateralmente comprimidas, son ganchudas en el extremo.

\section{EL ORFO COMUN-IDUS MELANOTUS}

CARACTERES, - Es uno de los ciprinidos mas grandes, porque alcanza $0^{m}, 50$ y aun $0^{\circ}, 55$ de longitud con mas de tres kilógramos de peso, bien que por lo comun no crece tanto. Su coloracion varia, segun la morada, la estacion, edad, ctc. En la primavera y en la época del celo es negro gris con brillo de oro en el dorso, un tanto mas claro en los costados y platcado en el vientre; la parte superior de la cabeza y los opérculos son color de oro; las aletas dorsal y cau. dal varian de azul gris á morado, y las demás aletas son en. carnadas. En otoño se vuelven estos colores mas oscurns, el lomo pasa de verde azul á negruzco, y el brillo dorado se vuelve blanco amarillento.

\section{EL ORFO ROJO-IDUS MINIATUS}

CARACTERES, - Ya en tiempo de Gessner se distin. guia esta variedad de la especie anterior, como fija. Puede competir perfectamente con los peces rojos ó de color en cuanto á magnificencia de coloracion, pues tiene el lomo y los costados de un anaranjado muy subido 6 bien de color de minio, mientras que el abdómen es de un brillo plateado; una faja longitudinal ancha, mal limitada $\delta$ esfumada de co. lor morado corre á lo largo del costado y separa el rojo subido del dorso del pálido inferior, pasando mas abajo á plateado. Las aletas son rojas en la base s blancas en la punta

DISTRIBUCION GEOGRAFICA.-Se encuentra el orfo comun en todos los lagos grandes y medianos de Europa y noroeste de Asia; y el rojo, como especie criada en diferentes rios pequerios, arrojos y estanques, como en el lago del parque del castillo de Laxenburg cerca de Viena; despues en el Regnitz, Pegnitz, Rednitz, Woernitz, en algunas balsas de los alrededores de Dinkelsbuehl en Franconia, y en algu. nos puntos cerca del Rhin y del Mein. En la Alemania del norte no se le ha criado hasta ahora. La especie comun en cambio, dice Eckstroem, vive tambien en el mar, como por ejemplo, entre los islotes de la costa de Noruega, donde es tan comun como en las corrientes y lagos cristalinos de la Escandinaria.

USOS, COSTUMBRES Y REGIMEN. - Agua pura, limpia y profunda es condicion indispensable para la vida y salud de este pez Rara vez acude à la orilla, y hácia la tarde solamente á la superficie tranquila. Durante el invierno permanece en la profundidad. Su alimento consiste en gusanos é insectos, acaso tambien en pececillos, bien que no es rapaz como el aspio. Hácia principios de mayo se presenta en el macho la erupcion cutánea, y entonces no tardan los orfos en salir de su lago para pasar álos rios que le atraviesan ó desembocan en él, y buscar alli los sitios arenosos ó cubier. tos de plantas acuáticas para deponer su freza. Cuando el tiempo es favorable empiezan el desove temprano, en abril, á veces en marzo, otras mas tarde, en junio, julio y aun en agosto.

PESCA Y UTILIDAD.-Se le pesca en el tiempo de la freza con red y sedal cebado con saltamontes, coleópteros ó pececillos. Ia carnc ticnc fama de sabrosa, pero se paga po. co en atencion á sus muchas espinas, alcanzando rara vez mas de cinco reales el kilógramo. Jaeckel dice que el orfo rojo, si bien figura alguna que otra vez en la mesa, se le emplea mas como gurrdian de carpas; porque á causa de gustarle mucho agitarse en las capas superiores del agua en las balsas, ve al punto al águila de rio, $y$ bajando súbitamente álas capas inferiores, avisa á las carpas á tiempo el peligro. Desde hace poco se les emplea tambien para adornar los estanques y surtidores en vez de los peces de color chinos, por manera que alora son objeto de un comercio bastan. te activo en Dinkelsbuehl desde donde se remiten á pun. tos muy lejanos con el nombre de orfo dorado 6 peces de color falsos.

\section{LAS ESCARDINIAS - SCARDINIUS}

CARACTÉRES. - Estos ciprinidos tienen el cuerpo fornido, con la boca hendida en el extremo del hocico y dirigida oblicuamente hácia arriba; los dientes faringeos forman dos hileras respectivamente de tres y cinco dientes en cada 
lado, $y$ cuyas coronas, comprimidas lateralmente, presentan en el lado interior puntas relativamente largas.

\section{LA ESCARDINIA COMUN - SGARDINIUS ERYTHROPHTHALMUS}

CARACTERES. - Este pez mide de $0^{\circ}, 25$ á $\left(1^{\prime \prime}, 3^{\circ}\right.$ de largo y pesa de 500 hasta Soo gramos. La coloracion es tan variable como en otros ciprínidos, pero por lo comun es ver de pardusca en el dorso, amarilla de azófar brillante en los costados, y blanca plateada en el vientre; las puntas ó extre. mos de las aletas dorsales $y$ anal son siempre rojos de sangre, alguna vez ofrecen los de la dorsal y casi siempre los de la caudal el mismo tinte. Hay empero tambien individuos que tienen el rojo mas pálido $\delta$ bien mas subido; en otros reemplaza un azul negruzco muy oscuro todos los colores del cuerpo, etc. La aleta dorsal estál sostenida por tres y ocho 6 nueve radios, la pectoral por tres y diez ú once, y la caudal por diez y nueve.

DISTRIBUCION GEOGRAFICA.-Se encuentra esta especie en todos los paises de Europa desde el mediodia de Italia hasta la Laponia, y desde la Irlanda hasta el Ural, é igualmente en la cuenca del Ob en Asia.

USOS, COSTUMBRES Y REGIMEN. - La escardi. nia prefiere aguas de corriente mansa ó lagos y estanques hasta la altura de 1,600 metros sobre el nivel del mar, porque no solamente vive a la manera de las tencas y carasios, sino que le gusta tambien estar en compañia de estos peces. Sus movimientos son vivos, á pesar de ser pez arisco y cauto, Plantas acuáticas, insectos y gusanos que busca en su mayor parte en el cieno, constitusen su principal alimento. En la época del celo se vuelven los colores mas oscuros, y una multitud compacta de granitos cubre el occipucio $y$ las escamas del lomo. El desove tiene lugar en abril, mayo y junio en sitios cubiertos de yerbas acuáticas y á intervalos. A los pocos dias nacen los pequeños.

USOS Y PRODUCTOS. - Solo las clases mas pobres consumen estos peces en los paises donde no hay otros, por las muchas espinas que tiene su carne, que se paga à cinco reales el kilógramo, y que desdeñan no solo las clases aco. modadas sino hasta muchas aves ictiófagas. En ninguna parte se pescan adrede; á pesar de lo cual se cogen frecuente y accidentalmente cantidades tan grandes que se emplean como abono para los cainpos 6 para alimentar á los cerdos, bien que seria mas provechoso echarlos á los criaderos de peces de tmas valor.

\section{LOS LEUCISCOS-LEUCISCUS}

CARACTÉRES. - Hasta hace muy poco tiempo hánse confundido las escardinias con los leuciscos, dándóles el nom. bre genérico de estos, $y$ en efecto tienen los peces de ambos grupos la mayor semejanza entre si, por manera que las personas poco prácticas solo reconocen los leuciscos por los dientes faringeos que forman hilera simple $y$ en nímero de cinco en el hueso faringeo derecho $y$ de cinco á seis en el izquicrdo. Las coronas de los dientes anteriores son cónicas; y están comprimidas lateralmente en los posteriores con el plano oblicuo.

\section{EL LEUCISCO ROJO-LEUCISCUS RUTILUS}

CARACTÉRES. - El cuerpo es mas ó menos oblongo y cumprimido lateralmente, la boca se halla abierta en el ex tremo del hocico, las éscamas son grandes, pero la coloracion varia lo mismo que el perfil del cuerpo segun la morada y el réginen, dando lugar á numerosas variedades mas 6 me. nos fijas. Por lo regular es azul ó negro verdoso el lomo, y los costados mas claros pasando hácia el vientre á blanco plateado. Las aletas abdominales y anal son á menudo casi tan rojas como las de la escardinia; las pectorales son de un blanco agrisado, y la dorsal y caudal gris con viso rojizo. Fi número de radios es respectivamente tres $y$ nueve ó diez en la dorsal; uno y quince en la pectoral; uno y ocho en la ab. dominal; uno y diez en la anal, y diez y nueve en la caudal. Rara vez se encuentran individuos de mas de $0^{\prime}, 50$ y de un peso de 1.50 kilógramos, aunque Pennant vió uno que pesaba 2,50 kilógramos.

DISTRIBUCION GEOGRÁFICA-Los leuciscos forman el género mas extendido y comun de todos los ciprinidos; puesto que habitan los lagos, estanques, corrientes grandes y pequenas $y$ aun los mares menos salados de toda la Europa central, inclusa la Gran Bretaña, una gran parte de la oriental y el noroeste del Asia. Son raros en el mar del Norte, pero numerosísimos en el Báltico.

USOS, COSTUMBRES Y REGIMEN - Respecto á estos no discrepan en nada de las escardinias. Constantemente van en bandadas que se alimentan de gusanos, insec. 105, freza, pececitos y plantas acuàticas, revolviendo en busca de los primeros el cieno que cubre el fondo. Nada con rapidez; es vivaz, arisco, pero poco cauto, puesto que se mercla frecuentemente con gran perjuicio suyo con otros peces, con lo cual hasta ha dado lugar á ciertos adagios, bien que este instinto de sociabilidad no es tanto que le haga desconocer el peligro que ofrece la proximidad del lucio, su enemigo mas temible, pues tan contento como parece el leucisco en compañía de otros peces, tan inquicto se vuelve cuando vis. lumbra á este rapaz, el mas terrible de todos los peces de rapiña de nuestras aguas dulces. El leucisco desova en mayo 6 junio, á veces ya en marzo y abril, y otras hasta en julio. Entonces abandona en masas compactas las profundidades de los lagos donđe pasa el invierno, remonta los rios y de. posita en sitios de abundante yerba acuática su freza, nadan. do arriba $y$ abajo con visible inquietud, batiendo el agua vivamente con la cola y dando saltos fuera del agua. Lund dice, que aparecen en estos sitios puntualmente en banda. das, primero de cincuenta á cien machos, á estos sigue cierto número de hembras, en pos de estas otros cuantos machos, y despues proceden al desove. Los machos presen. tan en esta época tambien pequeñas protuberancias blan. quizcas y cónicas diseminadas por el occipucio y las escamas. Se ha observado que estos peces son-mas cautos que sus afines cuando se hallan ocupados en su reproduccion, pues no bien notan que álguien los observa, se hunden al monzen. to en la profundidad. Multiplicanse mucho porque aun los pequeños, en apariencia medio adultos, son ya capaces de reproducirse.

USOS Y PRODUCTOS. - Tambien en este concepto podria repetirse lo que se dijo respecto á la utilidad de las. escardinias. Su carne no se aprecia en ninguna parte, pagán. dose el kilógramo por término medio a dos reales y en casos excepcionales á cinco, sin que esto sea obstáculo para que se cojan en todas partes en grandisima cantidad, ya para con. sumirlos frescos 6 curados al humo, en cuya forma se exportan en Pomerania tierra adentro, hasta á la l'olonia rusa, ó finalmente para alimentar con ellos otros peces ó los cerdios.

\section{ELLEUCISCO DONCELLA-IEUCISCUS PIGUS}

CARACTERES. - Tiene la cabeza pequeña y de frente abultada, la boca se halla un poco debajo de la mandibuia superior; la aleta caudal es larga, y la coloracion un verde 
manzana que varia hasta azul celeste, con fuerte reflejo me. tálico, excepto las aletas abdominales, anal y caudal donde es anaranjada. Alcanza una longitud de $(1)^{m}: 40$ y un peso de un kilógramo. Su carne tiene fama de sabrosa.

DISTRIBUCION GEOGRÁFICA.-Fsta especie habita la cuenca del Danubio.

\section{EL LEUCISCOAPERLADO-LEUCISCUS GRIS-} LAGINE

CARACTÉRES:-Difiere esta especic de sus afines por su estructura oblonga y casi cilindrica, pudiendo alcanzar la longitud de $0^{*}, 55$ y el peso de 5 kilógramos. La carne tiene, como la del anterior, fama de sabrosa.

DISTRIBUCION GEOGRAFICA.-Hasta ahora se ha encontrado esta especie solo en los lagos de Atter, Mondy. Chiem de la cuenca del Danubio.

\section{LOS DÓBULOS-SQUALIUS}

CARACTERES.-Distinguese este género por su cuer. po redondeado, cabeza relativamente grande, aleta dorsal y anal muy cortas, cscamas bastante grandes, y los dientes $f_{2}$. ríngeos colocados en cada lado en doble hilera respectivainente de dos y de cinco dientes, de corona lateralmente comprimida, y de extremo ganchudo.

DISTRIBUCION GEOGRAFICA.-1.0s dóbulos son comunes en roda la Europa, en Asia y la América del norte.

EL DOBBULO COMUN-5QUALIUS CEPHALUS

CARACTERES.-Hé àquí cómo Ásonio celebra á este pez, tan conocido de los antiguos:

6 Sobre la fresca arena entre matas de yerba brilla el dó. bulo de relucientes escamas y carne tiernisima, pero llena de espinas, é impropio para la mesa á las seis horas de ser cogido.

Se caracteriza por la cabeza relativamente muy grande, lo que le ha valido el nombre de repholus ó cabezudo; cl hocico es aplastado, y la boca abierta en la punta del hocico $y$ hen. dida hasta muy atrás. El cuerpo es casi redondo, verdinegro el dorso, amarillo de oro 6 blanco de plata los costados, blanco con viso de rojo pálido el vientre; las mejillas y los opérculos son de color rosado con reflejo de oro; los labios rojizos: las aletas dorsal y caudal son negruzcas con viso rojizo; la anal y pectorales de un tinte encarnado subido, 8 todas las escamas cubiertas en el borde y hácia el centro de un pigmento hosco. En la aleta dorsal se cuentan tres $y$ ocho radios, en la pectoral uno y diez y seis á diez y siete; en la abdominal dos y ocho; en la anal tres y siete hasta nueve, $y$ en la caudal diez y nueve. Puede alcanzar una longitud de $0^{*}, 60$ y un peso de cuatro kilógramos y mas tam. bien.

DISTRIBUCION GEOGRÁFICA.-El dóbulo es uno de los peces mas comunes en todas las corrientes y lagos de la Europa central desde el extremo oeste hasta el Ural, y desde el nivel del mar hasta mil metros de elevacion. Es raro empero en las islas Británicas, puesto que liarrell no pudo lograr mas que un solo individuo.

USOS, COSTUMBRES Y REGIMEN.-En su juven. tud prefiere el dóbulo arroyos ó riachuelos de fondo guijar. roso 6 arenoso donde relozan juntos y á centenares; al menor ruido huyen como sactas disparadas; pero cuando se vuelven vicjos relíranse á rios y lagos, ya en la llanura, ya en sierras de elevacion mediana. Al principio se alimentan de gusanos $\varepsilon$ insectos que nadan 6 que hotan en el agua 6 bien cogen los que vuelan cerca de la superficie; pero á medida que crecen $y$ buscan sitios mas profundos 6 cuando se trasladan $a$ lagos y rios mayores, se vuelven rapaces verdaderos y persi. guen á los peces menores, cangrejos, ranas y hasta ratones, por lo cual en algunos puntos se les ha dado el nombre de ratoneros. Cuando no les falta alimento aumentan rápida. mente de volúmen, tanto que cada ano adquieren, segun opi. nion de pescadores prácticos, por lo menos medio kilógramo de peso. La época del desore cae en los meses de inayo y junio, y dura casi cuatro semanas.

USOS Y PRODUCTOS.-El dóbulo cs, segun Gessner, sun per de poca apariencia y de carne fofa $y$ sosa, pero cuando es crecido, no desagradan ni su carne ni sus huevas en cualquiera estacion del año, menos en medio del verano; es mas sabroso frito que cocido, y mas si es de rios grandes y de agua clara que de lagos y de balsas. Dicese tambien que se le guarda en sal para los dias de ayuno. Se cogen en gran nimero con anzuelo cebado con saltamontes, moscas, mos. quitos y pequeños trocitos de seso de buey.

Ahora se pesca muy poco, sobre todo alli donde no faitan otros peces mejores; pero se emplea mucho para alimentar los peces de estanque y de criadero como hucos, truchas asalmonadas, lucios, liciopercas y otros peces rapaces de mas precio, excepto, segun Heckel, en la temporada en que está en thor la lila, porque entonces enferman y mueren como es sabido de una erupcion cutánea. Además se hallan expues. tos en los estanques á otras enfermedades, enflaquecen, la cabeza adquiere un tamaño excesivo, los ojos se hunden, $y$ los animales cesan de crecer. Cuando asi sucede es menester sacarlos, porque esta enfermedad se comunica á los otros peces.

\section{EL DÓBULO LEUCISCO-SQUALIUS
LEUCISCUS}

CARACTERES.-Esta especie casi tan frecuente y quizás mas diseminada que la anterior, se caracteriza por la ca. beza y cuerpo algo comprimidos lateralmente; boca angosta y abierta debajo de la mandíbula superior, y finalmente por la estructura de las escamas y la coloracion. El color dominante del lomo es un azul negruzco á menudo con reflejo metálico; el lomo s el vientre son tan pronto amarillentos como blancos y relucientes; las aletas pares son ya de un amarillo pálido, ya de un rojo anaranjado; la dorsal y caudal son fuscas. En la dorsal hay tres y siete radios; en la torácica uno y diez $y$ seis 6 diez y siete; en la abdominal dos $y$ ocho; en la anal tres y ocho ó nueve, y en la caudal diez. nueve. La longitud rarisimas veces pasa de $0 \%, 25$.

DISTRIBUCION GEOGRAFICA.-El área de dispersion del dóbulo leucisco abarca todas las cuencas hidrográfi. cas de la Europa central, incluso las de la Gran Bretaña, donde no es nada raro segun Yarrell; y segun otros, encuén. trasele tambien en Italia y en la Francia meridional.

USOS, COSTUMBRES Y REGIMEN.-Como su afinc, no hace este dóbulo ninguna distincion entre aguas cor rientes y estancadas; elige los sitios profundos y tranquilos, se alimenta de insectos y gusanos, y persigue muy particularmente las moscas é insectos que han caido al agua y que hotan en la superficie, cogiéndolos con la misma codicia que la trucha. La época del desore cae en marzo y abril y se anuncia por una erupcion cutánea. Se multiplican muchi. simo.

USOS Y PRODUCTOS. - La carne de este pez solo tiene mérito para los pescadores de caña, por ser un exce. lente cebo para toda especic de salmones. Gessner dice: $\$$ I. carne del dóbulo leucisco es muy sana en abril, mayo, se- 
tiembre 5 octubre; en otras épocas es dañina, á causa de un parásito que vive entonces en el interior de estos peces, los cuales en invierno están bastante flacos; los de rio son mejo. res que los de lago.»

\section{LOS TELESTOS - TELESTES}

CARACTERES. - Los individuos de este género se ca racterizan por sus dientes faríngeos colocados en doble hile. ra en ambos lados, respectivamente de dos $y$ cinco dientes en el uno, $y$ de dos y cuatro en el otro, de corona comprimida y ganchuda, y por sus aletas dorsal y anal muy cortas, la primera inserta verticalmente encima las abdominales.

\section{EL TELESTO DE AGASSIZ - TELESTES AGASSIZII}

CARACTERES.-Esta especie, representante del género 6 subgénero de los telestos, alcanza una longitud de $\theta^{\infty}, 15$ a $0^{\circ}, 20$, á lo mas $0^{\prime \prime}, 22$. Tiene el cuerpo prolongado y casi cilindrico, hocico un poco saliente $\mathrm{g}$ un tanto abovedado. El color es gris tirando á azul de acero en la parte superior del cuerpo, $y$ de brillo plateado en la inferior, además de una lista negruzca de anchura variable que empieza en la frente y acaba en la cola despues de haber pasado por el costado. Sostienen la aleta dorsal dos $y$ ocho radios; la anal tres y ocho ó nueve; la torácica uno y trece $\delta$ catorce; la abdomi nal dos $y$ ocho, $y$ diez y nueve la caudal.

DISTRIBUCION GEOGRÁFIGA.-Pertenece al sistema orográfico de los Alpes y es frecuente en Italia y Suiza. En Alemania solo se le ha encontrado hasta hoy en los afluentes superiores del Rhin y del Danubio, particularmen. te en el Neckar, Inn, Lech, Isar, Iller, Amper y Wurm, asi como en varios lagos. En los demás afluentes de aquellos grandes rios no se ha observado, quizás por mera casualidad; y en las demás cuencas hidrográficas de Alemania no existe tampoco segun parece.

USOS, COSTUMBRES Y RÉGIMEN. - Respecto de este particular no se sabe nada, siendo esta especie una de las menos conocidas de Alemania.

\section{LOS FOXINOS - PHOXINUS}

CARACTERES, - Los peces de cste género figuran entre los ciprinidos mas pequeños que pueblan las aguas dulces de nuestro continente; son fornidos, de cuerpo redondo, boca pe. queña, hocico obtuso y escamas peq̨ueñas tambien; las aletas dorsal y anal son cortas, la primera einpieza detrás de las abdominales; los dientes faríngeos están dispuestos en dos hileras en cada lado, en nímero de dos y de cinco en el uno $y$ de tres y cuatro en el otro, rara vez en ambos lados de dos y cuatro; las coronas están lateralmente comprimidas y son en su extremo ganchudas.

\section{EL FOXINO LISO-PHOXINUS LAEVIS}

CARACTERES. - Esta especie, representante del género foxina, es conocidisima en Alemania donde lleva distintos. nombres. Brehm cita cuarenta y uno, segun las diferentes provincias y localidades, lo que prueba que este pececillo es tan popular y bien conocido como interesante. El color del dorso es un verde aceitunado que varia hasta gris sucio, y está mas ó menos oscurecido por manchitas pardas, que á veces se juntan hasta formar una lista longitudinal negra, la cual ocupa el centro del lomo en toda su longitud hasta la cola; los costados son amarillos verdosos con brillo metálico; los ángulos de la boca son de un rojo carmin, la garganta negra y el pecho escarlata. Aparte de esto obsérvase una lista de color y brillo de oro que arranca detrás de cada ojo para recorrer el cuerpo á ambos lados del lomo y acabar en la base de la cola; las aletas son de un amarillo pálido, oscure. cido en la dorsal, anal y caudal por la acumulacion de un pig. mento pardo, mientras que las aletas pares pueden presentar un tinte purpúreo brillante, que en ciertos casos se extien. de en algunos individuos tambien á la caudal. Tanta magni. ficencia de coloracion es independiente de la influencia del celo, segun Siebold, puesto que la presentan machos $y$ hem. bras hasta en el rigor del invierno; pero en la época de la reproduccion presentan ambos una erupcion en el occipucio, en forma de prominencias puntiagudas, y granitos compactos en el borde posterior de todas las escamas, á manera de una orla. Hay tres $y$ siete radios en la aleta dorsal; uno $y$ quince, hasta diez y seis en la torácica; dos y ocho en la ab. dominal; tres y siete en la anal, y diez y nueve en la caudal. Respecto à longitud, alcanzan, algunos individuos hasta $0^{\prime \prime}, 12$, pero la mayorf́a apenas llega á $0^{\circ}, 0$.

DISTRIBUGION GEOGRÁFICA. - Brehm dice que es especie que se encuentra en todas partes, pero debe en. tenderse que con esto se refiere á su pais, á Alemania.

USOS, COSTUMBRES Y REGIMEN.-El foxino liso vive en las corrientes grandes y pequeñas, desde su origen en las sierras hasta sus desembocaduras, con tal que el agua sea limpida y el fondo arenoso ó cascajoso; en algunos arro. yos es el línico pez que los habita, encontrándose en sitios de que todos los demás peces se alejan $\delta$ que son inaccesibles para ellos, $y$ donde el foxino se encuentra, al parecer, muy á su gusto. Casi nunca se ven solos, sino en grandes bandadas, retozando cerca de la superficie, dando brincos ligeros, y huyendo espantados a cada ruido que perciben; y $\tan$ grande puede ser el pavor que se apodera de ellos, que llegan á penetrar, conforme vió Rusegger, en el interior de una galeria de minas hasta miles de metros de distancia de sus aguas, siguiendo las que desembocan de la mina. Durante los grandes calores abandonan á veces los sitios en que habitaban, para remontar la corriente hasta donde el agua es mas fresca, ó bien penetran en sus afluentes, que entonces remontan tambien venciendo obstáculos al parecer fuera de toda proporcion con su talla reducida, pero cuando ha pasa. do uno, le siguen los demás á todo trance. Un observador, amigo de Cornelius, comunicó a este los datos siguientes so. bre los viajes del foxino. En las provincias rhinianas se pre. sentan estos peces, especialmente en el rio I.enne, en grandes bandadas durante la época del desove y con preferencia cuan. do hace buen tiempo y el nivel del aguz está en su punto me. dio; pues si es bajo les presentan obstáculos las muchas fábricas establecidas en la orilla. Cada bandada, que los chicos de aquellos pueblos observan en grandísimo número y con no poca satisfaccion desde los puentes, tiene como medio metro de ancho, pero es tan compacta, que los peces están unos encima, debajo y al lado de otros como las sardinas en un barril, $y$ una bandada sigue á otra sin interrupcion todo el dia, de modo que pueden calcularse por millones los foxinos que entonces alberga el Lenne.

Su alimento consiste en sustancias vegetales, gusanos insectos, y quizás en otras materias animales, puesto que un inglés observó un grupo de foxinos que se dejaban arrastrar por la corriente formando como una estrella todos con la cabeza hácia el centro, el cual resultó ocupado por el cadá. ver de uno de ellos que los demás estaban devorando.'

La época del desove ocurre en los meses de la primavera, por lo regular en mayo y en algunos puntos en junio. Para esta operacion eligen estos peces sitios arenosos y de poca 
agua, y cada hembra aparece acompanada de dos ó tres ma. chos que aguardan el momento del desove, para deshacerse de su liguido seminal. Los experimentos hechos por Davy han permitido ver que los pequeños nacen á los scis dias; en agosto miden $0^{\circ}, 02$, despues crecen con mas lentitud $y$ solo pueden reproducirse á los tres $\delta$ cuatro años.

PESCA. - A pesar del reducido tamano de estos peces $y$ de su sabor amargo, no faltan aficionados que los coman, por cuya razon se pescan en todas partes; en el Lenne, segun el mismo observador, en inaso y junio cuando viajan á bandadas, con bolecha, pero principalmente con nasas $y$ buitrones que se fijan en los sitios de agua tranquila, dirigidos con la aberiura contra la corriente, y que se sacan de cuando en cuando para vaciarlos. Deberia prohibirse esta pesca porque como se cogen al mismo tiempo crias de peces de mas mérito, en especial de salmon, se causa un daño muy considerable á la industria pesquera.

USOS Y PRODUGtos.-Además de ser el fuxino un manjar que tiene muchos aficionados, sirve tambien de cebo a los pescadores, y de alimento a otros peces mayores y rapaces que se crian en estanques. Por otra parte soporta la cautividad y recrea mucho \& causa de sus pocas necesida. des, su mucha destreza y su movilidad.

\section{LOS CONDROSTOMOS} - CHONDROSTOMA

CARACTÉRES. - Con cste género suelen cerrar los naturálistas la familia de los ciprínidos. Las pocas especies que cuenta se caracterizan por la cubierta cartilaginosa de la mandibula superior de la cual forma como un corteó arista; por la mandibula superior mas ó menos prolongada; por la hendidura bucal y trasversal debajo con bordes córneos muy afilados, y finalmente por los dientes faringeos dispuestos en hilera simple de cinco, seis 6 siete dientes de coronas pro. longadas, lateralmente muy comprimidos y que se desgastan en un lado en toda su extension.

\section{EL NASON-CHONDROSTOMA NASUS}

CARACTERES. - I a nariz ó prolongacion de la man. dibula superior es larga, redondeada, un poco comprimida lateralmente y cubierta de pequenas escamas. Fuera de la época del desove, la coloracion de este pez es verdinegra en el dorso, blanca con brillo plateado en los costados y vientre, y cn las aletas rojiza, excepto las dorsales que son oscu. ras. Al llegar la citada época, suben todos estos colores; en los extremos de la boca y en la articulacion de las aletas to. rácicas sale un hermoso tinte anaranjado, y el lomo se vuclve mas oscuro y se presenta como listado de negro. La aleta dorsal está sostenida por tres y nueve radios; cada pec. toral por uno y quince hasta diez y scis; cada abdominal por dos y nueve; la anal por tres y die\% ú once, y la caudal por diez y nueve. La longitud puede llegar hasta $0^{n}, 50$, y el peso hasta 1,jo kilógramos, bien que los nasones de este jeso son en extremo raros.

DISTRIBUCION GEOGRÁFICA.-Abunda esta es. pecie en la Alemania meridional y oriental, siendo poco co. nocida en el norte. En Suiza es numerosa, y bastante en el Oder y Vistula. En las cuencas del Danubio y del Rhin no falta casi en ninguna corriente ni lago.

USOS, COSTUMBRES Y RÉGIMEN.-Es pez socia. ble, que vive casi siempre en grandes bandadas é invariablemente en el fondo en un mismo sitio donde suele revolcarse á menudo, segun dice Schinz, viéndose desde bastante léjos el brillo plateado de su vientre. En verano se aproxima á los muros que se elevan en las orillas para encauzar el rio junto á las poblaciones, y pasa rodando sobre piedras apenas cubiertas de agua. Lo mismo hace sobre las gradas que condu. cen al agua, y con tanta regularidad, que los gatos lo echan de ver $y$ acechan desde alli $\mathbf{a}$ estos peces con mas 6 menos buen éxito. Su alimento consiste en restos vegetales, en especial diferentes algas que cubren las piedras y otros cuerpos sumergidos. En Wurzburg los llaman, segun dice Siebold, "vomitadores, porque cuando los cogen arrojan mucho cieno, que probablemente no será otra cosa sino el mucilago vegetal que en el momento de ser pescados, tienen entre sus dientes faringeos.

Hácia la temporada del desove, que cae en abril y mayo, se reunen los nasos en innumerables bandadas para aban. donar el rio principal y entrar en sus tributarios, y de estos á sus pequeños afluentes, arroyos y torrentes, aunque lleven agua turbia. Alli buscan los sitios guijarrosos de gran corriente para depositar su frcza. Entonccs presentan, además de la coloracion mas viva, la erupcion tan comun en otros muchos ciprinidos, y que cubre particularmente el occipucio, la parte superior de los opérculos, y los lados del hocico y de la cara los pequeños nacen á los quince dias segun parece, y se trasladan paulatinamente á la corriente principal.

PESCA Y UTILIDAD.-Se pescan los nasones con caña mas por gusto y entretenimiento que para la mesa, y se ceba el anzuclo con la mosca comun de habitacion, pero en la época de la freza se cogen en grandes cantidades; en el Wertach junto a Augsburgo hasta quince mil kilógramos y mas en cierta temporada que dura dos a tres semanas cada año, segun dice Grundaner; otras pescas anúlogas se efec. túan en las desembocaduras del Birs y del Glatte. Se paga por término medio el kilógramo á.tres reales y á cinco cuan. do va caro. Gessner dice: Se alaba mucho á los que se co. gen en la primavera, porque entonces están gordos, y tam. bien se estiman los de invierno; pero la verdad es que su carne merece pocas alabanzas por ser siempre desabrida, de mal olor y llena de espinas, sobre todo cerca de la cola. Con todo, son mejores fritos que cocidos.

\section{LOS ACANTÓPSIDOS- ACANTHOPSID压}

CARACTERES. - Ias lochas son les peces que mas afinidad tienen con los ciprínidos. Agregadas, segun los diferentes ictiólogos, tan pronto á una familia como á otra, fue. ron definitiva $y$ finalmente reunidas por Heckel en una familia independiente, la de los acantópsidos ó lochas. Su cuerpo es prolongado, la cabeza pequeña y cubierta de una membrana que deja libre su abertura branquial muy angos. ta; el hueso intermaxilar forma el borde de la mandibula superior; el borde orbital inferior y en algunas especies tam. bien los opérculos, acaban en una ó varias espinas; la boca se halla rodeada de labios chupadores y de barbillas; la alcta dorsal, que es corta, solo tiene radios blandos; la cubierta consiste en escamas pequeñas; los dos huesos faringeos in. feriores están guarnecidos de dientes endebles, y la rejiga natatoria, cuando existe, está dividida en una mitad derecha y otra izquierda.

DISTRIBUCION GEOGRÁFICA.-Esta familia, que cuenta aproximadamente ochenta especies, tiene representantes en los continentes de ambos hemisferios, pero en Europa no hay mas que un género, cuya descripcion bastara a nuestro propósito. 


\section{LAS LOCHAS- COBITIS}

CARACTERES. Estos consisten en la cabeza pequeña cuya abertura bucal esta rodeada de labios abultados y de barbillas; en los huesos faringeos cubiertos con una hilera simple de dientes puntiagudos s numerosos, y finalmente en la aleta dorsal inserta en la parte posterior y encima de las abdominales.

DISTRIBUCION GEOGRÁFICA. - Extiéndese este género por una gran parte de Europa. Las tres especies que habitan las aguas de Alemania son tambien comunes al resto de la Europa central, excepto la Gran Bretaña en donde solo has dos.
USOS, COSTUMBRES Y REGIMEN.-Las unas pre. fieren aguas estancadas y fangosas, las otras las necesitan limpidas y corrientes, pero todas suelen vivir por lo regular en el fondo, descansando de dia ocultas en el cieno 6 debajo de piedras, y cazando desde la puesta del sol, ó antes cuando el tiempo es lluvioso, toda clase de sabandijas acuáticas. Dos especies son de natural delicado, mientras que la tercera re. siste muy bien a las circunstancias adreraas y principalmente al agua corrompida, gracias á su estructura especial que le permite respirar de un modo diferente de los demás peces, puesto que en ciertos casos pueden respirar por el intestino en lugar de las agallas. Para hacerlo se trasladan estas lochas, segun Siebold, a la superficie, donde tragan, con el hocico

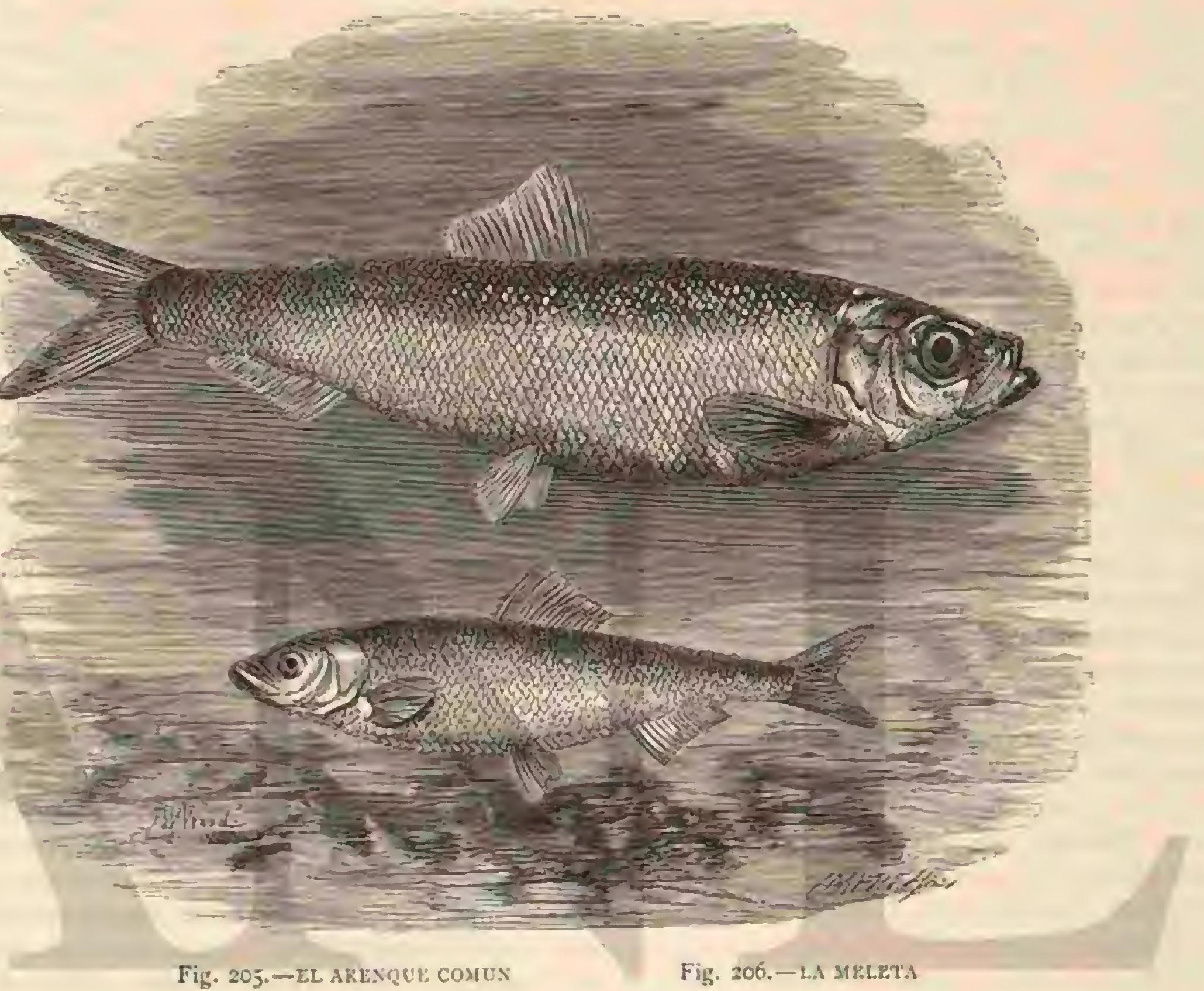

fuera del agua, cierta cantidad de aire que hacen pasar, apretando fuertemente los općrculos, al intcstino rccto, arrojando al propio tiempo, mediante un esfuerzo y ruido distinto, cicrto número de burbujas de aire por el ano. Erman fué cl que descubrió que esta inhalacion y exhalacion son dos funciones de respiracion intestinal, pues los ictiólogos antiguos se limitan á decir que la locha de sequedal, que es la especie con la cual Erman hizo sus experimentos, emite una especie de silbido. Bloch dice que ha visto salir frecuentenente burbujas de aire del ano de esta locha, cosa quue negó Schneider, ale gando que solo la habia visto expeler aire con cierto ruido por la boca. El análisis que hizo Erman del aire expelido por el ano, y que habia recorrido el tubo intestinal del animal, hizo patente que habia sufrido idéntica trasformacion que si hubiese pasado por un verdadero aparato de respiracion. Bischoff repitió estos experimentos, obteniendo el mismo resultado, y otros estudios mas recientes y completos han confirmado en un todo los datos de ambos naturalistas. De las observaciones de Siebold resulta tambien que las demás lochas pueden servirse asimismo de su tubo digestivo como aparato respiratorio. No lo hacen por lo comun en agua fresca y muy oxigenada, y en estado libre no se ha observado Tosio $\mathrm{r}$ nunca, pero se ren obligadas luego á ello en la cautividad, cuando no se les renueva constantemente el agua. Hay quien supone que se sirven de la respiracion intestinal en libertad solo cuando el sitio que habitan ha quedado en seco, 5 se ven obligadas á enterrarse en el cieno ó fango.

CAUTIVIDAD. - Las lochas de sequedal que cuidó Jaeckel murieron antes que las escardinias y tencas, cuando no se les renosaba el agua, contra todo lo que se esperaba;y las otras lochas, el lobo y la especie comun no resistieron tanto como los rodios, lo que concuerda perfectamente con mis propias observaciones; pero respecto á la primera especic hablaré mas adelante.

USOS Y PRODUCTOS.-En nuestro pais hay muchos aficionados por lo menos á dos especies de lochas, que hasta se crian adrede para la venta en estanques especiales; $y$ no hay duda que estos pececillos son un manjar realmente deli. cioso si se guisan al salir del agua.

\section{LA LOCHA DE SEQUEDAL-COBITIS FOSSILIS}

CARACTERES.-Esta especie tiene la boca rodeada de 
diez barbillas, cuatro en el labio superior y seis en el inferior; el color del fondo es negruzco en todo el cuerpo menos en el vientre que tiene un tinte mas claro; sobre aquel se desta. can cinco listas longitudinales amarillas y pardas, y sobre este motas negras. En la alcta dorsal cuéntanse tres medios radios y cinco ó seis enteros; en la torácica, uno incompleto y nueve $\delta$ diez completos; en la abdominal dos y cinco respectiva. mente; en la anal tres y cinco, 8 en la caudal diez, y seis. La longitud viene $\{$ ser poco mas 6 menos de $0 *$, 30 .

DISTRIBUCION GEOGRÁFICA. - Esta locha se extiende por una gran parte de la Europa septentrional y oriental; pero solo se encuentra en rios y lagos de fondo cenago. so, y no es frecuente en ninguna parte.

USOS, COSTUMBRES Y REGIMEN. - Pasa cl in vierno oculta en el cieno, y lo mismo hace en verano cuando se deseca el sitio que habita. En esta situacion resiste mu. chos meses sin el menor daño y sin aletargarse siquiera, antes al controrio se muere muy alegre y satisfecha apenas se la saca y se la mete en agua, por cuya razon se pueden pescar estos peces en verano con azadon en terrenos turbosos, exac. tamente como hacen los singaleses con los ofididos; y los cerdos que alli se ceban, se regalan en grande cuando las des. cubren, removiendo el fango.

Estas lochas son muy sensibles a la electricidad, pues cuando el tiempo se pone tempestuoso, no pueden estar quietas; agitanse abandonando el fondo, suben á la superfi. cie donde respiran aire continuamente $y$ con visible angustia, y como esto sucede veinticuatro horas antes de estallar la tempestad, se las tiene con razon por una especie de ba. rómetros.

A pesar de las $\$ 40,000$ huevas que las hembras ponen en abril y mayo cerca de la orilla, es muy escasa la multiplica. cion de estos bonitos peces, quizás porque otros peces de rio se aprovechan para devoratlos de que el hombre los per. siga poco, ya á causa de la mucosidad que los cubre, 6 ya por el sabor húmedo de su carne, que desaparece en parte si se tienen estas lochas una temporada en cajones flotantes y cruzados por agua corriente, y cubriéndolas con sal y ceniza antes de guisarlas, lo cual las obliga a moverse vivamen. te y á limpiarse con su mutuo roce.

CAUTIVIDAD. - Ia locha de sequedal soporta la cau. tidad aun en el vivero mas reducido mejor que otro pez alguno, puesto que le basta un tarro de vidrio, ó una pecera con una capa de arena de una pulgada de grueso en el fondo, y cuya agua se renueva dos veces y aun una sola vez por semana, y algunas migajas de pan por-todo alimento. Para remitir estos peces vivos á otra parte, basta meterlos en una vasija llena de musgo mojado, cuyo interior comunique con cl aire ambiente; de esta manera se conservan mejor que si se remiten metidas en agua.

Antiguamente se servian los juglares de estas lochas para enseñarlas al público como una especie de viboras en sus funciones callejeras y de ferias, segun cuenta Gessner.

\section{LA LOCHA-LOBO-COBITIS BARBATULA}

CARACTERES. - Esta locha alcanza una longitud de $\left(0^{\oplus}, 10\right.$ a $0^{\circ}, 15$, siendo su color verde oscuro en el dorso, amarillento en los costados, gris claro en la parte inferior, $y$ con puntos, manchas y listas irregulares negras parduscas en la cabeza, lomo $y$ costados. Las aletas dorsal, caudal y torácicas tienen manchas; la anal y las abdominales son blancas amarillentas sin manchas. En Ia dorsal hay tres y siete radios; en la pectoral uno y diez; en la abdominal dos y seis; en la anal tres y cinco, y en la caudal diez y scis.

DISTRIBUCION GEOGRÁfICA. - La locha-lobo se encuentra como sus afines en una gran parte de Europa; pero no al sur de los Alpes, segun Heckel y Kner; en direccion al este se la conoce hasta los montes Úrales; en Suecia Ia introdujo desde Alemania Federico I, segun dice Linneo. Sin ser rara en ningun país al norte de los Alpes, abunda bastante en Sajonia, Brandeburgo, Hesse, Suiza y Tirol.

USOS, COSTUMBRES Y REGIMEN. - Diferente de la especie anterior, vive esta locha cuando no exclusiva, al menos preferentemente en rios, y mas aun en simples arro. yos de fondo pedregoso ó arenoso, $y$ de poca agua pero de corriente fuerte. Alli pasa el dia oculta debajo de piedras, sin abandonar su escondrijo mas que en determinados casos, como por ejemplo cuando se le presenta alguna presa; hácia la puesta del sol sale á cazar y recorre probablemente toda la noche su distrito. Nada muy bien, como lo hace suponer su aleta caudal relativamente grande, pero siempre á intervalos $\delta$ empujones, pues no le gusta recorrer de una vez grandes trechos. Si se alza poco. á poco la piedra que la oculta continua un rato inmóvil, pero de repente huye como una flecha disparada, da media vuelta, se deja caer súbitamente al fondo y desaparece en otro escondrijo.

Cuando amenaza tempestad manifiesta mucha inquictud, como si le incomodase la tension eléctrica. Difiere de la es. pecie anterior por su complexion débil, pues muere apenas se le saca del agua, por manera que es imposible trasladarle vivo á alguna distancia. Su alimento son gusanos acuáticos, larvas, insectos, freza y acaso sustancias vegetales, porque en los viveros y estanques donde se los tiene se les da simientes de lino, de cánano y de adormidera. Desovan en los prine. ros meses de primavera: en marzo y abril se presentan los ovarios henchidos de huevas innumerables y diminutas, y desde mayo a julio hormiguean ciertos sitios de hijuelos recien salidos $\{$ luz. Lennis dice que el macho escarba un hoyo en la arena donde la hembra deposita la freza; aquel la fecunda s no se separa del nido hasta haber nacido la cria.

USOS Y PRODUCTOS. - L La carne de estos peces, dice Gessner, merece ser alabada por todos conceptos; es agrada. ble al paladar, sin saber demasiado á pescado; es sana, de digestion fácil, y cria buena sangre, por cuyas razones sc permite su uso en muchas cafermedades; en todo tiempo es buena, pero dicen que vale mas desde Navidad a la Pas. cua de Resurreccion. Tanto es asi que en algunas partes, como por ejemplo, en Bohemia, se guardan las lochas-lobos que se cogen en criaderos que no suelen ser otra cosa sino horos de un metro de profundidad, por tres de largo y una anchura correspondiente, revestidos interiormente de esteras de mimbre, forrando el espacio entre estas y la tierra con estiércol de carnero $\mathbf{a}$ fin de que se crien alli larvas de in. sectos. No ha de faltar la renovacion constante de agua fresca, $\sin$ lo cual no medrarian las lochas-lobos medio cau tivas en estos viveros; en cambio, cuando se encuentran bien, aumentan extraordinariamente, y la especulacion resulta entonces bastante lucrativa, aunque rara vez se pague el kilógramo de estos peces á mas de cinco reales. Lo malo es que no pueden trasportarse y venderse léjos, porque se dice que no valen nada cuando no se comen inmediatamente al salir del agua; y que son mas sabrosos cuando se ahogan en leche $\delta$ vino. Se preparan de diferente manera, los unos los prefieren hervidos y aderezados con vinagre, á otros les pare. cen mejor fritos ó en conserva con una salsa picante.

ENEMIGOS.-Además del hombre, persiguen à esta lo cha las ratas de agua, los musgaños, los patos y otras aves acuáticas, y mas que todos el martin pescador, que segun toda probabilidad, se alimenta casi exclusivamente de estos peces. Entre sus congéneres son mas peligrosas para cllos las especies que viven en el fondo. 
CAUTIVIDAD. - En viveros bien montados se mantiene la locha-lobo mucho tiempo cautiva, pero no es pez divertido. Lo propio que en estado libre, pasa la mayor parte del dia en el fondo, del cual no se separa sino cuando el tiempo está lluvioso; entonces sube á la superficie haciendo un mo. vimiento ondulatorio vigoroso $y \hat{s}$ veces aspira alli el aire ambiente para expulsarlo luego por el ano; de este modo continúa buen rato hasta que se deja caer tan pesadamente al fondo que á veces baja rodando de piedra en piedra. En los acuarios es donde se puede uno formar idea de su vora. cidad, pues devora cantidades increibles de gusanos y otras sabandijas con tanta vehemencia como si hubiese de sujetar presas colosales. Primero revuelve violentamente el fondo con sus alctas pectorales y abdominales, enturbiando el agua de una manera que es imposible distinguirle; entonces es cuando devora su presa; y luego sale repentinamente para ocultarse en otro escondrijo, como si necesitase descansar de un pesado trabajo.

\section{LA LOCHA COMUN-COBITIS TAENIA}

CARACTERES. - Esta especie es la mas pequeña del género, pues apenas llega á $\left({ }^{n}, 10\right.$. Su coloracion es muy bo. nita; sobre fondo anaranjado vénse manchas redondeadas y negras dispuestas en hileras; una de ellas compuesta de man. chas mayores, recorre los costados por su centro, y encima lleva otra mas pequeña, además de otras manchas irregulares y de muchas pintas que cubren tambien los costados y la cola, pero faltan en la garganta, el pecho y el vientre. Encima del ojo nace una línea negro-pardusca que pasa al labio superior y continua hácia atrás hasta la punta del opérculo; otra paralela á ella pasa por las mejillas.

Casi todos los individuos presentan tambieu una mancha negrisima perfectamente marcada en la base de la parte superior de la aleta caudal. En la aleta dorsal hay hileras longitudinales de puntos oscuros, y en la caudal otras trasversales. Inas pectorales, abdominales y anal son de un amarillo pálido.

DISTRIBUCION GEOGRÁFICA.-Heckel y Kner di cen que esta locha es la única especie del géncro que vive en el sur de los Alpes y se extiende hasta Dalmacia. Hácia el norte lllega hasta el mar, por el este á Rusia y por el oeste a la Gran Bretaña, pero en este último pais lo mismo que en Alcmania es siempre mas rara que la especic lobo.

USOS, COSTUMBRES Y REGIMEN.-Respecto de su género de vida se sabe poco, por lo menos nada de terminante sobre los puntos en que difiere de la especie anterior. Vive en rios, arroyos, zanjas, estanques y lagos, oculta debajo de las piedras. Se alimenta de larvas de insectos, gusanos y cosas análogas. Desova en abril, mayo y junio, y crece poco.

USOS Y PRODUCTOS. - La carne de esta locha se aprecia poco porque es seca y dura, lo cual no impide que se consuma en algunos puntos antes del desove, pero en ninguna parte se pesca sistemáticamente.

CAUTIVIDAD.-Dicen que está muy inquieta en un acuario reducido, moviendo sin cesar los labios como hacen los conejos y algunas ranas, cosa que no he podido observar en las que yo he cuidado.

\section{LOS OSTEOGLÓSIDOS- OSTEOGLOSSID屃}

CARACTERES. - Son notables estos peces por su gran tamaño y cuerpo cubierto de escamas duras que forman co. mo un mosaico; la cabeza está desprovista de ellas, pero es huesosa; una serie de aberturas anchas forman la linea del costado; las aletas dorsal y anal están colocadas muy atrás y tocan casi á la caudal, y finalmente la abertura branquial es muy ancha.

\section{LOS ARAPAIMAS-ARAPAIMA}

CARACTÉRES.-Este género, el único de la familia, comprende solo cinco especics conocidas hasta hoy, y se caracteriza por las escamas grandes que cubren el cuerpo oblongo, lateralmente comprimido y redondo en el vientre; por la cabeza huesosa y aplastada, la dorsal larga y escamo. sa inserta en frente de la anal que es larga tambien; los dien. tes cónicos en ambas mandibulas y otros de púa en el vó. mer $y$ hueso palatino. La membrana branquial contiene once radics.

\section{EL ARAPAIMA-ARAPAIMA GIGAS}

CARACTERES. - La coloracion de este pez es, segun Schomburgk, la nıas abigarrada imaginable, porque no solamente las escamas, sino tambien las aletas tienen brillo tornasolado y reflejan todos los matices desde el gris oscuro hasta el rojo y el azulado; á lo que Keller-Leuzinger añade que cada escama, cuyo ancho es de tres dedos, tienc una orla bien determinada de color escarlata. La longitud puede llegar hasta cuatro metros.

Hé aqui lo qque dice Schomburgk sobre este pez:

«Los indios nos trajeron, entre una gran inultitud de peces, el gigante de las aguas dulces de la Guajana, el arafaima, y quedamos pasmados al ver este animal gigantesco que llenaba casi toda la embarcacion, siendo su longitud como de tres metros y su peso seguramente de cien kilógra. mos. De todos los rios de la Guayana inglesa, kinicamente el Rupununi alberga al arapaima, pero en cambio este en gran número. Dicen que tambien es frecuente en el Rio Branco, en el Negro y en el smazonas.

$\checkmark$ Se le pesca con anruelo, y se le mata tambiená flechazos. Esta caza es indudablemente una de las mas interesantes y animadas que pueden verse. Generalmente se juntan para ella varias barcas que se reparten en diferentes puntos del rio. Hácese una señal cuando se divisa alguno de estos peces, y entonces se acerca la barca tripulada por los tirado. res mas hábiles procurando no hacer ruido hasta tener el animal á tiro; parte una flecha, y el pez desaparece con ella, siendo esto la scinal de la batida general; apenas sale de la superficie el extremo de la flecha guarnecido de plumas, todos tienden sus arcos para disparar al asomar el cuerpo del arapaima, que con esta segunda descarga se sumerge de nuevo; pero entonces ya no tarda tanto en subir y en recibir otra descarga, que se van repitiendo hasta que los cazadores pueden apoderarse de la presa y acercarla á la orilla, donde deslizan debajo del animal la embarcacion y la ponen con el pez á flote despues de extraer el agua de que se ha llenado necesariamente al coger el pez por debajo; hecho esto vuelven todos alegres al lugar donde habitan.

Entre nuestros remeros habia un mudo, pescador apasio. nado si los hay. Apenas hubimos plantado nuestras tiendas, cuando cogió el cordel y se fut en uno de los botes á un pequeño banco de arena cerca de la orilla opuesta. En el campamento todo el mundo dormia profundamente, cuando nos despertó repentinamente un aullido extrano y horrible. Al principio nadie podia adivinar de donde salian tan paro. rosos acentos, hasta que uno grito: a No puede ser sino el mudo. $\$ \mathrm{Al}$ momento saltamos armados de fusil y de navajas 
en una lancha para rolar en su auxilio, porque los gritos siniestros no dejaban duca de que lo necesitaba y le urgia. Llegado que hubimos al banco, observamos tan bien como lo permitia la oscuridad que una fuerza invisible zarandeaba de una parte á otra al pobre pescador, mientras él reunia to. das las suyas para no ceder, aullando desesperadamente. No tardamos en llegar \& su lado, pero sin poder descubrir qué era lo que tiraba de él con tanta fuerza, hasta que se observó que procedia del cordel de pescar, enrollado con cinco bseis vueltas a su muneca. Debiamos por tanto suponer que habria quedado prendido del anzuelo algun animal monstruoso $y$ asi era en efecto. Un enorme arapaima estaba enganchado en el y tiraba de la cuerda con tanta fuerza que el mudo ni podia sacarle átierra' ni librar sil mano de las vueltas de la cuerda: si hubiésemos tardado solo algunos minutos mas, quedaba el pobre desfallecido y habria seguido al pez dentro del rio. Todos se pusieron di tirar, y el monstruo quedó al fin sobre la arena, mientras el pobre mudo nos enseiaba, entre las risotadas de todos, la muneca en cuya carne habia penetrado la cuerda, y procuraba explicarnos, haciendo las gesticulaciones mas ridiculas, la angustia que liabia pasado y el dolor que le causaba la herida.

- A pesar de estar muy avanaada la noche, fué llevada la presa al campamento f despedazada; se atizaron los fuegos, se llenaron las ollas, y se comió su contenido; pasamos toda la noche guisando, porque la idea de tener pescado que al dia siguiente estaria pasado no dejó dormir à ninguno de los indios y negros que me acompañaban.

Esta carrie es muy sabrosa cuando fresca; pero hay algu. nas tribus que no la comen."

Keller Leuringer no participa de esta opinion y jurga la carne del arapaima, que conoció en el rio Amazonas y en sus afluentes con el nombre de Pirazuca, menos favorablemente. Véase lo que dice: Aqui es cosa general y comun la caza de este pez; el muchacio de color ya acompaña á su padre y acecha, con la pesada azagaya en la mano, la llegada del animal; pero la carne de este pez gigantesco, poco agradable cuando fresca, es un manjar horrible cuando está curada con sal y al aire, en cuyz forma se expiden miles de quintales de ella desde Para hasta la frontera del Perú, cionde la consumen los indios, los mestizos y los blancos sin distincion. Se abre el pez por el lomo de arriba abajo, se le saca la espina dorsal y se prepara la carne en pencas de un dedo de grue. so, que se salan y secan al aire, operacion que se hace muy imperfectamente en las tierras bajas y humedas junto al rio; pero aunque sc hicicra bicn, volveria la carnc à absorber hu. medad, en cuyo caso se corrompe y se pone hedionda, por manera que hay que volverla á secar de cuando en cuando, y como los tenderos (pulperos) no disponen de oiro local mejor para esta operacion que las piedras de la acera ardien. tes bajo los rayos del sol tropical, resulta que las narices de la gente del pueblo $\mathrm{y}$ de los forasteros se regalan con este pez aun mas que los estómagos. El hueso lingual, largo y guarnecido de agudos dientes, se emplea como raspa.

\section{LOS CLUPEIDOS Ó ARENQUES - CLUPEIDE}

La sola palabra arengue basta para expresar la importancia de los peces en la economia humana. Puede vivirse sin aba. dejo; las platijas y otros peces de mar se consumen casi exclusiramente en las poblaciones maritimas; los peces de agua dulce son manjar raro en la mesa del habitante del interior; mientras que el arenque $y$ sus afines representan la riqueza del mar hasta en la choza mas humilde y apartada. Si hay algun pescado que merezca el epiteto de alimento del polre, lo es el arenque, que estando al alcance de la familia mas indigente, sustituye en no pocas casas ála carne. No hay otro pez mas indispensable que este, por cuya razon se ha dado a toda la familia, que cuenta mas de doscientas especies, el nombre de arenques 6 elupeidos.

CARACTERES. - Son peces escamosos sin alcta adiposa; la boca se halla limitada en el centro por el hueso interma. xilar, y en los lados por la mandibula superior; las branquias están muy desarrolladas y no solamente son notables por su abertura ancha, sino tambien por sus ramas subdivididas $\delta$ ramificadas a su vez lateralmente, á manera de dientes, for. mando en conjunto un colador muy perfecto. El estómago tiene buche y el canal digestivo ciegos en la mayor parte de las especies. La dentadura varia en los diferentes grupos. A esios caractéres añade Juan Mueller los siguientes: algunas especies se distinguen por un parpado vitreo y trasparente que cubre una gran parte del ojo, y que en otras se halla reemplazada por una prolongacion gelatinosa de la piel. En varias comunica la vejiga natatoria por medio de canales aéreos con el laberinto.

USOS, cosTUMBRES $\times$ REGIMEN. - No todos los clupeidos habitan el mar; los hay tambien que remontan puntualmente los rios para efectuar alli el desove, estando naturalmente adaptado su genero de vida ś esta diferencia de circunstancias, bien que en general, y sobre todo respecto á las especies mas importantes, concuerda con el de los rencos que vienen a ser para el agua dulce lo que los arenques son para cl mar. Fuera del tiempo del desove, no abandonan las grandes profundidades que habitan y solo el instinto de re. produccion los impulsa a subir \& las capas superiores. Todos son al parecer/rapaces que no solo se alimentan de animalillos y pequerias sabandijas acuáticas sino que tambien cazan peces. No és muy considerable su reproduccion, pero como abundan tanto, aumenta sobremanera su número á cada cria; sin embargo, la persecucion que sufren es tan activa que se nota ya cierta disminucion en ellos, $y$ ha llegado ya el tiempo de ver cómo se fomenta su cria, pues el ternor de que mengüe la riqueza del mar despues de muchos siglos de constantes y siempre crecientes cosechas, no es de ningun modo inmotivado, y se hará forzoso fijar tambien para los clupeidos un tiempo de veda á fin de que se multipliquen sin ser molestados, si no queremos exponernos á una nérdida en extremo sensible.

\section{LOS ARENQUES PROPIAMENTE DICHOS - CLUPEA}

CARACTERES. - Tienen el cuerpo comprimido lateralmente, y como aserrado en la arista abdominal por las escamas que sobresalen a manera de dientes de sierra. Ia man. dibula superior es ancha, un tanto arqueada en los bordes, $y$ la dentadura abundante y variada, pues hay dientes pequeños, pero en gran número, en las mandibulas superior, inferior है intermaxilar, una hilera de otros mas grandes en el vómer $y$ la lengua, y dos $\delta$ tres temporales en el hueso palatino.

\section{EL ARENQUE COMUN-CLUPEA HARENGUS}

CARACTERES. - Todo el mundo sabe que la longitud de este pez (fig. 205) rara vez pasa de $0^{D}, 30$; las aletas pectorales y abdominales son pequeñas; la dorsal se halla inserta en la mitad del lomo, y la anal muy atrás; la caudal está profundamente ahorquillada. Las escamas son grandes y poco adherentes. El color es verde mar ó azul verdoso en la parte 
superior del cuerpo, plateado en la inferior y brilla con diferentes matices segun la direccion de la luz; las alctas dorsal y caudal tienen un tinte oscuro, y claro las demás. Hay de diez y siete hasta diez y nueve radios en la aleta dorsal, de quince á diez $\&$ siete en cada torácica; nueve en cada abdo. minal; catorce hasta diez y seis en la anal, y diez y ocho hasta veinte en la caudal. La columna vertebral consta de cincuenta y seis vértebras.

DISTRIBUCION GEOGR ÁFICA-La parte septentrional del Atlántico, inclusos los mares del Norte, Glacial y Bältico son la patria del arenque. Antes se creia que el arenque salia cada año del mar Glacial para visitar otras aguas, y Andersson, no contentándose con esto, describió minucio. samente hasta la ruta que, segun él, seguia este pez en su viaje periódico para satisfaccion de naturalistas y pesca dores.

Del mar Glacial, decia, sale una masa incalculable de es tos peces para dividirse despues en dos ramas que pasan al rededor de Islandia y la Gran Bretaña y penetran, la una en el Báltico, y la otra por el canal de la Mancha, en las costas de Francia y de Holanda, etc. Bloch consideró el asunto de otra manera, pues dudaba que los arenques pudiesen realizar desde la primavera hasta otoño un viaje tan largo; hizo notar su escasez en el extremo norte comparada con la gran abun dancia en el mar del Norte y el Báltico, donde se coge todo el año, y dijo que este per. en la temporada de su aparicion subia sencillamente de una gran profundidad a la superficie Pusiéronse de su parte otros naturalistas; en Inglaterra se acabó tambien por reconocer la verdad, y hoy ya no duda nadie de la exactitud del hecho. Es extraño, dice Cárlos Vogt, que se haya falseado y adornado tanto por pescadores y novelistas la historia del arenque, pez tan comun en el mar del Norte. Lo que ha dado lugar á estas fábulas, que á pe. sar de las explicaciones precisas de los naturalistas, predo. minan todavia en escritos populares $y$ libros de escuelas, es la aparicion súbita y en época fija de inmensos bancos de arenques en las costas septentrionales de Europa y de América, y su desaparicion misteriosa de ciertos puntos donde antes cran numerosos.

* La verdad es que el arenque no habita exclusivamente el mar Glacial, ni emprende viajes dilatados. Vive en las pro. fundidades de aquellos mares en cuyas costas desova; alli se le pesca en corto número tambien en el resto del año con aparatos que bajan á estas profundidades, abandonadas únicamente por el pez en la época de la freza para dirigirse $a$ la costa donde deposita sus huevas, como sucede en la misma costa de Moldefiord, donde la pesca del arenque no está ligada a ninguna estacion fija, y es por el contrario mas abundante en julio, cuando este pez está muy gordo y no tiene lodavia ni huevas ni lechaza.

- Cuando se examina el mapa topográfico del fondo del mar del Norte, se ve que la Gran Bretaña ocupa una meseta espaciosa, separada de Francia, Holanda, Alemania del Nor. te $y$ Dinamarca por un valle cuya profundidad no pasa en ningun punto de doscientos metros; es decir que todos estos países formarian un solo continente si el nivel del mar subiera estos doscientos metros. Este continente estaria separado de Noruega por un brazo de mar estrecho pero profundo, y se extenderia al oeste solo hasta unas diez leguas mas allí de la costa actual de Inglaterra y de la Bretaña francesa donde bajaria repentinamente formando orilla escarpada hasta el fondo del Ocćano Atlántico. En aquel valle sub.marino es donde habita el arenque, y de alli sube para desovar á las mesetas altas y naturalmente hácia la costa, lo cual ex. plica porqué la pesca del arenque es tan insignificante en la costa orienial de Inglaterra mientras que por el contrario es tan extraordinaria en las costas de Escocia, de Irlanda, en el Canal de"la Mancha y cn Noruega. 1

USOS, COSTUMBRES Y REGIMEN.-El tiempo del desove, que es el de la pesca principal, cae en invierno, pero se anticipa ó retrasa algunas semanas y aun meses segun el estado de la atmósfera y otras circunstancias apenas conocidas. Los pescadores se rigen por ciertos indicios para conocer la aproximacion de las bandadas, pero estos indicios son tan poco exactos que los holandeses suelen decir que regalarian un gran tonel lleno de oro al que les diera una seùal segura para conocer la época y sitio exactos de la aparicion de los arenques. Estos varian además de un año para otro en cantidad, habiendo sitios donde se presentan en invierno en masas incalculables, cuando al siguiente solo se cogen algunos individuos aislados.

La prueba de que los arenques no hacen esos supuestos viajes desde el mar Polar es muy fácil c irrefutable. Ëntre los arenques distinguense razas, si bien todos son miembrus de la misma especie. El arenque del Báltico es el mas débil y de menor talla; el de Holanda y de Inglaterra es mayor y el de las costas de Noruega y de las islas de Shetland el mas grande de todos. Los pescadores distinguen por otra parte, como hacen entre los salmones, el arenque que vire en las embocaduras de los rios y en la costa del que acude alli desde mas léjos. Pues bien, si las bandadas ó bancos de arenques saliesen de un centro comun como seria el mar Gla. cial, ¿cómo podrian agruparse las distintas razas segun su diferente talla y cualidad para presentarse en épocas fijas á manera de otros tantos regimientos y batallones de un mis. mo cjército, sin q̨ue el instinto de reproduccion, el amor que todo lo que vence é iguala provoque cruzamientos que borren las diferencias de raza? La mejor prueba empero está, por un lado, en la escasez relativa de esta especie en las re. giones mas septentrionales, $s$ por otro en la diferencia del tiempo en que aparece en los diversos sitios. Al rededor de la Groenlandia, donde segun los antiguos, pasaba una rama principal de la emigracion en direccion á América, es tan raro el arenque, que muchos naturalistas ni siquiera le men. cionan en la fauna del pais; y en las costas de Islandia, donde segun los mismos naturalistas se bifurca la masa de los peces emigrantes, se conoce el arenque, pero como pez tan poco numeroso que jamás se ha organizado una pesca sistemática del mismo; y lo mismo sucede en la region de Finn. mark en Noruega, donde se cogen tan pocos arenques que ni siquiera vale la pena de salarlos, mientras que en el mediodia de aquel pais, entre Trondhjem y el cabo Lindesnaes, constituje la pesca del arenque casi el único recurso de los habizantes. ¿Cómo seria posible semejante distribucion si estos peces viniesen desde el norte? y ¿cómo se explicaria que aparecieran primero en las costas mas meridionales de su área de dispersion, en Holanda y cerca de Stavanger antes que en las de Escocia y de Irlanda, como ha sucedido con frecuencia? Finalmente ¿en qué consiste que se cojan todo el año en las costas citadas arenques de todos tamaños si no naciesen, creciesen y muriesen en estos sitios?

«Ha querido aducirse en apojo de los viajes del arenque la circunstancia de que su pesca era antes muy lucrativa en el Báltico y en particular cerca de Gothenburgo en la costa de Suecia, cuando ahora ha cambiado tanto que los pescadores de aquel distrito gimen en la miseria mas espantosa. Esta misma circunstancia empero parece comprobar ca. balmente nuestro modo de ver; porque en apojo del supuesto viaje no hay razon alguna que justifique la aversion de estos peces á volver á estas playas sino los vapores que aho. ra cruzan por el Kattegat. Lo que hay es que el Báltico es una cuenca limitada y poco profunda, explotada en tales 
términos que si no se ha exterminado al arenque, se le ha disminuido notablemente, sobre todo en los canales angostos entre los islotes de Gothenburgo; y que el arenque de fuera, el del mar del Norte, no trata en lo mas minimo de doblar el cabo Lindesnaes y penetrar en el Báltico para llenar alli el racio que han dejado los pescadores en las filas de sus afines. Mas les valdria á los suecos, si quieren volver á pescar arenqques, vedar algun tiempo completamente esta pesca, dejando asi á estos peces espacio para volver á multiplicarse, que no esperar a que un rej de arenumes vuelva a condu. cir su bandada á aquellas costas.

Fuera de estos datos respecto a lo imaginario de los viajes, no tiene la ciencia que consignar ningun descubrimiento nuevo que pudiera aclarar los muchós puntos oscuros que ofrece todavía el género de vida de los arenques. Su aparicion en las capas superiores del mar es, segun se ha dicho, mur variable, $y$ los que llegan no son siempre peces fecundos, sino que cada año se presentan tambien numerosisimas bandadas de arenques que llaman en aquellas costas cioncilias y en Holanda matjes. Sobre su vida en la profundidad del mar no sabemos cási nada; solo que recientemente se la llegado á probar que, á la manera de la ballena, se alimentan los arenques mas 6 menos exclusivamente de especies de cangrejos en su mayor parte microscópicos; pero en cantidades incal. culables. Tampoco tienen época fija para el desove, porque fuera de los meses de junio y diciembre se pescan siempre individuos con los ovarios y testiculos rep?etos; lo cual tiene su explicacion mas racional en que desovan probablemente en distinios meses segun su mayor 6 menor edad; bien nุue sobre este punto siguen todavia los experimentos y observa. cionés dé los naturalistas; pero en general puede admitirse que la época principal del desove cae en los meses de in. vierno, principiando en enero y continuando hasta marzo y abril; y que en julio comienza una segunda temporada que dura hasta diciembre. En Inglaterra consideran como época principal de la reproduccion primaveral los meses de febrero y marzo, $y$ los de agosto y setiembre para la segunda época; y lo mismo parece suceder en el Báltico. Se supone con mucho fundamento que los arenques desovan, al igual de otros peces, en los mismos sitios donde nacicron; pero que determinadas circunstancias, como por ejemplo las atmosfé. ricas y cambios de corrientes, pueden distraer á estos peces en cicrtos años de acudir $\$$ los sitios de desove donde nacicron. Además son muy sensibles á los grandes cambios que á veces ocurren en dichos sitios, como por ejemplo cuando se destruyen las planias acuáticas que los poblaban 6 cuando se les pesca en número demasiado crecido, en cuyos casos puede suceder que se alejen de tales sitios durante muchos años: Este es otro punto que hay que tencr presente si se quiere la reproduccion de los peces, pues no basta vedar temporalmente su pesca, si no se impide tambien la destruc. cion de la vegetacion en los sitios dé desove.

La gran masa de los arenques que se cogen cerca de la superficic acude alli indudablemente con el objeto de des. hacerse de su freza, operacion que efectúan \& poca diferencia como los rencos y otros peces que viven a gran profundidad, es decir, suben en número incalculable, pasan dos 6 tres dias cerca de la superficic en masas compactas, empujándose unos á otros, sobre todo cuando el tiempo es tempestuo. so, y dejan cacr al agua las huevas y el liquido seminal, 5 veces en cantidad tan grande, que se enturbia el agua 5 las redes se cubren de una espesa costra, despidiendo un hedor repugnante y perceptible á grandisima distancia.

La persona que no ha visto con sus propios ojos estos bancos de arenques, dificilmente puede formarse una idea de ellos, y todas las relaciones de testigos oculares le pare- cerán exageraciones y cuentos, pero su gran unanimidad no deja lugar á duda. Asi dice Schilling: «Los pescadores prác. ticos á quienes yo acompañaba me enseñaron en la oscuri. dad bandadas de arenques que ocupaban leguas cuadradas de superficie, y que solo se conocian por el reflejo luminoso del aire. Nadan en masas tan compactas que las lanchas que se meten entre ellos corren peligro de zozobrar; se les puede coger á paletadas y echarlos en la embarcacion, y un re. mo largo introducido al acaso en esta masa viva se sostiene derecho. Otros observadores refieren cosas análogas, y algunos hasta aseguran que las barcas que intentan cruzar es. tas bandadas son levantadas al aire por los peces. Schilling opina que los bancos de arenques van guiados por bandadas menores que eligen su rumbo segun el viento, la corriente y el estado atmosférico. Otros no participan de esta opinion, á pesar de que hacen mencion expresa de las irregularidades que se observan en la aparicion de estos peces.

Segun la temperatura del agua nacen los pequeños mas temprano ó mas tarde, en mayo, quizás á los quince hasta diez y ocho dias, y en agosto, á los seis hasta los ocho dias. Al nacer tienen los pequeños, que por lo trasparentes son entonces poco menos que invisibles, una longitud de $0^{\circ}, \mathrm{co}_{7}$ á poca diferencia; \& los ocho ó diez dias han reabsorbido su resicula vitelina, empiezan á moverse y llenan á miles de millones durante largo tiempo las aguas donde salieron á luz Se los ye durante todo el año cerca de la costa, y á varias profundidades segun su edad respectiva; los mas diminutos, segun Schilling, en el agua salobre de las embocadu. ras y los mas grandecitos mas lejos ya de la orilla; de mocio que puede demostrarse prácticamente su adelanto progresivo hácia mnyores profundidades. Al mes de haber nacido alcanzan, segun Widegren, por término medio $0^{m}, 015$, \& los dos meses $\left(1 \%, 025\right.$, al tercero $0^{\circ}, 037$, al cabo de un año miden ya aproximadamente $0^{m}, 09 y$ a los dos años $0^{m}$, i 5 hasta 0,$18 ; 2$ los tres años su longitud es de $0^{\mathrm{*}}, 20 \mathrm{y}$ entonces pueden ya reproducirse.

ENEMIGOS. - Innumerables como los arenques son tambien sus enemigos; todo el tiempo que aquellos permanecen en las capas superiores del mar, Jos rapaces terrestres, alados y maritimos, ya sean estos otros peces 6 mamiferos, se mantienen casi exclusivamente de ellos. En Noruega anuncian la llegada de los arenques las marsopas que acuden para esperarlos, y muchos pescadores de aquel país están persuadidos de que estos mamiferos los empujan hácia aque. llas costas, papel que atribuyen igualmente á ciertos peces de rapiña, sin hablar del rey de los arenques que, segnn creen, manda y conduce las bandadas. Tarea inútil seria querer evaluar los destrozos que todos estos animales causan en las filas de los arenques, pero lo que si puede admitirse es que el daño de todos juntos no es nada en comparacion con los estragos que el hombre les causa.

PESCA. - Hay noticias de la pesca del arenque desde el comienzo de la edad media en antiguos documentos y lejes inglesas de aquella época que tenian por objeto regularizarla; pero esta pesca estaba en su infancia y continuó asi hasta fines del siglo $x \cdots$, en cuya época se aprendió $\delta$ se volvió á aprender á salar los arenques y á enviar asi at interior los que antes se perdian por no pocierlos colocar ni conservar, con lo cual tomó la pesca un incremento extraordinario. Los primeros que la practicaron en grande escala fueron los ho. landeses; despues los imitaron los noruegos y las ciudades anseáticas. Los ingleses, que en el dia son los maestros en este ramo, empezaron solo hace dos siglos á enviar sus buques á la pesca del arenque.

En Noruega emplean, además de las redes usuales, otras que llaman wate con las cuales pueden cerrar bahias y calas 
despues que los arenques han penetrado en ellas, cogiendo asi con frecuencia de una vez cantidades rerdaderamente increibles. Pontoppidan dice: \&Los exiranjeros apenas creerán lo que ahora diré, pero yo puedo apelar al testimonio de toda la poblacion de Bergen, y es que de una sola redada se cogie. ron en la cala de Sundfjord tantos arenques que se llenaron con ellos cien barcos, otros dicen ciento cincuenta, pero yu prefiero contar solo el número mas bajo, de cien toneladas cada uno. A veces han de permanecer los arenques mucho tiempo, como dos ó tres semanas, encerrados en las bahías ó calas por no poderlos despachar mas pronto, lo que hace que desmerezcan mucho por el hambre que pasan, cuando no se pierden del todo, llenando todo el ámbito de un he. dor tan insoportable, que ahuyenta á los demás arenques por tres y cuatro años de los sitios que acaso antes preferian. En 1748 los labradores de la parroquia de Svanoe habian encerrado en su cala de la manera indicada un número in. calculable de arenques de primavera, que cedieron $a$ un vecino de Bergen por cien rixdales y una pipa de aguardiente. Este llenó ochenta barcos con estos peces y abandonó un número mucho mayor, muertos y perdidos en la cala.

Hoy se hace la pesca del arenque en Noruega con mas método, principalmente en toda la costa entre Trondhjem y Lindesnaes. Se colocan redes grandes que dan cada una hasta millon $y$ medio de peces, pero sin renunciar al sistema de cerrar bahias enteras, por cuyo medio cogen á veces, se. gun Blom, algunos miles de toneladas de á veinticuatro mil arenques cada una. Ahora que han aprendido en aquel pais s. curarlos bien, se exporta anualmente millon y medio de toneladas.

En este ramo es donde se ve mas palpable el atraso de los alemanes; pues mientras que todas las demás naciones han estudiado y mejorado sus útiles y disposiciones de pesca, aquellos solo empiezan á aprender. La importancia actual de este ramo en Holanda compite aun con la de Noruega, a pesar de haber ido constantemenic en disminucion de algunos años á esta parte, al paso que la pesca de los ingleses ha aumentido.

«La pesca del arenque, de la haréngula y de la sardina, dice Bertram, dura con una corta interrupcion casi todo el año, pero la del primero cae principalmiente en otoño, desde agosto hasta octubre. Entonces se cubre el mar en las costas de Escocia, Irlanda é Ingiaterra de embarcaciones; cada costa tiene su flotilla de barcas, cada bahía y cala su pesque. ria, y en los puntos principales reúnense flotas muy considerables. In todos estos puntos tienen lus salaclures espaciosus almacenes y corrales provistos de barriles, sal y demás acce. sorios. Otros menos afortunados establecen su taller en la misma costa donde el sitio lo permite; en el mar se reune la flota mas $\delta$ menos numerosa y en tierra se forma una pobla. cion abigarrada de vendedores de sal, de cuberos, de muchachas del campo y de montañeses en busca de trabajo. Acuden luego predicadores ambulantes, apóstoles de nucvas sectas para ensayar la fuerza de su fe y de su palabra en las mentes de los que quieren escucharlos y que nunca faltan. Luego, cuando empieza ya la temporada verdadera de la pesca, se apodera de todos los ánimos una especie de delirio; todos los pensamientos, las conversaciones y ocupacion de la gente reunida alli, versan sobre el arenque. Los unos trabajan en lós preparativos, los demás los contemplan, los viejos se acuerdan de su juventud y cuentan con entusiasmo cómo se pescaba veinte ó treinta años atrás; los jórenes examinan las barcas, las redes y aparejos; casadas y solteras, por supuesto siempre novias, remiendan $y$ repasan las redes viejas $y$ los hervidores de catecú ofrecen su liquido pardo para conservar las redes y el velámen. En toda la costa se repiten estas esce. nas, y todas estas muchedumbres tienen fijo su pensamiento en la pesca, deseando que sea abundante. Las muchachas ruegan á Dios que proteja la barca de su novio, porque entonces es probable que se cumpla su mayor deseo, el de ca. sarse. Ios ojos del salador brillan con la esperanza de un buen negocio; los propietarios de barcas sin estrenar no caben en si de gozo, y hasta las criaturas se contagian porque ellas tambien hablan de arenques. Se hacen apuestas, pronósticos, comparaciones y suposiciones, se ruega á Dios y se invoca al diablo, aqui oraciones y esperanzas, alli blasfemias y dudas. El saludo matinal es: « ¿Pesca esta mañana? y la contestacion: Poco ó mucho si. La poblacion de las ciudades próximas aumenta rápidamente; con los misioneros y predicadores acu. den tambien todos los vagabundos del pais, los buhoneros y mercaderes que plantan sus barracas y puestos de venta en los mercados, $y$ las voces de estos, y los organillos desafmados forman un ruido confuso capaz de perturbar la mente mas serena.

\Solo una pequeña parte de los hombres que van al mar para pescar son pescadores de oficio; en su mayoria son braceros alqquilados, gente del campo, industriales, marineros y vagabundos, lo cual explica las muchas desgracias que cn cada pesca hay que lamentar. Para csta se emplean abora con preferencia redes de fondo de 40 metros de largo y ro de ancho, que las barcas mayores llevan $a$ veces en número tan grande que juntas ocupan en el inar una distancia de una milla inglesa. Hácia la noche se las echa al agua con los pesos necesarios para que vayan al fondo, y con bornoles de corcho, botas y barricas vacias para sostenerlas por el otro lado en la superficie 6 cerca de ella, segun la profundidad. Las mallas son de una dimension que deja pasar los arenques jóvenes, pero que detienen los viejos que suelen quedar cogidos con sus opérculos al qquerer forzarlas. Al despuntar el alba se sacan los peces y se conducen sin pérdida de tiempo á tierra y á los saladeros, pues cuanto mas pronto recibe el arenque la sal, mejor es.

Un curioso quiso hacer una excursion á una pesqueria $y$ se embarcó con algunos amigos, en una noche muy oscura, tranquila y calurosa, en una lancha hácia donde estaban los pescaciores, que con sus cantos les indicaban la direccion que habian de tomar; pero era dificilisimo aproximarse por el laberinto de redes y cuerdas tendidas en todos sentidos; al fin gracias á los gritos de aviso de los pescadores pudieron llegar al centro de la fotilla, donde todo estaba en movi. miento, porque algunas redes estaban ya llenas, mientras que en otras solo se habian prendido algunos peces dispersus y rezagados. La llegada de los forasteros parecio gustar mucho a los pescadores, porque de todos lados les regalaban aren. ques, pero con tanta liberalidad, probablemente intenciona. da, que la lancha amenazaba pronto zozobrar con el peso de los peces que casi ahogaban con su ntimero a los visitantes; los cuales al tin hubieron de suplicar á aquella gente por amor de Dios que cesara en sus regalos.

Por lo que hace à Alemania, solo pesca la Soriedail pesquic. ra de arengues en Emden, á la manera de los ingleses, y coge cada año unos 6,000 barriles de un valor de 50 pesetas cada uno, lo que no paga todavia los gastos é intereses del capi. tal invertido, $y$ en muchos años no cubren siquiera el valor del demérito $y$ desgaste del material á pesar de que los arenques de Emden, gracias à su esmerada preparacion, son superiores a todos los demás. La major parte de los aren. ques que se cogen en el Bálico se curan al humo, el resto se consume en estado fresco ó en conserva. 'Alli se paga el kilogramo de los f́rescos á real y medio ó á dos reales, y en las costas del mar del Norte á un real hasta real y medio.

Suélese comparar la pesca del arenque con los juegos de 
azar; tal año da grandes beneficios, y tal otro no cubre los gastos. A veces se presentan los arenques muchos años seguidos en la misma bahía y en el mismo punto sa miles de millones; otras veces no acuden, $y$ los pescadores vuelven con las barcas vacias. Mucho contribuirá á estos desengaños la codicia ignorante de esta gente, ya que está ahora fuera de toda duda que en ciertos puntos del mar se han exterminado completamente estos clupéicos, que empezaron á desapare. cer primero de la proximidad de las poblaciones grandes, y despues de las bahias cionde la pescra era fácil; lo que prueba que estos peces no vieren de léjos y que buscan para el desove poro mas ó menos los mismos sitios. Mas adentro del mar no es tan fija la direccion que toman, como fácil. mente se comprende, y las bandadas pasan tan pronto in poco mas acá cómo mas alla de su ruta media.

Dificil es emitir un juicio respecto \& la cantidad total de arenques que cada ano se cogen en las costas curopeas, pero es probable que entre años buenos y malos se pesquen, por término medio, mas de diez mil millones de ellos.

CAuTruidad.-Solo cuando es may jóven soporta el arenque unos cuantos dias la cautividad: si son viejos, pierden en seguida en vivero ó acuario casi todas sus escamas y mucren á las pocas horas.

\section{LA MELETA - CLUPEA SPRATUS}

CARACTÉRES. - Esta especie (fig. 206) tiene la arista ó quilla ciel vientre fuertemente dentada; cl dorso es azul oscuro con viso verde y el resto del cuerpo blanco plateado; las aletas dorsal y caudal son de un tinte oscuro, las demás blancas; en aquella se cuentan diez y siete radios; en cada pectoral quince, en cada abdominal siete, en la anal diez y ocho, $y$ en la caudal dier $y$ nueve. La columna vertebral se compone de cuarenta y ocho vértebras, y la longitud del pez es aproximadamente de $0^{\circ}, 15$.

DISTRIBUCION GEOGRÁFICA.-Este pez, afine del arenque, habita los mares alemanes.

USOS, COSTUMBRES Y REGIMEN. A pesar de no tener la importancia del arenque para la economía domés: tica, no deja de ser uno de los peces nuas notables del mar del Norte $y$ del Báltico, en cuyas costas es numerosísimo. Por su género de vida se asemeja tambien al anterior, pues vivé á gran profundidad $y$ acude cada año en bandadas innumerables á las costas 6 sitios de poca agua, pero sin que su apari. cion tenga nada que ver con el desove, puesto que son pocos entre los que se pescan entonces los que tienen su freza desarrollada, circunstancia que viene en apoyo de la opinion, probablemente errónea, de los que consideran á este pez solo como un arenque jóren; en cambio es indudable que al pescarlo se cogen tambien cientos de miles y aun millones de verdaderos arenques jóvenes, to que disminuye considerablemente la abundancia de estos.

PESC s. - Se emplean redes de malla angosta donde quedan prendidos peces pequeños, por cuya razon se coge toda clase de especies qque cuando no pueden venderse se $\mathrm{cm}$. plean como abono para los campos, como se ha visto muchas veces en Inglaterra. Esta pesca suele ocupar durante el invierno en las costas de Inglaterra de 400 a 500 barcas; cógense miles de toneladas que se venden al precio de cinco á seis reales el hectólitro. En cl invierno de 1829.30 se cogieron tantas meletas, que la ciudad de l.óndres, cuyo estómago es insaciable, solo pudo consumir una pequeña parte de ellas, habiendo de arrojarse al campo cientos de millares de hectólitros. Semejante destruccion deberia llamar la atencion general, pues aunque se otorgue $\{1$ la meleta el carácter de especie independiente, y se convenga que entre los millares de millones que se cogen se encuentra tan solo cierto núme. ro de arenques jóvenes, no deja de contribuir la destruccion de estos paulatina pero positivamente al empobreciniento de los criaderos. Tambien se cogen muchas meletas en las costas de Alemania, en particular en el Báltico, y alli solamente junto á Eckernfoerde, unos diez y seis millones cada año por término medio, que curadas al humo se expiden al interior. En Noruega ponen esta especie en conserva y la venden con el nombre de anchoas. En los puntos de pesca se vende el kilógramo de meletas frescas á pocos céntimos de peseta.

\section{LAS ALOSAS - ALAUSA}

CARAGTERES. - Estos clupéidos, que algunos ictiólo. gos no reconocèn como género aparte por no encontrar di. ferencias bastantes para justificar su separacion de los aren. ques, caracterizanse por su cuerpo lateralmente comprimido con arista ventral cortante y dentada á manera de sierra; por una profunda escotadura que divide el hueso intermaxilar, y por la dentadura que consiste en dientes muy finos, puntiagudos y poco adheridos que guarnecen únicamente la mandíbula superior e intermaxilar, careciendo de ellos la inferior, el vómer y los huesos palatinos y linguales.

USOS, COSTUMBRES X REGMMEN. - Difieren las alosas de los demís clupéidos que habitan los mares europeos, en que remontan los rios para desovar.

\section{EL SÁBALO Ó ALOSA COMUN-ALAUSA VULGARIS}

CARACTÉRES;-La hendidura de la boca de esta especie (fig. 208) llega hasta debajo del ojo, que está parcial. mente cubierto por un párpado anterior $\mathrm{y}$ otro posterior cartilaginoso, en forma de media luna. I os arcos branquiales están cubiertos en su lado cóncavo de plaquitas numerosas, delgadas, largas y tendidas. El color del dorso es un hermoso verde aceitunado con brillo metálico, los costados tienen reffejo de oro; una mancha grande, oscura y esfumada en el ángulo superior de la ancha abertura branquial, $y$ de tres á cinco manchas mas pequeñas, que siguen á aquella, tienen viso aceitunado. Las aletas parecen mas $\delta$ menos oscuras y negras á causa de un pigmento granujiento oscuro. Se cuentan de cuatro a cinco y de quince a diez y seis radios en la aleta dorsal; uno y catorce á quince en la torácica; uno y ocho en la abdominal; tres $y$ dc vcinte hasta veinticuatro en la anal, y diez y nueve en la caudal. La longitud es de (1",60, y mas; el peso de 1,50 hasta 2,50 kilógramos.

\section{LA SABOGA-ALAUSA FINTA}

CARACTERES. - Esta especie, afine de la anterior, es mucho mas pequeña, pues á lo mas alcanza $0^{\circ}, 45$ de longitud con un kilógramo de peso, y difiere además por los apén. dices cortos, gruesos, poco numerosos y aislados al lado cóncavo de los arcos branquiales. In coloracion es á poca diferencia idéntica.

DISTRIBUCYON GEOGRÁFICA.-Habita esta especie todos los mares que bañan las costas europeas.

USOS, COSTUMBRES Y RÉGIMEN. - Ambas alosas se parecen en su género de vida. Viven á bastante profundidad y penetran en los rios mas 6 menos tarde, cuando el agua ha vuelto á adquirir su limpidez despues del deshielo y derretimiento de la nieve, para remontarlos y deponer en cllos su freza, con cuyo motivo recorren casi toda la cuenca hidrográfica, puesto que remontan las corrientes me- 
nores hasta donde pueden. En Alemania las llaman peces de mayo, porque en este mes es cuando se presentan con la mayor puntualidad. Los pescadores las conocen muy bien por su modo de moverse, mas ruidoso que el de otros peces, pues cuando viajan cerca de la superficie se creeria á veces que hay una manada de cerdos en el rio. Isa saboga emprende generalmente su viaje cuatro semanas mas tarde que el sábalo, bien que su comportamiento es igual. El ruido que producen, $y$ que en efecto tiene analogia con el gruñido de los cerdos, procede de los coletazos que descargan cuando arrojan su freza cerca de la superficie, despues de lo cual regresan poco á poco al mar, pero tan débiles $y$ Hacas, que apenas puede comerse su carne, la cual, aun en la mejor es- tacion, es tan poco apreciada, que se paga el kilógramo de uno á cuatro reales y en el caso mas farorable a siete. Mu. chas perecen durante su regreso exhaustas y con frecuencia se lleva el rio gran numero de estos peces mucros. En octubre se ven pequeños sábalos de $0^{\mathrm{n}}, 05$, y en la primavera siguiente otros de $6^{\circ}, 10$ a $0^{\circ}, 5,5$, pero ya en direccion del mar. Se alimeritan de pececillos y de crustáceos blandos.

Los antiguos conocian muy bien las alosas. Gessner dice: Estos peces son de los primeros de los de mar que remontan los rios; en el agua salada son flacos y desabridos; pero en la dulce mejoran, engordan y constituyen un manjar bueno. Semejantes ai arenque, mueren apenas se los saca del agua. Dicese que tienen una aficion particular \& los sonidos

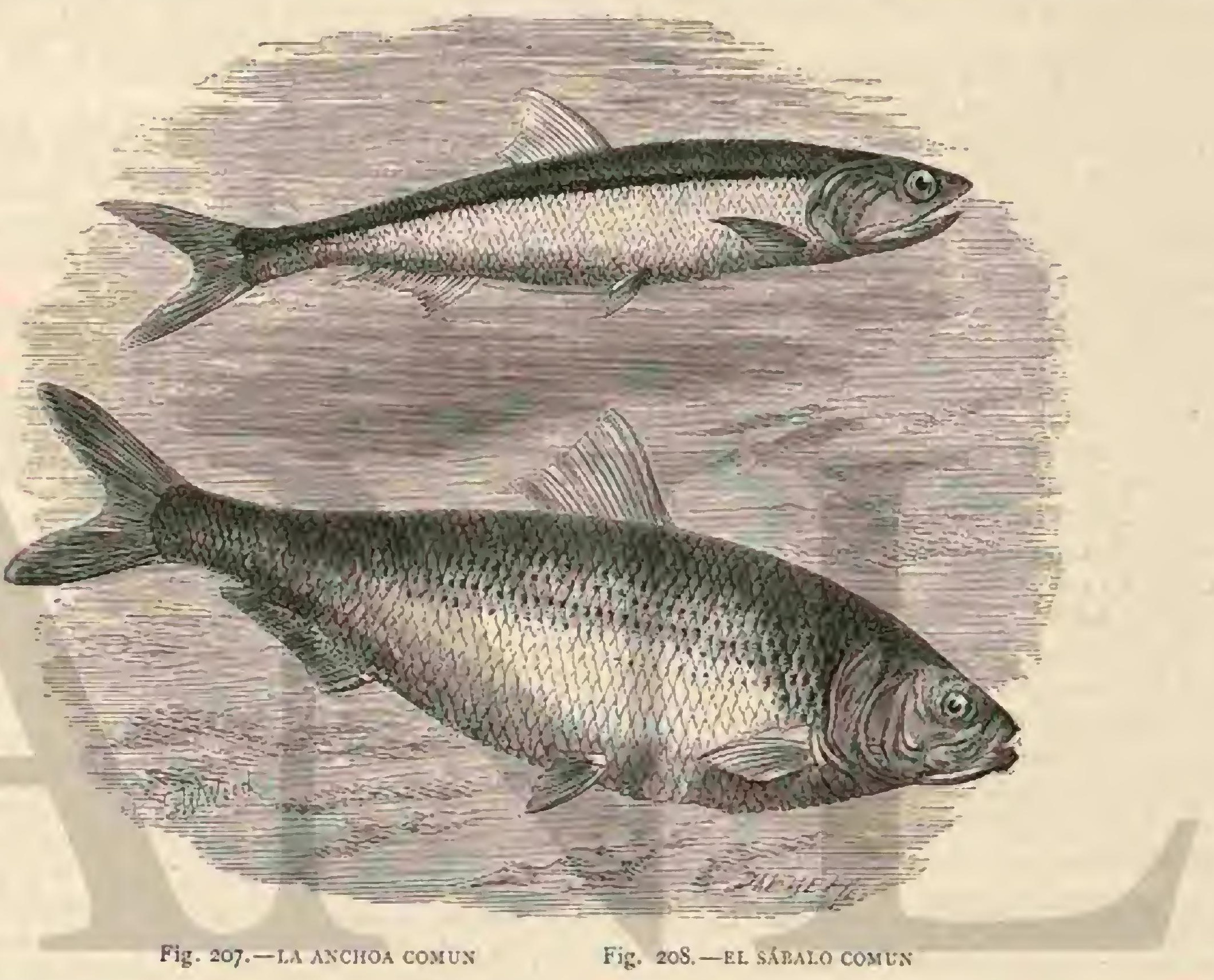

como de campanas y cascabeles; de lo cual se aprovechan los pescadores para cogerlos, y con este objeto hacen nolar delante de la red un pedazo de madera encorvado del cual suspenden cascabeles; los peces siguen al ruido y entran en grandes masas en la red. Tambien es positivo que el trueno los paraliza, por cuya razon eligen la primavera para subir los rios y se vuelven al mar cuando se acerca el verano. Son un manjar excelente en el mes de mayo, pero á muchas perso. nas se les resiste por su gran número de espinas. Se dice tambien que causan sed $y$ sueño al que los come. Los mejores son los que se cogen en agua dulce, y de los del mar no se hace caso.)

Vida, poeta religioso, alaba la inteligencia que las alosas manifiestan en subir los rios, cabaimente en la cuaresma, cuando están mas gordas y no se puede comer carne.

\section{LA SARDINA-ALAUSA PILCHARDUS}

CARACTERES.-Mucho mas importante que las dos alosas descritas es la sardina, que tiene el aspecto del arenque, pero es mas pequeña y mas gruesa: siendo su longitud de $0^{\circ}, 18$ hasta $0^{\circ \prime}, 20,5$ a lo mas $0^{\circ}, 25$. El color es verde томо $\mathrm{V}$ azulado en la parte superior, y blanco plateado en el vientre y costados, con reflejo de oro en los opérculos y listado de un tinte mas oscuro. Hay diez y ocho radios en la aleta dor. sal; diez y seis en la torácica; ocho en la abdorninal; diez y ocho en la anal, s diez y nueve en la caudal.

DISTRIBUCION GEOGRAFICA.-La sardina pertenece al oeste de Europa; es frecuente en el sur de Inglaterra y á lo largo de las costas de lirancia y de España hasta cerca del estrecho de Gibraltar. En la costa de Cornualles se pesca todo el año, pero ian pronto en capas profundas, como en sitios de poca agua.

USOS, COSTUMBRES Y RÉGIMEN.-Antes se creia que la sardina era un pez de paso, habitante de los mares mas septentriunales, que emigraba a los del sur, pero ahora se conoce mejor su género de vida gracias a ubservaciones minuciosas, y con mucha razon se supone que sus costum. bres se parceen à las del arenque. Couch dice que las saroinas viven en enero aisladas en el fondo del mar, que hácia marzo se juntan en bandadas que tan pronto se disuclven como vuelien \& reunirse hista el mes de julio. Los motivos de estas reuniones, separaciones y movimientos generales han de buscarse en la major ó menor abundancia de ali- 
mento en ciertos puntos del mar, como tambien en la repro. duccion. Son en extremo voraces, bien que comen casi exclusivamente pequeños crustáceos, 5 principalmente una especie de molusco enano que se encuentra á reces á millares en su estómago repleto y que determina su residencia en el fondo del mar, donde registra la arena y los huecos entre las piedras á semejanza de los ciprinidos. Pescadores fidedignos aseguran haber visto à veces millares de cuentos de sardinas ocupadas de esta manera en el fondo del mar. Sin embargo, no puede dudarse que tambien comen otras cosas, porque muerden en los anzuelos cebados con gusanos, y se las atrae con freza de abadejo. Desovan en otoño, pero segun los años se encuentran ya en mayo michas sardinas á punto de desovas, por manera que no deben tener una época fija para la reproducción.

PEsca. - En las costas bribánicas es muy considerable; y Couch dice que solo en Cornualles se ocuparon en el año de $1 \delta_{2} 7$ unas cuatrocientas embarcaciones con mas de diez mil personas en esta pesca. Hay ocasiones en que se coge un rilimero increible de una sola redada, habiendo contado un pescador al autor citado que en una de las tiradas en que tomó parte se habian llenado dos mil duscientas barricas con las sardinas cogidas, y hasta consta un caso en que se cogieron diez mil barricas que vienen a representar veinti. cinco millones de sardinas. Esta pesca tiene de singular que se hace con redes de jorro cogiendo los peces en el fondo, y solo una pequeña parte se pesca en la epoca de la frera, de modo que es indispensable tener bien estudiado el terrena submarino doncie paran estas bandadas para poder coparlas. El empleo de grancies redes de fondo presta á esta pesca cierta analogia con la del atun, porque en ambas depende el éxito de la habilidad y conocimientos del patron, ja pará coger los peces, ya para no dejarlos escapar cuando se hallan cogidos. Se sala gran cantiuad de sardinas, pero la mayor parte se hierve en aceite despues de haber estado algun tiempo en salmuera, $y$, se ponen en latas para la venta Francia exporta anualmente mas de diez millones de estas latas o sea aproximadamente doscientos millones de sardi. nas en conserva.

\section{LA ANCHOA COMUN-ENGRAULIS ENCRA- SICHOLUS}

CARACTERES.-Ios antiguos, que desconocian el arenque, la meleta y la sardina, conocian muy bien la anchoa, (fig. 207) que se caracteriza por los siguientes distintivos: cuerpo comprimido, carena del vientre lisa, boca ancha y hendida hasta mas alla del ojo; hocico obtuso y saliente, párpados pequeños, hueso mandibular superior recto y es. trecho, y dientes muy puntiagudos que guarnecen los diferentes huesos de la boca. Alcaniza este pez cuando mas una longitud de $0^{\circ}, 15$. Ia coloracion es azul pardusca en el dorso, blanca en los costados y vientre, y algo dorada en la cabeza.

DISTRIBUCION GEOGRAFICA.-Es per muy numeroso en el Mediterráneo, desde donde se extiende a lo largo de las costas europeas del Allántico hasta las septentriona. les del mar del Norte y aun penetra en el Báltico.

USOS, COSTUMBRES Y REGIMEN. - Bajo este concepto difieren las anchoas muy poco de los demás clu. péidos.

PESCA. - Para la region septentrional del área de dispersion de esta especie tan apreciada, no tiene importancia su pesca, aun cuando tambien se la aprovecha; pero en la paste meridional es muy distinto; en la Bretaria francesa produce millones de francos, y en el Mediterráneo es el clupéido mas apreciado en la industria pesquera. EEliano dice que estos pececillos llegan en bandadas tan compactas, que no se separan aunque penetre entre ellos una barca, ni aunque se les golpee con los remos. Los pescadores los cogen como quien coge granos de un monton, $y$ aun asi se adhieren tanto unos á oiros que algunos dejan siempre la cabeza $\delta$ la cola al arrancarlos de la masa, por manera que á veces se llenan muchas embarcaciones con ellos. Estos datos que sacamos de Gessner son en el fondo exactos, puesto que se presentan las anchoas en tal cantidad que á menudo se sacan de una sola redada las sulicientes para llenar mas de cuarenta barriles de a $;$ hasta 8,000 anchoas cada uno. Luego de cogidas se les quita la cabeza, se destripan y se salan; trabajo que suele estar a cargo de las mujeres de los pesca. dores que tienen una destreza admirable en quitar de un solo golpe la cabera y las tripas con la uña muy crecida de su dedo pulgar.

Los antiguos las curaban de un modo análogo, y las empleaban iambien en la célebre salsa conocida con el nombre de garo. "En Iralia, sigue diciendo Gessner, se consumen muchas anchoas en los dias de ayuno; alli las salan y las preparan de muchas maneras, porque excitan el apetito, quitan las mucosidades del estómago y las enfermedades que estas engendran. En la Provenza se cogen en grandisima cantidad de noche con el auxilio de fogatas que se encienden en las barcas. Se comen tambien crudas con nceite y peregil. Otros hacen con ellas una salsa sacúndolas de la salmuera, y revol. viéndolas sobre la lumbre con accite, vinagre y peregil hasta que se deshacen.

\section{LOS GIMNÓTIDOS- GYMNOTIDE}

CARACTERES. - Hé aqui cómo los describe Juan Mucller que es el que caracterizó este grupo: \&Ia boca está limitada en la parte anterior por la intermaxilar, y lateralmente por la mandíbula superior; el aparato espaldar va fijado directamente en la cabeza; el intestino presenta varios ciegos, y el ano se encuentra junto a la garganta; los ovarios forman un canal, y los testiculos tienen conductos seminales. A esto pociemos anadir que no existe la aleta dorsal, pero sf una anal muy larga, y que hay dos vejigas natatorias unidas por canales aéreos.

Desde últimos del siglo xvH, cuando Richter viajaba por la Guayana, han mencionado muchos médicos y naturalistas un pez de una capacidad y fuerza eléctrica mucho mayor que las de todos los demás peces conocidos que poseen esta cualidad. Alejandro de Humboldt tienc el tnerito de habernos dado noticias mas detalladas sobre este pez, completadas recientementc por las que Sachs ha suministrado.

( Ios españoles, dice Humboldt, llaman fembladores á todos los peces eléciricos. Los hay en el mar de las Antillas en las costas de Cumaná. Los indios guayqueries, que son los pescadores mas hábiles y laboriosos de aquella comarca, nos trajeron un pez que segun ellos les ponia las manos yertas. Era una especic nucva de raya con manchas en los cos. tados, pero apenas visibles, $y$ bastante parecida al torpedo. Era en extremo vivaz y sus movimientos musculares muy vigorosos, pero las sacudidas eléctricas que nos descargaba, eran mus débiles. En los rios Colorado, Guarapiche y en muchos arroyos de las misiones de los indios Chaymas exis. ten oiros tembladores, verdaderos gimnotos, frecuentes tam. bien en los grandes tios de la América del sur, el Orinoco, Amazonas y Meta, solo que alli es dificilisimo cogerios á causa de la profundidad del agua y de la corriente; de modo 
que los indios al nadar y hañarse reciben sus descargas clec. tricas antes de ver á sus autores. Estos peces abundan tambien en los llanos, particularmente cerca de Calabozo, entre los ranchos de Morichal y las misiones de arriba y de abajo, en las aguas estancadas y en los afluentes del Orinoco.

\Primero nos propusimos hacer experimentos en nuestra casa en Calabozo, pero el pueblo tiene tanto miedo álos golpes del gimnoto que pasamos tres dias antes de lograr alguno, á pesar de que se dejan coger fácilmente y de que ofrecimos á los indios dos pesos fuertes por cada uno de estos peces si era grande y robusto. Este miedo de los indios era tanto mas de extrañar, cuanto que ellos aseguran que hay un medio infalible para no sentir las sacudidas de estos peces, el cual consiste en mascar tabaco cuando se les quiere tocar sin perjuicio. Esta fábula de la influencia del tabaco sobre la electricidad animal está tan extendida en el continente americano como entre los marineros europeos la de la influencia del sebo y de los ajos sobre la aguja magnética.

$\checkmark$ Cansados de aguardar, despues que un gimnoto vivo pero muy desfallecido que habiamos conseguido, nos habia dado resultados muy ambiguos, nos fuimos al Caño de Bera, para hacer nuestros experimentos al aire libre y junto al agua misma.

- Es dificil coger estos peces con redes, porquic se ocultan á manera de las culebras en el cieno. I a raiz de Pisciáca Eirithryna, de Jacquinia armiliaris y de algunas especies de Pigyllastisus tienen la cualidad de atontar ó embriagar á los peces si se arrojan a un estanque, pero ro quisimos valernos de este remedio que en el pais llaman barbnsco, porque habria debilitado a los gimnotos. En vista de esto nos propusieron los indios pescarlos con caballos, y en efecto, no tardaron en reunir en el páramo unos treintá caballos y mulos silvestres que hicieron entrar en el agua.

$\checkmark$ El estrépito que causan los caballos con sus patadas en el agua sicmpre silenciosa, hace salir à los peces del fondo y los excita a atacar à los molestos intrusos. El combate que se traba alli entre animales tan diferentes es el espectáculo mas pintoresco que puede imaginarse Los indios, armados de azagayas y largas cañas, forman un cordon compacto al rededor de la balsa; algunos se encaraman sobre las ramas de los árboles que se extienden horizontalmente sobre el agua, y con su gritería y las cañas espantan á los caballos cuando quieren ganar la orilla y los obligan á entrar de nuevo en el rio. Entre tanto los gimnotos aturdidos se defienden con repetidas descargas eléctricas, y por espacio de mucho tiempo parece que han de quedar al fin vencedores. Algunos caballos sucumben á sus golpes invisibles que influyen directamerte en los órganos mas esenciales, y se ahogan; otros con las crines erizadas, los ojos iuera de las órbitas, llenos de indecible angustia, caen, vuelven a levantarse $y$ procuran huir del fatal elemento, pero los indics los hacen volver á él; algunos, sin embargo, mas dichosos, logran engañar la vigilancia de los hombres, salen ála orilla tropezando á cada paso y se dejan caer finalmente sobre la arena exhaustos y yertos. Cinco minutos despues de haber empezado la batalla ya se habian ahogado dos caballos; porque el gimnoto, que tiene metro y medio de largo, se acerca al vientre del cuadrúpedo y le descarga la electricidad en toda la longitud de su cuerpo, recibiendo de este modo dircctamente el corazon, todos los intestinos y nervios abdominales, el terrible golpe; 9 se comprende que estos golpes han de ser mucho mas terribles que los que el hombre puede recibir cuando toca dichos peces con la mano 6 los piés. No puede negarse que el golpe no es mortal para los caballos, pero los aturde y como no les deja fuerza para levantarse, se ahogan en la confusion del combate que prosi. gue a su alrededor.
Creíamos que todos los animales sucumbirian victimas de los gimnotos y que no se salvaria ni uno solo, pero no fué asi; poco á poco se apacigua el ardor de los combatientes y los peces se dispersan cansados para recuperar en un prolon. gado descanso y con abundantes alimentos la pérdida de su fuerza galvánica. Los indios aseguran que cuando se echan caballos a una balsa de gimnotos dos dias seguidos, no se pierde ya ninguno, ni demuestran los animales tanto terror el segundo dia; su mirada es mas tranquila y no se les erizan las crines. Al cabo de un rato se acercaron los gimnotos cau. telosos á la orilla, donde los indios los cogieron con sus azagayas atadas á cuerdas largas, y asi logramos tener en pocos minutos cinco de estas grandes anguilas, la mayor parte con heridas leves; por la noche se cogió otra partida de la misma manera.

SSeria peligroso exponerse á las primeras descargas de un gimnoto grande e irritado. Cuando se recibe por casualidad uno de estos golpes antes de estar herido 6 rendido el pez, son tan violentos $y$ momentáneos el dolor $y$ el entorpecimiento que es inposible darse cuenta de ellos. Jamas he recibido descargas de una botella grande de Leide que hubiesen podido compararse con la terrible que experimenté al poner impruden. temente ambos piés sobre un gimnoto que acababan de sacar del agua Todo el dia senti dolores violentos en las rodillas y en casi todas las articulaciones. Si se quicre observar la di. ferencia, bastante notable, entre el efecto de una pila de Volta y de un pez eléctrico, hay que tocar uno de estos cuan. do ya está casi enteramente desfallecido; entonces tanto los torpedos como los gimnotos causan en los tendones unas vibraciores á manera de saltos desde el miembro que toca el órgano eléctrico hasta el codo, que parece sentirse a cada golpe una vibracion interior que dura dos ó tres segundos y que va seguida de un entorpecimiento doloroso; por cuya razon, en el idioma expresivo de los tamanacos se da á este pez el nombre de arimsa, que quiere decir paralisador. La sensacion que me produjeron las descargas débiles del gim. noto, me pareció análoga á las punzadas dolorosas que sentia cuando me aplicaban dos metales opuestos y en contacto con las llagas que me habia heclıo en la espalda con cantáridas. Esta diferencia entre la sensacion que produce la descarga de un pez electrico; y la que resulta de una pila de Volta 6 botella de Ieide poco cargada, ha sido notada por todas las personas observadoras; pero esto no impide que ambas fuen. tes de electricidad sean una misma cosa; cuyo efecto varia segun la estructura del órgano cléctrico, fuerza y velocidad de. la corriente 6 segun un modo especial de manifestarse.

\$ En la Guayana holandesa, como por ejemplo en Deme. rary, se utilizaban antes los gimnotos para curar las parálisis; y en la época del apogeo de la electricidad aplicada a la medicina, publicó un cirujano de Esequibo, un tal Van der Lott, un tratado sobre la virtud curativa del gimnoto. En la antigua Grecia estuvieron ya en uso ciertos metodos curativos por la electricidad, como lo están todavia entre los salvajes de América: Escribonio, Largo, Galeno y Dioscórides nos dicen que el torpedo cura cl dolor de cabeza y la gota. En las colonias españolas que he recorrido no he oido nunca hablar de semejante cosa, pero lo cierto es que tanto Bonpland como yo, despues de pasar cuatro horas trabajando con gimnotos, sentimos hasta el dia siguiente debilidad muscular, dolor en las coyunturas y un malestar general como consecuencia de una exciacion extraordinaria del sistema nervioso. $x$

\section{LOS GIMNOTOS - GYMNOTUS}

CARACTERES. - I Los preces de este género difieren de 
los demás ginunótidos por la carencia de escamas, por las aletas pectorales y anal cubiertas de una membrana, y por la dentadura que consiste en muchos dientes finos y puntiagudos en las mandibulas, en otra hilcra pequeña en la parte anterior del paladar, y en dos hileras detrás de los dientes que guarnecen la parte anterior de la mandibula inferior.

\section{EL GIMNOTO ELÉCTRICO-GYMNOTUS ELECTRICUS}

CARACTERES. - Este pez puede alcanzar una longitud de dos metros y un peso de Is hasta zo kiló́g amos. Un gimnoto de mas de un metro que Humboldt observo, pesaba 5 kilógramos. Ia parte superior tiene, segun Sachs; un hermo so tinte verde aceitunado con partes mas oscuras; la parte inferior del cuerpo es anaranjado-rojiza; dos ó mas hileras de manchas amarillas claras, del tamaño de una guinda, recor. ren el lomo y á veces tambien los costados desde la cabeza hasta la cola; la aleta anal, sumamente larga, es de color de pizarra orlada de blanco, 5 en algunos de encarnado. Cada una de las manchas citadas tiene en su centro un caral 6 conducto secretorios; la piel está siempre cubierta de una mucosidad, que como ya lo ha demostrado Volta, conduce veinte $\mathrm{g}$ treinta veces mejor la electricidad que el agua pura; la lengua es carnosa y está cubierta de verruguitas amarillas; el estómago es calloso, la vejiga natatoria muy grande, pues mide 0,80 y se prolonga mucho mas allí del intestino á lo largo de los músculos del dorso, mientras que el resto des. èmboca cerca de la cabeza en la décimaquinta parte de la longitud total del pez. Los órganos eléctricos ocupan cuatro

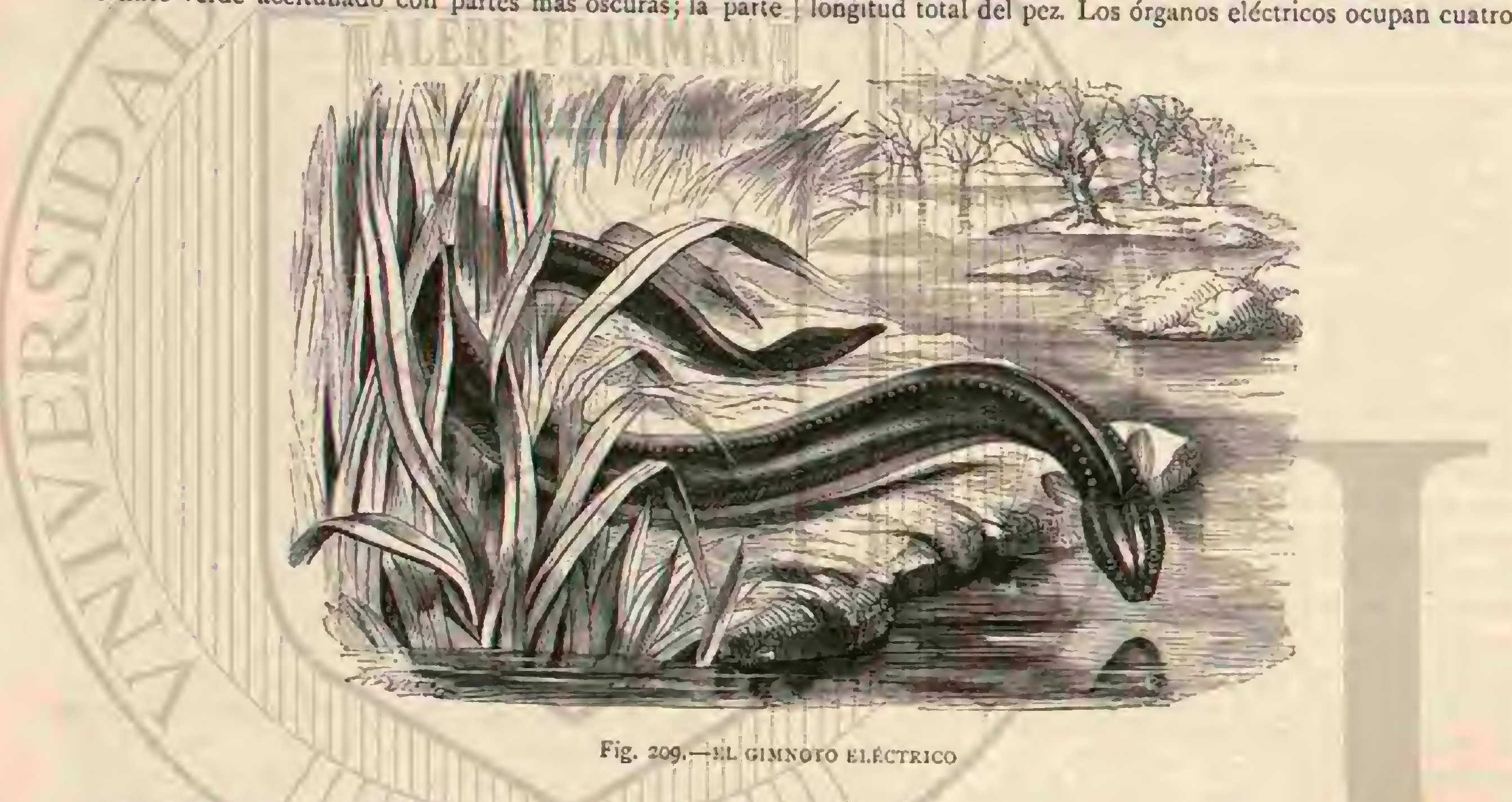

quintas partes de la longitud. Son en número de cuatro, co. locados á un lado del vientre desde el extremo de la cavidad abdominal hasta la punta de la cola; siendo su peso un buen tercio del total. Consisten en una sustancia blanda, gelatino. sa y traslúcida, de color amarillo rojizo claro, compuesta de hacecillos longitudinales formados á su vez de un gran nú. mero de plaquitas membranosas, casi horizontales, colocadas una al lado de la otra $y$ divididas en celdillas por membranas longirudinales.

Los primeros viajeros que observaron estos peces nos han dejado datos sobre los efectos que producen j que han sido posteriormente confirmados. Desde luego conocieron que el animal produce las descargas eléctricas á su voluutad. Bajon tocó uno con el dedo y no sintió nada, pero cuando lo puso sobre el lomo recibió pequeños choques, 5 cuando el mismo pez cayó al suelo al mudarle el agua y todos los negros se resistian á alzarlo, lo cogió él mismo por la cola, recibiendo una descarga tan terrible que le faltó poco para caerse, y tuvo mucho tiempo la cabeza como atontada. Un gato que quiso morder un gimnoto casi muerto, retrocedió dando un brinco y un maullido terrible, $y$ lo mismo le sucedió a un perro que se puso á lamer à otro de dichos peces. Walsh pegó una lami nita de metal sobre un vidrio plano que partió en seguida por medio; puso una de estas mitades en contacto con el pez y al irritarlo, vió saltar una chispa entre los dos trozos de vidrio. rCuando se toca el cuerpo húmedo del pez con dos conductores entre los cuales solo medie un centimetro de distancia, dice Humboldt, recibe tan pronto el uno como el otro una descarga eléctrica, lo que prueba que estas arguilas dominan perfectamente la emision en cualquier parie de su cuerpo, y que no pueden compararse con una máqqu:na cléctrica. Cuando se separa la cabeza y con ella el cerebro y el corazon, cesa el efecto eléctrico junto con el movimiento muscular, mientras que las culebras y angrilas en estado análogo sufren convulsiones á la menor excitacion. El corazon de un gimnoto, despues de sacado del cuerpo, siguió palpitando "un cuarto de hora, y galvanizándolo luego vol. vio a palpitar veinte minutos mas; la cabeza separada morió la mandibula diez minutos, pero ni esta, ni otra parte algu. na del cuerpo se movia al aplicarles un elemento de zinc $y$ plata. En otros individuos sucede al parecer lo contrario. Creíase que para sentir la descarga, era menester cerrar el circuito, es decir, estar en dos puntos en contacto con el pez; pero esto no es menester, tambien se recibe la descarga si se toca al pez solo en un punto y estando aislado. Si se le toca con un pedazo de madera seca no se siente nada, pero si el experimentador se pone sobre esta madera no conductora, e irrita el animal con un alambre, siente en seguida la con. mocion en los brazos y rodillas, sin percibir su paso por los mus!os. En esto difiere el gimnoto del torpedo, pues cuando se sostiene á este sobre una placa de metal no se siente nada, pero se recibe el golpe si se toca con la otra mano su órgano eléctrico. El cristal, el lacre, el azufre y la madera seca no conducen la electricidad del pez; pero el zinc es buen 
conductor, s despues de él el oro, el hierro, la plata y el co. bre. Dos personas en contacto sienten á menudo corrientes débiles, pero cuando es fuerte las siente solo la persona que toca al pez. La descarga no atraviesa el agua aunque se acer. que el dedo al pez hasta la distancia de un milimetro tan solo. Observadores anteriores dicen lo contrario, como Van der Lot que refiere el caso de un hombre que tenia metidos los dedos en una barca llena de agua, en !a cual habia un gimnoto, y aunque estaba a seis metros del animal, sintió la conmocion cuando Lot le tocó. Bancroft asegura tambicn que la descarga se trasmite en el agua á tres metros de dis. tancia, y Humboldt explica cstas contradicciones admitiendo que todo depende del capricho del animal. El gimnoto no siente cuando se le toca con un alambre, pero ve á los peces a los que envia una descarga al traves del agua cuando le da la gana. Varios gimnotos reunidos en el mismo virero viven en paz, sin poder hacerse daño, conforme se ve cuando se traslada la descarga del uno al otro por medio de un alam. bre. Si se pasa una lámina de zinc por un agujero ó corte hecho en la aleta pectoral y se toca la punta con un objeto de plata, se agita convulso todo el animal, inientras que el hombre por el que atraviesa la corriente eléctrica nada nota; de consiguiente ha de ser la electricidad del animal infinita. mente mayor que la exterior que conmuere sus músculos. El dolor que sufre el pez en este experimento ha de ser grande a juzgar por lo mucho que se retuerce y hasta saca la cabeza fuera del agua. Sachs, que viajó por América casi con el objeto exclusivo de observar el gimnoto, no ha podido publicar los resultados de sus observaciones, á causa de su repentina muerte, dejando así muchos puntos indecisos que nadie como él habria podido esclarecer.

DISTRIBUCION GEOGRÁFICA.-El gimnoto habita

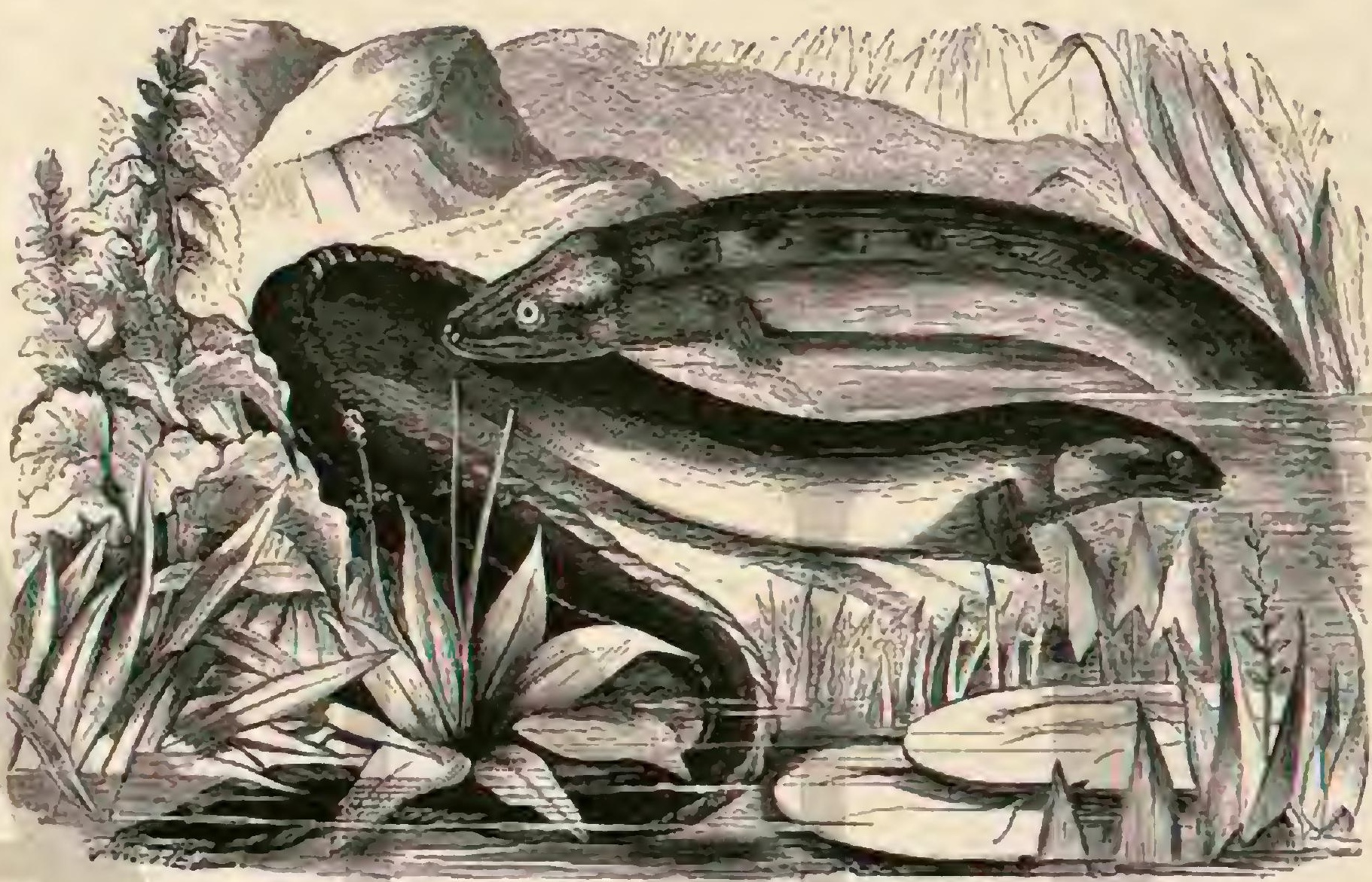

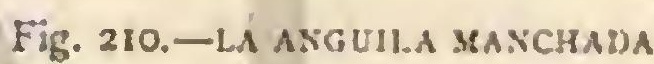

Fig. 211.-La Axgura comus

una gran parte de la América meridional, en especial todo el nordeste del Brasil, la Guayana, y Venezuela, pero solo en aguas cuya iemperatura oscila entre veintiseis y veintisiete grados; por cuya razon se aleja de las sierras, donde las aguas son mas frias, $y$ en las cuales, segun se dice, disminuye y casi desaparece del todo su fuerza eléctrica; de modo que vive al parecer exclusivamente en los llanos.

USOS, COSTUMBRES Y RÉGIMEN.-Segun Sachs, prefiere el gimnoto charcos ó arroyos muy sombreados, estre. chos y cenagosos. Alli está, por lo menos durante el dia, sobre el fondo, si bien sube cada médio minuto á la superficie para absorber aire atmosférico con la boca fuera del agua y con ruido perfectamente perceptible, y hundirse otra ver. expeliendo por las aberturas branquiales el aire consumido. De las ob. servaciones del mismo autor resulta que no existe verdadera respiracion branquial, y por esta razon los indigenas conocen la presencia del gimnoto por el indicado ruido que hace al respirar el aire. Al oscurecer empieza dicho pez a moverse y á cazar, y su aparato eléctrico le hace mas terrible que el pez mas rapaz para los habitantes del agua. Coge todo lo que puede engullir, peces, crustáceos é insectos que caen al agua. Nada en línea recta ó describiendo una ligera curva con mas gracia que ningun otro pez y tan bien hácia ade. lante como hácia atrás, gracias al movimiento ondulatario de su aleta anal membranosa y ulanda, semejante a la quilla de un buque, solo que la hace ondular en el sentido que quiere. Al llegar cerca de su presa descarga su fuerza parali. zadora, cuyo efecto es tan grande que al punto flotan de lado é inmóviles todos los peces y crustáceos que se hallan dentro del fatal circuito. El gimnoto elige su victima entre ellos, y se la engulle con un movimiento de absorcion tan fuerte que se oje como un chasquido bastante estrepitoso. Cuando empieza á secarse el lecho que habita y se ha des. cuidado de emigrar mientras su balsa $\delta$ arroyo comunicaba con otras aguas, se oculta en el cieno, revolviéndose sin cesar para hacer el agujero, pues no puede viajar por tierra ni si. quiera sobre el fango húmedo, y perece como los demás pe. ces fuera del agua.

Tampoco ha podido Sachs observar nada respecto \& la reproduccion, pero refiere como cosa singular que los gimno. tos suelen reunirse en ciertas circunstancias por sexos, puesto que cogió una vez solo machos, y otra exclusivamente hembras, en las que encontró en febrero huevas maduras de uno â dos milimetros de grueso. Supone Sachs que esta agrupacion temporal por sexos está en relacion con el des. ove, bien que no se ve razon alguna que la apoye, á no ser que fuese verdad lo que dicen los indigenas de la Guayana, esto es, que el gimnoto es viviparo, á pesar de las huevas maduras que encontró Sachs en la hembra.

USOS Y PRODUCTOS.-Los habitantes del pais temen y odian al gimnoto, cuya carne llena de espinas, si no es sa. brosa, tampoco es del todo mala; pero el órgano eléctrico 
es grasiento $y$ de un sabor desagrable, por cuya razon se separa cuidadosamente del resto ý se tira. La columna vertebral se guarda, pues reducida a polvo tiene fama de facilitar los partos, y por cicrto que no se descuida aquella gente de emplearla en casos dificiles. Se odia á este pez porque, segun dice Humboldt, se le atribuye el exterminio de los peces en las balsas y estanques de los llanos. Un gimnoto mata muchos mas peces de los qque devora. Los indios dicen que cuando se cogen en redes muy fuertes pequeños crocodilos $y$ gimnotos no ofrecen estos últimos lesion alguna, porque antes de que aquellos les puedan hacer daño ya los han entorpecido. Todos los habitanies del agua huyen de estos peces: los lagartos, tortugas y ranas se retiran a pantanos donde se hallén léjos de cllos. Cerca de Uritucu fú menester cambiar la direccion de una carretera, porque los gimnotos se habian multiplicado tanto en un rio que todos los años sucumbian muchas de las acémilas que tenian que vadearlo. Ias ranas, tortugas y otros anfibios y rcptilcs quc se echan en los riveros donde hay gimnotos cautivos, se apresuran á huir de tan terrible vecino. Sachs no encontró en una balsa pez alguno, fuera de los gimnotos, de lo cual déduce que estos debieron exterminarlos poco \& poco.

PESCA. - Ya no se rerifica como en tiempo de Humboldt, sino con redes que se arrastran hácialos yeces. Sc coloca una red con sus pesos en la parte superior de la cor. riente; despues, contando con la curiosidad de los gimnotos, se echan piedras al agua para atraerlos, $y$ en seguida se los encierra con otra red que se echa un poco mas abajo, y se arrastra la primera barriendo el fopdo del rio hácia la última. En vano, refiere Sachs, lanzan furiosos sus descargas eléctricas de cuya fuerza terrible son buena prueba los peces y ranas que aparecen súbitamente muertos en la superficie, asi como los ayes de algun pescador que está dentro del agua; el gimnoto queda cogido y sacado del rio, ponién. dose en seguida á serpentear sobre la arena para rolver a su elemento.

CAUTIVIDAD.-Sobre este punto abundan las noticias, porque no solamente han sido observados estos animales en su patria por todos los naturalistas que han viajado por aquellos paises, sino que los han traido vivos a Europa y los han tenido entre otros en el jardin zoológico de Lóndres. Citaré lo que dice Sachs. Colocado el gimnoto en una vasija reducida, empieza \& nadar inquicto describiendo círculos y pro. curando salirse, lo que logra con frecuencia; pero tan pronto como se ve en un punto mas espacioso, se tranquiliza y se conforma con su suerte, se estira y permanece por lo regular todo el dia inmóvil en los sitios mas oscuros del fondo, sal. vo los movimientos que hace para respirar. A la entrada de la noche se anima. Se excita de un modo extraordinario cuando se alumbra repentinamente su estancia. A pesar de que puede pasar semanas sin comer, es en extremo voraz cuando tiene á su disposicion abundancia de alimento. Siempre que Sachs echaba á sus cautivos peces pequeños 6 cangrejos empezaban a cazarlos. Por lo regular bastaba una primera des. carga para paralizar \& la victima, pero algunas veces lograban los animalitos saltar fuera delagua y entonces los seguia su perseguidor como el rajo y los atrapaba al vuelo, engu. lléndolos inmediatamente sin mas preparativo. Las observa. ciones minuciosas de Sachs han puesto tambien fuera de toda duda que las descargas de un gimnoto no causan la mas minima impresion á los individuos de la misma especie.

\section{LOS ANGUÍLIDOS- MUR压NID压}

CARACTERES.-Esta familia numerosa, compuesta de mas de 250 especies agrupadas recientemente en muchos géneros, se caracteriza por su cuerpo prolongado semejante al de las culebras, mas ó menos redondeado, casi siempre comprimido lateralmente en la region de la cola, desnudo 6 bien cubierto de escamas no sobrepuestas y distribuidas en forma de S S; por la boca limitada únicamente por el hueso intermaxilar, y la mandibula superior oculta en la carne; por la colocacion del aparato dorsal fijo en la columna vertebral bastante hảcia atrás en lugar de estarlo en la cabeza; por el estómago provisto de buche; por el tubo intestinal sin ciego, y por la falta de conducto de salida del aparato sexual. En cuanto á la dentadura y las aletas pueden variar mucho, se. gun resulta de lo que se dirá luego.

DISTRIBUCION GEOGRAFICA.-LOS anguilidos viven en las zonas ecuatorial y templadas; algunas especies pasan el círculo polar, pero son raras y desaparecen á los pocos grados tnas de latitud norte.

USOS, COSTUMBRES Y REGIMEN.-Loshay que ha. bitan cl mar, y otros viven en las aguas dulces; muchas especies, como nuestra anguila de rio, suben del mar á los rios, ó bajan de estos á aquel. Para morada prefieren aguas de fondo cenagoso, pues alli encuentran su alimento y refugio contra las persecuciones de sus enemigos. Todos son rapaces; pero algunas especies lo son muchisimo nas que otros que se contentan con animalillos pequeños.

USOS Y PRODUCros. - Los anguílidos han tenido siempre grandísima importancia para la cconomia humana, por cuya razon se les pesca en todas partes con afan. Su carne constituye en general un alimento excelente, y su fecun. didad, su dilatada área de dispersion, su vitalidad, y su fácil traspiorte, ya frescos, ya preparados de diferentes maneras, aumentan su valor.

\section{LA ANGUILA COMUN-ANGUILLA VULGARIS}

CARACTÉRES.-Este representante del géncro (figura 210) se caracteriza por tener las aberturas branquiales muy angostas y situadas delante de las aletas pectorales; por las aletas dorsal y anal, las cuales se confunden con la caudal que acaba en punta, y por los dientes aterciopelados que guarnecen la intermaxilar, la mandibula inferior y el vómer; la cabeza ocupa una octava parte de la longitud total; los ojos son pequeños y están cubiertos de una membrana; los labios son abultados y carnosos; las fosas nasalcs sencillas; la abertura branquial tiene forma de media luna con el lado convexo hácia adelante; los diez arcos branquiales van soldados a la membrana que cubre la cabeza; la aleta dorsal ocupa las dos terceras partes del cuerpo, es baja por delante y aumenta de altura hácia la cola confundiéndose con ella.y continuándose sin interrupcion en la anal; las torácicas son cortas y ovaladas. La cubierta escamosa consiste en plaqui. tas córneas, delicadisimas por lo delgadas, trasparentes, oblongas y metidas de tal manera en la piel espesa y viscosa, que aparecen inclinadas una contra la otra en ấngulo recto, dejando de consiguiente entre si huecos que llena la piel, arrugada en estos puntos, en forma de S S. La parte superior del cuerpo es verde oscura, mas aun en la cabeza donde tira á pardo; la inferior es blanca con un débil brillo plateado; las aletas dorsal, caudal y la parte posterior de la anal son todavia mas oscuras que el lomo; las torácicas son negras parduscas y orladas de negro. Estando todas las aletas cu. bierras de una membrana gruesa, no pueden contarse los radios blandos y flexibles, excepto las torácicas donde figuran en número de dier. y ocho á diez y nueve. Respecto á longitud, pasa la anguila solo en casos muy raros de $1^{" ~}, 30, y$ en cuanto á peso apenas excede de seis kilogramos; con to- 
do, Yarrell menciona dos que pesaron juntas 25 kilógramos. La forma de la anguila varia segun las circunstancias de su género de vida y la edad, lo que ha inducido á algunos naturalistas, en especial á Risso y à Yarrell, á admitir y describir diferentes formas como especies. Ya Aristóteles y Plinio hablan de anguilas de cabeza puntiaguda, y de cabeza ancha y redonda, que tomó Risso por especies y álas que Yarrell añadió otras. Los pescadores conocen muy bien todas estas variedades, y los franceses admiten además otra. Muchas razones abogan en favor de la opinion de Hechel s kner que suponen que la diferente forma de la cabeza depende de una diferencia sexual.

DISTRIBUCION GEOGRAFICA.-Gessner dice: ILa anguila es animal conocidisimo en toda la Alemania y fuera de ella, pero hay que saber que no se encuentra en ciertas cor. rientes, como por ejemplo en el Danubio, donde mueren al momento. Dicese que tambien se cogen muy pocas en el lago de Lausana y en sus afluentes. En cuanto al Danubio, tiene mucha razon este autor antiguo, pues mi cn fl ni en sus tributarios hay anguilas, y caso de encontrarse alguna, se puede tener la seguridad de que han entrado accidentalmen. te, ya por haber venido de otra cuenca atravesando el confin que la separa de la del Danubio, ga porque álguien las haya trasladado adrede. Lo mismo sucede con los mares Negro y Caspio y las cuencas hidrográficas de sus afluentes, mientras que se hallan en todo el resto de Europa desde San Peters. burgo hasta Sicilia. Tampoco existen en Asia, por lo menos puede decirse que nadie las conoce en el pais del Ob; á pe. sar de que uno de los pescadores mas instruidos nos asegurb alli, durante nuestro viaje à Siberia, que habia cogido, una vez en toda su vida, una anguila, sosteniendo que estaba seguro de no haberla confundido con ninguna lamprea, pero esto no impide que aquel hombre estuviese en realidad equi. vocado, aunque solo fuese por la extrañeza que le causara el que este pez. se presentase tan aislado en una cuenca tan farorable a sus costumbres como lo es la del Ob.

la anguila prefiere las aguas profundas con fondo cena. goso á todas las otras, pero sin circunscribirse á ellas de un modo absoluto, porque siendo viajera, visita tambien hasta aquellas que reunen condiciones enteramente opuestas.

USOS, COSTUMBRES Y REGIMEN.-La anguila pasa el invierno oculta y dormida en el cieno, por lo menos no se la ve cazar: pero con la estacion templada empieza su vida veraniega, nada con rapidez y culebreando en las dife. rentes capas del agua que habita, se desliza con adnirable destreza por huecos y aun cañerias, pasando con regularidad à los conductos de aguas de las ciudades que no filtran las aguas antes de entregarlas al consumo, sube hasta varios pisos, y atravesando cañerias medio obstruidas, se escapa de los estanques donde las crian y conservan. Existe todavia la creencia de que las anguilas abandonan de noche el agua para buscar en tierra, especialmente en los plantios de guisantes y arvejas, limazas y gusanos. Alberto Magno ya sabia esto segun se re en el pasaje de su Liliro de los amimales citado por Siebold: $\$$ Dicen que la anguila sale $\mathbf{a}$ veces de noche del agua para ir à los campos sembrados de lentejas, guisan. tes ó habichuelas. Desde entonces habrá pasado esta creen. cia de una generacion à otra, puesto que en el dia se repite casi siempre con las mismas palabras. Hé aqui lo que solia referir Stahr, hombre formal 6 inteligente y nada iluso, establecido en Lubech: 4 En 1844 , estando yo de criado en casa de un labrador de Wilmsdorf, fui una noche de verano á la tres de la madrugada, con otro mozo de la casa, al campo para ordeñar las vacas que se quedaban alli al aire libre; al pasar junto á un plantio de guisantes separado del lago de Hemmelsdorf por una estrecha faja de prado, llamó nuestra atencion un ruido, $\mathrm{y}$ buscando lo que era vimos varias anguilas entre los guisantes en flor y parte de ellos en vaina. Al momento volví atrís para avisar al gañan de la casa que acudió con el arado y abrió inmediatamente tres surcos á lo largo del guisantal dentro de la tierra del prado. En estos surcos frescos cogimos una multitud de anguilas que metimos en un saco y llevamos en su mayor parte á Lubeck donde las vendimos. El señor Fed, á cuya amabilidad debo esta relacion, dice que Stahr siente no poder citar los nombres de los demás testigos, porque el otro criado murió, y no sabe dónde paran ahora los mozos de labranza que recogieron las anguilas, pero que él está pronto á confirmar su relacion con solemne juramento. De cuando en cuando se leen en los periódicos noticias parecidas, pero unas y otras han de admitirse con precaucion, porque en cllas como en todo puede haber error. Estas excursiones de las anguilas no son imposibles, puesto que otros peces las realizan tambien segun hemos visto; pero no faltan razones que susciten tambien dudas, como por cjemplo el hecho de que estas excursiones, á pesar de ser la anguila animal frecuente, ocurren tan raras veces, que los pescadores mas prácticos jamás las han observado, que es posible se hayan encontrado individuos dejados casualmente en seco por una inundacion anterior $y$, finalmente, por lo que refiere Spallanzani del pais de Comacchio, donde hace largo tiempo que se pesca la anguila en grande escala sin haberla encontrado jamás en tierra, y donde ni una sola anguila se atrevió á salvarse en el mar ni en el Po, á pesar de estar tan próximo, trasladíndose á ellos cuando el agua corrompida de las lagunas de Comacchio las mataba a millares. Si estos peces abandonasen su elemento por motiros fútiles, ceómo no habian de hacerlo cuando veian que peligraba su vida, y como harian en casos análogos los glanos y peces laberinticos? Ni faltarian tampoco abundantes datos sin tener que ir en busca de testigos oculares fidedig. nos. No cabe duda de que las anguilas respiran siempre aire, pudiendo por consiguiente vivir fuera del agua un dia 6 mas; pero esto no prueba de ninguna manera que hagan aquellas excursiones.

El alimento de la anguila consiste principalmente en animales inferiores, como crustáceos y gusanos; pero tambien come ranas $y$ pececillos, y hasta se dice que es aficionada a la carne muerta. Su voracidad es grande, pero no su rapaci. dad, porque lo impide la pequeñez de la boca.

Nada prueba mejor nuestra ignorancia en punto \& 200logía como lo poco que sabemos acerca de la anguila, uno de los peces mas extendidos y comunes. Ya en tiempo de Aristótcles se cuestionaba sobre su reproduccion, y hoy está aun por resolver esta cuestion. Los doctisimos autores, dice Gessner, que han escrito sobre el origen de estos ani. males, representan tres opiniones. Unos dicen que nacen espontáneamente, como ciertos otros animales acuáticos, de tierra húmeda y viscosa; otros que estos peces se frotan sus vientres desprendiendo asi de sus cuerpos una mucosidad que se trasforma despues en nuevas anguilas, que por lo de. más no tienen diferencias sexuales; y los terceros finalmente dicen que la reproduccion se hace como en otros peces, es deci, por medio de huevas ó bien las viejas paren las peque. nas vivas, pues se asegura que en Alemania se han visto y co. gido anguilas que tenian en su vientre anguilillas vivas como hilitos, que cuando se habian muerto las viejas salian deellas en grandisimo número; lo mismo afirman tambien nuestros pescadores, añadiendo que las anguilillas miden al nacer como el ancho de dos dedos y nacen en todas las épo. cas del año. A estas opiniones de la gente doctisima han venido \& agregarse otras, como por ejemplo, que si se tiran crines de caballo al agua se hinchan 8 acaban por trasfor- 
murse poco á poco en anguilas; pero lo mejor es lo que dice Helmont: «Si se toman dos trozos de césped humedecidos por el rocio de majo, y se ponen uno encima del otro con las yerbas hácia dentro, nacerá, si se exponen al sol, en pocas horas un gran número de anguilillas. . Hoy excitan estas fá. bulas nuestra sonrisa. Verdad es que todavía ignoramos la manera de reproducirse las anguilas, porque no las hemos podido observar durante esta funcion, pero sabemos que ponen huevos, y no andaremos muy equirocados si admitimos que su reproduccion no diferirá mucho ó acaso nada de la de otros peces.

Durante largo tiempo se han esforzado los naturalistas en descubrir un aparato sexual en las anguifas, hista que Mundinus y Mueller descubrieron los ovarios en dos membranas largas y rizadas con numerosas escotaduras $y$ pliegues tras. versales, situadas á lo largo de la columna vertebral. Rathke, Hornschuch y otros confirmaron el hecho despues de haber encontrado tambien las huevas valiéndose de microscopios poderosos. Hasta aqui se ha liegado, pero todavia queda por descubrir el aparato sexual masculino y hasta entonces no podrá impugnarse la opinion de aquellos naturalistas que sostienen el hermafrodismo de las anguilas. En el dia nadie cree sa que sean vivíparas, aunque solo se tenga en consideracion el considerable aumento de estos peces, porque todos los viviparos engendran relativamente pocos hijuelos.

Respecto al desove, tampoco se sabe mucho. Es positivo que las anguilas adultas abandonan los rios para pasar en gran número al mar, donde podemos suponer con funda. mento que desoran. Estas emigraciones tienen lugar, como es sabido, en otoño, desde octubre hasta diciembre y con preferencia en las noches oscuras y borrascosas. Entonces no están todavia en disposicion de reproducirse, conforme lo han demostrado investigaciones escrupulosisimas; pero á fines de abril, lo mas tarde en mayo, remontan los rios an. guilas pequeñas cuya longitud no pasa de $0^{\circ}, 09$ con el grue. so de un gusano, y que serán probablemente la cria delas viejas que emigraron en otoño; admitiendo esta suposicion como exacta, ha de caer la época del desove en los meses de diciembre \& febrero. Ahora, si es verdad que algunas anguilas desovan tambien en lagos de agua dulce como algunos pretenden, ó si todas pasan al mar cundo se hallan en esta. do de reproducirse, como probablemente lo hace el mayor número, 6 si finalmente, segun opinion de algunos, se quedan para siempre en el mar las anguilas que han desovado, cosas son que aun restan por averiguar.

El viaje de las anguilas pequeñas desde el mar rios arriba ha sido observado muchas veces en todas las grandes corrientes. Ya hemos leido en Redi que una cria de anguilas remonta cada año el Arno desde fin de enero hasta últimos de abril, y que se cogieron en dicho rio junto d Pisa en el año 1667 , en el trascurso de cinco horas, tres millones de libras de estas anguilillas que median de tres á doce centi. metros de largo. Spallanzani y Coste cuentan que en las lagunas de Comacchio se abren desde febrero á abril ciertas esclusas para facilitar á las anguilas el acceso álos estanques circuidos de diques, desde donde procuran llegar al mas cinco $\delta$ stis años despues, en cuyo tiempo se pescan. Estas angúlas, que son del grueso de un bramante, entran tambien a millones cada primavera, es decir, en marzo, abril y, mayo, en el lago de Orbitello, sobre todo cuando el tiempo es bor. rascoso. Hé aqui lo que dice Vogt: En los meses de mar. 20 y de abril penetran de noche en las desembocaduras de los rios millones de millones de pececillos trasparentes, de $0^{3}, 05$ de largo poco mas ó menos.

En algunos parajes, como por ejemplo en los rios france. ses donde se dáá este fenómeno el nombre de la montée, forman dichas bandadas una masa sólida que se saca del agua con cedazos y cubos, comiéndose por lo general en tortilla. Son pequeñas anguilas que desde los sitios donde nacieron remontan los rios, llegando á medir alli á los dos años unos $0^{\prime \prime}, 60.8$ Crespon habla tambien de estas inmigraciones; segun el, júntanse las anguilillas en la embocadura del R6. dano, por cuyas aguas suben formando una masa no interrumpida del grueso de una cuba grande, por lo regular una en cada orilla. Couch dice que hasta atraviesan cascadas, y un tal Arderon refiere el caso de otras bandadas que pasaron por encima de las estacas de las obras hidráulicas de Norwich, $y$ de las esclusas para llegar ́a las aguas superiores, á pe. sar de estar las tablas acepilladas y de tener dos metros de altura. Alli se observó que cuando llegaban á la esclusa descansaban aguardando que su mucosidad fuese lo suficientemente pegajosa para subir por la madera rertical, y entonces trepaban por ella con la misma facilidad que si hubiesen estado horizontales. Jesse dice por su parte que la inmigracion se realiza cada año por la misma época, continuando duran. te dos ó tres dias en bandadá no interrumpida y con una velocidad de dos millas y media inglesas por hora. A veces abandonan sin motivo visible una orilla, cruzan el rio y pasan á la otra Al llegar ś una embocadura se dividen, una parte sube por el afluente, y la otra, despues de bregar con la corriente que desemboca, la vence y sigue su camino rio arriba. Asi va desmembrándose el ejército hasta que todos sus individuos se hallan bien distribuidos y alojados en las diferentes partes de la cuenca. No las arredran obstáculos, y los cientos de miles que sucumben en el camino.no tienen importancia si se los compara con los millares de millones que quedan. «Me encontré un dia, dice Davy, hácia últimos de julio en Ballyshannon en Irlanda a orillas de un rio que durante todo el mes anterior habia sufrido una notable crecida. En la proximidad de una cascada ví el agua entur. biada por millonés de anguilillas que se esforaban en subir por las peñas húmedas á ambos ilados de la cascada, lo que costó la vida á millares de ellas, cuyos cuerpos, húmedos tambien y viscosos, servian á las otras de escalera para continuar su ruta, $y$ tan grande era su tenacidad y perseverancia en trepar por las rocas verticales ó deslizarse por el musgo, que llegaron al lago de Arno en masas incalculables todavia.» Tampoco les impide la cascada del Rhin junto á Schafhousa llegar hasta el lago de Constanza; ni es obstáculo para ellas la cascada del Ródano. Nilson dice que nunca lograron pasar la del Trollhaetta, pero desde que se establecieron esclusas para facilitar la navegacion, pueblan el lago de Wener $y$ todos sus tributarios. Hé aquí una relacion de Ehlers: "Cuando subimos una mañana á últimos de junio ó princi. pios de julio sobre el dique construido en la misma orilla del Elba para proteger la aldea de Dreenhausen contra las inundaciones, vimos una faja oscura que se movia á largo de la orilla; como todo lo que pasa en aquel rio interesa à los ha. bitantes de la comarca, nos llamó tambien la atencion el citado fenómeno, que resultó ser una bandada innumerable de anguilillas, las cuales remontaban el rio tan inmediatas á la orilla que seguian todas sus curvas con la mayor exactitud. El ancho de esta faja de pececillos podia ser en el sitio don. de estábamos, como de \|\|$^{10}, 30$, pero no nos fué dable conocer su profundidad. Iban tan compactos que no era posible meter una vasija en el agua sin coger un considerab!e núme. ro de ellos, cosa en extremo molesta para los habitantes de aquellos contornos, porque no pudieron sacar agua del rio para su uso mientras duró aquel paso. Las anguilillas median como de $\left(1^{\prime \prime}, 08\right.$ \& $0^{\circ}, 10$ de largo, siendo su grueso como el cañon de una pluma de ganso. Entre esta multitud iban suel. tas otras anguilas mayores, pero que no pasaban al parecer 
de $l^{n}, 20$. Esta extraña procesion duró todo el dia y parte del siguiente, y al amanecer del tercer dia ya habian desaparecido todas las anguilas.

ENEMIGOS. - Todos los animales ictióvoros mayores persiguen a las anguilas con el mayor afan. Presénciase un espectáculo divertido cuando se echan unas cuantas docenas de pequerias anguilas vivas en el agua donde haya una nutria cautiva y hambrienta. Este mustélido, segun dijimos en su lugar, no se da punto de reposo mientras exista ani. mal viviente á su alrededor. Apenas ve las anguilas, se preci. pita al agua, coge una, le tritura la cabeza de un mordisco, la deja sobre una piedra, y vuelve al agua en busca de otra. Entre tanto se ha deslizado al agua la primera, a la que creia muerta y que culebrea ya en su elemento como si no le hu. biera sucedido nada. Furiosa la nutria, da varios mordiscos á la segunda, 5 vuelve al agua en busca de la primera, mien. tras que la otra se escapa á su ver, continuando este juego hasta que la nutria se determina á devorar unas cuantas á medida que las atrapa; operacion muy fácil para el mustélido provisto de afilados dientes, pcro dificilisima cuando el animal de rapiña es una ave; y si no véase lo que se habia ya observado en tiempo de Gessner: Warias especies de aves comen anguilas y particularmente la llamada falacrocora.: Esta las engulle enteras; el pez se desliza por el intestino y sale vivo por el ano; el ave la vuelve á engullir y la anguila á salir, repitiéndose esta operacion a menudo nueve veces has. ta que el pobre pez, cansado y exhausto, queda por fin en el estómago del ave. Asi sucede en efecto, pero solo con aves

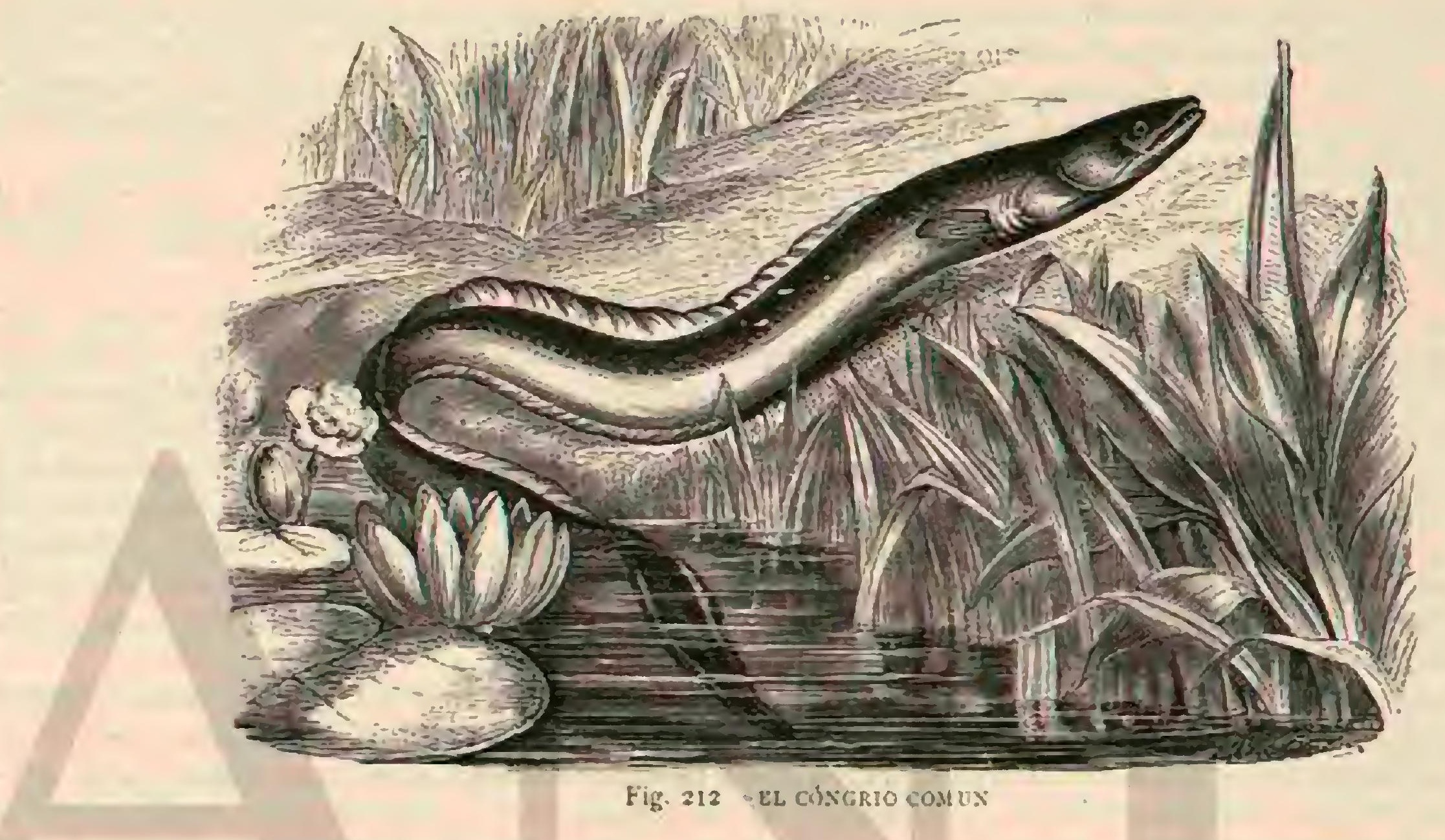

jórenes, puesto que las garzas y colimbos deșpedazan siempre la anguila antes de engullirla, porque conocen su cuali. dad laxante por experiencia.

No son tan solo los animales los que conocen la vitalidad de la anguila; pues tampoco hay cocinera que no sepa lo que quiere decir matar una anguila. Lenz dice lo siguiente: «Siempre que visité las pescaderias de cifrta ciudad maritima, vi que las vendedoras tenian las anguilas grandes uadando en cubas, mientras que las que miden hasta 0,60 estaban amon. tonadas sobre grandes mesas moviéndose sin cesar. Cuando las pescaderas tenian un momento libre, cogian una de es. tas anguilas, le hacian una incision alrededor del cuerpo por detrás de la cabeza y la despellejaban asi hasta la cola, lo que no impedia que el desgraciado animal se retorciese todavia mucho riempo.

PESCA.-En todas partes se pesca la anguila con afan, y muchos siglos hace que existen pesquerias en grande escala en las ya mencionadas lagunas de Comacchio donde setras. formaron pantanos antes siliestres y mortíleros, por medio de esclusas, zanjas y laberintos, en estanques ordenados para servir de vastos viveros á innumerablés anguilas. Comacchio, ciudad pequeña y miscrable, es el centro de esta pesca à la que se dedica su poblacion casi exclusiramente. Los pesca. dores propiamente dichos forman un gremio especial que se rige por leyes quedatan de la Edad Media, y que juntamente con su aislamiento, los hacen subsistir en un estado de em. urutecimiento sin ejemplo; mas por lo que se refiere al co. nocimiento de la anguila, saben mas que todos sus colegas Tosso $\mathrm{V}$ de otros paises, puesto que estos animalesforman el centro al. rededor del cual gira toda su vida, susafanes y sus pensamientos: Cuando suben del mar las anguilillas, toda la poblacionse anima; viejos y jóvenes observan las bandadas, disputan sobre su cantidad y trabajan para encaminarlas á determinados estanques-viveros provistos de antemano de otros pececillos para servir de abundante pasto á las anguilas. En Comacchio empiezan a aparecer estas crias el 2 de febrero, continuando las inmigraciones hasta fin de abril; entonces se cierran las entradas y todos se ocupan en distribuir conre. nientemente el agua haciéndola venir en parte del mar y en parte del Po que pasa á poca distancia. En agosto, despues de una misa solemne, cmpieza la pesca, por ser esta la época en que las anguilas de cinco s seis años quieren volver al mar, viaje que alli han de emprender reuní́ndose en determinados sitios y pasando por canales dispuestos á manera de laberinto, en donde se las pesca con la mayor facilidad. Una partida se vende en las poblaciones próximas, otra se tras. porta cocida, otra en salmuera y otra curada al humo. Las anguilas que consumen en Venecia, Roma, Nápoles y otras grandes ciudades de Italia proceden casi exclusivamente de Comacchio; y el beneficio que saca este pueblo de su pesca es considerable.

En Slesrig. Hoistein y las provincias limitrofes del Báltico se cogen ambien muchas anguilas; y en las costas del mar del Norte tambien, sobre todo en Holanda, de donde se pro. vee Inglaterra y en especial la ciudad de Lóndres. Dos socie. dades poseedoras de cinco buques construidos á propósito 
conducen en cada viaje entre 7 y 10,000 kilogramos de an. guilas vivas á Inglaterra, donde pagan solo trece chelines ingleses de derecho de arancel. Las anguilas que se consu. men en Berlin llegan tambien en su magor parte del mar del Norte.

USOS Y PRODUCTOS. - La carne de anguila figura entre la mejor de los peces de nuestras aguas dulces, por cuya razon es grande su consumo, y el precio casi en todas partes varia entre siete y medio y diez reales el kilógramo, excepto en algunos distritos muy abundantes en anguilas, dondeá pesar de esto nunca se venden á menos de cinco reales el kilógramo. En las costas de Alemania constituye la anguila, ya fresca, ya curada al humo $\delta$ juesta en conserva, un articulo de comercio muy regular que sé remite en parte a San Petersburgo y un parte \& Rumania.

CAUTIVIDAD. - Young echó en 28 de abril de I 842 cierto número de anguilas jóvenes sacadas del rio en un es. tanque bien resguardadu, donde se desarrollaron, alcanzando rápidanente un tamaño considerable; á la aproximacion del invierno desaparecieron para volver á mostrarse á la pri mavera y seguir en el segundo verano creciendo en proporcion, midiendo las que se examinaron en 2 I de octúbre de $18 .+311^{\circ}, 65$ de largo. Trevelgan tuvo anguilas en una balsa de jardin durante nueve a diez años. Tambien estas pasaban el invierno aletargadas en la lama, apareciendo solo algunos dias cuando el sol caldeaba la ntmósfera. A fines de abril empezaban a comer algunos gusanos, pero en verano eran insaciables, pues habia algunas que se comian de veinte á treinta lombrices largas de una vez, y como al principio nadie se habia acordado de darles de comer, devoraban las mas robustas á sus compañeras mas débiles. Por lo general parecian tranquilas en el fondo de la balsa, mas apenas se acercaba una persona de la casa, cuando acudian a la superficie para ver si habia algo para ellas, tomando lo que seles daba con la mano. 6 jugando con el dedo cuando se les alargaba Hácia fin de julio manifestaban cierta inquietud y buscaban el modo de escaparse, y á últimos de agosto $\delta$ principios de setiembre retirábanse para ocultarse y entorpecerse.

\section{LA ANGUILA MANCHADA-ANGUXLIA MA- CULATA}

CARACTERES.-La especie de este nombre (fig. 211) tiene la cabeza mas grande que la anterior; la mandibula inferior sobresale de la superior, como sucede en la especie comun, con la cual ofrece bastante semejanza; entre los ojos se ve una callosidad, que constituye un carácter distintivo; el número de radios de las aletas, lo misno que el de la membrana branquial, difiere igualmente. El color de esta anguila consiste en un verde mar, con un gran número de manchas negras en la parte superior del cuerpo, viéndose otra a cada lado de la cabeza. El tamaño de esta especie es muy variable, pero comunmente alcanza grandes dimensiones.

DISTRIBUCION GEOGRÁ FICA.- Habita en las mis. mas aguas, poco mas ó menos, que la especie comun, y segun dicen algunos, se le encuentra muy á menudo on el Mediterránco.

\section{LOS CONGRIOS-CONGER}

CARACTERES. - Aun cuando en general son estos peces muy semejantes á las anguilas, difieren de ellas por la dorsal larga que ocupa casi toda la arista superior del cuerpo empezando encima ó inmediatamente despues de las pecto. rales; y además por la mandibula superior prolongada sobre la inferior y la carencia de las escamas en el interior de la piel que es lisa $y$ viscosa.

\section{EL CONGRIO COMUN-CONGER VULGARIS}

CARACTERES. - El congrio (fig. 212) es pez de gran tamaño que puede alcanzar una longitud de mas de cincuenta kilógramos. El color es en la parte superior un pardo pálido liso, que en los costados se vuelve mas claro para pasar en el vientre á blanco sucio. Las aletas dorsal y anal son blanquizcas y cstán orladas de negro; la línea del costado resalta bien, gracias a su color mas claro.

Algunos naturalistas creian que el congrio cra simplemen te una anguila en su estado de mayor desarrollo en el mar, pero las diferencias que ofrecen ambos peces son tan consi. derables que solo merece mencion la opinion citada à causa de su singularidad; la forma del cuerpo, la colocacion de las aletas, la coloracion, el número de vértebras y otras particularidades en la estructura interior, separan suficientemente una especie de la otra.

Distribucion GEOGRÁFica. - Esta especie, el representanie mas conocido del género, habita las costas europeas.

USOS, COSTUMBRES Y REGIMEN.-En el mar del Norte y en el Báltico busca el congrio las orillas de roca, cuyas cavidades y grietas le sirven de escondrijo; en sitios de fondo arenoso se oculta de otro modo, hundiéndose en la arena. Es animal en extremo voraz que no perdona ni á los individuos de su propia especie si son mas debiles que el. Yarrell encontró en el cstómago de uno tres platijas y una anguila jóven de mar de un metro de largo. La fuerza de su mandibula es tanta que tritura las conchas con mucha facilidad.

Es de crer que algun congrio se introduzca en las nasas 6 canastas donde se tienen las langostas cogidas y metidas en el már interin se venden, cn cuyo caso suele pagar su atrevimiento con la vida. Al contrario de la anguila, se distinguen muy bien los dos sexos, por lo menos durante la estacion fria. El tiempo del desove cae en diciembre ó enero. Durante el verano se ven en las costas peñascosas hijuelos de un dedo de largo.

Las investigaciones recientes permiten creer que los congrios pequeños están sujetos à una trasformacion siquiera parcial, ó permanecen en un estado de desarrollo inferior; en una palabra, prevalece hoy la opinion de que los peces llamados cristalinos, con Ins cunales se habia formado una familia aparte, la de los leptocefalidos (Leproceplsalifac), no sean mas que anguilas de mar en estado de larva. Estos cristali. nos son animales pequeños, perfectamente trasparentes, cla. ros como el agua, con huesos apenas desarrollados y faltos todavia de costillas; la forma que mas comunmente se ve es la llamada angaila cristalina (Leplocephalus Morrisii), la misma que Gill y Günther creen ser la larva del congrio; tiene cuerpo lateralmente muy comprimido á manera de cinta y ahusado en ambos extremos, con aleta dorsal y abdominal insertas muy atrás, y que se confunden con la anal, y una hilera de dientes en las mandibulas superior e inferior. De la coloracion es excusado hablar, puesto que el animal parece formado de agua, siendo su trasparencia tal que puesto sobre un papel impreso ó escrito se lee perfectamente al través del cuerpo, segun dice Bennett. Miden como $0^{\circ}$, ro de largo. La estructura interior es muy caracteristica, atendido que los intestinos forman un canal angosto y recto que se extiende desde la cabeza hasta el vientre sin ensancharse en ningun punto. Para observar el tubo digestivo basta colocar el animal sobre una placa de vidrio y mirarlo al trasluz 
Pennant recibió la primera anguila cristalina del distrito de Holyhead; posteriomente se fueron cogiendo en el espacio de pocos años hasta veinte individuos en diferentes sitios de las costas inglesas. Uno de estos animales dió muestras de gran vitalidad; puesto que para remitirlo a un natura. lista se le envolvió en papel, recibiéndolo el interesado á las tres horas todavia vivo, y puesto en agua salada se rehizo para vivir unas cuantas horas mas. Dicen que sus movimientos eran muy graciosos. Bennett, que cogí́ pececillos de estos en alta mar, los colocó en vasijas con agua de mar, y compara sus movimientos y su destreza con los de las anguilas. Ademis de la especie de leptocefálidos citada, los naturalistas distinguen otras, entre ellas el triquiuro, el de $M$ Mesi na y el tenia (figs. 213,214 y 215 ).

PESCA Y PRODUCTOS.-No tiene gran estima la carne de congrio, pero se pesca con mucha actividad porque las clases menos acomodadas la consumen en gran cantidad por ser barata. Antes se secaban al aire en las costas de Inglaterra y se exportaban á Francia y Espara; en algunos puntos se reducian á una especie de polvo que se empleaba en guisados y sopas.

En las costas de Cornualles se pescan con preferencia con sedales de mano $\delta$ de volantin cebados con sardinas; mien. tras que los pescadores franceses prefieren los amonites. Cuanto mas oscura es la noche mas congrios se pescan. Couch asegura que á veces cogen dos hombres en una sola noche hasta 2,000 kilógramos de estos peces. En las Orcadas los pesca á veces la nutria, que en aquellas islas caza tambien en el mar para aquellos miseros habitantes, porque de los congrios que coge y lleva á su madriguera en tierra, solo devora una pequeña parte, abandorando el resto å aque llos que conocen su retiro y quieren ir a buscarlo.

CAUTIVIDAD. - Los congrios se acostumbran pronto a vivir hasta en un acuario reducido, donde eligen un escon. drijo á su gusto, y se ocultan aunque sea debajo de una tortuga viva, pasando el dia en la mayor indolencia; pero de noche no paran. Gracias a su insaciable voracidad reconocen pronto la persona que los cuida, y aun abandonan de dia su retiro al verla para tomar de su mano la racion. Crecen rápi damente cuando se les alimenta bien.

\section{LA MORENA GRIEGA-MURAENA HELENA}

CARACTERES.-Difiere esta especie (fig. 216), que representa el género, de sus afines por la carencia de las aletas pectorales; pero tiene aleta dorsal, anal y caudal. En cada costado de la cabeza existe una abertura branquial muy pequeña; una hilera de dientes largos y puntiagudos guarnece. las mandibulas superior $\varepsilon$ inferior; la piel es desnuda, y el color de la parte anterior un amarillo hermoso y subido, pasando hácia atrás á pardusco, veteado todo de manchas pardas separadas una de otra por orlas ó fajas oscuras. La longitud puede llegar hasta cerca de metro y medio, y el peso á seis kilógramos.

DISTRIBUCION GEOGRÁfrCA.- Habita el Mediterráneo y en menor número el mediodia del Atlántico, ex. tendiéndose a veces hasta las costas británicas, conforme sucedio en octubre de 1834 .

- USOS, COSTUMBRES Y REGIMEN. - I M motena habita el fondo de los sitios profundos, y se acerca en pri. mavera s. la costa para efectuar el desove. Cangrejos y liebres de mar (aplisias) constituyen su alimento preferido, pero son tan voraces que á falta de otra cosa devora una la cola de la otra. Cuando se ven cogidas, resisten con furia desusada y causan heridas peligrosas al pescador torpe.

Entre los romanos antiguos gozaba la carne de morena de gran fama, y para tenerlas á mano en sus orgias gastronómicas cercaban estanques y lagunas donde las criaban en grandísimo número. Plinio dice que Hirio fué el primero que estableció uno de estos viveros tan poblado que pudo pre. sentar en el banquete que dió á sus amigos con motivo de la entrada triunfal de César, seis mil de estos peces. Gessner cuenta: \$icese de Craso, patricio romano, que tenia en un estanque una morena muy hermosa y grande, á la cual que. ria tanto que la tenia adornada con joyas de oro. Esta morena reconocia \&s su amo por la voz, acudia á la orilla cuando la llamaba, y tomaba la comida de su mano; cuando murió, su amo la enterró, la lloró y llevó luto por ella Otro caso se cuenta que á ser verdad probaria hasta qué horribles ex. cesos pudo llevar á algunos romanos la aficion á este pez. Dicen que cuando Vidio Polion tuvo noticia de que las morenas se cebaban mejor con carne humana, les arrojó los esclavos que cometian alguna falta. Lo cierto es que los antiguos conocian este pez como ningun otro, ájuzgar por lo que se contaba de sus costumbres y género de vida. Haciendo caso omiso de aquello de «su cruzamiento singular con serpientes terrestres y viboras de que hablan no solamente los gentiles, sino tambien algunos célebres teólogos y comenta. ristas de la Sagrada Escritura por haoerlo oido de gente del pueblo, se referian otras noticias sobre enemistades y luchas de las morenas, segun nos dice Gessner que ha compilado concienzudamente todos los datos existentes en su tiempo, como por ejemplo:

Las morenas viven en los huecos de las peñas y rocas donde encuentran conchas pequeñas, porque son animales carniceros, y tienen particular aficion ś la jibia. Tan à su gusto viven en agua salada como en la dulce, pero no remontan rios; pueden vivir mucho tiempo fuera del agua como las anguilas gracias á sus reducidas agallas. Desovan durante todo el año sin tener época fija como la mayor parte de los peces. Sus huevas son pequeñas, muchas en número y crecen rápidamente. Pasan el invierno ocultas en agujeros, por lo cual rara vez se las coge. Digno de nota es que estos peces tienen su centro vital en la cola, porque cuando se les golpea esta, mueren en seguida, pero si se les pega en la cabeza cuesta trabajo matarlos. Cuando se les da vinagre se ponen furiosos, embisten, luchan $y$ hieren con sus dientes que son de dos clases. Odian a los congrios y les arrancan la cola cuando pueden llcgar á cllos; existe tambien una grandisima enemistad entre la jibia, la langosta y la morena. No le vale á la jibia su cualidad de cambiar de color y tomar el de la roca á la cual está pegada, porque la morena la conoce, al verla nadar se precipita sobre ella, la muerde y la obliga á luchar, hasta que le ha cortado y devorado los brazos y hecho pedazos su cuerpo. En cambio la persigue y excita la langosta metiendo sus tentáculos en los agujeros donde se halla retira. da la morena que no tarda en salir furiosa y atacar á su cnemiga, la cual no la teme protegida como está por su caparazon cubierto de afiladas espinas, sino que la coge con sus tenazas y no la sueita, hasta que la morena retorciendose en todos sentidos se hiere ella misma en las púas y muere.

PESCA. - Se la pesca con sedal y buitron. Cuando la mo. rena ha mordido el cebo y siente que la tiran por el anzuelo, opone toda la resistencia posible y se agarra hasta con la cola a cuerpos extraños. Hoy como antes tiene su carne fama de sabrosa. 


\section{SEXTO ÓRDEN}

\section{PLECTOGNATOS - PLECTOGNATHI}

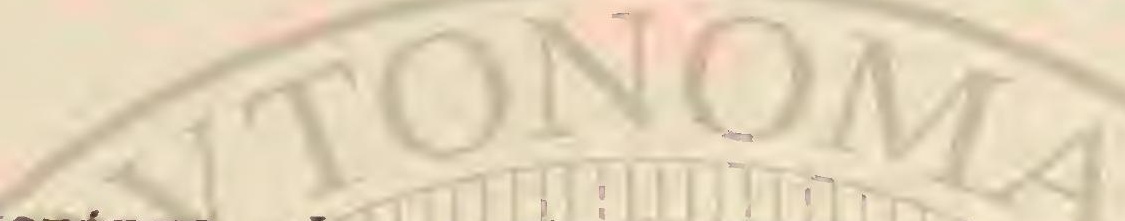

CARACTÉRES. - Los que quieran profundizar la sa. biduría divina desde su punto de vista utilitario humano en las criaturas animadas, se ven confundidos y perdidos al contemplar los peces plectognatos. Asi dice Giebel, y tiene razon. De nada sirven al hombre estos séres singulares; su carne tiene un sabor pésimo, sin contar con que, segun al gunos, es hasta venenosa en cierta estacion. En la economia general de la naturaleza desempeñan igualmente un papel harto inferior, pues ni destruyen cantidades notables de ani. males demasiado reproductivos, ni son alimento de importancia para otros; sus costumbres son tan singulares como su figura Son peces extraños que solo por lo raros llaman nuestra atencion.

Las particularidades que presentan los plectognatos en su configuracion $y$ modo de ser son tan chocantes que Cuvier se vió obligado á formar con estos peces un órden especial, cuyo carácter principal respecto á estructura interior consiste en la boca pequeña con los huesos de la mandibula superior soldados definitivamente entre sí. Verdad es que todos los de este órden tienen dicha estructura, y que se observa una cosa análoga en algunos peces de otros órdenes, pero como los plectognatos tienen al propio tiempo una cubierta dis tinta de la de todos los demás peces, es fácil distinguirlos. Algunas especies tienen la piel completamente desnuda y lisa otras la tienen cubierta de escudetes romboidales ó espinosos que contribuyen en gran manera á la impresion extraña que producen estos peces. Los opérculos están debajo de la piel, con una rendija angosta delante de las aletas pectorales por única abertura. I.a dentadura corresponde $a$ las demás particularidades raras, puesto que en algunas especies guarnecen las mandibulas dientes muy fuertes, $y$ en otras forma cada mandibula como un diente único, estando cubiertas directamente de esmalte. Las aletas tambien son diferentes de las de otros peces; las verticales existen siempre; tambien se presentan desarrolladas la caudal y las pectorales; pero las abdominales suelen faltar. Examinando la estructura interior se descubre que las costillas existen en estado rudimentario; los huesos tardan mucho en endurecerse; el canal digestivo no tiene ciegos; el estómago suele ir precedido de un buche dilatable, la vejiga natatoria es voluminosa y existe casi siempre, etc.

DISTRIBUCION GEOGRÁFICA. - Todos los plec. tognatos pertenceen á los climas cálidos, siendo muy raros los individuos aislados que á veces recorren las aguas de las zonas mas templadas. Habitan cl mar, peroalgunas especies suelen subir por los rios, siendo mus probable que pasen la mayor parte de su vida en esas aguas.

USOS, COSTUMBRES Y REGIMEN. - IA extraĩa configuracion de estos peces hace que sus movimientos en el agua sean tambien muy distintos de los habituales de su clase. Consiste, por lo comun, su nutricion en pequeiros crustáceos y moluscos, como tambien en plantas marinas, habiendo algunas especies que en ciertas épocas suelen alimentarse, mas $\delta$ menos exclusivamente, de madréporas;-ad-

quiere entonces su carne, sin duda á causa de este pasto, propiedades venenosas. A pesar de las descripciones bas. tante detalladas que se tienen de algunas especies, poco sabemos respecto á la reproduccion $y$ otras funciones, con referencia alórden en su conjunto.

\section{LOS GIMNODONTES -GYMNODONTES}

CARACTERES. - En esta familia, que cuenta mas de noventa especies, aparecen reunidos aquellos peces que tienen revestidas las mandibulas de una sustancia como marfil, compuesta de varins láminas, cuso conjunto repreeste, se va renovando el pico de un papagayo, que, como en me, va renovando á medida que se gasta por la continua masticacion. Tienen membranas branquiales, con cinco ra. dios apenas visibles; á excepcion de un solo género, poseen todos los gimnociontes una vejiga natatoria de tamaño extraordinario; muchos pueden inflarse como globos, aspi. rando al aire atmosférico, con el que llenan su csólago, de piel blanda y elástica, hasta el punto de tomar una forma casi completamente esferica; de este modo se defienden de sus enemigos, volviendo la parte abdominal hácia arriba, y presentándoles un cuerpo erizado de espinas $y$ aristas por todos lados. Antiguamente atribuíase á estos plectognatos un aparato respiratorio especial; pero la verdad es que no hincharse, manera alguna del de otros peces: cuando quieren 6 pharse, tragan el aire y lo llevan hácia el inmenso buche 6 papera, formado por ténues tejidos celulares, que ocupa toda la cavidad abdominal. Una espesa capa muscular rodea las fauces, sirviendo para impedir la salida del aire aspirado.

\section{EL PEZ ERIZO Ó DIODON-DIODON} HYSTRIX

CARACTERES. - La longitud de este pez, represen tante de la especie, llega á $\left(1^{\circ}, 35\right.$. El color es pardo de orin con manchas pardas. La aleta dorsal cuenta catorce radios, cada pectoral veintiuno, la anal diez y siete $y$ la cau. dal diez. Las espinas redondas tienen tres raices sobrepues. tas a manera de escamas, siendo una de ellas la continuacion de la misma espina, $y$ su longitud llega hasta ()$^{m}, 05$. La mandibula en forma de pico no presenta el surco medio $y$ divisorio al igual de otras especies de este género.

USOS, COSTUMBRES Y RÉGIMEN.-Hé aquí lo que refiere Darwin respecto ś este particular. "Un dia me divirtió mucho un pez erizo cogido cerca de la orilla. Es sabido q̨ue estos animales pueden dilatarse hasta tomar una forma esférica. Despues de haberle tenido un corro rato fuera del agua, al volverle á ella absorbió una cantidad considerable de líquido y aire por la boca y quuizás tambien por las aberturas branquiales. Esta operacion se realiza del nodo 
siguiente: El pez traga el aire y lo empuja dentro de la cavidad abdominal donde queda retenido ś merced $a$ una contraccion muscular visible por fuera, mientras que el agua penetra sin cesar en la boca abierta é inmóvil, lo que hace suponer que el animal la absorbe chupando. La piel del vientre es mucho mas fofa que la del dorso, y por esto se dilata mas la parte inferior que la superior cuando el pez se hincha, nadando como siempre de espalda, y aunque $\mathrm{Cu}$. vier lo pone en duda, es sin embargo así.

\$os diodones no avanzan solamente en línea recta, sino que pueden girar à ambos lados, para lo cual se valen exclu. sivamente de sus aletas pectorales, sin que la cola contribuya para nada á estos movimientos. Luego que el citado pez se hubo lleaado suficientemente de aire, salieron las aberturas branquiales fuera del agua, y siempre que la to- maba por la boca rolvia a salir por aquellas. Cuando habia permanecido suficiente tiempo inflado, solia expulsar aire y agua por las agallas y la boca con notable fuerza. Podia sol. tar 2 voluntad una parte del agua, lo que hace pensar que la debe absorber en gran parte para equilibrar su peso.

- Este erizo tiene diferentes medios de defensa; podia pegar fuertes mordiscos y arrojar agua por la boca hasta cierta distancia, produciendo al mismo tiempo un ruido singular con sus mandibulas. Mientras se hinchaba se ponian tiesas y puntiagudas las verruguitas que cubren su piel, siendo lo mas extraño que cuando se le tenia en la mano segregaba una materia fibrosa de un liermosísimo carmin que teñia el mar. fil $y$ el papel de un modo permanente, y cuja utilidad y naturaleza no he comprendido nunca.

UTILIDAD Y PESCA.-Du Tertre cuenta que en las

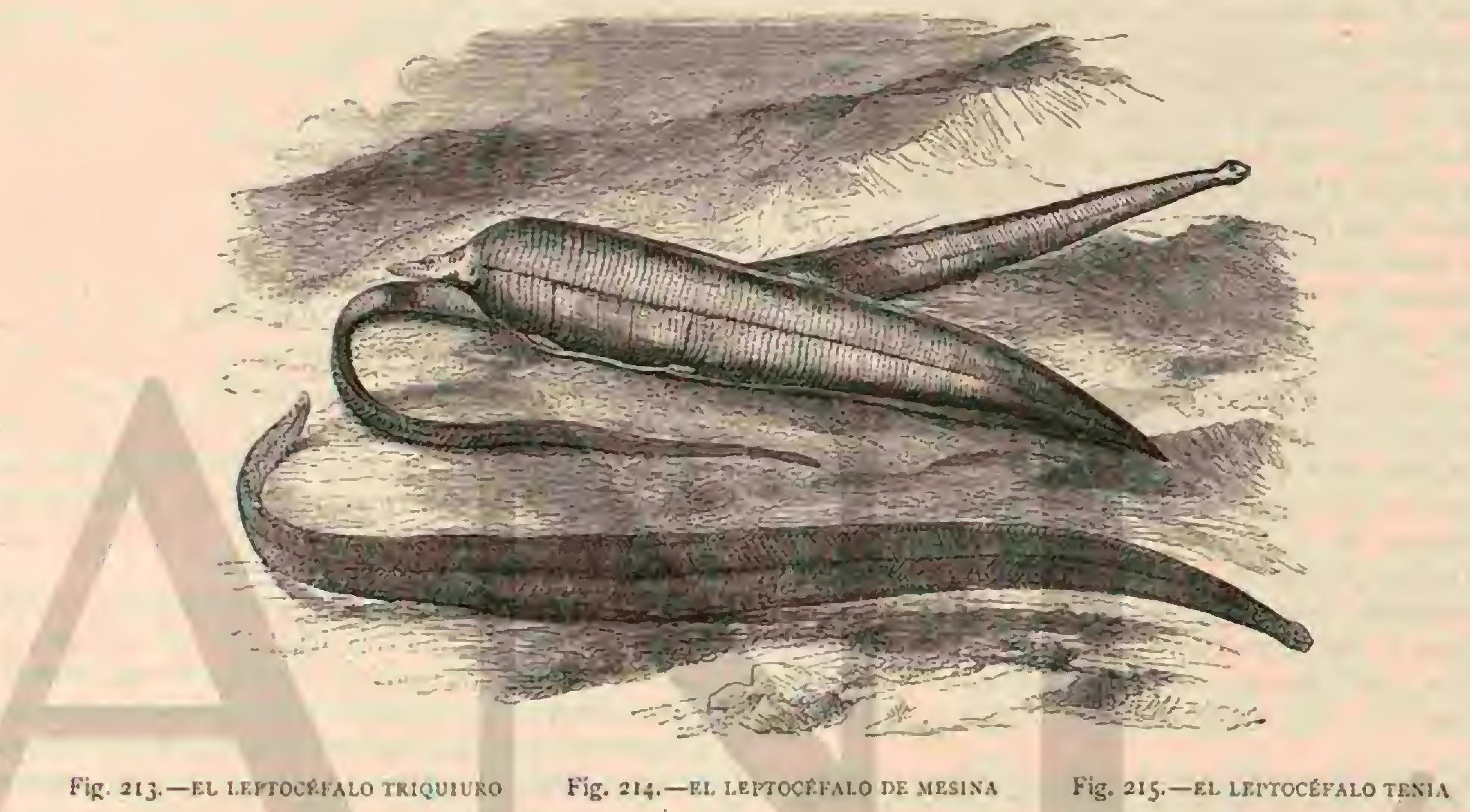

Antillas cogen este per para divertirse, puesto que su carne no se come; á este efecto ceban el anzuelo con una cola de cangrejo. El sedal causa miedo al crizo, que da vueltas alrededor del cebo mucho rato hasta que se determina con gran cautela á probar la cola; si la caña y el sedal no se mueven, se anima, se precipita sobre el cebo y lo traga. Apenas conoce que le han cogido se infla, da volteretas, eriza las puras, y poniéndose furioso como un pavo, procura herir todo lo que encuentra á su alcance. Cuando se persuade de que con esto nada logra, adopta otro método; entonces arroja aire y agua $y$ dobla las espinas que se ponen lacias, regular. mente para dejarse ir a fondo, mas como luego se convence de la inutilidad de la estratagema, vuelve s hincharse $y$ á enderezar sus espinas. Este espectáculo dura mucho tiempo con gran diversion de los espectadores que, cuando se han recreado bastante martirizando al animal, lo tiran al suelo, donde sigue defendiéndose con valor y se eriza de modo que no puede cogersele, hasta que al cabo de algunas horas se cansay muere.

\section{LOS TAMBORES-TETRODON}

CARACTERES. En las especies de este género se hallan divididas las mandibulas en el centro por un surco ó sutura longitudinal, lo que hace que cada mandibula parezca doble y produce al propio tiempo doble número de dien tes, es decir cuatro en lugar de dos. El cuerpo está cubierto de pequeñas espinas. En algunas especies remata la nariz en una verruga alta y esférica.

\section{EL TAMBOR RAYADO-TETRODON II- NEATUS}

CARACTÉRES.-Fs la especie de tambor mas conocida (fig. 217 ), llamada fahoh por los árabes: tiene unos $6^{m}, 25$ de largo, la cabeza voluminosa y de frente ancha, ojos colo. cados muy arriba con una protuberancia delante, dos barbillas y el vientre guarnecido de espinas delgadas 5 afiladas, estando el resto del cuerpo casi desnudo y viscoso. Los colores son hermosos y vivos como en los demás afines suyos; el dorso es azul negruzco, los costados presentan listas de un amarillo subido, el vientre es amarillento, la garganta blanquisima y la aleta caudal de un vivo amarillo. En la dorsal se cuentan once radios, en cada pectoral diez y ocho, en la anal nueve 6 diez, y en la caudal nueve.

DISTRIBUCION GEOGRÁFICA.-El tambor rayado sube á veces desde el Mediterránco al Nilo, y entonces suele vérsele con frecuencia, pero raras veces se le coge. Hasselquist fué el primero que hablo de él; y mas tarde le observó Geof. froy durante la inundacion de aquel rio, creyendo que ba. jaba de la cuenca superior y se extraviaba, \& causa de la crecida, por las ramificaciones artificiales de aquel rio, don: 
de se le veia á menudo en gran número metidó en el fango y la arena. TTodos, dice Groffroy, se alegran cuando llegan los \{ahakes; los muchachos juegan con ellos como los nuestros con cscarabajos ó grillos, los hacen flotar inflados sobre el agua; los secan, por supuesto llenos de aire, á manera de vejigas, y se sirven despues de ellos en lugar de pelotas.» Hoy ya no sucede asi, porqque este pez es uno de los objetos que los viajeros, cada año mas numerosos, compran para lievarlos á su pais como recuerdo de la tierra de los Faraones.

USOS, COSTUMBRES Y REGIMEN. - Rajo este concepto parécense los tambores muchísimo á los diodones ó erizos. En la profundidad nadan como otros peces, aunque con cierta torpeza; pero al menor peligro suben $\{1$ la superficie para aspirar aire é hincharse, hasta trasformar su cuerpo, antes lleno de arrugas, en pelota de piel lisa, pero erizada en toda su superficie de espinas; asi se van flotando de espáldas, puesto que en este estado no pueden naçar, pero se salian de los rapaces qque no pueden ni tragarse una pelota tan roluminosa, ni hincarle el diente á causa de sus muchas púas; y que despues de hacerlos rodar un rato para ver si por algun lado los pueden coger mejor, los abandonan cuando se han convencido de lo infructuoso de sus esfuerzos.

Al coger uno de estos peces se observa cómo el animal trabaja para aspirar á toda prisa mas aire del que ya tiene, prueba evidente de que reconoce en esto un medio de de fensa. Cuando cree que el peligro ha pasado, deja escapar una parte del aire que al salir produce una especie de silbi. do; despues arroja el resto, adquiere otra vez la forma de pez regular, y se pone á nadar sirviendose de sus aletas. Además de este medio singular de defensa, sirvese el tam. bor tambien de sus dientes con tanta cnergia que parte fu. rioso todo lo que puede coger. Tiene mucha vitalidad y puede pasar bastante tiempo fuera del agua.

USOS Y PRODUCTOS.-Ta gente mas pobre del valle del Nilo come este pez: pero sus huevas tienen fama de ve. nenosas.

\section{LOS ORTAGORISCOS -ORTHAGO- RISCUS}

CARACTERES. - Distinguense las especies hasta ahora conocidas de este género, por su cuerpo extraordinariamente corto y recogido; aletas dorsal y anal muy altas, puntiagudas y unidas a la caudal, que es corta, ancha y fuera de toda proporcion con las pectorales, las cuales son pequenas y re. dondas. La dentadura es semejante á la de los diodones, atendido que los ortagoriscos carecen tambien del surco divisor en el esmalte que reviste la mandibula. Respecto á la estructura interior hay que notar la pequeñez dél cstómago unido inmediatamente al esófago, faltando de consiguiente el buche y con él la facultad de hincharse. Tampoco tie. nen vejiga natatoria, $\mathrm{s}$ el bulbo arterial, dotado de robustos músculos, tiene cerca del corazon cuatro válvulas lunadas.

\section{EL PEZ LUNA-ORTHAGORISCUS MOLA}

CARACTÉRES. - Este animal monstruoso (fig: 218) se llama en casi todos los idiomas pez luna 6 sol, luna ó sol marino, mola, cabeza flotante, etc, nombres todos que involuntariamente se le ocurren á cualquiera que sea este pez por primera vez El cuerpo es corto, ovalado, y casi circular cuando jóven, la piel gruesa y áspera, la coloracion consiste por lo comun en un pardo agrisado sucio, algo mas claro hácia el vientre. En la aleta dorsal hay quince radios, en la pectoral once, en la anal quince, y en la caudal trece. El tamaño es mayor que en sus afines, habiéndose encontrado individuos de $1^{\prime \prime}, 70$ de largo con un peso de mas de $200 \mathrm{ki}$ lógramos.

DISTRIBUGION GEOGRÁFICA.-El pe: luna vive en todos los mares de las zonas tórrida y templadas, pero donde mas se le ha observado ha sido en el Mediterráneo, á pesar de que los antiguos no tenian segun parece noticia de él.

USOS, COSTUMBRESY REGIMEN. - El primer autor que menciona este pez es Salvani, y Gessner le describe ya con mucha exactitud, añadiendo algunos detalles que, á pe. sar de parecer increibles, no han sido hasta hoy contradichos por nadie. Dicen que gruñe en el agua como un cerdo cuando le cogen; de noche brillan ciertas partes de su cuerpo como el fuego ó cualquiera otra llama, de suerte que á veces las personas que le han visto han recibido un susto de consideracion. Otros naturalistas hablan tambien de este fenómeno, mientras que nada de esto mencionan los observadores mas modernos. Lo poco que sabemos sobre el género de vida de este pez; lo debemos á los ingleses que le han observado de cuando en cuando en sus aguas. Yarrell dice: \&Los marineros del canal le, ven con bastante frecuencia cuando hace buen tiempo, durmiendo al parecer en la superficie, es decir, echado de lado y flotando á merced de las olas, de suerte que muchos que no le conocen, le toman por un per muerto. Couch opina gue el pez luna hace grandes correrias, que por lo regular debe estar en la profundidad cerca del fondo, en. tre plantas acuáticas que son su aliniento, y que solo stibe à la superficie en tiempo de bonanza para dormir alli la siesta. Si entonces se le aproxima álguien con cuidado, puédesele coger y sacar del agua sin ninguna dificultad, porque por lo regular hace pocos esfuerzos para escaparse, si bien puede suceder lo contrario. Hé aqui todo lo que hasta hoy se sabe acerca del pez luna.

ÚSOS Y PRODUCTOS. - La came de este pez, cuando cocida, no es ras que pura cola, igual a la que se fabrica de pieles, dice Gessner, 6 como la de las jibias saladas, tiene un olor nauseabundo, por cuya razon nadie la come. Su grasa es muy abundante y se la utiliza para el alumbrado, pero despide hedor de pescado. Dicese que en algunos puntos se usa la carne cocida en lugar de cola, pues adquiere el aspecto de engrudo por la coccion. Tambien se dice que el higado cocido en vino es un plato finísimo.

\section{LOS OSTRACIÓNIDOS- OSTRACIONID压}

CARACTERES. - Los ostraciónidos ó cofres, que solo figuraban en la clasificacion de Cuvier como un género de la familia anterior, son considerados justamente por Miiller como un grupo distinto, pues discrepan en gran manera de todos los demás peces que van descritos. Su cuerpo, angulo. so é informe, se halla protegido, en vez de escamas, por una coraza compuesta de placas óseas, de forma regular $y$ exago. nal, y que solo permite el movimiento á las aletas, ì la cola y á los labios; aquellas se proyectan por aberturas á través de la coraza, de modo que aparecen como piezas insertas en la misma. Fuertes aristas cónicas, que contribuyen á aumentar el extraño aspecto de séres tan especiales, suelen presentarse en algunos de estos, dispuestos simétricamente por pares. la boca, de tamaño muy reducido, se encuentra en la extremidad del hocico, las mandíbulas están armadas de diez, y á veces de doce dientes cónicos; el borde de las agallas aparece tan solo guarnecido por una especie de pequeño labio cu. táneo, debajo del cual está el opérculo y seis radios bran. quiales. La lengua es corta é inmovil, y el estómago fuerte y 
voluminoso. Delante de los ojos, que son grandes, bien for mados y colocados en lo alto de la cabeza, se ven á menudo un par de las aristas que hemos indicado, y que manifiestamente sirven de poderoso escudo á órganos tan importantes.

\section{EL OSTRACYON CORNUDO-OSTRACYON QUADRICORNIS}

CARACTERES. - Este pez (fig. 219), representante del único género $y$ de las veinte especies que aproximadamente constituyen la familia, presenta dos aguijones delante de los ojos, y otros dos que parecen reemiplazar álas aletas abdominales en la parte posterior del vientre. Alcanza una longitud de $0^{\circ}, 30$ a $0^{\circ}, 35$; el cuerpo afecta la forma de triángulo y estí cubierto de una coraza compuesta de escudos ásperos exagonales y guarnecidos de perlitas; las aletas son redondeadas y pequeñas, mientras que la cola es robusta y larga como principal aparato motor del pez, puesto que las demás aletas poco pueden contribuir al movimiento. En la mandibula superior cuéntanse catorce dientes, en la inferior doce. La coloracion principal es un hermoso pardo rojizo con man. chas mas oscuras, oblongas y de forma indeterminada. La

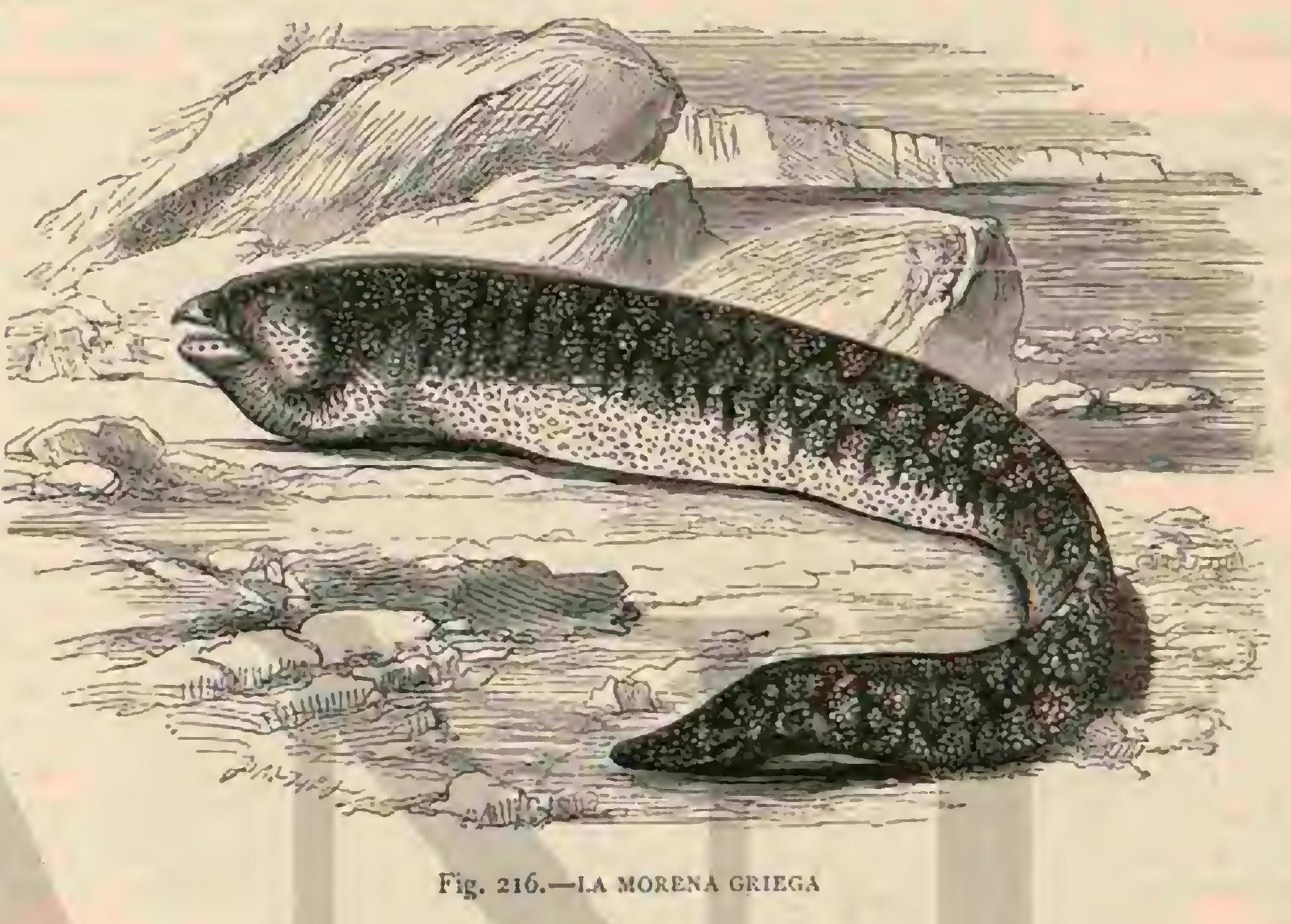

cola ofrece un tinte que tira mas á amarillento y sus man. chas son mas redondeadas; las aletas son amarillentas. El número de radios es de siete ú ocho en la dorsal; de once 6 doce en cada torácica; de diez en la anal y en la caudal.

DISTRIBUCION GEOGRÁ FICA. - Habita como todos los peces de esta familia los mares intertropicales.

USOS, COSTUMBRES Y REGIMEN.-Casi nada se sabe sobre el género de vida de estos peces, sino que viven entre arrecifes 6 en bajios pedregosos; nadan tan mal que se dejan coger con la mano, suben poco álas capas superiores y mueren tan luego como se les saca del agua. Mantienense de crustáceos y de moluscos. De una especie que vive en el mar Rojo dicen los pescadores que le gusta comer el algodion con que alli calafatean los buques.

ÚSOS Y PRODUCTOS.-Algunas especies se cogen, ya para aprovechar su hígado grasiento, ya por su carne que, segun dicen, es sabrosa, mientras que la de otras tiene fama de venenosa. Antes se recogian y vendian como objetos raros las corazas sólidas é indestructibles de estos peces.

\section{LOS ESCLERODERMOS - SCLERODERMI}

CARACTERES.-Esta familia, la mas numerosa del ór den de los plectognatos, pues comprende unas cien especies, se caracteriza por su cubierta consistente en escamas duras, y por las espinas robustas que muchas especies tienen en la aleta dorsal. En todo lo demás parécense mucho sus indivi. duos á los anteriormente descritos.

\section{LAS BALLESTAS - BALISTES}

CARACTERES, - Consisten estos en la cubierta formada de escamas grandes $y$ duras; en la dentadura compuesta

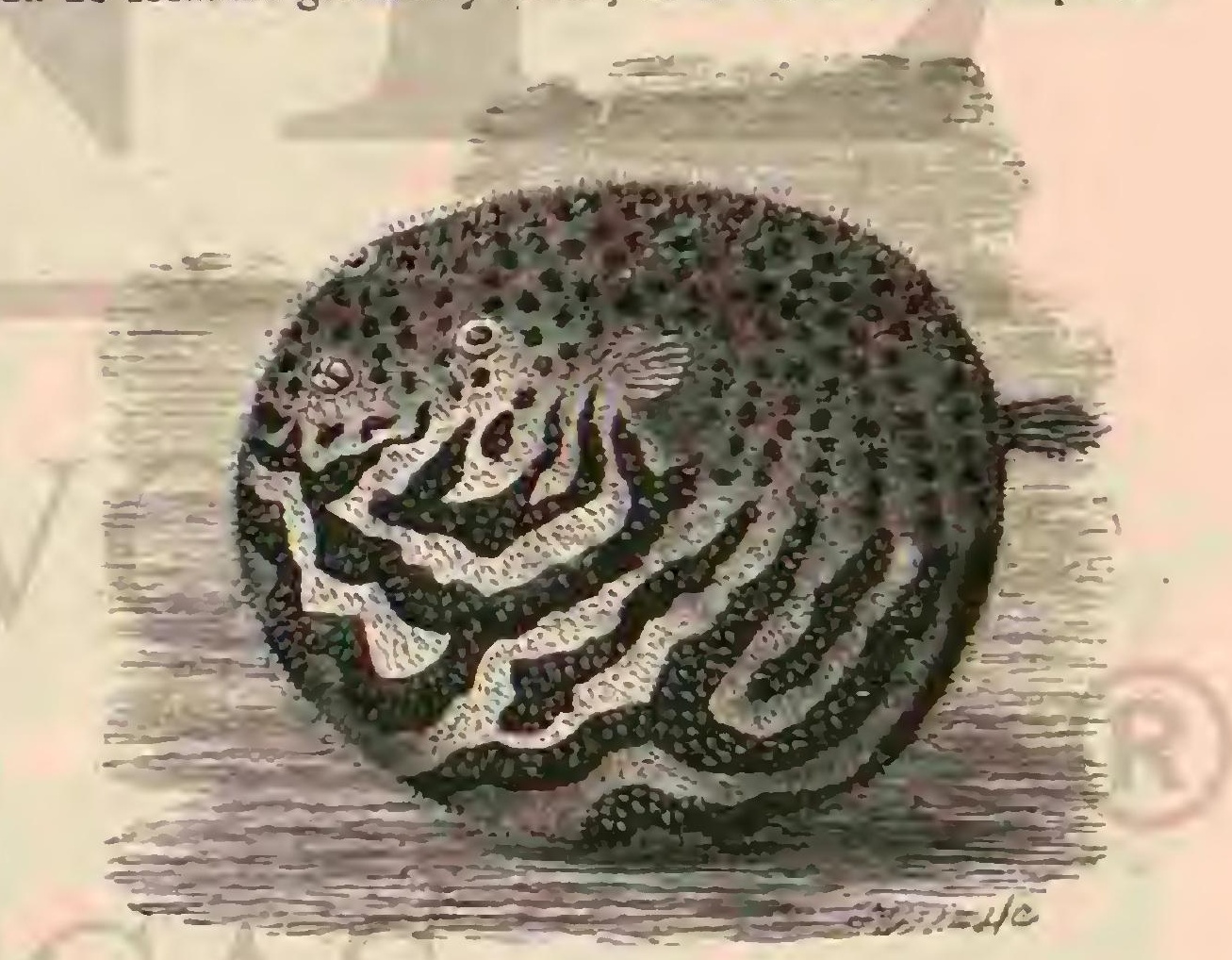

Fig. 217.-EL TSMHOR RAISDO

de ocho dientes en la mandibula superior y otros tantos en la inferior; en tres radios espinosos que se encuentran en la primera aleta dorsal; despues en la prominencia que forma en el vientre el extremo áspero del hueso de la cadera, detrás del cual suele haber por lo comun algunos radios, y finalmente, en una segunda aleta dorsal blanda y larga, inserta sobre la anal, que es de forma análoga. 


\section{EL PEZ BALLESTA-BALISTES CAPRISCUS}

CARACTERES. - El color es azul y a trechos algo roji20 á manera de manchas poco marcadas, que despues de muerto el animal pasa á un tinte pardo pálido liso. El dorso es mas oscuro que los costados y el vientre. Sostienen la ale. ta dursal de veintitres á veintiocho radios; cada pectoral quince; la anal veintiseis y catorce la caudal. La longitud llega â $0^{\circ}, 30$ hasta $1^{\circ}, 4^{\circ}$.

DISTRIBUGION GEOGRÁFICA.-Extiéndese estaespecie por el Mediterráneo y parte del Atlántico liasta las costas inglesas, si bien es rara en ellas.

\section{EL COCHINO-BALISTES VETULA}

CARACTERES. - Esta especie (fig. 220) carece de espinas en la cola, y se caracteriza además por lá forma corva de las aletas dorsal y anal. El tamaño es à poca diferencia cl mismo de la anterior y la coloracion un pardo amarillento con listas azules en la parte superior, en la cola $y$ las costi. Ilas. Sostienen la dorsal tres y veintiocho radios, cada toráci$\mathrm{ca}$ catorce, la anal veinticinco y la caudal, profundamente escotada, doce.

DisTRIBUCION GEOGRÁEICA.-Habita el Océano Indico.

\section{LA BALLESTA CHINA-BALISTES CHINENSIS}

CARACTÉRES. - La primera aleta dorsal de este pez se reduce á un radio muy largo y fuerte, guarnecido en su parte posterior de dos lineas de dientes pequeños, pudiéndolo ocultar el pez a su antojo en una foseta que existe entre las dos aletas del dorso. La linea lateral comienza detrás de los ojos, inclinase despues hácia abajo, y se pierde casi en medio de cuatro series de aguijones que crizan los lados de la cola; la aleta que termina esta última parte es redon. deada; la ventral presenta trece radios, encerrados, por de. cirlo así, en una espesa piel, excepto el primero. La ballesta china es de color gris en las regiones superiores, blanquizco en las inferiores; cubierto, por lo comun, el fondo de unas manchitas de color de oro (fig. $22 \mathrm{I}$ ).

DISTRIBUCION GEOGRÁFICA, -..Esta especie existe en el mar que baña las costas de la China; habita igualmen. te en las aguas del Brasil.

USOS Y PROVECHO.-Todas las ballestas tienen entre los habitantes y marinos de aquellas aguas malisima fama por los accidentes graves que ocasiona el uso de su carne. Se supone que el animal adquiere cualidades venenosas del coral-esponja de que se alimenta algunas reces, y principalmente cuando, segun dicen en aquellas costas, el coral está en flor, es decir, cuando las ballestas comen con preferencia estos pólipos diminutos, mientras que su carne es inofensiva, aunque desabrida, cuando se alimentan de algas. Se sabe que muchos animales análogos al pólipo dcl coral causan en la piel, y muchisimo mas en las mucosas, un escozor dolorosisimo, cualidad que, segun parece, comunican á la carne de los peces que los comen. Se cree que los perros y gatos pue. den comer carne de ballesta en cualquiera época del año sin inconveniente alguno, pero en el hombre produce su uso terribles accidentes, que empiezan por un agudísimo dolor de vientre seguido de contraccion convulsiva en todos los miembros, la lengua se hincha, la mirada se pone fija, la res. piracion es fatigosa, los músculos de la cara se contraen, $y$, segun dice el doctor Munier, el enfermo muere irremisible. mente si no acude á tiempo el médico; pues cuando ya ha jenetrado una parte de este alimento fatal en el canal diges. tivo, se presentan los síntomas mas graves. El remedio mas eficaz son los vomitivos aceitosos, capaces de envolver y de hacer expeler lo que el enfermo ha comido, y aplicados a tiempo dura la enfermedad unos ocho dias, pero los dolores en las articulaciones y las recaidas no desaparecen sino al cabo de mucho tiempo.

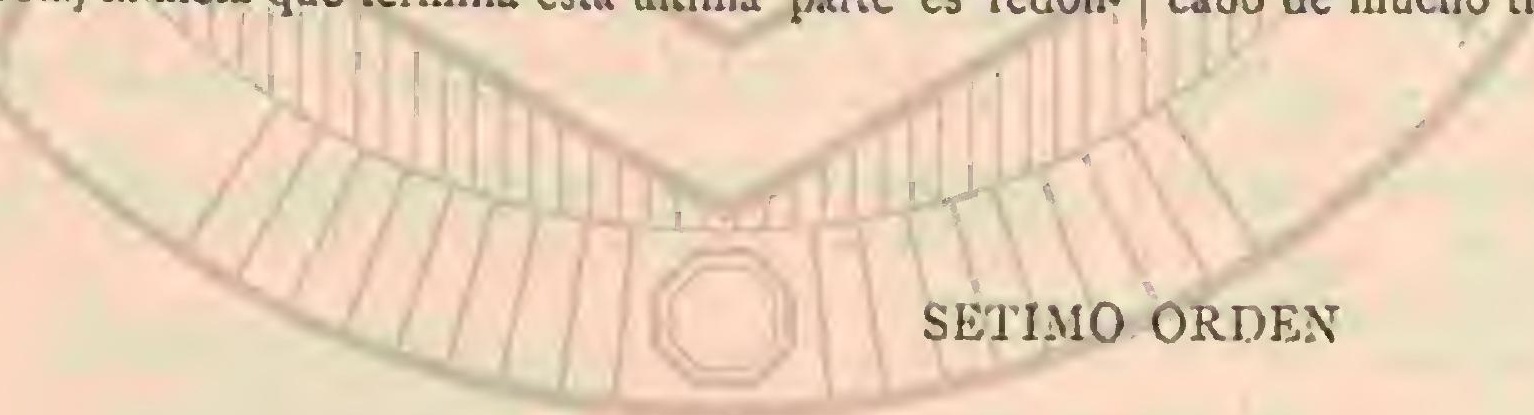

\section{LOFOBRANQUIOS - LOPHOBRANCHII}

CARACTERES. - Respecto á los pocos peces que for. man este órden, puede repetirse casi lo mismo que se dijo de los plectognatos. Son, como estos últimos, animales de aspecto singular, de ninguna utilidad para la economía hu. mana, $s$, al parecer, sin objeto alguno en la naturaleza.

Liámanse lofobranquios porque sus branquias, en vez de hallarse dispuesias en láninas ó dientes de peine, se presentan á modo de borlitlas colocadas por pares á lo largo de los arcos branquiales. Son además distintivos no menos importantes de este órden: el hocico prolongado en forma tubular; la movilidad de los huesos de la mandibula supe: rior; el operculo adherido casi en toda su extension por una membrana que solo deja abierto un orificio muy pequeño, y las fajas ó bandas óseas que revisten el cuerpo, por lo co. mun muy prolongado. La estructura interna presenta todos los caractéres de los peces óseos, estando formado el esque. leto de verdaderos huesos. El intestino no ofrece nada de notable; la vejiga natatoria es, relativamente al cucrpo, de tamaño extraordinario.

Los lofobranquios pertenecen al periodo de creacion mas reciente puesto que hasta ahora ningun vestigio se ha $\mathrm{en}$. contrado de ellos en las capas geológicas de épocas ante. riores.

DISTRIBUCION GEOGRÁFICA.-LOS lofobranquios habitan, sin excepcion alguna, el mar, y en mayor abundan. cia y diversidad las costas meridionales que las del norte.

USOS, COSTUMBRES Y REGIMEN.-Estos peces frecuentan regularmente las riberas, permaneciendo con preferencia entre las plantas marinas; y se alimentan de peque. ños crustáceos, moluscos, etc, y muy probablemente tam. bien de las huevas de otros peces. Su modo de reproduccion ha sido durante largo tiempo objeto de discusion entre los naturalistas. Harlasz, no habiendo encontrado lechaza en los lofobranquios que examinó, los tenia por hermafroditas que 
daban á luz pequeñuelos vivos; Bloch fuc el primero que observó los huevos, pero como lo hiciera en la bolsa abdo. minal del macho, donde los coloca la hembra para su fe. cundacion, dedujo de ahi equivocadamente tambien que eran ovoviviparos. Recientes observaciones nos han acla. rado, por fin, el misterio de la reproduccion de estos peces, y sabemos que los huevos son depositados por la hembra en una especie de bolsa exterior del macho, dentro de la cual son fecundados y se desarrollan los germenes.

\section{LOS SINGNATIDOS- SYNGNATHID无}

CARACTLRES.-Estos peces, llamados tambien «agld. jas de mar, tienen el cuerpo anguloso, largo y muy delgado, disminugendo gradualmente su diámetro á medida que se acerca \& la region caudal; el hocico se prolonga en forma tubular, por la disposicion en este sentido de los huesos de

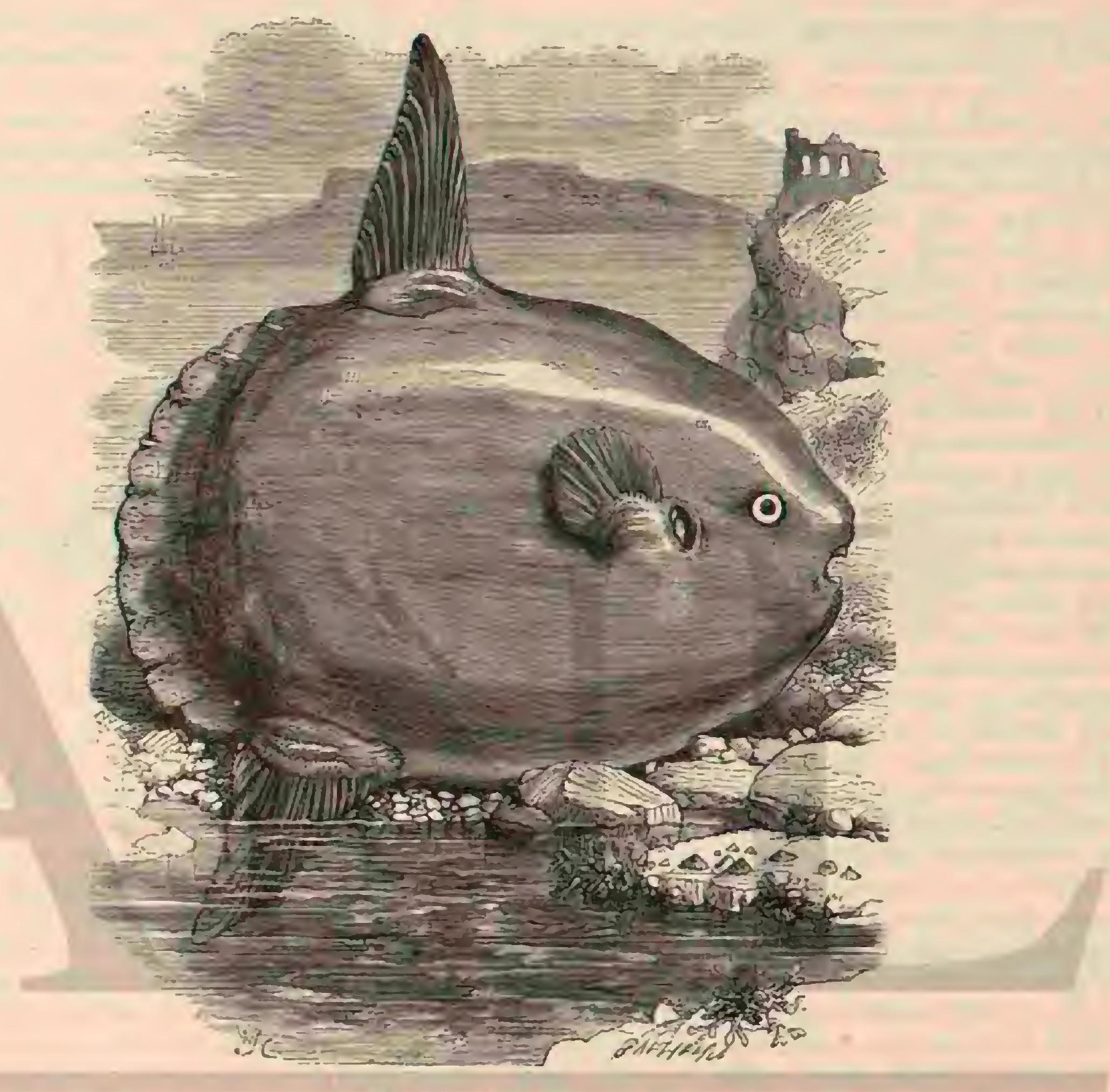

Fig. 218. - E1. PYภ. I.Uล

la cara, y lleva en su extremo la boca, hendida casi vertical. mente; los orificios respiratorios se hallan situados cerca de la nuca. Faltan las aletas ventrales; las pectorales, que se encuentran inmediatamente detrás de las aberturas branquiales, son pequeñas, pero bien desarrolladas; la dorsal es nota. ble por su tamaño extraordinario, y la caudal se extiende en forma de abanico en la afilada punta de la cola.

DISTRIBUCION GEOGR A FICA.-I as ciento cincuenta especies que constituyen a poca diferencia esta familia, que viene á ser el núcleo del órden, habitan todos los mares de la zona tórrida y de las templadas.

USOS, COSTUMBRES Y REGIMEN. - Las huevas se desarrollan en una especie de bolsa, continuacion de la piel debajo del vientre ó de la cola del macho; los pequeños $\mathbf{s a -}$ len despues de nacidos por una hendidura. Dicese que muchas especies muestran por su cria una solicitud extraordinaria, y que vuelven á recoger en la bolsa álos pequeños siem. pre que estos necesitan de este refugio. Difieren las varias especies de esta familia en su género de vida solo en cuanto lo exige su diferente forma, que determina tambien las dos subfamilias.

\section{LAS AGUJAS DE MAR-SYNG- NATHINAE}

CARACTERES. - Este grupo suele ocupar el primer puesto, ya porque contiene el major número de especies, ya por la variedad que estas ofrecen, $y$ finalmente por su mayor área de dispersion. Caracteriza á estos peces su cuerpo pro. longadisimo y del cual la cabeza no es mas que una especie dé continuacion que no sale del inismo plano. La rair de la aleta dorsal tampoco sobresale del lomo; la caudal esta en cambio bicn desarrollada, y la bolsa donde han de incubarse las huevas se abre hácia abajo.

\section{LA AGUJA DE MAR COMUN-SXNGNATHUS ACUS}

CARACTERES.-Es un pececito delgadisimo (fig. 22 3 ) 
pero cuya longitud puede llegar hasta $0^{\circ}, 60$; el color es pardo pálido con listas mas oscuras. Hay cuarenta radios en la aleta dorsal, doce en cada torácica, cuatro en la anal, y diez en la caudal.

DISTRIBUCION GEOGRAFICA. - Se encuentra esta aguja en todà la parte oriental del Atlántico desde el norte de Europa hasta el cabo de Buena Esperanza, asi como en los mares que comunican con dicho Océano, es decir, el Me. diterráneo, el Negro, el del Norte y el Bältico, donde escresea bastante, siendo en cambio frecuentísima en los sitios á pro pósito de las costas del mediodia de Europa.

USOS, COSTUMBRES Y REGIMEN.-Prefieren para morada los prados sub-matinos, marismas 5 lagunas panta nosas, donde prosperan las yerbas marinas de larga hoja, en las cuales se ven frecuentemente reunidas en crecido nume. ro y en las posturas mas variadas, unas verticales $\mathrm{y}$ cabeza arriba, otras al revés, cabeza abajo, cstas horizontales, aque llas paradas en posicion oblicua, ó nadando cada una en la posicion que ha tomado. Considerada la pequeñez de las aletas torácicas y caudal, junto con la extraordinaria longitud de estos peces, se comprende que el aparato motor prin cipal es la aleta dorsal que facilita la locomocion por un movimiento ondulatorio no interrumpido. Es tácil convencerse de esta manera de moverse observandola en los acua rios donde ahora son frecuentes las agujas de mar, viéndose de yaso que las aletas torácicas y caudal solo trabajan para regularizar la direccion; y por defectuoso que parezca todo este aparato, no deja de permitir que estos pececitos hagan todos los movimientos que apetecen, y explica su presencia léjos de la orilla y en la profundidad. Aliméntanse de toda clase de sabandijas diminutas, crustáccos pequerios y de cáscara blanda, moluscos, gusanos, etc, con tal quue no ofrezcan resistencia, por cuya razon es tambien poco menos que imposible alimentar las agujas artificialmente.

En un ejemplar de esta especie descubrió Eckstroem el modo de reproducirse los lofobranquios. En el cuerpo del macho existe un surco triangular desde la cola hasta las dos terceras partes de la longitud total con los dos cantos un tanto escotados y prolongados que al tocarse cierran la cavidad interior. Estas membranitas ú hojas tapaderas estân caidas y metidas en el surco en otoño é invierno, pero al acercarse la época de la freza, en abril, se hinchan y el surco se llena de mucosidad. En este surco es donde la hembra deposita en mayo las huevas que forman una sarta; despues se juntan los bordes y los embriones quedan encerrados hasta últimos de julio. En casos de peligro los pequeñuclos buscan y vuelven al surco protector cuando ya le habian abando. nado. Extraño es que entre las agujas de mar abunden mu. cho mas las hembras que los maclios, al revés de lo que vemos en los demás peces y en los vertebrados en general. De las observaciones de Walcot resulta que las agujas puedén reproducirse cuando llegan á tener de 11,10 a $0^{4}, 12$ de largo.

USOS Y PRODUCTOS. - La carne de estos peces, conforme he podido convencerme muchas veces, dice Gess. ner, es compacta y agradable al paladar de cualquier modo que se prepare. En algunas partes ponen las agujas en sal y las comen asi al igual de otros muchos pececillos marinos. Yo no sé si este aserto tiene algun fundamento; por mi parte puedo decir que nada de esto he oido ni leido, en cuanto á nuestra epoca se refiere, ni menos que se pesquen estos animalillos que tan poco atractiro ofrecen al paladar.

\section{EL CABALLO MARINO COMUN-HUPPO- CAMPUS ANTIQUORUM}

CARActrREs, - He áqquí cómo describe el viejo Gess. ner este animal: đEn muchísimos séres maravillosos se ma. nifiesta la grandeza de Dios y de su obra, la naturaleza; pero en ninguno como en este animal 6 pez marino, cuya cabeza, cuello, boca, pecho y crines se asemejan enteramente á los del caballo terrestre, siendo solo diferente la parte posterior ó cola. Algunos aventureros enseñan estos peces diciendo que son basiliscos, porque su extremidad se enrosca en cual. quier sentido, $y$ tal como se encuentra retorcida se queda cuando el animal ha muerto. \$ Los caractéres principales de este representante del grupo consisten en tener el cuerpo muy comprimido y formando con la cabeza un ángulo muy agudo, y en la cola prensil desprovista de aletas. El hocico es relativamente corto con la boca pequeña, abierta casi en el centro; la cabeza se halla adornada de excrecencias cartilaginosas a manera de barbillas, y la cola de puntas insertas en los lados. El cuerpo está cubierto de escudos anchos y la cola de cuatro anillos planos, provistos de protuberancias de filamentos formando mechones. La coloracion general es pardo-cenicienta clara, que segun el ángulo de reflexion de la luz ofrece un ligero viso azul ó verde. La longitud varia de entre $0^{\prime \prime}, 15$ y $0^{\circ}, 18$ (fig. 222).

DISTRIBUGION GEOGRÁFICA. - CoIno patria ver. dadera del caballo de mar debe considerarse el Mediterráneo, desde donde se extiende por el Atlántico hasta el golfo de Vircaja y aun mas hácia el norte, presentándose individuos sueltos en las aguas inglesas y en el mar del Norte. Por otra parte se encuentra tambien en la Oceania.

USOS, COSTUMBRES Y REGIMEN.-A semejanza de su afine la aguja marina, solo vive el caballo en los sitios en que una abundante vegetacion cubre el fondo del mar, donde encuentran su alimento $y$ donde se ven ngarrados a las plantas ó madando entre ellas muy despacio. Lukis, que los ha observado y estudiado en cautividad, ba descrito sus movimicntos y costumbres. «Cuando nadan, dice este autor, se mantienen en posicion vertical, con la cola siempre preparada à agarrarse al primer objeto qque les conviene, como por ejemplo á una alga, poniéndose luego á escudriñar lo que pasa á su alrededor, y precipitándose sobre la presa que atis. ban $\delta$ persiguiéndola con mucha destreza. Cuando se encuentran dos de ellos suelen enroscar mutuamente las colas para separarse en seguida tirando violentamente uno de otro, á cuyo fin suelen cogerse con la barba á una planta marina y asi aumentan la violencia de sus esfuerzos. Sus ojos se mueven independientes uno del otro, como sucede con los del camaleon, lo cual, unido á su cambio de color, excita vivamente el interés del pescador. Por mi partc me deciaro conforme con lo que precede, pero no participo de la opinion de Lukis cuando dice que no hay habitante del mar que divierta mas $y$ que muestre mas inteligencia que este animal. He observado y cogido millares de caballos marinos en las marismas de Venecia, y he cuidado y estudiado centenares de ellos por espacio de meses enteros sin que jamás haya visto cosa alguna que confirmara lo dicho por este autor. Ni son divertidos ni inteligentes, sino muy al contrario, por demás monótonos y estúpidos, si bien llaman la atencion por su figura extraña, su postura singular, sus movimientos lentos y casi solemnes, y su cambio de color, cosas que fácil. mente pueden inducir á un observador poco prácticó áemitir un juicio tan favorable. Acaso se califiquen acertadamente llamándolos peces bonitos $\delta$ lindos. Su alimento consiste principal, cuando no exclusivamente, en crustáceos y molus. cos microscópicos que recogen de las hojas y algas marinas; y como es imposible proporcionar á los caballos marinos cautivos estos séres diminutos en cantidad suficiente aunque se viva á orillas del mar, resulta que cuantos se desea conservar, están irremisiblemente condenados á morir 
de hambre mas ó menos pronto. Sin esto ya mueren muchos al sacarlos del agua, y cuando descarga una tempestad suelen sucumbir todos de golpe.

La reproduccion se efectúa del mismo modo que en las agujas de mar; es decir, que la hembra deposita las huevas en el vientre del macho donde quedan adheridas s son fecun dadas por cste, y luego se va formando una hipertrofia de la epidermis que constituye la bolsa en la cual se hace la incubacion.

USOS Y PRODUCTOS.- En ninguna nacion se comen estos peces, dice Gessner, porque tienen fama de venenosos y originan graves desórdenes en el cuerpo humano. Bien puede ser que tenga razon $y$ que los antiguos hablaran por experiencia, porque el régimen alimenticio deberá influir sin duda en la carne del caballo marino como influye en la de otros peces. Para uso y provecho de los homeópatas, añadiré lo siguiente copiandolo tambien de Gessner: Dicese que llevando estos animales sobre el cuerpo excitan la concupiscencia. Tostado, reducido á polvo y tomado interiormente, le atribuyen una eficacia milagrosa contra las mordeduras de perros rabiosos; y quemado, sirven las cenizas combinadas con grasa y salitre para repoblar las calvicies. El polvo del caballo de mar tostado alivia el dolor 5 punzadias decos. tado, y tomado en la comida es un excelente remedio contra la retencion de orina.

\section{LOS FILOPTÉRIX-PHYLLOPTERYX}

CARACTÉRES. - Distinguese este género por una extraordinaria abundancia de apéndices espinosos en forma de cintas que están pegados á casi todos los escudos y clielgan del per como jirones y harapos. La aleta dorsal está inserta casi exclusivamente sobre la parte del cuerpo correspondiente a la cola; las espinas son cortas, robustas y puntiagudas;

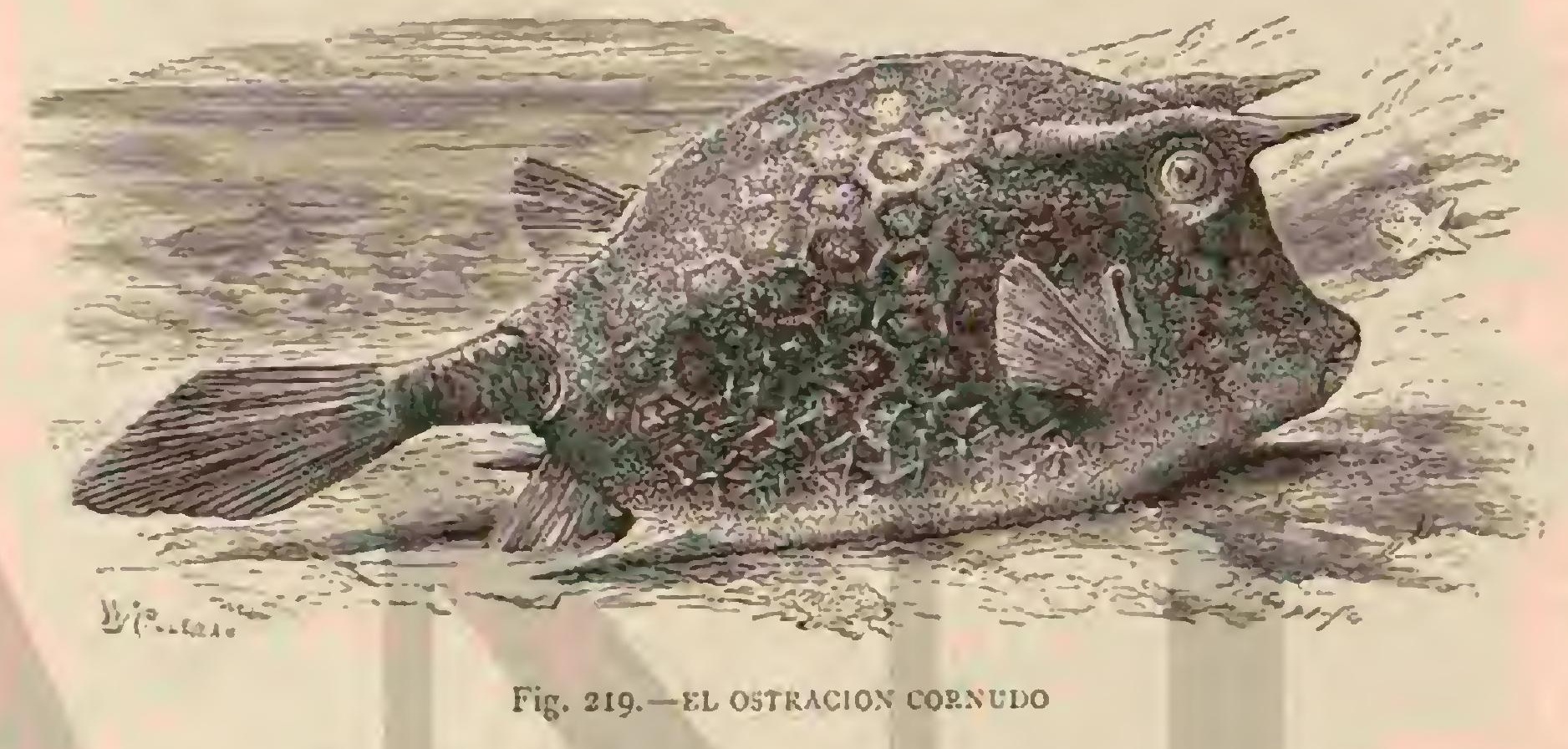

las prolongaciones en forma de cintas ó jirones son recias, pero los demás apéndices son delgados y flexibles. Fuera de la aleta dorsal, que es muy visible, y de la torácica, muy reducida, las demás se encuentran solo en estado rudimentario ó reemplazadas por las citadas excrecencias, que probablemente sirven al animal para agarrarse y pegarse \& las plantas ma. rinas.

DISTRIBUCION GEOGRAFICA. - Este género vive en el mar de la Oceania, donde reemplaza y representa en parte al caballo de mar.

\section{EL PEZ JIRON-PHYLLOPTERIX EOUES}

CARACTÉRES.-Disecado tiene este pez, color de sue la, y es probable que vivo sea encarnado. I a aleta dorsal tiene treinta y sicte radios.

USOS, COSTUMBRES \ RÉGIMEN. - No hay datos respecto as su género de vida, pero casi puede admitirse como cierto, que en este punto no varía el pez jiron de los demás caballos de mar.

\section{LOS PEGASOS-PEGASSUS}

CAR ACTERES. - Casi todos los peces de este géneto tienen sus aletas peciorales conformadas y extendidas de tal modo, que pueden sostener al individuo con facilidad, y durante cierto tiempo, no solo en el seno de las aguas, sino en el aire, que agitan con fuerza: son en cierto modo peces alados, álos que se ha querido considerar como representantes de los arimales terrestres que poseen asimismo la facultad de elevarse sobre la superficie del globo. Se ha comparado á estos séres con aquel famoso corcel que la antigua mitología situó en la doble colina, dándole un nombre célebre desde la mas remota antiguiedad. Y evocando el recuerdo de las mas maravillosas suposiciones, de las imágenes mas notables, y de las mas extraordinarias formas, se ha visto por otra parte en estos peces un simil, aunque en muy pequeñas pro. porciones, de aquel sér fabuloso, que creado por el genio de los primeros trovadores, adoptado por la ignorancia y divinizado por el temor, se conservó en todas las edades y en to dos los pueblos, aunque variando siempre su figura fantástica y acrecentando su tamaño, segun el capricho de las inmor tales producciones de la celeste poesia. Sin embargo, no cabe duda que son muy remotas las analogias que existen entre estos pequeños peces descubiertos en las aguas de las Indias y el enorme dragon cuya imágen, trazada por-hábil mano, ha servido para atemorizar \& los niños, recrear á los jovenes é interesar á los hombres de edad madura; pero bien puede conservấrsele el calificativo, porque seguramente no inducirá a ninguno á error, y porque al mismo tiempo recuerda las admirables producciones de nuestros antepasados, sus atrevidos inventos, sus ingeniosas alegorias y sus cuadros encan. tadores.

\section{EL PEGASO ESPÁTULA-PEGASSUS NATANS}

CARACTERES. - El pegaso espátula (fig. 224) difiere de los hipocampos por la forma de la cola, cuya parte anterior es tan voluminosa como la posterior del cuerpo propia mente dicho; este último es además menos ancho á proporcion que el largo del animal; el hocico, que se prolonga mucho, es aplanado y redondo en su extremidad, y como se ensancha además bastante, afecta la forma de una espátula, y carece de dientes en los lados. Las aletas pectorales, mu- 
cho mas pequeñas que las de los otros pegasos, no parecen apropiadas para que este cartilaginoso pueda lanzarse sobre la superficie liquida. Los anillos escamosos que cubren la cola figuran en mayor numero que en las otras especies de la misna familia, contándose algunas veces hasta una docena; el prisma, ó mas bien la pirámide que componen tiene cuatro caras, siendo la inferior mas ancha que las otras tres; el anillo que se halla mas distante de la cabeza está armado de dos pequeñas puntas. El pegaso espátula es de un color amarillo subido en la parte superior del cuerpo, $y$ de un blanco bastante puro en la inferior; las aletas pectorales son de un tinte violado, $y$ las otras pardas.

DISTRIBUCION GEOGRÁFICA.-No se ha visto viva esta especie sino en los mares de las grandes Indias, pero entre los fósiles que se encuentran en el monte Bolca, cerca de Verona, se han reconocido restos de este pegaso.

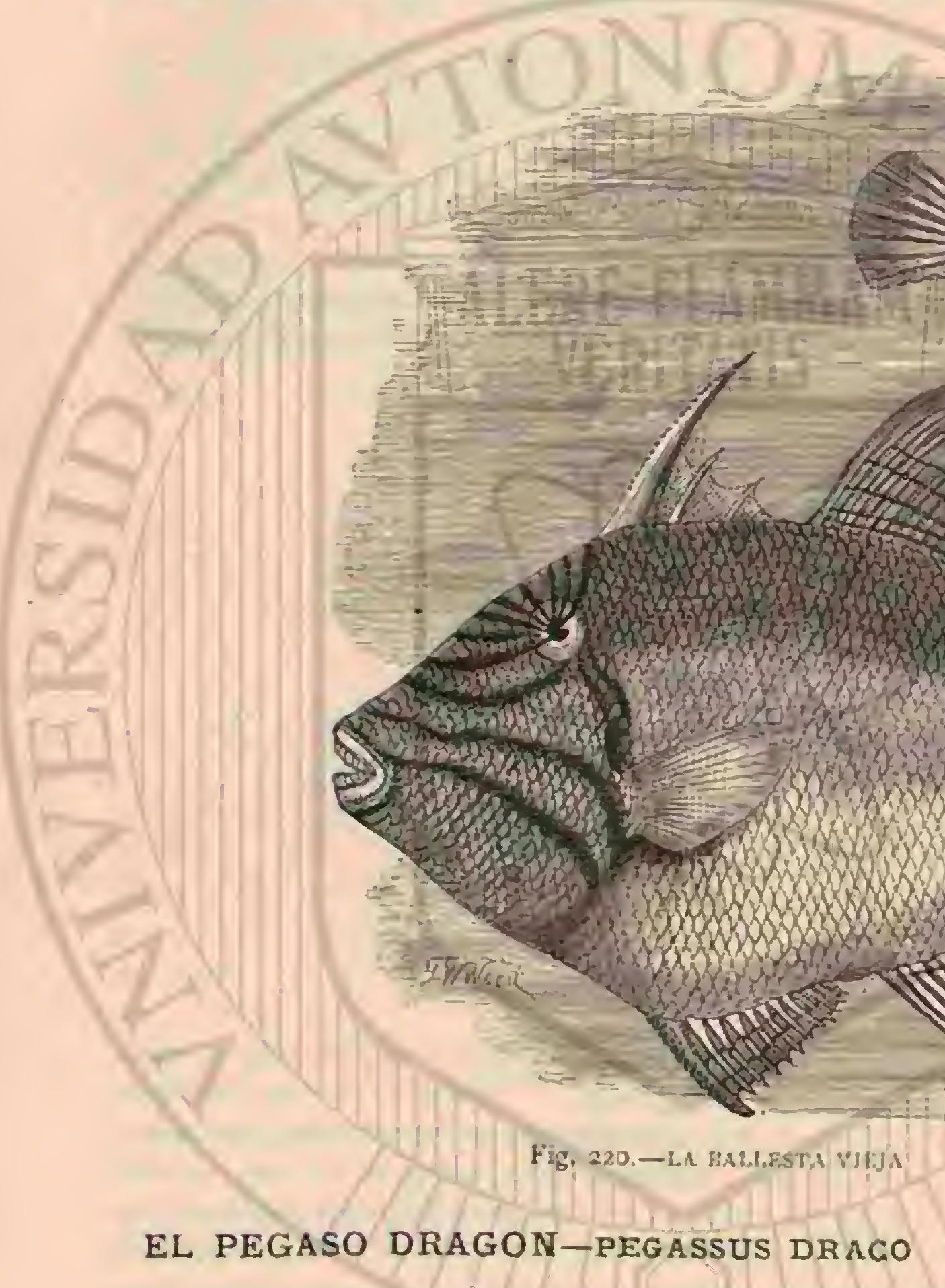

CARACTERES, - El pegaso dragon (fig. 225) tiene todo el cuerpo cubierto de piezas desiguales en extension, bastan. te grandes, duras, escamosas, y por consiguiente análogas á las que se han supuesto en los dragones; son casi cuadradas en el rentro del dorso, triangulares en los costados; é inde. pendientemente de esta coraza, la cola, que es larga, estre cha, y muy marcada, aparece contenida en una especie de estuche compuesto de ocho ó nueve anillos escamosos y ar. ticulados, que ofrecen mucha analogia con los que rodean el cuerpo y cola de los singnatos; comprimidos del mismo modo en la parte superior 6 inferior, asi como en los lados, ofrecen comuninente cuatro caras, y constituyen por su reunion una especie de prisma. Por debajo del hocico, que es muy prolongado, algo cónico y escotado lateralmente, se ve la abertura bucal, situada casi como la de los escualos y los acipénseres; y lo mismo que la de estos últimos cartilagino. sos, tiene unos bordes que el animal puede encoger ó prolon. gar í su antojo. Las mandibulas estann guarnecidas de dientes muy pequeños: los ojos son grandes, salientes, mus movi. bles, y se hallan situados en las caras laterales de la cabeza; el íris es amarillo; el opérculo de las branqquias radiado. Por cada lado del cuerpo avanza una prolongacion cubierta de escanas, en cuya extremidad está fija la aleta pectoral, que es grande y reciondeada, pudiendo desplegarse con tanta mas facilidad, cuanto que una porcion considerable de la membrana separa entre sí los radios; todos estos son además sencillos, no se articulan, y parten de un centro, ó de una base muy cstrecha. Gracias á semejante conformacion puede el pez cvitar, con mas seguridad, el ataque de su enemigo, pues se lanza sobre la superficie del agua, y no cae hasta despues de haber recorrido un espacio bastante extenso. En la parte inferior del cuerpo, que es muy ancha, se ve una pequeña eminencia longitudinal, en la que se fijan las aletas ventrales, reducidas á una especie de radio muy largo, bastante desarrollado, blando y flexible. La aleta dorsal, situada sobre la cola, es muy pequeña, asi como la caudal y la anal. El pegaso dragon es comunmente azulado, la parte superior del cuerpo aparece guarnecida de tubćrculos de un tinte pardo. Este pez no suele tener mas de un decimetro de largo; circunstancia que lo separa ciertámente del sér poético cuyo nombre lleva.

DISTRIBUCION GEOGRÁFICA.-Ia especie habita en el Octano Índico, y muy principalmente en las aguas de Java. 


\title{
TERCERA SUB-CLASE-GANOIDEOS
}

\author{
OCTAVO ORDEN
}

\section{HOLOSTEOS - HOLOSTEI}

Caracteres.-El estudio de los peces en tiempos anteriores al actual y su comparacion con los existentes hoy, ha demostrado que algunas especies de nuestros tiempos son las representantes que nos quedan de importantes agrupaciones de la clase. A Müller corresponde principalmente el mérito de haber fijado los límites de estas agrupaciones ó sub-clases, pues aunque otros naturalistas habian ya deter. minado la relacion de los ganoideos de nuestros dias con ciertas especies fósiles, es positivo que á los resultados obtenidos por Müller en la diseccion de centenares de distintas especies debemos el completo deslinde y claro concepto de esta importante agrupacion.

Iin las varias capas de la corteza terrestre se encuentran restos petrificados de ganoideos, que atestiguan de una manera indudable que estos peces han constituido una inipor. tante seccion del reino animal desde los tiempos mas antiguos. Han pasado por las mismas vicisitudes que ciertos cuadrúpedos y reptiles acorazados; hánse extinguido gra. dualmente, $y$ en la actualidad se encuentran reducidos á unas cuantas especies, que en su mayor parte son los repre. sentantes de otros tantos generos y familias. Las especies ac. tuales no presentan grande analogía entre sí, y es poco sóli. do el lazo que las une; pero comparando é intercalando las extinguidas, se establece, como sucede tambien en los vertebrados de las clases superiores que quedan descritas, la debida relacion entre unas y otras; y se obtiene un concepto general de la afinidad del conjunto $y$ de sus numerosas sub. divisioncs.

El señor Miüller fija como sigue los caractéres de los ganoideos. Estos peces presentan el cuerpo cubierto de escamas mas $\sigma$ menos redondeadas y revestidas de esmalte, 0 de escudos óseos, ó bien tienen la piel enteramente lisa. Muyá menudo se encuentra el borde anterior de las aletas provisto de una fila sencilla 6 doble de láminas espinosas; la caudal está prendida á veces en su parte superior á la extremidad de la columna vertebral, que en algunos casos se prolonga hasta el remate de aquella. Las dobles aberturas nasales se parecen á las de los peces óseos; las branquias son libres y se hallan cubiertas por una membrana como en aquellos; al. gunos tienen en el aparato respiratorio otra membrana superior.

nLos huevos salen de la caridad abdominal por medio de conductos especiales. Ios nervios ópticos no se entrecruzan; la vejiga natatoria tiene un canal de expulsion, como la de muchos peces óseos; las aletüs ventrales están colocadas en la parte posterior del abdómen; el esqueleto es óseo, ó en parte cartilaginoso.

«Esta demostrado, dice en conclusion Müller, que estos peces se diferencian totalmente de los óseos, pero que tam. poco pueden agregarse á los cartilaginosos; deben, por lo tanto, constituir una seccion propia, colocada entre estos y aquellos, presentando reunidos los caractéres de unos y otros, los opérculos y la nariz de los primeros, y la branquia accesoria, los espiráculos, las válvulas, los músculos, el oviducto y el modo de funcionar de los nervios ópticos de los segundos.

CARACTERES. - Segun la estructura del esqueleto forman los peces ganoideos dos grupos principales que se consideran como otros tantos órdenes. En el primero reuniremos, siguiendo á Juan Mülier, todas aquellas especies que por su esqueleto osificado difieren tan completamente de las otras que los naturalistas anteriores pudieron consideratlas como afines de los clupéidos y lucios, siendo de configuracion re. gular, oblongos, cubiertos de escamas que no dejan espacio entre si y provistos de todas las aletas. Es empero digno de notar que en este grupo empieza la caudal á ser con frecuencia de una estructura irregular. Las mandibulas están guarnecidas de dientes cuya forma y tamaño varian en gran manera segun las especies, $\$$ que se extienden en algunas hasta a los huesos que forman la bóveda palatina.

El órden de los holosteos, tan abundante y variado en las épocas anteriores de la terrestre historia, hállase actualmente representado por pocas especies. Lo poco que conocemos de su género de vida no nos permite formar concepto acerca de los usos y costumbres de las especies extinguidas, de modo que es imposible trazar una descripcion del conjunto del órden.

\section{EL PEZ CAIMAN - LEPIDOSTEUS OSSEUS}

CARACTERES. - Este pez (fig. 226), representante de la familia, que se reduce á tres especies, tiene una estructura singularísima; cuerpo muy prolongado, hocico de crocodilo, y escamas duras como la piedra que cubren hasta los radios extremos y superiores de las aletas. La mandíbula superior se compone de muchas piezas, y la inferior del mismo núme. ro que la de los reptiles. Las vértebras se articulan una con otra por cavidades y cabezas. Las mandibulas, prolongadas hasta formar una especie de pico muy largo, llevan numero. sos dientes cónicos grandes y pequeños seguidos en la parte interior de otros finos de púa. Existen cuatro branquias completas, es decir, dobles. El estómago carece de ciego, pero tiene muchos apéndices pilóricos ciegos y cortos; la vejiga natatoria es celular y comunica con las fauces por una rendija abierta en la parte superior de la faringe. Todos los radios de las aletas son articulados; las pectorales están in. 
sertas muy hácia la parte anterior, las abdominales en el centro, y la dorsal y anal muy atrás, cerca de la caudal que está inserta oblicuamente. Las escamas dispuestas tambien en hileras oblicuas, tienen forma de corazon en el dorso, cuadrada en los costados, romboidea en el vientre y punti. aguda en las aletas. La coloracion es verdosa en el dorso, amarillenta en los costados, y rojiza en el vientre; las aletas son de este último tinte con manchas negras en la parte posterior. La longitud vara entre un metro y metro y medio.

Agassiz opina que existe mas de una especie de pecescaimanes, con cuyo nombre se han confundido hasta ahora por lo menos veinte especies. Otros naturalistas no lo admi. ten asi, pero Günther distingue tres.

DISTRIBUCION GEOGRÁFICA-Estos peces viven en los rios y lagos de los estados meridionales de la América del norte.

USOS, COSTUMBRES Y REGIMEN.-LOS escasisimos datos que tenemos respecto á los hábitos y género de vida del pez-caiman, redúcense á que es algo abundante en las aguas dulces de los paises cirados, que es muy voraz y muer de fácilmente el anzuelo, y que su carne crasa y sabrosa se parece mucho á la del lucio y se guisa de un modo análogo.

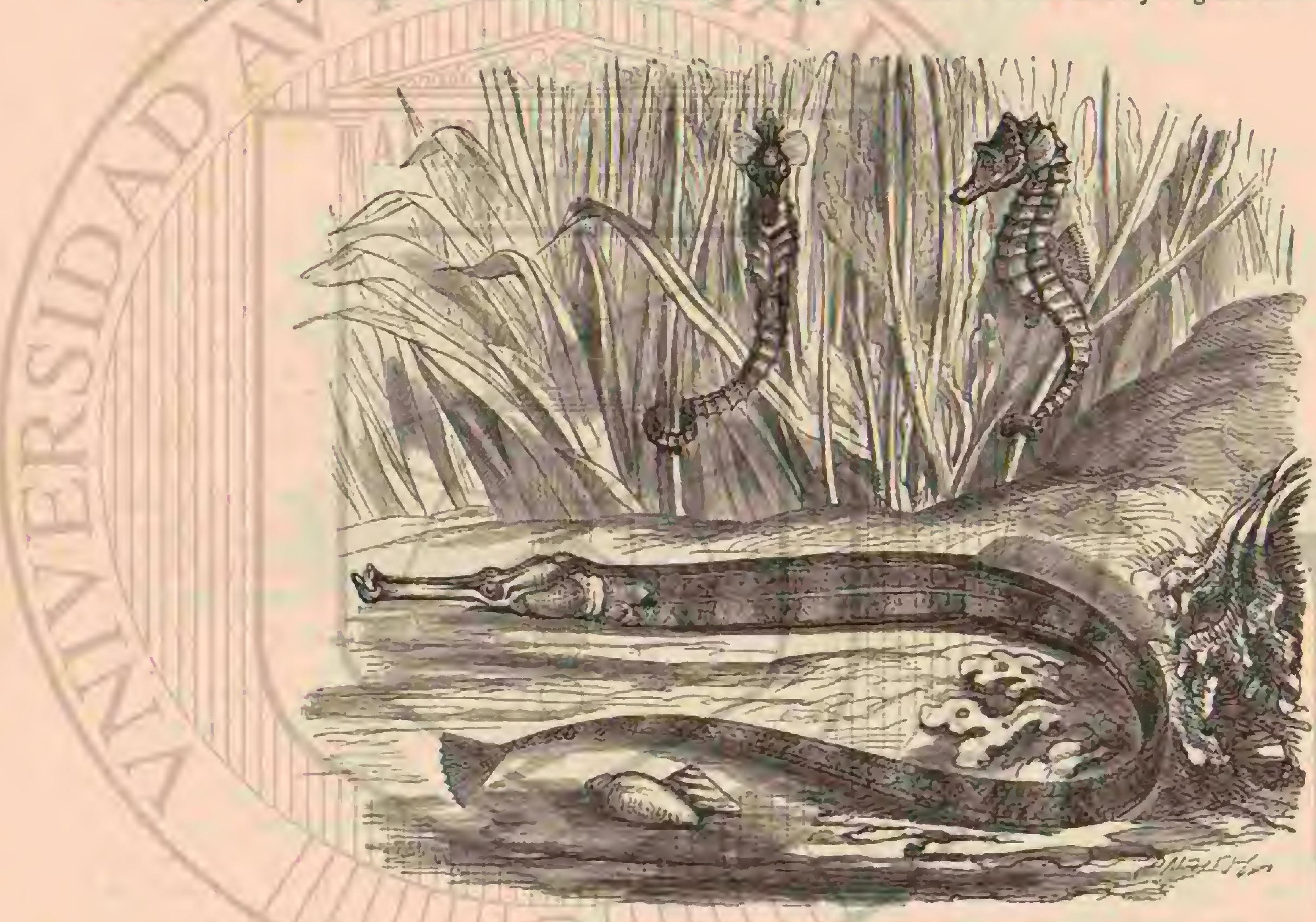

Fig. 222. -EL CABAI.LO MaRINO
Fig. 223.-LA ACUiS DE MAK
CARACTERES.-1)istinguese esta especie que, junta. mente con otra, constituye toda la familia de los poliptéridos, por su forma larga y cilindrica; el hocico obtuso; las aletas pectorales y abuominales poco desarrolladas, y la dorsal subdividida en gran número de aletillas separadas $y$ sostenidas cada una por un radio de aguijon robusto seguido de algunos blandos; la caudal todea el extremo de la cola y va separada de la anal solo por un pequeño intervalo. I.as alctas abdominales, muy reducidas, se hallan colocadas muy atrís. Ia mandibula superior no cstá dividida en varios hucsos, pero la inferior tiene jos que corresponden as 'la clase, como en general todo el cráneo difiere poco del tipo general de los peces. Las vértebras son cóncavas eriambos extremos. Ia nariz es mas complicada que en todos los demás peces: en la gran cavidad cubierta por los huesos nasales, se en cuentra un laberinto de cinco senos membranosos alrededor de un mismo eje; cada uno de estos senos contiene varios pliegues dispuestos a manera de branquias. La abertura nasal anterior ticne la forma de un tubo membranoso, mientras que la posterior consiste en una pequena hendidura con cubierta de la misma naturaleza. El estómago forma buche, $y$ el intestino tiene un ciego; la vejiga natatoria es doble y se 
misma fuerte caida de agua; al menos, en ningun otro punto se le pesca con tanta abundancia como en el oasis de Fajum.

USOS, COSTUMBRES Y RÉGIMEN.-Encuéntrase á menudo este pez en los sitios cenagosos y menos profundos del rio ó de los pantanos que se forman cuando las aguas se retirnn, y á veces en pequeños charcos que mas tarde se

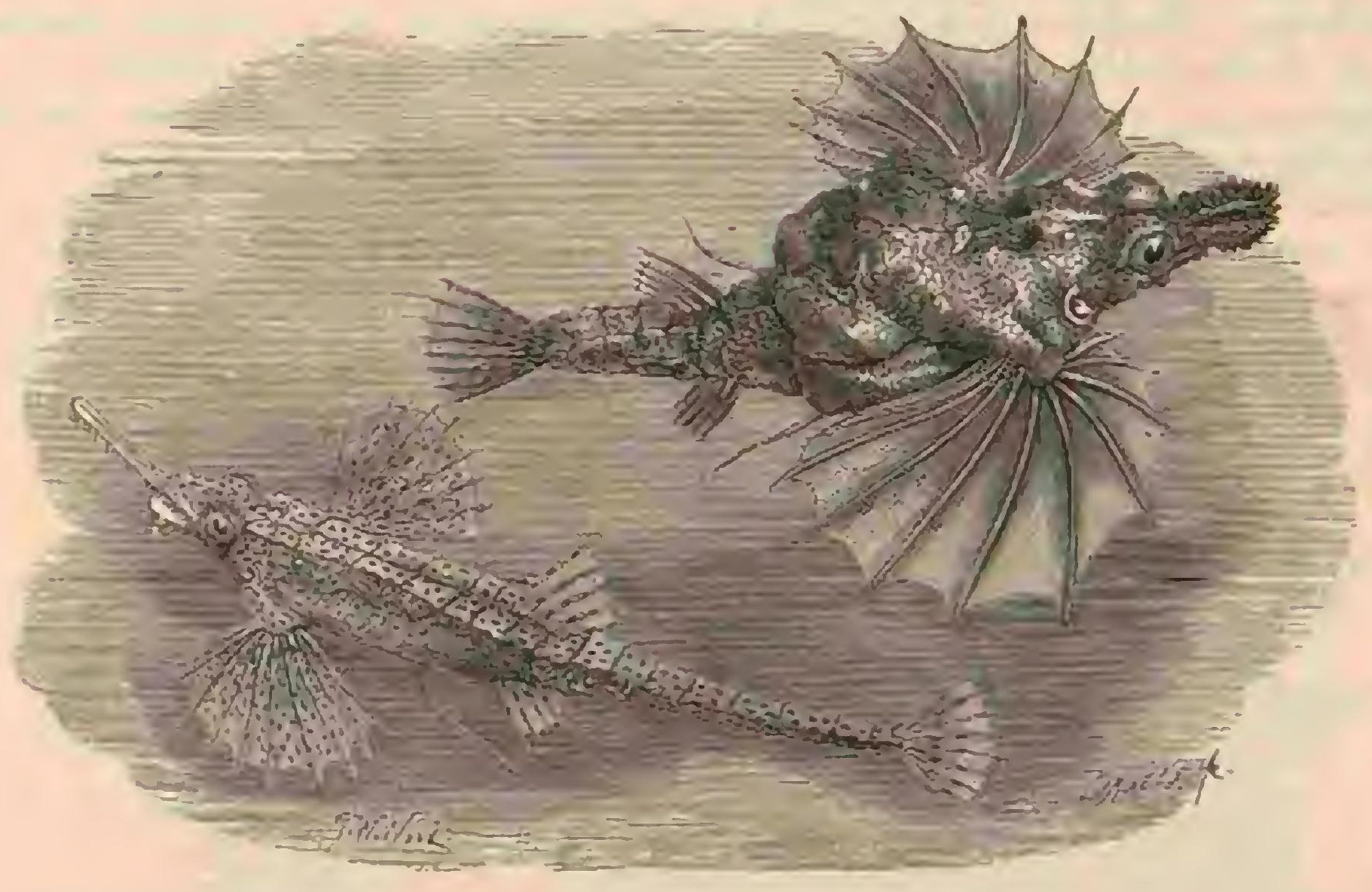

Fig. 224. -EL PBGGASO ESPRTULA

Fig. 225.- EL I'EGASO DRAGOX

secan por completo. Asegrirase que el bichir, lo mismo que la masor parte de los peces del Africa central, acostumbra á ocultarse debajo del limo cuando empieza la época de la sequia, permaneciendo en aquel fondo húmedo en un estado de letargo, $\delta$ de reposo, hasta la próxima estacion de las llu. vias. Consiste su alimento en peces y otros animales acuáti. cos. En cuanto al modo de reproducirse, ni Heuglin ni Geoffroy pudicron proporcionarse dato alguno fidedigno. Muerde con facilidad el anzuelo, y es muy buscado á causa de su carne blanca y apetitosa. Sus escamas forman una coraza tan compacta y dura, que solo despues de cocido el pescado entero puede separarse de cllas la carne.

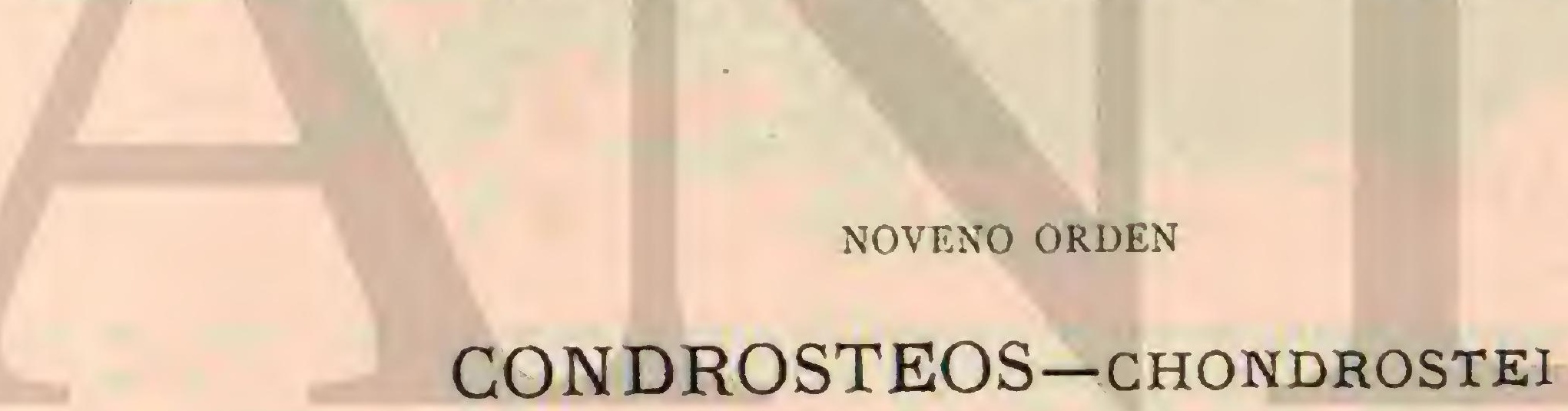

CARACTERES. - El esqueleto en parte ternilloso y el cordon blando reemplazando á la columna vertebral; tales son los rasgos principales que separan a los individuos de este órden de los holosteos.

En los ticmpos primitivos, tambien los condrosteos figuraban en notable y variada abundancia; pero en la actualioad hállanse reducidosá dos familias, de las cuales solo una es algo numerosa, mientras que la otra ni siquiera es reconocida por muchos naturalistas, que incluyen en aquella todas las especies del órden. Parécenos, pues, innecesario trazar una monografia detallada de estos peces, pues seria /una mera repeticion de lo que vamos á decir luego al tratar de los es. turiones en particular.

\section{LOS ACIPENSÉRIDOS- ACIPENSERID.Æ}

CARACTERES. - El cuerpo de estos peces es prolongado; el hocico, mas ó menos puntiagudo, acaba en una especie de trompa inmóvil con la boca abierta debajo de ella; los opérculos no cubren la abertura branquial en su totalidad; la membrana de esta úlima carece de radios, y la cubierta consiste en grandes escudos óseos dispuestos en cinco hile. ras longitudinales. Los ejes del esqueleto no se osifican, y la columna vertebral continúa hasta la extremidad del lóbulo superior de la aleta caudal. Llevan además cuatro opérculos $y$ radios branquiales huesosos, un aparato dorsal y otro de cadera para la articulacion de las aletas toracicas y abdomi nales; costillas numerosas y piezas de sosten para las aletas impares.

La cabeza es mas ó menos prismática, cuadrada y prolongada en un hocico, ya ancho, ya estrecho, en forma de trom. pa y formado por el hueso nasal y estenóides soldados en uno solo debajo del vómer, que resalta á manera de liston y lleva en una prolongacion huesosa cuatro barbillas que sirven de tentáculos de diferente forma y colocacion segun la especic. Detrás de ella está la boca abierta trasversalmente en una depresion y apoyada por una protuberancia cartilaginosa compuesta de tres piezas articuladas y de consiguiente movi. 
bles; el borde superior está rodeado de un labio abultado y carnoso que continúa, si bien muy menguado, en la mandíbula inferior 5 por lo regular solo en los ángulos de la boca. Los ojos, á menudo de diferente diámetro en un mismo individuo, se hallan colocados en ambos lados del cráneo detrás de las fosas nasales. Las placas ó escudos de la cabeza corresponden en la parte superior á los huesos análogos de un verdadero cránco huesoso, y en parte al suborbitario. Las branquias están, como en los teleosteos, sobre cinco arcos movibles, son pectiniformes $y$ sus extremos libres, con otra branquia accesoria pero igualmente pectiniforme en la parte interior, cubierta solo en parte por el opérculo, é inmediatamente detrás, en el borde superior del mismo, el espiráculo. Hácia abajo cierra la abertura branquial la membrana del mismo nombre que rodea el opérculo en forma de media luna sin estar sostenida por radio alguno. Cinco hileras de escudos óseos cubren el cuerpo: una, que recorre el lomo, llega hasta la aleta dorsal, otra á cada lado, hasta la caudal, y una á cada lado del borde del vientre se extiende desde el hueso dorsal hasta cerca de la aleta abdominal. Los escudos tienen en el centro una cresta mas ó menos aguda ó terminada en punta, y juntos dan al pez la forma prismática pentagonal. La piel entre las hileras de los escudos puede ser desnuda y lisa, 6 estar cubierta parcial y mas ó menos espesamente, ya de escudos menores, ya de granulaciones óseas de diferente forma y tamaño; el extremo de la cola y el lóbulo caudal superior están cubiertos de escamas óseas pequeñas, cuadradas, llanas y. apretadas; y dos escudos grandes resguardan la region de la clavicula. Todos los escudos varian y se desgastan con la edad, y los del vientre desaparecen á menudo totalmente, lo

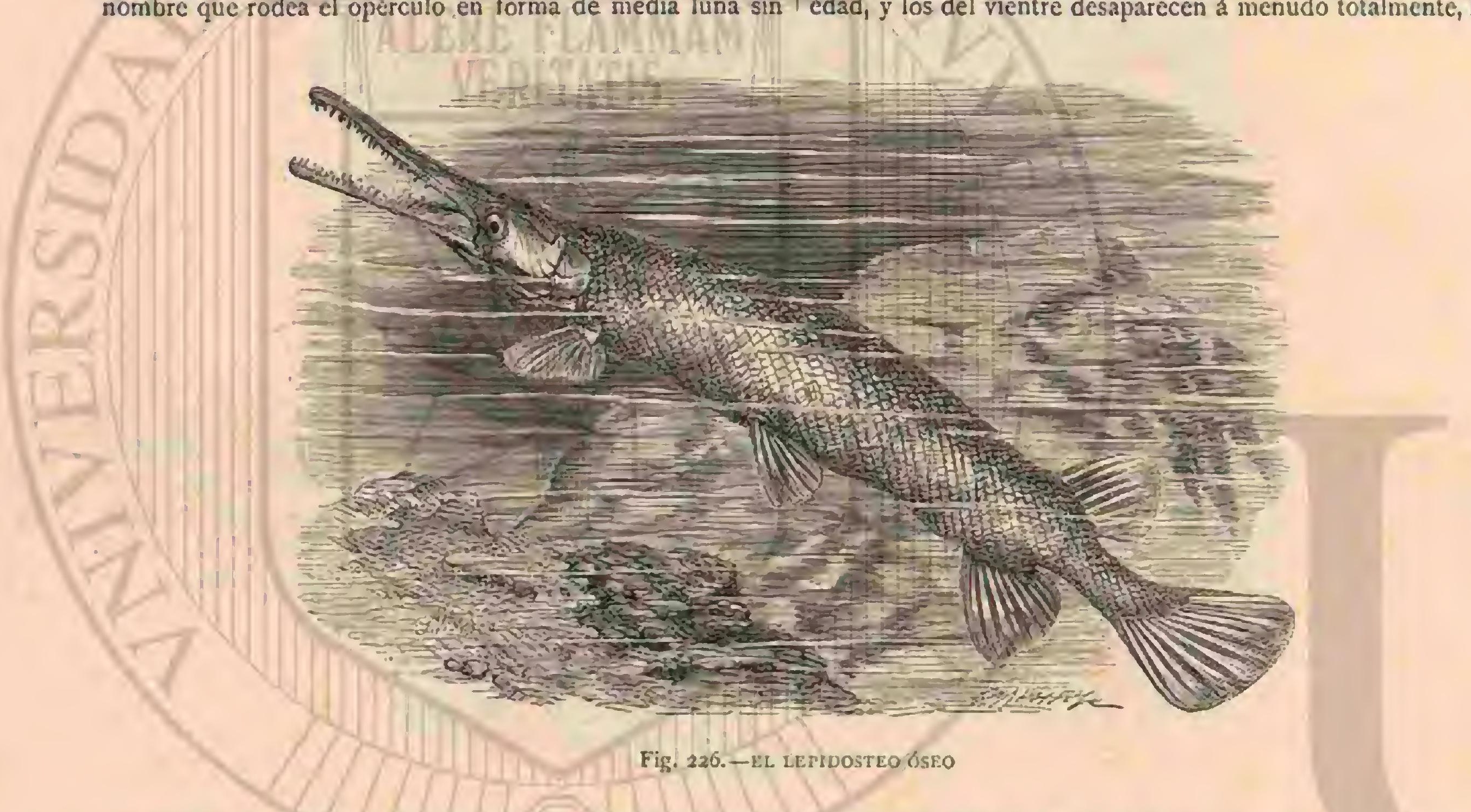

que cambia el aspecto y sobré todo el perfil trasversal del pez, que de pentagonal se vuelve mas cilindrico. Los radios. de las aletas son numerosos, articulados, casi siempre flexi. bles y finamente dentados en ambos lados; solo las torácicas, muy robustas, tienen el primer radio huesoso; las abdominales, colocadas muy atrás, son pequeñas; la dorsal tambien se halla en la parte posterior en frente de la anal; la caudal es notable por su gran tamaño y por la forma curva, semejante â una hoz, del lóbulo superior. Merecen tambien atencion el tubo digestivo corto, separado del estómago carnoso por una válvula; el hígado dividido en dos lóbulos principales y un gran número de otros menores; los riñones muy prolongados y cuyo urtere es á la vez oviducto y canal seminal; los ova. rios y testículos tan grandes que se extienden por tocia la cavidad abdominal; la vejiga natatoria grande, simple, ovala. da ú ovoidea; el bulbo arterial provisto de dos hileras de válvulas; la aorta grande que corre á lo largo y debajo de la columna vertebral cartilaginosa dentro de un surco á propó. sito, y otros caractéres de estructura interna.

DISTRIBUCION GEOGRÁFICA.-Los acipenséridos habitan la zona templada del hemisferio boreal, sin pasar muy al norte ni al mediodia. Por lo comun viven en el mar, ó en los grandes lagos del interior, pero los abandonan en determinada estacion para entrar en los rios donde pasan meses enteros.

USOS, COSTUMBRES REGIMEN.-Todos son ra- paces é insaciables; los grandes 6 medio adultos atacan ani. males mayores, mientras quue los peq̨ueños se contentan con gusanos, moluscos, freza y cosas por el estilo. A pesar de multiplicarse de un modo extraordinario, disminuye su nú. mero de año en año á causa del sistema vicioso con que todos los pescadores explotan los mares y los rios.

\section{LOS ACIPÉNSERES-ACIPENSER}

Comprende este único género siete especies que viven en los rios de Europa, siendo la mas conocida la siguiente:

\section{EL ESTURION Ó SOLLO PROPIAMENTE DICHO - AGIPENSER STURIO}

CARACTERES.-El hocico de este pez (fig. 227) es medianamente largo, el labio superior estrecho, el inferior abultado y dividido en el centro, las barbillas son sencillas, los escudos del costado son grandes y colocados uno juntoá otro, y los del dorso altos en el centro y bajos delante y de. trás. El color de la parte superior del cuerpo es pardo mas ó menos oscuro hasta gris ó amarillo pardusco: el inferior es blanco plateado; los escudos tienen un tinte blanco sucio. En la aleta dorsal hay respectivamente once $y$ reintinueve radios, en cada torácica uno y treinta y ocho; en cada abdominal y en la anal once y catorce, y en la caudal veintidos y 
setenta y cinco. La longitud puede llegar hasta seis metros, bien que por lo general no pasa de dos.

DISTRIBUCION GEOGRAFICA. - El Atlíntico, el Mediterráneo, el mar del Norte y el Báltico sou la patria del esturion. No existe en el mar Negro, ni se le ha enconirado tampoco en la cuenca del Danubio. Remonta el Rhin, pero apenas llega hasta Maguncia, y su presencia cerca de Basilea es un caso excepcional; en cl Weser se le encuentra hasta la confluencia del Werra y el Fulda, pero en el Elba sube hasta la Bohemia y por el Moldau y sus afluentes; mientras que re. monta desde el Báltico el Oder, el Vistula y sus afluentes.

\section{EL ESTURION ESTERLETA-AGIPENSER RUTHENUS}

CARACTERES. - Esta especic ha sido confundida con la anterior por muchos naturalistas deł sur de Alemania, a pesar de diferir por su hocico largo y delgado; las barbi. llas, bastante largas, forman hácia dentro ia modo de un neco; el labio superior es estrecho $y$ algo escotado, el inferior está dividido en el centro; los escudos del dorso son poco elevados en la parte anterior del cuerpo, pero hácia atrás van subiendo hasta que los últimos acaban en punta. Ia co-

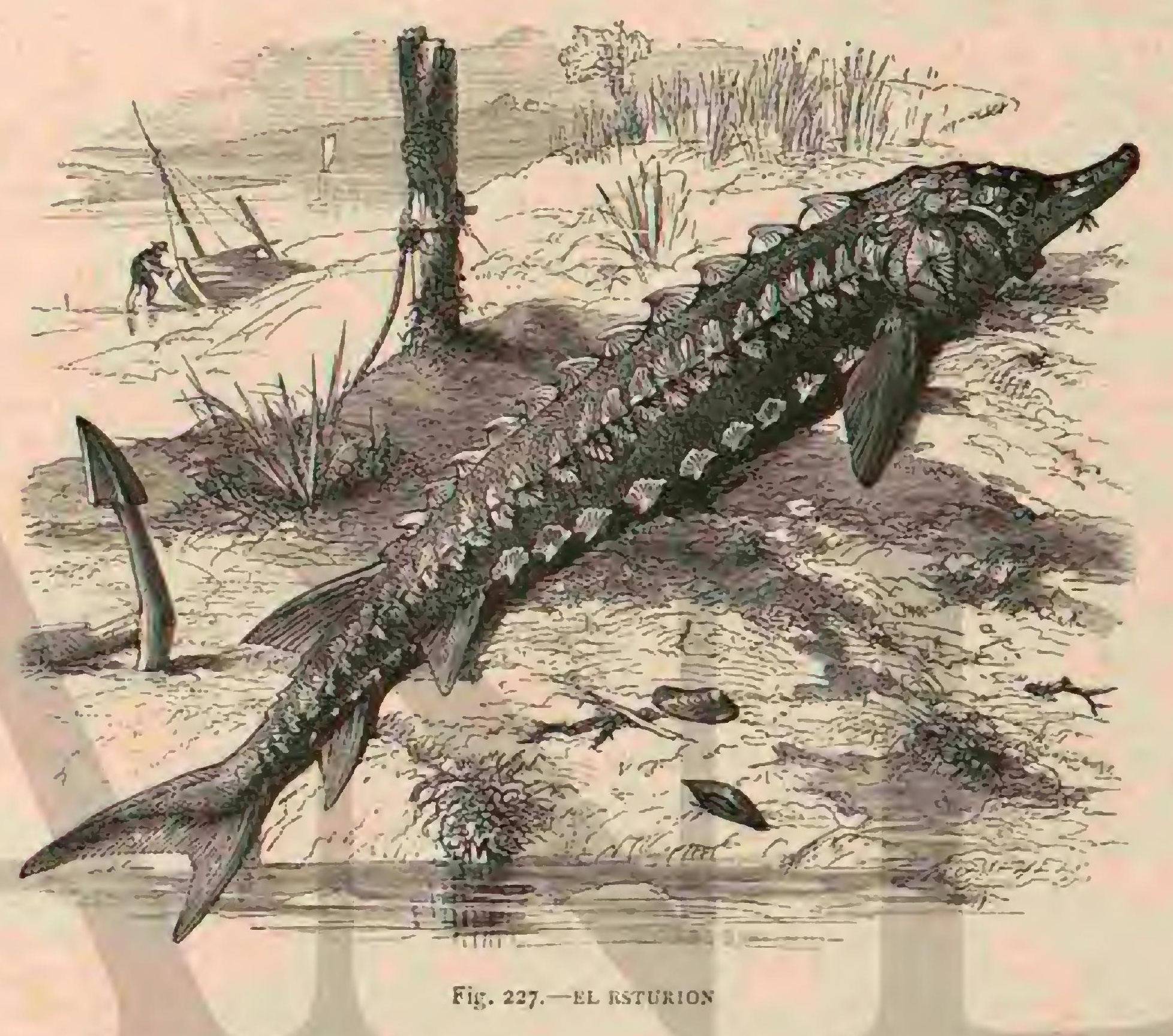

loracion es un gris oscuro en el dorso, y claro en el vientre; las aletas dorsal, caudal y pectorales tienen un tinte gris, las abdominales y la anal blanco sucio. Los escudos del dorso tienen el color de cstc, y los del costado y vientre son blanquizcos. El número de radios es respectivamente de trece $y$ veintiocho en la alcta dorsal, uno y veinticuatro en cada torácica, nueve y trece en cada abdominal, nueve y catorce en la anal, y trcinta y tres, trece y sesenta y sietc en la caudal. La longitud casi nunca excede de un metro, ni el peso de doce kilógramos.

DISTRIBUCION GEOGRAFICA.-El esterleta habita el mar Negro y el Caspio y remonta todos sus tributarios y los afluentes de estos. Abunda junto á Viena en el Danubio, no siendo raro en Linz, y hasta se le ha pescado cerca de Ulm. Tambien se encuentra en los rios de Siberia $y$ particularmente en el Ob.

Se han hecho repetidas tentativas para aclimatarlo en el norte de Alemania, pero sin éxito.

\section{EL ESTURION ESTRELLADO- ICIPENSER STELLATUS}

CARACTERES. - Esta especie alcanza unos dos metros de largo y hasta 25 kilógramos de peso, y se caracteriza por Tomo $\mathrm{V}$ su hocico largo y puntiagudo en forma de daga; las barbillas son sencillas, el labio superior escotado, el inferior rudimentario; los escudos del costado no se tocan. El lomo es pardo rojizo claro; pasando á menudo á negro azulado; la parte inferior del hocico es de color de carne, los costados y el vientre blancos y los escudos blancos sucios. Hay once $y$ cuarenta radios en la espina dorsal; uno y veintiocho hasta treinta y uno en cada torácica; diez y veinte en cada abdominal; once $y$ diez y siete en la anal, y treinta $y$ cinco, diez y seis y noventa en la caudal.

DISTRIBUCION GEOGRÁFICA.-Habita los mismos mares que el anterior, pero en el bajo Danubio es menos. frecuente que aquel.

\section{EL ESTURION HUSO-MCIPENSER HUSO}

CARACTERES. - Esta especie es la mas importante de las mencionadas hasta aqui, y. el gigante de la familia, pues puede tener una longirud de ocho metros g un peso de mil sciscientos kilógramos. Se caracteriza por su hocico corto y triangular, las barbillas aplanadas, el labio superior un tanto escotado, el inferior dividido en el centro, los es. cudos pequeños, altos en el centro y bajos por delante $y$ de. trás, y separados uno del otro. El color sucle ser en la parte 
superior gris oscuro, en el vientre y los escudos blanco sucio; el hocico es blanco amarillento. Sostienen la aleta dorsal catorce y cuarenta y nucve radios; cada torácica uno s treinta y seis 6 treinta y sicte; cada abdominal doce y diez y ocho; la anal trece $y$ diez $y$ seis; $y$ la caudal treinta y cinco, diez $y$ ocho y setenta y nueve.

DISTRIBUCION GEOGRÁFICA.-El área de dispersion se limita al mar Negro $g$ a sus tributarios.

USOS, COSTUMBRLS Y REGIMEN. - Lo que sabemos hoy del género de vida de los peces en general nos permite creer que bajo este punto de vista se parecen todos los esturiones. Son, como ya se ha dicho, propiamente habitan tes del mar y solo pasan a los rios para éfectuar el acto de la reproduccion $\delta$ para pasar en ellos su sueño invernal. So. bre su vida en el mar, la profundidad á que habitan, y los alimentos que alli buscan, nada sabemos; pero no puede caber duda que alli preferirán tambien fondo arenoso fino ó cenagoso, donde se moverán medio metidos en la lamá ó mas bien á rastras que nadando, removiendo el cieno y cogiendo lo que encuentran con sus labios protráctiles. En el estómago de los que habian penetrado ya en los rios, se han encontrado, además de sustancias animales, restos destroza. dos de vegetales, pero estos pueden haberse introducido en el accidentálmente. Sea como quicra, los esturiones figuran entre los peces rapaces; de las especies mas conocidas se sabe de cierto que al remontar los rios persiguen a los ciprínidos que suben como aquellas \& desovar, y que consti. tuyen hasta su alimento exclusivo. Con motivo de estos viajes periódicos pasan naturalmente $\mathbf{z}$ las capas superiores donde se mueven con bastante rapide\%. De este modo viven descle marzo á mayo todas las diferentes especies y regre. san \& fines de otoño en sociedades cuyo número varia segun la localidad y circunstancias. Han disminuido muchisimo estos peces en los rios donde se les pesca mucho, y cuanto mas se perfecciona esta industria mas se conoce la disminucion; pero todaria hay corrientes donde son numerosisimos, cuando por la misma extension del agua no sc ha podido hasta aquí explotar su riqueza. Los esturiones de todas las especies figuran entre los peces mas fecundos que se conocen; se han cogiỏo hembras de huso de mil cuatrocientos kilógramos, de cuyo peso correspondian cuatrocientos \& los ovarios. Depositan sus huevas sobre el fondo del rio y vuel. ven en seguida al mar; pero los pequeños permanecen al parecer en los rios mucho tiempo, quizás los dos primeros años de su vida.

USOS Y PROVECHO. - La carne de todos los sollos es sabrosa, $y$ la de algunos pucde figurar en primera linea, por cuya razon es buscada en todas partes. Se consume fresca, seca y ahumada. Fintre los antiguos gozaba de grandísima fama á juzgar por lo que dice Marcial:

Mandad sollo á las mesas palatinas,

A fin de que manjar tan raro embellezca el banquete an. brosiaco.

Los opulentos anfitriones romanos presentaban este pez en la mesa muy adornado y cubierto de flores. En Grecia se le consideraba como el plato mas escogido; en China se reservaban los sollos para la mesa del emperador; en Inglaterra y Francia constituian un monopolio de los principes y señores de alta nobleza; cn Rusia existia un uso análogo, y á pesar de todo esto no se cogen estos peces tanto por su carne como por sus huevas y vejiga natatoria. De aquellas se hace caviar y de esta una cola finisima llamada cola de pescado ó ictiocola. Parn preparar el caviar se baten prinero los ovarios con una escoba hecha de ramas, se ciernen luego a fin de separar las huevas de las membranas, despues se salan, se cumbalar en barricas y sc expiden asi. las clase mas inferior de caviar es aquel que solo se lia limpiado de las materias fibrosas mas bastas, curado despues con sal al aire sobre esteras y pisoteado en seguida en las cubas. Iil caviar mas apreciado es el granuloso, mezclado con sal en grandes ariesas, secado despues hasta cierto grado sobre cedazos ó re. des y finalmente embalado para el consumo. Una clase su. perfina se coloca, despues de separar las membranas, en sacos de lienzo que se ponen por algun tiempo en salmuera y se cuelgan al aire, para acondicionarla en barricas despues de estar bien escurrida. Las especies mas pequeñas de sollo, el csterleta y el estrellado, dan el caviar mas fino.

PESCA. - Esta pesca tiene en el dia poca importancia en Alemania, puesto que su producto anual en las desembo. caduras del Elba y del Weser llega solo á algunos miles de individuos. En el bajo Danubio, đque antes proveia a Hun. gria y Austria de carne de sollo y caviar, se tocan ahora las consecuencias de la pesca irracional que hasta hoy ha esta. do en uso. Ya no basta la enorme fecundidad de estos peces para llenar los vacios que la codicia del hombre ha producido en sus masas, y' al fin habrá que fijar de grado 6 por fuerza un tiempo de reda, ó suspender por algun tiempo la pesca del todo si se quiere ir cosechando como hasta aquí.

En Rusia es donde se explota en major escala la pesca de esturion, sobre todo en los rios que desembocan en el mar Negro y Caspio. Las principales pesquerías rusas del primero están situadas, segun Kohl, en las desembocaduras de los grandes rios como el Dniester, el Dnieper, el Danu bio, los estrechos de Jenikalé 6 Cafa, grandes puertos donde se reunen todos los peces cuyo género de vida les hace tan necesaria el agua salada como la dulce. Por esta razon cxistén en todos esos puntos pueblos de pescadores, y'a perma nentes, ya temporales, que se construyen en primavera para desaparecer en otoño. El ducño de una pesqueria, ruso ó griego, arrienda un espacio de costa donde levanta una gran choza de caña y enea, compra barcas, redes y demás utensi. lios, invita a asociarse con bl \& un grupo de gente de la que alli acude, rusos, griegos, tártaros, moldavos ó polacos, y se establece con ellos por un verano en la playa. Las chozas de la gente son espaciosas, y se levantan tan cerca del agua co. mo es posible, pero siempre fuera del alcance de la marca; pónense en cada una de doce á veinte camas; en el fondo las cubas para recibir los peces, barriles de sal, molinos para triturarla, y sobre todo un santo, y á ambos lados de la puerta pilitas de agua bendita. Fuera de la choza se abre una ex. cavacion que sirve de hogar, del cual se encarga algun viejo práctico en guisar, llevar agun, moler sal, etr. Cuando la pesca m bien, se aumenta la dotacion con perros para guardar casa y pescado, cierto número de galinas para poder añadir algunos huevos al rancho, varios carneros para tener un asado los dias de fiesta, etc, etc.; y sobre todo se cuenta con el esturion, que ha de set el despensero principal que llenará los calderos y ollas. Cerca del agua plantan un mástil inclinado sobre el mar con un tonel en el extremo para que se coloque en él un vigia y anuncie la llegada de los peces, á fin de que los pescadorcs puedan salir á su cncuentro; y son tan prácticos estos hombres que no solamente ven venir a gran distancia las bandadas, sina que distinguen perfectamente la especie á que pertenecen. Para su objeto dividen tocios los peces en dos clases, rojos y blancos, entendiendo por rojos los esturiones.

Tocias estas empresas suclen hacer uso de redes, pero cuando el hielo cubre la superficie y los esturiones duermen, como dice Lepechin, su sueño de invierno con la cabeza metida en el limo y la cola fuera, como si toda la bandada formase un bosque submarino de gruesas estacas, entonces se hace la pesca de otra manera. Los pescadores, dice Pallas, 
observan los sitios hondos del rio donde se han reunido en otoño los sollos echados uno junto $\{$ otro; $y$ cuando han dado con ellos adquieren un perniso de pesca y tratan de la manera, dia y sitio de pescarlos. Un cañonazo es la señal convenida para la operacion; apenas lo oyen cuando cada interesado acude sin perder tiempo en su trineo al punto que le toca; alli abre un agujero en el hielo y baja un gan. cho de hierro fijo en el extremo de una pértiga larga de seis a diez y si es menester hasta reinte metros y lastrada con hierro. Los peces, espantados por el ruido causado por la rotura del hielo, empiezan à desfilar rio abajo y chocan al pasar contra la pértiga, señal que aprovecha el pescador para ver si de un tiron engancha uno. Hay individuos que tienen suerte y cogen así en un dia diez y mas esturiones grandes, mientras que otros pasan dias sobre el hielo sin sentir en su pértiga la menor sacudida y ganando apenas en todo el mes que dura la pesca, lo suficiente para pagar sus gastos. Hans. teen, que observ́́ esta pesca en el rio Ural, asegura que alli unos 4,000 cosacos cogen en dos horas por valor de mas de 40,000 rublos de esturiones. El primer pez que cogen se regala á la iglesia, $y$ los demás se cargan en trineos y se envian sin pérdida de tiempo al contratista, si no acude allí desde muy léjos para comprar los peces á medida que se cogen, salar y curar la carne y las huevas y mandarlos á sus corres. ponsales. Cuando el frio es muy grande y permanente, no se sala el pescado en el campo sino á su llegada al depósito. El producto de la pesca de esturion es muy considerable. En tiempo de Pallas ascendia en el mar Negro y Caspio á unos dos millones de rublos al año, y ahora pasa de cinco millones, ápesar de ir disminuyendo el número de estos peces.

\section{LOS ESCAFIORINCOS-SCAPHIO- RHYNGHUS}

CARACTERES. - Fste género está representado por peces cuyo carácter mas distintivo consiste en la curiosa forma de la cabeza, que es aplanada y redondeada; el cuerpo bastante prolongado, se adelgaza gradualmente, y está protegido por cinco series de placas huesosas.

\section{EL ESCAFIORINCO CATAFRACTO Ó DE ES- CAMAS ACERADAS - SCAPHIORHYNCHUS CATAFRACTUS}

CARACTERES. - Ia cabeza de este pez, sumamente aplanada y ancha, se asemeja en cierto modo á una especie de paleta; el hocico es tambien achatado, convero en la cara superior y cóncavo en la inferior, hallándose el hocico situa. do por debajo; el cuerpo, prolongado como el de los acipén. seres, y no menos robusto, se adelgaza gradualmente; proté. genle cinco series de placas liuesosas, de gran tamaño en el individuo adulio; las aletas están dispuestas poco mas ó menos lo mismo que en los acipénseres. Por el color y el tanaño, difieren poco de los peces del género anterior.

DISTRIBUGION GEOGRAFICA. - Este escafiorinco habita principalmente en las aguas de la América del norte.

USOS, COST UMBRES X REGIMEN. - Cunto se ha dicho sobre este particular de los esturiones es en un todo aplicable á los escafiorincos.
Junto á los monstruosos reptiles que poblaban en los tiempos antiguos de la historia terrestre las aguas dulces y las marinas, vivian tambien enormes peces, de los que solo algunos representantes han llegado hasta nuestros dias. De los numerosos restos fósiles que á menudo se encuentran, puede decirse que estos peces existieron en gran numero, como tambien que excedian considerablemente en magnitud á sus afines de la actualidad, siendo hasta probableque muchos igualaran a las ballenas en este respecto. Por lo que toca á su estructura, todo parece indicar su analogia, en lo mas esencial, con las especies que han sobrevivido, dc modo que debian presentar, nas ó menos marcados, los mismos caraciéres de nuestros escualos y rayas.

CARACTERES. - Aunque en la clasificacion se colo quen los peces cartilaginosos detrís de los óseos, no les son en mancra alguna inferiores, pues aunque su esqueleto no alcanza la consistencia ósea de estos, permaneciendo siem. pre ternilloso, el desarrollo del cerebro, la disposicion de las risceras, su modo de reproduccion y los cuidados que algu. nos manifiestan por sus pequeñuelos, los colocan en primera linea entre todos los individuos de la clase.

«El cráneo de estos peces, dice Cárlos Vogt, se compone de una sola pieza, à manera de saco, que protege el cerebro, encierra el órgano auditivo y forma á cada lado $y$ en la por. cion anterior huecos, que son el asiento de los ojos y del aparato olfatorio, generalmente bastante complicado. Is su. perficie interior de esta cavidad ternillosa forma al mismo tiempo la bóveda palatina en la cavidad bucal, y hácia ade. lante la mandibula superior, en la que están implantados los dientes; esta última disposicion es propia de una sola familia, pues en las demás aparece movible la indicada mandibu. la, á la que se adhieren por detrás utras piezas yue representan la primera porcion de la bóveda del paladar. La mandi. bula inferior se preşenta siempre movible $y$ compuesta de una sola pieza arqueada; casi todas las especies tienen tam. bien cartilagos labiales, que jamás alcanzan un completo desarrollo. El cráneo propiamente dicho está tan solo cubierto por la piel, pero sus huecos $y$ depresiones exteriores se encuentran a menudo rellenos de tal cantidad de materia grasienta ú gelatinosa, que la forma externa de la cabeza difiere notablemente de la configuracion de aquel. Respecto á la estructura de la columna vertebral, hay bastante desemejan. za entre las varias especies. En algunas aparece tociavia un cordon vertebral continuo, cuya vaina $\delta$ estuche se prolonga hácia arriba en forma de tubo y encierra la médula; en otras tiene el cordon en su interior abiques divisorios que repre. sentan las vértebras, mientras que en las demás se ven estas mas desarrolladas, con sus correspondientes cavidades á cada lado, pero constantemente de naturaleza cartilaginosa. Las aletas pectorales comunican siempre con una especic de aparato tumbien cartilaginoso, que $\delta$ está prendido á la porcioa occipital del cráneo, $6 \dot{a}$ la parte anterior de las vérte- 
bras cervicales, y que, extendiéndose por la region abdomi. nal, encierra el corazon. Las ventrales están situadas muy hácia atrás, cerca del ano, y provistas las de los machos, en su borde interno, de ciertos apéndices, que parecen servir para sujetar á la hembra. Las aletas impares y tambien las pares, menos en las rayas, hâllanse sostenidas por gran nú. mero de radios de fibras cómeas, muy distintos de los que se ven en todos los demás peces. Las dorsales tienen asimis. mo radios espinosos de forma muy particular; presentan todas una larga espina, fuerte y puntiaguda, por lo comun encorvada á manera de sable s dentada como una sierra en su borde posterior; compuesta de verdadera materia cbúrnea, es hueca, y aplanándose y afilàndose hácia su base, tiene esta implantada en una protuberancia ternillosa, á veces movible.

I a piel de los selacios está completamente desnuda 6 aparece revestida de excrecencias duras, que los distinguen de los demás individuos de la misma clase. En algunos casos estas excrecencias son aristas mas 6 menos corvas, formadas de la misma materia que las espinas de las aletas dorsales y arrancan de un tejido esponjoso que les sirve de base; otras veces toda la piel está cubierta de pequeñas pun. tas ganchudas de igual naturaleza.

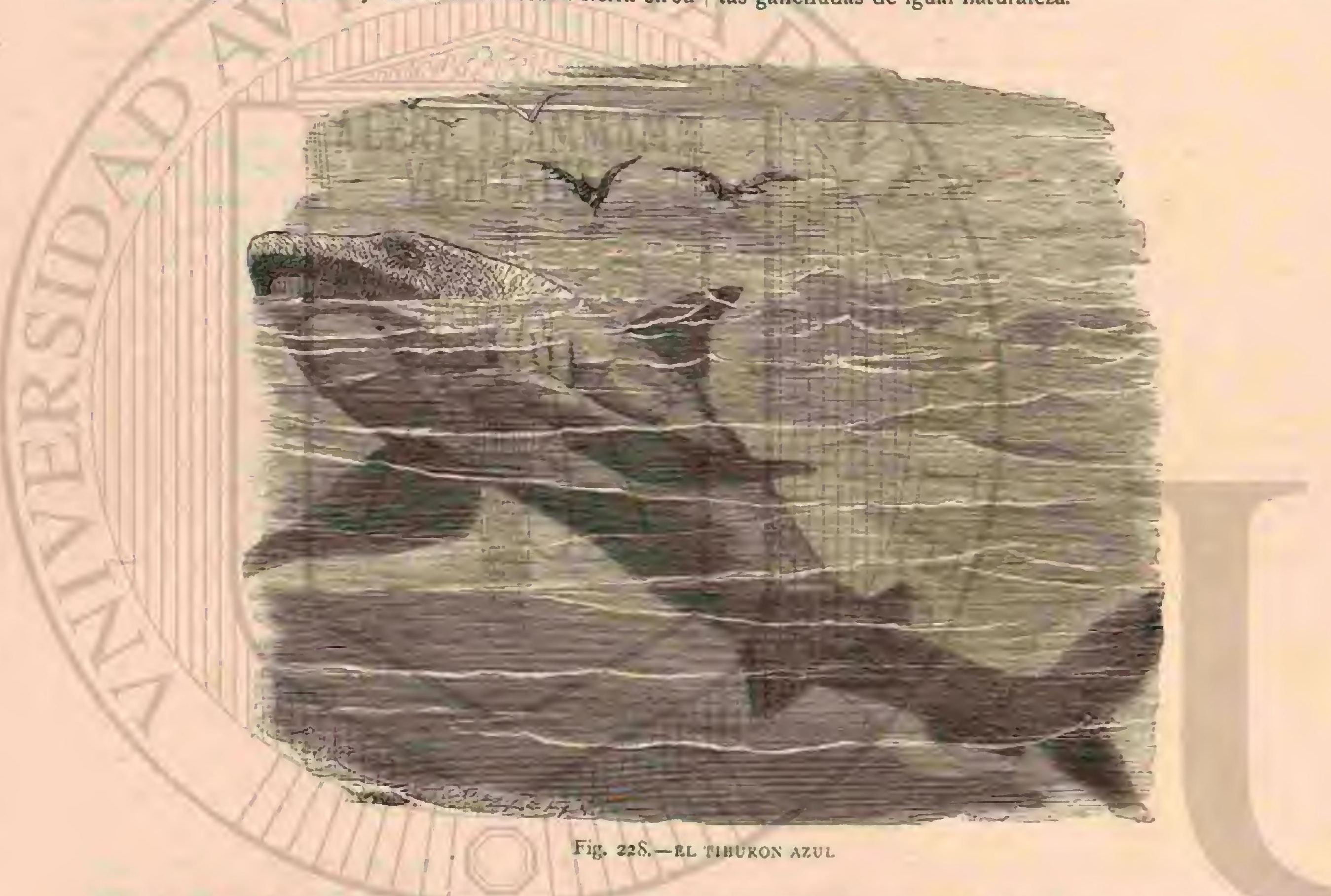

\$Por mucha que sea la diversidad, en cuanto á la forma y disposicion, de los dientes de estos peces, tienen todos un carácter general, á saber: el no estar jamás implantados en la misma masa ternillosa de la mandibula, sino insertos, cn. mo una raiz esponjosa \& veces, en la piel gruesa $s$ viscosa que la reviste. Fistos dientes se sustituyen unos á otros de tal modo, que cuando el mas exterior, que es el que funcio. na, se gasta con el uso, va adelantando el que está inmedia. tamente detrás hasta ocupar el puesto de aquel. El estómago es por lo general ancho; el intestino corto y casi sin circunvolucion alguna, no faltando nunca la llamada válvula espinal, que consiste en un conducto adherido á las paredes de aquel, y que afecta la forma indicada.

El aparato respiratorio difiere tambien bastante del de otros peces. Vénse en los arcos branquiales varias láminas, que no solo están unidas con aquellos en su base, sino tam:bien en toda la longitud de uno de sus bordes y en su porcion mas extrema con tabiques intermedios, de modo que solo aparece libre el borde que está del lado de la abertura branquial, mientras que los indicados tabiques tienen á cada lado una fila de borlillas. Por medio de la membrana intermedia, sostenida por cartilagos, se forma una serie de bolsas con una abertura trasversal hácia dentro en las fauces, y á veces tambien otra en la parte exterior; así se ven á menudo en los dos lados del cuello ó en el abdómen, un poco delante de las aletas pectorales, seis ó siete abcrturas branquiales; únicimente las lijas presentan una sola abertura.

En los selacios hay rerdadera cópula, siendo pocas las hembras que ponen huevos, revestidos de una cáscara dura y córnea, y à veces muy exiravagante; algunos en forma de paralelepipedos oblicuos, cuyos ángulos se prolongan en cordones córneos; las demás dan á luz pequeñuelos vivos que se desarrollan en una porcion mas ensanchada del oviducto.

Los embriones están casi siempre sueltos y se desarro. llan a expensas, ya de la yema 6 ya del medio albuminoso en que se hallan; pero en una especie de este órden se ha visto que la membrana de la yema está cubierta de folículos que encajan entre otros del oviducto, formando juntos como un rudimento de placenta. Los embriones presentan; aparte de otras particularidades, la de tener branquias exteriores en las aberturas branquiales y por lo general tambien en los espiráculos, como los que se ven en las salamandras. Los filamentos exteriores desaparecen mucho tiempo antes de salir el animal á luz. 


\title{
PLAGIOSTOMOS-PLAGIOSTOMATA
}

\begin{abstract}
CARACTERES. - La existencia de algunas escasas especies de una familia en su mayor parte extinguida, y que difieren de un modo muy notable de todas las demás por la

formacion de la boca, ha inducido á dividir la serie ó sub.cla. se en cos órdenes, de los cuales el primero comprende la gran mayoria de las familias, géneros y especies aun existen-
\end{abstract}

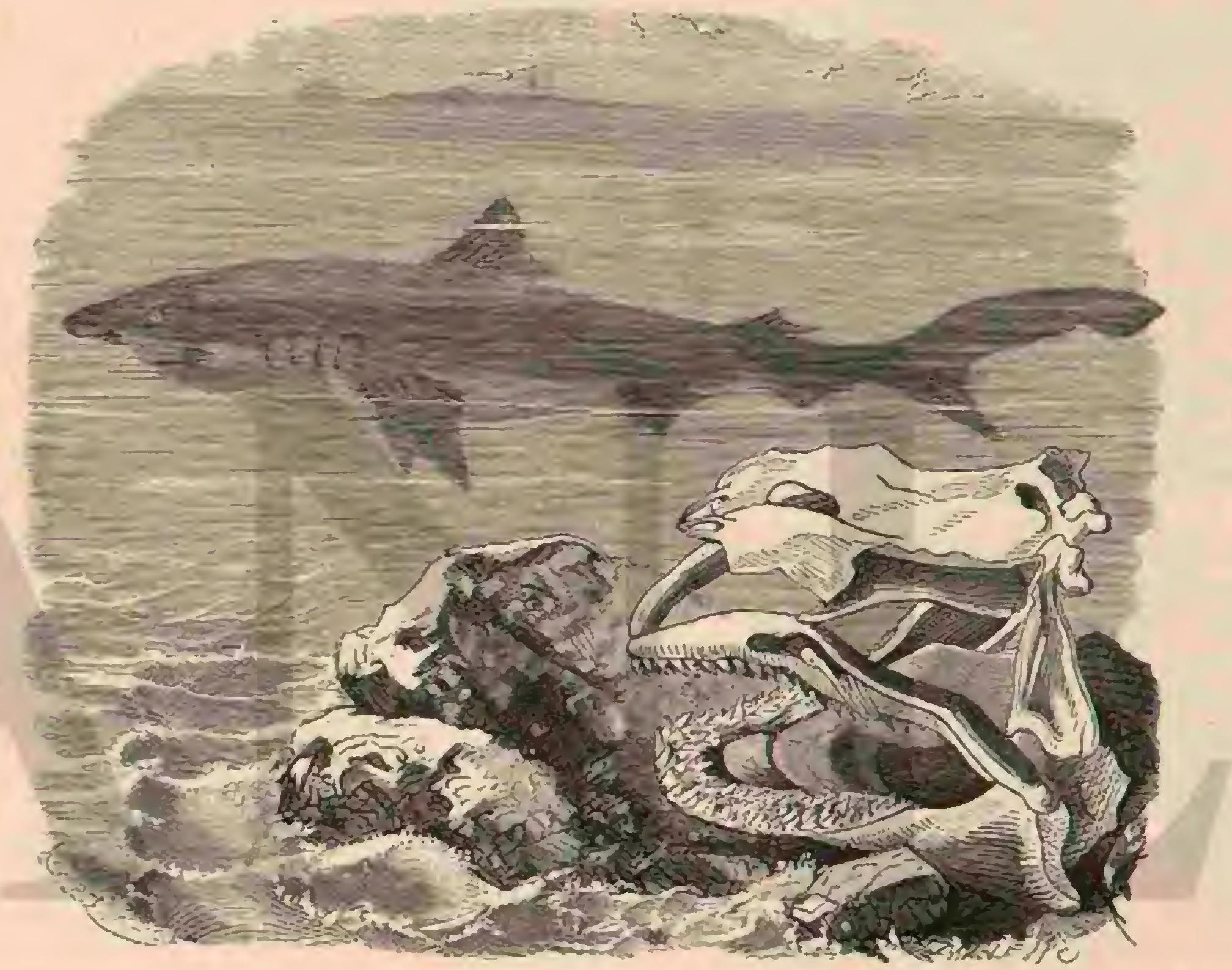

Fig. 229. - EL TIBURON VPRDร.MAK

tes, y se caracteriza por la boca ancha, hendida trasversal. mente debajo del hocico y muy atrás en forma de curva, y además por los espiráculos abiertos generaimente encima de la cabeza detrás de los ojos y comunicando con las fauces; por las branquias perfectamente desarrolladas con compartimientos independientes que se abren separadamente hácia fuera, y por la piel pocas reces desnuda y casi siempre cu bierta de la manera indicada mas arriba. En la columna vertebral se distingue la division en vértebras, así como su arti culacion con el cránco, consistente en una cavidad esférica

\section{LOS SELACOIDEOS -} SELACHOIDEI

CARACTÉRES. - Estos selacios tienen forma ahusada, cola gruesa, aberturas branquiales en los lados del cuello, y las aletas pectorales separadas de la parte posterior de la cabeza.

DISTRIBUCION GEOGRÁEICA. - Viven exclusivamente en el mar, pero dispersados por todas las zonas.
USOS, COSTUMBRES Y REGIMEN. - Son en sU mayor parte vivfparos y exclusivamente zoólagos.

USOS Y PRODUCTOS.-Para el hombre son estos ani. males tan daninos como temibles; los únicos rapaces del mar que, a cxcepcion de algunos cefalópodos gigantescos consi. derados mucho tiempo como legendarios, atacan directa. mente al hombre para alimentarse de él. Nada tiene pues de extraño el odio y la guerra de exterminio que este ha declarado siempre y en todas partes á animal tan terrible, y mientras se cogen otros peces por la utilidad que sacamos de ellos, pescamos y matamos los tiburones y en general los selacoi deos grandes, no por el insignificante provecho que ellos nos reporten, sino con la intencion de exterminar el mayor nú. meto posible.

\section{LOS CARCARIDOS- CARCHARIID压}

CARACTERES.-Comprende esta familia unas setenta especies de peces voraces é insaciables en alto grado y de 
una ferocidad tan grande que son el terror de todos los marinos y poblaciones marítimas de las zonas templadas y tórrida. Caracterizanlos sus ojos que tienen conjuntiva ó pár. pado faiso, la colocacion de las dos aletas dorsales.entre las torácicas y abdominales y la pequeñez de la anal. No tienen espiráculos, por lo menos los adultos; las aberturas branquia. les posteriores están encima de las aletas torácicas. La cabeza cs aplanada, la parte anterior del hocico muy larga, y las fosas nasales bastante desarrolladas. Guarnecen la ancha boca dientes voluminosos, triangulares, puntiagudos é incisivos, en su mayor parte con el borde cortado ámanera de sierra, y colocados en varias filas. El cuerpo está cubierto de escamas pequeinas y en el canal digestivo recmplaza a la vál. vula espiral un repliegte enrollado.

\&

\section{EL TIBURON AZUL-CARCHARIAS Ó SQUA- LUS CCERULEUS}

CARACTERES. - Esta especie, una de las mas conoci. das (f́. 228 ), alcanza una longitud de tres á cuatro metros y acaso mas. El hocico es muy puntiagudo, los dientes de la mandibula superior forman cuatro filas oblicuas; los de la inferior son esbeltos y en la primera edad triangulares, en la vejez lanceolados. Las aletas pectorales son largas, en forma de hoz y llegán hasta donde empieza la dorsal, que está mas cerca de las abdominales que de aquellas; la caudal es larga. La parte superior de la cabeza es de un hermoso color azul pizarra, Cigual tinte ofrecen el lomo con sus alctas, la mayor parte de la cola y la cara superior de las aletas pecto. rales y abdominales, mientras que el resto del cuerpo es blanco.

DISTRIBUCION GEOGRAFICA.-Desde el Mediterrúneo, que se considera como la patria verdadera del tibu. ron, se extiende este rapaz por una gran parte del Atlántico, y hácia cl norte hasta la Inglaterra 9 Escandinavia, cupas costas suele visitat regularmente en verano. Couch dice que es pez viajero, porque estí probado que jamás se le ve en las costas de Cornualles antes de mediados de junio.

USOS, COSTUMBRES Y REGIMEN.- Todos los carcáridos tienen idéntico género de viàa. Les gusta estar cerca de la costa y en las capas superiores del agual. Por lo comun se los distingue de léjos, porque nadan tan cerca de la superficie que una gran parte de la aleta dorsal sale fuera de ella y se les puede tirar con bala como yo les he tirado muchas veces. Nadan acompasadamente y con regular ve. locidad mientras no, persigan una presa deterninada, pero cuando se presenta este caso acrecen su rapidez hasta no ceder en ella peces, sobre todo en cuanto á la facilidad de girat rápida. inente, pero a pesar de esto son mas listos de lo que suele suponerse, y suplen con sus ataques imprevistos la falta de flexibilidad. Deben tener los sentidos muy desarrollados, porque su vista es excelente, y casi no cabe duda de que en cuanto á olfato ganan a los demás peces, sin que falten observadores que están persuadidos de que este sentido es en los carcáridos el mas perfecto de todos, y que los cuerpos que despiden mucho olor los atraen mas que otros, por cuya razon atacan mas á los negros que \& los blancos. Respecto al oido no hay datos.

Del comportamiento de los tiburones se deduce que sus facultades intelectuales son mas perfectas que las de otros peces á pesar de su ciega rapacidad, pues para convencerse de ello basta observar su modo sistemático de cazar, la re. gularidad con que visitan determinados sitios, la memoria que patentizan en catos casos, la intimidad que los liga con el pez piloto cuyos servicios saben aprovechar tan bien, la tenacidad con que acompañan á los buques, que siempre les proporcionan algo; el cariño que manifiestan hácia sus hi. juelos, conforme se dice por lo menos, y otras muchas pruebas. Todo esto desaparece por supuesto cuando se considera su hambre insaciable é increible que los impele \& ejecutar las acciones mas impremeditadas y estúpidas. De cuanto hemos visto hasta aqui resulta que la voracidad es uma de las cualidades mas sobresalientes de los peces en general, y de estos los mas voraces son los tiburones «Son peces, dice Gessner acertadamente, muy listos y veloces para su talla; rapaces, traidores, hambrientos, descarados, rudos y tan atrevidos que hảsta saquean las redes y nasas de los pesca. dores.

Fin efecto atorméntales continuamente un hambre canina que nada es capaz de aplacar, y cuanto se diga de su insa. ciabilidad tay que entenderlo al pié de la letra. Todo lo que engüllen lo expelen á medio digerir, y por esta razon se ven forzados a llenar su estómago sin parar. Devoran todo lo que es y parece comestible, pues en sus estómagos se han encontrado los objetos mas extraños; por ejemplo, medio jamon, algunas piernas de carnero, la parte posterior de un cerdo, la cabeza y patas anteriores de un perro buldog, una gran cantidad de carne de caballo, un trozo de arpillera y un rascador de buqué, que se encontraron en el estómago de un solo individuo de la especie blanca. A otros se les ha visto tragar los objetos mas diversos que se les tiran desde \{ bordo, ya sean ropás vicjas, o ya tocino, abadejo y sustan. cias vegetales que/nada alimentan. Bennett los compara á los avestruces y opina que nada resiste a su capacidad di. gestiva, puesto que no pueden llevar toda la vida en el vientre objetos como jarras de estaño que tambien engullen. Cetti asegura que en las almadrabas se cogen animales de estos que pesan de 1,500 á 2,000 kilógramos, y añade que bien es menester que sean tan grandes para tragarse de una ver, como se tragan, ocho ó diez atunes. Los dueños de estos establecimientos temen continuamente verlos penetrar de. trás de sus presas en las redes, pues hacen en ellas un terrible destrozo, sin pagar ni medianamente siquicra el espanto que causan a los pescadores. En alta mar se llenan el vientre de toda clase de animales marinos con que tropiezan. Un tiburon que examino Bennett, tenia el estómago lleno hasta reventar de peces pequeños de toda especie, calamares y otros cefalópodos, con gran admiracion del citado natura. lista, que no comprendia al principio cómo este gigante podia coger presas tan ágiles, hasta que mas tarde supuso que el tiburon'no se debe limitar a volverse de lado para atra. par una presa, sino que tambien debe tragar todo lo que le penetra en la boca, la cual lleva abierta mientras nada en una direccion 9 con un objeto cualquiera.

Pocos serán los hombres que en nuestros dias tengan la fortuna del profeta Jonás', pero dicese que ha sucedido real y positivamente un caso análogo, pudiendo garantizarse su certeza ; es decir, que un tiburon se tragó á un marinero y le vomitó tan luego como el capitan del buque hirió mortal mente al animal con una bala de cañon. Yo sefiero el caso sin asumir responsabilidad alguna, porque no me parece creible; pero lo que si tengo por cierto es que el tiburon suelta a veces al hombre que ha cogido, y tambien que haya habido hombres que lucharan con este animal y salieran victoriosos, pues no faltan ejemplos de negros de la costa occi. dental de Airica que armados de afilado cuchillo atacan al tiburon en su elemento $y$ le abren el vientre, y Dixon ase. gura haber visto indigenas de las islas Sandwich disputando en el mar á los tiburones los intestinos de cerdo que desde un buque se habian tirado al mar. No citaré aq̧ui niuguno de los muchos casos en que sucede enteramente lo contra. 
rio, porque apenas habrá persona de cuantas han viajado por mar que no liaya oido contar otros análogos. Gessner ya ha. bla de haberse encontrado hombres enteros en el estó. mago de algunos tiburones: ten Marselln una ver un hombre completamente armado jos ictiólogos modernos pueden añadir á este mas de cien casos parecidos.

El hombre que en los mares ecuatoriales y aun en el Mediterráneo cae al agua, encuentra invariablcmente su tumba en el estómago del tiburon, y cuando estos han probado carne humana se atreven á todo. Durante mi estancia en Alejandria no podian tomarse baños de mar porque un tiburon se habia llevado en poco tiempo varias personas al pié de los muros de las mismas casas. En la costa meridional del mar Rojo varó un monstruo de estos lievado por la furia con que perseguia a un individuo que se estaba bañando y que pudo salvarse á tiempo en tierra. El doctor Alexander se vió ata. cado en la playa de Singapore por tiburones, mientras se ocupaba en buscar conchas metido en el agua hasta las rodillas, y habria sido infaliblemente victima de ellos, si una lan. cha no hubiese acudido $y$ hecho huir á los feroces animales, que no se fueron sin llevarse ia botay el pantalon junto con un trozo de piel de la canilla de la pierna derecha del sabio profesor. Durante las largas traveslas distrae mucho observar al tiburon y su piloto, pero no cuando se ceba la fiebre amarilla en la gente y un cadáver tras otro ha de tener su sepul. cro en el mar; entonces hasta los corazones valientes se sienten transidos de horror al ver la actividad de estos peces. In la batalla naval de Abukir, los tiburones acecharon y devoraron s los infulices soldados que caian al mar en medio de los buques de ambas flotas, sin que les atemorizara el horroroso estrépito de los cañonaz.os.

Todavia no se sabe nada de fijo sobre la reproduccion de los carcáridos, pero sí respecto de la cópula, que segun todos los datos en este punto concordantes, efectúan en realidad. Los tiburones se aproximan á la orilla; varios machos se disputan la hembra, y durante la cópula naca la pareja cerca de la superficie de una parte á otra. Los huevos, en número de treinta ó cuarenta, se desarrollan en el vientre de la madre y los pequeños nacen ya en perfecto desarrollo y dispuestos á alimentarse por si solos, bien que la madre los vigila y guia algun tiempo y los recoge en su boca 6 estómago en caso de peligro, puesto que está fuera de toda duda que se han encontrado tiburones vivos en el estómago de individuos mayores; pero como son animales de una viralidad extraordinaria y por otra parte tan voraces, pueden explicarse estos casos de un modo bien distinto de como lo hacen los autores anti. guos y nuestros marinos modernos.

PESCA.-Son poco menos que insuficientes las armas de fuego portátiles parn exterminar à los tiburones. Cuando uno de ellos se siente herido de un balazo, se aleja con la mayor velocidad y furia, de modo que nunca se sabe si la herida es mortal o no. Las redes tampoco sirven de nada, porque las rompe 6 las corta con sus terribles dientes y se escapa, mas á pesar de esto se cogen algunos asi. El instru. mento mas eficaz es el anzuclo fuctte, afianzado en una cadena y cebado con un pedazo de tocino, un per, y á falta de otra cosa mincjor con un puñado de estopa, puesto que estos monstruos muerden todo lo que se les arroja de á bordo.

En uno de los viajes de Heuglin por el mar Rojo mató este naturalista un dia un planga blanco, nque el servicial timonel se apresuro ó ir á buscar, pero apenas estaba $\{$ bordo $y$ habia vuelto chorreando agua á ocupar su puesto en la caña del timon, cuando se presentó un tiburon á popa y buscando una presa pasó como el rajo por el costado del buque; rel pobre Rachid se asustó y solo me pudo señalar al terrible huesped con el dedo; pero en cl mismo instante $y$ con igual velocidad llegó otro g un monento despues un tercero, este último de un tamaño colosal. Entonces se convino unånime. mente en cazar estas liicnns del mar. A cstc efecto sacaron un anzuelo de hierro de unos 30 centímetros de largo con su correspondiente cadena, lo cebaron con un per medio curado al humo, ataron la cadena à una maroma y lo echaron al monstruo. Apenas se habia metido el cebo como una braza en el agua, cuando el mas pequeño de los tiburones nad6 directamente hácia el, y poniéndose de costado, lo mordió. El marinero que sostenia la maroma tiró de ella, aunque demasiado pronto, y el tiburon aflojó la presa, pero solo para morderla mejor, de suerte que fué izado triunfalmente sobre cubierta a fuerza de brazos y por medio de un torno, y alli le descargaron recios golpes con arpones, machetes y palos basta dejarle atontado. En seguida se arrojó al mar otra vez. el gan. cho cebado de nuevo, y á los cinco minutos turimos el segundo huésped á bordo donde se le recibió como á su camara. da. Entre tanto habia desaparecido el tercero, pero reapareció al cabo de un buen rato; solo que en lugar de morder la carne de carnero con que se habia cebado el anzuelo, se limitó á describir ćrculos al rededor de ella, tan tranquilo como si no la viera; pero cuando se hizo bajar mas y mas el cebo, se aproximó con cautela y mordió al fin. Como habria sico peligroso arrojarlo vivo sobre cubierta, le disparamos primero dos balazos en el críneo mientras colgaba en el aire, se introdujo en una de las heridas un arpon y con gran trabajo se logró ponerlo subre cubierta. Media unos tres metros de largo, y la tripulacion estimó su peso en mas de 200 kilógramos.

A esto añade el citado autor: «Como esios animales se resistian á morir y daban golpes tan furiosos que hacian tem. blar el buque, les echaron los marineros algunos cubos de agua dulce en las fauces, diciendo que esto los mataba en seguida, cosa que no pude comprobar, porque de paso se entretenian otros en triturarles el cráneo, de modo que al fin espiraron de veras; y sin pérdida de tiempo se dedicaron todos a destrozarlos. Se les extrajeron los higados (el del úl. timo cogido media un metro de largo), y se guardaron en el mismo estómago de los animales para sacar mas tarde el aceite que sirve alli para calafatear las embarcaciones. Se les cortaron las aletas pectorales, dorsal y caudal para venderlas en Masaua desde donde exportan este articulo en gran can tidad para la India en cuyo pais lo emplean para pulir objetos de metal, y para afilar instrumentos cortantes, y sus cucrpos se arrojaron al mar, porque no se come la carne de tiburones adultos y grandes.

Los marinos europeos cogen los tiburones de idéntica ma. nera; los izan fuera del agua hasta que las branquias quedan completamente descubiertas, en cuya situacion dejan que se debilite el animal para subirlo despues sobre cubierta donde le cortan primero la cola, y aprovechan el resto.

No bien se siente cogido el tiburon parece enloquecer de rabia. Hay veces que se pone á dar vucltas sobre si mismo con una velocidad vertiginosa hasta que destuerce completa. mente la maroma, $\delta$ se enreda tanto en ella que no se le pucde sacar sin cortarla. Seria imprudente pescarlo en lanchas, porque tan pequeñas embarcaciones no pueden resistir las arremetidas del aninoal.

USOS Y PRODUCTOS. - La carne es indigesta, engen. dra malos hunores y melancolia, dice Gessner; Bennett viene á decir lo mismo: No puede considerarse el tiburon como alimento, por lo menos no puede figurar en la mesa de un epicúreo, pues su carne es dura, insipida é indigesta, pero hay personas que prefieren los tiburones jóvenes á los atu. nes.

CAUTIVIDAD. - Nada he oido respecto de este punto; solo recuerdo haber leido en alguna parte que se han conser. 
vado viros peces de esta fzrnilia durante cierto tiempo en un vivero gigantesco.

\section{EL TIBURON VERDEMAR - SQUALUS GLAUCUS}

CARAGTERES. - Los dientes de este escualo (fig. 229), triangulares, prolongados g agudos, no ofrecen dentelladuras en los bordes como los de la especie anterior, ni son tampoco algo cónicos. La primera aleta dorsal está mas próxima á la cabeza que las ventrales; en la parte superior de la extremidad de la cola existe una foseta; y el lóbulo superior de la aleta caudal es tres veces mas largo que el inferior. La piel de este tiburon es menos áspera que la de casi todos los demás escualos. Este pez ofrece bonitos colores cuando está vivo: toda la parte superior de la cabeza, del cuerpo, de la cola y de las aletas es de un azul verdoso, semejante al que se observa en las aguas del mar cuando no están agitadas por los vientos ni se reflejan en ellas los rayos del sol; las regio. nes inferiores, de un color blanco brillante, contrastan agradablemente con el azul verdoso. Por lo que hace al tamaño, los representantes de esta especie alcanzan tambien notables dimensiones, siendo frecuente encontrar individuos de cinco

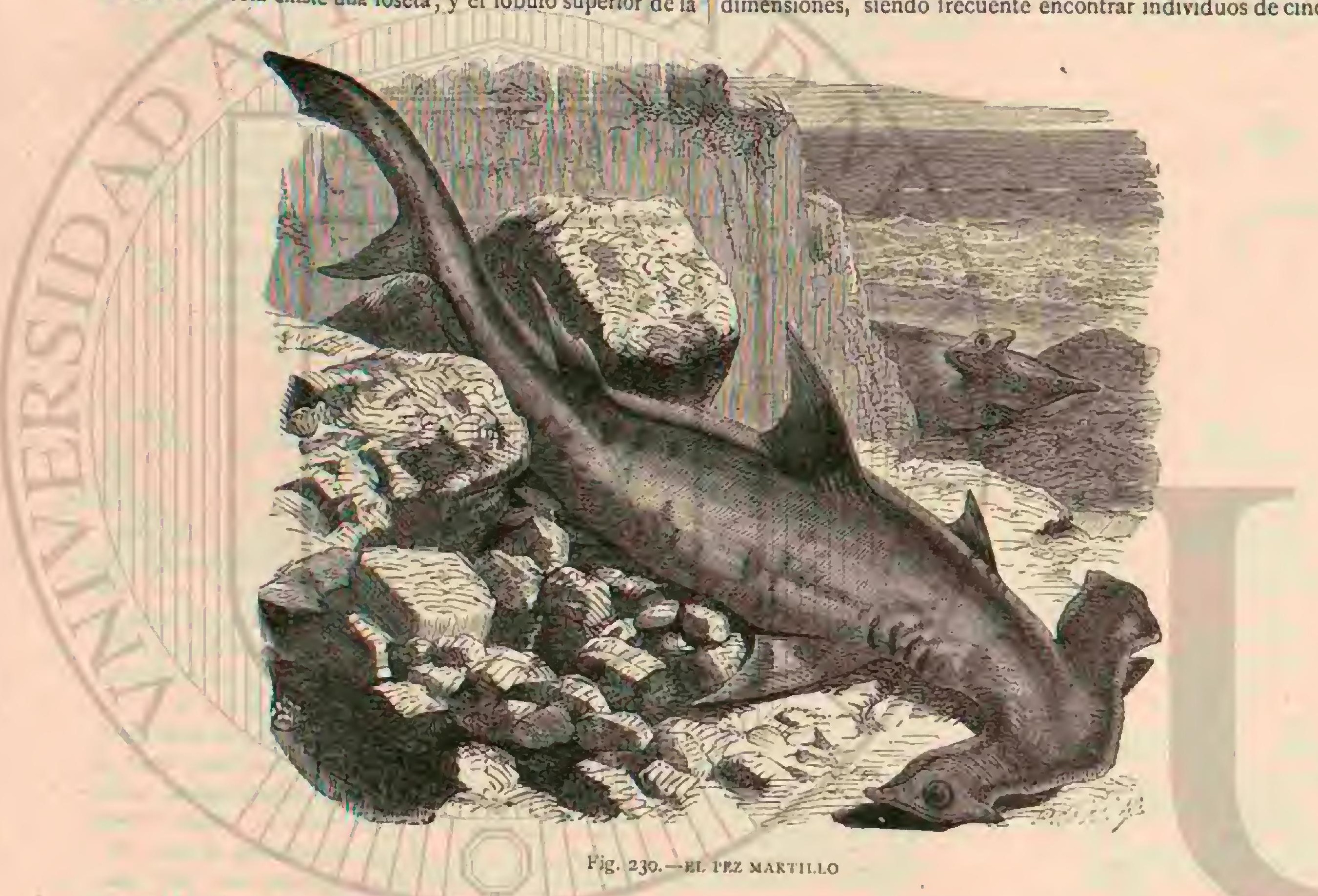

metros. Algunos autores dicen que cuando miden ocho piés de largo, su circunferencia es de cuatro, pesando entonces el animal unas doscientas libras

DISTRIBUCION GEOGRÁrICA.-Esta especie habita en todas las latitudes, desde la isla de la Ascension hasta los mares del Polo.

USOS, COSTUMBRES Y REGIMEN. - Hácia el mes de junio, segun varias observaciones, suele acercarse este pez con f́recuencia a las costas, y no menos voraz que ia es. pecie antes descrita, causa grandes destrozos entre los demás habitantes de las aguas que no pueden oponerle resistencia. Acostumbra tambien seguir \& los buques para devorar cuanto de ellos cae; en la estacion en que los pescadores tienden las redes, destroza muchas con el objeto de alimentarse de los peces que contienen. Este tiburon es tanto mas peligroso cuanto que a su gran lamaño y voracidad reune la circuns. tancia de que, confundiéndose su color con el de las aguas del mar, acércase ian de improviso, que rara vez escapan las victimas a su furor. Es probable que los antiguos mitólogos y poetas de-los tiempos heróicos adoptaran la denominacion de glauco, empleada por los naturalistas para designar esta especie, solo teniendo en cuenta la distribucion de los colores, que podrian ser los de aiguna de sus divinidades ó semidioses marinos.
PESCA.- I a del tiburon verdemar no ofrece menos peli gros que la del anterior, porque este pez se defiende con igual vigor y coraje, y no es fácil apoderarse de él sino despues de una sostenida lucha. Una vez sobre cubierta, se deben adoptar infinitas precauciones, porque aunque esté muy mal herido puede descargar un golpe de muerte al que se aproxime imprudentemente (1).

\section{LOS GALEOS-GALEUS}

CARACTÉRES. - Los peces de este género tienen dos aletas dorsales, desprovistas de radios espinosos ambas, ha. llándose la primera entre las torácicas y las abdominales, y una sola anal; dientes con el borde interior liso ó poco aser. rado, y el exterior áspero y profundamente aserrado; espirá. culos prolongados; fosas nasales cubiertas a medias por la piel y situadas encima de la boca; $y$ aletas relativamente pe. querias, exceptuando la caudal que es poderosisima.

(1) Además de las especies descritas, suelen frecuentar las costas de

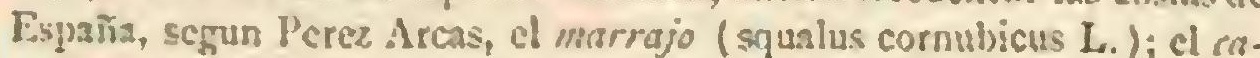
son (sq. musichus L.); la zorra if mar (s7. vulpes L. ), y algunas otras menos nolables. 
EL GALEO PERRO-GALEUS CANIS

CARACTERES.-Es un tiburon de uno á dos metros de largo, de colos agrisado en la region dorsal y blanquizco en la ventral.

DISTRIBUCION GEOGRÁFICA,- Es muy frecuente en el Mediterráneo; existe igualmente en el Atlántico, y en las costas inglesas es huésped algo frecuente.

USOS, COSTUMBRES Y REGIMEN.-En la antigüe dad, y aun en tiempo de Gessner, prevalecia la creencia de que este pertiene una extraordinaria aficion á las.partes blancas y desnudas del cuerpo humano, como las piernas y piés de los pescadores, conforme cuenta Plinio de uno de ellos. Hoy no se le teme por su aficion á las piernas huma. nas, pero sí como rapar dañino que perjudica mucho la pesca: Multiplicase bastante, segun Couch, ya porque la hembra pare treinia y mas pequeños cada vey, ya porque estos úlii. mos se desarrollan tan de prisa que álos dos años han alcan. zado toda su talla.

USOS Y PRODUCTOS.-La carne de csta especie tiene fama de ser mejor que la de otros tiburones, pero no se come, y todo el beneficio que se saca de ell se reduce al aceite que

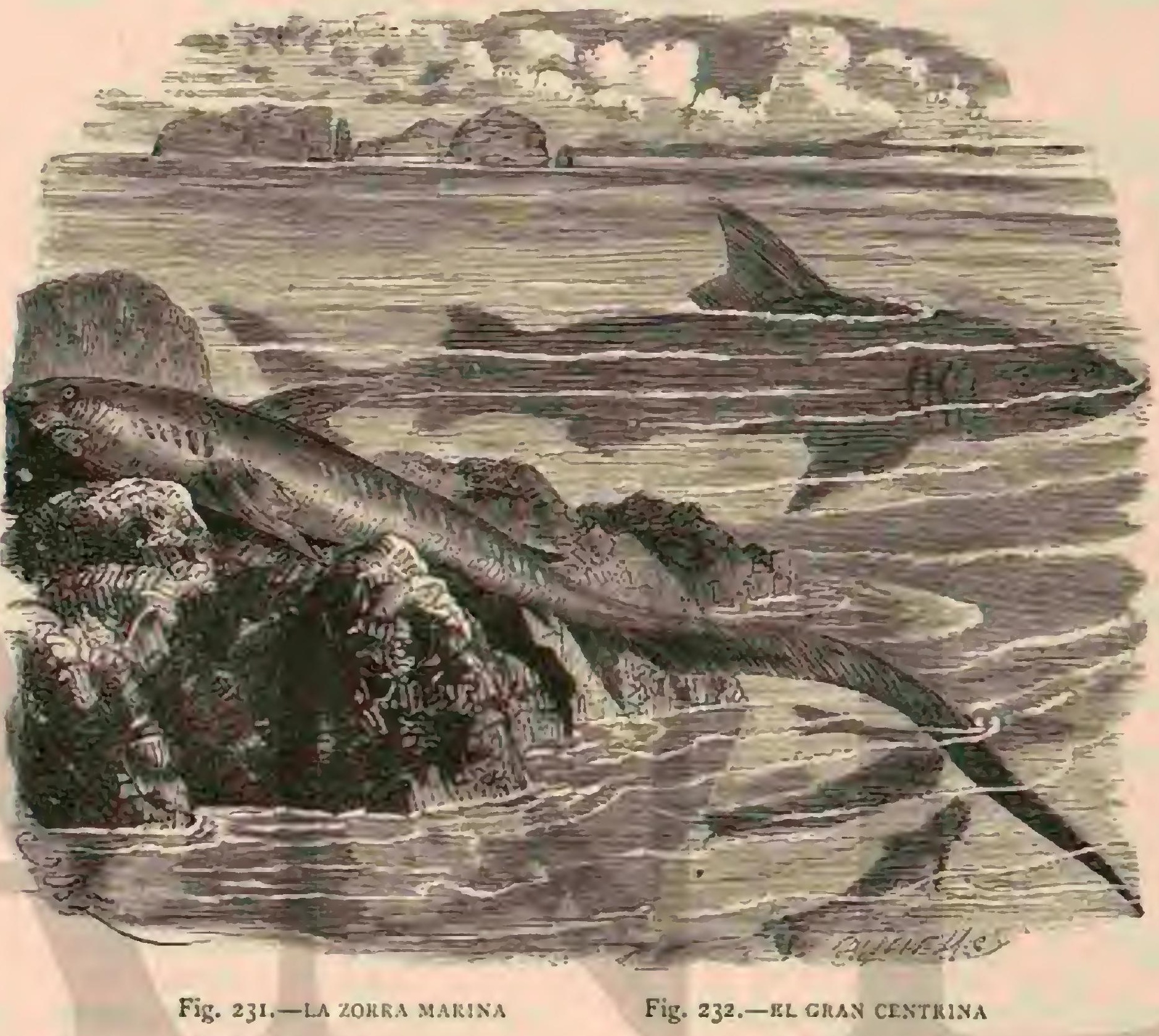

da el higado, $y$ á lo que producen en venta la piel y las aletas.

\section{LAS CORNUDILLAS-ZYGANINA}

CARACTERES.-Los selacios ofrecen mas de una variedad de la forma tipica de pez, pero la que presentan las cornudillas no tiene igual en todo el sub reino animal de los vertebrados. Estos peces singulares, que han liamado la atencion desde los tiempos mas remotos, se parecen á los carcíridos en el número y colocacion de las aletas, en la falta de la conjuntiva $\delta$ párpado falso j del espirículo; pero difieren de ellos y de todos los vertebrades por la prolongacion late. ral del cráneo, en especial de los huesos y cartilagos orbitales, que presta á la cabeza el aspecto de un martillo, en cuyas dos caras extremas se hallan los ojos, mientras que las fosas nasales se hallan tambien distautes on el extremo inferior de la cabeza delante del hocico, hendido en forma de herradura 9 guarnecido de tres á cuatro hileras de dientes.

\section{LA CORNUDILLA COMUN Ó PEZ MARTILLO ZYGANA MALLEUS}

CARACTERES.-De las cinco especies que constituyen csta sub-familia, es para nosotros la presente (fig. 230) la томо $\mathrm{V}$ que ofrece mayor interés por ser la mas conocida en las costas europeas. Alcanza una longitud de tres á cuatro metros, y un peso de doscientos hasta trescientos y mas kilógramos. El cuerpo está cubicrto de una picl finamente granulada, dc color pardo gris en la parte superior, $y$ blanco sucio en la in. ferior; los ojos, grandes y protegidos por párpados, son amarillos como el oro. Los dicntes, son largos, cortantes, casi triangulares y aserrados en los bordes.

DISTRIBUCION GEOGRAFICA. - Se encuentra esta especie en el Mediterráneo, pero de vez en cuando llega tambien á las costas septentrionales de Europa.

USOS, COSTUMBRES Y REGIMEN.-Poco difiere el pez martillo en sus hábitos de las demás especies del sub. órden, $\mathrm{y}$ la única diferencia que se ha querido encontrar es que prefiere para morada el fondo cenagoso del mar á todos los demís sitios, porque caza principalmente rayas y pla. tijas, aparte de otros peces de fondo, pero tambien sube á las capas superiores, rodea los buques hasta los anclados y llega \& ser peligroso para el hombre mismo. Eon animales muy grandes, horribles y feroces, dice Gessner, que nunca se aproximan á la orilla, por cuya razon solo se cogen los pequeños que se extravian. Comen toda especic de peces $y$ devoran tambien las personas que sorprenden nadando. Se cree que su aparicion es señal de desgracia.» 
En la reproduccion parécense tambien á los tiburones, pues son vivíparos, $y$ los pequeños que paren en gran número y de una vez 6 uno tras otro, nacen ya perfectamente formados. En uno de estos peces que se coyió en las costas de Inglaterra encontráronse treinta y nueve hijuelos del todo formados, de unos (1) 30 de largo.

PESCA Y PRODUCTOS. - Se pescan las cornudillas casi exclusivamente con anzuelo de fondo, porque es raro que alguno que otro se introduzca en las redes barrederas. Del hígado se saca aceite, pero la carne no se aprovecria, porque segun Gessner, «es dura, desagradable y de olor re. pugnante aun cuando en Koma la comen. Los datos modernos concuerdan perfectamente con estos, con la diferencia de que acusan a los árabes de ser consumidores de tan pésimo mınjar.

\section{LOS MUSTELINOS-MUSTELINA}

CARACTERES.-Los peces de esta sub-familin se ca. racterizan por sus dientes pequeños de ádoquin; los espiráculos son un poco mas grandes que en las especies anteriores y la colocacion de las aletas es tambien algo diferente.

\section{EL CAZON Ó NIOTO-MUSTELUS VULGARIS}

Caractéres. - Esta especie, la mas comun del grupo, tiene el dorso gris, á menudo manchado de blanco. Los dientes son pequeños, parecidos á simples, protuberancias de raiz ovoidea y con una diminuta punta en medio; forman en la mandibula superior doce hileras y en la inferior catorce. Todas las aletas, menos la caudal, tienen forma de cuna. Ia longitud es por lo regular de un metro á lo mas mctro y medio.

DISTRIBUGION GEOGRÁFICA. - El cazon habita todos los mares.

USOS, COSTUMBRES Y REGIMEN.-ES Uno de los individuos mas inofensivos de su órden, indolente, quieto, sociable, y se alimenta, como corresponde a su dentadura, de moluscos y en especial de crustáceos que mas bien tritura que despedaza; para cogerlos suele vivir en las capas pro fundas, con preferencia en las de fondo arenoso, segun dice Couch. Los pequeños, que nacen en el mes de noviembre completamente formados y en número de doce, pasan luego á los parajes profundos que ya no abandonan hasta mayo. «Plutarco dice de estos animales que cuando temen algun peligro se tragan la criat, para vomilarla cuando se les ha pasado el temor, $y$ los egipcios, cuando querian describir una persona glotona, que despues de comer mucho romita para volver á comer, pintaban uno de estos peces. $\gg$ Asi se expresa Gessner, pero en cuanto $\{$ la primera parte de su relacion, nada dicen los naturalistas modernos.

PESCA Y PRODUCTOS. Sin ser el cazon precisamente voraz, no deja de morder muy bien el anzuelo, y se pesca bastante en las costas de Italia donde se vende tambien en carne en las pescaderias, pero no es mas apreciada que la de sus afines, $y$ solo la consume la gente pobre.

\section{LOS LÁMNIDOS- LAMNID压}

CARACTERES.-Estos peces se asemejan por su forma g hábitos á ciertos delfines, pero mejor se les podria comparar con los atunes sus presas favoritas, porque las diez. espe. cies de familia que hasta ahora se han descrito se parecen mucho á ellos, ya por el perfil general, ya por la colocacion de las aletas. Tienen dos dorsales desprovistas de radios es. pinosos, una anal, espiráculos grandes, aberturas branquia. les anchas, situadas antes de las aletas pectorales, hocico muy prolongado, una boca monstruosa y dientes en forma de lengua, de bordes lisos, pero provistos de puntas accesorias $y$ de tubos medulares ramificados $y$ reticulares en el interior del diente.

\section{EL MARRAJO-LAMNA CORNUBIA}

CARACTERES. - Hé aqul cómo Gessner describe esta especie representantedel género lamia : Es un pez grandísi. mo, tanto que alguna vez ha sido menester emplear dos ca. ballos para tirarle sobre un carro, y los de tamaño regular pesan liasta mil libras. Tiene cl lomo y la cabeza tan anchos q̨ue Plinio le coloca entre los pleuronéctidos ó sean platijas; su piel es áspera como una lima y la cubre una capa de grasa; el espiráculo, la boca, cl esófago y el estómago son muy an. chos: los dientes son duros, cortantes, triangulares, aserrados en ambos lados y dispuestos en seis hileras, estando los de la primera encorvados hácia fuera de la boca, los de la segunda derechios, y los restantes formando cuatro series encorvadas hácia dentro; los ojos son grandes y redondos, etc. Ia descripcion es muy cxacta, debiendo añadirse que la longitud de este pez puede llegar á tres y cuatro metros y acaso mas; crece muy de prisa, segun cree Couch, porque encontró en individuos muy grandes solo la segunda hilera de dientes apta para masticar. La piel es lisa y su color un negro agrisado uniforme que por lo regular se trasforma hácia abajo en blanco; una lista formada de muchas pintas corre desde el extremo del hocico hasta los ojos, detrás de los cuales hay otras pintas mas oscuras; delante de las fosas nasales se ven inanchas triangulares de color oscuro; el iris es azul oscuro.

DISTRIBUCION GEOGRÁFICA. - Este tiburon vive tambien en el Medizerráneo, de donde pasa alguna que otra vez hasta las costas inglesas.

USOS, COSTUMBRES Y REGIMEN.-Las personas que han observado el marrajo aseguran que es una de las es. pecies de tiburon mas sociales, vivaces $y$ hambrientas. Los ingleses le llaman tiburon 6 perro delfin, porque suele perseguir á estos cetáceos cuando los ve reunidos en pequeñas bandadas, y visto de léjos se le confunde con ellos. Ataca á todos los peces que puede con furia indescriptible. Couch encontró en su estómago restos de selacios, calamares y merluzas. Barron vió cómo perseguia atunes y otras especies afines, como por cjemplo, caballas grandes; y Risso presenci反 cómo uno destrozaba un pez-espada tan grande como él. El tiempo del celo cae en agosto y excita aun mas su arrojo y rapacidad, tan grande ya de si. Es inútil decir que respeta tan poco al hombre como ásus compañeros del mar, sin que esto signifique que fuera cabalmente un animal de esta es. pecie «el que se tragó á Jonás, el profeta, y lo vomitó al ter. cer dia en la playa.»

USOS Y PRODUCTOS. - Se tiene la carne del marrajo por mejor que la de sus afines, $y$ hasta dicen que en el Me. diterráneo es apreciada. Quizás sea la misma especie citada ya por los antiguos romanos como plato muy en boga. Ron. delet habla detalladamente de este particular, y (iessner lo resume en las palabras siguientes: Este pez es voraz, carnivo. ro y antropófago, conforme nos enseña la experiencia diaria; su carne, blanca y poco dura, no tiene el sabor y olor tan re. pugnantes y propios de la carne de los demás tiburones, ni hay que hacer caso de que este animal coma tambien personas, porque tampoco se abstienen de ellas otros peces menores y sin embargo son muy apreciados. Tampoco sorprenderá 
que los curanderos de la antiguiedad hayan hecho servir cicrtas partes de este selacio para sus remedios. Ios plateros engarzaban los dientes en plata y los vendian con el nombre de lenguas de serpiente, asegurándose que colgados al cuello de los niños debian facilitar la denticion y precaver las convulsiones. Otros reducidos a polvo servian como dentífrico y nadie dudaba de su cficacia para conservar los dientes per. fectamente blancos.

\section{LAS ZORRAS MARINAS-ALO- PECIAS}

CARACTERES. - El carácter principal de este género consiste en la longitud extraordinaria del lóbulo caudal superior.

\section{LA ZORRA MARINA COMUN-ALOPE- CXAS VULRES}

CARACTERES. - Ya era conocida esta especie en tiern. po de Gessner que la describe del modo siguiente: tTiene el lúbulo superior de la cola nuy largo. Es el animal mas astuto del mar como la zorra lo es en ticrra. Se aparta de los cebos, y si acaso ha mordido alguno, busca la cuerda $y$ la corta, por manera que se han cogido zorras de mar que tenian tres ó cuatro anzuelos en el.vientre. La parte anterior del cuerpo es robustísima, la primera dorsal alta y encorvada en forma de hoz; las pectorales afectan una forma semejante, pero son todavia mas grandes; las abdominales y la anal son en cambio inuy pequeñas; el hocico es corto y cónico; los cspiráculos existen, pero son tan reducidos, que muchos naturalistas no los supieron ver; las fosas nasales tambien son pequeñas y están provistas en su borde superior de una mem. brana corta; las aberturas branquiales son cortas como en los riburones propiamente dichos. I a dentadura consiste en dientes triangulares y no aserrados, dispuestos en tres ó cuatro hileras, rectos en la primera $\varepsilon$ inclinados bácia fuera ó al lado en las otras. Las escamas son pequeñas y triangula. res, etc. La longitud de este pez puede llegar a cinco metros y mas, correspondiendo casi la mitad al lobulo superior de la cola. El color del lomo y de los costados es azul oscuro; la parte inferior del cuerpo salpicada de blanco (fig. 231).

DISTRIBUCION GEOGRAFICA.-Es una de las especies mas comunes de todos los selacoideos del Mediter. ráneo; no parece ser rara en el Atlántico, puesto que se le ve de ver en cuando en las costas británicas.

USOS, COSTUMBRES Y REGIMEN.-Se llama esta especie zorra marina por su modo especial de atacar, pues en lugar de servirse de su boca, descarga golpes tan recios con el lobulo mayor de la cola, que se oyen los chasquidos a gran distancia. A menudo se re, dice Couch, que una zorra marina se aproxima á una bandada de delfines, los cuales, no sospechando peligro alguno, nadan y cazan con la mayor trancquilidad hasta que un coletazo de la zorra los hace huir como conejos sorprendidos por perro. Ya vimos al hablar del pez-espada que la zorm marina se atreve tambien con cetáceos mayores y que se asocia a veces para estas empresas con aquel.

En ninguna parte encuentro datos respecto $\$$ su reproduccion, $y$ en cuanto á régimen y pesca me parece excusado hablar de ello.

\section{LOS SELACIOS PROPIAMENTE DICHOS - SELACHE}

CARACTERES. - Lil hocico es corto $y$ obtuso; los espi- ráculos son pequeños, las aberturas branquuiales tan grandes que casi abarcan todo el cuello; los dientes son pequeños, algo cónicos y encorvados hácia dentro; finalmente las esca. mas presentan numerosas puntas.

\section{EL SELACIO GRANDE - SELACHE MAXIMA}

CARACTERES, - Este representante del género es el gignnte de los tiburones, puesto que alcanza, segun dicen, hasta doce metros de longitud con un peso que puede llegar \{ 8,000 kilógramos. El color general es negro pardusco con viso azulado, y el abdómen blanquizco.

DISTRIBUCION.GEOGRÁFICA.-Este monstruo vive en las profundidades de los mares mas septentrionales, desde alli pasa á veces al mar del Norte y al Atlántico, sobre todo cuando ha soplado algun tiempo el levante. Se le ha visto muchas veces en las costas de Curnualles, Gales, Devon, Dorset y Sussex, y se le ha cogido mas de una en Francia, como sucedió en el año I j\$7 ea San Maló con uno que midio once metros de largo por ocho de circunferencia, y en 1802 pescaron otro cerca de Boloña, que acababa de sos. tener una lucha de trcinta y seis horas con una ballena.

USOS, COSTUMBRES Y REGIMEN.-Se dice que el selacio vive en el mar Glacial á grande profundidad, donde se mantiene, como los cetáceos, de animales pequeños, particularmente de medusas, y segun Rinck tambien de ba. llenas muertas, y se añade que se deja coger fácilmente con anzuclo. Tambien refiere Gessner, obispo noruego, varias particularidades de este animal que hasta hoy no han sido impugnadas por nadie. Dice que este tiburon gigantesco no tiene nada de la ferocidad de sus afines, y que por lo contra. rio, es animal inofensivo que muestra una indolencia, indife. rencia y estupidez verdaderamente pasmosas. Perseguido por una lancha, la deja acercar hasta que se le puede arrojar una azagaya, y cuando flota en la superficie para tomar el sol, hasta permite que le toquen con la mano. Solo cuando siente penetrar en sus carnes la azagaya levanta con fuerza la cola y se sumerge; y si observa que todos sus esfuerzos por huir son vanos, empieza a nadar con una rapidez y vigor tan asumbrosos que es capaz de arrastrar contra el viento una embarcacion de setenta toneladas. Asi brega á veces veinti. cuatro horas antes de rendirse.

USOS Y PROVECHO.-Se pesca el selacio grande solo por utilizar su higado, que segun Gunner, puede tener un peso de 1,000 kilógramos, y da un excelente aceite. La carne es coriácea y de sabor desagradable, mas á pesar de esto se come tambien en el norte, y cunndo no, se acecina para em. plearla como cebo para otros peces.

\section{LOS CENTRINAS-CENTRINA}

CARACTERES. - Con los peces de cste nombre se ha formado un pequeño género cuyós representantes sé recono. cen desde luego entre los demás selacios por tener una espe. cie de púa muy dura y fuerte en cada una de las alctas dorsales, distinguiéndose ademís por la forma general del cuerpo, que representa un prisma triangular.

\section{EL GRAN CENTRINA-GENTRINA MAXIMUS}

CARACTERES.-Laespecie de dardos que tiene este pe (figura 232) en sus aletas dorsales son sumamente sólidos; el cuerpo, como hemos dicho antes, afecta la forma de un pris. ma triangular, constituyendo el vientre una de sus caras; el dorso, por consiguiente, se eleva en carena; y como esta úl. tima parte baja hácia la cola y la cabeza, que es pequeña y 
aplanada, el animal presenta como una pirámide triangular de muy poca altura cuando se mira de lado á un indiviouo. I a piel, revestida de una única gruesa y adiposa, hállase cubierta de tubérculos duros y salientes. La mandíbula supe. rior está armada de tres filas de dientes, y la inferior de una sola, siendo todos cllos muy agudos. Las aletas dorsales se hallan muy próximas a la cabeza; la segunda sobre las ven trales; la cola y la aleta que guarnece su extremidad son bastante cortas a proporcion de la longitud del cuerpo. El color del centrina es pardo en el dorso y blanquizco en el vientre. Este selacio suele medir comunmente de cinco á seis piés de largo cuando parece alcanzar todo su desarrollo.

DISTRIBUCION GEOGRAFICA. - La especie habita en el Océano y én el Mediterráneo, pareciendo frecuentar con preferencia en ciertas ocasiones algunas costas de Inglaterra.

USOS, COSTUMBRES Y REGIMEN. - El centrina no sucle frecuentar las orillas; prefiere vivir en el fondo cena. goso de los mares, costumbre que le ha valido por parte de ciertos observadores el nombre de cerdo de mar. Se alimenta de otros peces, y tambicn de crustáceos.

UTILID A DES. - Pocas son las que reporta este pez, pues su carne es dura y falamentosa, y no suele servir de alimento. Lo que mas se aprovecha es la piel, muy apropiada para pu. limentar los cuerpos duros.

\section{LOS ESCÍLIDOS-} SCYLLIID死

CARACTERES.-Son selacios oviparos, tiburones pe queños que se caracterizan por sus dos aletas dorsales colo. cadas muy atrás, y la anal bastante desarrollada; la caudal es muy larga sin ser bifurcada, antes al contrario achatada en el

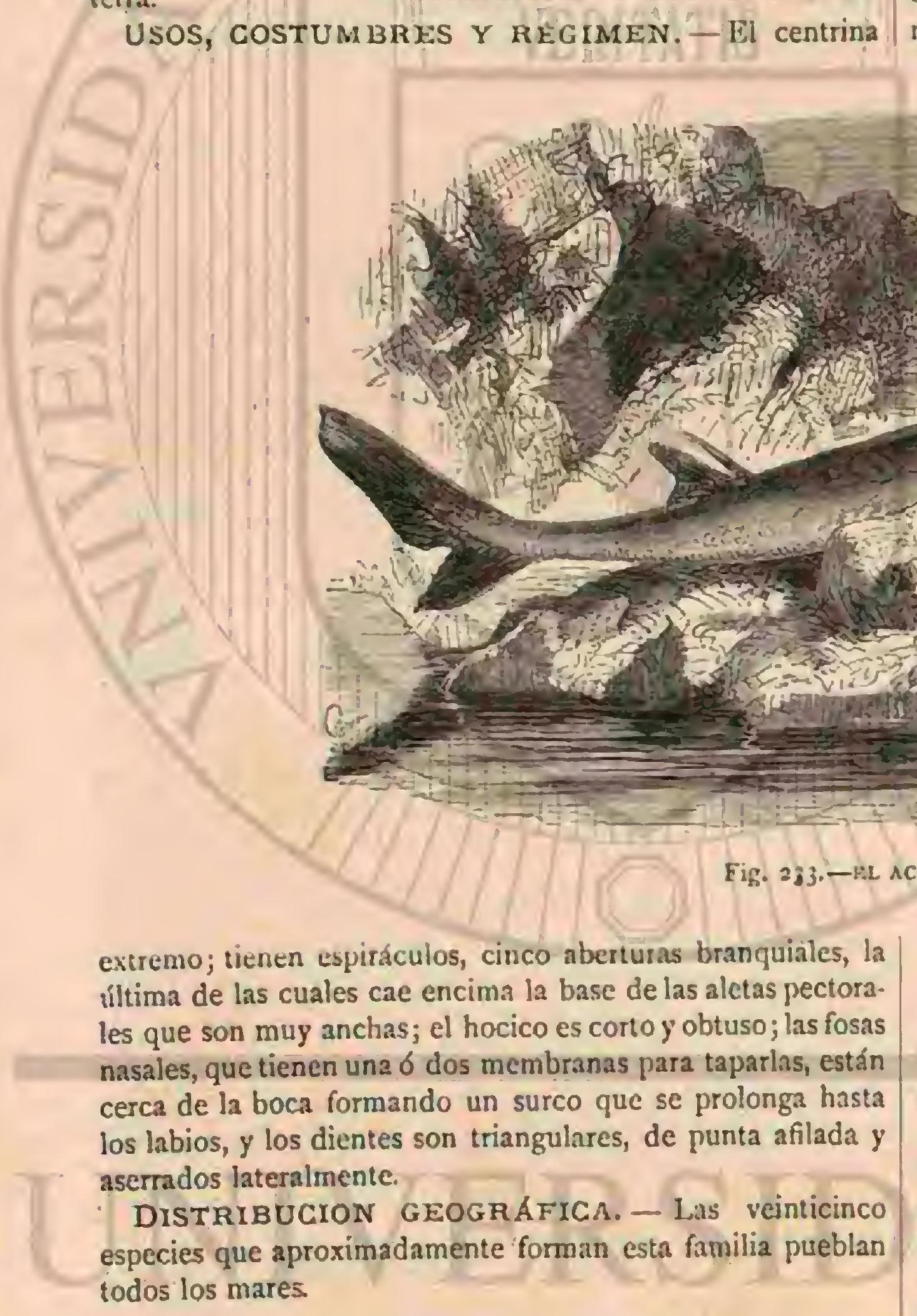

\section{LAS LIJAS - SCYLLIUM}

CARACTERES, - Consisten en la colocacion de las ale tas dorsales, hallíndose la primera entre las torácicas y la anal, y la segunda entre esta última y la caudal.

DISTRIBUCION GEOGRAFICA. - Las dos especies principales son muy frecuentes en los mares europens.

\section{LA LIJA MENOR - SCYLLIUM CANICULA}

CARACTERES. - Alcanza una longitud de $0^{\circ}, 50$, y $\$ 10$ sumo de $0^{\circ}, 60$. La coloracion es en la parte superior rojiza salpicada de espesas manchas pequeñas y pardas, y blanca en la region abdominal.

\section{LA LIJA MAYOR - SCYLLIUM CATULUS}

CARACTERES.-Difiere de la anterior por su mayor longitud que llega á un metro, y por las manchas mas grandes y menos numerosas.

DISTRIBUCION GEOGRAFICA. - Ambas especies habitan los mares de las zonas tórrida y templadas, y respecto á Luropa, principalmente el Mediterráneo, sin que falten por esto ni en el Atlántico, ni en el mar del Norte.

USOS, COSTUMBRES Y REGIMEN.-Coinciden las lijas mayor y menor en sus hábitos lo propio ņue en la dispersion; ambas viven a una profundidad media, por lo general cerca del fondo donde persiguen $\{$ todos los peces que pueden engullir, además de crustáceos y acaso moluscos de varias especies. Las dos lijas son los enemigos mas acérrimos de los arenques, y aumentan de un modo prodigioso donde estos abundan, con gran disgusto y perjuicio de los pesca. dores, ya por los estragos que causan entre aquellos peces, á cuyas bandadas siguen, ya porque destrozan las redes con sus dientes y golpes violentos y desesperados. Se dice que cuando topan con bandadas 6 bancos de arenques durante sus viajes á los puntos de desove, tragan tantos como pueden, y cuando ya no les caben mas, vomitan y vuelven a devorar otros tantos hasta que continuando asi se cansan. Cuando las lijas rodean en gran número los arenques y las redes, difun- 
den a gran distancia un penetrante olor de aceite de pescado, y la superficie del agua brilla con la grasa que la cubre. Hácia el año 30 de nuestro siglo habian aumentado tanto las lijas en el canal de la Mancha que los pescadores á duras penas lograron exterminarlas. En $1 \$ 27$ fueron unos pescadores á un banco de arena situado á dos millas de la costa y como a cuatro al este de la ciudad de Hastings con el objeto de pescar abadejos. Colocaron palangres con unos cuatro mil anauelos y cuando los reconocieron al cabo de media hora vieron que casi habia una lija en cada anzuelo, y de abadejos tan solo la cabeza con un pedazo del espinazo de uno; el resto lo habian devorado las lijas, con la circunstancia de que ninguna de las que se cogieron presentaba señales de haber sido mordida, de lo cual se infiere que estos peces no deben dañarse mutuamente.

La reproduccion empicza en otoño, pero continúa, segun parece, todo el invicrno, porque al examinar á las hembras en este tiempo se encuentran en los ovarios y oviductos hucvas, por lo comun de dos en dos, en los diferentes estados de des. arrollo. Las huevas, que en los diferentes idiomas del nor. te se llaman bolsas ó ratones marinos, son, segun la expresion de Gessner epellejudas, duras, traslúcidas como el asta; y por su forma semejantes á una almohada con largos cordo. nes 6 hebras enroscadas en los cantus. El color es un ama. rillo pálido y córneo; el tamaño de la cápsula llega a 0 \#,06; los apéndices enroscados y ensortijados que salen de las cuatro esquinas son mas largos que el huevo, el cual tiene en cada extremo una hendidura para dar entrada al agua. La hembra empieza a poner estas huevas al principiar el invicrno, siendo probable que las deposite siempre entre plantas marinas, de cuyas hojas quedan prendidas merced a sus largos apéndices, cuando cl embrion tiene ya figura de tiburon y se pueden ver sus movimientos al través de la cáscara tras. lúcida que rompe cuando está mas desarrollado. En este es.

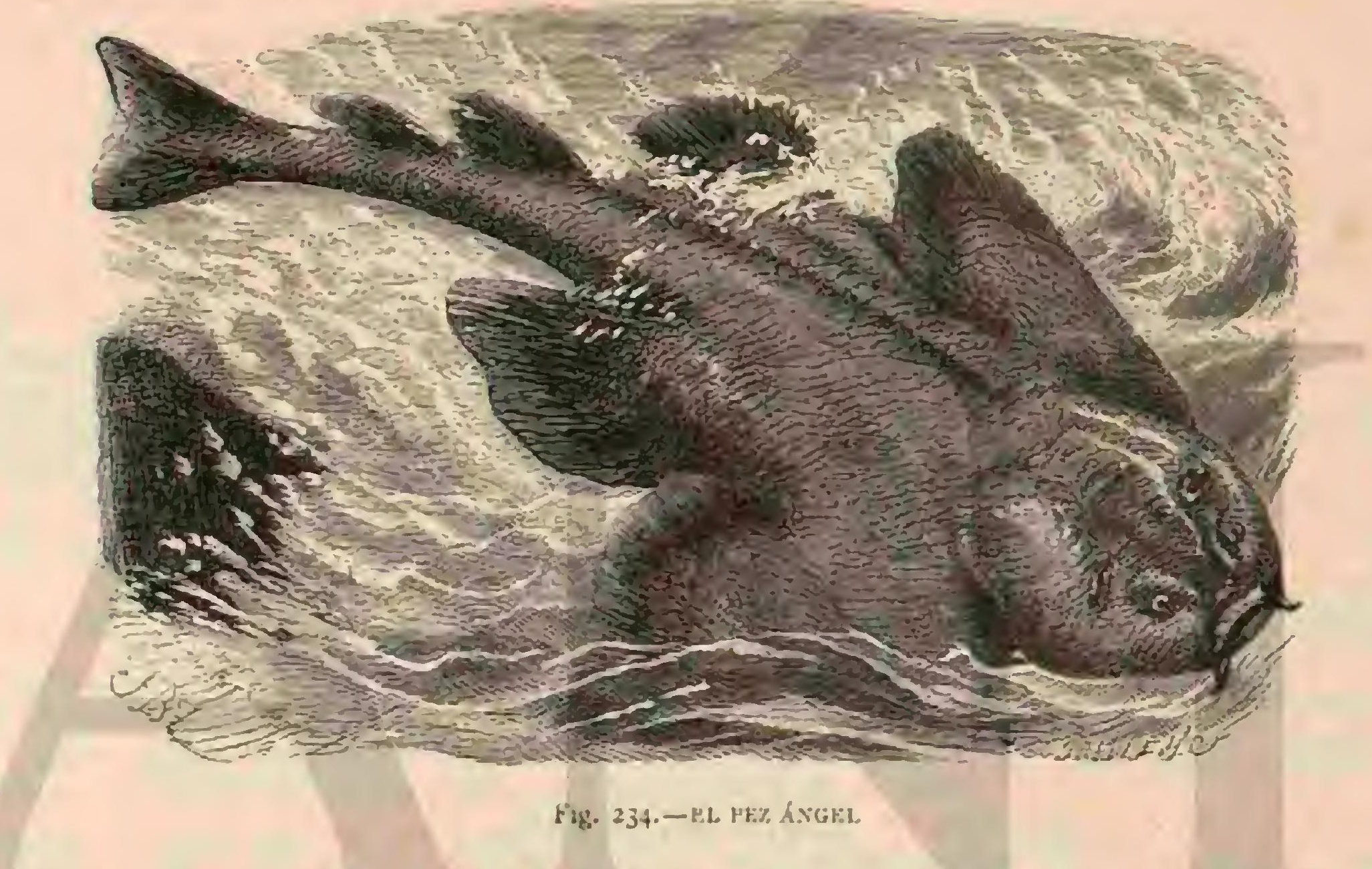

Ladu tiene todavia su vesicula vitelina que comunica con el tubo digestivo por un vaso \& propósito, y mientras el cuerpo reabsorbe su contenido, se van formando los dientes de tal sucrte, que la pequeña lija puede cazar cuando la vesícula lia desaparecido. Algunos observadores dicen que la hembra pone las huevas en partidas de diez á veinte á cada puesta; otros aseguran que son menos, pero todos convienen en que estos peces son relativamente muy fecundos. Los dos sexos se juntan varias veces durante el aỉo, y la cópula se efectúa agarrándose el macho ála hembra con los apéndices que ticne cerca del ano.

USOS Y PROVECHO.-La came, que es coriácea y dura, solo se consume cuando la necesidad obliga; pero la piel se utiliza y sirve para pulimentar objetos de madera y de metal. Del higado se saca un cxcelente aceite, que pene. trando toda la carne del pez, hace que sea tan indigesta, y los pescadores dicen que hay casos en que el hígado aceitoso ha producido graves desórdenes a las personas que lo habian comido, confirmándolo asi el médico francés Saurage que refiere el caso siguiente: $₫$ Cuatro personas que habian comido higado de lija sintieron en menos de media hora una de. bilidad y sueño extraordinarios y tan fuertes que hasta al tercer dia no volvieron en si. Las cuatro se despertaron con grandes náuseas y la cara encendida, cuya epidermis, al igual de la de toda la cabeza, se iba desprendiendo á grandes tro- $z o s$, sin que desaparecieran los accidentes hasta que quedo toda despellejada.

CAUTIVIDAD. - Las lijas no resisten la cautividad en vivero angosto, á pesar de su notable vitalidad; permanecen siempre inmóviles en el fondo $y$ hasta dejan pasar delante de ellas otros peres sin molestarlos, ó se agitan inquietas desde el primer momento sin parar de una parte á otra, rompién. dose el hocico contra las paredes de su circel hasta que mueren miserablemente: En cambio se han aclimatado muy bien 5 hasta reproducido las que Coste liene colocadas en una gran balsa abierta cerca del mar y en comunicacion con este. La hembra de una pareja colocada á principios de abril en una de las dívisiones de la balsa, puso al cabo de un mes diez y ocho huevas de las cuales nacieron nueve meses des. pues, es decir, en los primeros dias de diciembre, pequer̃os muy robustos y vivaces.

\section{LOS ESPINÁCIDOS-SPI- NACID屃}

CARACTERES.-Comprende esta familia mas de vein. te especies que se distinguen por dos aguijones puntiagudos que sostienen cada aleta dorsal por delante y por la falta de la anal. Tienen espiráculos; los dientes son afilados $y$ sus 
coronas sencillas, por lo comun triangulares, delgadas y lateralmente comprimidas.

\section{EL ACANTIAS COMUN-AGANTHIAS VULGARIS}

CARACTERES.-Esta especie, representante del géne. ro, tiene el cuerpo oblongo, la cabeza aplanada en forma de cuña, estrecha por delante, con la punta redondeada; las fosas nasales se hallan á igual distancia de la boca y de la punta; los espiráculos son grándes. La boca perfectamente redonda, pero hendida en forma de medialuna, está armada de tres hileras de dientes largos, puntiagudos y un poco aserrados en el borde I as aletas torácicas son muy grandes y las abdominales pequeñas. La coloracion de la parte superior es un gris pizarroso unido; las partes inferiores son blaticas amarillen. tas. Los pequeños suelen ser manchados de blanco. La lon. gitud no excede casi nunca de un metro, ni el peso de diez kilógramos (figura 233 ).

DISTRIBUGGION GEOGRÁFICA.-De todos los selacios que habitan los mares europeos es el acantias el mas frecuente, $y$ puebla las aguas en número asombroso; formando, especialmente en la pleamar y cerca de la playa, verdaderos ejércitos que siguen á los peces que buscan la orilla para desovar, causando asi gravisimo daño å la pesca.

USOS, COSTUMBRES Y RÉGIMEN,-Couch dice que á veces se presenta esta especie en nimero realmente incalculable con gran sentimiento de los pescadores, porque les corta todos los sedales; the oido hablar de haberse cogido en una sola red barredera unos 20,000, y quue los pequeños de menos de $0^{\circ}, 15$ siguen en estas excursiones a los mayores y mas robustos, sin que se presuma el objeto que los quia, puesto que es inposible que lo hagan con la idea de atacarlos y devorarlos. Para servirse de los aguijones de sus aletas dorsales, se enrosca cl acantias con la fuerza de un resorte ya en un sentido ya en otro; pero siempre con tanto acierto que hiere infaliblemente la mano que le toca, $y$ sin dañarse nunca á si mismo.s En el mes de marzo de $1 S_{5} \delta$ apareció al oeste de Uig (Escocia) un cjército tan numeroso de estos peces, que cubria el mar en una superficie de veinte ś treinta leguas de ancho, llenando todos los puertos, bahias y ensenadas, de suerte que los pescadores tuvieron en pocas horas las barcas llenas de ellos hasta el borde. La hembra pare de una vez de seis á treinta pequeños completamente formados.

USOS Y PROVECHO. - La carne es dura y no tiene nada de sabrosa, pero en Escocia se seca y se consume ast. La carne de los pequeños tiene en cambio gran fama y mayor aun en muchos puntos las huevas durante su desarrollo.

De los hígados se saca el aceite, la piel se vende para lija, los desechos sirven de abono para los campos, y los aguijones, que se creen venenosos á causa de las heridas dolorosas que producen, se vendian antes para mondadientes.

\section{LOS LEMARGOS-LEMARGUS}

CA RACTERES. - I.os peces de este género no difieren del grupo anterior sino por la falta de los aguijones delante de las aletas dorsales. Los dientes son de diferente estruc. tura en las dos mandibulas; en la inferior son anchos con la punta dirigida hácia fuera, de modo que la cara interior no aserrada va dirigida hácia arriba, $y$ los de la superior son es. beltos, cónicos, los anteriores casi rectos, y los laterales en. corvados con la punta hácia fuera.

\section{ELLEMARGOBOREAL-LAMARGUS BOREALIS}

CARACTERES. - Alcanza una longitud de cuatro á seis metros y su color es ceniciento en todo el cuerpo.

DISTRIBUCION GEOGRAFICA.-Habita el mar Glacial del hemisferio borcal.

USOS, COSTUMBRES Y REGIMEN. - Vive en alta mar y \& grandes profundidades, puesto que solo se acerca á la costa cuando persigue 6 es perseguido.

Todas las noticias están contestes en que el lemargo no cede $\{$ ninguna otra especie de su familia en arrojo y voracidad. Devora, segun Fabricio, todo lo que se le presenta, peces de toda especie, particularmente platijas, abadejos, sus propios afines, rayas jóvenes, delfines, balénidos y tambien personas. Scoresby bice: « Este selacio es un enemigo de la baliena á la que nuerde y atormenta en vida, y á la que devora cuando la encuentra muerta. Cuando los marineros descuartizan alguno de estos cetáccos, el lemargo trabaja por su cuenta á porfia con ellos, y mientras estos cortan al animal por arriba, arranca el un trozo tras otro del costado. Scoresby añade que cuando algun ballenero se resbala del lomo de este gigante cayendo al agúa, no le hacen ningun daño los lemargos reunidos en gran número al rededor; pero Fabricio asegura que suele sumergir con su hocico los esquifes de piel de foca de los groenlandeses y cortar las piernas del hombre que los dirige, por cuya razon aquellos pescadores huyen à toda prisa apenas le columbran. Su rapacidad es tan grande que no perdona $\{$ los individuos de su propia especie. Un lapon perdió una vez un lemargo que habia cogido y llevaba á remólque. No tardó en coger otro y icuál no seria su asombro al encontrar en el estómago de cste al que habia desaparecido sin saber cómo! Gunner cita uno en cuyo estómago se encontró un rengifero sin astas, y otro que se habia tragado una foca.

Los groenlandeses dicen que este pez tiene un oido muy fino, y que apenas oye las voces de dos personas sube de su profundidad à la superficie, por cuya razon no se habla en los sitios donde le temen; pero Scoresby viene á decir todo lo contrario: \&Los marineros creen que el lemargo es ciego, porque no hace el mas minimo caso del hombre; lo cierto es que apenas hace un ligero movimiento cuando recibe una lanzada ó una cuchillada. Su indiferencia al dolor es verdaderamente extraña; uno que habia sido atravesado con un cuchillo por un marinero que se ocupaba en descuartizar una ballena, huyó, pero volvió en seguida al mismo sitio. El corazon de los lemargos es pequeño y solo da de seis á ocho latidos por minuto, pero palpita muchas horas despues de sacado del cuerpo; lo mismo sucede con cualquier pedazo del cuerpo, por lo que es dificil matar á estos animales, y peli. groso tocar ó querer examinar su boca armada de un bosque de afilados dientes, aunque hayan pasado muchas horas des. pues de haber sido separada la cabeza del tronco.

PESCA. - Es fícil apoderarse de estos animales tan excesivamente voraces. Se ata un saņuito con carne pasada 6 una cabeza de foca á un gancho y se lleva á remolque. El lemar. go acude, rodea el cebo, lo prueba y lo suelta; pero cuando se le retira el cebo, entonces se despierta su codicia, precipitase de repente sobre la carne y se la traga. Entonces es de ver cómo salta para librarse. Primero procura cortár la cadena, pero como es imposible, se revuelve furioso y finalmente se destroza él mismo su estómago cón el gancho. Cuando la tripulacion se ha recreado bastante en sus tor. mentos le iza, pero antes de subirle sobre cubierta le ro. dean al cuerpo una cuerda gruesa y le cortan la cabeza y la cola, porque con esta última, aunque ya no tuviera cabeza, puede causar las mas fatales desgracias. 
Lo mas extraño es que este animal tan atrevido, tenga un miedo tan cerval del catodon, á cuyos afines devora sin embargo al igual de otros peces, $y$ cuando lo ve huye $y$ hasta vara en la playa donde muere, sin atreverse á acercarse á dicho cetáceo aunque lo vea muerto.

USOS Y PRODUCTOS. - Tanto entre los groenlandeses como en Islandia se tiene la carne del lemargo por la mejor de todos los tiburones, $y$ la consumen en aquellos paises ya fresca, ya seca, ó tambien despues de haberla dejado podrir hasta cierto grado. Del higado se saca un aceite que se usa mas como lubrificante que para el alumbrado; y con la piel pulimentan los palos de las tiendas 6 la emplean para calzado s arreos de caballos.

\section{EL PEZ ANGEL-RHINA SQUATINA}

CARACTERES.-Esta especie (fig. 234) es el único representante de su género $y$ familia. En Alemania le llaman pez ángel 6 ángel marino 《a causa de su forma, dice Gessner, pues sus aletas anteriores le dan cierto parecido con las alas de un ángel.s Algo forzada es la comparacion. 'Tiene la cabeza grande, el cuerpo aplanado en sentido vertical, y en. sanchado adeinás por sus grandes aletas torácicas y abdominales dirigidas hácia adelante; las aberturas branquiales se hallan en la parte superior entre las aletas dorsal y pectoral; la boca está armada en la parte anterior de dientes cónicos dispuestos en varias hileras; las fosas nasales están debajo del ángulo del labio superior, que es muy ancho; existen los es. piráculos, la piel es áspera y está cubierta parcialmente de escamas cónicas y diseminadas en la superficic.

Lste pez alcanza una longitud de dos á tres metros. El color de su áspero lomo es un pardo de chocolate con man. chas negruzcas é indeterminadas; la parte inferior del cuerpo es lisa y blanco-amarillenta.

DISTRIBUCION GEOGRAFICA.-EI pez ángel vive en todos los mares de las zonas írrida y templadas. Es co. mun en el Mediterráneo, no escasea en el Atlántico, vésele en bastante número en algunos puntos del mar del Norte, como en la costa oriental de la Frisia s la meridional de Inglaterra, y en gencral es uno de los selacios mas comunes en donde se presenta.

USOS, COSTUMBRES Y REGIMEN. - Vive, conforme lo permite suponer su configuracion, en el fondo del mar, donde se mantiene principalmente de rayas y platijas de toda especie. Como á ellas, le gusta estar oculto en la arena, con la vista alerta dirigida hácia arriba para no perder ninguna presa. A veces se le encuentra en pequenas tribus.

Sobre la época de reproduccion no están acordes las noticias. Algunos dicen que en otoño, otros que en primarera da la hembra a luz sus pequeños completamente formados en número de siete á veinte. Tambien se contaba antes que la hembra demuestra un cariño extraordinario á sus hijuelos, y que en casos de peligro «los engulle para volverlos á arrojar despues ; pero los observadores modernos nada dicen sobre este punto.

PESCA. - Como el pez àngel no cede en roracidad álas demás especies de selacios, es tambien fácil cogerlo; bien que se ha de proceder con gran cuidado, al coger á los indi. viduos grandes, á causa de los peligros que hacen correr á los pescadores con su defensa desesperada.

CAUTIVIDAD. - Los peces de esta clase cautivos que he tenido ocasion de observar cran por demás indolentes, tanto que permanecian muchos dias seguidos en un mismo sitio sin moverse y sin comer, muriendo a las pocas semanas.

USOS Y PRODUCTOS. - La carne coriácea y tenaz de esta especie tiene un sabor desagradable, y se hace de con. siguiente poco caso de ella; pero la piel se aprovecha yn como lija, ya para puños de espadas, vainas de machetes y cuchillos, etc. Antiguamente se preparaban remedios con la came, higado, huevos, piel, etc.

\section{LOS BATOIDEOS- BATOIDEI}

CARACTERES. - Este sub-órden comprende los pla. giostomos de cuerpo plano $y$ ensanchado á manera de disco á causa de tener las aletas pectoralcs muy desarrolladas y que empiezan detrás de la misma cabeza; las aberturas bran. quiales están en la cara inferior del cucrpo; la cola es por lo general tan larga como delgada, semejante sa un látigo, y suele llevar las aletas dorsales.

\section{LOS PRISTIDOS--PRISTID死}

CARACTERES.-Comprende esta familia los peces que despues de los rínidos forman el segundo grado de trảnsito entre los tiburones $y$ las rayas, y se los podria llamar rayas con forma de tiburon. Solo se conocen de esta familia cinco especies que se asemejan á los selacios en su cuerpo prolongado, y aplanado en la parte anterior; en el hocico largo $y$ en la colocacion de las nadaderas; $y$ á las rayas en la boca trasversal abierta debajo del hocico, $y$ en los dientes de adoquir. Además tienen los prístidos como caractéres particulares la prolongacion de la mandibula superior que forma una lámina larga y estrccha, llamada sierra, guarnecida en los dos bordes de dientes solidamente encajados, y represen. tando en su totalidad el hocico cartilaginoso de los peces de boca trasversal desarrollado hasta el exceso. Detrếs de los ojos hay dos pequeños respiraderos que pueden cerrarse a voluntad por una especie de piston. Estos peces carecen de aleta anal.

\section{EL PEZ-SIERRA-PRISTIS ANTIQUORUM}

CARACTERES. - Esta especie (fig. 235) alcanza una longitud de cuatro á cinco metros, de la cual ocupa la sierra la tercem parte. La piel es áspera $\$$ el color gris pardusco bastante igual en la parte superior del cuerpo y algo mas cla. ro en la inferior.

DISTRIBUCION GEOGRAFICA. - Se pretende haber encontrado este pez en todos los mares de ambos hemisfe. rios desde el ecuador hasta cerca de los polos. En el Mediterráneo es muy frecuente.

USOS, COSTUMBRES X RÉGIMEN.-Escasos son los datos que tenemos respecto á los hábitos y género de vida del pez sierra, y en cuanto á las numerosas historias de su ferocidad y sed de sangre, conviene admitirlas con reserva. Dicese que es uno de los enemigos mas terribles y feroces de las ballenas, á las que ataca por debajo abriéndoles y destrozándoles el vientre con su tremenda sierra, y con las cuales lucha horas enteras hasta que el cetáceo queeda muerto ó él queda desarmado por rompérsele la sierra; lucha tremenda $y$ estruenciosa por los golpes con que revuelven los dos gigantes las olas y que los balleneros contemplan desde una prudente distancia sin moverse hasta que todo ha concluido, porque el pez-sierra vencedor solo se come la lengua de su adversario y abandona el resto. Asi lo relata Martens, el alcalde de Hamburgo śquien he citado varias veces en el curso de esta obra, y de cuya viva imaginacion hemos visto otra muestra al hablar del arenque. Lo cierto es que la colocacion de la boca indica mas bien que este per pasa su 
vida en el fondo del mar á la manera de los ráyidos, y que se mantiene como estos de peces pequeños, crustíceos, mo. luscos, etc, en lugar de trabar combates como los indicados.

Es posible que algunos le hayan confundido con el pez. espada del cual se refieren cosas análogas, pero con mas fundamento; $y$ tarnbien puede suceder que alguna que otra ver, dominado de ciego furor, hunda su arma en el cuerpo de grandes ballenas ú otros peces.

Es vivíparo, como la mayor parte de los peces plagiosto. mos, y los pequeños nacen completamente formados con dientes y sierra que, segun ha observado Bennett, les salen antes de romper el huevo en el cuerpo de la madre, solo que necesitanalgun tiempo para endurecerse, durante cl cual viven los hijuelos de la sustancia que llevan en la vesícula vitelina.

USOS Y PRODUCTOS. - La carne es dura y desabrida y solo se come i falta de otro alimento mejor. La piel tiene las mismas aplicaciones que la de los demás selacios; y a la sierra se le atribuye cierta virtud curativa.

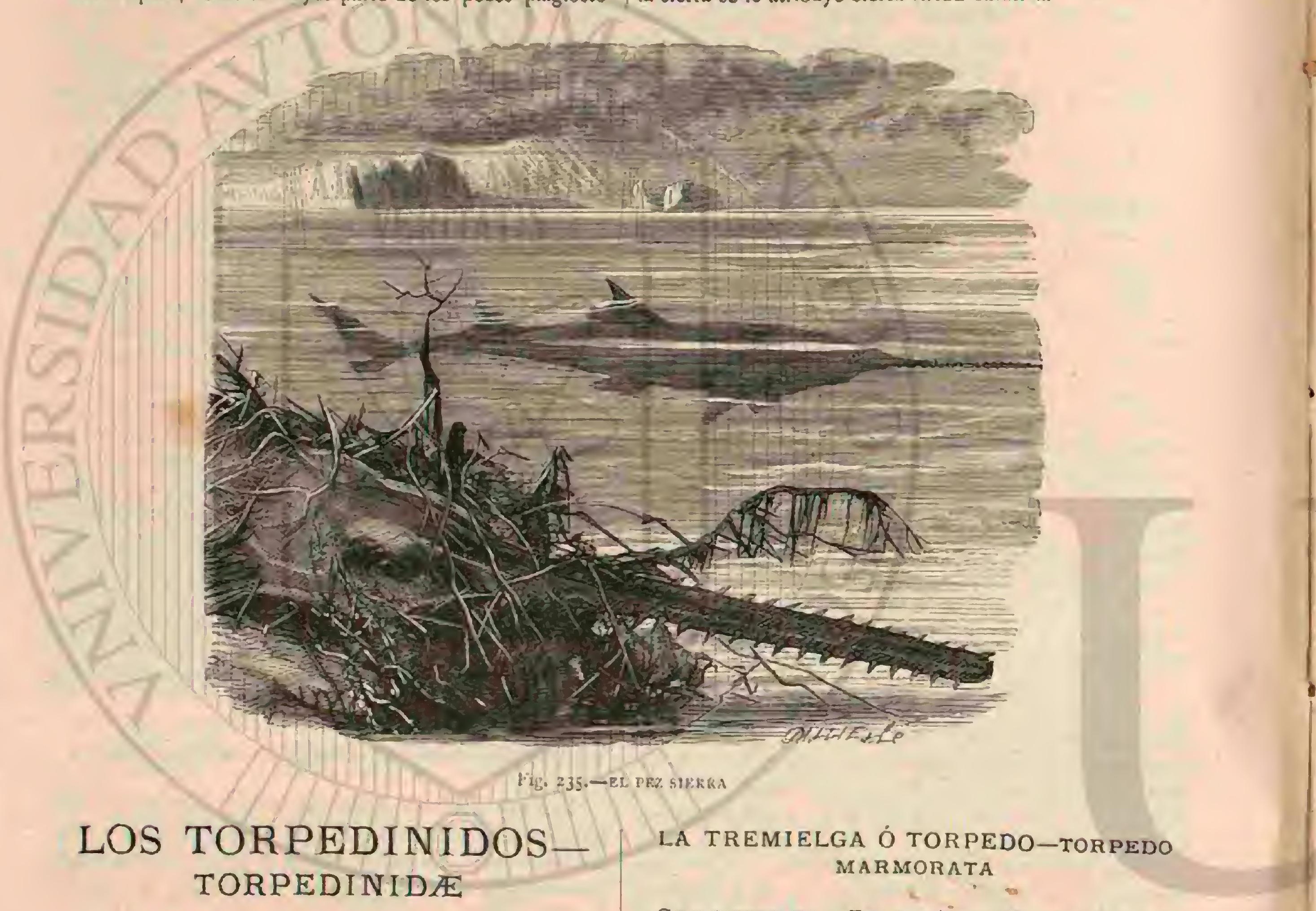

CARACTÉRES.-De los batoideos que habitan los mares europeos, suelen citarse, inmediatamente despues de los pristidos, aquellos que ya eran conocidos en la antigüedad por su facultad de producir sacudidas eléctricas, la cual les ha valido el nombre de tembladores ó tembladeras, que en número de unas veinte especies forman la familia de los torpedinidos. Son peces planos como discos, sin escamas ni espinas; con las aletas dorsales insertas á continuacion de las torácicas; de cola corta, carnosa, redonda, pero en la ralz aplanada, con arista lateral que lleva una, dos ó tres aletas dorsales y en el extremo una caudal de forma triangular. El espacio entre la cabeza, las branquias y las alctas torácicas está ocupado por el órgano eléctrico formado de células pe. queiras y colocadas una al lado de la otra $a$ manera de pa. nal, separadas por membranitas y cruzadas de numerosas ramificaciones de nervios. Los dientes son puntiagudos.

DISTRIBUGION GEOGRÁFICA. - Habilan estos peces preferentemente los mares de la zona tórrida.

\section{LAS TREMIELGAS -TORPEDO}

CARACTERES. - Son los que distinguen it la familia.

CARACTERES. - Este pez (fig. 236), conocidisimo desde remotos tiempos, alcanza metro y medio de largo, poco menos de un metro de ancho, $y$ un peso de veinticinco á treinta kilogramos. El color es en la parte superior una mez. cla de jardo oscuro, pardo claro y blanco, predominando tan pronto el uno como el otro de estos colores.

USOS, COSTUMBRES Y REGIMEN. - Los autores de la antigüiedad mencionan la tremielga en numerosos pasajes de sus obras 6 igualmente la han representado en mu chos objetos de alfarería, no siendo aventurado decir que los griegos y romanos de anuellos tiempos sabian ya todo lo que nosotros sabemos acerca de los hábitos y género de vida de este animal, y que por lo mismo conocian su fuerza eléctri ca, aunque no sabian explicarsela. Hé aquí to que dice Gessner:

QEstos peces viven en los sitios arcillosos y cenagosos del naar y en las marismas, nadan indolentes y calmosos con el cucrpo horizontal moviendo las aletas posteriores, y pasan el invierno en el fondo del mar. Es animal vivíparo, y ocul. ta su cria en la boca cuando les amenaza algun peligro. A fin de compensar la lentitud de sus movimientos, le ha dado la naturaleza un medio para apoderarse de los peces mas velo ces. Todo animal que la tembladora toca queda entorpeci- 
do, cansado, paralizado 6 muerto; y por este motivo perma nece sobre $\mathrm{cl}$ fondo inmóvil 8 haciendo la mortecina para dejar que otros peces se acerquen y paralizarlos y devorarlos en seguida. No emplea solamente esta fuerza cuando quiere apoderarse de peces $u$ otros animales, sino tambien contra el hombre, es decir, contra los pescadores cuando la han cogido en sus redes, puesto que se trasmite if estos al través de las cucrdas, redes y sedales que en este caso no pueden ya sostener con las manos. Los pescadores no lo ig. noran y por esto se guardan bien de tocar dichos peces, pues de otra suerte quedaria el micmbro que los toca entorpeci. do, frio y yerto, y lo mismo dicen sucede con solo tocar el agua donde hay una tremielga, y aun sirviéndose de una per. tiga, vara ó azagaya pasaria esta fuerza al través de ella y paralizaria la mano que la tiene cogida. Solo poseen dicha fuerza mientras viven, porque cuando han muerto, cualquie. ra las puede tocar y comer sin peligro alguno. Una tremielga se quedó en cierta ocasion en la playa durante la bajamar y se puso á dar saltos para alcanzar otra vez cl agua, cuando un jóven acudió y le puso los piés encima para impedir que huyera, pero en el mismo momento se puso á temblar y que. dó sin fuerza, porque este per no solo paraliza los micm. bros que le tocan sino que causa tambien un fuerte temblor.)

Nadie extraliará que en aquellos tiempos en que todos creian en milagros y virtudes sobrenaturales, se hayan aprove. chado en la medicina de unos animales de fuerza tan grande y misteriosa Se atribuyeron los cfectos mas maravillosos á su carne tomada como alimento, y en gencral los médicos de aquella época contaban tales cosas acerca de las virtudes

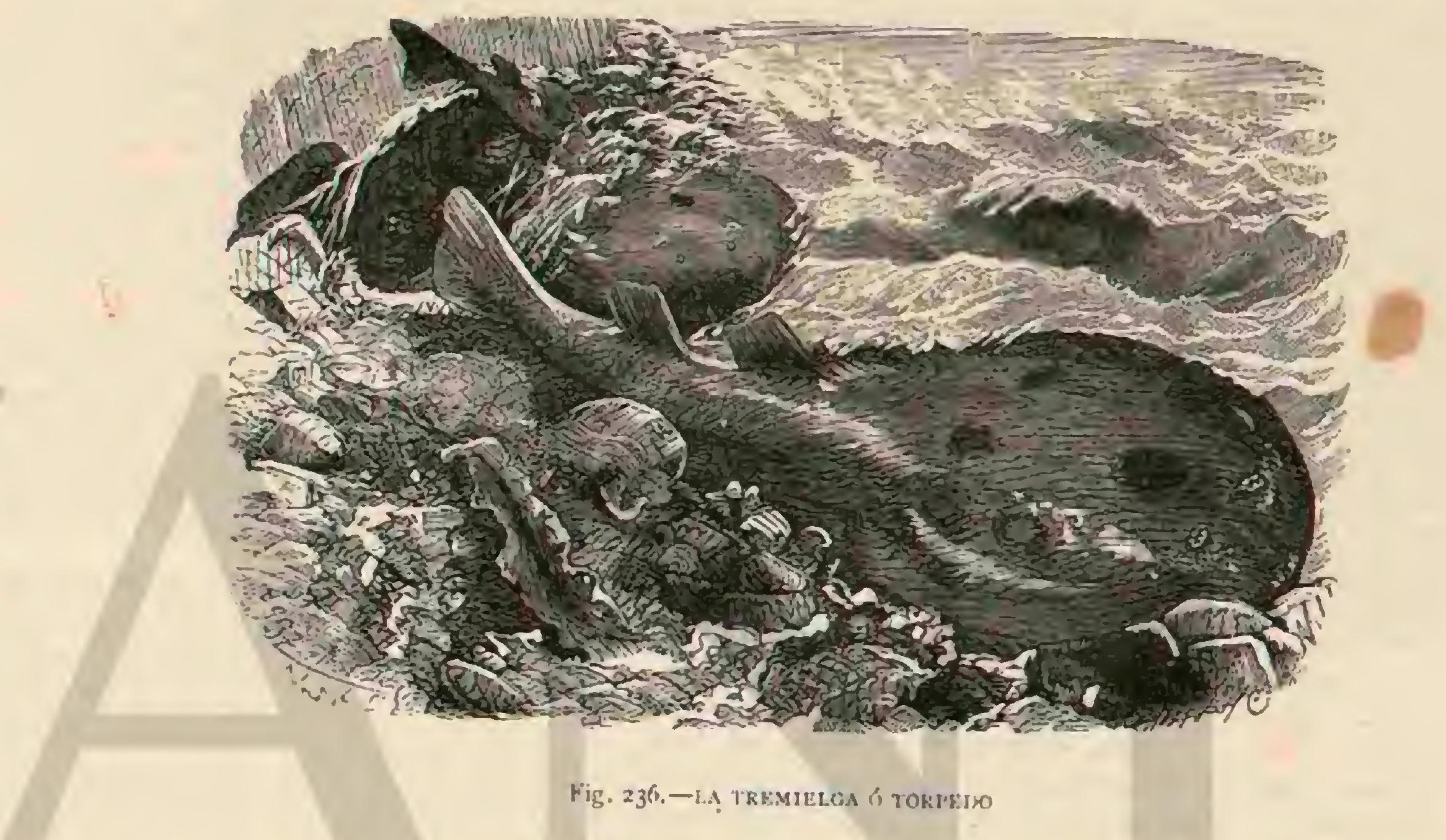

inherentes \& estos peces, que solo encuentran competidores en las relaciones de nuestros homeópatas y otros curan deros.

El primero que hizo experimentos exactos con el torpedo y que trató de descubrir las causas 5 leyes que producen tan extraños efectos fué Redi; Reaumur, Bancroft, Humboldt y Geoffroy los continuaron y aclararon mucho is cuestion; $y$ de todos estos estudios resulta que el órgano eléctrico de este pez puede compararse á un elemento galvánico ó bate. ria eléctrica. El cfecto es mucho menor que el producido por el gimnoto, pero no deja de ser bastante doloroso, y solo cuando el pez se ha debilitado á fuerza de prodigar sus des. cargas, se siente un temblor al sacarle del agua. Estas des cargas son mas violentas debajo del agua y tanto mas sensibles cuanto mayor superficie se toca. El animal las emite á voluntad, y si se le irrita despide una tras oira en gran número. Los animales pequeños quedan atontados y aun muertos cn cl acto, por manera que este b́rgano cléctrico sirve al pez tanto para apoderarse de sus presas, como para defenderse de otros rapaces mas fuertes. Creo excusado entrar aqui en mayores detalles respectó los experimentos hechos por los citados naturalistas, ya que todo lo que se dice de los efectos de una batería eléctrica es tambien aplicable á estos animales, aparte de que ya nos hemos ocupado de esta facultad especial al hablar de los gimnotos.

Todas las especies de torpedos que se conocen son vivf. томо $\mathrm{V}$ paras y dan \& luz de ocho a catorce hijuelos de una sola vez. Hay verdadera cópula, como ya lo sabian los antiguos, Y la efectúan vientre contra vientre. Los huevos se desarrollan poco mas ó menos todos por igual en los oviductos que corren á cada lado del abdómen en direccion torcida y se unen sobre el estómago para correr $\{$ lo largo del vientre hasta la salida, donde se cierran por medio de tapaderas do. bles. Los antiguos dicen que la madre recoge en la boca 1 sus hijuelos en momentos de peligro, pero los naturalistas modernos no han observado nada de esto.

USOS Y PRODUCTOS.-Es insignificante la utilidad de las tremielgas para la economia humana, y por consiguiente no se las pesca adrede.

\section{LOS RÁYIDOS-RAJIDE}

CARACTERES. - La configuracion de estos peces es romboidea; el hocico prolongado; la cola, que lleva cerca de su extremidad đos alctas dorsales y un rudimento de aleta final, es delgadia y redonda; las aletas abdominales están subdivididas en diferentes lóbulos; la piel es mas ó menos áspera, cubierta de espinas finas, y en el macho, particular. mente en la época de la reproduccion, de afilados aguijones en las aletas torácicas; la dentadura puede consistir en dien. tes ya planos, ya puntiagudos.

DISTRIBUCION GEOGRÁFICA.-Las cuarenta espe- 
cies que a poca diferencia componen esta familia se hallan distribuidas por todos los mares.

USOS, COSTUMBRES Y RÉGIMEN.-Respecto á este particular existe bastante diferencia entre las rayas y los torpedos, á pesar de ser tan afines por lo demás, puesto que aquellas no disponen de la terrible arma de estos. La reproduccion tambien es diferente, porque las rayas son oviparas, y los pequeñuelos no nacen hasta que las huevas han perma. necido expuestas bastante tiempo $\{$ la influencia del agua.

USOS Y PRODUCTOS. - Algunas veces dan lugar á una pesca regular, a pesar de la dureza de su carne.

\section{LA ROMAGUERA-RAJA-BATIS}

CARACTERES. - Es csta una de las contadas especies que viven en el mar del Norte (tig. 238). Alcanza una longitud de mas de un metro y un peso de 50 kilogramos poco mas ó nienos. Caracterizase por el hocico puntiagudo; dos hasta cincuenta y seis filas de dientes en la mandibula supe. rior; la configuracion mas ancha que larga; picl lisa 6 por lo menos poco áspera; por las espinas que tiene detrás del ojo y en la cola, y el color aceitunado oscuro muy uniforme, bien que puede haber casos en que la cara superior presente numerosas manchas blancas, y lainferior, de color gris oscuro, esté salpicadal Te negro.

\section{LA RAYA ESPINOSA-RAJA CLAVATA}

CARACTERES.-Las dimensiones que alcanza esta es. pecie (fig. 237) en los mares septentrionales exceden raras veces de metro y medio de largo por uno de anclio, pero en el mediodia pueden llegar respectivamente a tres y cuatro y f dos y tres metros con un peso de 200 kilogramos. La cola es allgo mas larga que el cuerpo, aplanada por debajo y provista en la extremidad de aletas; la abdominal está dividida en dos lóbulos desiguales; el cuerpo presenta casi una forma rectangular; $l_{a}$ piel es áspera, cubicrta de espinas blandas, $y$ de otras duras $y$ semejantes a las de las rosas en el dorso y vientre de los individuos viejos. El color domi. nante de la cara superior es un pardo vistoso salpicado de innumerables manchas mas claras, que á veces se confunden en las aletas torácicas. La cara inferior es puramente blanca.

DISTRIBUCION GEOGRÁFICA.-Súrea de dispersion es dilatadisima; abunda en las costas curopeas, y se pre senta tambien en el Báltico.

USOS, COSTUMBRES Y REGIMEN.-Todas las es. pecies viven casi siempre hundidas en los fondos arenosos $\checkmark$ cenagosos del mar, desde donde observan el agua que las cubre, y cuando ven pasar alguna presa se precipitan sobre ella y la devoran. Ia estructura de sus dientes no les permi te embestir s peces majores, y por esto han de contentarse con crustáceos, lenguados y otros peces pequeños y camaro. nes. Al acercarse la primavera, quizás antes, ticne lugar la reproduccion, y cuando concluye, ó en verano, pone la hem. bra, seis, ocho y mas huevas nuy parecidas á las de la lija, solo que tienen la forma mas cuadrada y apéndices mas cortos en las cuatro esq̨uinas; los pequeños nacen luego tan desarrollados que apenas les queda vesicula vitelina, y cuando la han reabsorbido, adoptan los hábitos de los viejos.

USOS Y PRODUCTOS.-Ta carne es despreciada en algunos puntos, $y$ tenida por sabrosa en otros. Fin Lóndres son muy buscadas y se venden al año cientos de millares, mientras que en el norte de Inglaterra se emplea la came de raya solo para cebo, bien que en I.óndres solo se come en otoño é invierno, porque en el resto del año, antes y despues
del desove, tiene pésimas cualidades.
PESCA.-Se pesca mas comunmente con palangre cebado con crustáceos, moluscos y peces; de esta manera se cogen millares de rayas espinosas que se salan y se consumen en invierno.

CAUTIVIDAD. - Para peces de acuarios reducidos dificilmente habrá otros mas interesantes que las rayas. $A$ duras penas se acostumbran à la cautividad y al nuevo régimen alimenticio, prefiriendo muchas morir de hambre, pero las que quieren comer, se conservan muchisimos años y entre. tienen con sus movimientos, diferentes de los de otros peces de fondo, porque en lugar de estar como estos pegados con todo su cuerpo contra el suelo, solo se apoyan en él con las aletas torácicas, formando debajo de su cuerpo un hueco por donde pasa el agua que respiran las branquias. Esta opera. cion la cfectuan abriendo las ventosas y retirando los pisto. nes; con esto se llenan las bolsas branquiales; despues se cierran aquellas y el agua consumida sale por las aberturas branquiales. En esta posicion, con el cuerpo cubierto mas ó menos de arena y gujarros y las aletas torácicas hundidas en el fondo, permanecen todo el dia sin hacer el menor caso de lo que pasa alrededor suyo, ni tampoco de los animales mayores que eligen su ancho dorso como teatro de sus retozos; pero al oscurecer se despiertan y ya nodescansan hasta el amanecer. Entonces empiezan á registrar el fondo nadando por encima de el y comiendo lo que encuentran.

La cara inferior del cuerpo es tan sensible, bien al contra. rio de la superior, que toda clla sirve al animal a manera de tentáculo de gran superficic, y apenas tocan una presa, se revuclven instantáneamente, la cubren con su cuerpo, la cogen con la boca y la engullen mascándola visibleniente. Es de suponer que de igual manera recorran en libertad una gran extension del fondo del mar.

Cuando cstán hartas suben a la superficie recreándose en toda clase de ejercicios singulares de natacion, y por tosca que parezca su estructura no dejan de nadar con gracia y li. gereza. El movimiento progresivo se produce con las alctas torácicas, sirviendo la cola de timon. Se comprende que la raya nade con la misma facilidad en cualquiera posicion, horizontal 6 vertical; en el primer caso parecen aves de rapinิa al atravesar el agua, y en el último diriase que bailan, tanto mas, cuanto que se complacen entonces en subir y bajar alternativamente, ora sacando la punta del hocico del agua, ora desapareciendo en la profundidad.

Viven entre si en la mayor armonia, sin enfurecerse cuan. do algun compañero pasa 6 lo que es peor se pone encima de ellos; su modo de comer excluye por otra parte todo ma tivo de disputa que podria motivar la envidia.

\section{LOS TRIGÓNIDOS-TRY- GONID㤅}

CARACTERES.-Los peces de esta familia tienen en conjunto la forma de las rayas, pero una cola muy larga y delgada sin linea lateral ni aleta superior; en cambio llevan uno 6 varios aguijones guarnecidos en los lados de dientes. La cabeza se halla completamente rodeaca por las aletas pectorales, $y$ la boca guarnecida de dientes ovalados $y$. provistos de prominencias trasrersales.

DISTRIBUCYON GEOGRÁFYCA,-Las cincuenta especies que á poca diferencia constituyen esta familia viven diseminadas en todos los mares.

USOS, COSTUMBRES Y REGIMEN. - Tambien figura entre los peces planos la raya vaca, el animal mas venenoso de cuantos viven en el mar. Tiene piel lisa, sin escamas, una cola semejante ála de rata, en medio de la cual lleva una 
especie de gancho, anzuelo 6 flecha cortante, de un dedo de largo hasta un pié, a veces acompañado de otros dos, uno á cada lado. Este aguijon tiene en toda su longitud otros ganchos en direccion contraria á manera de puntas de anzuclo, siendo por esto dificilisimo sacarlo de la herida donde se ha clavado, y que queda además envenenada. Esta raya venenosa sabe defenderse en toda circunstancia, hiere á los pescadores y á cualquier sér que la ataque, y se oculta admirablemente en el cieno. No come ningun per si antes no lo ha muerto ella misma. Su punzada es tan fatal que el hombre 0 el animal que la han recibido han de morir iremisiblemente si no reciben al momento asistencia médica; $y$ hasta se dice que si el pez hinca su aguijon en un árbol vivo y lozano, el tronco se seca desde aquel mismo instante.

No faltan pescadores que hoy repiten lo mismo casi literalmente, y sobre todo que la raja vaca envenena la herida que causa.

Para hacerse cargo de lo dolorosas y peligrosas "que son realmente estas heridas, léase la siguiente descripcion de Schomburgk: Entre los numerosos peces que son propios del Tacutu, ocupan los trigónidos el primer pucs. to por su número. Se ocultan tan bien con su cuerpo plano en la arena 6 lama, que solo quedan los ojos libres y pasan desapercibidos de los que andan ocupados en el agua, aun que fuese la mas clara. Apenas tiene uno la desgracia de po ner el pié sobre este animal traidor, cuando ya siente que el aguijon le destroza las carnes, produciendo una herida fatalisima que no solo causa convulsiones peligrosisimas, sino tambien la muerte. Nuestros indios que conocian perfecta. mente á tan peligroso cnemigo, no se descuidaban nunca do remover el fondo con un remo ó palo cuando tenian que pasar las barcas á rastras sobre un banco de arena, mas a pesar de esta precaucion fue herido dos veces en la planta del pié uno de nuestros remeros. Apenas se sintió herido el infelic, se fué tambaleando hasta la arena donde cayó y se revolcó presa del dolor mas atroz, mordiéndose los labios, pero sin que se le escapara ni una lágrima ni un solo grito de angustia. Estábamos ocupados en curar al pobre y calmar sus dolores en cuanto nos fué dable, cuando hubimos de fijar en otra parte nuestra atencion. Un muchacho indio acababa de ser punzado tambien, y como no poseia la firmeza de ca. rácter del otro para no manifestar su dolor, empezó á dar penetrantes gritos, y se arrojó al suelo hundiendo la cara y la cabeza en la arena que mordió fuera de si. En toda mi vida habia visto, ni aun en los epilépticos, convulsiones tan terribles como las que sufria el pobre chico. Ambos desgra. ciados sentian vivisimos dolores en los costados, en la region del corazon y sobaco, á pesar de tener la herida en la planta del pié. Si las convulsiones del indio viejo ofrecian un as pecto horroroso, presentábanse en el muchacho tan terribles que todos temiamos que sucumbiera a ellas. Hicimos chupar las heridas $y$ las vendamos; despues las lavamos y las cubrimos sin parar un instante con cataplasmas calientes de pan de banano. En general todos los accidentes tenian mu. chisima analogia con los que suceden álas mordeduras de serpientes renenosas. Otro trabajador muy robusto y vigoroso que pocos dias antes de nuestra partida de Demerara habia sido herido por una raya vaca, murió entre convulsiones aterradoras. En vista de estos hechos se inclina Schomburgk á creer que los trigónidos son realmente animales venenosos, ¿ pesar de que puede sostenerse con seguridad que todo el mal proviene de la forma especial del arma que hace las he. ridas tan dolorosas y excita una irritacion de nervios tan intensa, pues no cabe duda que un aguijon de acero hecho exactamente igual, $y$ clavado en las carnes con la misma fuerza, produciria dolores y accidentes idénticos.

\section{LA RAYA VACA-TRYGON PASTINACA}

CARACTERES. - Es la especie de que liablan los antiguos; alcanza una longitud de cosa de un metro con cinco ó seis kilógramos de peso, y es de color negro amarillento en la parte superior, y blanco sucio en la inferior.

DISTRIBUCION GEOGRAFICA.-Vive en casi todos los mares curopeos.

USOS, COSTUMBRES Y REGIMEN,-Couch dice que estos animales viven en el fondo arenoso de los mares, y que les gusta pasar en verano á las charcas y marismas que solo comunican con el mar en las aguas crecientes. Alli en cuentran su alimento, consistente en pececillos, crustáceos y moluscos. El modo cómo hace uso de su arma peligrosa prueba que sabe y conoce lo que vale. Cuando se la coge ó espanta descarga al objeto enemigo un golpe con su cola, larga y flexible como si fuera un lazo, $y$ le clava su dardo en la carne. Muchos observadores aseguran que realmente as. roja su aguijon con la rapidez de una hecha \& cualquicr blanco que elige sin errar el golpe, cosa que saben todos los pes. cadores, los cuales se guardan mucho de tocar a este pez mientras vive.

USOS Y PRODUCTOS. - Ia carne es aceitosa, dura y de gusto desagradable, pero se come á pesar de esto en al. gunas localidades. El higado se aprovecha para sacar el accite, y el dardo sirve àlos indios bravos de punta para sus flechas

\section{LOS MILIOBATIDOS- MYLIOBATIDE}

CARACTERES. - Comprende esta familia mas de veinte especies que se caracterizan por las aletas pectorales limitadas, que dejan despejada la cabeza, si bien esta tienc un apéndice á manera de aleta; la cola está tambien provista de un dardo y delante del mismo hay una aleta dorsal. Los dientes son planos 6 mas bien son placas dispuestas on hileras. La boca es muy grande.

\section{EL MILIOBATES AGUILA-MYIIOBATIS AQUILA}

CARACTERES.-Es pez de un metro a metro y medio de ancho con ocho á doce kilógramus de peso; puede al. canzar tambien dimensiones gigantescas y un peso de dos. cientos á trescientos kilógramos. Ei color es pardo oscuro en la parte superior, algo mas claro en los costados, y blanco sucio en el abdómen; los ojos son grandes, eliris de un tinte rerde gris y la pupila negra.

DISTRIBUCION GEOGR Á FICA. - El miliobates águila vive en iodos los mares de las zonas tórrida y templadas; Risso dice que siempre se le ve en Niza; Sonnini le encon tró en las costas del Egipto; los que examinaron los natu. ralistas ingleses fueron cogidos en las mismas costas de su país; y Couch recibió hasta huevas en un estado de desar. rollo suficicnte para determinar la especie.

USOS, COSTUMBRES Y REGIMEN.-El águila di. fiere poco de la raya vaca en hábitos y género de vida, pero dicen que nada mejor. Mucho se temen tambien las heridas que causa con su aguijon, y hasta la ley prohibe en Italia presentar estos peces ála venta mientras tienen el dardo.

USOS Y PROVECHOS, - La carne es manjar del.pueblo bajo, pero el higado figura como bocado muy exçuisito en la
mesa del gastrónomo. 


\section{LOS DICEROBATOS Ó MANTAS -DICEROBATIS}

CARACTERES. - Las especies de este grupo se distin. guen de las anteriores tanto por su configuracion como por su tamaño. Tambien tienen las aletas pectorales muy anchas y cortadas en dos, distinguiéndose en pectorales propiamente dichas y en cranianas, solo que estas últimas están coloca. das en los dos lados de la cabeza formando como dos cuer. nos. Ia cola redonda lleva una aleta dorsal y detrás de esta un dardo robusto; los ojos están en los dos lados; la boca delante de los dos cuernos, y lleva varias hileras de dientes pequeños, puntiagudos 6 llenos de prominencias.

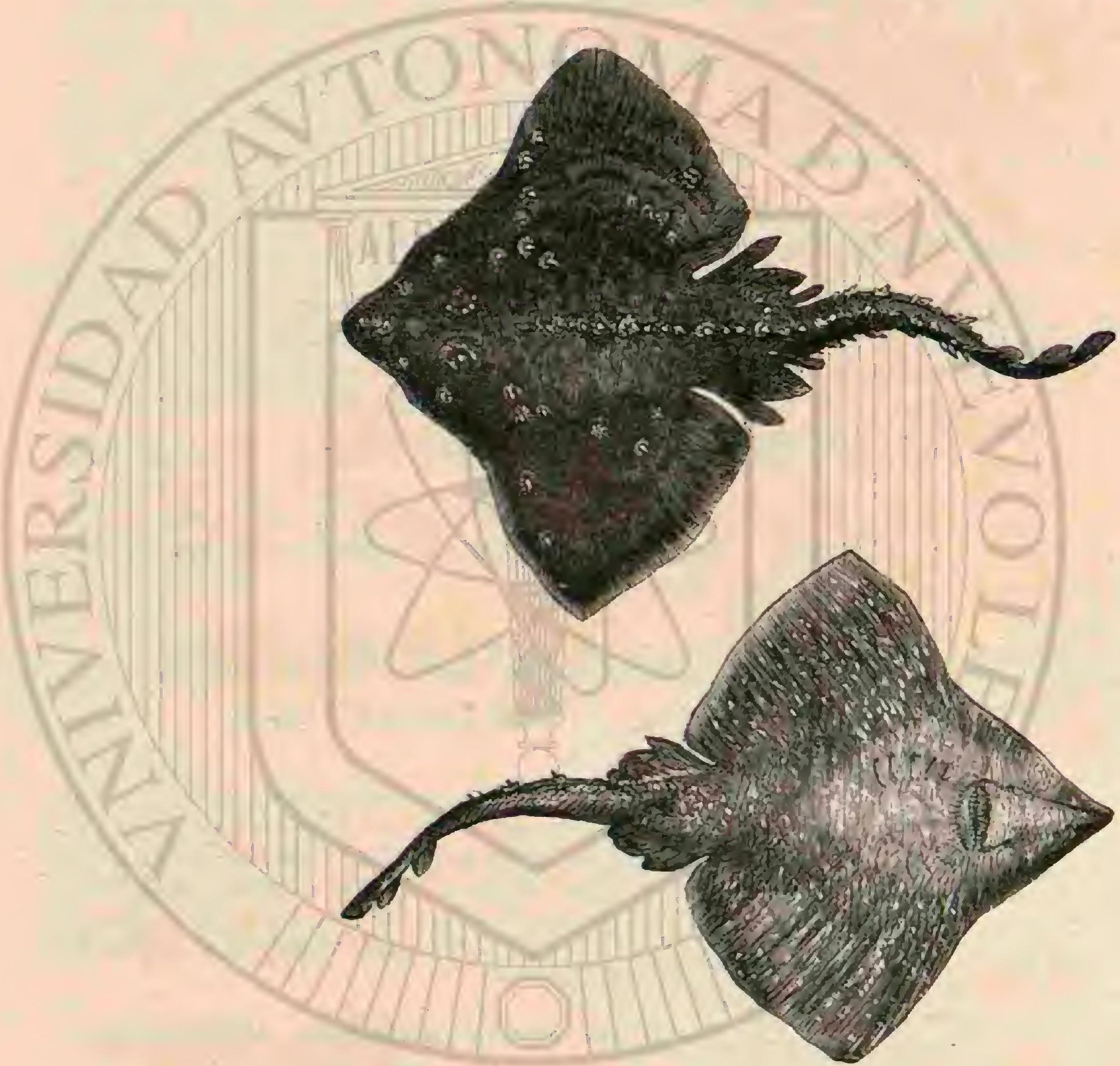

Fig. $237 .-2 A$ RAYA ESBRTOS.

Fig. 23 S. - I.A RAYA RONAGULRA

USOS, COSTUMBRES Y REGIMEN. - El diablo (Ia Marita). IGran ruido y movimiento \& bordo! Todos buscan alguna arma y pronto no se ven mas que lanzas, arpones y escopetas. Tambien me agregué a cllos, y al punto me designaron un pez como una raya muy grande, solo que tenia dos cuernos como un toro. Iba acompañado de otro pez blanco que le dejaba de cuando en cuando como para ir \& la descubierta, volviendo empero pronto para ocultarse debajo del grande, el cual llevaba en la cabeza entre los dos cuernos otro pez pequeño de color gris, que la gente llamaba el piloto del dialilo porque le guiaba y le pellizcaba siempre que via otros peces, sobre los cuales se precipitaba entonces el disolo con la rapidez de una fiechay

Esto reficre un autor que fué á últimos del siglo xirl á Siam, 8 publicó en $\mathrm{I}_{6} \$_{5} \mathrm{la}$ descripcion de su viaje. Posteriormente mencionan otros viajeros y naturalistas el mismo pez, entre otros, y por cicrto detalladamente, Levaillant que le observó á los $10^{\circ}$ de latitud norte. Tambien iban en com pañia de pilotos los que observó este sabio, y cada uno lle. vaba sobre el cuerno en la parte anterior de la cabeza un pez largo y del grueso de un brazo que parecia guiar al grande. Tuvicron la suerte de coger uno, ef mas pequeño de los diablos que vieron, y que resulto ser una raya que mcdia nueve metros de ancho y sin la cola, que tenia $0^{\circ}, 60$, siete metros de largo. Ia boca era tan grande que el animal podia tragarse un hombre sin dificultad. El color era pardo en el dorso $\mathrm{y}$ blanco en el vientre. El peso se evaluó en mil ki. lógramos.

Podrian calificarse de fantásticas estas relaciones, si re. cientemente no se hubiesen ouservado y cogido varias veces gigantes análogos; por ejemplo, uno que se pescó y mató cerca de Nueva-York, tenia casi el tamaño de una ballena, un peso de 5,000 kilogramos, y cuyo cuerpo medja cinco metros de largo 5 la cola uno, con un ancho de seis metros de punta á punta de las aletas pectorales; para sacar este monstruo fue. ra del agua a la playa se necesitaron dos yuntas de buejes, dos caballos y veintidos personas. Fl americano Elliot ha descrito tambien hace poco una caza de diablo 6 de manta, pez que segun él se presenta, si no con frecuencia, á lo menos bastantes reces en el golfo de México, y que nada contanta destreza como velocidad; \& veces se revuelca y salta de una manera particular; saca una y otra nadadera del agua, ó se 
enmaraña en las amarras, que arranca, y viendo que no puede con el ancla, tira furioso de la cadena de una parte á otra. 4 veces, dice, puede uno acercarse d este pez gigantesco cuando caza en poca agua pececillos y crustáceos, pero ha de procederse con grandisimo cuidado, para precaverse de sus movimientos que son tan rápidos como los de un ave. Asi va describiendo su caza y cómn por fín logró clavar en una de estas mantas su azagaya y sacarla a tierra, donde vió que media de punta á punta de las aletas pectorales cerca de seis metros.

De todas estas descripciones resulta que este pez pertene. ce al género de los dicerobatos.

\section{EL DICEROBATO GIORNA-DICEROBATIS GIORN AE}

CARACTERES.-Es muy probable que esta especic fuese conocida en la antiguiedad, pero la primera descripcion exacta se debe á Risso. Mide esta raya de un metro á metro y medio de largo sin contar la cola que tiene triple longitud que el resto del cuerpo; el peso no parece pasar de 25 kilú gramos. La coloracion es en la parte superior parda oscura, en los costados verde aceituna $y$ en la parte inferior blanca; los apéndices de la aleta son negruzcos.

Otra raya de este género que como la anterior fué pescada tambien en el Mediterráneo, media dos metros de largo, cuatro de ancho y pesaba 600 kilógramos. Sus aletas roráci- cas eran mas escotadas y el dardo de la cola tenia forma de necha; y otra cogida en el mismo mar media mas de ires metros de largo y pesaba tambien 600 kilógramos. Todios estos peces han sido descritos como otras tantas especies, pero es muy probable que no formen mas que una sola.

Parece que Kisso ha observado la raya manta $\delta$ el dicero. bato Gioma, que segun él se aproxima en verano á la cosia, donde se coge en el mes de julio con mas frecuencia. A causa de sus cuernos llaman los italianos a este pez fernera y cuando es muy grande zara. Se supone que los dos sexos viven durante cierto tiempo reunidos y que se tienen algun afecto, porque en cierta ocasion en que una hembra se metió en una almadraba, el macho no se apartó de las redes duran. te dos dias, procurando de vez en cuando introducirse, y al tercer dia se le encontró muerto en el mismo compartimiento de la hembra. Su alimento consiste principalmente en cefa. lópodos $y$ en segundo lugar en peces. La hembra pone en julio y agosto hucvas largas $y$ amarillentas de las que nacen los pequeños en setiembre.

CAUTIVIDAD. - Al revés de otros peces planos mueren los dicerobatos apenas se los saca del agua, y hasta cuando despues de cogidos se los conserva en el mar, como si la cautividad los matara.

USOS Y PRODUCTOS - La carne es roja, tenaz, dura, de digestion dificil y de consiguiente poco estimada, pero las clases pobres la consumen á pesar de esto. Del hígado se obtiene un aceite muy hediondo.
CARACTÉRES.- Habita los mares septentrionales un pez extraño, que si bien tiene varios puntos de semejanza con los plagiostomos y muy especialmente con los escualos, pre senta por otra parte caractéres tan particulares, que no solo es considerado como representante de un género y de una familia distintos, sino que se ha creido necesario para su me jor clasificacion, constituir con él un nuevo órden dentro de la sub clase de los selacios. Reconócese este per, lo mismo que otro congénere que aparece en los mares del hemisferio opuesto, por el cuerpo prolongado en forma de huso, con la cola muy larga y delgada, y la cabeza gruesa y cuneiforme; por la agalla única á cada lado, en la que desembocan los cuatro espacios interbranquiales, y que está protegida por un opérculo ternilloso; por las enormes aletas pectorales, apare ciendo por encima de ellas la primera dorsal, tambien de gran tamaño y sostenida en su porcion anterior por espinas arqueadas, y siguiendo á esta la segunda, muy larga y a penas separada de la caudal, que da la vuelta á la cola en toda su extension; y finalmente, por la pequeña boca, hendida tras. versalmente y armada de sencillas placas dentadas, que es. trechándose hácia fuera proyectan à manera de pico. De mayor importancia todavia son ciertos caractéres de la estructura interna: véase cómo los describe Cárlos Vogt: eIos holocéfalos ticnen tan solo un cordon dorsal, indiviso, con arcos superiores ternillosos 5 piezas intermedias, además de las apófisis inferiores de la misma materia, que corresponden a las trasversales de las vértebras de otros peces. Este cordon dorsal se prolonga hasta la cápsula cónica del cráneo, formando con esta un todo conexo, cuyo borde anterior hace las veces de mandibula superior, que falta por completo: de modo que las placas dentadas de esta region están aplicadas a la superficic inferior del indicado borde. Las órbitas, lo mismo que los ojos que encierran, son de gran tamaño. Las grandes fosas nasales se abren en la porcion mas baja del hocico, cruzndo por varios conductos pituitarios. Exceptuan do estas particularidades, hay completa analogia, en el orga nismo interior, entre los holocćalos y los plagiostomos.

En Épocas antiguas debió contar este órden gran número de especies, á lo menos las muchas placss dentadas, fósiles que de ellas se han encontrado, especialmente en el terreno jurásico, acusan considerable diversidad de formas.

\section{LA QUIMERA MONSTRUOSA-CHIMARA MONSTRUOSA}

CARACTERES. - Esta especie, representante del genero y de la familia, tiene un metro hasta metro y medio de longitud, y cierta belleza extraña. El cuerpo es muy largo s acaba en una cola larga y de punta finisima. El hocico es saliente y un tanto cónico; la aleta posterior es muy larga y apenas está separada de la caudal que tambien lo es. Fl ma. cho tiene entre los ojos una excrecencia delgada, huesosa 
inclinada hácia delante, que ha motivado el nombre de pe. je-rey con que designan en Noruega á este pez. La piel es lisa y refleja los colores amarillo de oro, pardo y blanco; los ojos son grandes, el íris blanco y la pupila verde.

El primer naturalista que ha descrito la quimera $y$ ha dado un diseño, si no bueno por lo menos bien caracteristico, de este pez, fué Gessner; Linneo le dí su nombre científico.

DISTRIBUCION GEOGRÁFICA. - Habita el Mediterráneo, la parte septentrional del mar del Norte s el Glacial, donde prefiere nadar entre las islas flotantes de hiclo.

USOS, COSTUMBRES Y REGIMEN, - Se dice que rara vez abandona las profundidades, pero que sube á la superficie junto con los arenques, en cuya ocasion se le suele coger. Se alimenta de conchas, crustáceos y pececillos de los que viven en el fondo del mar. Son oviparos; en la época del celo se encuentran en sus ovarios un gran número de huevas en todos los periodos de desarrollo; las mas formadas tienen una cáscara córnea.

USOS Y PRODUCTOS. - La carne es dura y mala, pero las huevas pasan por ser una golosina. En Noruega es mas apreciado el higado, y Pontoppidan dice: «Si se pone en una vasija á fuego lento se va derritiendo poco á poco hasta formar todo él un liquido aceitoso, el cual cura tan bien toda clase de heridas, que un boticario de gran experiencia me ha dicho que si tuviera algun mal exterior dejaria sus tarros y drogas por este aceite.

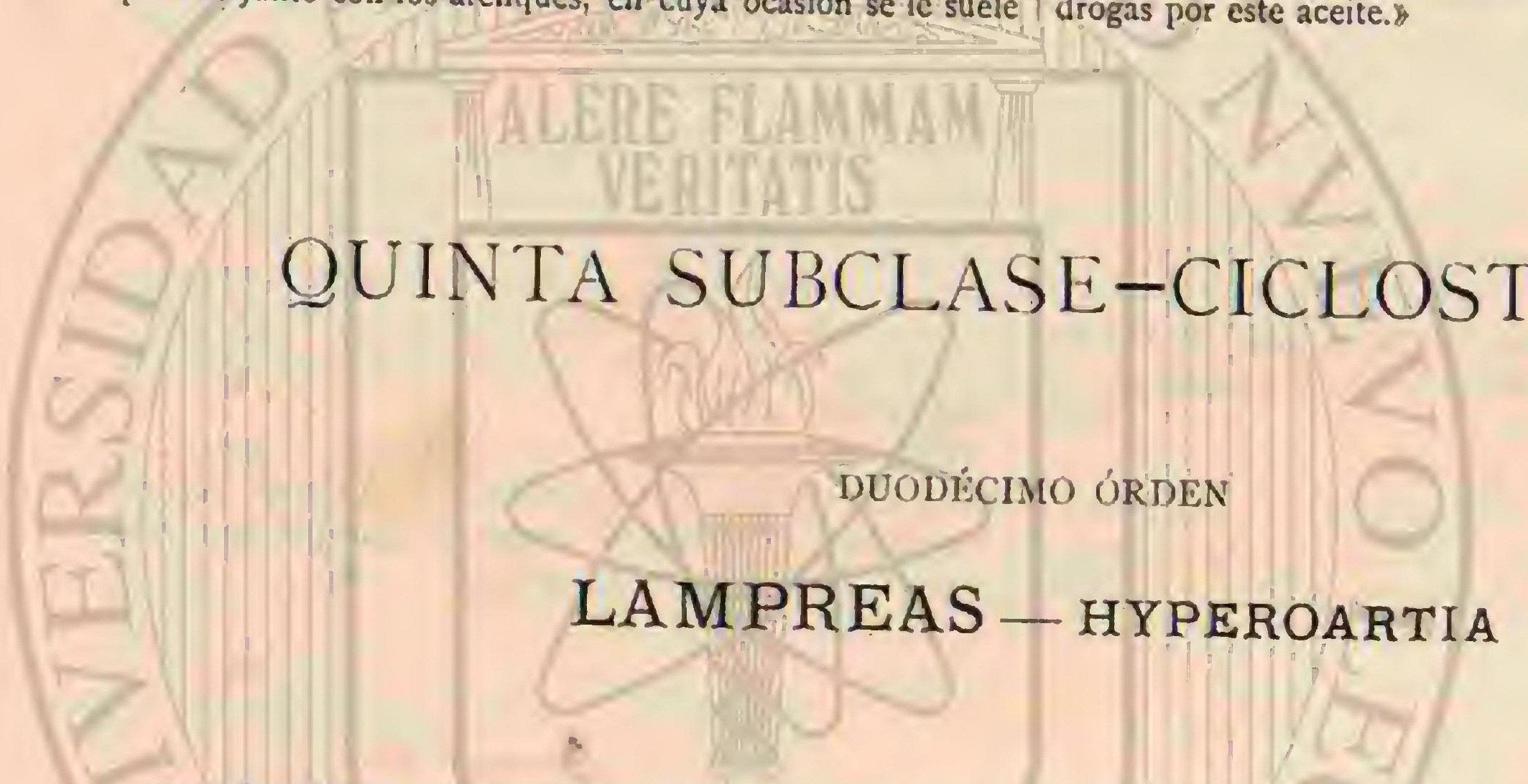

CARACTERES. - I/ incertidumbre que resulta por lo general de la comparacion de los peces cartilaginosos con los óseos, para deciáir á cuál de estas dos secciones principales de la clase corresponde el primer lugar en la clasificacion, cesa por completo al tratarse de los ciclostomos; encuén transe estos con efecto en un grado tan infimo de desarro. 1lo, que no cabe duda alguna de que solo pueden figurar en última linea entre los peces y los vertebrados.

Distinguense exteriormente los ciclostomos por su cuerpo vermiforme y casi de un mismo grueso en toda su extension, la piel dura y viscosa, sin escama alguna, y la completa atro. fia de todas las aletas pares; en la estructura interna, el esqueleto ternilloso, compuesto tan solo de un sencillo cordon vertebral, sin costillas, y de la porcion cefálica. El cráneo ofrece un aspecto embrionario; pues no se observa en él ninguna de sus naturales divisiones, faltando por completo las mandibulas, las cuales se ven sustituidas en cierto modo por algunos cartilagos que sostienen los labios; en su extremidad anterior se encuentra la abertura nasal, que se prolonga hácia dentro en forma de bolsa tubular y desemboca en las fauces. Isa boca ancha, pero que se estrecha interiormente manera de embudo, esta limitada por un labio redondo $y$ semicircular, y armada en la superficie interior de pequeños dientes cónicos, ó mejor dicho, de pequeñas protuberancias de la piel, viscosas y de consistencia córnea, que hacen las veces de aquellos. En la parte mas estrecha y postcrior de la boca empieza el esófago, que se prolonga sencillo y recto hasta el ano, sin divisiones estomacal é inteśtinal propiamente dichas. Encuéntrase el higado, pero parece haber carencia absoluta de toda otra glándula secretoria. Los órganos de la generacion aparecen prendidos 2 manera de festones en el cordon dorsal, $y$ vierten la esperma y los huevos en la cavidad abdominal, de donde son expelidos al exterior, y por medio de varios pequeños orificios en la inmediacion del ano. El corazon está relativamente bien desarrollado, tenien.

do bien marcado un tronco arterial con dos válvulas. A cada lado del esófago están las branquias, que desembocan en aquel por medio de tantas aberturas cuantos son los espacios interbranquiales, $\delta$ de un solo canal membranoso parecido á una tráquea, con el que están en comunicacion; abriéndose hácia fuera cada una aisladamente, ó reuniéndose tambien sus intervalos en un canal comun sa cada lado.

Una circunstancia muy interesante en estos peces, es la de haberse observado en algunos una verdadera metamorfósis.

\section{LAS LAMPREAS - PETRO- MYZONTIDOS}

CARACTERES. - Como complemento de los caracléres anteriores añadiremos que las aletas verticales están sosteni. das por numerosos radios cartilaginosos, y que existen siete aberturas branquiales exteriores y redondas, llamadas bolsas branquiales.

DISTRIBUCION GEOGRÁFICA. - Las doce especies bien distintas que constituyen la única familia y el brden, se hallan diseminadas por todos los mares de nuestro planeta.

\section{LAS LAMPREAS-PETROMYZON}

CARACTERES. - I as especies de este género, el mas importante de la familia, ofrecen los distintivos siguientes: Tienen dos aletas dorsales, confundiéndose la segunda con la caudal; la boca ventosa ó chupadora es redonda, con el ierente del disco cubierto de protuberancias córneas de di. ferente estructura; el tubo digestivo es recto y tiene una vál. vula espiral. Los dientes no son mas que protuberancias mucosas, sienderentes formas, cubiertas de varias capas de amarillento la la mas exterior, que tiene un color pardo amarillento, la mas dura, viniendo a consistir en una vaina 
córnea que se desprende fácilmente y es reemplazada por la capa de mucosa que la sigue. La piel es lisa, viscosa y des. nuda. I os ojos son medianos y están cubiertos de una capa epidérmica trasparente y delgada. Las siete aberturas branquiales están distantes una de la otra sin comunicarse por ningun surco longitudinal, $y$ las cavidades correspondientes se hallan rodeadas de un esqueleto cartilaginoso compuesto y movible, y cuyos movimicntos excitan la renovacion del agua que requiere la respiracion. No existe la vejiga natato. ria. El aparato sexual no es doble sino cuadruple y desem. boca en la cavidad abdominal de donde pasan los clementos reproductores al exterior por un conducto que se encuentra detrás del ano.

\section{LA LAMPREA DE MAR-PETROMYZON MARINUS}

CARACTERES. - Ls la especie mas impottante de las tres que se encuentran en nuestras aguas, puesto que pucde alcanzar hasta un metro de largo con un peso de 3 kilógra. mos. 'liene el cuerpo mas prolongado que todos sus afines y se caracteriza además por un circulo espeso de flecos deshilachados en el borde interior de sus abultados labios. El disco chupador tiene en la circunferencia de la boca varios circulos de dientes pequeños, sencillos y puntiagudos, que son mayores cerca del centro; en la region que corresponde á la intermaxilar hay una placa corta de dientes dobles $y$ en la de la mandíbula inferior otrá placa dental arqueada con siete ú ocho puntas; el espacio entre ambas se balla guarnecido en cada lado de cuarenta plaquitas pequeñas de dobles dientes. Isa primera aleta dorsal empieza mas allá del punto medio del dorso, consistiendo en una membrana larga $y$ un tanto arqueada; la segunda, separada de la anterior por un espacio libre, es bastante alta al principio, baja hácia atrás y se confunde imperceptiblemente con la caudal que no es mas que un fieco ú orla angosta y membranosa, y que ensan. chándose $y$ redondeándose un poco, da la vuelta por debajo hasta al ano. La coloracion principal es un blanco verdoso salpicado de manclias pardas negruzcas 6 verdes aceituna. das en el dorso y los costados.

DISTRIBUCYON GEOGRÁFICA. - La lamprea marina habita todos los mares europeos excepto el Negro, y se encuentra tambien en la costa occidental del Africa y en las del norte de América.

USOS, COSTUMBRES Y RÉGIMEN. - Pasa la mayor parte de su vida en el mar, pero hácia la primavera sube álos rios para desovar.

\section{LA LAMPREA DE RIO-PETROMYZON FLU- VIATILIS}

CARACTERES. - Esta especic excede raras vieces de $0^{\circ}, 40$, si bien se encuentra alguno que otro individuo que llega a $0^{\mathrm{m}}, 50$ con un peso de roo gramos poco mas ó menos. El arco maxilar inferior lleva siete puntas dentales, y la pla ca que representa la mandibula superior y se halla en frente del anterior, tiene en el centro un borde cortante que termina en cada extremo en una punta dental. Ias dos aletas dorsales están separadas, la primera es corta, redondeada y algo mas baja que la segunda, la cual se confunde con la caudal y la anal; esta útima no existe sino en estado rudimentario, como una especie de arista. La parte superior del cuerpo es azul verdosa y reluciente; color que pasa en los costados a blanco amarillento y en el vientre á blanco plateado; las alctas tienen un tinte morado.

DISTRIBUGION GEOGRÁFICA.-A pesar de llamar se esta especie de rio, vive en el mar, particularmentc en los mares que banan las costas de Europa, de la América del norte $y$ del Iapon. Remonta los rios para desovar, pero se cree que vive tambien constantemente en ciertos lagos de] interior y en rios caudalosos.

\section{LA LAMPREA DE PLANER-PETROMYZON PLANERI}

CARACTERES. - Bien que semejante á sus congeneres anteriormente descritas, difiere empero por su menor lama. no, por la dentadura y por la disposicion de las aletas lo sufi. ciente para no confundirla con ellas. I.a placa que representa la mandibula inferior presenta doce puntas dentales; la boca lleva en su circunferencia un fieco espeso de apéndices $\delta$ verrugas cortas, entre las cuales se distinguen tambien pe. queños dientes. Fuera de esto se asemeja la dentadura á la de la lamprea de rio. La primera aleta dorsal, o se confunde con la segunda, $\delta$ está solamente separada de ella por un pequeño espacio. En cuanto á la coloracion, tira en el dorso mas á un tinte verdoso aceitunado. La longitud oscila entre $0^{\mathrm{F}}, 20$ y $0^{\mathrm{E}}, 40$.

DISTRIBUCION GFOGRÁFICA.-Segun Yarrell, en. cuéntrase esta lamprea tambien en el mar, pero habita prin. cipalmente y en gran número todas las sguas dulces de Europa y del norte de América, hasta los arrojos mas pequeños cuyo fondo le es propicio, es decir, de arena fina ó cenagoso.

USOS, COSTUMBRES Y REGIMEN DE LAS LAMPREAS. - Las lampreas se mueven con rapidez y destreza en el agua á pesar del poco desarrollo de sus aletas, En sitios de poca corriente avanzan culebreando de costado, pero cuando quieren ir contra corrientes fuertes, aunque sean de rios caudalosos, progresan como á saltos, adhiriéndose $\mathbf{a}$ cada uno de estos á un objeto sólido como para descansar, y volviendo en seguida á emprender su marcha. Acaso nadan tambien muchas veces agarradas á otros animales, conforme dice el autor antiguo: Tambien acompanan \& los salmones, adhiriéndose con la boca á su cuerpo cuando suben del mar a los rios. Ninguna observacion hemos visto en contra de este ascrto, que Guenther parece querer confirmar cuando dice hablando de la lamprea de mar: «Estos peces se cogen casi cada año en la primavera cerca de Heilbronn, y aun en el Ennns, y todo el mundo cree que en esta época suben á los rios para desprenderse de su freza; pero como no puede admitirse que en tan poco tiempo recorran un camino tan largo, puesto que nadan tan mal, me parecte probable que hacen la travesía agarndos con la boca á otros peces, supo. sicion que viene corroborada por su aparicion simultánea cón la del salmon y de la alosa bastarda ó finta, y porque hasta hoy nadie ha visto todaria crias de lampreas en el Neckar. Esto no puede aplicarse sin embargo á las otras especies de lamprea, por lo menos en términos tan generales, puesto que tampoco median las mismas circunstancias, porque micntras la de mar se encuentra exclusivamente en la cuenca supe. rior de un rio, las otras especies pueblan hasta los afuenies mas pequeños en los que se reproducen poco menos que exclusivamente. Ahora veremos sin embargo que todos estos viajes rio arriba no reconocen por causa la reproduccion; aunque es positivo que todas las lampreas son parśsitas, $y$ para algunos peces hasta de la peor especie. dado que se adhieren á ellos como á otros cuerpos.

Hablando de su régimen se suele citar como alimento principal de las lampreas, gusanos, cria de peces é insectos en diferentes estados de desarrollo, pero lo cierto es, y en esto cstán acordes todos los observadores, que tambien se 
alimentan de la carne y sangre de otros animales, y que cuando se adhieren \& un objeto es por lo regular para ali. mentarse chupando su sustancia, y no exclusivamente para tener un punto de parada. Cuando una lamprea ha fijado su boca chupadora en el cuerpo de un pez, empieza á trabajar con sus dientes de raspa para perforar la cubierta, y tragán. dose las materias desprendidas, penetra mas y mas en el in. terior de su victima, haciendo en su cuerpo viro ó muerto agujeros profundisimos, que por lo comun se observan en peces cogidos en anzuelos de palangre, pero bien puede su. ponerse que los hagan tambien en peces sanos, libres y ro. bustos.

El tiempo del desove cá en los primeros meses de prima. vera y en circunstancias cnteramente especiales. Baldner, autor antiguo, dice: Desovan en abril, en fondos pedrego sos y arrastran con la boca piedras de dos libras para formar el hoyo. Una cosa análoga refiere Jardiner. Carecen de aparatos como otros peces para hacer hoyos donde poner sus huevas, pero los suplen con su boca con la cual se adhieren á piedras de considerable tamaño que acarrean así, dando prueba de una fuerza pasmosa. Construido el hoyo, lo ocupa la pareja, agarrándose cada lamprea á una de las piedras mayores y asi desovan. Baldner obscrvó tambien la lamprea de Planer durante la reproduccion y sobre esto dice: 8 Viven agarradas en gran número a las piedras en puntos de fuerte corriente; alli construyen hoyitos profundos en los cuales se juntan vientre contra vientre para cfectuar la cópula, cosa que no he observado en ningun pez mas que en las lam. preas de rio, que desovan en sitios de poca agua donde es fácil observarlas.

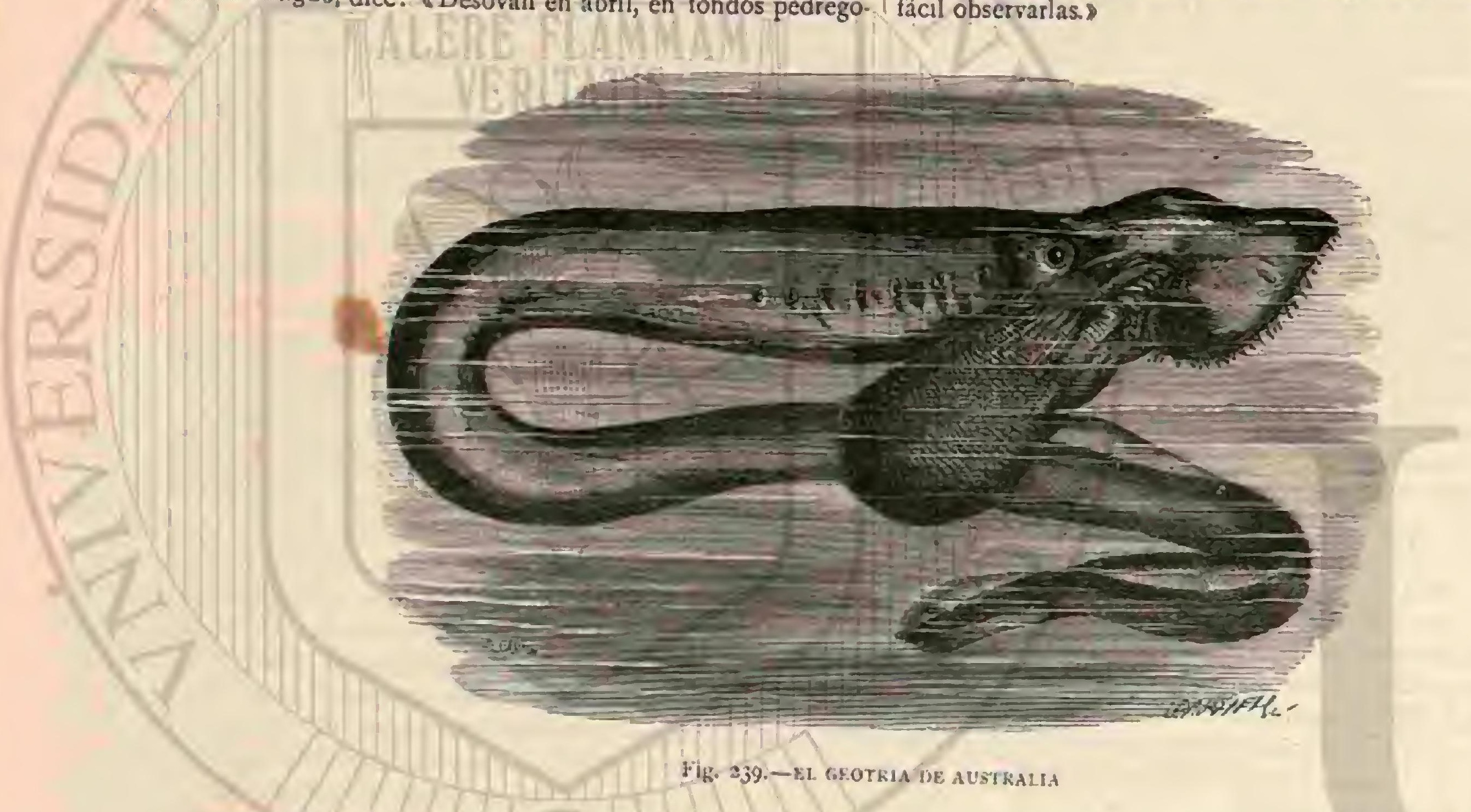

Augusto Mueller, que pudo observar la operacion del des ove de la lamprea de Planer en el Panke cerca de Berlin. confirma lo que precede en todos sus puntos esenciales. Vió unos diez ó mas individuos en confuso monton, y observó cómo algunos machos se adherian con la bocá la nuca de la hembra, y en esta posicion torcian el cuerpo hácia el vien. tre de la misma para ir fecunciando las hucvas á medida que eran expelidas.

Hasta que se publicaron las investigaciones de Mueller se habia observado en los sitios de desove de la lamprea de Pianer un pez-gusano (Ansmocales branchialis), animal muy comun descrito ya por Aldrowandi, $y$ que suele tener $0^{*}, 18$ de largo con el grueso de una pluma de ganso; la cabeza es muy pequeña y los ojos apenas visibles; las aberturas bran. quiales son dos agujeros situados en un surco longitudinal bastante hondo; la piel presenta anillos y el color es plateado mate que pasa en las nadaderas a blanco amarillento. Es bastante frecuente en las aguas de fondo cenagoso ó arenoso y en todas sus costumbres se parece mucho mas a los gusa. nos que á los peces, á cuya clase no se le agregú hasta que se le hubo disecado y estudiado anatómicamente. Penetran en el cieno como rerdaderos gusanos y casi nunca abandonan su agujero, pues cuando hacen uso de sus nadaderas es únicamente pam volverse a ocultar, en cuya ocasion les gusta meterse en los haces de lino que se tienen durante cierto número de dias en el agua para descortezar despues los tallos

mejor, entre los cuales se encuentran cuando los cxtienden al sol. En algunos puntos se pescan adrede, se les quita la cabeza, y los guisan con manteca, vino 5 zumo de limon, plato muy estimado por lo sabroso; pero el pucblo los mira con repugnancia por su aspecto de gusano, y el pescador solo los emplea como cebo vivo, porque tienen una vitalidad tan grande que aunque cstén gravemente heridos, viven ó por lo menos se mueven muchos dias. Todos los naturalistas estaban antes acordes en mirar este animal como pez muy semejante \$ la lamprea, sin que $\{$ ninguno se le ocurriera que entre am. bos pudiera existir acaso un lazo mas intimo que el de mera afinidad.

Con el objeto de estudiar el desarrollo de las huevas fecun. dadas á su presencia, las llevó Mueller á su casa y obtuvo á los diez y ocho dias pececillos que con gran admiracion suya no se diferenciaban en nada de los ammoccetes branchiolis descritos mas arriba, 5 que despues de crecidos resultaron ser enteramente idénticos. En vista de este resultado era natural suponer que este animal no cra ninguna especie particular, sino la larva de la lamprea de Planer, y en efecto Mueller logró descubrir y estudiar los diferentes grados de desarrollo y trasformacion desde el gusano ciego hasta la lamprea desar. rollada de ojos grandes. No puede dudarse en vista de este resultado que las otras lampreas pasan por identicas irasformaciones; es decir, de las huevas nacen amocetos que a los tres 6 cuatro años han alcanzado una longitud de $0^{\circ}, 18$ a 
$0^{\circ}, 20, y$ se trasforman entonces en pocos dias en verdaderas lampreas.

Con este descubrimiento se aclaró otra circunstancia observada en estos peces por los naturalistas antiguos y que consiste, segun decian: «en q̨ue menguan y mueren á causa del excesivo movimiento, algunos hasta antes de desovar ó parir.» Además se sabia que durante el verano se encuentran pocos ó ninguno, y que se habian visto flotar muertos; y un natura. lista italiano, Panizza, dice claramente que pueden pescarse lampreas de mar muertas despues del desove. En efecto, á pesar de sus minuciosas pesquisas, no pudo encontrar Mue. ller ninguna lamprea viva en el Panke, y sí solo algunas muertas despues de haber concluido el desove, $y$ eso que abundan bastante en este pequeno rio, y cxaminando los ova. rios de las muertas no encontró en ninguna huevas en dife. rentes estados de desarrollo como sucede en otros animales, sino solo las cápsulas vacias del ovario, de lo que dedujo que las lampreas perecen concluido el desove. Suponiendo que todo ocurra de esta manera, resultaria que dichos animales, que ocupan un grado tan bajo entre los rertebrados, pasarian á semejanza de tantos invertebrados una vida muy larga en estado de larva, y' solo pocos dias en el de animal perfecto, es decir, como peces adultos y formados.

PESC A. - Para coger lampreas se emplean nasas de varios compartimientos, hechas de juncos y colocadas en sitios de gran corriente; en algunos puntos se las pesca tambien con redes, y finalmente con arpones y fitoras para sacar las que están sobre el fondo. I,a pesca principal tiene lugar en primavera cuando suben del mar, pero se cogen tambien las lampreas de rio en gran cantidad en otoño, epoca en que vuelven al mar. Para venderlas se tuestan un poco y despues se ponen en una salsa picante.

USOS Y PRODUCTOS. - En Alemania es muy apre. ciada la carne de lamprea, a pesar de lo cual rara vez se pa.

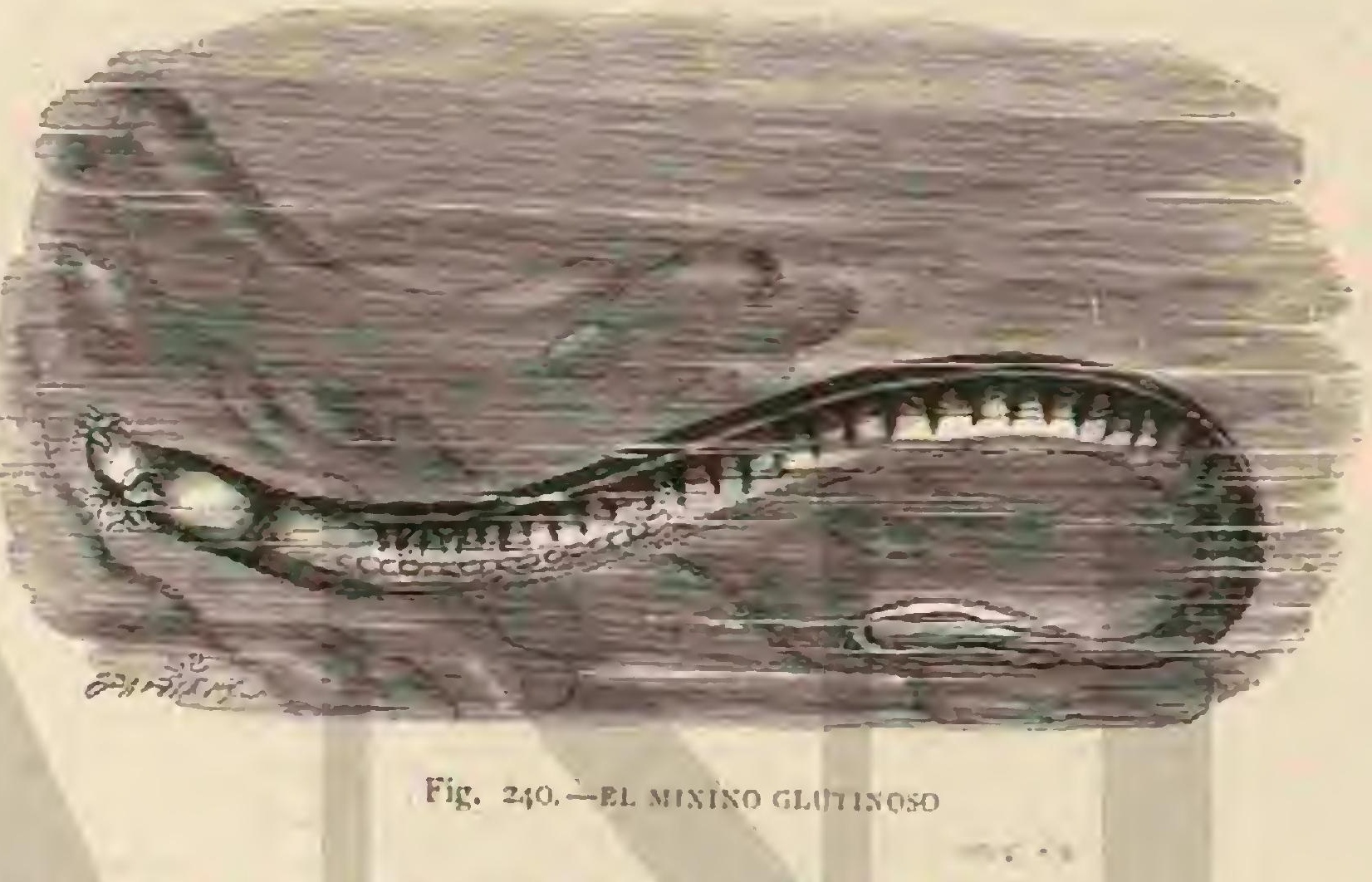

ga á mas de tres reales el kilogramo. Gessner dice: «En pri. mavera son excelentes las lampreas, y cuanto mas grandes mas sabrosas son. Es manjar muy agradable, pero crian una sangre espesa y mucosa, por cuya razon se condimentan con vino bueno y especias. In Francia gozaban de gran fama en la Edad media, habiendo entonces vendedores que se li. nitaban exclusivamente \& este artículo, y el consumo era tan grande que hubo necesidad de publicas una Realórden pro. hibiendo salir al camino al encuentro de dichos vendedores para comprarles las lampreas antes yue entrasen con ellas en la ciudad. Tambien eran y son todavia apreciados estos pe. ces en Inglaterra, pero, segun dice Parnell, los pescadores de Escocia arrojan al mar todas las lampreas que cogen accidentalmente, porque tienen desde antigua fecha una aversion invencible á estos peces.

CAUTIVIDAD. - No se conservan las lampreas aunque se tengan en acuarios y viveros perfectamente dispuestos, porque rehusan toda clase de alimento. Se agarran con la boca a cualquier objeto, aunque sea el cristal mas liso, y res. piran con trabajo moviendo visibleınente el cartilago bran. quial; pero á esto se limitan sus movimientos si no se les mo. lesta, y al fin caen muertas al fondo.

\section{LOS GEOTRIAS-GEOTRIAS}

CARACTERES.-Con los singulares peces à que se dió este nombre se ha formado un género independiente, cujos representantes difieren por caractéres muy notables de los

Toso $v$ del anterior. El mas saliente consiste en tener la piel de la parte inferior de la garganta prolongada de tal modo que forma un gran saco ó bolsa, segun se representa en el grabado que acompaña. Las dimensiones de estos peces son no. tables; el cuerpo muy prolongado; la cabeza voluminosa y los ojos grandes, viéndose á continuacion de ellos siete orifi cios muy marcados.

\section{EL GEOTRIA DE AUSTRALIA-GEOTRIA}

CARACTERES.-El geotria de Australia (fig. 239), conocido tambien con el nombre de lamprea de holsa, tiene el cuerpo sumamente prolongado, parecido al de una serpiente; la forma de la cabeza se asemeja en cierto modo al casco de un caballo, y es de las mas singulares que pueden verse en los peces; el hocico estŕ conformado de tal modo, que no es posible que el animal pueda adherirse á los cuerpos du. ros, como lo hacen las especies del precedente género; la boca, muy ancha, hâllase provista de fuertes dientes en to. do el interior del disco, $y$ en la lengua se ven otros dos mus puntiagudos. En esta especie no se ven mas aletas que la que termina la cola. El color del geotria de Australia es amarillento pardo, predominando este úlimo tinte en el dorso, y el primero en las regiones inferiores. Los individuos de la especie suclen adquirir grandes dimensiones.

DISTRIBUCION GEOGRÁFICA.-Este per habita en los rios y lagos del sur de Australia. 
USOS, COSTUMBRES Y REGIMEN, - NO es bien conocido el género de vicia de la especie, pues se ha obser vado muy poco; solo sabemos que acostumbra á permanecer en el fondo de las aguas, donde se oculta entre el cieno. Es probable que su régimen sea con corta diferencia el mismo que el de la lamprea.

\section{DECIMOTERCIO ORDEN}

\section{HIPEROTRETIDOS Ó PECES CIEGOS-HYPEROTRETA}

CARACTERES. - Son verdaderos gusanos, tanto porsu forma como por sus hábitos y género de vida, y forman una familia única dividida en dos géneros y cinco especiés cono. cidas hasta ahora! Juan Mueller juzgó tan importantes los caractérés de estos peces que formó con ellos un órden independiente. I a major parte de los naturalistas aceptan este modo de ver, mientras que algunos clasifican los jeces ciegos entre las lampreas.

\section{LOS MIXINIDOS MYXINID在}

CARACTERES - Fil cuerpo cilindrico lleva únicamentè en el extremo caudal adelgazado una aleta redonda is modo de palai en el labio hay barbillas toscas reforzadas por carti. lagos; el paladar lleva un diente, y la lengua algunos mas dispuestos en dos hileras á manera de peine No existen ojos visibles en cl exterior, pero si rudimentos debajo de la piel y los músculos. Las fosas nasales conducen á un tubo formado de anillos cartilaginosos que se abre en el paladar donde se cierra por una válvula movible. Existe una cápsula auditiva, pero sin huesecillos. I.as bolsas branquiales se hallan colo. cadas muy hácia atrás, desembocan interiormente cn el esó. fago, y hácia afuera, cada una por un conducto único 6 por seis $\delta$ siete agujeros. El cerebro y lá médula están en el cor. don rertebral que es de consistcncia geiatinosa y está formado por una envoltura filamentosa doble que hácia la cabeza se vuelve cartilaginosa.

\section{LOS MIXINOS - MYXINE}

CARACTERES. - Consisten en la boca redonda con ocho barbillas; la lengua lleva en cada hilera de ocho á nueve dientes duros como hueso; el diente del paladar es hue. co, cartilaginoso $y$ un poco corvo. No hay ojos; y las aberturas branquiales se reunen debajo de la piel en un conducto único, que en cada lado comunica con el exterior por un agujero. La piel segrega abundante mucosidad. La longitud viene å ser de unos $0^{\circ}, 20, \mathrm{y}$ el color blanco con viso azul in. determinado.

\section{EL MIXINO GLUTINOSO-MYXINE GLUTINOSA}

CARACTÉRES. - I InnCo creia que esta especie (figu. ra 240), la mas conocida de la familia, era un helminto in. testirial, y efectivamente se parece mas á estos animales que á un pez.

DISTRIBUCION GEOGRAFICA.-El mixino glutinoso habitalos mares del norte, y se le coge prixcipalmente en las costas de Groenlandia, Noruega, Suecia é Inglaterra. Tambien se le encuentra en el mar del Norte, como por ejemplo en la bahía de Jahde, donde parece preferir los fondos cenagosos muy profundos.

USOS, COSTUMBRES Y RÉGIMEN.-EI mixino es una prueba palpable de aquel axioma de que el hábito y gé. nero de vida dependen de la forma del animal, $y$ como esta esjecic es un pez gusano, claro está que vive como un pa. rásito sobre y dentro del cuerpo de sus compañeros de clase. No se sabe cómo se arregla para apoderarse de su presa, pero sí que se iniroduce entre los músculos y en los intes. tinos de muchos péces, en particular en los abadejos del Báltico llamados Dorsch, en las molvas, hipoglosos, sollos y Lamios, a los que chupa y devora hasta no dejar mas que la piel y los huesos. A veces causa daños de consideracion en los peces cogidos en red barredera y de iondo, pero tambien ataca peces perfectamente libres y vigorosos. Debe suponerse que á falta de ojos le sirven sus barbillas de tentícu. los, $y$ tan luego como merced á ellas descubre una presa, cosa qque naturalmente le es mas fácil entre los peces cogidos en la red ó el anzuelo, se aủhieréá ellos con su boca que hace las veces de ventosa y se desliza en el interior del cuerpo, ya por el agujero que hace horadando, ya por la boca 6 el nno. Se le ha encontrado tambien en peces muertos, pero no se sabe si el mixino era la causa de su muerte $\delta$ si los devora cuando los encuentra así. De todos modos se comporta como verdadero gusano, viniendo por consiguiente à ser un tránsito entre los peces y los anélidos, pues tanto tiene de unos como de otros. Se reproduce por medio de huevos bastante regulares, amarillentos, de cáscara córnea y con apéndices filamentosos propios para agarrarse á objetos extraños.
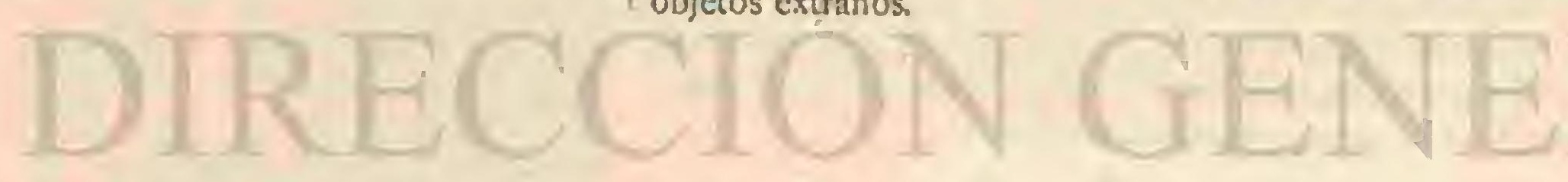


\title{
SEXTA SUBCLASE-LEPTOCARDIOS
}

\author{
DECIMOCUARTO ÓRDEN
}

\section{CIRROSTOMOS-CIRROSTOMI}

Llegamos al fin de los vertebrados, encontrándonos en último férmino con un sér que figura entre los feeces, porque solo en esta clase del reino animal puede tener cabida, si bien presenta tan poca analogía con todos los demás individuos de la misma, que es á la vez el tipo de la sub-clase, de la familia, del órden y del género que han debido constituirse para poder clasificarlo con alguna propiedad. El con. cepto primitivo y caracteristico del vertebrado deja ya de ser aplicable \& este animal, pues ni tiene vértebras, ni siquiera columna dorsal articulada. Asi como el mixino glutinoso (myxine glustirosa de Linneo), del órden anterior, es considerado por algunos como el eslabon entre los peces y los gusanos, puede decirse igualmente que la especie que nos ocupa, representa el tránsito de aquellos á los moluscos. El clasificador que, celoso de metodismo, se aferre â uno de tantos sistemas, casi siempre concebidos en el sentido mas estrecho y limitado, y pretenda sujetar al mismo todas las producciones de la naturaleza, se hallará, de seguro, perplejo en presencia de este pequeño sér; pero el que haya compren. dido que la naturaleza no obra bajo sistema alguno, sino que ella es la unidad y nosotros los que la descomponemos, dividimos y limitamos, para poder orientamos en medio de su infinita variedad, ese, juzgando librensente, no tendrá duda aiguna en reconocer como pez al leptocardio, que Pallas, su descubridor, comparó 1 una limaza.

\section{EL ANFIOXO LANCEOLADO-AMPHIOXUS LANCEOLATUS}

CARACTERES. - Este pez (fig. 24I) tiene cl cuerpo de unos $0^{\prime \prime}, 05$ de largo, tendido, estrecho y anguloso, con ambas extremidades aguzadas casi en igual proporcion, y provista Ia posterior de una fina aleta vertical, que como angosto ribete de la piel se extiende á lo largo de una buena parte del dorso, $y$ en la region inferior hasta cerca del ano, terminan. do en la cola en forma de lanceta. Ia boca, situada debajo de la extremidad anterior del cuerpo, está rodeada de pun. tas ternillosas que doblándose sirven, á lo que parece, para cerrar aquella abertura. Inmediatamente detrás de la bo. ca, cmpieza el ancho canal branquial, compuesto de varias tiras térnillosas paralelas é inclinadas de arriba abajo, y se. parado, hácia dentro, del intestinal por medio de un replie. gue anular. El agua absorbida penetra por los espacios que dejan entre si los cuerpos ternillosos, en la cavidad abdominal, y es expelida por un conducto que se abre en aquella region. El canal intestinal se ensancha para formar un ciego glandular, que corresponde al higado, estrechándose en forma de arco hasta el orificio posterior. Todas las membranas viscosas están cubiertas de pequeños filamentos, que mo. viéndose continuamente, activan el paso del agua para la respiracion. El cordon tendinoso que sustituye la columna vertebral se extiende desde la punta del hocico hasta la terminal de la cola; su túnica extcrior forma un canal para la médula, pero sin presentar abultamiento alguno, y sosteniendo en la extremidad anterior, sobre cortas ramas, dos protuberancias que algunos han calificado de rudimentarias de los ojos, asi como otros creen haber descubierto un órgano olfa. torio.

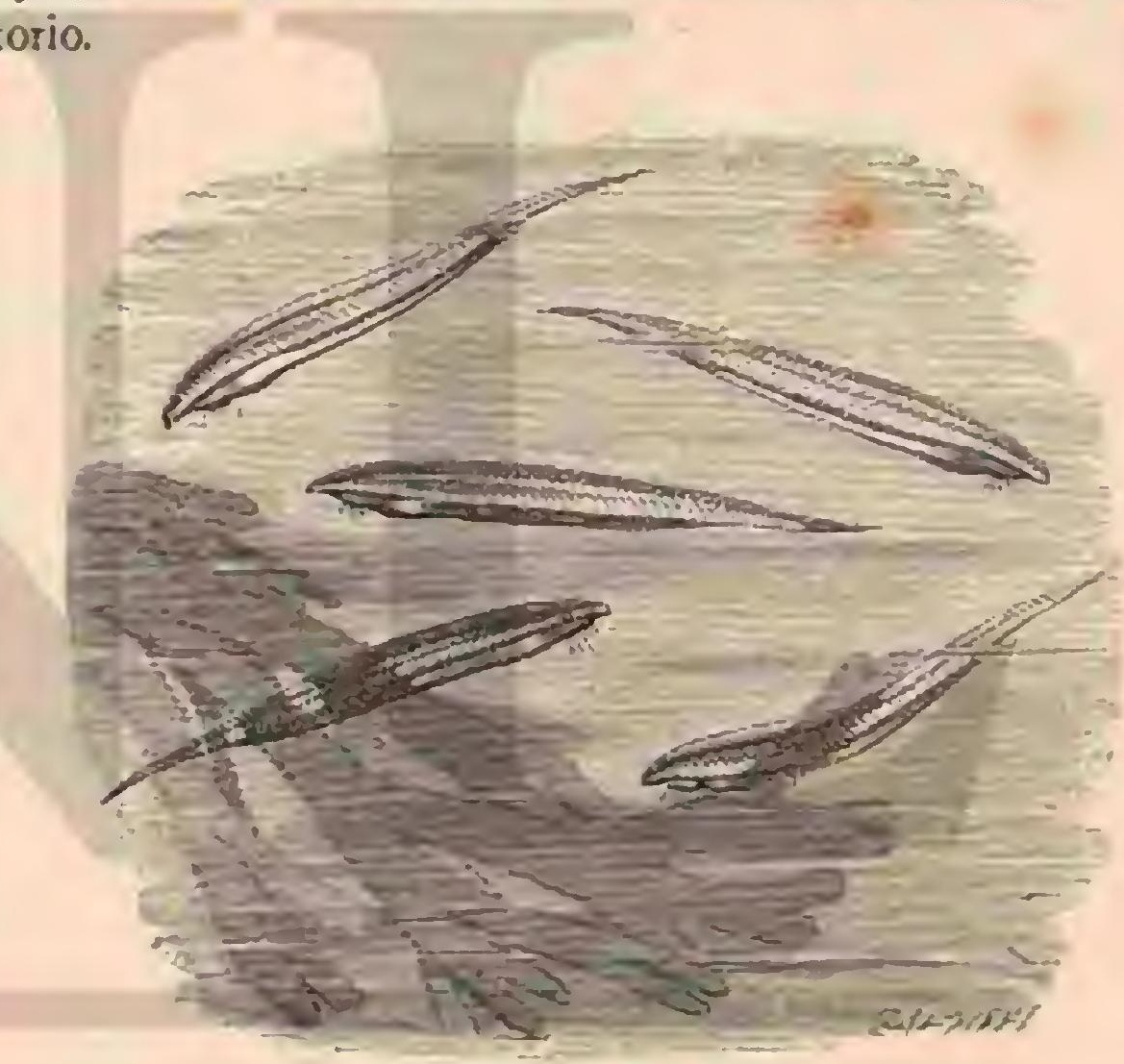

Fig. 241.-EL ANFIOSO BANGROLABO

DISTRIBUCION GEOGRÁFICA.-Su área de dispersion abraza todos los mares de las zonas tórrica y templadas.

USOS, COSTUMBRES Y REGIMEN-En la actualidad se sabe muy poco sobre el género de vida de este animal que ocupa el último grado en la cscala de los vertebrados; todo lo que sabemos se reduce casi a lo relativo i su estructura anatómica. Vive en la arena fina, tan oculto, que esto unido á su coloracion igual á la de aquel medio, hace que solo se le descubra cuando se pasa la arena por un tamiz de mallas finisimas. Es probable que alli donde vive sea mucho mas numeroso de lo que suele admitirse, puesto que no es difícil coger muchos en pocas horas en sitios á propósito. Cuando se ve obligado á abandonar la arena nada ondulan. do con tal velocidad que apenas se le divisa, para desapare. cer otra vez en la arena. Dice Couch que cuando nadan, apenas se puede distinguir la cabeza de la cola; y Wilde, que cautivos en un vaso se mueren con rápidas ondulacio- 
nes à la manera de las anguilas, y á pesar de su vista poco desarrollada, si es que poseen este sentido, saben desviarse cuando se les pone el dedo 6 algun otro obstáculo. Estos pequeños sćres, añade el observador que acabamos de citar, ticmen la faculıad especial de adherirse unos á otros, forman. do $\{$ veces como un ovillo, yotras un cordon de seis á ocho pulgadas de largo; el conjunto se mueve por los esfuerzos comunes y regulares de todos, y en el último caso con ondulaciones como las serpientes. Cuando nadan de este modo en fila, oprimense entre sí por el lado mas ancho, y de modo que la cabeza de cada uno se encuentra aproximadamente en el último tercio del cuerpo del que le precede.

Por lo que toca á la reproduccion y al modo de ser de la progenic de estos peces, no sabemos que se haya hecho ob. servacion alguna hasta ahora, siendo muy posible que el por. venir nos depare sobre puntos tan interesantes las mayores sorpresas, pues solo el conocimiento perfecto de su generacion y desarrollo podrá darnos á conocer si el extraño pe\%, cuya descripcion termina la lítima página de la historia de los peces, es verdaderamente el último de los icrlebrados.
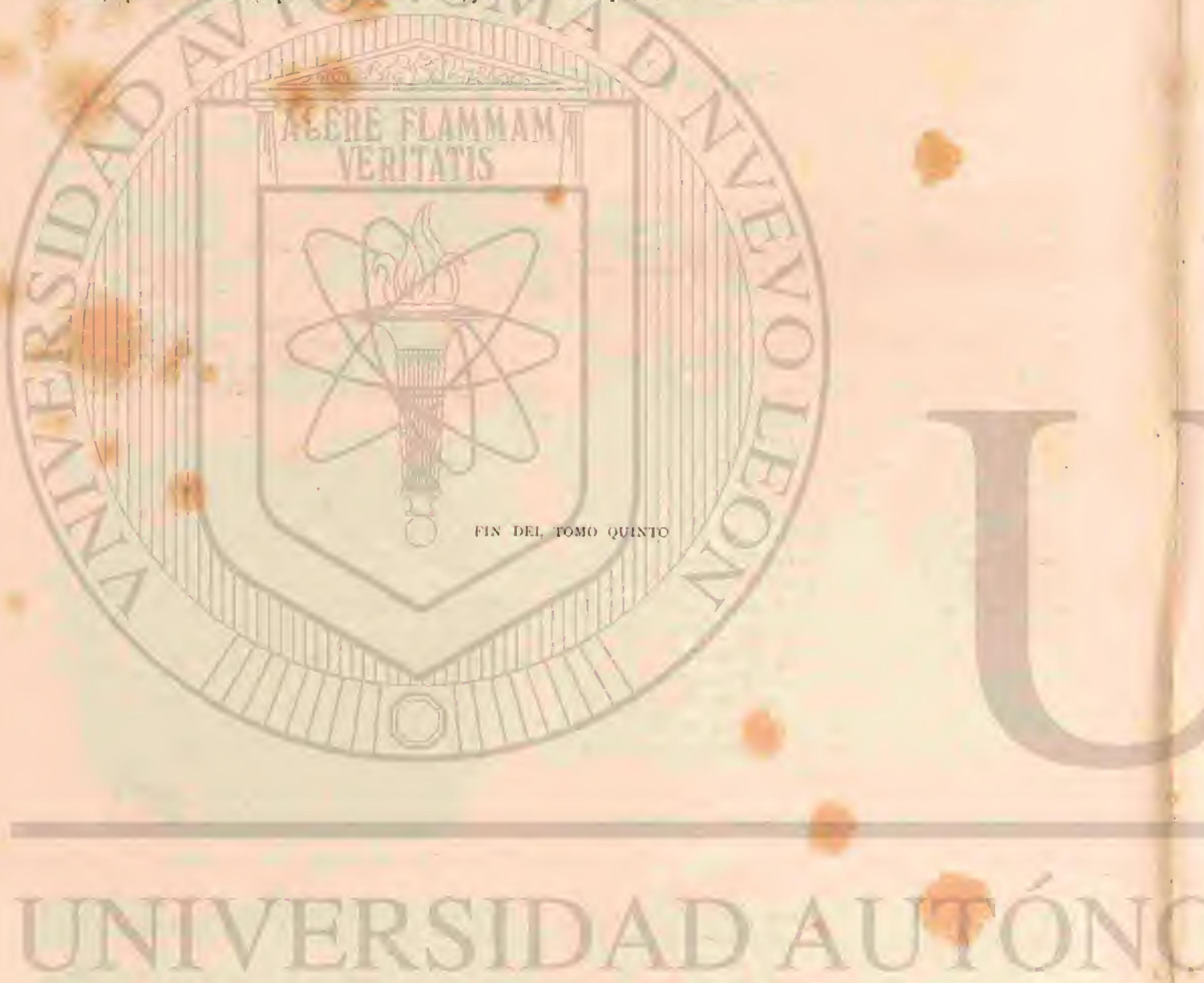

v
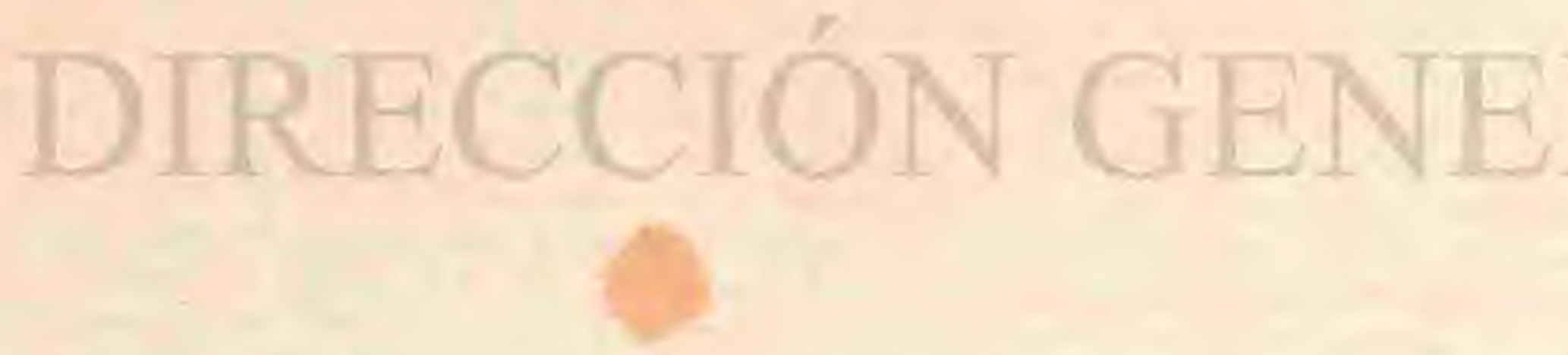


\section{INDICE ALFABÉTICO}

DE LAS CLASES, FAMLLAS, TRIBUS, GENKROS Y ESPECIIS CONTENIDOS EN EL TONO QUINTO

Abadejos 446

Abadejo comun idem

Idem lusco 449

Ablefaro comun 97

Acantias comun 556

Acantodáctilos So

Acantodáctilo comun idem

Acantolis 225

Acantofis cerastino iden

Acantópsidos 510

Acantopterigios 355

Acanturos $4: 8$

Acanturo cirujano idem

Accipenseridos 541

Accipenseres 542

Acerinas 359

Acorazados 38 I

Acris $: \$ 9$

Acris grillo 290

Acrocordidos 199

Acrocordo de Java idem

Acronuridos 428

Adonis 425

Agamas ro1

Agama de los colonos idem

Agamidos 97

Aglosos 309 .

Agujas de mar 535

Aibacora 404

Alburnos 504

Alectos 225

Alecto corto idem

Alites 300

Alites comadron idem

Alondras marinas 425

Alosas 518

Altidos 300

Ambistomes 3 rs

Amblirinco marino 17

Amblistomas 326

Amblistoma mexicano idem

Ameivas 83

Ameividos So

Amfiumas $3 j^{2}$

Amoditinos 454

Amodites lanceolado idem

Anabas 429

Anaba senal $43^{\circ}$

Anableps 492

Anacantinos $4+5$

Anaconda 159

Anclioa comun 520

Anfioxo lanceolado 569

Anfisbenidos 133

Anguila comun 52 if

Idem manchadia 528

Anguílidos 524

Anillados $\times 32$

Anolinos 108

Anolis 109

Anon 448

Anuros 278

Aprones 358

Arapaimas 513
Arenques 514

Arenque comun idem

Arqueros 368

Arquero sagitario idem

Ascalobates 126

Aspid de Egipto 220

Aspio rapaz 505

Astcrodáctilo pipa 310

Aterinidos 134

Aterinios jdem

Aterinos idem

Atunes 400

Atun comun iciem

Azemiofidios 149

Bacalaos 146

Bagrinos 462

Bagro ariete idem

Ballestas 533

Ballesta china 534

Barbada 453

Larbos 197

Basiliscos I ro

Basilisco de capucha 111

Batoideos 557

Batracios 271

Batraco gruinidor 421

Batraquidos 420

Tiermejuelas 499

Bichir 540

Blefaris $\$ 12$

Blenia mariposa 42.

Blenidos 423

Boa divino 157

Boeinos idem

Bogas $37 \mathrm{I}$

Boga comun 372

Bombinatoridos 301

Bonito 404

Botrops 267

Botrops atro\% 269

Idem hierro de lanza 268

Idem jararaca 266

Idem verde 267

Bremos 501

Brosmios 453

Brosmio conun idem

Bucéfalo del Cabo 195

Bufonidos 30.4

Bufos 305

bungaros 209

\section{Cabaillas $39 \$$}

Caballeros 388

Caballero de talabarte 380

Caballo de nar 536

Caimanes 57

Caiman chacare ide:n

Idem del Mississippi 60

Idem negro 59

Calamaridos 150

Calamaria de vientre blanco iden

Calionimidos $\$$ ' 9

Calionimos idem
Calionimo lira 4 ig

Calofis 208

Calofis de anillos idem

Idem de Maccelland idem

Calotes 100

Calote de color variable idem

Canialion comun 123

Camalcontidos 122

Camesauros 89

Campaneros 301

Campanero igneo 302

Caracinos 465

Caramel 434

Carangas 411

Carasios 495

Carcaridos 547

Carpas 493

Catafractos I

Catafractos 372

Idem propiantente dichos $j 8$

Caron $55^{2}$

Cecilias 337

Celopeltis 192

Celopeltis lacertino idem

Cencris 265

Centrinas 553

Centrina (gran) idem

Centriscidos 439

Centrisco trompeta idem

Centronotos 425

Centropomos $35 \mathrm{~S}$

Centropomo undecimal idem

Ceos 408

Ceo 6 pez de S. Pedro idem

Cepolidos 437

Cepola rojizo idem

Cerastes 247

Cerastes de Egipto idem

Ceratofris 299

Ciclopteros 420

Ciclostomos 56

Cicluros 114

Cicluro lofoma idem

Cinixis 13

Cinixis de Home idem

Cinostermos 2 I

Cinostermo de Pensilvania idem

Cionocranios 67

Ciprinidos 492

Ciprinodontidos $49 \mathrm{I}$

Cirrostomos 569

Cistignates 297

Clamidosauros 101

Clariinos 462

Clemis 20

Clupeidos 514

Cochino 534

Colubridos 170

Colubrinas 174

Comeforo del Baikal 427

Condrosteos 541

Condrostomos 510

Condrostomo nariz idem

Cóngrio comun 528 
Conocercos 205

Conolóos 116

Conolofo terrestre idem

Corifenas 408

Corifodones i 80

Corifodonte pantera idem

Coritofanos 112

Coritofano camaleopsis idem

Cornudillas $55^{1}$

Coronelas 1 I I

Coronelinas idem

Corrinas $38_{3}$

Corvina negra idem

Cotos 372

Coto de rio idem

Cotos acorazados 351

Cotos alados 377

Cotos espinosos 373

Coto escorpion 374

Crángidos 4 it

Crenilabros idem

Criptobráncos 329

Criptobranquintos 329

Crocodilos 38

Crocodilo del Nilo 49

Idemi de los pantanos 56

Crorodilos propiamente dichos $\div$ ?

Crocodilo de hócico largo 43 Idem listado 46

Crotaliidos : 50

Crótalos idem

Crotalo de diamante $25 i$

Idem durisso $25 \mathrm{I}$

Idem hórrido $25 \mathrm{~s}$

Culebras 174

Culebra de cuatro rayas 1 i $\delta$

Idem de Esrulapio 175

Idem dorndal 196

Idem negra 181

Idem viperina 1 Sg

Cheltopusic S6

Dabojas 243

Daboya de Rusell idem

Dactiloptero volador $3 \$_{4}$

Idem oriental idem

Dendrobates 307

Dendrobate oscuro idem

Dendrofinos 195

Dendrofis idem

Dendrofis pintado idem

Denton 371

Diacranteras 181

Diagramas $38 \mathrm{~g}$

Diagrama listado idem

Dicerobatos 562

Dicerobato giorna 56.3

Diodon $53^{\circ}$

Dipneos 353

Dipsadidos 196

Dipsas 197

Dipsa dentrofilo idem

Discobolos 420

Discobolo ciclóptero idem

Dobleandadora cenicienta-13.1

Dobulos 508

Docidofrines 308

Doradas 369

Dorada comun idem

Dorados 400

Doras $46_{3}$

Dragones 98
Drióflidos 193

Driofinos 195

Elafis 178

Elañs de cadena Ii?

Idem de cuatro rayas 178

Idern moteado 179

Elaps 206

Elaps coralino idem

Emididos 16

Limisauros 21

Emisauro aligator 22

Emperadores 367

Ensulones 380

Fmulon de cútro lineas idesn

Eperlano $47^{18}$

Fipibulos 443

Evibulo insidioso idem

Equeneidos 406

Eyuiunos 245

Equidno ariete idem

Equis 24 ?

Eremias 80

Fremias namaqués idem

Ericinos 156

Erix-Hecha idem

Expetrodias 194

Erpetrodinos 19.4

Escafiópes 303

Escafiope solitario idem.

Liscafiorincos $5 \$ 5$

Escafiorinco catafracto idem

Liscarnipenes 364

liscamiosos 62

Escardinias 506

Escardinia comun 507

Escaro de Creta 44t

Idem harid idem

Escienas ${ }_{5} \mathrm{~S}_{7}$

Esciena àguila 388

Escienidos 356

Escilidos $5 \overline{5} 4$

Escincoideos 89

Escinco oficinal g!

Escitálidos I 98

Escitalos idem

Escitalo coronado idem

Esclerodermos 533

Escolecofidios 147

Escombresúcidos $4{ }_{7}$

Escombresúccos prop. dichos ass

Escombridos $39 \mathrm{~S}$

Escorpina 360

Escorpinas 376

Escorpina roja $37 \overline{7}$

Esfarginidos 37

Lsfirenidos 390

Esfirena comun 392

Idem picuda idem

Eslizones 92

Fslizon calcidico 93

Esoceos $4 S_{5}$

Esparidos $3^{69}$

Espilotes I 80

Espinacidos 555

Estelios 103

Estelio espinoso 105

Idem vulgar 103

Esturion estrelet $5 \$ 3$

Idem estrellado idem

Iden huso idem

Idem propiamente dicho $54^{2}$

Eunectes 159
Exocetos 489

Exoceto rolador 491

Falso cordilo 86

Fancrobranquiatos 333

Faríngeos 440

Filomedusas aso

Filomedusa bicolor idem

Filopterix 5.37

Fisostomos 459

Fistularidos 439

Fistularia pipa idem

Foxinos 509

Foxino liso idem

Frinosominos 120

Furias 225

Gádidos 445

Galápagos 17

Galeos 550

Galeo perro 551

Gallos de mar a ro

Gallo de mar comun idem

Cianoideos 539

Gásterostcidos 392

Gasterosteo de cola aguda idem

Idem de hocico largo 393

Idem de nueve espinas $39^{2}$

Gaviales $4 I$

Gavial del Ganges idem

Ciecotidos 128

Geotrias $56 i$

Gimnodontes 530

Gimnofionidos 336

Gimmótidos 520

Gimnotos 52 I

Gimnoto eléctrico 522

Glano +60

Crlano anguila 462

Gobiesocidos 438

Gobidos a 16

Gobios $4 \mathrm{r} 7$

Gobio comun ó negro idem

Idem de rio 41 ?

Gobios de rio 498

Gobio comun 495

Idem uranoscopo 499

Gramatóforos 106

Gramatóforo espinoso 10T

Gunelio comun 425

Gurami 433

Hasar $4 \mathrm{C}_{4}$

Hatéridos 66

Hateria puntcada idem

Helicopos InI

Helicopo de cola aquillada $\mathrm{x} 93$

Helodermos $\$$.

Helodermo hórrido idem

Hemidáctilos 129

Henidáctilo verrugoso idem

Hemitripteros 375

Heniocos 360

Hidrófidos 226

Hidrofis de anillos negros iden

Hidromedusas $2 S$

Hidromedusa de Maximiliano iden

Hidrosaurios $\hat{3} 8$

Hidrosauros 60

Hidrosauro de fajas idem

Hilas $2 \delta_{3}$

Hilidos 2 \&2

Hilinos $2 S_{3}$ 
Hilodes a $\$ 8$

Hilodes de la Martinica idem

Hiperotrétidos 568

Hipoglosos 454

Hipogloso comun idem

Hipostomatinos $4 \mathrm{O}_{4}$

Hipselopinos 119

Hipsibato pintado idem

Holocantos 367

Holocéñlos $56_{3}$

Holosteos 539

Homalocéfalo 129

Homalopsidos 190

Hoplostetes 380

Hoplostetes del Mediterráneo idem

Hoplurinos 120

Huco $\$ 77$

Ibijara 133

Ictioideos 329

Iguanas 112

Iguana tuberculosa idem

Iguanidos 107

Istiuros 108

Istiuro porta.cresta idem

Jifias 413

Iifidos idem

Jurel comun 41 I

Jirelas $4+2$

Jirela vulgar idem

Laberinticos 429

Labridos 440

Labros idem

Lacertidos i I

Lagartos de collar 74

Lagarto ágil 76

Idem comun $4:$

Idem de las paredes 77

Idem ojo de serpiente 80

Idem perlado 9

Idem verde $7:$

Idem viviparo 76

Lamuidos 552

Lampreas 564

Lampuga 409

Laquesis 260

Laquesis mudo 261

Laud 37

Lecriodontos 326

Lemargos 556

Lemargo boreal idem

Lenguados $45^{6}$

Lepadogastros 439

Lepadogastro nanchado idem

Lepidosirena 353

Leptocardios 569

Lcucaspio rayado 505

Leuciscos 507

Lijas 554

Limandela 456

Liquias 412

Lobo trepador \& 24

Lochas 511

Lodos 478

Lodo capelan idem

Lofio pescador 421

Lofobrånquios 534

Loricarias 464

Loriga acorazado idem

Loro de mat 444

Lotas 45 I
Lota comun 45 I

Lubion 141

Luciones 93

Lucion comun iden

Luciopercas 357

Lucioperca comun idem

Lucios 485

Macropo comun 43

Malapteruro eléctrico 46.1

Malto escorpion 422

Mantas 562

Mapo comun 417

Marrajo 552

Mecodontos 313

Meleta 5 is

Menobranco lateral 335

Merlangos 440

Merluzas 450

Merluza comun idem

Miliobatidos $56 \mathrm{I}$

Miliobates águila idem

Mixinidos 568

Mixinos idem

Mixino glutinoso idem

Hocasin comun 266

Idem de agua idem

Moloch 105

Molva comun 452

Monocentros 379

Monocentro del Japon iden

Morelias I 70

Morelia Argos idem

Morena griega 529

Motelas 453

Motela comun idem

Mucosos 423

Mujoles 4.35

Mujol capiton idem

Iden cabezudo idem

Mugilidos idem

Múlidos $3^{6}$ I

Murcićlagos de mar $\$ 22$

Mustelinos 552

Narvaja 449

Nasones 420

Natricinos I 84

Nayas 212

Naya haya 220

Nototremas 287

Ofiocefálidos 437

Ofididos 453

Ofidios 134

Ofiofagos 223

Ofiolago real 224

Ofioftalminos 96

Ofisauros 80

Ofisauro ventrudo idem

Ombrinas 388

Dmbrina comun iden

Opetiodontes 208

Oreasomes 3 So

Orfios $4 \$ S$

Orfio idem

Orfos 506

Drtagoriscos 532

Ortagorisco luna idem

Osfromenos 433

Osmeros $47 \mathrm{~S}$

Osteoglosidos $5^{1} 3$

Ostracion cornudo 53.3
Oxibelis 196

Oxibelis brillante idem

Pageles 370

Pagel comun idem

Pamah 200

Paragudu idem

Paquisauros 70

Paquisauro de garganta blanca idem

Paseritas 196

Paserita purpúreo icjem

Peces 339

Peces ciegos 568

Peces de color $\$ 96$

Peces sapos 421

Peces voladores $38_{3}$

Pediculados 421

Pegasos 537

Pelamidos 227

Yelamido bicolor idem

Pelecos 503

Peleco comun idem

Pelobates 301

Pelobates oscuro idem

Perca comun de rio 356

Percofis $36 \mathrm{I}$

Percofis del Brasil idem

Percidos 355

Perioftalmos $41 \%$

Periónidos 183

Periops de herradura $1 \delta_{4}$

Pez.angel 557

Pez.ballesta 534

Pez-coral 365

Pez-correa 427

Pez de Tobias 454

Pez diablo 370

Pez-erizo 530

Pez-espada 414

Pez-jiron 537

Pez-martillo $55 \mathrm{I}$

Pez sierra 557

Pigicéfalos 298

Pigicéfalo salpicado iưem

Pigopodinos 97

Pigopodo estriado idem

Idem de Nueva Holanda idem

Pilotos 405

Piloto comun idem

Piraya 465

Pitónidos 150

Pitoninos 163

Pitones africanos 166

Pitones propiamente dichos $16_{3}$

Plagiostomos 547

Platicéfalos 375

Platicéfalo de grande espina idem

Platicercos 226

Platidáctilos $12 S$

Platidáctilo de pared idem

Platijas 455

Platija comun 456

Idem salpicada idem

Platisternos 2 I

Platisterno de cabeza grande idem

Platuros 226

Platuro de cola ancha idem

Plectognatos 534

Plepsias 378

Plepsias trilobado idem

Plestiodontes 92

Pleurodelos 317

Pleurodelo de llialt 318 
Pleuronéctidos $45+$

Podocnemis 24

Podocnemis ancho idem

Pogonias 389

Pogonia (gran) idem

Polipedatinos 289

Poliprion pardo 360

Preñadilla $4_{6}{ }_{3}$

Pristidos 557

Proteos 333

Proteo anguiforme idem

Pseudopos Só

Quélidos 24

Quelis :9

Ouelis matamata idem

Quelmones 365

Quelmon longirostro idem

Quelones 32

Quelónidos idem

Quelon verde idem

Idem carey 36

Quelonios I

Quersemidos 5

Quetodones 364

Quimera monstruosa 56.4

Quironecles 42 I

Quironectes erizado 422

Quirote mexicano 133

Quirotidos 132

Racoforos: 280

Racoforo de Reinwardt iden

Ranas 294

Rariidos 290

Raninos 29I

Raquiodones igs

Raquiodon áspero idem

Raya espinosa 560

Idem vaca 56 :

Rémoras 406

Rémora comun idem

Iden austral 407

Rencos 479

Rinequis $\mathrm{I}_{4}$

Idem escalonado idem

Rinofrinos 300

Rinofrino de raya dorsal idem

Ripsoglosos 12 I

Róbalos $35^{-S}$

Róbalo comun idem

Rodaballo 455

Rodillos- 149

Rodillo coralino idem

Idem rojo idem

Rodios 499

Romaguera 560

Rombos 455

Rombo mayor idem

Sábalo comun 5 is

Saboga idem

Salamandras 314

Salamandra negra 317 Idem terrestre ó manchada 314

Salamandridos 3 I 3

Salamandrinos 325

Salamandrino de anteojos idem

Salamanquesa de pared i2S Idem indica idem

Salmones 467
Salmon comun 468

Salmonetes $3^{6} 3$

Salmonete de barbas idem

Idem de lago $\$ \mathrm{C}_{2}$

Idem de listas $36 \hat{3}$

Idem rojo 476

Salmónidos 466

Samofidos Ig $2^{2}$

Samosauros 70

Samosauro gris idem

Sapos propiamente dichos 308

Sapo comun 305

Idem de agua jos

Idem de los pantanos idem

Idem variable idem

Sardina propiamente dicha 519

Sargos 369

Sargo anular idem

Saurios 62

Sauronido tetradáctilo 86

Sebastes 376

Selacios 545

Idem propiamente dichos 553

Selacio grande idem

Selacoideos 547

Serpientes 134

Idem venenosas 200

Iden de toca 2 I 4

Serpiente de anteojos 212

Serranos 360

Serrasalmos 465

Seudoequis 210

Sifonopos 337

Sifonopo anillado idem

Sifosomas 162

Silagos 361

Siluridos $\$ 60$

Siluros idem

Singnatidos 535

Sirenoideos 353

Sirenos 13,6

Sireno lacertino idem

Sollo 542

Tambores 531

Tambor rayado idem

Tapaya 12 I

Taragira $S_{4}$

Tarántula 129

Tarbofis 197

Tautogas 444

Trutoga de fajas 445

Tejús 8I

l'ejú 82

Teleosicos 355

Telestos 509

Telesto de Agassiz idem

Tencas 496

Tenca comun idem

Teraclis 400

Idem de mancha idem

Terois volador 377

Terrapenes 14

Terrapene de la Carolina idem

Testudinidos 5

Tetragonuros 434

Tetragonuro de Cuvier idem

liburon azul $54 \$$

Idem verde mar 550

Tifope dobleandadora $\mathrm{I}_{4} \mathrm{~S}$

Tiflopidos 847
Timalos $4^{8} 4$

Timalo comun idenı

Tordo de mar 442

Torpedinidos 558

Torpedo manchado idem

Tortricidos 149

Tortrix idem

Tortrix coralino idem

Tortuga coriácea 37

Idem clegante 9

Idem griega 6

Idem pixis 16

Idem polifemo 8

Idem salpicada idem

Tortugas gigantes 10

Tortugas marinas in

Tortugas ierrestres ó

Traquidermidos $S_{4}$

Traquidromos 85

I'raquinidos $3^{8} 4$

Traquinos $3 \delta_{5}$

Traquiptéridos 427

'Traquipteros $42 \mathrm{~S}$

Traquiptero ártico idem

Traquisauros 92

Traquisauro rugoso idem

'remiclgas $55^{8}$

Trepadores 424

Trigla golondrima $3 S_{2}$

Idem gunardo idem

Idem lira idem

Triglinos idem

Trigonidos 560

Trigonocéfalos 262

Trigonocéfalo hales 263

Trimeresuros $26_{7}$

Trioniquidos 29

Trionix 30

Trionix feroz 31

Triquiuridos 392

Triquiuros idem

Triquiuro plateado idem

Tritones 3 ig

Tropidonotos 184

Tropiduro de collar 120

Trucha asalmonada $46_{3}$

Idem comun idem

Upeneos 364

Upeneo de tres fajas idem

Uranoscopos $3^{\delta_{5}}$

Urodclos 3 ro

Uromastix 104

Lropeltidos 149

Uropeltis filipino idem

Varal 437

Varinidos 67

Varanos 68

Velero de las Indias 414

Viboras 230

Vibora áspid $23 \mathrm{~S}$

Idern ammodites ó cornuda 241

Idem comun 230

Viperidos 229

Zamenis I $\mathrm{I}$

Zoarce vivíparo 426

\%onuridos $\mathrm{S}_{5}$

7omuros iden

Zorras marinas 553 